University of Nebraska - Lincoln

DigitalCommons@University of Nebraska - Lincoln

Publications from USDA-ARS / UNL Faculty

U.S. Department of Agriculture: Agricultural

Research Service, Lincoln, Nebraska

1935

\title{
Manual of the Grasses of the United States
}

A. S. Hitchcock

USDA

Follow this and additional works at: https://digitalcommons.unl.edu/usdaarsfacpub

Part of the Agriculture Commons, and the Botany Commons

Hitchcock, A. S., "Manual of the Grasses of the United States" (1935). Publications from USDA-ARS / UNL Faculty. 2487.

https://digitalcommons.unl.edu/usdaarsfacpub/2487

This Article is brought to you for free and open access by the U.S. Department of Agriculture: Agricultural Research Service, Lincoln, Nebraska at DigitalCommons@University of Nebraska - Lincoln. It has been accepted for inclusion in Publications from USDA-ARS / UNL Faculty by an authorized administrator of DigitalCommons@University of Nebraska - Lincoln. 


\title{
UNITED STATES
}

DEPARTMENT OF AGRICULTURE

Miscellaneous Publication No. 200

Washington, D.C.

\section{MANUAL OF THE GRASSES OF THE UNITED STATES}

\author{
$\mathrm{Br}$ \\ A. S. HITCHCOCK \\ Principal Botanist \\ Division of Plant Exploration and Introduction \\ Bureau of Plant Industry
}

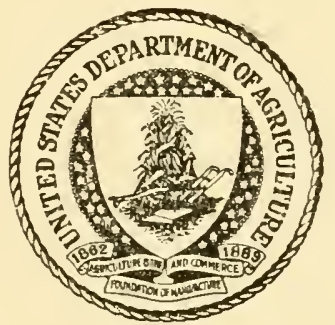

UNITED STATES

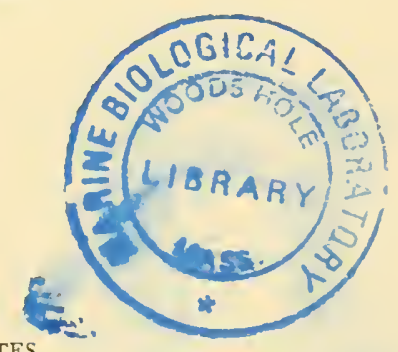

GOVERNMENT PRINTING OFFICE

WASHINGTON : 1935 



\section{MANUAL OF THE GRASSES OF THE UNITED STATES}

By A. S. НІтснсоск, principal botanist, Division of Plant Exploration and Introduction, Bureau of Plant Industry

\begin{tabular}{|c|c|c|c|}
\hline & CON' & NTS & \\
\hline troduction. & $\begin{array}{r}\text { Page } \\
1\end{array}$ & Descriptions of the tribes and keys to the & Page \\
\hline Uses of grasses & & genera-Continued. & \\
\hline Distribution of grasses. & 5 & Tribe 12. Paniceae. & \\
\hline Morphology of grasses.. & 6 & Tribe 13 . Andropogoneae. & \\
\hline Classification of grasses & 10 & Tribe 14. Tripsaceae.. & \\
\hline Nomenclature. & 12 & Descriptions of genera and species & \\
\hline Common names. & 14 & Tribe 1. Bambuseae & \\
\hline Scop & 14 & Tribe 2. Festuceae . & \\
\hline ramineae (Poaceae), the grass family & 15 & Tribe 3. Hordeae & \\
\hline ptions of the subfamilies and keys to the & & Tribe 4. A veneae. & \\
\hline 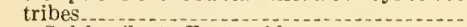 & 16 & Tribe 5. Agrostideae & \\
\hline Subfamily 1 . Fes & 16 & 6. Zoysieae & \\
\hline Subfamily 2. Panicoideae. & 1 ? & Tribe 7 . Chlorideae & \\
\hline Descriptions of the tribes and keys to the & & Tribe 8. Phalarideae & \\
\hline gene & 17 & 9. $\mathrm{O}$ & \\
\hline Tribe 1. Bambuse & 17 & Tribe 10. Zizanieae. & \\
\hline Tribe 2. Fest & 17 & Tribe 11. Melinideae... & \\
\hline Tribe 3 . Hor & 20 & Tribe 12. Pani & \\
\hline Tribe 4. Ave & 2 & Tribe 13. Andropogoneae... & \\
\hline Tri & 22 & Tribe 14. Tripsaceae & \\
\hline 6. Zoy & 2 & Synonymy ............... & \\
\hline Chle & 21 & Unidentified names & \\
\hline Phal & 25 & Persons for whom grasses bave been named.- & \\
\hline Ory & 25 & Glossary & \\
\hline 10. $\mathrm{Zi}$ & 2 & Additions and corrections & \\
\hline Tribe 11. Melinideae... & 20 & Index & \\
\hline
\end{tabular}

\section{INTRODUCTION}

Of all the plants of the earth the grasses are of the greatest use to the human race. To the grasses belong the cereals, sugarcane, sorghum, and the bamboos; and, since they furnish the bulk of the forage for domestic animals, the grasses are also the basis of animal industry.

USES OF GRASSES

The grasses furnish the principal breadstuffs of the world and a large part of the food of domestic animals; they are also used in the industrial arts and extensively as greensward and ornamentals in parks and gardens.

\section{FOOD GRASSES}

The most important food plants for the human race are the cereals, including wheat, corn (maize), rice, barley, rye, oats, and many kinds of grain sorghums. For primitive peoples the seed of certain other grasses, such as pearl millet, common millet, broomcorn millet, Japanese millet, and African millet (ragi), have played an important role. The seeds of the cereals are also extensively used as feed for domestic animals.

FORAGE GRASSES

Forage grasses are used for hay, for pasturage, for soiling, and for silage. 
The grasses together with the clovers and alfalfa are the basis of permanent meadows. The most important perennial grasses used for tame hay are: Timothy (Phleum pratense), redtop (Agrostis alba), orchard grass (Dactylis glomerata), meadow fescue (Festuca elatior), smooth brome (Bromus inermis), and Johnson grass (Sorghum halepense). A few other species are used occasionally or rarely: Rhodes grass (Chloris gayana), Dallis grass (Paspalum dilatatum), crested wheatgrass (Agropyron cristatum), velvet grass (Holcus lanatus), Natal grass (Tricholaena rosea), tall oatgrass (Arrhenatherum elatius), and slender wheatgrass (Agropyron pauciflorum). Some of the grasses used primarily for pasture are also occasionally used for hay.

Markethays from grasses usually consist of timothy, prairie grasses, Johnson grass, or grain (wheat, oats, and wild oats). The prairie hays are divided into upland prairie and midland prairie. The species of most importance in the upland prairie are Agropyron smithii and Stipa comata (northern Great Plains), Andropogon furcatus and A. scoparius (eastern Great Plains), A. saccharoides (Texas), and Panicum virgatum (Kansas to Texas). Midland prairie is invariably composed of Spartina pectinata. Tussock sedge (Carex stricta) is harvested in large quantities on the marshes of Wisconsin for use as packing hay.

For temporary meadows the grasses most used are the cereals, which, with wild oats, furnish the grain hay of the Pacific coast, the sorghums, including Sudan grass, and millet (Setaria italica).

PASTURE GRASSES

The more common grasses used for permanent pasture are: Kentucky bluegrass (Poa pratensis), Bermuda grass (Cynodon dactylon), redtop (Agrostis alba), colonial bent (A. tenuis), orchard grass (Dactylis glomerata), smooth brome (Bromus inermis), Italian ryegrass (Lolium multiflorum), perennial ryegrass (L. perenne), meadow fescue (Festuca elatior), Dallis grass (Paspalum dilatatum), carpet grass (Axonopus compressus), Canada bluegrass (Poa compressa), and sheep fescue (Festuca ovina). Many of the meadow grasses mentioned above are also used for pasture.

Temporary pasture is furnished by the cereals and by rescue grass (Bromus catharticus), Italian ryegrass, and Sudan grass.

Two grasses, important in the Tropics but in the United States grown only in southern Florida and southern Texas, are Guinea grass (Panicum maximum) and Para grass (P. purpurascens).

SOILING GRASSES

Grasses used for soiling are for the most part the cereals, millet, and other annual grasses used for temporary meadows, and in addition but only locally, pearl millet (Pennisetum glaucum), teosinte (Euchlaena mexicana), and Napier grass (P. purpureum).

SILAGE GRASSES

Any grass may be cut and stored in silos, but corn (maize) and sorghum are the ones most used. 


\section{RANGE GRASSES}

A large number of grasses make up much of the wild pasture, known in the West as the range, only the more abundant and valuable of which are recognized by stockmen as important. Probably the best known range grass is buffalo grass (Buchloë dactyloides), a sod-forming "short grass" dominant over much of the Great Plains. Throughout the same region two tufted short grasses, blue grama (Bouteloua gracilis) and hairy grama ( $B$. hirsuta), are abundant. In Texas the dominant grass over much of the range is curly mesquite (Hilaria belangeri) a sod-former similar to buffalo grass.

In the prairie region of the Mississippi Valley and in the eastern part of the Great Plains certain "tall grasses" in earlier days furnished excellent hay and pasture, but in recent times these fertile grasslands have been broken up for cultivated fields. The more impritant tall grasses are bluejoint turkeyfoot (Andropogon furcatus), prairie beardgrass (A. scoparius), switch grass (Panicum virgatum), side-oats grama (Bouteloua curtipendula), and Indian grass (Sorghastrum nutans).

The marsh hay of the northern Mississippi Valley consists of bluejoint (Calamagrostis canadensis), reed canary grass (Phalaris arundinacea), and a few other wet-land species.

The forage grasses of the Great Basin include species of Poa, Festuca, Bromus, Aristida, and Stipa. In the Southwest, the gramas, species of Bouteloua, dominate the range. A large bunchgrass, sacaton (Sporobolus wrightii), and alkali sacaton (S. airoides) furnish much forage.

A few of the many nutritious species found in the Northwestern States are greenleaf fescue (Festuca viridula), bluebunch fescue ( $F$. idahoensis), pinegrass (Calamagrostis rubescens), slender wheatgrass (Agropyron pauciflorum), California bromegrass (Bromus carinatus), and in the semiarid regions bluebunch wheatgrass (Agropyron spicatum).

GRASSES IN THE INDUSTRIAL ARTS

The most important species of the industrial arts group is the sugarcane (p. 718). This might be included among grasses that furnish food, but sugar is a manufactured product.

The chief fiber-producing grasses are esparto (Lygeum spartum and Stipa tenacissima) also known as alfa, natives of Spain and north Africa. The leares and stems are utilized in paper making. The pith of the cornstalk and the oil of the corn grain find many uses in the arts.

Certain aromatic grasses furnish essential oils used in perfumery. The best known are the lemon grass (Cymbopogon citratus), citronella grass (C. nardus), and vetiver (Vetiveria zizanioides).

The bamboos, the largest of the grasses, are of vast importance in the Indo-Malay region and are receiving increasing attention in the United States. The larger kinds reach a height of 30 meters and are 15 to 25 or 30 centmeters thick below, tapering to the summit. The culms or stems are very strong' and are used in building houses and bridges. When the stems are split, flattened out, and the partitions at the joints removed they make very durable boards, a foot or more wide, for floors and walls. Rafts and floats are made of the hollow stems closed at the joints by natural airtight partitions. With the partitions removed bamboo stems furnish water pipes or 
conduits. Sections of the stem closed at one end by the partition form convenient vessels for holding water. Much of the furniture and many of the utensils and implements used by the Malays are made wholly or in part of bamboo. Slender bamboo stems are familiar to us in the form of fishing rods and walking canes. Shoots of Phyllostachys edulis, Bambusa beecheyana, and other species of bamboo are a choice vegetable in the Orient and an expensive dainty in the United States.

Brooms are made from the seed heads of broomcorn, a variety of sorghum. Leghorn hats are made of a kind of wheat straw cut young and bleached. Straw of rice and oats is used for matting and for hats.

Starch and alcohol are made from the grain of maize, wheat, and other cereals. The stallss, grain, and cobs of maize furnish a great variety of products, such as wallboard, glucose, oil, red rubber, and corncob pipes.

\section{SOIL-HOLDING GRASSES}

Grasses used to hold soil in place and prevent erosion by wind or water possess strong creeping rhizomes.

Sand-binding grasses in addition are able to grow up through the deepening sand. The most effective sand binders for seacoast drifting sand are the European beachgrass (Ammophila arenaria) and its American relative (A. breviligulata). The dunes of the Netherlands, southwestern France, northern and western Denmark, and other parts of Europe and areas on Cape Cod are planted with beachgrass. These fixed dunes act as barriers, protecting the land behind them. The land now occupied by Golden Gate Park, once an area of drifting sand, was first held in place with bcachgrass and later planted to shrubs and trees. Calamovilfa longifolia and Redfieldia flexuosa are effective native sand binder's on sand dunes of the interior.

Grasses with strong rhizomes are used to hold the sides of cuts and banks and to protect them against erosion. Bermuda grass in the South and quackgrass (Agropyron repens) in the North have been used successfully for this purpose. Rhizome-bearing species of Elymus and Agropyron have been used in the Northwest to hold railway embankments along the Columbia River.

Shallow-water marshes and lagoons are in many places being converted into dry land by native plants growing therein that accumulate soil and gradually raise the level of the bottom. Grasses, especially species of Spartina, play an important part in the process. Recently artificial plantings of $S$. townsendii have been used with great success in the south of England, northern France, and in parts of the Netherlands to convert marshes and mud flats along the coast into dry land.

\section{GRASSES FOR LAWNS AND GOLF COURSES}

The lawn is a most important part of a well-planned landscape, park, or garden. For the humid regions of the Northern States, Kentucky bluegrass, also used for pasture, is the best-known lawn grass. Rough bluegrass (Poa trivialis) is often used as a lawn grass in shady places. In the Southern States Bermuda grass takes the place of bluegrass. Two other species are becoming prominent as grasses for lawns and putting greens, creeping bent (Agrostis palustris), and colonial bent (A. tenuis). Along southern coasts St. 
Augustine grass (Stenotaphrum secundatum) and centipede grass (Eremochloa ophiuroides) are planted, being propagated by cuttings. Some of the fescue grasses are used in mixtures for lawns. These are red fescue (Festuca rubra), sheep fescue ( $F$. ovina), hard fescue ( $F$. ovina var. duriuscula), and shade fescue ( $F$. rubra var. heterophylla).

Among typical ornamentals the plumegrasses, giant reed (Arundo donax), Ravenna grass (Erianthus ravennae), eulalia (Miscanthus sinensis), and pampasgrass (Cortaderia selloana) are the most popular for parks and large areas. Dwarf bamboo (Bambusa nana) is used for hedges in the South, and the smaller species of Phyllostachys for masses of evergreen foliage. Sasa japonica, an aggressively spreading hardy bamboo, is rather common in parks. Fountain grass (Pennisetum ruppelii) and blue fescue (Festuca ovina var. glauca) are used for borders. Ribbon grass (Phalaris arundinacea var. picta) is a familiar grass in old gardens. Basket grass (a variegated form of Oplismenus hirtellus) will fall in long festoons from hanging baskets.

\section{DISTRIBUTION OF GRASSES}

One of the most widely distributed of the families of flowering plants, the grasses are found over the land surface of the globe, in marshes and in deserts, on prairies and in woodland, on sand, rocks, and fertile soil, from the Tropies to the polar region and from sea level to perpetual snow on the mountains.

The different grasses, like other kinds of plants, thrive best under certain conditions of soil, moisture, temperature, exposure, and altitude. The conditions under which a plant normally grows is its habitat. Some species are narrowly restricted in their habitatbeing found only in sand or on rocks, in salt marshes or on alpine summits, for example, whereas others are tolerant of wide variations of habitat. Red fescue (Festuca rubra) is an example of wide distribution of a species tolerant of a variety of habitats. It is found from the arctic regions south at low altitudes to Georgia and central California and in the mountains farther south, and from the seacoast marshes to mountain tops.

Each species is found growing over a rather definite geographic area but within this area it is confined to its particular habitat.

In mountain regions altitude is an important factor in modifying range, each species thriving within certain limits of altitude. Species found at high altitudes in one range of mountains may reappear at about the same altitude on other ranges. Certain grasses growing at low levels in the north are found in the mountains and at increasingly higher elevations southward.

The geographic range is of importance and is given in some detail for each species in the manual. The range as given is based upon the study of a vast amount of material, both in the herbarium and in the field. For convenience in keeping the records of distribution a series of outline maps, one for each species or variety, has been prepared in the grass herbarium of the United States National Herbarium. The known range of each species is indicated upon these maps by a dot on each State from which specimens are in the herbarium or have been examined by the author. (A few extensions 
of range have been found since the maps were engraved. These are included in the text.) Local floras, lists, and records of distribution have been checked and efforts have been made to verify the records that scemed to indicate an extension of range. Other herbaria have been visited or have lent specimens, and many correspondents have submitted specimens for verification. No additions have been made without a study of the specimens.

The ranges of native species are usually fairly well defined and continuous. A species of the Coastal Plain extends, for example, from New Jersey to North Carolina or from Virginia to Florida and Texas, without a conspicuous break. Mountain plants extend along mountain ranges where similar conditions prevail. Some species have in the main a continuous range but are found also in isolated and distant localities. Bouteloua hirsuta extends over the Great Plains east to Wisconsin and Louisiana, and again occurs abundantly and apparently native on Sanibel Island, Fla. Some Coastal Plain species appear again around the head of Lake Michigan. In these cases it is probable that the species do not occur in the intermediate areas.

Certain arctic or northern species also show interrupted range, being found within the limits of the United States only on isolated mountain tops. The arctic grass, Phippsia algida, for example, is known within the United States only from alpine summits in Colorado. What appear to be interrupted ranges along the northern or southern borders are mostly due to extensions into this country from the main ranges in Canada or Mexico.

The distribution of recently introduced species is often very erratic. A single introduction may maintain itself or even spread considerably for several years before coming to the notice of botanists. Introduced species often travel rapidly along railroads by means of cattle cars, or they spread as impurities in the seed of crop plants. That seeds may travel great distances through the air has been shown by experiments in which airplanes have collected seeds, insects, and other objects at varying heights in the atmosphere. For example, spikelets of Paspalum dilatatum and $P$. urvillei were taken at altitudes up to 5,000 feet in Louisiana.

Grasses introduced into cultivation may spread or "escape" from cultivation and become established over wide areas. Kentucky bluegrass (Poa pratensis) and the ryegrasses (Lolium perenne and $L$. multiflorum) are familiar examples. Johnson grass is an excellent forage grass, but if it escapes into cultivated fields may become a troublesome weed

Other cultivated grasses, such as the grains, frequently spread from fields but are unable to maintain themselves for long. Eulalia (Miscanthus sinensis) has been cultivated for ornament in the enstern part of the United States for many years. Only recently has it shown a tendency to spread by seed. It is now becoming a nuisance in some localities because of its aggressiveness in old fields.

\section{MORPHOLOGY OF GRASSES}

The organs of grasses undergo many modifications or departures from the usual or typical structure. A knowledge of the structure and modifications of the organs, especially of the parts of the spikelet, is essential for the interpretation of relationships. 


\section{VEGETATIVE ORGANS}

In size grasses vary from minute species only 2 or $3 \mathrm{~cm}$ high to the giant bamboos $30 \mathrm{~m}$ tall. The regetative organs, however, consist, in all cases, of root, stem, and leaves. A single unbranched stem with the attached leaves, is a shoot.

ROOT

The roots of grasses are fibrous with little modification. The primary root persists only a short time after germination, its place being taken by secondary roots produced from the nodes of the young culm. Besides the original root system at the base of the plant, secondary roots are often formed from nodes above the ground as in maize (prop roots), or from the nodes of creeping culns (rhizomes or stolons). Roots are never produced from the internodes of the culms.

STEMI

The jointed stem of a grass, called a culm, is made up of a series of nodes and internodes. The internode is hollow (wheat), or solid (maize); the node or joint is always solid. The culm may branch at the base as in wheat (stools) or above the base as in Muhlenbergia. Creeping culms, modified for propagation, may be below ground (rhizomes) or above ground (stolons). The lower internodes may thicken into corms (timothy, species of Melica, Arrhenatherum elatius var. bulbosum), sometimes referred to as bulbs. Perennial grasses may form a sod or mass of individuals by means of rhizomes or stolons, or they may form a crown or tuft by the continual formation of upright branches within the lower sheaths.

LEAF

The leaves are borne on the culm in two ranks, one at each node The leaf consists of sheath and blade. The sheath envelops the culm above the node, the margins overlapping (open) or infrequently united into a cylinder for a part or a whole of the distance to the summit (closed).

The blades are typically flat, narrow, and sessile. In dry regions they are usually involute or convolute; in tropical shade they are often comparatively short and wide (lanceolate, ovate, or elliptic); in most of the bamboos they are narrowed into a short petiole articulate with the sheath.

Some grasses (especially the Hordeae) bear, one on either side at the base of the blade, appendages known as auricles. At the junction of the blade and sheath on the inside is a membranaceous or ciliate appendage called the ligule. The region on the back of the leaf at the junction of the sheath and blade is called the collar.

\section{PROPHYLLUM}

At the point where a branch shoot originates from a main shoot, (in the axil of a sheath) there is produced on the side next to the parent shoot a two-keeled organ (the first leaf of the shoot) called the prophyllum. At first the prophyllum completely covers the bud but later opens as the shoot develops. The organ is usually concave toward the parent shoot but clasps the new shoot by its margins. 
FLORAL ORGANS

The floral organs of all flowering plants are modified shoots. The flowers of grasses consist of stamens and pistils with no floral envelops or perianth, except as they are represented by the lodicules.

THE INFLORESCENCE

The unit of the grass inflorescence is the spikelet. The spikelets are nearly always aggregated in groups or clusters which constitute the inflorescence. 'The tassel of maize, the spike or head of wheat or timothy, and the panicle of the oat or bluegrass are examples of inflorescences.

The simplest inflorescence is the raceme, in which the spikelets are pediceled along an axis. The typical raceme, as in Pleuropogon, is rare in grasses. Modified spikelike racemes are characteristic of Paspalum, Digitaria, and allied genera, in which the spikelets are paired and short-pedicellate, and of most Andropogoneae, in which the spikelets are paired, one sessile the other pedicellate. The inflorescences of the groups mentioned may best be considered as specialized panicles.

The spike differs from the raceme in having sessile spikelets. In the Hordeae the spikes are symmetrical, in the Chlorideae they are one-sided.

The panicle is the commonest kind of grass cluster. In this the spikelets are pediceled in a branched inflorescence. The panicle may be open or diffuse as in Panicum capillare or contracted as in millet. Compact panicles, especially if cylindric like timothy, are called spikelike panicles.

Numerous small inflorescences may be aggregated into a large or compound inflorescence. Many Andropogoneae have compound inflorescences, for example, the broomsedge (Andropogon virginicus).

Panicles often expand at the time of flowering (anthesis). Such expansion or spreading of the branches and branchlets is brought about by the swelling of motor organs (pulvini) in the axils of the inflorescence.

Sometimes the ultimate branches of an inflorescence are sterile instead of bearing spikelets. The sterile branchlets of Setaria, Pennisetum, and Cenchrus are modified into bristles around the spikelets.

THE SPIKELET

A typical spikelet consists of a short axis (rachilla) on which the flowers are borne in the axils of two-ranked imbricate bracts. The spikelet is, therefore, a reduced modified shoot in which the rachilla is a stem bearing at each node a reduced leaf (bract). The flowers are secondary reduced shoots borne in the axils of the bracts, the first bract (palea) on the secondary shoot being a modified prophyllum and the stamens and pistil being modified leaves or bracts. The bracts of the lowest pair on the rachilla, being always empty, are distinguished as ghumes. The succeeding bracts are called lemmas (flowering glumes of some authors). The glumes and lemmas represent the sheath of the leaves, the blades not developing (in proliferous spikelets the parts are partially developed into typical leaves). The lemma, palea, and included flower are called the floret. The branchlet bearing the spikelet is the pedicel. 
The spikelet may be reduced to a single floret (Agrostideae), sometimes with a prolongation of the rachilla behind, as in Calamagrostis. In Andropogon a fertile spikelet is paired with a sterile one in which the pistils or both pistils and stamens are absent. The upper florets of the spikelet are often reduced in Festuceae and the lower lemmas may be empty in some genera (Uniola, Distichlis). In Melica and Chloris the upper florets may be reduced and form a club-shaped body. In Phalaris there is one fertile floret with a pair of sterile florets below, each reduced to a small appressed scale. In Lamarckia and Cynosurus there are prominent sterile spikelets mixed with the fertile ones.

In Paniceae the spikelet has a perfect terminal floret and below this a sterile floret, consisting of a sterile lemma similar to the glumes, either empty or with a hyaline palea or sometimes with a staminate flower.

In a few grasses (Amphicarpum, Chloris chloridea) there are, in addition to the usual inflorescence aboveground, cleistogamous spikelets borne on underground culms.

\section{RACHILLA}

The axis bearing the florets, the rachilla, usually disarticulates between the florets when the spikelet is more than one-flowered. In many species of Eragrostis it is continuous, usually bearing the persistent paleas, after the remainder of the florets have fallen. When the rachilla disarticulates the break is usually just below the florets so that the rachilla joint remains attached as a little stipe back of the palea. The disarticulation is near the middle of the internode in Trichoneura and Festuca subuliflora. The rachilla disarticulates just above the floret in Phragmites, the rachilla remaining as a plumose stipe below it. The rachilla is short-villous or pilose in many genera of Aveneae (the callus of the floret often pilose also).

In some genera with one-flowered spikelets (Calamagrostis, Cinna, Cynodon) the rachilla is prolonged behind the floret as a slender, often villous, joint or bristle, and in several genera with several-flowered spikelets (Koeleria, Poa) it is prolonged beyond the uppermost floret.

\section{GLUMES}

The glumes are usually similar in shape and texture, the first often smaller and with fewer nerves. Rarely the first glume is longer than the second (species of Aristida). The first may be much reduced or wanting (Axonopus, Paspalum, Digitaria). Rarely both glumes are wanting (Leersia, Reimarochloa). In Eriochloa the first glume is reduced or wanting, the first rachilla joint being a hard ring below the spikelet. In Andropogoneae the first glume is usually indurate, sometimes strongly so. In some Hordeae the glumes are bristlelike.

\section{LEMMAS}

The lemmas in the more primitive grasses are typically similar to the glumes but may be variously modified. In Panicum the fertile lemma is much harder than the glumes; in Andropogoneae they are much thinner than the glumes, of ten hyaline. The indurate cylindric lemma of Stipa and Aristida bears a sharp callus at base, formed by the oblique articulation with the rachilla. 
PALEA

The palea is mostly two-keeled and often concave between the keels. It is homologous with the prophyllum. Sometimes the two nerves of the palea are so close together as to appear like a single nerve (Cinna); sometimes the two nerves are marginal and widely separated as in rice. The keels may be ciliate (Eragrostis), bearded (Triplasis), or winged (Pleuropogon). The palea is much reduced or wanting in species of Agrostis. Usually the palea falls with its lemma but in many species of Eragrostis it persists upon the rachilla after the fall of the lemma.

FLOWER

The flower proper consists of the stamens and pistil. The stamens are usually 3 but may be 1 to 6 , rarely more. The slender filaments bear two-celled anthers which are basifixed but so deeply sagittate as to appear versatile. The pistil is one-celled, with one ovule; the styles are usually 2 but may be 1 or 3 ; the stigmas may arise from a single style or directly from the ovary. The style of Zea is greatly elongate and stigmatic over much of the exserted surface.

The lodicules are small organs found at the base of the floret outside the stamens. There are usually two, rarely three, the function of which is to open the floret at anthesis by their turgidity. They probably represent much reduced divisions of a perianth.

Typically the grasses are adapted to cross-pollination, but many species are cleistogamous in part. The axillary inflorescences of some species (Panicum clandestinum and allies, Leersia oryzoides) are enclosed in the sheaths and are self-pollinated. The florets of wheat expand for only a short time, when cross-pollination may take place, but for the most part are self-pollinated.

The fruit of the grasses is usually a caryopsis, in which the single seed is grown fast to the pericarp, forming a seedlike grain. In a few genera (Sporobolus, Eleusine), the seed is free from the pericarp. The caryopsis may be free from the lemma and palea, as in wheat, or it may be permanently enclosed, as in the oat and in the Paniceae. The grain (caryopsis) may enlarge during ripening and greatly exceed the glumes, lemma, and palea, as in maize and Pennisetum glaucum.

The embryo lies on the side of the caryopsis next to the lemma, and can be easily seen as an oval depression (the "germ" of maize and wheat). The hilum is the dot or line opposite the embryo which marks the point of attachment of the seed to the pericarp. The part of the caryopsis not occupied by the embryo is the endosperm or nourishment for the germinating seed.

\section{CLASSIFICATION OF GRASSES}

A natural classification of plants is one in which the different kinds or species are arranged in groups according to their resemblances as shown by their structure, especially (in the grasses and other flowering plants) by the structure of their flowers. The plants of today represent a cross section of the lines of descent from countless generations that have preceded them. It is generally accepted that there has been much variation during the evolutionary process, and that all living plants are genetically connected through their lines of descent. Some of the gaps in present-day knowledge of relationship are filled by fossil remains but relatively few of the ancestors of living plants 
are represented by fossils. Knowledge of the ancestry of the kinds of plants now on the globe is necessarily very incomplete. Hence, ideas of the relations of groups to each other are largely inferences based upon morphological resemblances. Those individuals which are so much alike as to appear to be of one kind, with, presumably, a common ancestor in recent geological times, are regarded as belonging to the same species. The species is the unit of classification. For convenience, species are grouped into genera and genera into families. For example, the white oak, red oak, black oak, and other kinds or species of oak belong to the oak genus (Quercus), all the species of which have one character in common-the fruit is an acorn. The oak genus, the beech genus, the chestnut genus, and a few allied genera are grouped together as a family.

The grass family (Gramineae or Poaceae) is one of the largest in number of genera and species, and, among flowering plants, is probably the largest in the number of individuals and is one of the most widely distributed. Some genera, such as the bluegrasses (Poa), the bromegrasses (Bromus), and the immense genus Panicum, contain numerous often closely allied species. Some genera contain but a few species or even but one.

When an attempt is made to classify a group of related variable species the question always arises whether there are several closely related but distinct species or a few distinct species, each of which shows great variation. It is but natural that botanists should differ in their conclusions. This explains in part the different classifications of the same group given by botanists of different periods or even of the same period. A satisfactory classification depends upon the study of abundant material both in the field and in the herbarium. By observation in the field one learns the range of variability of a species, while in the herbarium one can compare plants from different localities, interpreting the dried specimens in the light of field experience.

In the classification of variable species it is found convenient sometimes to separate variants as varieties. A variety comprises those individuals of a species that show a definite tendency to vary in a certain direction, but which are connected with the species by rather numerous intergrades. Sometimes a variety is founded on a single variation which is distinct but trivial, for example, pubescent specimens of a glabrous species. A variation supported by a distinct geographical range or even by a distinct habitat is given greater weight than is a variation found in a few individuals growing among plants of the typical form.

The study of a vast amount of material in field and herbarium during some 30 years has resulted in the recognition of relatively few varieties, the intergrades proving to be more numerous than fairly clear-cut variants. Well-marked varieties are given a separate paragraph in the text, but are not usually given in the keys. Less well-marked varieties are given in the paragraph with the species. Many additional forms are indicated in a descriptive statement without being formally recognized as species or varieties. For example, under Digitaria gracillima appears, "A tall plant with * * * has been called D. bakeri (Nash) Fernald"; and under Eriochloa michauxii, "a form with * * * has been described as $E$. mollis var. longifolia Vasey." 
The arrangement of the genera in this manual is, in general, from the simple to the complex. It is, of course, impossible to arrange all the genera in linear sequence and at the same time represent a gradual increase in complexity because plants have not developed in a single line, but have diverged in all directions, their relationships being a complex network. The highest genus of one tribe may be much more complex than the lowest genus of the next tribe above. On the average the Bambuseae seem to be the most primitive and the Tripsaceae the most complex. A grass with a spikelet consisting of glumes and several florets, the lemmas and glumes being similar and resembling bracts, is a primitive form. Grasses with spikelets in which the parts are reduced, enlarged, or much differentiated, are derived or complex forms. Derived forms may be simple from the reduction of parts and yet not be primitive. In the main the genera of grasses fall readily into a few large groups or tribes, but several genera of uncertain affinities are, for convenience, placed in the recognized tribes on artificial characters, with the hope that further study and exploration will bring to light their true relationships.

The grasses of the world (about 510 genera) have been grouped in to 14 tribes, all of which are represented in the United States.

The sequence of tribes and genera in the manual with a few minor changes, is that found in The Genera of Grasses of the United States.

\section{NOMENCLATURE}

The cooperative study of botany depends for progress and success on definiteness in the application of the names of plants. Research workers in all branches of botany must use the names of plants in the same sense or serious misunderstandings will result. One of the functions of systematic botany is to determine the correct names of plants. The study of the application of plant names is nomenclature. By common consent of the botanists of the world Latin has been accepted as the language for technical plant names.

Modern nomenclature commences with the publication in 1753 of Linnaeus' Species Plantarum in which the binomial system of naming plants was first proposed. During the nearly 200 years following that date many thousands of plants have been described. During this time there has been a lack of uniformity in the use of names, causing much confusion, and resulting in frequent changes. The same species has been described under different names at different times, and the same name has been given to different plants. This confusion has been especially embarrassing to the agriculturist, ranger, seedsman, pathologist, entomologist, and to all others interested in plants, but not familiar with nomenclature and the history of the names used.

The difference in the Latin names applied in different books to the same kind of grass is due to several causes.

(1) A species is described as new by one author without knowing that the same species had been previously described by another author. The second name is known as a synonym.

(2) An author applies a new name to a variant of a species already described. The author recognizes the variant as a distinct species. Other botanists may consider it to be only a variety of the older species or may consider it as a variant not sufficiently distinct to be worthy of varietal rank.

\footnotetext{
1 HitchCocK, A.S. THE GENERA OF GRASSES OF THE UNITED STATES, WITH SPECIAL REFERENCE TO THE ECONOMIC SPECIES. U.S. Dept. Agr. Bull. 772, 307 pp., illus. 1920.
} 
(3) Authors have different concepts of the limits of genera. The genus Triticum was described by Linnaeus. A later botanist thought that many of the species of this genus were different enough to constitute a distinct genus, Agropyron, and transferred quackgrass, first described as Triticum repens to Agropyron, as $A$. repens.

(4) Authors sometimes misidentify species. Linnaeus described one of the cordgrasses as Spartina cynosuroides. Later, Michaux used the specific name for a different species, (Trachynotia cynosuroides, based on S. cynosuroides L.) This error was corrected and the species described by Michaux was given a new name, S. michauxiana. Only recently the loan of the type of Spartina pectinata Link, poorly described many years earlier, shows that that name is the valid one for the species.

It will be seen that the differences in names are due in part to differences of opinion as to the generic, specific, or varietal distinctness of forms; in part to lack of knowledge as to what plants have been described previously; and in part to errors of identification.

All the preceding shows the need of rules of nomenclature. To enable users of this manual to coordinate the names published to date a synonymy ${ }^{2}$ has been appended in which all the names published for grasses in the United States have been arranged under the names here adopted, that is, under the oldest valid name for each species. In determining the valid names of the species the International Rules of Botanical Nomenclature have been followed. Under these rules certain generic names are conserved though they are not the earliest. The names of genera of grasses on the conserved list are as follows: Tragus, Zoysia, Leersia, Hierochloë, Crypsis, Coleanthus, Corynephorus, Cynodon, Ctenium, Buchloë, Diarrhena, Lamarckia, Glyceria.

Certain other names of genera are used for different reasons. Digitaria antedates Syntherisma with which it is synonymous. Setaria was proposed as a conserved name at the Cambridge International Botanical Congress and was referred to a committee along with other names. It was also proposed at the Cambridge Congress (and referred to a committee) that the standard species of Holcus be $H$. lanatus and of Aira be A. praecox, thus validating Sorghum and Deschampsia.

The synonymy attempts to record all the effectively published names given to species and varieties described from the United States or known to grow in the United States. In addition many names are given which have been published as synonyms or without sufficient description (nomina nuda). Whether such names have been included depends upon whether they have appeared in such works as the Index Kewensis or have some connection with effectively published names. When a species is transferred from one genus to another, a new name results. The basis of the transfer is given in each case. If the name was published as new the original published locality is given. Statements enclosed in brackets following the original locality are based upon unpublished evidence.

Forms (formae) are included in the synonymy so far as they have been indexed in the grass herbarium. The index includes all forms recently published in this country. Misapplied names have not been included among the synonyms but are mentioned in a paragraph at the end of the synonymy of the valid species, and then only names that have appeared in recent manuals are given.

${ }^{2}$ For convenience the names of the genera are arranged alphabetically and under each genus the valid names of the species are given in alphabetic order in boldface type, the synonyms of each species (in italics) being arranged chronologically under the valid name. 
So far as possible the names have been confirmed or identified by examination of the types. The type of a species or variety is the specimen which an author had ehiefly in mind when he wrote the original deseription. The type specinen determines the application of the name. The type specimens of the early American botanists are mostly in European herbaria. The types of species described by Vasey and other botanists eonnected with the Department of Agriculture are mostly in the United States National Herbarium. Types not in Washington have been studied in other herbaria and photographs and drawings made of them by the agrostologists of the Department of Agriculture, or have been lent by the curators of the herbaria in which they are deposited. 'Through the courtesy of these curators many fragments of types have been deposited in the United States National Herbarium. A few type specimens have not been loeated, and doubtless in some of these cases there are no types in existence to confirm original descriptions. A relatively small number of published names still remain unidentifiable. These names are listed following the synonymy. Certain exotie species, mentioned by horticultural writers as being oceasionally cultivated for ornament, have been included in notes appended to the genera to which they belong. It has not been practicable in all cases to verify the applieation of the names on a type basis, and the species are admitted under the names they bear in cultivation.

\section{COMMON NAMES}

The common or English names of plants are often uncertain in their application, different plants bearing the same name or the same plant bearing different names in different localities. A recent work, Standardized Plant Names, ${ }^{3}$ has coordinated and standardized the common names. One of the authors of this work, Frederick V. Coville, has standardized the common names of the grasses for this manual.

\section{SCOPE OF THE MANUAL}

The manual includes descriptions of all grasses known to grow in the continental United States, exeluding Alaska. There are 159 numbered genera and 1,100 numbered species. Of these, 44 genera and 151 species are introduced, mostly from the Eastern Hemisphere.

In addition to the numbered speeies, whieh may be considered permanent constituents of the flora of the United States, there are a number of speeies which are known only as ballast plants or as waifs in the interior, or are only rarely cultivated. These appear not to be established and are mentioned, without numbers, in paragraphs appended to their nearest allies. They are not included in the keys.

The manual is based mainly on the material in the United States National Herbarium, the grass collection of which is the largest in the world, numbering more than 210,000 sheets. In addition all the larger collections of grasses in the United States have been consulted and the curators have lent specimens for study and have aided in other ways. Many smaller collections have contributed information, especially on the ranges of species. The cooperation of the Forest Service, United States Department of Agriculture, has been invalu-

3 american Joint Commitee on Horticultural Nomenclature. standardized plant namas. Prepared by F, L. Olmsted, F. V. Coville, and H. P. Kelsey. 546 pp. Salem, Mass. 1923. 
able. The Forest Service maintains in its Washington office, a rangeplant herbarium, consisting of the collections made by forest officers, especially those located in western national forests and forest experiment stations. The grasses of this range-plant herbarium have been placed at the disposal of the writer and have furnished important data on distribution.

Many botanists throughout the country have rendered valuable assistance in recent years by contributing specimens which have added species previously unknown from the United States, have extended ranges, and have helped to solve the position of puzzling species and varieties. ${ }^{4}$

Nearly all the species have been illustrated. ${ }^{5}$

To aid the users of this work in pronouncing the Latin names the accented syllable is indicated. The accent mark is used to show the accented syllable without reference to the length of the vowel.

\section{GRAMINEAE (POACEAE), THE GRASS FAMILY}

Flowers perfect (rarely unisexual), small, with no distinct perianth, arranged in spikelets consisting of a shortened axis (rachilla) and 2 to many 2-ranked bracts, the lowest two being empty (the glumes, rarely one or both obsolete), the one or more succeeding ones (lemmas) bearing in their axils a single flower, and, between the flower and the rachilla, a second 2-nerved bract (the palea), the lemma, palea, and flower together constituting the floret; stamens 1 to 6 , usually 3 , with very delicate filaments and 2-celled anthers; pistil 1, with a 1-celled 1 -ovuled ovary, 2 (rarely 1 or 3 ) styles, and usually plumose stigmas; fruit a caryopsis with starchy endosperm and a small embryo at the base on the side opposite the hilum.

Herbs, or rarely woody plants, with hollow or solid stems (culms) closed at the nodes, and 2-ranked usually parallel-veined leaves, these consisting of two parts, the sheath, enveloping the culm, its margins overlapping or sometimes grown together, and the blade, usually flat; between the two on the inside, a membranaceous hyaline or hairy appendage (the ligule).

The spikelets are almost always aggregated in spikes or panicles at the ends of the main culms or branches. The perianth is usually represented by 2 (rarely 3 ) small hyaline scales (the lodicules) at the base of the flower inside the lemma and palea. The grain or caryopsis (the single seed and the adherent pericarp) may be free, as in wheat, or permanently enclosed in the lemma and palea, as in the oat. Rarely the seed is free from the pericarp, as in species of Sporobolus and Eleusine. The culms of bamboos are woody, as are also those of a

- The more important are: Brother G. Arsène, Sacred Heart Tralning College, Las Vegas, N.Mex., collections from Louisiana and New Mexico; H. L. Blomquist, Duke University, Durham, N.C., collections from North Carolina; B. F. Bush, Courtney, Mo., collections from Missouri and Texas; V. H. Chase, Peoria, Ill., collections from Llinois; Charles C. Deam, research forester, lndiana, collections from Indiana; H. 1. Featherly, Agricultural and Mechanical College, Stillwater, Okla., collections from Oklahoma; the late Willam C. Ferguson, Hempstead, N.Y., collections from Long Island; A. O. Garrett, East High School, Salt Lake City, collections from Utah; James E. Nelson, Salem, Oreg., collections from Oregon including ballast plants near Portland; J. B. S. Norton, University of Maryland, collections from Maryland; W. A. Silveus, San Antonio, Tex., collections from Texas, especially in the vicinity of San Antunio, including several novelties; B. C. Tharp, University of Texas, collections from Texas.

5 The drawings illustrating the genera (previously published in U.S. Department of Agriculture Bulletin 772 , The Genera of Grasses of the United States . .) and nearly half of the others were made by $M$ tary Wright Gill; the remainder were drawn by Edna May Whitehorn; the spikelet drawings are by Agnes Chase. In each case the specimen from which the drawing was made is cited, for example (Nash 2198, Fla.). 
few genera, such as Olyra and Lasiacis, belonging to other tribes. The culms are solid in our species of the tribes Tripsaceae and Andropogoneae and in several other groups. The margins of the sheaths are grown together in species of Bromus, Danthonia, Festuca, Melica, Glyceria, and other genera.

The parts of the spikelet may be modified in various ways. The first glume, and more rarely also the second, may be wanting. The lemmas may contain no flower, or even no palea, or may be reduced or rudimentary. Rarely, as in species of Agrostis and Andropogon, the palea is obsolete.

The division of the family into two subfamilies is somewhat artificial. The tribes Zoysieae, Oryzeae, Zizanieae, and especially Phalarideae, do not fall definitely into either of the recognized subfamilies. They are placed as indicated largely for convenience.

\section{DESCRIPTIONS OF THE SUBFAMILIES AND KEYS TO THE TRIBES}

\section{SUBFAMILY 1. FESTUCOIDEAE}

Spikelets 1- to many-flowered, the reduced florets, if any, above the perfect florets (except in Phalarideae; sterile lemmas below as well as above in Ctenium, Uniola, and Blepharidachne); articulation usually above the glumes; spikelets usually more or less laterally compressed.

\section{Key to the tribes of Festucoideae}

Plants woody, the culıns perennial. Spikelets several-flowered.

1. BambUseat (p. 17)

Plants herbaceous, the culms annual (somewhat woody and persistent in Arundo).

Spikelets with 2 (rarely 1) staminate, neuter, or rudimentary lemmas unlike and below the fertile lemma; no sterile or rudimentary floret above.

8. Phalakideae (p. 25)

Spikelets without sterile lemmas below the perfect floret (or these rarely present and like the fertile ones, a dissimilar pair below and a rudimentary floret above in Blepharidachne).

Spikelets unisexual, falling entire, 1-flowered, terete or nearly so.

10. Zizanieae (p. 26)

Spikelets perfect (rarely unisexual but then not as above), usually articulate above the glumes.

Spikelets articulate below the glumes, 1-flowered, very flat, the lemma and palea about equal, both keeled. Glumes small or wanting.

9 . ORYZEAE (p. 25)

Spikelets articulate above the glumes (rarely below, but the glumes, at least one, well developed).

Spikelets 1-flowered (or the staminate 2-flowered) in groups (short spikes) of 2 to 5 (single in Zoysia), the groups racemose along a main axis, falling entire; lemma and palea thinner than the glumes.

6. ZOYSIEAE (p. 24)

Spikelets not as above.

Spikelets sessile on a usually continuous rachis (short-pedicellate in Leptochloa and Trichoneura; the rachis disarticulating in Lepturus, Pholiurus, Hordeum, Sitanion, and in a few species of allied genera).

Spikelets on opposite sides of the rachis; spike terminal, solitary.

3. HORDEAE (p. 20)

Spikelets on one side of the rachis; spikes usually more than 1, digitate or racemose............. 7. Chlorideate (p. 24) Spikelets pedicellate in open or contracted, sometimes spikelike, panicles, rarely racemes.

Spikelets 1-flowered (occasionally some of the spikelets 2-flowered in Muhlenbergia asperifolia and $M$. arenacea).

5. Agrostideae (p. 22) 
Spikelets 2- to many-flowered.

Glumes as long as the lowest floret, usually as long as the spikelet (sometimes shorter in Sphenopholis); lemmas awned from the back (spikelets awnless in species of Trisetum, Koeleria, Sphenopholis; and Schismus) _...... 4. Aveneae (p. 21)

Glumes shorter than the first floret (except in Dissanthelium with long rachilla joints); lemmas awnless or awned from the tip or from a bifid apex........... 2. FESTUCEAE (p. 17)

\section{SUBFAMILY 2. PANICOIDEAE}

Spikelets with one perfect terminal floret (disregarding those of the few monoecious genera and the staminate and neuter spikelets) and a sterile or staminate floret below, usually represented by a sterile lemma only, one glume sometimes (rarely both glumes) wanting; articulation below the spikelets, either in the pedicel, in the rachis, or at the base of a cluster of spikelets, the spikelets falling entire, singly, in groups, or together with joints of the rachis; spikelets, or at least the fruits, more or less dorsally compressed.

\section{Key to the tribes of Panicoideae}

Glumes membranaceous, the sterile lemma like the glumes in texture.

Fertile lemma and palea thinner than the glumes. Sterile lemma awned from the notched summit....... Melinideae (p. 26)

Fertile lemma and palea indurate or at least firmer than the glumes.

12. Paniceat (p. 26)

Glumes indurate; fertile lemma and palea hyaline or membranaceots, the sterile lemma like the fertile one in texture.

Spikelets unisexual, the pistillate below, the staminate above, in the same inflorescence or in separate inflorescences _... 14. TRIPSACEAE (p. 29)

Spikelets in pairs, one sessile and perfect, the other pedicellate and usually staminate or neuter (the pedicellate one sometimes obsolete, rarely both pedicellate). Lemmas hyaline........ 13. AndropogoneaE (p. 27)

\section{DESCRIPTIONS OF THE TRIBES AND KEYS TO THE GENERA}

\section{TRIBE 1. BAMBUSEAE}

Culms woody, perennial, usually hollow; spikelets 2- to severalflowered, in panicles or racemes, or in close heads or fascicles; often 1 or more sterile lemmas at base of spikelet; lemmas usually awnless; blades usually articulated with the sheath, flat, rather broad. Only one genus, Arundinaria, is native within our limits. Several species of this and other genera are cultivated in the Southern States.

\section{TRIBE 2. FESTUCEAE}

Spikelets more than 1-flowered, usually several-flowered, in open, narrow, or sometimes spikelike panicles (rarely in racemes); lemmas awnless or awned from the tip, rarely from between the teeth of a bifid apex; rachilla usually disarticulating above the glumes and between the florets.

A large and important tribe, mainly inhabitants of the cooler regions. The lemma is divided into several awns in Pappophorum and its allies, is deeply 2-lobed in Triplasis and in a few species of Triodia, 3-lobed in Blepharidachne, several-toothed in Orcuttia, and slightly 2 -toothed in Bromus and in a few other genera, the awn, when single, arising from between the teeth. The paleas are persistent upon the continuous rachilla in most species of Eragrostis. Scleropogon, 
Monanthochloë, Distichlis, and a few species of Poa and Eragrostis are dioecious. Gynerium, Cortaderia, Arundo, and Phragmites are tall reeds. In Blepharidachne there is a pair of sterile florets at the base of the single fertile floret, and a rudiment above. In some species of Melica there is, above the fertile florets, a club-shaped rudiment consisting of one or more sterile lemmas. In Uniola there are one to four sterile lemmas below the fertile ones. In Melica imperfecta and M. torreyana there may be only one perfect floret.

\section{Key to the genera of Festuceae}

1a. Plants dioecious, (sometimes monoecious), the sexes very dissimilar, the pistillate lemmas with 3 long twisted divergent awns, the staminate lemma awnless or mucronate......................... 38. ScLeropogon.

1b. Plants with perfect flowers, or, if dioecious, the sexes not dissimilar in appearance.

2a. Lemmas divided at the summit into 5 to several awns or awnlike lobes. Awnlike lobes 5. Inflorescence an erect raceme or simple panicle.

Awns 9 or more.

34. Orcuttia.

Awns unmixed with awned teeth; all the florets falling attached, their awns forming a pappuslike crown, the lower 1 to 3 fertile; panicles narrow _............................... 37. PAPPOPHORUM.

Awns mixed with awned teeth; florets not falling attached, the rachilla disarticulating between them; panicles somewhat open 36 . Cotrea.

2 b. Lemmas awnless, with a single awn, or, if with 3 , the lateral awns minute. 3a. Tall stout reeds with large plumelike panicles. Lemmas or rachilla with long silky hairs as long as the lemmas.

Leaves crowded at the base of the culms......... 25. Cortaderia. Leaves distributed along the culms.

Lemmas naked. Rachilla hairy .............. 26. Phragmites.

Lemmas hairy.

Rachilla naked

Rachilla hairy

3b. Low or rather tall grasses, rarely more than $1.5 \mathrm{~m}$ tall.

24. Arundo.

4a. Plants dioecious, perennial. Lemmas glabrous; grasses of salt or alkaline soils.

Plants low, creeping; spikelets obscure, scarcely differentiated from the short crowded rigid leaves _.......... 18. Monanthochlö̈.

Plants erect from creeping rhizomes; spikelets in a narrow simple exserted panicle_............ 19. Distichlis.

4b. Plants not dioecious (except in a few species of Poa with villous lemmas and in an annual species of Eragrostis).

5a. Spikelets of two forms, sterile and fertile intermixed. Panicle dense, somewhat one-sided.

Fertile spikelets 2- or 3-flowered; sterile spikelets with numerous rigid awn-tipped glumes; panicle dense, spikelike_._ 22. Cynosoros.

Fertile spikelets with 1 perfect floret, long-awned; sterile spikelets with many obtuse sterile lemmas; panicle branchlets short, nodding ................................. Lamarckia.

5 b. Spikelets all alike in the same inflorescence.

6a. Lemmas 3-nerved, the nerves prominent, often hairy.

7a. Inflorescence a few-flowered head or capitate panicle overtopped by the leaves or partly concealed in them. Lemmas toothed or cleft; low plants of the arid regions.

Inflorescence hidden among the sharp-pointed leaves, not woolly; plants annual (Chlorideae) _.......... 106. Munroa.

Inflorescence a capitate woolly panicle, not concealed; plants perennial.

Lemmas cleft either side of the midnerve to near the base, the lower two sterile, the third floret fertile, the fourth reduced to a 3-awned rudiment......... 35. BLEPharidachNe.

Lemma 2-lobed but not deeply cleft, all fertile but the upper-

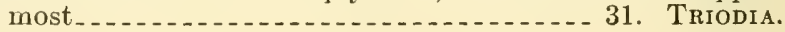


7b. Inflorescence an exserted open or spikelike panicle.

8a. Lemmas pubescent on the nerves or callus (except in Triodia albescens), the midnerve usually exserted as an awn or mucro.

Nerves glabrous. Callus densely hairy; lemmas firm; panicle large, diffuse................. 17. REDFIELdia.

Nerves hairy at least below, the lateral ones often conspicuously so.

Palea long-ciliate on the upper half _..._._. 32. TRIPLASIS. Palea sometimes villous but not long-ciliate on the upper half. Perennials............. Triodia.

8b. Lemmas not pubescent on the nerves nor callus (the internerves sometimes pubescent), awnless.

Glumes longer than the lemmas; lateral nerves of lemma marginal, the internerves pubescent..... 16. Dissanthelium.

Glumes shorter than the lemmas; lateral nerves of lemma not marginal, the internerves glabrous.

Lemmas chartaceous; grain large, beaked, at maturity forcing the lemma and palea open

Lemmas membranaceous; if firm, the grain neither large nor beaked.

Spikelets subterete; palea longer than the lemma, bowed out below.

Spikelets compressed; palea not longer than the lemma, not bowed out below.

Lemmas truncate; spikelets 2-flowered

13. Catabrosa.

Lemmas acute or acuminate; spikelets 3- to manyflowered. Rachilla continuous, the paleas persistent after the fall of the lemmas (rachilla disarticulating in Sect. Cataclastos) _......12. Eragrostis.

6b. Lemmas 5- to many-nerved, the nerves sometimes obscure.

Spikelets with 1 to 4 empty lemmas below the fertile florets; nerves obscure; lemmas firm .........

Spikelets with no empty lemmas below the fertile florets; nerves usually prominent; lemmas membranaceous (firm in a few species of Bromus and Festuca).

Lemmas flabellate; glumes wanting; inflorescence dense, cylindric. Low annual. .............. 33. Anthochloa.

Lemmas not flabellate; glumes present; inflorescence not cylindric.

Lemmas as broad as long, the margins outspread; florets closely imbricate, horizontally spreading ....... 11. BRIzA.

Lemmas longer than broad, the margins clasping the palea; florets not horizontally spreading.

Callus of fiorets bearded.

Lemmas erose at summit, awnless_._._. S. Fluminea. Lemmas bifid at summit, awned...- 29. Schizachne.

Callus not bearded (lemmas cobwebby at base in Poa).

Lemmas not erose (slightly in Puccinellia).

9a. Lemmas keeled on the back (somewhat rounded in Poa scabrella and its allies).

Spikelets strongly compressed, crowded in one-sided clusters at the ends of the stiff, naked panicle branches _.............. DACTYLIS.

Spikelets not strongly compressed, not crowded in onesided clusters.

Leminas awned from a minutely bifid apex (amnless or nearly so in Bromus catharticus and B. brizaeformis); spikelets large _..._..._. 2. Bronus. Lemmas awnless; spikelets small _.... 10. PoA.

9b. Lemmas rounded on the back (slightly keeled toward the summit in Festuca and Bromus).

Glumes papery; lemmas firm, strongly nerved, scariousmargined; upper florets sterile, often reduced to a club-shaped rudiment infolded by the broad upper lemmas. Spikelets tawny or purplish, usually not green... 
Glumes not papery; upper florets not unlike the others. Nerves of lemma parallel, not converging at summit or but slightly so.

Spikelets in racemes.

Racemes short, dense, overtopped by the leaves; spikelets awnless_..._._ 7. ScLerochloa.

Racemes elongate, loose, exserted; spikelets awned or mucronate......... 9. Pleuropogon.

Spikelets in open or contracted panicles.

Nerves prominent; plants usually rather tall, growing in woods or fresh-water marshes.

6. Glyceria.

Nerves faint; plants low, growing in saline soil.

5. Puccinellia.

Nerves of lemma converging toward summit, the lemmas narrowed at apex.

Lemmas awned or awn-tipped from a minutely bifid apex (awnless in $B$. brizaeformis).

2. BRomus.

Lemmas entire, pointed, awnless or awned from the tip (minutely toothed in Festuca elmeri and F. gigantea).

Spikelets awned (awnless in a few perennial species); lemmas pointed _... 3. FEsTuCA. Spikelets awnless.

Second glume 5- to 9-nerved; spikelets mostly $1 \mathrm{~cm}$ or more long; lemmas broad, manynerved, firm ...... 30. VASEY OCHLOA.

Second glume 1- to 3-nerved; spikelets smaller; lemmas 5-nerved, membranaceous, not pointed.

Spikelets on slender pedicels in compound panicles; perennials........ 10. POA.

Spikelets on thick short pedicels in simple panicles; annual_..._. 4. ScleropoA

TRIBE 3. HORDEAE

Spikelets 1- to several-flowered, sessile on opposite sides of a jointed or continuous axis forming symmetrical spikes (not one-sided, but spikelets sometimes turned to one side in some species).

This small but important tribe, found in the temperate regions of both hemispheres, includes our most important cereals, wheat, barley, and rye. The rachis is flattened or concave next to the spikelets, or in some genera is thickened and hollowed out, the spikelets being more or less enclosed in the hollows. In Triticum and its allies there is one spikelet at each node of the rachis; in Hordeum and its allies there are 2 or 3 at each node. In Lolium and its allies the spikelets are placed edgewise to the rachis, and the first or inner glume is suppressed except in the terminal spikelet. The rachis of the spikes disarticulates at maturity in several genera. In some species of Elymus and especially in Sitanion the glumes are very slender, extending into long awns, in the latter genus sometimes divided into several slender bristles. The spikes are rarely branched or compound, especially in Elymus condensatus. In this tribe the blades of the leaves bear on each side at the base a small appendage or auricle.

\section{Key to the genera of Hordeae}

1a. Spikelets solitary at each node of the rachis (rarely 2 in species of Agropyron, but never throughout).

2a. Spikelets 1 -flowered, sunken in hollows in the rachis. Spikes slender, cylindric; low annuals. 
Lemmas awned; florets lateral to the rachis

50. Scribneria.

Lemmas awnless; florets dorsiventral to the rachis.

First glume wanting ................... 48. LEPTURUS.

First glume present, the pair standing in front of the spikelet.

49. Pholiurus.

2b. Spikelets 2- to several-flowered, not sunken in the rachis.

Spikelets placed edgewise to the rachis. First glume wanting except in the terminal spikelet.......................... 47. LoLiUM,

Spikelets placed flatwise to the rachis.

Plants perennial

39. Agropyron.

Plants annual.

Spikelets turgid or cylindric

41. Aegilops.

Spikelets compressed.

Glumes ovate, 3-nerved....... 40. Triticum,

Glumes subulate, 1-nerved.... SEcale.

1b. Spikelets more than 1 at each node of the rachis (solitary in part of the spike in some species of Elymus).

Spikelets 3 at each node of the rachis, 1-flowered, the lateral pair pediceled, usually reduced to awns._._.

Spikelets 2 at each node of the rachis, alike, 2 - to 6 -flowered.

Glumes wanting or reduced to 2 short bristles; spikelets horizontally spreading at maturity. Spikes very loose _.......... 45. Hystrix.

Glumes usually equaling the florets (reduced in Elymus interruptus); spikelets appressed or ascending.

Rachis continuous (rarely tardily disarticulating); glumes broad or narrow, entire ..... Elymus.

Rachis disarticulating at maturity; glumes subulate, extending into long awns, these and the awns of the lemmas making the spike very bristly ................ Sitanion.

\section{TRIBE 4. AVENEAE}

Spikelets 2- to several-flowered in open or contracted panicles, or rarely in racemes (solitary in Danthonia unispicata); glumes usually as long as or longer than the first lemma, commonly longer than all the florets; lemmas usually awned from the back or from between the teeth of a bifid apex, the awn usually bent, often twisted, the callus and rachilla joints usually villous.

A rather small tribe widely distributed in both warm and cool regions. In our genera the rachilla is prolonged beyond the upper floret as a slender stipe (except in Aira). The lemma is awnless or nearly so in Schismus, two species of Trisetum, one species of Koeleria, and in most of the species of Sphenopholis. Koeleria and Sphenopholis are placed in this tribe because they appear to be closely allied to Trisetum with which they agree in having oblanceolate glumes about as long as the first floret.

\section{Key to the genera of Aveneae}

Florets 2, one perfect, the other staminate.

Lower floret staminate, the awn twisted, geniculate, exserted.

58. Arrhenatherum.

Lower floret perfect, awnless; upper floret awned............ 59. HoLcus.

Florets 2 or more, all alike except the reduced upper ones.

Articulation below the glumes, the spikelets falling entire.

Lemmas, at least the upper, with a conspicuous bent awn; glumes nearly

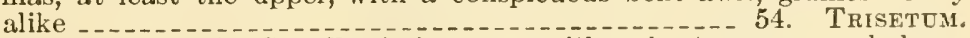

Lemmas awnless or (in $S$. pallens) the upper with a short awn; second glume much wider than the first_._._._._._._. 53. SPHENOPHOLIS.

Articulation above the glumes, the glumes similar in shape.

Spikelets several-flowered. Lemmas bifid at apex, awned or mucronate between the lobes. 
Spikelets $1 \mathrm{~cm}$ or more long; awns conspicuous, flat, bent.

60. Danthonia. Spikelets not more than $5 \mathrm{~mm}$ long; awns minute or nearly obsolete.

51. Schismos.

Spikelets 2-flowered, sometimes with a rudimentary third floret.

Spikelets large, the glumes more than $1 \mathrm{~cm}$ long......... 57. Avena.

Spikelets less than $1 \mathrm{~cm}$ long.

Lemmas keeled, the awn when present from above the middle.

Rachilla joints very short, glabrous or minutely pubescent; lemmas awnless or with a straight awn from a toothed apex.

52. Koeleria.

Rachilla joints slender, villous; lemmas with a dorsal bent awn (awnless or nearly so in 2 species) _........... 54. Trisetum.

Lemmas convex, awned from below the middle.

Rachilla prolonged behind the upper floret; lemmas truncate and erose-dentate at summit . . . . . . . . . . . 55. Deschampsia.

Rachilla not prolonged; lemmas tapering into 2 slender teeth.

TRIBE 5. AGROSTIDEAE

56. AIra.

Spikelets 1-flowered, usually perfect, in open, contracted, or spikelike panicles, but not in true spikes nor in 1-sided racemes.

A large and important tribe, inhabiting more especially the temperate and cool regions. The articulation of the rachilla is usually above the glumes, the mature floret falling from the persistent glumes, but in a few genera the articulation is below the glumes, the mature spikelet falling entire (Alopecurus, Cinna, Polypogon, Lycurus, and Limnodea). The palea is small or wanting in some species of Agrostis. In a few genera the rachilla is prolonged behind the palea as a minute bristle, or sometimes as a more pronounced stipe (Brachyelytrum, Limnodea, Cinna, Gastridium, Calamagrostis, Ammophila, Lagurus, and a few species of Agrostis). In some genera the rachilla joint between the glumes and the lemma is slightly elongated, forming a hard stipe which remains attached to the mature fruit as a pointed callus. The callus is well marked in Stipa (especially in S. spartea and its allies) and in Aristida, the mature lemma being terete, indurate, and convolute, the palea wholly enclosed. In many genera the lemma is awned either from the tip or from the back, the awn being trifid in Aristida.

\section{Key to the genera of Agrostideae}

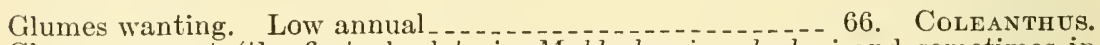
Glumes present (the first obsolete in Muhlenbergia schreberi and sometimes in Brachyelytrum and Phippsia).

1a. Articulation below the glumes, the spikelets falling entire.

Spikelets in pairs in a spikelike panicle, one perfect, the other staminate or neuter, the pair falling together... Spikelets all alike.

Glumes long-awne

70. POLYPOGON.

Glumes awnless.

Rachilla not prolonged behind the palea; panicle dense, spikelike; glumes united toward the base, ciliate on the keel.

69. Alopecurus.

Rachilla prolonged behind the palea; panicle narrow or open, not dense; glumes not united, not ciliate on the keel.

Panicle narrow; lemma with a slender bent twisted awn from the bifid apex

Panicle open, drooping; lemma with a minute straight awn just below the entire apex (rarely awnless) _.......... 67. Crnna.

1b. Articulation above the glumes.

Fruit dorsally compressed, indurate, smooth and shining, awnless.

81. Milium. 
Fruit laterally compressed or terete, awned or amnless.

2a. Fruit indurate, terete, awned, the nerves obscure; callus well developed, oblique, bearded.

Awn trifid, the lateral divisions sometimes short, rarely obsolete (when obsolete no line of demarcation between awn and lemma as in the next)

Awn simple, a line of demarcation between the awn and the lemma.

Awn persistent, twisted and bent, several to many times longer than the fruit.

Edges of lemma overlapping (rarely only meeting), enclosing the palea; callus sharp-pointed, usually narrow and acuminate.

S4. STIPA.

Edges of lemma not meeting, exposing the indurate sulcus of the palea, this projecting from the summit as a minute point; callus short, acutish _._._._._._._. S3. PIPTochaetium.

Awn deciduous, not twisted, sometimes bent, rarely more than 3 or 4 times as long as the plump fruit; callus short, usually obtuse.

82. ORYzopsis.

2b. Fruit thin or firm, but scarcely indurate, if firm, the nerves prominent or evident; callus not well developed.

3a. Glumes longer than the lemma (lemma equaling the glumes in certain species of Agrostis.)

Panicle feathery, capitate, nearly as broad as long; spikelets woolly.

Panicle not feathery; spikelets not woolly.

$$
\text { 74. LAGURU'S. }
$$

Glumes compressed-carinate; panicle dense, cylindric or ellipsoid.

Glumes not compressed-carinate, not ciliate.

72. Phleuar.

Glumes saccate at base; lemma long-awned; panicle contracted, shining

Glumes not saccate at base; lemma awned or awnless; panicle open or contracted.

Florets bearing a tuft of hairs at the base from the short callus, the hairs at least half as long as the lemma; palea present. 61. CALAMAGrostis.

Florets without hairs at the base or with short hairs, rarely as much as half the length of the lemma (Agrostis hallii); palea usually small or wanting _._._. 64. Agrostis.

3b. Glumes not longer than the lemma, usually shorter (the awn tips longer in Muhlenbergia racemosa).

Lemma awned from the tip or mucronate, 3 - to 5-nerved (lateral nerves obscure in Muhlenbergia repens).

Rachilla prolonged behind the palea; floret stipitate.

SO. BRACHYELYTRUM.

Rachilla not prolonged; floret not stipitate_- 75. MUHLENBERGiA.

Lemma awnless or awned from the back.

Florets bearing a tuft of hairs at the base from the short callus; lemma and palea chartaceous, awnless.

Panicles spikelike; rachilla prolonged...... 62. AмmopHILA.

Panicles open; rachilla not prolonged..... 63 . Calamovilfa.

Florets without hairs at base.

Nerves of lemma densely silky....... 77. BLEpharoneuron.

Nerves of lemma not silky.

Caryopsis at maturity falling from the lemma and palea; seed loose in the paricarp, this usually opening when ripe; lemma 1-nerved.

Inflorescence capitate in the axils of broad bracts.

78. Crypsis.

Inflorescénce an open or contracted panicle.

76. Sporobolts.

Caryopsis not falling from the lemma and palea, remaining permanently enclosed in them; seed adnate to the pericarp.

Panicles few-flowered, slender, rather loose; glumes minute, unequal, the first often wanting. Low arctic-alpine perennial........... 
Panicles many-flowered, spikelike; glumes well developed, about equal.

Panicle short, partly enclosed in the sheath; low annual. 79. HeLEOCHLOA.

Panicle elongate; perennial....... 75. Muhlenbergia.

\section{TRIBE 6. ZOYSIEAE}

Spikelets subsessile in short spikes of 2 to 5 (single in Zoysia), each spike falling entire from the continuous axis, usually 1 -flowered, all perfect, or perfect and staminate together in the same spike; glumes usually firmer than the lemma and palea, sometimes awned, the lemma awnless.

This small and unimportant tribe is known also as Nazieae. In Zoysia the spikelets are single and have only one glume, this coriaceous, much firmer than the lemma and palea, the palea sometimes obsolete.

\section{Key to the genera of Zoysieae}

Spikelets single; first glume wanting

87. ZoYsia.

Spikelets in clusters of 2 to 5 ; first glume present.

Spikelets bearing hooked spines on the second glume, the group forming a little bur....

Spikelets not bearing hooked spines, mostly cleft and awned.

Groups of spikelets ereet, the inflorescence not 1-sided..... 88. Hilaria. Groups of spikelets nodding along one side of the delicate axis.

\section{TRIBE 7. CHLORIDEAE}

89. Aegorogon.

Spikelets 1 - to several-flowered, in 2 rows on one side of a continuous rachis, forming 1-sided spikes or spikelike racemes, these solitary, digitate, or racemose along the main axis.

A large and rather important tribe, confined mostly to warm regions. The group is heterogeneous, the only common character of the genera (aside from the characters that place them in Festucoideae) being the arrangement of the spikelets in 1-sided spikes. Chloris and the allied genera form a coherent group, in which the spikelet consists of 1 perfect floret and, above this, 1 or more modified or rudimentary florets. Leptochloa, Eleusine, and their allies, with several-flowered spikelets, are more nearly related to certain genera of Festuceae. The spike is reduced to 2 or 3 spikelets or even to 1 spikelet and is sometimes deciduous from the main axis (Cathestecum and Sect. Atheropogon of Bouteloua). In Ctenium there are 2 sterile florets below the perfect one.

\section{Key to the genera of Chlorideae}

Plants monoecious or dioecious. Low stoloniferous perennial__ 107. BuCHLÖ̈. Plants with perfect flowers.

1a. Spikelets with more than 1 perfect floret.

Inflorescence a few-flowered head or capitate panicle hidden among the sharppointed leaves. Low spreading annual........... 106. Munroa. Inflorescence exserted.

Spikes solitary, the spikelets distant, appressed, several-flowered.

Spikes more than 1 (sometimes 1 in depauperate Eleusine).

92. Tripogon.

Spikes numerous, slender, racemose on an elongate axis.

Rachilla and callus of floret glabrous or nearly so; glumes acute, less than $5 \mathrm{~mm}$ long......

Rachilla and callus of floret strongly pilose; glumes long-acuminate, about $1 \mathrm{~cm}$ long. .......... TrichoneURA.

Spikes few, digitate or nearly so.

Rachis of spike extending beyond the spikelets.

Rachis not prolonged 94. DACTYLOCTENIUM. 
1b. Spikelets with only 1 perfect floret, of ten with additional imperfect florets above or below.

2a. Spikelets without additional modified florets, the rachilla sometimes prolonged.

Rachilla articulate below the glumes, the spikelets falling entire.

Glumes unequal, narrow ........ S9. Spartiva.

Glumes equal, broad, boat-shaped

Rachilla articulate above the glumes.

Spikes digitate; rachilla prolonged .............. 95. CYNodon.

Spikes racemose along the main axis; rachilla not prolonged.

Spikes slender, divaricate, the main axis elongating and becoming loosely spiral in fruit............. 97. SchedoNNARdus.

Spikes short and rather stout, appressed, the axis unchanged in fruit. 96. WiLlKomia.

2 b. Spikelets with 1 or more modified florets above the perfect one.

Spikelets with 2 sterile florets below the perfect one; second glume bearing a squarrose spine on the back; spike single, arcuate.

100. Ctenitum.

Spikelets with no sterile florets below the perfect one; second glume without a squarrose spine; spikes usually several.

Spikes digitate or nearly so.

Fertile lemma 1-awned or awnless _..._._._._. 102. Chloris. Fertile lemma 3-awned _........ Thichloris.

Spikes racemose along the main axis.

Spikelets distant, appressed; spikes slender, elongate.

101. Gymnopogon.

Spikelets approximate or crowded, not appressed; spikes usually short and rather stout.

Spikelets 3 in each spike, the 2 lateral staminate or rudimentary; spikes falling entire.............. 105. Cathestecum.

Spikelets 2 to many (rarely 1) in each spike, all alike; spikes falling entire or persistent, the florets falling.

104. Bouteloua.

\section{TRIBE 8. PHALARIDEAE}

Spikelets with one perfect terminal floret and, below this, a pair of staminate or neuter florets (one sometimes obsolete in Phalaris).

A small tribe of about six genera, only three of which are found in the United States. In Phalaris the lower florets are reduced to minute scalelike lemmas closely appressed to the edges of the fertile floret. In Hierochlö the lateral florets are staminate and as large as the fertile floret.

\section{Key to the genera of Phalarideae}

Lower florets staminate; spikelets brown and shining ..... 108. Hierochlö̈. Lower florets neuter; spikelets green or vellowish.

Lower florets reduced to small awnless scalelike lemmas; spikelets much compressed lateially . . . . . . Phalaris.

Lower florets consisting of awned hairy sterile lemmas exceeding the fertile floret; spikelet subterete................. 109. Anthoxanthum.

\section{TRIBE 9. ORYZEAE}

Spikelets 1-flowered, perfect, strongly laterally compressed, paniculate; glumes reduced or wanting; palea apparently 1-nerved; stamens 6 .

A small tribe whose affinities are not evident. It includes rice, the important food plant.

\section{Key to the genera of Oryzeae}

Glumes minute; lemma of ten awned 111. ORYZA.

Glumes wanting; lemma awnless 112. LEERSIA. 


\section{TRIBE 10. ZIZANIEAE}

Spikelets unisexual, the pistillate terete or nearly so; glumes shorter than the lemma, usually one or both obsolete, the pedicel disarticulating below the spikelet. Glumes well developed in Pharus, a tropical genus placed in this tribe provisionally.

A small tribe of uncertain affinities, aquatic or subaquatic grasses (except Pharus) of no economic importance except the Indian rice (7izania).

\section{Key to the genera of Zizanieae}

Blades elliptic, 2 to $4 \mathrm{~cm}$ wide 117. Pharus. Blades much longer than wide.

Culms slender; plants low; staminate and pistillate spikelets borne in separate inflorescences.

Inflorescence a few-flowered raceme; plants not stoloniferous

116. HydRochloA.

Inflorescence a panicle; plants stoloniferous _........... 115. LUziolA.

Culms robust; plants tall; staminate and pistillate spikelets borne in the same panicle.

Pistillate spikelets on the ascending upper branches, the staminate on the spreading lower branches of the panicle; plants annual or perennial.

113. Zizania.

Pistillate spikelets at the ends, the staminate below on the same branches of the panicle; plants perennial _............ 114. Zizaniopsis.

\section{TRIBE 11. MELINIDEAE}

Spikelets disarticulating below the glumes, these very unequal, the first minute, the second and the sterile lemma equal, membranaceous, strongly nerved, the latter bearing a slender awn from the notched summit; fertile lemma and palea thinner in texture, awnless.

A tribe of about a dozen genera represented in the United States by an introduced species, Melinis minutiflora.

\section{TRIBE 12. PANICEAE}

Spikelets with one perfect terminal floret and below this a sterile floret and two glumes; fertile lemma and palea indurate or at least firmer than the glumes and sterile lemma, a lunate line of thinner texture at the back just above the base, the rootlet protruding through this at germination; articulation below the spikelet.

A large tribe, confined mostly to warm regions, and containing relatively few economic species. The first glume is wanting in some genera, such as Paspalum, and rarely the second glume also (Reimarochloa). The spikelets are usually awnless, but the glumes and sterile lemma are awned in Echinochloa and Oplismenus, and the second glume and sterile lemma in Tricholaena. In Eriochloa and in some species of Brachiaria the fertile lemma is awn-tipped. In Setaria there are, beneath the spikelet, one or more bristles, these representing sterile branchlets. In Pennisetum similar bristles form an involucre, falling with the spikelet. In Cenchrus the bristles are united, forming a bur. The spikelets are of two kinds in Amphicarpum, aerial and subterranean. The culms are woody and perennial in Lasiacis and Olyra.

Spikelets of two kinds.

\section{Key to the genera of Paniceae}

Spikelets all perfect, but those of the aerial paricle not perfecting grains, the fruitful spikelets borne on subterranean branches _ 138. AMPHICARPOM.

Spikelets unisexual, the pistillate above, the staminate below on the branches of the same panicle. Blades broad, elliptic............ 139. OLYra. 
Spikelets all of one kind.

Spikelets sunken in the eavities of the flattened corky rachis.

123. Stenotaphrum.

Spikelets not sunken in the rachis.

1a. Spikelets subtended or surrounded by 1 to many distinct or more or less connate bristles, forming an involucre.

Bristles persistent, the spikelets deciduous . -

Bristles falling with the spikelets at maturity.

135. Setaria.

Bristles not united at base, slender, often plumose _- 136. Pennisetum.

Bristles united into a burlike involucre, the bristles retrorsely barbed.

137. Cenchrus.

1b. Spikelets not subtended by bristles.

Glumes or sterile lemma awned (awn short and concealed in the silky hairs of the spikelet in Tricholaena; awn reduced to a point in Echinochloa colonum).

Inflorescence paniculate; spikelets silky _....... 134. Tricholaena. Inflorescence of unilateral simple or somewhat compound racemes along a common axis; spikelets smooth or hispid, not silky.

Blades lanceolate, broad, thin; culms creeping--_ 132. Oplismenus.

Blades long, narrow; culms not ereeping..... 133. Echinochloa. Glumes and sterile lemma awnless.

2a. Fruit cartilaginous-indurate, flexible, usually dark colored, the lemma with more or less prominent white hyaline margins, these not inrolled.

Spikelets covered with long silky hairs, arranged in racemes, these panicled................ 120. Trichachne.

Spikelets glabrous or variously pubescent but not long-silky (somewhat silky in Digitaria villosa).

Spikelets in slender racemes more or less digitate at the summit of the culms ........................ 121. Digitaria.

Spikelets in panicles.

Fruiting lemma boat-shaped; panicles narrow.

119. Anthaenantia.

Fruiting lemma convex; panicles diffuse _..- 122. Leptoloma.

2b. Fruit chartaceous-indurate, rigid.

Spikelets placed with the back of the fruit turned away from the rachis of the racemes, usually solitary (not in pairs).

First glume and the rachilla joint forming a swollen ringlike callus below the spikelet................... 124. Eriochloa.

First glume present or wanting, not forming a ringlike callus below the spikelet.

First glume present (next to the axis); racemes racemose along the main axis........ 125. BRACHIARIA.

First glume wanting; racemes digitate or subdigitate.

126. Axonopus.

Spikelets placed with the back of the fruit turned toward the rachis

(first glume, when present, away from the axis) of the spikelike

racemes, or pedicellate in panicles.

Fruit long-acuminate; both glumes wanting_ 127. Reimarochloa.

Fruit not long-acuminate; at least one glume present.

First glume typically wanting; spikelets plano-convex, subsessile in spikelike racemes...._......... 128. Paspalum.

First glume present; spikelets usually in panicles.

Second glume inflated-saccate, this and the sterile lemma much exceeding the stipitate fruit....... 131. Sacciolepis.

Secono glume not inflated-saccate.

Culms $\pi$ oody, bamboolike; fruit with a tuft of down at the apex ........ 130. Lasiacis.

Culms herbaceous; no tuft of down at the apex of the fruit.

TRIBE 13. ANDROPOGONEAE

129. PANICUN.

Spikelets in pairs along a rachis, the usual arrangement being one of the pair sessile and fertile, the other pedicellate and staminate or neuter, rarely wanting, only the pedicel present; fertile spikelet consisting of one perfect terminal floret and, below this, a staminate or neuter floret, the lemmas thin or hyaline, and two awnless glumes, one or usually both firm or indurate. 
A large tribe, confined mostly to warm regions. The rachis is usually jointed, disarticulating at maturity, with the spikelets attached to the joints. In a few genera it is thickened. Sometimes the racemes are shortened to 1 or 2 joints and borne on branches, the whole forming a panicle (as in Sorghum and Sorghastrum) instead of a series of racemes. In a few genera the spikelets of the pair are alike. In Trachypogon the fertile spikelet is pedicellate and the sterile one nearly sessile. The most important economic plants in this tribe are sugarcane and sorghum.

\section{Key to the genera of Andropogoneae}

1a. Spikelets all perfect, surrounded by a copious tuft of soft hairs.

Rachis continuous, the spikelets falling; the spikelets of the pair unequally pedicellate.

Racemes in a narrow spikelike panicle; spikelets awnless_-- 140. IMPERATA. Racemes in a broad fan-shaped panicle; spikelets awned.

141. Miscantrus.

Rachis breaking up into joints at maturity with the spikelets attached; one spikelet sessile, the other pedicellate.

Spikelets awnless.

142. SACCHARUM.

Spikelets awned

1b. Spikelets unlike, the sessile perfect, the pedicellate sterile (sessile spikelet staminate, pedicellate spikelet perfect in Trachypogon).

2a. Pedicel thickened, appressed to the thickened rachis joint (at least parallel to it) or adnate to it; spikelets awnless, appressed to the joint.

Rachis joint and pedicel adnate. Annuals.

Perfect spikelet globose; sterile spikeiet conspicuous.

155. HACKELOCHLOA.

Perfect spikclet oblong; sterile spikelet minute_... 153. RoTrBoELIA.

Rachis joint and pedicel distinct, the sessile spikelet appressed to them, its first glume lanceolate.

Racemes subcylindric; rachis joints and pedicels glabrous, much thicker at the summit, the spikelets sunken in the hollow below; sterile spikelet rudimentary _................. 154. Manisuris.

Racemes flat; rachis joints and pedicels woolly, not much thicker at the summit; sterile spikelet staminate or neuter _..- 152. Elyonurus.

2b. Pedicel not thickened (if slightly so the spikelets awned), neither appressed nor adnate to the rachis joint, this usually slender; spikelets usually awned.

3a. Fertile spikelet with a hairy-pointed callus, formed of the attached supporting rachis joint or pedicel; awns strong.

Racemes reduced to a single joint, long-peduncled in a simple open panicle......... 149 . RHaphis.

Racemes of several to many joints, single.

Primary spikelet subsessile, sterile, persistent on the continuous axis after the fall of the fertile pedicellate spikelet_ 151. Trachypogon.

Primary spikelet sessile, fertile; pedicellate spikelet sterile. Lower few to several pairs of spikelets all staminate or neuter.

150. HETEROPOGON.

3b. Fertile spikelet without a callus (a short callus in Hyparrhenia), the rachis disarticulating immediately below the spikelet; awns slender.

Blades ovate. Annual.................. Art4.

Blades narrow, elongate.

Racemes of several to many joints, solitary, digitate, or aggregate in panicles.

Lower pair of spikelets like the others of the raceme.

145. ANDROPOGON.

Lower pair of spikelets sterile, awnless. Racemes in pairs on slender flexuous peduncles................ 146. Hyparrhenia.

Racemes reduced to one or few joints, these mostly peduncled in a subsimple or compound panicle.

Pedicellate spikelets staminate $\ldots \ldots \ldots \ldots \ldots . . .147$. Sorghom.

Pedicellate spikelets wanting, the pedicel only present.

148. Sorghastrum. 


\section{TRIBE 14. TRIPSACEAE}

Spikelets unisexual, the staminate in pairs, or sometimes in threes, 2-flowered, the pistillate usually single, 2-flowered, the lower floret sterile, embedded in hollows of the thickened articulate axis and falling attached to the joints, or enclosed in a thickened involucre or sheath or, in Zea, crowded in rows on a thickened axis (cob); glumes membranaceous or thick and rigid, awnless; lemmas and palea hyaline, awnless. Plants monoecious.

This small tribe of seven genera is scarcely more than a subtribe of Andropogoneae, differing chiefly in the total suppression of the sterile spikelet of a pair, the fertile spikelet being pistillate only and solitary; staminate spikelets paired. It is also known as Maydeae.

\section{Key to the genera of Tripsaceae}

Staminate and pistillate spikelets in separate inflorescences, the first in a termina] tassel, the second in the axils of the leaves.

Pistillate spikes distinct, the spikelets embedded in the hardened rachis, this disarticulating at maturity

Pistillate spikes grown together forming an ear, the grains at maturity much exceeding the glumes.......... ZEA.

Staminate and pistillate spikelets in separate portions of the same spike, the pistillate below.

Spikes short, the 1- or 2-flowered pistillate portion enclosed in a beadlike sheathing bract...... Corx.

Spikes many-flowered, the pistillate portion breaking up into several 1 -seeded joints; no beadlike sheathing bract.............. 157. Tripsacum.

\section{DESCRIPTIONS OF GENERA AND SPECIES}

TRIBE 1. BAMBUSEAE

\section{ARUNdinária Michx. Cane}

Spikelets few- to many-flowered, large, compressed, the rachilla disarticulating above the glumes and between the florets; glumes unequal, shorter than the lemmas, the first sometimes wanting; lemmas acute, acuminate, or mucronate, faintly many-nerved; palea about as long as the lemma, prominently 2-keeled; stamens 6 . Shrubs or tall reeds, with woody perennial branching culms, flat petiolate blades, articulate with the sheaths, and loose racemes or panicles. Type species, Arundinaria macrosperma Michx. (A. gigantea.) Name from Latin Arundo, a reed.

Panicles on leafy branches; culms as much as $10 \mathrm{~m}$ tall_._._. 1. A. Gigantea. Panicles on leafless shoots from creeping rhizomes.....

1. Arundinaria gigantéa (IValt.) Chapm. Southern Cane. (Fig. 1.) Cülms as much as $10 \mathrm{~m}$ tall, erect from stout rhizomes; sheaths bearing several bristles at the summit on each side, these disappearing with age, the collar prominent, pubescent; blades oblong-lanceolate to linear-lanceolate, rounded to a somewhat cuneate petiole, acuminate, finely tessellate with numerous cross veins, sharply serrulate on the margin, 10 to $20 \mathrm{~cm}$ long, mostly 1 to $2 \mathrm{~cm}$ wide or on vigorous shoots as much as $3 \mathrm{~cm}$ wide; flowering branchlets in fascicles on the main culm or short branches, their sheaths bladeless or nearly so, the racemes or simple panicles 1- to several-flowered; spikelets 3 to $7 \mathrm{~cm}$ long, mostly 8- to 12 -flowered; glumes distant; lemmas pubescent, at least toward base, or glabrescent, acuminate, about $2 \mathrm{~cm}$ long. 24 (A. macrosperma Michx.)-Growing in colonies, 
MISC. PUBLICATION 200, U. S. DEPT. OF AGRICULTURE

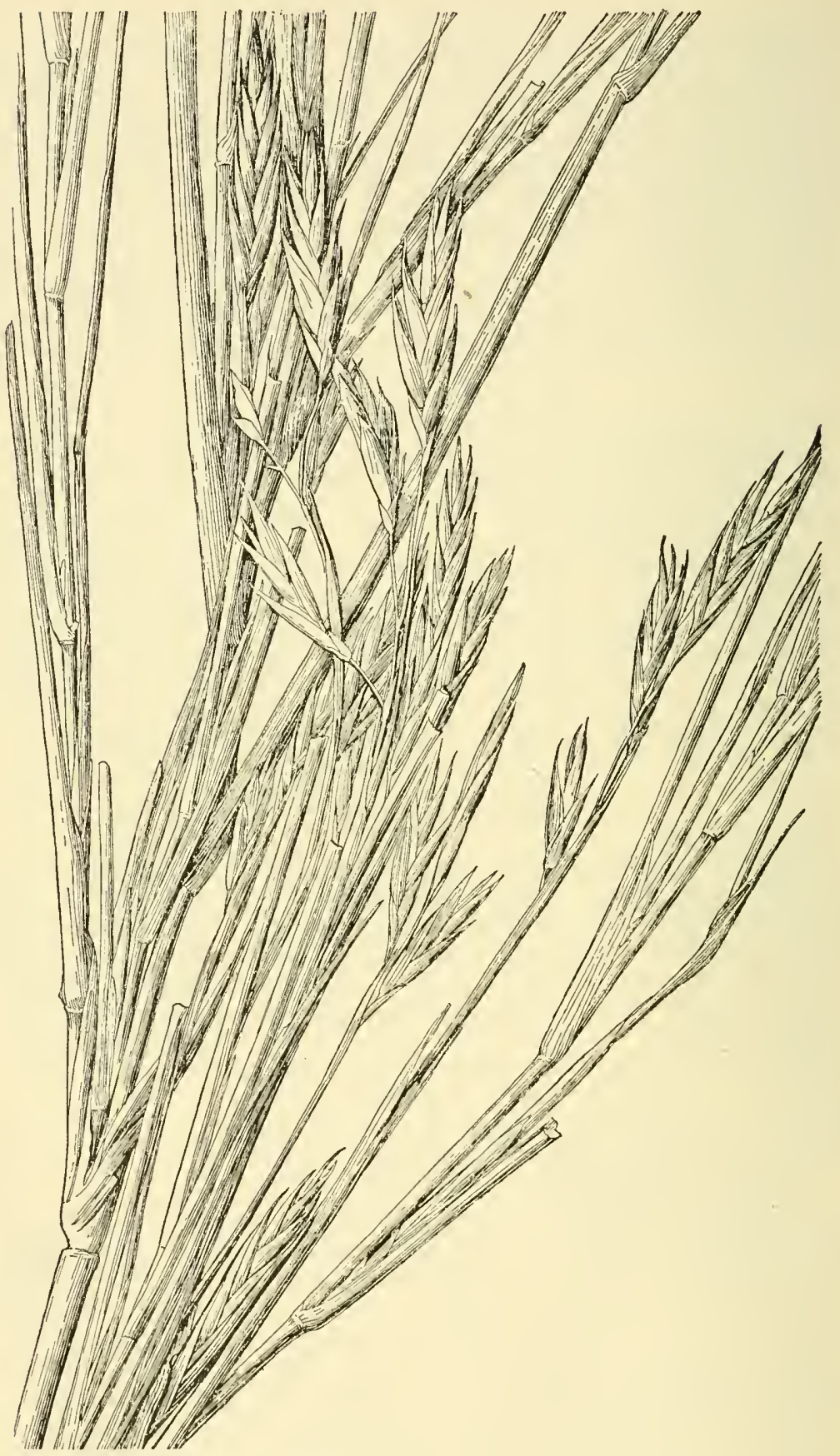

Figure 1.-Arundinaria gigantca, $\times 1$. (Chase 5880, Va.) 
sometimes over large areas called canebrakes, common in the lowlands of the larger rivers, Virginia to southern Ohio and Illinois, south to Florida, eastern Texas, and Oklahoma (fig. 2). The species flowers at infrequent intervals and then over a wide area simultaneously. Livestock eagerly eat the young plants, leaves, and seeds, and canebrakes furnish much forage. The young shoots are sometimes used as a pot herb. The culms are used for fishing rods, pipestems, baskets, mats, and a variety of other purposes. Early travelers speak of the abundance of this species and state that the culms may be as much as 2 or even 3 inches in diameter. It is said that the plants are easily destroyed by the continuous grazing of cattle and by the rooting of swine.

aren 2. Arundinaria técta (Walt.) Muhl. Sirall Cane. (Fig. 3.) Culms usually not more than $2 \mathrm{~m}$ tall, from stout rhizomes; racemes produced on leafless or nearly leafless shoots from the base of the plant or from creeping rhizomes; otherwise like the preceding. \& -Coastal Plain, Maryland (Stony Run) to Florida and Louisiana (fig. 4). Nuttall reports this (under the name Miegia pumila) from what is now southeastern Oklahoma. Also called switch cane. This species may be only a small form or variety of $A$. gigantea.

Several species of bamboos are cultivated for ornament in parks and gardens, especially in Florida and California. Deseriptions of these may be found in L. H. Bailey's Standard Cyclopedia of Horticulture and in Hortus (Hortus, L. H. and E. Z. Bailey, 1930). They belong to the genera Arundinaria, Bambusa, Cephalostachyum, Chusquea, Dendrocalamus, Phyllostachys, Sasa, and Thamnocalamus. One of the commonest of the cultivated species is Sasa japonica (Sieb.

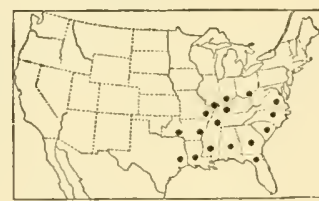

FIGURE 2.-Distribution of Arundinaria gigantea. and Zucc.) Makino (Arundinaria japonica Sieb. and Zucc.). Growing in dense colonies, 2 to $3 \mathrm{~m}$ tall with vigorous rhizomes; branches cylindric; blades evergreen, 10 to $20 \mathrm{~cm}$ long, 2 to $5 \mathrm{~cm}$ wide.

The genus Phyllostachys may be distinguished by the branches flattened on one side. $P$. aurea $\mathrm{A}$. and $\mathrm{C}$. Riviere is frequent; branches yellowish, often bright yellow, the lower internodes very short; plant 3 to $5 \mathrm{~m}$ tall.

\section{TRIBE 2. FESTUCEAE}

\section{BROMUS L. Bromegrass}

Spikelets several- to many-flowered, the rachilla disarticulating above the glumes and between the florets; glumes unequal, acute, the first 1 - to 3-nerved, the second usually 3 - to 5-nerved; lemmas convex on the back or kecled, 5- to 9-nerved, 2-toothed, awned from between the teeth or awnless; palea usually shorter than the lemma, ciliate on the keels. Low or rather tall annuals or perennials with closed sheaths, usually flat blades, and open or contracted panicles of large spikelets. Standard species, Bromus sterilis (type species, B. secalinus). Name from bromos, an ancient Greek name for the oat, from broma, food.

The native perennial species of bromegrass form a considerable portion of the forage in open woods of the mountain regions of the Western United States. Bromus carinatus, California brome, and 


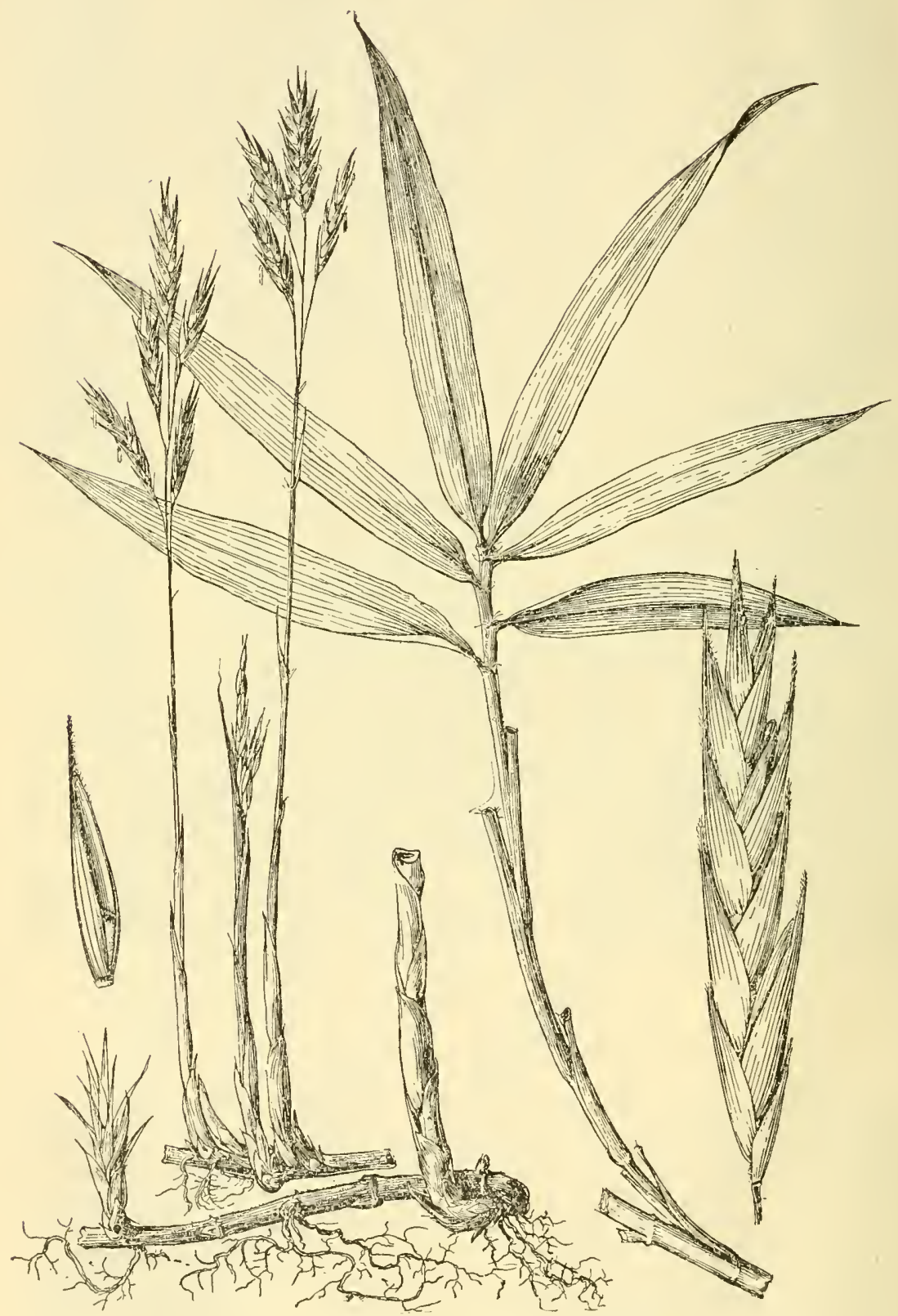

Figure 3.-Arundinaria tecta. Flowering shoot and leafy shoot, $\times 1 / 2$; spikelet and floret, $\times 2$. (Chase 5881, $\mathrm{Va}$.) 
its more eastern form, B. marginatus, are abundant from the Rocky Mountains to the Pacific coast. Before maturity, they are relished by all classes of stock. Horses and sheep are particularly fond of the seed heads. Bromus anomalus, B. pumpellianus, and B. ciliatus, of the Rocky Mountain region, are abundant up to 10,000-11,000 feet altitude, and are of first rank for all classes of stock. Several other species are nutritious but are usually not abundant enough to be of importance in the grazing regions. The most important species agronomically is smooth brome, $B$. inermis, a native of Europe, which is cultivated for hay and pasture in the northern part of the Great Plains. (See p. 39.) It is more drought-resistant than timothy and can be grown farther west on the plains, but does not thrive south of central Kansas. It is recommended for holding canal banks. Also called smooth, awnless, and Hungarian brome. Rescue grass, $B$. catharticus, is cultivated for winter forage in the Southern States from North Carolina to Texas and in the coast district of southern California.

The annuals are weedy species introduced mostly from Europe. The best known of these is chess, Bromus secalinus, a weed of waste places sometimes infesting grain fields. Formerly it was believed by the credulous that under certain conditions wheat changéd into chess or "cheat." Chess in a wheat field is due to chess seed in the soil or in the wheat sown. This species is utilized for hay in places in Washington, Oregon, and Georgia. On the Pacific coast the annual bromegrasses cover vast areas of open ground at lower altitudes where they form a large part of the forage on the winter range. They mature in spring or early summer and become unpalatable. Those of the section Eubromus are, at maturity, a serious pest. The narrow,

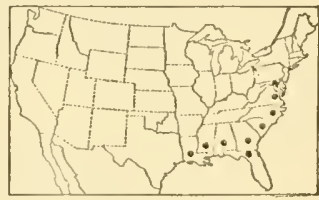

Figure 4.-Distribution of Arundinaria tecta. sharp-pointed minutely barbed florets (or fruits) with their long rough awns work into the eyes, nostrils, and mouths of stock, causing inflammation and often serious injury. Sometimes the intestines are pierced, and death results. On the Pacific coast, $B$. rigidus, the chief offender, is called ripgut grass by stockmen, and the name is sometimes applied to other species of the section.

Spikelets strongly flattened, the lemmas compressed-keeled.

Section 1. Ceratochloa.

Spikelets terete before anthesis or somewhat flattened, but the lemmas not compressed-keeled.

Plants perennial

Plants annual. Introduced, mostly from Europe.

Section 2. Bromopsis.

Awn straight or divaricate, sometimes minute or obsolete, not twisted and geniculate; teeth of the lemma sometimes slender but not aristate.

Lemmas broad, rounded above, not acuminate, the teeth mostly less than $1 \mathrm{~mm}$ long. ............ Section 3. Bromidm.

Lemmas narrow, with a sharp callus, gradually acuminate, bifid, the teeth 2 to $5 \mathrm{~mm}$ long. Awns usually more than $1.5 \mathrm{~cm}$ long.

Section 4. Eubromus.

Awn geniculate, twisted below; teeth of the lemma aristate. Approaches Trisetum Section 5 .

NEOBROMUS.

Section 1. Ceratochloa

Lemmas awnless or nearly so

Lemmas awned, the awn more than $3 \mathrm{~mm}$ long.

Panicle branches elongate, slender, drooping, bearing 1 or 2 large spikelets at the end, the lowermost naked for as much as 10 to $15 \mathrm{~cm}$. Sheaths smooth; Washington.

2. B. SITCHENSIS. 
Panicle branches not greatly elongated.

Panicle branches ascending, rather stifi, naked below, bearing 1 or 2 large spikelets. Washington_.................. 3. B. ALEUTENsis.

Panicle branches short and ascending or longer and drooping, with some short branches at the base.

Blades canescent, densely pilose, narrow, often involute

4. B. BREVIARISTATUS.

Blades not canescent, glabrous or somewhat pilose, usually more than $3 \mathrm{~mm}$ wide

5. B. CARINATUS.

\section{Section 2. Bromopsis}

1a. Creeping rhizomes present; lemmas awnless or short-awned; panicle erect, somewhat open, the branches ascending.

Lemmas glabrous . Lemmas pubescent near the margins............ B. PUMPLLIANus.

1b. Creeping rhizomes wanting (base of culm decumbent in B. laevipes).

2a. Panicle narrow, the branches erect.

Lemmas glabrous or evenly scabrous _............. 8. B. ERECTUS.

Lemmas appressed-pubescent on the margins and lower part.

2b. Panicle open, the branches spreading or drooping.

9. B. SUKSDORFII.

3a. Lemmas glabrous.

Blades broad and lax, more than $5 \mathrm{~mm}$, at least some of them $10 \mathrm{~mm}$, wide. (var. laeviglumis) _.................. B. ciliatus.

Blades narrow, not more than $6 \mathrm{~mm}$ wide...... 3b. Lemmas pubescent.

4a. Lemmas pubescent along the margin and on lower part of the back, the upper part glabrous.

First glume 3-nerved; plant pale or glaucous. Culms decumbent at base.

13. B. LAEVIPES.

First glume 1-nerved, or only faintly 3-nerved near the base; plants dark green.

Ligule prominent, 3 to $5 \mathrm{~mm}$ long; lemmas narrow; awn usually more than $5 \mathrm{~mm}$ long..........

Ligule inconspicuous, about $1 \mathrm{~mm}$ long; lemmas broad; a wn 3 to $5 \mathrm{~mm}$

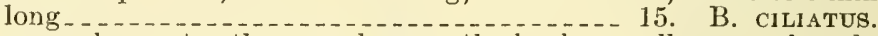

4b. Lemmas pubescent rather evenly over the back, usually more densely so along the lower part of the margin.

Panicle branches short, stiffly spreading; blades short, mostly on lower part of culm .....

Panicle branches lax or drooping; blades along the culm, mostly elongate.

Panicle small, drooping, usually not more than $10 \mathrm{~cm}$ long. Spikelets densely and conspicuously pubescent.

Sheaths and blades sparsely pilose to subglabrous; blades mostly 2 to $4 \mathrm{~mm}$ wide (rarely 5 to $6 \mathrm{~mm}$ ).... 19. B. ANomalus.

Sheaths and blades (except uppermost in some) eonspicuously pubescent; blades 5 to $10 \mathrm{~mm}$ wide ....... 20. B. Kalmir.

Panicle larger, erect, the branches more or less drooping. Blades mostly wide and lax.

Ligule 3 to $4 \mathrm{~mm}$ long; blades pilose above, scabrous or smooth beneath; panicle large, open, the slender branches long, clrooping

Ligule short; blades pubescent or pilose on both surfaces, or glabrous or scabrous.

Blades densely short-pubescent on both surfaces.

Blades more or less pilose or glabrous.

11. B. GRANDIS.

Sheaths, at least the lower, retrorsely pilose; blades mostly more than $5 \mathrm{~mm}$ wide.

Sheaths shorter than the internodes; nodes 4 to 6 .

16. B. PURGANS.

Sheaths longer than the internodes; nodes 10 to 20 .

17. B. Latiglumis.

Sheaths glabrous; blades mostly less than $5 \mathrm{~mm}$ wide.

21. B. FRONDOSUS. 


\section{Section 3. Bromium}

Panicle contracted, rather dense, the branches erect or ascending.

Lemmas glabrous........ B. Racemosts.

Lemmas pubescent.

Spikelets compressed; lemmas rather thin and narrow_ 26. B. Molliformis.

Spikelets turgid; lemmas rather thick, broader........ 25. B. MOLLIs.

Panicle open, the branches spreading.

Awn short or wanting; lemmas obtuse, inflated (see also short-awned forms of B. secalinus) Awn well developed.

Sheaths glabrous

Sheaths pubescent.

Branches of the panicle rather stiffly spreading or drooping, not flexuous; awn straight_._._.

Branches slender, lax or flexuous.

Panicle 8 to $11 \mathrm{~cm}$ (rarely to $15 \mathrm{~cm}$ ) long; branches and pedicels conspicuously flexuous or curled; lemmas pubescent_ 30 . B. ARENARIUS.

Panicle 15 to $25 \mathrm{~cm}$ long (smaller in depauperate specimens), the long branches spreading or drooping, somewhat flexuous but usually not curled; lemmas glabrous or scaberulous.

Palea distinctly shorter than its lemma; awn flexuous, somewhat divergent in drying; spikelets rather turgid . 28. B. JAPONICUS.

Palea about as long as its lemma; awn straight or nearly so in drying; spikelets thinner and flatter, scarcely turgid_ 29. B. Arvensis.
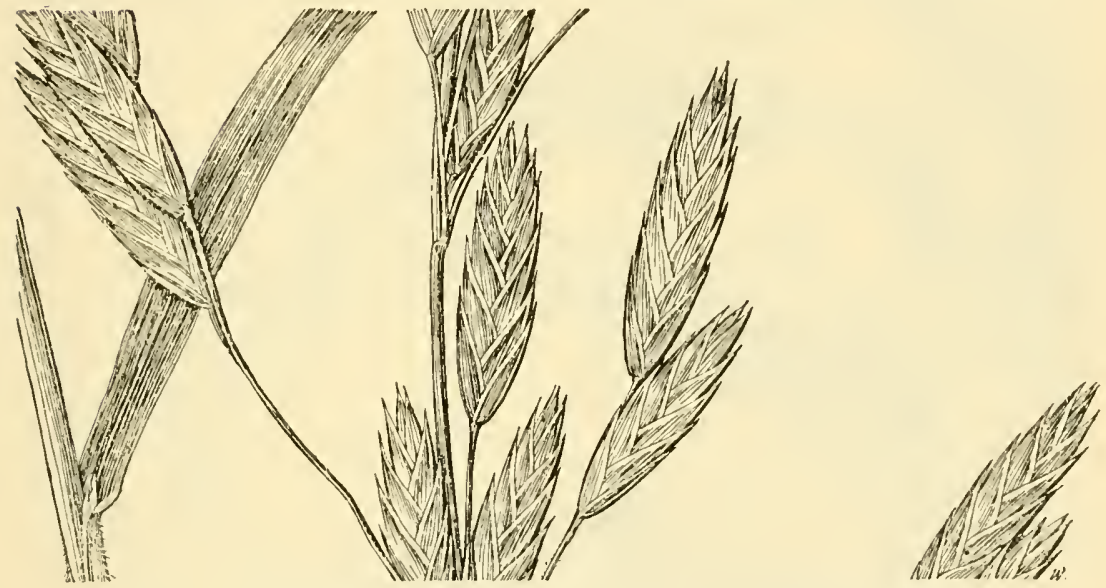

Figure 5.-Bromus catharticus, $\times 1$. (Peebles, Harrison, and Kearney 1271, Ariz.)

Section 4. Eubromus

Panicle contracted, erect; awn 12 to $20 \mathrm{~mm}$ long.

Culms pubescent below the dense panicle._Culms glabrous below the scarcely dense panicle_.... 34. B. MADRITENsis.

Panicle open, the branches spreading.

Second glume usually less than $1 \mathrm{~cm}$ long; pedicels capillary, flexuous.

35. B. TECTORUM.

Second glume more than $1 \mathrm{~cm}$ long; pedicels sometimes flexuous but not capillary.

Awn about $2 \mathrm{~cm}$ long; first glume $8 \mathrm{~mm}$ long........ 32. B. STERILIs. Awn 3 to $5 \mathrm{~cm}$ long; first glume about $15 \mathrm{~mm}$ long_..... 31. B. IRigidus.

A single species

Section 5. Ncobromus

36. B TRINII.

Section 1. Ceratóchloa (Beauv.) Griseb.

Anmuals, biennials, or perennials; spikelets large, distinctly compressed; glumes and lemmas keeled, rather firm. 
1. Bromus cathárticus Vahl. Rescue grass. (Fig. 5.) Annual or biennial; culms erect to spreading, as much as $100 \mathrm{~cm}$ tall; sheaths glabrous or pubescent; blades narrow, glabrous or sparsely pilose; panicle open, as much as $20 \mathrm{~cm}$ long, the branches as much as $15 \mathrm{~cm}$ long, naked at base, in small plants the panicles reduced to a raceme of a few appressed short-pediceled spikelets; spikelets 2 to $3 \mathrm{~cm}$ long,

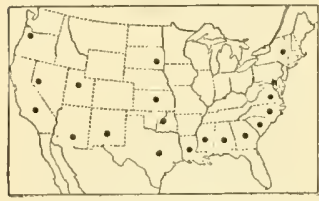

Figure 6.-Distribution of Bromus catharticus. 6- to 12-flowered; glumes acuminate, about 1 $\mathrm{cm}$ long; lemmas glabrous, scabrous, or sometimes pubescent, acuminate, $1.5 \mathrm{~cm}$ long, closely overlapping, concealing the short rachilla joints, awnless or with an awn 1 to $3 \mathrm{~mm}$ long; palea two-thirds as long as the lemma. $\odot \quad(B . u n-$ ioloides H. B. K.)-Cultivated in the Southern States as a winter forage grass. Escaped from cultivation or sparingly introduced in waste places throughout the Southern States and rarely northward (fig. 6). Known also as Schrader's bromegrass.

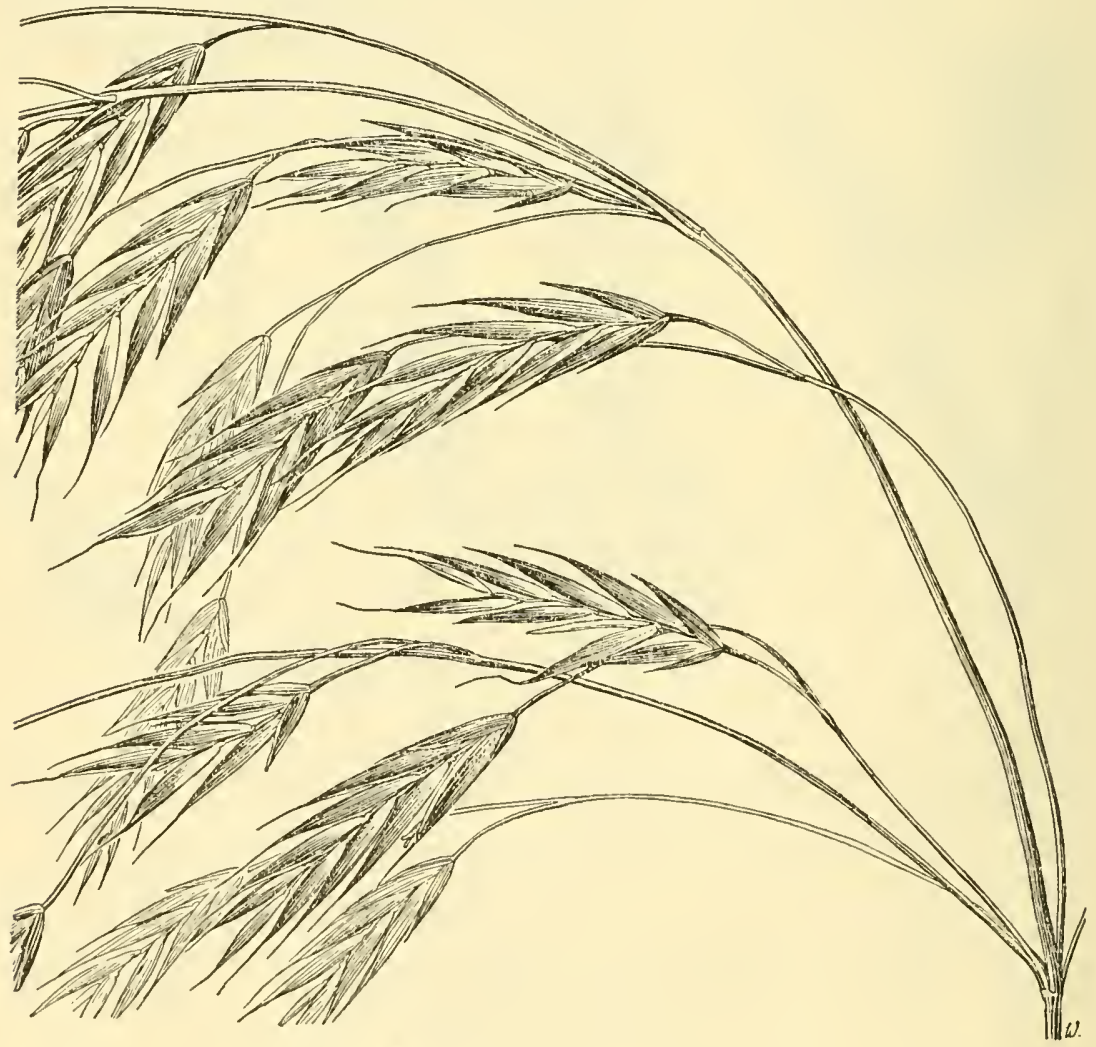

Figure 7.-Bromus sitchensis, $\times 1$. (Piper 3013, Alaska.)

2. Bromus sitchénsis Trin. (Fig. 7.) Stout smooth perennial; culms 120 to $180 \mathrm{~cm}$ tall; sheaths glabrous; blades elongate, 7 to $12 \mathrm{~mm}$ wide, sparsely pilose on the upper surface; panicles large, lax, drooping, 25 to $35 \mathrm{~cm}$ long, the lower branches ( 2 to 4 ) as much as $20 \mathrm{~cm}$ 
long, naked below for as much as 10 or $15 \mathrm{~cm}$, few-flowered; spikelets 2.5 to $3.5 \mathrm{~cm}$ long, 6 - to 12 -flowered, the rachilla joints longer than in $B$. catharticus, exposed at anthesis; lemmas scabrous, sometimes hirtellous toward base; awn 5 to $10 \mathrm{~mm}$ long. 24 -Woods and banks near the coast, Washington to Alaska.

3. Bromus aleuténsis Trin. (Fig. S.) Culms rather stout, erect from a usually decumbent base, 50 to $100 \mathrm{~cm}$ tall; sheaths sparsely retrorse-pilose or glabrous; blades sparsely pilose, 5 to $10 \mathrm{~mm}$ wide; panicle erect, loose, 10 to $20 \mathrm{~cm}$ long, the branches rather stiflly ascending, bearing 1 or 2 (rarely 3 ) spilielets, the lower as much as $10 \mathrm{~cm}$ long; spikelets 2.5 to $3.5 \mathrm{~cm}$ long, 3 - to 6 -flowered; glumes subequal, the first 3 -nerved, the second 5 - or indis-

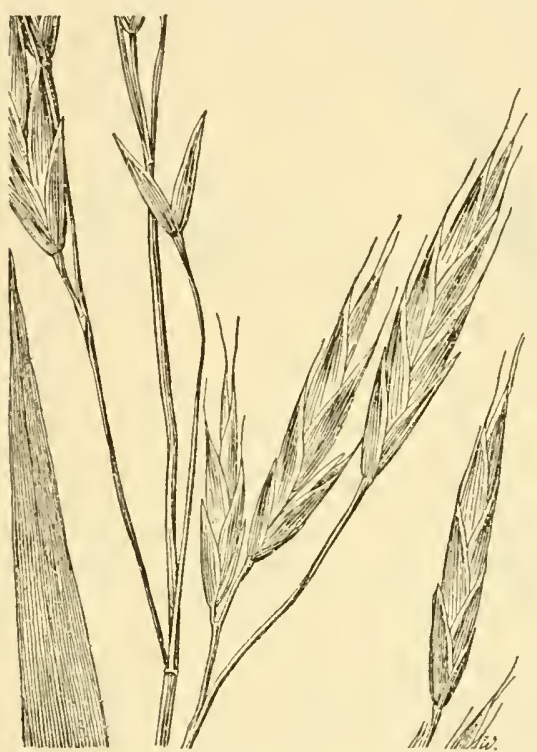

Figure 8.-Bromus aleutensis, $\times 1$. (Evans 550, Alaska.) tinctly 7-nerved; lemmas broadly lanceolate, $7-$ nerved, scariousmargined, smooth to scabrous-pubescent, about 15 $\mathrm{mm}$ long; awn mostly about 1 cm long. 2 Open ground, Aleutian Islands to the Olympic Mountain region. 4. Bromus breviaristátus Buckl. (Fig. 9.) Erect tufted perennial; culms 25 to $50 \mathrm{~cm}$ tall; sheaths canescent to densely retrorse-pilose; blades narrow, becoming involute, canescent and

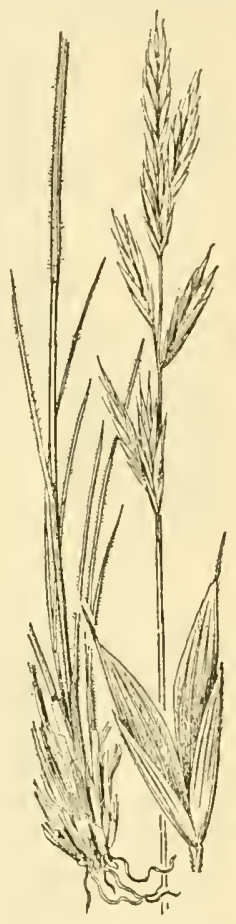

FiguRE 9.-Bromus breviaristatus. Plant, $\times 1 / 2$; spikelet, $\times 5$.

also pilose with spreading hairs, mostly erect or ascending, often only

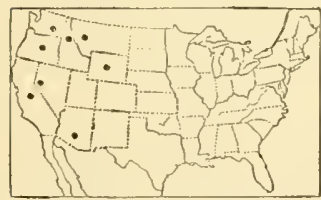

Frgure 10.-Distribution of Bromus breviaristatus. 1 to $2 \mathrm{~mm}$ wide; panicle narrow, erect, 5 to 15 $\mathrm{cm}$ long, the branches short, appressed, often bearing only one spikelet; spikelets 2 to $3 \mathrm{~cm}$ long; lemmas appressed-puberulent; awn 3 to $10 \mathrm{~mm}$ long. 21 (B. subvelutinus Shear.)Dry wooded hills and meadows, Wyoming to eastern Washington, California, and Arizona (fig. 10).

5. Bromus carinátus Hook. and Arn. CALIFORNIA BROME. (Fig. 11.) Erect annual or biennial; culms 50 to 100 $\mathrm{cm}$ tall; sheaths retrorsely pilose to nearly glabrous; blades flat, sparsely pilose or nearly glabrous, mostly 3 to $8 \mathrm{~mm}$ wide; panicle as much as 20 $\mathrm{cm}$ long with spreading, often deflexed, branches, in small plants reduced 
to a raceme; spikelets (excluding awns) 2 to $3 \mathrm{~cm}$ long, mostly 5- to 10flowered, the florets in anthesis little or not at all overlapping, exposing the rather long rachilla joints; glumes acuminate, 10 to $15 \mathrm{~mm}$ long; lemmas more or less appressed-pubescent, rarely glabrous, about $2 \mathrm{~mm}$ wide as folded, 10 to $20 \mathrm{~mm}$ long; awn 7 to $15 \mathrm{~mm}$ long; palea gradually acuminate, nearly as long as the lemma, the teeth shortawned. 2 Open ground, open woods, and waste places, at low and middle altitudes, common on the Pacific coast, extending into

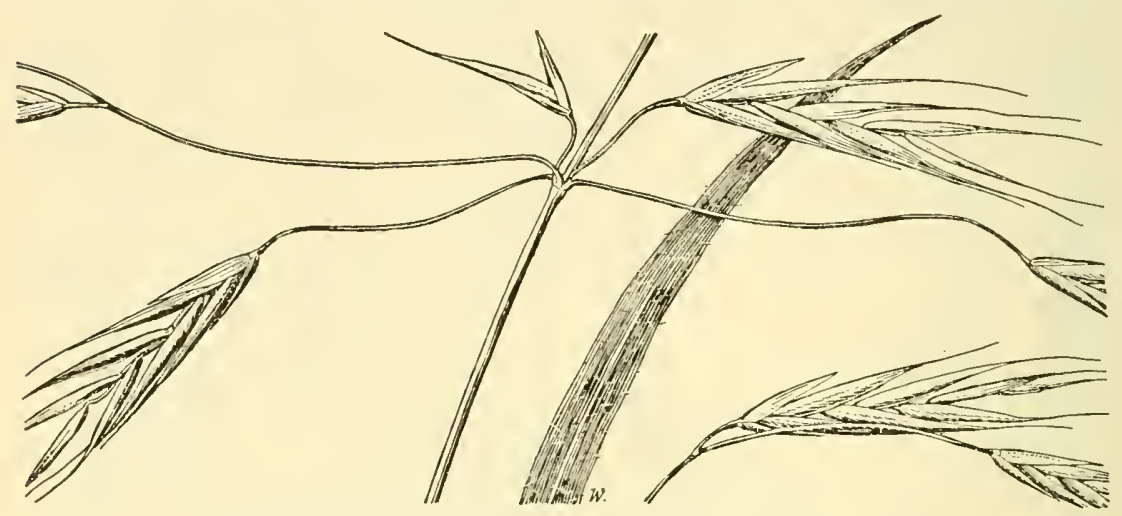

Figure 11.-Bromus carinatus, $\times 1$. (Hitchcock 2704, Calif.)

British Columbia, Idaho, through Montana to New Mexico and northern Mexico; introduced in Indiana (fig. 12).

Closely allied to Bromus carinatus are the following forms which may be considered members of a variable and polymorphous species. These forms are by some given the rank of species, but they are connected by numerous intergrades which can be distinguished only arbitrarily.

Bromus marginatus Nees. Mostly perennial; spilielets on the average broader than in $B$. carinatus, the awn usually less than $7 \mathrm{~mm}$ long; panicles large and open with spreading or drooping but not deflexed branches, or reduced to racemes with a few appressed spikelets; glumes often pubescent; lemmas usually pubescent. 24 -Open woods, open ground, and waste places, common on the Pacific coast, extending north to British Columbia, east to South Dakota, Colorado, and western Texas,

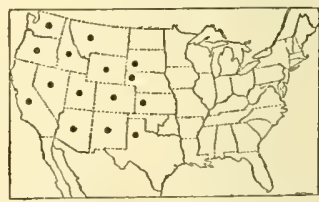

FIGURE 12.-Distribution of Bromus carinatus. and south into northern Mexico; introduced in Alaska, Iowa, Illinois, Maine, and sparingly at other points.

Bromus marínimus (Piper) Hitchc. Perennial; eulms robust, mostly less than $60 \mathrm{~cm}$ tall, more or less geniculate at base with numerous leafy basal shoots; sheaths smooth or minutely scaberulous; blades 12 to $30 \mathrm{~cm}$ long, mostly 6 to $8 \mathrm{~mm}$ wide, scabrous; panicle mostly 10 to $20 \mathrm{~cm}$ long, strict, the branches short, erect; spikelets 3 to $4 \mathrm{~cm}$ long. 2 (B. marginatus maritimus Piper.)-Near the coast from Sonoma County to Monterey County, Calif.

Bromus polyánthus Scribn. Stout perennial as much as $100 \mathrm{~cm}$ tall, with smooth sheaths, scabrous blades, erect or somewhat spread- 
ing panicles, and smooth or somewhat scabrous lemmas; awns 4 to 6 mm long. 24 -Montana to eastern Washington, south to Colorado, Arizona, and (rarely) California. A larger laxer form with more spreading panicles, the upper part somewhat nodding, has been called $B$. polyanthus paniculatus Shear; mountains of Colorado, whence originally described, to Utah, south to New Mexico and Arizona.

Brondes laciniátus Beal. Tall slender perennial; blades flat; panicles 20 to $30 \mathrm{~cm}$ long, open, drooping; spikelets flattened, about $3 \mathrm{~cm}$ long, mostly purplish; lemmas keeled, awned. 2' (B. pendulinus Sessé.) - Occasionally cultivated for ornament; Mexico.

\section{Section 2. Bromópsis Dum:}

Perennials; panicles mostly open; spikelets rather elongate, subterete or slightly compressed before flowering; florets closely overlapping.

6. Bromus inérmis Leyss. Sмоотн BRome. (Fig. 13.) Culms erect, 50 to $100 \mathrm{~cm}$ tall, from creeping rhizomes; ligule 1.5 to $2 \mathrm{~mm}$ long; blades smooth or nearly so, 5 to $10 \mathrm{~mm}$ wide; panicle 10 to $20 \mathrm{~cm}$ long, erect, the branches whorled, spreading in flower, contracted at maturity; spikelets 2 to $2.5 \mathrm{~cm}$ long, subterete before flowering; first glume 4 to $5 \mathrm{~mm}$ long, the second 6 to $8 \mathrm{~mm}$ long; lemmas 9 to $12 \mathrm{~mm}$ long, glabrous or somewhat scabrous, rarely villous, obtuse, emarginate, mucronate, or with an awn 1 to $2 \mathrm{~mm}$ long. 24 Cultivated as hay and pasture grass, especially from Minnesota and Kansas to eastern Oregon and Washington, occasionally eastward to Michigan and Ohio, now running wild in these regions; introduced along roads and in waste places in the northern half of the United States. Also used for reseeding western mountain ranges.

7. Bromus pumpelliánus Scribn. (Fig. 14.) Resembling $B$. inermis; culms 50 to $120 \mathrm{~cm}$ tall, from creeping rhizomes; sheaths glabrous or pubescent; blades rather short, mostly glabrous beneath,

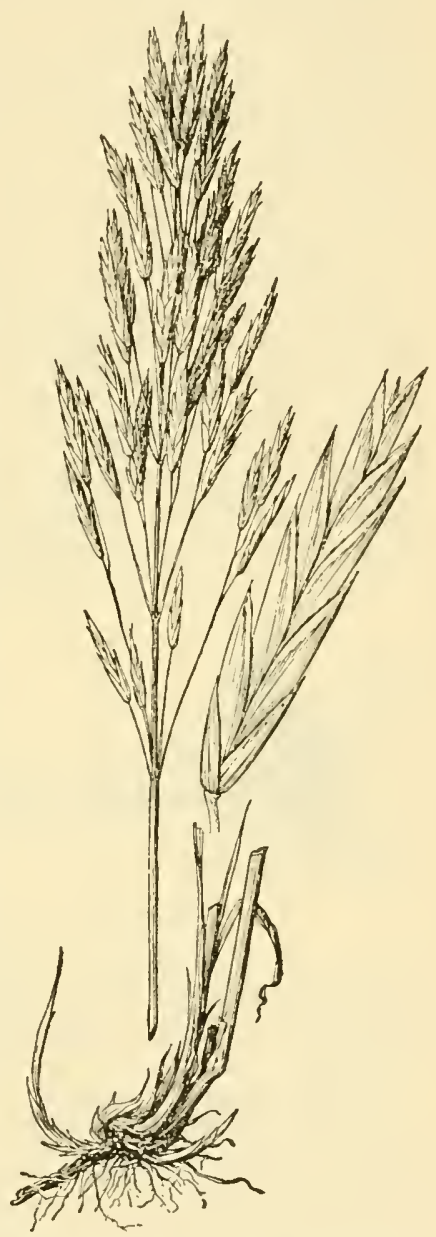

FIGURE 13.-Bromusinermis. Plant, $\times 1 / 2$; spikelet, $\times 2 \frac{1}{2}$. (Deam 11633, lnd.) scabrous or somewhat pubescent on upper surface; panicle 10 to $20 \mathrm{~cm}$ long, rather narrow, erect, the branches short, erect, or ascending; spikelets 7 - to 11 -flowered, 2 to $3 \mathrm{~cm}$ long; first glume 1-nerved, the second 3nerved; lemmas 10 to $12 \mathrm{~mm}$ long, 5- to 7 -nerved, pubescent along the margin and across the back at base, slightly emarginate; awn mostly 2 to $3 \mathrm{~mm}$ long. 24 -Meadows and grassy slopes, Colorado to the Black 
Hills of South Dakota, Idaho, and Alaska; introduced in Micliga? (fig. 15). Bromus pumpellianus var. Tweédy Scribn. Diflering in having lemmas more densely pubescent. 24 -Alberta to Colorado.

8. Bromus eréctus Huds. Culms tufted, erect, 60 to $90 \mathrm{~cm}$ tall, slender; sheaths sparsely pilose or glabrous; ligule $1.5 \mathrm{~mm}$ long; blades narrow, sparsely pubescent; panicle 10 to $20 \mathrm{~cm}$ long, narrow, erect, the branches ascending or erect; spikelets 5- to 10-flowered; glumes acuminate, the first 6 to $8 \mathrm{~mm}$, the second 8 to $10 \mathrm{~mm}$ long; lemmas 10 to $12 \mathrm{~mm}$ long, glabrous or evenly scabrous-pubescent over the back; awn 5 to $6 \mathrm{~mm}$ long. 21 -Established in a few localities from Maine to New York; also in Washington and Alabama; introduced from Europe.

9. Bromus suksdórfii Vasey. (Fig. 16.) Culms 60 to $100 \mathrm{~cm}$ tall; panicle 7 to 12 cm long, the branches erect or ascending; spikelets about $2.5 \mathrm{~cm}$ long, longer than the pedicels; first glume mostly 1-nerved, 8 to $10 \mathrm{~mm}$ long, the second 3-nerved, 8 to $12 \mathrm{~mm}$ long; lemmas

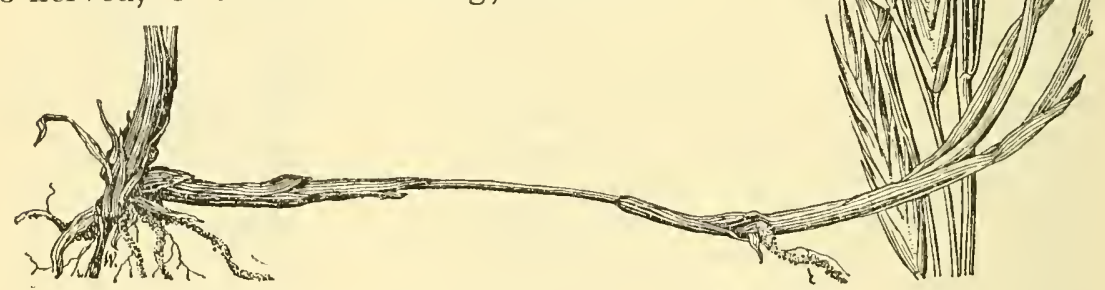

Figure 14.-Bromus pumpellianus, $\times 1$. (Umbach 453, Mont.)

12 to $14 \mathrm{~mm}$ long, appressed-pubescent near the margin and on the lower part of midnerve; awn 2 to $4 \mathrm{~mm}$ long. 21 -Rocky woods and slopes, Washington to the southern Sierra Nevada of California.

10. Bromus orcuttiánus Vasey. (Figr. 17.) Culms 80 to $120 \mathrm{~cm}$ tall, erect, leafy below, nearly naked above, pubescent at and below the nodes; sheaths pilose or more or less velvety or sometimes glabrous; blades rather short and erect; panicle 10 to $15 \mathrm{~cm}$ long, narrow-pyramidal, the few rather rigid short branches finally divaricate; spikelets about

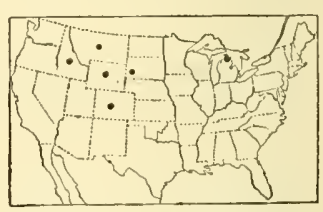

FIGURE 15.-Distribution of Bromus pumpellianus. $2 \mathrm{~cm}$ long, not much flattened, on short pedicels; glumes narrow, smooth, or scabrous, the first 6 to $8 \mathrm{~mm}$ long, acute, 1-nerved, or sometimes with faint lateral nerves, the second 8 to 10 mm long, broader, obtuse, 3-nerved; lemmas 10 to $12 \mathrm{~mm}$ long, narrow, inrolled at margin, obscurely verved, scabrous or scabrous- 
pubescent over the back; awn 5 to $7 \mathrm{~mm}$ long. 4 -Open woods, Washington to California; Arizona (Huachuca Mountains).

Bromus orcutrianus var. HÁllii Hitchc. Blades soft-pubescent on both surfaces; glumes and lemmas pubescent. 2| - Dry, mostly wooded ridges and slopes, 1,500 to $3,000 \mathrm{~m}$ elevation, California.

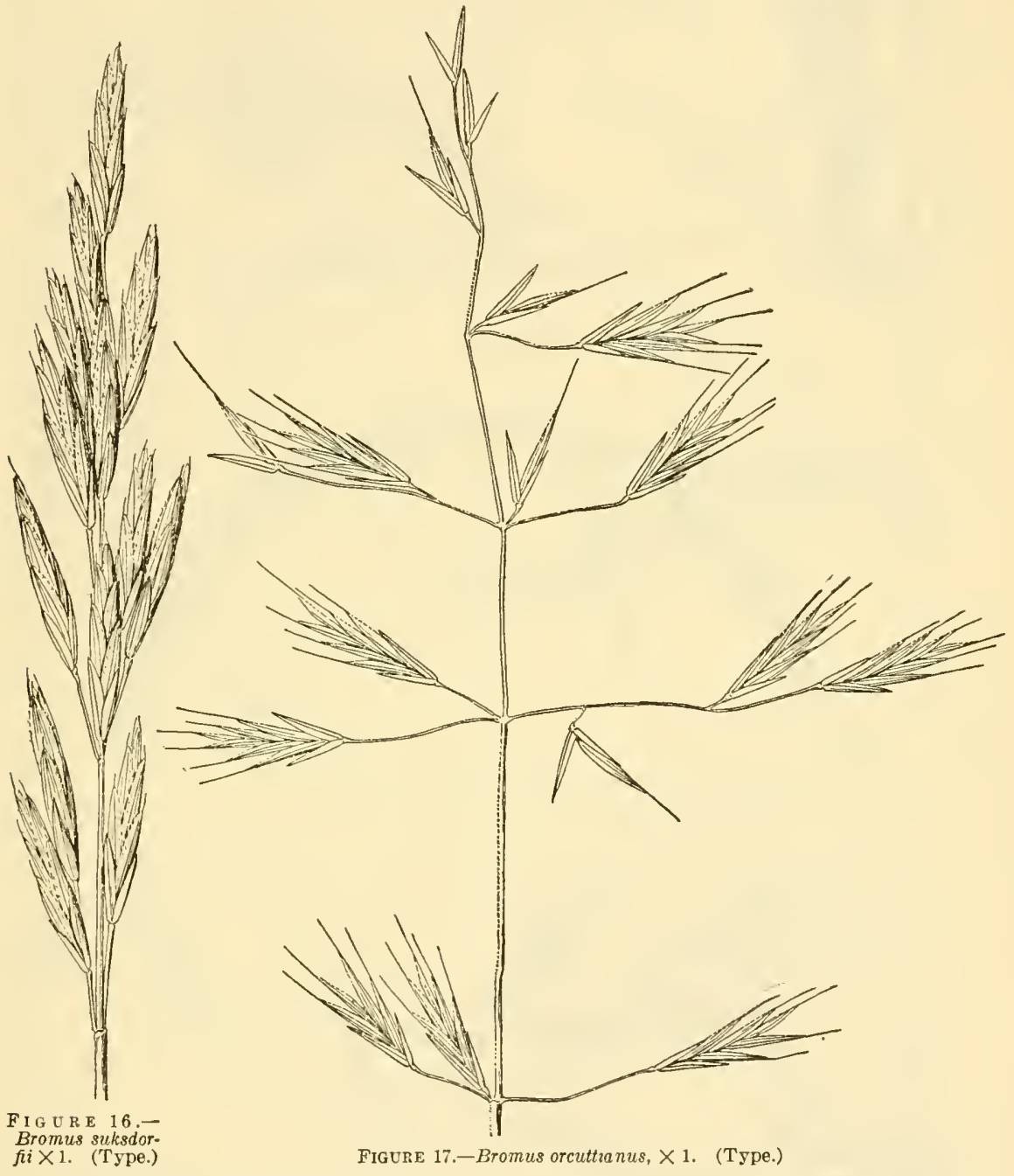

11. Bromus grândis (Shear) Hitchc. (Fig. 18.) Culms 1 to $1.5 \mathrm{~m}$ tall; sheaths softly retrorsely pubescent; blades elongate, rather lax, spreading, densely short-pubescent on both surfaces; panicle 15 to $20 \mathrm{~cm}$ long, broad, open, the branches slender, drooping, naked below, the lower usually in pairs, as much as $15 \mathrm{~cm}$ long; spikelets 2 to $2.5 \mathrm{~cm}$ long, on subflexuous pedicels; first glume usually 
distinctly 3-nerved, the second 3-nerved; lemmas 12 to $15 \mathrm{~mm}$ long, densely pubescent all over the back; awn 5 to $7 \mathrm{~mm}$ long. 24 -Dry hills at moderate altitudes, Monterey and Madera Counties, Calif., south to San Diego.

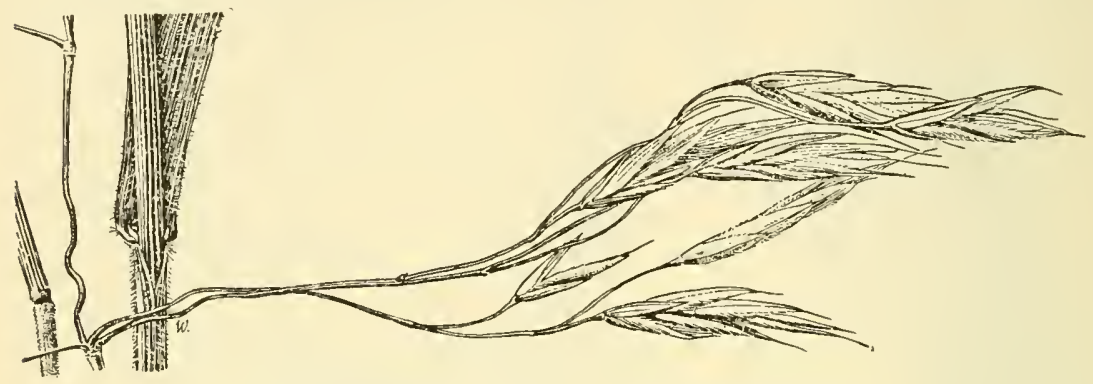

FiguRe 18. - Bromus grandis, $\times 1$. (Johnston 1407, Calif.)

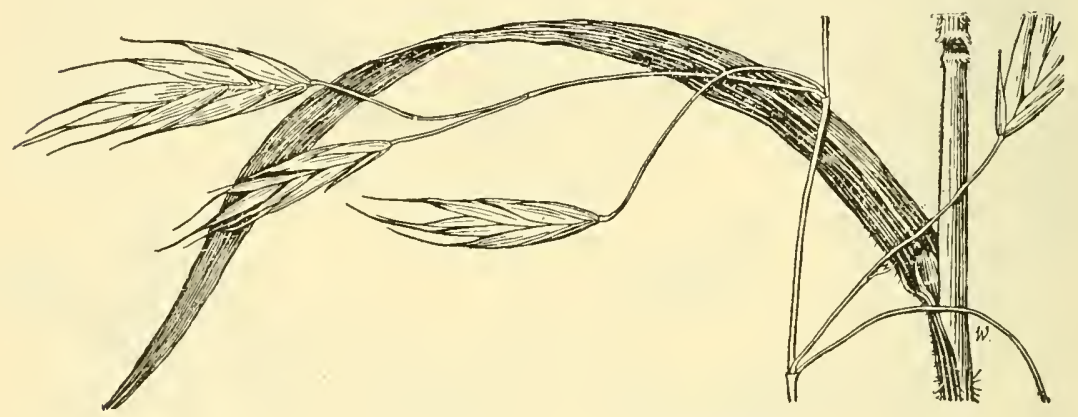

Figure 19.-Bromus pacificus, $\times 1$. (Elmer 1957, Wash.)

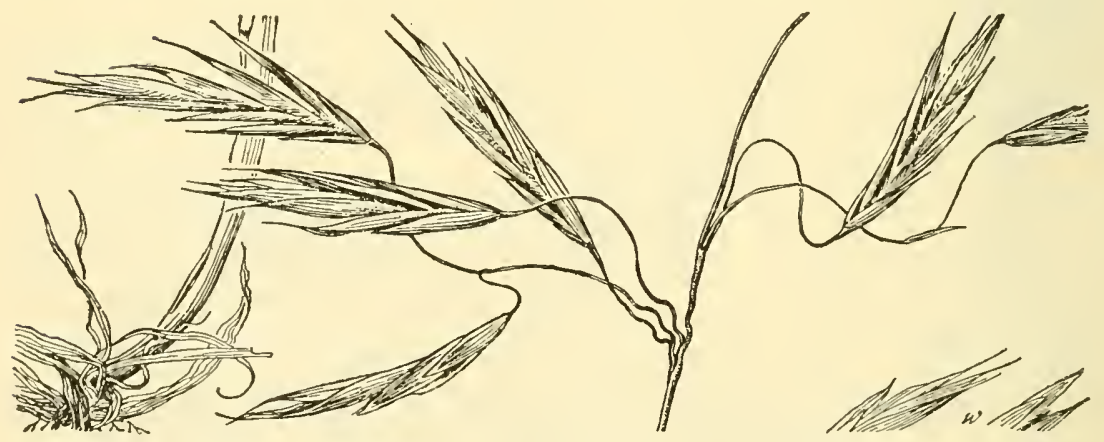

Figure 20.-Bromus laevipes, $\times 1$. (Amer. Gr. Natl. Herb. 866, Calif.)

12. Bromus pacíficus Shear. (Fig. 19.) Culms 1 to $1.5 \mathrm{~m}$ tall, stout, erect, pubescent at the nodes; sheaths sparsely pilose; ligule 3 to $4 \mathrm{~mm}$ long; blades sparsely pilose on upper surface, scabrous or smooth beneath, 8 to $10 \mathrm{~mm}$ wide; panicle very open, 10 to $20 \mathrm{~cm}$ 
long, the branches slender, drooping; spikelets 2 to $2.5 \mathrm{~cm}$ long, coarsely pubescent throughout; lemmas 11 to $12 \mathrm{~mm}$ long, the pubescence somewhat dense on the margin; awn 4 to $6 \mathrm{~mm}$ long. 24 -Moist thickets near the coast, southern Alaska to Western Oregon.

13. Bromus laévipes Shear. (Fig. 20.) Light green or glaucous; culms 50 to $100 \mathrm{~cm}$ tall, from a decumbent base, often rooting at the lower nodes; ligule 2 to $3 \mathrm{~mm}$ long; blades 4 to $7 \mathrm{~mm}$ wide; panicles broad, 15 to $20 \mathrm{~cm}$ long, the branches slender, drooping; first glume 3nerved, 6 to $8 \mathrm{~mm}$ long, the second 5-nerved, 10 to $12 \mathrm{~mm}$ long; lemmas obtuse, 7 -nerved, 12 to $14 \mathrm{~mm}$ long, densely pubescent on the margin nearly to the apex and on the back at base; awn 3 to $5 \mathrm{~mm}$ long. 2 Moist woods and shady banks, southern Washington to California, Nevada (Charleston Mountains), and Arizona (Tanner Canyon).

14. Bromus vulgáris (Hook.) Shear. (Fig. 21.) Culms slender, 80 to 120 cm tall, the nodes pubescent; sheaths pilose; ligule 3 to $5 \mathrm{~mm}$ long; blades more or less pilose; panicle 10 to $15 \mathrm{~cm}$ long, the branches slender, drooping; spikelets narrow, about $2.5 \mathrm{~cm}$ long; glumes narrow; sparsely pubescent, the first acute, 1 -nerved, 5 to $8 \mathrm{~mm}$ long, the second broader, longer,

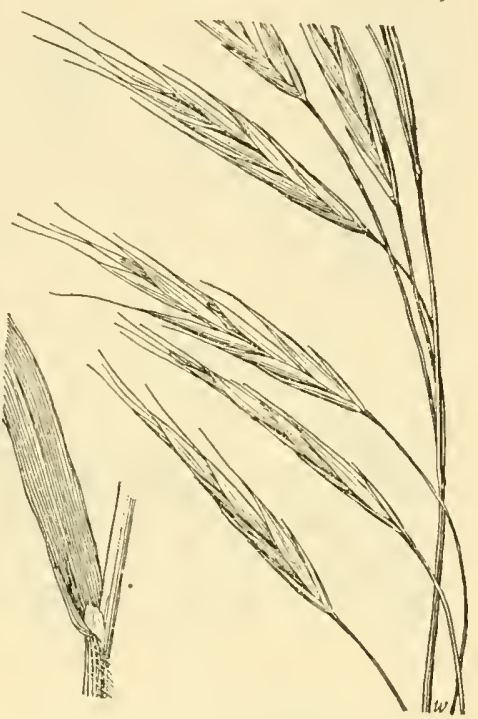

FIGURE 21.-Bromus rulgaris, $\times 1$. (Chase 4945, Wash.) obtuse to acutish, 3-nerved; lemmas 8 to $10 \mathrm{~mm}$ long, sparsely pubescent over the back, more densely near the margin, or nearly glabrous; awn 6 to $8 \mathrm{~mm}$ long. 24 -Rocky woods and shady ravines, western Montana and Wyoming to British Columbia and California (fig. 22). Two scarcely distinct robust rarieties have been described: $\vec{B}$. vul-

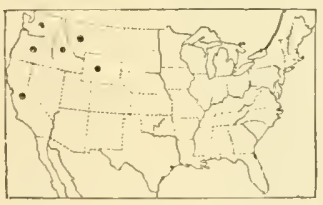

Figure 22.-Distribution of Bromus rulgaris. garis var. eximius Shear, a form with glabrous shea ths and nearly glabrous lemmas, Washington to Mendocino County, Calif.; and B. vulgaris var. robustus Shear, with pilose sheaths and large panicle, British Columbia to Oregon.

15. Bromus ciliátus L. Fringed BROME. (Fig. 23, A.) Culms slender, 70 to $120 \mathrm{~cm}$ tall, glabrous or pubescent at the nodes; sheaths glabrous or the lower short-pilose, mostly shorter than the internodes; blades rather lax, as much as $1 \mathrm{~cm}$ wide, sparsely pilose on both surfaces to glabrous; panicle 15 to $25 \mathrm{~cm}$ long, open, the branches slender, drooping, as much as $15 \mathrm{~cm}$ long; first glume 1 -nerved, the second 3-nerved; lemmas 10 to $12 \mathrm{~mm}$ long, pubescent near the margin on the lower half to three-fourths, glabrous or nearly so on the back; awn 3 to $5 \mathrm{~mm}$ long. 24 -Moist woods and rocky slopes, Newfoundland to Washington, south to New Jersey, Tennessee, Iowa, western Texas, and southern California (San Bernardino 


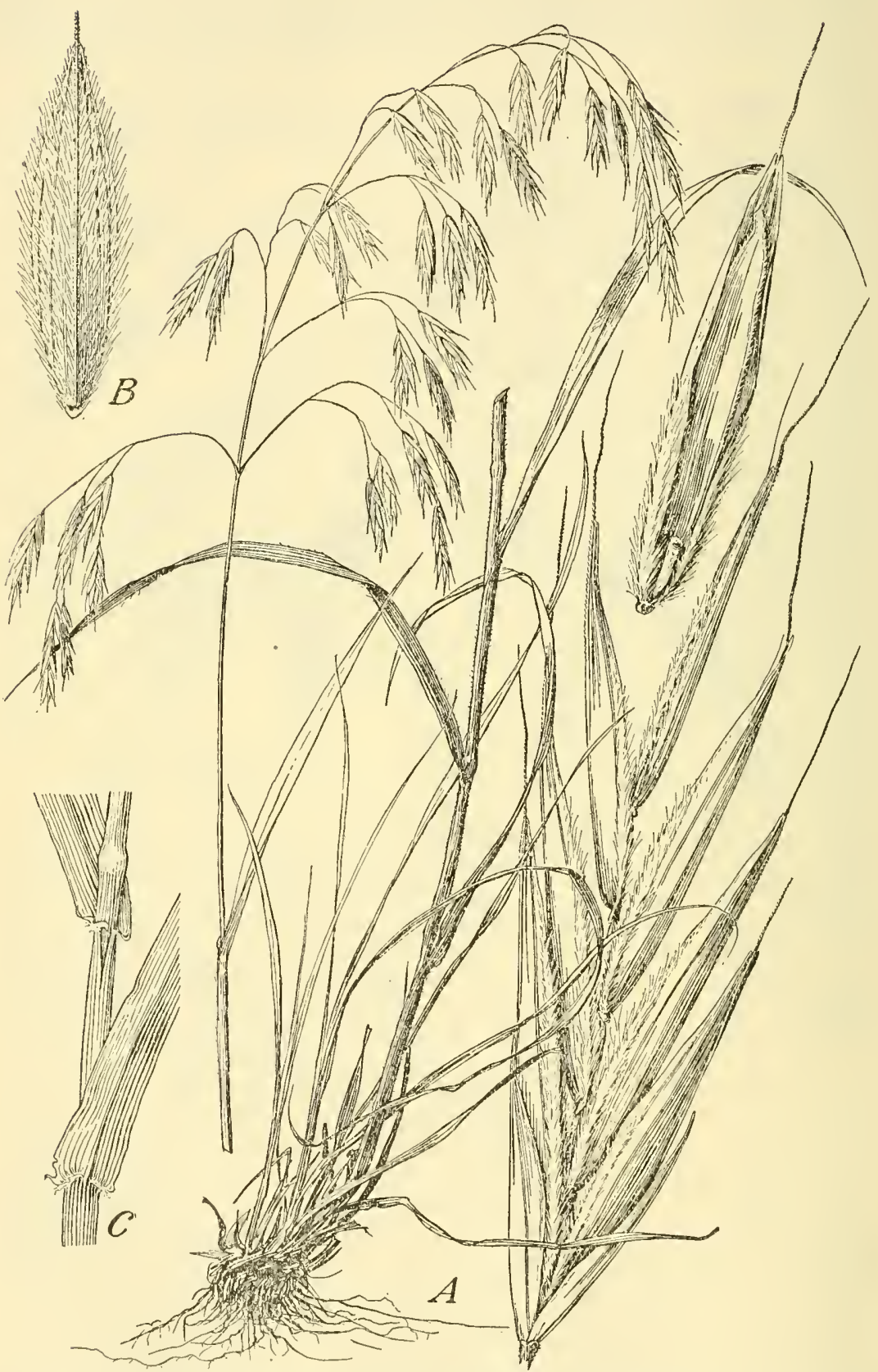

Figure 23.-A, Bromus cilialus. Plant $\times 1 / 2$; spikelet and floret $\times 5$. (Hitcheock, Vt.) B, B. purgans. Floret, $\times 5$, (Deam 279s2, Ind.) $C, B$. latiglumis. Base of blades, $\times 1$. 
Mountains) (fig. 24). B. richardsoni Link is a form that has been distinguished by its larger spikelets and lemmas and more robust habit, but it grades freely into $B$. ciliatus and can scarcely be ranked even as a variety. This is the common form in the Rocky Mountains.

Bronus ciliatus var. laeviglúmis Scribn. Culms stout, leafy, mostly more than $1 \mathrm{~m}$ tall; sheaths shorter or longer than the internodes, glabrous to pubescent, not strongly pilose; blades elongate,

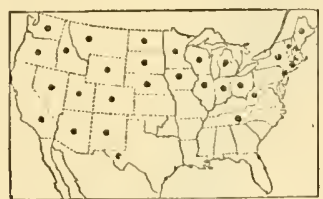

FIGURE 24.-Distribution of Bromus ciliatus.

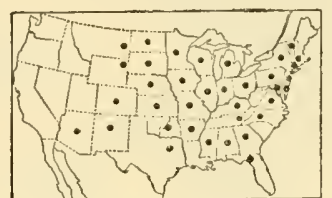

Figure 25.-Distribution of Bromus purgans.

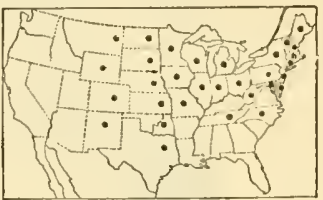

FIGURE 26.-Distribution of Bromus latiglumis.

as much as $1 \mathrm{~cm}$ wide or even wider; panicle large, open; lemmas glabrous or nearly so.-Woods and river banks, rare. Known from Maine, Vermont, New York, Ontario, Michigan, North Dakota, Maryland, West Virginia, Virginia, North Carolina, and Kansas.

16. Bromus púrgans L. Canada Brome. (Fig. 23, B.) Resembling $B$. ciliatus; nodes mostly 4 to 6 ; sheaths, except the lower 1 or 2 , shorter than the internodes, more or less retrorsely pilose, or sometimes all glabrous; blades narrowed at base, and without flanges or auricles; pubescence of lemma nearly uniform, sometimes more dense on the margins, sometimes sparse and short on the back or scabrous only. 2 -Moist woods and rocky slopes, Massachusetts to Alberta, south to northern Florida and Arizona (fig. 25).

17. Bromus latiglúmis (Shear) Hitche. (Fig. 23, C.) Differing from $B$. purgans in having usually 10 to 20 nodes; sheaths overlapping, longer than the internodes, more or less pilose, especially about the throat and collar; base of blades with prominent flanges on each side, these usually prolonged into auricles. Where the ranges of $B$. purgans and B. latiglumis overlap, the latter flowers several weeks later than the other. 4 -Alluvial banks of streams, Maine to eastern

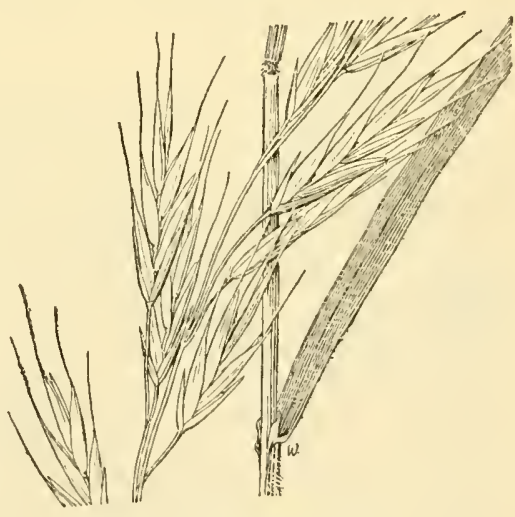

FIgure 27.-Bromus texensis, $\times 1$. (Tracy 8881, Tex.) Montana, south to North Carolina and Oklahoma (fig. 26). A form with densely canescent sheaths has been called B. incanus (Shear) Hitchc.-Vermont to North Dakota, south to Pennsylvania, Delaware, Maryland, Ohio, and lowa; western Texas, Colorado, and New Mexico.

18. Bromus texénsis (Shear) Hitchc. (Fig. 27.) Culms slender, mostly solitary, 40 to $70 \mathrm{~cm}$ tall; sheaths much shorter than the 
internodes, softly retrorsely pilose; blades pubescent on both surfaces, mostly 3 to $6 \mathrm{~mm}$ wide; panicle mostly not more than $10 \mathrm{~cm}$ long, few-flowered, drooping; lemmas scabrous to nearly smooth;

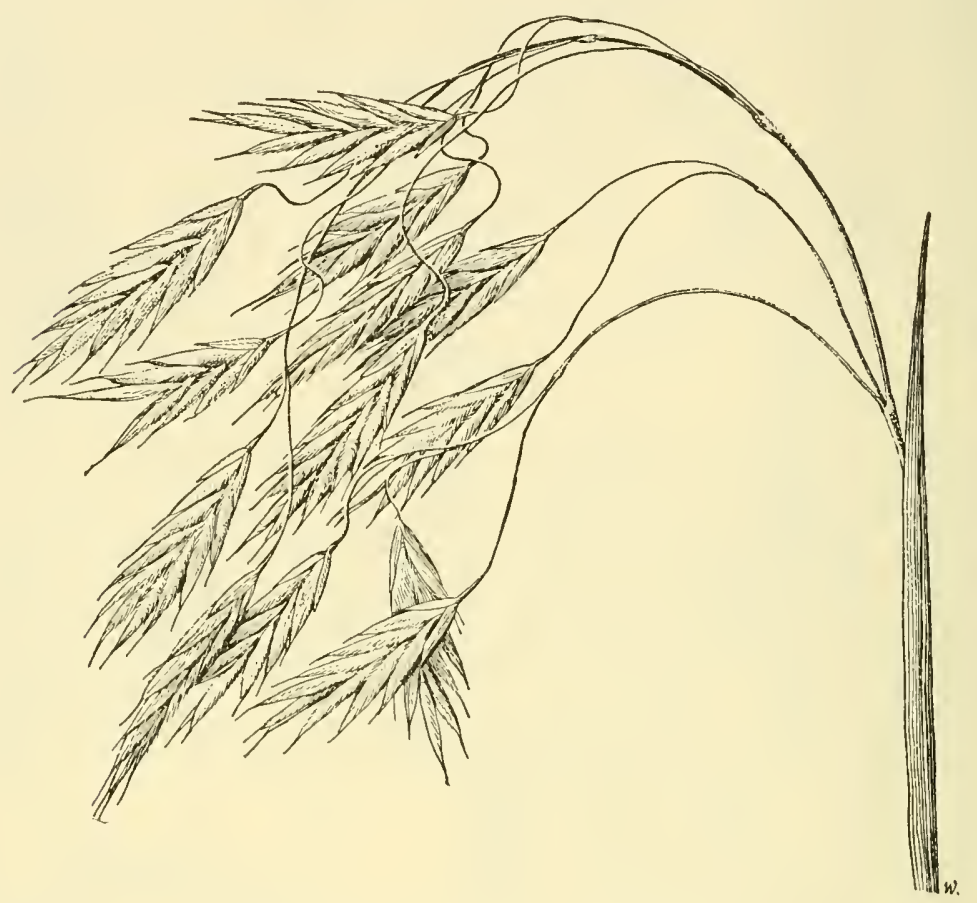

Figure 28.-Bromus anomalus, $\times 1$. (Pammel, Colo.)

awn 5 to $7 \mathrm{~mm}$ long. 24 -Among brush, Texas (Bexar County and Corpus Christi) apparently rare; northern Mexico.

19. Bromus anómalus Rupr. Nodding Brome. (Fig. 28.) Culms slender, 30 to $60 \mathrm{~cm}$ tall, the nodes pubescent; sheaths sparsely pilose to glabrous; ligule about $1 \mathrm{~mm}$ long; blades scabrous, mostly 2 to $4 \mathrm{~mm}$ wide; panicle about $10 \mathrm{~cm}$ long, often less, few-flowered, drooping; first glume 3 -nerved, the second 5-nerved, lemmas about $12 \mathrm{~mm}$ long, evenly and densely pubescent over the back; awn 2 to $4 \mathrm{~mm}$ long. 24 (B. porteri Nash.)-Open woods, Saskatchewan and Idaho, to western Texas, southern California, and Mexico (fig. 29).

Bromus anomalus var. Lanátipes (Shear)

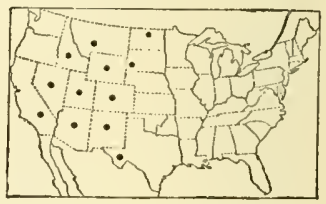

FIGURE 29,-Distribution of Bromus anomalus.

Hitchc. More robust, with woolly sheaths and usually broader blades. 24 (B. porteri lanatipes Shear.)-Colorado to western Texas and Arizona.

20. Bromus kálmii A. Gray. (Fig. 30.) Culms slender, 50 to $100 \mathrm{~cm}$ tall, usually pubescent at and a little below the nodes; sheaths usually shorter than the internodes, pilose or the upper glabrous; 
blades usually sparsely pilose on both sides, 5 to $10 \mathrm{~mm}$ wide; panicle

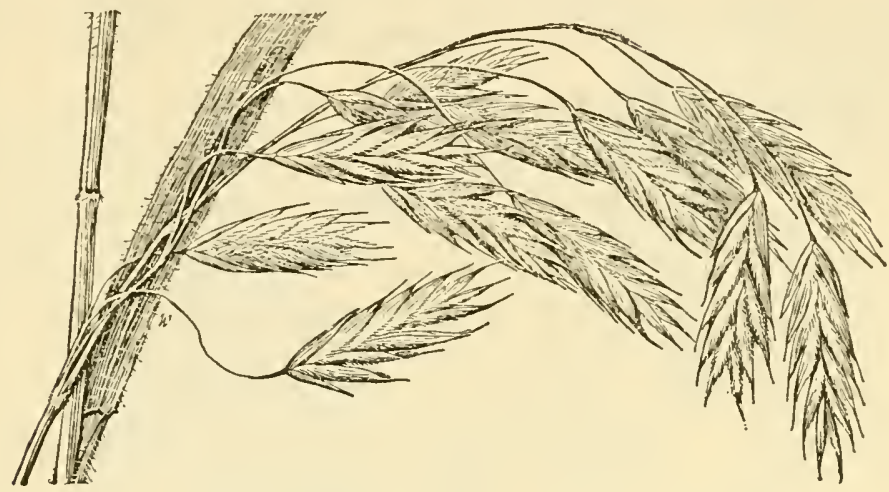

FlgURE 30.-Bromus kalmii, $\times 1$. (Chase 186612, Ind.)

rather few-flowered, drooping, mostly 5 to $10 \mathrm{~cm}$ long, the branches slender, flexuous, bearing usually 1 to 3 spikelets; first glume 3-nerved, the second 5-nerved; lemmas 7 to $10 \mathrm{~mm}$ long, pubescent over the back, more densely so near the margins; awn 2 to $3 \mathrm{~mm}$ long. 2 -Dry or sandy ground and open woods, Maine to Minnesota and South Dakota, south to western Maryland and Iowa (fig. 31). Called wild chess.

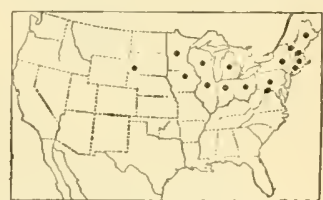

FIGURE 31.-Distribution of Bromus kalmii

21. Bromus frondósus (Shear) Woot. and Standl. (Fig. 32.)

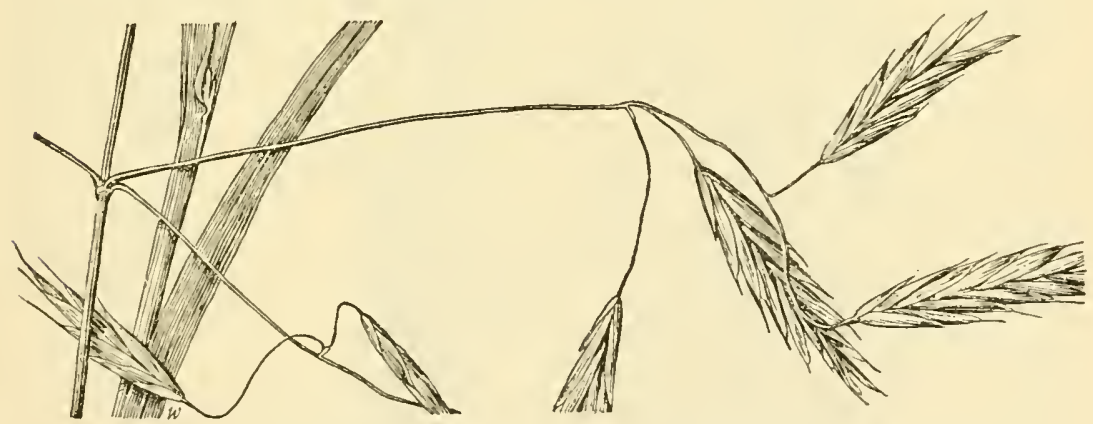

Figure 32.-Bromus frondosus, $\times 1$. (Hitchcock 132S2, N.Mex.)

Culms erect to weakly reclining, $S 0$ to $100 \mathrm{~cm}$ tall; sheaths gla-

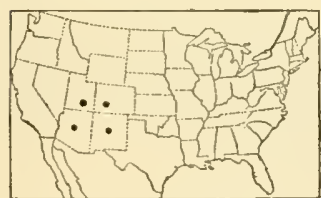

FIGURE 33.-Distribution of Bromus frondosus. brous or the lower pilose; blades pale green, scabrous, mostly less than $5 \mathrm{~mm}$ wide, occasionally to $10 \mathrm{~mm}$, rarely wider; panicle open, drooping, the slender lower branches naked below; first glume 2- to 3-nerved; lemmas pubescent all over, rarely nearly glabrous. 21 (B. porteri frondosus Shear.)Open woods and rocky slopes. Colorado, Utah, New Mexico, and Arizona (fig. 33). 
Section 3. Brómidu Dum.

Annuals; spikelets subcompressed; glumes and lemmas comparatively broad, elliptic or oblong-elliptic. Introduced, mostly from Europe.

22. Bromus brizaefórmis Fisch. and Mey. Rattlesnake chess. (Fig. 34.) Culms 30 to $60 \mathrm{~cm}$ tall; sheaths and blades pilose-pubescent; panicle 5 to $15 \mathrm{~cm}$ long, lax, secund,

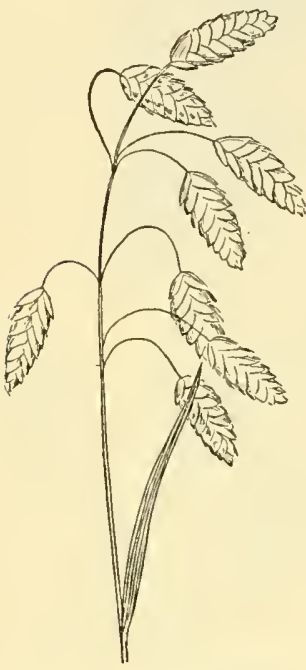

FIgURE 34.-BTomus brizaeformis, X 1/2. (Leckenby 40, Wash.) drooping; spikelets rather few, oblong-ovate, 1.5 to $2.5 \mathrm{~cm}$ long, about $1 \mathrm{~cm}$ wide; glumes broad, obtuse, the first 3 - to 5-nerved, the second 5- to 9-nerved, about twice as long as the first; lemmas $10 \mathrm{~mm}$ long, very broad, inflated, obtuse, smooth, with a broad scarious margin, nearly or quite awnless. $\odot$ - Sandy fields and waste ground, occasional from Washington and Idaho to California, rare eastward to Massachusetts and Delaware (fig. 35); introduced from Europe. Sometimes cultivated for ornament.

23. Bromus secalínus L. Chess. (Fig. 36.) Culms erect, 30 to $60 \mathrm{~cm}$ tall; sheaths glabrous or the lower sometimes puberulent; panicle pyramidal, nodding, 7 to $12 \mathrm{~cm}$ long, the lower branches 3 to 5, unequal, drooping; spikelets ovoid-lanceolate, becoming somewhat turgid at maturity, 1 to $2 \mathrm{~cm}$ long, 6 to $8 \mathrm{~mm}$ wide; glumes obtuse, the first 3- to 5-nerved, 4 to 6 $\mathrm{mm}$ long, the second 7 -nerved, 6 to $7 \mathrm{~mm}$ long; lemmas 7-nerved, 6 to $8 \mathrm{~mm}$ long, elliptic, obtuse, smooth or scaberulous, the margin strongly involute at maturity, shortly bidentate at apex, the undulate awns usually 3 to $5 \mathrm{~mm}$ long, sometimes very short or obsolete; palea about as long as lemma. $\odot$-Introduced from Europe, a weed in grainfields and waste places, more or less throughout the United States. Also called cheat. Occasionally utilized for hay in Washington and Oregon. In fruit the turgid florets are somewhat distant so that, viewing the spikelet sidewise, the light passes through the small openings at base of each floret. Bronus SECALINUS var. veLÚTINUS (Schrad.) Koch. Spikelets pubescent. $\odot$-Oregon (Corvallis, Dalles). Europe.

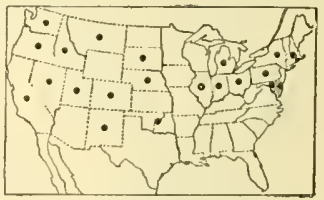

FIGURE 35-Distribution of Bromus brizaeformis

The species of the group containing Bromus secalinus, B. commutatus, B. mollis, and B. racemosus are closely allied, differentiated only by arbitrary characters. The forms are recognized as species in most recent European floras and this disposition is here followed. 


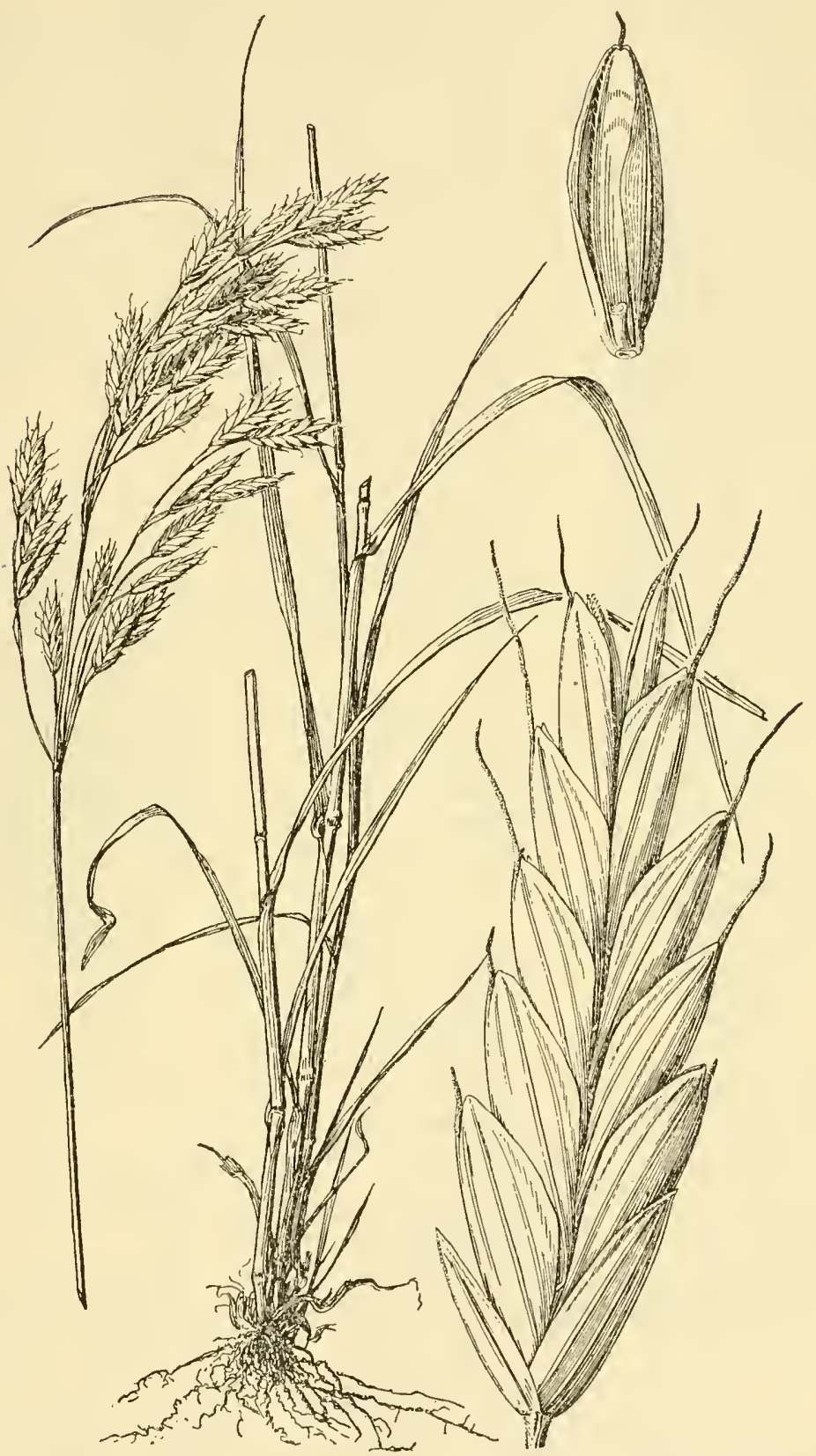

Figure 36.-Bromus secalinus. Plant, $\times 1 / 2$; spikelet and floret, $\times 5$ (Chase, III.) 
24. Bromus commutátus Schrad. Hairy chess. (Fig. 37.) Resembling $B$. secalinus, but the sheaths retrorsely pilose; lemmas at maturity less plump and more overlapping; awn commonly somewhat longer. $\odot$-Introduced from Europe,

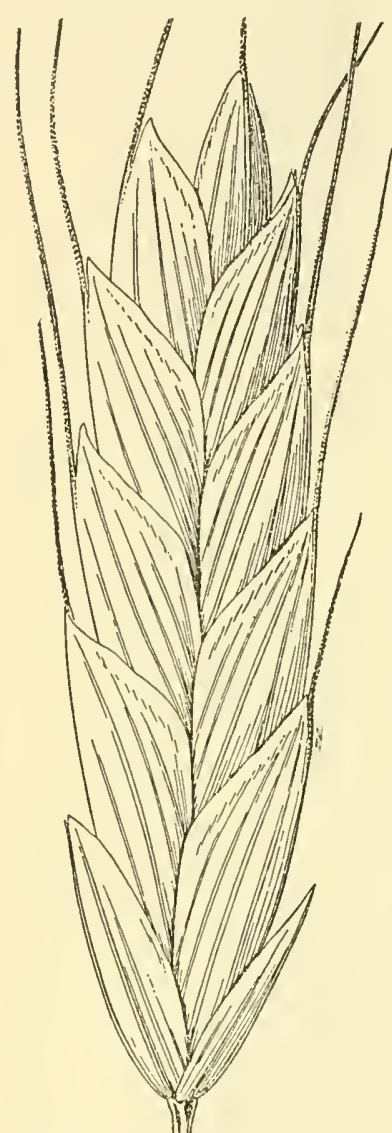

FIGURE 37.-Bromus commutatus, $\times 5$. (Amer. Gr. Nat. Herb. 890, Va.) a weed in fields and waste places, Washington to California and Montana and eastward through the Northern States, thenceless commonly southward. Bromus COMMUtatus var. APRICóRUM Simonkai. Lemmas pubescent. $\odot$ - Washington to California; rare. Introduced from Europe.

25. Bromus móllis L. Soft chess. (Fig. 38.) Softly pubescent throughout; culms erect, 20 to $80 \mathrm{~cm}$ tall; panicle erect, contracted, 5 to $10 \mathrm{~cm}$ long, or, in depauperate plants, reduced to a few spikelets; glumes broad, obtuse, coarsely pilose or scabrouspubescent, the first 3 - to 5 -nerved, 4 to 6 $\mathrm{mm}$ long, the second 5- to 7-nerved, 7 to 8 mm long; lemmas broad, soft, obtuse, 7-nerved, coarsely pilose or scabrouspubescent, rather deeply bidentate, 8 to $9 \mathrm{~mm}$ long, the margin and apex hyaline; a w $\mathrm{n}$ rather stout, 6 to $9 \mathrm{~mm}$ long; palea a bout threefourths as long as lemma. $\odot$ - Weed

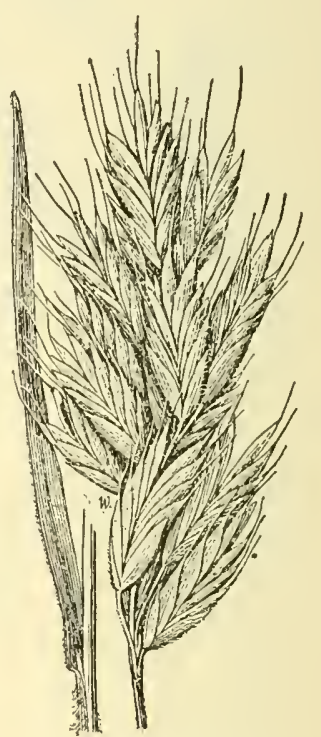

FIGURE 38.-Bromus mollis, $\times$ 1. (Hall 258, Calif.) in waste places and

cultivated soil, introduced from Europe, abundant on the Pacific coast, occasional eastward to Nova Scotia and south to North Carolina (fig. 39). This has been referred to B. hordeaceus L., a distinct European species.

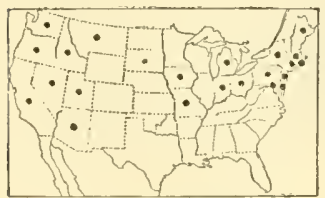

Figure 39.-Distribution of Bromus mollis.

26. Bromus mollifórmis Lloyd. (Fig. 40.) Culms erect, mostly 10 to $20 \mathrm{~cm}$ tall, sometimes taller; lower sheaths felty-pubescent, the upper glabrous; blades narrow, the upper surface with scattered rather stiff hairs; panicle 2 to $4 \mathrm{~cm}$ long, ovoid, dense, few-flowered; spikelets oblong, compressed, 12 to $18 \mathrm{~mm}$ long; glumes about $6 \mathrm{~mm}$ long, the second broader, loosely pilose, the hairs spreading; lemmas thinner and narrower than in $B$. mollis, closely imbricate, about $8 \mathrm{~mm}$ long, 
pilose with appressed hairs, the margin whitish; awn from below the entire apex, 5 to $7 \mathrm{~mm}$ long; palea a little shorter than the lemma; anthers $0.4 \mathrm{~mm}$ long, about as broad. $\odot$-Open ground, southern California; introduced from Europe.

27. Bromus racemósus L. (Fig. 41.) Differing from B. mollis in the somewhat more open panicle and glabrous or scabrous lemmas. $\odot$ (Including what in this country has been called $B$. hordeaceus glabrescens Shear, B. hordeaceus var. leptostachys Beck, and $B$. mollis f. leiostachys Fernald.)-Weed in waste places, chiefly on the Pacific coast and east to Idaho,

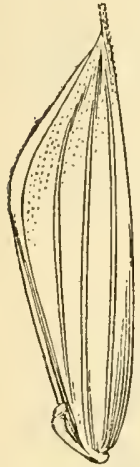

Figure 41.Bromus rac(Hitch cock 2667, Calif.' Colorado, and Arizona; a few points from Illinois to Maine and North Carolina (fig. 42); introduced from Europe.

Bromus scopárius L. Resembling $B$. molliformis; culms 20 to $30 \mathrm{~cm}$ tall; sheaths soft-pubescent; blades glabrous, scabrous or sparingly pilose; panicle contracted, erect, 3 to $7 \mathrm{~cm}$ long; spikelets about $1.5 \mathrm{~cm}$ long, 3 to $4 \mathrm{~mm}$ wide; lemmas about $7 \mathrm{~mm}$ long,

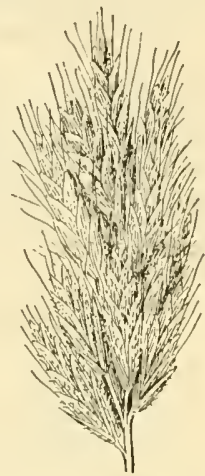

FigUre $40 .-B$ Bro mus molliformis, $\times 1$. (Chase 5564 , Calif.) narrow, glabrous; awn 5 to $8 \mathrm{~mm}$ long, finally divaricate. $\odot$-Introduced from Europe in California (Mariposa) and Virginia (Newport News, on ballast).

Bromus macróstachys L. Annual; culms erect, 30 to $60 \mathrm{~cm}$ tall ; panicle narrow, compact, consisting of a few large spikelets about $3 \mathrm{~cm}$ long. $\odot \quad-W o o l$ waste, Yonkers, N.Y. Sometimes cultivated for ornament. Mediterranean region.

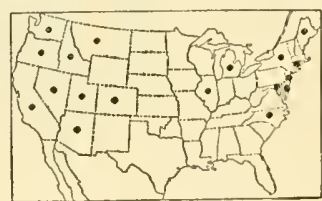

Figure 42.-Distribution of Bromus racemosus.

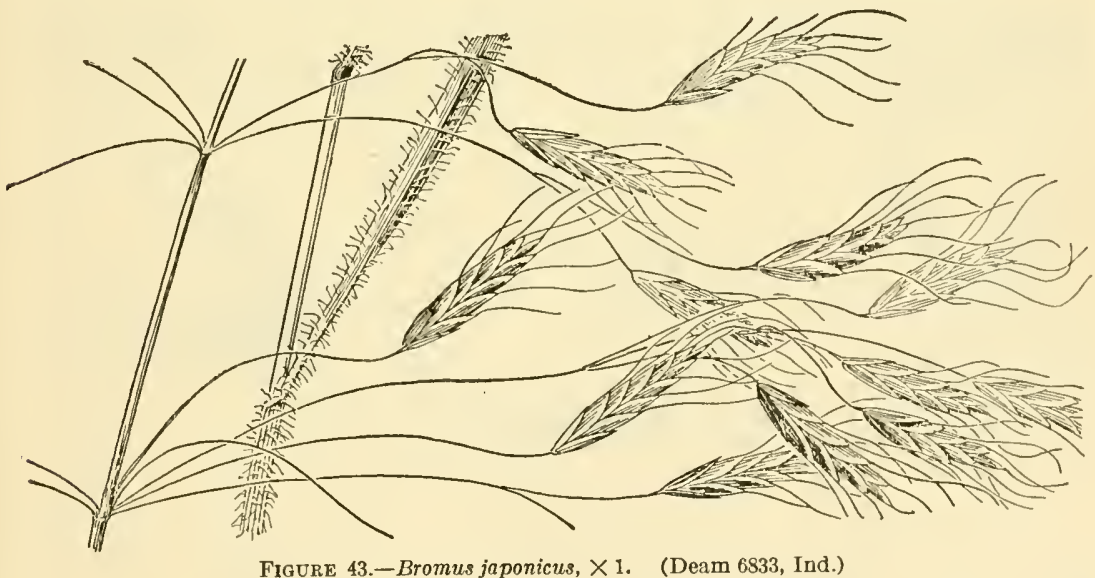

28. Bromus japónicus Thunb. Japanese chess. (Fig. 43.) Culms erect or geniculate at base, 40 to $70 \mathrm{~cm}$ tall; sheaths and 
blades pilose; panicle 12 to $20 \mathrm{~cm}$ long, broadly pyramidal, diffuse, somewhat drooping, the slender lower branches 3 to 5 , all the branches flexuous; glumes rather broad, the first acute, 3-nerved, 4 to $6 \mathrm{~mm}$ long, the second obtuse, 5-nerved, 6 to $8 \mathrm{~mm}$ long; lemmas broad,

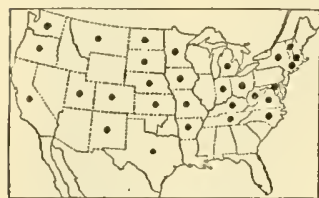

TIGURE 44.-Distribution of Bromus japonicus. obtuse, smooth, 7 to $9 \mathrm{~mm}$ long, 9-nerved, the marginal pair of nerves faint, the hyaline margin obtusely angled above the middle, the apex emarginate; awn 8 to $10 \mathrm{~mm}$ long, somewhat twisted and strongly flexuous at maturity, those of the lower florets shorter than the upper; palea 1.5 to $2 \mathrm{~mm}$ shorter than the lemma. $\odot$ (B. patulus Mert. and Koch)-Weed in waste places, Vermont to Washington, south to North Carolina and California (fig. $44)$; widely distributed in the Old World.

29. Bromus arvénsis L. (Fig. 45.) Resembling B. japonicus, foliage downy to subglabrous; spikelets thinner, flatter (less turgid),

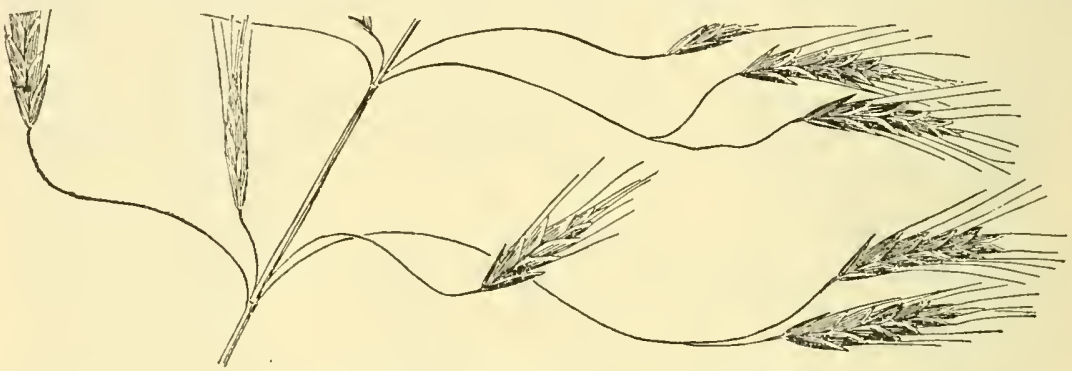

Figure 45.-Bromus arnensis, $\times 1$. (Gray, Md.)

often tinged with purple; awn straight or nearly so in drying; palea as long as the lemma or only slightly shorter. $\odot-$ Open ground, cultivated soil, rare, eastern Maryland; introduced from Europe.

30. Bromus arenárius Labill. Australian chess. (Fig. 46.)

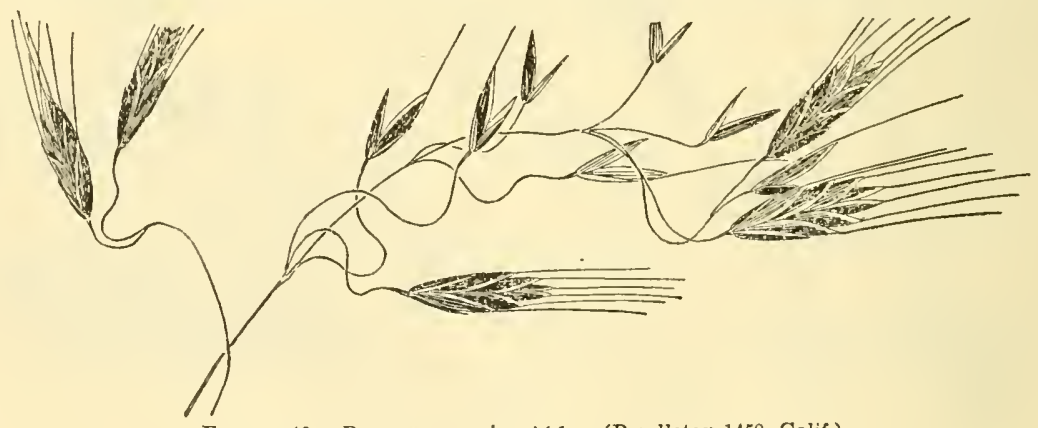

Figure 46. - Bromus arenarius, $\times 1$. (Pendileton 1459, Calif.)

Culms slender, 15 to $40 \mathrm{~cm}$ tall, sheaths and blades pilose; panicle open, pyramidal, nodding, 8 to 11 (rarely 15) $\mathrm{cm}$ long, the spreading branches and pedicels sinuously curved; glumes densely pilose, acute, scarious-margined the first narrower, 3-nerved, $8 \mathrm{~mm}$ long, the 
second 7-nerved, $10 \mathrm{~mm}$ long; lemmas densely pilose, 7 -nerved, $10 \mathrm{~mm}$ long; awn straight, 10 to $16 \mathrm{~mm}$ long. $\odot$ - Sandy roadsides, gravelly or sterile hills, Oregon, California, and Nevada; introduced from Australia.

\section{Section 4. Eubrómus Godr.}

Tufted annuals; spikelets compressed; glumes and lemmas narrow, long-awned; first glume 1-nerved, the second 3-nerved; lemma 5 - to 7-nerved, cleft at the apex, the hyaline teeth 2 to $5 \mathrm{~mm}$ long; floret at maturity with a sharp hard point or callus. Introduced from Europe.

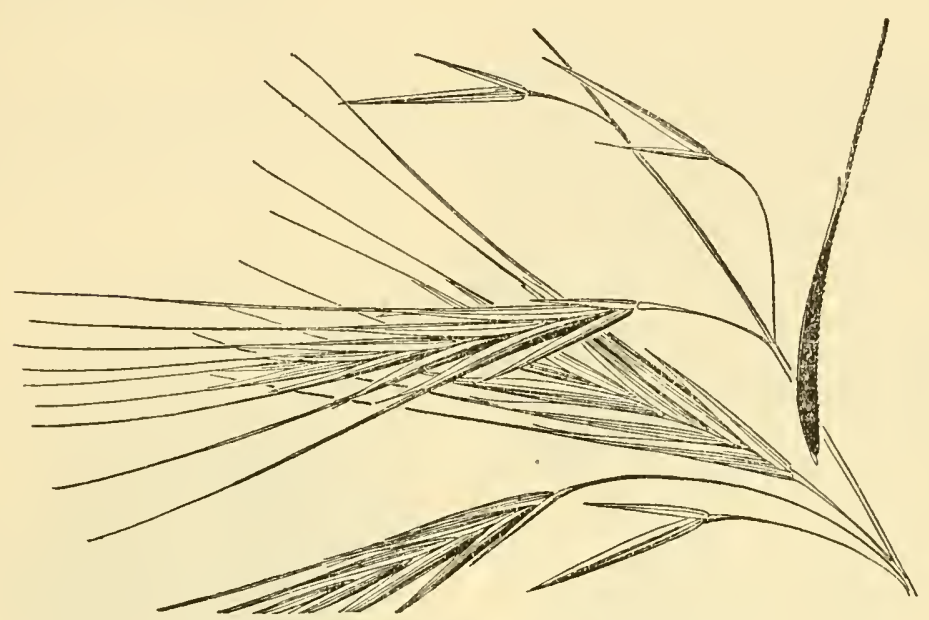

Figure 47,-Bromus rigidus, $\times 1$. ('Tracy 4702, Calif.)

31. Bromus rígidus Roth. Ripgut grass. (Fig. 47.) Culms 40 to $70 \mathrm{~cm}$ tall; sheaths and blades pilose; panicle open, nodding, rather few-flowered, 7 to $15 \mathrm{~cm}$ long, the lower branches 1 to $2 \mathrm{~cm}$ long; spikelets usually 5- to 7-flowered, 3 to $4 \mathrm{~cm}$ long; glumes smooth, the first 1.5 to $2 \mathrm{~cm}$ long, the second 2.5 to $3 \mathrm{~cm}$ long; lemmas 2.5 to $3 \mathrm{~cm}$ long, scabrous or puberulent, the tecth 3 to $4 \mathrm{~mm}$ long; awn stout, 3.5 to $5 \mathrm{~cm}$ long. $\odot \quad$ (B. villosus Forsk. not Scop.; B. maximus Desf. not Gilib.)-Common weed in open ground and waste places in the southern half of California, forming dense stands over great areas in the lowlands, occasional north to British Columbia and east to Idaho, Nevada, and Arizona; rare in the Eastern States, Maryland, Virginia, Texas (fig. 48). Distinguished from the other species of the section by the long awns. Bromus rigidus var. gussónei (Parl.) Coss.

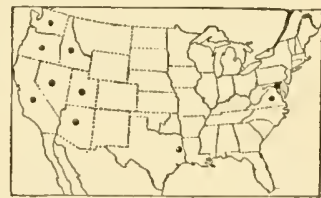

Figure 48--Distribution of Bromus rigidus. and Dur. Differing in having more open panicles, the stiffer, more spreading lower branches as much as 10 to $12 \mathrm{~cm}$ long. $\odot-W e e d$ like $B$. rigidus, growing in similar places, Washington to California, and Arizona: more common than the species in middle and northern California. 
32. Bromus stérilis L. (Fig. 49.) Resembling B. rigidus, less robust; culms 50 to $100 \mathrm{~cm}$ tall; sheaths pubescent; panicle 10 to 20

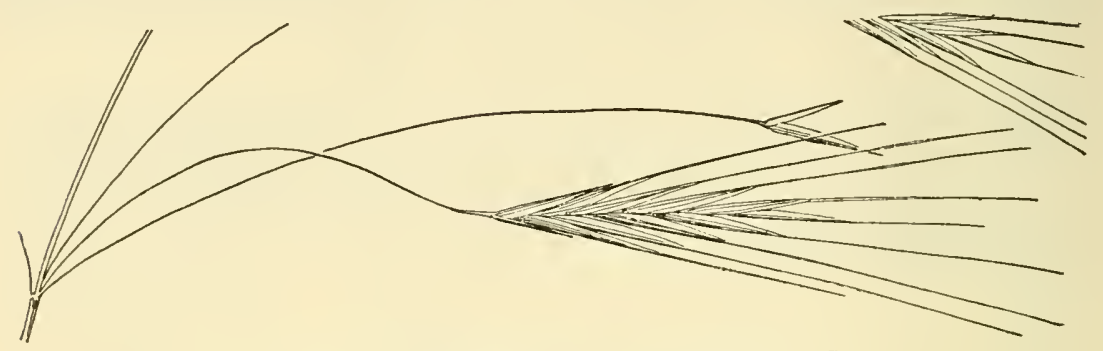

Figure 49,-Bromus sterilss, $\times 1$. (Boettcher 2423, D.C.)

cm long, the branches drooping; spikelets 2.5 to $3.5 \mathrm{~cm}$ long, 6- to 10-flowered; glumes lanceolate-subulate, the first about $8 \mathrm{~mm}$ long; lemmas 17 to $20 \mathrm{~mm}$ long, scabrous or scabrous-pubescent, the teeth $2 \mathrm{~mm}$ long; awn 2 to $3 \mathrm{~cm}$ long. $\odot$-Fields and waste places, introduced in a few localities from British Columbia to California and Colorado, and the Eastern States from New England and Illinois to Virginia and Alabama (fig. 50).

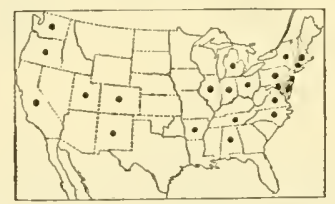

FIGURE 50.-Distribution of Bromus sterilis.

33. Bromus rúbens L. FoxTAIL Chess. (Fig. 51.) Culms 15 to $40 \mathrm{~cm}$ tall, puberulent below the panicle; sheaths and blades pubescent; panicle erect, compact, ovoid, usually 4 to $8 \mathrm{~cm}$ long, usually purplish; spikelets 4- to 11flowered, about $2.5 \mathrm{~cm}$ long; first glume 7 to $9 \mathrm{~mm}$ long, the second 10 to $12 \mathrm{~mm}$ long; lemmas, scabrous, 12 to $16 \mathrm{~mm}$ long, the teeth 4 to $5 \mathrm{~mm}$ long; awn 18 to $22 \mathrm{~mm}$

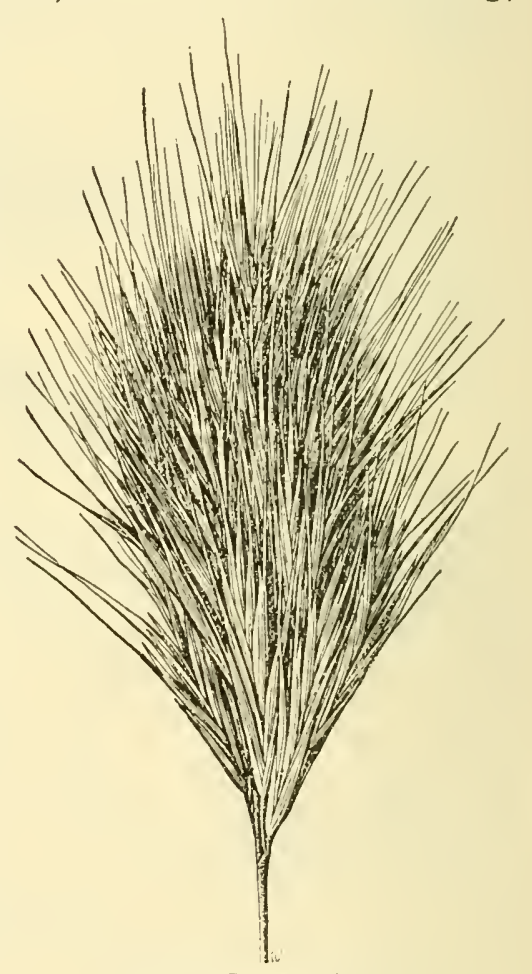

Figure 51.-Bromus rubens, $\times 1$. (Blankenship 36, Calie.) long, somewhat spreading at maturity. $\odot-$ Dry hills and in waste or cultivated ground, Washington to southern California, very abundant over extensive areas, and east to Utah and Arizona; Massachusetts (fig, 52). 
34. Bromus madriténsis L. (Fig. 53.) Resembling B. rubens but the culms smooth below the less dense panicles; sheaths mostly smooth; blades puberulent or glabrous; panicle 5 to $10 \mathrm{~cm}$ long, oblong-ovoid (in dried specimens more or less fan-shaped); lemmas a little longer than in $B$. rubens, the teeth 2 to $3 \mathrm{~mm}$ long; awn rather stout, 16 to $22 \mathrm{~mm}$ long. $\odot$-Open ground and waste places, Oregon and California; less common

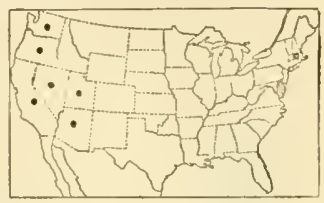

FIgURE 52,-Distribution of Bromus rubens. than B. rubens. Occasionally cultivated for ornament.

35. Bromus tectórum L. Downy chess. (Fig. 54.) Culms erect or spreading, slender, 30 to $60 \mathrm{~cm}$ tall; sheaths and blades pubescent;

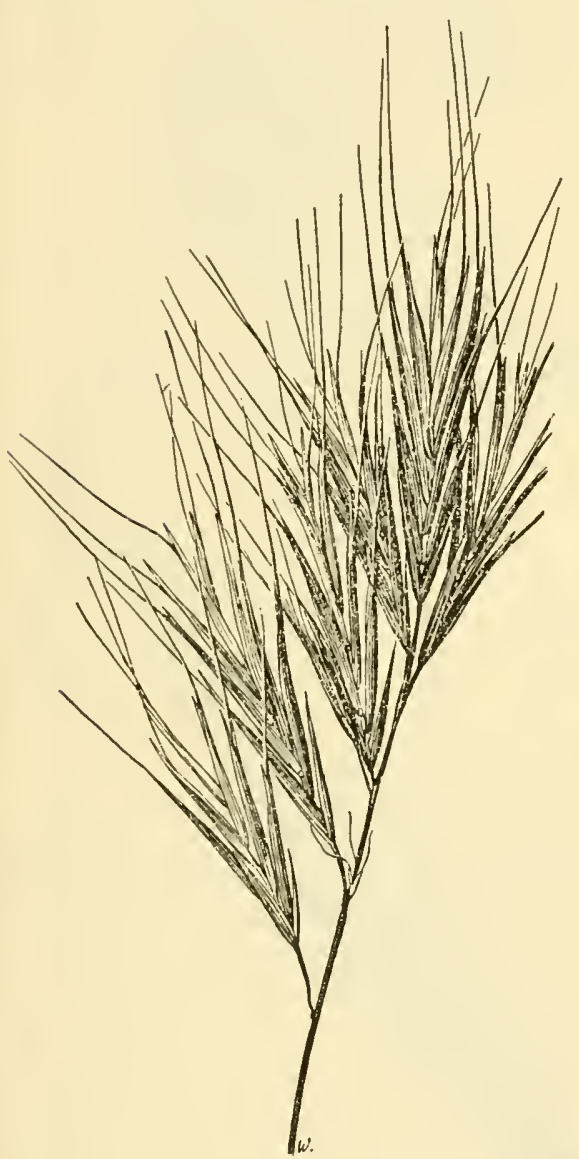
panicle 5 to $15 \mathrm{~cm}$ long, rather dense, soft, drooping, often purple; spikelets nodding, 12 to 20 $\mathrm{mm}$ long; glumes villous, the first 4 to $6 \mathrm{~mm}$ long, the second 8 to $10 \mathrm{~mm}$ long; lemmas lanceolate, villous or pilose, 10 to 12 $\mathrm{mm}$ long, the teeth 2 to $3 \mathrm{~mm}$ long; awn 12 to $14 \mathrm{~mm}$ long. $\odot$-Along roadsides, banks, and waste places, common on the Pacific coast, especially in Washington and Oregon, and here and there throughout the United States as far south as Virginia and Mississippi (fig. 55). BROMUS TECTORUM var. GLABRÁtus Spenner. Differing in having glabrous spikelets.

(B. tectorum var. nudus Klett and Richt.)-About the same range as the species, less common.

\section{Section 5.-Neobrómus Shear, as subgenus}

Annual; lemmas lanceolate, deeply bifid, the teeth aristate; awn twisted, geniculate. Approaches Trisetum.

36. Bromus trínii Desv.

CHILIAN CHESS. (Fig. 56.)

Culms 30 to $60 \mathrm{~cm}$ or even 100 $\mathrm{cm}$ tail, erect or branched and spreading below, often pubescent FIGURE 53. - Bromus madritensis, $\times$ 1. (Eastwood, Calif.) at the nodes; sheaths and blades pilose-pubescent to nearly smooth; panicle 8 to $20 \mathrm{~cm}$ long, narrow, rather dense, erect, the branches erect or the lower more or less 


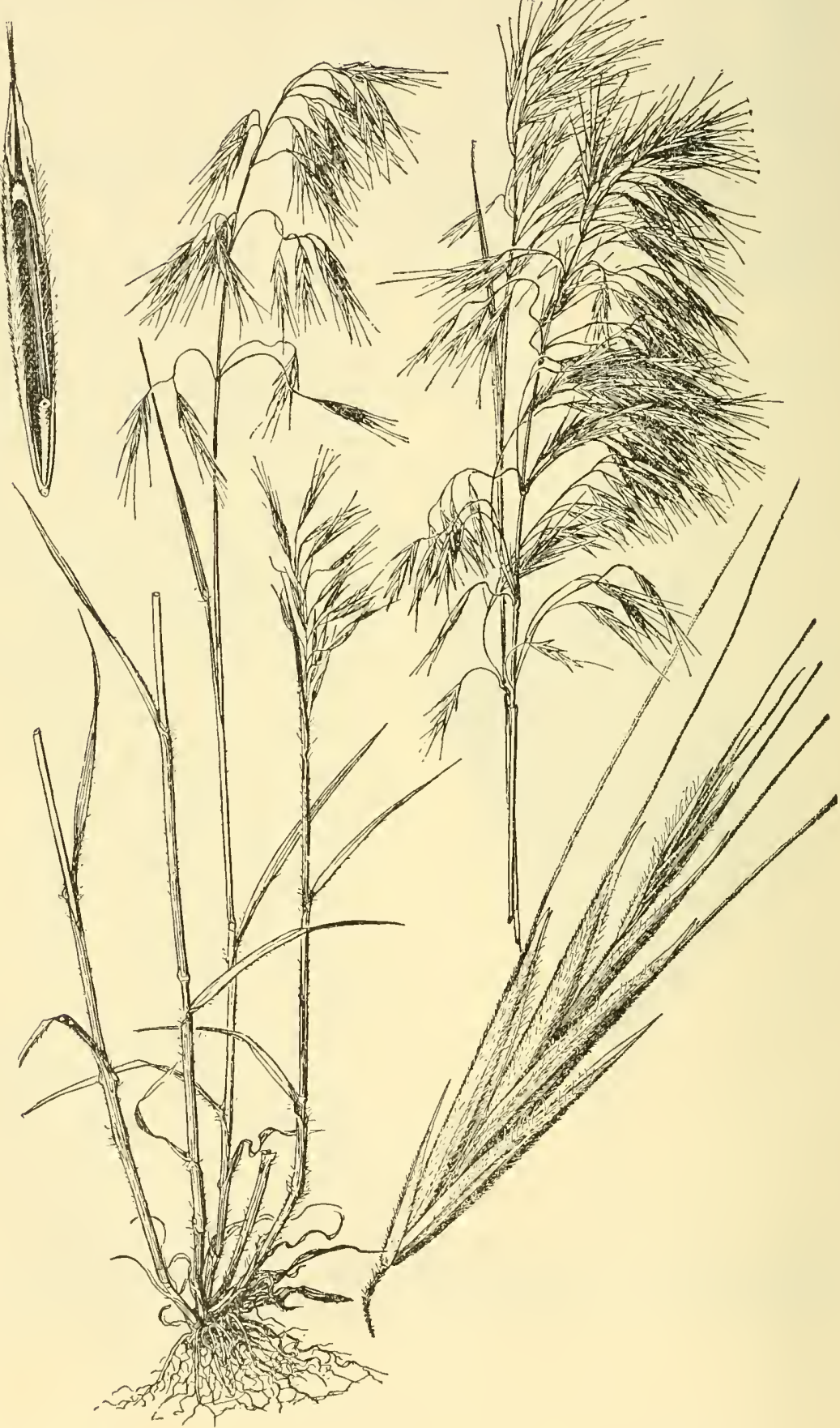

Figure 54,-Bromus tectorum. Plant, $\times 1 / 2$; spikelet and floret, $\times$ 5. (Chase 2051, Ind.) 
spreading or flexuous; spikelets narrow, 1.5 to $2 \mathrm{~cm}$ long, 5- to 7flowered; glumes lanceolate, acuminate, the first mostly 1-nerved, 8 to $10 \mathrm{~mm}$ long, the second mostly 3 -nerved, 12 to $16 \mathrm{~mm}$ long; lemmas 5-nerved, 12 to $14 \mathrm{~mm}$ long, pubescent, acuminate, with narrow teeth 2 to $3 \mathrm{~mm}$ long, the teeth aristate; awn 1.5 to $2 \mathrm{~cm}$ long, twisted below, bent below the middle and strongly, divaricate when old. $\odot$ (Including $B$.trinii var. pallidiflorus Desv.) - Dry plains and rocky or wooded slopes, Oregon, California, and Baja California, rarely eastward to Colorado; introduced from Chile (fig. 57).

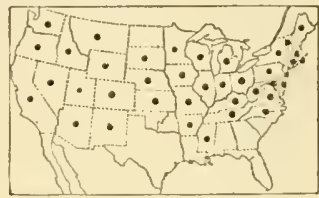

FIGURE 55.-Distribution of Bromus tectorum.

Bromus trini var. Excélsus Shear. Differing in having larger spikelets, 7-nerved lemmas, and divaricate but not twisted or bent awns; teeth of the lemma acuminate, but not aristate. $\odot-A$ little-

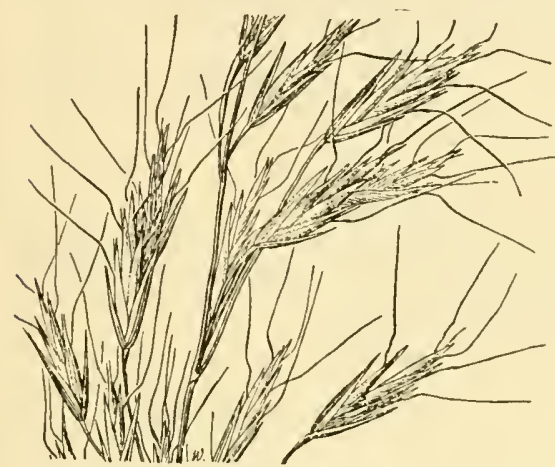

Figure 56.-Bromus trinii, $\times 1$. (Eastwood, Calif.) known form from the Panamint Mountains, Calif.

The genus Brachypódium Beauv. is represented in the United States by one species found only on ballast, and another occasionally cultivated. The genus is placed in Festuceae though it resembles Agropyron, differing from it in having short-pediceled spikelets. Lemmas, rounded on the back. B R A C HY PODIUM DISTÁCHYON (L.) Beauv. (Bromus distachyos L.) is an annual 10 to $20 \mathrm{~cm}$ tall, with short flat blades and an erect stiff raceme of 1 to few appressed almost sessile awned spikelets. $\odot$ - On ballast, New Jersey (Camden) and Oregon (Portland). Adventive from Europe. BrachYPODidm sylváticum (Huds.) Beauv. is a perennial with usually several spikelets in a raceme. 24 -Occasionally cultivated for ornament. Europe.

\section{FESTÚCA L. Fescue}

Spikelets few- to several-flowered (rarely 1-flowered in some of the spikelets of a panicle), the rachilla disarticulating above the glumes and between the florets, the uppermost floret reduced; glumes narrow, acute, unequal, the first sometimes very small; lemmas rounded on the back, membranaceous or soniewhat indurate, 5-nerved, the nerves often obscure, acute or rarely obtuse, awned from the tip, or rarely from a minutely bifid apex, sometimes awnless. Low or rather tall annuals or perennials, the spikelets in narrow or open panicles.

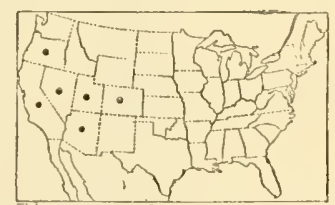

FIGURE 57.-Distribution of Bromus trinii.

The blades are sometimes somewhat auriculate as in the Hordeae. Standard species, Festuca ovina. Name from Festuca, an old Latin name for a weedy grass.

Many of the perennial species of fescue are important forage grasses in the grazing regions of the West. Festuca arizonica, Arizona fescue, 
of northern Arizona and $F$. idahoensis, bluebunch fescue, of the region from Colorado to central California and northward, are important, though they become rather tough with age. $F$. viridula, greenleaf fescue, locally called mountain bunchgrass, is an outstanding grass in subalpine regions of the Northwestern States, and $F$. thurberi, Thurber fescue, is important in similar regions from Colorado to Montana. F. ovina, sheep fescue, is a good grazing grass though not abundant, but its variety brachyphylla, alpine fescue, furnishes much of the forage above timber line from the Rocky Mountains westward. $F$. occidentalis, western fescue, in open woods up to 10,000 feet in the Northwest, and F. rubra, red fescue, widely distributed at various altitudes in the West, are valuable in proportion to their abundance.

The most important cultivated species is $F$. elatior, meadow fescue, a native of Europe, used for hay and pasture in the humid region, especially in Tennessee, Missouri, and Kansas. F. ovina, and its allies, and F. rubra, are cultivated to a limited extent in the Eastern States as lawn or pasture grasses, usually in mixtures.

Plants annual.

Section 1. Vulpia. Plants perennial SeCtion 2. EUfestuca.

\section{Section 1. Vulpia}

1a. Spikelets mostly more than 5-flowered. Lowest lemma 4 to $5 \mathrm{~mm}$ long, the margin inrolled, not scarious......

1b. Spikelets mostly less than 5-flowered (sometimes 6-flowered in $F$. dertonensis and $F$. sciurea). Lemmas usually scarious-margined.

2a. Panicle narrow, the branches appressed.

Lemmas appressed-pubescent over the back, about $3 \mathrm{~mm}$ long.

Lemmas glabrous, scabrous or ciliate, not pubescent over the back.

2. F. SCIUREA.

Lemmas ciliate toward the apex .............. 3. F. MEGALURA.

Lemmas not ciliate.

First glume two-thirds to three-fourths as long as the second.

4. F. DERTONENSIS.

First glume much shorter than the second, 1 to $2 \mathrm{~mm}$ long.

5. F. MYUROS.

2b. Panicle rather short, the branches and often the spikelets spreading (scarcely spreading in $F$. arida).

3a. Spikelets glabrous.

Pedicels appressed; lower branches of the panicle usually finally reflexed; spikelets usually 3- to 5-flowered.......... 6 . F. PACrFica.

Pedicels or nearly all of them finally refiexed, notably those of the upper part of the main axis; branches of the panicle reflexed; spikelets mostly 1- or 2-flowered._._......

3b. Spikelets pubescent, the pubescence on glumes or lemmas or on both.

4a. Pedicels appressed or slightly spreading; lower branches of panicle usually spreading or reflexed.

Lemmas glabrous; glumes pubescent__._. . . . 7. F. CONFUSA.

Lemmas pubescent.

Lemmas hirsute; glumes glabrous or pubescent; lower branches of panicle spreading or reflexed............. 8. F. GRAYI. Lemmas woolly-pubescent; glumes glabrous; panicle nearly simple, the branches scarcely spreading._..._...... 9. F. ARIDA.

4b. Pedicels and panicle branches all finally spreading or reflexed.

Glumes glabrous; lemmas pubescent_..._._._. 11. F. Microstachys. Glumes pubescent; lemmas pubescent....... 12. F. EASTWOOdAE. Glumes pubescent; lemmas glabrous............ 13. F. TRACY. 


\section{Section 2. Eufestuca}

1a. Blades flat, rather soft and lax (except in F. kingii), mostly more than $3 \mathrm{~mm}$ wide.

Lemmas awned, the awn usually more than $2 \mathrm{~mm}$ long.

Floret long-stipitate, the rachilla appearing to be jointed a short distance below the floret.......

Floret not stipitate.

Lemmas indistinctly nerved; awn terminal; blades 3 to $10 \mathrm{~mm}$ wide.

15. F. SUBULATA.

Lemmas distinctly 5 -nerved; awn from between 2 short teeth; blades 2 to $4 \mathrm{~mm}$ wide $\ldots \ldots$ 16. F. ELMERI.

Lemmas awnless or with an awn rarely as much as $2 \mathrm{~mm}$ long.

Spikelets oblong to linear, mostly 8 - to 10 -flowered and more than $10 \mathrm{~mm}$ long

Spikelets ovate or oval, mostly not more than 5-flowered, less than $10 \mathrm{~mm}$ long.

Panicles narrow, the branches short, appressed; blades firm, erect.

18. F. KINGIT.

Panicles open, the branches spreading, naked below; blades lax, spreading. Lemmas acuminate, sometimes with an awn as much as $2 \mathrm{~mm}$ long, membranaceous, distinctly nerved, 6 to $9 \mathrm{~mm}$ long. 19 . F. SORoRiA Lemmas awnless, obtuse to acutish, rather firm, indistinctly nerved.

Lemmas 5 to $7 \mathrm{~mm}$ long, acutish_......... 20. F. versuta.

Lemmas about $4 \mathrm{~mm}$ long, relatively blunt, rather turgid.

Spikelets loosely scattered in a very open panicle with long slender branches_..

Spikelets somewhat aggregate toward the ends of rather short branches of a less open nodding panicle _... 22. F. SHorti.

1b. Blades involute or if flat less than $3 \mathrm{~mm}$ wide (sometimes flat in $F$. californica but firm and soon involute).

Ligule 2 to $4 \mathrm{~mm}$ long or longer. Lemmas awnless or cuspidate.

Lemmas $7 \mathrm{~mm}$ long.... THURBER. Lemmas $4 \mathrm{~mm}$ long

Ligule short.

Collar and mouth of sheath villous. Culms tall and stout (rather short in var. parishii)

Collar and mouth of sheath not villous.

Panicle branches densely ciliate on the angles. Blades about $1 \mathrm{~mm}$ wide, flat or folded ...

Panicle branches not ciliate on the angles.

Culms decumbent at the usually red, fibrillose base, in loose tufts. Awn of lemma shorter than the body; blades smooth_-- 29. F. RUBRA.

Culns erect.

Leinmas 7 to $10 \mathrm{~mm}$ long, scabrous. Culms densely tufted, rather stout, usually scabrous below the panicle; lemmas acute, rarely short-awned -.....

Lemmas mostly not more than $7 \mathrm{~mm}$ long.

Lemmas awnless (see also $F$, arizonica).

Lemmas 6 to $7 \mathrm{~mm}$ long; culms slender, loosely tufted.

2S. F. VIRIDULA.

Lemmas about $3 \mathrm{~mm}$ long............ 32. F. CApillata.

Lemmas awned.

Awn as long as or longer than body of the lemma; blades soft, glabrous, sulcate

Awn shorter than body of the lemma; blades slender, numerous, usually scabrous.

Blades mostly not more than half as long as the culms; panicle narrow, often almost spikelike, few-flowered, mostly less than $10 \mathrm{~cm}$ long; culms mostly less than $30 \mathrm{~cm}$ tall.

31. F. OVINA.

Blades elongate; panicles 10 to $20 \mathrm{~cm}$ long, somewhat open; culms 30 to $100 \mathrm{~cm}$ tall.

Awn 2 to $4 \mathrm{~mm}$ long.

33. F. IDAHOENSIS.

Awn short or obsolete

34. F, ARIZONICA. 


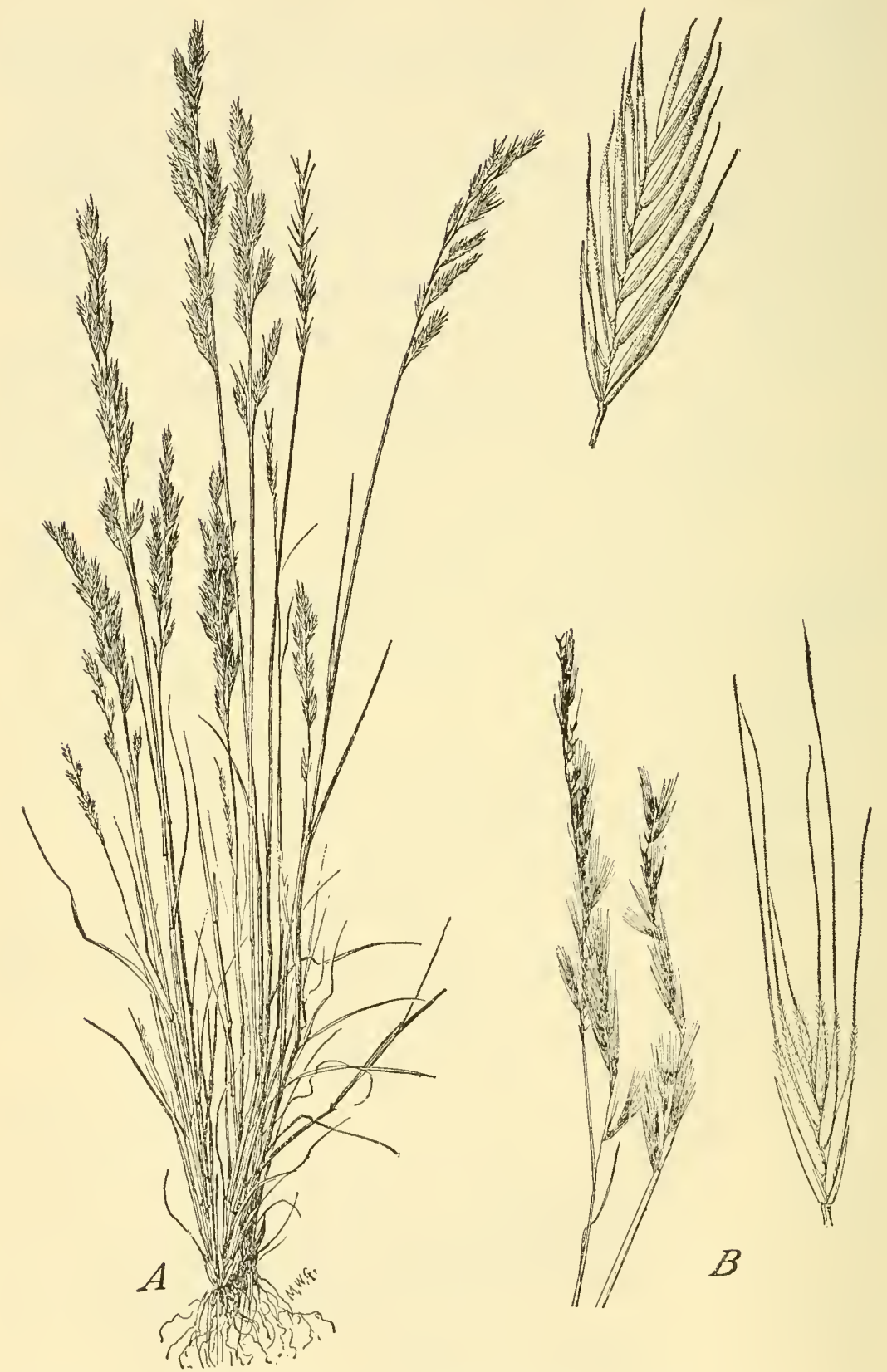

Figure 58.-A, Festuca octofiora. Plant, $\times 1 / 2$; spikelet, $\times 5$. (Chase 1776, Ind.) B, F. sciurea. Panicle $\times 1 / 2$; spikelet, $\times 5$. (Reverchon, Tex.) 
Section 1. Vúlpia (Gmel.) Reichenb.

Slender annuals; lemmas awned; stamens usually 1, sometimes 3; flowers usually self-pollinated. Some of the species, especially numbers 7 to 13 , resemble each other closely. The differences, though small, appear to be constant, hence the recognizable forms are maintained as species, rather than reduced to varieties under leading species.

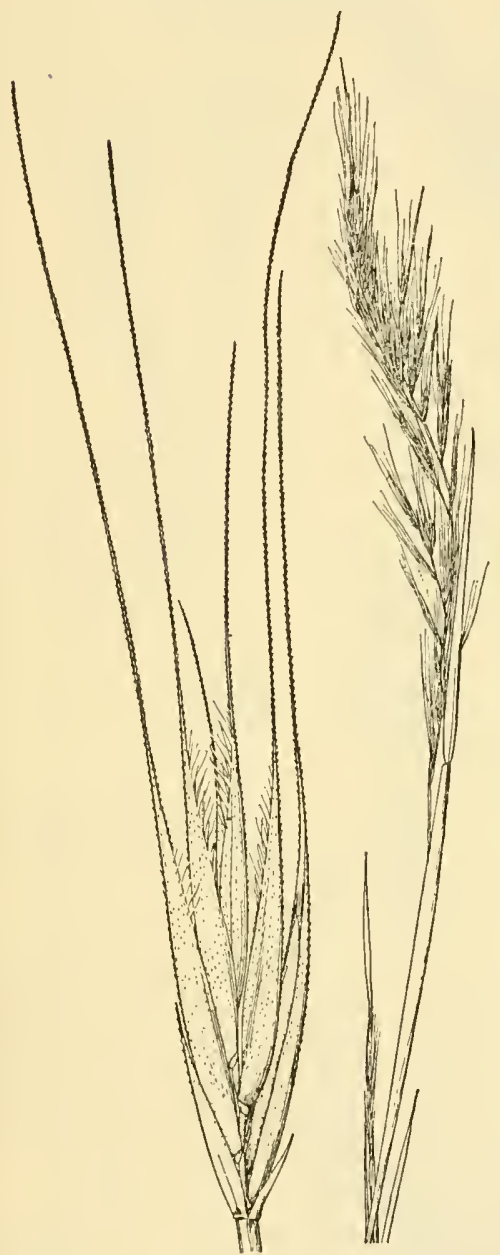

Figure 60-Feotuca megatura, Panicle, $\times 1$; spikelet, $\times 5$. (Leiberg 150, Oreg.)

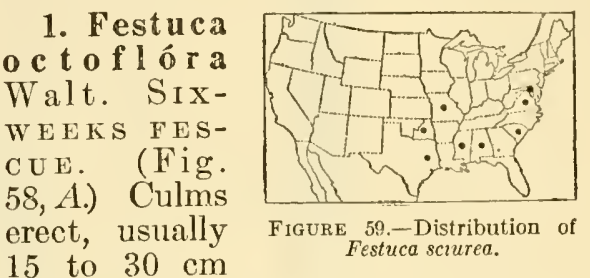
tall, sometimes as much as $50 \mathrm{~cm}$; blades narrow, involute, 2 to $10 \mathrm{~cm}$ long; panicle narrow, the branches short, appressed, rarely spreading; spikelets 6 to $8 \mathrm{~mm}$ long, densely 5to 13-flowered; glumes subulatelanceolate, the first 1-nerved, the second 3-nerved, $4 \mathrm{~mm}$ long; lemmas firm, convex, lanceolate, glabrous or scabrous, 4 to $5 \mathrm{~mm}$ long, the margins not scarious; awn commonly 2 to $5 \mathrm{~mm}$ long. $\odot$ (F. tenella Willd.)-Open sterile ground, throughout the United States and southern Canada at low altitudes, extending into Baja California. FesTUCA OCTOFlora var. hiRTélla Piper. Plants low and spreading; foliage sometimes pubescent; lemmas hirtellous or pubescent. $\odot$ - Texas to southern California, southward in Baja California and northward to

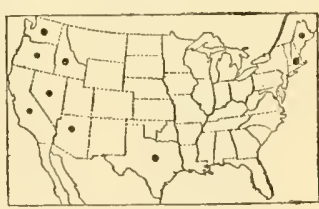

Figure 61.-Distribution of Festuca megalura.

Nevada, Montana, and Washington.

2. Festuca sciúrea Nutt. (Fig. 58, B.) Culms erect, 15 to $50 \mathrm{~cm}$ tall; blades less than $1 \mathrm{~mm}$ wide, often capillary, soft, mostly involute, 1 to $10 \mathrm{~cm}$ long; panicle narrow, 5 to $20 \mathrm{~cm}$ long; spikelets 4 - to 6 -flowered, 4 to $5 \mathrm{~mm}$ long; first glume $2 \mathrm{~mm}$ long, the second $3.5 \mathrm{~mm}$ long; lemmas 3 to $3.5 \mathrm{~mm}$ long, sparsely appressed-pubescent; awn 6 to $11 \mathrm{~mm}$ long. $\odot-$-Open ground, Maryland to Florida, west to Oklahoma and Texas (fig. 59).

3. Festuca megalúra Nutt. Foxtail fescue. (Fig. 60.) Culms 20 to $60 \mathrm{~cm}$ tall; sheaths and narrow blades glabrous; panicle narrow, 
7 to $20 \mathrm{~cm}$ long, the branches appressed; spikelets 4- or 5-flowered; first glume 1.5 to $2 \mathrm{~mm}$ long, the second 4 to $5 \mathrm{~mm}$ long; lemmas

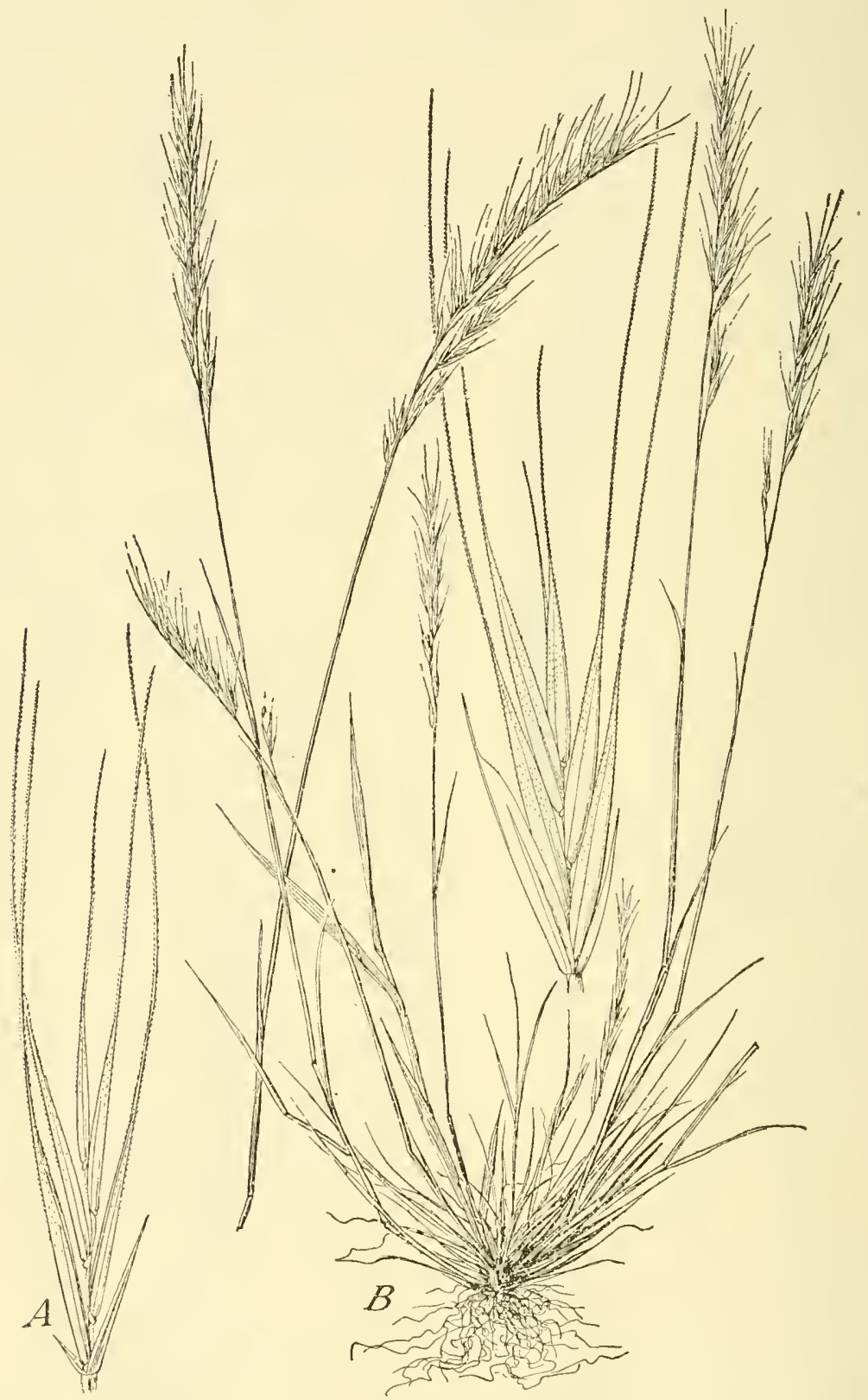

Figure 62.-A, Festuca myutos, spikelet, $\times 5$. (Chase 2393, D. C.) B, F. dertonensis. Plant, $\times 1 / 2$; spike-

linear-lanceolate, scabrous on the back especially toward the apex, ciliate on the upper half; awn 8 to $10 \mathrm{~mm}$ long. $\odot$-Open sterile 
ground, British Columbia to Baja California, common in the Coast Ranges of California, east to Idaho and Arizona and 'a few localities eastward; Pacific slope of South America (fig. 61). In mature lemmas the cilia may be obscured by the inrolling of the edges; moistening the floret will bring the cilia to view.

4. Festuca dertonénsis (All.) Aschers. and Graebı. (Fig. 62, B.)

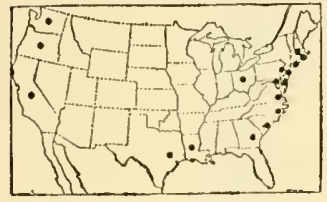

FIgure 63.-Distributlon of Festuca myuros.

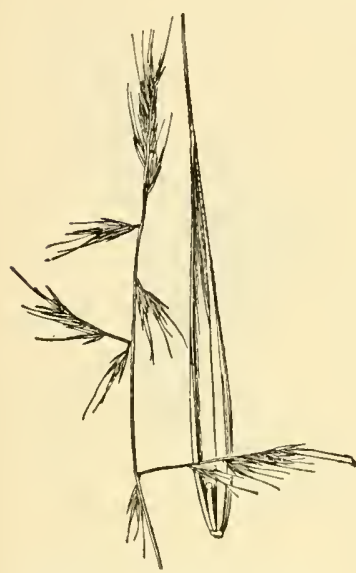

Figure 64.-Festuca pacifica. Panicle, $\times 1 / 2$; floret, $\times 5$ (Type.)

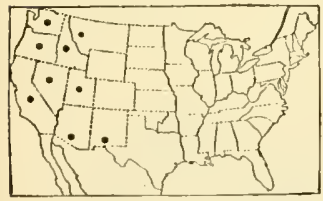

FIGURE 65.-Distribution of Festuca pacifica.
Resembling $F$. megalura, the panicles.on the average shorter, usually less dense; glumes longer, the first about $4 \mathrm{~mm}$ long, the second 6 to 7 $\mathrm{mm}$ long; lemma lanceolate, scabrous on the back toward the apex, 7 to $8 \mathrm{~mm}$ long; awn 10 to 13 mm long. $\odot-$ Dry hills and meadows, British $\mathrm{Co}$ lumbia to southern California; rare as a waif in the Eastern States; introduced from Europe. This species has been referred to $F$. bromoides L. by American authors. 5. Festuca myúros L. (Fig. 62, A.) Differing from $F$. megalura chiefly in the absence of cilia on the lemma; panicle usually smaller, first glume 1 to 1.5 $\mathrm{mm}$, the second 4 to $4.5 \mathrm{~mm}$, long. $\odot-O p e n$ ground, Coastal Plain, Massachusetts to

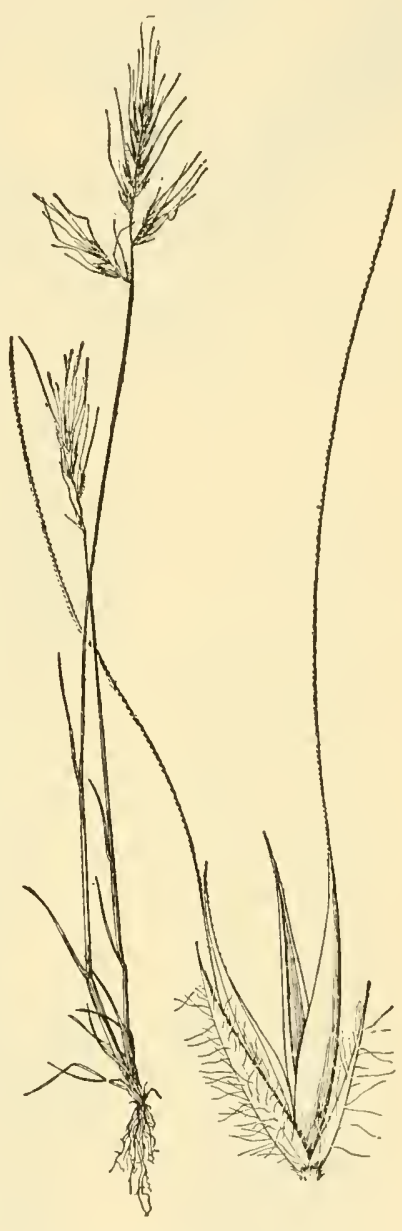

Figure 66.- Festuca confusa. Plant $\times 1$; spikelet, $X 5$. (Type.)

Texas; Ohio; Pacific coast, Washington to southern California (fig. 63); introduced from Europe.

6. Festuca pacífica Piper. (Fig. 64.) Culms erect or geniculate at base, 30 to $60 \mathrm{~cm}$ tall; blades soft, loosely involute, glabrous, 3 to 5 $\mathrm{cm}$ long; panicle 5 to $12 \mathrm{~cm}$ long, the lower branches solitary, somewhat distant, subsecund, spreading, 1 to $3 \mathrm{~cm}$ long; spikelets 3 - to 6-flowered; first glume subulate-lanceolate, about $4 \mathrm{~mm}$ long, the second lanceolate-acuminate, about $5 \mathrm{~mm}$ long; lemmas lanceolate, glabrous or scaberulous, 6 to $7 \mathrm{~mm}$ long; awn 10 to $15 \mathrm{~mm}$ long. 


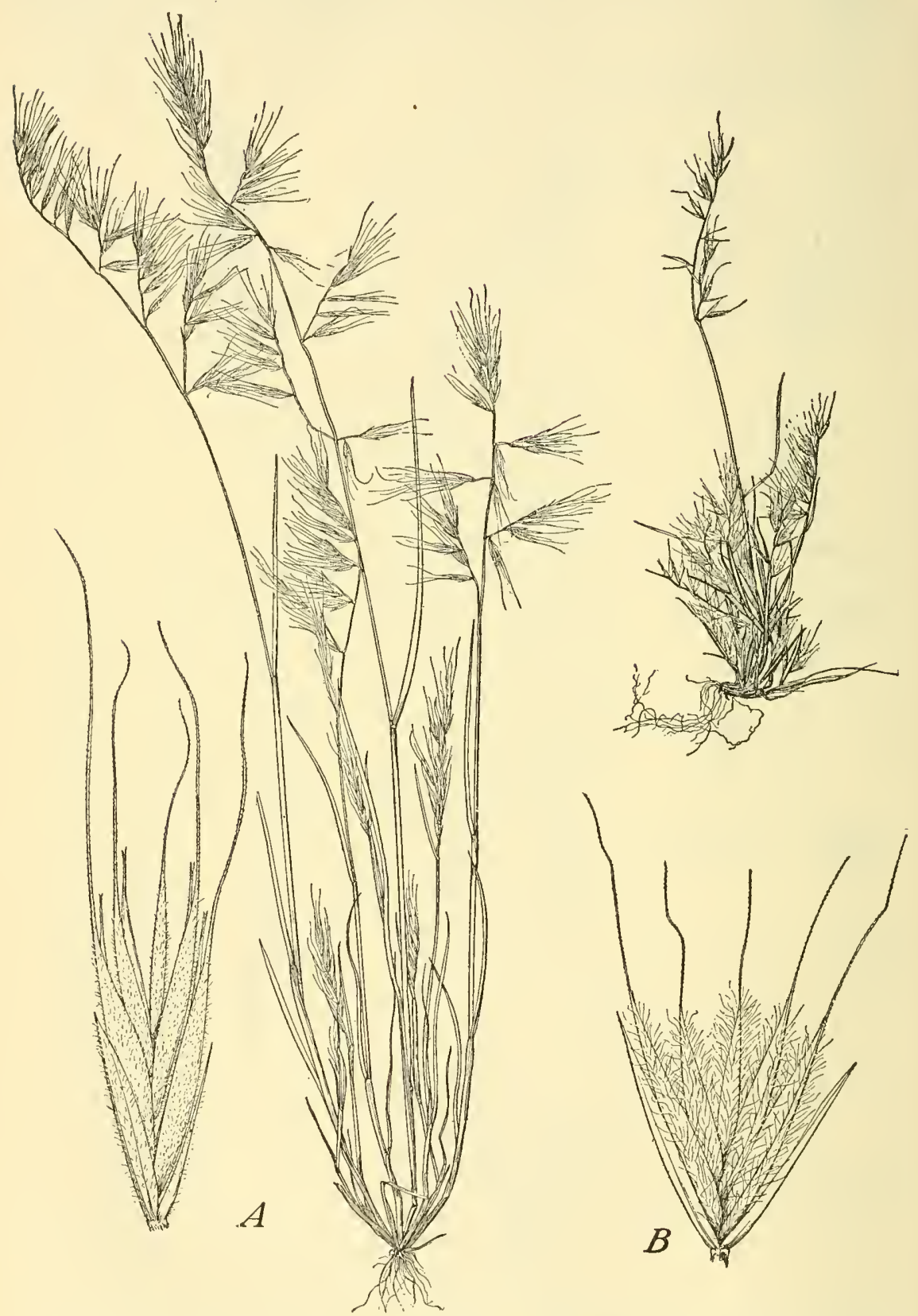

Flgure 67,- A, Festuca grayi. Plaat, $\times 1 \frac{1}{2}$; spikelet, $\times 5$. (Pringle, Ariz.) $B, F$, arida, Phnt, $\times 1 / 2$; spikelet, $\times 5$. (Type.) 
- -Open ground, mountain slopes, and open woods, British Columbia to Baja California, east to western Montana and New Mexico (fig. 65).

7. Festuca confúsa Piper. (Fig. 66.) Pesembling F. pacifica; sheaths retrorsely pilose; foliage pubescent; spikelets usually 2 - or 3 -flowered;

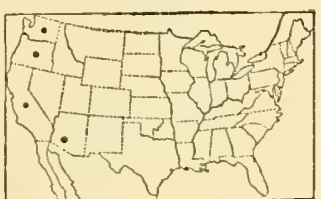

FIGURE 68.-Distribution of Festuca grayi. glumes hirsute with long spreading hairs; lemmas glabrous. $\odot$-Dry hillsides, Washington to southern California.

8. Festuca gráyi (Abrams) Piper. (Fig. $67, A$.) Resembling $F$. pacifica, often somewhat

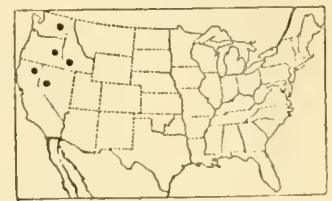

FIGURE 69.-Distribution of Festuca arida.

stouter; sheaths and sometimes blades pubescent; glumes glabrous to sparsely villous; lemmas pubescent, puberulent or sometimes villous. ( $(F$. microstachys var. grayi Abrams.)-Open ground and rocky slopes, Washington to southern California and Arizona (fig. 68).

9. Festuca árida Elmer. (Fig. $67, B$.) Culms erect or spreading, mostly less than $15 \mathrm{~cm}$ tall; sheaths and blades glabrous, the blades loosely involute, mostly less than $4 \mathrm{~cm}$ long; panicle narrow, 2 to 5 cm long, the branches appressed or the lowermost somewhat spreading; glumes about equal, glabrous, 5 to $6 \mathrm{~mm}$ long; lemmas densely woolly, about $5 \mathrm{~mm}$ long; awn 5 to $10 \mathrm{~mm}$ long. $\odot$ - Sandy or dry ground, rare, eastern Washington and Oregon, southwestern Idaho, nor theastern California, and western Nevada (fig. 69).

10. Festuca refléxa Buckl. (Fig. 70, B.) Culms 20 to 40 $\mathrm{cm}$ tall; sheaths glabrous or pubescent; blades narrow, flat to subinvolute, 2 to $10 \mathrm{~cm}$ long; panicle 5 to $12 \mathrm{~cm}$ long, the solitary branches and the spike-

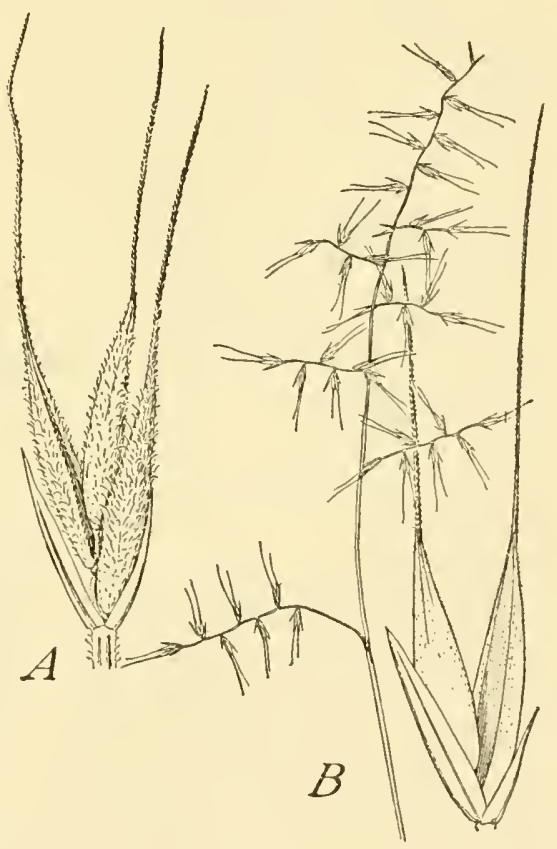

FIgCre 70.-A, Festuca microstachys. Spikelet, $\times 5$. (Allen, Calif.) $\quad B, F$.reflexa. Panicle, $X 1 / 2$; spikelet, $\times 5$. (Brandegee 71 , Calif.) lets all at length divaricate; spikelets mostly 1 - to 3 -flowered, 5 to $7 \mathrm{~mm}$ long; first glume 2 to $4 \mathrm{~mm}$ long, the second 4 to $5 \mathrm{~mm}$ long; lemmas glabrous or seaberulous, 5 to $6 \mathrm{~mm}$ long; awn usually 5 to $8 \mathrm{~mm}$ long. $\odot$-Mesas, rocky slopes, and wooded hills, Washington to southern California, east to Arizona and Utah (fig. 71). 
11. Festuca micróstachys Nutt. (Fig. 70, A.) Resembling $F$. reflexa; glumes glabrous; lemmas pubescent. -Open ground, Washington to California; rare.

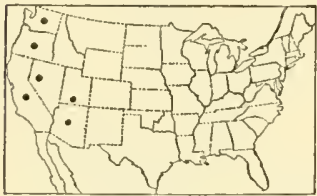

Figure 71.-Distribution of Festuca reflexa.

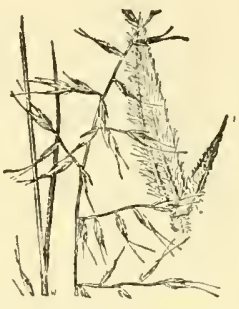

Figure 72,-Festuca eastwoodae. Panicle, $\times 1 / 2$; glumes, $\times 5$. (Type.)

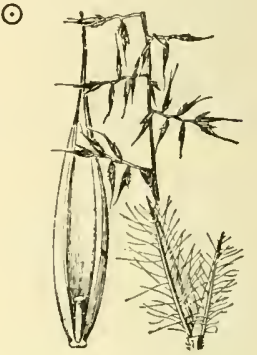

Figure 73.-Festuca tracyi, Panicle, $\times 15$; glumes. $\times 5$; fluret, $\times 5$. (Type.)

12. Festuca eastwoódae Piper. (Fig. 72.) Resembling F. reflexa; glumes hirsute; lemmas hirsute, the awn 4 to $5 \mathrm{~mm}$ long. $\odot$-Open ground, Oregon, Arizona, and California; rare.

13. Festuca trácyi Hitchc. (Fig. 73.) Resembling $F$. reflexa; glumes rather sparsely hispid-villous, the first 1.5 to $2 \mathrm{~mm}$ long, acute, the second 3 to $4 \mathrm{~mm}$ long, obtusish or abruptly acute; lemmas glabrous, about $4 \mathrm{~mm}$ long; awn 4 to 7 mm long. $\odot$ Open rocky ground, Washington (Bingen) and California (Kings and Napa Counties).

Section 2. Eufestúca Griseb.

Perennials; culms simple; stamens 3.

14. Festuca subuliflóra Scribn. (Fig. 74.) Culms erect, slender, 60 to $100 \mathrm{~cm}$ tall; blades flat (or loosely involute in drying), lax, pubescent on the upper surface, those of the culm mostly 2 to $4 \mathrm{~mm}$ wide, those of the innovations narrower; panicle loose, lax, 10 to $20 \mathrm{~cm}$ long, nodding, the branclies drooping, the lower naked at base; spikelets loosely 3- to 5-flowered, the rachilla pubescent or hispid, the internodes of the rachilla as much as $2 \mathrm{~mm}$ long: floret long-stipitate,

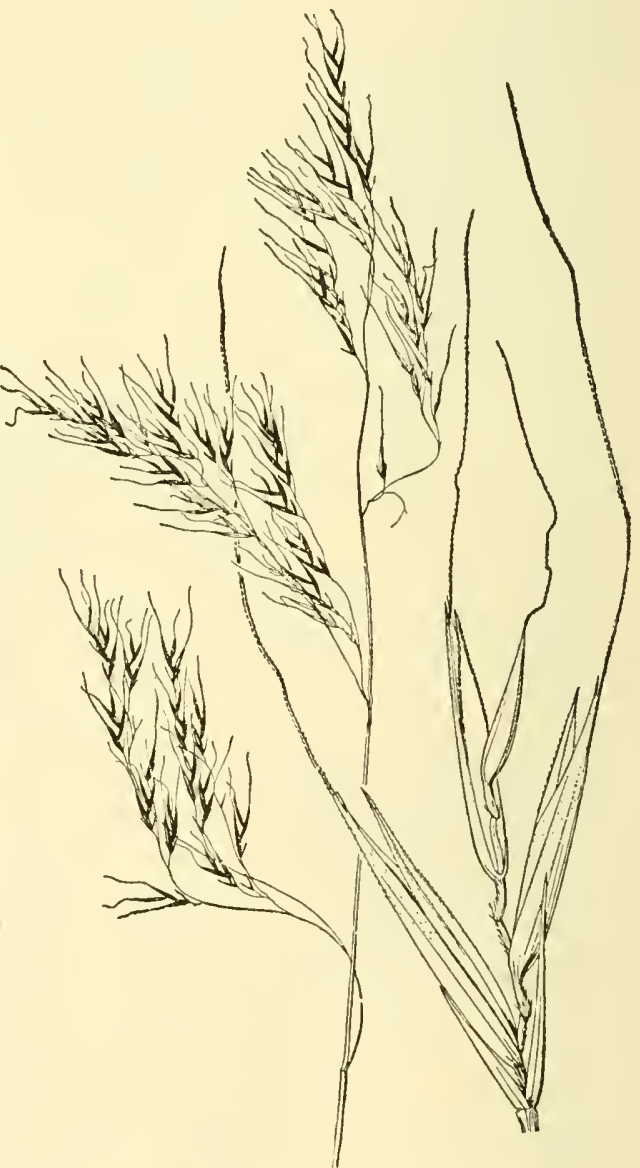

FIGURE 74.-Festuca subulıfora. Panicle, $\times 1 \frac{1}{2}$; spikelet, $\times 5$. (Howell 19, Oreg.)

the rachilla appearing to be jointed a short distance below the floret; glumes very narrow, acuminate, the first 3 to $4 \mathrm{~mm}$, the second 4 to 
$5 \mathrm{~mm}$, long; lemmas scaberulous toward the apex, 6 to $8 \mathrm{~mm}$ long; awn somewhat flexuous, 10 to $15 \mathrm{~mm}$ long. 2 - Moist shady places from sea level to $1,000 \mathrm{~m}$, British Columbia to northern California, mostly near the coast. Peculiar in the stipitate base of the lemma. Aspect of $F$. subulata.

15. Festuca subuláta Trin. BEARDED FESCUE. (Fig. 75.) Culms erect, mostly 50 to 100 cm tall; blades flat, thin, lax, 3 to $10 \mathrm{~mm}$ wide; panicle loose, open, drooping, 15 to $40 \mathrm{~cm}$ long, the branches mostly in twos or threes, naked below, finally spreading or reflexed, the lower as much as

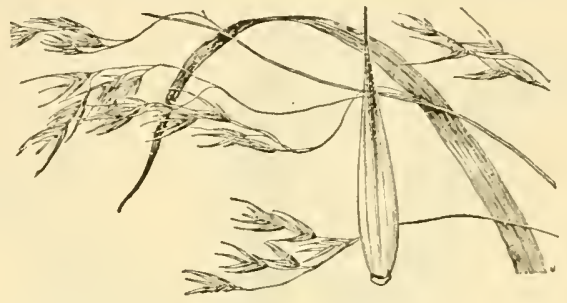

FIGCPE 75.-Festuca subulata. Panicle, X1/2; floret, $\times 5$. (Hitchcock 23511, Oreg.) $15 \mathrm{~cm}$ long; spikelets loosely 3- to 5-flowered; glumes narrow, acuminate, the first about $3 \mathrm{~mm}$, the second about $5 \mathrm{~mm}$, long; lemmas somewhat keeled, scaberulous toward the apex, the intermediate nerves o b s c u re,

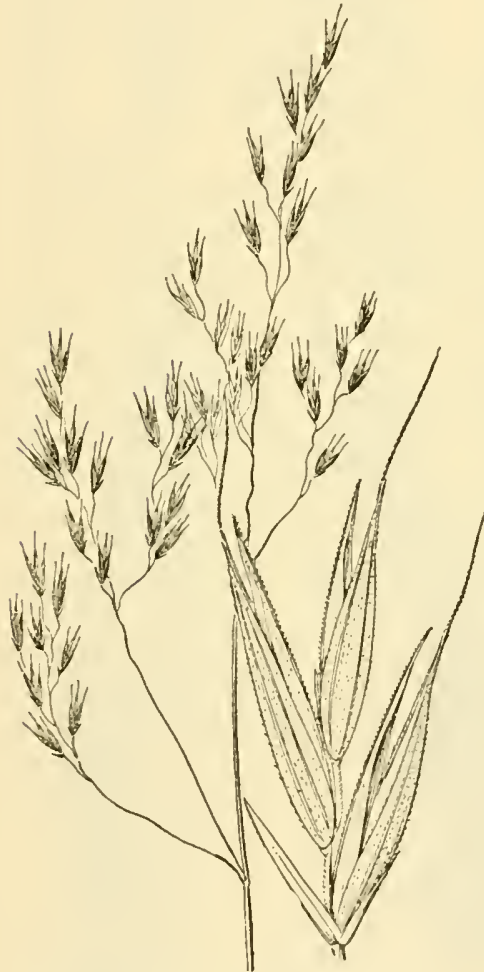

Figure 77.-Festuca elmeri. Panicle, $\times 1 / 2$; spikelet, $\times 5$. (Type.)

the tip attenuate into an awn 5 to 20 mm long. 2 -Shadybanks and moist thickets, up to $2,0000 \mathrm{~m}$,

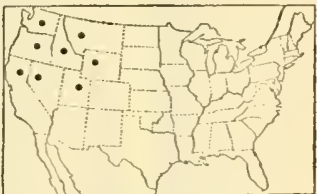

Figure 76.-Distribution of Festuca subulata. southeastern Alaska to Wyoming, Utah, and northern California (fig. 76).

16. Festuca eiméri Scribn. and Merr. (Fig. 77.) Culms loosely tufted, slender 40 to $100 \mathrm{~cm}$ tall, or even taller; blades flat, scabrous or pubescent on upper surface, 2 to 4 $\mathrm{mm}$ wide, those of the innovations narrower, more or less involute; panicle loose, open, 10 to $20 \mathrm{~cm}$ long, the branches slender, somewhat drooping, raked below, the lower as much as $10 \mathrm{~cm}$ long; spikelets 3 or 4 -flowered; glumes lanceolate-acuminate, the first 2 to $2.5 \mathrm{~mm}$, the second 3 to $4 \mathrm{~mm}$, long; lcmmas membranaceous, hispidulous, about $6 \mathrm{~mm}$ long, the nerves rather prominent, the apex minutely 2-toothed; awn 2 to $8 \mathrm{~mm}$ long. 24 - Wooded hillsides, up to $500 \mathrm{~m}$, mostly in the Coast Ranges, Oregon to central California. Festuca elmeri var. conférta (Hack.) Hitche. More luxuriant; spikelets often 5- or 6-flowered and somewhat congested on the panicle branches. 24 ( $F$. jonesii var. conferta Hack.) - Coast Ranges of California. 
17. Festuca elátior L. Meadow fescue. (Fig. 78.) Culms 50 to $120 \mathrm{~cm}$ tall; blades flat, 4 to $8 \mathrm{~mm}$ wide, scabrous above; panicle erect, or nodding at summit, 10 to $20 \mathrm{~cm}$ long, contracted

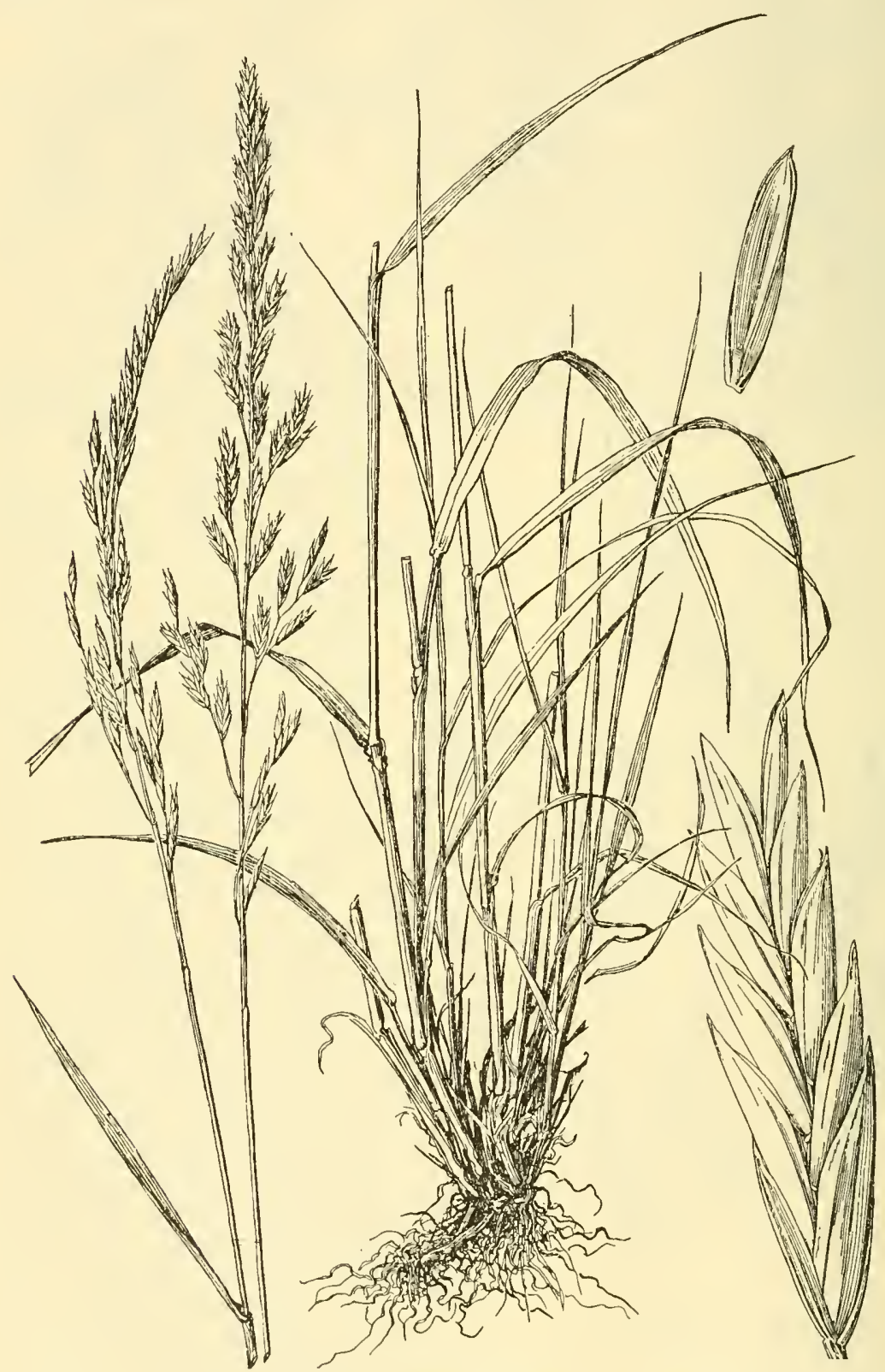

Figure 78. - Festuca elatior. Plant, $\times 1 / 2$; spikelet and floret, $\times 5$. (Amer. Gr. Nat. Herb. 488.)

after flowering, much-branched or nearly simple, the branches spikelet-bearing nearly to base; spikelets usually 6- to 8-flowered, 8 to $12 \mathrm{~mm}$ long; glumes 3 and $4 \mathrm{~mm}$ long, lanceolate; lemmas oblong-lan- 
ceolate, coriaceous, 5 to $7 \mathrm{~mm}$ long, the scarious apex acutish, rarely shortawned. 2 (Festuca pratensis Huds.)-Meadows, roadsides, and waste places; introduced throughout the cooler parts of North America; native of Eurasia. Cultivated for meadow and pasture. Sometimes called English bluegrass. Festuca elatior var. ARUNDINÁCEA (Schreb.) Wimm. Larger form with open panicles and spikelets usually with 4 or 5 florets. 24 -Introduced sparingly from Europe, New York to Washington.

Festuca gigan téa (L.) Vill. Blades broad, flat, thin; panicles open; lemmas long-awned, the awn flexuous and two or three times as long as the lemma. 21 Dobbs Ferry, N.Y.; adventive from Europe.

18. Festuca kíngii (S. Wats.) Cassidy. SPIKE FESCUE. (Fig. 79.) Culms in large dense bunches, stout, erect, 40 to $100 \mathrm{~cm}$ tall, occasionally producing short rhizomes, these usually wanting in herbarium specimens; sheaths

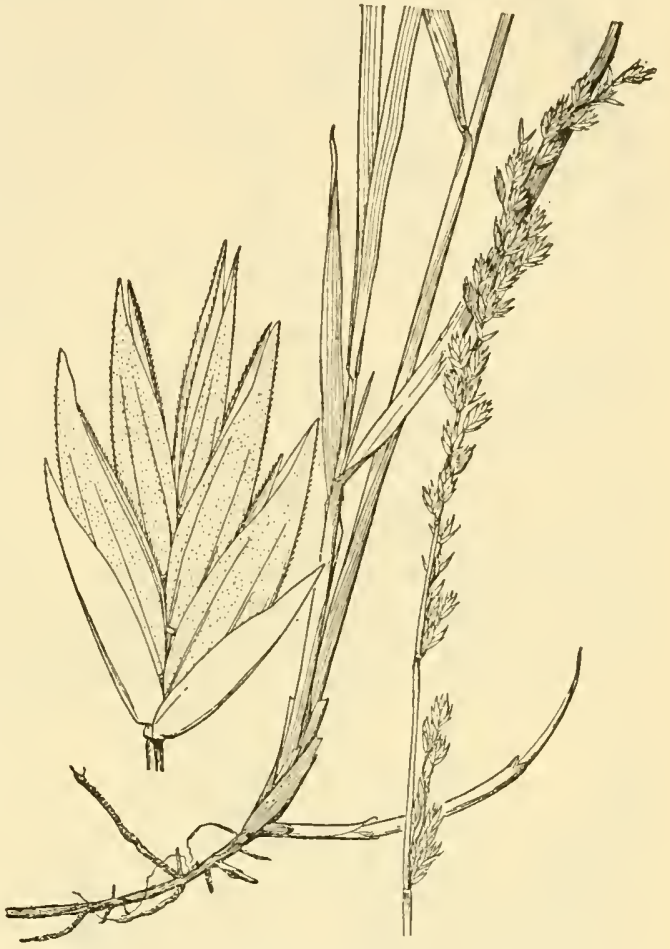

Figure 79.-Festuca kingii. Plant, $\times 1 / 2$, spikelet, $\times 5$. (Osterhout 1897, Colo.)

smooth, striate; blades firm, flat or becoming loosely involute, coarsely striate, 3 to $6 \mathrm{~mm}$ wide; panicle narrow, erect, 7 to $20 \mathrm{~cm}$ long, the branches short, appressed, floriferous nearly to base; spikelets mostly 10 to $12 \mathrm{~mm}$ long; glumes broadly

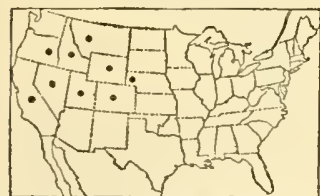

Figure 80.-Distribution of Festuca kingii. lanceolate, subscarious, nearly smooth, the first 3 to $4 \mathrm{~mm}$ long, the second a half longer; lemmas orate, acuminate, convex, faintly nerred, scabrous, 5 to $8 \mathrm{~mm}$ long, awnless. 2 ( $F$. confinis Vasey; Hesperochloa kingii Rydb.)Dry mountains and hills, 2,000 to $3,500 \mathrm{~m}$, Oregon to southern California, east to Montana and Colorado (fig. 80). Festuca KINGII var.

RABIósA (Piper) Hitchc. Blades involute; lemmas short-awned. 2 I - Knnown only from Wyoming (Crazy Womans Creek) and Montana (Beaverhead Forest).

19. Festuca sorória Piper. (Fig. 81.) Culms erect, loosely tufted, 60 to $90 \mathrm{~cm}$ tall; blades flat, thin, smooth except the scabrous margins, 3 to $6 \mathrm{~mm}$ wide; panicle loose, open, nodding, or sometimes somewhat condensed, 10 to $15 \mathrm{~cm}$ long, the branches solitary or in twos, naked below; spikelets rather loosely 3 - to 5-flowered; glumes lanceolate, the first about $3 \mathrm{~mm}$, the second about $5 \mathrm{~mm}$ long; lemmas membrana- 
ceous, somewhat keeled, scaberulous or nearly smooth, the nerves

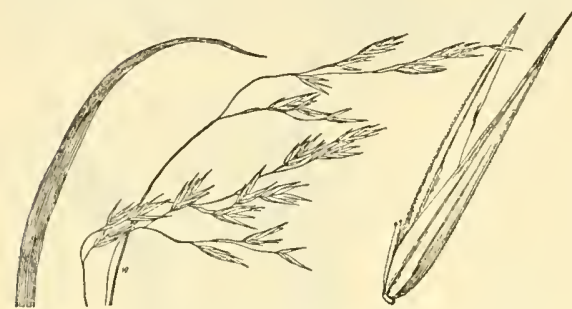

Figure 81.-Festuca sororia. Panicle, $\times 1 / 2$; floret, $\times$ 5. (Baker 36, Colo.)

evident but not prominent, the apex tapering into a fine point or an awn as much as $2 \mathrm{~mm}$ long. $24-O p e n$ woods, 2,000 to $3,000 \mathrm{~m}$, southern Colorado and Utah to New Mexico and Arizona (fig. 82).

20. Festucaversúta Beal. (Fig. 83.) Culms slender, 50 to $100 \mathrm{~cm}$ tall; blades flat, mostly 2 to $5 \mathrm{~mm}$ wide; panicle open, 10 to $15 \mathrm{~cm}$ long, the spreading lower branches bearing a few spikelets above the middle; spikelets 2- to 5-flowered; glumes narrow, acuminate, nearly equal, 5 to $6 \mathrm{~mm}$ long; lemmas firm, obscurely nerved at maturity, 5 to $7 \mathrm{~mm}$ long, acute, awnless. $24 \quad(F$. texana Vasey; $F$. johnsoni Piper.)--Shady banks, Texas and Oklahoma.

21. Festuca obtúsa Spreng. Noding FESCUE. (Fig. 84.) Culms solitary or few in a tuft, mostly 50 to $100 \mathrm{~cm}$ tall; blades flat, 4

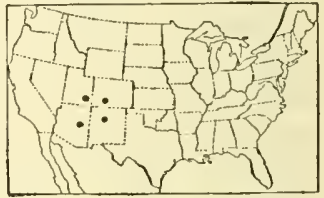

Figure 82.-Distribution of Festuca sororia. to $7 \mathrm{~mm}$ wide; panicle very loose and open, the branches spreading,

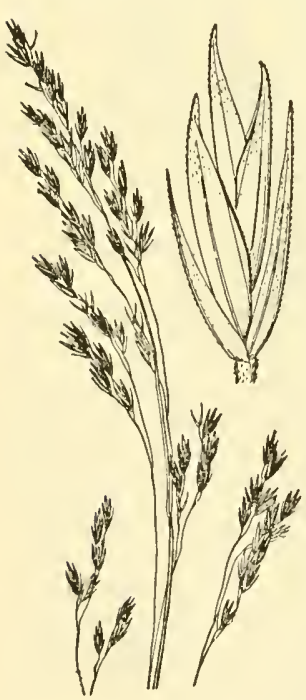
spikelet-bearing toward the ends, the lower usually reflexed at maturity; spikelets $3-$ to 5 , flowered; glumes about 3 and $4 \mathrm{~mm}$ long; lemmas coriaceous, rather turgid, about $4 \mathrm{~mm}$ long, obtuse

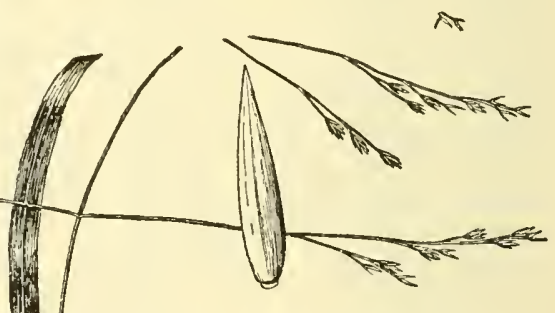
or a cutis h, Figure 84. - Festuca obfusa. Panicle, $\times 1 / 2$; floret, $\times 5$, the nerves very obscure. 2 (F. nutans Spreng.)-Low or rocky woods, Quebec to Manitoba, south to northcrn Florida and eastern 'Texas (fig. 85).

22. Festuca shórtii Kunth. (Fig. 86.) Resembling $F$. Figure 83.-Festuca versuta. obtusa; culms tufted; pani$\underset{\text { 5. (Johnson, Tex.) }}{\stackrel{1}{\text { Panicle }} \times{ }^{1 / 2} \text { s sikelet, }} \times$ cle nodding, less open than 5. (Johnson, Tex.) in F. obtusa, the branches

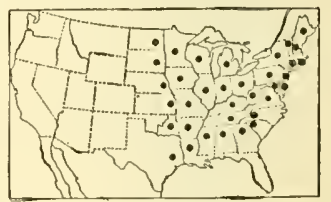

Figure 85.-Distribution of Festuca obtusa.

arched-drooping, the spikelets somewhat crowded toward the ends; spikelets 3- to 6-flowered. 21-Prairies, low, open ground, and 
thickets, Pennsylvania and South Carolina to Iowa and eastern Texas (fig. 87.)

23. Festuca thurbéri Vasey. Thurber fescue. (Fig. 88.) Culms densely tufted, rather stout, erect, 60 to $90 \mathrm{~cm}$ tall; ligule 2 to $4 \mathrm{~mm}$ long; blades involute, scabrous, firm, erect; panicle 10 to $15 \mathrm{~cm}$ long, the branches usually solitary, somewhat remote, ascending or spreading, naked below; spikelets 3- to 6-flowered; glumes

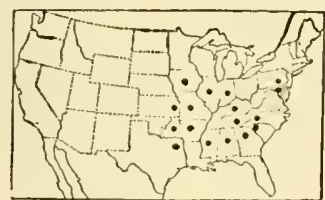

Figure 87.-Distribution of Festuca shortii. rather broad, about 4 and $5 \mathrm{~mm}$ long; lemmas rather firm, faintly nerved, glabrous or nearly so, acute or cuspidate, 7 to $8 \mathrm{~mm}$ long. 2 -Dry slopes and rocky hills, 2,500 to $3,500 \mathrm{~m}$, Wyoming to

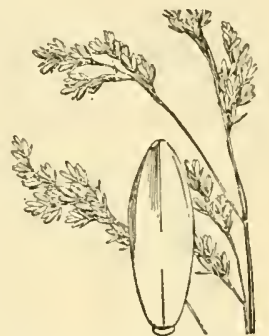

Figure S6.-Festuca shortii Panicle, $\times 1$; ; floret, $\times 5$ (Palmer 34672, Mo.)

New Mexico and Utah (fig. 89).

24. Festuca liguláta Swallen. (Fig. 90.) Culms slender, loosely tufted, erect from a decumbent often rhizomatous base, scabrous

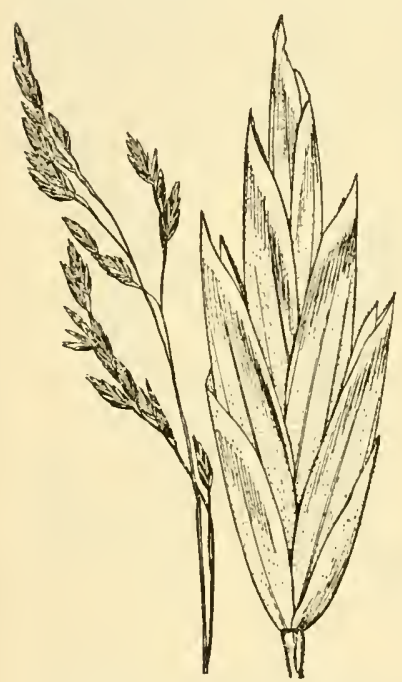

FIgURe 88.-Festuca thurberi. Panicle, $\times 1 / 2$; spikelet, $\times 5$. (Pammel, Colo.) below the panicle; sheaths glabrous; blades 6 to $20 \mathrm{~cm}$ long, those of the innovations as much as $30 \mathrm{~cm}$ long, flat and 1 to $2 \mathrm{~mm}$ wide or mostly involute, scabrous, rather firm; ligule 3 to $3.5 \mathrm{~mm}$ long; panicle 6 to $10 \mathrm{~cm}$ long, the 1 or 2 scabrous branches stiffly ascending or spreading, few-flowered, naked below; spikelets $6 \mathrm{~mm}$ long, 2- to 3 -flowererl, the pedicels (mostly shorter than the spikelets) appressed; glumes acute or acutish, scabrous, the first $3 \mathrm{~mm}$ long, 1 -nerved, the second $4 \mathrm{~mm}$ long, 3 -nerved; lemmas 4 to $5 \mathrm{~mm}$ long, acutish, scabrous, obscurely nerved, awnless, the palea slightly exceeding it. 2 - Mo is t s hady slopes, Guadalupe and Chisos Mountains, Tex.

25. Festuca scabrélla Torr. Rough FESCUE. (Fig. 91.) Culms densely

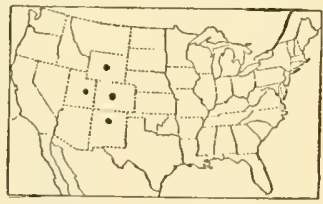

Fugure 89.-Distribution of Festuca thurberi.

tufted, erect, 30 to $90 \mathrm{~cm}$ tall; ligule very short; blades firm, erect, scabrous, involute, or those of the culm sometimes flat but narrow; panicle narrow, 5 to $15 \mathrm{~cm}$ long, the branches solitary or in pairs, the lowermost sometimes in threes, appressed or ascending, naked below; spikelets 4- to 6 -flowered; glumes somewhat unequal, lanceolate, 7 to $9 \mathrm{~mm}$ long; lemmas firm, rather strongly nerved, scaberulous, acute to cuspidate or short-awned, 7 to $10 \mathrm{~mm}$ long. 2) ( $F$. hallii 
Piper.)-Prairies, hillsides, and open woods, up to about 2,000 m (probably alpine in Colorado), Newfoundland to British Columbia, south to Oregon, North Dakota, and Colorado (fig. 92.) FestuCa SCABrélla var. Májor Vasey. Culms on the average taller; panicle larger and more spreading; lemmas more strongly nerved. 24. (F. campestris Rydb.)-Hills and dry woods, Michigan (Roscommon), Montana to Washington.

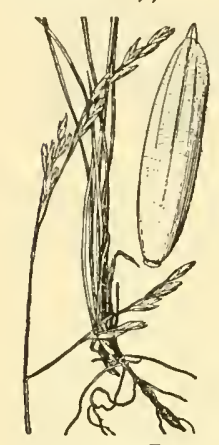

Figure 90.-Festuca ligulata. Plant, $X$ $12 ;$ floret, $\times 5$. ('Type.)

26. Festuca califórnica Vasey. CaliFORNIA FESCUE. (Fig. 93.) Culms tufted, rather stout, 60 to $120 \mathrm{~cm}$ tall; sheaths somewhat scabrous, the collar pubescent or pilose; blades firm, usually involute, sometimes flat, scabrous; panicle open, 10 to $30 \mathrm{~cm}$ long, the rather remote branches usually in pairs, spreading or drooping, naked below; spikelets mostly 4- or 5-flowered; glumes somewhat unequal, 5 to $8 \mathrm{~mm}$ long; lemmas firm, faintly nerved, scaberulous, acuminate or short-awned. 2 (F. aristulata Shear.) - Open dry ground, thickets and open woods, up to about $1,500 \mathrm{~m}$, Oregon and California, west of the Sierra

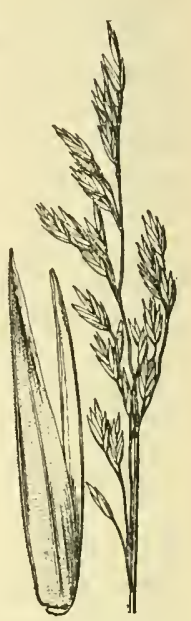

FIGURE 91.-Festuca scabrella. Panicle, $\times 1 / 2$; floret, $\times 5$. (Rydberg 2106, Mont.)

Nevada. A smaller form with pubescent lower sheaths, and shorter

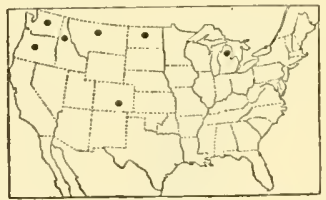

Figure 92.-Distribution of Festuca scabrella.

mostly glabrous blades, has been called F. californica var. parishii

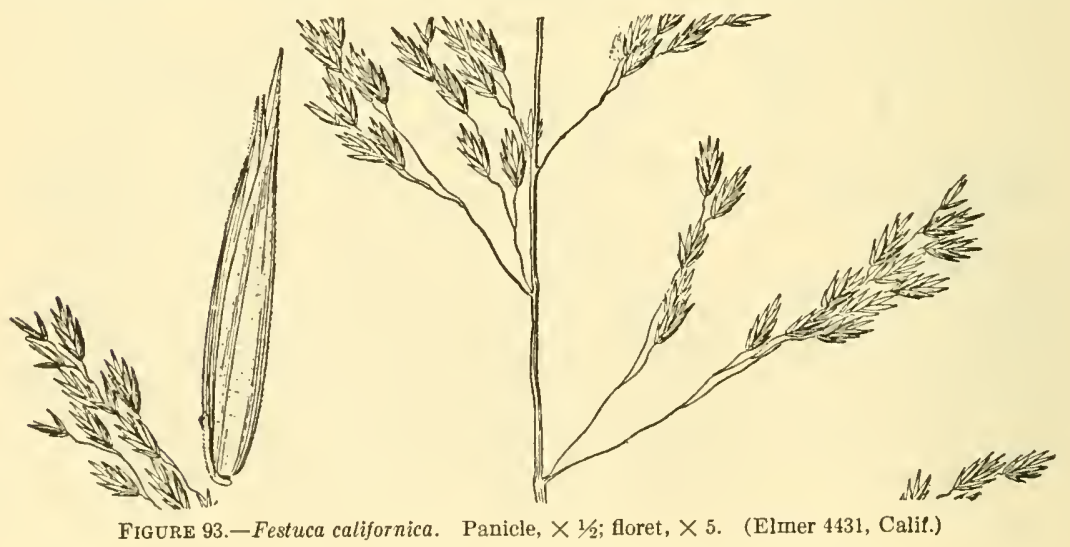

(Piper) Hitchc.-Oregon and California (San Bernardino Mountains). 
27. Festuca dasýclada Hack. (Fig. 94.) Culms 20 to $40 \mathrm{~cm}$ tall; blades folded, about $2 \mathrm{~mm}$ wide when spread, those of the culm 4 to $6 \mathrm{~cm}$ long, those of the innorations 10 to $15 \mathrm{~cm}$ long; panicle open, 7 to $12 \mathrm{~cm}$ long, the branches rather stiffly and divaricately spreading, softly pubescent; angles ciliate; spikelets pale, long-pediceled, 2-flowered; glumes lanceolate, acuminate, the first about $4 \mathrm{~mm}$, the second about $6 \mathrm{~mm}$ long; lemmas rather thin, somewhat keeled, rather strongly nerved, scaberulous, about $6 \mathrm{~mm}$ long; awn about $2 \mathrm{~mm}$ long, from between 2 minute teeth. 4 -Rocky slopes, rare, Utah.

Festuca Rigéscens (Presl) Kunth. Densely tufted, about $30 \mathrm{~cm}$ tall; blades firm, involute, sharp-pointed; panicle narrow, few-flowered, 5 to $10 \mathrm{~cm}$ long; spikelets about 3 -flowered, 6 to $7 \mathrm{~mm}$ long; lemmas ovate, thick, convex, awnless or mucronate, 4 to $4.5 \mathrm{~mm}$ long. 2 -There is a

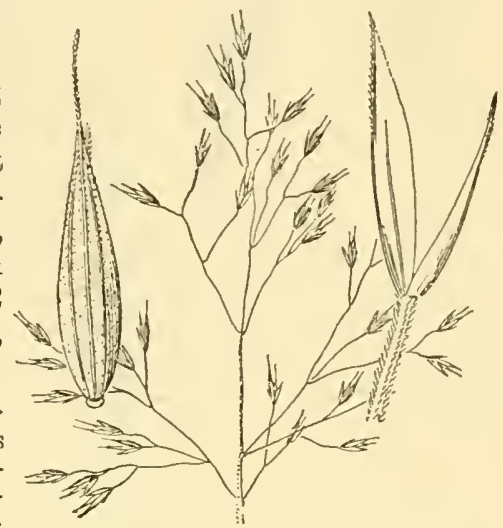

Figure 94.-Festuca dasyclada. Panicle, $\times 1 / 2$;. glumes and floret, $\times 5$. (Dupl. type.) single specimen of this species in the United States National Herbarium, labeled "Arizona, Tracy?" On the sheet is a note made by Professor Piper (Feb. 12, 1904) quoting Tracy, "In open pine woods

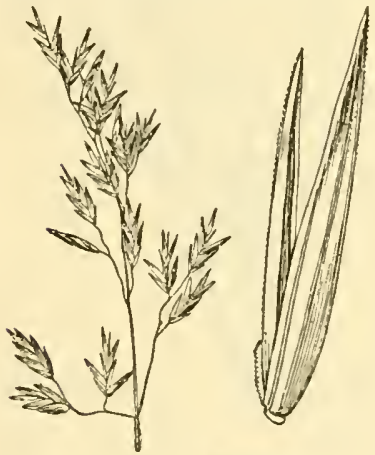

Figure 95.-Festuca riridula. Panicle. $\times 1 / 2$; floret, $\times 5$. (Cusick 2431 . Oreg.) 4 miles southeast of Flagstaff, about June 20, 1857." This agrees exactly with specimens of this species from Peru, whence originally described. Since the species is not known north of Peru, except from this specimen, it seems probable that the label has been misplaced.

28. Festuca virídula Vasey. GreenLEAF FESCUE. (Fig. 95.) Culms rather loosely tufted, erect, 50 to $100 \mathrm{~cm}$ tall; blades soft, erect, those of the culm flat or loosely involute, those of the innovations slender, involute; panicle open, 10 to $15 \mathrm{~cm}$ long, the branches mostly in pairs, ascending or spreading, slender, somewhat remote, naked below; spikelets 3- to 6flowered; glumes lanceolate, somewhat unequal, 5 to $7 \mathrm{~mm}$ long; lemmas membranaceous, acute or cuspidate, glabrous, 6 to $8 \mathrm{~mm}$ long. 4 -Mountain meadows and open slopes, 1,000 to 2,000 $\mathrm{m}$, British Columbia to Alberta, south to central California and Idaho (fig. 96). An important forage grass in the mountains of the Northwestern States. Festuca howellii Hack., differing from $F$. viridula in having more scabrous lemmas and awns $2 \mathrm{~mm}$ long, does not seem sufficiently distinct to be recognized

as a species. 4 -Known from a single collection (Josephine County, Oreg.).

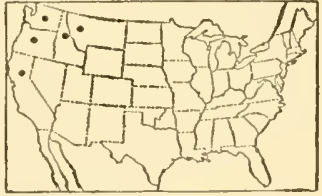

Figure 96.-Distribution of Festuca viridula. 


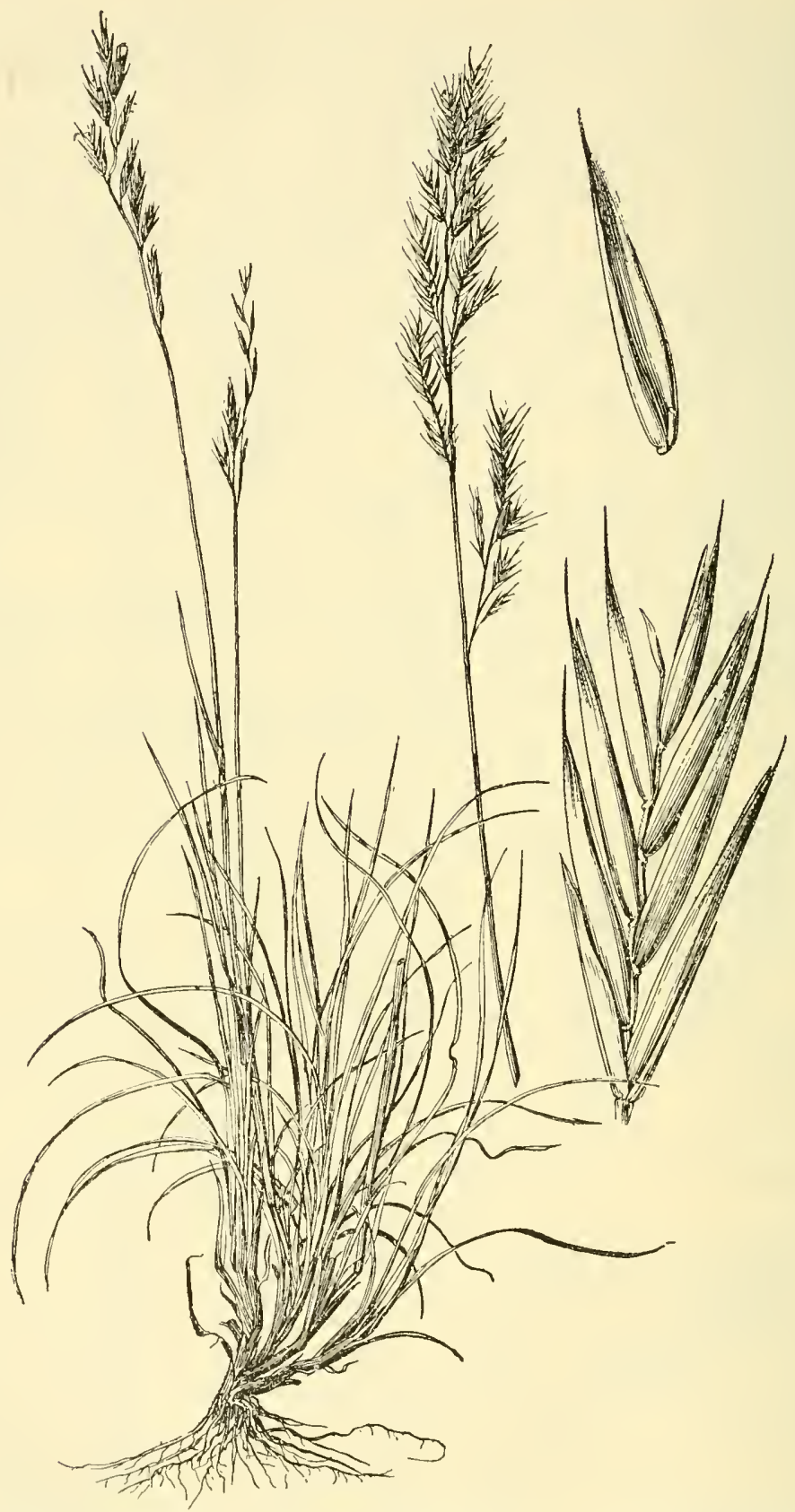

FIGURE 97.-Festuca rubra. Plant, $\times 1 / 2$; spikelet and floret, $\times 5$. (Hitchcock 4201, Alaska.) 
29. Festuca rúbra L. RED fescue. (Fig. 97.) Culms usually loosely tufted, bent or decumbent at the reddish or purplish base, occasionally closely tufted, erect to ascending, 40 to $100 \mathrm{~cm}$ tall; lower sheaths brown and fibrillose; blades smooth, soft, usually folded or involute; panicle 3 to $20 \mathrm{~cm}$ long, usually contracted and narrow, the branches mostly erect or ascending; spikelets 4- to 6-flowered, pale green or glaucous, often purple-tinged; lemmas 5 to $7 \mathrm{~mm}$ long, smooth,

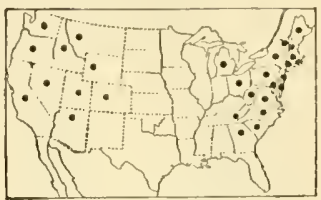

Figure 99.-Distribution of Festuca rubra. or scabrous toward apex, bearing an awn about half as long. $24-$ Meadows, hills, bogs, and marshes,

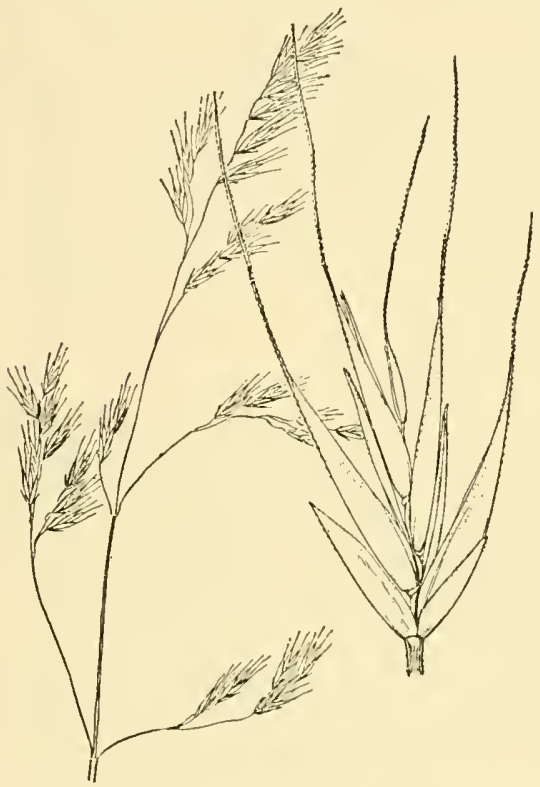

Figure 99.--Festuca occidentalis. Panicle, $\times 1 / 2$; spikelet, $\times 5$. (Piper 4908, Wash.) in the cooler parts of the northern hemisphere, extending south in the Coast Ranges to Monterey, in the Sierra Nevada to the San Bernardino Mountains, in the Rocky Mountains to Colorado, San Francisco Mountains of Arizona, in the Allegheny Mountains and in the Atlantic coastal marshes to Georgia (fig. 98); Eurasia, North Africa. Occasionally used in grass mixtures for pastures in the Northem States. Festuca rubra var. Lanuginósa Mert. and Koch. Lemmas pubescent. 24 -Oregon to Wyoming and northward; Michigan, Vermont to Connecticut; Europe. A proliferous form ( $F$. rubra var. prolifera Piper, $F$. prolifera Fernald) is found in the White Mountains of New Hampshire, in Maine and northward. Festuca RUBRa var. COMMUtáta Gaud. (F. fallax Thuill.) Chewings FESCUE. A form with more erect culms, producing a firmer sod, commonly cultivated in New Zealand and occasionally in the United States. 24 Festuca rubra var. heterophŕlla (Lam.) Mut. Shade fescue. Densely tufted; basal blades filiform; culm blades flat. 24 Used for lawns in shady places. Europe.

30. Festuca occidentális Hook. Western FEscue. (Fig. 99.) Culms tufted, erect, slender, 40 to $100 \mathrm{~cm}$ tall; blades mostly basal, slender, involute, sulcate, soft, smooth or nearly so;

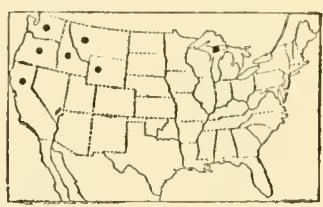

FIgure 100.-Distribution of Festuca occedentalis. panicle loose, 7 to $20 \mathrm{~cm}$ long, often drooping above, the branches solitary or in pairs; spikelets loosely 3 - to 5 -flowered, 6 to $10 \mathrm{~mm}$ long, mos tly 
on slender pedicels; lemmas rather thin, 5 to $6 \mathrm{~mm}$ long, scaberulous toward the apex, attenuate into a slender awn about as long or longer. 24 -Dry rocky wooded slopes and banks, British Columbia to central California, east to Wyoming, northern Michigan, and western Ontario (fig. 100).

31. Festuca ovína L. Sheep fescue. (Fig. 101.) Culms densely tufted, usually 20 to $40 \mathrm{~cm}$ tall; blades slender, involute, from very scabrous to glabrous, the innovations numerous in a basal cluster, 5 to $10 \mathrm{~cm}$ long or sometimes longer; panicle narrow, sometimes almost spikelike, 5 to $8 \mathrm{~cm}$ long, sometimes longer; spikelets mostly 4- or 5-flowered; lemmas about 4 to $5 \mathrm{~mm}$ long, short-awned. 2 ( $F$. saximontana Rydb.; $F$. calligera Rydb.; F. minutiflora Rydb., a rare form with

FIG UR E 101. Festuca ovina. Panicle, $\times 1 / 2$ floret, $\times 5$ (Robbins 8692, Colo.) small florets; $F$. ovina var. pseudovina Hack. of Piper's revision of Festuca.) - Open woods and stony slopes, North Dakota to Washington and Alaska, south to Arizona and New Mexico; introduced eastward through Michigan, Maine, Illinois, and South Carolina (fig. 102). Eurasia. Festuca ovina, $F$. ovina var. duriuscula, and $F$. capillata are occasionally cultivated in lawn mixtures.

Festuca ovina var. duriúscula (L.) Koch. Hard fescue. Blades smooth, wider and firmer than in $F$. ovina. 24 -Maine to Iowa and Virginia; introduced from Europe.

FESTUCA OVINA var. BRACHYPHÝLIA (Schult.) Piper. Alpine fescue. An alpine and high northern form differing in the lower culms, mostly 5 to $20 \mathrm{~cm}$ tall, and the smooth short rather laxblades. 24 (F.brachyphylla Schult.;

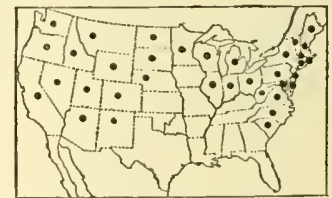

FIGURE 102,-Distribution of Festuca ovina. $F$. ovina var. supina Hack. of Piper's revision of Festuca.) - Rocky slopes, at high altitudes, mostly above timber line in the United States, arctic regions south to San Bernardino Mountains, San Francisco Mountains and, in the Rocky Mountains, to northern New Mexico; also in the high mountains of Vermont, New Hampshire, and New York.

Festuca ovina var. Glaúca (Lam.) Koch. Blue FESCUE. Blades elongate, glancous. 2 (F.glauca Lam.)Cultivated as a border plant.

32. Festuca capilláta Lam. Hair fescue. (Fig. 103.) Densely tufted, more slender and lower than $F$. ovina; blades capillary, flexuous, usually more than half as iong as the culm; spikelets smaller; lemmas about $3 \mathrm{~mm}$ long, awnless. 24 -Lawns and waste places, Newfoundland and Maine to North Carolina and Illinois; Oregon; introduced from Festuca capillata. Plant, $\times 1 / 4$; floret, $X$ 5. (Hitcheock 23624, Newf.) Europe.

33. Festuca idahoénsis Elmer. Bluebunch fescue.

(Fig. 104.) Culms usually densely tufted in large bunches, 30 to $100 \mathrm{~cm}$ tall; blades numerous, usually elongate, very scabrous, rarely smooth, filiform, involute; panicle narrow, 10 to $20 \mathrm{~cm}$ long, the branches ascending or appressed, somewhat spreading in anthesis; spike- 
lets mostly 5 - to 7 -flowered; lemmas nearly terete, about $7 \mathrm{~mm}$ long; awn usually 2 to $4 \mathrm{~mm}$ long. 2 ( $F$. ovina var. ingrata Beal.)Open woods and rocky slopes, British Columbia to Alberta, south to northern New Mexico and Arizona and central California (fig. 105).

34. Festuca arizónica Vasey. Arrzona FEsCUE. (Fig. 106.) Resembling $F$.idahoensis; differing in the stiffer glaucous foliage, somewhat smaller awnless or nearly awnless lemmas. 2 -Open pine woods, Arizona, Nevada, New Mexico, and Colorado (fig. 107). Often called pinegrass.

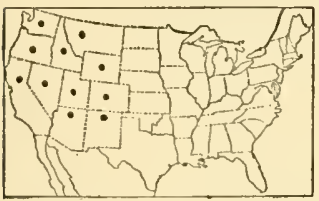

FIGURE 105.-Distribution of Festuca idahoensis
Festuca amethístina L. Slender tufted perennial; blades filiform, 15 to $25 \mathrm{~cm}$ long; panicle 5 to $10 \mathrm{~cm}$ long, rather narrow; spikelets about as in $F$. ovina, of ten purplish.

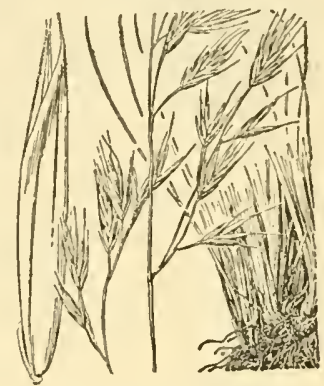

FIgURE 104.-Festuca idahoensis. Plant, $\times 1 \frac{1}{2}$; floret, $\times 5$ (Heller 3318, Idaho.)

2 -Sometimes cultivated for ornament. Europe.

Festuca geniculáta (L.) Cav. Annual; culms slender, geniculate below, 20 to $50 \mathrm{~cm}$ tall; panicle 3 to $6 \mathrm{~cm}$ long, rather compact; spikelets awned. $\odot$-Sometimes cultivated for ornament. Portugal.

\section{SCLEROPPOA Griseb.}

Spikelets several-flowered, linear, somewhat compressed, the thick rachilla disarticulating above the glumes and between the florets; glumes unequal, short, acutish, strongly nerved, the first 1-nerved, the second 3-nerved; lemmas nearly terete, obscurely 5 -nerved, obtuse, slightly scarious at the tip. Annuals with slightly branched 1-sided panicles. Type species, Scleropoa rigida. Name from Greek skleros, hard, and poa, grass, alluding to the stiff panicle.

1. Scleropoa rígida (L.) Griseb. (Fig. 108.) Culms erect or spreading, 10 to $20 \mathrm{~cm}$ tall; blades flat, 1 to $2 \mathrm{~mm}$ wide; panicles narrow, stiff, condensed, 5 to $10 \mathrm{~cm}$ long, the branches short, floriferous to base, these and the thick pedicels somewhat divaricately spreading in anthesis;

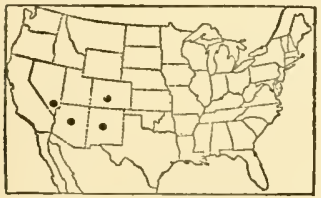

FigueE 107.-Distribution of Festuca arizonica. spikelets 4 - to 10 -flowered, 5 to $8 \mathrm{~mm}$ long; glumes about $2 \mathrm{~mm}$ long; lemmas about $2.5 \mathrm{~mm}$ long. $\odot-W$ aste places and fields, sparingly introduced from Europe, Massachusetts; Florida to Mississippi; South Dakota; Washington to California.

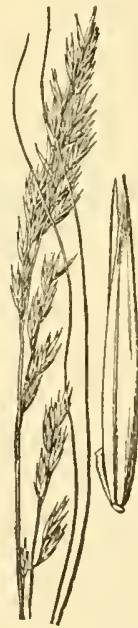

FIgURE 106 . Festuca arizonica. Panicle. $\times 1 / 2$. cle, $\times 1 / 2$ (Leiberg 5685 , Ariz.)

\section{PUCCINéllia Parl. Alkali-grass}

Spikelets several-flowered, usually terete or subterete, the rachilla disarticulating above the glumes and between the florets; glumes unequal, shorter than the first lemma, obtuse or acute, rather firm, 
often scarious at tip, the first 1-nerved or sometimes 3-nerved, the second 3-nerved; lemmas usually firm, rounded on the back, obtuse or acute, rarely acuminate, usually scarious and often erose at the tip, glabrous or puberulent toward base, rarely pubescent on the nerves, 5-nerved, the nerves parallel, indistinct, rarely rather prominent; palea about as long as the lemma or somewhat shorter. Low

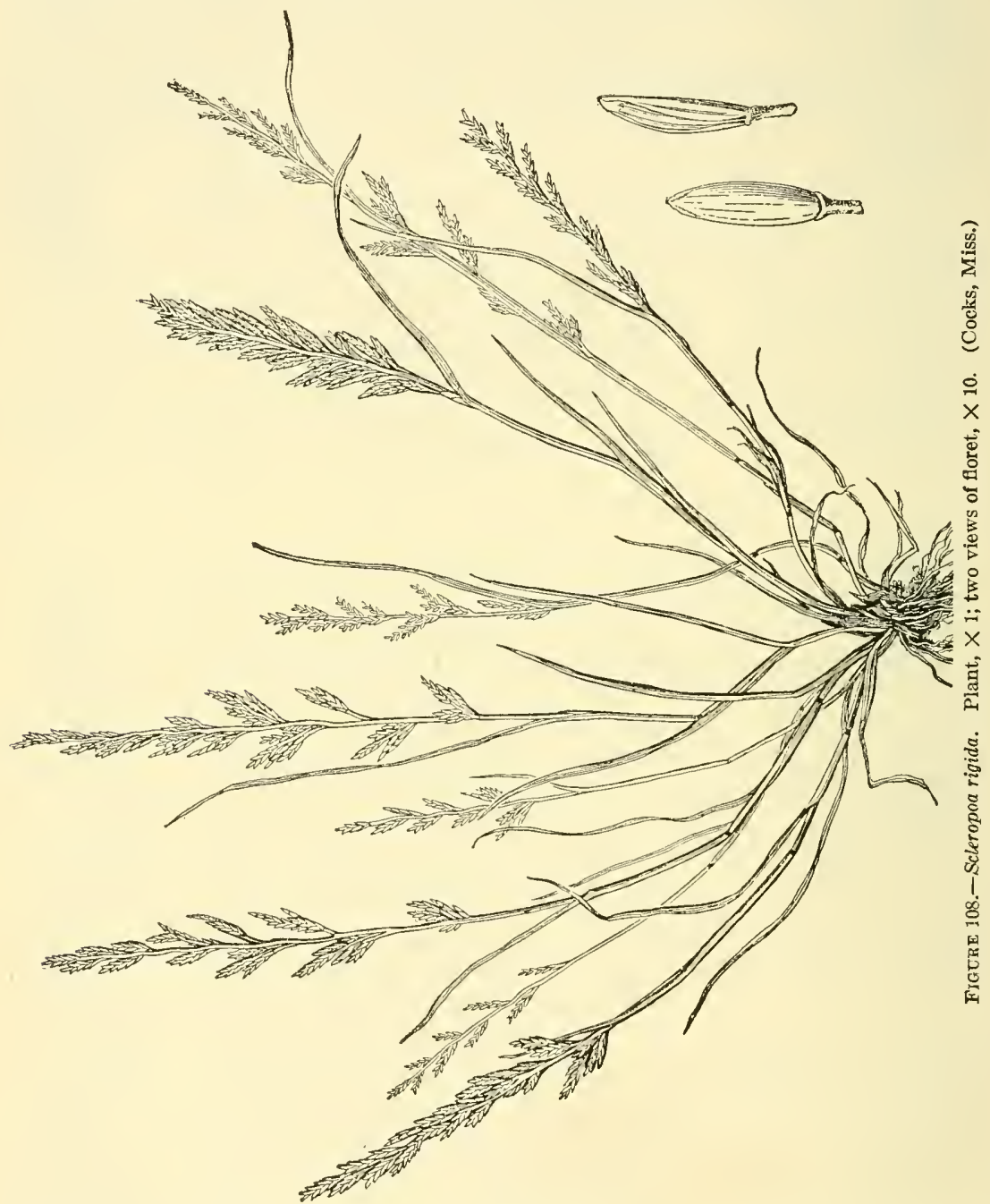

pale smooth tufted annuals or perennials with narrow to open panicles. Type species, Puccinellia distans. Named for Prof. Benedetto Puccinelli.

The species of the interior are grazed by stock. One, P. nuttalliana, furnishes considerable forage in the regions where it is common. A form of this, called Zawadke alkali-grass, is cultivated in Montana. 
Lemmas obtuse, pubescent on the nerves for half or three-fourths their lengtli.

Dwarf annual............ P. PARISHII.

Lemmas glabrous or, if pubescent, the hairs not confined to the nerves.

Panicles narrow, strict, the branches appressed, mostly with one spikelet; annual, mostly less than $20 \mathrm{~cm}$ tall; lemmas acute, more or less pubescent .......... P. SIMPLEX.

Panicles narrow or open, not strict; annual or perennial; lemmas glabrous or pubescent only at base.

Panicles ellipsoid, rather compact, less than $10 \mathrm{~cm}$ long, the branches floriferous nearly to base. Lemmas rather coriaceous; culms rather stout. Spikelets 5 to $8 \mathrm{~mm}$ long; lemmas 3 to $3.5 \mathrm{~mm}$ long - 3 . P. RUPEstris. Spikelets 3 to $4 \mathrm{~mm}$ long; lemmas 2 to $2.5 \mathrm{mn}$ long.

4. P. Fasciculati.

Panicles pyramidal or elongate, some of the branches naked below, or reduced, narrow, and few-flowered.

Leaves mostly in a short basal tuft, the blades involute, 5 to $10 \mathrm{~cm}$ long. Panicle 5 to $10 \mathrm{~cm}$ long, open and spreading; lemmas $3.5 \mathrm{~mm}$ long, glabrous, acute

Leaves distributed, not in a basal tuft.

Anthers about $2 \mathrm{~mm}$ long. Lemmas 4 to $5 \mathrm{~mm}$ long, pubescent at base

Anthers $1 \mathrm{~mm}$ long or less.

Lemmas about $2 \mathrm{~mm}$ long; panicle open; the slender branches spreading or reflexed.

Lemmas broad, obtuse or truncate, not narrowed above; lower panicle branches usually reflexed ......... 7. P. DIsTans.

Lemmas narrow, narrowed into an obtuse apex; panicle branches spreading, usually not reflexed......_ 8. P. NUTTALLIANA.

Lemmas 3 to $4 \mathrm{~mm}$ long; panicle narrow, the branches ascending or finally spreading.

Plants lax, usually 10 to $30 \mathrm{~cm}$ tall; panicle 5 to $10 \mathrm{~cm}$ long, the branches finally spreading ............. 9. P. PUMILA.

Plants usually 40 to $60 \mathrm{~cm}$ tall; panicle 10 to $20 \mathrm{~cm}$ long, the branches ascending or appressed _...... 10. P. NUTKAENSIS.

1. Puccinellia paríshii Hitchc. (Fig. 109.) Annual; culms 3 to $10 \mathrm{~cm}$ tall; blades flat to subinvolute, less than $1 \mathrm{~mm}$ wide; panicle narrow, few-flowered, 1 to $4 \mathrm{~cm}$ long; spikelets 3 - to 6-flowered, 3 to $5 \mathrm{~mm}$ long; lemmas about $2 \mathrm{~mm}$ long, obtuse to truncate, scarious and somewhat erose at the tip, pubescent on the mid and lateral nerves nearly to the apex, and on the intermediate nerves about half way. $\odot$-Known only from Rabbit Springs, San Bernardino County, Calif.

2. Puccinellia símplex Scribn. (Fig. 110.) Annual; culms 7 to $20 \mathrm{~cm}$ tall; blades narrow, soft, flat; panicle narrow, about half the length of the entire plant, the branches few, short, appressed, mostly with 1 spikelet; spikelets 6 to $8 \mathrm{~mm}$ long, appressed; glumes strongly 3-nerved, 1 and 2 $\mathrm{mm}$ long; lemmas $2.5 \mathrm{~mm}$ long, tapering from below the middle to the acute apex, more or less pubescent over the back. $\odot$-Alkaline soil, California; rare.

3. Puccinellia rupéstris (With.) Fern. and Weath. (Fig. Figure 109-111.) Annual; culms rather stout, mostly 10 to $20 \mathrm{~cm}$ tall; $\begin{gathered}\text { Puccinellia } \\ \text { parishii. }\end{gathered}$ blades flat, 2 to $6 \mathrm{~mm}$ wide; panicle ellipsoid, glaucous, Panicle, $x$ rather dense, mostly 3 to $6 \mathrm{~cm}$ long, the branches mostly 10. (Type.) not more than $1.5 \mathrm{~cm}$ long, stiffly ascending, floriferous nearly to base; spikelets 3 - to 5 -flowered, 5 to $8 \mathrm{~mm}$ long, sessile or nearly so; glumes 3 - to 5 -nerved, 1.5 and $2.5 \mathrm{~mm}$ long; lemmas 3 to $3.5 \mathrm{~mm}$ 
long, firm, obscurely nerved, glabrous, obtuse, the apex entire or nearly so. $\odot-B a l l a s t$ near New York and Philadelphia. Europe.

4. Puccinellia fasciculáta (Torr.) Bicknell. (Fig. 112.) Apparently perennial; culms rather stout, 20 to $50 \mathrm{~cm}$ tall, sometimes taller; blades flat, folded, or subinvolute, 2 to $4 \mathrm{~mm}$ wide; panicle ellipsoid, 5 to $15 \mathrm{~cm}$ long, the branches fascicled, rather stiffly ascending,

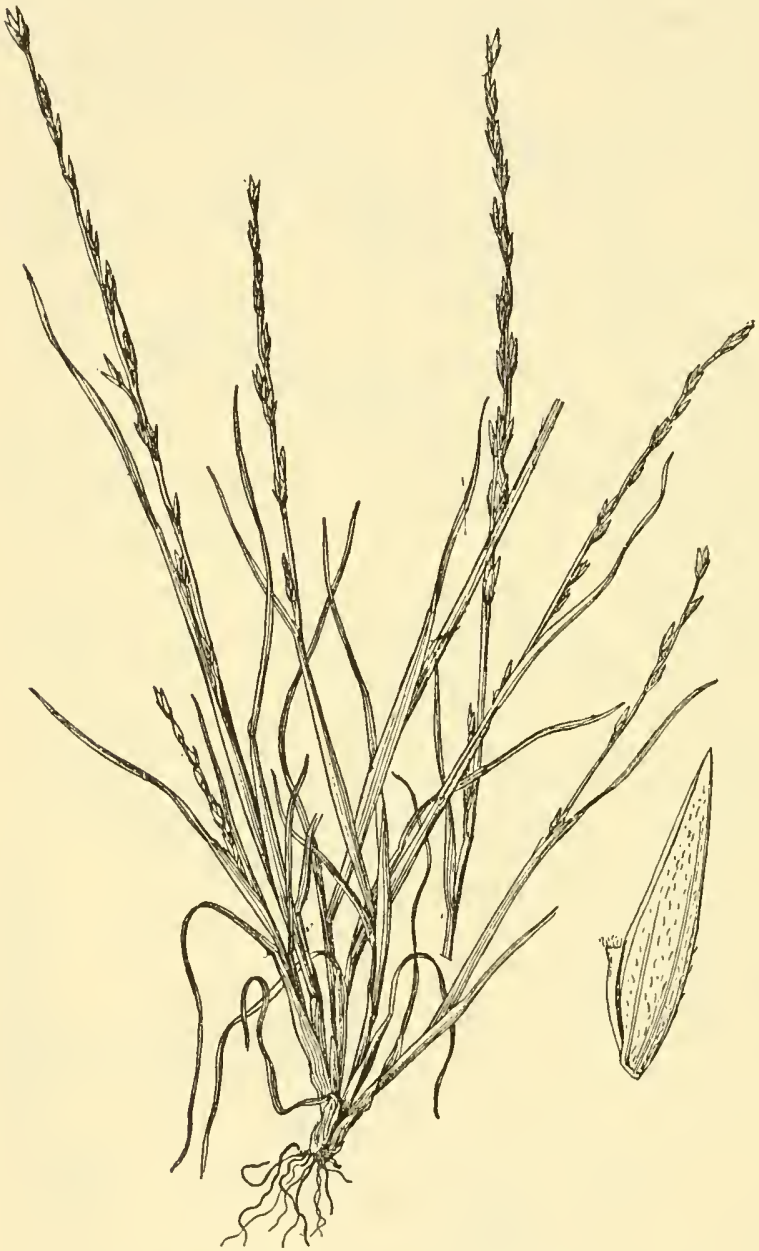

Figure 110.-Puccinellia simplex. Plant, $\times 1$; floret, $\times 10$. (Type.)

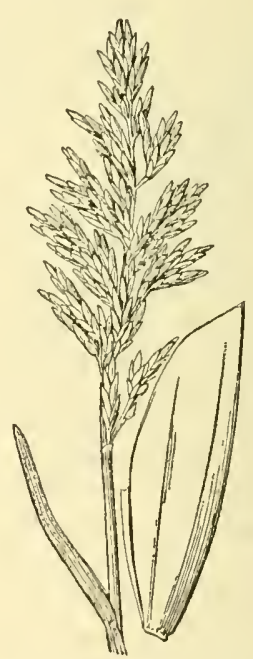

FIGURE 111.-Puccinellia rupestris. Panicle, $\times 1$; floret, $\times 10$ (Martindale, N.J.)

some naked at base but with short basal branchlets, all rather densely flowered; spikelets 2- to 5 -flowered, 3 to $4 \mathrm{~mm}$ long; glumes ovate, 1 and $1.5 \mathrm{nmm}$ long; lemmas 2 to $2.5 \mathrm{~mm}$ long, firm, obtuse. 24 ( $P$. borreri Hitchc.)-Salt marshes along the coast, Nova Scotia to Delaware; Utah (fig. 113); Europe.

5. Puccinellia lemmóni (Vasey) Scribn. (Fig. 114). Perennial; culms erect, slender, 15 to $30 \mathrm{~cm}$ tall; leaves mostly in an erect basal 
tuft, the slender blades involute, 5 to $10 \mathrm{~cm}$ long; panicle pyramidal, open, 5 to $10 \mathrm{~cm}$ long, the slender flexuous branches fascicled, the lower spreading, the longer ones naked on the lower half; spikelets

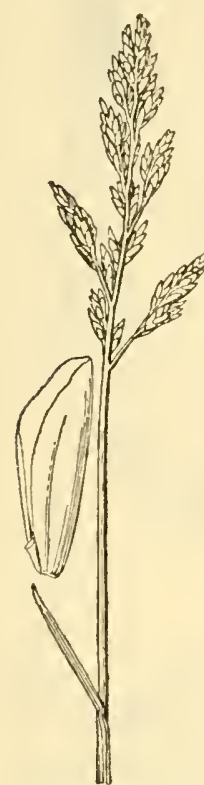

FJGURE 112.-Puccinellia fasciculata. Panicle, $\times 1$; floret $\times 10$. (Stebbins, Maine.) narrow, 3- to 5-flowered, the rachilla often exposed; glumes about 1 and $2 \mathrm{~mm}$ long; lemmas narrow, acute, glabrous, about $3.5 \mathrm{~mm}$ long; anthers $1.5 \mathrm{~mm}$ long. 2 -Moist alkaline soil, southern Idaho and Washington to Utah and California (fig. 115).

6. Puccinellia marítima (Huds.) Parl. (Fig. 116). Perennial; culms erect, rather coarse, 20 to $40 \mathrm{~cm}$ tall, sometimes taller; blades 1 to $2 \mathrm{~mm}$ wide, usually becoming involute; panicle mostly 10 to $20 \mathrm{~cm}$ long, the branches ascending or appressed, or spreading in anthesis; spikelets 4- to 10-flowered; glumes 3 -nerved, 2 to 3 and 3 to $4 \mathrm{~mm}$ long; lemmas 4 to $5 \mathrm{~mm}$ long, pubescent on the base of the lateral nerves and sometimes sparingly between the nerves; anthers 1.5 to $2 \mathrm{~mm}$ long. 24 - Salt marshes and brackish shores, Nora Scotia to Rhode Island; Washington; on ballast, Philadelphia (fig. 117); Europe.

7. Puccinellia dístans (L.) Parl. (Fig. 118.) Perennial; culms erect or decumbent at base, 20 to $40 \mathrm{~cm}$ tall, sometimes taller; blades flat or more or less involute, mostly 2 to 4 $\mathrm{mm}$ wide; panicle pyramidal, loose, 5 to $15 \mathrm{~cm}$ long, the branches fascicled, rather distant, the lower spreading or finally reflexed, the longer ones naked

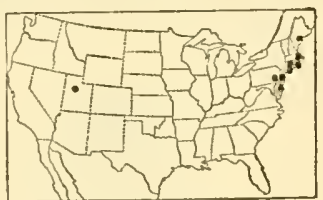

FigURE 113.-Distribution of Puccinellia fasciculata.

half their length or more; spikelets 4 - to 6 -flowered, 4 to $5 \mathrm{~mm}$ long; glumes 1 and $2 \mathrm{~mm}$ long; lemmas rather thin, obtuse or truncate, 1.5 or usually about $2 \mathrm{~mm}$ long, with a few short hairs at base; anthers

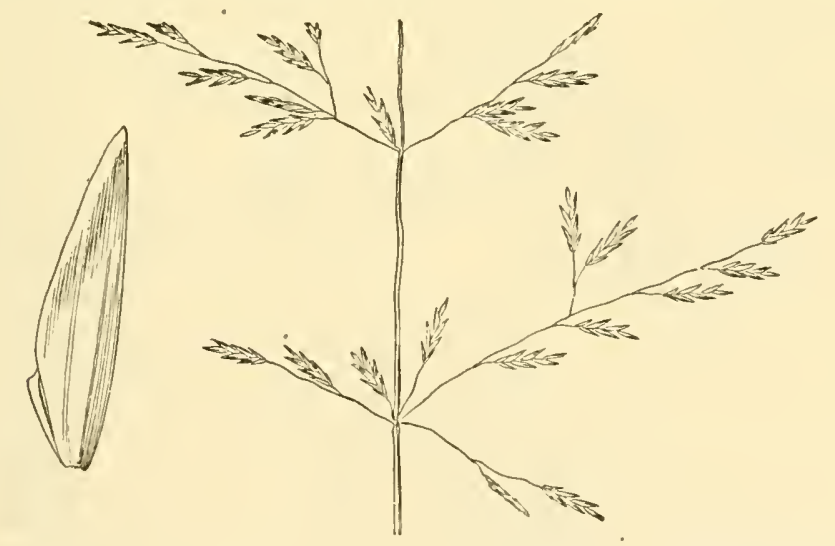

Figdre 114.-Puccinellia lemmoni. Panicle, $\times 1$; floret, $\times 10$. (Jones 4115, Nev.)

about $0.8 \mathrm{~mm}$ long. 24 -Moist, more or less alkaline soil, Quebec to Alaska, south to Maryland, Michigan, Wisconsin, and North 
Dakota; Washington, south to New Mexico and California (fig. 119); introduced from Eurasia. The more slender specimens are the form described as $P$. distans var, tenuis (Uechtritz) Fern. and Weath.

8. Puccinellia nuttalliána (Schult.) Hitchc. Nuttall alkali-grass. (Fig.

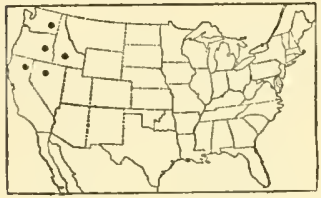

FIGURE 115.-Distribution of Puccinetlia lemmoni.

120.) Perennial; culms usually erect, slender, rather stiff and firm at base, mostly 30 to $60 \mathrm{~cm}$ rarely to $1 \mathrm{~m}$ tall; blades 1 to $3 \mathrm{~mm}$ wide, flat, or becoming involute; panicle pyramidal, open, mostly 10 to $20 \mathrm{~cm}$ long, the distant scabrous branches fascicled, spreading, naked below, as much as $10 \mathrm{~cm}$ long; spikelets 3 - to 6 -flowered, 4 to $7 \mathrm{~mm}$ long, the florets rather distant, the rachilla often exposed; pedicels scabrous; glumes 1.5 and $2 \mathrm{~mm}$ long; lemmas 2 to $3 \mathrm{~mm}$ long, rather narrow, somewhat narrowed into an obtuse apex; an-

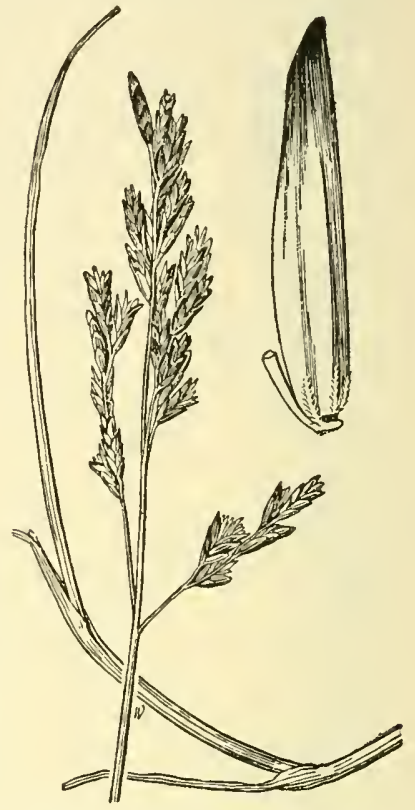

Figure 116.-Puccinellia maritimn. Plant, $\times 1$; foret, $\times 10$. (Fernald and Long 20051, Nova Scotia.)

thers about $0.7 \mathrm{~mm}$ long. 2 (P. airoides Wats. and Coult.)-Moist, usually alkaline soil, Minnesota to British Columbia, south to Kansas, New Mexico, and California; introduced in Maine and Vermont (fig. 121). The form with lemmas 2.5 to $3 \mathrm{~mm}$ long has been called P. cusickii Weatherby.-Alberta to Wyoming and Oregon.

\section{Puccinellia púmila} (Vasey) Hitchc. (Fig. 122.) Perennial; culms lax, erect or ascending from a de-

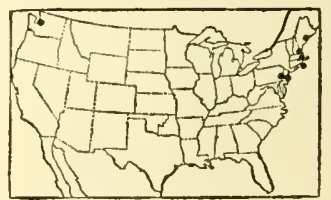

Figure 117.-Distribution of Puccinellza maritima. cumbent base, 10 to $30 \mathrm{~cm}$ tall; blades rather soft, mostly flat, 1 to $2 \mathrm{~mm}$ wide; panicle pyramidal, open, mostly 5 to $10 \mathrm{~cm}$ long, the lower branches naked below, usually finally spreading or even reflexed; spikelets 4- to 6-flowered; glumes 1.5 and $2.5 \mathrm{~mm}$ long; lemmas 3 to $4 \mathrm{~mm}$ long, rather broad, narrowed toward the obtuse nearly entire apex,

Figure 118.-Puccinellia distans. Panicle, $\times 1 / 2 ;$ floret, $\times 10$ (Schuette, Wis.)

ear base or glabrous; anthers 0.8 to $1 \mathrm{~mm}$ 
long. 4 ( $P$. paupercula Fern. and Weath., $P$. paupercula var. alaskana Fern. and Weath.) - Salt marshes and shores, Labrador to

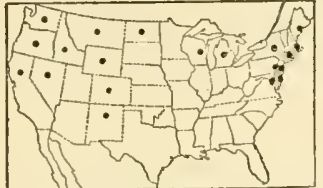

FigURE 119.-Distribution of Puccinellia distans.
Alaska, south to Connecticut and Oregon (fig. 123).

10. Puccinellia nutkaénsis (Presl)

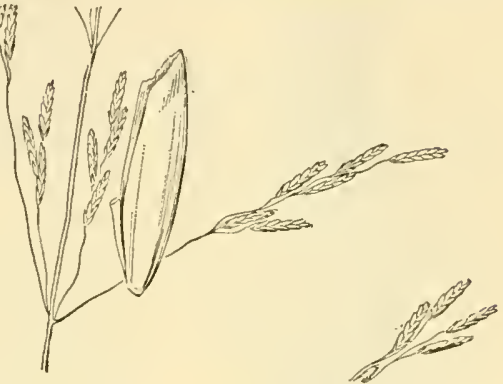

Figure 120.-Puccinellia nuttalliana. Panicle, $X$ 1; floret, $\times 10$. (Rydberg 2135, Mont.)

Fern. and Weath. (Fig. 124.) Perennial; culms rather stout, 40 to

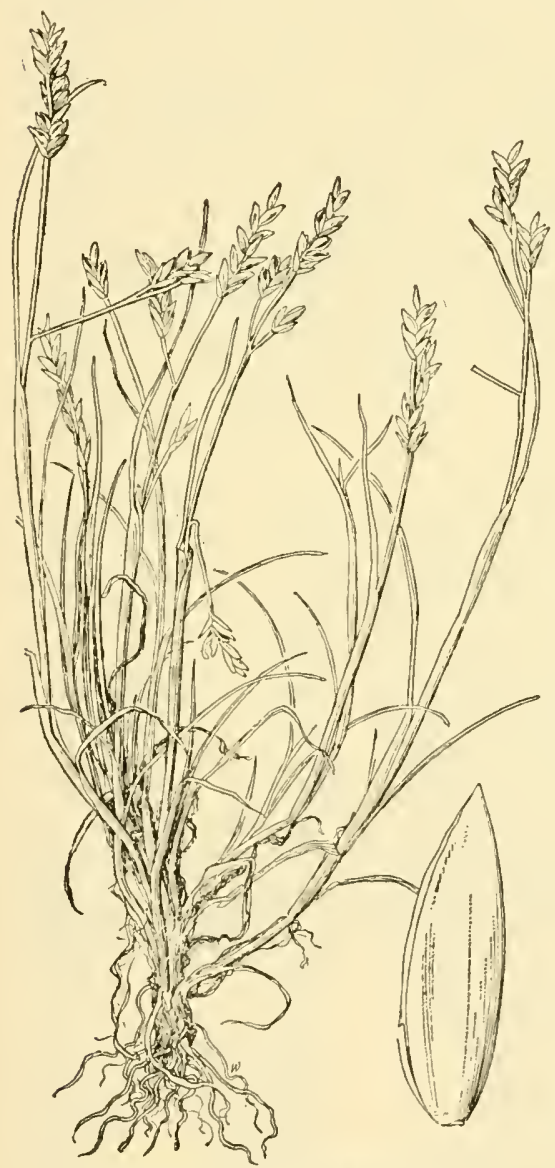

Figure 122.-Puccinellia pumi/a. Plant, X 1 ; floret, $\times 10$. (Type.)

$70 \mathrm{~cm}$ tall; blades 1 to $2 \mathrm{~mm}$ wide, subinvolute; panicle narrow, 10 to $20 \mathrm{~cm}$ long, usually included at base, the lower branches usually as much as $7 \mathrm{~cm}$ long; spikelets 4- to 9-flowered, 6 to $10 \mathrm{~mm}$ long; glumes about 1.5 and $2 \mathrm{~mm}$

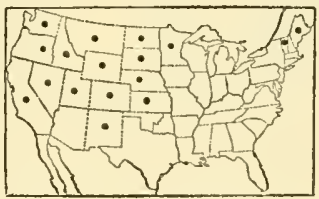

Figure 121.-Distribution of Puccinella nuttallana.

long; lemmas 3 to $4 \mathrm{~mm}$ long, narrowed to an obtuse apex, the tip minutely fimbriate, the base with a few hairs; anthers about $0.7 \mathrm{~mm}$ long. 2f - Salt marshes and saline soil near the coast, Alaska to central California.

\section{GLYCERIA R. Br. Mannagrass}

(Panicularia Heist.)

Spikelets few- to many-flowered, subterete or slightly compressed, the rachilla disarticulating above the glumes and between the florets; glumes unequal, short, obtuse or acute, usually searious, mostly 1-nerved; lemmas broad, convex on the back, firm, usually obtuse; scarious at the apex, 5- to 9-nerved, the nerves 
parallel, usually prominent. Usually tall aquatic or marsh perennials,

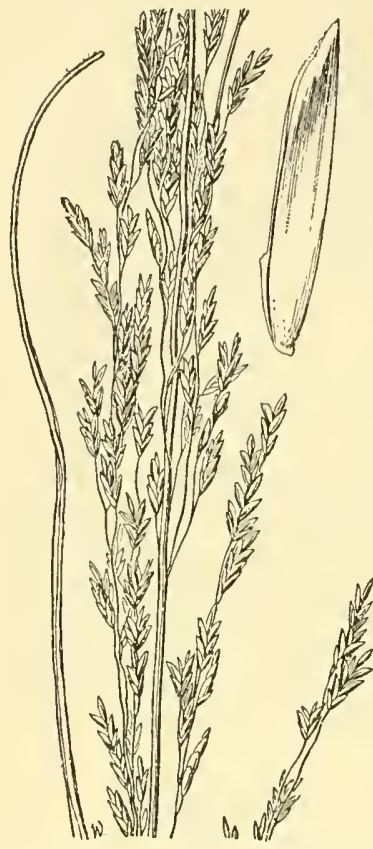

FIGURE 124.-Puccinellia nutkaensis. Panicle, $\times 1$; floret, $\times 10$. (Macoun 66, Br. Col.) with creeping and rooting bases or with creeping rhizomes, simple culms, closed or partly closed sheaths, flat blades, and open or contracted panicles. Type species, Glyceria fluitans. Name from the Greek glukeros, sweet, the seed of the type species being sweet.

The species are all palatable grasses but are usually of limited distribution and most of them are confined to marshes or wet land. Glyceria elata, tall mannagrass, is a valuable component of the forage in moist woods of the Northwestern States. G. striata, fowl mannagrass, widely distributed, $G$. grandis, American mannagrass, in the Northern States, and

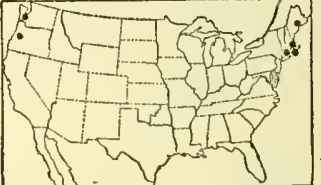

Figure 123.-Distribution of Puccinellia pumila.

G. pauciflora, weak mannagrass, of the Northwest, are marsh species but are often grazed.

Spikelets linear, nearly terete, usually as much as 1 cm long, appressed on short pedicels; panicles narrow, erect.......... SECTION 1. Euglyceria. Spikelets ovate or oblong, more or less compressed, usually not more than $5 \mathrm{~mm}$ long; panicles usually nodding.......... SECTION 2. HYDROPOA.

Section 1. Euglyceria

Lemmas acute, much exceeded by the palea............ 1. G. Acutiflora. Lemmas obtuse; patea about as long as the lemma (or longer in $G$. septentrionalis and $G$. fluitans).

Lemmas glabrous between the slightly scabrous nerves_..._. 2. G. Borealis. Lemmas scaberulous or hirtellous between the usually distinctly scabrous nerves.

Lemmas about $3 \mathrm{~mm}$ long, broadly rounded at the summit.

First glume $1.5 \mathrm{~mm}$ long; lemmas scaberulous _... 3. G. LEPTOSTACHYA. First glume 2 to $2.5 \mathrm{~mm}$ long; lemmas hirtellous.... 4. G. ARKansana.

Lemmas 4 to $7 \mathrm{~mm}$ long.

Lemmas pale or green, not tinged with purple, about $4 \mathrm{~mm}$ long; palea usually exceeding the lemma; Eastern States.

5. G. SEPTENTRIONALis.

Lemmas usually tinged with purple near the tip, 4 to $6 \mathrm{~mm}$ long; palea rarely exceeding the lemma; Western States_ _ 7. G. occidentalis.

Lemmas slightly tinged with purple near the tip, 5 to $6 \mathrm{~mm}$ long; palea about as long as the lemma, sometimes slightly exceeding it; North-

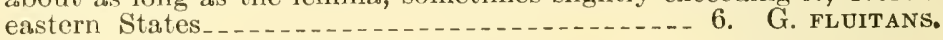

\section{Section 2. Hydropoa}

Lemmas with 5 prominent nerves.

Panicle ovate or pyramidal, open.

8. G. PAUCiFlora.

Panicle narrow, the branches ascending

Lemmas with 7 usually prominent nerves.

Panicle contracted, narrow.

Lemmas about 3 to $4 \mathrm{~mm}$ long; panicle oblong, dense, usually not more than $10 \mathrm{~cm}$ long 
Lemmas 2 to $2.5 \mathrm{~mm}$ long; panicle rather loose, nodding, 15 to $25 \mathrm{~cm}$ long Panicle open, lax.

Nerves of lemma evident but not prominent ...... 12. G. Canadensis.

Nerves of lemma prominent.

Culms decumbent, weak.

Blades 4 to $8 \mathrm{~mm}$ wide; anthers $1 \mathrm{~mm}$ long........ 17. G. Pallida. Blades 1 to $3 \mathrm{~mm}$ wide; anthers 0.2 to $0.5 \mathrm{~mm}$ long-- 18 . G. NEOGAEA. Culms erect, usually stout.

First glume $1 \mathrm{~mm}$ long or less.

Blades 2 to $4 \mathrm{~mm}$ wide, sometimes to $8 \mathrm{~mm}$, rather firm, often folded; first glume $0.5 \mathrm{~mm}$ long _........ G. STRiata.

Blades 6 to $12 \mathrm{~mm}$ wide, flat, thin, lax; first glume about $1 \mathrm{~mm}$ long. Lemma narrowed into a hyaline tip with no colored border.

Lemma broad at summit with a purple zone just below.

14. G. elata.

15. G. OTISII.

First glume $1.5 \mathrm{~mm}$ long. Panicle large, compound _- 16. G. Grandis.

\section{Section 1. Euglycéria Griseb.}

Spikelets linear, nearly terete, usually more than $1 \mathrm{~cm}$ long, appressed on short pedicels; panicles narrow, erect, the branches appressed or ascending after anthesis. The species of Euglyceria, with the exception of Glyceria acutiflora, are very closely allied and appear to intergrade.

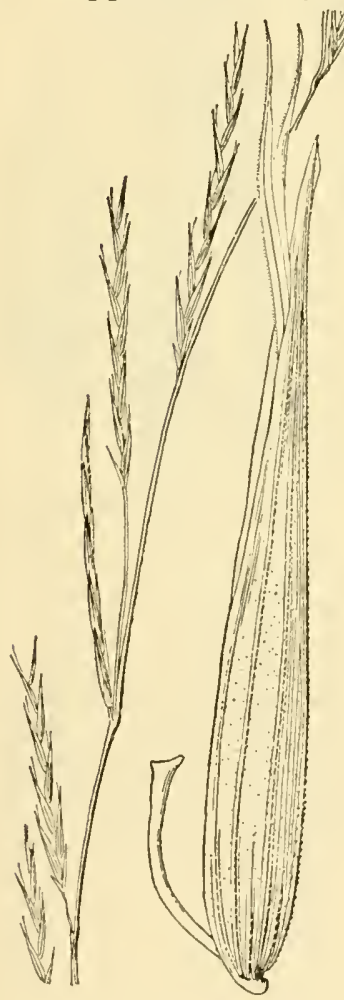

Figure 125.-Glyceria acutiflora. Panicle, $\times 1$; floret, $\times 10$. (Knowlton 866, Mass.)

\section{Glyceria acutiflóra} Torr. (Fig. 125.) Culms compressed, lax, creeping and rooting below, 50 to $100 \mathrm{~cm}$ long; blades flat, lax, 10 to $15 \mathrm{~cm}$ long, 3 to $6 \mathrm{~mm}$ wide, scabrous on the upper surface; panicle 15 to $35 \mathrm{~cm}$ long, of ten partly included, the branches rather stiff, bearing 1 or 2 spikelets, or the lower 3 or more; spikelets 5- to 12 -flowered, 2 to $4 \mathrm{~cm}$ long, 1 to $2 \mathrm{~mm}$ wide, the lateral pedicels 1 to 3 mm long; glumes about 2 and $5 \mathrm{~mm}$ long; lemmas 7-nerved, acute, scabrous, 6 to $8 \mathrm{~mm}$ long, exceeded by the acuminate, 2-toothed paleas. 24 (Panicularia acutiflora Kuntze.)-Wet soil and shallow water, New Hampshire to Delaware, west to Michigan and Temessee (fig. 126); also northeastern Asia.

\section{Glyceria boreális (Nash)}

Batchelder. NortherN MANNAGRASS. (Fig. 127.) Culms erect or decumbent at base, slender, 60 to $100 \mathrm{~cm}$ tall; blades flat or folded, usually 2 to $4 \mathrm{~mm}$ wide, sometimes

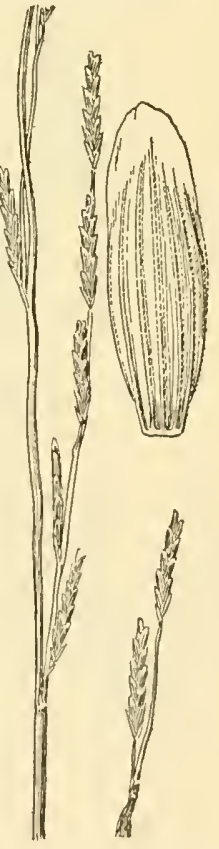

IGURE 127.-Glyceria borealis. Psnicle, $x$ 1: floret, $\times 10$. (Fernald 193, Maine.) 
wider; panicle mostly 20 to $40 \mathrm{~cm}$ long, the branches as much as 10 $\mathrm{cm}$ long, bearing several appressed spikelets; spikelets mostly 6 - to 12-flowered, 1 to $1.5 \mathrm{~cm}$ long; ghumes about 1.5 and $3 \mathrm{~mm}$ long;

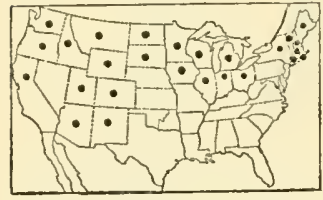

FigURE 128.-Distribution of Glyceria borealis. lemmas rather thin, obtuse, 3 to $4 \mathrm{~mm}$ long, strongly 7 -nerved, scarious at the tip, glabrous between the hispidulous nerves. 21 (Panicularia borealis Nash.) - Wet places and shallow water, Newfoundland to southeast Alaska, south to Comnecticut, northwestern Indiana, Iowa, South Dakota, and in the mountains to New Mexico and central California (fig. 128).

3. Glyceria leptostáchya Buckl. (Fig. 129.) Culms 1 to $1.5 \mathrm{~m}$ tall, rather stout or succulent; sheaths slightly rough; blades flat, scaberulous on the upper surface, 4 to $7 \mathrm{~mm}$ wide, rarely $1 \mathrm{~cm}$ wide; panicle 20 to $40 \mathrm{~cm}$ long, the branches ascending,

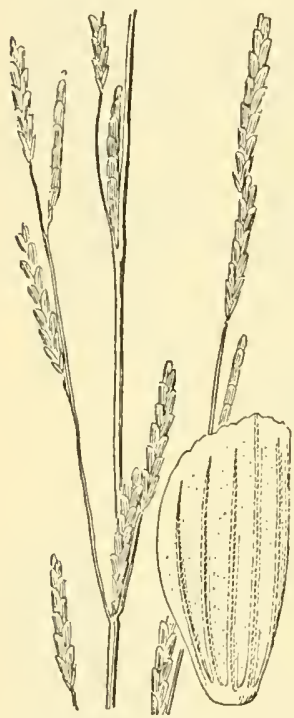

Figure 129.- Glyceria leptostachya. Panicle, $\times 1$; floret, $\times 10$. (Heller 5606, Calif.) panicle 20 to $40 \mathrm{~cm}$ long, the
mostly in 2 's or 3 's, severalflowered, often bearing secondary branchlets; spikelets 1 to 2 cm long, 8- to $14-$ flowered, often purplish; glumes 1.5 and $3 \mathrm{~mm}$ long; lemmas firm, broadly rounded toward apex, about 3 mm long, 7-nerved, scaberulous on the nerves and between them. 2 (Panicularia davyi Merr.)-Shallow water, up to $1,200 \mathrm{~m}$, rare, Washington to central California.

4. Glyceria arkansána Fernald. (Fig. 130.) Resembling $G$. septentrionalis; first glume 2 to $2.5 \mathrm{~mm}$ long; lemnas $3 \mathrm{~mm}$ long, hirtellous rather than scaberulous. 2 Wet ground, Louisiana,

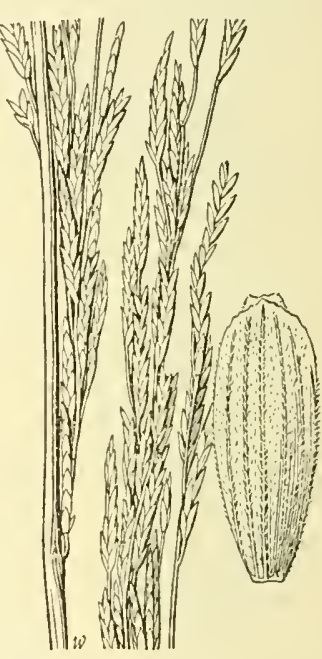

FIGURE 130--Glyceria arkansana. Panicle, $\times 1$; floret, $\times$ 10. (Ball 362, La.)

Arkansas, and Texas (fide

Fernald). There is a specimen labeled "western New York"; this locality should be confirmed.

5. Glyceria septentrionális Hitche. EAstern Mannagrass. (Fig. 131.) Culns 1 to $1.5 \mathrm{~m}$ tall, somewhat succulent; sheaths smooth; blades flat, mostly 10 to $20 \mathrm{~cm}$ long, 4 to $8 \mathrm{~mm}$ wide, usually smooth beneath, slightly scaberulous on the upper surface and margin; panicle 20 to $40 \mathrm{~cm}$ long, somewhat open, the branches as much as 10 cm long, several-Howered, often spreading at anthesis; spikelets 1 to 2 
cm long, 6- to 12-flowered, the florets rather loosely imbricate; glumes 2 to 3 and 3 to $4 \mathrm{~mm}$ long; lemmas green or pale, about $4 \mathrm{~mm}$ long, narrowed only slightly at the summit, scaberulous, the paleas usually exceeding them. 21 (Panicularia septentrionalis

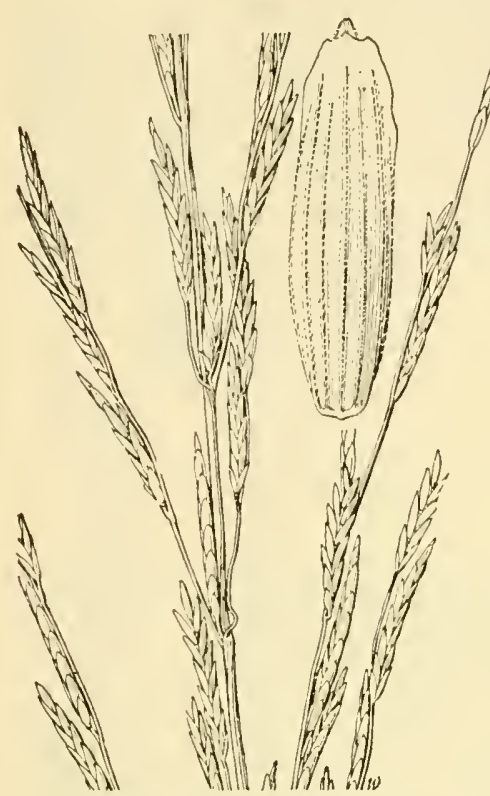
Bickn.) - S h allow water and wet places, Quebec to Minnesota, south to South Carolina and eastern Texas (fig. 132).

\section{Glyceria flúi-} tans (L.) R. Br. Mannagrass. (Fig. 133.) Resembling $G$. septentrionalis in habit; first glume usually only onethird as long as the first lemma; lemmas scaberulous, the nerves distinct but not raised prominently above the tissue of the internerves; tip of palea usually exceeding its

F1Gure 131.-Glyceria septentrionalis. Panicle, lemma. 2) (Panic$\times 1$; floret, $\times 10$. (Deam 3184, Ind.) ularia fluitans Kuntze; P. brachyphylla Nash.)-Shallow water, Newfoundland to Quebec and New York; South Dakota; Eurasia.

7. Glyceria occidentális (Piper) J. C. Nels. (Fig. 134.) Culms flaccid, 60 to $100 \mathrm{~cm}$ tall; blades 3 to $12 \mathrm{~mm}$ wide, smooth beneath, somewhat scabrous on the upper surface; panicle loose, spreading at

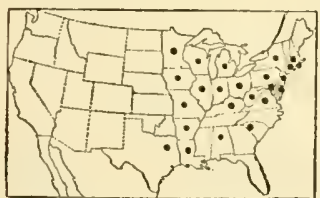

Figure 132.-Distribution of Glyceria septentrionalis. anthesis, 30 to $50 \mathrm{~cm}$ long; spikelets, 1.5 to $2 \mathrm{~cm}$ long; first glume mostly about 2 $\mathrm{mm}$ long; lemmas usually tinged with purple near the tip, 4 to $6 \mathrm{~mm}$ long, rather strongly scabrous, 7- to 9nerved, the nerves prominent, raised above the tissue of the

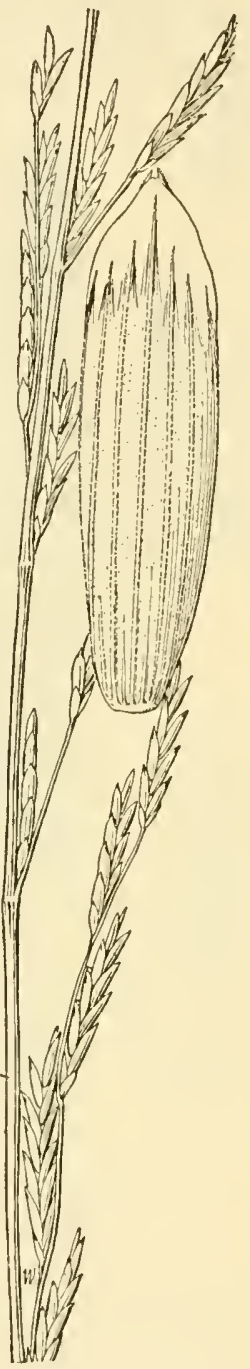

FigURE 133.-Glyceria fluitans. Panicle, $\times 1$; floret, $\times 10$. (M I cIntosh 1076, S.Dak.) internerves; palea about as long as its lemma, sometimes slightly exceeding it. 24 (Panicularia occidentalis Piper.)-Marshes, shallow water, and wet places, Idaho to British Columbia and northern California (fig. 135). The seeds are used for food by the Indians. 
Section 2. Hydrópoa Dum.

Spikelets more or less laterally compressed, ovate to oblong, usually not more than $5 \mathrm{~mm}$ long; panicles open or condensed but not long and narrow (except in G. melicaria).

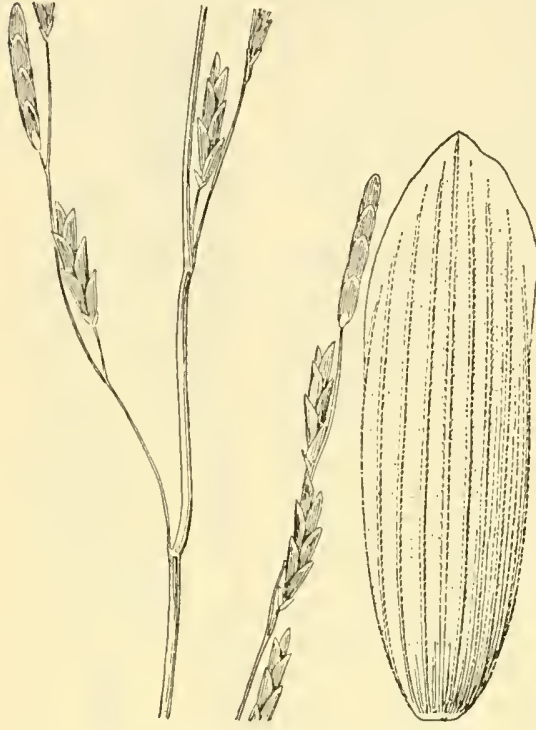

Floure 134.-Glyceria occidentalis. Panicle, $\times 1$; floret, $\times 10$. (Type.)

8. Glyceria pauciflóra Presl. WEAK MANNAGRASS. (Fig. 136.) Culms 50 to $120 \mathrm{~cm}$ tall; sheaths smooth or scaberulous; blades thin, flat, lax, scaberulous, mostly 10 to $15 \mathrm{~cm}$ long, 5 to $15 \mathrm{~mm}$ wide; panicle open or rather dense, nodding, 10 to $20 \mathrm{~cm}$ long,

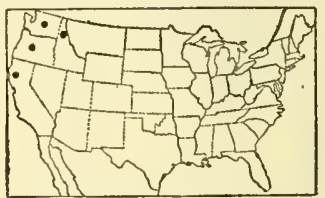

FIGURE 135.-Distribution of Glyceria occidentalis.

the branches ascending or spreading, rather flexuous, the spikelets crowded on the upper half, the lowermost usually 2 to 4 ; spikelets mostly 5- or 6-flowered, 4 to $5 \mathrm{~mm}$ long, often purplish; glumes broadly ovate or oval, about 1 and $1.5 \mathrm{~mm}$ long, the margins erose-scarious; lemmas oblong, about $2 \mathrm{~mm}$ long, with 5
prominent nerves and an outer short faint pair near the margins, scaberulous on the nerves and somewhat so between them, the tip rounded, scarious, somewhat erose. 21 (Panicularia pauciflora Kuntze.)Shallow water, marshes and wet meadows, Alaska to South Dakota,

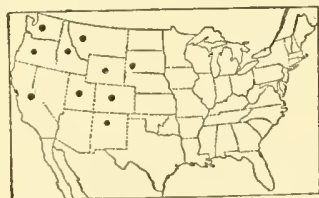

Figure 137.-Distribution of Glyceria pauciflora.

south to California and New Mexico, rising in the mountains to timber line (fig. 137).

9. Glyceria erécta Hitchc. (Fig.

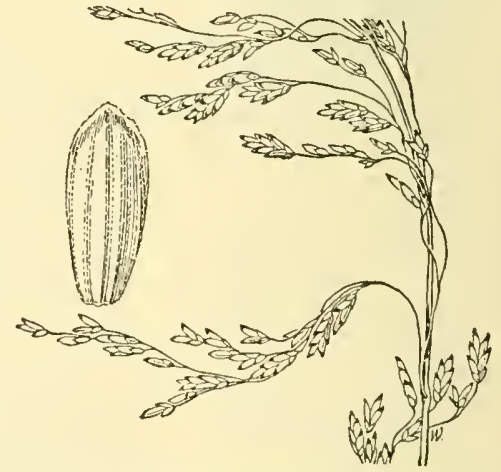

FIGURE 136.-Glyceria pauciflora. Panicle, $\times 1$; floret, $\times 10$. (Sandberg, Heller, and McDougal 636 , Idaho.) 138.) Differing from $G$. pauciflora. in the smaller size, mostly 30 to $40 \mathrm{~cm}$ tall, and in the narrow erect panicles, 3 to $8 \mathrm{~cm}$ long, with ascending or appressed few-flowered branches; lemmas about $3 \mathrm{~mm}$ long. 2l (Panicularia erecta Hitche.)- Springy or boggy places, mostly near or above timber line, Crater Lake, Oreg., to Mount Whitney, Calif., and Glenbrook, Nev. Passes in to the preceding species, of which it may be an alpine variety. 
10. Glyceria obtúsa (Muhl.) Trin. (Fig. 139.) Culms erect, often decumbent at base, 50 to $100 \mathrm{~cm}$ tall, rather firm; blades elongate, erect, mostly smooth, flat or folded, 2 to $6 \mathrm{~mm}$ wide; panicle erect, oblong or narrowly elliptic, dense, 5 to $15 \mathrm{~cm}$ long, the branches ascending or appressed; spikelets mostly 4- to 7 -flowered, 4 to $6 \mathrm{~mm}$ long, green or tawny, the rachilla joints very short; glumes broad, scarious, 1.5 and $2 \mathrm{~mm}$ long; lemmas firm, faintly nerved, smooth, 3 to $4 \mathrm{~mm}$ long, obtuse, the scarious tip narrow, often revolute. 2 (Paniculariaobtusa Kuntze.)-Bogs and marshy places, Nova Scotia to North Carolina, near the coast (fig. 140).

11. Glyceria melicária (Michx.) F. T. Hubb. (Fig. 141.) Culms slender, solitary or few, 60 to $100 \mathrm{~cm}$ tall; blades elongate, scaberulous, 2 to $5 \mathrm{~mm}$ wide; panicle narrow but rather loose, nodding, 15 to $25 \mathrm{~cm}$ long, the branches erect, rather distant; spikelets 3- or 4-flowered, about $4 \mathrm{~mm}$ long, green; glumes about 1.5 and $2 \mathrm{~mm}$ long, acutish; lemmas firm, 2 to $2.5 \mathrm{~mm}$ long, acutish, smooth, the nerves rather faint. 2 (G.torreyana

FIGURE 138.Glyceria erecta. Panicle, $\times 1$; (Hitchcock 3059, Oreg.) Hitchc.; Panicularia torreyana Merr.; $P$. melicaria.Hitchc.)-Swamps and wet woods, New Brunswick to Ohio, south to the mountains of North Carolina (fig. 142).

12. Glyceria canadénsis (Michx.) Trin. RatTlesnake mannagrass. (Fig. 143.) Culms erect, solitary or few in a tuft, 60 to $150 \mathrm{~cm}$ tall; blades scabrous, 3 to $7 \mathrm{~mm}$

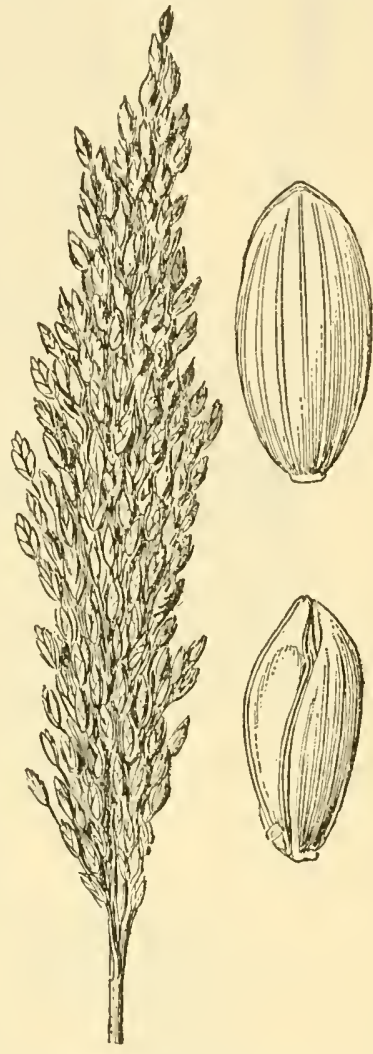

Figure 139.-Glyceria obtusa. Pan icle, $\times 1 ; 2$ views of Horet, $\times 10$. (Miller, N.Y.) wide; panicle open, 15 to $20 \mathrm{~cm}$ long, nearly as wide, the branches rather distant, drooping, naked below; spikelets ovate or oblong, 5- to

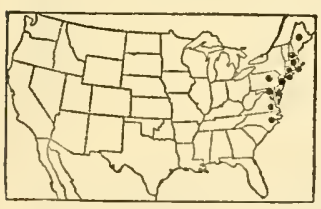

Figure 140.-Distribution of Glyceria obtusa. 10 -flowered, 5 to $6 \mathrm{~mm}$ long, the florets crowded, spreading; glumes about 2 and $3 \mathrm{~mm}$ long; lemmas 3 to $4 \mathrm{~mm}$ long, the 7 nerves obscured in the firm tissue of the lemma; palea bowed out on the keels, the floret somewhat tumid. 2 (Panicularia canadensis Kuntze.)-Bogs and wet places, Newfoundland to Minnesota, south to Maryland and Illinois (fig. 144).

Glyceria Canadensis var. LÁxa (Scribn.) Hitchc. On the average taller, with looser panicles of somewhat smaller 3- to 5-flowered spikelets. 24 (Panicularia laxa Scribn.)Wet places, Nova Scotia to New York, Maryland, and West Virginia; Michigan. 
13. Glyceria striáta (Lam.) Hitche. Fowl mannagrass. (Fig.

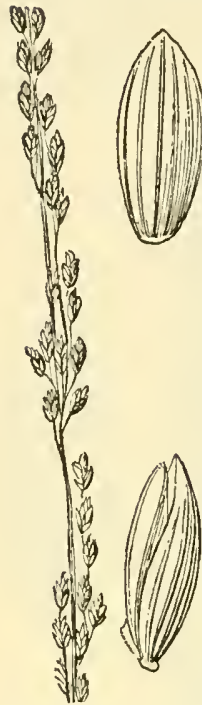

FIGURE 141.-Glyceria melicarza. Panicle, $\times 1 ; 2$ views of floret, $x$ 10. (Harvey 1322, Maine.) 145.) Plants in large tussocks, pale green; culms erect, slender, rather firm, 30 to $100 \mathrm{~cm}$ tall, sometimes taller; blades erect or ascending, flat or folded, moderately firm, usually 2 to $6 \mathrm{~mm}$ wide, sometimes to $9 \mathrm{~mm}$; panicle ovoid, open, 10 to $20 \mathrm{~cm}$ long, nodding, the branches ascending at base, drooping, naked below; spikelets ovate or oblong, 3- to 7 -flowered, 3 to $4 \mathrm{~mm}$ long, often purplish, somewhat crowded toward the ends of the branchlets; glumes about 0.5 and $1 \mathrm{~mm}$ long, ovate, obtuse; lemmas oblong, prominently 7 -nerved, about $2 \mathrm{~mm}$ long, the scarious tip inconspicuous; palea rather firm, about as long as the lemma, the smooth keels prominent, bowed out. 2 (G. nervata Trin.; Panicularia nervata Kuntze.)-Moist meadows and

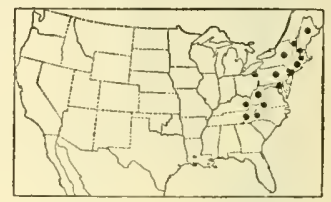

FIGURE 142.-Distribution of Glyceria melicaria.

wet places, Newfoundland to British Columbia, south to northern Florida, Texas, Arizona, and northern California. A low strict northern form has been called $G$. striata var. stricta Fernald $(G$. nervata var. stricta Scribn.)

14. Glyceria eláta (Nash) Hitchc. Tall mannaGRass. (Fig. 146.) Resembling G. striata; plants dark green; culms 1 to $2 \mathrm{~m}$ tall, rather succulent; blades flat, thin, lax, 6 to $12 \mathrm{~mm}$ wide; panicle oblong, 15 to $30 \mathrm{~cm}$ long,

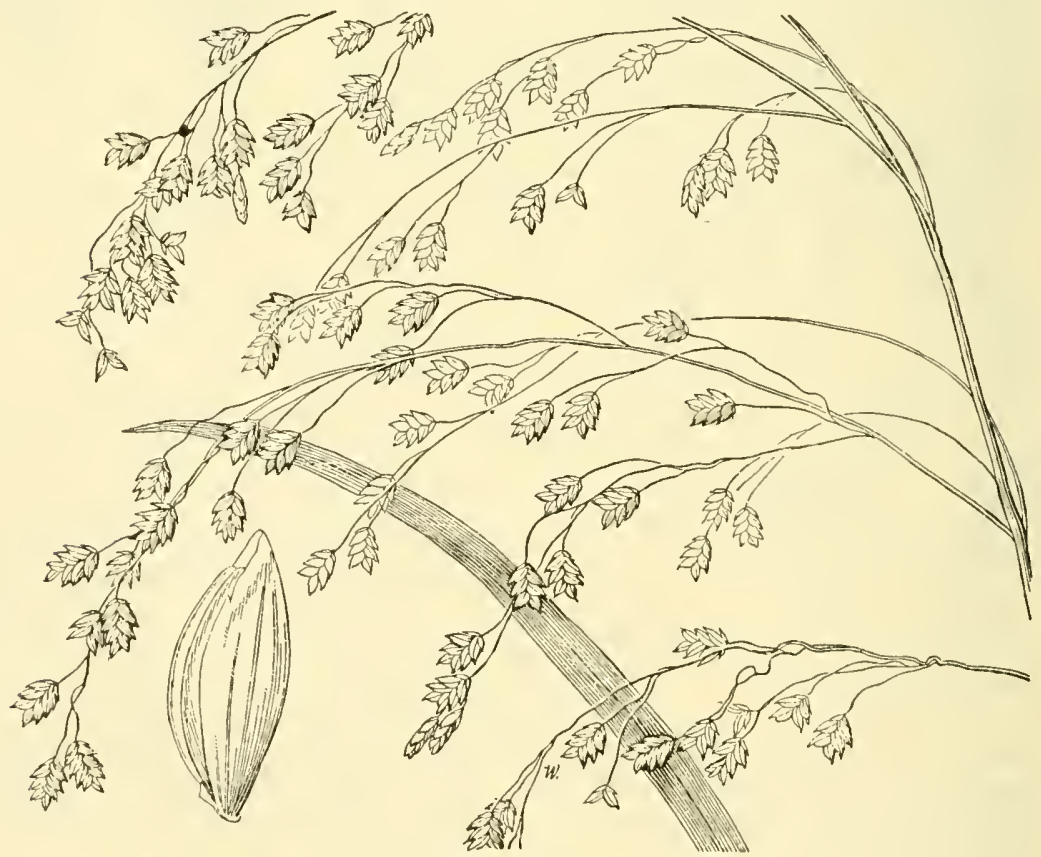

Figure 143.-Glyceria canadensis. Panicle, $\times 1$; floret, $\times 10$. (Kneucker, Gram. 464, Conn.) 


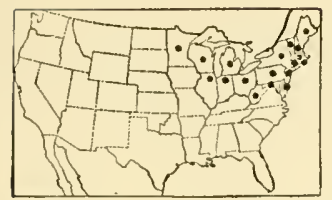
FIGURE 144.-Distribution of
Glyceria canadensis.

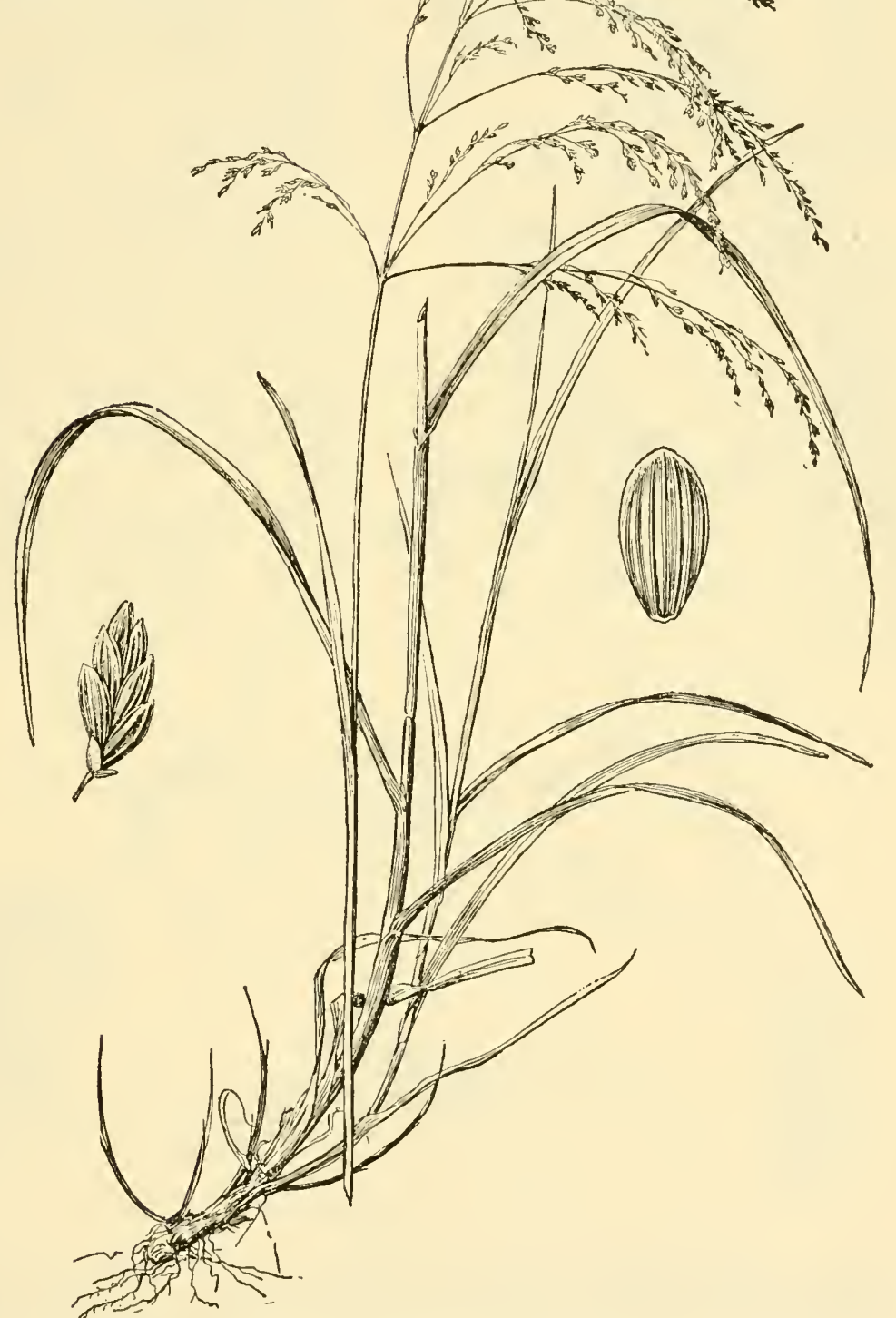

Figure 145.-Glycetia striata. Plant, $\times 1 / 2$; spikelet, $\times 5$; floret, $\times 10$. (V. H. Chase 60, Ill.) 
the branches spreading, the lower often reflexed; spikelets 6 - to 8-

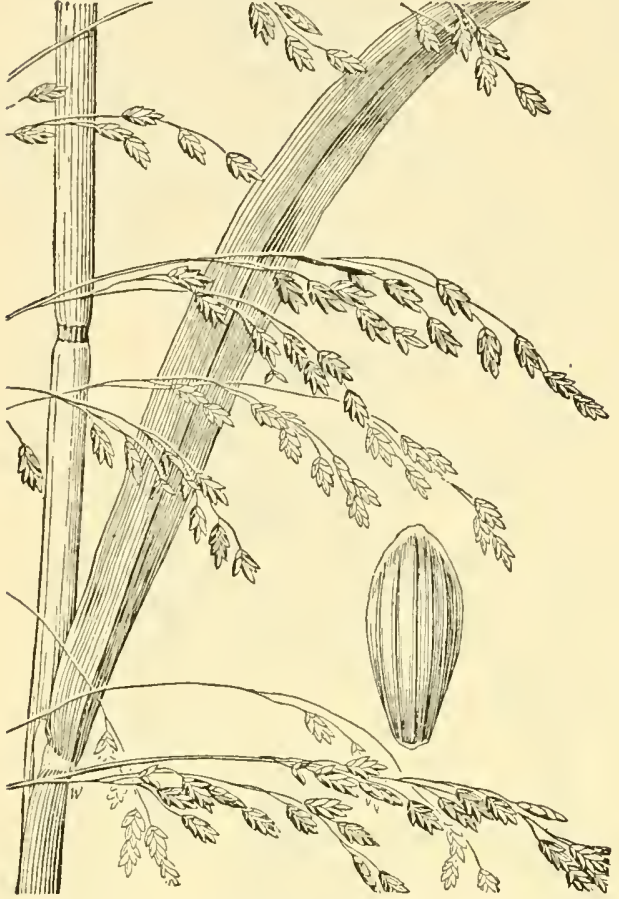

FigURE 146.-Glyceria elata. Plant, $\times 1$; floret, $\times 10$. (Hitchcock 2731, Calif.) flowered, 3 to $5 \mathrm{~mm}$ long; glumes and lemmas a little longer than in $G$. striata. 21 (Panicularia elata Nash; P. nervata elata Piper.) - Wet meadows, springs, and shady moist woods, Montana to British Columbia, south in the mountains to New Mexico and southern California.

15. Glyceria otísii Hitchc. (Fig. 147.) Resembling $G$. elata; spikelets broader, oblong, with on the average more florets, the glumes broader; lemmas broader, especially at the summit, very scabrous, the prominent hyaline tip contrasting with the purple zone just below, the lower part of the lemma green. 24 -Timber, Jefferson County, Wash. Known only from the type collection.

16. Glyceria grándis $\mathrm{S}$. Wats. American ManNaGrass. (Fig. 148.) Culms tufted, stout, 1 to $1.5 \mathrm{~m}$ tall; blades flat, 6 to $12 \mathrm{~mm}$ wide; panicle large, very compound, 20 to 40
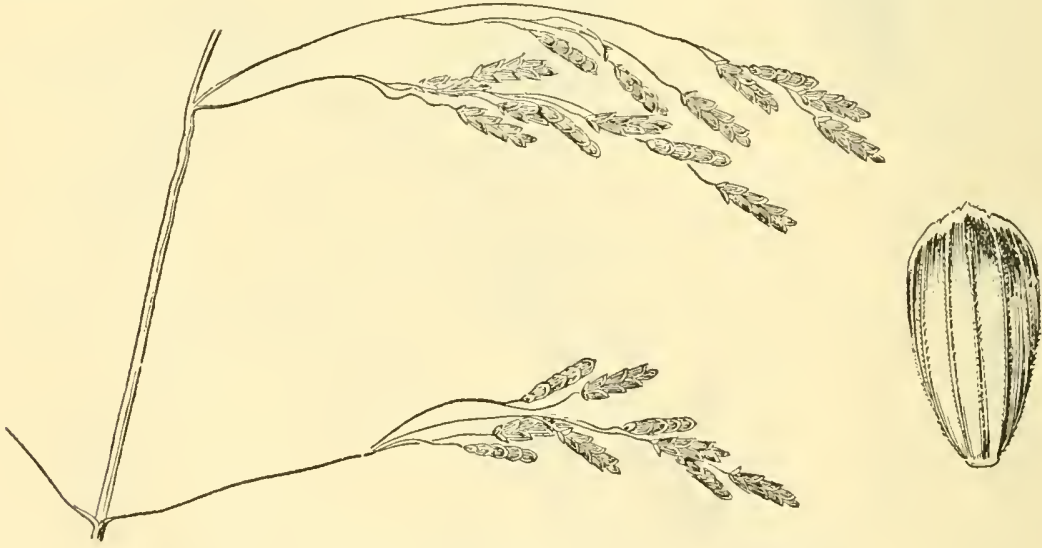

Figure 147.-Glyceria otisii. Panicle, $\times 1$; floret, $\times 10$. (Type.)

cm long, open, nodding at summit; spikelets 4- to 7 -flowered, 5 to 6 $\mathrm{mm}$ long, glumes whitish, about 1.5 and $2 \mathrm{~mm}$ long; lemmas purplish, 
about $2.5 \mathrm{~mm}$ long; palea rather thin, about as long as the lemma. 2 (Panicularia americana MacM.) - Banks of streams, marshes, and

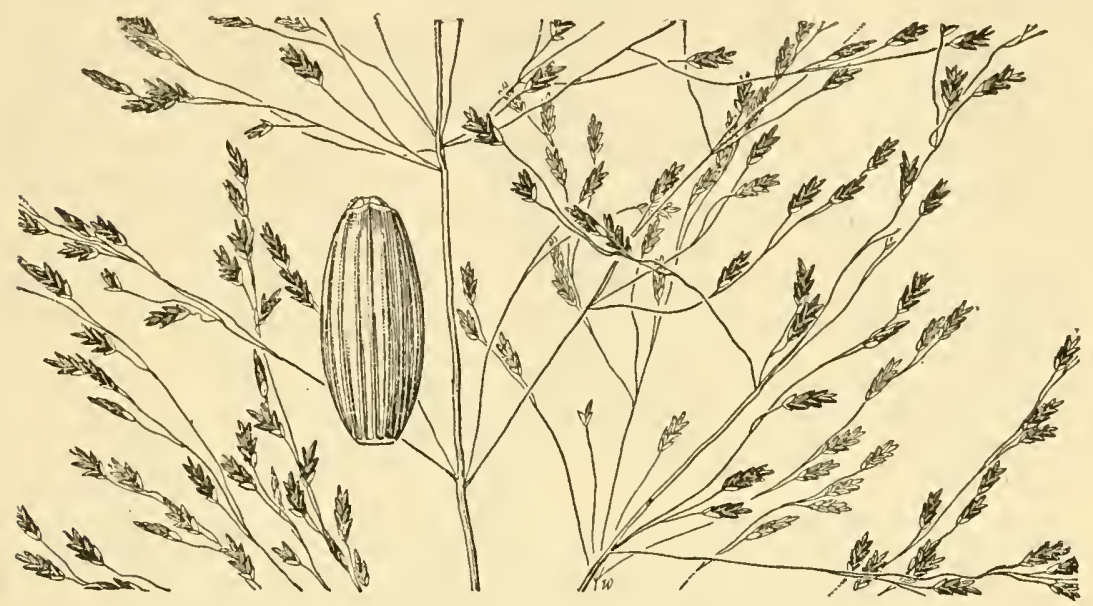

Figure 148.-Glyceria grandis. Panicle, $\times 1$; floret, $\times 10$. (Pearce, N.Y.)

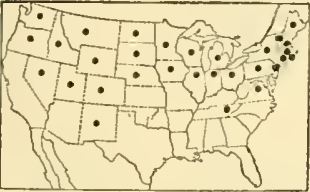

FIGURE 149.-Distribution of Glyceria grandis.

wet places, Prince Edward Island to Alaska, south to Tennessee, Ohio, Iowa, Nebraska, New Mexico, and eastern Oregon (fig. 149).

Glyceria nubígena W.A. Anderson. Similar to G. grandis; culms more slender and less succulent; spikelets 3- to 5-flowered; glumes purplish, not pale and translucent as in $G$. grandis; lemmas on the average longer and

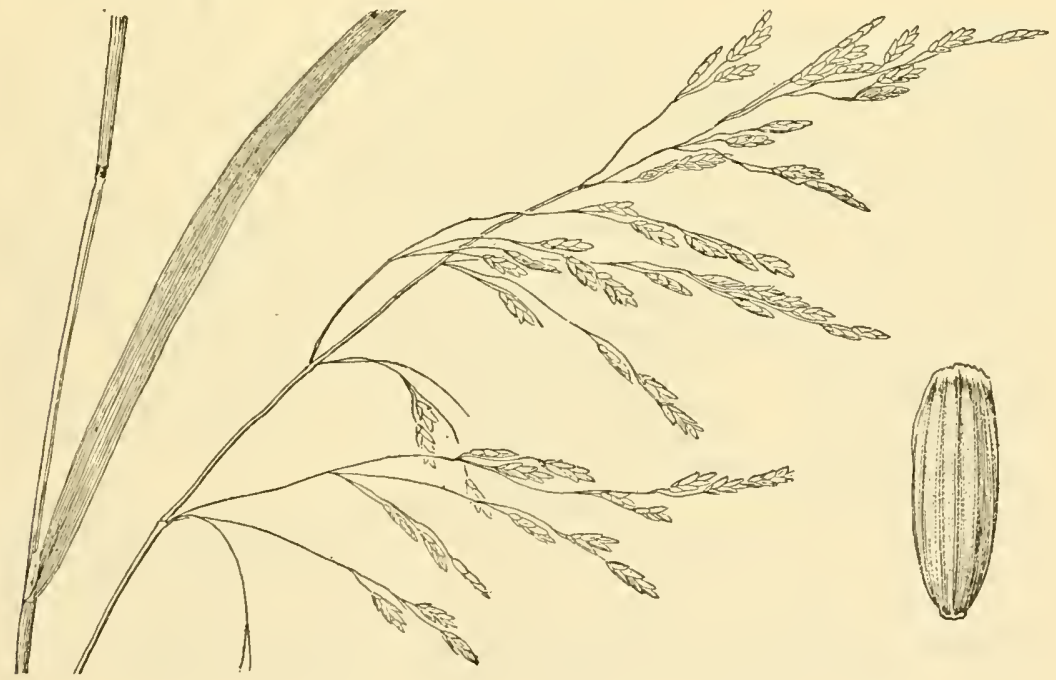

Figure 150.-Glyceria pallida. Plant, $\times 1$; floret, $\times 10$. (Pearce, N.Y.)

wider, the nerves farther apart and less prominent; palea firmer, rather coriaceous. 24-Boggy openings in forest, Clingmans 
Dome, Great Smoky Mountains, Tenn. A rare and apparently distinct species based upon fragnentary material. More specimens

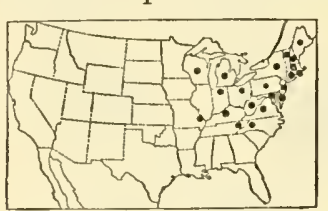

Figure 151.-Distribution of Glyceria pallida. are needed.

17. Glyceria pállida (Torr.) Trin. (Fig. 150.) Culms slender, lax, ascending from a decumbent rooting base, 30 to $100 \mathrm{~cm}$ long; blades mostly 4 to $8 \mathrm{~mm}$ wide; panicle pale green, open, 5 to $15 \mathrm{~cm}$ long, the branches ascending, flexuous, finally more or less spreading; spikelets somewhat elliptic, 4- to 7flowered, 6 to $7 \mathrm{~mm}$ long; glumes 1.5 to 2 and 2 to $2.5 \mathrm{~mm}$ long; lemmas 2.5 to $3 \mathrm{~mm}$ long, scaberulous, obtuse, the scarious tip erose; anthers linear, about $1 \mathrm{~mm}$ long. 24 (Panicularia pallida Kuntze.)-Shallow cold water, Maine to Wisconsin, south to North Carolina and Missouri (fig. 151). Resembles species of Poa.

18. Glyceria neogaéa Steud. (Fig. 152.) Resembling $G$. pallida and appearing to grade into it; culm more slender, 20 to $40 \mathrm{~cm}$ long; blades 1 to $3 \mathrm{~mm}$ wide; panicle on the average smaller, the branches finally spreading or reflexed; spikelets mostly 3 - to 5-flowered, 4 to $5 \mathrm{~mm}$ long; glumes and lemmas a little shorter than in $G$. pallida; anthers globose, 0.2 to $0.5 \mathrm{~mm}$ long. 24 ( $G$. fernaldii St. John.)-Shallow water, Newfoundland to Minnesota, south to Connecticut (fig. 153).

\section{SCLERÓCHLOA Beauv.}

Spikelets 3-flowered, the upper floret sterile; rachilla continuous, broad, thick, the spikelet falling entire; glumes broad, obtuse, rather firm, with hyaline margins, the first 3-nerved, the second 7-nerved; lemmas rounded

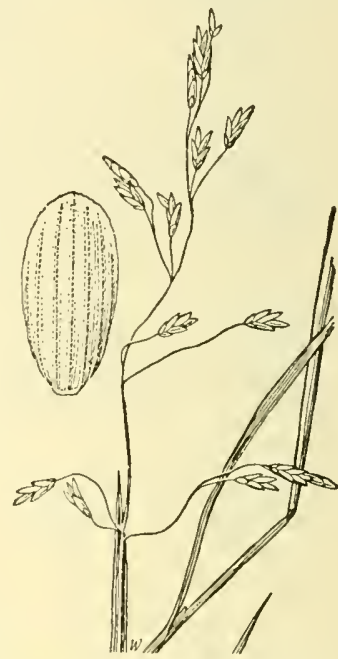

Figure 152.-Glyceria neogaea. Plant, $\times 1$; floret, $\times 10$. (Collins, Fernald, and Pease; Que.) on the back, obtuse with 5 prominent parallel nerves and hyaline margins; palea hyaline, sharply keeled. Low tufted annual, with

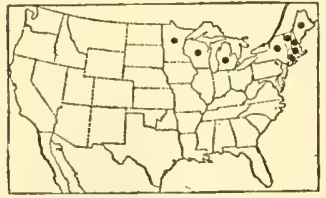

FIGURE 153.-Distribution of Glyceria neogaea. broad upper sheaths, folded blades with boatshaped tips, and dense spikelike racemes, the spikelets subsessile, imbricate in two rows on one side of the broad thick rachis. Type species, Sclerochloa dura. Name from Greek skleros, hard, and chloa, grass, alluding to the firm glumes.

1. Sclerochloa dúra (L.) Beauv. (Fig. 154.) Culms erect to spreading, 2 to $7 \mathrm{~cm}$ long; foliage glabrous, the lower leaves very small, the upper increasingly larger, with broad overlapping sheaths; blades 7 to $18 \mathrm{~mm}$ long, 1 to $3 \mathrm{~mm}$ wide, the upper exceeding the raceme, the junction with the sheath obscure; raceme 1 to $2 \mathrm{~cm}$ long, nearly half as wide; spikelets 6 to 7 
$\mathrm{mm}$ long on very short thick pedicels; first glume about one-third, the second half as long as the spikelets; lower lemma $5 \mathrm{~mm}$ long.

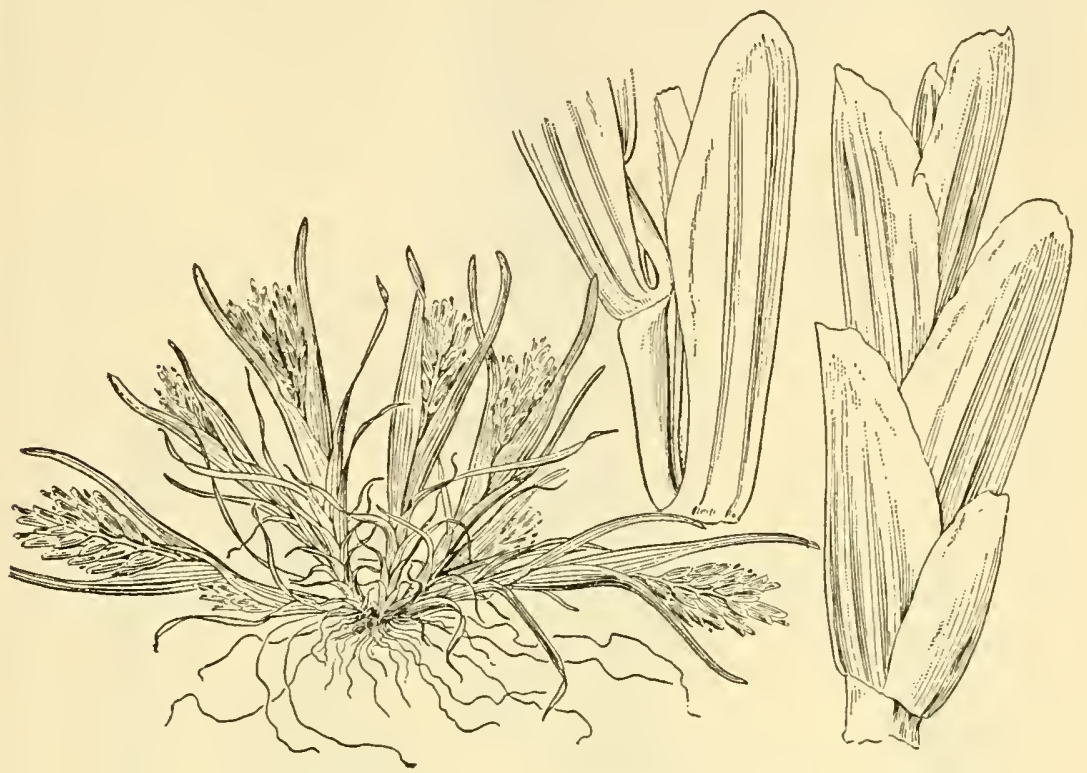

Figure 154.-Sclerochloa dura. Plant, $\times 1$; spikelet and floret, $\times 10$. ('Type.)

$\odot$-Dry sandy or gravelly soil, Washington, Idaho, Colorado, and Utah (fig. 155); introduced from southern Europe.

\section{FLUMÍNEA Fries}

\section{(Scolochloa Link)}

Spikelets 3- or 4-flowered, the rachilla disarticulating above the glumes and between the florets; glumes nearly equal, somewhat

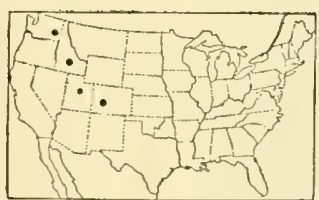

Figure 155.-Distribution of Sclerochloa dura.

scarious and lacerate at summit, the first 3 -nerved, the second 5-nerved, about as long as the first lemma; lemmas firm, rounded on the back, villous on the callus, 7-nerved, the nerves rather faint, unequal, extending into a scarious lacerate apex; palea narrow, flat, about as long as the lemma. Tall perennials, with succulent rhizomes, flat blades, and spreading panicles. Type species, Fluminea festucacea. Name from Latin flumen, a river, the grass commonly growing along river margins.

The single species has some value for forage and is often a constituent of marsh hay.

1. Fluminea festucácea (Willd.) Hitchc. (Fig. 156.) Culms erect, stout, 1 to $1.5 \mathrm{~m}$ tall, from extensively creeping, succulent rhizomes; blades elongate, scabrous on the upper surface, mostly 5 to 


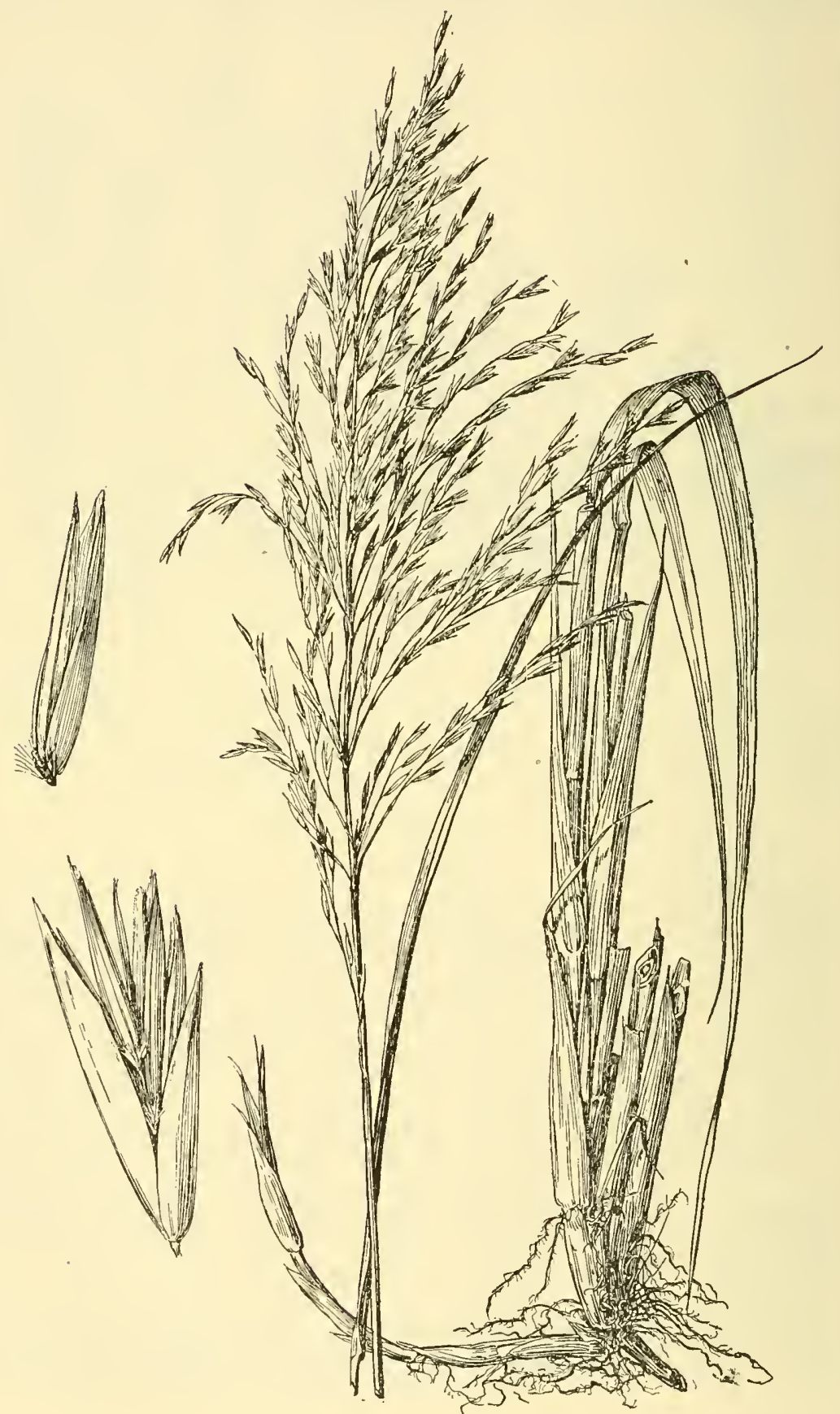

Figure 156.-Fluminea festucacea. Plant, $\times 1 \frac{1}{2}$; spikelet and floret, $\times$ 5. (Griffiths 870, S.Dak.) 
$10 \mathrm{~mm}$ wide, extending into a fine point; panicle 15 to $20 \mathrm{~cm}$ long, loose, the distant branches fascicled, ascending, naked below, the lowermost nearly as long as the panicle; spikelets about $8 \mathrm{~mm}$ long, the florets approximate; lemmas about $6 \mathrm{~mm}$ long. 24 -Shallow water and marshes, Manitoba to British Columbia, south to northern Iowa, Nebraska, and eastern Oregon (fig. 157); northern Eurasia.

\section{Pleuropógon R. Br. Semaphore-grass}

Spikelets several- to many-flowered, linear, the rachilla disarticulating above the glumes and between the florets; glumes unequal, membranaceous or subhyaline, scarious at the somewhat lacerate tip, the first 1-nerved, the second obscurely 3-nerved; lemmas membranaceous, 7-nerved, with a round indurate callus, the apex entire or 2-toothed, the midnerve extending into a short mucro or into an awn; keels of the palea winged on the lower half. Soft annuals or perennials, with simple culms, flat blades, and loose racemes of rather large spikelets on a slender flexuous axis. Type species, Pleuropogon sabinii R. Br. Name from Greek pleura, side, and pogon, beard, the palea of the type species having a bristle on each side at the base.

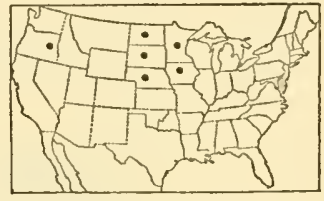

FIGURE 157.-Distribution of Fluminea festucacea.

Palatable grasses, but too infrequent to be of economic value. Lemmas about $6 \mathrm{~mm}$ long; plants annual; spikelets ascending.

1. P. CALifornicus. Lemmas about $8 \mathrm{~mm}$ long; plants perennial; spikelets finally reflexed or drooping. 2. P. REFRACTUS.

1. Pleuropogon califórnicus (Nees) Benth. (Fig. 158.) Annual; culms tufted, erect or decumbent at base, 30 to $60 \mathrm{~cm}$ tall; blades flat or folded, seldom more than $10 \mathrm{~cm}$ long, 2 to $5 \mathrm{~mm}$ wide; raceme 10 to $15 \mathrm{~cm}$ long, with 5 to 10 rather distant short-pediceled spikelets; spikelets 6 - to 12 -flowered, mostly about $2.5 \mathrm{~cm}$ long, erect, or somewhat spreading; glumes obtuse, erose, 4 to $6 \mathrm{~mm}$ long; lemmas scabrous, 5 to $6 \mathrm{~mm}$ long, the nerves prominent, the tip obtuse, scarious, erose, the awn usually 6 to $12 \mathrm{~mm}$ long; wings of palea prominent, cleft, forming a tooth about the middle. $\odot$-Wet meadows and marshy ground, Mendocino County to the San Francisco Bay region, Calif.

2. Pleuropogon refráctus (A. Gray) Benth. Nodding semaphoreGrass. (Fig. 159.) Perennial; culms 1 to $1.5 \mathrm{~m}$ tall; blades elongate, the uppermost nearly obsolete, 3 to $7 \mathrm{~mm}$ wide; raceme about as in $P$. californicus, the spikelets as many as 12 , about $3 \mathrm{~cm}$ long, finally reflexed or drooping; lemmas about $8 \mathrm{~mm}$ long, less scabrous and the nerves less prominent than in P. californicus; awn from $12 \mathrm{~mm}$ long to nearly obsolete; palea narrow, keeled to about the middle, scarcely or minutely toothed. $21-$ Bogs, wet meadows, and mountain streams, Washington to Mendocino County, Calif., west of the Cascades. 


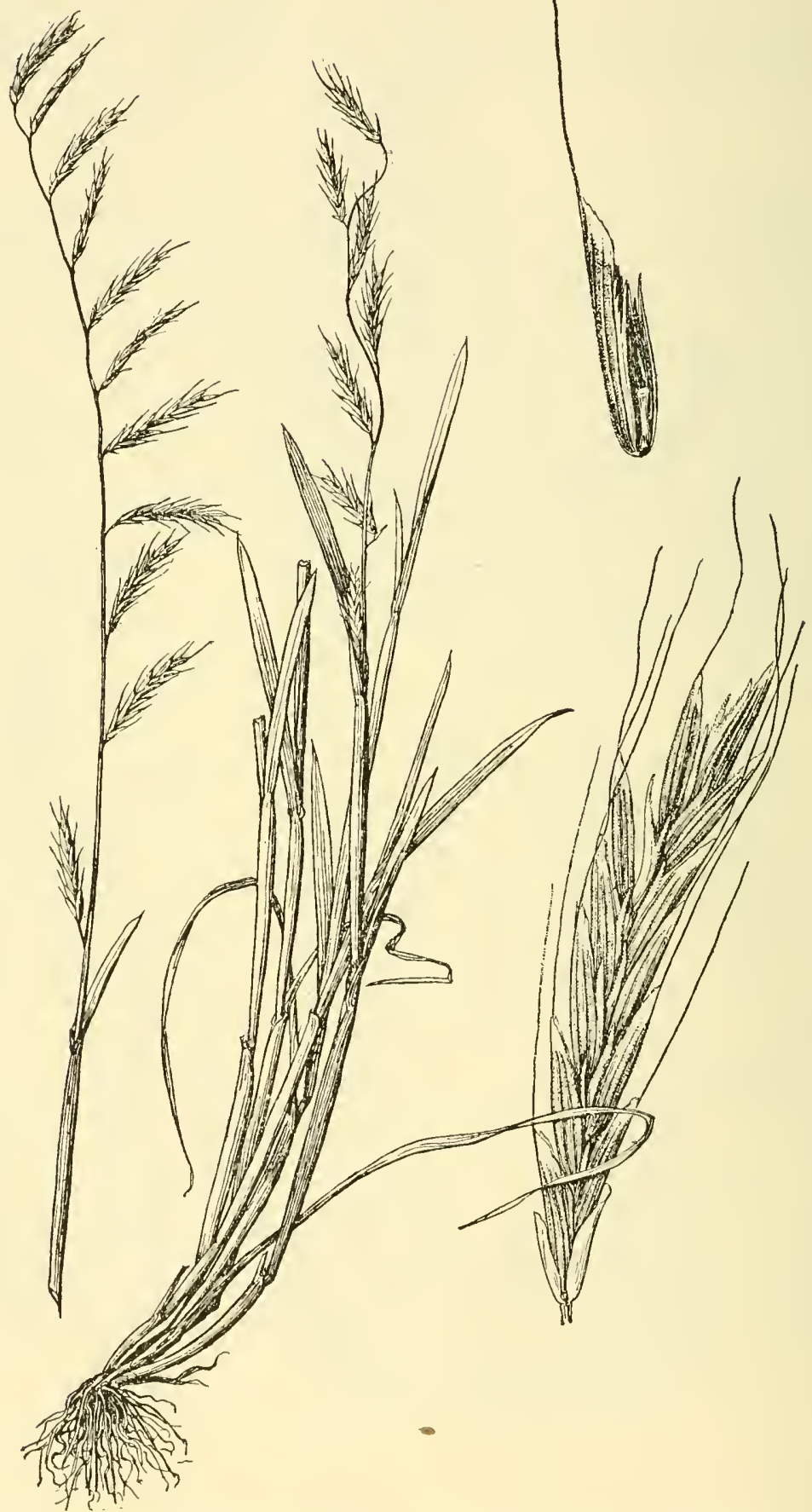

Figure 158.-Pleuropogon californicus. Plant, $\times 1 / 2$; spikelet, $\times 3$; floret, $\times 5$. (Bolandei 6075, Calif.) 


\section{PÓA L. Bluegrass}

Spikelets 2- to several-flowered, the rachilla disarticulating above the glumes and between the florets, the uppermost floret reduced or rudimentary; glumes acute, keeled, somewhat unequal, the first usually 1-nerved, the second usually 3-nerved; lemmas somewhat keeled, acute or acutish, rarely obtuse, awnless, membranaceous, often somewhat searious at the summit, 5-nerved (intermediate nerves, that is, the pair between the keel and the marginal nerves, rarely obsolete), the nerves sometimes pubescent. Low or rather tall slender annuals or usually perennials with spikelets in open or contracted panicles, the relatively narrow blades flat, folded, or involute, ending in a boat-shaped tip. Standard species, Poa pratensis. Name from Greek, poa, grass.

There are several groups of Poa that present many taxonomic difficulties. In the groups containing, for example, $P$. nervosa, $P$. arctica, $P$. scabrella, and $P$. nevadensis, many species have been proposed which are not here recognized as valid, because they were based upon trivial or variable characters. The keys are based upon average specimens but the student may find occasional intermediates between the valid species.

The bluegrasses are of great importance because of their forage value, some species being cultivated for pasture and others forming a large part of the forage on the mountain meadows of the West. The most important is Poa pratensis, commonly known as bluegrass or Kentucky bluegrass. In the cooler parts of the United States it is cultivated for lawns and is the standard pasture grass in the humid regions where the soil contains plenty of lime. It has been extensively used in the improvement of badly depleted western mountain ranges. P. compressa, Canada bluegrass, is cultivated for pasture in the Northeastern States and Canada, especially on poor soils. P. trivialis and $P$.palustris, are oecasionally grown in meadow mixtures but are of little agricultural importance. $P$. arachnifera, Texas bluegrass, has been used in some parts of the South for winter pasture and as a lawn grass. $P$. annua is a common weed in

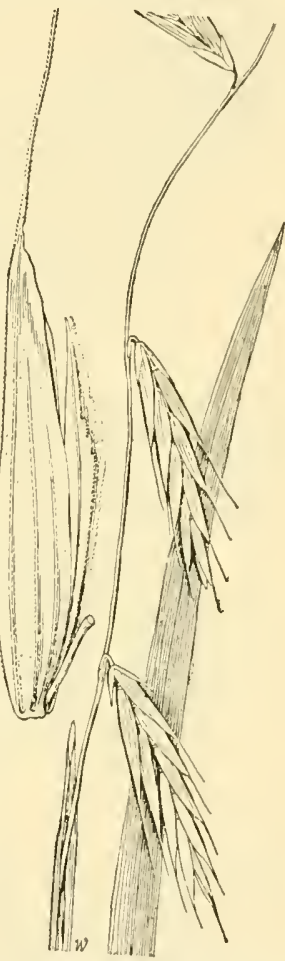

FIGURE 159.-Pleuropogon refractus. Plant, X1; floret, $\times 5$. (Sandberg and Leiberg 734, Wash.) lawns and gardens. P. bulbosa is cultivated about Medford, Oreg., and elsewhere.

With very few exceptions the bluegrasses are palatable and nutritious and are often the most important grasses in many parts of the West. At high altitudes, $P$. alpina, $P$. arctica, $P$. epilis and $P$. rupicola are important. In the mountains mostly below timber line are found $P$. fendleriana (mutton grass), $P$. longiligula, $P$. nervosa, $P$. secunda (Sandberg bluegrass), P. canbyi, and P. juncifolia, all of wide distribution. P. interior is mostly in the Rocky Mountains; P. scabrella 
is probably the most important forage grass of the lower elevations in California; $P$. gracillima and $P$. ampla are mostly in the Northwestern States; $P$. arida is the most valuable bluegrass of the Plains. $P$. bigelovii, an annual, is important in the Southwestern States. $P$. macrantha and $P$. confinis are native sandbinders of the sand dunes on the coast of Washington and Oregon, but are not cultivated.

Spikelets little compressed, narrow, much longer than wide, the lemmas convex on the back, the keels obscure, the marginal and intermediate nerves usually faint. All bunchgrasses.

Lemmas crisp-puberulent on the back toward the base (the pubescence sometimes obscure or only at the very base) ........... 6 . Scabrellat. Lemmas glabrous or minutely scabrous, but not crisp-puberulent.

7. Nevadenses.

Spikelets distinctly compressed, the glumes and lemmas keeled.

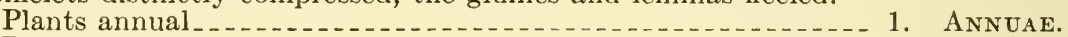

Plants perennial.

Creeping rhizomes present._..................... 2. Pratenses.

Creeping rhizomes wanting.

Lemmas webbed at base _.......................... 3. PAlustres.

Lemmas not webbed at base (sometimes sparsely webbed in $P$. laxa and $P$. pattersoni).

Lemmas pubescent on the keel or marginal nerves or both, sometimes pubescent also on the internerves........... 4. AlpinaE. Lemmas glabrous (minutely pubescent at base in $P$. unilateralis).

\section{Annuae}

5. EPIles.

Lemmas glabrous, except the scabrous keel, webbed at base. Sheaths glabrous.

Lemmas pubescent.

1. P. BOLANDERI.

Lemmas pubescent on the back especially toward the base, but not distinctly villous on the keel and nerves, slightly webbed at base. Sheaths usually scabrous; panicle open....... 2. PoweLLII. Lemmas pubescent on the nerves, sometimes also on the internerves.

Panicle narrow, contracted, usually interrupted; sheaths scabrous. Lemmas webbed, pubescent on the internerves below _...... 3. P. BIGELOVII.

Panicle oblong or pyramidal, the branches spreading; sheaths glabrous.

Lemmas with webby hairs at base, distinctly 3 -nerved, the intermediate nerves obscure; anthers 0.1 to $0.2 \mathrm{~mm}$ long - - 4. P. CHApManiana.

Lemmas not webbed at base, distinctly 5 -nerved; anthers 0.5 to $1 \mathrm{~mm}$ long.

5. P. ANNUA.

\section{Pratenses}

1a. Culms strongly flatiened, 2-edged.

1b. Culms terete or slightly flattened, not 2-edged.

6. P. COMPRESSA.

2a. Plants dioecious.

Panicle oblong, the two sexes unlike in appearance, the pistillate spikelets woolly, the staminate glabrous or nearly so. Plains of Texas.

7. P. ARACHNIFERA.

Panicle oblong or ovoid, the two sexes similar. Seacoast, California and northward.

Glumes and lemmas about $8 \mathrm{~mm}$ long _......... 8. P. Macrantha.

Glumes and lemmas not more than $6 \mathrm{~mm}$ long.

Panicle densely ovoid; lemmas $6 \mathrm{~mm}$ long, slightly villous below.

Panicle somewhat open; lemmas $3 \mathrm{~mm}$ long, scaberulous.

9. P. DOUGLASII.

10. P. CONFINIS.

2b. Plants not dioecious, the florets perfect.

3a. Blades involute. Glumes and lemmas 4 to $5 \mathrm{~mm}$ long.

3b. Blades flat or folded.

11. P. RHIzomata.

4a. Lemmas not pubescent nor webbed.

Panicle almost spikelike, erect; glumes $2 \mathrm{~mm}$ long.

12. P. ATROPURPUREA. 
Panicle open, nodding; glumes 3 to $4 \mathrm{~mm}$ long.

Blades broad and short; lower panicle branches reflexed.

Blades elongate; panicle branches ascending

13. P. CURTA. 4b. Lemmas pubescent.

5a. Lemmas glabrous except for the web at the base.

15. P. KELLOGGII.

5b. Lemmas pubescent on the nerves or back, sometimes also webbed at base.

6a. Internerves glabrous, the keel and marginal nerves pubescent.

Lower sheaths retrorsely pubescent, purplish; lemmas pubescent on keel and marginal nerves, not webbed_ 14. P. NERvosA.

Lower sheaths glabrous (scaberulous in $P$. laxiflora); lemmas webbed at base.

Culms retrorsely scabrous _............. 16. P. LAxiflora.

Culms glabrous.

Lower panicle branches in a whorl of usually five; blades mostly shorter than the culm _...... 17. P. PRATENSIS. Lower panicle branches usually in twos, spreading, spikeletbearing near the ends; blades about as long as the culm.

18. P. CUSPIDATA.

6b. Internerves pubescent near base, the keel and marginal nerves pubescent.

Panicle contracted, the branches appressed; blades folded, firm and stiff. Plains and alkali meadows at medium altitudes.

Panicle open, the branches spreading.

19. P. ARIDA.

Plants mostly more than $50 \mathrm{~cm}$ tall; panicle narrow, 10 to $20 \mathrm{~cm}$ long, the lower branches mostly in threes.

20. P. GLAUCIFOLIA.

Plants mostly less than $50 \mathrm{~cm}$ tall; panicle pyramidal, 5 to $10 \mathrm{~cm}$ long, the lower branches mostly in twos. Alpine meadows.

\section{Palustres}

21. P. ARCTICA.

1a. Lemmas glabrous, or the keel sometimes pubescent.

Sheaths retrorsely scabrous. Culms decumbent and often rooting at base; keel of lemma glabrous or slightly pubescent_...... 22. P. TRIVIALIS. Sheaths glabrous.

Panicle narrow, drooping, the branches appressed or ascending.

Panicle very open, 23. P. MARCIDA. drooping.

Lemmas villous on the keel; panicle branches mostly in fours or fives.

Lemmas glabrous on the keel; panicle branches mostly in 24 P. ALSODEs. Lemmas obtuse..... Lemmas acute... 26. P. SALTUENSIS.

1b. Lemmas pubescent on keel and marginal nerves.

2a. Sheaths distinctly retrorse-scabrous (sometimes faintly so). Cuims usually stout, 40 to $120 \mathrm{~cm}$ tall; panicle usually large and open, mostly

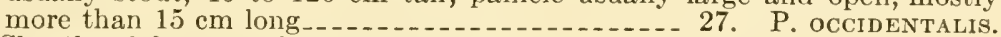

$2 b$. Sheaths glabrous or faintly scaberulous.

3a. Lower panicle branches distinctly reflexed at maturity.

Panicle oblong, erect, mostly more than $15 \mathrm{~cm}$ long, the branches several (usually more than 3 ) in a whorl_.......... 29. P. sYLVESTRIS.

Panicle nodding, mostly less than $15 \mathrm{~cm}$ long, the branches 1 to 3 together.

3 b. Lower panicle branches not reflexed.

30. P. REFLEXA.

4a. Panicle narrowly pyramidal, erect, 15 to $20 \mathrm{~cm}$ long. Lemmas $4 \mathrm{~mm}$ long, pubescent on nerves and internerves; webbed at base; New Mexico _... TRACY.

4b. Panicle broadly pyramidal, usually nodding.

5a. Intermediate nerves of lemma distinct ...........31. P. WoLFI.

5 b. Intermediate nerves of lemma obscure.

6a. Lower panicle branches in pairs, elongate, capillary, bearing a few spikelets near the ends. 
Spikelets rather broad, the rachilla joints short, hidden by the florets; sheaths smooth; culms in dense tufts; alpine rocky slopes . . . . . $32 . \quad$ P. PAUCispicula.

Spikelets narrow, the rachilla joints slender, somewhat elongate, usually not hidden by the florets; sheaths minutely roughened; culms solitary or in small tufts; shady bogs.

Intermediate nerves of lemma distinct; uppermost ligule acute, 3 to $4 \mathrm{~mm}$ long; western mountains below timber line.

33. P. LEPTOCOMA.

Intermediate nerves of lemma obscure; uppermost ligule truncate, 0.3 to $1.5 \mathrm{~mm}$ long; Great Lake region at low altitudes.

34. P. PALUDIGENA.

6b. Lower panicle branches often more than 2 , if only 2 not capillary and elongate.

Florets usually converted into bulblets with dark purple base; culms swollen and bulblike at base....... 35. P. BULBosa.

Florets normal; culms not bulblike at base.

Glumes narrow, acuminate, about as long as the first lemma; ligule very short _..._.......... 36. P. NEMORALIS.

Glumes lanceolate, acute, shorter than the first lemma; ligules rather prominent, those of the culm leaves 1 to $3 \mathrm{~mm}$ or more long.

Spikelets about $6 \mathrm{~mm}$ long; lemmas $4 \mathrm{~mm}$ long.

37. P. Macroclada.

Spikelets about $4 \mathrm{~mm}$ long; lemmas 2.5 to $3 \mathrm{~mm}$ long.

Culms decumbent at the purplish base; panicle 10 to $30 \mathrm{~cm}$ long, large and open ......... 38. P. PALUstris.

Culms erect from a green or tawny base; panicle mostly less than $10 \mathrm{~cm}$ long, comparatively small and few-flowered.

\section{Alpinae}

39. P. INTERIOR.

Blades folded or invoıtue, firm, rather stiff.

Ligule very short, not noticeable when viewed from the side of sheath.

Ligule prominent, easily seen in side view, 5 to $7 \mathrm{~mm}$ long.

40. P. FENDLERIANA.

Blades flat or, if involute, rather lax or soft.

41. P. LONGILIGULA.

Panicle branches slender, spreading or drooping, the lower naked and simple for 3 to $4 \mathrm{~cm}$ or more _................. 42 . P. AUTUMNaLIs.

Panicle branches not long and spreading.

Panicle broadly pyramidal, condensed, about as broad as long, the lower branches spreading or reflexed. Spikelets broad, subcordate.

Panicle longer than broad.

43. P. ALPINA.

Panicle nodding, the lower branches slender, arcuate-drooping.

Panicle erect, the lower branches short.

44. P. STENANTha.

Panicle rather loose, lower branches naked below, ascending (see also P. macroclada).

Plants glaucous, culms stiffly erect

45. P. GLAUCA.

Plants not glaucous; culms rather lax

Panicle narrow, condensed, the branches short (see also $P$. unilateralis).

Culms rather lax, not much longer than the numerous basal leaves.

47. P. PATTERSONI.

Culms stiff, much longer than the basal leaves_- 48. P. Rupicola.

\section{Epiles}

Panicle open, 10 to $15 \mathrm{~cm}$ long. Blades involute, slender.... 49. P. involuta. Panicle contracted, or if open less than $10 \mathrm{~cm}$ long.

Blades scabrous, filiform _._._.

Blades glabrous.

Lemmas minutely pubescent at base.

51. P. unilathralis.

Lemmas glabrous.

Blades of the culm 2 to $3 \mathrm{~mm}$ wide, flat, those of the innovations slender or filiform 
Blades of the culm and innovations similar. Panicle few-flowered.

Panicle short, open, the capillary branches bearing 1 or 2 spikelets. Culms 10 to $20 \mathrm{~cm}$ tall_.............. 53. P. VASEYOChloA.

Panicle narrow.

Lemmas 5 to $6 \mathrm{~mm}$ long; panicle usually pale or silvery.

Lemmas less than $4 \mathrm{~mm}$ long; panicle usually purple.

54. P. PRINGLEI.

Glumes about as long as the first and second florets; panicle mostly not exceeding the short soft blades_... 55. P. LETTERMANI.

Glumes shorter than the first floret; panicle usually much longer than the usually stiff blades.........56. P. LEIBERGI.

\section{Scabrellae}

Sheaths somewhat scabrous....................... 57. P. SCABrella.

Sheaths glabrous.

Panicle rather open, the lower branches naked at base, ascending or somewhat spreading; culms usually decumbent at base _._._. 58 . P. GRACILlima.

Panicle contracted, the branches appressed or at anthesis somewhat divergent.

Culms slender, on the average less than $30 \mathrm{~cm}$ tall; numerous short innovations at base. Blades usually folded _._..... 59. P. SECUNDA.

Culms stouter, on the average more than $50 \mathrm{~cm}$ tall; innovations usually not numerous

60. P. CANBY1.

\section{Nevadenses}

Sheaths scaberulous. Ligule long, decurrent_______. 61. P. Nevadensis. Sheaths glabrous.

Ligule prominent; blades broad and short _........... 62. P. curtifolia.

Ligule short; blades elongate.

Blades involute.

63. P. JUNCIFOLIA.

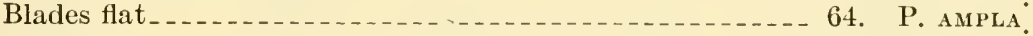

1. Ánnuae.-Annuals; culns seldom more than $50 \mathrm{~cm}$ tall; panicles open (contracted in $P$. bigelovii).

1. Poa bolandéri Vasey. (Fig. 160.) Culms erect, 15 to 60 cm tall; sheatlis glabrous; blades relatively short, 3 to $5 \mathrm{~mm}$ wide, abruptly narrowed at tip; panicle about half the length of the entire plant, at first contracted, finally open, the branches few, distant, glabrous, stiffly spreading, naked below; spikelets usually 2- or 3flowered, the internodes of the rachilla long; glumes broad, 2 and 3 mm long; lenma scantily webbed at base, acute, the marginal nerves rather indistinet, the intermediate nerves obsolete. $\odot$-Open ground or open woods, 1,500 to $3,000 \mathrm{~m}$, Washington and Idaho to western Nevada and the southern Sierras in California (fig. 161).

2. Poa howéllii Vasey and Seribn. Howell Bluegrass. (Fig. 162.) Culms 30 to $60 \mathrm{~cm}$ tall; sheaths retrorsely seabrous to glabrous; blades narrower than in $P$. bolanderi, gradually acuminate; panicle one third to half the entire height of the plant, open, the branches in rather distant fascicles, spreading, scabrous, naked below, some short branches intermixed; spikelets 3 to $5 \mathrm{~mm}$ long, usually 3 - or 4-flowered; glumes narrow, acuminate, 1.5 and $2 \mathrm{~mm}$ long; lemmas webbed at base, 2 to $3 \mathrm{~mm}$ long, ovate-lanceolate, pubescent on the lower part, the nerves all rather distinct. $\odot$-Rocky banks and shaded slopes, mostly less than 1,000 m, Vancouver Island to southern California, especially in the Coast Ranges.

3. Poa bigelóvii Vasey and Scribn. Bigelow Bluegrass. (Fig. 163.) Culms erect, 15 to $35 \mathrm{~cm}$ tall; blades 1 to $5 \mathrm{~mm}$ wide; panicle narrow, interrupted, 7 to $15 \mathrm{~cm}$ long, the branches short, appressed; spikelets about $6 \mathrm{~mm}$ long; glumes acuminate, $4 \mathrm{~mm}$ long, 3-nerved; lemmas about $3 \mathrm{~mm}$ long, sometimes $4 \mathrm{~mm}$, webbed at base, conspicu- 
104 MISC. PUBLICATION 200, U. S. DEPT. OF AGRICULTURE

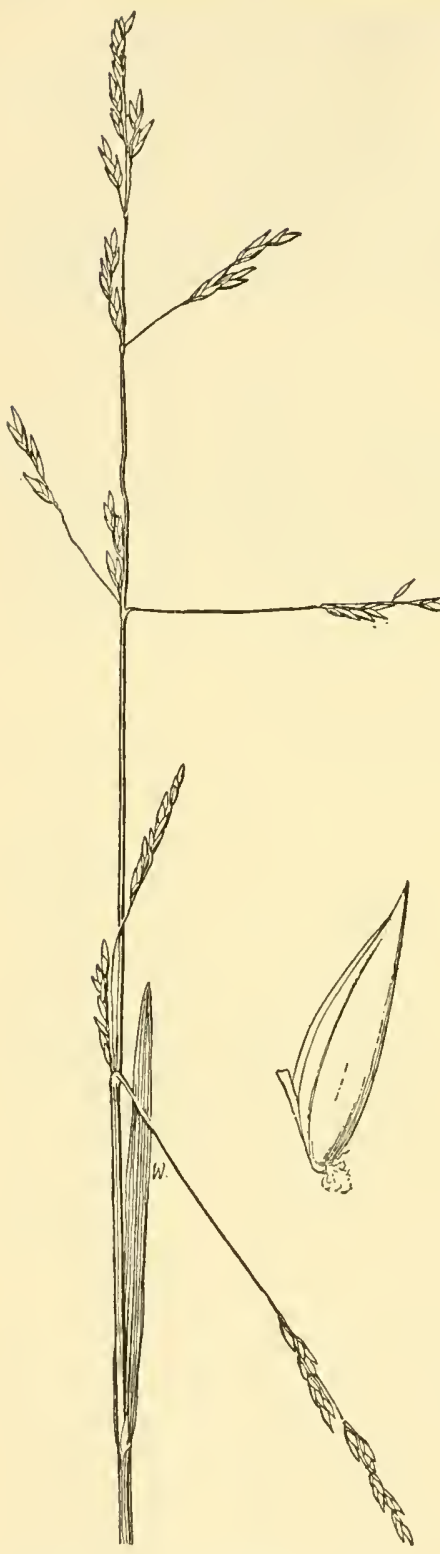

Figure 160,-Poa bolanderi. Panicle, $X$ 1 ; foret, $\times 10$. (Swallen 799, Calif.)
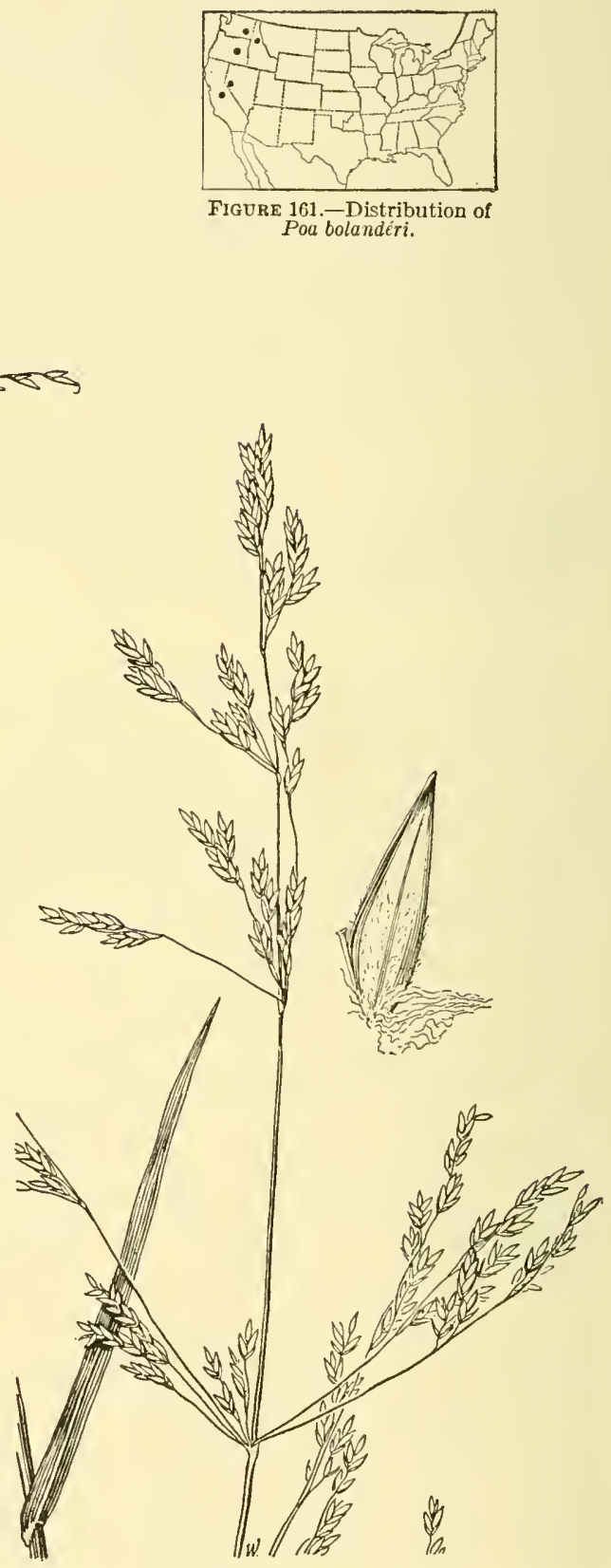

Figure 162.-Poa howellii. Panicle, $\times 1$; floret, $\times 10$. (Suksdorf 10464, Wash.) 
ously pubescent on the lower part of keel and lateral nerves, sometimes sparsely pubescent on lower part of internerves. $\odot$-Open ground, at medium altitudes, Oklahoma and western Texas to Colorado, Nevada, and southern California; northern Mexico (fig. 164).

4. Poa chapmaniána Scribn. (Fig. 165.) Plant drying pale or tawny; culms densely tufted, slender, 10 to $30 \mathrm{~cm}$ tall; blades 1 to $1.5 \mathrm{~mm}$ wide; panicle oblong-pyramidal, 3 to $8 \mathrm{~cm}$ long, open, the

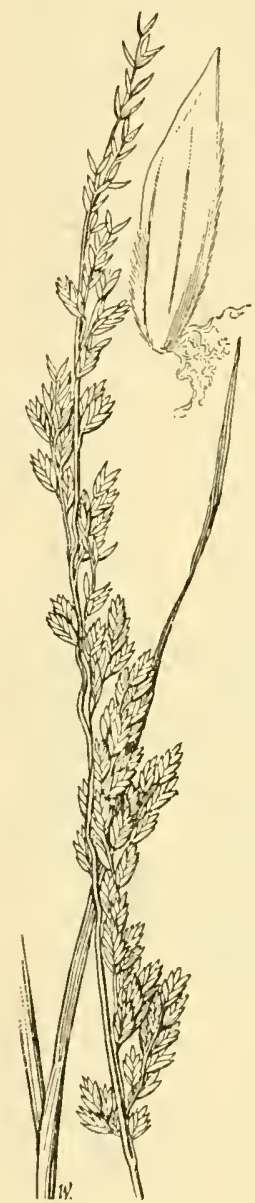

Figure 163.-Poa bigelovii. Panicle, $\times 1$; floret, $\times 10$.
931, N.Mex.) lower branches spreading; spikelets 3 to $4 \mathrm{~mm}$ long, mostly 3 - to 5 -flowered; glumes 2 and $2.5 \mathrm{~mm}$ long; lemmas about $2 \mathrm{~mm}$ long, webbed at base, strongly pubescent on the keel and lateral nerves, the intermediate nerves obscure; anthers 0.1 to $0.2 \mathrm{~mm}$ long. $\odot$ - Open ground and cultivated fields, Delaware to Iowa, south to Georgia and Texas (fig. 166).

5. Poa ánnua L. Annual Bluegrass. (Fig. 167.) Tufted, bright green, erect to spreading, sometimes rooting at the lower nodes, usually 5 to $20 \mathrm{~cm}$ tall, sometimes taller, forming mats; culms flattened; blades soft, lax, mostly 1 to $3 \mathrm{~mm}$ wide; panicle pyramidal, open, 3 to 7 cm long; spikelets crowded, 3 - to 6-flowered, about $4 \mathrm{~mm}$ long; first glume 1.5 to 2 , the second 2 to $2.5 \mathrm{~mm}$ long; lemma not webbed at base, distinctly 5-nerved, more or less pubescent on the lower half of all the nerves, the long hairs on the lower part of the keel sometimes simulating a web; anthers 0.5 to 1 mm long. $\odot-$ Open ground, lawns, pastures, waste places, and openings in woods, Newfoundland and Labrador to

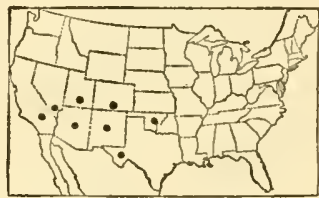

Figure 164.-Distribution of Poa bigelovii.

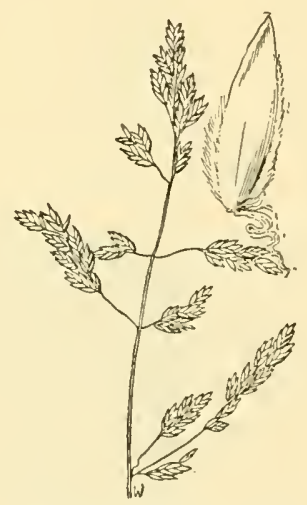

Figure 165.-Poa chapmaniana. Panicle, $\times 1$; floret, $\times 10$. (V. H. Chase 3557,

III.)

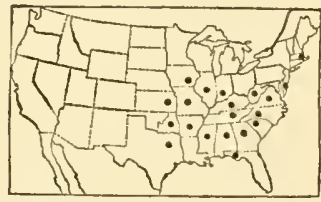

FIGURE 166.-Distribution of Poa chapmaniana. Alaska, south to Florida and

California ; tropical America at high altitudes; introduced from Europe. In warmer parts of the United States the species thrives in the winter; in intermediate latitudes it is a troublesome weed in lawns, growing luxuriantly in spring, drying in early summer and leaving unsightly patches. 
2. Praténses.-Perennials with slender creeping rhizomes. Several species dioecious.

6. Poa compréssa L. Canada bluegrass. (Fig. 168.) Culms solitary or few together, often gregarious, strongly flattened, wiry,

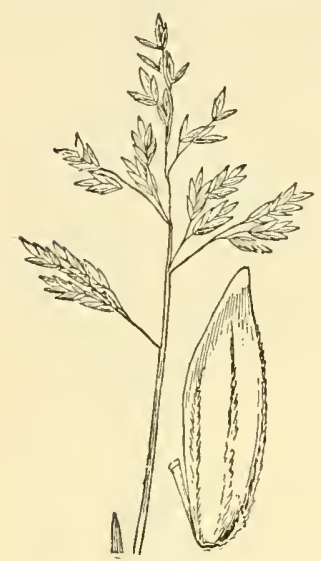

FIGURE 167.-Poa annua, Panicle, $\times 1$; floret, $\times 10$ (Hitchcock, D.C.) decumbent at base, bluish green, 15 to $50 \mathrm{~cm}$ tall; blades rather short, mostly 1 to $4 \mathrm{~mm}$ wide; panicle narrow, 3 to $7 \mathrm{~cm}$ long, the usually short branches in pairs, spikelet-bearing to the base; spikelets crowded, subsessile, 3 - to 6-flowered, 4 to $6 \mathrm{~mm}$ long; glumes 2 to $3 \mathrm{~mm}$ long; lemmas firm, 2 to $3 \mathrm{~mm}$ long, the web at base scant or wanting, the keel and marginal nerves slightly pubescent toward base, the intermediate nerves obscure. 24 --Open ground, open woods, meadows, and waste places, Newfoundland to Alaska, south to Georgia, Tennessee, Alabama, Oklahoma, New Mexico, and California;introduced from Europe. Cultivated for pastures in poor soil.

7. Poa arachnífera Torr. Texas Bluegrass. (Fig. 169.) Plants dioecious; culms tufted, 30 to $50 \mathrm{~cm}$ tall; blades mostly 2 to $4 \mathrm{~mm}$ wide, scabrous above; panicle narrow, compact, more or less lobed or interrupted, 5 to $12 \mathrm{~cm}$ long; spikelets mostly 5- to 10 -flowered, the pistillate conspicuously cobwebby, the lemmas 5 to $6 \mathrm{~mm}$ long, acuminate, copiously long webby at base, the strongly compressed keel and lateral nerves ciliate-fringed along the lower half; staminate lemmas glabrous or with a scant web at base. 24 -Prairies and plains, southern Kansas to Texas and Arkansas; introduced eastward to South Carolina and Florida; Idaho (fig. 170). Sometimes cultivated for winter pasture.

8. Poa macrántha Vasey. (Fig. 171.) Plants dioecious; culms erect from a decumbent base, with extensively creeping rhizomes, and also long runners creeping over the sand, 15 to $40 \mathrm{~cm}$ tall; sheaths tawny, papery; blades involute, subflexuous; panicle contracted, sometimes dense and spikelike, 5 to $12 \mathrm{~cm}$ long, pale or tawny; spikelets about $12 \mathrm{~mm}$ long, about 5flowered; glumes 3 -nerved, or the second indistinctly 5 -nerved, about $8 \mathrm{~mm}$ long; lemmas about $8 \mathrm{~mm}$ long, short-webbed at base, pubescent on the keel and marginal nerves below, slightly scabrous on the keel above; pistillate florets with abortive stamens. 24 - Sand dunes along the coast, Washington to northern California.

9. Poa douglásii Nees. (Fig. 172.) Plants dioecious,

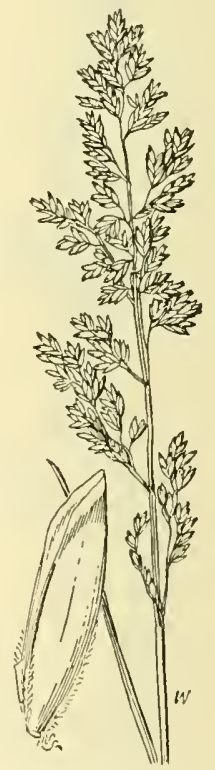

FIGURE 168.- $P$ Pa compressa. Panicle, $\times 1$; floret, $X$ 10. (Gayle 750, Maine.) the two kinds similar; culms ascending from a decumbent base, usually less than $30 \mathrm{~cm}$ tall; rhizomes slender; sheaths glabrous, tawny and papery; blades involute, some of them usually exceeding the culm; panicle 
ovoid, dense, spikelike, 2 to $5 \mathrm{~cm}$ long, 1 to $2 \mathrm{~cm}$ wide, pale or purplish; spikelets 6 to $10 \mathrm{~mm}$ long, about 5 -flowered; glumes broad,
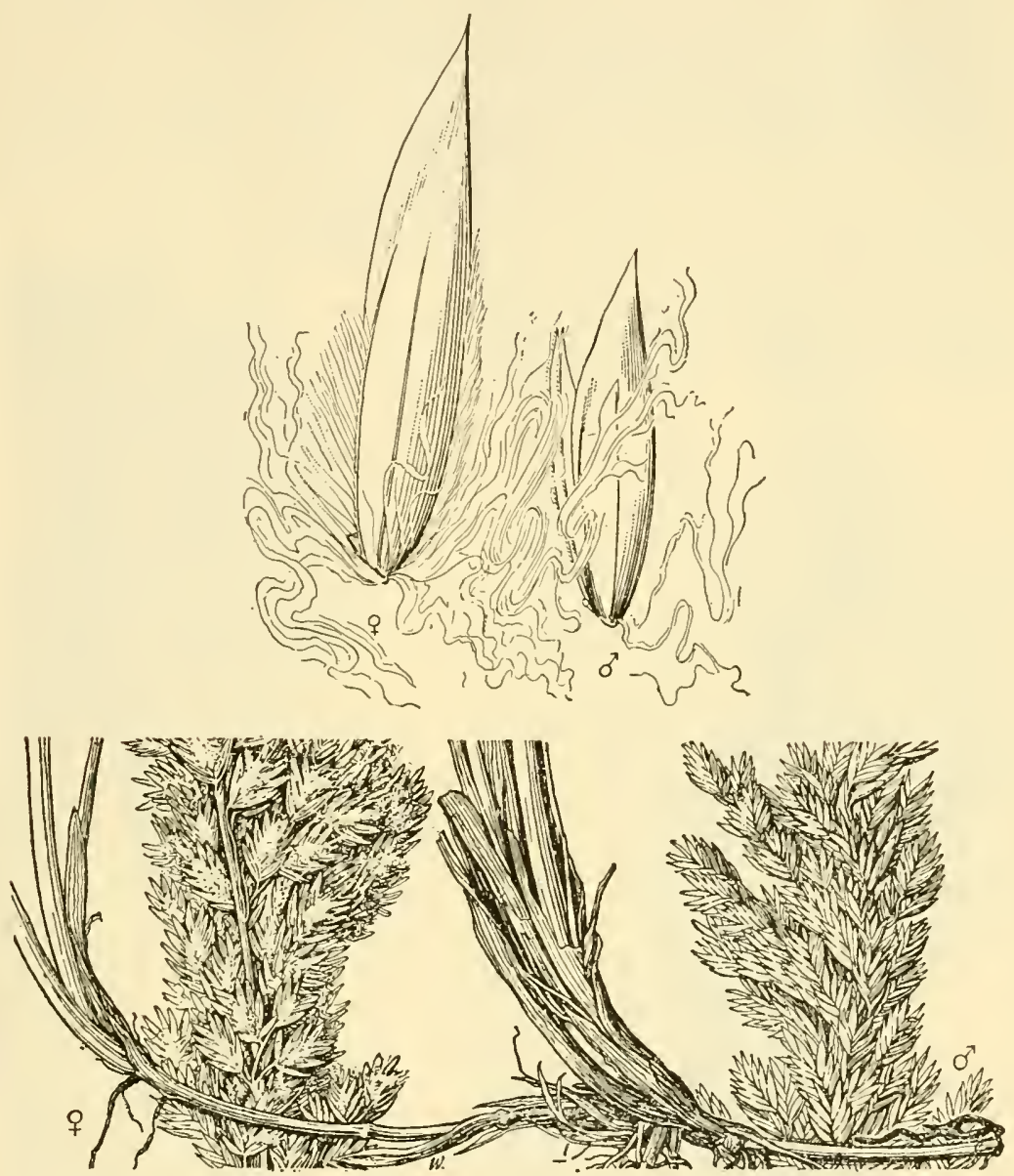

FIGURE 169.-Poa arachnifera. Plant and pistillate $(q)$ and staminate ( $\left.\sigma^{\top}\right)$ panicles, $\times 1$; pistillate ( $($ ) and staminate $\left(\sigma^{*}\right)$ florets, $\times 10$. (Blackman, Tex.)

3-nerved, 4 to $6 \mathrm{~mm}$ long; lemmas 6 to $7 \mathrm{~mm}$ long, slightly webbed at base, pubescent on the lower part of the keel and marginal nerves,

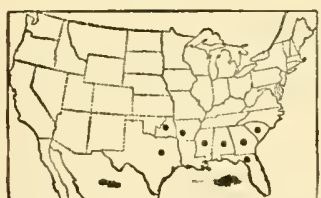

FIGURE 170.-Distribution of Poa arachnifera. seabrous on the upper part of the keel, usually with 1 to 3 pairs of intermediate nerves. 2 - Sand dunes near the coast, California, Point Arena to Monterey.

10. Poa confínis Vasey. (Fig. 173.) Plants dioecious, the two kinds similar; culms often genieulate at base, usually less than $15 \mathrm{~cm}$ tall, sometimes as much as $30 \mathrm{~cm}$; blades involute, those of the innovations numerous; panicle narrow, 1 to $3 \mathrm{~cm}$ long, tawny, the short branches ascending or appressed; spikelets 4 to $5 \mathrm{~mm}$ long, mostly 3 - or 4 -flowered; glumes 
unequal, the second $3 \mathrm{~mm}$ long; lemmas $3 \mathrm{~mm}$ long, scaberulous, sparsely webbed at base, the nerves faint; pistillate florets with minute abortive anthers, the staminate often with rudimentary pistil. 4 - Sand dunes and sandy meadows near the coast, British Columbia to Mendocino County, Calif.

11. Poa rhizómata Hitchc. (Fig. 174.) Culms tufted with numerous innovations, 40 to $60 \mathrm{~cm}$ tall; lower sheaths usually scaberulous with a puberulent collar; ligule rather prominent on the culm leaves, inconspicuous on the leaves of the innovations; blades involute or sometimes flat, firm, less than $1 \mathrm{~mm}$ thick, flexuous, mostly basal, 2 on the culm, usually puberulent on the upper surface; panicle open, 5 to 8 $\mathrm{cm}$ long, the lower branches mostly in pairs, 2 to $3 \mathrm{~cm}$ long; spikelets,

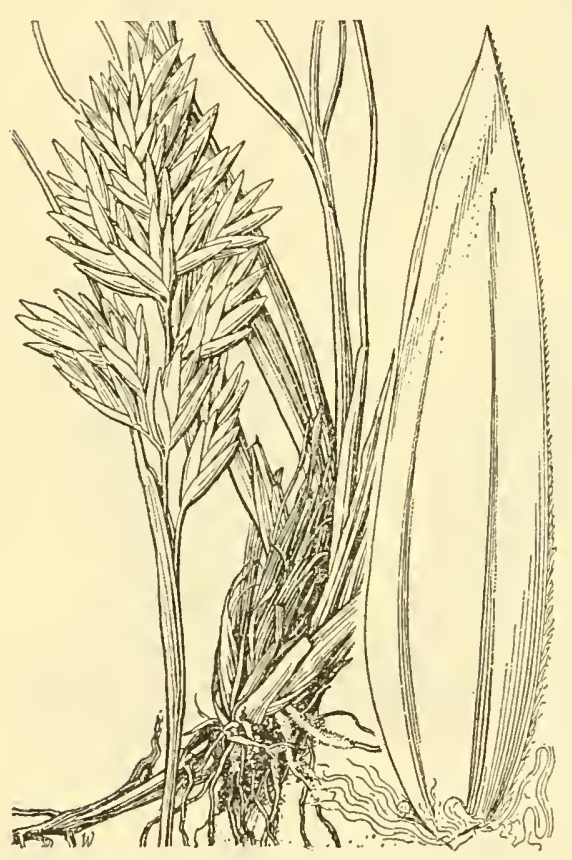

Figure 171.-Poa macrantha. Plant, $\times 1$; floret, $\times 10$. (Hitcheock 2822, Oreg.)

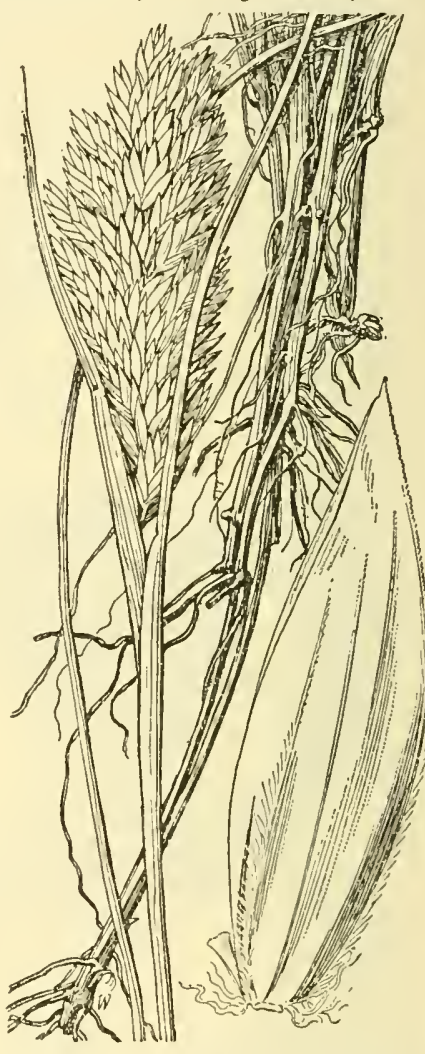

Figure 172.- Poa douglasii. Plant, $\times 1$; flore $t, \times 10$. (Bolander 60\%4, Calif.)

3 - to 5-flowered, 6 to $10 \mathrm{~mm}$ long; glumes 3 to $5 \mathrm{~mm}$ long; lemmas 4 to $5 \mathrm{~mm}$ long, with a rather short web at the base, scaberulous at least on the rather distinct nerves, pubescent on the lower part of keel. $24-D r y$ slopes, southwestern Oregon and northwestern California; apparently rare.

12. Poa atropurpúrea Scribn. (Fig. 175.) Culms erect, 30 to $40 \mathrm{~cm}$ tall; blades mostly basal, the uppermost culm leaf below the middle of the culm, folded or involute, firm; panicle contracted, almost spikelike, purple-tinged, 3 to $5 \mathrm{~cm}$ long; spikelets 3 to $4 \mathrm{~mm}$ long, rather thick; glumes broad, less than $2 \mathrm{~mm}$ long; lemmas about 
$2.5 \mathrm{~mm}$ long, broad, glabrous, not webbed at base, the nerves faint. 2 -Known only from Bear Valley, San Bernardino Mountains, Calif.

13. Poa cúrta Rydb. (Fig. 176.) Culms few in a loose tuft, 40 to $80 \mathrm{~cm}$ tall, rather lax; sheaths glabrous or minutely roughened; ligule truncate, about $1 \mathrm{~mm}$ long; blades 3 to $6 \mathrm{~mm}$ wide; panicle open, 5 to $15 \mathrm{~cm}$ long, nodding, the rather distant branches spreading or reflexed,

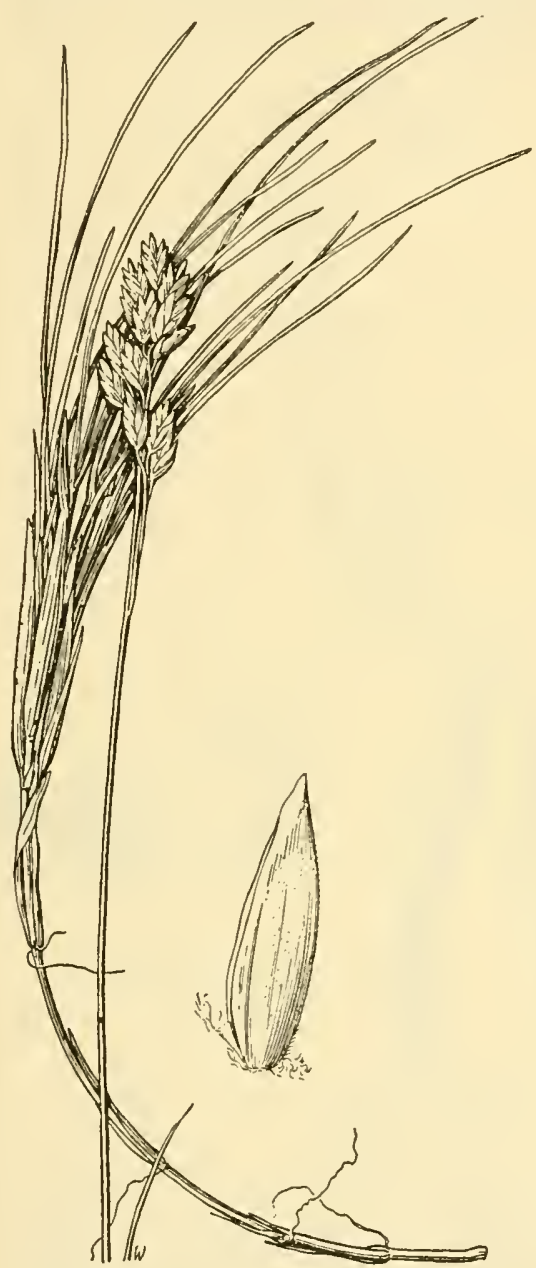

FIGURE 173. - Poa confinis. Plant, $\times 1$; floret, $\times 10$. (Piper 4910, Wash.)

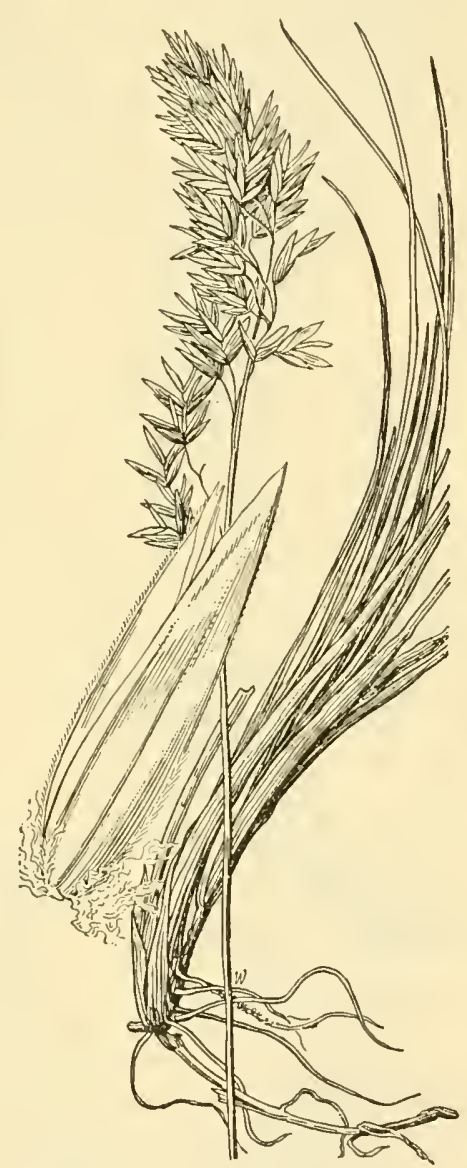

Figure 174. - Poa rhizomata. Plant, $\times 1$; floret, $\times 10$. (Type.)

naked below; spikelets 5 to $10 \mathrm{~mm}$ long, 2- to 6-flowered; lemmas lanceolate, subacute, slightly scaberulous, sometimes slightly pubescent on the back at base, without a web, 4 to $5.5 \mathrm{~mm}$ long, rather strongly nerved or iutermediate nerves faint. 24 -Moist shady places at medium altitudes, western Wyoming, southern Idaho, and Utah.

14. Poa nervósa (Hook.) Vasey. Wheeler bluegrass. (Fig. 177.) Culms erect, 30 to $60 \mathrm{~cm}$ tall; sheaths glabrous or the lower 
retrorsely pubescent, often purple, the collar often puberulent; ligule 1 to $2 \mathrm{~mm}$ long; blades sometimes folded; panicle open, usually 5 to 10 cm long, the apex nodding, the branches mostly in twos or threes, naked below; lemmas rather strongly nerved, glabrous or pubescent on the lower part of the nerves. 24 ( $P$. wheeleri Vasey; $P$. olneyae Piper.)-Open woods at medium altitudes, Alberta and British Columbia, south in the mountains to Colorado, New Mexico, and California (fig. 178). Typical P. nervosa (including $P$. olneyae), found mostly in Washington and Oregon, has glabrous to scaberulous strongly nerved lemmas and glabrous sheaths, and a loose open panicle, the capillary lower branches in whorls of 3 or 4 , drooping, as much as $8 \mathrm{~cm}$ long; typical $P$. wheeleri, originally

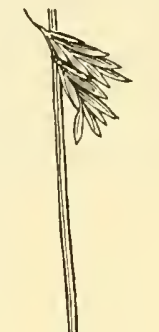

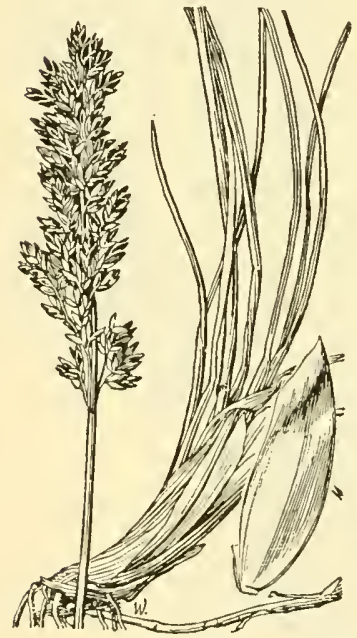

Figure 175.-Poa atropurpurea. Flant, $\times 1$; floret, $\times 10$. (Type.).

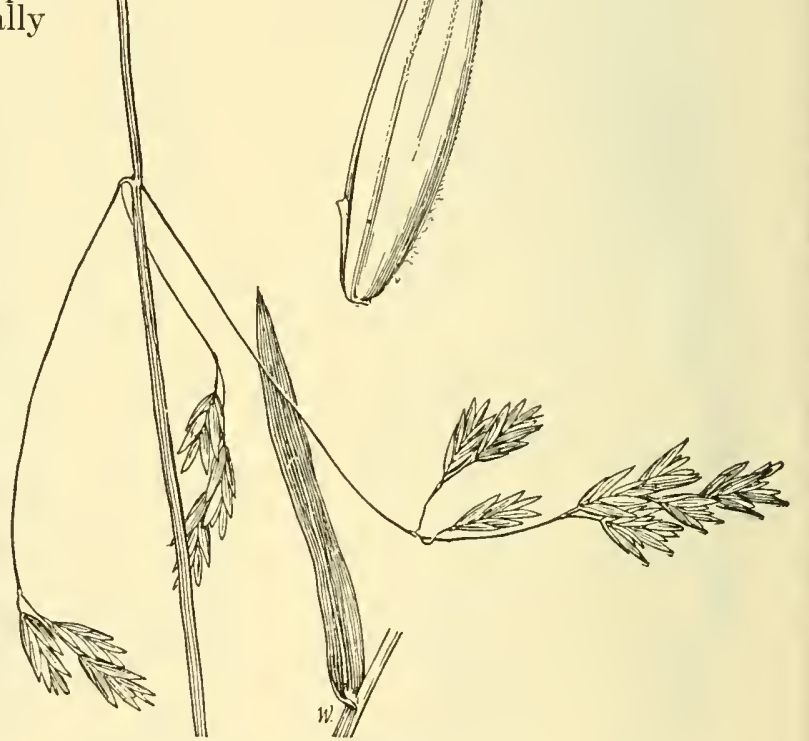

Figure 176.-Poa curta. Panicle, $\times 1$; floret, $\times 10$. (Jones 5573, Utah.)

described from Colorado, has firmer, less strongly nerved lemmas, more or less pubescent on the lower part of the keel and marginal nerves, and purplish retrorsely pubescent lower sheaths. These characters are not coordinated and the forms grade into each other, both as to characters and range.

15. Poa kellóggii Vasey. (Fig. 179.) Culms 30 to $60 \mathrm{~cm}$ tall; sheaths slightly scabrous; blades flat or folded, 2 to $4 \mathrm{~mm}$ wide; panicle pyramidal, open, 7 to $15 \mathrm{~cm}$ long, the branches mostly solitary or in twos, spreading or reflexed, bearing a few spikelets toward the ends; spikelets rather loosely flowered, 4 to $6 \mathrm{~mm}$ long; glumes 3 and $4 \mathrm{~mm}$ long; lemmas acute or almost cuspidate, 4 to 5 
mm long, glabrous, rather obscurely nerved, conspicuously webbed at base. 24 -Moist woods and shady places, Coast Ranges from

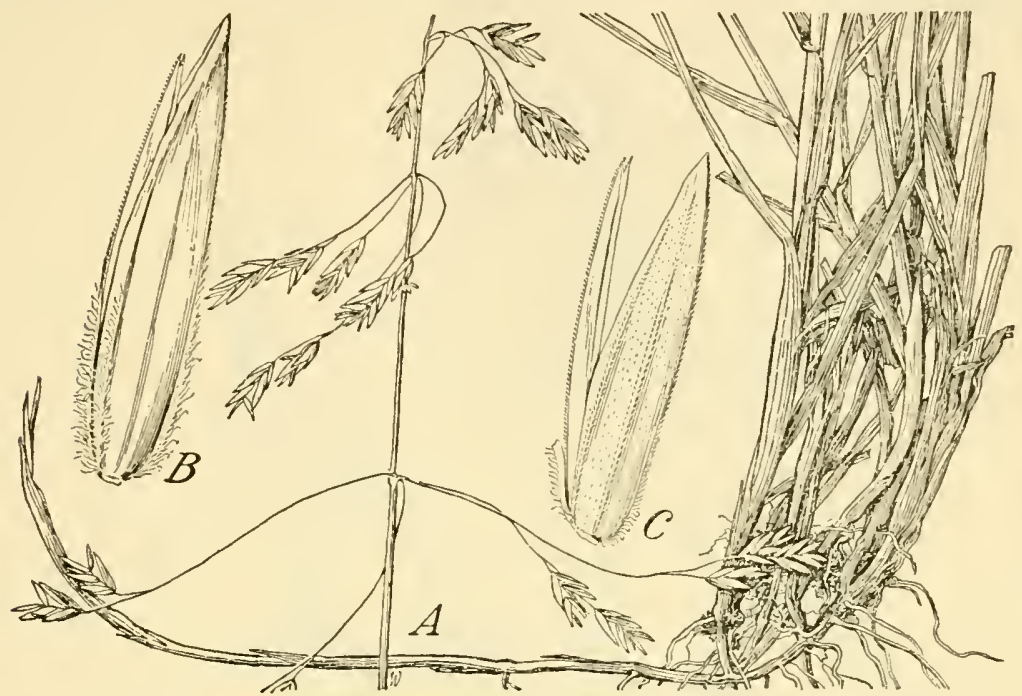

Figure 177.-Poa nerrosa. A, Plant, $\times 1$. (Suksdorf 10364, Wash.) B, Floret, $\times 10$. (Type of $P$. whecleri.) $C$, Floret, $\times 10$. ('Type of $P$. nerrosa.)

Corvallis, Oreg., to Santa Cruz County, Calif.

16. Poa laxiflóra Buckl. (Fig. 180.) Culms retrorsely scabrous, 100 to $120 \mathrm{~cm}$ tall; sheaths slightly retrorse-scabrous; ligule 3 to $5 \mathrm{~mm}$ long; blades lax, 2 to $4 \mathrm{~mm}$ wide; panicle loose, open, nodding or drooping, 10 to $15 \mathrm{~cm}$ long, the lower branches in

Figure 178.-Distribution of Poa nervosa. whorls of 3 or 4 ; spikelets 3 - or 4-flowered,

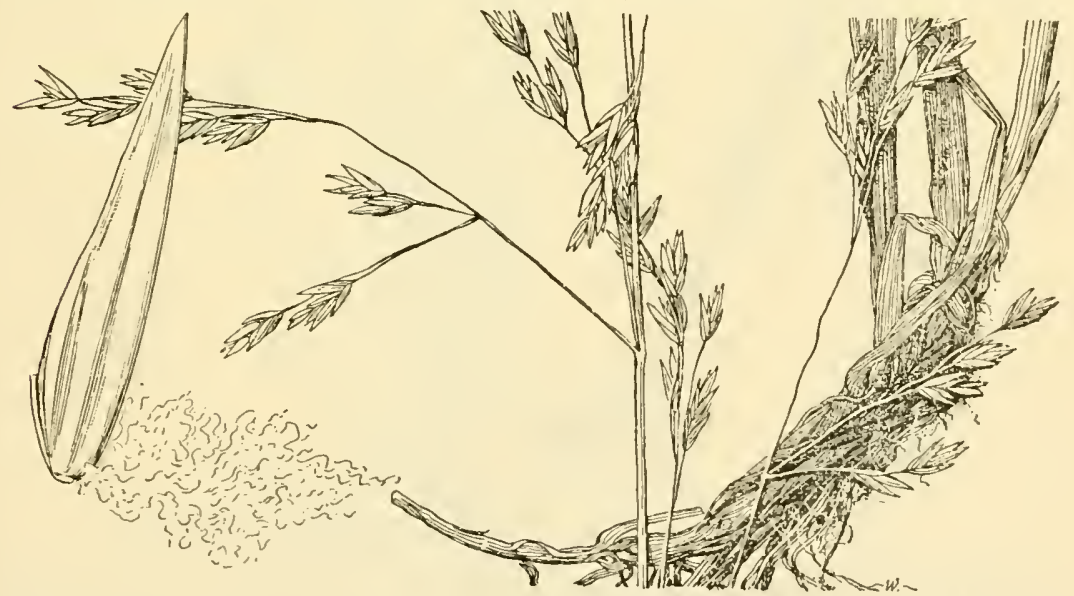

FigURE 179, - Poa kelloggii. Plant, $\times 1$; floret, $\times 10$. (Kellogg and Bolander 14, Calif.)

5 to $6 \mathrm{~mm}$ long; lemmas about $4 \mathrm{~mm}$ long, webbed at base, rather sparsely pubescent on lower part of the nerves. 4 -Moist $55974^{\circ}-35-8$ 
woods, southeastern Alaska (Cape Fox, Hot Springs), Sol Duc Hot Springs, Olympic Mountains, Wash. Sauvies Island (near Portland), Oreg.

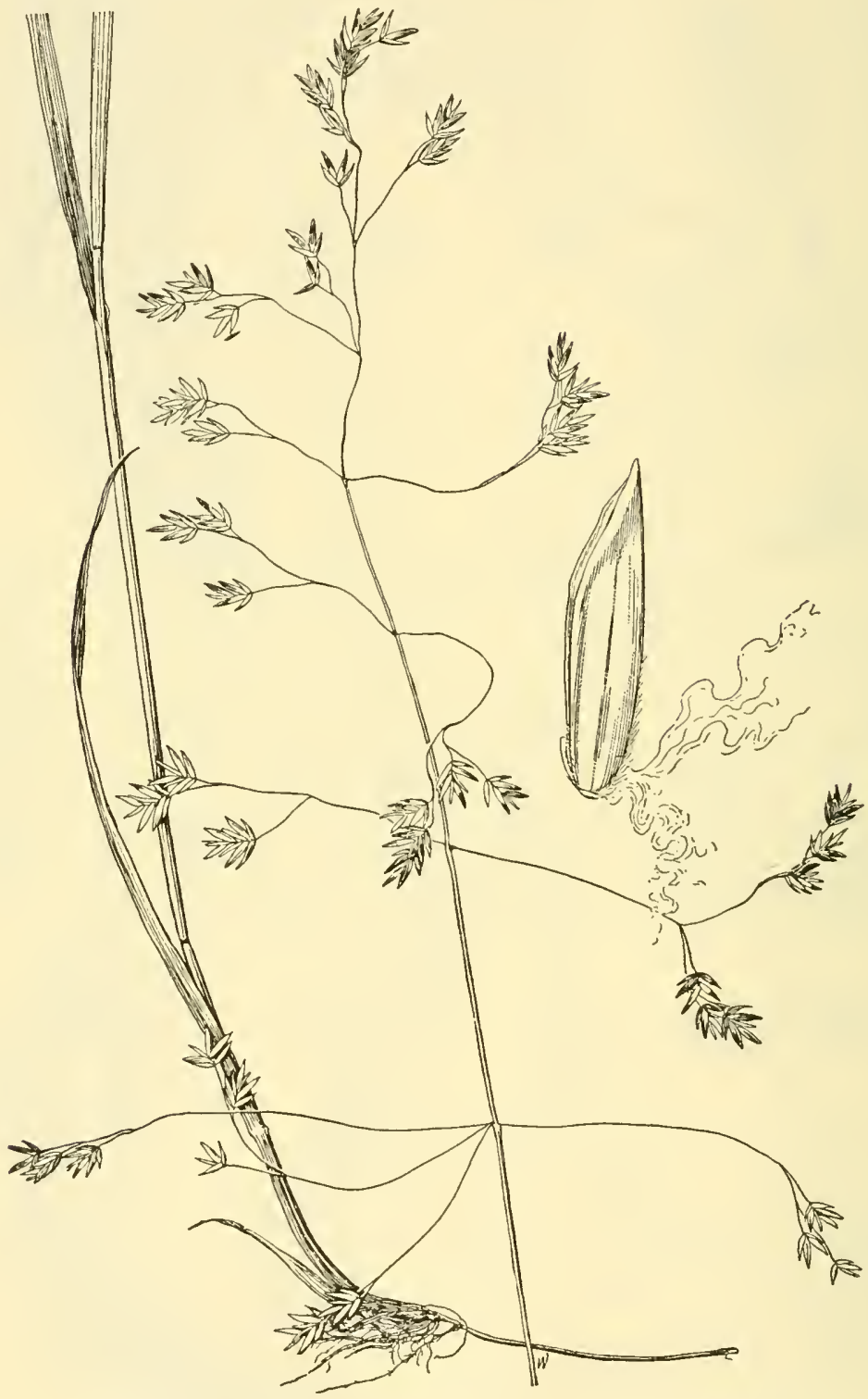

Figure 180.-Poa laxiflora. Plant, $\times 1$; floret, $\times 10$. (Hitchcock 23468, Wash.)

17. Poa praténsis L. Kentucky bluegrass. (Fig. 181.) Culms tufted, erect, slightly compressed, 30 to $100 \mathrm{~cm}$ tall; sheaths somewhat keeled; ligule about $2 \mathrm{~mm}$ long; blades soft, flat or folded, mostly 


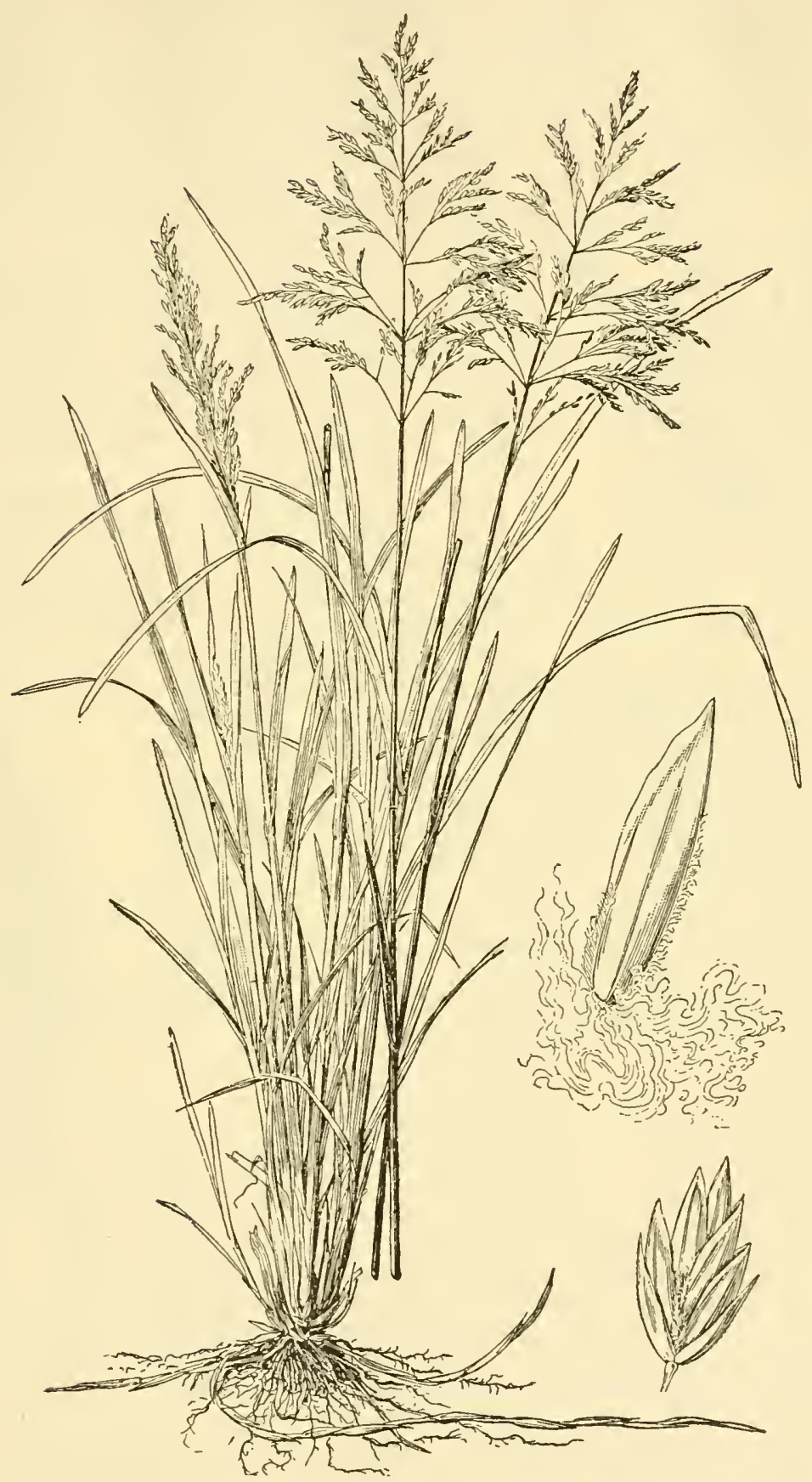

Figure 181.-Poa pratensis. Plant, $\times 1 / 2$; spikelet, $\times 5$; foret, $\times 10$. (Williams, S.Dak.) 
2 to $4 \mathrm{~mm}$ wide, the basal often elongated; panicle pyramidal or oblong-pyramidal, open, the lowermost branches usually in a whorl of 5 , ascending or spreading, naked below, normally 1 central long one, 2 shorter lateral ones and 2 short intermediate ones; spikelets

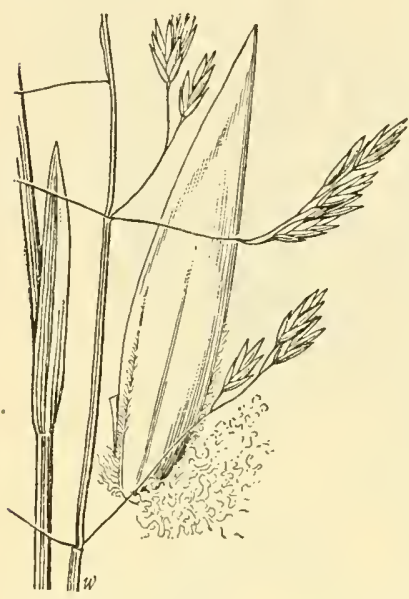

Figure 182.-Poa cuspidata. Panicle $\times 1$; floret, $\times 10$. (Smith $27, \mathrm{~Pa}$. crowded, 3 - to 5 -flowered, 3 to $6 \mathrm{~mm}$ long; lemmas copiously webbed at base, silkypubescent on lower half or two-thirds of the keel and marginal nerves, the intermediate nerves distinct, glabrous. 24 Open woods, meadows, and open ground, widely distributed throughout the United States and northward, except in arid regions, found in all the States

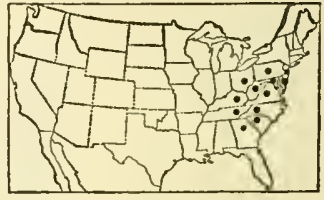

FIGURE 183.-Distribution of Poa cuspidata.

(but not common in the Gulf States) and at all altitudes below alpine regions; introduced from Europe. Bluegrass is commonly cultivated for lawns and pasture in the humid northern parts of the United States.

18. Poa cuspidáta Nutt. (Fig. 182.) Culms in large lax tufts, 30 to $50 \mathrm{~cm}$ tall, scarcely longer than the basal blades; blades lax, 2 to $3 \mathrm{~mm}$ wide, abruptly cuspidate-pointed; panicle 7 to $12 \mathrm{~cm}$ long, open, the branches mostly in pairs, distant, spreading, spikeletbearing near the ends; spikelets 3 - or 4 -flowered; lemmas 4 to $6 \mathrm{~mm}$ long, tapering to an acute apex, webbed at base, sparingly pubescent on the keel

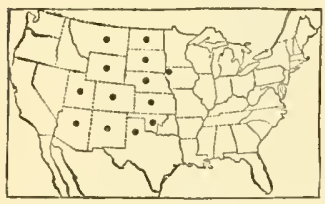

Figure 185.-Distribution of Poa arida. and marginal nerves, the intermediate nerves distinct, glabrous. 2 (P. brachyphylla Schult.)-Rocky woods, New Jersey to Ohio, south to Georgia and eastern Tennessee (fig. 183).

19. Poa árida Vasey. Plains BLUEGrass. (Fig. 184.) Culms erect, 20 to $50 \mathrm{~cm}$ tall; blades mostly basal, firm, folded, usually 2 to $3 \mathrm{~mm}$ wide, a single culm leaf usually below the middle of the culm, its blade short; panicle narrow, somewhat contracted, 2 to $10 \mathrm{~cm}$ long, the branches appressed or ascending; spikelets rather thick, 5 to $7 \mathrm{~mm}$ long, 4- to 8-flowered; lemmas 3 to $4 \mathrm{~mm}$ long, densely villous on the keel and marginal nerves and more or less villous on the lower part of the intermediate nerves. 24 ( $P$. sheldoni Vasey.)-Prairies, plains, and alkali meadows, up to $3,000 \mathrm{~m}$, Manitoba to Alberta, south to western Iowa, Texas, and northern Arizona (fig, 1S5). 
20. Poa glaucifólia Scribn. and Will. (Fig. 186.) Plants glaucous; culms in loose tufts, 60 to $100 \mathrm{~cm}$ tall; blades 2 to $3 \mathrm{~mm}$ wide; panicle narrow, open, mostly 10 to $20 \mathrm{~cm}$ long, the branches usually in somewhat distant whorls, mostly in threes, ascending, very scabrous, naked below; spikelets 2- to 4flowered; glumes 4 to $5 \mathrm{~mm}$ long; lemmas about $4 \mathrm{~mm}$ long, villous on the lower half of the keel and marginal nerves and more or less so on the intermediate nerves below. 21 -Moist places, ditches, and open woods at medium altitudes, British Columbia and Alberta t, h r o u g h

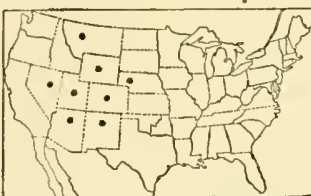

Figure 187.-Distribution of Poa glaucifolia.

Montana to Nebraska, New Mexico, Arizona, and Nevada (fig. 187).

21. Poa árctica R.

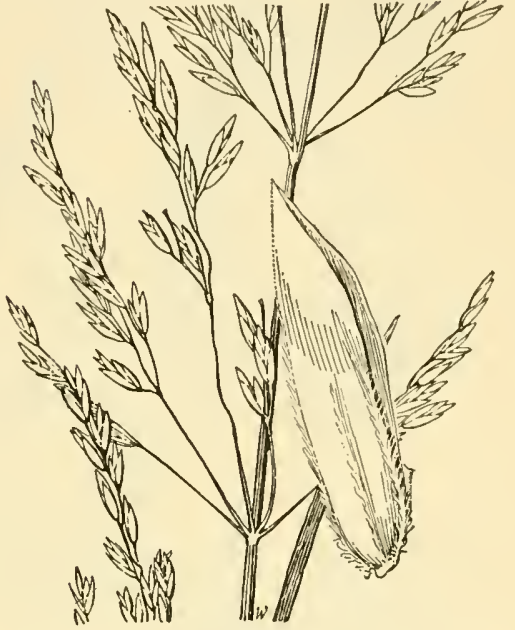

Figure 186.-Poa glaucifolia. Panicle, $\times 1$; floret, $\times$ 10. (Rydberg 32s8, Mont.)

Br. Arctic bluegrass. (Fig. 188.) Culms loosely tufted, erect from a decumbent base, 10 to $30 \mathrm{~cm}$ tall; ligule pointed, up to $4 \mathrm{~mm}$

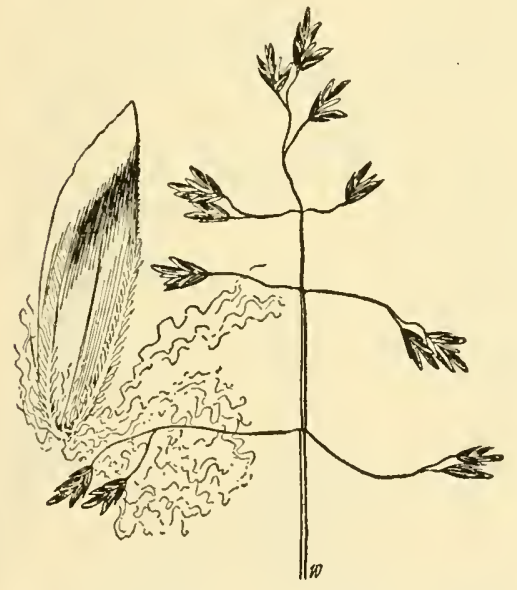

Figure 188.-Poa arctica. Panicle, $\times 1$; floret, $\times 10$. (Bell 64, Hudson Bay.) long; blades mostly basal, flat or folded, mostly 2 to $3 \mathrm{~mm}$ wide, one short blade about the middle of the culm; panicle open, pyramidal, 5 to $10 \mathrm{~cm}$ long, the lower branches usually 2, spreading, sometimes reflexed, bearing a few spikelets toward the tip; spikelets 5 to $8 \mathrm{~mm}$ long, 3 - or 4 -flowered; lemmas densely villous on the keel and marginal nerves and pubescent on the lower part of the internerves, the base often webbed. 2 (P. grayana Vasey; $P$. aperta Scribn. and Merr., a form with pale, rather

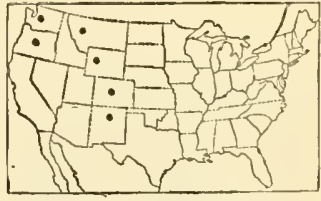

Figure 189.-Distribution of Poa arctica.

lax panicles longer than wide.)-Meadows, mostly above timber line, arctic regions, south to Nova Seotia, in the Rocky Mountains to northern New Mexico, and in the Caseades to Oregon (fig. 189). 


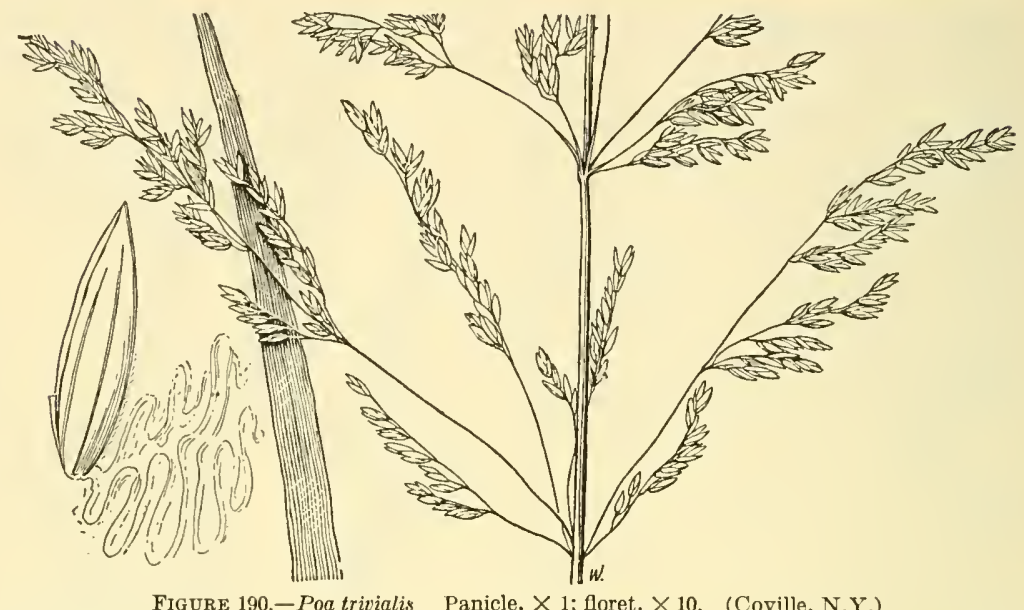

3. Palústres.-Perennials without creeping rhizomes; lemmas webbed at base, glabrous, or pubescent on the nerves.

22. Poa triviális L. Rough BLUEGRass. (Fig. 190.) Culms erect from a decumbent base, of ten rather lax, scabrous below the panicle, 30 to $100 \mathrm{~cm}$ tall; sheaths retrorsely scabrous or scaberulous, at least toward the summit; ligule 4 to $6 \mathrm{~mm}$ long; blades scabrous, 2 to $4 \mathrm{~mm}$ wide; panicle oblong, 6 to $15 \mathrm{~mm}$ long,

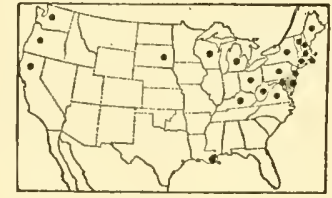

Figure 191.-Distribution of Poa tritialis.

the lower branches about 5 in a whorl; spikelets usually 2- or 3flowered, about $3 \mathrm{~mm}$ long; lemma 2.5 to $3 \mathrm{~mm}$ long, glabrous except the slightly pubescent keel, the web at base conspicuous, the nerves prominent. 24 -Moist places, Newfoundland and Ontario to Virginia, West Virginia, Michigan, South Dakota, and on the Pacific coast from southern

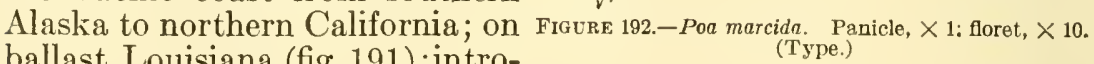
ballast, Louisiana (fig. 191); intro-

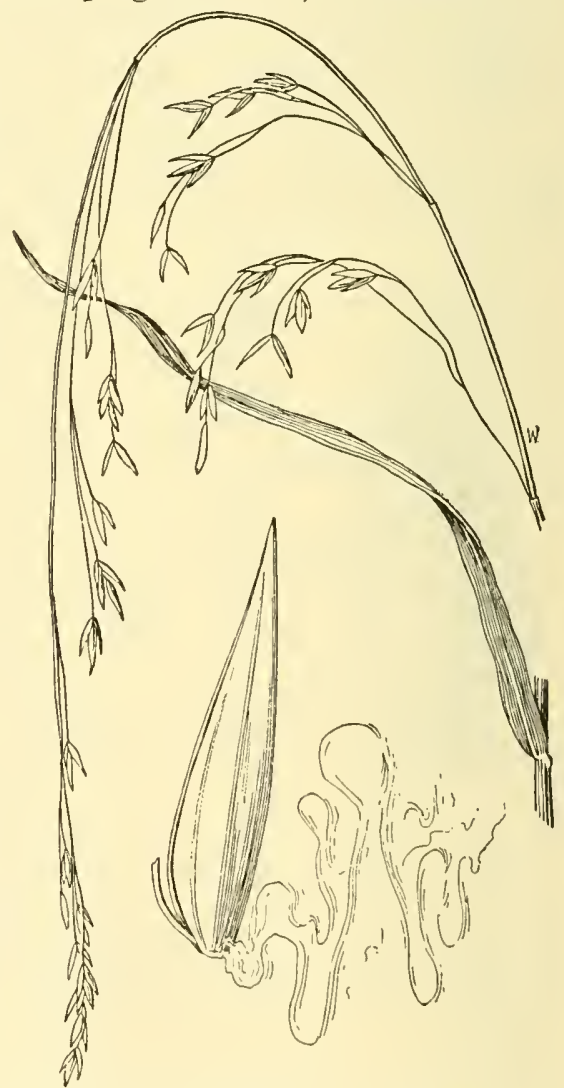

duced from Europe. Sometimes used in mixtures for meadows and upastures der the name rough-stalkedn meadow grass. 
23. Poa márcida Hitchc. (Fig. 192.) Culms erect, in small tufts, 40 to $100 \mathrm{~cm}$ tall; ligule very short; blades thin, 1 to $3 \mathrm{~mm}$ wide; panicle drooping, narrow, 10 to $18 \mathrm{~cm}$ long, the capillary branches

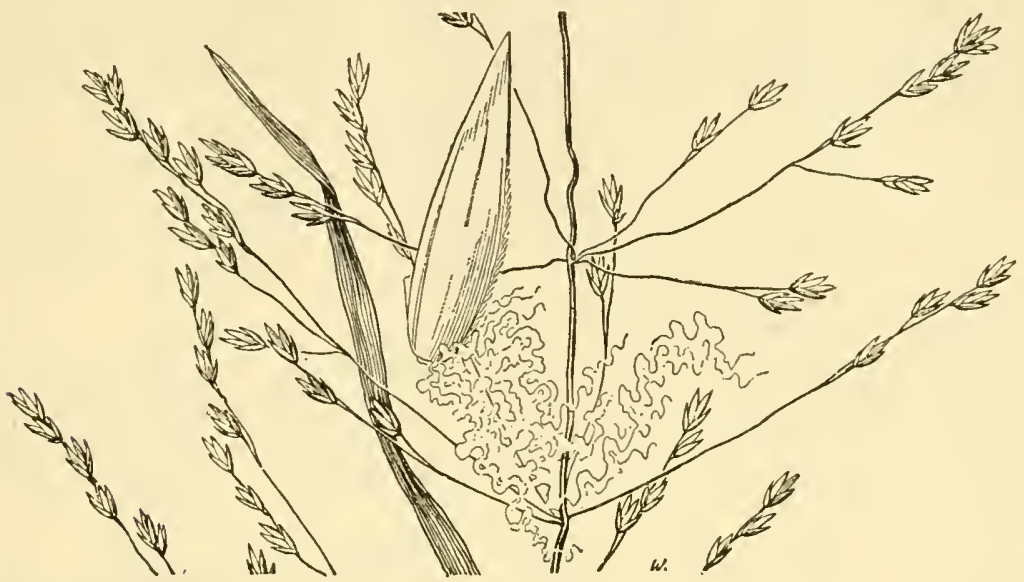

Figure 193.-Poa alsodes. Panicle, $\times 1$; floret, $\times 10$. (Wilson, N.Y.)

somewhat distant, solitary or in pairs, ascending or appressed; spikelets mostly 2-flowered; glumes about $3 \mathrm{~mm}$ long; lemmas narrowly lanceolate, acuminate, 4 to $5 \mathrm{~mm}$ long, glabrous, long-webbed at

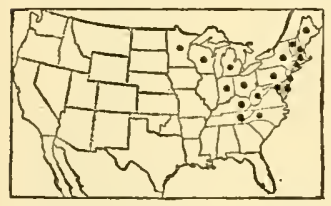

Figure 194.-Distribution of Poa alsodes. base. $21-$ Bogs and wet shady places, Vancouver Island to the coast mountains of Oregon.

24. Poa alsódes A. Gray. (Fig. 193.) Culms in lax tufts, 30 to $60 \mathrm{~cm}$ tall; blades thin, lax, 2 to $5 \mathrm{~mm}$ wide; panicle 10 to $20 \mathrm{~cm}$ long, very open, the slender branches in distant whorls of threes to fives, finally widely spreading, naked below, few-flowered; spikelets 2- or 3flowered, about $5 \mathrm{~mm}$ long; lemmas gradually acute, webbed at base, pubescent on the lower part of the keel, otherwise glabrous, faintly nerved. 21 -Rich or moist woods, Maine to Minnesota, south to Delaware and the mountains of North Carolina and Tennessee (fig. 194).

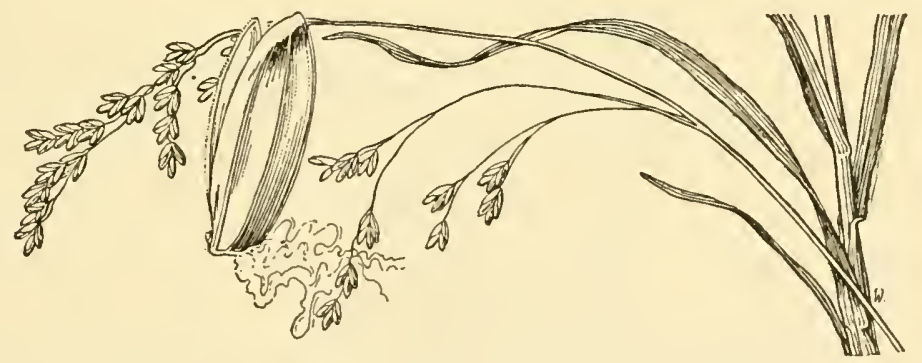

Figure 195. - Poa languida. Panicle, $\times 1$; floret, $\times 10$. (Chase 7511, N.Y.)

25. Poa lánguida Hitchc. (Fig. 195.) Culms weak, in loose tufts, 30 to 60 or even $100 \mathrm{~cm}$ tall; ligule about $1 \mathrm{~mm}$ long; blades lax, 2 to $4 \mathrm{~mm}$ wide; panicle nodding, 5 to $10 \mathrm{~cm}$ long, the few slender branches 
mostly in twos or threes, ascending, few-flowered toward the ends; spikelets 2- to 4 -flowered, 3 to $4 \mathrm{~mm}$ long; lemmas 2 to $3 \mathrm{~mm}$ long, glabrous except the webbed base, oblong, rather obtuse, at maturity firm. 24 (P. debilis Torr., not Thuill.)-Dry

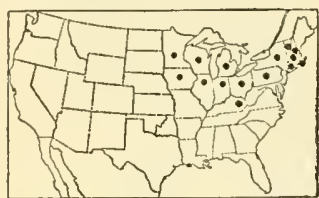

FigURe 196.-Distribution of Poa languida. or rocky woods, Newfoundland and Quebec to Wisconsin, south to Pennsylvania, Kentucky, and Iowa (fig. 196).

26. Poa saltuénsis Fern. and Wieg. (Fig. 197.) Resembling $P$. languida; differing in the thinner, acute, somewhat longer lemmas. 24 -Woodland thickets, Quebec and Newfoundland to Minnesota, south to Connecticut and Maryland (fig. 198).

27. Poa occidentális Vasey. New Mexican bluegrass. (Fig. 199.) Culms erect, few in a tuft, usually rather stout, scabrous, as much as 1 to $1.5 \mathrm{~m}$ tall; sheaths somewhat keeled, retrorsely scabrous (sometimes faintly so); ligule 2 to $8 \mathrm{~mm}$ long; blades scabrous, 10 to $20 \mathrm{~cm}$ long, 3 to $6 \mathrm{~mm}$ wide; panicle open, 15 to $30 \mathrm{~cm}$ long, the branches in distant whorls of threes to fives, spreading to reflexed, the lower as much as $10 \mathrm{~cm}$ long, spikelet-bearing toward the ends; spikelets $3-$ to 6flowered; lemmas 4.5 to $5 \mathrm{~mm}$ long, conspicuously webbed at base, villous on the lower part of the keel and the

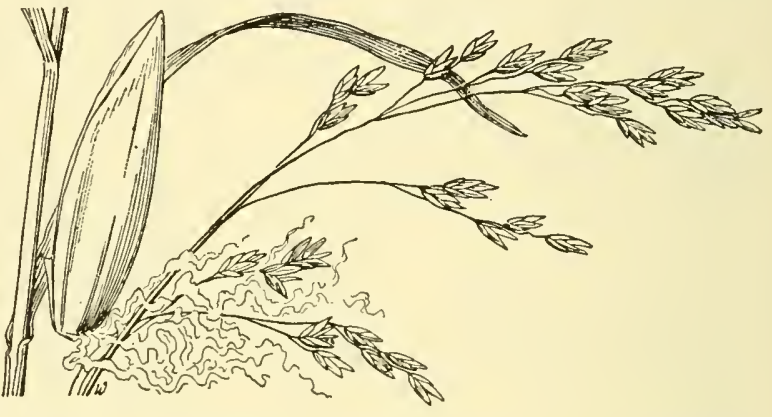

Figure 197. - Poa saltuensis. Panicle, $\times 1$; floret, $\times 10$. (Fernald and Pease 24875, Que.) marginal nerves and sometimes sparingly pubescent on the internerves below. 2 -Open woods and moist banks at medium altitudes, Colorado and New Mexico (fig. 200).

28. Poa trácyi Vasey. (Fig. 201.) Culms erect, 60 to $80 \mathrm{~cm}$ tall; sheaths glabrous, keeled; ligule truncate, about $2 \mathrm{~mm}$ long; blades 3 to $5 \mathrm{~mm}$ wide; panicle narrowly pyramidal, 15 to $20 \mathrm{~cm} \mathrm{long}$, the branches in distant whorls of 2 to 5 , spreading, naked on the lower

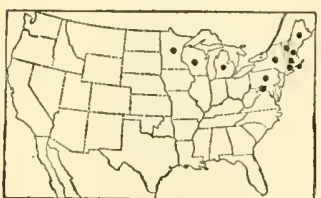

FIGURE 198.-Distribution of Poa saltuensis.

half or two-thirds; spikelets 2- or 3-flowered; lenmas about $3.5 \mathrm{~mm}$ long, oblong-lanceolate or the upper lanceolate, webbed at base, villous on keel and marginal nerves, and more or less so on the internerves below, the intermediate nerves distinct. 2 -Known only from Raton, N.Mex. May be a form of P. occidentalis.

29. Poa sylvéstris A. Gray. (Fig. 202.) Culms tufted, erect, 30 to $100 \mathrm{~cm}$ tall; sheaths glabrous or rarely pubescent, the lower usually antrorsely scabrous; ligule about $1 \mathrm{~mm}$ long; blades lax, 2 to $6 \mathrm{~mm}$ wide; panicle erect, 10 to $20 \mathrm{~cm}$ long, much longer than wide, the slender flexuous branches spreading, usually 3 to 6 at a node, the lower usually reflexed; 
spikelets 2- to 4 -flowered, 3 to $4 \mathrm{~mm}$ long; lemmas 2.5 to $3 \mathrm{~mm}$ long, webbed at base, pubescent on the keel and marginal nerves and more or less pubescent on the internerves. 24 -Rich, moist, or rocky woods, New York to Wisconsin, south to Florida and Texas (fig. 203). Sheaths pubescent in a specimen from St. Louis, Mo.

30. Poa refléxa Vasey and Scribn. Nodding Bluegrass. (Fig. 204.) Culms solitary or in small tufts, erect, 20 to $40 \mathrm{~cm}$ tall; blades

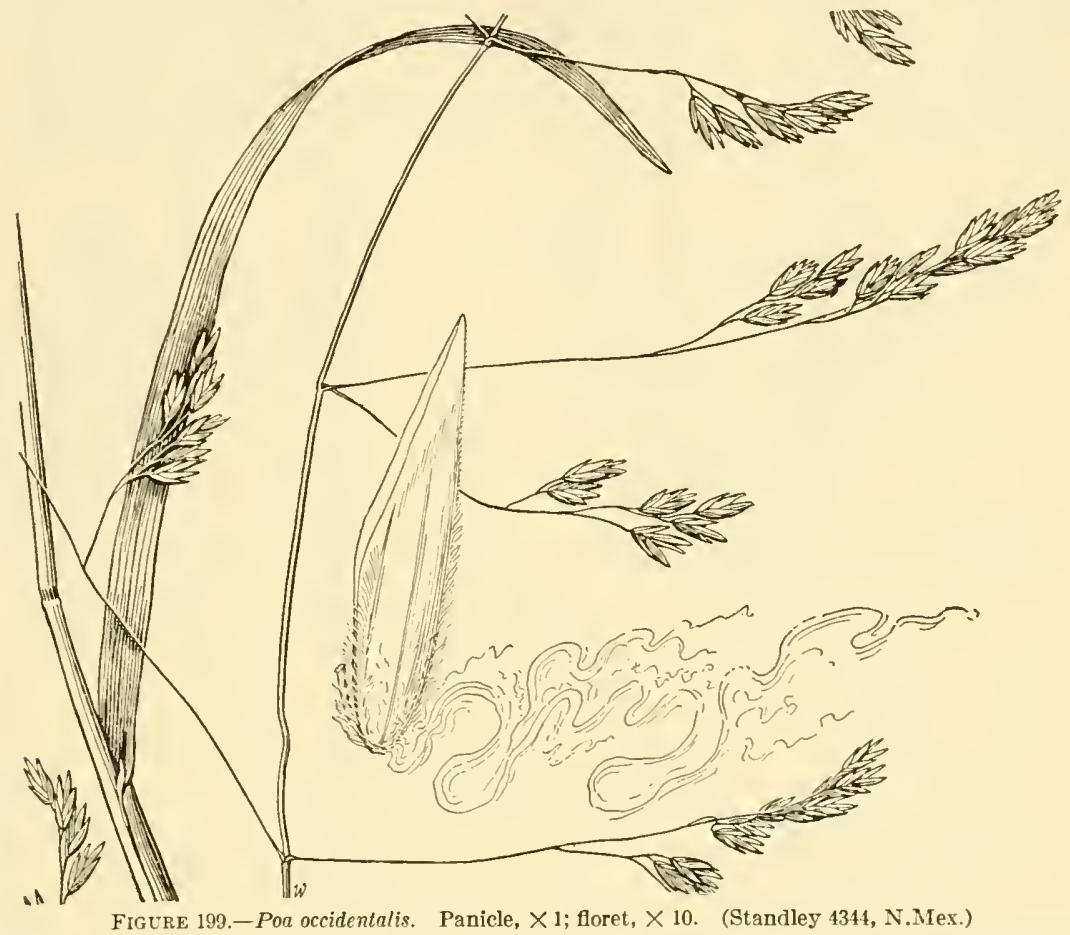

rather short, 1 to $4 \mathrm{~mm}$ wide; panicle nodding, 5 to $15 \mathrm{~cm}$ long, the branches naked below, solitary, in pairs, or in threes, the lower usually reflexed, sometimes strongly so; spikelets 2- to 4-flowered; lemmas

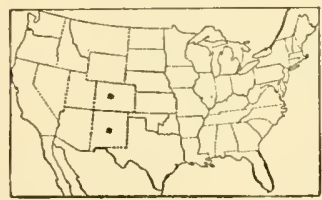

FIGURE 200.-Distribution of Poa occidentalis. about $3 \mathrm{~mm}$ long, oblong-elliptic, webbed at base, villous on keel and marginal nerves, sometimes on intermediate nerves. 24 Open slopes and alpine meadows, 2,000 to 4,000 $\mathrm{m}$, Montana to eastern British Columbia, south in the mountains to New Mexico and Arizona (fig. 205).

31. Poa wólfii Scribn. (Fig. 206.) Culms tufted, erect, 40 to $80 \mathrm{~cm}$ tall; sheaths slightly scabrous; blades crowded toward the base of the culms, mostly 1 to 2 $\mathrm{mm}$ wide; panicle drooping, 8 to $15 \mathrm{~cm}$ long, the branches ascending, bearing a few spikelets toward the ends, the lower mostly in pairs; spikelets 2- to 4-flowered, 5 to $6 \mathrm{~mm}$ long; lemmas 3.5 to $4.5 \mathrm{~mm}$ long, acute, webbed at base, pubescent on the keel and marginal nerves, the intermediate nerves distinct. 24 -Moist woods, Ohio to Minnesota and Missouri (fig. 207). 
32. Poa paucispícula Scribn. and Merr. (Fig. 208.) Culms tufted, leafy, rather lax, 10 to $30 \mathrm{~cm}$ tall, the base often decumbent; blades 1 to $2 \mathrm{~mm}$ wide; panicle lax, few-flowered, 2 to $8 \mathrm{~cm}$ long, the branches

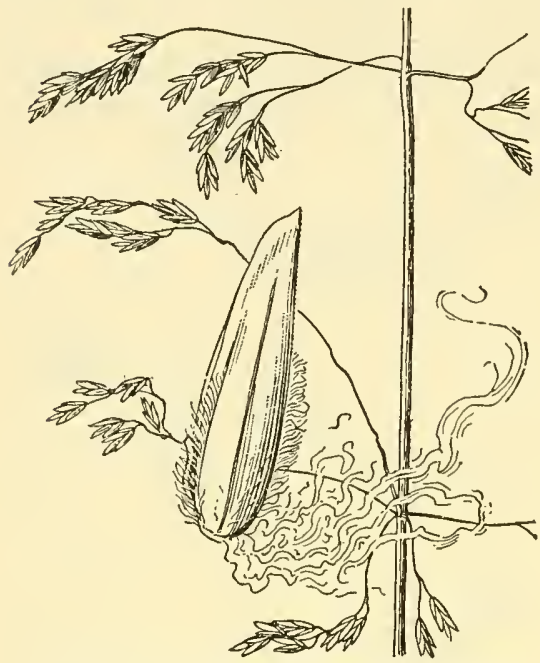

Figure 201.-Poa tracyi. Panicle, $\times 1$; floret, $\times 10$. (Туре.)

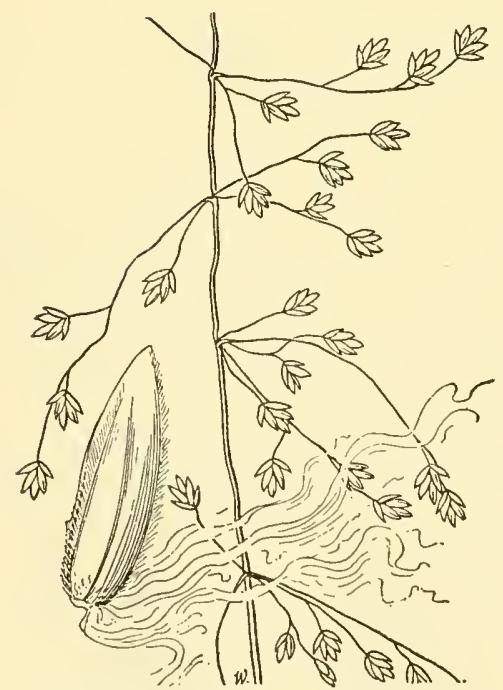

Figure 202. - Poa sylvestris. Panicle, $\times 1$; floret, $\times 10$. (Wheeler 6, Mich.)

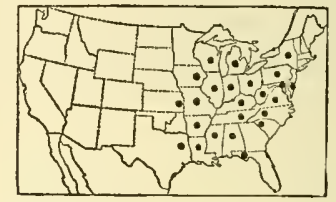

Figure 203.-Distribution of $P$ oa sylvestris.

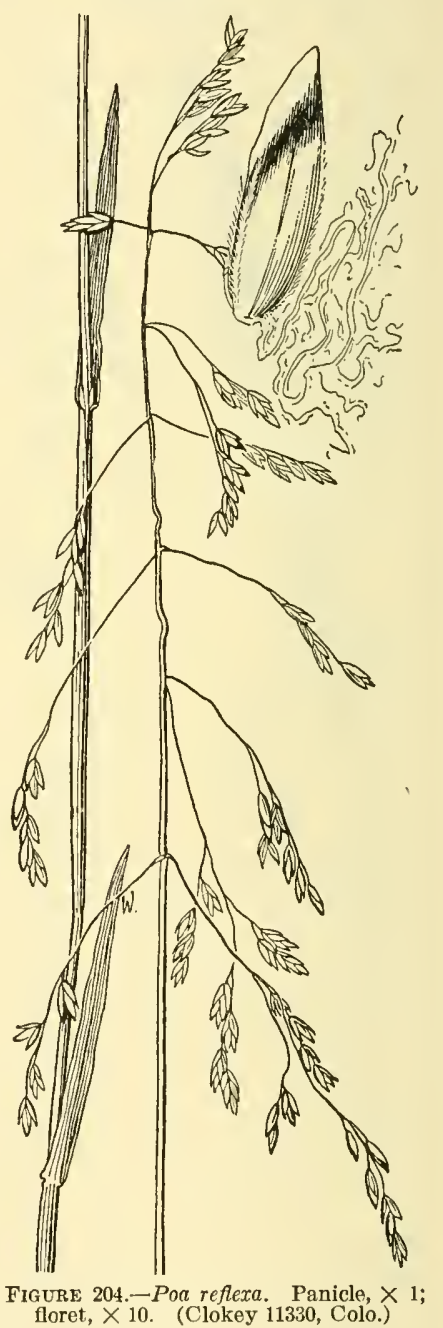

in pairs or solitary, naked below; spikelets ovate, purple, 4 to $6 \mathrm{~mm}$ long, 2- to 5-flowered; glumes rather broad, acute, 3 to $4 \mathrm{~mm}$ long; lemmas 3 to $4 \mathrm{~mm}$ long, oblong, obtuse, webbed at base (the web sometimes scant) pubescent on the keel and marginal nerves below. 
21 -Rocky slopes, Alaska to Washington (alpine slopes, Mount Rainier, Mount Baker); Glacier National Park, Mont. More leafy than P. leptocoma, more tufted, the panicle branches not so long; spikelets broader.

33. Poa leptocóma Trin. Bog Bluegrass. (Fig. 209.) Culms slender, solitary, or few in a tuft, 20 to $50 \mathrm{~cm}$ tall, often decumbent at base; sheaths usually slightly scabrous; ligule acute, the uppermost 3 to $4 \mathrm{~mm}$ long; blades short, lax, mostly 2 to $4 \mathrm{~mm}$ wide; panicle nodding, delicate, few-flowered, the branches

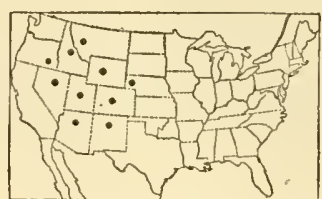

Figure 205.-Distribution of Poa reflexa. capillary, ascending or spreading, subflexuous, the lower mostly in

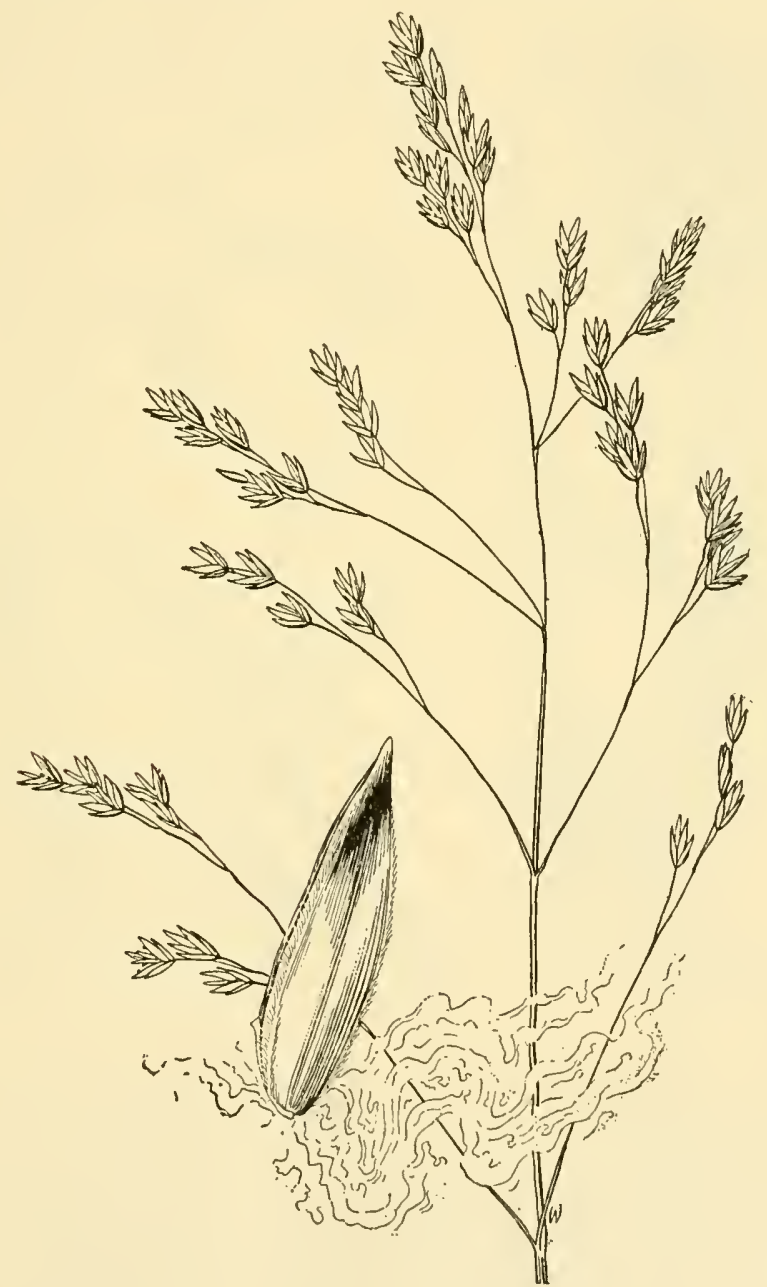

Figure 206. - Poa wolfit. Panicle, $\times 1$; floret, $\times 10$. (Deam 33821, Ind.)

pairs; spikelets narrow, 2- to 4-flowered; glumes narrow, acuminate; lemmas 3.5 to $4.5 \mathrm{~mm}$ long, acuminate, webbed at base, pubescent on 
the keel and marginal nerves or sometimes nearly glabrous, the intermediate nerves distinct. 24 -Bogs, Alaska, south in the mountains to northern New Mexico, Utah, Nevada, and California (Mount Dana) (fig. 210).

34. Poa paludígena Fern. and Wieg. (Fig. 211.) Culms slender, solitary or in small tufts, 15 to $70 \mathrm{~cm}$ tall; sheaths minutely scabrous; ligule short, truncate, the uppermost as much as $1.5 \mathrm{~mm}$ long; blades

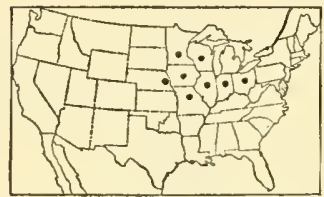

Figure 207.-Distribution of Poa wolfi.

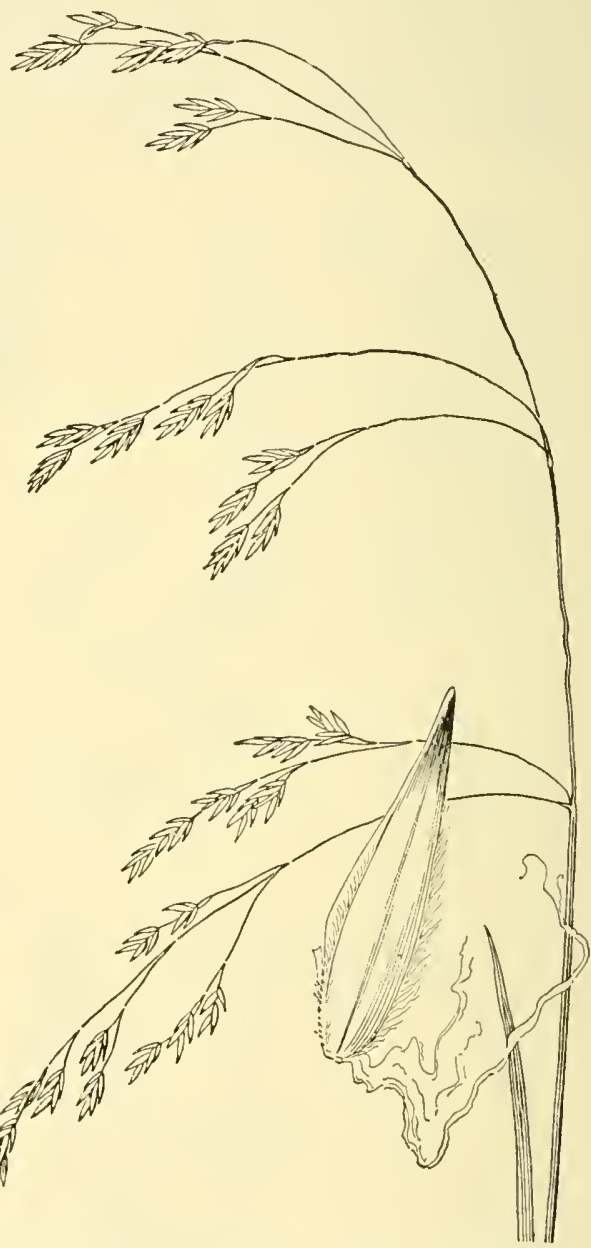

Figure 209.-Poa leptocoma. Panicle, $\times 1$; floret $\times, 10$. (Arsène and Benedict 15562, N.Mex.)
Figure 208.--Poa paucispicula. Panicle, $\times 1$; floret, $\times 10$. (Hitcheock 11711, Wash.)

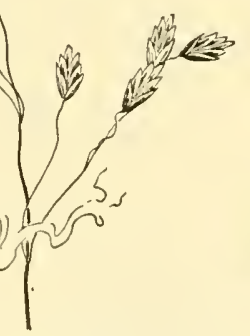

rather lax, mostly erect, 0.3 to $2 \mathrm{~mm}$ wide; panicle loose and open, mostly 5 to $10 \mathrm{~cm}$ long, the branches long and slender, distant, the lower mostly in twos, spikelet-bearing above the middle; spikelets mostly 4 to $5 \mathrm{~mm}$ long, narrow, 2- to 5 -flowered; lemmas 2.5 to $3.5 \mathrm{~mm}$ long, webbed at base with a few long hairs, the keel and lateral nerves pubescent on the lower half or two-thirds, the intermediate nerves glabrous, obscure. $24-$ Bogs and springy places, New York and Pennsylvania to Illinois and Wisconsin (fig. 212). 
35. Poa bulbósa L. Bulbous Bluegrass. (Fig. 213.) Culms densely tufted, more or less bulbous at base, 30 to $60 \mathrm{~cm}$ tall; blades flat or loosely involute, 1 to $2 \mathrm{~mm}$ wide; panicle ovoid, mostly 5 to $8 \mathrm{~cm}$ long, somewhat contracted, the branches ascending or appressed, some floriferous to base; spikelets mostly proliferous, the florets converted into bulblets; bulblets with a dark purple base (about $2 \mathrm{~mm}$ long), the bracts extending into slender green tips 5 to $15 \mathrm{~mm}$

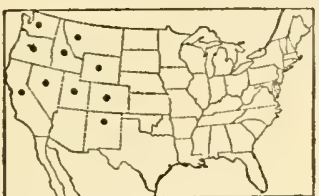

FIgURE 210.-Distribution of Poa leptocoma.

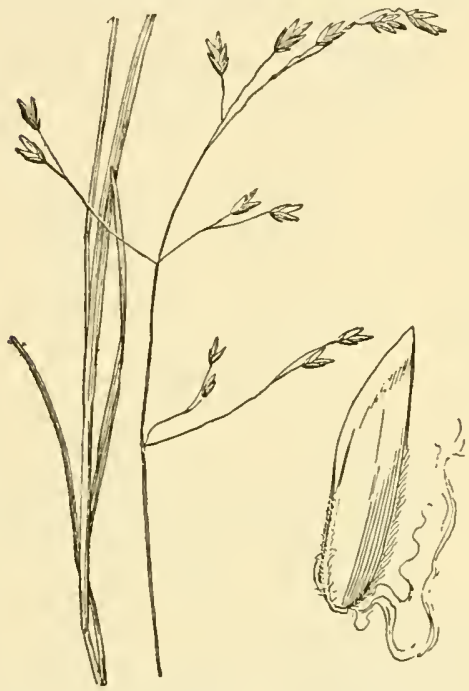

Figure 211.-Poa paludigena. Panicle, $\times 1$; floret, $\times 10$. (Eames and Wiegand 9250, N.Y.)

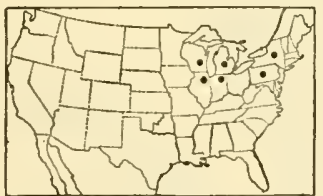

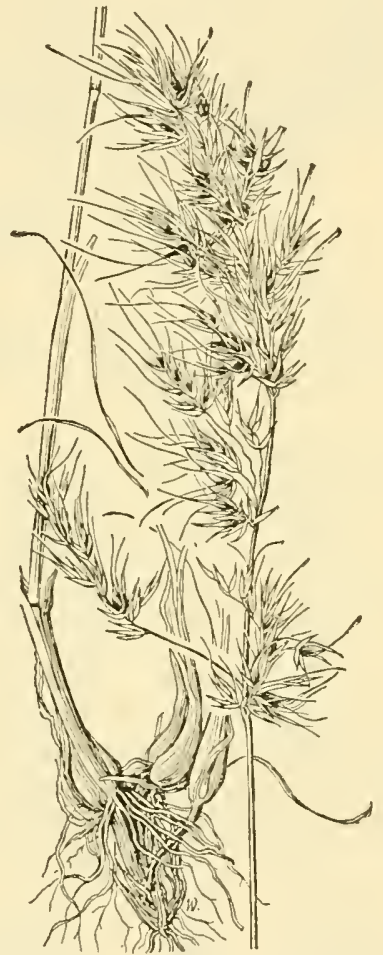

Figure 213.-Poa bulbosa, $\times 1$. (Henderson 6136, Idaho.)

Figure 212.-Distribution of Poa paludigena.

long; unaltered spikelets about 5-flowered; lemmas $2.5 \mathrm{~mm}$ long, webbed at base, densely silky on the keel and marginal nerves, the intermediate nerves faint. 24 -Fields and meadows, Virginia and North Carolina; North Dakota; Idaho to British Columbia, and California; Utah; Oklahoma (fig. 214); introduced from Europe.

36. Poa nemorális L. Wood Bluegrass. (Fig. 215.) Culms tufted, 30 to $70 \mathrm{~cm}$ tall; ligule very short; blades rather lax, about $2 \mathrm{~mm}$ wide; panicle 4 to $10 \mathrm{~cm}$ long, the branches spreading; spikelets 2 - to 5 -flowered, 3 to $5 \mathrm{~mm}$ long; glumes narrow, sharply acuninate, 
about as long as the first floret; lemmas 2 to $3 \mathrm{~mm}$ long, sparsely webbed at base, pubescent on the keel and marginal nerves, the intermediate nerves obscure. 24 -Occasional in meadows from New-

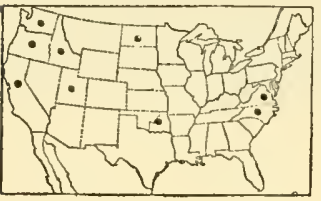

FIgURE 214.-Distribution of Poa bulbosa. foundland to Delaware and Michigan; Oregon (ballast, near Portland) (fig. 216); introduced from Europe. Differing from P. palustris and $P$. interior in the very short ligule and the narrow acuminate glumes.

37. Poa macrocláda Rydb. (Fig. 217.) Culms 50 to $80 \mathrm{~cm}$ tall, glabrous; ligule prominent, 2 to $3 \mathrm{~mm}$ long; blades 2 to $3 \mathrm{~nm}$ wide; panicle open, 10 to $20 \mathrm{~cm}$ long, pyramidal, the branches spreading, distant, in twos or threes, as much as $8 \mathrm{~cm}$ long, naked on the lower half or two-thirds; spikelets about $6 \mathrm{~mm}$ long, 2or 3 -flowered, purple; glumes 3.5 to $4 \mathrm{~mm}$ long; lemmas 4 to $4.5 \mathrm{~mm}$

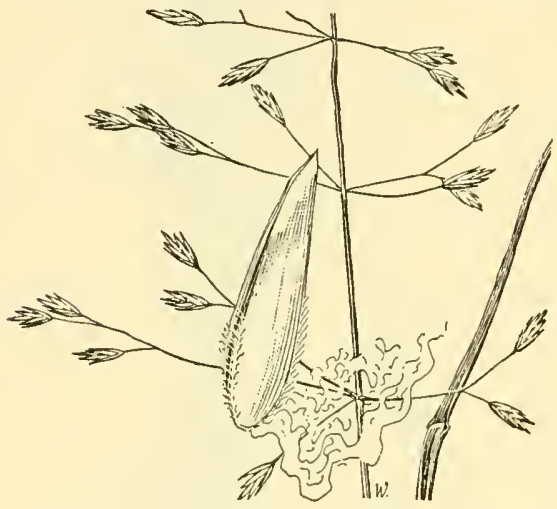

Figure 215. - Poa nemoralis. Panicle, $\times 1$; floret, $\times 10$. (Hitchcock 23662, New foundland.) long, pubescent on the keel and marginal nerves, the web scant or wanting. 24 -Moist places, at medium altitudes, Colorado,

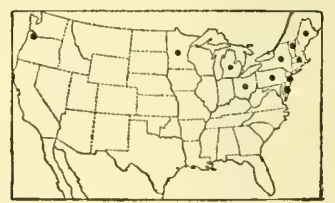

FIGURE 216.-Distribution of Poa nemoralis.

Montana, and Idaho; a little known species, allied to $P$. palustris, but with larger spikelets.

38. Poa palústris L. FowL BLUEGRASS. (Fig. 218.) Culms loosely tufted, glabrous, decumbent at the flattened purplish base, 30 to $150 \mathrm{~cm}$ tall; sheaths keeled, sometimes scaberulous; ligule 3 to $5 \mathrm{~mm}$ long, or only $1 \mathrm{~mm}$ on the innovations; blades 1 to $2 \mathrm{~mm}$ wide; panicle

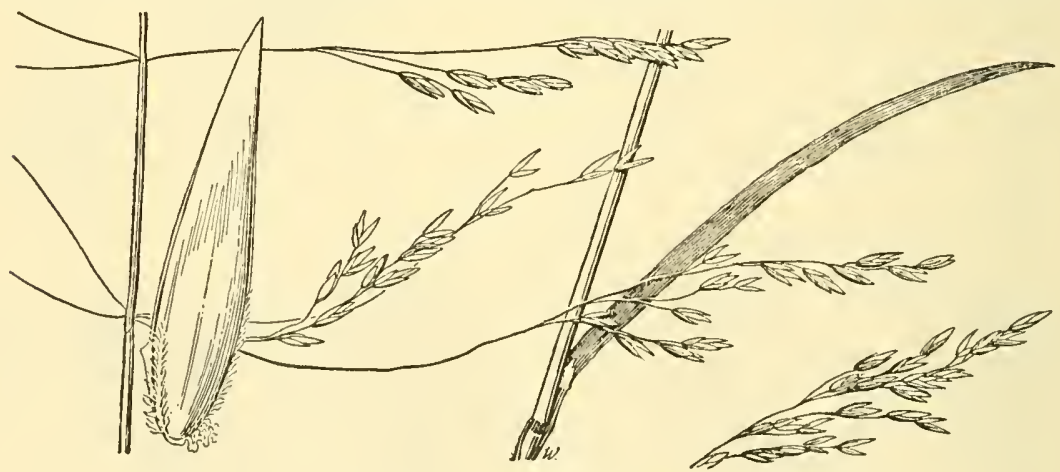

Figure 217. - Poa macroclada. Panicle, $\times 1$; floret, $\times 10$. (Dupl. type.)

pyramidal or oblong, nodding, yellowish green or purplish, 10 to $30 \mathrm{~cm}$ long, the branches in rather distant fascicles, naked below; 
spikelets 2- to 4-flowered, about $4 \mathrm{~mm}$ long; glumes lanceolate, acute, shorter than the first floret; lemmas 2.5 to $3 \mathrm{~mm}$ long, usually bronzed at the tip, webbed at base, villous on the keel and marginal nerves, the intermediate nerves faint. 2 4 -Meadows and moist open

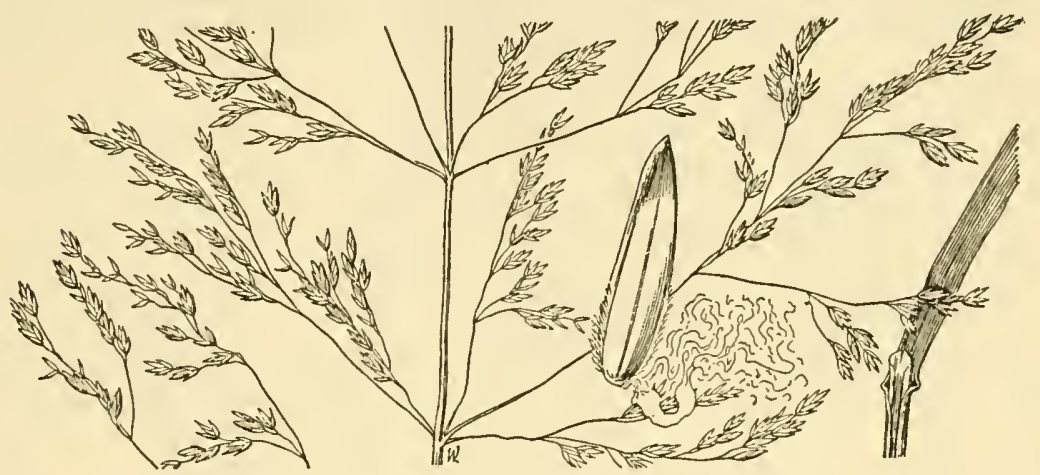

Figure 218. - Poa palustris. Panicle, $\times 1$; floret, $\times 10$. (Suksdorf 7022, Wash.)

ground, at low and medium altitudes, Newfoundland and Quebec, south to Virginia, Missouri, Nebraska, New Mexico, and California (Sierra Valley) (fig. 219); Eurasia.

39. Poa intérior Rydb. Inland bluegrass. (Fig. 220.) Culms erect from a usually densely tufted erect base, commonly rather stiff, often scabrous below the panicle, 20 to $50 \mathrm{~cm}$ tall; sheaths slightly keeled or terete; ligule evident but usually less than $1 \mathrm{~mm}$ long; blades 1 to 2 $\mathrm{mm}$ wide; panicle narrowly pyramidal, 5 to 10 cm long, the branches ascending; spikelets about as in P.palustris. 21 -Grassy slopes

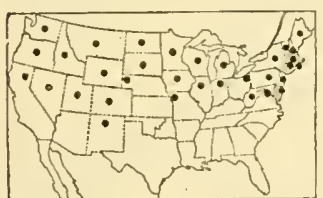

Figure 219.-Distribution of Poa palustris. and open woods at medium altitudes, usually not extending much above timber line, Quebec to British Columbia and Washington, south to Vermont, Michigan, Minnesota, western Nebraska, New Mexico, and Arizona (fig. 221).

4. Alpínae.-Perennials without creeping rhizomes; lemmas not webbed at base, pubescent on the keel or on the marginal nerves, or both, sometimes also pubescent on internerves.

40. Poa fendleriána (Steud.) Vasey. Mutron

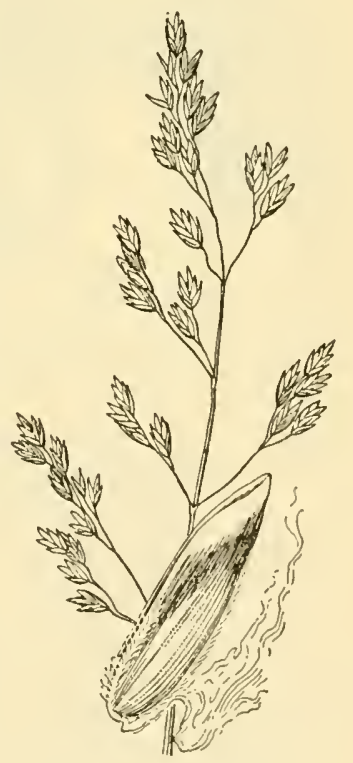

Figere 220.-Poa interior. Panicle, $\times 1$; floret, $\times 10$. (Clements 297, Colo.)

GRASS. (Fig. 222.) Incompletely dioecious; culms erect, tufted, seabrous below the panicle, 30 to $50 \mathrm{~cm}$ tall; sheaths somewhat scabrous; ligule less than $1 \mathrm{~mm}$ long, not noticeable viewed from the side of the sheath; blades mostly basal, folded or involute, firm and stiff; panicle long-exserted, oblong, contracted, pale, 2 to $7 \mathrm{~cm}$ long; spikelets 5- 
or 6-flowered, about $8 \mathrm{~mm}$ long; glumes broad, $3 \mathrm{~mm}$ long; lemmas 4 $\mathrm{mm}$ long, villous on lower part of keel and marginal nerves, the intermediate nerves obscure; pistillate spikelets with minute stamens, the anthers about $0.2 \mathrm{~mm}$ long. 4 -Mesas, open dry woods, and rocky hills at medium altitudes, Manitoba to British Columbia, south through western South Dakota (Black Hills) and Idaho to western Texas

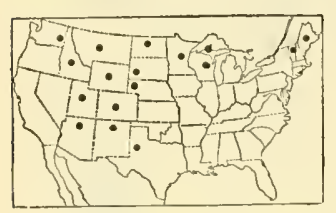

Figure 221.-Distribution of Poa interior.

(Chisos Mountains) and California; n or the r $\mathrm{n}$ Mexico (fig. 223). A very small proportion of specimens have been found with well-developed stamens having large anthers, the pistil also developed.

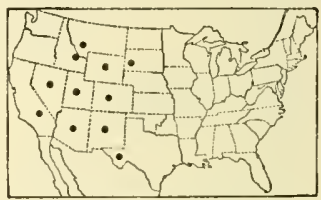

FIGURE 223.-Distribution of Poa fendleriana.

41. Poa longilígula Scribn. and Will. Longtongue mutton grass. (Fig. 224.) Differing from P. fendleriana in the prominent ligule, as

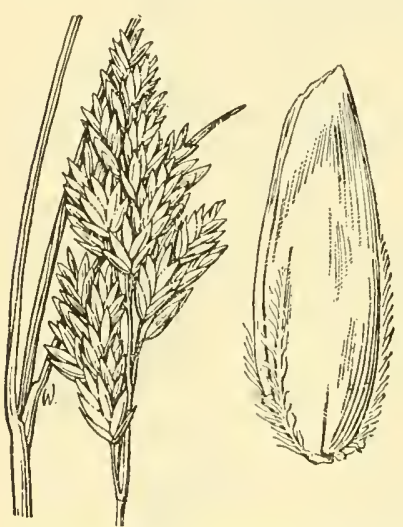

Figure 222.--Poa fendletiana. Panicle, $\times 1$; tloret, $\times 10$. (Eggleston 6463, N.Mex.)

lous on the keel and marg much as 5 to $7 \mathrm{~mm}$ long and in the looser, often longer usually greenish panicle. 2 - North Dakota to Oregon, south to New Mexico and California (fig. 225).

42. Poa autumnális Muhl. (Fig. 226.) Culms in rather large lax tufts, 30 to $60 \mathrm{~cm}$ tall; blades 2 to $3 \mathrm{~mm}$ wide, numerous at base; panicle 10 to $20 \mathrm{~cm}$ long, about as broad, very open, the capillary flexuous branches spreading, bearing a few spikelets near the ends; spikelets 4- to 6-flowered, Figure 224-about $6 \mathrm{~mm}$ long; lemmas ob- Poa lonoiligula. long, obtusely rounded at the scarious compressed apex, vil-

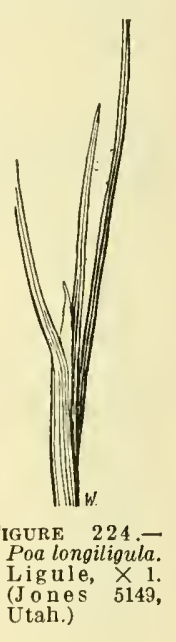

lous on the keel and marginal nerves, pubescent on the internerves below or sometimes nearly to apex. 24-Moist woods, New Jer-

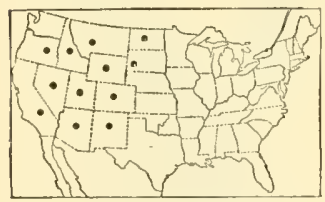

FIgure 225.-Distribution of Poa longiligula. sey to Michigan and Illinois, south to Florida and Texas (fig. 227).

43. Poa alpína L. Alpine bluegrass. (Fig. 228.) Culms erect from a rather thick vertical crown, rather stout, 10 to $30 \mathrm{~cm}$ tall; blades short, 2 to $5 \mathrm{~mm}$ wide, the uppermost about the middle of the culm; panicle ovoid or short-pyramidal, rather compact, 1 to $8 \mathrm{~cm}$ long, the lower branches often reflexed; spikelets broad, purple or purplish; glumes broad, abruptly acute; lemmas 3 to $4 \mathrm{~mm}$ long, strongly villous on the keel and marginal nerves, pubescent on the internerves below, the intermediate nerves faint. 24 -Mountain meadows, arctic regions of the Northern Hemisphere, extending south to Quebec, northern Michigan (Keweenaw Point), and the alpine summits of Colorado, Utah, and Oregon (Wallowa Mountains); Mexico (fig. 229). 
44. Poa stenántha Trin. (Fig. 230.) Culms tufted, 30 to $50 \mathrm{~cm}$ tall; ligule prominent, as much as $5 \mathrm{~mm}$ long; blades flat or loosely involute, rather lax, mostly basal, 1 to $2 \mathrm{~mm}$ wide, the uppermost culm leaf below the middle of the culm; panicle nodding, 5 to $15 \mathrm{~cm}$ long, the branches in twos or threes, arcuate-drooping, naked below, with a few spikelets at the ends; spikelets 3 - to 5 -flowered, 6 to $8 \mathrm{~mm}$ long; lemmas about $5 \mathrm{~mm}$ long, pubescent on the lower part of keel

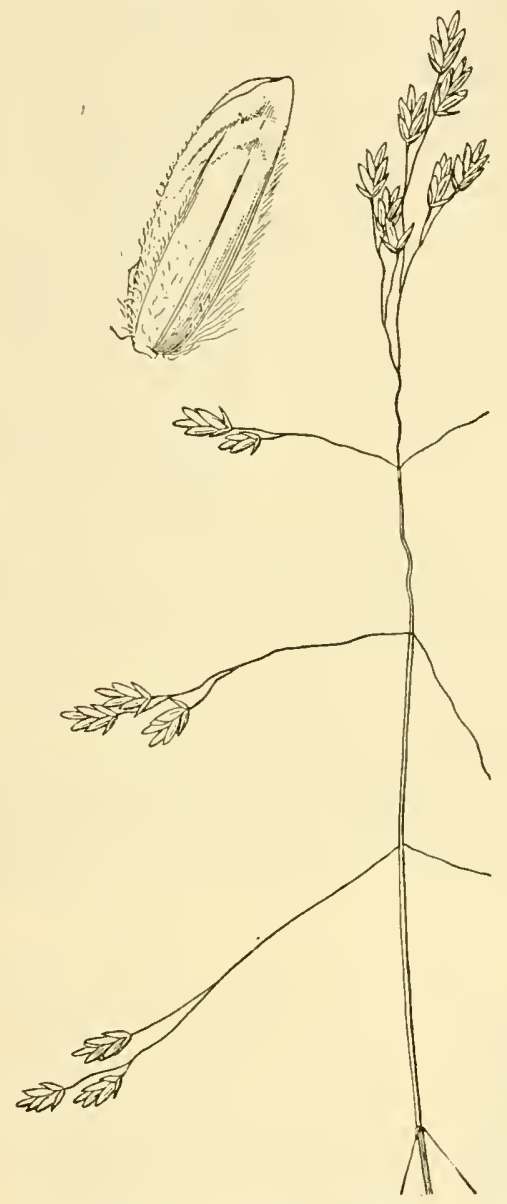

Figure 226. - Poa autumnalis. Panicle, $\times 1$; floret, $\times 10$. (Curtiss 6787, Ga.)

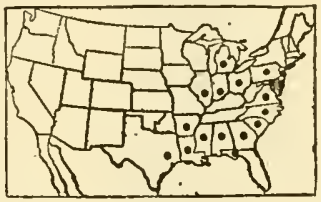

Figure 227.-Distribution of Poa autumnalis.

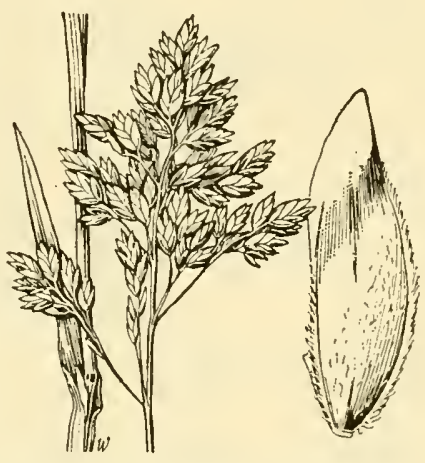

Figure 228.- Poa alpina. Panicle, $\times 1$; floret, $\times 10$. (Eggleston 11824, Colo.)

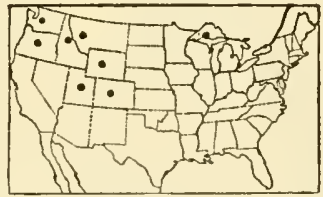

Frgure 229.-Distribution of Poa alpina.

and marginal nerves, sparsely pubescent on the internerves below. 2 - Moist open ground, Alaska, Alberta, and British Columbia, extending into Montana, Colorado (White River Forest), Idaho, Washington (Nooksack River), and Oregon (Crater Lake) (fig. 231).

45. Poa glaúca Vahl. (Fig. 232.) Plants glaucous, in close or loose tufts; culms erect, stiff, 10 to $30 \mathrm{~cm}$ tall, sometimes taller, naked above, the uppermost leaf lisually much below the middle; ligule of uppermost leaf about $2 \mathrm{~mm}$ long; blades mostly basal, 3 to $5 \mathrm{~cm}$ long, 1 to $2 \mathrm{~mm}$ wide; panicle 3 to $7 \mathrm{~cm}$ long, narrow, rather compact, the 
branches erect or ascending, few-flowered; spikelets mostly 2- or 3flowered, 5 to $6 \mathrm{~mm}$ long; lemmas 3 to $4 \mathrm{~mm}$ long, strongly pubescent on the lower half of the keel and marginal nerves and slightly pubescent on the faint intermediate nerves. 2 - Rocky slopes, arctic

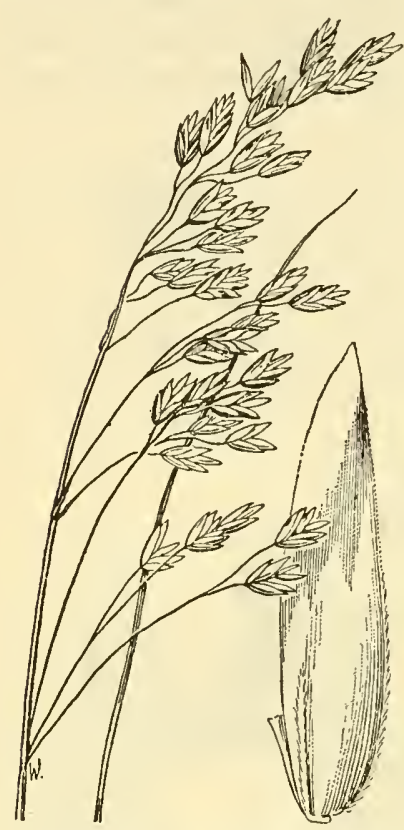

Figure 230.-Poa stenantha. Panicle, $\times 1$; floret, $\times 10$. (B) ankinship, Mont.) regions south to the alpine summits of New Hampshire and Vermont. Common in Greenland.

46. Poa láxa Haenke. (Fig. 233.) Plants in loose lax bunches; culms weak and slender, 10 to 20 or sometimes 30 $\mathrm{cm}$ tall; ligule truncate, about $1 \mathrm{~mm}$ long; blades mostly basal, lax, mostly about 1 $\mathrm{mm}$ wide; panicle narrow but loose, fewflowered, 2 to $6 \mathrm{~cm}$ long, the branches ascending, naked below; spikelets 2to 4-flowered, about $5 \mathrm{~mm}$ long; lemmas 3 to $3.5 \mathrm{~mm}$ long, densely villous on the lower half of the

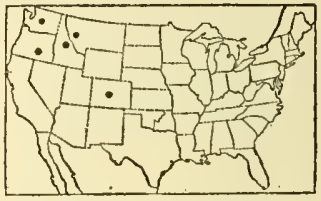

Figure 231.-Distribution of Poa stenantha.

keel and marginal nerves, sometimes sparsely webbed at base. 24 -Rocky slopes, Newfoundland and Quebec to the alpine summits of Maine, New Hampshire, Vermont, and New York (fig. 234); Europe. Common on the upper cone of Mount Washington.

47. Poa pattersóni Vasey. Patterson Bluegrass. (Fig. 235.) Culms in dense tufts with numerous basal leaves, 10 to $20 \mathrm{~cm}$ tall; blades usually folded, rather lax, mostly less than $10 \mathrm{~cm}$ long, about $1 \mathrm{~mm}$ wide;

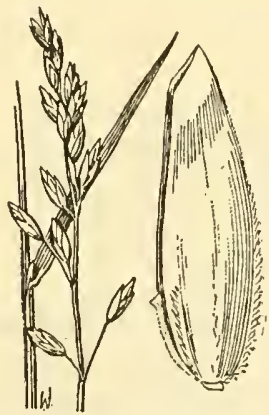

FIGURE 232.-Poa gtauca. Panicle, $\times 1$; floret, $\times 10$.

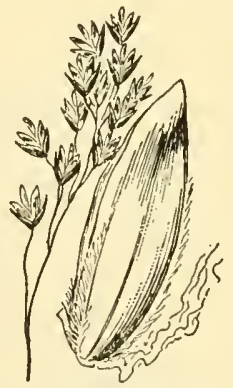

F I G URE 233 - P Oa laxa. Panicle, $\times 1$; floret, $\times 10$. (Fernald, Maine.)

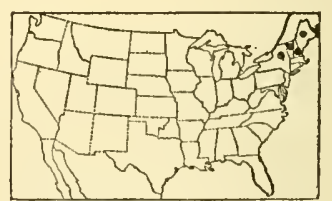

FIGURE 234.-Distribution of Poa laxa.

panicle narrow, condensed, purplish, 1 to $4 \mathrm{~cm}$ long; spikelets 2or 3 -flowered, 5 to $6 \mathrm{~mm}$ long; lemmas about $4 \mathrm{~mm}$ long, strongly pubescent on the keel and marginal nerves, short-pubescent on the internerves, sometimes sparscly webbed at base. 24 -Alpine 
regions, Montana, Wyoming, Utah, and Colorado; Oregon (Mount Hood) (fig. 236).

48. Poa rupícola Nash. Timberline bluegrass. (Fig. 237.)

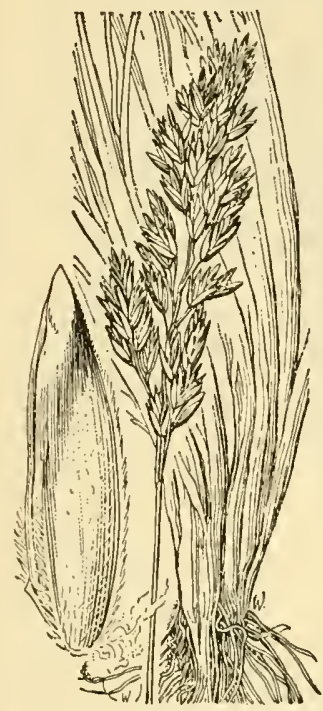

FIGURE 235.-Poa pattersoni. Plant, $\times 1$; floret, $\times 10$ (Patterson 154, Colo.) Culms densely tufted, erect, rather stiff, often scaberulous below the panicle, 10 to $20 \mathrm{~cm}$ tall; blades short, 1 to $1.5 \mathrm{~mm}$ wide; panicle narrow, purplish, 2 to $4 \mathrm{~cm}$ long, the short branches ascending or appressed; spikelets usually purple, about 3 -flowered; lemmas villous below on keel and marginal nerves and sometimes pubescent on the internerves below. 24 - Rocky slopes, British Columbia, south in the mountains, at high altitudes through Montana to northern New Mexico,

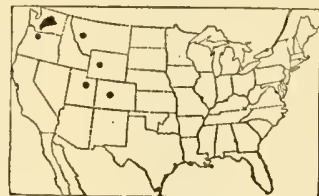

FIgure 236.-Distribution of Poa pattersoni. Arizona, Oregon (Mount Hood and Wallowa Mountains), and California (Mono Pass, Sheep Mountain) (fig. 238). Small specimens of $P$. interior, which resemble this, differ in having a small web at the base of the lenma.

5. Épiles.-Perennials without rhizomes; lemmas not webbed at base, glabrous or scabrous (minutely pubescent in $P$. unilateralis).

49. Poa involúta Hitchc. (Fig. 239.) In dense pale tufts; culms slender, 30 to $40 \mathrm{~cm}$ tall; ligule very short; blades involute, slender, 15 to 25 $\mathrm{cm}$ long, glabrous or slightly scabrous; panicle open, 10 to $15 \mathrm{~cm}$ long, the branches in pairs, few-flowered near the ends; spikelets mostly 3 - or 4 -flowered, 5 to $6 \mathrm{~mm}$ long; lemmas 3 to $4 \mathrm{~mm}$ long, scabrous. 21 -Known only from the Chisos Mountains, Tex.

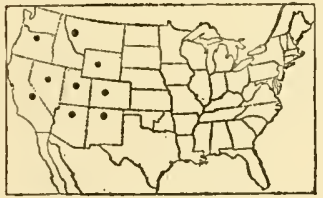

FIGURE 238.-Distribution of Poa rupicola.
50. Poa cusíckii Vasey. Cusick bluegrass. (Fig. 240.) Culms in dense often large tufts, erect, 20 to $60 \mathrm{~cm}$ tall; ligule very short; blades filiform, erect, scabrous, mostly basal; panicle usually pale or tawny, narrow, oblong, contracted, or somewhat open at anthesis, 3 to $8 \mathrm{~cm}$ long; spikelets 7 to $9 \mathrm{~mm}$ long; lemmas 4.5 to $6 \mathrm{~mm}$ long, smooth or scabrous. \& -Dry or rocky slopes at medium and high altitudes, Alberta to British Columbia, south to Colorado, Nevada, and the central Sierras of California (fig. 241).

51. Poa unilaterális Scribn. (Fig. 242.) Culms in dense tufts, 10 to $40 \mathrm{~cm}$ tall, sometimes decumbent at base; sheaths

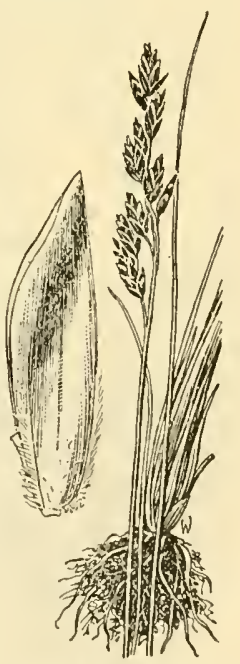

Figure 237.-Poa rupi cola, Plant, $\times 1$ floret, $\times 10$. (Swal. len 1348 , Colo.) 
tawny, papery; blades flat or folded, shorter than the culms; panicle

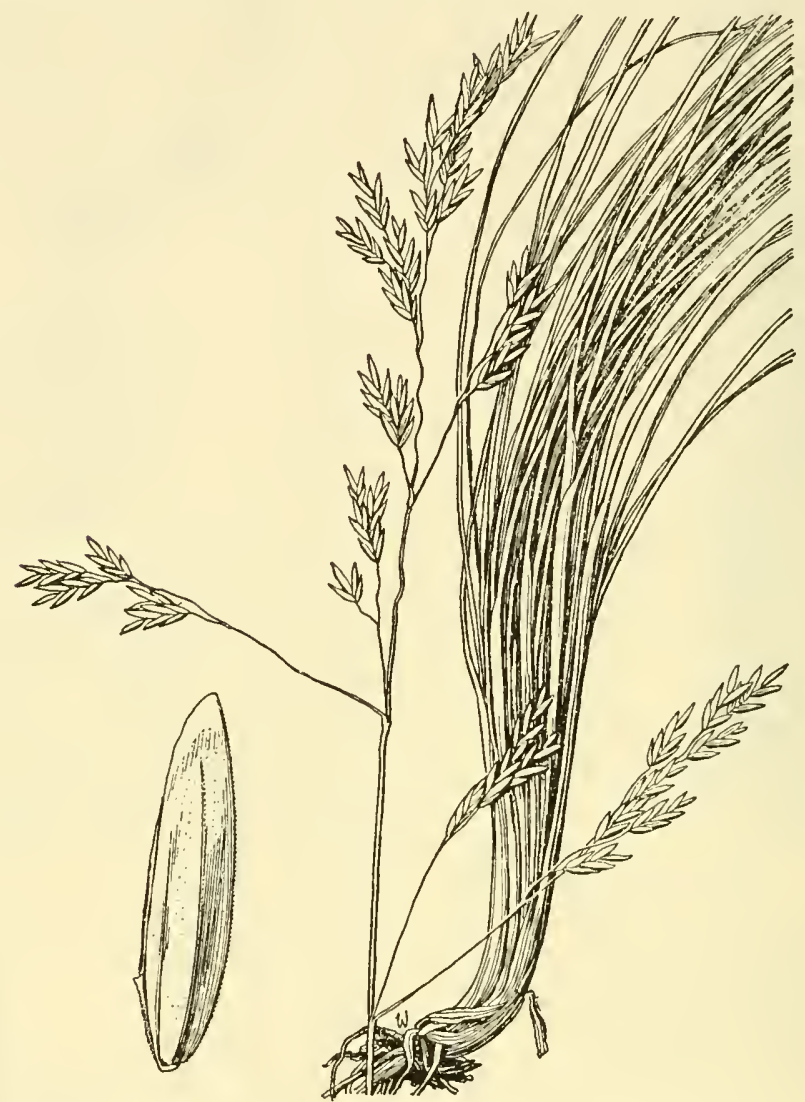

FIGURe 239. - Poa involuta. Plant, $\times 1$; floret, $\times 10$. (Swallen 1110, Tex.)

oblong, dense and spikelike or somewhat interrupted below, 2 to $6 \mathrm{~cm}$

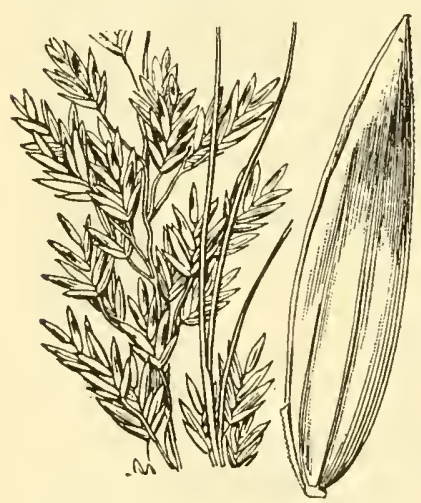

Figure 240-Poa cusickii. Panicle, $X$ 1; floret, $\times 10$. (Howell 183, Oreg.) long; spikelets 6 to $8 \mathrm{~mm}$ long; glumes broad, acute; lemmas 3 to $4 \mathrm{~mm}$ long, glabrous except for a few short hairs on the nerves below. 21 (P. pachypholis Piper.)

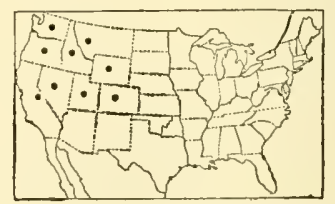

Figure 241.-Distribution of
Poa cusickii.

-Cliffs, bluffs, and rocky meadows near the seashore, Washington (Ilwaco); California (Humboldt Bay to Monterey).

52. Poa épilis Scribn. Skyline blueGRASS. (Fig. 243.) Culms erect from a rather loose base, solitary or 
few in a tuft, 20 to $40 \mathrm{~cm}$ tall; ligule about $3 \mathrm{~mm}$ long; blades of the culm about 3 , flat, 3 to $6 \mathrm{~cm}$ long, 2 to $3 \mathrm{~mm}$

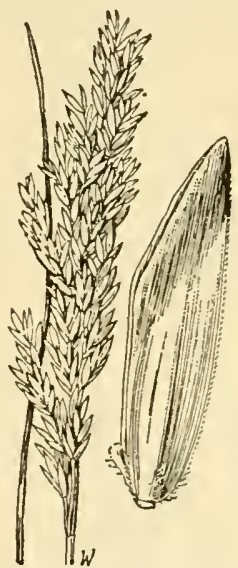

Figure 242.-Poa uni. lateralis. Panicle, $X$ 1; floret, $\times 10$. (Chase 5653 , Calif.) wide, of the innovations narrow, longer and usually folded or involute; panicle usually condensed, ovoid, 2 to $6 \mathrm{~cm}$ long, long-exserted, usually purple, the lower branches naked below, ascending or appressed; spikelets 3-flowered, about $5 \mathrm{~mm}$ long; lemmas 4 to 5 or even $6 \mathrm{~mm}$ long, glabrous or minutely scabrous. 2 -Mountain meadows, mostly above timber line, Alberta to British Columbia, south to Colorado, Utah, Nevada, and California (fig. 244).

53. Poa vaseyóchloa Scribn. (Fig. 245.) In small dense soft lax tufts; culms erect, 10 to $20 \mathrm{~cm}$ tall; ligule acute,

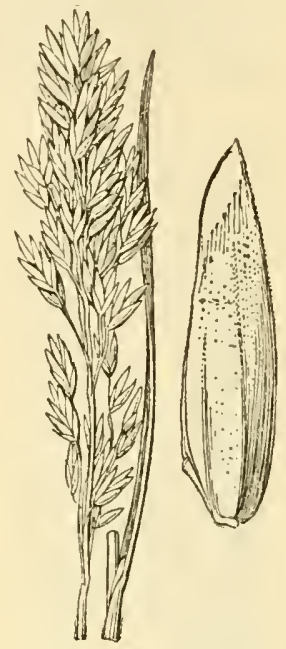

Figure 213.-Poa epilis Panicle, $\times 1$; floret, $\times 10$ (Type.)

about $3 \mathrm{~mm}$ long; blades lax, mostly folded or involute, in a basal tuft, mostly less than $5 \mathrm{~cm}$ long, with one or two short ones on the culm, narrow or filiform; panicle ovate, 2 to $4 \mathrm{~cm}$ long, few-flowered, open, the slender branches spreading, bearing 1 or 2 spikelets; spikelets purple, 3 - to 6flowered; glumes 2 to $3 \mathrm{~mm}$ long, rather broad; lemmas smooth or minutely scabrous, $3 \mathrm{~mm}$

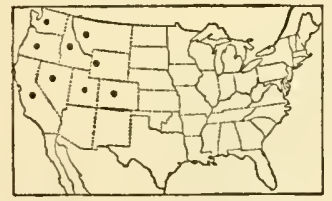

FIGURE 244.-Distribution of long. $2-\mathrm{Rocky}$ slopes, Cascade Mountains of Washington and Oregon in the vicinity of Columbia River, and the Wallowa Mountains of Oregon.

54. Poa prínglei Scribn. (Fig. 246.) Densely tufted; culms 10 to $20 \mathrm{~cm}$ tall; lower sheaths loose, papery; blades mostly basal, involute, mostly 2 to $5 \mathrm{~cm}$ long, sometimes longer, glabrous on the exposed surface, puberulent on inner surface; panicle narrow, condensed, usually pale or silvery, few- to several-flowered, 1 to $5 \mathrm{~cm}$ long; spikelets $3-$

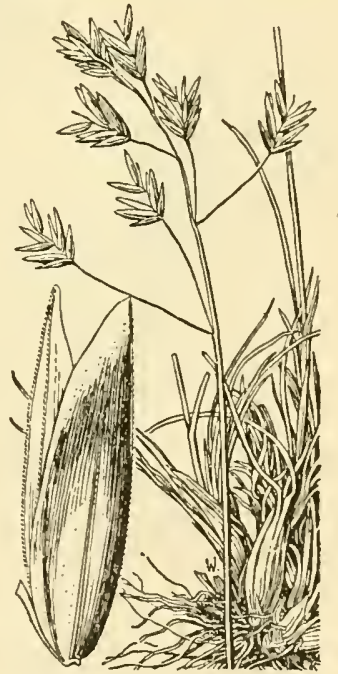

FIG URE 245.-Poa vaseyochloa. Plant, $\times 1$; floret, $\times$ 10. (Туре.) to 5 -flowered, 6 to $8 \mathrm{~mm}$ long; glumes equal, broad, 4 to 5 or rarely $7 \mathrm{~mm}$ long; lemmas 5 to 6 , rarely $8 \mathrm{~mm}$ long, smooth or scabrous. 
2 -Rocky alpine summits, Montana to Washington, south to Nevada (Mount Rose) and California (fig. 247).

55. Poa lettermáni Vasey. (Fig. 248.) In low lax tufts; culms mostly less than $10 \mathrm{~cm}$ tall, usually scarcely exceeding the blades;

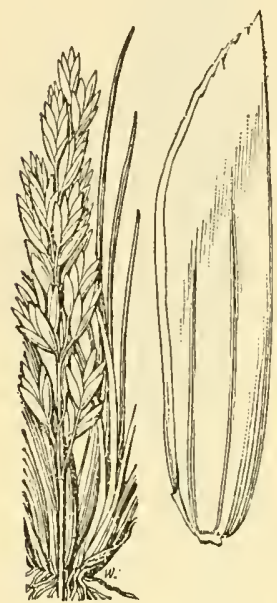

Figure 246.-Poa pringlei. Plant, $\times 1$; floret, $\times 10$.

(Henderson 3080, Idaho.) ligule 1 to $2 \mathrm{~mm}$ long; blades lax, usually not more than 1 $\mathrm{mm}$ wide; panicle narrow, contracted, 1 to $3 \mathrm{~cm}$ long; spikelets 3 - or 4 -flowered, 4 to $5 \mathrm{~mm}$ long; glumes equal, somewhat acuminate, about as long as the first and second florets; lenmas erose at summit, 2.5 to $3 \mathrm{~mm}$ long. 24 - Rocky alpine summits, British Columbia, Washington, Colorado (fig. 249).

56. Poa leibérgii Scribn. Leiberg bluegrass. (Fig.250) Usually densely tufted; culnus 10 to $30 \mathrm{~cm}$ tall, erect; ligule 1 to $2 \mathrm{~mm}$ long; blades mostly basal, firm, involute, usually less than $10 \mathrm{~cm}$ long; panicle narrow, 2 to $5 \mathrm{~cm}$ long, often purple, the branches short, appressed or ascending; spikelets 2 - to 4 -flowered, 4 to $6 \mathrm{~mm}$ long; lemmas 3 to $4 \mathrm{~mm}$ long, smooth or scaberulous. 24 -Alpine meadows and sterile gravelly alpine flats, eastern Oregon and the Sierras of California.

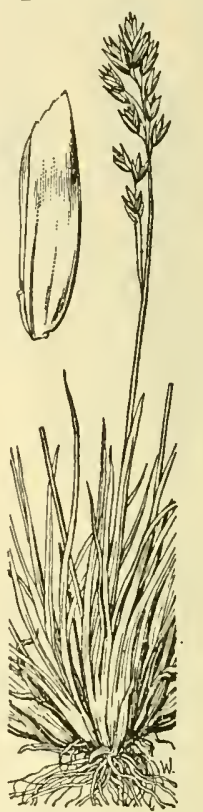

Figure 248.-Poa lettermani. Plant, $\times 1$; floret, $\times 10$. (Letterman, Colo.)

6. Scabréllae.-Perennials, without rhizomes, tufted, with numerous basal leaves; spikelets little compressed, narrow, much longer than wide; lemmas convex, crisp-puberulent on the back towards the base, the keels obscure, the marginal and intermediate nerves usually faint. The whole group of Scabrellae is made up of closely related species which appear to intergrade.

57. Poa scabrélla (Thurb.) Benth. Pine BlueGrass. (Fig. 251.) Culms erect, 50 to $100 \mathrm{~cm}$ tall, usually scabrous at least below the panicle;

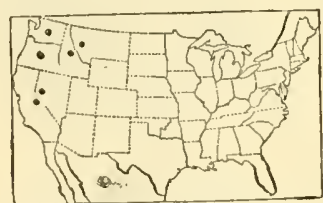

FIgURE 247.-Distribution of Poa pringlei.

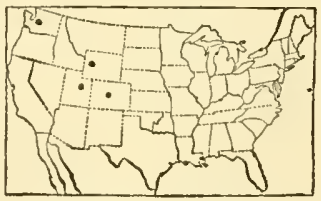

FigURE 249.-Distribution of Poa lettermani.

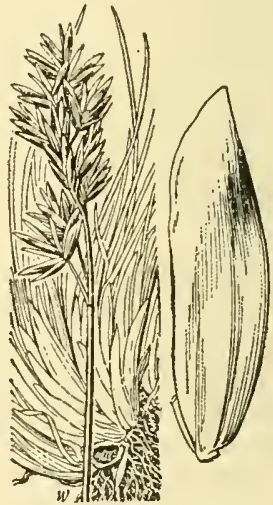

Figure 250.-Poa leibergii. Plant, $\times 1$; floret, $\times 10$. (Type.)

sheaths scaberulous; ligule 3 to $5 \mathrm{~mm}$ long; blades mostly basal, 1 to $2 \mathrm{~mm}$ wide, lax, more or less scabrous; panicle narrow, usually contracted, sometimes rather open at base, 5 to $12 \mathrm{~cm}$ long; 


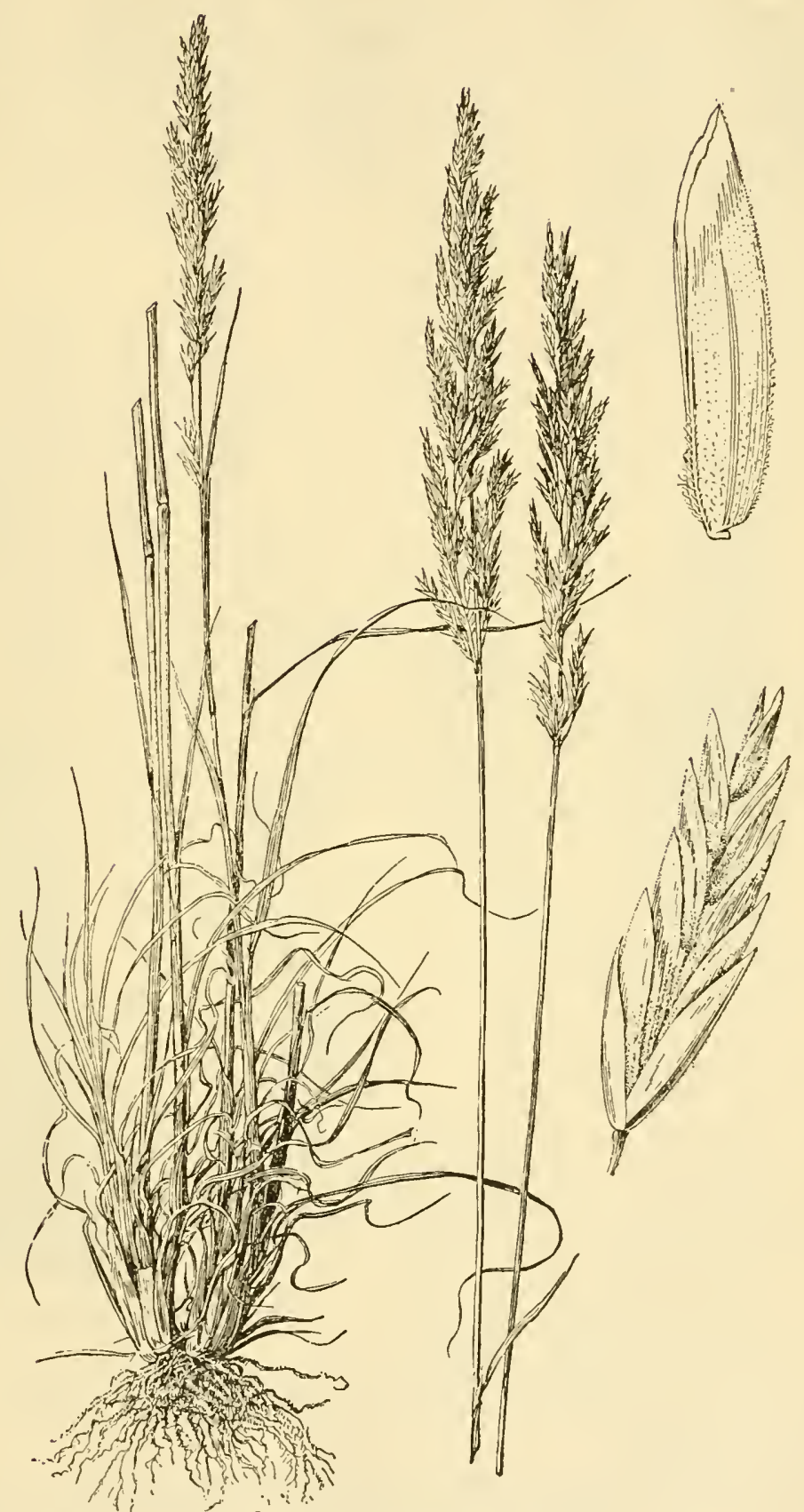

Figure 251. - Poa scabrella. Plant, $\times 1 / 2$; spikelet, $\times 5$; floret, $\times 10$. (Chase 5697, Calif.) 
spikelets 6 to $10 \mathrm{~mm}$ long; glumes $3 \mathrm{~mm}$ long, scabrous; lemmas 4 to $5 \mathrm{~mm}$ long, crisp-puberulent on the back toward base. 24 -Meadows, open woods, rocks, and hills, at low and medium altitudes, western Montana and southern Washington to California; Baja California (fig. 252). A form, like $P$. scabrella in other respects but with smooth lemmas, has been differentiated as $P$. limosa Scribn. and Will.-California (Mono Lake and Truckee).

58. Poa gracíllima Vasey. Slender bluegrass. (Fig. 253.) Culms rather loosely tufted, 30 to $60 \mathrm{~cm}$ tall, usually decumbent at base; ligule 2 to $5 \mathrm{~mm}$ long, shorter on the innovations; blades flat or folded, lax, from filiform to 1.5 mm wide; panicle pyramidal, loose,

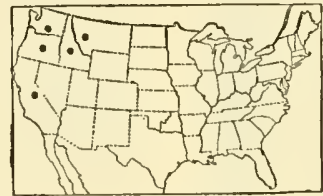

Figure 252.-Distribution of Pon scabrella.

rather open, 5 to $10 \mathrm{~cm}$ long, the branches in whorls, the lower in twos to sixes, spreading or sometimes reflexed, naked below; spikelets 4 to $6 \mathrm{~mm}$ long; second glume 3 to $4 \mathrm{~mm}$ long; lemmas minutely scabrous, crisp-pubescent near

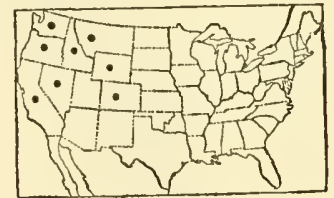

Figure 254. Distribution of Poa gracillima.

base, especially on the nerves. 21 -Cliffs and rocky slopes, Alberta to Alaska, south to Wyoming, northern Nevada, and the southern Sierras of California (fig. 254). Poa tenerrima Scribn. is a form with open few-flowered panicles; Southern Coast Ranges, California; $P$. multnomae Piper is a loose lax form in which the ligules on the innovations are short and truncate; wet cliffs, Multnomah Falls, Oreg.

59. Poa secúnda Presl. Sandberg bluegrass. (Fig. 255.) Culms erect from a dense often extensive tuft of short basal foliage, commonly not more than $30 \mathrm{~cm}$, but sometimes up to $60 \mathrm{~cm}$ tall; ligule acute, 
rather prominent; blades rather short, soft, flat, folded, or involute; panicle narrow, 2 to $10 \mathrm{~cm}$ long, the branches short, appressed, or somewhat spreading in anthesis; spikelets about as in $P$. gracillima. 21 (P. sandbergii Vasey.) - Plains, dry woods, rocky slopes, at medium and upper altitudes, but not strictly alpine, North Dakota to Yukon Territory, south to Nebraska, New Mexico, Utah, Nevada, and southern California; Chile (fig. 256).

60. Poa cánbyi (Scribn.) Piper. Canby bluegrass. (Fig. 257.) Green or glaucous; culms 50 to $120 \mathrm{~cm}$ tall; ligule 2 to $5 \mathrm{~mm}$ long; blades flat or folded; panicle narrow, compact or rather loose, 10 to

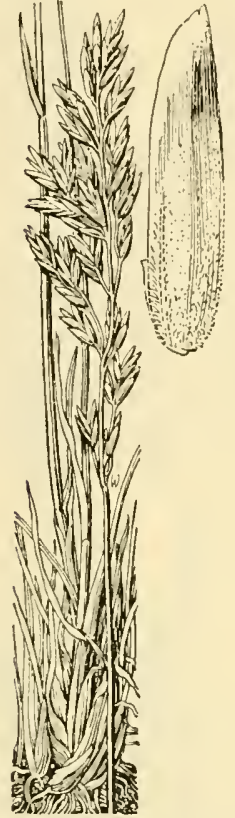

Figure 255. Poa secunda. Plant, $\times 1$; floret, $\times 10$. (Hitchcock 23202, Wyo.)
$15 \mathrm{~cm}$ long, sometimes as much as $20 \mathrm{~cm}$, the branches short, appressed; spikelets 3- to 5-flowered; lemmas more or less crisp-pubescent on lower part of back. 2 (P. lucida Vasey; P. laevigata Scribn.) - Sandy or dry ground, Michigan (Isle Royal) and Minnesota to Yukon Territory, south to western Nebraska, Colorado, Arizona, eastern Oregon, and eastern Washington; Quebec (fig. 258). Poa lucida has a slender but somewhat loose pale or shining panicle; $P$. canbyi has a denser, compact, dull green panicle, but the two forms grade into each other. Poa lucida is more common in Colorado and Wyoming; $P$. canbyi more common in Montana. The pubescence on the lemma may be obvious or obscure.

7. Nevadénses.-Perennials, without rhizomes, tufted; spikelets little compressed, narrow, much longer than wide; lemmas convex on the back, glabrous or minutely scabrous, not crisp-puberulent; keels obscure, marginal and intermediate nerves usually faint.

61. Poa nevadénsis Vasey. Nevada bluegrass. (Fig. 259.) Culms erect, 50 to $100 \mathrm{~cm}$ tall; sheaths scabrous, sometimes only slightly so; ligule about $4 \mathrm{~mm}$ long, shorter on the innovations, decurrent; blades usually elongate, narrow, involute, sometimes almost capillary, rather stiff; panicle narrow, 10 to $15 \mathrm{~cm}$ long, pale, rather loose, the branches short-appressed; spikelets 3 -to 5 -flowered, 6 to 8 $\mathrm{mm}$ long; glumes narrow, the second about as long as the lowest floret; lemmas 4 to $5 \mathrm{~mm}$ long, rather obtuse at the scarious tip. 24 - Low 
meadows and wet places, Montana to eastern Washington and Yukon Telritory, south to Colorado and the Sierras and San Bernardino Mountains, California; on wool waste in Maine (North Berwick) (fig. 260).

62. Poa curtifólia Scribn. (Fig. 261.) Culms several in a tuft from firm branched crowns, 10 to $20 \mathrm{~cm}$ tall; ligule prominent, the uppermost as much as $5 \mathrm{~mm}$ long; blades short, the lower 1.5 to $2 \mathrm{~cm}$ long, 2 to $3 \mathrm{~mm}$ wide, the upper successively smaller, the uppermost near the panicle, much reduced; panicle narrow, 3 to $6 \mathrm{~cm}$ long; spikelets about 3 -flowered; glumes equal, $5 \mathrm{~mm}$ long, the first acuminate, the second broad, rather obtuse; lemmas 5 to $5.5 \mathrm{~mm}$ long.

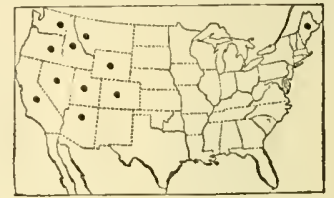

Figure 260.-Distribution of Poa nevadensis. 24 -Known only from central Washington.

63. Poa juncifólia Scribn. Alkali bluegrass. (Fig. 262.) Pale; culms erect, 50 to $100 \mathrm{~cm}$ tall; ligules short, those of the innovations not visible from the sides; blades involute, smooth, rather stiff; panicle narrow, 10 to $20 \mathrm{~cm}$ long, the branches appressed; spikelets 3- to 6-flowered, 7 to $10 \mathrm{~mm}$ long; glumes about equal; lemmas about $4 \mathrm{~mm}$ long. 2t (P. brachyglossa Piper.) - Alkaline meadows, Montana to British Columbia, south to Colorado and east of the Cascades to northeastern California (fig. 263).

64. Poa ámpla Merr. Big BLueGrass. (Fig. 264.) Green or glaucous; culms 80 to $120 \mathrm{~cm}$ tall; sheaths smooth, rarely scaberulous; ligule short, rounded; blades 1 to 3 $\mathrm{mm}$ wide; panicle narrow, 10 to 15 cm long, usually rather dense; spikelets 4- to 7 -flowered, 8 to 10 $\mathrm{mm}$ long; lemmas 4 to $6 \mathrm{~mm}$ long. $24-$ Meadows and moist open ground or dry or rocky slopes, Montana to Yukon Territory, south to New Mexico, Arizona, and California (fig. 265). The typical form is robust and more or less glaucous: this grades into a smaller green form, more common in the eastern part of the range (P. confusa Rydb.).

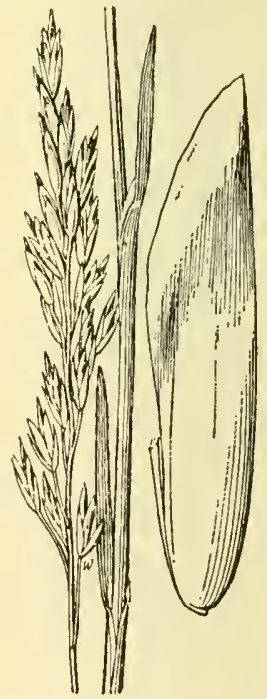

Figure 261.-Poa curti, folia. Panicle, $\times 1$; floret, $\times 10$, (Dupl. type.) $\times 1$; floret, $\times 10$ (Parish Bros. 1543, Calif.)

Occasional specimens of the typical form have short rhizomes. 


\section{BRÍZA L. Quaking grass}

Spikelets several-flowered, broad, often cordate, the florets crowded and spreading horizontally, the rachilla disarticulating above the glumes and between the florets; glumes about equal, broad, paperychartaceous, with scarious margins; lemmas papery, broad, with scari-

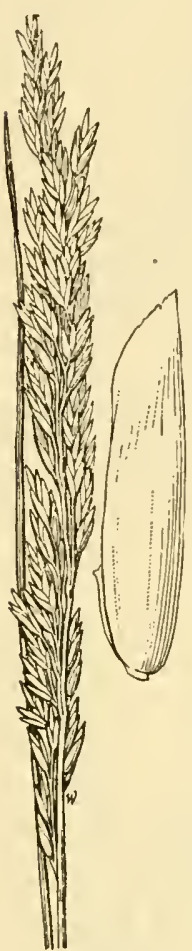

Figure 262-Poa juncifolia. Panicle, $\times 1$; floret, $\times 10$. (T ype.) ous spreading margins, cordate at base, several-nerved, the nerves often obscure, the apex in our species obtuse or acutish; palea much shorter than the lemma. Low annuals or perennials, with erect culms, flat blades, and usually open, showy panicles, the pedicels in our species capillary, allowing the spikelets to vibrate in the wind. Standard species, Briza media. Name from Greek, Briza, a kind of grain, from brizein, to nod.

The three species found in this country are introduced from Europe. They are of no importance agriculturally except insofar as B. minor occasionally forms an appreciable part of the spring forage in some parts of California. B. maxima is sometimes

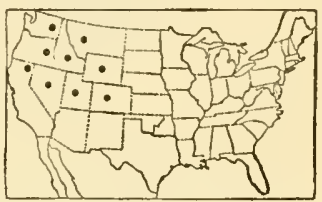

FIGURE 263.-Distribution of Poa juncifolia.

cultivated for ornament, because of the large showy spikelets.

Panicle drooping; spikelets $10 \mathrm{~mm}$ wide_...... 1. B. Maxima. Panicle erect; spikelets 4 to $5 \mathrm{~mm}$ wide.

Plants perennial; upper ligule $1 \mathrm{~mm}$ long; spikelets about 5 $\mathrm{mm}$ long ............. B. MEDIA.

Plants annual; upper ligule $5 \mathrm{~mm}$ or more long; spikelets about $3 \mathrm{~mm}$ long. 2. B. MINOR.

1. Briza máxima L. Big QUAKING GRASS. (Fig. 266, B.) Annual; culms erect or decumbent at base, 30 to $60 \mathrm{~cm}$ tall; panicle drooping, few-flowered; spikelets ovate, $12 \mathrm{~mm}$ long or more, $10 \mathrm{~mm}$ broad, the pedicels slender, drooping; glumes and lemmas usually purple or brown margined. $\odot$-Sometimes cultivated for ornament;

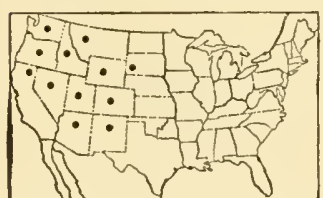

Ftgure 265.-Distribution of Poa ampla. sparingly escaped in California (Monterey County).

2. Briza mínor L. LITTLE QUAKING GRASS. (Fig. 266, A.) Annual; culms erect, 10 to 40 $\mathrm{cm}$ tall; ligule of the upper leaf $5 \mathrm{~mm}$ long

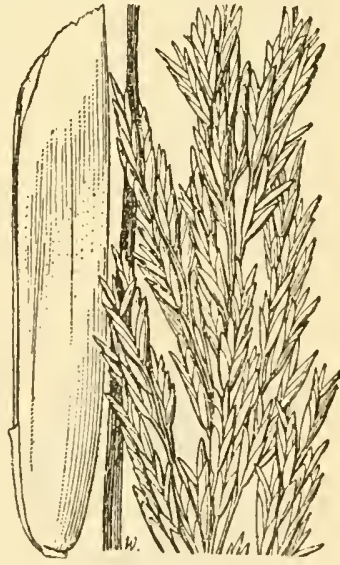

Figure 264.-Poa ampla. Panicle, $\times 1$; floret, $\times 10$. (Crandall 205, Colo.)

or more, acute; blades 2 to $10 \mathrm{~mm}$ wide; panicle 5 to $12 \mathrm{~cm} \mathrm{long}$, the branches stiffly ascending, the spikelets pendent, triangular-ovate, 3 - to 6 -flowered, about $3 \mathrm{~mm}$ long. $\odot$-Introduced at several 


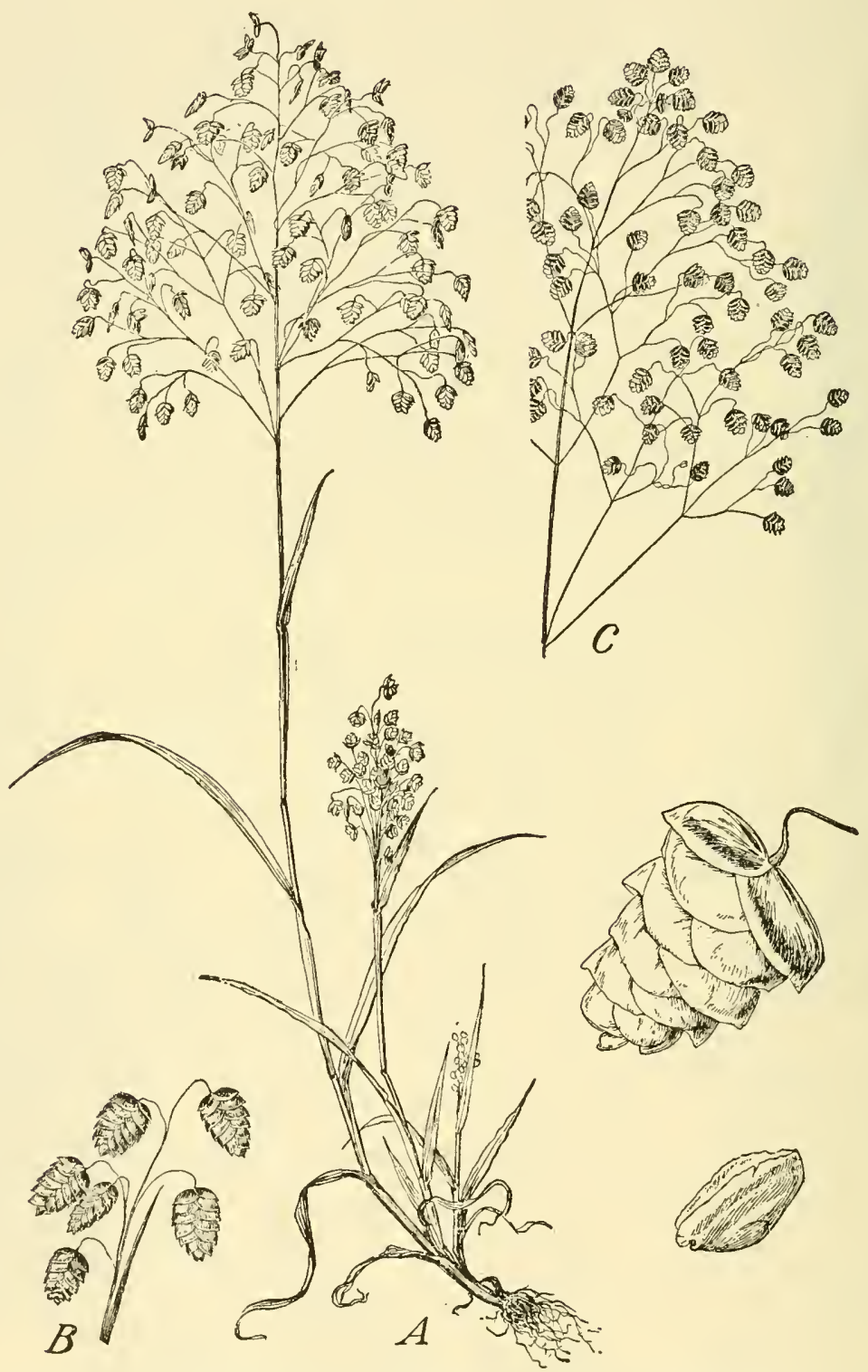

Figure 266.-A, Briza minor. Plant, $\times 1 \frac{1}{2}$; spikelet and floret, $\times$ 5. (Hitchcock 2597, Calif.) B, B. maxima. $\times 1 / 2$. (Baenitz, Dalmatia.) $C, B$. media. Panicle, $\times 1 / 2$. (Oakes, Mass.) 
localities in the Eastern States from Canada to Alabama and Arkansas, becoming common on the Pacific coast. especially in California (fig. 267).

3. Briza média L. (Fig. 266, C.) Perennial; culms 15 to $60 \mathrm{~cm}$ tall; ligule of the upper leaf about $1 \mathrm{~mm}$ long, truncate; blades 2 to 5 $\mathrm{mm}$ wide; panicle erect, 5 to $10 \mathrm{~cm}$ long, the branches rather stiff, ascending, naked below; spikelets 5- to 12 -flowered, orbicular, about $5 \mathrm{~mm}$ long. 24 Fields and waste places, sparingly introduced, Ontario to Connecticut and Michigan (fig. 268).

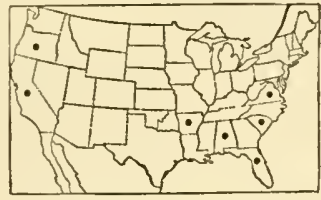

FigURE 267,-Distribution of Briza minor.

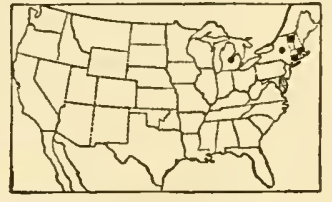

FIGURE 268.-Distribution of

Desmazéria sícula (Jacq.) Dum. Low annual; culms spreading with ascending ends; panicles simple, 3 to $5 \mathrm{~cm}$ long, with large flat 2-ranked spikelets. $\odot$-Occasionally cultivated for ornament. Europe. (Name sometimes spelled Demazeria.)

\section{ERAGRÓSTIS Bequv. Lovegrass}

Spikelets few- to many-flowered, the florets usually closely imbricate, the rachilla disarticulating above the glumes and between the florets, or continuous, the lemmas deciduous, the paleas persistent; glumes somewhat unequal, shorter than the first lemma, acute or acuminate, 1-nerved, or the second rarely 3-nerved; lemmas acute or acuminate, keeled or rounded on the back, 3-nerved, the lateral nerves sometimes obscure; palea usually about as long as the lemma, the keels sometimes ciliate. Annuals or perennials of various habit, the inflorescence an open or contracted panicle. Type species, Eragrostis eragrostis Beauv. (E. poaeoides). Name from the Greek eros, love, and agrostis, a kind of grass.

Although the species are numerous, they in general appear to have little forage value. Eragrostis intermedia is said to furnish forage on the grazing lands of Arizona and New Mexico.

1a. Plants annual.

2a. Plants creeping, rooting at the nodes, forming mats.

Plants with perfect flowers; anthers $0.2 \mathrm{~mm}$ long ..... 11. E. HYPNOIDEs.

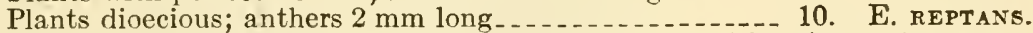

$2 \mathrm{~b}$. Plants of ten decumbent at base but not creeping and forming mats.

3a. Palea prominently ciliate on the keels, the cilia usually as long as the width of the lemma.

Panicle interruptedly spikelike, rarely somewhat open; spikelets usually 3 to $4 \mathrm{~mm}$ long .......... E. CILIARIS.

Panicle narrow but open, the pedicels ascending or spreading; spikelets $2 \mathrm{~mm}$ long....

3b. Palea scabrous to short-ciliate.

4a. Panicle long, narrow, rather dense, tawny or stramineous; spikelets 2 to $3 \mathrm{~mm}$ long._.

4b. Panicle more or less open; spikelets usually more than $3 \mathrm{~mm}$ long.

5a. Spikelets sessile or nearly so_._........... 12. E. SIMPLEx. $5 \mathrm{~b}$. Spikelets pediceled.

6a. Spikelets mostly less than 5 -flowered; lemmas obscurely nerved, scarcely keeled. 
Panicles two-thirds the entire length of the plant or more, diffuse: pedicels more than $5 \mathrm{~mm}$ long; culms erect, closely tufted.

14. E. CAPILlaris.

Panicles less than half the entire length of the plant, oblong, open but scarcely diffuse; pedicels mostly less than $5 \mathrm{~mm}$ long; culms spreading or decumbent at base......... 15 . E. FRANKII.

6 b. Spikelets mostly more than 5 -flowered.

7a. Spikelets ovate to oblong, flat, the florets spreading, closely imbricate......

7b. Spikelets oblong to linear, the florets appressed.

8a. Plants with minute glandular depressions on the branches and of ten on the keels of the lemmas.

Lemmas not glandular on the keel.

Panicle narrow, rather dense, the branches with scattering glandular depressions.......... 22. E. LUTESCENS.

Panicle open, the branches and pedicels widely spreading, the latter with a glandular depression below the spikelet.

28. E. SUAVEOLENS.

Lemmas glandular on the keel.

Spikelets 2.5 to $3 \mathrm{~mm}$ wide; panicle usually rather dense; anthers $0.5 \mathrm{~mm}$ long_._._._. 23. E. CILIANENSIs.

Spikelets about $1.5 \mathrm{~mm}$ wide; panicle open; anthers 0.2 $\mathrm{mm}$ long ................. 24. E. POAEOIDES.

8b. Plants not glandular on the branches nor lemmas, sometimes glandular on the sheaths ( $E$. neomexicana) and below the nodes ( $E$. barrelieri).

Spikelets about $1 \mathrm{~mm}$ wide, linear, slender.

Plant delicate; spikelets 3 to $5 \mathrm{~mm}$ long; lemmas 1 to 1.5 $\mathrm{mm}$ long.

Plant rather stout; spikelets 5 to $7 \mathrm{~mm}$ long; lemmas about 2 mm long _....... E. ORCUTtianA.

Spikelets $1.5 \mathrm{~mm}$ wide or wider, ovate to linear.

Panicle narrow, the branches ascending, spikelet-bearing nearly to base, few-flowered; spikelets linear, mostly 10- to 15-flowered ........... 25. E. BARRELIERI.

Panicle open, often diffuse.

Spikelets linear, mostly 8- to 15-flowered, on slender spreading pedicels mostly longer than the spikelets.

29. E. ARIDA.

Spikelets ovate to linear, if linear not on spreading pedicels.

Spikelets linear at maturity, appressed along the primary panicle branches, these naked at the base for usually 5 to $10 \mathrm{~mm}$. Lower lemmas $1.5 \mathrm{~mm}$ long. Primary panicle branches simple or the lower with a branchlet bearing 2 or 3 spikelets; spikelets loosely imbricate or sometimes not overlapping; plants slender, mostly less than $30 \mathrm{~cm}$ tall, the culms slender at base. Chiefly east of the 100th meridian............. E. PeCTINACEA.

Primary panicle branches usually bearing appressed branchlets with few to several-spikelets, the spikelets thus appearing imbricate or crowded along the primary branches; plants more robust, mostly more than $30 \mathrm{~cm}$ tall, the culms stouter at the base. Chiefly from Texas to southern California .............. 18. E. DIFFusA.

Spikelets ovate to ovate-oblong, rarely linear, if linear not appressed along the primary panicle branches.

Plants comparatively robust, usualiy more than 25 $\mathrm{cm}$ tall. Texas to southern California.

Panicle large, the branches many-flowered, ascending or drooping. Plant as much as $1 \mathrm{~m}$ tall, with blades as much as $1 \mathrm{~cm}$ wide, but often smaller.......... 26. E. NEOMEXICANA.

Panicle smaller and more open, the spreading branches few-flowered. Plant usually less than $30 \mathrm{~cm}$ tall....... 27. E. MEXicaNA. 
Plants delicate, mostly less than $25 \mathrm{~cm}$ tall; blades mostly not more than $2 \mathrm{~mm}$ wide (see also E. frankii var. brevipes).

Panicle lax, the branches usually naked at base; spikelets 4 to $7 \mathrm{~mm}$ long.

19. E. TEPhrosanthos.

Panicle rather stiff, the branches often floriferous nearly to the base; spikelets mostly not more than $3 \mathrm{~mm}$ long...... 20. E. PEREGRINA.

1b. Plants perennial.

9a. Panicle elongate, slender, dense, spikelike

9b. Panicle open or contracted, not spikelike.

10a. Plants with stout scaly rhizomes....... E. овтUsiflora.

10b. Plants without rhizomes.

11a. Spikelets subsessile or nearly so, the lateral pedicels not more than $1 \mathrm{~mm}$ long.

Spikelets subsessile, distant along the few stout panicle branches

Spikelets short-pediceled.

Panicle large, becoming a tumble weed, the axis and branches viscid.

3. E. CURTIPEDICELlata.

Panicle narrow (rarely open in E. secundiflora), not a tumble weed nor viscid; keels of palea forming a thick white band.

Lemmas $3 \mathrm{~mm}$ long, somewhat abruptly narrowed to the acute apex; panicle usually red-brown; anthers 0.2 to $0.3 \mathrm{~mm}$ long.

4. E. SECUNDIFLORA.

Lemmas $3.5 \mathrm{~mm}$ long, tapering to the acuminate apex; panicle pale or slightly pinkish; anthers 0.4 to $0.5 \mathrm{~mm}$ long.

5. E. BEYRICHII.

11b. Spikelets with pedicels more than $1 \mathrm{~mm}$ long (appressed along the branches in $E$. refracta; sometimes scarcely more than $1 \mathrm{~mm}$ long in $E$. chariis and $E$. bahiensis). Panicles large and open (sometimes condensed in E. bahiensis).

12a. Nerves of lemma obscure; lemma rounded on back, sometimes slightly keeled toward apex.

Axils of main panicle branches usually strongly pilose (rarely glabrous in $E$. intermedia).

Sheaths pilose or hirsute.

Culms mostly more than $50 \mathrm{~cm}$ tall; blades elongate, flat, not crowded at base of culm ...

Culms mostly less than $50 \mathrm{~cm}$ tall; blades rather short and crowded at base of culm......... 32. E. TRICHOCOLEA.

Sheaths glabrous or nearly so, except the pilose summit.

Spikelets about $1 \mathrm{~mm}$ wide, 3 - to 7 -flowered, 3 to $5 \mathrm{~mm}$ long; lemmas 1.3 to $1.5 \mathrm{~mm}$ long...... 31. E. LUGENS.

Spikelets about $1.5 \mathrm{~mm}$ wide; 3 - to 8 -flowered, 3 to $10 \mathrm{~mm}$ long; lemmas 1.8 to $2 \mathrm{~mm}$ long _....... 35. E. INTERMEDia.

Axils of main panicle branches glabrous or the lower sparsely pilose.

Pedicels bearing above the middle a glandular band or spot; axils glabrous. E. SWALLENI.

Pedicels without glandular band; lower axils sparsely pilose to glabrous.

Lemmas about $3 \mathrm{~mm}$ long _...

Lemmas about $2 \mathrm{~mm}$ long...

12b. Nerves of lemma evident, usually prominent; lemmas keeled.

Spikelets approximate in a somewhat condensed panicle, or along the main branches of a somewhat spreading panicle; florets mostly 15 to 30.

Paleas readily deciduous. _... _... E. CHARIIS,

Paleas persistent................ 46. E. BAHIENSIS.

Spikelets in an open panicle.

Panicle longer than broad, the branches not horizontally spreading.

Culms not more than $60 \mathrm{~cm}$ tall.

Spikelets 9- to 15-flowered; panicle less than one-third the entire length of culm, the branches not viscid _._ 37. E. TRACYr.

Spikelets 4- to 8-flowered; panicle more than half the entire length of culm, the branches viscid... 38. E. silveana. 
Culms usually $1 \mathrm{~m}$ or more tall.

Spikelets mostly not more than 6-flowered, purplish.

39 . E. TRICHODES. Spikelets mostly 8- to 15-flowered, stramineous to bronze.

Panicle at maturity about as broad as long.

40. E. PILIFERA.

Panicle purple, the branches slender but rigid.

Pani. E. SPECT

Panicle green to leaden, the branches capillary, fragile.

Spikelets appressed and distant along the nearly simple panicle branches _... . . Spikelets on long pedicels.

Lemmas $2 \mathrm{~mm}$ long.

42. E. ELLIOTTII.

Lemmas $3 \mathrm{~mm}$ long. 43. E. ACUTA.

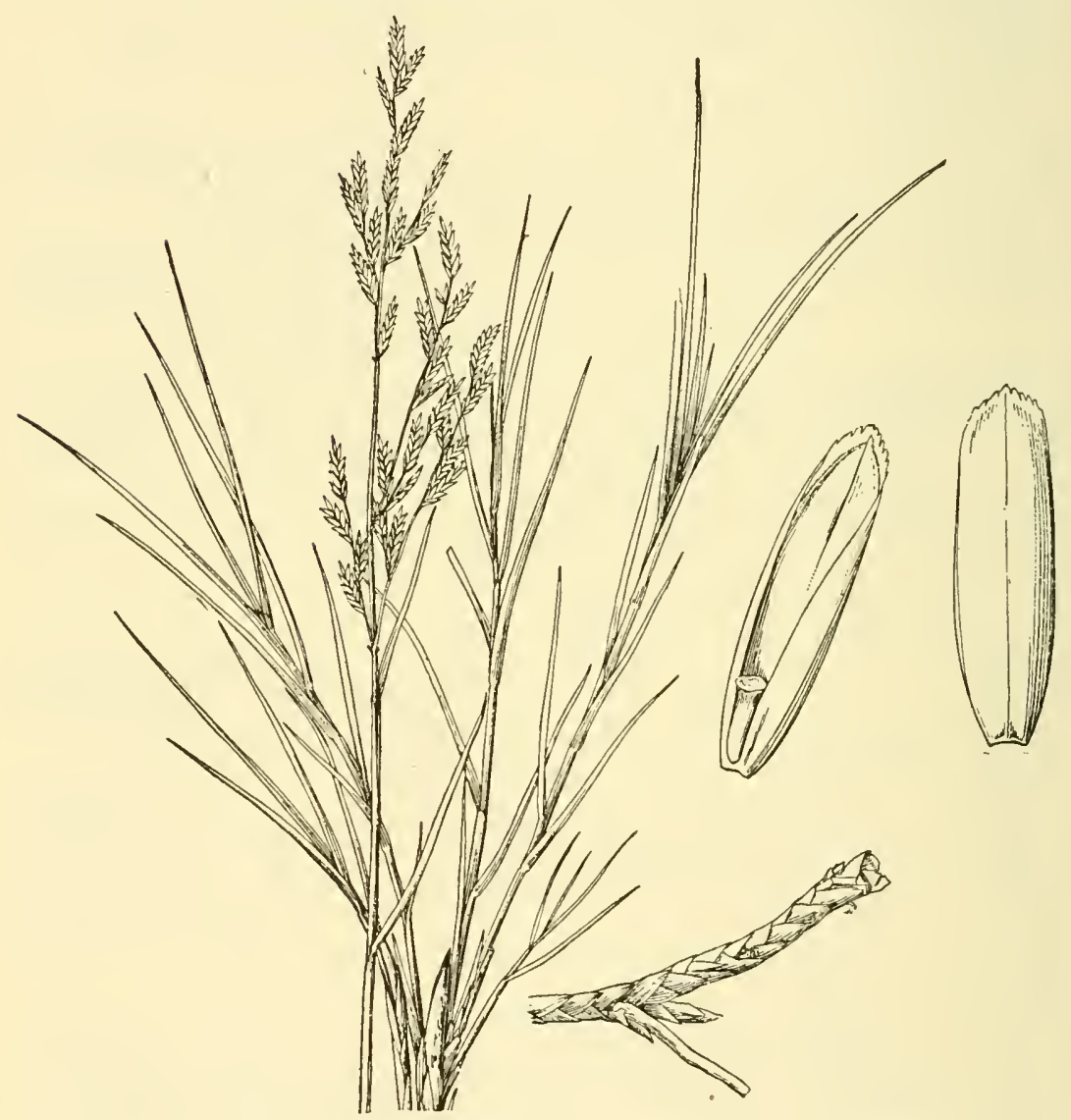

Figure 269.-Eragrostis obtusiflora. Plant, $\times 1 / 2$, two views of floret, $\times 10$. (Toumey, Ariz.)

\section{Section 1. Cataclástos Doell}

Rachilla of spikelets disarticulating between the florets at maturity.

1. Eragrostis obtusiflóra Scribn. (Fig. 269.) Culms erect or ascending, firm, wiry, 30 to $50 \mathrm{~cm}$ tall, from stout creeping rhizomes with closely imbricate hard spiny-pointed scales; sheaths pubescent or pilose at the throat; blades firm, glaucous, flat, becoming involute at least toward the spiny-pointed tip, 5 to $10 \mathrm{~cm} \mathrm{long,} 2$ to $3 \mathrm{~mm}$ wide 
at base; panicle 5 to $15 \mathrm{~cm}$ long, the rigid simple branches ascending, loosely flowered, 5 to $8 \mathrm{~cm}$ long; spikelets pale or purplish, 6- to 12flowered, 8 to $12 \mathrm{~mm}$ long, the pedicels about $1 \mathrm{~mm}$ long; glumes acute, 3 and $5 \mathrm{~mm}$ long; lemmas rounded on the back, rather loosely imbricate, obtuse, somewhat lacerate, about $4 \mathrm{~mm}$ long. 2 Alkali soil, Arizona (Sulphur Springs Valley and Wilcox), New Mexico (Las Playas); Mexico.

Scribner ${ }^{6}$ quotes Toumey as follows: "This species is one of the most abundant grasses in the extreme alkaline portions of Sulphur Springs Valley, where the large rootstocks in many places bind the shifting sands. It rarely flowers, and its superficial appearance,

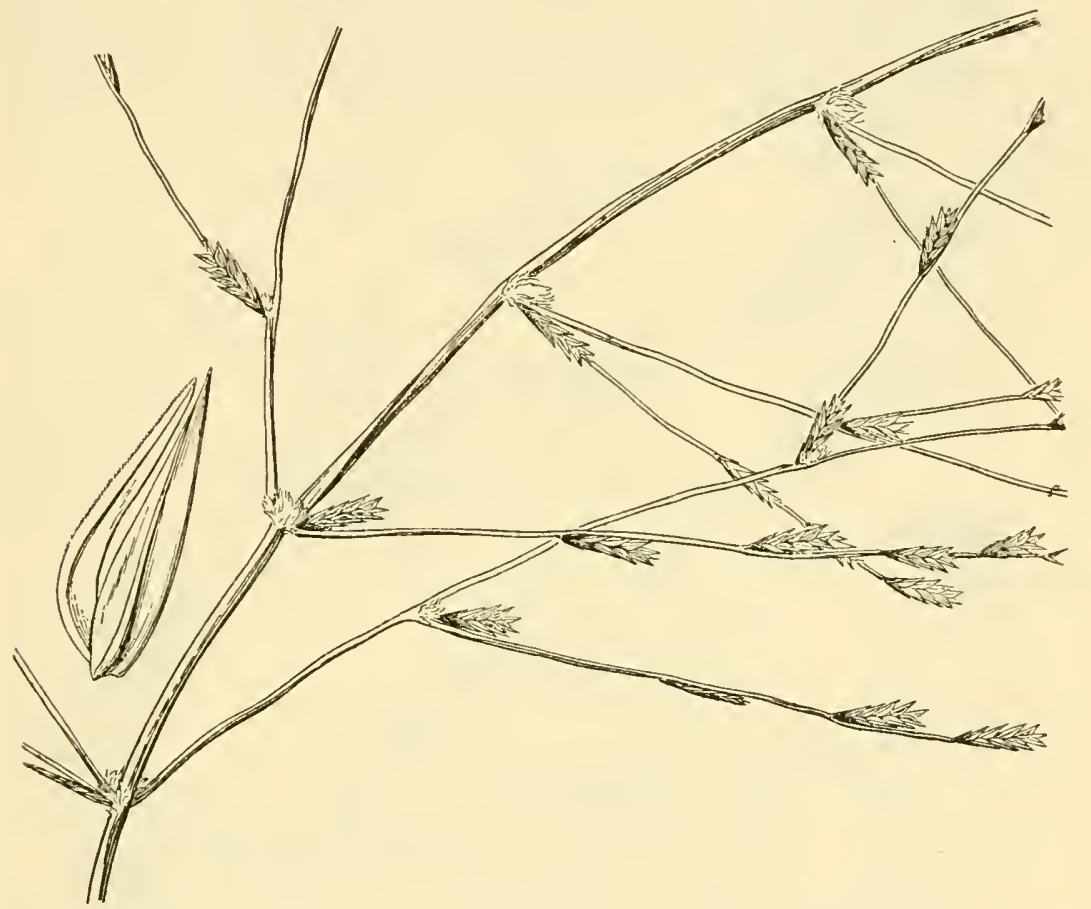

Figure 270.-Eragrostis sessilispica. Panicle, $\times 1$; floret, $\times 10 . \quad$ (Swallen 1791, Tex.)

without flowers, is much the same as our common salt grass (Distichlis spicata). It is a hard, rigid grass, but furnishes a large part of the forage of Sulphur Springs Valley, when other grasses are eaten off or are cut short by drought."

2. Eragrostis sessilispíca Buckl. (Fig. 270.) Perennial; culms tufted, erect, 20 to $40 \mathrm{~cm}$ tall, with 1 node above the basal cluster of leaves; sheaths glabrous, strongly pilose at the throat; blades flat to rather loosely involute, 1 to $2 \mathrm{~mm}$ wide; panicle loose, open, pilose in the axils, at first about half the entire length of the culm, elongating toward maturity, the axis curving or loosely spiral, as much as $40 \mathrm{~cm}$ long, the distant branches stiffly spreading, 5 to $15 \mathrm{~cm}$ long, floriferous to base, sometimes bearing below a few secondary branches, the

${ }^{8}$ LaMison-Scribaer, F. NEW Or little known Grasses. U.S. Dept. Agr., Div. Agros. Bull. 8, pt. I: 5-11, illus. 1897. (See p. 10.)

$55974^{\circ}-35-10$ 
whole panicle finally breaking away and tumbling before the wind; spikelets distant, nearly sessile, appressed, linear, 5- to 12-flowered, 8 to $12 \mathrm{~mm}$ long; glumes acute, about $3 \mathrm{~mm}$ long; lemmas loosely

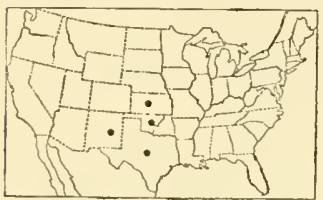

FIGURE 271.-Distribution of Eragrostis sessilispica. imbricate, acuminate, becoming somewhat indurate, 3 to $3.5 \mathrm{~mm}$ long, the lateral nerves prominent; palea prominently bowed out below. 21 (Acamptoclados sessilispica Nash.)-Plains and sandy prairies, Kansas to Texas, New Mexico, and northern Mexico (fig. 271).

3. Eragrostis curtipedicelláta Buckl. (Fig. 272.) Perennial; culms tufted, erect, 20 to $40 \mathrm{~cm}$ tall; sheaths pilose at the throat; blades flat or loosely involute, 1 to $3 \mathrm{~mm}$ wide; panicle open, spreading, at first 15 to $20 \mathrm{~cm}$ long, the axis and branches viscid, rather sparingly pilose in the axils, finally elongating, breaking away and tumbling

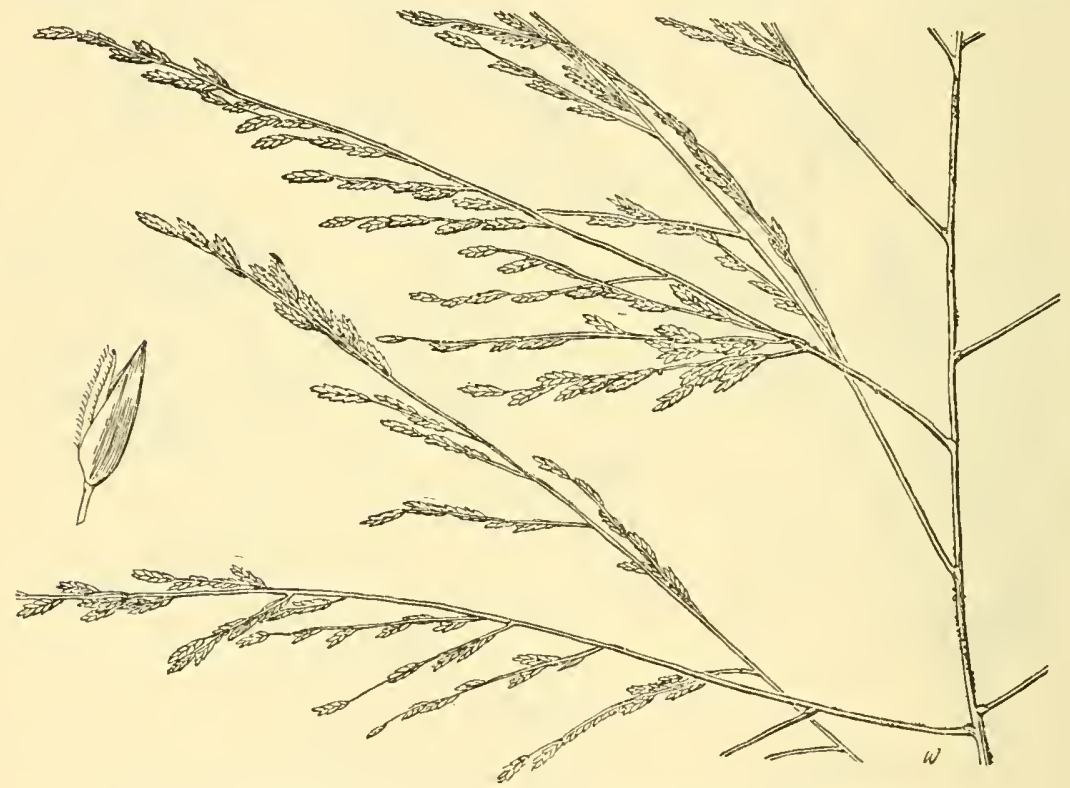

Figdre 272.-Eragroslis curtipedicellata. Panicle, $\times 1$; floret, $\times 10$. (Ball 898, Tex.)

before the wind, the branches stiffly ascending or spreading; spikelets oblong or linear, short-pediceled, somewhat appressed on the primary

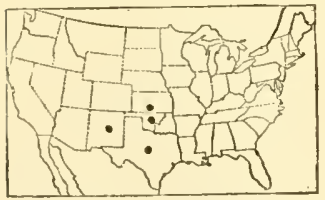

FIGURE 273.-Distribution of Eragrostis curtipedicellata. and secondary branches, 6 - to 12 -flowered, 3 to $6 \mathrm{~mm}$ long; glumes about $1.5 \mathrm{~mm}$ long; lemmas rather closely imbricate, oblong, acute, about $1.5 \mathrm{~mm}$ long; palea ciliate on the keels, not bowed out; grain $0.7 \mathrm{~mm}$ long. 24 -Plains, open woods, and dry slopes, southern Kransas to Texas and New Mexico (fig. 273).

4. Eragrostis secundiflóra Presl. (Fig. 274.) Perennial; culms tufted, suberect, 20 to $40 \mathrm{~cm}$ tall; sheaths pilose at the throat; blades flat, more or less involute in drying, 1 to $4 \mathrm{~mm}$ wide, tapering to a 
fine point; panicle condensed, more or less interrupted or with stiff ascending rather densely flowered branches, rarely somewhat open, 5 to $15 \mathrm{~cm}$ long, sometimes as much as $40 \mathrm{~cm}$ long, rarely sparsely pilose in the axils; spikelets usually redbrown, strongly compressed, subsessile, linear, mostly 10 - to 40 -flowered, 8 to $15 \mathrm{~mm}$ long; glumes acute, 1.5 and $2 \mathrm{~mm}$ long; lemmas closely imbricate, $3 \mathrm{~mm}$ long, somewhat

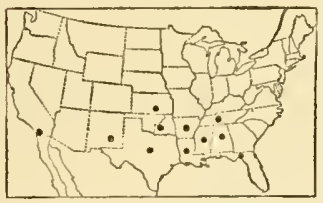

Figure 275.-Distribution of Eragrostis secundiflora. abruptly narrowed to an acute apex, the tip slightly spreading; palea bowed out below, the keels prominent; anthers 0.2 to $0.3 \mathrm{~mm}$ long, gray; grain $1 \mathrm{~mm}$ long. 24 -Sandy soil, northern Florida to Kansas and New Mexico, south to Oaxaca; also California (San Diego) (fig. 275).

5. Eragrostis beyríchii J. G. Smith. (Fig. 276.) Resembling E. secundiflora and possibly only a variety of that species; differing in the softer foliage and panicle, the plant on the average smaller, the panicle pale or slightly pinkish; lemmas 3.5 to $4 \mathrm{~mm}$

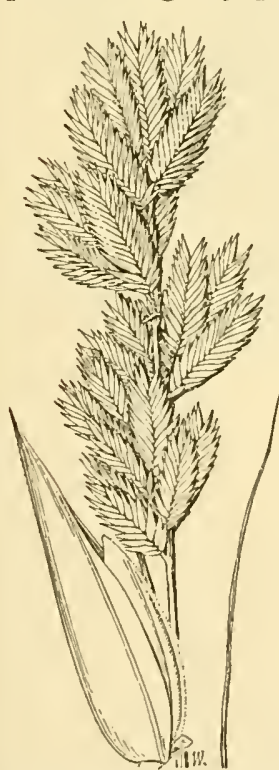

F I G URE 276. -Eragrostis beyrichii. Panicle, $\times 1$; Tex.)

7. Eragrostis ciliáris long (the lower shorter),
less firm, tapering to an broader and longer; anthers 0.4 to $0.5 \mathrm{~mm}$ long, yellowish. 24 - Sandy soil, Texas and Oklahoma (Wichita Mountains).

6. Eragrostis spicáta Vasey. (Fig. 277.) Perennial; culms tufted, erect, about $1 \mathrm{~m}$ tall; blades flat, elongate, more or less involute in drying, tapering to a slender point; panicle pale, slender, dense, spikelike, 10 to $30 \mathrm{~cm}$ long, 3 to $4 \mathrm{~mm}$ thick; spikelets strongly compressed, 2- or 3-flowered, $2 \mathrm{~mm}$ long, the somewhat pubescent pedicels less than $1 \mathrm{~mm}$ long; glumes rather broad, obtuse, unequal, the second about $1 \mathrm{~mm}$ long; lemmas about $2 \mathrm{~mm}$ long, all rising to about the same height, the lateral pair of nerves faint. 2 1 -Dry ground, Laredo and Brownsville, Tex.; Baja California; Paraguay, Argentina.

7. Eragrostis ciliáris (L.) R. Br. (Fig. 278.) Annual; culms branching, erect to spreading, slender, wiry, 15 to $30 \mathrm{~cm}$ tall;

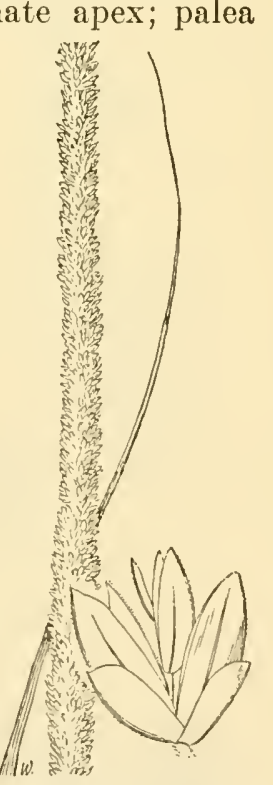

FIG URE 277.-Eragrostis spicata. Panicle, $\times 1$ : 1056, Tex.) spikelet, $\times 10$. (S'wallen 
blades flat to subinvolute, mostly less than $10 \mathrm{~cm}$ long, 1 to $3 \mathrm{~mm}$ wide; panicle often purplish, condensed, interruptedly spikelike, 3 to $10 \mathrm{~cm}$ long, sometimes looser with stiffly ascending short branches; spikelets 6- to 12 -flowered, 2 to $4 \mathrm{~mm}$ long; glumes about $1 \mathrm{~mm}$ long; lemmas oblong, 1 to $1.5 \mathrm{~mm}$ long, obtuse, the midnerve slightly excurrent;

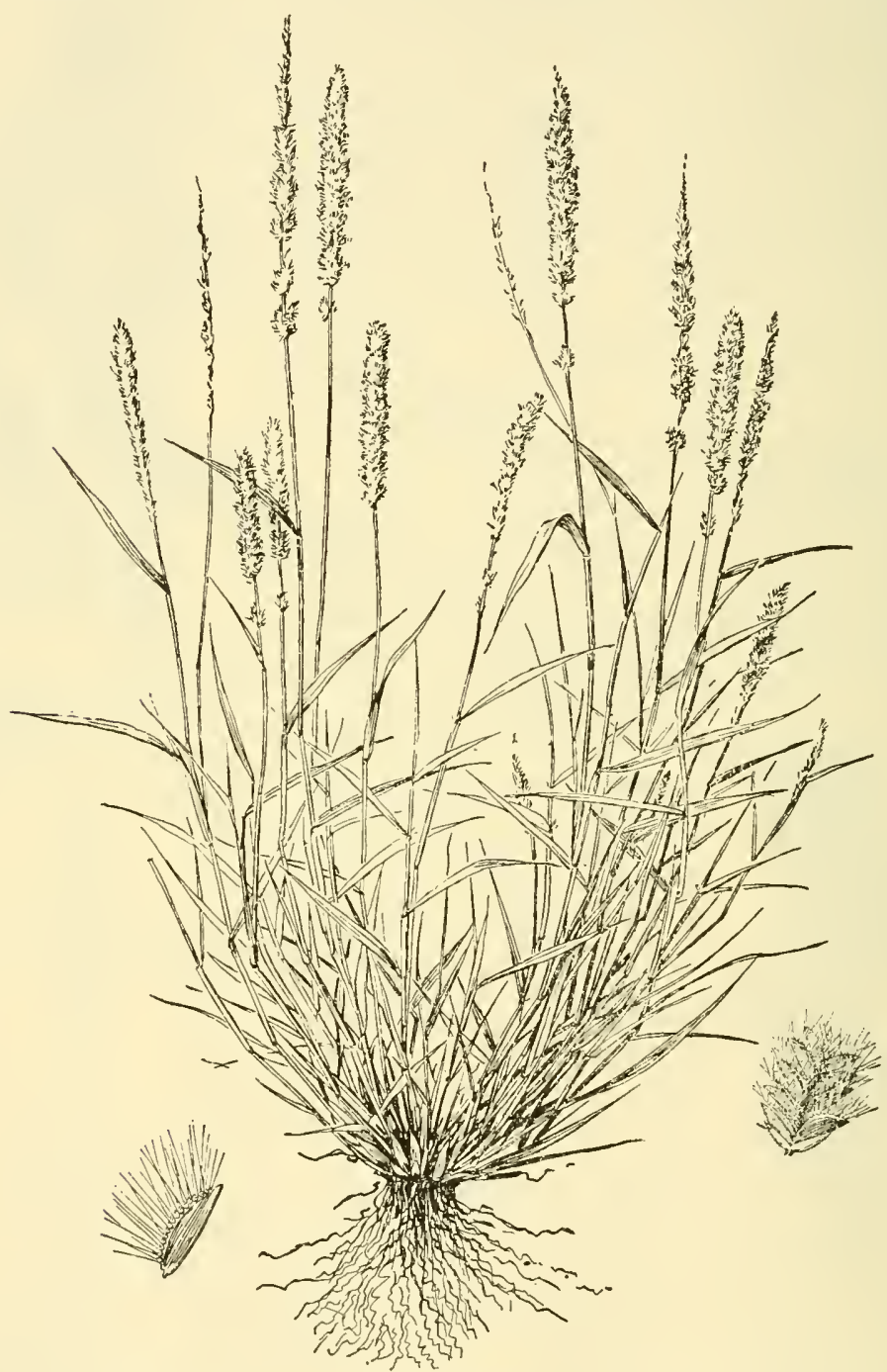

FIGURE 278. - Eragrostis ciliaris. Plant $\times$; 1/2; spikelet, $\times 5$; floret, $\times 10 . \quad$ (Nash 2104, Fla.)

keels of the palea conspicuously stiffly long-ciliate, the hairs 0.5 to $0.7 \mathrm{~mm}$ long; grain $0.5 \mathrm{~mm}$ long. $\odot-$ Sandy shores, rocky soil, and open ground, Georgia to Florida and Mississippi; Texas; New Jersey (ballast); West Indies and Mexico to Brazil and Peru (fig. 279); Africa; Asia. Specimens with laxer panicles of more spreading 
loosely flowered branches have been differentiated as E. ciliaris var. laxa Kuntze.

8. Eragrostis amábilis (L.) Wight and Arn. (Fig. 280.) Annual, resembling $E$. ciliaris; blades as much as $5 \mathrm{~mm}$ wide; panicle oblong or oblong-lanceolate, 2 to $4 \mathrm{~cm}$ wide, rather

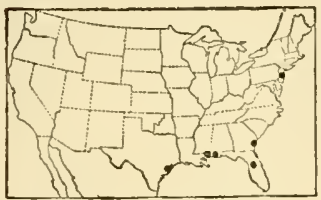

FIGURE 279.-Distribution of Eragrostis ciliaris.

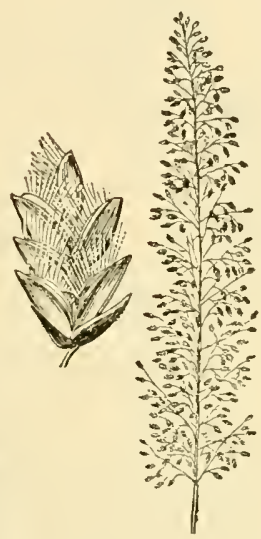

FTGURe 280.-Eragrostis a mabilis. Panicle, $\times 1 / 2$; spikelet, $\times 10$. (Meislahn 10, Fla.)

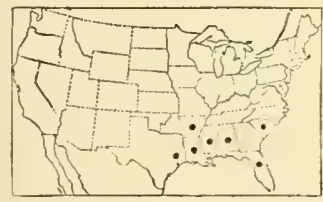

FIGURE 282.-Distribution of Eragrostis glomerata. open; spikelets 4 - to 8-flowered, about 2 $\mathrm{mm}$ long; glumes less than $1 \mathrm{~mm}$ long; lemmas ovate, obtuse, $1 \mathrm{~mm}$ long; keels of palea longciliate, the hairs about $0.3 \mathrm{~mm}$ long. - (E. plumosa Link.)-G a r d e n s and waste places, Georgia and Florida; Texas; tropical America; apparently introduced from the Old World. 9. Eragrostis glomeráta (Walt.) L. H. Dewey. (Fig. 281.) Annual; culms erect, 20 to $100 \mathrm{~cm}$ tall, branching below, the branches erect; blades flat, 3 to $8 \mathrm{~mm}$ wide, tapering to a fine point; panicle narrow, erect, densely flowered, somewhat interrupted, 5 to 50 $\mathrm{cm}$ long, greenish or tawny, the branches ascending or appressed, floriferous to base, many-flowered;spikelets shortpediceled, mostly 6 to 8 -flowered, 2 to $3 \mathrm{~mm}$ long; glumes minute; lemmas very thin, about 1 mm long; grain about 0.3 to $0.4 \mathrm{~mm}$ long. $\odot$ (E. con-

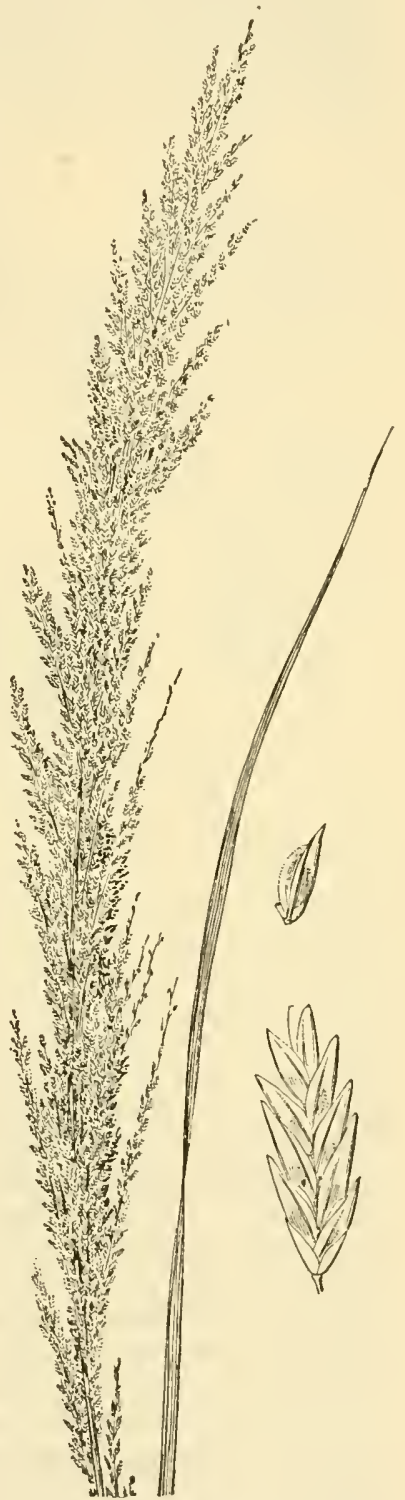

Figure 281.- Eragrostis glomerata. Panicle, $\times 1 / 2$, spikelet and floret, $\times 10$. (Eggert, Ark.)

ferta Trin.)-Banks of ponds and streams, and low ground, South Carolina to Florida, Arkansas, and eastern Texas, south through Mexico and West Indies to Uruguay (fig. 282). 


\section{Section 2. Pteroéssa Doell}

Rachilla of spikelet continuous, not disarticulating at maturity; palea usually persistent for a short time after the fall of the lemma (sometimes falling with it in E. unioloides and E. chariis).

10. Eragrostis réptans (Michx.) Nees. (Fig. 283.) Annual, dioecious; culms branching, creeping, rooting at the nodes, forming mats; blades flat, usually pubescent, mostly 1 to $3 \mathrm{~cm}$ long; panicles numerous, ovoid, usually rather dense or capitate, few- to several-

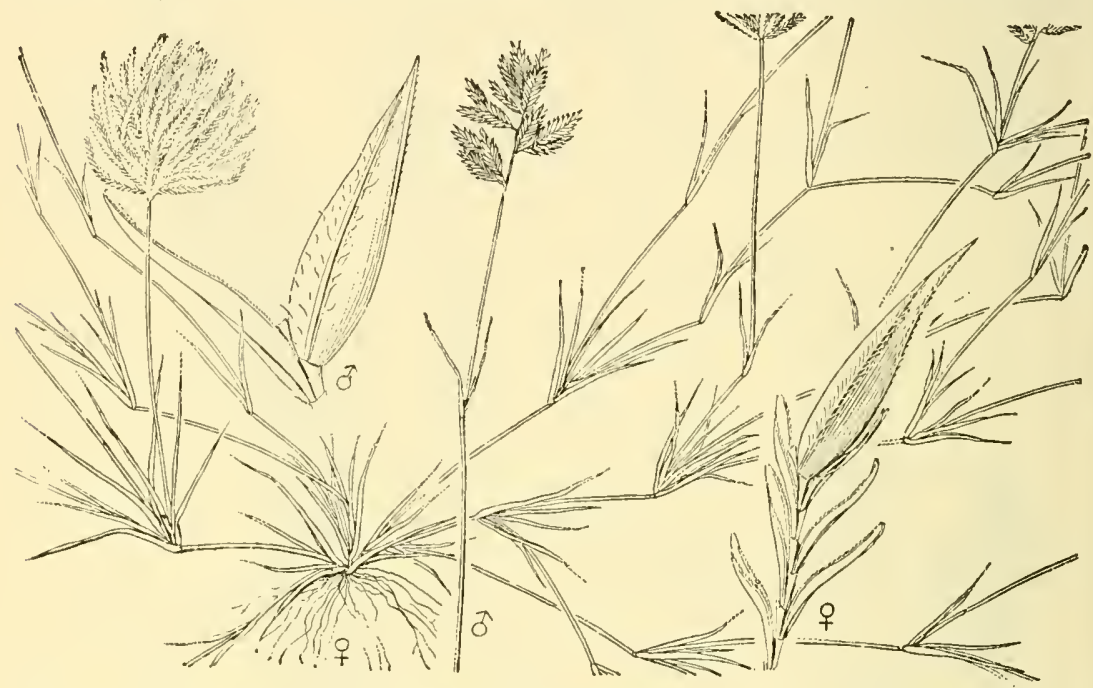

FIGURE 283.-Eragrostis reptans. Pistillate $(q)$ and staminate $\left(\sigma^{7}\right)$ plants, $\times 1 / 2$; floret, $\times 10$. (Bush $1306(\%)$ and $1307\left(\sigma^{7}\right)$, Tex.)

flowered, rarely many-flowered, mostly 1 to $2 \mathrm{~cm}$ long; spikelets several- to many-flowered, linear, at length elongate and more or less curved; lemmas closely imbricate, often sparsely villous, acuminate, about $3 \mathrm{~mm}$ long; palea of pistillate floret about half as long as the lemma, of the staminate floret as long as the lemma; grain ovoid, about $0.5 \mathrm{~mm}$ long; anthers before dehiscing, 1.5 to $2 \mathrm{~mm}$ long. $\odot$ (E. capitata Nash.)-River banks, sandy land, and open ground, Kentucky to South Dakota and Texas (fig. 284).

11. Eragrostis hypnoídes (Lam.) B. S. P. (Fig. 285.) Annual, branching, creeping, and matlike as in the preceding; blades scabrous or pubescent on the upper surface; panicles elliptic, loosely few-flowered, 1 to $5 \mathrm{~cm}$ long, sometimes somewhat capitate; spikelets several- to many-flowered, linear, mostly 5 to $10 \mathrm{~mm}$ long, sometimes as much as $2 \mathrm{~cm}$ long

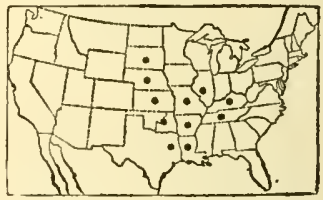

Figure 284.-Distribution of Eragrostis reptans. in a dense cluster; flowers perfect; lemmas glabrous, acute, 1.5 to $2 \mathrm{~mm}$ long; palea about half as long as the lemma; grain $0.5 \mathrm{~mm}$ long; anthers about $0.2 \mathrm{~mm}$ long. $\odot$-Sandy river banks and wet ground, Quebec to Washington, south through Mexico and the West Indies to Argentina; not found in the Rocky Mountains (fig. 286).

12. Eragrostis símplex Scribn. (Fig. 287.) Annual; culms spreading to suberect, 10 to $30 \mathrm{~cm}$ tall; blades flat, 1 to $3 \mathrm{~mm}$ wide; panicle narrow, 5 to $20 \mathrm{~cm}$ long, the main axis often curved, the branches 
solitary, distant, ascending or spreading, sometimes reflexed, floriferous to base, short, with a few crowded spikelets or as much as $5 \mathrm{~cm}$ long, with short branchlets; spikelets nearly sessile, linear, mostly 20 - to $50-$ flowered, 5 to $20 \mathrm{~mm}$ long; lemmas closely imbricate, ovate, acute, 1.5 to $2 \mathrm{~mm}$ long, the lateral nerves near the margin; grain about $0.5 \mathrm{~mm}$ long anthers about $0.1 \mathrm{mmlong}$. $\odot$ - Sandy woods, dooryards, and waste places, southern Georgia and Florida.

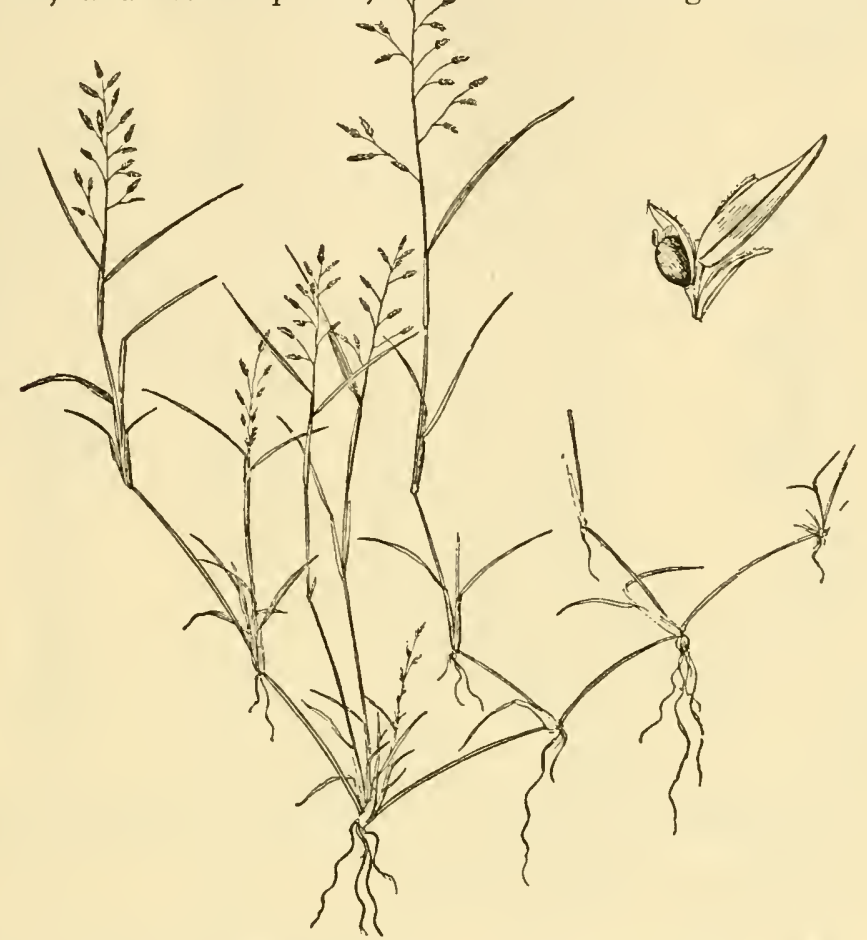

Figure 285.-Eragrostis hypnoides. Plant, $\times 1 / 2$; florets, $\times 10$. (Mearns 741, Minn.)

13. Eragrostis unioloídes (Retz.) Nees. (Fig. 288.) Annual; culms erect or ascending, 20 to $40 \mathrm{~cm}$ tall; blades flat, 2 to $4 \mathrm{~mm}$ wide; panicle elliptic, open, 10 to $15 \mathrm{~cm}$ long, about half as wide, the branches ascending; spikelets ovate-oblong, strongly compressed, truncate at

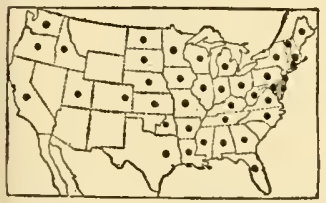

FIGURE 286.-Distribution of ETagrostis hypnoides. base, obtuse, 15- to 30 -flowered, 5 to $10 \mathrm{~mm}$ long, $3 \mathrm{~mm}$ wide, often pink or purplish; lemmas closely imbricate, nearly horizontally spreading, strongly keeled, acute, $2 \mathrm{~mm}$ long, the lateral nerves prominent; palea falling with the lemma or soon thereafter; grain about $0.7 \mathrm{~mm}$ long. $\odot \quad-$ Waste ground, Georgia and Florida; introduced from southern Asia.

14. Eragrostis capilláris (L.) Nees. LACEGrass. (Fig. 289.) Annual; culms erect, 20 to $50 \mathrm{~cm}$ tall, muchbranched at base, the branches erect; sheaths pilose, at least on the margin, long-pilose at the throat; blades flat, erect, pilose on upper surface near the base, 1 to $3 \mathrm{~mm}$ wide; panicle oblong or elliptic, open, 
diffuse, usually two-thirds the entire height of the plant, the branches and branchlets capillary; spikelets long-pediceled, 2- to 4-flowered,

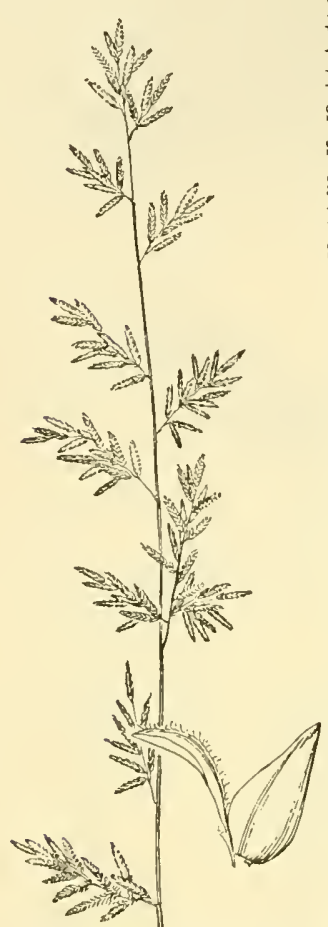

FIGURE 287-Eragrostis sim plex. Panicle, $\times 1 / 2$; floret, $\times$ 10. (Curtiss, Fla.)
2 to $3 \mathrm{~mm}$ long; glumes acute, $1 \mathrm{~mm}$ long; lemmas acute, about $1.5 \mathrm{~mm}$ long, obscurely nerved, rounded on the back, minutely scabrous toward the tip; grain $0.5 \mathrm{~mm}$ long, somewhat roughened. $\odot-$ Dry open ground, open woods, and fields, Maine to Wisconsin, south to Georgia, Kansas, and eastern Texas (fig. 290).

15. Eragrostis fránkii C. A. Meyer. (Fig. 291.) Resembling E. capillaris; culms usually lower, spreading to erect; sheaths glabrous except the pilose throat; blades glabrous; panicle less than half the entire height of the plant, open but not diffuse, mostly less than half as wide as long, the branches ascending, the shorter pedicels not much longer than the spikelets; spikelets 3- to 5flowered, 2 to $3 \mathrm{~mm}$ long. $\odot$ Sandbars, river banks, and moist open ground, New Hampshire to Minnesota, south to Florida

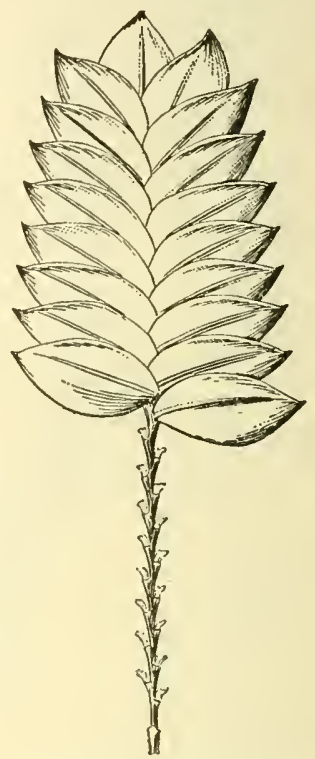

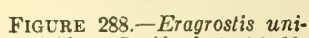
oloides. Spikelet, $\times 10$. (Curtiss 6598, Fla.)

GRostis FRANKII var. BRÉvipes Fassett. Spikelets 5- to 7-flowered,

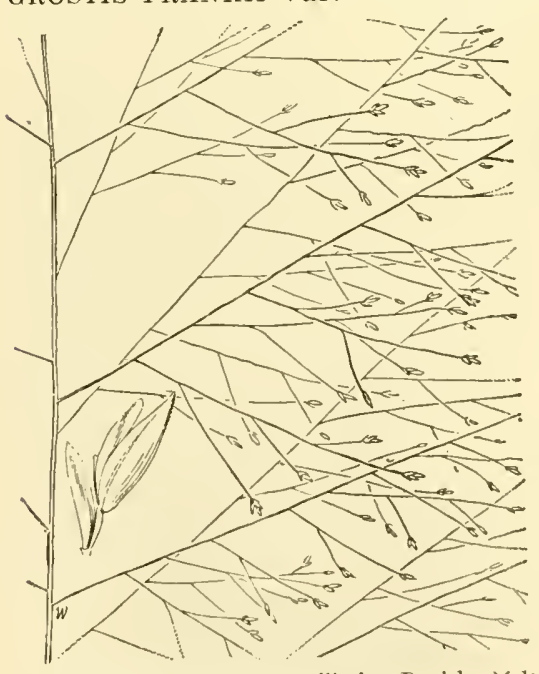

Figure 289.-Eragrostis capillaris. Panicle, $\times 1$; lloret, $\times 10$. (Dewey 35, D.C.) 3 to $4 \mathrm{~mm}$ long. $\odot-$ Wisconsin (Glenhaven), and Illinois.

16. Eragrostis pilósa (L.) Beauv. India lovegrass. (Fig. 293.) Weedy annual; culms slender, erect or ascending from

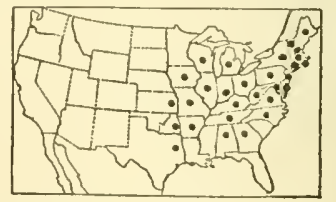

Figure 290.-Distribution of Eragrostis capillaris.

a decumbent base, 10 to $50 \mathrm{~cm}$ tall; blades flat, 1 to $3 \mathrm{~mm}$ wide; panicle delicate, open, becoming somewhat diffuse, 5 to $20 \mathrm{~cm}$ long, the branches capillary, flexuous, ascending or spreading, finally somewhat implicate, the lower fascicled, sparsely long-pilose in the 
axils; spikelets gray to nearly black, linear, scarcely compressed, 3 - to 9 -flowered, 3 to $5 \mathrm{~mm}$ long, about $1 \mathrm{~mm}$ wide, the pedicels spreading, mostly longer than the spikelets; glumes acute, the first a little less than, the second a little more than, $1 \mathrm{~mm}$ long; lemmas loosely imbricate, the rachilla more or less exposed, rounded on the back, acute, 1.2 to $1.5 \mathrm{~mm}$ long, $0.5 \mathrm{~mm}$ wide from keel to margin, the nerves obscure; grain $0.6 \mathrm{~mm}$ long. $\odot$-Moist open ground and waste places, Massachusetts to Colorado, south to Florida and Texas,

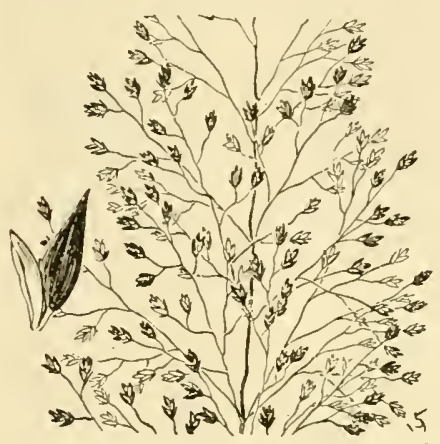

FIGURE 291.-Eragrostis frankii. Panicle, $\times 1$; floret, $\times 10$. (Chase 2005, Ill.) south through Mexico and West Indies to Argentina; California (fig. 294); introduced from Europe.

Eragrostis viréscens Presl. Annual; culms slender, 50 to $60 \mathrm{~cm}$ tall; blades 3 to $6 \mathrm{~mm}$ wide; panicle open, about one third the entire height of the culm, the lower branches mostly solitary, the axils glabrous or nearly so; branchlets and spikelets somewhat appressed along the primary branches; spike-

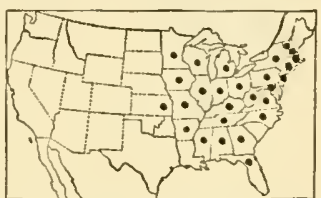

FIGURE 292.-Distribution of Eragrostis frankii.

lets linear, mostly 7 - to 9 -flowered, 4 to $5 \mathrm{~mm}$ long, pale or greenish, about $1 \mathrm{~mm}$ wide; lower lemmas scarcely $1.5 \mathrm{~mm}$ long. $\odot$-Ballast, Apalachicola, Florida; Chile. Resembling E. diffusa; spikelets smaller.

17. Eragrostis pectinácea (Michx.) Nees. (Fig. 295.) Resembling E. pilosa; panicles less delicate, the axils glabrous or obscurely pilose, the somewhat larger spikelets appressed along the branches and branchlets, often longer than the pedicels; spikelets at maturity mostly linear, 5 to $8 \mathrm{~mm}$ long; lemmas 1.5 to $1.6 \mathrm{~mm}$ long, the

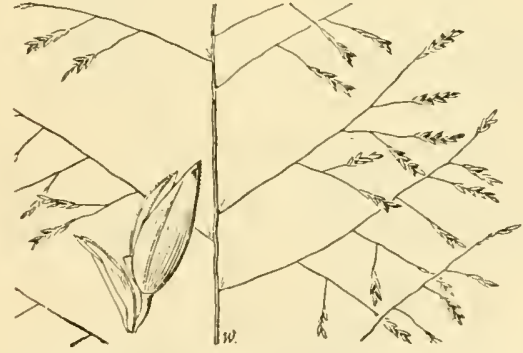

Figure 293.-Eragrostis pilosa. Panicle, $\times 1$; floret and palea, $\times 10$. (Ruth 514, Tex.) rachilla not or scarcely exposed, the nerves evident; grain $0.8 \mathrm{~mm}$

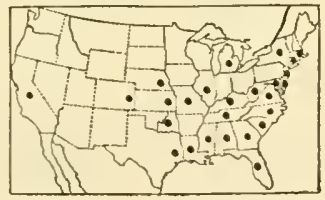

FIgURE 294.-Distribution of Eragrostis pilosa.

long. $\odot$ (E. caroliniana (Spreng.) Scribn.; E. purshii Schrad.)Fields, waste places, open ground, moist places, Maine to North Dakota, south to Florida and eastern Texas, rare in the Western States (fig. 296). The name E. pectinacea has been misapplied to E. spectabilis.

18. Eragrostis diffúsa Buckl. (Fig. 297.) More robust than E. pectinacea, usually 30 to $50 \mathrm{~cm}$ tall, sometimes taller; panicle larger, the primary branches bearing appressed secondary branches with few to several spikelets, the main panicle branches thus more 
densely flowered. $\odot-A$ common weed in fields and open ground, Oklahoma and Texas to Nevada and southern California; introduced

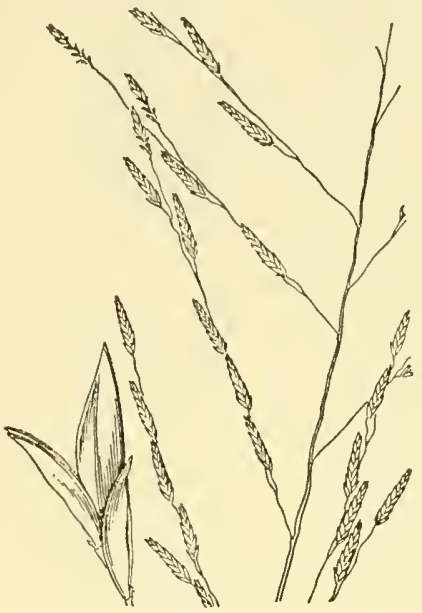
in Missouri, South Carolina, Alabama, and Louisiana; Mexico (fig. 298). In some speeimens the spikelets are ascending rather than appressed, thus making the panicle more open.

19. Eragrostis tephrosánthos Schult. (Fig. 299.) Annual, rather soft and lax; culms branching at base, erect to decumbent-spreading, 5 to $20 \mathrm{~cm}$ tall, sometimes taller; blades flat, usually 5 to $10 \mathrm{~cm}$ long, 1 to $2 \mathrm{~mm}$ wide; panicle open, mostly 4

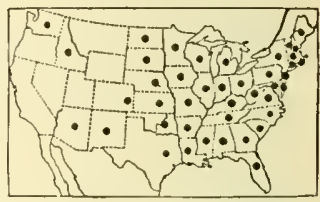

FIGURE 296.-Distribution of Eragrostis pectinacea. to $10 \mathrm{~cm}$ long, about half as wide, the branchos ascending or spreading, naked below, the spikelets appressed or ascendFigure 205--Eragrostis pectinacea. Pani- ing along the upper part, the lower axils

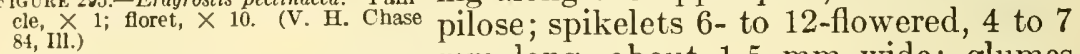

$\mathrm{mm}$ long, about $1.5 \mathrm{~mm}$ wide; glumes about 1 and $1.3 \mathrm{~mm}$ long; lemmas 1.5 to $2 \mathrm{~mm}$ long, the lateral nerves distinct. $\odot-$ Open ground, fields, and waste places, Florida to south-

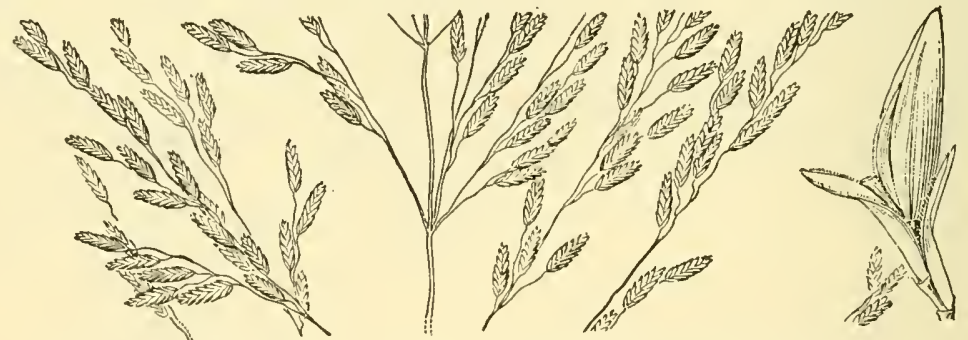

Figure 297.-Eragrostis diffusa. Panicle, $\times 1$; floret, $\times 10$. (Reverchon 1614, Tex.)

ern Texas and south through the lowland tropics to Brazil (fig. 300).

20. Eragrostis peregrína Wiegand. (Fig. 301.) Annual; re-

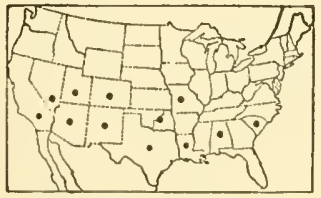

FIGURE 298.-Distribution of Eragrostis diffusa.

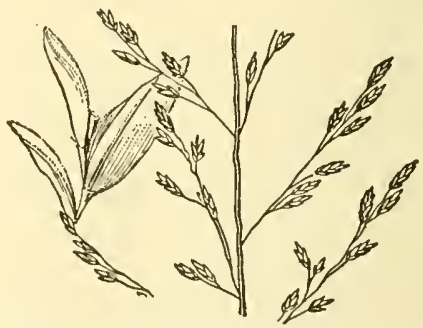

Figure 299.-Eragrostis tephrosanthos. Panicle, $\times 1$; floret, $\times 10$. (Curtiss 5930, Fla.)

sembling E. tephrosanthos but the axils of the panicle glabrous; panicle branches spikelet-bearing nearly to base; spikelets mostly 
4- to 8-flowered, mostly 3 to $4 \mathrm{~mm}$ long. $\odot \quad-W a s t e$ places, Maine to Michigan, south to Pennsylvania and Maryland: ballast, Portland, Oreg. (fig. 302); introduced from Europe.

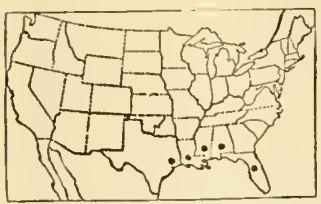

Figure 300.-Distribution of Eragrostis tephrosanthos.

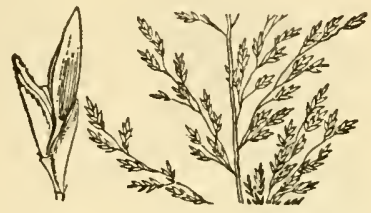

FIGURE 301.-Eragrostis peregrina. Panicle, $\times 1$; floret, $\times 10$. (Hotchkiss 1708, N.Y.)

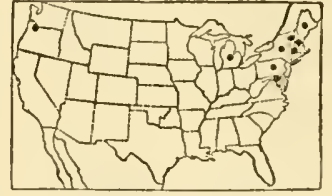

Figure 302-Distribution of Eragrostis peregrina.

21. Eragrostis orcuttiána Vasey. (Fig. 303.) Annual; culms ascending from a decumbent base, rather stout, 60 to $100 \mathrm{~cm}$ tall; blades flat, 2 to $6 \mathrm{~mm}$ wide; panicle open, 15 to $30 \mathrm{~cm}$ long, the

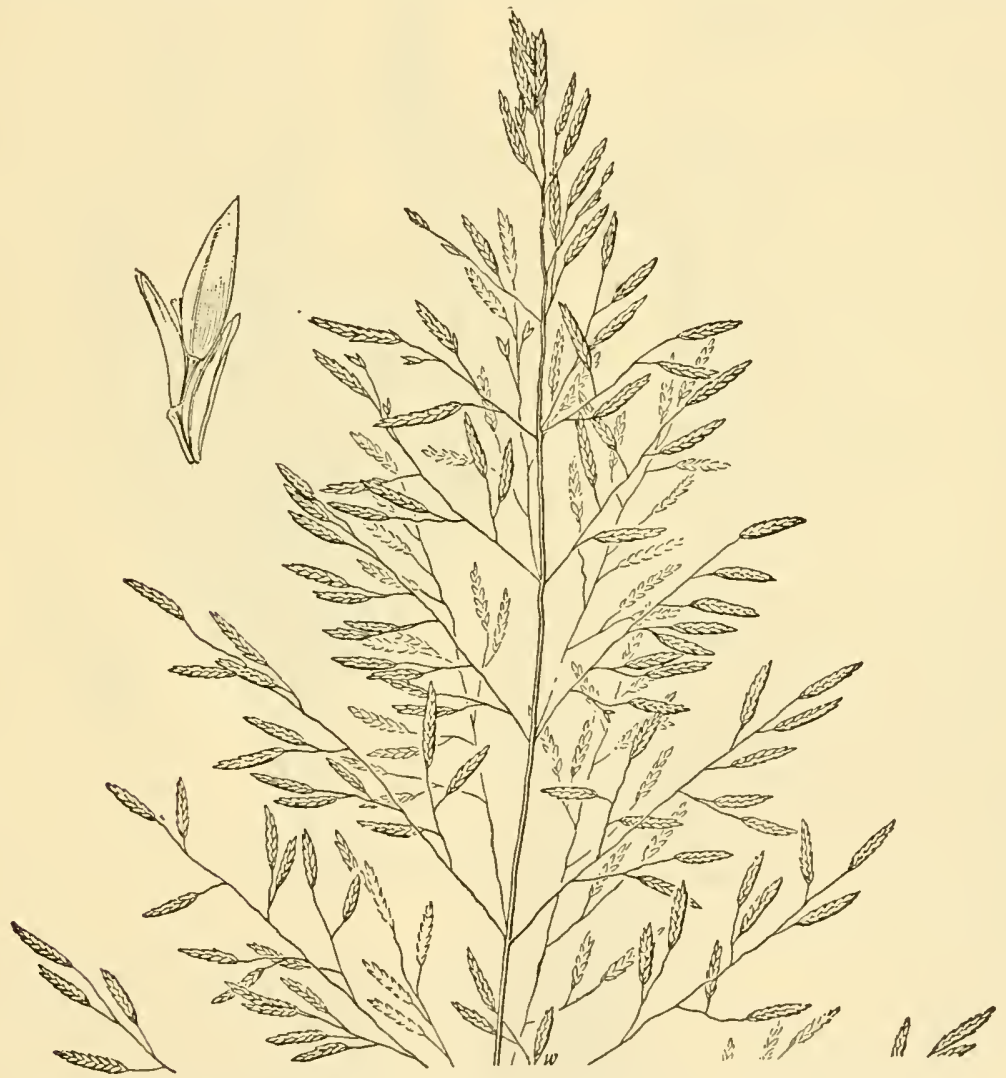

Figure 303.-Eragrostis orcuttiana. Panicle, $\times 1$; floret, $\times 10$. (Hitchcock 3063, Calif.)

branches, branchlets, and pedicels slender, spreading, flexuous, finally implicate, the axils glabrous; spikelets linear, 6- to 10-flowered, sometimes a little falcate, 5 to $7 \mathrm{~mm}$ long, about $1 \mathrm{~mm}$ wide; second glume a little more than $1 \mathrm{~mm}$ long; lemmas loosely imbricate, the 
rachilla often exposed, narrow, acutish, the lower $1.8 \mathrm{~mm}$ long; grain $0.8 \mathrm{~mm}$ long. $\odot-F i e l d s$, waste places, and sandy river banks,

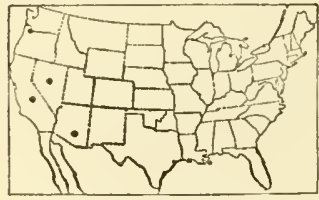

FIgURE 304.-Distribution of Eragrostis orcuttiana.

Oregon (ballast, Portland) and Nevada to Arizona and California (fig. 304).

22. Eragrostis lutéscens Scribn. (Fig. 305.) Annual; culms freely branching at base, erect or ascending, 5 to $20 \mathrm{~cm}$ tall; sheaths and blades with numerous glandular depressions; blades flat; panicles numerous, narrow, erect, pale or yellowish green, 2 to $10 \mathrm{~cm}$ long, the branches ascending or appressed, beset with glandular depressions; spikelets 6 - to 10 -flowered, 5 to $7 \mathrm{~mm}$ long, compressed; glumes acute, 1.5 and $2 \mathrm{~mm}$ long; lemmas about $2 \mathrm{~mm}$ long, acute, the nerves prominent; palea $1.5 \mathrm{~mm}$ long. $\odot$ - Sandy shores, Idaho to Washington, south to Arizona and California (fig. 306).

23. Eragrostis cilianénsis (All.) Link. Stinkgrass. (Fig. 307.) Weedy annual with disagreeable odor when fresh; culms ascending or spreading, 10 to $50 \mathrm{~cm}$ tall, with a ring of glands below the nodes; foliage sparsely beset with glandular depressions, the sheaths pilose at the throat; blades flat, 2 to 7 $\mathrm{mm}$ wide; panicle erect, dark gray-green to tawny, usually rather condensed, sometimes, especially in the Southwest, open, 5 to $20 \mathrm{~cm}$ long, the branches ascending; spikelets oblong, compressed, 10- to 40-flowered, 5 to $15 \mathrm{~mm}$ long, 2.5 to $3 \mathrm{~mm}$ wide; lemmas in side view

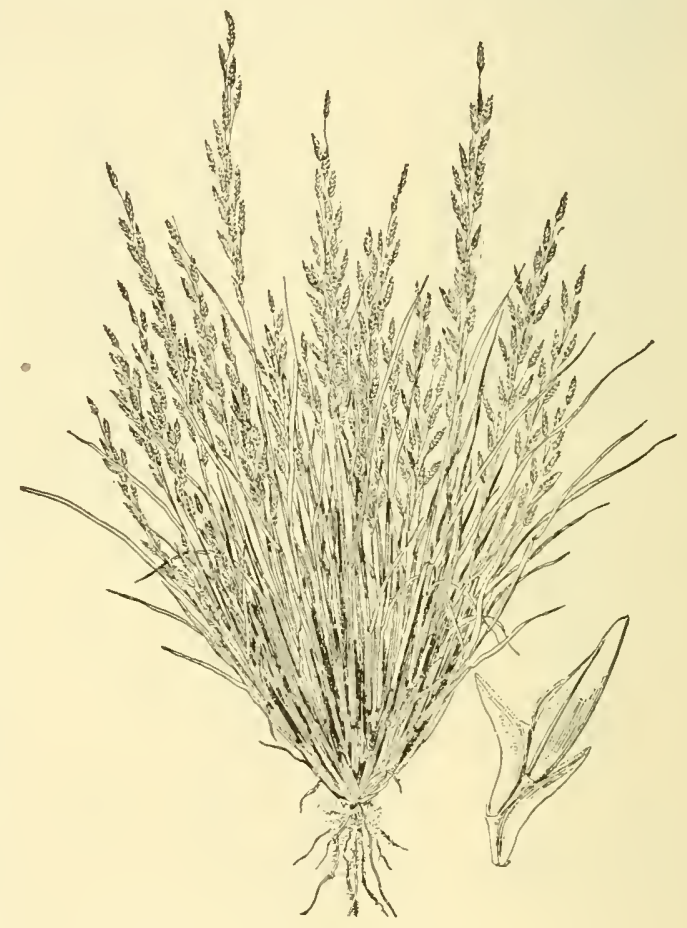

FIgURE 305.-Eragrostis lutescens. Plant, X 1/2; floret, X 10. (Type.) ovate, acutish, about $2.5 \mathrm{~mm}$ long, $1 \mathrm{~mm}$ wide from keel to

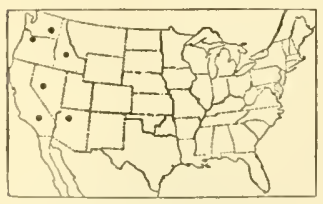

FIGURE 306.-Distribution of Eragrostis lutescens. margin, the keel scabrous toward apex and beset with a few glands, the lateral nerves prominent; palea about two-thirds as long as the lemma, minutely ciliate on the keels; grain ovoid, plump, $0.7 \mathrm{~mm}$ long; anthers $0.5 \mathrm{~mm}$ long. $\odot$ (E. major Host; E. megastachya Link.)Cultivated ground, fields, and waste places, Maine to Washington, south throughout the United States, sparingly in the Nortliwest, absent from the higher mountains; Mexico and West Indies, south to Argentina; introduced from the Old World. 


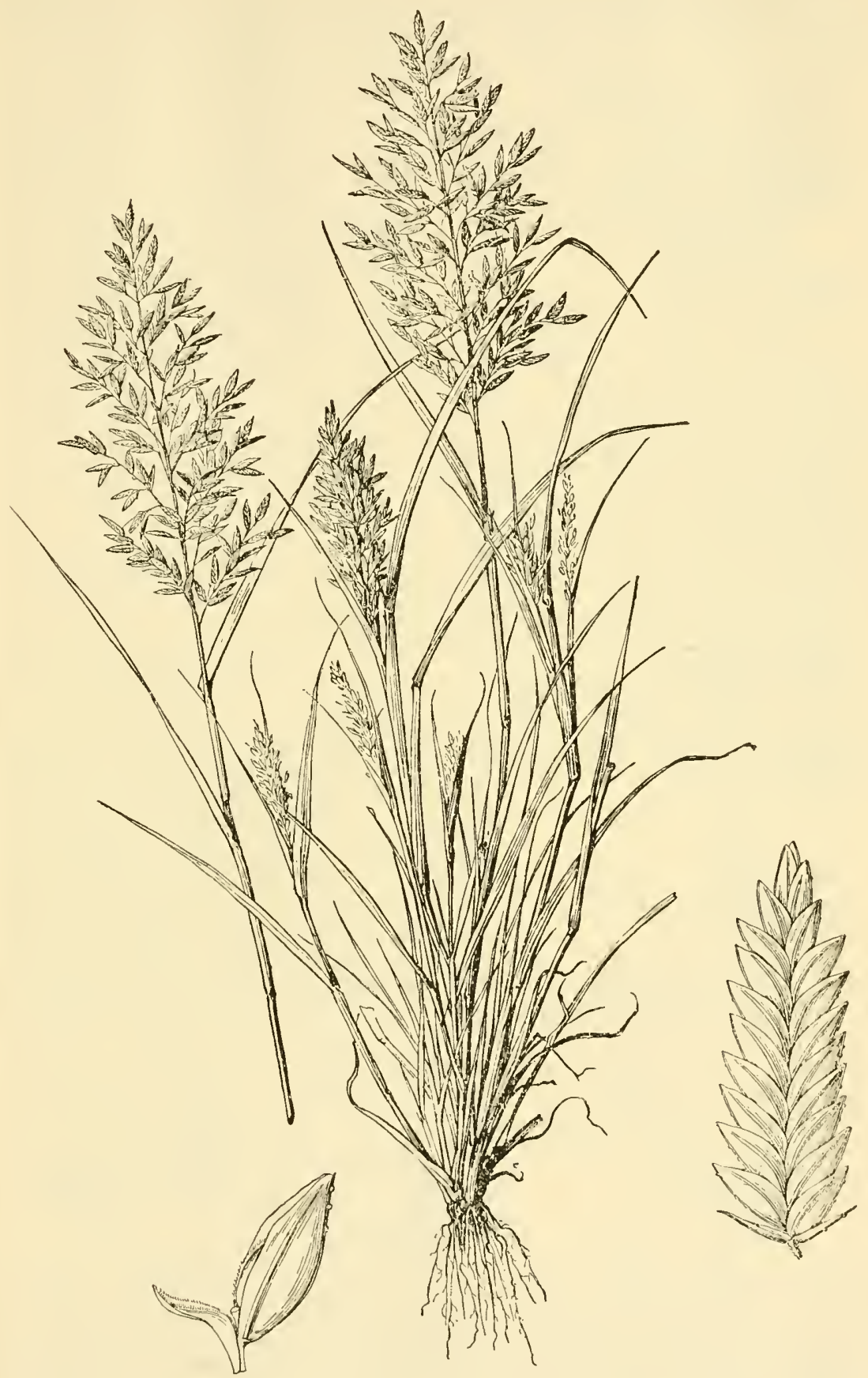

Figure 307. Eragrostis cilianensis. Plant, $\times 1 / 2$; spikelet, $\times 5$; floret, $\times 10 . \quad$ (Schuette 155 , Wis.) 
24. Eragrostis poaeoídes Beauv. (Fig. 308.) Annual; resembling E. cilianensis, mostly more slender; panicles rather more open, the spikelets smaller, 1.5 to $2 \mathrm{~mm}$ wide, the lemmas about $2 \mathrm{~mm}$ long, the

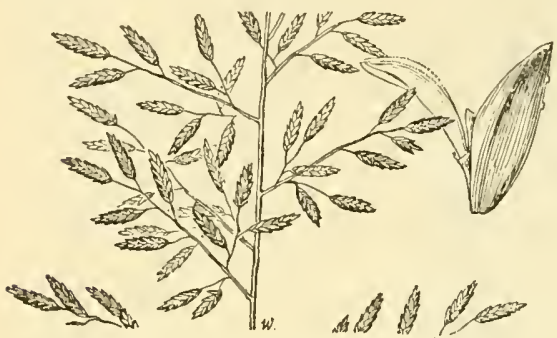

Figure 308.-Eragrostis poaeoides. Panicle, $X 1$; floret, $\times 10$. (Dutton $2235, \mathrm{Vt}$.) glands sometimes obseure; anthers about $0.2 \mathrm{~mm}$ long. $\odot$ (E. minor Host; E. eragrostis Beauv.)-Waste places, sparingly introduced from Europe, Vermont to Iowa, south to Georgia and Texas; Arizona and California (fig. 309).

25. Eragrostis barreliéri Daveau. (Fig. 310.) Annual; culms erect or decumbent at base, 20 to $50 \mathrm{~cm}$ tall, branching at base, sometimes with a glandular band below the nodes; sheaths pilose at the summit; blades flat, rather short, 2 to $4 \mathrm{~mm}$ wide; panicle erect, open but narrow, 8 to $15 \mathrm{~cm}$ long, the branches ascending or stiflly spreading, few-flowered, spikelet-bearing nearly to base, the axils glabrous; spikelets linear, usually $12-$ to $15-$ flowered, mostly about $1 \mathrm{~cm}$ long, and $1.5 \mathrm{~mm}$ wide; lemmas $2 \mathrm{~mm}$ long or slightly longer. $\odot$ -Waste places, Kansas, Texas; Arizona (Tombstone); California (Fresno); introduced from southern Europe.

26. Eragrostis neomexicána Vasey. (Fig.

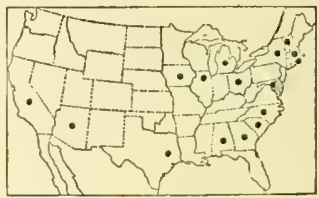

FIGURE 309.-Distribution of Eragrostis poaeoides. 311.) Annual; culms usually rather stout, often widely spreading, as much as $1 \mathrm{~m}$ tall; sheaths glabrous, pilose at the throat, often with glandular depressions along the keel or nerves;

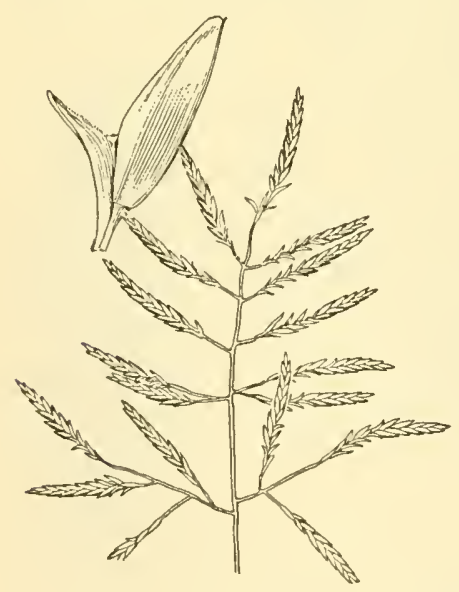

Fiaure 310.-Eragrostis barrelieri. Panicle, $\times 1$; floret, $\times 10$. (Hitchcock 5280, Tex.) blades flat, often elongate, 5 to 10 $\mathrm{mm}$ wide; panicle 20 to $40 \mathrm{~cm}$ long, smaller in depauperate specimens, open, the branches ascending or spreading but not divaricate, the branchlets at first appressed along the main branches, finally usually spreading, the axils glabrous; spikelets mostly dark grayish green, ovate to ovate-oblong, or rarely linear, mostly 8- to 12flowered, 5 to $8 \mathrm{~mm}$ long, about 2 $\mathrm{mm}$ wide; lemmas 2 to $2.3 \mathrm{~mm}$ long. $\odot$-Fields, waste places, and wet ground, 'Texas to southern California, south through Mexico; introduced in Maryland, Indiana, Iowa, and Missouri (fig. 312).

27. Eragrostis mexicána (Hornem.) Link. Mexican Lovegrass. (Fig. 313.) Resembling E. neomexicana, but lower, erect or spreading, often simple; panicle erect, comparatively small and few-flowered, less compound, the branches and pedicels 
spreading; spikelets usually not more than 7 -flowered. $\odot \quad$-Open ground, Texas to Arizona; introduced in Delaware and Iowa.

28. Eragrostis suavéolens Becker. (Fig. 314.) Annual culms spreading, 20 to $50 \mathrm{~cm}$ tall, a ring of glands below the nodes; sheaths with numerous small glandular depressions on the nerves; blades flat, sparsely long-pilose, 2 to 3 $\mathrm{mm}$ wide; panicles open, less than half the entire height of the culm, 10 to $15 \mathrm{~cm}$ or more long, the branches and pedicels spreading, the axils glabrous, the branchlets and pedicels bearing near the summit a glandular depression; spikelets linear-oblong, 5 to $7 \mathrm{~mm}$ long,

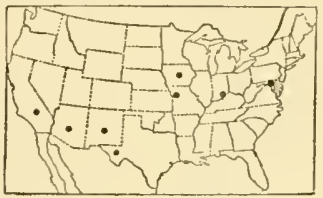

Figure 312.-Distribution of Eragrostis neomexicana.

mostly 7- to 9-flowered, rather soft; lemmas keeled, the lower about $2 \mathrm{~mm}$ long, the lateral nerves distinct. $\odot$-Introduced in the vicinity of Las Cruces, N.Mex.; southern Russia.

29. Eragrostis arida Hitchc. (Fig. 315.) Annual; culms branching at base, erect or more or less decumbent at base, 20 to $40 \mathrm{~cm}$ tall; sheaths not glandular, the hairs at summit in a

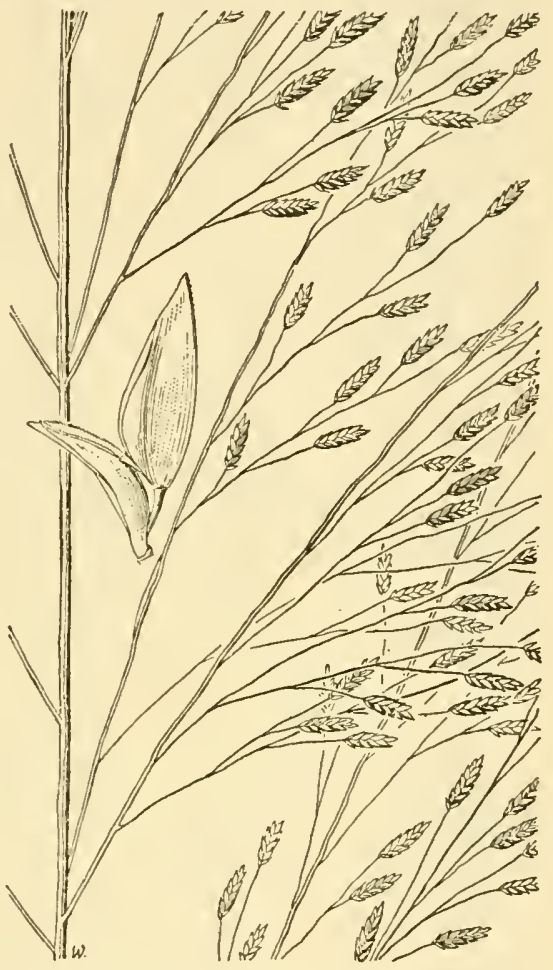

FIgure 311.--Eragrostis neomexicana. Panicle, $\times 1$; floret, $\times 10$. ('Type.) dense line part way along the collar; blades mostly fiat, glabrous, tapering to a fine point, mostly 4 to $8 \mathrm{~cm}$ long, 1 to $2 \mathrm{~mm}$ wide; panicle mostly one-third to half the entire length of the plant, open,

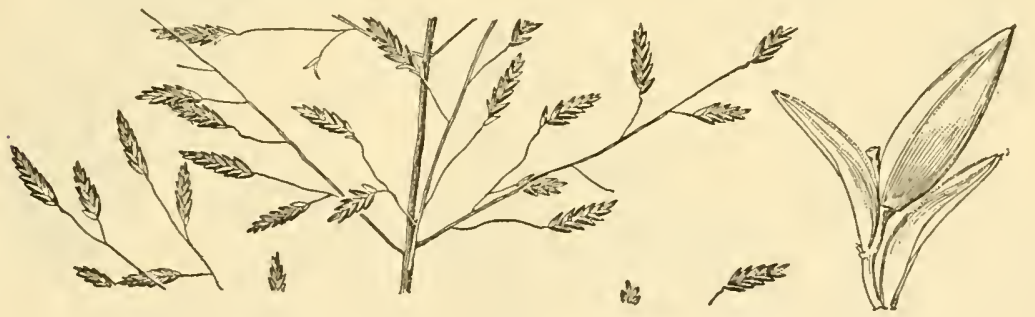

Figure 313.-Eragrostis mexicana. Panicle, $\times 1$; floret, $\times 10$. (Smith, N.Mex.)

the branches, branchlets, and pedicels flexuous, spreading, the lower axils sparsely pilose, the branches solitart c. lower in pairs; spikelets oblong to linear, stramineous or drab, mostly 8- to 15flowered, 5 to $10 \mathrm{~mm}$ long, 1.5 to $2 \mathrm{~mm}$ wide, somewhat compressed, 
the lateral pedicels 2 to $3 \mathrm{~mm}$ long; glumes acute, the first narrow, scarcely $1 \mathrm{~mm}$ long, the second a little longer and wider; lemmas 1.6

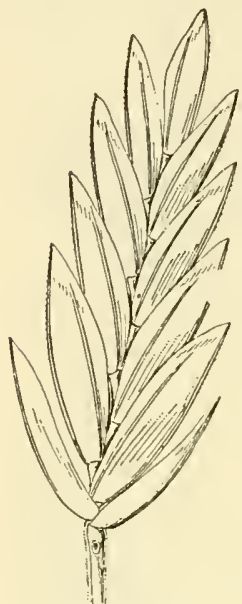

FIGURE 314.-Eragrostis suaveolens, $\times 10$ (Hitcheock 3812, N. Mex.)

to $1.8 \mathrm{~mm}$ long, acutish. $\odot$-Dry soil, Arkansas and Texas to Arizona and central Mexico.

30. Eragrostis hirsúta (Michx.) Nees. (Fig. 316.) Perennial; culms erect, tufted, 50 to $120 \mathrm{~cm}$ tall; sheaths hirsute to glabrous, pilose at the throat and especially along the collar at each side; blades flat, elongate, 5 to $10 \mathrm{~mm}$ wide, becoming more or less involute, tapering to a fine point, scabrous on the

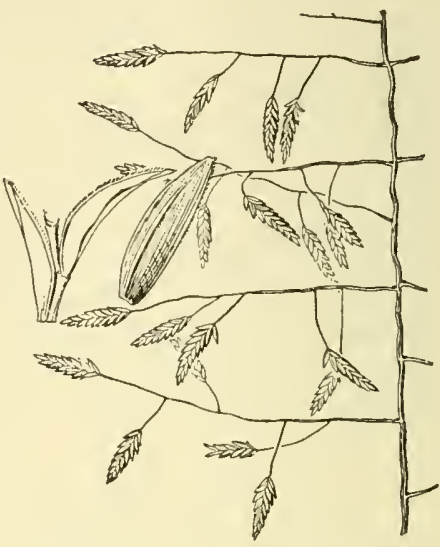

FIGURE 315.-Eragrostis arida. Panicle, $\times 1$; floret, $\times 10$. (T ype.)

upper surface; panicle diffuse, more than half the entire height of the plant, pilose in the axils, branching 4 or 5 times; spikelets on long flexuous pedicels, ovate to ovate-

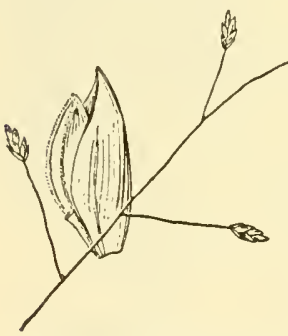
ered (rarcly to 8-flowered), 3 to $4 \mathrm{~mm}$ long; glumes acuminate, 1.5 and $2 \mathrm{~mm}$ long; lemmas rather

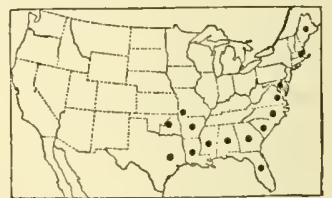

FIGURE 317-Distribution of Eragrostis hirsuta. turgid, $2 \mathrm{~mm}$ long, acute, the nerves obscure; grain oblong, $1 \mathrm{~mm}$ long, minutely striate and pitted. 24 -Dry soil, fields and open woods, Maryland to Missouri, Figure 316--Eragrostis hir- south to Florida and eastern Texas; introduced suta. Panicle, $\times 1$; floret,
$\times 10$.

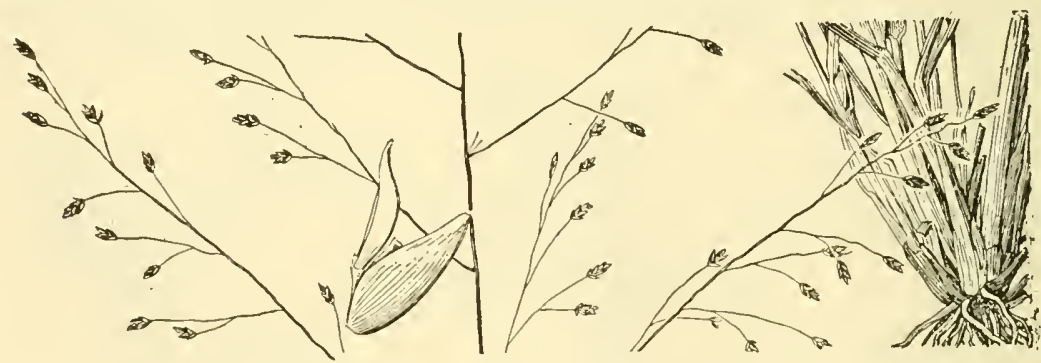

FIGURE 318.-Eragrostis lugens. Plant, $\times 1$; floret, $\times 10$. (Rererchon 16, Tex.)

31. Eragrostis lúgens Nees. (Fig. 318.) Perennial; culms tufted, rather wiry, sometimes geniculate below, sparingly branching; sheaths 
pilose in the throat, sometimes along the margin and on sides at summit; blades subinvolute, 10 to $25 \mathrm{~cm}$ long, 1.5 to $3 \mathrm{~mm}$ wide, pilose on the upper surface toward base, rarely beneath; panicle rather diffuse, 15 to $30 \mathrm{~cm}$ long, about two-thirds as wide, the axis and ascending to spreading branches capillary, flexuous, the lower branches in pairs or verticils, the axils except upper, conspicuously long pilose; spikelets on long pedicels, mostly glossy drab, 3- to 7 -flowered, 3 to $5 \mathrm{~mm}$ long, 1 to $1.2 \mathrm{~mm}$ wide; glumes thin, 0.7 and $1.2 \mathrm{~mm}$ long, falling early; lemmas closely imbricate, 1.3 to $1.5 \mathrm{~mm}$ long, abruptly acute; grain about $0.7 \mathrm{~mm}$ long. 24 -Dry prairie, Texas; also on ballast, Mobile, Alabama; Venezuela to Argentina.

32. Eragrostis trichocólea Hack. and Arech. (Fig. 319.) Perennial; culms erect, 30 to $60 \mathrm{~cm}$ tall, the leaves

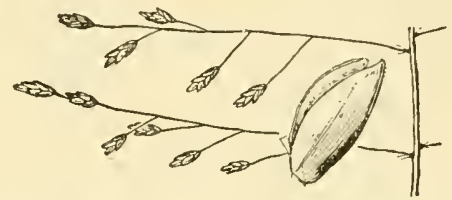

FIgURE 319.-Eragrostis trichocolea. Panicle, $\times 1$; floret, $\times 10$. (Curtiss, Fla.) rather short, mostly crowded at the base; sheaths, at least the lower, spreading, pilose; blades spreading, flat or, especially on the innovations, involute, mostly 8 to $12 \mathrm{~cm}$ long, 2 to $4 \mathrm{~mm}$ wide, pilose; panicle diffuse, 15 to $20 \mathrm{~cm}$ long, nearly or quite as wide, the branches

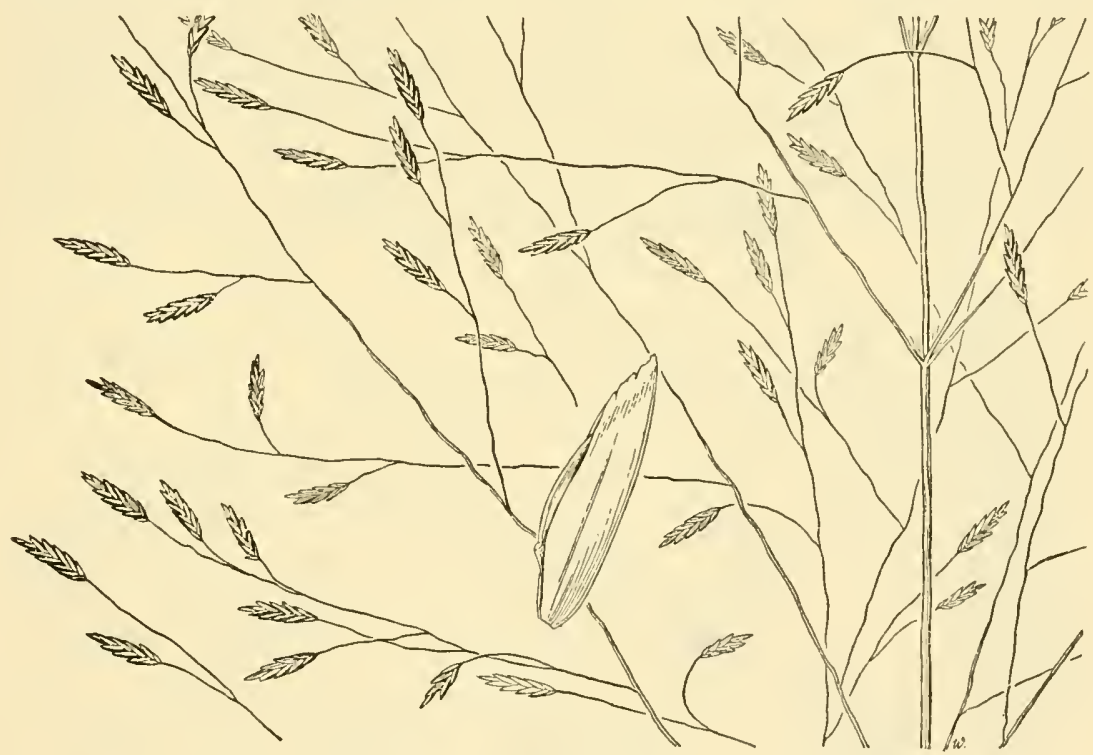

Figure 320.-Eragrostis erosa. Panicle, $\times 1$. (Skehan 58, N.Mex.); floret, $\times 10$. ('Type.)

stiffly and widely spreading, pilose in the axils; pedicels 2 or 3 times as long as the spilielets; spikelets 3 - to 5 -flowered, 3 to $4 \mathrm{~mm}$ long, about $1.5 \mathrm{~mm}$ wide; glumes 1 to 1.2 and 1.3 to $1.5 \mathrm{~mm}$ long; lemmas about $1.5 \mathrm{~mm}$ long. 2 -Sandy woods, Florida (Tampa, Lakeland); Mexico to Uruguay.

33. Eragrostis erósa Scribn. (Fig. 320.) Perennial; culms tufted, erect, 50 to $90 \mathrm{~cm}$ tall; blades mostly involute; panicle diffuse, less than half the entire height of the plant, usually about one-tbird, 
mostly more than half as wide as long, branching 2 or 3 times, sparsely pilose or glabrous in the axils; spikelets mostly 8 - to 9 -flowered, 5 to 10 $\mathrm{mm}$ long, 1.8 to $2 \mathrm{~mm}$ wide; lemmas 2.5 to $3 \mathrm{~mm}$ long, hyaline-margined toward summit, the tip erose. 24 -Rocky hills, western Texas

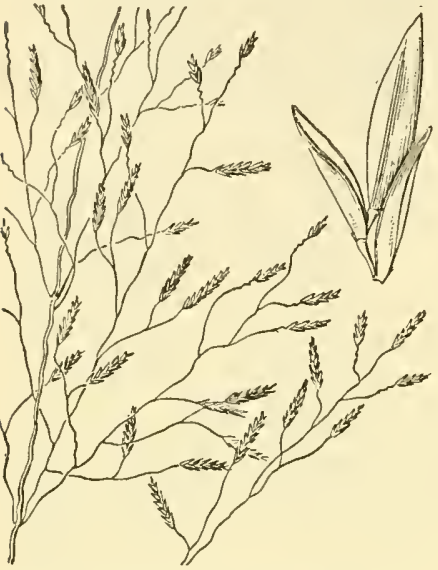

Figure 321.-Eragrostis palmeri. Panicle, $\times 1$; floret, $\times 10$. (Silveus 851 , Tex.) to New Mexico and northern Mexico.

34. Eragrostis palméri S. Wats. (Fig. 321.) Perennial; culms tufted, erect, about $70 \mathrm{~cm}$ tall; blades involute, elongate, erect; panicle open, oblong, 15 to $20 \mathrm{~cm}$ long, 5 to $7 \mathrm{~cm}$ wide, glabrous in the axils; spikelets 5 to $7 \mathrm{~mm}$ long, mostly 7- to 9-flowered, brownish; first glume about $1 \mathrm{~mm}$ long; second glume 1.5 to $2 \mathrm{~mm}$ long; lemmas rounded on the back, bronze-tipped, about $2 \mathrm{~mm}$ long. 24-Alkaline banks, Texas (Harlingen); Mexico (Juárez, Coahuila). Differs from E. erosa in the oblong panicle and smaller spikelets and lemmas.

35. Eragrostis intermédia Hitchc. Plains lovegrass. (Fig. 322.) Perennial; culms erect, tufted, mostly 40 to $80 \mathrm{~cm}$ tall; sheaths glabrous or the lowermost sparsely pilose, conspicuously pilose at the throat, the hairs extending in a line across the collar; blades flat to subinvolute, pilose on the upper surface near the base, otherwise glabrous or with a few scattered hairs, 10 to $25 \mathrm{~cm}$ long, 1 to $3 \mathrm{~mm}$ wide; panicle erect, open, often diffuse, 15 to $35 \mathrm{~cm}$ long,

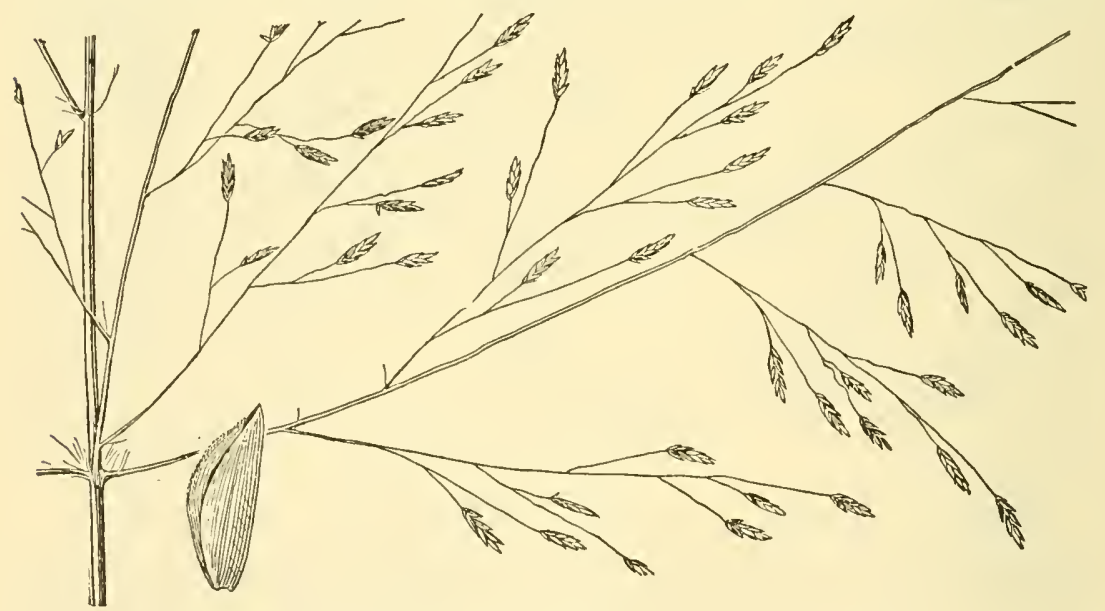

Figure 322.-Eragrostis intermedia. Panicle, $\times 1$; floret, $\times 10$. (Tуре.)

at maturity mostly about three-fourths as wide, the axils pilose, sometimes sparsely so or rarely glabrous, the branches slender but rather stiff, the lower in pairs or verticils, all spreading, often horizontal; spikelets usually $3-$ to 8 -flowered, 3 to $10 \mathrm{~mm}$ long, about $1.5 \mathrm{~mm}$ wide, grayish or brownish green, the pedicels somewhat flexuous, 1 to 
3 times as long as the spikelet; glumes acute, 1 to 1.2 and 1.2 to 1.4 $\mathrm{mm}$ long; lemmas turgid, obscurely nerved, 1.8 to $2 \mathrm{~mm}$ long, usually bronze-tipped, not hyaline margined; grain oblong, about $0.7 \mathrm{~mm}$ long. 24 -Dry or sandy prairies, Georgia; Louisiana and Missouri to southern California and south to Central America (fig. 323). A few specimens from New Mexico have long spikelets (as much as 13 -flowered) and glabrous axils.

36. Eragrostis swalléni Hitchc. (Fig. 324.) Perennial; culms in dense tufts, erect, 20 to $50 \mathrm{~cm}$ tall, an obscure glandular band below the nodes; sheaths sparingly pilose at the throat; blades involute, glabrous, arching-recurved, 10 to $30 \mathrm{~cm}$ long; panicle erect, open, 10 to $20 \mathrm{~cm}$ long, the branches ascending or spreading, glabrous, stiffly flexuous; spikelets oblong to linear, stramineous or grayish-green, 7 to $10 \mathrm{~mm}$ long, about $2 \mathrm{~mm}$ wide, mostly 8 - to 12 -flowered, the

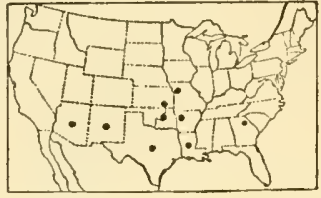

Figure 323.-Distribution of Eragrostis intermedia.

slender pedicels bearing above the middle a glandular band or spot; glumes acutish, rather broad, about 1.2 and $1.8 \mathrm{~mm}$ long; lemmas rather closely imbricate, acutish, about $2 \mathrm{~mm}$ long; palea minutely scabrous on the keels; grain nearly smooth, slightly narrowed toward the summit, $1 \mathrm{~mm}$ long. 21 - Sandy prairies, southern Texas. Known only from Sarita and nearby Riviera.

37. Eragrostis trácyi Hitchc. (Fig. 325.) Apparently perennial; culms erect, tufted, 30 to $80 \mathrm{~cm}$ tall; sheaths rather sparsely pilose

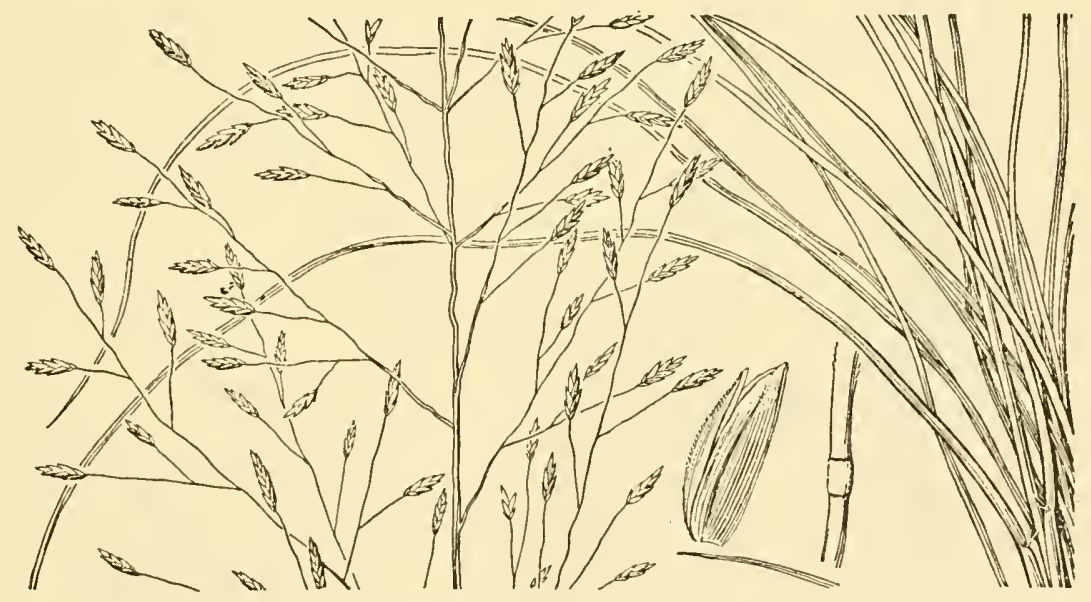

Figure 324,--Eragrostis swalleni. Plant and panicle, $\times 1$; floret, $\times 10$. (Type.)

at the throat; blades flat or, especially of the innovations, involute, 5 to $25 \mathrm{~cm}$ long, 1 to $3 \mathrm{~mm}$ wide; panicle erect, open, 10 to $15 \mathrm{~cm}$ long, 5 to $8 \mathrm{~cm}$ wide, the axils glabrous or nearly so, the branches ascending to spreading, flexuous; spikelets linear, mostly 9 - to 15 -flowered, 5 to 10 $\mathrm{mm}$ long, about $1.5 \mathrm{~mm}$ wide, pinkish or purplish, the flexuous pedicels spreading, 2 to $5 \mathrm{~mm}$ long; glumes acutish, about $1 \mathrm{~mm}$ and $1.5 \mathrm{~mm}$ long; lemmas 1.5 to $2 \mathrm{~mm}$ long, rather soft, loosely imbricate, the lateral nerves distinct; palea somewhat persistent; grain about 0.7 mm long. 2 - Sandy soil, known only from Sanibel Island, Fla. 
38. Eragrostis silveána Swallen. (Fig. 326.) Perennial; eulms densely tufted, erect from a knotty base, 40 to $50 \mathrm{~cm}$ tall; sheaths

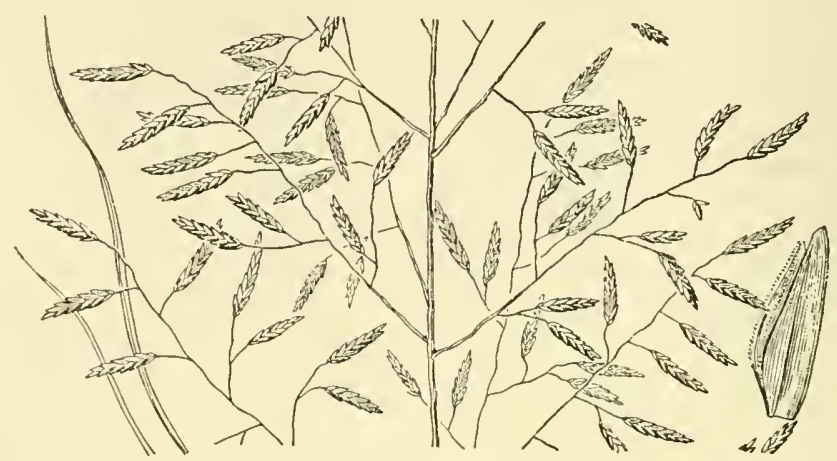

EFIgURE 325.-Eragrostis tracyi. Panicle, $\times 1$; floret, $\times 10$. (Type.)

glabrous; blades flat or loosely involute in drying, elongate, $3 \mathrm{~mm}$ wide, attenuate to a fine point, glabrous; panicle 25 to $35 \mathrm{~cm}$ long,

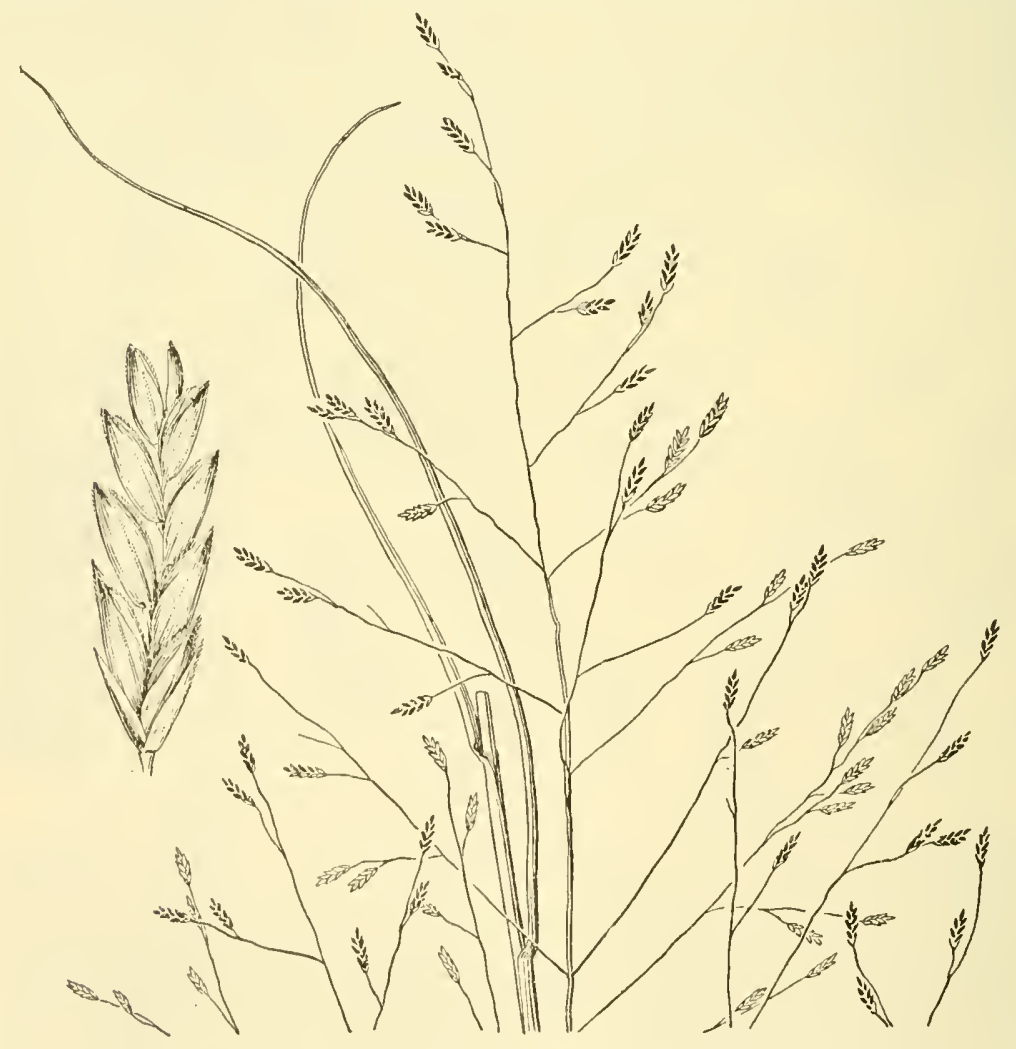

Fygure 326.-Eragrostis silveana. Panicle, $\times 1$; spikelet, $\times 10$. (Type.)

10 to $15 \mathrm{~cm}$ wide, the viscid seabrous branches stiffly ascending or spreading, naked at base, sparsely pilose in the axils; spikelets pur- 
plish, 4- to 8-flowered, 2.5 to $4 \mathrm{~mm}$ long, the ultimate pedicels short, usually appressed; glumes about $1 \mathrm{~mm}$ long; lemmas acutc, about $1.3 \mathrm{~mm}$ long, the lateral nerves prominent. 21 -Open ground, southern Texas.

39. Eragrostis trichódes (Nutt.) Nash. (Fig. 327.) Perennial; culms tufted, erect, 60 to $120 \mathrm{~cm}$ tall; sheaths pilose at the summit,

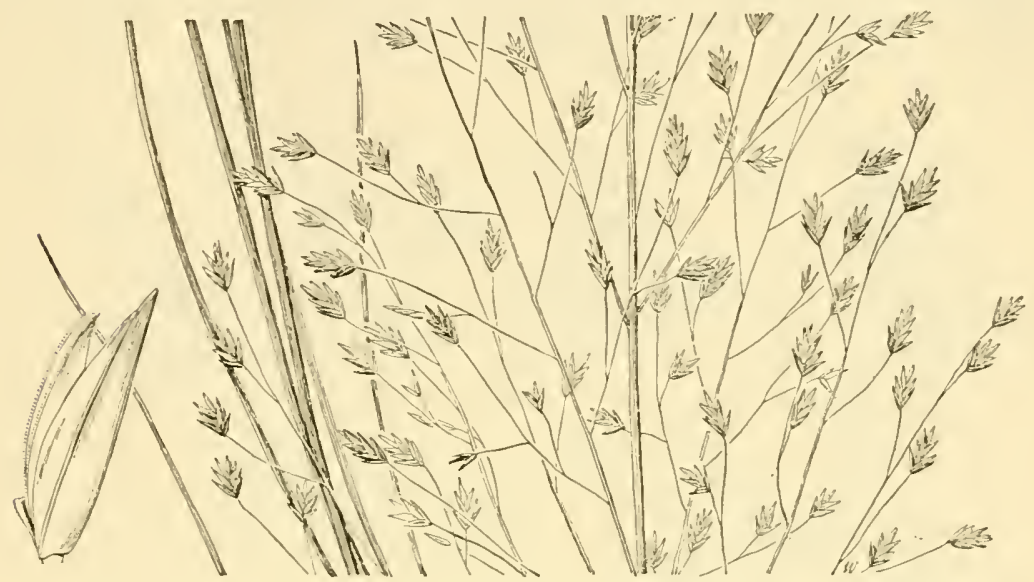

FIgURE 327.-Eragrostis trichodes. Panicie, $\times 1$; floret, $\times 10$. (Reverchon, Tex.)

sometimes on the upper half; blades flat to subinvolute, elongate, 2 to $6 \mathrm{~mm}$ wide, tapering to a slender point, scabrous on the upper surface; panicle usually purplish, diffuse, oblong, usually about half the entire height of the culm, branching 3 or 4 times, the branches capillary, loosely ascending, sparsely pilose in the axils; spikelets longpediceled, lanceolate to ovate-oblong, mostly 4 - to 6 -flowered, 4 to 7

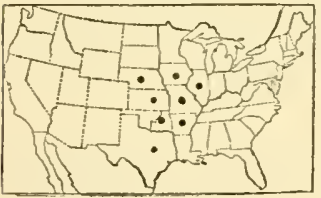

FIGURE 328.-Distribution of Eragrostis trichodes. mm long; glumes acuminate, nearly equal, 2.5 to $3 \mathrm{~mm}$ long, about as long as the first floret; lemmas 2.5 to $3 \mathrm{~mm}$ long, acute, subcompressed, the keel and lateral nerves strong; grain $1 \mathrm{~mm}$ long, minutely pitted; anthers a little more than $1 \mathrm{~mm}$ long. 24 - Sand barrens and open sandy woods, Illinois and Nebraska to Texas (fig. 328).

40. Eragrostis pilífera Scheele. (Fig. 329.) Resembling $E$. trichodes, often in smaller tufts and taller; panicle stramineous or golden-bronze; spikelets linear, 8 - to 15 -flowered, 8 to $12 \mathrm{~mm}$ long; glumes and lemmas about $3 \mathrm{~mm}$ long. 24 (E.grandiflora Smith and Bush.)-Sand hills and sand barrens, Illinois and Nebraska to Texas (fig. 330). Probably only a variety of E. trichodes.

41. Eragrostis spectábilis (Pursh) Steud. Purple lovegrass. (Fig. 331.) Perennial; culms in dense tufts, stiffly erect to spreading, 20 to $60 \mathrm{~cm}$ tall; sheaths glabrous or pilose, conspicuously hairy at the throat; blades flat or folded, rather firm, stiffly ascending, tapering to a fine point, glabrous or rarely pilose, mostly 3 to $8 \mathrm{~mm}$ wide; panicle at first included at base, two thirds the entire height of the culm, diffuse, bright purple, rarely pale, branching 3 or 4 times, the axis stiff, the branches stiffly spreading toward maturity, rarely pilose, 
strongly pilose in the axils, the lower shorter than the middle ones, finally reflexed, the whole panicle finally breaking away and tumbling before the wind; spilielets long-pediceled, short-pediceled toward the ends of the branches, oblong to linear, 6- to 12 -flowered, 4 to $8 \mathrm{~mm}$ long; glumes acute, a little more than $1 \mathrm{~mm}$ long; lemmas acute, about $1.5 \mathrm{~mm}$ long, slightly scabrous toward the tip, the lateral nerves prominent toward the base; palea somewhat bowed out, exposing the rather prominently short-ciliate keels; grain oval, dark-brown, 0.6

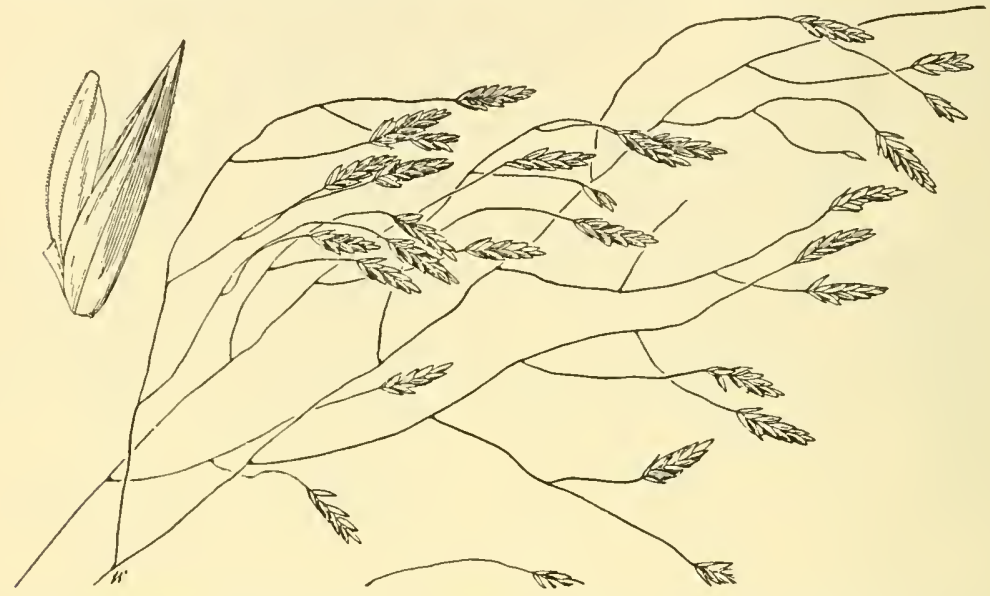

Figure 329.-Eragrostis pilifera. Panicle, $\times 1$; floret, $\times 10$. (Rydberg 1831, Nebr.)

mm long. 21 -Sandy soil, Maine to Minnesota, south to Florida, Kansas, Colorado, and Arizona; Mexico (San Luis Potosí) (fig. 332). This species has been generally referred to E. pectinacea.

42. Eragrostis elliốttii S. Wats. (Fig. 333.) Perennial; culms tufted, stiffly erect or spreading, 40 to $80 \mathrm{~cm}$ tall; sheaths glabrous, pilose at the throat; blades flat, elongate, scabrous on the upper surface, 2 to $4 \mathrm{~mm}$ wide; panicle diffuse, fragile, usually more than half the entire height of the plant, branching 3 or 4 times, the branches capillary, spreading; spikelets on long capillary spreading pedicels, linear, mostly 8 - to $15-$ flowered, 5 to $12 \mathrm{~mm}$ long, about $2 \mathrm{~mm}$ wide, pale or gray; glumes acute, 1 and $1.5 \mathrm{~mm}$ long; lemmas closely imbricate, acute, about $2 \mathrm{~mm}$ long, bowed out below, fitting into the angles of the zigzag rachilla; grain oval, $0.7 \mathrm{~mm}$ long. 21 -Low ground, wet meadows, and low pine woods, Coastal Plain, North Carolina to

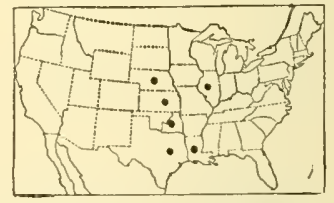

Figure 330.-Distribution of Eragrostis pilifera. Florida and eastern Texas; West Indies and eastern Mexico (fig. 334).

43. Eragrostis acúta Hitche. (Fig. 335.) Perennial; culms erect, 40 to $60 \mathrm{~cm}$ tall; sheaths glabrous, pilose at the throat; blades flat, becoming more or less involute, 2 to $4 \mathrm{~mm}$ wide; panicle diffuse, more than half the entire height of the plant, branching 3 or 4 times, the branches less fragile than in E. elliottii; spikelets on long spreading pedicels, oblong-elliptic, 10 - to 20 -flowered, 8 to $14 \mathrm{~mm}$ long, $3 \mathrm{~mm}$ wide, pale or stramineous; glumes acuminate, 2.5 and $3 \mathrm{~mm}$ long; lemmas acuminate, $3 \mathrm{~mm}$ long; grain $0.8 \mathrm{~mm}$ long. 21 -Low pine woods and moist sandy soil, peninsular Florida 


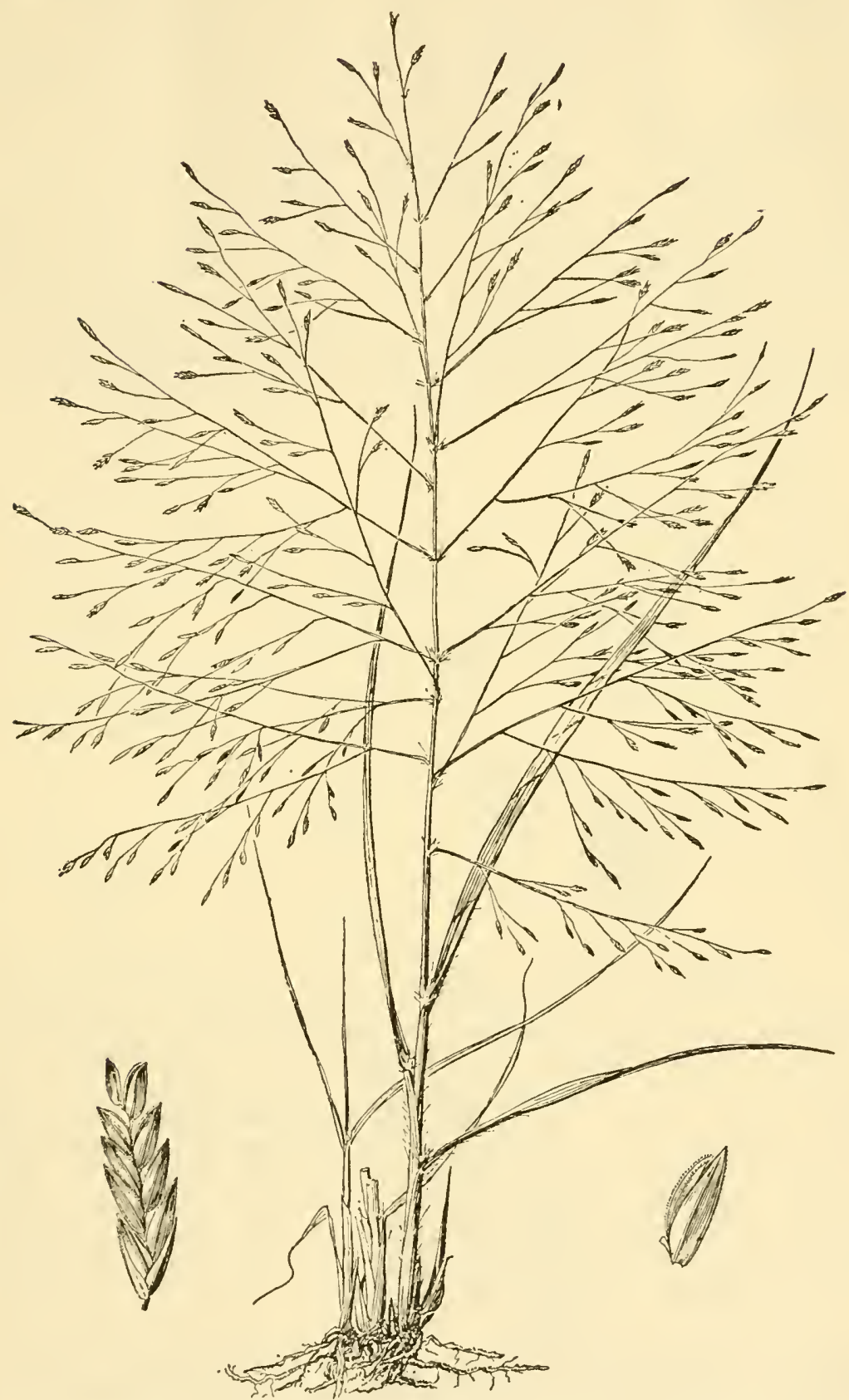

FIGURE 331.-Eragrostis spectabilis. Plant, $\times 1 / 2$; spikelet, $\times 5$; floret, $\times 10$. (Hitchcock 7849 , Md.) 
44. Eragrostis refrácta (Muhl.) Scribn. (Fig. 336.) Resembling $E$. elliottii; blades more or less pilose on the upper surface near base; lower panicle branches usually finally reflexed, long-pilose in the axils; spilielets short-pedicelled, appressed and distant along the

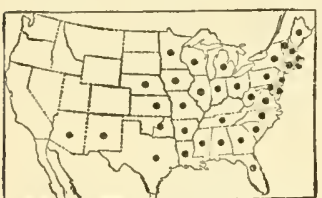

FIGUR E 332.-Distribution of Eragrostis spectabilis. nearly simple panicle branches, the lemmas on the average shorter than in $E$. elliottii. 24 -Low sandy soil, Coastal Plain, Delaware to Florida and eastern Texas (fig. 337).

45. Eragrostis cháriis (Schult.) Hitche. (Fig. 338, B.) Perennial; culms erect or ascending at base, 60 to $120 \mathrm{~cm}$ tall; panicle open, 7 to $15 \mathrm{~cm}$ long, nodding, the branches glabrous or with a few hairs in the axils, ascending, solitary, rather distant, naked below, rather closely flowered with ascending or appressed branchlets; spikelets linear, 5 to $10 \mathrm{~mm}$ long, 8 - to 20 -flowered; glumes about 1.3 and $1.7 \mathrm{~mm}$ long;

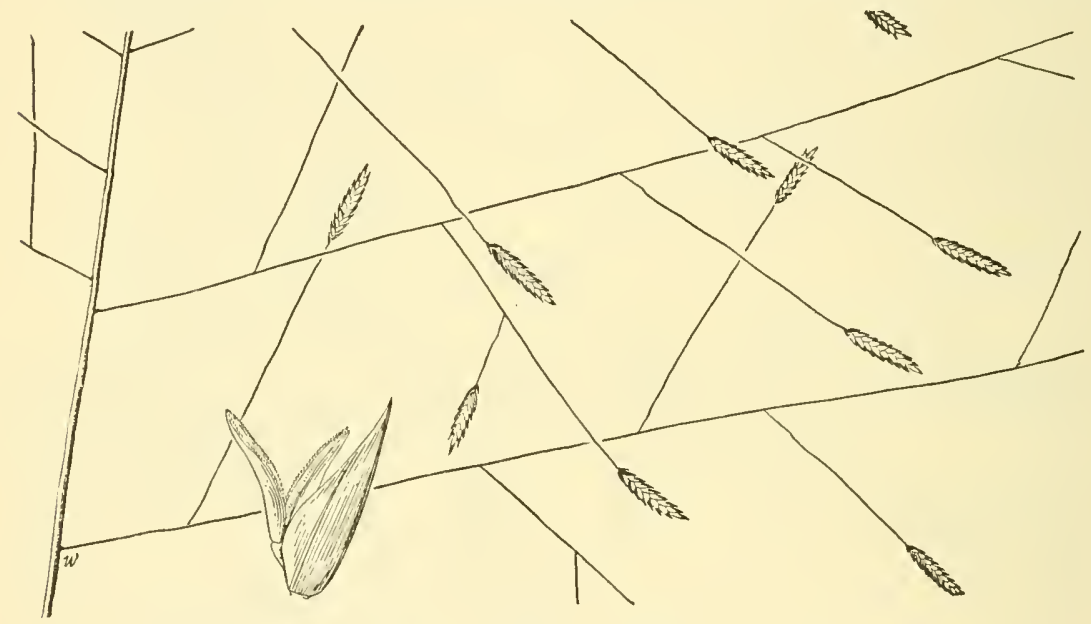

Figure 333.-Eragrostis elliotiii. Panicle, $\times 1$; floret, $\times 10$. (Tracy 7384, Fla.)

lemmas 1.5 to $2 \mathrm{~mm}$ long, imbricate; palea persistent only a short time after the fall of the lemma, the naked rachilla persisting. 24 - Sandy roadsides, Florida (St. Petersburg); introduced from southeastern Asia.

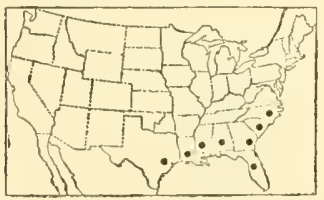

F IGlu R E 334.-Distribution of Eragrostis elliottii.

46. Eragrostis bahiénsis Schrad. (Fig. 338, A.) Resembling E. chariis; panicle often more or less condensed; spikelets as much as 30-flowered; lemmas about $2 \mathrm{~mm}$ long; palea persistent. 24 -Introduced, Florida (Milton, Pensacola), Alabama (Mobile), and Louisiana (Avery Island); Brazil.

Eragrostis stenophýlla Hochst. Erect smooth annual, 30 to $40 \mathrm{~cm}$ tall, with loosely involute blades and rather loose panicle with ascending branches, the linear spikelets several-flowered, the lemmas 1.3 
MANUAL OF THE GRASSES OF THE UNITED STATES 167

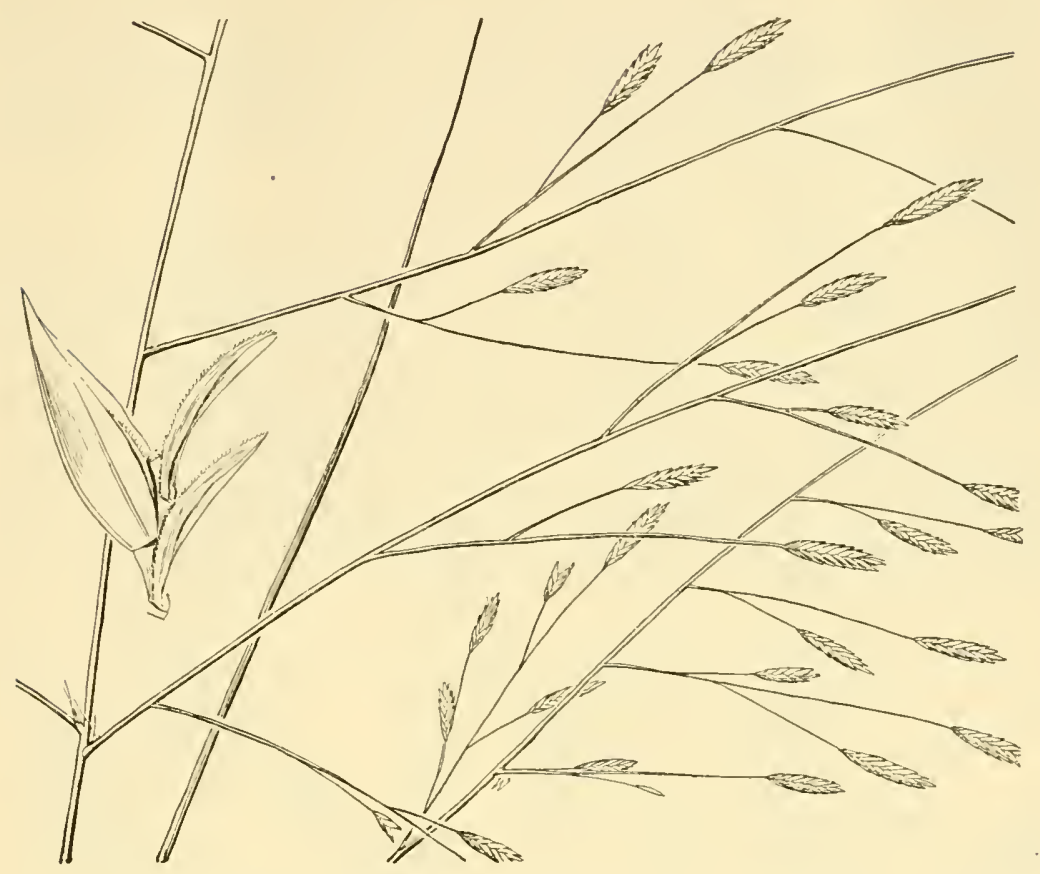

Figure 335.-Eragrostis acuta. Panicle, $\times 1$; floret, $\times 10$. (Type.)

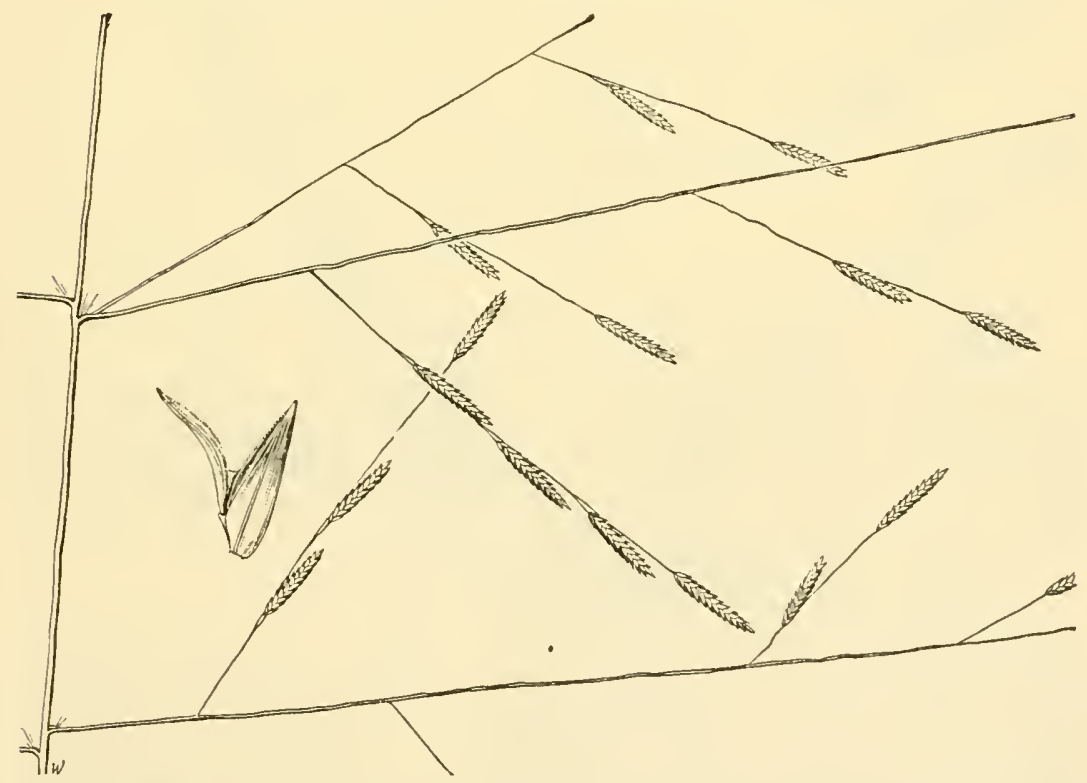

Figure 336.-Eragrostis refracta. Panicle, $\times 1$; floret, $\times 10$. (Kearney 1922, N. C.) 
mm long. $\odot$-Mississippi (Biloxi), probably escaped from grass garden. India.

Eragrostis cyperoídes (Thunb.) Beauv. Stiff stout stoloniferous perennial with sharp-pointed blades and narrow elongate interrupted panicles, the distant branches with naked thorn like tips; spikelets

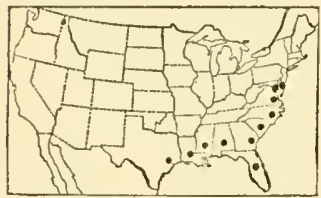

FIGURE 337.-Distribution of Eragrostis refracta. coriaceous, crowded. 24 -Oregon (Linnton), on ballast. South Africa.

Eragrostis a B ys ín ICA (Jacq.) Link. Teff. Annual; culms branching and spreading, 30 to $100 \mathrm{~cm}$ tall; panicle large and open; spikelets 5- to 9-flowered, 6 to $8 \mathrm{~mm}$ long. $\odot$-Occasionally cultivated for ornament. Africa, where the seed is used for food.

Eragrostis tenélla (L.) Beauv. Tall branching annual; blades long, lax; panicles numerous, pale, 20 to $50 \mathrm{~cm}$ long, narrow but loose; spikelets minute. $\odot$ (E. japonica Trin.)-Occasionally cultivated for ornament. Asia.

Eragrostis obtúsa Munro. Low branching perennial; panicles open, 5 to 10 cm long; spikelets gray-olivaceous, broadly ovate, the lemmas almost horizontally spreading. 24 -Occasionally cultivated for ornament. South Africa.

Eragrostis Chloroméi,as Steud. Branching perennial, 40 to $65 \mathrm{~cm}$ tall with

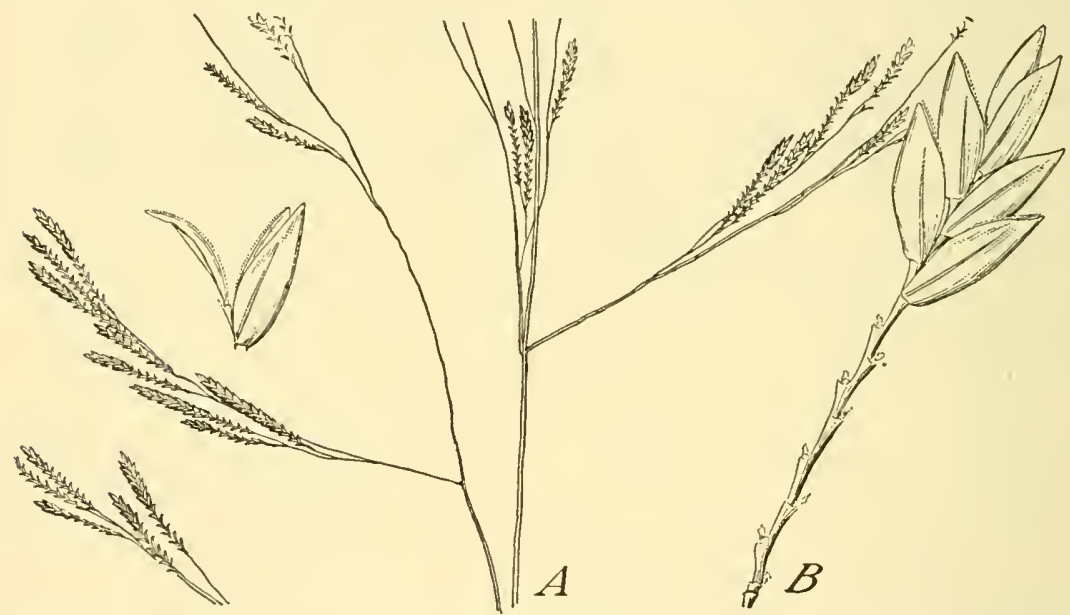

Figure 338.-A, Eragrostis bahiensis. Panicle, $\times 1$; floret, $\times 10$. (Hitchcock 19862, La.) B, E. chariis, $\times 10$. (Weatherwax 822 , Fla.)

hard tufted base; blades involute; panicle loose, 8 to $12 \mathrm{~cm}$ long; spikelets dark olivaceous. 2 -Occasionally cultivated for ornament. South Africa.

Eragrostis cúrvula (Schrad.) Nees. Tufted perennial, 60 to $120 \mathrm{~cm}$ tall; blades elongate, subinvolute with long flexuous setaceous tips; panicle 20 to 30 $\mathrm{cm}$ long, loose; spikelets dark olivaceous. 21 -Occasionally cultivated for ornament. South Africa.

\section{CATABRÓSA Beauv.}

Spikelets mostly 2-flowered, the florets rather distant, the rachilla disarticulating above the glumes and between the florets; glumes unequal, shorter than the lower floret, flat, nerveless, irregularly toothed at the broad truncate apex; lemmas broad, prominently 3-nerved, the nerves parallel, the broad apex scarious; palea about as long as the lemma, broad, scarious at the apex. Aquatic perennials, 
with creeping bases, flat soft blades, and open panicles. Type species, Catabrosa aquatica. Name from Greck katabrosis, an eating up or devouring, referring to the toothed or eroded glumes.

1. Catabrosa aquática (L.)

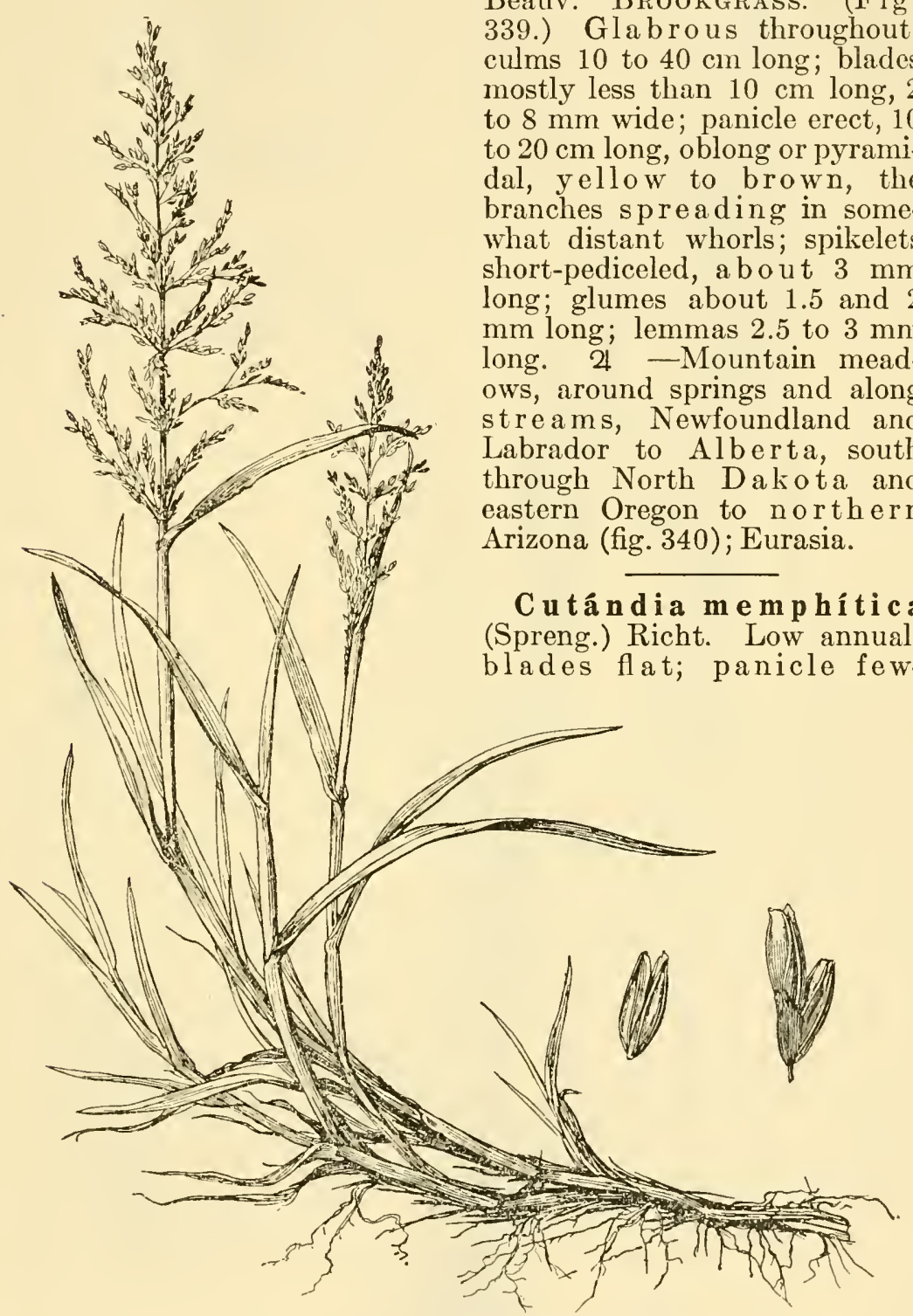

FIGURE 339.-Catabrosa aquatica. Plant, $\times 1 / 2$; spikelet and floret, $\times 5$. (Williams and Fernald, Que.)

flowered; spikelets on short pedicels, finally divergent on the zigzag branches. $\odot-$ San Bernardino Mountains, Calif.; introduced from the Mediterranean region. 

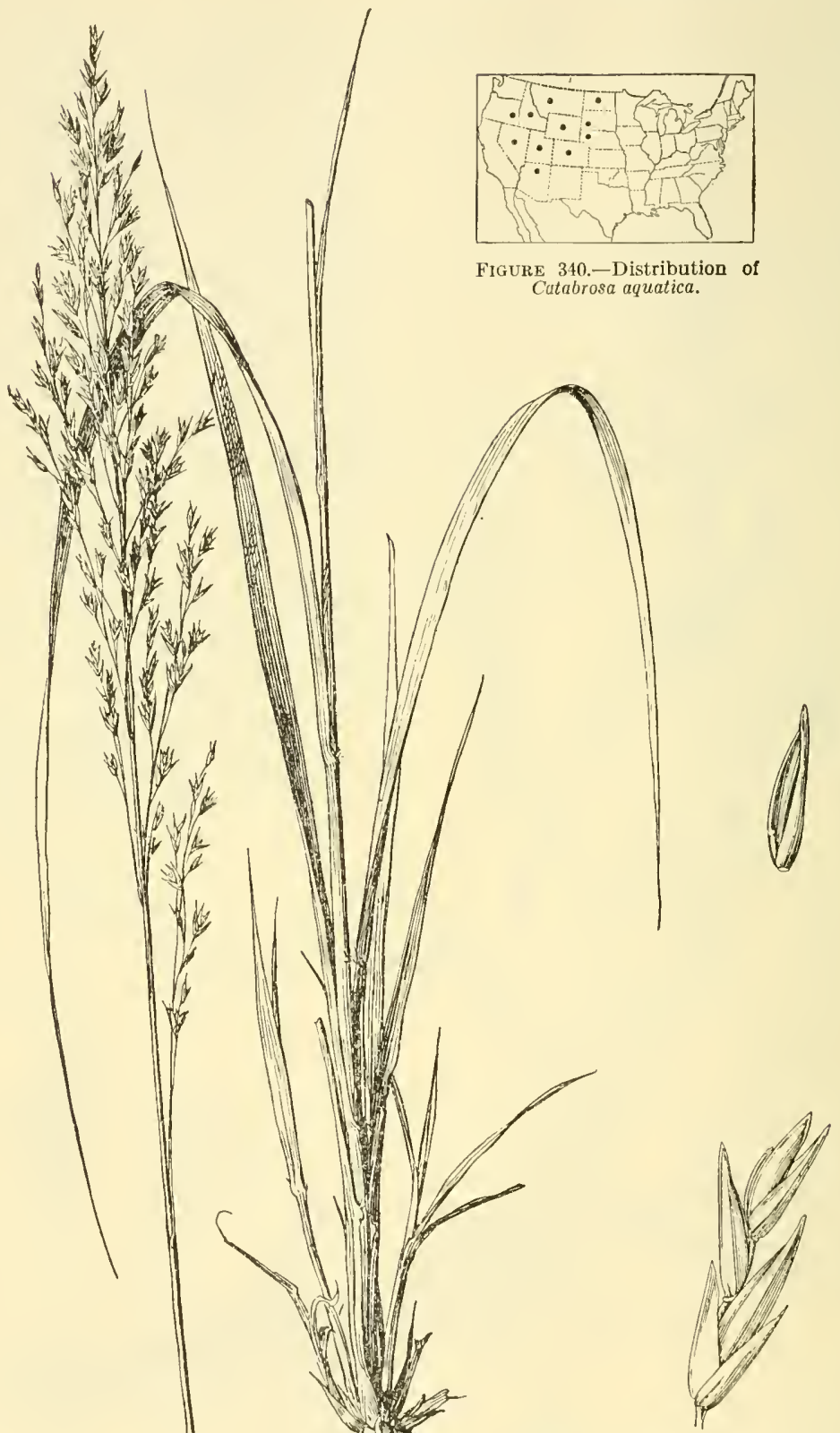

Figure 341,-Motinia caerulea. Plant, $\times 1 \frac{1}{2}$; spikelet and floret, $\times 5$. (Kirk 157, Vt.) 


\section{MOLINIA Schrank}

Spikelets 2- to 4-flowered, the florets distant, the rachilla disarticulating above the glumes, slender, prolonged beyond the upper floret and bearing a rudimentary floret; glumes somewhat unequal, acute, shorter than the first lemma, 1-nerved; lemmas membranaceous, narrowed to an obtuse point, 3-nerved; palea bowed out below, equaling or slightly exceeding the lemma. Slender tufted perennials, with flat blades and narrow, rather open panicles. Type species, Molinia caerulea. Named for J. I. Molina.

1. Molinia caerúlea (L.) Moench. (Fig. 341.). Culms erect, 50 to $100 \mathrm{~cm}$ tall; blades 2 to $7 \mathrm{~mm}$ wide, erect, tapering to a fine point; panicle 10 to $20 \mathrm{~cm}$ long, purplish, the branches ascending, rather densely flowered, mostly floriferous to the base; spikelets shortpediceled, 4 to $7 \mathrm{~mm}$ long; lemmas about $3 \mathrm{~mm}$ long. 24 -Meadows and fields, introduced in a few localities, Maine to Pennsylvania (fig. 342); Eurasia.

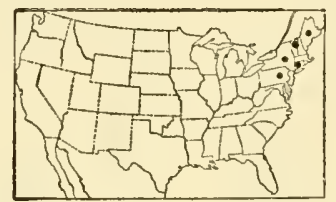

FIGURE 342.-Distribution of Molinia caerulea

\section{DIARRHÉNA Beauv.}

(Diarina Raf.)

Spikelets few-flowered, the rachilla disarticulating above the glumes and between the florets; glumes unequal, acute, shorter than the lemmas, the first 1-nerved, the second 3- to 5-nerved; lemmas chartaceous, pointed, 3-nerved, the nerves converging in the point, the upper floret reduced; palea chartaceous, obtuse, at maturity the lemma and palea widely spread by the large turgid beaked caryopsis with hard shining pericarp; stamens 2 or 3 . Perennials, with slender rhizomes, broadly linear, flat blades, long-tapering below, and narrow, few-flowered panicles. Type species, Diarrhena americana. Name from Greek dis, twice, and arren, male, alluding to the two stamens.

1. Diarrhena americána Beauv. (Fig. 343.) Culms slender, about $1 \mathrm{~m}$ tall; leaves approximate below the middle of the culm; sheaths pubescent toward the summit; blades elongate, 1 to $2 \mathrm{~cm}$ wide, scabrous to pubescent beneath; panicle long-exserted, drooping, 10 to $30 \mathrm{~cm}$ long, the branches few, appressed, the lower distant; spikelets 10 to $18 \mathrm{~mm}$ long, at first narrow, the florets expanded at maturity; lemmas 6 to $10 \mathrm{~mm}$ long. 24 (Diarina festucoides Raf.)-Rich or moist woods, West Virginia to Michigan and South Dakota, south to Tennessee, Arkansas, Oklahoma, and eastern Texas (fig. 344). 


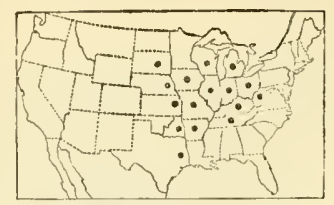

FIgure 344.-Distribution of Diarrhcna americana.

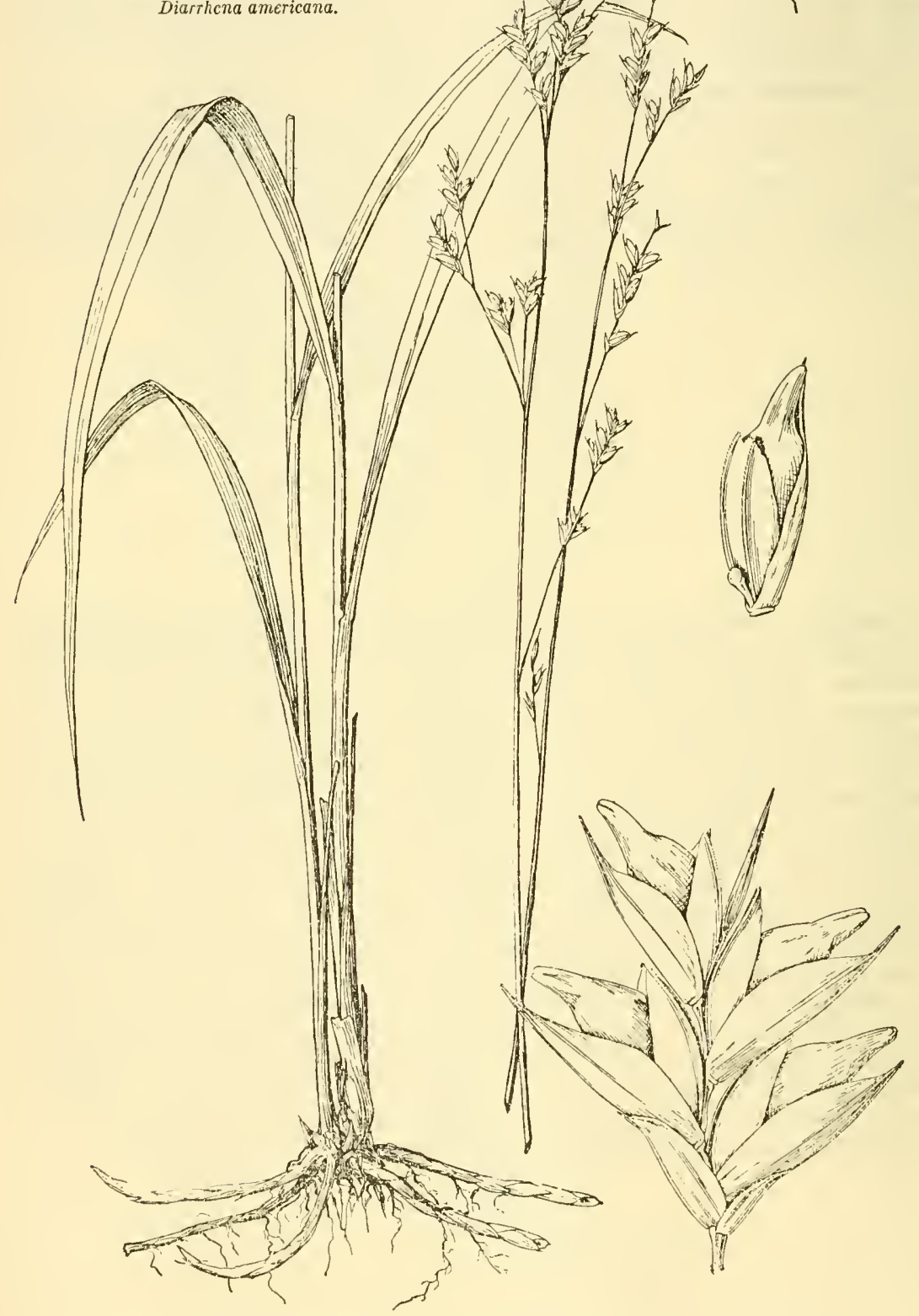

FIGuRe 343.-Diarrhena americana. Plant, $\times 1 / 2$; spikelet and floret, $\times 8$. (Wilcox 66, III.) 


\section{DISSANTHÉLIUM Trin.}

Spikelets mostly 2 -flowered, the rachilla slender, disarticulating above the glumes and between the florets; glumes firm, nearly equal, acuminate, much longer than the lower floret, mostly exceeding all the florets, the first 1-nerved, the second 3-nerved; lemmas strongly compressed, oval or elliptic, acute, 3-nerved, the lateral nerves near the margin; palea somewhat shorter than the lemma. Annuals or perennials with narrow panicles. Type species, Dissanthelium supinum Trin. Name from Greek, dissos, double, and anthelion, a small flower, alluding to the two small florets.

1. Dissanthelium califórnicum (Nutt.) Benth. (Fig. 345.) Annual, lax; culms more or less decumbent or spreading, about $30 \mathrm{~cm}$ tall; blades flat, 10 to $15 \mathrm{~cm}$ long, 2 to $4 \mathrm{~mm}$ wide; panicle 10 to $15 \mathrm{~cm}$ long, narrow but rather loose, the branches in fascicles, ascending, slender, flexuous, some of them floriferous to base; glumes narrow, acute, nearly equal, about $3 \mathrm{~mm}$ long; lemmas pubescent, nearly $2 \mathrm{~mm}$ long. $\odot-$ Open ground, islands off the southern coast of California and of Baja California.

\section{REDFIÉLDIA Vasey}

Spikelets compressed, mostly 3- or 4flowered, the rachilla disarticulating above the glumes and between the florets; glumes somewhat unequal, 1-nerved, acuminate; lemmas chartaceous, 3-nerved, the nerves parallel, densely villous at base; palea as long as the lemma; grain free. A rather tall perennial, with extensive rhizomes, and a large panicle with diffuse capillary branches. Type species, Redfieldia flexuosa. Named for J. H. Redfield.

1. Redfieldia flexuósa (Thurb.) Vasey. Blowout grass. (Fig. 346.) Culms tough, 60 to $100 \mathrm{~cm}$ tall, the rhizones long, slender; blades glabrous, involute, elongate, flexuous, tapering to a fine point; panicle oblong, one-third to half the entire length of the culm; spikelets 5 to $7 \mathrm{~mm}$ long, broadly Vshaped, the glumes acuminate, about half as long as the spikelet; lemmas acute, sometimes mucronate, 4 to $5 \mathrm{~mm}$ long. 21 - Sand hills, South Dakota to Oklahoma, west to Colorado (Fort Garland) and Arizona (Moki Reservation) (fig. 347).

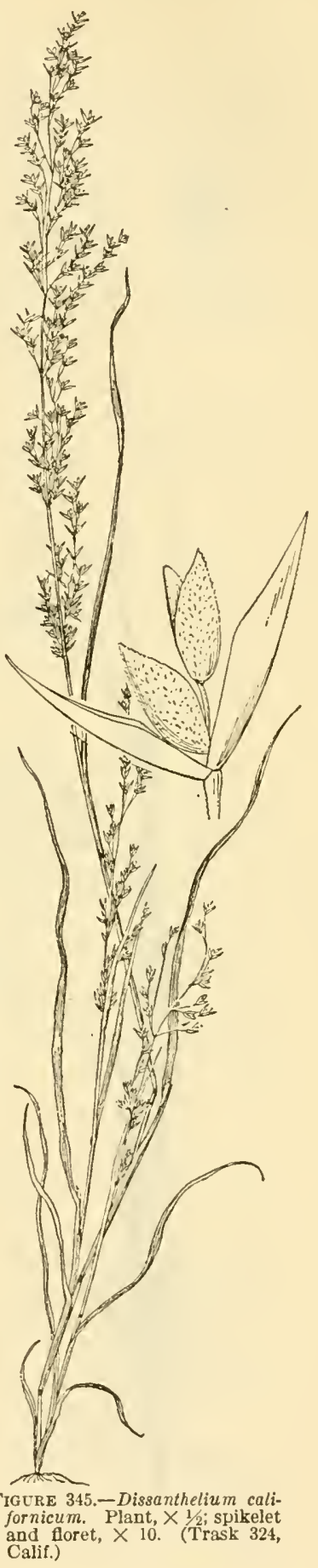

A sand-binding grass. 


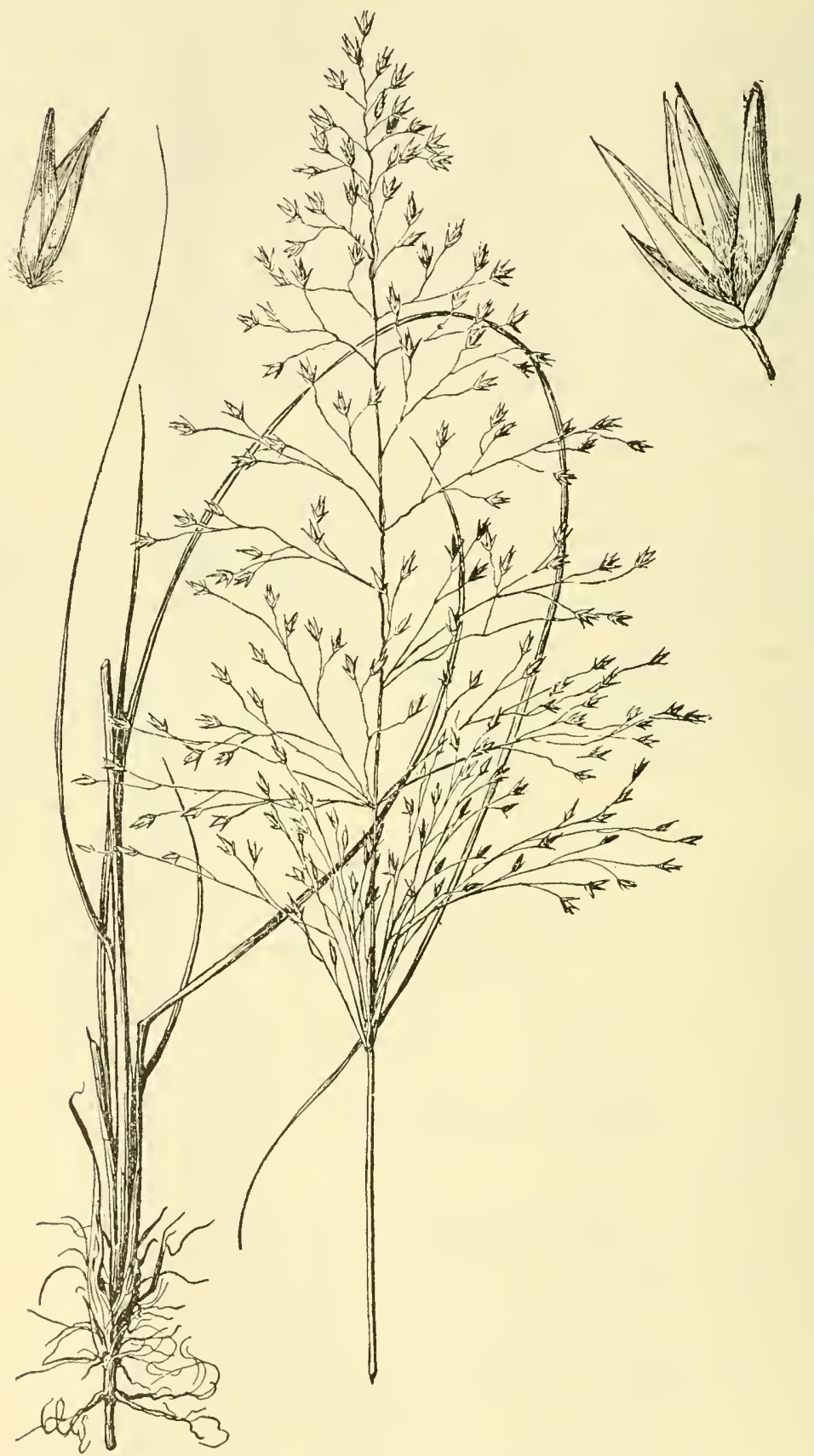

Figure 346.-Redfieldia flexuosa. Plant, $\times 1 \frac{1}{2}$; spikelet and floret, $\times 5$. (Over 2429, S.Dak.) 


\section{MONANTHOCHLOE Engelm.}

Plants dioecious; spikelets 3- to 5-flowered, the uppermost florets rudimentary, the rachilla disarticulating tardily in pistillate spikelets; glumes wanting; lemmas rounded on the back, convolute, narrowed above, several-nerved, those of the pistillate spikelets like the blades in texture; palea narrow, 2-nerved, in the pistillate spilselets convolute around the pistil, the rudimentary uppermost floret enclosed between the keels of the floret next below. A creeping wiry perennial, with clustered short subulate blades, the spikelets inconspicuous at the ends of the short branches, only a little exceeding the leaves. Type species, Monanthochloë littoralis. Name from Greek monos, single, anthos, flower, and chloe, grass, alluding to the unisexual flowers.

1. Monanthochloë littorális Engelm.

(Fig. 348.) Culms tufted, extensively creeping, the short branches erect; blades falcate, mostly less than $1 \mathrm{~cm}$ long, conspicuously distichous in distant to approximate clusters; spikelets 1 to

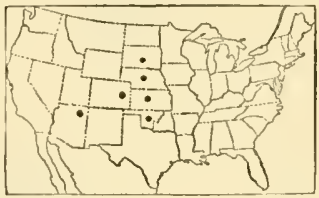

FIgURE 347.-Distribution of Redfieldia flexuosa. few, nearly concealed in the leaves. 24 -Muddy seashores and tidal flats, southern Florida, especially on the keys; Texas (Galveston and southward); southern California (Santa Barbara and southward); Mexico, Cuba.

\section{Dis'TíCHLIS Raf. SALtgrass}

Plants dioecious; spikelets several to many-flowered, the rachilla of the pistillate spikelets disarticulating above the glumes and between the florets; glumes unequal, broad, acute, keeled, 3- to 7-nerved, the lateral nerves sometimes faint; lemmas closely imbricate, firm, the pistillate coriaceous, acute or subacute, with 9 to 11 mostly faint nerves; palea as long as the lemma or shorter, the margins bowed out near the base, the pistillate coriaceous, enclosing the grain. Low perennials, with extensively creeping scaly rhizomes, erect, rather rigid culms, and dense, rather few-flowered panicles. Type species, Distichlis spicata. Name from Greek distichos, 2-ranked, alluding to the distichous leaves.

The species of Distichlis in general have little value for forage but in the interior basins, such as the vicinity of Salt Lake, $D$. stricta is grazed when better grasses are not available.

Plants mostly more than $30 \mathrm{~cm}$ tall; blades not conspicuously distichous, mostly 20 to $40 \mathrm{~cm}$ long; panicle more than $10 \mathrm{~cm}$ long; stolons present,

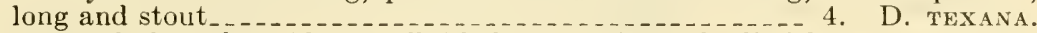
Plants mostly less than $30 \mathrm{~cm}$ tall; blades conspicuously distichous, mostly less than $10 \mathrm{~cm}$ long; panicle rarely more than $5 \mathrm{~cm}$ long; stolons wanting.

Palea as long as the lemma, firm, broad below, the broad wings of the keels finely dentate $\ldots$

Palea shorter than the lemma, rather soft, not much broader below, the narrow wings of the keels entire.

Panicles condensed, the spikelets imbricate, mostly 5- to 9-flowered.

1. D. SPICATA.

Panicles looser, the spikelets less imbricate, the individual spikelets plainly visible, mostly 9 - to 15 -flowered......... 2. D. STRICta. 

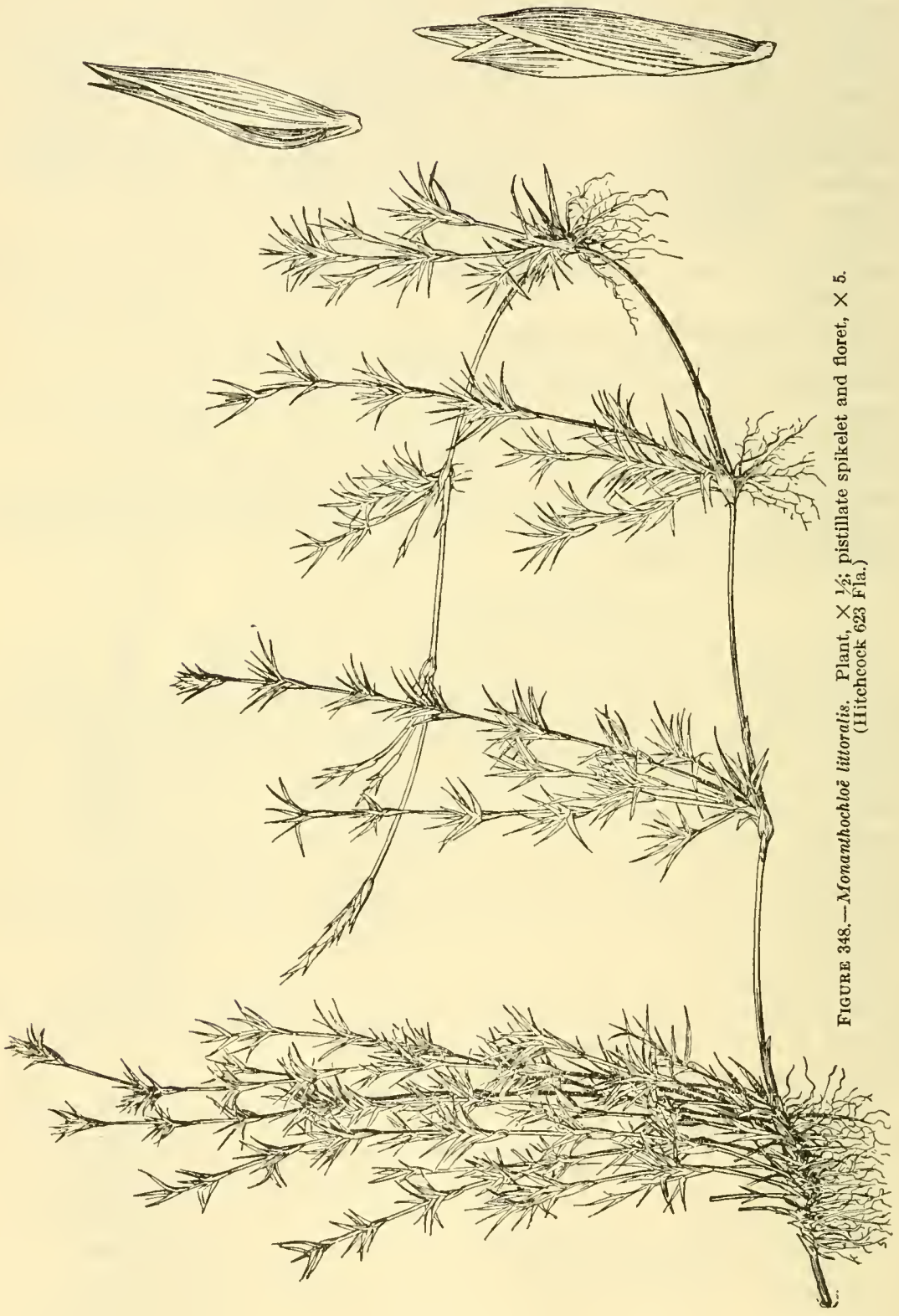
1. Distichlis spicáta (L.) Greene. Seashore Saltarass. (Fig. 349.) Culms 10 to $40 \mathrm{~cm}$ tall, sometimes taller; leaves numerous, the sheaths closely overlapping, the spreading blades conspicuously distichous, flat to involute, sharp-pointed, mostly less than $10 \mathrm{~cm}$ long; panicle usually pale or greenish, 1 to $6 \mathrm{~cm}$ long, rarely longer; spikelets mostly 5- to 9flowered, mostly 6 to $10 \mathrm{~mm}$ long, compressed; lemmas 3 to $6 \mathrm{~mm}$ long, the pistillate more coriaceous and more closely imbricate than the staminate; palea rather soft, narrow, the keels narrowly winged, entire; anthers about $2 \mathrm{~mm}$ long. 2 Seashores, forming dense colonies, Nova Scotia to Florida and Texas; British Columbia to California, Mexico and Cuba; Pacific slope of South America (fig. 350).

2. Distichlis strícta (Torr.) Rydb. Desert SAltgrass. (Fig. 351.) Resembling $D$. spicata; panicles less congested, the individual spikelets easily distinguished; spikelets, especially the staminate, with more florets. 2 -Alkaline soil of the interior, Saskatchewan to eastern Washington, south to Texas and California; Mexico (fig. 352). Staminate spikelets usually stramineous.

3. Distichlis dentáta Rydb. (Fig. 353.) Culms usually low, 10 to $20 \mathrm{~cm}$, much-branched, rather stout; blades on the average wider than in $D$. spicata; panicles usually overtopped by

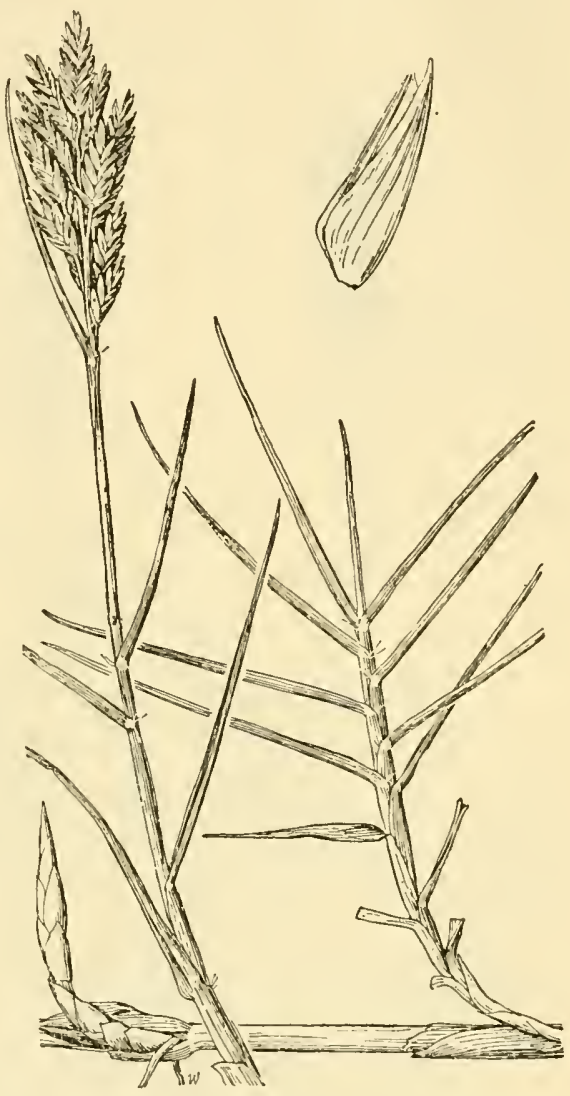

Figure 349.-Distichlis spicata. Plant, $\times 1$; floret, $\times 5$. (Hitcheock 2826, Oreg.) the leaves; spikelets usually many-flowered, the florets firm, closely imbricate; palea about as long as the lemma, firm, much broader below,

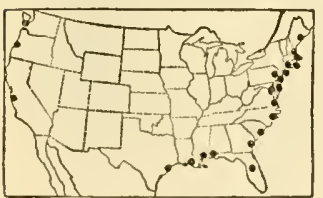

FIGURe 350.-Distribution of Distichlis spicata. the keels with wide finely dentate wings. 24 -Alkaline soil in the interior, western Colorado (Delta) to Washington, northern Arizona, and California (fig. 354). This and the two preceding species a ppear to be distinct for the most part but some specimens are intermediate.

4. Distichlis texâna (Vasey) Scribn. (Fig. 355.) Culms erect from a decumbent base, 30 to $60 \mathrm{~cm}$ tall, producing extensively creeping rhizomes and long stout stolons; blades flat, firm, glabrous beneath, scabrous on the upper surface, mostly 20 to $40 \mathrm{~cm}$ long, 2 to 


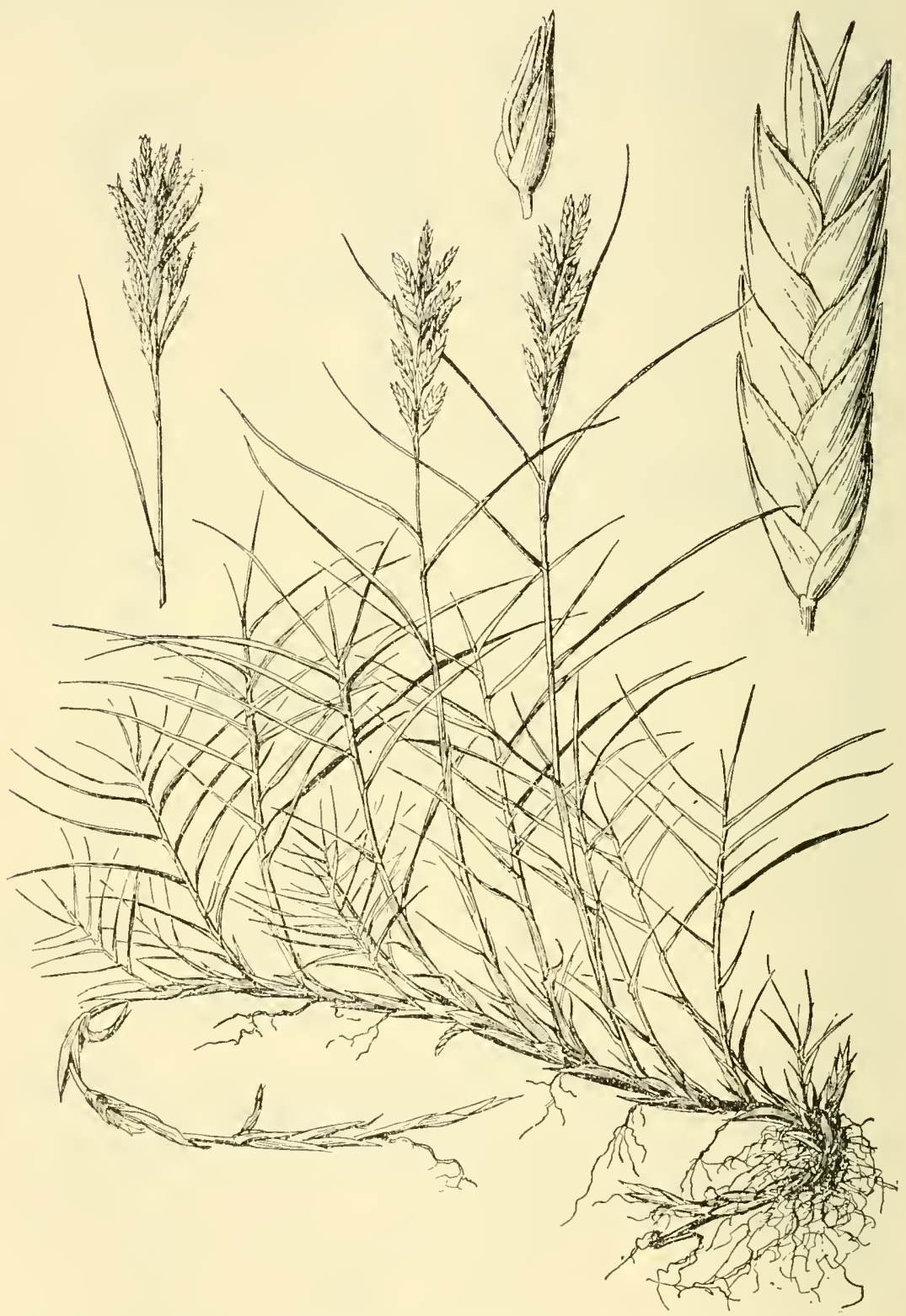

Fistichlis stricto. Staminate plant and pistilate panicle, $\times 1 / 2$; pistillate spikelet and floret, $\times 5$, (Mearns 3132, Calif.) 
$6 \mathrm{~mm}$ wide; panicle narrow, pale, 10 to $25 \mathrm{~cm}$ long, somewhat interrupted, the branches appressed; spikelets somewhat compressed, 4to S-flowered, 1 to $1.5 \mathrm{~cm}$ long; glumes 5 and $7 \mathrm{~mm}$ long, acute; lemmas of pistillate spikelets closely imbricate and appressed, about 8 $\mathrm{mm}$ long with 3 strong nerves, the intermediate nerves obscure, acute, the margins broad, hyaline; palea of pistillate spikelets shorter than the lemma, strongly bowed out below, closely convolute around the pistil, the keels with narrow erose or toothed wings;

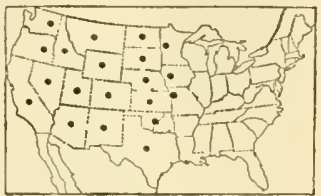

FIGURE 352.-Distribution of Distichlis stricta. lemmas of staminate spikelets more spreading, about $6 \mathrm{~mm}$ long;

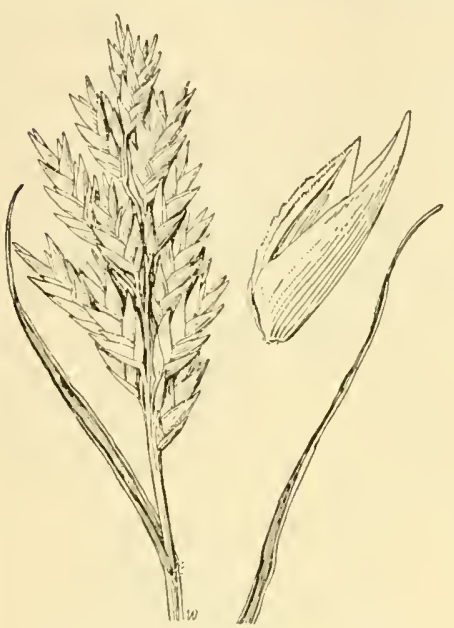

FIGURE 353.-Distichlis dentata. Panicle, $\times 1$; lloret, $\times 5$. (Dupl. type.)

palea about as long as the lemma, not bowed out, not convolute, the keels minutely scabrous, not winged; anthers $3 \mathrm{~mm}$ long. 2

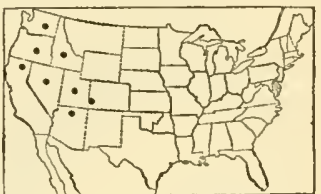

FIGURE 354.-Distribution of Distichlis dentata.

-Sand flats, Presidio, Tex., and northern Mexico.

\section{UNÍOLA L.}

Spikelets 3- to many-flowered, the lower 1 to 4 lemmas empty, the rachilla disarticulating above the glumes and between the florets; glumes compressedkeeled, rigid, usually narrow, 3- to 7-nerved, acute or acuminate, rarely mucronate; lemmas compressed, sometimes conspicuously flattened, chartaceous, many-nerved, the nerves sometimes obscure, acute or acuminate, the empty ones at the base and the uppermost usually reduced; palea rigid, strongly keeled, bowed out at base, weakly so in Uniola paniculata. Rather tall, erect perennials, with flat or sometimes convolute blades and narrow or open panicles of compressed, sometimes very broad and flat spikelets. Type species, Uniola paniculata. Ancient Latin name of a plant.

The inland species are not abundant enough to be of value for forage. Uniola latifolia is worthy of cultivation as an ornamental; $U$. paniculata is a sand binder along the southern seacoast; the seeds of $U$. palmeri Vasey of Mexico are used for food by the Cocopa Indians.

Rhizomes extensively creeping; blades firm, flat at base, taper-

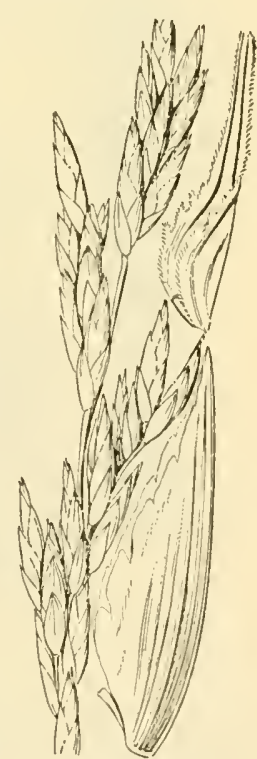

FIGURE 355.-Distichlis tezana. Panicle, $X$ 1 ; lemma and palea. $\times 5$. (Nealley, Tex.)

ing into a long flexuous involute point; empty lemmas about 4 ; coastal dunes. 
Rhizomes wanting or short and knotty; blades thin, flat; empty lemma 1 (2 or 3 in $U$. ornithorhyncha); rich or moist woods.

Spikelets 8- to 12 -flowered on slender pedicels; panicle nodding or drooping. 2. U. LATIFOLIA.

Spikelets 3- to 7-flowered, nearly sessile; panicle erect, nearly simple, the branches stiff.

Spikelets more than $10 \mathrm{~mm}$ (usually more than $12 \mathrm{~mm}$ ) wide, with 5 to 7 fertile florets.

Sterile lemma 1; panicle 10 to $15 \mathrm{~cm}$ long, the lower branches with 2 to 5 rather distant spikelets _.......

Sterile lemmas 2 or 3 ; panicle 3 to $8 \mathrm{~cm}$ long, the branches very short with approximate spikelets_.............. 4 . U. ORNITHORHYNCHA.

Spikelets rarely as much as $\mathrm{S} \mathrm{mm}$ wide at maturity, $\mathrm{V}$-shaped, with 1 to 4 fertile florets (rarely more), and 1 sterile lemma.

Collar of sheath pubescent, the sheaths commonly loosely long-pubescent, rarely glabrous _............

Collar and sheaths glabrous or nearly so. -

1. Uniola paniculáta L. Sea oats. (Fig. 356.) Culms stout, about $1 \mathrm{~m}$ tall, from extensively creeping rhizomes; blades flat, firm, elongate, becoming invo-

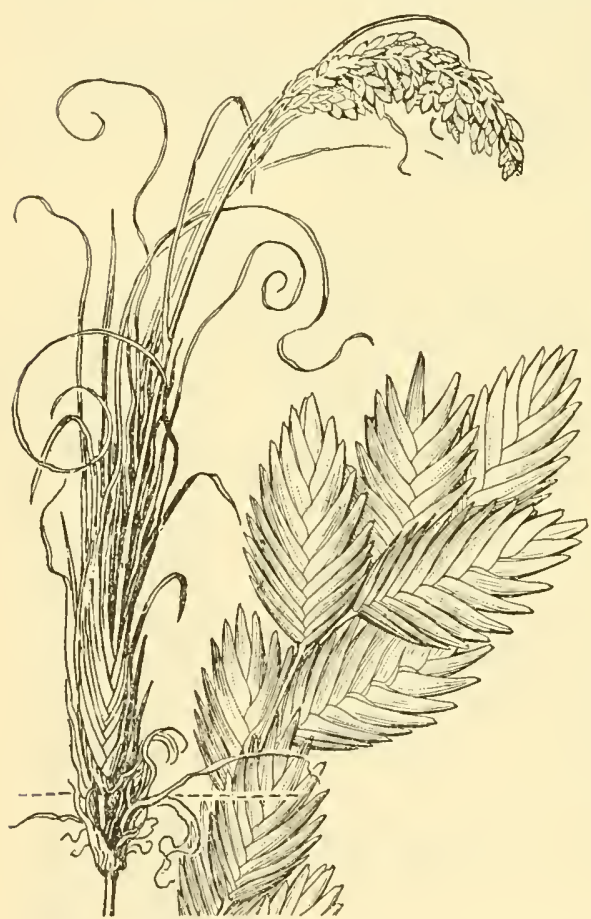

FIgure 356.-Uniola paniculata. Plant, $\times 1 / 10$; spikelets, $\times 1$. (Kearney 2134, Ia.) lute toward the long, fine flexuous point; panicle pale, narrow, condensed, heavy and nodding, 20 to $40 \mathrm{~cm}$ long, the branches arching and drooping, as much as $12 \mathrm{~cm}$ long; spikelets very flat, 10- to 20-flowered, mostly 2 to $2.5 \mathrm{~cm}$ long, $1 \mathrm{~cm}$ wide, the first 4 or 5 lemmas empty,

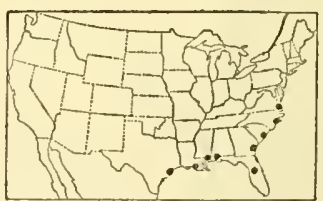

F1GURE 357.-Distribution of Uniola paniculata.

the slender pedicels shorter than the spikelets; lemmas about 9-nerved, strongly compressed-kecled, about $1 \mathrm{~cm}$ long, acute; palea acute, as long as the lemma, the strong wings of the keels ciliate. 24 -Sand dunes of the seacoast, Cape Henry to Florida and Texas; northern West Indies; eastern Mexico (fig. 357).

2. Uniola latifólia Michx. Broadleaf uniola. (Fig. 358.) Culms 1 to $1.4 \mathrm{~m}$ tall, with short strong rhizomes, forming colonies; blades flat, narrowly lanceolate, 10 to $20 \mathrm{~cm}$ long, mostly 1 to $2 \mathrm{~cm}$ wide; panicle open, drooping, 10 to $20 \mathrm{~cm}$ long, the branches bearing a few large, very flat spikelets, the pedicels capillary; spikelets 8- to 12 -flowered, 2 to $3.5 \mathrm{~cm}$ long, 1 to $1.5 \mathrm{~cm}$ wide, green or finally tawny, the first lemma empty; lemmas lanceolate, strongly compressed-keeled, acute, about $1 \mathrm{~cm}$ long, striate-nerved, the keel 


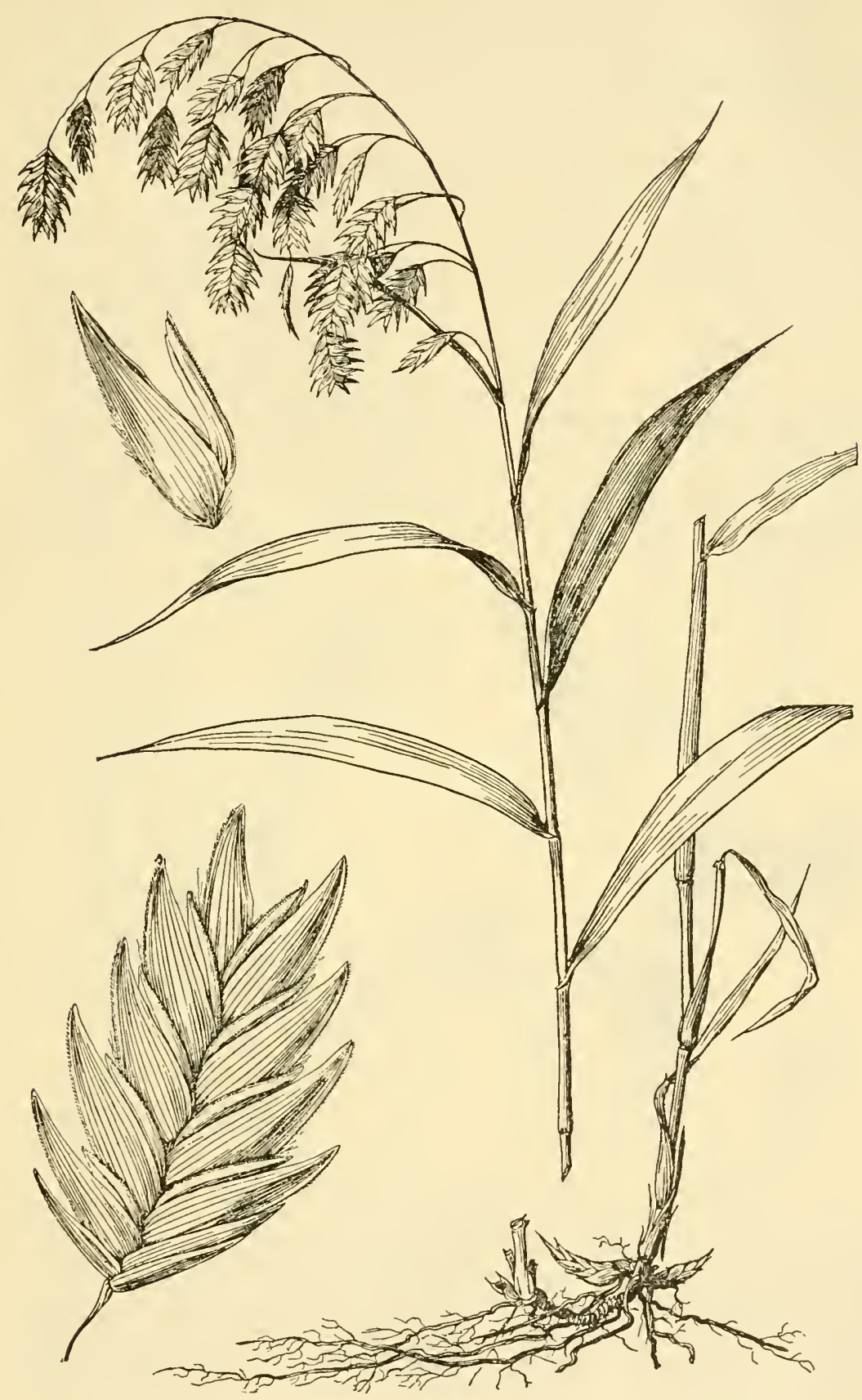

FIGURE 358.- Uniola latifolia. Plant, $\times 1 / 2$; spikelet and floret, $\times 3$. (Chase 5874, Md.) 
ciliate with soft ascending hairs, the callus pilose; palea shorter than the lemma, wing-keeled; caryopsis flat, oval, black, $5 \mathrm{~mm}$ long. 24 -Rich woods, Pennsylvania and New Jersey to Illinois and Kansas, south to Florida and Texas (fig. 359).

3. Uniola nítida Baldw. (Fig. 360.) Culms slender, 50 to $75 \mathrm{~cm}$ tall, erect, loosely tufted, with short rhizomes; blades flat, spreading,

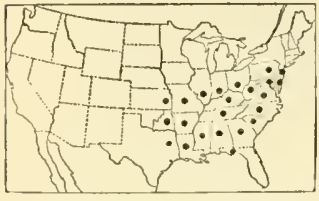

Figure 359.-Distribution of Uniola latifolia.

prominently winged. mostly less than $15 \mathrm{~cm}$ long, 4 to $8 \mathrm{~mm}$ wide; panicle open, few-flowered, 10 to $15 \mathrm{~cm}$ long, with a few spreading branches 3 to $8 \mathrm{~cm}$ long, bearing 2 to 5 nearly sessile spikelets; spikelets 4- to 7-flowered, 1 to $1.5 \mathrm{~cm}$ long, about $1 \mathrm{~cm}$ wide, the first lemma empty; lemmas spreading, 7 to $10 \mathrm{~mm}$ long, compressed-keeled, gradually acuminate, striate-nerved; palea equaling the lemma, acuminate, 2-toothed, the keels 21 -Moist woods, Sonth Carolina to Florida.

4. Uniola ornithorhýncha Steud. (Fig. 361.) Culms slender, 30 to $50 \mathrm{~cm}$ tall, loosely tufted with short rhizomes; sheaths pubescent on the collar; blades flat, thin, mostly less than $15 \mathrm{~cm}$ long, 3 to $6 \mathrm{~mm}$ wide; panicle narrow, 3 to $9 \mathrm{~cm}$ long, the short approximate branches with 1 to 3 nearly sessile spikelets or the lower somewhat

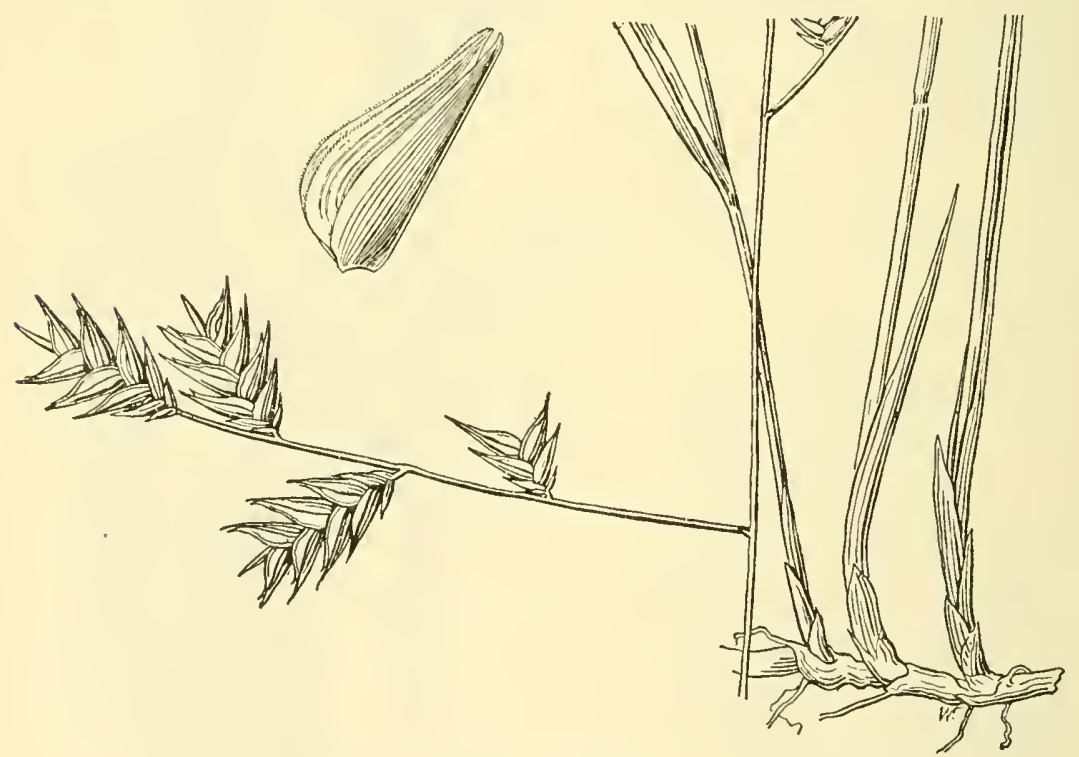

Figure 360.-Uniola nitida. Plant, $\times 1$; floret, $\times 5$. (Curtiss 3521, Fla.)

distant with 4 to 6 spikelets, pubeseent in the axils; spikelets very flat, with 3 or 4 widely spreading fertile florets, the 2 or 3 lower lemmas empty, appressed; fertile lemmas about $S \mathrm{~mm}$ long, narrow, gradually acuminate, striate-nerved; palea as long as or longer than the lemma, acuminate, 2-toothed, strongly bowed out below, the keels rather narrowly winged. 24 Low woods or hummocks in swamps, Alabama to Louisiana. 
5. Uniola sessiliflóra Poir. (Fig. 362.) Culms ereet, 0.5 to 1.5 $\mathrm{m}$ tall, in loose tufts with short rhizomes; sheaths pilose, at least toward the summit; blades elongate, firm, mostly sparsely pilose on the upper surface toward the base, 5 to $10 \mathrm{~mm}$ wide, tapering to base; panicle long-exserted, 20 to $50 \mathrm{~cm}$ long, narrow, the branches distant,

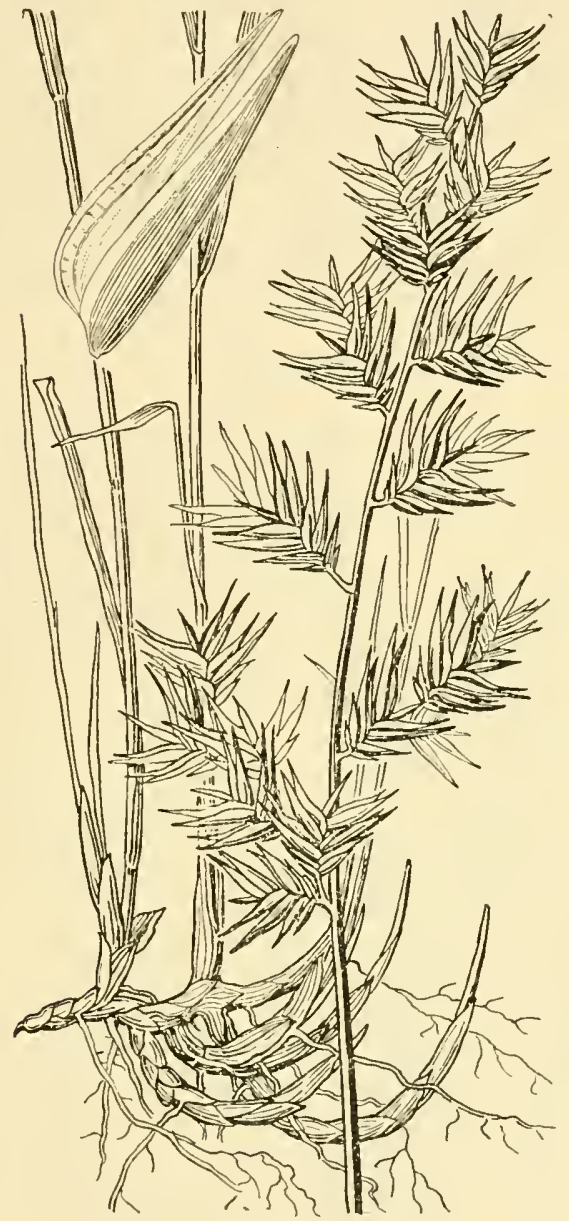

Figure 361-Uniola ornithorhyncha. Plant, $\times 1$. floret, $X$ 5. (Tracy and Lloyd 448 , Miss.) stiffly ascending or appressed, the lower as much as $7 \mathrm{~cm}$ long, the upper short, somewhat capitate; spikelets nearly sessile, aggregate in clusters, flat, usually 3- to 5-flowered, broadly $V$-shaped at maturity, the first

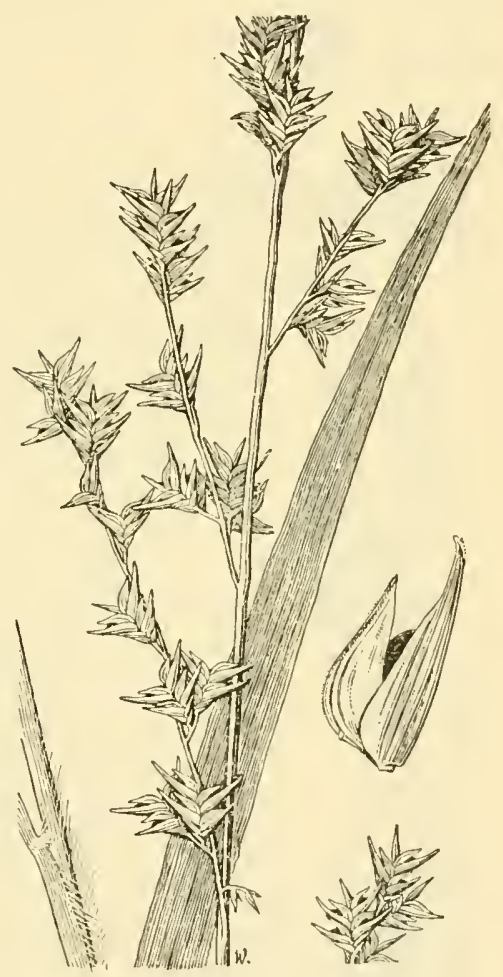

Figure 362.-Uniola sessiliflora. Plant, $\times 1$; floret, $X 5$. (Tracy, Miss.)

lemma empty; glumes about $2 \mathrm{~mm}$ long; lemmas spreading, about 5 $\mathrm{mm}$ long, acuminate, beaked, especially before maturity, striate nerved; palea shorter than the lemma, acute, broad, the keels narrowly winged; grain black, $3 \mathrm{~mm}$ long, at maturity spreading the lemma and palea. 24 ( $U$. longifolia Scribn.)-Rich woods, southeastern Virginia to Tennessee and Oklahoma, south to Florida and eastern Texas (fig. 363). 
6. Uniola láxa (L.) B.S.P. (Fig. 364.) Culms slender, 60 to 100 $\mathrm{cm}$ tall, erect to nodding from a loosely tufted sometimes knotty base; blades elongate, flat to sometimes loosely involute, 3 to $6 \mathrm{~mm}$ wide; panicle narrow, slender, 15 to $30 \mathrm{~cm}$ long, the branches short, appressed,

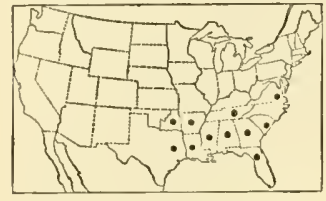

Figure 363.-Distribution of Uniola sessilifiora. approximate, the lower sometimes $3 \mathrm{~cm}$ long and distant; spikelets nearly sessile, approximate, flat, usually 3 - to 4-flowered, the first lemma empty; lemmas spreading, 4 to $5 \mathrm{~mm}$ long, gradually acuminate, striate-nerved; palea broad, the keels narrowly winged; grain black, $2.5 \mathrm{~mm}$ long, at maturity spreading the lemma and palea. 2 -Moist woods, Coastal Plain, Long Island to Florida and Texas, extending to western North Carolina, Kentucky, and Arkansas (fig. 365).

\section{DÁCtTYLIS L. Orchard grass}

Spikelets few-flowered, compressed, finally disarticulating between the florets, nearly sessile in dense 1-sided fascicles, these borne at the ends of the few branches of a panicle; glumes unequal, carinate, acute, hispid-ciliate on the keel; lemmas compressed-keeled, mucronate, 5-nerved, ciliate on the keel. Perennials, with

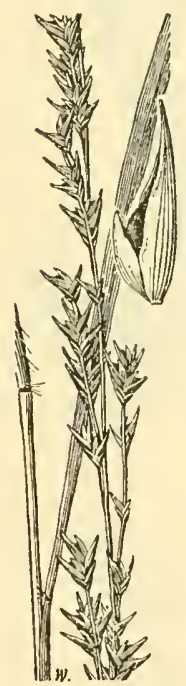

FIGURE 364.-Uniola laxa. Plant, $\times 1$; floret, $\times 5$. (Ván Eseltine and $M$ oseley 178, D.C.) flat blades and fascicled spikelets. Type species, Dactylis glomerata. Name from Greek dactulos, a finger, alluding to the stiff branches of the panicle.

1. Dactylis glomeráta L. Orchard Grass. (Fig. 366.) Culms in large tussocks, 60 to $120 \mathrm{~cm}$ tall; blades elongate, 2 to $8 \mathrm{~mm}$ wide; panicles 5 to 20 cm long, the few distant stiff solitary branches ascending, or spreading at anthesis, appressed at nıaturity, the lowermost sometimes as much as $10 \mathrm{~cm}$ long; lemmas about $8 \mathrm{~mm}$ long, mucro-

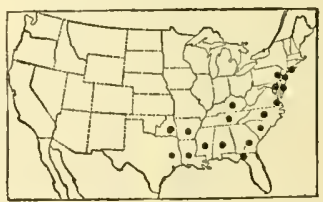

Figure 365.-Distribution of Uniola laxa. nate or short-awned. 24 - Fields, meadows, and waste places, Newfoundland to southeastern Alaska, south to Florida and central California; Eurasia. Commonly cultivated as a meadow and pasture grass. In England called cocksfoot. A variegated form (called by gardeners var. variegata) is occasionally cultivated for borders.

\section{CYNOSÚRUS L. Dogtail}

Spikelets of two kinds, sterile and fertile together, the fertile sessile, nearly covered by the short-pediceled sterile one, these pairs imbricate in a dense 1 -sided spikelike panicle; sterile spikelets consisting of 2 glumes and several narrow, acuminate, 1 -nerved lemmas on a continuous rachilla; fertile spikelets 2- or 3-flowered, the glumes narrow, the lemmas broader, rounded on the back, awn-tipped, the rachilla disarticulating above 


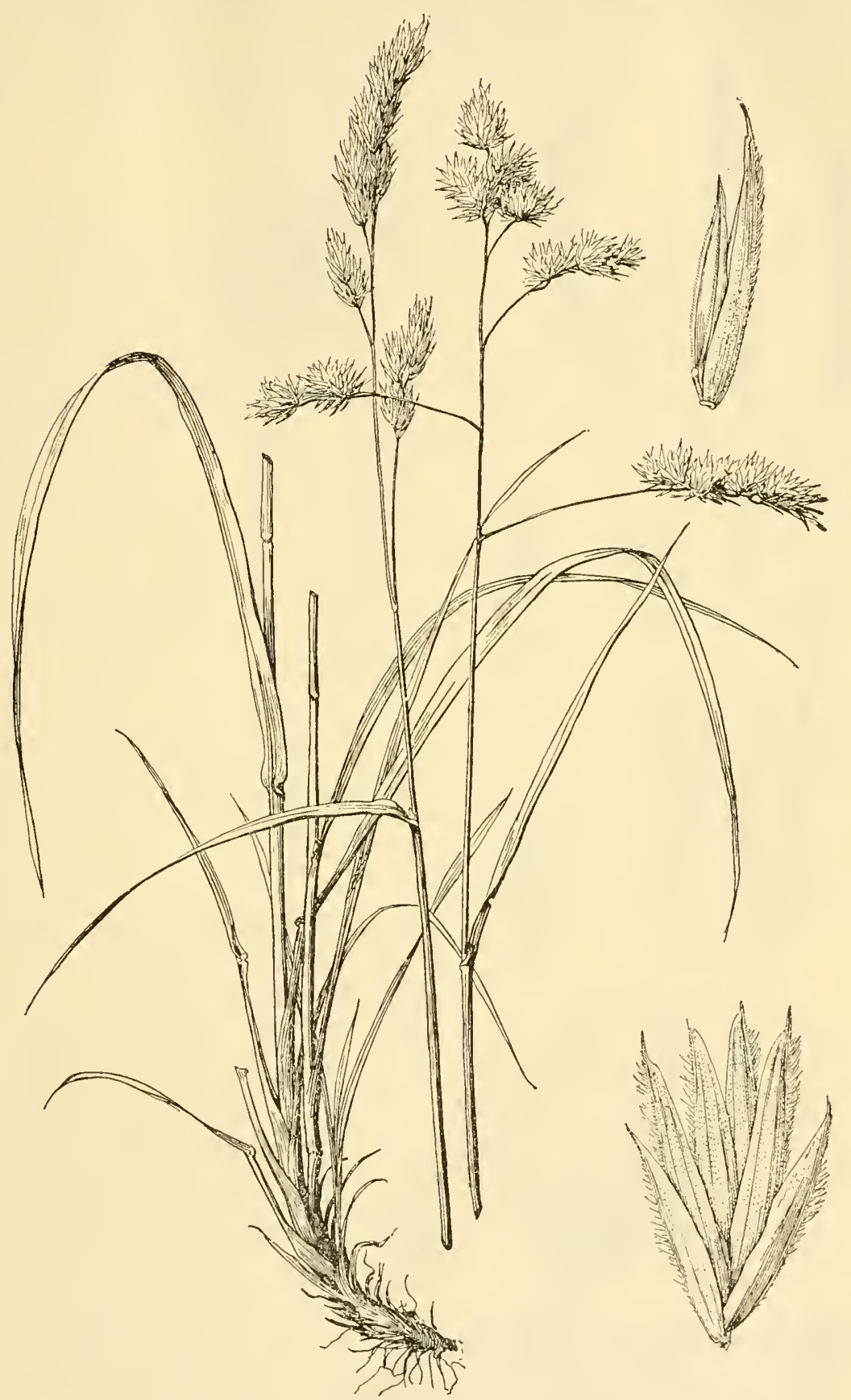

Figure 366.-Dactylis glomerata. Plant, $\times 1 / 2$; spikelet and floret, $\times 5$. (Wilson 1334 , Conn.) 
the glumes. Annuals or perennials with narrow flat blades and dense spikelike or subcapitate panicles. Type species, Cynosurus

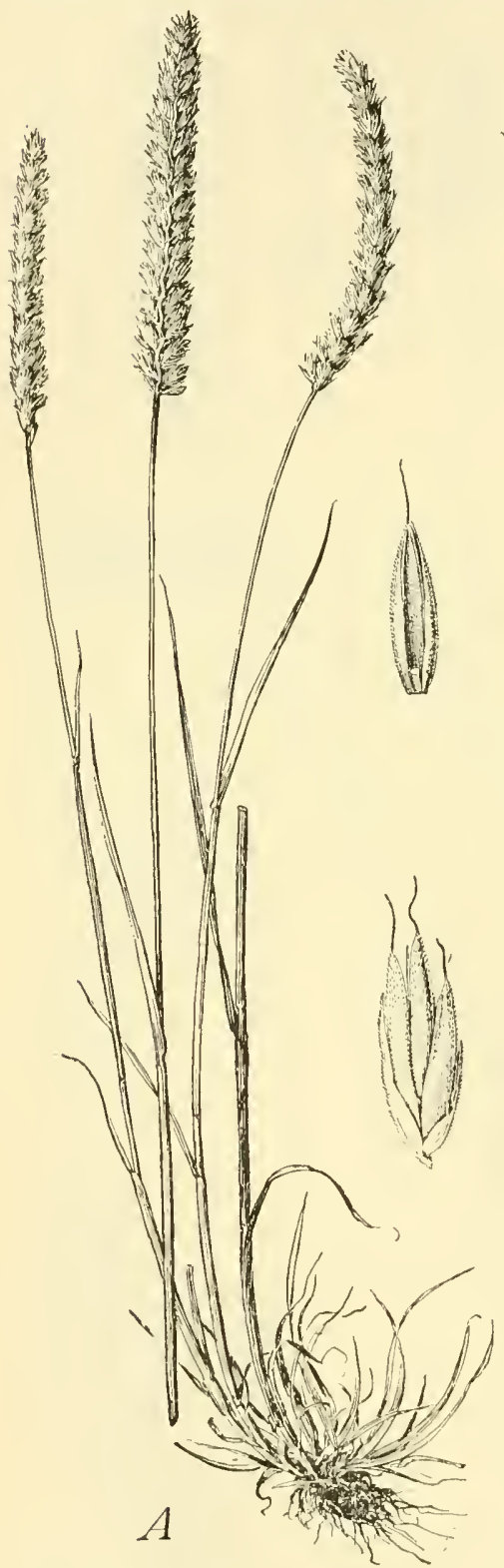

Figure $36 \%-A$. Cynosurus cristatus. Plant, $X$ $1 / 2$; fertile spikelet and floret, $\times 5$. (Waghorne floret, $\times 5$. (Macoun 80976 , Vancouver Isl.) 23, Newt.) $B$. C. cchinatus. Panicle $\times 1$; fertile

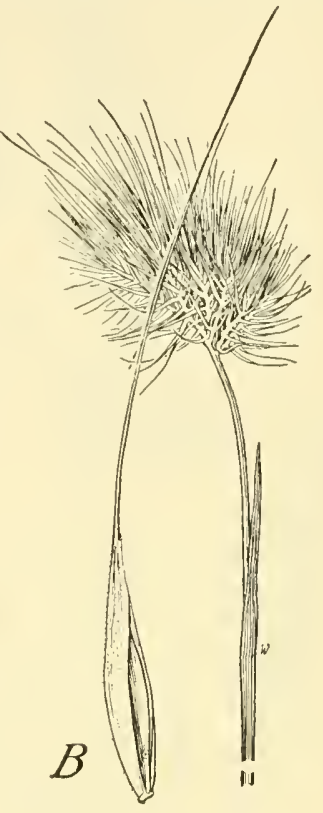

cristatus. Name from Greek kuon (kun-) dog, and oura, tail.

Plants perennial; panicles narrow, spikelike; awns inconspicuous 1. C. cristatus. Plants annual; panicles subcapitate; awns conspicuous - 2. C. ECHinatus.

\section{Cynosurus cristátus L.} Crested dogtail. (Fig. $367, A$.) Perennial; culms tufted or geniculate at base, erect, 30 to $60 \mathrm{~cm}$ tall; panicle spikelike, linear, more or less curved, 3 to $8 \mathrm{~cm}$ long; pairs of spikelets about $5 \mathrm{~mm}$ long; lemmas with awns mostly not more than $1 \mathrm{~mm}$ long. 24 -Fields and waste places, Newfoundland to Michigan and Virginia; Washing-
oduced from Europe. Occasionally ton and Oregon (fig. 368); introduced from Europe. Occasionally cultivated in mixtures for meadows but of little value. 
2. Cynosurus echinátus L. (Fig. 367, B.) Annual; culms 20 to $40 \mathrm{~cm}$ tall; blades short; panicle subcapitate, 1 to $4 \mathrm{~cm}$ long, bristly; pairs of spikelets 7 to $10 \mathrm{~mm}$ long; lemmas with awns 5 to $10 \mathrm{~mm}$ long. $\odot$-Open ground, British Columbia; Oregon to central California; introduced from Europe.

\section{LAMĀRCKIA Moench}

\section{(Achyrodes Boehmer)}

Spikelets of two kinds, in fascicles, the terminal one of each fascicle fertile, the others sterile; fertile spikelet with 1 perfect floret on a slender stipe and a rudimentary floret on a long rachilla-joint, both awned, the glumes narrow, acuminate or short-awned, 1-nerved; lemma broader, scarcely nerved, bearing just below the apex a delicate awn; sterile spikelets linear, 1 to 3 in each fascicle, consisting of 2 glumes similar to those of the fertile spikelet, and numerous imbricate, obtuse, awnless, empty lemmas, a reduced spikelet similar to the fertile one borne on the pedicel with one of the sterile ones.Low annual with flat blades and oblong, 1-sided, dense panicles, the crowded fascicles drooping, the fertile being hidden, except the awns, by the numerous sterile ones; fascicles falling entire. Type species, Lamarckia aurea. Named for J. B. Lamarck.

1. Lamarckia aúrea (L.) Moench. GoldenTop. (Fig. 369.) Culms erect or decumbent at base, 10 to $40 \mathrm{~cm}$ tall; blades soft, 3 to $7 \mathrm{~mm}$ wide; panicle dense, 2 to $7 \mathrm{~cm}$ long, 1 to $2 \mathrm{~cm}$ wide, shining, golden-yellow to purplish, the branches short, erect, the branchlets capillary,

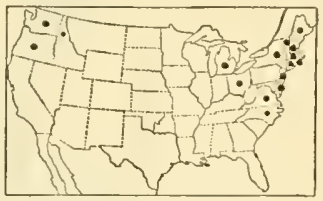

Figure 368,-Distribution of Cynosurus cristatus. flexuous; pedicels fascicled, pubescent, with a tuft of long whitish hairs at the base; fertile spikelet about $2 \mathrm{~mm}$ long, the awn of lemma about twice as long as the spikelet; sterile spikelet 6 to $8 \mathrm{~mm}$ long. $\odot$ -Open ground and waste places, Texas, Arizona, southern California, and northern Mexico; introduced from the Mediterranean region. Sometimes cultivated for ornament.

\section{ARUNDO L.}

Spikelets several-flowered, the florets successively smaller, the summits of all about equal, the rachilla glabrous, disarticulating above the glumes and between the florets; glumes somewhat unequal, membranaceous, 3-nerved, narrow, tapering into a slender point, about as long as the spikelet; lemmas thin, 3-nerved, densely and softly long-pilose, gradually narrowed at the summit, the nerves ending in slender teeth, the middle one extending into a straight awn. Tall perennial reeds, with broad linear blades and large plumelike terminal panicles. Type species, Arundo donax. Arundo, the ancient Latin name.

1. Arundo dónax L. Giant Reed. (Fig. 370.) Culms stout, in large clumps, 2 to $6 \mathrm{~m}$ tall, sparingly branching, from thick knotty rhizomes; blades numerous, elongate, 5 to $7 \mathrm{~cm}$ wide on the main culm, conspicuously distichous, spaced rather evenly along the culm, the margin scabrous; panicle dense, erect, 30 to $60 \mathrm{~cm}$ long; spikelets $12 \mathrm{~mm}$ long. 2 -Along irrigation ditches, Texas to southern 


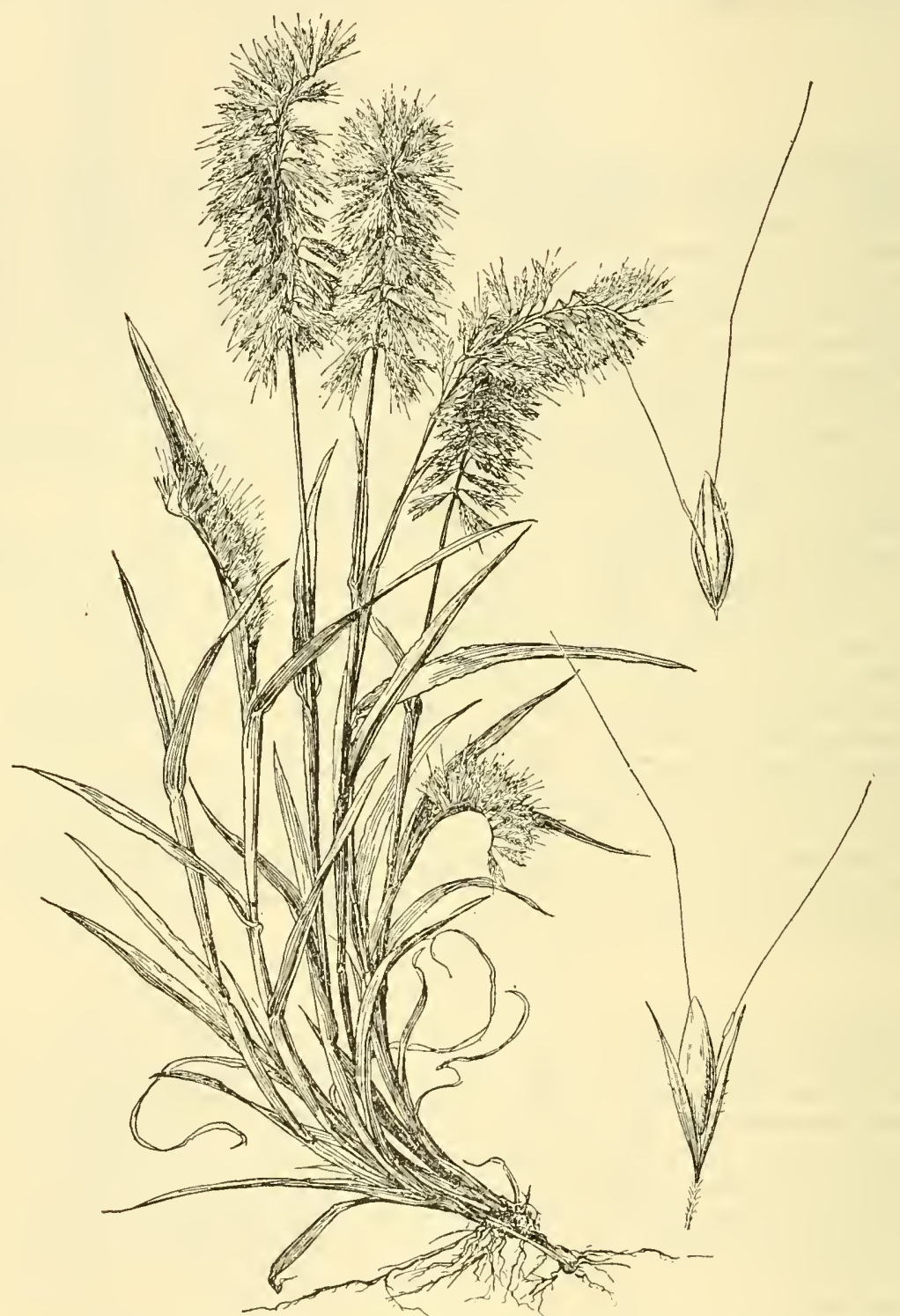

Figure 339.-Lamarclia aurea. Plant, $\times \frac{1}{2}$; fertils spikelet and floret, $\times 5$. (Baker 5275, Calif.) 


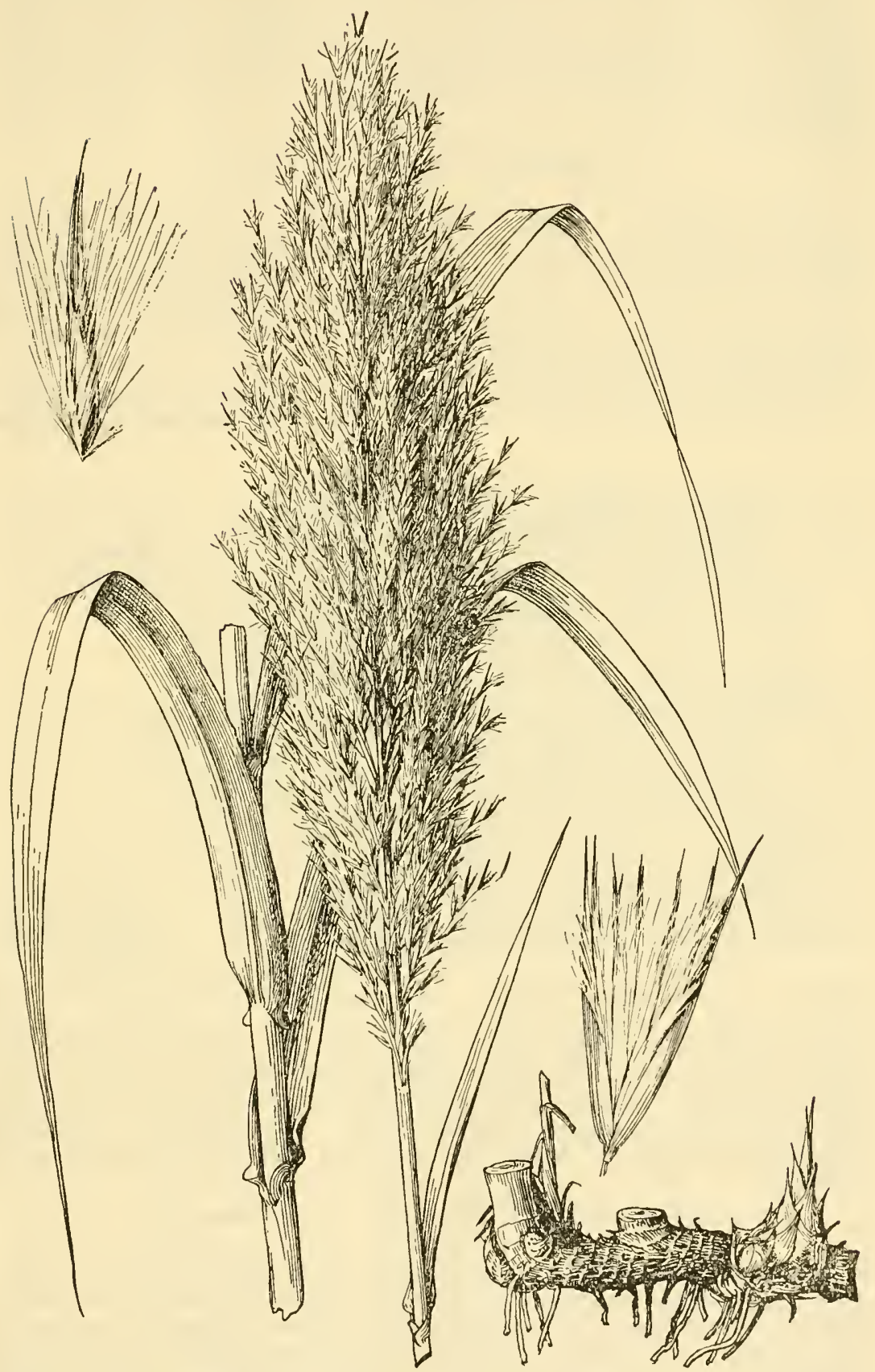

Figure 370.-Arundo donax. Plant, $\times 1 / 3$; spikelet and floret, $\times 3$. (Biltmore Herb. 7514, N.C.) 
California, occasionally established eastward; tropical America; introduced from the warm regions of the Old World. Frequently cultivated for ornament, including var. versicolor (Miller) Stokes, with white-striped blades. In the Southwest the culms are used for lattices, mats, and screens, and in the construction of adobe huts. In Europe the culms are used for making the reeds of clarinets and organ pipes.

\section{GYNÉRIUM Humb. and Bonpl.}

Plants dioecious; spikelets several-flowered, the pistillate with long-attenuate glumes and smaller long-silky lemmas, the staminate with shorter glumes and glabrous lemmas. Tall perennial reeds with plumelike panicles. Type species, Gynerium saccharoides (G. sagittatum). Name from Greek gune, female, and erion, wool, referring to the woolly pistillate spikelets.

Gynerium sagittátum (Aubl.) Beauv. Uva Grass. Culms as much as 10 or $12 \mathrm{~m}$ tall, clothed below with the overlapping old sheaths,
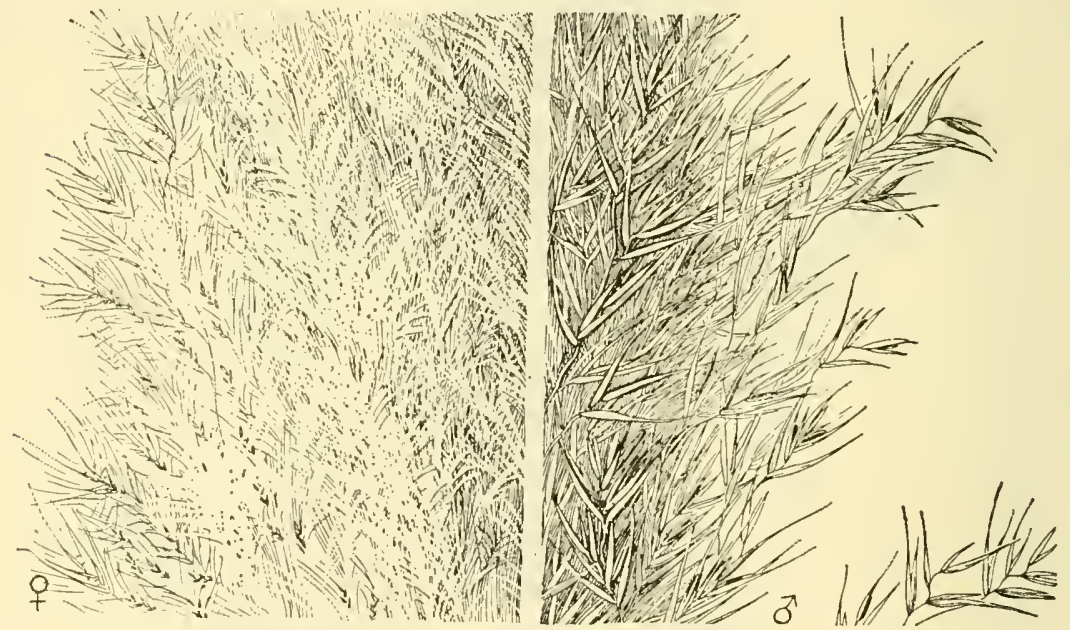

Figure 371.-Cortaderia selloana. Pistillate $(q)$ and staminate $\left(\sigma^{7}\right)$ panicles, $\times 1$. (Silveus 308, Tex.)

the blades having fallen; blades sharply serrulate, commonly $2 \mathrm{~m}$ long, 4 to $6 \mathrm{~cm}$ wide, forming a great fan-shaped summit to the sterile culms, panicle pale, plumelike, densely flowered, $1 \mathrm{~m}$ or more long, the main axis erect, the branches drooping. 21-Occasionally cultivated for ornament in greenhouses. River banks and wet ground, tropical America.

\section{CORTADÉRIA Stapf. Pampasgrass}

Spikelets several-flowered; rachilla internodes jointed, the lower part glabrous, the upper bearded, forming a stipe to the floret; glumes longer than the lower florets; lemmas of pistillate spikelets clothed with long hairs. Large tussock grasses, with leaves crowded at the base, the blades elongate, narrow, attenuate, the margins usually serrulate; panicle large, plumelike. Type species, Cortaderia 
argentea ( $C$. selloana). Name from the Argentine native name cortadera, eutting, beeause of the eutting edges of the blades.

1. Cortaderia selloána (Schult.) Aschers. and Graebn. PampasGRAss. (Fig. 371.) Dioecious peremnial reed, in large bunches; culms stout, erect, 2 to 3 or more m tall; panicle feathery, silvery white to pink, 30 to $100 \mathrm{~cm}$ long; spikelets 2- to 3 -flowered, the pistillate silky with long hairs, the staminate naked; glumes white, papery, long, slender; lemmas bearing a long slender awn. 2 (Gynerium argenteum Nees.)-Plains and open slopes, Brazil to Argentina and Chile. Cultivated as a lawn ornamental in the warmer parts of the United States; in southern California grown commercially for the plumes which are used for decorative purposes, the culms here being sometimes as much as $7 \mathrm{~m}$ tall.

Cortaderia rudiúscula Stapf. Differing from C. selloana in the looser yellowish or purplish panicle; spikclets somewhat smaller. 21 -Occasionally cultivated for ornament; Argentina. Has been called C. quila Stapf, but that name is ultimately based on Arundo quila Molino, which is a bamboo, Chusquea quila (Molino) Kunth.

Ampelodésmos mauritánicus (Poir.) Dur. and Schinz. Tall slender reed; blades with a half twist at base, elongate, thick, narrow, ending in a long scabrous setaceous tip; panicle 30 to $50 \mathrm{~cm}$ long, the slender branches drooping, naked at base, with large crowded spikelets toward the ends. 2l -Grown for ornament in California. Mediterranean region. Generic name often incorrectly spelled Ampelodesma.

\section{PHRAGMÍTES Trin.}

Spikelets several-flowered, the rachilla clothed with long silky hairs, disartieulating above the glumes and at the base of each joint between the florets, the lowest floret staminate or neuter; glumes 3-nerved, or the upper 5-nerved, lanceolate, acute, unequal, the first about half as long as the upper, the second shorter than the florets; lemmas narrow, long-acuminate, glabrous, 3-nerved, the florets successively smaller, the summits of all about equal; palea much shorter than the lemma. Perennial reeds, with broad, flat, linear blades and large terminal panicles. Type species, Arundo phragmites L. (Phragmites communis). Name from Greek in reference to its growth like a fence (phragma) along streams.

1. Phragmites commúnis Trin. Common Reed. (Fig. 372.) Culms erect, 2 to $4 \mathrm{~m}$ tall, with stout creeping rhizomes and often also with stolons; blades flat, 1 to $5 \mathrm{~cm}$ wide; panicle tawny, 15 to $40 \mathrm{~cm}$ long, the branches ascending, rather densely flowered; spikelets 12 to $15 \mathrm{~mm}$ long, the florets exceeded by the hairs of the rachilla. 2 (P. phragmites Karst.)-Marshes, banks of lakes and streams, and around springs, Nova Scotia to British Columbia, south to Delaware, Illinois, Louisiana, and California; Florida; Mexico and West Indies to Chile and Argentina (fig. 373); Eurasia, Africa, Australia.

In the Southwest this, in common with Arundo donax, is called by the Mexican name carrizo and is used for lattices in the construction of adobe liuts. The stems were used by the Indians for shafts of arrows, and in Mexico and Arizona for mats and screens, for thatching, cordage, and carrying nets. 


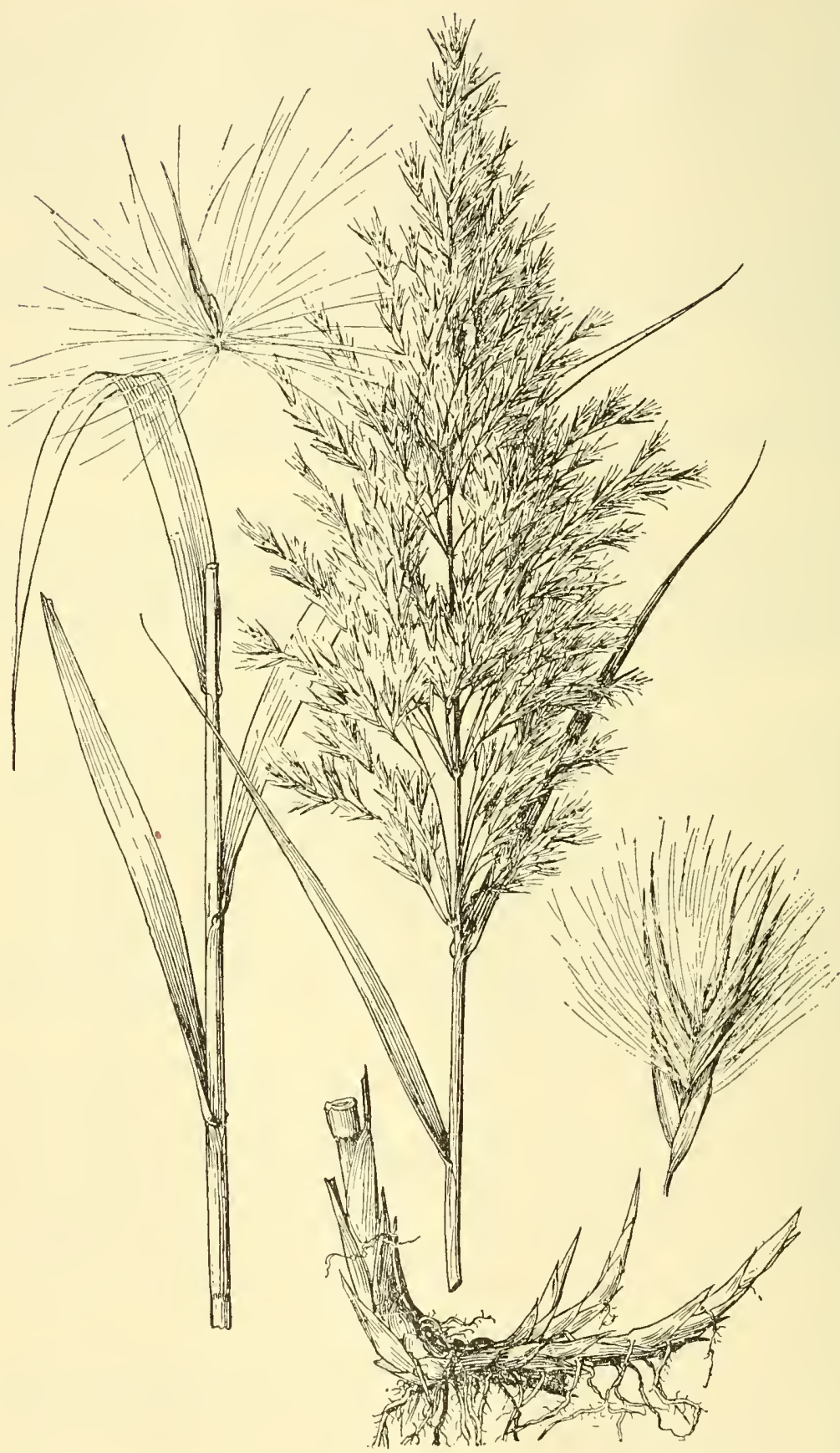

FIGURE 372.-Phragmites communis. Plant, $\times 1 / 3$; spikelet and floret, $\times 3$. (Hitchcock 5078, N.Dak.) 


\section{NEYRAŨDIA Hook. f.}

Spikelets 4- to 8-flowered; rachilla jointed about half way between the florets, the part below the joint glabrous, the part above bearded, forming a stipe below the mature floret; glumes unequal, 1-nerved; lemmas narrow, 3-nerved, acuminate, conspicuously long-pilose on the margins, awned from between 2 fine teeth, the awn recurved. A tall perennial with large open many-flowered panicles. Type species, Neyraudia madagascariensis (Kunth) Hook. f. (N. arundinacea (L.) Henr.) Name an anagram of Reynaudia, a genus of Cuban grasses.

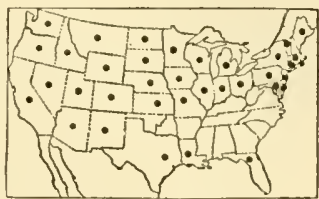

FIGURE 373.-Distribution of Phragmites communis.

1. Neyraudia reynaudiána (Kunth) Keng. (Fig. 374.) Reed-like perennial, 1 to $3 \mathrm{~m}$ tall, resembling Phragmites communis; sheaths

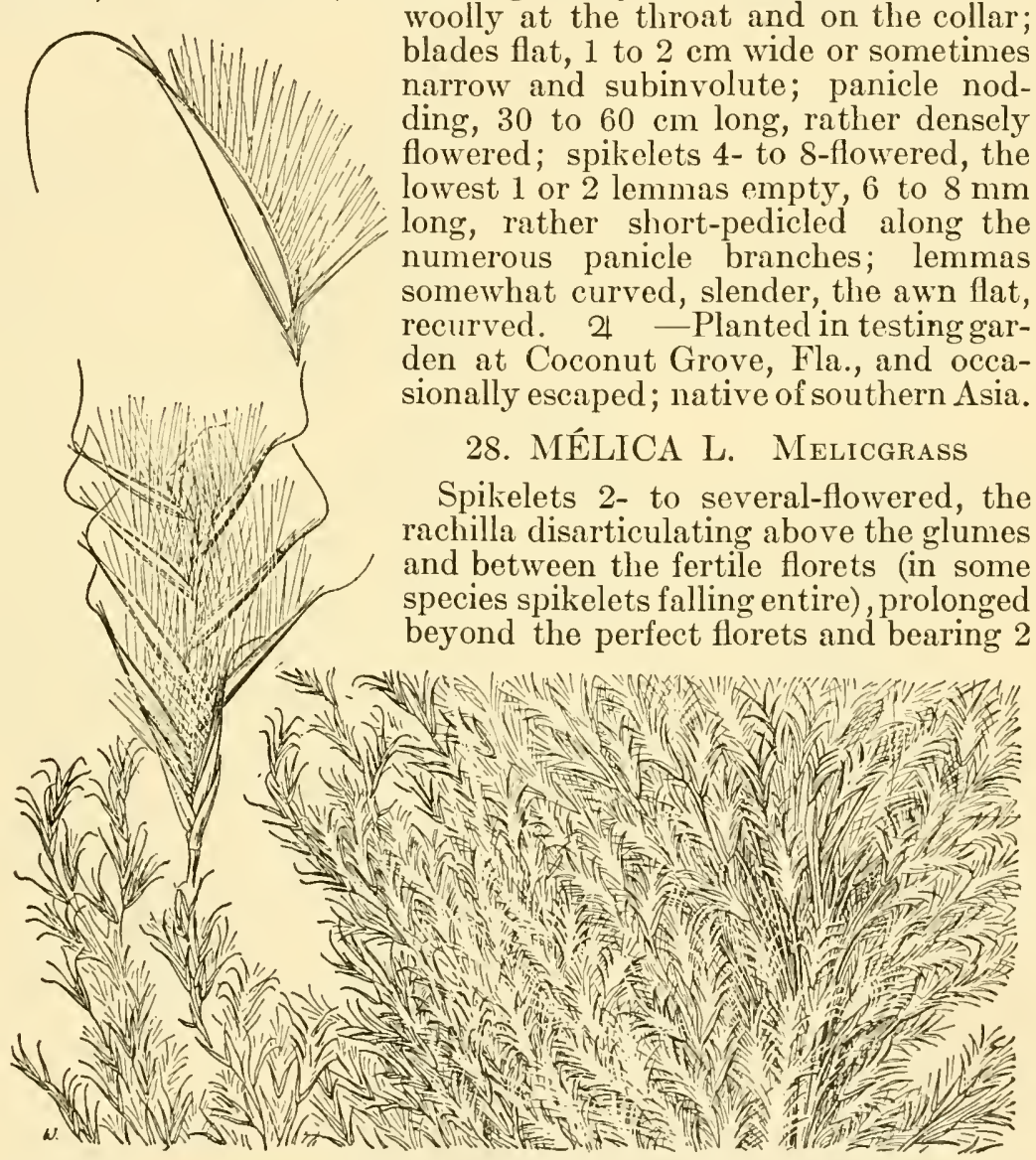

Figure 374.-Neyraudia reynaudiana. Panicle, $\times 1$; spikelet, $\times 5$; floret, $\times 10$. (Moldenke 432, Fla.)

or 3 approximate gradually smaller empty lemmas, each enclosing the one above; glumes somewhat unequal, thin, often papery, scarious-margined, obtuse or acute, sometimes nearly as long as the 
lower floret, 3- to 5-nerved, the nerves usually prominent; lemmas convex, several-nerved, membranaceous or rather firm, scariousmargined, sometimes conspicuously so, awnless or sometimes awned from between the teeth of the bifid apex, the callus not bearded. Rather tall perennials, the base of the culm often swollen into a corm, with closed sheaths, usually flat blades, narrow or sometimes open, usually simple panicles of relatively large spikelets. Type species, Melica nutans L. Melica, an Italian name for a kind of sorghum probably from the sweet juice (nel, honey).

The species are in general palatable grasses but, not being gregarious, do not furnish much forage. Important species are M. porteri, M. imperfecta, and M. subulata.

Spikelets narrow; lemmas acute (obtuse in $M$. harfordii) or awned.

Section 1. Bromelica. Spikelets broad; lemmas obtuse, awnless Section 2. Eumelica.

\section{Section 1. Bromelica}

Lemmas long-awned from a bifid apex.

Branches of panicle few, distant, spreading, naked on the lower half.

1. M. sмiтнir. Branches of panicle short, appressed, spikelet-bearing from near the base.

Lemmas awnless or minutely awned.

2. M. aristata.

Culms not bulbous at base; lemmas obtuse.

Culms bulbous at base; lemmas acute or acuminate.

Lemmas acuminate, usually pilose; panicle narrow, the branches short, usually appressed......... Lemmas acute; panicle broad, the branches long and spreading.

\section{Section 2. Eumelica}

5. M. GEYERI.

1a. Culms bulbous at base (see also $M$. californica).

Pedicels capillary, flexuous or recurved; panicle narrow _._ 6. M. SPectabilis.

Pedicels stouter, appressed.

Rachilla sof t, enlarged, wrinkled in drying, usually brownish _- 8. M.FugAx. Rachilla firm, whitish, not wrinkled.

Panicle rather dense, the branches short, appressed, usually imbricate; glumes thin, indistinctly nerved....... 7. II. BULBOSA.

Panicle loosely flowcred, the branches, or some of them, stiffly ascendingspreading in anthesis, usually somewhat distant, scarcely imbricate; glumes firm, distinctly nerved............... 9. M. INFLATA.

1b. Culms not distinctly bulbous at base (somewhat swollen in $M$. californica).

2 a. Spikelets falling entire, nodding to pendulous on capillary pedicels.

Panicle narrow; spikelets 4- or 5-flowered.

Spikelets reflexed; glumes 1 to $1.5 \mathrm{~cm}$ long______._. 10. M. STricta. Spikelets not reflexed; glumes less than $1 \mathrm{~cm}$ long ..... 11. M. PORTERI.

Panicle open, the lower branches spreading; spikelets mostly 2-or 3-flowered.

Glumes nearly as long as the usually 2 -flowered spikelet; apexes of the 2 florets about the same height; panicle simple or nearly so.

12. M. MUTICA.

Glumes shorter than the usually 3 -flowered spikelet; apex of second floret a little higher than that of the first; panicle compound.

13. M. NITENS.

2b. Spikelets not falling entire, not pendulous.

Spikelets 4 to $6 \mathrm{~mm}$ long; fertile florets 1 or 2 .

Fertile lemmas pubescent; fertile florets of ten 2 _.. 14. M. TORReyana.

Fertile lemmas glabrous; fertile floret usually 1.... 15. M. IMPERFECTA.

Spikelets 8 to $15 \mathrm{~mm}$ long; fertile florets 2 to several.

Spikelets silvery white; glumes about as long as the spikelet; plant tall, somewhat woody ............... 16. M. Futescens.

Spikelets tawny to purplish; glumes shorter than the spikelet; plant lower, herbaceous.

17. M. CALIFORNICA. 


\section{Section 1. Bromélica Thurb.}

Spikelets narrow; glumes usually narrow, scarious margined (papery in $M$. geyeri); sterile lemmas similar to the acute (obtuse in $M$. harfordii) or awned fertile lemmas.

1. Melica smíthii (Porter) Vasey. Snitit melic. (Fig. 375.) Culms slender, 60 to $120 \mathrm{~cm}$ tall; sheaths retrorsely scabrous; blades lax, scabrous, 10 to $20 \mathrm{~cm}$ long, 6 to $12 \mathrm{~mm}$ wide; panicle 12 to $25 \mathrm{~cm}$ long, the branches solitary, distant, spreading, naked below, sometimes reflexed, as much as $10 \mathrm{~cm}$ long; spikelets 3 - to 6 -flowered, 18 to $20 \mathrm{~mm}$ long, sometimes purplish; glumes acute; lemmas about $10 \mathrm{~mm}$ long, with an awn 3 to 5 mm long. 24 (Avena smithii Porter.)-Moist woodlands, western Ontario and northern Michigan to British Columbia, south to Wyoming (Teton Mountains) and Oregon (Wallowa Mountains) (fig. 376).

2. Melica aristáta Thurb. (Fig. 377.) Culms erect or decumbent below, 60 to $100 \mathrm{~cm}$ tall; sheaths scabrous to pubescent; blades 3 to $5 \mathrm{~mm}$ wide, more or less pubescent; panicle narrow, 10 to $15 \mathrm{~cm}$ long, the branches short, mostly appressed or ascending; spikelets, excluding awns, about $15 \mathrm{~mm}$ long; glumes 10 to $12 \mathrm{~mm}$ long; lemmas 7-nerved, scabrous, awned, the awn 6 to $10 \mathrm{~mm}$ long. 24 -Dry woods, meadows, and

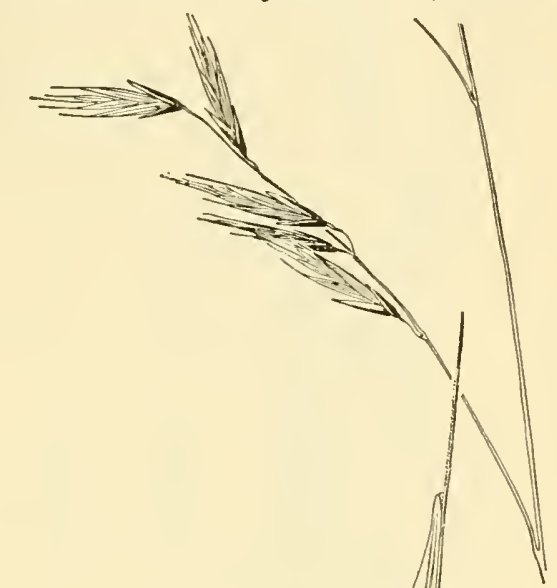
open slopes, Washington to the central Sierras of California.

3. Melica harfórdii Boland. Harford MElic. (Fig. 378.) Culms tufted, 60 to $120 \mathrm{~cm}$ tall, often decumbent

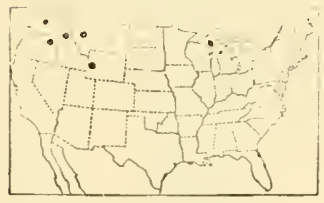

Figure 376.-Distribution of Melica smuthii. below; sheaths scabrous to villous; blades scabrous, firm, flat to subinvolute, 1 to 4 $\mathrm{mm}$ wide; panicle narrow, 10 to $15 \mathrm{~cm}$ long, the branches appressed; spikelets 1 to 1.5 cm long, short-pediceled; glumes 7 to $9 \mathrm{~mm}$ long, obtuse; lemmas rather faintly 7 -nerved, hispidulous below, pilose on the lower part of the margin, the apex emarginate, mucronate, or with an awn less than $2 \mathrm{~mm}$ long. 24 Open dry woods and slopes, British Columbia to the Cascade Mountains of Oregon, south to Monterey 


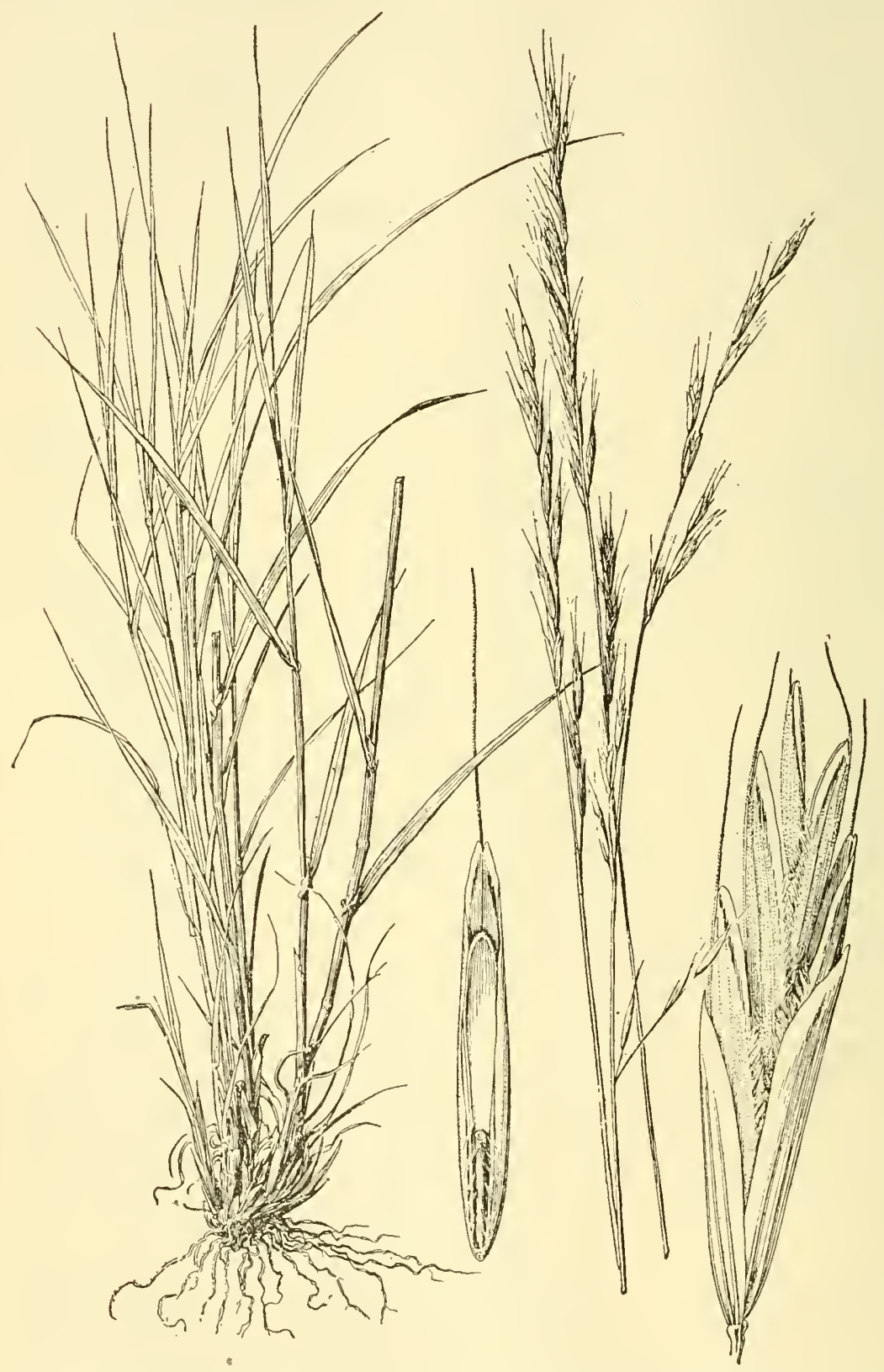

Figure 377.-Melica aristáta. Plant, $\times 1 \frac{1}{2}$; spikelet and floret, $\times 5$. (Cusick 2888, Oreg.) 
County and the Yosemite National Park, Calif. A smaller form with narrow involute blades has been called M. harfordii var. minor Vasey.

4. Melica subulâta (Griseb.) Scribn. Alaska oniongrass. (Fig.

379.) Culms 60 to $125 \mathrm{~cm}$ tall, mostly bulbous at base; sheaths re-

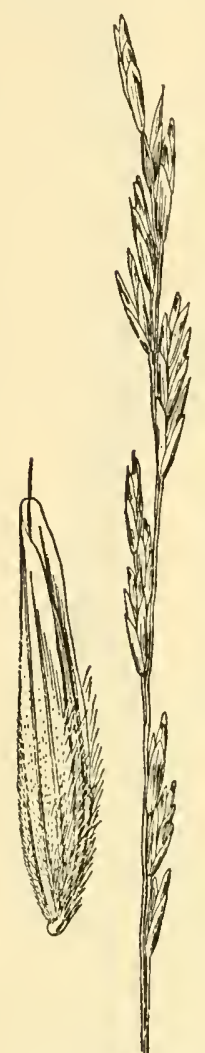

FIGURE 378,--Melica harfordii. Panicle, $X 1$; floret, $X$ 5. (Y a tes 457 , Calif.) trorsely scabrous, often pilose;

blades thin, usually 2 to $5 \mathrm{~mm}$ wide, sometimes wider; panicle usually narrow, mostly 10 to $15 \mathrm{~cm}$ long, the branches appressed or sometimes spreading; spikelets narrow, 1.5 to $2 \mathrm{~cm}$ long, loosely flowered; glumes narrow, obscurely nerved, the second about $8 \mathrm{~mm}$ long; lemmas prominently 7-nerved, tapering to an acuminate point, awnless, the nerves more or less pilose-ciliate. 2 -Meadows, banks, and shady slopes, western Wyoming and Montana to Alaska, south in the mountains to Mount Tamalpais and Lake Tahoe, Calif. (fig. 380); Chile.

5. Melicagéyeri Munro. Geyer oniongrass. (Fig. 381.) Culms 1 to $1.5 \mathrm{~m}$ tall, bulbous at base; sheaths usually glabrous, sometimes slightly scabrous or pubescent; blades scabrous (rarely puberulent), mostly less than $5 \mathrm{~mm}$ wide; panicle 10 to $20 \mathrm{~cm}$ long, open, the branches slender, rather distant, spreading, bearing a few spikelets above the middle; spikelets 12 to $20 \mathrm{~mm}$ long; glumes broad, smooth, papery, the second about $6 \mathrm{~mm}$ long; lemmas 7-nerved, scaberulous

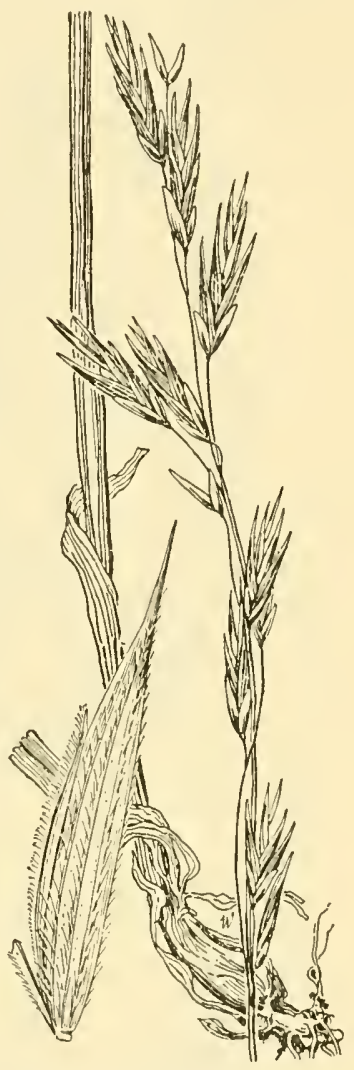

Figure 379.-Melica subulata. Panicle, $\times 1$; floret, $\times 5$. (Hitchcock 11631 , Wash.)

or nearly glabrous, narrowed to an obtuse point, awnless. 24 -Open dry woods and rocliy slopes, at medium altitudes, western Oregon to

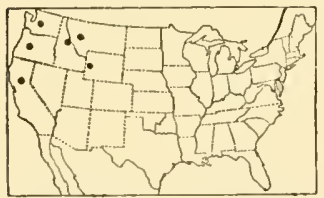

FIGURE 380 --Distribution of Melica subutata. central California in the Coast Range; infrequent in the Sierras to Placer County; Yellowstone Park, Wyo.

\section{Section 2. Eumélica Aschers.}

Spikelets broad; glumes broad; papery; lemmas awnless; sterile lemmas small, aggregate in a rudiment more or less hidden in the upper fertile lemmas.

6. Melica spectábilis Scribn. Purple oniongrass. (Fig. 382.) Culms 30 to $100 \mathrm{~cm}$ tall, bulbous at base; sheaths pubescent; blades flat to subinvolute, 2 to $4 \mathrm{~mm}$ wide; panicle mostly 10 to $15 \mathrm{~cm}$ long, 
narrow, the branches appressed; spikelets purple-tinged, rather turgid, 10 to $15 \mathrm{~mm}$ long, the pedicels capillary, flexuous; glumes broad, papery; lemmas strongly 7-nerved, obtuse, scarious-margined, imbricate. 24 -Rocky or open woods and thickets, Montana to

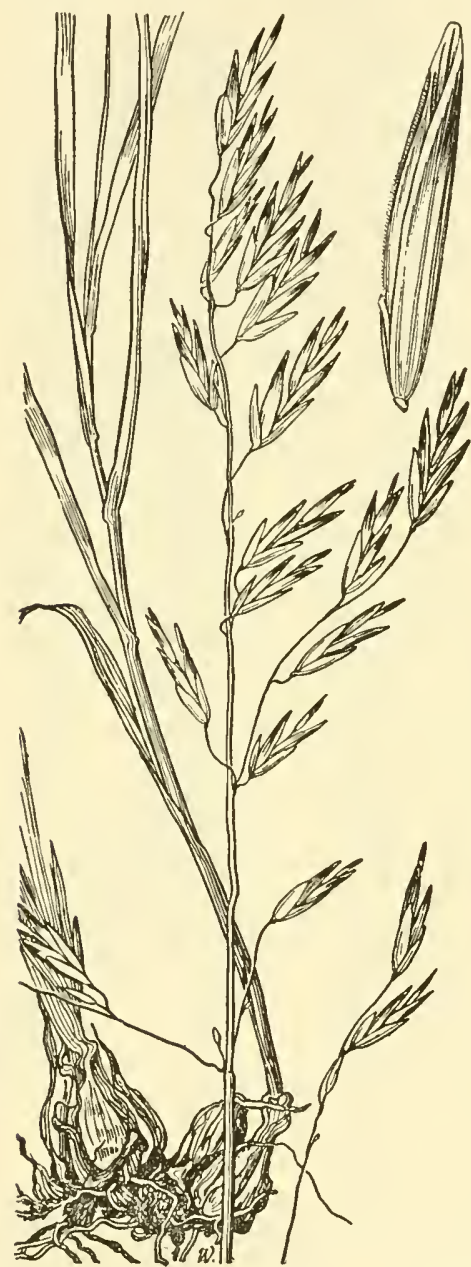

Figure 381.-Mclica geyeri. Plant, $\times 1$; floret, $\times 5$. (Heller 11932, Calif.)

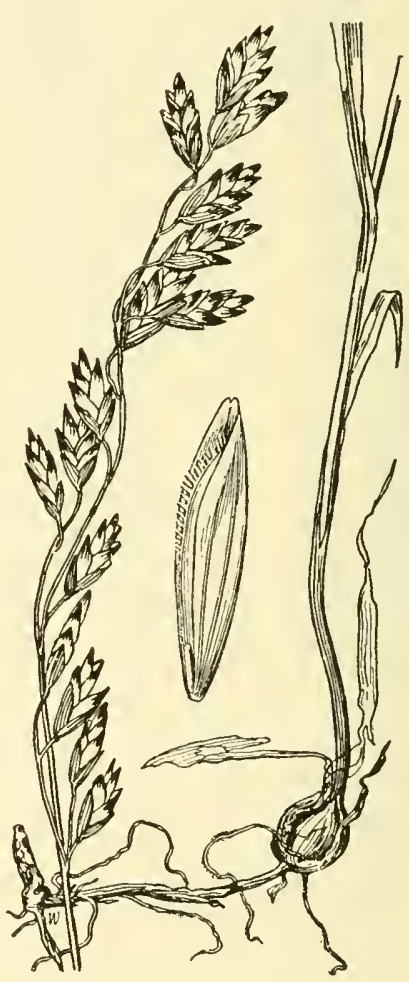

FIGURE 382,-Melica spectabilis. Plant, $\times 1$; floret, $\times 5$. (Tweedy 85 , Wyo.)

British Columbia, south to Colorado and northern California (fig. 383).

7. Melica bulbósa Geyer. Oniongrass. (Fig. 384.) Culms 30 to $60 \mathrm{~cm}$ tall, bulbous at base, resembling $M$. spectabilis; sheaths and blades flat to involute, 2 to $4 \mathrm{~mm}$ wide, glabrous, scabrous, or pubescent; panicle narrow, rather densely flowered, the branches short, appressed, rather stiff, mostly imbricate; spikelets papery with age, mostly 7 to $15 \mathrm{~mm}$ long, the short pedicels stiff, ereet; lemmas obscurely nerved, 
obtuse or slightly emarginate. 2 (M. bella Piper.)-Rocky woods

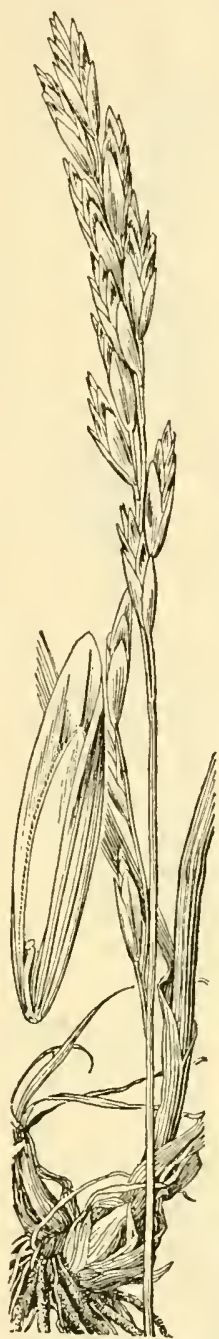

Figure 384--Melica bulbosa. Plant, $\times 1$; floret, $\times 5$. (Tidestrom 1252, Utah.)

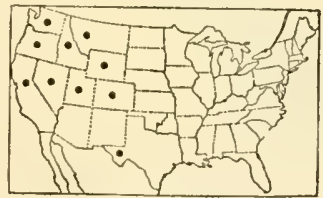

FIGURE 385.-Distribution of Melica bulbosa. and hills, Montana to British Columbia, south to Colorado and California; western Texas (Jeff Davis County) (fig. 385). Specimens with pubescent foliage have been differentiated as $M$. bella intonsa Piper.

8. Melica fúgax $\mathrm{Bo}$ land. Little onionGRASS. (Fig. 386.) Culms mostly 20 to 40 cm tali, in loose tufts, the bulbs prominent; sheaths retrorsely scabrous; blades 1.5 to $4 \mathrm{~mm}$ wide, scabrous, usually pubescent on the upper surface; panicle 8 to $15 \mathrm{~cm}$ long, the branches stiffly spreading or reflexed at anthesis, the lower 2 to $4 \mathrm{~cm}$ long; spikelets 8 to $14 \mathrm{~mm}$ long, the florets somewhat distant, usually purpletinged, the rachilla soft, wrinkled in drying, often brownish; second glume nearly as long as the lower lemma; lemmas obscurely nerved, obtuse or emarginate. 24 Dry hills and open woods, Washington to Nevada and central California (fig. 387).

9. Melica infláta (Boland.) Vasey. ( $\mathrm{Fig} .388$.) Culms 60 to 100 $\mathrm{cm}$ tall, bulbous at base; sheaths glabrous or pubescent; blades flat, 2 to $4 \mathrm{~mm}$ wide; panicle 15

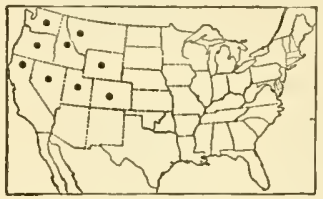

FIGURE 383.-Distribution of Melica spectabilis.

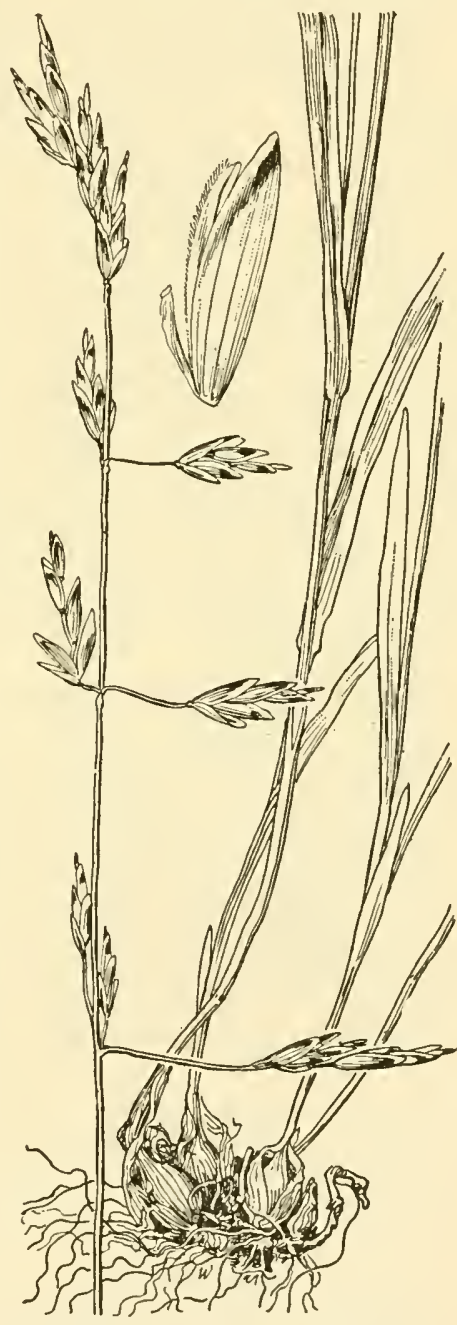

Figure 386.-Melica fugax. Plant, $\times 1$; floret, $\times 5$. (Vasey 9 , Wash.)

to $20 \mathrm{~cm}$ long, narrow, the rather distant branches, or some of them, 
stiffly ascending-spreading, in anthesis the lower as much as $5 \mathrm{~cm}$ long; spikelets somewhat inflated, 12 to $20 \mathrm{~mm}$ long; pale green; glumes scabrous on the strong nerves; lemmas strongly

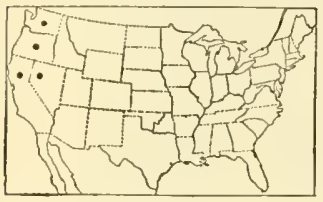

Frgure 387.-Distribution of Melica fugax. nerved, scabrous, acutish. $24-$ California (Yosemite National Park and Mount Shasta), Washington (Chelan County, the sheaths and blades pubescent).

10. Melica strícta Boland. Rock melic. (Fig. 389.) Culms 15 to $50 \mathrm{~cm}$ tall, densely tufted, the base somewhat thickened but not bulbous; sheaths scaberulous, sometimes pubescent; blades mostly 1 to $3 \mathrm{~mm}$ wide, scabrous, pubescent on the upper surface; panicle narrow, simple or with 1 or 2 short branches at base; spikelets 12 to $16 \mathrm{~mm}$ long, 4 - or 5-flowered, broadly $V$-shaped, reflexed on capillary pedicels, falling entire; glumes thin, shining, nearly as long as the spikelet; lemmas faintly nerved, scabrous, obtuse. 24 -Rocky slopes and banks, at medium altitudes, Utah (Cottonwood Canyon) to Oregon (Steins Mountains), the Sierras, and the mountains of southern California.

11. Melica portéri Scribn. Ponter MELIC. (Fig. 390.) Culms 50 to $100 \mathrm{~cm}$ tall, tufted; sheaths smooth or scabrous; blades 2 to $5 \mathrm{~mm}$ wide; panicle green or tawny, narrow, 1-sided, 15 to $20 \mathrm{~cm}$ long, the branches short, appressed, fewflowered; spikelets 10 to $15 \mathrm{~mm}$ long, 4or 5-flowered, narrow, reflexed on capillary pubescent pedicels, falling entire; glumes less than $1 \mathrm{~cm}$ long, shorter than the spikelet; lemmas with 5 strong nerves and several faint ones, scaberulous. 2 -Canyons, open woods, and moist places, mostly at 2,000 to $3,000 \mathrm{~m}$, western Missouri (Jackson County); Nebraska to Texas and Arizona (fig. 391).

12. Melica mútica Walt. 'Two-flower MELiC. (Fig. 392.) Culms 60 to $100 \mathrm{~cm}$ tall, erect, loosely tufted; sheaths scabrous or somewhat pubescent; blades flat, 2 to $5 \mathrm{~mm}$ wide; panicle 10 to 20 cm long, nearly simple, with 1 to few short, spreading, few-flowered 


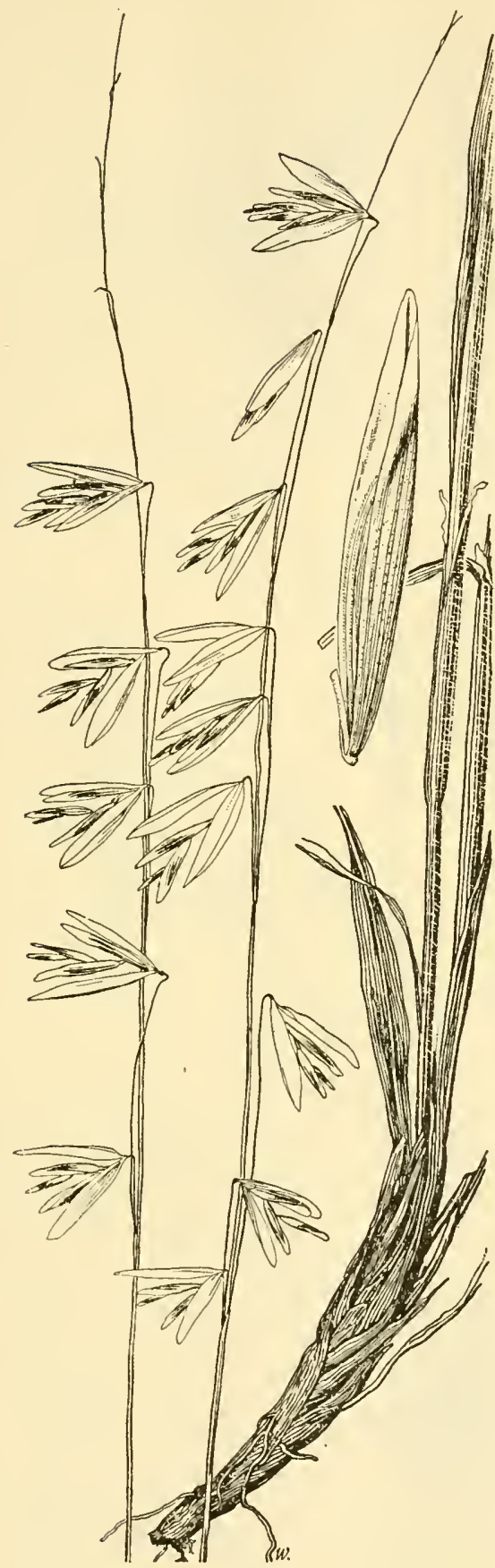

FIGURE 399.-Melica stricta. Plant, $\times 1$; floret, $\times 5$. (Swallen 720, Calif.)

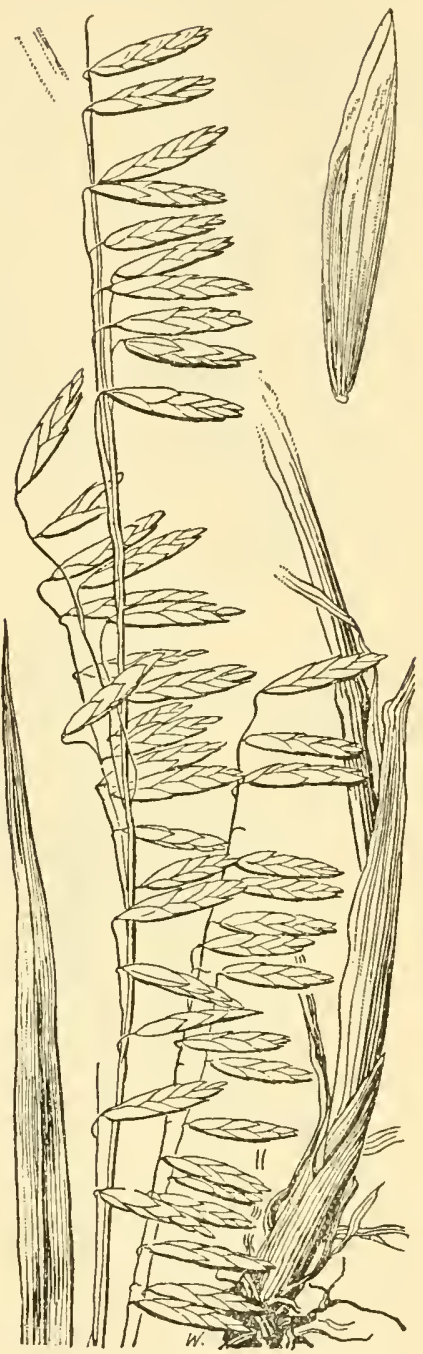

Figure 390--Melica porteri. Plant, $\times 1$; floret, $\times 5$. (Shear 725, Colo.)

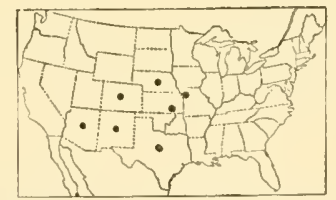

Figure 391.-Distribution of Melica porteri. 


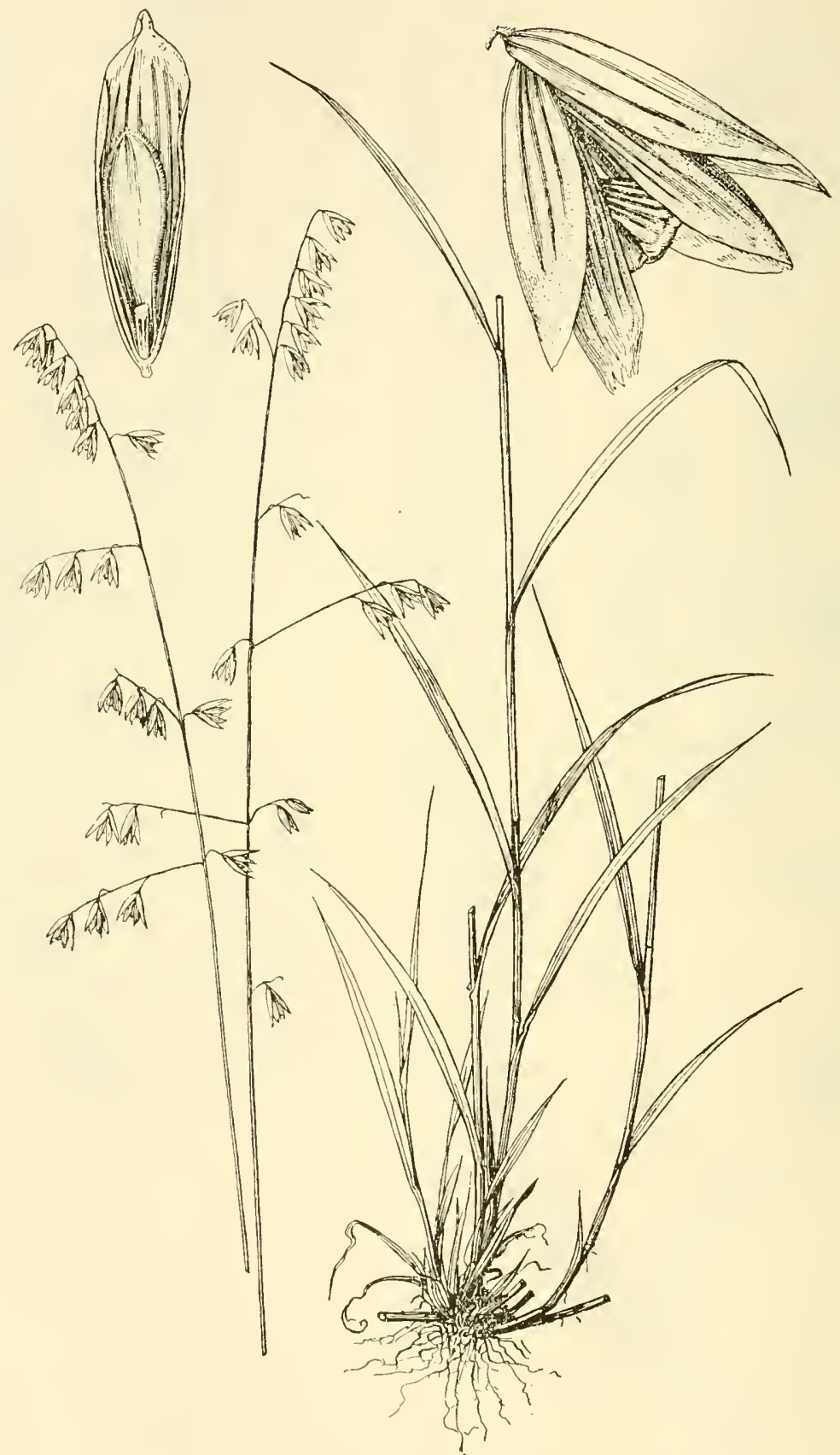

Flgure 392.-Melica mutica. Plant, $\times 1 / 2$; spikelet and floret, $\times 5$. (Chase 3695, Va.) 
branches below; spikelets broad, pale, 7 to $10 \mathrm{~mm}$ long, usually 2flowered, the florets spreading, pendulous on slender pedicels, pubescent at the summit, the spikelets falling entire; glumes nearly as long as the spikelet; lemmas scaberulous, strongly nerved, the two florets about the same height; rudiment obconic. 21-Rocky woods, Maryland to Iowa, south to Florida and Texas (fig. 393).

13. Melica nítens (Scribn.) Nutt. ThreEFLOWER MELIC. (Fig. 394.) Resembling $M$. mutica; on the average culms taller; sheaths glabrous or scabrous; blades 7 to $15 \mathrm{~mm}$ wide; panicle more compound with several spreading

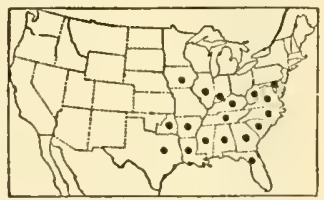

FigURE 393.-Distribution of Melica mutica. branches; glumes shorter than the usually 3flowered narrower spikelet; apex of the second floret a little higher than that of the first; lemmas acute. 21 -Rocky woods, Pennsylvania to Iowa and Kansas, south to Kentucky, Arkansas, Texas, and Arizona (fig. 395).

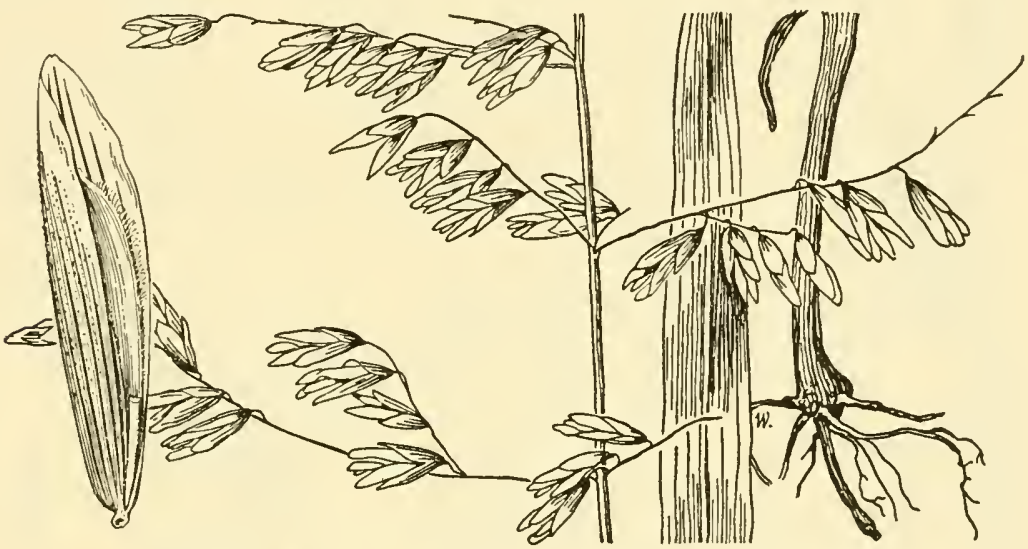

FIgure 394.-Melica nitens. Plant, $\times 1$; floret, $\times 5 . \quad$ (McDonald 15, Mr.)

14. Melica torreyána Scribn. Torrey melic. (Fig. 396.) Culms 30 to $100 \mathrm{~cm}$ tall, ascending from a loose decumbent not bulbous base; blades lax, 1 to $3 \mathrm{~mm}$ wide; panicle narrow, rather loose, 8 to 20 $\mathrm{cm}$ long, the branches more or less fascicled, appressed or ascending, the lower fascicles distant; spikelets 4 to $6 \mathrm{~mm}$ long, with 1 or 2 perfect florets and a minute obovoid, long-stiped rudiment; glumes strongly nerved, as long as the spikelet or nearly so; lemmas pubescent, subacute. 21 Thickets and banks at low altitudes, central California, especially in the Bay region.

15. Melica imperfécta Trin. California MELIC. (Fig. 397.) Resembling M.torreyana;

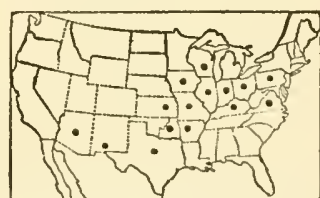

FIGURE 395.-Distribution of Melica nitens. culms erect or ascending; the base sometimes decumbent or stoloniferous; panicle 5 to $30 \mathrm{~cm}$ long, the lower branches commonly ascending to spreading; spikelets usually with 1 perfect floret and an oblong, short-stiped rudiment appressed to the palea; glumes 
indistinctly nerved; lemma a little longer than the glumes, glabrous, indistinctly nerved, obtuse. 2 - Dry open woods and rocky hillsides, at low and medium altitudes, central and southern California, especially in the Coast Ranges; Baja California. A few

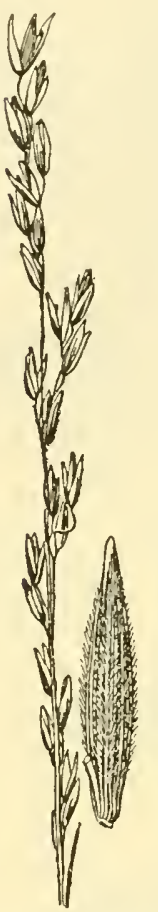

FIGURE 396.-Melica torreynna. Panicle, $\times 1$; floret, $\times 5$. (Chase 5686, Calif.)

forms have been distinguished as varieties: MELICA IMPERFECTA var. REFRÁCTA Thurb. Lower branches of panicle spreading or reflexed; blades pubescent. 2 - Southern California. Melica IMPERfECta var. FlÉxuosa Boland. Like the preceding but blades glabrous. 24 -Central and southern California. Melica imperfecta var. mínor Scribn. Culms less than $30 \mathrm{~cm}$ tall; blades glabrous, 1 to $2 \mathrm{~mm}$ wide. - Southern California.

16. Melica frutéscens Scribn. (Fig. 398.) Culms 0.75 to $2 \mathrm{~m}$ tall, sparingly branching, rather woody below, not bulbous at base; sheaths retrorsely scabrous; blades rather firm, 2 to $4 \mathrm{~mm}$ wide, those of the innovations, 1 to $2 \mathrm{~mm}$ wide, subinvolute; panicle silveryshining, narrow, rather dense, 10 to $30 \mathrm{~cm}$ long, the branches short, appressed; spikelets short-pediceled, 12 to $15 \mathrm{~mm}$ long; glumes nearly as long as the spikelet, prominently 5-nerved; lemmas subacute, faintly 7-nerved. 2 -Hills and canyons, at low and medium altitudes, southern California (Inyo County and southward); $\mathrm{Baja}$ California.

\section{Melica califórnica} Scribn. (Fig. 399.) Culms 60 to $120 \mathrm{~cm}$ tall, the base usually decumbent, often more or less bulbous; sheatlis glabrous or pubescent, the lower persistent, brown and shredded; blades 1 to $4 \mathrm{~mm}$ wide; panicle narrow, rather dense, 10 to $20 \mathrm{~cm}$ long, tawny to purplish, not silvery; spikelets shortpediceled, 10 to $12 \mathrm{~mm}$ long (rarely shorter) with 2 to 4 florets besides the rudiment; glumes scaberulous, a little shorter than the spikelets; lemmas rather prominently 7-nerved, scaberulous, subacute to obtuse, often emarginate. 24 (M. bulbosa Geyer; Thurb., not M. bulbosa of this work.)-Mountain meadows and rocky woods, at low and medium altitudes, Oregon (Malheur County) and California.

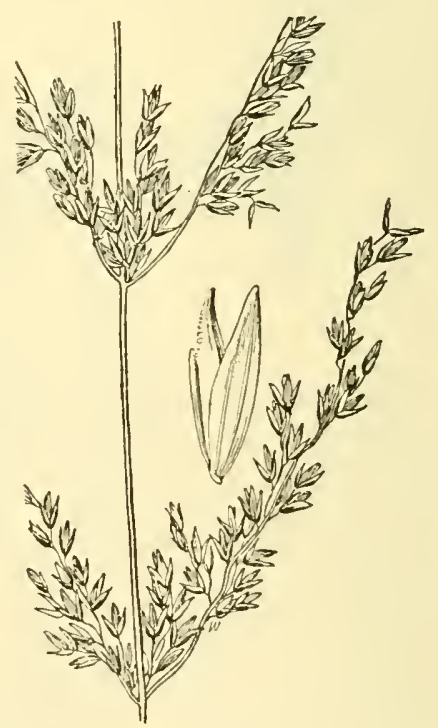

FIGUPE 397.-Melica imperfecta. Panicle, $\times 1$; spikelet, $\times 5$. (Elmer 4710 , Calif.)

Melica altíssima L. Tall perennial; blades 15 to $20 \mathrm{~cm}$ long, 5 to $10 \mathrm{~mm}$ wide; panicle narrow, dense, tawny to purple; spikelets about $12 \mathrm{~mm}$ long; glumes and lemmas broad, papery. 21 - Sometimes cultivated for ornament. Eurasia.

Melica ciliáta L. Panicle pale, narrow, condensed, silky. 4 -Occasionally cultivated for ornament. Europe. 


\section{SCHIZĀCHNE Hack.}

Spikelets several-flowered, disarticulating above the glumes and between the florets, the rachilla glabrous; glumes unequal, 3- and 5nerved; lemmas lanceolate, strongly 7 -nerved, long-pilose on the callus, awned from just below the teeth of the prominently bifid apex; palea with softly pubescent, thickened submarginal keels, the hairs longer toward the summit. Rather tall perennial with simple culms and open rather few-flowered panicles. Type species, Schizachne fauriei Hack. (S. purpurascens). Name from Greek schizein, to split, and achne, chaff, alluding to the bifid lemma.

1. Schizachne purpuráscens (Torr.) Swallen.

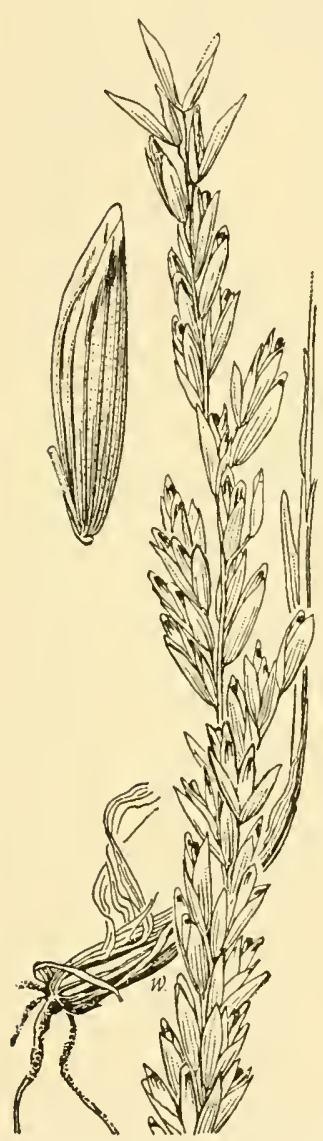

False melic. (Fig. 400 .) Culms erect from a loosely tufted decumbent base, 50 to $100 \mathrm{~cm}$ tall; sheaths closed; blades flat, narrowed at the base, 1 to $5 \mathrm{~mm}$ wide; panicle about $10 \mathrm{~cm}$ long, the branches single or in pairs, more or less drooping, bearing 1 or 2 spikelets; spikelets 2 to $2.5 \mathrm{~cm}$ long; glumes purplish, less than half as long as the spikelet; lemmas about $1 \mathrm{~cm}$ long, the awn as long as the lemma or longer. 21 (Melica striata Hitchc.; M. purpurascens Hitchc.; Avena torreyi Nash.)-Rocky woods, Newfoundland to southern Alaska, south to Pennsylvania, Kentucky, South Dakota, and Montana, and in the mountains from British Columbia to $\mathrm{New}$ Mexico (fig. 401); Siberia "and Japan.

\section{VASEYÓCHLOA Hitche.}

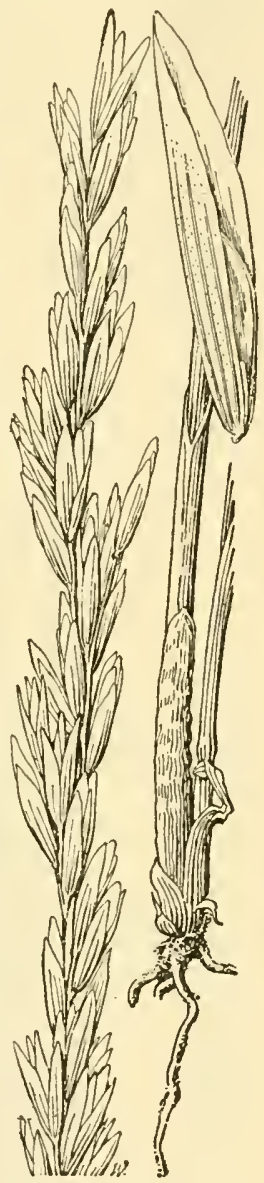

Figure 398.-Melica fru-

Spikelets subterete or tescens. Plant, $x$; slightly compressed, several- Johnston, and Harwood flowered, the rachilla disar-

ticulating above the glumes and between the florets, the joints very short; glumes rather

Figure 399.-Melica californica. Plant, $\times 1$; floret, $\times 5$. (Hoffman 37, Calif.)

firm, unequal, much shorter than the lemmas, the first 3- to 5-nerved, the second 7- to 9nerved; lemmas rounded on the back, firm, closely imbricate, 7- to 9-nerved, broad, narrowed to an obtuse entire apex, and with a stipelike hairy callus, pubescent on the lower part of the back and margins; palea shorter than the lemma, splitting at maturity, the 

areuate keels strongly wing-margined; caryopsis concavo-convex, oval, black, the base of the styles persistent as a 2-toothed crown. Slender perennial with elongate blades and somewhat open panicles. Type species, Vaseyochloa multinervosa. Named from Vasey and Greek, chloa, grass.

1. Vaseyochloa multinervósa (Vasey) Hitehe. (Fig. 402.) Culms erect, loosely tufted, 40 to $100 \mathrm{~cm}$ tall, with slender rhizomes; sheaths scaberulous, pilose at the throat; blades flat to loosely involute, 1 to $4 \mathrm{~mm}$ wide; panicle narrow, loose, 5 to $20 \mathrm{~cm}$ long, the branches few, at first appressed, later spreading, the lower as much as $8 \mathrm{~cm}$ long, bearing a few spikelets from about the middle; spikelets 12 to $18 \mathrm{~mm}$ long, 6- to 12-flowered, purple tinged; glumes acute, the first narrow, $4 \mathrm{~mm}$ long, the second broad, $5 \mathrm{~mm}$ long; lemmas narrowed to an obtuse point, about $6 \mathrm{~mm}$ long, the nerves becoming rather obscure toward maturity; grain 2.5 to $3 \mathrm{~mm}$ long, 1.5 to $2 \mathrm{~mm}$ wide, deeply concave on the ventral side. 2 (Melica multinervosa Vasey; Distichlis multinervosa Piper.) - Sandy open woods or open

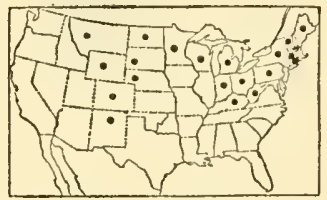

FIGCRe 401,-Distribution of Schizachne purpurascens. ground, southeastern Texas; rare. The rhizomes appear to break off readily, most herbarium specimens being without them.

\section{TRIODIA R. Br.}

\section{(Tridens Roem. and Schult.)}

Spikelets several-flowered, the rachilla disarticulating above the glumes and between the florets; glumes membranaceous, often thin, nearly equal in length, the first sometimes narrower, 1-nerved, the second rarely 3 - to 5-nerved, acute to acuminate; lemmas broad, rounded on the back the apex from minutely emarginate or toothed to deeply and obtusely 2-lobed, 3-nerved, the lateral nerves near the margin, the midnerve usually excurrent between the lobes as a minute point or as a short awn, the lateral nerves often exeurrent as minute points, all the nerves pubescent below (subglabrous in one species), the lateral ones sometimes conspicuously so throughout; palea broad, the two nerves near the margin, sometimes villous; grain concavo-convex. Erect, tufted perennials, rarely rhizomatous or stoloniferous, the blades usually flat, the inflorescence an open to contracted or eapitate panicle. Type species, Triodia pungens R. Br. Name from Greek tri, thrice, and odous, tooth, referring to the 3-toothed lemma.

In general the species of Triodia are of little importance economically, T.grandiflora, T.elongata, and T. pilosa being the most useful on the range. Triodia pulchella is often abundant, but is not relished by stock, the little dry plants seldom being eaten.

1a. Panicle capitate, exceeded by fascicles of leaves; low stoloniferous plants.

1. T. PULCHELLA.

1b. Panicle exserted, open or spikelike; plants not stoloniferous.

2a. Panicle open, or loose, not dense or spikelike.

Pedicels of the lateral spikelets less than $1 \mathrm{~mm}$ long _... 7. T. LANGLorsir. Pedicels all slender, more than $1 \mathrm{~mm}$ long (some short in T. buckleyana). 


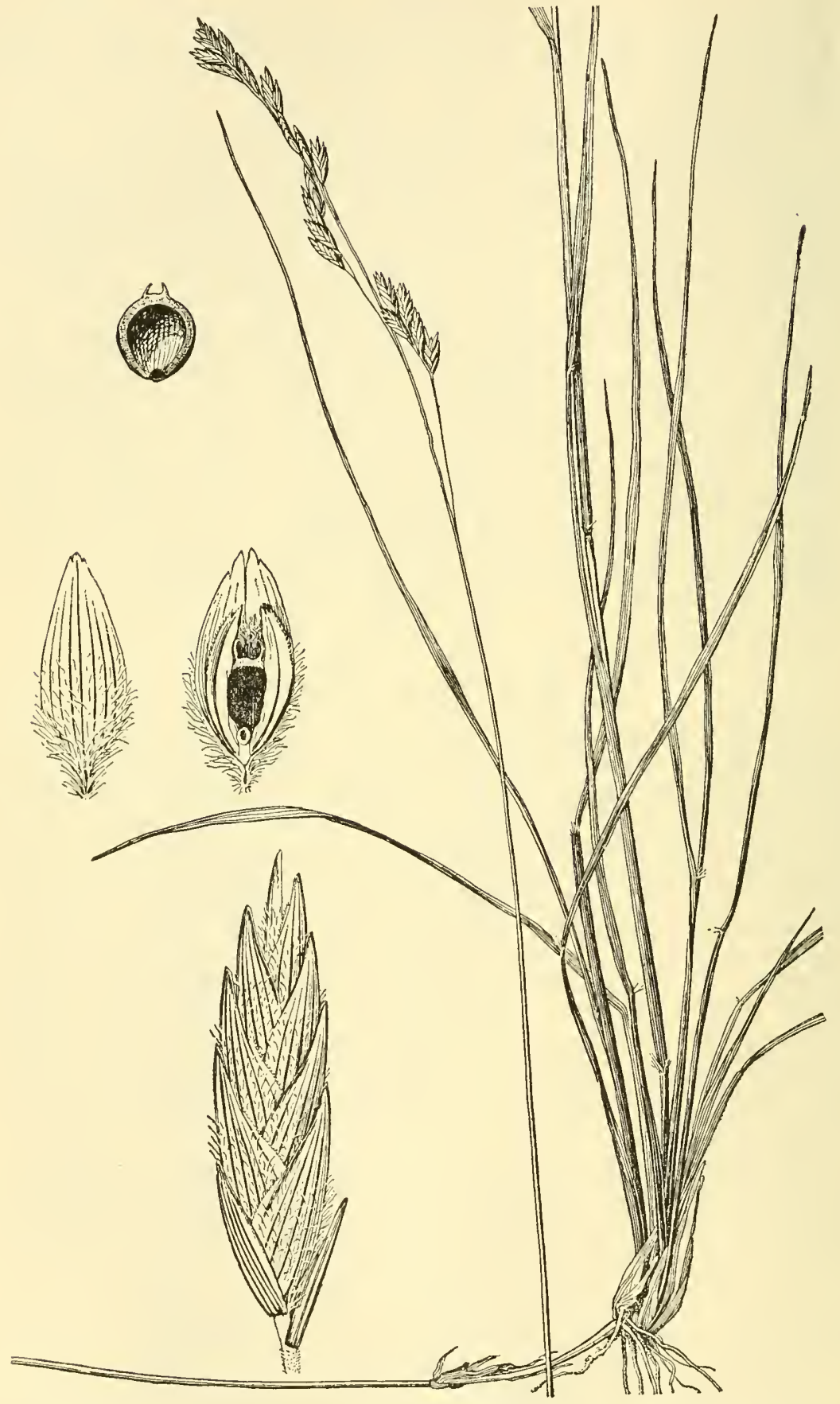

Finure 402.-Vaseyochloa multinerrosa. Plant, $X 1 / 2$; spikelet and floret, $X 5$. (Swallen 1854, Tex.) 
Lateral nerves not excurrent.

Spikelets not more than $5 \mathrm{~mm}$ long; lemmas $2 \mathrm{~mm}$ long.

8. T. ERAGROSTOIDES.

Spikelets 6 to $8 \mathrm{~mm}$ long; lemmas 4 to $5 \mathrm{~mm}$ long--5. T. BUCKLEYANA. Lateral nerves excurrent as short points.

Rhizomes present, scaly and creeping........ 6. T. DRUMMONDII. Rhizomes wanting.

Panicle 5 to $15 \mathrm{~cm}$ long; blades 1 to $3 \mathrm{~mm}$ wide_..- 10. T. TEXaNA.

Panicle 15 to $30 \mathrm{~cm}$ long, the branches viscid; blades 3 to $10 \mathrm{~mm}$

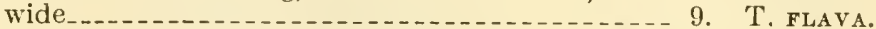

2b. Panicle narrow, contracted or spikelike, the branches appressed (see also T. drummondii).

Panicle dense, oval or oblong, mostly less than $10 \mathrm{~cm}$ long.

Lemmas deeply 2-lobed........ 2 . T. GRANDIFLorA.

Lemmas minutely notched, not lobed.

Panicle 1 to $2 \mathrm{~cm}$ long; lemma margins densely long-ciliate; palea half as long as the lemma _................. 3. T. PILOSA.

Panicle 4 to $10 \mathrm{~cm}$ long; lemma margins short-pilose near base; palea about as long as the lemma_..._._._. 4. T. CONGESTA.

Panicle slender, spikelike (long and dense in T. stricta).

Lemmas glabrous. Panicle whitish.......... 12. T. albescens. Lemmas pilose on the margins.

Lemmas mucronate; panicle dense ............... 11. T. stricta.

Lemmas not mucronate (rarely lowest lemma obscurely so); panicle not dense.

Glumes acuminate, longer than the lowest floret; blades mostly flat, some of them 2 to $4 \mathrm{~mm}$ wide......... 14. 'T. ELONGATA.

Glumes obtuse, short; blades mostly folded or involute, mostly about $1 \mathrm{~mm}$ wide ..........

1. Triodia pulchélla H.B.K. Fluffarass. (Fig. 403.) Low, tufted, usually not more than $15 \mathrm{~cm}$ high; culms slender, scabrous or puberulent, consisting of 1 long internode, bearing at the top a fascicle of narrow leaves, the fascicle finally bending over to the ground, taking root and producing other culms, the fascicles also producing the inflorescence; sheaths striate, papery-margined, pilose at base; blades involute, short, scabrous, sharp-pointed; panicle capitate, usually not exceeding the blades of the fascicle, consisting of 1 to 5 nearly sessile relatively large white woolly spikelets; glumes glabrous, subequal, broad, acuminate, awn-pointed, 6 to $8 \mathrm{~mm}$ long, nearly as long as the spikelet; lemmas $4 \mathrm{~mm}$ long, conspicuously longpilose below, cleft about halfway, the awn scarcely exceeding the obtuse lobes, divergent at maturity. 21 (Dasyochloa pulchella Willd.; Tridens pulchellus Hitchc.)-Mesas and rocky hills, especially in arid or semiarid regions, Texas to Nevada and southern California to southern Mexico (fig. 404).

2. Triodia grandiflóra Vasey. Shortleaf triodia. (Fig. 405.) Culms densely tufted, erect or geniculate below, 10 to $50 \mathrm{~cm}$ tall, often pubescent at the nodes; blades flat or folded, rather firm, whitemargined, appressed-pubescent, 1 to $2 \mathrm{~mm}$ wide, those of the culm less than $10 \mathrm{~cm}$ long; panicle dense, oblong, pale or sometimes purplish, 2 to $6 \mathrm{~cm}$ long, cleistogamous spikelets borne in the lower sheaths; spikelets 4- to 8-flowered, 5 to $12 \mathrm{~mm}$ long; glumes acuminate, about as long as the first floret; lemmas 4 to $6 \mathrm{~mm}$ long, conspicuously long-pilose on the margins, densely pilose on the back below, deeply lobed, the awn as long as the lobes, or exceeding them. 24-Rocky slopes, western Texas to southern Arizona and northern Mexico. This has been referred to T. avenacea H.B.K., a Mexican species with stolons and shorter purple panicles. 


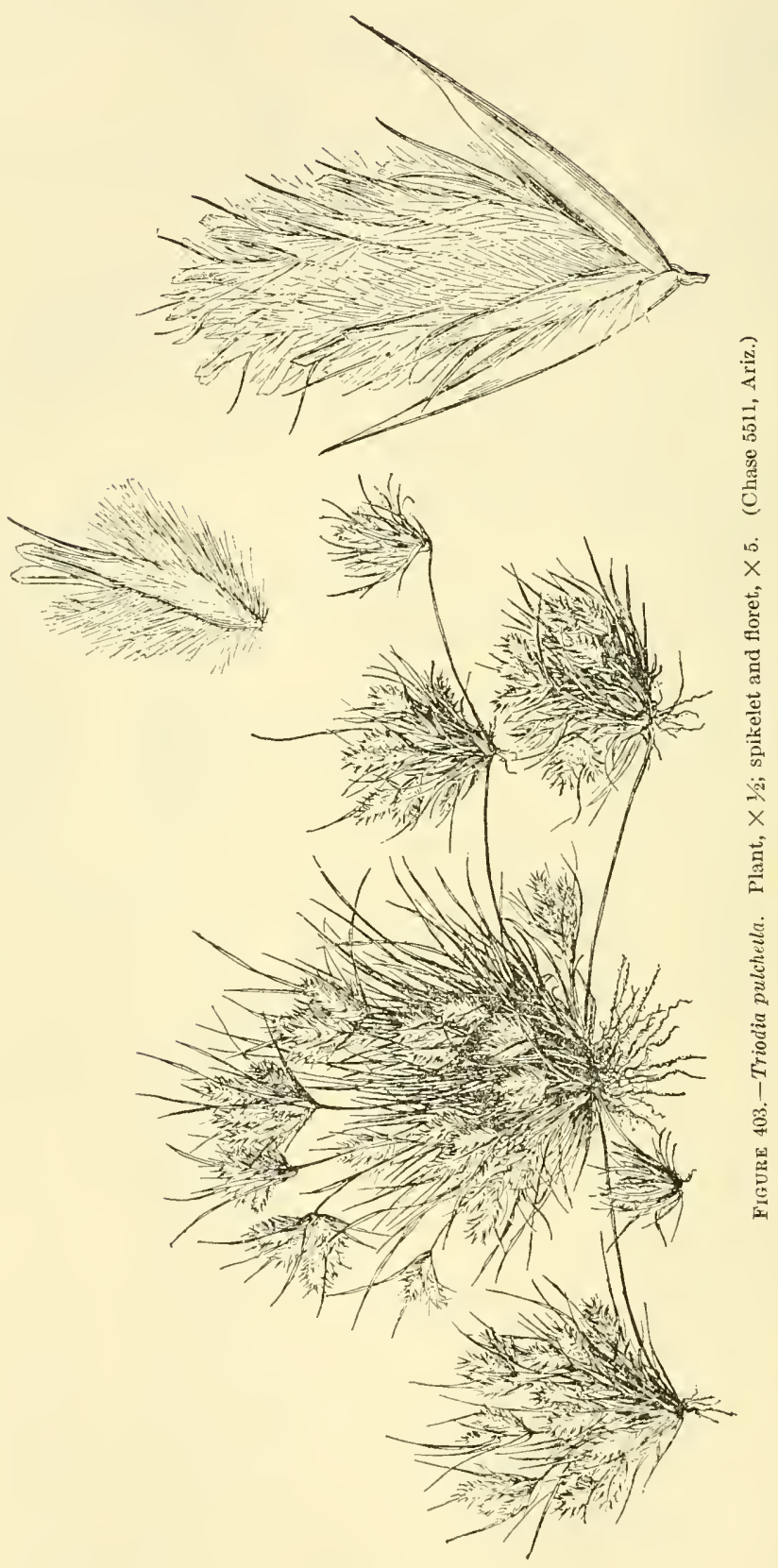


3. Triodia pilósa (Buckl.) Merr. Hairy triodia. (Fig. 406.) Culms crect, densely tufted, 10 to $30 \mathrm{~cm}$ tall, usually only 1 node showing, the tufts easily pulled up; sheaths pilose at the throat; blades 1 to $1.5 \mathrm{~mm}$ wide, flat or folded, mostly in a short basal cluster, somewhat pilose, the margins thick, white, the culm blades 1 to $2 \mathrm{~cm}$ long; panicle longexserted, ovoid, 1 to $2 \mathrm{~cm}$ long, pale or purplish, of 3 to 10 large short-pediceled spikelets; spikelets 6 - to 12 -flowered, 1 to $1.5 \mathrm{~cm}$ long, compressed, glumes about two-thirds as long

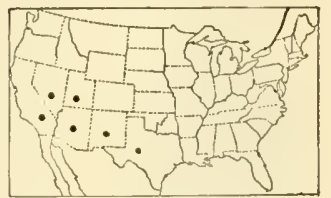

FigurF, 404.-Distribution of Triodia pulchella. as the lower florets; lemmas about $6 \mathrm{~mm}$ long, densely pilose toward the base, pilose on the margin toward the tip, acute, minutely 2-toothed, the awn 1 to $2 \mathrm{~mm}$ long; palea half as long as the lemma, pilose on the back and margins below. 24 (Triodia

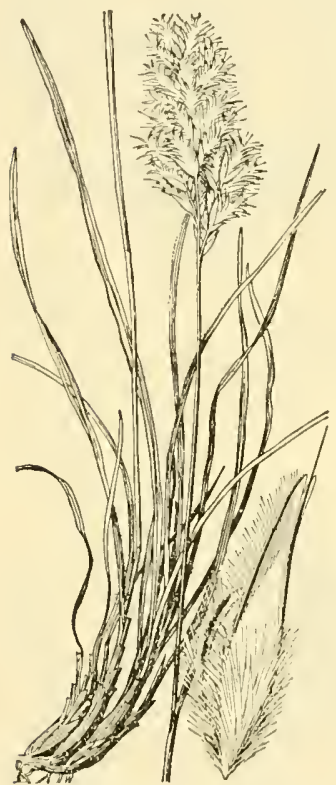

Figure 405.-Triodia grandiflora. Plant, $\times 1 / 2$; floret, $\times$ 5. (Eggleston 10973, Ariz.) acuminata Vasey; Tricuspis pilosa Nash; Erioneuron pilosum Nash.) Plains and rocky hills, western Kansas to Nevada, south to Texas, Arizona, and central Mexico (fig. 407).

4. Triodia congésta (L. H. Dewey) Bush. (Fig. 408.) Culms erect, tufted, 30 to $60 \mathrm{~cm}$ tall; blades flat, 2 to $3 \mathrm{~mm}$ wide, tapering to a fine point; panicle mostly dense, pale or pinkish, 4 to $10 \mathrm{~cm}$ long, sometimes interrupted below; spikelets rather turgid, 6- to 12-flowered, 5 to $10 \mathrm{~mm}$ long; lemmas 3 to $4 \mathrm{~mm}$ long, broad, obtuse, short-pilose on the midnerve and margin below, the apex slightly notched, the awn less than $1 \mathrm{~mm}$ long; palea about as long as the lemma,

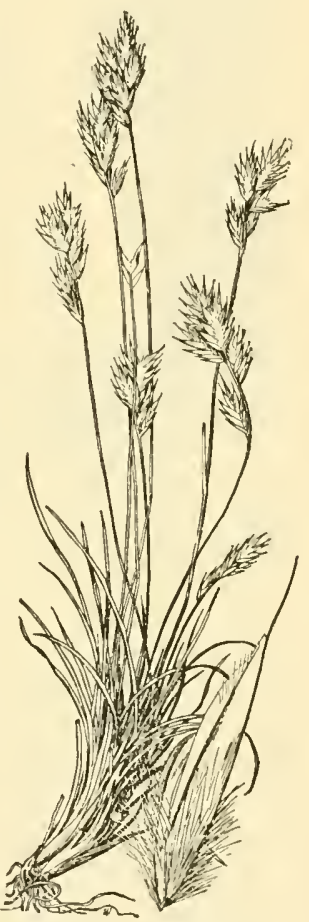

Figure 406.-Triodia pilosa. Plant, $\times 1 / 2 ;$ floret, $\times 5$. (Griffiths 6427, Tex.)

broad, abruptly bowed out below. 24 (Tridens congestus Nash.) Sandy or dry plains, southern Texas.

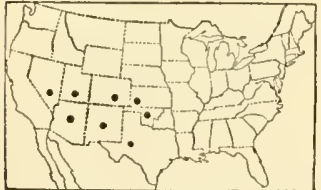

Figure 407.--Distribution of Triodia pilosa.

5. Triodia buckleyána (L. H. Dewey) Vasey. (Fig. 409.) Culms erect, tufted, 30 to $60 \mathrm{~cm}$ tall; sheaths, scaberulous, sometimes sparsely pilose; blades flat, 1 to $3 \mathrm{~mm}$ wide, tapering to a fine point; panicle 10 to $20 \mathrm{~cm}$ long, the few branches distant, ascending to spreading, as much as $7 \mathrm{~cm}$ long; spikelets pale to dark purple, short-pediceled, appressed, rather few and somewhat distant along the simple branches, 3 - to 5 -flowered, 6 to $8 \mathrm{~mm}$ long; glumes slightly shorter than the lower florets; lemmas 
4 to $5 \mathrm{~mm}$ long, pubescent on the callus and on the lower two-thirds of the midnerve and margin, the apex obtuse, entire, the midnerve not

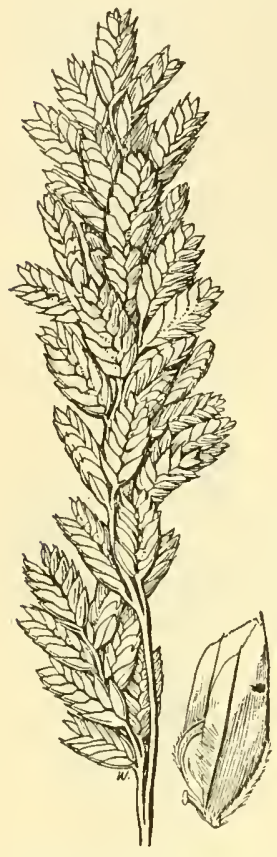

Figure 408.-Triodia con ${ }^{-}$ gesta. Panicle, $\times 1$; floret, $\times 5$. (Tracy 8879 , Tex.)

open, ovoid, pale 8 to $20 \mathrm{~cm}$ long, the branches ascending, 3 to $8 \mathrm{~cm}$ long; spikelets short-pediceled (p edicels less than $1 \mathrm{~mm}$ ) along the simple branches, 4- to 7-flowered, 4 to $6 \mathrm{~mm}$ long, nearly as broad, the florets crowded; glumes broad, subacute; lemmas 3 to $4 \mathrm{~mm}$ long, mucronate from a minutely lobed apex, the lateral nerves scarcely or barely exserted, pilose on the midnerve and margins on the lower half; palea nearly as long as the lemma, the keels bowed out below.

21 (T. ambigua Benth., not R. Br.; Tridens ambiguus Schult.)Wet pine barrens, on the coast, South Carolina to Florida and Texas (fig. 413). Plants of the Atlantic Coast (Triodia elliottii Bush) mostly have smaller spikelets with shorter lemmas than those of the Gulf region ( $T$. langloisiz), but there are numerous intergrades throughout the range. 
8. Triodia eragrostoídes Vasey and Scribn. (Fig. 414.) Culms slender, erect, densely tufted, 50 to $100 \mathrm{~cm}$ tall; blades flat, 1 to $4 \mathrm{~mm}$

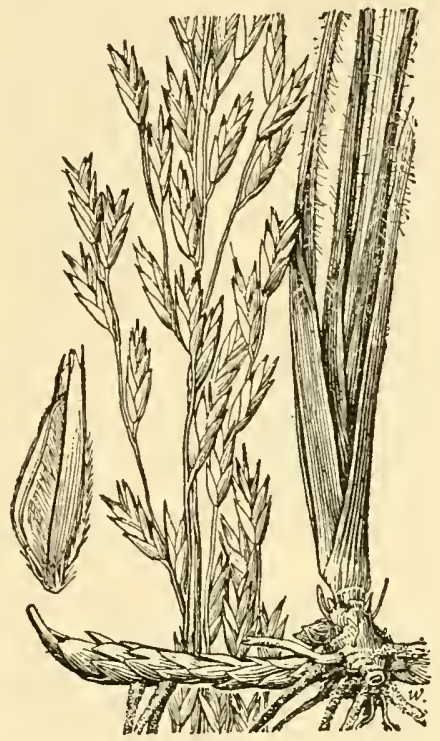

FIguRe 410-Triodia drummandii Plant, $\times 1$; floret, $X 5$. (Bartlett 3224 , Ala.) wide, setaceous-tipped; panicle open, 10 to $30 \mathrm{~cm}$ long, the branches rather distant, slender, flexuous, spreading or drooping, 5 to $15 \mathrm{~cm}$ long, nearly simple, rather few-flowered; spikelets on slender pedicels 1 to $10 \mathrm{~mm}$ long, oblong, mostly 6 - to 10-flowered, scarcely $5 \mathrm{~mm}$ long; glumes acuminate; lemmas about $2 \mathrm{~mm}$ long, obtuse, obscurely pubescent along the midnerve on the lower half, the margins pubescent, the midnerve minutely excurrent. 24 (Tridens eragrostoides

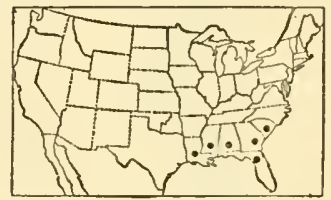

Figure 411.-Distribution of Triodia drummondii.

Nash.)-Dry ground among shrubs, Florida Keys, Texas, and northern Mexico; Cuba.

9. Triodia fláva (L.) Smyth. Purpletop. (Fig. 415.) Culms erect, solitary, tufted, 1 to $1.5 \mathrm{~m}$ tall; basal sheaths compressed-keeled; blades elongate, 3 to $10 \mathrm{~mm}$ wide, very smooth; panicle open, 15 to $35 \mathrm{~cm}$ long, usually purple or finally nearly black, rarely yellowish, the branches distant, spreading to drooping (sometimes

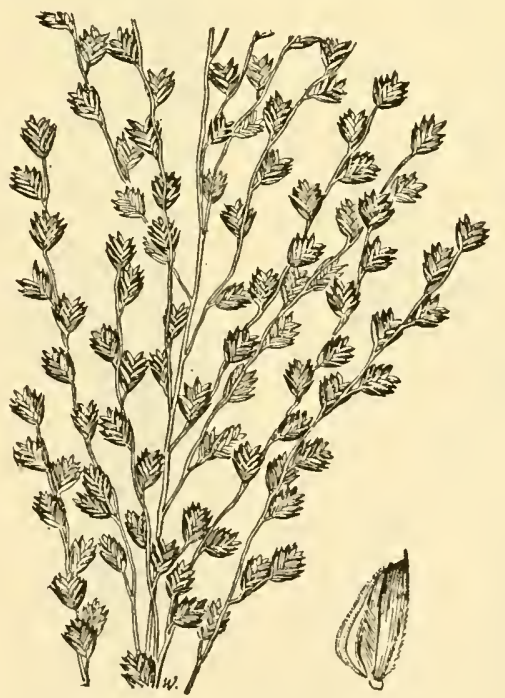

Figure 412.-Ttriodia langlorsii. Panicle, $\times 1$; floret, $\times 5$. (Curtiss 5020, Fla.)

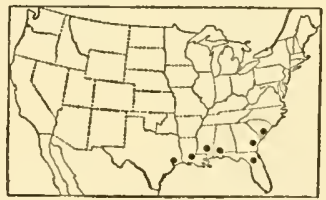

F1GURE 413.-Distribution of Triodia langloisii.

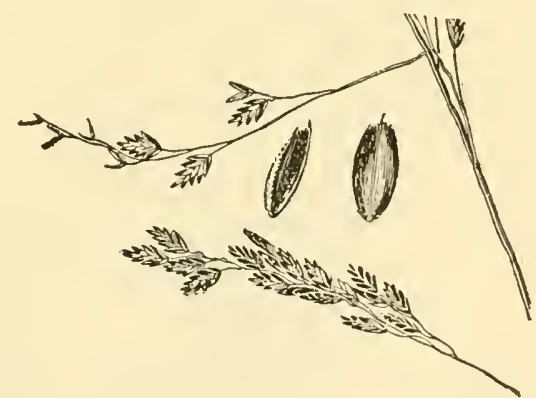

Figure 414.-Thiodia eragrostoides. Panicle, $\times 1$; two views of foret, $\times 5$. (Swallen 147l, Tex.)

shorter and stiffer), naked below, as much as $15 \mathrm{~cm}$ long with divergent slender branchlets, the axils pubescent, the axis, branches, branch- 


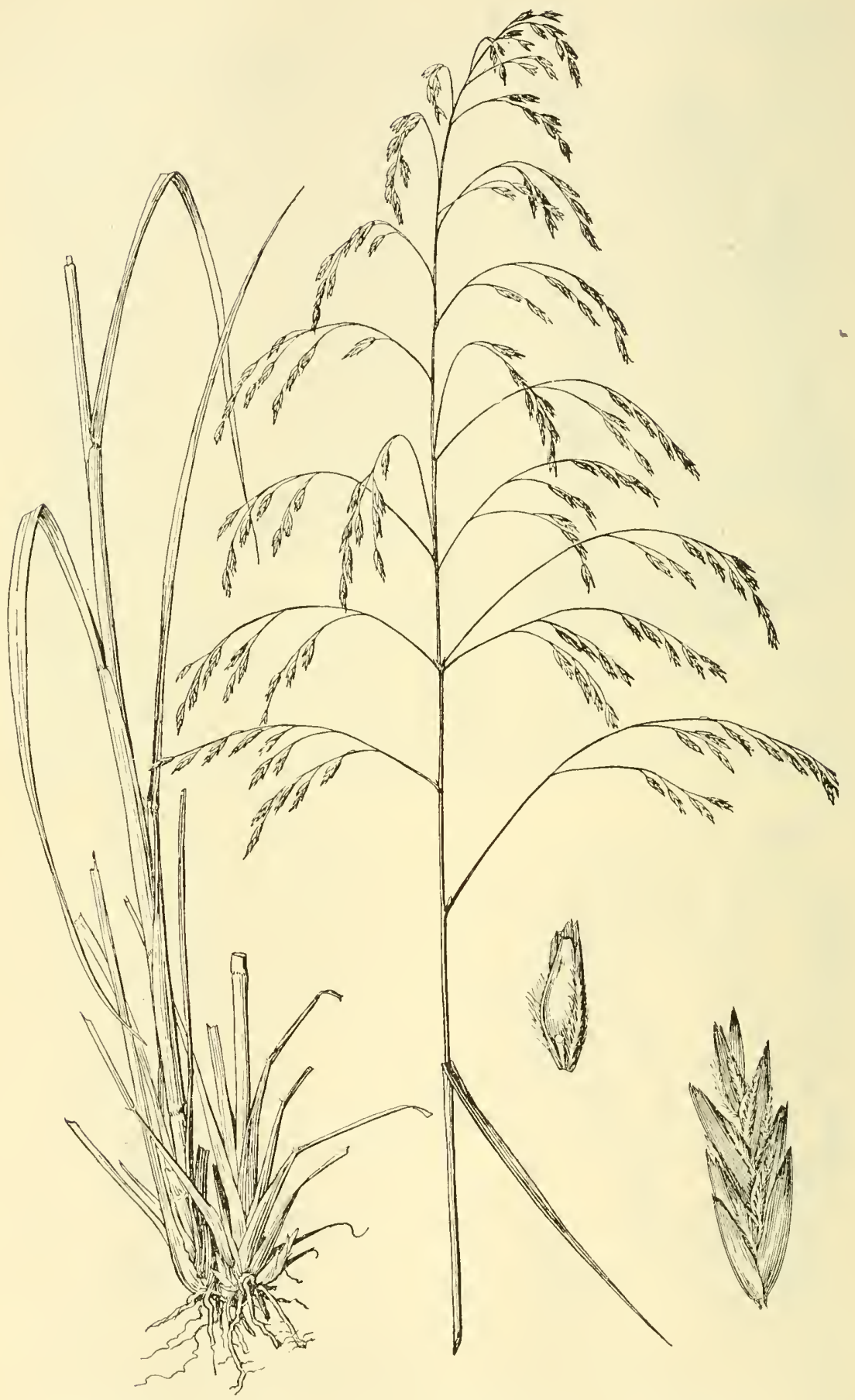

FIgURe 415.-Triodia flava. Plant, $\times 1 / 2$; spikelet and floret, $\times 5$. (Dewey 350, Va.) 
lets, and pedicels viscid; spikelets oblong, mostly 6 - to 8 -flowered, 5 to $8 \mathrm{~mm}$ long; glumes subacute, mucronate; lemmas $4 \mathrm{~mm}$ long, obtuse, pubescent on the callus and lower half of keel and margins, the 3 nerves excurrent; palea a little shorter than the lemma, somewhat bowed out below. 24 (Tricuspis seslerioides Torr.; Tridens seslerioides Nash; Tridens flavus Hitchc.) - Old fields and open woods, New Hampshire to Ne-

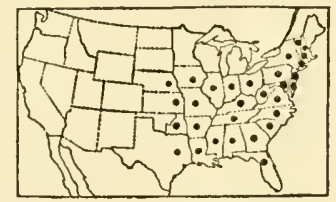

Figure $\begin{aligned} & \text { 416.-Distribution of } \\ & \text { Triodia flava. }\end{aligned}$

braska, south to Florida and Texas (fig. 416). The type specimen is the rare form with yellowish panicle. In some Florida specimens the excurrent nerves of the lemma are as much as $1 \mathrm{~mm}$ long.

10. Triodia texána S. Wats. (Fig.

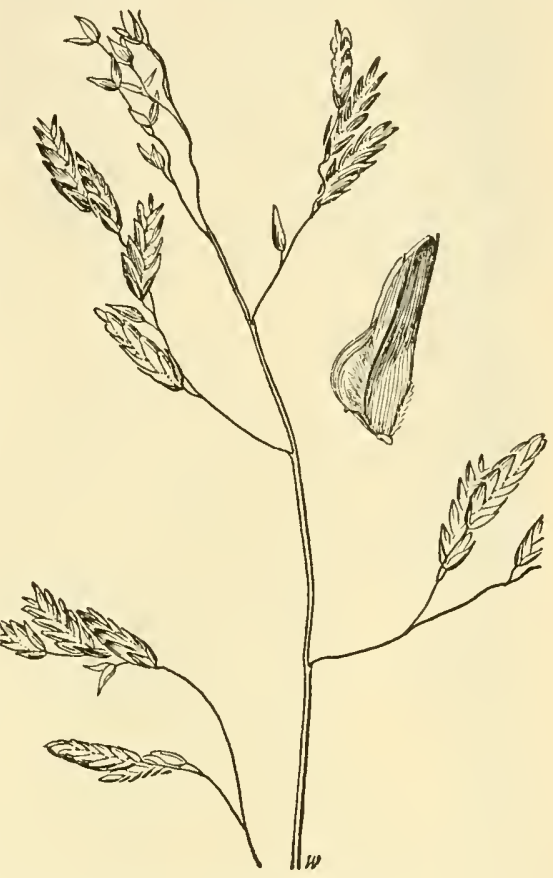

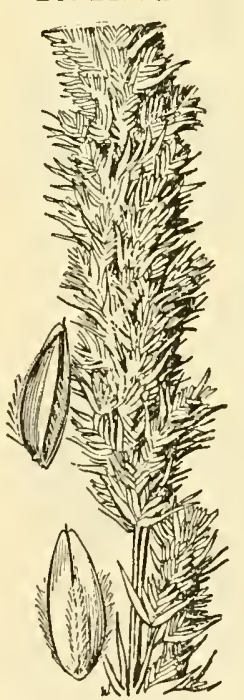

FIgure 418. - Triodia stricta. Panicle, $\times 1$; two views of thrort, $X$ 5. (Newlon, Kans.)
417 .) Culms Figure 417.-Triodia texana. Panicle, $\times 1$; floret, $\times$ erect, densely 5. (Wooton, Tex.)

tufted, 20 to $40 \mathrm{~cm}$ tall; sheaths pubescent at throat and collar; blades flat or subinvolute, 1 to $4 \mathrm{~mm}$ wide, tapering to a slender point; panicle open, 5 to $15 \mathrm{~cm}$ long, nodding, the branches rather distant, flexuous, drooping, few-flowered; spikelets oblong, 6- to 10flowered, 6 to $10 \mathrm{~mm}$ long, rather turgid, pink or purplish, more or less nodding on short pedicels; glumes broad, acute to obtuse; lemmas 4 to $5 \mathrm{~mm}$ long, obtuse, minutely lobed, the margins densely pilose near the base, the keel glabrous or sparsely pilose below, the 3 nerves short-excurrent; palea about as long as the lemma, strongly bowed out at base. 24 (Tridens texana Nash.)--Plains and dry slopes, central and southern Texas, and northern Mexico.

11. Triodia strícta (Nutt.) Benth. (Fig. 418.) Culms rather stout, erect, 1 to $1.5 \mathrm{~m}$ tall; blades elongate, flat or loosely involute, 3 to $8 \mathrm{~mm}$ wide; panicle dense, spikelike, more or less interrupted below, narrowed above, 10 to 
$30 \mathrm{~cm}$ long; spikelets short-pediceled, 4- to 6-flowered, about $5 \mathrm{~mm}$ long, the florets closely imbricate; glumes as long as the

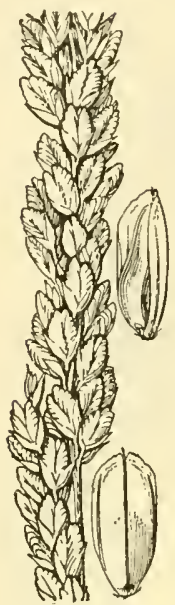

FIGURE 420.-TTtodia albescens. Panicle, $\times 1$; two views of fioret, $\times 5$. (B a 111652 , Tex.) spikelet, or nearly so, the apex spreading, the keel glandular-viscid toward maturity; lemmas about 3 $\mathrm{mm}$ long, obtuse, the keel and margins pilose on the lower half to two-thirds, the midnerve excurrent as a minute awn; palea about as long as the lemma, shortciliate on the sharp keels, not strongly bowed out. 24 (Tricuspis stricta A. Gray; Tridens strictus Nash.)-Low moist ground and low woods, Tennessee, Missouri, and Kansas to Alabama and Texas (fig. 419).

12. Triodia albéscens Vasey. White triodia. (Fig. 420.) Culms erect, tufted, 30 to $80 \mathrm{~cm}$ tall; blades flat to loosely involute, elongate, 2 to $4 \mathrm{~mm}$ wide,

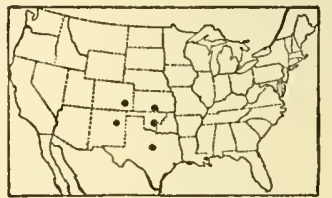

Figure 421-Distribution of Triodia albesccns. tapering to a fine point; panicle narrow, rather dense, greenish to nearly white, 10 to $20 \mathrm{~cm}$ long; spikelets short-pediceled, 8- to 12 -flowered, 5 to $7 \mathrm{~mm}$ long, the florets closely imbricate; glumes a little longer than the first lemma, subacute; lemmas 3 $\mathrm{mm}$ long, obscurely pubescent on the callus, otherwise glabrous, obtuse, the midnerve minutely or not at all excurrent; palea a little shorter than the lemma, bowed out below. 24 (Rhombolytrumalbescens Nash.)-Plains and open woods, Kansas and Colorado to Texas and New Mexico; northern Mexico (fig. 421).

13. Triodia mútica

(Torr.) Scribn. Suim TRIODIA. (Fig. 422.) Culms slender, densely tufted, 30 to $50 \mathrm{~cm}$ tall; sheaths and blades scaberulous, the sheaths usually loosely pilose, more densely so at the summit; blades flat or subinvolute, 1 to $3 \mathrm{~mm}$ wide, sometimes sparsely pilose; panicle narrow, rather dense, interrupted, the branches short, appressed; spikelets 6- to 8flowered, about $1 \mathrm{~cm}$ long, pale to purplish, nearly

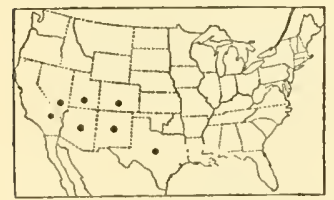

FIgURE 423--Distribution of Triodia mutica. terete; glumes scaberulous, about as long as the lower florets; lemmas about $5 \mathrm{~mm}$ long, densely pilose on the lower half of the nerves and on the callus, obtuse, entire or minutely notched, the midnerve not exserted; palea

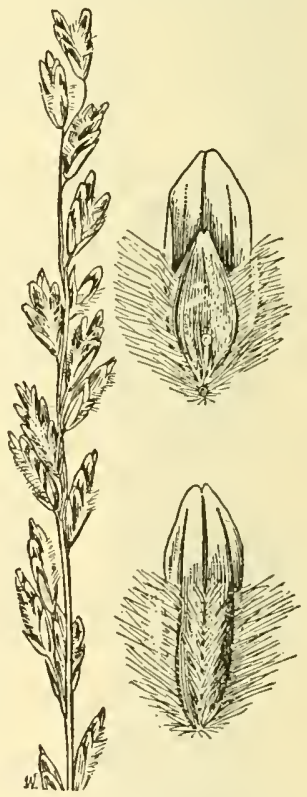

Figure 422,-Triodia mutica. Panicle, $\times 1$; two views of floret, $\times 5$. (Chase 5902, Tex.)

half or two-thirds as long as the lemma, densely pilose on the keels and puberulent on the back. 24 (Tridens muticus Nash.)-Plains and rocky slopes, Arkansas and Texas to southeastern California, north to Nevada, Utah, and Colorado (fig. 423). 
14. Triodia elongáta (Buckl.) Scribn. Rough triodia. (Fig. 424.) Culms erect, tufted, 40 to $80 \mathrm{~cm}$ tall; sheaths and blades scaberulous, sometimes sparsely pilose, the blades mostly flat, 2 to $4 \mathrm{~mm}$ wide, tapering to a fine point; panicle elongate, erect, pale or purple tinged, loosely flowered, 10 to $25 \mathrm{~cm}$ long, the branches rather distant, appressed, scarcely or not at all overlapping; spikelets similar to those of T. mutica, the glumes longer, the hairs on the florets not so long. 2 (Tridens elongatus Nash; Tricuspis elongata Nash.)-Plains, sandy prairies, and rocky slopes, Missouri and Kansas to Texas and Arizona (fig. 425).

\section{TRÍPLASIS Beauv.}

Spikelets few-flowered, V-shaped, the florets remote, the rachilla slender, disarticulating above the glumes and between the florets; glumes nearly equal, smooth, 1-nerved, acute; lemmas narrow, 3-nerved, 2-lobed, the nerves parallel, silky-villous, the lateral pair near the margin, the midnerve excurrent as an awn, as long as the lobes or longer; palea shorter than the lemma, the keels densely long-villous on the upper half. Slender tufted annuals or perennials, with short blades, short, open, few-flowered purple terminal panicles and cleistogamous narrow panicles in the axils of the leaves. Both species, have, in addition to the small panicles of cleistogamous spikelets in the upper sheaths, additional cleistogamous spikelets, reduced to a single large floret, at the bases of the lower sheaths. The culms break at the nodes, these mature cleistogenes remaining within the sheaths. Type species, Triplasis americana. Name from Greek triplasios, triple, alluding to the

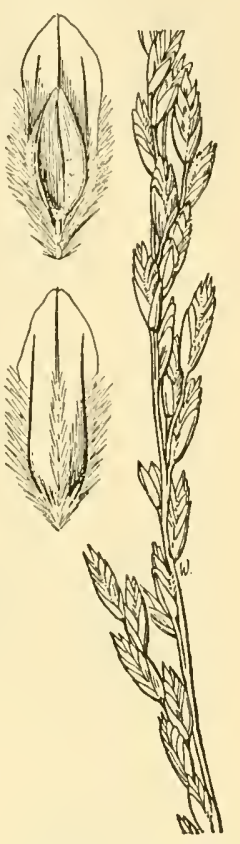

Figure 424.-Triodia elongata. Panicle, $X$ 1 ; two views of floret, $\times 5$. (Ball 1535, Tex.) awn and the two subulate lobes of the lemma. The species are of no importance except as they tend to hold sandy soil.

Lobes of lemma not subulate-pointed; awn shorter than the lemma; annual.

1. T. PURPUREA. Lobes of lemma subulate-pointed; awn longer than the lemma; perennial.

2. T. AMERICANA.

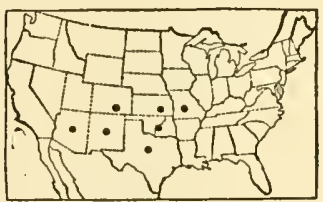

FIGURE 425.-Distribution of Triodia elongata.

1. Triplasis purpúrea (Walt.) Chapm. (Fig. $426, A$.) Annual, often purple; culms ascending to widely spreading, pubescent at the several to many nodes, 30 to $75 \mathrm{~cm}$ tall; blades flat or loosely involute, 1 to $3 \mathrm{~mm}$ wide, mostly 4 to $8 \mathrm{~cm}$ long; panicle 3 to $5 \mathrm{~cm}$ long, with few spreading few-flowered branches, the axillary more or less enclosed in the sheaths; spikelets short-pediceled, 2- to 4-flowered, 6 to $8 \mathrm{~mm}$ long; lemmas 3 to $4 \mathrm{~mm}$ long, the lobes broad, rounded or truncate, the nerves and callus densely short-villous, the awn about as long as the lobes 


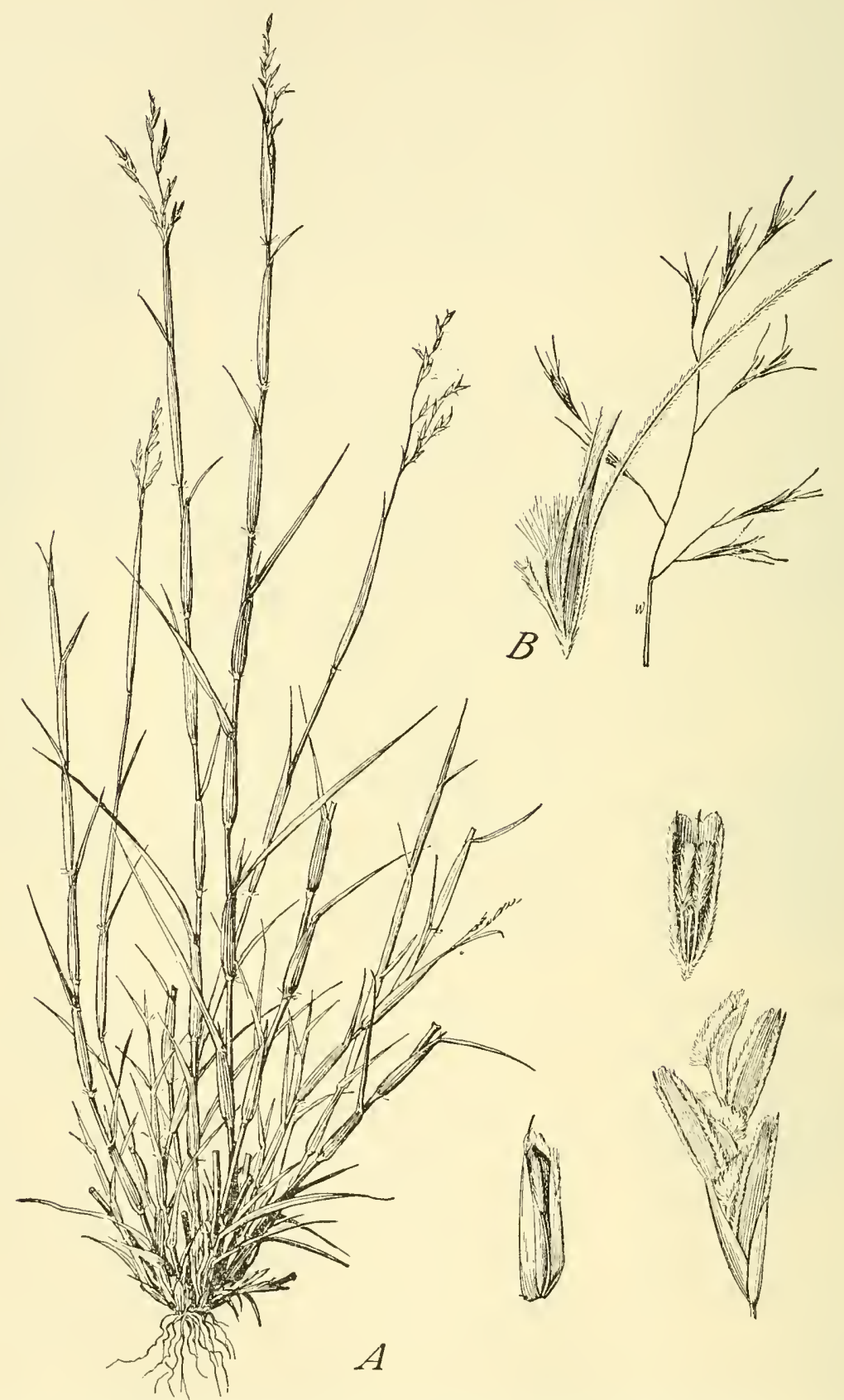

FIGURE 426.-A, Triplasis purpurea. Plant, $\times 1 / 2$; spikelet, floret, and cleistogamous spikelet, $\times 5$. (Commons 255, Del.) B, T. americana. Panicle, $\times 1$; floret, $\times 5$. (Curtiss 5570, Fla.) 
or somewhat exceeding them; palea conspicuously silky-villous on the upper half of the keels; grain about $2 \mathrm{~mm}$ long. $\odot-$ Dry sand, New Hampshire to Mimnesota and Nebraska, south to Florida and Texas (fig. 427). In autumnal culms the numerous short joints with sheaths swollen at the base, containing cleistogenes, are conspicuous. Plants with awns exceeding the lobes of the lemma have been differentiated as $T$. intermedia Nash.

2. Triplasis americána Beauv. (Fig. 426, B.) Perennial; culnus slender, tufted, mostly erect, 30 to $60 \mathrm{~cm}$ tall; blades flat or subinvolute,

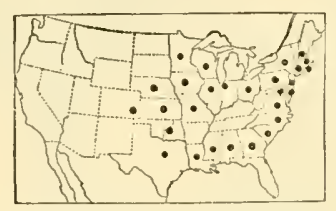

FIGURE 427.-Distribution of Triplasis purpurea.

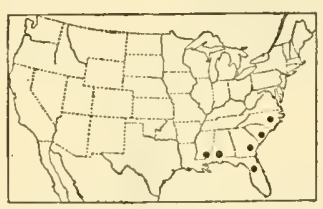

FIGURE 428.-Distribution of Triplasis americana.

mostly 15 to $18 \mathrm{~cm}$ long; panicle 2 to $5 \mathrm{~cm}$ long, the few slender ascending branches with 1 or. 2 spikelets; spikelets mostly 2 - or 3 flowered, about $1 \mathrm{~cm}$ long; lemmas 5 to $6 \mathrm{~mm}$ long, the lobes about half as long as the entire lemma, subulate-pointed, the nerves with a narrow stripe of silky hairs, the awn 5 to $8 \mathrm{~mm}$ long, pubescent below; keels of the palea long-villous, the hairs erect. 24. Dry sand, Coastal Plain, North Carolina to Florida and Mississippi (fig. 428).

\section{ANTHŌCHLOA Nees}

Spikelets few-flowered, subsessile, imbricate on a simple axis, the rachilla disarticulating above the glumes and between the florets; glumes (in our species) wanting; lemmas thin-membranaceous, flabelliform, whitish, petallike, many-nerved; palea narrower than the lemma, hyaline. Low annuals or peremials, with soft dense cylindric panicles. Type species, Anthochloa lepidula Nees. Name from Greek anthos, flower, and chloa, grass, alluding to the flowerlike appearance of the inflorescence.

1. Anthochloa colusána (Davy) Scribn. (Fig. 429.) Annual; culms ascending from a decumbent base, 7 to $30 \mathrm{~cm}$ long; leaves overlapping, pale green, scarious between the nerves, loosely folded around the culm, not differentiated into sheath and blade, about 12 $\mathrm{mm}$ wide at the middle, tapering to each end, 5 to $10 \mathrm{~cm}$ long, keeled on the back above, plicate, minutely ciliate, with raised glands on the margins and nerves; panicle pale green, at first partly included, never much cxserted, 3 to $7 \mathrm{~cm}$ long, 8 to $12 \mathrm{~mm}$ wide, the upper part of the axis bearing, instead of spikelets, lanceolate-linear empty bracts 8 $\mathrm{mm}$ long; spikelets subsessile, usually 5-flowered, 6 to $7 \mathrm{~mm}$ long, imbricate; glumes wanting; lemmas flabellate, very broad, manynerved, $5 \mathrm{~mm}$ long, ciliolate-fringed. $\odot$ - Known only from "near Princeton, Colusa County, Calif., bordering rain-pools on the hard uncultivated alkali 'goose-lands,' beside the stage road to Norman." Region now in rice culture. 


\section{ORCÚTTIA Vasey}

Spikelets several-flowered, the upper florets reduced; rachilla persistent, continuous, the florets falling away, or tardily disarticu-

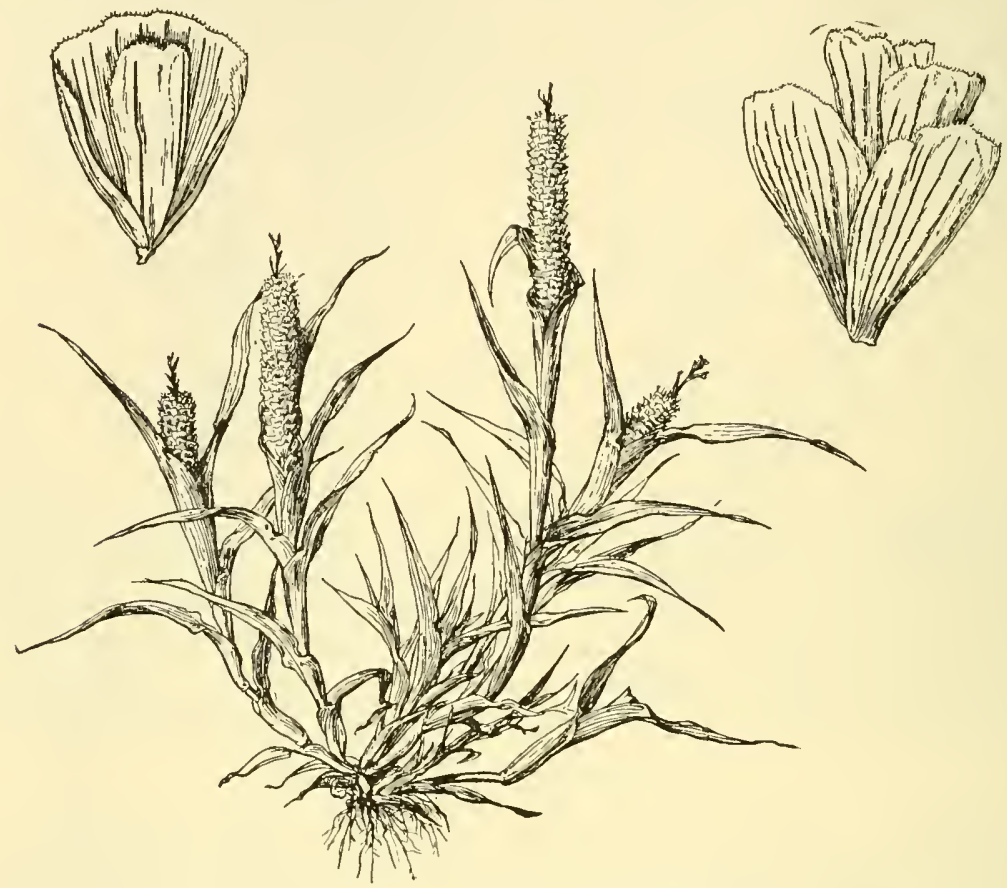

Figure 429.-Anthochloa colusana. Plant, $\times 1 / 2$; spikelet and floret, $\times 5$. (Type.)

lating; glumes nearly equal, shorter than the lemmas, broad, irregu-

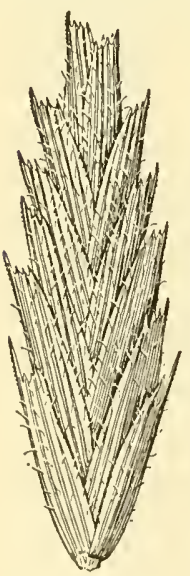
larly 2- to 5-toothed, many-nerved, the norves extending in to the teeth; lemmas firm, prominently 13- to 15nerved, the broad summit toothed; palea broad, as long as the lemma. Low tufted annuals, with short blades and solitary spikes or spikelike racemes, the subsessile spikelets relatively large, the upper aggregate, the lower more or less remote. Type species, Orcuttia californica. Named for C. R. Oreutt.

Lemmas with 7 to 11 short teeth.......... 1. O. GREENEI. Lemmas with 5 awn-tipped teeth.

Blades filiform, glabrous _._. Blades flat, 1.5 to $3 \mathrm{~mm}$ wide, pilose... 3. O. CAlifornica.

1. Orcuttia greénei Vasey. (Fig. 430.) Culms 15 to $20 \mathrm{~cm}$ tall, suberect; blades 2 to $3 \mathrm{~cm}$ long, subinvolute; raceme 3 to $7 \mathrm{~cm}$ long, pale; spikelets 10 to $15 \mathrm{~mm}$ long, loosely papillose-pilose; glumes 4 to $5 \mathrm{~mm}$ long; lemmas $6 \mathrm{~mm}$ long, the obtuse or truncate tip

F I G UR R $430 .-$ Orcuttza greenei.
Spikelet, $\times 5$. (Type.) spreading, 7 - to 11-toothed, the teeth mucronate but not awned. $\odot$-Known only from moist plains of the upper Sacramento near Chico, Calif.

2. Orcuttia ténuis Hitchc. (Fig. 431.) Culms in small tufts, slender, erect, 5 to $12 \mathrm{~cm}$ tall; leaves mostly basal, the blades firm, 
strongly nerved, filiform, 1 to $2 \mathrm{~cm}$ long; raceme more than half the entire height of the plant, the lower spikelets distant, the upper approximate but not crowded; spikelets purple-tinged, 12 to $15 \mathrm{~mm}$ long, the rachilla joints pubescent; glumes and lemmas scabrous, sometimes with a few hairs toward the base of the lemmas; glumes 3 to $4 \mathrm{~mm}$ long, sharply toothed; lemmas $5 \mathrm{~mm}$ long, 5-toothed, the teeth acuminate, awn-tipped, the rigid tips spreading or slightly recurved. $\odot$-Known only from sandy open ground, Goose Valley, Shasta County, Calif.

3. Orcuttia califórnica Vasey. (Fig. 432.) Culms 5 to $15 \mathrm{~cm}$ long, spreading with ascending ends, forming little mats; foliage thin, pilose, the sheaths loose, the blades 2 to $4 \mathrm{~cm}$ long; raceme loose below,
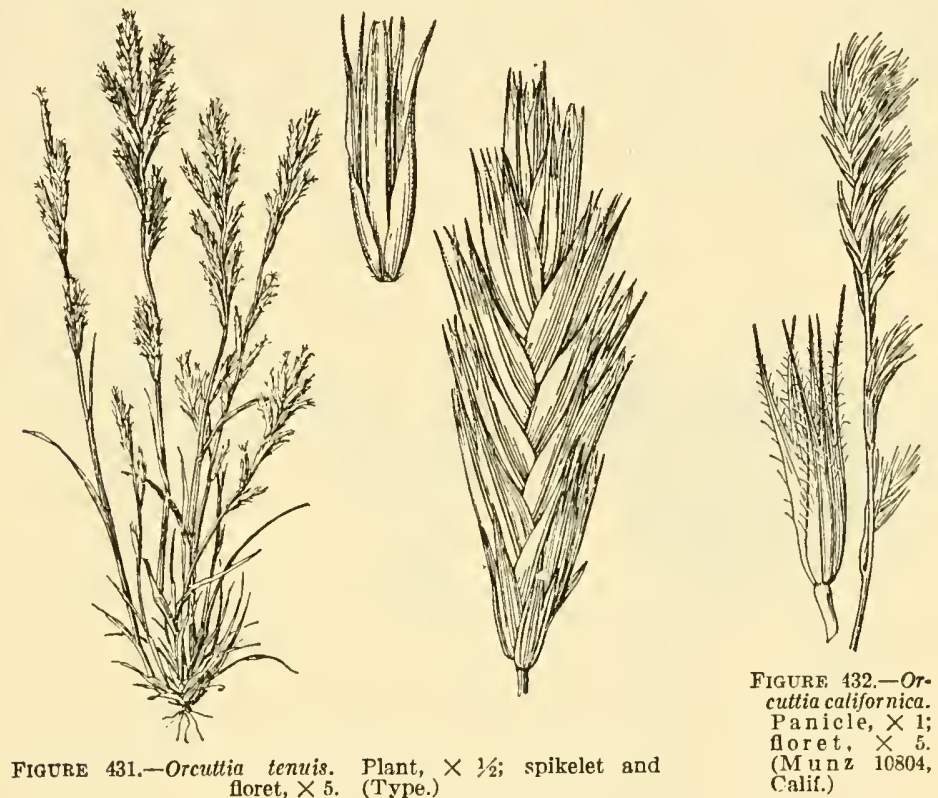

dense or subcapitate at the summit; spikelets 8 to $12 \mathrm{~mm}$ long; densely to sparsely pilose; glumes sharply-toothed; lemmas about 6 $\mathrm{mm}$ long, deeply cleft into 5 awn-tipped teeth. $\odot$-Drying mudflats, near Murietta, Hot Springs, Riverside County, Calif.; Baja California.

\section{BLEPHARIDÁCHNE Hack.}

Spikelets compressed, 4-flowered, the rachilla disarticulating above the glumes but not between the florets; glumes nearly equal, compressed, 1-nerved, thin, smooth; lemmas 3-nerved, the nerves extending into awns, dceply 3 -lobed, conspicuously ciliate, the first and second sterile, containing a palea but no flower, the third fertile, the fourth reduced to a 3-awned rudiment. Low annuals or perennials, with short, dense, few-flowered panicles scarcely exserted from the 
subtending leaves. Type species, Blepharidachne kingii. Name from Greek blepharis (blepharid-), eyelash, and achne, chaff, alluding to the ciliate lemma.

Glumes a little longer than the florets, acuminate; foliage scaberulous.

1. B. KINGII.

Glumes a little shorter than the florets, subacute; foliage densely grayish narshpuberulent

B. BIGELOVII.

1. Blepharidachne kíngii (S. Wats.) Hack. (Fig. 433.) Low tufted perennial with the aspect of Triodia pulchella, but not rooting at upper nodes; culms mostly less than $10 \mathrm{~cm}$ tall; sheaths with broad hyaline margins; blades less than $1 \mathrm{~mm}$ wide, involute, curved, sharp-pointed, 1 to $3 \mathrm{~cm}$ long; panicles subcapitate, pale or purplish, 1 to $2 \mathrm{~cm}$ long, exceeded by the upper blades; spikelets flabellate; glumes about $8 \mathrm{~mm}$ long, acuminate, exceeding the florets; sterile lemmas about $6 \mathrm{~mm}$ long, all the lemmas about the same height, long-ciliate on the margins, pilose at the base and on the callus, cleft nearly to the middle, the lateral lobes narrow, obtuse, the nerve at one margin, awn-tipped, the central lobe consisting of the

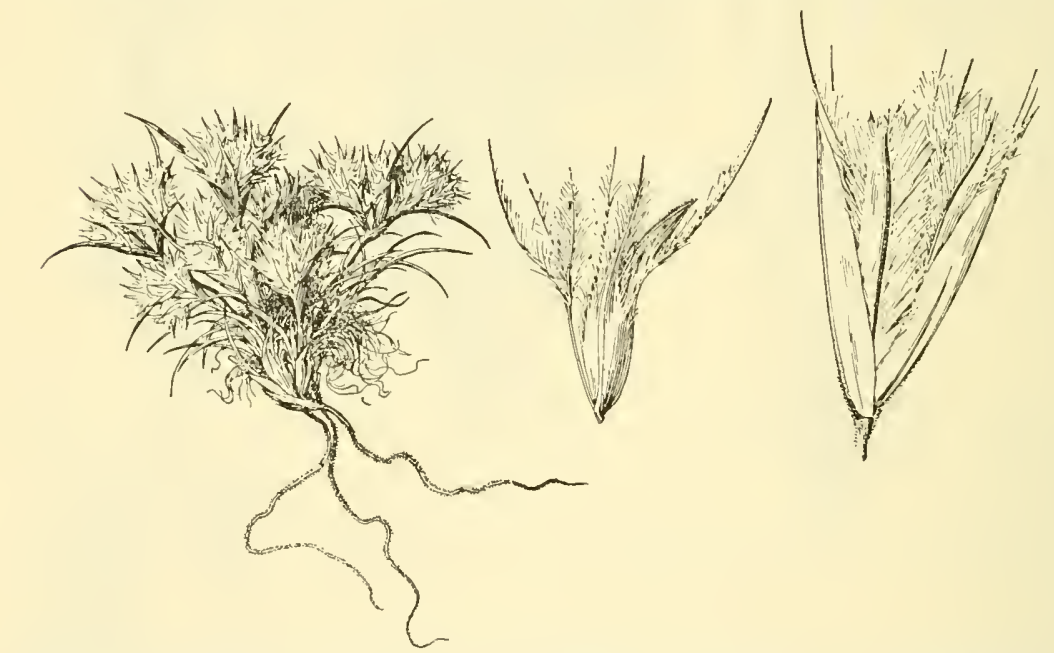

FIGURE 433.--Blepharidachne kingii. Plant, $\times 1$; spikelet and perfect floret, $\times 5$. (Jones 4094, Nev.)

awn, ciliate below, somewhat exceeding the lateral ones; palea much narrower and somewhat shorter than the lemma; fertile lemma similar to the sterile ones, the palea broad and as long as the lemma; upper sterile lemma on a rachilla joint about $3 \mathrm{~mm}$ long, reduced to 3 plumose awns; grain compressed, $2 \mathrm{~mm}$ long. 21 -Deserts, Nevada and California (Death Valley), apparently rather rare.

2. Blepharidachne bigelóvii (S. Wats.) Hack. (Fig. 434.) Perennial; culms stiff, 10 to $20 \mathrm{~cm}$ long, the culms and foliage harshpuberulent; sheaths broad, firm; blades coarser than in B. kingii; panicles dense, oblong, 1 to $3 \mathrm{~cm}$ long, the blades not exceeding the panicle; glumes about $6 \mathrm{~mm}$ long, subacute, shorter than the florets; sterile lemmas ciliate and awned as in $B$. kingii, cleft about $1 \mathrm{~mm}$. 24 -Known only from rocky hills, Frontera, above El Paso, Tex. 


\section{COTTEA Kunth}

Spikelets several-flowered, the uppermost reduced, the rachilla disarticulating above the glumes and between the florets; glumes about equal, nearly equaling the lower lemma, with several parallel nerves; lemmas rounded on the back, villous below, prominently 9to 11-nerved, some of the nerves extending into awns of irregular size and some into awned teeth; palea a little longer than the body of the lemma, the keels near the margin. An erect tufted branching perennial with flat blades and oblong loose panicle. Type species, Cottea pappophoroides. Named for Heinrich Cotta.

1. Cottea pappophoroídes Kunth. (Fig. 435.) Softly pubescent throughout; culms 30 to $50 \mathrm{~cm}$ tall; blades 3 to $7 \mathrm{~mm}$ wide; panicle 8 to $15 \mathrm{~cm}$ long, the branches loosely ascending; spikelets 4- to 7 -flowered, 5 to $7 \mathrm{~mm}$ long, about $5 \mathrm{~mm}$ wide, green or purplish; glumes 4 to $5 \mathrm{~mm}$ long; lemmas 3 to $4 \mathrm{~mm}$ long, the basal hairs conspicuous, at least the middle awn spreading. 21 -Plains and dry hills, western Texas to southern Arizona, south to central Mexico; Ecuador to Argentina. Cleistogamous spikelets, usually reduced to a single floret, are found in the lower sheaths, and often large, very turgid ones at the very base. Not abundant enough to have economic importance.

\section{PAPPOPHORUM Schreb. PAPPUsgrass}

Spikelets 2- to 5-flowered, the upper reduced, the rachilla disarticulating above the glumes but not or only tardily between the florets, the internodes very short; glumes nearly equal, keeled, thin-membranaceous, as long as the body of the florets or longer, 1- to several-nerved, acute; lemmas rounded on the back, firm, obscurely manynerved, dissected above into numerous spreading awns, the florets falling together, the awns of all forming a pappus-like crown; palea as long as the body of the lemma, the nerves near the margin. Erect tufted perennials, with narrow or spikelike whitish to tawny or purplish panicles. Type spe-

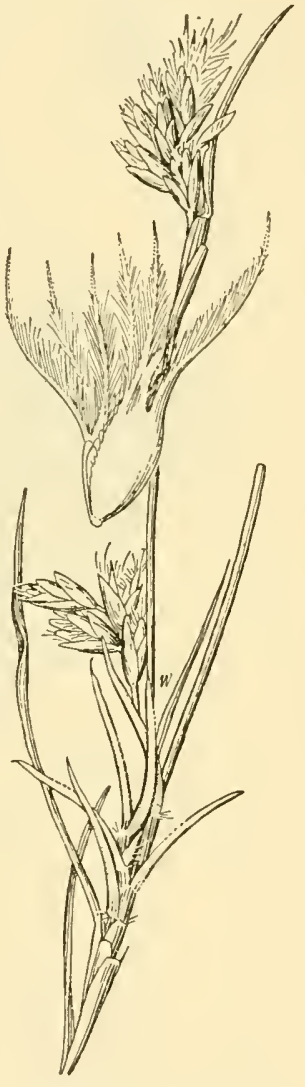

Fig CRE $434,-$ - Blepharidachne bigclovii. Plant, $\times 1$; fertile floret, $\times 5$. (Type.)

cies, Pappophorum alopecuroideum Vahl. Name from Greek pappos, pappus, and phoros, bearing, alluding to the pappus-like crown of the lemma. Our species are of minor economic importance, though the first two may constitute a fair proportion of the forage on sterile hills.

Awns plumose; panicle plumbeous, usually less than $5 \mathrm{~cm}$ long. 1 . P. WRightir. Awns scabrous; panicle tawny to pink, usually more than $5 \mathrm{~cm}$ long.

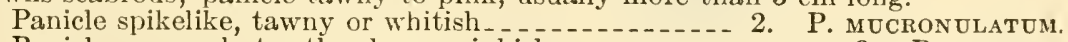

Panicle narrow but rather loose, pinkish 


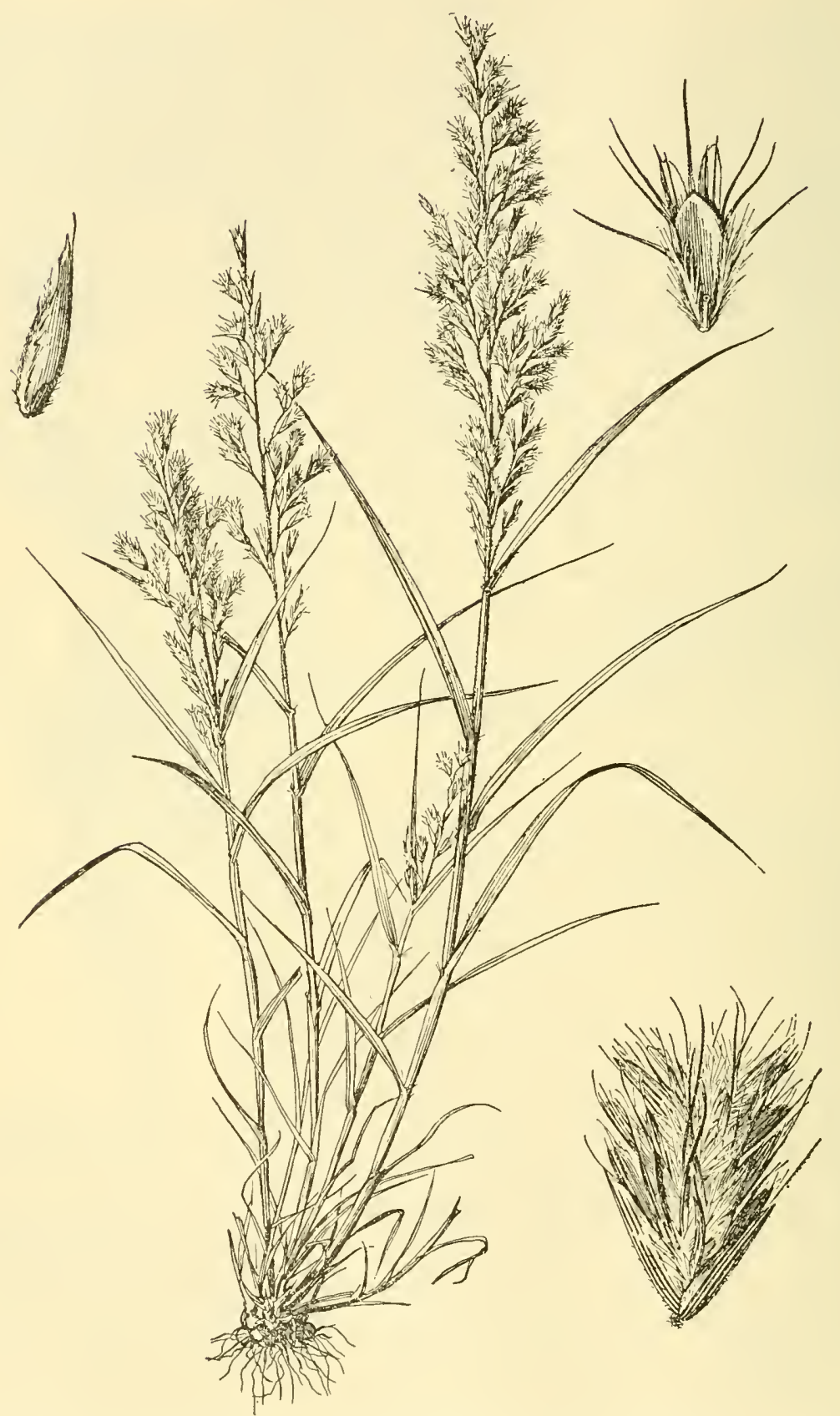

Figtre 435.-Cottea pappophoroides. Plant, $\times 1 / 2$; spikelet, floret, and cleistogene, $\times 5$. (Griffiths 5946, Ariz.) 


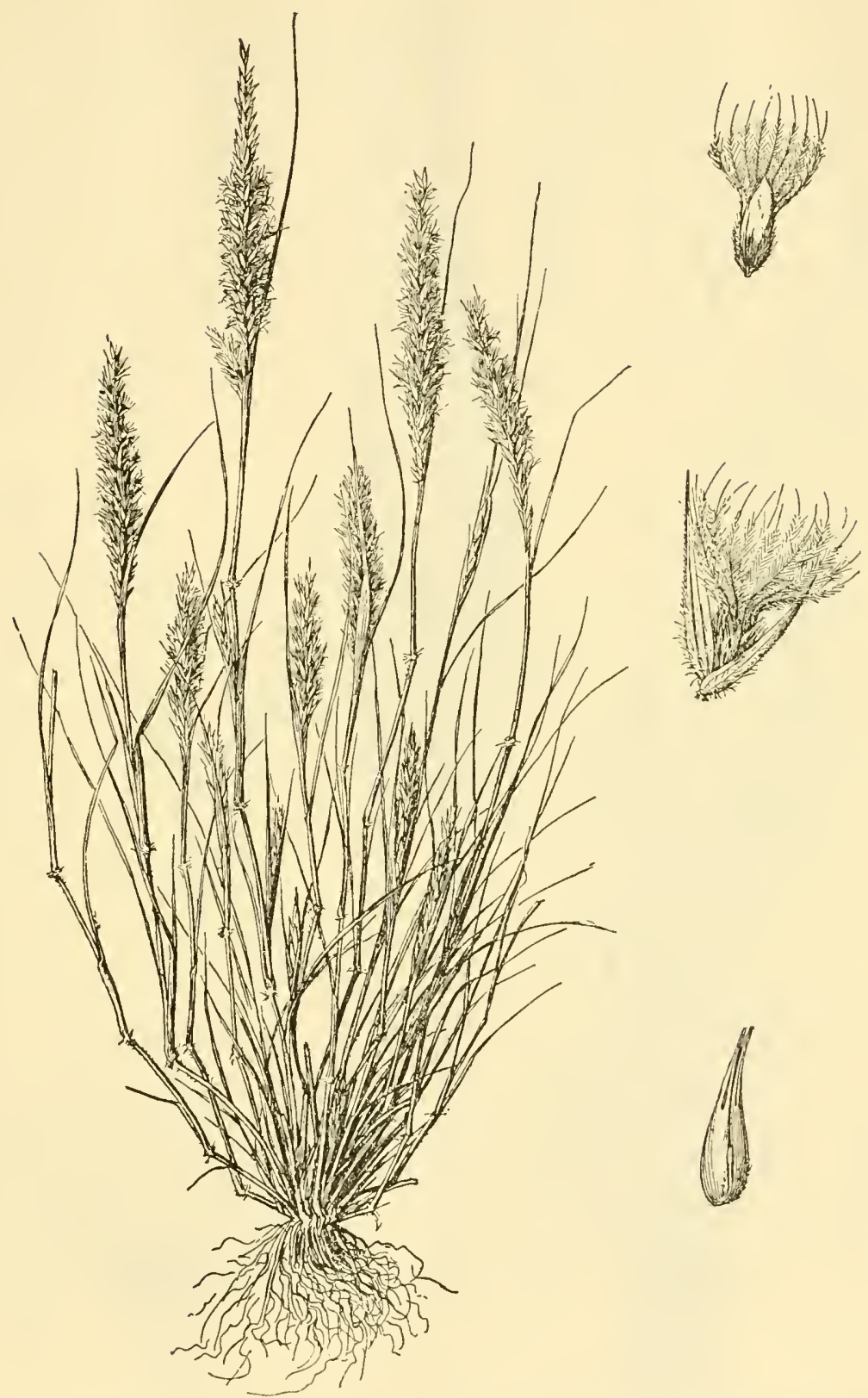

FIgURE 436.-Pappophorum urightii Plant, $\underset{8272, \text { Ariz.) }}{\times 1 / 2 ;}$, spikelet, perfect floret, and cleistogene, $\times 5$. (Purpus 


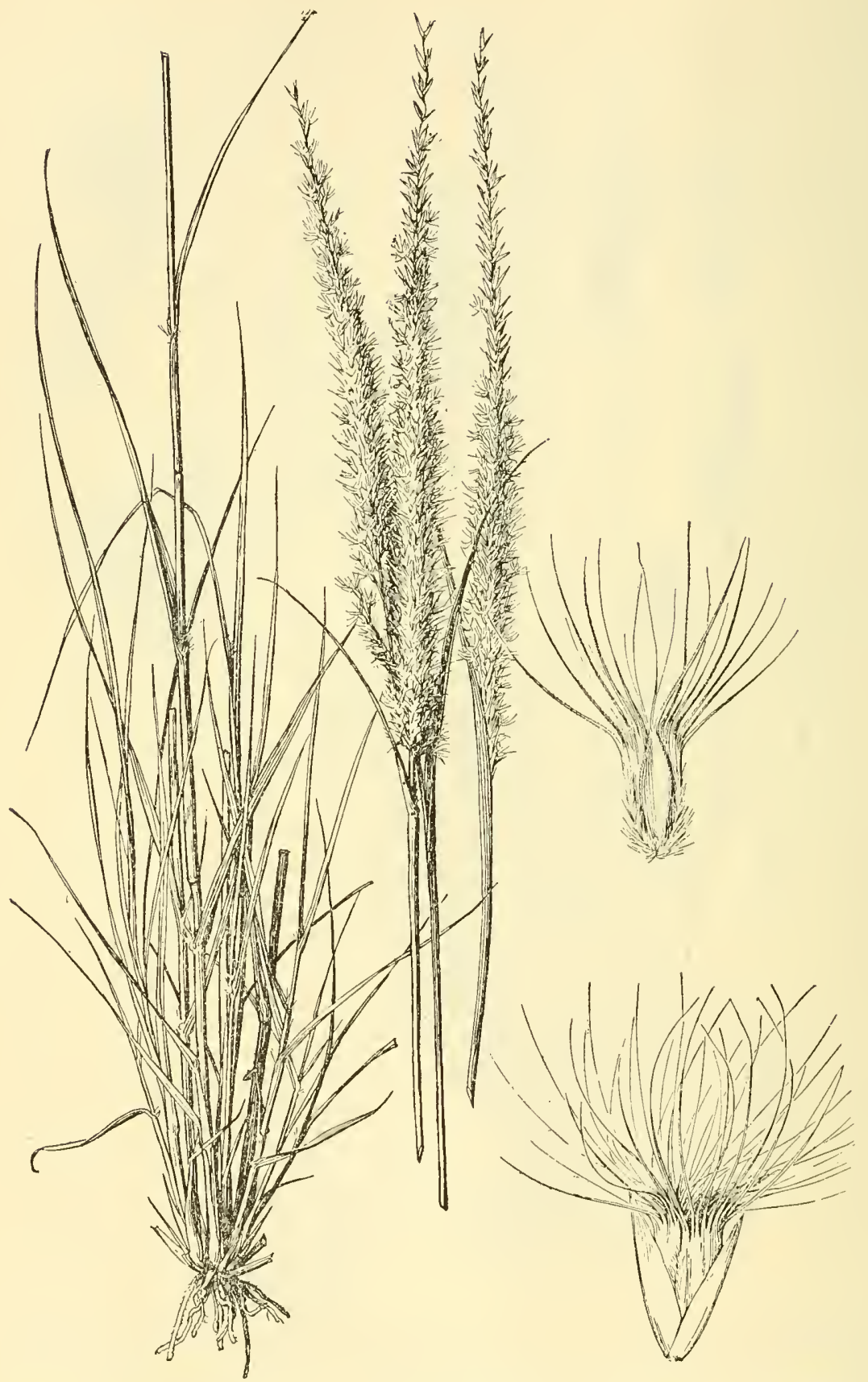

FigdRE 437.-Pappophorum mucronulatum. Plant, $\times \frac{1}{2}$; spikelet and perfect floret, $X 5$. (Pringle, Ariz.) 
Section 1. Enneapógon Trin.

Spikelets 3-flowered, the first floret fertile, the second smaller, sterile, the third rudimentary; awns 9 , plumose.

1. Pappophorum wríghtii S. Wats. Spike pappusgrass. (Fig. 436.) Culms numerous, slender, decumbent-spreading, 20 to $40 \mathrm{~cm}$ tall, the nodes pubescent; blades flat to subinvolute, about $1 \mathrm{~mm}$ wide; panicle spikelike, gray-green or drab, mostly 2 to $5 \mathrm{~cm}$ long, sometimes interrupted below; glumes 7-nerved; lemma of first floret (including awns) 4 to $5 \mathrm{~mm}$ long, the body about $1.5 \mathrm{~mm}$ long, villous, 9-nerved, the awns plumose. 2 -Dry plains and stony hills, Texas to Arizona, south to Oaxaca; Peru and Bolivia. Cleistogamous spikelets are produced in the lower sheaths. The cleistogenes are larger than the normal florets but the awns are almost wanting. The culms disarticulate at the lower nodes carrying the cleistogenes with them.

\section{Section 2. Polyráphis Trin.}

Spikelets 4- to 6-flowered, the lower 1 to 3 fertile, the upper reduced or rudimentary; awns more than 9 , seabrous.

2. Pappophorum mucronulátum Nees. (Fig. 437.) Culms erect, 60 to $100 \mathrm{~cm}$ tall; blades flat to subinvolute, 2 to $5 \mathrm{~mm}$ wide; panicle spikelike, tawny or whitish, tapering at summit, 10 to $20 \mathrm{~cm}$ long; spikelets short-pediceled with 1 or 2 fertile florets and 2 or 3 sterile reduced ones, the rachilla disarticulating below the fertile floret and tardily above it; glumes 1-nerved; fertile lemma subindurate, the nerves obscure, villous toward base, dissected into numerous unequal awns 2 to $5 \mathrm{~mm}$ long, the body about $3 \mathrm{~mm}$ long. 24 ( $P$. apertum Munro.)-Low places on plains and in ralleys, Texas, Arizona, and northern Mexico; South

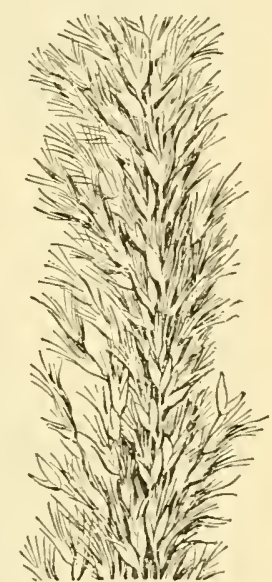

FigURE 438.- Poppophorum bicolor, $\times 1$. (Griffiths 6291 , Tex.) America; wool waste, Maine.

3. Pappophorum bícolor Fourn. (Fig. 438.) Culms erect, 30 to $80 \mathrm{~cm}$ tall; blades flat to subinvolute, 1 to $5 \mathrm{~mm}$ wide; panicle mostly 10 to $15 \mathrm{~cm}$ long, usually pink-tinged, rather loose, the branches 1 to $4 \mathrm{~cm}$ long; spikelets on pedicels 1 to $5 \mathrm{~mm}$ long, with 2 or 3 fertile florets and 1 or 2 sterile reduced ones, all about the same height in the spikelet, the rachilla not separating between the florets; glumes 1-nerved; lemmas somewhat indurate, obscurely nerved, pilose on the callus and on the lower half to two thirds of the midnerve and margins, dissected into about 12 somewhat unequal scabrous awns 2 to $4 \mathrm{~mm}$ long, the body about $3 \mathrm{~mm}$ long, the awns about as long. 24 -Open valley land, Texas, Arizona (La Noria, near Monument 111), and Mexico.

\section{SCLEROPOGON Phil.}

Plants monoecious or dioecious. Staminate spikelets sereralflowered, pale, the rachilla not disarticulating; glumes about equal, a perceptible internode between, membranaceous, long-acuminate, 1-nerved or obscurely 3-nerved, nearly as long as the first lemma; lemmas similar to the glumes, somewhat distant, 3-nerved or obscurely 


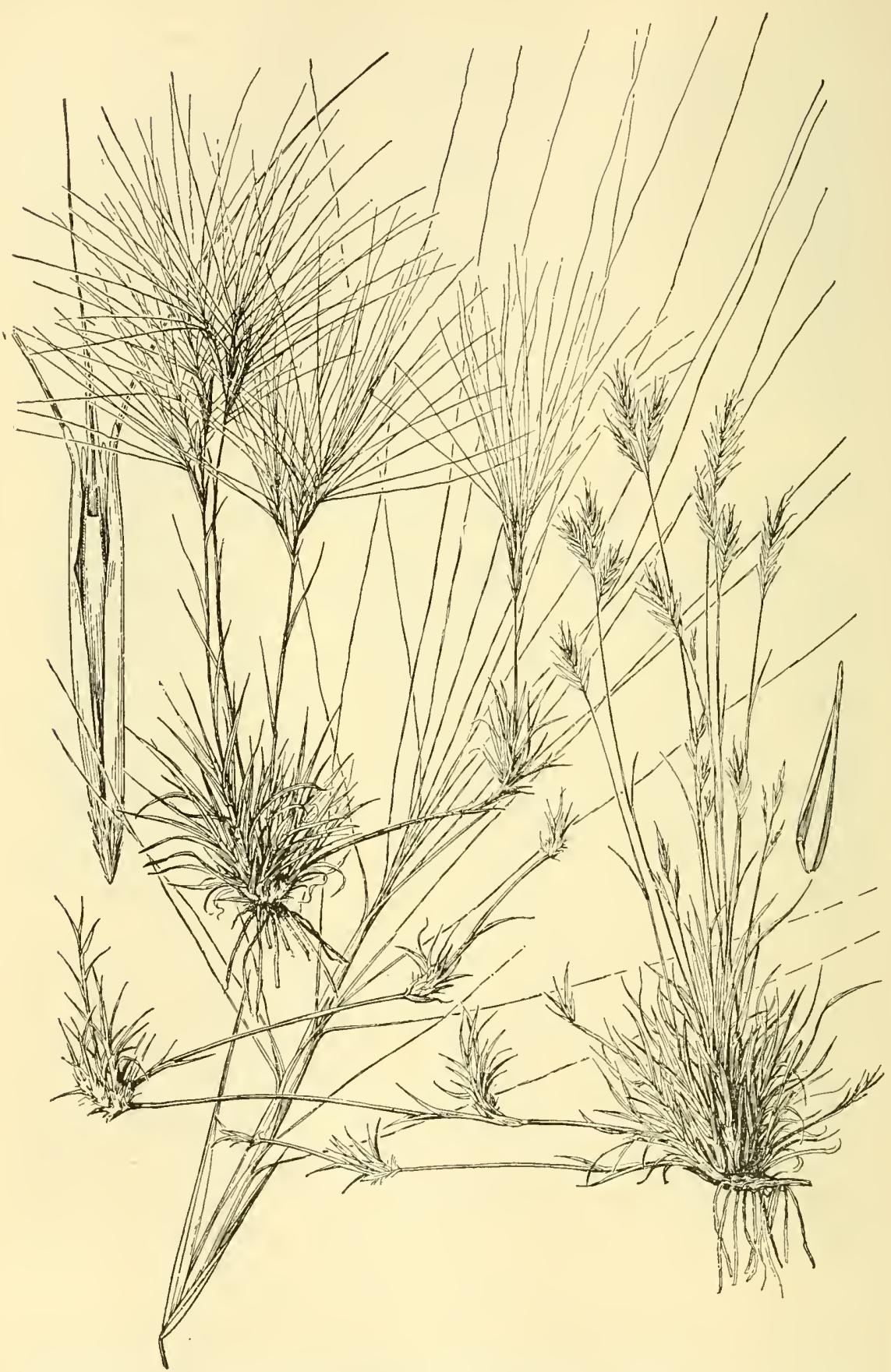

FIGURE 439.-Scleropogon brevifolius. Pistillate and staminate plants, $\times 1 \frac{1}{2}$; pistillate spikelet $\times 2$; pistillate and staminate florets, $\times 5$. (Zuck, Ariz.) 
5-nerved, mucronate; palea obtuse, shorter than the lemma. Pistillate spikelets several-flowered, the upper florets reduced to awns, the rachilla disarticulating above the glumes but not separating between the florets or only tardily so; glumes acuminate, 3-nerved, with a few fine additional nerves, the first about half as long as the second; lemmas narrow, 3-nerved, the nerves extending into slender, scabrous, spreading awns, the florets falling together, forming a cylindric many-awned fruit, the lowest floret with a sharp-bearded callus as in Aristida; palea narrow, the two nerves near the margin, produced into short awns. A stoloniferous perennial, with short flexuous blades and narrow fewflowered racemes or simple panicles, the staminate and pistillate panicles strikingly different in appearance. Staminate and pistillate panicles may occur on the same plant or rarely the two kinds of spikelets may be found in the same panicle. It may be that the seedlings produce two kinds of branches, each kind then reproducing its

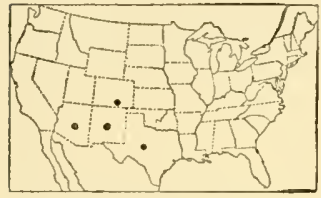

Figure $440 .-$ Distribution of Scleropogon brerifolius.

own sex. This should be investigated. Type species, Scleropogon brevifolius. Name from Greek skleros, hard, and pogon, beard, alluding to the hard awns.

1. Scleropogon brevifólius Phil. Burro grass

(Fig. 439.) Culms erect, 10 to $20 \mathrm{~cm}$ tall, tufted, producing wiry stolons with internodes 5 to $15 \mathrm{~cm}$ long; leaves crowded at the base, the blades flat, 1 to $2 \mathrm{~mm}$ wide, sharp-pointed; racemes, excluding awns, 1 to $5 \mathrm{~cm}$ long; staminate spikelets 2 to $3 \mathrm{~cm}$ long; body of pistillate spikelets 2.5 to $3 \mathrm{~cm}$ long, the awns 5 to $10 \mathrm{~cm}$ long, loosely twisted. 2 (S. karwinskyanus Benth.)-Semiarid plains and open valley lands, Texas to Colorado and Arizona, south to central Mexico; Argentina (fig. 440). The mature pistillate spikelets break away and with their numerous long spreading awns form "tumbleweeds" that are blown before the wind, the pointed barbed callus readily penetrating clothing or wool, the combined florets acting like the single floret of long-awned aristidas. Spikelets rarely staminate below and pistillate above. On overstocked ranges, where it tends to become established, it is useful in preventing erosion. Often important as a range grass, especially when young.

\section{TRIBE 3. HORDEAE}

\section{AGROPÝRON Gaertn. Wheatgrass}

Spikelets several-flowered, solitary (rarely in pairs), sessile, placed flatwise at each joint of a continuous (rarely disarticulating) rachis, the rachilla disarticulating above the glumes and between the florets; glumes equal, firm, several-nerved, rarely 2-nerved, 1-nerved, or nerveless, usually shorter than the first lemma, acute or awned, rarely obtuse or notched; lemmas convex on the back, rather firm, 5 to 7-nerved, acute or awned from the apex; palea about as long as the lemma. Perennials (our species except Agropyron triticeum), often with creeping rhizomes, with usually erect culms and green or purplish, usually erect spikes. Type species, Agropyron triticeum Gaertn. Name from Greek agrios, wild, and puros, wheat, the two original species being weeds in wheat fields.

Most of the species of Agropyron furnish forage and a few are among the most valuable range grasses of the Western States. In the valleys some species may grow in sufficient abundance to produce hay. 
Agropyron pauciflorum (A. tenerum) has been cultivated in the Northwestern States on a commercial scale under the name slender wheatgrass and the seed has been carried by seedsmen in that region. A. smithii, bluestem, often called also western wheatgrass and sometimes Colorado bluestem, is a source of hay in alkaline meadows through the Western States. A. spicatum, or bluebunch wheatgrass, and A. dasystachyum are important range grasses in the Northwestern States. A. pauciflorum and A. subsecundum (A. caninum, so-called) because of their abundance in the mountain grazing regions are also important. A. repens, quackgrass, is a good forage grass, but, because of its creeping rhizomes, is a troublesome weed, especially in the Eastern States where it is widely introduced. 'The species with strong creeping rhizomes are valuable for holding embankments or for holding sandy soils.

The divisions of the species into those with rhizomes and those without is convenient and usually definite when the entire base is present but some species normally without rhizomes (as A. spicatum) may rarely produce them and species in which rhizomes occur may not show them in herbarium specimens.

1a. Plants with creeping rhizomes.

Lemmas awned, the awn divergent at maturity.

Lemmas pubescent

9. A. Albicans.

Lemmas glabrous

Lemmas awnless or with a short straight awn.

Glumes rigid, gradually tapering into a short awn.

Culms 10 to $20 \mathrm{~cm}$ tall, usually shorter than the leaves; sandy seacoast,

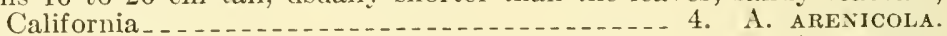

Culms 30 to $60 \mathrm{~cm}$ tall, exceeding the leaves; interior... 5. A. sirmiri.

Glumes not rigid, acute or abruptly awn-pointed.

Lemmas glabrous (sometimes pubescent in A. riparium).

Blades lax, flat, usually sparsely pilose on the upper surface.

Blades firm, stiff, often involute, not pilose.

2. A. REPENS.

Spikelets much compressed, closely imbricate, the spike dense.

3. A. PUNGENS.

Spikelets not much compressed, somewhat distant, the spike slender.

Lemmas pubescent.

8. A. RIPARIUM.

Spike 6 to $12 \mathrm{~cm}$ long; spikelets 1 to $1.5 \mathrm{~cm}$ long; glumes 6 to $9 \mathrm{~mm}$ long.

6. A. DASYSTACHYUM.

Spike longer, as much as $25 \mathrm{~cm}$ long; spikelets as much as $2.5 \mathrm{~cm}$ long; glumes as much as $13 \mathrm{~mm}$ long ............ 7. A. ELMERI.

1b. Plants without creeping rhizomes.

Spikelets much compressed, closely imbricate, divergent_ 1. A. cristatum.

Spikelets not much compressed nor closely imbricate.

Spikelets awnless or awn-tipped only.

Lemmas pubescent

14. A. LATiglume.

Lemmas glabrous.

Internodes of rachilla scaberulous; glumes rather narrow, about half as long as the spikclet.

Blades involute (rarely flat)

19. A. INERME.

Blades flat........ Parishir.

Internodes of rachilla villous; glumes broad, nearly as long as the spikelet

Spikelets awned.

Culms prostrate-spreading

Culms erect (decumbent at base in $A$. pringlei).

13. A. PAUCIFloRUM.

Rachis finally disarticulating.

Glumes narrow, 2-nerved; awns of lemma spreading, out-curved or recurved ....................... 22. A. SAXICOLA.

Glumes broader, with usually 3 to 5 distinct scabrous nerves; awn of lemma straight, erect.............. 23. A. SACNDERSII. 
Rachis continuous.

Awn straight or nearly so.

Spikelets about as long as the internodes of the rachis.

21. A. PARISHII.

Spikelets imbricate, longer than the internodes of the rachis.

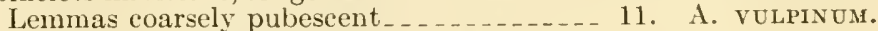
Lemmas glabrous or scabrous toward summit only.

12. A. SUBSECUNDUM.

Awn divergent, when dry.

15. A. BAKERI.

Spikelets imbricate

Spikelets 3 to 7 in a spike, about twice as long as the internode; spike 4 to $7 \mathrm{~cm}$ long ............. 16. ARINGLEI.

Spikelets mostly more than 7 in a spike, usually shorter than the internode; spikes mostly more than $\mathrm{S} \mathrm{cm}$ long.

Spike 8 to $15 \mathrm{~cm}$ long; blades 1 to $2 \mathrm{~mm}$ wide.

Spike 15 to $30 \mathrm{~cm}$ long; blades 4 to $6 \mathrm{~mm}$ wide.

1S. A. SPICATUM.

20. A. ARIZONICUM.

1. Agropyron cristátum (L.) Beauv. Crested wheatgrass. (Fig. 441.) Culms erect, in dense tufts, 60 to $100 \mathrm{~cm}$ tall; blades flat; spike dense, mostly 4 to $6 \mathrm{~cm}$ long, the internodes of the rachis pubescent, $1 \mathrm{~mm}$ long; spikelets compressed, glabrous to villous, closely imbricate, somewhat spreading, 5 to $15 \mathrm{~mm}$ long; glumes firm, keeled, tapering into a short awn; lemmas somewhat abruptly narrowed into an awn 2 to $4 \mathrm{~mm}$ long 2 - Introduced here and there in grainfields (North Dakota, South Dakota, Wyoming, Colorado); Eurasia. This grass is well adapted for hay and pasture in the northern Great Plains from North Dakota to eastern Washington and south to western Kansas and probably will be valuable in the northern parts of New Mexico and Arizona. It spreads readily by reseeding.

Agropyron tritíceum Gaertn. Annual, branching at base; culms slender, erect or usually decumbent, mostly 10 to $30 \mathrm{~cm}$ tall; blades flat, mostly less than $10 \mathrm{~cm}$ long, 2 to $3 \mathrm{~mm}$ wide; spike oval or ovate, 1 to $1.5 \mathrm{~cm}$ long; thick; spikelets crowded, about $7 \mathrm{~mm}$ long; glumes and lemmas acuminate. $\odot$-Absaroka Forest, Mont.; Mountain Home, Idaho. Sparingly introduced from southern Russia.

2. Agropyron répens (L.) Beauv. Quackgrass. (Fig. $442, A$.) Green or glaucous; culms erect or curved at base, 50 to $100 \mathrm{~cm}$ tall, sometimes taller, with creeping yellowish rhizomes; sheaths of the innovations often pubescent; blades relatively thin, flat, usually sparsely pilose on the

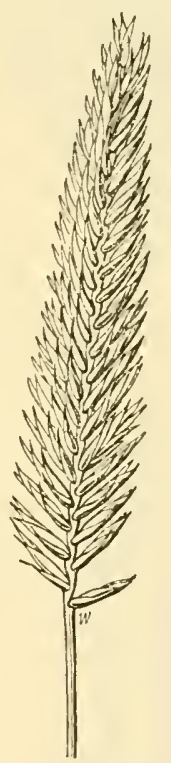

Fictre 441.-Agropyron cristatum, 1. (Ball 1768, Colo.) upper surface, mostly 6 to $10 \mathrm{~mm}$ wide; spike 5 to $15 \mathrm{~cm}$ long, the rachis scabrous on the angles; spikelets mostly 4 - to 6 -flowered, 1 to $1.5 \mathrm{~cm}$ long, the rachilla glabrous or scaberulous; glumes 3 - to 7 -nerved, awnpointed; lemmas mostly 8 to $10 \mathrm{~mm}$ long, the awn from less than $1 \mathrm{~mm}$ to as long as the lemma; palea obtuse, nearly as long as the lemma, scabrous on the keels. 2 - Waste places, meadows and pastures, Newfoundland to Alaska (Skagway), south to Nortlı Carolina, Arkansas, New Mexico, and California (fig. 443); introduced from Eurasia. Common in the Northern States; a troublesome weed in cultivated ground. Called also quitch grass and couch grass. Awned specimens have been described as Agropyron leersianum (Wulf.) Rydb. 


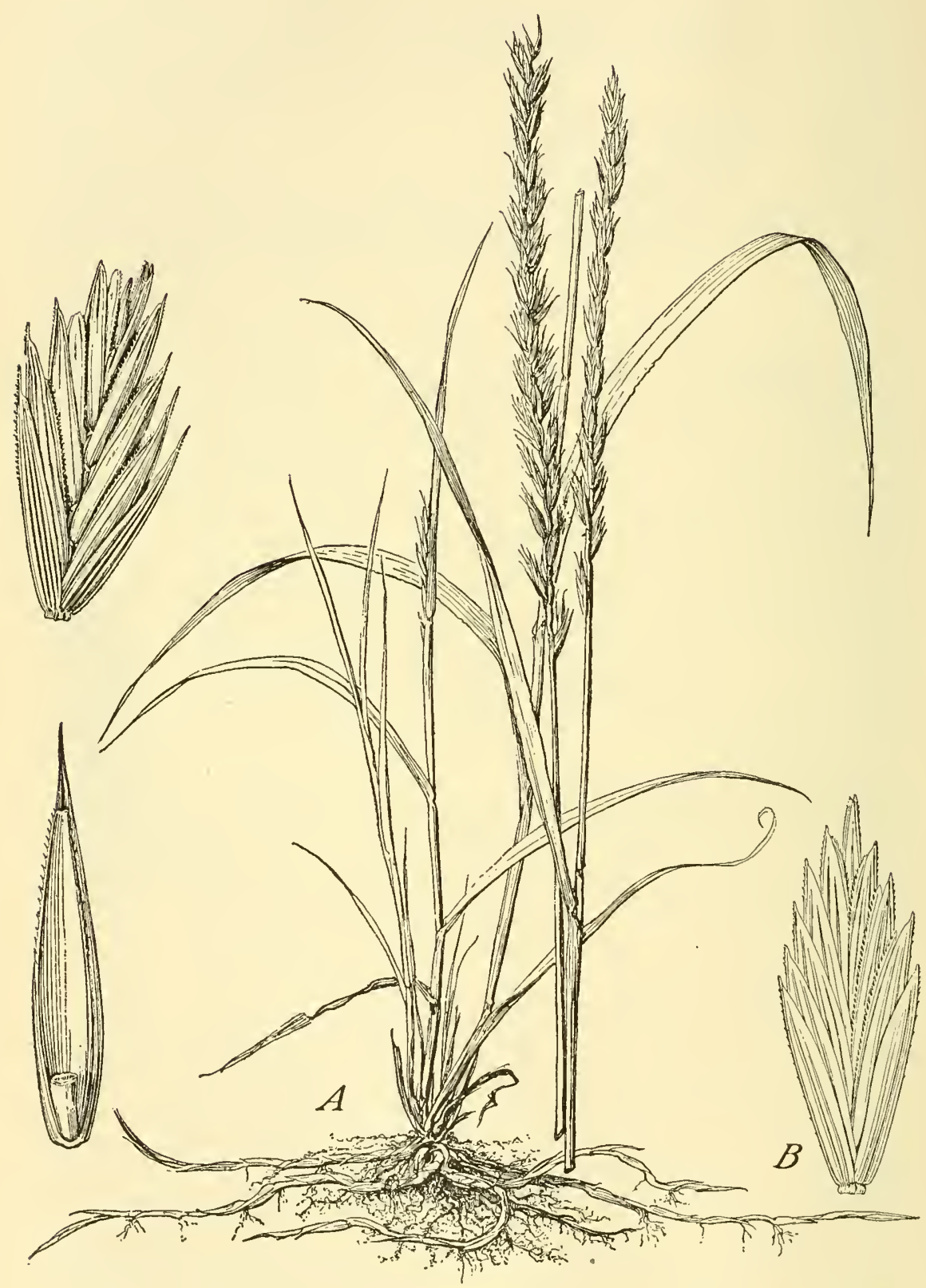

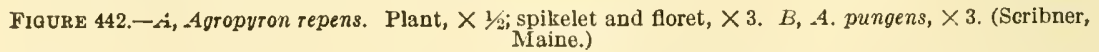


3. Agropyron púngens (Pers.) Roem. and Schult. (Fig. 442, B.) Glaucous, culms 50 to $80 \mathrm{~cm}$ tall, with pale or brownish rhizomes; blades firm, mostly involute. scabrois on the upper surface; spikelets awnless, compressed, often as much as 10-flowered, the florets closely imbricate; glumes firm, acute, obscurely nerved, scabrous on the keel. 24 -Seacoast, Maine

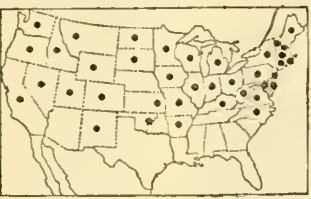

Figtre 443.-Distribution of Agropyron repens. (Cape Ellzabeth), Massachusetts (Harwich), Oregon (Linnton); introduced from Europe. 4. Agropyron arenicola Davy. (Fig. 444.) Culms low, more or less spreading, 10 to $20 \mathrm{~cm}$ tall, with slender extensively creeping rhizomes; blades involute, mostly longer than the culms, pungent-pointed; spike 2 to $5 \mathrm{~cm}$ long, the axis glabrous; spikelets few-flowered, about $15 \mathrm{~mm}$ long; glumes narrowly lanceolate, nerveless, firm, narrowed to a pungent point, ciliolate; lemmas about 1 cm long, obscurely nerved, scabrous toward margin and summit. 2 - Sandy seacoast, middle California. The structure of the spikelet suggests that this species may belong to Elymus though the spikelets are solitary at the nodes of the rachis.

5. Agropyron smíthii Rydb. Bluestem. (Fig. 445.) Usually glaucous; culms erect, 30 to $60 \mathrm{~cm}$ tall, sometimes taller, with creeping rhizomes; sheaths glabrous; blades firm, stiff, mostly flat when fresh, involute in drying, strongly nerved, scabrous or sometimes sparsely villous on the upper surface, mostly 2 to $4 \mathrm{~mm}$ wide, tapering to a sharp point; spike erect, mostly 7 to $15 \mathrm{~cm}$ long, the rachis scabrous on the angles; spikelets rather closely imbricate, occasionally two at a node, 6 - to 10 -flowered, 1 to $2 \mathrm{~cm}$ long, the rachilla scabrous or scabrouspubescent; glumes rigid, tapering to a short awn, rather faintly nerved, 10 to $12 \mathrm{~mm}$ long; lemmas about $1 \mathrm{~cm}$ long, firm, glabrous, often pubescent near the base, obscurely nerved, acuminate, mucronate, sometimes short-awned; palea scabrous-pubescent on the keels. 21 -Moist, usually alkaline soil, New York; Michigan and Ohio to Alberta and Washington, south to Texas, Arizona, and northeastern California; mostly introduced east of Iowa and Kansas (fig.

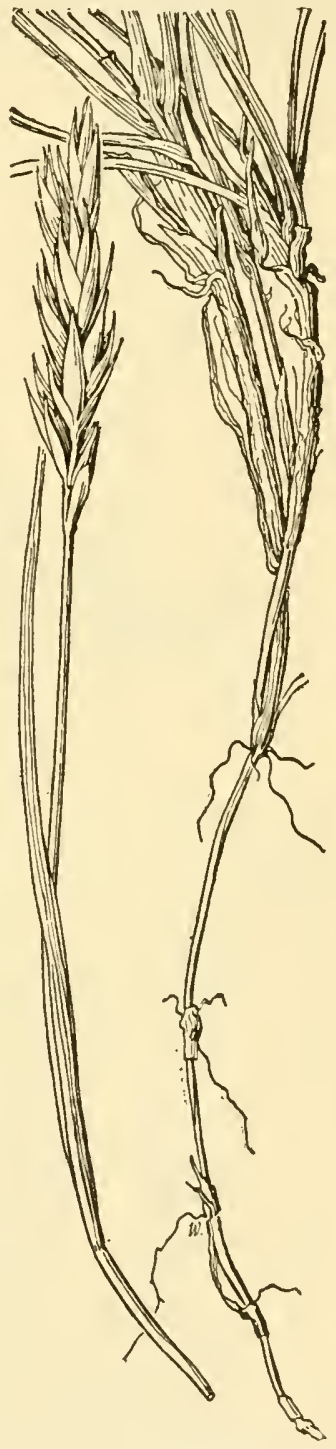

Figure 444.-Agropyron arenic. ola, $\times 1$. (Davy 6781 , Calif.) 446). Two varieties have been recognized. AGRoprron sMithiI var. MólLE (Scribn. and Smith) Jones. Lemmas and sometimes glumes more or less pubescent. 24 -About the same range as the species. AgroPYRON SMithi var. PALMÉrI (Scribn. and Smith) Heller. Lower sheaths pubescent. 24 -Colorado to Utah, south to New Mexico and Arizona. 
6. Agropyron dasystáchyum (Hook.) Scribn. Thickspike wheatGrass. (Fig. $447, A$.) Often glaucous; culms mostly 40 to $80 \mathrm{~cm}$ tall, with creeping rhizomes; blades flat to involute, 1 to $3 \mathrm{~mm}$ wide; spike mostly 6 to $12 \mathrm{~cm}$ long; spikelets loosely to closely imbricate, 4 - to 8 -flowered, 1 to $1.5 \mathrm{~cm}$ long, the rachilla pubescent on the convex side; glumes acute or awn-pointed, scabrous or pubescent (usually

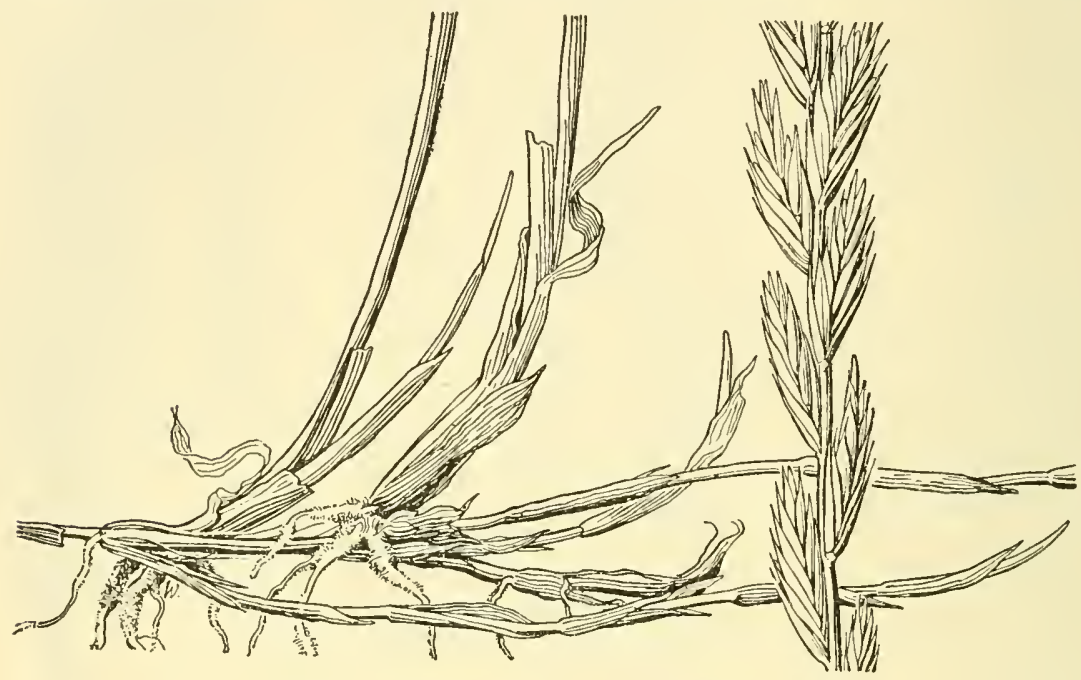

FIGURE 445.-Agropyron smithii, $\times 1$. (Nelson 3918, Wyo.)

less pubescent than the lemma), 6 to $9 \mathrm{~mm}$ long; lemmas densely to sparsely pubescent, sometimes nearly glabrous, awnless or mucronate, about $1 \mathrm{~cm}$ long; palea about as long as the lemma, obtuse. 2 Plains and sandy shores, Michigan to British Columbia, south to Illinois, Nebraska, Colorado, northern Arizona, Nevada, and Oregon (fig. 448). In the form growing on the sandy shores of Lake Michigan the lemmas are densely villous, but villous forms occur in other parts of the range of the species.

This and the four following species appear to intergrade, forming a polymorphous group.

7. Agropyron elméri Scribn. (Fig. 447, B.) Resembling $A$. dasystachyum; culms on the average taller, more robust, the spike longer (as much as $25 \mathrm{~cm}$ long), the spikelets larger

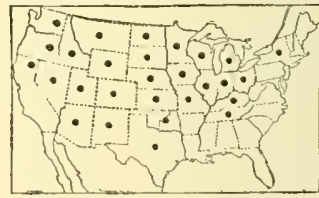

FIGURE 446.-Distribution of Agropyron smithii. (as much as 10-flowered and $2.5 \mathrm{~cm}$ long); glumes and lemmas usually longer (as much as $13 \mathrm{~mm}$ and $15 \mathrm{~mm}$, respectively); lemmas pubescent, sometimes sparsely so or scabrous only or pubescent only on the margins at base. 24 - Dry or sandy soil, British Columbia to Orgeon.

8. Agropyron ripárium Šcribn. and Smith. Streambank wheatGRAss. (Fig. 449.) Resembling A. dasystachyum, with vigorous rhizomes; blades usually narrower; spikelets usually more imbricate; lemmas glabrous or somewhat pubescent along the edges of the lower part of the lemma. 24-Dry or moist meadows and hills, North Dakota to Alberta and Washington, south to Oregon, Arizona, and Colorado (fig. 450). 
9. Agropyron álbicans Scribn. and Smith. (Fig. 451.) Similar to A. dasystachyum; glumes awn-pointed, about $1 \mathrm{~cm}$ long; awn

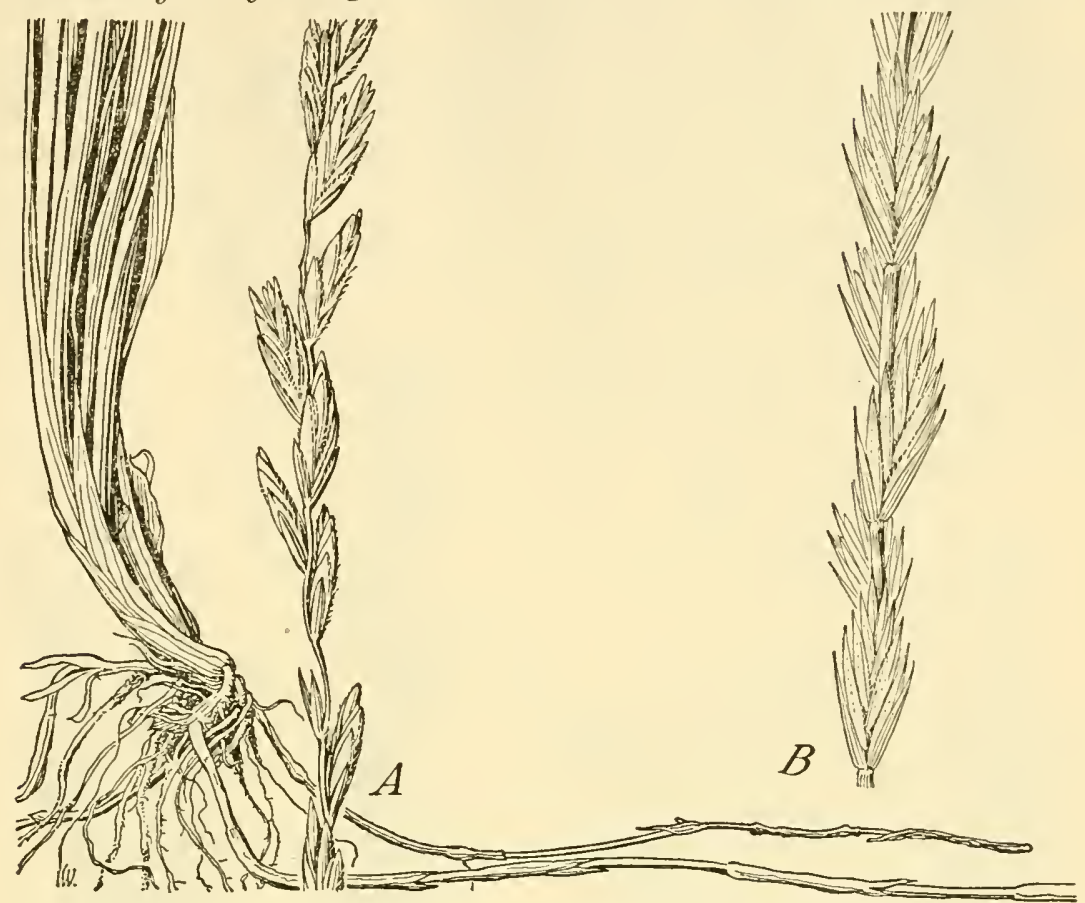

FigUre 447.-A, Agropyron dasystachyum, $\times 1$. (Griffiths 488, Wash.) B, A. elmeri, $\times 1$. (Type.)

of lemma 1 to $1.5 \mathrm{~cm}$ long, divergent when dry. 4 -Plains and dry hills, South Dakota to Alberta, and Colorado (fig. 452).

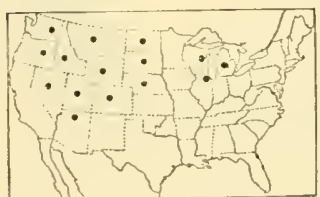

FigUre 448.-Distribution of A. dasystachyum.

10. Agropyron griffíthsii Scribn. and Smith. (Fig. 453.) Resembling A. albicans, differing chiefly in having glabrous lemmas. 21 -Open dry, sandy or alkaline soil, western North and South Dakota, Wyoming, and Colorado. In
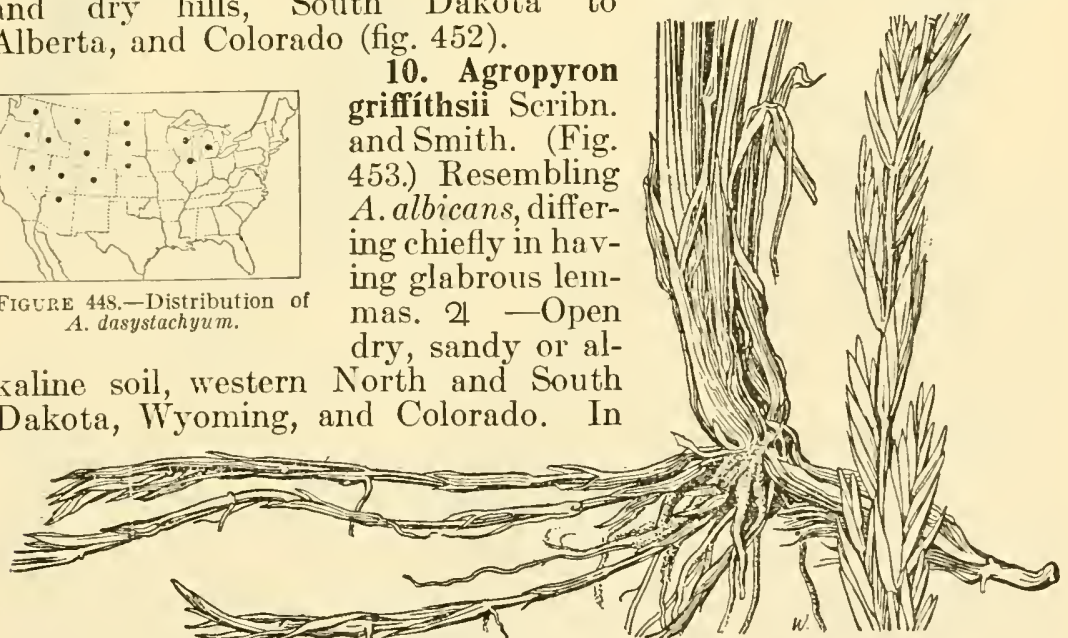

FIGURE 449.-Agropyron riparium, $\times 1$. (Nelson 3965, Wyo.)

the type specimen the lemmas are smooth but in several other specimens the lemmas are scabrous. Possibly only a glabrous form of $A$. albicans. 
Agropyron intermédium (Host) Beauv. Blades short, involute, acutish; glumes about 5-nerved; lemmas awnless. 24 -Ballast at Camden, N.J.; adventive from Europe.

Agropyron trichóphorum (Link) Richt. Blades flat; spikelets pubescent, awnless; glumes several-nerved, acutish. 24 -Lynn, Mass.; adventive from Europe.

Agropyron júnceum (L.) Beauv. Blades loosely involute; spikelets glabrous; glumes 9-nerved, acutish. 2 -Ballast near Portland, Oreg.; adventive from Europe.

11. Agropyron vulpínum (Rydb.) Hitche. (Fig. 454.) Culms 50 to $75 \mathrm{~cm}$ tall, somewhat geniculate at base; blades drying loosely involute, 10 to $12 \mathrm{~cm}$ long, 2 to 4 $\mathrm{mm}$ wide; spike nodding, 10 to 15 cm long, the rachis stiffly sca-

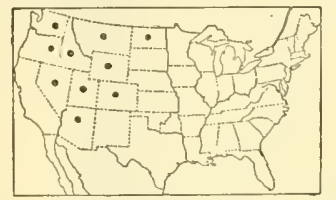

FIGURE 450.-Distribution of Agropyron riparium.

brous-ciliate on the angles; spikelets imbricate but not appressed, some toward the base two at a node, 3- to 5-flowered, the rachilla appressed-pubescent; glumes

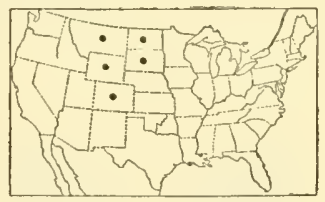

FIGURE 452.-Distribution of Agropyron albicans.

scabrous, strongly 5-nerved, awntipped; lemmas 5-nerved toward the minutely toothed apex, coarsely pubescent, the scabrous awn 8 to $10 \mathrm{~mm}$ long. 21 (Elymus vulpinus Rydb.) - Known only from wet meadows, Grant County, Nebr.

12. Agropyrom subsecúndum (Link) Hitche. Bearded wheatGrass. (Fig. 455.) Green or glaucous, without creeping rhizomes; culms erect, tufted, 50 to $100 \mathrm{~cm}$ tall; sheaths glabrous or rarely pubescent; blades flat, 3 to $8 \mathrm{~mm}$ wide; spike erect or slightly nodding, 6 to $15 \mathrm{~cm}$ long, sometimes unilateral from twisting of the spikelets to one side, the rachis scabrous or scabrous-ciliate on the angles, sometimes, disarticulating; spikelets rather closely imbricate, few-flowered the rachilla villous, the callus of the florets short-pilose; glumes broad rather prominently 4- to 7-nerved, nearly as long as the spikelet, 
tapering into an awn; lemmas obscurely 5 -nerved, the nerves becoming prominent toward the tip, the awn straight or nearly so, usually 1 to

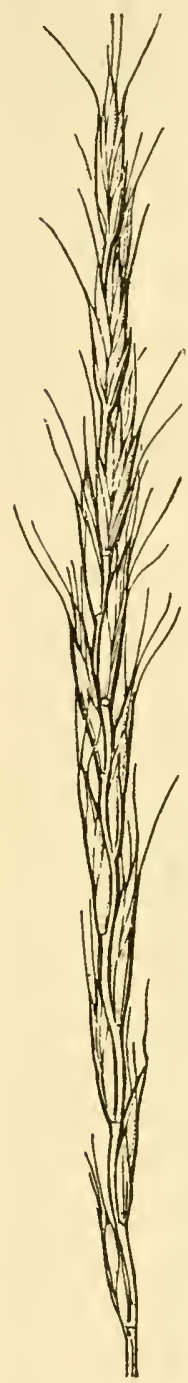

FIGURE 453. A gropyron oriffithsii, $\times 1$. (Williams and Griffiths 164 , Wyo.) $3 \mathrm{~cm}$ long. 2 -Moist meadows and open woods, Newfoundland to Alaska, south to the mountains of Maryland, to Indiana, Nebraska, New Mexico, Arizona, and California (fig. 456). Said by Malte to be self-pollinated. This is the species which has generally been called by American botanists $A$. caninum (L.) Beauv., which is a European species, differing in having 3-nerved glumes.

AGROPYRON SUBSECUNDUM var. ANDÍNum (Scribn. and Smith) Hitchc. Culms mostly not more than $50 \mathrm{~cm}$ tall, loosely tufted, usually geniculate at base; lower sheaths pale, usually papery; spike short; awns mostly 5 to $10 \mathrm{~mm}$ long, often curved. An alpine form of mountain meadows. 24 -Montana to Washington, south to Colorado and Nevada.

Agropyron canínum (L.) Beauv. Glumes 3-nerved. 24 - Ballast near Portland, Oreg.; adventive from Europe.

13. Agropyron pauciflórum (Schwein.) Hitchc. Slender wheatgrass. (Fig. 457.) Resembling A. subsecundum; sheaths glabrous or rarely pubescent; blades mostly 2 to $4 \mathrm{~mm}$ wide; spike usually more slender, 10 to $25 \mathrm{~cm}$ long, sometimes unilateral; spikelets from rather remote to closely imbricate; glumes and lemmas awnless or nearly so. 24 ( $A$. tenerum Vasey.)-Labrador to Alaska, south to the mountains of West Virginia, Missouri, New Mexico, and California; northwestern Mexico (fig. 458). Alpine plants lower, with shorter denser commonly purplish spikes, resemble $A$. subsecundum var. andinum but are awnless. They have been referred to $A$. violaceum (Hornem.) Lange, an arctic species, and to $A$. biflorum (Brignoli) Roem. and Schult.

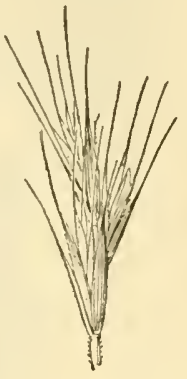

FIGURE 454, $A g$ ropyton vulpi$n u m, \times 1$. (Type.)

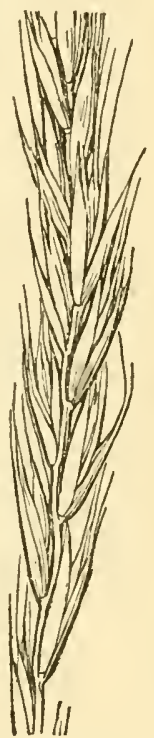

IGURE 455 .Agropyron subsecundum, $\times 1$. ( $S$ bear 452 , Mont.)

\section{Agropyron pseudorépens} Scribn. and Smith. Appears to be distinct, differing in the slender creeping rhizomes and villous rachilla joints. A. pseudorepens var. magnum Scribn. and Smith may be a large form. 21 - Open ground, thickets, and open woods, South Dakota to

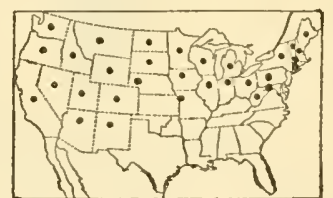

Figore 456.-Distribution of Agropyron subsecundum.

Washington, south to New Mexico, and northern Arizona; Michigan (Grand Island).

14. Agropyron latiglúme (Scribn. and Smith) Rydb. (Fig. 459.) Culms loosely tufted, curved or geniculate below, 20 to $50 \mathrm{~cm}$ tall; 
blades flat, short, 3 to $5 \mathrm{~mm}$ wide, pubescent on both surfaces; spike mostly 3 to $6 \mathrm{~cm}$ long, sometimes longer; spikelets usually closely imbricate; glumes rather broad and flat; lemmas pubescent, awnless or nearly so. 21 -Alpine regions, Montana to Labrador and Alaska.

15. Agropyron bakéri E. Nels. Baker wheatgrass. (Fig. 460.) Resembling A. subsecundum; culms erect. mostly 50 to $100 \mathrm{~cm}$ tall,

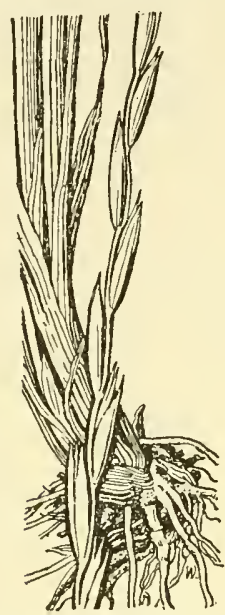

Figure 457.-Agropyron pauciflorum, $\times 1$. (Shear 404.)

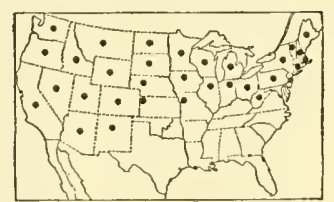

FIGURE 458.-Distribution of Agropyron paucifiorum.

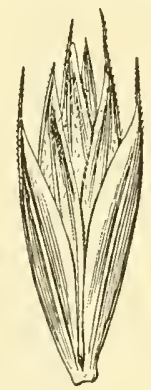

FigURE 459.-Agropyron latiglume, $\times 3$. (Type.)

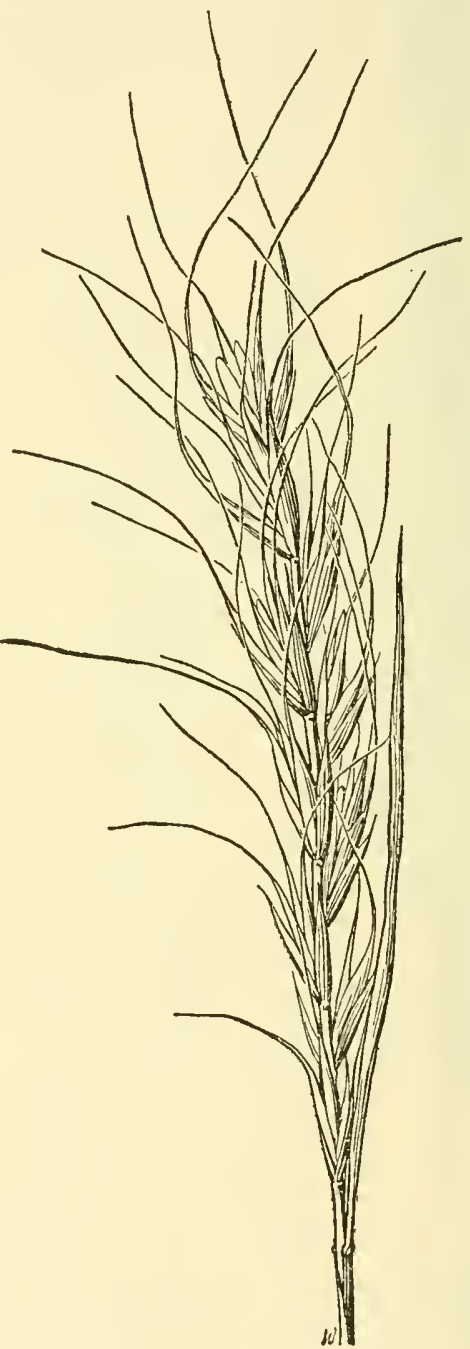

FIgURE 460.-Agropyton baketi, $\times 1$. (Hitchcock 1686, Colo.)

rather loosely tufted; spike mostly 5 to $12 \mathrm{~cm}$ long, the spikelets rather loosely imbricate; awns divergently curved when dry, 1 to 4 cm long. $21-$ Open slopes, upper altitudes, northern Michigan; Alberta to Washington and New Mexico (fig. 461).

16. Agropyron prínglei (Scribn. and Smith) Hitche. (Fig. 462.) Culms tufted, decumbent at base, 30 to $50 \mathrm{~cm}$ tall, the basal sheaths 
soft and papery; blades flat or loosely involute, mostly less than 10 $\mathrm{cm}$ long, 1 to $3 \mathrm{~mm}$ wide; spike more or less flexuous, 4 to $7 \mathrm{~cm}$ long, the rachis scabrous on the angles, slender, the middle internodes usually 8 to $10 \mathrm{~mm}$ long; spikelets mostly 3 to 7 in each spike, rather distant, the lower and middle ones (excluding awns) about as long as two internodes, mostly 3- to 5-flowered, the rachilla joints minutely scabrous, about $2 \mathrm{~mm}$ long; glumes rather narrow, about 3-nerved on the exposed side, 7 to $8 \mathrm{~mm}$ long, tapering into a straight awn about $5 \mathrm{~mm}$ long; lemmas tapering into a scabrous, strongly divergent awn 1.5 to $2.5 \mathrm{~cm}$ long; palea 10 to $12 \mathrm{~mm}$ long. 24 -Stony slopes,

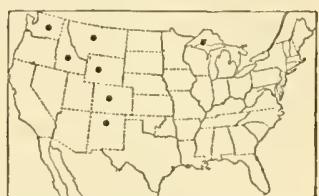

FlgURE 461.-Distribution of Agropyron bakeri.

2,500 to $3,500 \mathrm{~m}$, Sierra Nevada, Tulare County, to Sierra County, Calif.

17. Agropyron scribnéri Vasey. Spreading wheatgrass. (Fig. 463.) Culms tufted, prostrate or decumbent-spreading, often flexuous,

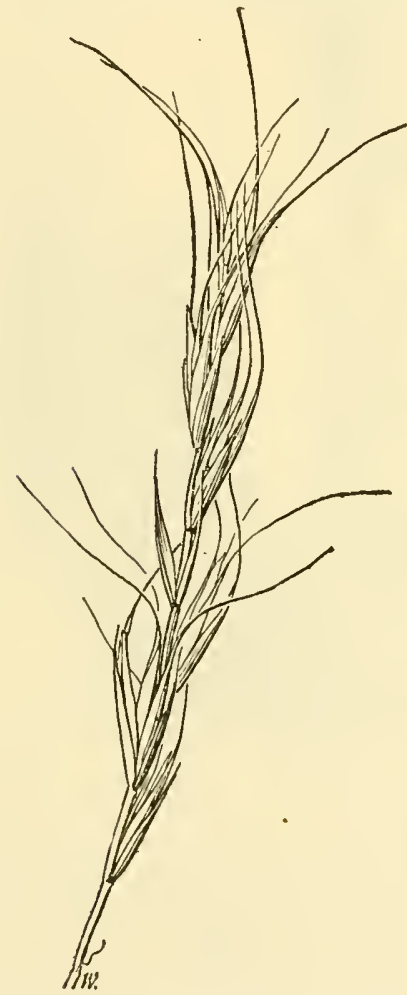

FigURE 462.-Agropyron pringlei, $\times 1$ (Pringle 504, Calif.)

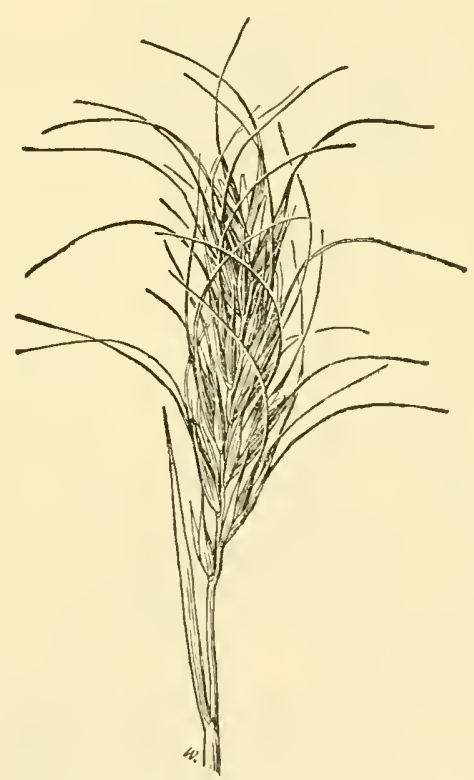

Figure 463,-Agropyron scribucri, $\times 1$. (Shear 1179, Colo.)

20 to $40 \mathrm{~cm}$ long; blades flat or, especially on the innovations, loosely involute, more or less pubescent, mostly basal, the 2 or 3 culm blades usually less than $5 \mathrm{~cm}$ long, 1 to $3 \mathrm{~mm}$ wide; spike long-exserted, of ten nodding or flexuous, dense, 3 to $7 \mathrm{~cm}$ long, the rachis disarticulating at maturity, the internodes glabrous, 3 to $5 \mathrm{~mm}$ long, or the lowermost 
longer; spikelets 3 - to 5-flowered, the rachilla internodes minutely scabrous, about $2 \mathrm{~mm}$ long; glumes narrow, one obscurely nerved, the other with 2 or 3 distinct nerves, tapering into a divergent awn similar to the awns of the lemmas; lemmas nerved toward the tip, tapering to a strongly divergent awn 1.5 to $2.5 \mathrm{~cm}$ long; palea a little longer than the body of the lemma, the apex with 2 short slender teeth. 2 -Alpine slopes, 3,000 to $4,000 \mathrm{~m}$, Montana to northern New Mexico, Nevada, and northern Arizona (fig. 464). Characterized by the hard leafy basal tussock with slender spreading flexuous culms.

18. Agropyron spicátum (Pursh) Scribn. and Smith. Bluebunch WHEATGRASS. (Fig. 465.) Green or glaucous; culms tufted, of ten in large bunches, erect, 60 to $100 \mathrm{~cm}$ tall; sheaths

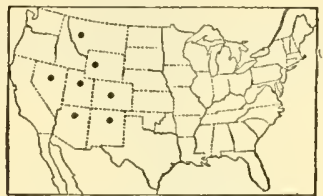

FIGURE 464.-Distribution of Agropyron scribneri.

glabrous; blades flat to loosely involute, 1 to $2 \mathrm{~mm}$, sometimes to $4 \mathrm{~mm}$ wide, glabrous beneath, pubescent on the upper surface; spike slender,

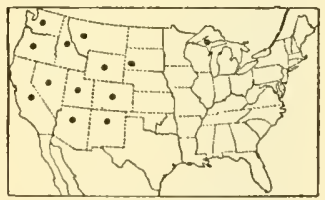

Figure 466.-Distribution of Agropyron spicatum.

mostly 8 to $15 \mathrm{~cm}$ long, the rachis scaberulous on the angles, 1 to $2 \mathrm{~cm}$ long, or the lowermost $2.5 \mathrm{~cm}$; spikelets

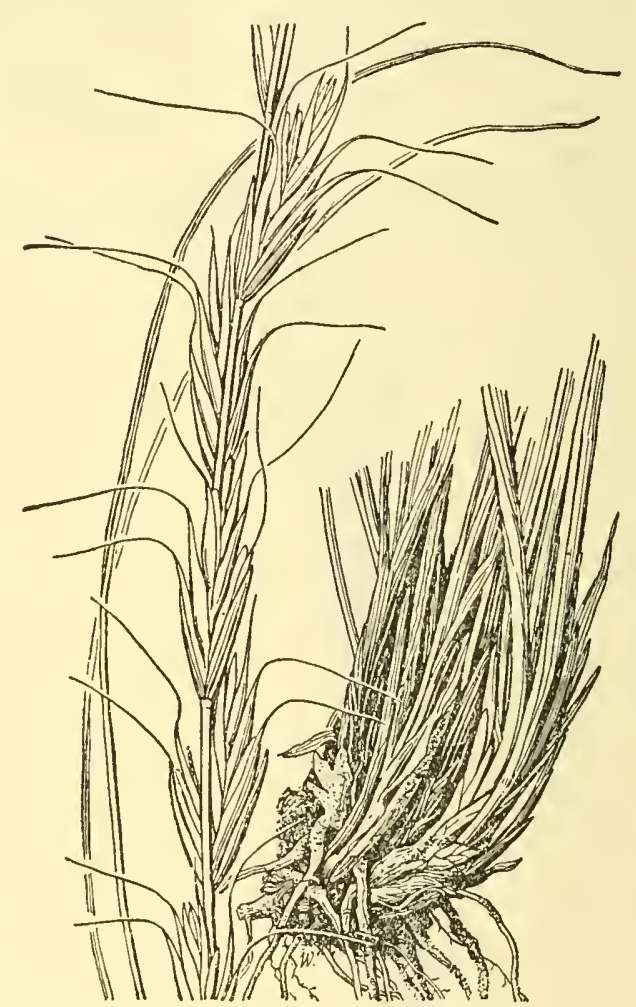

FIGURE 465.-Agropyron spicatum, $\times 1$. (Vasey, Wash.) distant, not as long (excluding the awns) as the internodes or slightly longer, mostly 6- to 8-flowered, the rachilla joints scaberulous, 1.5 to $2 \mathrm{~mm}$ long; glumes rather narrow, obtuse to acute, rarely short-awned, about 4-nerved, usually about half as long as the spikelet, glabrous or scabrous on the nerves; lemmas about $1 \mathrm{~cm}$ long, the awn strongly divergent, 1 to $2 \mathrm{~cm}$ long; palea about as long as the lemma, obtuse. 24 -Plains, dry slopes, canyons and dry open woods, northern Michigan to Alaska, south to western South Dakota, New Mexico, and California (fig. 466). A smaller form with smaller spikelets, found in desert regions of the Great Basin has been differentiated as A. vaseyi Scribn. and Smith. A. Spicatum var. pubéscens Elmer. Culms and foliage pubescent. 24 -Washington and Idaho. 
19. Agropyron inérme (Scribn. and Smith) Rydb. Beardless wheATGRAss. (Fig. 467.) Differing from A. spicatum in the awnless spikelets. 2 (A. spicatum var. inerme Heller.) - Dry plains and hills, Montana to British Columbia, south to Utah, Wyoming,

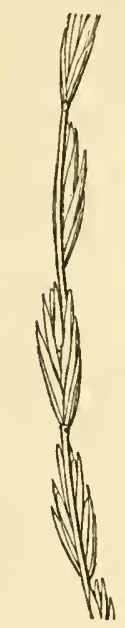

FIGURE 467,Agropyron inerme, $\times 1$. (Horner 571, Wash.)

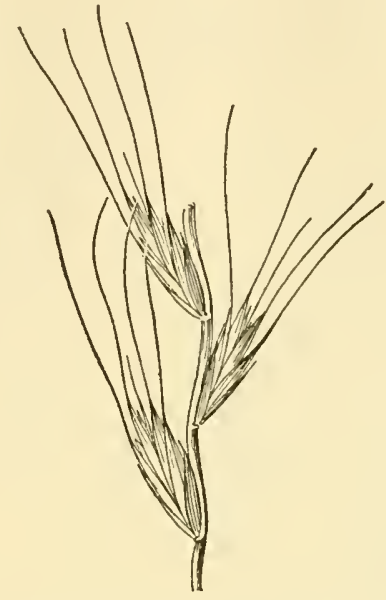

FIGURE 469.-Agropyron arizonicum, $\times 1$. (Туре.)

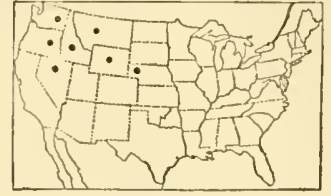

FrgURE 468.-Distribution of Agropyron inerme.

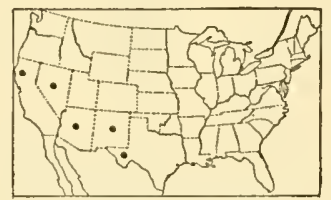

Figure 470.-Distribution of Agropyron arizonicum.

western Nebraska, and eastern Oregon (fig. 468). Closely related to $A$. spicatum but very different in appearance because awnless.

20. Agropyron arizónicum Scribn. and Smith. (Fig. 469.) Resembling $A$. spicatum, usually taller and coarser; blades commonly 4 to $6 \mathrm{~mm}$ wide; spike 15 to $30 \mathrm{~cm}$ long, flexuous, the rachis more slender; spikelets distant, mostly 3- to 5-flowered; glumes short-awned; awns of the lemmas stouter, mostly 2 to $3 \mathrm{~cm}$ long. 2 -Rocky slopes, western Texas, New Mexico, Arizona, Nevada, California (Eel Ridge), and Chihuahua (fig. 470).

Agropyron semicostátum (Steud.) Nees. Blades flat; spike nodding, 10 to $20 \mathrm{~cm}$ long; spikelets several-flowered, imbricate; glumes several-nerved, much shorter than the spikelet, acute but scarcely awned; awn of lemma flexuous or finally divergent, 1.5 to $3 \mathrm{~cm}$ long. $\quad$ | Ballast near Portland, Oreg. Native of Asia.

21. Agropyron paríshii Seribn. and Smith. (Fig. 471.) Culms 70 to $100 \mathrm{~cm}$ tall, the nodes retrorsely pubescent; blades flat or loosely involute, 2 to $4 \mathrm{~mm}$ wide; spike slender, nodding, 10 to $25 \mathrm{~cm}$ long, the internodes of the rachis 1.5 to $2.5 \mathrm{~cm}$ long; spikelets 4 - to 7 -flowered, mostly about $2 \mathrm{~cm}$ long, narrow, appressed, the rachilla

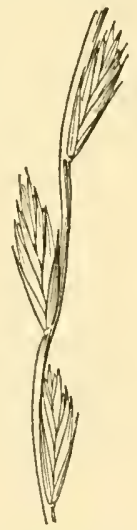

FIGURE 471.Agropyron parishii. $\times 1$. (Type.) joints scaberulous, about $2 \mathrm{~mm}$ long; glumes 3- to 5 -nerved, 1 to 1.5 $\mathrm{cm}$ long, acute; lemmas acute or with a slender awn 1 to $8 \mathrm{~mm}$ long; palea as long as the lemma, obtuse. 24-Canyons and rocky slopes, California (Monterey and San Bernardino Mountains); rare. AGro- 
PYRON PARISHII var. LAÉve Scribn. and Smith. Nodes glabrous; awns usually 1 to $2 \mathrm{~cm}$ long. 2) -California (Trinity County to San Diego County).

22. Agropyron saxícola (Scribn. and Smith) Piper. (Fig. 472.) Culms tufted, erect, 30 to $80 \mathrm{~cm}$ tall; sheaths glabrous or sometimes

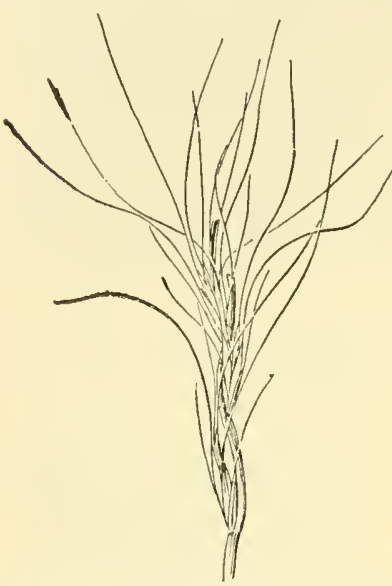

Figure 472,-Agropyron saxicola, pubescent; blades flat to loosely involute, glabrous or sometimes pubescent, 1 to 4 $\mathrm{mm}$ wide; spike 5 to $12 \mathrm{~cm}$ long, the rachis tardily disarticulating, the internodes more or less scabrous on the angles, 5 to $10 \mathrm{~mm}$ long; spikelets imbricate, sometimes in pairs, about twice as long as the internodes of the rachis, 4- to 6-flowered, the rachilla minutely scabrous; glumes narrow, 2nerved, the nerves sometimes obscure, sometimes with a third faint nerve, awned, the awn divergent, 5 to $20 \mathrm{~mm}$ long, sometimes with a tooth or short awn at the base of the main awn; lemmas about $8 \mathrm{~mm}$ long, the awn divergent, mostly 2 to $5 \mathrm{~cm}$ long, sometimes with 1 or 2 short additional awns; palea about as long as the lemma, obtuse or truncate. 2 -Dry or rocky slopes and plains, western South Dakota to Washington, south to Utah, Arizona, and California (fig. 473). This species is a transitionto Sitanion.

23. Agropyron saundérsii (Vasey) Hitchc. (Fig. 474.) Culms erect, 60 to $100 \mathrm{~cm}$ tall; blades flat or loosely involute; spike erect, 8 to $15 \mathrm{~cm}$ long, mostly purplish, the rachis tardily disarticulating; spikelets sometimes in pairs near the middle of the spike, 1 to 1.5

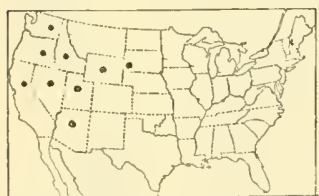

FigUre 473.-Distribution of Agropyron saxicola cm long (excluding awns), 2to 5-flowered; glumes variable, narrow with 2 nerves or widel with 3 to 5 nerves, the nerves strong and at least the midnerve scabrous, the awn 2 to $4 \mathrm{~cm}$ long, sometimes with a short lateral awn near the base; lemmas scabrous, the awn straight, 2 to $5 \mathrm{~cm}$ long. 2 (Elymus saundersii Vasey.) - Dry slopes, Colorado (Veta Pass) and Utah (Salt Lake City).

\section{TRÍTICUM L.}

Spikelets 2- to 5-flowered, solitary, placed flatwise at each joint of a continuous or articulate rachis, the rachilla disarticulating above the glumes and between the florets or continuous; glumes rigid,

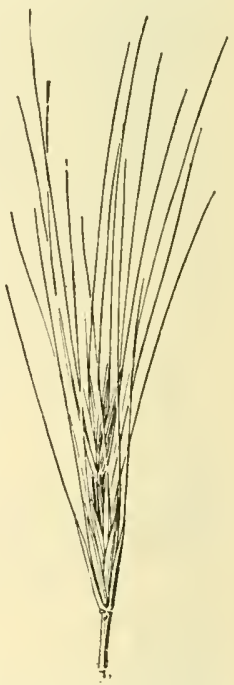

F I G UR E 474 - - Agropyron saundersii, $\times$ 1. (Type.) keeled, 3- to several-nerved, the apex abruptly mucronate or toothed or with one to several awns; lemmas broad, keeled, very asymmetric, many-nerved, abruptly pointed or awned. Low or rather tall annuals, with flat blades and thick spikes. Standard species, Triticum aestivum. Triticum, the old Latin name for wheat. 
1. Triticum aestivum L. WheAt. (Fig. 475.) Culms erect, freely branching at base, 60 to $100 \mathrm{~cm}$ tall; blades 1 to $2 \mathrm{~cm}$ wide; spike mostly 5 to $12 \mathrm{~cm}$ long; internodes of rachis 3 to $6 \mathrm{~mm}$ long; spikelets broad, glabrous or pubescent, long-awned to awnless; glumes usually strongly keeled toward one side, the keel extending into a mucro, the other side usually obtusely angled at apex. $\odot$ (T. vulgare Vill.; T. sativum Lam.) - Commonly cultivated; fields and waste places in the vicinity of cultivated fields or grain elevators, but scarcely established.

Spelt (T. spelta L.) and emmer ( $T$. dicoccum Schrank) are sometimes cultivated for the grain, used for stockfeed, and for forage. In these two species the rachis breaks up, each joint bearing a spikelet which remains entire, each floret permanently enclosing the grain. In spelt the spikelets are somewhat distant, exposing the rachis, in emmer the spikelets are closely imbricate, scarcely exposing the rachis. A large number of varieties of wheat are in cultivation; the lemmas may be glabrous or pubescent, the awns long or nearly or quite wanting.

On the basis of the number of chromosomes the wheats and their allies may be divided into three groups. The group with 7 chromosomes (probably the most primitive) includes einkorn ( $T$. monococcum L.). The group with 14 chromosomes includes durum wheat ( $T$. durum Desf.), poulard wheat (T. turgidum L.), Polish wheat (T. polonicum L.), and emmer ( $T$. dicoccum Schrank). The group with 21 chromosomes includes spelt and the varieties of wheat commonly cultivated in the United States, one series of which, with short compact heads, is club wheat (T. compactum Host). Alaska wheat is a variety of poulard wheat with branched heads. It is also known by several other names, such as Egyptian, miracle, and mummy. This variety is considered inferior commercially to standard varieties of wheat. Stories of varieties originating from seed found with mummies 3,000 years old have no basis in fact.

The origin of wheat is not known as there is no native species like any of the cultivated forms. Some botanists have suggested species of Aegilops, and others T. dicoccoides Kioern., a wild species of Palestine, as the possible ancestor.

\section{AÉGilops L. Goatgrass}

Spikelets 2- to 5-flowered, solitary, turgid or cylindric, placed flatwise at each joint of the rachis and fitting into it, the joints thickened at the summit, the spikelets usually not reaching the one above on the same side, exposing the rachis; spike usually disarticulating near the base at maturity, falling entire, or finally disarticulating between the spikelets. Annuals with flat blades and usually awned spikes. Type species, Aegilops ovata. Name from Aegilops, an old Greek name for a kind of grass.

The species of Aegilops have been recently introduced into the United States and give indications of becoming troublesome weeds. At maturity the spikes fall entire, the lowest rachis joint serving as a pointed callus to the 2- to several-jointed, strongly barbed fruits, which work their way into the mouths and noses of grazing animals and into the wool of sheep.

Spikelets subovate; rachis not disarticulating ........... 3. A. ovata. Spikelets cylindric; rachis finally disarticulating. 


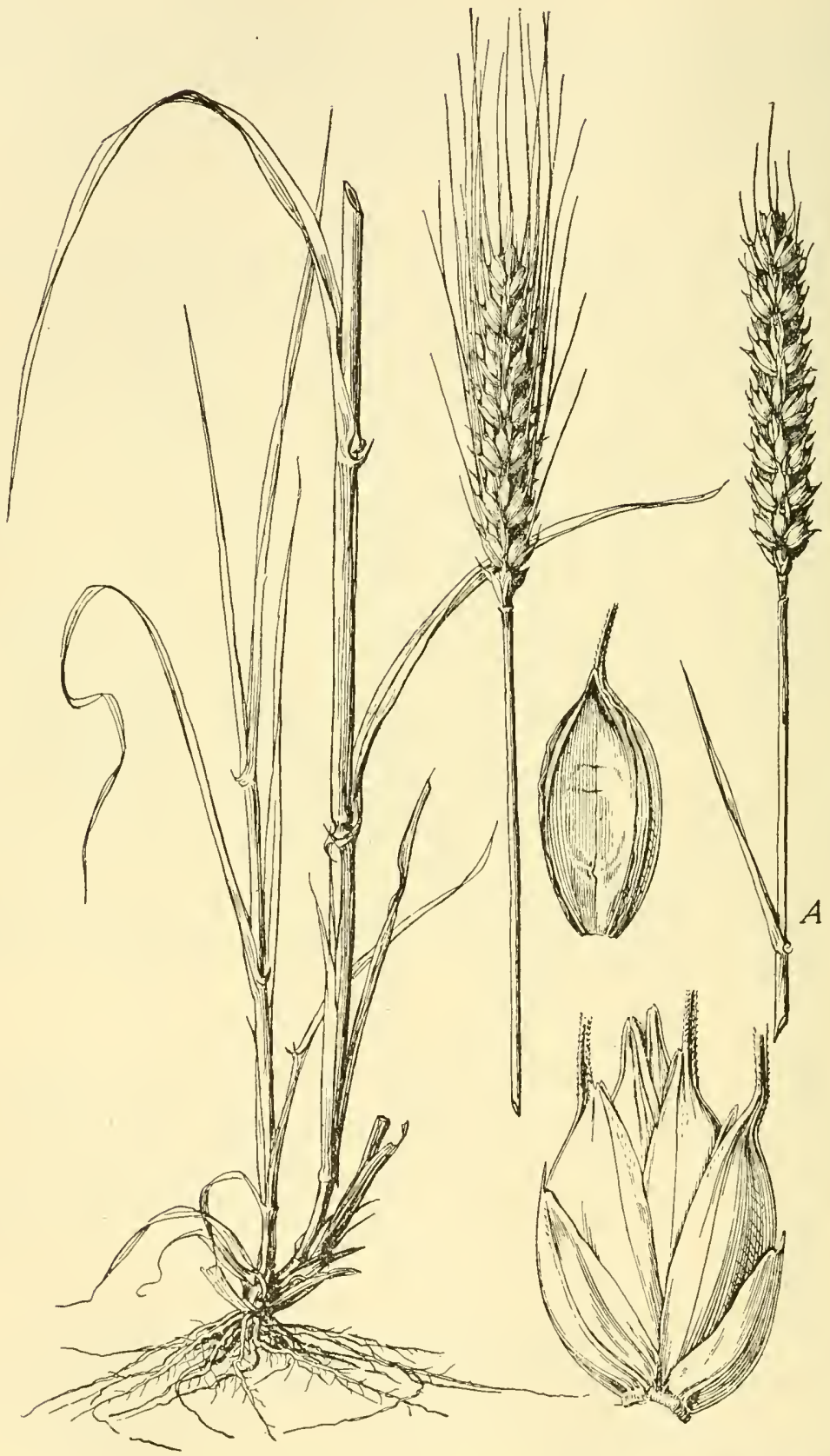

FIGURE 475.-Triticum aestivum. Plant with awned spikes (bearded wheat) and a nearly awnless spike $(A)$ beardless wheat, $\times 1 / 2$; spikelet and floret, $\times 3$. (Cult.) 
1. Aegilops cylíndrica Host. Jolnted goatgrass. (Fig. 476, B.) Culms erect, branching at base, 40 to $60 \mathrm{~cm}$ tall; blades 2 to $3 \mathrm{~mm}$ wide; spike cylindric, 5 to $8 \mathrm{~cm}$ long; internodes of rachis 6 to $8 \mathrm{~mm}$ long; spikelets 8 to $10 \mathrm{~mm}$ long, glabrous to hispid; glumes several-

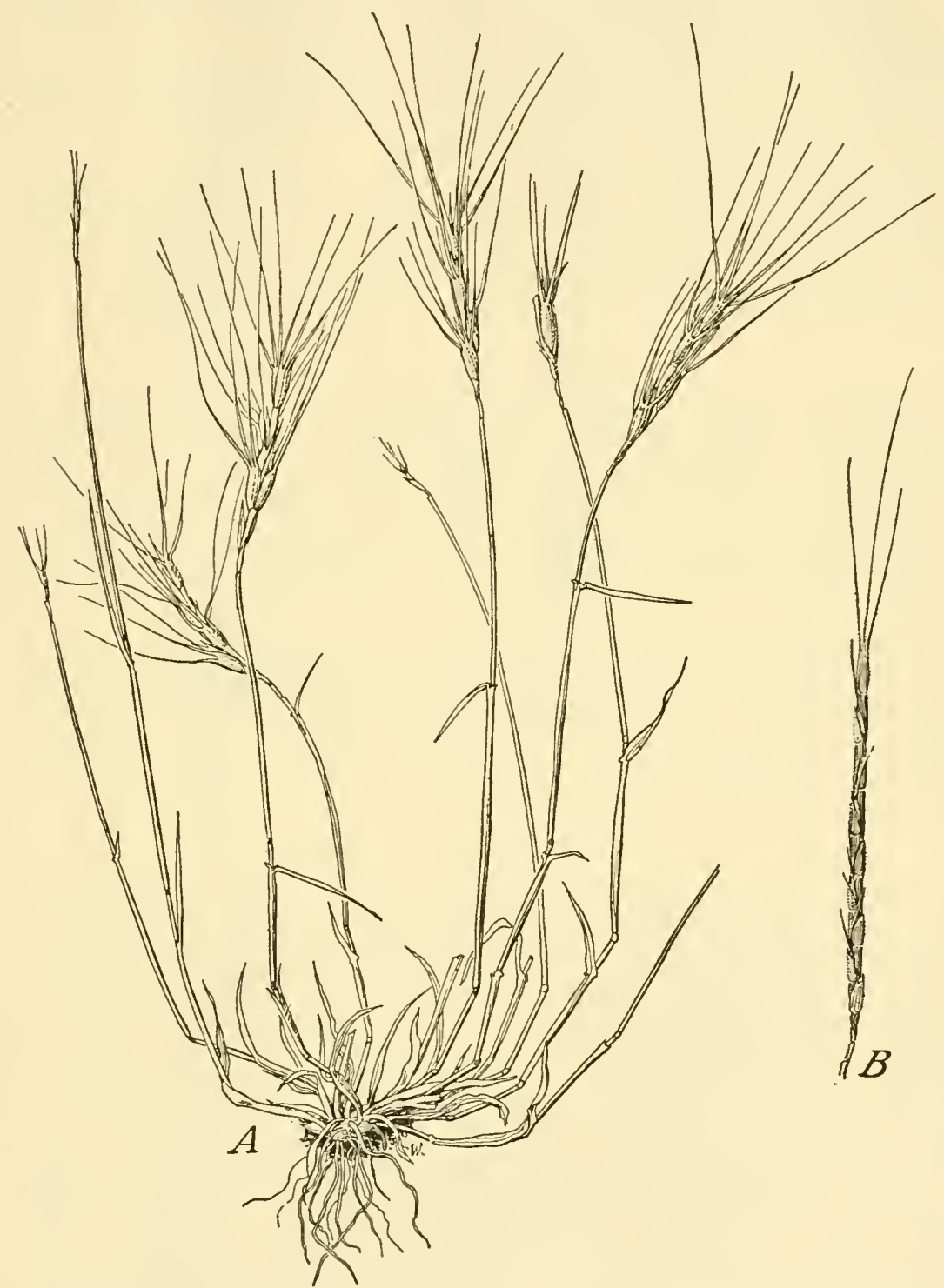

FIgure 476. A, Aegilops triuncialis, $\times 1 / 2$. (Cole, Calif.) B, A. cylíndrica, $\times 1 / 2 . \quad$ (Bush 72148, Mo.)

nerved, keeled at one side, the keel extending into an awn, the main nerve of the other side extending into a short tooth; lemmas mucronate, those of the uppermost spikelets awned like the glumes; awns very scabrous, those of the upper spikelets about $5 \mathrm{~cm}$ long, those of the 
lower spikelets progressively shorter. $\odot$-Weed in wheatfields, and waste places, Missouri, Kansas, Oklahoma, Colorado, and New Mexico; recently introduced from Europe.

2. Aegilops triunciális L. Barb goatgrass. (Fig. 476, A.) Culms branching and spreading at base, 20 to $40 \mathrm{~cm}$ tall; blades rather rigid, sharp-pointed, spreading; spike 3 to $4 \mathrm{~cm}$ long, 2 or 3 of the lower spikelets often reduced, the fertile spikelets 3 to 5 ; glumes with 3 strong scabrous, somewhat spreading awns, 4 to $8 \mathrm{~cm}$ long; lemmas with three rigid unequal awns. $\odot$-Troublesome weed on range land, California; introduced from Europe.

3. Aegilops ováta L. Culms tufted, geniculate at base, 15 to $25 \mathrm{~cm}$. tall; blades short, sharp-pointed; spike thick, of 2 to 4 subovate spikelets, the upper sterile; glumes with 4 stiff scabrous spreading awns 2 to $3 \mathrm{~cm}$ long; lemmas usually with 1 long and 2 short awns. $\odot$ Weed in fields, California and Virginia; introduced from Europe.

\section{SECÁLE L. RYE}

Spikelets usually 2-flowered, solitary, placed flatwise against the rachis, the rachilla disarticulating above the glumes and produced beyond the upper floret as a minute stipe; glumes narrow, rigid, acuminate or subulate-pointed; lemmas broader, sharply keeled, 5-nerved, ciliate on the keel and exposed margins, tapering into a long awn. Erect, mostly annual grasses, with flat blades and dense spikes. Type species, Secale cereale. Secale, the old Latin name for rye.

1. Secale cereále L. Rxw. (Fig. 477.) In habit resembling wheat but usually taller, the spike more slender, somewhat nodding, on the average longer. $\odot$ - Commonly cultivated; escaped from cultivation, in fields and waste places. This species is thought to be derived from S. montanum Guss., a perennial native in the mountains of southwestern Asia.

\section{3. ÉLYMUS L. WiLD-RYE}

Spikelets 2- to 6-flowered, in pairs (rarely 3 or more or solitary) at each node of a usually continuous rachis, placed as in Agropyron but the rachilla distorted at base, bringing the florets more or less dorsiventral to the rachis; rachilla disarticulating above the glumes and between the florets; glumes equal, somewhat asymmetric, usually rigid, sometimes indurate below, narrow to subulate, 1 - to severalnerved, acute to aristate; lemmas rounded on the back or nearly terete, obscurely 5-nerved, acute or usually awned from the tip. Erect, usually rather tall perennials (one annual), with flat or rarely convolute blades and slender or bristly spikes, the spikelets usually crowded, sometimes somewhat distant. Type species, Elymus sibiricus L. Name from Elumos, an old Greek name for a kind of grain. The species in which the spikelets are mostly solitary can be distinguished from Agropyron by the narrow or subulate glumes. The seed of certain species (e.g., E. mollis and E. canadensis) have been used for food by the Indians.

The species of Elymus are for the most part good forage grasses, and in some localities form a part of the native hay. In the wooded areas of the Northwest, $E$. glaucus is one of the valuable secondary grasses of the ranges. The species with creeping rhizomes are likely 


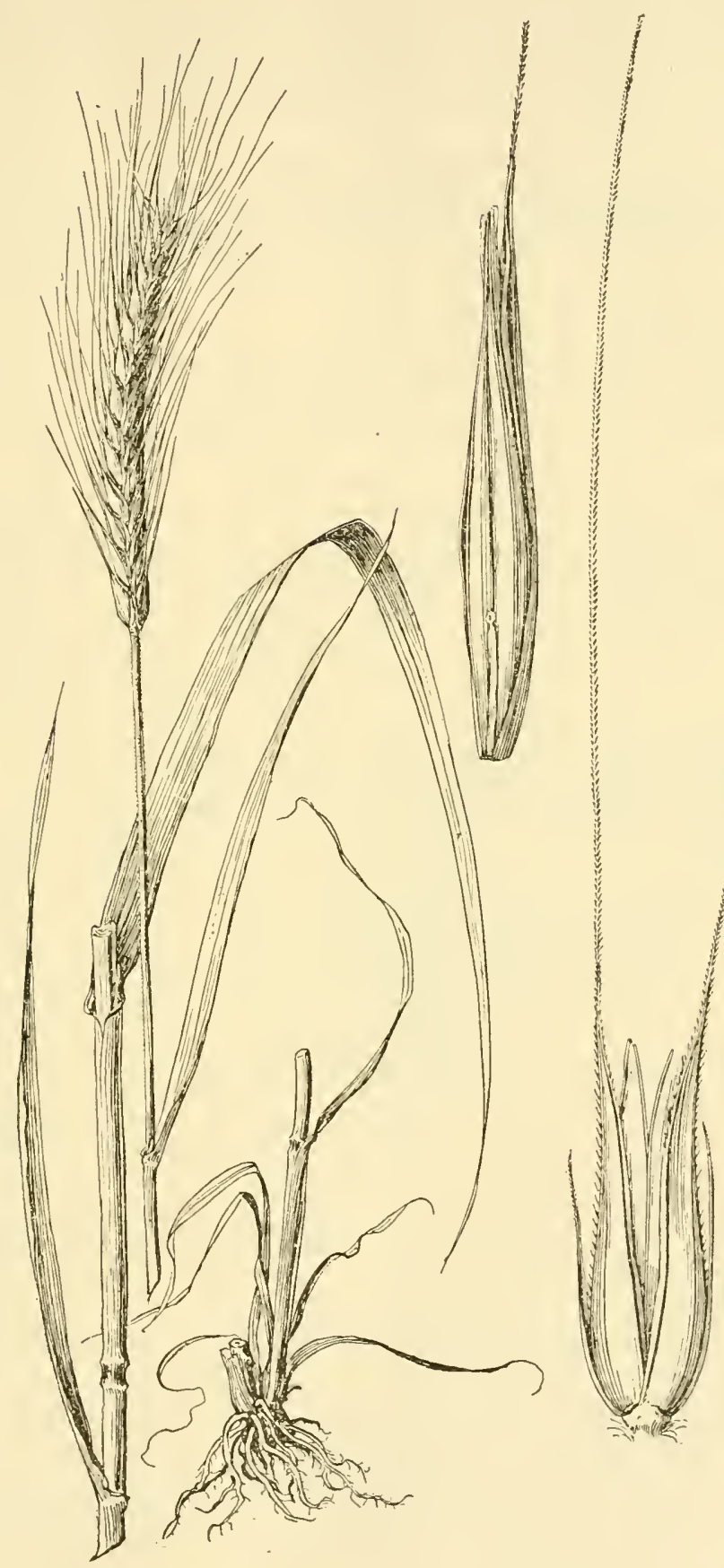

Figure 477.-Secale cereále. Plant, $\times 1 \frac{1}{2}$; spikelet, $\times 3$; floret, $\times 5$. (Hill, Ill.) 
to be of value as soil or sand binders. E. mollis is a natural sea dune grass and E. arenicola and E. flavescens are common on inland shifting dunes; $E$. triticoides is to be recommended for holding embankments. On the western ranges $E$. condensatus and $E$. triticoides are important.

1a. Plants annual; spike long-awned, nearly as broad as long.

1b. Plants perennial; spike much longer than broad.

1. E. CAPUT-MEDUSAE.

2a. Rhizomes present, slender, creeping.

Glumes lanceolate, awnless or awn-pointed. Plants of coastal dunes.

Glumes and lemmas papery, distinctly nerved...... 2. E. Moulis. Glumes and lemmas firm, faintly nerved (lemmas nerved at apex).

Glumes subulate or very narrow.

3. E. VANCOUVERENSIS.

Spikelets glabrous; lemmas short-awned_._._._._. 8. E. Tritrcordes.

Spikelets densely villous to coarsely, sometimes sparsely, pubescent.

Lemmas awned or awn-tipped; spike 5 to $15 \mathrm{~cm}$ long.

Lemmas copiously villous; awn 1 to $4 \mathrm{~mm}$ long _- 6 .

Lemmas hirsute or hirtellous; awn 5 to $10 \mathrm{~mm}$ long.

E. InNovatus.

7. E. HIRTIFLORUS.

Lemmas awnless; spike 10 to $25 \mathrm{~cm}$ long.

Glumes pubescent; lemmas soft, densely villous_-_4. E. FLAvescens. Glumes glabrous or nearly so; lemmas relatively firm, coarsely pubescent, sometimes sparsely so _...... 5. E. ARENICOLA.

2b. Rhizomes wanting (or short and stout in E. condensatus). Plants tufted.

3a. Rachis tardily disjointing. Glumes and lemmas awned.

Spike mostly 5 to $7 \mathrm{~mm}$ wide; spikelets mostly in twos; blades subinvolute.

15. E. MACOUNII.

Spike 8 to $10 \mathrm{~mm}$ wide; spikelets of ten in threes; blades flat, 5 to $10 \mathrm{~mm}$ wide.

16. E. ARIStatus.

3b. Rachis continuous.

4a. Glumes subulate to subsetaceous, not broadened above the base, the nerves obscure except in E. villosus.

Lemmas awnless or awn-tipped, the awn shorter than the body.

Spike thick, sometimes compound; spikelets commonly in twos to fours.

11. E. CONDENSATUS.

Spike slender; some or most of the spikelets solitary at the nodes, the paired spikelets near the middle.

Culms numerous in a close tuft, the leaves mostly basal; lemmas mostly awnless.....

Culms few, loosely tufted, the leaves scattered along the usually taller culms; lemmas awn-tipped, the awn 2 to $5 \mathrm{~mm}$ long.

Lemmas awned, the awn as long as the body or longer.

9. E. AMBIGUUS.

Awns straight; lemmas about $1.2 \mathrm{~mm}$ wide across the back.

17. E. villosus. Awns flexuous-divergent; lemmas about $2 \mathrm{~mm}$ wide across the back. 18. E. INTERRUPTUS.

4b. Glumes lanceolate or narrower, broadened above the base, strongly 3- to several-nerved.

Glumes relatively thin, flat, several-nerved, not indurate at base.

Lemmas sparsely long-hirsute on the margins toward the summit.

Lemmas glabrous or scabrous.

Lemmas awned

14. E. HIRSUTUS.

Lemmas awnless or minutely

Awns divergently curved when dry; base of glumes not terete.

Awns straight; base of glumes terete.

12. E. GLAUCUS. 13. E. VIRESCENS.

19. E. CANADENSIS.

Glumes about $1 \mathrm{~mm}$ wide about the middle, the bases not bowed out.

20. E. RIPARIUS.

Glumes 1.5 to $2 \mathrm{~mm}$ wide about the middle, the bases bowed out.

21. E. VIRGINICUS

1. Elymus cáput-medúsae L. (Fig. 478.) Annual; culms ascending from a decumbent, branching base, slender, 20 to $60 \mathrm{~cm}$ tall; blades 
narrow, short; spike very bristly, 2 to $5 \mathrm{~cm}$ long (excluding the long spreading awns); glumes subulate, smooth, indurate below, tapering into a slender awn 1 to $2.5 \mathrm{~cm}$ long; lemmas lanceolate, 3-nerved, $6 \mathrm{~mm}$ long, very scabrous, tapering into a flat awn 5 to $10 \mathrm{~cm}$ long. $\odot-$ Open ground, Washington to California, infrequent; introduced from Europe.

2. Elymus móllis Trin. American dunegrass. (Fig. 479.) Culms stout, pubescent below the spike, glaucous, 60 to $120 \mathrm{~cm}$ tall, with numerous overlapping basal leaves, the rhizomes widely creeping; blades firm, 7 to $12 \mathrm{~mm}$ wide, often involute in drying; spike erect,

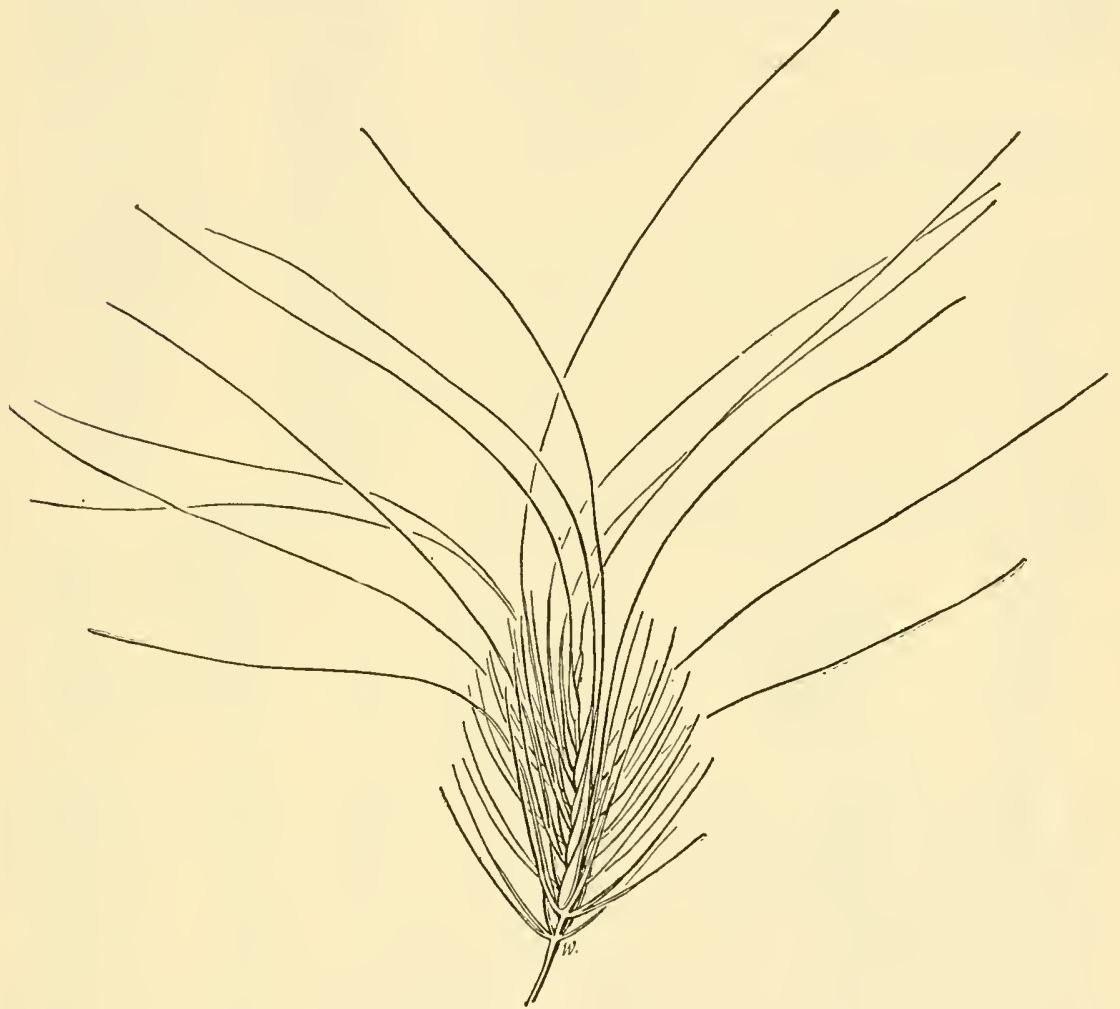

Figure 478.-Elymus caput-medusae, $\times 1$. (Vasey 3076, Wash.)

dense, thick, soft, pale, 7 to $25 \mathrm{~cm}$ long; glumes lanceolate, flat, many-nerved, scabrous or pubescent, 12 to $25 \mathrm{~mm}$ long, acuminate, about as long as the spikelet; lemmas scabrous to felty-pubescent, acuminate or mucronate. 2 - Sand dunes along the coast, Alaska to Greenland, south to Massachusetts and central California; along Lakes Superior and Michigan (fig. 480); also eastern Siberia to Japan. Closely related to the European E. arenarius L. with culm smooth below the spike and glabrous glumes. A form found along the coast of Washington with somewhat compound spikes has been differentiated as $E$, arenarius var. compositus (Abrom.) St. John. 
3. Elymus vancouverénsis Vasey. (Fig. 481.) Resembling E. mollis, less leafy; spike somewhat interrupted, purplish; glumes narrowly lanceolate, firm, gradually acuminate, 1 to 1.5 $\mathrm{cm}$ long, sparsely long-villous, especially toward the apex; lemmas firm, 1 to 1.5 $\mathrm{cm}$ long, tapering into a short awn. 2 -Dunes and sandy shores, British Columbia to northern California.

4. Elymus flavéscens Scribn. and Smith. (Fig. 482.) Culms erect, slender, glabrous, 50 to $100 \mathrm{~cm}$ tall, the rhizomes slender, nearly vertical from deep slender

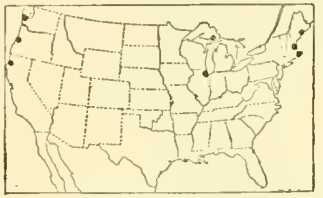

Figure 480.-Distribution of Elymus mollis.

horizontal rhizomes with brown scales; sheaths glabrous; blades firm, glabrous beneath, scabrous on the upper surface, 2 to $5 \mathrm{~mm}$ wide, flat, or involute in drying; spike 10 to $25 \mathrm{~cm}$ long, sometimes with short branches, somewhat nodding; spikelets 2 to $3 \mathrm{~cm}$ long, several-flowered, approximate or somewhat distant; glumes very narrow or subulate, pubescent, nerve-

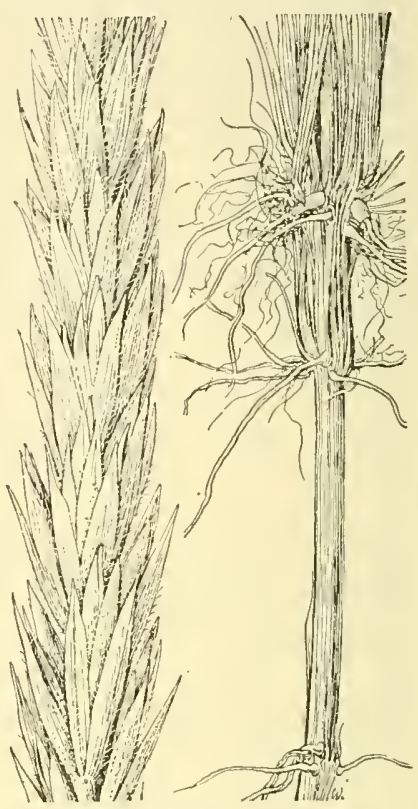

FigURE 479.-Elymus mollis, $\times 1$. (Henderson 2169, Wash.)

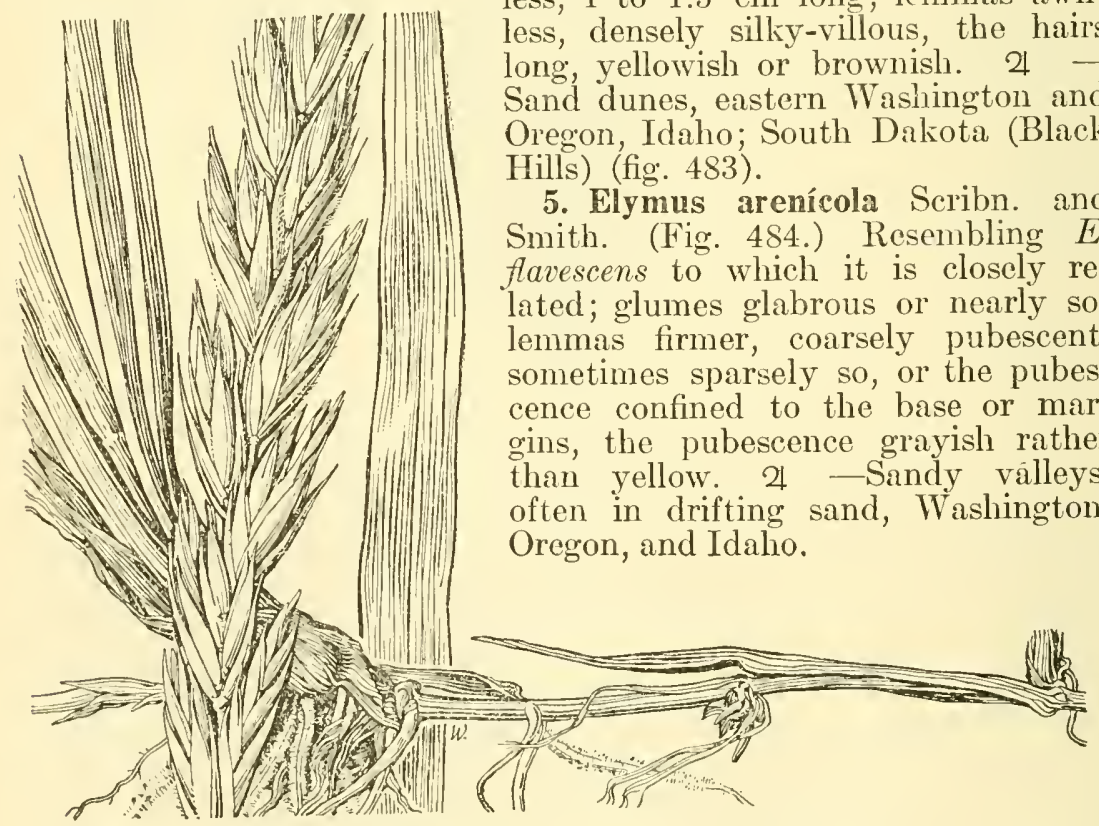

FIgURE 481.-Elymus vancouvcrensis, $\times 1$. (Piper \$12, Wash.) 
6. Elymus innovátus Beal. (Fig. 485.) Resembling E. flavescens; spike rather dense, 5 to $12 \mathrm{~cm}$ long, the axis villous; spikelets 1 to $1.5 \mathrm{~cm}$ long, the narrow glumes and the lemmas densely purplish or grayish-villous, the lemmas with an awn mostly 1 to $4 \mathrm{~mm}$ long. 24 -Open woods and gravelly flats, Alaska to British Columbia; Montana, Wyoming, and South Dakota (Black Hills).

\section{Elymus hirtiflórus}

Hitche. (Fig. 4S6.)

Culms erect, tufted, 40 to

$90 \mathrm{~cm}$ tall, with slender creeping rhizomes; blades firm, flat or usually involute, glabrous beneath, 5 to $20 \mathrm{~cm}$ long, 1 to $4 \mathrm{~mm}$ wide when flat; spike

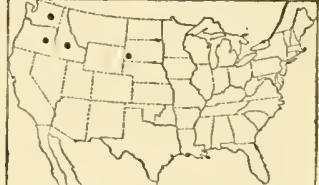

Figere 483.-Distribution of Elymus flavescens. erect, 5 to $15 \mathrm{~cm}$ long; spikelets 4 - to 6flowered; glumes firm, hirsute, narrow, tapering into an awn about as long as the body, the entire length 1 to $1.5 \mathrm{~cm}$; lemmas hirsute, some-

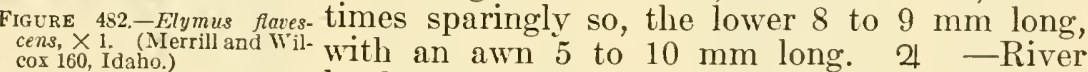
cens, $\times 1$. (Merril
$\operatorname{cox} 160$, Idaho.) banks, Wyoming.

8. Elymus triticoídes Buckl. Beardless wild-rye. (Fig. 487.)

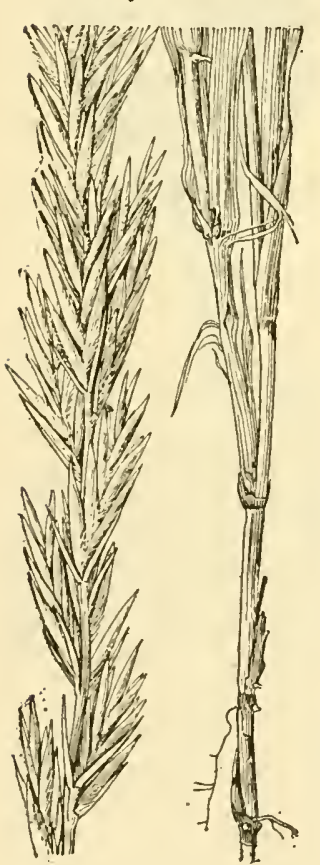

FIgURE 484-Elymus ate. nicola, $\times 1$. (Palmer 356, Idaho.)

Hitchc. Sheaths Culms usually glaucous, rarely pubescent below spike, 60 to $120 \mathrm{~cm}$ tall, commonly in large colonies from extensively creeping scaly rhizomes; ligule a truncate rim about $1 \mathrm{~mm}$ long; blades mostly 2 to $6 \mathrm{~mm}$ wide, flat or soon involute; spike erect, slender to rather dense, rarely compound; spikelets mostly 12 to $20 \mathrm{~mm}$ long; glumes very narrow to subulate, firm, nerveless or 1 - to 3-nerved, awn-tipped, 5 to $15 \mathrm{~mm}$ long, those of the upper spikelets usually reduced or obsolete; lemmas 6 to $10 \mathrm{~mm}$ long, glabrous, firm, brownish, purplish or tawny, awn-tipped. $24-$ Moist or alkaline soil, at low and medium elevations, Montana to Washington, south

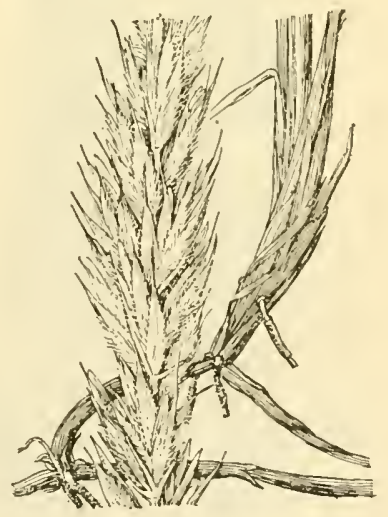

Figure 4S5.-Elymus innovatus, $\times$ 1. (Hayward 2719, S. Dak.)

to western Texas and Baja California (fig. 488). ElyMUS TRITICOIDES var. PUBÉSCENS
involute blades pubescent. 
California, Idaho, Nevada; rare. Elymus triticoides var. símplex (Scribn. and Will.) Hitchc. Usually less than $60 \mathrm{~cm}$ tall; blades rather short, involute; spike usually less than $10 \mathrm{~cm}$ long; spikelets mostly solitary; glumes often rather broad at base. 24 (E. simplex Scribn. and Will.) - Wyoming and Colorado to California (Tahoe) and eastern Oregon (Harney County).

9. Elymus ambíguus Vasey and Scribn. (Fig. 489.) Culms few, loosely tufted, erect, 30 to $70 \mathrm{~cm}$ tall; sheaths glabrous; blades flat to subinvolute, 2 to $5 \mathrm{~mm}$ wide, scabrous; spike erect, rather dense, 5 to $15 \mathrm{~cm}$ long; spikelets solitary toward the base and apex of the spike, mostly 2- to 4-flowered; glumes subulate, scabrous toward the awned tip; lemmas glabrous or scabrous on the back, about $1 \mathrm{~cm}$ long, shortawned, the awn 2 to $5 \mathrm{~mm}$ long. 4 -Open slopes at medium altitudes in the mountains, Colorado, rare in Montana and Utah. Elruus AMBiguUs var. strigósus (Rydb.) Hitchc. Lemmas strigose or pubescent. 2 (E. strigosus Rydb., lemmas strigose; $E$. villiflorus Rydb., lemmas pubescent.)-Wyoming, Colorado.

10. Elymus salína Jones. Salina wild-Rye. (Fig. 490.) Culms erect, 30 to $80 \mathrm{~cm}$ tall, sometimes scabrous below nodes and below spike; sheaths scabrous; blades firm, invo-

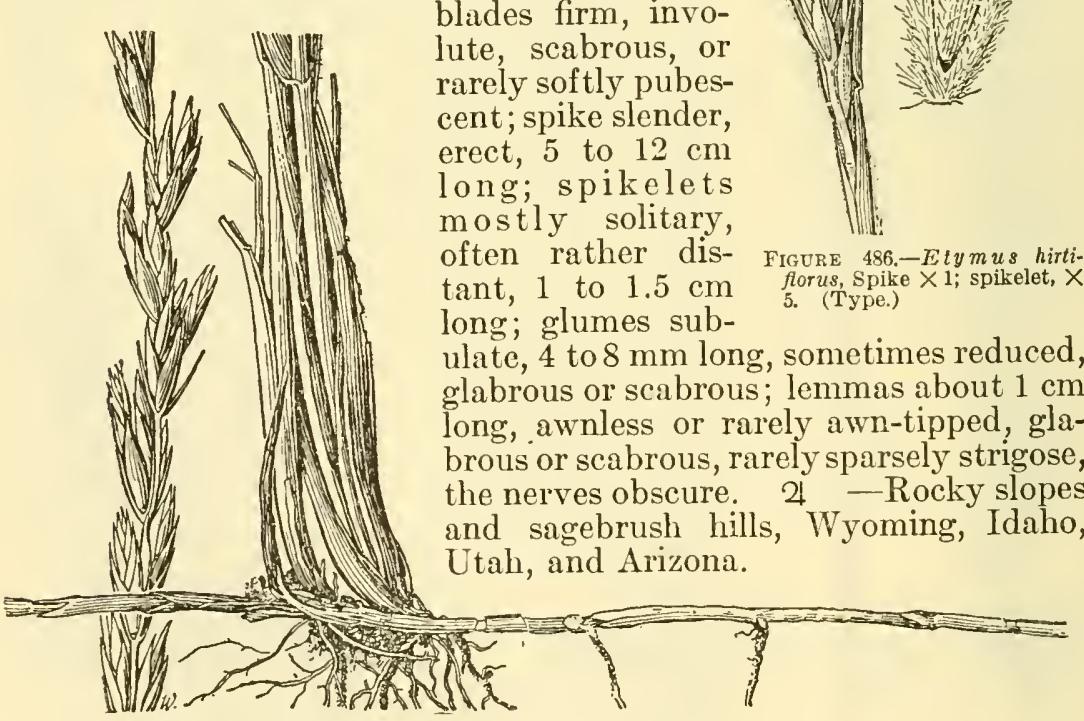

FIGURE 487.-Elymus triticoides, $\times 1$. (Cusick 763, Oreg.)

11. Elymus condensâtus Presl. Giant wild-Rye. (Fig. 491.) Culms in large tufts, stout, usually 1 to $3 \mathrm{~m}$ tall, sometimes puberulent, especially below the nodes, the rhizomes when present short and 
thick; ligule 2 to $5 \mathrm{~mm}$ long; blades firm, strongly nerved, flat, as much as $2 \mathrm{~cm}$ wide; spike erect, usually dense, 15 to $30 \mathrm{~cm}$ long, sometimes compound; spikelets often in threes to fives; glumes subulate, awn-pointed, usually 1-nerved or nerveless, about as long as the first lemma; lemmas glabrous to sparsely strigose, awnless or mucronate. 24 -Dry plains, slopes, sand hills, and along gullies and ditches up to medium altitudes, Minnesota to British Columbia, south to Colorado, New Mexico, and California (fig. 492). On the coast of California there is a form with robust culms as much as $3 \mathrm{~m}$ tall, compound spikes as much as $30 \mathrm{~cm}$ long and $4 \mathrm{~cm}$ thick, the ascending compound

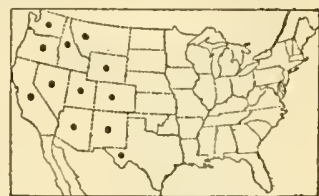

FIGURE 488.-Distribution of Elymus triticoides. branches sometimes $6 \mathrm{~cm}$ long. This form usually has pronounced rhizomes; possibly distinct. Elymus condensatus var. Púbens Piper (E. cinereus Scribn.

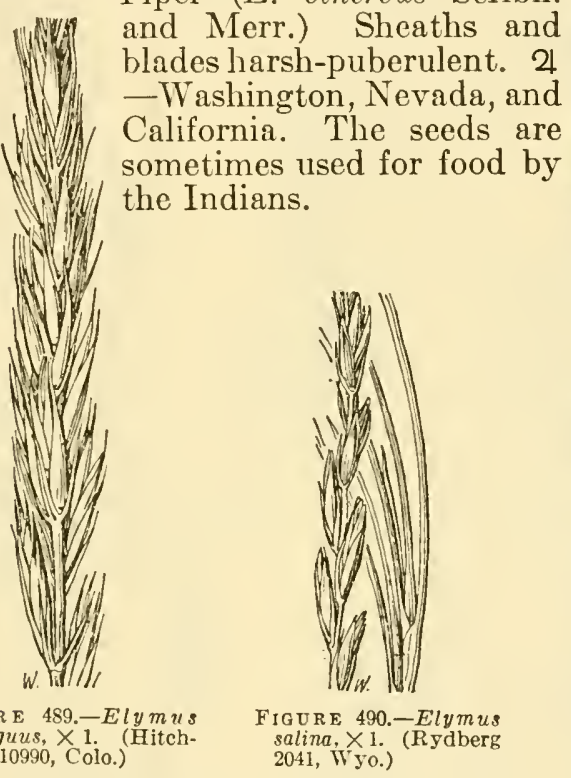

FIGURE 489.-Elymus cock 10990, Colo.) salina. $\times 1$. (Rydber 2041, Wyo.)

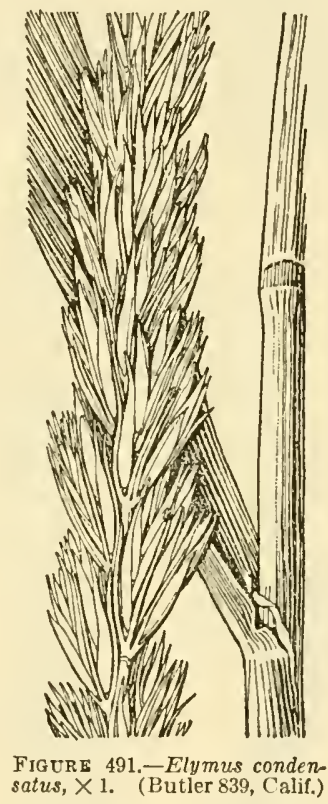

12. Elymus glaúcus Buckl. BLuE wild-RYE. (Fig. 493. )
ulms in loose to dense tufts, often bent at base, erect, 60 to $120 \mathrm{~cm}$ tall, without rhizomes, leafy; sheaths smooth or scabrous; blades flat,

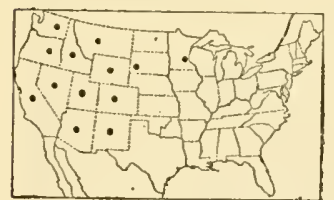

FIGURE 492,-Distribution of Elymus condensatus. usually lax, mostly 8 to $15 \mathrm{~mm}$ wide, usually scabrous on both surfaces, sometimes narrow and subinvolute; spike long-exserted, from erect to somewhat nodding, usually dense, commonly 5 to $20 \mathrm{~cm}$ long, occasionally longer; glumes lanceolate at base, 8 to $15 \mathrm{~mm}$ long, with 2 to 5 strong scabrous nerves, acuminate or awn-pointed; lemmas awned, the awn 1 to 2 times as long as the body, erect to spreading. 24 -Open woods, copses, and dry hills at low and medium altitudes, Ontario and Michigan to southern Alaska, south through South Dakota and Colorado to New Mexico and California; Missouri 
and Arkansas (fig. 494). Exceedingly variable, the commonest form is loosely tufted, with lax blades 10 to $15 \mathrm{~mm}$ wide and somewhat nodding spike, but plants with narrower blades and stiff spikes are frequent, the extreme form having been differentiated as $E$. angustifolius Davy. The original specimen described by Buckley is a rather

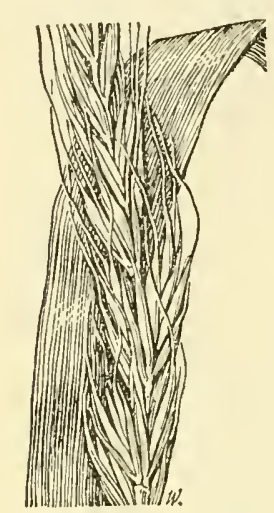

F I G U R $493,-E / y m u s$ glaucus, $\times 1$. (Chase 5150, Idaho.)

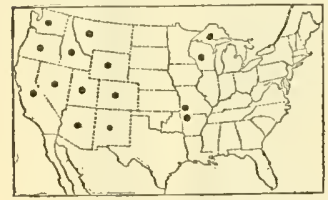

Frgure 494.-Distribution of Elymus glaucus.

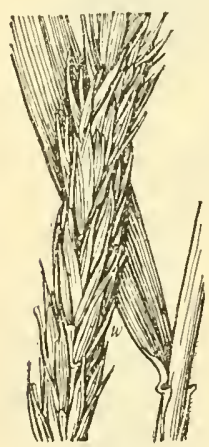

mas clabrous to scabrous, barely awn-tipped or with an awn 1 to $4 \mathrm{~mm}$ long. 2 - Moist woods, southern Alaska to California.

14. Elymus hirsútus Presl. (Fig. 496.) Culms solitary or in small tufts, 50 to $140 \mathrm{~cm}$ tall, rather weak; blades flat, lax, 4 to $10 \mathrm{~mm}$ wide, scabrous; spike drooping, mostly loose, the rachis exposed; spikelets mostly about $15 \mathrm{~mm}$ long; glumes? about

FIGURE 495.-Elymus virescens, $\times 1$. (Flett, Wash.) small plant intermediElymus glaucus var. JEPSóNI Davy. Sheaths and blades pubescent. 2 -British Columbia to California; Montana.

13. Elymus virescens sembling E. glaucus and nearly as variable in habit, often decumfrom glabrous to retrorsely pubescent, wide, glabrous to harsh-puberulent; spike 5 to $15 \mathrm{~cm}$ long, dense, spikeglumes flat, 1 to 2 $\mathrm{mm}$ wide, strongly nerved, pointed or awn-tipped; lem$1 \mathrm{~mm}$ wide, strongly nerved, awned; lemmas sparsely long-hirsute along the margin toward the summit, sometimes coarsely pubescent on the back, the slender awn flexuous or divergent, 1.5 to $2 \mathrm{~cm}$ long. 2 -Moist woods or open ground, Alaska to Oregon.

15. Elymus macoúnii Vasey. Macoun wild-RYe. (Fig. 497.) Culms densely tufted, erect, slender, 50 to $100 \mathrm{~cm}$ tall; sheaths glabrous or rarely pubescent; blades erect, rather firm, subinvolute, usually scabrous on both surfaces, 10 to $20 \mathrm{~cm}$ long, mostly 2 to $5 \mathrm{~mm}$ 
wide; spike slender, erect or somewhat nodding, 4 to $12 \mathrm{~cm}$ long, usually about $5 \mathrm{~mm}$ thick (excluding awns), the slender rachis tardily disarticulating; spikelets imbricate, appressed, mostly 2 -flowered, about $1 \mathrm{~cm}$ long, excluding the awns; glumes very narrow, scabrous, slightly divergent but not bowed out at base, the midnerve usually distinct; lemmas scabrous toward the apex, extending into slender straight awns 1 to $2 \mathrm{~cm}$ long. 2 -Meadows and open ground,

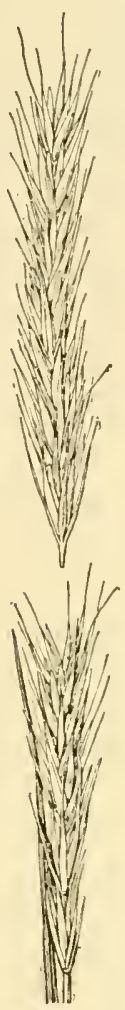

FIGURE 497.-Elymus macounii. Disarticulating spike, $\times 1$. (Anderson, Mont.)

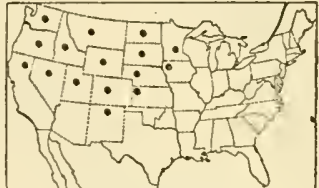

FIGURE 498.-Distribution of Elymus macounii.

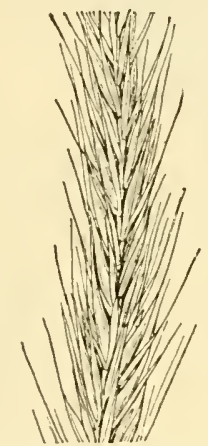

FIGURE 499.-Elymus aristatus, $\times 1$. (Chase 4762 , Idaho.)

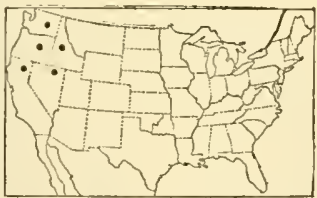

Figure 500.-Distribution of Elymus aristatus.

Minnesota to Alaska and eastern Washington, south to Iowa, Nebraska, New Mexico, and California (fig. 498).

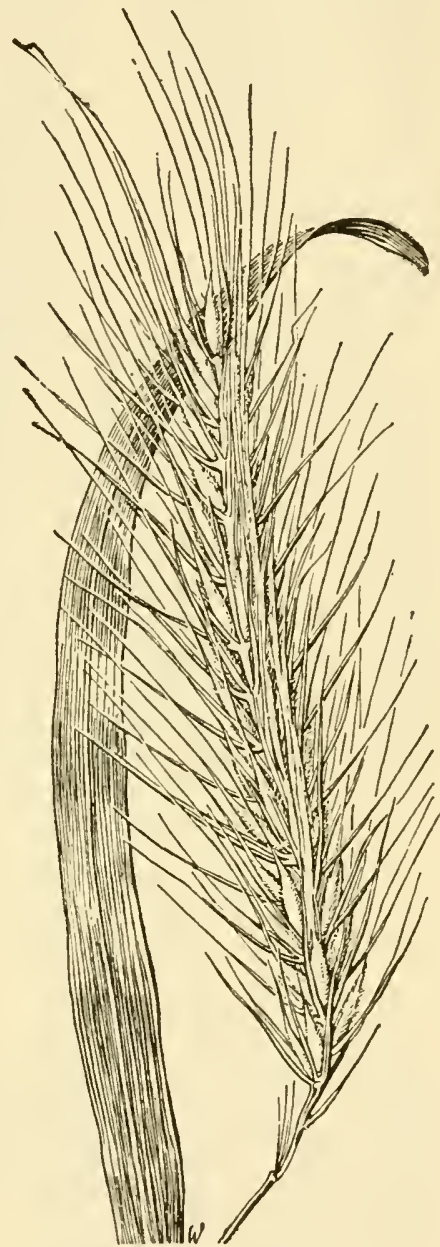

Figure 501.-Elymus villosus, $\times 1$. (Commons 163 , Del.)

16. Elymus aristátus Merr. (Fig. 499.) Culms tufted, rather leafy, erect, 70 to $100 \mathrm{~cm}$ tall; sheaths glabrous, blades flat, 5 to $10 \mathrm{~mm}$ wide; spike erect, dense, 6 to $14 \mathrm{~cm}$ long, 5 to $10 \mathrm{~mm}$ thick, the rachis tardily disarticulating; spikelets closely imbricate, of ten in threes, 1 - to 2 -flowered, about $1 \mathrm{~cm}$ long, excluding the awns; glumes subsetaceous, scabrous, 10 to $20 \mathrm{~mm}$ long; lemmas slightly wider than in E. macounii, sparsely scabrous at least on the upper half, the slender straight awn 10 to $20 \mathrm{~mm}$ long. 2 -Meadows and open slopes, at middle altitudes, Idaho and Washington, south to Nevada and California (fig. 500). 
17. Elymus villósus Muhl. (Fig. 501.) Culms tufted, ascending, slender, 60 to $100 \mathrm{~cm}$ tall; sheaths glabrous to sparsely pilose; blades flat, lax, pubescent on upper surface, glabrous or scabrous beneath; spike drooping, dense, 5 to $12 \mathrm{~cm}$ long; glumes subsetaceous, spread-

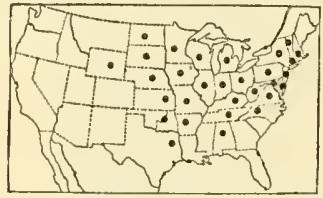

Figure 502.-Distribution of Elymus villosus. ing, distinctly nerved above the firm cylindric nerveless divergent or somewhat bowed-out base, hirsute, 12 to $20 \mathrm{~mm}$ long; lemmas nerved toward the tip, hispidulous to hirsute, 7 to 8 $\mathrm{mm}$ long, about $1.2 \mathrm{~mm}$ across the back, the straight slender awn 1 to $3 \mathrm{~cm}$ long. 2 (E. striatus, American authors, not Willd. Moist or dry woods and shaded slopes, Vermont to North Dakota and Wyoming, south to North Carolina, Alabama, and Texas (fig. 502). E. arkansanus Scribn. and Ball is a form with glabrous or scabrous spikelets.

18. Elymus interrúptus Buckl. (Fig. 503.) Culms erect, 70 to 130 cm tall; sheaths glabrous; blades flat scabrous, 5 to $12 \mathrm{~mm}$ wide; spike flexuous or nodding, 8 to $20 \mathrm{~cm}$ long; glumes setaceous or nearly so, 1 to $3 \mathrm{~cm}$ long, one or both reduced in occasional spikelets, mostly flexuous or spreading, the nerves obscure at least toward the base; lemmas hirsute to scabrous, or glabrous, about $1 \mathrm{~cm}$ long, about $2 \mathrm{~mm}$ across the back, the awn flexuous or divergent, 1 to $3 \mathrm{~cm}$ long.

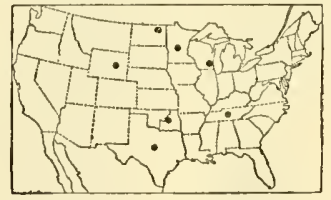

FIGURE 504.-Distribution of Elymus interruptus.

24 (E. diversiglumis Scribn. and Ball.)-Rich, open moist soil, Wisconsin to North Dakota and Wyoming; Tennessee, Oklahoma, Texas, and northern Mexico (fig. 504).

19. Elymus canadénsis L. Canada wild-Rye. (Fig. 505.) Green or often glaucous; culms erect, tufted, mostly 1 to $1.5 \mathrm{~m}$ tall; sheaths glabrous or rarely pubescent; blades flat, scabrous or sparsely hispid on the upper

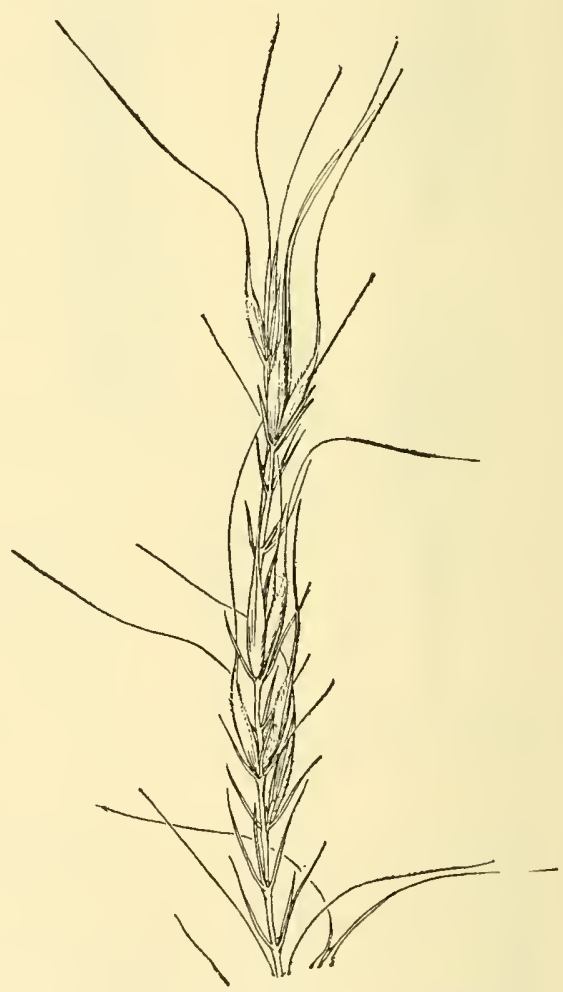

Figure 503.-Elymus interruptus, $\times$ 1. (Grant 3071, Minn.)

surface, mostly 1 to $2 \mathrm{~cm}$ wide; spike thick and bristly, nodding or drooping, often interrupted below, 10 to $25 \mathrm{~cm}$ long, sometimes glaucous; spikelets commonly in threes or fours, slightly spreading; glumes narrow, mostly 2- to 4-nerved, scabrous, sometimes hispid but less so than the lemmas, the bases somewhat indurate and divergent but scarcely bowed out, the awn about as long as the body; lem- 


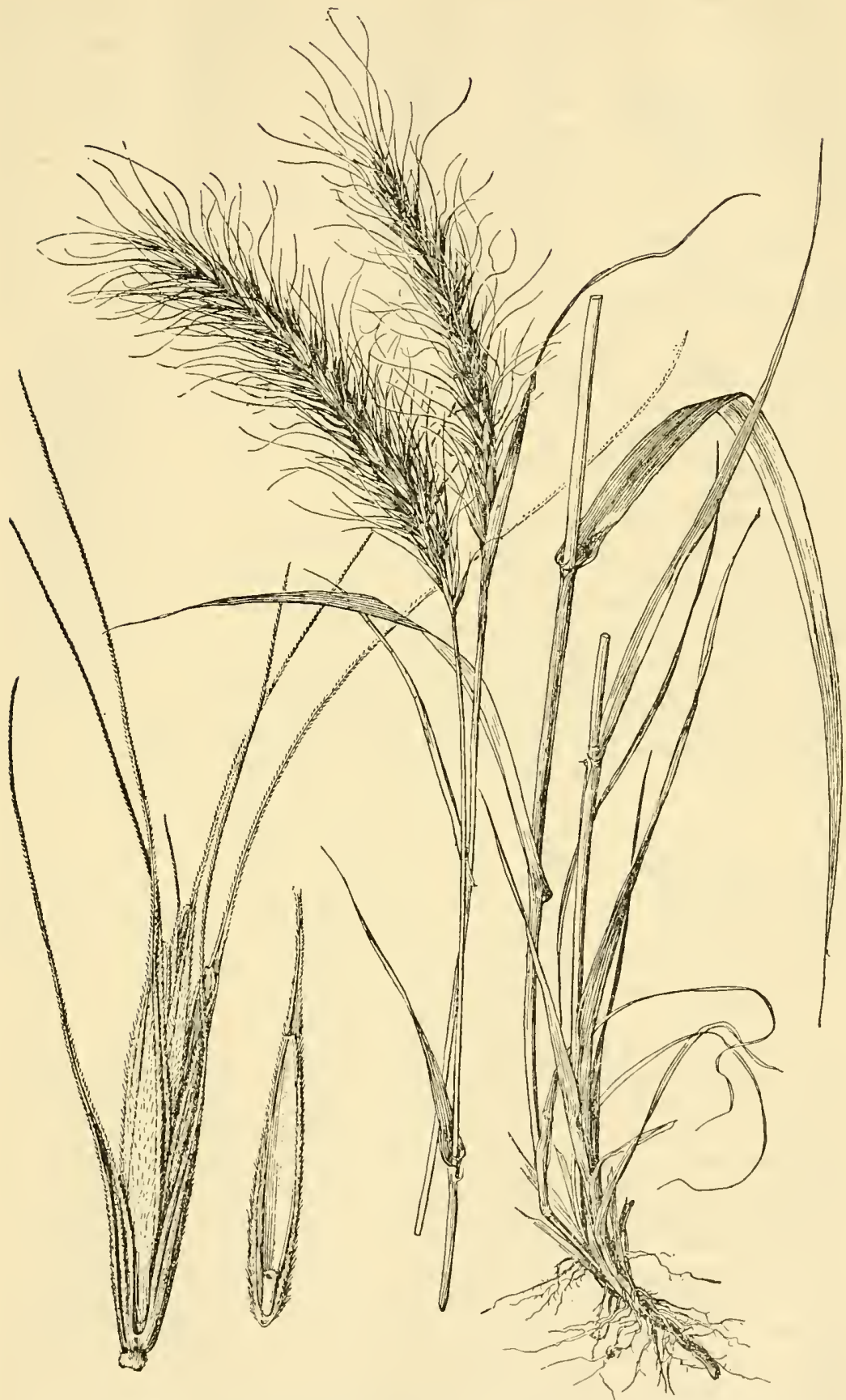

FIgURE 505.-Elymus canadensis. Plant, $\times 1 \frac{1}{2}$; spikelet and floret, $\times 5$. (Lansing 3240 , Mich.) 
mas scabrous-hirsute to hirsute-pubescent, rarely glabrous, strongly nerved above, the awn divergently curved when dry, 2 to $3 \mathrm{~cm}$

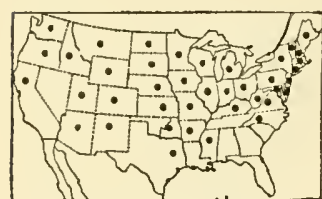

FIgURE 506.-Distribution of Elymus canadensis.

long. 24 -River banks, open ground, and sandy soil, Quebec to southern Alaska, south to North Carolina, Missouri, Texas, Arizona, and northern California (fig. 506). ELYMUS CANADENSIS var. ROBÚSTUS (Scribn. and Smith) Mackenz. and Bush. Differing in the stouter and denser only slightly nodding very bristly spikes. 24 -Prairies, Massachusetts to Montana, south to Kentucky, Missouri,

Texas, and Arizona.

Elymus CANADENSIS var BRACHÝSTACHYS (Scribn. and Ball) Farwell. Lemmas glabrous or nearly so. 2 -Moist open or partly shaded ground, Arkansas, Oklahoma, Texas, and New Mexico. Grades into E.canadensis; many specimens of E. canadensis from Kansas to North Dakota have sparingly hirsute lemmas, showing a transition to this variety.

20. Elymus ripárius Wiegand. (Fig. 507.) Culms ratherslender, erect, 1 to $1.5 \mathrm{~m}$ tall; sheaths glabrous; blades rather thin, flat, 5 to $15 \mathrm{~mm}$ wide, scabrous; spike somewhat nodding, 7 to $20 \mathrm{~cm}$ long; glumes narrow, about $1 \mathrm{~mm}$ wide at the middle, 2- to 4nerved, somewhat indurate but scarcely bowed out at base; lemmas minutely hispidulous to glabrous, the awn straight, mostly 2 to $3 \mathrm{~cm}$ long. 2 - River banks and low ground, Quebec and Maine to Michigan, south to North Carolina, Ohio, and

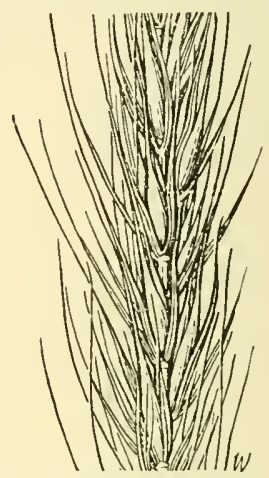

Figure 507.-Elymus riparius, $\times 1$. (Woodward, Conn.)

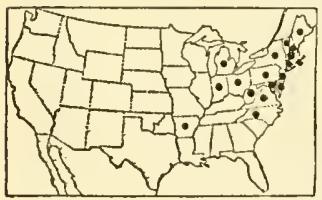

FIgURE 508.-Distribution of Elymus riparius.

Indiana; Arkansas (fig. 508). Differing from E. virginicus var. glabriflorus in the nodding spike and less indurate glumes; from $E$. canadensis in the straight awns and narrower and somewhat more indurate glumes. When the ranges of E. riparius and E. canadensis coincide the latter may be distinguished by the hirsutepubescent lemmas.

21. Elymus virgínicus L. Virginia Wild-

RYE. (Fig. 509.) Culms tufted, erect, 60 to $120 \mathrm{~cm}$ tall; sheaths glabrous; blades flat, scabrous, mostly 5 to $15 \mathrm{~mm}$ wide; spike usually erect, often partly included, 5 to $15 \mathrm{~cm}$ long; glumes strongly nerved, firm, indurate, yellowish, nerveless and bowed out at base leaving a rounded sinus, broadened above (1.5 to $2 \mathrm{~mm}$ wide), scabrous, the apex somewhat curved, tapering into a straight awn, about as long as the body or shorter; lemmas glabrous and nerveless below, scabrous and nerved above, tapering into a straight awn usually about $1 \mathrm{~cm}$ long. 21 -Moist ground, low woods, and along streams, Newfoundland

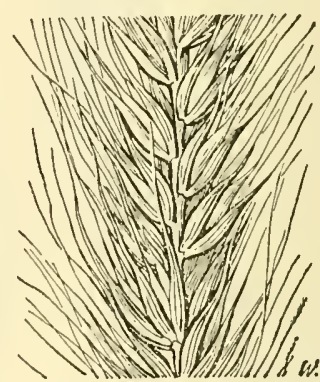

FIGURE 509.-Elymus virginicus, $\times 1$. (Hitcheock 79, Va.) to Alberta, south to Florida and Arizona (fig.510). Sometimes called 
Terrell grass. A variable species of which the following intergrading varieties may be distinguished.

Elymus virginicus var. glabriflórus (Vasey) Bush. Glumes mostly less bowed out; lemmas glabrous; awns mostly 2 to $3 \mathrm{~cm}$ long, the spike more bristly. 2 -Maine to Kansas, south to Florida and New Mexico.

Elymus virginicus var. halóphilus (Bickn.) Wiegand. More slender, usually glaucous; blades narrower, often becoming involute; spikes and spikelets somewhat smaller. 24 -Brackish marshes and moist sand along the coast, Maine to New Jersey.

Elymus virginicus var. submúticus Hook. Glumes and lemmas awnless or nearly so. 2 -Woods and open ground, Quebec to Washington, south to Rhode Island; Ohio and Kentucky to Oklahoma and Montana.

Elymus virginicus var. intermédius (Vasey) Bush. Glumes, lemmas, and rachis more or less hirsute, the awns about as in $E$. virginicus. 21 (E.hirsutiglumis Scribn.)-Thickets and low ground, Maine to Iowa, south to Florida and Texas.

Elymus virginicus var. austrális (Scribn. and Ball) Hitche. Differing from E. virginicus var. intermedius in the stouter, bristly spike and longer awns; differing from E. virginicus var. glabriflorus in the hirsute or strongly scabrous glumes and lemmas. 24 -Prairies, rocky hills, and open woods, Vermont to Iowa, south to Florida and Texas.

Elymus gigantéus Vahl. Robust perennial from stout rhizomes; blades numerous at base, elongate; spike dense, 15 to $20 \mathrm{~cm}$ long, about $2 \mathrm{~cm}$ thick; glumes and lemmas sharp-pointed, the glumes glabrous, the

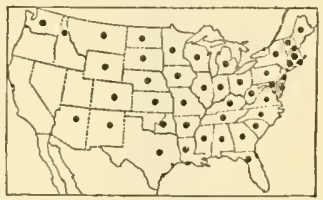

FIGURE 510-Distribution of Elymus virginicus.

lemmas pubescent below. 24 -Occasionally cultivated for ornament. Siberia

\section{SitÁnion Raf. Squirreltail}

Spikelets 2- to few-flowered, the uppermost floret reduced, usually 2 at each node of a disarticulating rachis, the rachis breaking at the base of each joint, remaining attached as a pointed stipe to the spikelets above; glumes narrow or setaceous, 1- to 3-nerved, the nerves prominent, extending into one to several awns, these (when more than one) irregular in size, sometimes mere lateral appendages of the long central awn, sometimes equal, the glume being bifid; lemmas firm, convex on the back, nearly terete, 5 -nerved, the nerves obscure, the apex slightly 2 -toothed, the central nerve extending into a long, slender, finally spreading awn, sometimes one or more of the lateral nerves also extending into short awns; palea firm, nearly as long as the body of the lemma, the two keels serrulate. Low or rather tall tufted perennials, with bristly spiles. Type species, Sitanion elymoides Raf. (S. hystrix). Name from Greek sitos, grain.

The species are exceedingly variable, being glabrous to densely pubescent and green to glaucous; the glumes and lemmas vary in division and length of awns. Some 15 to 25 variations have been recognized as species, but study of extensive collections shows that most of the characters used in differentiating the forms are inconstant and combine in various ways. 
The species are widespread in the Western States but do not form complete stands. They have forage value when young but at maturity the disarticulating joints of the spike, with their pointed rachis joints and long-awned spikelets, are blown about by the wind and often cause injury to stock, penetrating the mouth, nose, and ears, working in by means of the forwardly roughened awns, and causing inflammation. Grazed also after the heads are blown off. The commonest species is S. hystrix.

Spike much longer than broad; glumes narrowly lanceolate, 2- to 4-nerved.

1. S. HANSENI.

Spike as broad as long or broader; glumes bristle-like, 1- or obscurely 2-nerved.

Glumes cleft into at least 3 fine divisions........... 2. S. JоватUм.

Glumes entire or 2-cleft.... S. HYSTRIX

1. Sitanion hanséni (Scribn.) J. G. Smith. Hansen squirreltail. (Fig. 511.) Culms 60 to $100 \mathrm{~cm}$ tall; sheaths and blades glabrous or

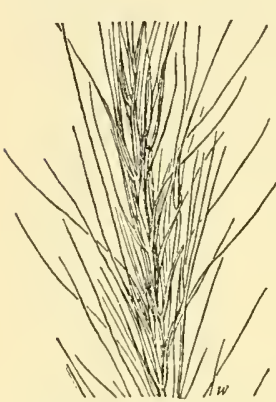

FIGURE 511.-Sitan?on hanseni $X_{1} \%$ (Suksdorf 5237, Wash.) scabrous to softly pubescent, the blades flat to subinvolute 2 to $8 \mathrm{~mm}$ wide; spike somewhat nodding or flexuous, 8 to $20 \mathrm{~cm}$ long; glumes narrowly lanceolate, sometimes bifid, 2- to 3nerved, long-awned, lower lemmas about $8 \mathrm{~mm}$ long, the awn 4 to $5 \mathrm{~cm}$ long, divergent when dry and mature. 24 -Open woods and rocky slopes, Idaho to eastern Washington, Utah, and California (fig. 512). Pubescent plants have been differentiated as S. anomalum J. G. Smith.

2. Sitanion jubátum J. G. Smith. BIg squirRELTAIL. (Fig. 513.) Culms erect to ascending, 20 to $60 \mathrm{~cm}$ tall, rarely taller; foliage glabrous or scabrous to white-villous, the blades flat, often becoming involute, mostly not more than $4 \mathrm{~mm}$ wide; spike erect, dense, 3 to $10 \mathrm{~cm}$ long, thick and bushy from the numerous long slender spreading awns; glumes split into 3 or more long awns; lenmas mostly 8 to $10 \mathrm{~mm}$ long, smooth, or scabrous toward apex, the awns and those of the glumes spreading, 3 to $10 \mathrm{~cm}$ long, rarely shorter. -Rocky or brushy hillsides and open dry woods and plains, Idaho to eastern Washington, south to Utah, Nevada, and Baja California (fig. 514). Occasionally a few of the glumes in a spike are divided into only 2 awns. Shortawned plants have been differentiated as $S$.

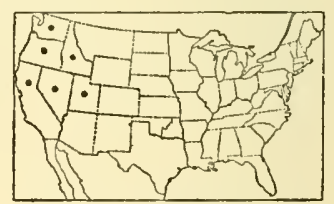

FIGURE 512.-Distribution of Sitanion hansen?. breviaristatum J. G. Smith and the more densely pubescent plants as S. villosum J. G. Smith.

3. Sitanion hýstrix (Nutt.) J. G. Smith. Squirreltail. (Fig. 515.) Culms erect to spreading, rather stiff, 10 to $50 \mathrm{~cm}$ tall; foliage from glabrous or puberulent to softly and densely white-pubescent, the blades flat to involute, rather stiffly ascending to spreading, 5 to 20 $\mathrm{cm}$ long, 1 to $3 \mathrm{~mm}$ wide, rarely as much as $5 \mathrm{~mm}$ wide; spike mostly short-exserted or partly included, erect, 2 to $7 \mathrm{~cm}$, rarely $10 \mathrm{~cm}$ long or longer, the glumes very narrow, 1 - to 2 -nerved, the nerves extending into scabrous awns, sometimes bifid to the middle, or bearing a bristle or awn along one margin; lemmas convex, smooth or scabrous to appressed pubescent, sometimes glaucous, the awns of glumes and lemmas widely spreading, 2 to $10 \mathrm{~cm}$ long. 2 -Dry hills, plains, 
open woods, and rocky slopes, South Dakota to British Columbia,

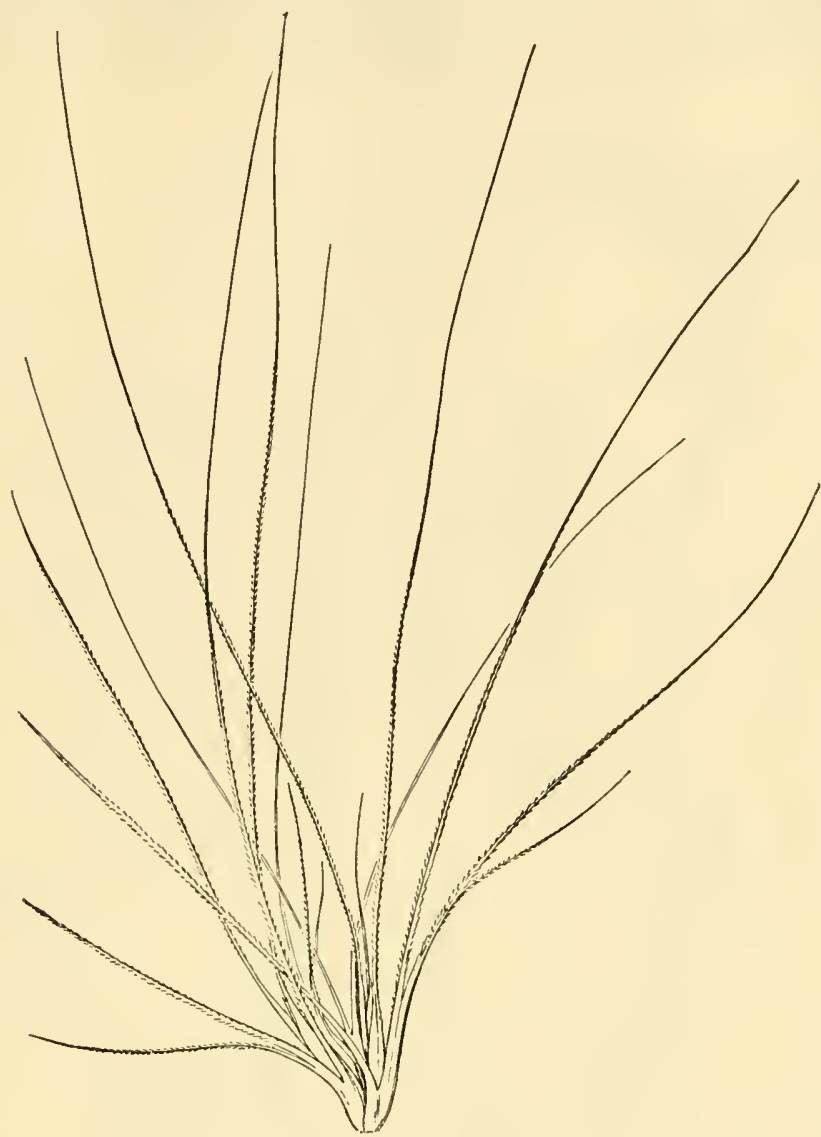

Fifure 513.-Sitanion jubatum. Pair of spiklets, $\times 2$. (Tyne.)

south to Missouri, Texas, California, and Mexico (fig. 516). At high altitudes plants often dwarf. Softly pubescent plants have been differentiated as $S$. cinereum J. G. Smith (the pubescence whitish) and $S$. velutinum Piper; short-awned plants as $S$. insulare J. G. Smith and S. marginatum Scribn. and Merr.; rather small plants with unusually slender awns as S.minus J. G. Snith, and tall plants with coarse spikes as S. brevi-

FIGURe 514.-Distribution of Sitanion jubatum. folium J. G. Smith, S. longifolium J. G. Smith, and S. montanum J. G. Smith.

\section{HŶSTRIX Moench}

Spikelets 2- to 4-flowered, 1 to 4 at each node of a continuous flattened rachis, horizontally spreading or ascending at maturity; glumes reduced to short or minute awns, the first usually obsolete, both often wanting in the upper spikelets; lemmas convex, rigid, tapering into long awns, 5-nerved, the nerves obscure except toward the tip; palea 
about as long as the body of the lemma. Erect perennials, with flat blades and bristly, loosely flowered spikes. Type species, Elymus hystrix L. (Hystrix patula). Hustrix, Greek name for the porcupine,

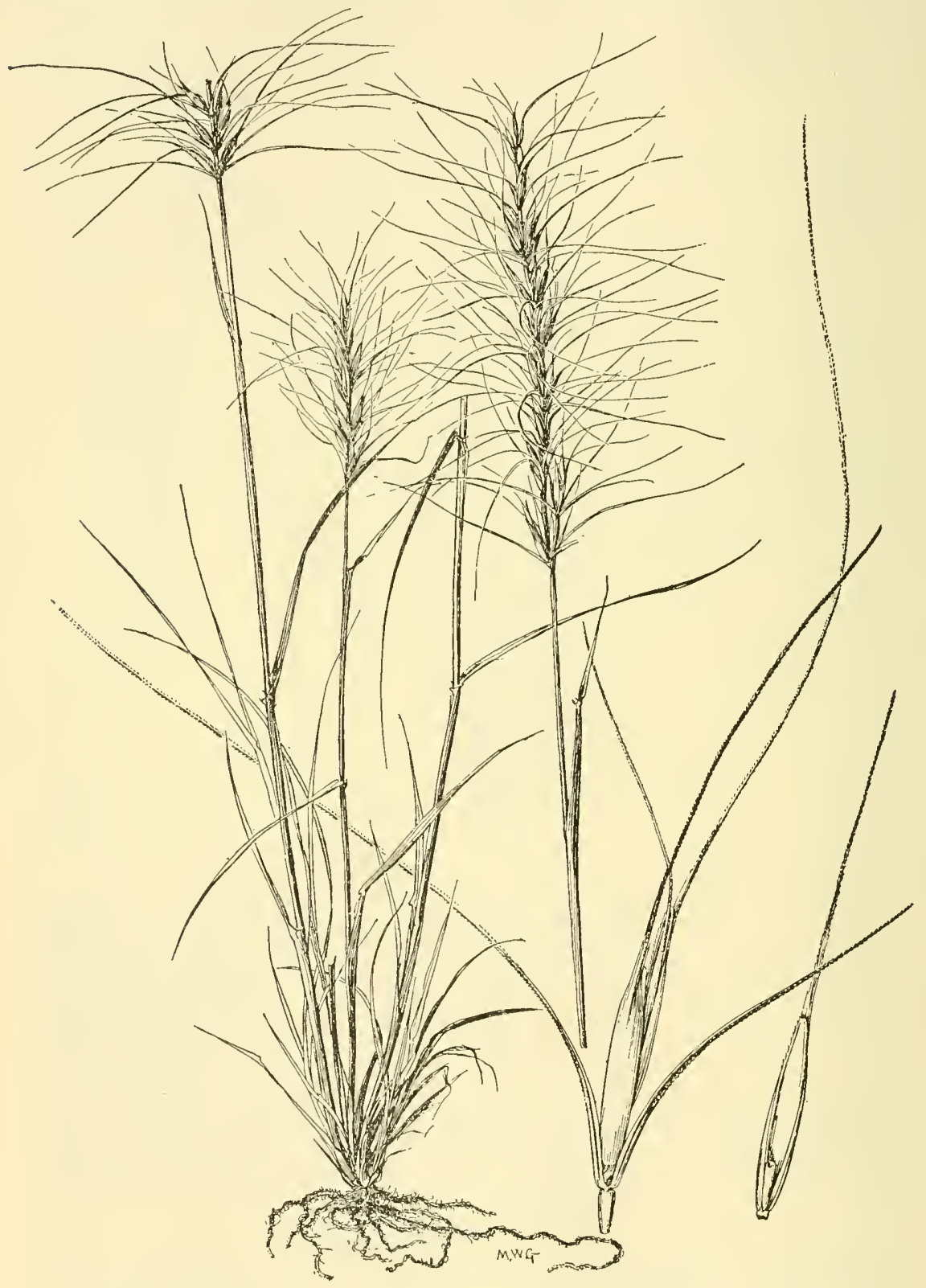

FIGURE 515.--Sitanion hystrix. Plant, $\times \frac{1}{2}$; spikelet and floret, $\times 3$. (Hitchcock 2289, Colo.)

alluding to the bristly spikes. The species have little forage value as they are nowhere abundant. The first species is worthy of cultivation for ornament. 
MANUAL OF THE GRASSES OF THE UNITED STATES 263

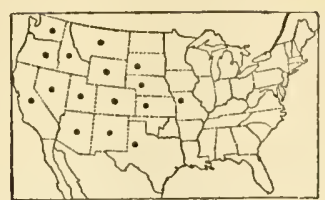

FIGURE 516.-Distribution of Sitanion hystrix.

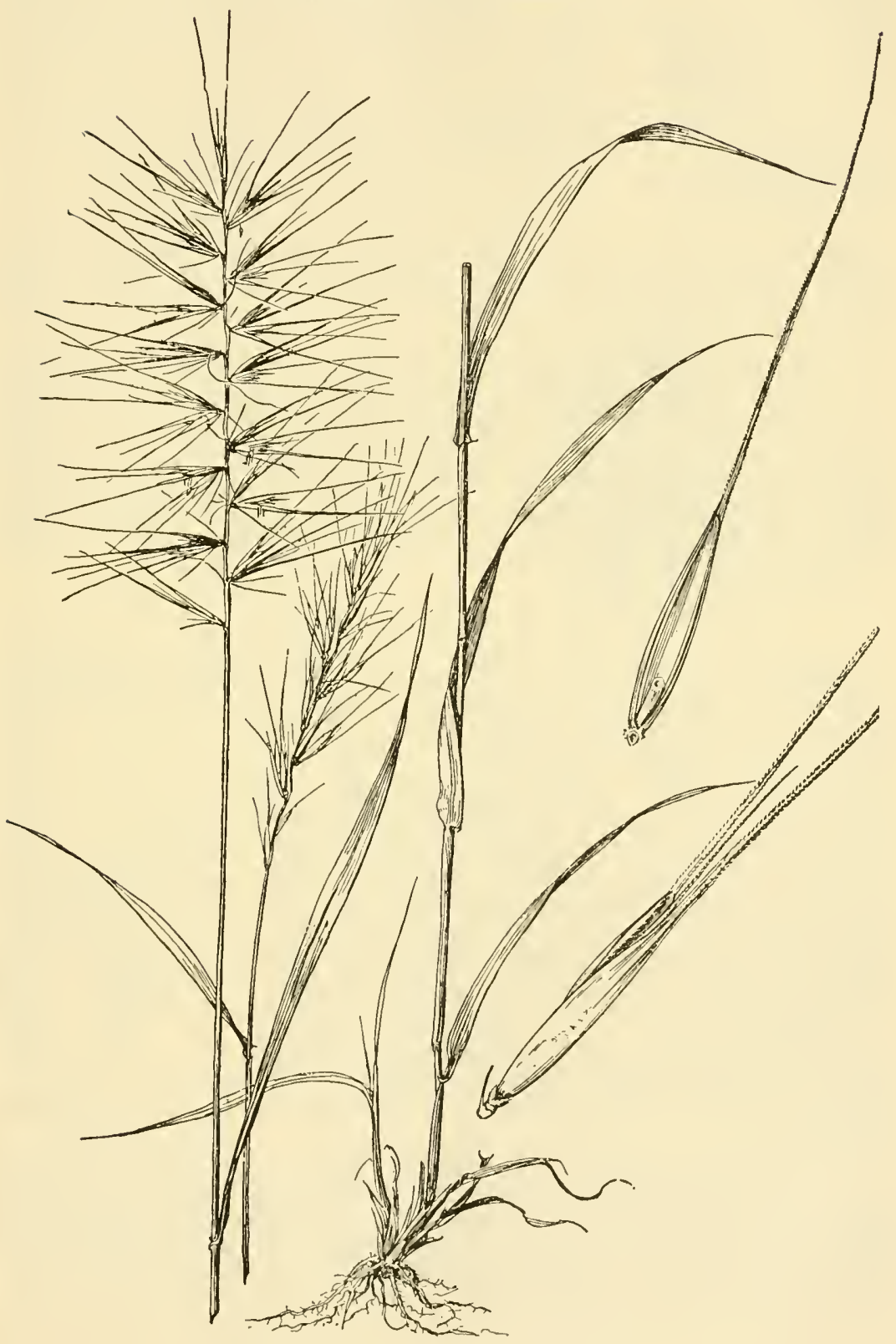

FIGURE 517. - Hystrix patula. Piant, $\times 1 / 2$; spikelet and floret, $\times 3$. (Moyer, Minn.) 
Spikelets soon divergent; lemmas glabrous or pubescent, not hispid.

Spikelets ascending or appressed; lemmas appressed-hispid.

1. H. patula.

2. H. CALIFORNICA.

1. Hystrix pátula Moench. Bottlebrush. (Fig. 517.) Culms slender, 60 to $120 \mathrm{~cm}$ tall; sheaths glabrous or scabrous, rarely re-

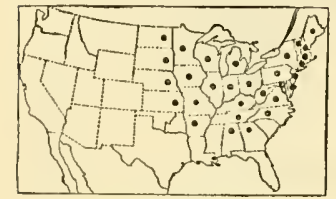

Figure 518.-Distribution of Hystrix patula. trorsely pubescent; blades mostly 7 to $15 \mathrm{~mm}$ wide; spike nodding, 8 to $15 \mathrm{~cm}$ long, the internodes of the slender rachis 5 to $10 \mathrm{~mm}$ long; spikelets mostly in pairs, 1 to $1.5 \mathrm{~cm}$ long, horizontally spreading toward maturity; lemmas glabrous or sometimes coarsely pubescent, the awns 1 to $4 \mathrm{~cm}$ long, slender, straight. 24 (H. hystrix Millsp.)-Moist or rocky woods, Nova Scotia to North Dakota, south to Georgia and Arkansas (fig. 518). Plants with pubescent lemmas have been differentiated as H. patula var. bigeloviana (Fernald) Deam. Such plants occur throughout the range, except from Delaware, Maryland, and southward.

2. Hystrix califórnica (Boland.) Kuntze. (Fig. 519.) Culms stout, 1 to $2 \mathrm{~m}$ tall; sheaths hispid or the upper smooth; blades as much as $2 \mathrm{~cm}$ wide; spike 12 to $25 \mathrm{~cm}$ long; spikelets usually 3 or 4 at a node, 1.2 to $1.5 \mathrm{~cm}$ long, thicker than in $H$. patula, ascending at maturity; lemmas hispidulous, the awn about $2 \mathrm{~cm}$ long. 2 -Woods and shaded banks, near the coast, Marin County to Santa Cruz County, Calif. In addition to the sessile spikelets there may be a short branch bearing one or two spikelets.

\section{HORDEUM L. BARLEY}

Spikelets 1-flowered (rarely 2-flowered), 3 (sometimes 2) together at each node of the articulate rachis (continuous in Hordeum vulgare), the back of the lemma turned from the rachis, the middle spikelet sessile, the lateral ones pediceled; rachilla disarticulating above the glumes and, in the central spikelet, prolonged behind the palea as a bristle and sometimes bearing a rudimentary floret; lateral spikelets usually imperfect, sometimes reduced to bristles; glumes narrow, often subulate and awned, rigid, standing in front of the spikelet; lemmas rounded on the back, 5-nerved, usually obscurely so, tapering into a usually long awn. Annual or perennial low or rather tall grasses, with flat blades and dense bristly spikes. Type species, Hordeum vulgare. Hordeum, the old Latin name for barley.

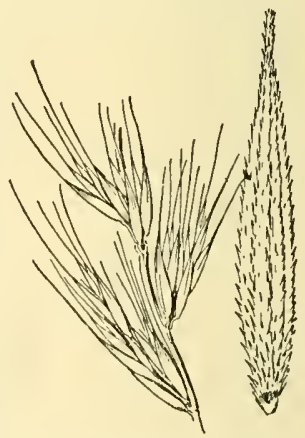

FIGURE 519.-Hystrix californica. Spike, $\times 1 / 2$; floret $\times 3$. (Vasey, Calif.)

Aside from the well-known cultivated barley, $H$. vulgare, the species are of relatively minor value. All furnish forage when young but many species are aggressive weeds and some (especially $H$. jubatum) are at maturity injurious to stock because of the sharp-pointed joints of the mature spikes, which pierce the nose and mouth parts. 
Plants perennial; awns slender.

Central spikelet usually 2-flowered; lateral spikelets short-pedicellate.

Central spikelet 1-flowered; lateral spikelets long-pedicellate.

Awns 2 to $5 \mathrm{~cm}$ long... Н. ЈUватUM.

Awns mostly less than $1 \mathrm{~cm}$ long ................ Hodosum.

Plants annual; awns stouter.

Glumes, or some of them, ciliate

7. H. MURINUM.

Glumes not eiliate.

Glumes of the fertile spikelet dilated above the base _... 4. H. PUSILLUM. Glumes not dilated.

Rachis continuous; floret of central spikelet about $1 \mathrm{~cm}$ long.

8. H. VULGARE.

Rachis disarticulating; floret of central spikelet less than $1 \mathrm{em}$ long.

Plant freely branching at base; awns stout, rigid, somewhat divergent at maturity _.................... 5. H. GUSONEANUM.

Plant simple or sparingly branching; awns setaceous, softer and less divergent at maturity _..._._._.

1. Hordeum montanénse Beal. (Fig. 520.) Culms 60 to $100 \mathrm{~cm}$ tall; sheaths glabrous; blades flat, lax, scabrous, 5 to $8 \mathrm{~mm}$ wide; spike nodding, 8 to $17 \mathrm{~cm}$ long; central spikelets usually 2 -flowered, with a rudiment of a third floret; lateral spikelets short-pedicellate or nearly sessile, usually well developed; glumes slightily broadened above the base, 1 to $3.5 \mathrm{~cm}$ long including awns; lower floret of central spikelet about $8 \mathrm{~mm}$ long, the awn 1.5 to $3.5 \mathrm{~cm}$ long. 24 (H. pammeli Scribn. and Ball.)-Prairies, Illinois, Iowa, South Dakota, Montana, and Wyoming; introduced at St. Jovite, Quebec (fig. 521). Variable

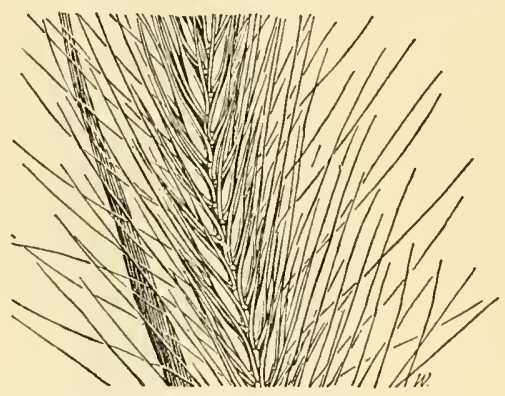

Figure 520.-- Hordeum montanense, X 1. (V. H. (hase 1467, Ill.) and somewhat anomalous; lateral spikelets sometimes with 2 florets. Approaches Elymus but lateral spikelets short-pedicellate.

2. Hordeum jubátum L. Foxtail barley. (Fig. 522.) Perennial, tufted; culms erect, or decumbent at base, 30 to $60 \mathrm{~cm}$ tall; blades 2 to $5 \mathrm{~mm}$ wide, scabrous; spike nodding, 5 to $10 \mathrm{~cm}$ long, about as wide, soft, pale; lateral spikelets reduced to 1 to 3 spreading awns; glumes of perfect spikelet awnlike, 2.5 to $6 \mathrm{~cm}$ long,

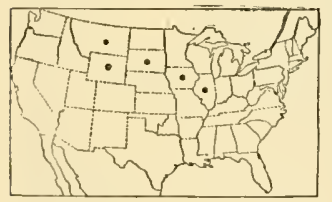

Ficure 521.-Distribution of Hordeum montanense. spreading; lemma 6 to $8 \mathrm{~mm}$ long with an awn as long as the glumes. 2 -Open ground, meadows and waste places, Newfoundland and Labrador to Alaska, south to Maryland, Illinois, Missouri, Texas, California, and Mexico; introduced in the Eastern States (fig. 523). A troublesome weed in the Western States, especially in irrigated meadows. HORDEUM jubatum var. Caespitósum (Scribn.) Hitche. Bobtail barlex. Awns 1.5 to $3 \mathrm{~cm}$ long. (H. caespitosum Scribn.) North Dakota to Alaska, south to Kansas and Arizona.

3. Hordeum nodósum L. Meadow barley. (Fig. 524.) Perennial, tufted; culms erect or sometimes spreading, 10 to $50 \mathrm{~cm}$ tall; foliage rather scant, blades flat; spike slender, 2 to $8 \mathrm{~cm}$ long; glumes all setaceous, 8 to $15 \mathrm{~mm}$ long; lemma of perfect spikelet 7 to $8 \mathrm{~mm}$ long, the awn exceeding the glumes; floret of lateral spikelets much reduced. 24 -Meadows, moist places, and open ground, Montana, 
to Alaska, south to New Mexico and California; introduced in several localities in the Eastern States (fig. 525); also in southern South America, and widely dispersed in the old World. Hordeum NodoSUM var. BOREÁle (Scribn. and Smith) Hitchc. As much as $1 \mathrm{~m}$ tall; blades as much as $8 \mathrm{~mm}$ wide; florets of lateral spikelets larger,

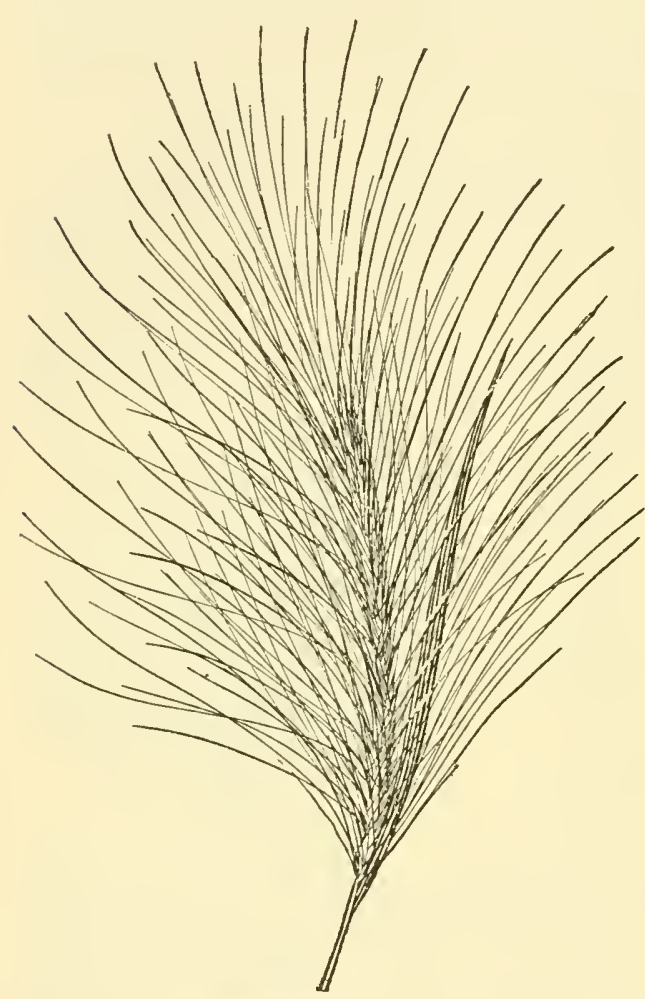

F1GURE 522.-Hordeum jubatum, $\times 1$. (Blankinship 189,

sometimes as large as the floret of the central spikelet. Intergrading with $H$. nodosum. 2 (H.boreale Scribn. and Smith.)--Near the coast, Alaska to Idaho and northern California.

4. Hordeum pusíllum Nutt. Little B A RLEY. (Fig. 526.) Annual; culms 10 to $35 \mathrm{~cm}$ tall; blades erect, flat; spike erect, 2 to $7 \mathrm{~cm}$ long, 10 to $14 \mathrm{~mm}$ wide; first glume of the lateral spikelets and both glumes of the fertile spikelet dilated above the base, attenuate into a slender awn 8 to 15 $\mathrm{mm}$ long, the glumes very scabrous; lemma of central spikelet awned, of lateral spikelets awn-pointed. $\odot$ -Plains and open, especially alkaline, ground, Delaware to Washington, south to Florida, southern California, and northern Mexico; also Maine; common westward, rare in the Atlantic States; also southern South America (fig. 527). HoRDEUM PUSILlum var. PÚBENs Hitche. Spikes broader; spikelets pubescent; dilated glumes wider. 24 -Texas to Utah and Arizona.

5. Hordeum gussoneánum Parl. Mediterranean Barley. (Fig. 528.) Annual; culms freely branching and spreading or geniculate at base, 15 to $40 \mathrm{~cm}$ tall; sheaths and flat blades, especially the lower, more or less pubescent; spike erect, 1.5 to $3 \mathrm{~cm}$ long, 10 to $15 \mathrm{~mm}$ wide; glumes setaceous, nearly glabrous to scabrous, about 12 $\mathrm{mm}$ long; lemma of central spikelet $5 \mathrm{~mm}$ long, the awn somewhat longer than the glumes; floret of lateral spikelets reduced, short-awned. $\odot \quad$ Fields and waste places, Utah to British Columbia, Arizona, and California; Massachusetts, New Jersey (fig. 529); introduced from Europe.

Hordeum marínum Huds. Differing from $H$. gussoneanum in the glabrous dissimilar glumes of the lateral spikelets, the outer subulate, the inner somewhat broader. $\odot$ (H. maritimum With.)-On ballast, Camden, N. J.; Europe.

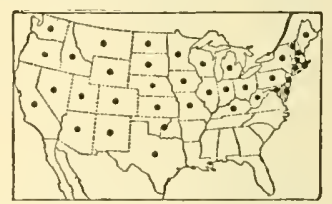

FIGURE 523.-Distribution of Hordeum jubatum. 


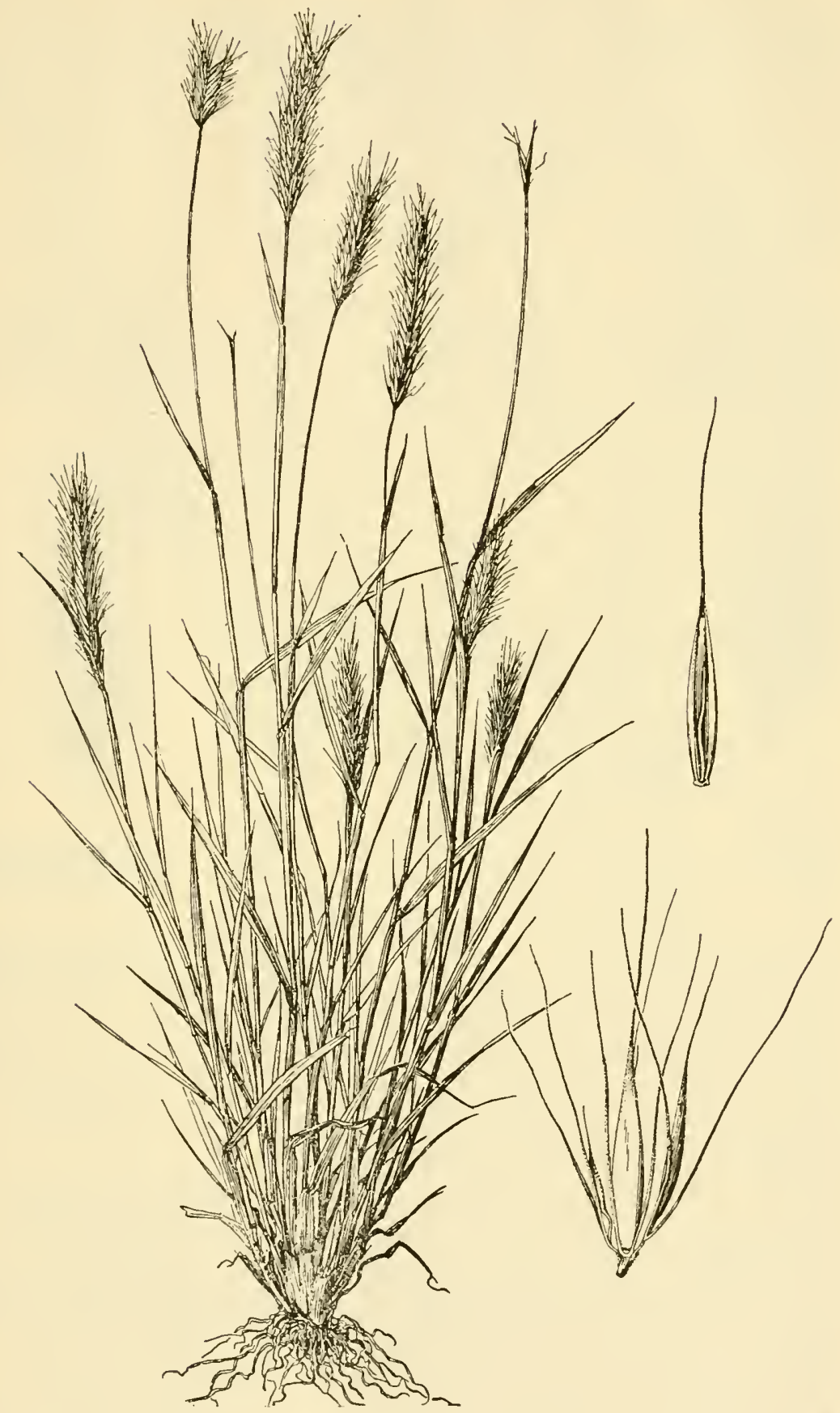

FIGURE 524.-Hordeum nodosum. Plant, $\times 1 / 2$; group of splkelets and floret, $\times 3$. (Whited 433, Wash.) 
6. Hordeum adscéndens H.B.K. (Fig. 530.) Annual; culms geniculate at base, 20 to $50 \mathrm{~cm}$ tall; spike erect, 3 to $6 \mathrm{~cm}$ long excluding awns; glumes all reduced to awns, scabrous, mostly 1.5 to

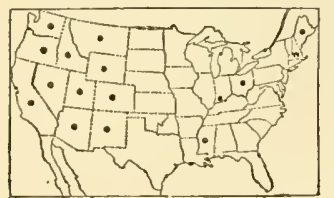

FIGURE 525.-Distribution of Hordeum nodosum. $2 \mathrm{~cm}$ long, somewhat spreading, the awn of the fertile floret as long as the glumes. $\odot-$ Dry open ground, Arizona and and Mexico.

\section{Hordeum murínum} L. MOUSE BARLEY. (Fig. 531.) Annual;

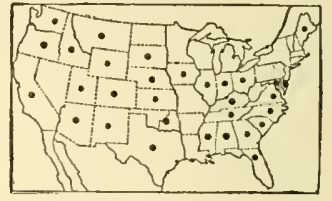

Figure 527.-Distribution of Hordeum pusillum.

culms bushy-branched, spreading; sheaths and blades smooth; spike 5 to $7 \mathrm{~cm}$ long, often partially enclosed by the uppermost inflated sheath; glumes of the central spikelet narrowly fusiform, 3-nerved, long-ciliate on both margins, the nerves scabrous,

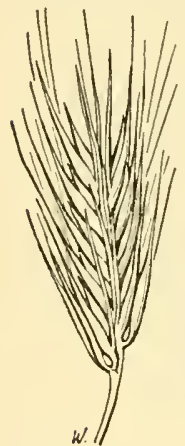

FIGURE 526. Hordeum pusillum, $\times 1$. (Hitchcock 11102, S. Dak.) the awn about $2.5 \mathrm{~cm}$ long; glumes of the lateral spikclets unlike, the inner similar to the central ones, the outer setaceous, not ciliate; lemmas all broad, 8 to $10 \mathrm{~mm}$ long, the awns somewhat exceeding those of the glumes. $\odot$-Fields, waste places, and open ground, introduced from Europe; here and there in the Eastern States from Maine to Alabama; common on the Pacific coast, Idaho and British Columbia, south to Utah, New Mexico, and California (fig. 532).

8. Hordeum vulgáre L. BARLEY. (Fig. 533.) Annual; culms erect, 60 to $120 \mathrm{~cm}$ tall; blades flat, mostly 5 to $15 \mathrm{~mm}$ wide; spike erect or nearly

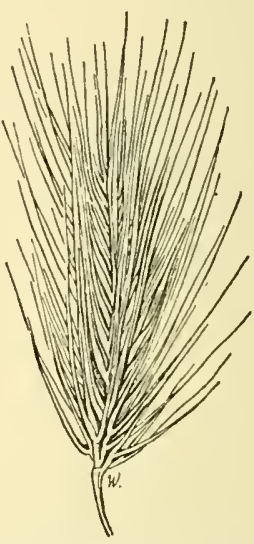

Figure 528.-Hordeum gussoneanum, $\times 1$. (Hitcheock 2688, Calif.)

so, 2 to $10 \mathrm{~cm}$ long, excluding awns;

glumes divergent at base, narrow, nerveless, gradually passing into a stout awn; awn of lemma straight, erect, mostly 10 to $15 \mathrm{~cm}$ long. $\odot$-Cultivated for the grain, sometimes spontaneous in fields and waste places but not persistent. There are two groups of the cultivated barleys. In the 2rowed forms (II. distichon $\mathrm{L}$.) the lateral spikelets are fairly well developed but sterile. The probable ancestor for at least a part of these is H. spontaneum Koch, of Asia. In the second group all the spikelets produce large seed. These are called 6-rowed (H.hexastichon L.) or, if the lateral florets orerlap, 4-rowed barleys

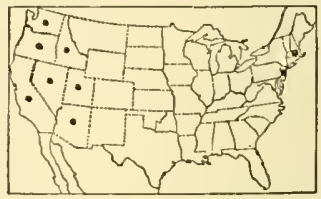

FIgURE 529,-Distribution of Hordeum gussoneanum. (in European literature). In some varieties the caryopsis is naked. The ancestor of the 6-rowed barleys is not known but probably was similar to some of our cultivated varieties of this group. Hordeum vULGARE var. TRIFURCÁtum (Schlecht.) Alefeld, BEARDLESS BARLEY. Awns suppressed or converted into irregular short lobes or teeth. 


\section{LOLIUM L. RYEGRASS}

Spikelets several-flowered, solitary, placed edgewise to the continuous rachis, one edge fitting to the alternate concavities, the rachilla disarticulating above the glumes and between the florets; first glume wanting (except on the terminal spikelet and rarely in 1 or 2 spikelets in

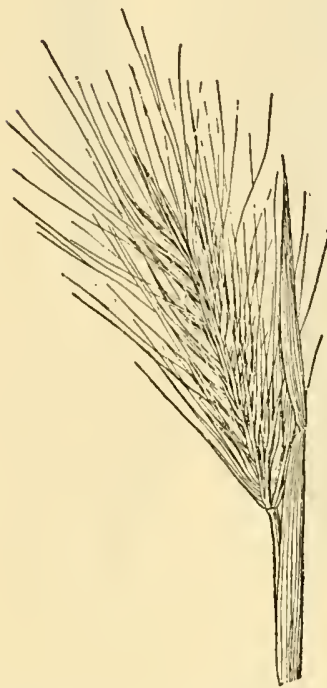

FIGURE 530.-Hordeum adscen. dens, $\times$ 1. (Thornber 536 , Ariz.) a spike), the second outward, strongly 3 - to 5-nerved, equaling or exceeding the second floret; lemmas rounded on the back, 5- to 7-nerved, obtuse, acute, or awned. Annuals or perennials, with flat blades and slender usually flat spikes. Type species, Lolium perenne. Lolium, an old Latin name for darnel.

Lolium perenne, perennial or English ryegrass, was the first meadow grass to be cultivated in Europe as a distinct segregated species, the meadows and pastures formerly being native species. This and L. multiflorum, Italian ryegrass, are probably the most important of the European forage grasses.

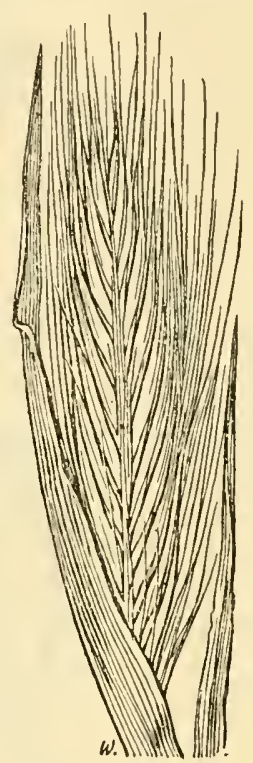

FIGURE 531.-IIordeum murinum, $\times 1$. (Mills paugh 4629 , Calif.)

Both species are used in the United States to a limited extent for meadow, pasture, and lawn. They are of importance in the south for winter forage. In the Eastern States the ryegrasses are often

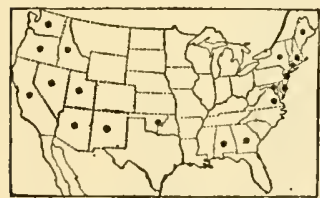

FIG ORE 532-Distribution of Hordeum murinum. sown in mixtures for parks or public grounds, where a vigorous early growth is required. The young plants can be distinguished from bluegrass by the glossy dark-green foliage. L. temulentum, darnel, is occasionally found as a weed 'in grainfields and waste places. It is in bad repute, because of the presence in the grain of a narcotic poison, said to be due to a fungus. Darnel is supposed to be the plant referred to as the tares sown by the enemy in the parable of Scripture.

Glume shorter than the spikelet; perennials.

Lemmas nearly or quite awnless ...................... 1. PERENNE. Lemmas, at least the upper, awned Glume as long as or longer than the spikelet; annuals.

Spike flat; spikelets much wider than the rachis...... 3. L. TEMULentuar. Spike subcylindric; spikelets scarcely wider than the rachis.

4. L. SUBULATUM

1. Lolium perénne L. Perennial ryegrass. (Fig. 534, B.) Short-lived perennial; culms erect or decumbent at base, 30 to $60 \mathrm{~cm}$ tall; foliage glossy, the blades 2 to $4 \mathrm{~mm}$ wide; spike often subfalcate, mostly 15 to $25 \mathrm{~cm}$ long; spikelets mostly 6 - to 10 -flowered; lemmas 


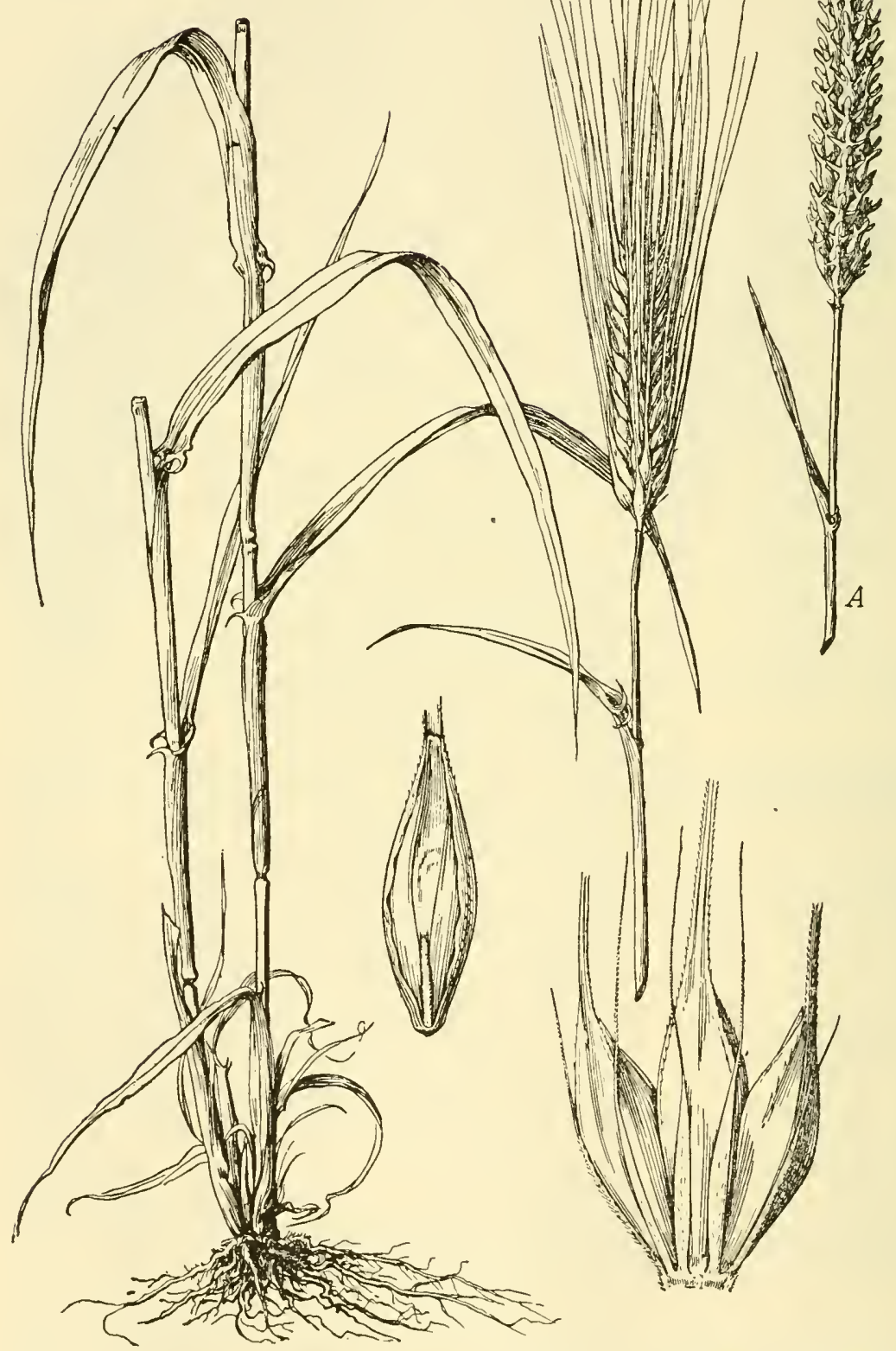

FIGURE 533. - Hordeum oulgare. Plant, $\times 1 / 2$; group of spikelets and floret, $\times 3$. Spike of beardless barley (A), $\times 1 / 2$. (Cult.) 


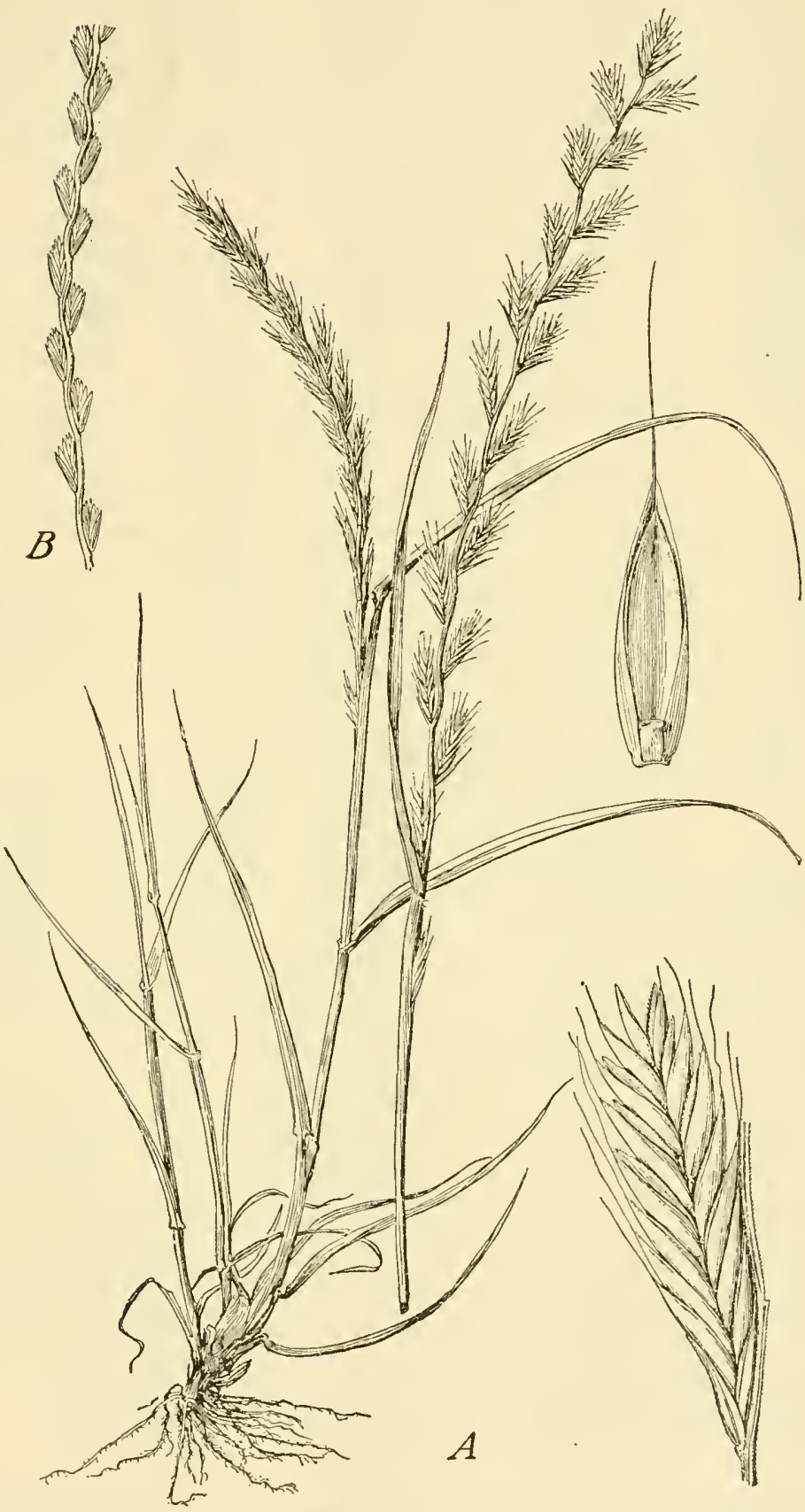

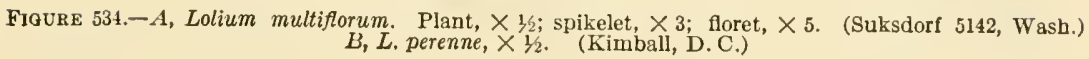


5 to $7 \mathrm{~mm}$ long, awnless or nearly so. 2 -Meadows and waste places, Newfoundland to Alaska and south to Virginia and California, occasionally farther south; cultivated in meadows, pastures, and lawns, introduced from Europe. Also called English ryegrass. Lolium Perenne var. Cristátum Pers. Spikes ovate, the spikelets crowded, horizontally spreading. 21 -Open ground, Wilmington, Del., and Washington, D. C.; ballast, Salem and Eola,

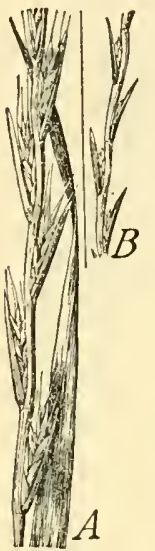

Figure 535.-A, Lolium temulen. tum, $\times 1 / 2$ (Leiberg 771 , Oreg.) $B, L$. subulatum, $\times 1 / 2$. (Sheldon, Oreg.) Oreg.; adventive from Europe.

Lolium stríctum Presl. Annual; branched and spreading at base, 10 to $30 \mathrm{~cm}$ tall; spike thickish, 5 to $10 \mathrm{~cm}$ long, the rachis thick but flattish and angled. $\odot$-Introduced at Berkeley, Calif.; Europe. Resembles $L$. subulatum but the spikelets not sunken in a cylindric rachis.

2. Lolium multiflórum Lam. ItaLIAN RYEgrass. (Fig. 534, A.) Differing from $L$. perenne in the more robust habit, larger spikelets, and awned lemmas; spikelets 10 - to 20 -flowered, 1.5 to $2.5 \mathrm{~cm}$ long; lemmas 7 to $8 \mathrm{~mm}$ long, at least the upper awned. 4 ( $L$. italicum A. Br.)-About the same range as L. perenne, especially common on the Pacific coast where it is often called Australian ryegrass. Introduced from Europe. Scarcely more than a variety of $L$. perenne but generally recognized as distinct agriculturally. A much reduced form has been called forma microstachyum Uechtritz.-California.

Lolium rígidum Gaudin. Annual; foliage blue-green; spikes rather stiff; otherwise like L. multiflorum. $\odot$ -Wheat fields, North Dakota (Milton, Calio); Europe.

3. Lolium temuléntum L. Darnex. (Fig. 535, A.) Annual; culms 60 to $90 \mathrm{~cm}$ tall; blades mostly 3 to $6 \mathrm{~mm}$ wide; spike strict, 15 to $20 \mathrm{~cm}$ long; glume about $2.5 \mathrm{~cm}$ long, as long as or longer than the 5- to 7-flowered spikelet, firm, pointed; florets plump, the lemmas as much as $8 \mathrm{~mm}$ long, obtuse, awned, the awn as much as $8 \mathrm{~mm}$ long. $\odot \quad$-Grainfields and waste places, occasional throughout the eastern United States and rather common on the $\mathrm{Pa}$ cific coast (fig. 536); introduced from Europe. Lolium temUlentum var. LEPTOCHAÉTON A. $\mathrm{Br}$. Lemmas awnless. $\odot$-Washington to California, occasional on the Atlantic coast, Maine to Texas; introduced from Europe.

4. Lolium subulátum Vis. (Fig. 535, B.) Annual; culms freely branching at base, stiffly spreading or prostrate; foliage scant, blades

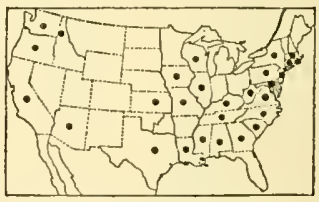

FIgure: 536.-Distribution of Lolium temulentum. short; spike subcylindric, rigid, often curved; spikelets sunken in the excavations of the rachis, the florets partly hidden by the appressed obtuse strongly nerved glume; lemmas $5 \mathrm{~mm}$ long. On ballast, near Portland, Oreg.; introduced from Europe.

Nárdus strícta L. Slender tufted perennial; sheaths crowded at the base of the plant; blades slender, involute, rather stiff; spike slender, 1-sided, 3 to $8 \mathrm{~cm}$ long; spikelets 1-flowered; first glume 
wanting; second glume minute; lemma narrow, acuminate or

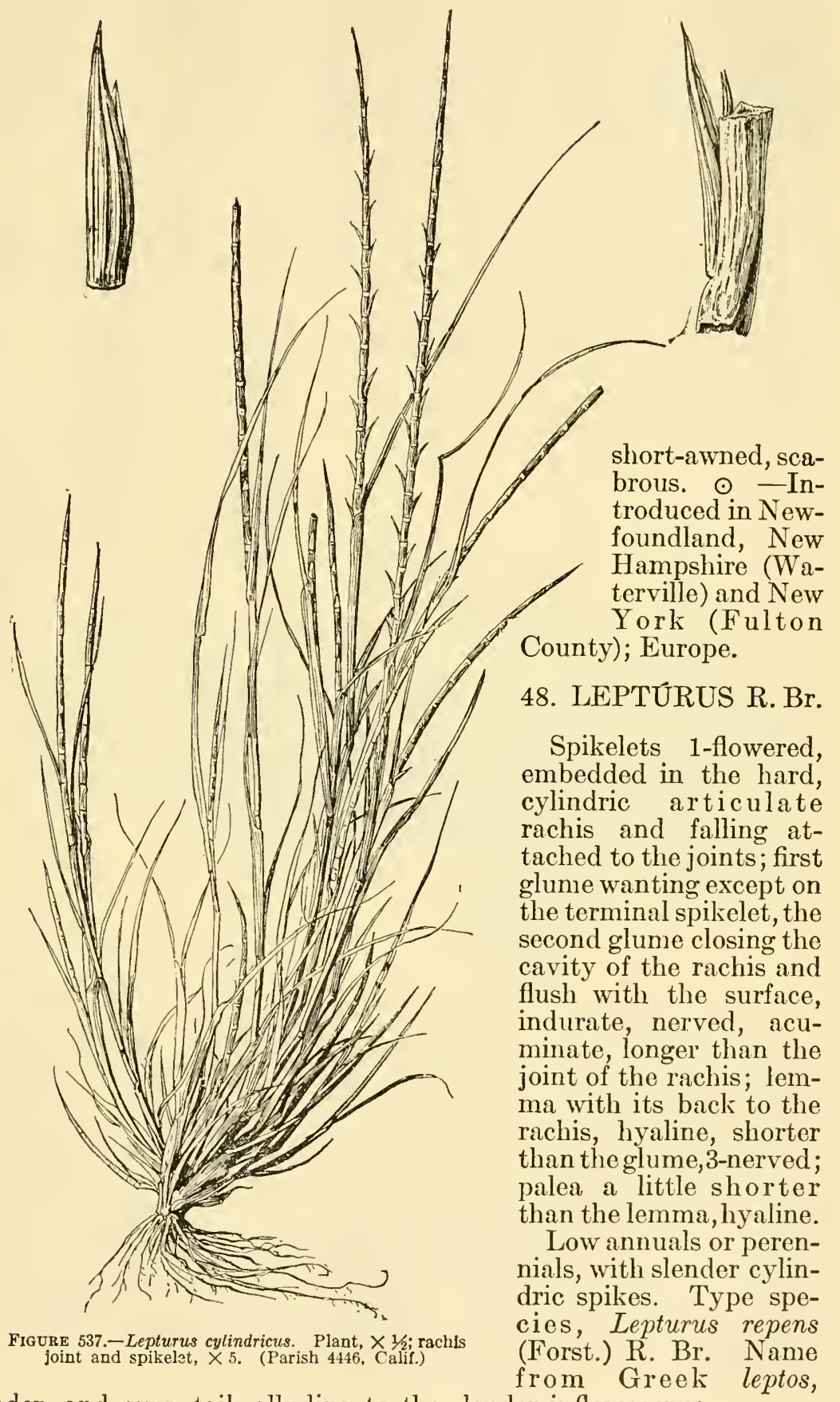

slender, and oura, tail, alluding to the slender inflorescence. 
1. Lepturus cylíndricus (Willd.) Trin. Thintail. (Fig. 537.) Annual; culms bushy-branched, spreading or prostrate, 10 to $30 \mathrm{~cm}$ tall; spike curved, narrowed upward; glume $6 \mathrm{~mm}$ long, acuminate; lemma $5 \mathrm{~mm}$ long, pointed; axis disarticulating at maturity, the spikelets remaining attached to the joints. $\odot$ - Salt marshes, San Francisco Bay, Calif., south to San Diego and Santa Catalina Island; introduced from the Old World.

\section{PHOLIÛRUS Trin.}

Spikelets 1- or 2-flowered, embedded in the cylindric articulate rachis and falling attached to the joints; glumes two, placed in front of the spikelet and enclosing it, coriaceous, 5-nerved, acute, asymmetric, appearing like halves of a single split glume; lemma with its back to the rachis, smaller than the glumes, hyaline, 1-nerved; palea a little shorter

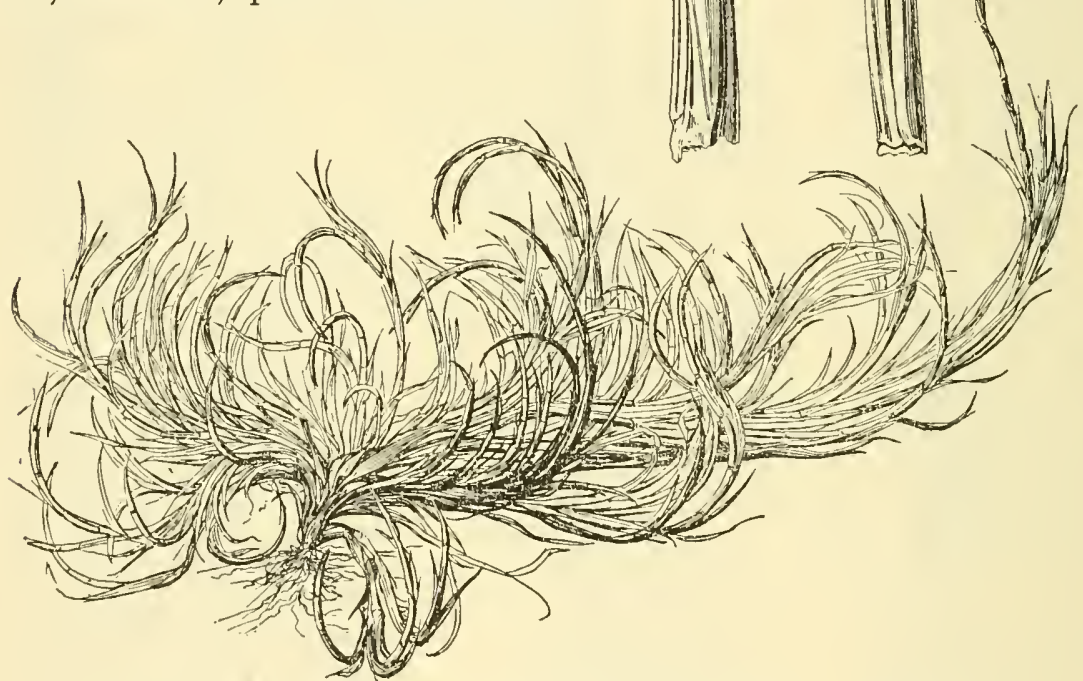

FIGURE 538.-Pholiurus incurvus. Plant, $\times \frac{1}{2}$; rachis joint and spikelet, $\times 5$. (Trask, Calif.)

than the lemma, hyaline. Low annuals, with slender cylindric spikes. Type species, Pholiurus pannonica (Host) Trin. Name from Greek pholis, horny scale, and oura, tail, alluding to the coriaceous spikes.

1. Pholiurus incúrvus (L.) Schinz and Thell. Sickle Grass. (Fig. 53S.) Culms tufted, decumbent at base, 10 to $20 \mathrm{~cm}$ tall; blades short, narrow; spike 7 to $10 \mathrm{~cm}$ long, cylindric, curved; spikelets $7 \mathrm{~mm}$ long, pointed. $\odot \quad(P$. incurvatus Hitchc.) -Mud flats and

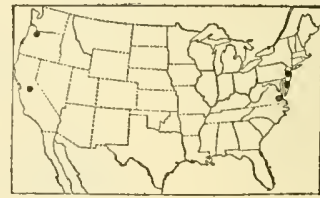

FIGURE 539.-Distribution of Pholiurus incurvus. salt marshes along the coast, New Jersey to Virginia; California; Portland, Oreg. (fig. 539); introduced from Europe. 


\section{SCRIBNÉRIA Hack.}

Spikelets 1-flowered, solitary, appressed flatwise against the somewhat thickened continuous rachis, the rachilla disarticulating above the glumes, prolonged as a very minute hairy stipe; glumes equal, narrow, firm, acute, keeled on the outer nerves, the first 2-nerved, the second 4-nerved; lemma shorter than the glumes, membranaceous, obscurely nerved, the apex short-bifid, the faint midnerve extending as a slender awn; palea about as long as the lemma; stamen 1. Low annual, with slender cylindric spikes. Type species, Scribneria bolanderi. Named for F. Lamson-Scribner.

\section{Scribneria bolandéri}

(Thurb.) Hack. (Fig. 540.) Culms branching at base, erect or ascending, 7 to $30 \mathrm{~cm}$ tall; foliage scant, the blades subfiliform; ligule about $3 \mathrm{~mm}$ long; spike about $1 \mathrm{~mm}$ thick, usually one third to half the entire height of the plant, the internodes 4 to $6 \mathrm{~mm}$ long; spikelets about $7 \mathrm{~mm}$ long; lemmas pubescent at base, the awn erect, 2 to $4 \mathrm{~mm}$ long. $\odot-$ Sandy or sterile ground, in the mountains, Washington to California; rare or overlooked, very inconspicuous

TRIBE 4. AVENEAE

\section{SCHÍSMUS Beauv.}

Spikelets several-flowered, the rachilla disarticulating above the glumes and between the florets; glumes subequal, longer

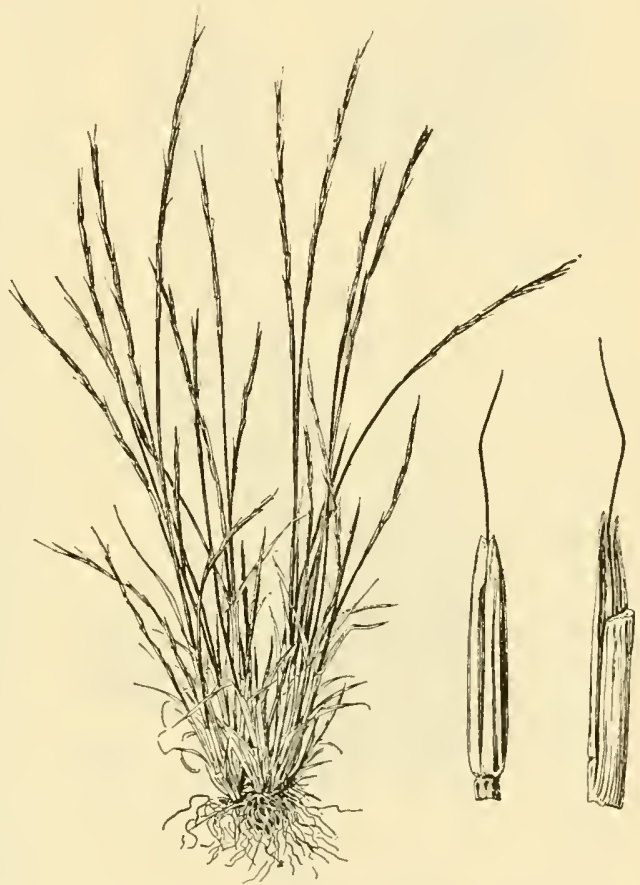

FIGURE 540.- Scribneria bolanderi. Plant, $\times 1 / 2$; rachis joint and spikelet, $\times 5$. (Suksdorf 217, Wash.)

than the first floret, usually as long as the spikelet, with white membranaceous margins; lemmas broad, rounded on the back, severalnerved, pilose along the lower part of the margin, bidentate; palea broad, hyaline, the nerves at the margin. Low tufted annuals with filiform blades and small panicles. Type species, Schismus marginatus Beauv. (S. barbatus). Name from Greek, schismos, a splitting, referring to the bidentate lemmas. This genus has usually been placed in the tribe Festuceae, but its characters place it more naturally in the tribe Aveneae.

1. Schismus barbátus (L.) Chase. (Fig. 541.) Culms tufted, erect to prostrate-spreading, 5 to $35 \mathrm{~cm}$ tall; blades usually less than 
$10 \mathrm{~cm}$ long; panicle oval to linear, 1 to $4 \mathrm{~cm}$ long, usually rather dense, pale or purplish; pedicels slender, finally disarticulating at base and falling with the spikelet or with the glumes; spikelets about 5 -flowered, 5 to $6 \mathrm{~mm}$ long; glumes about equaling the spikelet, 5 - to 7-nerved, acute; lemmas about $2 \mathrm{~mm}$ long, 9-nerved, the summit hyaline, nerveless, the margin appressed pilose on the lower half, the teeth minute, sometimes with a minute mucro between, the rachilla joints slender, flexuous; palea concave, as broad as the lemma and about as long. $\odot$ - Open ground in yards, along roadsides, and in dry river beds; introduced in southern Arizona; southern

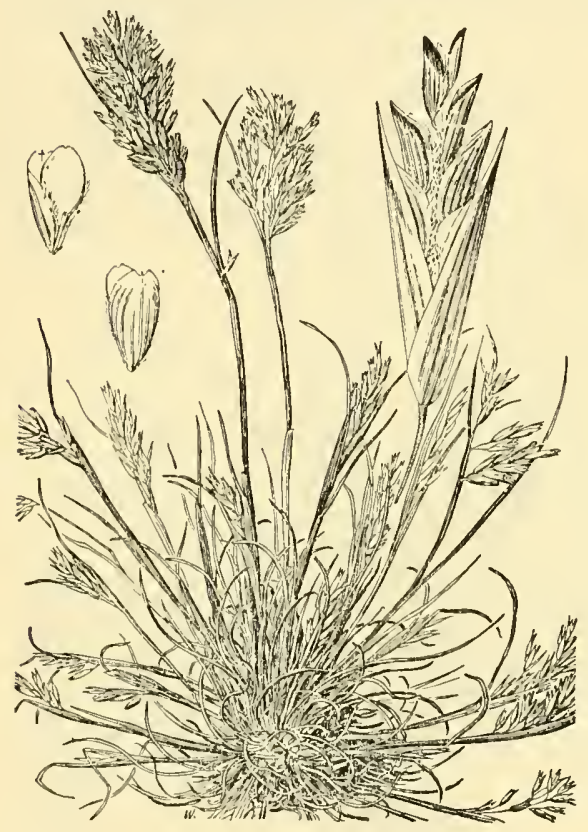

Figure 541.-Schismus barbatus. Plant, $\times 1 / 2$; spikelet and florets, $X 5$. (Peebles and Harrison, 846, Ariz.)

Europe to India and South Africa. Locally dominant, an excellent forage grass in winter.

\section{KOELERIA Pers.}

Spikelets 2- to 4-flowered, compressed, the rachilla disarticulating above the glumes and between the florets, prolonged beyond the perfect florets as a slender bristle or bearing a reduced floret at the tip; glumes usually about equal in length, unlike in shape, the lower narrow, sometimes shorter, 1-nerved, the upper wider than the lower, broadened above the middle, $3-$ to 5-nerved; lemmas somewhat scarious, shining, the lowermost a little longer than the glume, obscurely 5 -nerved, acute or short-awned, the awn, if present, borne just below the apex. Slender, low or rather tall annuals or perennials, with narrow blades and shining spikelike panicles. Type species, Koeleria cristata. Named for G. L. Koeler.

Koeleria cristata is a good forage grass and is a constituent of much of the native pasture throughout the Western States. The plants, however, are rather scattering.

Plants perennial

1. K. cristata. Plants annual ........ K. PHLOIDEs.

1. Koeleria cristáta (L.) Pers. Junegrass. (Fig. 542, A.) Tufted perennial; culms erect, puberulent below the panicle, 30 to $60 \mathrm{~cm}$ tall; sheaths, at least the lower, pubescent; blades flat or involute, glabrous or, especially the lower, pubescent, 1 to $3 \mathrm{~mm}$ wide; panicle erect, spikelike, dense (loose in anthesis), often lobed, interrupted, or sometimes branched below, 4 to $15 \mathrm{~cm}$ long, tapering at the summit; spikelets mostly 4 to $5 \mathrm{~mm}$ long; glumes and lemmas scaberulous, 3 
to $4 \mathrm{~mm}$ long, sometimes short-awned, the rachilla joints very short. 2 - Prairie, open woods, and sandy soil, Ontario to British Columbia, south to Delaware, Missouri, Louisiana, California, and Mexico

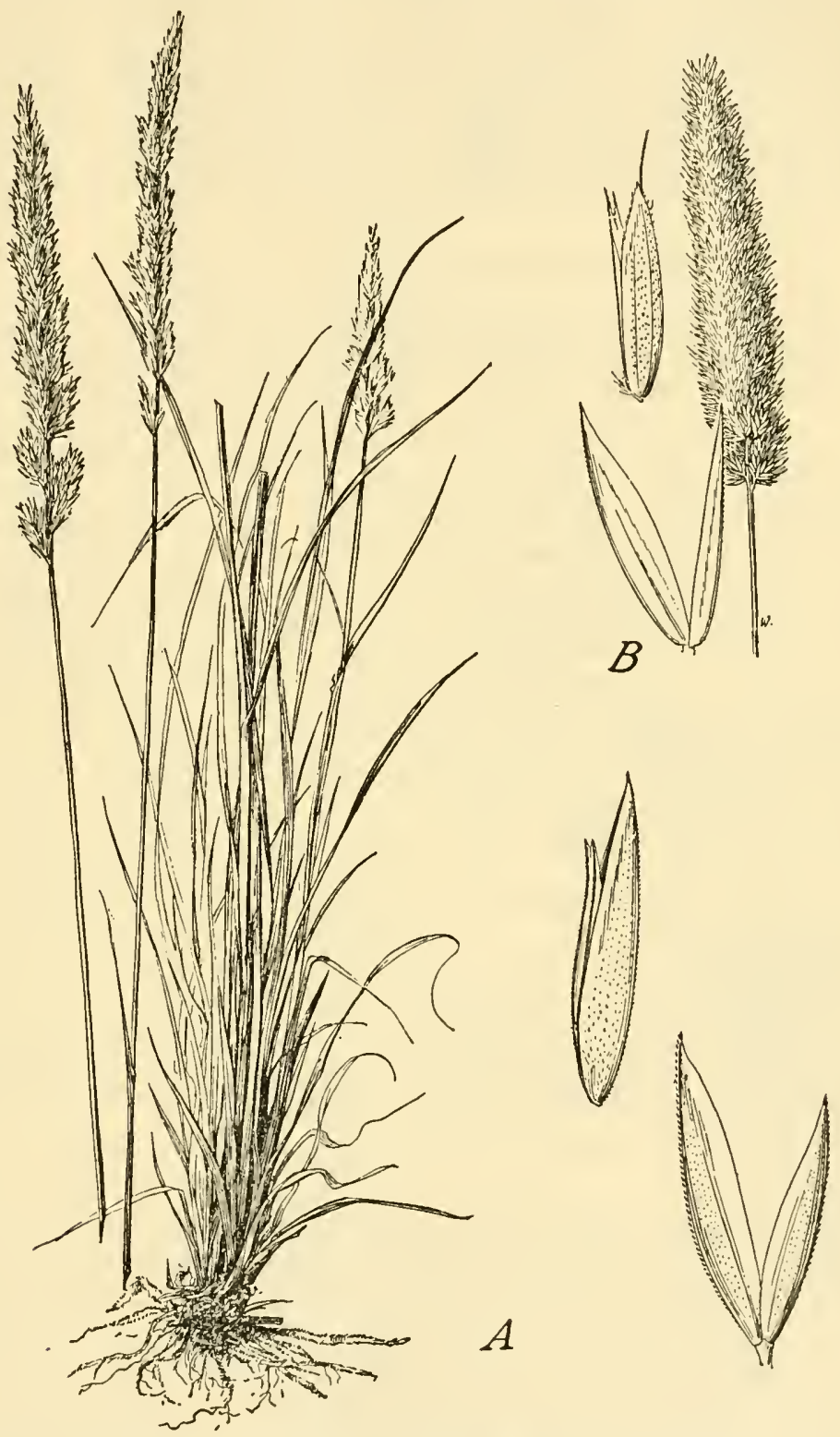

Figure 542. - A Koeleria cristata. Plant, $\times 1 / 2 ;$ glumes and floret, $\times 10$. (Bebb 2862, Ill.) $B, K$. phleoides. Panicle, $X 1$; glumes and thoret, $\times 10$. (Heller 11417, Calif.)

(fig. 543); widely distributed in the temperate regions of the Old World. Variable; several American varieties have been proposed, but the forms are inconstant and intergrading and it is not practicable 
to distinguish definite varieties. On the Pacific coast there is a rather large loosely tufted form (K. cristata var. longifolia Vasey) with long narrow or involute blades and somewhat open panicle.

2. Koeleria phleoídes (Vill.) Pers. (Fig. 542, B.) Annual; culms 15 to $30 \mathrm{~cm}$ tall, smooth throughout; sheaths and blades sparsely pilose; panicle dense, spikelike, 2 to $7 \mathrm{~cm}$ long, obtuse; spikelets 2 to $4 \mathrm{~mm}$ long; glumes acute; lemmas short-awned from a bifid apex; glumes and lemmas in the typical form papillose-hirsute on the back, but commonly papillose only. $\odot$-Introduced from Europe at Pensacola, Fla., Mobile, Ala., Portland, Oreg., and at several points in California.

\section{SPHENOPHOLIS Scribn. WEDGEgRASS}

Spikelets 2- or 3-flowered, the pedicel disarticulating below the glumes, the rachilla produced beyond the upper floret as a slender bristle; glumes unlike in shape, the first narrow, usually acute,

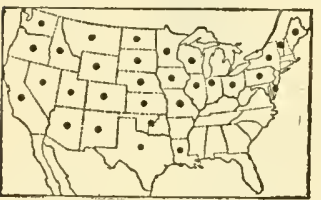

Figure 543.-Distribution of Koeleria cristata. 1-nerved, the second broadly obovate, 3- to 5 -nerved, the nerves sometimes obscure, mostly somewhat coriaceous, the margin scarious; lemmas firm, scarcely nerved, awnless or rarely with an awn from just below the apex, the first a little shorter or a little longer than the second glume; palea hyaline, exposed. Slender perennials (rarely annual) with usually flat blades and narrow shining panicles. Type species, Sphenopholis obtusata. Name from Greek sphen, wedge, and pholis, horny scale, alluding to the hard obovate second glume.

All the species are forage grasses but are usually not abundant. The most important are S. intermedia and S. obtusata.

Panicle dense, usually spikelike, erect or nearly so; second glume subcucullate. 1. S. овтUsata. Panicle not dense, lax, nodding, from very slender to many-flowered, but not spikelike.

Spikelets awned

Spikelets awnless (rarely awned in $S$. filiformis).

Second glume acute or subacute; panicle many-flowered. Second glume about $2.5 \mathrm{~mm}$ long _._._....... S. Intermedia. Second glume about $3.5 \mathrm{~mm}$ long Second glume broadly rounded at summit; panicle relatively few-flowered. Blades rarely more than $10 \mathrm{~cm}$ long, flat, 2 to $5 \mathrm{~mm}$ wide.

Blades elongate, flat to subinvolute, mostly less than $2 \mathrm{~mm}$ wide.

6. S. Pallens.

5. S. FILIFORMIS.

1. Sphenopholis obtusáta (Michx.) Scribn. Prairie wedgegrass. (Fig. 544, A.) Culms erect, tufted, 30 to $100 \mathrm{~cm}$ tall; sheaths glabrous to finely retrorsely pubescent; blades flat, glabrous, scabrous, or pubescent, mostly 2 to $5 \mathrm{~mm}$ wide; panicle erect or nearly so, dense, spikelike to interrupted or lobed, rarely slightly looser, 5 to $20 \mathrm{~cm}$ long; spikelets 2.5 to $3.5 \mathrm{~mm}$ long, the two florets closer together than in the other species; second glume very broad, subcucullate, somewhat inflated at maturity, 5-nerved, scabrous; lemmas minutely papillose in texture, rarely mucronate or with a short straight awn, the first about $2.5 \mathrm{~mm}$ long. 21 -Open woods, old fields, moist ground, and prairies, Maine to British Columbia, south to Florida, Arizona, and California; Mexico; Dominican Republic. Variable in 


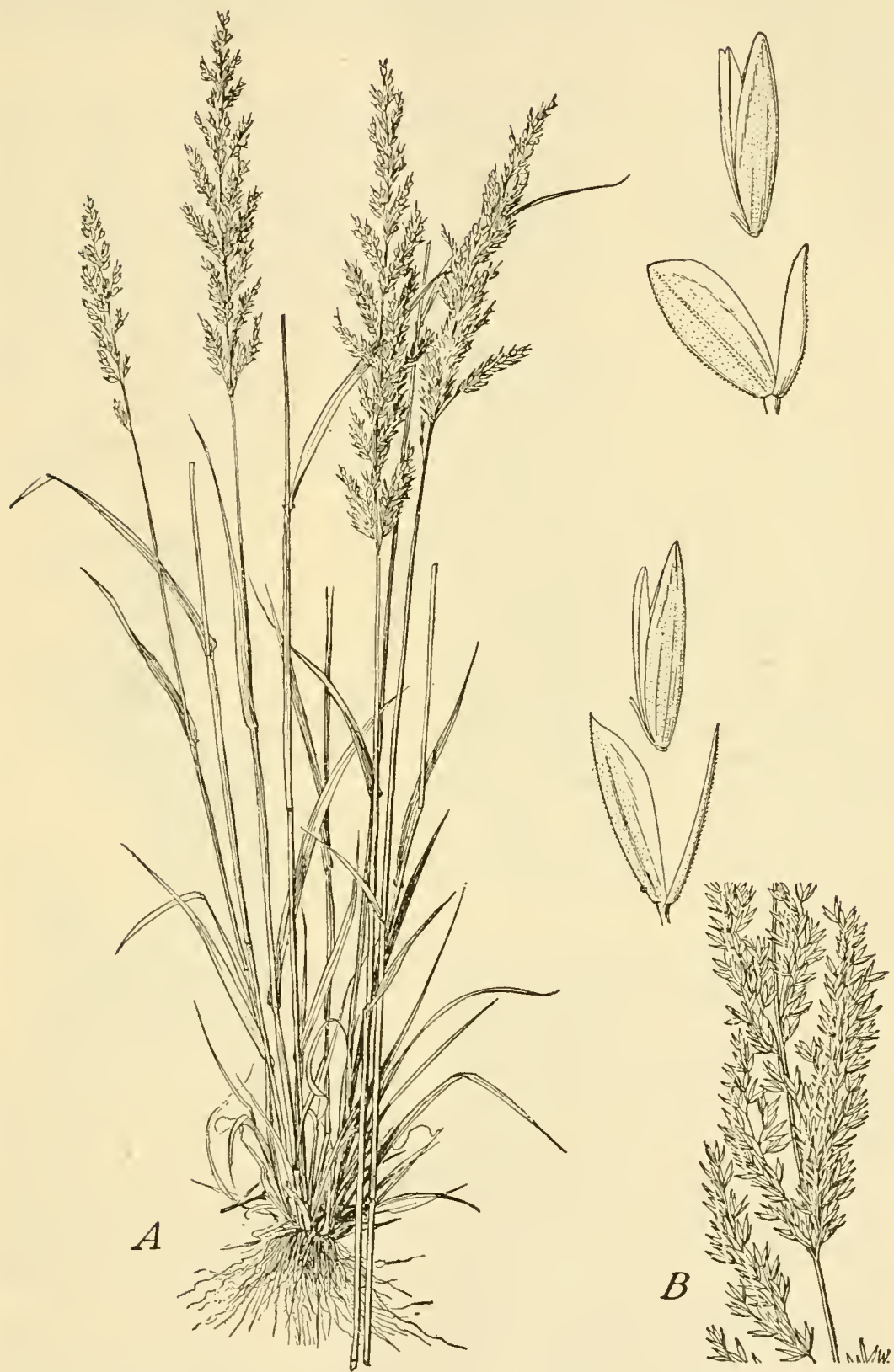

FIGURE 544. $-A$, Sphenopholis obtusata. Plant, $\times \frac{1}{2}$; glumes and floret, $\times 10$. (Hitchcock 1453, N. C.) $B$, S. intermedia. Panicle, $\times 1$; glumes and floret, $\times 10$. (Clark 1785, Ind.) 
size and in denseness of panicle. Sometimes annual or flowering the first season. Specimens with less dense and lobed panicles may be distinguished from denser panicled specimens of $S$. intermedia by the broader, firmer, subcucullate second glume and more approximate florets.

2. Sphenopholis intermédia (Rydb.) Rydb. Slender wedgeGrass. (Fig. 544, B.) Culms erect in small tufts, 30 to $120 \mathrm{~cm}$ tall;

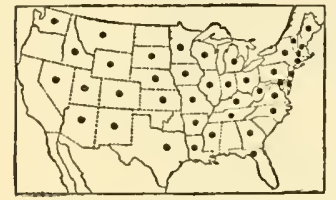

FIGURE 545.-Distribution of Sphenopholis intermedia.

sheaths glabrous or pubsecent; blades flat, often elongate, lax, mostly 2 to $6 \mathrm{~mm}$ wide, sometimes wider, mostly scaberulous, occasionally sparsely pilose; panicle nodding, from rather dense to open, mostly 10 to $20 \mathrm{~cm}$ long, the branches spikelet-bearing from base; spikelets 3 to $4 \mathrm{~mm}$ long; second glume relatively thin, acute or subacute, about $2.5 \mathrm{~mm}$ long; lemmas subacute, rarely mucronate, smooth or

rarely very minutely roughened, mostly 2.5 to $3 \mathrm{~mm}$ long. 24 Damp or rocky woods, slopes, and moist places, Newfoundland to British Columbia, south to Florida and Arizona; Tanana Hot Springs, Alaska. (Fig. 545.) Delicate plants with small panicles resembling $S$. nitida may be distinguished by the very narrow first glume, the acute to subacute second glume and lemmas, and usually by the glabrous foliage. Plants with rather dense panicles resembling $S$. obtusata may be distinguished by the thinner, less rounded, more compressed second glume. This is the species called Sphenopholis pallens (Spreng.) Scribn. in recent manuals. Sprengel's description of Aira pallens shows that Scribner misapplied the name (see no. 6).

3. Sphenopholis longiflóra (V asey) Beal. (Fig. 546.) Culms relatively stout, erect from a decumbent base, 40 to $70 \mathrm{~cm}$ tall; lower sheaths puberulent, the others glabrous; blades thin, flat, scaberulous, 5 to $18 \mathrm{~cm}$

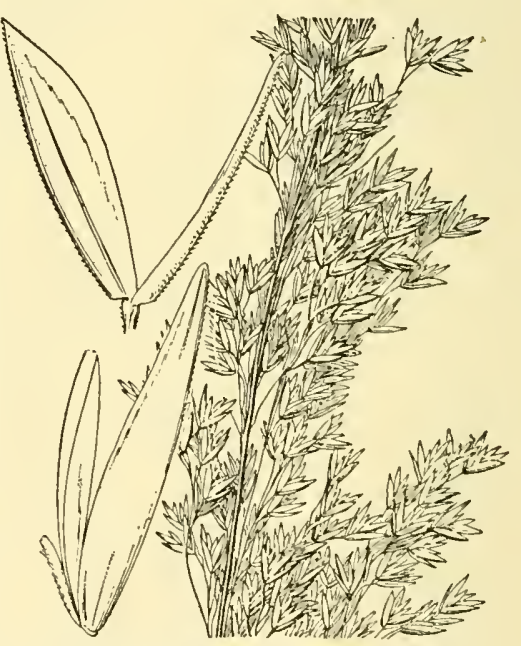

FIgure 546.--Sphenopholis longiflora. Panicle, $\times 1$; glumes and floret, $\times 10$. (Nealley, Tex.) long, 3 to $8 \mathrm{~mm}$ wide; panicle many-flowered, rather loose, slightly nodding, 10 to $18 \mathrm{~cm}$ long; spikelets mostly 2 -flowered, the rachilla hispidulous; glumes very scabrous on the green part, the second thin, acute, about $3.5 \mathrm{~mm}$ long; lemmas smooth, scaberulous toward the tip, the first about $4 \mathrm{~mm}$ long. 4 -Known only from Houston, Tex. Differing from S. intermedia in the larger spikelets and broader blades, and in the more tapering lemmas.

4. Sphenopholis nítida (Spreng.) Scribn. (Fig. 547.) Culms tufted, leafy at base, slender, shining, 30 to $70 \mathrm{~cm}$ tall; sheaths and blades mostly softly pubescent, occasionally glabrous, the blades 2 to $5 \mathrm{~mm}$ wide, 3 to $10 \mathrm{~cm}$ long, the basal sometimes longer; panicle rather few-flowered, mostly 8 to $12 \mathrm{~cm}$ long, the filiform branches 
distant, ascending, spreading in anthesis; spikelets 3 to $3.5 \mathrm{~mm}$ long; glumes about equal in length, usually nearly as long as the first floret, the first glume broader than in the other species, the second broadly rounded at sum-

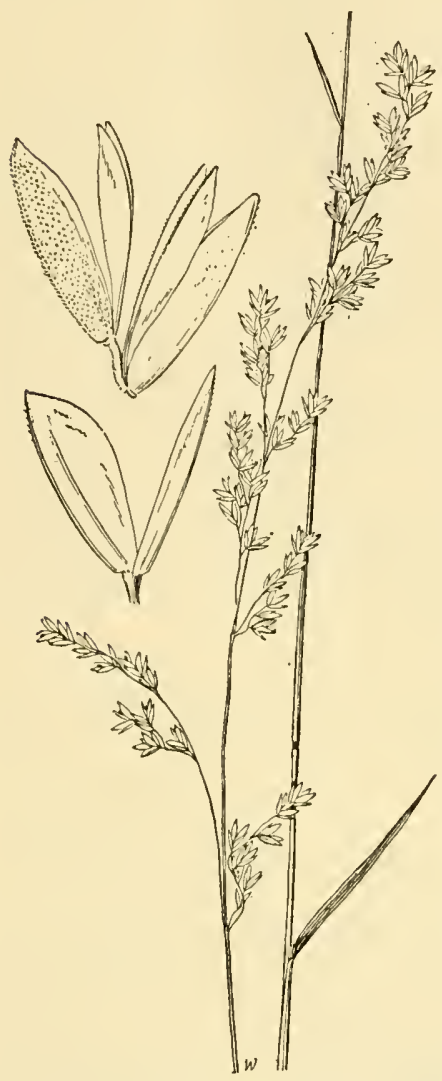

Figure 547.-Sphenopholis nitida. Panicle, $\times 1$; glumes and florets, $\times 10$. (House 1920 , S. C.) mit, at least the second lemma scabrous-p a pil lose. 24 -Dry or rocky woods, Massachusetts to North Dakota, south to Florida and Texas (fig. 548).

\section{Sphenopho- lis fil ifórmis} (Chapm.) Vasey. (Fig. 549.) Culms erect, very slender, 30 to $60 \mathrm{~cm}$ tall; blades slender, lax, flat to subinvolute, mostly less than $2 \mathrm{~mm}$ wide; panicle slender, often nodding, 5 to 15 $\mathrm{cm}$ long, the short branches rather distant, erect or ascending; spikelets 3 to $4 \mathrm{~mm}$ long, the two florets rather distant; second glume broadly rounded at summit, about $2 \mathrm{~mm}$ long; lemmas ob-

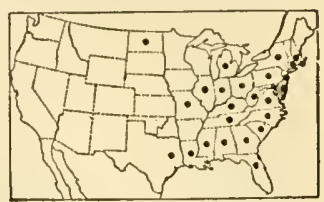

Figure 548.-Distribution of Sphenopholis nitida.

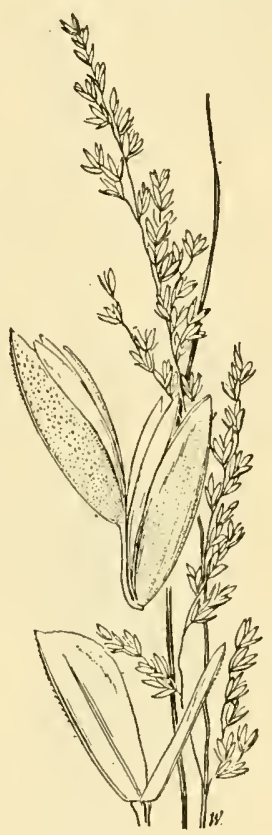

Figure 549. - Sphenopholis filiformis. Panicle, $\times 1$; glumes and florets, $\times 10$. (Hitchcock 1044, Ala.)

tuse to subacute, rarely with a short spreading awn; the first smooth, the second minutely roughened. 21 -Dry soil, Coastal Plain, North Carolina to Florida, Tennessee, and eastern Texas (fig.550). Occasional awned lemmas, either the first or second, are found in some panicles.

6. Sphenopholis pállens (Spreng.) Scribn.

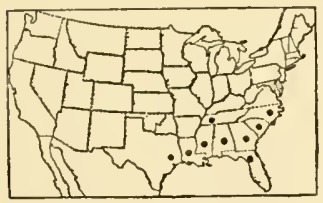

FIGURE 550.-Distribution of Sphenopholis filiformis. (Fig. 551.) Culms erect, about $60 \mathrm{~cm}$ tall; lower sheaths minutely pubescent, the upper glabrous; blades flat, glabrous, 1 to $2 \mathrm{~mm}$ wide; panicle narrow, nodding, loose, or somewhat compact, 15 to $25 \mathrm{~cm}$ long, the branches ascending, the lower distant; spikelets about as in $S$. intermedia, 2- or 3-flowered, 3 to $3.5 \mathrm{~mm}$ long; second floret scaberulous, usually awned just below the apex, the awn scabrous, geniculate, 1 to $2 \mathrm{~mm}$ long. 2 (Eatonia aristata Scribn. and Merr.) The type of Aira pallens Spreng. 
has not been examined, but it was received from Muhlenberg and may be assumed to be the same as the specimen in the Muhlenberg Herbarium described under Aira pallens by Muhlenberg. The only

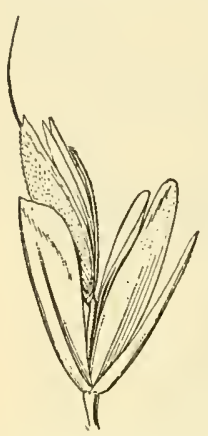

FI G UR E 551 .Sphenopholis pal. lens, $\times 10$. (Curtiss, S.C.)

other specimen known is the type of Eatonia aristata collected in South Carolina by Curtiss.

\section{TRISÉTUM Pers. Trisetum}

Spikelets usually 2-flowered, sometimes 3- to 5-flowered, the rachilla prolonged behind the upper floret, usually villous; glumes somewhat unequal, acute, the second usually longer than the first floret; lenmas usually short-bearded at the base, 2-toothed at apex, the teeth often awned, bearing from the back below the cleft apex a straight and included or usually bent and exserted awn (awnless or nearly so in Trisetum melicoides and T. wolfi). Tufted perennials (except Trisetum interruptum), with flat blades and open or usually contracted or spikelike shining panicles. Type species, T. flavescens. Name from Latin tri, three, and setum, bristle, alluding to the three awns of the lemma.

Several of the species are valuable for grazing. Trisetum spicatum constitutes an important part of the forage on alpine and subalpine slopes, and T. wolfii at medium altitudes.

Spikelets disarticulating below the glumes.

Plants perennial; panicle lax, somewhat open_._- 9. T. Pennsylvanicdm.

Plants annual; panicle narrow, dense, interrupted...- 10. T. INTERRUPTUM.

Spikelets disarticulating above the glumes.

Awn included within the glumes, or wanting.

Panicle rather lax, nodding

Panicle rather dense, erect....

Awn exserted.

Awn straight (see also T. montanum var. shearii) _ 3. T. овтноснаетUм. Awn geniculate.

Panicle dense, spikelike, sometimes slightly interrupted below; plants densely tufted........... 5 . T. SPICATUM.

Panicle loose and open to contracted, but not spikelike; plants in small tufts or solitary.

Panicle relatively few-flowered, loose, lax or drooping, the filiform branches naked below; florets distant__._._- 4. T. CERNUUM.

Panicle many-flowered, from rather loose to dense and interrupted; florets not distant.

Panicle yellowish; spikelets mostly 3- or 4-flowered; introduced.

8. T. FLAVESCENS.

Panicle pale green, sometimes purplish-tinged; spikelets usually 2-flowered.

Spikelets about $8 \mathrm{~mm}$ long _..._._._. 6. T. Canescens.

Spikelets 5 to $6 \mathrm{~mm}$ long........... T. MONTANUM.

1. Trisetum melicoídes (Michx.) Scribn. (Fig. 552.) Culms 50 to $100 \mathrm{~cm}$ tall; sheaths pubescent or scabrous; blades 2 to $8 \mathrm{~mm}$ wide, scabrous, sometimes pubescent on the upper surface; panicle somewhat open, nodding, 10 to $20 \mathrm{~cm}$ long, the branches slender, ascending, lax or drooping, as much as $7 \mathrm{~cm}$ long, rather closely flowered above the middle; spikelets scaberulous, 6 to $7 \mathrm{~mm}$ long; glumes 4 to 6 $\mathrm{mm}$ long, the second longer and broader; lemmas acute, 5 to $6 \mathrm{~mm}$ long, rarely with a minute awn just below the tip, the rachilla and callus hairs 1 to $2 \mathrm{~mm}$ long. 21 -River banks, lake shores, mostly in gravelly ground, Newfoundland to Vermont, Michigan, and Wisconsin (fig. 553). 
2. Trisetum wólfii Vasey. Wolfs trisetum. (Fig. 554.) Culms erect, 50 to $100 \mathrm{~cm}$ tall, loosely tufted, sometimes with short rhizomes; sheaths scabrous, rarely the lower pilose; blades flat, scabrous, rarely pilose on the upper surface, 2 to $4 \mathrm{~mm}$ wide; panicle erect, rather dense but scarcely spikelike, green or pale, sometimes a little purplish, 8 to $15 \mathrm{~cm}$ long; spikelets 5 to $7 \mathrm{~mm}$ long, 2-flowered, sometimes 3-flowered; glumes nearly equal, acuminate, about $5 \mathrm{~mm}$ long; lemmas obtusish, scaberulous, 4 to 5 $\mathrm{mm}$ long, awnless or with a minute awn below the tip, the callus hairs scant, about $0.5 \mathrm{~mm}$ long, the rachilla internode about $2 \mathrm{~mm}$ long, rather sparingly long-villous. 4 -Meadows and moist ground, at medium altitudes in the mountains, Montana to Washington, south to New Mexico and California.

3. Trisetum orthochaétum Hitchc.

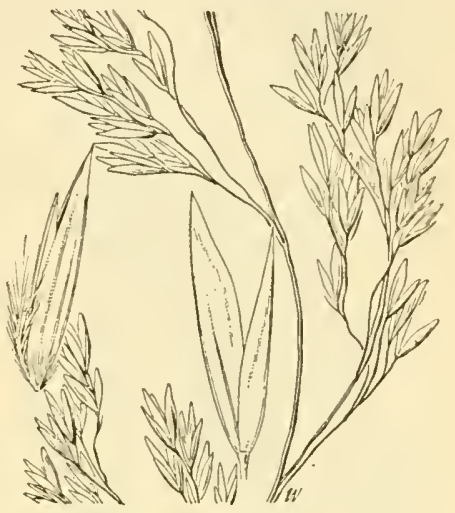

FIGURE 552.-Thisetum melicoides. Panicle, $\times 1$; glumes and floret, $\times 5$. (Pringle, $\mathrm{Vt}$.)

(Fig. 556.) Culms solitary, erect, slender, $110 \mathrm{~cm}$ tall;. sheaths glabrous; blades flat, scabrous, 8 to $20 \mathrm{~cm}$ long, 3 to $7 \mathrm{~mm}$ wide;

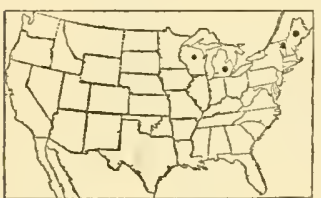

Frgure 553.-Distribution of Trisetum melicoides. panicle slightly nodding, lax, pale, about $18 \mathrm{~cm}$ long, the filiform branches loosely ascending, naked below, the lower fascicled, as much as $8 \mathrm{~cm}$ long; spikelets short-pediceled, somewhat appressed, mostly 3flowered, 8 to $9 \mathrm{~mm}$ long excluding awns, the rachilla appressed-silky; glumes acuminate, about $6 \mathrm{~mm}$ long, the second wider; lemmas rounded on the back, minutely scaberulous on the upper part, obscurely 5-nerved, the callus short-pilose, the apex acute, erose-toothed, awned about $2 \mathrm{~mm}$ below the tip, the awn straight or nearly so, exceeding the lemma about $3 \mathrm{~mm}$. 24 Known only from boggy meadows, Lolo Hot Springs, Bitterroot Mountains, Mont.

4. Trisetum cérnuum Trin. NODDING

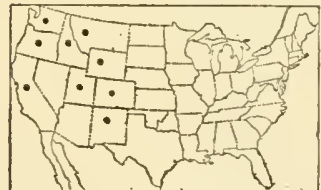

Figure 555.-Distribution of Trisetum wolfi Trisetun. (Fig. 557.) Culms rather lax, 60 to $120 \mathrm{~cm}$ tall; sheaths glabrous to sparsely pilose; blades thin, flat, lax, scabrous, 6 to 12 $\mathrm{mm}$ wide; panicle open, lax, drooping, 15 to $30 \mathrm{~cm}$ long, the branches verticillate, filiform, flexuous, spikelet-bearing toward the ends; spikelets 6 to $12 \mathrm{~mm}$ long, with usually 3 distant florets, the first longer than the second glume; first glume narrow, acuminate, 1 -nerved, 0.5 to $2 \mathrm{~mm}$ long, the second broad, 3-nerved, 3 to $4 \mathrm{~mm}$ long, occasionally reduced; lemma 5 to 6 
$\mathrm{mm}$ long, the teeth setaceous, the hairs of the callus 0.5 to $1 \mathrm{~mm}$ long, of the rachilla as much as $2 \mathrm{~mm}$ long, the awns slender, curved, flexuous or loosely spiral, mostly 5 to $10 \mathrm{~mm}$ long, attached 1 to $2 \mathrm{~mm}$ below tip. 24 -Moist woods, Alberta to southeastern Alaska, south to western Montana and northern California (fig. 558).

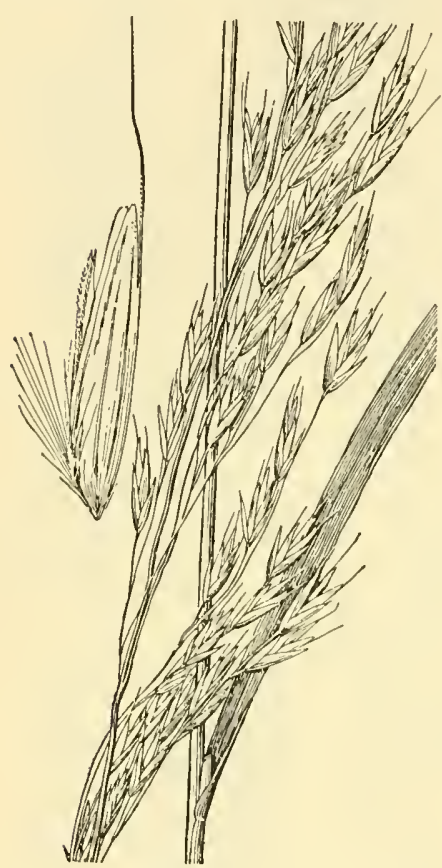

FIgURE 556.-Trisetum orthochaet um. Panicle, $\times 1$; glumes and floret, $\times 5$. (Type.)
5. Trisetum spicátum (L.) Richt. Spike trisetum. (Fig. 559, A.) Culms densely tufted, erect, 15 to $50 \mathrm{~cm}$ tall, glabrous to puberulent; sheaths and usually the blades puberulent; panicle dense, usually spikelike, often interrupted at base, pale or of ten dark-purple,

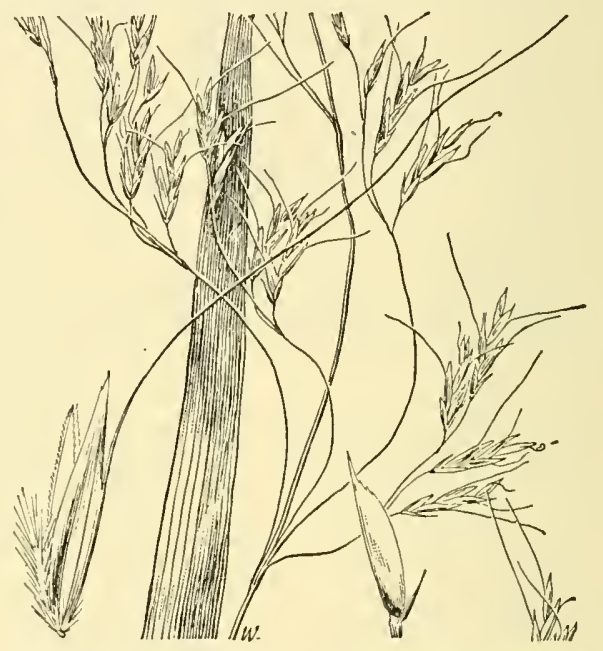

Figure 557.-Trisetum cernuum. Panicle, $\times 1$; glumes and floret, $\times 5$. (Elmer 1946, Wash.)

5 to $15 \mathrm{~cm}$ long; spikelets 4 to $6 \mathrm{~mm}$ long; glumes somewhat unequal in length, glabrous or scabrous except the keels, or sometimes pilose, the first narrow, acuminate, 1-nerved, the second broader, acute, 3nerved; lemmas scaberulous, $5 \mathrm{~mm}$ long, the first longer than the glumes, the teeth setaceous; awn attached about one third below

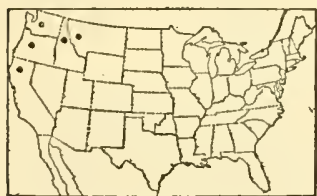

FIGURE 558.-Distribution of Trisetum cernuum. the tip, 5 to $6 \mathrm{~mm}$ long, geniculate, exserted. 2 -Alpine meadows and slopes, Arctic America, southward to Connecticut, Pennsylvania, northern Michigan and Minnesota, in the mountains to New Mexico and California; also on Roan Mountain, N. C. (fig. 560); high mountains through Mexico to the antarctic regions of South America; arctic and alpine regions of the Old World. In northern regions the species descends to low altitudes. Exceedingly variable; several varieties have been proposed, but the characters used to differentiate them are variable and are not correlated. 'Two rather more outstanding varieties, both intergrading with the species are: T. spicatum var. molle (Michx.) Beal, with densely pubescent foliage, and $T$. spicatum var. congdoni (Scribn. and Merr.) Hitchc., a nearly glabrous alpine form with slightly larger spikelets. 


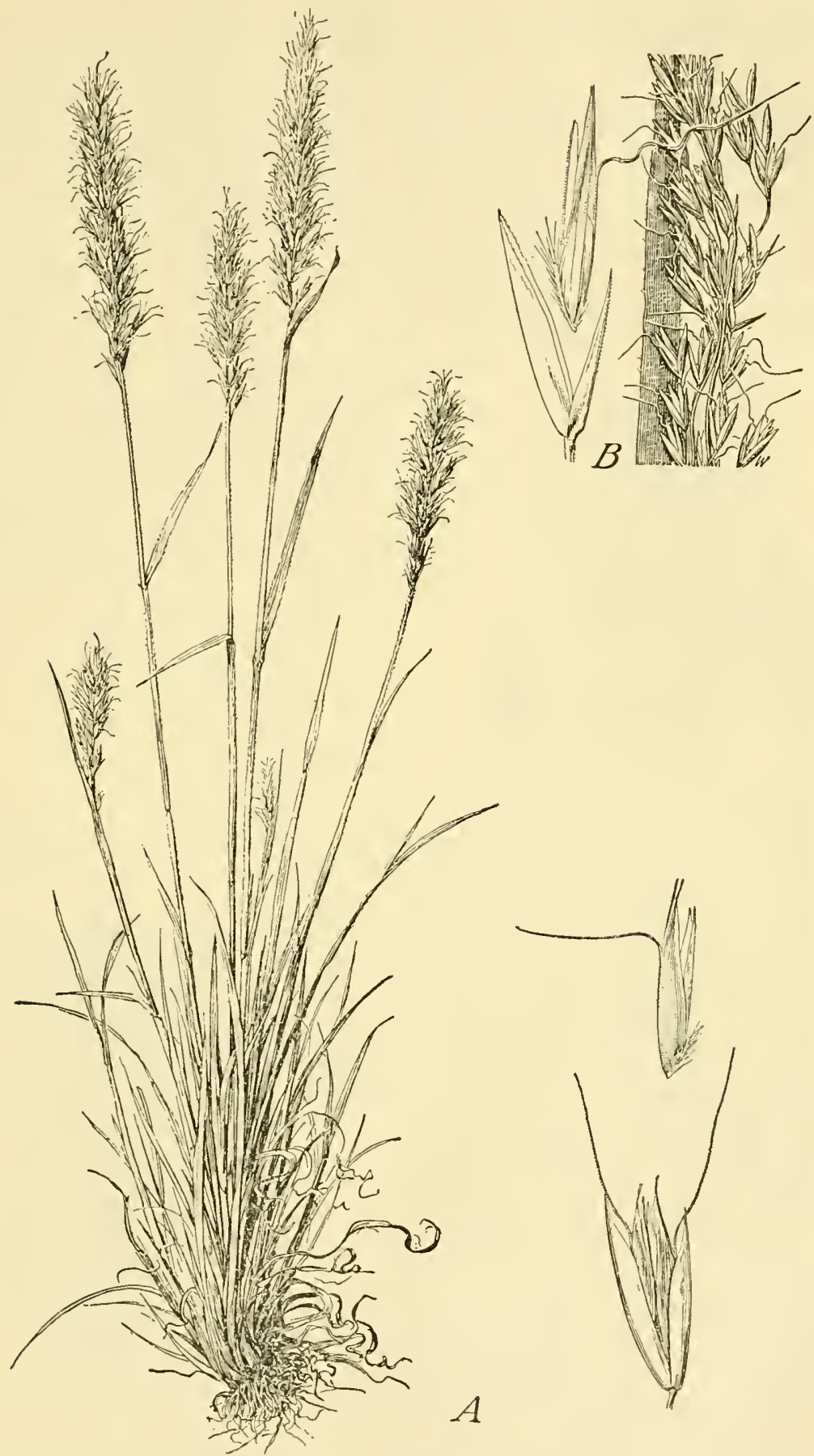

Figure 559.-A, Trisetum spicatum. Plant, $\times 1 / 2$; spikelet and floret, $\times$ 5. (Rydberg and Bessey 3593, Mont.); $B, T$. canescens. Panicle, $\times 1$; glumes and floret, $\times 5$. (Hitcheock 3409 , Calif.) 
6. Trisetum canéscens Buckl. Tali trisetum. (Fig. 559, B.) Culms erect, or decumbent at base, 60 to $120 \mathrm{~cm}$ tall; sheaths, at least

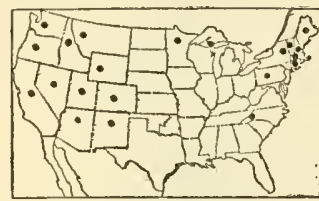

Figure 560.-Distribution of Trisetum spicatum. the lower, sparsely to densely and softly retrorse-pilose, rarely scabrous only; blades flat, scabrous or canescent, sometimes sparsely pilose, mostly 2 to $7 \mathrm{~mm}$ wide; panicle narrow, usually loose, sometimes interrupted and spikelike, 10 to $25 \mathrm{~cm}$ long; spikelets about $8 \mathrm{~mm}$ long, 2- or 3-flowered, the florets not so distant as in $T$. cernuum; glumes smooth, except the keel, the first narrow, acuminate, the second broad, acute, 3-nerved, 5 to $7 \mathrm{~mm}$ long; lemmas rather firm, scaberulous, the upper exceeding the glumes, 5 to $6 \mathrm{~mm}$ long, the teeth

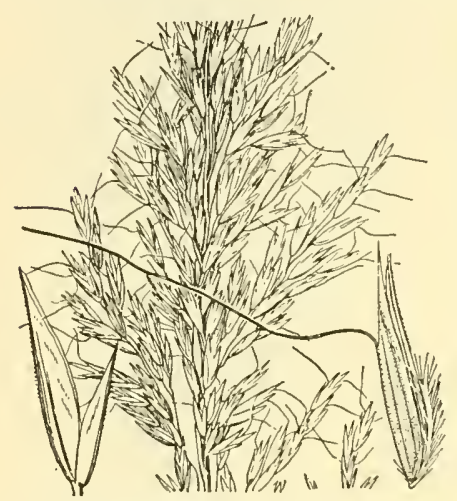

Figure 562.-Trisetum montanum. Panicle, $\times 1$; glumes and floret, $\times 5$. (Type.) aristate, the callus hairs rather scant, the rachilla hairs copious; awn geniculate, spreading, loosely twisted below, attached one-third below the tip, usually about $12 \mathrm{~mm}$ long. 24 -Mountain meadows, moist ravines and along streams, Montana to British Columbia, south to central California (fig, 561).

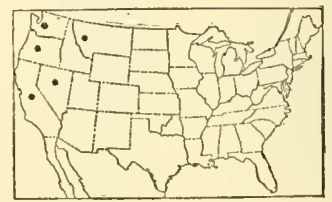

Figure 561.-Distribution of Trisctum canescens.

Plants with less pubescent sheaths and looser panicles resemble $T$. cernuum in that the spikelets are commonly 3-flowered, the florets distant. Plants with more velvety foliage and narrow panicles with short densely flowered branches, the lower in distant fascicles, have been differentiated as $T$. projectum Louis-Marie. Intergrading specimens are more numerous than the extreme described.

7. Trisetum montánum Vasey. (Fig. 562.) Resembling T. canescens, on the average smaller, the blades narrower; sheaths from nearly glabrous to softly retrorsely pubescent; panicles smaller than usual in $T$. canescens, more uniformly rather dense, often purpletinged; spikelets 5 to $6 \mathrm{~mm}$ long, the glumes and lemmas thinner than in $T$. canescens, the awn more delicate, 5 to $8 \mathrm{~mm}$ long. 24 -Moun-

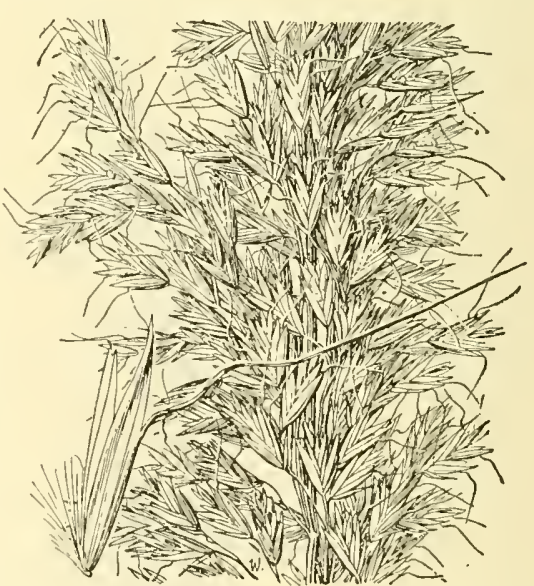

Figure 563.-Trisctum flavescens, Panicle, $\times 1$; floret, X 5. (Grant 26, Wash.) tain meadows, gulches and moist places on mountain slopes, between 2,000 and $3,300 \mathrm{~m}$, Colorado, Utah, and New Mexico. A form 
with purplish panicles and erect awns only 2 to $3 \mathrm{~mm}$ long, known from a single collection near Silverton, Colo., has been differentiated as T. montanum var. shearii Louis-Marie.

8. Trisetum flavéscens (L.) Beauv. (Fig. 563.) Resembling T. canescens; sheaths glabrous or the lower sparsely pilose; panicle usually yellowish, many-flowered, somewhat condensed; spikelets mostly 3-or 4-flowered; lemmas 4 to $6 \mathrm{~mm}$ long. 24 -Waste places, Vermont, New York, Missouri, Colorado, Washington, California, and probably other States; introduced from Europe.

Trisetum aúreum (Ten.) Ten. Annual; culms 10 to $20 \mathrm{~cm}$ tall; panicle ovate, contracted, 2 to 3 cm long; spikelets $3 \mathrm{~mm}$ long; awns 2 to $3 \mathrm{~mm}$ long. $\odot$-Ballast, Camden, N. J.; Europe.

9. Trisetum pennsylvánicum (L.) Beauv. (Fig. 564.) Culms slender, weak, usually subgeniculate at, base, 50 to $100 \mathrm{~cm}$ tall; sheaths glabrous or rarely scabrous; blades flat, scabrous, 2 to $5 \mathrm{~mm}$ wide; pan-

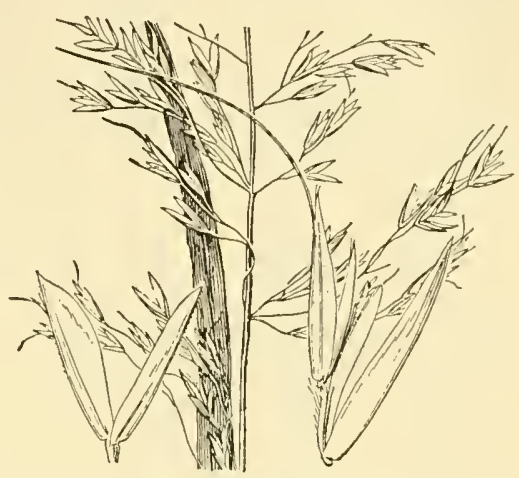

FIGURE 564.-Trisetum pennsylvanicum. Panicle, $X 1$; glumes and florets, $\times 5$. (Heller 4500 , Pa.) icle narrow, loose, nodding, 10 to $20 \mathrm{~cm}$ long; pedicels disarticulating about the middle or toward the base; spikelets 5 to $7 \mathrm{~mm}$ long, 2-flowered, the long rachilla joints slightly hairy; glumes mostly

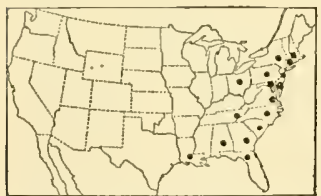

Figure 565.-Distribution of Trisetum pennsylvanicum.

Louisiana (fig. 565). 4 to $5 \mathrm{~mm}$ long, acute, the second wider; lemmas acuminate, the first usually awnless, the second awned below the 2 setaceous teeth, the awn horizontally spreading, 4 to $5 \mathrm{~mm}$ long. 24 Swamps and wet places, Massachusetts to Ohio, south on the Coastal Plain to Florida and west to Tennessee and

10. Trisetum interrúptum Buckl. (Fig. 566.) Annual; culms tufted, sometimes branching, erect or spreading, 10 to $40 \mathrm{~cm}$ tall; sheaths often scabrous or pubescent; blades flat, sometimes pubescent, 1 to $4 \mathrm{~mm}$ wide, mostly 3 to $10 \mathrm{~cm}$ long; panicle narrow, interrupted, from slender to rather dense but scarcely spikelike, 5 to $12 \mathrm{~cm}$ long, sometimes with smaller axillary panicles; pedicels disarticulating a short distance below the summit; spikelets about $5 \mathrm{~mm}$ long, 2-flowered, the second floret sometimes rudimentary; glumes about equal in length, acute, 4 to $5 \mathrm{~mm}$ long, the first 3-nerved,

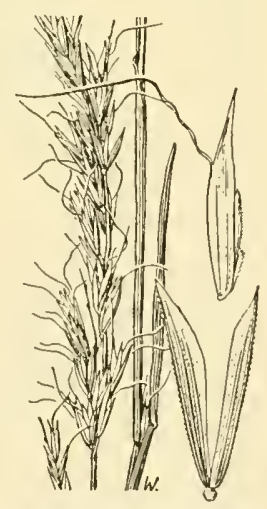

Figure 566.- Triset $u m$ interruptum. Panicle, $\times 1$; glumes and floret, $\times 5$. (Jermy, Tex.) the second a little broader, 5-nerved; lemmas acuminate with 2 setaceous teeth, the awns attached above the middle, flexuous, 4 to $8 \mathrm{~mm}$ long, that of the first lemma often shorter and straight. -Open dry ground, Texas to Colorado and Arizona (fig. 567). 


\section{DESCHÅMPSIA Beauv. HaIrgrass}

Spikelets 2-flowered, disarticulating above the glumes and between the florets, the hairy rachilla prolonged beyond the upper floret as a stipe, this sometimes bearing a reduced floret; glumes about equal, acute or acutish, membranaceous; lemmas thin, truncate and 2- to 4toothed at summit, bearded at base, bearing a slender awn from or below the middle, the awn straight, bent or

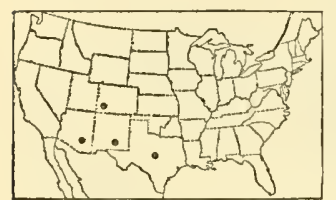

Figure 567.-Distribution of Trisetum interruptum. twisted. Low or moderately tall annuals or usually perennials, with shining pale or purplish spikelets in narrow or open panicles. Standard species, Deschampsia caespitosa. Included in Aira by some authors. Named for Deschamps.

Deschampsia caespitosa is often the dominant grass in mountain meadows, where it furnishes excellent forage.

Plants annual; foliage very scant Plants perennial; foliage not scant, one-third to half the entire length of the culm.

Panicle narrow, the distant branches appressed. Blades filiform, lax.

2. D. Elongata.

Panicle open or contracted, if narrow, not more than one-fourth the length of the culm.

Blades thin, flat; glumes exceeding the florets ..... 3. D. ATropUrpUREA. Blades firm or filiform; glumes not exceeding the upper floret. Blades filiform, flexuous; awn exserted, geniculate, twisted.

4. D. FLEXTOSA.

Blades flat or folded, stiff; awn included or slightly exserted, straight.

Panicle open, usually nodding or drooping . . . . . 5. D. Caespitosa. Panicle narrow, condensed, erect........ 6. D. HoLciFormis.

1. Deschampsia danthonioídes (Trin.) Munro. Annual hairGrass. (Fig. 568.) Annual; culms slender, erect, 15 to $60 \mathrm{~cm}$ tall; blades few, short, narrow; panicle open, 7 to $25 \mathrm{~cm}$ long, the capillary branches commonly in twos, stiffly ascending, naked below, bearing a few short-pediceled spikelets toward the ends; glumes 4 to $8 \mathrm{~mm}$ long, 3-nerved, acuminate, smooth except the keel, exceeding the florets; lemmas smooth and shining, somewhat indurate, 2 to $3 \mathrm{~mm}$ long, the base of the florets and the rachilla pilose, the awns geniculate, 4 to 6 $\mathrm{mm}$ long. $\odot$-Open ground, Alaska to Montana and Baja California; Texas (Buckley, but the locality possibly erroneous); also Chile (fig. 569). Variable in the size of the spikelets. A form described from southern California as D. gracilis Vasey, with somewhat laxer panicles, the rather more numerous spikelets only 4 to 5 $\mathrm{mm}$ long, grades into the usual form.

2. Deschampsia elongáta (Hook.) Munro. Slender harrgrass. (Fig. 570.) Culms densely tufted, slender, erect, 30 to $120 \mathrm{~cm}$ tall; blades soft, 1 to $1.5 \mathrm{~mm}$ wide, flat or folded, those of the basal tuft filiform; panicle narrow, as much as $30 \mathrm{~cm}$ long, the capillary branches appressed; spikelets on short appressed pedicels; glumes 4 to $6 \mathrm{~mm}$ long, 3-nerved, equaling or slightly exceeding the florets; lemmas 2 to $3 \mathrm{~mm}$ long, similar to those of $D$. danthonioides, the awns shorter, straight. 24 -Open ground, Alaska to Wyoming, south to Arizona and California; Mexico (fig. 571); Chile.

3. Deschampsia atropurpúrea (Wahl.) Scheele. Mountain hairGRASS. (Fig. 572.) Culms loosely tufted, erect, purplish at base, 40 to $80 \mathrm{~cm}$ tall; blades flat, rather soft, ascending or appressed, 5 to $10 \mathrm{~cm}$ long, 4 to $6 \mathrm{~mm}$ wide, acute or abruptly acuminate; 
panicle loose, open, 5 to $10 \mathrm{~cm}$ long, the few capillary drooping branches naked below; spikelets mostly purplish, broad; glumes about $5 \mathrm{~mm}$ long, broad, the second 3-nerved, exceeding the florets; lemmas scabrous, about $25 \mathrm{~mm}$ long, the callus hairs one-third to half asilong,

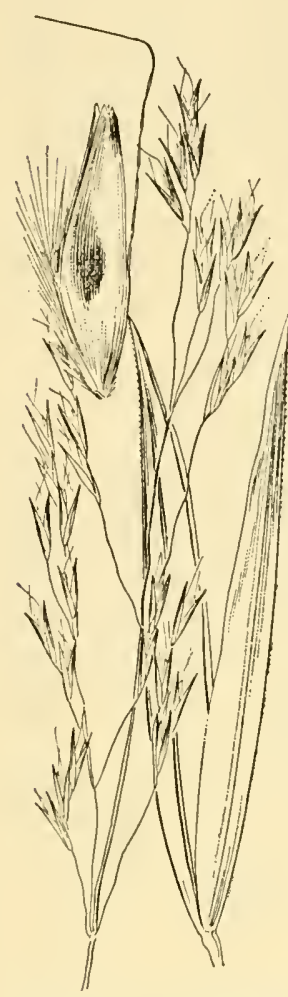

Figure 568.-Deschampsia danthonioides. Panicle, $\times$ 1 ; glumes and floret, $\times 5$. (Parish 3300, Calif.) the awn of the first straight, included, of the second, geniculate, exserted. 2 -Woods and wet meadows, Newfoundland and Labrador to Alaska, south to the White Mountains of New Hampshire; Colorado, and Oregon (fig. 573); northern Eurasia.

\section{Deschampsia flexuó-} sa (L.) Trin. Crinkled HAIRGRASS. (Fig. 574.) Culms densely tufted, erect, slender, 30 to $80 \mathrm{~cm}$ tall; leaves mostly in a basal tuft, numerous, the sheaths scabrous, the blades involute, slender or setaceous, flexuous; panicle loose, open, nodding, 5 to 12 cm long, the capillary branches naked below, the branchlets spikeletbearing toward the ends; spikelets 4 to $5 \mathrm{~mm}$ long, purplish or bronze, the florets approximate; glumes 1-nerved, acute, shorter than the florets; lemmas scabrous, the callus hairs about $1 \mathrm{~mm}$ long, the awn

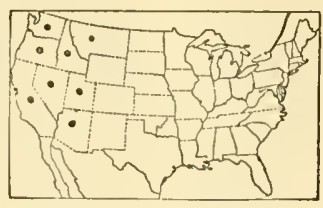

Figure 569.-Distribution of Deschampsia danthonioides.

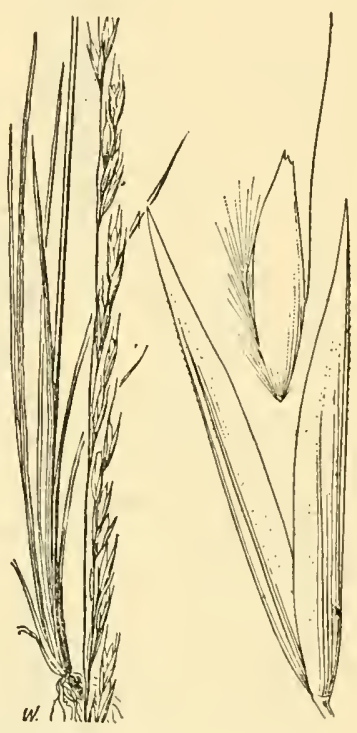

Figure 570.-Deschampsia elongata. Panicle, $\times 1$; glumes and floret, $\times 5$. (Swallen 780 , Calif.)

attached near the base, geniculate, twisted, 5 to $7 \mathrm{~mm}$ long. $\quad 2 \quad-$ Dry or rocky woods, slopes, and open ground, Greenland to Alaska, south to North Carolina, Michigan, and Wisconsin; Oklahoma (Le Flore County) (fig. 575); Eurasia. A form with yellow-

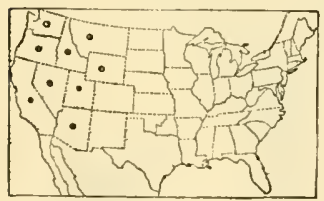

Figure 571.-Distribution of Deschampsia elongata. striped foliage (called by gardeners Aira foliis variegatis) is occasionally grown for ornament.

5. Deschampsia caespitósa (L.) Beauv. Tufted hairgrass. (Fig. 576.) Culms in dense tufts, leafy at base, erect, 60 to $120 \mathrm{~cm}$ tall; sheaths snooth; blades 1.5 to $4 \mathrm{~mm}$ wide, often elongate, rather firm, flat or folded, scabrous above; panicle loose, open, nodding, 10 to $25 \mathrm{~cm}$ long, the capillary scabrous branches and branchlets spikelet-bearing toward the ends; spikelets 4 to $5 \mathrm{~mm}$ long, pale or purpletinged, the florets distant, the rachilla joint half the length of the lower floret; glumes 1-nerved or the second obscurely 3-nerved, acute, 
about as long as the florets; lemmas smooth, the callus hairs short; awn

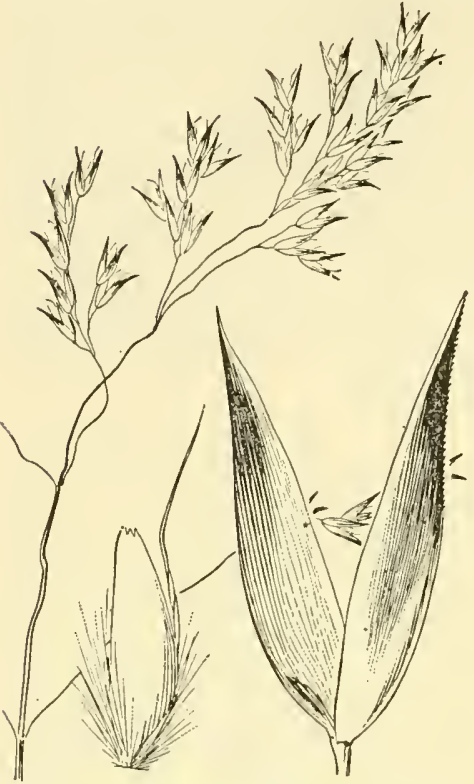

Figure 572.-Deschampsia atroputputea. Panicle, $\times 1$; glumes and floret, $\times 5$. (Leiberg 2952, Idaho.)

6. Deschampsia holcifórmis tufts with numerous basal leaves, erect, relatively robust, 50 to $125 \mathrm{~cm}$ tall; blades mostly folded, as much as 50 cm long, 2 to $4 \mathrm{~mm}$ wide, rather firm; panicle 10 to $25 \mathrm{~cm}$ long, condensed, many-flowered, the

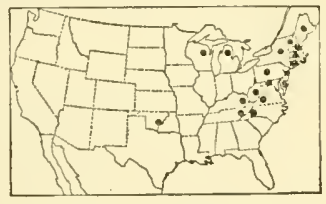

FIGURE 575.-Distribution of Deschampsia flexuosa.

branches appressed to subflexuous-ascending, purplish to brownish; spikelets 6 to $8 \mathrm{~mm}$ long; glumes and lemmas scaberulous, the glumes about equaling the spikelets or shorter, 3 -nerved, the lateral nerves of the first often obscure; lemmas awned from below the middle, the awns erect, exceeding the spikelet, the callus hairs short. 24-Marshes and sandy soil near the coast, Vancouver Island to central California. from near the base, from straight and included in the glumes to weakly geniculate and twice as long as the spikelet. $24-\mathrm{Bogs}$ and wet places, Greenland to Alaska, south to New Jersey, West Virginia, Illinois, North Dakota, New Mexico, and California (fig. 577); arctic and temperate regions of the Old World.

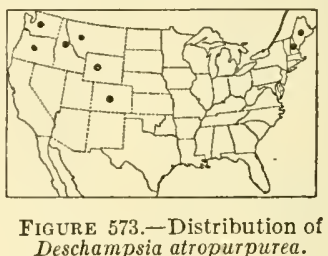

Variable in size, in width and texture of blades, in shape of the panicle, and in length of awn. The forms which have been segregated as species are inconstant and the characters used to distinguish them are not correlated. Rarely with proliferous spikelets.

Presl. (Fig. 578.) Culms in dense

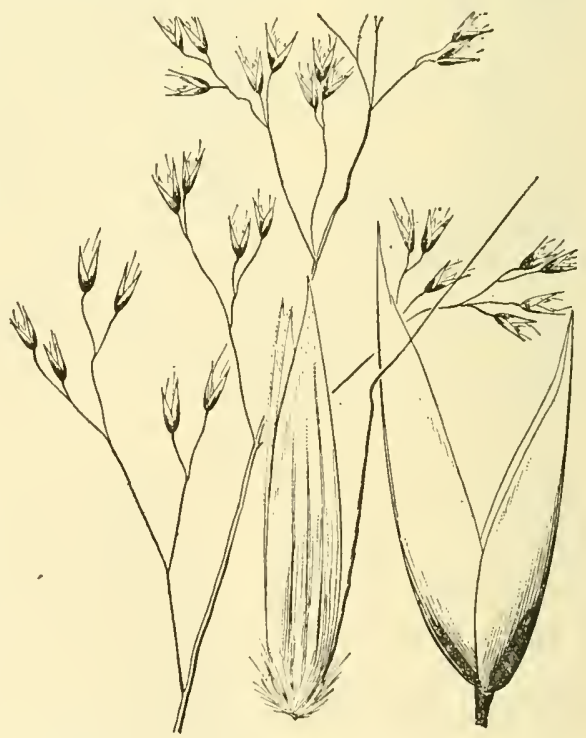

FIGURE 571-Deschampsia fleruósa. Panicle, $\times 1$ glumes and floret, $\times 5$. (Hitchcock 16059, N. H.) 


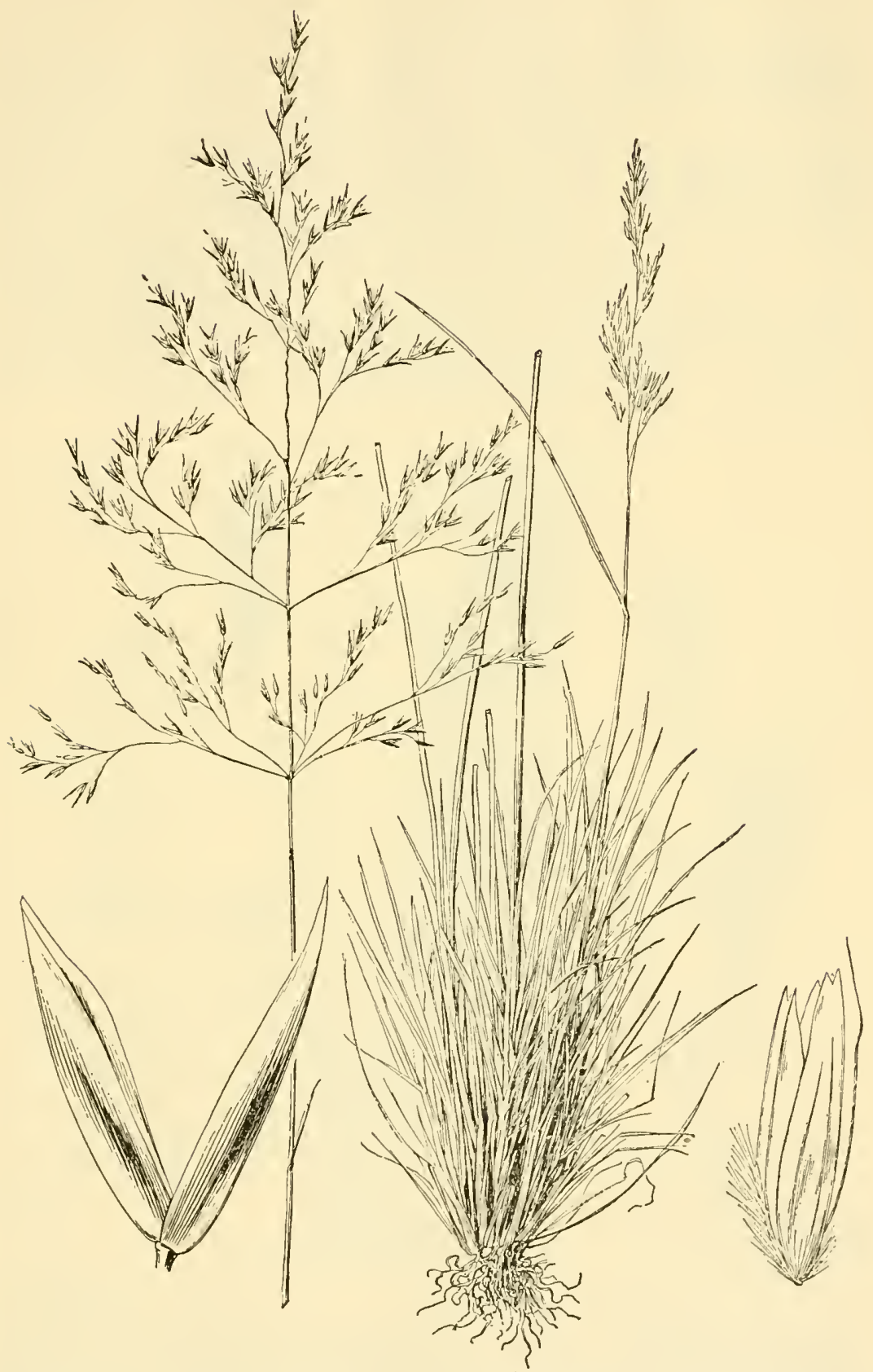

Figure 576. -Deschampsia caespitosa. Plant, $\times 1 / 2$; glumes and floret, $\times 5$. (Nelson 3623, Wyo.) 


\section{AÎRA L.}

\section{(Aspris Adans.)}

Spikelets 2-flowered, disarticulating above the glumes, the rachilla not prolonged; glumes boatshaped, about equal, 1-nerved or obscurely 3-nerved, acute, membranaceous or subscarious;

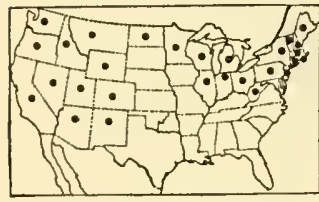

FIGURE 577.-Distribution of Deschampsia caespitosa. lemmas firm, rounded on the back, tapering into 2 slender teeth, bearing on the back below the middle a slender geniculate twisted usually exserted awn, this sometimes wanting in the lower floret or reduced; callus minutely bearded. Delicate annuals with lax, subfiliform blades and open or contracted panicles of small spikelets. Type species, Aira praecox. Aira, an old Greek name for a weed, probably darnel. Weedy grasses of no economic importance, introduced from Europe.

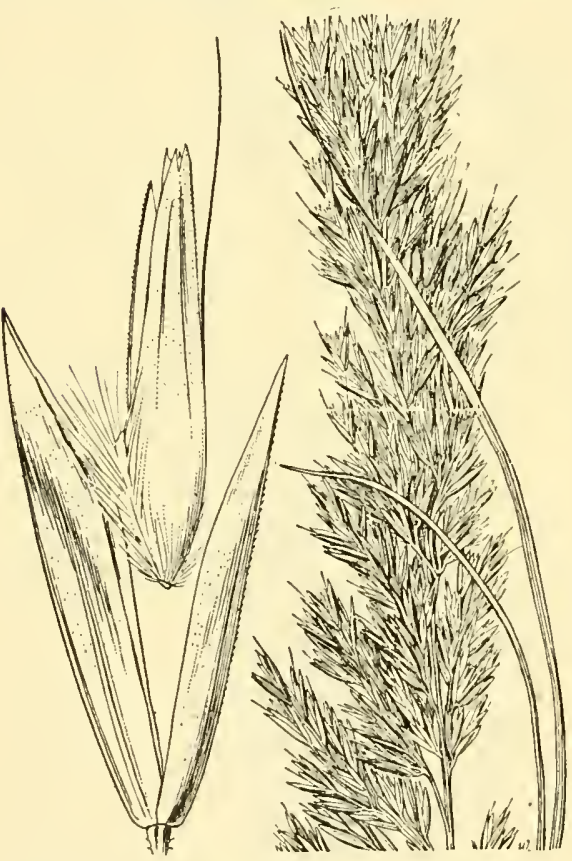

Figure 578--Deschampsia holciformis. Panicle, $\times 1$ glumes and floret, $\times 5$. (Bolander, Calif.)

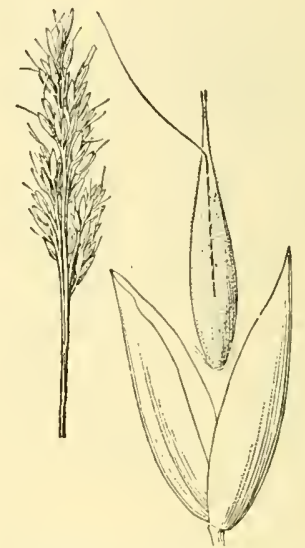

Figure 579.-Aira praecox. Panicle, $\times 1$; glumes and floret, $\times$ 5. (Amer. Gr. Nat. Herb. 375, Del.)

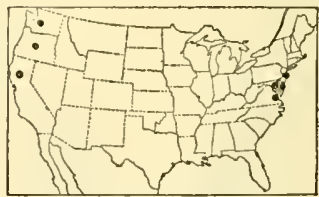

FIGURE 580.-Distribution of Aira praecox.

1. A. PRAECox.

Panicle dense, spikelike

Panicle open.

Lower floret with awn as long as that of the upper floret

2. A. CARYOPHYLLEA.

Lower floret awnless or nearly so

1. Aira praécox L. (Fig. 579.) Culms tufted, 10 to $20 \mathrm{~cm}$ tall, usually erect; panicle narrow, dense, 1 to $3 \mathrm{~cm}$ long; spikelets yellowish, shining, 3.5 to $4 \mathrm{~mm}$ long; lemmas with awns 2 to $4 \mathrm{~mm}$ long, that of the lower floret the shorter. $\odot-$ Sandy open ground, along the coast, New Jersey to Virginia; Vancouver to California (fig. 580). 
2. Aira caryophylléa L. Silver hairgrass. (Fig. 581.) Culms solitary or in small tufts, erect, 10 to $30 \mathrm{~cm}$ tall; panicle open, the silvery shining spikelets $3 \mathrm{~mm}$ long, clustered toward the ends of the

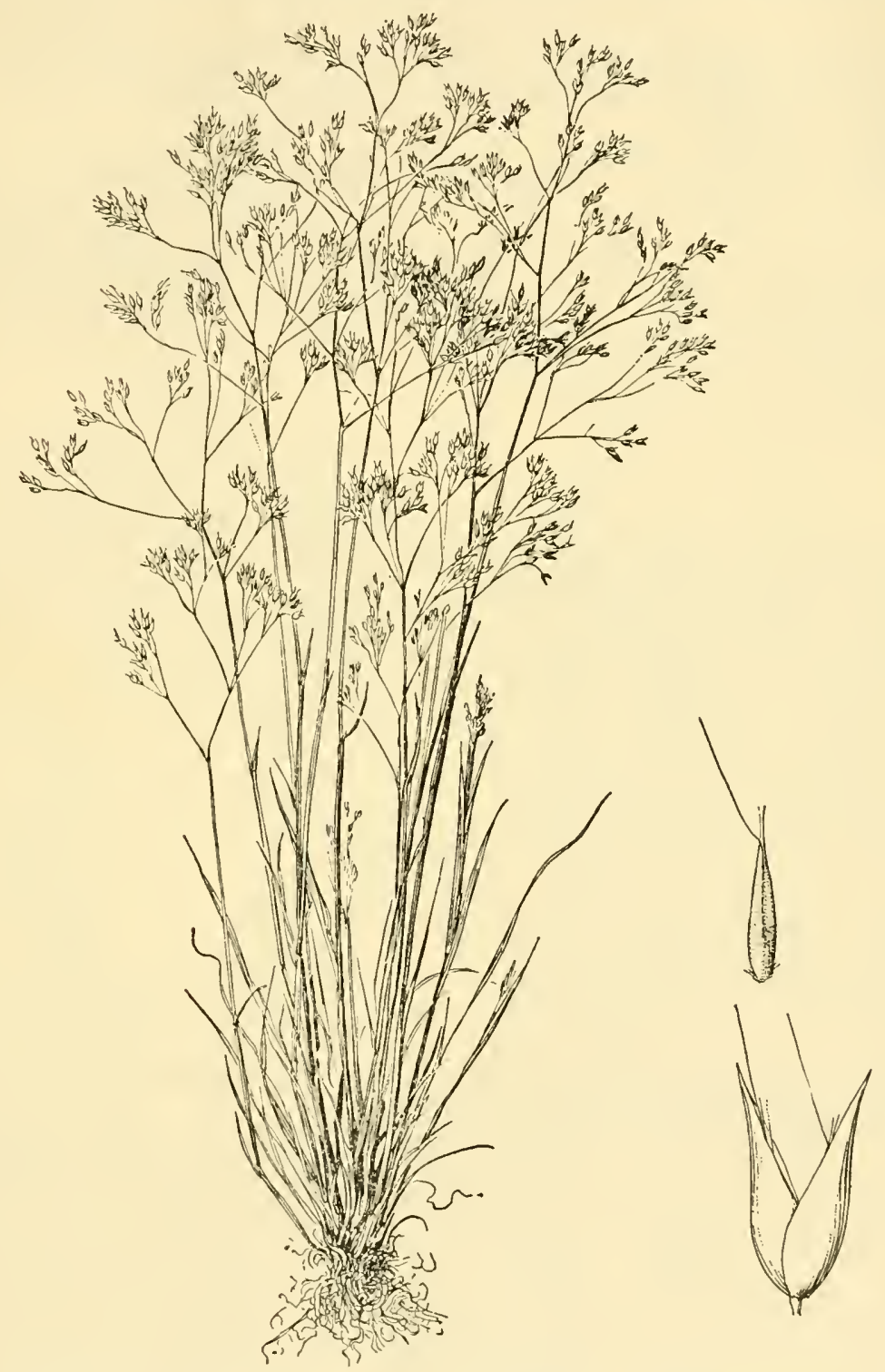

FIGUre 581.-Aira caryophyllea. Plant, $\times \frac{1}{2}$; spikelet and floret, $\times 10$. (Heller 3889, Wash.)

spreading capillary branches; both lemmas with awns about $4 \mathrm{~mm}$ long. $\odot-$ Open dry ground, Coastal Plain, Massachusetts to Florida and Louisiana; Ohio; common on the Pacific coast from British Columbia to California (fig. 582); southern South America. 
3. Aira capilláris Host. (Fig. 583.) Resembling A. caryophyllea; panicle more diffuse; spikelets $2.5 \mathrm{~mm}$ long, scattered at the ends of the branches; lemma of lower floret awnless or with a minute awn

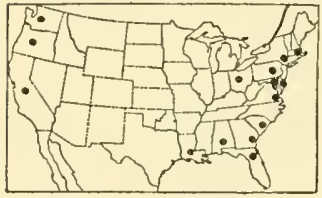

Figure 582.-Distribution of Aira caryophyllea. just below the apex, that of the upper floret with an awn $3 \mathrm{~mm}$ long. $\odot-$ Open ground, Coastal Plain, Maryland to Florida and Texas; Oregon and California, rare (fig. 584).

Corynéphorus canéscens (L.) Beauv. Low, tufted annual resembling Airacaryophyllea, with pale contracted panicle; lemmas membranaceous, the awns jointed about the middle, the joint with a minute ring of hairs, the lower part straight, brown, the upper slender, club-shaped. $\odot \quad$ (Weingaertneria canescens Bernh.)-Ballast at Philadelphia and Camden, N. J., on Marthas Vineyard, and on Long Island; adventive from Europe.

\section{AVENA L. OATS}

Spikelets 2 - to severalflowered, the rachilla bearded, disarticulating above the glumes and between the florets; glumes about equal, membranaceous or papery, mostly several-nerved, longer than the lower floret, usually exceeding the upper floret; lemmas indurate, except toward the summit, 5- to 9-nerved, bidentate at apex, bearing a dorsal bent and twisted awn (this straight and reduced in Avena sativa). Low or moderately tall annuals or perennials, with narrow or open, usually rather few-

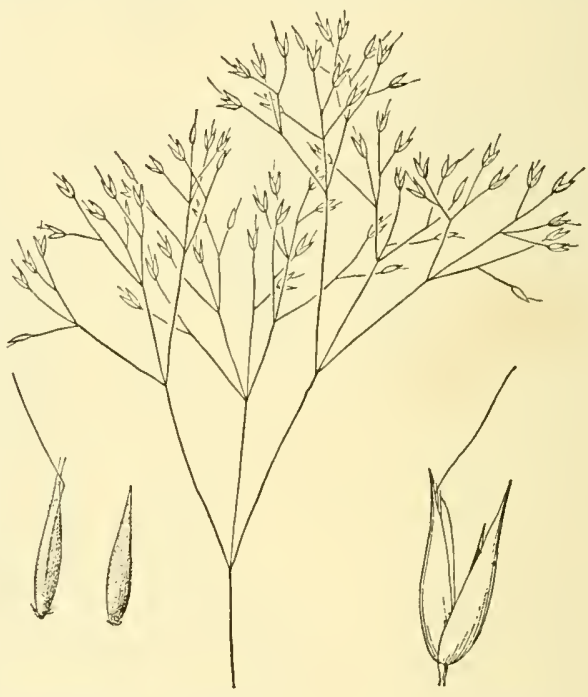

Figure 583.-Aira capillaris. Panicle, $\times 1$; spikelet and florets, $\times 5$. (Davis 2016, S. C.)

flowered panicles of usually large spikelets. Type species, Avena sativa. Avena, the old Latin name for oats.

The most important species of the genus is A. sativa, the familiar

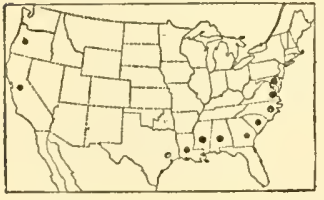

Figure 584.-Distribution of Aira capillaris. cultivated oat. Two other introduced species, $A$. fatua and $A$. barbata, are known as wild oats beeause of their close resemblance to the cultivated oat. These two species are common on the Pacific coast where they are weeds but are often utilized for hay. Much of the grain hay of that region is made from either cultivated or wild oats. The varieties of cultivated oat are derived from three species of Avena. The common varieties of this country and of temperate and mountain regions in general are derived from A. fatua. The Algerian oat grown in North Africa and Italy and the Lred oat of our Southern States 
(A. byzantina C. Koch) are derived from A. sterilis. A few varieties adapted to dry countries are derived from $A$. barbata. The two native species, found in the Rocky Mountain region, are of high palatability, but occur only scatteringly.

Plants annual.

Teeth of lemma setaceous; pedicels curved, capillary _.... 3. A. BARBata.

Teeth of lemma acute, not setaceous; pedicels stouter.

Spikelets mostly 2 -flowered, the florets not readily separating; awn usually straight or wanting; lemmas glabrous_............ 2. A. SATiva.

Spikelets mostly 3 -flowered, the florets readily separating; awn stout, geniculate, twisted; lemmas clothed with stiff brown hairs (hairs sometimes white or scant) _....... A. FATUA.

Plants perennial.

Blades involute; panicle 2 to $5 \mathrm{~cm}$ long

Blades flat or folded; panicle 5 to $15 \mathrm{~cm}$ long.

Sheaths, at least the lower, and blades pubescent_..... 4. A. pubescens.

Sheaths and blades glabrous_._._._._.

\section{Section 1. Euavéna Griseb.}

Annuals; spikelets pendulous, mostly more than $2 \mathrm{~cm}$ long. Introduced from Europe.

1. Avena fátua L. Wild oAt. (Fig. 585, A.) Culms 30 to 75 $\mathrm{cm}$ tall, erect, stout; leaves numerous, the blades flat, usually 4 to 8 $\mathrm{mm}$ wide, scabrous; panicle loose and open, the slender branches usually horizontally spreading; spikelets usually 3-flowered; glumes about $2.5 \mathrm{~cm}$ long; rachilla and lower part of the lemma clothed with long stiff brownish, or sometimes whitish, hairs, these sometimes scant; florets readily falling from the glumes; lemmas nerved above, about $2 \mathrm{~cm}$ long, the teeth acuminate, not setaceous; awn stout, geniculate, twisted below, 3 to $4 \mathrm{~cm}$ long. $\odot$-Cultivated soil and waste places; introduced from Europe; rare in the Eastern States; Maine to Pennsylvania, Missouri and westward, a common weed on the Pacific coast (fig. 586). Seed used for food by the Indians.

Avena stérilis L. Animated oats. Resembling $A$. fatua, the spikelets 3.5 to $4.5 \mathrm{~cm}$ long, the awns 5 to $7 \mathrm{~cm}$ long. $\odot$-Sometimes cultivated as a curiosity, occasionally spontaneous. When laid on a moist surface the fruits twist and untwist as the awns lose or absorb moisture.

2. Avena satíva L. OAт. (Fig. 585, B.) Differing from A. fatua in having mostly 2 -flowered spikelets, the florets not readily separating from the glumes; lemmas glabrous; awn usually straight, often wanting. - -Commonly cultivated and occasionally escaped. In A. nuda L., NA KED OAT, the caryopsis readily separates from the lemma and palea. A. brevis Roth is a form with smaller spikelets, the lemmas plunp, awned. A. strigosa Schreb. has a 1-sided panicle, the lemmas scabrous toward the apex, both florets awned.

3. Avena barbáta Brot. Slender oat. (Fig. 587.) Differing from A. fatua in the somewhat smaller, mostly 2-flowered spikelets on curved capillary pedicels; lemmas clothed with stiff red hairs, the teeth ending in fine points $4 \mathrm{~mm}$ long. $\odot-A$ common weed in fields and waste places, Washington, Oregon, to Arizona and California.

Cultivated oats fall into three groups according to the number of chromosomes. Group 1, 7 chromosomes, A. brevis, A. strigosa. Group 2, 14 chromosomes, $A$. barbata. Group 3, 21 chromosomes, $A$. 


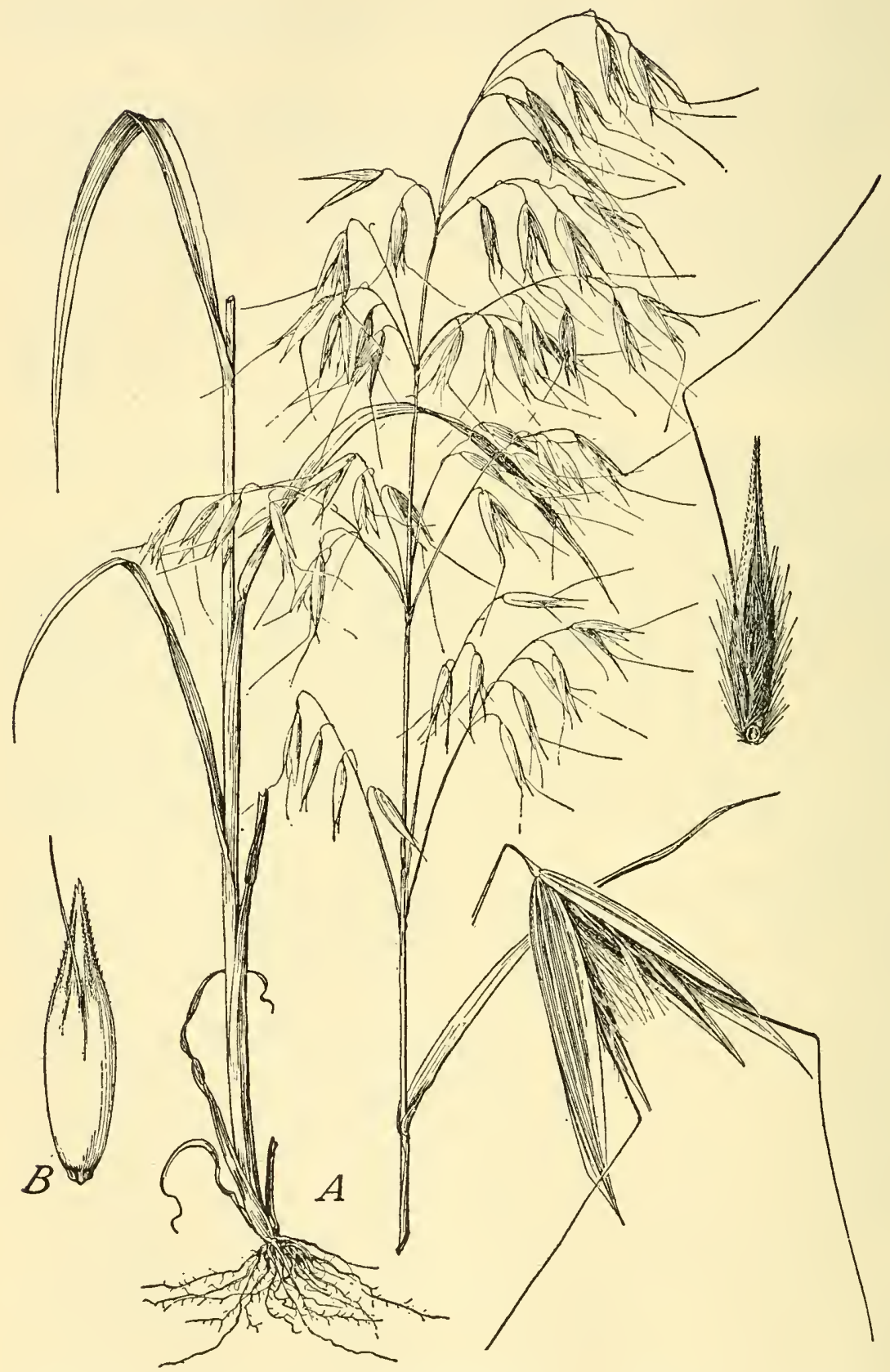

Figure 585. $-A$, Avena fatua. $\quad$ Plant, $\times \frac{1}{2}$; spikelet and floret, $\times 2$. (Umbach. Ill.) $\quad$ B, A. sativa, $\times 2$. (Deam, Ind.) 
sativa, A. fatua (including A. orientalis Schreb.), A. nuda, A. sterilis, $A$. byzantina (including $A$. sterilis var. algeriensis Trabut).

\section{Section 2. Avenástrum Koch}

Perennials; spikelets upright, mostly less than $2 \mathrm{~cm}$ long.

4. Avena pubéscens Huds. (Fig. 588.) Culms erect, 50 to $80 \mathrm{~cm}$ tall; sheaths pubescent; blades flat, pubescent; panicle narrow, open,

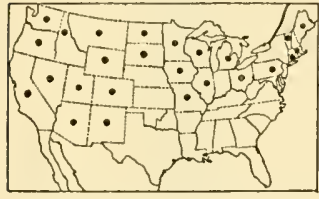

FiguRE 586.-Distribution of Avena fatua.

10 to $15 \mathrm{~cm}$ long, the flexuous branches ascending; spikelets mostly 3-flowered, 12 to $15 \mathrm{~mm}$ long, glumes and lemmas thin, shining, the rachilla with long white hairs; first glume 1- or 3 -nerved, the second 3-nerved; lemmas about $1 \mathrm{~cm}$ long; awn attached about the middle, 1.5 to $2 \mathrm{~cm}$ long. 24 -Waste places, Connecticut and Vermont; introduced from Europe.

5. Avena hookéri Scribn. Spike oat. (Fig. 589.) Culms densely tufted, 20 to $40 \mathrm{~cm}$ tall; blades firm, flat or folded, 1 to $3 \mathrm{~mm}$ wide, the margins somewhat thickened; panicle long-exserted, narrow, 5 to $10 \mathrm{~cm}$ long, the branches erect or ascending, 1-flowered, or the lower 2-flowered; spikelets 3- to 6-flowered, about $1.5 \mathrm{~cm}$ long; glumes very thin, slightly shorter than the spikelet; lemmas firm, brown, scaberulous, 1 to $1.2 \mathrm{~cm}$ long, the callus short-bearded, the rachilla joint white-villous; awn 1 to $1.5 \mathrm{~cm}$ long. 24 -Dry slopes and prairies, Manitoba to Alberta, Montana, and New Mexico (fig. 590).

6. Avena mortoniána Scribn. Alpine oat. (Fig. 591.) Culms densely tufted, 10 to $20 \mathrm{~cm}$ tall; blades erect, firm, usually involute;
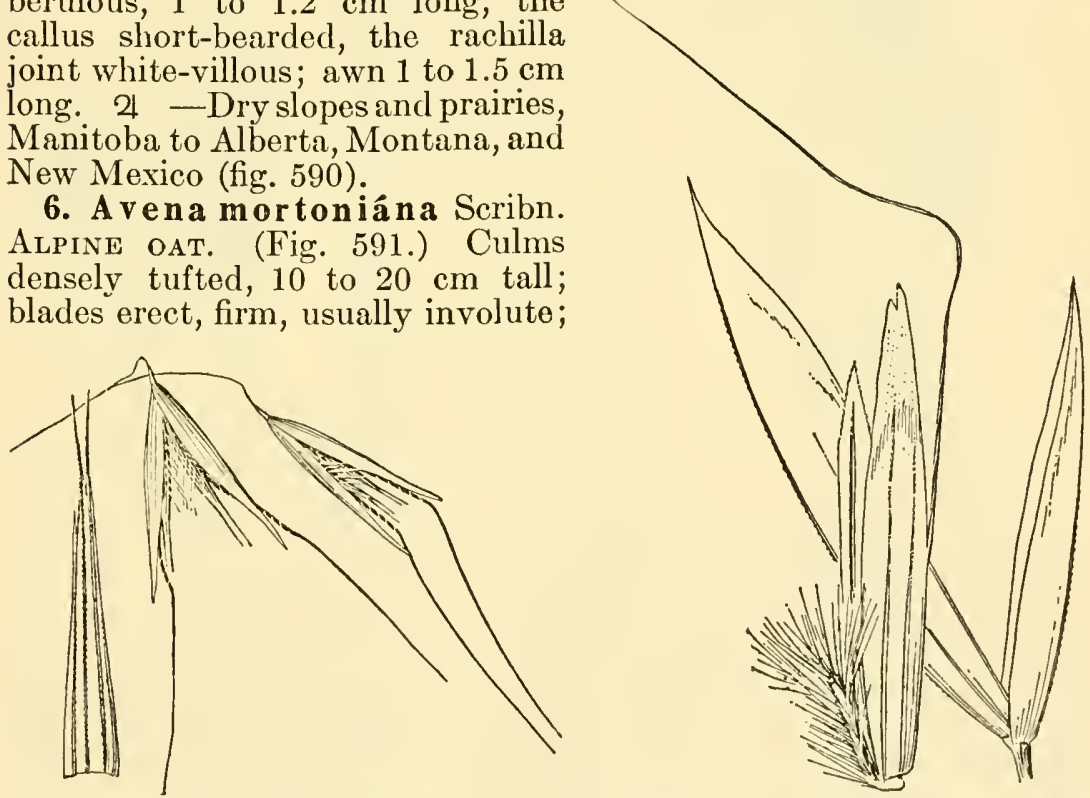

FigURE 587.-Avena barbata. Spikelets, $\times 1$; tip of Figure 588.-Avena pubescens. Glumes and floret lemma, $\times 5 . \quad$ (Davy 5023, Calif.) $\times$ 5. (Weatherby and Harger 4249 , Conn.)

panicle short-exserted, purplish, narrow, 2 to $5 \mathrm{~cm}$ long, the short branches erect, bearing usually a single spikelet, 10 to $12 \mathrm{~mm}$ long, mostly 2-flowered; glumes exceeding the florets; lemmas firm, glabrous, the apex with 4 soft teeth, the callus with a tuft of stiff hairs about $2 \mathrm{~mm}$ long, the rachilla long-villous; awn 1 to $1.5 \mathrm{~cm}$ long. 2 -Alpine meadows, Colorado, Utah, and New Mexico. 


\section{ARRHENÁTHERUM Beauv.}

Spikelets 2-flowered, the lower floret staminate, the upper perfect, the rachilla disarticulating above the glumes and produced beyond the florets; glumes

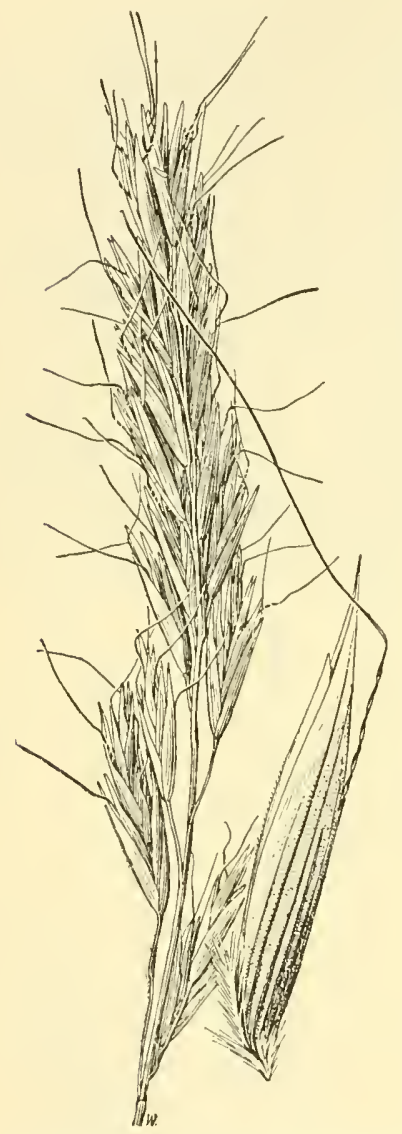

FIgure 589-Avena hooketi. Panicle, $\times 1$; floret, $\times 5$. (Scribner 372 , Mont.)

rather broad and papery, the first 1 nerved, the second a little longer than the first and about as long as the spikelet, 3-nerved; lemmas 5-nerved, hairy

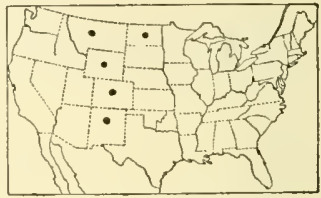

Figure 590.-Distribution of Avena hookeri.

on the callus, the lower bearing near the base a twisted, geniculate, exserted awn, the upper bearing a short straight slender awn just below the tip. Rather tall perennials, with flat blades and narrow panicles. Type species, Arrhenatherum avenaceum Beauv. (A. elatius). Name from Greek arren, masculine, and ather, awn, referring to the awned staminate floret.

1. Arrhenatherum elátius (L.) Mert. and Koch. TALL OATGRASS. (Fig. $592, A$.) Culms erect, 1 to $1.5 \mathrm{~m}$ tall; blades flat, scabrous, 5 to $10 \mathrm{~mm}$ wide; panicle pale or purplish, shining, 15 to 30 cm long, the short branches verticillate, spreading in

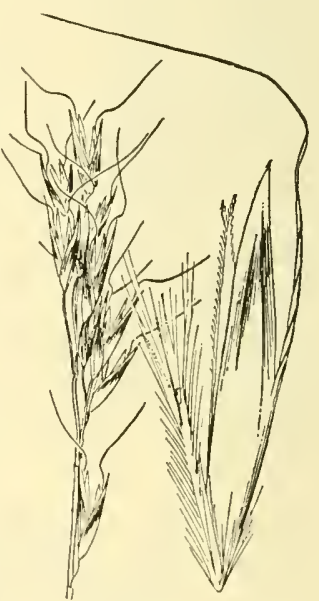

Figure 591--Avena mortoniana. Panicle, $\times 1$; floret, $\times 5 . \quad$ (Type.) anthesis, usually

spikelet-bearing from the base; spikelets 7 to $8 \mathrm{~mm}$ long; glumes minutely scabrous; lemmas scabrous, the awn of the staminate floret about twice as long as its lemma. 24 -Meadows, open ground, and waste places, Newfoundland to British Columbia, south to Georgia, Tennessee, Iowa, Idaho, and California; frequent in the Northern and Eastern States; introduced from Europe and escaped from cultivation. Cultivated in the northern humid regions as a meadow grass.

Arrhenatherum elatius var. Bulbósum (Willd.) Spenner. Tuber oatgrass. (Fig. 592, B.) Base of culm consisting of a series of closely approximate corms (shrot subglobose internodes) 5 to $10 \mathrm{~mm}$ in diameter. 2 -Occasionally introduced, Michigan, Virginia to Alabama. Europe. 


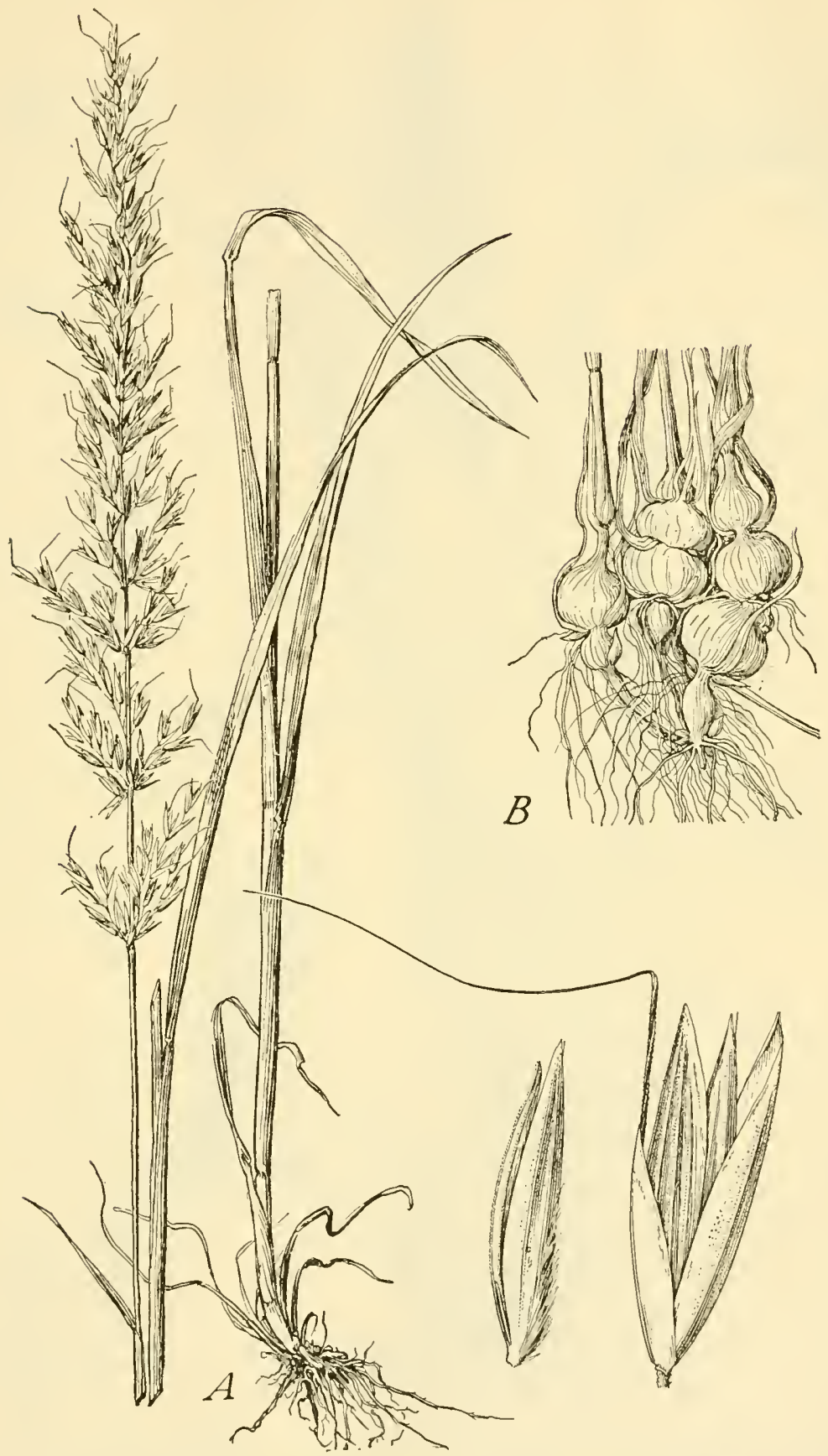

Figure 592. $-A$, Arrhenatherum elatius. Plant, $\times 1 / 2$; spikelot and upper floret, $\times 5$. (McDonald 46, 111.) $B$, Var. Gulbosum. Basal corms, $\times 1$. (Harper, Ala.) 


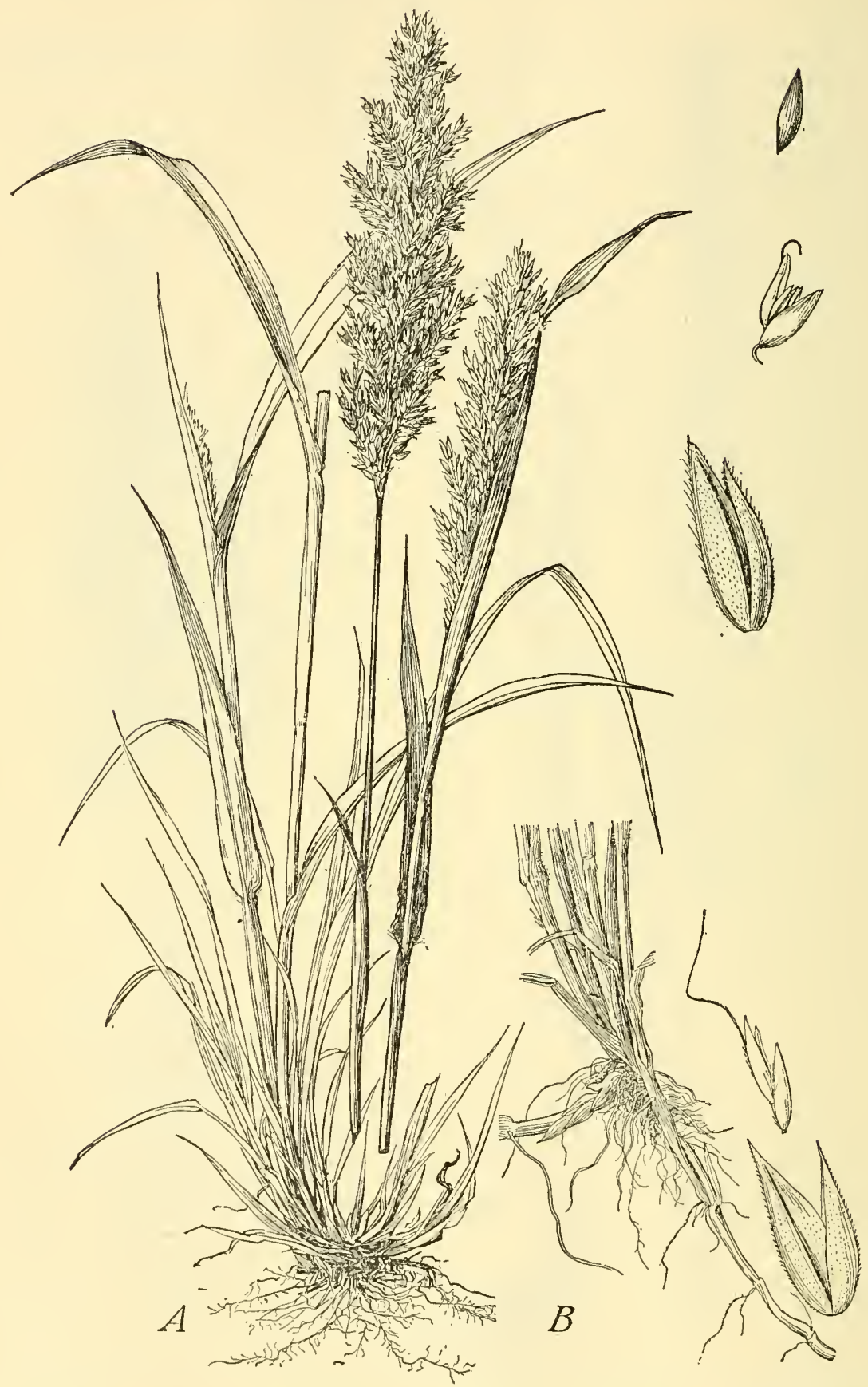

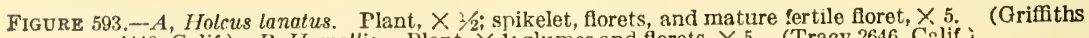
4449 , Calif.) $B, H$. mollis. Plant, $\times 1$; glumes and florets, $\times 5$. (Tracy 2646, Colif.j 


\section{HOLCUS L.}

\section{(Notholcus Nash)}

Spikelets 2-flowered, the pedicel disarticulating below the g]umes, the rachilla curved and somewhat elongate below the first floret, not prolonged above the second floret; glumes about equal, longer than the 2 florets; first floret perfect, the lemma awnless; second floret staminate, the lemma bearing on the back a short awn. Perennials with flat blades and contracted panicles. Standard species, Holcus lanatus. Holcus, an old Latin name for a kind of grain.

Rhizomes wanting ............................... H. LANATus. Rhizomes present

2. H. MOLLIS.

1. Holcus lanátus L. Velvet grass. (Fig. 593, A.) Plant grayish, velvety-pubescent; culms erect, 30 to $60 \mathrm{~cm}$ tall; blades 4 to 8 $\mathrm{mm}$ wide; panicles 8 to $15 \mathrm{~cm}$ long, contracted, pale, purple-tinged; spikelets $4 \mathrm{~mm}$ long; glumes villous, hirsute on the nerves, the second broader than the first, 3-nerved; lemmas smooth and shining, the awn of the second hooklike. 24 -Open ground, meadows, and

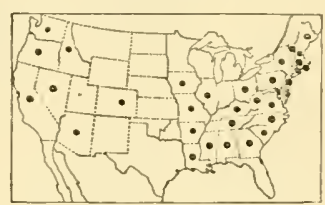

FIgURE 594.-Distribution of Holcus lanatus. moist places, Maine to Iowa, south to Georgia and Louisiana; common on the Pacific coast, British Columbia, and Idaho to Arizona and California (fig. 594); introduced from Europe; occasionally cultivated as a meadow grass on light or sandy land.

2. Holcus móllis L. (Fig. 593, B.) Culms glabrous, 50 to $100 \mathrm{~cm}$ tall, with vigorous slender rhizomes; sheaths, except the lower, glabrous; blades villous or velvety, 4 to $10 \mathrm{~mm}$ wide; panicle ovate or oblong, rather loose, 6 to $10 \mathrm{~cm}$ long; spikelets 4 to $5 \mathrm{~mm}$ long; glumes glabrous; awn of the second floret geniculate, exserted, about $3 \mathrm{~mm}$ long. 2 -Damp places, recently introduced from Europe and apparently spreading, Washington to California; Lewis County, N. Y.; ballast, Camden, N. J. (fig. 595).

\section{DANTHONIA Lam. and DC. OAtgRASS}

Spikelets several-flowered, the rachilla readily disarticulating above the glumes and between the florets; glumes about equal, broad,

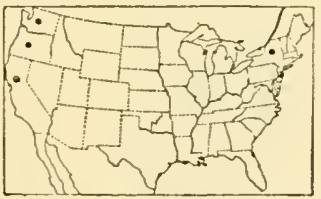

F1cure 585.-Distribution of Ilolcus mollis. papery, acute, mostly exceeding the uppermost floret; lemmas rounded on the back, obscurely several-nerved, the apex bifid, the lobes acute, usually extending into slender awns, a stout flat, twisted, geniculate awn arising from between the lobes. Tufted low or moderately tall perennials, with few-flowered open or spikelilse panicles of rather large spikelets. All our species produce cleistogenes (enlarged fertile, 1- or 2-flowered, cleistogamous spikelets) in the lower sheaths, the culms finally disarticulating at the lower nodes. Type species, Danthonia spicata. Named for Etienne Danthoine.

The species are found in grassland and contribute somewhat toward the forage value of the range but usually are not abundant. In California D. californica is considered a nutritious grass; $D$. compressa is important in the mountains of North Carolina and Tennessee.

\footnotetext{
7 CHASE, A. AXILlary Cleistogexes IN SOME AMERICAN grasses. Amer. Journ. Bot. 5: 254. 1918.
} 

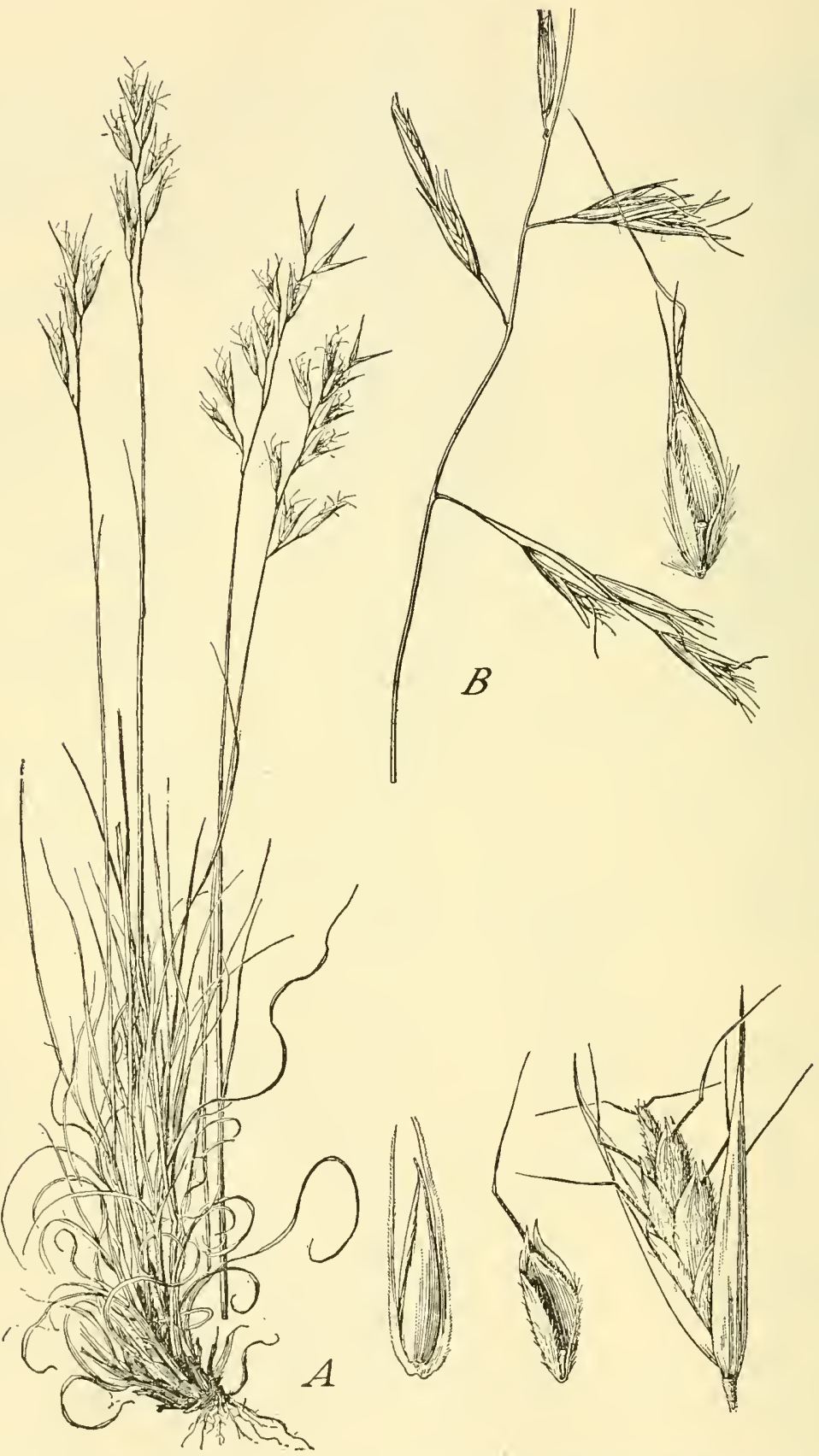

Figure 596. $-A$, Danthonia spicata. Plant, $\times 1 / 2$; spikelet, floret, and cleistogene, $\times 5$. (Gayle 787, Maine.) $B, D$. compressa. Panicle, $\times 1$; floret, $\times 5$. (Hitcheock 103, Tenn.) 
Lemmas glabrous on the back, pilose on the margin only.

Panicle narrow, the pedicels appressed .............

Panicle open, the slender pedicels spreading or reflexed.

Panicle usually of a single spikelet. . ............

Panicle of 2 to several spikelets

4. D. INTERMEDia.

7. D. UNISPICATA.

Lemmas pilose on the back, sometimes sparsely so.

Glumes mostly 20 to $22 \mathrm{~mm}$ long

Glumes 10 to $17 \mathrm{~mm}$ long.

Sheaths pilose, (rarely glabrous); glumes 12 to $17 \mathrm{~mm}$ long. Culms 50 to $100 \mathrm{~cm}$ tall $\ldots$

Sheaths glabrous or nearly so; glumes rarely more than $15 \mathrm{~mm}$ long.

Panicle simple or nearly so, usually contracted after anthesis; blades rarely more than $15 \mathrm{~cm}$ long, commonly less......... 1. D. SPICATA.

Panicle usually compound and somewhat open; blades or some of them more than $15 \mathrm{~cm}$, of ten as much as $25 \mathrm{~cm}$ long _. 2. D. COMPREssa.

1. Danthonia spicáta (L.) Beauv. Poverty oatgrass. (Fig. $596, A$.) Culms 20 to $70 \mathrm{~cm}$ tall, mostly not more than $50 \mathrm{~cm}$, slender, terete; leaves numerous in a basal cluster, the blades usually curled or flexuous; sheaths glabrous or sparsely pilose, with a tuft of long hairs in the throat; blades usually not more than $12 \mathrm{~cm}$ long, filiform to $2 \mathrm{~mm}$ wide, occasionally a few blades 15 to $20 \mathrm{~cm}$ long, subinvolute or in damp weather flat, glabrous or sparsely pilose; panicle 2 to 5 cm long, rarely longer, the stiff short branches bearing a single spikelet,

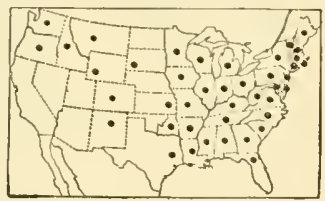

Figure 597.-Distribution of Danthonia spicata. or the lower longer with 2 (rarely 3 or 4), usually erect after anthesis; glumes 10 to $12 \mathrm{~mm}$ long (rarely longer); lemmas 4 to $5 \mathrm{~mm}$ long, sparsely villous except the 2 -toothed summit, the teeth acuminate to subsetaceous; terminal segment of awn about $5 \mathrm{~mm}$ long; palea broad, flat, obtuse, ciliolate, reaching to the base of the awn. 24 -Dry and sterile or rocky soil, Newfoundland to British Columbia, south to Florida, eastern Texas, and eastern Kansas, in the mountains to New Mexico and Oregon (fig. 597). Variable; tall specimens with longer blades and setaceous teeth resemble $D$. compressa. A rather

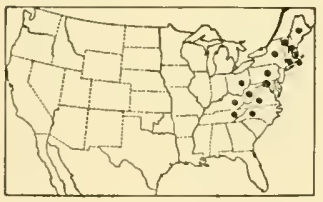

Figure 598,-Distribution of Danthonia compressa. stiff western form with subsetaceous teeth has been described as D.thermale Scribn.

2. Danthonia compréssa Austin. (Fig. 596, $B$.$) Culms on the average stouter and taller$ than in D. spicata, compressed, rather loosely tufted, sometimes decumbent or with short rhizomes, 40 to $80 \mathrm{~cm}$ tall; sheaths reddish above the nodes, glabrous, or sparsely pubescent on the collar, a conspicuous tuft of white hairs in the throat; blades elongate, some of them commonly 20 to $25 \mathrm{~cm}$ long, 2 to $3 \mathrm{~mm}$ wide, usually flat, sometimes involute and subfiliform, seabrous; panicle 5 to $8 \mathrm{~cm}$ long (rarely to $10 \mathrm{~cm}$ ), the slender branches bearing 2 or 3 spikelets, contracted after anthesis but looser than in $D$. spicata; glumes 10 to $14 \mathrm{~mm}$ (usually about $12 \mathrm{~mm}$ ) long; lemma and palea as in D. spicata but the teeth of the lemma aristate, 2 to $3 \mathrm{~mm}$ long. 24 -Meadows, and open woods, Nova Scotia to Quebec, south to the mountains of North Carolina (fig 598). Appears to intergrade with $D$. spicata.

3. Danthonia serícea Nutt. Downy oAtgrass. (Fig. 599.) Culms erect, densely tufted, 50 to $100 \mathrm{~cm}$ tall; sheaths, especially the lower, villous (rarely glabrous); blades 10 to $25 \mathrm{~cm}$ long, 2 to $4 \mathrm{~mm}$ 
wide, those of the innovations mostly involute, those of the culm mostly flat; panicle 5 to $10 \mathrm{~cm}$ long, relatively many-flowered, the branches bearing 2 to 6 spikelets, rather open or contracted after

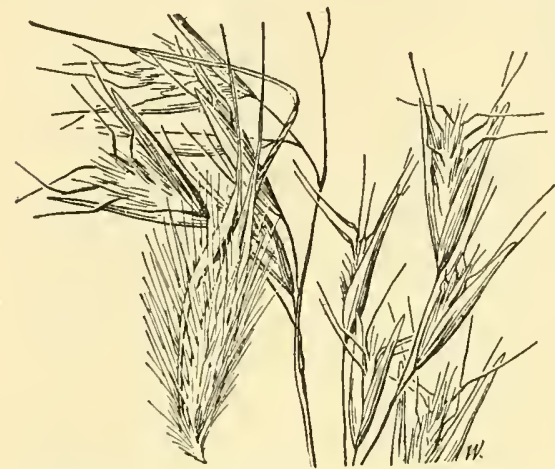

Figure 599.-Danthonia sericea. Panicle, $\times 1$; floret, $\times$ 5. (Kearney 1219, Va.)

anthesis; glumes 12 to $17 \mathrm{~mm}$ long; lemmas densely long-pilose especially along the margin, about $10 \mathrm{~mm}$ long, including the slender aristate teeth, the teeth about half the entire length; palea concave, narrowed toward the 2toothed apex. 2! - Sand barrens, chiefly Coastal Plain, Massachusetts (Sherborn); New Jersey to northern Florida, Tennessee, and Louisiana (fig. 600). A rare form with glabrous foliage has been called $D$. epilis Scribn. (D. glabra Nash, not Phil.) Virginia to Georgia.

4. Danthonia intermédia Vasey. Trmber oatgrass. (Fig. 601.) Culms 10 to $50 \mathrm{~cm}$ tall; sheaths glabrous (the lower rarely pilose) with long hairs in the throat; blades subinvolute, or those of the culm flat, glabrous or sparsely pilose; panicle purplish, narrow, few-flowered, 2 to $5 \mathrm{~cm}$ long, the branches appressed, bearing a single spikelet; glumes about $15 \mathrm{~mm}$ long; lemmas 7 to $8 \mathrm{~mm}$ long, appressed-pilose along the margin below and on the callus, the summit scaberulous, the teeth acuminate, aristatetipped; terminal segment of awn 5 to 8 $\mathrm{mm}$ long; palea narrowed above, notched at the apex. 2 -Meadows and bogs, northern and alpine regions. Newfound-

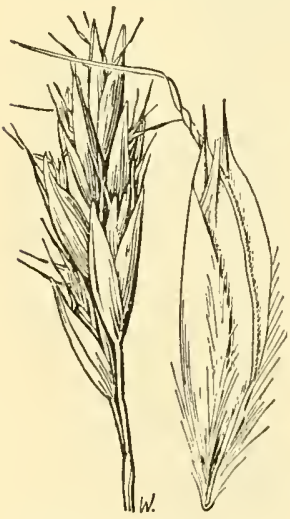

Figure 601.-Danthonia intermedia. Panicle, ' $\times 1$. floret, $\times 5$. (Hitchcock 11288, Mont.)

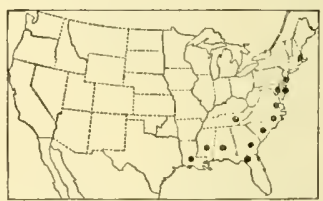

Figure 600.-Distribution of Danthonia sericea. land and Quebec to Alaska, south to northern Michigan, New Mexico, and California (fig. 602).

5. Danthonia párryi Scribn. Parry oatgrass. (Fig. 603.) Culms rather stout, in tough clumps, 30 to $60 \mathrm{~cm}$ tall, somewhat enlarged at base from the numerous overlapping firm persistent sheaths; sheaths glabrous, somewhat pilose at the throat, a glabrous or pubescent line or ridge on the collar, the lower blades falling from the sheaths; blades erect-flexuous, most-

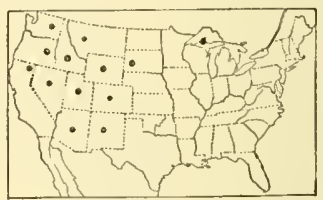

Figure 602.-Distribution of Danthonia intermedia.

ly 15 to $25 \mathrm{~cm}$ long, narrow or filiform, flat or involute, glabrous; panicle 3 to $7 \mathrm{~cm}$ long, usually with 3 to 8 spikelets, the branches more or less pubescent, ascending or appressed, the lowermost 1 to $2 \mathrm{~cm}$ long, with 1 or 2 spikelets; glumes 20 to $22 \mathrm{~mm}$ long, rarely less; lemmas about $1 \mathrm{~cm}$ long, rather densely to sparsely pilose over the back, strongly pilose on the callus at the sides, the rachilla glabrous, the teeth more or less aristate; 
terminal segment of awn 8 to $12 \mathrm{~mm}$ long; palea narrowed above, nearly as long as the lemma, 2-toothed. 24 -Open grassland, open woods, and rocky slopes, in the mountains, mostly below timber line, Alberta to New Mexico (fig. 604).

6. Danthonia califórnica Boland. California oatgrass. (Fig. 605.) Culms 30 to $80 \mathrm{~cm}$ tall, glabrous, tending to disarticulate at the nodes; sheaths glabrous, pilose at the throat; blades mostly 10 to $20 \mathrm{~cm}$ long, flat or, especially those of the

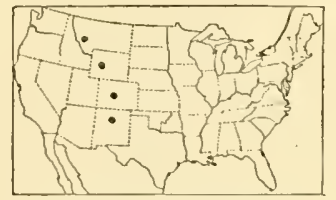

FIgURE 604.-Distribution of Danthonia parryi.

innovations, involute, glabrous; panicle bearing mostly 2 to 5 spikelets, the pedicels slender, spreading or somewhat reflexed, more or less flexuous, 1 to $2 \mathrm{~cm}$ long, a rather prominent pulvinus at the base of each; glumes 15 to $20 \mathrm{~mm}$ long (rarely less or more); lemmas, ex-

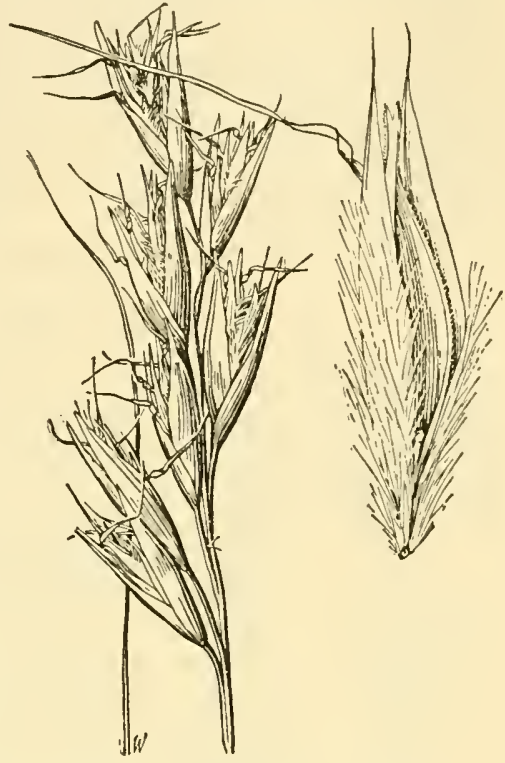

FIGURE 603.-Danthonia parryi. Panicle, $\times 1$; floret, $\times$ 5. (Hitcheock 10987, Colo.) cluding awns, 8 to $10 \mathrm{~mm}$ long, pilose on the lower part of the margin and on the callus, otherwise glabrous, the teeth long-aristate; terminal segment of awn 5 to $10 \mathrm{~mm}$ long; palea subacute, usually

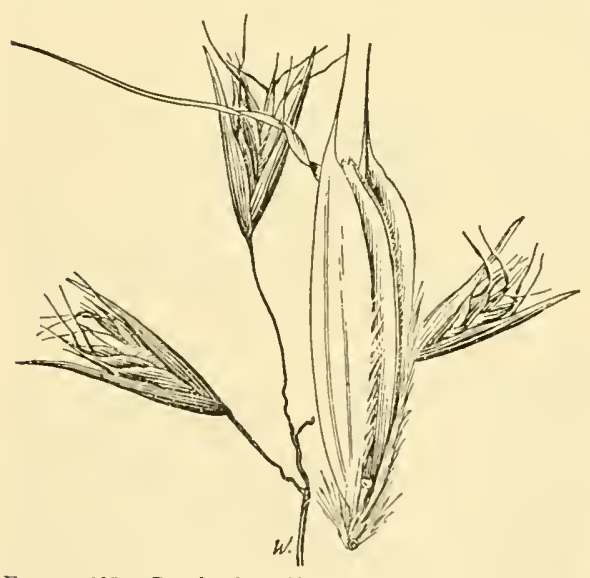

Figure 605,-Denthonia californica. Panicle, $\times 1$; floret, $\times 5$. (Eastwood 27, Calif.) extending beyond base of awn. 2 -Meadows and open woods, Montana to British Columbia, south to Colorado and California (fig. 606).

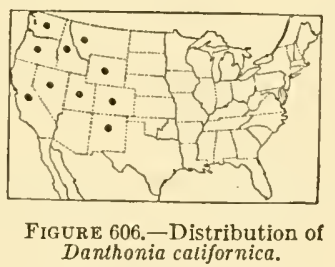

Danthonia CALIFornica var. AMERICÁNA (Scribn.) Hitche. Culms on the average shorter, the tufts usually more spreading; foliage sparsely to conspicuously spreading-pilose; spikelets on the average smaller, but large plants with large spikelets occur, with conspicuously pilose foliage. 24 -Montana and Wyoming to British Columbia, south to California; Chile. D. macounii Hitchc. appears to belong here, differing in 
having lemmas sparsely pilose on the back. Known only from Nanaimo, Vancouver Island (Macoun 78825).

7. Danthonia unispicáta Munro. One-spike oAtgrass. (Fig. 607.) Culms 15 to $25 \mathrm{~cm}$ tall, in dense spreading tufts; sheaths and blades pilose, the hairs on the sheaths spreading or reflexed; panicle reduced to a single spikelet or sometimes 2 , rarely 3 , spikelets, the lower spikelets usually reduced, their pedicels appressed or ascending, the long pedicel of the terminal spikelet jointed with the culm; spikelets on the average smaller than in D. californica. 2 -Open or rocky ground, Montana to British Columbia, south to Wyoming and California (fig. 608).

\section{TRIBE 5. AGROSTIDEAE}

\section{CALAMAGRÓS'TIS Adans. Reedgrass}

Spikelets 1-flowered, the rachilla disarticulating above the glumes, prolonged behind the palea (in our species, except Calamagrostis epigeios) as a short, commonly hairy bristle; glumes about equal, acute or acuminate; lemma shorter and usually more delicate than the glumes, usually 5 -nerved, the midnerve exserted as an awn, the callus bearing a tuft of hairs, these often

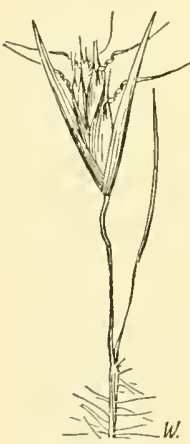

Figure 607.-Danthonia unispicata, $\times \quad 5 . \quad(\mathrm{D}$ av y copious and as long as the lemma. Perennial, usually moderately tall grasses, mostly with creeping rhizomes, with small spikelets in open or usually narrow, sometimes spikelike panicles. Type species, Arundo calamagrostis L. Name from Greek kalamos, a reed,

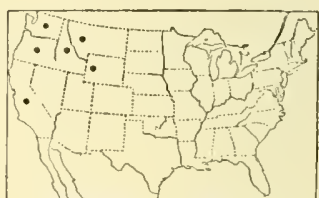

Figure 608.-Distribution of Danthonia unispicata. and agrostis, a kind of grass, the type species being a reedy grass. Our species (except C.epigeios) belong to the Section Deyeuxia, in which the rachilla is prolonged. In Section Epigeios, of the Old World, the rachilla is not prolonged.

Several species are important native forage grasses. Pinegrass, C. rubescens, is a leading range grass in the mountains of Oregon and Washington. Bluejoint, $C$. canadensis, is a source of much of the wild hay of Wisconsin and Minnesota. On the plains and bench lands of Wyoming and northward, C. montanensis furnishes forage, especially when young. In low wet lands of the Northern States $C$. inexpansa is grazed especially by horses and cattle.

1a. Awn longer than the glumes, geniculate.

2a. Panicle open, the branches spreading, naked below.

Blades scattered, 5 to $9 \mathrm{~mm}$ broad, flat. Plant mostly more than $1 \mathrm{~m}$ tall _...

Blades mostly basal, mostly not more than $2 \mathrm{~mm}$ wide, of ten involute.

Awn about $1 \mathrm{~cm}$ long, much longer than the glumes; blades nearly or quite as long as the flowering culms _._._.

Awn only a little exceeding the glumes; blades much shorter than the culms, capillary, sulcate, folded _........... 3. C. BREWERI.

2b. Panicle compact, the branches appressed, floriferous from base.

Blades scattered, broad and flat, 6 to $10 \mathrm{~mm}$ wide_... 4 . C. TwEEDri.

Blades mostly basal, firm, narrow, becoming involute.

Glumes about $1 \mathrm{~cm}$ long, gradually long-acuminate; awn nearly $1 \mathrm{~cm}$ long above the bend ........ 5. C. Foliosa.

Glumes 6 to $8 \mathrm{~mm}$ long, abruptly acute or acuminate; awn usually less than $5 \mathrm{~mm}$ above the bend.......... 6. C. PURPURASCENS. 
1b. Awn included or scarcely longer than the glumes, straight or geniculate.

3a. Awn geniculate, protruding sidewise from the glumes; callus hairs rather sparse, shorter than the lemma. (See C. cainii, p. 993)

Blades narrow, soon involute; plants low, usually less than $30 \mathrm{~cm}$ tall, not tufted, rhizomatous. Panicle compact, spikelike_ 7. C. nontanensis.

Blades flat, drying involute at tip; plants usually tall.

Sheaths pubescent on the collar.

Callus hairs about one-third as long as lemma; western species.

8. C. RUBESCENS.

Callus hairs half to three-fourths as long as lemma; eastern species.

Palea about as long as the lemma _........... 9. C. PORTERI.

Palea three-fourths as long as the lemma_..... 10. C. PERplexa.

Sheaths glabrous on the collar.

Panicle loose, the branches spreading or ascending. Plants 1 to $1.5 \mathrm{~m}$ tall; blades as much as $1 \mathrm{~cm}$ wide....... 11 . C. NUTKaEnsis.

Panicle compact.

Culms stout, mostly more than $1 \mathrm{~m}$ tall_._._... 12. C. DENSA. Culms more slender, mostly less than $1 \mathrm{~m}$ tall.

Spikelets $5 \mathrm{~mm}$ long; lemma as long as the glumes; panicle spikelike

13. C. KOELERIOIDES.

Spikelets about $4 \mathrm{~mm}$ long; lemma shorter than the glumes; panicle scarcely spikelike, some of the branches naked below.

14. C. PICKERINGII.

3b. Awn straight (somewhat bent in C. epigeios and C. lactea), included; callus hairs usually not much shorter than the lemma.

Sheaths pubescent on the collar (see also C. inexpansa var. barbulata).

Sheaths glabrous on the collar.

15. C. SCRIBNERI.

Panicle rather loose and open.

Callus hairs copious, about as long as the lemma; awn delicate, straight _... C. CANADENS1s.

Callus hairs rather scant, about half as long as the lemma; awn stronger, weakly geniculate_._._._._. 17. C. LACTEA.

Panicle more or less contracted.

Blades flat, rather lax.

Awn attached near the base; rachilla not prolonged.

Awn attached at or about middle; rachilla prolonged.

Glumes scabrous; plant green_..._._. 18. C. Cinnoides.

Glumes nearly smooth; plant pale... 19. C. SCOPULORUM.

Blades involute or, if flat, rigid and becoming involute.

Blades broad and short, as much as $5 \mathrm{~mm}$ wide, nearly smooth.

Blades elongate, smooth or scabrous.

22. C. CRASSIGLUMis.

Blades firm, scabrous, rather rigid; ligule 4 to $6 \mathrm{~mm}$ long; panicle firm .......... C. INEXPANSA.

Blades rather lax, narrow; ligule 1 to $3 \mathrm{~mm}$ long; panicle rather soft _....... 21. C. NEGLECTA.

1. Calamagrostis bolandéri Thurb. (Fig. 609.) Culms erect, 1 to $1.5 \mathrm{~m}$ tall, with slender rhizomes; sheaths scabrous; ligule 4 to $5 \mathrm{~mm}$ long; blades flat, 5 to $9 \mathrm{~mm}$ wide, scattered, nearly smooth; panicle open, 10 to $20 \mathrm{~cm}$ long, the branches verticillate, spreading, naked below, the longer 5 to $10 \mathrm{~cm}$ long; glumes 3 to $4 \mathrm{~mm}$ long, purple, scabrous, acute; lemma very scabrous, about as long as the glumes, the awn from near the base, geniculate, exserted, about $2 \mathrm{~mm}$ long above the bend, the callus hairs short; rachilla pilose, 1 to $2 \mathrm{~mm}$ long. $2-$ Bogs and moist ground, prairie or open woods, near the coast, Mendocino and Humboldt Counties, Calif.

2. Calamagrostis howéllii Vasey. (Fig. 610.) Culms densely tufted, rather slender, ascending, 30 to $60 \mathrm{~cm}$ tall; sheaths smooth or slightly scabrous; ligule 2 to $8 \mathrm{~mm}$ long; blades slender, scabrous on the upper surface, flat or soon involute, especially toward the tip, about as long as the culms, the two cauline shorter, about $1 \mathrm{~mm}$ wide; 
panicle pyramidal, 5 to $15 \mathrm{~cm}$ long, rather open, the lower branches in whorls, ascending, naked below, 3 to $5 \mathrm{~cm}$ long; spikelets pale or tinged with purple; glumes acuminate, 6 to $7 \mathrm{~mm}$ long; lemma acuminate, a little shorter than the glumes, the awn attached about $2 \mathrm{~mm}$ above the base, geniculate, exserted about $1 \mathrm{~cm}$; callus hairs and those of the rachilla about half as long as the lemma. 24 -On perpendicular cliffs, vicinity of the Gap of the Columbia River.

3. Calamagrostis brewéri Thurb. Shorthair. (Fig. 611.) Culms densely tufted, slender, erect 15 to $30 \mathrm{~cm}$ tall; leaves mostly basal,

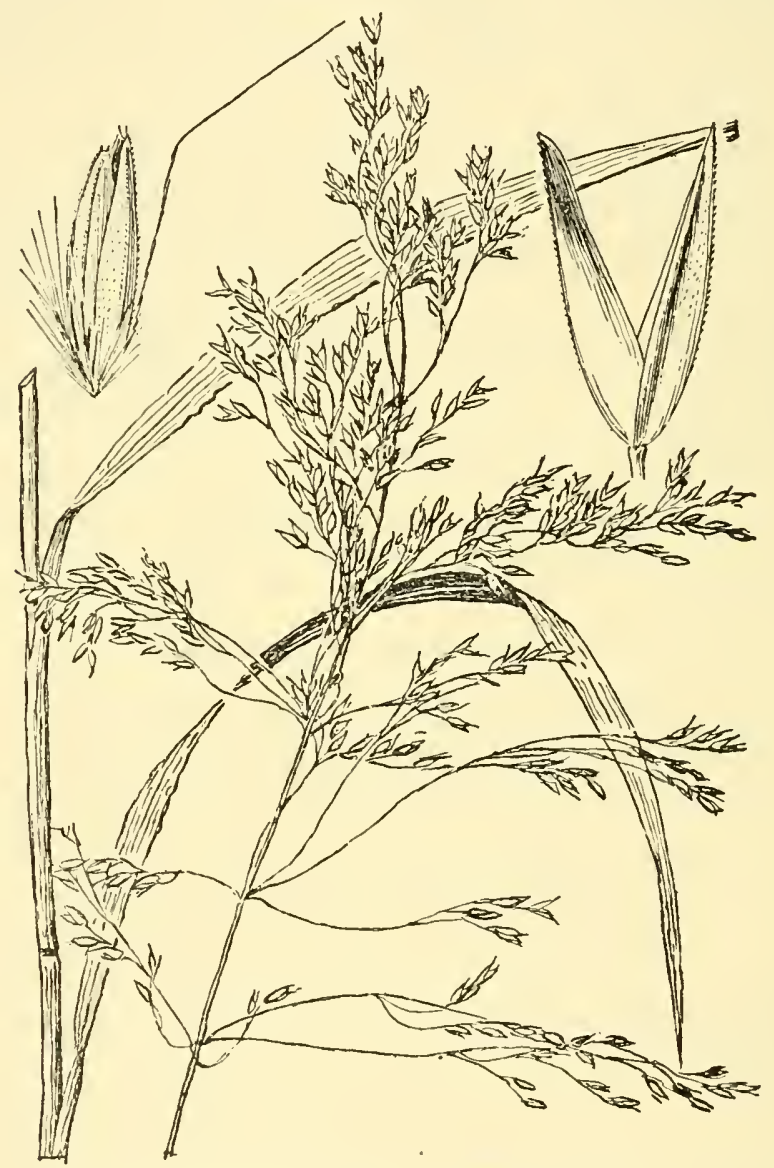

Figure 609.-Calamagrostis bolanderi. Panicle, $\times 1$; glumes and floret, $\times 10$. (Bolander, Calif.)

usually involute-filiform; panicle ovate, purple, 3 to $8 \mathrm{~cm}$ long, the lower branches slender, spreading, few-flowered, 1 to $2 \mathrm{~cm}$ long; glumes 3 to $4 \mathrm{~mm}$ long, smooth, acute; lemma nearly as long as glumes, cuspidate-toothed, the awn from near the base, geniculate, exserted, twisted below, about $2 \mathrm{~mm}$ long above the bend, the callus hairs short, scant; rachilla long-pilose, about half as long as the lemma. 24 -Mountain meadows of the high Sierra Nevada, Calif., where it is an important range grass. 
4. Calamagrostis tweédyi (Scribn.) Scribn. (Fig. 612.) Culms erect, 1 to $1.5 \mathrm{~m}$ tall, smooth, with short rhizomes; sheaths smooth, the lower becoming fibrous; blades flat, somewhat scabrous, the cauline 5 to $15 \mathrm{~cm}$ long, as much as $1 \mathrm{~cm}$ wide, those of the innovations narrower and longer; panicle oblong, rather compact, or interrupted below, about $10 \mathrm{~cm}$ long; glumes abruptly acuminate, purple-tinged, 6 to $7 \mathrm{~mm}$ long; lemma about as long as the glumes, the awn exserted about $5 \mathrm{~mm}$, the callus hairs scant, scarcely $1 \mathrm{~mm}$ long; rachilla

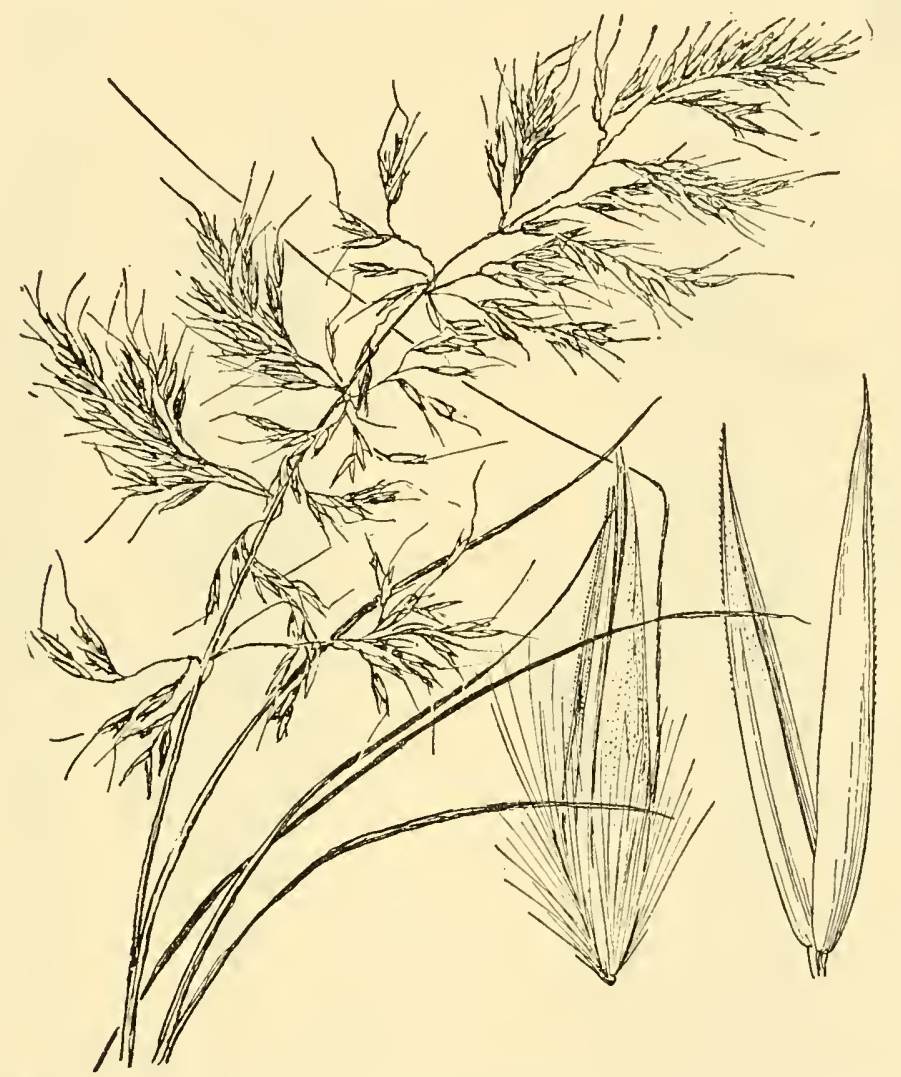

Figure 610.-Calamagrostis howellii. Panicle, $\times 1$; glumes and floret, $\times 10$. (Chase 4846, Oreg.)

pilose, $2 \mathrm{~mm}$ long. 21 -Known only from the type locality, the "Cascade Mountains, Washington."

5. Calamagrostis foliósa Kearney. (Fig. 613.) Culms tufted, erect, 30 to $60 \mathrm{~cm}$ tall; leaves numerous crowded toward the base, the sheaths overlapping, the blades involute, firm, smooth, nearly as long as the culm; panicle pale, dense, spikelike, 5 to $12 \mathrm{~cm}$ long; glumes about $1 \mathrm{~cm}$ long, acuminate; lemma 5 to $7 \mathrm{~mm}$ long, acuminate, the apex with 4 setaceous teeth, the awn from near base, geniculate, about $8 \mathrm{~mm}$ long above the bend, the callus hairs numerous, $3 \mathrm{~mm}$ long; rachilla pilose, nearly as long as lemma. 2 - Humboldt and Mendocino Counties, Calif. 


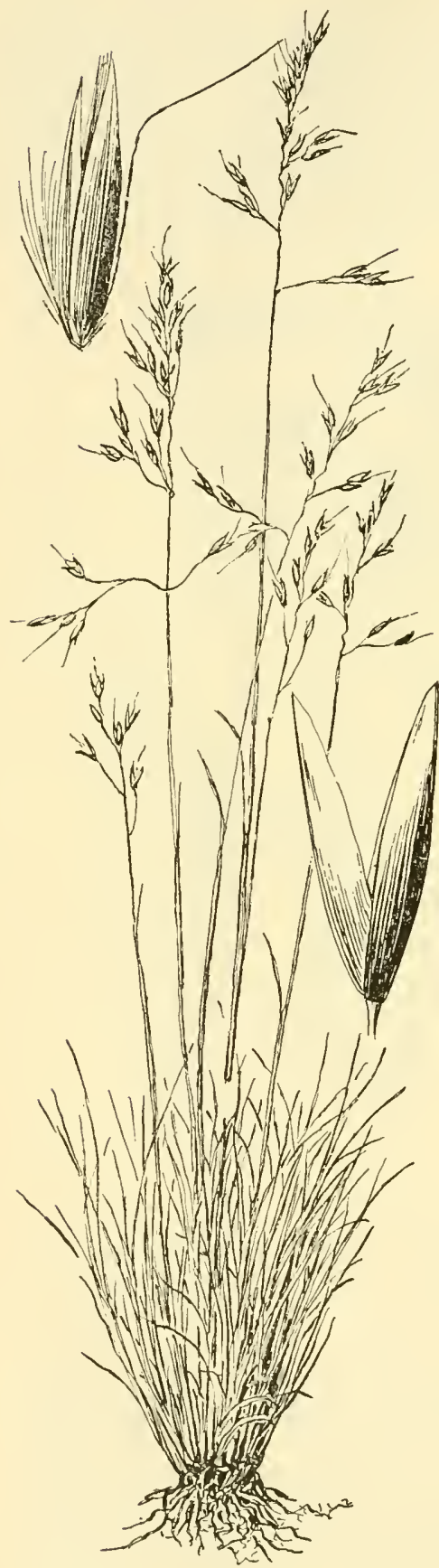

Figure 611-Calamagrostis breweri. Plant, $X$ 1 ; glumes and floret, $\times 10$. (Bolander 6098, Calif.)

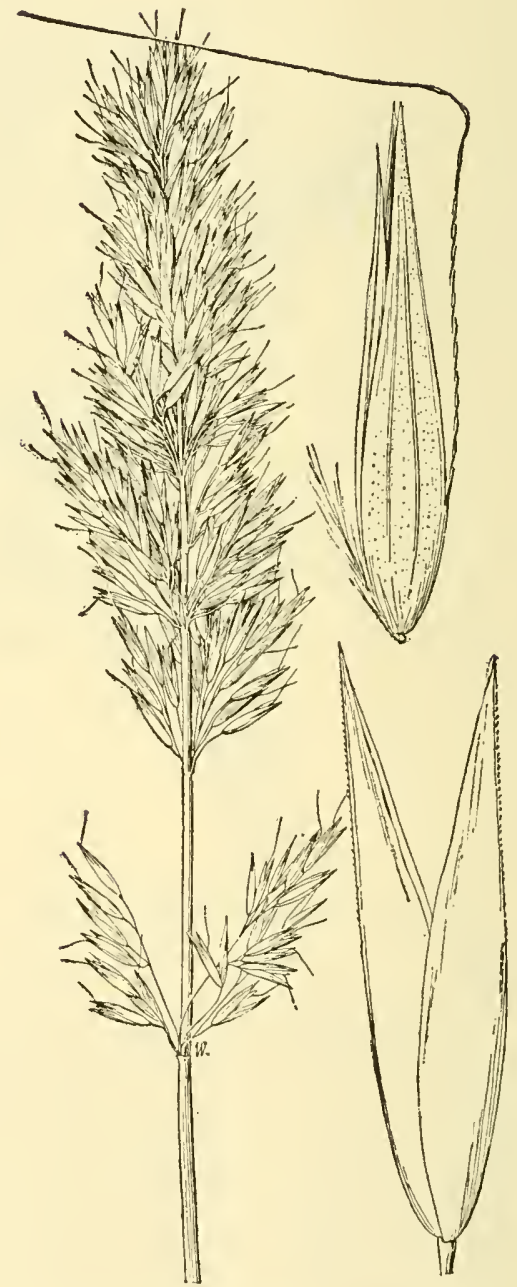

Figure 612.-Calamagrostis tweedyi. Panicle, $\times 1$; glumes and floret, $\times 10$. (Vasey, Wash.) 
6. Calamagrostis purpuráscens R. Br. Purple reedgrass. (Fig. 614.) Culms tufted, sometimes with short rhizomes, erect, 40 to 60 cm or even $100 \mathrm{~cm}$ tall; sheaths usually scabrous, the old sheaths

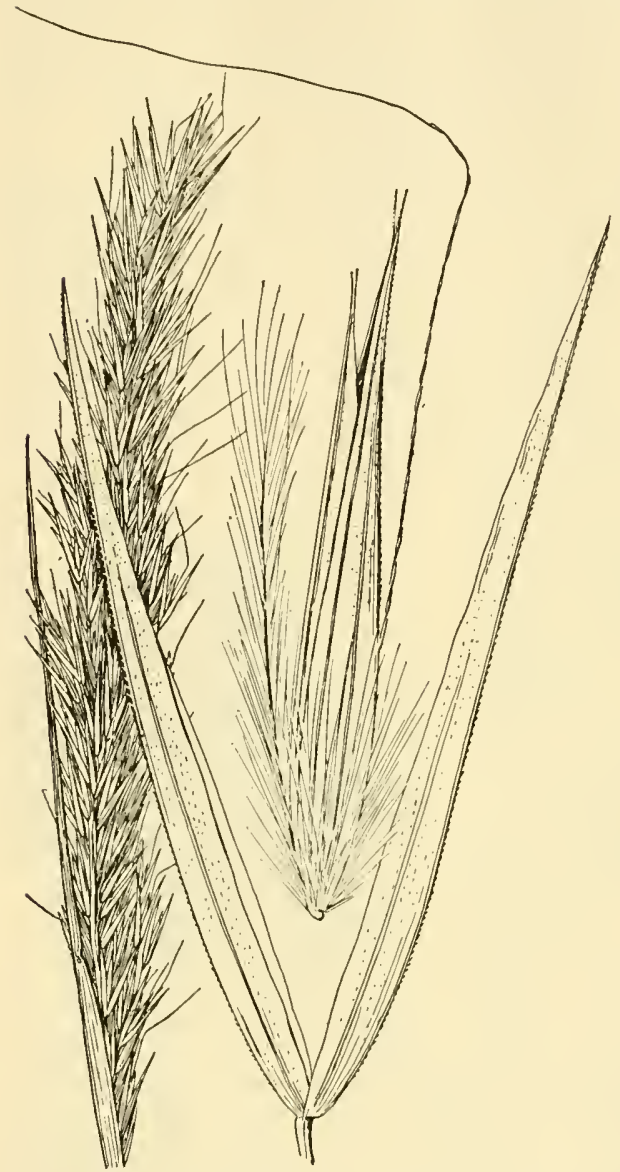

Fiaure 613.-Calamagrostis foliosa. Panicle, $\times 1$; glumes and floret, $\times 10$. (Davy 6602, Calif.)

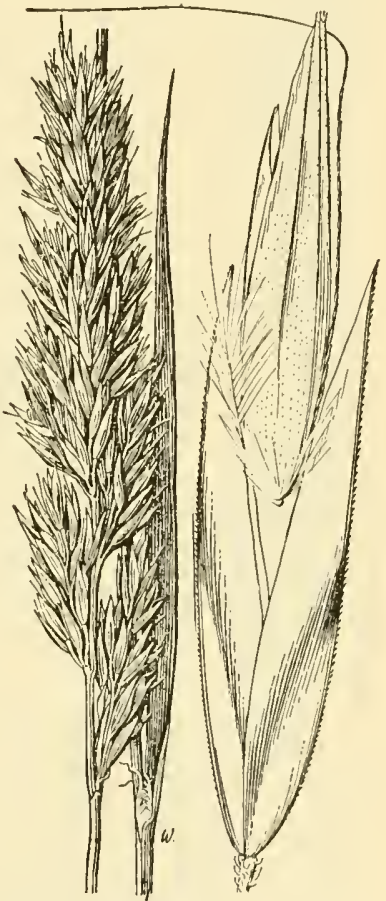

Figure 614-Calamagrostis purpurascens. Panicle, $\times 1$; glumes and floret, $\times 10$. (Goodding 375 , Wyo.)

persistent and fibrous; blades 2 to $4 \mathrm{~mm}$ wide, flat or more or less involute, rather thick, scabrous; panicle dense, usually pinkish or pur-

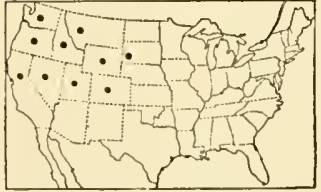

Figure 615.-Distribution of Calamagrostis purpurascens. plish, spikelike, 5 to $12 \mathrm{~cm}$ long, rarely longer; glumes 6 to $8 \mathrm{~mm}$ long, scabrous; lemma nearly as long as glumes, the apex with 4 setaceous teeth, the awn from near base, finally geniculate, exserted about $2 \mathrm{~mm}$; hairs of callus and rachilla about one-third as long as the lemma. $24(C$. vaseyi Beal.)-Rocks and eliffs, Greenland to Alaska, south to Quebec, South Dakota (Black Hills), Colorado, and California (fig. 615).

7. Calamagrostis montanénsis Scribn. Plains reedgrass. (Fig. 616.) Culms stiffly erect, scabrous below the panicle, usually 20 to 
$40 \mathrm{~cm}$ tall, sometimes taller, with slender creeping rhizomes; lower sheaths rather papery, smooth; blades erect, mostly less than $2 \mathrm{~mm}$ wide, more or less involute, scabrous, sharp-pointed; panicle dense, erect, more or less interrupted, usually pale, 5 to $10 \mathrm{~cm}$ long; spikelets 4 to $5 \mathrm{~mm}$ long, the pedicels very scabrous; glumes acuminate, scabrous; lemma nearly as long as the glumes, finely 4-tootned, the awn attached about $1 \mathrm{~mm}$ above base, about equaling the lemma, slightly geniculate and protruding from side of glumes; palea nearly as long as the lemma; hairs of callus and rachilla rather abundant, about half as long as the lemma. 4 Plains and dry open ground, Manitoba to Alberta, south to South Dakota, Wyoming, and Idaho (fig. 617).

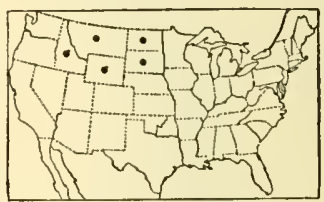

FIGURE 617.-Distribution of Calamagrostis montanensis.

8. Calamagrostis rubéscens Buckl. Pinegrass. (Fig. 618.) Culms slender, tufted, 60 to $100 \mathrm{~cm}$ tall, with creeping rhizomes; sheaths smooth, but pubescent on the collar, sometimes obscurely so; blades erect, 2 to $4 \mathrm{~mm}$ wide, flat or somewhat involute, scabrous; panicle narrow, spikelike or somewhat loose or interrupted, pale or purple, 7 to $15 \mathrm{~cm}$ long; glumes 4 to $5 \mathrm{~mm}$ long, narrow, acuminate; lemma pale, thin, about as long as glumes, smooth, the nerves obscure, the awn from near base, geniculate, exserted from side of glumes, 1 to $2 \mathrm{~mm}$

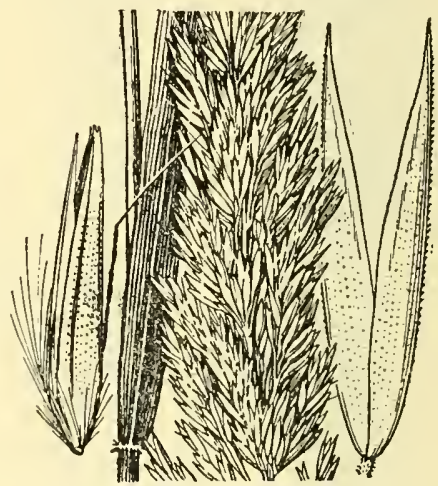

Figure 618.-Calamagrostis rubescens. Panicle, $\times 1$; glumes and floret, $\times 10$. (Sandberg and Leiberg, Wash.)
FIGUR E 616 . Cala magrostis montanensis.

Panicle, $\times 1$ :

glumes and

floret, $\times 10$.

Mont.)

long above the bend, the callus hairs scant, about onethird as long as the lemma; rachilla $1 \mathrm{~mm}$ long, the sparse hairs extending to $2 \mathrm{~mm}$. 2 4 -Open pine woods, prairies, and banks, Manitoba to British Columbia, south to northern Colorado and central California (fig. 619). A valuable range grass. A large form with dense lobed panicle has been called $C$. cusickii Vasey.

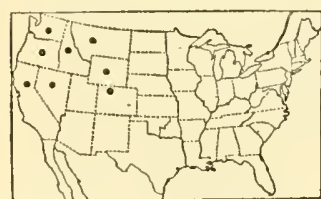

Figure 619.-Distribution of Calamagrostis rubescens.

9. Calamagrostis portéri A. Gray. (Fig. 620.) Culms slender, 60 to $120 \mathrm{~cm}$ tall, with slender rhizomes; sheaths pubescent on the collar; blades flat, spreading, lax, 4 to $8 \mathrm{~mm}$ wide; panicle narrow but rather loose, erect or somewhat nodding, 10 to $15 \mathrm{~cm}$ long; glumes 4 to 6 $\mathrm{mm}$ long, scaberulous; lemma slightly shorter than the glumes, toothed at apex, the awn from near base, about as long as the lemma, bent and protruding from side of glumes; palea about as long as the lemma; callus hairs 
rather scant, nearly half as long as the lemma; rachilla hairs scant, extending to about $3 \mathrm{~mm}$. 24 -Dry rocky soil, New York, Pennsylvania, Virginia (Luray), and West Virginia (fig. 621).

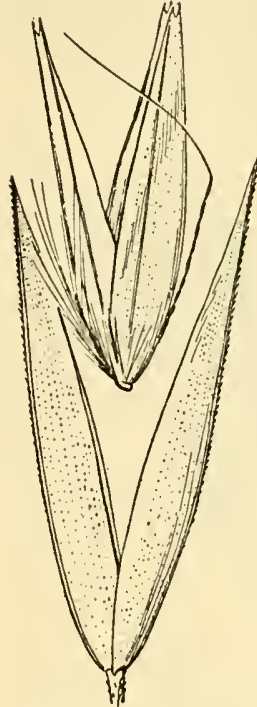

Figure 620.-Calama. grostis porteri, $\times 10$. (Porter, Pa.)

10. Calamagrostis perpléxa Scribn. (Fig. 622.) Resembling $C$. porteri, differing in the somewhat larger, denser panicle and in the more copious callus hairs about three-fourths as long as the lemma, and in the more delicate awn. 21 -Wet rocks and sandy shores, Maine (Elliotsville), New Hampshire (White Mountains), New York ('Thatcher's Pinnacle, near Ithaca, type locality), Ontario (Lake Nipagon), and Minnesota (Fond du Lac).

11. Calamagrostis $\mathrm{nut}$ kaénsis (Presl) Steud. (Fig. 623.) Culms stout, 1 to $1.5 \mathrm{~m}$ tall with short rhizomes (not usually present in herbarium specimens); ligule 6 to $8 \mathrm{~mm}$

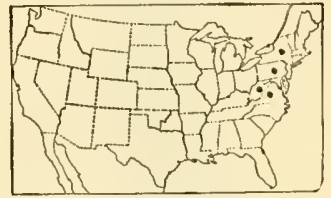

Figure 621-Distribution of Calamagrostis porteri. long; blades elongate, 8 to $12 \mathrm{~mm}$ wide, flat becoming involute, gradually narrowed into a long point, scabrous; panicle usually purplish, narrow, rather loose, 15 to $30 \mathrm{~cm}$ long, the branches rather stiffly ascending; glumes 5 to $7 \mathrm{~mm}$ long, acuminate; lemma about $4 \mathrm{~mm}$ long, indistinctly nerved, the geniculate, about equaling the lemma or shorter; hairs of callus and rachilla scarcely half as long. 2 -Along the coast in moist soil or wet wooded hills, from Alaska to central California.

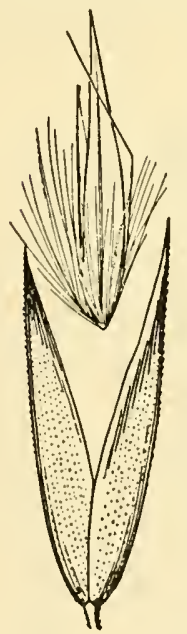

12. Calamagrostis dénsa Vasey. Cuyamaca ReedGrass. (Fig. 624.) Culms rather stout, densely tufted, smooth or scabrous just below the panicle, mostly more than $1 \mathrm{~m}$ tall, with rather stout rhizomes; sheaths slightly scabrous; ligule 3 to $5 \mathrm{~mm}$ long; blades flat, or subinvolute, scabrous, 15 to $25 \mathrm{~cm}$ long, 3 to $8 \mathrm{~mm}$ wide, the uppermost shorter; panicle spikelike, dense, FIgURE 622-Calama- pale, 10 to $15 \mathrm{~cm}$ orostis perplexa. long; glumes 4.5 to
Glumes and floret. $\underset{5668, N \text {. Y.) }}{\times}$ (Metcalf $5 \mathrm{~mm}$ long, acuminate, scaberulous;

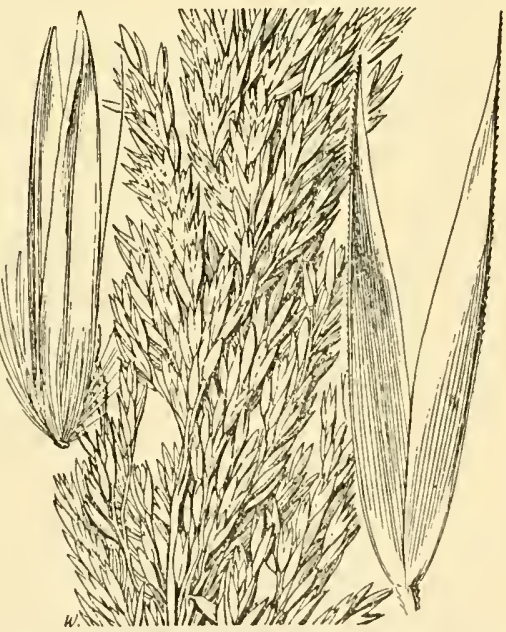

Figure 623.-Calamagrostis nutkaensis. Panicle, $\times 1$; glumes and floret, $\times 10$. (Hitcheock 23576 , Oreg.)

lemma 3.5 to $4 \mathrm{~mm}$ long, the awn bent, about as long as the lemma, more or less exserted at the side, the hairs of callus and rachilla scant, 
about $1 \mathrm{~mm}$ long. 24 -Dry hills, among shrubs, mountains east of San Diego, Calif.

13. Calamagrostis koelerioídes Vasey. (Fig. 625.) Differs from C. densa in the more slender culms and (often purplish) panicles. 24 -Dry hills, banks, and meadows, Wyoming to Washington, south to southern California. (Fig. 626.) Probably a form of $C$. densa.

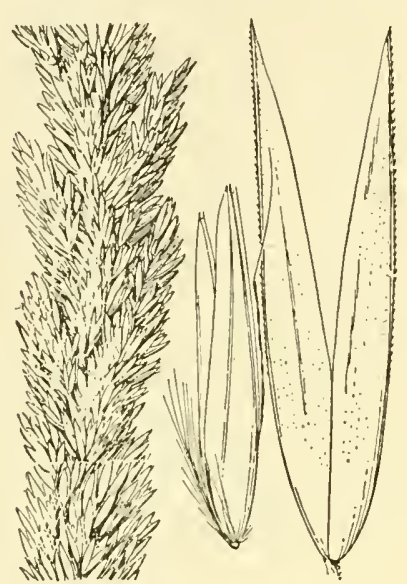

Figure 624.-Calamagrostis densa. Panicle, $\times 1$; glumes and floret $\times 10$. (Hitcheock 13163, Calif.)

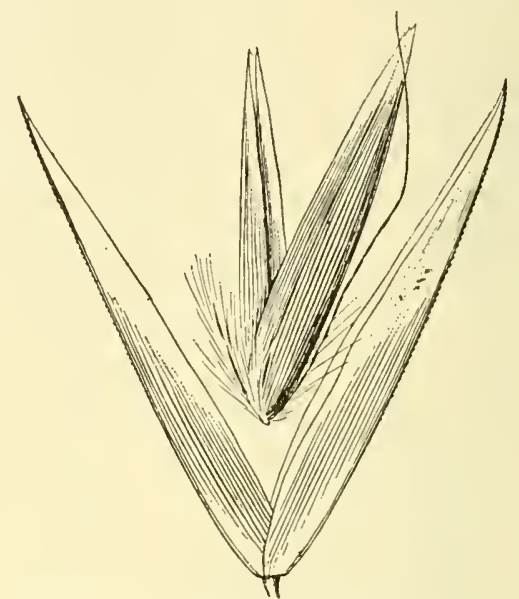

FigdRE 625.-Calamagrostis koelerioides, $\times 10$. (Hitchcock 23558, Oreg.)

14. Calamagrostis pickeríngii A. Gray. (Fig. 627.) Culms solitary or few in tufts, rather rigid, scabrous below the panicle, 30 to 60 $\mathrm{cm}$ tall, with creeping rhizomes; blades erect, flat, 4 to $5 \mathrm{~mm}$ wide; panicle purplish, erect, contracted and rather dense, 7 to $12 \mathrm{~cm}$ long; glumes acute, about 4 to $4.5 \mathrm{~mm}$ long; lemma a little shorter than the glumes, scaberulous, narrowed to an obtuse point, the awn attached about $1 \mathrm{~mm}$ above the base, about as long as the lemma, slightly bent and protruding somewhat from the side of the glumes; callus hairs scant, about $0.5 \mathrm{~mm}$ long;

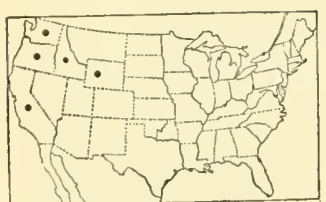

Figure 626.-Distribution of Calamagrost is koelerioides. rachilla about $1 \mathrm{~mm}$ long, the hairs short, rather scant. 24 -Bogs, wet meadows, and sandy beaches, Newfoundland and Labrador to the mountains of Massachusetts and New York; Isle Royal, Mich. (fig. 628). Slender plants with slightly smaller spikelets have been differentiated as $C$. pickeringii var. debilis (Kearney) Fern. and Wieg.

15. Calamagrostis scribnéri Beal. Scribner REEDGrass. (Fig. 629.) Culms tufted, with numerous creeping rlizomes, slender, 60 to 100

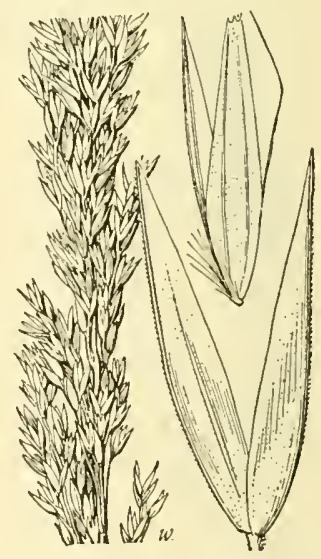

F I G U R E 627.-Calamagrostts pickeringii. Panicle, $\times 1$; glumes and floret, $\times 10$.
(Hubbard 634 , Miass.) $\mathrm{cm}$ tall; lower sheaths loose, thin, upper scabrous, retrorsely pubescent on the collar; ligule about $5 \mathrm{~mm}$ long; blades thin, elongate, 4 to $7 \mathrm{~mm}$ wide, scabrous; panicle pale or purplish, narrow but rather 
lax, 10 to $15 \mathrm{~cm}$ long (rarely longer); glumes about $4 \mathrm{~mm}$ long, acuminate; lemma a little shorter than the glumes, sharply toothed, the awn about as long as the glumes or a little longer, feebly bent, the callus hairs about half as long as the lemma; rachilla minute, its hair's nearly as long as the lemma. 4 -Moist meadows, Montana and Washington to Colorado and Oregon; infrequent (fig. 630).

16. Calamagrostis canadênsis (Michx.) Beauv. Bluejornt. (Fig. 631, A.) Culms suberect, tufted, 60 to $150 \mathrm{~cm}$ tall, with numerous creeping rhizomes; sheaths glabrous or rarely obscurely pubescent; blades numerous, elongate, flat, rather lax, scabrous, 4 to $8 \mathrm{~mm}$ wide; panicle nodding, from narrow and rather dense to loose and relatively open, especially at base, 10 to $25 \mathrm{~cm}$ long; glumes usually 3 to $4 \mathrm{~mm}$ long, smooth or more commonly scabrous, acute to acuminate; lemma

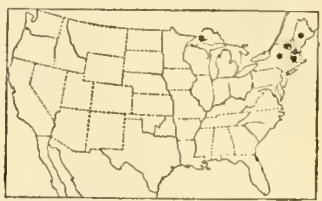

Figure 628.-Distribution of Calamagrostis pickeringii. nearly as long as glumes, smooth, thin in texture, the awn delicate, straight, attached just below the middle and extending to or slightly beyond its tip, the callus hairs abundant, about as long as lemma; rachilla delicate, sparsely long-pilose. 2 -Marshes, wet places,

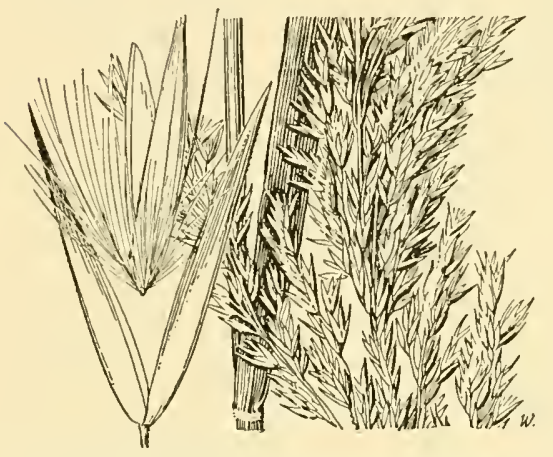

FIgure 629.-Calamagrostis scribneri. Panicle, $\times 1$; glumes and floret, $X 10$. (Rydberg 3083, Mont.) open woods, and meadows, Greenland to Alaska, south to Maryland, North Carolina (Roan Mountain), Missouri, Kansas, Colorado, Arizona, and California (fig. 632). A widely distributed and exceedingly variable species. Characters used to differentiate the many proposed varieties are not correlated in the larger proportion of specimens. The panicle varies in density and the glumes in size and scabridity. The following varieties are recognizable but are connected with the species by many intergrading specimens.

Calamagrostis canadensis var. scábra (Presl) Hitche. (Fig. $631, B$.) Differing in having spikelets 4.5 to $6 \mathrm{~mm}$ long, the glumes rather firm, hispidly short-ciliate on the keel, strongly scabrous otherwise, but the greater scabridity not constant. 24 -Mountains of New England, New York, and northward, and along the Pacific coast from Washington to Alaska. This form has been referred to C.langsdorfii (Link) Trin., which proves to be an Old World species not found in America.

Calamagrostis Canadensis var. macouniÁna (Vasey) Stebbins. (Fig. 631,C.) Differing from $C$. canadensis in the smaller spikelets, about $2 \mathrm{~mm}$ long. Scarcely a distinct variety. 2

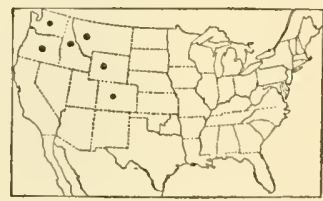

FIGURE 630.-Distribution of Calamagrostis scribneri.

- Saskatchewan (Macoun 44, 45), Minnesota (Bemidge), South Dakota (Chamberlin, Redfield), Iowa, Nebraska (Central City), Missouri (Lake City, Little Blue), Montana (Manhattan), Yellowstone Park, Washington (Spokane County), Oregon (Crook County). 


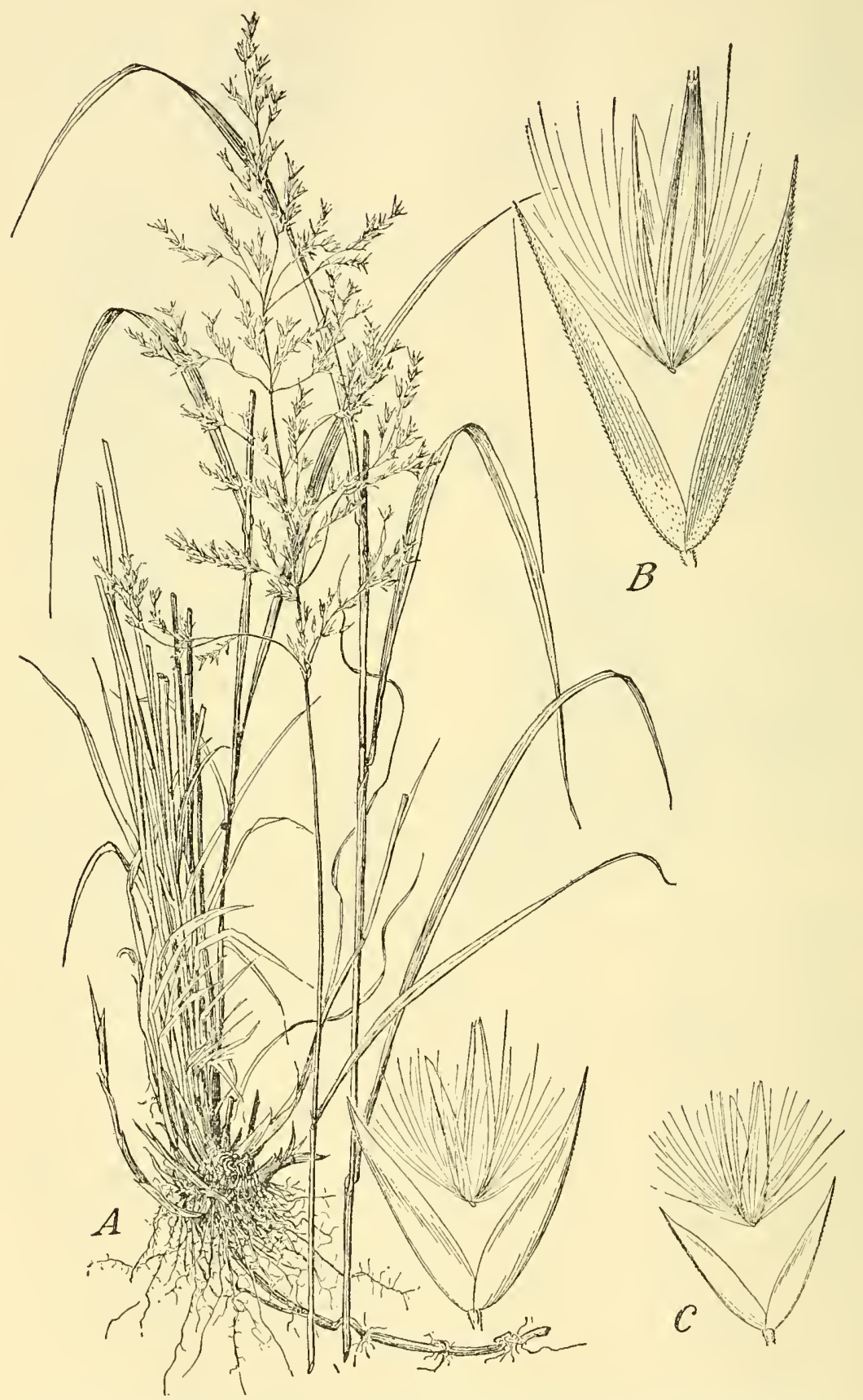

Figure 631.-A, Calamagrostis canadensis. Plant, $\times 1 / 2$; glumes and floret, $\times 10 . \quad$ (Chase 5077, Mont.), B, Var. scabra, $\times$ 10. (Pringle, N. H.) C, Var. macouniana, $\times 10$. (Pammel 891, Minn.) 
17. Calamagrostis láctea Beal. (Fig. 633.) to $150 \mathrm{~cm}$ tall, weak, the nodes subgeniculate, with a short knotty rhizome; sheaths scaberulous; ligule rather firm, 3 to $5 \mathrm{~mm}$ long; blades elongate, flat, lax, scabrous, 6 to 12 $\mathrm{mm}$ wide; panicle pale, narrowly pyramidal, 12 to $20 \mathrm{~cm}$ long, loosely flowered; glumes 5 to $6 \mathrm{~mm}$ long, scabrous, acuminate; lemma shorter than the glumes, scabrous, the apex setaceous-toothed, the awn attached near the

Culms ascending, 80

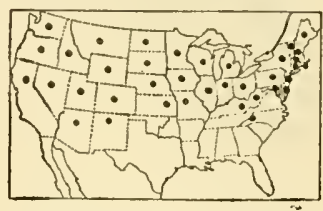

FIGURE 632.--Distribution of Calamagrostis canadensis. base, about equaling the lemma, weakly geniculate; palea slightly
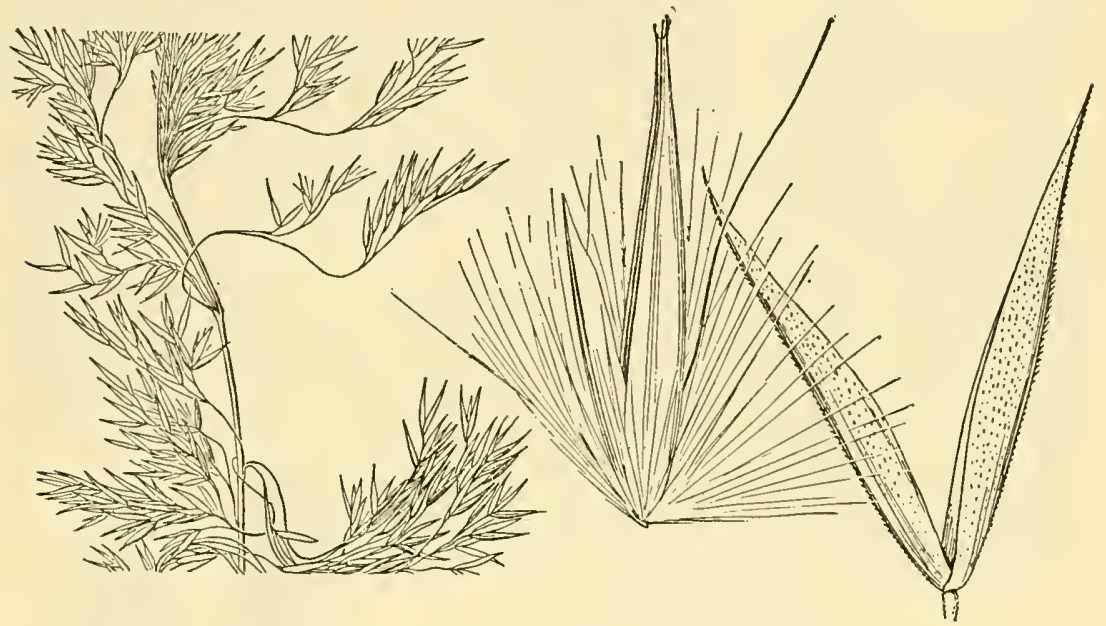

Figure 633.-Calamagrostis lactea. Panicle, $\times 1$; glumes and floret, $\times 10$. (Dupl. type.)

exceeding the lemma, the callus hairs about half as long; rachilla

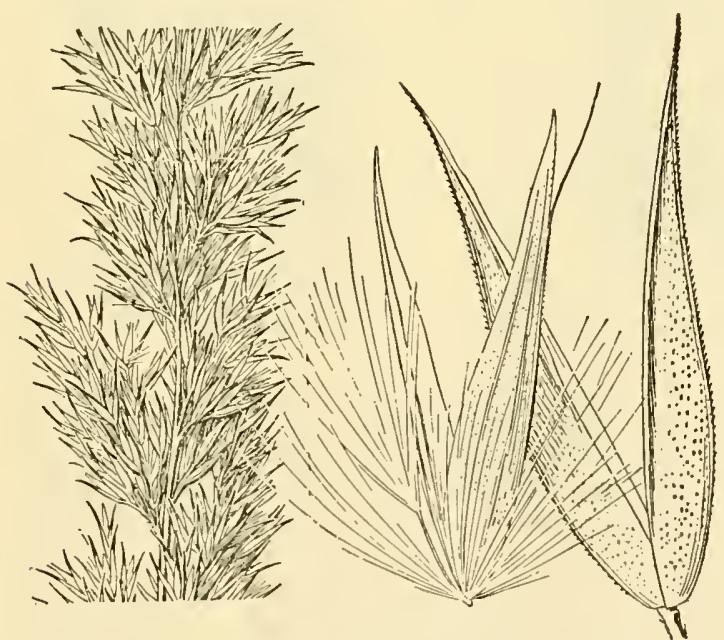

FlGURe 634,-Calamagrostis cinnoides. Panicle, $\times 1$; glumes and floret, $\times 10$. (Chase 7518, Md.) minute, sparsely pilose. 21 -Mountain slopes, Washington and Oregon, apparently rare.

18. Calamagrostis cinnoídes (Muhl.) Barton. (Fig. 634.) Glaucous; culms rather stout, erect, 80 to $150 \mathrm{~cm}$ tall, with slender rhizomes readily broken off; sheaths and blades very scabrous, sometimes sparsely hirsute, the blades flat, 5 to $10 \mathrm{~mm}$ wide; panicle erect, dense, more or less lobed (somewhat open at an thesis), 8 to $20 \mathrm{~cm}$ long, purple-tinged; glumes 6 to $7 \mathrm{~mm}$ long, scabrous, long-acuminate 
or awn-pointed; lemma firm, acuminate, scabrous, shorter than the glumes, the awn attached about one fourth below the tip, not much exceeding the lemma, the callus hairs copious, about two-thirds as long; rachilla about $1 \mathrm{~mm}$ long, glabrous below, with a brush of long white hairs at the tip about equaling the lemma. 24-Bogs and moist ground, Maine to New York, south to Alabama (fig. 635).

19. Calamagrostis scopulórum Jones. (Fig.

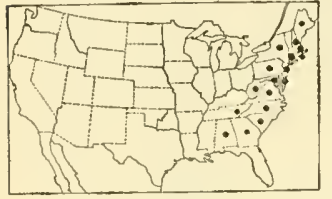

FIGURE 635.-Distribution of Calamagrostis cinnoides. 636.) Pale, glaucous; culms erect, 50 to 80 $\mathrm{cm}$ tall, with short rhizomes; blades elongate, flat, scabrous, 3 to $7 \mathrm{~mm}$ wicie; panicle pale to purplish, contracted, sometimes spikelike, $\mathrm{S}$ to $15 \mathrm{~cm}$ long; glumes 4 to $6 \mathrm{~mm}$ long, somewhat scabrous, acute or acuminate, not awn-pointed; lemma about as long as the glumes, minutely pilose, the awn attached above the middle, straight, about as long as the lemma, the callus hairs about two-thirds as long; rachilla rather sparsely long-pilose, especially on the upper part. 24 - Moist soil in gulches, Wyoming (Wild Cat Peak), Colorado (Pagosa Peak), and Utah.

20. Calamagrostis inexpánsa A. Gray. Northern reedgrass. (Fig. 637.) Culms tufted, 40 to $120 \mathrm{~cm}$ tall, with rather slender rhizomes, often scabrous below the panicle; sheaths smooth, or somewhat scabrous, the basal ones numerous, withering but persistent; ligule 4 to $6 \mathrm{~mm}$ long; blades firm, rather rigid, flat or loosely involute, very scabrous, 2 to $4 \mathrm{~mm}$ wide; panicle narrow, dense, the branches mostly erect and spikelet-bearing from the base; 5 to $15 \mathrm{~cm}$ long; glumes 3 to $4 \mathrm{~mm}$ long, abruptly acumi-

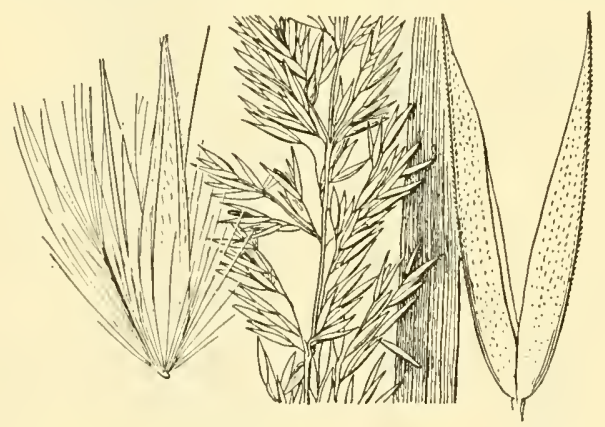

Figure 636.-Calamagrostis scopulorum. Panicle, $\times 1$; glumes and floret, $\times 10$. (Jones 1145, Utah.)

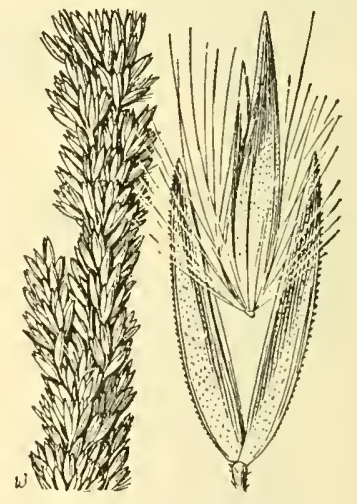

Figure 637.-Calamagrostis inexpansa. Panicle, $\times 1$; glumes and floret, $\times 10$. (Ehlers 566, Mich.)

nate, scaberulous; lemma as long as glumes, scabrous, the awn attached about the middle, straight or nearly so, about as long as glumes, the callus hairs half to three-fourths as long; rachilla $0.5 \mathrm{~mm}$ long, some of the hairs reaching to tip of lemma. 24-Meadows, marshes, and wet places, Greenland to Alaska, south to Maine, New York, Illinois, Missouri, Nebraska, New Mexico, and California (fig. 638). Calamagrostis inexpansa var. novae-Ángliae Stebbins. Panicle more loosely flowered, the longer branches naked below. 24 -Wet granite ledges, Maine to Vermont. Calamagrostis inexpansa var. BarBULÁtA Kearney. Culms robust, puberulent below the nodes; collar of sheaths puberulent; awn minute or obsolete, callus hairs nearly as long as the lemma. 21 - Known only from Mason County, Wash. 
Calamagrostis califórnica Kearney. (Fig. 639.) Resembling $C$. inexpansa but panicles longer and somewhat looser and callus hairs shorter. 2 -Known only from the type speeimen, "Sierra Nevada." The status of this form is doubtful.

21. Calamagrostis neglécta (Ehrh.) Gaertn. Mey. and Schreb. (Fig. 640.) Resembling $C$. inexpansa, on the average smaller; ligule 1 to $3 \mathrm{~mm}$ long; blades smooth or nearly so, lax and soft, narrow, often filiform; panicles on the average smaller; glumes rather thinner in texture, often smooth. 24 - Marshes, sandy shores, and wet places, Greenland to Alaska,

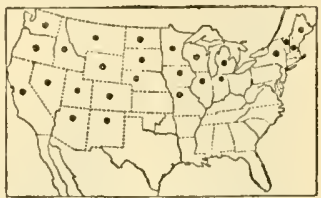

Figure 638.-Distribution of Calamagrostis inexpansa. south to Maine, Vermont, New York, Michigan, Wisconsin, Colorado,

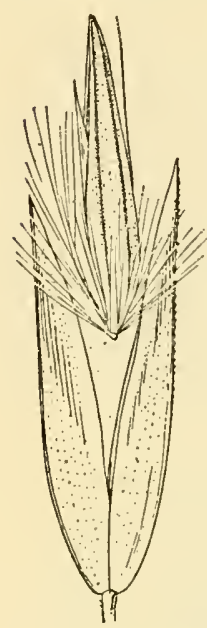
Utah, and Oregon (fig. 641); northern Eurasia. 22. Calamagrostis crassiglúmis Thurb. (Fig. 642.) Culms rather rigid, 15 to 40 $\mathrm{cm}$ tall, with short rhizomes; lower sheaths overlapping, somewhat papery; blades flat, or somewhat involute, smooth, firm, about 4 to $5 \mathrm{~mm}$ wide; panicle narrow, dense, spikelike, 2 to $5 \mathrm{~cm}$ long, dull purple; glumes 3 to $4 \mathrm{~mm}$ long, ovate, rather abruptly acuminate, purple, scaberulous, firm or almost indurate; lemma about as long as glumes, broad, obtuse or abruptly pointed, the awn attached about the middle, straight, about as long as lemma, the callus hairs abundant, about $3 \mathrm{~mm}$ long; rachilla $1 \mathrm{~mm}$ long, the hairs reaching to apex of lemma. 21-Swampy soil, Vaneouver Island, Washington (WhatFigure 639.-Cala- com Lake), California (Mendocino

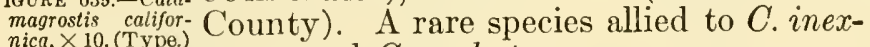
nica, $\times 10$. (Type.) pansa and $C$. neglecta.

23. Calamagrostis epigeíos (L.) Roth. (Fig. 643.) Culms slender, 1 to $1.5 \mathrm{~m}$ tall, with creeping rhizomes; ligule about $4 \mathrm{~mm}$ long, rather firm; blades elongate, mostly 4 to $5 \mathrm{~mm}$ wide, flat, scabrous; panicle

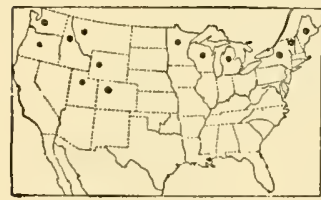

FIGURE 641.-Distribution of Calamagrostis neglecta. pale, erect, narrow, rather dense, 25 to $30 \mathrm{~cm}$ long, narrowed at the summit; glumes subequal, 4 to $5 \mathrm{~mm}$ long, narrowly lanceolateattenuate; lemma 2 to $2.3 \mathrm{~mm}$ long, strongly 2 toothed at the opaque apex, the awn from a little below the middle, about as long as the glumes, somewhat bent at the middle; callus hairs rather copious, about as long as the glumes; rachilla obsolete. $24-(C$. arenicola Fernald.) - Sandy woods in dense colonies, Harwich, Mass.; said to be established also at Gloucester, Mass., and Montgomery County, Pa.; Eurasia.

\section{AMMOPHILA Host. Beachgrass}

Spikelets 1-flowered, compressed, the rachilla disarticulating above the glumes, produced beyond the palea as a short bristle, hairy above; glumes about equal, chartaceous; lemma similar to and a 
little shorter than the glumes, the callus bearded; palea nearly as long as the lemma. Tough, rather coarse, erect perennials, with hard, scaly, creeping rhizomes, long, tough, involute blades, and pale, dense spikelike panicles. Type species, Ammophila arenaria.

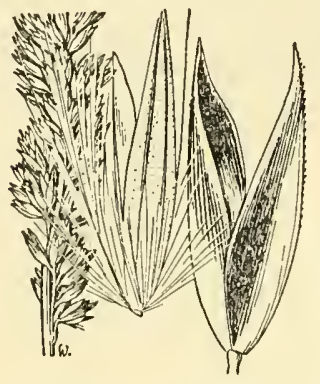

Figure 642.-Calamagrostis crassiglumis. Panicle, $\times 1$; glumes and floret, $\times 10$. (Suksdorf 1024, Wash.)

Named from the Greek ammos, sand, and philos, loring, alluding to the habitat.

The species of Ammophila are important sand-binding grasses, $A$. arenaria being used in northern Europe to hold the barrier dunes along the coast. In this country it has been tried with success on Cape Cod and at Golden Gate Park, San Francisco. Called also marram, psamma, and sea sandreed.

Ligule thin, 10 to $30 \mathrm{~mm}$ long-_...-1. A. ARENARIA. Ligule firm, 1 to $3 \mathrm{~mm}$ long-- 2. A. BREviligulata.

1. Ammophila arenária (L.) Link. European BeACHGRASS. (Fig. $644, B$.) Culms 50 to 150 $\mathrm{cm}$ tall, with deep extensively creeping rhizomes; ligule thin, 1 to $3 \mathrm{~cm}$ long, blades elongate, firm, soon involute, tapering to a fine point, the upper surface puberulent; panicle 10 to $20 \mathrm{~cm}$ long; spikelets 1.2 to $1.5 \mathrm{~cm}$ long; glumes glabrous, scabrous on the keels, the first 1-nerved, the second 3-nerved; lemma scabrous, the callus hairs about $3 \mathrm{~mm}$ long, the rachilla about $2 \mathrm{~mm}$ long. 21 - Sand dunes along the coast from San Francisco to Oregon; intro-

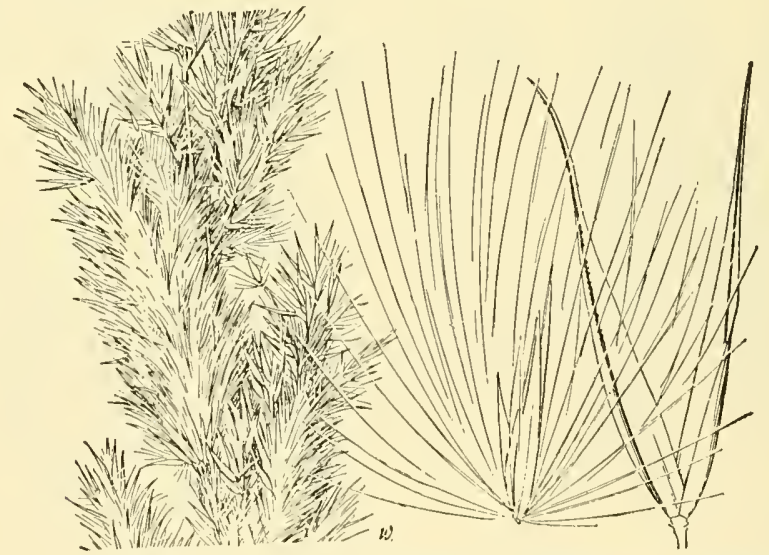

Figure 643.-Calamagrostis epigeios. Panicle, $\times 1$; glumes and floret, $\times 10$. (Fernald 757, Mass.)

duced as a sand binder in the vicinity of San Francisco and now established at several places to the north; coast of Europe.

2. Ammophila breviliguláta Fernald. AMERICAN BEACHGRAss. (Fig. 644, A.) Similar to A. arenaria; ligule firm, 1 to $3 \mathrm{~mm}$ long; blades scaberulous on the upper surface; callus hairs shorter. 24 - Sand dunes along the coast from Newfoundland to North Carolina, and on the shores of the Great Lakes from Lake Ontario to Lake Superior and Lake Michigan (fig. 645). 
MANUAL OF THE GRASSES OF THE UNITED STATES 321

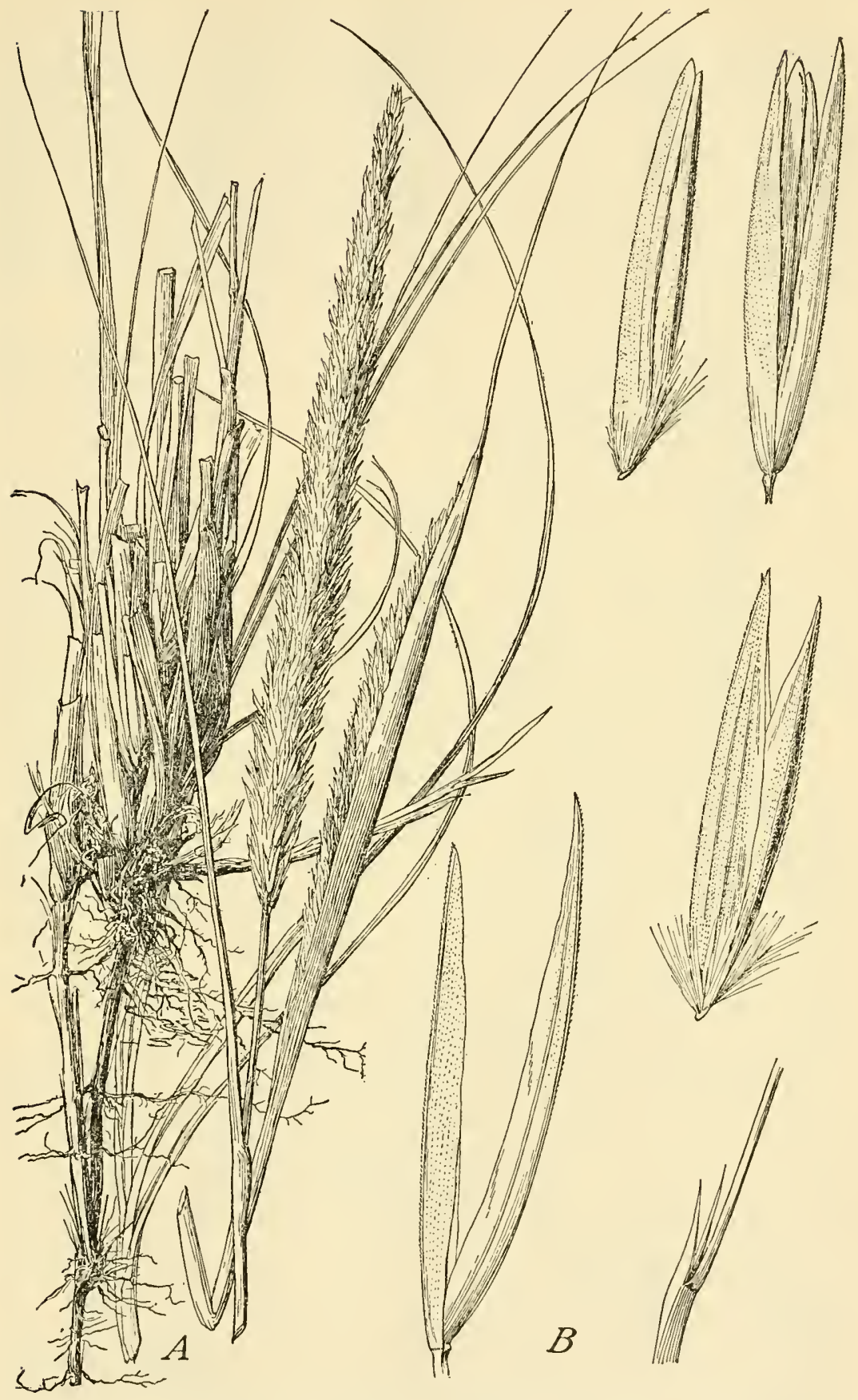

Figure 644.- $A, A m m o p h i l a$ breviligulata. Plant, $\times 1 / 2 ;$ spikelet and floret, $\times 5$. (Sherff, Ind.) $B$, Ammophila arenaria. Glumes, floret, and ligule, $\times 5$. (Heller 5670, Calif.) 


\section{CALAMOVÍLFA Hack.}

Spikelets 1-flowered, the rachilla disarticulating above the glumes, not prolonged behind the palea; glumes unequal, chartaceous, 1nerved, acute; lemma a little longer than the second glume, chartaceous, 1-nerved, awnless, glabrous or pubescent, the callus bearded; palea about as long as the lemma. Rigid, usually tall perennials, with narrow or open panicles, some species with creeping rhizomes. Type species, Calamovilfa brevipilis. Name from Greek kalamos, reed, and Vilfa a genus of grasses. Calamovilfa longifolia is of some value for forage but is rather coarse and woody; a variety of this and also $C$. giganiea are inland sand binders.

Rhizomes short and thick.

Panicle narrow, contracted._._. C. CúRTissir.

Panicle subpyramidal, rather open Rhizomes extensively creeping.

Lemma glabrous (except for the callus hairs)

Lemma villous on the back above the callus hairs

3. C. LONGIFOLIA.

1. Calamovilfa curtíssii (Vasey) Scribn. (Fig. 646.) Culms tufted from a short, thick horizontal rhizome, about $1 \mathrm{~m}$ tall;

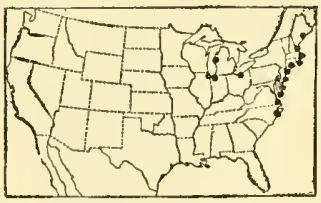

Figure 645-Distribution of Ammophila breviligulata. lower sheaths firm, overlapping, persistent; blades elongate, 2 to $3 \mathrm{~mm}$ wide, flat to involute, those of the innovations subfiliform; panicle contracted but not dense, 15 to $20 \mathrm{~cm}$ long; spikelets pale, about $5 \mathrm{~mm}$ long; glumes acute, the first $4 \mathrm{~mm}$, the second $5 \mathrm{~mm}$ long; lemma as long as the second glume, acute, villous on the back below, the callus hairs 1 to $1.5 \mathrm{~mm}$ long; palea sparsely villous along the keels. 21 - Low pine barrens, East Florida; also Santa Rosa County, Fla.

2. Calamovilfa brevípilis (Torr.) Scribn. (Fig. 647.) Culms solitary or few, compressed, 60 to $120 \mathrm{~cm}$ tall, the base as in $C$. curtissii; blades elongate, 2 to $3 \mathrm{~mm}$ wide, flat to subinvolute; panicle subpyramidal, rather open, 10 to $25 \mathrm{~cm}$ long, the branches ascending, flexuous, glabrous, naked below; spikelets brownish, 5 to $6 \mathrm{~mm}$ long; glumes acuminate, the first 2 to $2.5 \mathrm{~mm}$ long, the second about 4 mm long; lemma villous on the back below, the callus hairs 1.5 $\mathrm{mm}$ long; palea exceeding the lemma, villous on the back. Marshes and river banks, New Jersey, North Carolina, rare.

3. Calamovilfa longifólia (Hook.) Scribn. (Fig. 648.) Culms mostly solitary, 50 to $180 \mathrm{~cm}$ tall, with strong scaly creeping rhizomes; sheaths usually more or less appressed-villous, especially near the summit; blades firm, elongate, flat or soon involute, 4 to $8 \mathrm{~mm}$ wide near base, tapering to a long fine point; panicle 15 to 35 $\mathrm{cm}$ long, rather narrow or contracted, the branches ascending or appressed, sometimes slightly spreading; spikelets pale, 6 to $7 \mathrm{~mm}$ long; glumes acuminate, the first about $2 \mathrm{~mm}$ shorter than the second; lemma somewhat shorter than the second glume, glabrous, the callus hairs copious, more than half as long as the lemma. 24 - Sand hills and sandy prairies or open woods, Michigan to Alberta, south to Indiana, Colorado, and Idaho (fig. 649). Calamovilfa Longifolia var. MÁGna Scribn. and Merr. Panicle more open and spreading. 24-Sandy ridges and dunes along Lake Huron and Lake Michigan. 
4. Calamovilfa gigantéa (Nutt.) Scribn. and Merr. (Fig. 650.) Culms robust, mostly solitary, usually 1.5 to $2 \mathrm{~m}$ tall, as much as $6 \mathrm{~mm}$ thick at base, with strong creeping rhizomes; sheaths glabrous; blades elongate, 5 to $10 \mathrm{~mm}$ wide at base, tapering to a long involute tip; panicle open, as much as $60 \mathrm{~cm}$ long, the branches rather stiffly spreading, as much as $25 \mathrm{~cm}$ long; spikelets similar to those of $C$. longifolia, but somewhat larger; lemma and palea villous along the back; callus hairs copious, half as long as the lemma. 2 -Sand dunes, North Dakota to Texas and west to Arizona (fig. 651).

\section{AGRÓSTIS L. Bentgrass}

Spikelets 1-flowered, disarticulating above the glumes, the rachilla usually not prolonged; glumes equal or nearly so, acute, acuminate, or sometimes awn-pointed, usually scabrous on the keel and sometimes on the back; lemma obtuse, usually shorter and thinner than the glumes, awnless or dorsally awned, often hairy on the callus; palea usually shorter than the lemma, 2-nerved in only a few species, usually small and nerveless or obsolete. Delicate to moderately tall annuals

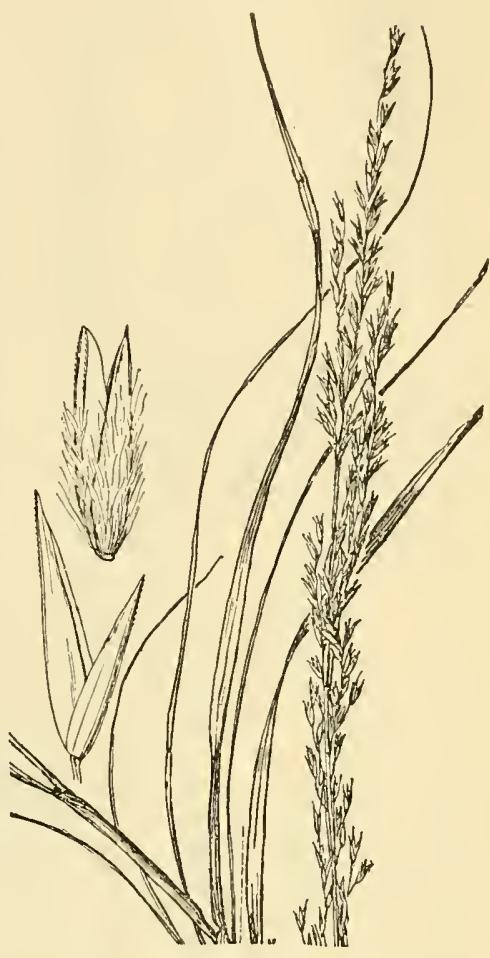

Figure 646.-Calamovilfa curtissii. Plant, $X$ $1 / 2$; glumes and floret, $\times 5$. (Garber, Fla.) or usually perennials, with flat or sometimes involute, scabrous blades, and open to contracted panicles of small spikelets. Type

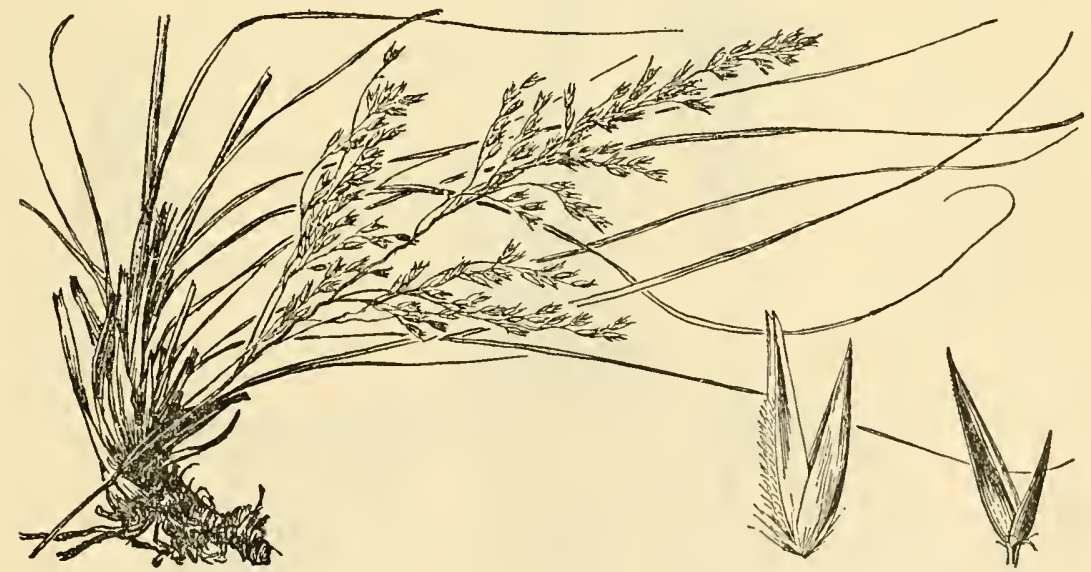

Figure 647.-Calamovilfa brevipilis. Plant, $\times \frac{1}{2}$; glumes and floret, $\times 5$. (Brinton. N. J.)

species, Agrostis stolonifera. Name from Greek agrostis, a kind of grass, from agros, a field; the word agrostology is from the same root. 


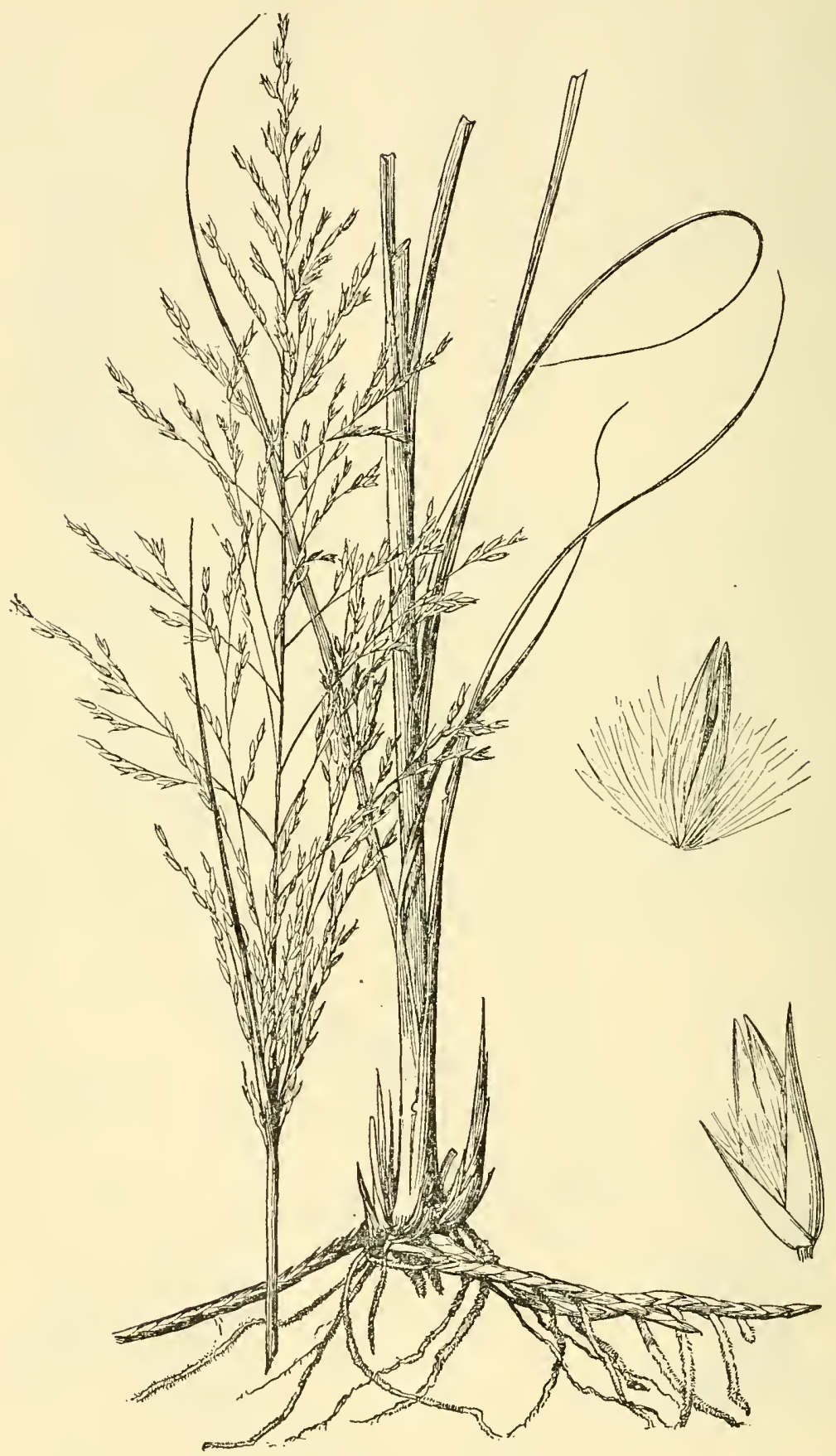

FIGURE 648.-Calamovilfa longifolia. Plant, $\times \frac{1}{2}$; spikelet and floret, $\times 5$. (Babcock, 
The rachilla is regularly prolonged in a few species and in occasional spikelets of other species.

Most of the species are important forage plants, either under cultivation or in the mountain meadows of the Western States. The three important cultivated species are redtop, Agrostis alba, used for meadows, pastures, lawns, and sports turf, Colonial bent, A. tenuis, used for pastures, lawns, and sports turf, and creeping bent, $A$. palustris, used for lawns and golf greens. Velvet bent, A. canina, is sometimes

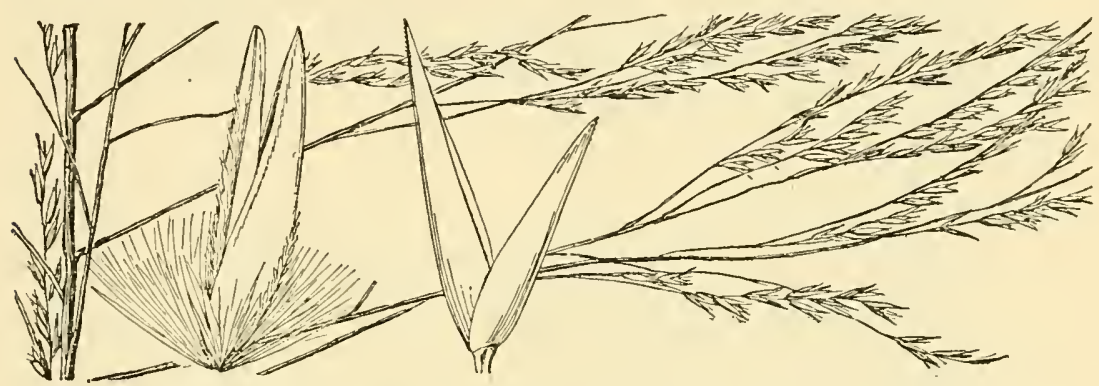

Figure, 650.-Calamovilfa gigantea. Panicle, $\times \frac{1}{2}$; glumes and floret, $\times 5$. (White, Okla.)

used for putting greens. Recently forms of A. palustris called

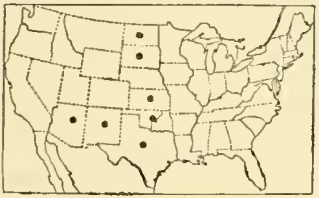

Figure 651.-Distribution of Calamorilfa gigantea.

Washington bent and Metropolitan bent, have come into use for lawns and especially for golf greens. They are propagated by the stolons. Fiorin is a name applied in England to A. palustris.

The native species abundant enough to be of importance as forage plants are $A$. exarata, throughout the western half of the United States, $A$. oregonensis in Oregon, and $A$. rossae in alpine regions of the Northwest.

1a. Palea evident, 2-nerved, at least half as long as the lemma.

2a. Rachilla prolonged behind the palea as a minute bristle.

Lemma pubescent. .......... A. Retrofracta. Lemma glabrous.

Lemma awned; plants annual.

Panicle open, the branches naked below _..._._. 2. A. SPICA-venti.

Panicle narrow, contracted, interrupted, the branches, or some of them floriferous from the base _.............. 3. A. INTERRUPTA.

Lemma awnless; plants perennial.

Spikelets $2 \mathrm{~mm}$ long_... Spikelets $3 \mathrm{~mm}$ long.................................

2b. Rachilla not prolonged.

Glumes scabrous on the keel and on the back; panicle contracted, lobed, the short branches densely verticillate ....... 6. A. verticillata.

Glumes scabrous on the keel only; panicle open or, if contracted, not lobed nor with densely verticillate branches.

Plants tufted; dwarf alpine species.............. 12. A. Humuls.

Plants with rhizomes or stolons; taller species of low and medium altitudes.

Branches of panicle naked at base, the panicle open and delicate; ligule as much as $2 \mathrm{~mm}$ long on culm leaves, less than $1 \mathrm{~mm}$ on the innovations...................... 11. A. TENUIS.

Branches of panicle or some of them floriferous from base; ligule as much as $6 \mathrm{~mm}$ long.

Panicle contracted, the branches appressed; long stolons developed in isolated plants. Culns decumbent at base_ 8 . A. PAlustris. 
Panicle open, the branches ascending, no long stolons developed.

Culms producing rather stout creeping leafy stolons. 9. A. NIGRA. Culms decumbent at base; rhizomes wanting. 7. A. stolonifera. Culms erect; rhizomes present. .

1b. Palea obsolete, or a minute nerveless scale (in $A$. exarata and $A$. californica as much as $0.5 \mathrm{~mm}$ long or more).

3a. Plants annual; lemma with a slender awn 5 to $10 \mathrm{~mm}$ long.

Awn flexuous; Southeastern States............ 15. A. ELliottiana. Awn straight; Pacific coast.

Spikelets 5 to $6 \mathrm{~mm}$ long; lemma awned from the middle. Spikelets about $1.5 \mathrm{~mm}$ long; lemma awned below the tip........... 14. A. EXIGUA.

3b. Plants perennial; lemma awned or awnless, the awn when present not much exserted.

4a. Plants spreading by creeping rhizomes (those of A. lepida short).

Hairs at base of lemma 1 to $2 \mathrm{~mm}$ long........... 16. A. HALLiI.

Hairs at base of lemma minute or wanting.

Rhizomes short; alpine tufted plants

17. A. LEPIDA.

Rhizomes long and slender.

Panicle spikelike.

18. A. PALLENS.

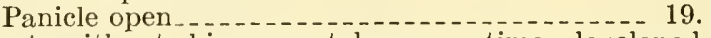

A. DIEGOENSIS.

4b. Plants without rhizomes, stolons sometimes developed.

5a. Panicle narrow, contracted, at least some of the lower branches spikelet-bearing from near the base.

Culms slender, in dense tufts with numerous basal leaves; blades not more than $5 \mathrm{~cm}$ long, less than $2 \mathrm{~mm}$ wide; panicles seldom more than $5 \mathrm{~mm}$ wide.

Blades involute; culms spreading; panicles strict.-- 20. A. BLASDALEI.

Blades flat; culms erect; panicles not strict_..... 21. A. Rossae.

Culms stouter, not in tufts with dense basal foliage; blades or some of them at least 8 to $10 \mathrm{~cm}$ long and 4 to $5 \mathrm{~mm}$ wide, commonly much larger.

Panicle from loose to dense, if dense, in glomerules or interrupted; glumes, except the keel, smooth to scaberulous; palea less than one fourth as long as the lemma ........ 22. A. EXARATA.

Panicle dense and spikelike; glumes very scabrous; palea one fourth to one third as long as the lemma ...... 23. A. CALIFORNICA.

5b. Panicle open, sometimes diffusely spreading; lower branches not spikelet-bearing at the base.

Awn attached near the base of the lemma; panicle diffuse.

24. A. HOWELLII.

Awn when present attached about the middle of the lemma or above.

Panicles very diffuse, the scabrous capillary branches branching toward the end or (in A. hiemalis var. geminata) above the middle.

25. A. HIEMALIS.

Panicles open but not diffuse, the branches branching at or below the middle.

Lemmas awnless (occasional plants with awned lemmas; see also A. bakeri).

Spikelets about $1.5 \mathrm{~mm}$ long; plants of high altitudes, delicate, 10 to $30 \mathrm{~cm}$ tall ..... A. IDAHOENSIS. Spikelets 2 to $3 \mathrm{~mm}$ long; more robust plants of low and medium altitudes.

Panicles rather lax, sometimes delicate and divaricately spreading; blades flat, as much as $6 \mathrm{~mm}$ wide; eastern United States ..... A. PERENNANS.

Panicles rather stiff, the branches whorled and rather stiffly ascending; Pacific coast.......... 29. A. OREGONENSIS. Lemmas awned.

Spikelets about $2 \mathrm{~mm}$ long; introduced.

30. A. canina. Spikelets 2.5 to $3 \mathrm{~mm}$ long; native.

Branches of panicle nearly smooth. Foliage mostly basal.

Branches of panicle scabrous.

Awn short and straight.

31. A. BOREALIS.

Awn geniculate, exserted

27. A. BAKERI.

32. A. LONGILIGULA. 
1. Agrostis retrofrácta Willd. (Fig. 652.) Perennial; culms tufted, erect or decumbent at base, 20 to $60 \mathrm{~cm}$ tall; sheaths smooth; ligule of culm leaves 3 to $5 \mathrm{~mm}$ long; blades flat, scabrous, 1 to $2 \mathrm{~mm}$ wide; panicle diffuse, 15 to $30 \mathrm{~cm}$ long, the branches in distant whorls, capillary, reflexed at maturity, divided above the middle; glumes acuminate, 3 to $4 \mathrm{~mm}$ long; lemma about half as long as the glumes, thin, pubescent, short-bearded on the callus, and bearing about the middle a slender geniculate and twisted awn exserted about the length of the glumes; palea nearly as long as the lemma; rachilla slender, pilose, from half to as long as the lemma. 21 -Introduced in central California (15 miles south of Stockton), Texas (Kent), and Ohio (Painesville); common in Hawaiian Islands and Polynesia.

2. Agrostis spíca-vénti L. (Fig. 653,A.) Annual; culms branched at base, mostly 40 to $60 \mathrm{~cm}$ tall; ligule as much as $6 \mathrm{~mm}$ long; blades

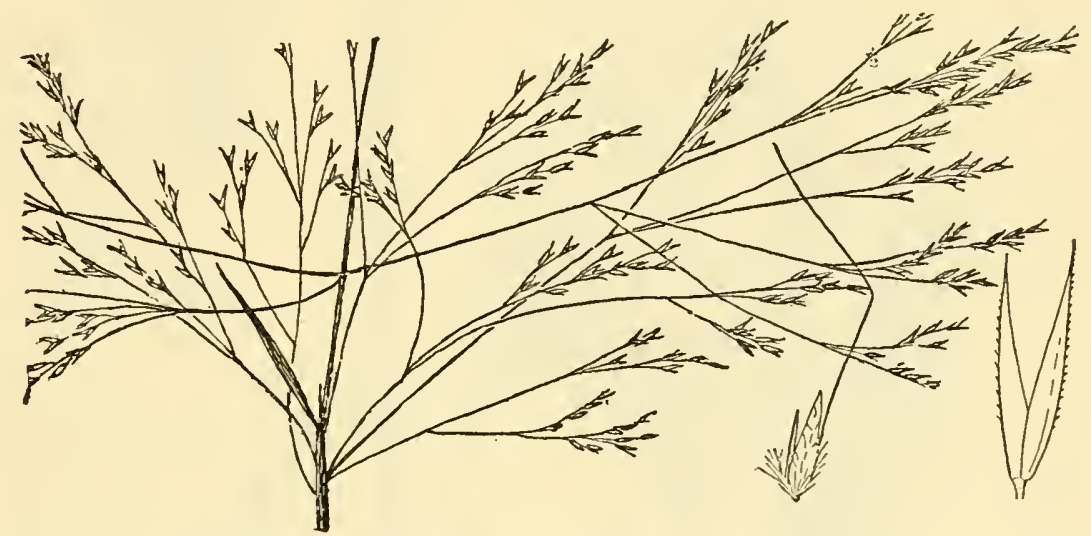

FigUre 652.-Agrostis retrofracta. Panicle, $\times \frac{1}{2}$; glumes and floret, $\times 10$. (Tracy and Earle 403, Tex.)

flat, 1 to $3 \mathrm{~mm}$ wide; panicle 10 to $20 \mathrm{~cm}$ long, usually less than half as broad, the branches capillary, spreading, whorled, naked at base; spikelets 2 to $2.5 \mathrm{~mm}$ long; glumes somewhat unequal, the first shorter and narrower; lemma about as long as the second glume, scaberulous, with a slender awn from below the apex, the awn about twice as long as the glumes; palea about as long as the lemma; rachilla less than 0.5 mm long. $\odot$-Introduced at a few points from Maine to Maryland; Ohio; Portland, Oreg. (fig. 654); Europe.

3. Agrostis interrúpta L. (Fig. 653, B.) Similar to A. spica-venti; panicle narrower, more condensed, interrupted, the branches or some of them floriferous from the base; awn of lemma about $1 \mathrm{~cm}$ long $\odot$-Introduced in Missouri (St. Louis), Washington (Spokane), Oregon (Portland), Idaho (Nezperce Forest), and British Columbia (Okanogan); Europe.

4. Agrostis thurberiána Hitchc. Thurber redtop. (Fig. 655.) Culms slender, in small tufts, erect, 20 to $40 \mathrm{~cm}$ tall; leaves somewhat crowded at base, the blades about $2 \mathrm{~mm}$ wide; panicle rather narrow, lax, more or less drooping, 5 to $7 \mathrm{~cm}$ long; spikelets green, pale, or purple, $2 \mathrm{~mm}$ long; lemma nearly as long as the glumes, the palea about two thirds as long; rachilla hairy, $0.3 \mathrm{~mm}$ long. $24-B o g s$ and moist places, at medium and upper altitudes, Colorado to British Columbia and south in the Sierras to central California (fig. 656). 


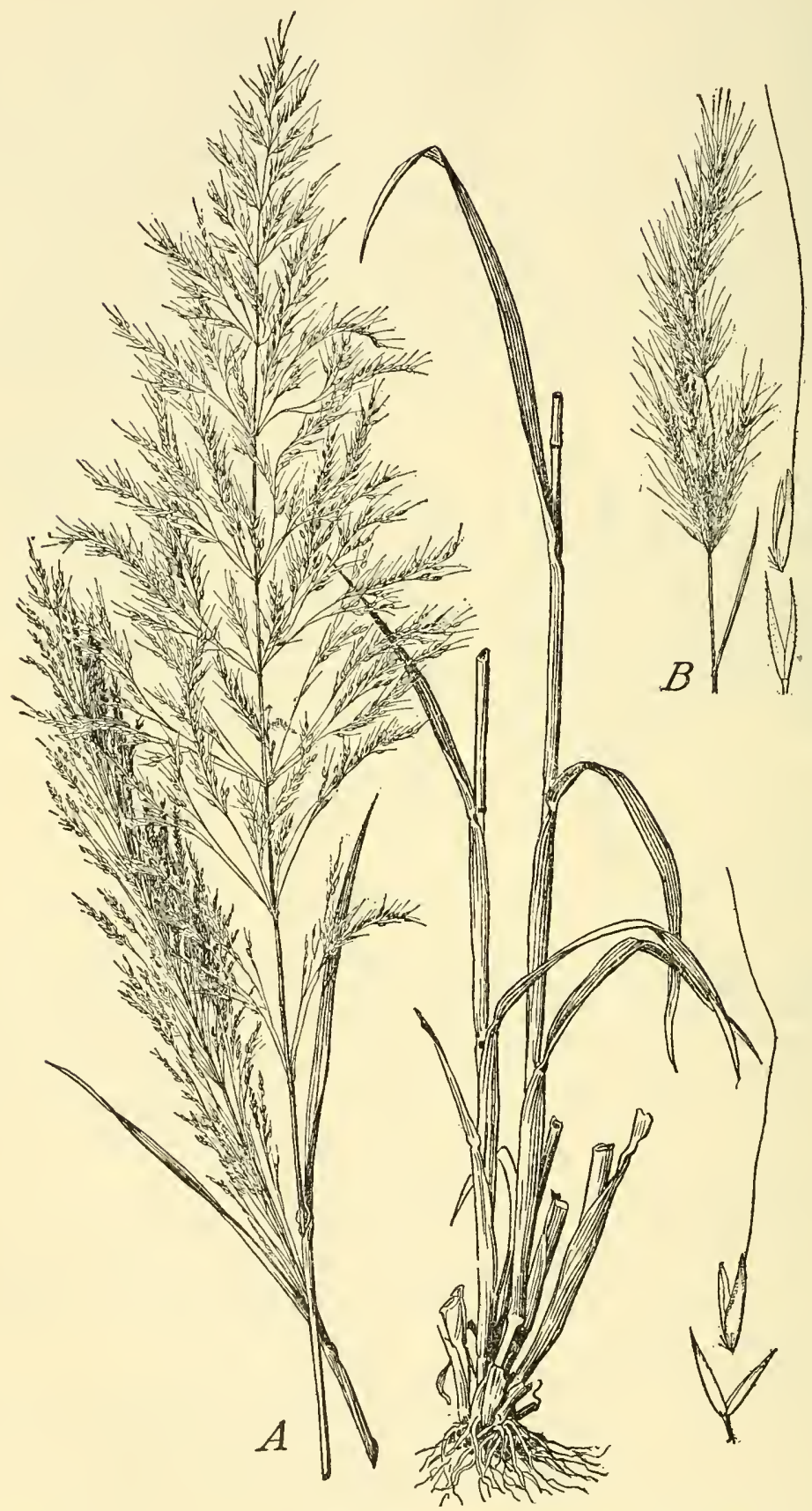

Froure 653.-A, Agrostis spica-venti. Plant, $\times \frac{1}{2}$; glumes and floret, $\times 5$. (Martindale, N. J.) $B, A$. interrupta. Panicle, $\times \frac{1}{2}$; glumes and floret, $\times 5$. (Bonser 3, Wash.) 
5. Agrostis aequiválvis (Trin.) Trin. (Fig. 657.) Similar to A. thurberiana; culms on the average taller, blades longer; panicle usually purple, 5 to $15 \mathrm{~cm}$ long; spikelets about 3 to $4.5 \mathrm{~mm}$ long; palea nearly as long as the lemma; prolongation of the rachilla minutely pubescent, one fifth to half as long as the lemma. 2 -Wet meadows and bogs, Alaska, southward (rare) in the Cascade Mountains to Oregon.

6. Agrostis verticilláta Vill. Water bent. (Fig. 658.) Culms usually decumbent at base, sometimes with long creeping and rooting stolons; blades firm, mostly relatively short

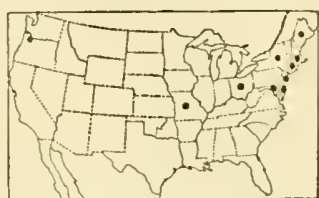

FIGURE 654.-Distribution of Agrostis spica-venti. and broad, but in luxuriant specimens elongate; panicle contracted, 3 to $10 \mathrm{~cm}$ long, densely flowered, lobed with short verticillate branches, especially at base, the branches spike-

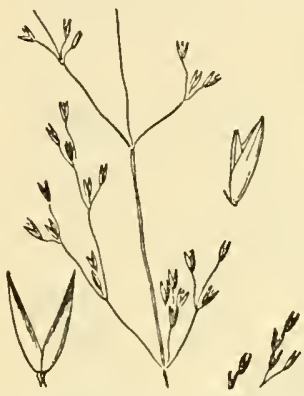

FIGURE 6055.-Agrostis thurberiana. Panicle, $\times 1$; glumes and floret, $\times 5$. (Type.) let-bearing from the base; spikelets usually falling entire; glumes equal, narrowed to an obtuse tip, scabrous on back and keel, $2 \mathrm{~mm}$ long; lemma $1 \mathrm{~mm}$ long, awnless, truncate and toothed at apex; palea nearly as long as the lemma. 24 Moist ground at low altitudes, especially along irrigation ditches (in irri-

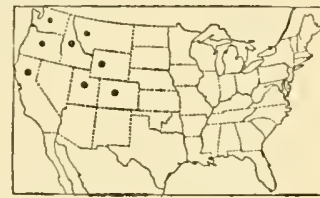

FIgURE 656.-Distribution of Agrostis thurberiana. gated regions), Texas to California, north to southern Utah and Washington; on ballast at some Atlantic ports. Introduced in America, south through the drier parts to Argentina (fig. 659); warmer parts of the Eastern Hemisphere.

7. Agrostis stolonífera L. (Fig. 660.)

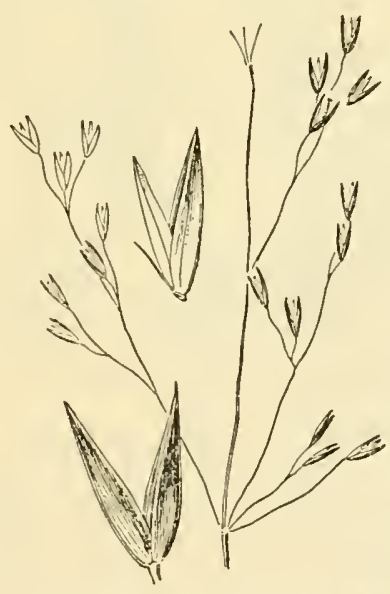

FIGURE 657-Agrostis aequivalitis. Panicle, $\times 1$; glumes and floret, $\times$ 5. (Ilowell 1712, Alaska.) Culms ascending from a spreading base, the decumbent portion rooting in wet soil, 20 to $50 \mathrm{~cm}$ tall; ligule as much as $6 \mathrm{~mm}$ long; blades flat, mostly 1 to $3 \mathrm{~mm}$ wide; panicle oblong, 5 to $15 \mathrm{~cm}$ long, pale or purple, somewhat open, the branches or some of them spikelet-bearing from near the base; spikelets 2 to $2.5 \mathrm{~mm}$ long; glumes acute, glabrous except the scabrous keel; lemma shorter than the glumes, awnless or rarely awned from the back; palea usually half to two thirds as long as the

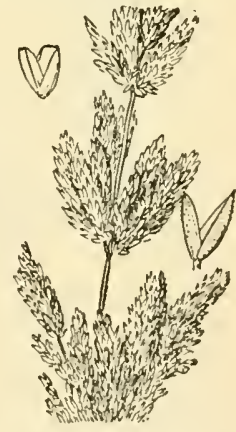

FIGURE 658.-Agrostis rerlicillata. Panicle $\times 1$; glumes and floret, $\times 5$. (Schoenfeldt 3159 , Calif.)

lemma. 24 -Moist grassy places, Newfoundland to Alaska, south to New Jersey in the East and to Oregon in the West (fig. 661); northern Europe. This species appears to be native in northern North America. 
8. Agrostis palústris Huds. Creeping Bent. (Fig. 662.) Differing from $A$. stolonifera chiefly in the long stolons, the narrow stiff appressed blades, and the condensed (sometimes somewhat open) panicle. 24 (A. maritima Lam.) - Marshes along the coast, from

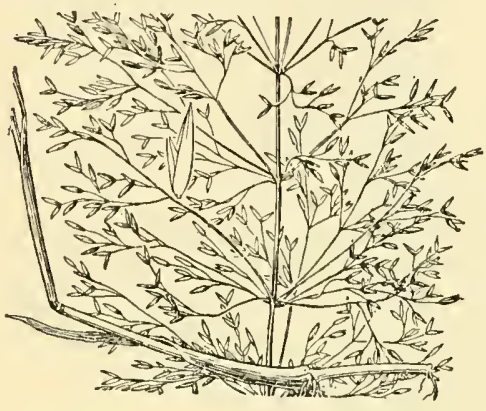

Figure 660.-Agrostis stolonifera. Panicle, $\times 1$; floret, $\times 5$. (Hitcheock 23899, Newf.)

$\mathrm{Newf}$ oundland to Maryland; British Columbia to northern California; sometimes occupying extensive areas, as at Coos B a y, Oreg.; introduced at various places in the interior of

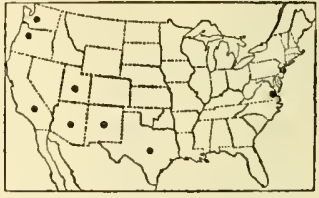

Figure 659.-Distribution of Agrostis verticillata.

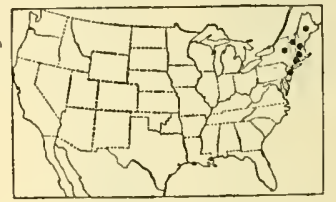

FIGURE 661.-Distribution of Agrostis stolonifera.

southern Can-

ada and northern United States and occasionally as far south as Texas and New Mexico, especially along ditches (fig. 663); Eurasia. Forms of this species, known as seaside, Coos Bay, and Cocoos bents (propagated by seed), and Metropolitan and Washington bents (propagated by stolons, and formerly called car-

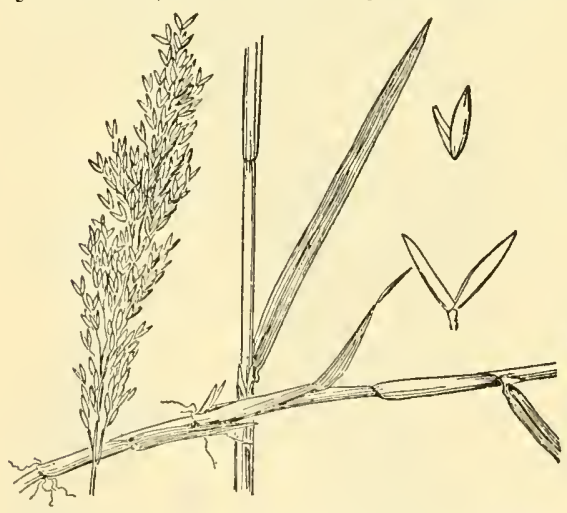

Figure 662.-Agrostis palustris. Plant, $\times 1$; glumes and floret, $\times 5$. (Hiteheock 11713, Wash.)

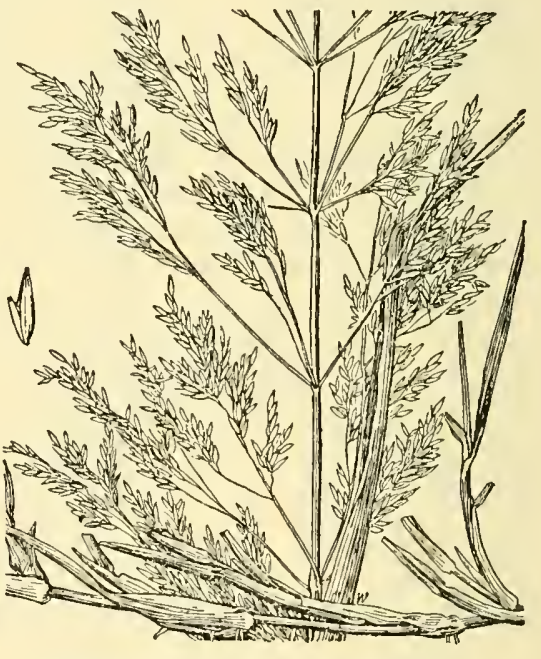

Figure 664.-4grostis nigra. Plant, $\times 1$; floret, 5 . (Moore 47, cult. Mo. Bot. Gard.)

pet bent), are used for lawns and extensively for putting greens.

9. Agrostis nígra With. BLACK BENT.

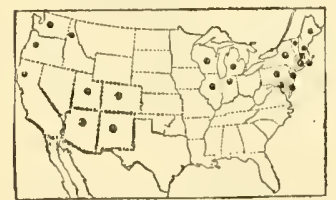

Figure 663.-Distribution of Agrostis palustris. (Fig. 664.) Culms long-decumbent at base, also with rather stout leafy stolons, the fertile branches ascending or erect, 20 to $30 \mathrm{~cm}$ tall; ligule as in A. alba; panicle brown, open as in $A$. alba, but on the average more condensed along the branches, the base usually partly included. 2 -Sometimes found mixed with "South German" bent (creeping bent), hence may be a constituent of lawns grown from imported seed; Europe. 


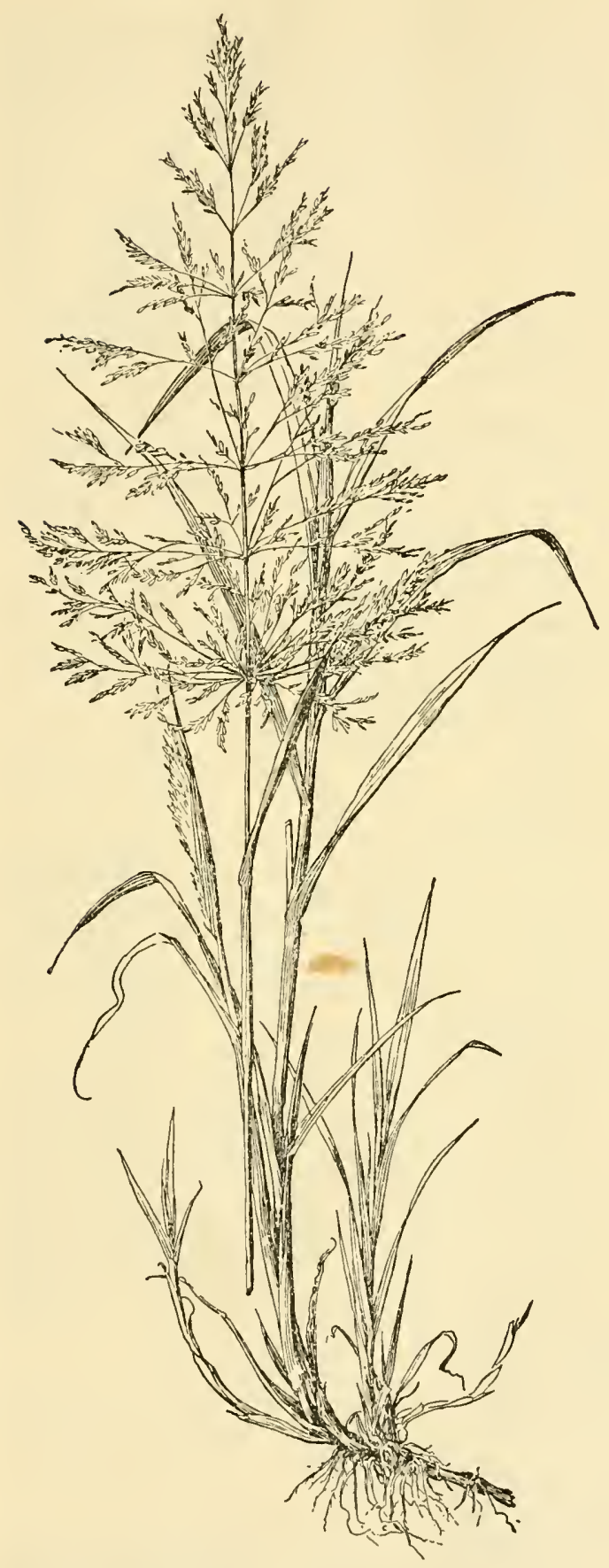

10. Agrostis alba L. Redtop. (Fig. 665.) Differing from $A$. stolonifera in its usually erect more robust culms, sometimes as much as 1 to $1.5 \mathrm{~m}$ tall, the base erect or decumbent, with strong creeping rhizomes; blades flat, 5 to $10 \mathrm{~mm}$ wide; panicle pyramidal-oblong, reddish, as much as 20 cm long, the branches spreading in anthesis, sometimes contracting later; lemmas rarely awned. 24 -This is the common redtop cultivated for meadows, pastures, and lawns, extensively escaped in all the cooler parts of the United States; Eurasia. This form appears not to be native in America. Plants growing without cultivation may tend to take on the aspect of A. stolonifera. This and the two preceding are closely allied and appear to intergrade. The name $A$. palustris has been erroneously applied to this species in recent works.

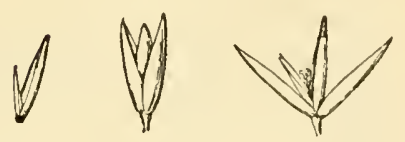

Figure 665.-Agrostis alba. P!ant, $\times 1 / 2 ; 2$ spikelets and floret, $\times$ 5. (Chase 5191, Mont.) 
11. Agrostis ténuis Sibth. Colonial bent. (Fig. 666, A.) Culms slender, erect, tufted, usually 20 to $40 \mathrm{~cm}$ tall, with short

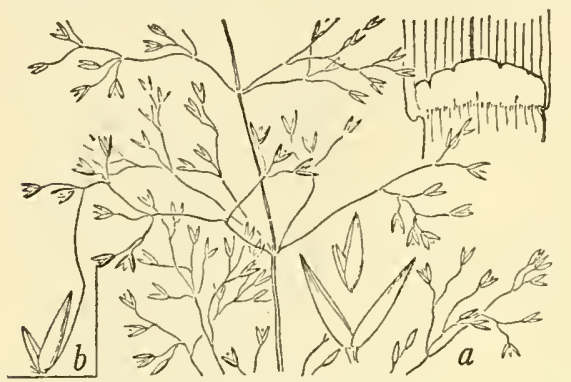

Figure 666-A, Agrostis tenuis. Panicle, $\times 1$; glumes, floret, and ligale, $\times 5$. (Waghorne, Newf.) $B$, Var. aristata. Floret, $\times$ 5. (Gayle 786, Maine.)

stolons but no creeping rhizomes; ligule short, less than 1 $\mathrm{mm}$ or on the culm as much as $2 \mathrm{~mm}$ long; blades mostly 5 to $10 \mathrm{~cm}$ long, 1 to $3 \mathrm{~mm}$ wide; panicle mostly 5 to 10 cm long, open, delicate, the slender branches naked below, the spikelets not crowded. 2 (A. vulgaris With.) - Cultivated for pastures and lawns in the northeastern United States; escaped and well established throughout those regions; Newfoundland south to Maryland, West Virginia, and Michigan; British Columbia to California (fig. 667); Europe. This species appears not to be native in America; it has been referred to A. capillaris L., a distinct species of Europe. In older works this has been called Rhode Island bent. Forms of this species are sometimes called Prince Edward Island, New Zealand, and Rhode Island Colonial bent (noncreeping forms) and Astoria and Oregon Colonial bent (creeping forms).

Agrostis tenUis var. aristáta (Parn.)

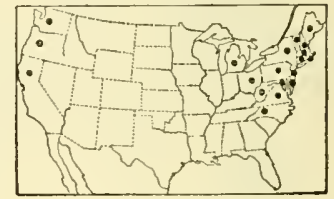

FIgURE 667 . Distribution of Agrostis tenuis.

Druce. (Fig. 666, B.) Differing from A. tenuis in having lemma awned from near the base, the awn usually geniculate and exceeding

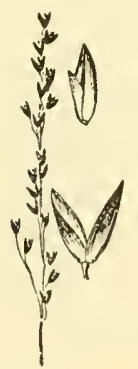

Figure 668.-Agrostis humilis. Panicle, $X$ 1 ; glumes and floret, $\times 5$. (Type.) the glumes. 21 -Fields and open woods, Nova Scotia and Quebec to North Carolina; Alaska to Vancouver Island; northern California; Europe. This form appears to be native, at least in the more northerly part of its range.

12. Agrostis húmilis Vasey. (Fig. 668.) Culms low, tufted, mostly not more than $15 \mathrm{~cm}$ tall; leaves mostly basal, the blades flat or folded, usually not. more than $1 \mathrm{~mm}$ wide; panicle narrow, purple, 1 to $3 \mathrm{~cm}$ long, the branches appressed to somewhat spreading; spikelets about $2 \mathrm{~mm}$ long; lemma nearly as long as the glumes, awnless; palea about two thirds as long as lemma. 2 -Bogs and alpine meadows at high altitudes, Wyoming and Colorado to Washington and Oregon (fig. 669).

13. Agrostis hendersónii Hitchc. (Fig. 670.) Annual; culms about $10 \mathrm{~cm}$ tall; ligule 2 to $3 \mathrm{~mm}$ long; blades flat or loosely involute, 1 to $3 \mathrm{~cm}$ long, about $1 \mathrm{~mm}$ wide; panicle condensed, about $2.5 \mathrm{~cm}$ long, purplish; spikelets short-pediceled, 5 to $6 \mathrm{~mm}$ long; glumes subequal, setaceous-tipped; lemma about $3 \mathrm{~mm}$ long, finely 2-toothed, awned from the middle, the awn about $1 \mathrm{~cm}$ long, geniculate, the callus pubescent; palea obsolete. $\odot$-Wet ground. Known only from Sams Valley, near Gold Hill, Jackson County, Oreg. 
14. Agrostis exígua Thurb. (Fig. 671.) Annual; culms delicate, 3 to $10 \mathrm{~cm}$ tall, branching from the base; blades 5 to $20 \mathrm{~mm}$ long, subinvolute, scabrous; panicle half the length of the plant, finally

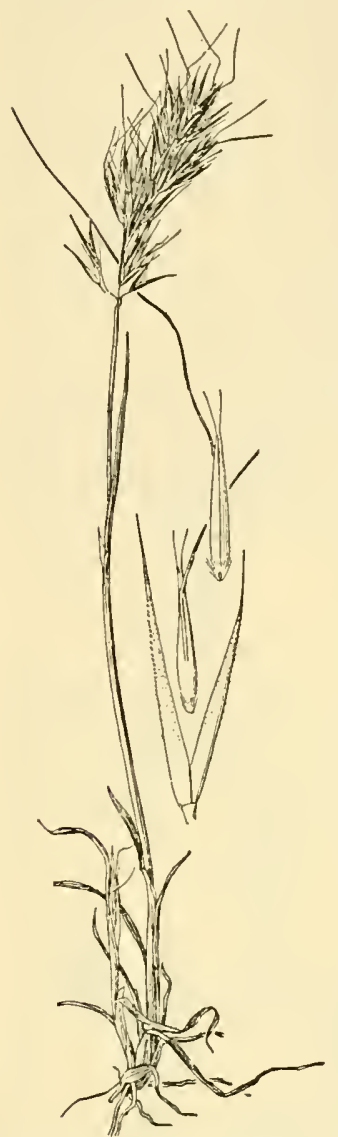

FIGURE 670.-Agrostis hendersonii. Plnat, $X 1$; glumes and 2 views of floret, $\times 5$. (Type.)

open; glumes $1.5 \mathrm{~mm}$ long, scaberulous; lemma equaling the glumes, scaberulous toward the 2-toothed apex, bearing below the tip a delicate bent awn 4 times as long; palea wanting. $\odot$-Known only from "foothills of the Sierras" (the type) and Howell Mountain, Napa County, Calif.

\section{Agrostis elliottiána} Schult. (Fig. 672.) Annual; culms slender, erect or decumbent at base, 10 to $40 \mathrm{~cm}$ tall; blades flat, about $1 \mathrm{~mm}$ wide; panicle finally diffuse, about half the entire height of the plant, the branches capillary, fascicled, the spikelets toward the ends of the branchlets, the whole panicle breaking away at maturity; spikelets 1.5 to $2 \mathrm{~mm}$ long; glumes acute; lemma 1 to $1.5 \mathrm{~mm}$ lorg, minutely toothed, the awn attached below the tip, very slender, flexuous, delicately shortpilose, 5 to $10 \mathrm{~mm}$ long, sometimes wanting; palea wanting. $\odot$ - Fields, waste places, and open ground, Maryland to Illinois, Mis-

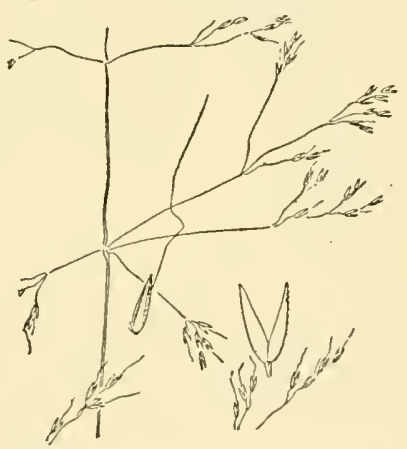

FIGUre 672.-Agrostis elliottiana. Panicle, $\times 1$; glumes and floret, $\times 5$. (Johnson, Miss.)

souri, and Kansas, south to Georgia, Alabama, and eastern Texas; introduced in Maine and Massachusetts (fig. 673); Yucatan.

16. Agrostis hállii Vasey. (Fig. 674.) Culms

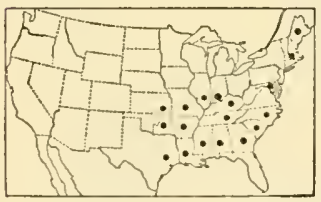

Figure 673,-Distribution of Agrostis ellottiana. erect, 60 to $90 \mathrm{~cm}$ tall, with creeping rhizomes; ligule usually conspicuous, 2 to $7 \mathrm{~mm}$ long; blades flat, 2 to $5 \mathrm{~mm}$ wide; panicle 10 to 15 cm long, narrow but loose, the branches verticillate; glumes about $4 \mathrm{~mm}$ long; lemma awnless, $3 \mathrm{~mm}$ long, with a tuft of hairs at base about half as long; palea wanting. 24 -Mostly in woods near the coast from Oregon to Santa Barbara, Calif. Agrostis halli var. Prínglei (Scribn.) Hitche. Branching, foliage stramineous; blades narrow, usually involute; panicle narrow, compact. 2 -Near the coast in sand, Mendocino County, Calif. 
17. Agrostis lépida Hitchc. (Fig. 675.) Culms tufted, 30 to 40 $\mathrm{cm}$ tall, erect, with numerous short rhizomes; ligule, at least on the

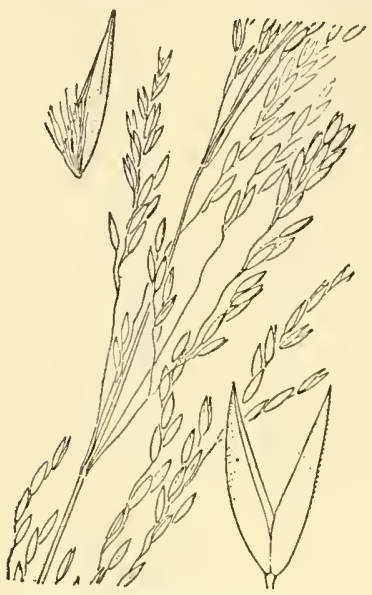

Figure 674.-Agrostis hallii. Panicle, $\times 1$; glumes and floret, $\times 5$. (Bioletti 110, Calif.) innovations, as much as $4 \mathrm{~mm}$ long; leaves mostly basal, the blades firm, erect, flat or folded, the upper culm leaf below the middle of the culm, the blade $3 \mathrm{~cm}$ long or less; panicle purple, 10 to $15 \mathrm{~cm}$ long, the branches verticillate, becoming divaricately spreading, the lowermost 2 to $5 \mathrm{~cm}$ long; glumes $3 \mathrm{~mm}$ long, smooth or nearly so; lemma 2 $\mathrm{mm}$ long; palea wanting or very minute. 24 - Meadows and open woods, Sequoia National Park, and San Bernardino Mountains, Calif., at upper altitudes.

18. Agrostis pállens Trin. Dune bent. (Fig. 676.) Culms erect, 20 to $40 \mathrm{~cm}$ tall, with creeping rhizomes; ligule rather firm, 2 to $3 \mathrm{~mm}$ long; blades flat or somewhat involute, 1 to $4 \mathrm{~mm}$ wide; panicle contracted, almost spikelike, 5 to $10 \mathrm{~cm}$ long; glumes 2.5 to $3 \mathrm{~mm}$ long; lemma a little shorter than the glumes, awnless; palea wanting. $24-$ Sand dunes along the coast, Washington to central California. Probably only a seacoast form of $A$. diegoensis.

19. Agrostis diegoénsis Vasey. Thingrass. (Fig. 677.)' Culms erect, as much as $1 \mathrm{~m}$ tall with creeping rhizomes; blades flat, lax, 2 to 6 $\mathrm{mm}$ wide; panicle narrow, open, 10 to $15 \mathrm{~cm}$ long, the branches ascending, rather stiff, some of them naked below; spikelets about as in $A$. pallens, awned or awnless. 24 Meadows and open woods at low and medium altitudes, Montana and British Columbia to southern California and Nevada (fig. 678).

20. Agrostis blasdâlei Hitchc. (Fig. 679.) Culms 10 to $15 \mathrm{~cm}$ tall, densely tufted; blades narrow or filiform, rigid, involute, 2 to $4 \mathrm{~cm}$ long; panicle strict, narrow, almost spikelike, 2 to $3 \mathrm{~cm}$ long, the short branches closely appressed; spikelets 2.5 to $3 \mathrm{~mm}$ long; lemma about 1.8 $\mathrm{mm}$ long, awnless or with a very

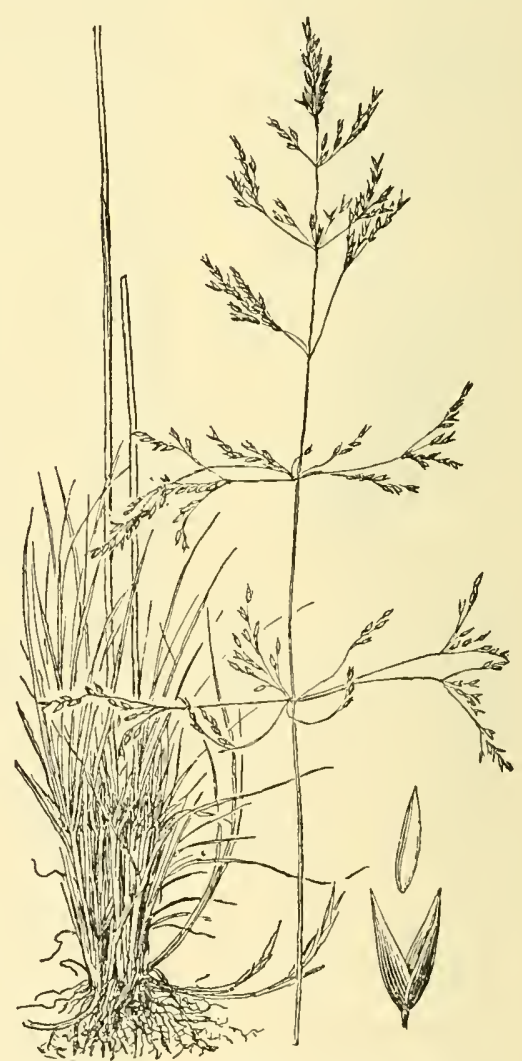

Figure 675.-Agrostis lepida. Plant, $\times 1 / 2$; glumes and floret, $\times 5$. (Type.) short awn just above the middle; palea about $0.3 \mathrm{~mm}$ long, nerveless. 2 -Cliffs near Fort Brage, Mendocino County, Calif. Previously referred to $A$. breviculmis Fitchc. of Peru. 
21. Agrostis róssae Vasey. Ross redtop. (Fig. 680.) Culms 10 to $20 \mathrm{~cm}$ tall, densely tufted; blades mostly not more than $1 \mathrm{~mm}$ wide; panicle contracted, 2 to $6 \mathrm{~cm}$ long, the branches appressed;

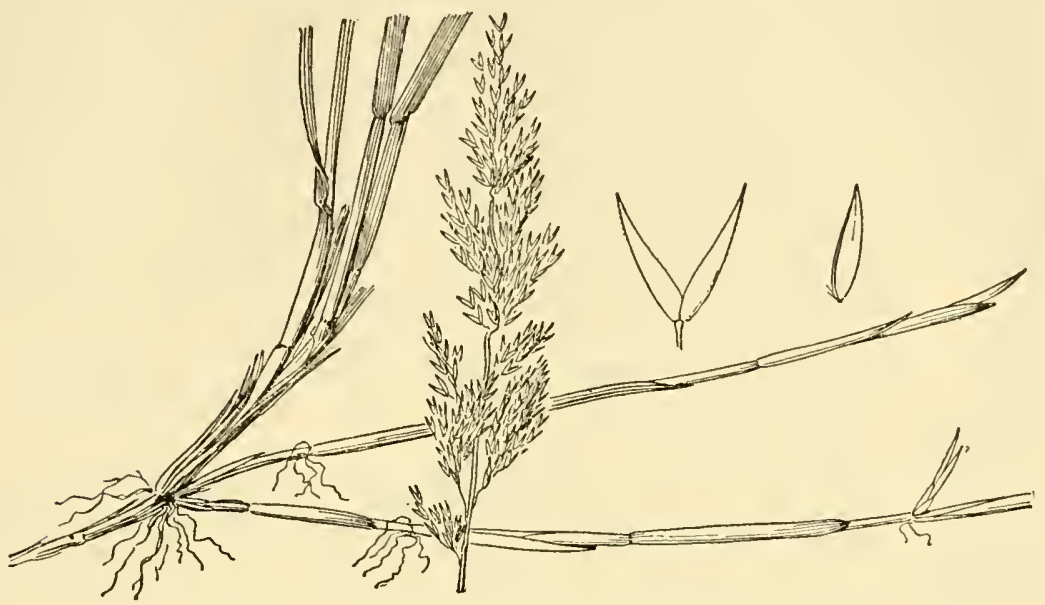

FIGURe 676.-Agrostis pallens. Plant, $\times 1$; glumes and floret, $\times 5$. (Howell, Oreg.)

spikelets green or purple, about $2 \mathrm{~mm}$ long; lemma $1.5 \mathrm{~mm}$ long, awnless; palea minute. 24 -Rocky creeks and mountain slopes at high altitudes, Colorado and Utah to Alberta, Washington, and California. (Fig. 681.) Differs from A. exarata

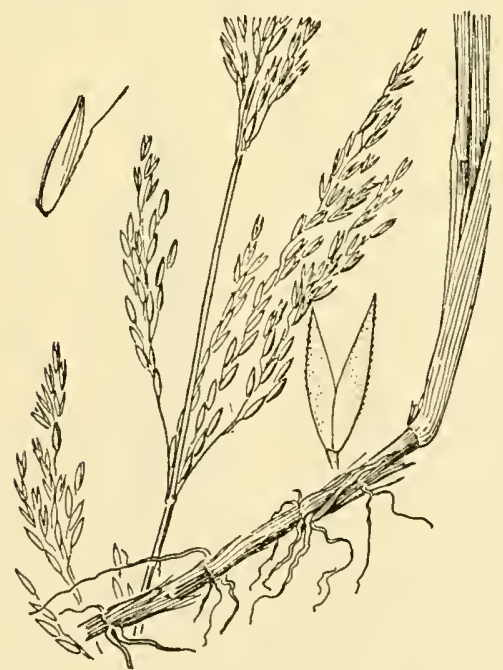

Figure 677.-Agrostis diegoensis. Plant, $\times 1$; glumes and floret, $\times 5$. (Orcutt, Calif.) in the hard tufted base, the smaller size and the narrower fewer-flowered panicle with a p pressed

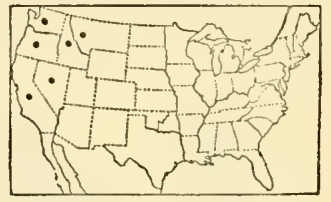

FIGURE 678.-Distribution of Agrostis diegoensis.

branches. What appears to be an awned form occurs in Colorado (Breckenridge and Mount Massive) and British Columbia (Revelstoke).

\section{Agrostis exaráta}

Trin. SPIKE REDTOP. (Fig. 682, A.) Culms 20 to $120 \mathrm{~cm}$ tall, mostly tufted, FIGURE 679.sheaths smooth or some- Agrostis blas. what s cabrous; ligule cle, $\times$ what sca brous; ligule glumes and prominent; blades flat, 1 to floret, $\times 5$. $8 \mathrm{~mm}$ wide; panicle narrow,

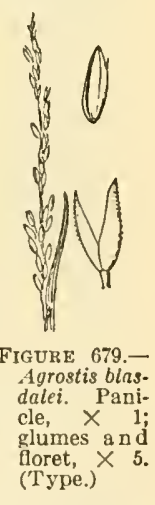

from somewhat open to close and spikelike, sometimes interrupted, 1 to $25 \mathrm{~cm}$ long; glumes acuminate or awn-pointed, nearly equal, 2.5 to $4 \mathrm{~mm}$ long, scabrous on the keel and of ten scaberulous on the back; lemma about $2 \mathrm{~mm}$ long, awnless or bearing from about the middle 
of the back a straight or bent exserted awn; palea less than $0.5 \mathrm{~mm}$ long. 21 - Moist or rather dry open ground, at low and medium altitudes, western Nebraska to Alberta and Alaska, south to New Mexico, California, and Mexico (fig. 683). A variable species. Agrostis exarata var. monolépis (Torr.) Hitche. (Fig. 682, B.) Panicle narrow, often interrupted, lemma awned. 2 (A. inflata

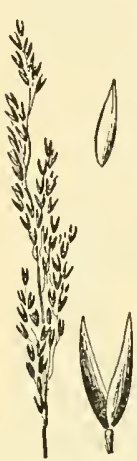

Figure 680.Agrostis rossae. Panicle, $\times 1$; glumes and floret, $\times 5$. Hitchcock 23173 Wyo.)

Scribn., A. exarata var. microphylla Hitchc.)-Washington to California. Agrostis exarata var. Ámpla (Hitche.) Hitchc. Robust, panicle large, rather loose, lemma awned. $2 \mid A$. grandis Trin. is a form with dense panicle as much as $30 \mathrm{~cm}$ long. $A$. scouleri 'Trin. is a northern form with somewhat open panicle. A. filiculmis Jones is a slender form with narrow blades and slender fewflowered panicle.

23. Agrostis califórnica Trin. (Fig. 684.) Culms tufted, usually rather stout, erect or somewhat spreading at base, 15 to $60 \mathrm{~cm}$ tali; sheaths sometimes slightly scabrous; ligule truncate, usually shorter than in $A$. exarata, puberulent; blades flat, firm, strongly nerved on the

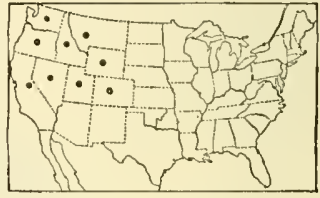

FIGURE 681,-Distribution of Agrostis rossae.

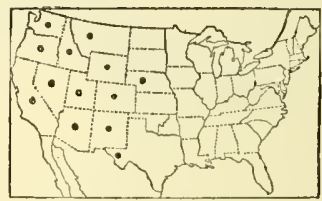

Figure 683.-Distribution of Agrostis exarata.

upper surface, usually not more than $10 \mathrm{~cm}$ long, those of the culm comparatively broad and short, of ten 3 to $5 \mathrm{~cm}$ long and 3 to 5 $\mathrm{mm}$ wide, rarely as much as $10 \mathrm{~mm}$ wide; panicle dense, spikelike, sometimes slightly interrupted, mostly 2 to $10 \mathrm{~cm}$ long and 5 to $15 \mathrm{~mm}$

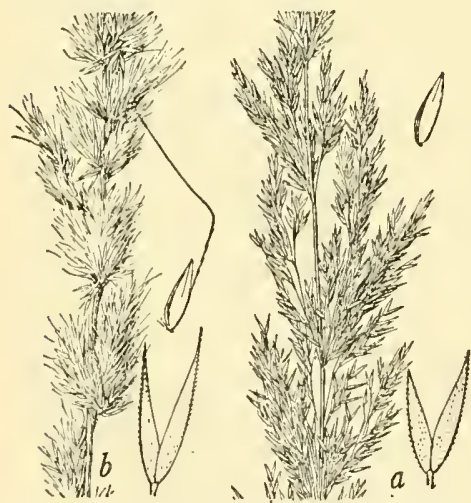

Figure 682.- A, Agrostis exarata. Panicle, $X$ 1; glumes and tloret, $X \mathbf{5}$. (Sheldon 10876 , Oreg.) B, Var and floret, $\times 5$. (Congdon, Calif.)

wide; spikelets about $3 \mathrm{~mm}$ long; glumes acute or acuminate, prominently scabrous on the keel and strongly scabrous on the sides; lemma a little shorter than the glumes, awnless or with a straight awn from minute to somewhat exceeding the glumes; palea onefourth to one-third as long as the lemma. 21 (A. densiflora Vasey.) - Sandy soil and clifis near the sea,

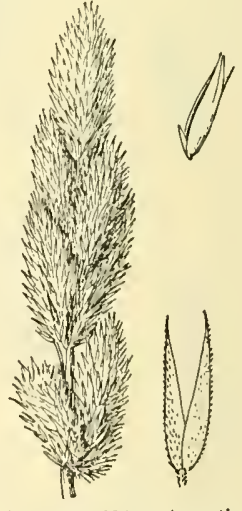

FigurE 684.-Agrostis californica. Panicle. $\times 1$; glumes and lloret, $\times 5$. (Anderson, Calif.)

Mendocino County

to Santa Cruz, Calif. This species has been confused with A. exarata and with A. glomerata (Presl) Kunth of Peru, which is referable to A. tolucensis H.B.K.

24. Agrostis howéllii Scribn. (Fig. 685.) Culms erect or decumbent at base, 40 to $60 \mathrm{~cm}$ tall; blades lax, as much as $30 \mathrm{~cm}$ long, 3 to $5 \mathrm{~mm}$ wide; panicle loose and opci, 10 to $30 \mathrm{~cm}$ long, the branchec 
flexuous, scabrous; spikelets pale, clustered toward the ends of the branches; glumes acuminate, rather narrow and firm, somewhat scabrous on the keel, the first about $3.5 \mathrm{~mm}$ long, the second a little shorter; lemma acute, $2.5 \mathrm{~mm}$ long, 4-toothed, bearing from near the base an exserted bent awn about $6 \mathrm{~mm}$ long; palea wanting. 4 Known only from Oregon (Multnomah and Hood River Counties).

25. Agrostis hiemális (Walt.) B.S.P. Ticklegrass. (Fig. 686.) Culms slender, usually tufted, 20 to $80 \mathrm{~cm}$ tall, leaves usually mostly basal, the blades narrow or almost setaceous; panicle very diffuse, as much as $30 \mathrm{~cm}$ long, the branches few, scabrous, long, stiff, and capillary, bearing spikelets near the ends; glumes 1.5 to $2 \mathrm{~mm}$ long, acute or acuminate; lemma two-thirds to three-fourths as long as glumes, awnless or rarely awned; palea wanting. 2 (1. scabra

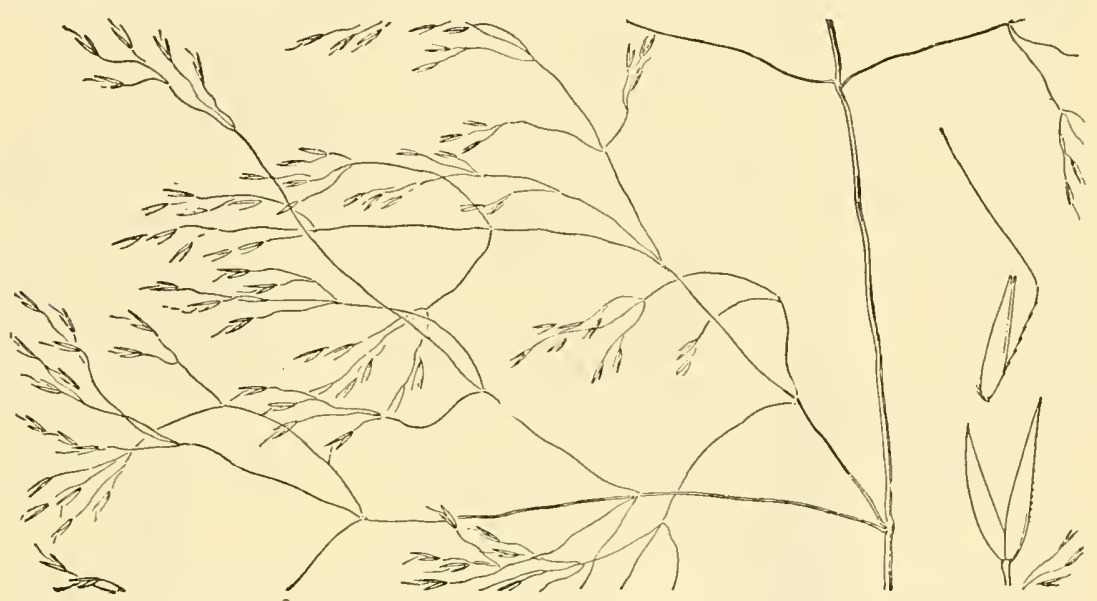

Figure 685.-Agrostis howellii. Panicle, $\times 1$; glumes and floret, $\times 5$. (Type.)

Willd.)-Meadows and moist open ground at low and medium altitudes, in reduced forms extending into alpine regions, Newfoundland to Alaska, south to Florida, California, and Mexico. At maturity the panicle branches spread widely and the whole panicle breaks away and rolls before the wind. Agrostis hiemalis var. geminatita (Trin.) Hitchc. Branches of paniele short and divaricate; lemma awned or awnless. The type specimen, from Alaska, is awned; a large number of specimens over a wide range agree in other respects but are awnless. 2 - At high latitudes and altitudes, Newfoundland to Alaska, south to New Hampshire, North Dakota, Colorado, and California.

26. Agrostis idahoénsis Nash. Idaho Redtop. (Fig. 687.) Culms slender, tufted, 10 to $30 \mathrm{~cm}$ tall; leaves mostly basal, the blades narrow; paniele loosely spreading, 5 to $10 \mathrm{~cm}$ long, the branches capillary, flexuous, minutely scabrous; spikelets 1.5 to $2 \mathrm{~mm}$ long; lemma about $1.3 \mathrm{~mm}$ long, awnless; palea minute. 4 -Nountain meadows, at medium and high altitudes, western Montana to Washington, south to New Mexico and the high mountains of California; Fairbanks, Alaska (fig. 685). Differs from A. hiemalis in the narrower panicle with shorter branches and smaller spikelets, 
27. Agrostis bakéri Rydb. (Fig. 689.) Differing from A. idahoensis in the larger usually dark purple spikelets (about $2.5 \mathrm{~mm}$ long) and in the less flexuous and divaricate panicle branches; lemma with a delicate straight awn or awnless. 2 -Alpine meadows, rare,

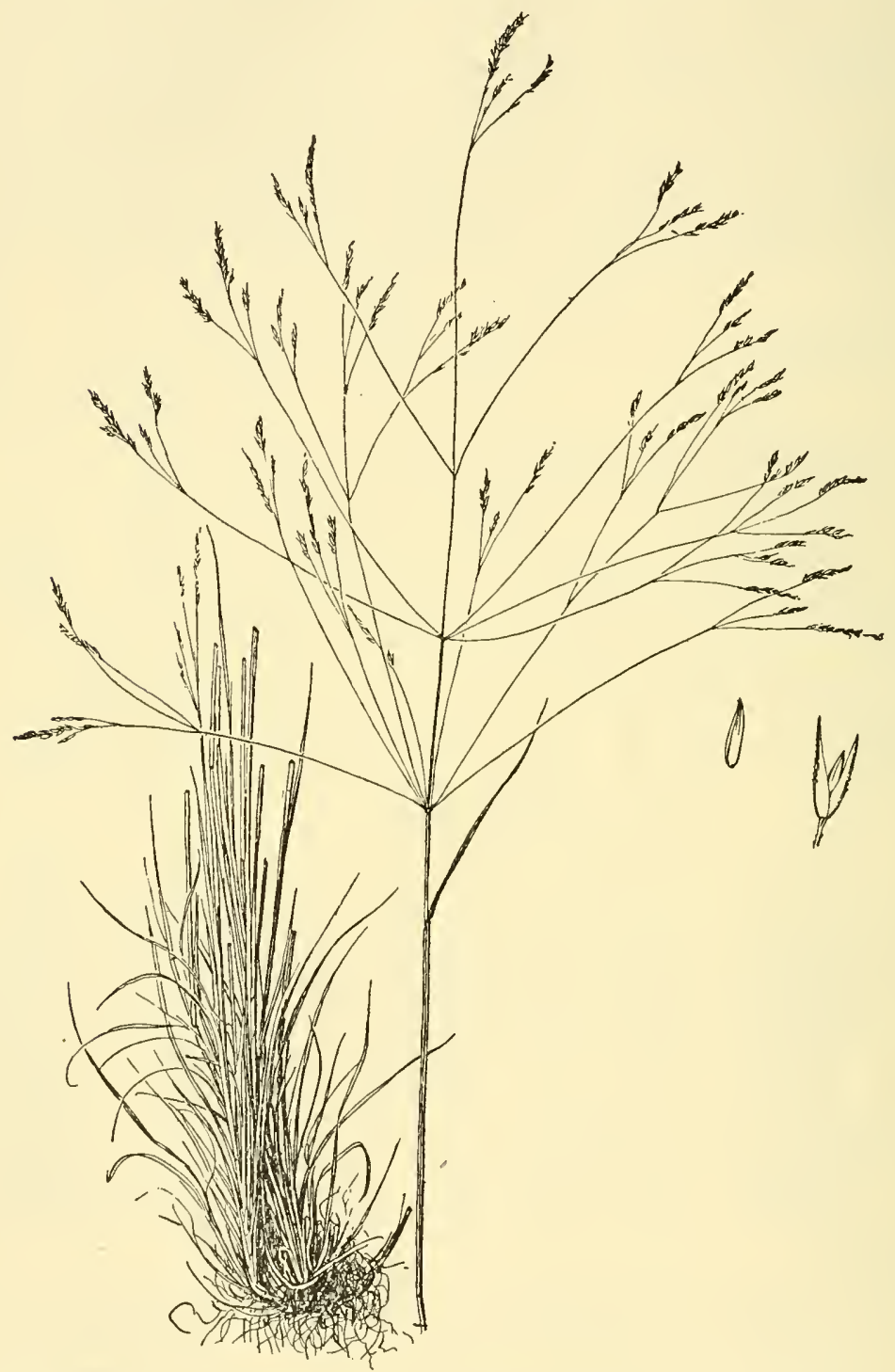

Figure 686.-Agrostis hiemalis. Plant, $\times 1 / 2$; glumes and foret, $\times 5$. (Deam 6514, Ind.)

Colorado, Wyoming, Alberta, and Washington. The type has awned spikelets. Awnless specimens referred to this species resemble $A$. idahoensis but have larger spikelets. Probably a form of A. borealis.

28. Agrostis perénnans (Walt.) Tuckerm. Autumn Bent. (Fig. 690.) Culms erect or somewhat decumbent at base, varying from 
weak and lax to relotively stout and tall, 30 to $100 \mathrm{~cm}$ tall; leaves rather numerous, the blades lax or stiffly upright, corresponding to the

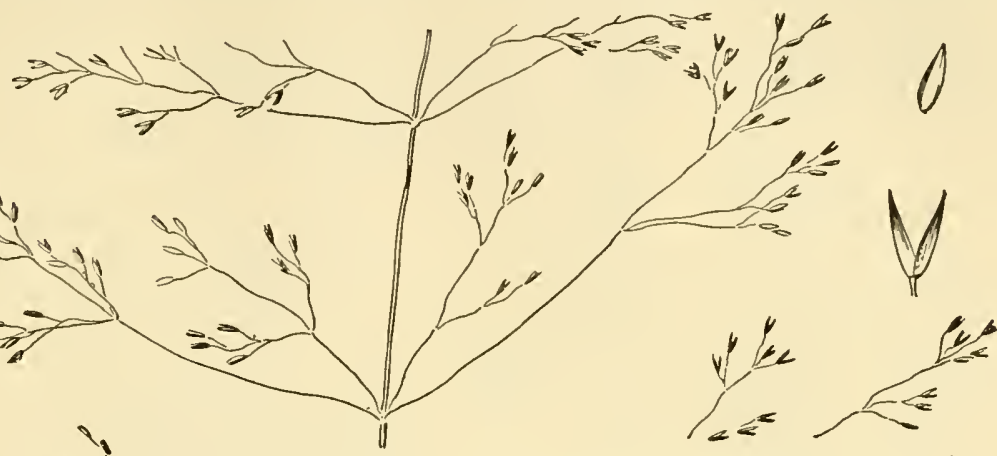

Figure 687.-Agrostis idahoensis. Panicle, $\times 1$; glumes and floret, $\times 5$. (Chase 5162, Idaho.)

culms, 1 to $6 \mathrm{~mm}$ wide, 10 to $20 \mathrm{~cm}$ long; panicle pale, open, oblong, the branches ascending, branching again about the middle; spikelets 2 to $3 \mathrm{~mm}$ long;

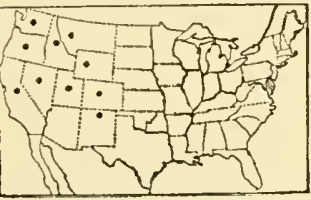

FIGURE 688.-Distribution of Agrostis idahoensis. glumes nearly equal, acute or acuminate; lemma 1.5 to $2 \mathrm{~mm}$ long, awnless (rarely awned); palea obsolete or nearly so. 2 -Open ground, old fields, open woods, in rather dry soil

from sea level to the tops of the mountains, FIGURE 689-Agrostis bakeri. Panflowering in late summer or autumn, Quebec to Minnesota, south to Florida and eastern

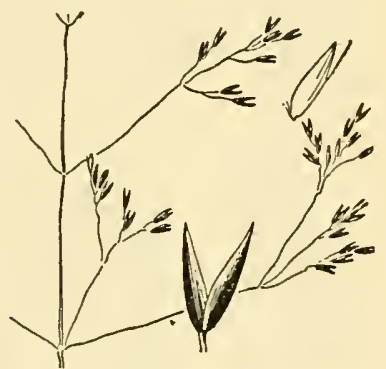
icle, $\times 1$; glumes and floret, $\times 5$. (Dupl. type.) Texas (fig. 691). In dry open ground the culms are erect and rather

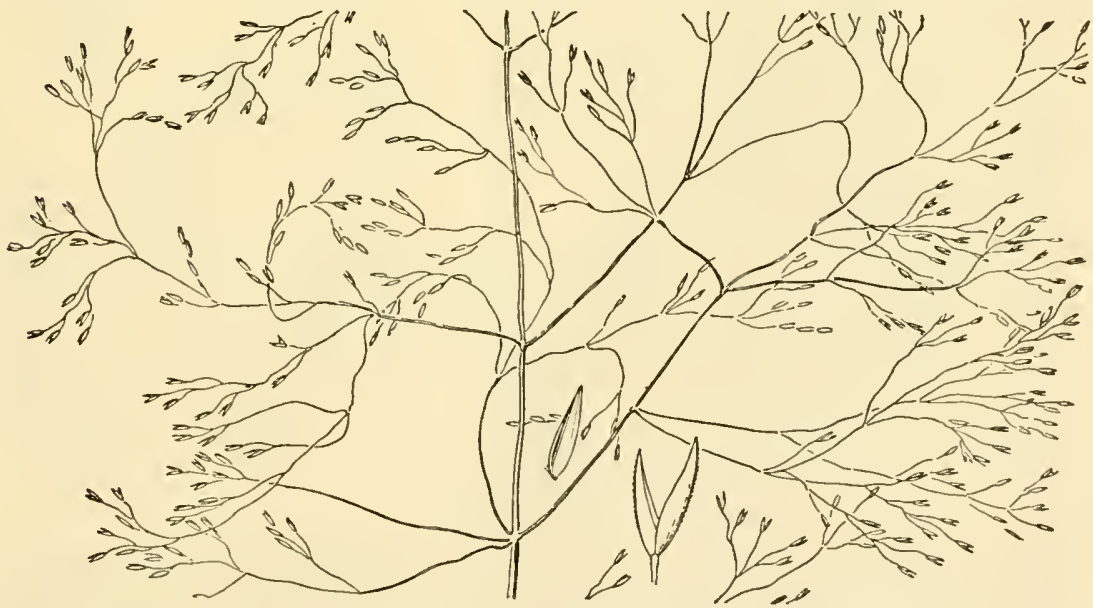

Figure 690.-Agrostis perennans. Panicle, $\times 1$; glumes and floret, $\times 5$. (Millspaugh 53, W.Va.)

stout; in shady places the plants are lax and the panicle lax with divaricate branchlets. 
Agrostis perennans var. eláta (Pursh) Hitchc. Differing in the more slender and elongate culms, often decumbent at base, but particularly in the crowding of the spikelets toward the ends of the branchlets, causing them to droop somewhat. 4 -Marshes and bogs mostly near the coast, New Jersey to Mississippi.

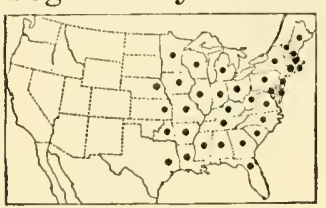

Figure 691.-Distribution of Agrostis perennans.

29. Agrostis oregonénsis Vasey. Oregon REDTOP. (Fig. 692.) Culms 60 to $90 \mathrm{~cm}$ tall; blades 2 to $4 \mathrm{~mm}$ wide; panicle oblong, 10 to $30 \mathrm{~cm}$ long, open, the branches verticillate, rather stiff and ascending, numerous in the lower whorls, the longer 5 to $10 \mathrm{~cm}$ long, branching above the middle; glumes 2.5 to 3 $\mathrm{mm}$ long; lemma $1.5 \mathrm{~mm}$ long, awnless; palea about $0.5 \mathrm{~mm}$ long. 24 - Marshes, bogs, and wet meadows, Montana to British Columbia, south to Wyoming and California (fig. 693).

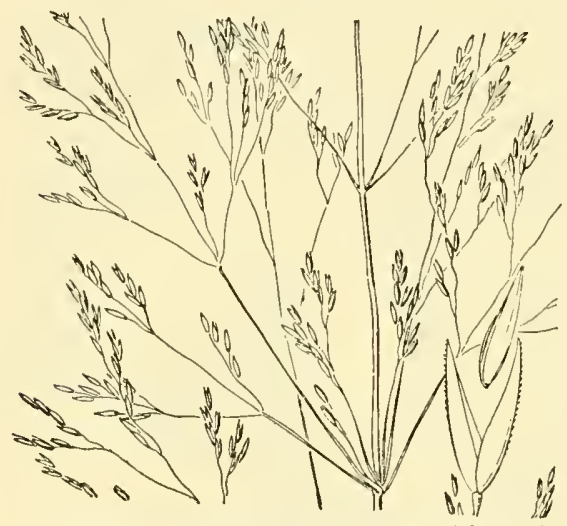

Figure 692-Agrostis oregonensis. Panicle, $\times 1$ glumes and floret, $\times 5$. (Hitcheock 23524, Oreg.)

30. Agrostis canína L. Velvet BENT. (Fig. 694.) Culms tufted, 30 to $50 \mathrm{~cm}$ tall; blades mostly short and n a r r o w, those of the culm 3 to 6 cm long, usually not more than $2 \mathrm{~mm}$ wide;

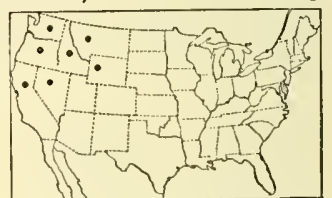

FIGURE 693.-Distribution of Agrostis oregonensis. panicle loose and spreading, mostly 5 to $10 \mathrm{~cm}$ long; glumes equal, acute, $2 \mathrm{~mm}$ long, the lower minutely scabrous on the keel; lemma a little shorter than the glumes, awned about the middle, the awn exserted, bent; callus minutely hairy; palea minute. 2 Meadows and open ground, Newfoundland to Quebec, south to Delaware and Michigan; possibly native northward but introduced in the United States (fig. 695); Europe. Sometimes cultivated for putting greens.

31. Agrostis boreális Hartm. (Fig. 696.) Culms tufted, 20 to $40 \mathrm{~cm}$ tall, or, in alpine or high northern plants, dwarf; leaves mostly basal, the blades 5 to $10 \mathrm{~cm}$ long, 1 to $3 \mathrm{~mm}$ wide; panicle pyramidal, 5 to $15 \mathrm{~cm}$ long, the lower branches whorled and spreading; glumes 2.5 to $3 \mathrm{~mm}$ long, acute; lemma a little shorter than the glumes, awned, the awn usually bent and exserted; palea obsolete or nearly so. $24-$

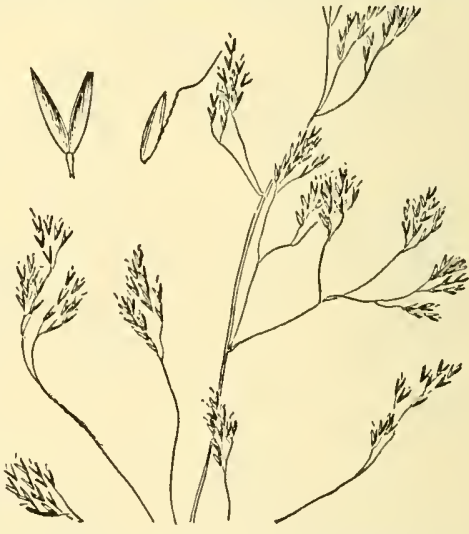

FIgUre 694.-Agrostis canina. Panicle, $\times 1$; glumes and floret, $\times 5$. (Commons 99, Del.) Rocky slopes and moist banks at high latitudes and altitudes, Newfoundland and Greenland to Alaska, south to the high mountains of New England and New York; West Virginia; summit of Roan Mountain, N.C. (fig. 697); northern Europe. 
32. Agrostis longilígula Hitchc. (Fig. 698.) Culns erect, about 60 $\mathrm{cm}$ tall; ligule 5 to $6 \mathrm{~mm}$ long; blades 10 to $15 \mathrm{~cm}$ long, 3 to $4 \mathrm{~mm}$ wide, scabrous; panicle narrow, but loosely flowered, bronze-purple, 10 to 15 $\mathrm{cm}$ long, the branches very scabrous; glumes $4 \mathrm{~mm}$ long; lemma $2.5 \mathrm{~mm}$ long, bearing at the middle a bent exserted awn; palea min-

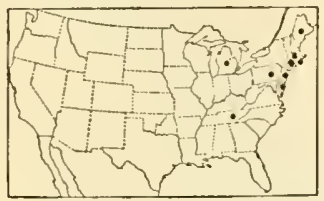

FIGURE 695.-Distribution of Agrostis canina.

ute. 2 -Bogs and marshes at

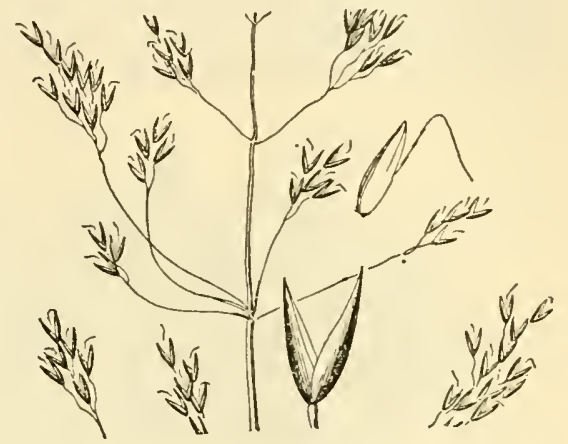

low altitudes, Tillamook County, FIGURE 696.-Agrostis borealis. Panicle, $\times 1$; glumes Oreg., to Mendocino County, Calif.

and floret, $\times 5$. (Faxon 99, N.H.)

Agrostis nebolósa Bois. and Reut. Cloudgrass. Culms slender, branching about $30 \mathrm{~cm}$ tall; foliage scant; panicle delicate, oblong, half as long as the plant, the branches in verticils; spikelets $1 \mathrm{~mm}$ long. $\odot$ (Sometimes called A. capillaris, not A. capillaris L.)-Cultivated for dry bouquets. Spain.

\section{PHÍPPSIA (Trin.) R. Br.}

Spikelets 1-flowered, the rachilla disarticulating above the glumes, not prolonged; glumes unequal, minute, the first sometimes wanting; lemma thin, somewhat keeled, 3 -nerved, abruptly acute; palea a little shorter than the lemma, dentate. Dwarf, tufted perennial, with narrow, few-flowered panicles of small spikelets. Type species, Phippsia algida. Named for C. J. Phipps.

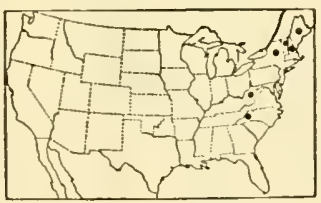

Figure 697.-Distribution of Agrost is borealis.

1. Phippsia álgida (Soland.) R. Br. (Fig. 699.) Culms densely tufted, 2 to $10 \mathrm{~cm}$ tall; blades soft, narrow, with boat-shaped tip; lemma about 1.5 mm long. 21 - Summit of Gray's Peak, Colo.; Arctic regions of both hemispheres.

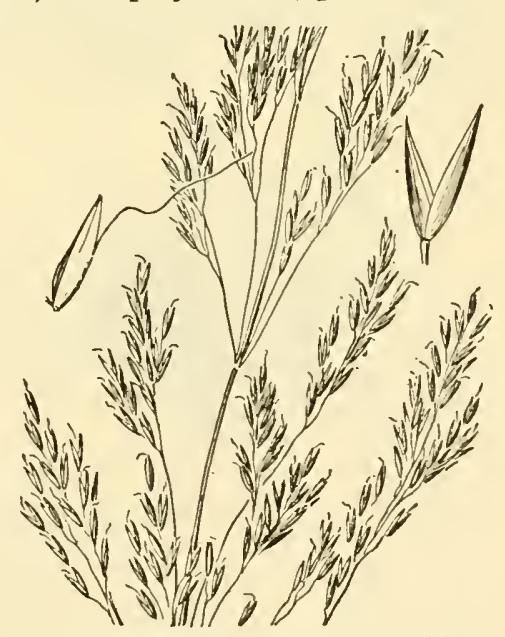

Figure 698.-Agrostis longiligula. Panicle, $\mathrm{X}$ 1 ; glumes and floret, $\times 5$. (Type.)

\section{COLEÁNTHUS Seidel}

Spikelets 1-flowered; glumes wanting; lemma ovate, hyaline, terminating in a short awn; palea broad, 2-toothed, the leels awn-tipped. Dwarf annual, with short flat blades and small panicles. Type species, Coleanthus subtilis. Name from Greek koleos, sheath, and anthos, flower, alluding to the sheaths enclosing the base of the panicles. 
1. Coleanthus súbtilis (Tratt.) Seidel. (Fig. 700.) Culms spreading, forming little mats, mostly less than $5 \mathrm{~cm}$ long; panicle 5 to 10 $\mathrm{mm}$ long, the short branches verticillate; lemma about $1 \mathrm{~mm}$ long, the awn about equaling the dark caryopsis. $\odot$-Mud flats along the lower Columbia River, Oregon and Washington, well established but probably introduced; northern Eurasia.
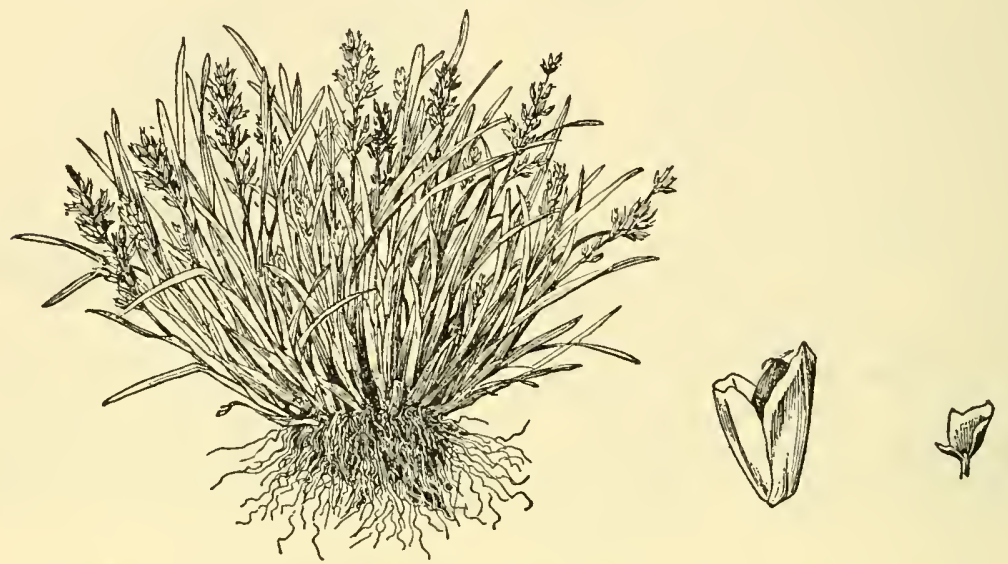

Figure 699.-Phippsia algida. Plant, $\times 1 \frac{1}{2}$; glumes and floret, $\times 10$. (Oldmixon, Alaska.)

,Mibóra mínima (L.) Desv. Delicate annual 3 to $10 \mathrm{~cm}$ tall with short narrow blades and slender racemes of 6 to 8 appressed purple spikelets, $2 \mathrm{~nm}$ long, the glumes obtuse, the lemma and palea shorter, pubescent. $\odot$-Plymouth, Mass.; introduced from Europe.
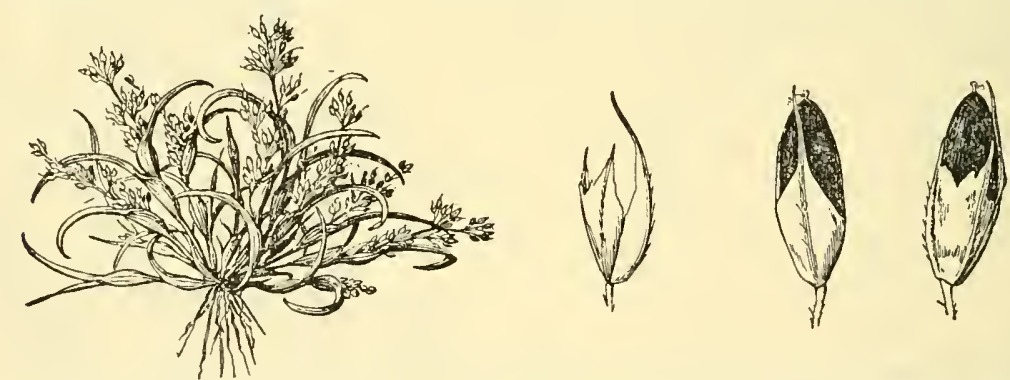

Figure 700.-Coleanthus subtilis. Plant, $\times 1$; lemma and palea and two views of spikelet with ripe caryopsis, $\times 20$. (Howell, Oreg.)

\section{CÍNNA L. Woodreed}

Spikelets 1-flowered disarticulating below the glumes, the rachilla forming a stipe below the floret and produced behind the palea as a minute bristle; glumes equal or subequal, 1- to 3-nerved; lemma similar to the glumes, nearly as long, 3-nerved, bearing a minute, short, straight awn just below the apex (rarely awnless); palea 1-keeled. Tall perennials with flat blades and close or open panicles. Type species, Cinna arundinacea. Cinna (kinna) an old Greek name for a grass. 


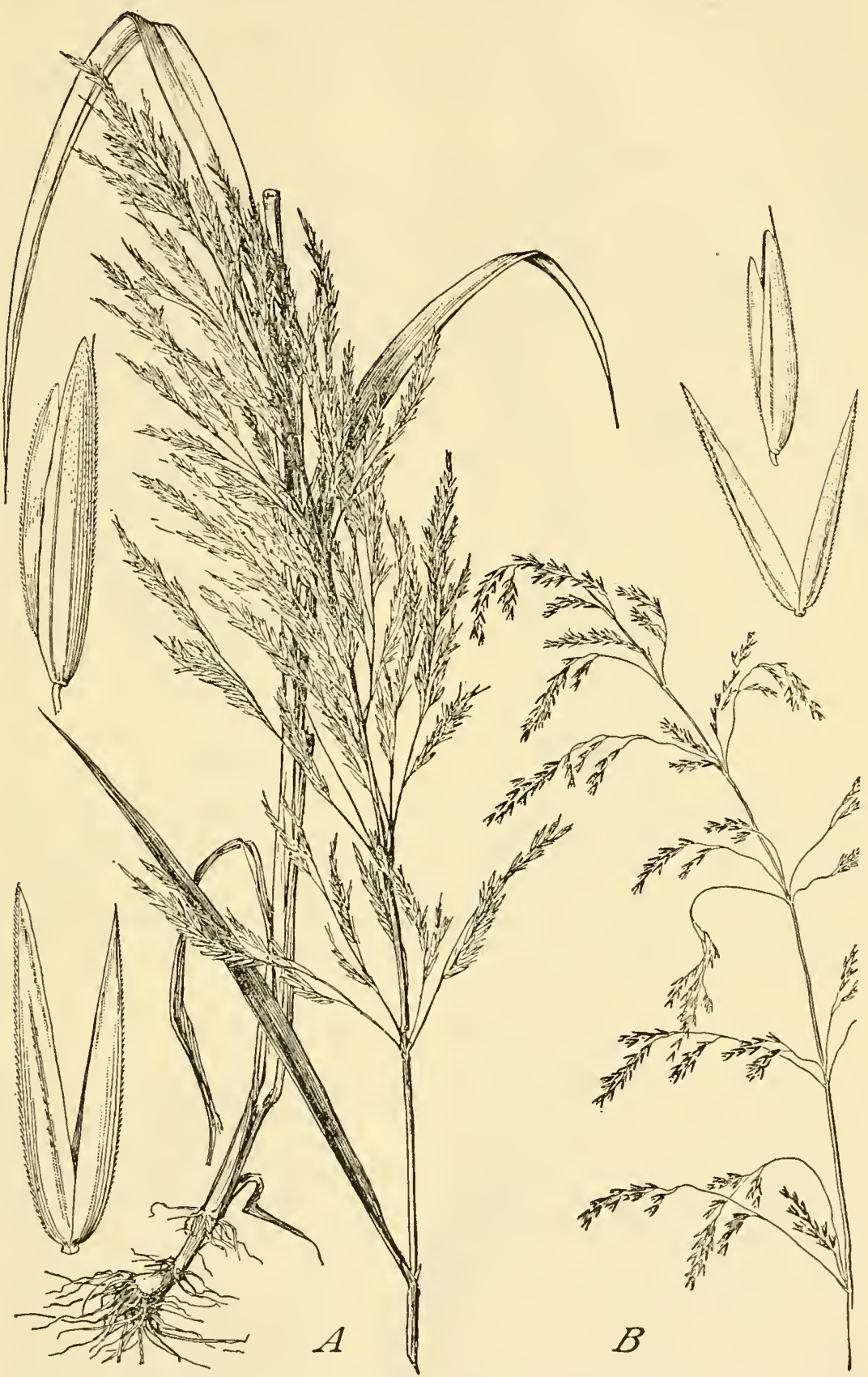

Figure 701. $-A$, Cinna arundinacea. Plant, $\times 1 / 2$; glumes and floret, $\times 10$. (Dewey 336, Va.) $B, C$. latifolia. Panicle, $\times 1$; glumes and floret, $\times 10$. (Sandberg 713, Minn.) 
Our two species furnish highly palatable forage but usually are not abundant enough to be of much importance.

Spikelets $5 \mathrm{~mm}$ long; panicle rather dense, the branches ascending.

1. C. ARUNDinacea. Spikelets 3.5 to $4 \mathrm{~mm}$ long; panicle loose, the branches spreading or drooping.

2. C. Latifolia.

1. Cinna arundinácea L. Stout woodrend. (Fig. 701, A.) Culms erect, usually 1 to $1.5 \mathrm{~m}$ tall, often somewhat bulbous at base, solitary or few in a tuft; sheaths glabrous; ligule rather prominent, thin; blades flat, scabrous, mostly less than $1 \mathrm{~cm}$ wide; panicle many-flowered, nodding, grayish, 15 to $30 \mathrm{~cm}$ long, the branches ascending; spikelets about $5 \mathrm{~mm}$ long; glumes somewhat unequal, acute, the second 3-nerved; lemma usually a little longer than the first glume, bearing below the tip a minute straight awn; palea apparently 1-nerved. 24 -Moist woods, Maine to South Dalsota, south to Georgia and eastern Texas (fig. 702).

2. Cinna latifólia (Trevir.) Griseb. Drooping woodreed. (Fig. $701, B$.) Resembling $C$. arundinacea; blades shorter and on the average wider, as much as $1.5 \mathrm{~cm}$ wide; panicle green, looser, the branches fewer, spreading or drooping, naked at base for as much as

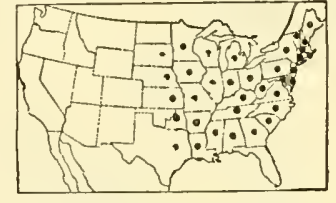

FIGURE 702,-Distribution of Cinna ar undinacea.

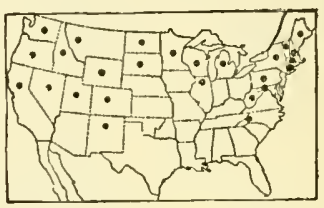

FIGURE 703.-Distribution of Cinna latifolia.

$5 \mathrm{~cm}$; spikelcts about $4 \mathrm{~mm}$ long; awn of lemma sometimes as much as $1 \mathrm{~mm}$ long (rarcly wanting); palea 2 -nerved, the nerves very close together. 2 -Moist woods, Newfoundland and Labrador to Alaska, south to Connecticut, in the mountains to North Carolina, to Michigan, Illinois, South Dakota, in the Rocky Mountains to northern New Mexico, to Utah and central California (fig. 703); northern Eurasia.

\section{LIMNÓDEA L. H. Dewey}

Spikelets 1-flowered, disarticulating below the glumes, the rachilla prolonged behind the palea as a short slender bristle; glumes equal, firm; lemma membranaceous, smooth, nerveless, 2-toothed at the apex, bearing from between the teeth a slender bent awn, twisted at base; palea a little shorter than the lemma. Slender annual with flat blades and narrow panicles. Type species, Limnodea arkansana. Name altered from Limnas, a genus of grasses.

1. Limnodea arkansána (Nutt.) L. H. Dewey. (Fig. 704.) Culms branching at base, 20 to $40 \mathrm{~cm}$ tall; blades more or less pubescent on both surfaces; panicle 5 to $15 \mathrm{~cm}$ long, narrow but loose; spikelets 3.5 to $4 \mathrm{~mm}$ long; glumes hispidulous or pilose; awn 8 to $10 \mathrm{~mm}$ long. 2| -Dry soil, prairies and river banks, Coastal Plain, Florida 
to Texas, Arkansas, and Oklahoma (fig. 705). The form with pilose glumes has been called L. arkansana var. pilosa (Trin.) Scribn.

\section{ALOPECÚRUS L FoxTAIL}

Spikelets 1-flowered, disarticulating below the glumes, strongly compressed laterally; glumes equal, usually united at base, ciliate on the keel; lemma about as long as the glumes, 5-nerved, obtuse, the margins united at base, bearing from below the middle a slender dorsal awn, this included or exserted two or three times the length of the spikelet; palea wanting. Low or moderately tall perennials or rarely annuals, with flat blades and soft, dense, spilielike panicles. Type

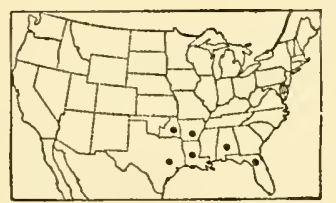

Figure 705.-Distribution of Limnadea arkansana.

species, Alopecurus pratensis. Name from Greek alopex, fox, and oura tail, alluding to the cylindric panicle.

The species of Alopecurus are all palatable and nutritious forage grasses, but usually are not found in sufficient abundance to be of great importance. A. pratensis, meadow foxtail, is sometimes used as a meadow grass in the eastern United States; $A$. aequalis is the most common on the western ranges.

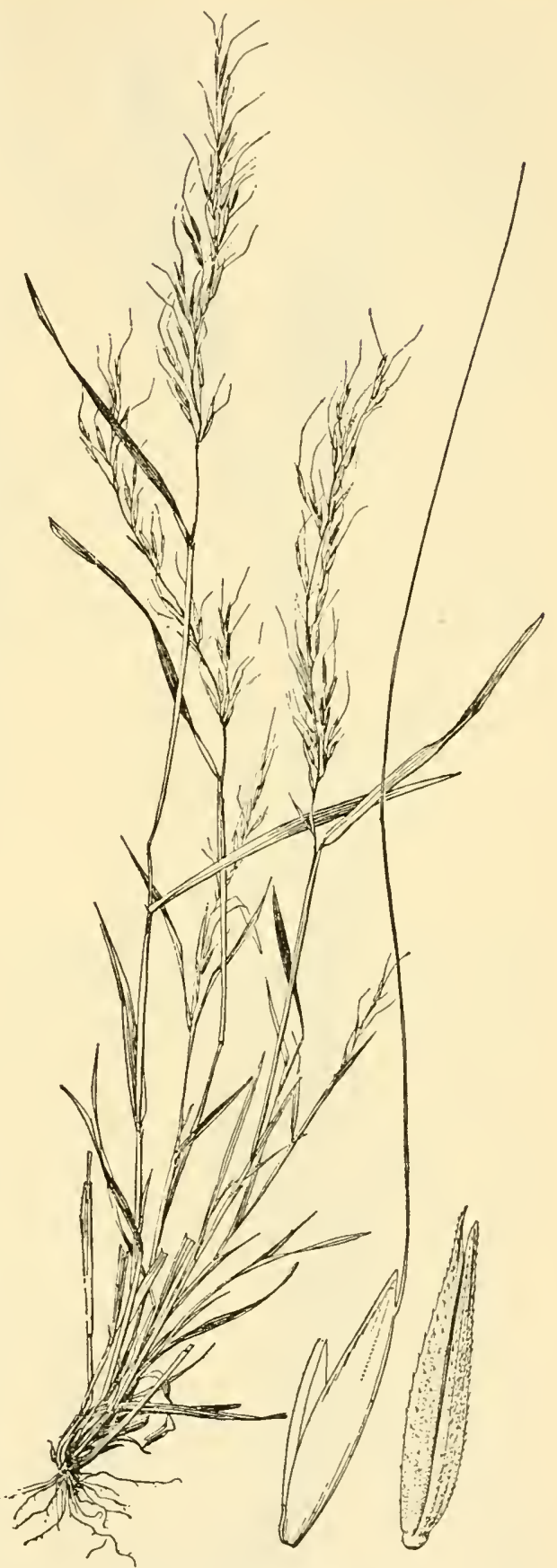

Figure 704.- Limnodea arkansana. Plant, $\times 1 / 2$; glumes and 


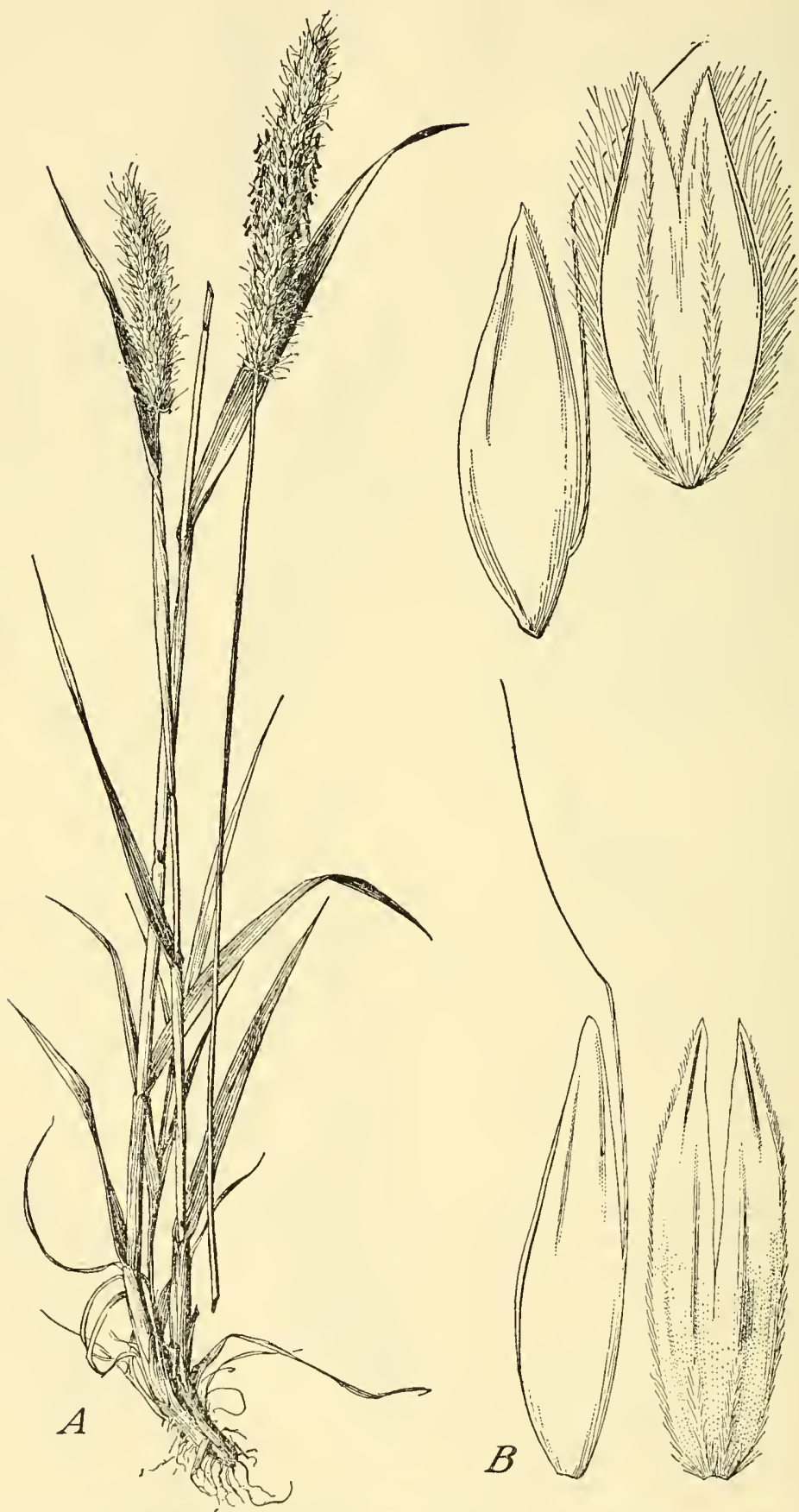

Figure 706. $-A$, Alopecurus pratensis. Plant, $\times 1 / 2$; glumes and floret, $\times 10$. (Henderson, Oreg.) $B, A$. myosuroides. Glumes and floret, $\times 10$. (Commons 14, Del.) 
Spikelets 5 to $6 \mathrm{~mm}$ long. Introduced perennials.

Panicle slender, tapering at each end; glumes scabrous on the keel.

1. A. Myosuroides.

Panicle cylindric, dense; glumes conspicuously ciliate on the keel.

Spikelets 2 to $4 \mathrm{~mm}$ long (rarely $5 \mathrm{~mm}$ in $A$. saccatus, annual). Native species.

Plants perennial.

Spikelets densely woolly all over; panicle oblong, 1 to $5 \mathrm{~cm} \mathrm{long,} \mathrm{about}$ $1 \mathrm{~cm}$ thick...

Spikelets not woolly; panicle linear or oblong-linear, less than $1 \mathrm{~cm}$ thick.

Awn scarcely exceeding the glumes........... 5. A. AEqualrs:

Awn exserted $2 \mathrm{~mm}$ or more.

Awn exserted 2 to $3 \mathrm{~mm}$; panicle 3 to $4 \mathrm{~mm}$ thick; spikelets $2.5 \mathrm{~mm}$ long. 6. A. gENicUlatus.

Awn exserted 3 to $5 \mathrm{~mm}$; panicle 4 to $6 \mathrm{~mm}$ thick; spikelets about $3 \mathrm{~mm}$ long

Plants annual.

Spikelets 4 to $5 \mathrm{~mm}$ long; panicle relatively loose_..... 9. A. SAccatus.

Spikelets 2 to $3.5 \mathrm{~mm}$ long; panicle dense.

Spikelets 2 to $2.5 \mathrm{~mm}$ long; anthers $0.5 \mathrm{~mm}$ long-.- 7. A. carolinianos.

Spikelets 3 to $3.5 \mathrm{~mm}$ long; anthers about $1 \mathrm{~mm}$ long-- 8 . A. HOWELLII.

1. Alopecurus myosuroídes Huds. (Fig. 706, B.) Perennial; culms tufted, slightly scabrous, 10 to $50 \mathrm{~cm}$ tall, erect or decumbent at base; blades usually 2 to $3 \mathrm{~mm}$ wide; panicle slender, somewhat tapering at each end, 4 to $10 \mathrm{~cm}$ long, 3 to $5 \mathrm{~mm}$ wide; glumes $6 \mathrm{~mm}$

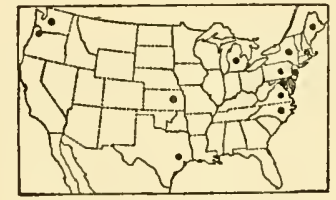

FIGURE 707.-Distribution of Alopecurus myosuroides.

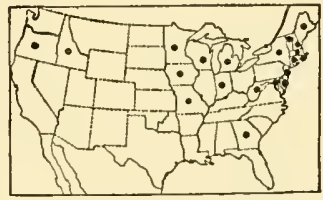

FIGURE 708.-Distribution of Alopecurus pratensis.

long, pointed, whitish with 3 green nerves, glabrous, scabrous on the keel, short-ciliate at base; lemma about as long as the glumes, the awn bent, exserted 5 to $8 \mathrm{~mm}$. 2 (A. agrestis L.)-Fields, waste places, and ballast ground, Maine to North Carolina, Washington, and Oregon (fig. 707); introduced, rare; Eurasia.

2. Alopecurus praténsis L. Meadow foxtall. (Fig. 706, A.) Perennial; culms erect, 30 to $80 \mathrm{~cm}$ tall; blades 2 to $6 \mathrm{~mm}$ wide; panicle 3 to $7 \mathrm{~cm}$ long, 7 to $10 \mathrm{~mm}$ thick; glumes $5 \mathrm{~mm}$ long, villous on the keel and pubescent on the sides; awn exserted 2 to 5 $\mathrm{mm}$. 2 -Fields and waste places, Newfoundland and Labrador to Alaska, south to Delaware, Iowa, Idaho, and Oregon (fig. 708); introduced; Eurasia. Occasionally cultivated as a meadow grass.

3. Alopecurus alpínus J. E. Smith. Alpine Foxtail. (Fig. 709.) Perennial; culms erect or often decumbent at base, rather stiff and rushlike, 10 to $80 \mathrm{~cm}$ tall, with slender rhizomes; sheaths glabrous, often inflated; blades 3 to $5 \mathrm{~mm}$ wide; panicle ovoid or oblong, 1 to $3 \mathrm{~cm}$ long, about $1 \mathrm{~cm}$ wide, woolly; glumes 3 to $4 \mathrm{~mm}$ long, woolly; lemma awned near the base, the awn exserted slightly or as much as $5 \mathrm{~mm}$. 2 -Mountain meadows and along brooks, Greenland to Alaska, south in the Rocky Mountains to Colorado (fig. 710); Arctic regions and northern Eurasia.

4. Alopecurus palléscens Piper. Washington Foxtail. (Fig. 711.) Perennial, tufted, pale-green; culms 30 to $50 \mathrm{~cm}$ tall, erect, or lower nodes geniculate; sheaths somewhat inflated; panicle pale, 
dense, 2 to $7 \mathrm{~cm}$ long, 4 to $6 \mathrm{~mm}$ thick; glumes about $3 \mathrm{~mm}$ long, ciliate on the keel, appressed-pubescent on the sides; awn attached near base of lemma, exserted 3 to $5 \mathrm{~mm}$; anthers about $2 \mathrm{~mm}$ long. $21-$

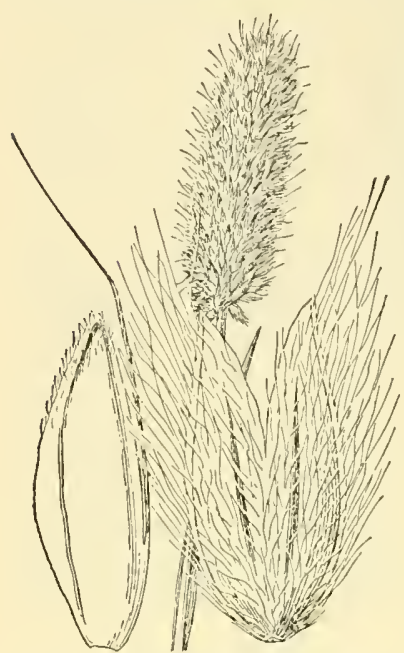

Figure 700.-Alopecurus alpinus. Panicle, $\times 1$; glumes and floret, $\times 10$. (Hall and Fiarbour 682, Colo.)

Edges of ponds and wet places, Idaho to Washington and northern California (fig. 712).

5. Alopecurus aequális Sobol. ShortAWn Foxtail. (Fig. 713.) Perennial; culms erect or spreading, usually not rooting at the nodes, 15 to $60 \mathrm{~cm}$ tall; blades 1 to $4 \mathrm{~mm}$ wide; panicle slender, 2 to $7 \mathrm{~cm}$ long, about 4 $\mathrm{mm}$ wide; spikelets $2 \mathrm{~mm}$ long; awn of leinma scarcely exserted; anthers about $1 \mathrm{~mm}$ long.

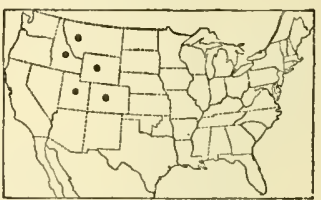

Figure 710.-Distribution of Alopecurus alpinus.

21 (A. aristulatus Michx.) - In water and wet places, Greenland to Alaska, south to Pennsylvania, Illinois, Kansas, New Mexico, and California (fig. 714); Eurasia.

6. Alopecurus geniculátus L. WATER Foxtall. (Fig. 715.) Differing from $A$. aequalis chiefiy in the usually more decumbent culms rooting at the nodes and the longer awn exserted 2 to $3 \mathrm{~mm}$; giving the panicle a softly bristly appearance; spikelets about $2.5 \mathrm{~mm}$ long, the tip dark purple; awn of lemma about as long again as the spikelet; anthers about $1.5 \mathrm{~mm}$ long. 21 - In water and wet places, Newfoundland to Saskatchewan and British Columbia, south through New England to New York, New Jersey, and Virginia, and through Washington to California; Montana,

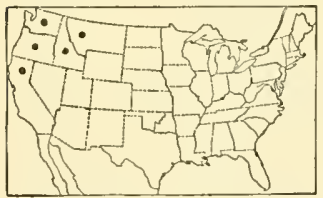

Figure 712,-Distribution of Alopecurus pallescens. Colorado, Arizona (fig. 716); Eurasia.

7. Alopecurus caroliniánus Walt. (Fig. 717.) Annual; culms tufted, much branched at base, 10 to $50 \mathrm{~cm}$ tall; similar to $A$. geniculatus and $A$. aequalis, but panicle more slender than in the former; spikelets 2 to 2.5 $\mathrm{mm}$ long, pale, the awn as in $A$. geniculatus; anthers about $0.5 \mathrm{~mm}$ long. $\odot \quad$ (A. ramosus Poir.)-Moist open ground, old fields, and wet places, New Jersey to British Columbia, south to Florida, Texas, Arizona, and California (fig. 718).

8. Alopecurus howéllii Vasey. (Fig. 719.) Annual; culms 15 to $30 \mathrm{~cm}$ tall, commonly geniculate at lower nodes; sheaths, especially the uppermost, more or less inflated; panicle oblong to linear, 2 to 6 
$\mathrm{cm}$ long, 4 to $7 \mathrm{~mm}$ wide; glumes 3 to $3.5 \mathrm{~mm}$ long, ciliate on the keel, appressed-pilose on the lateral nerves; awn attached less than $1 \mathrm{~mm}$ from the base of lemma, bent, exserted 3 to $5 \mathrm{~mm}$; anthers orange, about 1 $\mathrm{mm}$ long. $\odot$--Wet places, Oregon and California. This species and the following are closely related and may not be distinet. Both have dwarf specimens with small panicles short-exserted or partly included in the inflated upper sheath.

\section{Alopecurus saceátus} Vasey. (Fig. 720.) On the average somewhat lower than $A$. howellii, the upper sheaths inflated, the panicle 2 to $4 \mathrm{~cm}$ long, rather less dense, short exserted or partly included; spikelets 4 to $5 \mathrm{~mm}$ long, the awn exserted 5 to $8 \mathrm{~mm}$;

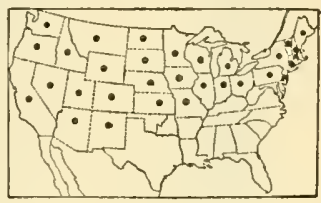

Figure 714-Distribution of 1lopecutus aequalis. anthers $1 \mathrm{~mm}$ long. $\odot$-Wet places, along the Columbia River, Washington and Oregon, California (Colusa County).

Alopecurus créticus. Trin. Annual, 10 to 40 $\mathrm{cm}$ tall; panicle dense; spikelets wedge-shaped, FIGURE 713.-Alopecurus $4 \mathrm{~mm}$ long; glumes firm, the keels broadly winged

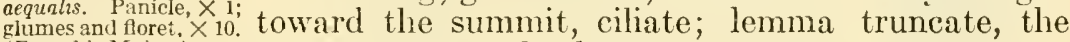
(Fernald, Maine.) awn from near the base.

Ballast, Philadelphia, Pa.; Europe.

\section{POLYPÓGON Desf.}

Spikelets 1-flowered, the pedicel disarticulating a short distance below the glumes, leaving a short-pointed callus attached; giumes equal, entire or 2-lobed, awned from the tip or from between the lobes, the awn slender, straight; lemma

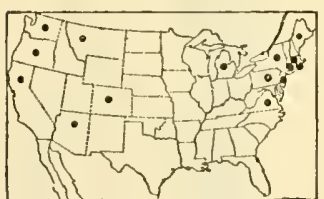

FIGURE 716.-Distribution of Alopecurus geniculatus. much shorter than the glumes, hyaline, usually bearing a slender straight awn shorter than the awns of the glumes. Usually decumbent annuals or perennials with flat scabrous blades and dense, bristly, spikelike panicles. Type species, Polypogon monspeliensis. Name from Greek polus, much, and pogon, beard, alluding to the bristly inflorescence.

One species, $P$. monspeliensis, is palatable to stock and is sometimes sufficiently abundant on low meadows to be of importance in the West. Plants annual.

Glumes slightly lobed, the lobes not ciliate

1. P. MONSPELIENSis.

Glumes prominently lobed, the lobes ciliate-fringed. -

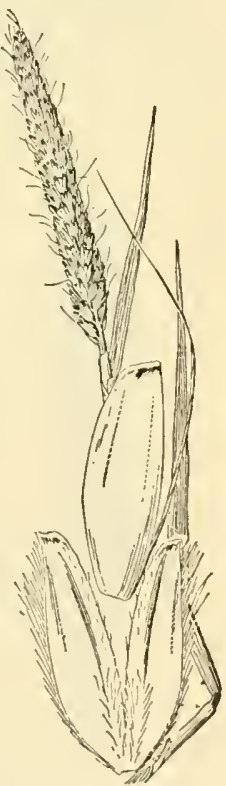

Figure 715.-Alopecurus geniculalus. Panicle, $X$ 1 ; glumes and floret, $X$ 10. (Weatherby 3391 . Mass.)

\section{Plants perennial.}

$$
\text { 2. P. MARITIMUS. }
$$

Awns rather stiff and straight; glumes 2.5 to $3 \mathrm{~mm}$ long ...- 3. P. Lutosus. Awns delicate, flexuous; glumes 1.5 to $2 \mathrm{~mm}$ long....... 4. P. AUstralis. 
1. Polypogon monspeliénsis (L.) Desf. Rabitrfoot grass. (Fig. $721, A$.) Annual; culms erect or decumbent at base, 15 to $50 \mathrm{~cm}$

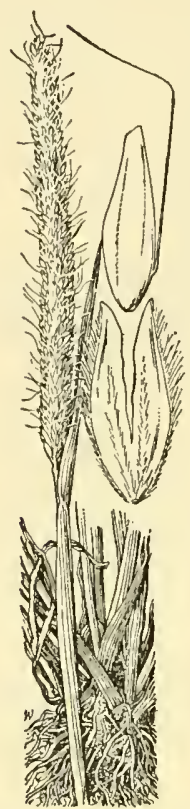

Figure 717.-Alopecurus carolinianus. Plant $\times 1$; glumes and floret, $\times 10$ (Kearney 1147, Va.)

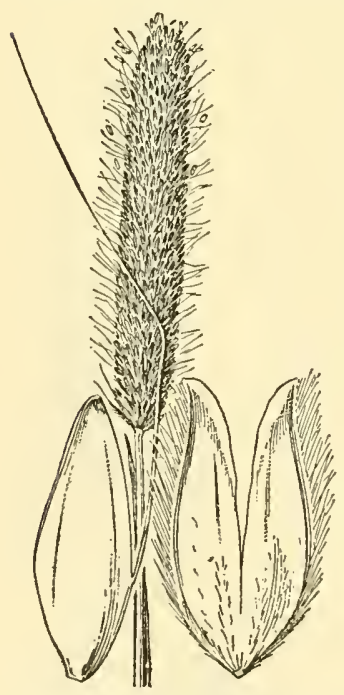

Figure 719.-Alopecurus howellii. Panicle, $\times 1$; glumes and floret, $\times 10$. (Gilbert 78, Oreg.) tall (sometimes depauperate ligule 5 to $6 \mathrm{~mm}$ long; blades in average plants 4 to $6 \mathrm{~mm}$ wide; panicle dense, spikelike, 2 to $15 \mathrm{~cm}$ long, 1 to $2 \mathrm{~cm}$ wide, tawny-yellow when mature; glumes hispidulous, about $2 \mathrm{~mm}$ long, the awns 6 to $8 \mathrm{~mm}$ long, rarely longer; lemma smooth and shining, about half as long as the glumes, the delicate awn slightly exceeding them. $\odot$-Ballast and waste places, New Brunswick to Georgia, west to Alaska and California, infrequent in the East, mostly confined to the coastal States, a common weed in the Western States; at low altitudes, south to Argentina (fig. 722); introduced from Europe.

\section{Polypogon marítimus} Willd. (Fig. 721, B.) Annual; culms 20 to $30 \mathrm{~cm}$ tall, upright or spreading; ligule as much as $6 \mathrm{~mm}$ long; blades usually less than 5 $\mathrm{cm}$ long, 2 to $4 \mathrm{~mm}$ wide; panicle mostly smaller and less dense than in P. monspeliensis; glumes about $2.5 \mathrm{~mm}$ long, hispidulous below, the deep lobes ciliate-fringed, the awns 7 to $10 \mathrm{~mm}$ long; lemma awnless. $\odot$ -Introduced, Georgia (Tybee Island), California (Napa and New York Falls, Amador County); Mediterranean region.

3. Polypogon lutósus (Poir.) Hitche. Ditch POLYPOGON. (Fig. 723.) Perennial; culms tufted, geniculate at base, 30 to $80 \mathrm{~cm}$ tall; ligule 2 to $5 \mathrm{~mm}$ long or the uppermost longer; blades commonly 4 to $6 \mathrm{~mm}$ wide; panicle oblong, 5 to $15 \mathrm{~cm}$ long, more or less interrupt-

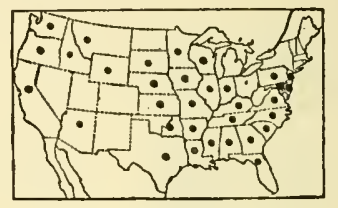

FIGURE 718.-Distribution of Alopecurus carolinianus.

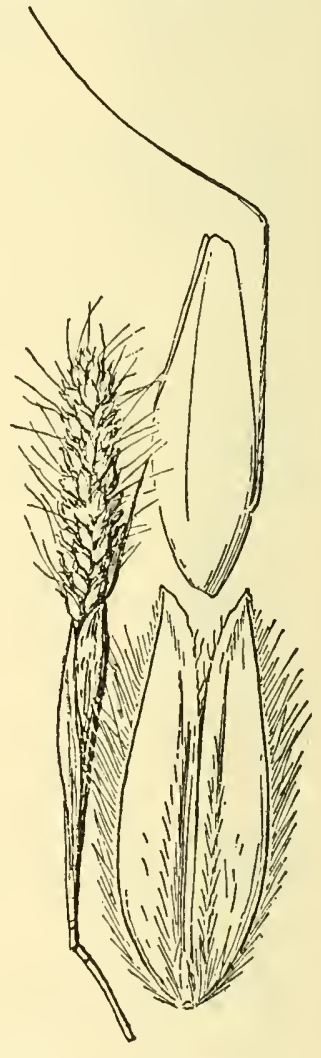

Figure 720-Alopecurus saccatus. Panicle, $\times 1$; glumes $\times$ and floret, 10. (Suksdorf 188 , Wash.)

ed or lobed; glumes equal, 2.5 to $3 \mathrm{~mm}$ long, scabrous, the awns 3 to 5 
MANUAL OF THE GRASSES OF THE UNITED STATES

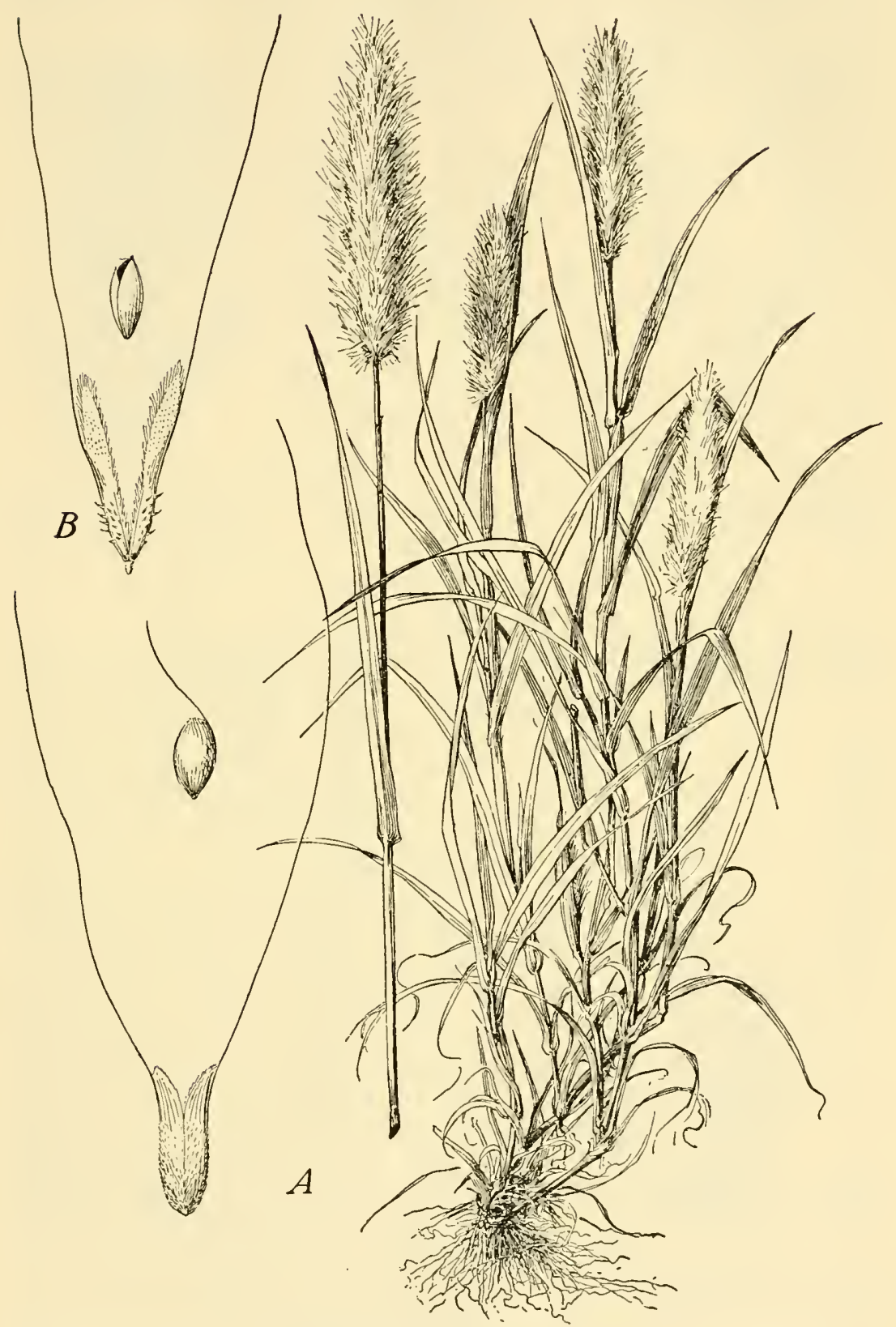

Figure 721. $-A$, Polypogon monspeliensis. Plant, $\times 1 / 2$; glumes and floret, $\times 10$. (Chase 5584, Calif.) $B, A$. maritimus, $\times 10$. (Hansen 607 , Calif.) 
mm long; lemma smooth and shining, $1 \mathrm{~mm}$ long, minutely toothed at the truncate apex, the awn exceeding the glumes. 2 -Ditches and wet places at low altitudes, British Columbia to New Mexico and, California, east to Louisiana, south to Argentina; a few localities from Alabama to Texas (fig. 724); introcluced from Europe.

4. Polypogon austrális Brongn. (Fig. 725.) Perennial; culms as much as $1 \mathrm{~m}$ tall; ligule 2

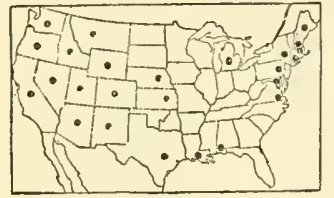

FIgure 722.-Distribution of Polypogon mons petiensis. to $3 \mathrm{~mm}$ long, fragile; blades commonly 5 to 7 $\mathrm{mm}$ wide; panicle soft, lobed or interrupted, mostly 8 to $15 \mathrm{~cm}$ long, the numerous awns purplish; glumes 1.5 to $2 \mathrm{~mm}$ long, hispidulous, the awn flexuous, delicate, 4 to 6 mm long; lemma about two thirds as long as the glumes, the awn about $3 \mathrm{~mm}$ long. $\quad 2 \quad(P$. crinitus Trin., not Nutt.)-Introduced at Bingen, Wash.; Chile and Argentina.

\section{LYCÚRUS H.B.K.}

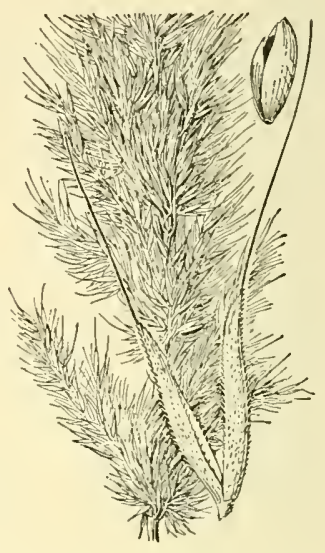

Figure 723.-Polypogon $l u$ tosus. Panicle, $\times 1$; glumes and floret, $\times 10$. (Hitcheock 2686, Calif.)

Spikelets 1-flowered; glumes awned, the first usually 2-awned; lemma narrow, firm, longer than the glumes, tapering into a slender awn. Slender perennial, with grayish, bristly spikelike panicles, the spikelets borne in pairs, the lower of the pair sterile, the two falling together. Type species,

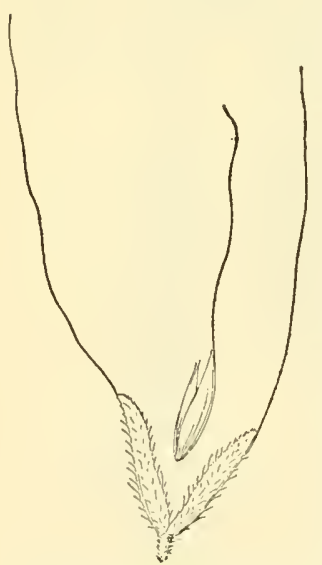

FIGURE 725.-Polypogon auslralis $\times 10$. (Suksdorf 10091 , Wash.) Lycurus phleoides. Name for Greek lukos, wolf, and oura, tail, alluding to the spikelike panicles.

1. Lycurus phleoídes H.B.K. Wolftail. (Fig. 726.) Culms densely tufted, 20 to $60 \mathrm{~cm}$ tall, compressed, erect or decumbent at base; blades flat or folded, 1 to $2 \mathrm{~mm}$ wide, those of the culm mostly less than $10 \mathrm{~cm}$ long; panicle 3 to $6 \mathrm{~cm}$ long, about $5 \mathrm{~mm}$ thick;

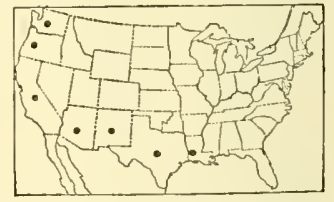

FIGURE 724.-Distribution of Polypogon lutosus.

spikelets including awns about $5 \mathrm{~mm}$ long, the glumes shorter than the lemma, the first 2 - or 3-awned, the second usually 1-awned, the awns slightly spreading; lemma 3-nerved, pubescent at the margins, the awn 2 to $3 \mathrm{~mm}$ long; palea about as long as the lemma, pubescent. $24-$ Plains and rocky hills, Colorado to Texas and Arizona, south to southern Mexico (fig. 727). An important southwestern forage grass.

\section{PhLÉ LM L. Timothy}

Spikelets 1-flowered, laterally compressed, disarticulating above the glumes; glumes equal, membranaceous, keeled, abruptly mucronate or awned or gradually acute; lemma shorter than the glumes, hyaline, broadly truncate, 3 - to 5-nerved; palea narrow, nearly as long as the 
lemma. Annuals or perennials, with erect culms, flat blades, and dense, cylindric panicles. Type species, Phleum pratense. Name from Greek phleos, an old name for a marsh reed.

The common species, $P$. praiense, or timothy, is our most important hay grass. It is cultivated in the humid regions, the Northeastern States, south to the Cotton Belt, and west to the 100th meridian, and also in the humid region of Puget Sound and in mountain districts. The native species, $P$. alpinum, alpine timothy, furnishes forage in mountain meadows of the Western States.

Panicle cylindric, several times longer than wide_......... 1. P. PRatense. Panicle oroid or oblong, usually not more than twice as long as wide.

2. P. Alpinum.

1. Phleum praténse L. Tiмотнy. (Fig. 728, A.) Culms 50 to $100 \mathrm{~cm}$

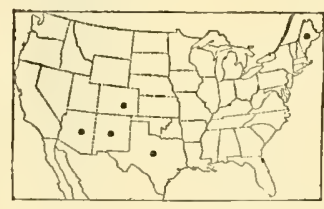

FIGURE 727.-Distribution of Lycurus phicoides.

tall, from a swollen or bulblike base, forming large chumps; blades elongate, mostly 5 to $8 \mathrm{~mm}$ wide; panicle cylindric, commonly 5 to $10 \mathrm{~cm}$ long, often longer, the spikelets crowded, spreading; glumes about $3.5 \mathrm{~mm}$ long, truncate with a stout awn 1 $\mathrm{mm}$ long, pectinate-ciliate on the keel. 2! -Commonly escaped from cultivation along roadsides and in fields and waste places throughout the United States; Eurasia. In some localities known as herd's grass.

2. Phleum alpínum L. Alpine тімотну. (Fig. 728, B.) Culms 20 to $50 \mathrm{~cm}$ tall, from a decumbent, somewhat creeping, densely tufted base; blades mostly less than $10 \mathrm{~cm}$ long, 4 to $6 \mathrm{~mm}$ wide; panicle ellipsoid or short-cylindric, bristly; glumes about $5 \mathrm{~mm}$ long, hispidciliate on the keel, the awns $2 \mathrm{~mm}$ long. 24 -Common in

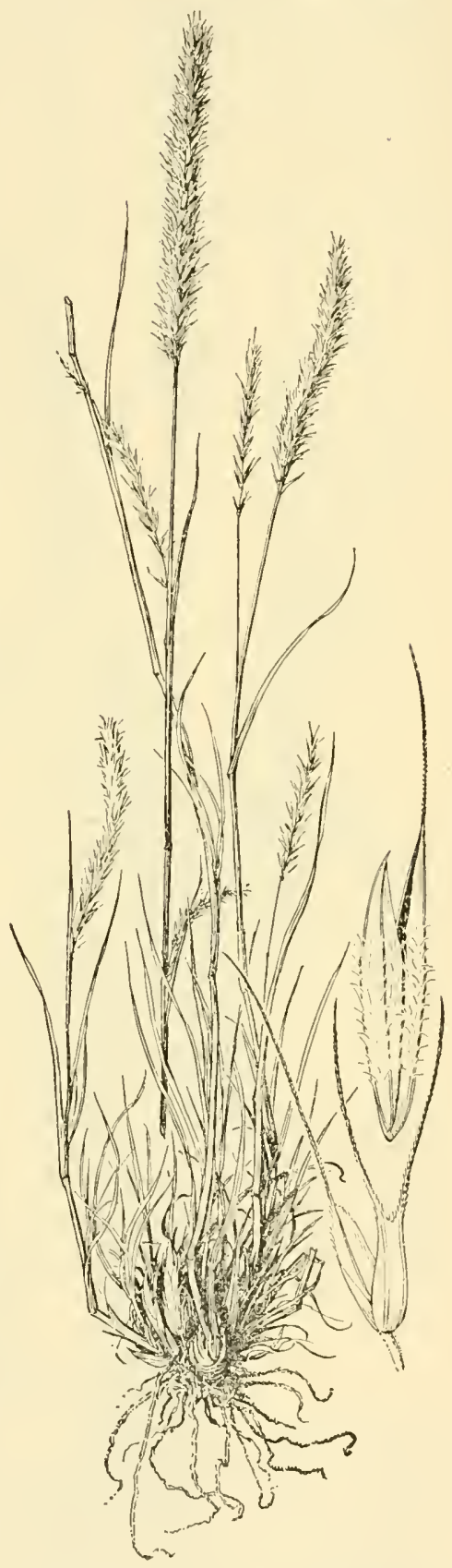

FigURE 726. - Lycurus phleoides. Plant, $\times 1 / 2$; glumes and floret, $\times 10$. (Rydberg 2363 , Colo.) 


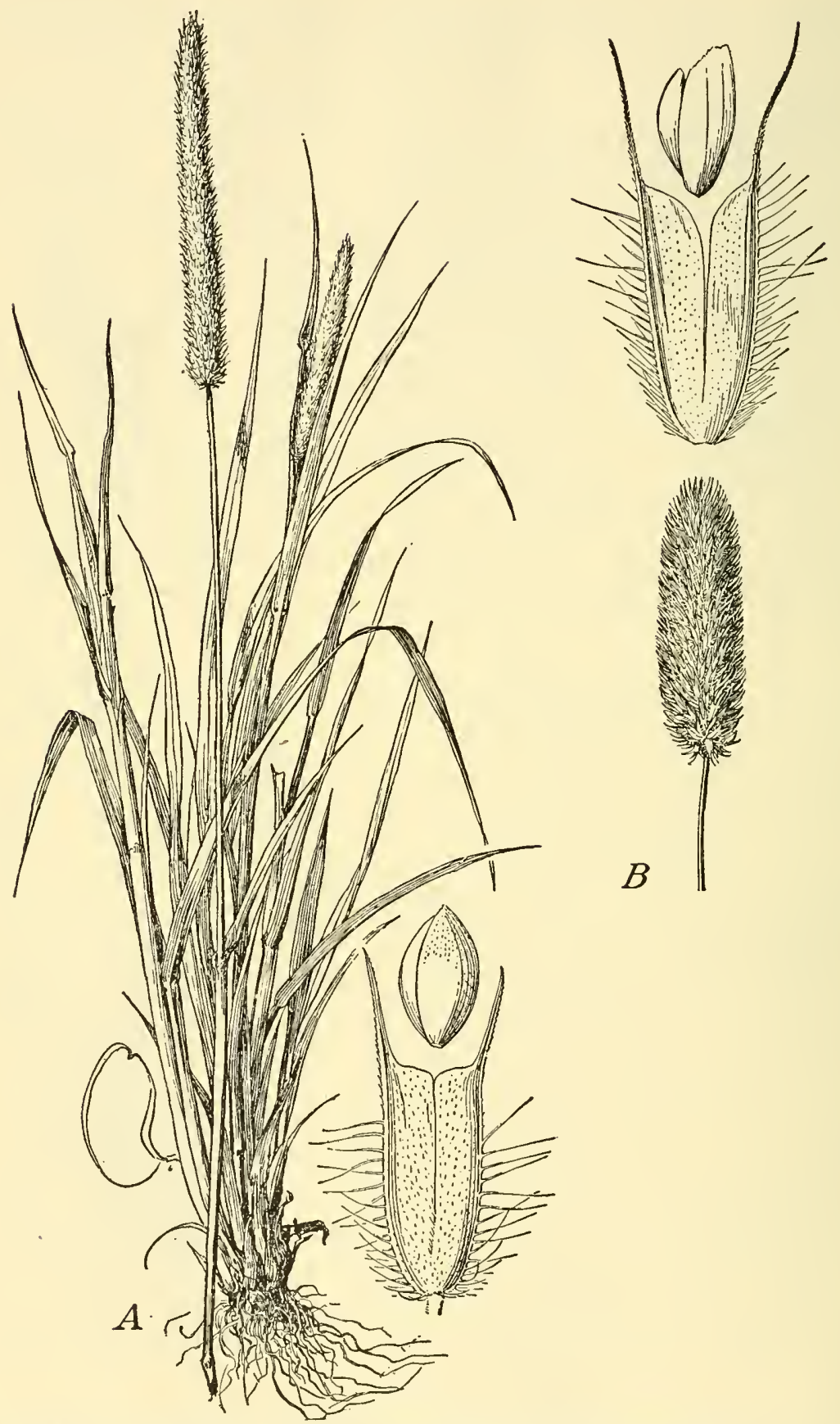

Higure 728. A, Phleum pratense. Plant, $\times 1 / 2$; glumes and floret, $\times 10$. (Mearns 2209, wyo.) $B, P$. alpinum. Panicle, $\times 1$; glumes and floret, $\times 10$. (Clements 337, Colo.) 
mountain meadows, in bogs and wet places, Greenland to Alaska, south in the mountains of Maine and New Hampshire; northern Michigan; in the mountains of the Western States to New Mexico and California, also on the seacoast at Fort Bragg, Calif., and northward (fig. 729); Eurasia and Arctic and alpine regions of the Southern Hemisphere.

Phleum arenárium L. Annual; culms tufted, 5 to $30 \mathrm{~cm}$ tall; foliage scant, mostly basal, the blades 2 to $4 \mathrm{~cm}$ long; panicle 1 to $3 \mathrm{~cm}$ long, somewhat tapering at each end; glumes acuminate, strongly ciliate on the keel. $\odot$-Ballast near Portland, Oreg.; coast of Europe and North Africa.

Phleum subulátum (Savi) Aschers. and Graebn. Annual; culms 10 to $20 \mathrm{~cm}$ tall; blades 2 to $5 \mathrm{~cm}$ long; panicle linear-oblong, mostly 3 to $8 \mathrm{~cm}$ long, 4 to $5 \mathrm{~mm}$ thick; glumes $2 \mathrm{~mm}$ long, scaberulous, subacute, the tips approaching. $\odot$-Ballast, Philadelphia, Pa., and near Portland, Oreg.; Mediterranean region.

Phleum paniculátum Huds. Annual; culms 10 to $30 \mathrm{~cm}$ tall; foliage scabrous; panicle cylindric, 2 to $5 \mathrm{~cm}$ long, 3 to $6 \mathrm{~mm}$ thick; glumes $2 \mathrm{~mm}$ long, glabrous, hard, widened upward to a truncate swollen summit, with a hard awn-point

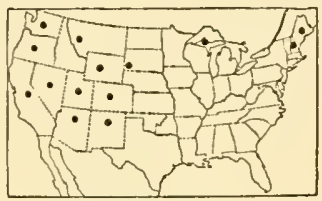

FIGURE 729.-Distribution of Phleum alpinum. at the tip. $\odot-$ Ballast near Portland, Oreg.; Mediterranean region.

\section{GASTRIDIUM Beaur.}

Spikelets 1-flowered, the rachilla disarticulating above the glumes, prolonged behind the palea as a minute bristle; glumes narrow, unequal, somewhat swollen at the base; lemma much shorter than the glumes, hyaline, broad, truncate, awned or awnless; palea about as long as the lemma. Annual with flat blades and pale, shining, spikelike panicles. Type species, Milium lendigerum L. (G. ventricosum). Name from Greek gastridion, a small pouch, alluding to the slightly saccate glumes.

1. Gastridium ventricósum (Gouan) Schinz and Thell. NitGRASS. (Fig. 730.) Culms 20 to $40 \mathrm{~cm}$ tall; foliage scant, blades scabrous; panicle 5 to $8 \mathrm{~cm}$ long, dense, spikelike; spikelets slender, about $5 \mathrm{~mm}$ long; glumes tapering into a long point, the second about one fourth shorter than the first; floret minute, plump, pubescent, the delicate awn $5 \mathrm{~mm}$ long, somewhat geniculate. $\odot-$ Open ground and waste places, Oregon to California; Texas; also Boston, Mass.; introduced from Europe. A common weed on the Pacific coast, but of no economic value.

\section{LAGURUS L.}

Spikelets 1-flowered, the rachilla disarticulating above the glumes, pilose under the floret, produced beyond the palea as a bristle; glumes subequal, thin, 1-nerved, villous, gradually tapering into a plumose awn-point; lemma shorter than the glumes, thin, glabrous, bearing on the back above the middle a slender, exserted, somewhat geniculate, awn, the summit bifid, the divisions delicately awn-tipped; palea narrow, thin, the two keels ending in minute awns. Annual, with pale, dense, ovoid or oblong woolly heads. Type species, Lagurus 


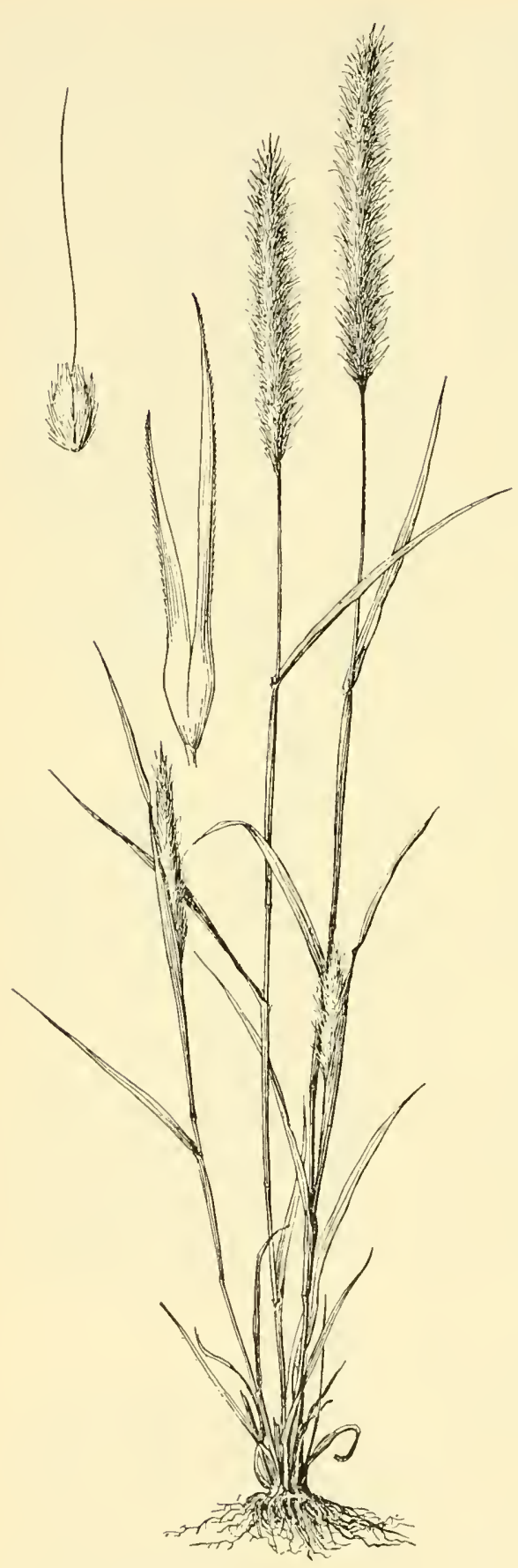

Figure 730.-Gastridium ientricosum. Plant, $\times$ 1/2; glumes and foret, $\times 10$. (Davy and Blasdale 5340 , Calif.) ovatus. Name from Greek lagos, hare, and oura, tail, alluding to the woolly heads.

1. Lagurus ovátus L. (Fig. 731.) Culms branching at the base, 10 to $30 \mathrm{~cm}$ tall, slender, pubescent; sheaths and blades pubescent, the sheaths somewhat inflated, the blades flat, lax; panicle 2 to 3 $\mathrm{cm}$ long, nearly as thick, pale and downy, bristling with dark awns; glumes very narrow, $10 \mathrm{~mm}$ long, the awns of the lemmas much exceeding them. $\odot$-Cultivated for ornament and sparingly escaped; has been found at Pacific Grove, San Francisco, and Berkeley, Calif.; ballast, Beaufort, N.C.; Mediterranean region.

\section{MUHLENBER GIA Schreb. Muhly}

Spikelets 1-flowered (oceasionally 2 -flowered in M.asperifolia), the rachilla disartieulating above the glumes; glumes usually shorter than the lemina, sometimes as long, obtuse to acuminate or awned, keeled or convex on the back, the first sometimes small, rarely obsolete; lemma firmmembranaceous, 3-nerved (the nerves sometimes obseure or rarely an obscure additional pair), with a very short callus, rarely long-pilose, usually minutely pilose, the apex acute, awned from the tip or just below it, or from between very short lobes, sometimes only mucronate, the awn straight or flexuous. Perennial or rarely annual low or moderately tall or rarely robust grasses, tufted or rhizomatous, the culms simple or much-branched, the inflorescence a narrow (sometimes spikelike) or open paniele. 
Type species, Muhlenbergia schreberi. Named for G. H. E. Muhlenberg. Many of the western species are important range grasses and often

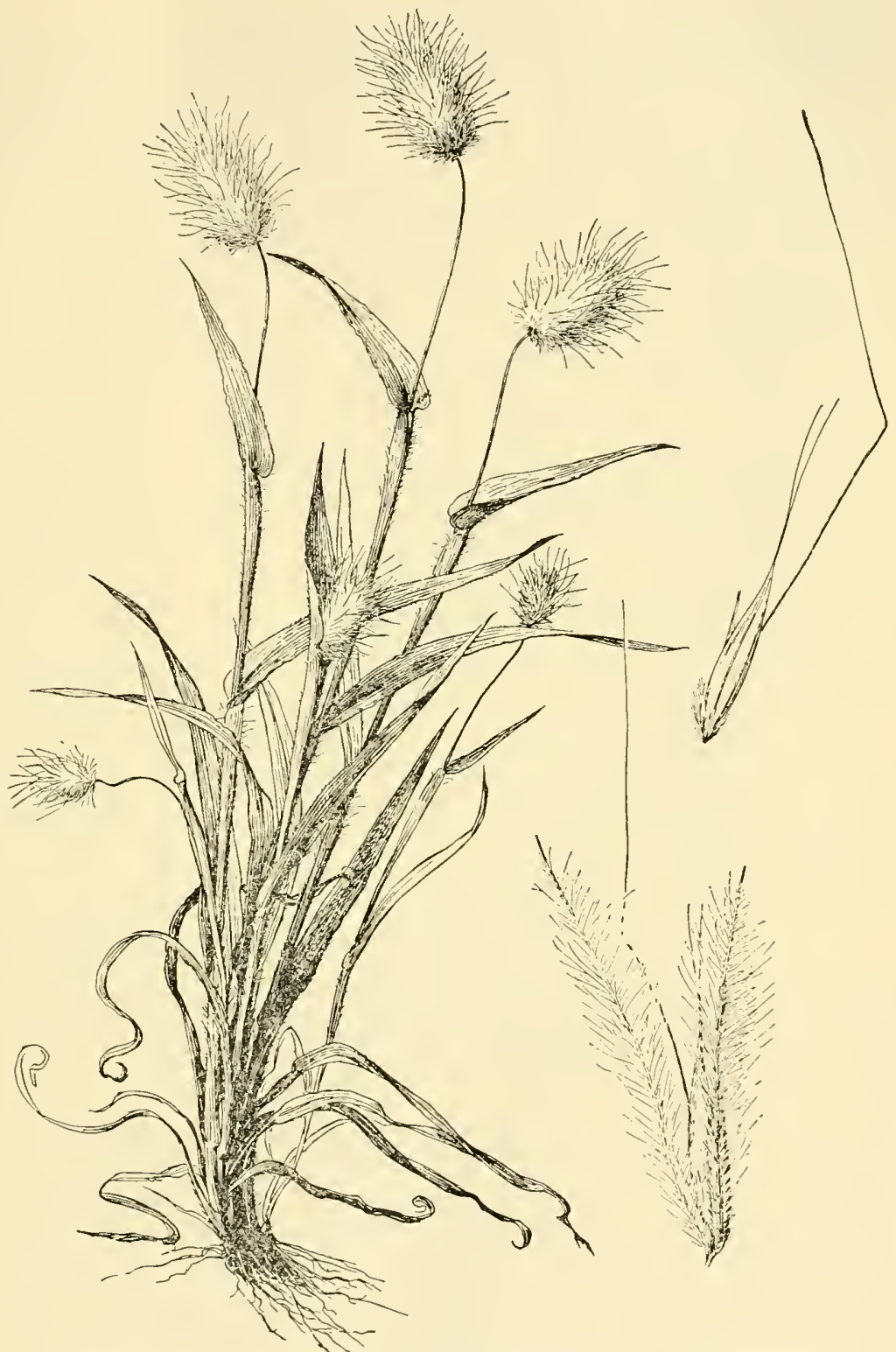

Figure 731.-Lagurus ovatus. Plant, $\times \frac{1}{2}$; spikelet and floret, $\times 5$. (Heller 5340, Calif.)

form a considerable proportion of the grass flora of the arid and semiarid regions. The most important of these are $M$. montana on 
mesas and rocky hills of the Western States, $M$. pauciflora, $M$. emersleyi, and $M$. wrightii in the Southwest.

1a. Plants annual (see also M. uniflora).

Glumes pilose; spikelets on slender pedicels

1. M. TEXANA.

Glumes glabrous; spikelets on short thick pedicels.

Panicles narrow but loose; awn 1 to $3 \mathrm{~cm}$ long-.-.- 2. M. microsperma.

Panicles more or less spikelike; awn reduced to a mucronate point, sometimes as much as $1 \mathrm{~mm}$ long.

Lemma about $4 \mathrm{~mm}$ long

3. M. DEPAUPERATA.

Lemma about $2 \mathrm{~mm}$ long

4. M. FILIFORMIS.

1b. Plant perennial.

2a. Creeping rhizomes present or the slender decumbent base rooting at the nodes (rhizomes short in $M$. dumosa and $M$. californica).

3a. Rhizomes wanting; base of slender branching culms decumbent and rooting at nodes.

Spikelets awnless.

15. M. UNIFLORA.

Spikelets awned.

Glumes minute, the first often obsolete

30. M. SCHREBERI.

Glumes evident (see also M. schreberi var. palustris).

31. M. CURTisetosa.

3b. Rhizomes usually prominent, scaly, creeping.

4a. Panicles open, the spikelets on slender pedicels.

Spikelets awned, 4 to $5 \mathrm{~mm}$ long; blades involute _- 16. M. PUNGens. Spikelets awnless, acutish or mucronate, 1 to $2 \mathrm{~mm}$ long; blades flat.

Panicle oblong; eastern species_........... 14 . M. Torreyana. Panicle as broad as long; western species.

Ligule 1 to $2 \mathrm{~mm}$ long, auricled....... 12. M. ARENACEA.

Ligule minute, not auricled

4b. Panicles narrow, more or less condensed, the spikelets on short pedicels.

5a. Hairs at base of floret copious, as long as the body of the lemma.

5b. Hairs at base of floret inconspicuous, not more than 32 . ANDINA. the lemma.

6a. Blades $2 \mathrm{~mm}$ wide or less, mostly short and involute,

Culms tall, stout, somcwhat woody at base, as much as $6 \mathrm{~mm}$ thick, 1 to $3 \mathrm{~m}$ tall

Culms lower, slender.

Blades mostly 5 to $10 \mathrm{~cm}$, rarely $15 \mathrm{~cm}$ long_ 20. M. GLAUCA. Blades mostly less than $5 \mathrm{~cm}$ long.

Culms widely creeping, the blades fine, conspicuously recurvedspreading. Culms smooth. Ligule less than $1 \mathrm{~mm}$ long.

Spikelets about $3 \mathrm{~mm}$ long_-_._._. 5. M. REPENS.

Spikelets about $2 \mathrm{~mm}$ long _......... 6. M. UTILIS.

Culms erect or decumbent at base, not widely creeping (sometimes spreading in $M$. squarrosa).

Glumes ovate, about half as long as the floret; ligule 2 to 3 $\mathrm{mm}$ long. Culm nodulose-roughened.

7. M. SQUARROSA.

Glumes a little shorter than the floret; ligule minute.

Plants forming dense cushions; sheaths glabrous; leaves crowded toward the base, the blades involute; lemma mucronate to short awned....... 8. M. THURBERI.

Plants forming loose bunches; sheaths pubescent; leaves not crowded, the blades flat; lemma with an awn 1 to $3 \mathrm{~mm}$ long

6b. Blades flat, at least some of them more than $3 \mathrm{~mm}$ wide.

7a. Panicles loosely flowered, slender, much exceeding the leaves (see also $M$. sylvatica); glumes broad below, abruptly pointed, shorter than the body of the lemma.

Culms slender, rather weak, becoming much branched, glabrous or slightly scabrous below the nodes. Lemma acuminate, 2.5 to $3.5 \mathrm{~mm}$ long, awned ...... 24. M. BRACHY PHYLla. Culms erect, simple or sparingly branched.

Spikelets 1.5 to $2.5 \mathrm{~mm}$ long; lemma awnless or awn-tipped; blades commonly not more than 5 to $7 \mathrm{~mm}$ wide.

22. M. SOBOLIFERA. 
Spikelets 3 to $4 \mathrm{~mm}$ long; lemma with an awn 2 to 5 times as long as the body; blades commonly $8 \mathrm{~mm}$ or more wide.

23. M. TENUIFLORA.

7b. Panicles usually densely flowered (sometimes loosely in $M$. sylvatica); culms commonly freely branching (sparingly so or even simple in $M$. racemosa); blades mostly not more than 5 $\mathrm{mm}$ wide, usually ascending; glumes tapering from base to apex.

Glumes with stiff awn-tips, much exceeding the awnless lemma; panicles terminal on the culm or leafy branches, compact, interrupted, bristly _........... 25. M. RACEMOSA.

Glumes acuminate, sometimes awn-tipped but not stiff and exceeding the lemma; panicles terminal and axillary, numerous, not bristly.

Culms glabrous below the nodes; panicles not compact, the branches ascending; plants sprawling-topheavy, the branchlets geniculate-spreading .... 26. M. MEXICANA.

Culms strigose below the nodes; panicles compact or if not the branches erect or nearly so; plants of ten bushy-branching but not sprawling with geniculate branchlets.

Callus hairs wanting; lemma nearly smooth, awnless.

27. M. GLABRIFLORA.

Callus hairs present; lemma pubescent below.

Panicles not compactly flowered; lemma with awn as much as $10 \mathrm{~mm}$ or more long (sometimes awnless); some of the blades 10 to $15 \mathrm{~cm}$ or more long.

28. M. SYLVATICA.

Panicles compactly flowered or, if not, lemma awnless; blades commonly less than $10 \mathrm{~cm}$ long, but sometimes longer.

Sheaths glabrous............ 29. M. Foliosa.

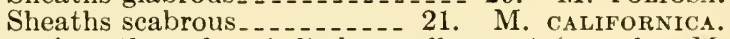

2b. Creeping rhizomes wanting, the culms tufted, usually erect (see also $M$. uniflora).

8a. Second glume 3 -toothed (rarely not toothed in M. filiculmis).

Lemma 2.5 to $3 \mathrm{~mm}$ long; culms filiform, 10 to $20 \mathrm{~cm}$ tall.

17. M. Filiculmis.

Lemma $4 \mathrm{~mm}$ long; culms stouter, 30 to $60 \mathrm{~cm}$ tall ..... 34 . M. MONTANA.

$8 \mathrm{~b}$. Second glume usually acute or awned, sometimes erose-toothed, not distinctly 3 -toothed.

9a. Panicle narrow or spikelike, the branches floriferous from the base or nearly so ( see also $M$. metcalfei).

Lemma acuminate, mucronate or short-awned.

Blades involute.

Panicle elongate and spikelike............ 55. M. RIGENs.

Panicle narrow but scarcely spikelike, the branches loosely flowered.

Blades mostly in a short basal cluster; panicle 5 to $8 \mathrm{~cm}$. long.

33. M. JONESII.

Blades not in a short basal cluster; panicle 10 to $30 \mathrm{~cm}$ long.

Blades flat, folded, or loosely involute.

45. M. DUBIA.

Panicle more or less spikelike.

Culms delicate; ligule about $2 \mathrm{~mm}$ long_... 4 . M. FILIFormis. Culms wiry; ligule minute.

Panicle slender, rather loosely flowered.- 10. M. cuspidata.

Panicle dense, interrupted, the branches closely flowered.

Panicle narrow but not spikelike.

11. M. WRIGHTII.

Lemma villous below

54. M. EMERSLEYI.

Lemma glabrous or obscurely pubescent.

Lower sheaths compressed-keeled.

Glumes about as long as the floret.. 52. M. LINDHEIMERI. Glumes distinctly shorter than the floret.

Lower sheaths not compressed.--
with an awn as much as $5 \mathrm{~mm}$ long.

53. M. INVOLUTA.

51. M. LONGILIGULA.

Lemma with an awn as much as $5 \mathrm{~mm}$ long.

Old sheaths becoming flat and more or less coiled at base of plant.

35. M. VIRESCENS. 
Old sheaths not flat and coiled.

Lemma pilose on lower part.

Culms loosely tufted, hard and wiry at base; floret loosely villous below.

Glumes and floret about equal.

36. M. POLYCAULIS. Glumes about half as long as floret.... 37. M. ARswner.

Culms closely or somewhat loosely tufted, slender but not hard and wiry at base; floret densely pilose at base.

38. M. MONTICOLA.

Lemma scaberulous, not pilose.

Glumes less than $1 \mathrm{~mm}$ long........... 39. M. PARvigLUmis.

Glumes about $2 \mathrm{~mm}$ long

9b. Panicle open, or at least loose, the branches naked at base (sometimes shortly so in $M$. metcalfei).

Plants widely spreading, much branched, wiry, the base knotty.

Plants erect, not widely spreading and much branched.

41. M. PORTERI.

Blades flat, short Blades elongate or, if short, involute.

Blades short in a basal cluster, involute.

Panicle mostly less than $15 \mathrm{~cm}$ long; blades 1 to $3 \mathrm{~cm}$ long, curled or falcate .

Panicle mostly more than $20 \mathrm{~cm}$ long; blades commonly 5 to 8 $\mathrm{cm}$ long

Blades elongate, flat or involute.

10a. Panicle usually not more than twice as Jong as wide at maturity, the branches and pedicels stiff; awn of lemma less than $5 \mathrm{~mm}$ long.

Plants with fibrous tuft at base; lemma awnless or with an awn as much as $2 \mathrm{~mm}$ long _..._... 49 . M. EXPANSA.

Plants without fibrous tuft at base; lemma with an awn 2 to $5 \mathrm{~mm}$ long._.

10b. Panicle elongate, at least 4 times as long as wide at maturity; awns of lemmas, or some of them, usually $10 \mathrm{~mm}$ long or more.

Panicle relatively dense, the branches short; pedicels mostly shorter than the spikelets......... 4 47. M. METCALFEI.

Panicle loose, the capillary branches ascending to spreading. Blades involute, subfiliform, scabrous; panicle pale or tawny. 44. M. SETIFOLIA.

Blades coarser, flat to involute; panicle purple (often tawny in M. emersleyi).

Panicle branches, or most of them, more than $10 \mathrm{~cm}$ long, the panicle diffuse at maturity -- 48. M. Capillaris.

Panicle branches not more than $10 \mathrm{~cm}$ long, the panicle not diffuse.

Lower sheaths compressed-keeled; glumes as long as lemma or a little longer..... 54. M. EMERSLEYI.

Lower sheaths not compressed-keeled; glumes much shorter than lemma.......... 46. M. RIGIDA.

1. Muhlenbergia texána Buckl. (Fig. 732.) Annual; culms delicate, erect or decumbent at base, 10 to $20 \mathrm{~cm}$ tall; blades mostly less than $5 \mathrm{~cm}$ long, about $1 \mathrm{~mm}$ wide, scabrous; panicle oblong, more than half the entire height of the plant, open, the delicate branches ascending or spreading, 2 to $3 \mathrm{~cm}$ long; spikelets 1.5 to $2 \mathrm{~mm}$ long, the capillary pedicels longer than the spikelets; glumes acute, about two thirds as long as the lemma, sparsely hirsute; lemma minutely silky on midnerve and margins below, 2-lobed, the delicate awn 1 to $2 \mathrm{~mm}$ long. $\odot-$ Open gravelly places, western Texas and New Mexico to northern Mexico.

2. Muhlenbergia microspérma (DC.) Kunth. Littleseed MUHLY. (Fig. 733.) Annual; culms densely tufted, branching and spreading at base, of ten purple, 10 to $30 \mathrm{~cm}$ tall; blades mostly less than $3 \mathrm{~cm}$ long, 1 
to $2 \mathrm{~mm}$ wide, scabrous; panicles narrow, 5 to $15 \mathrm{~cm}$ long, the branches rather distant, ascending; spikelets on short thick pedicels; glumes broad, obtuse, subequal, less than $1 \mathrm{~mm}$ long; lemma narrow, 3 to $4 \mathrm{~mm}$ long, scabrous, the slender awn 1 to 3 cm long. $\odot$-Open dry ground, Arizona and southern California to Peru. Cleistogamous spikelets are developed at the base of lower sheaths, solitary or few in a fascicle in each axil, each spikelet included in an indurate thickened, tightly rolled narrowly conical reduced sheath, which readily disarticulates from the plant at maturity. The glumes are wanting and awn of lemma reduced, but the grain is larger than that of the spikelets in the terminal inflorescence, being about the same length $(2 \mathrm{~mm})$ but much thicker.

3. Muhlenbergia depauperáta Scribn. (Fig. 734.) Annual; culms in dense tufts, 5 to 10 or rarely 15 cm tall, erect; blades scabrous, pubescent on the upper surface, mostly less than $3 \mathrm{~cm}$ long, about $1 \mathrm{~mm}$ wide; panicle narrow, loosely spikelike, usually more than half the entire length of the plant, the branches ap-

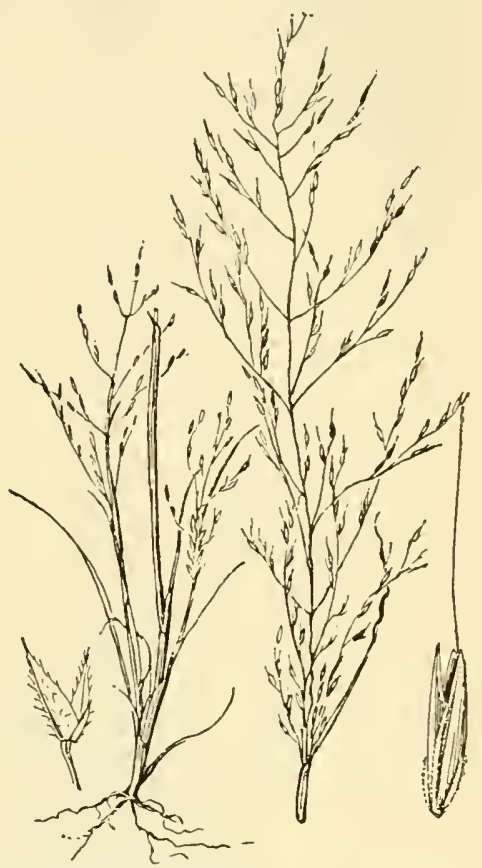
pressed; glumes narrow, scabrous, the first irregularly bidentate or

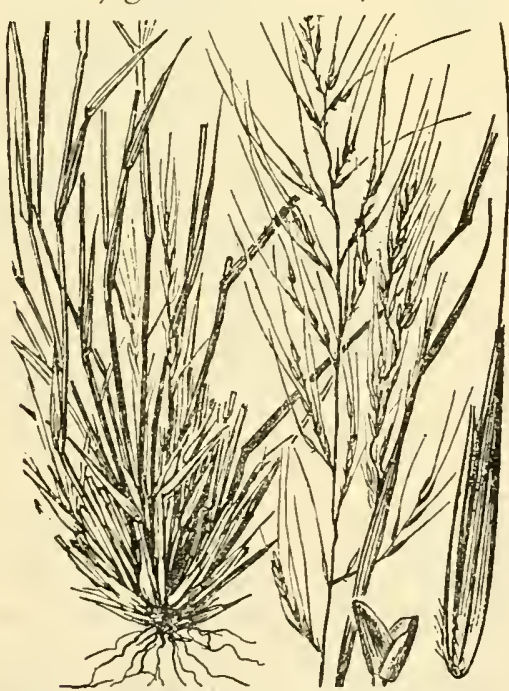

Figure 733. - Muhlenbergia microsperma. Plant, $X$ 1 ; glumes and floret, $X 10$. ( Mearns 2780 , Ariz.) entire, mostly 1 to $2 \mathrm{~mm}$ long, occasionally reduced, the second, a little longer; lemma narrow, terete, prominently 3-nerved, slightly pubescent along the internerves, about $4 \mathrm{~mm}$ long, the delicate awn straight, about $1 \mathrm{~cm}$ long. $\odot-$ Open gravelly places, Colorado, New Mexico, and Arizona; Mexico.

\section{Muhlenbergia filifórmis} (Thurb.) Rydb. Pull-up nuhli. (Fig. 735.) Annual, tufted, rather soft and lax, erect or somewhat spreading; culms filiform, usually 5 to $15 \mathrm{~cm}$ tall, sometimes as much as $30 \mathrm{~cm}$; ligule about $2 \mathrm{~mm}$ long, blades flat, usually less than $3 \mathrm{~cm}$ long; panicle narrow, interrupted, few-flowered, usually less than $5 \mathrm{~cm}$ long; glumes orate, $1 \mathrm{~mm}$ long; lemma lanceolate, acute, mucronate, $2 \mathrm{~mm}$ long, minutely pubescent, scaberulous at tip. $\odot$-Open 
woods and mountain meadows, South Dakota and Kansas to British Columbia, south to New Mexico and California (fig. 736). A somewhat stouter form with thicker panicles has been called $M$. simplex Rydb.

5. Muhlenbergia répens (Presl) Hitchc. Creeping muhly. (Fig. 737.) Perennial with widely creeping scaly rhizomes; culms decum-

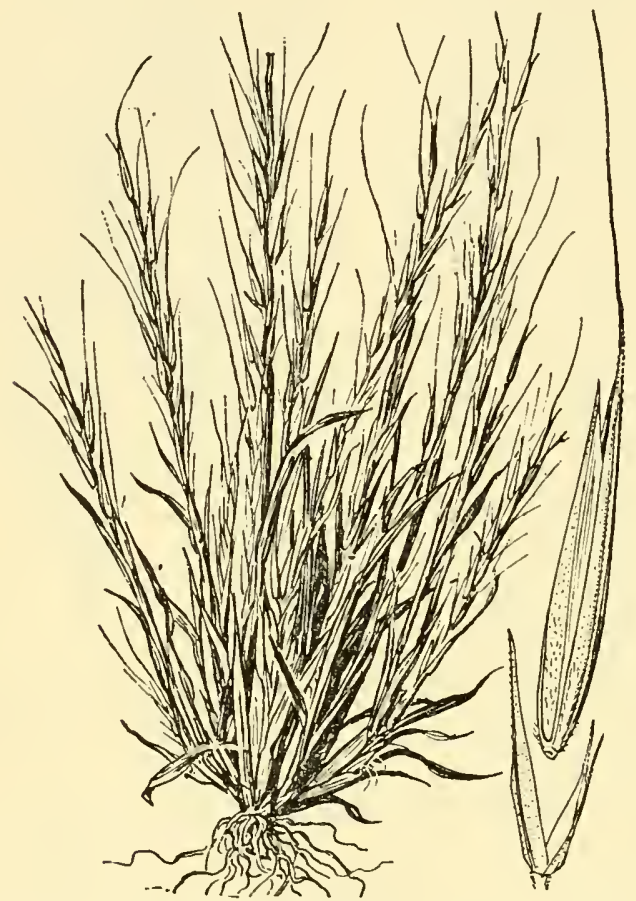

Figure 734.-Muhlenbergia depauperata. Plant, $\times 1$; glumes and floret, $\times 10$. (Metcalfe 671 , N.Mex.)

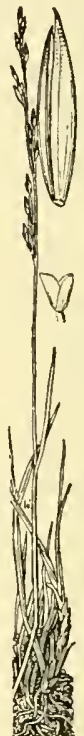

FIGURE 735.-Muhlenbergia filiformis.

Plant, $\times 1$; glumes

and floret, $\times 10$

(Nelson 4011, Wy.)

bent, branching, spreading, the flowering branches 5 to $20 \mathrm{~cm}$ long; blades mostly 1 to $2 \mathrm{~cm}$ long, flat or soon involute; panicle narrow, 1 to $4 \mathrm{~cm}$ long, sometimes longer, interrupted; spikelets about $3 \mathrm{~mm}$ long; glumes more than half as long as the lemma or a little more, acutish; lemma narrowed to a more or less apiculate summit, minutely roughened, usually darker than the glumes, the lateral nerves obscure. 2 -Dry rocky or sandy open ground, Texas to Arizona; known in Mexico only from the type collection.

6. Muhlenbergia útilis (Torr.) Hitchc. Aparejo grass. (Fig. 738.) Similar to $M$. repens; usually more delicate with finer leaves;

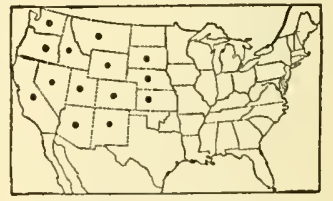

FIGURE 736.-Distribution of Muhlenbergia filiformis. spikelets about $2 \mathrm{~mm}$ long, less pointed, the glumes sometimes less than half as long as the paler lemma. 24 (Sporobolus utilis Scribn.) -Wet places, marshy soil, and along ditches and streams, Texas, Arizona, southern California, Nevada, and Mexico. Used for stuffing pack saddles. 
7. Muhlenbergia squarrósa (Trin.) Rydb. Mat miuhly. (Fig. 739.) Perennial from numerous hard creeping rhizomes; culms wiry, nodulose-roughened, erect or decumbent at base, from $5 \mathrm{~cm}$ to as much as $60 \mathrm{~cm}$ long; ligule 2 to $3 \mathrm{~mm}$ long; blades usually involute, 1 to $5 \mathrm{~cm}$ long, rarely longer; panicle narrow, interrupted, or sometimes rather close and spikelike, 2 to $10 \mathrm{~cm}$ long; spikelets 2 to $3 \mathrm{~mm}$ long, the glumes about half as long, ovate; lemma lanceolate, acute, mucronate. 24 -Dry or moist open often alkaline soil, New Brunswick and Maine to Alberta, south to South Dakota and in the moun-

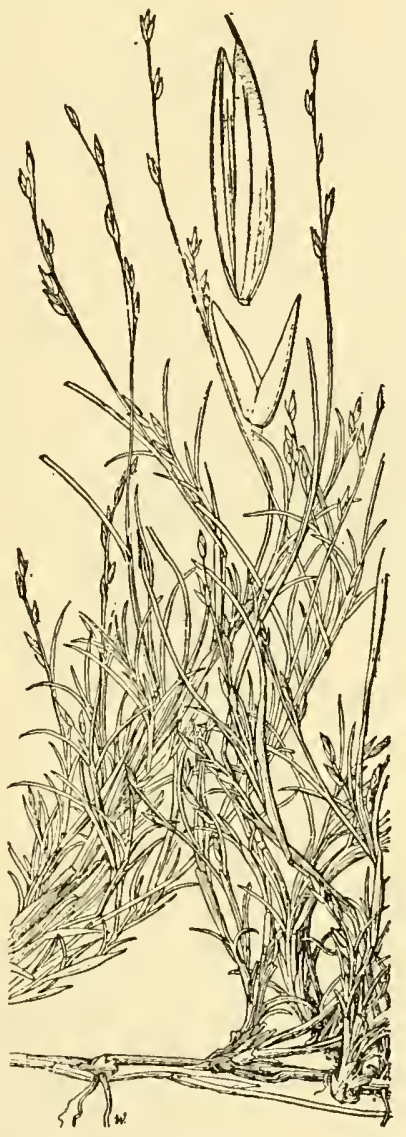

Figure 737.- Muhlenbergia repens. Plant, $\times 1$; glumes and floret, $\times 10$. (Silveus 831, Tex.) tains to New Mexico, through eastern Washington to California, Arizona, and southern Mexico (fig. 740). The typical form (Vilfa squarrosa Trin.; Vilfa depauperata Torr.; Sporobolus depauperatus Scribn., not Muhlenbergia depauperata Scribn.) is rather stout, decumbent or somewhat spreading, Wyoming to Washington and California; a common form

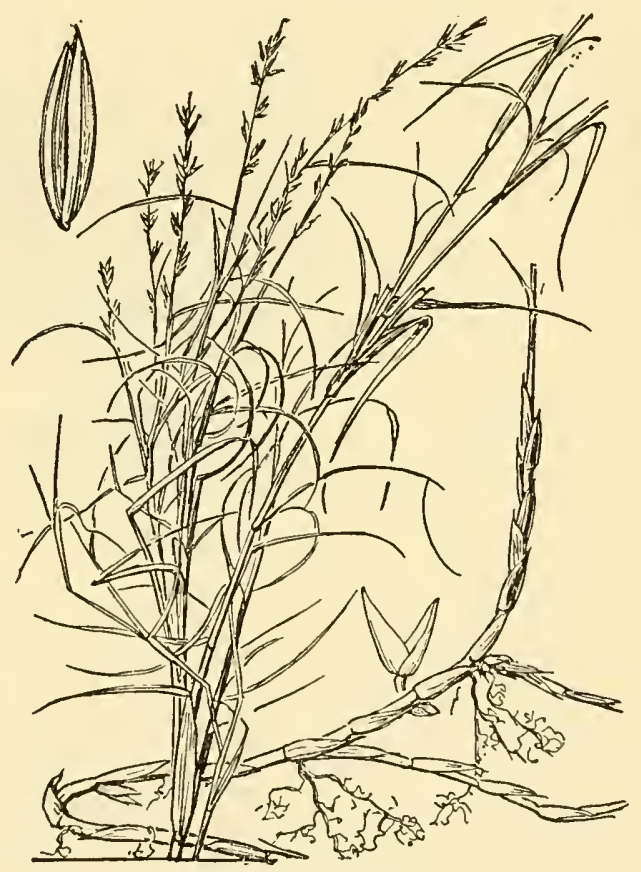

FIgUre 738. $\rightarrow$ Muhlenbergia utilis. Plant, $\times 1$; glumes and floret, $\times 10$. (Lindheimer 559, Tex.)

(Vilfa richardsonis Trin.; Sporobolus richardsonis Merr.) has slender erect culms. These forms intergrade.

8. Muhlenbergia thurbéri Rydb. (Fig. 741.) Perennial, with creeping rhizomes; culms slender, 10 to $20 \mathrm{~cm}$ tall, branched at base, the branches erect, tufted, the tufts on branches of the rhizome; sheaths glabrous; blades involute, slender, mostly 1 to $3 \mathrm{~cm}$ long; panicle pale, narrow, slender, 3 to $7 \mathrm{~cm}$ long, the branches short, appressed, few-flowered; spikelets 3.5 to $4 \mathrm{~mm}$ long; glumes a little 
shorter than the lemma, acute; lemma and palea villous on lower half, the lemma mucronate to short-awned. 24 -Dry hills, Texas, New Mexico, Nevada, Arizona; rare (fig. 742).

9. Muhlenbergia curtifólia Scribn. (Fig. 743.) Perennial, with creeping rhizomes; culms 10 to $20 \mathrm{~cm}$ tall, loosely tufted, few from

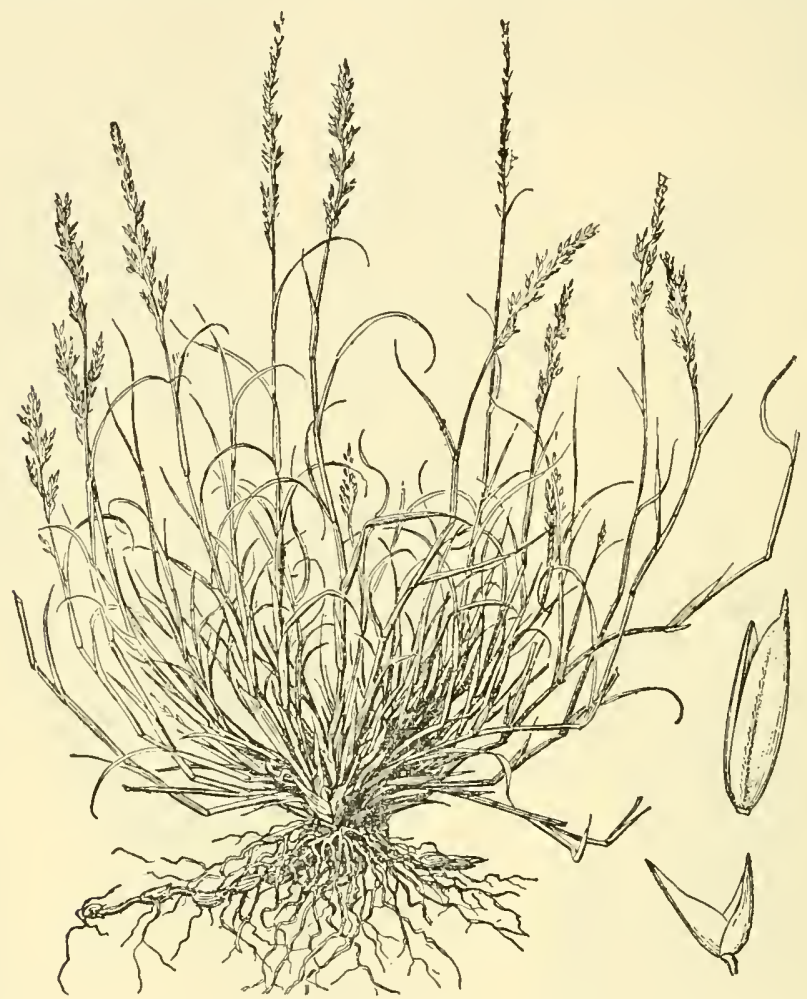

FIGURE 739.-Muhlenbergia squarrosa. Plant, $\times \frac{1}{2}$; glumes and lemma, $\times 10$. (Jones 5743 , Utah.)

the branches of the rhizome; sheaths glabrous or pubescent; blades 1 to $2.5 \mathrm{~cm}$ long, $2 \mathrm{~mm}$ wide or less, rigidly spreading, pungently pointed, more or less pubescent; panicle 4 to $8 \mathrm{~cm}$ long, slender, the branches appressed; spikelets 3 to $3.5 \mathrm{~mm}$ long; glumes acute, a little

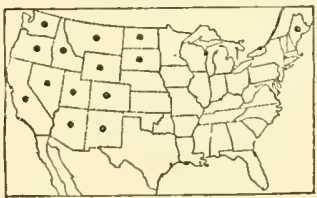

Figure 740.-Distribution of Muhlenbergia squarrosa. shorter than the floret; lemma and palea villous on the lower half, scabrous above, tapering into an awn 1 to $3 \mathrm{~mm}$ long. 24 -Roeky soil, southern Utah, southern Nevada, and northern Arizona.

10. Muhlenbergia cuspidáta ('Torr.) Rydb. Plains muhly. (Fig. 744.) Culms slender, wiry, 20 to $40 \mathrm{~cm}$ tall, erect, in dense tufts with hard bulblike scaly bases; ligule minute; blades flat or loosely involute, erect or ascending, 1 to $2 \mathrm{~mm}$ wide; panicle narrow, somewhat spikelike, 5 to $10 \mathrm{~cm}$ long, the short branches appressed; spikelets about $3 \mathrm{~mm}$ long; glumes subequal, acuminate-cuspidate, about two-thirds as long as the spikelet; lemma acuminate-cuspi- 
date, minutely pubescent. 21 - Prairies and gravelly or stony slopes, Michigan, Wisconsin to Alberta, south to Ohio and New Mexico (fig. 745).

11. Muhlenbergia wríghtii Vasey. Spike muhly. (Fig. 746.) Culms closely tufted from a hard crown, erect, wiry, 30 to $60 \mathrm{~cm}$ tall; sheaths compressed-keeled; ligule 1 to $2 \mathrm{~mm}$ long, sometimes longer; blades flat, 1 to $3 \mathrm{~mm}$ wide; panicle spikelike, interrupted below, 5 to $10 \mathrm{~cm}$ long; spikelets about $2.5 \mathrm{~mm}$ long, the glumes rather thin, mostly about half as long as the spikelet, broad at base, tapering to an awn point; lemma glabrous, acuminate, awn-tipped. 4 Plains and open slopes at medium altitudes, Colorado, Utah, New Mexico, Arizona, and northern Mexico (fig. 747).

12. Muhlenbergia arenácea (Buckl.) Hitchc. (Fig. 748.) Perennial, with creeping rhizomes; culms tufted from the branches of the

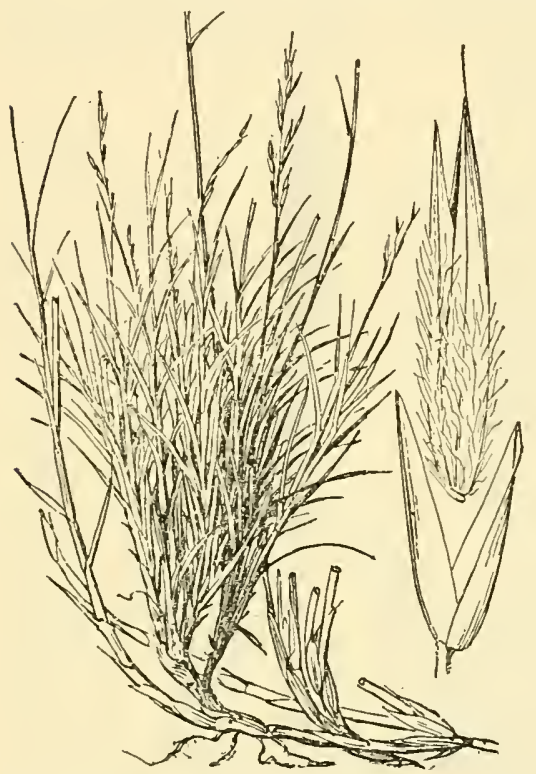

FIGCRE 741.-Muhlenbergia thurberi. Plant, $\times 1$; glumes and floret, $\times 10$. (Standley 7345, Ariz.)

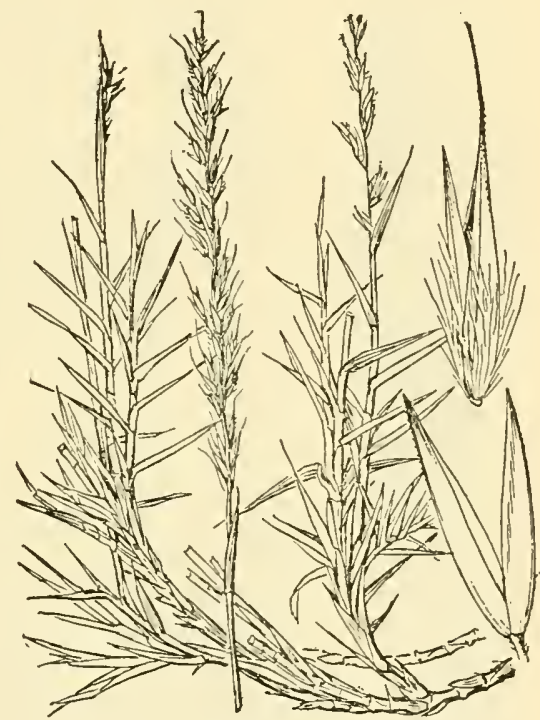

Figure 743.-Muhlenbergia curtifolia. Plant, $\times 1$ glumes and floret, $\times 10$. (Type.)

ihizomes, sometimes decumbent at base, 10 to $20 \mathrm{~cm}$ tall; ligule prominent, decurrent, 1 to $2 \mathrm{~mm}$ long, the margins usually split

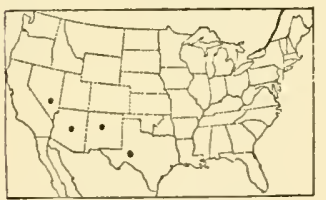

Figtre 742,-Distribution of Muhlenbergia thurberi. away, forming an erect auricle at each side; blades flat, wavy, mostly 1 to $3 \mathrm{~cm}$ long, about $1 \mathrm{~mm}$ wide, sharp-pointed, the margins and midnerve white and cartilaginous; panicle diffuse, 7 to $12 \mathrm{~cm}$ long, about as broad, the branches and pedicels capillary; spikelets about $2 \mathrm{~mm}$ long, rarely 2 -flowered; the glumes about half as long, abruptly apiculate or subacute; lemma glabrous, abruptly mucronate. 2

(Sporobolus auriculatus Vasey.) - Low places in mesas, Texas to Arizona and Sonora. This species and the next three are placed in Muhlenbergia because of the 3-nerved mucronate lemma. The 


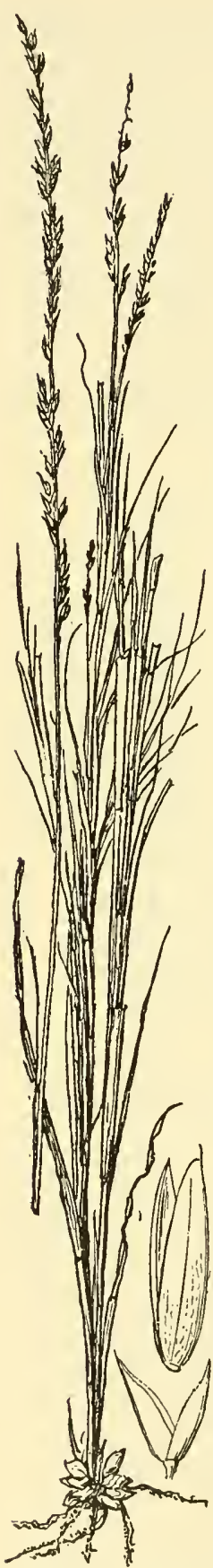

Figure 744-Muh lenbergia cuspidata. Plant, $\times 1$; glumes and floret, $\times 10$. (Cratty, Iowa.) caryopsis does not fall from the lemma and palea as in most species of Sporobolus, nor can the pericarp be separated from the grain by moistening it.

13. Muhlenbergia asperifólia (Nees and Mey.) $\mathrm{Pa}-$ rodi. Scratchgrass. (Fig. 749.) Perennial, pale or glaucous, with slender scaly rhizomes; culms branching at base, spreading, slender, compressed, 10 to 40 $\mathrm{cm}$ tall, the branches ascending or erect; sheaths somewhat compress ed-keeled,

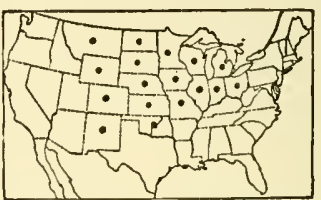

FIGURE 745.-Distribution of Muhlenvergia cuspidata. usually overlapping; ligule minute, erose-toothed; blades flat, crowded, scabrous, mostly 2 to $5 \mathrm{~cm}$ long, 1 to $2 \mathrm{~mm}$ wide; panicle diffuse, 5 to $15 \mathrm{~cm}$ long, about as wide, the capillary scabrous branches finally widely spreading, the panicle at maturity breaking away; spikelets 1.5 to $2 \mathrm{~mm}$ long, occasionally 2 -flowered, the pedicels capillary; glumes acute, from half to nearly as long as the spikelet; lemma thin, broad, minutely mucronate from an obtuse apex. 21 (Sporobolus asperifolius Nees and Mey.) Damp or marshy, often alkaline soil, along irrigation ditches and banks of streams, Illinois and Alberta to British Columbia,

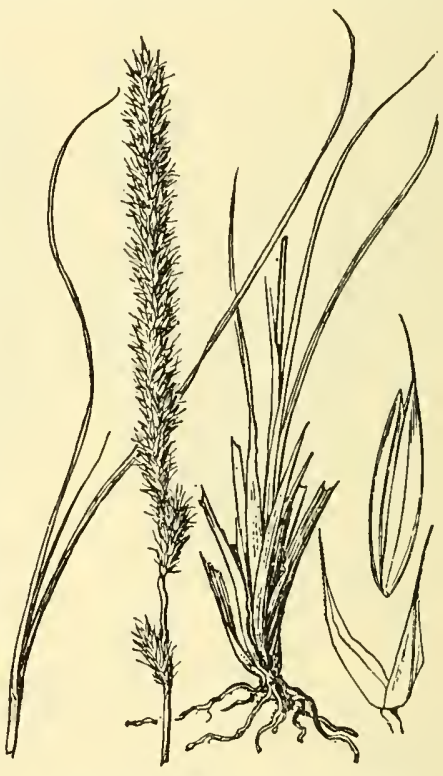

FIGURE 746.- Muhlenbergia wrightit. Plant, $\times 1$; glumes and floret, $\times 10$. (Standley 8249, N.Mex.) south to Texas, California, and Mexico (fig.750); southern South America. The caryopsis is frequently affected by a fungus (Tilletia asperifolia Ell. and Everh.) which produces a large globular body. 14. Mu h le $n$ bergia torreyána (Schult.) Hitchc. (Fig. 751.) Perennial, strongly compressed at base, with short very scaly rhizomes; culms simple, or

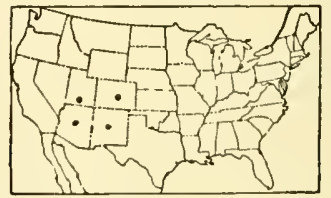

FIGURE 747.-Distribution of Muhlenbergia wrightii. sparingly branching at base, erect, 30 to $60 \mathrm{~cm}$ tall; blades elongate, rather firm, flat or folded, 1 to 3 
$\mathrm{mm}$ wide; panicle oblong, open, 10 to $20 \mathrm{~cm}$ long, the capillary branches and pedicels ascending; spikelets about $2 \mathrm{~mm}$ long, the glumes subequal, slightly shorter; lemma and palea minutely scaberulous-puberulent. 2| (Sporobolus compressus Kunth; S. torreyanus Nash.)-Moist pine barrens and meadows, New Jersey and Delaware; Georgia (Sumter County).

15. Muhlenbergia uniflóra (Muhl.) Fernald. (Fig. 752.) Perennial, but often appearing like an annual, tufted, of ten with decumbent

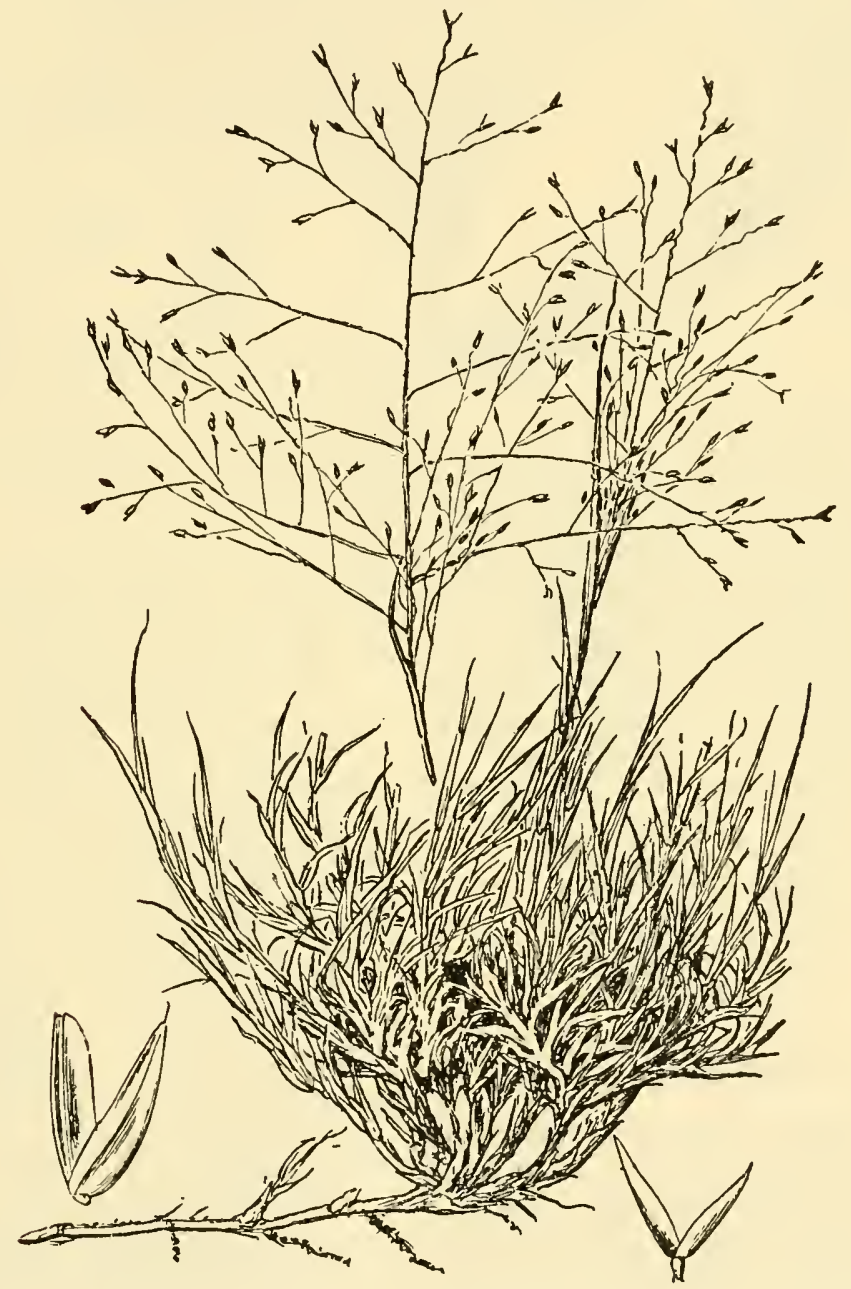

Figure 748. - Muhlenbergia arenacea. Plant, $\times 1$; glumes and floret, $\times 10$. (Tracy 7909, Tex.)

bases; culms slender, erect, 20 to $40 \mathrm{~cm}$ tall, the base and lower sheaths compressed; blades flat, crowded along the lower part of the culm, about $1 \mathrm{~mm}$ wide; panicle loose, open, oblong, 7 to $20 \mathrm{~cm}$ long, 2 to 4 $\mathrm{cm}$ wide, the branches and pedicels capillary; spikelets dark purplish, about $1.5 \mathrm{~mm}$ long, rarely 2 -flowered; glumes scarcely half as long as the spikelet, subacute: lemma faintly 3-nerved, acutish. 24 (Sporo- 
bolus serotinus A. Gray; S. uniflorus Scribn. and Merr.)--Bogs and wet meadows, Newfoundland to Michigan and New Jersey (fig. 753).

16. Muhlenbergia púngens Thurb. (Fig. 754.) Perennial, with

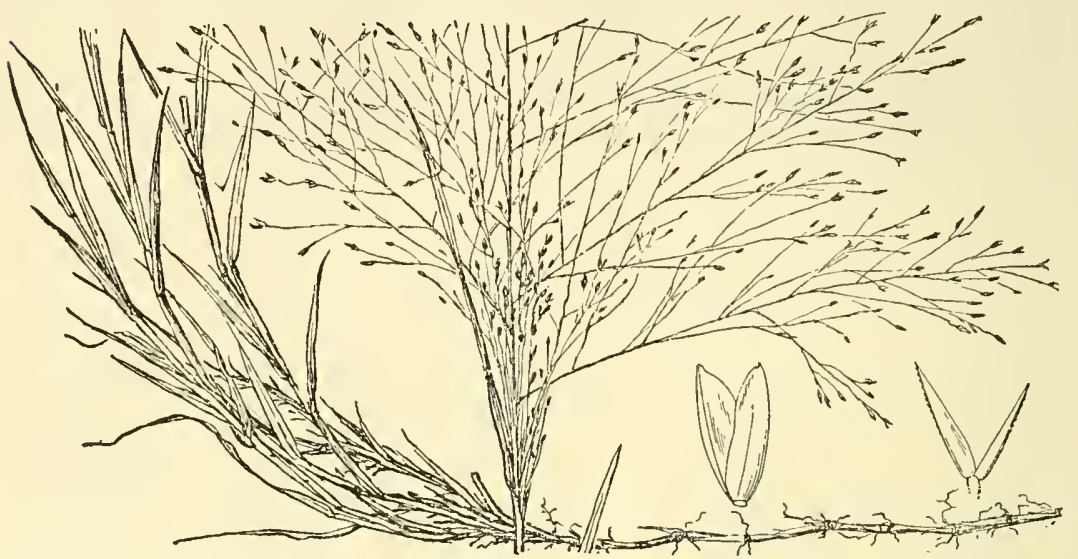

FIGURE 749.-Muhlenbergia asperifolia. Plant, $\times 1$; glumes and floret, $\times 10$. (Griffiths 212, S.Dak.)

strong creeping rhizomes; culms tufted, erect from a decumbent leafy base, 20 to $40 \mathrm{~cm}$ tall, sometimes taller; blades short, involute, sharppointed; panicle long-exserted, open, oblong, 5 to $15 \mathrm{~cm}$ long; the main branches 3 to 5 , these dividing into fascicles of capillary finally spreading or divaricate very scabrous branchlets; spikelets purple to brownish, 4 to $5 \mathrm{~mm}$ long, the glumes about one third as long, sca-

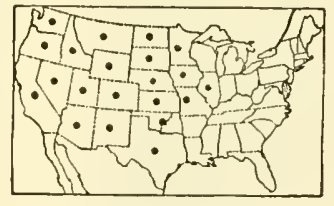

Figure 750.-Distribution of Muhlenbergia asperifolia.

brous, often erose or toothed, the midnerve extending into a short awn;lemma terete, tapering into an awn about $1 \mathrm{~mm}$ long; palea about as long as the lemma, the keels awntipped. 4 -Dry hills and sandy plains, South Dakota, Colorado, and Utah to New Mexico and Arizona (fig. 755). 17. Muhlenbergia filicúlmis Vasey. SLiмsтем мuнцу. (Fig. 756.) Culms densely tufted, erect, filiform, 10 to $20 \mathrm{~cm}$ tall, the leaves in a short basal cluster; ligule prominent; blades involute, filiform, mostly less than $5 \mathrm{~cm}$ long; panicle slender, the branches erect, mostly 2 to $5 \mathrm{~cm}$ long, sometines as much as $10 \mathrm{~cm}$; spikelets about 
2.5 to $3 \mathrm{~mm}$ long, the glumes about half as long, awn-tipped, the first rather narrow, acuminate, the second broader, 3-nerved, sharply 3toothed, rarely entire or erose only; lemma pubescent on the lower haif, tapering to an awned tip. 24 -Open sandy or rocky soil, 2,000 to $3,000 \mathrm{~m}$ altitude, Wyoming, Colorado, and New Mexico.

18. Muhlenbergia arizónica Scribn. (Fig. 757.) Perennial, in close tufts; culms slender, erect or decumbent at base, 15 to $40 \mathrm{~cm}$ tall; sheaths keeled; ligule thin, 1 to $2 \mathrm{~mm}$ long, decurrent; blades flat or folded, mostly less than $5 \mathrm{~cm}$ long, 1 to $2 \mathrm{~mm}$ wide, the margins and midnerve white, cartilaginous; panicle open, 5 to $12 \mathrm{~cm}$ long, 4 to $8 \mathrm{~cm}$ wide, the branches capillary, compound; spikelets long-pedicellate, about $3 \mathrm{~mm}$ long, the glumes about one third as long, ovate, subacute; lemma narrowly lanceolate, minutely pubescent along the midnerve and margins below, the awn about $1 \mathrm{~mm}$ long, from a minutely notched apex. 24 Stony hills, southern Arizona and northwestern Mexico.

19. Muhlenbergia dumósa Scribn. (Fig. 758.) Perennial, with short, stout creeping scaly rhizomes; culms robust, solid, thick, and sealy at base (here as much as $6 \mathrm{~mm}$ thick), the main culm erect or leaning, 1 to $3 \mathrm{~m}$ tall, the lower part clothed with bladeless sheaths, freely branching at the middle and upper nodes, the branches numerous, fascicled,

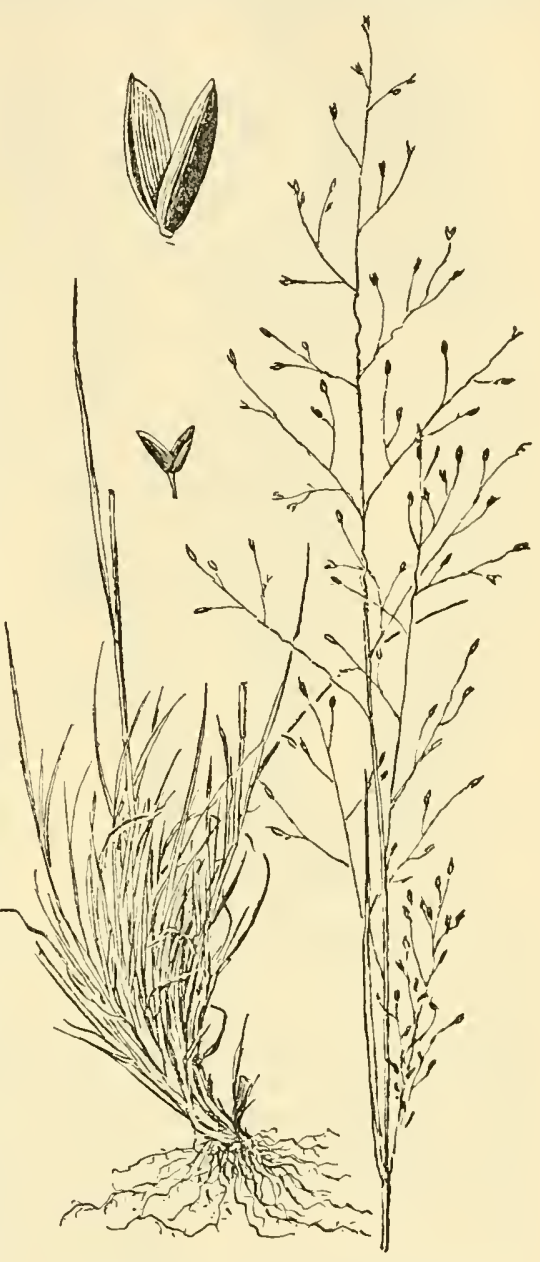

Figúre 752.-M Nuhlenbergia uniflora. Plant, $\times 1$; glumes and floret, $\times 10$. (Chamberlain 147, Maine.) spreading, decompound, the ultimate branchlets filiform; blades flat or soon involute, smooth, those of the branches mostly less than $5 \mathrm{~cm}$

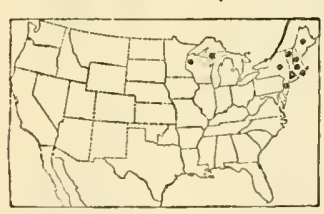

FTGURE 753.-Distribution of Muhlenbergia unifiora. long and $1 \mathrm{~mm}$ wide; panicles numerous on the branches, commonly exceeded by the leaves, 1 to $3 \mathrm{~cm}$ long, narrow, somewhat flexuous; spikelets, excluding the awn, about $3 \mathrm{~mm}$ long, the glumes scarcely half as long, thin, pale with a green midnerve, usually minutely awn-tipped; lemma narrow, pubescent about the base and margin, pale with green nerves, the awn from the slightly notched apex, flexuous, 3 to $5 \mathrm{~mm}$ long. 24-Canyons and valley flats, southern Arizona to Jalisco Mexico. Has the aspect of a small bamboo. 
20. Muhlenbergia glaúca (Nees) Mez. (Fig. 759.) Perennial, from a slender creeping branching woody rhizome; culms slender, wiry, erect

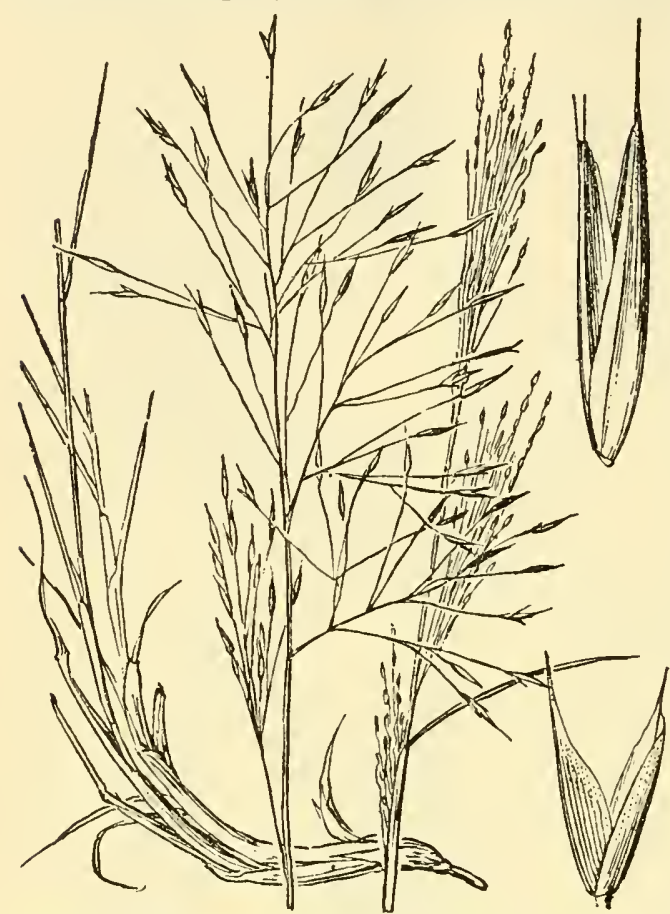

Figure 754.-Muhlenbergia pungens. Plant, $\times 1$; glumes and floret, $\times 10$. (Jones 6046, Utah.)

or ascending, 30 to $60 \mathrm{~cm}$ tall, branching from the lower nodes; blades flat to subinvolute, mostly 5 to 10 $\mathrm{cm}$ long, 1 to $2 \mathrm{~mm}$ wide; panicle 5 to $12 \mathrm{~cm}$ long, narrow, contracted, interrupted, the branches short, appressed; spikelets 3 to $4 \mathrm{~mm}$ long, the glumes nearly as long, acuminate; lemma sparsely pilose on the lower part, acuminate into an awn usually 1 to 3 $\mathrm{mm}$ (rarely as much as 6 $\mathrm{mm}$ ) long. 24 (M. lemmoni Scribn.)-Deserts, western Texas to southern California (Jamacha) and northern Mexico (fig. 760).

21. Muhlenbergia califórnica Vasey. (Fig. 761.) Perennial, pale, leafy, the base more or less creeping and rhizomatous; culms ascending, somewhat woody below, 30 to $60 \mathrm{~cm}$ tall, branching below; sheaths scaberulous; blades flat, 4 to $6 \mathrm{~mm}$ wide, scabrous, usually short; panicle narrow, dense but interrupted, 7 to $15 \mathrm{~cm}$ long; spikelets 3 to $4 \mathrm{~mm}$ long, the glumes slightly shorter, scabrous, acuminate, awn-tipped; lemma scabrous, acuminate, awn-tipped, with sparse callus hairs about half as long as the lemma. 24 -Stream borders and gullies, foothills and mountain slopes up to $2,000 \mathrm{~m}$,

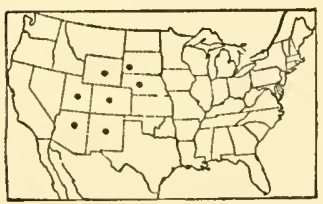

FIGURE 755.-Distribution of Muhlenbergia pungens. confined to southern California.

\section{Muhlenbergia sobolífera} (Muhl.) Trin. (Fig. 762, A.) Perennial, with numerous creeping scaly rhizomes 2 to $3 \mathrm{~mm}$ thick; culms erect, slender, solitary or few in a tuft, glabrous, 60 to $100 \mathrm{~cm}$ tall, sparingly branching, the branches erect; blades flat, spreading, scabrous, those of the main culm 5 to $15 \mathrm{~cm}$ long, 3 to $8 \mathrm{~mm}$ wide, occasionally larger, at time of flowering aggregate along the middle part of the culm; panicles slender, somewhat nodding, mostly 5 to $15 \mathrm{~cm}$ long, the distant branches appressed, floriferous from base, over-lapping or the lower more distant; spikelets mostly 2 to $2.5 \mathrm{~mm}$ long, the glumes about two thirds as long, abruptly acuminate

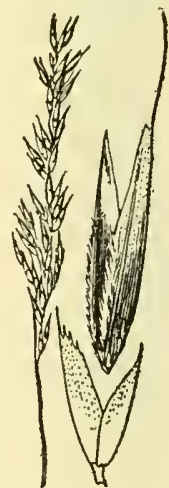

FIGURE 756.Muhlenbergia filic $u l \mathrm{~m}$ is. Panicle $\times 1$; g l um $\mathrm{s}$ and floret, $\times 10$. (Type.) or awn-tipped; lemma elliptic, bluntish, pubescent on the lower part, usually apiculate. 24 -Dry rocky woods and cliffs, New Hamp- 
shire to Iowa, south to Virginia, Tennessee, and Texas (fig. 763).

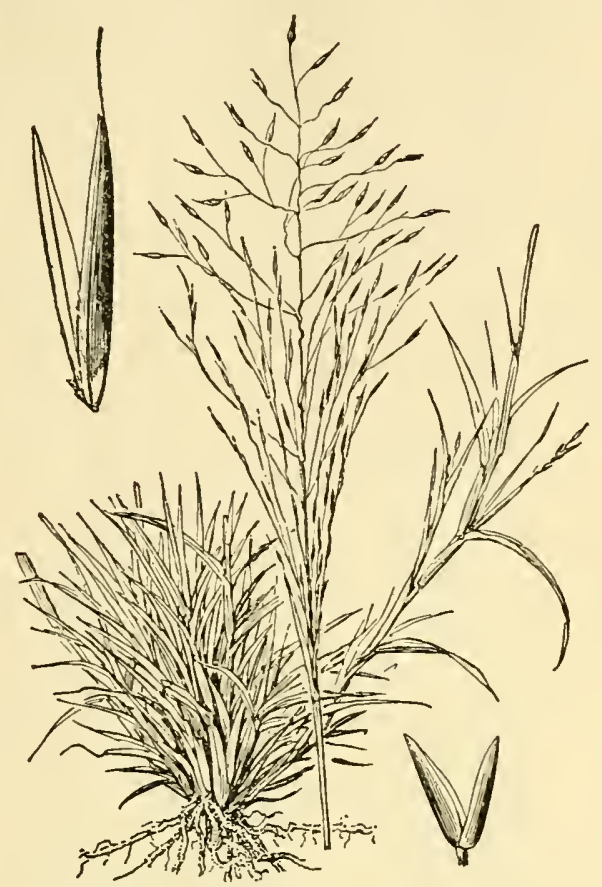

FIGURE 757.-Nuhlenbergia arizonica. Plant, $\times 1$; glumes and floret, $\times 10$. (Griffiths 3368, Ariz.)

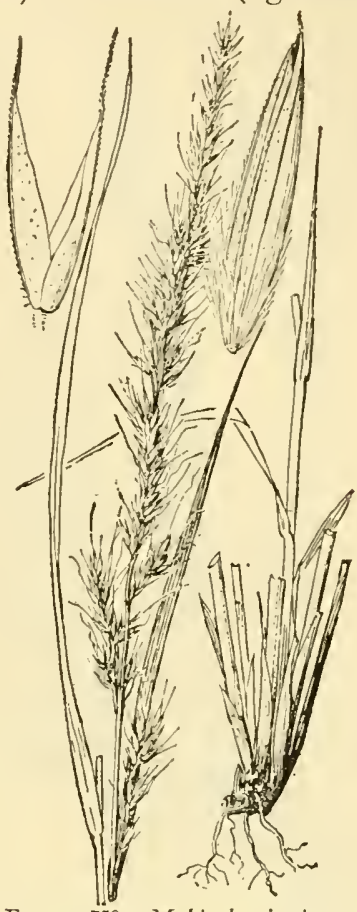

FIGURE 759.-Muhlenbergia glauca. Plant, $X 1$; glumes and floret, $X$ 10. (Nealley 726, Tex.)

Muhlenbergia sobolifera var. setígera Scribn. (Fig. 762, B.)

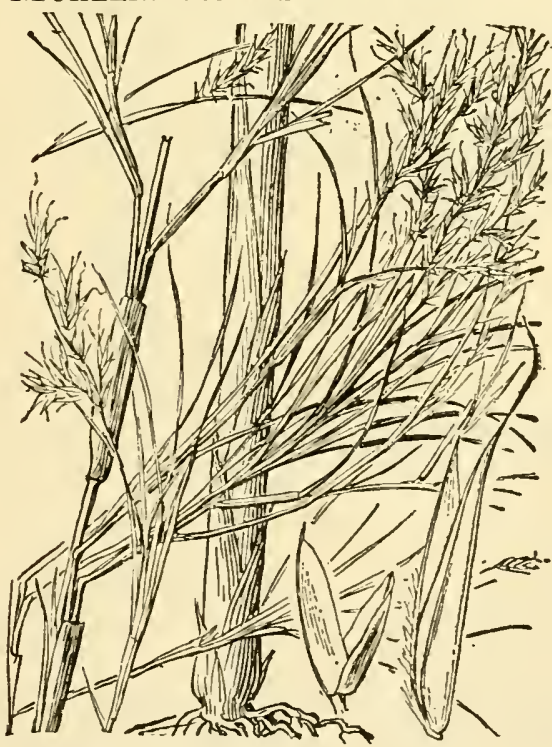

Figure 758,-Muhlenbergia dumosa. Plant, $\times 1$; glumes and floret, $\times 10$. (Pringle, Ariz.)

Branching more freely in the later stages; lemma with an awn 1 to $3 \mathrm{~mm}$ long. 2 Dry woods, Arkansas and Texas.

23. Muhlenbergia tenuiflóra (Willd.) B.S.P. (Fig.

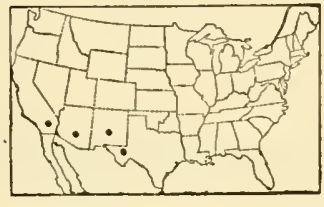

FIGURE 760.-Distribution of Muhlenbergia glauca.

764.) Similar to M. sobolifera in habit; culms often more robust; blades mostly 10 to 18 $\mathrm{cm}$ long and 6 to $10 \mathrm{~mm}$ wide; panicles on the average longer; culms retrorsely puberulent at least around the nodes; sheaths puberulent or scaberulous toward the summit; 
spikelets (excluding the awns) 3 to $4 \mathrm{~mm}$ long, the glumes about half

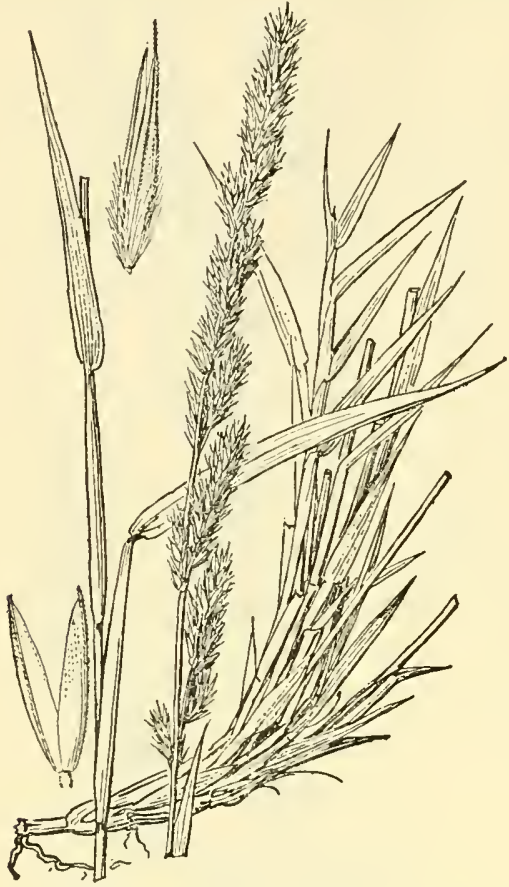

Figure 761 - Muhlenbergia californica. Plant, $X$ 1; glumes and floret, $\times 10$. (Parish 2113, Calif.)

as long, broad at base, abruptly acuminate, scaberulous; lemma narrow, pubescent toward the base, tapering into a slender straight awn 3 to $10 \mathrm{~mm}$ long. 21 -Rocky woods, Ontario and Vermont to Iowa, south to Virginia, Tennessee, and Oklahoma (fig. 765).

24. Muhlenbergia brachyphýlia Bush. (Fig. 766.) Perennial, with numerous slender scaly rhizomes; culms slender, suberect, frecly branching at the middle nodes, the branches lax, glabrous or obscurely scabrous below the nodes; blades flat, spreading, scaberulous, mostly 7 to $15 \mathrm{~cm}$ long and 3 to $5 \mathrm{~mm}$ wide; panicles on filiform peduncles, very slender, lax, relatively few-flowered, mostly 8 to 15 cm long; spikelets, excluding the awn, about $3 \mathrm{~mm}$ long, the glumes about two-thirds as long, awntipped; lemma minutely pubescent toward the base, tapering into a slender awn 3 to $6 \mathrm{~mm}$ long, rarely shorter. 24 -Low woods, Indiana to Nebraska, south to Texas (fig. 767). Resembling M. tenuiflora but with numcrous filiform branches and more slender panicles.

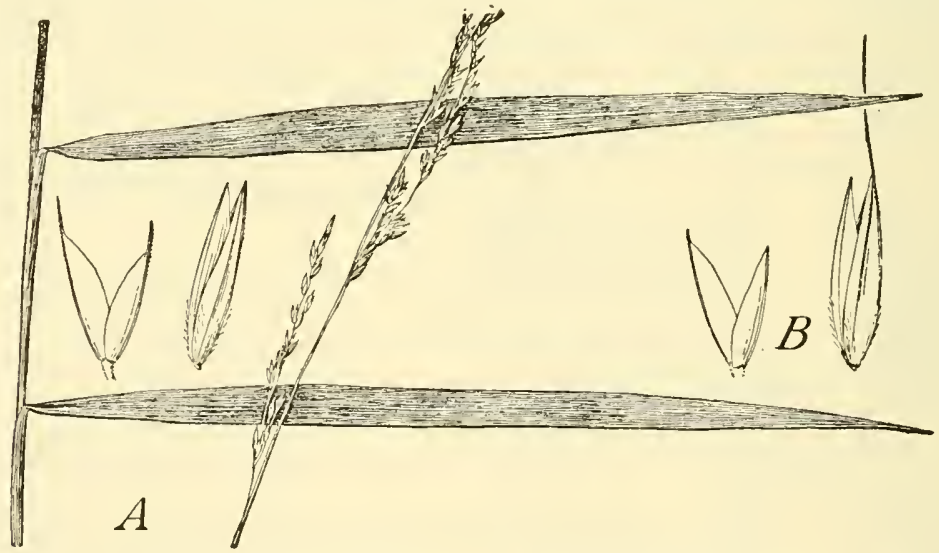

FIgURE 762.-A, Muhlenbergia sobolifera. Plant, $\times 1$; glumes and floret, $\times 10$. (Metcalf 1589, N.Y.) $B$, Var. stigcra, $\times 10$. (Reverchon 1049 , Tex.)

25. Muhlenbergia racemósa (Michx.) B.S.P. MaRsh MUHLY. (Fig. 768.) Perennial, from stout creeping scaly rhizomes; culms erect or reclining, 50 to $100 \mathrm{~cm}$ tall, or even more, slightly roughened 
below the nodes, simple or sparingly branching, the branches erect; sheaths smooth, keeled; blades flat, mostly appressed, scabrous, 5 to $10 \mathrm{~cm}$ long, 2 to $5 \mathrm{~mm}$ wide; panicle narrow, compact or lobed, bristly, 3 to $10 \mathrm{~cm}$ long; spikelets 4 to $6 \mathrm{~mm}$ long, the narrow subequal glumes stiffly awn-tipped; lemma acuminate, about $3 \mathrm{~mm}$ long, pilose on lower part. 2 -Moist meadows and low ground, Newfoundland to British Columbia, south to Maryland, Kentucky, Oklahoma, and Arizona (fig. 769).

26. Muhlenbergia mexicána (L.) Trin. WIRESTEM MUHLY. (Fig. 770.) Perennial, with

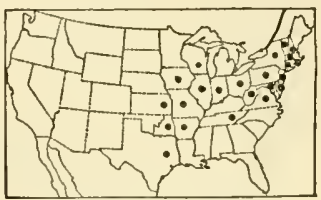

FIGURE 763.-Distribution of Muhlenbergia sobolifera. creeping scaly rhizomes; culms decumbent and rooting at base,

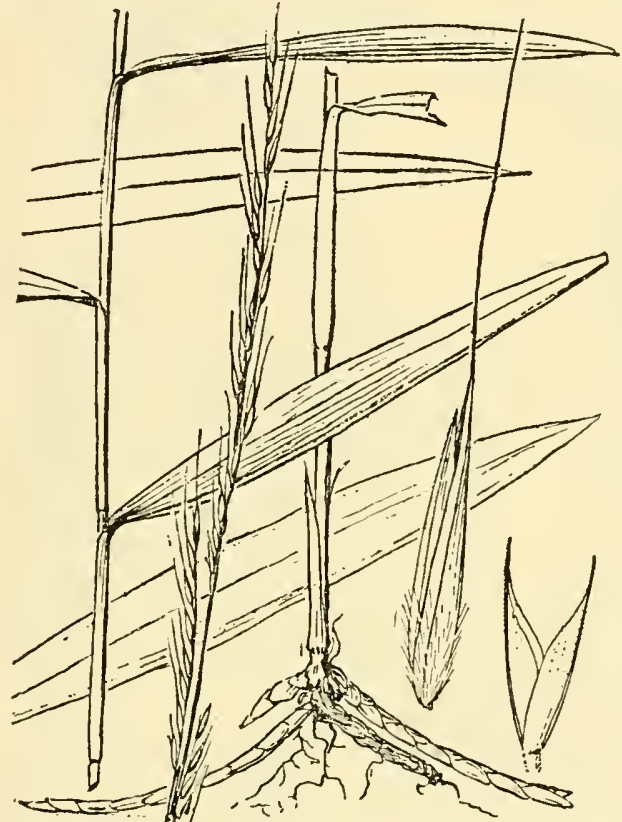

Figure 764.-Muhlenbergia tenuiflora. Plant, $\times 1$; glumes and floret, $\times 10$. (Mosley, Ohio.) freely branching from all the nodes, the branches ascending, the plants becoming topheavy and bushy, the culms glabrous below the nodes; blades flat, scabrous, usually less than $10 \mathrm{~cm}$ long, but sometimes as much as 15 $\mathrm{cm}, 3$ to $7 \mathrm{~mm}$ wide; panicles numerous, short-exserted or partly included, terminal and axillary, the larger as much as $10 \mathrm{~cm}$ long, the axillary shorter, narrow, the branches ascending, mostly densely flowered from the base; glumes 2 to $3 \mathrm{~mm}$ long or slightly longer, narrow, tapering into an awn-tip; lemma about equaling the glumes, acuminate, short-pilose at base. 2 -Thickets, low ground, and waste places, New Brunswick to North Dakota, south to the mountains of Georgia and Texas (fig. 771). This species does not grow in Mexico. It was originally described from a garden specimen cultivated by Linnaeus in his Upsala Garden and erroneously credited to Mexico. Muhlenbergia mexicana var. commutáta Scribn. Lemmas awned, the awns 4 to $10 \mathrm{~mm}$ long. 2 -Quebec and Maine to South Dakota, south to Virginia and Missouri; less common than the species. May be distinguished from $M$. foliosa var. setiglumis, which it sometimes resembles, by the culms smooth

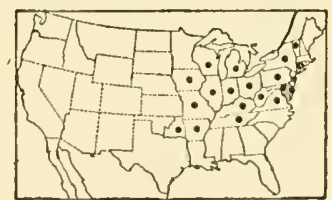

Figure 765.-Distribution of Muhlenbergia tenuiflora. below the nodes and the included or scarcely exserted panicles.

27. Muhlenbergia glabriflóra Scribn. (Fig. 772.) In habit resembling M1. mexicana, freely branching; culms scaberulous below the 
nodes as in $M$. sylvatica; blades numerous, short, narrow, appressed; panicles on the average shorter and narrower than in $M$. mexicana;

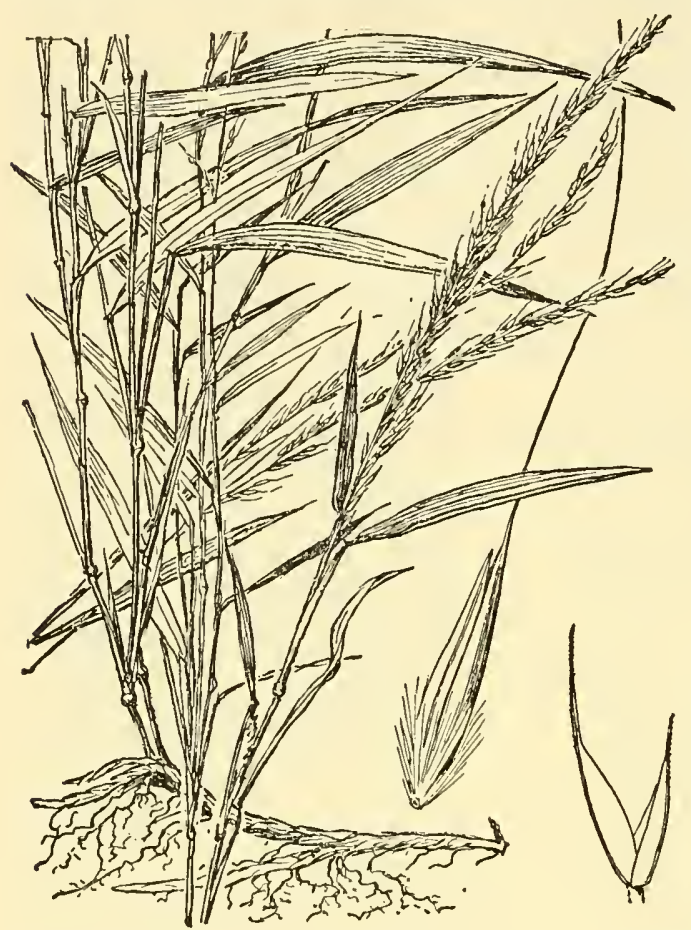

Figdre 766.-Muhtenbergia brachyphylla. Plant, $\times 1$; glumes and floret, $X 10$. (V. H. Chase 3759 , Ill.) spikelets about as in $M$. mexicana but the lemma glabrous. 24 - Low woods, Maryland, Indiana, Illinois, Missouri, and Texas (fig. 773).

28. Muhlenbergia sylvática Torr. (Fig. 774.) Resembling $M$. mexicana in habit, the branches

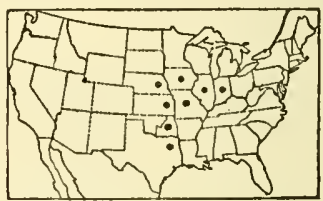

FIGURE 767.-Distribution of Muhlenbergia brachyphylla.

usually more slender and lax; culms retrorsely scaberulous below the nodes; panicles slender, nodding, the branches distant, appressed, overlapping, or the lower scarcely so; glumes lanceolate, rather abruptly acuminate or awnpointed, about $2 \mathrm{~mm}$ long; lemma a little longer than the glumes, somewhat pilose below, tapering into an awn 5 to $10 \mathrm{~mm}$ long. 2 (M. umbrosa Scribn.)-Moist woods and thickets, Maine to South Dakota, south to Alabama and Texas; Arizona (fig. 775). Awns sometimes reduced or wanting.

29. Muhlenbergia foliósa (Roem. and

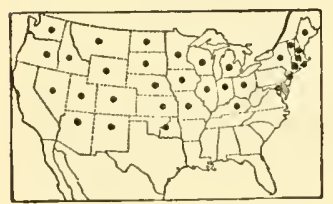

Figure 769.-Distribution of Muhlenbergia racemosa. Schult.) Trin. (Fig. 7 76.) Resembling $M$. mexicana and $M$. sylvatica in habit; culms scaberulous below the nodes; panicles mostly exserted, often rather long-exserted, narrow, of numerous short appressed densely flowered somewhat aggregate branches; spikelets 2 to $3 \mathrm{~mm}$ long; glumes narrow, attenuate into a short

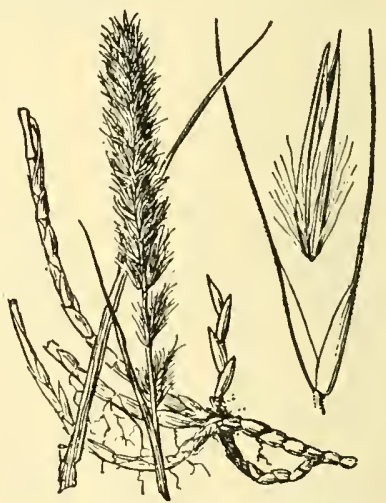

F1GURE 768.-Muhlenbergiaracemosa. Plant, $\times 1$; glumes and floret, $X$ 10. (Macoun 26241, Ont.) awn, about as long as the acuminate to awn-tipped lemma, the lemma long-pilose below. 4 -Moist thickets, low woods, 
and low open ground, Quebec and Maine to Montana, south to North Carolina, Indiana, Kansas, New Mexico, and Arizona (fig. 777). Muhlenbergia foliosa var. Setiglúmis (S. Wats.) Scribn. Lemmas awned, the awn 4 to $10 \mathrm{~mm}$ long. 4 -About the same range as the species; also Washington to northern California and Nevada.

\section{Muhlenbergia schrebéri} Gmel. Nimblewill. (Fig. 778, A.) Culms slender, branching, spreading and decumbent at base, usually rooting at the lower nodes, but not

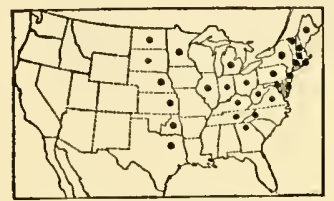

FIGURE 771.-Distribution of Muhlenbergia mexicana.

forming definite creeping rhizomes, the flowering branches ascending, 10 to $30 \mathrm{~cm}$ long; blades flat, mostly less than 5 $\mathrm{cm}$ long, and 2 to $4 \mathrm{~mm}$ wide; panicles terminal and axillary, slender, loosely flowered, lax, nodding, 5 to $15 \mathrm{~cm}$ long; glumes minute, the first often obsolete, the second rounded,

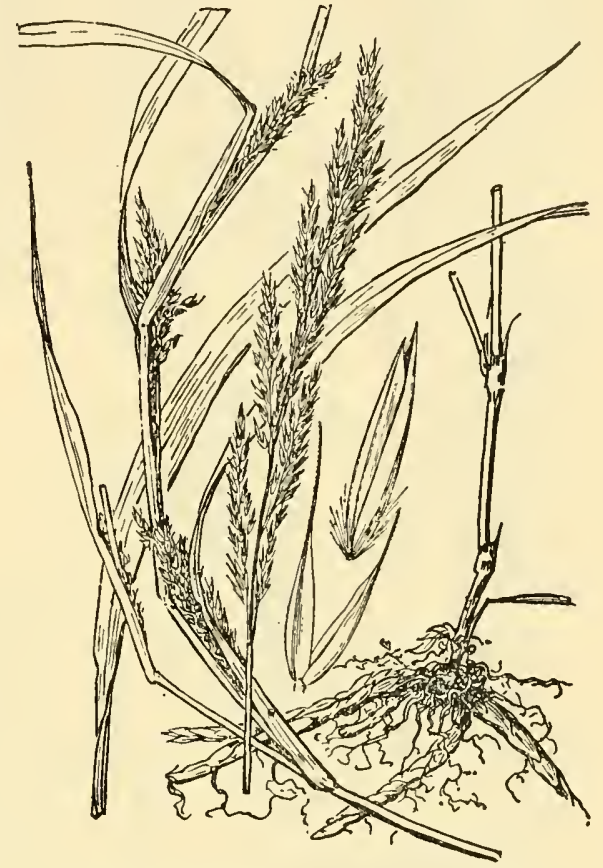

FIgURE 770.-M Mhlenbergia mexicana. Plant, $\times 1$; glumes and floret, $\times 10$. (V. H. Chase 1166, 111.)

0.1 to $0.2 \mathrm{~mm}$ long; lemma narrow, somewhat pubescent around the base, the body about $2 \mathrm{~mm}$ long, the slender awn 2 to $5 \mathrm{~mm}$ long.

21 -Damp shady places, New Hampshire to Wisconsin and eastern Nebraska, south to Florida and Texas; eastern Mexico (fig.

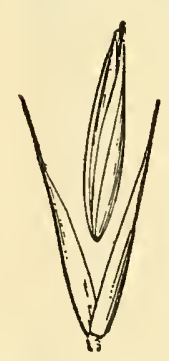

Figure 772.Muhlenbergia glabriflora, $X$ 10. (Type.) 779). In spring and early summer the culms are short and erect with spreading blades, the plants being very different in appearance from the flowering phase of fall. Muhlenbergia SCHREBERI var. PALÚSTRIS (Scribn.) Scribn. Glumes developed, as much as $1 \mathrm{~mm}$ long. 2 -Washington, D.C.

31. Muhlenbergia curtisetósa (Scribn.) Bush. (Fig. 778, B.) A little-known form, differing from $M$.

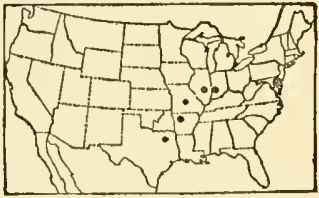

FIGURE 773.-Distribution of Muhlenbergia glabriflora. schreberi in having stouter culms, coarser panicles, the glumes evident, rarely as much as $2 \mathrm{~mm}$ long, the lemma 2.5 to $3 \mathrm{~mm}$ long, the awn 1 to $2 \mathrm{~mm}$ long. 2 Illinois (Clinton), Missouri (Eagle Rock). It may be a hybrid.

32. Muhlenbergia andína (Nutt.) Hitche. Foxtail Muhly. (Fig. 780.) Perennial, with numerous scaly rhizomes; culms erect or some- 
times spreading, scabrous-puberulent below the nodes and the panicle,

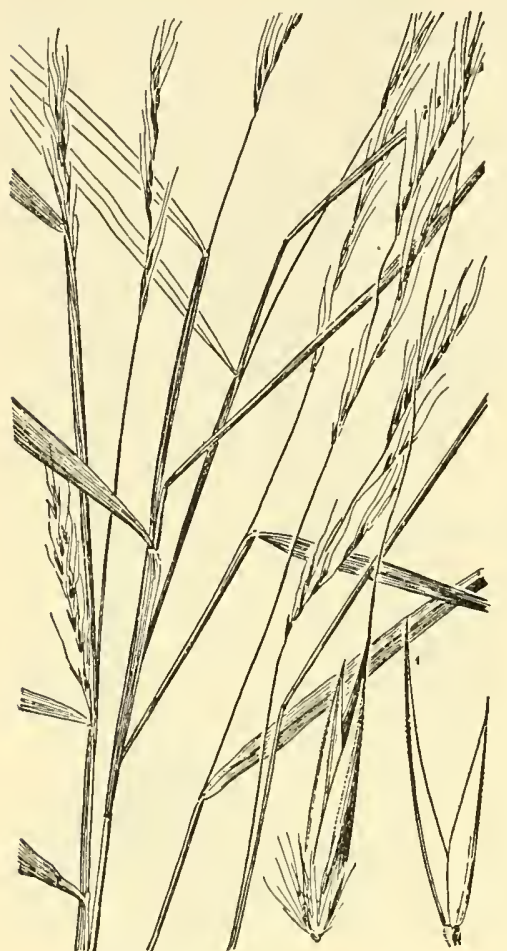

Figure 774.-Muhlenbergia sylvatica. Plant, $X$ 1 ; glumes and floret, $\times 10$. (Conant, Mass.) 50 to $100 \mathrm{~cm}$ tall; sheaths smooth or slightly scabrous, keeled; ligule $1 \mathrm{~mm}$ long, membranaceous, shortciliate; blades flat, 2 to $6 \mathrm{~mm}$ wide, scabrous; panicle narrow, spikelike, usually more or less lobed or interrupted, grayish, silky, often purpletinged, 7 to $15 \mathrm{~cm}$ long; glumes narrow, acuminate, ciliate-scabrous on the keels, 3 to $4 \mathrm{~mm}$ long; lemma $3 \mathrm{~mm}$ long, tapering into a capillary awn 4 to $8 \mathrm{~mm}$ long, the

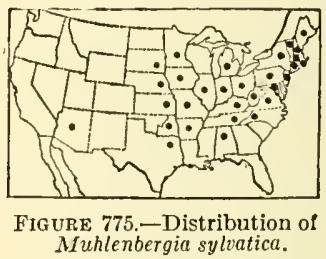

hairs at base of floret copious, nearly as long as the body of the lemma. 2 (M. comata Benth.)-Meadows, moist thickets, gravelly river beds, and open ground, at medium altitudes, Montana to eastern Washington, south to New Mexico and central California (fig. 781).

33. Muhlenbergia jonésii (Vasey) Hitche. (Fig. 782.) Perennial, closely tufted; culms erect, 20 to $40 \mathrm{~cm}$ tall; leaves mostly basal, the

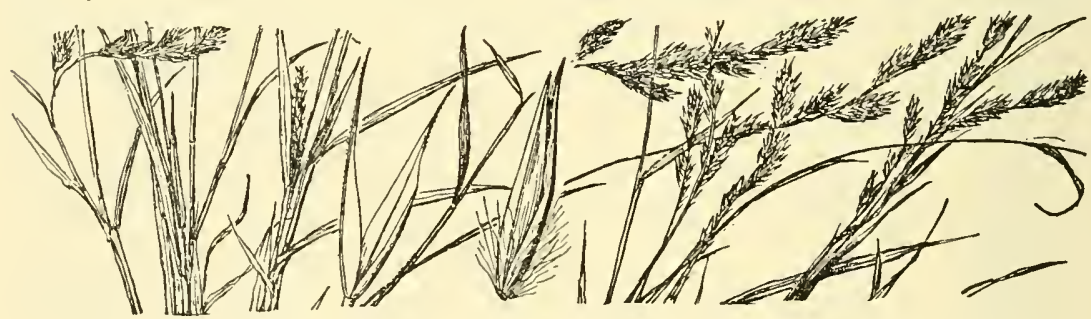

Figure 776.-Mfuhlenbergia foliosa. Plant, $\times 1$; glumes and floret, $\times 10$. (Deam 19225, Ind.)

numerous lower sheaths finally flattened and loose; ligule 2 to $4 \mathrm{~mm}$ long; blades subfiliform, involute, scabrous; panicle narrow, 5 to $8 \mathrm{~cm}$ long, the branches ascending, rather loosely flowered; spikelets 3 to $4 \mathrm{~mm}$ long; glumes broad, scabrous-puberulent, about one-third as long as the spikelet, obtuse, often erose; lemma obscurely pubescent below, tapering to an acuminate or awned tip. 21 -Open ground, northeastern California.

34. Muhlenbergia montána (Nutt.) Hitchc.

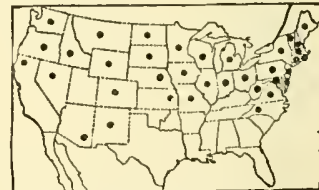

FIGURE 777.-Distribution of Muhlenbergia foliosa. Mountain muhly. (Fig. 783.) Perennial; culms densely tufted,erect, 
30 to $60 \mathrm{~cm}$ tall; shea ths glabrous, mostly basal, becoming flat and loose; blades flat to involute, 1 to $2 \mathrm{~mm}$ wide; panicle narrow, rather loose, 5 to

Figure 778. $-A$, Muhlenbergia schreberi. Plant, $\times 1 / 2$; glumes and rloret, $\times 10$. (Curtiss 3400 , Tenn.) $B, M$. curtisetosa. Glumes and floret, $\times 10$. (Wolf 30,111 .)

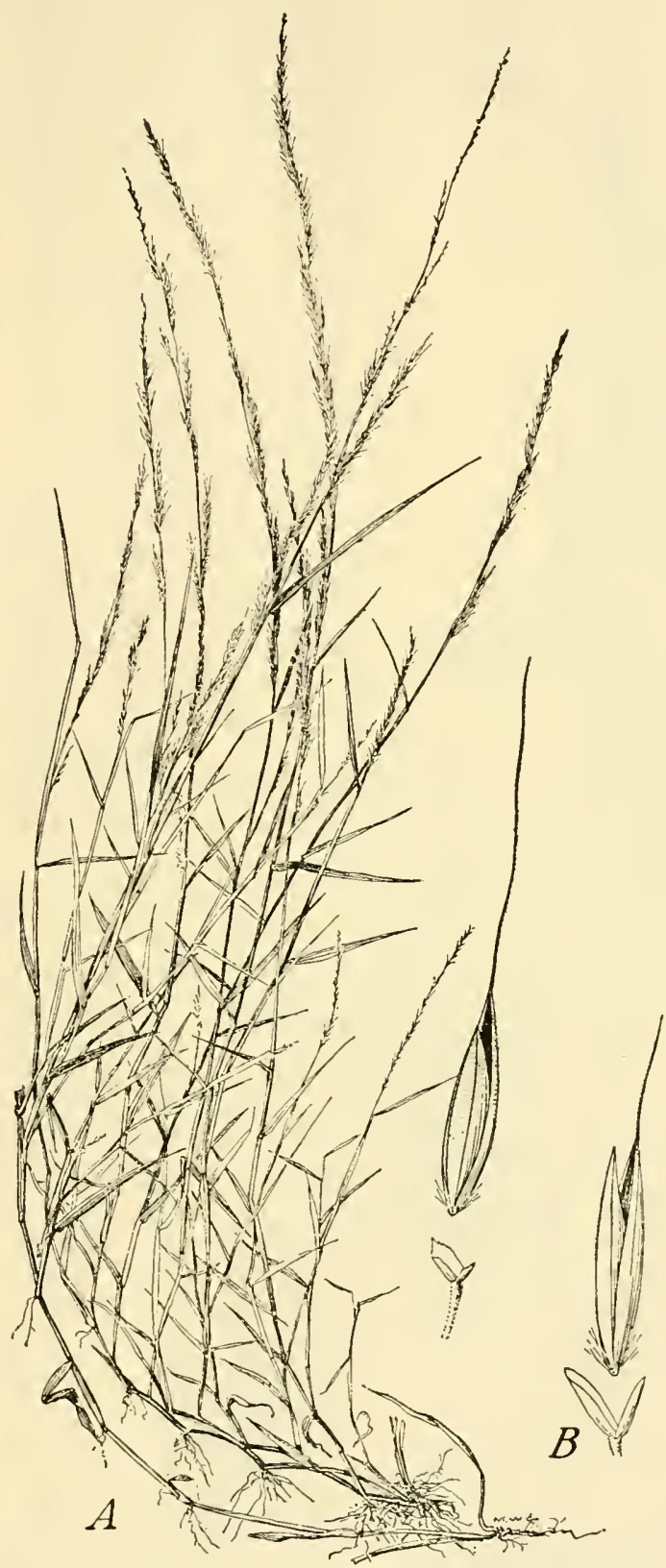

$15 \mathrm{~cm}$ long, the branches ascending or appressed, floriferous from base; first glume acute, 1.5 $\mathrm{mm}$ long, the second longer, broader, 3nerved, 3 -toothed; lemma about $4 \mathrm{~mm}$ long, pilose below, scaberulous above, the awn slender, flexuous, 1 to $1.5 \mathrm{~cm}$ long, sometimes shorter. 2 (M. trifida Hack., M. gracilis of authors, not Kunth.) Canyons, mesas, and rocky hills, 2,000 to 3,000 meters, Montana to Utah and central California, south to western

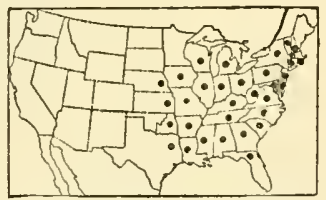

Figure 779.-Distribution of Muhlenbergia schreberi.

Texas and southern Mexico (fig. 784).

35. Muhlenbergia viréscens (H.B.K.) Kunth. SCREWleaf MuHly. (Fig. 785.) Perennial; culms densely tufted, erect, 40 to $60 \mathrm{~cm}$ tall, the old basal sheaths flattened and more or less coiled; ligule, except the margin, delica te, 3 to $10 \mathrm{~mm}$ long; blades flat or those of the innorations involute, mostly elongate and flexuous; panicle narrow but rather loose, 5 to $10 \mathrm{~cm}$ long, the branches erect; spikelets, excluding awns, about $5 \mathrm{~mm}$ long, the glumes slightly shorter, acute, the second 3-nerved; lemma and palea pubescent on the lower half, the lemma
tapering into a slender flexuous awn 1 to $1.5 \mathrm{~cm}$ long. 24 - Cap 
yons, rocky hills, and mesas, New Mexico and Arizona to central

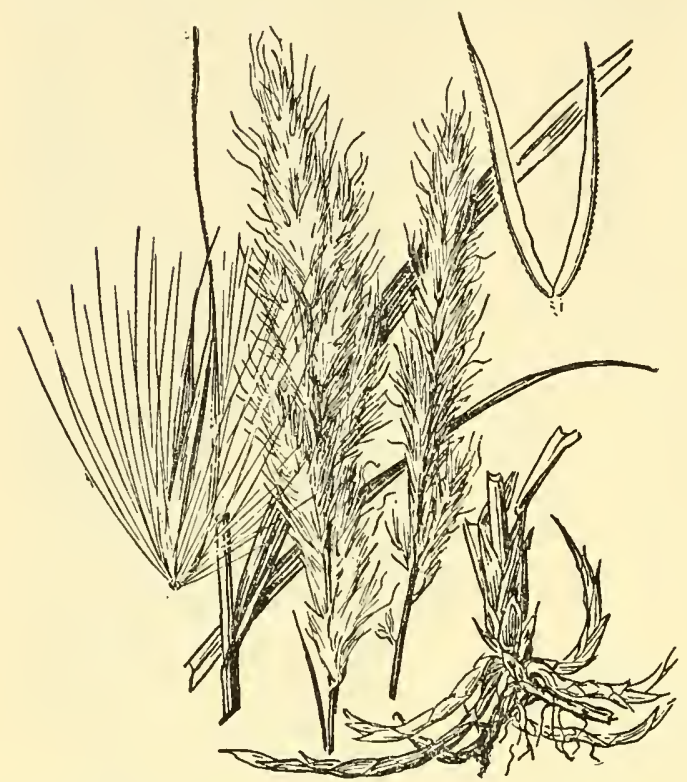

Figure 780--Muhlenbergia andina. Plant, $\times 1$; glumes and floret, $\times 10$. (Elmer 558, Wash.)

\section{Mexico.}

36. Muhlenbergia polycaúlis Scribn. (Fig. 786.) Perennial, from a firm crown; culms numerous, wiry, decumbent and scaly at base, 30 to $50 \mathrm{~cm}$ tall; blades

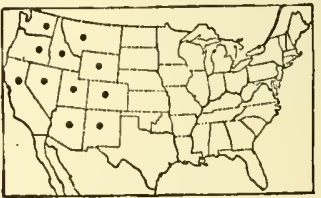

Figure 781.-Distribution of Muhlenbergia andina.

mostly flat and less than $5 \mathrm{~cm}$ long, about $1 \mathrm{~mm}$ wide; panicle narrow, contracted, interrupted, 3 to $8 \mathrm{~cm}$ long; spikelets, excluding awns, 2.5 to $3 \mathrm{~mm}$ long, the glumes a little shorter, tapering to slender awntips; lemma and palea loosely villous below, the lemma tapering into a delicate awn 1 to $2 \mathrm{~cm}$ long. 2 Shaded ledges and grassy slopes, western Texas; southern Arizona to central Mexico.

37. Muhlenbergia arsénei Hitchc. (Fig. 787.) Perennial, without rhizones but the spreading base sometimes rhizomatous in appearance, loosely tufted; culms wiry, 10 to $30 \mathrm{~cm}$ tall, branched below, the branches erect; leaves crowded toward the base, the blades slender, involute, sharp-pointed, 1 to $3 \mathrm{~cm}$ long; panicle narrow, rather loose, purplish, 2 to $10 \mathrm{~cm}$ long, the branches ascending, floriferous from base; spikelets, excluding the awns, 4 to $5 \mathrm{~mm}$ long, the glumes shorter, acute or subacute, awnless; lemma sparsely pubescent below, tapering into a flexuous awn 6 to $10 \mathrm{~mm}$ long. 24 -Arid slopes, northern New Mexico and southeastern Utah.

38. Muhlenbergia montícola Buckl. Mesa muhly. (Fig. 788.) Perennial; culms tufted, slender, erect or decumbent at base, 30 to $50 \mathrm{~cm}$ tall, branching at the lower and middle nodes, leafy through-

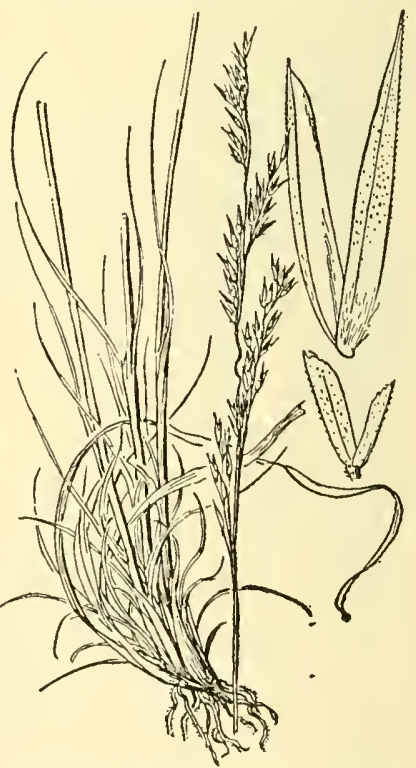

Figure 782.-Muhlenbergia jonesii. Plant, $\times 1$; glumes and floret, $\times 10$. (Austin 1230, Calif.) out; blades 3 to $7 \mathrm{~cm}$ long, narrow, flat, or soon involute; panicle soft, 
narrow, contracted, 5 to 10 , sometimes to $15 \mathrm{~cm}$ long, the branches appressed or slightly spreading; spikelets, excluding awns, about 3 $\mathrm{mm}$ long, the glumes about two-thirds as long, subacute to obtuse and erose at tip; lemma pubescent at base and on lower half of margin, tapering into a delicate flexuous awn 1 to $2 \mathrm{~cm}$ long. 2 - Rocky hills and canyons, western Texas to Arizona and central Mexico.

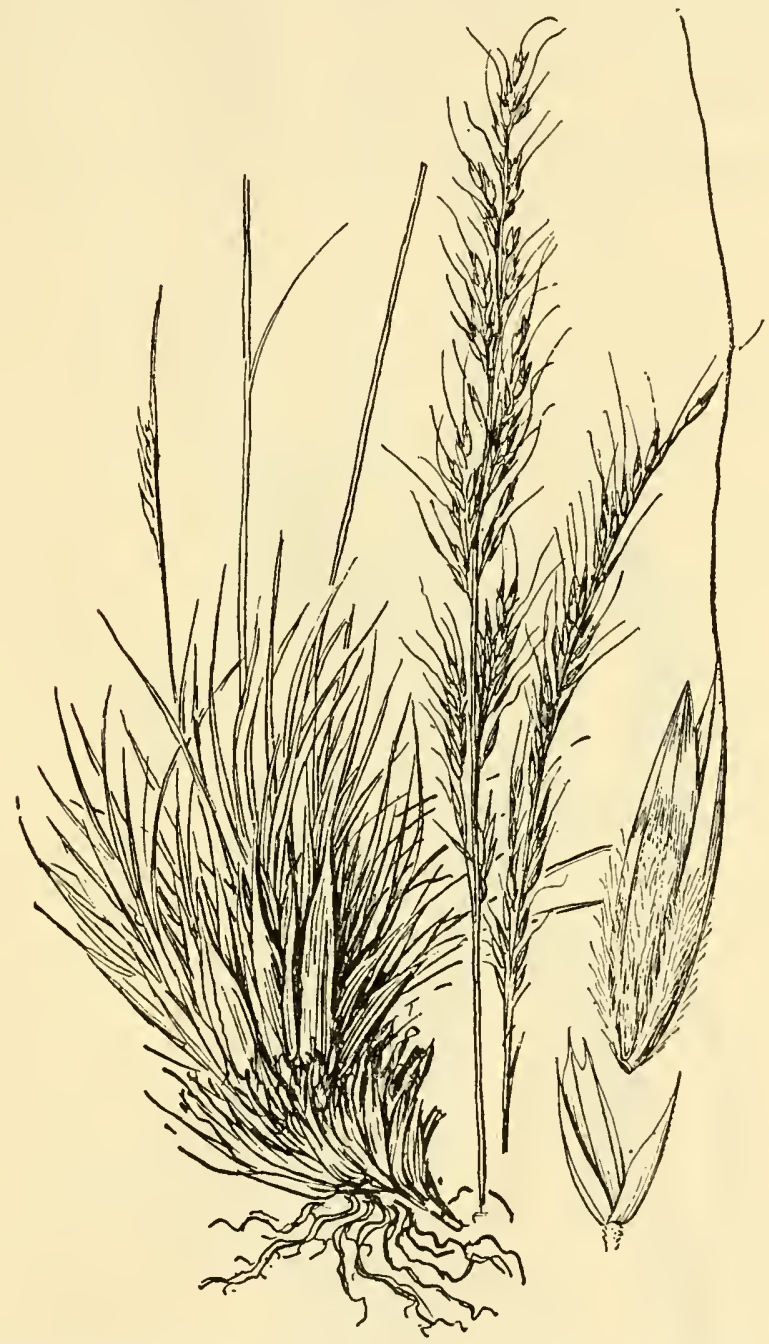

Figure 783. - Muhlenbetgia montana. Plant, $\times 1$; glumes and floret, $\times 10$. (Patterson 156, Colo.)

39. Muhlenbergia parviglúmis Vasey. (Fig. 789.) Perennial, with the habit of $M$. monticola; blades on the average somewhat longer, 1 to $3 \mathrm{~mm}$ wide; spikelets as in $M$. monticola, but the glumes minute, erose, subacute to truncate; lemma scaberulous only, tapering into a delicate awn 2 to $4 \mathrm{~cm}$ long. 2 -Canyons, Texas and northern Mexico; Cuba. 
40. Muhlenbergia pauciflóra Buckl. New Mexican Muhly. (Fig. 790.) Pcrennial; culms loosely tufted, wiry, erect, branch-

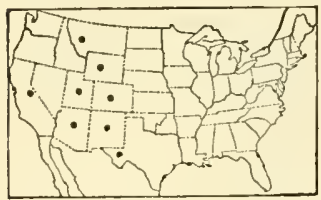

FIGURE 784.-Distrihution of Muhlenbergia montana. ing at the lower nodes, 30 to $50 \mathrm{~cm}$ tall; blades $1 \mathrm{~mm}$ wide or less; panicle narrow, contracted, interrupted, 5 to $10 \mathrm{~cm}$ long, the branches erect or ascending; spikelets, excluding awn, about $4 \mathrm{~mm}$ long, the glumes about half as long, acuminate to awntipped; lemma scaberulous only, tapering into a slender flexuous awn, 5 to $12 \mathrm{~mm}$ long. 2 - Rocky hills and canyons, western Texas to Colorado and Arizona, south to northern Mexico (fig. 791).

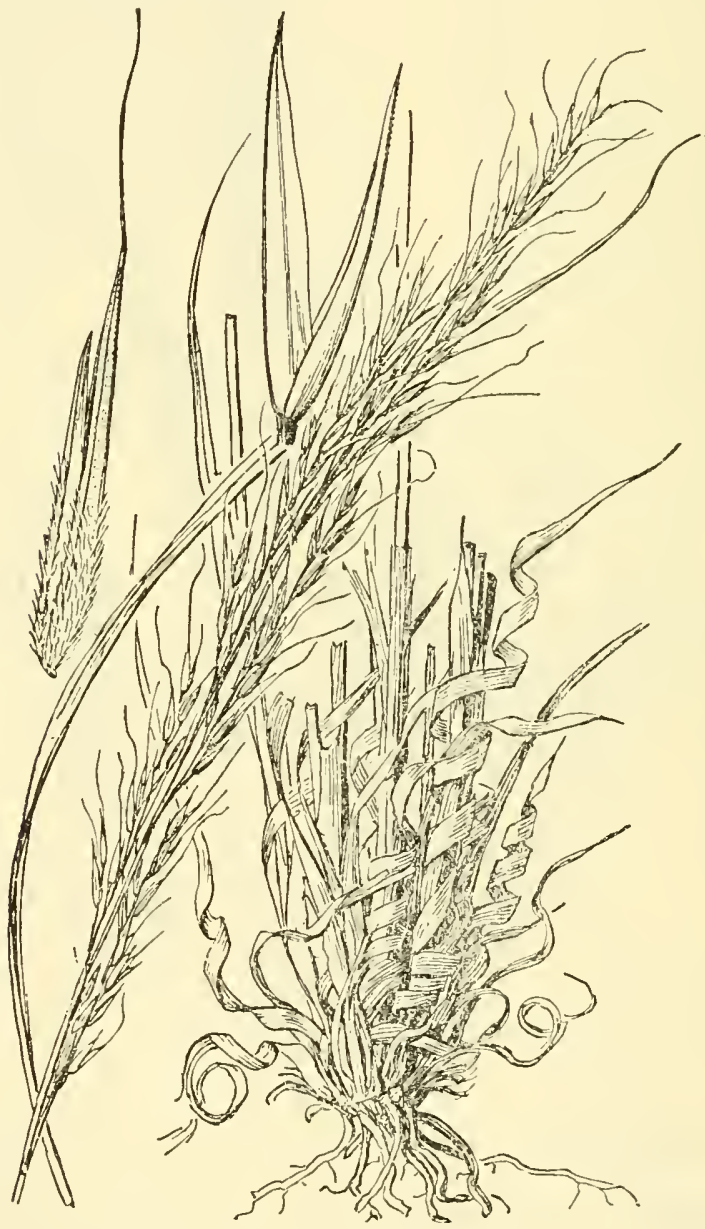

Figure 785.-Muhlenbergia virescens. Plant, $\times 1$; glumes and floret, $\times 10$. (Palmer 565, Ariz.)

41. Muhlenbergia portéri Scribn. Bush muhly. (Fig. 792.) Perennial; culms woody or persistent at base, numerous, wiry, widely spreading or ascending through bushes, scaberulous, mostly branching from all the nodes, 30 to $100 \mathrm{~cm}$ tall or more; sheaths 
smooth, spreading away from the branches, the prophyllum conspicuous; blades mostly about $1 \mathrm{~mm}$ wide, flat, 2 to $5 \mathrm{~cm}$ long, early deciduous from the sheaths; panicle 5 to $10 \mathrm{~cm}$ long, open, the.slender branches and branchlets brittle, widely spreading, bearing rather few long-pedicled spikelets; glumes narrow, acuminate, slightly unequal, the second about $2 \mathrm{~mm}$ long; lemma purple, acuminate, sparsely pubescent, 3 to $4 \mathrm{~mm}$ long, with a delicate awn about 5 to $8 \mathrm{~mm}$ long. 2 - Dry mesas and hills, canyons, and rocky deserts, western Texas to Colorado, Nevada, and southern California, south

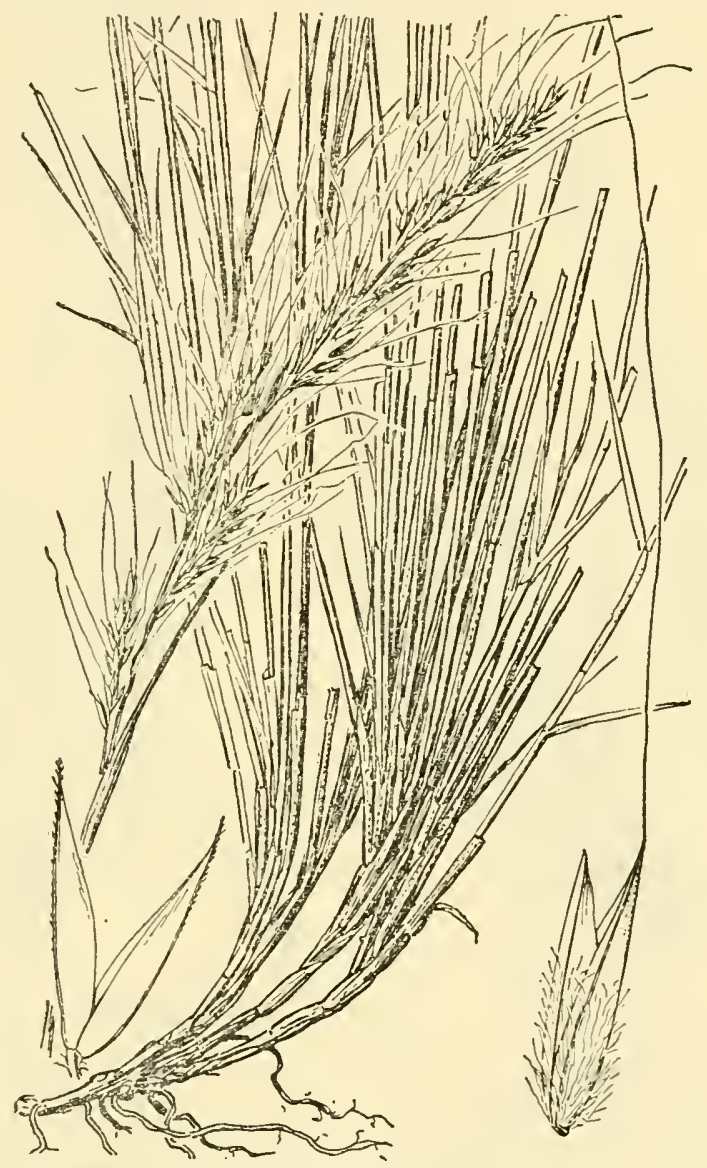

Figure 786.-Mfuhlenbergia polycaulis. Plant, $\times 1$; glumes and floret, $\times 10 . \quad$ (Type.)

to northern Mexico (fig. 793). Known also as mesquite grass and black grama.

42. Muhlenbergia torréyi (Kunth) Hitchc. Ringarass. (Fig. 794.) Perennial in loose tufts, with numerous innovations, the base decumbent or forming short rhizomes, the plants usually gregarious, sometimes forming large patches or "fairy rings"; culms slender, 10 to $30 \mathrm{~cm}$ tall; leaves in a short basal cluster; blades closely involute, usually 2 to $3 \mathrm{~cm}$ long, falcate or flexuous, forming a crisp curly cushion; panicle open, usually about half the entire length of the 
culm, commonly purple, the capillary branches finally spreading, the pedicels mostly as long as the spikelets or longer; spikelets about $3 \mathrm{~mm}$ long, the glumes, including the awn-tip, about two-thirds as long; lemma nearly glabrous, tapering into a delicate awn about $3 \mathrm{~mm}$ long. 2 (M. gracillima Torr.)-Plains, mesas, and dry hills, western Kansas and Colorado to Texas and Arizona (fig. 795).

43. Muhlenbergia arenícola Buckl. (Fig. 796.) Resembling $M$. torreyi; culms taller, mostly 30 to $50 \mathrm{~cm}$ tall; blades usually straight and on the average longer; panicle larger, mostly pale, the branches and pedicels appressed; spikelets slightly longer, the lemma scabrous.

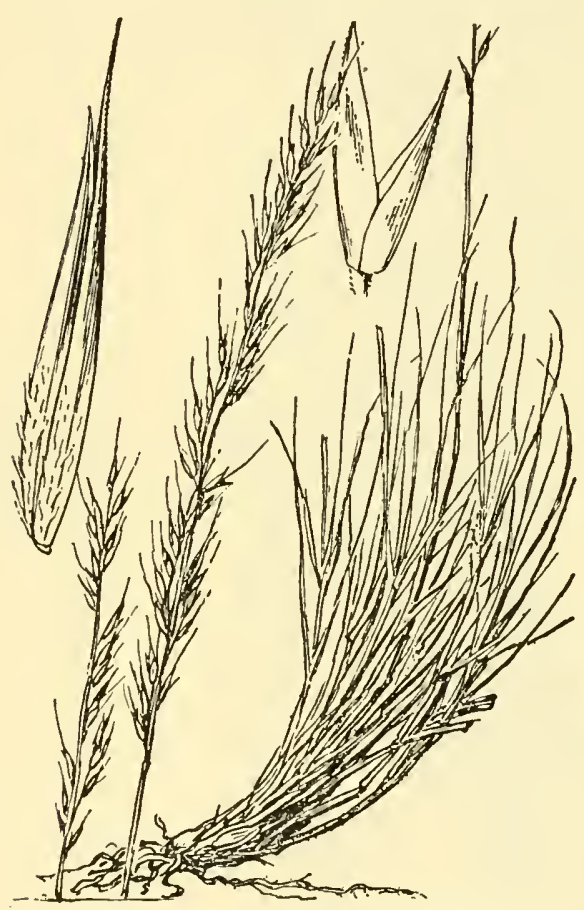

Fioure 787.-Muhlenbergia arsenei. Plant, $\times 1$; glumes and floret, $\times 10$. ('Type.)

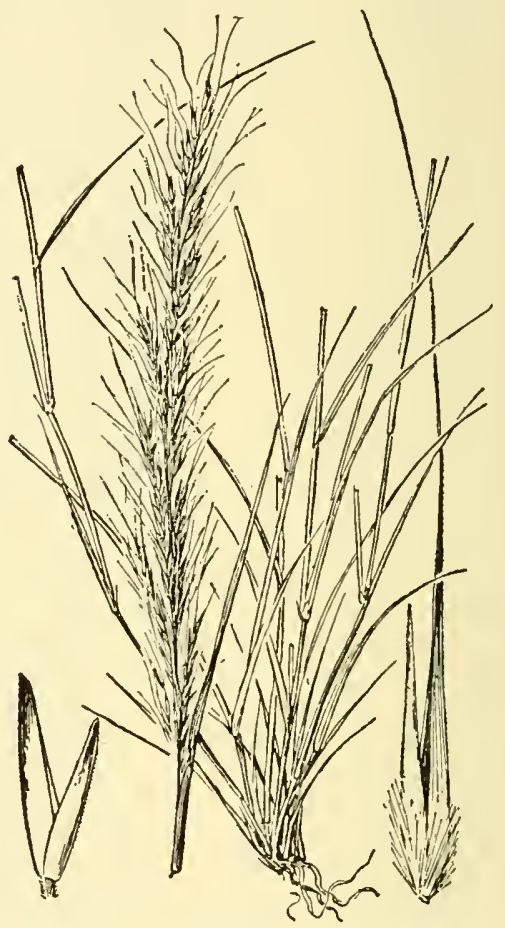

Figure 788.-Muhlenbergia monticola. Plant, $X$ 1 ; glumes and floret, $\times 10$. (Nealley 399 , Tex.)

2 - Sandy plains and mesas, western Kansas to Arizona, south to northern Mexico (fig. 797).

44. Muhlenbergia setifólia Vasey. (Fig. 798.) Perennial, tufted; culms erect, hard, wiry, 50 to $80 \mathrm{~cm}$ tall; sheaths with erect auricles, 2 to $10 \mathrm{~mm}$ long; blades involute, fine, scarcely $0.5 \mathrm{~mm}$ thick, very scabrous, flexuous, as much as $20 \mathrm{~cm}$ long; panicle narrow, open, 10 to $15 \mathrm{~cm}$ long, the capillary branches ascending, flexuous; spikelets, excluding awns, about $5 \mathrm{~mm}$ long, the glumes one-third to half as long, obtuse to subacute, often with a short delicate awn; lemma hairy on the callus, otherwise smooth, tapering into a flexuous awn 1.5 to $2 \mathrm{~cm}$ long. $24-$ Rocky hills, western Texas to Arizona and northern Mexico.

45. Muhlenbergia dúbia Fourn. Pine muhly. (Fig. 799.) Perennial, closely tufted; culms erect, hard and wiry at base, 30 to 100 
$\mathrm{cm}$ tall; sheaths with erect firm auricles, 4 to $10 \mathrm{~mm}$ long, rarely longer; blades involute, scabrous; panicle narrow, sometimes almost spikelike, grayish, 10 to $30 \mathrm{~cm}$ long, rarely longer; spikelets about $4 \mathrm{~mm}$ long; glumes about half as long as the spikelet, minutely scaberulous, obtuse; lemma minutely scaberulous, with an awn as much as $4 \mathrm{~mm}$ long, rarely acuminate only. 24 (M. acuminata Vasey;

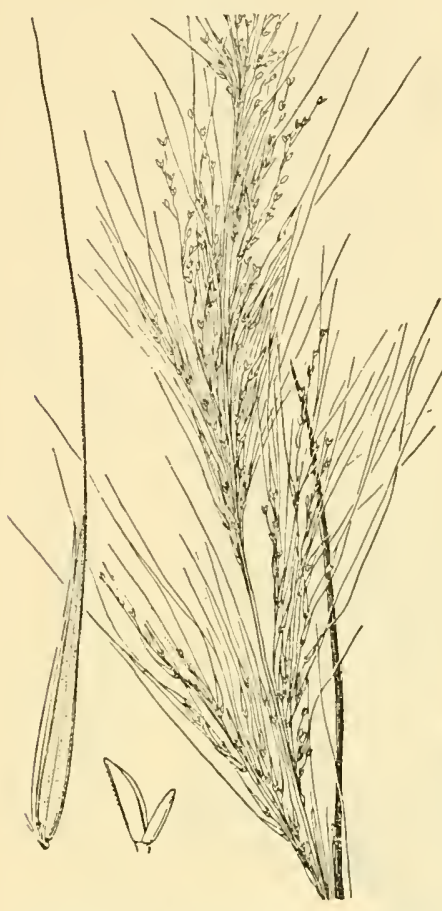

FIGURE 789.-Muhlenbergia parriglumis. Panicle, $\times 1$; glumes and floret, $\times 10$. (Vasey, Tex.)

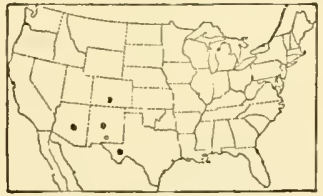

FIgURE 791.-Distribution of Muhlenbergia pauciflora.

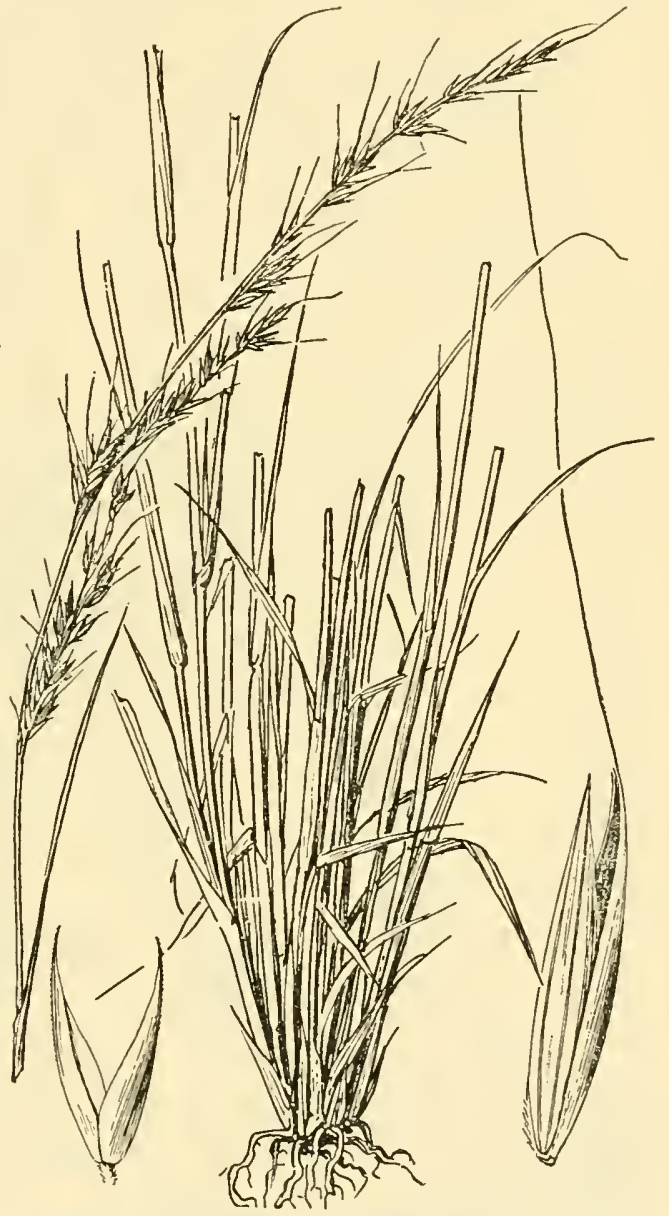
FIGURE 790.- Muhlenbergia pauciflora. Plant, $\times 1$; glumes
and floret, $\times 10$. (Wright 732 , Tex.)

Sporobolus ligulatus Vasey and Dewey.)—Canyons and rocky hills, western 'Texas to Arizona and northern Mexico.

46. Muhlenbergia rígida (H.B.K.) Kunth. PurPle muhly. (Fir. S00.) Perennial, densely tufted; culms erect, 60 to $100 \mathrm{~cm}$ tall; leaves crowded at base, old sheaths persistent, the sheaths with auricles 2 to $5 \mathrm{~mm}$, rarely longer; blades flat or soon involute, flexuous, those of the innovations involute; panicle dark purple, narrow, finally loose and open, 15 to $30 \mathrm{~cm}$ long, the capillary branches ascending, 
the lower as much as $10 \mathrm{~cm}$ long; spikelets, excluding awns, about $4 \mathrm{~mm}$ long, the glumes from minute to about one-fourth as long, acute to erose-obtuse; lemma strongly nerved, hairy on the callus

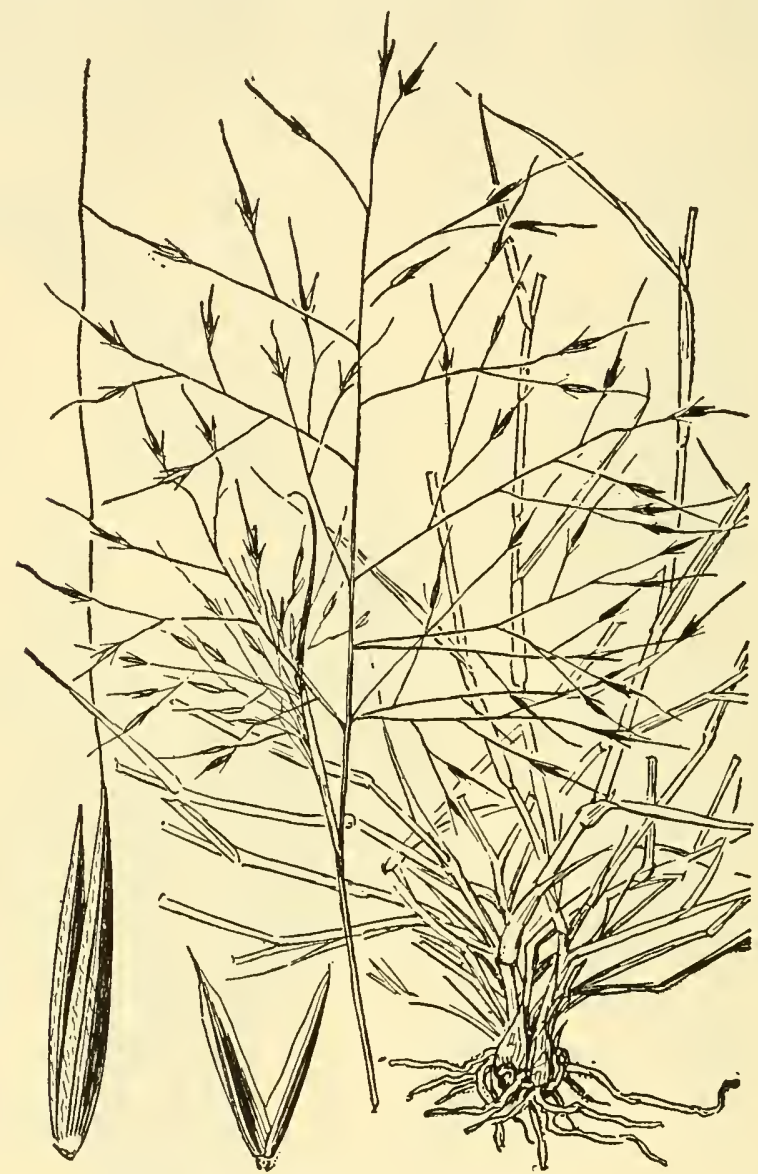

Figure 792.-Muhlenbergia porteri. Plant, $\times 1$; glumes and floret, $\times 10$. (Chase 5887, Tex.)

and with a flexuous awn 1 to $1.5 \mathrm{~cm}$ long. 24 (M. berlandieri Trin.)-Rocky or gravelly soil, Texas to Arizona and northern Mexico.

47. Muhlenbergia metcálfei Jones. (Fig. 801.) Perennial, in close tufts; culms erect, 50 to $80 \mathrm{~cm}$ tall; ligule 3 to $10 \mathrm{~mm}$ long, sometimes longer; blades involute, slender, flexuous, scabrous, sometimes only slightly so, not crowded at base; panicle narrow but somewhat loose, pale or slightly purplish, 15 to 25 $\mathrm{cm}$ long, the branches usually naked at base;

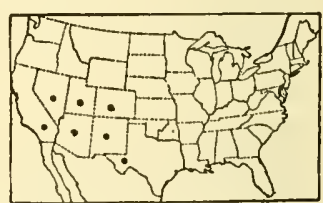

Figure 793.-Distribution of Muhlenbergia porteri. spikelets tapering to summit, about $4 \mathrm{~mm}$ long; glumes nearly equal, obtuse, a little less than half as long as spikelet; lemma scaberulous toward summit, the awn 5 to $10 \mathrm{~mm}$ long. 24 -Rocky hills, Texas, New Mexico, and Arizona. 
48. Muhlenbergia capilláris (Lam.) Trin. (Fig. 802.) Perennial,

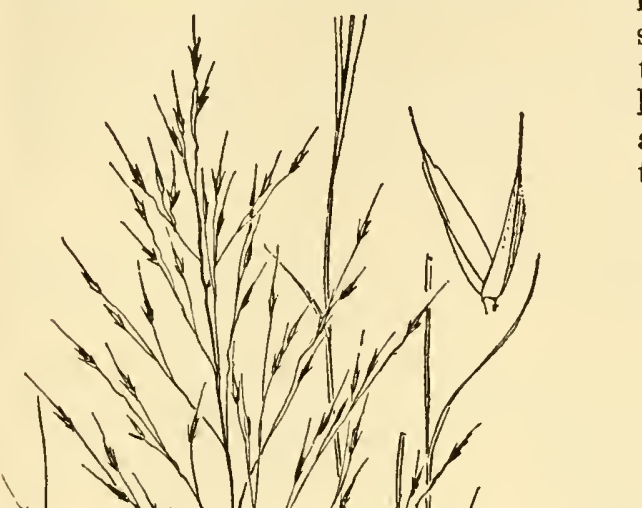

in tufts; culms rather slender, erect, 60 to $100 \mathrm{~cm}$ tall; sheaths scaberulous, at least toward the summit, and with auricles mostly 3 to $5 \mathrm{~mm}$ long; blades elon-

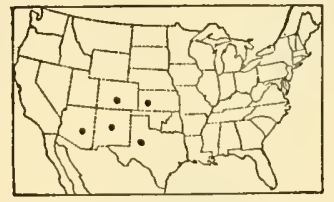

FIGURE 795.-Distribution of Muhlenbergia torreyi.

gate, flat or involute, 1 to 4 $\mathrm{mm}$ wide, those of the innovations narrower, involute; panicle purple, oblong diffuse, one-third to half the entire height of the culm,

the branches capillary, flexuous, the branchlets and pedicels finally spreading; spikelets, excluding awns, 3 to $4 \mathrm{~mm}$ long, the glumes

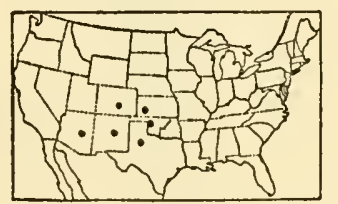

Figure 797.-Distribution of Muhlenbergia arenicola.

one-fourth to two-thirds as long, acute, the second often short-awned; lemma scaberulous, minutely hairy on the callus and with a delicate awn 5 to $15 \mathrm{~mm}$ long. 2 -Rocky or sandy woods, Massachusetts to 
Indiana and Kansas, south to Florida and Texas; West Indies, eastern Mexico (fig. 803).

Muhlenbergia Capillaris var. Fílipes (M. A. Curtis) Chapm. Culms stouter; blades mostly involute; glumes with delicate awns, mostly longer than the lemma; lemma with a delicate setaceous tooth each side of the awn. 24 (M. filipes M. A. Curtis.)-Moist pine barrens near the coast, North Carolina, Florida, Mississippi, and Texas.

49. Muhlenbergia expánsa (DC.) Trin. (Fig. 804.) Resembling M. capillaris, in denser tufts, the old basal sheaths forming a curly fib-

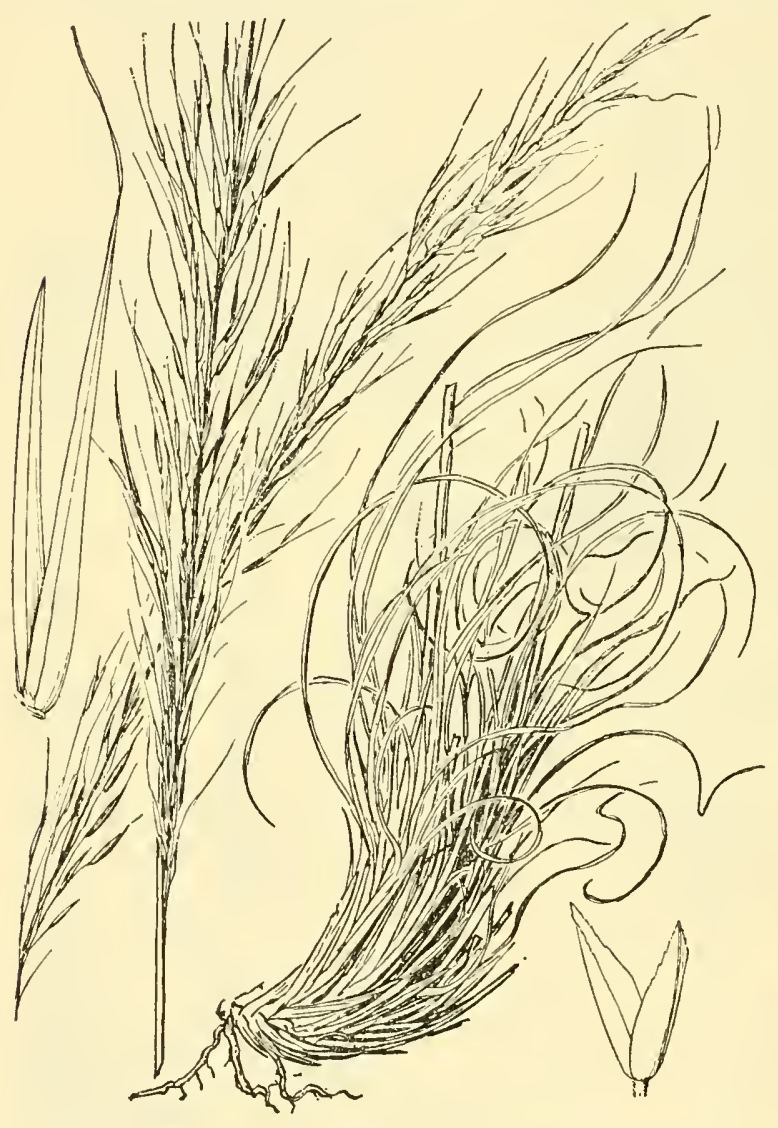

Figure 798.-Muhlenbergia setifolia. Plant, $\times 1$; glumes and floret, $\times 10$ (Hitcheock 13507, N.Mex.) rous mass; blades narrow, flat, becoming involute; panicle relatively smaller, narrower, the capillary branches and branchlets mostly straight; spikelets

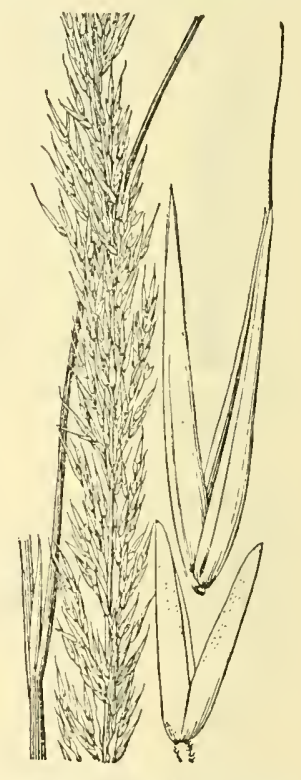

Figure 799.-Muhlenbergia dubia. Plant, $\times 1$; glumes and floret, $\times 10$. (Hitchcock 3775 , N.Mex.)

3.5 to $5 \mathrm{~mm}$ long, the glumes one-third to two-thirds as long, acute to acuminate; lemma scaberulous, nearly glabrous at base, awnless or with an awn as much as $2 \mathrm{~mm}$ long, rarely longer. 24 (M. trichopodes Chapm.) - Moist pine barrens near the coast, North Carolina to Florida and Texas (fig. 805).

50. Muhlenbergia reverchóni Vasey and Scribn. (Fig. 806.) Resembling $M$. expansa, culms more slender, foliage finer; glumes less than half as long as the lemma, subacute or erose; lemma with an awn 2 to $5 \mathrm{~mm}$ long. 2 -Rocky prairies, Texas. 
51. Muhlenbergia longilígula Hitchc. (Fig. S07.) Culms erect, about $1 \mathrm{~m}$ tall, the base hard, wiry, cylindric, the lower sheaths expanded; ligule (or auricle of sheath) firm, usually about $1 \mathrm{~cm}$ long; blades as much as $50 \mathrm{~cm}$ long, 2 to $5 \mathrm{~mm}$ wide, flat to subinvolute, very scabrous, usually drying involute; panicle narrow, somewhat

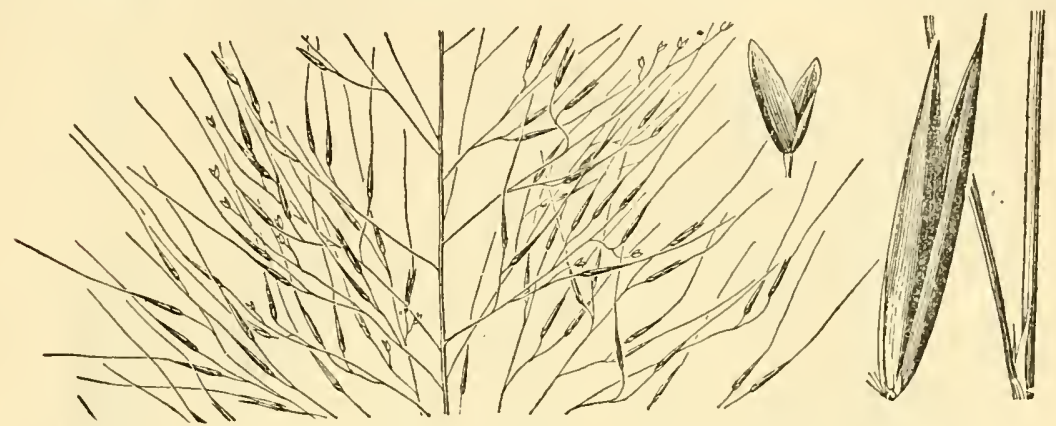

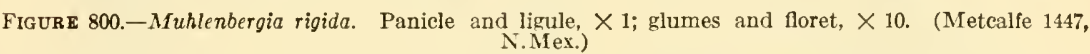

loose, erect, 20 to $40 \mathrm{~cm}$ long, the branches ascending or appressed; spikelets 2 to $3 \mathrm{~mm}$ long; glumes subequal, acutish, usually glabrous; lemma usually about as long as the glumes, glabrous, awnless, rarely with a minute awn. 24 (Epicampes ligulata Scribn., not Muhlenbergia ligulata Scribn. and Merr.)-Canyons and rocky slopes, western New Mexico, Arizona, southern Nevada, and northern Mexico.

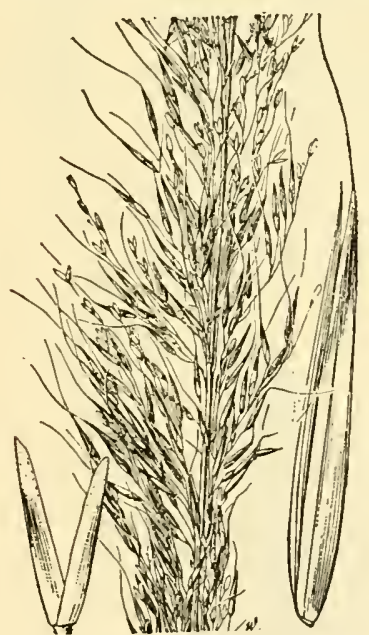

Figure 801.-Muhlenbergia met-

calfei. Panicle, $\times 1$; glumes and
floret, $\times 10$. (Metcalfe, N.Mex.)

52. Muhlenbergia lindheiméri Hitchc. (Fig. 808.) Culms erect, 1 to $1.5 \mathrm{~m}$ tall, the numerous overlapping lower sheaths keeled; ligule rather thin, elongate, mostly hidden in the folded base of the blade; blades elongate, firm, flat or usually folded, about $3 \mathrm{~mm}$ wide, scaberulous or glabrous; panicle narrow, pale, somewhat loose, erect, 20 to $40 \mathrm{~cm}$ long, the branches ascending or appressed; spikelets 2.5 to $3 \mathrm{~mm}$ long; glumes acute to rather obtuse, scabrous-puberulent; lemma a little shorter to a little longer than the glumes, 3-nerved, glabrous or obscurely pubescent, awnless or rarely with an awn as much as $3 \mathrm{~mm}$ long. 2 -Rocky slopes, Texas.

53. Muhlenbergia involúta Swallen. (Fig. 809.) Culms erect, densely tufted, 60 to $135 \mathrm{~cm}$ tall; sheaths compressed-keeled; scabrous; ligule about $10 \mathrm{~mm}$ long; blades elongate, involute, wiry, scabrous; panicle erect, narrow, 30 to $40 \mathrm{~cm}$ long, the subcapillary branches ascending or appressed, naked toward the base, the lower as much as $20 \mathrm{~cm}$ long; spikelets 3 to $4.5 \mathrm{~mm}$ long; glumes acute or somewhat erose, scabrous, 2 to $2.5 \mathrm{~mm}$ long; lemma densely pubescent on the margin toward the very base, the minutely toothed apex awned from just below the tecth, the awn slender, 1.5 to $2 \mathrm{~mm}$ long. 2 -Canyons and ravines, southern Texas. 


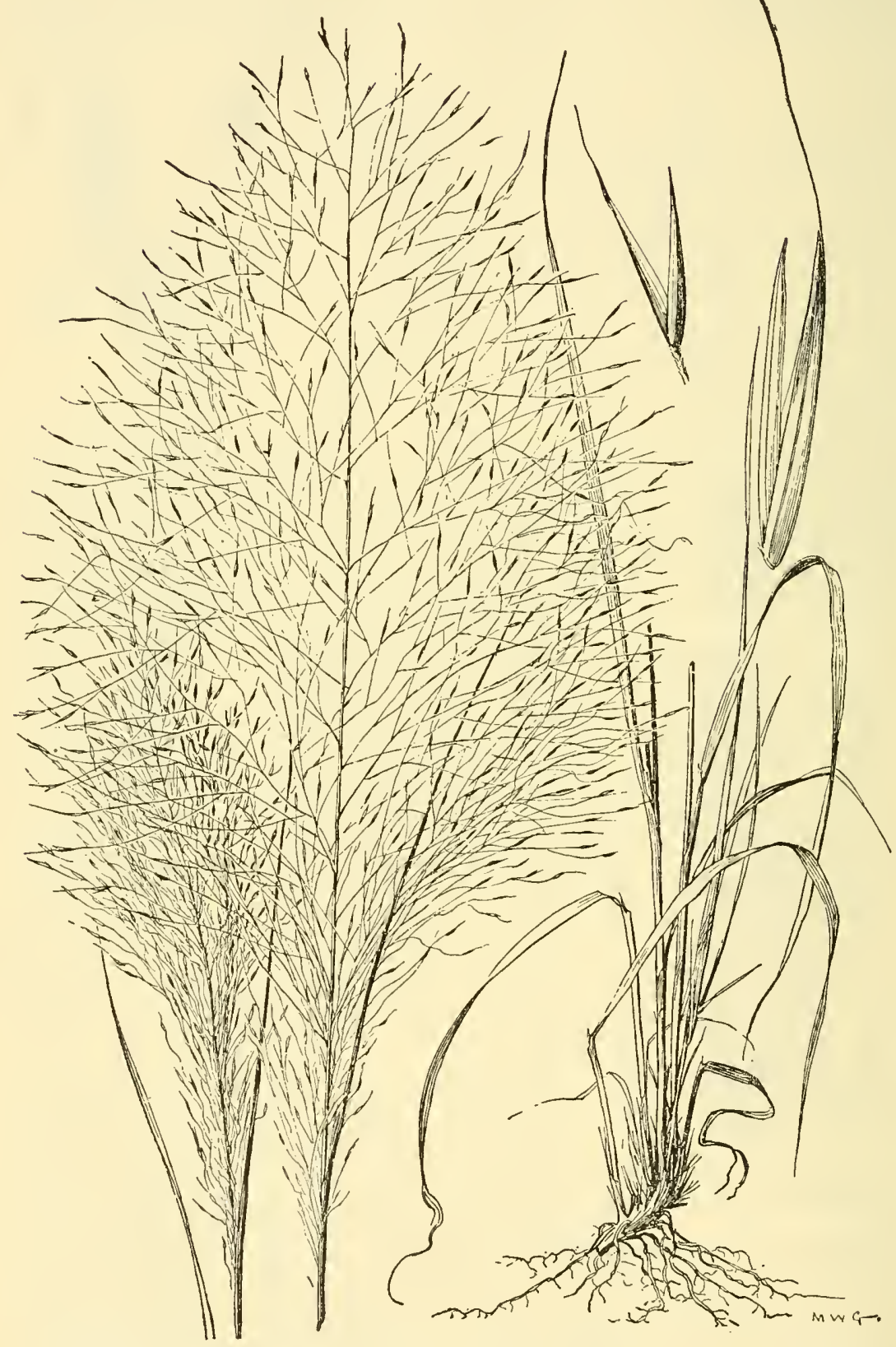

Frgure 802. - Muhlenbergia capillaris. Plant, $\times 1 / 2$; glumes and floret, $\times 10$. (Scribner, Tenn.) 
54. Muhlenbergia emersléyi Vasey. Bullgrass. (Fig. 810.) Culms in large clumps, erect, 50 to $100 \mathrm{~cm}$ tall; sheaths glabrous, slightly scabrous, compressed-keeled, especially those of the innovations; ligule softly membranaceous, 1 to $2 \mathrm{~cm}$ long; blades flat or

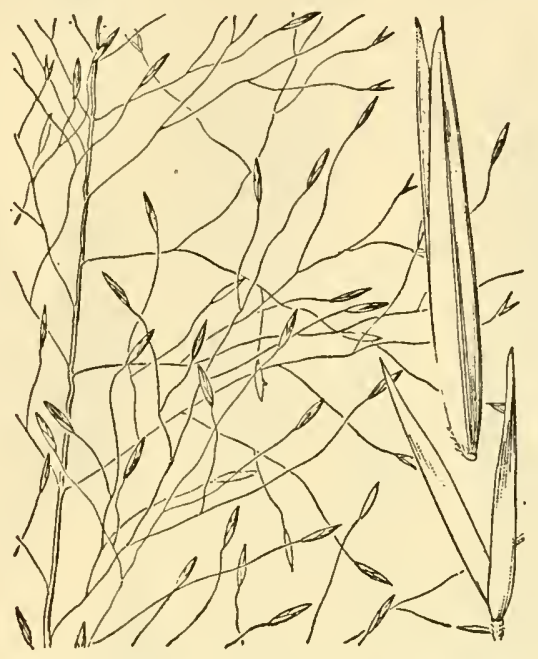

Figure 804-Muhlenbergia expansa. Panicle, $X$ 1 ; glumes and floret, $\times 10$. (Tracy 3701, Miss.)

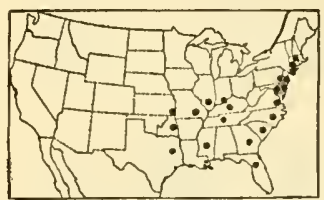

Figure 803.-Distribution of Muhlenbergia capillaris.

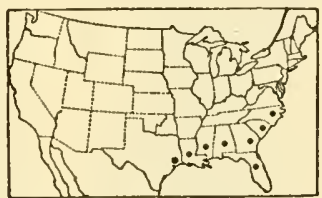

FiguRe 805.-Distribution of Muhlenbergia expansa.

folded, scabrous, 1 to $4 \mathrm{~mm}$ wide, the lower as much as $50 \mathrm{~cm}$ long; panicle narrow but rather loose, erect or nodding, mostly 20 to 40 cm long, the branches ascending, more or less fascicled or whorled, naked below; spikelets 3 to $4 \mathrm{~mm}$ long, often purplish; glumes thin,

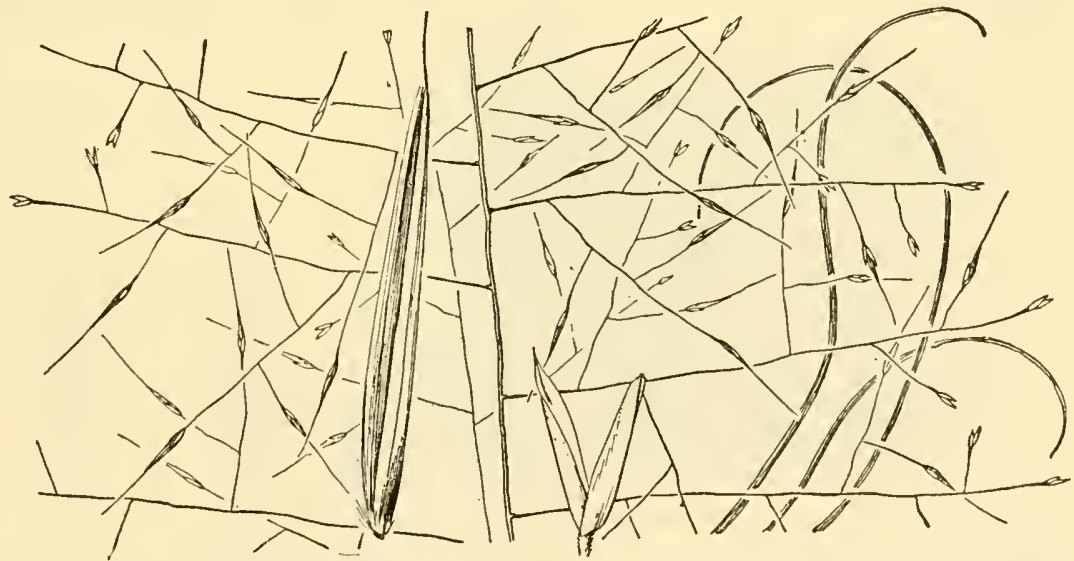

Figure 806.-Mfuhlenbergia reverchoni. Panicle, $\times 1$; glumes and floret, $\times 10$. (Reverchon, Tex.)

equal, acutish, scabrous; lemma about as long as the glumes, narrowed and scabrous above, villous below, with a delicate flexuous awn, about $1 \mathrm{~cm}$ long, or sometimes awnless. 2 -Rocky woods and ravines, Texas to Arizona and Mexico. The awnless form with usually more open panicle has been differentiated as Epicampes subpatens Hitchc. 
55. Muhlenbergia rígens (Benth.) Hitchc. Deergrass. (Fig. 811.) Culms rather slender stiffly erect, in small bunches, with a hard tough base, sometimes with short rhizomes, 1 to $1.5 \mathrm{~m}$ tall; sheaths smooth or slightly scabrous, mostly overlapping, the lower crowded, expanded, somewhat papery; ligule firm, truncate, 1 to $2 \mathrm{~mm}$ long; blades scabrous, elongate, involute, tapering into a long slender point; panicle grayish or pale,

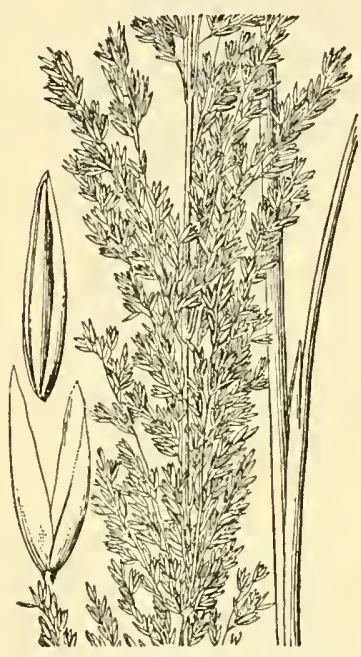

FIgure 807.-Muhlenbergin longiligula. Panicle and ligule, $\times 1$ glumes and floret, $\times 10$. (Jones,
Ariz.)

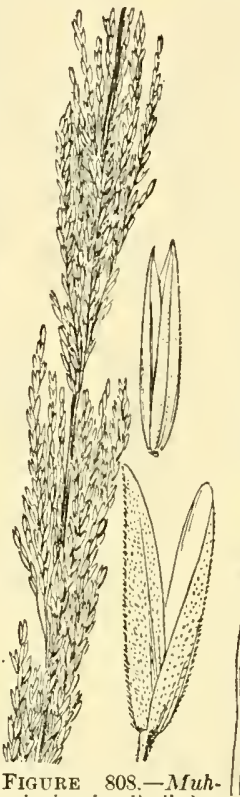

Figure 80s,- $\mathrm{M}$ uh. lenbergia lindheim eri. Panicle, $\times 1$; $\times 10$. ('Type.)

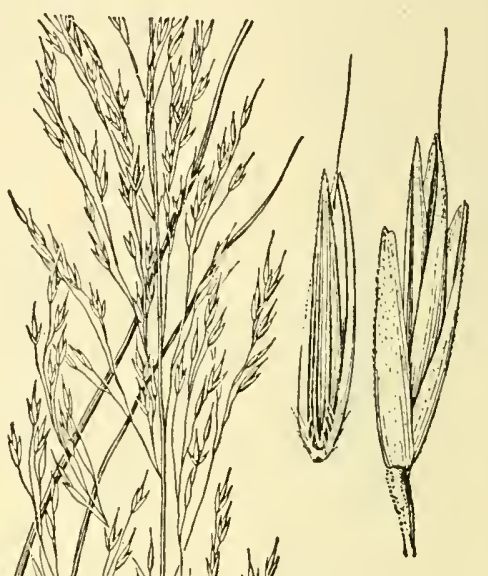

Figure 809.-Muhlenbergia inooluta. Pant. cle and ligule, $\times 1$; spikelet and floret, $\times 10$. (Type.)

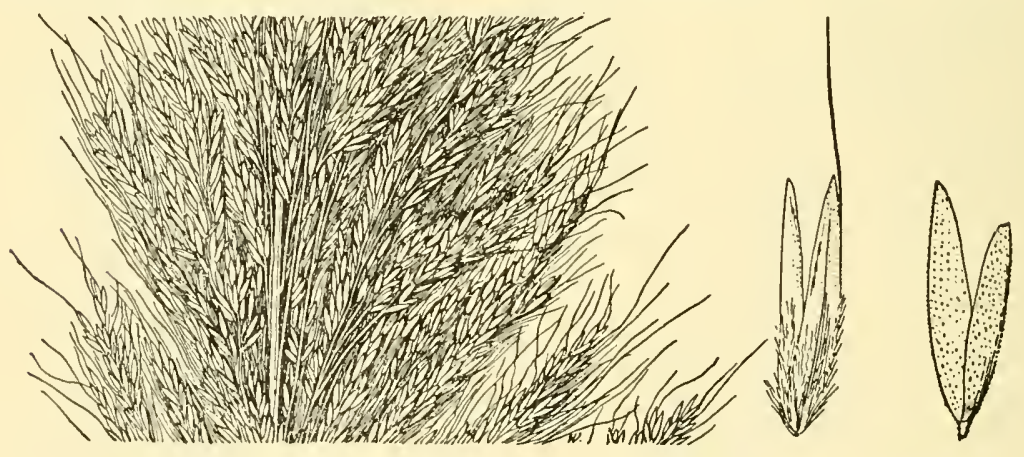

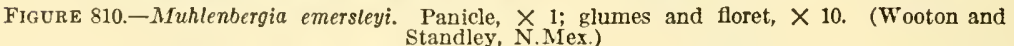

slender, spikelike, 15 to $30 \mathrm{~cm}$ long or more; glumes 2 to $3 \mathrm{~mm}$ long, from acute to obtuse or somewhat erose, scabrous-puberulent, rarely frintly 3-nerved; lemma slightly exceeding the glumes, scaberulous, sparsely pilose at base, 3-nerved toward the narrowed summit, awnless. 24 (Epicampes rigens Benth.)-Dry or open ground, hillsides, gullies, and open forest, Texas to southern California and northern Mexico (fig. 812). 


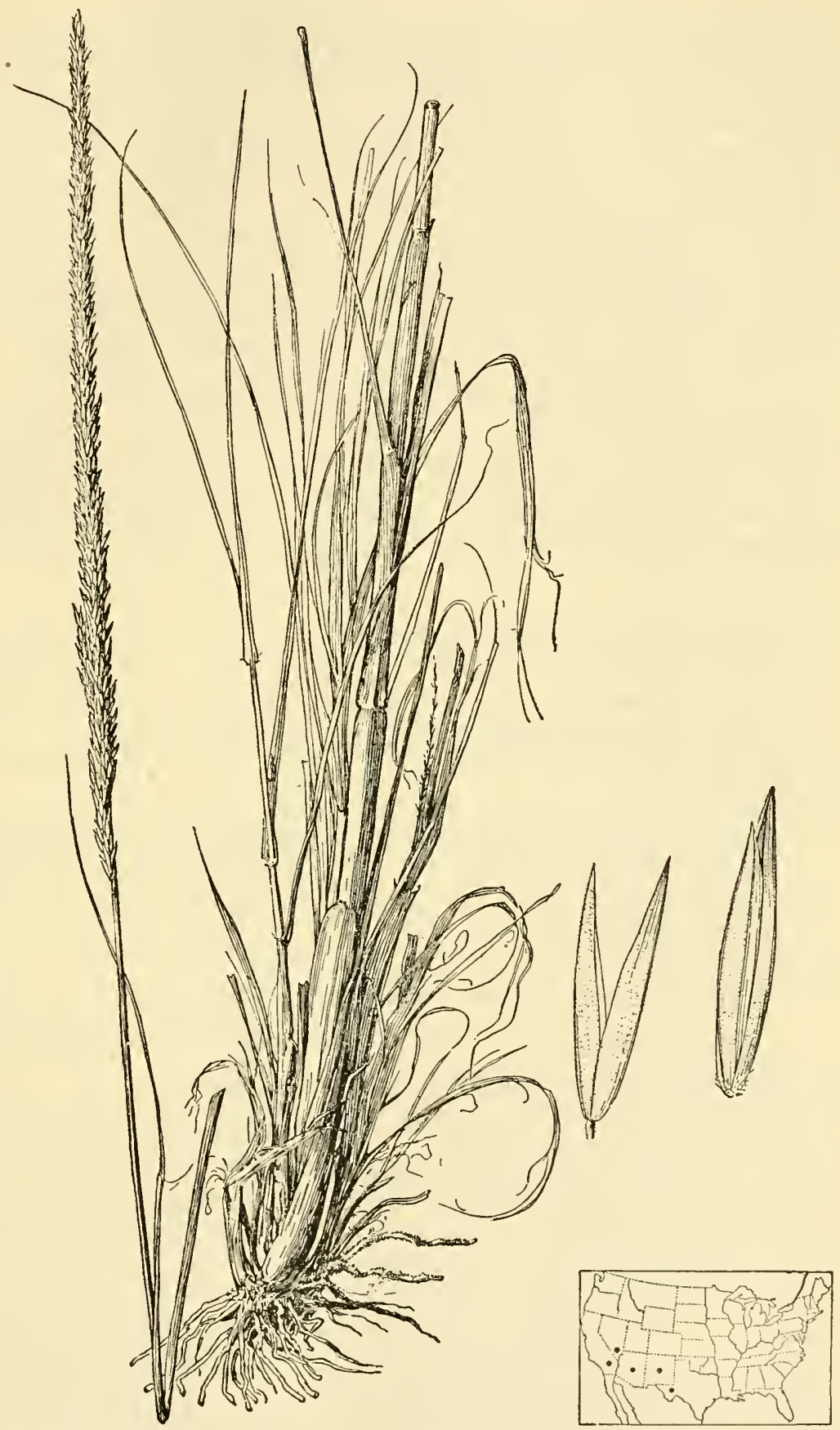

FIGURE $811 .-$ Muhlenbergia rigens. Plant, $\times 1$; glumes and
floret, $\times 10 . \quad$ (Metcalfe 10, N.Mex.)

FIGURE 812 -Distribution of
Muhlenbergia rigens 


\section{SPORÓBOLUS R. Br. Dropseed}

Spikelets 1-flowered, the rachilla disarticulating above the glumes; glumes 1-nerved, usually unequal, the second often as long as the spikelet; lemma membranaceous, 1-nerved, awnless; palea usually prominent and as long as the lemma or longer; caryopsis free from the lemma and palea, falling readily from the spikelet at maturity, the pericarp free from the seed, usually thin and closely enveloping it, but readily slipping away when moist. Annuals or perennials, with small spikelets in open or contracted panicles. Type species, Sporobolus indicus. Name from Greek spora, seed, and ballein, to throw, alluding to the free seeds. In some species of this genus the palea splits at maturity, giving the impression of extra lemmas. The first glume is early deciduous in some species. The size of the spikelets is often variable in the same panicle.

Most of the perennial species are palatable forage grasses, but few of the them are abundant enough to be of importance. Two species of the Southwest, $S$. airoides and $S$. wrightii, are valuable grasses in the arid and semiarid regions; S. interruptus is common on the Arizona Plateau; and the widely distributed S. cryptandrus is also important. The seed of S. flexuosus and S. cryptandrus have been used for food by the Indians.

1a. Plants annual.

Panicle narrow, few-flowered, spikelike.

Lemma pubescent

Lemma glabrous

6. S. Vaginiflords.

Panicle open, many-flowered.

Pedicels very short, appressed; glumes glabrous_____._- 1. S. RAMDLosus.

Pedicels elongate, spreading; glumes usually sparsely pubescent.

1b. Plants perennial.

2. S. microspermus.

2a. Plants producing creeping rhizomes. Panicle narrow or spikelike.

Rhizomes extensively creeping; leaves numerous, crowded, the blades involute, conspicuously distichous; panicle spikelike__-_ 3 . S. virginicus.

Rhizomes short; leaves not numerous nor crowded nor involute; panicle narrow but loose

2b. Plants without creeping rhizomes.

3a. Glumes nearly equal; much shorter than the lemma. Panicle narrow or spikelike.

Panicle branches short and appressed, the panicle spikelike.

Panicle branches slender, ascending, the panicle scarcely spikelike.

4. S. POIRETII.

5. S. INDICOS.

$3 \mathrm{~b}$. Glumes unequal or if equal as long as the spikelet.

4a. Spikelets mostly 3 to $7 \mathrm{~mm}$ long. Plants usually less than $1 \mathrm{~m}$ tall. Second glume shorter than the lemma; panicle contracted, more or less included in the sheath.

Lemma glabrous, the palea not exceeding it_.....-. 8. S. ASPER. Lemma pubescent, the palea acuminate, exceeding it.

10. S. CLANDESTINUS. Second glume about as long as the lemma; panicle open (contracted in S. purpurascens), not included.

Branches of the narrow panicle in distinct whorls, usually less than $4 \mathrm{~cm}$ long.

Branches 2 to $3 \mathrm{~cm}$ long, somewhat distant, more or less spreading, the panicle open.

Branches 1 to $2 \mathrm{~cm}$ long, ascending or appressed, overlapping, the panicle contracted.... S. PURPURASCENS.

Branches of the open panicle not in distinct whorls, usually more than $4 \mathrm{~cm}$ long. 
Spikelets short-pediceled and appressed along the main paniclebranches.

Spikelets about $4 \mathrm{~mm}$ long, purplish_....... 13. S. CURTIssir. Spikelets about $3 \mathrm{~mm}$ long, pale....... 29. S. THARPII.

Spikelets not appressed, the branchlets and pedicels somewhat spreading.

Blades terete

Blades flat or folded.

14. S. TERETIFOLIUg.

Glumes about equal, as long as the lemma.

Glumes unequal.

15. S. FLORIDANUS.

Blades elongate

Blades mostly less than half as long as culm.

11. S. INTERRUPTUS,

4b. Spikelets 1 to $2.5 \mathrm{~mm}$ long (sometimes $3 \mathrm{~mm}$ in $S$. giganteus).

5a. Lower panicle branches in distinct whorls, the mature panicle pyram-

idal; spikelets about $1 \mathrm{~mm}$ long .......... 18. S. ARGUTUS.

5b. Lower panicle branches not in distinct whorls (occasionally whorled

in $S$. domingensis); spikelets 1.5 to $2.5 \mathrm{~mm}$ long.

6a. Basal sheaths compressed-keeled. Panicle branches few, widely spreading, naked for about one-third their length; spikelets

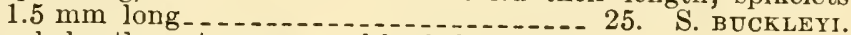

6b. Basal sheaths not compressed-keeled.

7a. Sheaths with a conspicuous tuft of white hairs at summit.

Culms robust, 1 to $2 \mathrm{~m}$ tall; spikelets 2.5 to $3 \mathrm{~mm}$ long.

Culms more slender, mostly less than $1 \mathrm{~m}$ 24. S. GIGANTEus. mm long.

Panicle open, often large, the branches and branchlets flexuous, the spikelets loosely arranged.....-21. S. FLExuosus.

Panicle open or compact, if open the spikelets crowded on the branchlets.

Panicle, or the exserted portion, somewhat open, the branches naked below (sometimes entirely enclosed).

Base of plant a close tuft_..... 20. S. CRYPTANDRUS. Base of plant a cluster of knotty rhizomes. Culms erect, slender, mostly less than $30 \mathrm{~cm}$ tall; blades short, involute, spreading ......... 22. S. NEALLEYI.

Panicle compact, spikelike, usually exserted.

23. S. Contractus.

7b. Sheaths naked or nearly so at the summit.

Pedicels elongate, capillary.

Pedicels short.

28. S. TEXANUS.

Panicle 1 to 2 times as long as wide, loose, the branches not crowded; blades mostly involute...- 26. S. AIROIDEs.

Panicle more than 3 times as long as wicie, relatively dense; blades mostly flat.

Panicle not more than $20 \mathrm{~cm}$ long, usually smaller.

Panicle commonly $50 \mathrm{~cm}$ long. S. DOMINGENsis. $\mathrm{cm}$

1. Sporobolus ramulósus (H. B. K.) Kunth. Red DRopseEd. (Fig. 813.) Annual; culms spreading, branching at the lower nodes, 10 to $20 \mathrm{~cm}$ tall; blades flat, lax, mostly 1 to $3 \mathrm{~cm}$ long, $1 \mathrm{~mm}$ wide or less; panicle oblong, 2 to $5 \mathrm{~cm}$ long, the branches ascending, the pedicels short, stiff, appressed along the main branches; spikelets about $1 \mathrm{~mm}$ long; glumes broad, obtuse, about equal, half as long as the spikelet; lemma rather turgid, acutish. $\odot$ Open dry ground, Colorado, New Mexico, Arizona, south to Guatemala.

2. Sporobolus microspérmus (Lag.) Hitchc. Sixweers dropsend. (Fig. 814.) Annual; culms erect or spreading, branching below, 10 to $30 \mathrm{~cm}$ tall; blades flat, lax, mostiy less than $10 \mathrm{~cm}$ long, 1 to $2 \mathrm{~mm}$ wide; panicle oblong, open, half or two-thirds as long as the entire culm, the slender pedicels spreading, club-shaped below the spikelets; spike- 
lets 1 to $1.8 \mathrm{~mm}$ long; glumes obtuse, about equal, about half as long as the spikelet or a little more, sparsely sometimes obscurely pilose; lemmas obtuse, minutely pubescent on midnerve and margins. $\odot$ (S. confusus Vasey; S. minutissimus Hitchc.) - Sandy or rocky open ground, Montana to eastern Washington, south to Nebraska, Texas,

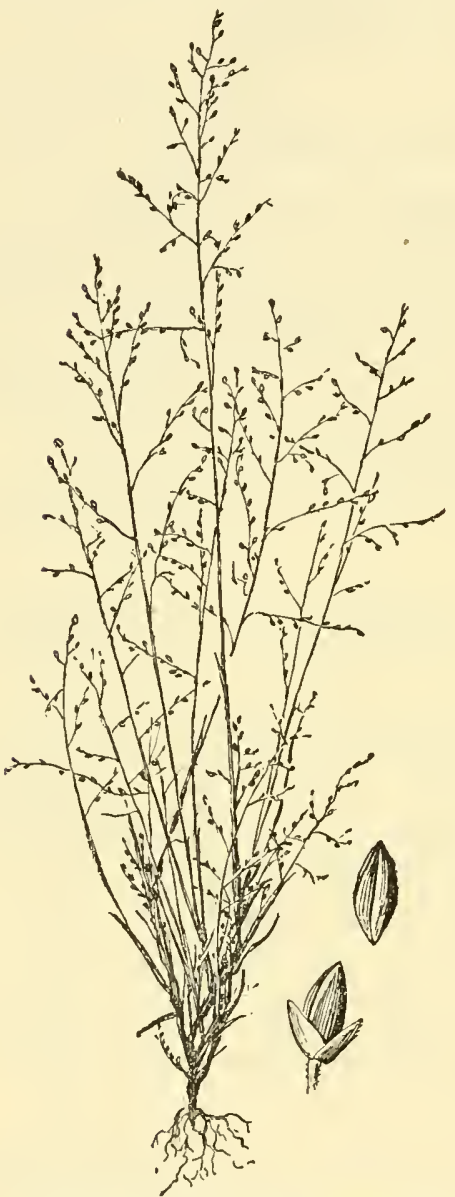

Figure 813.-Sporobolus ramulosus. Plant, $\times 1$; glumes ancl floret, $\times 10$. (Hitcheock 7661 , Mex.)

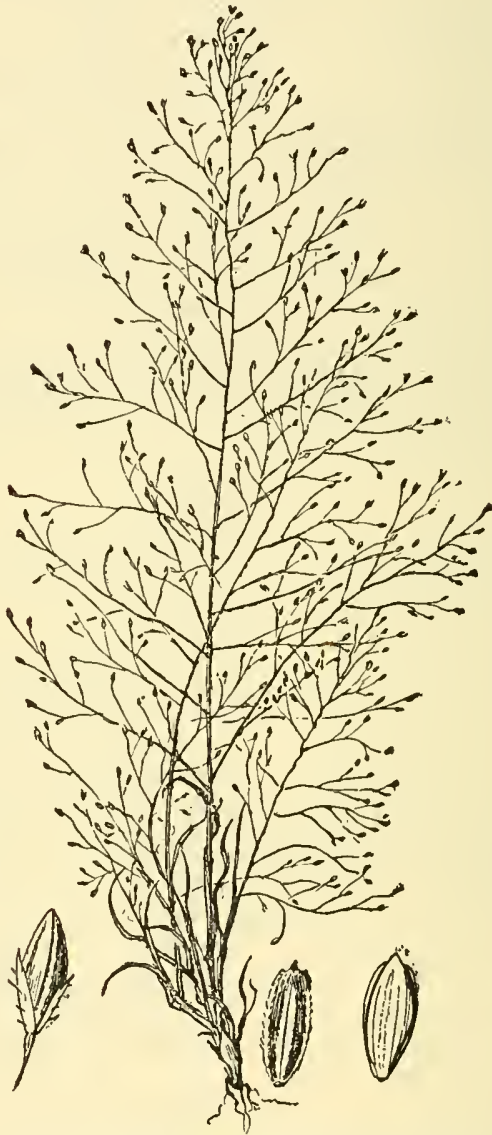

Figure 814.-Sporobolus microspermus. Plant, $\times 1$; spikelet and 2 riews of floret, $\times 10$. (Hitchcock 3788, N.Mex.)

and New Mexico, west to southern California, and south to Costa Rica (fig. 815).

3. Sporobolus virgínicus (L.) Kunth. (Fig. 816.) Perennial, with numerous branching widely creeping slender rhizomes (yellowish in drying); culms erect, 10 to $40 \mathrm{~cm}$ tall; sheaths overlapping, more or less pilose at the throat; blades flat or becoming involute especially toward the fine point, conspicuously distichous, mostly less than $5 \mathrm{~cm}$ long or on the innovations longer; panicle pale, contracted or spikelike, 2 to $8 \mathrm{~cm}$ long, 5 to $10 \mathrm{~mm}$ thick; spikelets 2 to $2.5 \mathrm{~mm}$ long; glumes and lemma about equal. 24 - Sandy or muddy seashores and saline marshes, forming extensive colonies, with relatively few flower- 
ing culms, southeastern Virginia (Gron. Fl. Virg.) to Florida and Texas, south through the West Indies to Brazil (fig. 817). A robust form (S. littoralis Kunth), with culms as much as $1 \mathrm{~m}$ tall and panicles as much as $15 \mathrm{~cm}$ long, is found in the West Indies and extends into Florida.

4. Sporobolus poirétii (Roem. and Schult.) Hitche. Smutgrass. (Fig. 818, A.) Perennial; culms erect, solitary or in small tufts, 30 to $100 \mathrm{~cm}$ tall; blades flat to subinvolute, rather firm, 2 to $5 \mathrm{~mm}$ wide at base, elongate, tapering

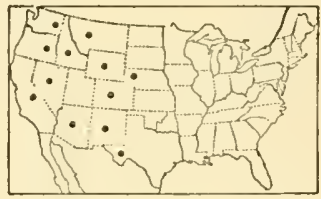

Figure 815.-Distribution of Sporobolus microspermus. to a fine point; panicle usually spikelike but more or less interrupted, 10 to $40 \mathrm{~cm}$ long, the branches appressed or ascending; spikelets about

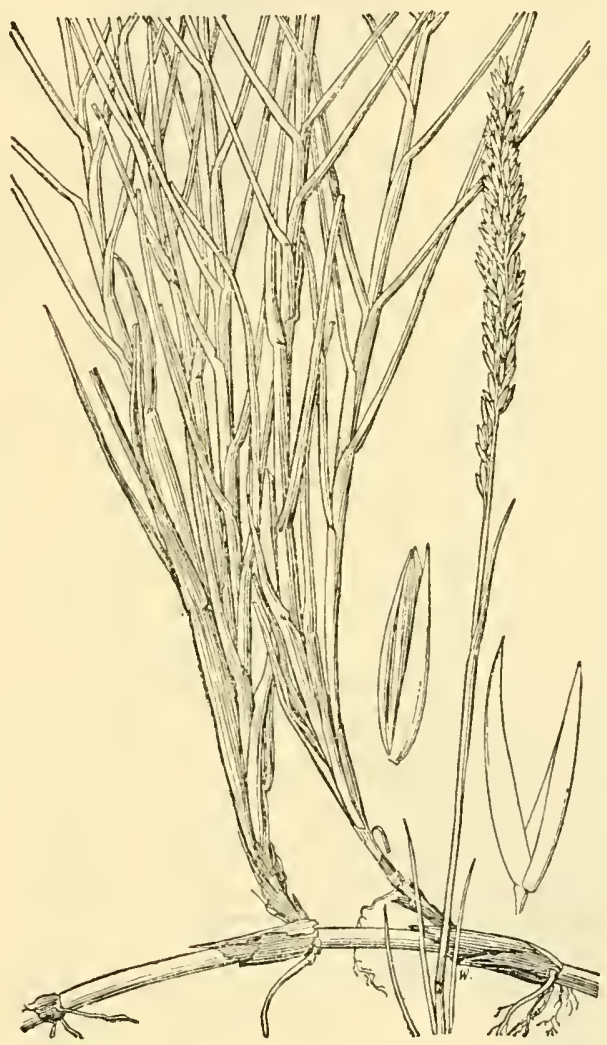

FIgURE 816.--Sporobolus rirginicus. Plant, $\times 1$; glumes and floret, $\times 10$. (Nash 2467 , Fla.) $2 \mathrm{~mm}$ long; glumes obtuse, somewhat unequal, about half as long as the spikelet or less; lemma acutish. 24 (Sporobolus berteroanus Hitchc. and Chase.)-Open ground and waste places, Virginia to Tennessee and Arkansas, south to Florida, Texas, and the warmer parts of America to Argentina; on ballast in Oregon and New Jersey (fig. 819); tropical Asia, apparently introduced in America. At maturity the extruded reddish caryopses remain for some time sticking to the panicle by the mucilaginous

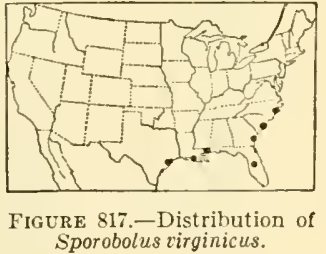

pericarp. Often affected with a black fungus. This species has been referred to the Australian S. elongatus R. Br., which seems to be distinct, differing in its looser panicle.

5. Sporobolus índicus (L.) R. Br. (Fig. 818, B.) Resembling $S$. poiretii, but the blades more slender, especially at base, and the panicle branches longer, more slender, less densely flowered, loosely ascending to somewhat spreading, the panicle not spikelike. If Punta Gorda, Fla.-Ballast, Mobile, Ala.; tropical America.

6. Sporobolus vaginiflórus (Torr.) Wood. (Fig. 820.) Annual, branching from base; culms erect to spreading, mostly 20 to $40 \mathrm{~cm}$ tall, sometimes as much as $75 \mathrm{~cm}$; blades slender, subinvolute; the 
lower elongate; panicles terminal and axillary, slender, mostly not more than $3 \mathrm{~cm}$ long, the terminal exserted or partly included, the

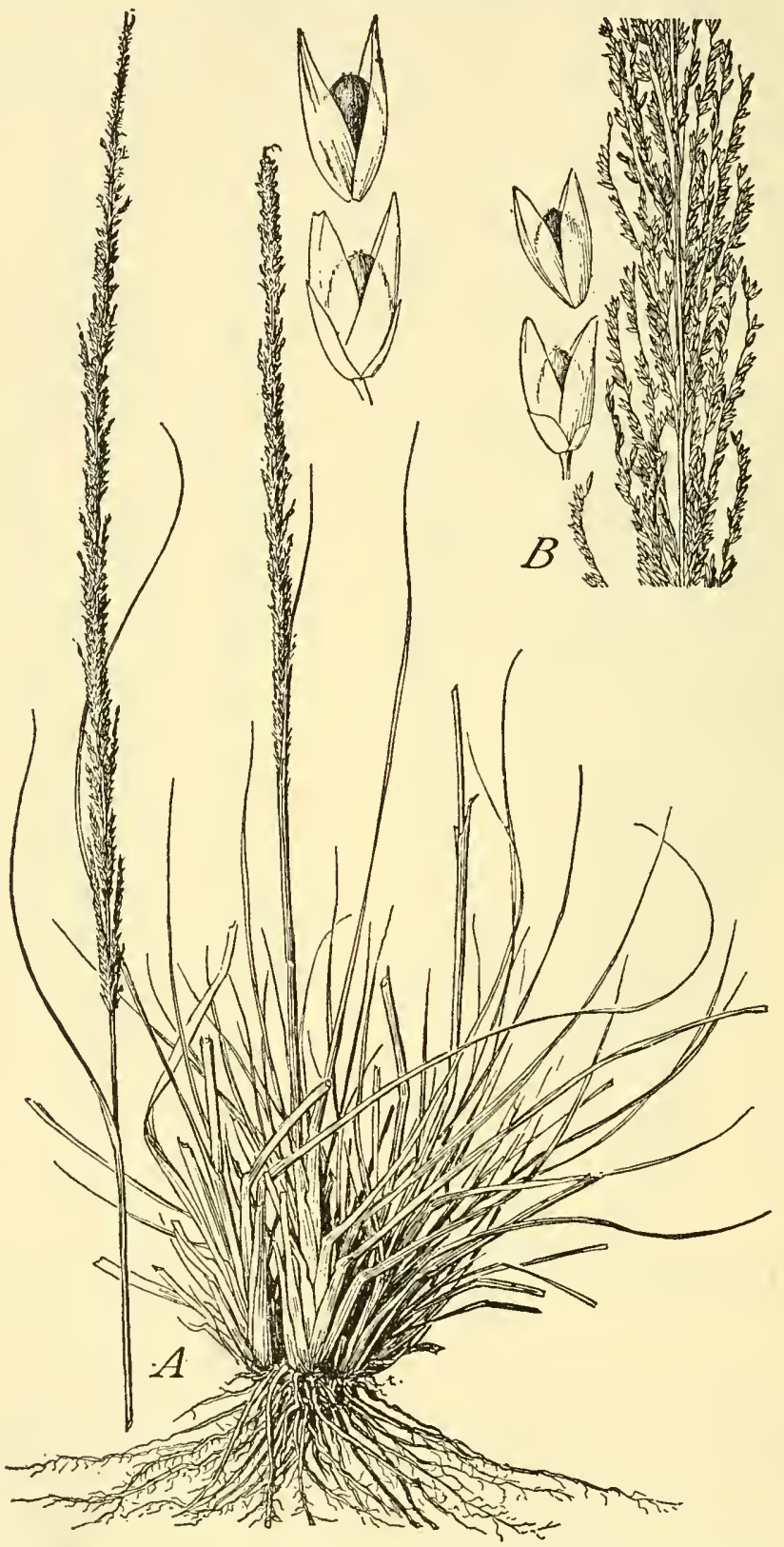

FIGURE 818. $-A$, Sporobolus poiretii. Plant, $\times 1 / 2$; spikelet and floret, $\times 10$. (Chase 7043, Fla.) B, S. indicus. Panicle, $\times 1$; spikelet and floret, $\times 10$. (Leon 867, Cuba.)

axillary included in the sheaths or slightly exserted, late in the season the sheaths swollen and containing cleistogamous spikelets; glumes 
acute, about equal, 3 to $5 \mathrm{~mm}$ long; lemma as long as the glumes or exceeding them, acute or acuminate, rather sparsely pubescent, sometimes mottled with dark spots; palea acuminate, sometimes longer than the lemma. $\odot \quad$-Sandy soil or open waste ground, Maine and Ontario to Minnesota and Nebraska, south to Georgia, Texas, and Arizona (fig. 821).

7. Sporobolus negléctus Nash. (Fig. 822.) Differing from $S$. vaginiflorus chiefly in the smaller, paler, plumper spikelets, 2 to $3 \mathrm{~mm}$ long, and in the glabrous lemma; lower blades

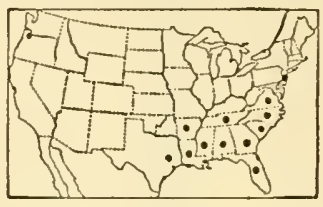

Figure 819,-Distribution of Sporobolus poiretii. often sparsely pilose; panicles usually entirely hidden in the more

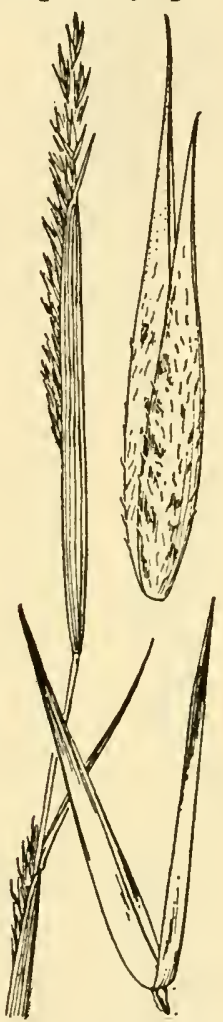

Figure $820-$-Sporobolus vaginiflorus. Plant, $\times 1$; glumes and floret, $\times 10$. (Deam 39615 , Ind.)

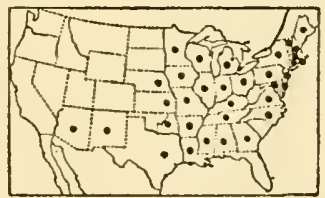

Figure 821.-Distribution of Sporobolus vaginiflorus. swollen sheaths

Dry open ground and sandy fields, Quebec and Maine to North Dakota, south to Maryland, Tennessee, and Texas; also Washington and Arizona (fig. 823). A form from Missouri (Ozark Mountains), with rather strongly pilose leaves, has been called S. ozarkensis Fernald.

\section{Sporobolus ásper} (Michx.) Kunth. (Fig. 824.) Perennial; culms erect, often rather stout, solitary or in small tufts, 60 to $120 \mathrm{~cm}$ tall; blades elongate, flat, becoming involute, 1 to $4 \mathrm{~mm}$ wide at base, tapering to a fine point; panicle terminal and axillary, pale or whitish, sometimes purplish, contracted, more or less spikelike, usually enclosed at base or sometimes entirely in the inflated uppersheath, 5 to $15 \mathrm{~cm}$ long; spikelets 4 to $6 \mathrm{~mm}$ long glumes rather broad, keeled, subacute, the first about half as long as the spikelet, the second two-thirds to three-fourths as long; lemma and palea sub-

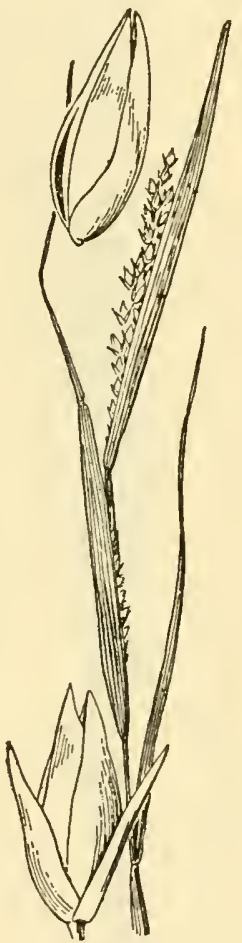

Figure 822.- Sporobolus neglectus. Plant, $\times 1$; spikelet and floret, $X$ i0. (Deam 33426, lnd.)

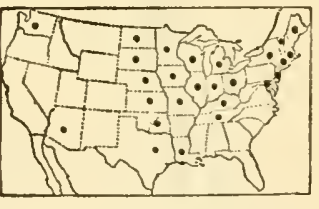
equal, glabrous, the tip Figure 823.-Distribution of b o a t-shaped. $21-$ Sporobolus neglectus.

Prairies and sandy meadows, Vermont to Michigan, North Dakota, and Utah, south to Louisiana and New Mexico; eastern Washington(fig. 825). 


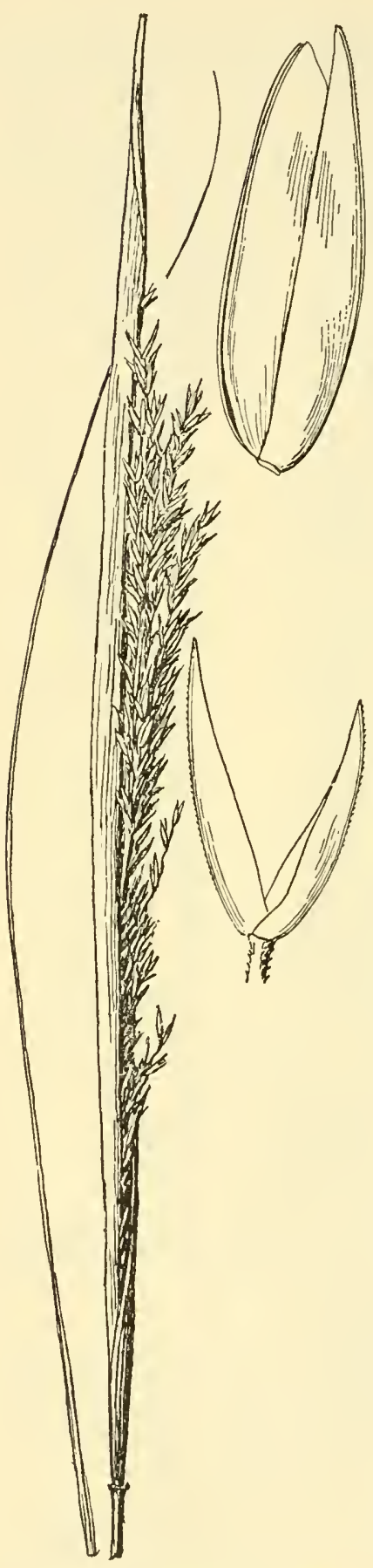

Figure 824.-Spotobolus asper. Plant, $\times$ 1; glumes and floret, $\times$ 10. (Deam 42707 , Ind.)
Sporobolus Asper var. pILósus (Vasey) Hitchc. Sheaths and blades more or less pilose. 2 (S. pilosus Vasey.) - Prairies and rocky hills, Kansas (Saline County and westward), Texas (Del Rio).

SPOROBOLUS ASPER VAT. HOOKÉRI (Trin.) Vasey. Less robust, the more slender fewer-flowered panicle looser; spikelets usually smaller, 3 to $5 \mathrm{~mm}$ long. 24 (S. attenuatus Nash; $S$. drummondii Vasey.)-Plains, Missouri, Mississippi, Texas, and Oklahoma. Foliage rarely somewhat villous.

9. Sporobolus mácrus (Trin.) Hitche. (Fig. 826.) Perennial, with short scaly rhizomes; culms erect, 50 to $70 \mathrm{~cm}$ tall; blades flat, 10 to $20 \mathrm{~cm}$ long, 1 to $2 \mathrm{~mm}$ wide, sometimes wider, pilose on the upper surface near base and at the throat of the sheath; panicle narrow, often enclosed at base, 5 to 15 cm long, the branches erect; spikelets 4 to $5 \mathrm{~mm}$ long, the glumes keeled, the first about two-thirds as long, the second a little longer than the first; lemma and

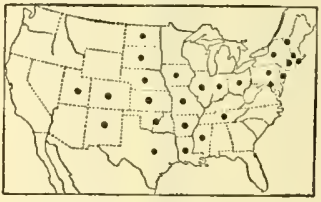

Figure 825,-Distribution of Sporobolus asper. palea subequal, the tips boat-shaped. 2 - Wet pineland, Oklahoma, Mississippi, and Louisiana. Except for the rhizomes this species resembles $S$. asper var. hookeri.

10. Sporobolus clandestínus (Spreng.) Hitche. (Fig. 827.) Perennial; culms relatively stout to slender, erect to spreading, 50 to $100 \mathrm{~cm}$ tall; lower sheaths sometimes pilose; blades flat, becoming involute, with a long fine point; panicle narrow, contracted, 5 to $10 \mathrm{~cm}$ long, usually partly enclosed; spilielets 5 to $7 \mathrm{~mm}$ long, the glumes keeled, acute or subacute, the first more than half as long as the spikelet, the second longer than the first; lemma sparsely appressed-pubescent, acuminate, the palea longer, sometimes as mucl as $10 \mathrm{~mm}$ long. 21 (S.canovirens Nash.) Sandy fields, pine barrens, hills, and prairies, Connecticut to Illinois and Kansas, south to Florida and Texas (fig. 828). 
11. Sporobolus interrúptus Vasey. Black dropseed. (Fig. 829.) Perennial, densely tufted; culms erect, 30 to $60 \mathrm{~cm}$ tall, the leaves crowded at base, about 2 on the culm; sheaths more or less pilose;

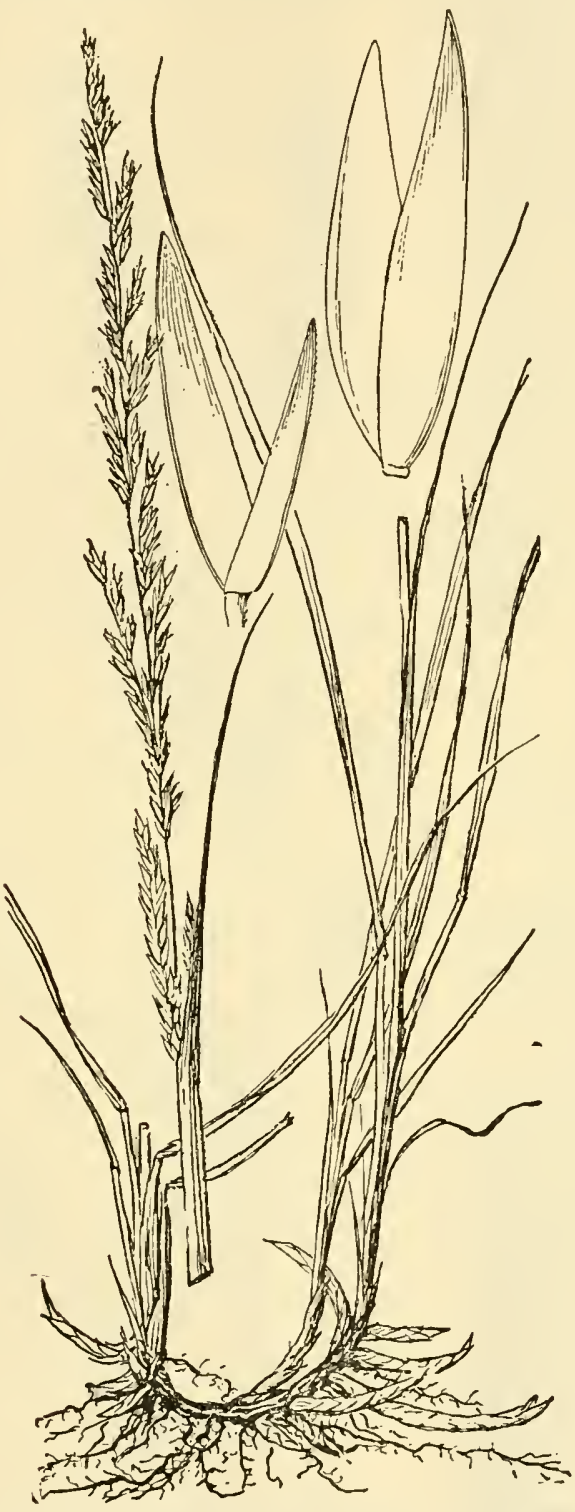

FigUre 826.-Sporobolus macrus. Plant, $\times 1$; glumes and floret, $\times 10$. (Chase 4341 , Miss.)

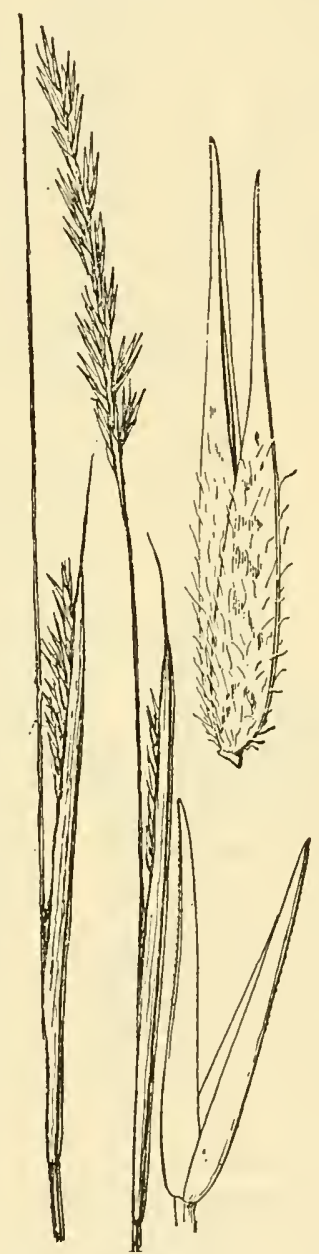

FIGURE 827.-Sporobolus clandestinus. Plant, $\times 1$; glumes and floret, $\times 10$. (Chase 4265 , Fla.)

blades flat or folded, sparsely pilose to glabrous, 1 to $2 \mathrm{~mm}$ wide; panicle 10 to $20 \mathrm{~cm}$ long, brownish-leaden, the branches distant, finally spreading, naked at base; spikelets about $6 \mathrm{~mm}$ long, short$55974^{\circ}-35-26$ 
pediceled; glumes acute, the first 2 to $3 \mathrm{~mm}$, the second 4 to $6 \mathrm{~mm}$ long; lemma and palea acute, about equal. 24 - Grassy plains and hills, Arizona. The second glume and lemma may have wrinkles toward the summit that look like nerves.

12. Sporobolus heterólepis A. Gray. Prairie dropseed. (Fig. 830.) Perennial, in dense tufts; culms erect, slender, 30 to $70 \mathrm{~cm}$ tall; sheaths somewhat pilose at the throat, the lower sometimes sparsely pilose on the back; blades elongate, flat, becoming involute at the slender attenuate tip, $2 \mathrm{~mm}$ or less wide; panicle, 5 to 20 cm long, the branches ascending or spreading, 3 to $6 \mathrm{~cm}$ long, naked below, few-flowered above; spikelets grayish; glumes acuminate, the first 2 to $4 \mathrm{~mm}$ long, the second 4 to $6 \mathrm{~mm}$ long; lemma shorter than the second glume, palea slightly longer than the lemma; caryopsis globose, nutlike, nearly $2 \mathrm{~mm}$ thick, finally splitting

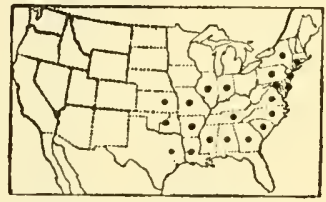

FIGURE 828.-Distribution of Sporobolus clandestinus.

the palea. 21 -Prairies, Quebec to Saskatchewan and Wyoming, south to Connecticut, Illinois, Arkansas, and eastern Texas (fig. 831).

13. Sporobolus curtíssii (Vasey) Small. (Fig. 832.) Perennial, in dense tufts; culms slender, 30 to $70 \mathrm{~cm}$ tall; basal sheaths pilose at the throat; blades flat or folded, flexuous, about $1 \mathrm{~mm}$ wide, pilose on the upper surface near the base; panicle pyramidal, open, 7 to $20 \mathrm{~cm}$ long, the branches solitary or in twos, ascending; spikelets appressed along the main branches, bronze or purplish, about $4.5 \mathrm{~mm}$ long; glumes about equal, acuminate, as long as or longer than the lemma and palea. 24 -Dry pine barrens, North Carolina, Georgia, and Florida.

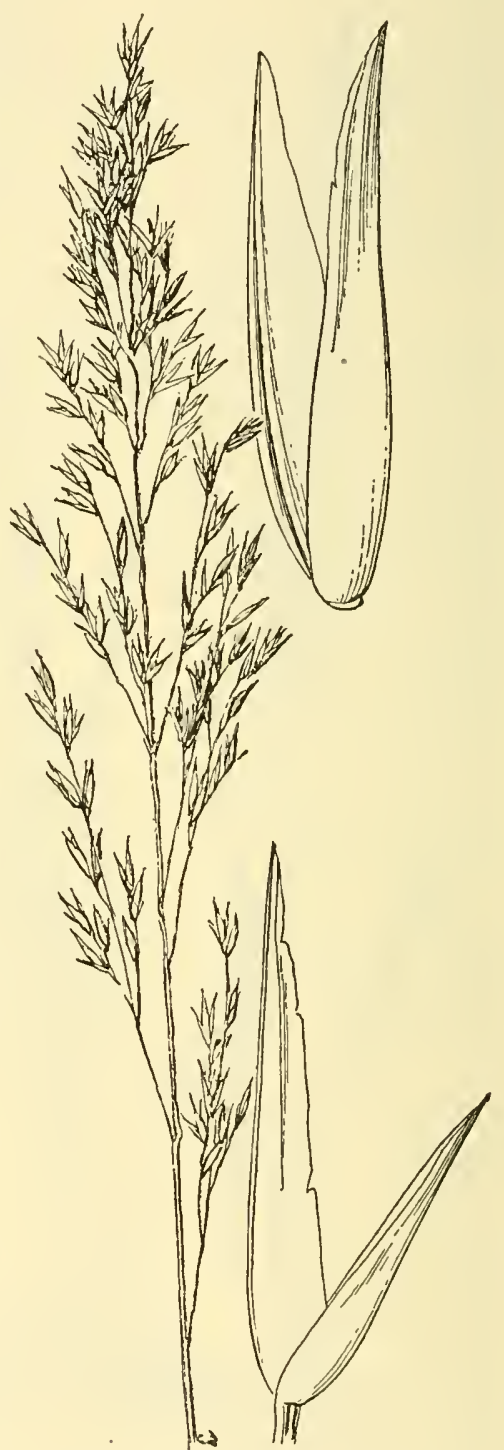

Figure 829.-Sporobolus interruptus. Plant, $\times$ 1; glumes and floret, $\times 10$. (Rusby, Ariz.)

14. Sporobolus teretifólius Harper. (Fig. 833.) Perennial, in tufts; culms erect, wiry, 60 to $80 \mathrm{~cm}$ tall, sheaths pilose at the throat; blades elongate, slender, terete, wiry, flexuous, pilose on the upper surface at base; panicle pyramidal, open, 15 to $20 \mathrm{~cm}$ long, the capil- 
lary branches, branchlets, and pedicels ascending to spreading; spikelets purplish-brown, about $4 \mathrm{~mm}$ long; glumes acute, the first half as long, the second as long as the equal lemma and palea. 2 -Moist pine barrens, Georgia.

15. Sporobolus floridánus Chapm. (Fig. 834.) Plants more robust than S. curtissii, as much as $1 \mathrm{~m}$ tall; sheaths keeled, the basal ones somewhat pilose at throat, the base indurate and shining, blades folded at base, usually flat above, 2 to $5 \mathrm{~mm}$ wide, abruptly narrowed at apex; panicle narrow, open, 15 to $35 \mathrm{~cm}$ long, the branches and branchlets ascending; spikelets 4 to $5 \mathrm{~mm}$ long; glumes acute, subequal, about as long as the lemma and palea. 24 -Low pine barrens, Georgia and Florida.

\section{Sporobolus gráci-} lis (Trin.) Merr. (Fig. 835.) Perennial, in dense bunches; culms erect, slender, about 3-noded, 30 to $60 \mathrm{~cm}$ tall; blades folded or involute, slender, glabrous; panicle mostly bronze-brown, oblong or narrowly pyramidal, open, 7 to $15 \mathrm{~cm}$ long, 2 to $5 \mathrm{~cm}$ wide, the flexuous branches (2 to $3 \mathrm{~cm}$ long) in rather regular whorls 1 to $3 \mathrm{~cm}$ apart, widely spreading to ascending, naked at base, the short-pediceled spikelets appressed along the upper part; spikelets

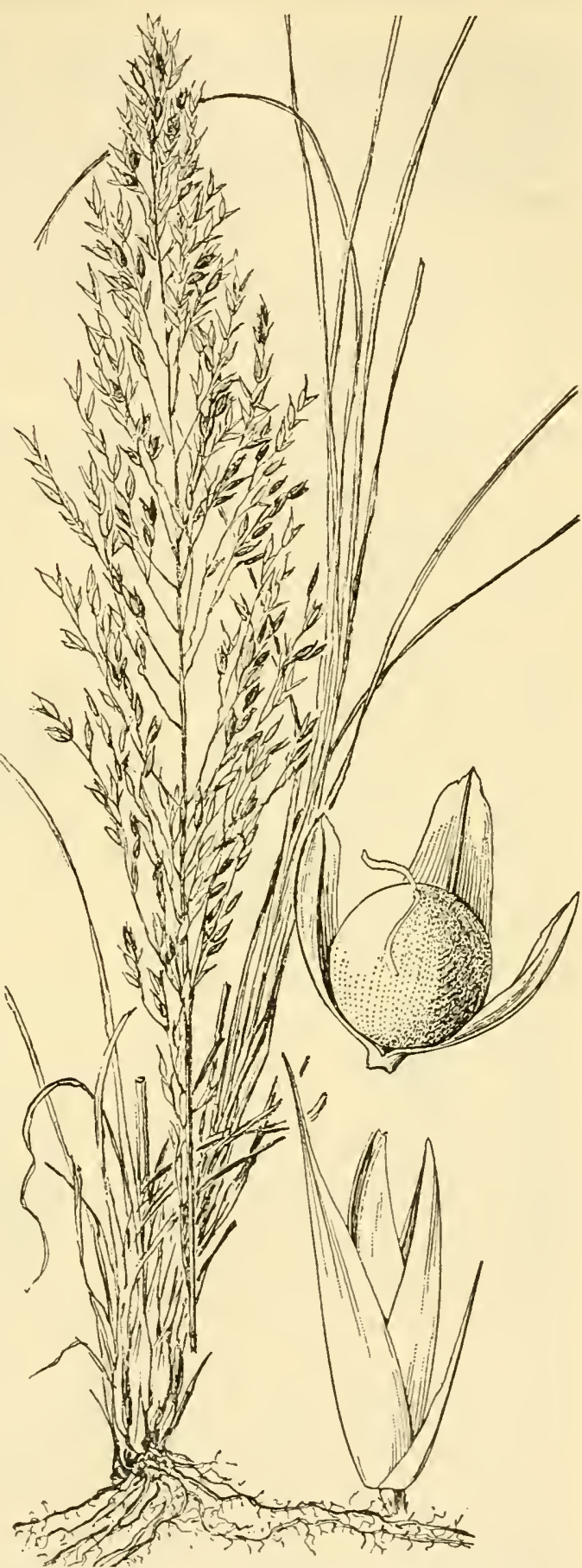

FIGURE 830.-Sporobolus heterolepis. Plant, $\times 1$; spikelet and floret with caryopsis and split palea, $\times 10$. (McDonald, Ill.) 
about $3 \mathrm{~mm}$ long; first glume about half as long, the second glume as long as the acute lemma or a little longer. 24 (S. junceus Kunth.) Pine barrens of the Coastal Plain, southeastern Virginia to Florida and Texas (fig. 836). Common in the high pineland of Florida.

17. Sporobolus purpuráscens (Swartz) Hamilt. (Fig. 837.) Resembling S. gracilis; blades flat or folded, 1 to $3 \mathrm{~mm}$ wide; panicle

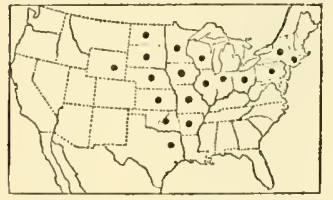

Figure 831.-Distribution of Sporobolus heterotepis. 10 to $15 \mathrm{~cm}$ long, more contracted than in $S$. gracilis, the shorter branches numerous in the whorls, ascending or appressed, floriferous nearly to the base; spikelets about as in $S$. gracilis, greenish-purple. 4 -Sandy prairies, southern Texas and eastern Mexico; West Indies to Brazil.

18. Sporobolus argútus (Nees) Kunth. (Fig. 838.) Perennial, in spreading or prostrate tufts; culms 10 to $40 \mathrm{~cm}$ tall; leaves crowded at the base, the sheaths pilose at the throat; blades flat, mostly less than $10 \mathrm{~cm}$ long, 2 to $4 \mathrm{~mm}$ wide, sparsely long-ciliate toward the base; panicle pale, pyramidal, 3 to $7 \mathrm{~cm}$ long, rarely longer, the branches spreading, somewhat viscid, 1 to $3 \mathrm{~cm}$ long, naked below, closely flowered above, the lowermost in a distinct whorl; spikelets a little more than $1 \mathrm{~mm}$ long; first glume minute, the second as long as the lemma and palea. 24 - Sandy or gravelly soil, especially along streets and along the seashore and in the interior in alkaline soil, Kansas and Colorado to Louisiana and Texas; Arizona; southern Florida; tropical America (fig. 839).

19. Sporobolus domingénsis (Trin.) Kunth. (Fig. 840.) Differing from $S$. argutus in the usually larger size (culms sometimes as much as $1 \mathrm{~m}$ tall), broader blades, 3 to $6 \mathrm{~mm}$ wide, and stiffer longer panicles, the branches ascending or appressed, overlapping, less regularly in whorls; spikelets about $2 \mathrm{~mm}$ long, the first glume half as long. 24 -Coral sand

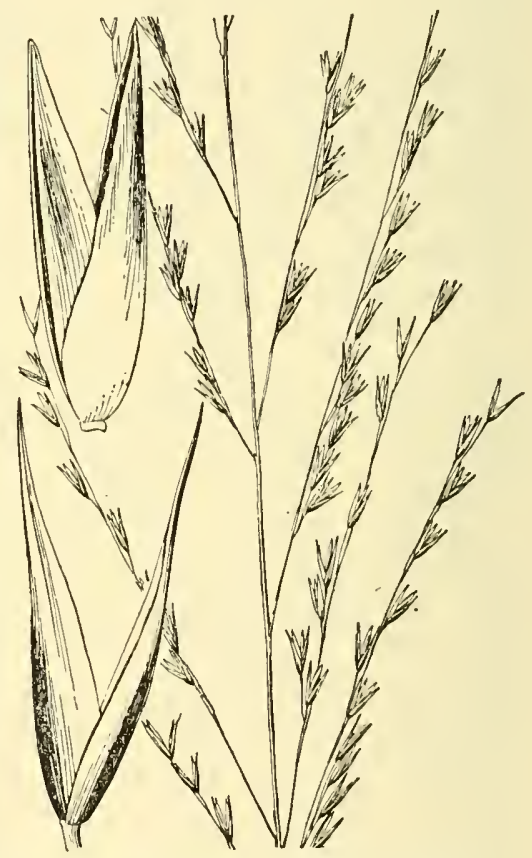

Figure 832.-Sporobolus curtissii. Panicle, $\times 1$; glumes and floret, $\times 10$. (Bitting 1050, Fla.) and rocks along the coast of southern Florida, mostly on the Keys, north to Sanibel Island; West Indies.

20. Sporobolus cryptándrus (Torr.) A. Gray. SANd Dropseed. (Fig. 841, A.) Perennial, usually in rather small tufts; culms erect or spreading, sometimes prostrate, 30 to $100 \mathrm{~cm}$ tall; sheaths with a conspicuous tuft of long white hairs at summit; blades flat, 2 to $5 \mathrm{~mm}$ wide, more or less involute in drying, tapering to a fine point; panicles 
terminal and axillary, usually included at base, sometimes entirely

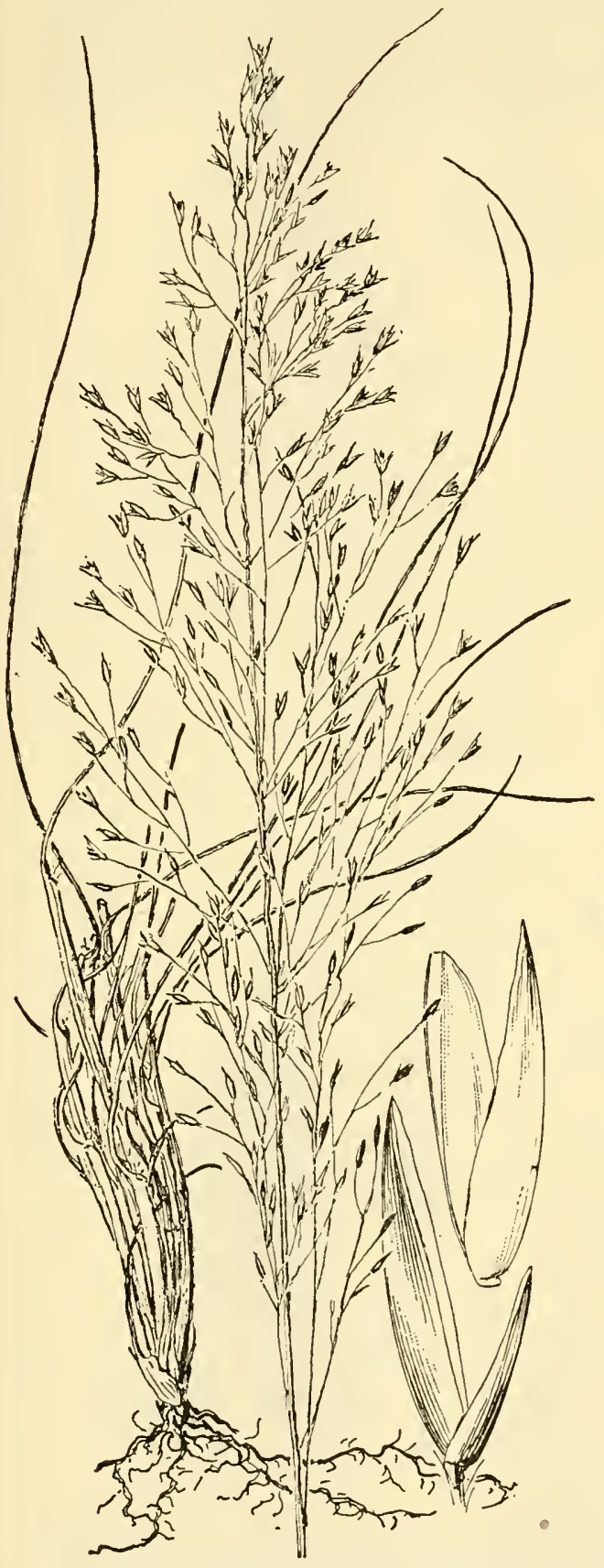

Figure 833.-Sporobolus teretifolzus. Plant, $\times 1$; glumes and floret, $\times 10$. (Harper $677, \mathrm{Ga}$.

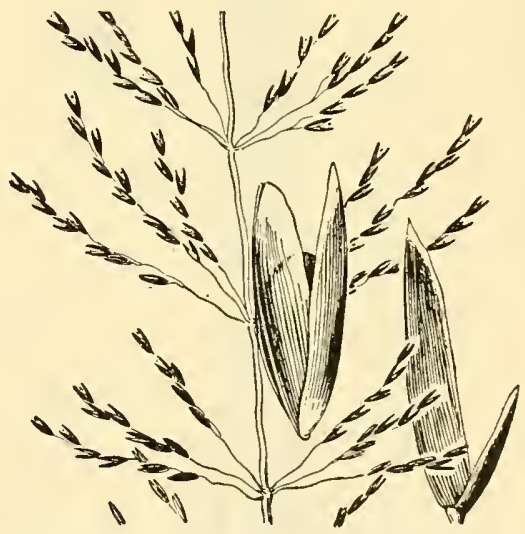

Figure 835-Sporobolus gracilis. Panicle, $\times 1$; glumes and floret, $\times 10$. (Curtiss 4056 , Fla.)

FIGURE 834.-Sporobolus floridanus, $\times$

10. (Curtiss 4054, Fla.)

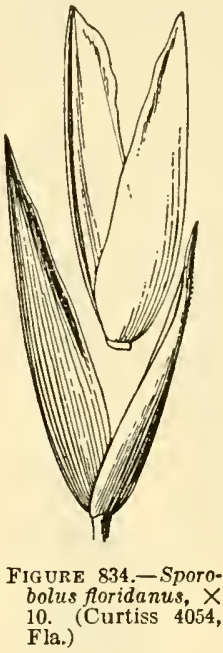

included, the well-developed terminal panicles open, as much as 25 
cm long, the branches spreading or sometimes reflexed, rather distant, naked at base, as much as $8 \mathrm{~cm}$ long or even more, the spikelets crowded along the upper part of the main branches; spikelets from pale to leaden, 2 to $2.5 \mathrm{~mm}$ long; first glume one-third to half as long, the second about as long, as the acute lemma and palea. 21-Sandy open

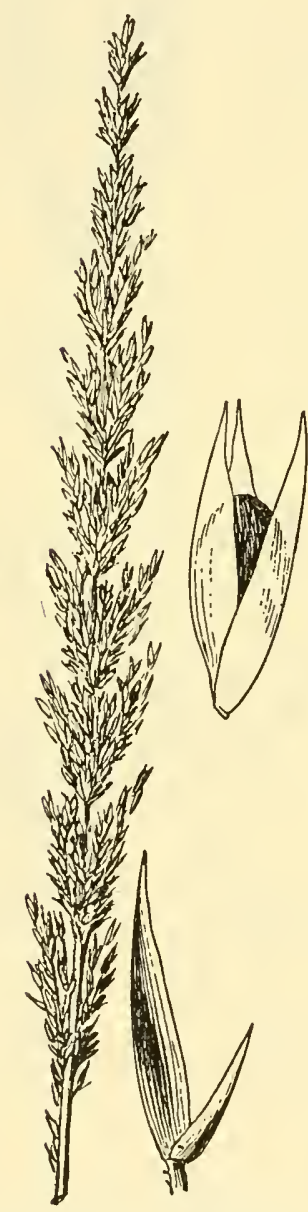

FIGURE 837.-Sporobolus purpurascens. Panicle, $\times 1$; glumes and floret, $\times 10$. (Hitchcock, Tex.)

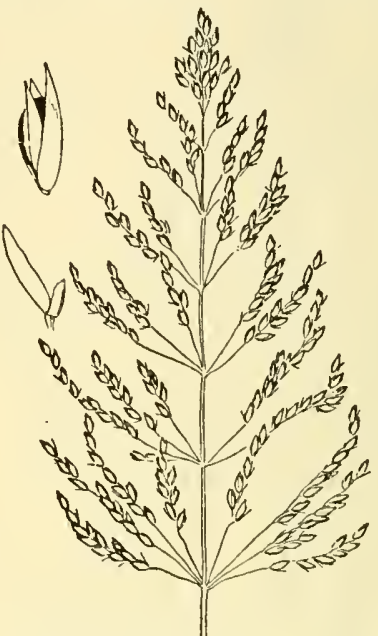

Figure 838.-Sporoholus argutus. Panicle, $\times 1$; glumes and floret, $\times 10$. (Hitchcock 5343, Tex.)

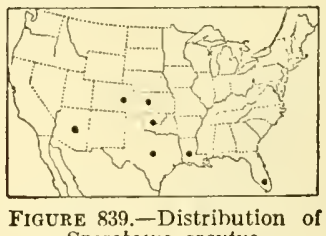
Sporobolus argutus.

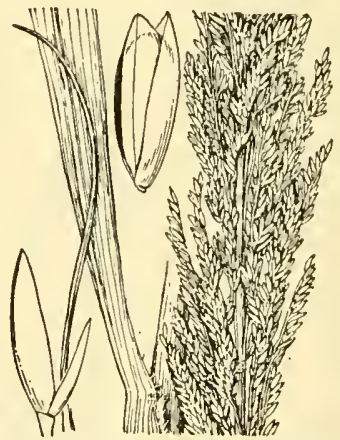

Figure 840.-Sporobolus do min. gensis. Plant, $\times 1$; glumes and floret, $\times$ 10. (Hitchcock 530, Fla.)

ground, Maine and Ontario to Alberta and Washington, south to North Carolina, Indiana, Louisiana, Arizona, and northern Mexico (fig. 842).

21. Sporobolus flexuósus (Thurb.) Rydb. Mesa DROPsend. (Fig. 841, B.) Resembling S. cryptandrus, differing in the more open often elongate panicles, the slender branches and branchlets spreading 
MANUAL OF THE GRASSES OF THE UNITED STATES 405

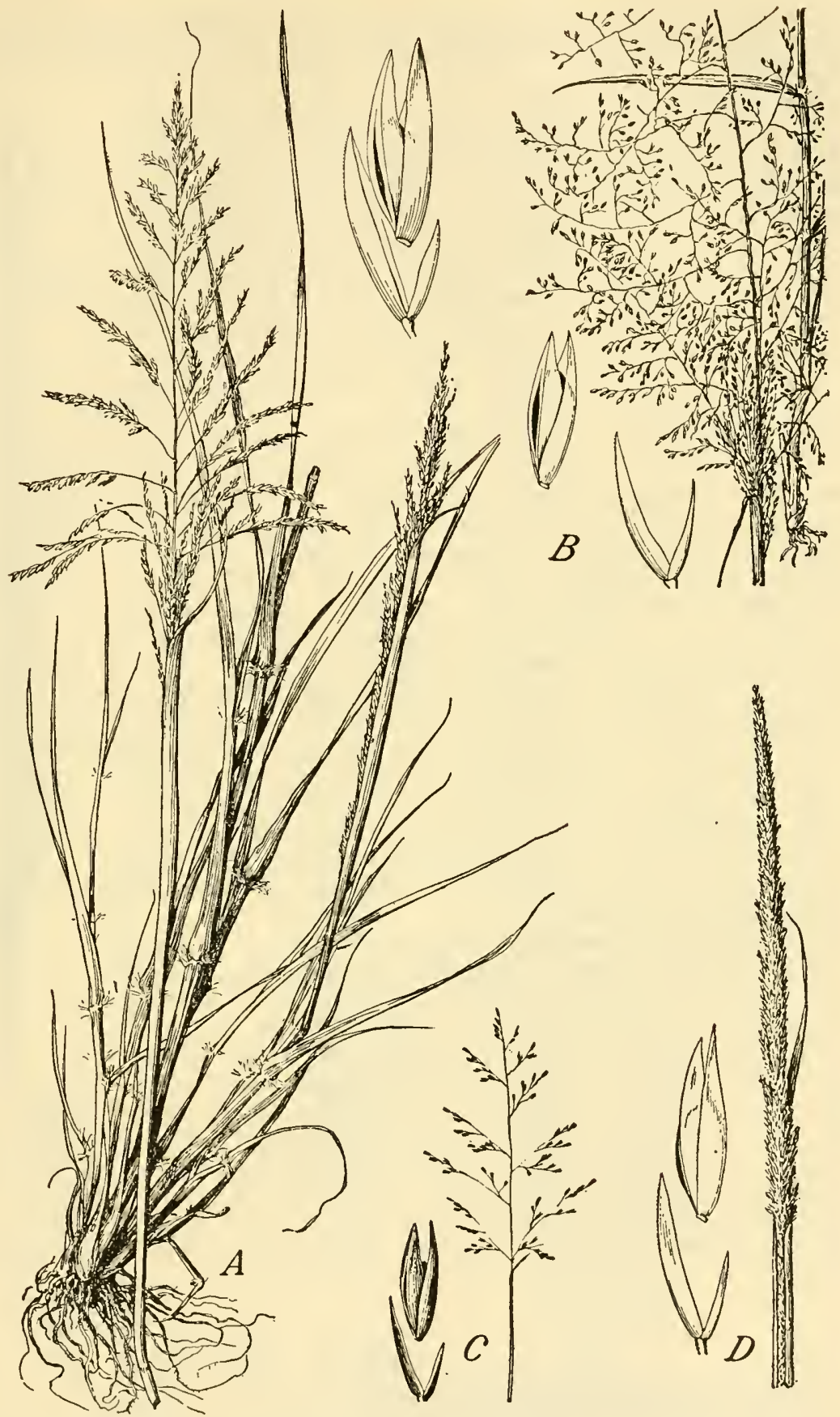

Figure 841- -4 , Sporobolus cryptnndrus. Plant, $\times 1 / 2$; glumes and floret, $\times 10$. (Shear 253, Nebr.) $B$, $S$. Rexusus. Plant, $\times 1 / 2$; glumes and floret, $\times 10$. $^{2}$ (Vasey, N.Mex.) $C, S$. nealleyi. Panicle, $\times 1 / 2$; glumes and floret, $\times 10$. (Nealley, Tex.) D, S. contractus. Panicle, $\times 1 / 2$; glumes and floret, $\times 10$. (Pringle, Ariz.) 
or drooping, flexuous, loosely flowered. 21 -Mesas, western Texas to southern Utah, southeastern California, and northern Mexico (fig. 843).

22. Sporobolus nealléyi Vasey. Nealley dropseed. (Fig. 841, C.) Resembling dwarf forms of S. cryptandrus, but differing in the loose rhizomatous base; culms slender, erect, 15 to $40 \mathrm{~cm}$ tall; blades slender, involute, squarrose-spreading, mostly less than $5 \mathrm{~cm}$ long; panicle

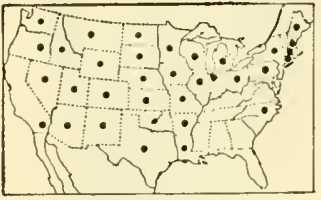

Frgure 842.-Distribution of Sporobolus cryplandrus. delicate, open, 3 to $8 \mathrm{~cm}$ long sometimes enclosed in the sheaths, the branches and branchlets spreading, the spikelets less crowded than in S. cryptandrus. $24-\mathrm{G}$ y p su $\mathrm{m}$ sands, western Texas and New Mexico.

23. Sporobolus contráctus Hitchc. SPIKE DRoPsEed. (Fig. $841, D$.) Differing from S. cryptandrus in the spikelike panicle as much as $50 \mathrm{~cm}$ long, usually included at the base, rarely entirely included in the sheath. 24 ( $S$. strictus Merr.)-Mesas, dry bluffs, and sandy fields, Colorado to Nevada, south to western Texas, south-

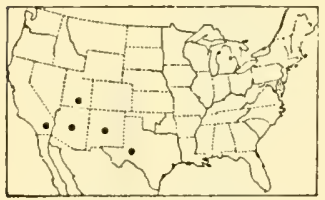

Figure 843.-Distribution of Sporobolus flexuosus. eastern California, and Sonora; adventive in Maine (fig. 844).

24. Sporobolus gigantéus Nash. GIANT DROPSEED. (Fig. 845.) Resembling S. cryptandrus and $S$. contractus; culms 1 to $2 \mathrm{~m}$ tall, erect, robust; blades as much as 1 $\mathrm{cm}$ wide; panicle usually thicker than in S. contractus, less spikelike; spikelets 2.5 to $3 \mathrm{~mm}$ long. 2 -Mesas and sandhills, western Texas to Arizona.

25. Sporobolus buckléyi Vasey. (Fig. 846.) Perennial, the base strongly compressed; culms erect, slender, 40 to $80 \mathrm{~cm}$ tall; sheaths keeled, pubescent on the margin

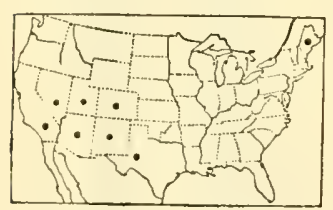

FIGURE 844.-Distribution of Sporobolus contractus. and collar; blades flat, 4 to $7 \mathrm{~mm}$ wide; panicle open, 10 to $30 \mathrm{~cm}$ long, the slender branches widely spreading, as much as $10 \mathrm{~cm}$ long, solitary, rather distant, naked below, with closely-flowered shortappressed branchlets above; spikelets about $1.5 \mathrm{~mm}$ long;

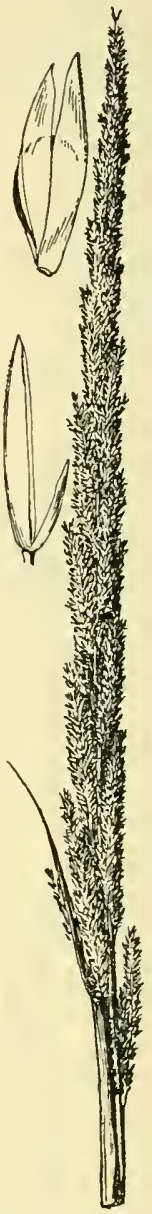

FIGURE 845.Sporobolus giganteus. Panicle, $\times 1 / 2$; glumes and floret, $\times 10$. ( Nealley, Tex.) glumes narrow, the first a little shorter, the second a little

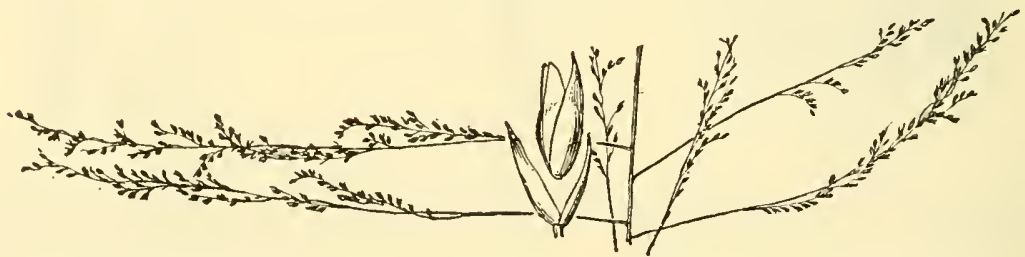

Figure 846. -Sporobolus buckleyi. Panicle, $\times 1 / 2$; glumes and floret, $\times 10$. (Nealley, Tex.) 


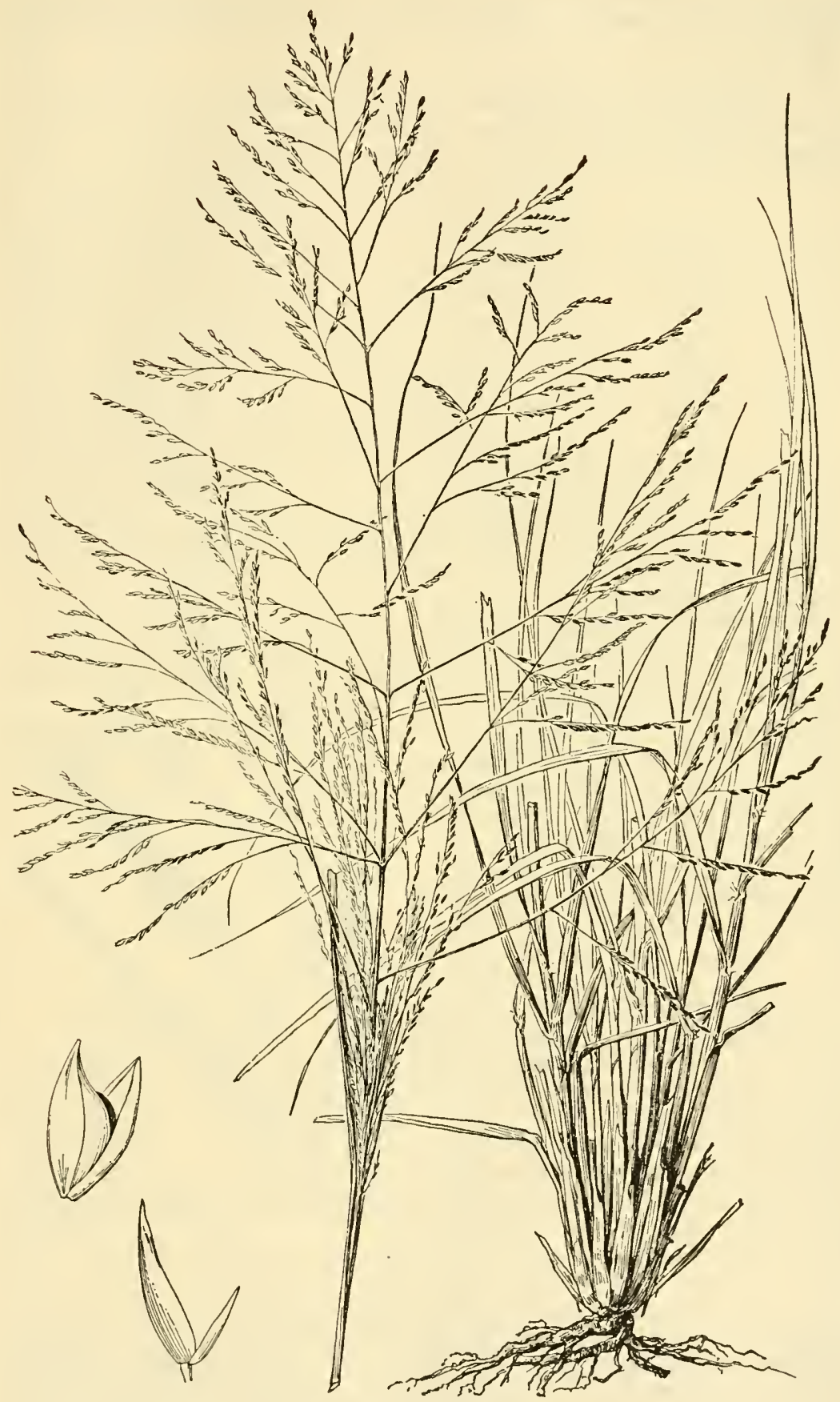

Figure 847.-Sporobolus airoides. Plant, $\times 1 \frac{1}{2}$; glumes and floret, $\times 10$. (Metcalfe, N.Mex.) 
longer, than the acute lemma; palea about as long as the lemma, splitting as the grain (1 mm long) ripens. 21 -Texas and eastern Mexico.

26. Sporobolus airoídes (Torr.) Torr. Alkali sacaton.

(Fig. 847.) Perennial, in large tough bunches; culms erect to spreading, 50 to $100 \mathrm{~cm}$ tall; sheaths pilose at the throat; ligule pilose; blades elongate, flat, soon becoming involute, usually less than $4 \mathrm{~mm}$ wide, often flexuous; panicle nearly half the entire height of the plant, at

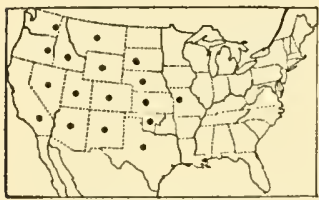

Figure 848.-Distribution of Sporobolus airoides. maturity half to two-thirds as wide as long, the stiff slender branches and branchlets finally widely spreading, naked at base, the spikelets aggregate along the upper half to two-thirds; spikelets 2 to $2.5 \mathrm{~mm}$ long, the first glume about half as long, commonly falling toward maturity; second glume, lemma, and palea about equal, the palea splitting as the grain ripens. $21-$ Meadows and valleys, especially in moderately alkaline soil, South Dakota to eastern Washington, south to Texas and southern California (fig. 848). Mature spikelets with the first glume fallen and the palea split to the base are puzzling to the beginner. Less mature complete spikelets will usually be found at the base of the panicle. A good forage grass in alkaline regions; often called bunchgrass.

27. Sporobolus wríghtii Munro. SaCaton. (Fig. 849.) Perennial, in large dense tufts; culms robust, erect, firm and hard, 1 to $2 \mathrm{~m}$ tall; sheaths sparsely pilose at the throat; ligule pilose; blades elongate, flat, involute in drying, 3 to 6 $\mathrm{mm}$ wide; panicle pale, narrow, open, mostly 30 to $60 \mathrm{~cm}$ long, the branches crowded, straight, stiffly ascending, the branchlets appressed, closely flowered from the base or nearly so; spikelets 2 to $2.5 \mathrm{~mm}$ long, the first glume about one-third as long, the second two-thirds to three-fourths as long, acute; lemma and palea about equal. 2 -Mesas and valleys, southern and western Texas to southern California and central Mexico (fig. 850). Useful for grazing when young; also furnishes hay and makes good winter range.

28. Sporobolus texánus Vasey. (Fig. 851.) Perennial, in close hemispherical tufts; culms erect to spreading, slender, wiry, 30 to $50 \mathrm{~cm}$ tall;

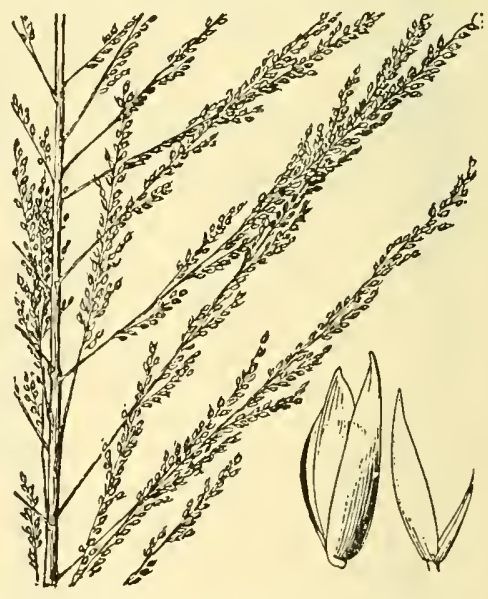

Figure 849.-Sporobolus wrightii. Panicle, $\times 1 /$ glumes and floret, $\times 10$. (Hitchcock 3648 , Ariz.)

sheaths pilose at the throat, the lower of ten papillose-pilose on the surface; blades flat, involute in drying, mostly less than $10 \mathrm{~cm}$ long, 1 to $4 \mathrm{~mm}$ wide; panicle open, rather diffuse, breaking away at maturity, 15 to $30 \mathrm{~cm}$ long, about as wide, the capillary scabrous branches, branchlets, and long pedicels stiffly spreading; spikelets about $2.5 \mathrm{~mm}$ long, the first glume acute, one-third to half as long, the second acuminate, slightly exceeding the acute lemma and palea, the palea early splitting. 2 -Mesas, valleys, and salt marshes, Kansas to Colorado, Texas, and New Mexico (fig. 852). 
29. Sporobolus thárpii Hitchc. (Fig. 853.) Perennial, densely tufted; culms 60 to $100 \mathrm{~cm}$ tall; sheaths glabrous, the lower firm, loose, shining; blades elongate, involute, flexuous, about $1 \mathrm{~mm}$

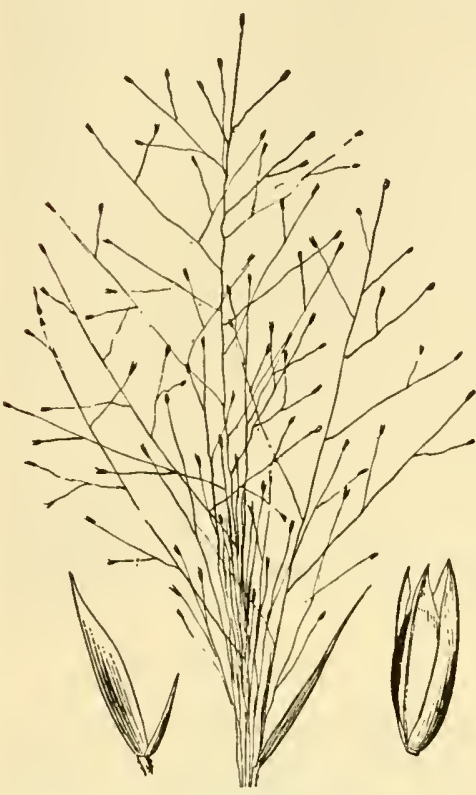

Figure 851.-Sporobolus texanus. Panicle, $X$ 1/2; glumes and floret with caryopsis, $X 10$. (Nealley, Tex.)

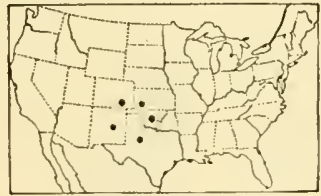

Figure 852.-Distribution of Sporobolus texanus.

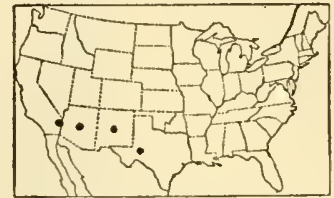

FIGURE 850.-Distribution of Sporobolus wrightii.

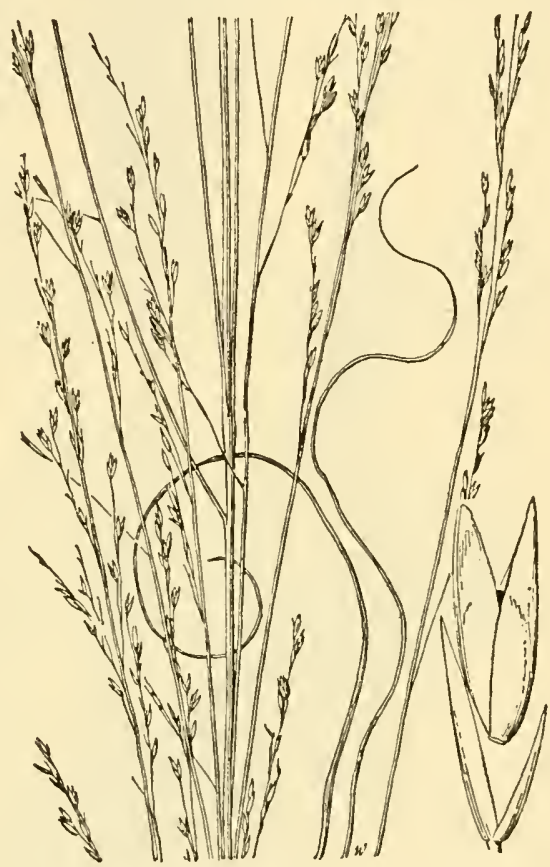

Figure 853.-Sporobolus tharpii. Panicle, $\times 1$; glumes and floret, $\times 10$. (Type.)

thick, tapering to a long fine point, long-ciliate at base; panicle open, as much as $30 \mathrm{~cm}$ long, the branches stiffly ascending, the lower as much as $15 \mathrm{~cm}$ long; spikelets appressed along the nearly simple branches and branchlets, about $3 \mathrm{~mm}$ long; first glume narrow, acuminate, about half as long as the spikelet, the second glume, lemma, and palea acute, about equal. 24 -Known only from Padre Island, Tex.

\section{BLEPHARONEÚRON Nash}

Spikelets 1-flowered, the rachilla disarticulating above the glumes; glumes subequal, rather broad; lemma 3-nerved, the nerves densely silky villous; palea densely villous between the two nerves. Tufted perennial, with open, narrow panicles. Type species, Blepharoneuron tricholepis. Name from Greek blepharis, eyelash, and neuron, nerve, alluding to the villous nerves of the lemma. 
1. Blepharoneuron trichólepis (Torr.) Nash. Hairy dropseed.

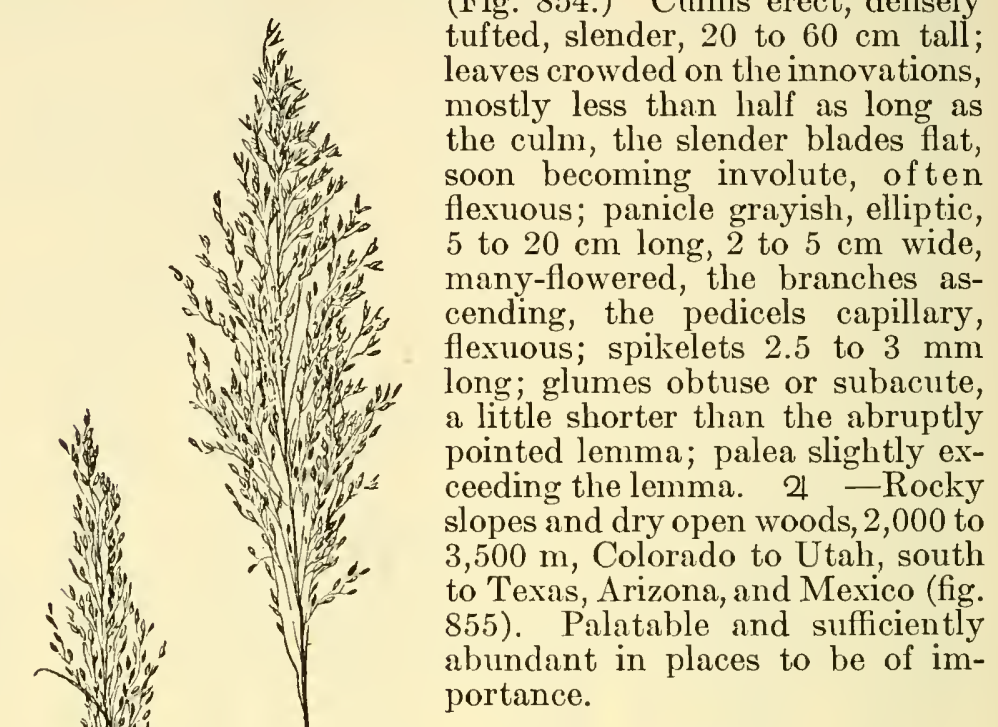

\section{CRÝPSIS Ait.}

Spikelets 1-flowered, disarticulating below the glumes; glumes about equal, narrow, acute; lemma broad, thin, 1-nerved; palea similar to the lemma, about as long, splitting between the nerves;
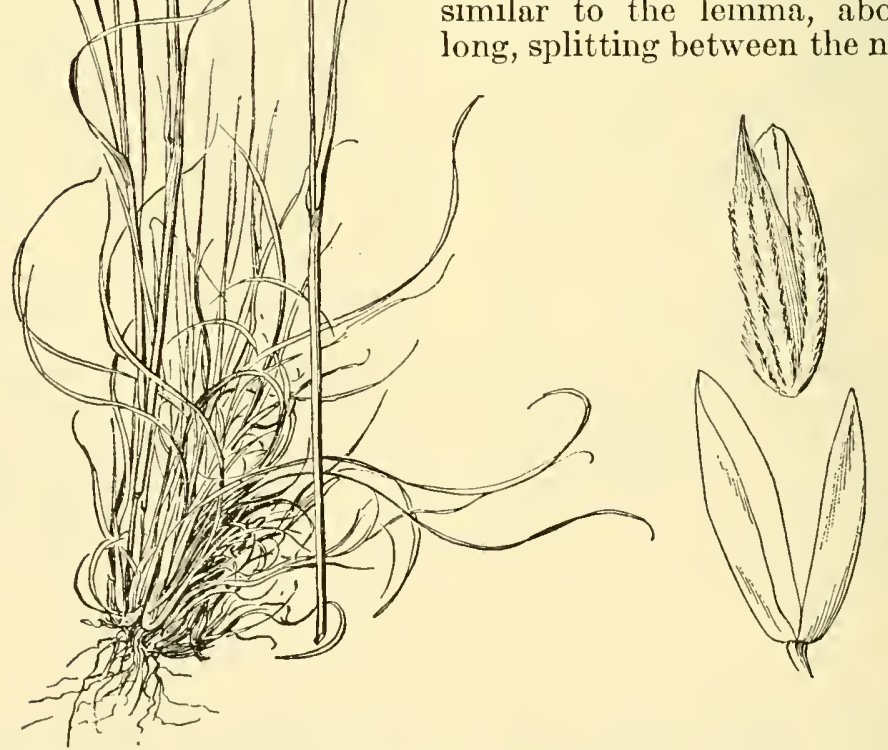

FigUre 854.-Blephatoneuron tricholepis. Plant, $\times 1 \frac{1}{2}$; glumes and floret, $\times 10$. (Shear 1182, Colo.) fruit readily falling from the lemma and palea, the seed free from the 
thin pericarp (easily removed when wet). Spreading annual, with capitate inflorescences in the axils of a pair of broad spathes, these being enlarged sheaths with short rigid blades. Type species, Crypsis aculeata. Name from Greek krupsis, concealment, alluding to the partially hidden inflorescence.

1. Crypsis aculeáta (L.) Ait. (Fig. 856.) Freely branching, prostrate, the mats $30 \mathrm{~cm}$ in diameter, or of ten depauperate, 1 to $2 \mathrm{~cm}$ wide; blades small, sharp-pointed; heads numerous, 4 to $5 \mathrm{~mm}$ high, the spathes broader than long, their blades spreading; glumes about $3 \mathrm{~mm}$

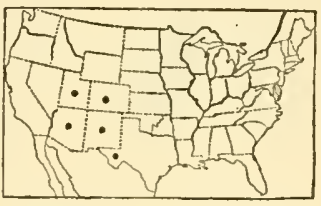

Figure 855.-Distribution of Blepharoneuron tricholepis. long, ninutely hispid; lemma about as long as the glumes, scabrous on the keel. $\odot$-Overflowed land of the interior valley, California; introduced from Europe.

\section{HELEOCHLOA Host}

Spikelets 1-flowered, the rachilla disarticulating above the glumes; glumes about equal, narrow, acute; lemma broader, thin, 1-nerved, a little longer than the glumes; palea nearly as long as the lemma, readily splitting between the nerves. Low spreading annuals with

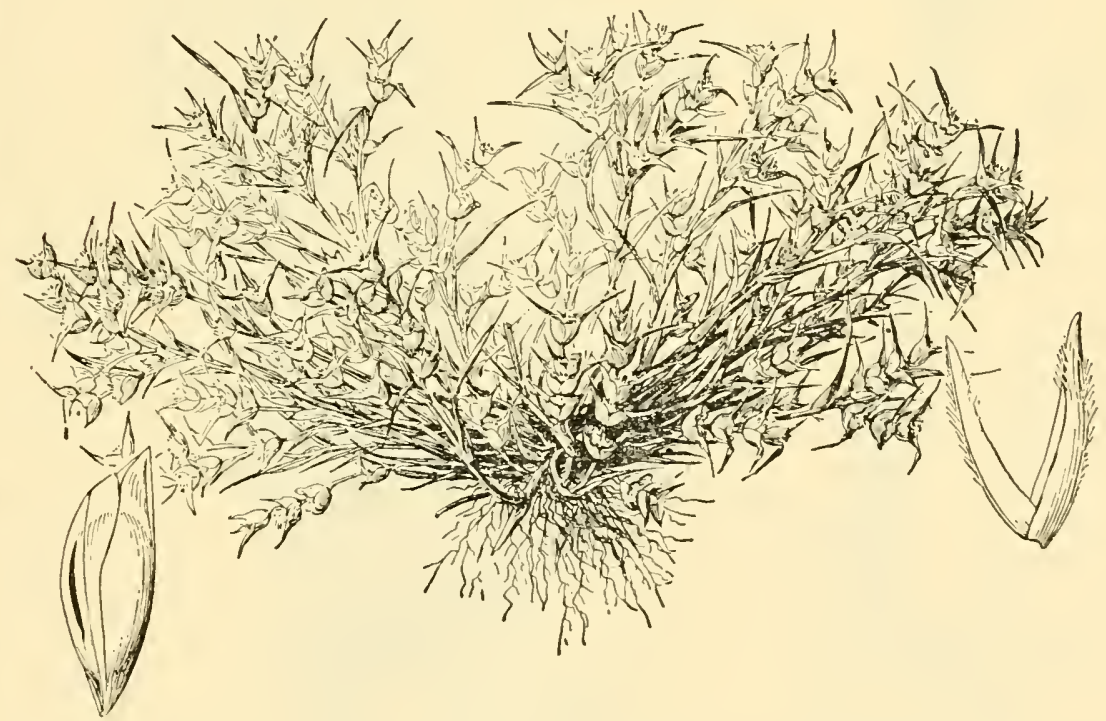

Figure 856.-Crypsis aculeata. Plant, $\times 1 / 2$; glumes and floret, $\times 10$. (Brandegee, Calif.)

oblong, dense, spikelike panicles, the subtending leaves with inflated sheaths and reduced blades. Type species, Heleochloa alopecuroides. Name from Greek helos, marsh, and chloa, grass, alluding to the habitat of the type species.

1. Heleochloa schoenoídes (L.) Host. (Fig. 857, A.) Culms tufted, branching, erect to spreading and geniculate, 10 to $30 \mathrm{~cm}$ long; sheaths often somewhat inflated; blades flat, with involute slender tips, mostly less than $10 \mathrm{~cm}$ long, 2 to $4 \mathrm{~mm}$ wide; panicle pale, 1 to $4 \mathrm{~cm}$ 
long, 8 to $10 \mathrm{~mm}$ thick; spikelets about $3 \mathrm{~mm}$ long. $\odot \quad-$ Waste

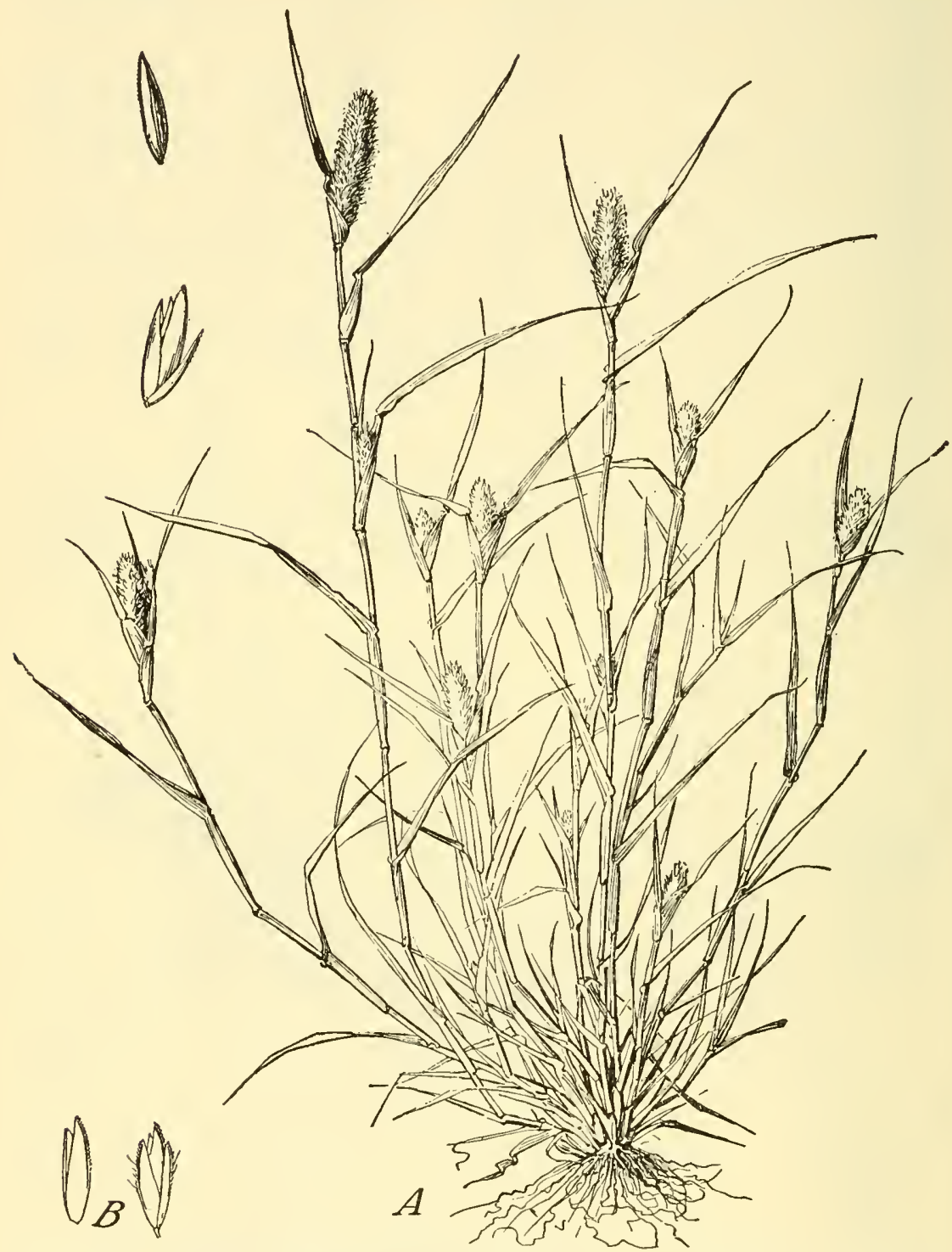

Figure 857. $-A$, Heleochloa schoenoides. Plant, $\times 1 / 2$; spikelet and floret, $\times 5$. (Smith, Pa.) $B, H$. alopecuroides, $\times 5$. (Burk, Pa.)

places, Massachusetts to Delaware, Michigan, and Illinois (fig. 858); introduced from Europe.

Heleochloa alopecuroídes (Pill. and Mitterp.) Host. (Fig. 857, B.) Differing from H. schoenoides in the more slender panicles, 4 to $5 \mathrm{~mm}$ thick, exserted at maturity; spikelets about 2 $\mathrm{mm}$ long. $\odot$-Ballast, Philadolphia and near Portland, Oreg. Europe.

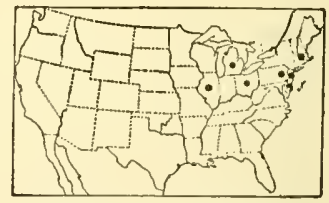

Figure 858.-Distribution of Heleochloa schoenoides. 
MANUAL OF THE GRASSES OF THE UNITED STATES 413

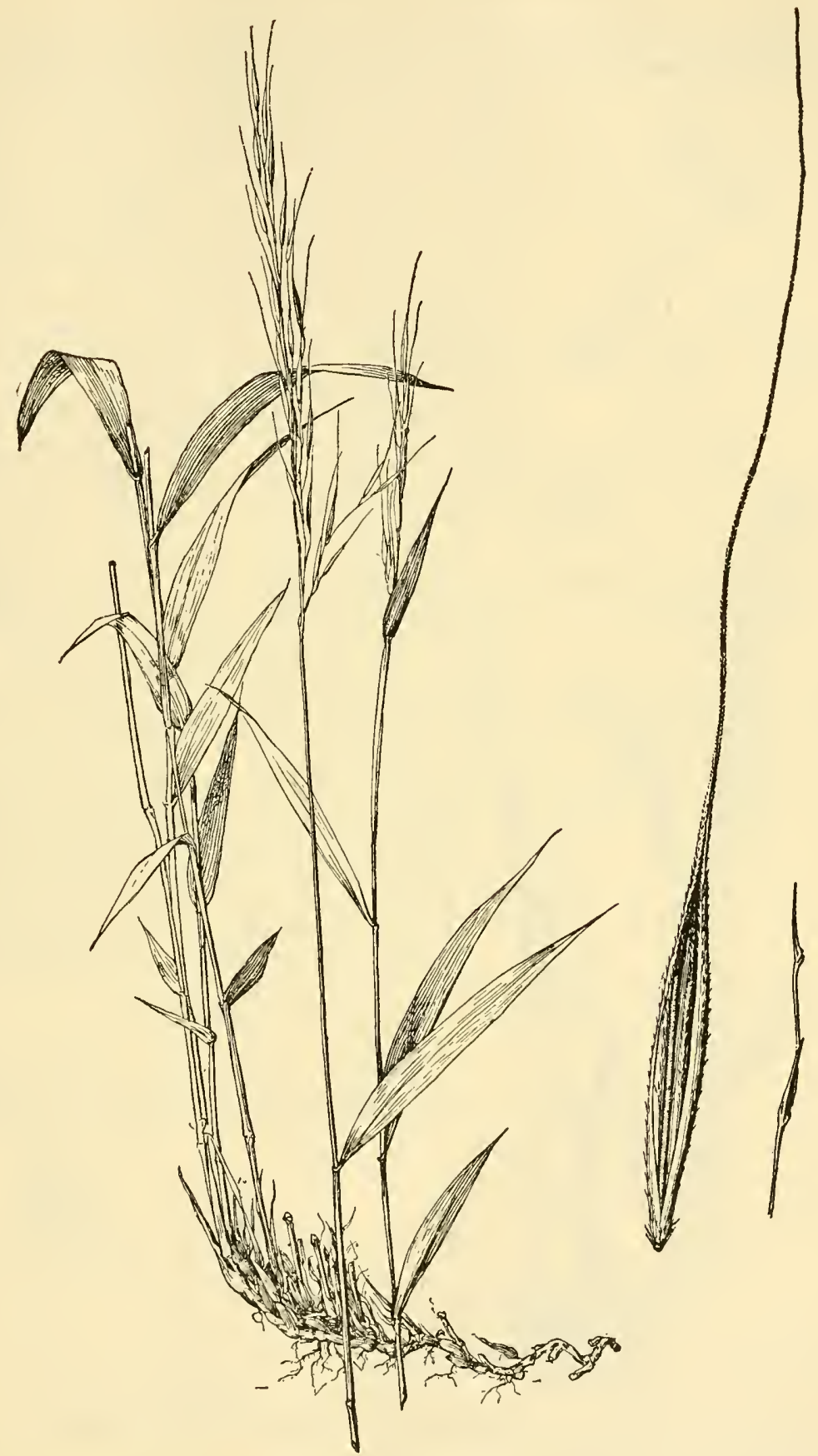

FIGURE 859.-Brachyelytrum erectum. Plant, $\times 1 / 2$; branchlet with glumes of t,wo spikelets, and floret, $\times 5$ (Bissell, Conn.) 


\section{BRACHYÉLYTRUM Beauv.}

Spikelets 1-flowered, the rachilla disarticulating above the glumes, prolonged behind the palea as a slender naked bristle; glumes minute,

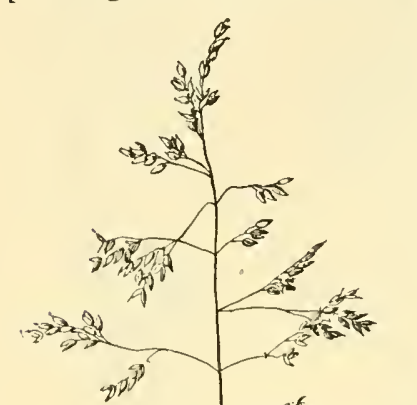

the first often obsolete, the second sometimes awned; lemma firm, narrow, 5nerved, the base extending into a pronounced oblique callus, the apex terminating in a long straight scabrous awn. Erect, slender perennials with short knotty rhizomes, flat blades, and narrow, rather few-flowered panicles. Type species, Brachyelytrum erectum. Name from Greek brachus, short, and elutron, cover or husk, alluding to the short glumes.

1. Brachyelytrum eréctum (Schreb.) Beauv. (Fig. 859.) Culms 60 to 100 $\mathrm{cm}$ tall; sheaths sparsely retrorse-hispid, rarely glabrous; blades mostly 7 to 15 cm long, 1 to $1.5 \mathrm{~cm}$ wide, scabrous, sparingly pilose beneath, at least on the nerves and margin; panicle 5 to 15 cm long, the

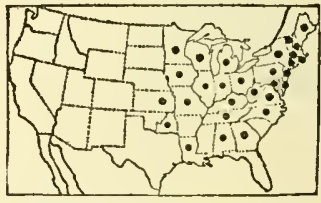

Figure 860.-Distribution of Brachyelytrum erectum. short branches appressed; second glume 0.5 to $2 \mathrm{~mm}$ long; lemma subterete, about $1 \mathrm{~cm}$ long, scabrous, the nerves sometimes hispid, the awn 1 to $3 \mathrm{~cm}$ long. 2 4 -Moist or rocky woods, Newfoundland to Minnesota, south to Georgia and Oklahoma (fig. 860).

\section{MÍLIUM L.}

Spikelets 1-flowered, disarticulating above the glumes; glumes
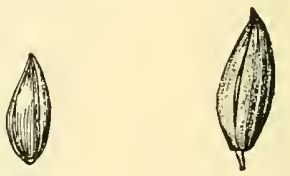

Figure 861.-Milium effusum. Plant, $\times 1 / 2$; spikelet and floret, $\times 5$. (Phillips, Maine.)

equal, obtuse, membranaceous, rounded on the back; lemma a little shorter than the glumes, obtuse, obscurely nerved, rounded on the back, dorsally compressed, in fruit becoming indurate, smooth and 
shining, the margins enclosing the lemma as in Panicum. Moderately tall grasses with flat blades and open panicles. Type species, Milium effusum. Milium, old Latin name for millet.

1. Milium effúsum L. (Fig. 861.) Smooth perennial, somewhat succulent; culms slender, erect from a bent base, 1 to $1.5 \mathrm{~m}$ tall; blades mostly 10 to $20 \mathrm{~cm}$ long, flat, lax, 8 to $15 \mathrm{~mm}$ wide; panicle 10 to $20 \mathrm{~cm}$ long, the slender branches in remote spreading or drooping pairs or fascicles, naked below; spikelets pale, 3 to $3.5 \mathrm{~mm}$ long; glumes scaberulous. 21-Damp or rocky woods, Quebec and Nova Scotia to Minnesota, south to Maryland and Illinois (fig. 862); Eurasia.

\section{ORY'ZÓPSIS Michx. RICEgRASS}

Spikelets 1-flowered, disarticulating above the glumes; glumes about equal, obtuse to acuminate; lemma indurate, usually about as long as the glumes, broad, oval or oblong, nearly terete, usually pubescent, with a short, blunt, oblique callus, and a short deciduous, sometimes bent and twisted awn; palea enclosed by the edges of the lemma. Mostly slender perennials, with flat or often involute blades and terminal narrow or open panicles. Type species, Oryzopsis asperifolia. Name from oruza, rice, and opsis, appearance, alluding to

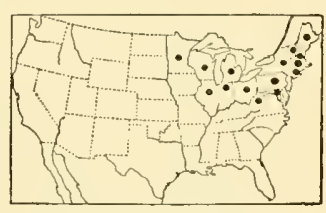

FIGURE 862.-Distribution of Milium effusum. a fancied resemblance to rice.

Nearly all the species are highly palatable to stock, but are usually not in sufficient abundance to be of importance, except $O$. hymenoides (Indian ricegrass), which is common in the arid and semiarid regions of the West and furnishes much feed. The seed has been used for food by the Indians. Locally important may be O. micrantha in the Black Hills region and O. kingii in the high Sierras. O. miliacea is sometimes cultivated for forage in California.

Lemma smooth (rarely pubescent in O. micrantha).

Blades flat, $5 \mathrm{~mm}$ wide or more. Spikelets numerous, about $3 \mathrm{~mm}$ long.

Blades more or less involute, less than $2 \mathrm{~mm}$ wide.

Panicle branches spreading or reflexed; fruit about $2 \mathrm{~mm}$ long, pale.

2. O. MICRANTHA.

Panicle branches ascending or appressed; fruit about $4 \mathrm{~mm}$ long, dark brown.

Lemma pubescent.

3. O. HENDERSONI.

Pubescence on lemma long and silky.

Panicle-branches and the capillary pedicels divaricately spreading.

Panicle-branches and pedicels erect or ascending.

12. O. HYMENOIDES.

Awn $6 \mathrm{~mm}$ long; culms usually not more than $30 \mathrm{~cm}$ tall.

Awn $12 \mathrm{~mm}$ long; culms 30 to $60 \mathrm{~cm}$ tall_........ 10. O. BLOOMERI.

Pubescence on lemma short, appressed.

Spikelets, excluding awn, 6 to $9 \mathrm{~mm}$ long; blades flat.

Basal blades elongate, uppermost not more than $1 \mathrm{~cm}$ long.

Basal blades reduced, upper elongate _........... 9. O. RACEMOSA.

Spikelets, excluding awn, $5 \mathrm{~mm}$ long or less; blades involute or subinvolute.

Panicle branches erect or appressed.

Blades and panicle stiff, erect; awns about $5 \mathrm{~mm}$ long- 4 . O. Exigua. Blades flexuous, the panicle somewhat so; awns at least $10 \mathrm{~mm}$ long.

Panicle branches loosely ascending or spreading.

7. O. KINGII.

Awn not more than $2 \mathrm{~mm}$ long, straight or nearly so 5 . O. pUNGENs.

Awn 10 to $20 \mathrm{~mm}$ long, weakly twice-geniculate _- 6. O. CANADENSIS.

$55974^{\circ}-35-27$ 
1. Oryzopsis miliácea (L.) Benth. and Hook. (Fig. 863.) Culms relatively stout, sometimes branching, erect from a decumbent base, 60 to $150 \mathrm{~cm}$ tall; ligule about $2 \mathrm{~mm}$ long; blades flat, 8 to $10 \mathrm{~mm}$ wide; panicle 15 to $30 \mathrm{~cm}$ long, loose, the branches spreading with numerous short-pediceled spikelets beyond the middle; glumes acuminate, $3 \mathrm{~mm}$ long; lemma smooth, $2 \mathrm{~mm}$ long, the straight awn about $4 \mathrm{~mm}$ long. 24 -Introduced in a few localities in California; ballast, Camden, N.J., and Philadelphia, Pa.; Mediterranean region.

2. Oryzopsis micrantha (Trin. and Rupr.) Thurb. Littrleseed RICEgrass. (Fig. S64.) Culms densely tufted, ereet, slender, 30 to

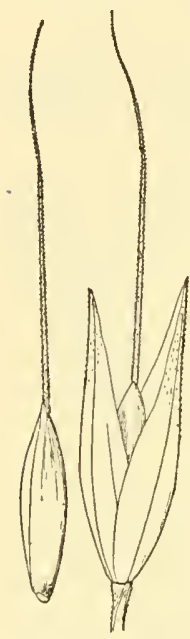

Figure 863.-Oryzopsis miliacea, $\times 5 . \quad(\mathrm{Kralik}$, Europe.)
$70 \mathrm{~cm} \mathrm{tall}$; ligule about $1 \mathrm{~mm}$ long; blades slender, scabrous, flat or involute, 0.5 to $2 \mathrm{~mm}$ wide; panicle open, 10 to $15 \mathrm{~cm}$ long, the branches distant, single or in pairs, spreading or finally reflexed, 2 to $5 \mathrm{~cm}$ long, with short-pediceled appressed spikelets toward the ends; glumes thin, acuminate, 3 to $4 \mathrm{~mm}$ long; lemma elliptic, glabrous, or rarely appressed-pilose, 2 to 2.5 $\mathrm{mm}$ long, yellow or brown, the straight awn 5 to $10 \mathrm{~mm}$ long. 21 -Open dry woods and rocky slopes, me-

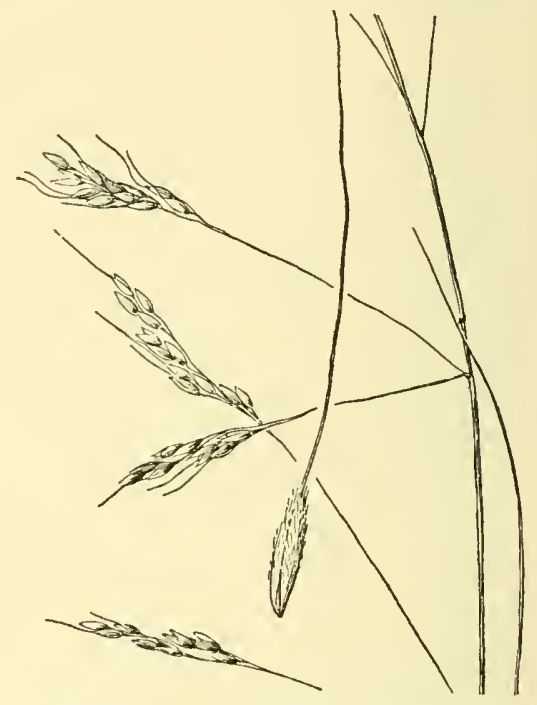

FIGURE 864.-Oryzopsis micrantha. Panicle, $\times 1$; floret $\times 5$. (Hitcheock 22993, N. Mex.)

dium altitudes, Saskatchewan to Montana, south to New Mexico and Arizona (fig. 865). The form with pilose lemmas is found from Colorado to Arizona.

3. Oryzopsis hendersóni Vasey. (Fig. 866.) Culms densely tufted, scabrous, 10 to $40 \mathrm{~cm}$ tall; leaves mostly basal, the sheaths

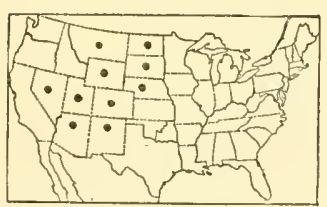

Figure 865.-Distribution of Oryzopsis micrantha. broad, papery, glabrescent; ligule very short; blades subfiliform, involute, scabrous, firm, mostly less than $10 \mathrm{~cm}$ long, the one or two culm blades 4 to $5 \mathrm{~cm}$ long; panicle fewflowered, 5 to $12 \mathrm{~cm}$ long, the few scabrous branches appressed or ascending, spikeletbearing toward the ends, the lower as much as $8 \mathrm{~cm}$ long; spikelets short-pediceled; glumes abruptly acute, 5 to $6 \mathrm{~mm}$ long; lemma nearly as long as the glumes, glabrous, dark brown at maturity, the awn early deciduous, nearly straight, 6 to $10 \mathrm{~mm}$ long. 24 - Dry or gravelly soil. Known only from Mount Clements, Wash., and from the Ochoco National Forest, Oreg.

4. Oryzopsis exígua Thurb. Little ricegrass. (Fig. 867.) Culms densely tufted, stiffly erect, scabrous, 15 to $30 \mathrm{~cm}$ tall; sheaths smooth or somewhat scabrous; ligule 2 to $3 \mathrm{~mm}$ long; blades involutefiliform, stiffly ereet, scabrous, 5 to $10 \mathrm{~cm}$ long, the culm blades about 
2 , shorter; panicle narrow, 3 to $6 \mathrm{~cm}$ long, the branches appressed, the lower 1 to $2 \mathrm{~cm}$ long; spikelets short-pediceled, glumes abruptly acute, $4 \mathrm{~mm}$ long; lemma appressed-pilose, about as long as the glumes, the awn about $5 \mathrm{~mm}$ long, not twisted, geniculate. 21 -Dry open

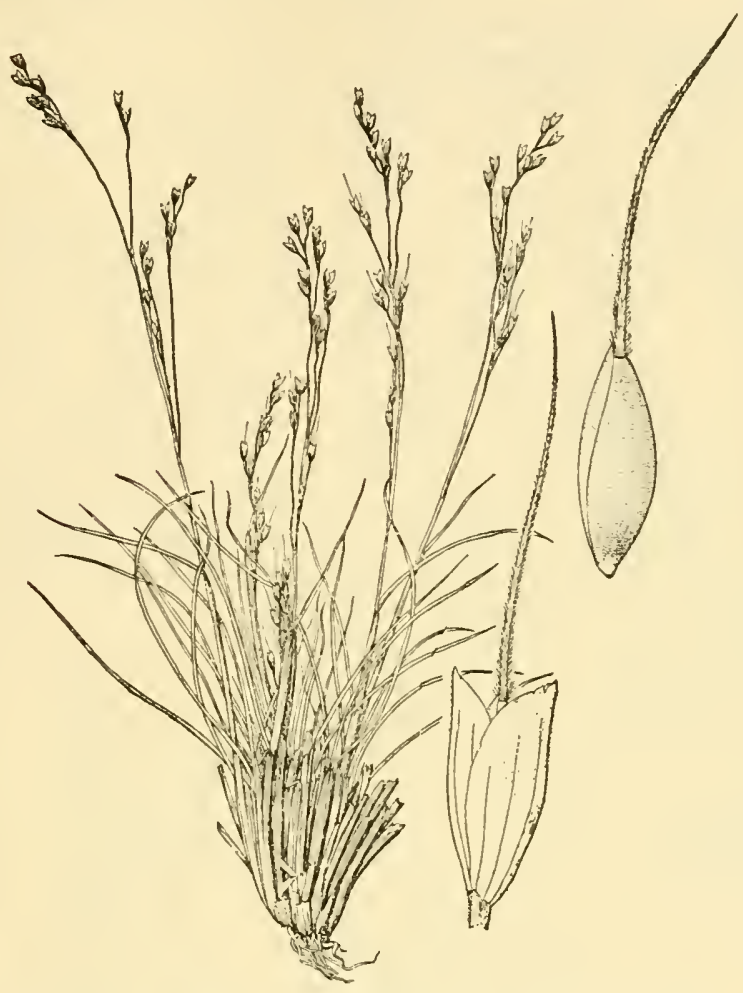

FigURE 866.-Oryzopsis hendersoni. Plant, $\times 1 / 2$; spikelet and floret, $\times 5$. (Type.)

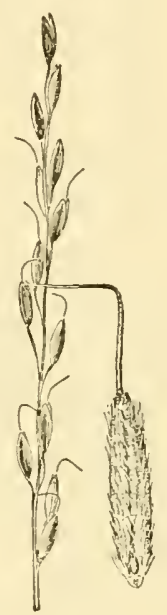

FIGURE 867.-Oryzopsis exigua. Panicle, $\times 1$; floret, $\times 5$. (Nelson 6511, Wyo.)

ground or open woods, at moderately high altitudes, Montana to Washington, south to Colorado, Oregon, and Nevada (fig. 868).

5. Oryzopsis púngens (Torr.) Hitchc. (Fig. 869.) Culms tufted, erect, slender, 20 to $50 \mathrm{~cm}$ tall; blades elongate, slender, flat or

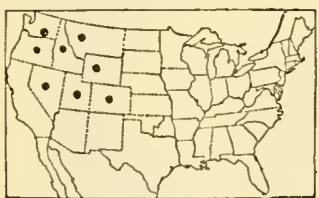

Figtre 868.-Distribution of Oryzopsis exigua. involute, less than $2 \mathrm{~mm}$ wide; panicle narrow, 3 to $6 \mathrm{~cm}$ long, the branches erect or ascending or spreading in anthesis; spikelets long-pediceled; glumes 3 to $4 \mathrm{~mm}$ long, obscurely 5 -nerved, obtuse; lemma about as long as the glumes, rather densely pubescent, the awn usually 1 to 2 mm long. 21 -Sandy or rocky soil, Labrador to British Columbia, south to Connecticut, Indiana, South Dakota, and Colorado (fig 870).

6. Oryzopsis canadénsis (Poir.) Torr. (Fig. 871.) Culms slender, tufted, erect, 30 to $70 \mathrm{~cm}$ tall; ligule about $2 \mathrm{~mm}$ long; blades flat to involute, scabrous; panicle open, 5 to $10 \mathrm{~cm}$ long, the slender flexuous branches ascending or spreading, naked below, few-flowered above; 
spikelets long-pediceled; glumes 4 to $5 \mathrm{~mm}$ long, abruptly acute; lemma about $3 \mathrm{~mm}$ long,

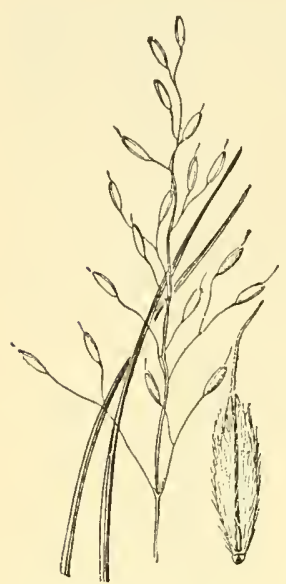

Figure S69.-Oryzopsis pungens. Panicle, $\times 1$; floret, $\times 5$. (Grout, $\mathrm{Vt}$.) rather sparsely appressedpilose, the awn 1 to $2 \mathrm{~cm}$ long, weakly twice geniculate. $24-$ Woods and thickets, Newfoundland to Alberta, south to New Hampshire, New York, northern Michigan, and northern Minnesota (fig. 872).

7. Oryzopsis kíngii (Boland.) Beal. (Fig. 873.) Culms tufted, slender, 20 to $40 \mathrm{~cm}$ tall; leaves numerous at the base, the blades involute, filiform, flexuous;

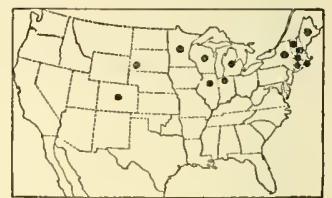

FIGURE 870.-Distribution of Oryzopsis pungens.

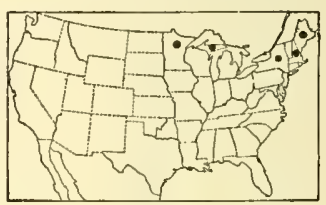

Figure 872,-Distribution of Oryzopsis canadensis. ligule about $1 \mathrm{~mm}$ long; panicle narrow, loose, the short slender branches appressed or ascending, few-flowered; spikelets rather short-pediceled; glumes broad, papery, nerveless, obtuse, purple at base, the first about $3.5 \mathrm{~mm}$ long, the second a little longer; lemma elliptic, 3 to $3.5 \mathrm{~mm}$ long, rather sparingly appressed-pubescent; awn bent in a wide curve or indistinctly geniculate below the middle, not twisted, minutely pubescent, about $12 \mathrm{~mm}$ long, not readily deciduous. 2 -Meadows at upper altitudes, central Sierra Nevada, Calif.

8. Oryzopsis asperifólia Michx. (Fig. 874.) Culms tufted, the innovations erect, the fertile culms widely spreading or prostrate, 20 to $70 \mathrm{~cm}$ long, nearly naked, the two or three sheaths bearing reduced or obsolete blades; basal blades erect, firn,

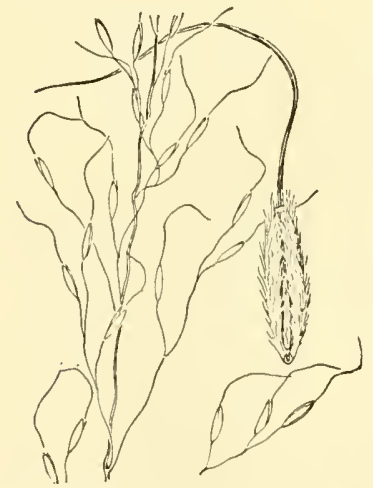

Figure 871.-Oryzopsis canadensis. Panicle, $\times 1$; floret, $\times 5$. (Rand, Maine.) scabrous, flat to somewhat revolute, elongate, 3 to 8 $\mathrm{mm}$ wide, tapering toward each end, glaucous beneath; panicle nearly simple, rather few-flowered, 5 to $8 \mathrm{~cm}$ long, the branches appressed; spikelets on appressed pedicels 3 to 6 $\mathrm{mm}$ long; glumes 6 to $\mathrm{S}$ $\mathrm{mm}$ long, somewhat obovate, about 7-nerved, abruptly pointed or apiculate; le mma about as long as the glumes, sparingly pubescent, more densely so on the callus, pale or yellowish at

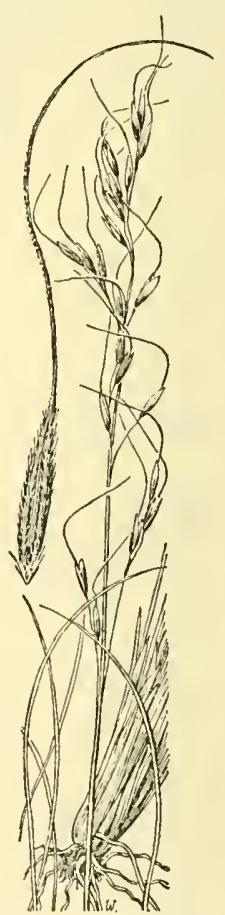

Figure 873.-Oryzopsis kingii. Plant, $\times 1$; floret, $\times 5$. (Bolander 6097, Calif.) maturity, the awn 5 to $10 \mathrm{~mm}$ long. 21 - Wooded slopes and 


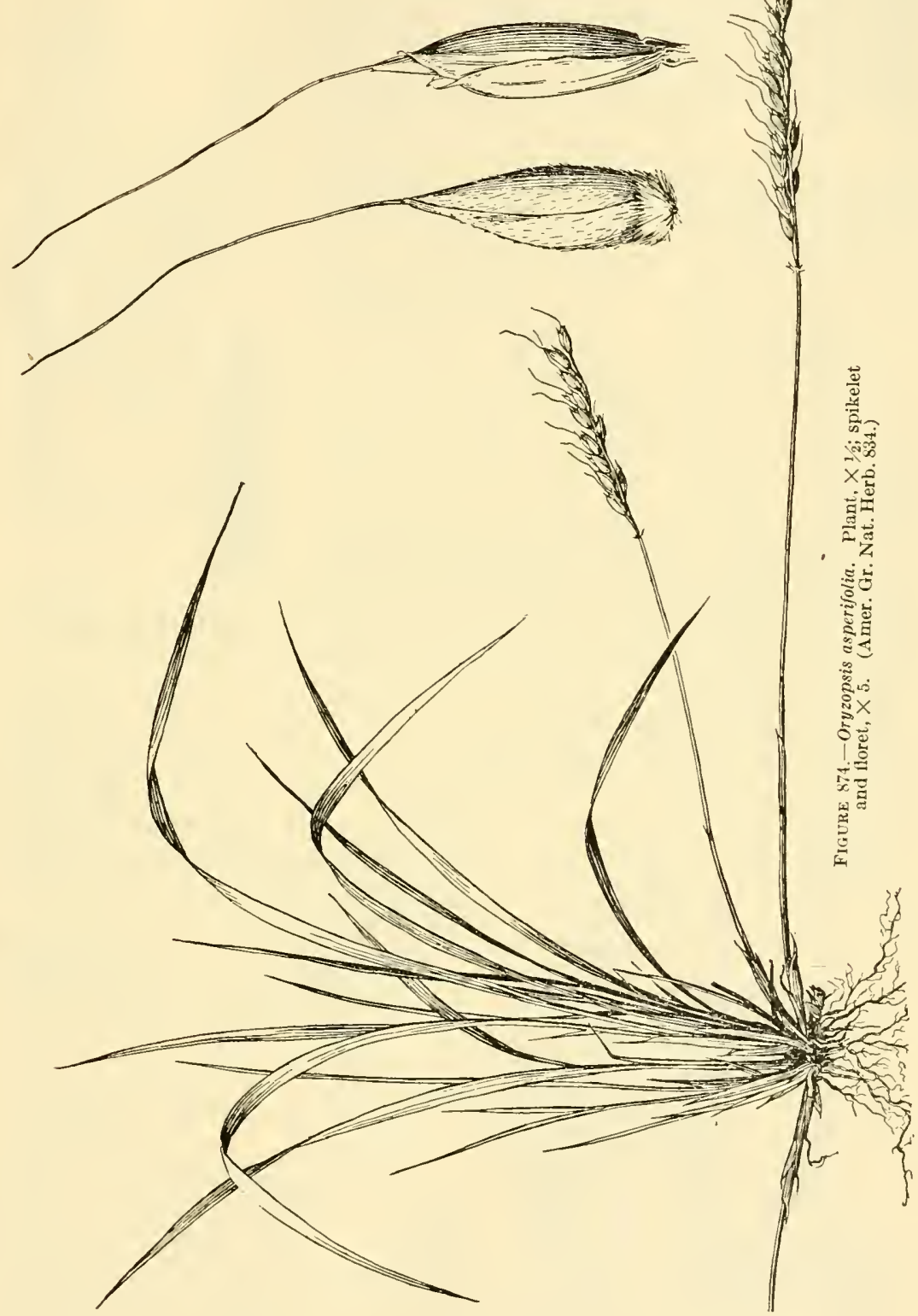


dry banks, Newfoundland to British Columbia and Montana, south to Connecticut, Indiana, South Dakota, and New Mexico (fig. 875).

9. Oryzopsis racemósa (J. E. Smith) Ricker. (Fig. 876.) Culms tufted, from a knotty rhizome, erect, 30 to $100 \mathrm{~cm}$ tall; culm leaves several, the lowermost blades reduced, the others elongate, flat, 5 to $15 \mathrm{~mm}$ wide, tapering at both ends, rather thin, scabrous above, pubescent beneath; panicle 10 to $20 \mathrm{~cm}$ long, the branches distant,

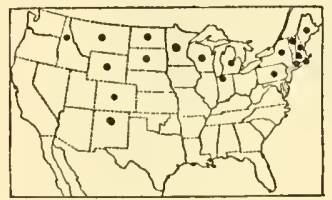

Figure 875.-Distribution of Oryzopsis asperifolia. the lower spreading or reflexed at maturity, bearing a few spikelets toward the end; glumes 7 to $9 \mathrm{~mm}$ long, about 7-nerved, abruptly acuminate; lemma slightly shorter than the glumes sparsely pubescent, nearly black at maturity, the awn 1.5 to $2.5 \mathrm{~cm}$ long, slightly flexuous. 24 -Rocky woods, Quebec to Minnesota and South Dakota, south to Delaware, Kentucky, and Iowa (fig. 877).

10. Oryzopsis blooméri (Boland.) Ricker. (Fig. 878.) Culms tufted, 30 to $60 \mathrm{~cm}$ tall; leaves crowded at the base; ligule about $1 \mathrm{~mm}$ long; blades narrow, involute, firm; panicle 7 to $15 \mathrm{~cm}$ long, the branches slender, rather stiffly ascending, the longer 5 to $7 \mathrm{~cm}$ long,

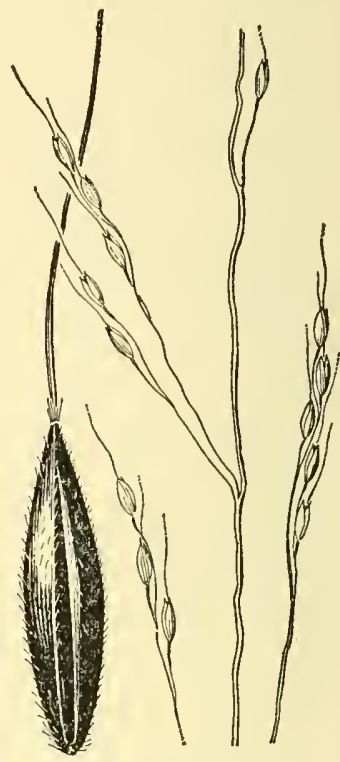

Figure 876.-Oryzopsis racemosa. Panicle, $\times 1 / 2$; floret, $X 5$. (Sartwell, N.Y.) spikelet-bearing from about the middle; spikelets rather long-pediceled; glumes broad, indistinctly 3- to 5-nerved, rather abruptly acuminate, 8 to $10 \mathrm{~mm}$ long; lemma elliptic, $5 \mathrm{~mm}$ long, densely long-

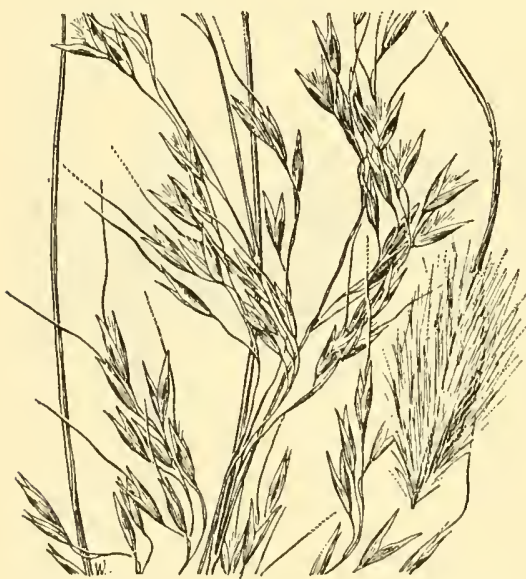

Figure 878.-Oryzopsis bloomeri. Panicle, $\times 1$; floret, $\times 5$. (Sandberg and Leiberg 231, Wash.) villous; awn about $12 \mathrm{~mm}$ long, tardily deciduous, slightly twisted and appressed-villous below, weakly geniculate. 4 -Dry ground, medium altitudes, Montana to eastern Washington, south to New Mexico and California, rather rare (fig. 879).

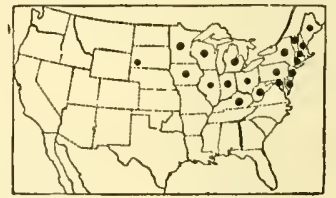

FIGURE 877.-Distribution of Oryzopsis racemosa.
11. Oryzopsis webbéri (Thurb.) Benth. (Fig. 880.) Culms densely tufted, erect, 15 to $30 \mathrm{~cm}$ tall; blades involute, filiform, scabrous; panicle narrow, 2.5 to $5 \mathrm{~cm}$ long, the branches appressed; glumes about $8 \mathrm{~mm}$ long, narrow, obscurely 5nerved, minutely scaberulous, acuminate; lemma narrow, $6 \mathrm{~mm}$ long, densely long-pilose, the awn about $6 \mathrm{~mm}$ long, straight or bent, not twisted. 24 -Deserts and plains, Colorado, Nevada, and California. 
12. Oryzopsis hymenoídes (Roem. and Schult.) Ricker. INDIAN RICEgRASS. (Fig. 881.) Culms densely tufted, 30 to $60 \mathrm{~cm}$ tall; ligule about $6 \mathrm{~mm}$ long, acute; blades slender, involute, nearly as long as the culms; panicle diffuse, 7 to $15 \mathrm{~cm}$ long, the

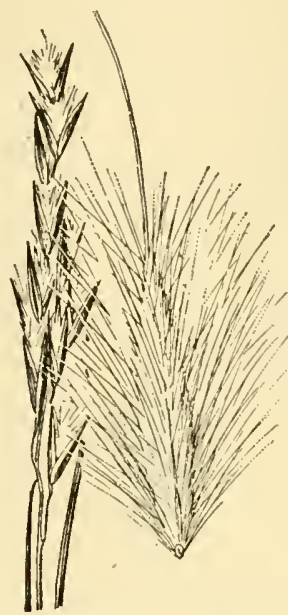

Figure 880.--Oryzopsis uebberi. Panicle, $\times 1$; floret, $\times 5$. (Hillman, Nev.) slender branches in pairs, the branchlets dichotomous, all divaricately spreading, the ultimate pedicels capillary, flexuous; glumes about 6 to 7 $\mathrm{mm}$ long, puberulent to glabrous, rarely hirsute, papery, ovate, 3 - to 5 -nerved, abruptly pointed; lemma fusiform, turgid, about $3 \mathrm{~mm}$ long, nearly black at maturity, densely long-pilose with white hairs $3 \mathrm{~mm}$ long; awn about $4 \mathrm{~mm}$ long, straight, readily deciduous. $24-$ Deserts and plains, medium altitudes, Manitoba

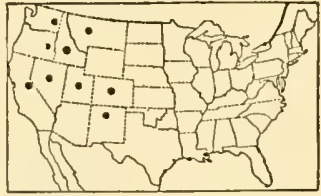

Figure 879.-Distribution of Oryzopsis bloomeri. to British Columbia, south to Texas, California, and northern Mexico (fig. 882).

Nassélla májor (Trin. \& Rupr.) Desv. Slender tufted perennial; blades narrow, flat or loosely involute; panicle narrow, 3 to $5 \mathrm{~cm}$ long, the few branches appressed, 1 to $1.5 \mathrm{~cm}$ long; glumes $4 \mathrm{~mm}$ long, awn-pointed; mature lemma flattish, obovate-oblong, gibbous at apex, smooth and shining, $2 \mathrm{~mm}$ long; awn geniculate, $1 \mathrm{~cm}$ long, soon deciduous.-Ballast, Portland, Oreg. Introduced from Chile.

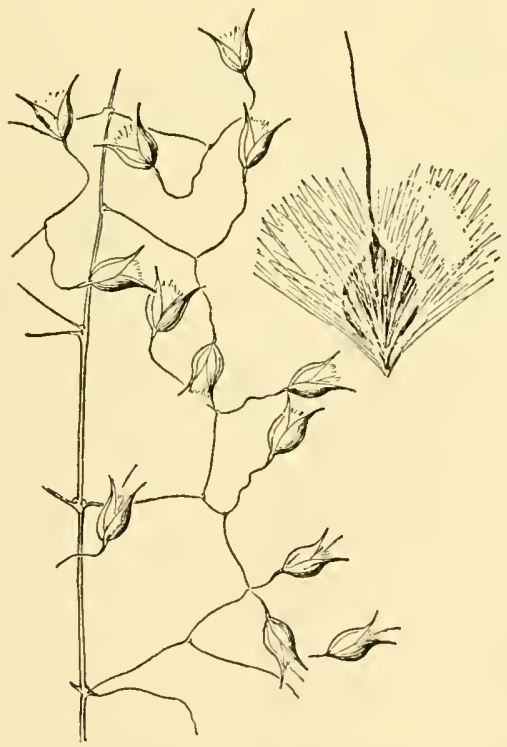

FIGURE 851.-Oryzopsis hymenoides. Panicle, $X$ 1; floret, $\times 5$. (Mearns 2583, Wyo.)

\section{PIPTOCHAETIUM Presl}

Spikelets 1-flowered, disarticulating above the glumes, the callus of the floret short, acutish, usually bearded; glumes about equal, broad, ovate, convex on the back, thin, abruptly acuminate; fruit brown or

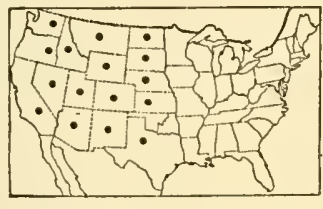

FIgURE 882.-Distribution of Oryzopsis hymenoides.

dark gray, coriaceous, obovate, shorter than the glumes, glabrous or hispid above the callus, often minutely striate, sometimes tuberculate near the summit, the lemma turgid, usually somewhat compressed and keeled on the back, gibbous near the summit back of the awn, the edges not meeting but clasping the sulcus of the palea, 


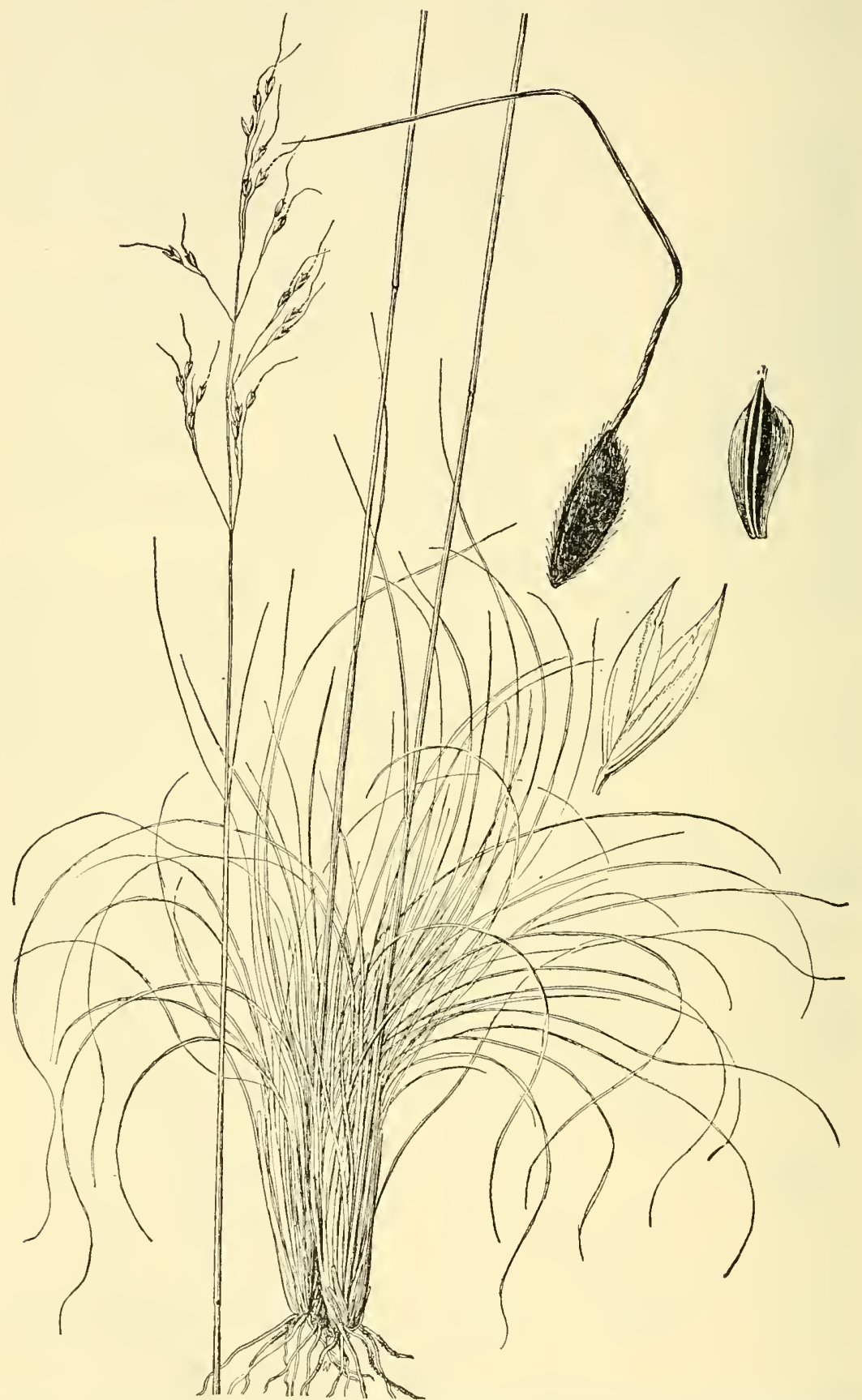

Figure $883,-$ Piptochaetium fimbriatum. Plant, $\times 1 / 2$; glumes, floret and palea, $\times 5$. (Hitchcock 13511, N.Mex.) 
the summit sometimes expanded into a crown; awn deciduous or persistent, curved, flexuous or geniculate, often twisted below; palea narrow, indurate, except toward the margins, central keel consisting of two nerves and a narrow channel or sulcus between, the apex of the keel projecting above the summit of the lemma as a minute point. Tufted perennials with narrow usually involute blades and rather few-flowered panicles. Type species, Piptochaetium setifolium Presl. Name from Greek piptein, to fall, and chaite, bristle, alluding to the deciduous awns of the type species.

1. Piptochaetium fimbriátum (H.B.K.) Hitchc. Pinyon ricegrass. (Fig. 883.) Culms densely tufted, erect, slender, 40 to $80 \mathrm{~cm}$ tall; blades involute-filiform, flexuous, elongate; panicle open, 5 to $15 \mathrm{~cm}$ long, the slender branches spreading, few-flowered toward the ends; spikelets long-pediceled; glumes about 5 mm long, abruptly acuminate, 7 -nerved; lemma a little shorter than the glumes, appressedpubescent, especially on the callus, dark brown at maturity with a circular ridge at the base of the awn; awn weakly twice geniculate, 1 to $2 \mathrm{~cm}$

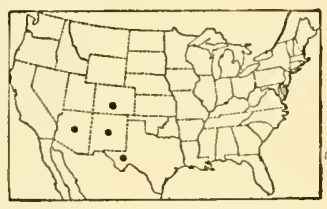

Figure 884.-Distribution of Piptochaetium fimbriatum.

long. 24 (Oryzopsis fimbriata Hemsl.) - Open rocky woods, Colorado to western Texas, Arizona, and Mexico (fig. 884). A fine forage grass.

\section{STÍPA L. Nemdlegrass}

Spikelets 1-flowered, disarticulating above the glumes, the articulation oblique, leaving a bearded, sharp-pointed callus attached to the base of the floret; glumes membranaceous, often papery, acute, acuminate, or even aristate, usually long and narrow; lenima narrow, terete, firm or indurate, strongly convolute, rarely the margins only meeting, terminating in a prominent awn, the junction of body and awn evident, the awn twisted below, geniculate, usually persistent; palea enclosed in the convolute lemma. Tufted perennials, with usually convolute blades and mostly narrow panicles. Type species, Stipa pennata L. Name from Greek stupe, tow, alluding to the feathery awns of the type species.

The species are for the most part valuable forage plants. Several, all western, such as Stipa comata, S. occidentalis, S. lemmoni, and S. neomexicana, are grazed chiefly when young. Stipa lettermani is important at high altitudes, in the mountains of the West; S. columbiana at medium altitudes; $S$. viridula in the Rocky Mountains; $S$. pulchra, S. thurberiana, and S. speciosa in California. Some of the species, when mature, particularly $S$. spartea and $S$. comata, are injurious, especially to sheep, because of the hard sharp points to the fruits which penetrate the skin. Sleepy grass, S. robusta, acts as a narcotic (see p. 436). One of the Old World species, S. tenacissima L., furnishes a part of the esparto or alfa grass of Spain and Algeria that in used in the manufacture of paper and cordage (see p. 439).

1a. Terminal segment of awn plumose.

Awn 12 to $18 \mathrm{~cm}$ long

1. S. NEOMEXICANA.

Awn 1.2 to $1.5 \mathrm{~cm}$ long._._._._.

1b. Terminal segment of awn not plumose.

2a. First segment of the once-geniculate awn strongly plumose, the ascending hairs 5 to $8 \mathrm{~mm}$ long

2b. First segment of awn sometimes plumose but the hairs not more than $2 \mathrm{~mm}$ long. 
3a. Mature lemma 2 to $3 \mathrm{~mm}$ long. Awn capillary, flexuous, about $5 \mathrm{~cm}$ long

3b. Mature lemma at least $5 \mathrm{~mm}$ long.

4a. Lemma densely appressed-villous with white hairs 3 to $4 \mathrm{~mm}$ long, rising above the summit in a pappuslike crown _.... 5 . S. Coronata.

4 b. Lemma of ten villous but the hairs not more than $1 \mathrm{~mm}$ long, or sometimes those at the summit as much as $2 \mathrm{~mm}$ long.

$5 \mathrm{a}$. Summit of mature lemma smooth, cylindric, whitish, forming a ciliate crown 0.5 to $1 \mathrm{~mm}$ long (see also $S$. pulchra).

5 b. Summit of mature lemma not forming a crown.

\section{S. LEUCOTRICHA.}

6a. Lemma 2-lobed at summit, the lobes extending into awns 2 to $3 \mathrm{~mm}$ long on each side of the central awn ___ 4. S. STILLMANII. 6b. Lemma not lobed at summit or only slightly so.

7a. Awn plumose below, the hairs ascending or spreading (compare S. pulchra, with appressed-hispid awn).

Sheaths pubescent.

Awns once or obscurely twice-geniculate.

22. S. CURVIFOLIA. Awns distinctly twice geniculate.

Lemmas 6 to $7 \mathrm{~mm}$ long; glumes thin_._. 17. S. ELMERI.

Lemmas 8 to $9 \mathrm{~mm}$ long; glumes firm.- 18 . S. LATiglume.

Sheaths glabrous.

Ligule 3 to $6 \mathrm{~mm}$ long_._._._._._. 16. S. THURBeriana.

Ligule very short.

Hairs on upper part of the lemma much longer than those below

Hairs short all over the lemma_.... 19. S. Occidentalis.

7b. Awn scabrous or nearly glabrous, rarely appressed-hispid, not

plumose.
8a. Lemma more than $7 \mathrm{~mm}$ (often 1 to $2 \mathrm{~cm}$ ) long, glabrous or sparsely pubescent above the callus, mostly cylindric (somewhat fusiform in $S$. pulchra).

Mature lemma pale or finally brownish, sparsely pubescent to summit, mostly more than $1 \mathrm{~cm}$ long-- 10. S. CoMATA.

Mature lemma dark.

Lemma 8 to $10 \mathrm{~mm}$ long.

Glumes 3-nerved. Summit of lemma hispidulous-ciliate, the hairs erect, nearly $1 \mathrm{~mm}$ long; lemma somewhat fusiform, pubescent in lines above the callus.

11. S. PULChRA.

Glumes 5- to 9-nerved.

Lemmas glabrous above the base, minutely roughened at apex; callus with fine sharp point. 8 . S. AVENACEA.

Lemmas sparsely pubescent to apex; callus rather blunt_..... S. PRINGLEI.

Lemma 12 to $25 \mathrm{~mm}$ long, cylindric.

Mature lemma glabrous above the callus.

7. S. AVENACIOIDES.

Mature lemma more or less pubescent above the callus.

9. S. SPARTEA.

8b. Lemma less than $7 \mathrm{~mm}$ long, or if as long as 7 to $8 \mathrm{~mm}$, distinctly pubescent on the upper part.

Panicle open, the branches spreading or ascending, naked at base.

Panicle diffuse, the branches divergent, drooping; lemma about $5 \mathrm{~mm}$ long; awn about $2 \mathrm{~cm}$ long.

6. S. RICHARDSONI.

Panicle open but not diffuse.

Ligule 3 to $6 \mathrm{~mm}$ long; awn about $5 \mathrm{~cm}$ long, the terminal segment flexuous. Ligule $1 \mathrm{~mm}$ long or less; awn 2.5 to $4 \mathrm{~cm}$ long.

14. S. LEPIDA

Panicle narrow, the branches appressed.

Hairs on lemma copious, at least at summit, $2 \mathrm{~mm}$ long.

Lemmas evenly villows all over; summit with lobes 0.8 to

$1.5 \mathrm{~mm}$ long..... S. LOBATA.

Lemmas conspicuously villous above, less so below; summit not lobed or obscurely so. 
Lemma about $8 \mathrm{~mm}$ long, villous at summit, pubescent below ... Lemma about $5 \mathrm{~mm}$ long, villous all over but more so above _................ 30. SINETORUM. Hairs not copious, usually not more than $1 \mathrm{~mm}$ long at summit.

Glumes broad, abruptly acuminate, rather firm, the first 5-nerved,................ 24EMMONI.

Glumes narrow, gradually acuminate, usually hyaline, the first usually 3-nerved.

Awn 4 to $6 \mathrm{~cm}$ long, obscurely geniculate, the terminal segment flexuous _........... 31. S. ARIDA.

Awn mostly less than $5 \mathrm{~cm}$ long, if as much as $4 \mathrm{~cm}$ long, twice-geniculate and the terminal segment straight or nearly so.

Sheaths, at least the lowermost, pubescent.

Sheaths glabrous.

29. S. Williamsir.

Sheaths villous at the throat; fruit rather turgid, the callus broad and short; lower nodes of panicle villous.

Glumes thin, papery; plants rather slender, mostly less than $1 \mathrm{~m}$ tall; panicle rather slender, open ......... 25. S. viridula.

Glumes firm, the nerves inconspicuous; plants robust, mostly more than $1 \mathrm{~m}$ tall; panicle larger, more compact _... 26. S. Rов Usta.

Sheaths not villous at the throat or only slightly so; fruit slender, the callus narrow, sharp-pointed; nodes of panicle glabrous or nearly so.

Awn mostly more than $2 \mathrm{~cm}$ long; hairs at summit of lemma about as long as the others. 27. S. Columbiana.

Awn mostly less than $2 \mathrm{~cm}$ long; hairs at summit of lemma longer than those on the body 1 to $1.5 \mathrm{~mm}$ long -.-_ 28. S. LetTermani'

1. Stipa neomexicána (Thurb.) Scribn. New Mexican featherGRASS. (Fig. 885.) Culms mostly 40 to $80 \mathrm{~cm}$ tall; sheaths glabrous or the lower minutely pubescent; ligule very short, ciliate; blades slender, firm, convolute, glabrous beneath, the basal 10 to $30 \mathrm{~cm}$ long, scarcely $1 \mathrm{~mm}$ wide when unrolled; panicle narrow, 3 to $8 \mathrm{~cm}$ long; spikelets pale, more or less shining; glumes 3 to $5 \mathrm{~cm}$ long, tapering to a fine point; lemma about $15 \mathrm{~mm}$ long including the pilose callus 4 to $5 \mathrm{~mm}$ long; awn readily deciduous, 12 to $18 \mathrm{~cm}$ long, the lower one-fourth to one-third straight, strongly twisted, appressed-villous, the middle segment 1 to $2 \mathrm{~cm}$ long, the terminal segment flexuous, plumose, the hairs about $3 \mathrm{~mm}$ long. 2 -Mesas, canyons, and rocky slopes, western Texas and Colorado to Utah and Arizona (fig. 886).

2. Stipa speciósa Trin. and Rupr. Desert needlegrass. (Fig. 887.) Culms numerous, 30 to $60 \mathrm{~cm}$ tall; sheaths brownish, smooth or the lower pubescent or even felty at the very base, the throat densely short-villous; ligule short; blades elongate, involute-filiform, mostly basal, more or less deciduous from the outer and older persistent sheaths; panicle narrow, dense, 10 to $15 \mathrm{~cm}$ long, not much exceeding the leaves, white or tawny, feathery from the plumose awns; glumes smooth, 14 to $16 \mathrm{~mm}$ long, 3-nerved, long-acuminate, papery; lemma 7 to $9 \mathrm{~mm}$ long, narrow, densely short-pubescent, the callus sharp and smooth below; awn with one sharp bend, the first section 1.5 to $2 \mathrm{~cm}$ long, densely long-pilose on the lower half or twothirds, the hairs 5 to $8 \mathrm{~mm}$ long, the remaining portion of the awn 
scabrous, the second segment about $2.5 \mathrm{~cm}$ long. 21 -Deserts, canyons, and rocky hills, Colorado to southern California; southern South America (fig. 888).

3. Stipa leucótricha Trin. and Rupr. Texas needlegrass. (Fig. 889.) Culms 30 to $60 \mathrm{~cm}$ tall, the nodes pubescent; blades 10 to $30 \mathrm{~cm}$ long, flat, of ten becoming involute, hispidulous beneath, 2 to $4 \mathrm{~mm}$ wide; panicle narrow, mostly not more than $10 \mathrm{~cm}$ long; glumes 12 to $18 \mathrm{~mm}$ long; lemma about $1 \mathrm{~cm}$ long, the slender callus about $4 \mathrm{~mm}$ long, the body oblong, brownish, appressed-pubescent on the lower part, papillose-roughened at least toward the summit, abruptly narrowed into a cylindric smooth neck about $1 \mathrm{~mm}$ long, the crown ciliate with short stiff hairs; awn 6 to $10 \mathrm{~cm}$ long, rather stout, twice-geniculate, the first segment hispidulous, twisted, 2 to

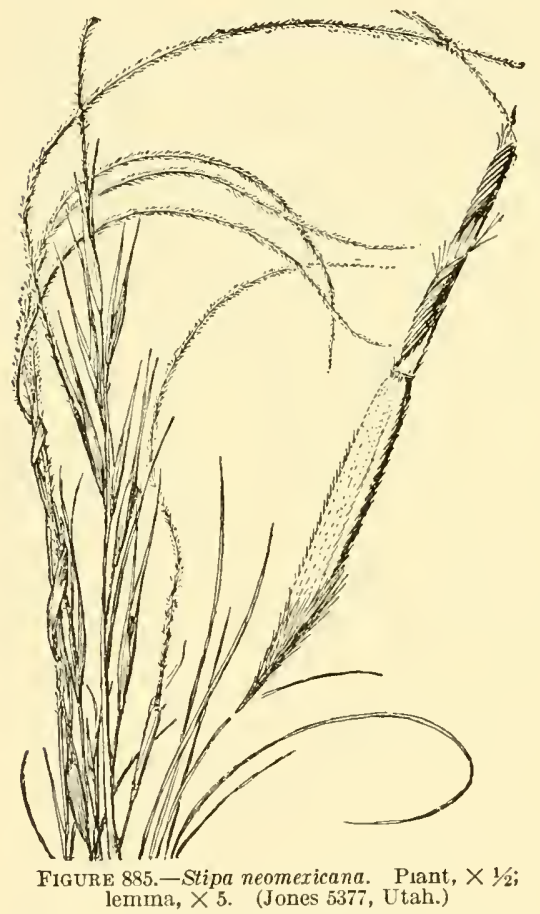

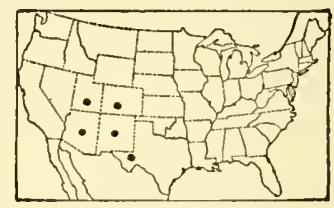

FIGURE 886.-Distribution of Stipa neomexicana.

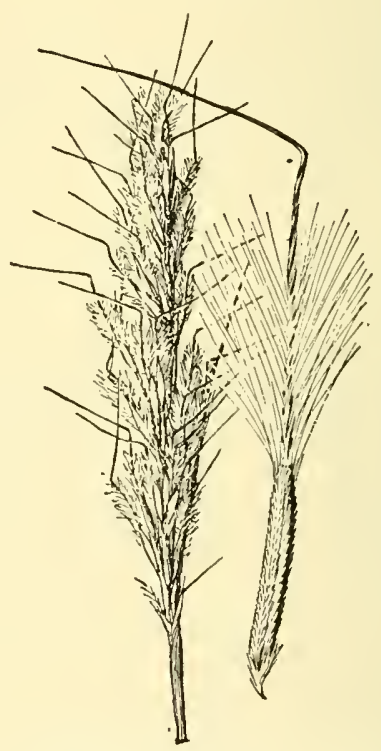

Figure 857.-Stipa speciosa. Panicle, $\times 1 / 2$; floret, $\times 5$. (Reed 4853, Calif.)

$3.5 \mathrm{~cm}$ long. 2 -Dry, open grassland, Oklahoma to central Mexico. Cleistogamous spikelets with glumes obsolete and lemma nearly awnless are borne in basal sheaths just after maturity of panicle.

4. Stipa stillmanii Boland. (Fig. 890 .) Culms stout, 60 to $100 \mathrm{~cm}$ tall; sheaths smooth, puberulent at the throat and collar; ligule very short; blades elongate, scattered, folded or involute, firm, the uppermost filiform; panicle 10 to $20 \mathrm{~cm}$ long, narrow, dense or interrupted at base, the branches short, fascicled; glumes equal, 14 to $16 \mathrm{~mm}$ long, papery, minutely scabrous, acuminate into a scabrous 
awn-point, the first 3-nerved, the second 5-nerved; lemma $9 \mathrm{~mm}$ long, short-pilose, bearing 2 slender teeth at the apex, the callus short; awn about $2.5 \mathrm{~cm}$ long, once- or indistinctly twice-geniculate, scabrous. 24 -Rocky slopes, Sierra Nevada, from Lassen National Forest to Tahoe National Forest, Calif.; apparently rare.

5. Stipa coronáta Thurb. (Fig. 891.) Culms stout, 1 to $2 \mathrm{~m}$ tall, as much as $6 \mathrm{~mm}$ thick at base, smooth or pubescent below the nodes; sheaths smooth, the margin and throat villous; ligule about $2 \mathrm{~mm}$ long, ciliate; blades elongate, 4 to $6 \mathrm{~mm}$ wide, flat to subinvolute with a slender involute point; panicle 30 to 40 cm long, contracted, erect, purplish; glumes gradually acuminate, 3 -nerved, the first about 2 $\mathrm{cm}$ long, the second 2 to $4 \mathrm{~mm}$ shorter; lemma about $8 \mathrm{~mm}$ long, densely villous with long appressed hairs 3 to $4 \mathrm{~mm}$ long; awn usually 4 to

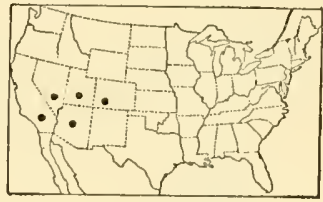

Figure 888-Distribution of Stipa speciosa.

$5 \mathrm{~cm}$ long, scabrous, twice-geniculate, the first and second segments about $1 \mathrm{~cm}$ long. 24 -Open ground in the Coast Range, California, from Monterey to Baja California.

Stipa coronata var. depauperáta (Jones) Hitche. Culms usually 30 to $50 \mathrm{~cm}$ tall; blades 10 to $20 \mathrm{~cm}$ long; panicle 10 to $15 \mathrm{~cm}$ long, rather few-flowered, the spikelets commonly smaller than in the species, the lemma 6 to $7 \mathrm{~mm}$ long, the awn about $2.5 \mathrm{~cm}$ long, once-geniculate, the first segment twisted and scabrous-pubescent,

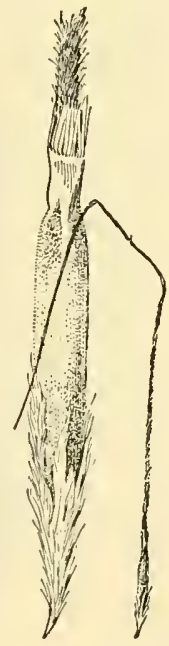

FIGURE 889 Stipa lcucotricha. Floret, $\times 1$; lemma, $X$ 5. (Hitehcock 5135, Tex.)

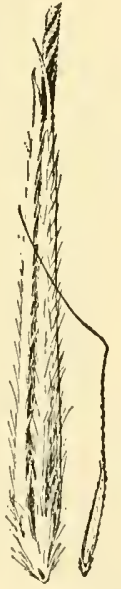

$$
\begin{aligned}
& \text { Figure } 890 .- \\
& \text { Stipa stilt- } \\
& \text { manti. Flo- } \\
& \text { ret, } \times 1 \text {; lem- } \\
& \text { ma, } \times \text { 5. } \\
& \text { (Bolander, } \\
& \text { Calif.) }
\end{aligned}
$$

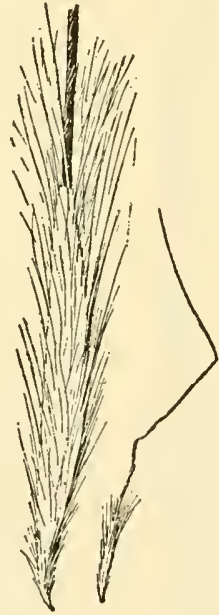

FIgURE 891. - Stipa coronatr. Floret, $X$ 1; $\operatorname{lemma}$, $\times 5$ (Orcutt 1068, Calif.)

about $1 \mathrm{~cm}$ long, the second segment bent about horizontally. $\quad 2$ Dry or rocky slopes, Utah and Nevada to Arizona and southern California. Many intermediates occur between the variety and the species.

6. Stipa richardsóni Link. Richardson NEedlegrass. (Fig. 892.) Culms 50 to $100 \mathrm{~cm}$ tall; blades mostly basal, usually 15 to 25 
cm long, involute, subfiliform, scabrous; panicle 10 to $20 \mathrm{~cm}$ long,

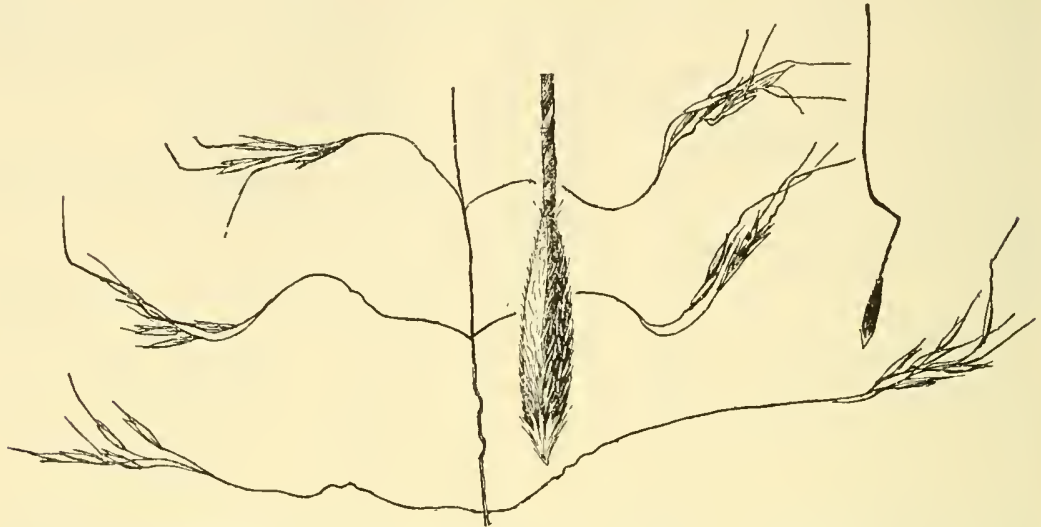

Figure 892.-Stipa richardsoni. Panicle, $\times 1 \frac{1}{2}$; floret, $\times 1$; lemma, $\times 5$. (Hitchcock 11468, Alberta.)

open, the branches slender, distant, spreading or drooping, naked below; glumes 8 to $9 \mathrm{~mm}$ long; lemma about $5 \mathrm{~mm}$ long, subfusiform, brown at maturity; awn 2.5 to $3 \mathrm{~cm}$ long. 24 -Bottom lands and wooded slopes, Saskatchewan to Colo-

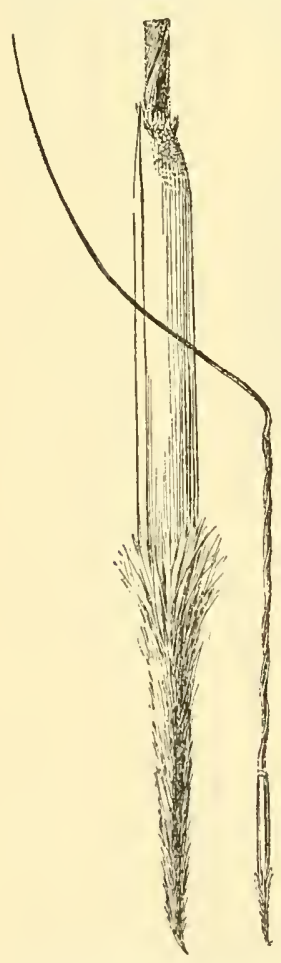

Figure 894.-Stipa avenacioides. Floret, $\times 1$; lemma, $\times 5$. (Curtiss 5831, Fla.) bearing 1 or 2 spikelets;

Nash. (Fig. 894.) Culns about $1 \mathrm{~m}$ tall; ligule 2 to 3 $\mathrm{mm}$ long; blades elongate, involute, subfiliform; panicle 10 to $25 \mathrm{~cm}$ long, open, the branches slender, spreading, naked below; glumes about $2 \mathrm{~cm}$ long; lemma brown, linear, 1.5 to $2 \mathrm{~cm}$ long including the callus $7 \mathrm{~mm}$ long, the body glabrous, minutely papillose at the slightly contracted summit, slightly hispidulous on the crown; awn 8 to $11 \mathrm{~cm}$ long, scabrous, twice geniculate. 2 - Dry pine woods, peninsular Florida.

8. Stipa avenácea L. Blackseed NeEdlegrass. (Fig. 895.) Culms 60 to 100 $\mathrm{cm}$ tall; ligule about $3 \mathrm{~mm}$ long; blades 20 to $30 \mathrm{~cm}$ long, $1 \mathrm{~mm}$ wide, flat or involute; panicle 10 to 15 $\mathrm{cm}$ long, open, the slender branches 2 to $4 \mathrm{~cm}$ long,

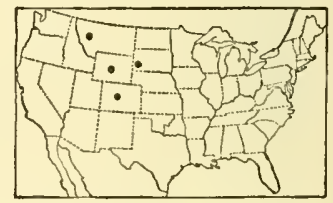

Figure 893.-Distribution of Stipa richardsoni.

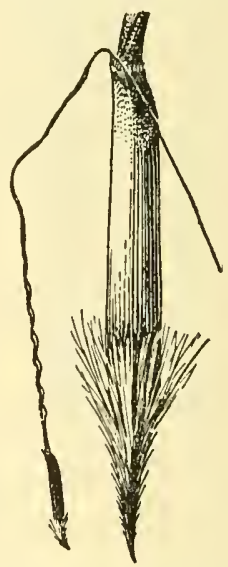

FIGURE 895.-Stipa avenacea. Floret, $\times 1$; lemma, $\times 5$. (Kneucker, Gram. 564, Md.)

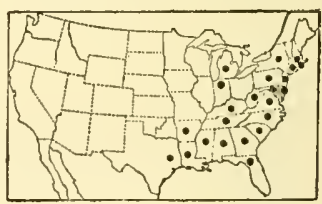

Figure 896.-Distribution of Slipa avenacea.

glumes $1.5 \mathrm{~cm}$ long; lemma dark brown, 9 to $10 \mathrm{~mm}$ long, the 
MANUAL OF THE GRASSES OF THE UNITED STATES 429

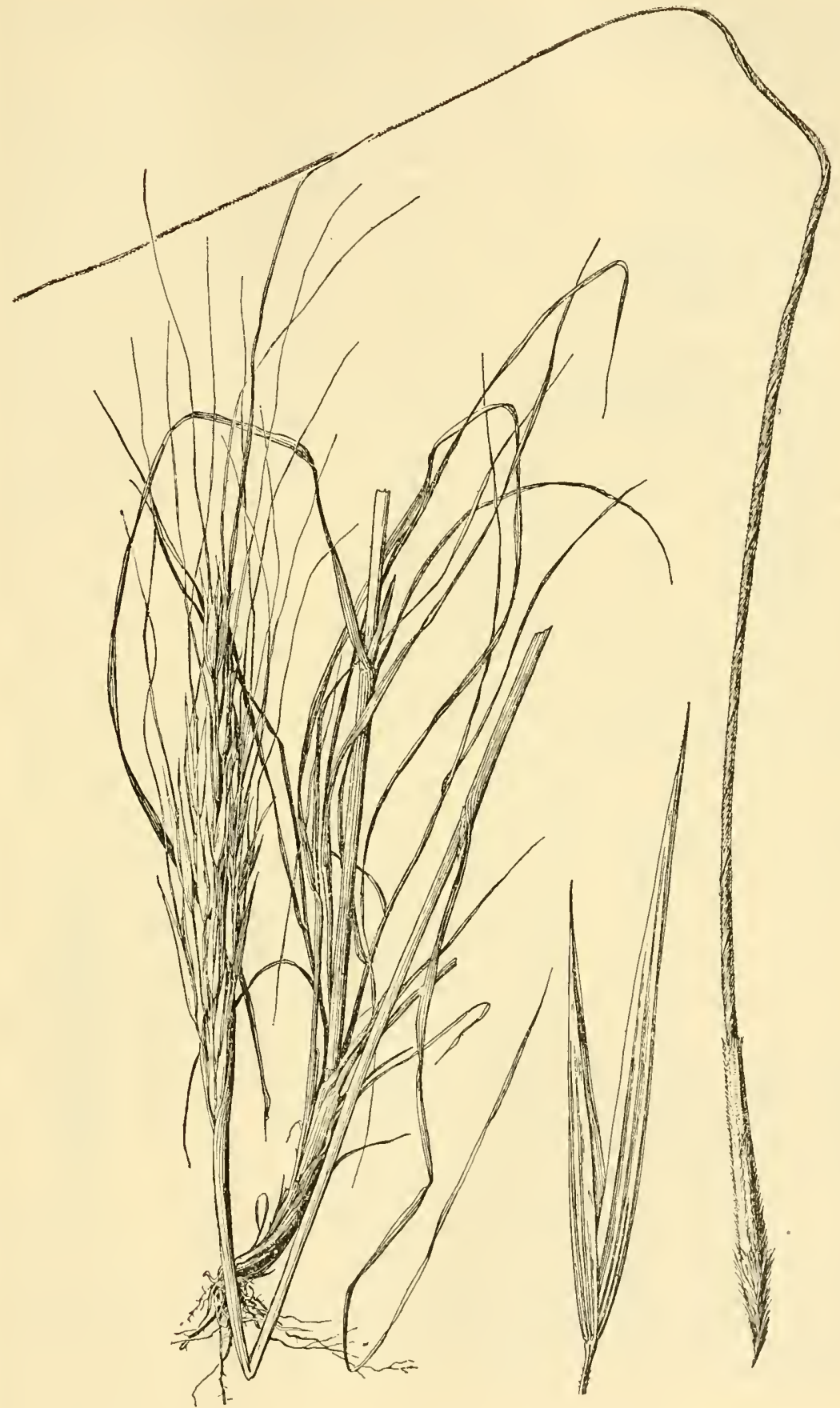

Figure 897.-Stipa spartea. Plant, $\times 1 / 2$; glumes and floret, $\times 2$. (McDonald 16, Ill.) 
callus $2 \mathrm{~mm}$ long, the body glabrous, papillose-roughened toward the summit, awn scabrous, 4.5 to $6 \mathrm{~cm}$ long, twice-geniculate. 24 -Dry or rocky open woods, Massachusetts to Michigan south to Florida and Texas, mostly on the Coastal Plain (fig. 896).

9. Stipa spártea Trin. Porcupine grass.

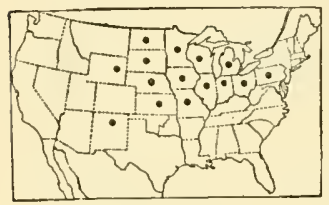

Figure 898.-Distribution of Stipa spartea. (Fig. 897.) Culms about $1 \mathrm{~m}$ tall; ligule rather firm, 4 to $5 \mathrm{~mm}$ long; blades 20 to $30 \mathrm{~cm}$ long, 3 to $5 \mathrm{~mm}$ wide, flat, involute in drying; panicle 15 to $20 \mathrm{~cm}$ long, narrow, nodding, the few slender branches bearing 1 or 2 spikelets; glumes 3 to $4 \mathrm{~cm}$ long; lemma subcylindric, brown, 1.6 to $2.5 \mathrm{~cm}$ long, the callus about $7 \mathrm{~mm}$ long, the body pubescent below, glabrous above except for a line of pubescence on one side, the crown erect-ciliate; awn stout, 12 to $20 \mathrm{~cm}$ long, twice geniculate. 21 -Prairies, Ontario to British Columbia, south to Pennsylvania, Indiana, Kansas, and New Mexico (fig. 898). Stipa spartea var. Curtiséta Hitchc. Glumes 2 to 3 cm long; lemma 12 to $15 \mathrm{~mm}$ long; awn mostly not more than 7 or $8 \mathrm{~cm}$ long. 24 -Manitoba to Alberta, Montana, South Dakota, and Wyoming.

10. Stipa comáta Trin. and Rupr. NeEdle-AND-THREAd. (Fig. 899.) Culms 30 to $60 \mathrm{~cm}$ tall, sometimes taller; ligule thin, 3 to $4 \mathrm{~mm}$ long; blades 10 to $30 \mathrm{~cm}$ long, 1 to $2 \mathrm{~mm}$ wide, flat or involute, panicle commonly included at base, narrow, 10 to $20 \mathrm{~cm}$ long; glumes 1.5 to $2 \mathrm{~cm}$ long, the attenuate tips subhyaline; lemma 8 to 12 $\mathrm{mm}$ long, mostly about $1 \mathrm{~cm}$, pale or finally

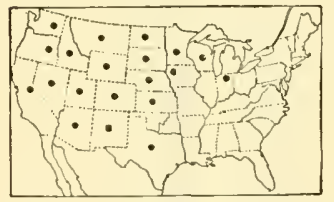

Figure 900,-Distribution of Stipa comata. brownish, the callus about $3 \mathrm{~mm}$ long, the body sparsely pubescent or glabrate toward the summit; awn 10 to $15 \mathrm{~cm}$ long, indistinctly twice-geniculate, very slender, loosely twisted below, flexuous above, of ten deciduous. 24 -Prairies, plains, and dry hills, Indiana to Yukon Territory, south to Texas and California (fig. 900.) A form from Washington with pubescent foliage has been called S. comota var. intonsa Piper. Stipa comata var. Intermedia Scribn. and Tweedy. Differing from S. comata in the shorter straight third segment of

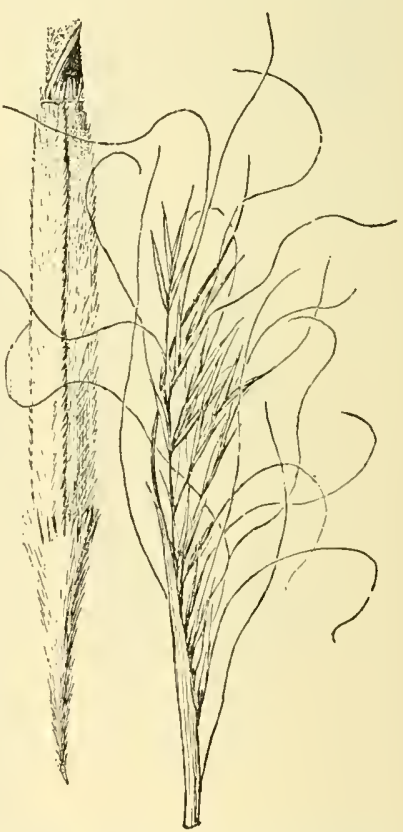

FIgure 899.-Stipa comata. Panicle, $\times 1 / 2 ;$ lemma, $\times 5$. (Hitcheock 1700 , Colo.) the awn; glumes and lemma on the average a little longer; panicle usually exserted; ligule long, as in $S$. comata.-Montana to Washington, south to New Mexico and California. 
11. Stipa púlchra Hitche. Purple needlegrass. (Fig. 901.) Culms 60 to $100 \mathrm{~cm}$ tall; blades long, narrow, flat or involute; ligule about $1 \mathrm{~mm}$ long; panicle nodding, about $15 \mathrm{~cm}$ long, loose, the branches spreading, slender, some of the lower 2.5 to $5 \mathrm{~cm}$ long; glumes narrow, long-acuminate, purplish, 3-nerved, the first about $2 \mathrm{~cm}$ long, the second 2 to $4 \mathrm{~mm}$ shorter; lemma 8 to $10 \mathrm{~mm}$ long, fusiform, sparingly pilose, some times only in lines above, minutely papillose-roughened, the callus about $2 \mathrm{~mm}$ long, the summit sometimes with a smooth neck and a ciliate crown (as in S. leucotricha); awn 4 to $6 \mathrm{~cm}$ long, short-pubescent to the second bend, the first segment 1.5 to $2 \mathrm{~cm}$ long, the second shorter, the third slender, flexuous. 24 -Open ground, central California to Baja California, mostly in the Coast Ranges.

12. Stipa prínglei Scribn. PrinGLE NEEDLEGRASS. (Fig. 902.$)$ Culms, about $1 \mathrm{~m}$ tall; ligule about $2 \mathrm{~mm}$ long; blades 10 to $30 \mathrm{~cm}$ long, 1 to $3 \mathrm{~mm}$ wide, flat or those of the innovations involute, firm, erect, scabrous, panicle nodding, 10 to 15

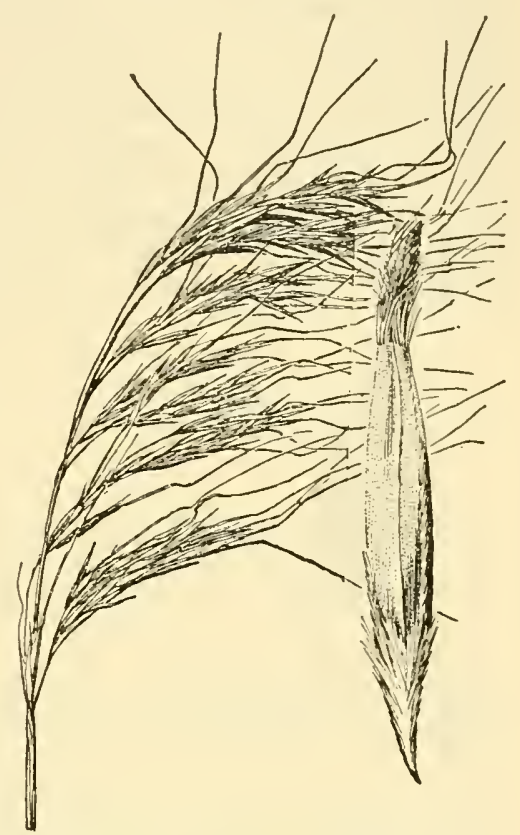

Figure 901.-Stipa pulchra. Panicle, $\times 1 / 2$; lemma, $\times 5$. (Chase 5598, Calif.) $\mathrm{cm}$ long, the branches ascending,

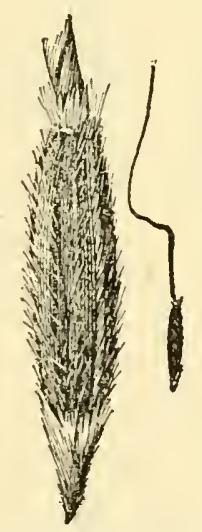

FIGURE 902.-Stipa pringlet. Floret, $\times 1$; lemma, $\times 5$ (Hitehcock 7691 , Mex.) few-flowered, naked below; glumes about $1 \mathrm{~cm}$ long, broad, rather abruptly narrowed into a short point, 7- to 9-nerved; lemma 7 to $8 \mathrm{~mm}$ long, oblong-elliptic, brown, minutely papillose and brownish pubescent, the callus $1 \mathrm{~mm}$ long; awn about $3 \mathrm{~cm}$ long, obscurely twice-geniculate. $21-\mathrm{Rocky}$ woods and slopes, Texas, New Mexico, and Arizona to Chihuahua, Mex.

13. Stipa éminens Cav. (Fig. 903.) Culms slender, rather wiry, 80 to $120 \mathrm{~cm}$ tall; ligule 3 to $6 \mathrm{~mm}$ long; blades mostly elongate, flat or involute, 1 to $4 \mathrm{~mm}$ wide; panicle nodding, open, 10 to $20 \mathrm{~cm}$ long, usually densely pilose on the lower node, the branches slender, spreading, often flexuous, usually 3 to 4 or even more at the node; glumes about $1.5 \mathrm{~cm}$ long; lemma pale, 5 to $7 \mathrm{~mm}$ long, pubescent; awn 3 to $6 \mathrm{~cm}$ long, obscurely twice-geniculate,

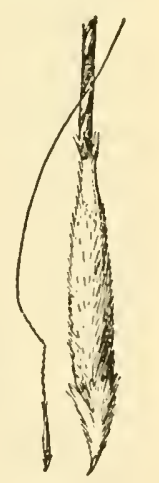

FIgURE 903 Stipa eminens. Floret, $\times 1$ lemma, $\times 5$ (Palmer 523, Mex.) the third segment flexuous. 24-Rocky hills, Texas to Arizona and central Mexico. 
14. Stipa lépida Hitchc. Foothild Needlegrass. (Fig. 904.) Culms slender, puberulent below the nodes, 60 to $100 \mathrm{~cm}$ tall; sheaths smooth, rarely puberulent, sparingly villous at throat; ligule very short; blades 10 to $30 \mathrm{~cm}$ long, flat, 2 to $4 \mathrm{~mm}$ wide, pubescent on upper surface near base; panicle rather loose and open, usually 15 to $20 \mathrm{~cm}$ long, sometimes more than $30 \mathrm{~cm}$ long, the branches distant, slender; glumes 3-nerved, smooth, acuminate, the first 6 to $10 \mathrm{~mm}$ long, the second about $2 \mathrm{~mm}$ shorter; lemma about 6 $\mathrm{mm}$ long, brown, sparingly villous, nearly glabrous toward the hairy-tufted apex; awn indistinctly twice-geniculate, about 2.5 to $4 \mathrm{~cm}$

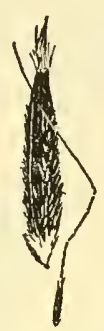

FIgURe 904.-Stipa lepida. Floret, $\times 1$; lemma, $\times 5$. (Chase 5609, Calif.)

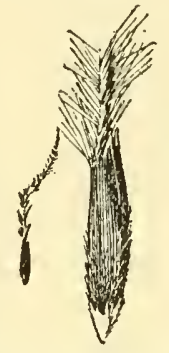

FIGURF 905.-Slipa porteri. Floret, $\times 1$; lemma, $\times 5$. (Wolf 1109 Colo.)

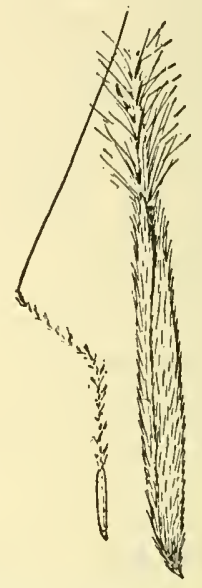

Figure 906.-Stipa thutberiana Floret, $\times 1$; lemma, $\times 5$. (Chase 4689, Idaho.)

long, scabrous. 24 -Dry hills, open woods, and rocky slopes, central California to Baja California, in the Coast Range. STIPA LEPIDA var. ANDERSónI (Vasey) Hitchc. Differing only in the more slender culms, the slender involute blades, and in the narrow or reduced panicle.- Same range as the species.

15. Stipa portéri R ydb. (Fig. 905.) Culms 20 to $35 \mathrm{~cm}$ tall; ligule 2 to $3 \mathrm{~mm}$ long; blades 2 to $12 \mathrm{~cm}$ long, involute, subfiliform, sulcate, scaberulous; panicle mostly 5 to $10 \mathrm{~cm}$ long, open, the branches distant, capillary, flexuous, few-flowered; glumes 5 to 6 $\mathrm{mm}$ long; lemma about $5 \mathrm{~mm}$ long, oblong-elliptic, softly pilose on the lower half, scaberulous above, lobed at summit; awn 12 to $15 \mathrm{~mm}$ long, plumose with hairs 1 to $2 \mathrm{~mm}$ long, with a single bend onethird from the base, the first segment weakly twisted. 21 -High mountains of Colorado.

16. Stipa thurberiána Piper. Thurber NEEDlegrass. (Fig. 906.) Culms mostly 30 to $60 \mathrm{~cm}$ tall; sheaths scaberulous or the upper glabrous; ligule hyaline, 3 to $6 \mathrm{~mm}$ long; blades

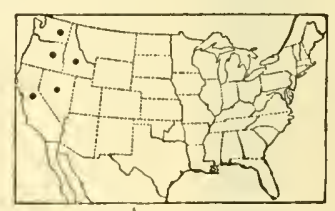

FIGURE 907.-Distribution of Stipa thutberiana.

10 to $25 \mathrm{~cm}$ long, filiform, involute, scabrous, flexuous; panicle mostly 8 to $15 \mathrm{~cm}$ long, narrow, the ascending branches few flowered; glumes 11 to $13 \mathrm{~mm}$ long, the acuminate summit hyaline; lemma 8 to $9 \mathrm{~mm}$ long, appressed-pubescent, callus about $1 \mathrm{~mm}$ long; awn 4 to $5 \mathrm{~cm}$ long, twice-geniculate, the first and second segments plumose with hairs 1 to $2 \mathrm{~mm}$ long. 21 -Mesas and rocky slopes. Idaho to Washington and central California (fig. 907). 
17. Stipa elméri Piper and Brodie. (Fig. 908.) Culms 60 to 100 $\mathrm{cm}$ tall, more or less puberulent, especially at the nodes; sheaths pubescent; ligule very short; blades 15 to $30 \mathrm{~cm}$ long, 2 to $4 \mathrm{~mm}$ wide,

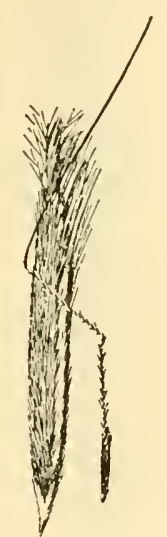

FIG URE, 908. Slipa elmeri.

Floret, $\times 1$; lemma, $\times 5$ (Hitchcock 3336 , Calif.)

flat or becoming involute, pubescent on the upper surface, or those of the innovations also on the lower surface; panicle narrow, 15 to $35 \mathrm{~cm}$ long, rather loose; glumes 12 to $14 \mathrm{~mm}$ long, long-acuminate, hyaline except toward base; lemma about $7 \mathrm{~mm}$ long, appressedpubescent, the callus $1 \mathrm{~mm}$ long; awn 4 to $5 \mathrm{~cm}$ long, distinctly twice-geniculate, the segments nearly equal, the first and second finely plumose. 24 Dry hills, sandy plains, and open woods, Washington and Idaho to California and Nevada (fig. 909).

18. Stipa latiglúmis Swallen. (Fig. 910.) Culms slender, erect, strigose below, 50 to $110 \mathrm{~cm}$ tall;

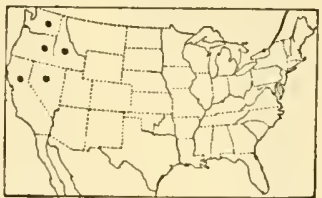

Figure 909.-Distribution of Stipa elmeri. sheaths, at least the lower, pubescent; blades flat or loosely involute, pilose on the upper surface, glabrous beneath; ligule 1 to $4 \mathrm{~mm}$ long; panicle narrow, loosely flowered, 15 to $30 \mathrm{~cm}$ long, the branches distant, slender, the lower as much as $10 \mathrm{~cm}$ long; glumes about equal, firm, rather abruptly acute or acuminate, 3 -nerved, tinged with purple, 13 to $15 \mathrm{~mm}$ long, $1.5 \mathrm{~mm}$ wide from keel to margin; lemma densely pubescent, 8 to $9 \mathrm{~mm}$ long, the sharp callus $1 \mathrm{~mm}$ long; awn twice-

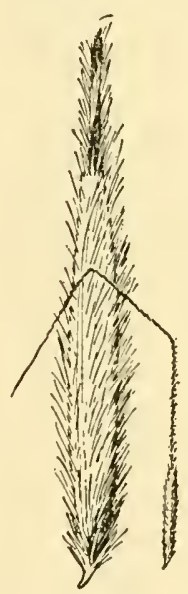

Figure $910-S t i$ pa latiglumis. Floret, $\times 1$; lemma, $\times 5$ (Type.) geniculate, 3.5 to $4.5 \mathrm{~cm}$ long, the first and second segments plumose. 24 - Sierras of central California at medium altitudes.

19. Stipa occidentális Thurb. Western NEedlegrass. (Fig. 911.) Culms mostly 25 to $40 \mathrm{~cm} \mathrm{tall;}$

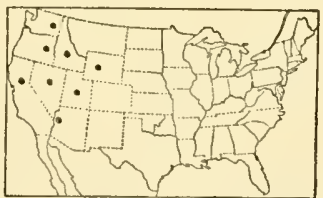

Figure 912.-Distribution of Stipa occidentalis.

sheaths glabrous; ligule about $0.5 \mathrm{~mm}$ long; blades 10 to $20 \mathrm{~cm}$ long, 1 to 2 mm wide, flat or usually involute, glabrous beneath; panicle 10 to $20 \mathrm{~cm}$ long, lax, the few slender branches narrowly ascending; glumes about 12 $\mathrm{mm}$ long, the attenuate tips hyaline; lemma pale brown, about $7 \mathrm{~mm}$ long, rather sparsely appressedpubescent; awn 3 to $4 \mathrm{~cm}$ long, twice-geniculate, the first and second segments plumose, the hairs about $1 \mathrm{~mm}$ long. 2/ - Plains, rocky hills, and open woods, Wyoming to Washington and Califurnia (fig. 912).

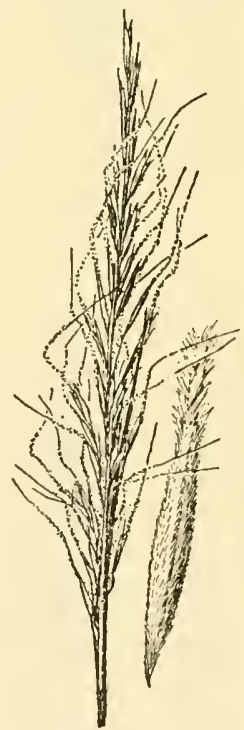

FIGURE 911 - Stipa occidentalis. Panicle, $\times 1 / 2$; lemma, $\times 5$ (Hit cheock 11740 , Oreg.) 
20. Stipa lobáta Swallen. (Fig. 913.) Culms densely tufted, erect, scaberulous below the panicle, 35 to $85 \mathrm{~cm}$ tall; blades flat or loosely folded toward the base, tapering into a fine point, as much as $50 \mathrm{~cm}$ long, 1 to $4 \mathrm{~mm}$ wide at the base, scabrous on the upper surface, glabrous beneath; ligule less than $0.5 \mathrm{~mm}$ long; panicle

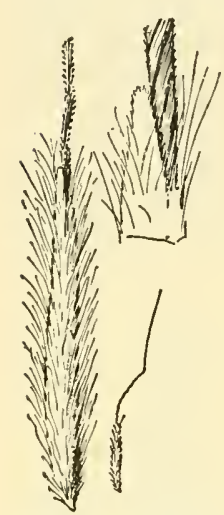

FIGURE 913.-Stipa lobata. Floret, $\times$ 1 ; lemma, $\times$; summit of lemma, $\times 15$. ('Type.)

narrow, 10 to $18 \mathrm{~cm}$ long, the branches appressed; glumes about equal, acuminate, 3-nerved, scabrous, 9 to $10 \mathrm{~mm}$ long; lemma brownish, $6 \mathrm{~mm}$ long, densely pubescent with hairs 1 to 2 $\mathrm{mm}$ long, the callus very short, blunt, the summit 2-lobed, the lobes 0.8 to $1.5 \mathrm{~mm}$ long, awned from between the lobes; awn twice-geniculate, 12 to 16 $\mathrm{mm}$ long, the first and second segments appressed-hispid. 2 -Rocky hills at medium altitudes, western Texas and New Mexico.

21. Stipa califórnica Merr. and Davy. (Fig. 914.) Culms 75 to $125 \mathrm{~cm}$ tall; ligule rather firm, 1 to $2 \mathrm{~mm}$ long; blades 10 to $12 \mathrm{~cm}$ long, 1 to $4 \mathrm{~mm}$ wide, flat, becoming involute, those of the innovations slender and involute;

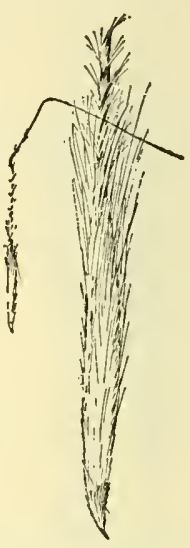

Figure 914.-Stipa californica. Floret, $\times 1$; lemma, $\times 5$. (IIall 2556, Calif.)

panicle 15 to $30 \mathrm{~cm}$, sometimes to $50 \mathrm{~cm}$, long, slender, pale; glumes about $12 \mathrm{~mm}$ long; lemma 6 to $8 \mathrm{~mm}$ long, rather sparsely villous with ascending white hairs, those at the summit about $1.5 \mathrm{~mm}$ long; awn 2.5 to $3.5 \mathrm{~cm}$ long, twice-geniculate, the first and second seg-

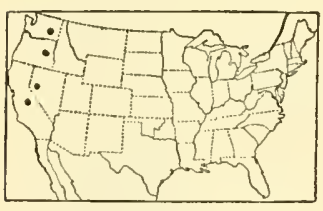

Figure 915.-Distribution of Stipa californica. ments plumose. 24 -Dry open ground, Washington to California and western Nevada (fig. 915).

22. Stipa curvifólia Swallen. (Fig. 916, A.) Culms densely tufted, erect, about $35 \mathrm{~cm}$ tall; leaves clustered toward the base, the lowermost sheaths pubescent, the blades involute, becoming curved with age; panicle 7 to $8 \mathrm{~cm}$ long, dense, the branches short, appressed; glumes about $10 \mathrm{~mm}$ long; lemma $5.5 \mathrm{~mm}$ long, light brown, evenly white pilose; awn once or obscurely twicegeniculate, 22 to $25 \mathrm{~mm}$ long, twisted and densely plumose below the bend. 24 - Known only from limestone cliffs, Guadelupe Mountains, N.Mex.

23. Stipa scribnéri Vasey. Scribner neEDLegrass. (Fig. 916, B.) Culms 30 to $70 \mathrm{~cm}$ tall; sheaths villous at the throat; ligule less than $1 \mathrm{~mm}$ long; blades 15 to $25 \mathrm{~cm}$ long, 2 to

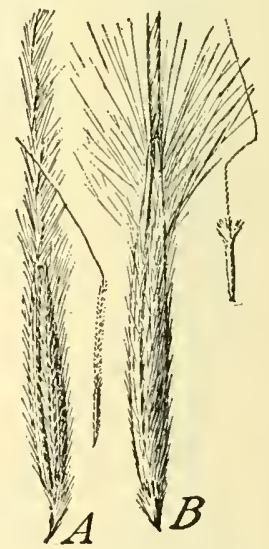

Figure 916.- $A$, Stipa curvifolia. Floret, $\times 1$; lemma, $\times 5$. (Type.) $B$, S. scribneri. Floret, $\underset{\text { (Vasey, N.Mex.) }}{\times 1 \text {. lemma, }} \times 5$. $4 \mathrm{~mm}$ wide, flat or sometimes involute; panicle 10 to $25 \mathrm{~cm}$ long, contracted, the rather short stiff branches erect; glumes 10 to 15 $\mathrm{mm}$ long, relatively firm, attenuate; lemma about $8 \mathrm{~mm}$ long, pale, 
narrow-fusiform, villous with white hairs, those at the summit about $2 \mathrm{~mm}$ long, forming a brushlike tip; awn 14 to $20 \mathrm{~mm}$ long, twice-

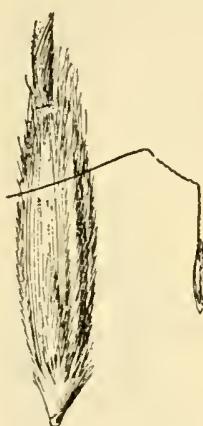

FIGURE 918.-Stipe lemmoni. Floret, $\times 1$; lemma, $\times 5$ (Butler 830, Calif.) geniculate. 24 -Mesas and rocky slopes, Colorado, Utah, New Mexico, and Arizona (fig. 917).

24. Stipa lemmóni (Vasey) Scribn. Lemmon NeEDLEGRASS. (Fig. 918.) Culms 30 to $80 \mathrm{~cm}$ tall, scaberulous, usually puberulent below the nodes; ligule 1 to $3 \mathrm{~mm}$ long; blades 10 to $20 \mathrm{~cm}$ long, flat or involute, 1 to $2 \mathrm{~mm}$ wide, or those of the innovations very narrow; panicle 5 to $12 \mathrm{~cm}$ long, narrow, pale or purplish; glumes 8 to $10 \mathrm{~mm}$ long, rather broad and firm, somewhat ab-

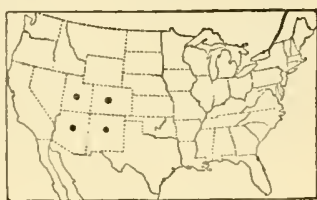

FIGURE 917.-Distribution of Stipa scribneri. ruptly acuminate, the first 5 -nerved, the second 3-nerved; lemma 6 to $7 \mathrm{~mm}$ long, pale or light brown, the callus rather blunt, the body fusiform, $1.2 \mathrm{~mm}$ wide, villous with appressed hairs; awn 20 to $35 \mathrm{~mm}$ long, twice-geniculate, appressed-pubescent to the second bend. 24-Dry open ground and open woods, British Columbia to Idaho and California

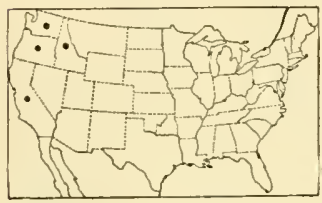

Figure 919.-Distribution of Stipa lemmoni. (fig. 919).

25. Stipa virídula Trin. GreEN NeEdlegrass. (Fig. 920.) Culms 60 to $100 \mathrm{~cm}$ tall; sheaths villous at the throat, often rather sparingly so, more or less hispidulous in a line across the collar; ligule about $1 \mathrm{~mm}$ long; blades 10 to $30 \mathrm{~cm}$ long, 1 to 3 or even $5 \mathrm{~mm}$ wide, flat or, especially on the innovations, involute; panicle 10 to $20 \mathrm{~cm}$ long, narrow, rather closely flowered, greenish or tawny

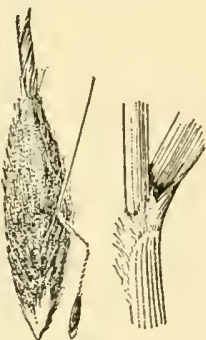

FIGURE 920--Stipa viridula. Flor et. $\times 1$; lemma and summit of sheath, $\times$ 5. (Griffiths 201, S.Dak.) at maturity; glumes 7 to $10 \mathrm{~mm}$ long, hyaline-attenuate; lemma 5 to $6 \mathrm{~mm}$ long, fusiform, at maturity plump, more than $1 \mathrm{~mm}$ wide, the body at maturity brownish, appressed-pubescent, the callus rather blunt; awn 2 to $3 \mathrm{~cm}$ long, twice-geniculate. 2 -Plains and dry slopes, New York (Cobbs Hill, Rochester), Wis-

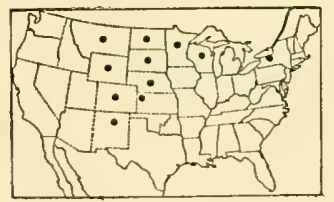

Figure 921.-Distribution of Stipa viridula. consin to Alberta, south to Kansas and New Mexico (fig. 921).

26. Stipa robústa Scribn. SLEEPY GRASS. (Fig. 922.) Culms robust, mostly 1 to $1.5 \mathrm{~m}$ tall; sheaths villous at the throat and on the margin, a strong hispidulous line across the collar; ligule 2 to 4 mm long; blades elongate, flat or on the innovations involute, those of the culm as much as $8 \mathrm{~mm}$ wide; panicle narrow, compact, often

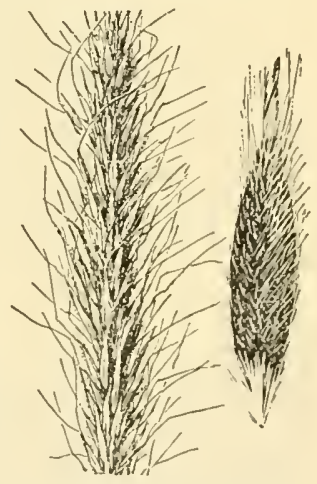

Figcre 922.-Stipa robusta. Panicle, $\times 1 / 2 ;$ lemma, $\times 5$. (Hitchcock 132s0, N.Mex.) more or less interrupted below, as much as $30 \mathrm{~cm}$ long and $2 \mathrm{~cm}$ thick; glumes about $1 \mathrm{~cm}$ long, attenuate into a fine soft point; 
lemma 6 to $8 \mathrm{~mm}$ long, about as in S. viridula; awn 2 to $3 \mathrm{~cm}$ long, rather obscurely twice-geniculate. 24 (S. vaseyi Scribn.)-Dry plains and hills and dry open woods, Colorado to northern Mexico (fig. 923). Said to act as a narcotic on animals that graze upon it, especially affecting horses. ${ }^{8}$

27. Stipa columbiána Macoun. Columbia needlegrass. (Fig. 924.) Culms mostly 30 to $60 \mathrm{~cm}$ tall, sometimes as much as $1 \mathrm{~m}$; sheaths naked at the throat; ligule 1 to $2 \mathrm{~mm}$ long; blades 10 to $25 \mathrm{~cm}$ long, 1 to $3 \mathrm{~mm}$ wide, mostly involute, especially on the innovations, those of the culm sometimes flat; panicle 5 to $15 \mathrm{~cm}$ long, narrow, mostly rather dense, often purplish; glumes

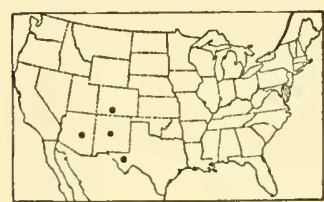

FIGURE 923.-Distribution of Stipa robusta. about $1 \mathrm{~cm}$ long; lemma 6 to 7 $\mathrm{mm}$ long, pubescent as in S. viridula, the body narrower, the callus sharper; awn 2 to $2.5 \mathrm{~cm}$ long, twice-geniculate. 24 (S. minor Scribn.) - Dry plains, meadows, and open woods, at medium and high altitudes, $\mathrm{Wy}$ oming to Yukon Territory, south to Texas and California (fig. 925). Differing from $S$. viridula in the glabrous throat of the sheath and in the shape of the fruit.

Stipa columbiana var. Nelsóni (Scribn.) Hitchc. Differing in its usually larger size, often as much as 1 $\mathrm{m}$ tall, the broader culm blades, and the larger and

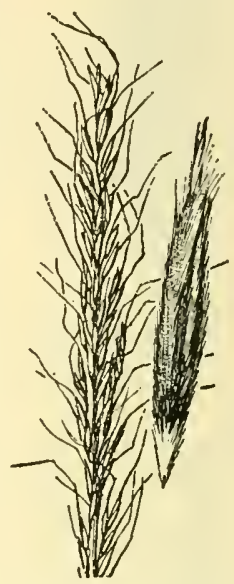

F I G U R E 924.--Stipa columbiana. Panicle, $\times 1 / 2$; lemma, $\times 5$ (Nelson 7478 , Wyo.) denser panicle; lemma 6 to $7 \mathrm{~mm}$ long; awn as much as $3.5 \mathrm{~cm}$ long, sometimes longer. 2 -Alberta to Washington, south to Colorado and Baja California.

28. Stipa lettermáni Vasey. Letterman needlegrass. (Fig. 926.) Resembling small forms of S. columbiana; culms often in large tufts, 30 to $60 \mathrm{~cm}$ tall; blades slender, involute; panicle slender, narrow,

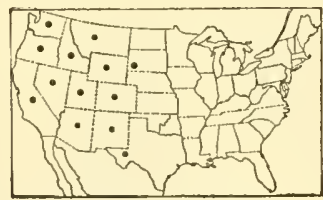

FigURE 925.-Distribution of Stipa columbiana.

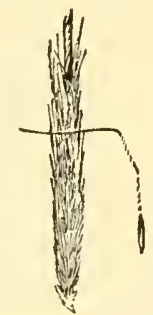

Figure 926.-Stipa lettermani. Floret, $\times 1$; lemma, $\times 5$. (Letterman 102, Idaho.)

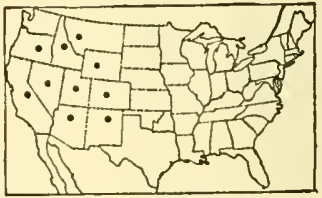

Figure 927.-Distribution of Stipa lettermani.

loose, 10 to $15 \mathrm{~cm}$ long; glumes about $6 \mathrm{~mm}$ long; lemma 4 to $5 \mathrm{~mm}$ long, slender and more copiously hairy than in S. columbiana; awn 1.5 to $2 \mathrm{~cm}$ long. 24 -Open ground or open woods at upper altitudes, Wyoming to Montana and Oregon, south to New Mexico and California (fig. 927). 
29. Stipa williámsii Scribn. Williams needlegrass. (Fig. 928.) Differing from $S$. columbiana chiefly in having more or less pubescent culms, sheaths, and blades; culms 60 to $100 \mathrm{~cm}$ tall; panicle 10 to 20 $\mathrm{cm}$ long; lemma about $7 \mathrm{~mm}$ long; awn usually 3 to $5 \mathrm{~cm}$ long. 2 Dry hills and plains, Montana to Washington, south to Colorado and California (fig. 929).

30. Stipa pinetórum Jones. (Fig. 930.) Culms in large tufts, 30 to $50 \mathrm{~cm}$ tall; ligule very short; leaves mostly basal, the blades 5 to $12 \mathrm{~cm}$ long, involute-filiform, more or less flexuous, slightly scabrous; panicle narrow, 8 to $10 \mathrm{~cm}$ long; glumes about $9 \mathrm{~mm}$ long; lemma 5

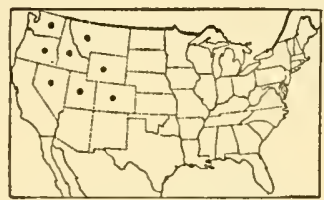

Figure 929.-Distribution of Stipa williamsii

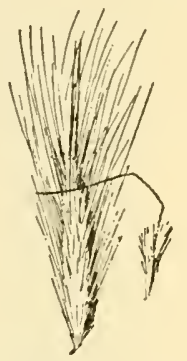

Figure 930,-Stipa pinetorum. Floret, $\times 1$; lemma, $\times 5$. (Jones 6023 , Colo.)

mm long, narrowly fusiform, clothed especially on the upper half with hairs $2 \mathrm{~mm}$ long, forming a conspicuous tuft exceeding the body of the lemma; awn about $2 \mathrm{~cm}$ long, twice-geniculate, nearly glabrous. 2 -Open pine woods at high altitudes, rare, Colorado, Utah, Nevada, and California (fig. 931).

31. Stipa árida Jones. (Fig. 932.) Culms 40 to 80 $\mathrm{cm}$ tall; blades 10 to $20 \mathrm{~cm}$ long, 1 to $2 \mathrm{~mm}$ wide, flat or involute, scabrous; panicle 10 to $15 \mathrm{~cm}$ long, narrow, compact, pale or silvery; glumes 8 to $12 \mathrm{~mm}$ long; lemma

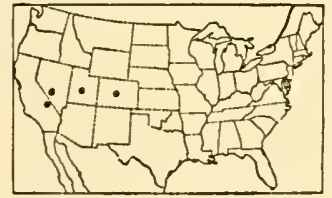

FIgure 931.-Distribution of Stipa pinetorum. about $5 \mathrm{~mm}$ long, appressed-pubescent on the lower half and along the margin, slightly roughened toward the summit; awn 4 to $6 \mathrm{~cm}$ long, capillary, scaberulous, loosely twisted for 1 or $2 \mathrm{~cm}$, flexuous beyond. 2 -Rocky slopes, rare, southwestern Colorado, Utah, and Arizona.

32. Stipa tenuíssima Trin. (Fig. 933.) Culms in large tufts, slender, wiry, 30 to $70 \mathrm{~cm}$ tall; ligule $2 \mathrm{~mm}$ long; blades 15 to $30 \mathrm{~cm}$ long, sometimes longer, filiform, wiry, closely involute; panicle 10 to $30 \mathrm{~cm}$ long, narrow, soft, nodding; glumes about $1 \mathrm{~cm}$ long; lemma 2 to $3 \mathrm{~mm}$ long, oblong-elliptic, glabrous, minutely papillose-roughened, the short callus densely pilose; awn about $5 \mathrm{~cm}$ long, capillary, flexuous, obscurely geniculate about the middle. 24 -Dry open ground, rocky slopes, and open dry woods, Texas and New Mexico to central Mexico; Argentina. 


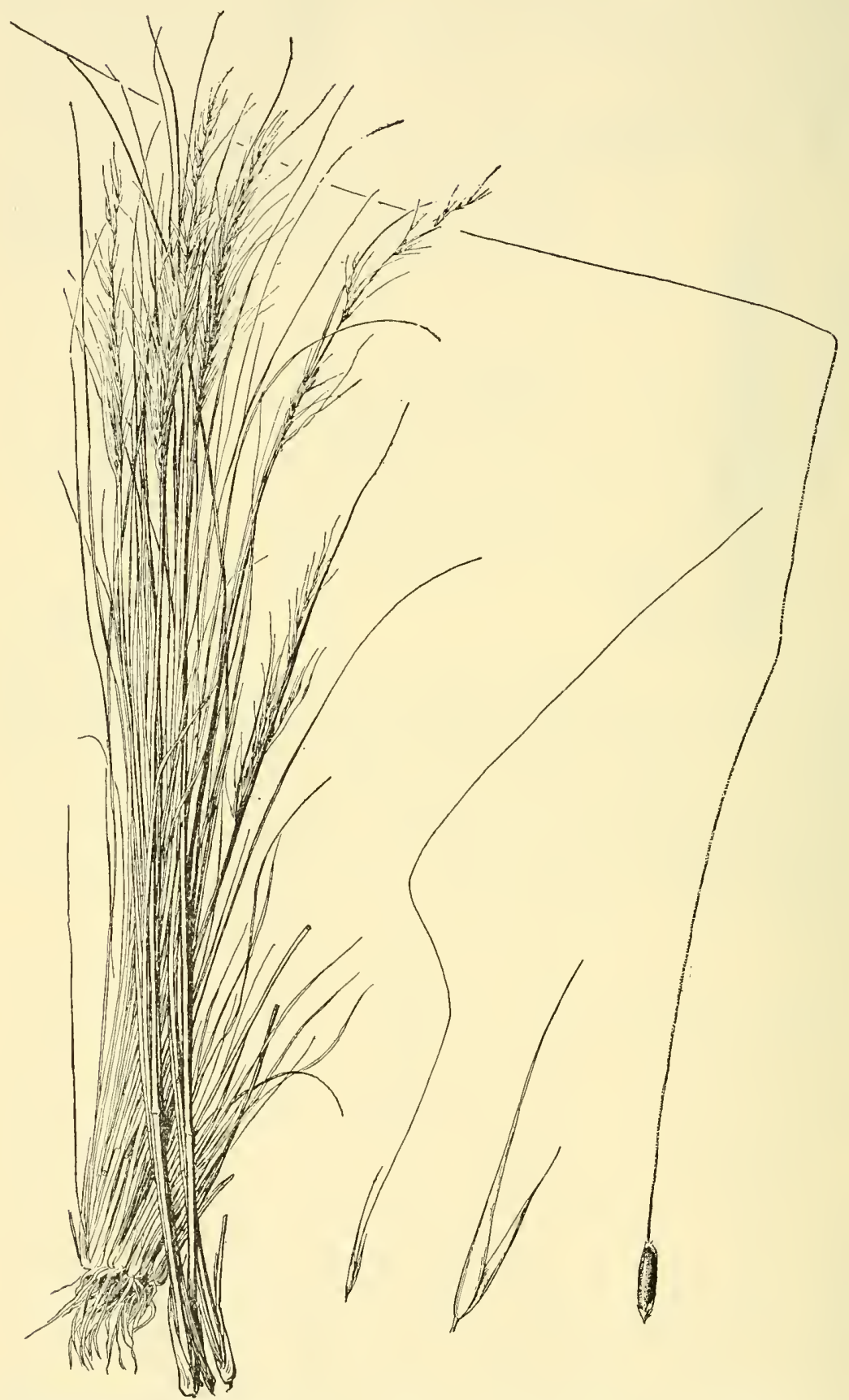

FIGURE 933.-Stipa tenuissima. Plant, $\times 1 \frac{1}{2}$; spikelet, $\times 2$; glumes and floret, $\times 5$. (Bailey 694, Tex.) 
Stipa neesiana Trin. and Rupr. Related to S. leucotricha but with shorter lemma with thickened erose crown. 24 -Ballast, Mobile. Ala.; South America.

Stipa brachychaéta Godr. Blades firm, flat, or loosely involute; panicle narrow, open, the few spikelets on slender pedicels; glumes 8 $\mathrm{mm}$ long; lemma $5 \mathrm{~mm}$ long, brown, pubescent in lines; awn $12 \mathrm{~mm}$ long. 24 -Ballast near Portland, Oreg.; Argentina.

Stipa elegantíssima Labill. Tufted perennial; foliage scant; panicle commonly half the height of the plant, the filiform spreading branches conspicuously feathery; spikelets purple, long-awned. 2 -Sometimes cultivated for ornament; Australia.

Stipa PENnÁta L. Tufted perennial; blades elongate, involute; panicle fewflowered, the large spikelets with awns 25 to $35 \mathrm{~cm}$ long, eonspicuously feathery above the bend. 21 - Sometimes eultivated for ornament; Europe.

Stipa Tenacíssima L. Esparto. Tufted perennial with tough branching base; blades elongate, involute, tomentose at base and with erect auricles 3 to $10 \mathrm{~mm}$ long; panicle narrow, dense; awns 4 to $6 \mathrm{~cm}$ long, feathery below the bend. 2 Sometimes cultivated for ornament; Spain and Algeria, where it is gathered for making paper and cordage.

\section{ARISTIDA L. Three-AwN}

Spikelets 1-flowered, the rachilla disarticulating obliquely above the glumes; glumes equal or unequal, narrow, acute, acuminate, or awn-tipped; lemma indurate, narrow, terete, convolute, with a hard, sharp-pointed, usually minutely bearded callus, terminating above in a usually trifid awn (the lateral divisions reduced or obsolete in Section Uniseta), the base sometimes undivided, forming a column. Annual or perennial, mostly slender tufted grasses, with narrow, frequently convolute blades and narrow or sometimes open panicles. Type species, Aristida adscensionis L. Name from Latin arista, awn.

The species are of distinctly minor importance for forage except in the Southwest, where several, such as $A$. longiseta, are eaten by stock before the flowers are produced. The ripe fruits of several species are troublesome to stock on the plains because of the sharp hard points. These fruits are produced sometimes in vast numbers and are carried far and wide by the wind in open country. Aristida adscensionis is one of the annuals that make up the "six-weeks" grasses of the Southwest.

Lemma articulate with the column of the awns; awns nearly equal.

Lemma not articulate.

Section 1. Arthratherum.

Lateral awns minute (less than $1 \mathrm{~mm}$ long) or wanting_Section 2. Uniseta. Lateral awns more than $1 \mathrm{~mm}$ long (rarely obsolete in A. ramosissima), usually well developed........................ Section 3. Chaetaria.

Section 1. Arthratherum

Plants annual.

Column very short

Column 10 to $15 \mathrm{~mm}$ long, twisted... Plants perennial.

Culms pubescent.

Culms glabrous........ 4. A. A

Section 2. Uniseta

Awn (column) tiwsted at base

7. A. ORCUTTIANA

Awn not twisted.

Branches of panicle distant, spreading, mostly more than $5 \mathrm{~cm}$ long, naked at base; awn straight or abruptly divergent ......... 5. A. TERNipes.

Branches of panicle short, approximate, 3 to $5 \mathrm{~cm}$ long, floriferous nearly to base; awn curved and flexuous ...................... FLoRIDANA 


\section{Section 3. Chaetaria}

1a. Central awn spirally coiled at the base, the lateral straight. Plants annual. (Group Dichotomae.)

Lateral awns half to two-thirds as long as the central, somewhat spreading.

8. A. Basiramea.

Lateral awns much shorter than the central, 1 to $3 \mathrm{~mm}$ long, erect.

Glumes nearly equal, 6 to $8 \mathrm{~mm}$ long; lemma sparsely appressed-pilose, 5 to

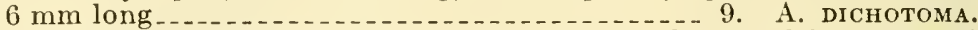
Glumes unequal, the second longer, about $1 \mathrm{~cm}$ long; lemma glabrous except the keel, scabrous toward the apex, about $1 \mathrm{~cm}$ long -10 . A. curTissir.

1b. Central awn not spirally coiled (in a few species all the awns loosely contorted in the lower part).

2a. Plants annual. (Group Adscensiones.)

Awns mostly 4 to $7 \mathrm{~cm}$ long, about equal, divergent_. 11 . A. oligantha. Awns mostly less than $2 \mathrm{~cm}$ long, often unequal.

Central awn with a semicircular bend at base, spreading or reflexed.

Lateral awns much reduced; lemma about $2 \mathrm{~cm}$ long.

12. A. RAMOSISSIMA.

Lateral awns one-third to half as long as the central; lemma 4 to $5 \mathrm{~mm}$

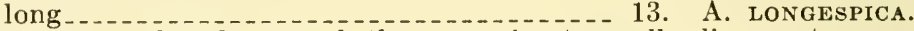

Central awn not sharply curved, the awns about equally divergent.

Glumes unequal; awns flat at base, 10 to $15 \mathrm{~mm}$ long.

14. A. ADSCENSIONIS.

Glumes about equal; awns terete, 15 to $20 \mathrm{~mm}$ long.

15. A. INTERMEDia.

2b. Plants perennial.

3a. Panicle open, the branches spreading (in $A$. pansa ascending), naked at base. (Group Divaricatae.)

Panicle branches stiffly and abruptly spreading or reflexed at base.

Branchlets divaricate and implicate........... 16. A. BARBATA. Branchlets appressed.

Summit of lemma narrowed into a twisted neck 2 to $5 \mathrm{~mm}$ long.

Summit of lemma somewhat narrowed but not twisted.

17. A. DIVARICATA.

18. A. HAMULOSA.

Panicle branches drooping or ascending, not abruptly spreading at base. Lateral awns onc-fourth to half as long as the central one.

19. A. patula. Lateral awns about as long as the central, at least more than half as

long ........

b. Panicle narrow, the branches ascending or appressed (branches sometimes somewhat spreading in $A$. parishii and A. purpurea).

Column $1 \mathrm{~cm}$ or more long, twisted; glumes awned_ 21. A. SPICIFormis.

Column less than $1 \mathrm{~cm}$ long.

Creeping rhizomes present. Glumes unequal, awned; awns loosely twisted at base, the central a little longer, 18 to $24 \mathrm{~mm}$ long.

31. A. RHIZOMOPHORA.

Creeping rhizomes wanting (sometimes short ones in $A$. stricta).

4a. First glume about half as long as the second (as much as two-thirds as long in $A$. glauca). (Group Purpureae.)

Lemma tapering into a slender somewhat twisted beak 5 to $6 \mathrm{~mm}$ long; awns 1.5 to $2.5 \mathrm{~cm}$ long, widely spreading.

Lemma beakless or only short-beaked.

22. A. GLA DCA.

Branches of the rather loose and nodding panicle slender and flexuous (see also $A$. longiseta var. rariflora).

Lemma about $1 \mathrm{~cm}$ long; awns 3 to $5 \mathrm{~cm}$ long.

Lemma 7 to $8 \mathrm{~mm}$ long; awns about $2 \mathrm{~cm}$ long.

23. A. PURPUREA.

24. A. ROEMERIANA.

Branches of the erect panicle stiff and appressed, or the lowermost sometimes somewhat flexuous.

Panicle mostly more than $15 \mathrm{~cm}$ long, the branches severalflowered; awns about $2 \mathrm{~cm}$ long. Sheaths with a villous line across the collar ........... 25. A. WRIGHTIr.

Panicle mostly less than $15 \mathrm{~cm}$ long, the branches few flowered; awns 2 to several cm long. 
Lemma gradually narrowed above, scaberulous on the upper half; leaves mostly in a short curly cluster at the base of the plant_.......... 27. A. FENDLERIANA.

Lemma scarcely narrowed above, scaberulous only at the tip; leaves not conspicuously basal_ 26. A. LONGISETA.

4b. First glume more than half as long as the second. (Usually the glumes about equal or the first sometimes a little longer.)

Sheaths lanate-pubescent. Panicle branched, somewhat spreading; central awn 1.5 to $2.5 \mathrm{~cm}$ long, spreading or reflexed from a curved base.....

Sheaths not lanate-pubescent.

Column of awn at maturity 3 to $5 \mathrm{~mm}$ long, distinctly twisted.

29. A. ARIZONICA.

Column of awn less than $3 \mathrm{~mm}$ long, or if so long, not twisted. Blades villous on upper surface near base, involute.

30. A. stricta.

Blades not involute and villous at base.

Awns at maturity about equally divergent, sometimes slightly twisted but not spirally contorted at base.

Lemma about $7 \mathrm{~mm}$ long; awns horizontally spreading; panicle usually more than $20 \mathrm{~cm}$ long.

32. A. PURPURASCENS.

Lemma 10 to $12 \mathrm{~mm}$ long; awns somewhat spreading but scarcely horizontal; panicle mostly 10 to $15 \mathrm{~cm}$ long. 33. A. PARISHII.

Awns at maturity unequally divergent or spirally contorted at base.

Awns not spirally contorted at base; central awn more spreading than the others, curved at base, sometimes reflexed.

Lateral awns erect, two-thirds to three-fourths as long as the central.

Glumes about $12 \mathrm{~mm}$ long_._._._ 34. A. AfFinis.

Glumes about $6 \mathrm{~mm}$ long...... 35 . A. virgata.

Lateral awns spreading or reflexed. Panicles nearly simple.

Glumes 6 to $7 \mathrm{~mm}$ long; spikelets mostly in pairs. 36. A. SIMPLICIFLORA. Glumes about $1 \mathrm{~cm}$ long; spikelets solitary.

37. A. MOHRII.

Awns spirally contorted at base, spreading.

Blades flat.

Panicle slender, the branches short, rather distant, few-flowered .......... 35. A. TENUISPICA.

Panicle rather thick, the branches as much as $10 \mathrm{~cm}$ long, rather densely many-flowered.

39. A. CONDENSATA.

Blades involute .............. 40. A. GYRATis.

Section 1. Arthrátherum (Beauv.) Reichenb.

Lemma articulate with the column of the awns, the latter finally deciduous; glumes 1-nerved; awns nearly equal.

1. Aristida desmántha Trin. and Rupr. (Fig. 934.) Annual; branching, as much as $80 \mathrm{~cm}$ tall; sheaths of ten woolly; blades folded or involute, 2 to $3 \mathrm{~mm}$ wide; panicle as much as $20 \mathrm{~cm}$ long, the branches stiffly ascending, very scabrous, bearing 1 to few spikelets; glumes slightly unequal, the body about $1 \mathrm{~cm}$ long, tapering into an awn about half as long; lemma 7 to $8 \mathrm{~mm}$ long, glabrous below, somewhat laterally compressed and slightly twisted at summit, the densely pubescent callus about $2 \mathrm{~mm}$ long; awns 2 to $2.5 \mathrm{~cm}$ long, united for 1 to $2 \mathrm{~mm}$, the bases curved in a semicircular somewhat contorted bend, the upper part thus usually deflexed. $\odot$ - Open sandy soil or sandy woods, Illinois, Nebraska, and Texas. 
2. Aristida tuberculósa Nutt. (Fig. 935.) Annual; culms branching, 30 to $60 \mathrm{~cm}$ or even $1 \mathrm{~m}$ tall; blades involute, 2 to $4 \mathrm{~mm}$ wide when flat; panicle $10^{\prime}$ to $20 \mathrm{~cm}$ tall, the branches stiffly ascending; glumes about equal, gradually narrowed into an awn, about $2.5 \mathrm{~cm}$ long, including the awn; lemma 11 to $13 \mathrm{~mm}$ long, glabrous, except for the slightly scabrous summit, extending downward into a densely pubescent callus 3 to $4 \mathrm{~mm}$ long; column of awns twisted, 10 to 15 $\mathrm{mm}$ long, the upper 2 or $3 \mathrm{~mm}$ twisted but not united, above this forming a semicircular bend, the terminal straight part of the awns usually deflexed, 3 to $4 \mathrm{~cm}$ long. $\odot$ - Open sandy woods, Massachusetts to Georgia and Mississippi near the coast; around the southern

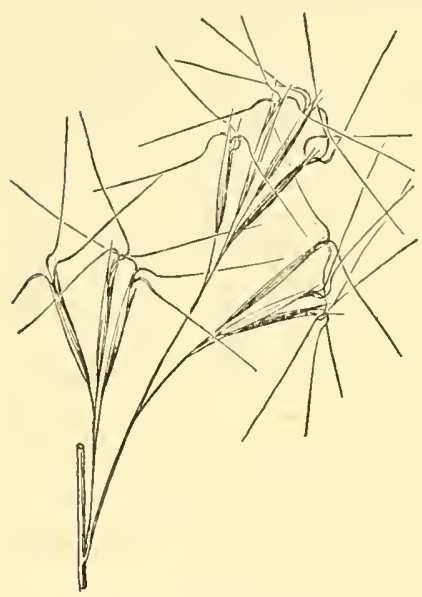

Figure 934.-Aristida desmantha, $\times 1$. (Reverchon 3428 , Tex.)

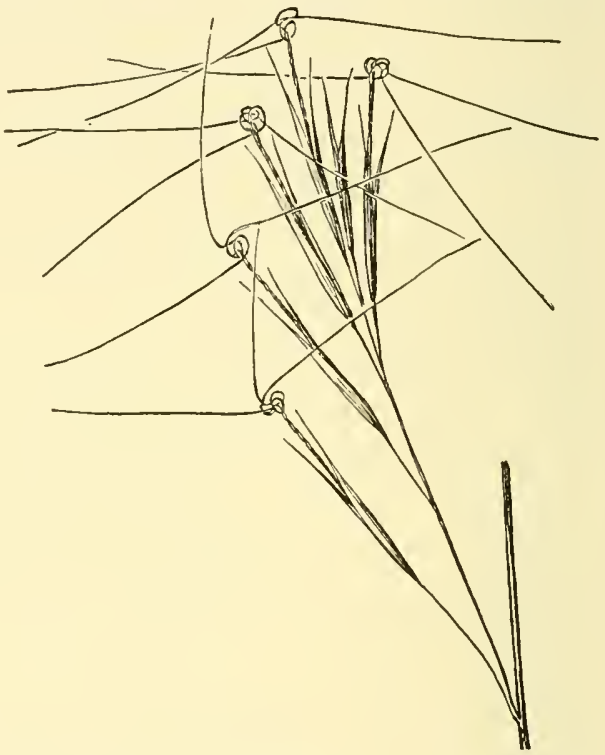

Figure 935.-Aristida tuberculosa, X1. (V. H. Chase 322, Ind.)

end of Lake Michigan and in other localities in Wisconsin, Indiana, Illinois, Iowa, and Minnesota (fig. 936).

3. Aristida califórnica Thurb. (Fig. 937.) Perennial, tufted, much branched at base; culms pubescent, 10 to $30 \mathrm{~cm}$ tall; blades mostly involute and less than $5 \mathrm{~cm}$ long; panicles numerous, mostly reduced to few-flowered racemes; first glume about $8 \mathrm{~mm}$ long, the second about $12 \mathrm{~mm}$ long; lemma 5 to $7 \mathrm{~mm}$ long, glabrous below, scaberulous toward the summit, the strongly pubescent callus 1.5 to 2 $\mathrm{mm}$ long; column 15 to $20 \mathrm{~mm}$ long, the awns about equal, 2.5 to $3.5 \mathrm{~cm}$ long, spreading horizontally, the bases arcuate and slightly

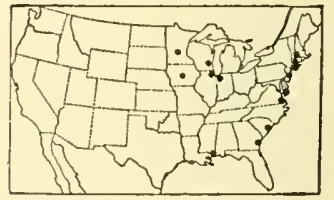

FIGURE 936.-Distribution of Aristida tuberculosa. contorted. 2| -Dry sandy or gravelly soil, deserts of southern California, southwestern Arizona, and northern Mexico.

4. Aristida glabráta (Vasey) Hitche. (Fig. 938.) Perennial; culms erect, branched, glabrous, 20 to $40 \mathrm{~cm}$ tall; blades mostly involute, those of the culm 1 to $3 \mathrm{~cm}$ long; panicle narrow, 3 to $6 \mathrm{~cm}$ long; first glume 5 to $6 \mathrm{~mm}$, the second 10 to $12 \mathrm{~mm}$ long; lemma 5 to $7 \mathrm{~mm}$ long, 
the twisted column 6 to $14 \mathrm{~mm}$ long; awns about equal, divergent, 2 to $3 \mathrm{~cm}$ long. 2 -Open dry ground, southern Arizona to Baja California.

\section{Section 2. Uniséta Hitche.}

Lateral awns minute (less than $1 \mathrm{~mm}$ long) or wanting, (see also $A$. dichotoma and $A$. ramosissima of Section Chactaria); lemma not articulate with the column of the awn.

5. Aristida térnipes Cav. Spider grass. (Fig. 939.) Perennial; culms erect, 50 to $100 \mathrm{~cm}$ tall; blades flat, involute toward the end

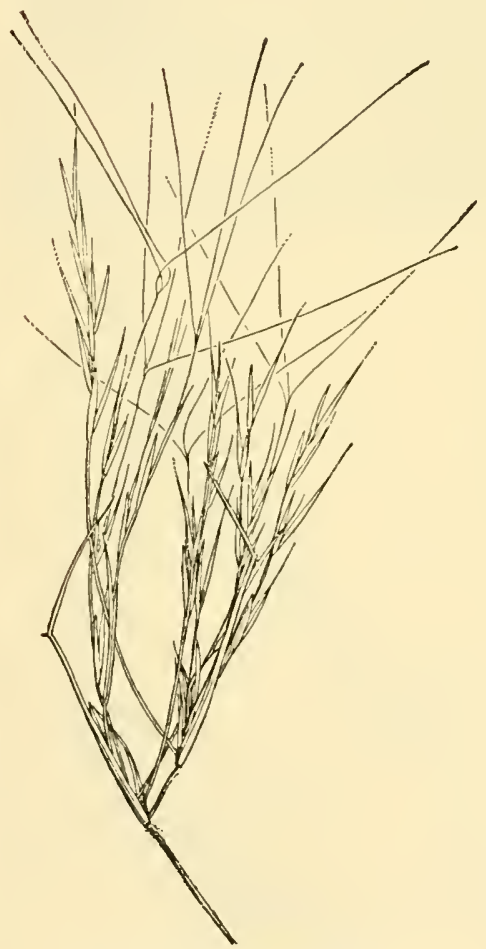

Figure 937.-Aristida californica, $\times 1$. (Kearney 3524, Ariz.)

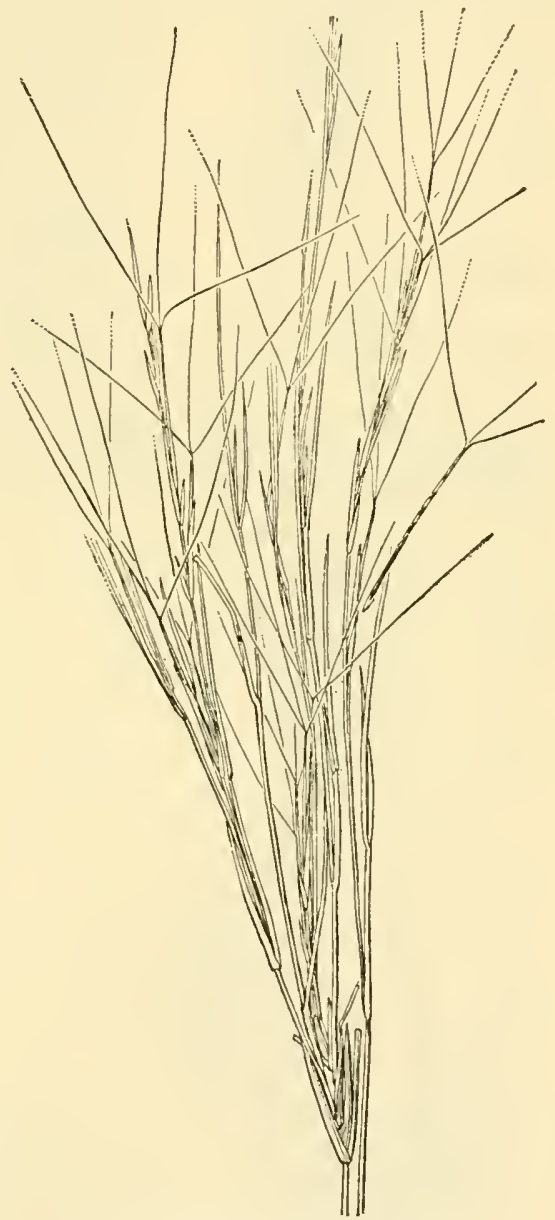

Figure 938.-Aristida glabrata, $\times 1$. (Griffiths 7312, Ariz.)

and tapering into a fine point as much as $40 \mathrm{~cm}$ long, 2 to $3 \mathrm{~mm}$ wide; panicle open, one third to half the entire height of the culm, the branches few, distant, spreading, scabrous, mostly naked at the base; spikelets appressed at the ends of the branches; glumes about equal, 8 to $10 \mathrm{~mm}$ long; lemma glabrous, often strongly scabrous on the keel, gradually narrowed into a laterally compressed scabrous falcate beak, 
1-nerved on each side, this extending into a single straight or divergent scabrous nearly terete awn, the obsolete cr minute lateral awns about $17 \mathrm{~mm}$ above the lemma, the central awn 10 to $15 \mathrm{~mm}$ long.

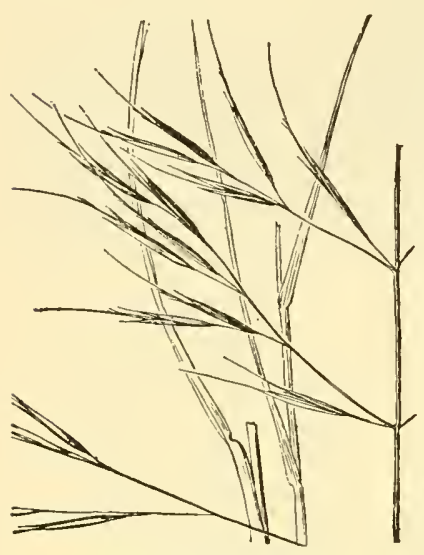

24 (A. scabra Kunth.)-Rocky hills and dry plateaus, New Mexico and Arizona to northern South America; Bahamas, Cuba.

ARISTIDA TERNIPES var. MíNor (Vasey) Hitchc. Smaller and often prostrate or ascending, the panicle usually more than half the length of the entire plant, less diffuse, the shorter branches usually stiffly spreading or somewhat deflexed. $24(A$. divergens Vasey.)-Rocky hills and plains, Texas, New Mexico, Arizona; Nicaragua.

6. Aristida floridána (Chapm.) Vasey. (Fig. 940.) Resembling A. ternipes, but differing in having a narrow panicle with ascending branches 3 to $5 \mathrm{~cm}$ long, spikelet-bearing nearly to the base; awns sickleshaped, the column somewhat twisted. 24 Figure
(Griffiths $72 \overline{1}$, Ariz.) from Key West, Fla.

7. Aristida orcuttiána Vasey. BegGartick Grass. (Fig. 941.) Perennial; culms erect, 30 to $60 \mathrm{~cm}$ or even $1 \mathrm{~m}$ tall; blades flat or the upper involute, as much as $3 \mathrm{~mm}$ wide; panicle open, as much as 30

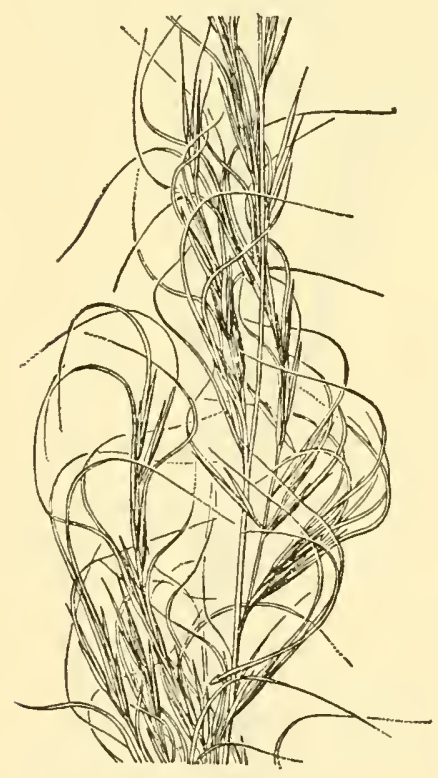

FIgure 940.-Aristida foridana, $\times 1$. (Blodgett, Fla.)

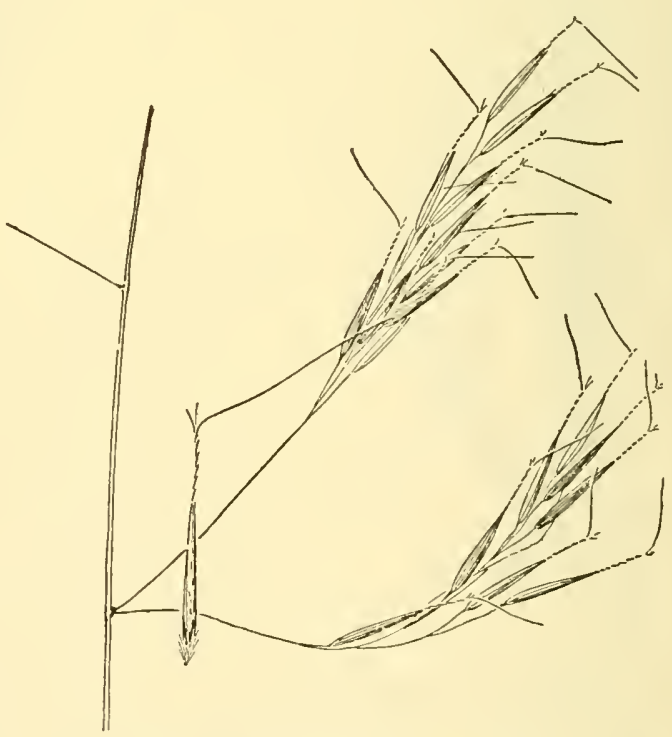

Figure 941.-Aristida orcuttiana. Panicle, $\times 1$; floret, $\times 2$. (Smith, N.Mex.)

cm long, nodding or drooping, the branches few, distant, spreading or drooping, as much as $20 \mathrm{~cm}$ long; glumes equal or nearly so, 10 to $15 \mathrm{~mm}$ long; lemma 8 to $10 \mathrm{~mm}$ long, gradually narrowed into a 
scabrous twisted column, the total length to the bend 10 to $17 \mathrm{~mm}$; central awn divergent, 5 to $10 \mathrm{~mm}$ long, the lateral awns from obsolete to as much as $1 \mathrm{~mm}$ long, erect.

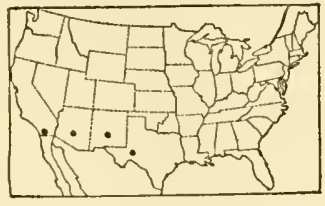

FIGURE 942.-Distribution of Aristida orcuttiana.

- Rocky hills and plains, Texas to southern California (San Diego), and northwest Mexico (fig. 942).

\section{Section 3. Chaetária (Beauv.) Trin.}

Lateral awns more than $1 \mathrm{~mm}$ long, usually well developed; lemma not articulate with the column of the awns.

8. Aristida basirámea Engelm. (Fig. 943.) Annual; branching at base, 30 to $50 \mathrm{~cm}$ tall; blades flat, as much as $15 \mathrm{~cm}$

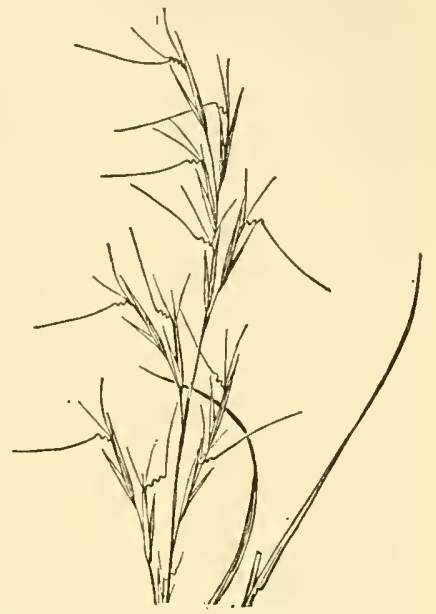

Figure 943.-Aristida basiramea, $\times 1$. (Pammel 174, Iowa.) long and $1.5 \mathrm{~mm}$ wide; panicles terminal and axillary, the terminal 5 to $10 \mathrm{~cm}$ long, the axillary mostly enclosed in the sheaths; glumes somewhat unequal, 12 to $15 \mathrm{~mm}$ long; lemma about $1 \mathrm{~cm}$ long; cen-

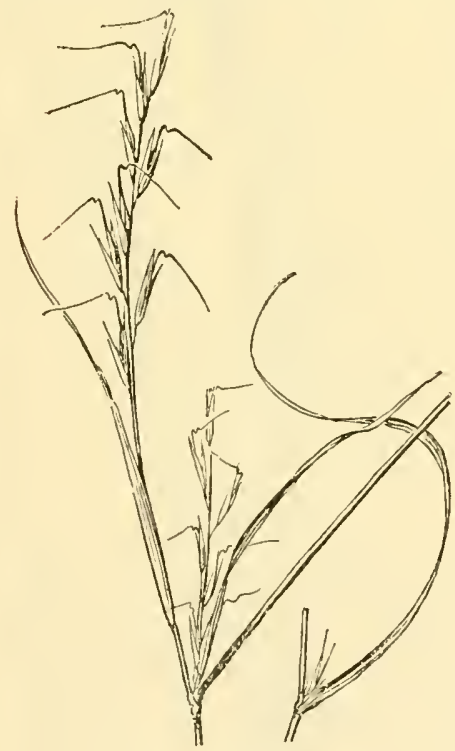

FIGURE 945.-Aristida dichotoma, $\times 1$ (Jackson 1829, Del.) tral awn coiled at base, 10 to $15 \mathrm{~mm}$ long, the lateral awns half to two-thirds as long, somewhat spreading. $\odot-$ Open barren or sandy soil, Michigan and North Dakota to Illinois and Kansas; introduced in Maine (fig. 944).

9. Aristida dichótoma Michx. (Fig. 945.) Annual; culms branched at base,

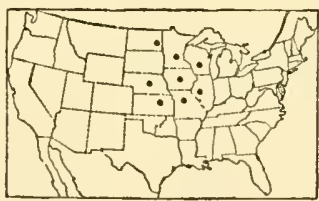

Figure 944.-Distribution of Aristida basiramea.

20 to $40 \mathrm{~cm}$ tall; blades short, the lower mostly flat, scarcely $1 \mathrm{~mm}$ wide, the upper involute; panicles terminal and axillary, the terminal usually less than $10 \mathrm{~cm}$ long, the lateral small; glumes about equal, 6 to $8 \mathrm{~mm}$ long; lemma 5 to $6 \mathrm{~mm}$ long; central awn spirally coiled, horizontally bent, 3 to $6 \mathrm{~mm}$ long, the lateral awns erect, about $1 \mathrm{~mm}$ long. - - Dry open ground, Maine to eastern Kansas, south to Florida and Texas (fig. 946).

10. Aristida curtíssii (A. Gray) Nash. (Fig. 947.) Annual; similar to $A$. dichotoma, differing in the less branching habit, the longer 
and more conspicuous blades, the looser panicles of larger spikelets, the more unequal glumes, the longer second glume (about $1 \mathrm{~cm} l o n g$ ), the longer smooth lemma (about $1 \mathrm{~cm}$ long) and central awn, and the usually longer lateral awns; central awn about $1 \mathrm{~cm}$ long, the lateral

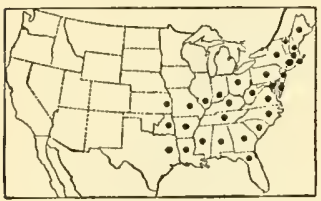

Figure 946.-Distribution of Aristida dichotoma. awns 2 to $4 \mathrm{~mm}$ long. $\odot-O p e n$ dry ground, Maryland to West Virginia; Florida; Illinois to Wyoming and Oklahoma (fig. 948).

11. Aristida oligántha Michx. Pramre THREE-AWN. (Fig. 949.) Annual, much branched; culms 30 to $50 \mathrm{~cm}$ tall; blades flat or loosely involute, usually not more than $1 \mathrm{~mm}$ wide; paniele loose, 10 to $20 \mathrm{~cm}$ long; spikelets short-pediceled the lower of ten in pairs; glumes about equal, 2 to $3 \mathrm{~cm}$ long, tapering into an awn, the first $3-$ to 5 nerved; lemma about $2 \mathrm{~cm}$ long, the awns about equal, divergent, 4 to $7 \mathrm{~cm}$ long, somewhat spirally eurved at base. $\odot$-Open dry ground, Massachusetts to South Dakota, south to Florida and Texas; Oregon to Arizona (fig. 950).

12. Aristida ramosíssima Engelm. (Fig. 951.) Annual, much branched; culms 30 to $50 \mathrm{~cm}$ tall; blades flat or involute, about $1 \mathrm{~mm}$ wide; panicle narrow, 8 to $12 \mathrm{~cm}$ long; glumes $3-$ to 5-nerved, the first about $15 \mathrm{~mm}$, the second about $2 \mathrm{~cm}$ long, including an awn 3 to $5 \mathrm{~mm}$ long; lemma about $2 \mathrm{~cm}$ long, tapering into a neck about $5 \mathrm{~mm}$ long; central awn with a semicircular bend or part of a coil at base, 15 to $20 \mathrm{~mm}$ long, spreading, the lateral awns reduced or as much as $6 \mathrm{~mm}$ long, rarely longer. $\odot \quad$ Open sterile soil, Indiana to Iowa, south to Tennessee, Louisiana, and Texas (fig. 952).

13. Aristida longespíca Poir. (Fig. 953.) Annual, branched; culms 20 to $40 \mathrm{~cm}$ tall; blades flat or involute, about $1 \mathrm{~mm}$ wide; panicles narrow, slender, the terminal 10 to $15 \mathrm{~cm}$ or even $20 \mathrm{~cm}$ long; glumes about equal, $5 \mathrm{~mm}$ long; lemma 4 to $5 \mathrm{~mm}$ long;

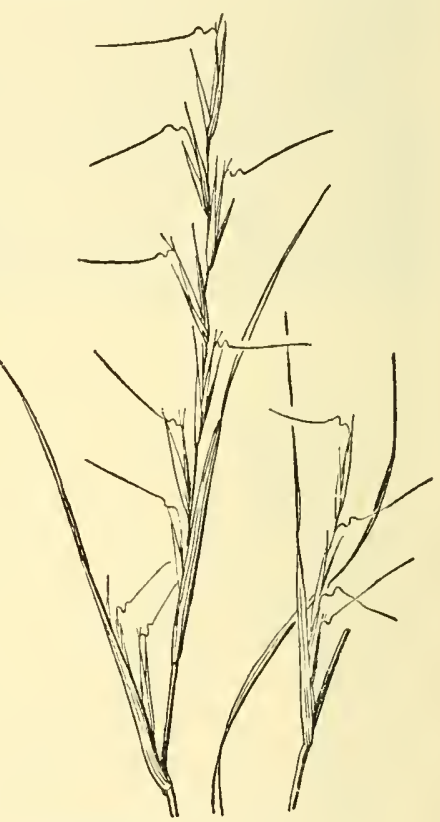

Figure 947.-Aristida curtissii, X 1. (Waite, 11l.) central awn sharply curved at base, spreading, 5 to $15 \mathrm{~mm}$ long, the lateral awns erect, one-third to half as long as the central, some-

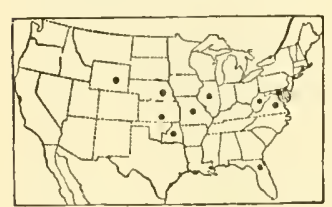

FIGURE 948.-Distribution of Aristida curtissii. times only $1 \mathrm{~mm}$ long. $\odot$ (A. gracilis Ell.) -Sterile or sandy soil, New Hampshire to Michigan, south to Florida and Texas, especially on the Coastal Plain (fig. 954). In the typical form the lateral awns are short; in var. geniculata Fernald ( $A$. geniculata Raf.) the lateral awns are more than one-third as long as the central one.

14. Aristida adscensiónis L. Sixweeks three-awn. (Fig. 955.) Annual, branched at base, erect or spreading; eulms 10 to $80 \mathrm{~cm}$ 


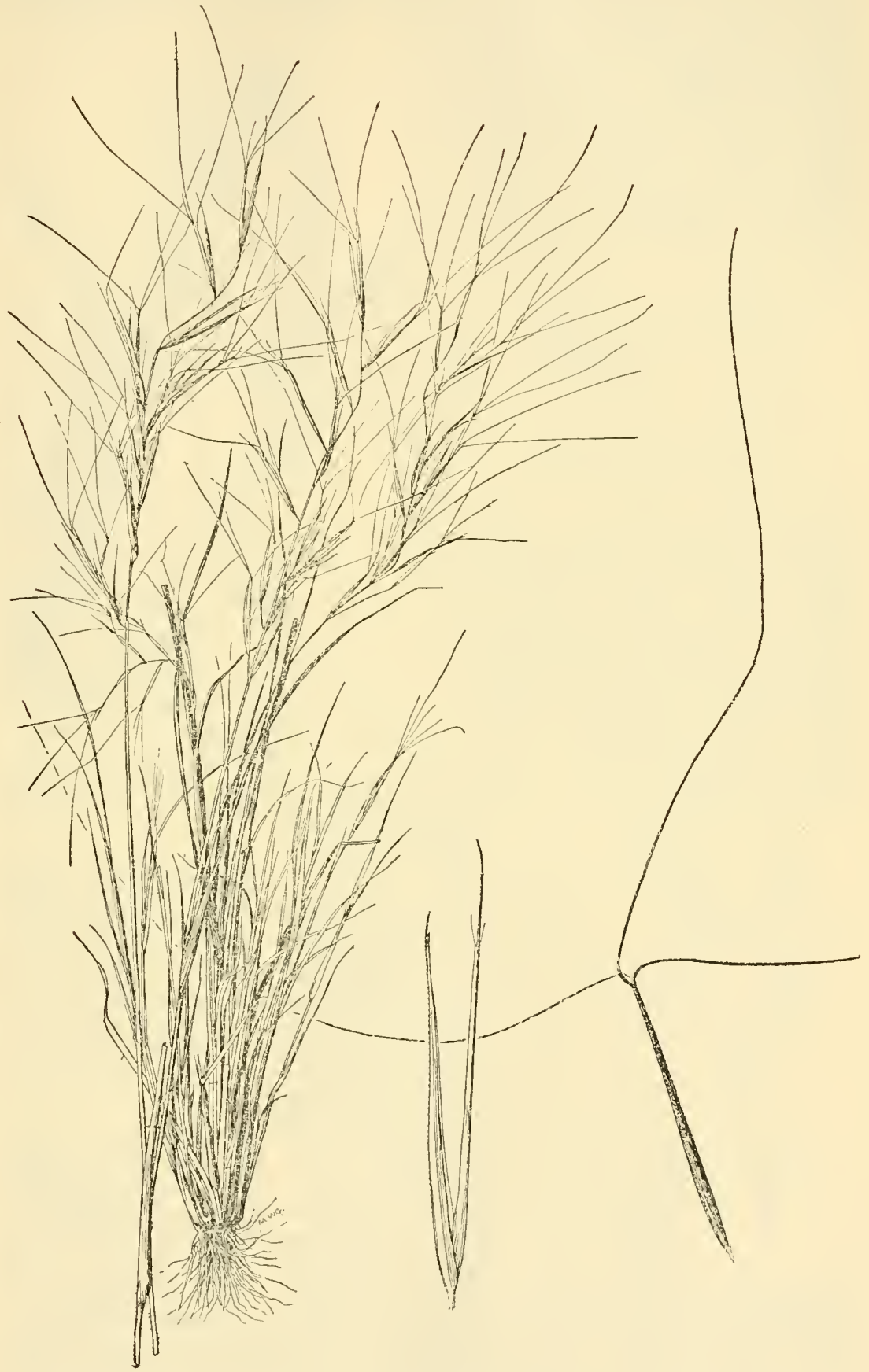

Figure 949.-Aristida oligantha. Plant, $\times 1 / 2$; glumes and floret, $\times 2$. (Fitzpatrick 21, Iowa.) $55974^{\circ}-35-29$ 
tall; panicle narrow and usually rather compact, 5 to $10 \mathrm{~cm}$ long, or longer in large plants; first glume 5 to $7 \mathrm{~mm}$ long, the second 8 to $10 \mathrm{~mm}$ long; lemma 6 to $9 \mathrm{~mm}$ long, compressed toward the scarcely beaked summit, scabrous on the upper part of the keel; awns about equal (the lateral rarely shorter) mostly 10 to $15 \mathrm{~mm}$ long, about equally divergent at an angle of as inuch as 45 degrees, flat

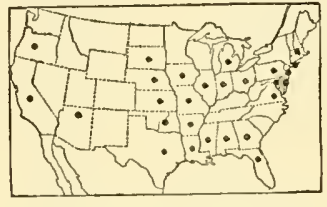

Figure 950.-Distribution of Aristida oligantha.

and without torsion at base. $\odot$-Dry open ground, Missouri (Courtney); southern Kansas to Texas, west to Nevada and southern California, southward (fig. 956); warmer parts of the Old World. Originally described from Ascension Island. Variable in size from depauperate plants a few centimeters tall with shorter

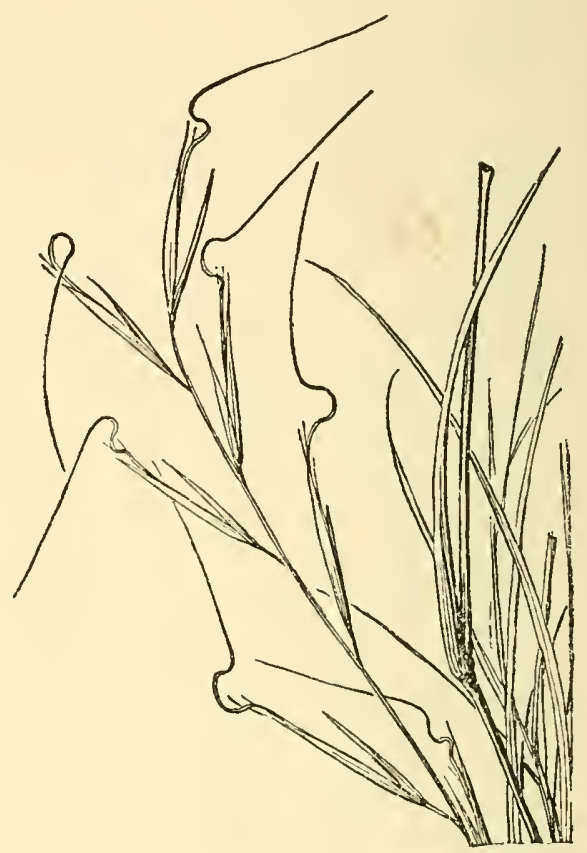

FIGURE 951.-Aristida ramosissima, $\times 1$. (Deam 18549, Ind.)

contracted panicle ( $A$. bromoides H. B. K.) to tall slender plants

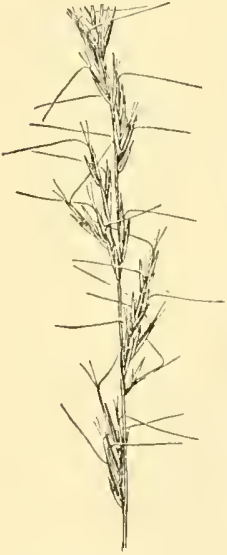

FIgure 953.-Aristida longespica, × 1 (Vasey, D.C.) with large open panicle ( $A$. fasciculata Torr.).

\section{Aristida intermédia} Scribn. and Ball. (Fig. 957.) Annual, simple or branched, 20 to $40 \mathrm{~cm}$ tall; blades flat or involute, mostly less than $10 \mathrm{~cm}$ long and $2 \mathrm{~mm}$ wide; panicle narrow, slender, loosely flowered, 10 to $20 \mathrm{~cm}$ long; glumes about equal, $1 \mathrm{~cm}$ long; lemma 8 mm long; awns about equal, all somewhat divergent, 1.5 to $2 \mathrm{~cm}$ long. $\odot \quad$ Low sandy soil, Indiana to Nebraska, south to Mississippi and Texas (fig. 958).

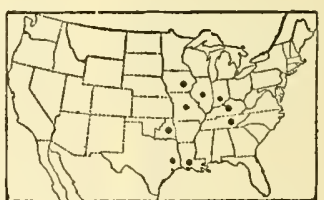

Figure 952.-Distribution of Aristida ramosissima.

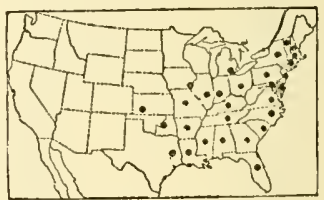

FIGURE 954.-Distribution of Aristida longespica.

The measurements of the spikelet are sometimes less than those given, especially in plants attacked by smut. 
16. Aristida barbáta Fourn. Havard three-awn. (Fig. 959.) Perennial, forming hemispherical tufts as much as $30 \mathrm{~cm}$ in diameter,

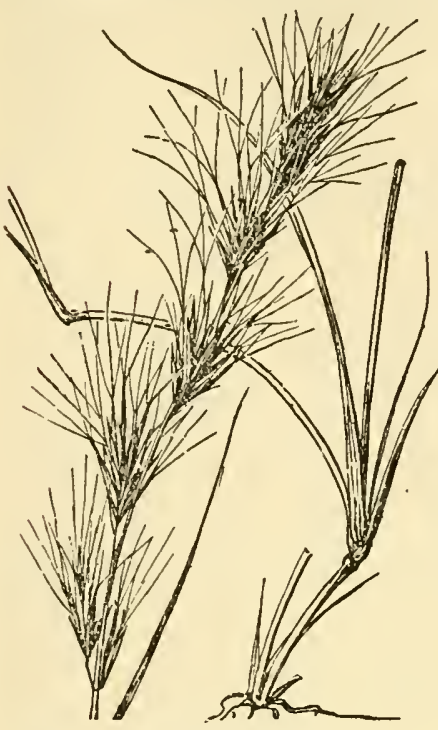

Figure 955.-Aristida adscensionis, $\times 1$. (Earle 559, N.Mex.) the culms rather stiffly radiating in all directions, 15 to $30 \mathrm{~cm}$ long; blades closely involute, mostly less than 10 $\mathrm{cm}$ long and $0.5 \mathrm{~mm}$ thick; panicles about half the length of the entire culm, open, the branches divaricately spreading or somewhat reflexed, mostly 3 to $6 \mathrm{~cm}$ long, in pairs or with short basal branchlets, but without long naked base, the branchlets and pedicels implicate or flexuous, the whole pan-

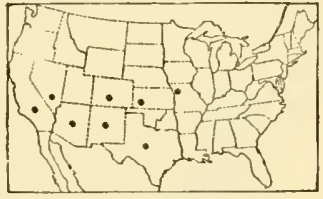

FIGURE 956.-Distribution of Aristida adscensionis. icle fragile at maturity, breaking away and rolling before the wind; glumes about equal, $1 \mathrm{~cm}$ long; lemma gradually narrowed into a straight or twisted scaberulous beak, the entire length 8 to $10 \mathrm{~mm}$; awns somewhat divergent, nearly equal, 15 to $20 \mathrm{~mm}$ long. 2 (A. havardii Vasey.)-Hills and plains, western Texas to Arizona and central Mexico.

17. Aristida divaricáta Humb. and Bonpl. Poverty three-Awn. (Fig. 960.) Perennial; culms erect or prostrate-spreading, usually 30 to $60 \mathrm{~cm}$ long, sometimes longer; blades flat or usually loosely involute, or the basal

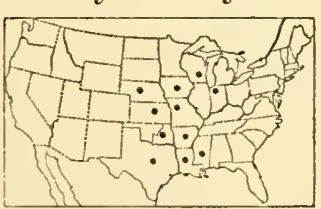

FigURE 958.-Distribution of Aristida intermedia.

closely involute, mostly less than 3 $\mathrm{mm}$ wide; panicle large, diffuse, usually as much as half the entire length of the culm, the branclies spreading or reflexed, naked below; glumes nearly equal, $1 \mathrm{~cm}$ long; lemma $1 \mathrm{~cm}$ long, narrowed into a twisted beak 2 to $5 \mathrm{~mm}$ long; awns about equal, 10 to $15 \mathrm{~mm}$ long. 2 4 -Dry hills and plains, Kansas to southern California, south to Texas and Guatemala (fig. 961).

18. Aristida hamulósa Henr. (Fig. 962.) Resembling $A$. divaricata; lemma somewhat narrowed at summit but not twisted, central awn a little longer than the two lateral ones. 2 -Dry hills

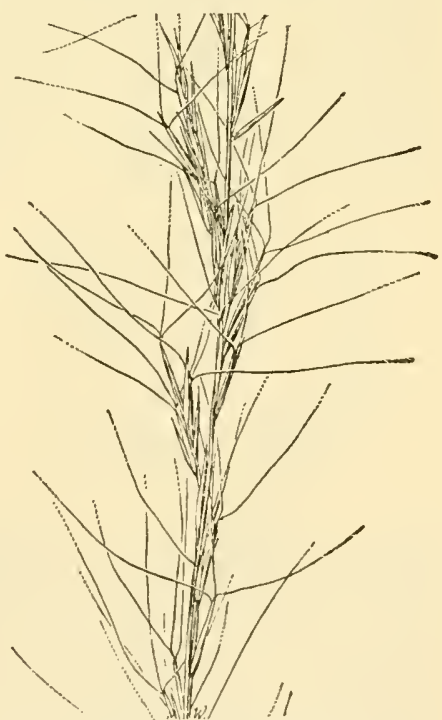

Figure 957.-Aristida intermedia, $\times 1$. (Kearney 236, Miss.) and plains, western Texas to southern California, south to Guatemala (fig. 963). In Arizona more common than $A$. divaricata. 
19. Aristida pátula Chapm. (Fig. 964.) Perennial, erect, as much as $1 \mathrm{~m}$ tall; blades flat, becoming involute especially at the slender tip, elongate, 2 to $4 \mathrm{~mm}$ wide; panicle loose and open, one third to half the entire length of the culm, the branches drooping, naked below, as much as $20 \mathrm{~cm}$ long; glumes 12 to $15 \mathrm{~mm}$ long,

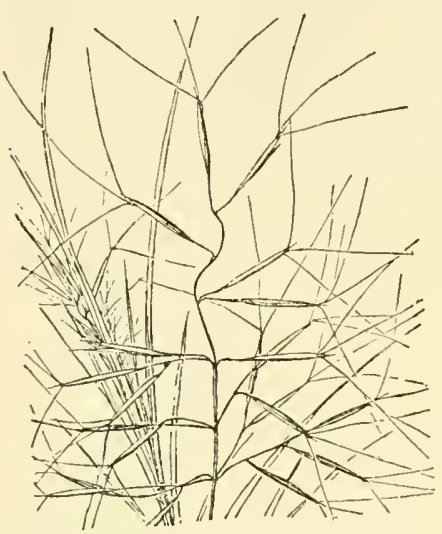

FIgURE 959--Aristida barbata, $\times 1$. (Wooton, N.Mex.) nearly equal; lemma 10 to $12 \mathrm{~mm}$ long; central awn straight, 2 to $2.5 \mathrm{~cm}$ long, the lateral scarcely diverging, 5 to 10 mm long. 24 -Moist sandy pine barrens and low open ground, peninsular Florida.

20. Aristida pánsa Woot. and Standl. Wooton threE-AWN. (Fig. 965.) Perennial; culms stiflly erect, slender, wiry, 20 to $40 \mathrm{~cm}$ tall; blades closely involute, $0.5 \mathrm{~mm}$ thick; panicle narrow, open, rather stiffly upright, 10 to $20 \mathrm{~cm}$ long, the branches stiffly ascending, 4 to 8 $\mathrm{cm}$ long; first glume 5 to $7 \mathrm{~mm}$ long, the second 7 to $10 \mathrm{~mm}$ long; lemma about as long as the second glume, tapering into a scabrous slightly twisted beak about $2 \mathrm{~mm}$ long; awns about equal, divergent or finally nearly horizontally spreading, 10 to $20 \mathrm{~mm}$ long, the bases finally somewhat curved or warped. 24 -Plains and open ground, western Texas to Arizona.

21. Aristida spicifórmis Ell. (Fig. 966.) Perennial; culms strictly erect, 50 to $100 \mathrm{~cm}$ tall; blades erect, flat or usually involute, elongate, 1 to $3 \mathrm{~mm}$ wide; panicle erect, dense and spikelike 10 to $15 \mathrm{~cm}$ long, more or les, spirally twisted; glumes uns equal, abruptly long-awned-

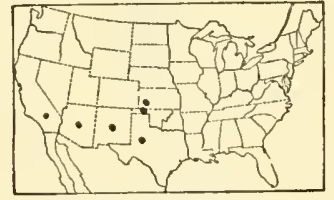

FIGURE 961.-Distribution of Aristida divaricata.

the first $4 \mathrm{~mm}$ long, the second 8 to $10 \mathrm{~mm}$ long, the awns usually 10 to $12 \mathrm{~mm}$ long; lemma 5 to $6 \mathrm{~mm}$ long, extending in to a slender twisted column 1 to $3 \mathrm{~cm}$ long; awns about equal, 2 to $3 \mathrm{~cm}$ long, divergent or horizontally spreading, more or less curved or warped at base. 24 Pine barrens along the coast, South Carolina to Florida and Mississippi; Cuba, Puerto Rico (fig. 967). 
22. Aristida glaúca (Nees) Walp. Reverchon three-Awn. (Fig. 968.) Perennial; culms erect, 20 to $40 \mathrm{~cm}$ tall; blades involute, mostly curved or flexuous, 5 to $10 \mathrm{~cm}$ long, about $1 \mathrm{~mm}$ thick; panicle

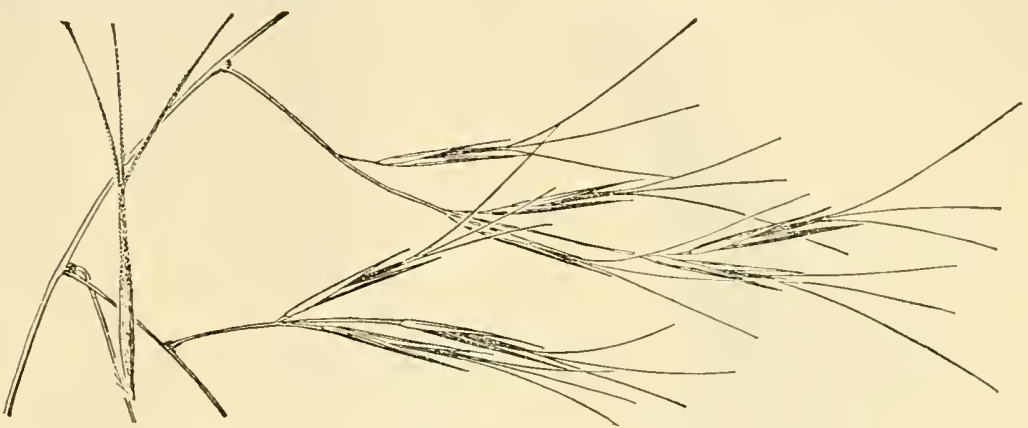

Figure 962.-Aristida hamulosa. Panicle, $\times 1$; floret, $\times 3$. (Type.)

narrow, erect, rather few flowered, mostly 8 to $15 \mathrm{~cm}$ long, the branches stiffly appressed; first glume 5 to $8 \mathrm{~mm}$ long, the second

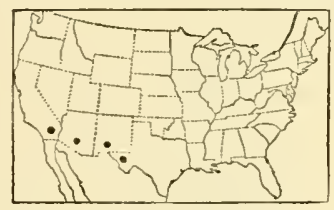

FIGURE 963.-Distribution of Aristida hamulosa.

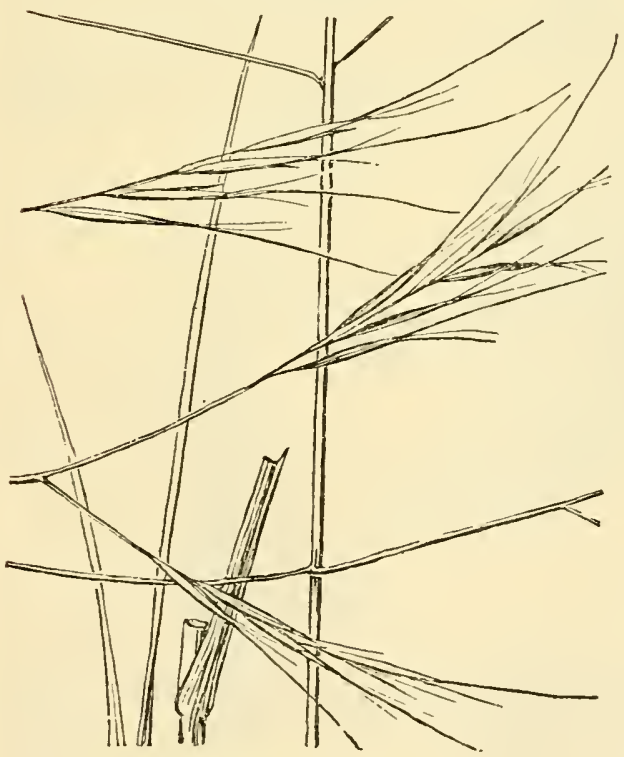

Figure 964.-Aristida patula, X 1. (Hitchcock, Fla.)

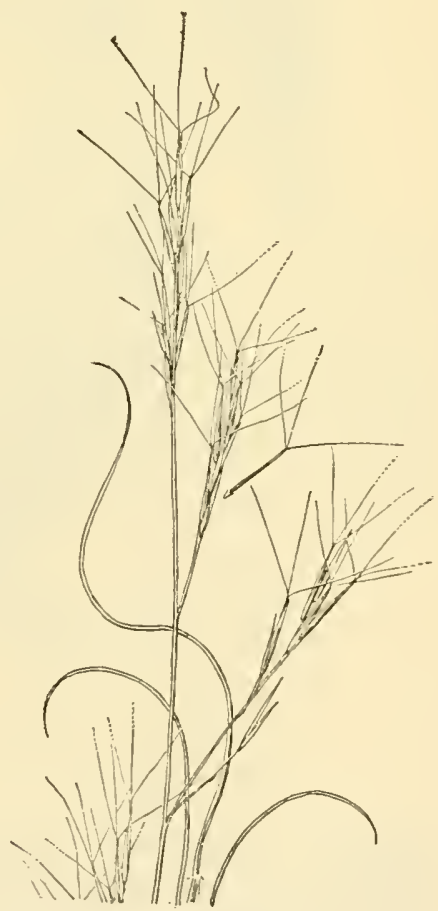

Figure 965.-Aristida pansa, $\times 1$. (Wooton, N. Mex.)

about twice as long; lemma 10 to $12 \mathrm{~mm}$ long, tapering in to a minutely scabrous, slender, somewhat twisted beak about half the total length of the lemma; awns equal, divergent or horizontally spreading, 1.5 to 
$2.5 \mathrm{~cm}$ long. 2 (A. reverchoni Vasey.)-Dry or rocky hills and plains, Texas to Utah, Nevada, and southern California, south to

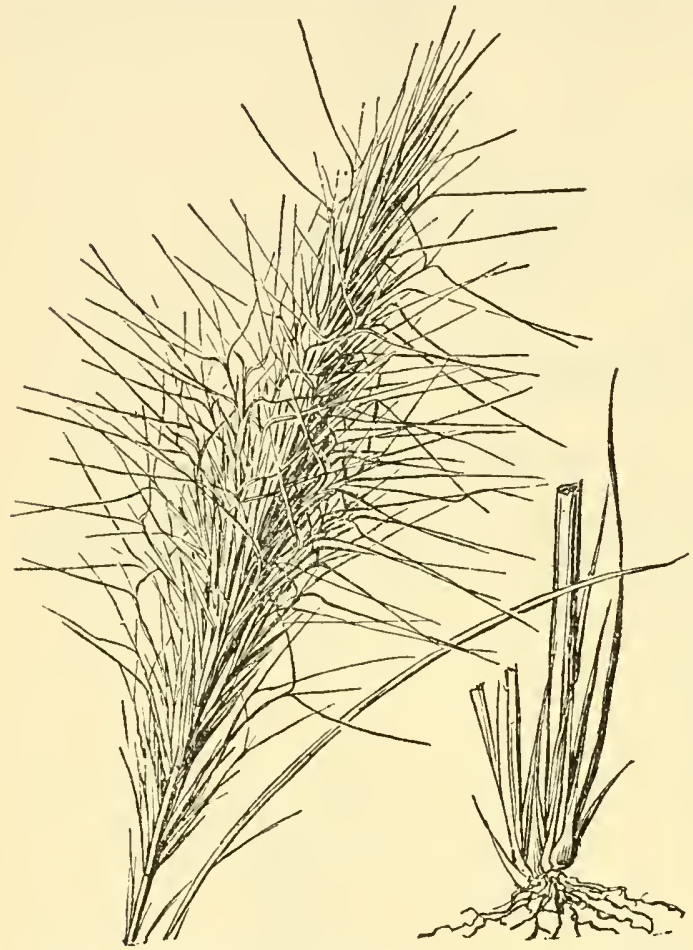

Figure 966.-Aristida spiciformis, $\times 1$. (Combs and Baker 1115 , Fla.)

the body tapering to a scarcely beaked summit, tuberculate-scabrous in lines from below the middle to the summit; awns nearly equal, spreading, 3 to $5 \mathrm{~cm}$ long. 2 $\quad$-Dry hills and plains, Arkansas and Kansas to Utah and southern

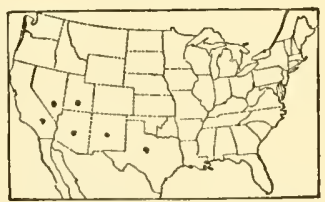

Figure 969.-Distrihution of Aristida glauca.

California, south to northern Mexico (fig. 971). Aristida pUrpurea var. LAXiflónA Merr. Panicle few-flowered, the capillary branches bearing 1 or 2 spikelets. 24 -Texas to Arizona.

24. Aristida roemeriána Scheele. (Fig. 972.) Differing from A. purpurea chiefly in the smaller spikelets; first glume 4 to $5 \mathrm{~mm}$

23. Aristida purpúrea Nutt. Purple threeAwn. (Fig. 970.) Perennial, often in large tufts; culms 30 to 50 cm tall; blades usually involute and less than $10 \mathrm{~cm}$ long, 1 to $1.5 \mathrm{~mm}$ wide when unrolled;

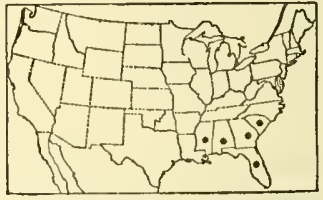

Figure 967.-Distribution of Aristida spiciformis.

panicle narrow, nodloose, usually purplish, 10 to $20 \mathrm{~cm}$ long, the branches and longer pedicels capillary, more or less curved or flexuous; first glume 6 to 8 $\mathrm{mm}$ long, the second about twice as long; lemma about $1 \mathrm{~cm}$ long,

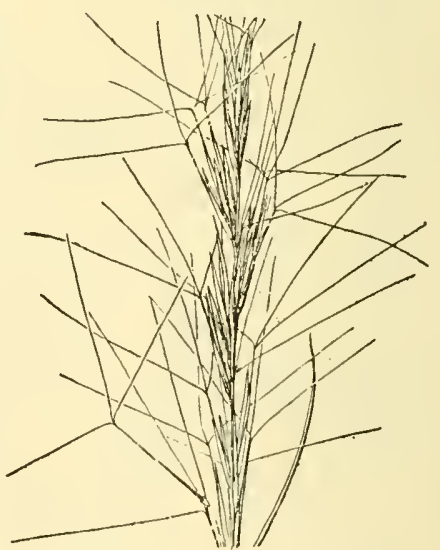

Figure 968.-Aristida glauca, $\times 1$. (Reverchon 1237, Tex.) ding, rather lax and

Puebla, Mexico (fig. 969). 
long; lemma 7 to $8 \mathrm{~mm}$ long, the awns about $2 \mathrm{~cm}$ long. 24 ( $A$. micrantha Nash.) - Texas, New Mexico, and northern Mexico.

25. Aristida wríghtii Nash. (Fig. 973.) Perennial; culms tufted, erect, 30 to $60 \mathrm{~cm}$ tall; sheaths villous at the throat and with a more or less hispid or villous line across the collar; blades involute, curved or flexuous; panicle erect, narrow, 15 to $20 \mathrm{~cm}$ long; first glume 6 to $7 \mathrm{~mm}$

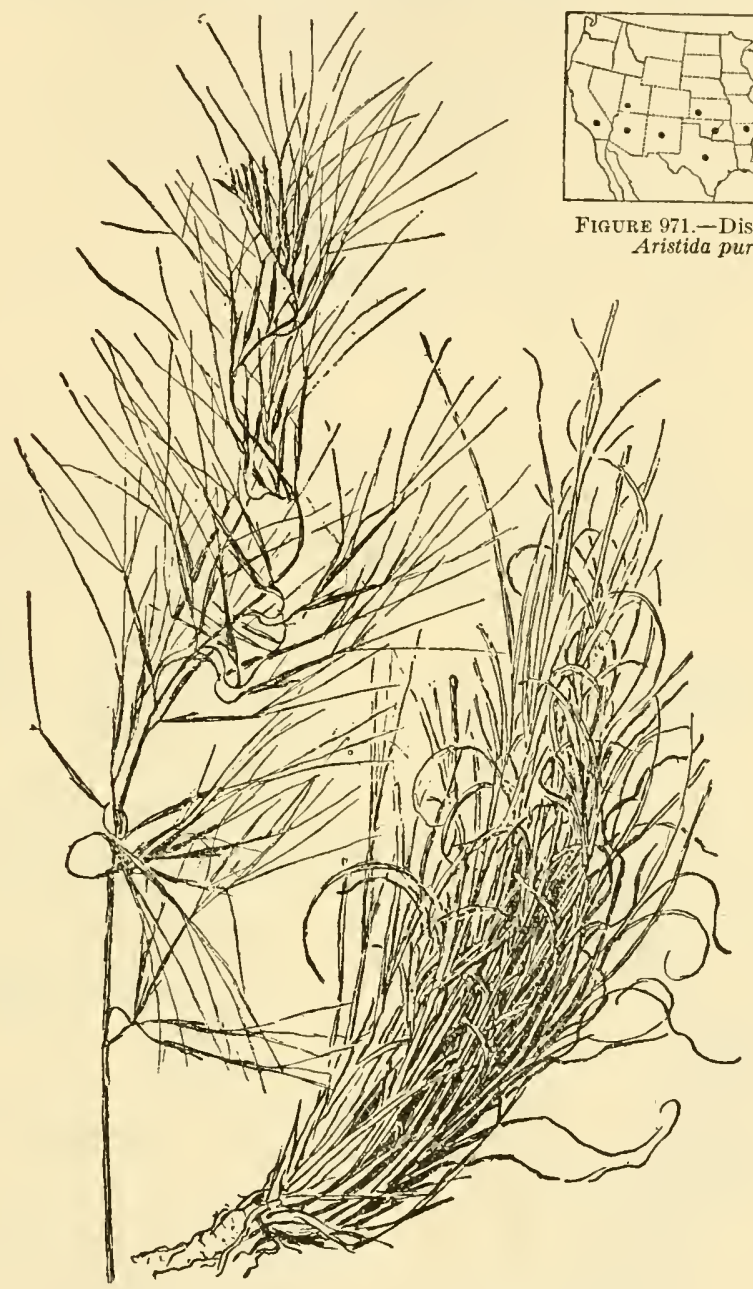

Figure 970.-Aristida purpurea, $\times 1$. (Bush 665, Tex.)

long, the second about twice as long; lemma 10 to $12 \mathrm{~mm}$ long; awns nearly equal, about $2 \mathrm{~cm}$ long, divergent. 21 - Dry plains and hills, Texas, Colorado, and Utah to southern California and central Mexico (fig. 974)

26. Aristida longiséta Steud. Red three-Awn. (Fig. 975.) Perennial, of ten in large bunches; culms 20 to $30 \mathrm{~cm}$ tall; blades involute, curved or flexuous, usually less than $15 \mathrm{~cm}$ long; panicle narrow, erect 
but not stiff, few-flowered, the axis only a few $\mathrm{cm}$ long, the branches ascending or appressed, or the lower more or less curved or flexuous; first glume 8 to $10 \mathrm{~mm}$ long, the second about twice as long; lemma terete, 12 to $15 \mathrm{~mm}$ long, only slightly narrowed above, glabrous or

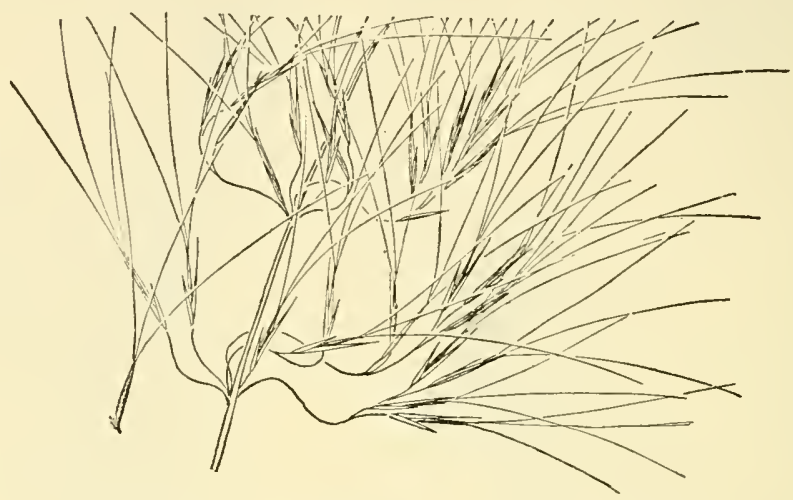

FIgure 972.-Aristida roemeriana, $\times 1$. (Swallen 1585, Tex.)

the upper part scaberulous but scarcely tuberculate-scabrous in lines as in $A$. purpurea; awns about equal, divergent, 6 to $8 \mathrm{~cm}$ long. 2 Plains and foothills, North Dakota to Montana, south to Texas, Arizona, and northern Mexico (fig. 976). Aristida longiseta var.

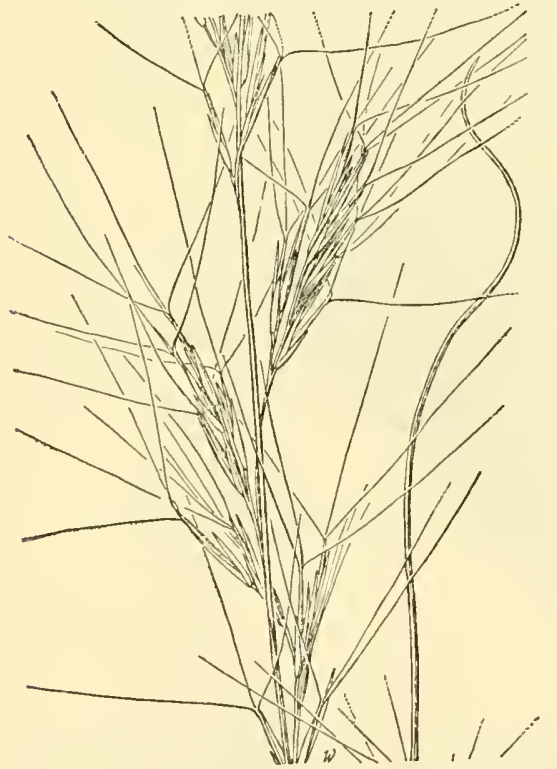

Figure 973.-Aristida wrightii, $\times 1$. (Ball 1511, Tex.) RARIFlóra Hitchc. Differing in the few-flowered panicles with capillary flexuous branches bearing 1 or 2 spikelets. 4 -Texas to Colorado and Arizona.

Aristida longiseta var. ROBústa Merr. Taller and more robust, 30 to $50 \mathrm{~cm}$ tall, the blades

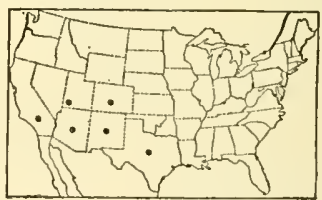

Figure 974.-Distribution of Aristida wriphtii.

longer and not in conspicuous basal tufts, the panicle longer, stiffer, and the branches more stiffly ascending, the awns mostly 4 to 5 cm long. 21 -Same range but more common northward, extending east to Minnesota and west to Oregon and Washington.

27. Aristida fendleriána Steud. Fendeer three-Awn. (Fig. 977.) Resembling $A$. longiseta; differing in the numerous short curly blades at the base of the plant, the shorter glumes (the first about $7 \mathrm{~mm}$ long), the gradually narrowed lemma, scaberulous on the upper half, 
and the shorter awns ( 2 to $5 \mathrm{~cm}$ long). 2 -Dry plains and hills, South Dakota to Montana, south to Texas, Utah, and southern California (fig. 978).

28. Aristida lanósa Muhl. (Fig. 979.) Perennial; culms solitary or few in a tuft, rather robust, 1 to $1.5 \mathrm{~m}$ tall; sheaths lanate-pubescent or rarely glabrous; blades flat, elongate, as much as $4 \mathrm{~mm}$ wide; panicle narrow, rather loose, as much as $40 \mathrm{~cm}$ long; first glume 12 to

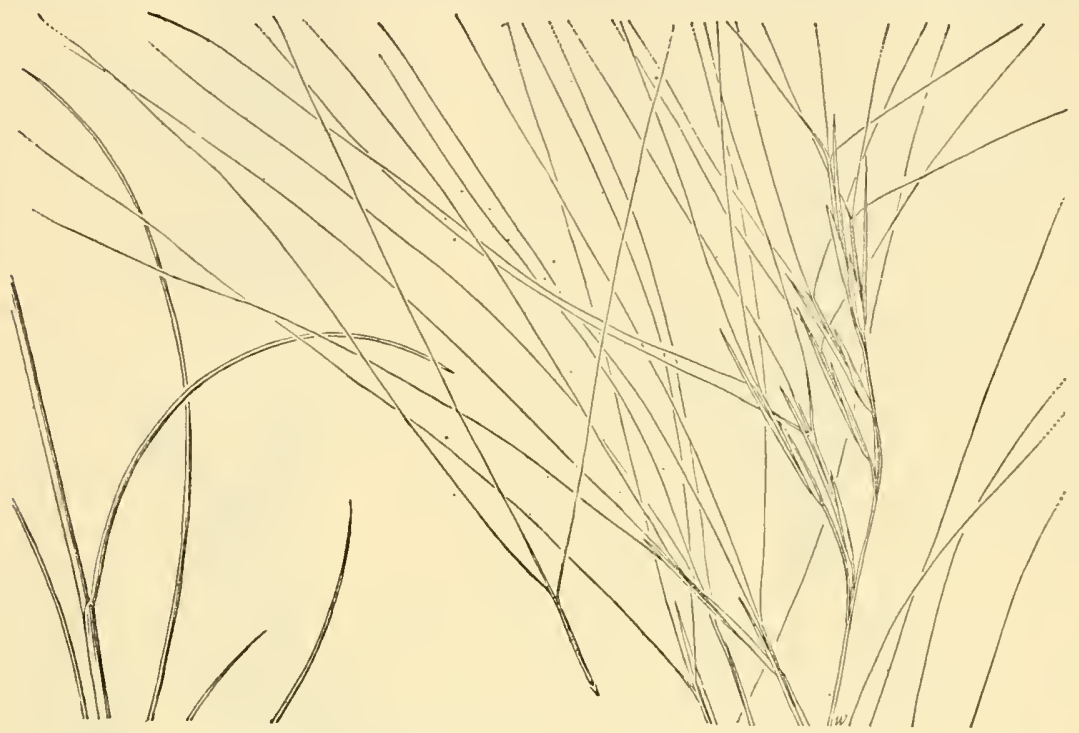

Figure 975.-Aristida longiseta, $\times 1$. (Thompson 63, Kan.)

$14 \mathrm{~mm}$ long, the second about $10 \mathrm{~mm}$, lemma 8 to $9 \mathrm{~mm}$ long; central awn horizontally spreading or reflexed from a curved base, 1.5 to 2.5 cm long, the lateral half to two-thirds as long, erect or spreading. 2! Dry sandy soil of the Coastal Plain, New Jersey to Florida and Texas, north to Oklahoma and Missouri (fig. 980).

29. Aristida arizónica Vasey. Arizona three-Awn. (Fig. 981.) Perennial; culms erect, 30 to $120 \mathrm{~cm}$ tall; blades flat, narrowed to a

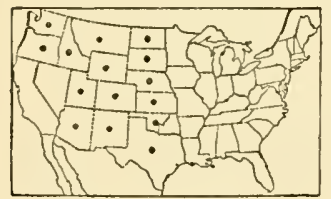

Figure 976.-Distribution of Aristida longiseta. fine involute point or some of them involute throughout, 1 to $4 \mathrm{~mm}$ wide, the old ones usually curled or flexuous; panicle narrow, erect, closely flowered or more or less interrupted at base, 10 to $25 \mathrm{~cm}$ long; glumes equal or nearly so, awn-pointed, 10 to $15 \mathrm{~mm}$ long; lemma 1 to $1.5 \mathrm{~cm}$ long, including the more or less twisted beak of about 3 to $5 \mathrm{~mm}$; awns about equal, ascending, 1 to $2 \mathrm{~cm}$ long. 21 -Dry plains, stony hillsides, and open forest, mostly at 1,500 to $2,500 \mathrm{~m}$ altitude, southern Colorado, western Texas, New Mexico, and Arizona, south through Mexico (fig. 982).

30. Aristida strícta Michx. Pineland three-awn. (Fig. 983.) Perennial; culms erect, 50 to $100 \mathrm{~cm}$ tall; blades closely involute, villous on the upper surface above the base (the hairs visible without unrolling the blade), elongate, $1 \mathrm{~mm}$ thick; panicle slender, as much as $30 \mathrm{~cm}$ long; glumes about equal, 7 to $9 \mathrm{~mm}$ long; lemma about 6 
$\mathrm{mm}$ long, scarcely beaked; awns divergent, the central 1 to $1.5 \mathrm{~cm}$ long, the lateral a little shorter. 24-Common in pine barrens, North Carolina to Florida, west to Mississippi (fig. 984).

31. Aristida rhizomóphora Swallen. (Fig. 985.) Perennial; culms tufted, erect, 65 to $80 \mathrm{~cm}$ tall, producing well developed scaly rhizomes; blades firm, flat or folded, 7 to $10 \mathrm{~cm}$ long, 1 to $2 \mathrm{~mm}$ wide, those of the innovations flexuous, as much as $30 \mathrm{~cm}$ long; panicle flexuous, 20 to

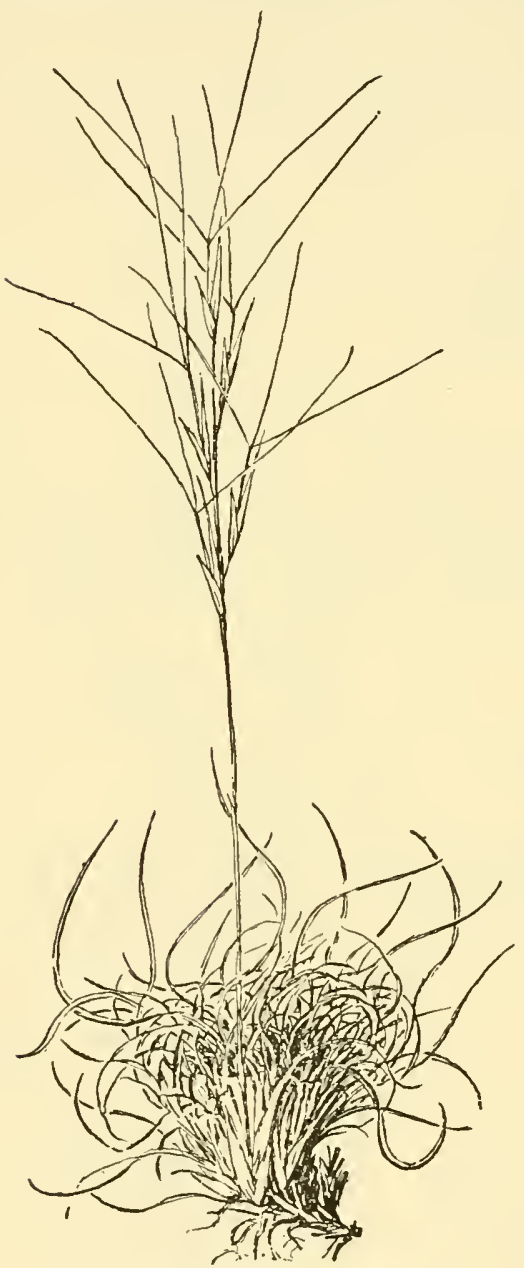

Figdre 977.-Aristida fendleriana, $\times 1$.

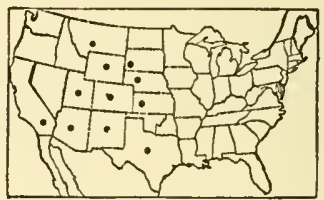

Figure 978.-Distribution of Aristida fendleriana.

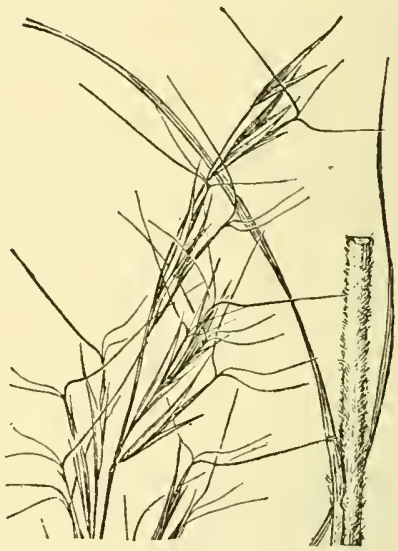

Figure 979.-Aristida lanosa, $\times 1$. (Canby, Md.)

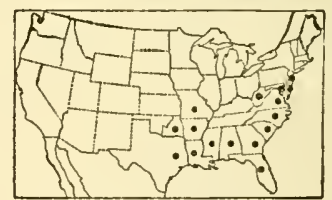

Figure 980.-Distribution of Aristida lanosa.

$30 \mathrm{~cm}$ long, the distant branches somewhat spreading, few-flowered, spikelet-bearing from near the base; glumes acuminate, usually awned, the first 8 to $14 \mathrm{~mm}$ long, the second 12 to $17 \mathrm{~mm}$ long (including the awn); lemma 9 to $12 \mathrm{~mm}$ long, the callus $1 \mathrm{~mm}$ long, the awns flexuous, curved or loosely twisted at base, spreading, the central of ten reflexed by a semicircular bend, 18 to $28 \mathrm{~mm}$ long, the lateral 15 to $20 \mathrm{~mm}$ long. 2 -Prairies, peninsular Florida.

32. Aristida purpuráscens Poir. Arrowfeather. (Fig. 986.) Perennial; culms tufted from a rather thin weak sometimes decumbent 
base, slender, 40 to $70 \mathrm{~cm}$ or even $1 \mathrm{~m}$ tall; blades flat, rather lax

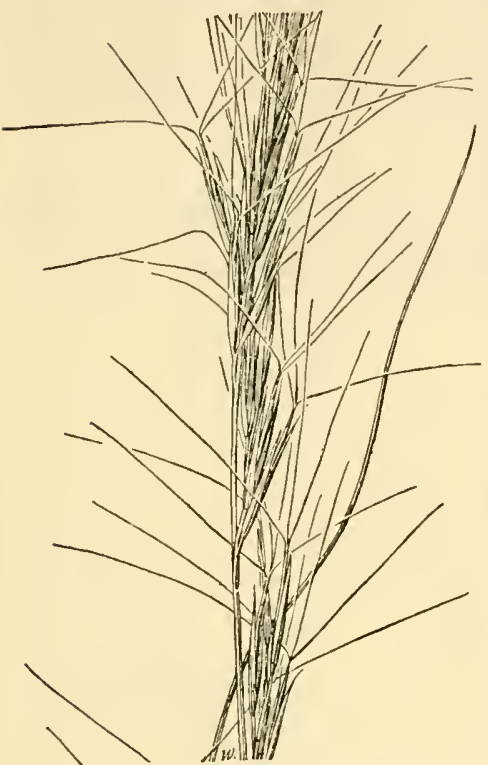
and flexuous (especially the old ones), usually less than $2 \mathrm{~mm}$ wide; panicle narrow, rather lax and nodding, onethird to half the entire length of the culm; glumes about equal, 9 to $12 \mathrm{~mm}$ long; lemma about $7 \mathrm{~mm}$ long; awns about equal, divergent or somewhat reflexed, 1.5 to $2.5 \mathrm{~cm}$ long. 2 Dry sandy soil, Massachusetts to Kansas, south to Florida and Texas (fig. 987).

33. Aristida paríshii Hitchc. (Fig. 988.) Per-

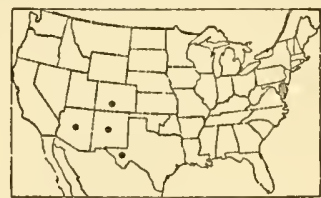

FIgURE 982.-Distribution of Aristida arizonica. ennial; culms erect, 30 to $50 \mathrm{~cm}$ tall; blades more or less involute, sometimes flat, 1 to $2 \mathrm{~mm}$ wide; panicle narrow, about $15 \mathrm{~cm}$ long; glumes short-awned, the first $12 \mathrm{~mm}$ long, the second 1 or

FIGURE 981.-Aristida arizonica, $\times 1$; $2 \mathrm{~mm}$ longer; lemma about 12

$\mathrm{mm}$ long, tapering into a short straight or obscurely twisted beak; awns about equal, divergent, about $2.5 \mathrm{~cm}$ long. $24-$ Dry or rocky soil, Arizona and southern California.

34. Aristida affínis (Schult.) Kunth. (Fig. 989.) Perennial; culms tufted from a hard thickened base, stiffly erect, rather stout, 1 to

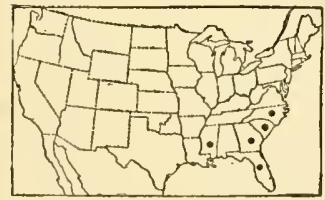

FIGLRE 984.-Distribution of Aristida stricta. $1.5 \mathrm{~m}$ tall; blades flat, becoming loosely involute, elongate, as much as $3 \mathrm{~mm}$ wide; panicle narrow, virgate, as much as $50 \mathrm{~cm}$ long; glumes equal, about 12 $\mathrm{mm}$ long, the first with a distinct nerve on one side (thus 2-nerved); lemma $8 \mathrm{~mm}$ long, the straight beak about $1 \mathrm{~mm}$ long; central awn horizontally spreading, 1.5 to $3 \mathrm{~cm}$ long, the lateral awns erect, two-thirds to three-fourths as long. 24 (A. palustris Vasey.)-Low pine barrens and flatwoods, North Carolina and Kentucky to Florida and Texas, on the Coastal Plain (fig. 990).

35. Aristida virgáta Trin. (Fig. 991.) Frgure 983.-Aristida stricta, $\times 1$ : Perennial; culms tufted from a rather slender

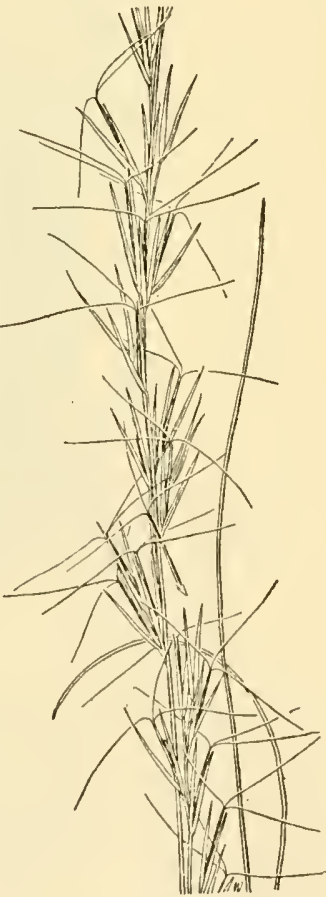
soft base, erect, 50 to $80 \mathrm{~cm}$ tall; blades flat, rather lax, usually not 
more than $2 \mathrm{~mm}$ wide; panicle slender, erect, though not very stiff, rather loosely flowered, one-third to half the entire length of the culm; glumes about equal, 6 to $7 \mathrm{~mm}$ long; lemma 4 to $5 \mathrm{~mm}$ long; central awn horizontally spreading or somewhat reflexed, 1.5 to $2 \mathrm{~cm}$ long, the lateral awns erect, about two-thirds as long as the central. 21 (A. chapmaniana Nash.)-Moist sandy soil of the Coastal Plain, New Jersey to Florida and Texas (fig. 992).

36. Aristida simpliciflóra Chapm. (Fig. 993.) Perennial; culms erect from a rather delicate base, slender, 30 to $60 \mathrm{~cm}$ tall; blades flat, 5 to $15 \mathrm{~cm}$ long, $1 \mathrm{~mm}$ wide; panicle slender, somewhat nodding, 10

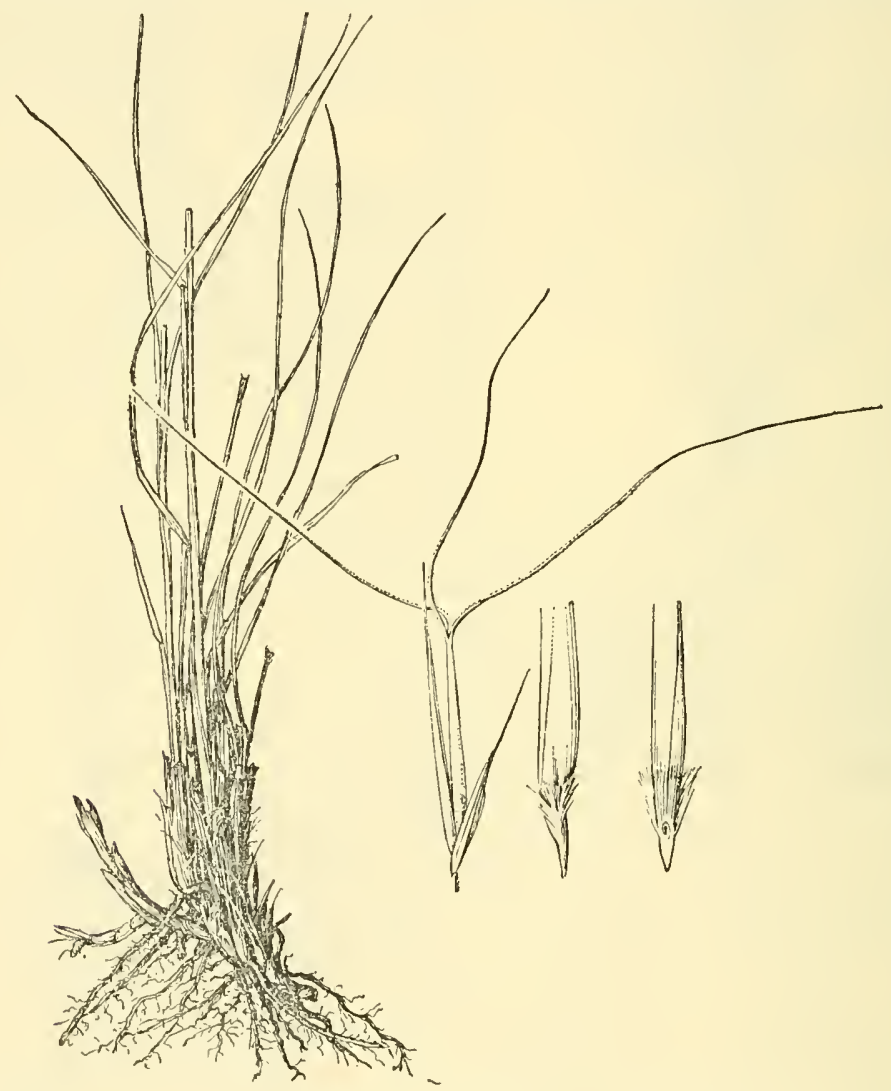

FIfURE 985.-Aristida rhizomophora. Plant, $\times 1 \frac{1}{2}$; spikelet, $\times 2$; two views of callus, $\times 10$. (Type.)

to $20 \mathrm{~cm}$ long, few-flowered, the spikelets mostly in pairs; glumes equal, 6 to $7 \mathrm{~mm}$ long; lemma a little shorter than the glumes; central awn finally reflexed by a semicircular bend, 1 to $1.5 \mathrm{~cm}$ long, the lateral awns horizontally spreading, a little shorter than the central one. 2 -Moist pine woods, rare, western Florida; Mississippi (McNeill).

37. Aristida móhrii Nash. (Fig. 994.) Perennial; culms erect, 40 to $60 \mathrm{~cm}$ tall; blades flat or those of the innovations involute, 10 to $15 \mathrm{~cm}$ long, 1 to $2 \mathrm{~mm}$ wide, the uppermost reduced; panicle slender, strict, as much as $30 \mathrm{~cm}$ long; spikelets solitary, appressed, distant, 

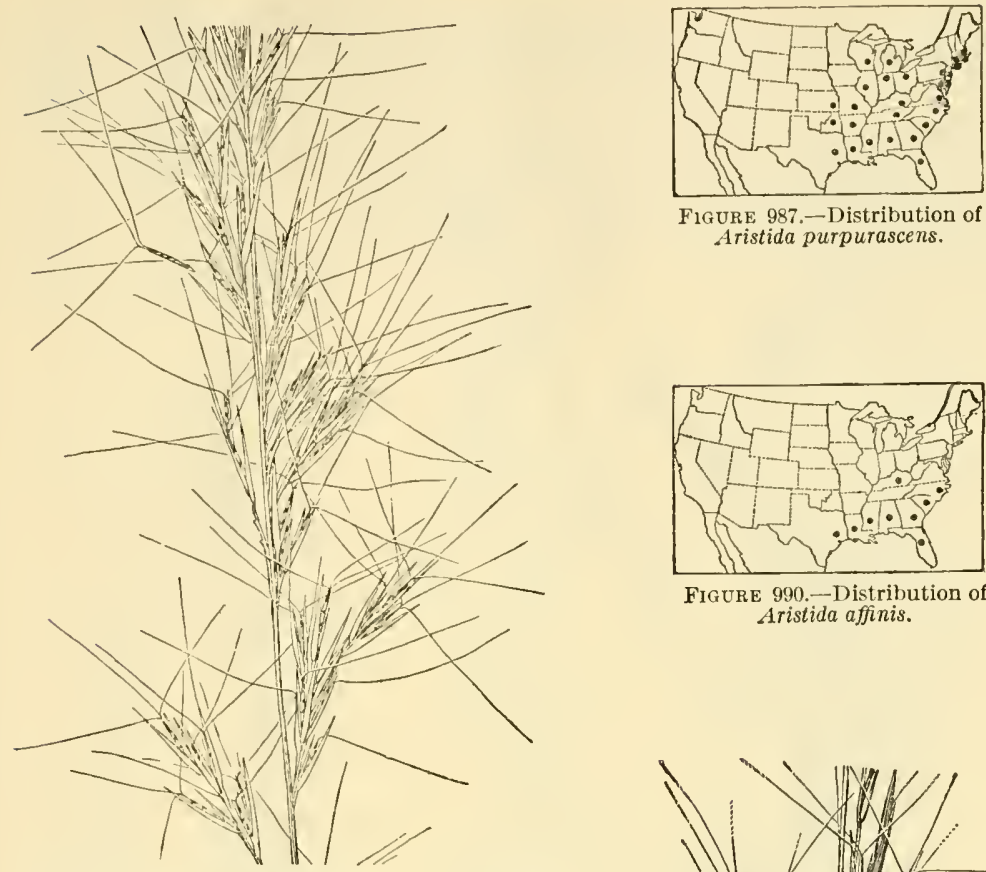

F1GURE 987,-Distribution of Aristida purpurascens.

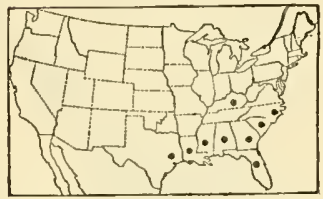

Figure 990.-Distribution of Aristida affinis.

Figure 986.-Aristida purpurascens, $\times 1$. (Chase 4563 , N.C.)

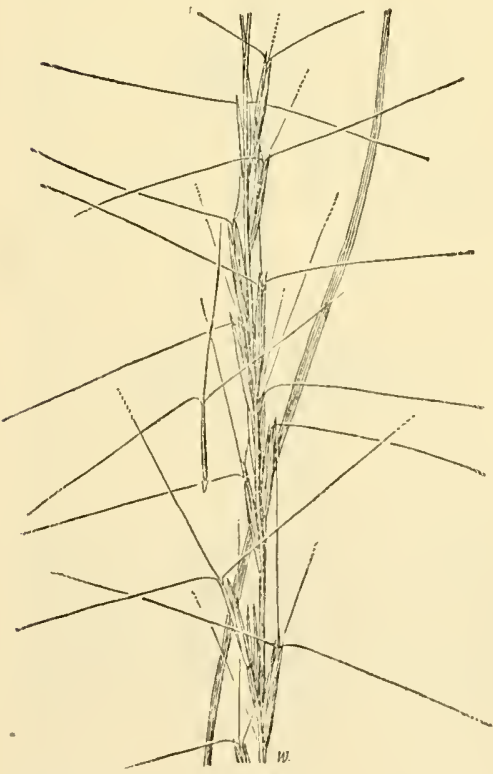

Figure 989.-Aristida affinis, $\times 1$. (Combs 688 , Fla.)

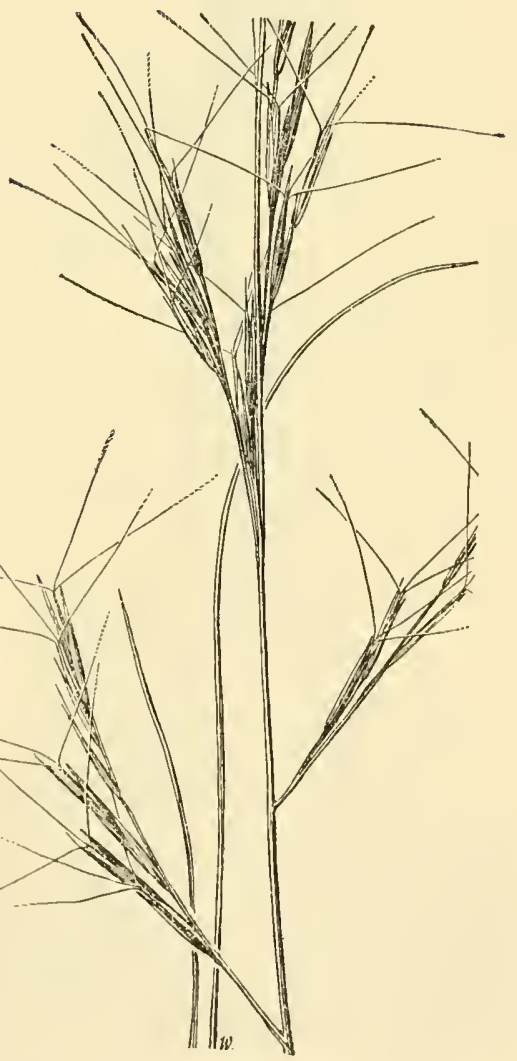

Figure 988.-Aristida parishii, $\times 1$. (Parish $1029 \mathrm{~A}$, Calif.) 
even the upper not overlapping; glumes equal, firm, rather broad toward the mucronate apex, $1 \mathrm{~cm}$ long; lemma terete, a little shorter than the glumes; awns divergent, the central one reflexed by a semicircular bend near the base, 1.5 to $2 \mathrm{~cm}$ long, the lateral ones scarcely shorter than the central, horizontally spreading or reflexed. 24 Known only from Spring Hill, near Mobile, Ala.

38. Aristida tenuispíca Hitchc. (Fig. 995.) Perennial; culms slender, 60 to $100 \mathrm{~cm}$ tall; blades flat, 10 to $20 \mathrm{~cm}$ long, 1 to 2

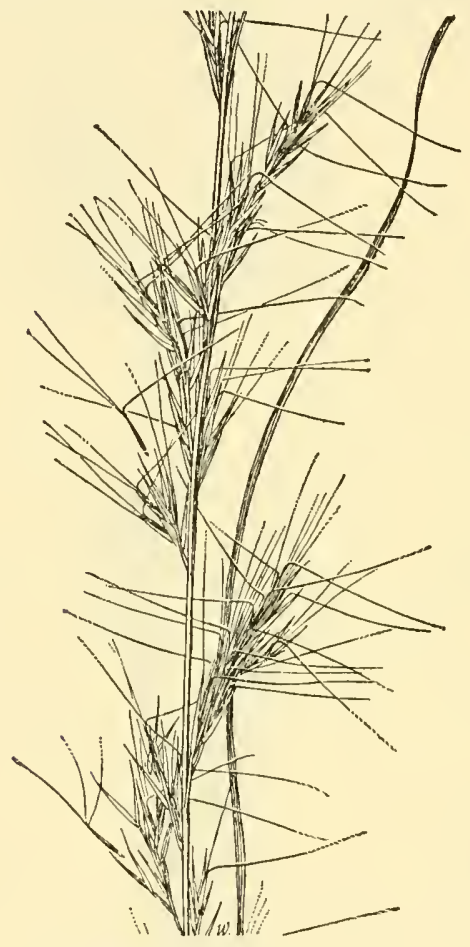

FIgURE 991.-Aristida virgata, $\times 1$. (Tracy 4667, Miss.)

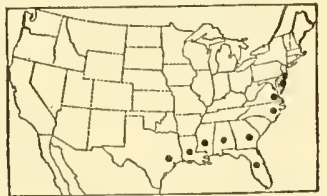

FIGURE 992.-Distribution of Aristida virgeta.

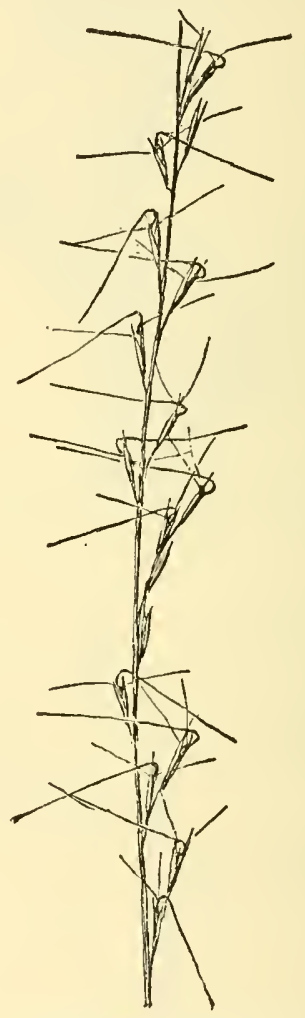

Figure 993.-Aristida simpliciflora, $\times 1$. (Chapman, Fla.)

$\mathrm{mm}$ wide, bearing scattered long hairs on the upper surface; panicle slender, about half the entire length of the culm; glumes nearly equal, about $8 \mathrm{~mm}$ long; lemma $7 \mathrm{~mm}$ long including a 1 $\mathrm{mm}$ long beak; awns equal, 12 to $15 \mathrm{~mm}$ long, spreading or reflexed, somewhat spirally contorted at base. 2 -Low pine. barrens, peninsular Florida. 
39. Aristida condensáta Chapm. (Fig. 996.) Perennial; culms

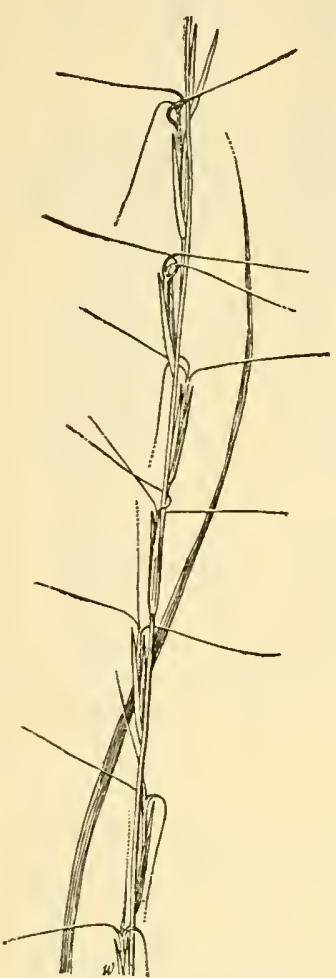
rather robust, a meter or more tall; blades firm, flat, becoming involute, elongate, 2 to $3 \mathrm{~mm}$

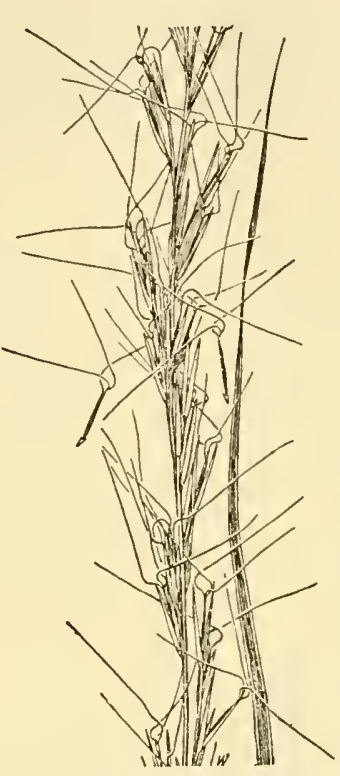

FIgURE 995.-Aristida tenuispica,

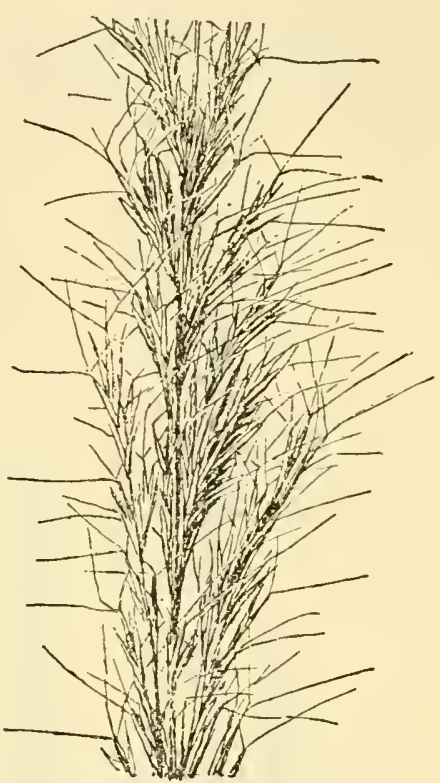

FigURE 996.-Aristida condensata, $\times 1$. (Chapman, Fla.)

FIGURE 994-Aristida mohrii, wide; panicle narrow, as much as $30 \mathrm{~cm}$ long, $\times 1$. (Mohr 53, Ala.) the branches 5 to $10 \mathrm{~cm}$ long, ascending, closely flowered; glumes equal, 8 to 9 $\mathrm{mm}$ long; awns equal, divergent, 10 to $15 \mathrm{~mm}$ long, the base more or less contorted, finally forming a loose spiral. 2 or oak barrens, Georgia, Florida, and Alabama, on the Coastal Plain.

40. Aristida gýrans Chapm. (Fig. 997.) Perennial; culms erect, slender, 40 to $70 \mathrm{~cm}$ tall; blades involute, 10 to $15 \mathrm{~cm}$ long, $1 \mathrm{~mm}$ wide; panicle slender, rather lax, 15 to $30 \mathrm{~cm}$ long, the branches appressed, not at all or only slightly overlapping, bearing mostly 1 to 3 spikelets; first glume 7 to 8 inm long, the second 10 to $11 \mathrm{~mm}$ long; lemma about $6 \mathrm{~mm}$ long, the callus $1.5 \mathrm{~mm}$ long, sharp; awns equal, divergent, 1 to $1.5 \mathrm{~cm}$ long, about equally contorted at

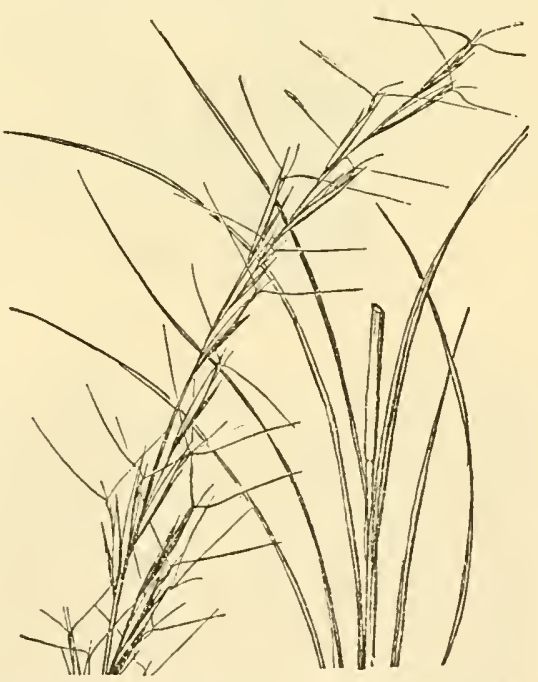

Figure 997.-Aristida gyrans, $\times 1$. (Combs 1289, Fla.) base in a loose spiral. 24 -Dry sandy soil, Georgia and Florida. 
TRIBE 6. ZOYSIEAE

86. TRÁGUS Hall.

(Nazia Adans.)

Spikelets 1-flowered, in small spikes of 2 to 5 , the spikes subsessile, falling entire, the spikelets sessile on a very short zigzag rachis, the first glumes small, thin, or wanting, appressed to the rachis, the second
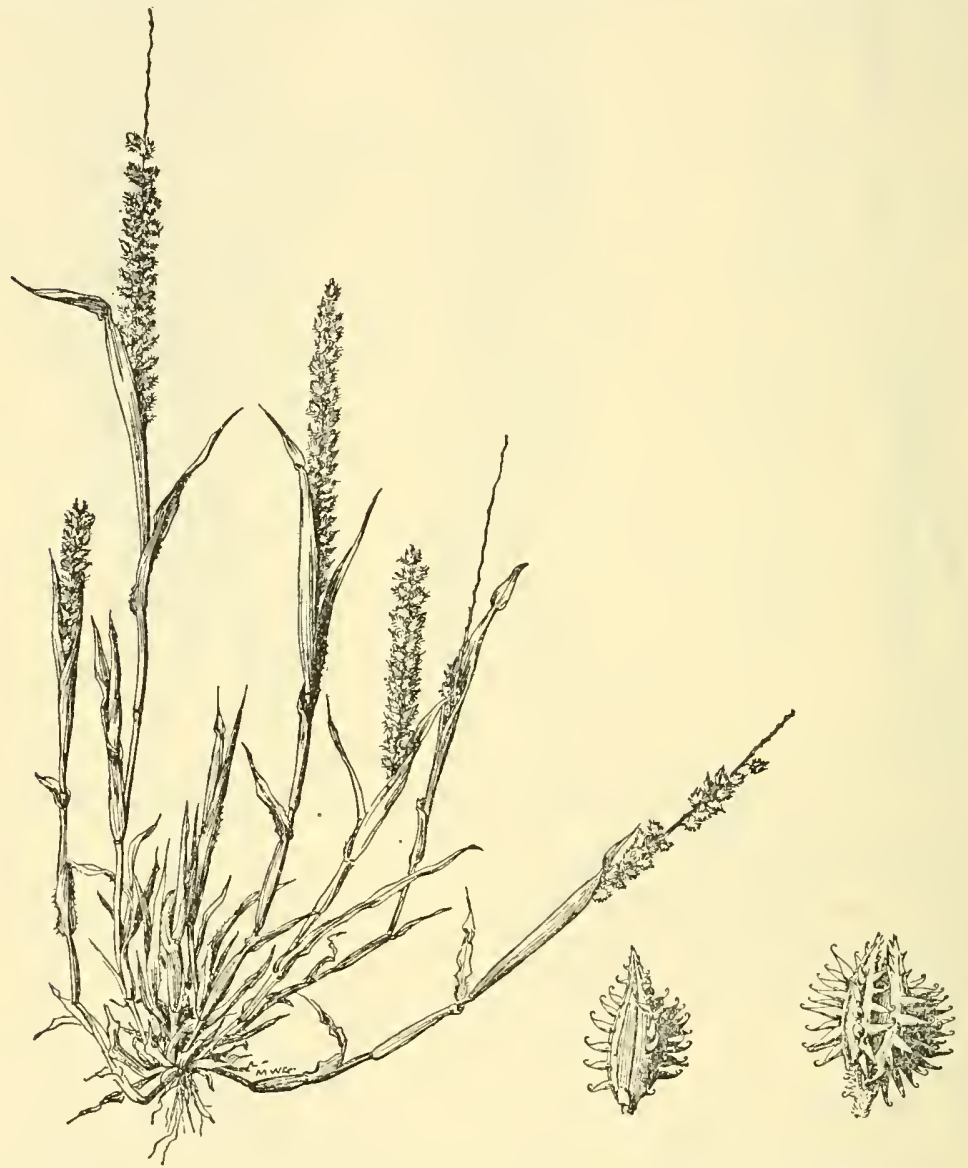

Figure 998.-Tragus berteronianus. Plant, $\times 1 / 2$; bur and spikelet, $\times 5$. (Hitcheock 3745, N.Mex.)

glumes of the two lower spikclets strongly convex with 3 thick nerves bearing a row of squarrose, stout hooked prickles along each side, the two second glumes forming the halves of a little bur, the upper 1 to 3 spikelets reduced and sterile; lemma and palea thin, the lemma flat, the palea strongly convex. Low annuals, with flat blades and terminal inflorescence, the burs or spikes rather closely arranged along an elongate, slender axis. Type species, Tragus racemosus. Name from Greek tragos, he-goat, applied by Plinius to a plant.

Spikelets 2 to $3 \mathrm{~mm}$ long, the apex scarcely projecting beyond the spines, the bur nearly sessile _............................ 1. T. BERTERONIANUS. Spikelets 4 to $4.5 \mathrm{~mm}$ long, the acuminate apex projecting beyond the spines, the

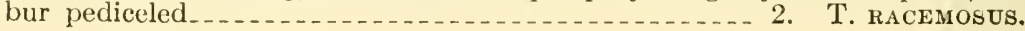


1. Tragus berteroniannus Schult. (Fig. 998.) Culms bran'ched at base, spreading, 10 to $40 \mathrm{~cm}$ long; blades firm, mostly less than 5

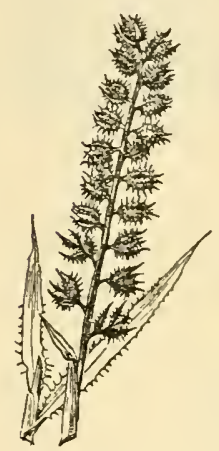

Figure 999.-Tragus racemosus, $\times 1$. (Griffiths 1529, Ariz.)

burs. (Nazia racemosa Kuntze.) - Waste ground and on ballast at a few places from Maine to North Carolina; Texas to Arizona (fig. 1000); introduced from the Old World.

\section{ANTHÉPHORA Schreb.}

Spikelets with 1 perfect floret and a sterile lemma below, in clusters of 4 , the indurate first glumes united at base, forming a pitcher-shaped pseudo-involucre, the clusters subsessile and erect on a slender flexuous continuous axis, deciduous at maturity. Type species, Anthephora elegans Schreb. (A. hermaphrodita). Name from anthe, blossom, and pherein, to bear.

Anthephora hermaphrodíta (L.) Kuntze. Leafy ascending or decumbent annual; culms mostly 20 to $50 \mathrm{~cm}$ tall; blades flat, thin, 5 to $10 \mathrm{~mm}$ wide; spikes erect, 5 to $10 \mathrm{~cm}$ long; first glume 5 to $7 \mathrm{~mm}$ long, about 9-nerved; second glume narrow, acuminate, shorter than the first, pubescent; sterile lemma 5-nerved, about as long as the fertile floret. $\odot$-Escaped from Experiment Station plots, Florida (Gainesville); a common weed in tropical America.

\section{ZOÝSIA Willd.}

\section{(Osterdamia Neck.)}

Spikelets 1-flowered, laterally compressed, appressed flatwise against the slender rachis, glabrous, disarticulating below the glumes; first glume wanting; second glume coriaceous, mucronate, or shortawned, completely infolding the thin lemma and palea, the palea sometimes obsolete. Low perennials, with creeping rhizomes, short, pungently pointed blades, and terminal spikelike racemes, the spikelets on short appressed pedicels. Type species, Zoysia pungens Willd. Named for Karl von Zois.

Several years ago a species of this genus was introduced into the United States as a lawngrass under the names Korean lawngrass and Japanese lawngrass. It was recommended for the Southern States and was said to be hardy as far north as Connecticut. The species $55974^{\circ}-35-30$ 
then introduced appears to be Zoysia japonica Steud. Recently a fine-leaved species, Zoysia tenuifolia Willd. (Mascarene grass), has been introduced in Florida and southern California (called in the latter region Korean velvet grass) and has given favorable results. These species may escape from cultivation. The original species, $Z$. matrella (L.) Merr. ( $Z$. pungens Willd.), called Manila grass (fig. 1001), is common in the Philippine Islands.

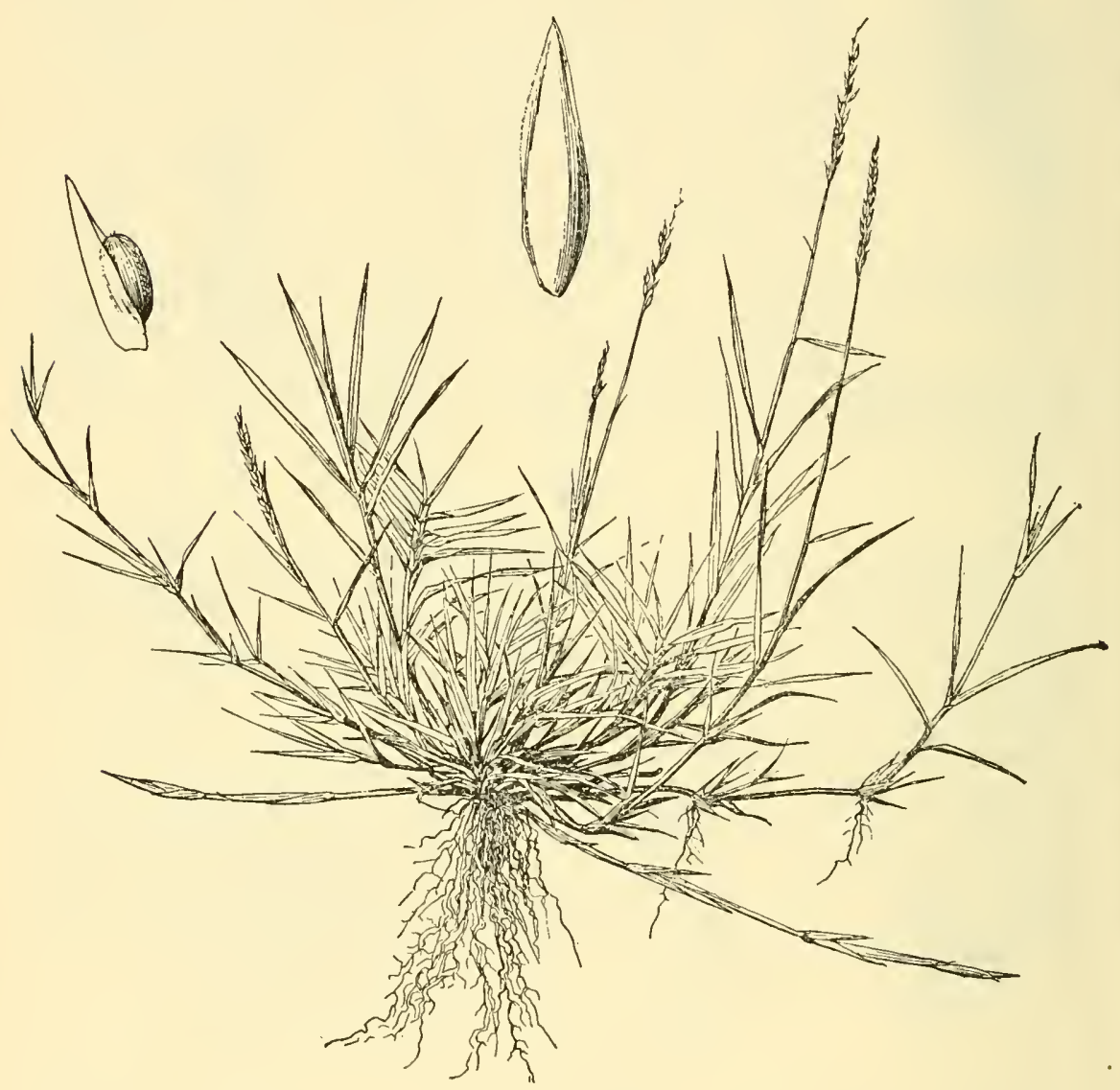

Figure 1001.-Zoysia matrella. Plant, $\times 1 / 2$; spikelet and foret, $\times 10$. (Whitford 1303, P.I.)

In $Z$. japonica (Japanese lawngrass) the blades are flat and rather stiff, 2 to $4 \mathrm{~mm}$ wide, the spikelets about $3 \mathrm{~mm}$ long and a little more than $1 \mathrm{~mm}$ wide. The rhizomes are underground. In $Z$. tenuifolia the blades are involute-capillary, the spikelets much narrower than in $Z$. japonica. The stolons are at or near the surface of the soil. In $Z$. matrella the spikelets are about $2.5 \mathrm{~mm}$ long and a little less than $1 \mathrm{~mm}$ wide. 


\section{HILĀRIA H.B.K.}

Spikelets sessile, in groups of 3 , the groups falling from the axis entire, the central spikelet (next the axis) fertile, 1-flowered (occasionally 2 -flowered), the 2 lateral spikelets staminate, 2 -flowered (occasionally 3 -flowered); glumes coriaceous, those of the 3 spike-

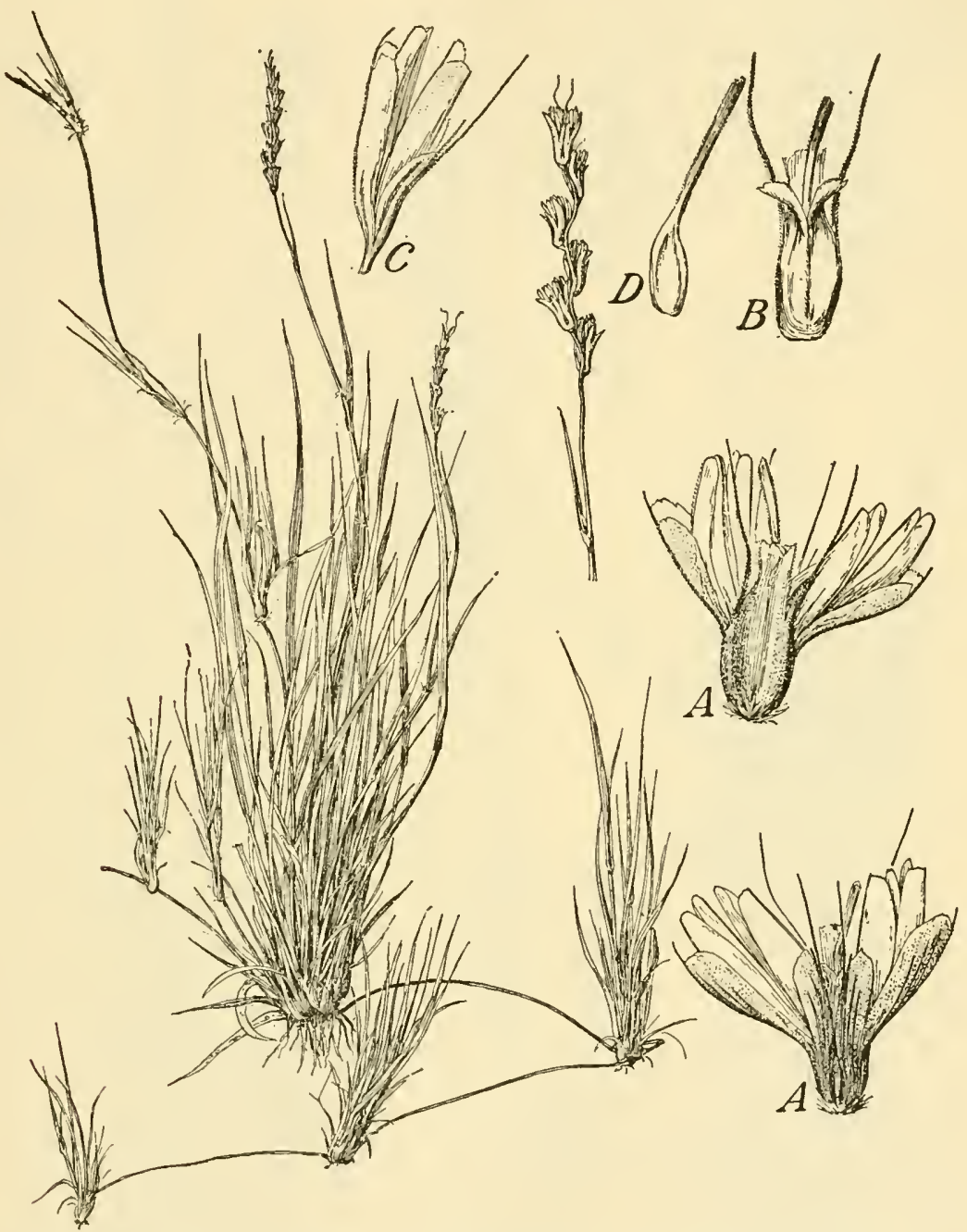

FIGURE 1002,-Ifilaria belangeri. Plant, $\times 1 \frac{1}{2}$; single spike, $\times 1$; group of spikelets, two views $(A), \times 5$; fertile spikelet $(B)$, staminate spikelet $(C)$, and fertile foret $(D), \times 5$. (Hitchcock, Tex.)

lets forming a false involucre, in some species connate at the base, more or less asymmetric, usually bearing an awn on one side from about the middle (extension of the midnerve of the asymmotric glume); lemma and palea hyaline, about equal in length. Perennials, with stiff, solid culms and narrow blades, the groups of spikelets 
appressed to the axis, in terminal spikes. Type species, Hilaria cenchroides H.B.K. Named for Auguste St. Hilaire.

All the species are important range grasses. Curly mesquite is the dominant "short grass" of the Texas plains. The larger species are well known on the range in the arid and semiarid regions of the Southwest. They resist close grazing.

Culms white felty pubescent

4. H. RIGIDA.

Culms not felty pubescent.

Cluster of spikelets not flabellate; glumes of lateral spikelet narrowed toward summit.

3. H. JAMESII.

Cluster of spikelets flabellate; glumes (at least the outer one) of lateral spikelets broadest toward summit.

Glumes subhyaline and fimbriate at summit; plants tufted, not stoloniferous _._.

Glumes firm, not fimbriate; plants stoloniferous (except in var. longifolia) ....... BELANGERI.

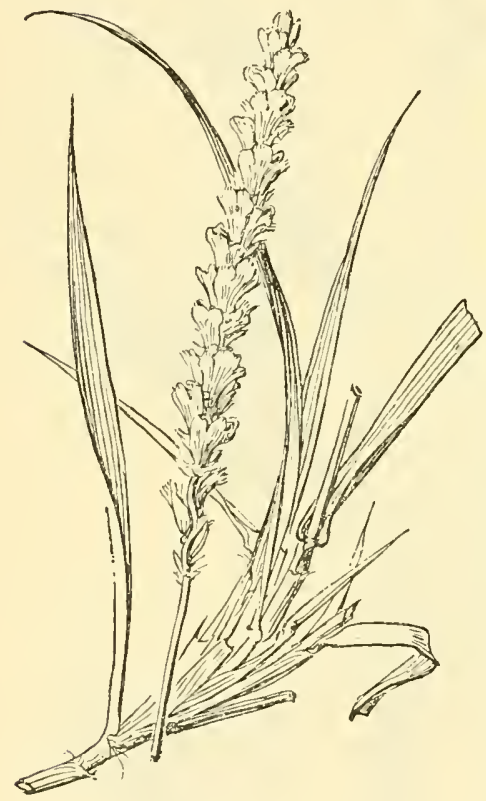

Figure 1003.- Hilatia mutica, $\times 1$. (Toumey, Ariz.)
1. Hilaria belangéri (Steud.) Nash. CURly MESQUITE. (Fig. 1002.) Plants in tufts, sending out slender stolons, these producing new tufts, the internodes of the stolons wiry, 5 to $15 \mathrm{~cm}$ long; culms erect, slender, 10 to $30 \mathrm{~cm}$ tall, villous at the nodes; blades flat, curly, 1 to $2 \mathrm{~mm}$ wide, usually short, crowded at base, forming a curly tuft, but sometimes longer and erect; spike usually 2 to $3 \mathrm{~cm}$ long, with mostly 4 to 8 clusters of spikelets, the axis flat, the internodes alternately curved, 3 to $5 \mathrm{~mm}$ long; group of spikelets 5 to $7 \mathrm{~mm}$ long; lateral spikelets attenuate at base, the glumes united below, firm, scabrous, the outer lobe broadened upward, 2- to 3-nerved, the inner much reduced, the midnerve of both glumes extending into short awns, the first glume smaller, the lateral nerves sometimes excurrent into awns or teeth (the glumes variable in a single spike); fertile spikelet usually shorter than the sterile, rounded at base; glumes firm with deeply lobed thinner upper part, the midnerves extending into awns mostly exceeding the staminate spikelets; lemma compressed, narrowed above, awnless. 2 (II. texana Nash.)-Mesas and plains, 'Texas to Arizona and northern Mexico. H. cenchroides H.B.K., to which this species has commonly been referred, is confined to Mexico. Hilaria belangeri var. longifólia (Vasey) Hitche. Stolons wanting; blades elongate. 24 ( $H$. longifolia Vasey.) - Arizona and Sonora.

2. Hilaria mútica (Buckl.) Benth. Tobosa grass. (Fig. 1003.) Culms from a tough rhizomatous base, 30 to $60 \mathrm{~cm}$ tall, glabrous, the nodes pubescent; blades flat or somewhat involute, rather rigid, 2 to 3 $\mathrm{mm}$ wide; spikes 4 to $6 \mathrm{~cm}$ long; group of spikelets about $7 \mathrm{~mm}$ long; bearded at base; glumes of lateral spikelets very unsymmetrical, 


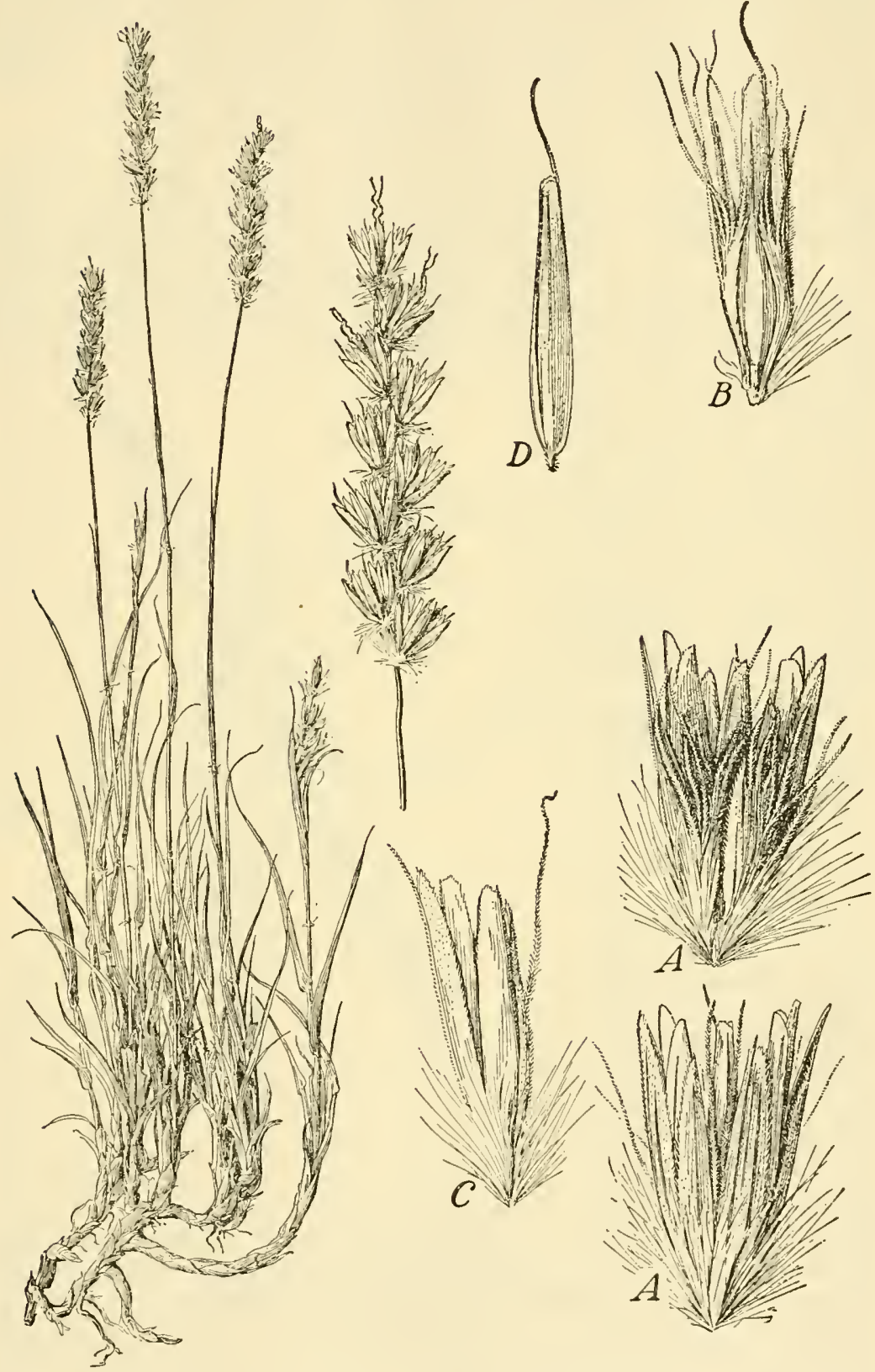

FIgURE 1004,- Hilaria jamesii. Plant, $\times 1 / 2$; single spike, $\times 1$; group of spikelets, two views $(A), \times 5$; fertile spikelet $(B)$, staminate spikelet $(C)$, and fertile floret $(D), \times 5$. (Tidestrom 1449, Utah.) 
widened toward the ciliate summit, the nerves flabellate, not excurrent or barely so; fertile spikelet about equaling the lateral ones, its glumes strongly lieeled, cleft into few to several narrow ciliate lobes

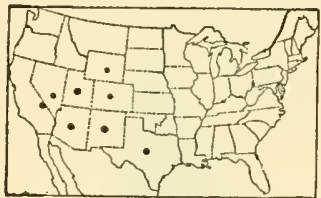

FIgURE 1005.-Distribution of Hilaria jamesii. and slender awns; lemma exceeding the glumes, mucronate between 2 rounded lobes. 24 (Pleuraphis mutica Buckl.)-Dry plains and hills, Texas to Arizona and northern Mexico.

3. Hilaria jamésii (Torr.) Benth. Galleta. (Fig. 1004.) Plants erect, the base often decumbent or rhizomatous, bearing also tough scaly rhizomes; culms glabrous, the nodes villous; sheaths glabrous or slightly scabrous, sparingly villous around the short membranaceous ligule; blades mostly 2 to 5 $\mathrm{cm}$ long, 2 to $4 \mathrm{~mm}$ wide, rigid, soon involute, the upper reduced; group of spikelets 6 to $8 \mathrm{~mm}$ long, long-villous at base, similar to those of $H$. rigida, but the glumes of lateral spikelets acute, usually with a single awn; lemma of the fertile spikelet exceeding its glumes. 24 (Pleuraphis jamesii Torr.) Deserts, canyons, and dry plains, Wyoming and Utah to Texas and Inyo County, Calif. (fig. 1005).

4. Hilaria rígida (Thurb.) Benth. Big GALLETA. (Fig. 1006.) Plants rather robust at base, branching, the branches mostly erect or ascending, the base rather woody, decumbent or rhizomatous; culms numerous, rigid, felty-pubescent, glabrate and scabrous above, 50 to $100 \mathrm{~cm}$ tall; leaves felty or glabrous, usually woolly at the top of the sheath; blades spreading, 2 to $5 \mathrm{~cm}$ long, or longer on sterile

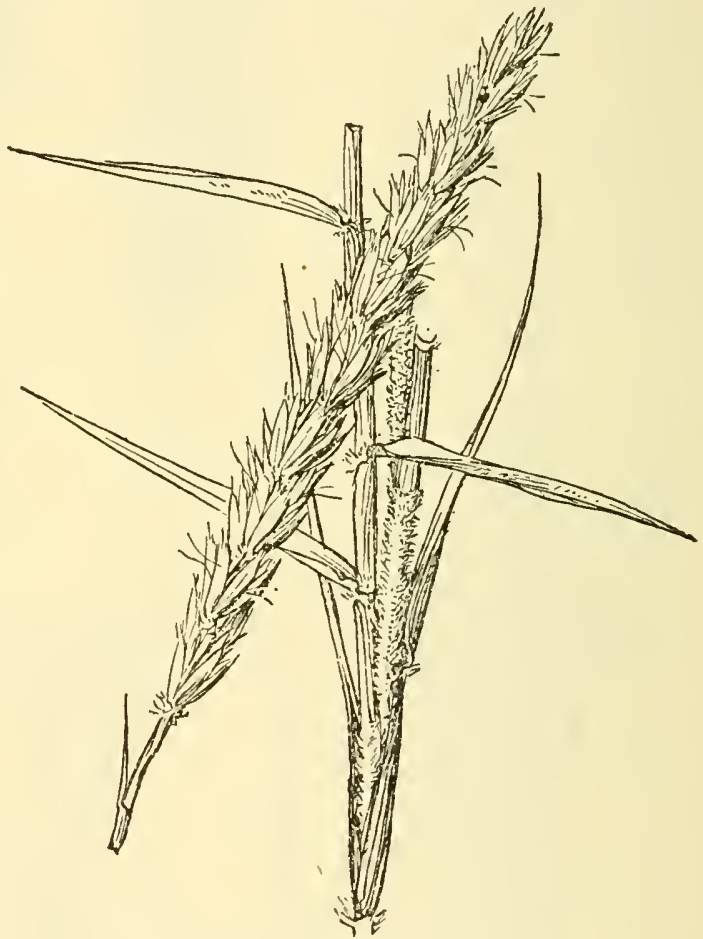

FigUre 1006.-Hilaria rigida, $\times 1$. (Palmer 494, Utah.) shoots, 2 to $4 \mathrm{~mm}$ wide, more or less involute, acuminate into a rigid coriaceous point; group of spikelets about $8 \mathrm{~mm}$ long, densely bearded at base; glumes of lateral spikelets thin, long-ciliate, about 7-nerved, usually 2- to 4-lobed at the broad summit and with 1 to 3 nerves excurrent into slender awns, nerves sometimes obscure and scarcely 
excurrent (variable in a single spike); fertile spikelet about equaling the lateral ones, its narrow glumes deeply cleft into few to several acuminate ciliate lobes and slender awns; lemma scarcely exceeding the glumes, thin, ciliate, 2 -lobed, the midnerve excurrent into a short awn. 21 (Pleuraphis rigida Thurb.) -Deserts, southern Utah and Nevada to southern California and Sonora (fig. 1007).

\section{AEGOPOGON Humb. and Bonpl.}

Spikelets short-pedicellate, in groups of 3, the group short-pedunculate, spreading, the peduncle disarticulating from the axis and forming a pointed stipe below the group, this falling entire; central spikelet shorter pedicellate, fertile, the 2 lateral ones longer pedicellate and staminate or neuter; glumes membranaceous, notched at the apex, the midnerve extending into a delicate awn; lemma and palea thinner than the glumes, extending beyond them, the lemma 3 -nerved, the central nerve and sometimes also the lateral ones extending into awns, the palea 2-awned. Low, lax annuals, with short, narrow, flat blades and loose racemes of delicate groups of spikelets. Type species, Aegopogon cenchroides Humb. and Bonpl. Name from Greek aix, goat,

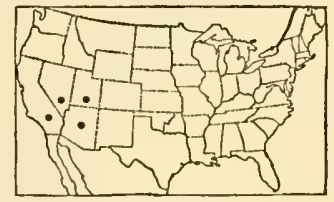

Figure 1007.-Distribution of Hilaria rigida. and pogon, beard, alluding to the fascicle of awns of the spikelets.

1. Aegopogon tenélius (Cav.) Trin. (Fig. 1008.) Culms 10 to $20 \mathrm{~cm}$ long, usually spreading or decumbent; blades 1 to $2 \mathrm{~mm}$ wide; racemes 3 to $5 \mathrm{~cm}$ long; spikelets, excluding awns, about $2 \mathrm{~mm}$ long; lemma and palea of lateral spikelets broad and rounded at summit with a single delicate awn, those of the fertile spikelet narrower, with one long and 2 short awns. $\odot$-Open ground, mountains of southern Arizona and south to northern South America.

\section{TRIBE 7. CHLORIDEAE}

\section{LEPTÓCHLOA Beauv. Sprangletop}

Spikelets 2- to several-flowered, sessile or short-pediceled, approximate or somewhat distant along one side of a slender rachis, the rachilla disarticulating above the glumes and between the florets; glumes unequal or nearly equal, awnless or mucronate, 1-nerved, usually shorter than the first lemma; lemmas obtuse or acute, sometimes 2-toothed and mucronate or short-awned from between the teeth, 3-nerved, the nerves sometimes pubescent. Annuals or perennials, with flat blades and numerous usually slender spikes or racemes borne on a common axis forming a long or sometimes shert panicle. Type species, Leptochloa virgata. Name from Greek leptos, slender, and chloa, grass, alluding to the slender spikes.

The only species of Leptochloa important as a forage grass is $L$. dubia, or sprangletop, of the Southwest, useful for grazing and for hay.

\section{Plants perennial.}

Lemmas broad, notched at apex, the lateral nerves glabrous _.. 1. L. DuBia.

Lemmas acute or awned, the lateral nerves pubescent.

Lemmas about $3 \mathrm{~mm}$ long; panicle flabellate, the axis short.

2. L. CHLORIDIFORMIS. 


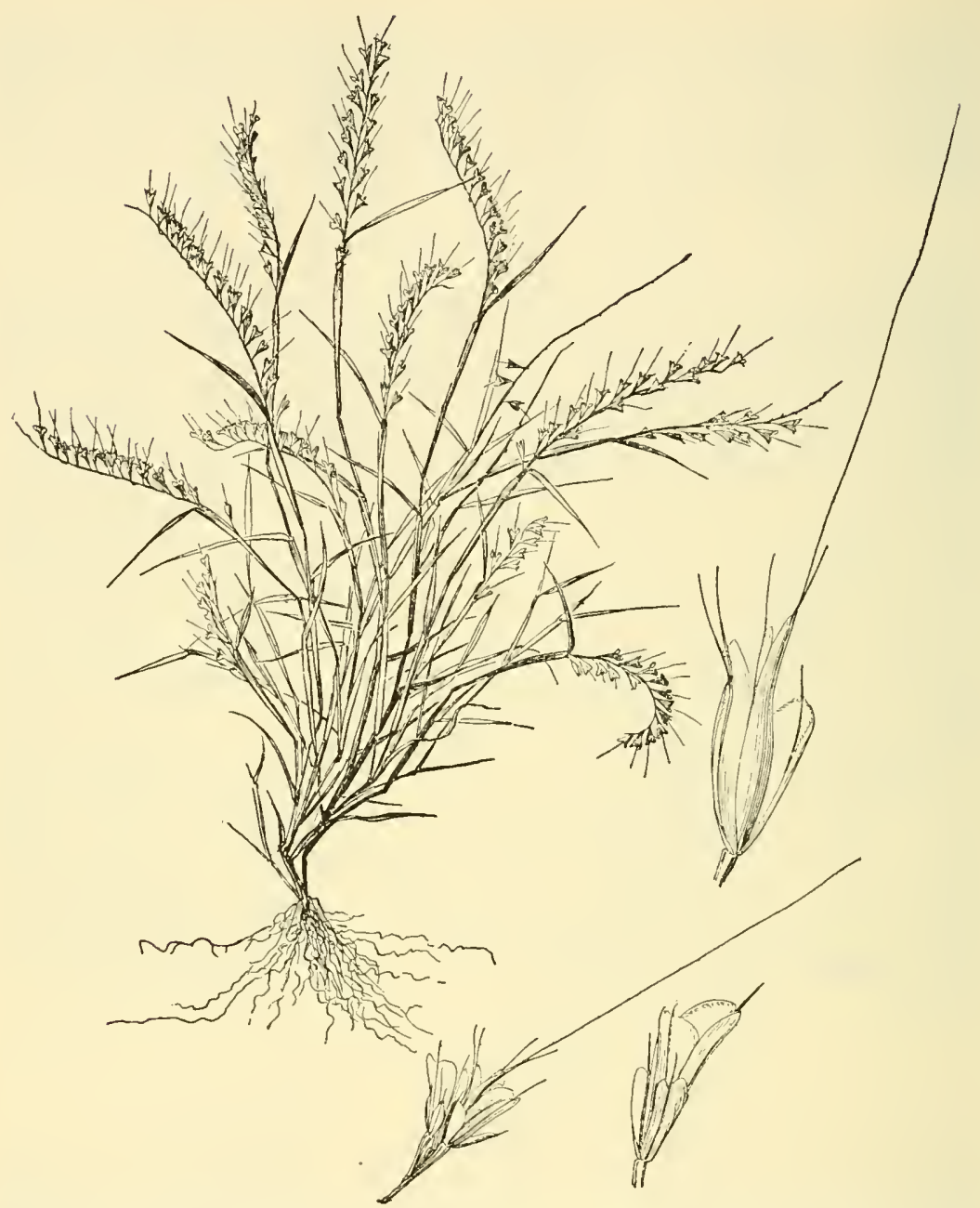

FIGURE 1008.-Aegopogon tenellus. Plant, $\times 1 / 2$; group of spikelets, $\times 5$; lateral spikelets and central spikelet, $\times 10$. (Pringle 1407, Mexico.)

Lemmas about $1.5 \mathrm{~mm}$ long; panicle oblong, the axis relatively long. Sheaths and blades glabrous; lemmas awnless or nearly so.

3. L. VIRGATA.

Sheaths and blades sparsely pilose; lemmas awned_. 4. L. Domingensis.

Plants annual.

Sheaths papillose-pilose; first floret not longer than the second glume; spikelets mostly 1 to $2 \mathrm{~mm}$ long .........

Sheaths smooth or scabrous, not pilose; spikelets more than $2 \mathrm{~mm}$ long.

Lemmas awned, awns sometimes minute. Culms freely branching.

Lemmas viscid on the back; panicle oval, usually less than $10 \mathrm{~cm}$ long, the longer branches usually less than $5 \mathrm{~cm}$ long; second glume 1.5 $\mathrm{mm}$ long ......... Lemmas not viscid; panicle more than $10 \mathrm{~cm}$ long, the longer branches usually as much as $10 \mathrm{~cm}$ long; second glume $3 \mathrm{~mm}$ long.

7. L. FASCICULARIS. 
Lemmas awnless or mucronate only.

Florets obtuse, sometimes mucronate.

Spikelets 5 to $7 \mathrm{~mm}$ long, 6- to 9-flowered, lead color.

8. L.UNINERVia.

Spikelets 2 to $3 \mathrm{~mm}$ long, 3- to 4-flowered, pale.... 9. L. NEALLEYI.

Florets acuminate.

Sheaths scabrous, keeled and compressed_....... 10. I. Scabra.

Sheaths smooth or slightly scabrous near apex, scarcely keeled or

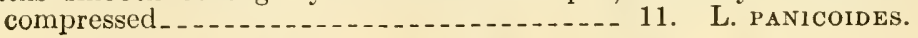

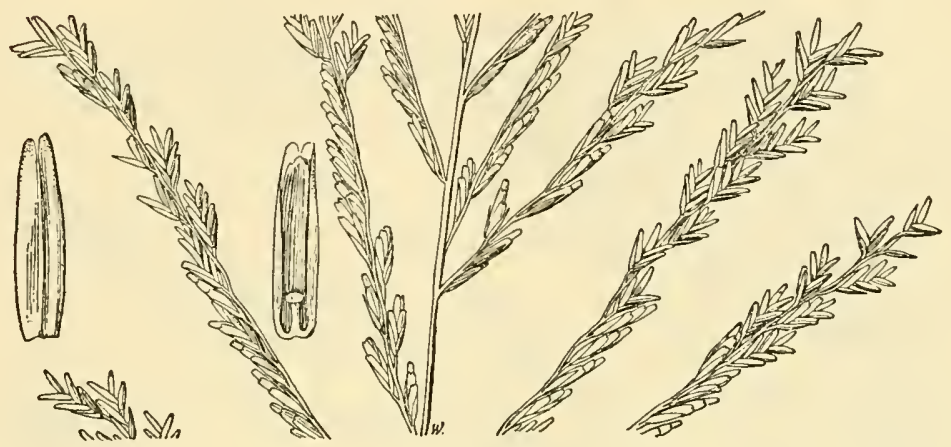

FJgURE 1009.-Leptochloa dubia. Panicle, $\times 1$; two views of floret, $\times 10$. (Small, Carter, and Small 3572 , Fla.)

1. Leptochloa dúbia (H. B. K.) Nees. Green sprangletop. (Fig. 1009.) Perennial; culms wiry, erect, 50 to $100 \mathrm{~cm}$ tall; sheaths glabrous; blades flat or sometimes folded or loosely involute, scabrous, as much as $1 \mathrm{~cm}$ wide, but usually narrower; panicle of few to many spreading or ascending racemes 3 to $12 \mathrm{~cm}$ long, approximate or somewhat distant on an axis as much as $15 \mathrm{~cm}$ long; spikelets 5 - to 8 -flowered or in reduced specimens only 2 -flow-

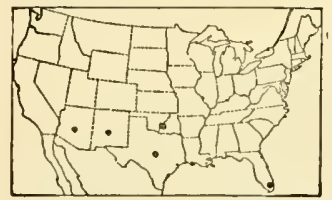

Figure 1010.-Distribution of Leptochloa dubia. ered, 5 to $10 \mathrm{~mm}$ long; lemmas broad, glabrous on the internerves, obtuse or emarginate, the midnerve sometimes extending into a short point, the florets at maturity widely spreading, very different in appearance from their early phase. 24 -Rocky hills and canyons and sandy soil, southern Florida; Oklahoma (Fort Sill) and Texas to Arizona, south through Mexico; (fig. 1010) Argentina. Racemes of cleistogamous spikelets are often found in the sheaths.

2. Leptochloa chloridifórmis (Hack.) Parodi. (Fig. 1011.) Robust tufted perennial, somewhat glaucous; culms erect, 80 to $150 \mathrm{~cm}$ tall; sheaths scaberulous; ligule a dense line of white hairs, 1 to $2 \mathrm{~mm}$ long; blades erect, elongate, flat, rather firm, 3 to $4 \mathrm{~mm}$ wide, villous on the upper surface near the base, the margins scabrous, long-attenuate; panicle long-exserted; spikes numerous (usually 10 to 15), pale or stramineous, erect at base, flabellate or outcurved above, 10 to 15 $\mathrm{cm}$ long, aggregate in 2 or 3 whorls on an axis 3 to $4 \mathrm{~cm}$ long; spikelets closely imbricate on a rachis $0.5 \mathrm{~mm}$ wide, about 4 -flowered, about $4 \mathrm{~mm}$ long; glumes acute, the first $1.5 \mathrm{~mm}$ long, the second 2.5 to $3 \mathrm{~mm}$ long; lemmas keeled, pilose on the margins nearly to apex, the midnerve extending beyond the obtuse tip as a minute mucro, the first and second florets about $3 \mathrm{~mm}$ long, the other shorter, not 
extending much beyond the first two. 24 -Dry open ground, Cameron County, Tex.; Paraguay and Argentina.

3. Leptochloa virgáta (L.) Beauv. (Fig. 1012.) Perennial; culms wiry, erect, 50 to $100 \mathrm{~cm}$ tall; blades flat; racemes several to many,

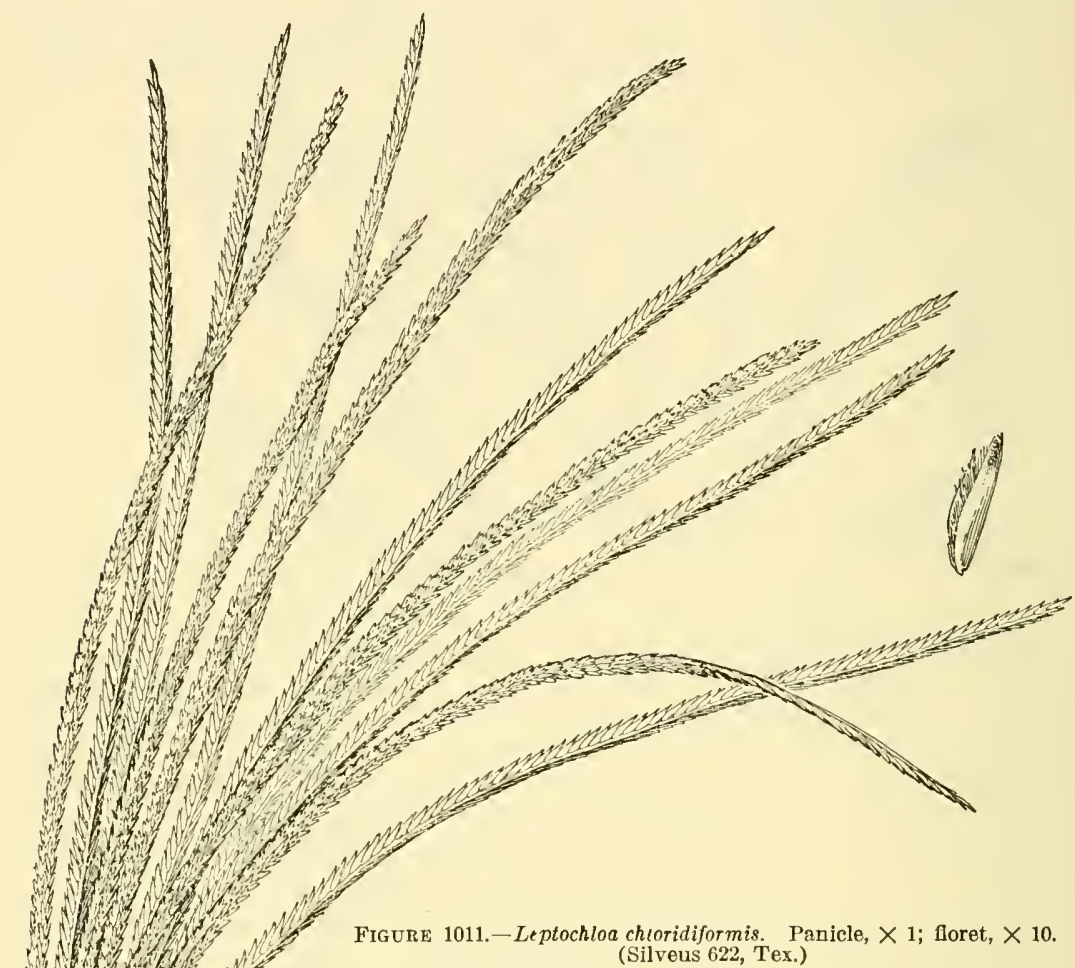
(Silveus 622, Tex.)

slender, laxly ascending, 5 to $10 \mathrm{~cm}$ long, the lower distant, the others often aggregate; spikelets nearly sessile, mostly 3- to 5-flowered; lemmas 1.5 to $2 \mathrm{~mm}$ long, awnless or the lower with a short awn. 21-Open ground and grassy slopes, southern Florida and southern Texas; tropical America.

4. Leptochloa domingénsis (Jacq.) Trin. (Fig. 1013.) Resembling L.virgata; sheaths and blades sparsely pilose; panicle more elongate, the racemes shorter and more numerous; lemmas appressed-pubescent on the internerves, awned, the awn of the lower florets 1 to $3 \mathrm{~mm}$ long. 2 -Open ground and grassy slopes, southern Florida; tropical America.

5. Leptochloa filifórmis (Lam.) Beauv. RED SPRANGLETop. (Fig. 1014.) Annual; the foliage and panicles often reddish or purple; culms erect, or often branching and geniculate below, 40 to $70 \mathrm{~cm}$ tall, or often dwarf; sheaths papillose-pilose, sometimes sparsely so; blades flat, thin, as much as $1 \mathrm{~cm}$ wide; panicle somewhat viscid, of numerous approximate slender racemes 5 to $15 \mathrm{~cm}$ long, on 
an axis mostly about half the entire length of the culm; spikelets 3- to 4-flowered, 1 to $2 \mathrm{~mm}$ long, rather distant on the rachis; glumes acuminate, longer than the first floret, often as long as the spikelet; lemmas awnless, pubescent on the nerves, $1.5 \mathrm{~mm}$ long. $\odot$ ( $L$. mucronata Kunth.)-Open or shady ground, a common weed in gardens and fields, Virginia to southern Indiana and eastern Kansas, south to Florida and Texas, west to southern California; Massa-

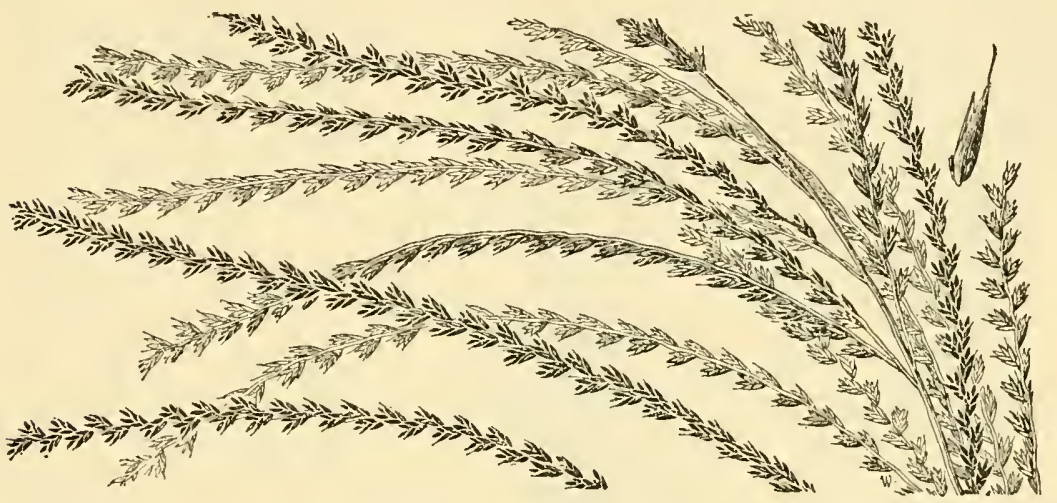

FIGURE 1012.-Leptochloa virgata. Panicle, $\times 1$; floret, $\times 10$. (Wilson 9402, Cuba.)

chusetts; throughout tropical America (fig. 1015). Much of the material from the Southwest has shorter racemes. Smaller forms occur throughout. These have been called $L$. attenuata (Nutt.) Steud.

6. Leptochloa víscida (Scribn.) Beal. (Fig. 1016.) Annual, freely branching at base and from all the nodes, spreading or prostrate, the foliage and panicles somewhat viscid; culms 10 to $30 \mathrm{~cm}$ tall; blades

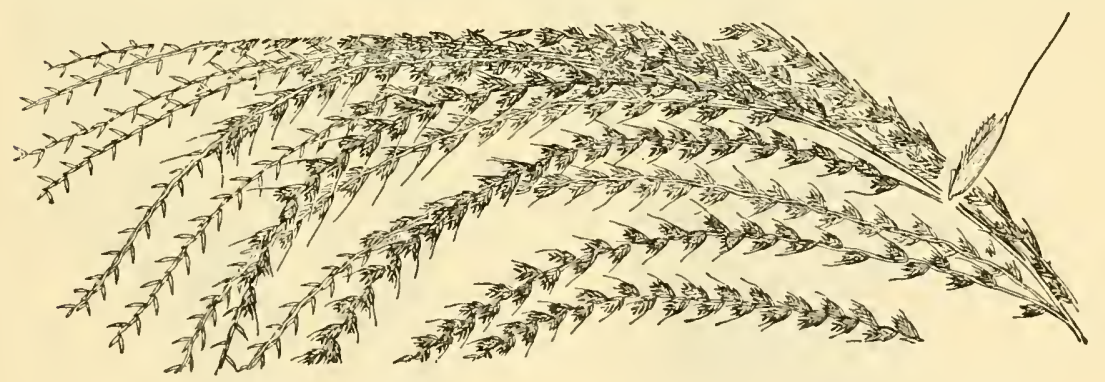

FIGURE 1013.-Leptochloa domingensis. Panicle, $\times 1$; floret, $\times 10$. (Hitcheock 10055, Trinidad.)

flat; panicles ovoid, rather dense, 1 to $8 \mathrm{~cm}$ long, tinged with purple, included at base; spikelets 3 to $5 \mathrm{~mm}$ long, 5- to 7-flowered; lemmas pubescent on the nerves, about $2 \mathrm{~mm}$ long, short-awned. $\odot-$ Open ground and waste places, New Mexico, Arizona, and northern Mexico.

7. Leptochloa fasciculáris (Lam.) A. Gray. (Fig. 1017.) Annual, somewhat succulent; culms erect to spreading or prostrate, freely branching, 30 to $100 \mathrm{~cm}$ tall; blades flat to loosely involute; panicles more or less included, mostly 10 to $20 \mathrm{~cm}$ long, often smaller, occasionally longer, the racemes several to numerous, as much as $10 \mathrm{~cm}$ 


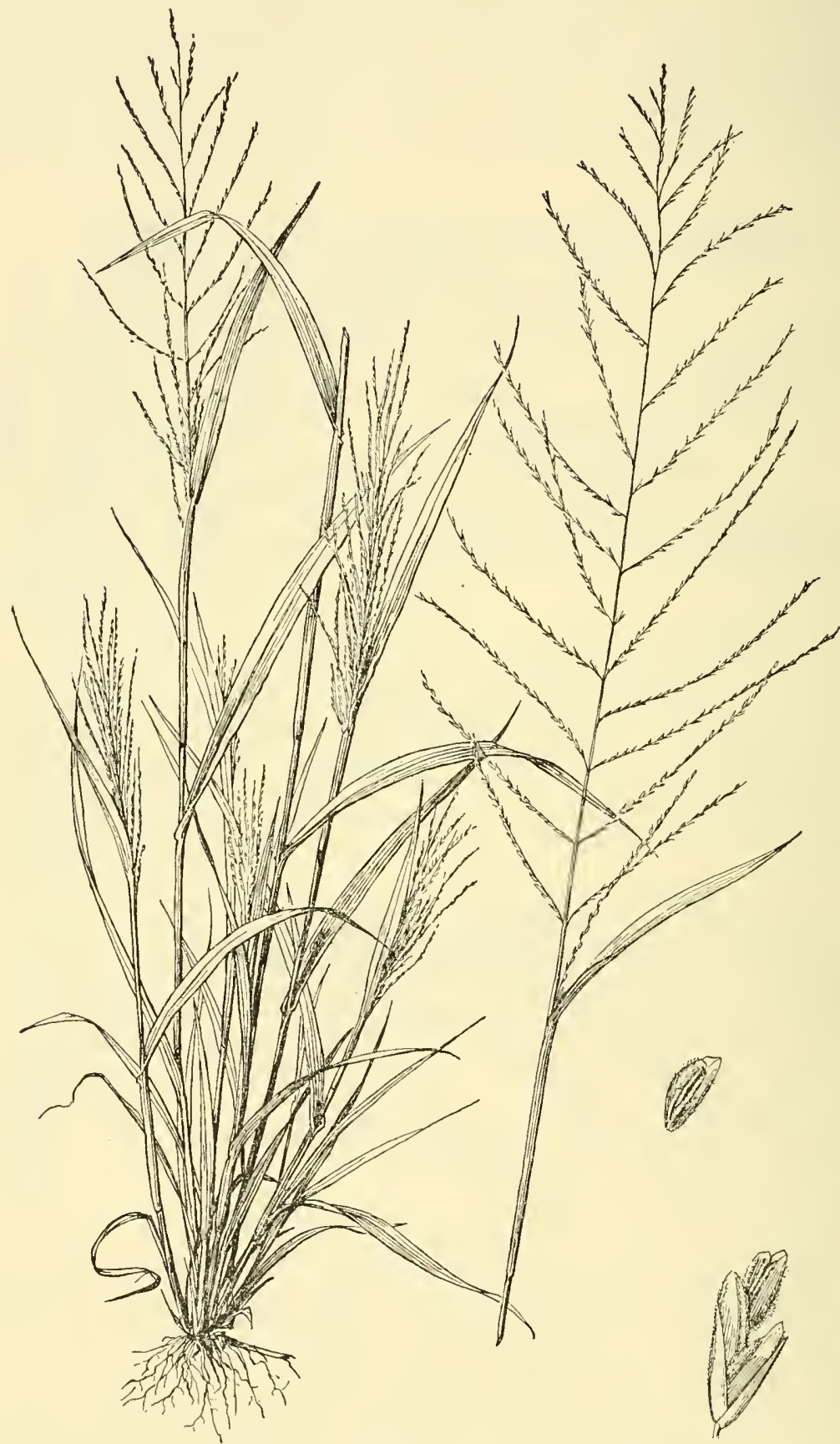

Figure 1014.-Leptochloa filiformis. Plant, $\times 1 / 2$; spikelet and floret, $\times 10$. (Ruth 51, Tenn.) 
long, usually ascending or appressed, or at maturity spreading; spikelets usually overlapping, 7 to $12 \mathrm{~mm}$ long, 6- to 12 -flowered; lemmas 4 to $5 \mathrm{~mm}$ long, the lateral nerves pubescent below, acuminate, the awn from short to as long as the body. $\odot$ (Diplachne fascicularis Beauv.) - Brackish marshes along the coast, New Hampshire to Florida and Texas and in alkali flats, ditches, and marshes, Illinois and South Dakota to Texas, west through Colorado and New Mexico to California; also Washington (Bingen) and Oregon; south through tropical America to Argentina (fig. 1018.) A prostrate form has been called Dip-

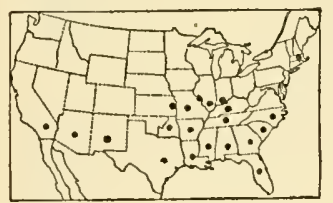

FIGURE 1015.-Distribution of Leptochloa filiformis.

lachne procumbens (Muhl.) Nash and D. maritima Bickn.

8. Leptochloa uninérvia (Presl) Hitchc. and Chase. (Fig. 1019.) Resembling $L$. fascicularis, rather sparingly branching, usually strictly erect, the panicle more oblong in outline, with shorter, denser-flowered racemes; spikelets 5 to $7 \mathrm{~mm}$ long, 6- to 9-flowered, lead-color; glumes broader, more obtuse; lemmas scarcely narrowed toward tip, apiculate but not awned, the lateral nerves more or less excurrent. $\odot \quad$ (L. imbricata Thurb.)-Ditches and moist places, Mississippi to Colorado and southern California, south to Mexico;

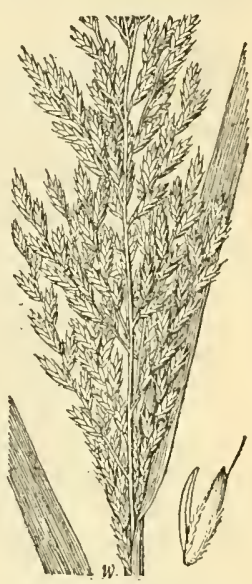

Figure 1016. - Leptochloa viscida. Panicle, $\times$ 1; floret, $\times 10$. (Mearns 833, Ariz.)

\section{Peru to Argentina; introduced from Maine to New Jersey (fig.} 1020).

9. Leptochloa nealléyi Vasey. (Fig. 1021.) Annual, usually erect and rather robust; culms mostly 1 to $1.5 \mathrm{~m}$ tall, simple or sparingly

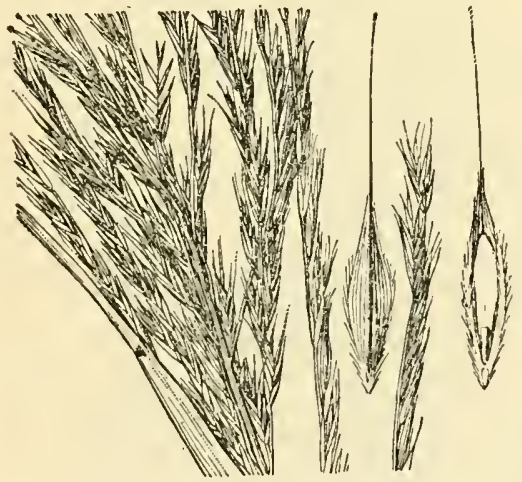

Figure 1017.-Leptochloa fascicularis. Panicle, $X$ 1 ; two views of floret, $\times 10$. (Hitchcock 7876 , Md.) branching at base; sheaths glabrous or slightly scabrous, mostly keeled; blades elongate, flat to loosely involute; panicle commonly

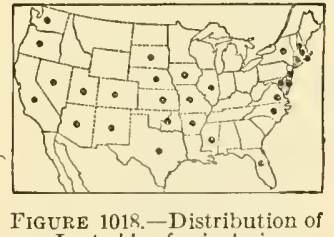

Leptochloa fascicularis.

25 to $50 \mathrm{~cm}$ long, not more than $4 \mathrm{~cm}$ wide, the racemes subverticillate, overlapping, 2 to $4 \mathrm{~cm}$ long, a ppressed or ascending; spikelets crowded,

3 - or 4-flowered, 2 to $3 \mathrm{~mm}$ long; lemmas about $1.5 \mathrm{~mm}$ long, the apex obtuse, the nerves sparingly pubescent, the lateral close to the margin. $\odot$-Marshes, mostly near the coast, Louisiana (Cameron) and Texas; also eastern Mexico. 
10. Leptochloa scábra Nees. (Fig. 1022.) Annual; culms erect, about $1 \mathrm{~m}$ tall, somewhat robust and succulent, sparingly branching; sheaths and blades scabrous, the blades elongate, 8 to $12 \mathrm{~mm}$ wide;

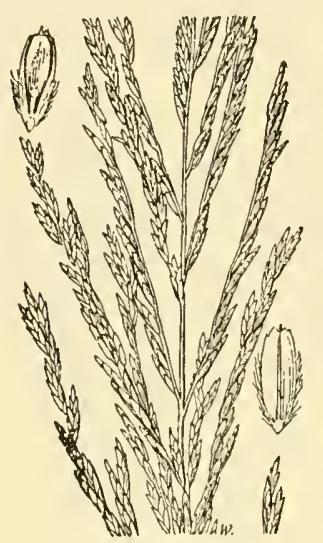

FIgURE 1019.-Leptochloa uninervia. Panicle, $\times 1$; two views of floret, $\times 10$. ('Tharp 3123 , Tex.) panicle 20 to $40 \mathrm{~cm}$ long, not more than $7 \mathrm{~cm}$ wide, usually less, the slender racemes crowded, 4 to $8 \mathrm{~cm}$ long, ascending or somewhat drooping, usually curved or flexuous; spikelets crowded, mostly 3 -flowered, about $3 \mathrm{~mm}$ long; lemmas acute, awnless, the nerves pubescent. $\odot$ - Marshes and ditches, Louisiana (near New Orleans) and tropical America.

\section{Leptochloa pani-} coídes (Presl) Hitche. (Fig. 1023.) Annual;

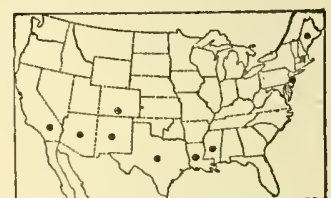

Figure 1020.-Distribution of Leptochloa uninervia.

culms erect or spreading, 50 to $100 \mathrm{~cm}$ tall, branching; sheaths glabrous; blades thin, 5 to $10 \mathrm{~mm}$ wide, scaberulous; panicle oblong, 10 to $20 \mathrm{~cm}$ long, 3 to $5 \mathrm{~cm}$ wide, the racemes approximate, 3 to $5 \mathrm{~cm}$ long, ascending, rather lax; spikelets 5 - to 7 -flowered, 4 to $5 \mathrm{~mm}$ long; lemmas $2.5 \mathrm{~mm}$ long, apiculate, the lateral nerves minutely pubescent at base. $\odot(L$. floribunda Doell.) - Indiana (Posey County), Mississippi (Holmes County), Louisiana, Texas; Brazil (fig. 1024).

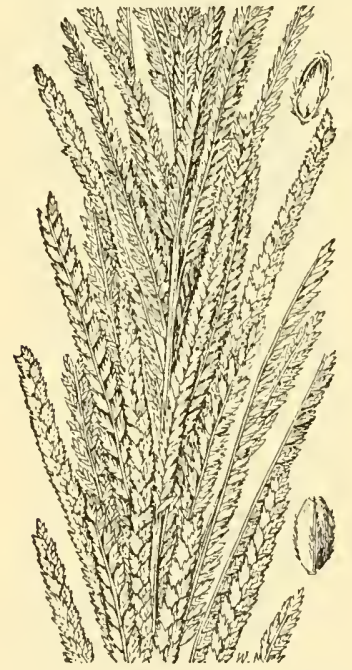

Figure 1021-Leptochloa nealleyi. Panicle, $\times 1$; two views of floret, $\times 10$. (Fisher 25, Tex.)

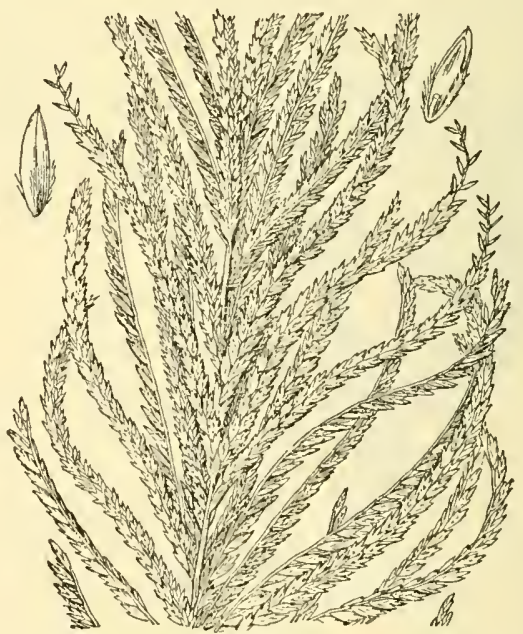

Figure 1022.-Leptochloa scabra. Panicle, $\times 1$; two views of floret, $\times 10$. (Tracy 838s, La.)

\section{TRICHONEÚRA Anderss.}

Spikelets few-flowered, the rachilla disarticulating above the glumes, the internodes pilose at base, disarticulating near their summit, the upper part forming a short callus below the floret; glumes about 
equal, 1-nerved, long-acuminate, mostly as long as the spikelet or longer; lemmas bidentate, 3-nerved, the lateral nerves near the margin, the midnerve usually excurrent as a short awn, the margins long-ciliate; palea broad, the nerves near the margin. Annuals or perennials with simple panicles, the spikelets short-pediceled along one side of the main branches. Type species, Trichoneura hookeri Anderss. Name from Greek thrix, hair, and neuron, nerve, alluding to the ciliate nerves of the lemma.

1. Trichoneura élegans Swallen. (Fig. 1025.) Annual, branching at base; culms erect, rather robust, or ascending, 40 to $110 \mathrm{~cm}$ tall, several-noded; sheaths scaberulous; blades flat, or subinvolute toward the tip, scabrous, elongate, 3 to $7 \mathrm{~mm}$ wide; panicle erect, 10 to $18 \mathrm{~cm}$ long, the axis angled, scabrous; branches numerous, stiflly ascending, the lower 5 to $8 \mathrm{~cm}$ long, rather densely flowered; spikelets mostly 5- to S-flowered, 9 to $10 \mathrm{~mm}$ long; glumes about equaling the spikelet, the setaceous tips slightly

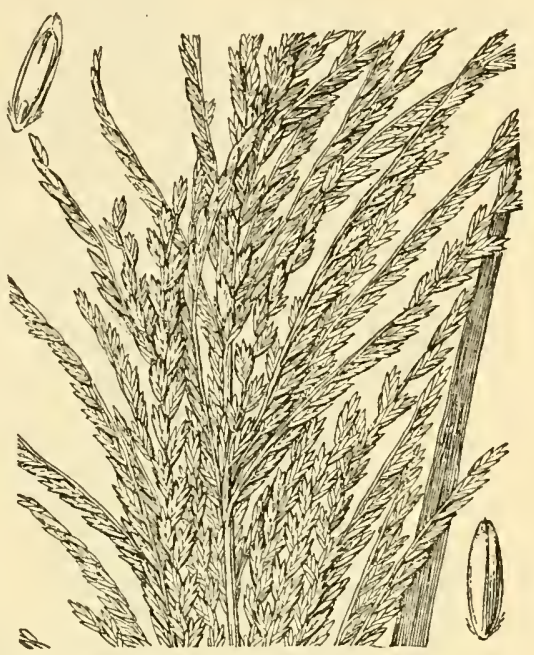

Figure 1023.-Leptochloa panicoides. Panicle, $\times 1$. two views of floret, $\times 10$. (Tracy 7451, Miss.) spreading; lemmas scaberulous toward the obtuse minutely lobed summit, the awn minute, the margins conspicuously ciliate on the lower half to two-thirds, the hairs as much as $1 \mathrm{~mm}$ long. $\odot$-Sandy soil, southern Texas.

\section{TRIPOGON Roth}

Spikelets several-flowered, subsessile, appressed in two rows along one side of a slender rachis, the rachilla disarticulating above the

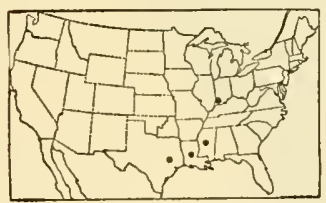

FigURE 1024.-Distribution of Leptochloa panicoides. glumes and between the florets; glumes somewhat unequal, acute or acuminate, narrow, 1-nerved; lemmas narrow, 3-nerved, bearing at base a tuft of long hairs, the apex bifid, the midnerve extending as a short awn. Our species a low, tufted perennial, with capillary blades and slender solitary spikes, the spikelets somewhat distant. Type species, Tripogon bromoides Roth. Name from Greek treis, three, and pogon, beard, alluding to the hairs at the base of the three nerves of the lemma.

1. Tripogon spicátus (Nees) Ekman. (Fig. 1026.) Culms 10 to 20 $\mathrm{cm}$ tall; spike from one-fourth to half the entire height of the plant; spikelets 5 to $8 \mathrm{~mm}$ long. 24 -Rocky hills, central Texas, Mexico; Cuba; South America. 


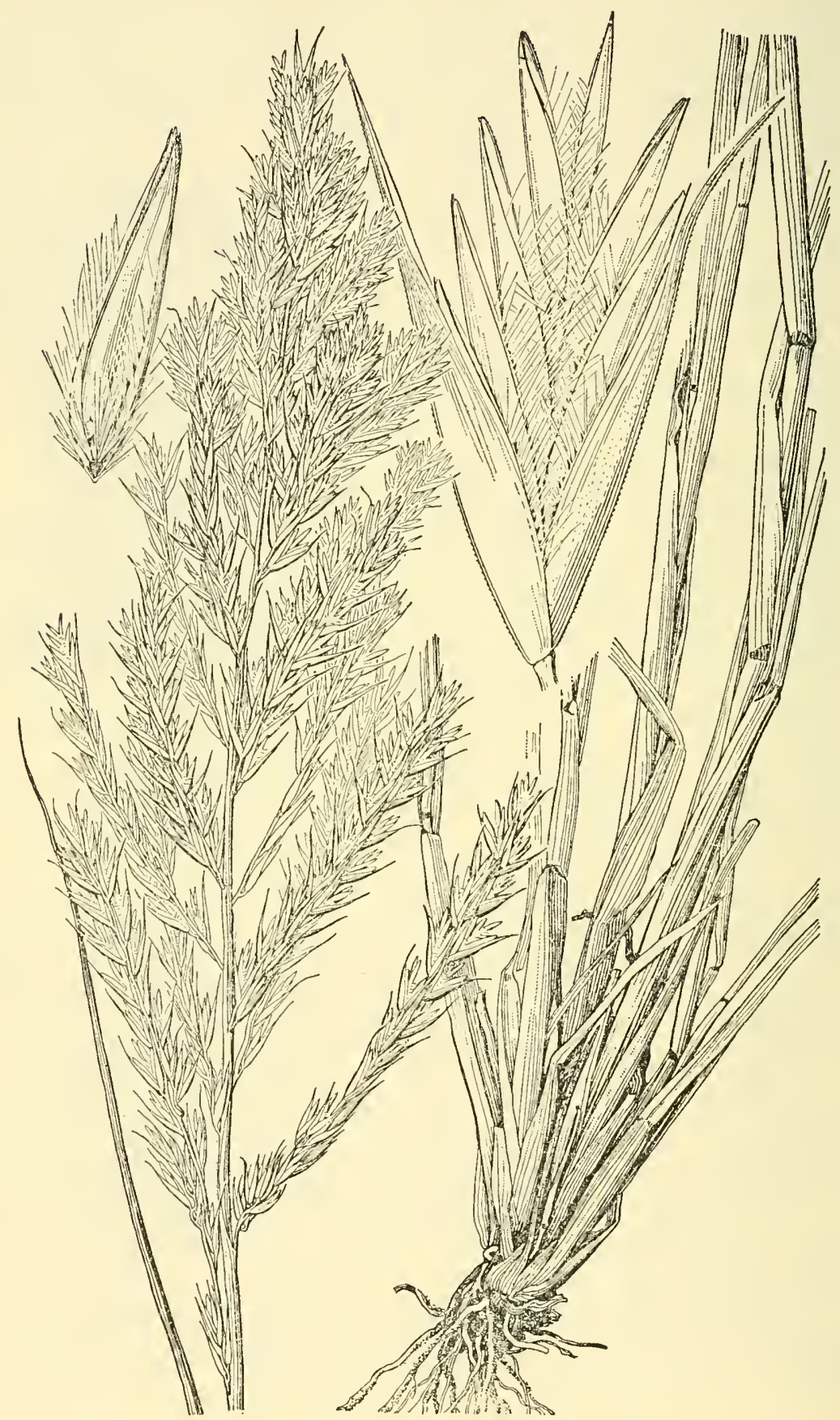

FIGURE 1025.-Trichoneura elegans. Plant, $\times 1$; spikelet and floret, $\times 10$. (Type.) 


\section{ELEUSÍNE Gaertn.}

Spikelets few to several-flowered, compressed, sessile and closely imbricate, in two rows along one side of a rather broad rachis, not prolonged beyond the spikelets; rachilla disarticulating above the glumes and between the florets; glumes unequal, rather broad, acute, 1-nerved, shorter than the first lemma; lemmas acute, with 3 strong
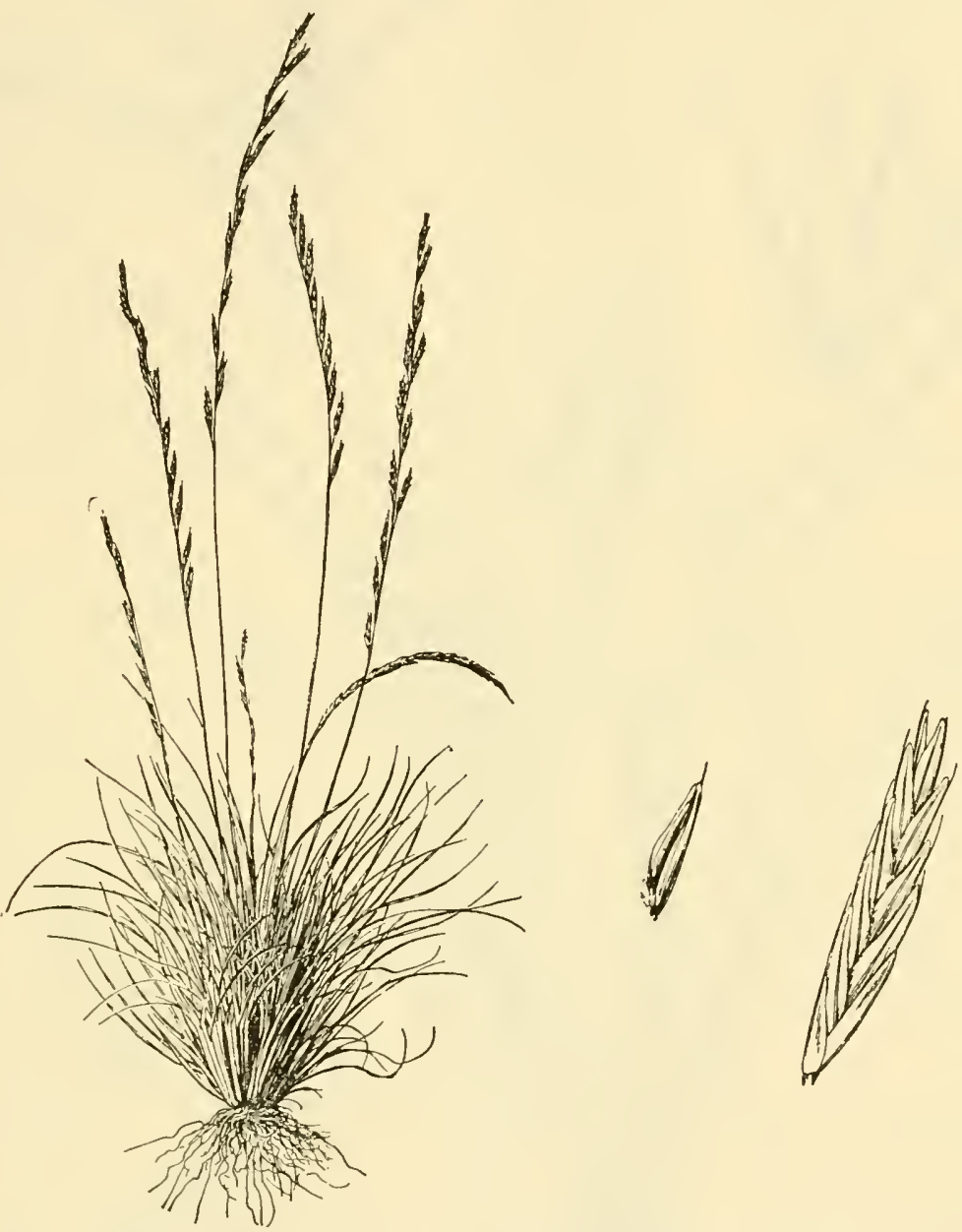

FigURE 1026.-Tripogon spicatus. Plant, $\times \frac{1}{2}$; spikelet and floret, $\times 5$. (Nealley 78, Tex.)

green nerves close together forming a keel, the uppermost somewhat reduced; seed dark brown, roughened by fine ridges, loosely enclosed in the thin pericarp. Annuals, with two to several rather stout spikes, digitate at the summit of the culms, sometimes with one or two a short distance below, or rarely with a single spike. Type species, Eleusine coracana. Name from Eleusis, the town where Demeter was worshipped. 


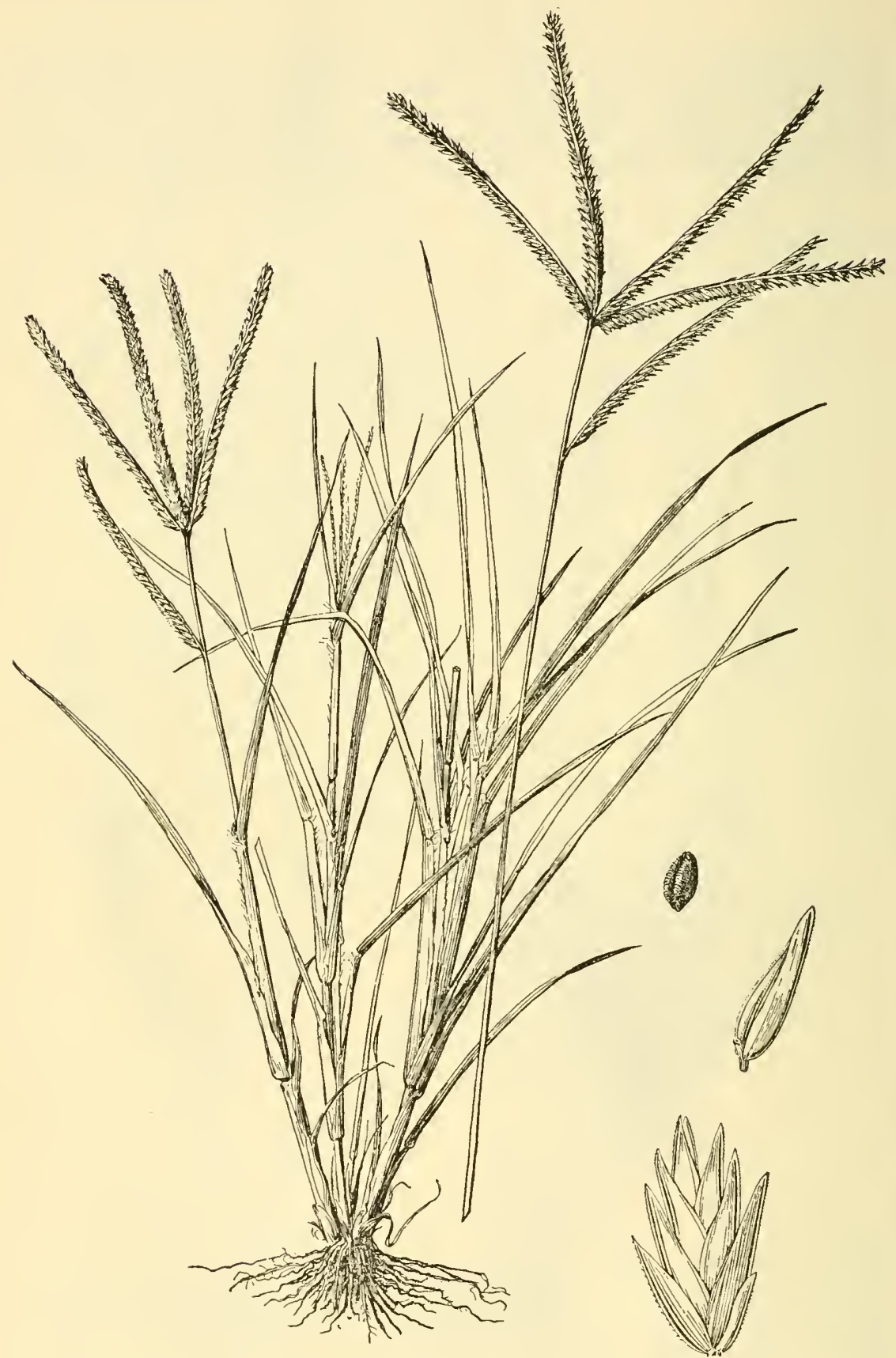

FIGURE 1027.-Eleusine indica, Plant, $\times 1 / 2$; spikelet, floret, and seed (without pericarp), $\times 5$. (Fredholm 
1. Eleusine índica (L.) Gaertn. Goosegrass. (Fig. 1027.) Branching at base, ascending to prostrate, very smooth; culms compressed, usually less than $50 \mathrm{~cm}$ long, but sometimes as much as $1 \mathrm{~m}$; blades flat or folded, 3 to $8 \mathrm{~mm}$ wide; spikes mostly 2 to 6 , rarely more, or but 1 in depauperate plants, flat, 4 to $15 \mathrm{~cm}$ long. $\odot-$ Waste places, fields, and open ground, Massachusetts to South Dakota and Kansas, south to Florida and Texas; occasional in Oregon and California (fig. 102S); introduced; a common weed in the warmer regions of both hemispheres.

Eleusine tristáchya Lam. Spikes 1 to 3 , rarely more, 1 to $2.5 \mathrm{~cm}$ long, 8 to $10 \mathrm{~mm}$ thick; resembling $E$. indica, but the spikes short and thick. $\odot-$ On ballast, Camden, N.J. and Mobile, Ala.; Portland, Oreg. and elsewhere; tropical Africa; introduced in tropical South America.

Eleusine coracána (L.) Gaertn. African MiLlet. More robust than E. indica; spikes thicker, heavier, sometimes incurved at the tip, brownish at maturity. A cultivated form of E. indica; the seed used for food among primitive peoples in Africa and southern Asia. $\odot-$ Occasionally grown at experiment stations. Called also ragi, coracan millet, and finger millet.

\section{DACTYLOCTÉNIUM Willd.}

Spikelets 3- to 5-flowered, compressed, sessile and closely imbricate, in two rows along one side of the rather narrow flat rachis, the end projecting in a point beyond the spikelets; rachilla disarticulating above the first glume and between the florets; glumes somewhat unequal, broad, 1-nerved, the first persistent upon the rachis, the second mucronate or short-awned below the tip, deciduous; lemmas firm, broad, keeled, acuminate or short-awned, 3-nerved, the lateral nerves indistinct, the upper floret reduced; palea about as long as the lemma; seed subglobose, ridgred or wrinkled, enclosed in a thin, earlydisappearing pericarp. Annuals or perennials with flat blades and two to several short thick spikes, digitate and widely spreading at the summit of the culms. Type species, Dactyloctenium aegyptium. Name from Greek daktulos, finger, and ktenion, a little comb, alluding to the pectinate arrangement of the spikelets.

1. Dactyloctenium aegýptium (L.) Richt. (Fig. 1029.) Culms compressed, spreading with ascending ends, rooting at the nodes, branching, commonly forming radiate mats, usually 20 to $40 \mathrm{~cm}$ long, sometimes as much as $1 \mathrm{~m}$; blades flat, ciliate; spikes 1 to $5 \mathrm{~cm}$ long. $\odot-$ Open ground, waste places, and fields, Coastal Plain, North Carolina to Florida and Arizona, also occasional at more northern points (Maine to New Jersey; Illinois); tropical America (fig. 1030); introduced from tropical regions of the Old World.

\section{CÝNODON Rich.}

(Capriola Adans.)

Spikelets 1-flowered, awnless, sessile in two rows along one side of a slender continuous rachis and appressed to it, the rachilla disarticulating above the glumes and prolonged behind the palea as a 


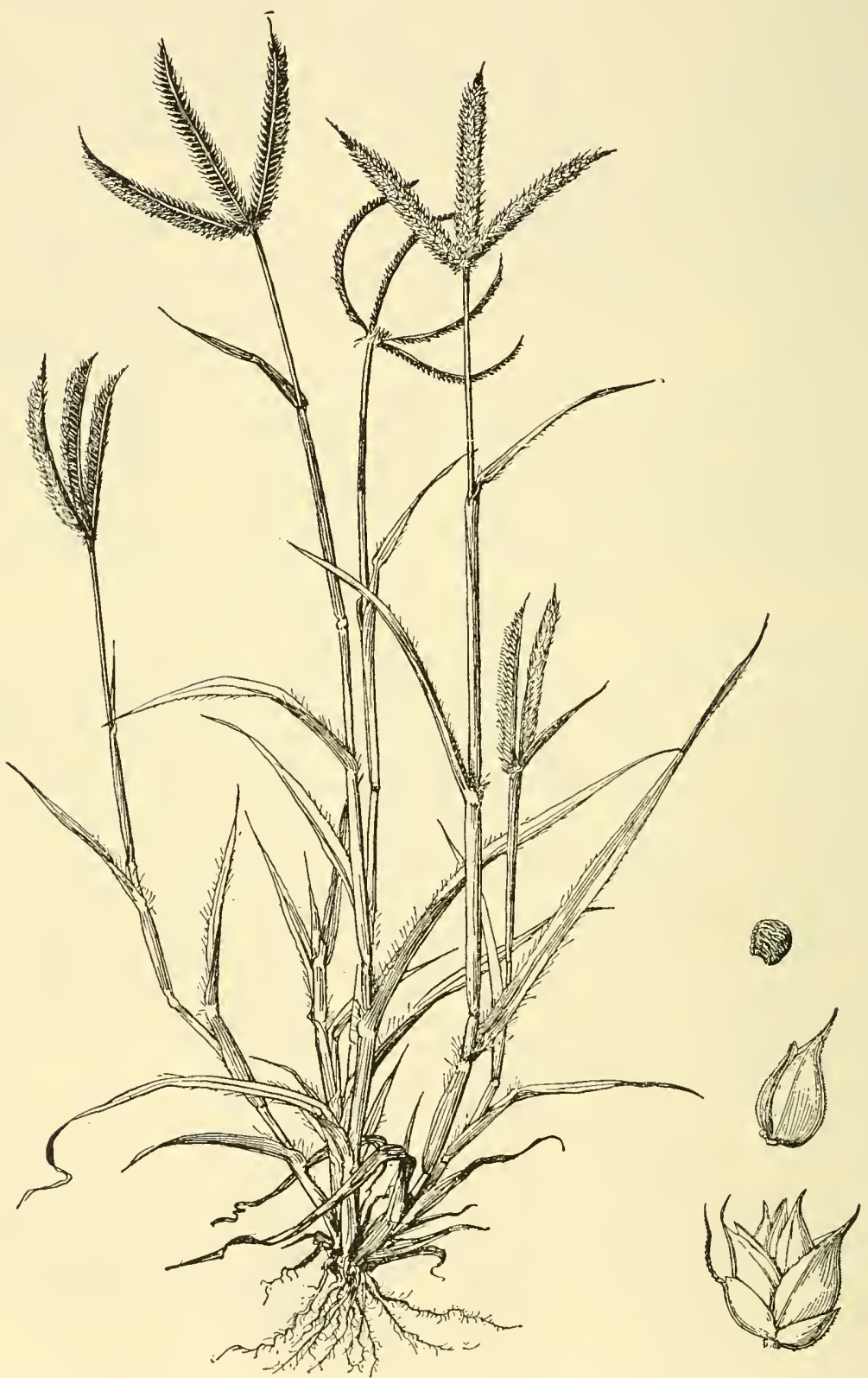

FIGURE 1029,-DactyLctenium aegyptium. Plant, $\times 1 / 2$; spikelet, floret, and seed (without pericarp), $\times 5$. (Small and Heller 378, N.C.) 
slender naked bristle, sometimes bearing a rudimentary lemma; glumes narrow, acuminate, 1-nerved, about equal, shorter than the floret; lemma firm, strongly compressed, pubescent on the keel, 3-nerved, the lateral nerves close to the margins. Perennial, usually low grasses, with creeping stolons or rhizomes, short blades, and several slender spikes digitate at the summit of the upright culms. Type species, Cynodon dactylon. Name from kuon (kun-), dog, and odous, tooth, alluding to the sharp hard scales of the rhizome.

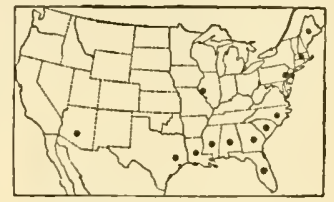

FIGURE 1030.-Distribution of Dactyloctenium aegyptium.

1. Cynodon dáctylon (L.) Pers. Bermuda grass. (Fig. 1031.) Extensively creeping by scaly rhizomes or by strong flat stolons, the

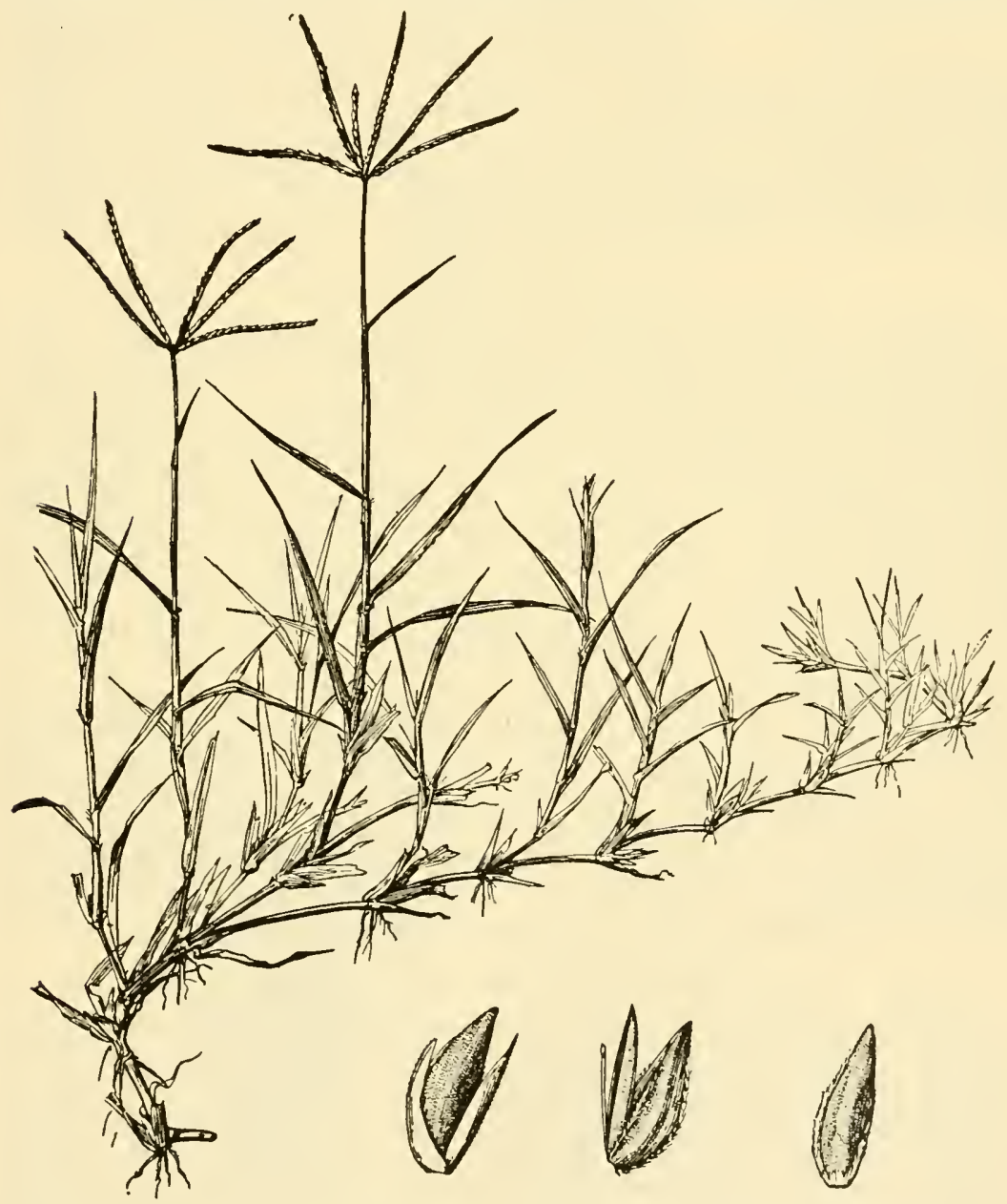

Figure 1031.-Cynodon dactylon. Plant, $\times 1 \frac{1}{2}$; spikelet and two views of floret, $\times 5 . \quad$ (Kearney, Tenn.) old bladeless sheaths of the stolon and the lowest one of the branches of ten forming conspicuous pairs of "dog's teeth"; flowering culms flattened, usually erect or ascending, 10 to $40 \mathrm{~cm}$ tall; ligule a con- 
spicuous ring of white hairs; blades flat, those of the innovations often conspicuously distichous; spikes usually 4 or $5,2.5$ to $5 \mathrm{~cm}$ long; spikelets imbricate, $2 \mathrm{~mm}$ long, the lemma boat-shaped, acute. 21 (Capriola dactylon Kuntze.)-Open ground, grassland, fields, and waste places, common, Maryland to Oklahoma, south to Florida and Texas, west to California; also occasional north of this region (New

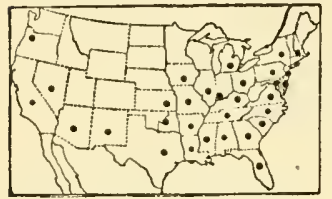

Figure 1032.-Distribution of C'ynodon dactylon. Hampshire to Michigan, Oregon) (fig. 1032); warm regions of both hemispheres, introduced in America. Bermuda grass is the most important pasture grass of the Southern States, and is also widely utilized there as a lawngrass. On alluvial ground it may grow sufficiently rank to be cut for hay. It propagates readily by its rhizomes and stolons, and on this account may become a troublesome weed in cultivated fields. This grass is known also as wire-grass (especially the weedy form in fields). A more robust form, found along the seacoast of Florida, has been called C. maritimus, though the type of that (from Peru) is characteristic $C$. dactylon. There are large areas of Bermuda grass around the Roosevelt Dam, Ariz., where it survives submergence and furnishes grazing at low water.

\section{WILLKOMMIA Hack.}

Spikelets 1-flowered, dorsally compressed, sessile in two rows on one side of a slender rachis and appressed to it, the rachilla somewhat lengthened below and above the second glume, disarticulating just above it, not prolonged above the floret; glumes thin, unequal, the first narrow, nerveless, the second 1-nerved; lemma awnless, 3-nerved, the lateral nerves near the margin, the back of the lemma sparingly pubescent between the nerves, the margins densely covered with silky hairs; nerves of the palea densely silky hairy. Annuals or perennials, with several short spikes racemose on a slender axis; our species a low tufted perennial. Type species, Willkommia sarmentosa Hack. Named for H. M. Willkomm.

1. Willkommia texána Hitchc. (Fig. 1033.) Culms erect to spreading, 20 to $40 \mathrm{~cm}$ tall; blades flat or more or less involute, short; spikes few to several, 2 to $5 \mathrm{~cm}$ long, somewhat overlapping or the lower distant, appressed, the axis 4 to $15 \mathrm{~cm}$ long; spikelets about 4 $\mathrm{mm}$ long, narrow, acute; first glume about two-thirds as long as the second, obtuse; second glume subacute; lemma about as long as the second glume. 21 - Spots of "hard pan", central and southern Texas. A stoloniferous form has been found in Argentina.

\section{SCHEDONNÁRDUS Steud.}

Spikelets 1-flowered, sessile and somewhat distant in two rows on one side of a slender, continuous 3-angled rachis, appressed to its slightly concave sides, the rachilla disarticulating above the glumes, not prolonged; glumes narrow, stiff, somewhat unequal, acuminate, 1-nerved; lemmas narrow, acuminate, a little longer than the glumes, 3-nerved. Low, tufted perennial, with stiff, slender, divergent spikes arranged rather remotely along a common axis. Type species, Schedonnardus texanus Steud. (S. paniculatus). Name from Greek schedon, near, and Nardus, a genus of grasses (Steudel places Schedonnardus next to Nardus in his classification). 


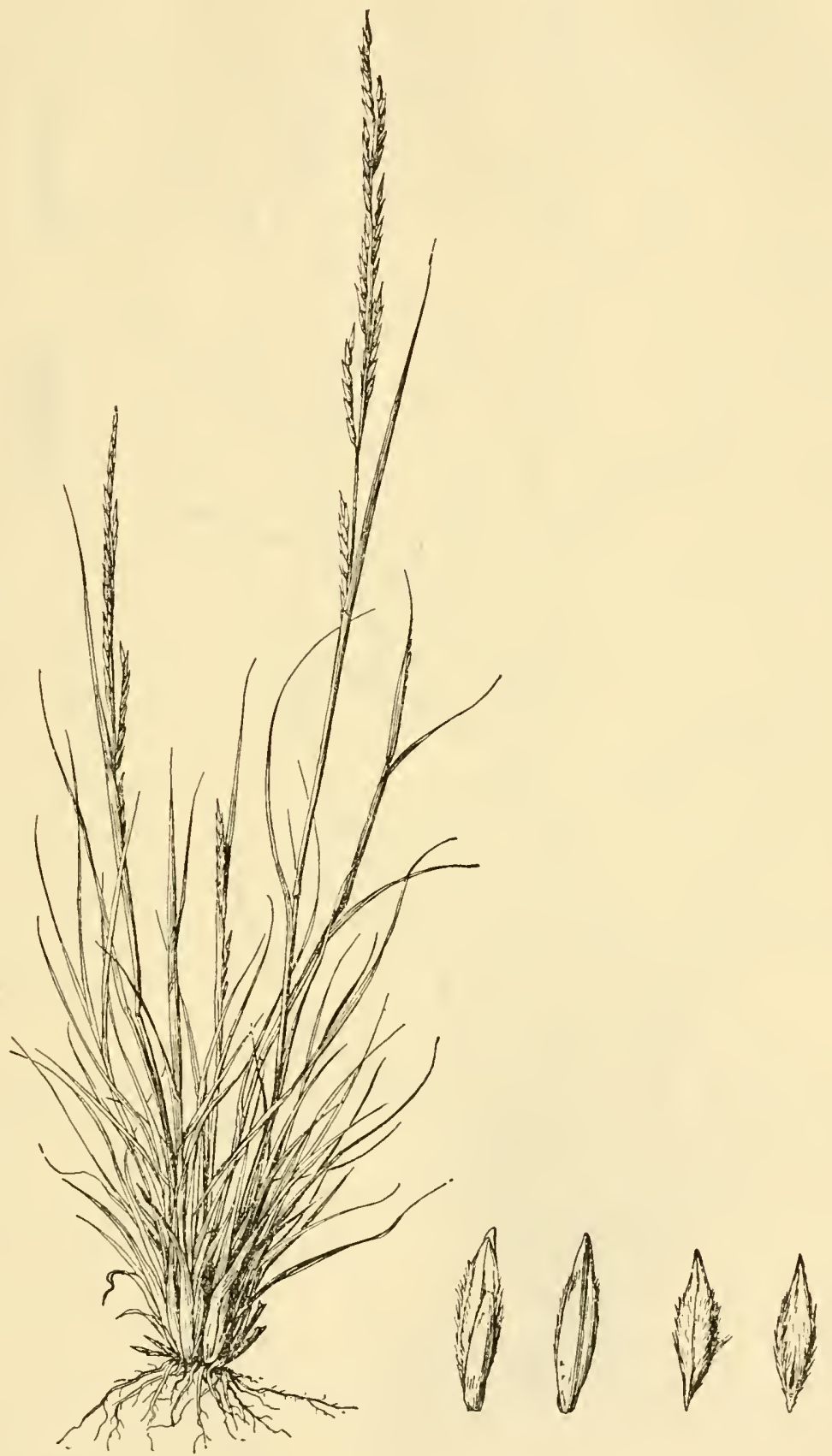

Figure 1033.-W'illkommia texana. Plant, $\times 1 / 2$; two views of spikelet and floret, $\times 5$. (Tracy 8903 , Tex. 


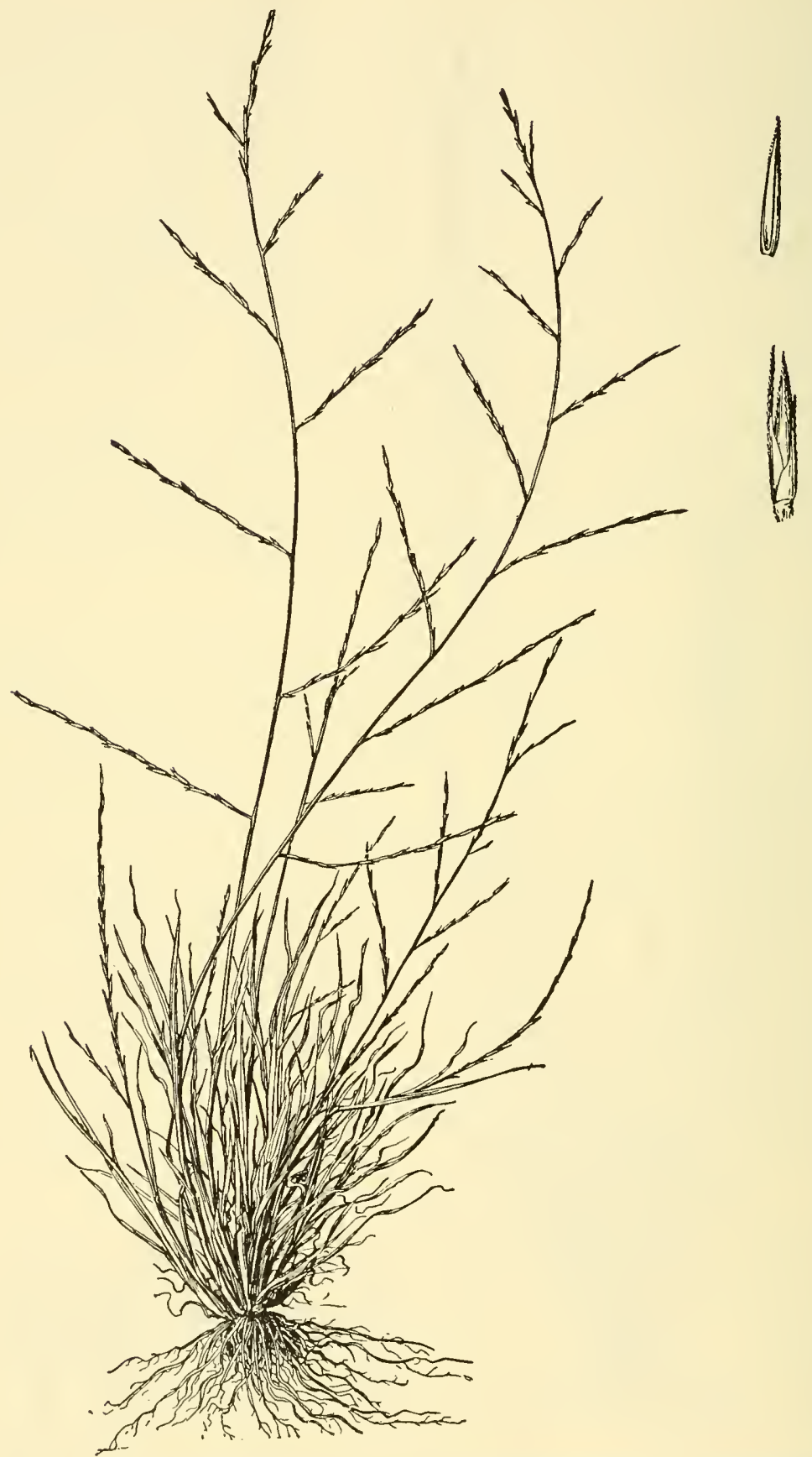

FIGURE 1034,-Schedonnardus panicuiatus. Plant, $\times 1 \frac{1}{2}$; spikelet and foret, $\times 5$. (Hall 797, Tex.) 
1. Schedonnardus paniculátus (Nutt.) Trel. Tumblegrass. (Fig. 1034.) Culms 20 to $40 \mathrm{~cm}$ tall; leaves crowded at the base; blades flat, mostly 2 to $5 \mathrm{~cm}$ long, about $1 \mathrm{~mm}$ wide, wavy; spikes 2 to 10 $\mathrm{cm}$ long; spikelets narrow, acuminate, about $4 \mathrm{~mm}$ long. The axis of the inflorescence elongates after flowering, becoming 30 to $60 \mathrm{~cm}$ long, curved in a loose spiral; the whole breaks away at maturity and rolls before the wind as a tumbleweed. 24 - Prairies and plains, Illinois to Saskatchewan and Montana, south to Texas and Arizona; Argentina (fig. 1035). This species forms an inconsiderable part of the forage on the Great Plains.

\section{BECKMÁNNIA Host. Sloughgrass}

Spikelets 1- or 2-flowered, laterally compressed, subcircular, nearly sessile and closely imbricate, in two rows along one side of a slender

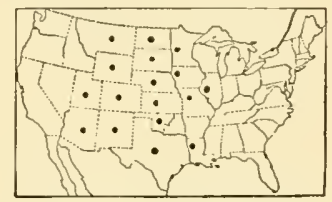

FigURE 1035.-Distribution of Schedonnardus paniculatus. continuous rachis, disarticulating below the glumes, falling entire; glumes equal, inflated, obovate, 3 -nerved, rounded above but the apex apiculate; lemma narrow, 5-nerved, acuminate, about as long as the glumes; palea nearly as long as the lemma. Erect, rather stout annuals with flat blades and numerous short appressed or ascending spikes in a narrow more or less interrupted panicle. Type species, Beckmannia erucaeformis (L.) Host, to which our species was formerly referred. Named for Johann Beckmann.

1. Beckmannia syzigáchne (Steud.) Fernald. American sloughGRASS. (Fig. 1036.) light green; culms 30 to $100 \mathrm{~cm}$ tall; panicle 10 to $25 \mathrm{~cm}$ long, the erect branches 1 to $5 \mathrm{~cm}$ long; spikes crowded, 1 to $2 \mathrm{~cm}$ long; spikelets 1-flowered, $3 \mathrm{~mm}$ long; glumes transversely wrinkled and with a deep keel, the acuminate apex of the lemma protruding. $\odot-$ Marshes and ditches, Manitoba to Alaska, south to Illinois, Kansas, New Mexico, and California; New York, Ohio (fig. 1037); Asia. The European B. erucaeformis (L.) Host has 2flowered spikelets. Our species is palatable to stock, sometimes sufficiently abundant locally to be an important forage grass, and is not infrequently cut for hay.

\section{SPARTÍNA Schreb. CoRdgrass}

Spikelets 1-flowered, much flattened laterally, sessile and usually closely imbricate on one side of a continuous rachis, disarticulating below the glumes, the rachilla not produced beyond the floret; glumes keeled, 1-nerved, acute or short-awned, the first shorter, the second often exceeding the lemma; lemma firm, keeled, the lateral nerves obscure, narrowed to a rather obtuse point; palea 2-nerved, keeled and flattened, the keel between or at one side of the nerves. Erect, often stout tall perennials, with usually extensively creeping, firm, scaly rhizomes (wanting in Spartina spartinae, S. bakeri, and sometimes in S. patens var. caespitosa), long tough blades, and two to many appressed or sometimes spreading spikes racemose on the main axis, the slender tips of the rachises naked, often prolonged. Type species, Spartina schreberi Gmel. Name from Greek spartine, a cord made from spartes (Spartium junceum), probably applied to Spartina because of the tough leaves. 


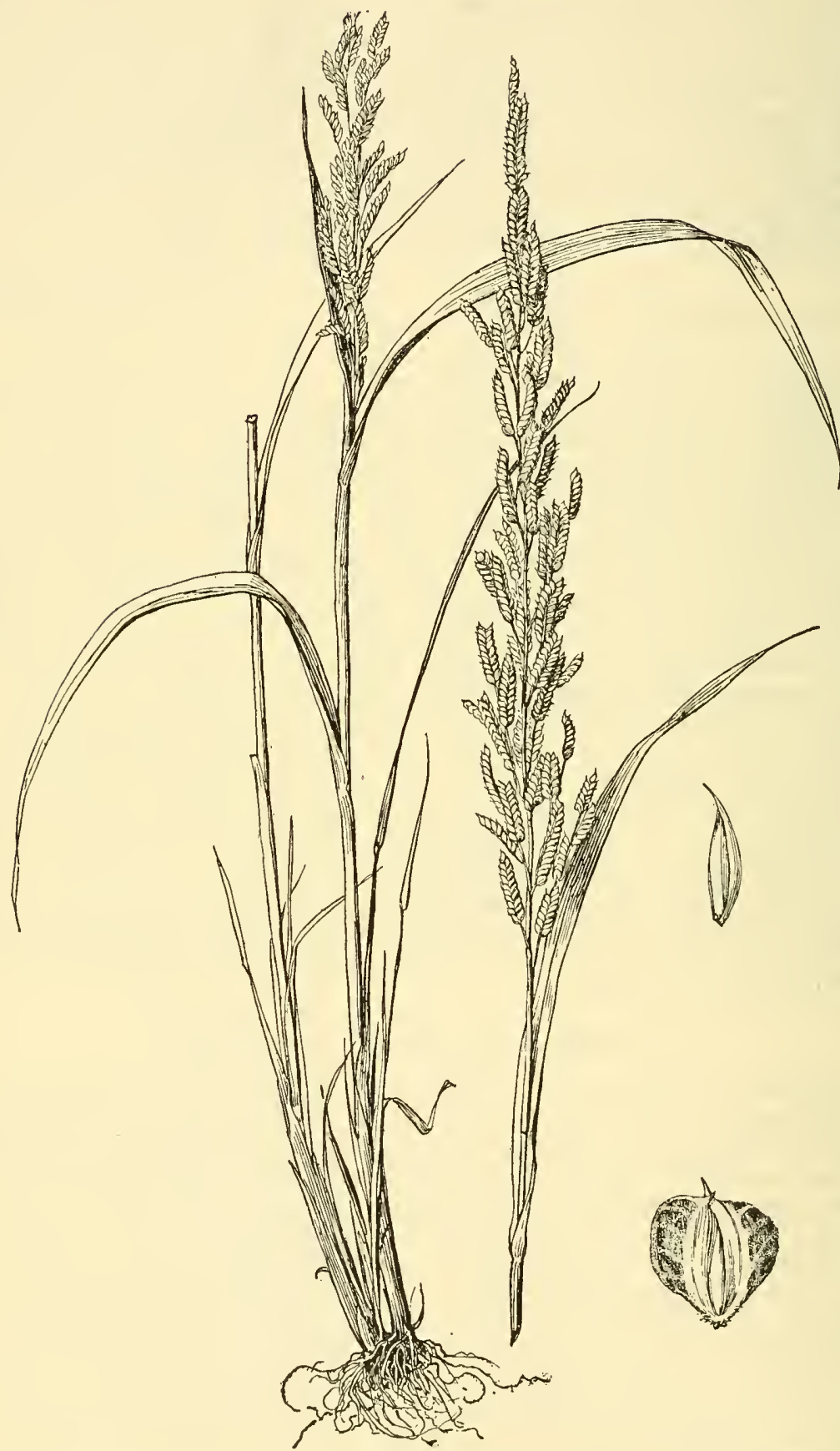

Figure 1036.-Beckmannia syzigachne. Plant, $\times 1 / 2$; spikelet and floret, $\times 5$. (Hitchcock 4668, Alaska.) 
The species with rhizomes often form extensive colonies to the exclusion of other plants. They are important soil binders and soil builders in coastal and interior marshes. A European species, S. townsendi H. and J.Groves, has in recent years assumed much importance, especially in southern England, the Netherlands, and northern France, as a soil builder along the coast where it is reclaiming extensive areas of marsh land. The marsh hay of the Atlantic coast, much used for packing and formerly for bedding, often consists largely of $S$. patens.

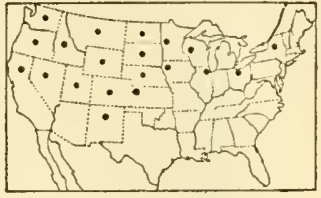

Figure 1037.-Distribution of Beckmannia syzigachne.

Blades usually more than $5 \mathrm{~mm}$ wide, flat when fresh, at least at base, the tip involute; plants mostly robust and more than $1 \mathrm{~m}$ tall.

First glume as long as the floret, slender-acuminate, the second with an awn as much as $7 \mathrm{~mm}$ long; spikes somewhat distant, mostly more or less spreading _............ 1. S. PECTINATA.

First glume shorter than the floret, acute, the second acute or mucronate but not slender-a wned; spikes approximate, usually appressed.

Blades very scabrous on the margins; glumes strongly hispid-scabrous on the keels _............. S. CYNOSURoIDEs.

Blades glabrous throughout or minutely scabrous on the margins; glumes glabrous or usually softly hispidulous or ciliate on the keels.

Inflorescence dense and spikelike, the spikes closely imbricate; the spikelets mostly comewhat curved, giving a slightly twisted effect; blades mostly comparatively short_............. 3. S. LEIANTHA. Inflorescence less dense, the spikes more slender, less crowaed, the spikelets not curved, the inflorescence with no suggestion of a twist.

4. S. ALTERNIFLORA.

Blaces less than $5 \mathrm{~mm}$ wide (rarely more in $S$. gracilis); involute (sometimes flat in S. gracilis); plants mostly slender and less than $1 \mathrm{~m}$ tall (taller in S.bakeri). Inflorescence dense, cylindric; spikes numerous_._._... 5. S. SPARTinaE. Inflorescence not cylindric; spikes not more than 10, usually fewer.

Creeping rhizomes absent (see also $S$. patens var. caespitosa); plants in large hard tufts with tall culms $(1.5$ to $2 \mathrm{~m}$ ) and long slender blades.

6. S. BAKERI.

Creeping rhizomes present (except in $S$. patens var. caespitosa); plants usually less than $1 \mathrm{~m}$ tall.

Spikelets crowded, the spikes mostly thick, erect; Western States.

7. S. GRACILIS.

Spikelets less crowded, the spikes relatively slender, ascending; Atlantic seacoast............ 8. S. PATENS.

1. Spartina pectináta Link. Prairie cordgrass. (Fig. 1038.) Culms 1 to $2 \mathrm{~m}$ tall, firm or wiry; blades elongate, flat when fresh, soon involute in drying, as much as $1.5 \mathrm{~cm}$ wide, very scabrous on the margins; spikes mostly 10 to 20 , sometimes fewer or as many as 30 , mostly 4 to $8 \mathrm{~cm}$ long, ascending, sometimes appressed, rarely spreading, on rather slender peduncles; glumes hispid-scabrous on the keel, the first acuminate or short-awned, about as long as the floret, the second exceeding the floret, tapering into an awn as much as $7 \mathrm{~mm}$ long; lemma glabrous except the scabrous keel, 7 to $9 \mathrm{~mm}$ long, the apex with two rounded teeth; palea usually a little longer than the lemma. 21 (S. michauxiana Hitchc.)-Fresh-water marshes, Newfoundland and Quebec to eastern Washington and Oregon, south to North Carolina, Kentucky, Illinois, Arkansas, Texas, and New Mexico; in the Eastern States extending into brackish marshes along the coast (fig. 1039).

2. Spartina cynosuroídes (L.) Roth. Big cordgrass. (Fig. 1040.) Culms 1 to $3 \mathrm{~m}$ tall, stout, the base sometimes as much as $2 \mathrm{~cm}$ thick; blades flat, 1 to $2.5 \mathrm{~cm}$ wide, very scabrous on the margins; spikes 

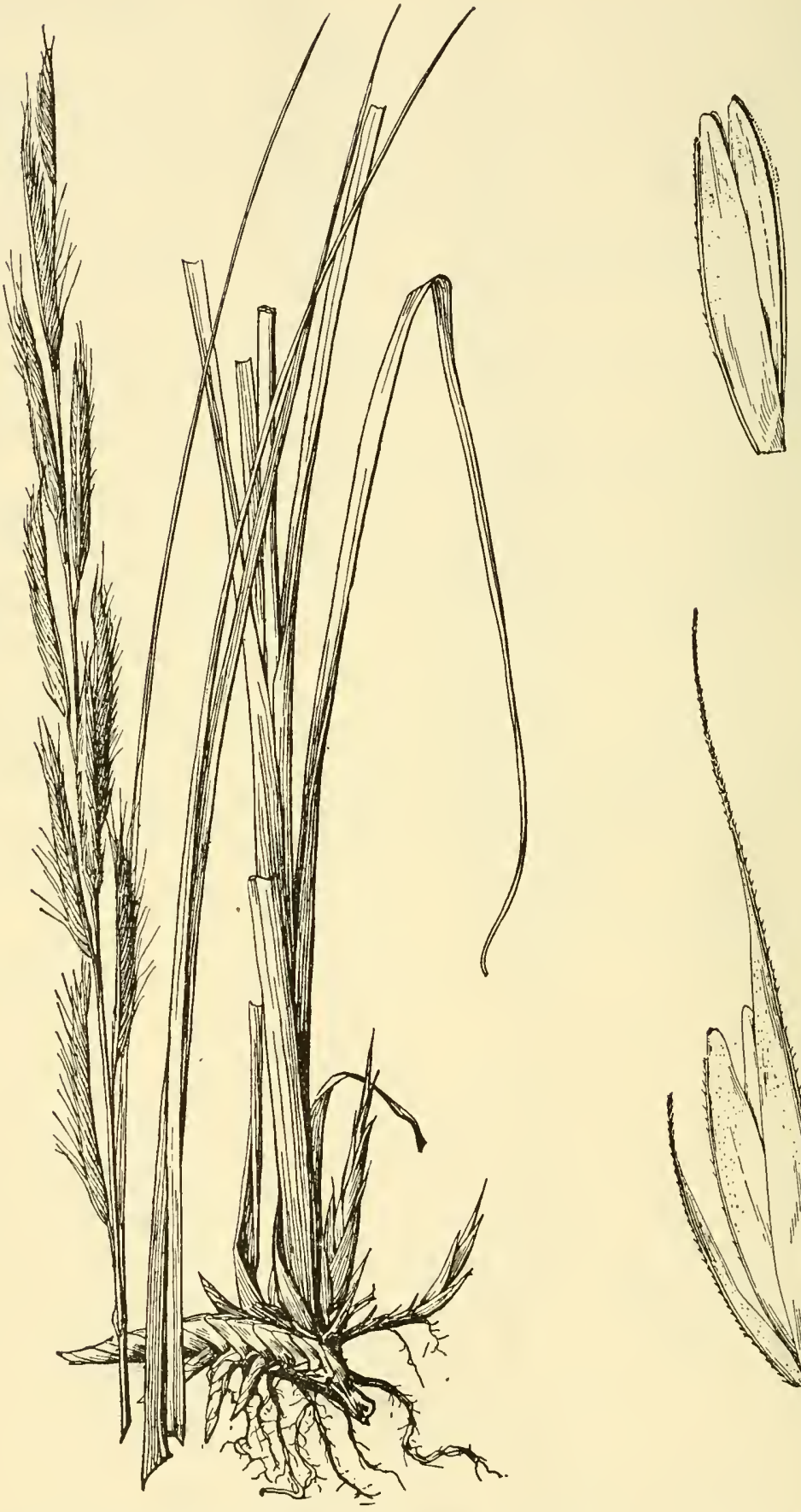

FIGURE 1038. - Spartina pectınata. Plant, $\times 1 / 2$; spikelet and floret, $\times 5$. (Worthern, Mass.) 
numerous, ascending, approximate, often dark colored, usually more or less peduncled, mostly 3 to $8 \mathrm{~cm}$ long; spikelets about $12 \mathrm{~mm}$ long; glumes acute, hispidscabrous on the keel, the first much shorter than the floret, the second longer than the floret, sometimes rather long-acuminate; lemma not toothed at apex; palea a little longer than the lemma. 21 (S. polystachya Beauv.) - Salt or brackish marshes along the coast, Massachusetts to Florida and Texas (fig. 1041).

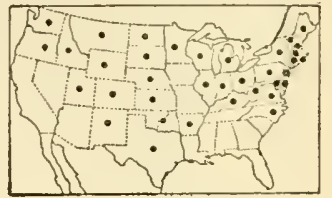

FIgure 1039.-Distribution of Spartina pectinata.

3. Spartina leiántha Benth. (Fig. 1042.) Culms 30 to $120 \mathrm{~cm}$

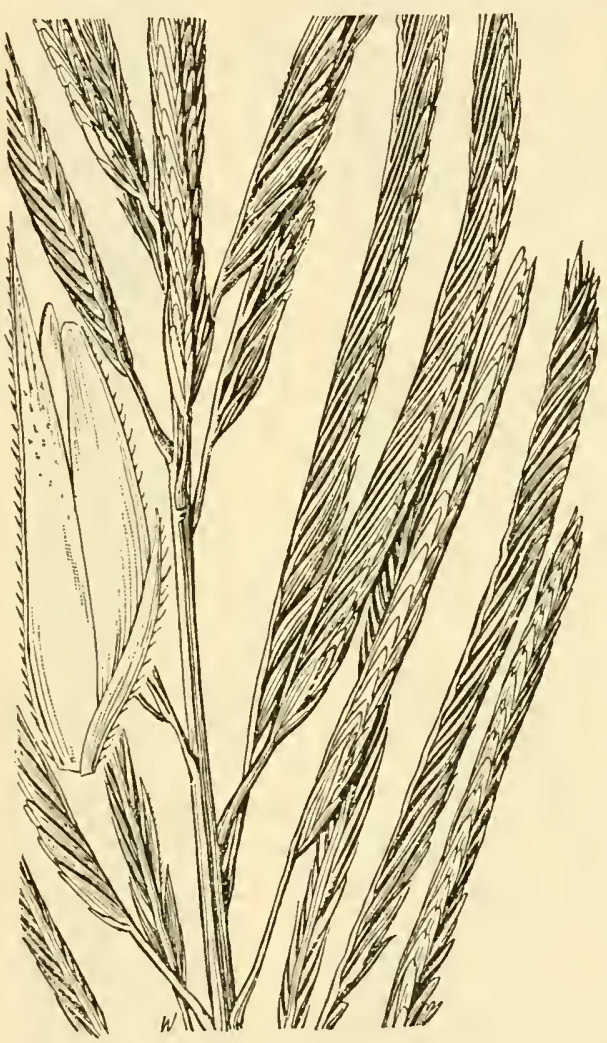

Figure 1040.-Spartina cynosuroidcs. Panicle, $\times 1$; spikelet, $\times 5$. (Boet tcher $444, \mathrm{Va}$.) tall, stout, as much as $1 \mathrm{~cm}$ thick at base, somewhat spongy, usually rooting from the lower nodes; blades 8 to $12 \mathrm{~mm}$ wide at the flat base, gradually narrowed to a long involute tip, smooth throughout; inflorescence dense, spikelike, about $15 \mathrm{~cm}$ long; spikes numerous, approximate, closely appressed, 3 to $5 \mathrm{~cm}$ long; spikelets very flat, 9 to $12 \mathrm{~mm}$ long, occasionally longer; glumes firm, glabrous or hispid-ciliate on keel, acute, the first narrow, half to twothirds as long as second, smooth, the second sparingly hispidulous and striatenerved; lemma hispidulous on sides, mostly smooth on keel, shorter than the second glume; palea thin, longer than the lemma. 2 (S. foliosa Trin.) - Salt marshes along the coast from San Francisco Bay, Calif., to Baja California.

\section{Spartina alterniflóra}

Lois. SMOOTH CORDGRASS. (Fig. 1043.) Smooth throughout or the margins of the blades minutely scabrous,

0.5 to $2.5 \mathrm{~m}$ tall; the culms soft and spongy or succulent at base, often $1 \mathrm{~cm}$ or more thick; blades flat, tapering to a long involute tip, 0.5 to $1.5 \mathrm{~cm}$ wide; spikes appressed, 5 to $15 \mathrm{~cm}$ long; spikelets somewhat remote, barely overlapping or sometimes more imbricate, mostly 10 to $11 \mathrm{~mm}$ long; glumes glabrous or hispid on the keel, the first acute, narrow, shorter than the lemma, the second obtusish, a little

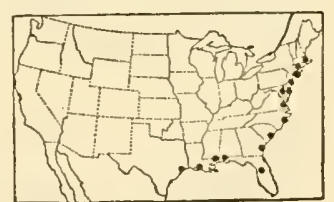

FIGURE 1041-Distribution of Spartina cynosuroides. 
longer than the lemma; floret sparingly pilose or glabrous. 2 Salt marshes along the coast, of ten growing in the water, Quebec and Newfoundland to Florida and Texas (fig. 1044); Atlantic coast of Europe. Through the southern part of the range of the species the spilselets are often more imbricate. The imbricate form with glabrous spikelets has been

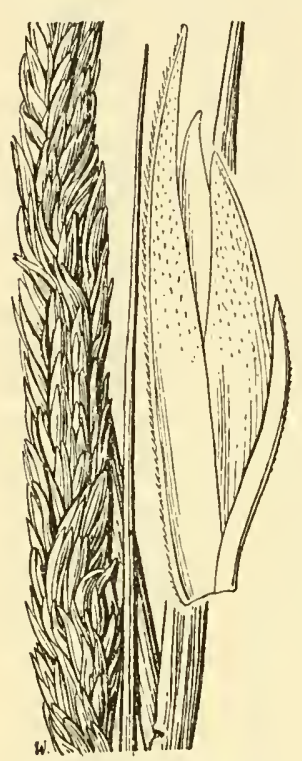

Frgure 1042.-Spartina leiantha. Panicle, $\times 1$; spikelet $\times 5$. (Heller 13871, Calif.) differentiated as $S$. alterniflora var. glabra (Muhl.) Fernald; that with sparsely pilose spikelets as $S$. alterniflora var. pilosa (Merr.) Fernald.

\section{Spartina spartínae} (Trin.) Merr. (Fig. 1045.) In large dense tufts without rhizomes; culms stout, 1 to $2 \mathrm{~m}$ tall; blades narrow, firm, strongly involute; spikes short and appressed, closely imbricate, forming a dense cylindric inflorescence 10 to $30 \mathrm{~cm}$ long; spikelets closely imbricate, 6 to $8 \mathrm{~mm}$ long; glumes hispid-ciliate on the keel, the first shorter than the lemma, the second usually a little longer. 24 (S. junciformis Engelm. and Gray.)-Marshes, swamps, and moist prairies near the coast, Florida

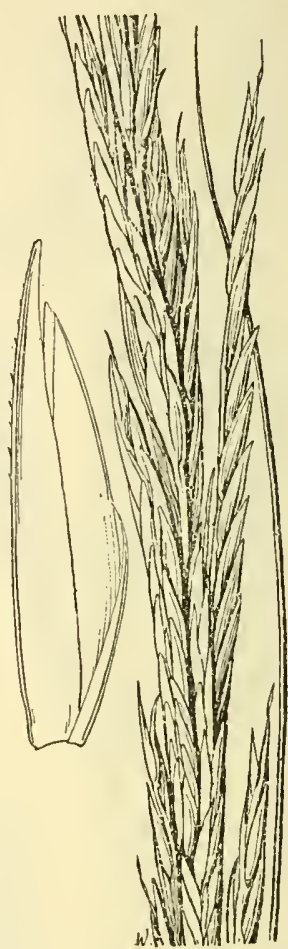

Figure 1043.-Spartina alterniflora. Panicle, $\times 1$; spikelet, $X$ 5. (Scribner 155, Maine.)

\section{to Texas and eastern Mexico (fig.1046).}

6. Spartina bakéri Merr. (Fig. 1047.) In large dense tufts without rhizomes; culms stout, 1 to $2 \mathrm{~m}$ tall; blades 4 to $8 \mathrm{~mm}$ wide, involute or occasionally flat; inflorescence

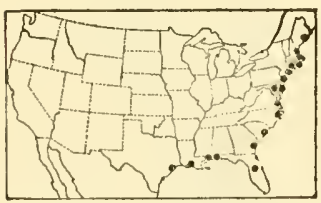

Figure 1044.-Distribution of Sparlina alternifora. 12 to $18 \mathrm{~cm}$ long, the spikes 5 to 12,3 to $6 \mathrm{~cm}$ long, appressed; spikelets closely appressed, 6 to 8 $\mathrm{mm}$ long; glumes scabrous, hispid-ciliate on the keel, the first about half as long as the lemma, the second longer, acuminate. 4 Sandy soil, South Carolina, Georgia, and Florida.

7. Spartina grácilis Trin. Alkali cordgrass. (Fig. 1048.) Culms 60 to $100 \mathrm{~cm}$ tall; blades flat, becoming involute, 15 to $20 \mathrm{~cm}$ long, very

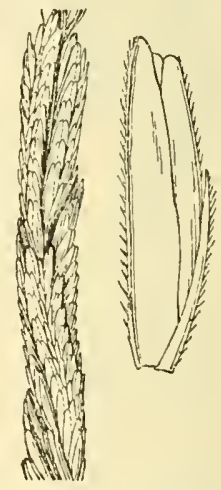

Figure 1045.-Spartina spartinae. Panicle, $\times 1$; spikelet, $\times 5$. (iitchcock, Tex.) scabrous above, mostly less than $5 \mathrm{~mm}$ wide; spikes few, 4 to 8 , 
closely appressed, 1 to $1.5 \mathrm{~cm}$ long; spikelets 6 to $8 \mathrm{~mm}$ long; glumes, ciliate on the keel, acute, the first about half as long as the second;

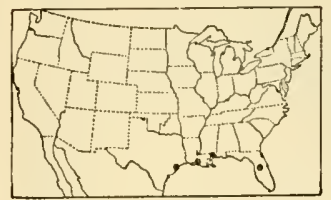

Figure 1046.-Distribution of Spartina spartinae.

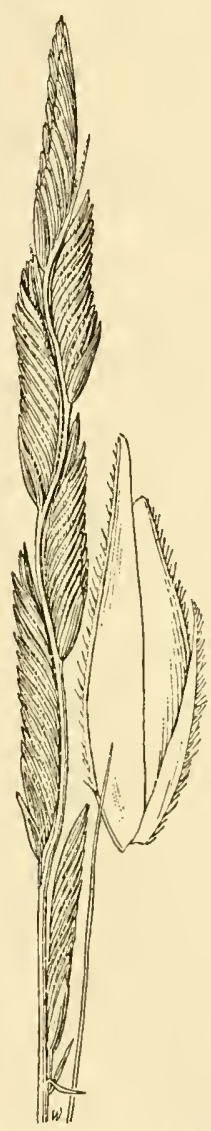

FjGUre 1018.-Spartina gracitis. Panicle, $\times 1$; spikelet, $\times 5$. (Rydberg 2080, Mont.) lemma nearly as long as second glume, ciliate on keel; palea as long as lemma, obtuse. 2 Alkaline meadows and plains, Saskatchewan to British Columbia, south to Colorado and through eastern Washington to Arizona (fig. 1049).

8. Spartina pátens (Ait.) Muhl. Saltmeadow cordgrass. (Fig. 1050.) Culms slender, mostly less than $1 \mathrm{~m}$ tall, with long slender rhizomes; blades sometimes flat but mostly involute, less than $3 \mathrm{~mm}$ wide; spikes 2 to several, appressed to somewhat spreading, 2 to $5 \mathrm{~cm}$ long, rather remote on the axis; spikelets 7 to $12 \mathrm{~mm}$ long; first glume about half as long as the floret, the second longer than the lemma; lemma 5 to $7 \mathrm{~mm}$ long, emarginate at apex; palea a little longer than the lemma. 21 -Salt marshes and sandy meadows along the coast, Quebec to Florida and Texas, and in saline marshes inland, New York and Michigan (fig:

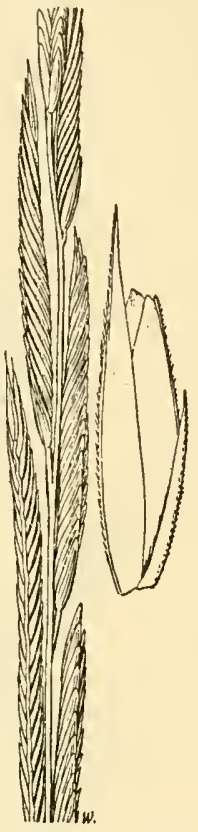

FIG URE 1047-Spar tina bakeri. Panicle, $\times 1$; spikelet $\times 5$. (Type. 1051). The smaller, more southern form, with slightly smaller and more closely imbricate spikelets has been distinguished as $S$. juncea (Michx.) Willd. (S. patens var. juncea Hitchc.)-New Jersey to Florida. Spartina PATENS var. CAESPITÓSA (A. A. Eaton) Hitchc. An ambiguous form resembling $S$. patens, but growing in large tufts without rhizomes. 24 -Salt marshes,

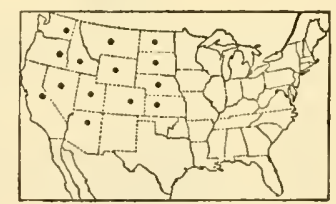

FIGURE 1049.-Distribution of Spartina gracilis.

New Hampshire to New York. Larger tufted forms with rhizomes are found at Chesapeake Beach, Md., and Virginia Beach, Va.

\section{CTÉNIUM Panz.}

\section{(Campulosus Desv.)}

Spikelets several-flowered but with only one perfect floret, sessile and pectinately arranged on one side of a continuous rachis, the rachilla disarticulating above the glumes; first glume small, hyaline, 
1-nerved, the second about as long as the lemmas, firm, 3- to 4-nerved, bearing on the back a strong divergent awn; lemmas rather papery, 3-

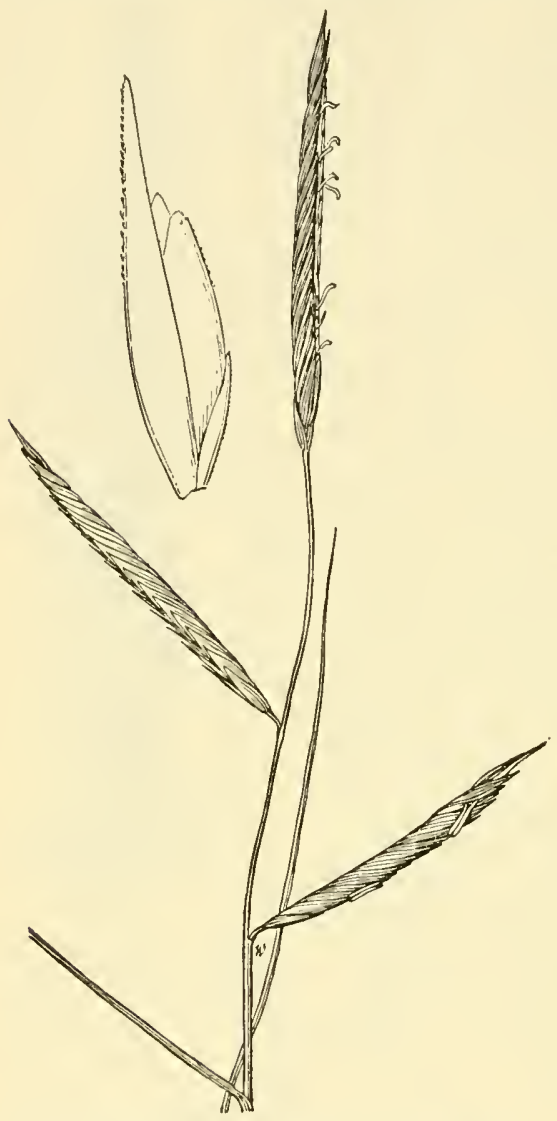

Figure 1050.-Spartina patens. Panicle, $\times$ 1 ; spikelet, $\times 5$. (Killip 6359 , Md.) nerved, with long hairs on the lateral nerves and a short straight or curved awn on the back just below the apex, the first and second lemmas empty, the third enclosing a perfect flower, the upper 1 to 3 empty and successively smaller. Erect, slender, rather tall perennials, with usrally solitary, often curved spikes. Type species, Ctenium. carolinianum Panz. $(C$. aromaticum). Name from Greek Fitenion, a little comb, alluding to the pectinate arrangement of the spikelets.

Plants forming dense tussocks; second glume with a row of prominent glands on each side of the midnerve; awn stout, at maturity horizontal or nearly so; ligule about $1 \mathrm{~mm}$ long

1. C. aromaticum.

Plants with slender scaly rhizomes; second glume glandless or with obscure glands; awn rather slender, not horizontally spreading; ligule 2 to $3 \mathrm{~mm}$ long

2. C. FLORIDANUM.

\section{Ctenium aromáticum} (Walt.) Wood. ToоTHache GRASS. (Fig. 1052.) Culms 1 to $1.5 \mathrm{~m}$ tall, the old sheaths persistent and fibrillose at base; ligule about $1 \mathrm{~mm}$ long; blades flat or involute, stiff; spike 5 to $15 \mathrm{~cm}$ long; spikelets 5 to $7 \mathrm{~mm}$ long. 2 (Ctenium carolinianum Panz.) - Wet pine barrens, Coastal Plain, Virginia to Florida and Louisiana (fig. 1053). The roots spicy when freshly dug. Furnishes fair cattle forage in moist pine barrens of Florida.

2. Ctenium floridánum (Hitchc.) Hitchc. (Fig. 1054.) Differs from C. aromaticum in having creeping scaly rhizomes, ligule 2 to 3 $\mathrm{mm}$ long, second glumes with longer, more slender awns and without glands or with only

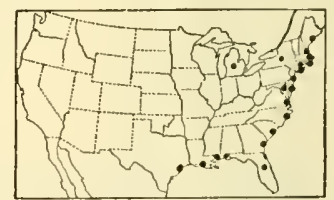

Figure 1051.-Distribution of Spartina patens. obscure ones. 24 (Erroneously referred by American authors to Campulosus chapadensis Trin.) -Moist pine barrens, Florida. 


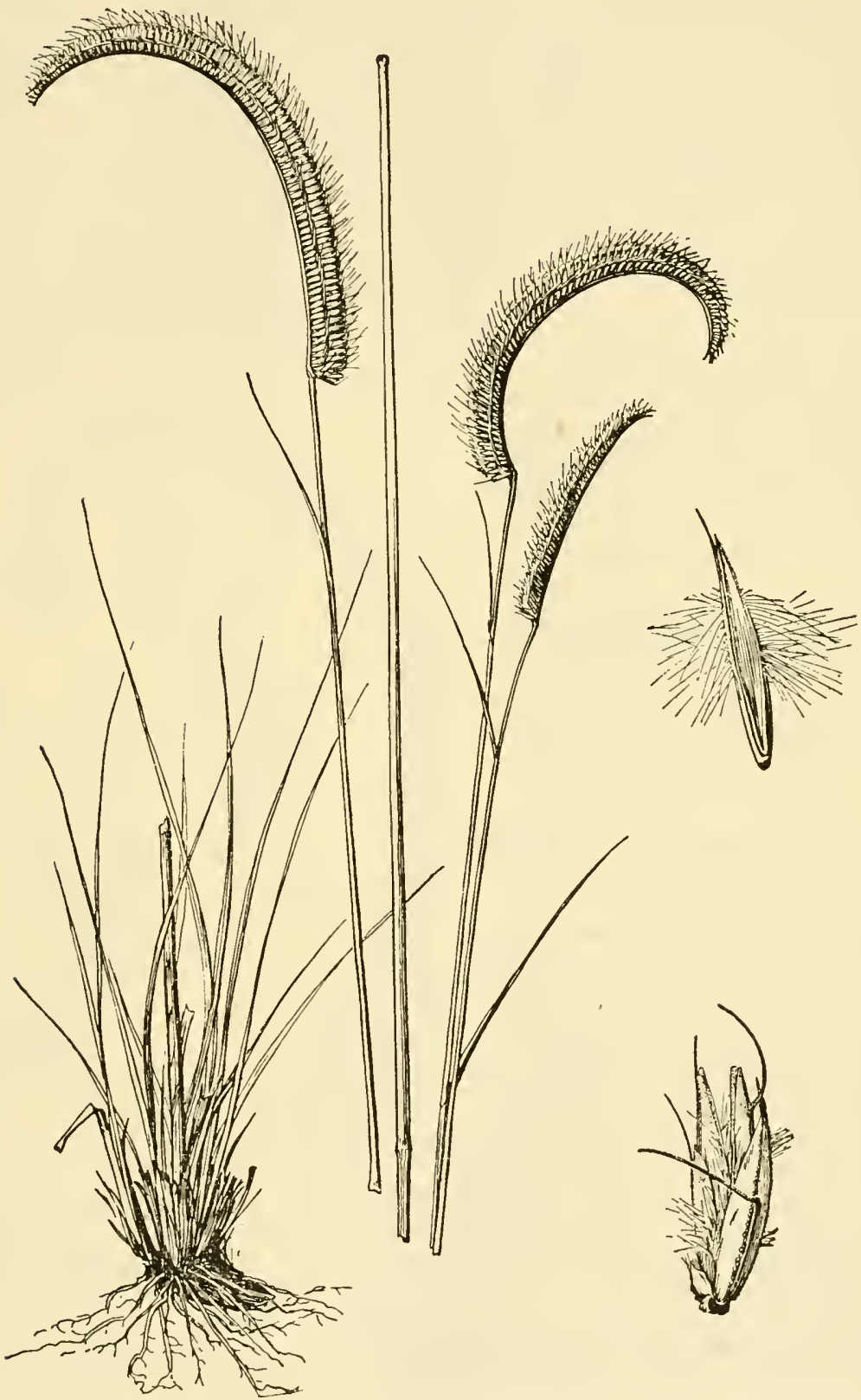

Ftgore 1052.-Ctenium aromaticum. Plant, $\times 1 / 2$; spikelet and fertile floret, $\times 5$. (McCarthy, N.C.) $55974^{\circ}-35-32$ 


\section{GYMNOPÓGON Beauv.}

Spikelets 1- or rarely 2- or 3-flowered, nearly sessile, appressed and usually remote in two rows along one side of a slender continuous rachis, the rachilla disarticulating above the glumes and prolonged

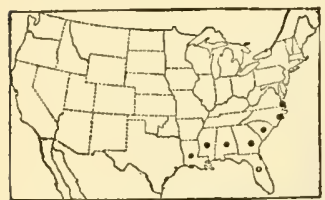

FIGURE 1053.-Distribution of Ctenium aromaticum. behind the one or more fertile florets as a slender stipe, bearing a rudiment of a floret, this sometimes with 1 or 2 slender awns; glumes narrow, acuminate, 1-nerved, usually longer than the floret; lemmas narrow, 3-nerved, the lateral nerves near the margin, the apex ninutely bifid, bearing between the teeth a slender awn, rarely awnless. Perennials or rarely annuals (ours perennial), with short, stiff, flat blades, often folded in drying, numerous long slender divergent or reflexed spikes, approximate on a slender stiff axis. Type species, Gymnopogon racemosus Beauv. (G. ambiguus). Name from Greek gumnos, naked, and pogon, beard, alluding to the naked prolongation of the rachilla.

Awn longer than the lemma

1. G. AMBIGUUS.

Awn shorter than the lemma or none.

Spikes subcapillary, naked for 1 to several $\mathrm{cm}$ at base; spikelets 1 -flowered.

2. G. BREVIFOLIOS. Spikes stouter, floriferous from base; spikelets 2- or 3-flowered, the rachilla zigzag

3. G. Chapmanianus.

\section{Gymnopogon ambíguus} (Michx.) B. S. P. (Fig. 1055.) Culms 30 to $60 \mathrm{~cm}$ tall in small clumps with short scaly rhizomes, suberect to spreading, rigid, sparingly branching; leaves numerous, approximate with overlapping sheaths, or the lower rather distant; blades spreading, 5 to $15 \mathrm{~mm}$, mostly about $10 \mathrm{~mm}$ wide, the base rounded-truncate; spikes

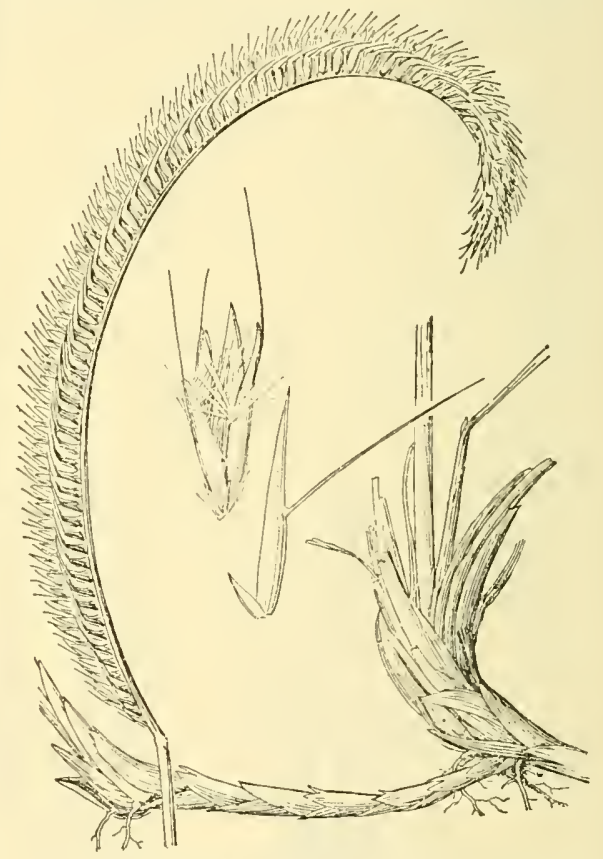

Frgure 1054-Ctenium fioridanum. Plant, $\times 1$; glumes and florets, $\times 5$. (Combs 702a, Fla.)

10 to $20 \mathrm{~cm}$ long, floriferous from base, the lower spikelets often remote; glumes 4 to $6 \mathrm{~mm}$ long; lemma with an awn 4 to $6 \mathrm{~mm}$ long, the rudiment bearing a delicate shorter awn. 21 -Dry pinelands, Coastal Plain, New Jersey to Florida and Texas; dry woods, Tennessee to Kansas and south (fig. 1056).

2. Gymnopogon brevifólius Trin. (Fig. 1057.) Differing from $G$. ambiguus in the longer, more slender, somewhat straggling culms, 


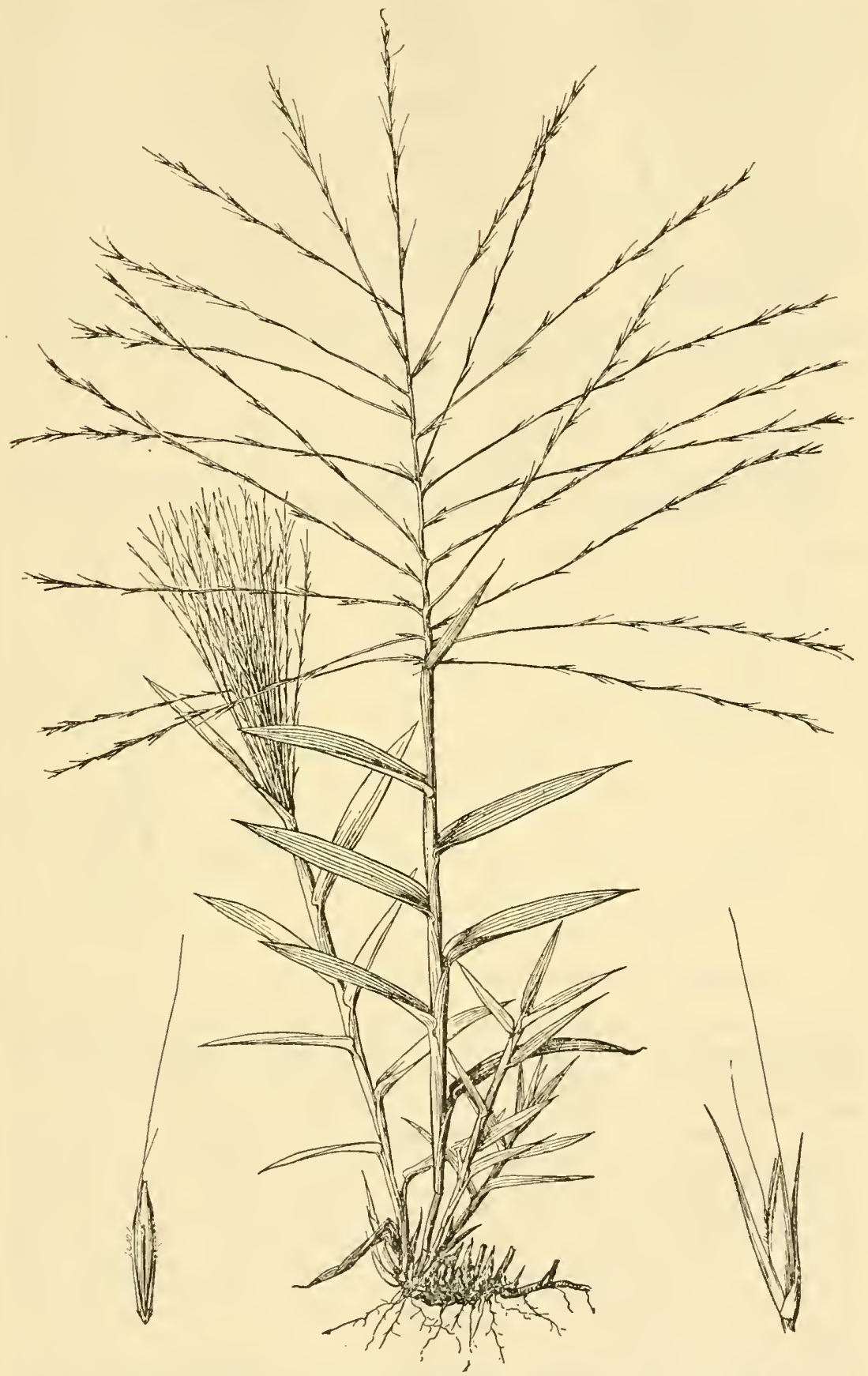

FIGURE 1055.-Gymnopogon ambiguus. Plant, $\times 13$; spikelet and floret, $\times 5$. (Tracy 8292, Tex.) 
narrower, less crowded blades, and in the subcapillary spikes, floriferous only on the upper half or third; lemma awnless or with a minute awn. 2 -Dry ground, Coastal Plain, New Jersey to Florida and Louisiana (fig. 1058).

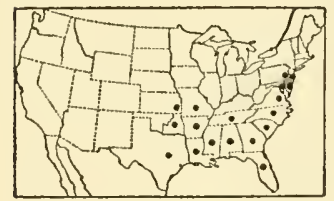

FIgure 1056.-Distribution of Gymnopogon ambiguus.

3. Gymnopogon chapmaniánus Hitchc. (Fig. 1059.) Culms 30 to $40 \mathrm{~cm}$ tall, in small tufts, ascending, sparingly branching from lower nodes, rigid; leaves approximate toward the base, the blades 5 to $6 \mathrm{~cm}$ long, about $5 \mathrm{~mm}$ wide, sharp-pointed, often subinvolute in drying; spikes ascending to spreading (not reflexed), floriferous from base, spikelets not remote, 2or 3-flowered, the florets somewhat spreading; lemmas pubescent, with a minute awn or awnless; palea very narrow, arched. 24 - Sandy pinelands, Florida.

\section{CHLORIS Swartz. Fingergrass}

Spikelets with 1 perfect floret, sessile, in two rows along one side of a continuous rachis, the rachilla disarticulating above the glumes,

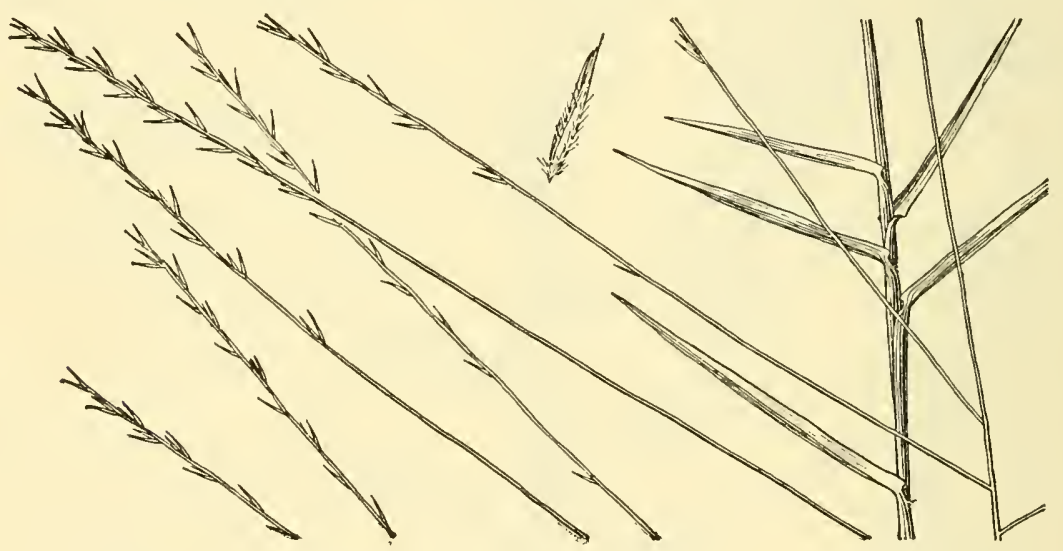

Figure 1057.-Gymnopogon brevifolius. Plant, $\times 1$; floret, $\times 5$. (Chase 5669, Va.)

produced beyond the perfect floret and bearing 1 to several reduced florets consisting of empty lemmas, these often truncate, and, if more than one, the smaller ones usually enclosed in the lower, forming a somewhat club-shaped rudiment; glumes somewhat unequal, the first shorter, narrow, acute; lemma keeled, usually broad, 1- to 5nerved, often villous on the callus and villous or long-ciliate on the keel or marginal nerves, awned from between the short teeth of a bifid apex, the awn slender or sometimes reduced to a mucro, the sterile lemmas awned or awnless. Tufted perennials or sometimes annuals

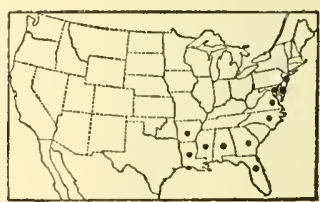

Figure 1058.-Distribution of Gymnopogon brevifolius. with flat or folded scabrous blades and two to several sometimes showy and feathery spikes aggregate at the summit of the culms. Type species, Chloris cruciata (L.) Swartz. Named for Greek Chloris, the goddess of flowers. 
Several species are found on the plains of Texas, where they form part of the forage for grazing animals. C. virgata is a rather common annual weed in the Southwest especially in alfalfa fields. It may be locally abundant and then furnishes considerable forage. C. gayana, Rhodes grass, is cultivated in the irrigated regions of the Southwest, where it is valuable as a meadow grass. It is also used in the Hawaiian Islands on some ranches in the drier regions.

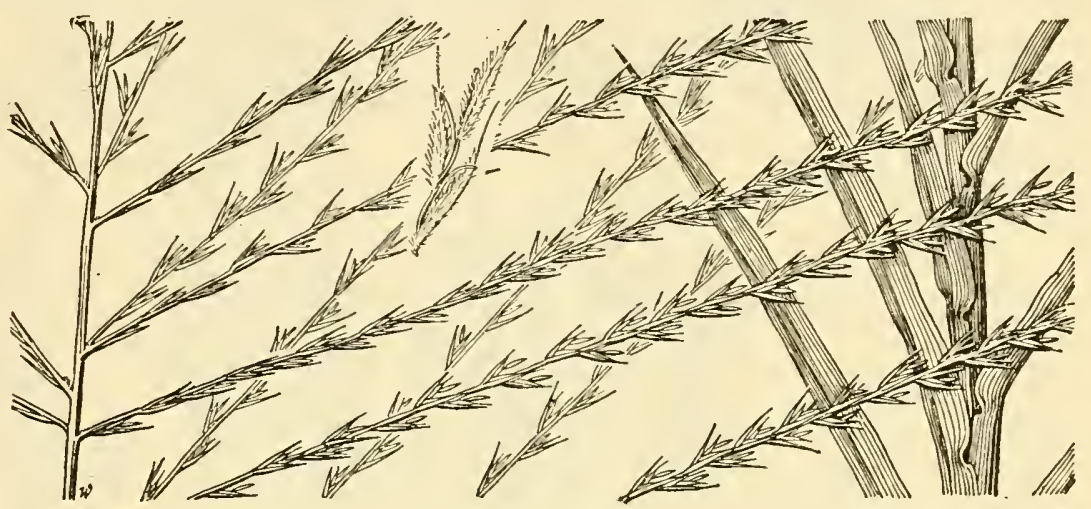

FIGURE 1059.-Gymnopogon chapmanianus. Plant, $\times 1$; florets, $\times 5$. (Tracy 7102, Fla.)

Lemmas firm, dark brown, awnless or mucronate. Perennials with strongly compressed culms and sheaths, and firm flat or folded blades abruptly rounded at the tip ........................... Eection 1. Eustachys. Lemmas distinctly awned, (awn very short in $C$. cucullata), pale or fuscous.

Section 2. Euchloris.

Section 1. Eustachys

Spikes numerous, usually more than 10_............. 1. C. GLAdCA. Spikes usually not more than 6 .

Spikelets $2 \mathrm{~mm}$ long; lemmas dark _.............. 2. C. Petraea. Spikelets $3 \mathrm{~mm}$ long; lemmas pale to golden brown until maturity.

Spikes 2, sometimes 1 or $3 \ldots \ldots$ C. Floridana. Spikes 4 to 6

\section{Section 2. Euchloris}

Rudiment narrow, oblong, acute, often inconspicuous. (Second rudiment truncate in C. gayana.)

Plant producing long, stout stolons ............. 5. C. GAYANA.

Plant not stoloniferous (occasionally with short stolons in C. andropogonoides).

Fertile lemma about $2.5 \mathrm{~mm}$ long; plants mostly less than $50 \mathrm{~cm}$ tall; spikes mostly less than $10 \mathrm{~cm}$ long ...... 7. C. ANDROPOGONOIDES.

Fertile lemma 4 to $7 \mathrm{~mm}$ long; plants 40 to $100 \mathrm{~cm}$ or more tall; spikes mostly more than $10 \mathrm{~cm}$ long.

Blades folded, abruptly acute or rounded; spikes whorled, naked at base. 8. C. TEXENSIS.

Blades flat, long-acuminate; spikes racemose on a short axis, solitary or in small fascicles..................... 6. C. CHLORIDEA.

Rudiment truncate-broadened at apex, usually conspicuous (rather narrow in C. virgata).

Lemma conspicuously ciliate-villous, the spikes feathery.

Plants annual. Lemma long-ciliate on the lateral nerves near apex.

Plants perennial.

9. C. virgata.

Spikes flexuous, nodding, mostly 10 to $15 \mathrm{~cm}$ long; hairs much exceeding the spikelets ............. C. POLYDACTYLA.

Spikes straight or subflexuous, 5 to $7 \mathrm{~cm}$ long; hairs about equaling the spikelets 
Lemma minutely ciliate on the nerves or glabrous, the spikes not feathery.

Awn of fertile lemma usually 3 to $6 \mathrm{~mm}$ long; spikes mostly 7 to $12 \mathrm{~cm}$ long, the spikelets not closely crowded _..... 12. C. Verticillata.

Awn of fertile lemma usually less than $3 \mathrm{~mm}$ long; spikes usually less than $6 \mathrm{~cm}$ long, the spikelets crowded.

Awns about $1 \mathrm{~mm}$ long; rudiment prominent, inflated, broadly triangulartruncate, about $1.5 \mathrm{~mm}$ wide as folded at summit.

15. C. CUCUllata.

Awns 2 to $3 \mathrm{~mm}$ long; rudiment not inflated, not more than $1 \mathrm{~mm}$ wide as folded at summit.

Rudiment oblong-cuneate, about $0.6 \mathrm{~mm}$ wide as folded at summit.

13. C. SUBDOLICHOSTACHYA.

Rudiment triangular-truncate, about $1 \mathrm{~mm}$ wide as folded at summit.

14. C. latisquamea.

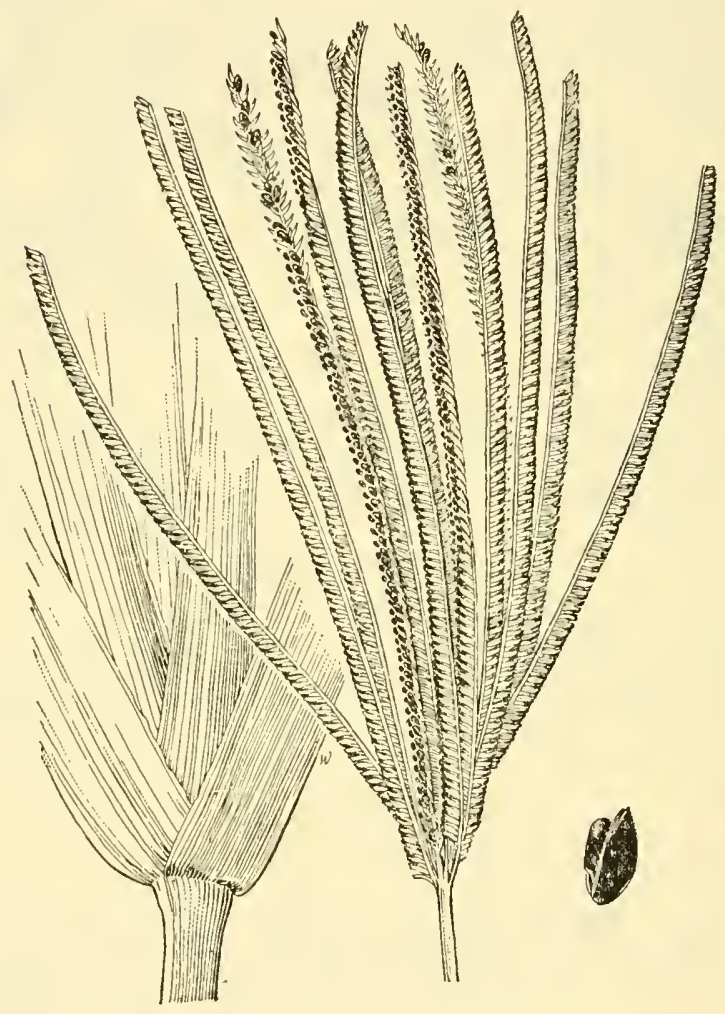

FIguRE 1060.-Chloris glauca. Plant, $\times 1$; florets, $\times 5$. (Combs and Baker 1143, Fla.)

Section 1. Eústachys (Desv.) Reichenb.

Lemmas firm, brown to blackish, awnless or mucronate only; glumes scabrous, the second mucronate from a notched or truncate summit. Perennials.

1. Chloris glaúca (Chapm.) Wood. (Fig. 1060.) Glaucous; culms erect, compressed, stout, 70 to $150 \mathrm{~cm}$ tall; basal sheaths several, broad, compressed, keeled, overlapping and equitant, those of the succeeding 1 or 2 distant nodes similar, 2 to 4 leaves aggregate; 
blades flat or folded, as much as $1 \mathrm{~cm}$ wide, the tip abruptly rounded;

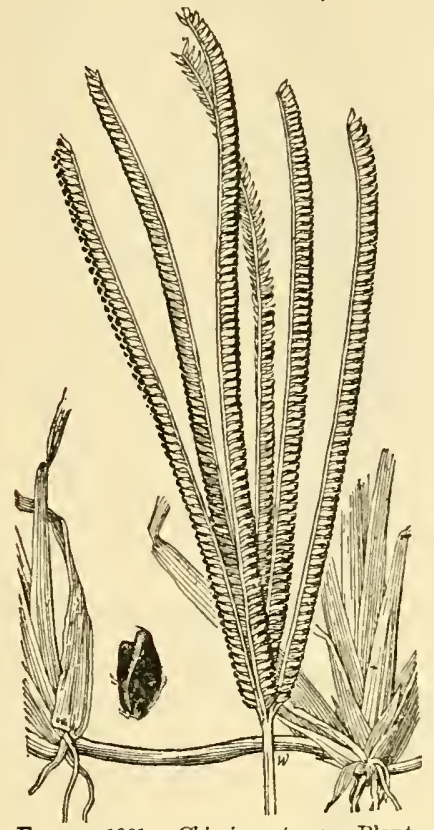

Figure 1061.-Chloris petraea. Plant, $\times 1$; florets, $\times 5$. (Curtiss, Fla.) spikes several to many (as many as 20), ascending, 7 to $12 \mathrm{~cm}$ long; spikelets about $2 \mathrm{~mm}$ long; lemma glabrous or scaberulous on the nerves. 2 (Eustachys glauca Chapm.)-Brackish marshes, wet prairies, and swamps, North Carolina (Wilmington), Georgia (Baker County), and Florida.

2. Chloris petraéa Swartz. (Fig. 1061.) Often glaucous, sometimes purplish; culms slender, as much as 100 $\mathrm{cm}$ tall, more or less decumbent and rooting or producing distinct sto-

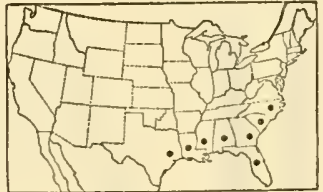

Figure 1052.-Distribution of Chloris petriea. lons; sheaths compressed, strongly keeled, usually 2 to 4 aggregate at the lower 1 or 2 nodes; blades 3 to $8 \mathrm{~mm}$ wide, often short and numerous on the stolons; spikes mostly 4 to 6,4 to $10 \mathrm{~cm}$ long; spikelets $2 \mathrm{~mm}$ long; lemma mucronate, short-ciliate on the nerves. 2 (Eustachys petraea Desv.) - Strands, sandy fields, and open pine woods, Coastal Plain, North Carolina to Florida and Texas; tropical America (fig. 1062).

3. Chloris floridána (Chapm.) Wood. (Fig. 1063.) Culms slender, 40 to $80 \mathrm{~cm}$ tall; sheaths compressed, crowded at base but not paired or aggregate at succeeding nodes; blades 3 to $7 \mathrm{~mm}$ wide, somewhat narrowed toward the acutish tip; spikes mostly 2, sometimes 1 or 3,5 to $10 \mathrm{~cm}$ long; spikelets $3 \mathrm{~mm}$ long; second glume with an awn about $1 \mathrm{~mm}$ long; lemma with a slender mucro 0.5 to $1 \mathrm{~mm}$ long, stiffly ciliate on keel and lateral nerves. 21 (Eustachys floridana Chapm.)-Dry sandy woods and open ground, Georgia and Florida.

4. Chloris neglécta Nash. (Fig. 1064.) Differing from C. floridana in having usually taller, stouter culms, the leaves sometimes paired at the lower nodes; spikes 3 to 8 , mostly 4 to $6.24 \quad$ (Eustachys neglecta Nash.) Open sandy woods and swamps, Florida.

Chloris distichophýlla Lag. Culms about $1 \mathrm{~m}$ tall; spikes several (as many as 20), drooping, feathery; lemma ciliate with silky hairs $1 \mathrm{~mm}$ long. 24 -Escaped from cultivation in southern California. A specimen from Bastrop, Tex., is probably also an escape from cultivation; South America.

Section 2. Euchlóris Endl.

Lemmas tawny to grayish or fuscous, awned; glumes acute to acuminate. Mostly perennial.

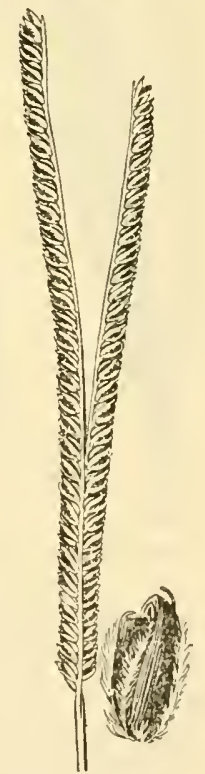

F1GURE 1063.Chloris floridana. Panicle. $\times 1$; florets, $\times$ Fla.) 
5. Chloris gayána Kunth. Rhodes grass. (Fig. 1065.) Culms 1 to $1.5 \mathrm{~m}$ tall with long, stout, leafy stolons, the internodes compressed, tough and wiry; blades 3 to $5 \mathrm{~mm}$ wide, tapering to a fine point; spikes several to numerous, erect or ascending, 5 to $10 \mathrm{~cm}$ long; spikelets crowded, pale-tawny; lemma $3 \mathrm{~mm}$ long, hispid on the margin near the summit, more or less hispidulous below, the awn 1 to 5 $\mathrm{mm}$ long; rudiment commonly of 2 florets, the lower rather narrow,

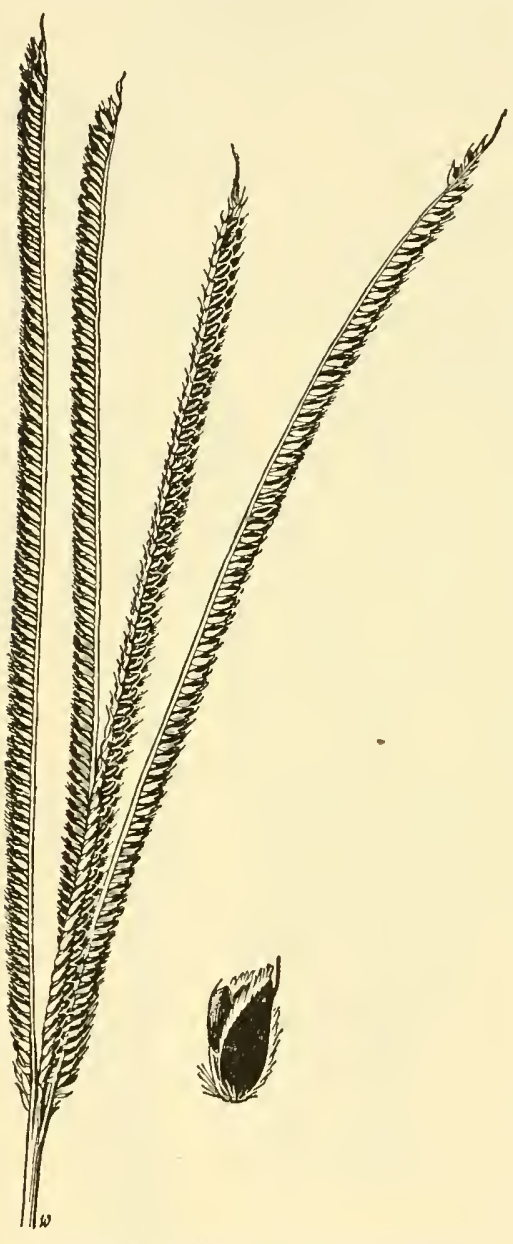

FIgURE 1064.-Chloris neglecta. Panicle, $\times 1$; florets, $\times 5$. (Curtiss 3445, Fla.) the awn usually somewhat shorter than that of the fertile lemma, the upper minute, broad, truncate. 2 -Cultivated for forage in warmer regions, escaped into fields and waste places, North Carolina and from Florida to southern California and in tropical America (fig. 1066); introduced from Africa. A promising meadow grass in irrigated regions.

6. Chloris chlorídea (Presl) Hitche. (Fig. 1067.) Culms slender, 60 to $100 \mathrm{~cm}$ tall; blades flat, 3 to $7 \mathrm{~mm}$ wide, long-acuminate; spikes slender, few to several, mostly 8 to $15 \mathrm{~cm}$ long, approximate on an axis 2 to $10 \mathrm{~cm}$ long; spikelets appressed, not crowded; lemma narrow, glabrous, somewhat scaberulous toward the tip, about $6 \mathrm{~mm}$ long, the awn 10 to $12 \mathrm{~mm}$ long; rudiment very narrow, awned. 24 (C. clandestina Scribn. and Merr.)-Open ground, Texas (Brownsville) and Mexico. Large cleistogamous spikelets are borne on slender underground branches, rather rare in herbarium specimens, either infrequent or readily broken off.

7. Chloris andropogonoides Fourn. (Fig. 1068.) Culms densely tufted, 20 to $40 \mathrm{~cm}$ tall, the leaves mostly basal; blades about $1 \mathrm{~mm}$ wide as folded; spikes slender, few to several, 5 to $10 \mathrm{~cm}$ long, whorled, divergent, floriferous from base; spikelets scarcely overlapping; lemma minutely pubescent on midnerve and margin or glabrous, 2 to $3 \mathrm{~mm}$ usually about $2.5 \mathrm{~mm}$ long, awned below the tip, the awn about $5 \mathrm{~mm}$ long; rudiment narrow, the awn usually shorter than that of the lemma. 2 (C. tenuispica Nash.)-Plains, Texas and northern Mexico.

8. Chloris texénsis Nash. (Fig. 1069.) Culms taller and stouter than in $C$. andropogonoides; blades 2 to $3 \mathrm{~mm}$ wide as folded; spikes 


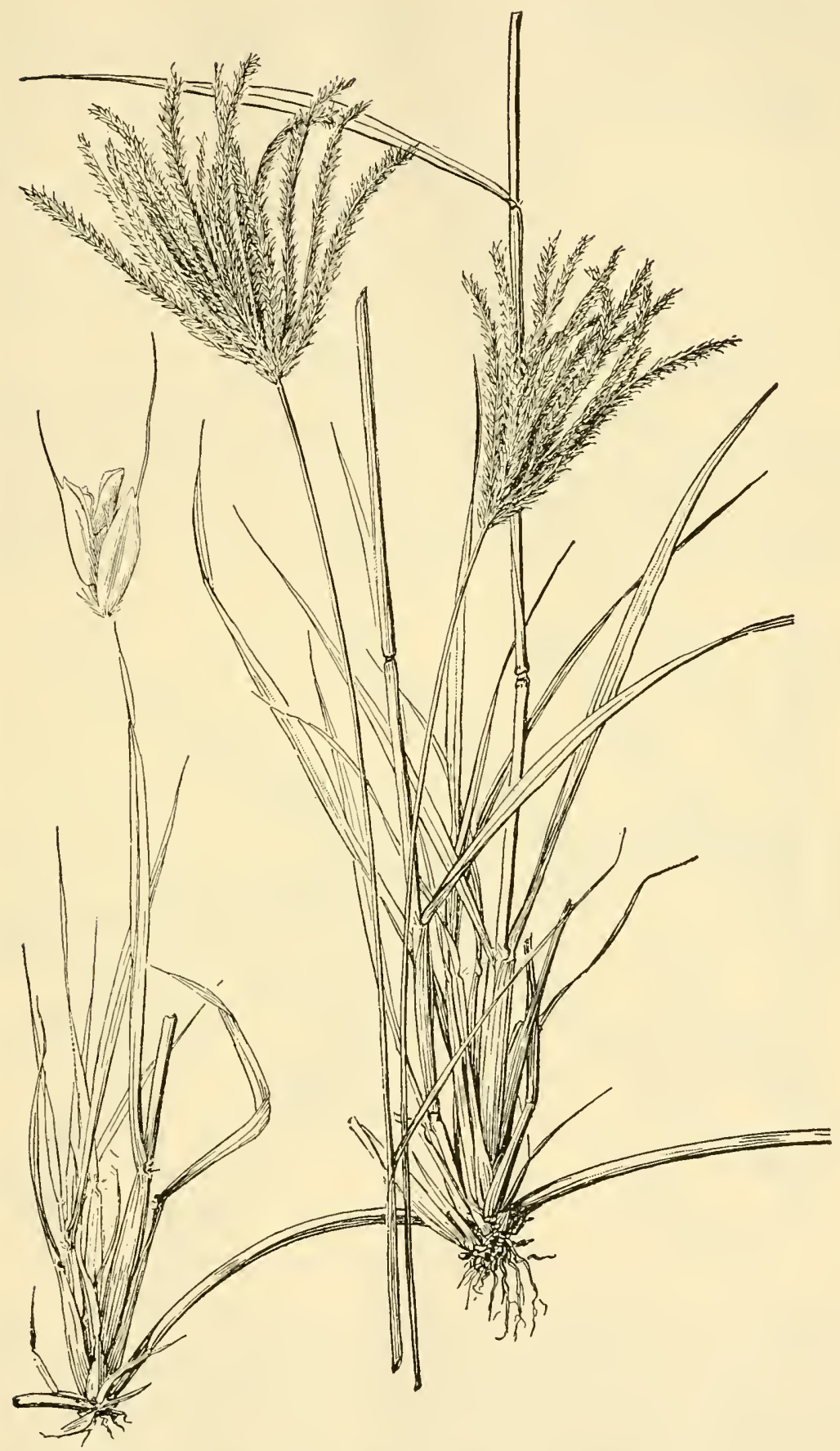

FIGURE 1065.-Chloris gayana. Plant, $\times \frac{1}{2}$; florets, $\times 5$. (Hitchcock 13667, Ariz.) 
slender, mostly about 15 to $18 \mathrm{~cm}$ long, naked for 1 to $4 \mathrm{~cm}$ at the base; spikelets appressed, not crowded; lemma about $4 \mathrm{~mm}$ long, naked on the midnerve, minutely pilose on margin toward summit; awn about $1 \mathrm{~cm}$ long. 24 (C. nealleyi Nash.)-Plains, Texas, rare.

Chloris prieúrii Kunth. Annual; culms 30 to $60 \mathrm{~cm}$ tall, of ten rooting at the lower nodes; blades 2 to $6 \mathrm{~mm}$ wide, the upper sheath

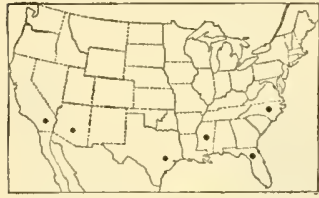

FigURE 1066.-Distribution of Chloris gayana. inflated; spikes 2 to 8 , erect, 5 to $8 \mathrm{~cm}$ long; fertile lemma $2.5 \mathrm{~mm}$ long, narrow, ciliate near the summit, with a delicate awn 7 to $10 \mathrm{~mm}$ long; rudiment narrow, of 3 or 4 reduced sterile lemmas each with a long delicate erect awn. $\odot$-Ballast, Wilmington, N. C., and Mobile, Ala.; West Africa.

9. Chloris virgáta Swartz. Feather fingerGRAss. (Fig. 1070.) Annual; culms ascending to spreading, 40 to 60 or even $100 \mathrm{~cm}$ tall; upper sheaths often inflated; blades flat, 2 to $6 \mathrm{~mm}$ wide; spikes several, 2 to $8 \mathrm{~cm}$ long, erect, whitish or tawny, feathery or silky; spikelets crowded; lemma $3 \mathrm{~mm}$ long, somewhat humpbacked on the keel, long-ciliate on the margins near the apex, the slender awn 5 to $10 \mathrm{~mm}$ long; rudiment narrowly cuneate, truncate, the awn as long as that of the

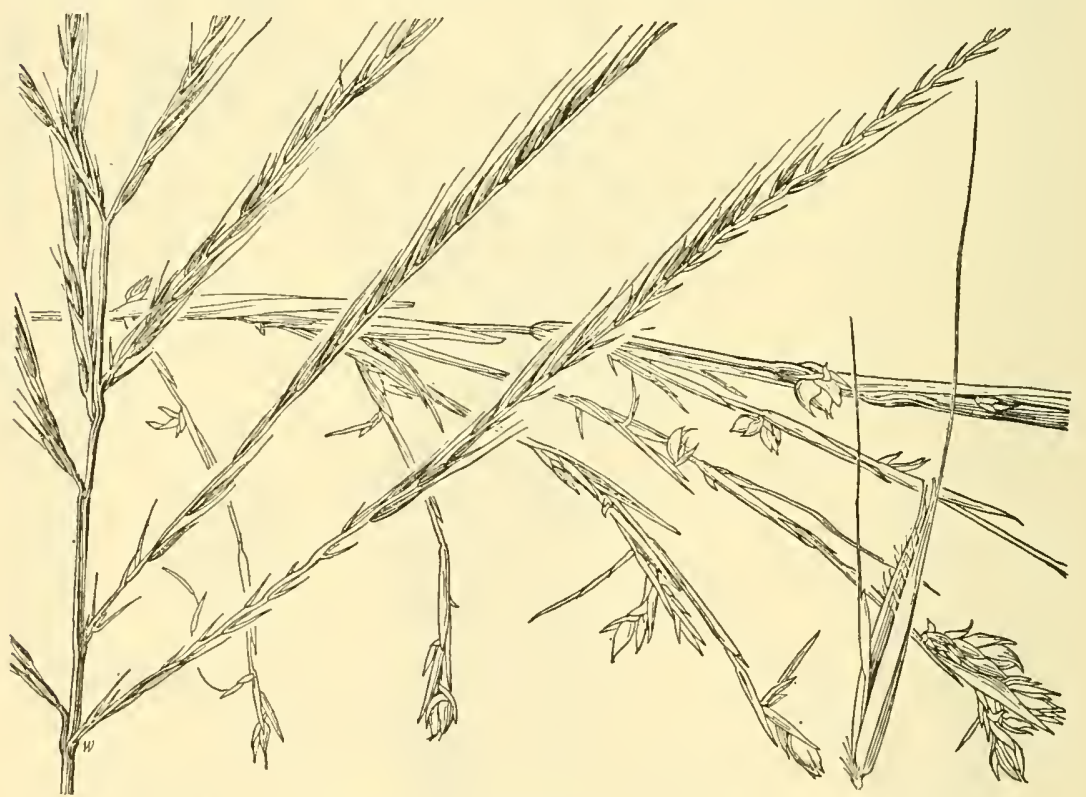

FIGURE 1067.-Chloris chloridea. Inflorescences, $\times 1$; florets, $\times 5$. (Silveus 379 , Tex.)

lemma. $\odot \quad(C$. elegans H.B.K.)-Open ground, a common weed in fields and waste places; Nebraska to Texas and southern California; Maine and Massachusetts, on wool waste; introduced in a few localities in the Eastern States (North Carolina, South Carolina, Missouri); tropical America (fig. 1071).

10. Chloris polydáctyla (L.) Swartz. (Fig. 1072.) Culms erect, wiry, 50 to $100 \mathrm{~cm}$ tall; blades as much as $1 \mathrm{~cm}$ wide; spikes several 
MANUAL OF THE GRASSES OF THE UNITED STATES 505

to many, mostly 10 to $15 \mathrm{~cm}$ long, flexuous, nodding, tawny, feathery; spikelets crowded; lemma ciliate with long silky hairs; rudiment

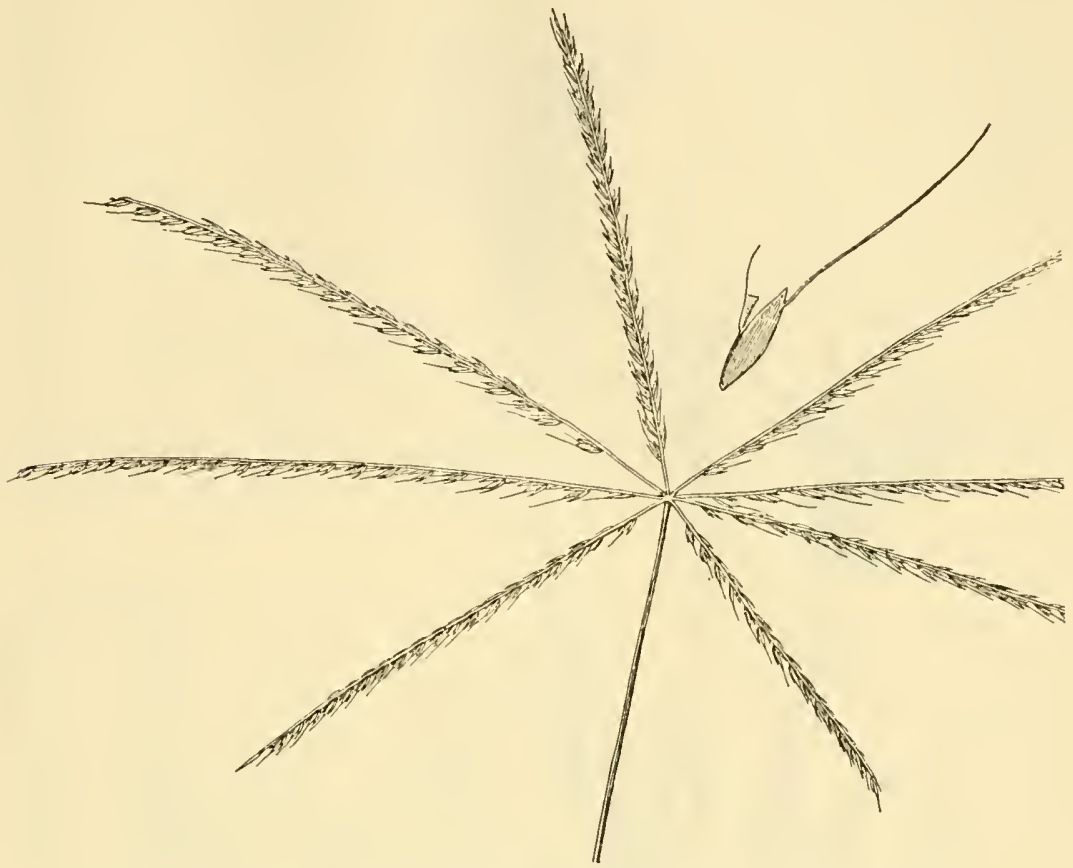

FIGURE 1068.-Chloris andropogonoides. Panicle $\times 1$; forets, $\times 5$. (Chase 6067, Tex.)

oblong, obliquely truncate, awns of lemma and rudiment about $3 \mathrm{~mm}$ long. 24 -Open sandy soil, southern Florida; West Indies to Paraguay.

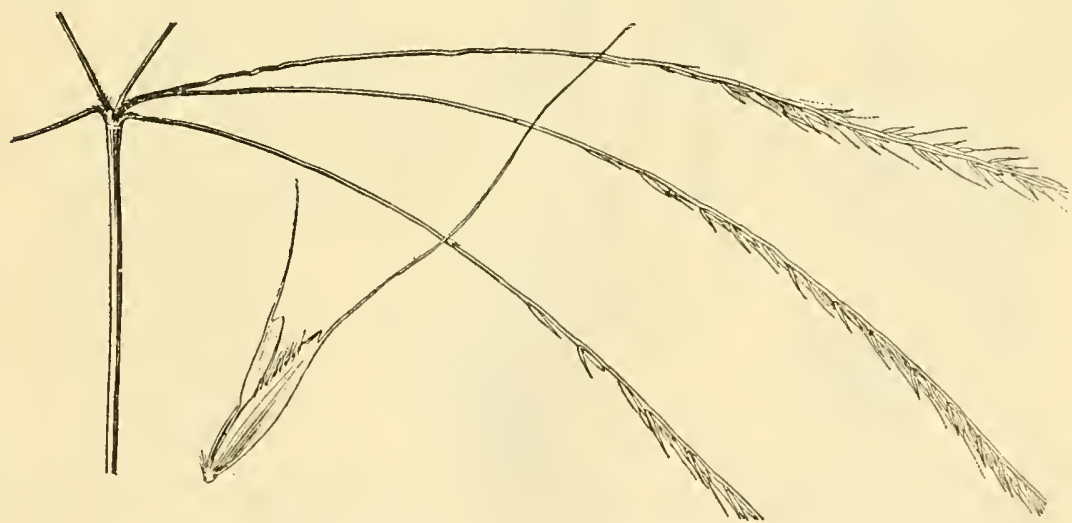

Figure 1069.-Chloris texensis. Panicle, $\times 1$; florets, $\times 5$. ('Thurow 8, Tex.)

11. Chloris ciliáta Swartz. (Fig. 1073.) Perennial; culms erect or ascending, 50 to $100 \mathrm{~cm}$ tall; leaves not aggregate toward the base, sheaths not much compressed; blades 3 to $5 \mathrm{~mm}$ wide, sharply 


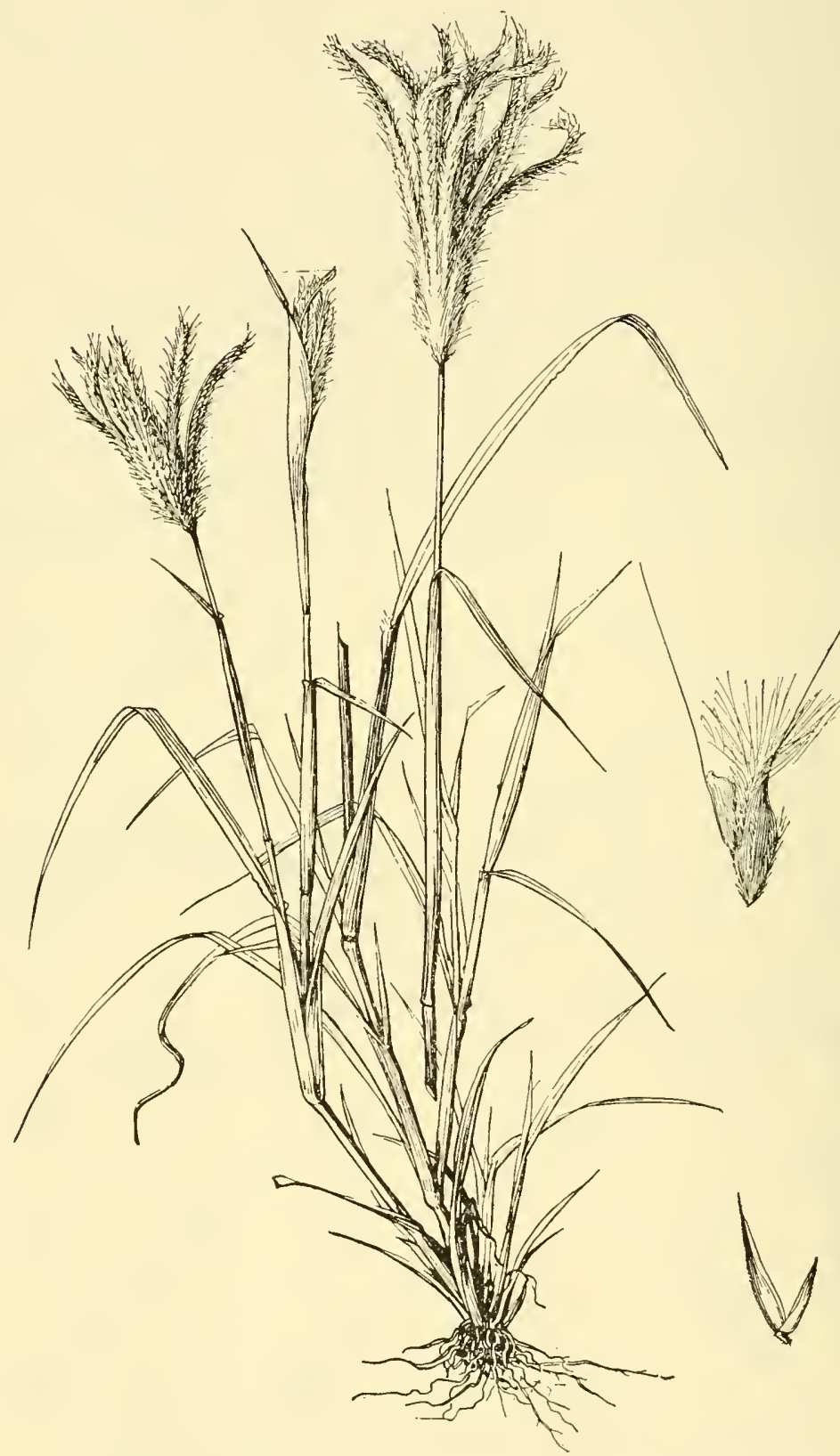

Figure 1070.-Chloris virgata. Plant, $\times 1 / 2$; glumes and florets, $\times 5$. (Tracy 8173, Tex.) 
acuminate; spikes mostly 3 to 6 , usually 5 to $7 \mathrm{~cm}$ long, digitate or nearly so, erect to spreading, somewhat flexuous; spikelets crowded, about $3 \mathrm{~mm}$ long; lemma densely long-villous on the keel and the middle of the margin, the awn shorter than the body; rudiment triangular-cuneate, about $2 \mathrm{~mm}$ wide. $24(C$. nashii Heller.)-Open grassland, southern Texas and Mexico.

12. Chloris verticilláta Nutt. Windmill Grass. (Fig. 1074.) Culms tufted, 10 to 40 $\mathrm{cm}$ tall, erect or decumbent at base, sometimes rooting at the lower nodes; leaves crowded at base, 2 to 4 sometimes aggregate at lower nodes; sheaths compressed, blades 1 to $3 \mathrm{~mm}$ wide,

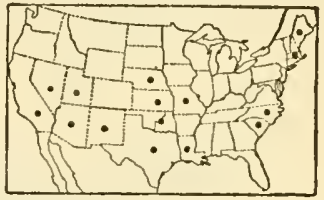

Figure 1071.-Distribution of Chloris virgata. obtuse; spikes slender, 7 to 10 or even $15 \mathrm{~cm}$ long, in 1 to 3 whorls, finally widely spreading; spikelets about $3 \mathrm{~mm}$ long; fertile lemma pubescent on the nerves, the awn mostly 5 to $8 \mathrm{~mm}$ long; rudiment cuneate-oblong, rather turgid, about $0.7 \mathrm{~mm}$ wide as folded, truncate,

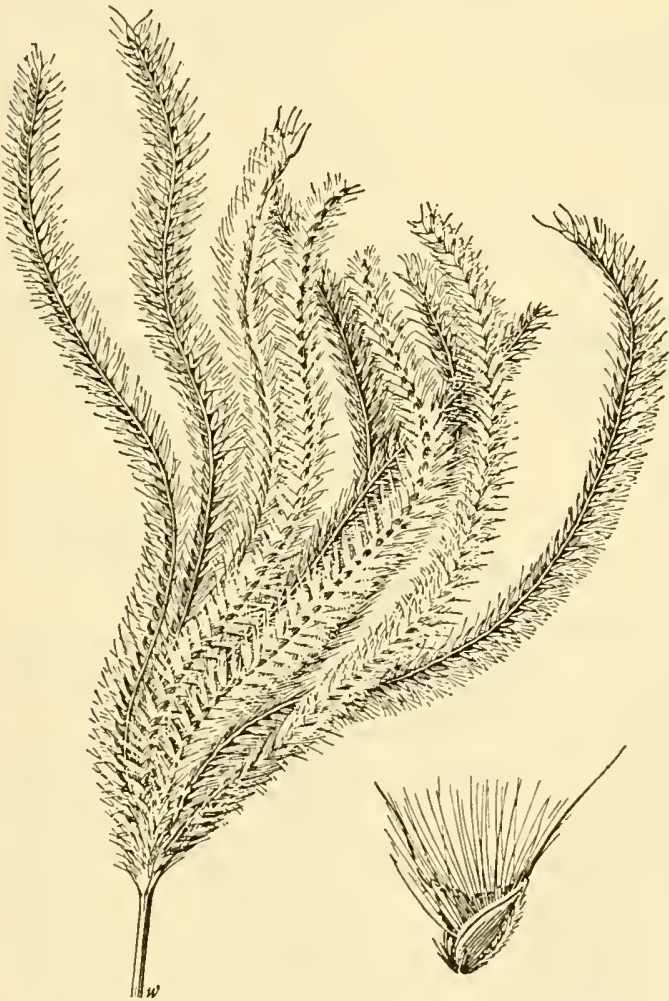

Figure 1072.-Chloris polydactyla. Panicle, $\times 1$; florets, $\times 5$. (Simpson, Fla.)

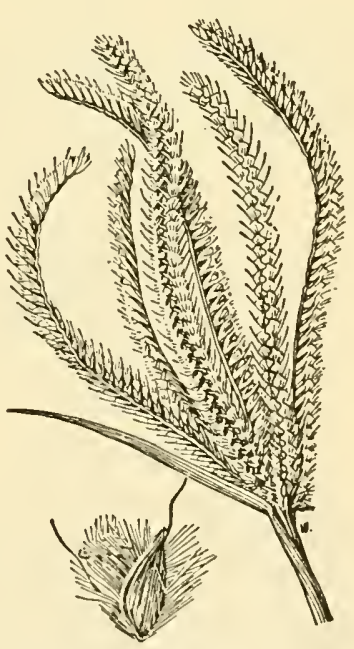

FIGURE 1073.-Chloris ciliata. Panicle, $\times 1$; florets, $\times 5$ (Tracy 8886, Tex.)

the awn about $5 \mathrm{~mm}$ long. 4 -Plains, Missouri to Colorado, south to Louisiana and New Mexico; introduced in Maryland, Illinois, Indiana, and California (Berkeley) (fig. 1075). The inflorescence at maturity breaks away and rolls before the wind as a tumbleweed. 
13. Chloris subdolichostáchya C. Muell. (Fig. 1076.) Similar to C. verticillata, but not more than $20 \mathrm{~cm}$ tall, spikes mostly less than 6 $\mathrm{cm}$ long, these more condensed and usually in one whorl or irregularly approximate; lemma 2 to $2.5 \mathrm{~mm}$ long, the awns mostly less than $3 \mathrm{~mm}$ long; rudiment oblong-cuneate, about $0.6 \mathrm{~mm}$ wide as folded. 21 (C. brevispica Nash.)-Plains, Texas.

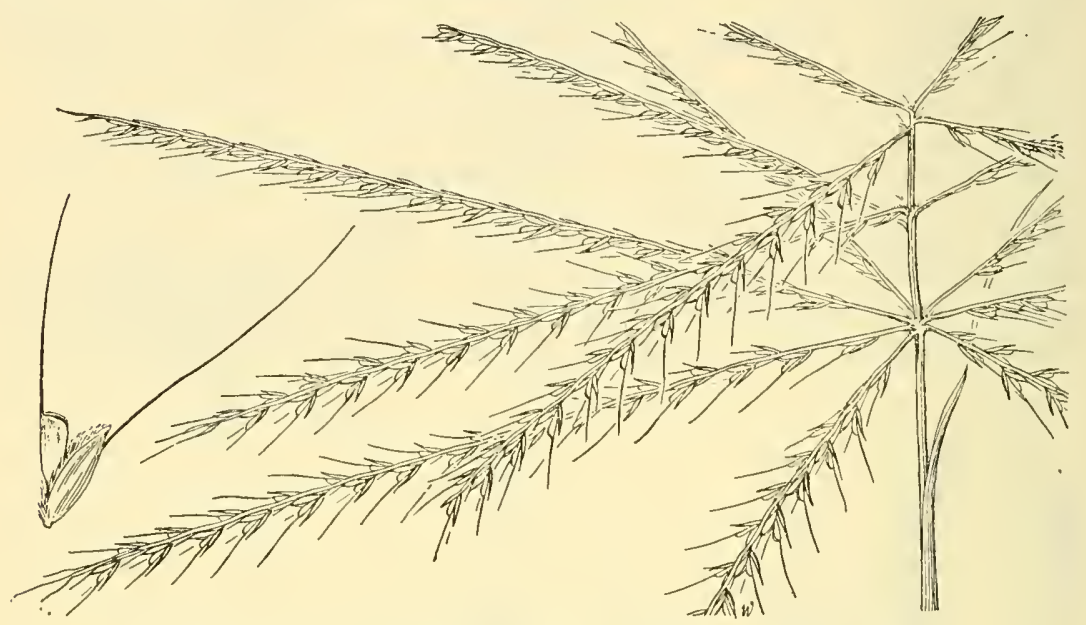

Figure 1074.-Chloris verticillata. Panicle, $\times 1$; florets, $\times 5$. (Ball 1112, Tex.)

14. Chloris latisquámea Nash. (Fig. 1077.) Culms densely tufted, 20 to $60 \mathrm{~cm}$ tall, very leafy at base, sometimes rooting at the lower nodes; sheaths compressed, 2 to 4 often aggregate at the lower node; blades 2 to $4 \mathrm{~mm}$ wide; spikes mostly 8 to 12 , relatively broad, 4 to $10 \mathrm{~cm}$ long, in 1 or 2

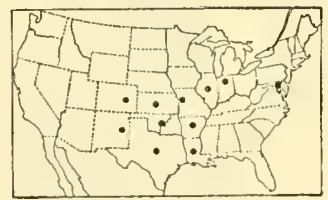

Figure 1075.-Distribution of Chloris verticillata.

whorls, spreading; spikelets rather crowded, pale, turning fuscous at maturity; lemma about $2.5 \mathrm{~mm}$ long, pubescent on the

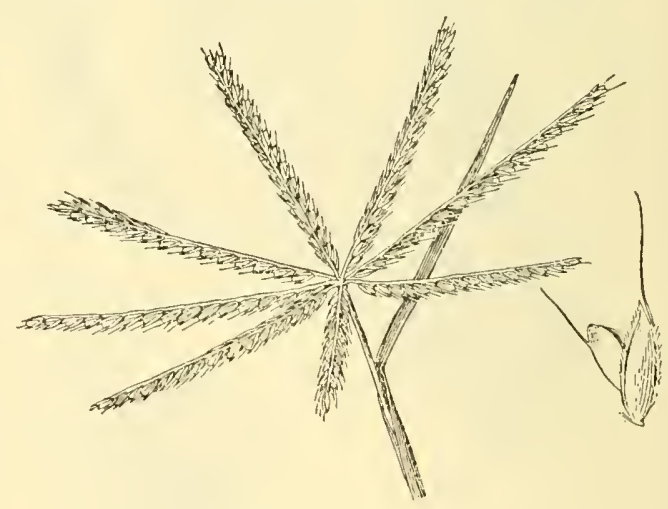

FIgURE 1076.-Chloris subdolichostachya. Panicle, $\times 1$; florets, $\times 5$. (Feller 1579 , T'cx.)

nerves, the awn 2 to $2.5 \mathrm{~mm}$ long; rudiment triangular cuneate, about $1 \mathrm{~mm}$ wide at summit as folded. 21 -Plains, Texas, Arizona. Resembling $C$. cucullata, but commonly taller with longer spikes, the rudiment longer than broad, less inflated, the awns 2 to $2.5 \mathrm{~mm}$ long.

15. Chloris cuculláta Bisch. (Fig. 1078.) Culms tufted, erect or somewhat spreading at base, 20 to $50 \mathrm{~cm}$ tall; sheaths compressed; 
blades 1 to $2 \mathrm{~mm}$ wide as folded, the uppermost often much reduced; spikes numerous, 2 to $5 \mathrm{~cm}$ long, digitate, radiating, flexuous or curled; spikelets crowded, stramineous, turning fuscous at maturity, triangular, about $2 \mathrm{~mm}$ long and about as broad; rudiment prominent, compressed-cupshaped, about $1.5 \mathrm{~mm}$ wide, the awns of lemma and rudiment about $1 \mathrm{~mm}$ long. 2 -Plains and sandy barrens, Texas and New Mexico.

Chloris radiáta (L.) Swartz. We edy branching annual; culms 30 to $40 \mathrm{~cm}$ long, decumbent; blades thin, 2 to $3 \mathrm{~mm}$ wide; spikes slender, several to many, 3 to $8 \mathrm{~cm}$ long; lemma narrow, $2.5 \mathrm{~mm}$ long, the narrow rudiment mostly included in its margins; awns of lemma and rudiment very slender, 5 to $10 \mathrm{~mm}$ long. $\odot \quad$-Ballast, near Portland, Oreg.; tropical America.

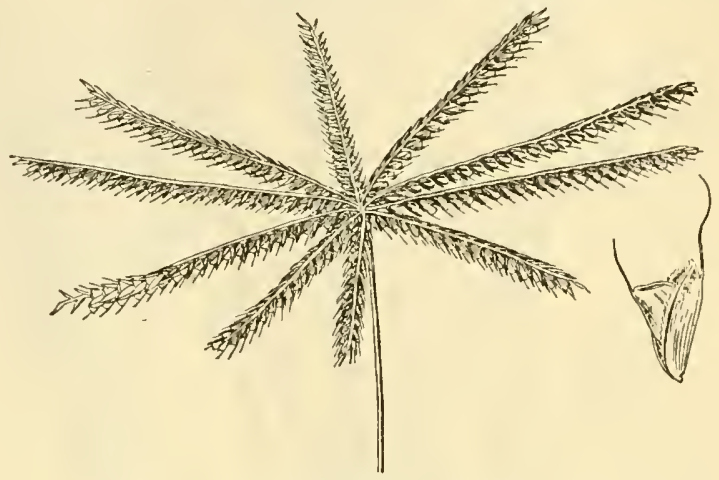

Figure 1077.-Chloris latisquamea. Panicle, $\times 1$; florets, $\times 5$. (Mearns 1233, Ariz.)

Chloris truncáta R. Br. Stoloniferous perennial; culms erect, 10 to 30 $\mathrm{cm}$ tall; spikes 6 to 10,7 to $15 \mathrm{~cm}$ long, horizontal or reflexed; spikelets $3 \mathrm{~mm}$ long, the awns 6 to $12 \mathrm{~mm}$ long. 2 -Occasionally cultivated for ornament under the name stargrass. Australia.

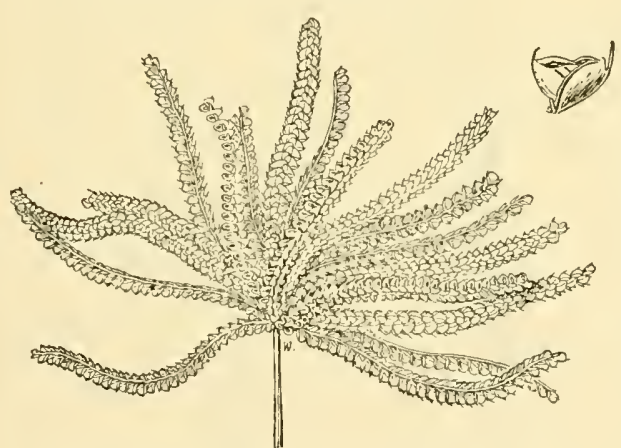

FIGURE 1078.-Chloris cucullata. Panicle, $\times 1$; florets, $\times$ 5. (Hitcheock 5497, Tex.)

\section{TRICHLORIS Fourn.}

Spikelets 2- to 5-flowered, nearly sessile, in two rows along one side of a continuous slender rachis, the rachilla disarticulating above the glumes and prolonged behind the uppermost perfect floret, bearing a reduced, usually awned floret; glumes unequal, acuminate, or short-awned, the body shorter than the lower lemma; lemmas narrow, 3-nerved, the midnerve and usually the lateral nerves extending into slender awns. Erect, slender, tufted perennials, with flat scabrous blades and numerous erect or ascending spikes, aggregate but scarcely digitate at the summit of the culms. Type species, Trichloris pluriflora. Name from Latin tri, three, and Chloris, a genus of grasses, the lemmas being 3-awned.

Spikelets 2-flowered, both lemmas with 3 long awns_..._. 1. T. MENdocina. Spikelets 3- to 5-flowered, the lateral awns of the lemmas more or less reduced, sometimes obsolete........... T. PLURIFLORA. 


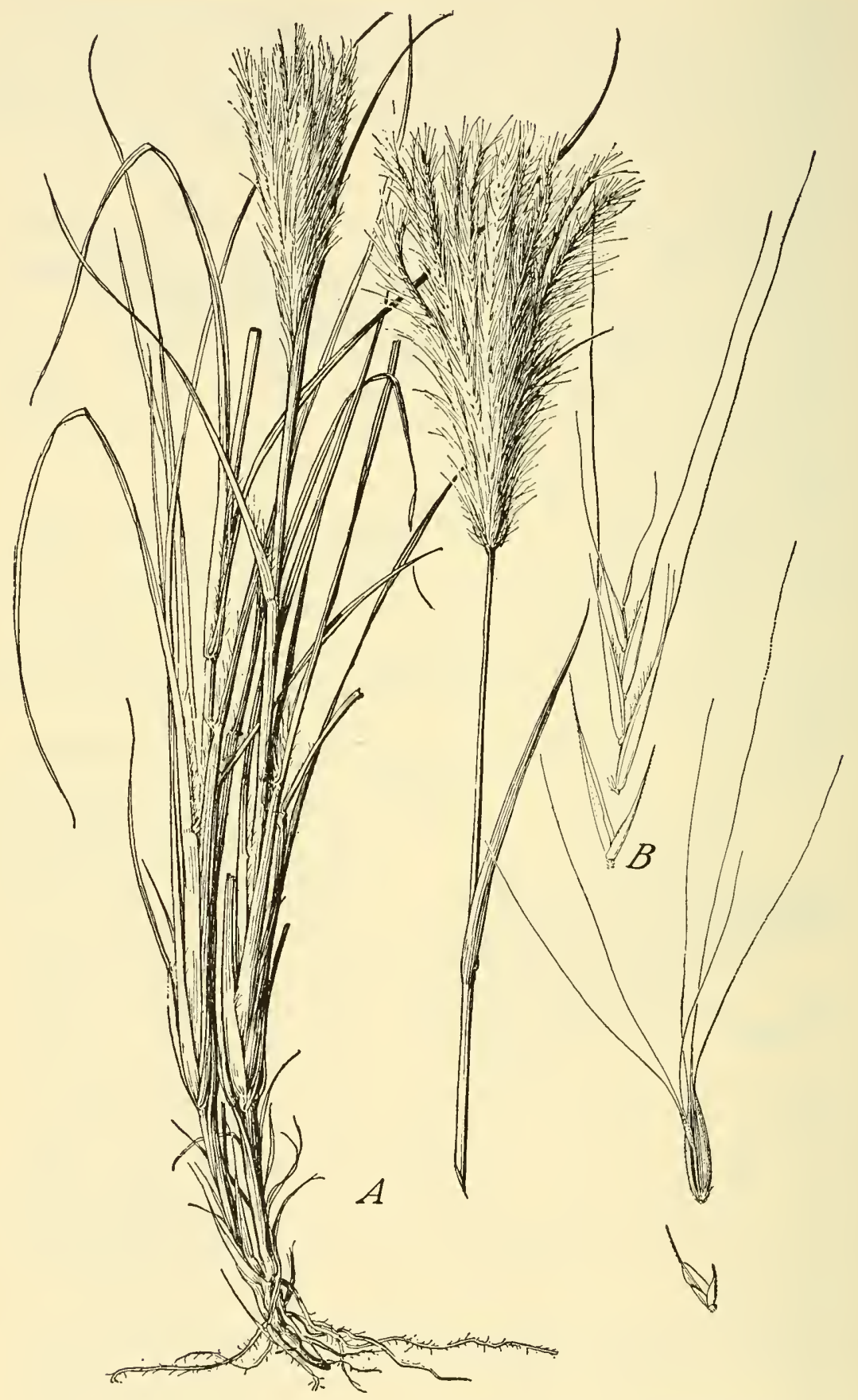

Frgure 1079. $-A$, Trichloris mendocina. Plant, $\times 1 / 2$; glumes and florets, $\times 5$. (Nealley, Tex.) $B, T . p l u r i-$ flora. Glumes and florets, $\times 5$. (Griffiths 6484 , Tex.) 
1. Trichloris mendocína (Phil.) Kurtz. (Fig. 1079, A.) Culms 40 to $100 \mathrm{~cm}$ tall; blades 2 to $4 \mathrm{~mm}$ wide; inflorescence dense, feathery, the spikes 5 to $10 \mathrm{~cm}$ long; spikelets crowded; fertile lemma about 3 $\mathrm{mm}$ long, the second lemma much reduced, both with delicate awns about $1 \mathrm{~cm}$ long. 2 -Plains, canyons, and rocky hills, western Texas to Arizona and northern Mexico; southern South America. Rarely cultivated for ornament (as T. blanchardiana Fourn.).

2. Trichloris pluriflóra Fourn. (Fig. 1079, B.) Culms 50 to 100 $\mathrm{cm}$ tall; blades 5 to $10 \mathrm{~mm}$ wide; inflorescence looser and less feathery than in T. mendocina; spikes 7 to $15 \mathrm{~cm}$ long; fertile lemma about 4 $\mathrm{mm}$ long, the others successively shorter, the middle awns of all 5 to $15 \mathrm{~mm}$ long, somewhat spreading, the lateral awns short or obsolete. 2 -Plains and dry woods, southern Texas and Mexico; southern South America.

\section{BOUTELOUA Lag. Grama}

Spikelets 1-flowered, with the rudiments of one or more florets above, sessile, in two rows along one side of the rachis; glumes 1nerved, acuminate or awn-tipped, the first shorter and narrower; lemma as long as the second glume or a little longer, 3-nerved, the nerves extending into short awns or mucros, the internerves usually extending into lobes or teeth; palea sometimes 2-awned; rudiment various, usually 3 -awned, the awns usually longer than those of the fertile lemma, a second rudimentary floret sometimes present. Perennial or sometimes annual, low or rather tall grasses, with two to several or many spikes racemose on a common axis, or sometimes solitary, the spikelets few to many in each spilie, rarely solitary, pectinate or more loosely arranged and appressed, the rachis of the spike usually naked at the tip. The sterile florets forming the rudiment are variable in all the species and commonly in individual specimens. The general pattern of rudiment is fairly constant for each species, the variability being in the reduction or increase in number and size of the sterile florets, the reduction from 3 awns to 1 , and in the amount of pubescence. Type species, Bouteloua racemosa Lag. (B. curtipendula). Named for the brothers Boutelou, Claudio, and Esteban. The genus was originally published as Botelua.

The many species are among our most valuable forage grasses, forming an important part of the grazing on the western ranges. $B$. gracilis, blue grama, and B. hirsuta, hairy grama, are prominent in "short grass" regions of the Great Plains; B. eriopoda, black grama, and B. rothrockii, Rothrock grama, are prominent in Arizona. Two annuals, $B$. barbata and $B$. parryi, form a part of the sixweeks grasses of the Southwest; $B$. curtipendula is widely distributed and is much used for grazing and for hay; $B$. trifida is important from Texas to Arizona.

Spikelets not pectinately arranged (except in $B$. chondrosioides), the spikes falling entire at maturity ................... Section 1. Atheropogon. Spikelets pectinately arranged, the spikes persistent, the florets falling from the persistent glumes...................... Section 2. Chrondrosium.

Section 1. Atheropogon

Plants annual

1. B. ARISTIDOIDES.

Plants perennial.

Spikes usually 20 to 50 ; awns short, inconspicuous. Spikes of 1 or 2 spikelets; culms very slender. Spikes of few to several spikelets; culms mostly stouter.

2. B. UNIFLORA.

3. B. CURTIPENDULA.

$55974^{\circ}-35-33$ 
Spikes fewer, awns conspicuous.

Glumes pubescent.

Spikes rhomboid-oblong, as much as $2 \mathrm{~cm}$ long, the spikelets somewhat pectinately arranged

Spikes cuneate-triangular, about $1 \mathrm{~cm}$ long (including the awns), the spikelets appressed, not pectinately arranged.

Culms 20 to $30 \mathrm{~cm}$ tall; leaves crowded at base; spikes mostly 6 to 8 .

4. B. RIGIDISETA.

Culms mostly 30 to $50 \mathrm{~cm}$ tall, leafy throughout; spikes mostly more than 10 Glumes glabrous or scabrous, not pubescent.

Base of plants hard, rhizomatous; culms simple; spikes 2 to $3 \mathrm{~cm}$ long.

7. B. RADICOsA.

Base of plants not rhizomatous; culms branching; spikes usually about $\mathbf{1 . 5}$ $\mathrm{cm}$, sometimes $2 \mathrm{~cm}$, long_.......

\section{Section 2. Chondrosium}

Plants annual (see also B. rothrockii); densely tufted, spreading.

Spike 1

Spikes 2 or more.

Rachis papillose-pilose

Rachis not pilose...

Plants perennial.

Plants decumbent or stoloniferous; culms white-lanate---- 16. B. Erropoda.

Plants erect or nearly so; culms not lanate, tufted.

Spikes normally 2, sometimes 1 or 3 .

Rachis prolonged beyond the spikelets as a naked point; glumes tuberculate _...

Rachis not prolonged; glumes not tuberculate (slightly so in B. gracilis).

Culms herbaceous, the base not woody _....... 14. B. GRAcILIs.

Culms woody and perennial at base......... 15. B. BREviseta.

Spikes normally 4 or more (see also $B$. gracilis var. stricta).

Culms 25 to $50 \mathrm{~cm}$ tall; awn 1 to $2 \mathrm{~mm}$ long; glumes scabrous; spikes spreading _...

Culms 10 to $20 \mathrm{~cm}$ tall; awn about $5 \mathrm{~mm}$ long; glumes glabrous; spikes usually appressed..................... B. TrIFIDA.

\section{Section 1. Atheropógon (Muhl.) Endl.}

Spikes deciduous from the main rachis; spikelets not pectinately arranged (somewhat so in B. chondrosioides). (Atheropogon Muhl. based on A. apludoides Muhl. (Bouteloua curtipendula).)

1. Bouteloua aristidoídes (H.B.K.) Griseb. Nendle grama. (Fig. 1080.) Annual, erect or spreading, branching; culms slender, 10 to $30 \mathrm{~cm}$ tall; blades small and few, in vigorous plants as much as 15 $\mathrm{cm}$ long; spikes mostly 8 to 14 on a slender axis, reflexed, readily falling, the base of the rachis forming a sharp, bearded point; spikelets 2 to 4 , narrow, appressed; rudiment of 3 scabrous awns about $5 \mathrm{~mm}$ long, exceeding the fertile floret. $\odot \quad$ (Triathera aristidoides Nash.)Mesas, deserts, and foothills in open ground, Texas to southern California and northern Mexico; Argentina (fig. 1081).

2. Bonteloua uniflóra Vasey. (Fig. 1082.) Resembles slender forms of $B$. curtipendula, culms slender, wiry, sometimes with slender stolons, the slender blades subinvolute, the spikes 8 to $9 \mathrm{~mm}$ long, with 1 or 2 spikelets, the scabrous rachis mostly longer than the first glume; lemma awnless; rudiment reduced to a single awn appressed to the back of the palea. 4 -Rocky hills and valleys, central and western Texas.

3. Bouteloua curtipéndula (Michx.) Torr. Side-oats grama. (Fig. 1083.) Perennial, with scaly rhizomes; culms erect, tufted, 50 to $80 \mathrm{~cm}$ tall; blades flat or subinvolute, 3 to $4 \mathrm{~mm}$ wide, scabrous; 
spikes 35 to 50,1 to $2 \mathrm{~cm}$ long, purplish, spreading or pendulous and mostly twisted to one side of the slender axis, this 15 to $25 \mathrm{~cm}$ long; spikelets 5 to 8 , appressed or ascending, 6 to $10 \mathrm{~mm}$ long; fertile lemma acute, mucronate; rudiment with 3 awns and subacute inter-

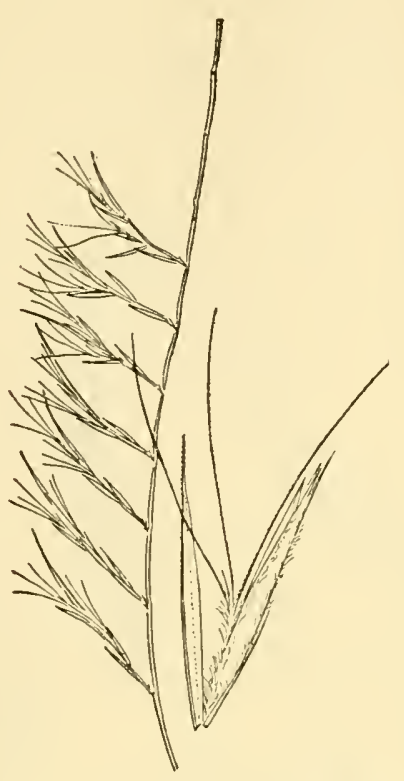

FIG URE 1080.-Bouteloxa aristidoides. Panicle, $\times 1$; spikelet, $\times 5$ (Griffiths 7308, Ariz.)

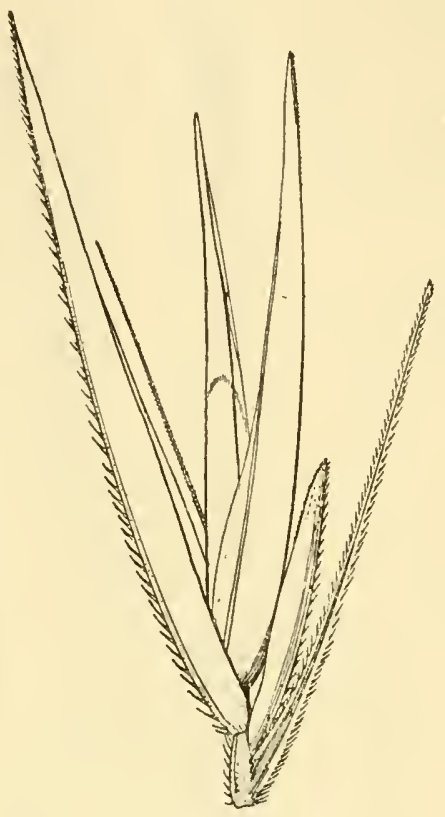

FIGURE 1082.-Bouteloua uniflora, $\times 10$. (Type.)

mediate lobes, often reduced and inconspicuous. 2 (Atheropogon curtipendulus Fourn.) - Plains, prairies, and rocky hills, Maine and Ontario to Montana, south to Maryland, Alabama, Texas, Arizona, and southern California; South Carolina (introduced) (fig. 1084).

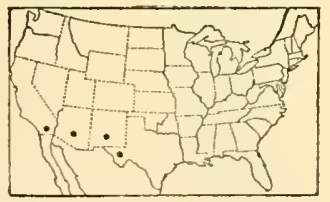

FIGURE 1081.-Distribution of Bouteloua aristidoides.

4. Bouteloua rigidiséta (Steud.) Hitchc. (Fig. 1085.) Perennial, tufted, leafy at base; culms ereet, 20 to $30 \mathrm{~cm}$ tall; blades narrow, flat or somewhat involute, 1 to $1.5 \mathrm{~mm}$ wide, sparingly papillose-pilose; spikes 6 to 8 , triangular-cuneate, spreading, about 1 to $1.2 \mathrm{~cm}$ long including the awns; spikelets mostly 2 to 4 , crowded, ascending; glumes pubescent; fertile lemma with 3 spreading awns, the intermediate lobes acute; rudiment with stout spreading awns, much exceeding those of the fertile lemma, the intermediate lobes firm, pointed, a second similar but smaller rudiment commonly developed. 24 ( $B$. texana S. Wats.; Polyodon texanus Nash.)-Plains and rocky hills, Oklahoma, Texas, and northern Mexico.

5. Bouteloua elúdens Griffiths. (Fig. 1086.) Perennial, densely tufted, leafy at base; culms erect, 25 to $60 \mathrm{~cm}$ tall; blades mostly 
514 MISC. PUBLICATION 200, U. S. DEPT. OF AGRICULTURE

1 to $1.5 \mathrm{~mm}$ wide; axis slender, flexuous, 6 to $8 \mathrm{~cm}$ long; spikes 10 to 20 , triangular, spreading, about $1 \mathrm{~cm}$ long including the awns; spikelets

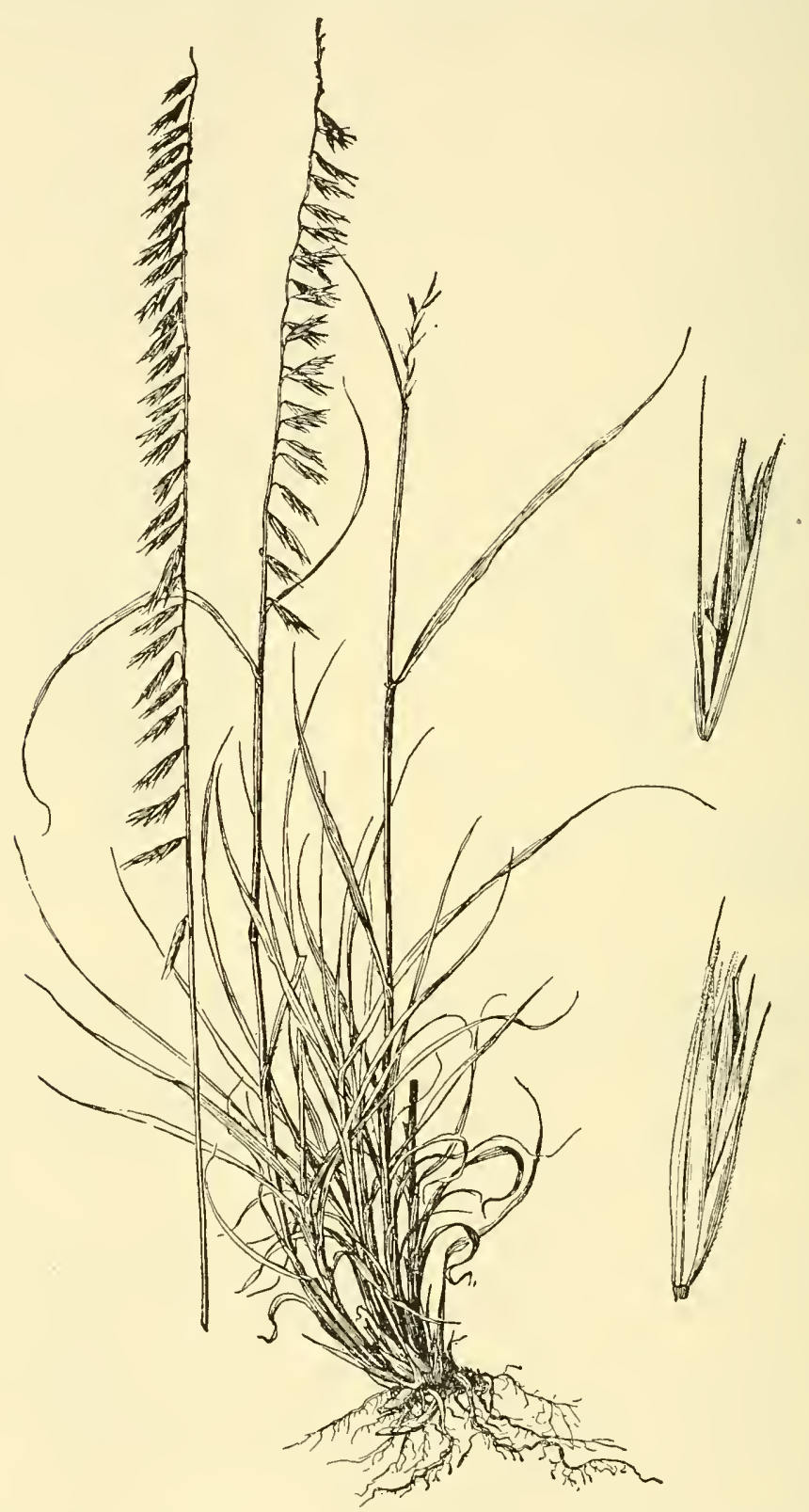

Figure 1083.-Bouteloua curtipendula. Plant, $\times 1 / 2$; spikelet and florets, $\times 5$. (Chase 5408, Colo.)

about 5 ; rachis and glumes densely pubescent; fertile lemma pubescent toward the summit, the apex 3 -cleft, the divisions awn-tipped; 
rudiment with stout pubescent awns about $5 \mathrm{~mm}$ long, the long narrow intermediate lobes glabrous; a second similar but smaller rudiment usually developed. 24 - Rocky hills, southern Arizona and Sonora, Mexico.

6. Bouteloua chondrosioídes (H.B.K.) Benth. (Fig. 1087.) Perennial, tufted, leafy at base; culms erect, 20 to $50 \mathrm{~cm}$ tall; blades 2 to $3 \mathrm{~mm}$ wide; axis 4 to $6 \mathrm{~cm}$ long; spikes 4 to 6, rhomboid-oblong, ascending, 1 to $2 \mathrm{~cm}$ long, the rachis densely pubescent, the tip 3-cleft; spikelets several, subpectinate; rachis broad, densely pubescent on the margin; glumes and fertile lemma densely pubescent, the lemma 3-cleft, the divisions awn-tipped; rudiment cleft nearly to the base, the middle awn broadly winged, the lateral ones slender, all spreading

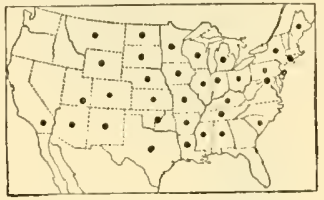

FIGURE 1084.-Distribution of Bouteloua curtipendula. $21-$ Mesas and rocky hills, western Texas, southern Arizona, and Mexico.

7. Bouteloua radicósa (Fourn.) Griffiths. Purple grama. (Fig. 10S8.) Perennial, tufted, from a stout rhizomatous base; culms erect, 60 to $80 \mathrm{~cm}$ tall; blades 2 to $3 \mathrm{~mm}$ wide,
sparsely papillose-ciliate on the margin, mostly aggre-
gate toward the lower part of the culm, the upper
part naked; axis 10 to $15 \mathrm{~cm}$ long; spikes mostly 7
to 12 , oblong, 2 to $3 \mathrm{~cm}$ long; spilielets mostly 8 to
glumes broader than in other species; fertile
lemma indurate down the center, with 3
awns, the middle longest, and no inter-
mediate lobes; rudiment with 3 awns 5 to
$8 \mathrm{~mm}$ long and no intermediate lobes,
usually containing a palea and staminate
flower, sometimes a perfect flower, the
lower floret being staminate. 24 - Rocky
hills, southern New Mexico to southern
California and Mexico. 8. Bouteloua filifórmis (Fourn.) Griffiths. Slender grama. (Fig. 1089.) Resembling B. radicosa; culms erect or geniculate-spreading, sparingly branching, the base not rhizomatous; spikes ascending to spreading, mostly about $1.5 \mathrm{~cm}$ long, sometimes as much as $2 \mathrm{~cm}$; spikelets mostly 6 to 10 , very like those of $B$. radicosa. 2 -Rocky hills, Texas to Arizona and Mexico.

Figure 1085,-Bouteloua rigidiseta. Panicle, $\times 1$; spikelet, lemma, and florets, $\times 5$. (Griffiths 6370 , Tex.)

\section{Section 2. Chondrósium (Desv.) Benth.}

Spikes persistent; spikelets crowded (looser in B. eriopoda), pectinate; fiorets falling from the glumes. (Chondrosium Desv. based on C. procumbens Durand (B. simplex).)

9. Bouteloua símplex Lag. Mat grama. (Fig. 1090.) Annual, tufted, prostrate or ascending; foliage scant; blades 2 to $3 \mathrm{~cm}$ long, about $1.5 \mathrm{~mm}$ wide; spike solitary, 1.5 to $2.5 \mathrm{~cm}$ long, strongly arcuate at maturity; spikelets mostly 20 to 30 , about $5 \mathrm{~mm}$ long; fertile lemma 
pilose at base with stout awns and subacute intermediate lobes; rudiment bearded at summit of rachilla-joint, cleft to the base or nearly so, the awns equal, a second rudiment, broad and awnless, sometimes developed. $\odot$ (B. procumbens Griffiths.)-Open ground, Texas to Colorado, Utah, Arizona, and Mexico; wool waste, Maine; Ecuador to Argentina (fig. 1091).

10. Bouteloua barbáta Lag. Sixweeks grama. (Fig. 1092.) Annual, tufted, branching, erect to prostrate, often forming mats with

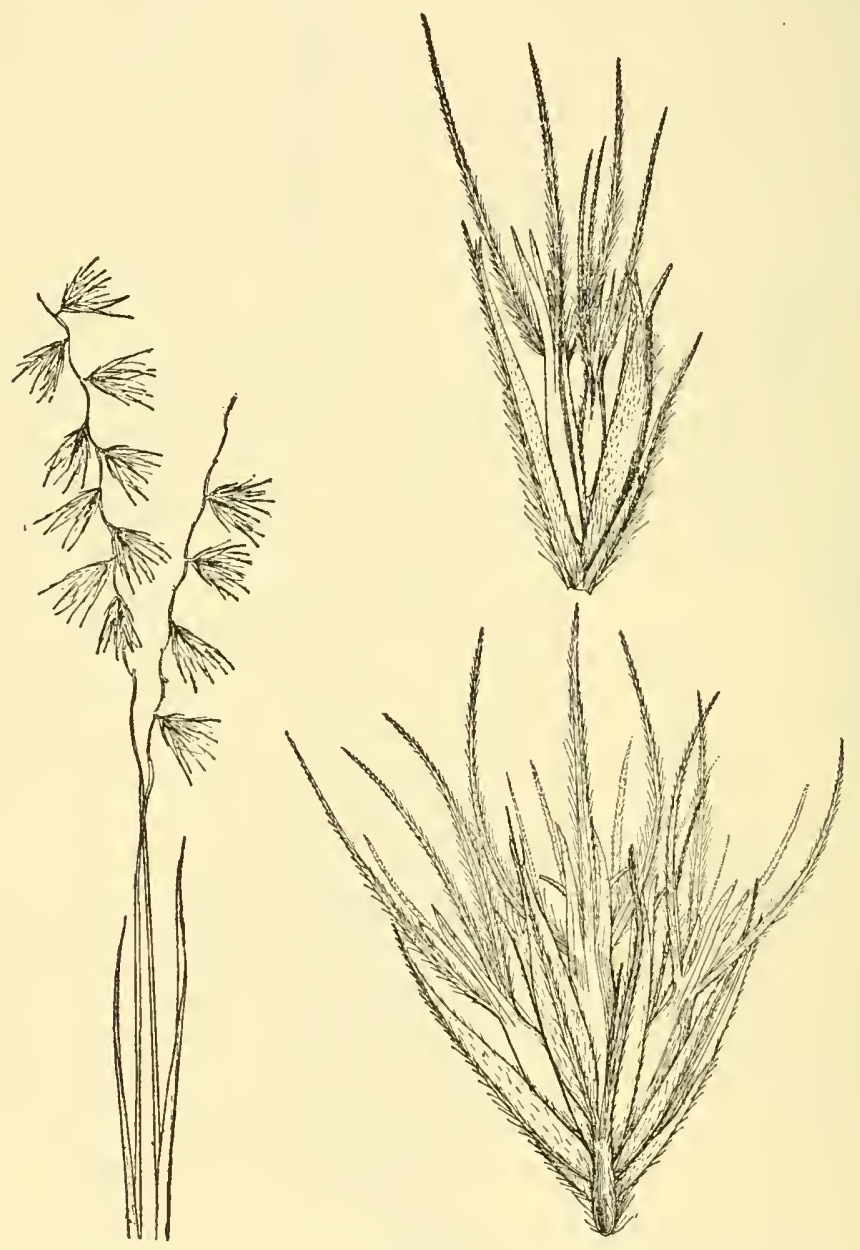

FigUre 1086.-Bouteloua eludens. Panicle, $\times 1$; spike and spikelet, $\times 5$. (Type.)

ascending ends, the culms as much as $30 \mathrm{~cm}$ long; foliage scant; blades 1 to $4 \mathrm{~cm}$ long, 1 to $1.5 \mathrm{~mm}$ wide; spikes 4 to 7,1 to $2 \mathrm{~cm}$ long; spikelets 25 to $40,2.5$ to $4 \mathrm{~mm}$ long, nearly as broad; fertile lemma densely pilose at least along the sides, usually throughout, the awns from minute to as long as the body, the intermediate lobes subacute to obtuse; rudiment from obscurely to conspicuously bearded at summit 
of rachilla joint, cleft nearly to the base, the intermediate lobes broad, subcucullate, the awns of rudiment and fertile lemma reaching about the same height, a second rudiment, broad and awnless, often developed $\odot$ (B. microstachya L. H. Dewey.) -Open ground, mesas, and rocky hills, Texas, $\mathrm{New}$ Mexico, southern Utah, Arizona, southeastern California, Mexico (fig. 1093). The awns vary in length. The form with shorter awns is that described as $B$. pumila Buckl.; the longer awned form is that described as B. arenosa Vasey.

11. Bou teloua párryi (Fourn.) Griffiths. ParrY GRAMA. (Fig. 1094.) Annual, resembling B. rothrockii; culms erect or gen-

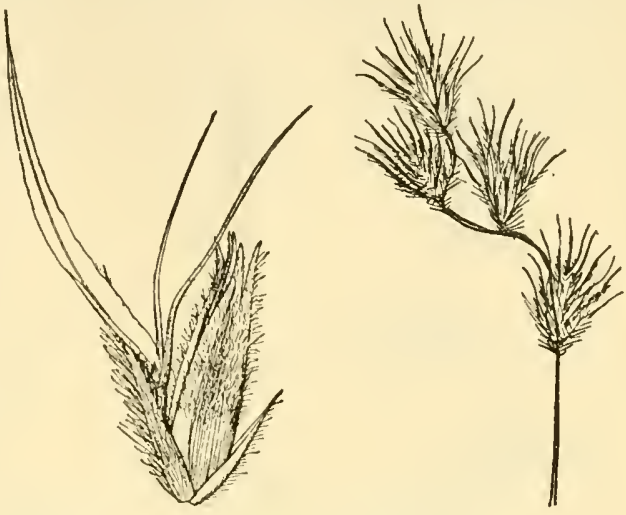

Figure 1087.-Bouteloua chondrosioides. Panicle, $\times 1$; spikelet, $\times 5$. (Type.)

iculate-spreading, sometimes branching; blades papillose-pilose; spikes 4 to 8 , often flexuous, commonly grayish purple, 2 to $3.5 \mathrm{~cm}$ long; rachis papillose-pilose; spikelets 40 to 65 , about $6 \mathrm{~mm}$ long; second glume awned from a bifid tip, the keel papillose-pilose with spreading hairs; fertile lemma densely pilose, deeply cleft, the awns spreading,

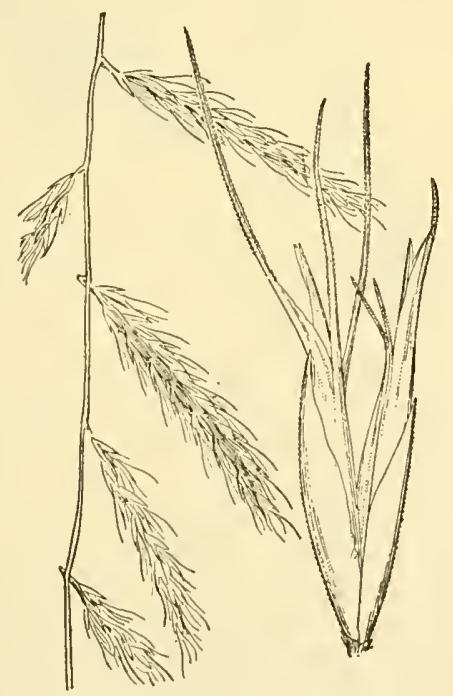

FIGURE 1085,-Bouteloua radicosa. Panicle, $\times 1$; spikelet, $\times 5$. (Griffiths 7181 , Ariz.)

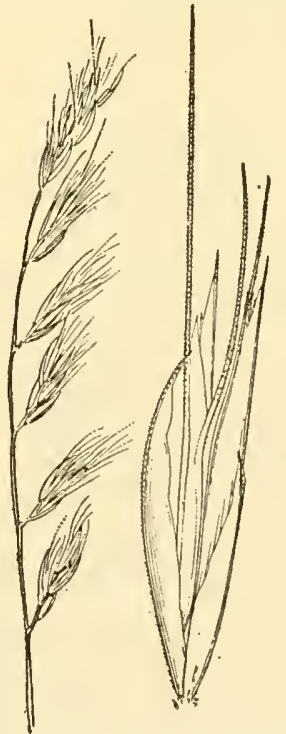

Figure 1089.-Bouteloua filiformis. Panicle, $\times 1$; spikelet, $\times 5$. (Griffiths 7199 , Ariz.)

the oblong intermediate lobes fimbriate; rudiment densely bearded at summit of rachilla, cleft nearly to the base, the lobes obovate, fimbriate, the awns exceeding those of the fertile lemma; a second rudi- 
ment, broad, awnless or with a single awn, usually developed.

Mesas and rocky hills, New Mexico, Arizona, and northern Mexico.

12. Bouteloua rothróckii Vasey. Rотнrock Grama. (Fig. 1095.)

Perennial, sometimes appearing to be annual; culms tufted, erect, 25

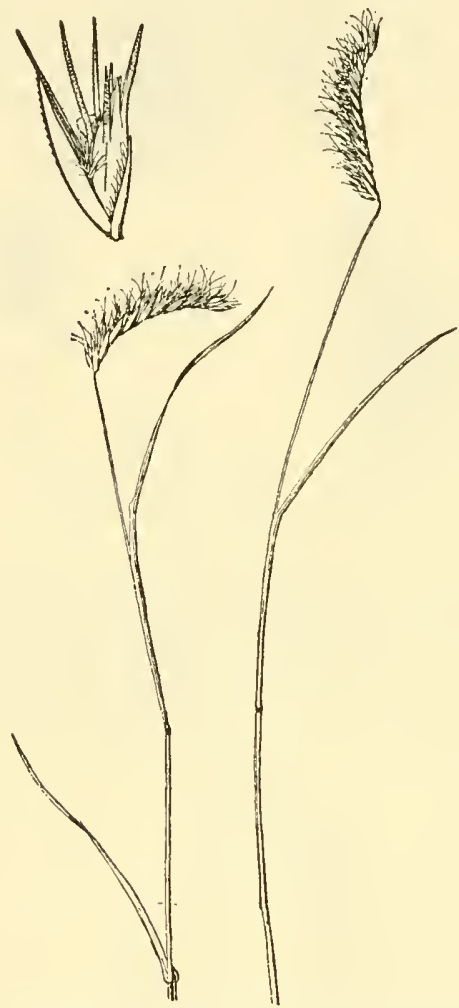

Figure 1090.-Bouteloua simpler. Plant, $\times 1$; spikelet, $\times 5$. (Griffiths 7362, Ariz.)

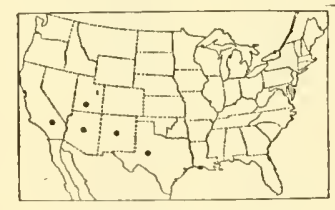

FIGURE 1093.-Distribution of Bouteloua barbata.

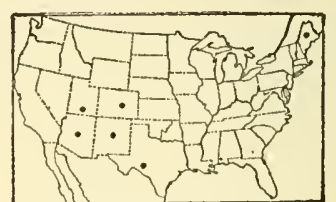

Figure 1091.-Distribution of Bouteloua simplex.

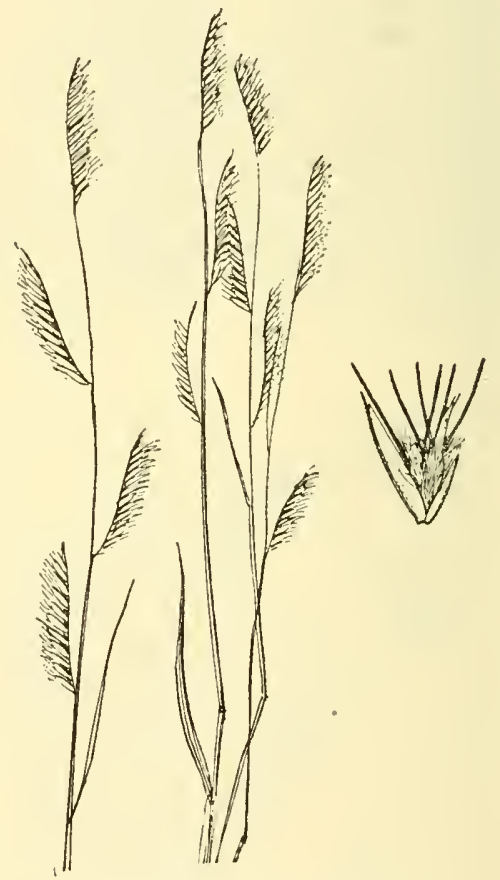

Figure 1092.--Bouteloua barbata, Plant, $\times 1$; spikelet, $\times 5$, (Griffiths 6095 , Ariz.)

to $50 \mathrm{~cm}$ tall; blades 2 to $3 \mathrm{~mm}$ wide; axis 10 to $25 \mathrm{~cm}$ long; spikes 4 to $12,2.5$ to $3 \mathrm{~cm}$ long, straight to subarcuate; spikelets 40 to 50 , about $5 \mathrm{~mm}$ long; fertile lemma pilose at base, deeply cleft, the awns ( 1 to $2 \mathrm{~mm}$ long) spreading, the intermediate and lateral lobes fimbriate; rudiment densely bearded at summit of rachilla joint, cleft nearly to the base, the lobes broad and rounded, the awns mostly cxceeding those of the fertile lemma; a second rudiment, broad and awnless, usually developed. 2 -Mesas, canyons, and rocky hills, in open ground, or among brush, Arizona and southern California (Jamacha), south to northern Mexico. 
13. Bouteloua hirsúta Lag. Hairy grama. (Fig. 1096.) Perennial, densely tufted; culms erect, 20 to $60 \mathrm{~cm}$ tall, leafy at base; blades flat or subinvolute, about $2 \mathrm{~mm}$ wide, flexuous; spikes 1 to 4 , usually $2,2.5$ to $3.5 \mathrm{~cm}$ long, the rachis extending beyond the spikelets as a slender point 5 to $8 \mathrm{~mm}$ long; spikelets 35 to 45 , about $5 \mathrm{~mm}$ long, second glume tuberculate-hirsute with spreading hairs, the tubercles black; fertile lemma 3-cleft, the divisions and margins of lemma pubescent, awn-tipped; rudiment from puberkilent to bearded at summit of

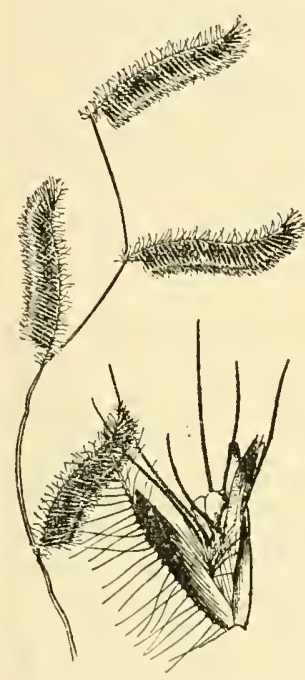

FIGURE 1094-Bouteloua parryi. Panicle, $\times 1$; spikelet, $\times 5 . \quad($ Griffiths 7277, Ariz.)

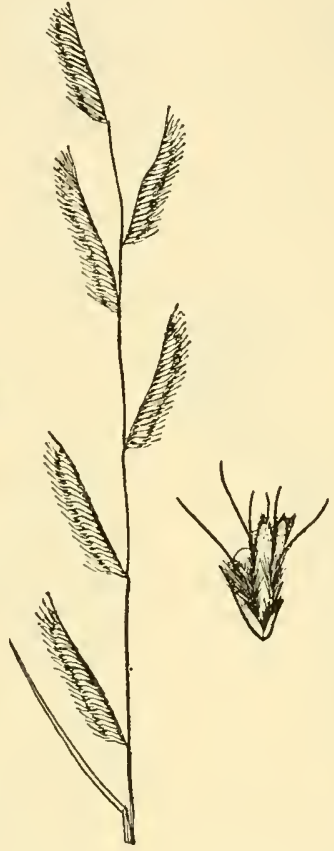

FIGURE 1095.-Bouteloua rothrockii. Panicle, $\times 1$; spikelet, $\times 5$. (Griffiths 7185, Ariz.)

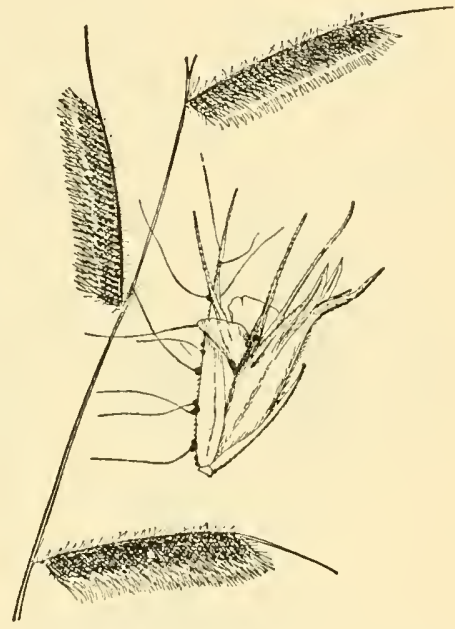

FigUre 1096.-Bouteloua hirsuta. Panicle, $\times 1$; spikelet, $\times 5$. (Griffiths 3371 , Ariz.)

rachilla, cleft nearly to the base, the lobes firm, broad, spreading, the awns black. 24 -Plains and rocky hills, Wisconsin and South Dakota to Texas, Colorado, Arizona, and California (Jamacha), south through Mexico; also peninsular Florida (fig. 1097). Bouteloua pectinata Featherly was differentiated from $B$. hirsuta by taller more robust culms and by a rudimentary spikelet at the end of the rachis. Such a spikelet is rarely developed in $B$. hirsuta, but it is not correlated with robust plants.

14. Bouteloua grácilis (H.B.K.) Lag. Blue grama. (Fig. 1098.) Perennial; densely tufted; culms erect, 20 to $50 \mathrm{~cm}$ tall, leafy at base; blades flat or loosely involute, 1 to $2 \mathrm{~mm}$ wide; spikes usually 2 , sometimes 1 or 3 , rarely more, 2.5 to $5 \mathrm{~cm}$ long, falcate-spreading at maturity, the rachis not projecting beyond the spikelets; spikelets numerous, as many as 80 , about $5 \mathrm{~mm}$ long; fertile lemma pilose, the awns slender, the intermediate lobes acute; rudiment densely bearded at summit of rachilla joint, cleft to the base, the lobes rounded, the 
awns slender, about equaling the tip of fertile lemma; one or two additional rudiments, broad and awnless, sometimes developed. 24 (B. oligostachya Torr.)-Plains, Wisconsin to Manitoba and

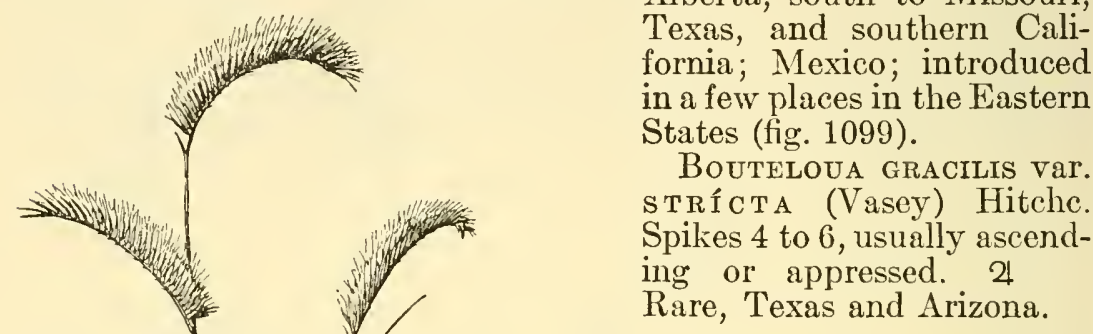

Alberta, south to Missouri, Texas, and southern California; Mexico; introduced in a few places in the Eastern States (fig. 1099).

BOUTELOUA GRACILIS var. STRÍcta (Vasey) Hitche. Spikes 4 to 6 , usually ascending or appressed. 2 Rare, Texas and Arizona.

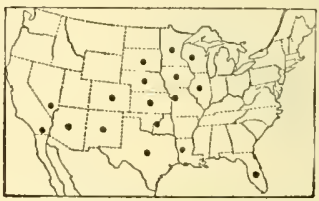

FIGURE 1097.-Distribution of Bouteloua hirsuta.

15. Bouteloua breviséta Vasey. (Fig. 1100.) Perennial, wiry, the base perennial, woody, loosely tufted; culms branching, 25 to $40 \mathrm{~cm}$ tall; blades 3 to $6 \mathrm{~cm}$ long, 1 to $1.5 \mathrm{~mm}$ wide, flat or becoming involute, sharppointed; spikes mostly 2, sometimes 1 , rarely 3,2 to $3 \mathrm{~cm}$ long; spikelets 30 to
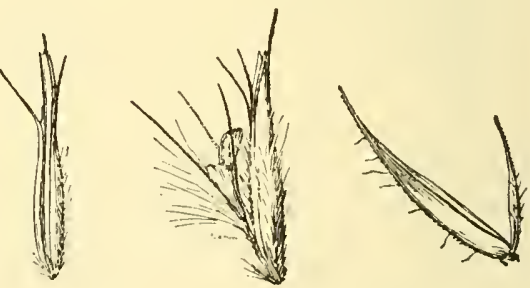

FIgURe 1098.-Bouteloua gracilis. Plant, $\times 1 / 2 ;$ glumes and forets, $\times 5$. (Amer. Gr. Nat. Herb. 384.)

45 , about $4 \mathrm{~mm}$ long; fertile lemma pubescent, with 3 awns and acuminate intermediate lobes; rudiment densely bearded at summit of rachilla joint, cleft nearly to the base, the rounded lobes obscured in the dense hairs. 2! (B. ramosa 
Scribn.)-Gypsum sands and calcareous rocks, western Texas, New Mexico, and northern Mexico. Resembling B. gracilis but with loose, woody base and wiry culms; rachis prolonged and bearing a rudimentary spikelet at the tip.

16. Bouteloua eriopóda (Torr.) Torr. BLACK Grama. (Fig. 1101.) Perennial; culms tufted, with

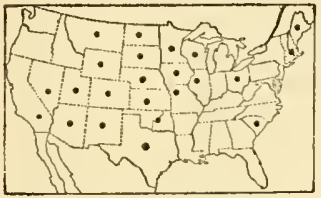

FIgURE 1099.-Distribution of Bouteloua gracilis. swollen bases, slender, wiry, widely spreading with arched internodes or stoloniferous, white-lanate, 40 to $60 \mathrm{~cm}$ long; blades 1 to $1.5 \mathrm{~mm}$ wide, flexuous; spikes 3 to 8 , commonly 4 or 5 , loosely ascending, 2 to $3 \mathrm{~cm}$ long; spikelets 12 to 20 , not crowded and pectinate, 7 to $10 \mathrm{~mm}$ long, narrow; fertile lemma acuminate, with a terminal awn, the lateral minute or obsolete; rudiment slender, cleft nearly to the base, the awns equaling the awn of the

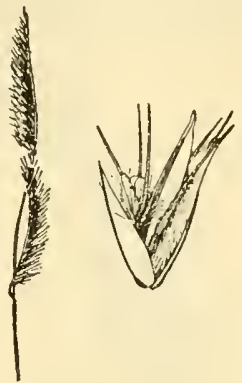

FIGURE 1100.-Bouteloua breviseta. Panicle, $X$ 1 ; spikelet, $\times 5$. (Nealley 669 , Tex.)

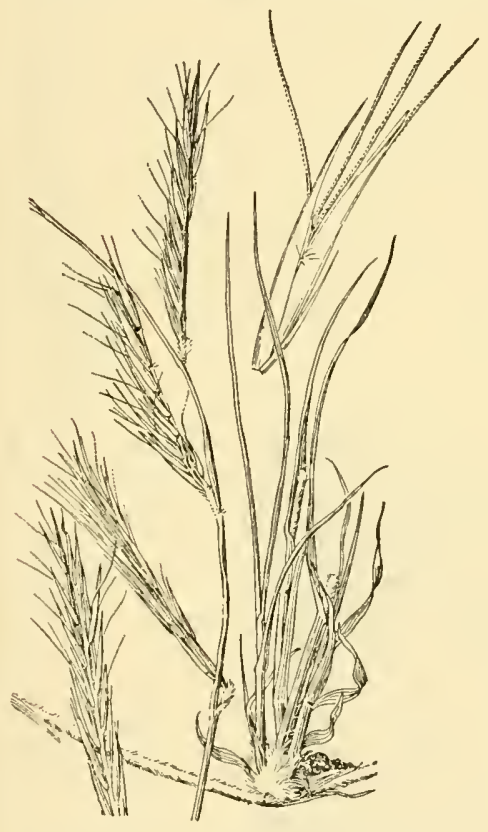

Figure 1101.-Bouteloua eriopoda. Plant, $X$ 1; spikelet, $\times 5$. (Hitchcock 13357, Tex.) fertile lemma, the lobes minute, narrow. 24 -Mesas, hills, and dry open ground, Texas to southern Utah and northern Mexico (fig. 1102).

17. Bouteloua trífida Thurb. (Fig. 1103.) Perennial, tufted, leafy at base, rather delicate; culms erect, 10 to $20 \mathrm{~cm}$ tall; blades usually only 1 to $2 \mathrm{~cm}$ long; spikes

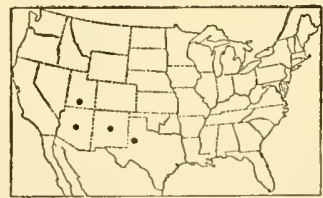

FIaURE 1102.-Distribution of Bouteloua eriopoda.

3 to 7,1 to $2 \mathrm{~cm}$ long, ascending or appressed; spikelets about 12 , purplish, 7 to $10 \mathrm{~mm}$ long; fertile lemma pubescent toward base, cleft more than half its length, with awns (5 $\mathrm{mm}$ long) winged toward base and no intermediate lobes; rudiment cleft to the base, the awns similar to those of the fertile lemma, about as long. 2 (B. trinii Griffiths; B. burkii Scribn.)-Mesas, ravines, and rocky hills, Texas to southwestern Utah and Arizona; California (Death Valley); northern Mexico (fig. 1104). Variable in length of the awns, the type of $B$. trifida being the longer-awned form. 


\section{CATHÉSTECUM Presl}

Spikes consisting of 3 spikelets, the upper or central perfect, the 2 lateral staminate or rudimentary, the spike falling entire; central spikelet with one perfect floret below and one or more reduced

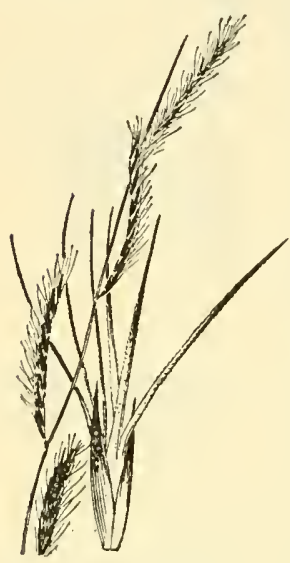

Figure 1103.-Bouteloua tri fida. Panicle, $\times 1$; spikelet, $\times 5$. (Amer. Gr. Nat. Herb. 669, Tex.) florets above; glumes unequal, the first a short, thin, nerveless scale in the central spikelet, narrow and acuminate in the lateral spikelets, the second about as long as the lemma, acuminate, all usually villous; lemma 3-nerved, the nerves extending into awns and the internerves into teeth; nerves of the palea extending into short awns; second and third floret with a fairly well developed lemma and palea, the fourth floret, if present, usually reduced. Low tufted or stoloniferous annuals or perennials, with short blades, and several to many short deciduous spikes approximate on a slender flexuous axis. Type species, Cathestecum prostratum Presl. Name from Greek kathestekos, set fast, stationary, the application not obvious.

1. Cathestecum eréctum Vasey and Hack. (Fig. 1105.) Perennial with wiry stolons having arched internodes and hairy nodes; culms slender, 10 to $30 \mathrm{~cm}$ tall; blades flat, about $1 \mathrm{~mm}$ wide, mostly basal; spikes 4 to 8 , ovoid, about $5 \mathrm{~mm}$ long; lateral spikelets about two-thirds as long as the central spikelet; lemmas of all spikelets similar, the sterile ones more deeply lobed; awns from about as long as the lobes to twice as long, hairy at base. 21 -Dry hills, western Texas, southern Arizona, and northern Mexico.

\section{MUNROA Torr.}

Spikelets in pairs or threes on a short rachis, the lower 1 or 2 larger, 3- or 4-flowered, the upper 2-or 3-flowered, the group (reduced spikes) enclosed in the broad sheaths of short leaves, usually about 3 in a fascicle, forming a cluster or head at the ends of the branches; rachilla disarticulating above the glumes and between the florets; glumes of the lower 1 or 2 spikelets equal, 1-nerved, narrow, acute, a little shorter than the lemmas, those of the upper spikelet unequal, the first much shorter or obsolete; lemmas 3-nerved, those of the lower

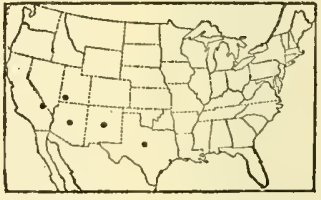

Figure 1104.-Distribution of Bouteloua trifida. spikelet coriaceous, acuminate, the points spreading, the midnerve extended into a mucro, those of the upper spikelet membranaceous; palea narrow, enclosing the oval, dorsally compressed caryopsis. Low spreading, much-branched annual, the short, flat, pungent leaves in fascicles. Type species, Munroa squarrosa. Named for William Munro.

1. Munroa squarrósa (Nutt.) Torr. False buffalo grass. (Fig. 1106.) Forming mats as much as $50 \mathrm{~cm}$ in diameter, the internodes of the prostrate culms scabrous, as much as $10 \mathrm{~cm}$ long, the fascicles 
at the nodes consisting of several short leafy branches, with 1 or 2 longer branches with slender internodes; blades stiff, mostly less than $3 \mathrm{~cm}$ long, 1 to $3 \mathrm{~mm}$ wide; fascicles of spikelets about $7 \mathrm{~mm}$ long; lemmas with a tuft of hairs on the margin about the middle. $\odot-$ Open ground, plains, and hills, at medium altitudes, common in old

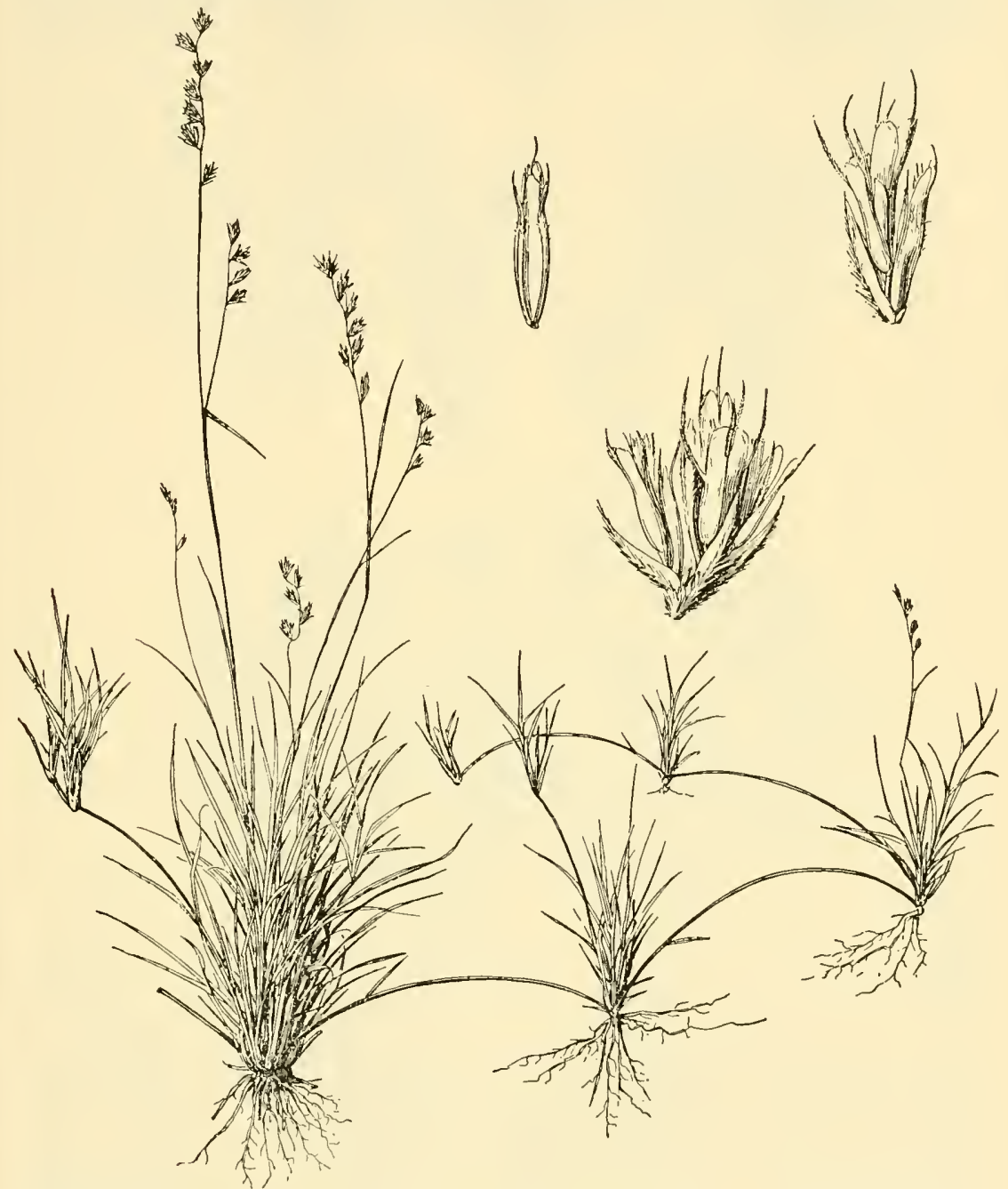

FIGURE 1105.-Cathestecum erectum. Plant, $\times 1 \frac{1}{2}$; group of spikelets, central spikelet, and fertile floret, $\times 5$. (Palmer 161, Mex.)

fields and recently disturbed soil, Alberta and North Dakota to Montana, south to Texas and Arizona (fig. 1107). Occasional plants are found with a white floccose covering, the remains of egg cases of a species of woolly aphid. The variety floccuosa Vasey was described from such a specimen. 


\section{BƯCHLOË Engelm.}

(Bulbilis Raf.)

Plants dioecious. Staminate spikelets 2-flowered, sessile and closely imbricate, in two rows on one side of a slender rachis, forming a short spike; glumes somewhat unequal, rather broad, 1-nerved, acutish; lemmas longer than the glumes, 3-nerved, rather obtuse,

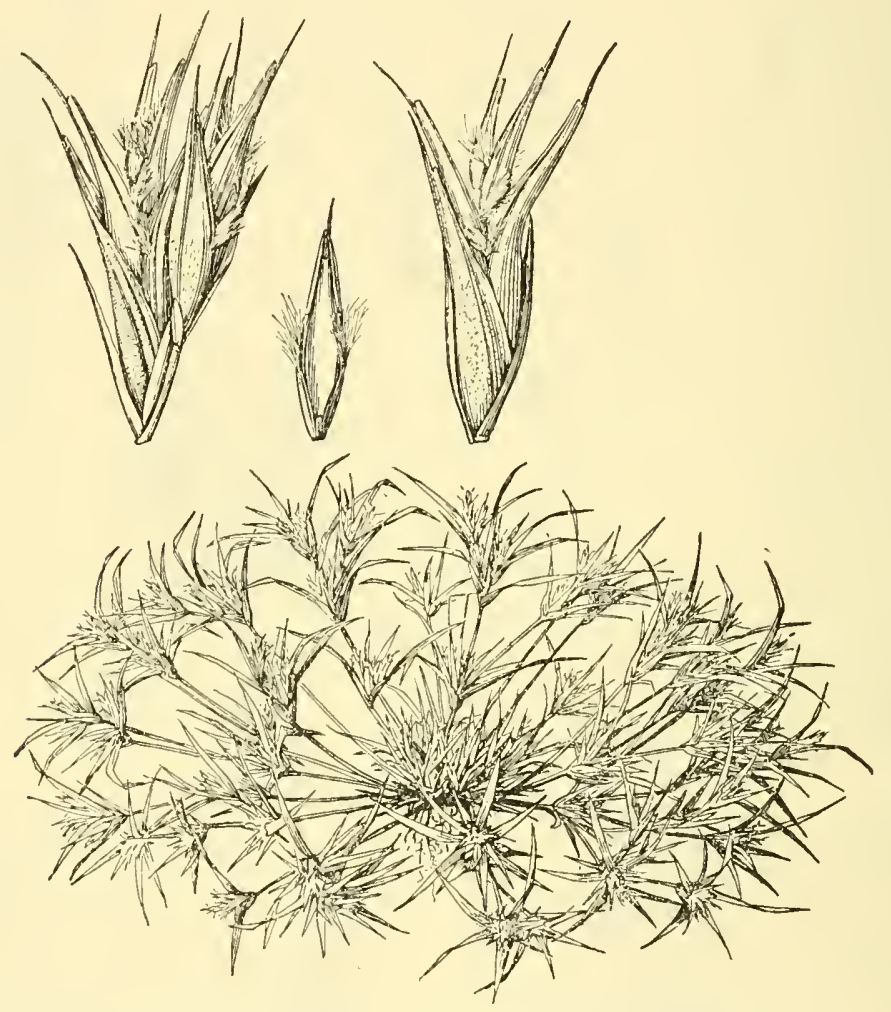

Figure 1106.-MUnroa squarrosa. Plant, $\times 1 / 2$; group of spikelets, spikelet, and floret, $\times 5$. (Zuck 43, Ariz.)

whitish; palea as long as its lemma. Pistillate spikelets mostly 4 or 5 in a short spike or head, this falling entire, usually 2 heads to the inflorescence, the common peduncle short and included in the somewhat inflated sheaths of the upper leaves, the thickened indurate rachis and broad outer (second) glumes forming a rigid white obliquely globular structure crowned by the green-toothed summits of the glumes; first glume (inside) narrow, thin, mucronate, well developed to obsolete in a single head; sccond glume firm, thick and rigid, rounded on the

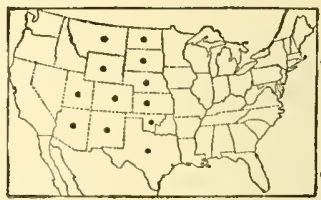

FIGURE 1107.-Distribution of Munroa squarrosa. back, obscurely nerved, expanded in the middle, with inflexed margins, enveloping the floret, abruptly contracted above, the summit with 3 green rigid acuminate lobes; lemma firm-membranaceous, 3 -nerved, dorsally compressed, broad below, narrowed into a 3-lobed 


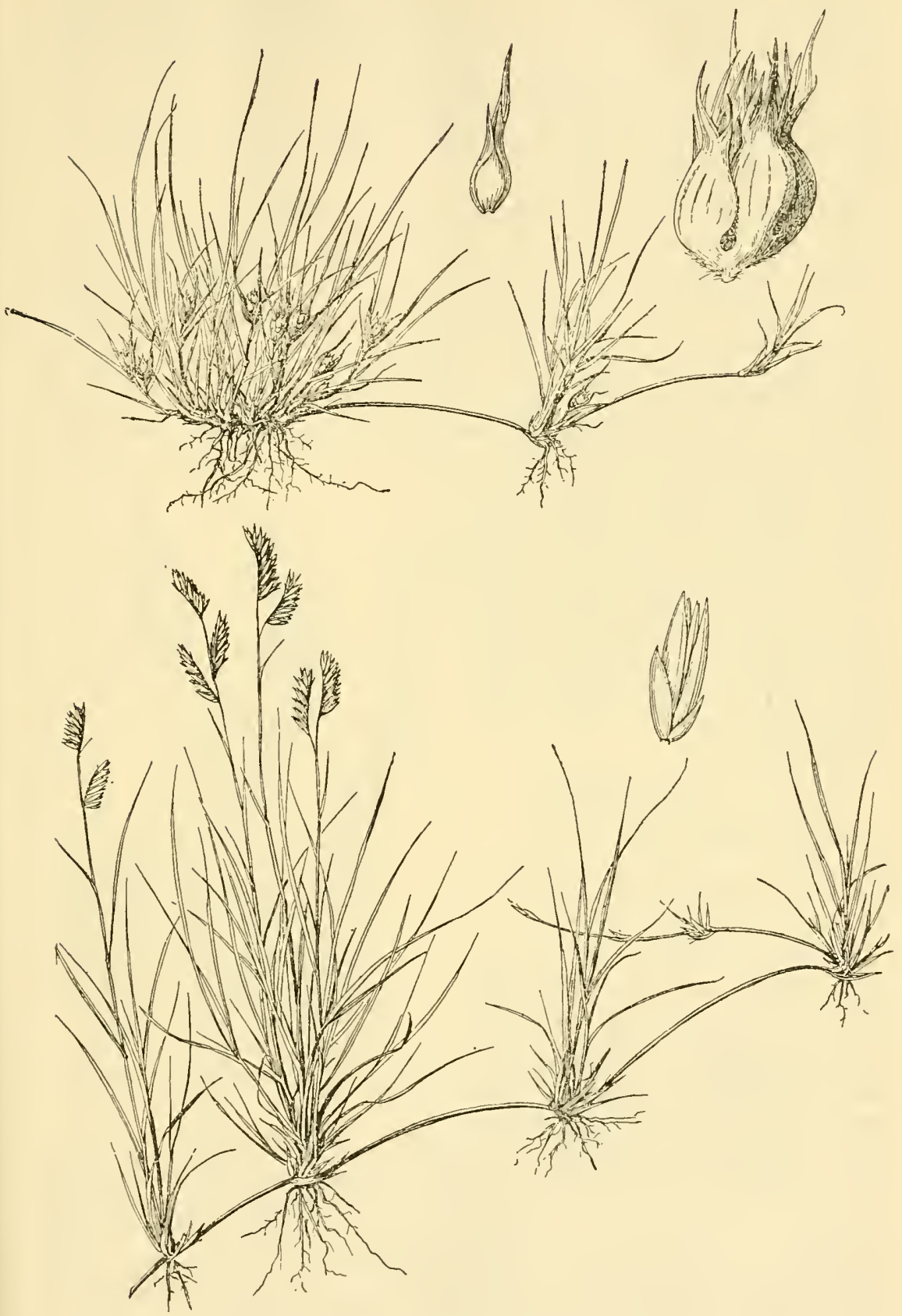

FIGUI:E 1108.-Buchloẽ dactyloides. Pistillate and staminate plants, $\times 1 / 2$; pistillate spike, and floret, $\times 5$; staminate spikelet, $\times 5$. (Ruth 156 , Tex.) 
green summit, the middle lobe much the larger; palea broad, obtuse, about as long as the body of the lemma, enveloping the caryopsis. A low stoloniferous perennial with short curly blades, the staminate flowers in 2 or 3 short spikes on slender. erect culms, the pistillate in sessile heads partly hidden among the leaves. Type species,

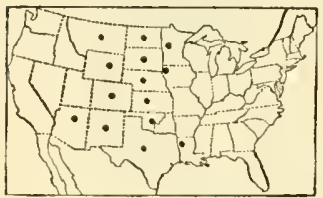

FIGURE 1109.-Distribution of Euchloè dactyloides. Buchlö dactyloides. Name contracted from Greek boubalos, buffalo, and chloë, grass, a Greek rendering of the common name, "buffalo grass."

1. Buchloë dactyloídes (Nutt.) Engelm. Buffalo grass. (Fig. 1108.) Gray-green, forming a dense sod, the curly blades forming a covering 5 to $10 \mathrm{~cm}$ thick; blades rather sparsely pilose, 1 to $2 \mathrm{~mm}$ wide; staminate culms slender, 5 to $20 \mathrm{~cm}$ tall, the spikes 5 to $15 \mathrm{~mm}$ long; pistillate lieads 3 to $4 \mathrm{~mm}$ thick. 21 -Dry plains, western Minnesota to central Montana, south to northwestern Iowa, Texas, western Louisiana, Arizona, and northern Mexico (fig. 1109). Buffalo grass forms, when unmixed with other species, a close soft grayish-green turf. It is dominant over large areas on the uplands of the Great Plains, colloquially known as the "shortgrass country", and is one of the most important grazing grasses of this region. The foliage cures on the ground and furnishes nutritious feed during the winter. The sod houses of the early settlers were made mostly from the sod of this grass.

\section{Tribe 8. PHALARIDEAE}

108. HIERÓCHLOË R. Br.

(Savastana Schrank; Torresia Ruiz and Pav.)

Spikelets with one terminal perfect floret and two staminate florets, disarticulating above the glumes, the staminate florets falling attached to the fertile one; glumes equal, 3 -nerved, broad, thin and papery, smooth, acute; stami-

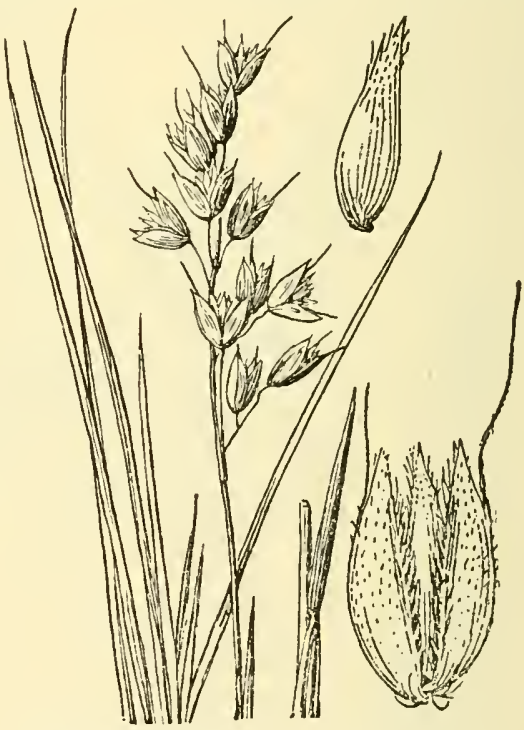

Figure 1110,-- Tierochloë alpina. Plant, $\times 1$; spikelet and floret, $\times 5$. (Fiitchcock 16058, N.. H.) nate lemmas about as long as the glumes, boat-shaped, hispidulous, hairy along the margin; fertile lemma somewhat indurate, about as long as the others, smooth or nearly so, awnless; palea 3-nerved, rounded on the back. Perennial, erect, slender, sweet-smelling grasses, with small panicles of broad, bronze-colored spikelets. 'Type species, Hierochloë antarctica (Labill.) R. Br. Name from Greek hieros, sacred, and chlö, grass, holy grass; H. odorata was used in parts of Europe for "strewing before the doors of churches on festival days." 
Flowering culms with short blades only (rarely to $10 \mathrm{~cm}$ long) with few to many long-leaved sterile shoots at base.

Staminate lemmas bearing exserted awns

1. H. ALPINA.

Staminate lemmas awnless or nearly so .............. 2. H. Odorata.

Flowering culms with blades 25 to $50 \mathrm{~cm}$ long . . . . 3.

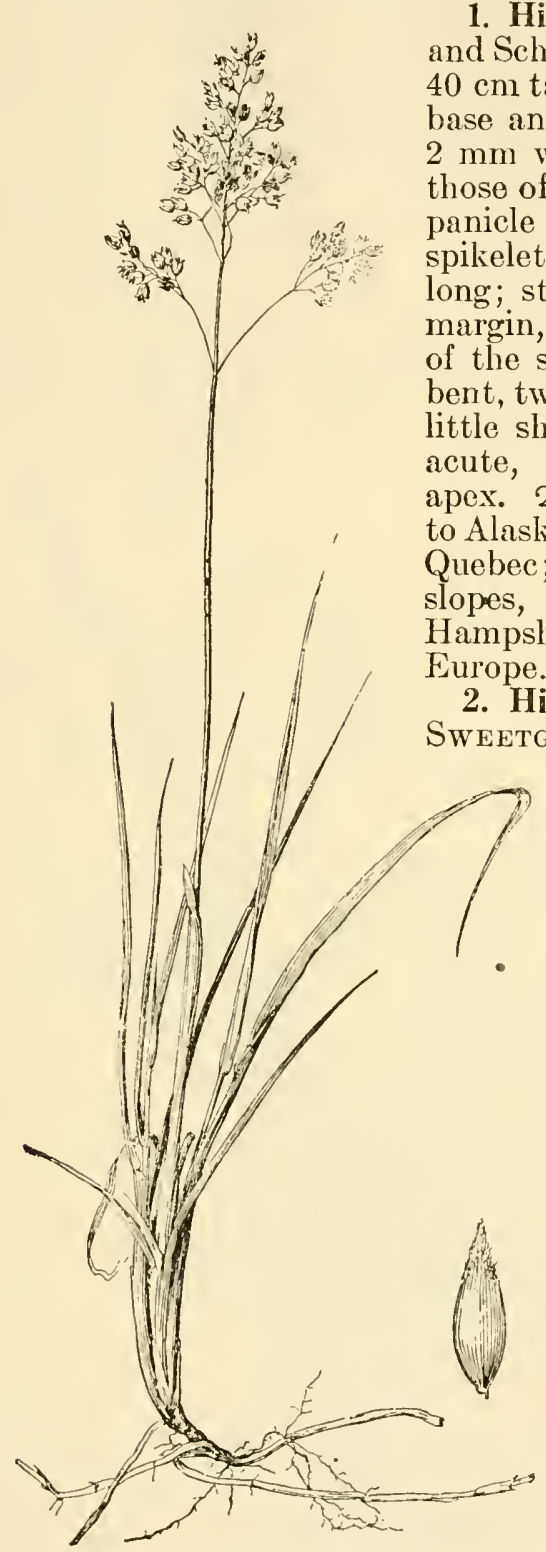

1. Hierochloë alpína (Swartz) Roem. and Schult. (Fig. 1110.) Culms 10 to $40 \mathrm{~cm}$ tall, tufted, with leafy shoots at base and short rhizomes; blades 1 to $2 \mathrm{~mm}$ wide, the basal ones elongate, those of the culm shorter and wider; panicle contracted, 3 to $4 \mathrm{~cm}$ long; spikelets short-pediceled, 6 to $8 \mathrm{~mm}$ long; staminate lemmas ciliate on the margin, awned below the tip, the awn of the second lemma 5 to $8 \mathrm{~mm}$ long, bent, twisted below, that of the first a little shorter, straight; fertile lemma acute, appressed-pubescent toward apex. 24 -Arctic regions, Greenland to Alaska, south to Newfoundland and Quebec; alpine meadows and rocky slopes, high mountains, Maine, New Hampshire, Vermont, and New York; Europe.

2. Hierochloë odoráta (L.) Beauv. Sweetgrass. (Fig. 1111.) Culms 30 to $60 \mathrm{~cm}$ tall, with few to several leafy shoots and slender, creeping rhizomes; blades 2 to $5 \mathrm{~mm}$ wide, sometimes wider, those of the sterile shoots elongate, those of the culm mostly less than $5 \mathrm{~cm}$ long, rarely to 10 cm long; panicle pyramidal, 4 to $12 \mathrm{~cm}$ long, from somewhat compact to loose with

Figure 1111.-Hierochloe odorata. Plant, $\times 1 / 2 ;$ spikelet, florets, and fertile floret, $\times 5$. (Shear 437 , Mont.)

slender drooping branches; spikelets mostly short-pediceled, $5 \mathrm{~mm}$ long; staminate lemmas awnless or nearly so, fertile lemma pubescent toward the apex. 24 -Meadows, bogs, and moist places, Labrador, 
to Alaska, south to New Jersey, Indiana, Iowa, Oregon, and in the mountains to New Mexico and Arizona (fig. 1112); Eurasia. The Indians use the grass, known as Seneca grass, to make fragrant baskets. Also called holy grass and vanilla grass. A tall form with culm blades 12 to $17 \mathrm{~cm}$ long, and a very loose

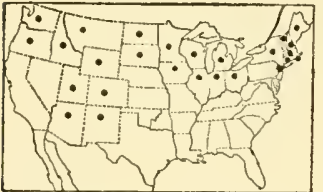

FIGURE 1112.-Distribution of IJierochloe odorata. lax panicle, found in Van Cortlandt Park, New York City, has been described as Hierochlö nashii Kaczmarek (Savastana nashii Bickn.).

3. Hierochloë occidentális Buckl. CaLlFornia SWEetgrass. (Fig.1113.) Culms 60 to $90 \mathrm{~cm}$ tall, with long leaves and creeping rhizomes; sheaths scabrous; blades flat, rather stiflly upright, 25 to $50 \mathrm{~cm}$ long, 8 to $15 \mathrm{~mm}$ wide, narrowed to the base, acuminate, scabrous beneath; panicle mostly open, 7 to $15 \mathrm{~cm}$ long, the subcapillary branches drooping, loosely flowered or the spikelets aggregate toward the ends, the lower branches 2.5 to $7 \mathrm{~cm}$ long; spikelets 4 to $5 \mathrm{~mm}$ long, the glumes with a pale shining margin; staminate lemmas awnless or nearly so; fertile lemma appressed-pubescent toward apex. 21 (H. macrophylla Thurb.) -Forests in the redwood belt, Oregon to Monterey, Calif., Bingen, Wash.

\section{AN'THOXÁNTHUM L. Vernalgrass}

Spikelets with 1 terminal perfect floret and 2 sterile lemmas, the rachilla disarticulating above the glumes, the sterile lemmas falling attached to the fertile floret; glumes unequal, acute or mucronate; sterile lemmas shorter than the glumes, empty, awned from the back; fertile lemma shorter than the sterile ones, awnless; palea 1-nerved, rounded on the back, enclosed in the lemma. Sweet-smelling annuals or perennials,

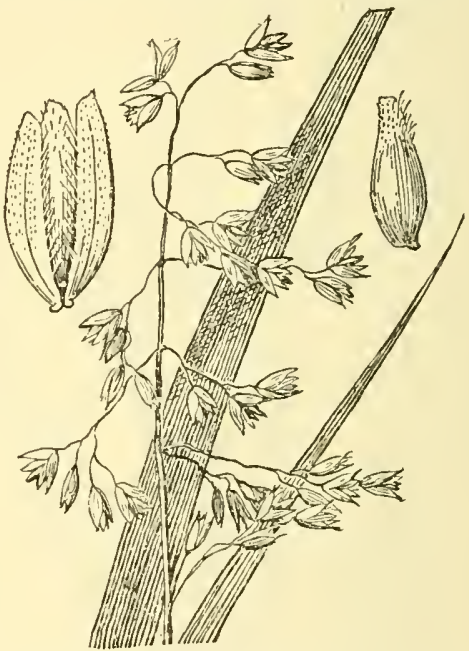

Figure 1113.-Hierochloē occidentalis. Plant, $\times 1$; spikelet and fertile floret, $\times 5$. (Bolander, Calif.) with flat blades and spikelike panicles. Types species, Anthoxanthum odoratum. Name from Greek anthos, flower, and xanthos, yellow, alluding to the yellow inflorescence.

Plants perennial

1. A. OdORATUM.

Plants annual

2. A. ARISTATUM.

1. Anthoxanthum odorátum L. Sweet vernalgrass. (Fig. 1114, A.) Culms tufted, erect, slender, 30 to $60 \mathrm{~cm}$ tall; blades 2 to $5 \mathrm{~mm}$ wide; panicle long-exserted, brownish yellow, acute, 2 to $6 \mathrm{~cm}$ long; spikelets 8 to $10 \mathrm{~mm}$ long; glumes scabrous, the first about half as long as the second; sterile lemmas subequal, appressed-pilose with golden hairs, the first short-awned below the apex, the second awned from near the base, the awn twisted below, geniculate, slightly 


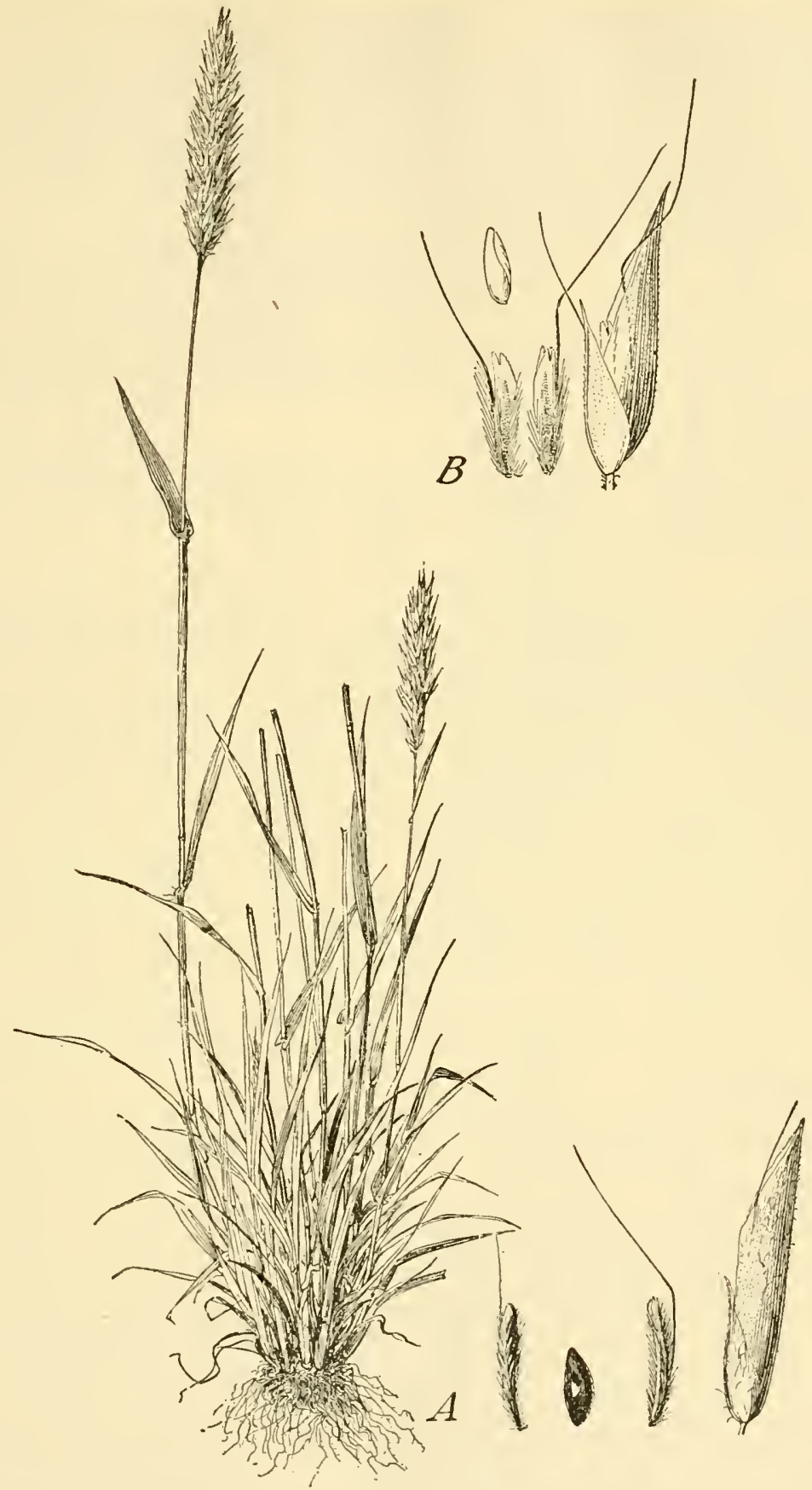

FIGURE 1114.-A, Anthoxanthum odoratum. Plant, $\times 1 / 2$; spikelet, sterile lemmas, and fertile floret, $\times 5$ (Biltmore Herb. 74 b., N.C.) B, A. aristatum. Spikelet, sterile florets, and fertile floret, $\times 5$. (White
$159 \mathrm{l}, \mathrm{N}$.Y.) 
exceeding the second glume; fertile lemma about $2 \mathrm{~mm}$ long, brown, smooth and shining. 24 - Meadows, pastures, and waste places, Greenland and Newfoundland to Louisiana and Michigan, and on the Pacific coast from British Columbia to northern

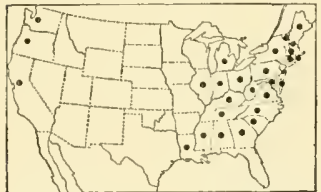

FIGURE 1115.-Distribution of Anthoxanthum odoratum.

little smaller. California (fig. 1115); introduced from Eurasia. Sometimes included in meadow mixtures to give fragrance to the hay but the grass has no forage value.

2. Anthoxanthum aristátum Boiss. (Fig. $1114, B$.) Differing from $A$. odoratum in being annual, the culms lower, often geniculate and buslyy branching; panicles looser; spikelets a -Waste places in several localities from Maine to Iowa, Florida, and Mississippi; Vancouver Island; Oregon (fig. 1116); introduced from Europe.

Anthoxanthum grícile Bivon. Tufted annual; culms $20 \mathrm{em}$ tall; blades pubescent; panicle silvery; spikelets about $12 \mathrm{~mm}$ long, conspicuously awned $\odot$-Oecasionally cultivated for dry bouquets. Italy.

\section{PHÁlaris L. Canary grass}

Spikelets laterally compressed, with 1 terminal perfect floret and 2 sterile lemmas below (obsolete in Phalaris paradoxa), the rachilla disarticulating above the glumes, the usually inconspicuous sterile lemmas falling closely appressed to the fertile floret; glumes equal, boat-shaped, often winged on the keel; sterile lemmas reduced to 2 small usually minute scales (rarely only 1); fertile lemma coriaceous, shorter than the glumes, enclosing the faintly 2nerved palea. Annuals or perennials, with numerous flat blades, and narrow or spikelike panicles. Type species, Phalaris canariensis. Phalaris, an old Greek name for a grass.

Spikelets in groups of 7, 1 fertile surrounded by 6 sterile, the group falling entire.

Spikelets all alike, not in groups falling entire.

Plants perennial.

Rhizomes wanting; panicle dense, ovate or oblong_-_- 8. P. CAIIFornica. Rhizomes present; paniele narrow, spreading during anthesis.

Plants annual.

Glumes broadly winged; panicle ovate or short-oblong.

Sterile lemma solitary; fertile lemma $3 \mathrm{~mm}$ long-

Sterile lemmas 2, fertile lemma 4 to $6 \mathrm{~mm}$ long.

Sterile lemmas $0.6 \mathrm{~mm}$ long or less_______._. 3. P. BRachystachys.

Sterile lemmas half as long as fertile_....... 2. P. Canariensis.

Glumes wingless or nearly so; panicles oblong or linear, dense.

Glumes wingless, acuminate; fertile lemma turgid, the acuminate apex smooth _.....

Glumes narrowly winged toward summit, acute or abruptly pointed; fertile lemma less turgid, villous to the acute apex.

Paniele tapering to each end, mostly 2 to $6 \mathrm{em}$ long (oecasionally longer). 5. P. CAROLINIANA. Paniele subcylindric, mostly 6 to $15 \mathrm{~cm}$ long (oeeasionally smaller).

6. P. ANGUSTA.

1. Phalaris paradóxa L. (Fig. 1117.) Annual, tufted, more or less spreading at base; culms 30 to $60 \mathrm{~cm}$ tall; panicle dense, oblong 
narrowed at base, 2 to $6 \mathrm{~cm}$ long, often enclosed at base in the uppermost enlarged sheath; spikelets finally falling from the axis in groups of 6 or 7 , those of the upper part of the panicle slender-pediceled, the central spikelet fertile, the subulate-acuminate glumes with a prominent tooth-like wing near the middle of the keel, the others sterile, with smaller pointed glumes with toothed-winged keels; fertile lemma $3 \mathrm{~mm}$ long, with only a few hairs toward the summit, the sterile lemmas obsolete; spikelets of lower part of panicle short-pediceled, the glumes of the outer four spikelets deformed, cuneate-clarate.

Occasional in grain fields and waste places, California; ballast, Philadelphia, New Orleans; introduced from Mediterranean region.

Phalaris paradoxa var. PRAEMórsa (Lam.) Coss. and Dur. Panicle mostly smaller, all the spikelets short-pediceled and with outer sterile spikelets having deformed clavate glumes, as in the lower part of panicle of the species; glumes of all spikelets subinduratc. $\odot$-Fields and waste places, Washington to California; ballast, Philadelphia; introduced from Mediterranean region.

\section{Phalaris canariénsis} L. Canary grass. (Fig. 1118.) Annual; culms erect, 30 to $60 \mathrm{~cm}$ tall; panicle ovate to oblongovate, dense, 1.5 to $4 \mathrm{~cm}$ long; spikelets broad, imbricate, pale with green

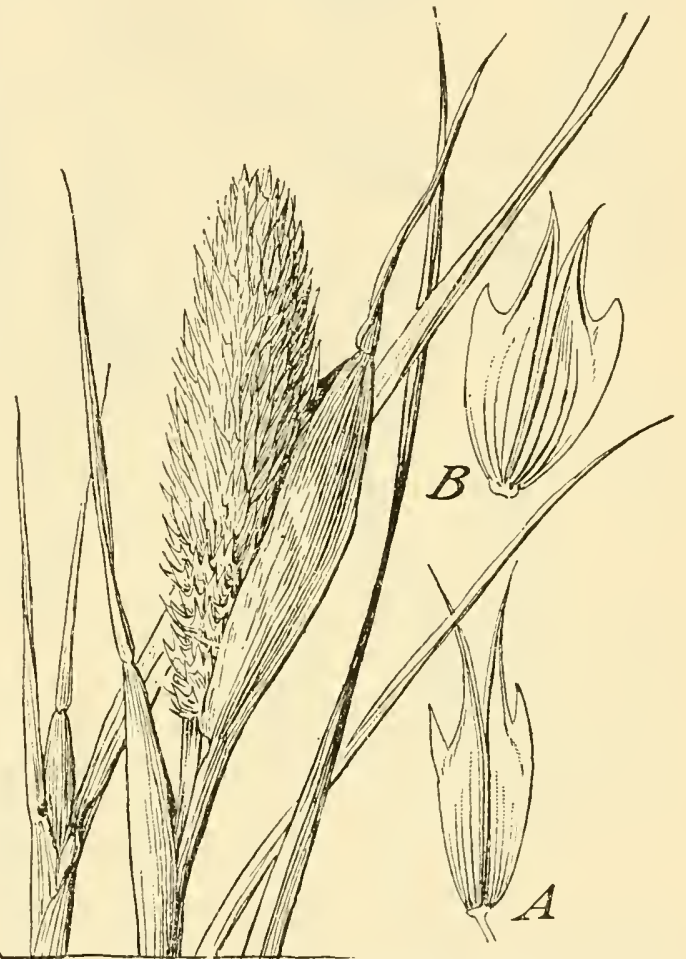

FIGURE 1117.- Phalaris paradoxa. Plant, $\times 1$; sterile $(A)$ and fertile $(B)$ spikelets, $\times 5$. (Heller 11391, Calif.)

stripes; glumes 7 to $8 \mathrm{~mm}$ long, abruptly pointed, the green keel with a prominent pale wing, broadened upward; fertile lemma 5 to $6 \mathrm{~mm}$ long, acute, densely appressed-pubescent; sterile lemmas at least half as long as fertile. $\odot$ - Waste places, infrequent, Nova Scotia to Alaska, south to Virginia, Kansas, Wyoming, and California, and occasionally southward (fig. 1119); introduced from the western Mediterranean region. This species furnishes the canary seed of commerce.

3. Phalaris brachýstachys Link. (Fig. 1120.) Differing from $P$. canariensis in having smaller spikelets, the glumes about $6 \mathrm{~mm}$ long, the fertile lemma 4 to $5 \mathrm{~mm}$ long, and especially in the short sterile lemmas not more than $0.6 \mathrm{~mm}$ long. $\odot$-Texas (Asherton); California (Butte County); Oregon (ballast, near Portland); introduced from the Mediterranean region. 
4. Phalaris minor Retz. (Fig. 1121.) Resembling P. canariensis; panicle ovate-oblong, 2 to $5 \mathrm{~cm}$ long; spikelets narrower, not so conspicuously striped; glumes 4 to $6 \mathrm{~mm}$ long, the wing of the keel narrower; fertile lemma lance-ovate, about $3 \mathrm{~mm}$ long, acute; sterile
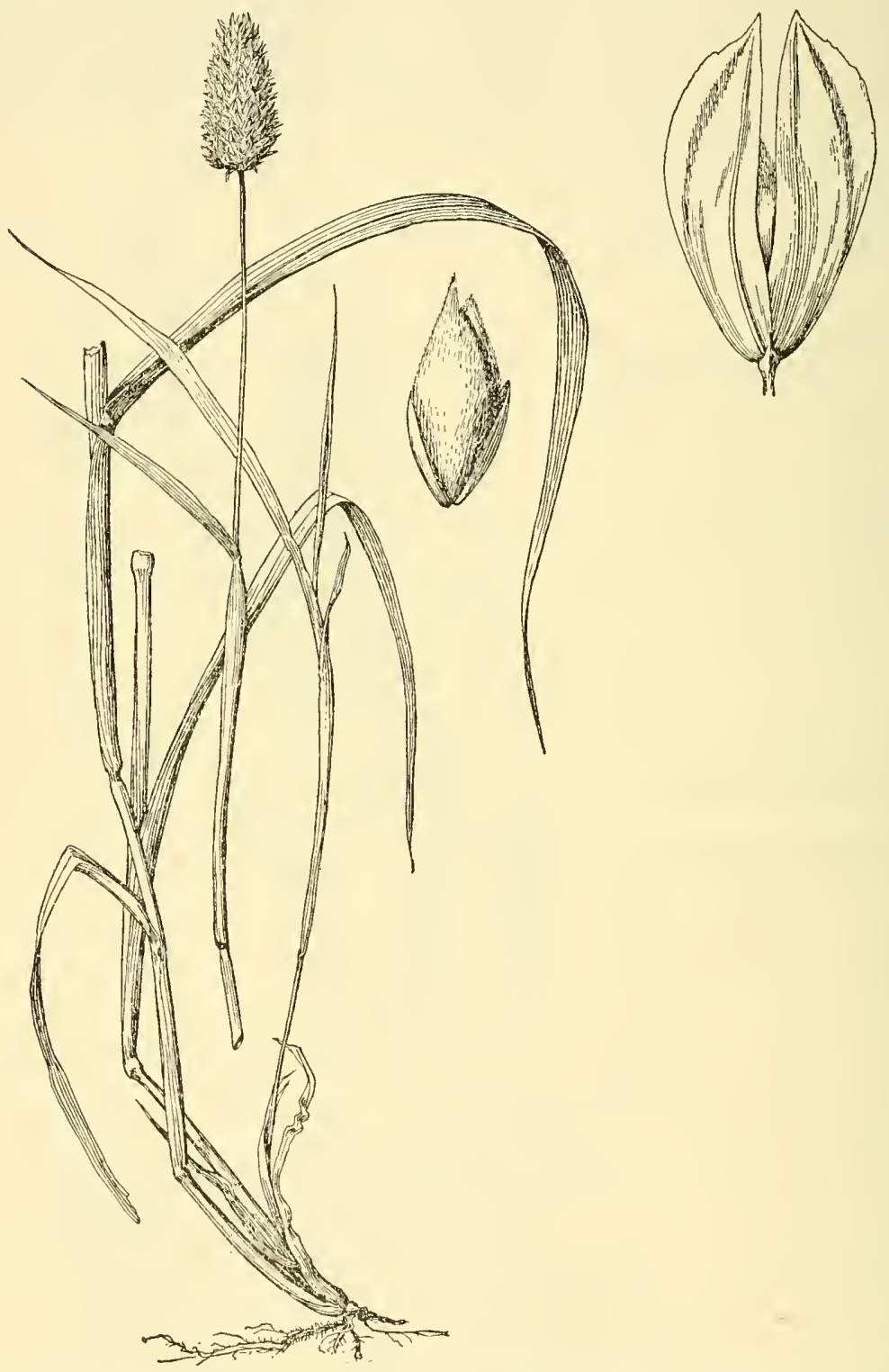

Figure 1118.-Phalaris canariensis. Plant, $\times 1 / 2$; spikelet and floret, $\times 5$. (Mearns 3376, Wyo.)

lemma solitary, about $1 \mathrm{~mm}$ long. $\odot$-Fields and waste places, New Brunswick to New Jersey, rare; Louisiana and Texas; Colorado; ballast, near Portland, Oreg.; frequent in California (fig. 1122); introduced from the Mediterranean region. 
5. Phalaris caroliniána Walt. (Fig. 1123.) Annual; culms erect, 30 to $60 \mathrm{~cm}$ tall or even more; panicle oblong, 2 to $6 \mathrm{~cm}$ long, occasionally longer, tapering to each end; glumes 5 to $6 \mathrm{~mm}$ long, oblong, rather abruptly narrowed to an acute apex, the keel scabrous and narrowly winged above from below the middle; fertile lemma lanceolate, acute, appressed-pubescent, about 3.5 to $4 \mathrm{~mm}$ long, the sterile lemmas one-third to half as long. $\odot$ - -Old fields, sandy soil, and moist places, Virginia to Colorado, south to Florida and Texas, west to Arizona, California, and Oregon (fig. 1124). A few specimens from

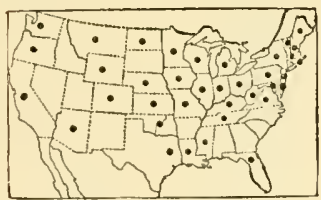

FlGURE 1119.-Distribution of Phalaris canariensis. the Pacific coast are relatively robust, up to $80 \mathrm{~cm}$ tall, and have panicles 3 to $8 \mathrm{~cm}$ long, some of them slightly lobed and not tapering to the base, the spikelets 6 to $6.5 \mathrm{~mm}$ long.

6. Phalaris angústa Nees. (Fig. 1125.) Annual; culms 1 to $1.5 \mathrm{~m}$ tall; panicle subcylindric, mostly 6 to $15 \mathrm{~cm}$ long, about $8 \mathrm{~mm}$ thick; glumes 3.5 to $4 \mathrm{~mm}$ long, narrow, abruptly pointed, the keel scabrous and narrowly winged toward the summit; fertile lemma ovatelanceolate, acute, appressed-pubescent, $3 \mathrm{~mm}$ long; sterile lemmas about one-third as long. $\odot$-Open

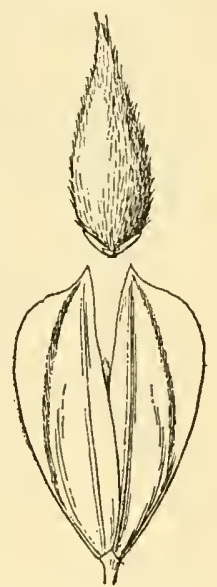

Figure 1120.-Pha. laris brachystachys. Spikelet and flodorf 1904, Oreg.) ground at low altitudes, Mississippi, Louisiana, and Texas; California; southern South America.

7. Phalaris lemmóni Vasey. (Fig. 1126.) Annual; culms 30 to

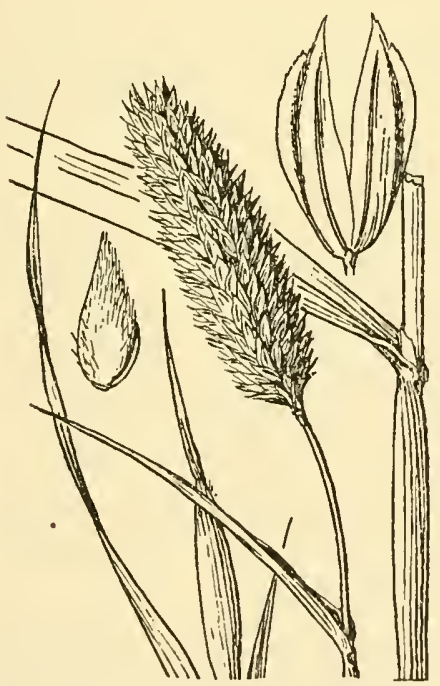

Figure 1121.-Phalaris minor. Plant, $\times$ 1; glumes and floret, $\times 5$. (Ball 1932 Calif.) $90 \mathrm{~cm}$ tall; panicle 5 to $15 \mathrm{~cm}$ long, subcylindric or lobed toward base, often purplish; glumes about $5 \mathrm{~mm}$ long, narrow, acuminate, scabrous, not winged on the keel; fertile lemma ovate-lanceolate, acuminate, 3.5 to $4 \mathrm{~mm}$ long, brown at maturity, appressed-pubescent, except the acuminate tip, st e r i 1 e lenmas ( 1 or 2 ) less than onethird as long. $\odot-\mathrm{M}$ o is t places, at low altitudes, in the coastal valleys,

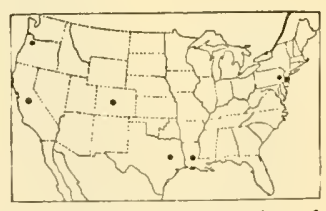

Figure 1122-Distribution of Phalaris minor. central and southern California.

8. Phalaris califórnica Hook. and Arn. (Fig. 1127.) Perennial, often in dense tussocks; culms erect, 75 to 150 $\mathrm{cm}$ tall; blades rather lax, 8 to $15 \mathrm{~mm}$ wide; panicle ovoid or oblong, 2 to $5 \mathrm{~cm}$ long, 2 to $2.5 \mathrm{~cm}$ thick, often purplish tinged; glumes 6 to $8 \mathrm{~mm}$ long, narrow, tapering from below the middle to an acute apex, the keel smooth or nearly so, sharp but not winged; fertile lemma ovate-lanceolate, about $4 \mathrm{~mm}$ long, rather sparsely appressed-pubescent, the palea 
often exposed, the sterile lemmas about half as long. $\quad 2 \quad$-Ravines and open moist ground in the Coast Range, southwestern Oregon to

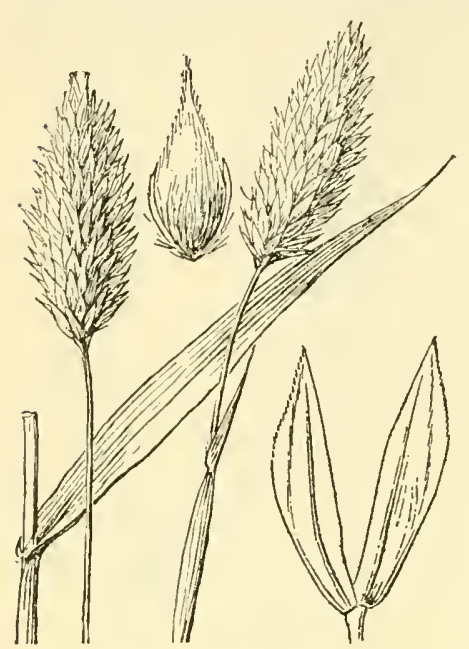

FIGURE 1123.-Phalaris carolniana. Plant, $\times 1$; glumes and floret, $\times 5$. (Hitehcock 1074, Miss.)

San Luis Obispo County, Calif.

9. Phalaris arundinâcea $L$. $R \mathrm{EED}$ CANARY GRASS. (Fig. 1128.) Perennial, with creeping rhizomes, glaucous; culms erect, 60 to $150 \mathrm{~cm}$ tall; panicle 7 to $16 \mathrm{~cm}$ long, narrow, the branches spreading during anthesis, the lower as much as 5 cm long; glumes about $5 \mathrm{~mm}$ long, narrow, acute, the keel scabrous, very narrowly winged; fertile

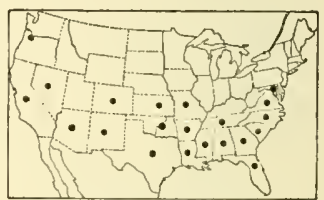

Figure 1124.-Distribution of Phalaris caroliniana.

lemma lanceolate, $4 \mathrm{~mm}$ long, with a few appressed hairs; sterile lemmas villous, $1 \mathrm{~mm}$ long. 2 -Marshes, river banks, and moist places, New Brunswick to southeastern Alaska (also at Tanana Hot Springs, Alaska), south to North Carolina, Kentucky, Oklahoma, New Mexico, Arizona, and northeastern California (fig. 1129); Eurasia. An important constituent of lowland hay from Montana

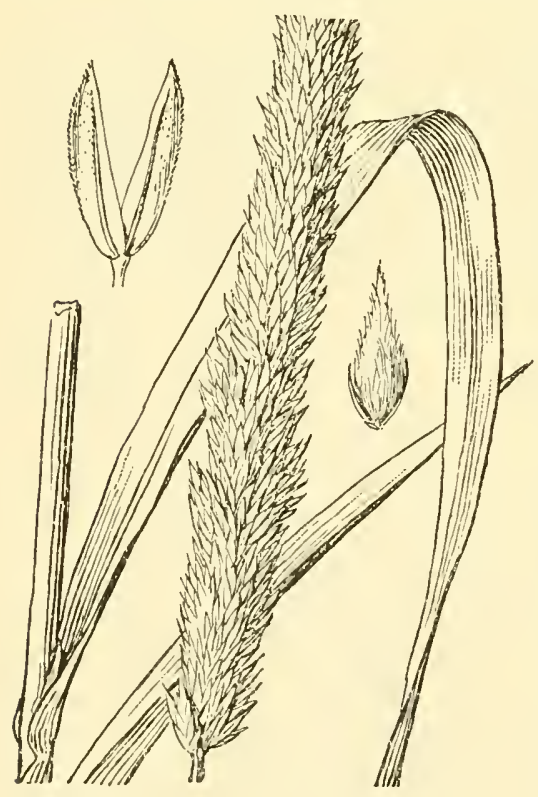

Figure 1125.-Phalaris angusta. Plant, $\times 1$; glumes and floret, $X 5$. (Suksdorf 32 , Calif.) to Wisconsin. Phalaris arUndiNACEA var. PICTA L. RiBBON GRASS. Blades striped with white. $\odot-$ Grown for ornament in gardens; also called gardener's garters.

Phalaris tuberosa var. stenóptera (Hack.) Hitchc. (Fig. 1130.) Perennial, with a loose branching, rhizomatous base; culms stout, as much as $1.5 \mathrm{~m}$ tall; panicle 5 to $15 \mathrm{~cm}$ long, 1.5 $\mathrm{cm}$ wide, slightly lobed; glumes 5 to 6 $\mathrm{mm}$ long, the keel scabrous, rather narrowly winged on the upper two-thirds; fertile lemma $4 \mathrm{~mm}$ long, ovate-lanceo-

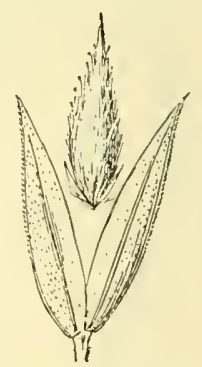

FIgure 1126:- Pha. laris lemmoni, $\times 5$. (Type.) late, acute, appressed-pubescent; sterile lemma usually solitary, about one-third as long as fertile lemma. 24 -About 1902 there appeared in Queensland, Australia, the source unknown, a species of Phalaris which gave promise of being a valualeb forage 
grass. About 1907 it was distributed from the Toowoomba Botanic Gardens, Queensland. Stapf, of Kew Gardens, identified this grass as $P$. bulbosa L. Hackel described it as a distinct species, $P$. stenoptera. It has been grown at the California Experiment Station, and

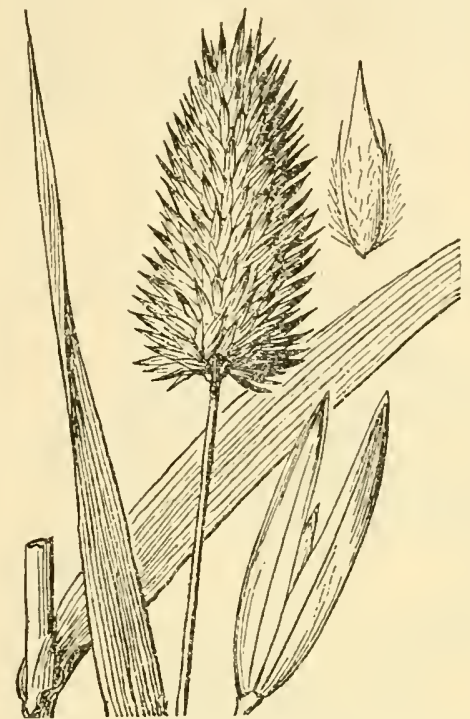

Figure 1127-Phalaris californica. Plant. $\times 1$; spikelet and floret, $\times 5$. (Heller 667\%, Calif.)

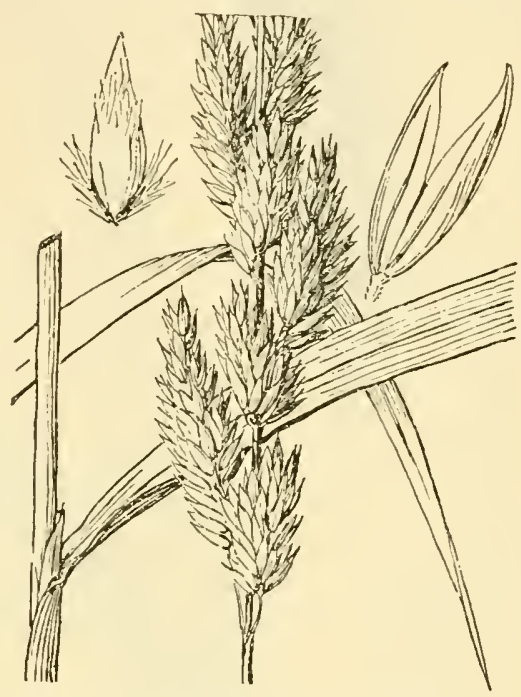

Figure 1128.-Phalaris arundinacea. Plant, $\times 1$; glumes and floret, $\times 5$. (Chase 7583, Mid.)

the above description was drawn from a plant supplied by Professor Kennedy from the University Farm at Davis, the seed being from South Africa. This differs from the typical P. tuberosa of the Mediterranean region in having short vertical or ascending, sometimes branching rhizomes, the base of the culms little or not at all swollen. It has been called Harding grass. Burbank has distributed it as $P$. stenophylla (error for stenoptera), calling it Peruvian winter grass. This species has been called $P$. bulbosa, but the true $P$.

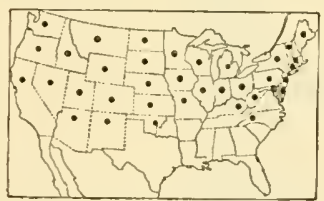

FIGURE 1129.-Distribution of Phalaris arundinacea. compressed, disarticulating below $(P$. tenue Schrad.; $P$. bulbosum (L.) Richt.).

\section{TRIBE 9. ORYZEAE}

\section{ORÝZA L. RICE}

Spikelets 1-flowered, laterally the glumes; glumes 2 , much shorter than the lemma,
narrow; lemma rigid, keeled, 5-nerved, the outer nerves near the margin, the apex sometimes awned; palea similar to the lemma, narrower, keeled, with a median bundle

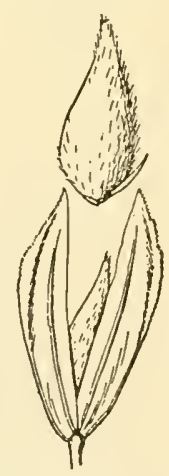

FIGURE 1130 Phalaris tuberosa var, stenoptera, $\times 5$ (M c Crary, N. C.) but with no strong midnerve on the back, 2-nerved close to the margins. Annual or sometimes perennial swamp grasses, of ten tall, with flat blades and spikelets in open panicles. Type species, Oryza sativa. Name from oruza, old Greek name for rice. 


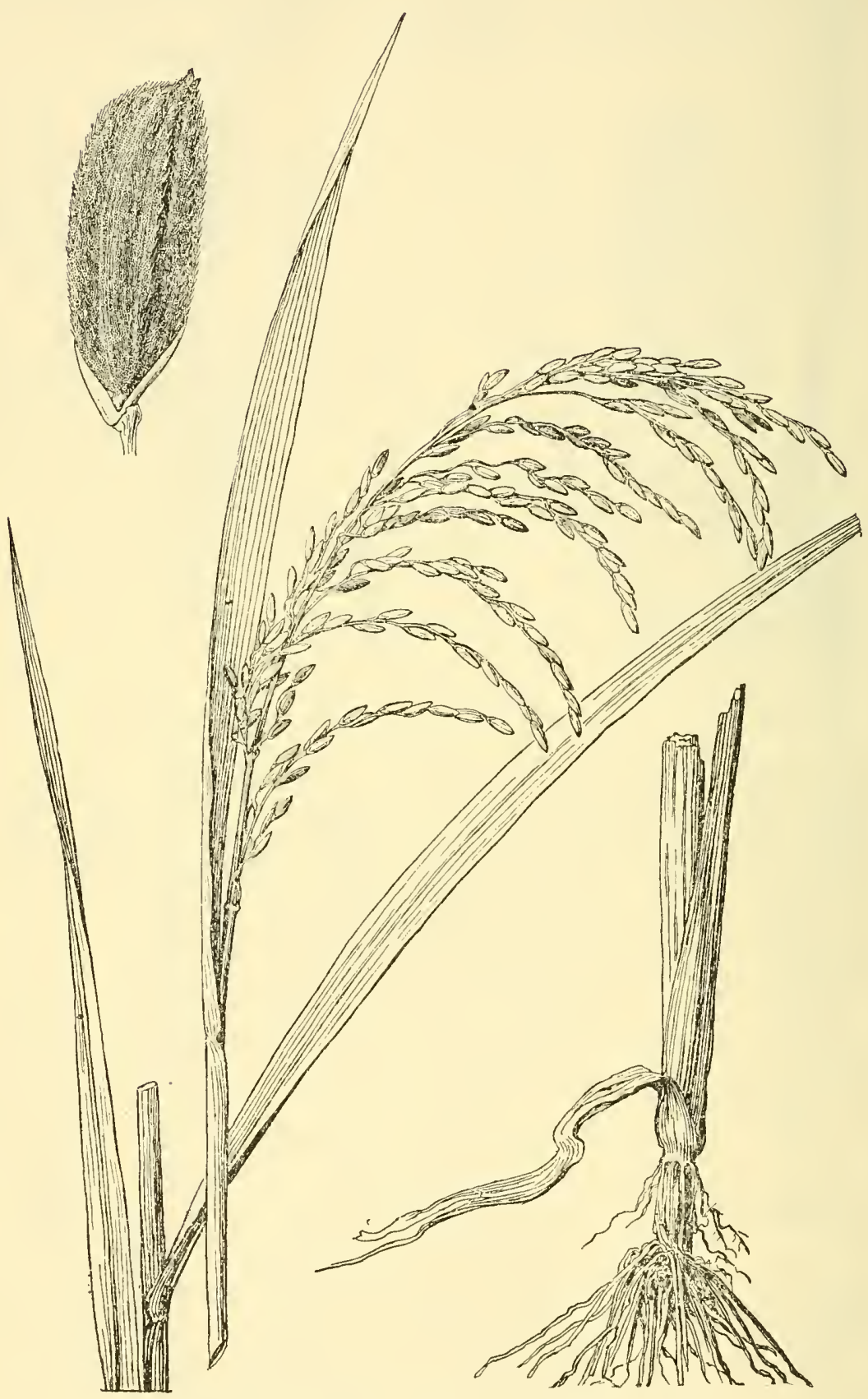

FIGURe 1131.-Oryza sativa. Plant, $\times 1 / 2$; spikelet, $\times 5$. (Cult.) 
1. Oryza satíva L. Rrce. (Fig. 1131.) Annual, or in tropical regions sometimes perennial; culms erect, 1 to $2 \mathrm{~m}$ tall; blades elongate; panicle rather dense, drooping, 15 to $40 \mathrm{~cm}$ long; spikelets 7 to $10 \mathrm{~mm}$ long, 3 to $4 \mathrm{~mm}$ wide; lemma and palea papillose-roughened and with scattered appressed hairs, the lemma from mucronate to long-awned. $\odot$-Cultivated in all warm countries at low altitudes where there is sufficient moisture; one of the world's most important food plants; sometimes adventive near the coast from Virginia to Florida and Texas.

\section{LEERSIA Swartz}

\section{(Homalocenchrus Mieg.)}

Spikelets 1-flowered, strongly compressed laterally, disarticulating from the pedicel; glumes wanting; lemma chartaceous, broad, oblong

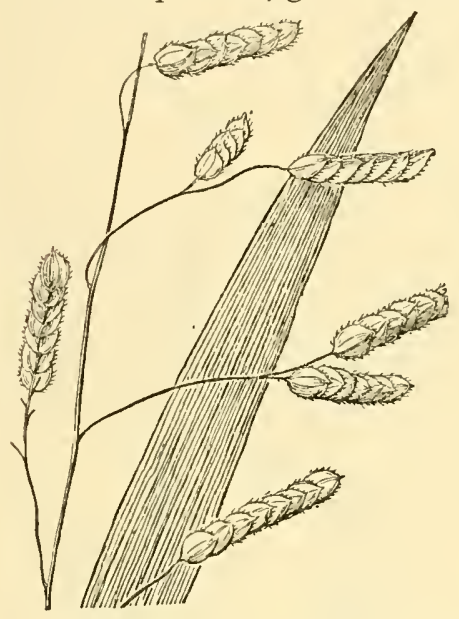

FIGURE 1132,-Leersia lenticularis, $\times 1$. (McDonald 68, Ill.) to oval, boat-shaped, usually 5-nerved, the lateral pair of nerves close to the margins, these and the keel often hispid-ciliate, the intermediate nerves sometimes faint; palea as long as the lemma, much narrower, usually 3nerved, the keel usually hispidciliate, the lateral nerves close to the margins, the margins firmly held by the margins of the

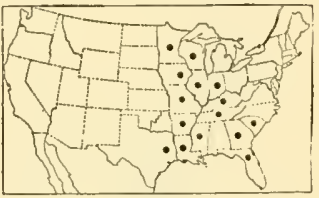

FIGURE 1133.-Distribution of Leersia lenticularis.

lemma; stamens 6 or fewer. Perennials, usually with creeping rhizomes, flat, scabrous blades, and mostly open panicles. Type species, Leersia oryzoides. Named for J. D. Leers.

Spikelcts broadly oval, 3 to $4 \mathrm{~mm}$ wide............... 1. L. LeNTICULARIS. Spikelets elliptic, not more than $2 \mathrm{~mm}$ wide.

Panicle narrow, the branches ascending or appressed....- 4. L. HExandra.

Panicle open, the capillary branches finally spreading.

Spikelets glabrous, about $2 \mathrm{~mm}$ long; culms tufted, erect; rhizomes wanting.

5. L. MONANDRA.

Spikelets hispidulous; culms decumbent at base; rhizomes present.

Lower panicle branches solitary; spikelets $3 \mathrm{~mm}$ long, $1 \mathrm{~mm}$ wide.

3. L. VIRGINICA.

Lower panicle branches fascicled; spikelets $5 \mathrm{~mm}$ long, 1.5 to $2 \mathrm{~mm}$ wide.

2. L. ORYZOIDES.

1. Leersia lenticuláris Michx. CAtchfly grass. (Fig. 1132.) Culms straggling, 1 to $1.5 \mathrm{~m}$ tall, with creeping scaly rhizomes; sheaths scabrous at least toward the summit; blades lax, 1 to $2 \mathrm{~cm}$ wide; panicle open, drooping, 10 to $20 \mathrm{~cm}$ long, the branches ascending or spreading, naked below, branched above, branchlets bearing closely imbricate spikelets along one side; spikelets pale, broadly oval, very flat, 4 to $5 \mathrm{~mm}$ long, sparsely hispidulous, the kecls bristly ciliate. $21-D i t c h e s$ and swamps, Indiana to Minnesota, south to South Carolina, Florida, and Texas (fig. 1133). 
538 MISC. PUBLICATION 200, U. S. DEPT. OF AGRICULTURE

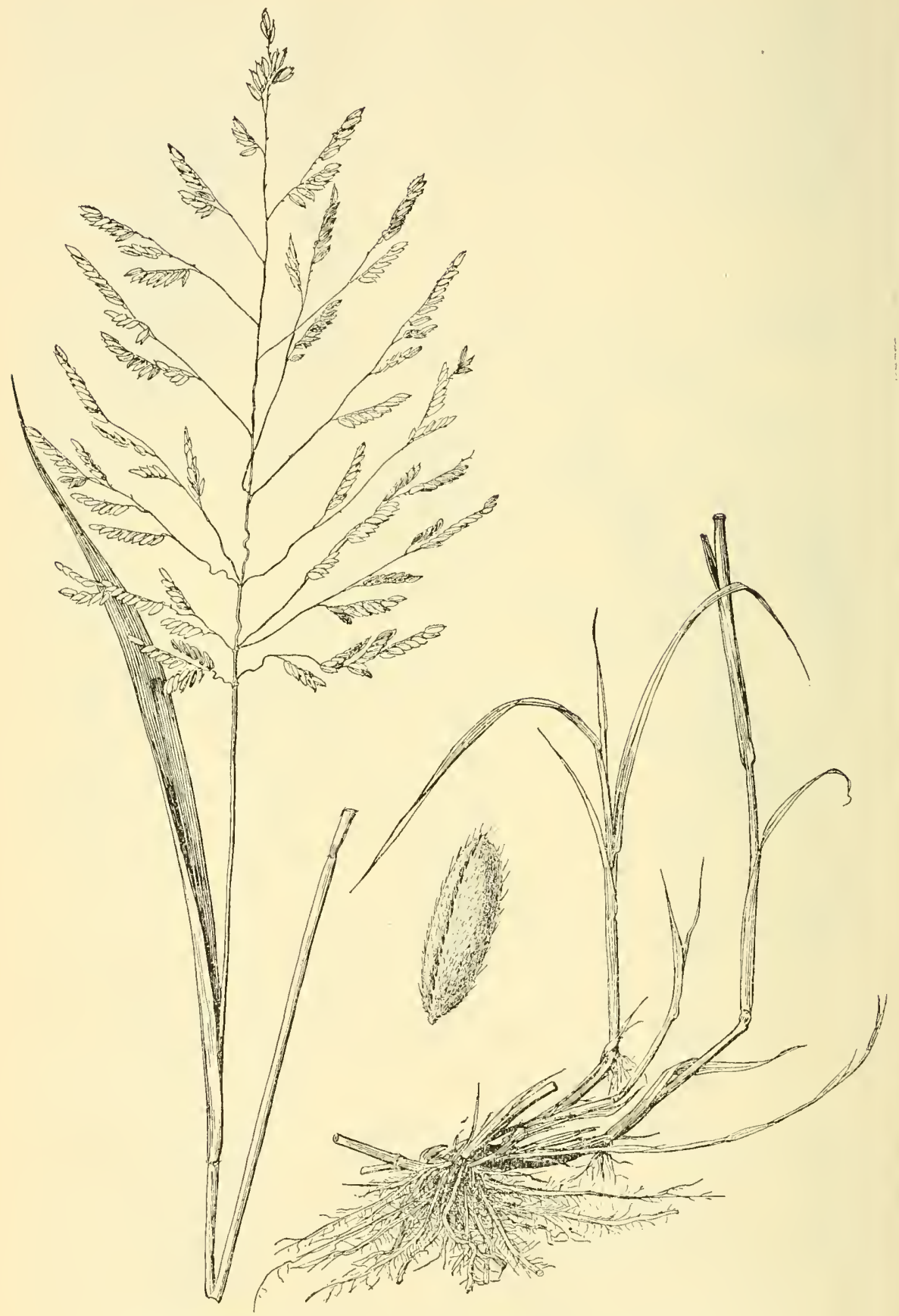

Figure 1134.-Leersia oryzoides. Plant, $\times 1 / 2$; spikelet, $\times 5$. (Hitchcock 5317, Tex.) 
2. Leersia oryzoídes (L.) Swartz. Rice cutgrass. (Fig. 1134.) Culms slender, weak, often decumbent at base, 1 to $1.5 \mathrm{~m}$ tall, with slender creeping rhizomes; sheaths and blades strongly retrorsely scabrous, the blades mostly 8 to 10 $\mathrm{mm}$ wide; panicles terminal and axillary, 10 to $20 \mathrm{~cm}$ long, the flexuous branches finally spreading, the spikelets more loosely imbricate than in L. lenticularis; spikelets elliptic, $5 \mathrm{~mm}$ long, 1.5 to $2 \mathrm{~mm}$ wide, sparsely hispidulous, the keels bristly ciliate;

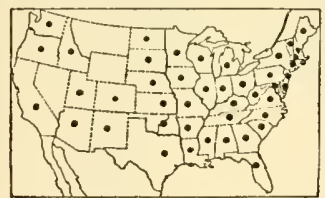

FIGURE 1135.-Distribution of Leersia oryzoides.

axillary panicles reduced, partly included in the sheaths, the spikelets cleistogamous. 2 -Marshes, river banks, and wet places, often forming a zone around ponds and lakes, Quebec and Maine to eastern Washington south to northern Florida, Texas, Colorado, Arizona, and southeastern California (fig. 1135); Europe.

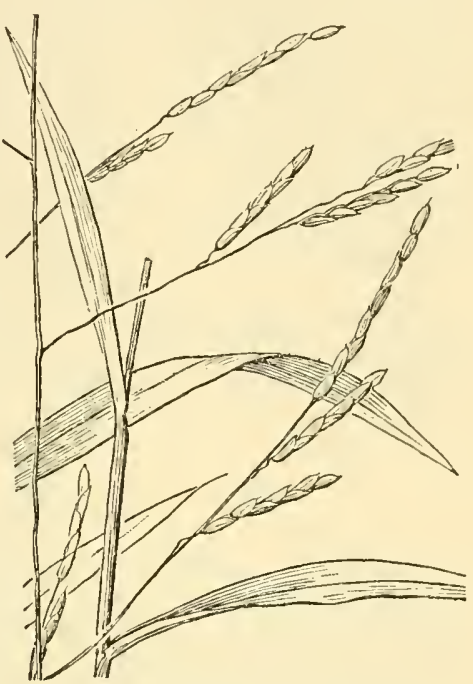

FIgure 1136.-Leersia virginica, $\times 1$,

(French, Iowa.)

The late cleistogamous phase has been described as L. oryzoides forma inclusa (Wiesb.) Dörfl.

3. Leersia virgínica Willd. Whitegrass. (Fig. 1136.) Culms

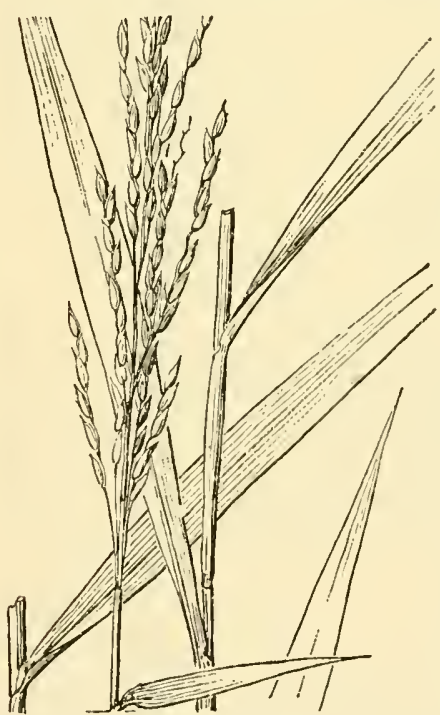

FIGURE 1138.-Leersia hexandra, $\times 1$. (Wurzlow, La.) slender, weak, branching, 50 to $120 \mathrm{~cm}$ tall, with clusters of very scaly rhizomes much stouter than the culm base; blades relatively short, 6 to $12 \mathrm{~mm}$ wide; panicle open, 10 to $20 \mathrm{~cm}$ long, the capillary branches rather distant, stiffly spreading, naked below, those of the branchessmaller, sometimes included in the sheath; spikelets oblong, closely appressed to the branchlets,about $3 \mathrm{~mm}$ long and $1 \mathrm{~mm}$ wid e,

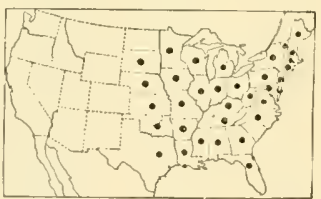

Figure 1137.-Distribution of Leersia virginica. sparsely hispidulous, the keels shorthispid. 24-Low woods and moist places, Quebec to South Dakota, south to Florida and Texas (fig. 1137).

4. Leersia hexándra Swartz. (Fig̣. 1138.) Culms slender, weak, usually long-decumbent from a creeping and rooting base, with slender rhizomes and extensively creeping leafy stolons; the flowering culms upright; blades rather stiff, 2 to $5 \mathrm{~mm}$ wide; panicle narrow, 5 to $10 \mathrm{~cm}$ long, the branches aseending or 
appressed, floriferous nearly to the base; spikelets oblong, about 4 to $5 \mathrm{~mm}$ long, a little more than $1 \mathrm{~mm}$ wide, often purplish, sparsely hispidulous, the keels bristly ciliate. 24 -Shallow water, ditches,

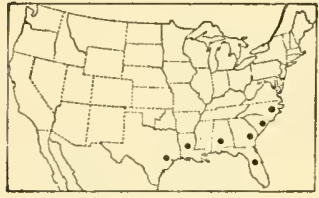

Figure 1139.-Distribution of Leersia hexandra. and wet places near the coast, North Carolina to Florida and Texas (fig. 1139); widely distributed in the tropics of both hemispheres.

5. Leersia monándra Swartz. (Fig. 1140.) Culms tufted, erect, wiry, 50 to $100 \mathrm{~cm}$ tall, without rhizomes; sheaths smooth or nearly so; blades elongate, 1 to $5 \mathrm{~mm}$ wide; panicle open, the capillary solitary branches spreading, naked below, the small spilielets near the ends; spikclets pale, broadly orate, glabrous, about $2 \mathrm{~mm}$ long. 24 -Rocky woods and prairies, Florida Keys, southern Florida, and southern Texas; West Indies.

\section{TRIBE 10. ZIZANIEAE}

\section{ZIZÁNIA L. Wildrice}

Spikelets unisexual, 1-flowered, disarticulating from the pedicel; glumes obsolete, represented by a small collarlike ridge; pistillate spikelet terete, angled at maturity; lemma chartaceous, 3-nerved, tapering into a long slender awn; palea 2-nerved, closely clasped by the lemma; grain cylindric, 1 to $2 \mathrm{~cm}$ long; staminate spikelet soft; lemma 5-nerved, membranaceous, linear, acuminate or awn-pointed; palea about as long as the glume, 3 -nerved; stamens 6 . Tall aquatic annuals or perennials, with flat blades and large terminal panicles, the lower branches ascending or spreading, bearing the pendulous staminate spikelets, the upper branches ascending, at maturity erect, bearing appressed pistillate spikelets, the staminate spiliclets early deciduous, the pistillate spikelets tardily deciduous. Type species, Zizania aquatica. Name from Zizanion, an old Greek name for a weed growing in grain, the tares of the Scripture parable.

The seeds of wild rice were used by the aborigines for food and are still used to some extent by some of the northern tribes of Indians. Wildrice is important as a food and shelter for water fowl and is sometimes planted for this purpose in marshes on game

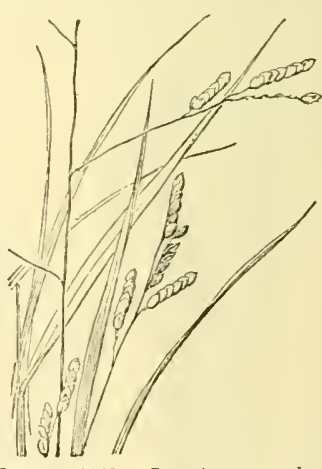

Figure 1140.-Leersia monandra, $\times 1$. (Nealley, Tex.) preserves. The thickened bases of the culms of the Asiatic Z. latifolia (Griseb.) Turcz. are used as a vegetable called Kau sun.

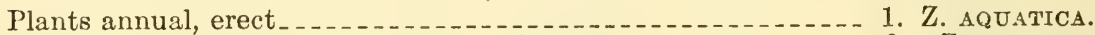
Plants perennial, long-decumbent at base_....... Z. TExANA.

1. Zizania aquática L. Annual wildrice. (Fig. 1141.) Annual; culms robust, usually 2 to $3 \mathrm{~m}$ tall; blades elongate, 1 to $4 \mathrm{~cm}$ wide, scaberulous; panicles mostly 30 to $50 \mathrm{~cm}$ long, the branches mostly 15 to $20 \mathrm{~cm}$ long. $\odot$ - Marshes and borders of streams and ponds, usually in shallow water, Quebec to North Dakota, south to Florida and Louisiana; Idaho (fig. 1142). 


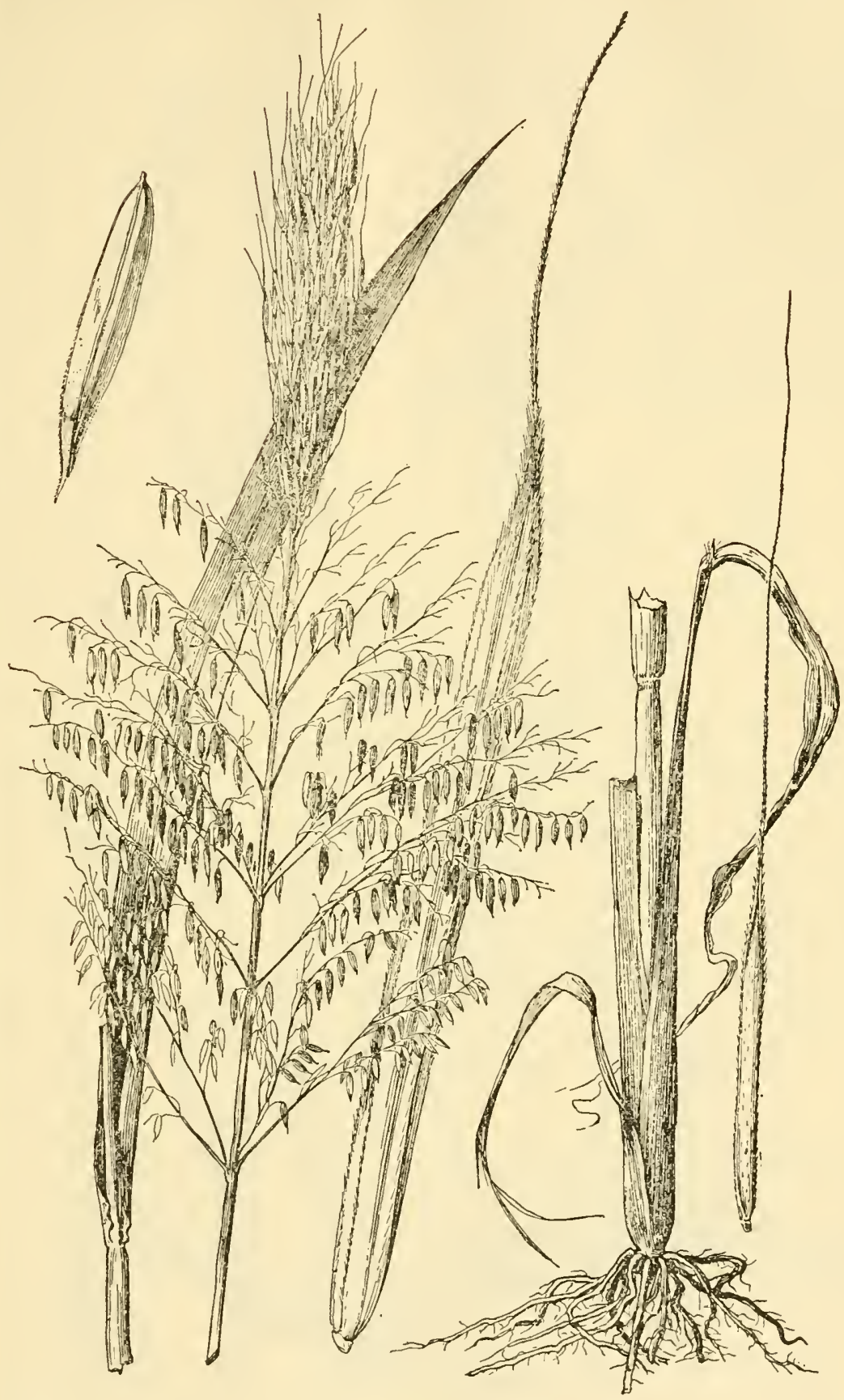

FIgURE 1141. - Zizania aquatica. Plant, $\times 1 / 2$; pistillate spikelet, $\times 2$; second view, $\times 5$; staminate spike. let, $\times 5$. (Fink, Iowa.) 
Zizania aquatica var. angustifólia Hitchc. Northern wildRICE. Culms usually not more than $1.5 \mathrm{~m}$ tall; blades usually not more than $1 \mathrm{~cm}$ wide. $\odot-$ Shallow water, Quebec and New Brunswick to North Dakota, south to New York and Nebraska.

2. Zizania texána Hitchc. Texas wildrice. (Fig. 1143.) Perennial; culms long-decumbent and rooting at base, 1 to $3 \mathrm{~m}$ long; blades elongate, 3 to 15 or even $20 \mathrm{~mm}$ wide; panicle 20 to $30 \mathrm{~cm}$ long, narrow, the lower (staminate) branches ascending, 5 to $10 \mathrm{~cm}$ long; staminate spikelets 7 to $8 \mathrm{~mm}$ long, 1.5

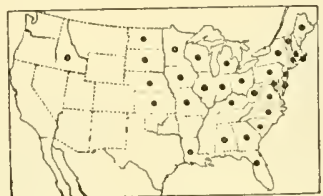

Figure 1142.-Distribution of Zizania aquatica.

mm wide; pistillate spikelets about 1 cm long, tapering into an awn 1 to 2 cnr long. 4 -Growing in rapidly flowing water, San Marcos, Tex. The grass grows in water 30 to $120 \mathrm{~cm}$ deep, the lower part of the plant prostrate or floating on the water, the upper part erect. Flowers from April to November and at warm periods during winter. Said to be troublesome in irrigation ditches.

\section{ZIZANIOPSIS Doell and} Aschers.

Spikelets unisexual, 1-flowered, disarticulating from the pedicel, mixed on the same branches of the panicle, the staminate below; glumes wanting; lemma 7-nerved, short-awned in the pistillate spike-

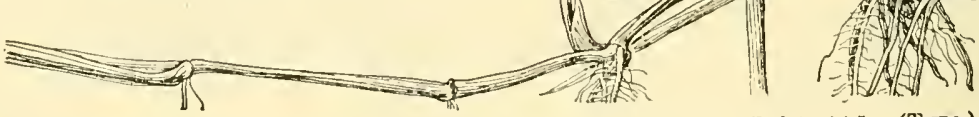

Figure 1143.-Zizania texana. Plant, $\times \frac{1}{2}$; pistillate and staminate spikelets, $\times 5$. (Type.)

lets; palea 3 -nerved; staminate spikelets with 6 stamens; styles rather long, united; fruit obovate, free from the lemma and palea, 


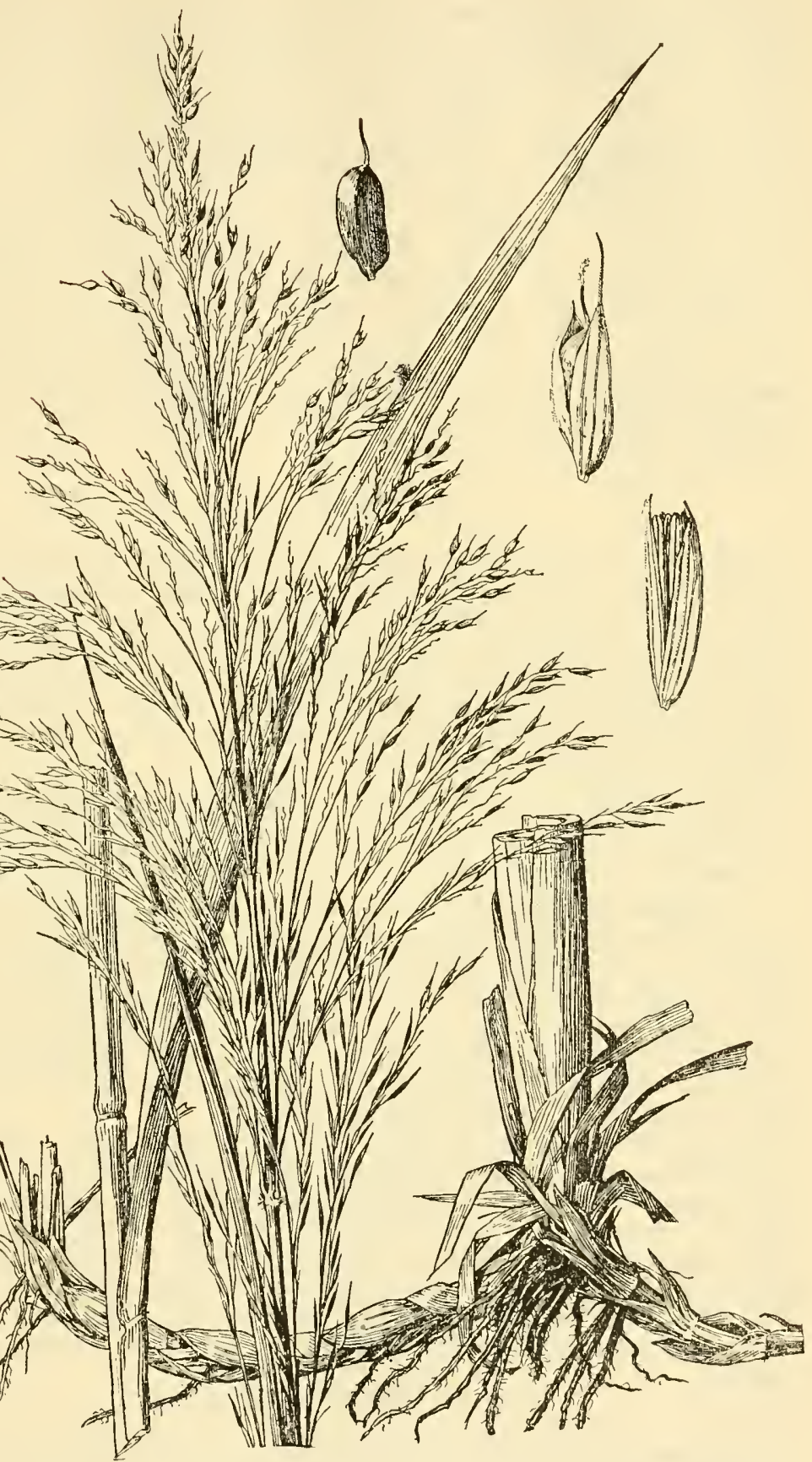

FIGURE 1144.-Zizaniopsis miliacea. Plant, $\times 1 / 2$; staminate spikelet, pistillate spikelet, and ripe caryopsis, $\times 5$. (Chase 7121, S.C.) 
coriaceous, smooth and shining, beaked with the persistent style; seed free from the pericarp. Robust perennial marsh grasses, with stout creeping rhizomes, broad flat blades, and large open panicles. 'Type species, Zizaniopsis microstachya Nees. Name from Zizania, a

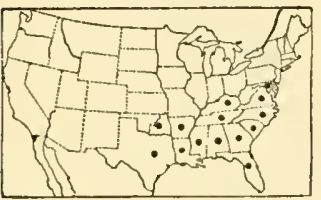

FIGURE 1145.-Distribution of Zizaniopsis miliacea. generic name, and Greek opsis, appearance, alluding to the similarity to Zizania.

1. Zizaniopsis miliácea (Michx.) Doell and Aschers. (Fig. 1144.) SoUtherN wILDRICE. Culms 1 to $3 \mathrm{~m}$ tall or even taller; blades glabrous except the very scabrous margins, 1 to $2 \mathrm{~cm}$ wide, the midrib stout; panicle rather narrow, nodding, 30 to $50 \mathrm{~cm}$ long, the numerous branches fascicled, as much as 15 to $20 \mathrm{~cm}$ long, naked at base; spikelets 6 to $8 \mathrm{~mm}$ long, short-awned, the staminate slender, the pistillate turgid at maturity. 4 -Marshes, creeks, and river banks, Maryland to Kentucky and Oklahoma, south to Florida and Texas (fig. 1145).

\section{LUZÍOLA Juss.}

Spikelets unisexual, 1-flowered, disarticulating from the pedicel, the staminate and pistillate spikelets in separate panicles on the same plant; glumes wanting; lemma and palea about equal, thin, several to many-nerved, lanceolate or oblong; stamens 6 or more; stigmas long, plumose; grain free, globose, finely striate. Creeping, low or delicate perennials, with narrow flat blades and terminal and axillary panicles. Type species, Luziola peruviana. Name modified from Luzula, a genus of Juncaceae.

Pistillate spikelets ovoid, about $2 \mathrm{~mm}$ long; staminate and pistillate panicles on the same shoot . . Pistillate spikelets oblong-lanceolate, 4 to $5 \mathrm{~mm}$ long; staminate and pistillate panicles on different shoots................. 2. L. BAHIENSIS.

1. Luziola peruviána Gmel. (Fig. 1146.) Culms slender, branching, the flowering shoots ascending, 10 to $40 \mathrm{~cm}$ tall; blades 1 to 4 $\mathrm{mm}$ wide, exceeding the panicles; staminate panicles terminal, narrow, the spikelets about $7 \mathrm{~mm}$ long; pistillate panicles terminal and axillary, 3 to $6 \mathrm{~cm}$ long, about as wide, the spikelets about $2 \mathrm{~mm}$ long, ovoid at maturity, abruptly pointed. 24-Muddy ground and wet meadows, Florida (Pensacola) and Louisiana (vicinity of New Orleans); Mexico and Cuba, south to Argentina.

2. Luziola bahiénsis (Steud.) Hitchc. (Fig. 1147.) Extensively stoloniferous, the flowering shoots not more than $15 \mathrm{~cm}$ tall, mostly less; blades 2 to $4 \mathrm{~mm}$ wide, much exceeding the panicles; panicles mostly terminal, the staminate few-flowered, the spikelets about 5 $\mathrm{mm}$ long; pistillate panicles 4 to $6 \mathrm{~cm}$ long, the few stiff branches finally spreading, with a few appressed oblong-lanceolate spikelets 4 to $5 \mathrm{~mm}$ long, the lemma and palea much exceeding the caryopsis. 2 -Lagoons and banks of streams, southern Alabama; Cuba. Brazil.

\section{HYDRÓCHLOA Beauv.}

Spikelets unisexual, 1-flowered, disarticulating from the pedicel, the staminate and pistillate spikelets in separate panicles on the same plant; glumes wanting; staminate spikelets with a thin 7 -nerved lemma, a 2 -nerved palea, and 6 stamens; pistillate spikelets with a 


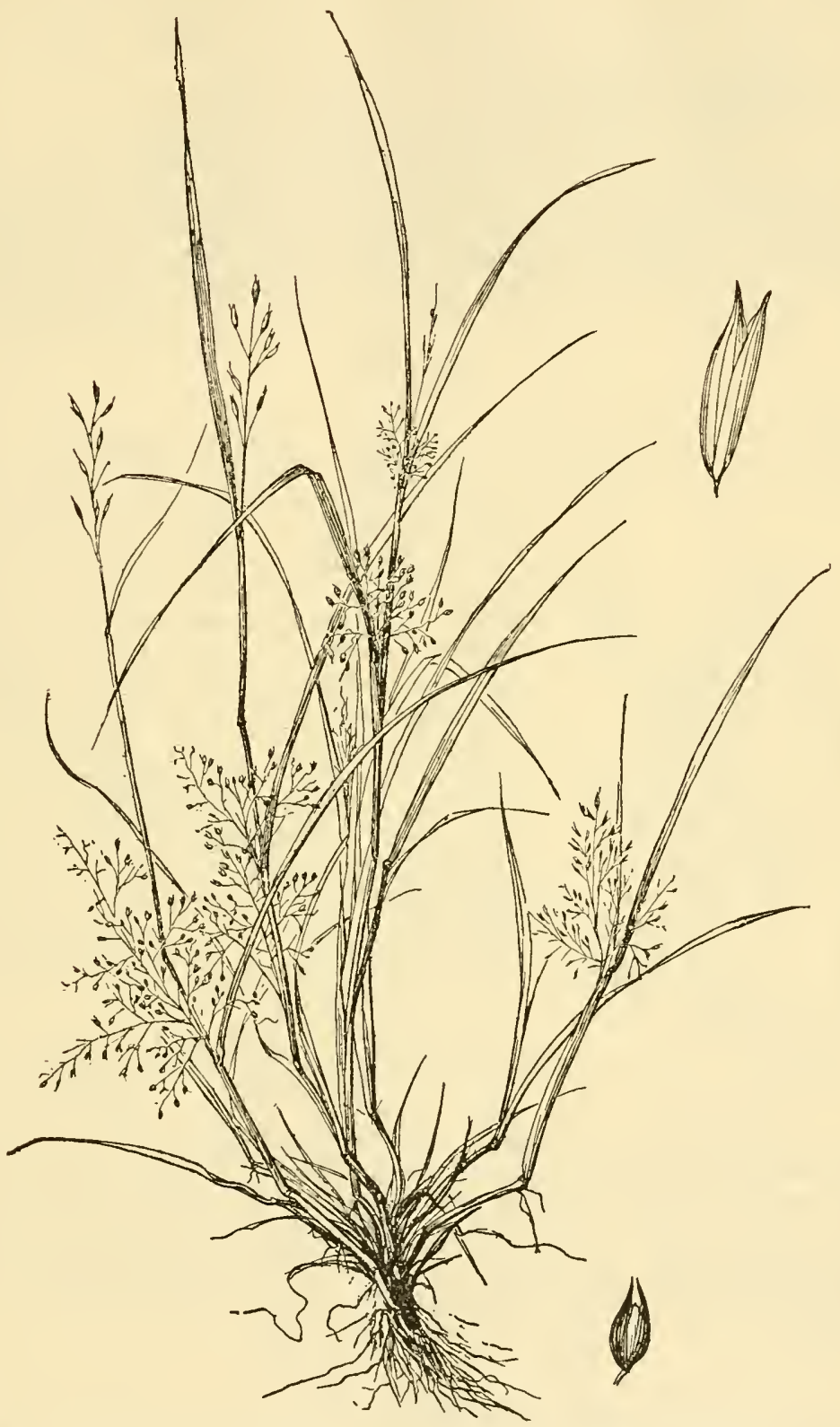

FIGURe 1146. - Luziola peruviana. Plant, $\times \underset{6871, \text { Fistillate }}{1 / 2}$ and staminate spikelets, $\times 5$ (Curtiss 
thin 7-nerved lemma and 5-nerved palea, the stigmas long and slender. A slender, branching, aquatic grass, probably perennial, the leaves floating; staminate spikelets in small few-flowered terminal racemes; pistillate spikelets in few-flowered racemes in the axils of the leaves. Type species, Hydrochloa caroliniensis. Name from Greek hudor, water, and chloa, grass, alluding to the habitat.

1. Hydrochloa caroliniénsis Beauv. (Fig. 1148.) Culms up to 1 $\mathrm{m}$ or more long, freely branching, leafy; blades flat, 1 to $3 \mathrm{~cm}$ long, 1 to $2 \mathrm{~mm}$ wide, in vigorous shoots as much as $6 \mathrm{~cm}$ long and $5 \mathrm{~mm}$ wide; spikelets inconspicuous and infrequent, the staminate about 4 $\mathrm{mm}$ long, the pistillate about $2 \mathrm{~mm}$. 24 -Ponds and slow-flowing streams, sometimes in sufficient abundance to become troublesome. South Carolina to Florida and Louisiana (fig. 1149). Eaten by livestock. Lemma 5- or 7-nerved; palea 4- to 7-nerved. (Weatherwax.)

\section{PHÁRUS L.}

Spikelets in pairs, appressed along the slender spreading, nearly simple panicle branches, one pistillate, subsessile, the other stami-

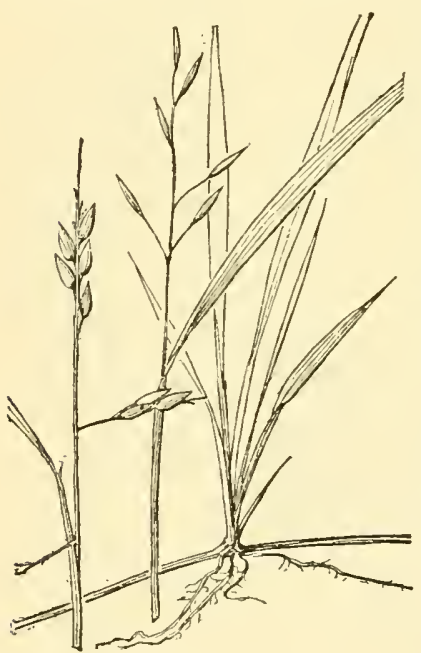

FIgURE 1147.-Luziola bahiensis, $\times 1$. (Mohr, Ala.) nate, pedicellate, much smaller than the pistillate spikelet; fertile lemma subindurate, terete, clothed, at least toward the beaked apex, with thick uncinate hairs; blades petioled (the petiole with a single twist reversing the upper and under surfaces of the blade), the nerves running from midnerve to margin, with fine transverse veins between the nerves. Perennials with broad flat elliptic or oblanceolate blades and terminal panicles with rather few stiffly spreading branches breaking readily at maturity, the terete pistillate spikelets appressed, the uncinate fruits acting like burs. Type species, Pharus latifolius L. Name from Greek pharos, cloth or mantle, possibly alluding to the broad blades.

1. Pharus parvifólius Nash. (Fig. 1150.) Culms long-decumbent and rooting at base, the flowering shoot 30 to 50 $\mathrm{cm}$ tall; blades elliptic, abruptly acuminate, 10 to $20 \mathrm{~cm}$ long, 2 to $4 \mathrm{~cm}$ wide; panicles mostly 10 to $20 \mathrm{~cm}$ long, about as wide; pistillate spikelets about $1 \mathrm{~cm}$ long, the glumes thin, brown, less than half as long as the lemma; staminate spikelets about $3 \mathrm{~mm}$ long, the slender pedicels appressed to the pistillate spikelets. $\quad 4$ -Rocky woods, Florida, rare (Pineola; Orange Lake); West Indies to Brazil.

\section{TRIBE 11. MELINIDEAE}

\section{MELÍNIS Beauv.}

Spikelets small, dorsally compressed, 1-flowered with a sterile lemma below the fertile floret, the rachilla disarticulating below the glumes; first glume minute; second glume and sterile lemma similar, membranaceous, strongly nerved, slightly exceeding the fertile floret; 
MANUAL OF THE GRASSES OF THE UNITED STATES 547

fertile lemma and palea subhyaline toward summit. Perennials

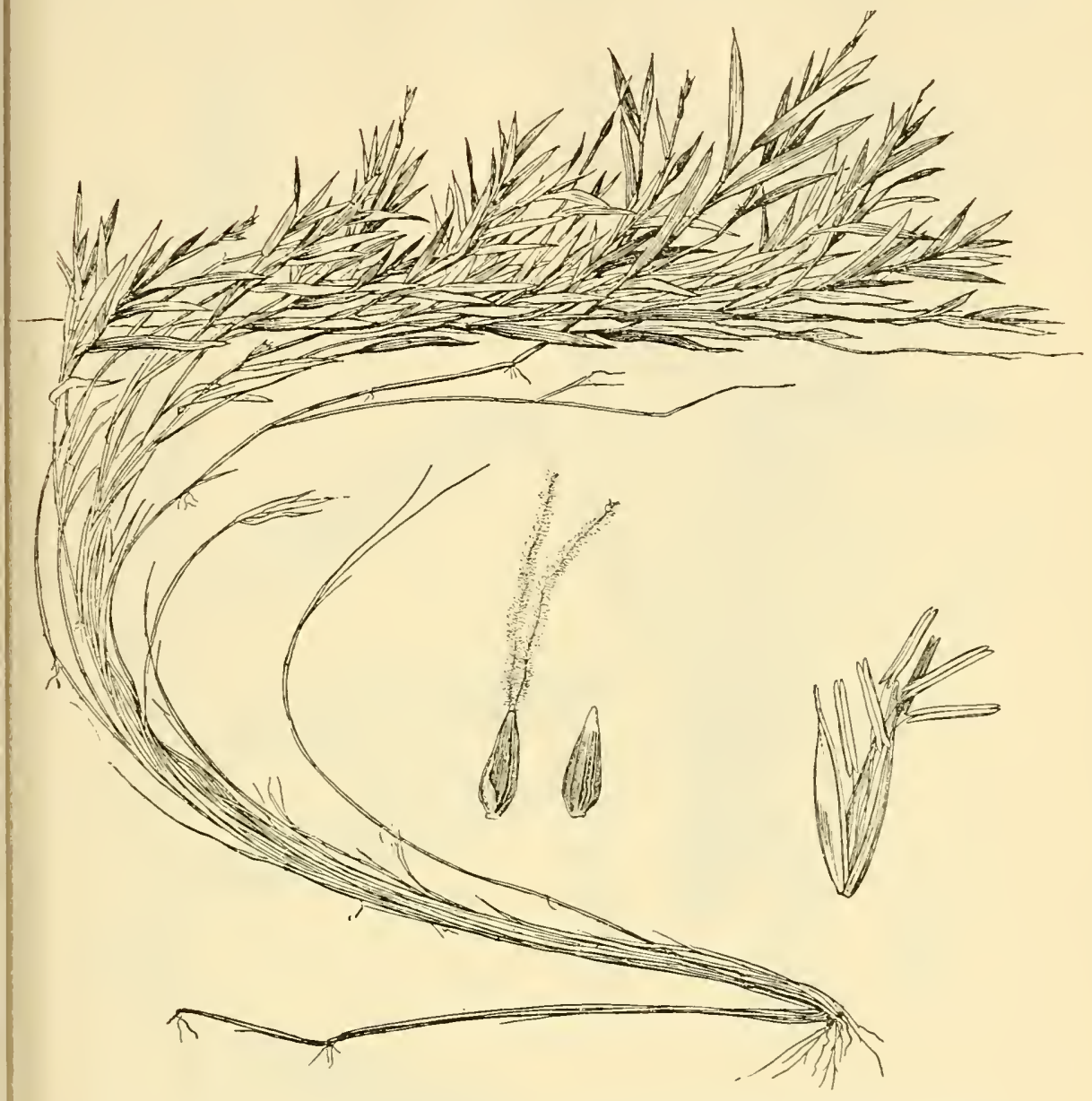

Figure 1148.-Hydrochloa caroliniensis. Plant, $\times 1 / 2$; two views of pistillate spikelet and staminate spikelet, $\times 5$. (Nash 1152, Fla.)

with slender, branching, decumbent culms and narrow many-flowered

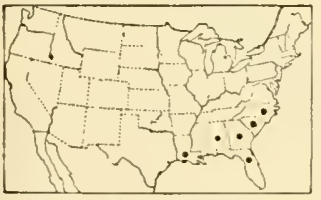

FIGURE 1149.-Distribution of Hydrochloa caroliniensis.

long, the sterile lemnia 2 2-lobed, with a delicate awn 1 to $10 \mathrm{~mm}$ long from between the lobes. 24 -Introduced from Brazil, though Type species, Melinis minutiflora. Name from Greek meline, millet.

1. Melinis minutiflóra Beauv. Molasses Grass. (Fig. 1151.) Culms ascending from a tangled much branched base, as much as $1 \mathrm{~m}$ tall; the foliage viscid-pubescent; blades flat, 5 to $15 \mathrm{~cm}$ long, 5 to $10 \mathrm{~mm}$ wide; panicle 10 to $20 \mathrm{~cm}$ long, purplish; spikelets about $2 \mathrm{~mm}$ panicles, with capillary branchlets and pedicels. 
548 MISC. PUBLICATION 200, U. S. DEPT. OF AGRICULTURE

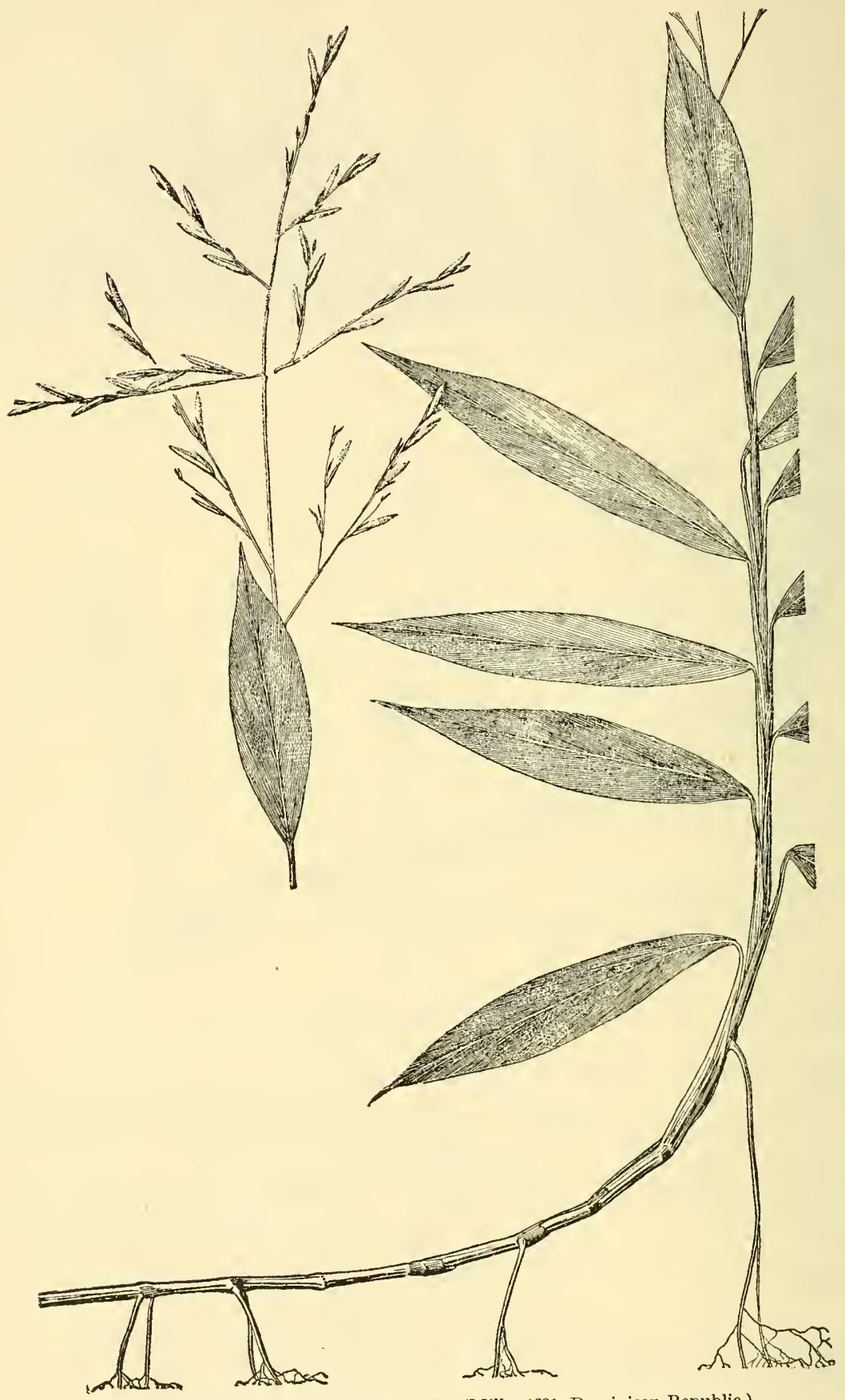

FIGURE 1150.-Pharus parvifolius, $\times 1 / 2$. (Miller 1231, Dominican Republic.) 
native of Africa. Cultivated for forage and spreading in open ground through Central and South America and the West Indies. It has been tried successfully in southern Florida. The grass has a heavy sweetish odor when fresh. Called in Brazil capím gordura.

Thysanoláña máxima (Roxb.) Kuntze. Robust perennial, 1 to $3 \mathrm{~m}$ tall; blades 3 to $7 \mathrm{~cm}$ wide; panicle commonly $1 \mathrm{~m}$ long, the slender densely-flowered branches drooping; spikelets about $2 \mathrm{~mm}$ long, pointed; fertile lemma long-ciliate. 24 -Introduced in southern Florida and southern California as an ornamental.

\section{TRIBE 12. PANICEAE}

\section{ANTHAENĀNTIA Beauv.}

Spikelets obovoid; first glume wanting; second glume and sterile lemma about equal, 5-nerved, the broad internerves infolded, densely villous, the sterile lemma with a small palea and sometimes with a staminate flower; fertile lemma cartilaginous, brown, with narrow pale hyaline margins, boat-shaped, 3-nerved, subacute. Erect perennials with short creeping rhizomes, narrow, firm, flat blades, the uppermost much reduced, and narrow panicles, the slender branches ascending or appressed. 'Type species, Anthaenantia villosa. Name from Greek anthos, flower, and enantios contrary. (Beauvois misinterpreted the structure of the spikelet. $)^{9}$

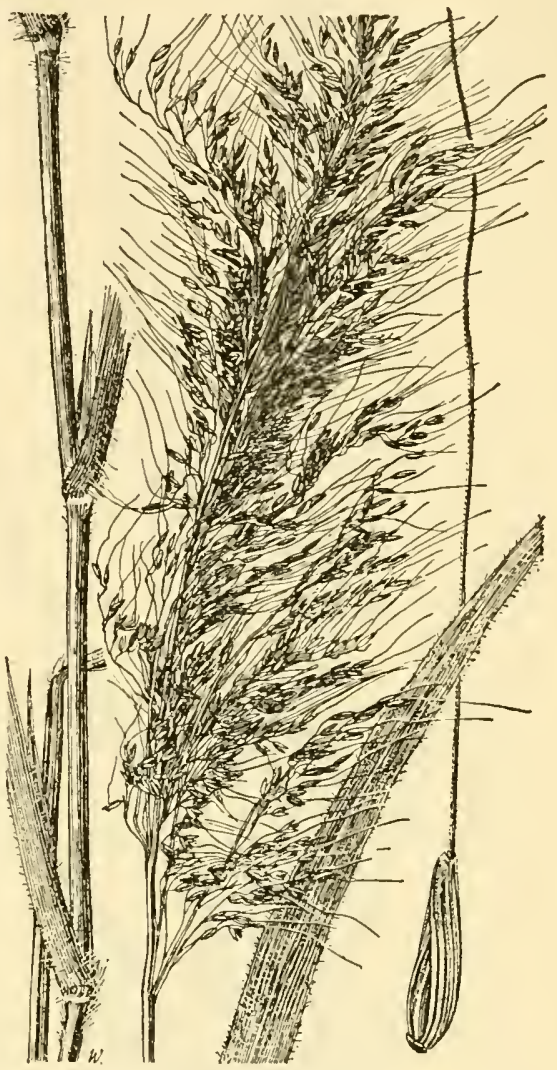

F1GURE 1151.-Melinis minutiflora. Plant, $\times 1$; spikelet, $\times 10$. (Moldenke 453, Fla.)

In pine barrens $A$. rufa may be an important element in the natural pasture.

Blades erect or spreading, rather blunt or rounded at the apex, linear, folded at base; panicle usually purple_._. Blades ascending or spreading (on the average shorter and broader than in $A$. rufa), tapering to the apex, rounded at base; panicle usually pale_- 2. A. villosa.

1. Anthaenantia rúfa (Ell.) Schult. (Fig. 1152, A.) Culms slender, 60 to $120 \mathrm{~cm}$ tall; blades elongate, 3 to $5 \mathrm{~mm}$ wide, often scabrous; panicle 8 to $15 \mathrm{~cm}$ long, usually purple; spikelets 3 to $4 \mathrm{~mm}$ long. 21-Moist pine barrens, Coastal Plain, North Carolina to Florida and castern Texas (fig. 1153).

2. Anthaenantia villósa (Míchx.) Beauv. (Fig. 1152, B.) Differing from $A$. rufa in the wider, mostly shorter, spreading blades and in the usually pale panicles. 24 - Dry pine barrens, Coastal Plain, North Carolina to Florida and Louisiana (fig. 1154).

\footnotetext{
O See Contr. U. S. Nat. Herb. 24: 170.1925.
} 

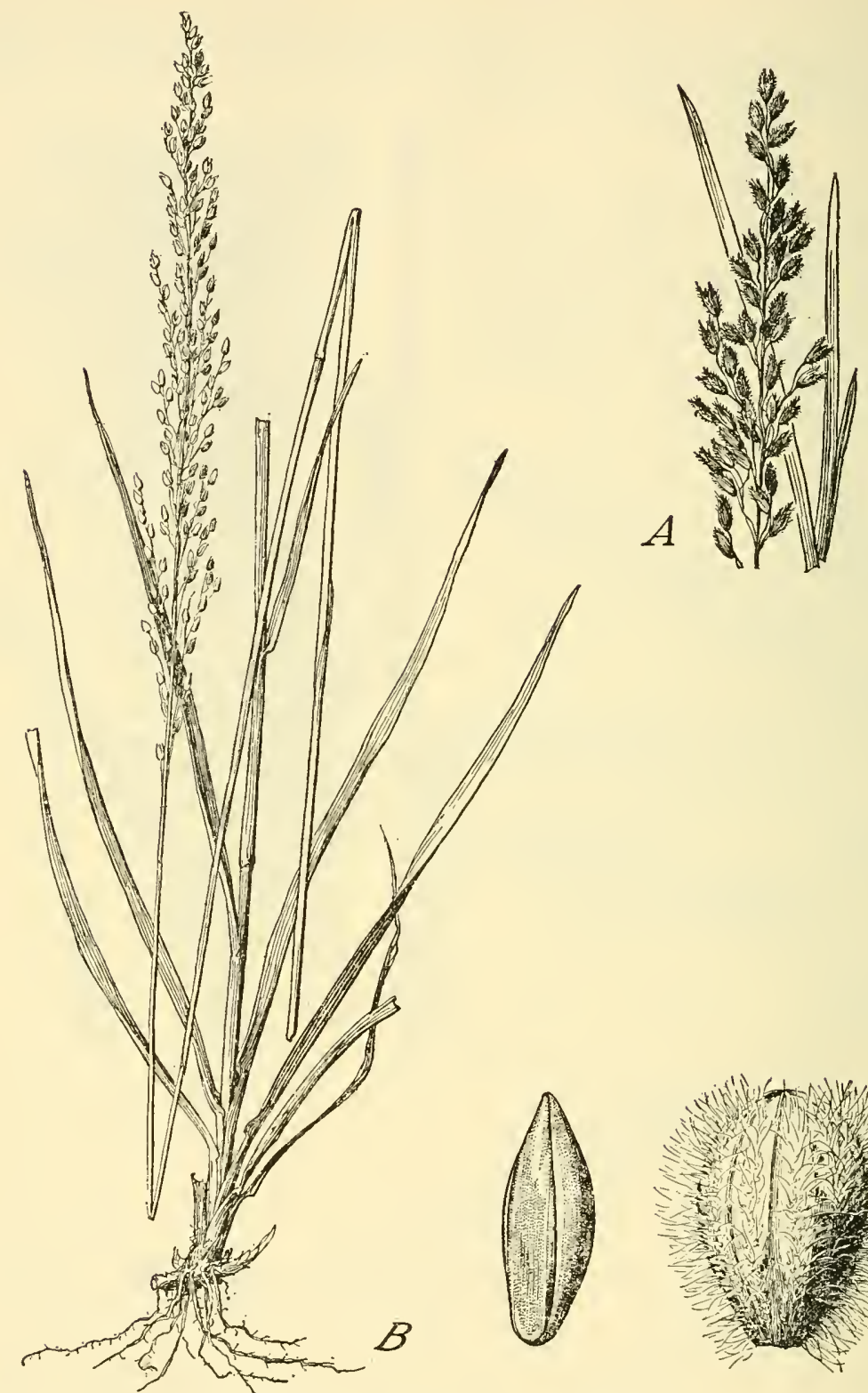

Figure 1152.-A, Anthaenantia rufa, $\times 1$. (Amer. Gr. Nat. Herb. 290, N.C.) B, A. villosa. Plant, $\times 1 / 2$; spikelet and floret, $\times 10$, (Chase 4605, N.C.)

\section{TRICHÁCHNE Nees}

(Valota Adans. inadequately published)

Spikelets lanceolate, in pairs, short-pediceled, in two rows along one side of a slender rachis; first glume minute, glabrous; second 
glume and sterile lemma about as long as the fruit, 3- to 5-nerved, copiously silky; fertile lemma cartilaginous, lanceolate, acuminate, usually brown, the flat white hyaline margins broad. Perennials with slender erect or ascending racemes, approximate to rather distant along a slender main axis, forming a white to brownish silky panicle. Type species, Trichachne insularis. Name from Greek thrix (trich-), hair, and achne, chaff, alluding to the silky spikelets.

Trichachne insularis is not relished by cattle,

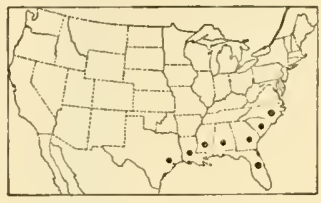

FIGURE 1153.-Distribution of Anthaenantia rufa. hence the name sourgrass by which it is called in the West Indies; T. californica is a constituent of the ranges of the Southwest, and furnishes fair forage.

Fruit $4 \mathrm{~mm}$ long; spikelets tawny-villous_._._._._._. 1. T. INSULARis. Fruit $3 \mathrm{~mm}$ or less long (rarely $3.5 \mathrm{~mm}$ ); spikelets white-villous.

Spikelets long-silky, the hairs exceeding the spikelet; fruit $3-3.5 \mathrm{~mm}$ long.

Panicle branches stiffly ascending or spreading, comparatively few flowered; fruit oblong-lanceolate, gradually pointed_....... 3. T. PATENS.

Panicle branches appressed, densely flowered; fruit obovate, abruptly pointed, the point scarcely indurate _....... 2. T. CALiforNica.

Spikelets short-silky, the hairs not exceeding the spikelet; fruit $2.4 \mathrm{~mm}$ long ....... T. HIтснсоскII.

1. Trichachne insuláris (L.) Nees. Sourgrass. (Fig. 1155.) Culms suberect from a hard scaly hairy swollen base, 1 to $1.5 \mathrm{mi}$ tall; leaves

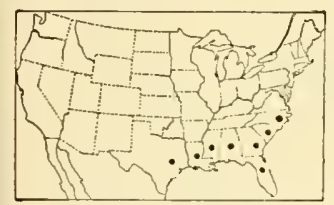

FIgURE 1154.-Distribution of Anthuenantia rillosu. numerous; the sheaths sparsely hirsute; blades elongate, 8 to $15 \mathrm{~mm}$ wide; panicle 15 to $30 \mathrm{~cm}$ long, the slender racemes mostly 10 to $15 \mathrm{~cm}$ long, somewhat nodding; spikelets approximate, excluding the hairs about $4 \mathrm{~mm}$ long, the tawny hairs much exceeding them. 2 (Valota insularis Chase.)-Low open ground and waste places, Florida, Alabama (Mobile), and southern Texas; Mexico, West Indies to Argentina.

2. Trichachne califórnica (Benth.) Chase. Cоттолтор. (Fig. 1156.) Culms erect from a knotty swollen felty-pubescent base, 40 to $100 \mathrm{~cm}$ tall; leaves numerous, the sheaths glabrous to sparsely pilose; blades mostly less than $12 \mathrm{~cm}$ long, 3 to $5 \mathrm{~mm}$ wide, from nearly glabrous to densely puberulent; panicle mostly 5 to $10 \mathrm{~cm}$ long, the few racemes usually 3 to $5 \mathrm{~cm}$ long, occasionally longer, erect or nearly so; spikelets approximate, excluding the hairs 3 to $4 \mathrm{~mm}$ long, the white to purplish hairs much exceeding them, often spreading, the middle internerves of the sterile lemma glabrous. 21 (T. saccharata Nash.)-Plains and dry open ground, Texas to Colorado, Arizona, and Mexico (fig. 1157).

3. Trichachne pátens Swallen. (Fig. 1158.) Culms tufted, erect, 40 to $90 \mathrm{~cm}$ tall; sheaths more or less papillose-pilose, the lowermost densely felty pubescent; blades 5 to $15 \mathrm{~cm}$ long, 1 to $4 \mathrm{~mm}$ wide, scabrous; panicle 10 to $18 \mathrm{~cm}$ long, the racemes stiffly ascending or spreading; spikelets remote, $4 \mathrm{~mm}$ long, densely silky, the hairs exceeding the spikelet; fruit $3 \mathrm{~mm}$ long, acute. 21 Dry fields, prairies, and roadsides, Texas.

4. Trichachne hitchcóckii (Chase) Chase. (Fig. 1159.) Culms tufted and branching at base, leafy below, slender, 30 to $50 \mathrm{~cm}$ tall; sheaths 


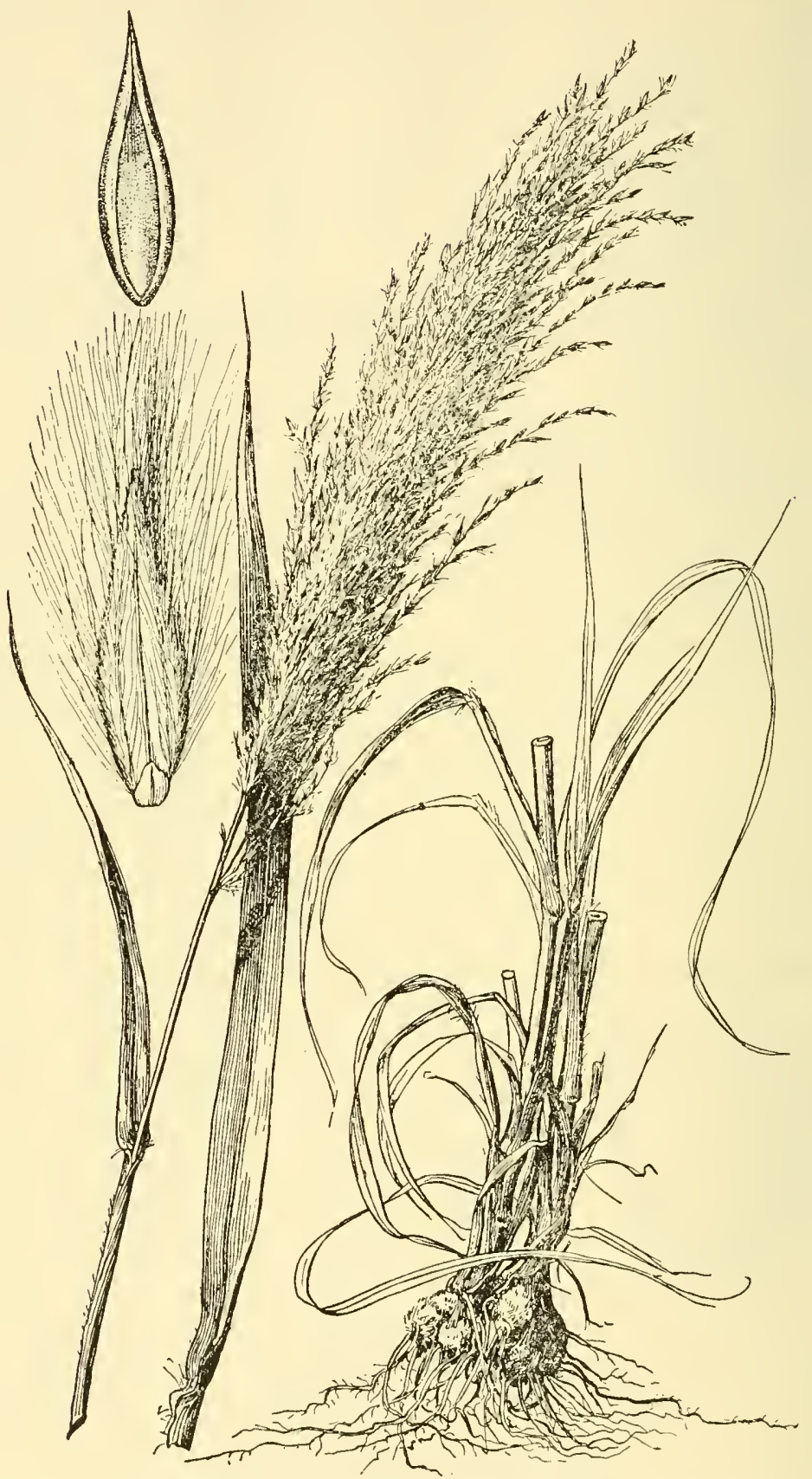

Figuke 1155.-Trichachne insularis. Plant $\times 1 / 2$; spikelet and floret, $\times 10$. (Baker and Wilson 602, Cuba.) 
and blades nearly glabrous to puberulent, sometimes densely so toward base, the blades 2 to $5 \mathrm{~cm}$ long, 2 to $3 \mathrm{~mm}$ wide; panicle long-exserted, 6 to $10 \mathrm{~cm}$ long, the few racemes 3 to $4 \mathrm{~cm}$ long, mostly rather remote and erect; spikelets 2.5 to $3 \mathrm{~mm}$ long, densely silky-villous, the prominent nerves not hidden, the grayish hairs not exceeding the spikelet. 24 -Dry plains, Texas; northern Mexico.

\section{DigITÁRIA Heister. Crabgrass}

\section{(Syntherisma- Walt.)}

Spikelets in twos or threes, rarely solitary, pediceled, alternate in two rows on one side of a 3 -angled winged or wingless rachis; spikelets lanceolate or elliptic, nearly planoconvex; first glume minute or wanting; second glume equaling the sterile lemma or shorter; fertile lemma cartilaginous, the hyaline margins pale. Annual or perennial, erect to prostrate, often weedy grasses, the slender racemes digitate or

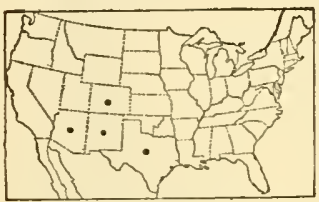

FIGURE 1157.-Distribution of Trichachne californica. approximate on a short axis. Type species, Digitaria sanguinalis. Name from Latin digitus, finger, alluding to the digitate inflorescence of the type species.

The species are in the main good forage grasses.

Digitaria sanguinalis, the common crabgrass, is a weed in cultivated soil. In the Southern States, where it produces an abundant growth in the late summer on fields from which crops have been gathered, it is utilized for forage and is sometimes cut for hay. This species and $D$. ischaemum are common weeds in lawns. They form a fine green growth at first but they start late and die in the fall.

subsessile or short-

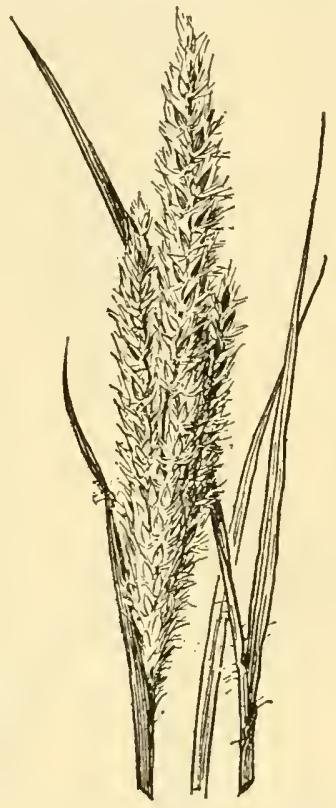

FIGURE 1156.-Trichachne californica, $\times 1$. (H itchcock 13608, Tex.)

1a. Rachis winged or flat-margined, the margin as wide as the central rib; plants annual, creeping at least at base.

Rachis bearing scattered long fine hairs (these rarely wanting); spikelets narrow, acuminate, nearly glabrous ......... 2. D. HORIzONTALIS.

Rachis not bearing hairs; spikelets elliptic, acute, pubescent.

Sheaths glabrous; fertile lemma brown.

Spikelets $2 \mathrm{~mm}$ long, $1 \mathrm{~mm}$ wide, the hairs or most of them capitellate.

3. D. ISCHAEMUM.

Spikelets 1.5 to $1.7 \mathrm{~mm}$ long, about $0.6 \mathrm{~mm}$ wide, the hairs not capitellate.

Sterile lemma with 5 distinct nerves; spikelets sparingly pubescent, $1.7 \mathrm{~mm}$ long; fertile lemma light brown; racemes, if more than 2 , not digitate..........

Sterile lemma with 3 distinct nerves; spikelets distinctly pubescent, $1.5 \mathrm{~mm}$ long, fertile lemma dark brown, racemes usually all

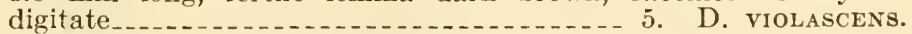

Sheaths pilose or villous; fertile lemma pale.

Spikelets 1.5 to $1.7 \mathrm{~mm}$ long; pedicels ferete, glabrous... 6. D. SERotiNa. Spikelets 2.5 to $3.5 \mathrm{~mm}$ long; pedicels angled, scabrous.

1. D. SANGUINALIS. 


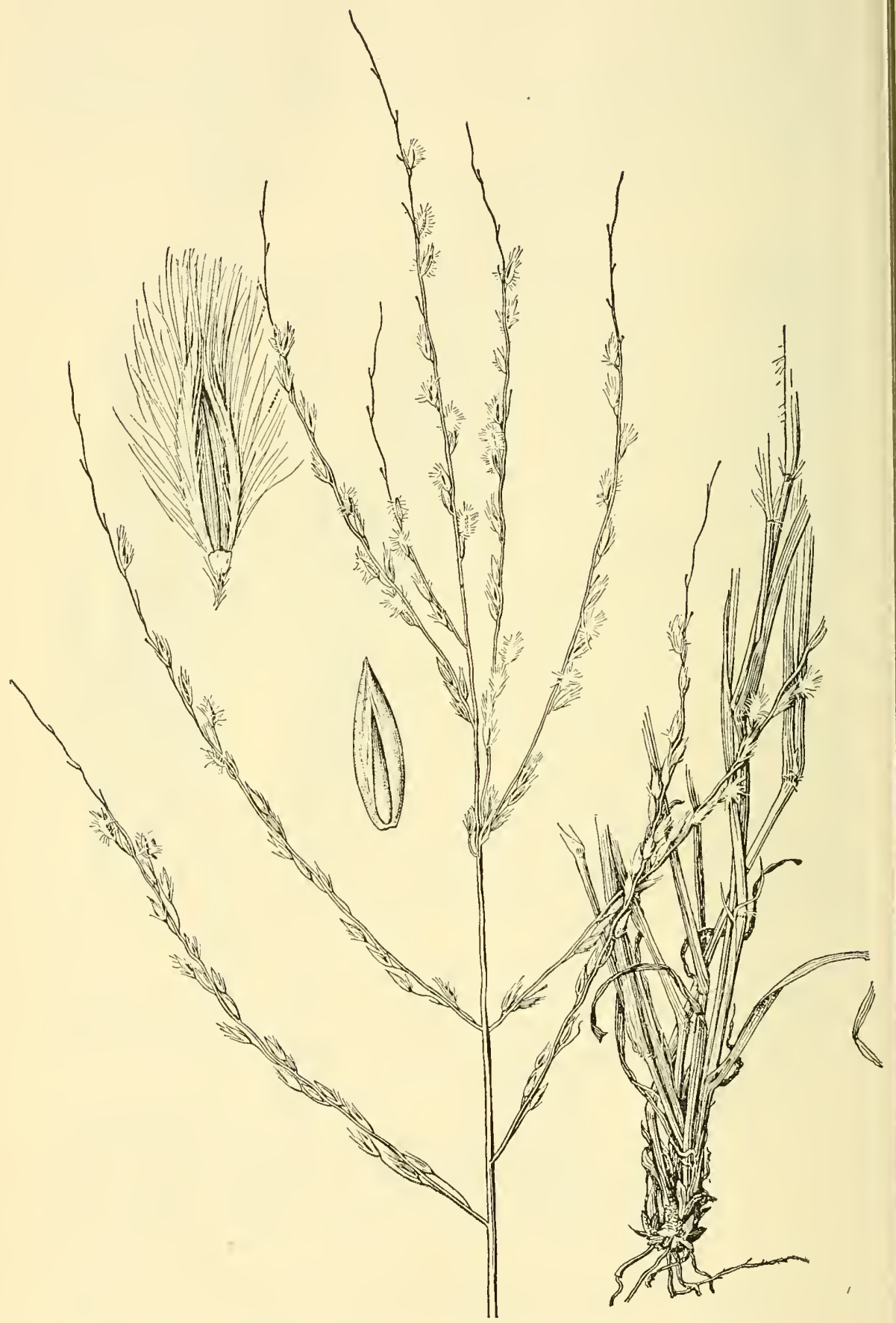

FIGURE 1158. - Trichachne patens. Plant, $\times 1$; spikelet and foret, $\times 10$. (Reed 11, Tex.) 
1b. Rachis wingless or with a very narrow margin (see also $D$. horizontalis), triangular; plants not creeping (except in $D$. texana), annual or perennial. 2a. Fertile lemma pale or gray.

Plants annual, decumbent and rooting at base. Spikelets $3 \mathrm{~mm}$ long, glabrous or nearly so

Plants perennial.

Spikelets densely or sparsely villous; racemes 5 to 10 .

Spikelets 3.5 to $4 \mathrm{~mm}$ long, sparsely to densely villous_ 15 . D. RUNYONI. Spikelets 2.3 to $2.8 \mathrm{~mm}$ long, rather sparsely villous_- 12 . D. TExaNA.

Spikelets glabrous to obscurely appressed-pubescent on the internerves; racemes 2 to 5 , some of them naked at base for 1 to $1.5 \mathrm{~cm}$.

First glume broad, hyaline, minute but obvious; spikelets $3.2 \mathrm{~mm}$ long, glabrous.

First glume obsolete or nearly so; spikelets 2.5 to $2.8 \mathrm{~mm}$ long, obscurely to obviously appressed-pubescent_....... 14. D. SUBCALVA.

2b. Fertile lemma dark brown. Plants erect or at least not rooting at the decumbent base; annual or sometimes apparently perennial.

Second glume and sterile lemma glabrous (see also $D$. laeviglumis under D. filiformis)

Second glume and sterile lemma capitellate-pubescent.

Spikelets 2 to $2.5 \mathrm{~mm}$ long

9. D. villosa.

Spikelets 1.5 to $1.7 \mathrm{~mm}$ long.

Blades folded or involute, flexuous

10. D. PANICEA. Blades flat

8. D. FILIFORMIS.

1. Digitaria sanguinális (L.) Scop. Crabgrass. (Fig. 1160.) Plant branching and spreading, often purplish, rooting at the decumbent base, the culms sometimes as much as 1 $\mathrm{m}$ long, the flowering shoots prostrate or ascending; sheaths, at least the lower, papillosepilose; blades 5 to $10 \mathrm{~mm}$ wide, pubescent to scaberulous; racemes few to several, 5 to $15 \mathrm{~cm}$ long, rarely longer, digitate, with usually $1 \mathrm{or}^{\circ}$ 2 whorls a short distance below; spikelets about $3 \mathrm{~mm}$ long; first glume minute but evident; second glume about half as long as the spikelet, narrow, ciliate; sterile lemma strongly nerved, the lateral internerves appressedpubescent, the hairs sometimes spreading at maturity ( $D$. fimbriata Link); fertile lemma pale. $\odot-F i e l d s$, gardens, and waste places, a troublesome weed in cultivated ground, throughout the United States, at low and medium altitudes, more common in the East and South; temperate and tropical regions of the world. Native of Europe. A specimen with nearly glabrous sheaths and inflorescences of 2 racemes collected by Tracy in Mississippi, said to be introduced, has been crroneously referred to Syntherisma barbatum (Willd.) Nash (Digitaria barbata Willd.).

2. Digitaria horizontális Willd. (Fig. 1161.) Resembling $D$. sanguinalis but the racemes more slender and lax, rachis scarcely winged,

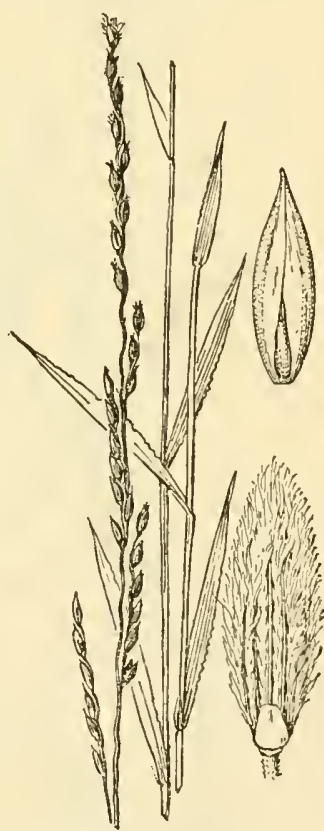

FIGURE 1159.-Trichachnchitchcockii. Plant, $\times 1$; spikelet and floret, $\times 10$. (Type.) bearing scattered long fine spreading hairs (these rarely wanting); spikelets narrow, about $2 \mathrm{~mm}$ long; first glume minute or obsolete; second glume half as long as the spikelet. $\odot$ (Syntherisma setosum Nash; $S$. digitatum Hitchc.)-Waste places, southern and central Florida; ballast, Mobile, Ala.; tropical regions of both hemispheres. 

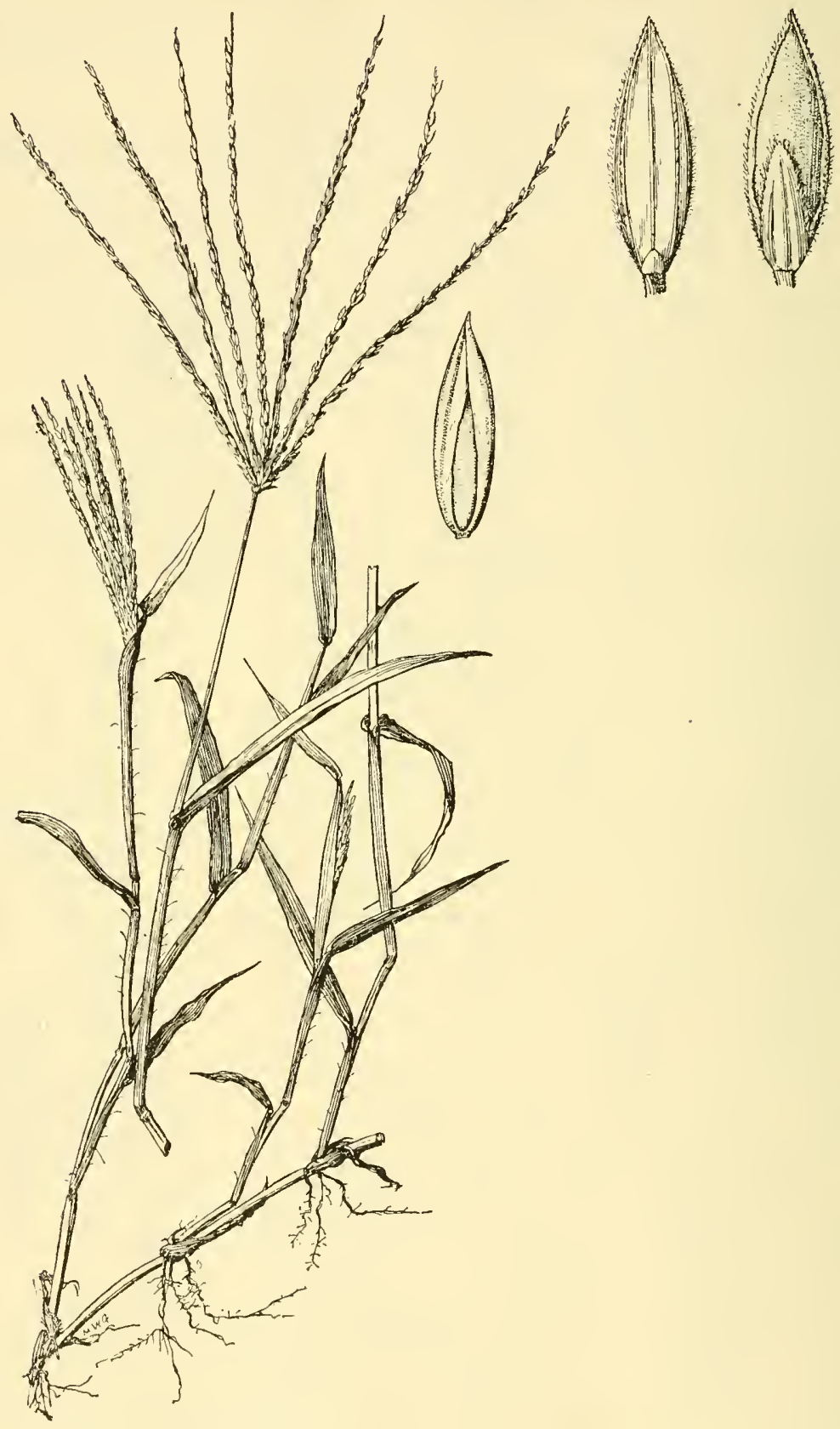

F1GUre 1160.-Digitaria sanguinalis. Plant, $\times 1 / 2 ;$ two views of spikelet, and floret, $\times 10$. (Norton 566, Kans.) 
3. Digitaria ischaémum (Schreb.) Muhl. Sмоoth CRABgrass. (Fig. 1162.) Erect or usually soon decumbent-spreading, resembling $D$. sanguinalis but not so coarse or tall; foliage glabrous, more purple; racemes mostly 2 to 6,4 to $10 \mathrm{~cm}$ long, the rachis with thin wings wider than the midrib; spikelets about $2 \mathrm{~mm}$ long; first glume hyaline, obscure; second glume and sterile lemma as long as the dark fertile lemma, pubescent with capitellate hairs. $\odot$ (Syntherisma humifusum Rydb.) - Waste places, often a troublesome weed in lawns, Quebec to North Dakota, south to South Carolina, Tennessee, and Arkansas, occasionally farther west (fig. 1163) ; introduced from Eurasia. The first glume is so thin as to be apparently wanting. Digitaria ischaEMUM var. Mississippiénsis (Gattinger) Fernald. Taller, the racemes mostly 5 to 7 , often 10 or even $15 \mathrm{~cm}$ long; first glume often more easily seen. $\odot$-Maryland, Tennessee, and South Carolina.

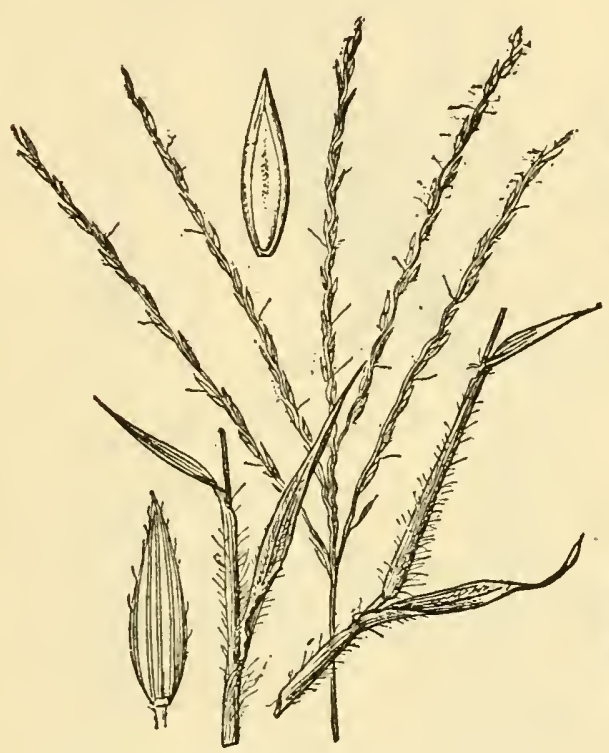

FIGURE 1161.-Digitaria horizontalis. Plant, $\times 1$; spikelet and floret, $\times 10$. (Nash 996, Fla.)

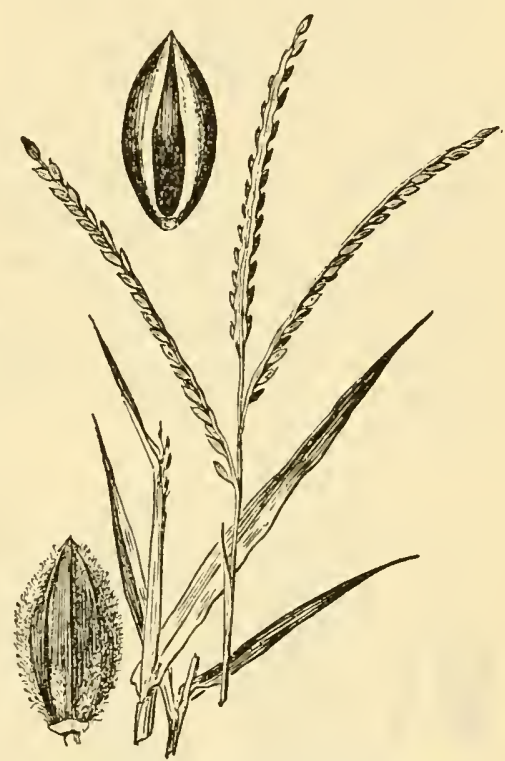

FIGURE 1162-Digitaria ischaemum. Plant, $\times 1$; spikelet and floret, $\times 10$. (Jones $1761, \mathrm{Vt}$.)

4. Digitaria floridána Hitchc. (Fig. 1164.) Culms tufted, decumbent at base, 20 to $30 \mathrm{~cm}$ tall; foliage glabrous except for a few long hairs around the mouth of the sheath; blades 4 to $7 \mathrm{~cm}$ long, 3 to $6 \mathrm{~mm}$ wide; racemes 3 or 4 , rather distant on the axis, 3 to $6 \mathrm{~cm}$ long, the rachis wings wider than the midrib; spikelets 1.5 to $1.7 \mathrm{~mm}$ long, rather sparingly pubescent; first glume wanting; second glume and sterile lemma about as long as the light brown fertile lemma. $\odot-$ Known only from sandy pine woods, Hernando County, Fla. The inflorescence resembles that of $D$. filiformis, but the rachis is winged; the spikelets are smaller than those of $D$. ischaemum.

5. Digitaria violáscens Link. (Fig. 1165, B.) Annual or apparently perennial; culms numerous in a tuft, spreading at base, slender, 10 to $40 \mathrm{~cm}$ tall; leaves mostly clustered near the base, the sheaths glabrous; blades flat, mostly less than $5 \mathrm{~cm}$ long, 3 to $6 \mathrm{~mm}$ 
wide, the upper culm blade distant, reduced; racemes slender, 2 to 5 , usually 2 or 3 , digitate or sometimes approximate on a short axis 3 to $6 \mathrm{~cm}$ long, at maturity spreading or curved, the rachis flat, winged, about 0.7 $\mathrm{mm}$ wide; spikelets closely set, elliptic, acutish, minutely pubescent, about $1.5 \mathrm{~mm}$ long; first glume wanting; second glume

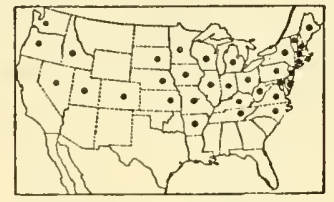

Figure 1163.-Distribution of Digitaria ischaemum.

about three-fourths as long as the spikelet; sterile lemma as long as the spikelet, with three distinct nerves and 1 or 2 obscure pairs; fertile lemma acute, dark brown at maturity. $\odot 2$ Open pineland in sandy soil, Arkansas (Ha mburg), Texas (Buna); tropical America; tropical Asia.

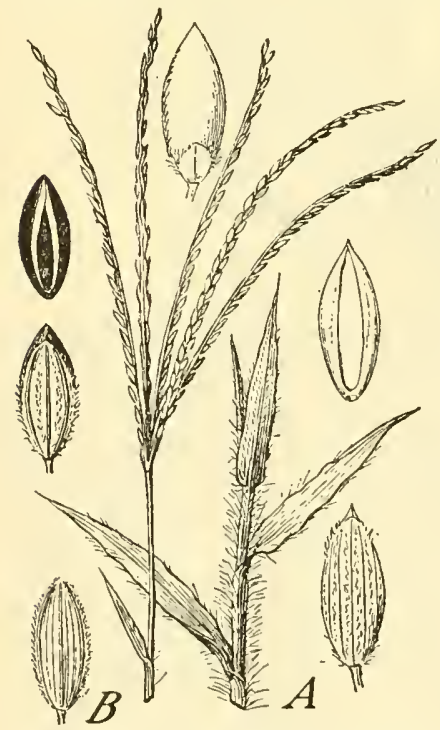

Figure 1165.-A, Digitaria serotina. Plant, $X 1$; two views of spikelet and floret, $\times 10$. (Tracy 4653 , Miss.) $B, D$. violascens. Two views of spikolet and floret, X 10. (Hitcheock 9396, Jamaica.)

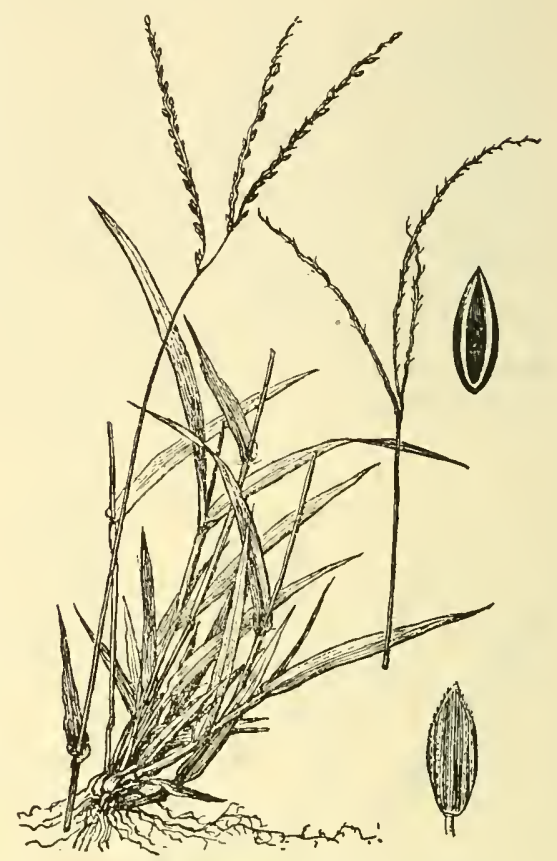

Figure 1164.-Digitaria floridana. Plant, $\times 1$; spikelet and fertile floret, $\times 10$. (Type.)

6. Digitaria serótina (Walt.) Michx. (Fig. 1165, A.) Creeping, sometimes forming extensive mats; flowering culms ascending or erect, 10 to $30 \mathrm{~cm}$ tall; leaves crowded on the creeping culms, the blades short; sheaths villous; blades 2 to $8 \mathrm{~cm}$ long, 3 to $7 \mathrm{~mm}$ wide; racemes usually 3 to 5 , slender, often arcuate, 3 to $10 \mathrm{~cm}$ long, the rachis with thin wings wider than the midrib; spikelets pale, about 1.7 $\mathrm{mm}$ long; first glume wanting;

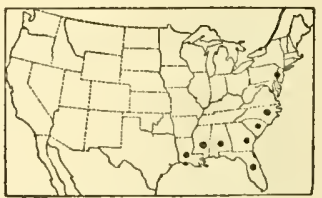

Figure 1166.-Distribution of Digitaria serotina. second glume about one-third as long as the sterile lemma, both finely pubescent; fertile lemma pale. $\odot$ - Pastures and waste places, Coastal Plain, North Carolina to Florida and Louisiana; Philadelphia (ballast); Cuba (fig. 1166).

7. Digitaria simpsóni (V asey) Fernald. (Fig. 1167.) Resembling $D$. sanguinalis in habit; sheaths papillose-pilose, those of the inno- 
vations compressed-keeled; blades not more than $6 \mathrm{~mm}$ wide, softly pilose; racemes 4 to 8 , ascending, pale, 8 to $12 \mathrm{~cm}$ long, the triangular rachis narrowly margined; spikelets about $3 \mathrm{~mm}$ long; first glume hyaline, obsolete or nearly so; second glume and sterile lemma finely 7- to 9-nerved, glabrous or very obscurely pubescent, barely exceeding

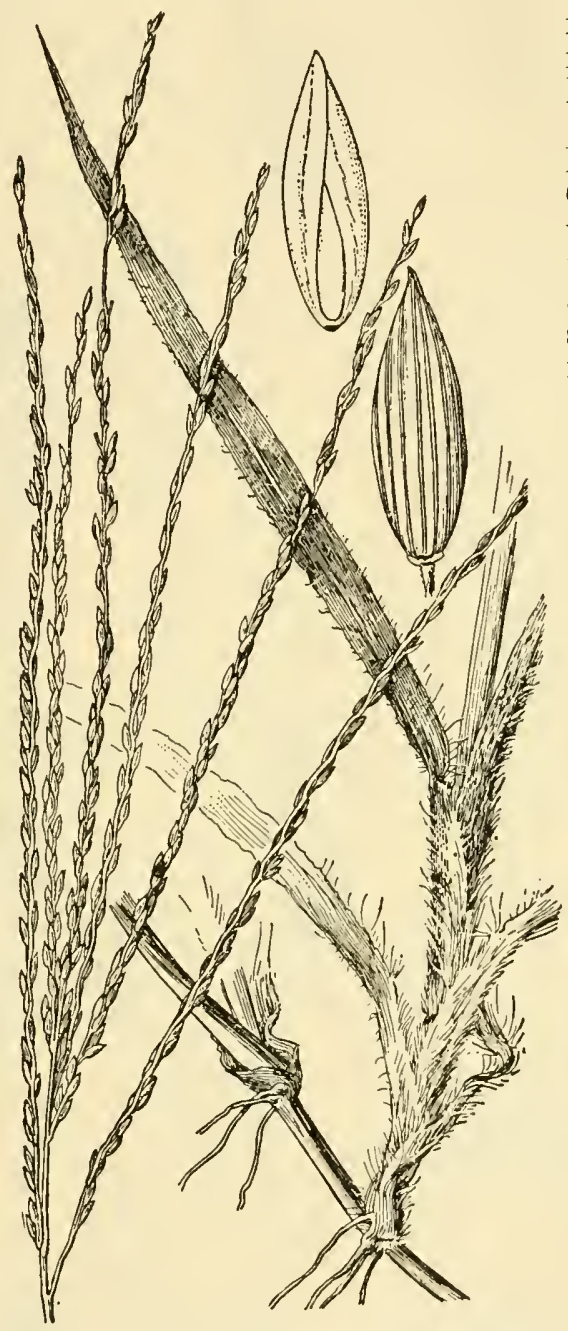

FigURE 1167-Digitatin simpsoni. Plant, $\times 1$; spikelet and floret, $\times 10$, (Curtiss 6422, Fla.) the pale, slightly apiculate fertile lemma. $\odot-$ Sandy fields, Florida, rare; Isla de Pinos, Cuba.

8. Digitaria filifórmis (L.) Koel. (Fig. 1168, A.) Culms in small tufts, slender, usually erect, 10 to $60 \mathrm{~cm}$ tall, rarely taller, those of a tuft very unequal; lower sheaths pilose, the upper mostly glabrous; blades

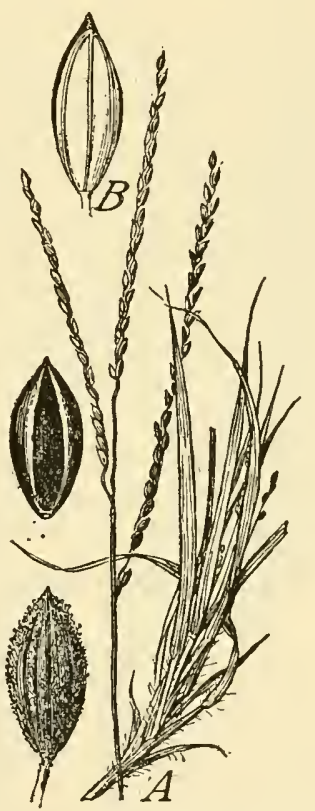

FigURE $1168-4$, Digitaria filiformis. Plant, $X 1$; spikelet and floret, $\times 10$. (Bissell, Conn.) B, D. laeriglumis. Spikelet, $\times 10$. (Type coll.)

erect, usually 5 to $15 \mathrm{~cm}$ long (longer in robust plants), 1 to 4 $\mathrm{mm}$ wide; racemes mostly 1 to 5 , unequal, erect or ascending, mostly less than $10 \mathrm{~cm}$ long, somewhat distant, not fascicled; spikelets 1.5 to $1.7 \mathrm{~mm}$ long; first glume wanting; second glume and sterile lemma pubescent with short capitellate hairs, sometimes nearly glabrous, the glume shorter than the spikelet; fertile lemma dark brown, slightly apiculate. $\odot$ Sandy fields and sterile open ground, New Hampshire to Iowa and Kansas, south to Florida, Texas. and Mexico 
(fig. 1169). A form with glabrous spilielets from Manchester, N.H., has been described as $D$. laeviglumis Fernald (fig. 1168, B).

9. Digitaria villósa (WValt.) Pers. (Fig. 1170.) Perennial at least in the Southern States, in large tufts, purplisil at base; culms 0.75 to $1.5 \mathrm{~m}$ tall, rarely branching; sheaths, at least the lower, grayish villous, sometimes sparsely so; blades elongate, 3 to $6 \mathrm{~mm}$ wide, often flexuous, from softly pilose to nearly glabrous; racemes 2 to 7 , narrowly ascending, rarely somewhat

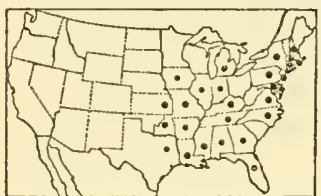

Figure 1169.-Distribution of Digitaria filiformis. spreading, very slender, usually 15 to $25 \mathrm{~cm}$ long, rather distant, often naked at base, sometimes interrupted; spikelets 2 to $2.5 \mathrm{~mm}$ long, usually densely pubescent with soft capitellate hairs, the hairs longer than in $D$. filiformis, and sometimes only obscurely capitellate, the spikelets otherwise very like those of D. filiformis. 2 -Sandy fields and woods, Maryland to Missouri, south to

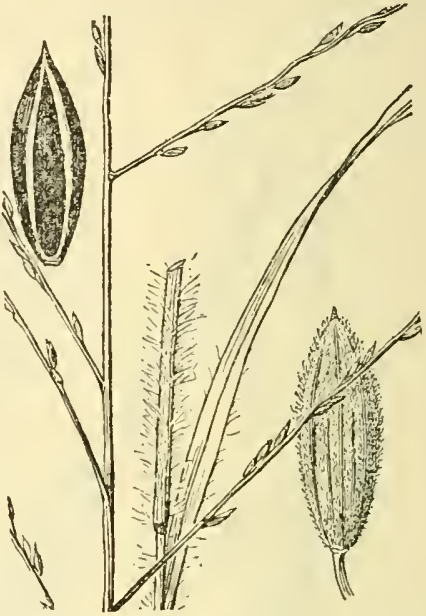

FIGtre 1170.-Digitaria villosa. Plant, $\times 1$; spikelet and floret, $\times 10$. (Curtiss
5300, Fla.) Florida and Texas; Cuba, Mexico (fig. 1171). This species and $D$. filiformis seem to intergrade to some extent. Plants from peninsular Florida with less strongly pubescent sheaths, 2 to 4 elongate racemes, and spikelets with longer hairs have been distinguished as D. leucocoma (Nash) Urban.

10. Digitaria panícea (Swartz) Urban. (Fig. 1172.) Resembling D. villosa, but more slender; blades folded or involute, flexuous, about $1 \mathrm{~mm}$ wide; racemes

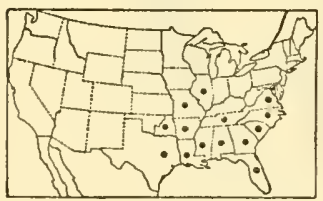

Frgure 1171.-Distribution of Digitaria villosa. mostly 1 to 3 , erect, 5 to $20 \mathrm{~cm}$ long, usually 10 to $15 \mathrm{~cm}$, very slender, loosely flowered; spikelets about $1.5 \mathrm{~mm}$ long, the capitellate hairs rather stiff and appressed. 24-Moist pine barrens and open ground, southern Florida; West Indies, Brazil.

11. Digitaria gracillima (Scribn.) Fernald. (Fig. 1173.) Perennial in dense tufts; culms 60 to $100 \mathrm{~cm}$ tall, erect; lower sheaths appressed-villous;

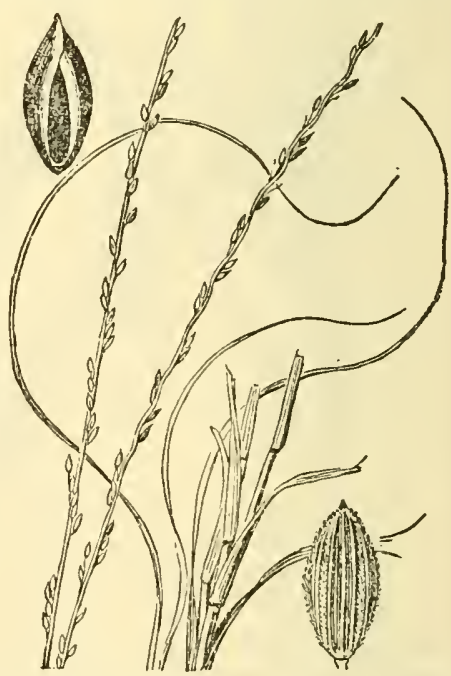

FIGURE 1172.-Digitaria panicea. Plant, $\times 1$; spikelet and foret, $\times 10$. (Tracy 9058, Fla.) blades elongate, 1 to $2 \mathrm{~mm}$ wide, often involute, more or less flexuous; racemes mostly 2 or 3 , distant (rarely as many as 5 and fairly approximate), very slender; spikelets rather remote, 
relatively long pediceled, about $2.3 \mathrm{~mm}$ long, glabrous; first glume obsolete, the second glume one-fourth to one-half as long as the dark brown fertile lemma; sterile lemma scarcely equaling the fruit. 21 - Sandy soil, high pineland, peninsular Florida, rare. A tall plant from Grasmere with 3 to 5 racemes, the spikelets having second glurnes about two-thirds as long as the fertile lemma, has been differentiated as D. bakeri (Nash) Fernald.

12. Digitaria texána Hitchc. (Fig. 1174.) Perennial, erect or somewhat decumbent and branching at base; culms 30 to $60 \mathrm{~cm}$ tall; lower sheaths, rarely all the sheaths, villous or velvetypubescent, the uppermost glabrous; ligule prominent; blades flat, the lower villous, the upper glabrate, 10 to 15 $\mathrm{cm}$ long, 3 to $5 \mathrm{~mm}$ wide; racemes mostly 5 to 10 , slender, pale, ascending or erect, 5 to $12 \mathrm{~cm}$ long, the axis 1 to $4 \mathrm{~cm}$ long; rachis angled,

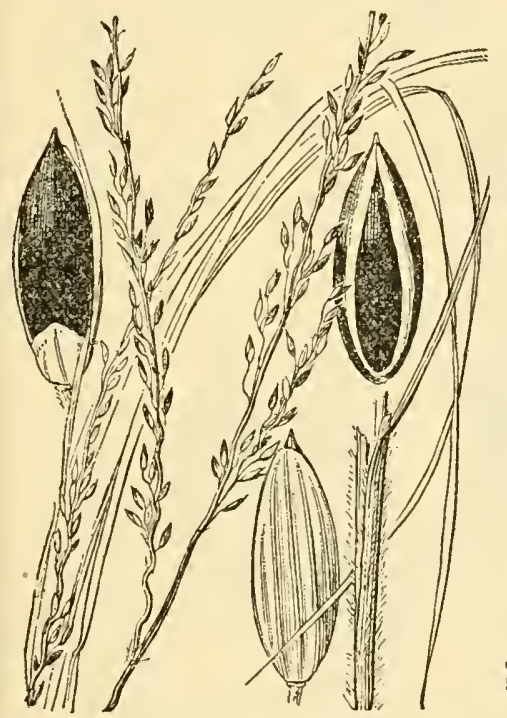

Figure 1173.-Digitaria qracillima. Plant, $\times 1$; two views of spikelet, and floret, $\times 10$. (Type.)

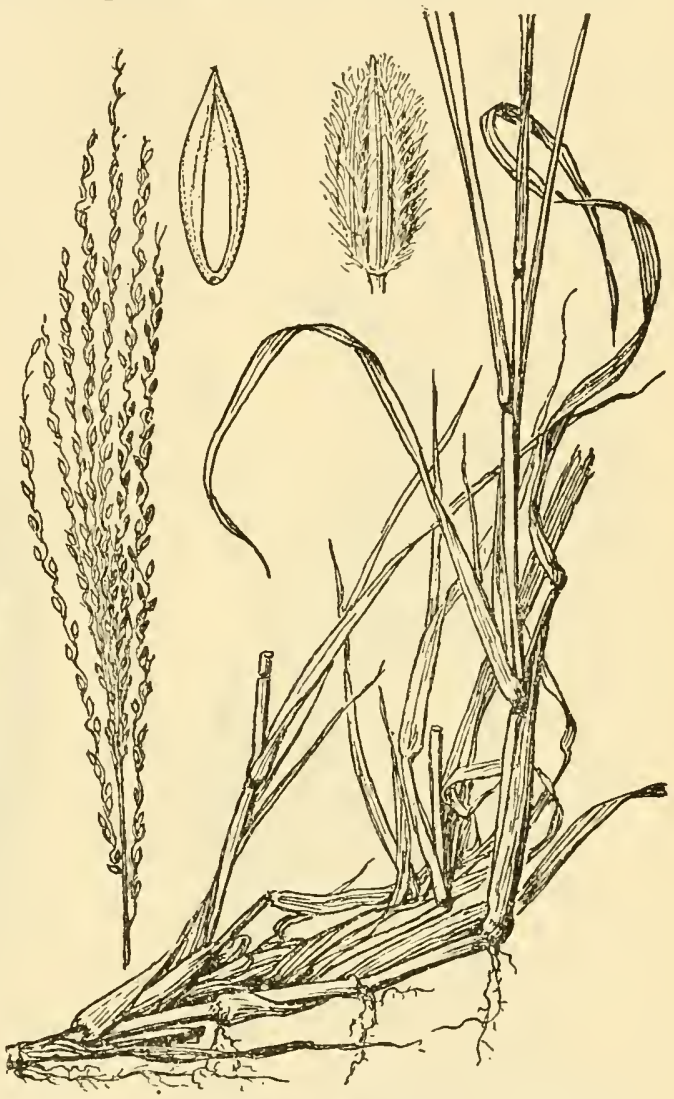

FIgure 1174.-Digitaria texana. Plant, $\times 1$; spikelet and floret, $\times 10$. (Type.)

the scabrous margins much narrower than the whitish center; spikelets mostly rather distant, 2 to $2.5 \mathrm{~mm}$ long, from short-villous to nearly glabrous, the silky hairs not at all capitellate; first glume obsolete; second glume and sterile lemma as long as the pale acute fertile lemma. 24 Sandy oak woods or sandy prairie, southern 'Texas.

13. Digitaria pauciflóra Hitchc. (Fig. 1175.) Perennial; culms erect or somewhat decumbent at base, 0.5 to $1 \mathrm{~m}$ tall, very slender, sparingly branching; foliage grayish-villous, the blades 6 to $12 \mathrm{~cm}$ 
long, about $2 \mathrm{~mm}$ wide; racemes 2 or 3 , ascending or erect, 5 to $11 \mathrm{~cm}$ long, the filiform rachis naked for 1 to $1.5 \mathrm{~cm}$ at base, or with distant abortive spikelets; spikelets rather distant, elliptic, about $3.2 \mathrm{~mm}$ long, glabrous; first glume minute with a hyaline erose margin; second glume and sterile lemma finely nerved, as long as the grayish fertile lemma. 24 -Pinelands, southern Florida.

14. Digitaria subcálva Hitchc. (Fig. 1176.) Perennial; culms tufted, slender, ascending from a curved base, 40 to $100 \mathrm{~cm}$ tall; sheaths papillose-pilose; blades flat, scabrous, the lower pilose, 3 to

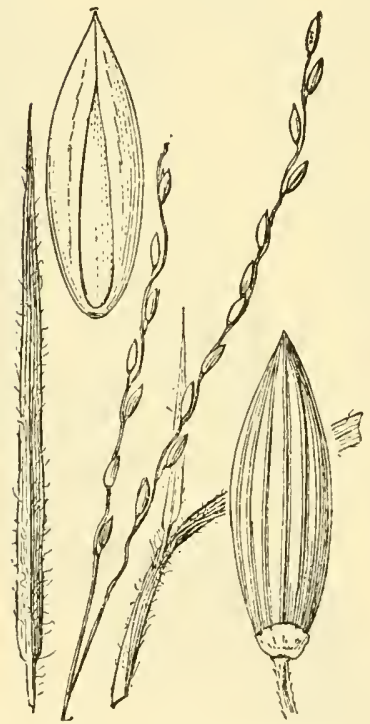

FIGURE 1175.-Digitaria paucifora. Plant, $X 1$; spikelet and eoret, $X$ 10. (Type.)

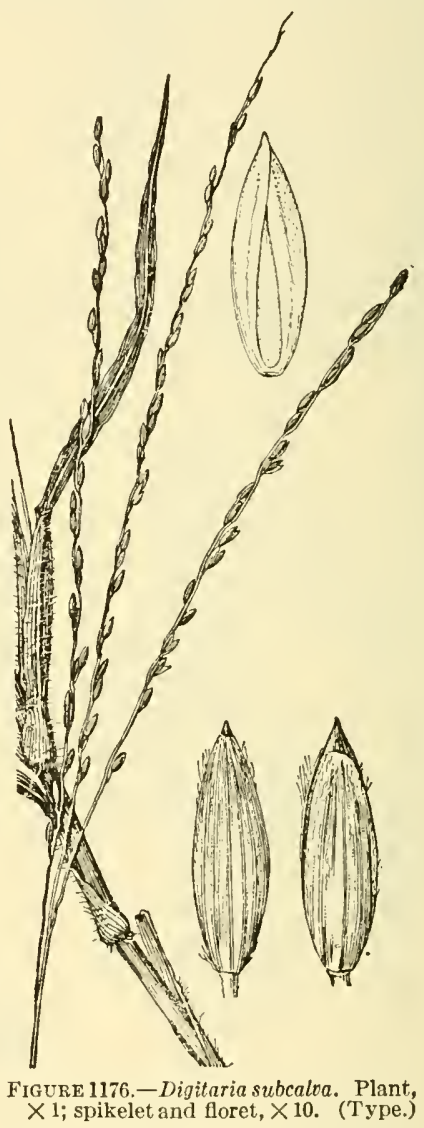

$\times 1$; spikelet and floret, $\times 10$. ('Type.)

$15 \mathrm{~cm}$ long 1 to $3 \mathrm{~mm}$ wide; racemes 2 to 4, narrowly ascending, 5 to $12 \mathrm{~cm}$ long, approximate, the rachis slender, triangular, mostly naked at base for 1 to $1.5 \mathrm{~cm}$; spikelets 2.5 to $2.8 \mathrm{~mm}$ long, acute; first glume obsolete; second glume and sterile lemma slightly shorter than the acute pale or drab fruit, the internerves from obscurely to distinctly appressed silky-pubescent. 24 -Known only from Plant City, Fla.

15. Digitaria runyóni Hitchc. (Fig. 1177.) Perennial; culms ascending, 40 to $70 \mathrm{~cm}$ tall, the base often long-creeping and rooting, many-noded; sheaths densely villous or the upper glabrate; blades flat, the lower densely velvety-villous, the upper sparingly pilose or glabrous, mostly less than $10 \mathrm{~cm}$ long, 3 to $6 \mathrm{~mm}$ wide; racemes 5 to 10 , 
on an axis 1 to $4 \mathrm{~cm}$ long, mostly suberect, 7 to $12 \mathrm{~cm}$ long, pale, sometimes naked at base, the rachis flat-triangular; spikelets narrowly lanceolate, acute, 2.8 to $3.5 \mathrm{~mm}$ long; first glume minute or obsolete; second glume and sterile lemma equal, sparsely to densely villous on the internerves, the lemma glabrous on the middle internerves; fertile lemma acuminate, usually a little shorter than the spikelet, pale at maturity. 24 -Sand dunes and sandy prairies along the coast, southern Texas.

\section{LEPTOLOMA Chase}

Spikelets on slender pedicels; first glume minute or obsolete; second glume 3-nerved, nearly as long as the 5- to 7-nerved sterile lemma, a more or less prominent stripe of appressed silky hairs down the internerves and margins of each, the sterile lemma enipty or enclosing a minute nerveless rudimentary palea; fertile lemma cartilaginous, elliptic, acute, brown, the delicate hyaline margins enclosing the palea. Branching perennials with brittle culms, felty pubescent at base, flat blades, and open or diffuse panicles, these breaking away at maturity, becoming tumbleweeds. Type species, Leptoloma cognatum. Name from Greek leptos, thin and loma, border, alluding to the thin margins of the lemma.

\section{Leptoloma cognátun (Schult.)} Chase. Fall witchgrass. (Fig. 1178.) Ascending from a decumbent base, often forming large bunches, pale green, leafy; culms 30 to $70 \mathrm{~cm}$ long; blades mostly less than $10 \mathrm{~cm}$ long, 2 to $6 \mathrm{~mm}$ wide, rather rigid; panicle onethird to half the entire height of the plant, purplish and short-exserted at maturity, very diffuse, the capillary branches soon widely spreading, pilose in the axils, the spikelets solitary on long capillary pedicels, narrowly elliptic, 2.5 to $3 \mathrm{~mm}$ long, abruptly acuminate. 24 (Panicum cognatum Schult., Panicum autumnale Bosc.)-Dry soil and sandy fields, New Hampshire to

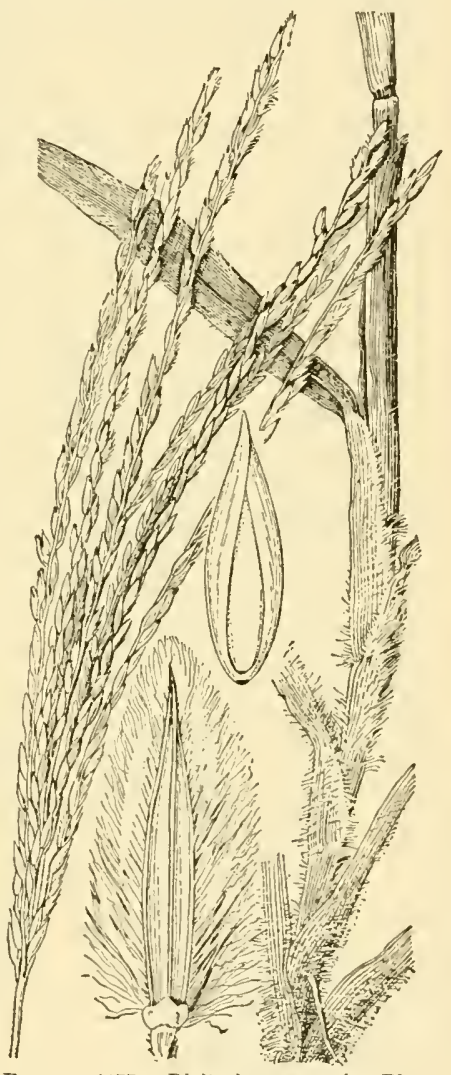

FIGURE 1177.-Digitaria runyoni. Plant, $\times 1$; spikelet and floret, $\times 10$. (Type.) Minnesota, south to Florida and 'Texas, west to Arizona (fig. 1179). A fairly palatable grass.

\section{STENOTÁPHRUM Trin.}

Spikelets embedded in one side of an enlarged and flattened corky rachis tardily disarticulating toward the tip at maturity, the spikelets remaining attached to the joints; first glume small; second glume and sterile lemma ahout equal, the latter with a palea or staminate 
564 Misc. PUBLICATION 200, U. S. DEPT. OF AGRICULTURE

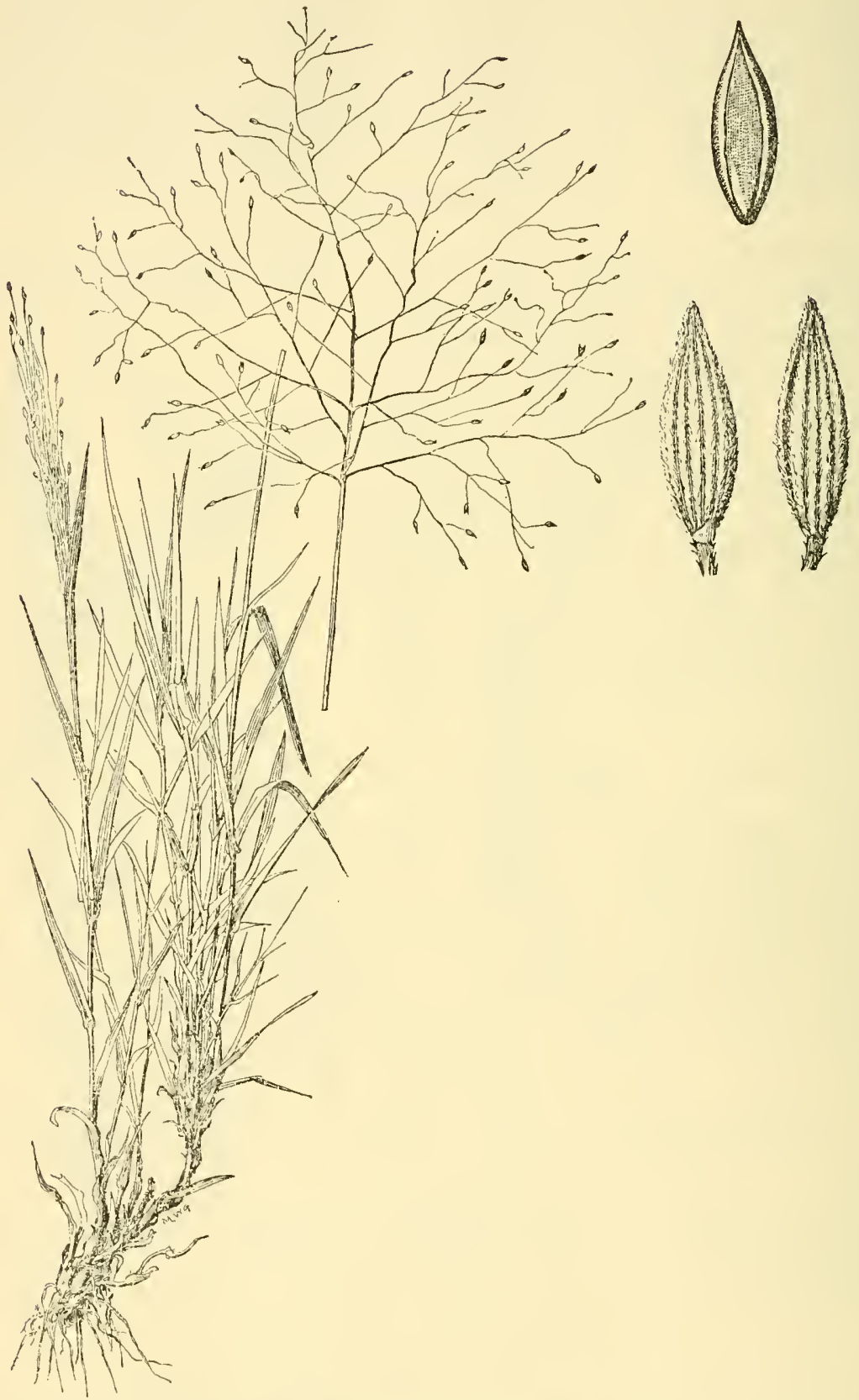

FigURe 1178.-Leptolom cognatum. Plant, $\times 1 / 2$; two views of spikelet, and floret, $\times 10$. (Tracy 8223 , Tex.) 
flower; fertile lemma chartaceous. Creeping stoloniferous perennials, with short flowering culms, rather broad and short obtuse blades, and terminal and axillary racemes. Type species, Stenotaphrum glabrum
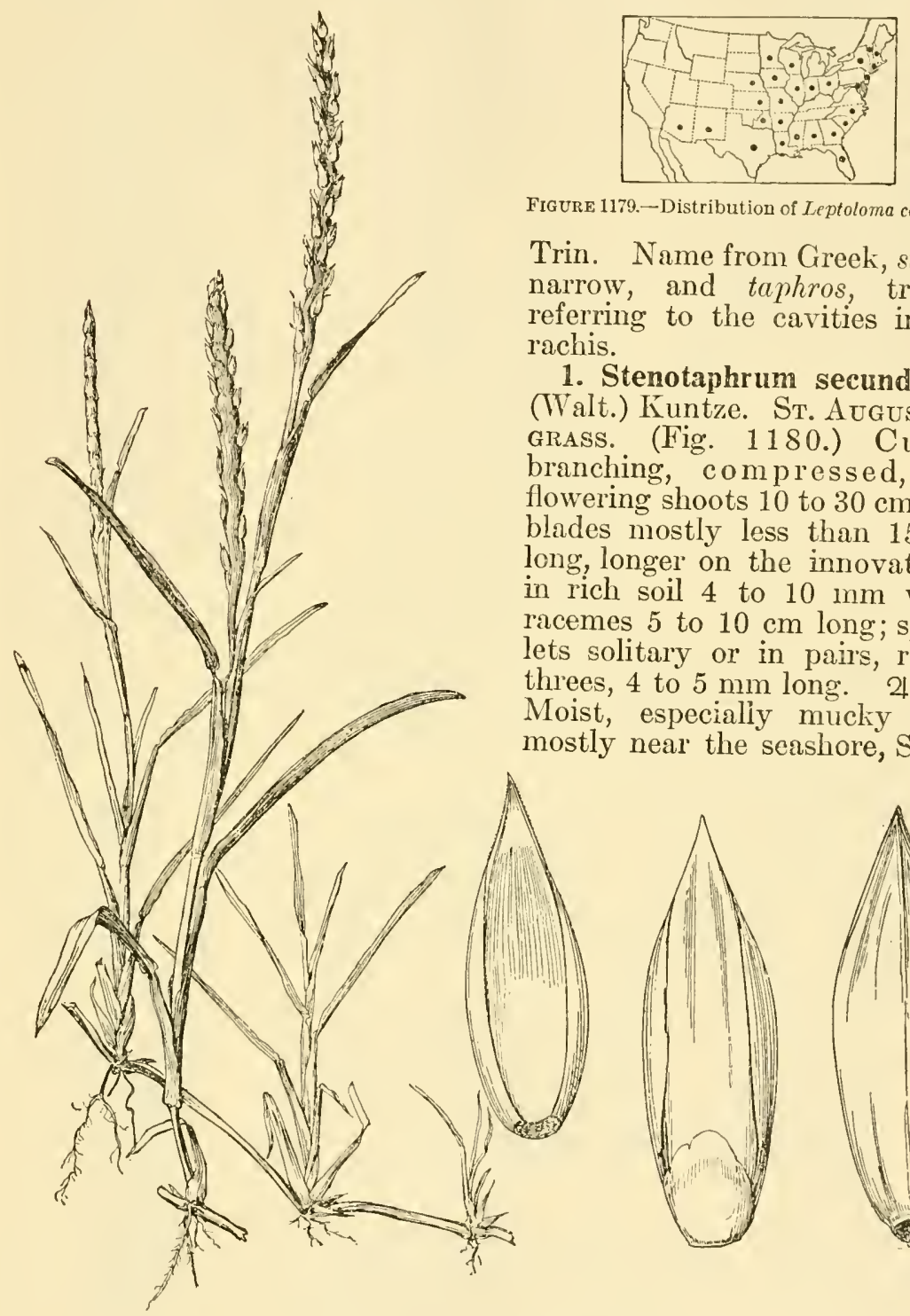

IGURE 1179.-Distribution of Leptoloma cognatum

Trin. Name from Greek, stenos, narrow, and taphros, trench, eferring to the cavities in the rachis.

1. Stenotaphrum secundátum Walt.) Kuntze. St. Augustine GRASS. (Fig. 1180.) Culms branching, compressed, the flowering shoots 10 to $30 \mathrm{~cm}$ tall; blades mostly less than $15 \mathrm{~cm}$ long, longer on the innovations, in rich soil 4 to $10 \mathrm{~mm}$ wide; racemes 5 to $10 \mathrm{~cm}$ long; spikeets solitary or in pairs, rarely threes, 4 to $5 \mathrm{~mm}$ long. $21-$ Moist, especialiy mucky soil, mostly near the seashore, South

Figube 1180.-Stenotaphrum secundatum. Plant, $\times 1 / 2 ;$ two views of spikelet, and fertile floret, $\times 10$.

Carolina to Florida and Texas (fig. 1181). Cultivated as a lawn grass in the coastal cities. The lawns have a coarse texture but are otherwise satisfactory. Propagated by cuttings of the stolons. A variegated form with leaves striped with white is used as a basket plant. Called by gardeners var. variegatum. 


\section{ERIÓCHLOA H.B.K. Cupgrass}

Spikelets more or less pubescent, solitary or sometimes in pairs, short-pediceled or subsessile, in two rows on one side of a narrow rachis, the back of the fertile lemma turned from the rachis; lower rachilla joint thickened, forming a more or less ringlike, usually darkcolored callus below the second glume, the first glume reduced to a minute sheath about this and adnate to it; second glume and sterile lemma about equal, the lemma usually enclosing a hyaline palea or sometimes a staminate flower; fertile lemma indurate, minutely papillose-rugose, mucronate or awned, the awn often readily deciduous, the margins slightly inrolled. Annual or perennial, often branching grasses, with terminal panicles of several to many spreading or appressed racemes, usually approximate along a common axis. The species are called cupgrasses because of the tiny cup made by the first glume at the base of the spikelet. Type species, Eriochloa distachya H.B.K. Name from Greek erion,

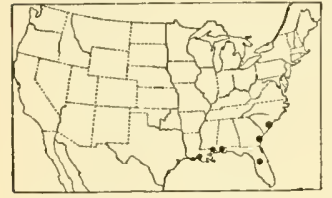

FIGURE 1181,-Distribution of Stenotaphrum secundatum. wool, and chloa, grass, alluding to the pubescent spikelets and pedicels.

A West Indian species, E. polystchaya H.B.K. (E. subglabra (Nash) Hitchc.), called malojilla in Puerto Rico, is used for forage. This has been tried along the Gulf Coast from Florida to southern Texas and has given excellent results in southern Florida and at Biloxi, Miss. It is similar in habit to Para grass, producing runners but less extensively, is suited to grazing, and will furnish a good quality of hay. It will not withstand either cold or drought. The name carib grass has been proposed for it. In Arizona E. gracilis has some value for forage in the national forests.

Spikelets, including slender awns, 7 to $10 \mathrm{~mm}$ long....... 1. E. ARISTATA. Spikelets not more than $6 \mathrm{~mm}$, awnless or awn-tipped.

Pedicels with erect hairs at least half as long as the spikelet; racemes dense, erect or appressed. (See also E. gracilis var. minor.)

Blades 2 to $3 \mathrm{~mm}$ wide, elongate.

Blades 5 to $15 \mathrm{~mm}$ wide, not more than $15 \mathrm{~cm}$ long.... 3. E. LEMMON!

Pedicels scabrous or short-pubescent.

Plants perennial.

Rachis velvety to villous; spikelets narrowly ovate_-_ 8. E. MICHAUXi1.

Rachis scabrous only; spikelets lanceolate_........ 7. E. PUNCTATA.

Plants annual.

Rachis scabrous only; racemes slender. Introduced_--- 4. E. Procera. Rachis pubescent; racemes stouter.

Blades glabrous; fruit apiculate. Blades pubescent; fruit with an awn about $1 \mathrm{~mm}$ long.

6. E. contracta.

1. Eriochloa aristáta Vasey. (Fig. 1182.) Annual; culms erect or spreading at base, 50 to $80 \mathrm{~cm}$ tall; blades flat, mostly 10 to 12 $\mathrm{mm}$ wide, glabrous; racemes several, ascending, overlapping, 3 to 4 $\mathrm{cm}$ long, the rachis pilose, the pedicels bearing several long stiff hairs; spikelets about $5 \mathrm{~mm}$ long, the glume and sterile lemma tapering into awns (awn of the glume about as long as the spikelet), appressedvillous on the lower half or two-thirds, the upper part scaberulous only; fruit $3.5 \mathrm{~mm}$ long, apiculate. $\odot$ - Open ground, Arizona (Tucson) and California (Fort Yuma); northern Mexico. 
2. Eriochloa serícea (Scheele) Munro. (Fig. 1183.) Perennial, in

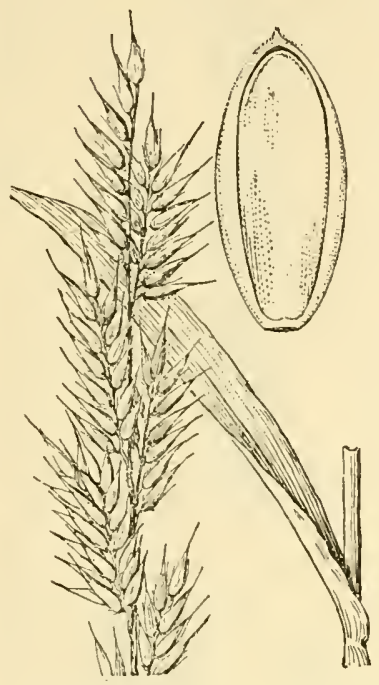

Figure 1182.-Eriochloa aristata. Plant, $\times 1$; floret, $\times 10$. (Thornber 98, Ariz.) long, rather turgid, dense tufts; culms simple, erect, 50 to $100 \mathrm{~cm}$ tall, the lowermost sheaths felty - pubesce n t ; blades elongate, 2 to $3 \mathrm{~mm}$ wid e, fiat or mostly involute, densely puberulent at the junction with the sheath; racemes several, appressed, somewhat distant, usually not overlapping, mostly 1.5 to $3 \mathrm{~cm}$ long, the rachis hirsute, the pedicels with copious stiff hairs half as long as the spikelet; spikelets $4 \mathrm{~mm}$

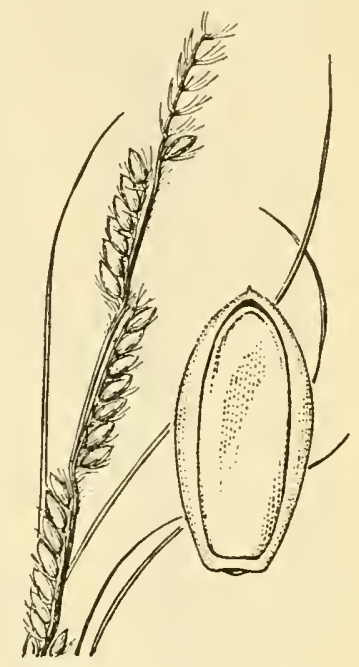

FIGUP.E 1183.--Eriochloa sericea. Plant, $\times 1$; floret, $\times 10$. (Rev. erchon 1170 , Tex.)

short-villous, the

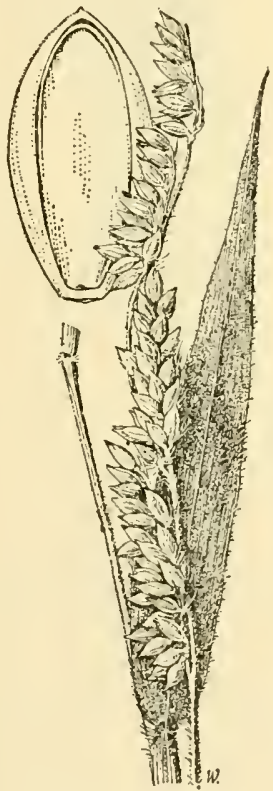

FIGURE 1184.-Eriochlor lemmoni. Plant, $\times 1$; floret, $\times 10$. (Peebles and Harrison 4703 , Ariz.) glume and sterile lemma acutish; fruit $3 \mathrm{~mm}$ long, apiculate. 4 -Prairies and hills, Texas and Oklahoma.

3. Eriochloa lemmóni Vasey and Scribn. (Fig. 1184.) Annual; culms decumbent at base, 30 to $60 \mathrm{~cm}$ tall; blades flat, only the larger as much as $15 \mathrm{~cm}$ long, 5 to $15 \mathrm{~mm}$ wide, velvety-pubescent on both surfaces; racemes erect, the upper overlapping, 1.5 to $3 \mathrm{~cm}$ long, the axis and rachis densely villous, the pedicels with several long hairs; spikelets $4 \mathrm{~mm}$ long, rather turgid, villous except the apex, abruptly narrowed to a short obtuse point;fruit $3 \mathrm{~mm}$ long, slightly apiculate. $\odot$-Canyons, southern Arizona and northern Mexico.

4. Eriochloa prócera (Retz.) Hubbard. (Fig. 1185.) Annual; culms spreading at base, 40 to $60 \mathrm{~cm}$ tall; blades flat, 2 to 4 $\mathrm{mm}$ wide; racemes loose, slender, ascending, 3 to $5 \mathrm{~cm}$ long, the rachis scabrous only; spikelets 3 to $3.5 \mathrm{~mm}$ long, appressed-pubescent, except toward the tip, the

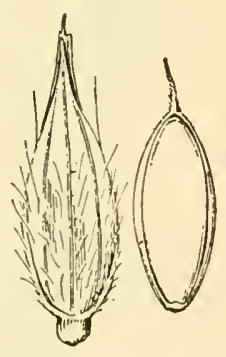

Figtre 1185.-Eriochloa procera, $\times 10$. (Griflit hs 1516 , Ariz.) glume and sterile lemma acuminate; fruit $2 \mathrm{~mm}$ long, the slender awn about $0.5 \mathrm{~mm}$ long. $\odot(E$. ramosa Kuntze.)-Introduced on the university campus at Tuscon, Ariz.; Cuba; tropical Asia.

5. Eriochloa grácilis (Fourn.) Hitche. (Fig. 1186, A.) Annual; culms erect or decumbent at base, 40 to $100 \mathrm{~cm}$ tall; blades flat, gla- 


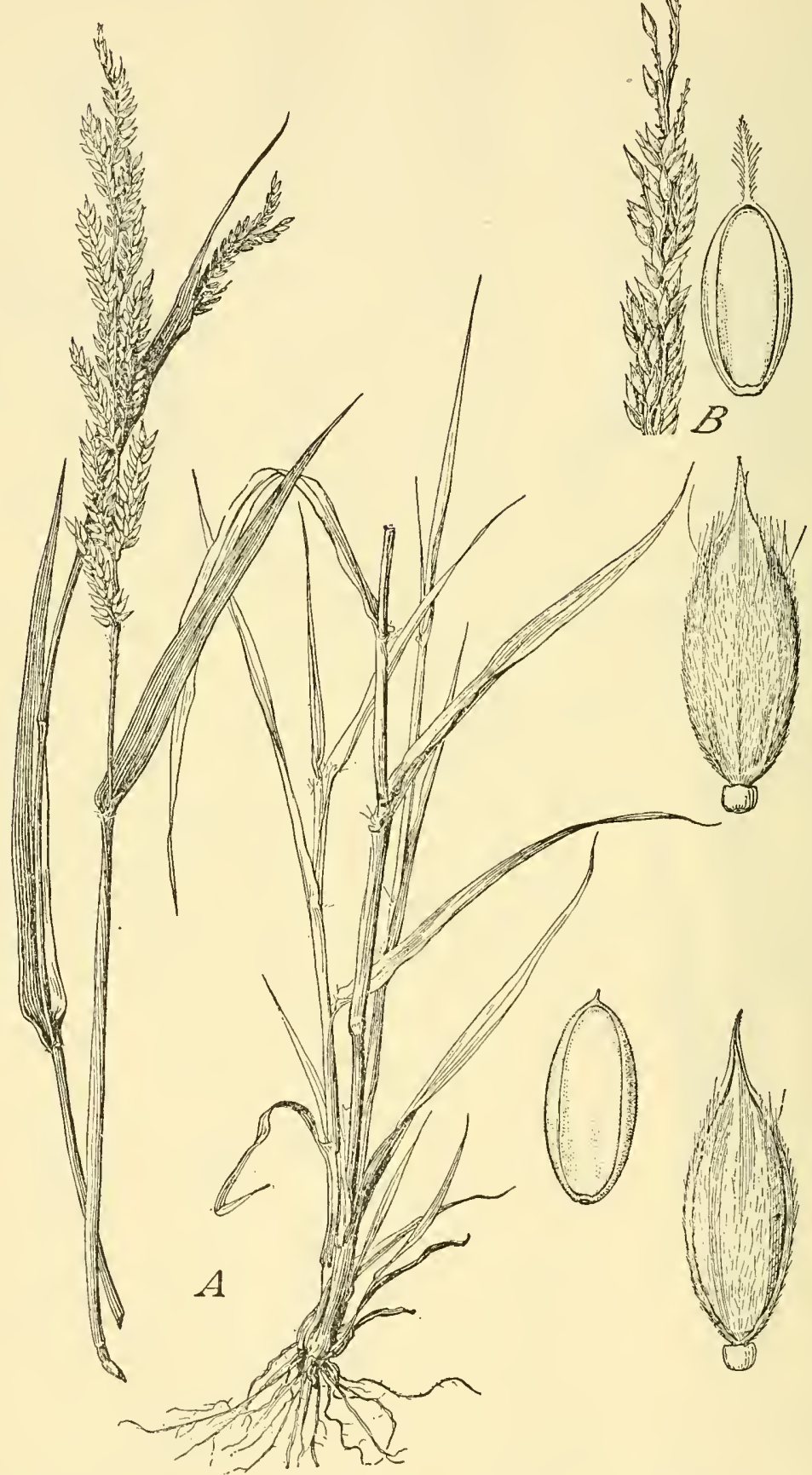

Figure 1186. A, Errochlon gracilis. Plant, $\times 1 / 2 ;$ two views of spikelet, and floret, $\times 10$. (McDougal, Ariz.) $B, E$. contracta. Panicle, $\times 1$; floret, $\times 10$. (Hitchcock 13420 , Tex.) 
brous, mostly 5 to $10 \mathrm{~mm}$ wide; racemes several to numerous, approximate, ascending to slightly spreading, 2 to $4 \mathrm{~cm}$ long, the axis and rachis softly pubescent, the pedicels short-pilose; spikelets 4 to $5 \mathrm{~mm}$ long, rather sparsely appressed-pubescent, acuminate, or the glume sometimes tapering into

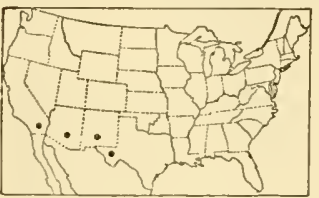

FIGCRE 1187,-Distribution of Eriochloa gracilis. an awn-point as much as $1 \mathrm{~mm}$ long; sterile lemma empty; fruit about $3 \mathrm{~mm}$ long, apiculate. $\odot-$ Open ground, often a weed in fields, western Texas to southern California, south through the

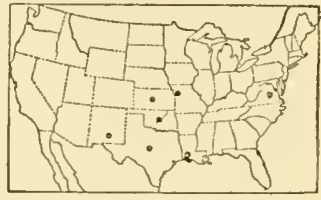

FIGURE 1188.-Distribution of Eriochloa contracta.

highlands of Mexico (fig. 1187). (This species has been referred to E. acuminata (Presl) Kunth, an unidentified species of Mexico.)

Eriochloa Gracilis var. mínor (Vasey) Hitchc. Mostly smaller, with more crowded, less acuminate spikelets, the pedicels with a few long hairs at the sumnit, fertile lemma about as long as the glume and sterile lemma (excluding the short points), obtuse or slightly apiculate. $\odot-O p e n$ ground, Texas, New Mexico, and Arizona.

6. Eriochioa contrácta Hitchc. Prairie Cupgrass. (Fig. 1186,

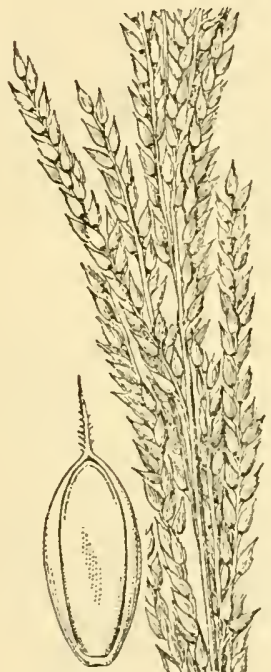

FIGURE 1189,-Eriochloa punctuta. Panicle, $\times 1$; floret, $\times 10$. (Hitchcock 9661, Jamaica.)
B.) Annual; culms erect or sometimes decumbent at base, pubescent at least about the nodes, 30 to $70 \mathrm{~cm}$ tall; blades pubescent, usually not more than $5 \mathrm{~mm}$ wide; panicle usually less than $15 \mathrm{~cm}$ long, contracted, cylindric, the racemes appressed, closely overlapping, 1 to $2 \mathrm{~cm}$ long, the axis and rachises villous; spikelets 3.5 to $4 \mathrm{~mm}$ long, excluding the awn-tip, appressed-villous; glume awn-tipped; sterile lemma slightly shorter, acuminate, empty; fruit 2 to 2.5

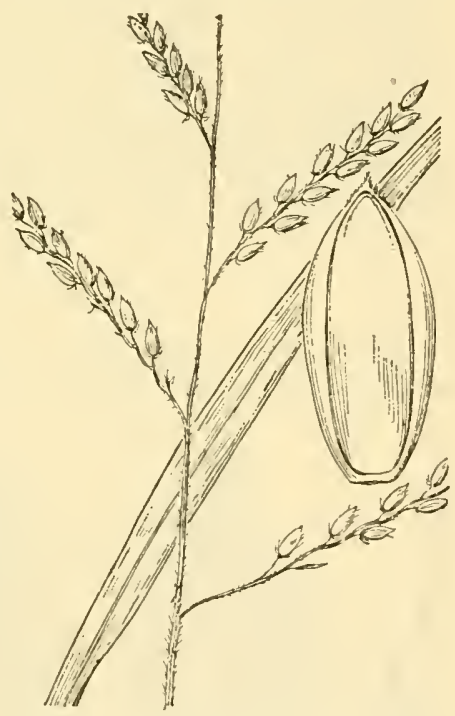

Figure 1190.-Eriochlon micharatii. Plant, $\times$ 1: floret, $\times 10$. (Amer. Gr. Nat. Herb. 237, Fla.)

$\mathrm{mm}$ long, with an awn nearly $1 \mathrm{~mm}$ long. $\odot-O p e n$ ground, ditches, low fields, and wet places, Kansas to Louisiana and New Mexico; introduced in Missouri and Virginia (fig. 11SS). Differing from $E$.gracilis in the pubescent foliage, subcylindric panicle, and the awned fruit.

7. Eriochloa punctáta (L.) Desv. (Fig. 1189.) Perennial; culms in tufts, usually 50 to $100 \mathrm{~cm}$ tall; blades flat, mostly 5 to $10 \mathrm{~mm}$ wide, 
glabrous; racemes several, ascending, overlapping, 3 to $5 \mathrm{~cm}$ long, the axis, rachises, and pedicels scabrous only; spikelets 4 to $5 \mathrm{~mm}$ long, lanceolate, rather sparsely appressed-pilose; glume tapering to an awn-point about $1 \mathrm{~mm}$ long; sterile lemma a little shorter than the glume, empty; fruit about half as long as the glume, awned, the awn $1 \mathrm{~mm}$ long or more. 24 -Marshes, river banks, and moist ground, southwestern Louisiana and southern Texas.

8. Eriochloa michaúxii (Roem. and Schult.) Hitche. (Fig. 1190.) Perennial; culms erect, rather stout, 60 to $120 \mathrm{~cm}$ tall; blades flat or, on the innovations, sometimes involute, elongate, 2 to $14 \mathrm{~mm}$ wide, usually less than $1 \mathrm{~cm}$, glabrous; racemes ascending or spreading, usually numerous, 3 to 5 or even to $15 \mathrm{~cm}$ long, the axis 15 to $30 \mathrm{~cm}$ long, this and the rachises densely velvety-pubescent; spikelets narrowly ovate, 4 to $5 \mathrm{~mm}$ long, appressed-villous, acute; sterile floret usually with a well-developed palea and stamens; fruit 3 to 4 $\mathrm{mm}$ long, hirsutulous at apex, apiculate or with an awn not more than $0.3 \mathrm{~mm}$ long. 24 (E. mollis Kunth.)-Brackish or fresh meadows and marshes and sandy prairies, southeastern Georgia and Florida. A form with narrow blades and relatively few racemes, the axis and rachis puberulent, has been described as $E$. mollis var. longifolia Vasey. It grades into the typical form with broader blades and more numerous racemes; the sterile floret contains a staminate flower.

Eriochloa michauxil var. simpsóni Hitche. Resembling the narrow-leaved form of the species; racemes few, appressed; sterile lemima empty. 2 -Moist places, Myers to Cape Sable, Fla.

Eriochloa nelsóni Scribn. and Smith. Tall annual with puberulent blades, few spreading racemes, the rachis very woolly, and rather blunt, turgid pubescent spikelets about $5 \mathrm{~mm}$ long. $\odot$-Ballast, near Portland, Oreg., Jalisco, Mex., to Nicaragua.

\section{BRACHIÁRIA (Trin.) Griseb.}

Spikelets solitary, rarely in pairs, subsessile, in two rows on one side of a 3-angled, sometimes narrowly winged rachis, the first glume
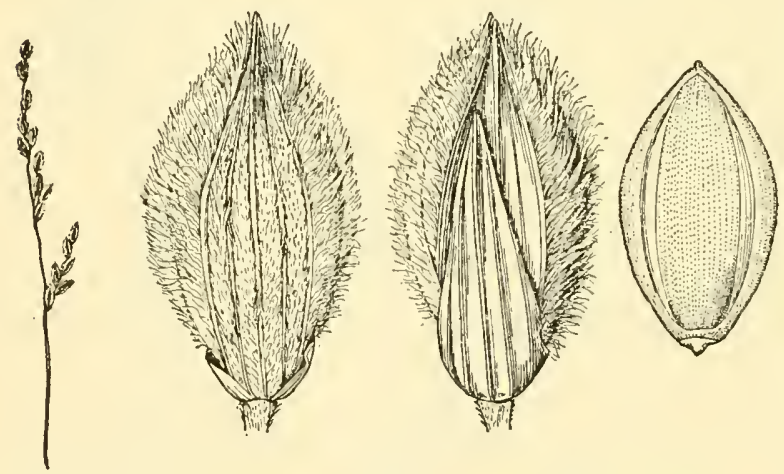

FIgURE 1191,- Brachiaria ciliatissima. Panicle, $\times 1$; two views of spikelet, and floret, $\times 10$. (Type.)

or bearing a short awn. Branching and spreading annuals or perennials, with linear blades and several spreading or appressed racemes approximate along a common axis. Type species, Brachiaria erucaeformis. Name from Latin brachium, arm, alluding to the armlike racemes. 
Spikelets densely silky-pubescent; plants perennial_...... 1. B. ciliatissima. Spikelets glabrous; plants annual.

Spikelet flat-beaked beyond the fruit

Spikelet not beaked beyond the fruit

2. B. EXTENSA.

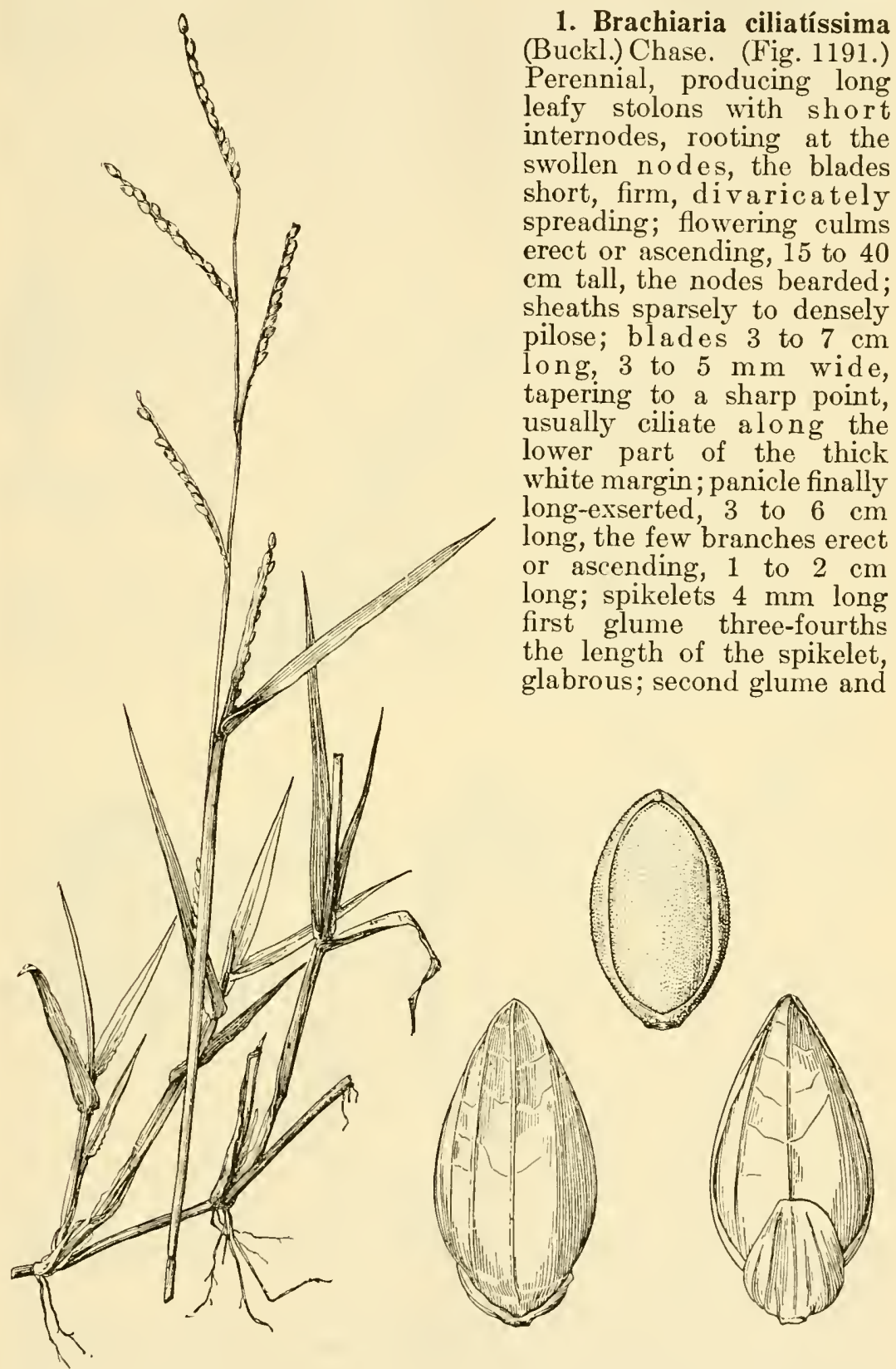

FIgURE 1192.-Brachiaria extensa. Plant, $\times 1 / 2 ; t$ wo views of spikelet, and floret, $\times 10$. (Nealley, Tex.) 
sterile lemma about equal, 5-nerved, the marginal part densely white-silky; fruit $3 \mathrm{~mm}$ long. 24 -Open sandy ground, Texas; Arkansas (Benton County).

2. Brachiaria exténsa Chase. (Fig. 1192.) Annual; culms decumbent, rooting at the lower nodes; blades rather thick, 4 to $12 \mathrm{~cm}$ long, 6 to $12 \mathrm{~mm}$ wide; panicle short-exserted or included at base; racemes 2 to 6 , distant, 3 to $8 \mathrm{~cm}$ long, ascending or

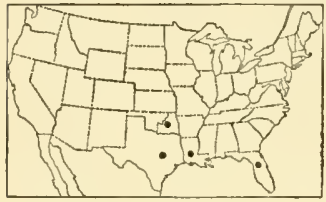

Figure 1193.-Distribution of Brachiaria extensa. spreading, the rachis winged, $2 \mathrm{~mm}$ wide; spikelets ovate, 4 to $4.5 \mathrm{~mm}$ long, about $2 \mathrm{~mm}$ wide; first glume scarcely onethird the length of the spikelet, blunt; second glume and sterile lemma equal, exceeding the fruit and forming a flat beak beyond it,3- to 5 -nerved, with transverse veinlets toward the summit; fruit $3 \mathrm{~mm}$ long, elliptic, papillose-roughened. $\odot$ (B. platyphylla Nash.)-Low, sandy, open ground, Florida; southern Louisiana, Texas, and Oklahoma; Cuba (fig. 1193).

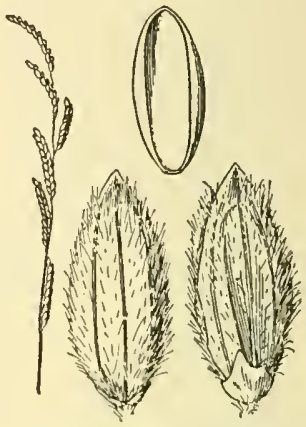

FIGURE 1195.-Brachiaria erucaeformis. Panicle, $\times 1$; two views of spikelet, and floret, $\times 10$. (Cult.)

3. Brachiaria plantagínea (Link) Hitche.

(Fig. 1194.) Resembling B. extensa, more widely creeping, usually taller, blades commonly wider; rachis 1 to $1.5 \mathrm{~mm}$ wide, the margins infolded; first glume strongly clasping; transverse veinlets wanting or obscure on the second glume and sterile lemma, these not
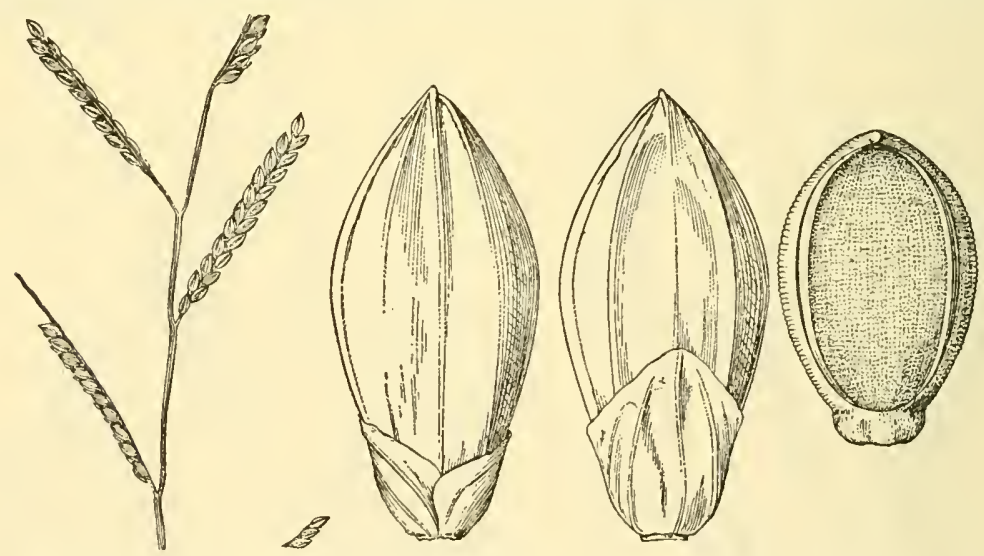

Figure 1194.-Brachiaria plantaginea. Panicle, $\times 1$; two views of spikelet, and floret, $\times 10$. (Pringle 3904, Mex.)

pointed beyond the fruit. $\odot$-Open, mostly moist, ground, Metcalf, Ga.; ballast, Philadelphia, Pa., and Camden, N.J.; Mexico to Bolivia and Brazil.

Brachiaria erucaefórmis (J. E. Smith) Griseb. (Fig. 1195.) Spreading annual with rather delicate erect racemes and pubescent spikelets $2.5 \mathrm{~mm}$ long. $\odot$ - Has been cultivated in grass gardens, occasionally escaped. Old World. 


\section{AXONOPUS Beauv.}

Spikelets depressed-biconvex, not turgid, oblong, usually obtuse, solitary, subsessile, and alternate, in two rows on one side of a 3-angled rachis, the back of the fertile lemma turned from the axis; first glume wanting; second glume and sterile lemma equal, the lemma without a palea; fertile lemma and palea indurate, the lemma oblong-elliptic, usually obtuse, the margins slightly inrolled. Stoloniferous or tufted perennials, rarely annuals, with usually flat or folded, abruptly rounded or somewhat pointed blades, and few or numerous, slender spikelike racemes, digitate or racemose along the main axis. Type

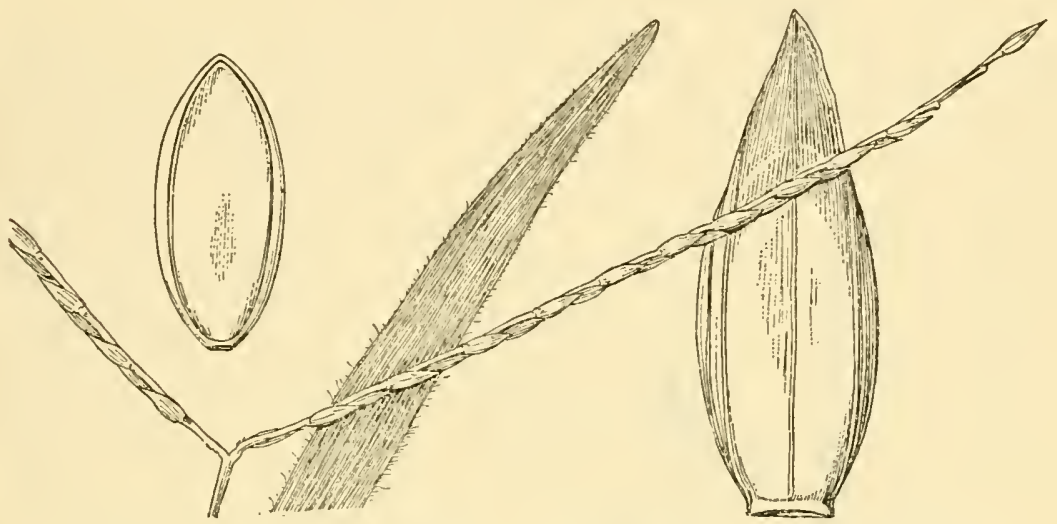

Figure 1196.-Azonopus furcatus. Plant, $\times 1$; spikelet and floret, $\times 10$. (Combs 1205, Fla.)

species, Axonopus compressus. Name from Greek axon, axis, and pous, foot.

One of the species, $A$. compressus, is a predominant pasture grass in the alluvial or mucky soil of the southern Coastal Plain. It is of little importance on sandy soil and does not thrive on the uplands. This species is also used as a lawn grass, for which purpose it is propagated by setting out pieces of the stolons.

Spikelets 4 to $5 \mathrm{~mm}$ long, glabrous; midnerve of glume and sterile lemma evi-

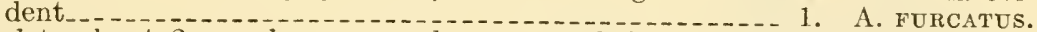
Spikelets about $2 \mathrm{~mm}$ long, sparsely appressed-silky; midnerve of glume and sterile lemma suppressed _._.................. 2. A. compressus.

1. Axonopus furcátus (Flügge) Hitchc. (Fig. 1196.) Plants stoloniferous; culns compressed, tufted, erect, or decumbent at base, 40

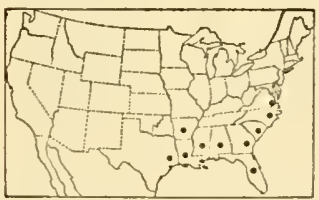

FIGURE 1197.-Distribution of Axonopus furcatus.

kansas (fig. 1197). misapplied to this species. Digitaria paspalodes Michx., upon which it is based, is Paspalum distichum L.) wide, glabrous, ciliate, or even hirsute; racemes 2 , digitate, rarely a third below, spreading, 5 to $10 \mathrm{~cm}$ long; spikelets 4 to $5 \mathrm{~mm}$ long (rarely less), glabrous, acute, glume and sterile lemma 5 -nerved; fruit about two-thirds as long as the spikelet. 24 -Marshes, river banks, and moist pine barrens, on the Coastal Plain, southeastern Virginia to Florida, Texas, and Arto $100 \mathrm{~cm}$ tall; blades flat, mostly 5 to $10 \mathrm{~mm}$ 
2. Axonopus compréssus (Swartz) Beauv. Carpet grass. (Fig. 1198.) Plants stoloniferous, the blades of the stolons often broader and shorter than those of the culm; flowering culms erect or ascend-

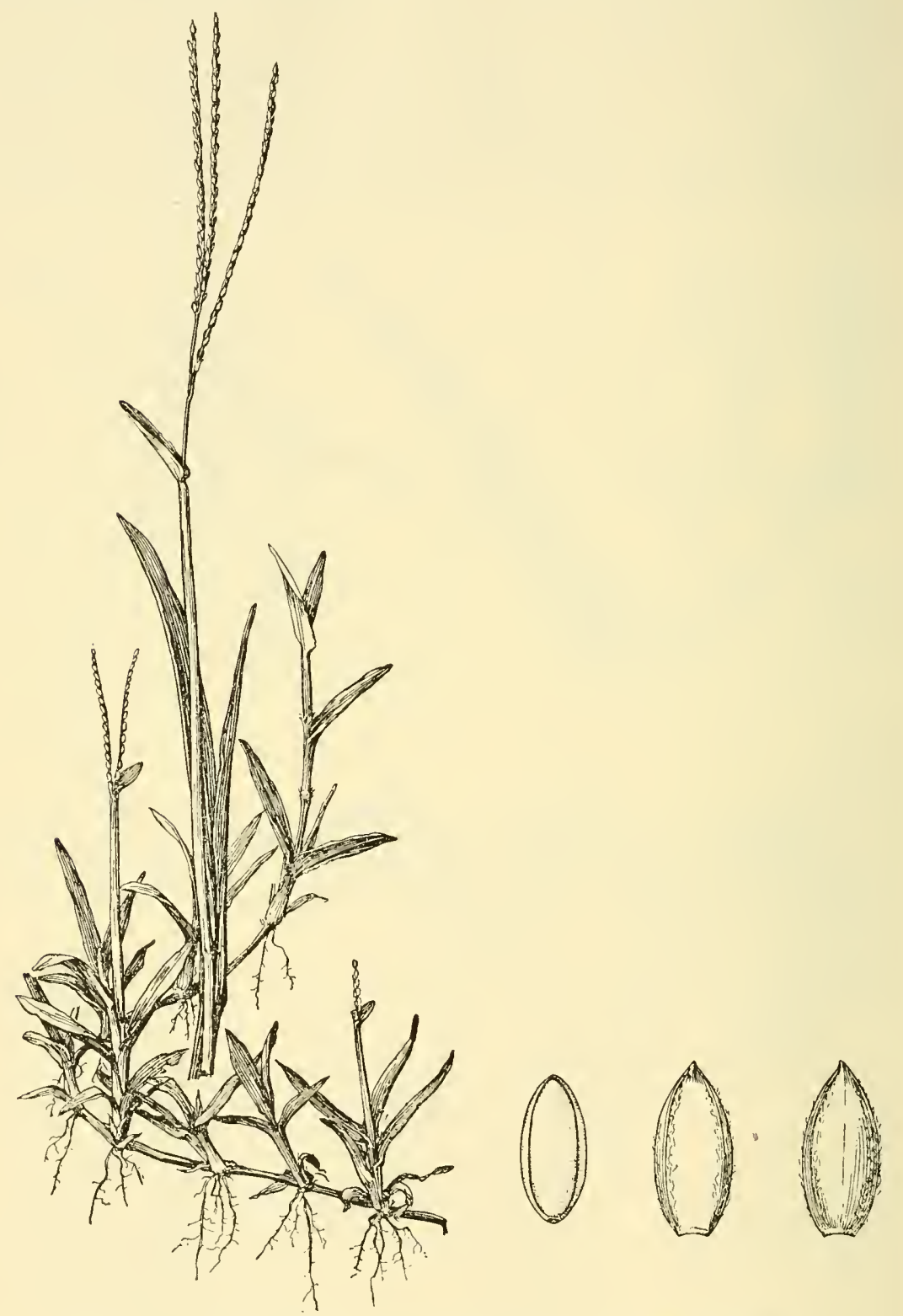

Figure 1198.-Axonopus compressus. Plant, $\times 1 / 2$; two views of spikelet, and floret, $\times 10$. (Combs 413, Fla.)

ing, compressed, usually 20 to $60 \mathrm{~cm}$ tall; blades flat, or folded in drying, 2 to $10 \mathrm{~mm}$ (commonly 4 to $8 \mathrm{~mm}$ ) wide, usually ciliate, at least near the base; peduncles terminal and axillary, very slender, 
ong-exserted; racemes usually 3 , a pair at the summit and 1 rarely 2 or even 3 below, usually a pair only on axillary peduncles, slender, ascending, 3 to $10 \mathrm{~cm}$ long; spikelets about $2 \mathrm{~mm}$ long, pale; glume and sterile lemma equaling the fruit or pointed beyond it, sparsely appressed-silky near the margin, 2 or 4 nerved, the nerves close to the margin, the midnerve suppressed. 24 (Anastrophus compressus Schlecht.; Anastrophus platycaulis Nash.)-Moist sandy or mucky soil, Coastal Plain, North Carolina to Florida, Texas, and Arkansas; tropical America (fig. 1199); introduced in tropical parts of the Old World.

\section{REIMARÓCHLOA Hitchc.}

Spikelets strongly dorsally compressed, lanceolate, acuminate, rather distant, subsessile, and alternate in two rows along one side of a narrow, flattened rachis, the back of the fertile lemma turned toward it; both glumes wanting, or the second sometimes present in the terminal spikelet; sterile lemma about equaling the fruit, the sterile palea obsolete; fertile lemma scarcely indurate, faintly nerved, acuminate, the margins inrolled at the base only, the palea free nearly half its length. Spreading or stoloniferous perennials, with flat blades and slender racemes, these subdigitate or racemose along a short axis,

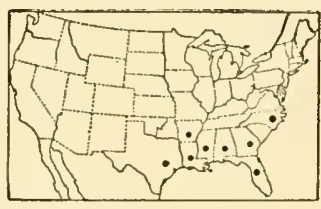

Figure 1199.-Distribution of Axonopus compressus. stiffly spreading or reflexed at maturity. Type species, Reimaria acuta Flügge (Reimarochloa acuta Hitchc.). Named for J.A.H. Reimarus, and Greek chloa, grass.

1. Reimarochloa oligostáchya (Munro) Hitchc. (Fig. 1200.) Glabrous; culms compressed, often long-decumbent and rooting at the lower nodes, the flowering shoots, 20 to $40 \mathrm{~cm}$ tall; sheaths loose; blades 2 to. $4 \mathrm{~mm}$ wide; racemes 1 to 4 , mostly 2 or 3,5 to $8 \mathrm{~cm}$ long; spikelets about $5 \mathrm{~mm}$ long. 2 (Reimaria oligostachya Munro.)In water or wet soil, Florida; Cuba. In general aspect resembles Paspalum vaginatum Swartz.

\section{PÁSPALUM L.}

Spilielcts planoconvex, usually obtuse, subsessile, solitary or in pairs, in two rows on one side of a narrow or dilated rachis, the back of the fertile lemma toward it; first glume usually wanting; second glume and sterile lemma commonly about equal, the former rarely wanting; fertile lemma usually obtuse, chartaceous-indurate, the margins inrolled. Perennials in the United States (except $P$. boscianum), with one to many spikelike racemes, solitary, paired, or several to many on a common axis. Type species, Paspalum dissectum. Name from Greek paspalos, a kind of millet.

Several species inhabiting meadows and savannas furnish considerable forage. Paspalum dilatatum is valuable for pasture, especially for dairy cattle in the Southern States, where it has been cultivated under the name water grass and recently Dallis grass. In the Hawaiian Islands, Australia, and some other countries, where it is called paspalum or paspalum grass, it is valuable as a pasture grass. $P$. pubiflorum var. glabrum is rather abundant in some regions and is considered a good forage grass. Vasey grass, $P$. urville $i$, is used to 
a limited extent for hay and, when young, for pasture; the panicles also make excellent whisk brooms for brushing lint. In the Southern

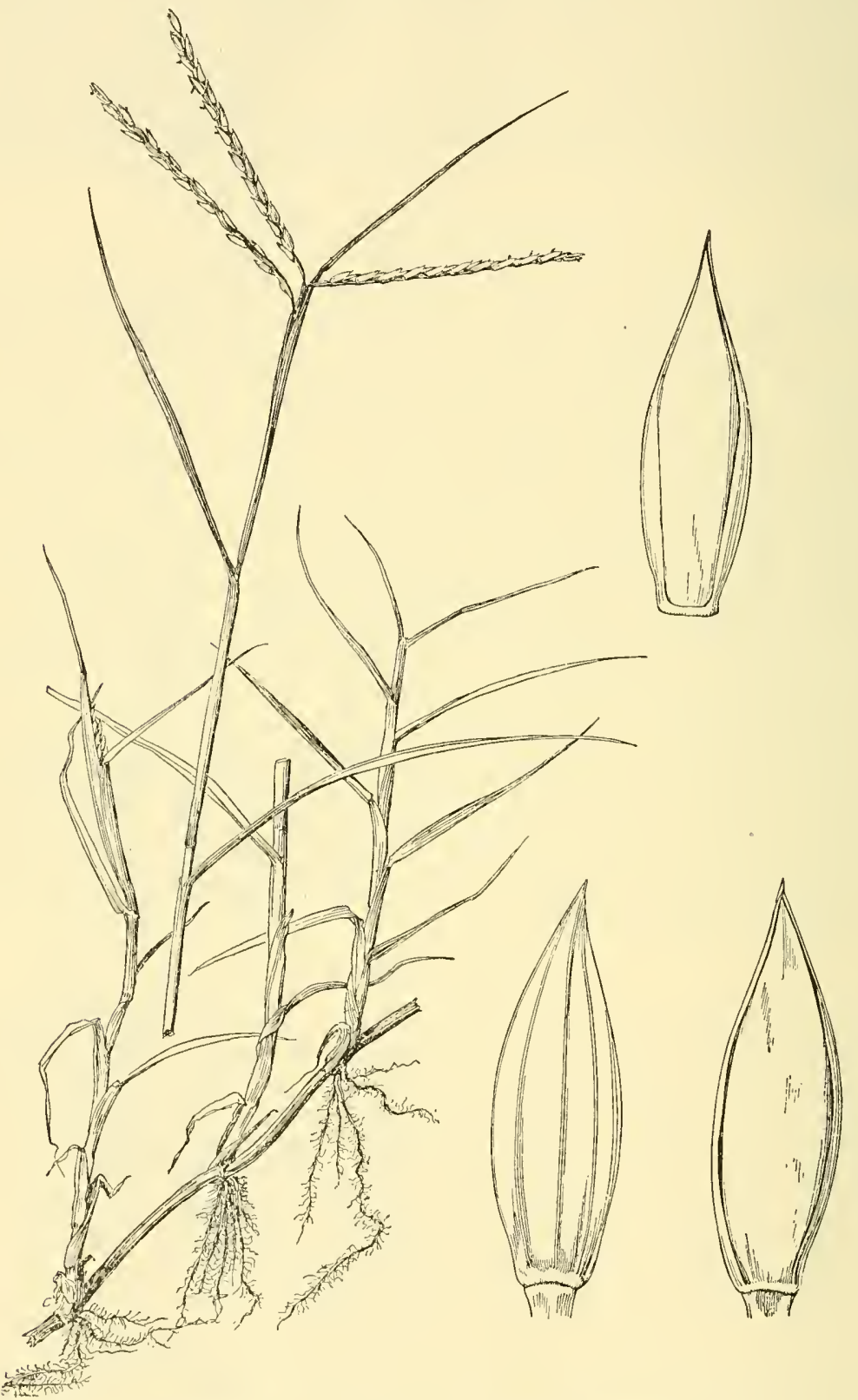

Figure 1200,-Reimarochloa oligostachya. Plant, $\times 1$; two views of spikelet, and floret, $\times 10$. (Curtiss $3596 \mathrm{~A}$, Fla.)

States (Virginia to Florida and even to California) $P$. distichum, because of its extensively creeping stolons, is useful for holding banks of streams and ditches. 
1a. Rachis foliaceous, broad and winged.

Racemes falling from the axis, rachis extending beyond the uppermost spikelet. .

Racemes persistent on the axis; rachis with a spikelet at the apex.

Spikelets $2 \mathrm{~mm}$ long, obovate-oval ......

Spikelets more than $3 \mathrm{~mm}$ long, pointed...... 2. Acuminatum.

1b. Rachis not foliaceous nor winged (slightly winged in $P$. boscianum).

2a. Racemes 2, conjugate or nearly so at the summit of the culm, rarely a third below.

Spikelets elliptic to narrowly ovate.

Plants with creeping rhizomes or stolons.

Second glume and sterile lemma glabrous; spikelets flattened.

4. P. VAGINATUM.

Second glume pubescent; spikelets relatively turgid_ 5. P. DIsTICHUM.

Plants in dense tufts, without creeping rhizomes....-. 11. P. ALAOM.

Spikelets suborbicular, broadly ovate or obovate.

Spikelets concavo-convex, sparsely long-silky around the margin; plant stoloniferous....... P. CONJUGATUM.

Spikelets plano-convex, not silky-margined; plants not stoloniferous.

Spikelets 2.5 to $3 \mathrm{~mm}$ long._._. P. NOTATUM.

Spikelets less than $2.5 \mathrm{~mm}$ long

$2 \mathrm{~b}$. Racemes 1 to many, racemose on the axis, not conjugate.

3a. First glume developed on at least one of the pair of spikelets (often obsolete in some pairs in nos. 22 and 23).

Spikelets turgidly biconvex._._.

Spikelets plano-convex.

Plants without rhizomes; culms tufted; spikelets pubescent.

Plants with stout 24. P. LANGEI. ( glabrous.

Blades flat, 8 to $15 \mathrm{~mm}$ wide_......... 22. P. unispicatum.

Blades folded at base, terete above, not more than $2 \mathrm{~mm}$ wide.

23. P. MONOSTACHYUM.

3b. First glume normally wanting (occasionally developed on 1 to few spikelets in a raceme).

4a. Racemes terminal and axillary, the axillary sometimes hidden in the sheaths; terminal inflorescence of 1 to 3 , rarely to 6 racemes (see also $P$. unispicatum and $P$. monostachyum).

5a. Spikelets not more than $1.8 \mathrm{~mm}$ long (or sometimes 1.9 in $P$. debile and $P$. propinquum), usually 1.5 to $1.7 \mathrm{~mm}$ (see also exceptional $P$. ciliatifolium).

Blades conspicuously ciliate, otherwise nearly glabrous.

Blades relatively short, rounded at base and recurved-ascending; foliage aggregate toward the base, the upper culm relatively naked; spikelets glabrous, mostly 1.5 to $1.6 \mathrm{~mm}$ long.

12. P. LONGEPEDUNCULATUM.

Blades mostly elongate, suberect, not aggregate toward the base; spikelets pubescent, 1.7 to $1.9 \mathrm{~mm}$ long - 20. P. PIROPINQUUM.

Blades and sheaths conspicuously pubescent throughout.

Culms slender, erect or suberect; foliage not aggregate at base; blades suberect, usually not more than $5 \mathrm{~mm}$ wide.

13. P. SETACEUM.

Culms stouter, mostly spreading; foliage more or less aggregate at base; blades spreading, usually more than $5 \mathrm{~mm}$ wide.

14. P. DEBILE.

5b. Spikelets 2 to $2.5 \mathrm{~mm}$ long (or 1.8 to $1.9 \mathrm{~mm}$ in $P$. ciliatifolium and $P$. propinquum).

Foliage, except margins, glabrous as a whole or nearly so (sparsely pubescent in exceptional $P$. ciliatifolium and lower sheaths usually pubescent in $P$. rigidifolium).

Blades stiff, usually not more than $6 \mathrm{~mm}$ wide; spikelets mostly 2.2 to $2.4 \mathrm{~mm}$ long.

Biades from lax to rather firm, if firm more than $6 \mathrm{~mm}$ wide; spikelets not more than $2.1 \mathrm{~mm}$ long.

Spikelets mostly $2 \mathrm{~mm}$ long, rounded at summit; blades mostly more than $8 \mathrm{~mm}$ wide........ 19. P. CILIATIFOLIOM. 
Spikelets 1.8 to $1.9 \mathrm{~mm}$ long, slightly pointed; blades not more than $8 \mathrm{~mm}$ wide $\ldots . . .20$. P. PROPINQUUN.

Foliage conspicuously pubescent (or sparsely so in exceptional specimens of $P$. pubescens).

Culms erect or nearly so.

Blades from sparsely to rather densely pilose, rather thin.

18. P. PUBESCENS.

Blades puberulent on both surfaces with long hairs intermixed or the lower surface nearly or quite glabrous except for a few long hairs along midrib and margin, usually rather firm.

17. P. Stramineum.

Culms widely spreading or prostrate.

Foliage coarsely hirsute; plants commonly relatively stout.

15. P. SUPINUM.

Foliage finely puberulent; plants usually grayish olivaceous.

16. P. PSAMMOPHILUM.

4b. Racemes terminal on the primary culm or leafy branches, no truly axillary racemes.

6a. Spikelets conspicuously silky-ciliate around the margin, the hairs as long as the spikelet or longer.

Racemes commonly 3 to 5 ; culms geniculate at base.

29. P. Dilatatum.

Racemes commonly 12 to 18 ; culms erect....... 30. P. URVILLEI. $6 \mathrm{~b}$. Spikelets not ciliate.

7a. Fruit dark brown and shining.

Plants perennial; sterile lemma wrinkled.--_ 40. P. PLICATULUM.

Plants annual; sterile lemma not wrinkled_._ 4.1. P. Bosciandm.

7b. Fruit pale to stramineous (brown but not shining in P. virgatum).

8a. Plants robust, 1 to $2 \mathrm{~m}$ tall.

Spikelets pubescent at least toward the summit; fruit brown at maturity .

Spikelets glabrous; fruit pale.

Culms ascending; leaves crowded toward the base.

Culms erect or suberect, leafy throughout.

36. P. DIFFORME.

Glume and sterile lemma slightly inflated and wrinkled, green . . .

Glume and sterile lemma not inflated and wrinkled, rustytinged... P. Giganteum.

8b. Plants not robust, if more than $1 \mathrm{~m}$ tall, culms relatively slender.

9a. Spikelets suborbicular or broadly obovate or broadly oval. Spikelets turgidly plano-convex, 3.5 to $4 \mathrm{~mm}$ long.

36. P. DIFFORME.

Spikelets depressed plano-convex or lenticular, 2.2 to $3.4 \mathrm{~mm}$ long.

Spikelets solitary; glume and sterile lemma firm.

Spikelets orbicular, 3 to $3.2 \mathrm{~mm}$ long, scarcely one-third as thick; blades usually equaling the base of the panicle or overtopping it_._._. 33 . P. CIRCULARE.

Spikelets longer than broad, more than one-third as thick; panicle usually much exceeding the blades.

Sheaths and blades pilose, mostly conspicuously so.

32. P. LONGIPILUM.

Sheaths and blades from glabrous to sparsely pilose.

3i. P. LAEVE.

Spikelets paired and solitary in the same raceme (rarely all solitary or all paired).

Spikelets 2.2 to $2.5 \mathrm{~mm}$ (rarely to $2.8 \mathrm{~mm}$ ) long; foliage not conspicuously villous _._._._ 34. P. PRAECOX.

Spikelets 2.7 to $3.4 \mathrm{~mm}$ long; lower sheaths and blades mostly conspicuously villous at least at base.

35. P. LENTIFERUM.

9b. Spikelets elliptic to oval or obovate.

Culms decumbent at base, rooting at the lower nodes (occasional plants in dry situations erect), branching.

Spikelets turgidly plano-convex, 3 to $3.2 \mathrm{~mm}$ long; culms rather stout............... P. PUBIFLORUM. 
Spikelets depressed plano-convex; culms rather slender.

Spikelets glabrous..._._._.

Spikelets pubescent......... 8. P. HARTWEGIANUM.

Culms erect to spreading, not rooting at the nodes.

Spikelets about $1.3 \mathrm{~mm}$ long, obovate, glandular-pubescent. 25. P. BLODGETTII.

Spikelets $1.5 \mathrm{~mm}$ or more long, elliptic or elliptic-obovate, the obscure pubescence not glandular.

Nodes or scme of them appressed-pilose; spikelets green or purplish_.............. 26. P. Caespitosum.

Nodes glabrous; spikelets pale or brownish.

27. P. LAXUM.

1. Dissécta.-Blades flat; rachis foliaceous. Aquatics, subaquatics, or plants of wet ground.

1. Paspalum disséctum L. (Fig. 1201.) Glabrous, olive-green, creeping, freely branching, the flowering branches ascending, 20 to 60 $\mathrm{cm}$ long; blades thin, 3 to $6 \mathrm{~cm}$ long, 4 to $5 \mathrm{~mm}$ wide; panicles terminal and axillary, the racemes 2 to 4 , usually erect, 2 to $3 \mathrm{~cm}$ long; rachis 2 to $3 \mathrm{~mm}$ wide; spikelets solitary, obovate, subacute, $2 \mathrm{~mm}$ long. 24 -On muddy and sandy banks of ponds and ditches or in shallow water, New Jersey and Missouri to Florida and Texas; Cuba (fig. 1202).

2. Paspalum acuminátum Raddi. 1203.) Culms decumbent at base, sometig. extensively creeping, 30 to $100 \mathrm{~cm}$ long; blades 4 to $12 \mathrm{~cm}$ long, 5 to $12 \mathrm{~mm}$ wide; racemes 3 to 5 , erect or ascending, 3.5 to $7 \mathrm{~cm}$ long; rachis 3 to $3.5 \mathrm{~mm}$ wide; spikelets solitary, $3.5 \mathrm{~mm}$ long, abruptly pointed. 2f - In shallow water or wet open ground from southern Louisiana and Texas to Argentina.

3. Paspalum répens Bergius. (Fig. 1204.) Culms mostly submerged, sometimes as much as $2 \mathrm{~m}$ long, the sheaths on the floating

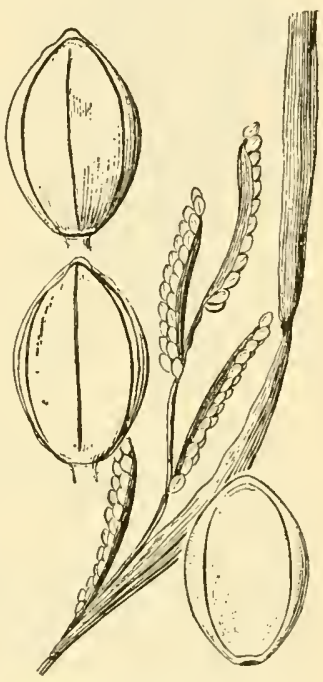

Figure 1201.-Paspalum dissectum. Panicle, $\times$ 1: two riews of spikelet, and floret, $\times 10$. (Commons 85 Del.)

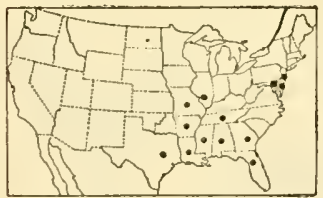

Figure 1202.-Distribution of Paspalum dissectum. branches inflated; blades usually 10 to $20 \mathrm{~cm}$ long, 12 to $15 \mathrm{~mm}$ wide; panicle 10 to $15 \mathrm{~cm}$ long, of numerous ascending, spreading, or recurved racemes, 3 to $5 \mathrm{~cm}$ long, falling entire, the rachis about $1.5 \mathrm{~mm}$ wide; spikelets solitary, elliptic, 1.4 to $2 \mathrm{~mm}$ long, usually pubescent, the sterile lemma pinkish at base. 24 (P. mucronatum Muhl.)-Floating in sluggish streams or standing water or creeping in wet places, South Carolina to Indiana, Kansas, and Texas, south to Argentina (fig. 1205).

Paspaldom Racemóstm Lam. Branching annual; blades 5 to $12 \mathrm{~cm}$ long, 1 to $2 \mathrm{~cm}$ wide; panicles tawny to purple; racemes numerous, 1 to $2 \mathrm{~cm}$ long; spikelets about $2.7 \mathrm{~mm}$ long, pointed; sterile lemma transversely fluted either side of the midnerve. $\odot$ - Sometimes cultivated for ornament. Peru.

2. Dísticha.-Creeping with wiry compressed culms and stolons or rhizomes; racemes mostly 2 , paired or approximate. 
4. Paspalum vaginátum Swartz. (Fig. 1206.) Flowering culms 8 to $60 \mathrm{~cm}$ tall; sheaths usually overlapping; blades 2.5 to $15 \mathrm{~cm}$ long,

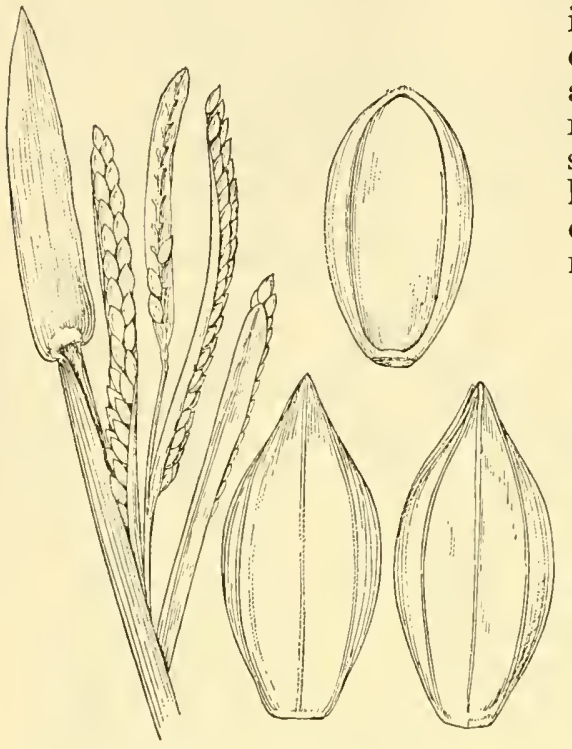

FigUre 1203.-Paspalum acuminatum. Panicle, $\times 1$; two views of spikelet, and floret, $\times 10$. (Arsène 3132, Mex.)
3 to $8 \mathrm{~mm}$ wide, tapering to an involute apex; racemes at first erect, usually spreading or reflexed at maturity, 2 to $5 \mathrm{~cm}$ long; rachis 1 to $2 \mathrm{~mm}$ wide; spikelets solitary, 3.5 to $4 \mathrm{~mm}$ long, ovatelanceolate, acute, pale-stramineous; first glume rarely developed; midnerve of the second glume

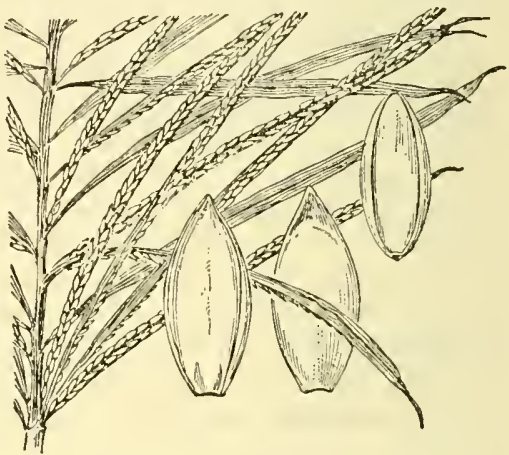

Figure 1201.-Paspalum repens. Panicle, $\times 1$ two views of spikelet, and floret, $\times 10$ (Hitcbock 9179, Canal Zone.)

and sterile lemma usually suppressed. 24-Seacoasts and brackish sands, often forming extensive colonies, North Carolina to Florida and Texas, south to Argentina (fig. 1207); tropies of Eastern Hemisphere.

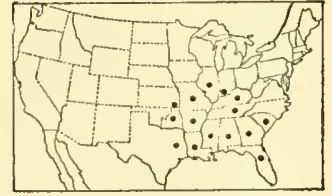

Figure 1205.-Distribution of Paspalum repens.

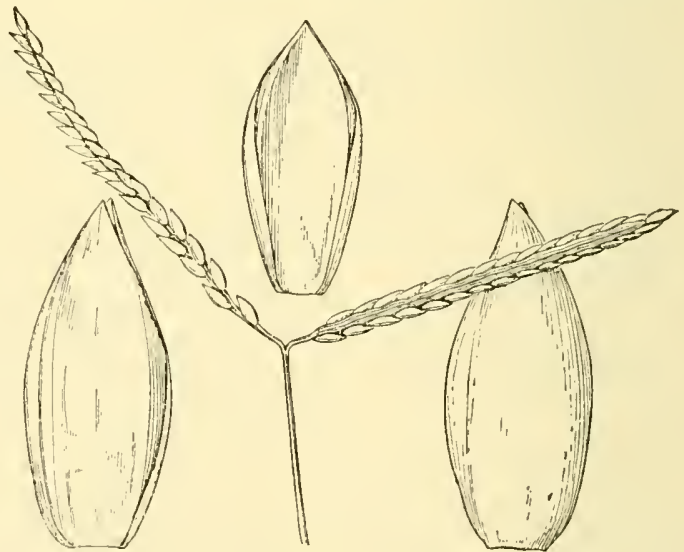

Figure 1206,-Paspalum raginatum. Panicle, $\times 1$; two views of spikelet, and floret, $\times 10$. (Hitchcock 9866 , Jamaica.)

5. Paspalum dístichum L. KNotgrass. (Fig. 1208.) Resembling $P$. vaginatum, sometimes with extensively creeping stolons with pubes- 
cent nodes; racemes 2 to $7 \mathrm{~cm}$ long, commonly incurved; spikelets 2.5 to $3.5 \mathrm{~mm}$ long, elliptic, abruptly acute, pale green;

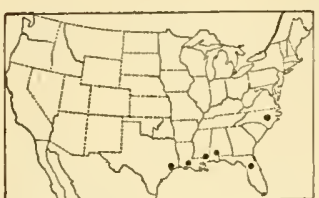

FIGURE 1207.-Distribution of Paspalum vaginatum.

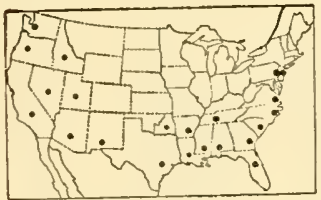

FIGURE 1209.-Distribution of Paspalum distzchum. first glume frequently developed; second glume appressed-pubescent, the midnerve in glume and sterile lemma developed. 2 -Ditches and wet, rarely brackish places, New Jersey to Florida, Tennessee, and Arkansas, west to California and north along the coast to Washington; Idaho; south to Argentina (fig. 1209); warm coasts of the Eastern Hemisphere.

Paspalum PaUCispicáTum Vasey. Resembling vigorous specimens of $P$. distichum, but with 3 to

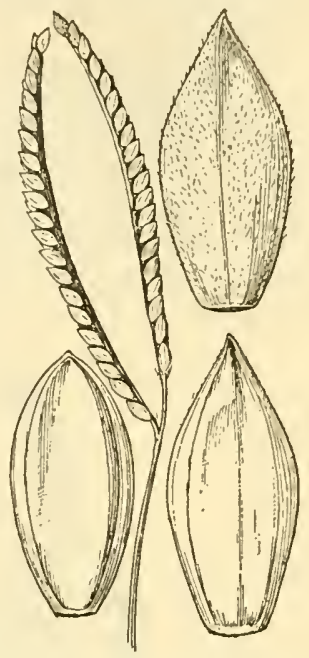

Figure 1208.-Paspalum distichum. Panicle, $\times 1$; two views of spikelet, and floret. $\times$ 10. (Hitcheock 9394, Jamaica.)

5 racemes with mostly paired spikelets. 24 A specimen collected by Palmer in 1888, said

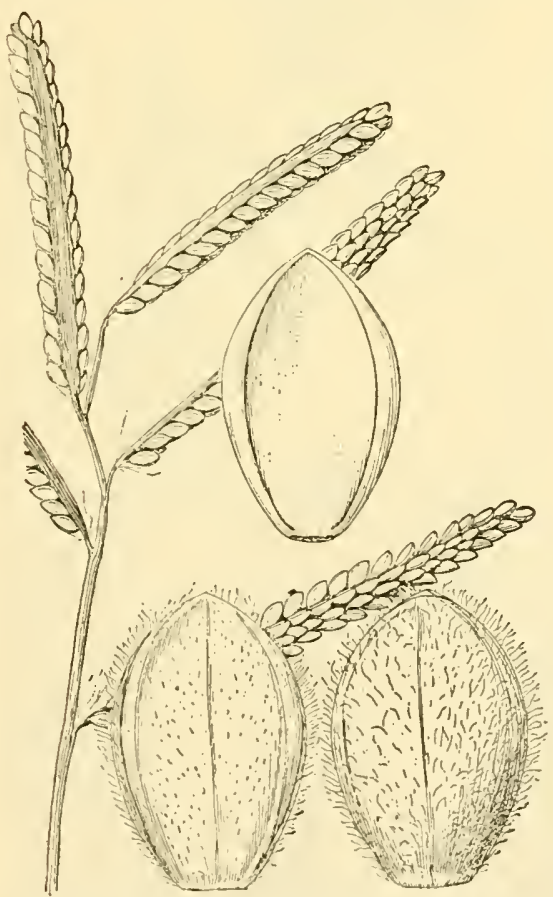

Figure 1210.-Paspalum pubiforum. Panicle, $\times 1$; two views of spikelet, and floret, $\times 10$. (Hitcheock $5555, \mathrm{Mex}$. mm long. 24 (P. hallii Vasey and Scribn.)-Moist open ground, to be from "Southern California", is in the United States National Herbarium. The locality is doubtful, the species ranging from Sonora to Oaxaca.

3. Lívida.-Culms compressed; racemes few to several, mostly plants of alkaline soil.

6. Paspalum pubiflórum Rupr. (Fig. 1210.) Culms decumbent at the base, 40 to $100 \mathrm{~cm}$ tall;

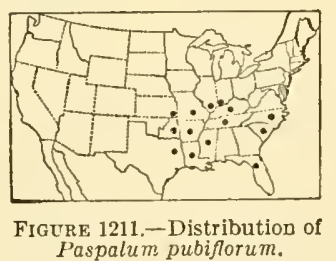

sheaths, at least the lower, sparsely papillose-pilose; blades flat, usually 10 to $15 \mathrm{~cm}$ long, 6 to 14 $\mathrm{mm}$ wide, usually with a few stiff hairs at the rounded base; racemes mostly 3 to 5,2 to $10 \mathrm{~cm}$ long, rather thick, erect to spreading, the rachis 1.2 to $2 \mathrm{~mm}$ wide; spikelets obovate, pubescent, about 3 
banks, low woods, along streams and irrigation ditches, especially in alkaline clay soil, Louisiana and Texas; Mexico and western Cuba (fig. 1211).

Paspalum pubiflorum var. glábrum Vasey. Somewhat more robust, the sheaths less pilose, the racemes commonly longer and often more than 5; spikelets glabrous. 2 (P. geminum Nash; P. laeviglume Scribn.)-Moist low open ground, woods, and ditch banks, North Carolina and Indiana to Florida, west to Kansas and Texas.

7. Paspalum lívidum Trin. Longtom. (Fig. 1212.) Glabrous; culms solitary or few in a tuft, from a decumbent or creeping base, 50 to $100 \mathrm{~cm}$ tall: blades 15 to $25 \mathrm{~cm}$ long, 3 to $6 \mathrm{~mm}$ wide; racemes

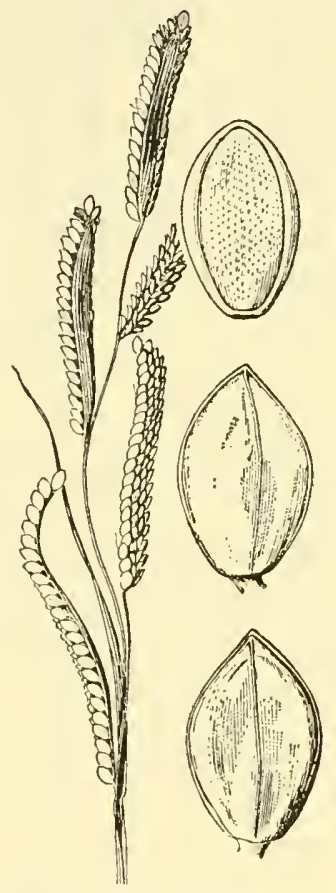

Figure 1212.-Paspalum lividum. Panicle, $\times 1$; two views of spikelet, and floret, $\times 10$. (Arsène 3176, Mex.)

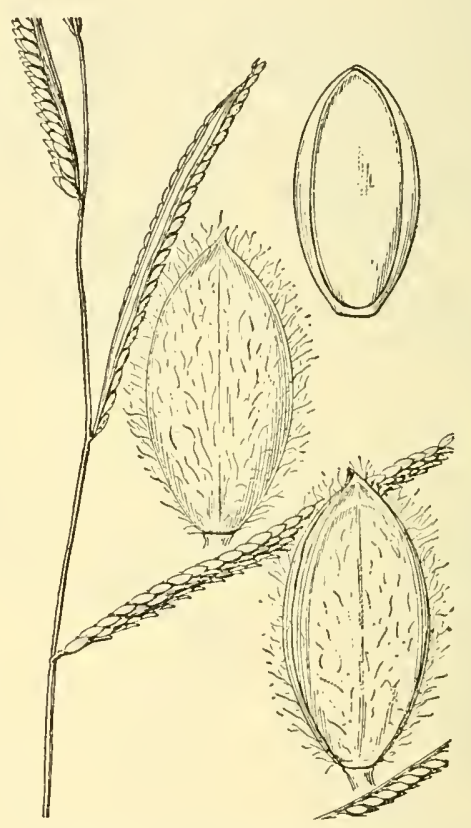

Figure 1213.-Paspalum hartwegianum. Panicle, $\times 1$; two views of spikelet, and
floret, $\times 10$. (Buckley, Tex.)

usually 4 to 7 , ascending, flexuous; rachis 1.5 to $2 \mathrm{~mm}$ wide, dark livid purple; spikelets 2 to $2.5 \mathrm{~mm}$ long, obovate, subacute. 2 Low ground, wet savannas, and swamps, and along streams and ditches, Alabama to Texas and Mexico, south to Argentina; Cuba.

8. Paspalum hartwegiánum Fourn. (Fig. 1213.) Culms ascending from a decumbent base, 50 to $150 \mathrm{~cm}$ tall; blades 10 to $35 \mathrm{~cm}$ long, 2 to $6 \mathrm{~mm}$ wide, the margins very scabrous; racemes usually 4 to 7 , ascending, 2 to $9 \mathrm{~cm}$ long; rachis 1 to $1.5 \mathrm{~mm}$ wide; spikelets imbricate, about $3 \mathrm{~mm}$ long, elliptic, apiculate, softly pubescent. $24(P$. buckleyanum Vasey.) - Wet prairies, alkaline meadows, and along irrigation ditches, sometimes growing in the water, southern Texas and throughout Mexico. 
4. Notáta.-Culms in dense tufts, compressed, leafy at base; sheaths keeled; racemes 2, rarely 3, paired or nearly so; spikelets solitary, glabrous.

9. Paspalum notátum Flügge. Bahia grass. (Fig. 1214.) Culms 15 to $50 \mathrm{~cm}$ tall from a short, stout, woody, horizontal rhizome;

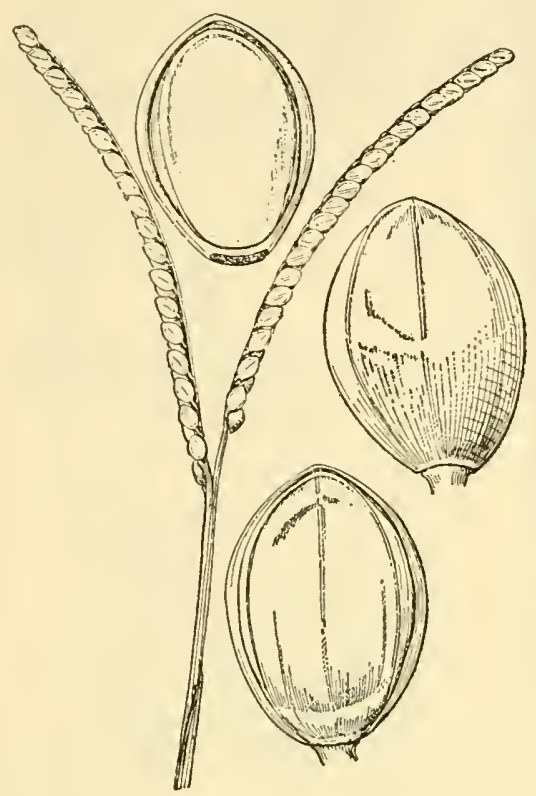

Figure 1214.-Paspalum notatum. Panicle, $X 1$; two views of spikelet, and floret, $\times 10$. (Chase 6639, P.R.) blades flat or folded; racemes recurved-ascending, usually 4 to $7 \mathrm{~cm}$ long; spikelets ovate to obovate, 3 to $3.5 \mathrm{~mm}$ long, smooth and shining.

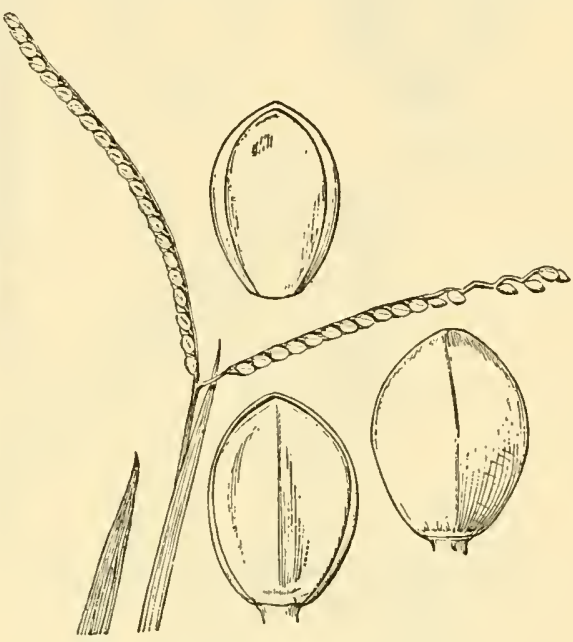

Figure 1215.-Paspalum minus. Panicle, $\times 1$; two views of spikelet, and floret, $\times 10$. (Type coll.)

24 -Introduced sparingly in New Jersey, Florida, and Louisiana; Mexico and the West Indies to South America.

10. Paspalum mínus Fourn. (Fig. 1215.) Resembling $P$. notatum, commonly in denser mats; culms rarely more than $30 \mathrm{~cm}$ tall; racemes more slender; spikelets 2 to $2.5 \mathrm{~mm}$ long, less shining than those of $P$. notatum. 2 -Open slopes and savannas, coast of Texas (Galveston Bay); Mexico to West Indies and Paraguay.

11. Paspalum álmum Chase. Combs Paspalum. (Fig. 1216.) Culms in very dense tufts; blades flat, 2 to $3 \mathrm{~mm}$ wide, long-hirsute on the upper surface at base, papillose-hirsute on the lower surface toward the ends, the margins stiffly ciliate toward base; racemes slender, approximate, scarcely raired, occasionally 3 , ascending, 5 to $9 \mathrm{~cm}$ long; rachis $1 \mathrm{~mm}$ wide, minutely wing-margined; spikelets $3 \mathrm{~mm}$ long, 1.8 to $2 \mathrm{~mm}$ wide, obovate-elliptic; sterile lemma slightly concave. 21 - Sandy or silty clay loam, Jefferson County, Tex.; Brazil and Paraguay, Argentina. An excellent forage grass.

5. Setácea.-Culms compressed from a knotted base or very short rhizome; blades mostly flat; inflorescence terminal and axillary, the axillary sometimes hidden in the sheaths; racemes 1 to few, slender, subcylindric; spikelets in pairs, crowded. Species closely related with frequent intergrades. 
12. Paspalum longepedunculátum LeConte. (Fig. 1217.) Culms slender, ascending or suberect, 25 to $80 \mathrm{~cm}$ tall; leaves mostly aggregate at the base, the sheaths ciliate on the margin; blades usually

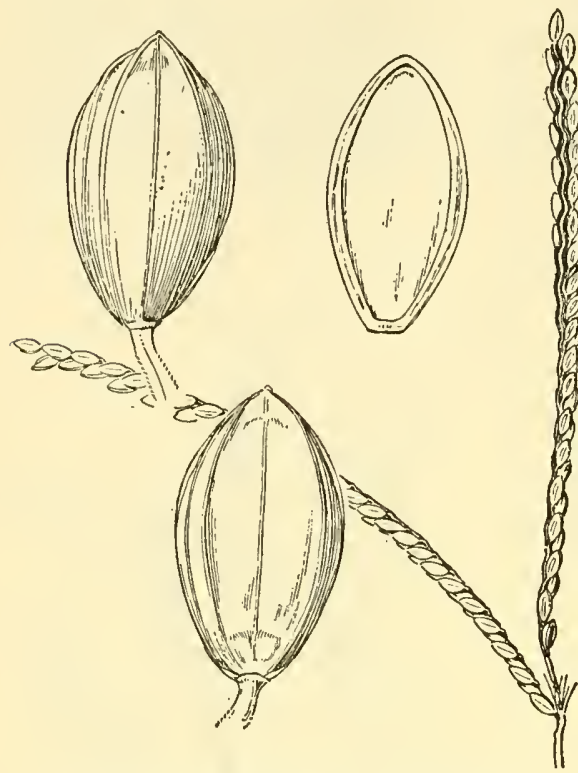

Figure 1216.-Paspalum almum. Panicle, $\times 1$; two views of spikelet, and floret, $\times 10$. (Type.)

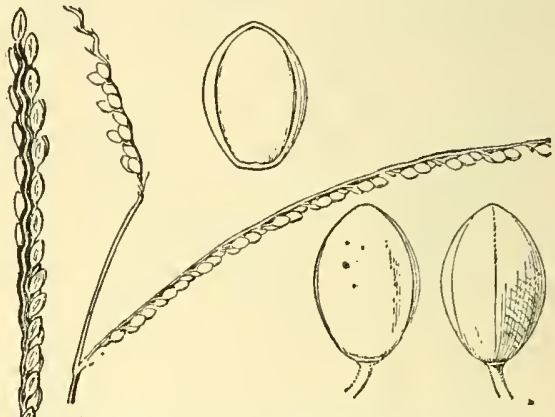

Figure 1217.-Paspalum longepedunculatum. Panicle, $\times 1$; two views of spikelet, and floret, $\times 10$. (Nash 2074, Fla.)

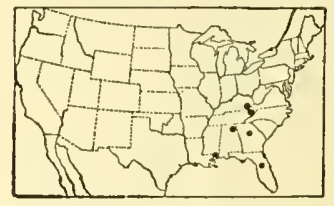

FIgURE 1218.-Distribution of Paspalum longepedunculatum.

folded at base, 4 to $10 \mathrm{~cm}$ long, rarely longer, 3 to $8 \mathrm{~mm}$ wide, stiffly papillose-ciliate on the margin, the hairs 1.5 to $3 \mathrm{~mm}$ long; racemes on very slender finally elongate peduncles, 1 or 2 , rarely 3 , on the pri-

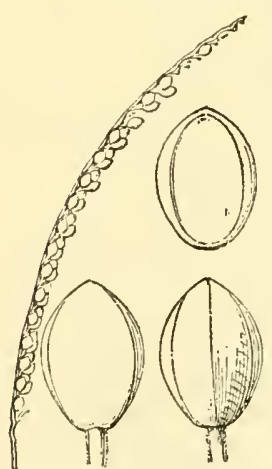

Figure 1219-Paspalum setaceum. Raceme $\times 1$; two views of spikelet, and floret, $\times 10$. (Hitchcock 30c, S.C.) mary, 1 on the axillary peduncles; racemes arching, 3 to $8 \mathrm{~cm}$ long; spikelets about $1.5 \mathrm{~mm}$ long, elliptic-obovate, glabrous. 24 - Sandy soil, mostly in low pine land or flat woods, Georgia and Kentucky to Florida and Mississippi (fig. 1218).

13. Paspalum setáceum Michx. (Fig. 1219.) Culms slender, erect, usually 30 to $50 \mathrm{~cm}$ tall; sheaths pilose; blades rather firm, erect or nearly so, linear, about 10 to $12 \mathrm{~cm}$ long, 2 to $6 \mathrm{~mm}$

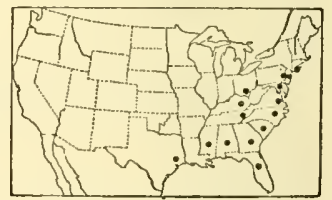

FIGURE 1220.-Distribution of Paspalum setaceum.

wide, densely pilose on both surfaces and papilloseciliate on the margin; racemes on slender peduncles, solitary or sometimes 2 , arching, 5 to 7 cm long; spikelets elliptic-obovate, about $1.5 \mathrm{~mm}$ long, glabrous or minutely pubescent. 4 Sandy soil, mostly open woods, of or near the Atlantic Coastal Plain, Long Island to Florida and Texas; Mexico (fig. 1220). 
14. Paspalum débile Michx. (Fig. 1221.) Differing from $P$. setaceum in the stouter, more spreading culms, the foliage more crowded at base, densely grayish villous, the blades on the average wider; racemes more commonly 2; spikelets 1.8 to $1.9 \mathrm{~mm}$ long, pubescent. 24 -Sandy, mostly dry soil, barrens and flatwoods, Long Island to Florida and Texas; Mexico and Cuba (fig. 1222).

15. Paspalum supínum Bosc. (Fig. 1223.) Culms relatively stout, widely spreading, 30 to $90 \mathrm{~cm}$ tall; sheaths usually hirsute; blades 15 to $25 \mathrm{~cm}$ long, 8 to $15 \mathrm{~mm}$ wide, hirsute; racemes usually 2 to 4 , rarely to 6,4 to $10 \mathrm{~cm}$ long; spikelets elliptic-obovate, $2 \mathrm{~mm}$

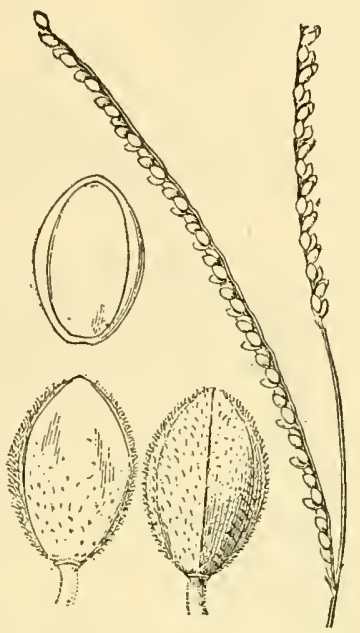

FIGURE 1221,-Paspalum debile. Panicle, $\times 1$; two views of spikelet, and floret, $\times 10$. (Nash 946, Fla.)

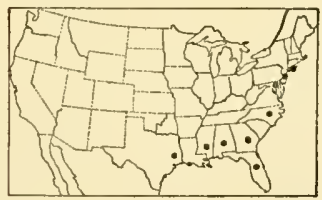

FIGURE 1222,-Distribution of Paspalum debile.

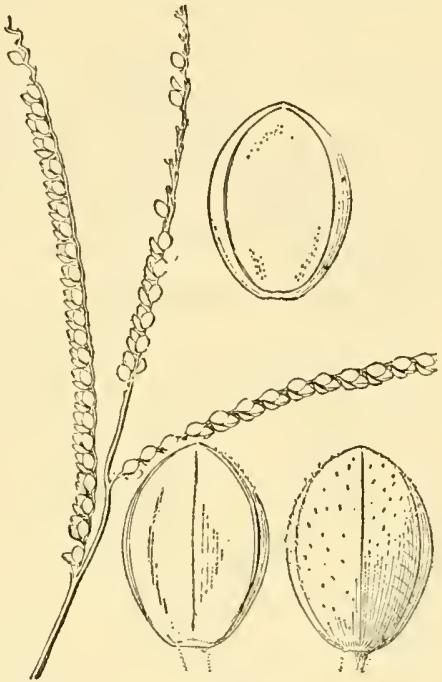

FIgURE 1223.-Paspalum supinum. Panicle, $\times 1$; two views of spikelet, and floret, $\times 10$. (Chase 4572 N.C.)

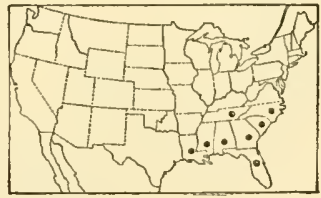

FIGURE 1224.-Distribution of Paspalum supinum.

long, glabrous, or the glume minutely pubescent. 24 -Dry, sandy, open ground and old fields, North Carolina to Florida and west to Louisiana (fig. 1224).

16. Paspalum psammóphilum Nash. (Fig. 1225.) Forming dense grayish-olivaceous mats, the culms usually prostrate, 25 to $100 \mathrm{~cm}$ long; sheaths appressed-pubescent; blades 4 to $16 \mathrm{~cm}$ long, 4 to $11 \mathrm{~mm}$ wide, densely appressed-pubescent; racemes 1 to 3 , commonly 2, 4 to $9 \mathrm{~cm}$ long, the axillary ones wholly or partly included in the sheaths; spikelets suborbicular, $2 \mathrm{~mm}$ long, the glume densely pubescent. 24 -Dry sandy soil, mostly near the coast, Massachusetts to New Jersey (fig. 1226).

17. Paspalum stramíneum Nash. (Fig. 1227.) Yellowish green, the culms erect, 40 to $100 \mathrm{~cm}$ tall; blades 6 to $25 \mathrm{~cm}$ long, rarely longer, 
6 to $15 \mathrm{~mm}$ wide, puberulent on both surfaces and sparsely pilose as well, or the lower surface nearly glabrous; racemes 2 or 3,6 to $14 \mathrm{~cm}$ long, the axillary ones often wholly or partly included in the sheaths, short racemes commonly borne in basal sheaths; spikelets subor-
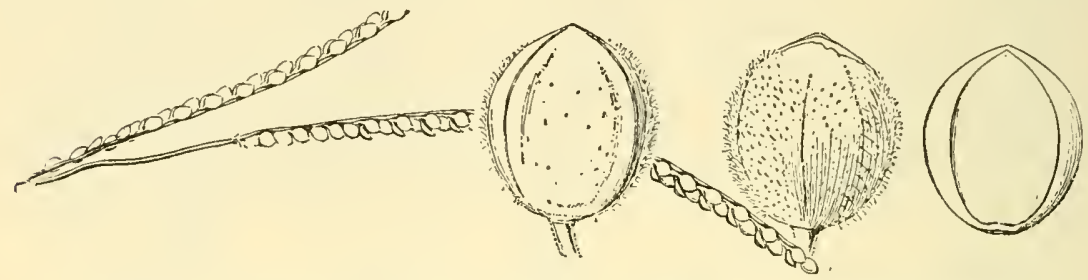

FIgure 1225.-Paspalum psammophilum. Panicle, $\times 1$; two views of spikelet, and floret, $\times 10$. (Graves, N. Y.)

bicular, 2.1 to $2.2 \mathrm{~mm}$ long, pale, from densely pubescent to glabrous. 2 (P. bushii Nash.) - Sandy soil, in open ground or open woods, Indiana to Minnesota, Texas, Arizona, and northwestern Mexico (fig. 1228).

18. Paspalum pubéscens Muhl. (Fig. 1229.) Culms ascending,

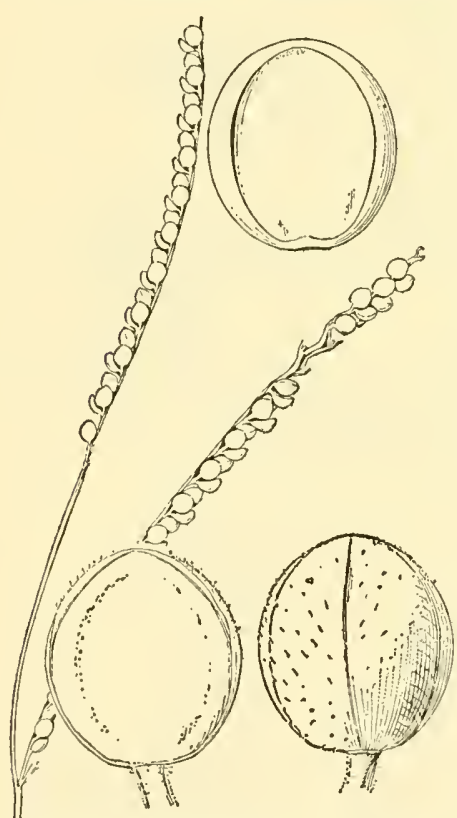

Figure 1227.-Paspalum stramine $u m$. Panicle, $\times 1$; two views of spikelet, and floret, $\times 10$. (Type.) 45 to $90 \mathrm{~cm}$ tall, often pilose at the summit; sheaths usually pilose toward the summit; blades 8 to $20 \mathrm{~cm}$ long, 2 to $10 \mathrm{~mm}$ wide (rarely larger), pilose on both surfaces; racemes 1 to 3,4 to 17 cm long; spikelets about $2 \mathrm{~mm}$ long, suborbicular, usually gla-

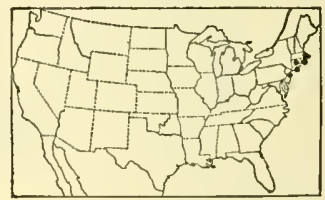

Figure 1226.-Distribution of Paspalum psammophilum. brous. 24 (P.muhlenbergii Nash.) Open ground or open woods, common in old fields and pastures, especially in sandy regions, Vermont to Florida, west to Michigan and Texas (fig. 1230).

\section{Paspalum} cilia tifól iu m Michx. (Fig.

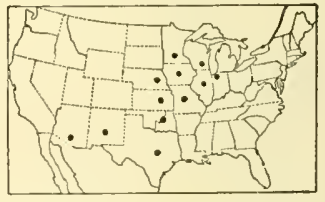

Figure 1228.-Distribution of Paspalum stramineum.

1231.) Culms erect to spreading, 35 to $90 \mathrm{~cm}$ tall; sheaths glabrous or the lower puberulent; blades 10 to $35 \mathrm{~cm}$ long, 7 to $20 \mathrm{~mm}$ wide (rarely larger), usually strongly ciliate along the margin and glabrous otherwise; racemes 1 to 3 , usually 7 to $10 \mathrm{~cm}$ long; spikelets about $2 \mathrm{~mm}$ long, suborbicular, the glumes often minutely pubescent. 24 ( $P$. chapmani Nash; $P$. eggertii Nash; $P$. blepharophyllum Nash; $P$. epile Nash.)-Open ground or open woods, mostly sandy, New Jersey to Florida, 
Tennessee, Arkansas, and Texas; Honduras and the West Indies (fig. 1232). This species is exceedingly variable. Pubescence on foliage and spikelets varies in a single plant. Rather stout, somewhat paler, seacoast plants, with firmer blades scarcely ciliate, are the form

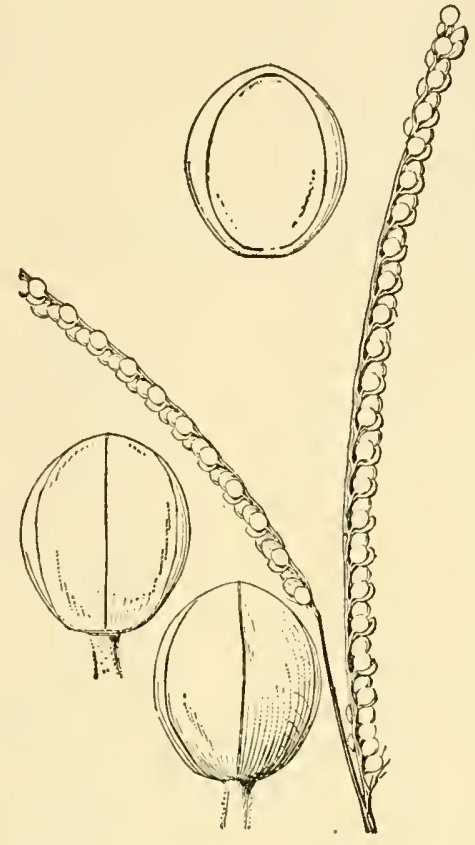

Figure 1229,- Paspalum pubescens. Panicle, $\times 1$; two views of spikelet, and foret, $\times 10$. (Hitchcock 298, Ga.)

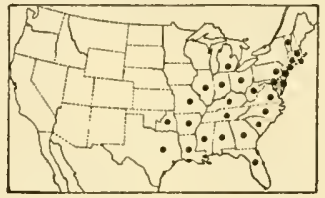

Figure 1230.-Distribution of Paspalum pubescens.

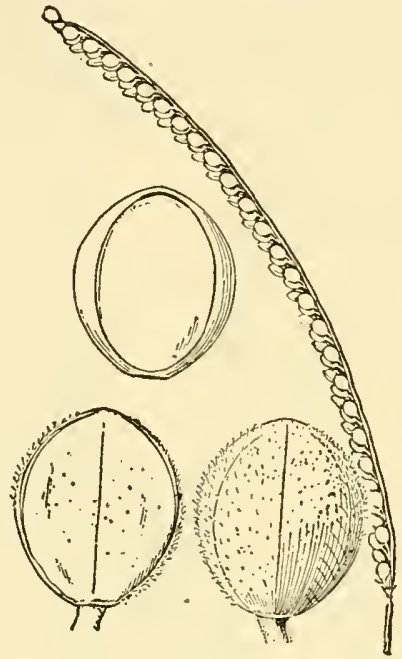

FIgURE 1231.-Paspalum ciliatifolium. Raceme, $\times 1$; two views of spikelet, and floret, $X$ 10. (Nash 1426, Fla.)

described as $P$. epile. Plants with softly pubescent lower sheaths, and blades but slightly ciliate, are the form described as $P$. eggertii. The shape of the spikelet varies in a single raceme from ellipticobovate to suborbicular. The spikelets tend to become rounder at maturity, but both mature and immature are found of both shapes.

20. Paspalum propínquum Nash. (Fig. 1233.)

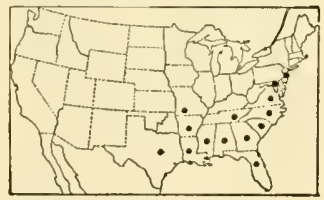

FIgURE 1232.-Distribution of Paspalum ciliatifolium.

Resembling P. ciliatifolium, the blades firmer and narrower, the spikelets slightly smaller, subacute. 24 Sandy savannas and sand barrens overlying limestone, peninsular Florida; West Indies; Vera Cruz to Panama.

21. Paspalum rigidifólium Nash. (Fig. 1234.)

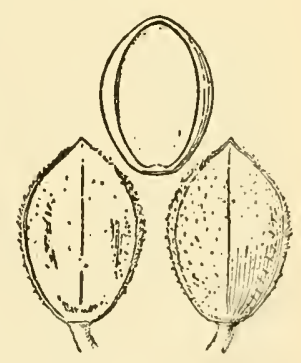

Figure 1233.-Paspalum propinquum. Two views of spikelet, and floret, $\times 10$. (Type.) Culms erect, rather stiff, purplish, 25 to $75 \mathrm{~cm}$ tall; sheatlis glabrous or the lower grayish-pubescent; blades firm, linear, mostly 10 to $15 \mathrm{~cm}$ long, 2 to $5 \mathrm{~mm}$ wide, usually not wider than the summit of the sheath, glabrous or minutely puberulent; racemes 1 or 2 , 
7 to $14 \mathrm{~cm}$ long; spikelets usually 2.2 to $2.4 \mathrm{~mm}$ long, obovate-elliptic, glabrous or nearly so. 2 - Sand barrens and high pineland, peninsular Florida to Texas (fig. 1235).

6. Dimorphóstachys.-Inflorescence terminal and axillary; racemes one to few, slender; spikelets in pairs, the first glume usually developed on one of the pair, often on both,or sometimes obsolete on both.

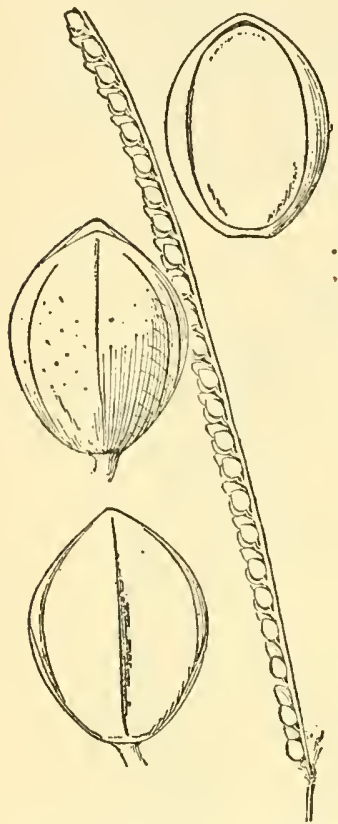

FIGURE 1234.-Paspalum rigidifolium. Raceme, $\times 1$; two views of spikelet, and floret, $\times 10$. (Type.)
22. Paspalum unispicátu m (Scribn. and Merr.) Nash. (Fig. 1236.) Culms one to few in a tuft from horizontal scaly rhizomes, erect or ascending, 50 to $80 \mathrm{~cm}$ tall, simple or with a single erect leafy branch; blades flat, rather stiff, 10 to $30 \mathrm{~cm}$ long, 8 to 15 $\mathrm{mm}$ wide, stiffly papillose-ciliate on the margin, sparsely papillose-hirsute on both surfaces, or scaberulous only; racemes usually solitary, one terminal and one from the axil of the uppermost sheath, 6 to $20 \mathrm{~cm}$ long; spikelets about $3.2 \mathrm{~mm}$ long, elliptic; first glume on the primary spikelet minute, sometimes obsolete, on secondary spikelet mostly half to threefourths as long as the spikelet. 21 -Meadows, savannas, open slopes, and banks, southern Texas to Venezuela and Argentina; Cuba.

23. Paspalum monostáchyum Vasey. (Fig. 1237.) Culms one to few from horizontal scaly rhizomes, erect, 50 to $120 \mathrm{~cm}$ tall; blades elongate, slender, terete, firm; racemes 1 or 2, 10 to $30 \mathrm{~cm}$ long; spikelets 3 to $3.5 \mathrm{~mm}$ long, subovateelliptic, the pedicels of the pair nearly equal; first glume often developed in few to several of the primary spikelets, commonly wanting or rudimentary. 24 (P. solitarium Nash.)-Moist places in flatwoods or coastal dunes, southern Florida and Texas.

24. Paspalum lángei (Fourn.) Nash. (Fig. 1238.) Culms ascending, 30 to $100 \mathrm{~cm}$ tall; blades flat, rather thin, 10 to $40 \mathrm{~cm}$ long, 6 to $15 \mathrm{~mm}$ wide, glabrous to sparsely pubescent, the lower tapering to a narrow base; peduncles 1 to 3 from the upper sheath, often also from the middle sheaths; racemes 2 to 5,4 to $10 \mathrm{~cm}$ long; spikelets 2.2 to $2.6 \mathrm{~mm}$ long, elliptic-obovate, pubescent and glandular-speckled; 
first glume minute or obsolete on the primary spikelet, one-fourth to one-third as long as the spikelet on the secondary. 21 (Dimorphostachys ciliifera Nash; Paspalum cilifferum Hitchc.)-Moist woods and shaded slopes and banks, occasionally in open ground, mostly at low altitudes, Florida, Louisiana, Texas; Greater Antilles to Venezuela.

7. Caespitósa.-Culms simple or with a single branch, its leaf sometimes hidden in the parent sheath, the inflorescence appearing

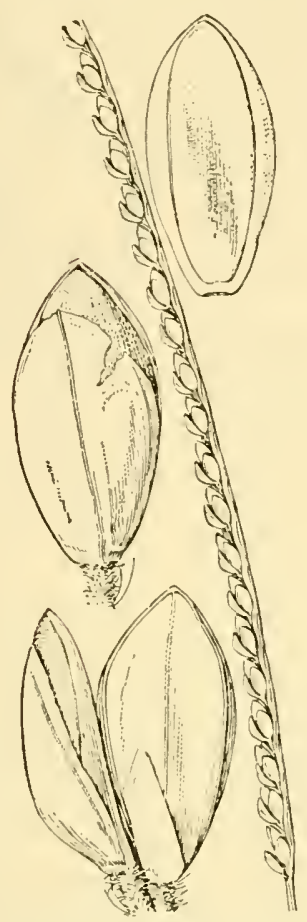

Figure 1237.-Pas $p$ alum monostachyum. Raceme, $X 1$; two riews of spikelet, and floret, $\times 10$. (Type.) to be axillary; racemes few to several.

25. Paspalum blodgéttii Chapm. (Fig. 1239.) Cespitose, with tough, commonly somewhat swollen and bulblike base, the scales densely pubescent; culms erect, slender, 40 to $100 \mathrm{~cm}$ tall; lower leaves crowded; blades flat, 5 to $25 \mathrm{~cm}$ long, mostly 5 to $10 \mathrm{~mm}$ wide; racemes usually 3 to 8 , slender, remote, 2 to $8 \mathrm{~cm}$

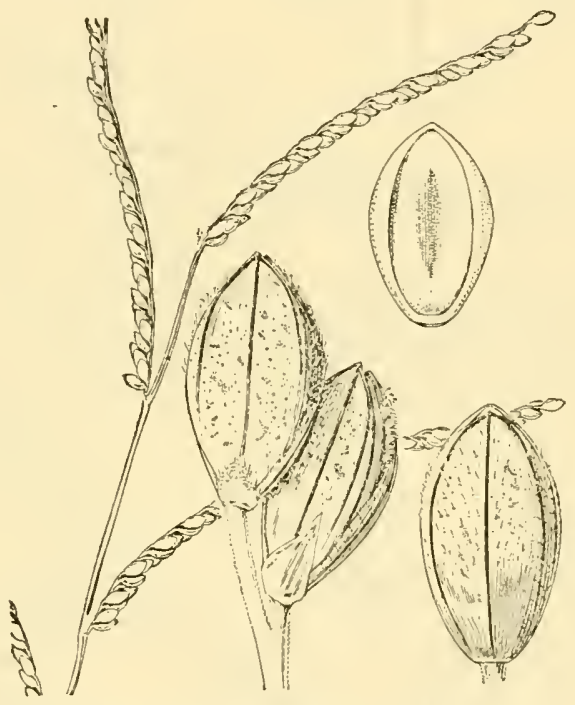

Figure 1238.-Paspalum langei. Panicle, $\times 1$; two views of spitelet, and floret, $\times 10$. (Pringle 3991 , Mex.)

long; spikelets about $1.3 \mathrm{~mm}$ long, obovate, the glume glandularpubescent. 24 (P. simpsoni Nash; P. gracillimum Nash.)-Open or brushy calcareous soil, southern Florida; Iucatan, Honduras, Bahamas, and the Greater Antilles.

26. Paspalum caespitósum Flügge. (Fig. 1240.) Cespitose, bluish green; culms erect, rather wiry, 30 to $60 \mathrm{~cm}$ tall; blades flat, folded or involute, 5 to $20 \mathrm{~cm}$ long, rarely longer, 4 to $10 \mathrm{~mm}$ nide; racemes usually 3 to 5 , relatively thick, remote, ascending, 1.5 to 6 $\mathrm{cm}$ long; spikelets 1.5 to $1.8 \mathrm{~mm}$ long, elliptic, sparsely appressedpubescent to nearly glabrous. 24 -Mostly in partly shaded humus in limestone soil or rock, sometimes in sandy pinelands; southern Florida, Mexico, Central America, and the West Indies. 
27. Paspalum láxum Lam. (Fig. 1241.) Culms mostly 50 to 75 $\mathrm{cm}$ tall, compressed, rigid, ascending; blades more or less involute, mostly 20 to $30 \mathrm{~cm}$ long, 3 to $8 \mathrm{~mm}$ wide, usually glabrous; racemes usually 3 to 5 , mostly remote, 3 to $10 \mathrm{~cm}$ long; spikelets about $2 \mathrm{~mm}$ long,

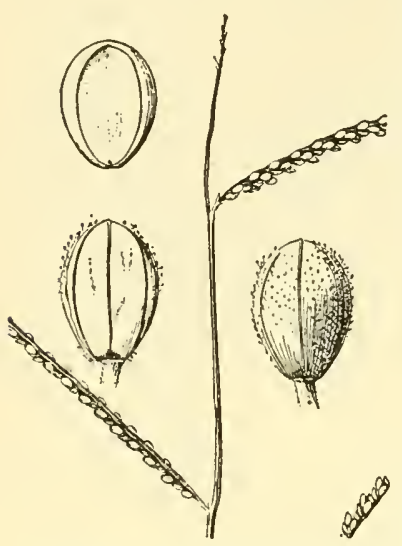

Figure 1239.-Paspalum blodgcttii. Panicle, $X 1$; two views of spikelet, and floret, $\times 10$. (Simpson, Fla.) elliptic-obovate, the glume pubescent. 2 (P. glabrum Poir.)-Sandy and limestone soils, characteristic of coconut groves, Key West, Fla.; West Indies.

8. Conjugáta.- Stoloniferous; blades flat; racemes 2, paired, rarely a third below, slender; spikelets flattened concavo-convex, solitary, silky-fringed.

28. Paspalum conjugátum Bergius. (Fig. 1242.) Extensively creeping, with long leafy stolons and ascending suberect flowering branches, 20 to $50 \mathrm{~cm}$ tall; nodes of stolons usually conspicuously pilose; blades rather thin, 8 to $12 \mathrm{~cm}$ long, 5 to $15 \mathrm{~mm}$

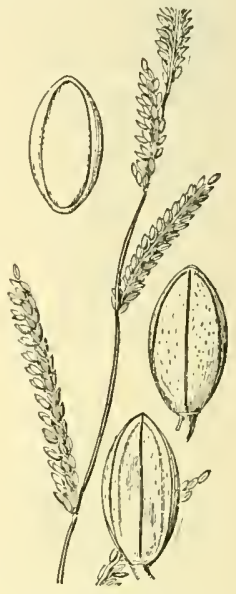

Figure 1240.-Paspalum caespitos $u m$. Panicle, $\times 1$; two views of spikelet, and floret, $\times 10$. (Poiteau, Dominican Republic.) wide, usually glabrous; racemes widely divaricate, 8 to $12 \mathrm{~cm}$ long; spikelets 1.4 to $1.8 \mathrm{~mm}$ long, ovate, light yellow, the margin

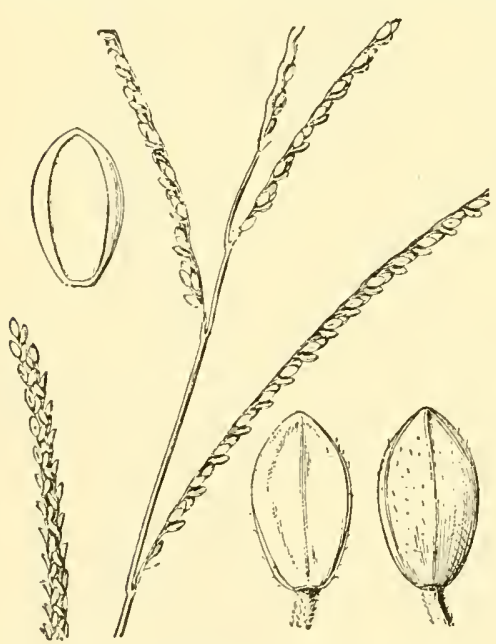

Figure 1241.-Paspalum laxum. Panicle, $\times 1$; two views of spiklet, and floret, $\times 10$ (Richard's specimen in Paris Herbarium.) conspicuously ciliate fringed. 24 A common weed in cultivated and waste ground, southern Florida to Texas, south to Argentina; West Indies (fig. 1243); tropics of Old World.

9. Dilatáta.-Rather stout, in leafy clumps; blades flat; racemes few to numerous, spikelets in pairs, flat, silky-fringed.

29. Paspalum dilatátum Poir. Dallis Grass. (Fig. 1244.) Culms tufted, leafy at base, mostly 50 to 150 $\mathrm{cm}$ tall, ascending or erect from a decumbent base; blades 10 to $25 \mathrm{~cm}$ long, 3 to $12 \mathrm{~mm}$ wide; racemes usually 3 to 5 , spreading, 6 to $8 \mathrm{~cm}$ long; spikelets ovate, pointed, 3 to $3.5 \mathrm{~mm}$ long, fringed with long white silky hairs and sparsely silky on the surface. 2 -In low ground, from rather dry prairie to marshy meadows, New Jersey to Tennessee and Florida, west to Arkansas and Texas; adventive in Oregon, Colorado, Arizona, and California; native of South 


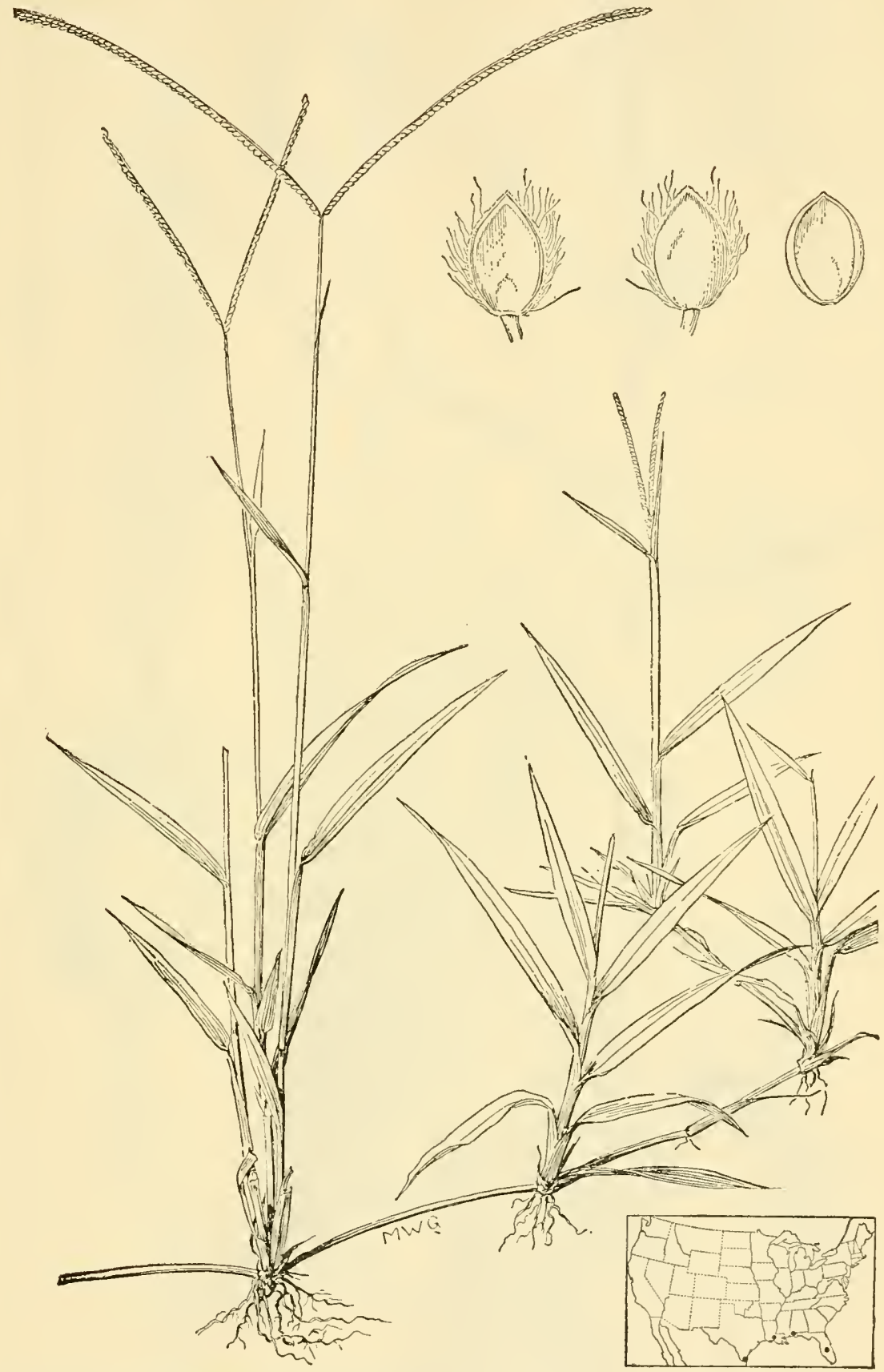

Figure 1242.-Paspalum conjugatum. Plant, $\times 1 / 2$; two views of spikelet, and floret, $\times 10$. (Baker 90, Cuba.)

Figure 2143.-Distribution of $55974^{\circ}-35-38$ Paspalum conjugatum. 


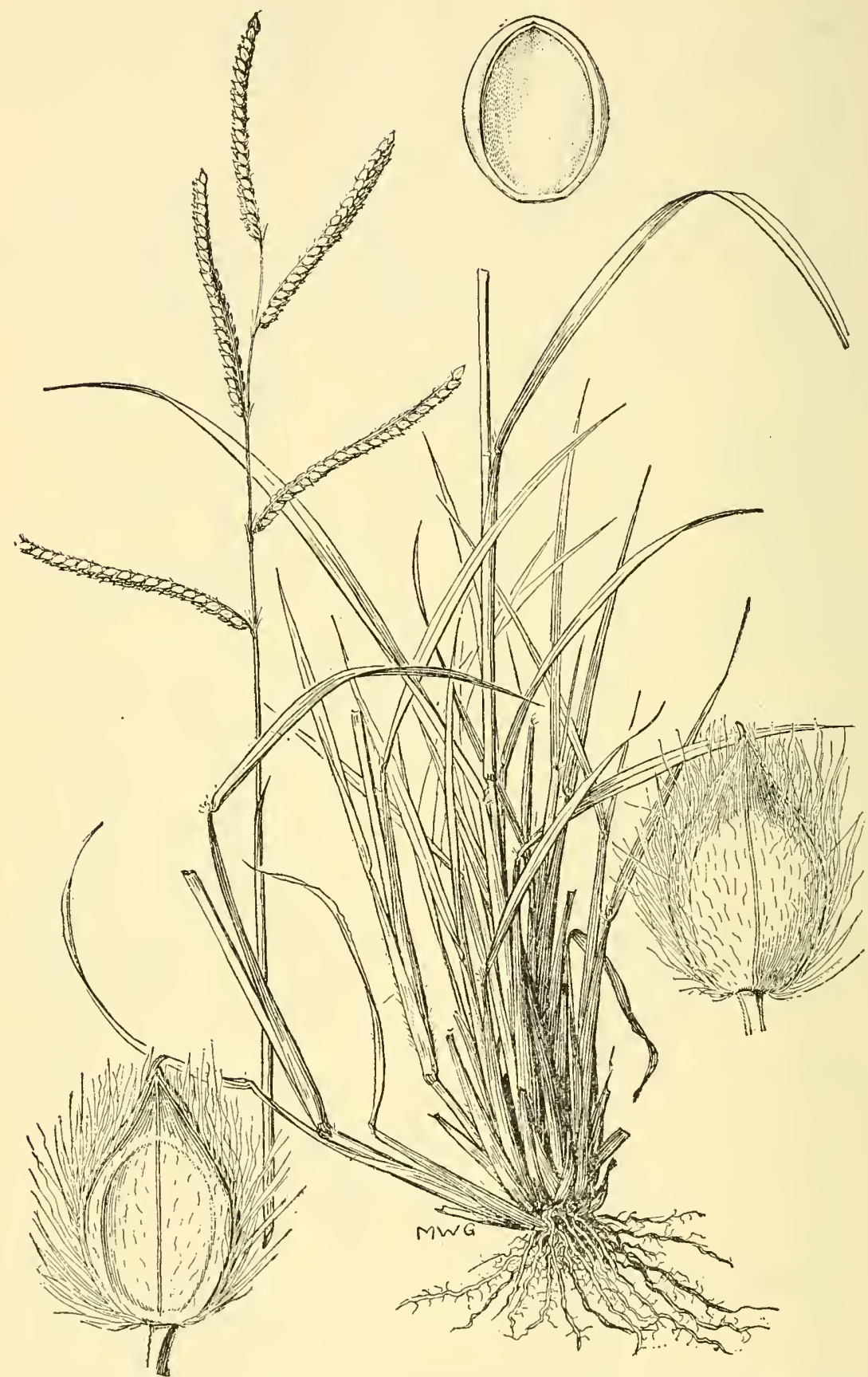

FIGURe 1244.-Paspalum dilatatum. Plant, $\times 1 / 2$; two views of spikelet, and floret, $\times 10$. (Hitcheock 297, La.) 
MANUAL OF THE GRASSES OF THE UNITED STATES 593

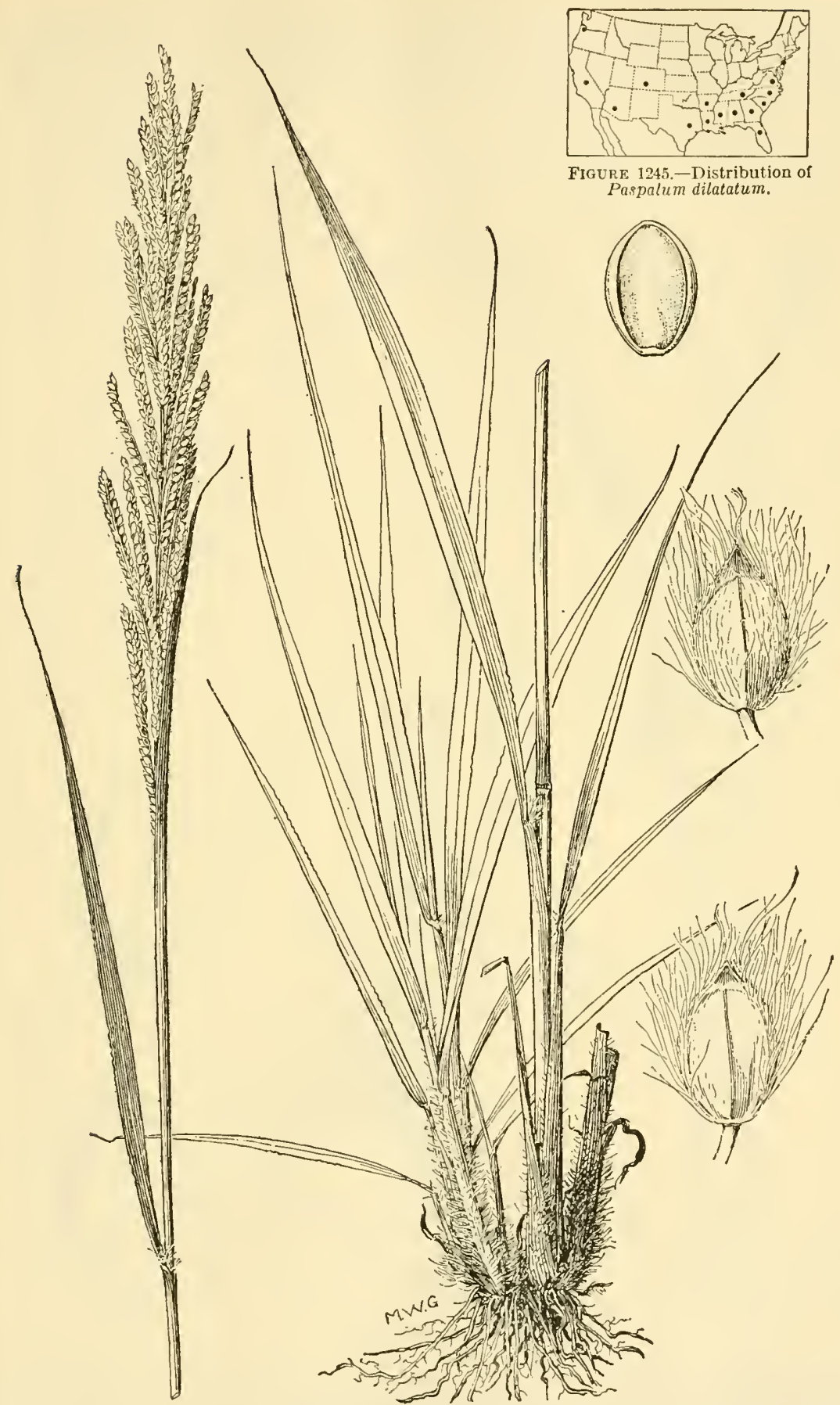

FIGURE 1246. - Paspalum urvillei. Plant, $\times 1 / 2$; two views of spikelet, and floret, $\times 10$. (Chase $4388, \mathrm{La}$.) 
America (fig. 1245). Widely known as paspalum-grass, water-paspalum, water-grass, or more commonly, simply paspalum. Introduced into the southern United States from Uruguay or Argentina about

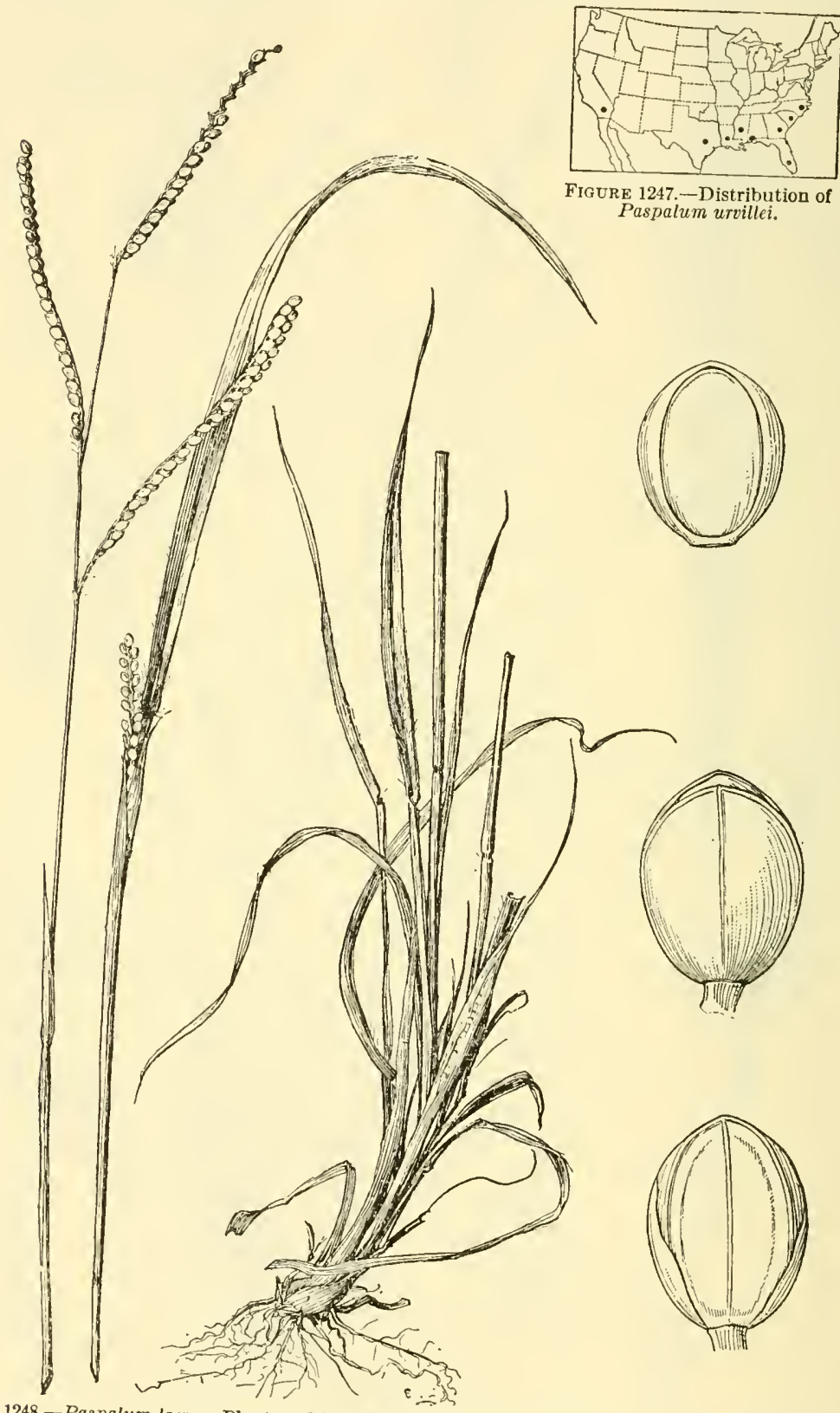

Figure 1248. - Paspalum laeve. Plant, $\times 1 / 2$; two views of spikelet, and floret, $\times 10$. (Chase 2600, D.C.) the middle of the last century, now common throughout the Gulf States. Valuable pasture grass. Dallis grass was named for A. T. Dallis of La Grange, Ga., who grew it extensively. 
30. Paspalum urvíllei Steud. Vasey grass. (Fig. 1246.) Culms in large elumps, erect, mostly 1 to $2 \mathrm{~m}$ tall; lower sheaths coarsely hirsute; blades mostly elongate, 3 to $15 \mathrm{~mm}$ wide, pilose at base; panicle erect, 10 to $40 \mathrm{~cm}$ long, of about 12 to 20 rather crowded, ascending racemes, 7 to $14 \mathrm{~cm}$ long ; spikelets 2.2 to $2.7 \mathrm{~mm}$ long, ovate, pointed, fringed with long white silky hairs, the glume appressed-silky. 24 (P.larranagai Arech.; P.vaseyanum, Scribn.)Along ditches and roadsides, and in waste ground, mostly in rather moist soil; North Carolina to Florida and west to Texas; southern California, south to Argentina (fig. 1247). 10. Laévia.-Rather tall, simple or occasionally with reduced flowering branches; blades mostly flat; racemes few to several; spikelets broadly oval to orbicular, depressed planoconvex, glabrous.

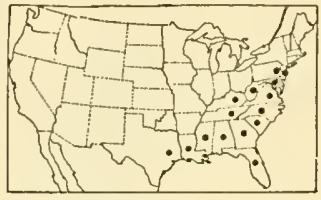

Figure 1249,-Distribution of Paspalum laeve.

31. Paspalum laéve Michx. (Fig. 1248.) Culms erect or ascending leafy at base, 40 to $100 \mathrm{~cm}$ tall; sheaths keeled, glaborus or nearly so; blades usually folded at base, flat or folded above, 5 to $30 \mathrm{~cm}$ long, 3 to 10 $\mathrm{mm}$ wide, glabrous to ciliate or sparsely pilose on the upper surface or sometimes toward the base beneath; racemes usually 3 or 4 , spreading, 3 to 10 cm long; spikelets broadly oval, 2.5 to $3 \mathrm{~mm}$ long.

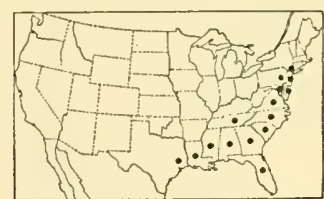

Figure 1251.-Distribution of Paspalum longipilum.

2 (P. angustifolium LeConte; $P$. australe Nash.)-Meadows, open woods, old fields, and waste ground, New Jersey and Pennsylvania to Florida, Arkansas, and eastern Texas (fig. 1249).

\section{Paspalum longí-}

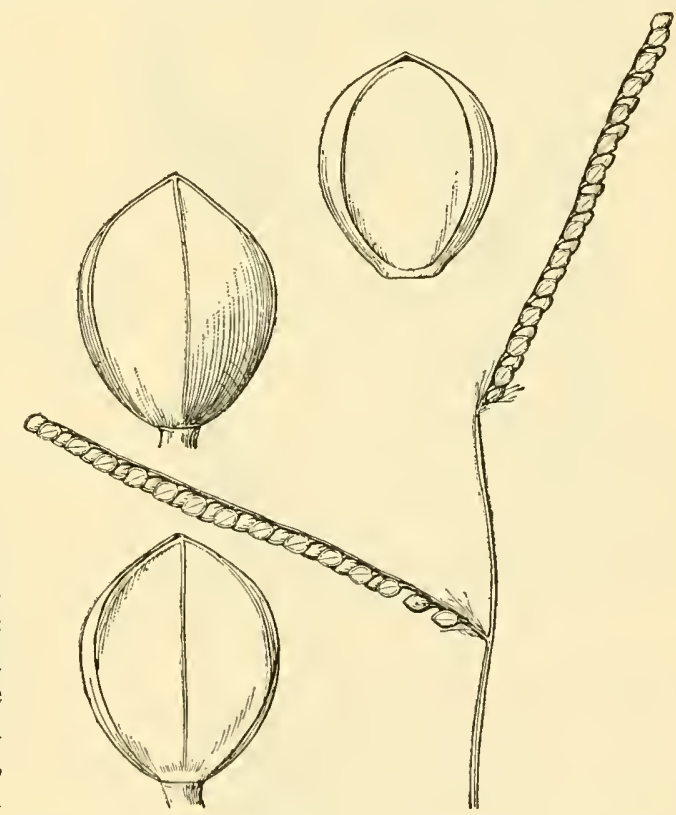

Figure 1250.-Paspalum longipilum. Panicle, $\times 1$; two views of spikelet, and floret, $\times 10$. (Type coll.) pilum Nash. (Fig. 1250.) Similar to P.laeve, usually less leafy at base,
sheaths and blades pilose; racemes somewhat more lax than in P. laeve. 2 (P. plenipilum Nash.)-Damp mostly sandy soil, savannas, open woods, and wet pine barrens, New York to T'ennessee, Florida, and Texas (fig. 1251).

33. Paspalum circuláre Nash. (Fig. 1252.) Culms in dense leafy clumps, 30 to $80 \mathrm{~cm}$ tall; sheaths pilose to nearly glabrous; blades mostly erect, commonly about equaling the inflorescence, 15 to 30 $\mathrm{cm}$ long, 5 to $10 \mathrm{~mm}$ wide, usually pilose on the upper surface; racemes 2 to 7 , mostly suberect, 5 to $12 \mathrm{~cm}$ long; spikelets nearly orbicular, 
about $3 \mathrm{~mm}$ long. 2 (P. praelongum Nash.)-Fields, meadows, and open waste ground, Connecticut to North Carolina and Mississippi, west to Kansas and Texas (fig. 1253).

34. Paspalum praécox Walt. (Fig. 1254.) Culms erect from short scaly rhizomes, 50 to $100 \mathrm{~cm}$ tall; sheaths keeled, glabrous, or the lower villous; blades 15 to $25 \mathrm{~cm}$ long, 3 to $7 \mathrm{~mm}$ wide, glabrous or nearly so; racemes usually 4 to 6 , ascending to arcuate-spreading,

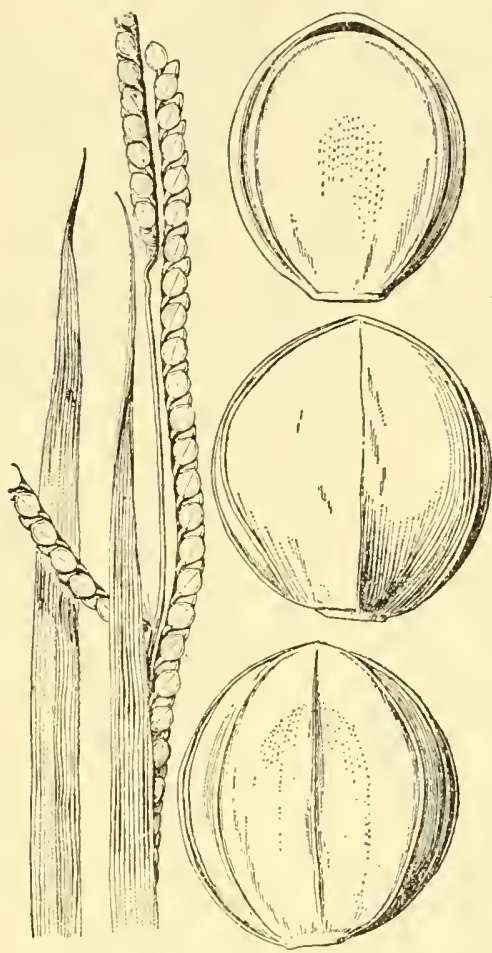

Figure 1252,-Pespalum circulare. Panicle, $\times 1$; two views of spikelet, and floret, $\times 10$. (Chase $3836, \mathrm{M} d$. .)

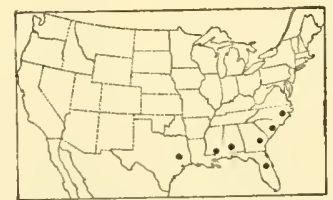

FIGURE 1255,-Distribution of Paspalum praecox.

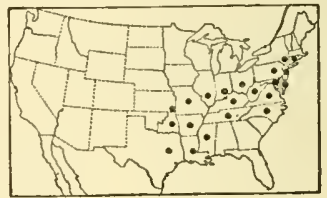

FigURE 1253,-Distribution of Paspalum circulare.

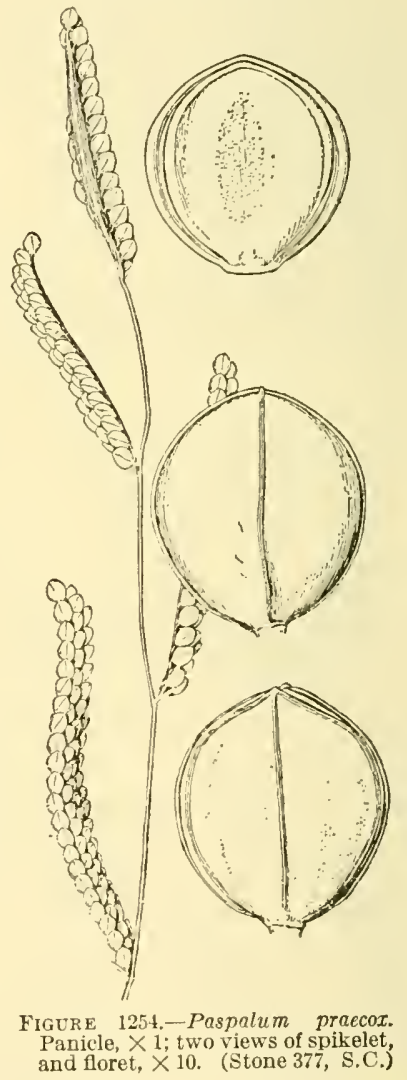

2 to $7 \mathrm{~cm}$ long, the common axis very slender; rachis about $1.5 \mathrm{~mm}$ wide, purplish; spikelets usually solitary and paired in each raceme, strongly flattened, suborbicular, 2.2 to $2.8 \mathrm{~mm}$ long, the glume and sterile lemma thin and fragile. 21 - Wet pine barrens, borders of cypress swamps, moist places in flatwoods, and wet savannas, in the Coastal Plain, North Carolina to central Florida and along the Gulf to Texas (fig. 1255). 
35. Paspalum lentíferum Lam. (Fig. 1256.) Similar to $P$. praecox; culms more robust, sometimes as much as $150 \mathrm{~cm}$ tall; sheaths less strongly keeled; blades usually more or less pilose; racemes usually 4 or 5 ; spikelets 2.7 to $3.4 \mathrm{~mm}$ long, broadly oval. 24 ( $P$. glaberrimum Nash; P. tardum Nash; $P$. kearneyi Nash; $P$. amplum Nash.)-Moist pine barrens, borders of flatwoods, and cypress swamps, and in savannas on the Coastal Plain, from North Carolina to southern Florida and along the Gulf to Texas (fig. 1257).

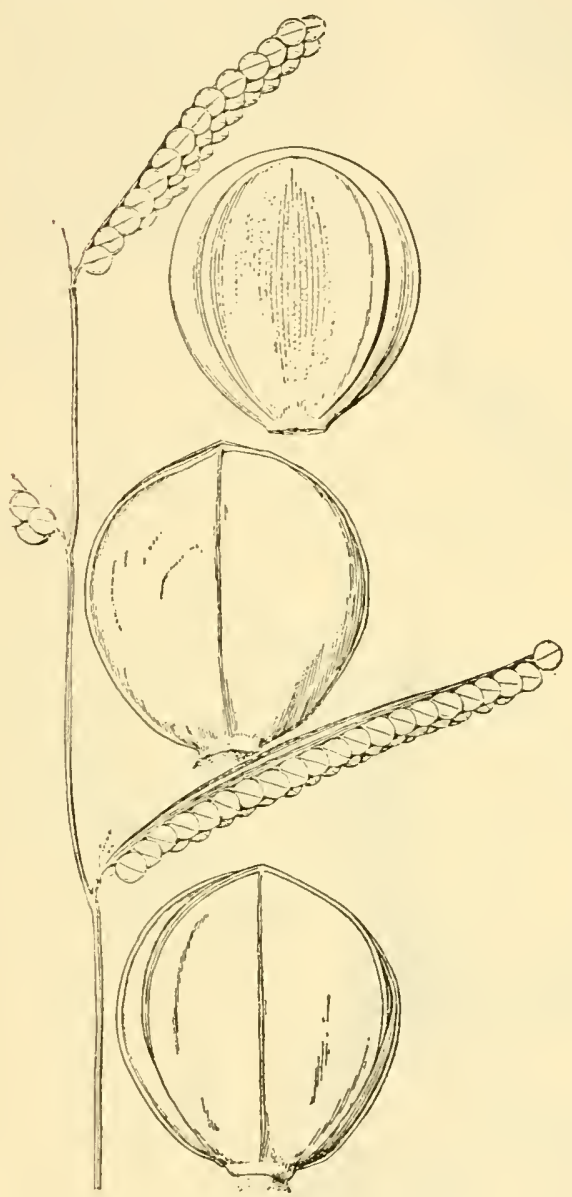

FIGURE 1256.-Paspalum lentifcrum. Panicle, $\times 1$; two views of spikelet, and floret, $\times 10$. (Harper $1629, \mathrm{Ga}$.)
11. Floridána.-Mostly robust, culms simple; blades mostly flat; racemes few; spikelets large, rather turgid, glabrous.

36. Paspalum diffórme LeConte. (Fig. 1258.) Culms solitary or few from a short knotty rhizome, rather stout, 35 to $75 \mathrm{~cm}$ tall; leaves commonly crowded at the base; blades 10 to $15 \mathrm{~cm}$ long, 5 to $10 \mathrm{~mm}$ wide, usually pilose on the upper surface toward base; racemes 2 to 4 , ascending to suberect, 3.5 to $8 \mathrm{~cm}$ long;

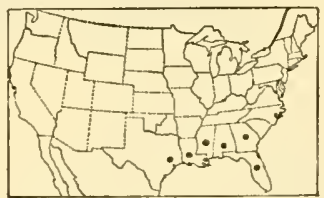

Figure 1257.-Distribution of Pcspalum lentiferum.

spikelets 3.5 to $4 \mathrm{~mm}$ long, oval to obovate. 24 -Moist sandy soil in open ground and in flatwoods, in the Coastal Plain, Georgia, to Orange County, Fla., west near the Gulf to Louisiana (fig. 1259).

37. Paspalum floridánum Michx. (Fig. 1260.) Culms solitary or few from short stout scaly rhizomes, 1 to $2 \mathrm{~m}$ tall; sheaths villous to nearly glabrous; blades firm, flat or folded, 15 to $50 \mathrm{~cm}$ long, 4 to $10 \mathrm{~mm}$ wide, usually vilious at least on the upper surface toward base; racemes usually 2 to 5,4 to $12 \mathrm{~cm}$ long; spikelets crowded, oval, about $4 \mathrm{~mm}$ long. 2 -Low moist sandy soil, pine woods, flatwoods, sarannas, and low prairies, in the Coastal Plain from Maryland to central Florida and along the Gulf to Texas, north in the valleys to Missouri and Oklahoma (fig. 1261). Paspalum Floridanum var. glabrátum Engelm. More robust, taller; foliage glabrous or nearly so; racemes longer, more spreading. 24 -Brackish marshes and low, sandy, 

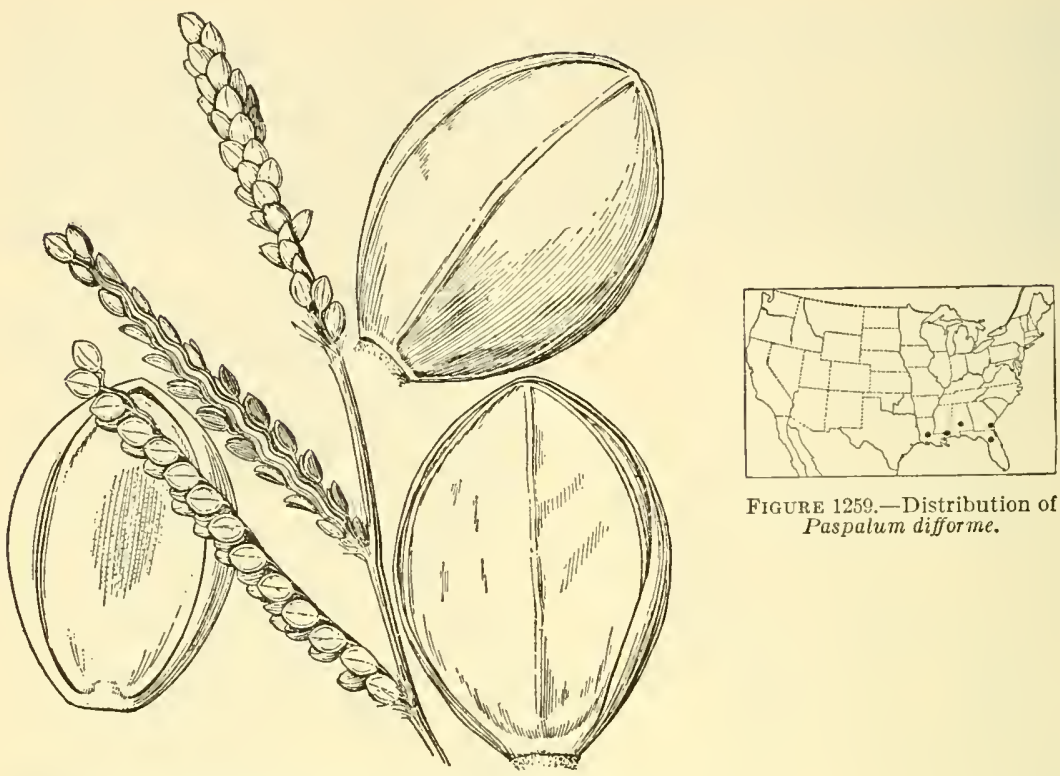

FIGURE 1250.-Distribution of Paspalum difforme.

Fictifforme. Panicle, $\times 1$; two views of spikelet, and floret, $\times 10$. (Type.)

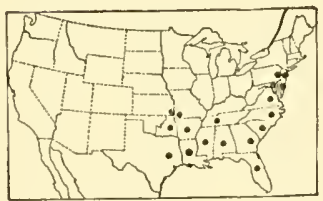

Figure 1261--Distribution of Paspalum floridanum.

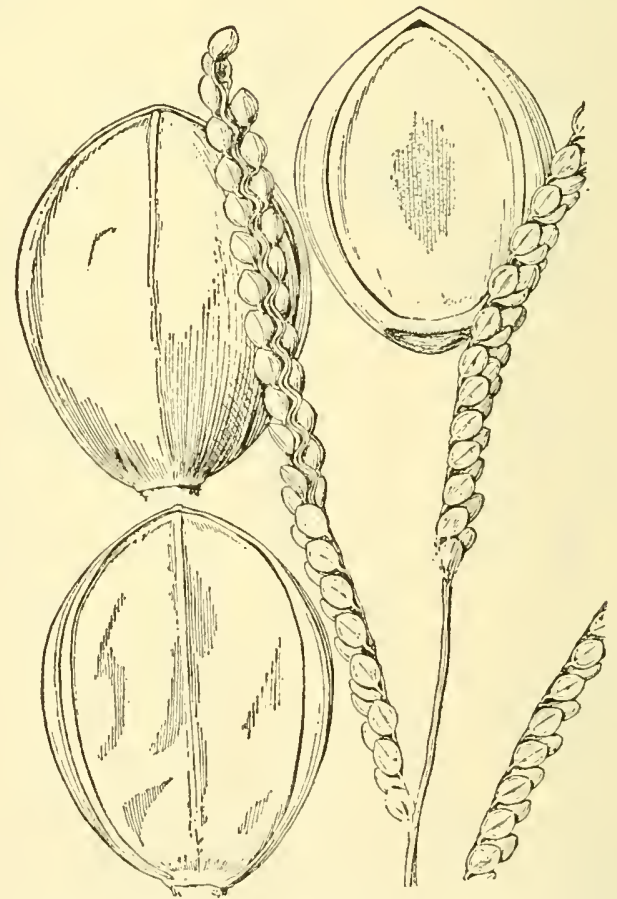

Figure 1260.-Paspalum floridanum. Panicle. $\times 1$; two views of spikelet, and floret, $\times 10$. (Chase 4221 , Fla.) 
mostly open ground, southern New Jersey to central Florida, west to Texas and southeastern Kansas.

38. Paspalum gigantéum Baldw. (Fig. 1262.) Culms mostly solitary from short scaly rhizomes, erect, 1.5 to $2 \mathrm{~m}$ tall; leares numerous at base; blades elongate, 10 to $20 \mathrm{~mm}$ wide, glabrous or nearly so; racemes commonly 3 or 4, 10 to $20 \mathrm{~cm}$ long; spikelets oval, about $3.5 \mathrm{~mm}$ long, usually russettinged. 24 (P.longicilium Nash.) -Moist sandy soil, open ground, stream banks, flatwoods, and hammocks, on the Coastal Plain from Georgia to southern Florida; Mississippi (Biloxi).

12. Virgáta.-Robust; blades firm with sharp-cutting edges; racemes several to numerous. Mostly tropical species.

39. Paspalum virgátum $L$. (Fig. 1263.) Culms, in large dense clumps, erect, 1 to $2 \mathrm{~m}$ tall; sheaths papillose-hirsute at margin and summit; blades elongate, flat, 1 to $2.5 \mathrm{~cm}$ wide; panicle slightly nodding, 15 to $25 \mathrm{~cm}$ long; racemes usually 10 to 16 , ascending or drooping, 5 to $15 \mathrm{~cm}$ long; spikelets crowded, obovate, about 2.2 to 2.5

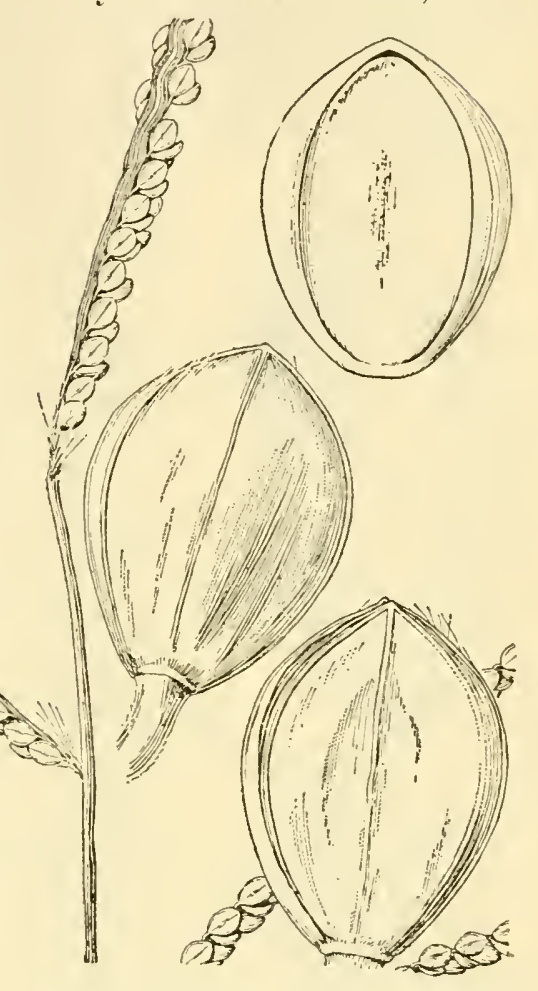

Figure 1262,-Paspalum giganteum. Panicle, $\times 1$; two views of spikelet, and floret, $X 10$. (Type.) $\mathrm{mm}$ long, brownish, pubescent along the margin at least toward the

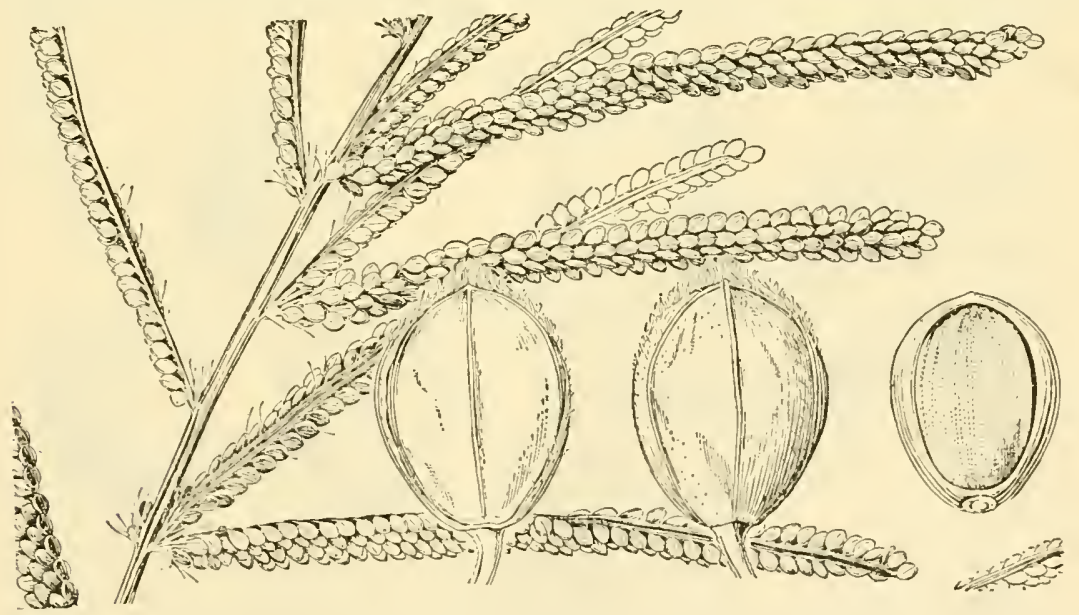

Figtre 1263.-Paspalum virgatum. Panicle, $\times 1$; two views of spikelet, and floret, $\times 10$. (Hitchcock 9555, Jamaica.)

summit. 24 -Open, mostly moist or swampy ground, southern Texas (Brownsville) to South America; throughout the West Indies. 
13. Plicátula.-Perennials and annuals with compressed purplish culms; blades flat or folded; racemes few to several; spikelets rather turgid, drab, turning brown or dark olivaceous; fruit dark brown, shining.

40. Paspalum plicátulum Michx. (Fig. 1264.) Culms in small

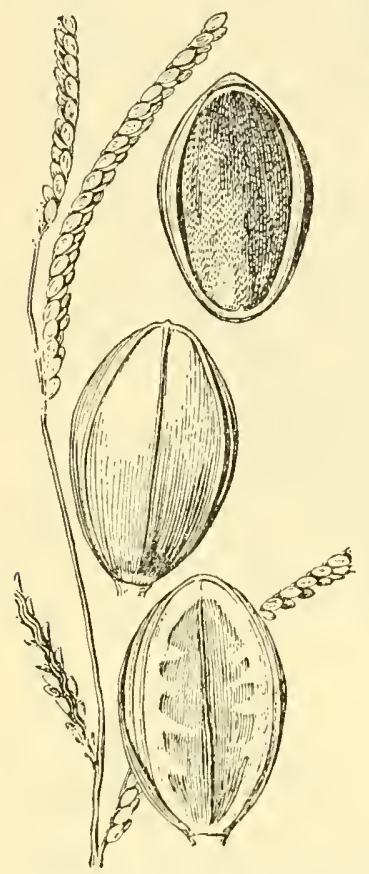

Figure 1264.-Paspalum plicatu. lum. Panicle, $\times 1$; two views of spikelet, and floret, $\times 10$. (Chase 7051, Ga.) tufts with numerous leafy shoots, suberect, 50 to $100 \mathrm{~cm}$ tall; blades folded at base, usually flat above, rather firm, elongate, 3 to $10 \mathrm{~mm}$ wide, usually pilose near base; racemes mostly 3 to 10 , arcuate-spreading, 3 to $10 \mathrm{~cm}$ long; spikelets usually 2.5 to $2.8 \mathrm{~mm}$ long, obovateoval, brown at maturity, glabrous or the glume appressed-pubescent, the sterile lemma with short transverse wrinkles just inside the slightly raised margin. 2 -Open ground or wet wood borders, Georgia and Florida to Texas, south to Argentina; throughout the West Indies (fig. 1265).

41. Paspalum bosciånum Flügge. BuLL PaSPalum. (Fig. 1266.) Rather succulent an-

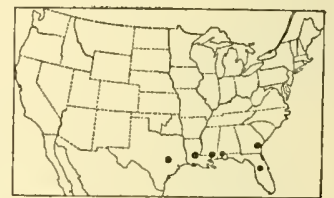

Figure 1265.-Distribution of Paspalum plicatulum. nual, branching at base and commonly from the middle nodes, usually conspicuously brownish purple, glabrous as a whole; culms 40 to $60 \mathrm{~cm}$ long, ascending or widely spreading; sheaths broad, loose; blades 10 to $40 \mathrm{~cm}$ long, 8 to $15 \mathrm{~mm}$ wide, papillose-pilose on upper surface near base; racemes 4 to 12 , usually 4 to $7 \mathrm{~cm}$ long; rachis 2 to $2.5 \mathrm{~mm}$ wide; spikelets crowded, obovate-orbicular, 2 to 2.2 $\mathrm{mm}$ long, glabrous, rust-brown at maturity.
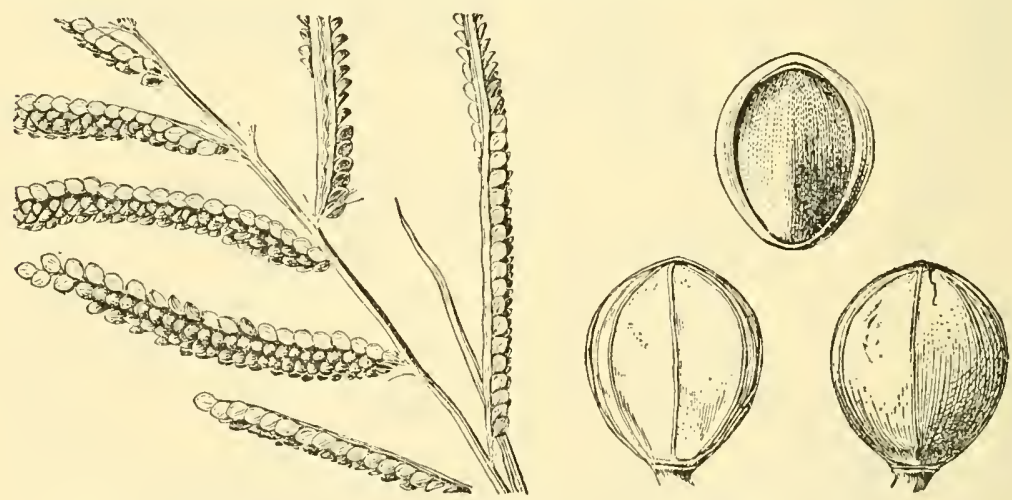

Figure 1266.-Paspalum boscianum. Panicle, $\times 1$; two views of spikelet, and floret, $\times 10$. (Kearney 152, Fla.)

$\odot \quad$ (Depauperate specimens have been described as $P$. scrobiculatum L.)-Moist or wet open ground, along ditches and ponds, sometimes a weed in cultivated fields, Pennsylvania (ballast), Virginia to Florida, Louisiana, and Arkansas, south to Brazil (fig. 1267). 
Paspalum scrobiculatum L. Stouter and with larger spikelets, unequally biconvex, the sterile lemma loose and wrinkled. $\odot$-Ballast, Camden, N.J.; Abilene, Tex.; Asia.

14. Bífida. - A single species approaching

Panicum; spikelets turgid; a minute first glume usually developed.

42. Paspalum bífidum (Bertol.) Nash. (Fig. 1268.) Culms erect from short rhizomes, 50 to $120 \mathrm{~cm}$ tall; blades flat, 10 to $50 \mathrm{~cm}$ long, 3 to $14 \mathrm{~mm}$ wide, villous to nearly glabrous:

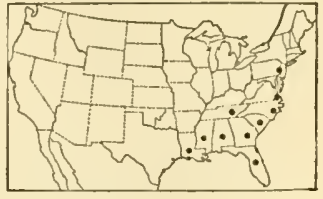

Figure 1267.-Distribution of Paspalum boscianum. racenes usually 3 or 4 , at first erect, 4 to $16 \mathrm{~cm}$ long; rachis slender,

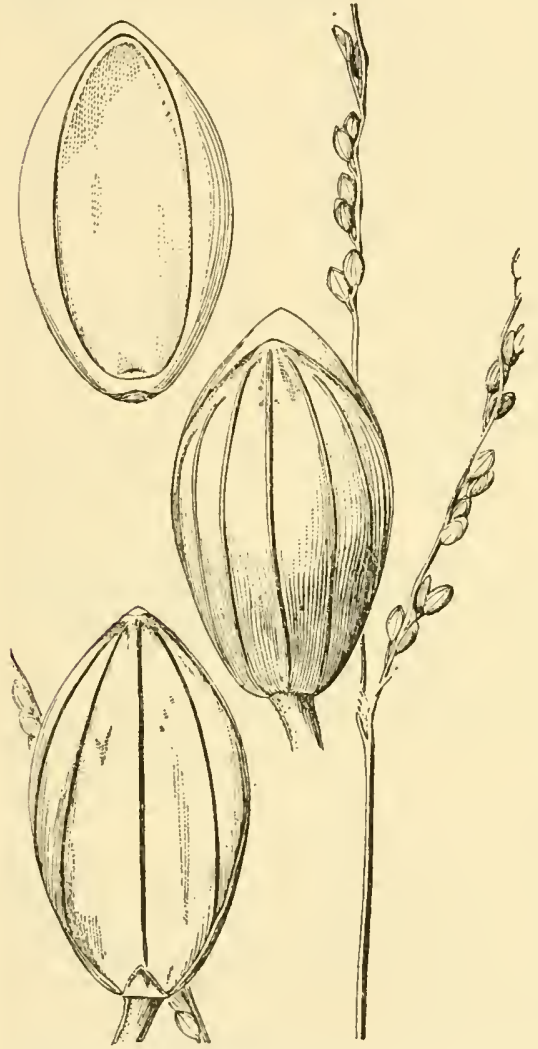

Figure 1268.-Paspalum bifidum. Panicle, $\times 1$; two views of spikelet, and floret, $\times 10$. (Curtiss 5590 , Fla.) subflexuous; spikelets distant to irregularly approximate, ellipticobovate, 3.3 to $4 \mathrm{~mm}$ long; second glume and sterile lemma conspicuously nerved. 24 - Sandy pine and oak woods, occasionally in hanmocks, nowhere common, on the Coastal Plain from South Carolina to Texas and Oklahoma (fig. 1269).

\section{PĀniCUM L. Panicum}

Spikelets more or less compressed dorsiventrally, in open or compact panicles, rarely racemes; glumes 2 , herbaceous, nerved, usually very unequal, the firs ${ }^{t}$ often minute, the second typically equaling the sterile lemma, the latter of the same texture and simulating a third glume, bearing in its axil a membranaceous or hyaline palea and sometimes a staminate flower, the palea rarely wanting; fertile lemma chartaceous-indurate, typically obtuse, the nerves obsolete, the margins inrolled over an enclosed palea of the same texture. Annuals or perennials of various habit. Type species, Panicum miliaceum. Panicum, an old Latin name for the common millet (Setaria italica).

Panicum miliaceum, proso millet, is cultivated to a limited extent in this country for forage. In Europe it is sometimes cultivated for the seed which is used for food. Two species are conmonly cultivated in the lowland tropics for forage, $P$. maximum, Guinea grass, an African species, said to have been introduced into Jamaica in 1774 , and $P$. purpurascens, Para grass, introduced into Brazil from Africa. Certain native species are constituents of wild hay or of the range.

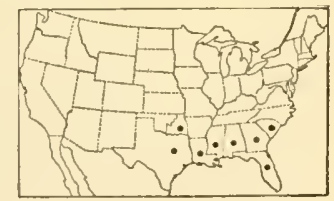

Figure 1269,-Distribution of Paspalum bifidum. $P$. virgatum, switch grass, of the eastern half of the United States, 
P. bulbosum and P. obtusum, of the Southwest, and Panicum texanum in Texas, furnish hay or forage. The seeds of $P$. sonorum Beal, of Northwest Mexico, are used for food by the Cocopa Indians.

Axis of branchlets extending beyond the base of the uppermost spikelet as a point or bristle 1 to $6 \mathrm{~mm}$ long......... Subgenus 1. Paurochaetium.

Axis of branchlets not extending into a bristle. (In P. geminatum and P. paludivagum the somewhat flattened axis is pointed but not bristle-form.)

Basal leaves usually distinctly different from those of the culm, forming a winter rosette; culms at first simple, the spikelets of the primary panicle not perfecting seed, later usually becoming much branched, the small secondary panicles with cleistogamous fruitful spikelets.

Subgends 2. Dichanthelium.

Basal leaves similar to the culm leaves, not forming a winter rosette; spikelets all fertile

Subgents 3. Eupanicum

\section{Subgenus 1. Paurochaetium}

Blades elongate, usually more than $15 \mathrm{~cm}$ long, narrowed toward the base.

Spikelets about $3.5 \mathrm{~mm}$ long _.......... P. REverChoni.

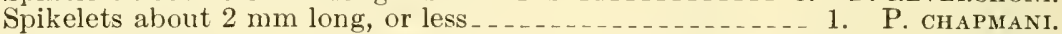

Blades usually less than $10 \mathrm{~cm}$ long, not narrowed toward the base; spikelets 2.5 to $3 \mathrm{~mm}$ long.

Blades of midculm long-acuminate, usually 2 to $3 \mathrm{~mm}$ wide.

Blades of midculm abruptly acute, usually 4 to $6 \mathrm{~mm}$ wide.

2. P. RAMISETUM.

\section{Subgenus 2. Dichanthelium}

4. P. FIRMULUM.

Blades elongate, not more than $5 \mathrm{~mm}$ wide, 20 times as long as wide; autumnal phase branching from the base only (from the lower nodes in $P$. werneri).

1. DEPAUPERATA.

Blades not elongate (or if so, more than $5 \mathrm{~mm}$ wide and autumnal phase not branching from base).

Plants branching from the base, finally forming rosettes or cushions, the foliage soft, lax. Blades prominently ciliate except in P. laxiflorum.

2. LAXIFLORA.

Plants branching from the culm nodes or rarely remaining simple.

Blades long, stiff; autumnal phase bushy-branched above.

Spikelets turgid, attenuate at base; mostly pustulose-pubescent; blades conspicuously striate, tapering from base to apex - 3. ANgustifolia.

Spikelets scarcely turgid, not attenuate at base; blades tapering to both ends_.............................. 4. Bicknelliana.

Blades not long and stiff (somewhat so in $P$. oligosanthes, $P$. malacon, $P$. commonsianum, and $P$. equilaterale); not bushy-branched.

Plants not forming a distinct winter rosette; spikelets attenuate at base, papillose........... 14 . PEdicellata.

Plants forming a distinct winter rosette; spikelets not attenuate at base. Spikelets turgid, blunt, strongly nerved (not strongly turgid in $P$. oligosanthes); blades rarely as much as $1.5 \mathrm{~cm}$ wide (sometimes $2 \mathrm{~cm}$ in $P$. ravenellii and $P$. xanthophysum).

Sheaths or some of them, papillose-hispid (sometimes all glabrous in $P$. helleri); spikelets 3 to $4 \mathrm{~mm}$ long (2.7 to $3 \mathrm{~mm}$ in $P$. wilcoxianum) .......................... 13. Oligosanthia.

Sheaths glabrous or minutely puberulent; spikelets 1.5 to $2.5 \mathrm{~mm}$ long, asymmetrically pyriform. Culms wiry ..... 12. LANCEARIA.

Spikelets not turgid, blunt, nor strongly nerved (somewhat so in $P$. roanokense and $P$. caerulescens).

Ligule of conspicuous hairs, usually 3 to $5 \mathrm{~mm}$ long. Slieaths glabrous or only the lowermost somewhat pubescent.

Sheaths strongly pubescent.

7. SPRETA.

8. LANUGinosa.

Ligule obsolete or nearly so (manifest in $P$. oricola, $P$. isugetorum, and P. curtifolium). 
Spikelets nearly spherical at maturity; blades glabrous, firm, cordate. Plants sparingly branching _........ 10. Sphakrocarpa. Spikelets usually obovate or elliptic.

Blades of midculm elongate, less than $1.5 \mathrm{~cm}$ wide. Culms usually tall; spikelets pointed, abruptly so in the velrety P. scoparium . Scoparia. Blades of midculm not elongate (somewhat so in $P$. equilaterale). Blades cordate, 1 to $3 \mathrm{~cm}$ wide ( 5 to $12 \mathrm{~mm}$ in $P$. ashei). Spikelets pubescent.

Spikelets 2.5 to $3 \mathrm{~mm}$ long. Sheaths glabrous or minutely puberulent................. 16. Commutata. Spikelets 3 to $5 \mathrm{~mm}$ long (sometimes but $2.7 \mathrm{~mm}$ long in the hispid-sheathed P. clandestinum) _.... 17. Latifolia.

Blades not cordate, less than $1 \mathrm{~cm}$ wide.

Sheaths crisp- or appressed-pubescent. Blades firm; spikelets pubescent_............ 9. Columbiana.

Sheaths glabrous or ciliate only in autumnal phase (sparsely pilose in $P$. curtifolium and the lower velvety in $P$. mattamuskeetense).

Vernal culms delicate (sometimes searcely so in $P$. albomarginatum and $P$. tenue); spikelets $1.5 \mathrm{~mm}$ or less long (1.6 to $1.7 \mathrm{~mm}$ in P. tenue) _. - 11. ExSIFolia. Vernal culms slender but not delicate, rarely less than $40 \mathrm{~cm}$ tall; spikelets 2 to $2.9 \mathrm{~mm}$ long $(1.5 \mathrm{~mm}$ in $P$. microcarpon and $P$. caerulescens).

Lower internodes short, upper elongate, producing a nearly naked culm, leafy at base; spikelets narrowly ovate, 2.7 to $2.9 \mathrm{~mm}$ long . . . . 5 . Nudicaulia. Lower internodes not shorter, the vernal culms about evenly leafy throughout; spikelets elliptic or obovate, not more than $2.5 \mathrm{~mm}$ long.

6. Diснотома.

\section{Depauperata}

Spikelets about $3.5 \mathrm{~mm}$ long, beaked_._._._. 5. P. DEPAUPERATUM ${ }^{*}$ Spikelets $3 \mathrm{~mm}$ long or less, (sometimes $3.2 \mathrm{~mm}$ long in $P$. perlongum) not beaked. Culms single or few in a tuft; spikelets turgid, blunt, 2.7 to $3.2 \mathrm{~mm}$ long. prairie plants.............. 6. PERLONGUM.

Culms in large tufts; spikelets not turgid, 2.2 to $2.7 \mathrm{~mm}$ long; plants of dry woods.

Sheaths pilose; spikelets 2.2 to $2.7 \mathrm{~mm}$ long, pilose_- 7. P. LINEARIFolıIUM.

Sheaths glabrous; spikelets 2.2 to $2.3 \mathrm{~mm}$ long, glabrous or sparingly pilose.

\section{Laxiflora}

8. P. WERNERI.

Sheaths retrorsely pilose; spikelets papillose-pilose.

Blades ciliate and more or less pilose on the surface; spikelets $2 \mathrm{~mm}$ long. 10. P. XALAPENSE. Blades glabrous or nearly so on the surface and margin; spikelets $2.2 \mathrm{~mm}$ long.

9. P. LAXIFLORUM.

Sheaths not retrorsely pilose; spikelets pubescent or glabrous.

Spikelets pubescent, about $2 \mathrm{~mm}$ long_........ 11. P. ciliatum. Spikelets glabrous.

Blades glabrous on the surface

Blades pilose on the surface.....

\section{Angustifolia}

Nodes bearded; plants grayish-villous; autumnal blades flat.

Spikelets $2 \mathrm{~mm}$ long

Spikelets 2.5 to $2.8 \mathrm{~mm}$ long .............. 16. P. Consanguineun.

Nodes not bearded; plants villous only at base, or nearly glabrous; autumnal blades involute or flat.

Autumnal blades flat; lower panicle branches spreading or reflexed.

17. P. ANGUSTIFOliUM. 
Autumnal blades involute; lower panicle branches more or less ascending.

Spikelets 3.3 to $3.5 \mathrm{~mm}$ long, pointed......... 18. P. Fusiforme.

Spikelets less than $3 \mathrm{~mm}$ long, not pointed, or obscurely so.

Plants glabrous or nearly so. Autumnal culms erect.

Spikelets subsecund along the suberect panicle branches.

21. P. NEURANTHUM.

Spikelets not subsecund, the paniele loose and open _- 20 . P. ovinum.

Plants pubescent, at least on the lower half.

Spikelets about $2.4 \mathrm{~mm}$, rarely only $2.1 \mathrm{~mm}$ long; vernal blades 7 to 12 $\mathrm{cm}$ long; autumnal blades not falcate__- 19. P. ARENICOLOIDES.

Spikelets not more than $2 \mathrm{~mm}$ long; vernal blades 4 to $6 \mathrm{em}$ long; autumnal blades much crowded, falcate...... 14. P. ACICULARE.

\section{Bicknelliana}

Spikelets 2.5 to $2.8 \mathrm{~mm}$ long; blades not more than $9 \mathrm{~mm}$ wide.

22. P. BicenelliI. Spikelets $3 \mathrm{~mm}$ long; blades as much as $12 \mathrm{~mm}$ wide... 23. P. CAlliphyllum.

\section{Nudicaulia}

A single species

24. P. NUDICAULE.

\section{Dichotoma}

1a. Nodes, at least the lower, bearded.

Spikelets 1.5 to $1.6 \mathrm{~mm}$ long, glabrous (occasional individuals with pubescent spikelets)

25. P. MICROCARPON.

Spikelets $2 \mathrm{~mm}$ long or more.

Spikelets glabrous, $2 \mathrm{~mm}$ long; autumnal phase topheavy-reclining.

Spikelets pubescent.

Blades all velvety; autumnal phase usually sparingly branching.

32. P. BARBULATUM.

27. P. ANNULUM.

Blades glabrous, or only the lower pubescent or velvety; autumnal phase freely branehing.

Spikelets $2 \mathrm{~mm}$ long; autumnal phase profusely branching.

26. P. NITIDUM.

Spikelets $2.2 \mathrm{~mm}$ long or more; autumnal phase less profusely branehing. Sheaths and upper nodes glabrous_.._._._. 29. P. CLUTEI. Lower sheaths and all nodes pubescent.

1b. Nodes not bearded.

28. P. mattamusketense.

2a. Spikelets pubeseent.

Culms erect, never becoming vinelike.

Primary blades spreading; panicles purplish; fruit exposed at summit.

Primary blades ereet; panicles green; fruit covered (wood forms with spreading blades may be distinguished from $P$. dichotomum by pubeseent spikelets, $2.2 \mathrm{~mm}$ long) _...... 30. P. BOREALE.

Culms soon prostrate, vinelike, the branches divarieate.

Plants bright green, culms lax; spikelets not more than $2.1 \mathrm{~mm}$ long.

Plants grayish green, culms stiff; spikelets $2.5 \mathrm{~mm}$ long.

36. P. LUCIDUM.

37. P. SPHAGNICOLA.

2b. Spikelets glabrous.

Culms soon prostrate.

Plants bright green, culms lax; spikelets not more than $2.1 \mathrm{~mm}$ long.

Plants grayish green, eulms stiff; spikelets $2.5 \mathrm{~mm}$ long.

36. P. LUCIDUM.

37. P. SPHAGNICOLA.

Culms ereet, or the autumnal phase topheavy, never prostrate.

Spikelets not more than $1.6 \mathrm{~mm}$ long; panicles narrow. Plants glaucous bluish green

Spikelets $2 \mathrm{~mm}$ long or more; panicles open.

Blades ereet, firm; spikelets turgid, strongly nerved. Plants grayish olive green........ P. ROANOKENSE. 
Blades spreading; spikelets not turgid.

Spikelets $2.2 \mathrm{~mm}$ long or more, pointed. Sheaths bearing pale glandular spots............. 33. PADKINENSE. Spikelets not more than $2 \mathrm{~mm}$ long, not pointed.

Autumnal phase erect, branched like a little tree; primary blades rarely more than $5 \mathrm{~mm}$ wide; second glume shorter than fruit and sterile lemma............ Р1. Р. рготомим.

Autumnal phase topheavy-reclining; primary blades 6 to $10 \mathrm{~mm}$ wide; second glume equaling fruit and sterile lemma.

32. P. BarbULATUM.

\section{Spreta}

Panicle narrow, one-fourth to one-third as wide as long

38. P. SPRETUM.

Panicle open, two-thirds as wide as long, or more.

Spikelets $1.5 \mathrm{~mm}$ long

Spikelets $1.3 \mathrm{~mm}$ long or less.

Culms and sheaths glabrous

Culms and sheaths appressed-pubescent.

Spikelets 1.2 to $1.3 \mathrm{~mm}$ long

Spikelets not more than $1 \mathrm{~mm}$ long

P. LONGILIGULATUM.

40. P. LEUCOTHRIX. 42. P. WRightianum.

\section{Lanuginosa}

1a. Spikelets not more than $2 \mathrm{~mm}$ long.

2a. Plants grayish, velvety-pubescent.

Spikelets 1.4 to $1.5 \mathrm{~mm}$ long; autumnal blades involute-pointed (see also $P$. albemarlense)

Spikelets 1.8 to $2 \mathrm{~mm}$ long; autumnal blades flat.

Plants dark or olive green when dry; spikelets 1.9 to $2 \mathrm{~mm}$ long.

Plants light or yellow green when dry.

50. P. THUROWII.

Autumnal phase prostrate, branching from base and lower nodes, forming close mats; blades not ciliate. Around hot springs.

55. P. THERMALE.

Autumnal phase ascending or spreading, branching from middle and upper nodes, the reduced, fascicled blades strongly ciliate.

48. P. LANUGinosum.

2b. Plants pubescent, often villous, but not velvety.

3a. Culms conspicuously pilose with long, horizontally spreading hairs. Ciilms branching before expansion of primary panicles.

51. P. PRAECocius.

3b. Culms variously pubescent, if pilose the hairs not long and horizontally spreading.

4a. Vernal blades glabrous or nearly so on the upper surface, firm in texture.

Autumnal culms branching from the lower nodes, forming a spreading bunch 10 to $15 \mathrm{~cm}$ high; Pacific slope_... 53. P. Occidentale. Autumnal culms branching from the middle nodes, forming widely spreading mats; Atlantic slope (see also form of $P$. huachucae var. fasciculatum) .............. P. TENNESSEENSE.

4b. Vernal blades pubescent on upper surface, sometimes pilose near base and margins only.

5a. Spikelets 1.3 to $1.5 \mathrm{~mm}$ long; vernal blades long-pilose on upper surface.

Autumnal phase widely decumbent-spreading, forming a mat; vernal culms soon geniculate-spreading; plants olivaceous.

44. P. ALBEMARLENSE.

Autumnal phase erect or leaning, never forming a mat; plants yellowish green.

Axis of panicle pilose, panicle branches tangled, the lower drooping.

45. P. implicatum.

Axis of panicle puberulent only, panicle branches not tangled, the lower ascending _...

5b. Spikelets 1.6 to $2 \mathrm{~mm}$ long; vernal blades pilose or pubescent.

Upper surface of blades pilose; spikelets 1.8 to $2 \mathrm{~mm}$ long; autumnal phase decumbent-spreading.

Spikelets pointed; culms weak and lax.... 56, P. LANGUidum. 
Spikelets obtuse; culms not weak and lax.

Culms leafy below, branching from base and lower nodes; Maine to Minnesota . .............. 52. P. subvillosum. Culms evenly leafy, branching from upper nodes; Pacific slope.

54. P. PACIFICUM.

Upper surface of blades appressed-pubescent or pilose toward the base only; spikelets 1.6 to $1.8 \mathrm{~mm}$ long; autumnal phase not decumbent-spreading. ......... P. HUACHUCAE.

1b. Spikelets $2.2 \mathrm{~mm}$ long or more.

Spikelets 2.2 to $2.4 \mathrm{~mm}$ long.

Pubescence on culms horizontally spreading; autumnal phase freely branching

Pubescence on culms appressed or ascending; autumnal phase rather sparingly branching.

Upper internodes shortened, the leaves approximate, the blades of ten equaling the panicle; pubescence sparse and stiff _- 60. P. SCOPARIOIDES. Upper internodes not shortened, the copious pubescence silky.

Spikelets 2.7 to $2.9 \mathrm{~mm}$ long.

58. P. PSEUDOPUBESCENS.

Culms stiff; blades conspicuously ciliate; southern Atlantic coast.

Culms weak; blades not ciliate; Pacific coast_....... 61. 59. P. Provale.

\section{Columbiana}

1a. Spikelets 2 to $3.2 \mathrm{~mm}$ long, mostly elliptic.

Winter blades 5 to $10 \mathrm{~cm}$ long. Spikelets $2 \mathrm{~mm}$ long; plants blue-green.

Winter blades 1 to $3 \mathrm{~cm}$ long.

- Spikelets $3.2 \mathrm{~mm}$ long; first glume conspicuously distant_ 62. P. MALACON. Spikelets not more than $2.9 \mathrm{~mm}$ long; first glume not distant.

Spikelets 2.8 to $2.9 \mathrm{~mm}$ long; vernal blades 8 to $15 \mathrm{~cm}$ long.

63. P. DEAMII.

Spikelets not more than $2.4 \mathrm{~mm}$ long; vernal blades not more than $8 \mathrm{~cm}$ long.

Spikelets about $2.4 \mathrm{~mm}(2.2$ to $2.4 \mathrm{~mm})$ long; panicle open, the branches stiffly spreading ................ 64 . P. COMMONSIANUM.

Spikelets 2 to $2.1 \mathrm{~mm}$ long; panicle rather dense, the branches ascending.

1b. Spikelets not more than $1.9 \mathrm{~mm}$ long, obovate, turgid.

65. P. ADDISONII.

Culms crisp-puberulent or appressed-pubescent with crimped hairs; plants

bluish or grayish green; panicle about 3 to $7 \mathrm{~cm}$ long.

Spikelets 1.8 to $1.9 \mathrm{~mm}$ long

Spikelets 1.5 to $1.6 \mathrm{~mm}$ long

Culms appressed or ascending-pilose; plants olivaceous; panicle rarely more

than $3 \mathrm{~cm}$ long. Spikelets not more than $1.5 \mathrm{~mm}$ long, rounded and turgid.

Spikelets $1.5 \mathrm{~mm}$ long; culms rather stout; autumnal phase branching from all the nodes ......

Spikelets 1.3 to $1.4 \mathrm{~mm}$ long; culms very slender; autumnal phase with branches mostly aggregate toward the summit.

68. P. COLUMBiandu var. THINiUm.

\section{Sphaerocarpa}

Culms spreading; blades obscurely nerved; panicle nearly as broad as long.

70. P. SPHAEROCARPON.

Culms erect or ascending; blades rather strongly nerved; panicle never more than two-thirds as broad as long, usually less.

Spikelets 1.5 to $1.6 \mathrm{~mm}$ long; blades lanceolate, the upper not reduced.

71. P. POLYANThes.

Spikelets 1 to $1.2 \mathrm{~mm}$ long; blades tapering from base to apex, the upper much

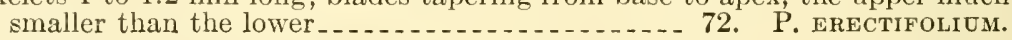




\section{Ensifolia}

Ligules about $1 \mathrm{~mm}$ long; sheaths or some of them sparsely spreading-pilose.

Ligules obsolete or nearly so; pubescence if present not spreading.

80. P. CURTIFolium.

Blades prominently white-lnargined, firm; spikelets densely puberulent.

Blades puberulent beneath, often above; sheaths and sometimes lower internodes ascending-pubescent.

Blades glabrous; sheaths glabrous or minutely eiliate only.

Uppermost culm blades much reduced; culms branching from lower nodes only, the branehes repeatedly branching- 74 . P. ALBOMARGINATUM.

Uppermost eulm blades about as long as the others; culms bearing short

branches from the upper and middle nodes._._. 75 . P. TRIFOLIUM.

Blades not white-margined or very obscurely so (or if white margin evident spikelets only $1.1 \mathrm{~mm}$ long); spikelets glabrous or puberulent.

Culms branching only at base; plants soft, light green - 79. P. vernale.

Culms branching at the nodes; plants firm or at least not soft.

Spikelets giabrous.

Spikelets 1.1 to $1.2 \mathrm{~mm}$ long; blades rarely as much as $5 \mathrm{em}$ long.

Spikelets 1.2 to $1.5 \mathrm{~mm}$ long.

81. P. CHAMAELONCHE.

Blades elongate, at least some of them 8 to $10 \mathrm{~cm}$ long.

Blades not more than $3 \mathrm{~cm}$ long _........... 78. P. ENSIFOLIUN.

Spikelets puberulent.

Spikelets $1.1 \mathrm{~mm}$ long. Winter blades bluish green, not glossy.

Spikelets 1.3 to $1.5 \mathrm{~mm}$ long.

77. P. Concinnius.

Blades involute, falcate, with long stiff hairs on margin near base.

Plants stiff and wiry _._._.

Blades not involute, or at tip only, not faleate.

Plants bright green; winter blades conspicuous, glossy green.

76. P. FLA Vovirens.

Plants olive; winter blades not conspicuous nor glossy.

\section{Lancearia}

78. P. ENSIFOLIUM.

Spikelets, 1.5 to $1.6 \mathrm{~mm}$ long

84. P. PORTORICENSE.

Spikelets $2 \mathrm{~mm}$ long or more.

Blades, or some of them at least $8 \mathrm{~mm}$ wide, glabrous on the upper surface; fruit papillose-roughened

Blades not more than $6 \mathrm{~mm}$ wide (or if wider, puberulent on the upper surface); fruit smooth and shining.

Spikelets 2.4 to $2.6 \mathrm{~mm}$ long. Blades narrowed toward the base.

Spikelets not more than $2.1 \mathrm{~mm}$ long.

88. P. PATENTIFOLIOM.

Blades firm, glabrous above; culms stiffly ascending - 85. P. LANCEARIUM. Blades lax, softly puberulent on both surfaces; culms decumbent.

\section{Oligosanthia}

86. P. Patulum.

Nodes bearded; blades velvety-pubeseent beneath.

Plants lax, soft-velvety throughout; spikelets not more than $3 \mathrm{~mm}$ long.

90. P. MALACOPHYLLUM.

Plants stiff, pubescence harsh; spikelets about $4 \mathrm{~mm}$ long- 94 . P. RAVENELII. Nodes not bearded (or but obscurely so in $P$. wilcoxianum); blades not velvety.

Panicle narrow, branches ereet, or spreading only at anthesis. Blades erect.

Spikelets not more than $3 \mathrm{~mm}$ long; blades not more than $6 \mathrm{~mm}$ wide.

Spikelets 3.7 to $4 \mathrm{~mm}$ long; blades 8 to $20 \mathrm{~mm}$ wide.

Blades papillose-hispid

89. P. WILCOXIANUM.

Blades glabrous on both surfaces

95. P. LEIBERGII. 96 . P. XANTHOPHYSUM.

Panicle about as wide as long.

Spikelets narrowly obovate, subacute; plants olivaceous, appressed-pubescent_.

Spikelets broadly obovate, turgid, blunt; plants green, the pubescenee, if present, not appressed.

Blades erect, not more than $6 \mathrm{~mm}$ wide; plants copiously hirsute throughout....... P. Wilcoxianum. 
Blades ascending or spreading, rarely less than $8 \mathrm{~mm}$ wide, usually wider; plants not hirsute throughout.

Spikelets 3.2 to $3.3 \mathrm{~mm}$ long; blades firm; sheaths or some of them more or less hispid................... 92. P. SCRIBNERIANUM.

Spikelets not more than $3 \mathrm{~mm}$ long; blades rather thin; sheaths or some of them glabrous or sparsely hispid_.. 91. P. HELLERI.

\section{Pedicellata}

Culms erect or leaning; blades thin, 5 to $9 \mathrm{~cm}$ long, narrowed toward the base. 97. P. PEDiCELlatum. Culms decumbent; blades thick, not more than $5 \mathrm{~cm}$ long, not narrowed

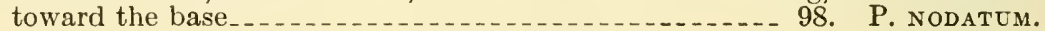

\section{Scoparia}

Pubescence soft-villous or velvety. Spikelets abruptly pointed.

Pubescence when present not velvety.

99. P. SCOPARIUM.

Spikelets elliptic; fruit $2 \mathrm{~mm}$ long............. 100. P. ACULEATUM. Spikelets ovate, that is, broadest below the middle; fruit $2 \mathrm{~mm}$ long or less.

Sheaths or some of them hispid, rarely glabrous; autumnal phase with crowded branchlets ................. 101. P. SCABRIUSCULUM. Sheaths glabrous; autumnal phase sparingly branching.

\section{Commutata}

102. P. CRYPTANTHUM.

Plants glaucous, glabrous. Basal blades conspicuously ciliate; vernal culms

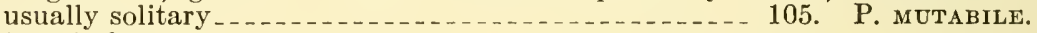

Plants not glaucous.

Blades nearly linear, that is, with parallel margins. First glume about half as long as the spikelet.................. 107. P. EQUILATERALE.

Blades lanceolate.

Culms crisp-puberulent; blades usually rigid, symmetrical, rarely more than $10 \mathrm{~mm}$ wide; spikelets about $2.5 \mathrm{~mm}$ long _....... 103. P. ASHEI.

Culms glabrous or softly puberulent; blades firm or lax; spikelets 2.7 to 3.2 mm long.

Culms erect, or autumnal phase leaning; blades symmetrical, broadly cordate.

Culms decumbent; blades usually asymmetrical and falcate, narrowed to

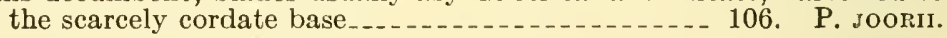

\section{Latifolia}

Sheaths strongly papillose-hispid, at least the lower and those of the branches.

Sheaths glabrous or sof tly villous.

108. P. CLANDESTINUM.

Nodes glabrous; spikelets 3.4 to $3.7 \mathrm{~mm}$ long_._._. . 109. P. LAtifolium.

Nodes bearded; spikelets 4 to $4.5 \mathrm{~mm}$ long

1a. Plants annual.

\section{Subgenus 3. Eupanicum}

Inflorescence consisting of several more or less secund spikelike racemes. Fruit transversely rugose

Inflorescence a more or less diffuse panicle.

Spikelets tuberculate

Spikelets not tuberculate.

First glume not more than one-fourth the length of the spikelet, truncate or triangular-tipped................ 4 . Dichóromiflora.

First glume usually as much as half the length of the spikelet, acute or

1b. Plants perennial. acuminate..................................... Capillaria.

2a. Spikelets short-pediceled along one side of the rachises, forming spikelike racemes (compare Agrostoidia with 1-sided but not spikelike panicle branches).

First glume nearly equaling the sterile lemma.

Racemes spreading; fruit not more than one-third the length of the spikelet....... 16. Gymnocarpa. Racemes appressed; fruit nearly as long as the spikelet.... 14. OBTUsA. 
First glume much shorter than the sterile lemma.

Fruit transversely rugose.

Nodes glabrous

1. Geminata.

Nodes bearded

Fruit not rugose

2b. Spikelets in open or sometimes contracted or congested panicles (somewhat 1-sided in Agrostoidia).

Fruit transversely rugose (obscurely so in P. plenum) -... 7. Maxima.

Fruit not transversely rugose.

Spikelets villous

13. Urvilleana.

Spikelets glabrous.

Sterile palea enlarged and indurate at maturity, expanding the spikelet. Blades scarcely wider than their sheaths; spikelets about $2.3 \mathrm{~mm}$ long, borne toward the ends of the few slender branches_ 11. LAXA. Sterile palea, if present, not enlarged.

Plants with conspicuous creeping scaly rhizomes.

Spikelets long-pediceled, not secund, arranged in an open or coritracted panicle ...................... 8. Virgata.

Spikelets short-pediceled, more or less secund along the nearly simple panicle branches............... 10. Agrostoidia.

Plants without creeping scaly rhizomes.

Panicles narrow and few-flowered; culms erect and wiry. Blades drying involute.......... Tenera.

Panicles open or contracted, many-flowered.

Spikelets short-pediceled along the nearly simple panicle branches... 10. Agrostoidia. Spikelets long-pediceled, the panicle open_.... 6. Diffusa.

\section{Geminata}

Spikelets $3 \mathrm{~mm}$ long; glumes and sterile lemma papery - 112 . P. PALudivagum. Spikelets not more than $2.4 \mathrm{~mm}$ long; glumes and sterile lemma not papery.

111. P. geminatum.

\section{Purpurascentia}

A single species

113. P. PURPU RASCENS.

\section{Fasciculata}

Spikelets 5 to $6 \mathrm{~mm}$ long

118. P. TEXANum.

Spikelets 2 to $4 \mathrm{~mm}$ long.

Spikelets strongly reticulate-veined, 2 to $3 \mathrm{~mm}$ long; glabrous.

Spikelets scarcely reticulatc-veined or only near apex.

Spikelets not more than $2 \mathrm{~mm}$ long, glabrous
Spikelets nore than $3 \mathrm{~mm}$ long, pubescent.

115. P. FASCICULATUM.

Spikelets more than $3 \mathrm{~mm}$ long, p
Rachis scabrous but not bristly

114. P. REPTANS.

Rachis bristly-hirsute

116. P. ADSPERSUM.

117. P. ARIZONICUM.

\section{Dichotomiflora}

Sheaths glabrous

119. P. DICHOTOMIFLORUM.

Sheaths papillose-hispid

120. P. BARTOWENSE.

\section{Capillaria}

Panicles drooping; spikelets 4.5 to $5 \mathrm{~mm}$ long

130. P. miliaceum.

Panicles erect; spikelets not more than $4 \mathrm{~mm}$ long.

Panicles more than half the length of the entire plant.

Panicles narrow, usually less than half as broad as long _- - 121. P. FLexile.

Panicles as broad as long.

Fruit without scar at base

125. P. Capillare.

Fruit with a lunate scar at base_...

Panicles not more than one-third the entire height of the plant.

Spikelets not more than $2 \mathrm{~mm}$ long, acute but not long-acuminate (sce also P. hirsutum).

Culms stout; blades about $1 \mathrm{~cm}$ wide; spikelets turgid.

122. P. GATTINGERI. 
Culms slender; blades not more than $6 \mathrm{~mm}$ wide; spikelets not turgid. Axillary pulvini pilose _..._._._. Axillary pulvini glabrous _............. 124. P. TUCKERMANI. Spikelets 2.7 to $4 \mathrm{~mm}$ long, acuminate.

First glume about one-third the length of the spikelet, subacute or blunt ...........

First glume usually more than half the length of the spikelet, acuminate.

First glume more than three-fourths the length of the spikelet; spikelets $4 \mathrm{~mm}$ long .......... 128. P. PAMINOSUM.

First glume half to two-thirds the length of the spikelet; spikelets not more than $3.3 \mathrm{~mm}$ long ................ 127. P. HiRticaule.

\section{Diffusa}

Second glume and sterile lemma elongate, at least three times as long as the

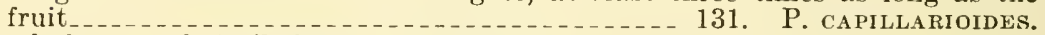
Second glume and sterile lemma not elongate.

Culms as much as $1 \mathrm{~cm}$ thick; blades $2 \mathrm{~cm}$ wide or more.- $136 . \quad$ P. hirsutum. Culms slender; blades not more than $1 \mathrm{~cm}$ wide.

Spikelets 4 to $4.2 \mathrm{~mm}$ long. Midnerves of glumes and sterile lemma scabrous toward the apex ................ 134. P. LEPIDULUM.

Spikelets usually less than $3.5 \mathrm{~mm}$ long.

Blades hirsute on both surfaces (sometimes glabrescent), not at all glancous _._.

Blades glabrous on both surfaces or with a few hairs on either surface, glaucous above.

Panicle much exceeding the leares; spikelets 3 to $3.5 \mathrm{~mm}$ long (rarely $3.7 \mathrm{~mm}$ ) Panicle usually equaled or exceeded by the uppermost blades; spikelets 2 to $2.6 \mathrm{~mm}$ long......

\section{Maxima}

Culms with a cormlike base

139. P. вULBOSUM.

Culms not cormlike at base.

Nodes hirsute; ligules 4 to $6 \mathrm{~mm}$ long; fruit strongly rugose.

Nodes glabrous; ligules $2 \mathrm{~mm}$ 137. P. Maximom.

\section{Virgata}

Spikelets not more than $2.5 \mathrm{~mm}$ long, first glume less than half the length of the spikelet.

Panicle loosely flowered; first glume truncate, about one-fifth the length of

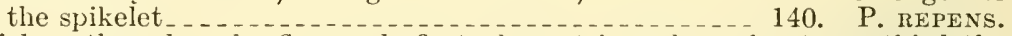

Panicle rather densely flowered; first glume triangular, about one-third the length of the spikelet. . . P. GOUINI.

Spikelets 3 to $7 \mathrm{~mm}$ long (sometimes less than $3 \mathrm{~mm}$ in $P$. virgatum var. cubense); first glume more than half the length of the spikelet.

Panicle elongate, strongly contracted; seacoast plants.

Culms rarely $1 \mathrm{~m}$ tall, solitary from the nodes of the horizontal rhizome ... P. AMARUM.

Culms 1 to $2 \mathrm{~m}$ tall, in dense tufts... 145. P. AMarulum.

Panicle diffuse, or only slightly contracted; plants sometimes of salt marshes but not littoral.

Spikelets 6 to $\mathrm{S} \mathrm{mm}$ long; culms solitary, with a creeping base.

143. P. HAVARDII.

Spikelets less than $5 \mathrm{~mm}$ long (in exceptional specimens $6 \mathrm{~mm}$ long); culms erect, producing numerous scaly rhizomes._._._. 142. P. VIRGATUM.

\section{Tenera}

A single species

146. P. TENERUM.

\section{Agrostoidea}

Rhizomes present; culms but little compressed; spikelets set obliquely on the appressed pedicels.

Panicles open; spikelets 3.4 to $3.8 \mathrm{~mm}$ long (shorter in exceptional specimens).

152. P. ANCEPS. 
Panicles more or less contracted; spikelets not more than $2.8 \mathrm{~mm}$ long.

153. P. RHIZONATUM.

Rhizomes wanting; culms strongly compressed with keeled sheaths; spikelets not obliquely disposed.

Ligule ciliate; basal leaves half as long as the culm or more; panicle much exceeding the upper leaves.

Spikelets not more than $2.7 \mathrm{~mm}$, usually $2.5 \mathrm{~mm}$ long, the first glume less than half that length; ligule 2 to $3 \mathrm{~mm}$ long - 150 . P. LONGIFoliou.

Spikelets 3 to $3.5 \mathrm{~mm}$ long; first glume two-thirds to three-fourths that length; ligule less than $1 \mathrm{~mm}$ long _........... 151. P. CoMBsir.

Ligule erose or lacerate, not ciliate; basal leaves in short tufts, the upper usually nearly equaling the terminal panicle.

Fruit stipitate; spikelets 2.5 to $2.8 \mathrm{~mm}$ long, conspicuously secund.

Fruit not stipitate; spikelets not conspicuously secund.

149. P. STipitatom.

Spikelets 1.8 to $2 \mathrm{~mm}$, in occasional specimens $2.2 \mathrm{~mm}$ long; panicle branches ascending or spreading _..._.... 147. P. AGROSTOIDES. Spikelets about $2.5 \mathrm{~mm}$ long; panicle branches erect or nearly so.

11. Laxa

148. P. CONDENSUM.

A single species

154. P. HIANS.

\section{Verrucosa}

Spikelets about $2 \mathrm{~mm}$ long, glabrous _............ 155. P. verrucosom. Spikelets more than $3 \mathrm{~mm}$ long, hispid 156. P. BRACHYANTHUM.

13. Urvilleana

A single species 157. P. urvilleanum.

\section{Obtusa}

A single species

158. Р. овтUSUM.

15. Hemitoma

A single species.

159. P. HеMitomon.

16. Gymnocarpa

A single species

160. P. GYMNOCARPON.

Subgenus 1. Paurochátium Hitche. and Chase

Perennials; culms tufted, erect, blades not more than $7 \mathrm{~mm}$ wide; panicle slender, the branches short, appressed, the ultimate branchlets bearing 1 to several spikelets, produced beyond the uppermost spikelet as a bristle 1 to $6 \mathrm{~mm}$ long; spikelets much swollen on the face, glabrous, strongly nerved; fruit transversely rugose, apiculate.

1. Panicum chapmáni Vasey. (Fig. 1270.) Culms ascending or spreading, slender, wiry, 40 to $100 \mathrm{~cm}$ tall; blades erect, rather firm, 15 to $40 \mathrm{~cm}$ long, 2 to $5 \mathrm{~mm}$ wide, more or less involute when dry; panicle mostly 20 to $30 \mathrm{~cm}$ long; bristle 3 to $6 \mathrm{~mm}$ long; spikelets 2 to $2.2 \mathrm{~mm}$ long, obovate; first glume about one-third as long as the spikelet, obtuse or truncate. 21 -Coral sand and shell mounds, southern Florida; Bahamas; Yucatan.

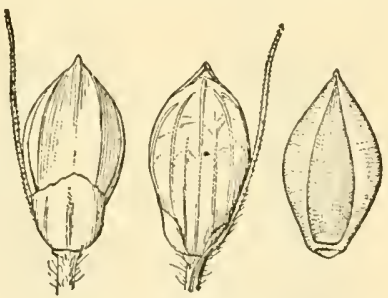

Figure 1270.-Panicum chapmani. Panicle, $X 1$; two views of spikelet, and floret, $\times 10$. (Type.)

2. Panicum ramisétum Scribn. (Fig. 1271.) Culms erect or ascending from short horizontal rhizomes, 25 to $60 \mathrm{~cm}$ tall; blades 5 to 
$12 \mathrm{~cm}$ long, 2 to $4 \mathrm{~mm}$ wide; panicle 5 to $20 \mathrm{~cm}$ long; bristle not exceeding the spikelet; spikelets about $2.5 \mathrm{~mm}$ long, obovate; first

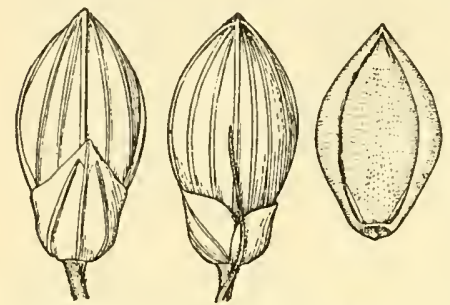

Figure 1271.-Panicum ramisetum. Two views of spikelet, and floret, $\times 10$. (Type.) glume about half as long as the spikelet. 21 - Sandy plains and prairies, southern Texas and northern Mexico.

3. Panicum reverchóni Vasey. (Fig. 1272.) Culms stiffly erect, from short rhizomes, 30 to $70 \mathrm{~cm}$ tall; blades erect, stiff, 5 to $20 \mathrm{~cm}$ long, 2 to $3 \mathrm{~mm}$ wide; panicle 5 to $20 \mathrm{~cm}$ long; spikelets mostly one to a branchlet, the bristle equaling or exceeding the spikelet; spikelets 3.5 to $3.8 \mathrm{~mm}$ long, elliptic; first glume about half as long as the spikelet. 2 Rocky or sandy prairies and limestone hills, Texas.

4. Panicum fírmulum Hitchc. and Chase. (Fig. 1273.) Culms ascending or decumbent at base, 30 to $40 \mathrm{~cm}$ tall, rather loosely tufted from creeping knotted rhizomes as much as $5 \mathrm{~cm}$ long; blades ascending or spreading, firm, 4 to $10 \mathrm{~cm}$ long, 4 to $7 \mathrm{~mm}$ wide; bristle 1 to 2 times as long as the spikelet; spikelets 3 to $3.2 \mathrm{~mm}$ long, obovate; first glume half as long as the spikelet. 24 -Sandy prairies, southern Texas.

Subgentes 2. Dichanthélium Hitchc. and Chase

Perennial, from a crown,
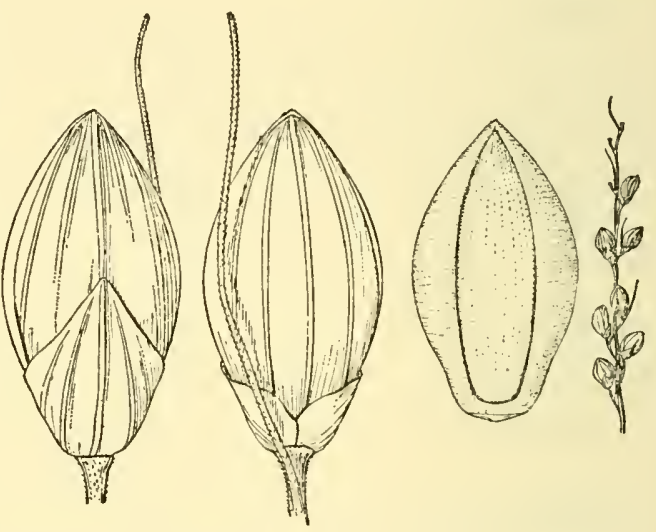

Figure 1272.-Panicum reverchoni. Panicle, $\times 1$; two views of spikelet, and floret, $\times 10$. (Type.) rarely from short matted rhizomes, surrounded by a more or less well-marked rosette of usually short winter leaves, in spring producing simple

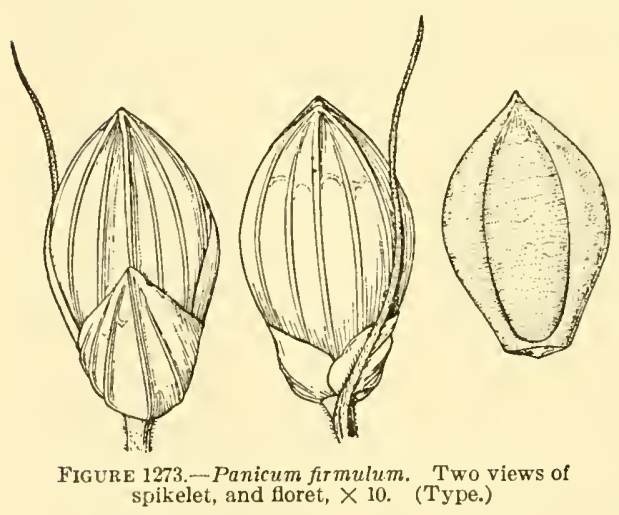
culms with mostly narrowly lanceolate blades and terminal panicles with numerous spikelets, these rarely perfecting seed; early culms branching at some or all of the nodes (in a few species from the base only) after the maturity of the primary panicles or sometimes before; branches often repeatedly branching, the short branchlets more or less fascicled and bearing usually much reduced leaves; the terminal one or two joints of the primary culm often finally falling, the whole producing an autumnal phase usually strikingly different from the vernal phase; secondary panicles reduced, 
the latest more or less included in the sheaths, the spikelets cleistogamous and perfecting their grains. The species of this subgenus are usually known as dichotomous panicums because they are related to Panicum dichotomum.

Key to the species irrespective of the groups

1a. Spikelets glabrous.

2a. Spikelets $3 \mathrm{~mm}$ long or more, strongly nerved.

Spikelets pointed; blades elongate. Spikelets blunt; blades not elongate.

5. P. DEPaUPERATUM.

Spikelets 3.2 to $3.3 \mathrm{~mm}$ long; blades firm; sheaths, or some of them, hispid. 92. P. SCRIBNERIANUM.

Spikelets not more than $3 \mathrm{~mm}$ long; blades rather thin; sheaths glabrous or sparsely hispid...

2b. Spikelets less than $3 \mathrm{~mm}$ long.

3a. Second glume and sterile lemma exceeding the fruit and pointed beyond it. Spikelets 2.2 to $2.9 \mathrm{~mm}$ long.

Blades clustered toward the base--

Blades not clustered toward the base.

Sheaths, at least the secondary, hispid..... 101. P. SCABRIUSCULUM. Sheaths glabrous.

Blades firm; fruit $1.5 \mathrm{~mm}$ long _......... 102. P. CRYPTANTHUM.

Blades thin; fruit nearly $2 \mathrm{~mm}$ long

$3 \mathrm{~b}$. Second glume and sterile lemma not pointed beyond the fruit.

4a. Ligule manifest, 1 to $3 \mathrm{~mm}$ long.

Culms rather stout; ligule 2 to $3 \mathrm{~mm}$ long; sheaths glabrous.

Culms slender; ligule $1 \mathrm{~mm}$ long; sheaths sparsely pilose.

38. P. SPRETUM.

80. P. CURTIFOLIUM.

4b. Ligule obsolete.

5a. Spikelets $1.5 \mathrm{~mm}$ or less long.

Nodes bearded

25. P. MICROCARPON.

Nodes not bearded.

Culms and blades pilose

Culms glabrous.

Blades conspicuously ciliate; plants branching at base only.

12. P. POLYCAULON.

Blades not ciliate; plants branching from middle or upper nodes.

Vernal culms $50 \mathrm{~cm}$ tall or more; spikelets turgid, strongly nerved; autumnal phase ereet, with fascicled branches shorter than the primary internodes.

35. P. Caerulescens.

Vernal culms usually much less than $50 \mathrm{~cm}$ tall; autumnal phase spreading or reclining.

Spikelets 1.1 to $1.2 \mathrm{~mm}$ long. Blades rarely as much as $5 \mathrm{~cm}$ long

Spikelets 1.2 to $1.4 \mathrm{~mm}$ long.

Blades elongate, at least some of them 8 to $10 \mathrm{~cm}$ long.

82. P. GLABRIFOLIUM. Blades not more than $3 \mathrm{~cm}$ long .... 78. P. ENSIFOLIUM.

5 b. Spikelets $2 \mathrm{~mm}$ long or more.

Blades elongate, some of them 20 times as long as wide; spikelets 2.2 to $2.8 \mathrm{~mm}$ long.

Blades erect; branches, when present, from the lower nodes only.

Blades spreading; branches from upper nodes_ 22. ${ }^{8}$ P. BICKNELLII.

Blades not elongate, about 10 times as long as wide.

Culms soon prostrate, vinelike; branches divaricate.

Plants bright green; culms lax; spikelets not more than $2.1 \mathrm{~mm}$ long .

Plants grayish green; culms stiff; spikelets $2.5 \mathrm{~mm}$ long.

37. P. SPHAGNICOLA. 
Culms not vinelike; branches not divaricate.

Spikelets 2.3 to $2.6 \mathrm{~mm}$ long.

Blades, or some of them, at least $8 \mathrm{~mm}$ wide; fruit papilloseroughened ............... 87 . P. WEBBERIANUM. Blades not more than $6 \mathrm{~mm}$ wide; fruit smooth and shining.

88. P. PATENTIFOLIUM.

Spikelets $2 \mathrm{~mm}$ long.

Culms wiry, crisp-puberulent; blades ciliate at base.

Culms glabrous; blades not ciliate.

85. P. LANCEARIUM.

Blades erect, firm; spikelets turgid, strongly nerved. Plants grayish olive _... P. ROANOKENSE. Blades spreading; spikelets not turgid.

Nodes glabrous; autumnal phase erect, branched like a little tree.............. 31. Р. ріснотомUм.

Nodes, at least the lowest, usually bearded; autumnal

1b. Spikelets pubescent. phase topheavy-reclining _..._- 32. P. BARBCLATUM.

6a. Spikelets $3 \mathrm{~mm}$ or more long.

7a. Blades elongate, those of the midculm at least 15 times as long as wide. Secondary panicles from basal sheaths only.

Spikelets pointed, about $3.5 \mathrm{~mm}$ long

5. P. DEPAUPERATUM.

Spikelets blunt, $3 \mathrm{~mm}$ long or less _._._....... P. PERLONGUM.

Secondary panicles from upper branches.

Spikelets attenuate at base, pustulose-pubescent; lowermost sheaths softly villous

Spikelets not attenuate at base, not pustulose; lowermost sheaths glabrous or hispid.

Upper leaves approximate; sheaths glabrous.

Upper leaves distant; at least the lower sheaths hispid.

107. P. EQUilaterale.

100. P. acUleatum.

7b. Blades not elongate, usually less than 10 times as long as wide.

8a. Blades velvety-pubescent beneath.

Spikelets $3 \mathrm{~mm}$ long. Plants velvety-villous throughout.

Spikelets $4 \mathrm{~mm}$ long or more.

90. P. MALACOPHYLLUM.

Sheaths ascending-hirsute, ligule 3 to $4 \mathrm{~mm}$ long.

Sheaths downy-pubescent; ligule obsolete.

94. P. Ravenelii.

110. P. BosciI var. MOLLE.

8b. Blades not velvety-pubescent beneath.

9a. Sheaths glabrous or minutely puberulent only.

Nodes bearded; spikelets $4 \mathrm{~mm}$ long or more _._._. 110. P. BosciI.

Nodes not bearded; spikelets not more than $3.8 \mathrm{~mm}$ long.

Spikelets 3.5 to $3.8 \mathrm{~mm}$ long. Blades $2 \mathrm{~cm}$ wide or more.

Spikelets scarcely more than $3 \mathrm{~mm}$ long.

109. P. LATifolidu.

Spikelets turgid, blunt; blades mostly less than $1 \mathrm{~cm}$ wide.

Spikelets not turgid; blades more than $1 \mathrm{~cm}$ wide.

91. P. helleri.

Panicle narrow, the branches ascending. Spikelets on long stiff pedicels._._._._._._._. 23. P. CALLIPHYLLUM.

Panicle as broad as long, the branches spreading.

Plants glaucous; basal blades conspicuously ciliate.

105. P. MUtABile.

Plants not glaucous; basal blades not ciliate, or at the base only.

Culms erect, or autumnal phase leaning; blades symmetrical, broadly cordate _.. 104. P. Commutatom.

Culms decumbent; blades usually unsymmetrical and falcate, narrowed to the scarcely cordate base.

106. P. JOORII. 
9b. Sheaths pubescent.

Pubescence ascending or appressed.

Spikelets 3 to $3.2 \mathrm{~mm}$ long; first glume conspicuously remote.

Spikelets 3.5 to $4 \mathrm{~mm}$ long; first glume not remote.

62. P. MALACON.

93. P. oligosanthes.

Pubescence spreading, sometimes sparse.

Plants robust, about $1 \mathrm{~m}$ tall; blades usually $2 \mathrm{~cm}$ or more wide.

108. P. ClandestinUm.

Plants rarely more than $50 \mathrm{~cm}$ tall; blades rarely more than $1.5 \mathrm{~cm}$ wide.

Panicle about as wide as long; blades ascending or spreading. Spikelets attenuate at base, 3.5 to $4 \mathrm{~mm}$ long.

See 14. Pedicellata. Spikelets not attenuate at base, not more than $3.3 \mathrm{~mm}$ long. Spikelets 3.2 to $3.3 \mathrm{~mm}$ long; blades firm; sheaths, or soine of them, more or less hispid_- 92. P. SCRIBNERIANUM. Spikelets not more than $3 \mathrm{~mm}$ long; blades rather thin; sleaths, or some of them, glabrous or sparsely hispid.

91. P. HELLERI.

Panicle narrow, the branches erect (sometimes ascending in $P$. wilcoxianum), or spreading at anthesis only; blades erect.

Spikelets not more than $3 \mathrm{~mm}$ long; blades not more than $6 \mathrm{~mm}$ wide_... P. Wilcoxianum.

Spikelets 3.7 to $4 \mathrm{~mm}$ long; blades 8 to $20 \mathrm{~mm}$ wide.

Blades papillose-hispid... 95 . PEIBERGII. Blades glabrous on both surfaces 96 . P. хаNтHOpHхSUM.

6b. Spikelets less than $3 \mathrm{~mm}$ long.

10a. Blades elongate, not more than $5 \mathrm{~mm}$ wide; secondary panicles at the base only or wanting.

Culms single or few in a tuft; spikelets turgid, 2.7 to $3 \mathrm{~mm}$ long.

6. P. PERLONGUM.

Culms in large tufts; spikelets not turgid, not more than $2.7 \mathrm{~mm}$ long.

Sheaths pilose.

7. P. LINEARIFOLIUM.

Sheaths glabrous... P. WERNERI.

$10 \mathrm{~b}$. Blades usually not elongate; secondary panicles not at the base.

11a. Spikelets attenuate at base, mostly prominently pustulose. Blades narrow, stiff, strongly nerved, tapering from base to apex.

Nodes bearded; plants grayish-villous. Autumnal blades flat.

Spikelets $2 \mathrm{~mm}$ long_...... 15 . P. CHRYSOPSIDIFOLIUM. Spikelets 2.5 to $2.8 \mathrm{~mm}$ long _....... 16. P. Consanguineum.

Nodes not bearded; plants villous only at the base, or nearly glabrous. Autumnal blades flat; lower panicle branches spreading or reflexed.

17. P. ANGUSTIFOLIUM.

Autumnal blades involute; lower panicle branches more or less ascending.

Plants glabrous or nearly so; autumnal culms erect. Spikelets subsecund along the suberect panicle branches.

21. P. NEURANTHUM. Spikelets not subsecund; panicle loose and open.

20. P. OVINUM.

Plants pubescent, at least on the lower half.

Spikelets about $2.4 \mathrm{~mm}$ long; vernal blades 7 to $12 \mathrm{~cm}$ long; autumnal blades not falcate_...- 19. P. ARENICOLOIDES. Spikelets not more than $2 \mathrm{~mm}$ long; vernal blades 4 to $6 \mathrm{~cm}$ long; autumnal blades falcate...... 14. P. ACICULARE.

11b. Spikelets not attenuate at base.

12a. Sheaths retrorsely pilose. Blades soft and lax.

Blades ciliate and more or less pilose on the surface; spikelets $2 \mathrm{~mm}$ long _........ 10. P. Xalapense.

Blades glabrous or nearly so on the surface and margin; spikelets $2.2 \mathrm{~mm}$ long ........ 9. P. LAXIFLORUM.

12b. Sheaths not retrorsely pilose.

13a. Ligule manifest, mostly 2 to $5 \mathrm{~mm}$ long, at least $1 \mathrm{~mm}$ long. Sheaths, or all but the lowest, glabrous; spikelets not more than $1.6 \mathrm{~mm}$ long.

Panicle narrow, one-fourth to one-third as wide as long.

38. P. SPRETUM. 
Panicle open, nearly as wide as long.

Spikelets $1.5 \mathrm{~mm}$ long _._._....

Spikelets $1.1 \mathrm{~mm}$ long Sheaths pubescent.

Ligule $1 \mathrm{~mm}$ long. Sheaths sparsely pilose; spikelets $1.4 \mathrm{~mm}$ long _... PURTIFOLIUM.

Ligule usually more than $1 \mathrm{~mm}$ long.

Ligule 1 to $1.5 \mathrm{~mm}$ long. Culms and sheaths appressedpubescent; spikelets $1.5 \mathrm{~mm}$ long or more.

Spikelets 2.8 to $2.9 \mathrm{~mm}$ long________ 63. P. DEAMII. Spikelets less than $2 \mathrm{~mm}$ long.

Spikelets 1.8 to $1.9 \mathrm{~mm}$ long; plants bluish green.

67. P. TSUGETORUM.

Spikelets $1.5 \mathrm{~mm}$ long, nearly globular; plants olivaceous.

Ligule 2 to $5 \mathrm{~mm}$ long.

Spikelets 1 to $1.3 \mathrm{~mm}$ long; culms and sheaths softly appressed-pubescent.

Spikelets 1.2 to $1.3 \mathrm{~mm}$ long_._._. 40. P. LEUCOTHRIX. Spikelets not more than $1 \mathrm{~mm}$ long

42. P. WRIGHTIANUM.

Spikelets mostly more than $1.5 \mathrm{~mm}$ long, if less, pubescence spreading............ See 8. LANUGINOSA.

13b. Ligule obsolete or less than $1 \mathrm{~mm}$ long.

14a. Nodes bearded (P. scoparium may appear to be bearded).

Spikelets nearly $3 \mathrm{~mm}$ long; plants velvety-villous throughout.

90. P. MALACOPHYLLUM.

Spikelets rarely as much as $2.5 \mathrm{~mm}$ long; plants not pubescent throughout.

Spikelets 1.5 to $1.6 \mathrm{~mm}$ long_-_.... 25. P. Microcarpon.

Spikelets $2 \mathrm{~mm}$ long or more.

Blades all velvety. Autumnal phase usually sparingly branching . .

Blades glabrous, or only the lower pubescent or velvety. Spikelets $2 \mathrm{~mm}$ long; autumnal phase prof usely branching.

Spikelets $2.2 \mathrm{~mm}$ long or more; autumnal phase less profusely branching.

Sheaths and upper nodes glabrous.... 29. P. CLUTEI. Lower sheaths and all nodes pubescent.

28. P. mattamuskeetense.

14b. Nodes not bearded.

15a. Plants densely gray-velvety throughout, a viscid, glabrous ring below the nodes......... 99. P. SCOPARICM.

15b. Plants not gray-velvety.

16a. Sheaths or some of them pilose or hispid.

Pubescence papillose-hispid.

Spikelets ovate, pointed, 2.3 to $2.6 \mathrm{~mm}$ long.

101. P. SCABRIUSCULUM.

Spikelets obovate, obtuse, nearly $3 \mathrm{~mm}$ long.

Blades about $2 \mathrm{~cm}$ wide..... 108. P. CLandestinum. Blades not more than $6 \mathrm{~mm}$ wide.

Pubescence ascending-pilose.

89. P. Wilcoxiantm.

Spikelets 2.8 to $2.9 \mathrm{~mm}$ long

Spikelets not more than $2.5 \mathrm{~mm}$ long.

Spikelets 2 to $2.5 \mathrm{~mm}$ long.

Winter blades elongate, 5 to $10 \mathrm{~cm}$ long; plants bluish green. Spikelets $2 \mathrm{~mm}$ long.

66. P. Wilmingtonense.

Winter blades 1 to $3 \mathrm{~cm}$ long; plants olivaceous.

Spikelets about $2.4 \mathrm{~mm}$ long; panicle open, branches stiffly spreading.

64. P. COMMONSIANUM.

Spikelets 2 to $2.1 \mathrm{~mm}$ long; panicle rather dense, branches ascending._._._ 65. P. ADDIsonil. 
Spikelets not more than $1.7 \mathrm{~mm}$ long.

Blades white-margined; spikelets 1.6 to $1.7 \mathrm{~mm}$ long, elliptic_._._.

Blades not white-margined; spikelets 1.3 to $1.4 \mathrm{~mm}$ long, nearly globular.

68. P. COLUMBIANUM var. THINIUM. $16 \mathrm{~b}$. Sheaths glabrous or puberulent only.

17a. Spikelets spherical, not more than $1.8 \mathrm{~mm}$ long. Blades cordate, ciliate at base.

17b. Spikelets not spherical.

See 10. Sphatrocarpa.

18a. Culms soon prostrate, vinelike; branches divaricate. Plants bright green; culms lax; spikelets not more than

$2.1 \mathrm{~mm}$ long._. . . . . _.. 36. P. LCIDUM.

Plants grayish green; culms stiff; spikelets $2.5 \mathrm{~mm}$ long.

37. P. SPHAGNICOLA.

18b. Culms not vinelike; branches not divaricate.

19a. Spikelets asymmetrically pyriform, strongly nerved. Culms wiry....- See 12. Lancearia. 19b. Spikelets not pyriform.

20a. Blades elongate, especially the upper, about 20 times as long as wide. Spikelets about 2.5 $\mathrm{mm}$ long, on long pedicels_-22. P. BICKNELLII.

(Continuation.)

20b. Blades not elongate. (See continuation.)

21a. Spikelets $2 \mathrm{~mm}$ long or more.

Spikelets 2.5 to $3 \mathrm{~mm}$ long; blades cordate, usually $1 \mathrm{~cm}$ or more wide.

Plants glaueous; basal blades conspi cuously ciliate $\ldots$-_ 105. P. мUTABile.

Plants not glaueous; basal blades ciliate at base only.

Culms crisp-puber:ilent; blades rarely more than $1 \mathrm{~cm}$ wide; spikelets about

$2.5 \mathrm{~mm}$ long ....

Culms glabrous or obscurely puberulent; blades usually $1.5 \mathrm{~cm}$ wide or

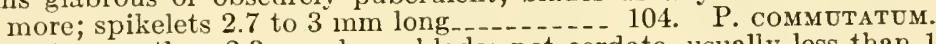

Spikelets not more than $2.3 \mathrm{~mm}$ long; blades not cordate, usually less than 1 $\mathrm{cm}$ wide.

Blades conspicuously ciliate, soft, lax, crowded at the base.

Blades not ciliate or at base only, not crowded at the base.

11. P. ciliatum.

Blades not more than $6 \mathrm{~mm}$ wide; plants not branching or rarely branching

from near the base

Blades $7 \mathrm{~mm}$ wide or more; plants branching from middle and upper nodes. Primary blades spreading; panicle purplish; fruit exposed at summit.

Primary blades erect; panicle green; fruit covered $-30 .{ }^{29}$ P. BOREALE.

21b. Spikelets not more than $1.7 \mathrm{~mm}$ long.

Culms crisp-puberulent. Spikelets turgid......... 68. P. columbianum.

Culms glabrous.

Blades white-margined, firm.

Blades puberulent beneath, often above......

Blades glabrous.

Uppermost blades much redueed; culms branching from lower nodes only, the branches repeatedly branching.

74. P. ALBOMARGINATUM.

Uppermost blades about as long as the others; culms bearing short branches from middle and upper nodes_._._- 75. P. TRIFOLIUM.

Blades not white-margined or very obscurely so (or if white margin is evident, spikelets only $1.1 \mathrm{~mm}$ long).

Culms branching only at base. Plants soft, light green_ 79. P.vernale.

Culms branching at the nodes.

Spikelets $1.1 \mathrm{~mm}$ long. Winter blades bluish green, not glossy.

Spikelets 1.3 to $1.5 \mathrm{~mm}$ long.

Blades involute, falcate, with long stiff hairs on margin near base. Plants stiff and wiry

Biades not involute or at tip only, not falcate.

Plants bright green; winter blades conspicuous, glossy green.

76. P. FLAVOVIRENS.

Plants olive; winter blades not conspicuous nor glossy.

78. P. ENSIFOLIOM. 
1. Depauperáta.-Ligule less than $1 \mathrm{~mm}$ long; blades elongate, the basal ones not forming a distinct rosette in autumn; spikelets strongly 7- to 9-nerved. Autumnal phase with short branches from lower nodes.

5. Panicum depauperátum Muhl. (Fig. 1274.) Vernal phase with culms several to many in a tuft, slender but rather stiff, erect or nearly

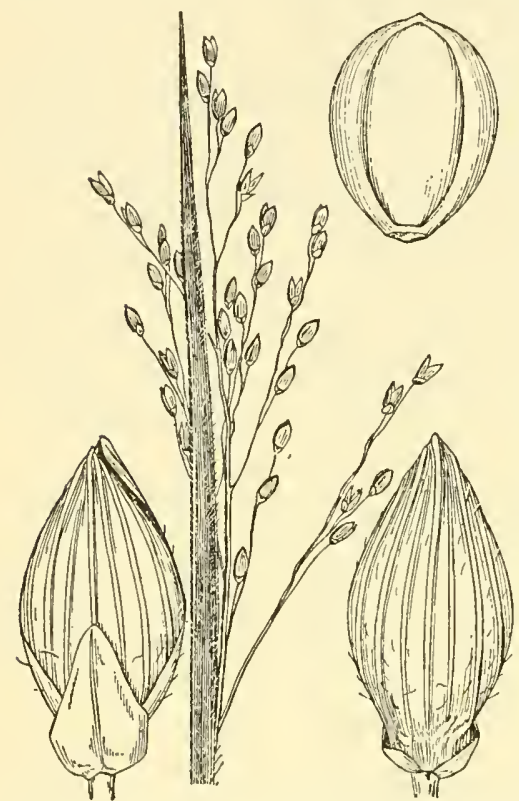

Figure 1274.-Panicum depauperatum. Panicle, $\times 1$; two views of spikelet, and floret, $\times 10$. (Amer. Gr. Nat. Herb. 78, D.C.) so; sheaths glabrous or papillosepilose; blades 6 to $15 \mathrm{~cm}$ long, 2 to 5 $\mathrm{mm}$ wide, often involute in drying; panicle exserted, usially not much exceeding the leaves, 4 to $8 \mathrm{~cm}$ long, few-flowered; spikelets 3.2 to 3.8 $\mathrm{mm}$ long, elliptic, pointed, glabrous or sparsely pubescent; second glume and sterile lemma extending beyond the fruit, forming a beak. Autumnal phase similar, the reduced panicles partly concealed in the b as al leaves.

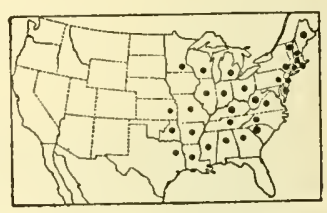

Figure 1275.-Distribution of Panicum depauperatum.

21 Open sterile woods, Quebec and Nova Scotia to Minnesota, south to Georgia and Texas (fig. 1275).

6. Panicum perlóngum Nash. (Fig. 1276.) Vernal phase similar to that of $P$. depauperatum; the tufts smaller, usually pilose, the panicle narrower; spikelets 2.7 to $3.2 \mathrm{~mm}$ long, oval, blunt, sparingly pilose, the glume and sterile lemma not extending beyond the fruit. Autumnal phase similar, the reduced panicles numerous. 24 -Prai-
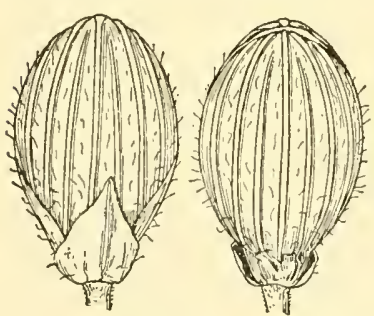

FIgURE 1276,-Panicum perlongum. Two views of spikelet, and floret, $\times 10$. (Type.) ries and dry soil, Indiana to Manitoba and North Dakota, south to Colorado and Texas (fig. 1277).

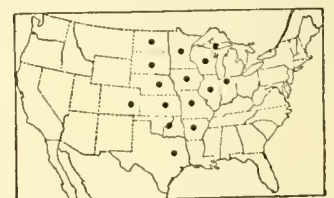

FIGURE 1277.-Distribution of Panicum perlongum.

7. Panicum linearifólium Scribn. (Fig. 1278.) Vernal phase in dense tufts; culms slender, erect, 20 to $45 \mathrm{~cm}$ tall; sheaths papillosepilose; blades erect, usually overtopping the panicles, 2 to $4 \mathrm{~mm}$ wide; panicle long-exserted, 5 to $10 \mathrm{~cm}$ long, the flexuous branches ascending; spikelets 2.2 to $2.7 \mathrm{~mm}$ long, oblong-elliptic, obtuse, sparsely pilose. Autumnal phase similar, the reduced panicles hidden among the basal leaves. 24-Dry woods, Quebec and Maine to Michigan, south to Georgia and Texas (fig. 1279). 
8. Panicum wernéri Scribn. (Fig. 1280.) Vernal phase similar to that of $P$. linearifolium, the culms usually stiffer, blades firmer, shorter and wider (15 cm long or less); nodes usually sparingly pilose; sheaths glabrous; spikclets 2.1 to $2.4 \mathrm{~mm}$ long, nearly or quite glabrous. Autumnal phase similar to the vernal, sometimes late in the season bearing simple branches from the lower nodes. 2 -Sterile woods and knolls, Quebec and Maine to Minnesota, south to Virginia, Kentucky, and Texas (fig. 1281). Intergrades with P. linearifolium.
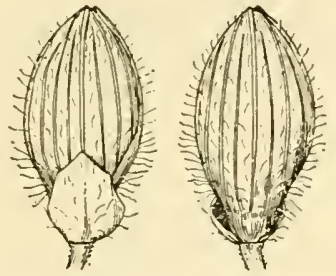

Flgure 1278.-Panicum lincarifolium. Two views of spikelet, and floret, $\times 10$. (Type.)

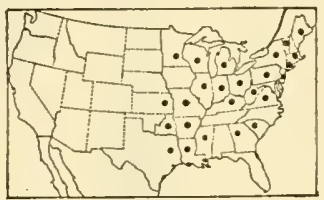

Figtre 1279.-Distribution of Panicum linearifolium.

2. Laxiflóra.-Tufted, erect to spreading; foliage aggregate toward base, light green, soft, the basal blades not in distinct rosettes in autumn; ligules nearly obsolete; primary panicles long-exserted; spikelets obovate, obtuse, turgid, 5- to 7-nerved. Autumnal phase branching near base, forming close flat tufts, with reduced panicles.

9. Panicum laxiflórum Lam. (Fig. 1282.) Vernal culms 20 to 60 $\mathrm{cm}$ tall, erect or geniculate below; nodes bearded with reflexed hairs; sheaths retrorsely pilose; blades 10 to $20 \mathrm{~cm}$ long, 7 to $12 \mathrm{~mm}$ wide, glabrous or sparsely ciliate; panicle 8 to $12 \mathrm{~cm}$ long, lax, few-flowered, the lower branches often reflexed; spikelets 2.2 to $2.3 \mathrm{~mm}$ long, papillose-pilose. Autumnal blades scarcely reduced, much exceeding the secondary panicles. 2 -Rich or damp woods, South Carolina to Florida and Alabama (fig. 1283).

10. Panicum xalapénse H.B.K. (Fig. 1284.) Vernal culms and blades on the average shorter than in $P$. laxiflorum, the blades pilose on one or both surfaces or nearly glabrous, usually short-ciliate; spike-
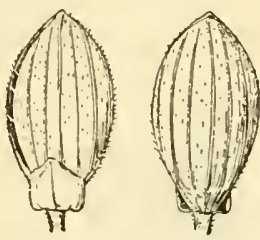

FIgURE 1280.-Panicum verneti. Two riews of spikelet, and floret, $\times 10$. (Type.)

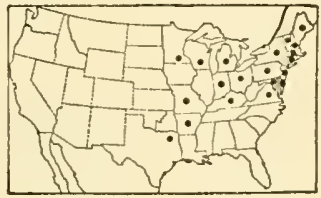

FIGURE 1281.-Distribution of Panicum verneri.

lets 1.9 to $2 \mathrm{~mm}$ long, pilose. Autumnal phase with usually denser tufts and shorter blades. 24 -Woods, Maryland to Illinois and Missouri, south to Florida and Texas; Mexico; Guatemala; Santa Domingo. Originally described from Xalapa (Jalapa), Mexico (fig. 1285). Panicum Xalapense var. Strictirámeum Hitchc. and Chase. Vernal panicles more compact, branches ascending, spikelets 1.7 $\mathrm{mm}$ long; blades shorter, narrower. 24 -Dry woods, Coastal Plain, South Carolina to Texas. 
11. Panicum ciliátum Ell. (Fig. 1286.) Vernal culms 5 to $30 \mathrm{~cm}$ tall; sheaths ciliate on the margin; blades 3 to $6 \mathrm{~cm}$ long, 3 to $8 \mathrm{~mm}$ wide, the uppermost often much smaller, ciliate with stiff hairs 2 to $3 \mathrm{~mm}$ long; panicle 3 to $4 \mathrm{~cm}$ long, the axis pilose, branches spreading; spikelets 1.8 to $2 \mathrm{~mm}$ long, pilose. Autumnal mats with slightly

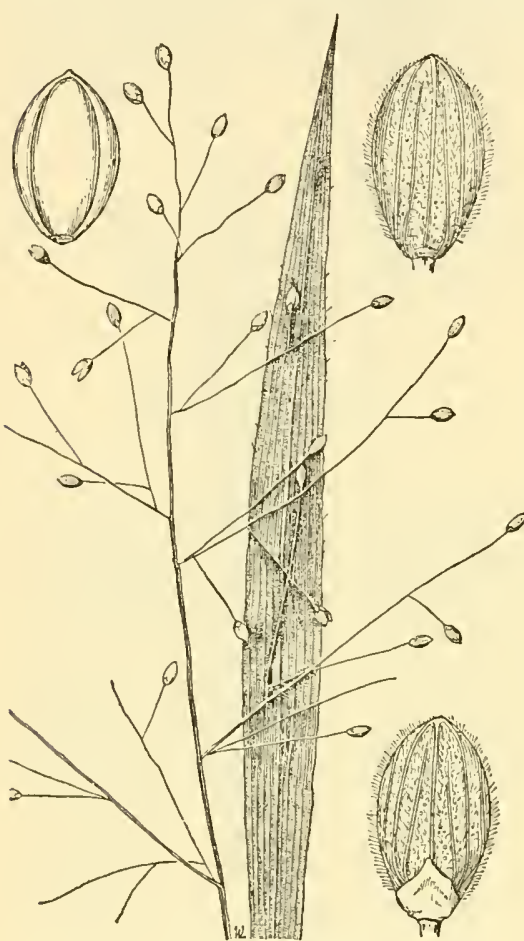

FIGURE 1282,-Panicum laxiflorum. Panicle, $\times 1$; two views of spikelet, and floret, $\times 10$. (Curtiss 6635, Fla.) smaller blades. 2 -Low pinelands and hammocks, Coastal Plain, North Carolina to Florida and Louisiana; Mexico (fig. 1287).

12. Panicum polycaúlon Nash. (Fig. 1288.) Vernal culms 10 to 20 $\mathrm{cm}$ tall; blades mostly narrower than in $P$. ciliatum, panicle similar; spikelets 1.5 to $1.6 \mathrm{~mm}$ long (rarely as much as $2 \mathrm{~mm}$ ), glabrous. Autumnal mats very dense. 24 Low pine woods, Coastal Plain, Florida, Alabama, and Mississippi; West Indies.

13. Panicum strigosum Muhl. (Fig. 1289.) Vernal culms 15 to 30 $\mathrm{cm}$ tall, the culms and sheaths sparsely pilose; nodes bearded; blades mostly 5 to $7 \mathrm{~mm}$ wide, pilose on both surfaces, stiffly ciliate; panicle 4 to $6 \mathrm{~cm}$ long, axis and branches pilose; spikelets 1.3 to 1.5 mm long, glabrous. Autumnal phase a dense mat. 4 - Sandy woods, Virginia and Tennessee to Florida and Louisiana; Mexico and Cuba to Colombia (fig. 1290).

3. Angustifólia.-Densely tufted, grayish green; ligules less than $1 \mathrm{~mm}$ long; blades narrow, usually stiff, with prominent nerves, sometimes longitudinally wrinkled, often ciliate at base; spikelets attenuate at base, rather strongly 7-nerved, papillose-pubescent; first glume narrow and

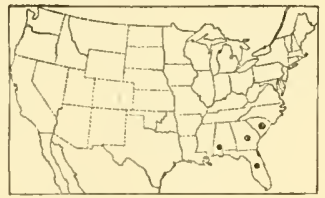

FIGURE 12s3.-Distribution of l'anic'sm laxiflorum.
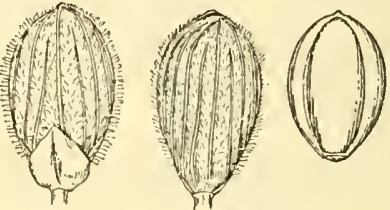

FIGURE 1284.-Panicum xalapense. Two views of spikelet, and tloret, $\times 10$. (Type.)

sheathing at base. Autumnal culnis repeatedly branching, forming bushy crowns; blades greatly reduced.

14. Panicum aciculáre Desv. (Fig. 1291.) Vernal culms ascending from a spreading base, 20 to $50 \mathrm{~cm}$ tall, appressed-pubescent below; 
lower sheaths villous; blades spreading or ascending, narrowed to an involute point, glabrous or the lower sparsely pilose, the middle culm blades 4 to $6 \mathrm{~cm}$ long, 2 to $5 \mathrm{~mm}$ wide; panicle 3 to $7 \mathrm{~cm}$ long, the flexuous branches spreading at maturity; spikelets 1.9 to $2 \mathrm{~mm}$ long, obovate. Autumnal phase bushy-branching, the culms 10 to $30 \mathrm{~cm}$ long, spreading, forming dense cushions, the blades involute, sharppointed, usually arcuate, mostly 1 to $3 \mathrm{~cm}$ long. 24 -Sandy pine woods, Coastal Plain, New Jersey; Virginia to northern Florida, Oklahoma, and Texas; West Indies (fig. 1292).

15. Panicum chrysopsidifólium Nash. (Fig. 1293.) Vernal culms ascending or spreading, 30 to $45 \mathrm{~cm}$ tall, grayish-villous, especially

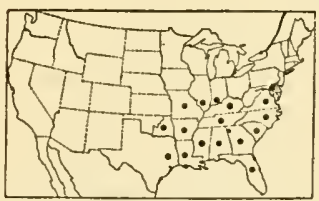

FIGURE 1285.-Distribution of Panicum xalapense.

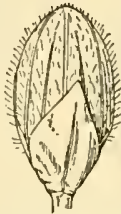

FIGURE 1286.-Panicum ciliatum. Two views of spikelet, and floret, $\times 10$. (Type.)

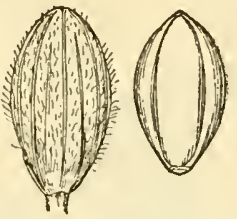

Figure 1287-Distribution of Panicum ciliatum.

below, the nodes bearded; sheaths villous; blades 5 to $10 \mathrm{~cm}$ long, 3 to $5 \mathrm{~mm}$ wide, villous on both surfaces; panicle 4 to $6 \mathrm{~cm}$ long; spikelets $2 \mathrm{~mm}$ long, obovate, villous. Autumnal phase spreading, forming mats; blades flat, becoming papery with age. 24 -Sandy pine woods, Coastal Plain, Florida to Arkansas and Texas; West Indies (fig. 1294).

16. Panicum consanguíneum Kunth. (Fig. 1295.) Vernal culms ascending or spreading, 20 to $50 \mathrm{~cm}$ tall, densely felty-villous below, the nodes bearded; sheaths villous, especially the lower; blades 7 to $11 \mathrm{~cm}$ long, 5 to $8 \mathrm{~mm}$ wide, villous, or nearly glabrous above; pan
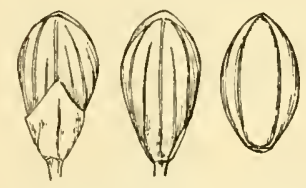

FIGURE 1298.-Panicum polvcaulon. Two views of spikelet, and floret, $X 10$. (Type.)

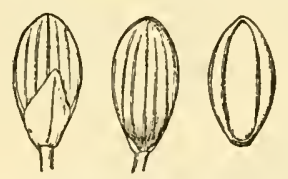

FIGURE 1289.-Panicum strigosum. Two views of spikelet, and floret, $\times 10$. (Type.)

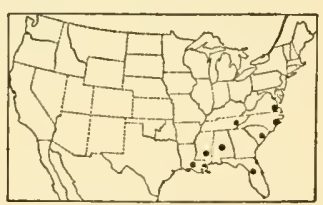

Figure 1290.-Distribution of Panicum strigosum.

icle 4 to $8 \mathrm{~cm}$ long, the lower branches narrowly ascending; spikelets 2.6 to $2.8 \mathrm{~mm}$ long, obovate, papillose-villous. Autumnal phase spreading or decumbent, the numerous branches somewhat flabellately fascicled, the blades 3 to $4 \mathrm{~cm}$ long, 2 to $3 \mathrm{~mm}$ wide, flat, thin, papery. 21 -Sandy pine woods, Coastal Plain, Virginia to northern Florida, west to Arkansas and Texas (fig. 1296).

17. Panicum angustifólium Ell. (Fig. 1297.) Vernal culms erect or nearly so, 30 to $50 \mathrm{~cm}$ tall, the lowermost internodes gray crispvillous; lower sheaths appressed-villous, the upper glabrous; blades stiffly ascending, 8 to $15 \mathrm{~cm}$ long, 4 to $8 \mathrm{~mm}$ wide, long-acuminate; panicle long-exserted, 4 to $10 \mathrm{~cm}$ long, loosely flowered, the branches widely spreading at anthesis, the lower of ten reflexed; spikelets 2.5 to $2.8 \mathrm{~mm}$ long, elliptic-obovate, papillose-villous. Autumnal phase 
ascending or somewhat topheavy-reclining, not spreading or matlike; blades very numerous, flat, appressed, rather thin and papery. 24 - Sandy pine woods, Coastal Plain, New Jersey to northern Florida and Texas; Tennessee (Knoxville); Nicaragua (fig. 1298).

18. Panicum fusifórme Hitche. (Fig. 1299.) Vernal phase as in $P$. angustifolium; culms 30 to $70 \mathrm{~cm}$ tall, the basal and lower blades softly pubescent beneath; spikelets 3.3 to $3.5 \mathrm{~mm}$ long, elliptic,

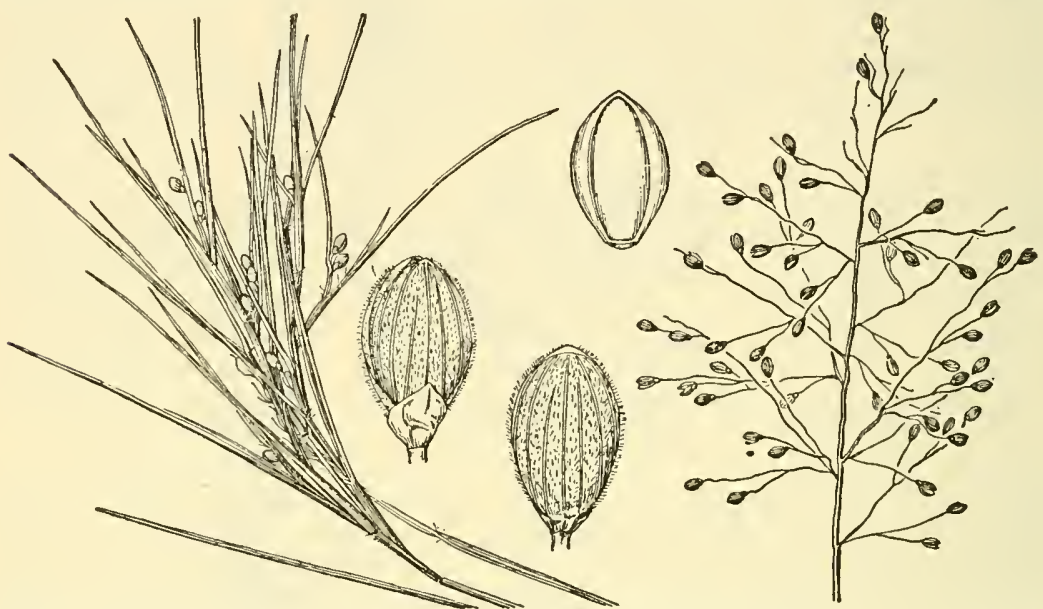

Figure 1291.-Panicum aciculare. Plant, $\times 1$; two views of spikelet, and floret, $\times 10$. (Vernal phase, Chase 7148, N.C.; autumnal phase, Hitchcock 317 , N.C.)

acutish or beaked beyond the fruit, long-attenuate at base, papillose-villous. Autumnal phase bushy, the blades soon involute, 3 to $5 \mathrm{~cm}$ long. $24-$ Sandy pine woods, southern Georgia to Florida and Mississippi; West Indies; British Honduras (fig. 1300).

19. Panicum arenicoloídes Ashe. (Fig. 1301.) Vernal phase intermediate between that of $P$. angustifolium and $P$. aciculare; culms 30 to $50 \mathrm{~cm}$ tall; lower sheaths and blades softly villous; blades

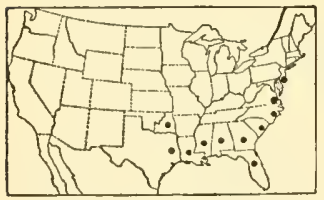

FIGURE 1292.-Distribution of Panicum aciculare.

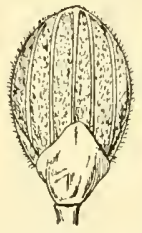

FIGURE 1293,-Panicum chrysopsidifolium. Two views of spikelet, and floret, $\times 10$. (Type.)
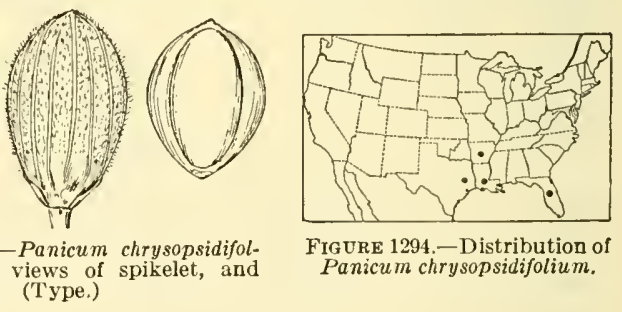

FIGURE 1294.-Distribution of Panicum chrysopsidifolium.

7 to $12 \mathrm{~cm}$ long, 3 to $4 \mathrm{~mm}$ wide, apex subinvolute; panicle 4 to 6 $\mathrm{cm}$ long, the lower branches ascending; spikelets 2.1 to $2.5 \mathrm{~mm}$ long, obovate, papillose-pilose. Autumnal phase bushy-branching, erect or topheavy, the blades involute. 24 - Sandy pine woods, Coastal Plain, North Carolina to Florida, Arkansas, and Texas; Cuba; Guatemala (fig. 1302).

20. Panicum ovínum Scribn. and Smith. (Fig. 1303.) Vernal culms erect or nearly so, not densely tufted, glabrous, 30 to $50 \mathrm{~cm}$ tall; sheaths glabrous or the lowermost appressed-pubescent; blades 
erect or ascending, 10 to $15 \mathrm{~cm}$ long, 3 to $6 \mathrm{~mm}$ wide, glabrous; vanicle 5 to $9 \mathrm{~cm}$ long, the lower branches ascending; spikelets 2.1 to $2.2 \mathrm{~mm}$ long, papillose-pubescent, sometimes minutely so. Autumnal phase erect or nearly so, the blades becoming loosely involute.

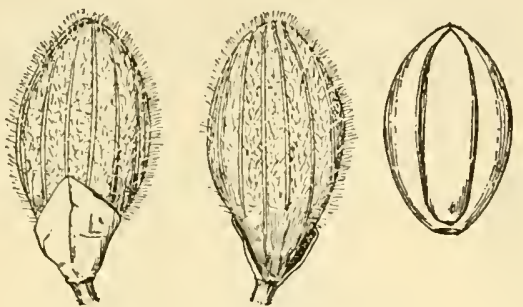

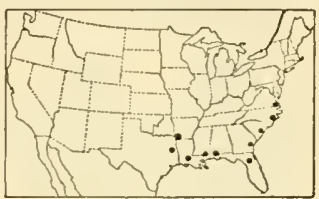

FIGURE 1296.-Distribution of Panicum consanguineum.

Figure 1295.-Panicum consanguineum. Two views of spikelet, and floret, $\times 10$. (Type.)

24 -Dry or moist open ground, Mississippi to Arkansas and eastern 'Texas; Mexico (fig. 1304).

21. Panicum neuránthum Griseb. (Fig. 1305.) Vernal phase ylabrous as a whole; culms 30 to $60 \mathrm{~cm}$ tall; blades erect or ascending,

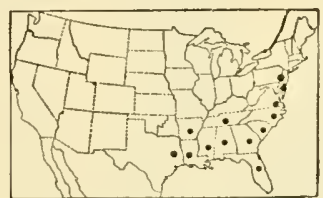

FIGURE 1298.-Distribution of Panicum angustifolium.
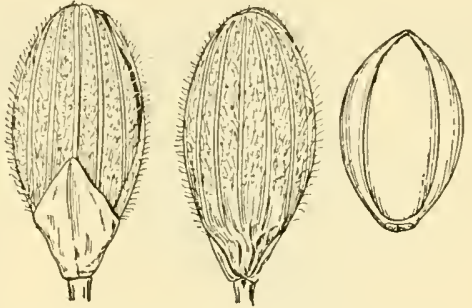

FIGURE 1297-Panicum angustifolium. TKO riews of spikelet, and floret, $\times 10$. (Type.)

the short basal blades few or wanting; panicle 5 to $9 \mathrm{~cm}$ long, narrow, the flexuous branches narrowly ascending, the branchlets appressed, the short-pediceled spikelets more or less secund along the branches;

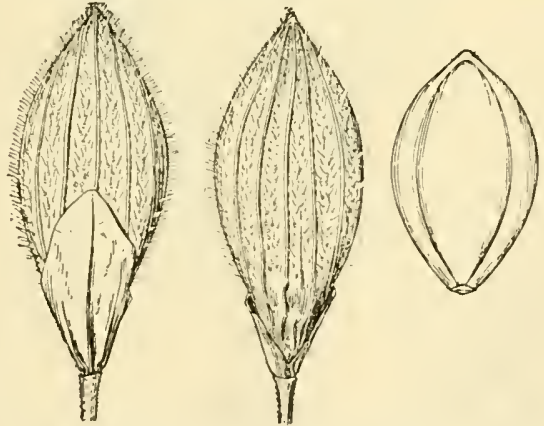

Figure 1299.-Panicum fusiforme. Two views of spikelet, and floret, $\times 10$. (Type.)

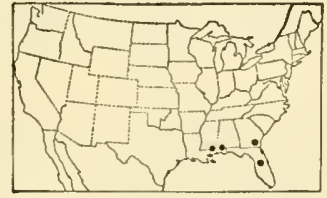

Figure 1300.-Distribution of Panicum fusiforme.

spikelets $2 \mathrm{~mm}$ long, finely papillose-pubescent. Autumnal culms erect, about as tall as the vernal phase; blades involute. 2 Savannas and open ground, southern Florida; Mississippi (Horn Island); Cuba. 
4. Bicknelliana.-In small tufts, erect or ascending; sheaths glabrous; ligules nearly obsolete; panicles few-flowered; spikelets long-pediceled, 7-nerved. Autumnal culms sparingly branching from upper or middle nodes, the blades not much reduced. Intermediate in habit between Depauperata and Dichotoma.

22. Panicum bicknéllii Nash. (Fig. 1306.) Vernal phase bluish green; culms 30 to $50 \mathrm{~cm}$ tall; nodes sparsely bearded or glabrous;

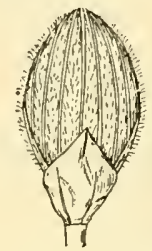

FIGURE 1301. Panicum arenicoloides. Two views of spikelet, and floret, $X$

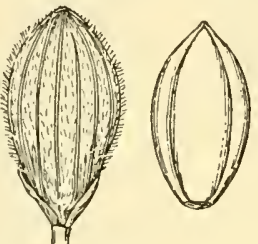

i0. (Type.)

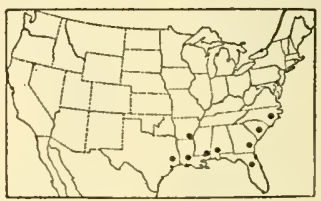

FIGURE 1302-Distribution of Panicum arenicoloides.

blades stiffly ascending, 8 to $15 \mathrm{~cm}$ long, 3 to $8 \mathrm{~mm}$ wide, the uppermost usually the longest, narrowed toward the usually ciliate base; panicle 5 to $8 \mathrm{~cm}$ long, the branches ascending; spikelets 2.3 to 2.8 $\mathrm{mm}$ long, sparsely pubescent or rarely glabrous. Autumnal culms erect, forming a loose bushy tuft, the stiffly ascending blades not much reduced, overtopping the narrow few-flowered panicles. 4 -Dry

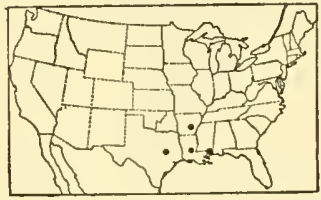

FigURE 1304.-Distribution of Panicum ovinum.

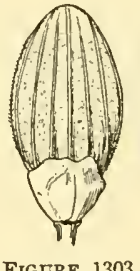

Figure 1303.-Panicum ovinum. Two views of spikelet, and floret, $\times 10$. (Type.)

sterile or rocky woods, Connecticut and Michigan to Georgia and Missouri (fig. 1307).

23. Panicum calliphýllum Ashe. (Fig. 1308.) Vernal phase yellowish green; culms 35 to $50 \mathrm{~cm}$ tall; nodes sparsely villous; blades ascending, 8 to $12 \mathrm{~cm}$ long, 9 to $12 \mathrm{~mm}$ wide, ciliate at the rounded base; panicle 7 to $9 \mathrm{~cm}$ long, with a few ascending branches; spikelets mostly $3 \mathrm{~mm}$ long, elliptic, sparsely pubescent. Autumnal culms

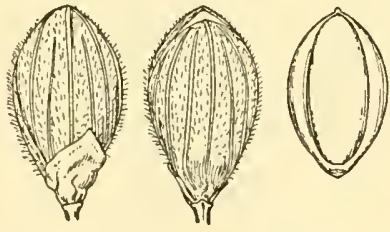

Figure 1305.-Panicum neuranthum. 'Two views of spikelet, and floret, $\times 10$. (Type.) sparingly branching from the middle nodes, the branches about as long as the internodes, erect. 24 - Woods, rare and local, Ontario, Massachusetts, New York, Ohio. 5. Nudicaúlia. $-A$ single rare and local species.

24. Panicum nudicaúle Vasey. (Fig. 1309.) Vernal culms erect from a somewhat spreading base, 40 to $60 \mathrm{~cm}$ tall, glabrous; sheaths glabrous; blades erect, rather thick, 4 to $10 \mathrm{~cm}$ long, 5 to $8 \mathrm{~mm}$ wide, the uppermost reduced, giving the culm a naked appearance; panicle long-exserted, 4 to $7 \mathrm{~cm}$ long, few-flowered, the branches ascending; spikelets 2.7 to $2.9 \mathrm{~mm}$ long, narrowly ovate, acuminate, glabrous. Autumnal phase 
unknown. 2 -Swamps, rare, western Florida, southern Alabama, and Mississippi.

6. Dichotóma. - Culms few to many in a tuft, glabrous, or only the nodes pubescent; sheaths mostly glabrous or nearly so; ligules minute; panicles open; spikelets 5- to 7-nerved. Autumnal culms usually freely branching, leaves and panicles usually much reduced.

25. Panicum microcárpon Muhl. (Fig. 1310.) Vernal culms tufted, erect or sometimes geniculate at base, 60 to $100 \mathrm{~cm}$ tall, the nodes densely bearded with reflexed hairs; sheaths of ten mottled with whitc spots between the nerves; blades spreading, the upper often

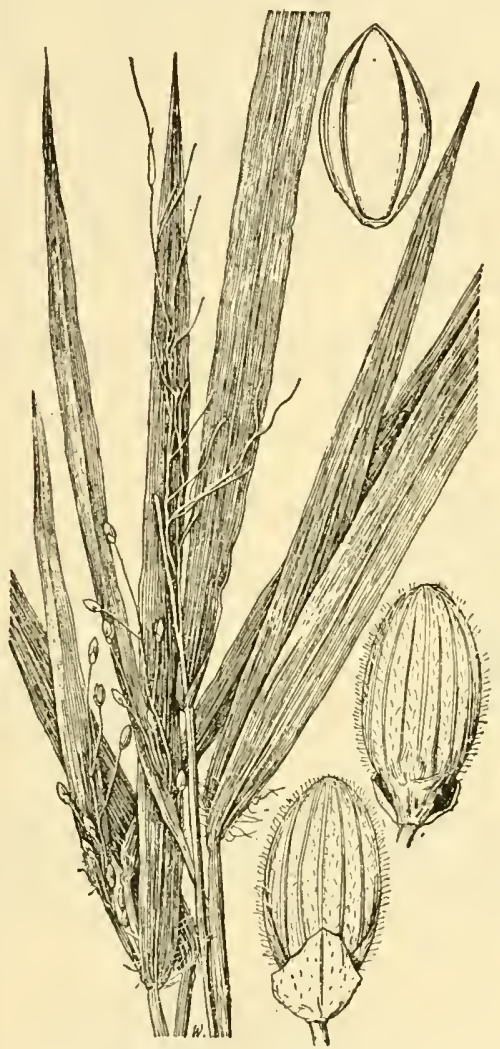

FIgUR 1306-Panicum bicknellii. Plant, $\times 1$; two views of spikelet, and tloret, $X 10$. (Porter, Pa.)

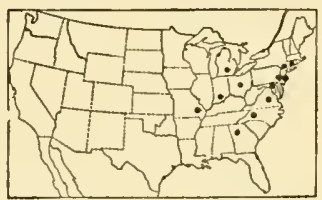

Figure 1307.-Distribution of Panicum bicknellii.
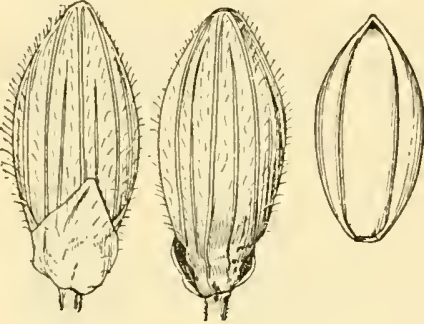

FIGURE 1308.-Panicum calliphyllum. Two views of spikelet, and floret, $\times 10$. (Type.)
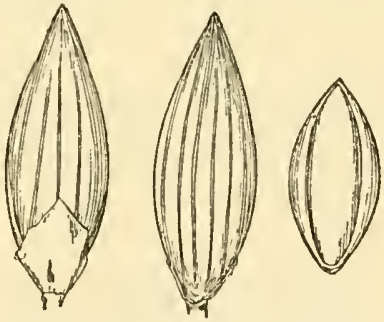

Figure 1309.- $P a n$ ic $u m$ nudicaule. Two views of spikelet, and floret, $\times 10$. (Type.)

reflexed, 10 to $12 \mathrm{~cm}$ long, 8 to $15 \mathrm{~mm}$ wide, glabrous, sparsely papillose-ciliate at base; panicle many-flowered, 8 to $12 \mathrm{~cm} \mathrm{long}$; spikelets $1.6 \mathrm{~mm}$ long, elliptic, glabrous (rarely minutely pubescent). Autumnal phase much branched from all the nodes, reclining from the weight of the dense mass of branches; blades flat, mostly 2 to $4 \mathrm{~cm}$ long. 2 - Wet woods and swampy places, Massachusetts to Illinois, south to northern Florida and eastern Texas (fig. 1311).

26. Panicum nítidum Lam. (Fig. 1312.) Vernal culms tufted, erect, 30 to $60 \mathrm{~cm}$ tall, the nodes bearded with reflexed hairs; upper 
sheaths often glandular-mottled; blades glabrous, 5 to $10 \mathrm{~mm}$ wide, the upper usually reflexed; panicle ovoid, 5 to $8 \mathrm{~cm}$ long, many-flowered; spikelets elliptic, $2 \mathrm{~mm}$ long, pubescent. Autumnal phase erect or reclining, the branchlets and foliage forming large clusters from the

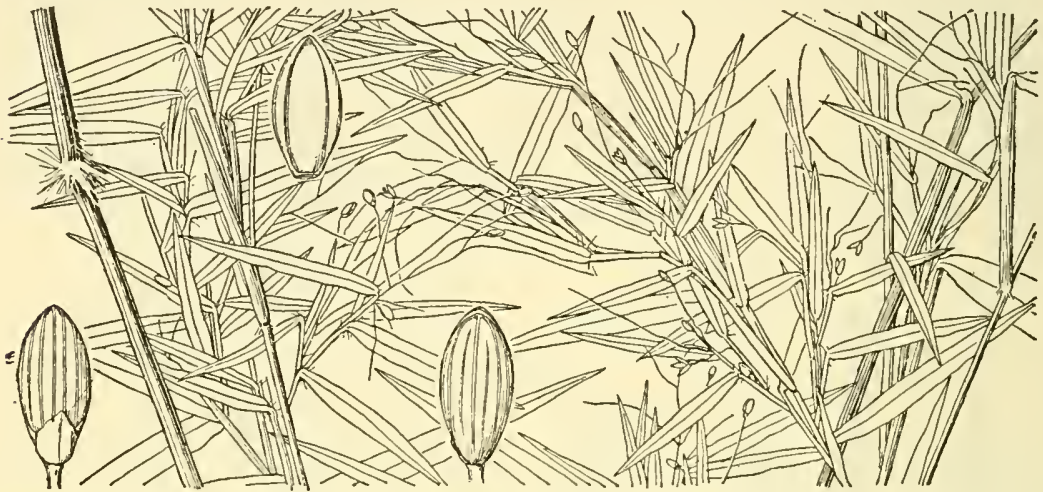

Figure 1310.-Panicum microcarpon. Plant, $\times 1$; two views of spikelet, and floret, $\times 10$. (Maxon and Standley 86, Md.)

nodes of the" primary culms. 4 -Low moist or marshy ground, Coastal Plain, Virginia to Florida and Texas; Missouri (Carter County); Bahamas, Cuba (fig. 1313).

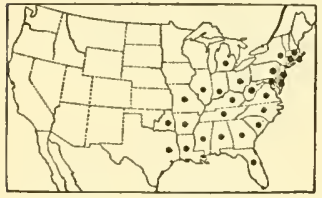
Panicum microcarpon.
Figure 1311.-Distribution of

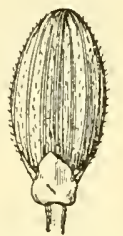

Figure 1312,-Panicum nitidum. Two views of spikelet, and floret, $\times 10$ (Type.)
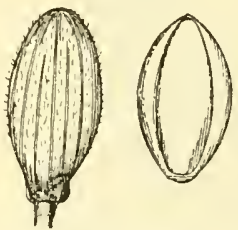

27. Panicum ánnulum Ashe. (Fig. 1314.) Vernal phase usually purplish, in small tufts or solitary; culms 35 to $60 \mathrm{~cm}$ tall, the nodes densely bearded; sheaths velvety-pubescent or the upper nearly glabrous; blades densely velvety-pubescent on both surfaces; panicle 6 to

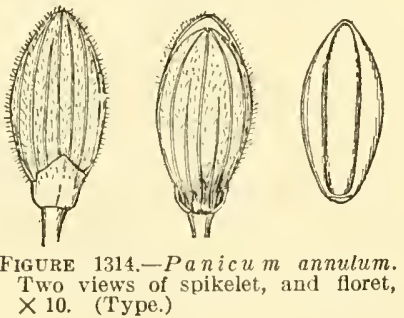

$8 \mathrm{~cm}$ long; spikelets $2 \mathrm{~mm}$ long, elliptic, pubescent. Autumnal phase suberect, bearing in late autumn a few short erect branches at the upper nodes. 24 -Dry woods, Coastal Plain, rare, Massachusetts to Florida and Mississippi; Michigan; Missouri (fig. 1315). 
28. Panicum mattamuskeeténse Ashe. (Fig. 1316.) Vernal phase olivaceous, 11sually tinged with purple; culms erect, of ten $1 \mathrm{~m}$ tall, the nodes bearded or the upper puberulent only; sheaths velvety-pilose or the upper sometimes glabrous: blades horizontally spreading, 8 to
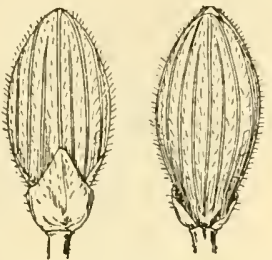

Figure 1316.-Panicum mattamuskeetense. Two views of spikelet, and floret, $\times 10$. (Type coll.)

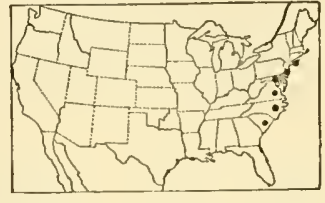

FIGURE 1317.-Distribution of Panicum mattanuskeetense.

$12 \mathrm{~cm}$ long, 8 to $12 \mathrm{~mm}$ wide, velvety-pubescent, or the upper glabrous; panicle 8 to $10 \mathrm{~cm}$ long, many-flowered; spikelets about $2.5 \mathrm{~mm}$ long, elliptic, pubescent. Autumnal phase erect or leaning, branching rather sparingly from the middle nodes. 21 -Low moist ground, Coastal Plain, New York to South Carolina (fig. 1317).

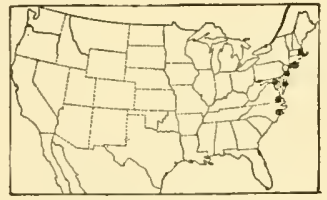

Figure 1319.-Distribution of Panicum clutei.
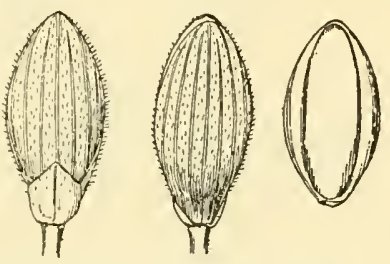

Figure 1318,-Panicum clutei. Two views of spikelet, and floret, $\times 10$. (Type.)

29. Panicum clútei Nash. (Fig. 1318.) Similar to P. mattamuskeetense but less pubescent, only the lowermost nodes, sheaths, and blades velvety; spikelets 2.2 to $2.3 \mathrm{~mm}$ long. 24 -Low moist ground and cranberry bogs, Massachusetts to North Carolina (fig. 1319). Intergrades with $P$. mattamuskeetense.

30. Panicum boreále Nash. (Fig. 1320.) Vernal culms usually erect, 30 to $50 \mathrm{~cm}$ tall, the nodes mostly glabrous; blades erect or

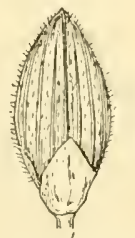

FIGURE 1320.-Panicum boreale. Two views of spikelet, and floret, $\times 10$. ('Туре.)

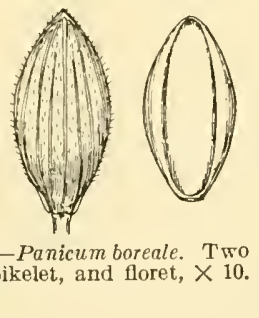

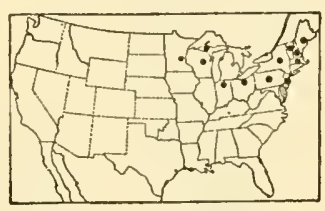

FIGURE 1321.-Distribution of Panicum boreale.

sometimes spreading, 7 to $12 \mathrm{~mm}$ wide, sparsely ciliate at the rounded base; panicle loosely rather few-flowered, 5 to $10 \mathrm{~cm}$ long; spikelets 2 to $2.2 \mathrm{~mm}$ long, elliptic, pubescent. Autumnal phase erect or leaning, sparingly branching from all the nodes in late summer, the branches erect, the leaves and panicles not greatly reduced. 2 Moist open ground or woods, Newfoundland to Minnesota, south to New Jersey and Indiana (fig. 1321). 

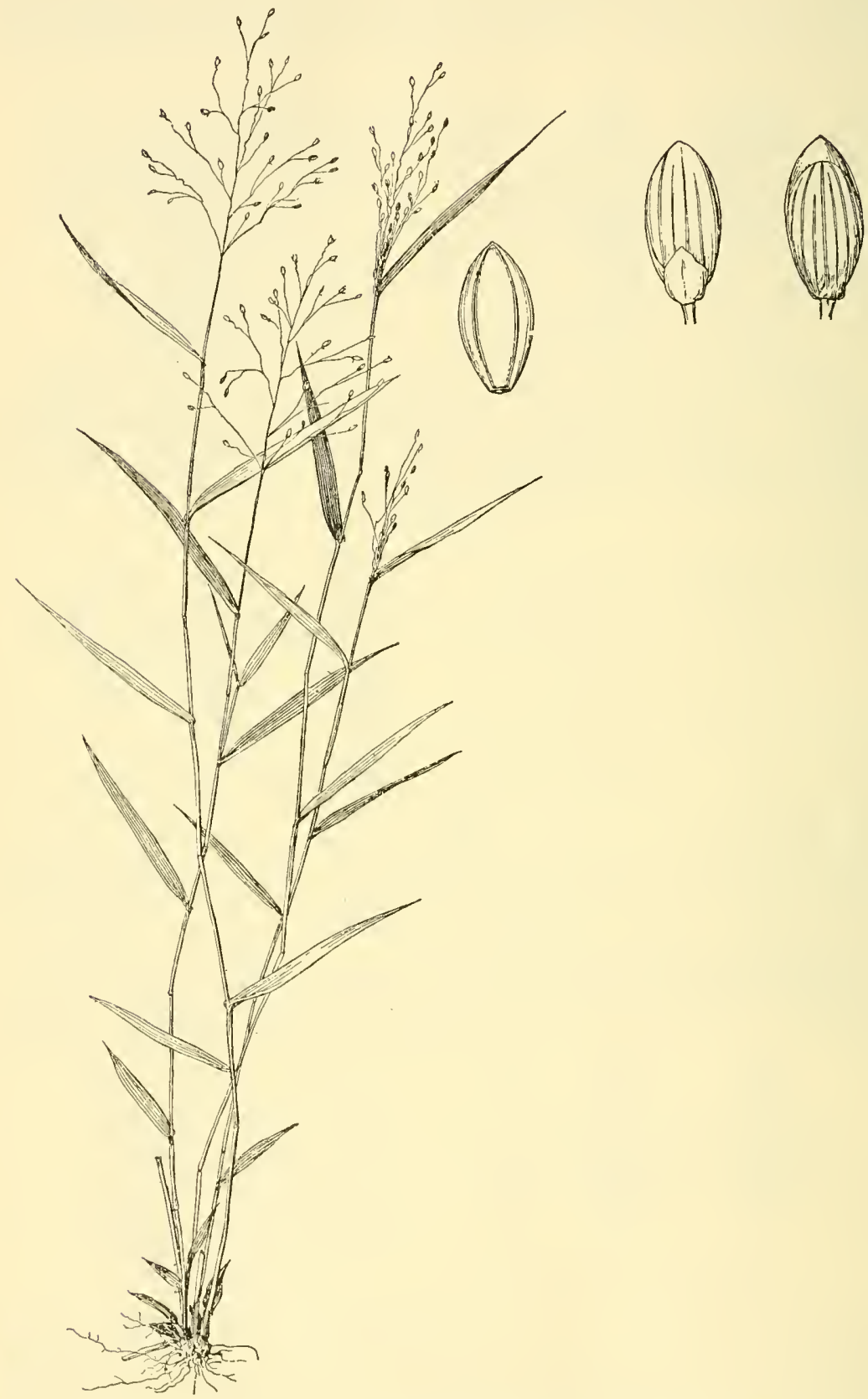

FIGURE 1322 -Panicum dichotomum. Plant, $\times 1 / 2$; two views of spikelet, and floret, $\times 10$. (Bissell 5576, Conn.) 
31. Panicum dichótomum L. (Fig. 1322.) Vernal phase often purplish; culms erect from a knotted crown, 30 to $50 \mathrm{~cm}$ tall, the lower nodes sometimes with a few spreading hairs; blades spreading, 4 to 8 $\mathrm{mm}$ wide, glabrous; panicle 4 to $9 \mathrm{~cm}$ long, the axis and spreading branches flexuous; spikelets $2 \mathrm{~mm}$ long, elliptic, glabrous (rarely pubescent); second glume shorter than the fruit at maturity. Autumnal phase much branched at the middle nodes, the lower part usually erect and devoid of blades, giving the plants the appearance of diminutive trees; blades numerous, of ten involute. 24 - Dry or sterile

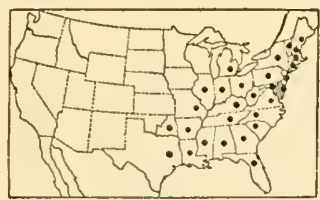

Figure 1323.-Distribution of Panicum dichotomum.

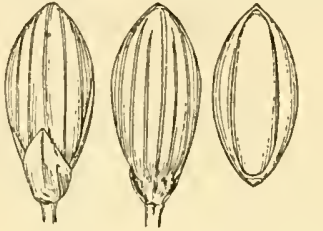

FIGURE 1324.-Panicum batbulatum. Two views of spikelet, and floret, $\times 10$. (Type.)

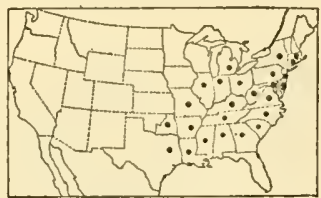

FIGURE 1325.-Distribution of Panicum barbulatum.

woods, New Brunswick to Illinois, south to Florida and eastern Texas (fig. 1323).

32. Panicum barbulátum Michx. (Fig. 1324.) Vernal phase, resembling that of $P$. dichotomum, the culms 50 to $80 \mathrm{~cm}$ tall, the lower nodes usually bearded; blades slightly wider, panicle slightly larger, spikelets $2 \mathrm{~mm}$ long, glabrous; second glume as long as the fruit at maturity. Autumnal phase diffusely branched, forming very large topheary reclining bunches, the slender branches recurved, the numerous flat blades horizontally spreading. 21 - Sterile or rocky woods, Massachusetts to Michigan and Missouri, south to Georgia and eastern Texas (fig. 1325). This species seems to intergrade with
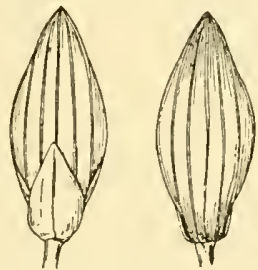

FIGURE 1326.-Panicum yadkinense. Two views of spikelet, and floret, $\times 10$. (Type coll.)

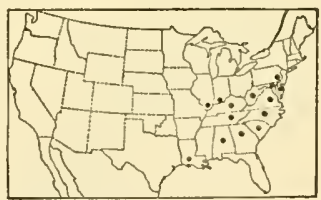

Figure 1327.-Distribution of Panicum yadkinense.

$P$. dichotomum, but typically the autumnal phases are distinctly different. The vernal culms of $P$. barbulatum are usually more robust and the lower nodes are rather strongly bearded.

33. Panicum yadkinénse Ashe. (Fig. 1326.) Vernal phase similar to that of $P$. dichotomum, the culms sometimes $1 \mathrm{~m}$ tall; sheaths bearing pale glandular spots; blades longer and 8 to $11 \mathrm{~mm}$ wide; panicle 10 to $12 \mathrm{~cm}$ long; spikelets 2.3 to $2.5 \mathrm{~mm}$ long, elliptic to subfusiform, pointed a little beyond the fruit, glabrous. Autumnal phase erect or leaning, loosely branching from the middle nodes, the blades not conspicuously reduced. $24-$ Moist woods and thickets, Pennsylvania to Illinois, south to Georgia and Louisiana (fig. 1327). Named from Yadkin River, N.C. 
34. Panicum roanokénse Ashe. (Fig. 1328.) Vernal phase somewhat glaucous olive green; culms erect or ascending, 50 to $100 \mathrm{~cm}$. tall; blades at first stifly erect, later somewhat spreading, 3 to $8 \mathrm{~mm}$ wide, glabrous; panicle 4 to $8 \mathrm{~cm}$ long; spikelets $2 \mathrm{~mm}$ long, turgid, elliptic, glabrous, the second glume often purple at base. Autumnal phase erect or decumbent, branching at the middle and upper nodes, the branches numerous but not in tufts, the reduced blades subinvolute. 21 -Open swampy woods or wet peaty meadows, Coastal Plain, southeastern Delaware to Florida and Texas; Jamaica (fig. 1329).

35. Panicum caeruléscens Hack. (Fig. 1330.) Vernal phase similar to that of $P$. roanokense; culms more slender; blades ascending

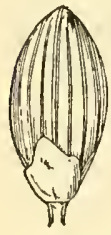

Figure 1328.-Panicum ronnokense. Two views of spikelet, and floret, $\times 10$. (Ashe, N.C.)

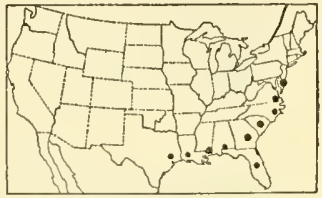

FigurE 1329.-Distribution of Pancum roanokcnse.

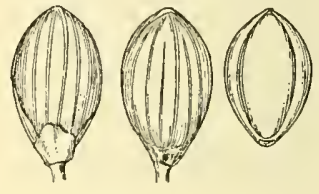

Figure 1330.--Panicum caerulescens. 'Two views of spikelet, and floret, $\times 10$. (Type.)

or spreading, commonly purplish beneath; panicle 3 to $7 \mathrm{~cm}$ long; spikelets $1 . \tilde{5}$ to $1.6 \mathrm{~mm}$ long, obovoid, turgid, glabrous. Autumnal phase erect or leaning, producing short densely fascicled branches at the middle and upper nodes, these tufts scarcely as long as the primary internodes. 21-Marshes and swampy woods, Coastal Plain, southern New Jersey to Florida and Mississippi; Cuba (fig. 1331).

36. Panicum lúcidum Ashe. (Fig. 1332.) Vernal phase at first erect and resembling that of $P$. dichotomum, but the weak culms soon decumbent; blades thin, shining, bright green, glabrous, at first erect but soon widely spreading, 4 to $6 \mathrm{~mm}$ wide; panicle resembling tha, of $P$. dichotomum but fewer-flowered; spikelets 2 to $2.1 \mathrm{~mm}$ longt

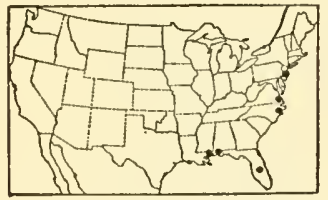

Figure 1331.-Distribution of Panicum caerulescens.

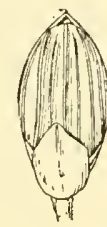

FIGUR E lucidum. $-P a n i c u m$ spikelet, and floret, $\times 10$. (Type.)

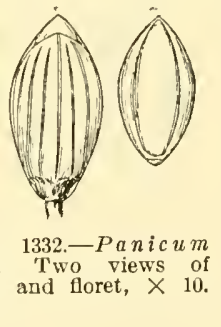

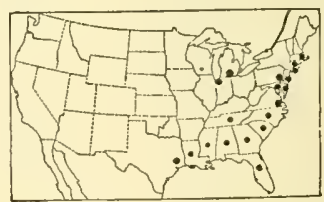

FIGURE 1333.-Distribution of Panicum lucidum.

elliptic, glabrous (rarely pubescent), the tip of the fruit exposed at maturity. Autumnal phase repeatedly branching, forming large clumps or mats of slender weak vinelike culms, the branches elongate and diverging at a wide angle, not fascicled, the blades waxy, flat, spreading. 2 -Wet woods and sphagnum swamps, Coastal Plain, Massachusetts to Florida, Arkansas, and Texas; Indiana (near Lake Michigan), Michigan (Port Huron) (fig. 1333).

37. Panicum sphagnícola Nash. (Fig. 1334.) Vernal phase grayish olive green; culms strongly flattened, erect or reclining, 50 to $100 \mathrm{~cm}$ tall; sheaths soon divaricate; blades glabrous, 3 to $7 \mathrm{~mm}$ wide; panicle narrow, 5 to $6 \mathrm{~cm}$ long; spikelets $2.5 \mathrm{~mm}$ long, elliptic, glabrous or 
minutely pubescent toward the summit. Autumnal phase decumbent or finally prostrate-spreading, divaricately branching from all the nodes, the branches slender, elongate. 2 -Edges of cypress swamps, in sphagnum bogs, and in similar moist shady places, southern Georgia and Florida.

7. Spréta.-Culms tufted, rather stiff, mostly glabrous or nearly so; ligules densely hairy, 2 to $5 \mathrm{~mm}$ long; blades mostly firm; spikelets 5- to 7-nerved, mostly pubescent. Autumnal culms with rather short-tufted branchlets and greatly reduced leaves and panicles. 38. Panicum sprétum Schult. (Fig. 1335.) Vernal culms 30 to 90
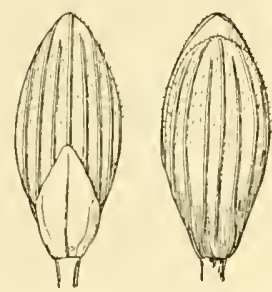

FIgURE 1334.-Panicum sphagnicola. Two views of spikelet, and lloret, $\times 10$. (Type.)

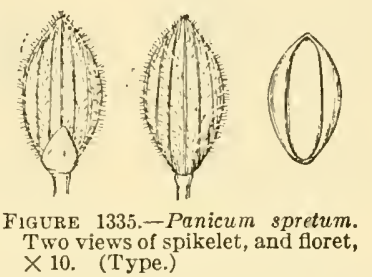

Two views of spikelet, and floret

$\mathrm{cm}$ tall, erect; sheaths glabrous; ligule 2 to $3 \mathrm{~mm}$ long; blades firm, ascending to reflexed, 4 to $8 \mathrm{~mm}$ wide, sparingly ciliate around the base; panicle 8 to $12 \mathrm{~cm}$ long, the branches ascending or appressed; spikelets about $1.5 \mathrm{~mm}$ long, elliptic, rarely glabrous. Autumnal phase mostly reclining, the early branches elongate, the subsequent branches in short fascicles. 4 -Wet usually sandy soil, Coastal Plain, Nova Scotia to Texas; Indiana (fig. 1336).

39. Panicum lindheiméri Nash. (Fig. 1337.) Vernal culms ascending or spreading, 30 to $100 \mathrm{~cm}$ tall, the

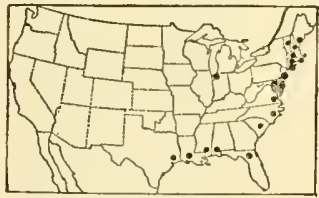

Figure 1336.-Distribution of Panicum spretum. lower internodes and sheaths sometimes a scendin g-pubescent; ligule 4 to $5 \mathrm{~mm}$ long; blades 6 to $8 \mathrm{~mm}$ wide, glabrous; panicle 4 to $7 \mathrm{~cm}$ long, about as wide; spikelets 1.4 to $1.6 \mathrm{~mm}$ long, obovate. Autumnal phase usually stiflly spreading or radiate-prostrate, with elongate in- FIGURE 1337-Panicum lindheimeri. Plant, ternodes and tufts of short appressed branches; blades involute-pointed, often conspicuously ciliate at base. 2 or open ground, Quebec and Maine to Minnesota, south to northern Florida and New Mexico; California (fig. 1338).

40. Panicum leucóthrix Nash. (Fig. 1339.) Vernal phase light olive green; culms 25 to $45 \mathrm{~cm}$ tall, erect or ascending, appressed papillose-pilose, the nodes pubescent; sheaths papillose-pilose; ligule $3 \mathrm{~mm}$ long; blades 3 to $7 \mathrm{~mm}$ wide, glabrous or sparsely villous on the upper 
surface, velvety-puberulent beneath; panicle 3 to $8 \mathrm{~cm}$ long, rather densely flowered; spikelets 1.2 to $1.3 \mathrm{~mm}$ long, densely papillosepubescent. Autumnal culms at first sending out from lower and middle nodes long branches similar to primary culms, later producing more or less fascicled branches. 24 -Low pinelands, Coastal Plain, New Jersey to Florida and Louisiana; West Indies (fig. 1340).

41. Panicum longiligulátum Nash. (Fig. 1341.) Vernal culms 30 to $70 \mathrm{~cm}$ tall; sheaths glabrous; ligule 2 to $3 \mathrm{~mm}$ long; blades 4 to 8 $\mathrm{mm}$ wide, glabrous on the upper surface, puberulent beneath; panicle 3 to $8 \mathrm{~cm}$ long, the slender branches stiffly ascending; spikelets 1.1 to $1.2 \mathrm{~mm}$ long. Autumnal culms reclining, the branches spreading,

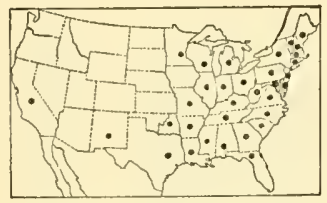

Figure 1338.-Distribution of Panicum lindheimeri.

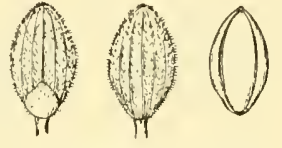

Figure $1339 .-$ Panicum leucothrix. Two views of spikelet, and floret, $\times 10$. (Type.)

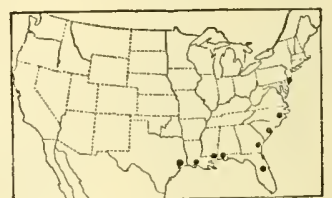

FIGURE 1340.-Distribution of Panicum leucothrix.

the branchlets crowded, the blades subinvolute. 24 -Low pine barrens and swamps, Coastal Plain, Pennsylvania (Bucks County), southeastern Virginia to Florida and Texas; Tennessee; Central America (fig. 1342).

42. Panicum wrightianum Scribn. (Fig. 1343.) Vernal culms weak, slender, ascending from a decumbent base, 15 to $40 \mathrm{~cm}$ tall, minutely puberulent; sheaths glabrous or puberulent; ligule 2 to $3 \mathrm{~mm}$ long; blades 2 to $4 \mathrm{~cm}$ long, 3 to $5 \mathrm{~mm}$ wide, glabrous or puberulent beneath and minutely pilose above; panicle 3 to $6 \mathrm{~cm}$ long; spikelets $1 \mathrm{~mm}$ long. Autumnal culms decumbent-spreading, sending out from lower and middle nodes numerous ascending branches, becoming
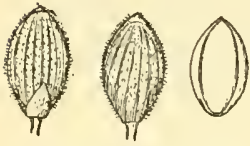

Figure 1341.-Panicum longiligulatum. T $\mathrm{T}$. views of spikelet, and floret, $\times 10$. (Type.)

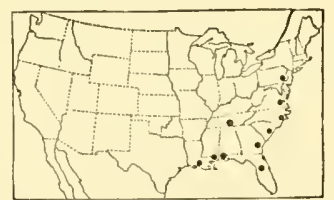

FIGURE 1342.-Distribution of Panicum longiligulatum.

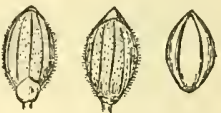

Figure 1343.-Panicum wrightianum. Tw o view of spikelet, and floret, $\times 10$. (Type.)

bushy-branched, the flat or subinvolute blades and secondary panicles not greatly reduced. $2-$ Margins of streams and ponds in sandy or mucky soil, Coastal Plain, Massachusetts to Florida and Mississippi; Cuba and Central America (fig. 1344).

8. Lanuginósa.-Mostly pubescent throughout; ligules densely hairy, 2 to $5 \mathrm{~mm}$ long; spikelets 5 - to 9 -nerved, pubescent. Autumnal culms usually freely branching, the leaves and panicles mostly greatly reduced.

43. Panicum meridionále Ashe. (Fig. 1345.) Vernal culms 15 to $40 \mathrm{~cm}$ tall, the lower internodes and sheaths pilose, the upper minutely appressed-pubescent; ligule 3 to $4 \mathrm{~mm}$ long; blades 1.5 to $4 \mathrm{~cm}$ long, 2 to $4 \mathrm{~mm}$ wide, long-pilose on the upper surface, the hairs erect; panicle 1.5 to $4 \mathrm{~cm}$ long, the axis appressed-pubescent to 
glabrous; spikelets 1.3 to $1.4 \mathrm{~mm}$ long. Autumnal culms erect, with fascicled branchlets from all the nodes; leaves and panicles not greatly reduced. 24 - Sandy or sterile woods and clearings, Nova Scotia to Wisconsin, south to Alabama (fig. 1346).

44. Panicum albemarlénse Ashe. (Fig. 1347.) Vernal phase olivaceous, grayish-villous throughout; culms 25 to $45 \mathrm{~cm}$ tall, at first erect, soon geniculate and spreading; blades 3 to $6 \mathrm{~mm}$ wide, the upper surface puberulent as well as long-villous; panicle 3 to $5 \mathrm{~cm}$ long, the axis puberulent; spikelets $1.4 \mathrm{~mm}$ long, pilose. Autumnal culms widely decumbent, spreading or ascending, frecly branching at all but the uppermost nodes, the branches narrowly ascend-

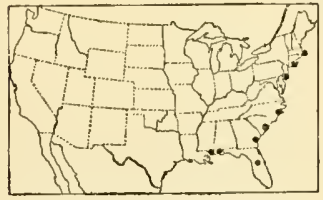

FIGURE 1344.-Distribution of Panicum wrightianum.
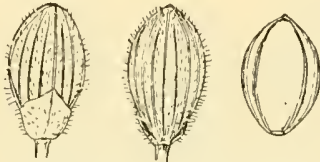

Figure 1345.-Panicum meridionale. 'Two views of spikelet. and floret, $\times 10$. ('Type.)

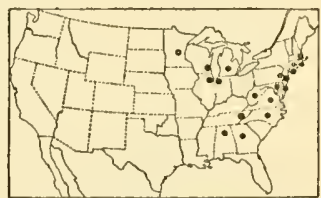

Figure 1346.-Distribution of Panicum meridionale.

ing. 24 -Low sandy woods or open ground, Coastal Plain, Massachusetts to North Carolina; Indiana to Wisconsin; Tennessee (fig. 1348).

45. Panicum implicátum Scribn. (Fig. 1349.) Vernal culms slender, 20 to $55 \mathrm{~cm}$ tall, erect or ascending, papillose-pilose with spreading hairs; sheaths papillose-pilose; ligule 4 to $5 \mathrm{~mm}$ long; blades more or less involute-acuminate, the upper surface pilose with erect hairs 3 to $4 \mathrm{~mm}$ long, appressed-pubescent beneath; panicle 3 to $6 \mathrm{~cm}$ long, the axis long-pilose, the branches flexuous, in typical specimens tangled or implicate; spikelets $1.5 \mathrm{~mm}$ long, papillose-pilose. Autum-
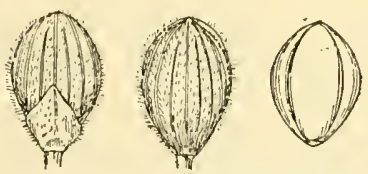

FIGURE 1347-Panicum albemar lense. Two views of spikelet, and floret, $\times 10$. (Type.)

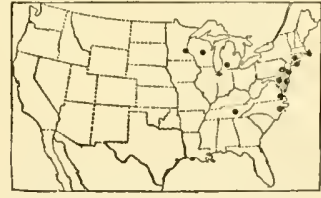

Figure 1348.-Distribution of Panicum albemarlense.

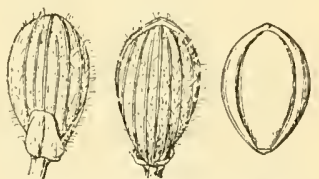

Figure 1349.-Panicum implicalum. Two views of spikelet, and floret, $\times 10$. (Type.)

nal culms erect or spreading, loosely branching from the lower and middle nodes. 2 -Wet meadows, bogs, and sandy soil, cedar and hemlock swamps, Newfoundland to Wisconsin, south to Delaware and Missouri (fig. 1350).

46. Panicum huachúcae Ashe. (Fig. 1351.) Vernal phase light olivaceous, often purplish, harsh to the touch from copious spreading papillose pubescence; culms usually stiffly upright, 20 to $60 \mathrm{~cm}$ tall, the nodes bearded with spreading hairs; ligule 3 to $4 \mathrm{~mm}$ long; blades firm, stiffly erect or ascending, 4 to $8 \mathrm{~cm}$ long, 6 to $8 \mathrm{~mm}$ wide, the upper surface copiously short-pilose, the lower densely pubescent; panicle 4 to $6 \mathrm{~cm}$ long, the axis and often the branches pilose; spikelets 1.6 to $1.8 \mathrm{~mm}$ long, obovate, papillose-pubescent. Autumnal culms stiffly erect or ascending, the branches fascicled, the crowded blades ascending, 2 to $3 \mathrm{~cm}$ long, much exceeding the panicles. $4-$ 
Prairies and open ground, Nova Scotia to Montana, south to North Carolina and Texas, westward here and there to southern California (fig. 1352).

Panicum huachucae var. Fasciculátum (Torr.) F. T. Hubb. Vernal culms taller, more slender, less pubescent, the culms 30 to $75 \mathrm{~cm}$ tall; blades thin, lax, spreading, 5 to $10 \mathrm{~cm}$ long, 6 to $12 \mathrm{~mm}$ wide,

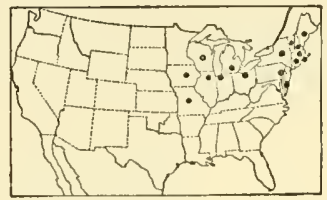

FIGURE 1350-Distribution of Panicum implicatum.
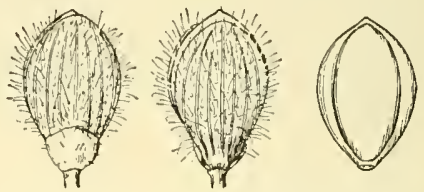

Figure 1351.-Panicum huachucae. Two views of spikelet, and floret, $\times 10$. (Type.)

the upper surface sparsely short-pilose or with copious long hairs toward the base, the lower surface pubescent and with a satiny luster. Autumnal culms more or less decumbent with numerous fascicled branches. 2 (P. huachucae var. silvicola Hitchc. and Chase.) Open woods and clearings, Quebec to Minnesota and Nebraska, south to northern Florida and Texas; Arizona ('Tucson).

Panicum huachucae, $P$. huachucae var. fasciculatum, $P$. tennesseense, and $P$. pacificum intergrade more or less. The descriptions apply to

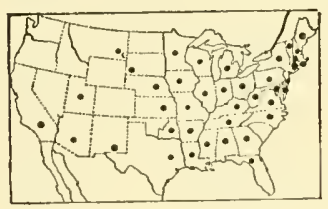

FIGURE 1352.-Distribution of Panicum huachucae.
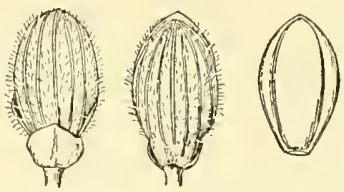

FiguRE 1353.-Panicum tennessernse. Two views of spikelet, and floret, $\times 10$. (Type.)

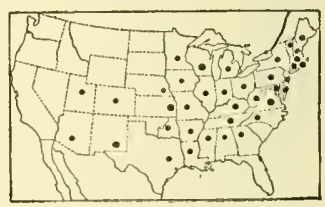

FIGURE 1354.-Distribution of Panicum tennesseense.

the great bulk of specimens but the distinctions fail to hold for occasional specimens.

47. Panicum tennesseénse Ashe. (Fig. 1353.) Vernal phase bluish green; culms suberect or stiffly spreading, 25 to $60 \mathrm{~cm}$ tall, papillose-pilose or the upper portion glabrous; ligule dense, 4 to 5 $\mathrm{mm}$ long; blades firm, with a thin white cartilaginous margin, 5 to 8 $\mathrm{mm}$ wide, the upper surface glabrous or with a few long hairs toward the base, the lower surface appressed-pubescent or nearly glabrous; panicle 4 to $7 \mathrm{~cm}$ long; spikelets 1.6 to $1.7 \mathrm{~mm}$ long. Autumnal culms widely spreading or decumbent, with numerous fascicled somewhat flabellate branches, often forming prostrate mats; blades usually ciliate at base. 2 -Open rather moist ground and borders of woods, Quebec to Minnesota, south to Georgia and Texas, and also at a few points west to Utah and Arizona (fig. 1354).

48. Panicum lanuginósum Ell. (Fig. 1355.) Vernal phase grayish olive-green, velvety-villous throughout; culms usually in large clumps, 40 to $70 \mathrm{~cm}$ tall, lax, spreading, often with a glabrous ring below the villous nodes; ligule 3 to $4 \mathrm{~mm}$ long; blades thickish but not stiff, somewhat incurved or spoon-shaped (when fresh), 5 to $10 \mathrm{~cm}$ long, 5 to $10 \mathrm{~mm}$ wide; panicle 6 to $12 \mathrm{~cm}$ long, the axis pubescent; spikelets 1.8 to $1.9 \mathrm{~mm}$ long. Autumnal culms widely spreading or 
decumbent, freely branching from the middle nodes, the branches repeatedly branching and much exceeding the internodes, the ultimate branchlets forming flabellate fascicles. 2 -Moist sandy woods, Coastal Plain, New Jersey to Florida and Texas (fig. 1356). The plants have much the aspect and pubescence of $P$. scoparium but are smaller and more slender.

49. Panicum aubúrne Ashe. (Fig. 1357.) Vernal phase grayish velvety-villous throughout; culms 20 to $50 \mathrm{~cm}$ tall, geniculate, widely

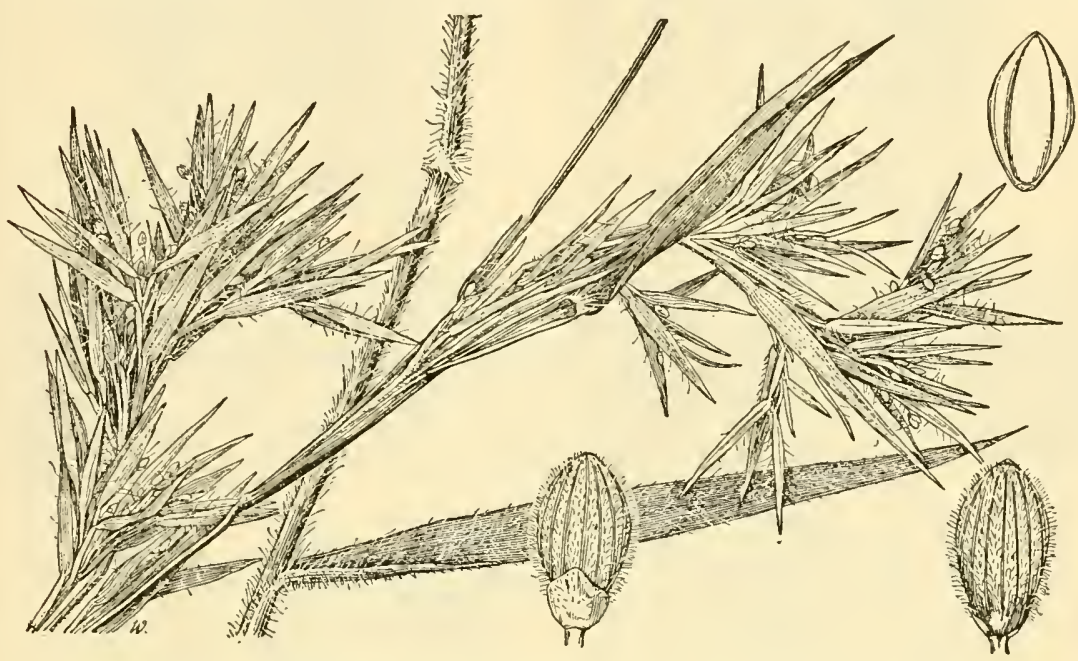

Figure 1355.-Panicum lanuginosum. Plant, $\times 1$; two views of spikelet, and floret, $\times 10$. (Hitchcock, N. C.)

spreading, soon becoming branched and decumbent; ligule 3 to 4 $\mathrm{mm}$ long; blades 3 to $7 \mathrm{~cm}$ long, 3 to $5 \mathrm{~mm}$ wide; panicle 3 to $5 \mathrm{~cm}$ long, the axis velvety; spikelets 1.3 to $1.4 \mathrm{~mm}$ long. Autumnal culms early becoming diffusely branched at all the nodes, prostratespreading, forming large mats, the branches curved upward at the ends. 2 -Sandy pine and oak woods, Coastal Plain, Massachusetts to northern Florida and Louisiana; Arkansas; Indiana, near Lake Michigan (fig. 1358).

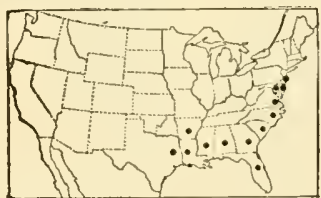

FIGURe 1356.-Distribution of Panicum lanugionsum.
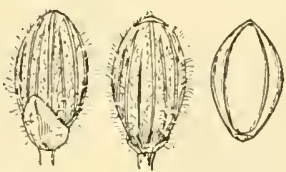

FIGURE 1357.-Panicum auburne. Two views of spikelet, and floret, $\times 10$. (Type.)

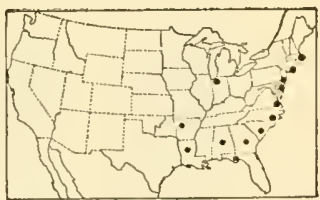

FIGURE 1358.-Distribution of Panicum auburne.

50. Panicum thurówii Scribn. and Smith. (Fig. 1359.) Vernal phase bluish green but drying olive; culms 35 to $70 \mathrm{~cm}$ tall, erect or ascending, villous, the nodes bearded, usually with a glabrous ring below; sheaths sparsely to densely villous; ligule $4 \mathrm{~mm}$ long; blades rather stiff, 6 to $10 \mathrm{~mm}$ wide, the upper surface sparingly pilose toward the base and margins, otherwise glabrous, the lower surface velvety-villous; panicle 7 to $11 \mathrm{~cm}$ long; spikelets $2 \mathrm{~mm}$ long. $\mathrm{Au}$ - 
tumnal culms erect, bearing at the middle nodes a few appressed fascicles of branches. 21 -Prairies and dry open woods, Alabama (Mobile) to Texas and Arkansas (fig. 1360).

51. Panicum praecócius Hitchc. and Chase. (Fig. 1361.) Vernal culms 15 to $25 \mathrm{~cm}$ tall, at first erect and simple, soon branching and geniculate, becoming 30 to $45 \mathrm{~cm}$ long, papillose-pilose with weak
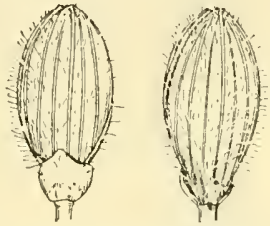

FIgUre 1359.-Panicum thurowii. Two views of spikelet, and floret, $\times 10$.
(Type.)

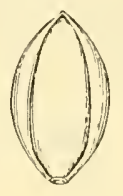

spreading hairs 3 to $4 \mathrm{~mm}$ long; sheaths pilose; ligule 3 to $4 \mathrm{~mm}$ long; blades 5 to $9 \mathrm{~cm}$ long, 4 to $6 \mathrm{~mm}$ wide, long-pilose on both surfaces, the hairs on the upper surface 4 to $5 \mathrm{~mm}$ long, erect; panicle 4 to $6 \mathrm{~cm}$ long, the axis pilose; spikelets 1.8 to $1.9 \mathrm{~mm}$ long, pilose. Autumnal culms in close bunches, 10 to $20 \mathrm{~cm}$ tall, the branches appressed, the scarcely reduced blades erect. 24 -Dry prairies and clearings,

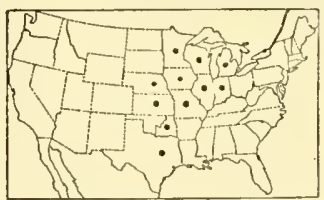

Figure 1362.-Distribution of Panicum praccocius.

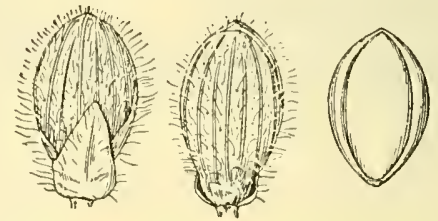

Figure 1361.-Panicum praecocius. Two views of spikelet, and floret, $\times 10$. (Type.)

Michigan to Minnesota, south to Missouri and eastern Texas (fig. 1362).

52. Panicum subvillósum Ashe. (Fig. 1363.) Vernal culms leafy below, 10 to $45 \mathrm{~cm}$ tall, ascending or spreading, pilose, the nodes short-bearded; sheaths sparsely pilose with ascending hairs; ligule $3 \mathrm{~mm}$ long; blades 4 to $6 \mathrm{~cm}$ long, 4 to $6 \mathrm{~mm}$ wide, both surfaces
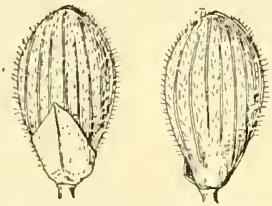

Figure 1363.-Panicum subvillosum. Two views of spikelet, and floret, $\times 10$. (Type.)

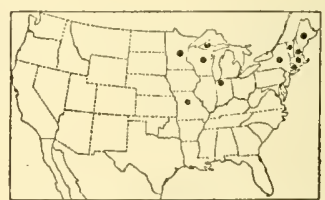

Figure 1364.-Distribution of Panicum subvillosum.

pilose, the hairs on the upper surface 3 to $5 \mathrm{~mm}$ long; panicle longexserted, 3 to $5 \mathrm{~cm}$ long; spikelets 1.8 to $1.9 \mathrm{~mm}$ long. Autumnal culms widely spreading or prostrate, sparingly branching from the lower nodes, the leaves and panicles not greatly reduced. 24-Dry woods and sandy ground, Nova Scotia to Minnesota, south to New York, Indiana, and Missouri (fig. 1364). 
53. Panicum occidentále Scribn. (Fig. 1365.) Vernal culms yellowish green, leafy toward base, 15 to $40 \mathrm{~cm}$ tall, spreading, sparsely pubescent; sheaths sparsely pubescent; ligule 3 to $4 \mathrm{~mm}$ long; blades firm, erect, or ascending, 4 to $8 \mathrm{~cm}$ long, 5 to $7 \mathrm{~mm}$ wide, the upper surface nearly glabrous, the under appressed-pubescent; panicle 4 to $7 \mathrm{~cm}$ long; spikelets $1.8 \mathrm{~mm}$ long. Autumnal culms branching from

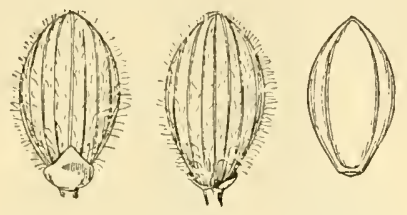

Figure 1365.-Panicum occidentale. Two views of spikelet, and floret, $\times 10$. (Type.)

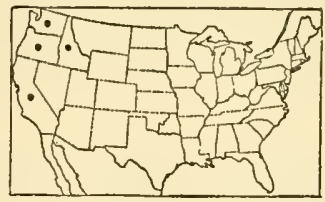

FigURE 1366.-Distribution of Panicum occidentale.

the lower nodes forming a spreading tussock 10 to $15 \mathrm{~cm}$ high; leaves and panicles reduced. 24 - Peat bogs and moist sandy ground, British Columbia and Idaho to southern California (fig. 1366).

54. Panicum pacíficum Hitchc. and Chase. (Fig. 1367.) Vernal phase light green; culms 25 to $50 \mathrm{~cm}$ tall, ascending or spreading, leafy, pilose, the nodes short-bearded; sheaths pilose; ligule 3 to $4 \mathrm{~mm}$

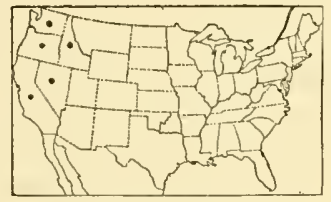

FIGURE 1368,-Distribution of Panicum pacificum.

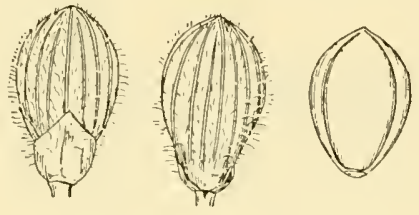

FIGURe 1367.-Panicum pacificum. Two views of spikelet, and floret, $\times 10$. (Type.)

long; blades erect or ascending, 5 to $10 \mathrm{~cm}$ long, 5 to $8 \mathrm{~mm}$ wide, the upper surface pilose, the lower surface appressed-pubescent; panicle 5 to $10 \mathrm{~cm}$ long; spikelets 1.8 to $2 \mathrm{~mm}$ long. Autumnal culms prostrate spreading, repeatedly branching from the middle and upper nodes. 24 -Sandy shores and slopes, and moist crevices of rocks,

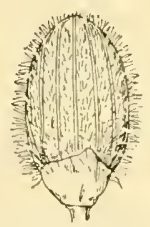

Figure 1369.-Panicum thermale. Two views of spikelet, and floret, $\times 10$. (Type.)

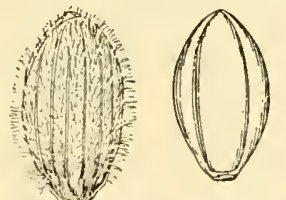

ascending to $1,600 \mathrm{~m}$, British Columbia and Idaho to Arizona and southern California (fig. 1368).

55. Panicum thermále Boland. (Fig. 1369.) Vernal phase grayish green, densely tufted, velvety-villous; culms 10 to $30 \mathrm{~cm}$ tall, ascending or spreading, the nodes with a dense ring of short hairs; ligule $3 \mathrm{~mm}$ long; blades thick, 3 to $8 \mathrm{~cm}$ long, 5 to $12 \mathrm{~mm}$ wide; panicle 3 to $6 \mathrm{~cm}$ long, the axis villous; spikelets 1.9 to $2 \mathrm{~mm}$ long, pilose. Autumnal culms widely spreading, repeatedly branching, the whole forming a 
dense cushion. 24-Wet saline soil in the immediate vicinity of geysers and hot springs, ascending to $2,500 \mathrm{~m}$, Alberta to Washington, south to Wyoming and California (fig. 1370).

56. Panicum lánguidum Hitchc. and Chase. (Fig. 1371.) Vernal culms 25 to $40 \mathrm{~cm}$ tall, weak, slender, ascending or spreading, pilose; sheaths pilose; ligule $3 \mathrm{~mm}$ long; blades thin, lax, ascending or spreading, 4 to $7 \mathrm{~cm}$ long, 4 to $9 \mathrm{~mm}$ wide, sparsely pilose on the upper surface, minutely appressed-pubescent beneath; panicle 3 to $6 \mathrm{~cm}$ long, the axis and branches sparsely long-pilose; spilkelets $2 \mathrm{~mm}$ long, pilose. Autumnal culms decumbent, branching from all the nodes, forming a
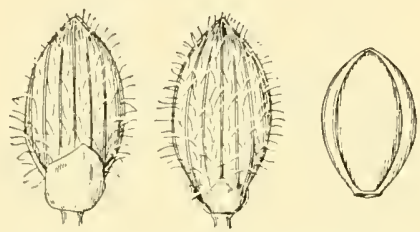

FIGURE 1371.-Panicum languidum. Two views of spikelet, and floret, $\times 10$. (Type.)
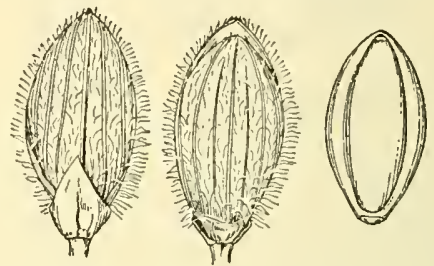

Figure 1372.-Panicum villosissimum. Two views of spikelet, and floret, $\times 10$. (Type.)

large loose straggling clump, the ultimate blades and panicles scarcely reduced. 21 -Dry or sandy open woods, Maine, Massachusetts, Vermont, and eastern New York, apparently rare.

57. Panicum villosíssimum Nash. (Fig. 1372.) Vernal phase light olive green; culms 25 to $45 \mathrm{~cm}$ tall, erect or ascending, pilose with spreading hairs $3 \mathrm{~mm}$ long; sheaths pilose; ligule 4 to $5 \mathrm{~mm}$ long; blades rather firm, 6 to $10 \mathrm{~cm}$ long, 5 to $10 \mathrm{~mm}$ wide, pilose on both surfaces; panicle 4 to $8 \mathrm{~cm}$ long, the branches stiffly ascending or spreading; spikelets 2.2 to $2.3 \mathrm{~mm}$ long, pilose. Autumnal culms finally prostrate, the leaves of the fascicled branches appressed, giving the cluster or mat a combed-out appearance. 24 -Dry sandy or

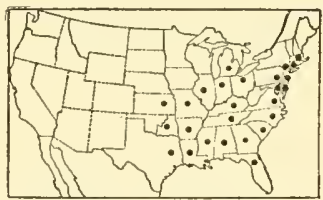

Figure 1373.-Distribution of Panicum villosissimum.
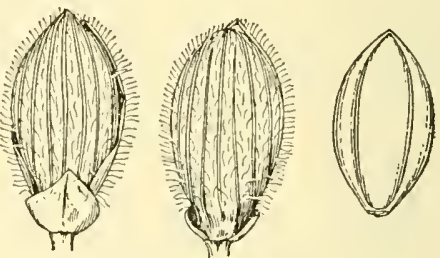

FIGURE 1374.-Danicum pseudopubescens. Two views of spikelet, and floret, $\times 10$ (Type.)

sterile soil, open woods, and hillsides, Massachusetts to Minnesota, south to Florida and Texas; Guatemala (fig. 1373).

58. Panicum pseudopubéscens Nash. (Fig. 1374.) Vernal phase similar to that of $P$. villosissimum; ligule 2 to $3 \mathrm{~mm}$ long; blades with the pubescence on the upper surface short, sparse or wanting down the center, occasionally glabrous; spikelets 2.2 to $2.4 \mathrm{~mm}$ long, pilose. Autumnal culms stiffly spreading, sometimes prostrate, sparingly branching from the middle and lower nodes. 24 - Sandy open woods, Connecticut to Wisconsin, south to Florida, Kansas, and Mississippi; Mexico (fig. 1375). 
59. Panicum ovále Ell. (Fig. 1376.) Vernal culms 20 to $50 \mathrm{~cm}$ tall, erect or ascending, rather stout, long-pilose below with ascending or appressed hairs, often nearly glabrous above, the nodes bearded; sheaths ascending-pilose; ligule 2 to $3 \mathrm{~mm}$ long, rather sparse; blades 5 to $10 \mathrm{~mm}$ wide, the upper surface nearly glabrous except for long hairs near the base and margins, the lower surface appressedpubescent; panicle 5 to $9 \mathrm{~cm}$ long; spikelets, 2.7 to $2.9 \mathrm{~mm}$ long. Autumnal phase spreading-decumbent, the stiff culms rather loosely

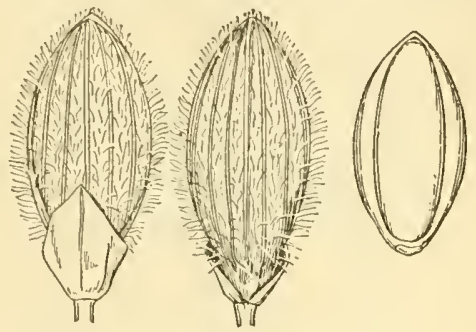

Flgure 1376.-Panicum ovale. Two views of spikelet, and floret, $\times 10$. (Type.)

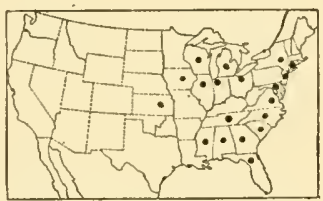

Figure 1375.-Distribution of Panicum pseudopubescens.

branching from the middle and upper nodes. 24 -Dry sandy woods, Coastal Plain, North Carolina to Florida; Kansas (Saline County), Texas (Waller County) (fig. 1377).

60. Panicum scoparioídes Ashe. (Fig. 1378.) Vernal phase light green; culms 30 to $50 \mathrm{~cm}$ tall, erect or ascending, pilose with ascending hairs or nearly glabrous; sheaths pilose to nearly glabrous; ligule 2 to 3 $\mathrm{mm}$ long; blades 6 to $10 \mathrm{~mm}$ wide, sparsely hispid on the upper surface, appressed-pubescent beneath; panicle 4 to $7 \mathrm{~cm}$ long; spikelets 2.2 to $2.3 \mathrm{~mm}$ long, pubescent. Autumnal culms erect or spreading, sparingly branching from the upper and middle nodes. 24 -Dry

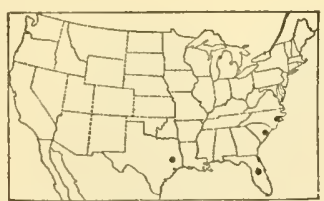

F1gure 1377.-Distribution of Panicum ovale.
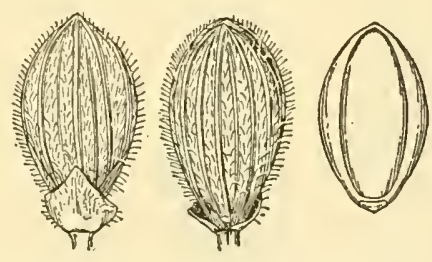

Figure 1378.-Panicum scoparioides. Two views of spikelet, and floret, $\times 10$. (Type.)

sandy or gravelly soil, Vermont to Delaware; Michigan to Minnesota and Iowa (fig. 1379).

61. Panicum shasténse Scribn. and Merr. (Fig. 1380.) Vernal culms 30 to $50 \mathrm{~cm}$ tall, pilose with ascending hairs, the nodes shortbearded; sheaths papillose-pilose, the hairs spreading; ligule sparse, 2 to $3 \mathrm{~mm}$ long; blades 6 to $8 \mathrm{~mm}$ wide, sparsely pilose on the upper surface, pilose beneath; panicle 6 to $8 \mathrm{~cm}$ long; spikelets 2.4 to 2.6 $\mathrm{mm}$ long. Autumnal culms spreading, with geniculate nodes and elongate arched internodes, rather sparingly branched from the middle nodes. 24 -Moist meadows. Known only from Castle Crag, Shasta County, Calif. 
9. Columbiána.-Culms and sheaths appressed-pubescent to crisppuberulent, the culms stiff; ligules mostly less than $1 \mathrm{~mm}$ long (sometimes to $1.5 \mathrm{~mm}$ in $P$. tsugetorum and $P$. oricola); blades firm, thick, stiffly ascending; spikelets 5- to 9-nerved, pubescent, the first glume mostly one-third to half as long as the spikelet. Autumnal culms freely branching, the branches and stiff blades mostly appressed.

62. Panicum málacon Nash. (Fig. 1381.) Vernal culms erect to stiffly spreading, purplish olive-green; culms and sheaths appressed-

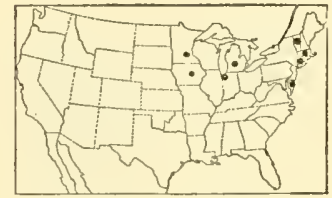

FIGURE 1379.-Distribution of Panicum scoparioides.

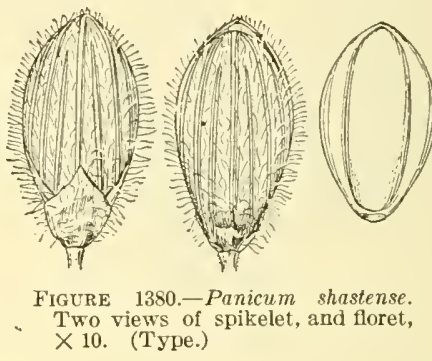

pubescent, the eulms 30 to $50 \mathrm{~cm}$ tall; blades 3 to $5 \mathrm{~mm}$ wide, sharply acuminate, puberulent beneath, puberulent to glabrous above; panicle 4 to $7 \mathrm{~cm}$ long, the branches few, stiffly ascending, the pedicels long and stiff; spikelets 3 to $3.2 \mathrm{~mm}$ long, obovate, the first glume distant, about half as long as the spikelet. Autumnal culms subdecumbent-spreading, branching from the lower and middle nodes, the branches appressed. 24 -Dry pine woods, high pineland, North Carolina (Wilmington); Florida.

63. Panicum deámii Hitchc. and Chase. (Fig. 1382.) Vernal phase yellowish green; culms 25 to $35 \mathrm{~cm}$ tall, erect or ascending,

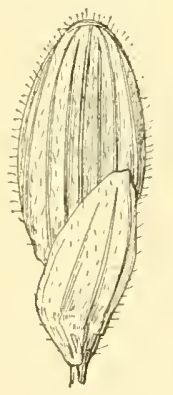

Figure 1381.-Panicum malacon. Two views of spikelet, and floret, $\times 10$. ('Type.)

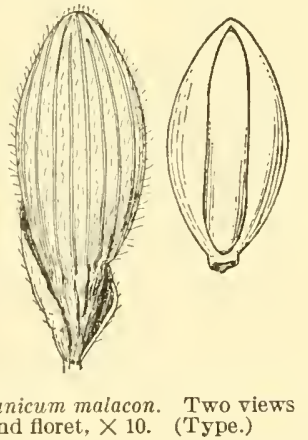

Figure 1382.-Panicum deamii. Two views of spikelet, and floret, $\times 10$. (Type.)

papillose-pilose; sheaths papillose-villous, densely so at base and summit; blades suberect, 8 to $15 \mathrm{~cm}$ long, 4 to $6 \mathrm{~mm}$ wide, sparsely villous on the upper surface, appressed-pilose beneath; panicle rather short-exserted, 6 to $10 \mathrm{~cm}$ long, the branches ascending; spikelets 2.8 to $2.9 \mathrm{~mm}$ long, pilose. Autumnal culms branching from the middle and upper nodes, forming a somewhat bushy summit, the culms sprawling. 24 Sand dunes, northern Indiana; Iowa.

64. Panicum commonsiánum Ashe. (Fig. 1383.) Vernal phase greenish olive, drying brownish; culms and sheaths appressed-pilose, 
the culms 20 to $50 \mathrm{~cm}$ tall, ascending or spreading, appressed-pilose; blades 4 to $7 \mathrm{~mm}$ wide, broadest near the rounded base, glabrous or nearly so on the upper surface, strigose or glabrous beneath; panicle 4 to $\dot{\delta} \mathrm{cm}$ long, the branches stiffly spreading; spikelets 2.2 to $2.4 \mathrm{~mm}$ long. Autumnal culms branching from the middle and upper nodes, finally spreading or prostrate in mats. 2 -Dunes and sandy woods near the coast, Massachusetts to northern Florida (fig. 1384).

65. Panicum addisóni Nash. (Fig. 1385.) Vernal phase similar to that of $P$. commonsianum; culms usually less than $40 \mathrm{~cm}$ tall, appressed-pilose below, puberulent above; sheaths sparsely ascending-

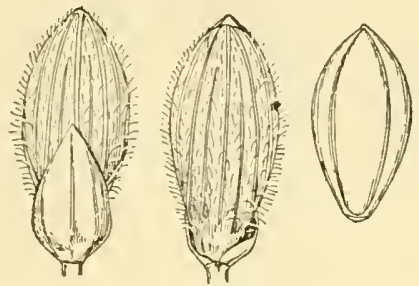

FIgURE 1383.-Panicum commonsianum. Two views of spikelet, and floret, $\times 10$. (Type.)

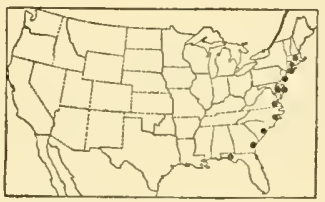

FIGURE 1384,-Distribution of Panicum commonsianum.

pilose, blades 3 to $6 \mathrm{~mm}$ wide, glabrous on the upper surface, pubescent or glabrous beneath; panicle 2 to $6 \mathrm{~cm}$ long, more densely flowered than in $P$. commonsianum; spikelets about $2 \mathrm{~mm}$ long. Autummal culms more or less spreading, rather freely branching from all the nodes, the branches appressed. 21 -Sand barrens, Coastal Plain, Massachusetts to South Carolina; Indiana (fig. 1386). Closely approaching $P$. commonsianum but having smaller spikelets.

66. Panicum wilmingtonénse Ashe. (Fig. 1387.) Vernal phase bluish green, culms solitary or in small tufts, slender, erect from an ascending base, 20 to $40 \mathrm{~cm}$ tall, pilose with soft ascending hairs;

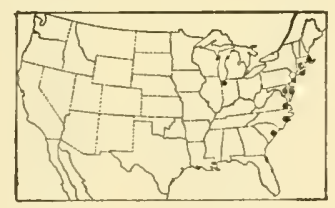

Figure 1386.-Distribution of Panicum addisoni.
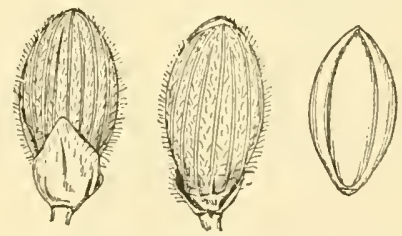

Figure 1385-Panicumaddisoni. Two views of spikelet, and floret, $\times 10$. ('Type.)

sheaths pubescent like the culms, densely villous-ciliate at the summit; blades 3 to $7 \mathrm{~mm}$ long, glabrous on the upper surface, softly pubescent or nearly glabrous beneath, strongly ciliate near the base, the thick cartilaginous margin white when dry; panicle 5 to $\mathrm{S} \mathrm{cm}$ long; spilielets $2 \mathrm{~mm}$ long. Autumnal culms spreading, branching from the middle and upper nodes. 21 -Sandy woods, North Carolina, South Carolina, and Alabama, rare.

67. Panicum tsugetórum Nash. (Fig. 138s.) Ternal phase usually pale bluish green; culms 30 to $50 \mathrm{~cm}$ tall, spreading or ascending, the lower nodes often geniculate, densely appressed-pubescent with short crisp hairs, long hairs more or less intermixed; sheaths 
pubescent like the culm; ligule 1 to $1.5 \mathrm{~mm}$ long; blades 4 to $7 \mathrm{~mm}$ wide, glabrous or nearly so on the upper surface, appressed-pubescent beneath; panicle 3 to $7 \mathrm{~cm}$ long; spikelets 1.8 to $1.9 \mathrm{~mm}$ long. Autum-
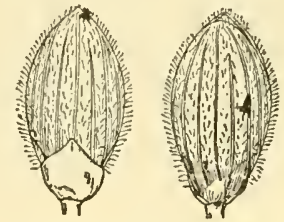

FIGURE 1387.-Panicum wilmingtonense. Two views of spikelet, and floret, $\times 10$. (Type.)

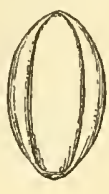

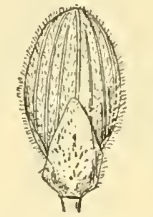
Figure 1388.-Panicum tsugetorum.
Two views of spikelet, and floret, $\times 10$. (Type.)

nal culms decumbent-spreading, branching from the lower and middle nodes. 24 - Sandy woods, Maine to Wisconsin, south to Georgia and Tennessee (fig. 1389).

68. Panicum columbiánum Scribn. (Fig. 1390.) Vernal culms 15 to $50 \mathrm{~cm}$ tall, ascending, densely crisp-puberulent; sheaths less pubescent than the culms; blades 3 to $6 \mathrm{~cm}$ long, 3 to $5 \mathrm{~mm}$ wide, usually glabrous on the upper surface, appressedpuberulent or glabrous beneath; panicle 2 to $4 \mathrm{~cm}$ long; spikelets 1.5 to $1.6 \mathrm{~mm}$ long. Autumnal culms branching from the middle and upper nodes, becoming widely spreading or decumbent at base. 24 Sandy woods and open ground, Maine to North Carolina; Indiana (fig. 1391).

Panicum Columbianum var. Thínium Hitche. and Chase. Vernal culms more slender, usu-

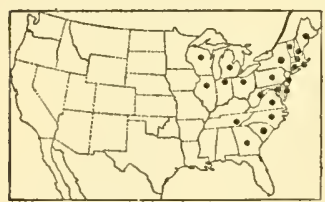

Figure 1389.--Distribution of Panicum tsugetorum. ally about $20 \mathrm{~cm}$ tall; blades rarely more than $3 \mathrm{~cm}$ long, sparsely pilose with long hairs on the upper surface; panicle 1.5 to $4 \mathrm{~cm}$ long; spikelets 1.3 to $1.4 \mathrm{~mm}$ long. Autumnal culms with branches more crowded and aggregate toward the summit. 24 -Dry sand, Massachusetts to Virginia.

69. Panicum orícola Hitche. and Chase. (Fig. 1392.) Vernal phase grayish, often purplish; culms and sheaths appressed-pilose, the culms 10 to $30 \mathrm{~cm}$ tall, spreading; ligule 1 to $1.5 \mathrm{~mm}$

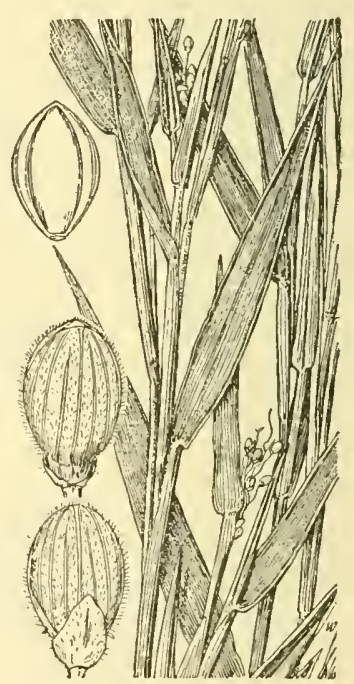

Figure 1390.-Panicum columbianum. Plant, $\times 1$; two views of spikelet, and floret, $\times 10$. (Type.)

long; blades 2 to $5 \mathrm{~cm}$ long, 2 to $4 \mathrm{~mm}$ wide, the upper surface pilose with hairs 3 to $5 \mathrm{~mm}$ long, the lower surface appressed-pilose; panicle short-exserted, ovoid, 1.8 to $3 \mathrm{~cm}$ long, rather densely flowered; spikelets $1.5 \mathrm{~mm}$ long, broadly obovate, turgid. Autumnal culms prostrate, forming mats, with short fascicled branches at all the nodes. 24 Sand barrens along the coast, Massachusetts to Virginia (fig, 1393). 
10. Sphaerocárpa. Glabrous as a whole; culms few in a tuft, relatively stout; ligules obsolete or nearly so; blades mostly thick, firm, cartilaginous-margined, cordate and ciliate at base, panicle branches mostly viscid; spikelets obovoid-spherical at maturity, oval when young, 5- to 7-nerved, puberulent. Autumnal culms remaining simple or only sparingly branching, the thick whitemargined blades of the winter rosette conspicuous.

70. Panicum sphaerocárpon Ell. (Fig. 1394.) Vernal phase light green; culms 20 to $55 \mathrm{~cm}$ tall, radiate-spreading, sometimes nearly

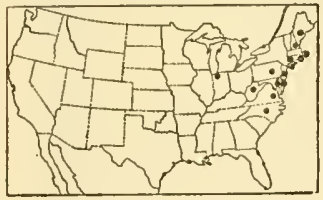

FlGURE 1391.-Distribution of Panicum columbianum.
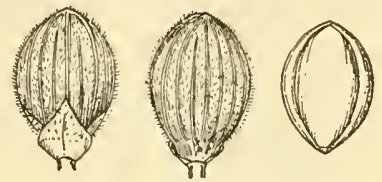

F I G URE 1392.-Panicum oricola. Two views of spikelet, and floret, $\times 10$. (Type.)

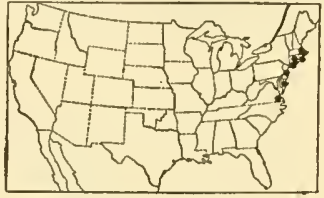

FIGURE 1393.-Distribution of Panicum oricola.

erect, the nodes appressed-pubescent; blades 7 to $14 \mathrm{~mm}$ wide; panicle 5 to $10 \mathrm{~cm}$ long, about as wide; spikelets 1.6 to $1.8 \mathrm{~mm}$ long. Autumnal phase prostrate-spreading, sparingly branched late in the season from the lower and middle nodes, the branches short, mostly

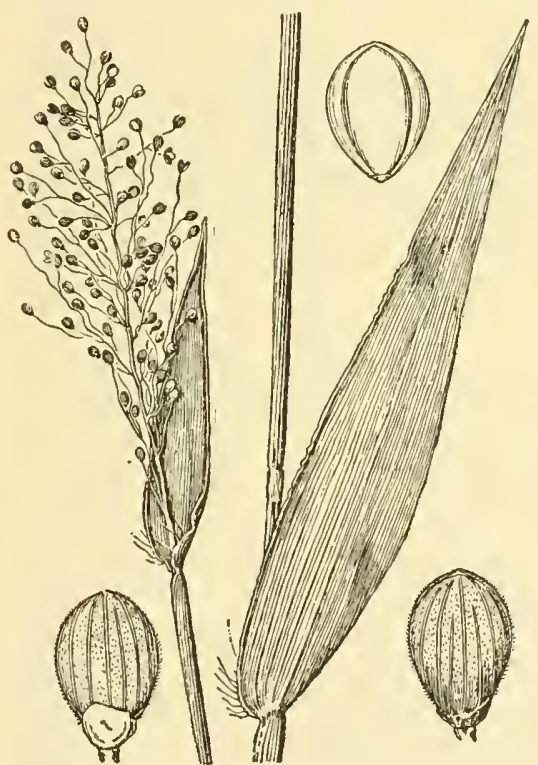

Figure 1394.-Panicum sphaerocarpon. Plant, $\times 1$; two views of spikelet, and floret, $\times 10$. (Deam, Ind.) simple. 24 -Sandy soil, Vermont to Kansas, south to northern Florida and Texas; Mexico to Venezuela (fig. 1395). Panicum SPHAEROCARPON Var. INFLÁTUM (Scribn. and Smith) Hitche. and Chase. Differing from P. sphaerocarpon in having a ligule as

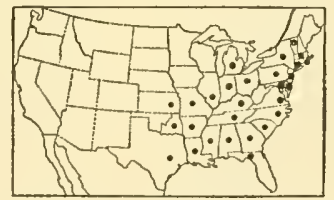

Figure 1395.-Distribution of Panicum sphaerocarpon.
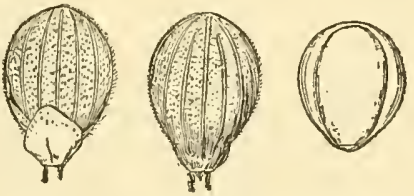

FIGURE 1396.-Panicum polyanthes. Two views of spikelet, and floret, $\times 10$. (Type.)

much as $1 \mathrm{~mm}$ long, spikelets 1.4 to $1.5 \mathrm{~mm}$ long, and more freely branching autumnal culms; many intergrades occur. 4 -Moist sandy soil, Coastal Plain, Delaware to Florida and Texas, north to Oklahoma and Missouri.

71. Panicum polyánthes Schult. (Fig. 1396.) Vernal culms erect, 30 to $90 \mathrm{~cm}$ tall, the nodes glabrous or nearly so; blades 12 to $23 \mathrm{~cm}$ long, 15 to $25 \mathrm{~mm}$ wide, the upper scarcely reduced; panicle 8 to 25 
cm long, one-fourth to half as wide, densely flowered; spikelets 1.5 to $1.6 \mathrm{~mm}$ long, minutely puberulent. Autumnal phase remaining erect, producing simple branches from the lower and middle nodes. 24 -Damp ground, woods, and openings, Connecticut to Oklahoma, south to Georgia and Texas (fig. 1397).

72. Panicum erectifólium Nash. (Fig. 1398.) Vernal culms 30 to $70 \mathrm{~cm}$ tall, erect or ascending; sheaths usually crowded at base; ligule very short; blades 7 to $13 \mathrm{~cm}$ long, 6 to $12 \mathrm{~mm}$ wide, the crowded lower ones usually much larger than the others; panicle 6 to $12 \mathrm{~cm}$ long, rather narrow, densely flowered, spikelets 1 to $1.2 \mathrm{~mm}$ long, nearly spherical, densely puberulent. Autumnal culms remaining

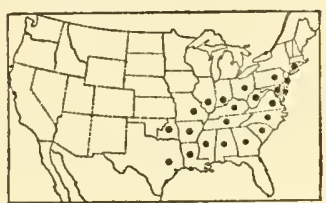

Figure 139i.-Distribution of Panicum polyanthes.
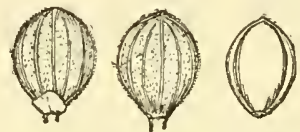

FIgURE 1398,-Panicum erectifolium. Two views of spikelet, and floret, $\times 10$. (Type.)

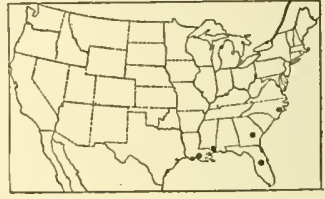

FIGURE 1399.-Distribution of Panicum erectifolium.

erect, late in the season producing branches from the third or fourth node, the branches nearly as long as the primary culms. 4 Moist pine barrens, swamps, and borders of ponds, North Carolina to Florida and Louisiana; Cuba (fig. 1399).

11. Ensifólia. Low and slender, mostly glabrous throughout (except in $P$. curtifolium and $P$. tenue); ligules nearly obsolete; spikelets 5- to 7-nerved. Autumnal culms simple to freely branching.

73. Panicum ténue Muhl. (Fig. 1400.) Vernal phase olive green; culms 20 to $55 \mathrm{~cm}$ tall, sometimes sparsely appressed-pubescent below; sheaths puberulent between the nerves or sparsely appressed-pilose, or the upper glabrous; blades distant, 2 to $5 \mathrm{~cm}$ long, 3 to $4 \mathrm{~mm}$ wide,
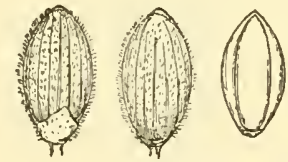

FIGURE $1400 .-P$ a $n$ ic $u m$ tenue. Two riews of spikelet, and floret, $\times 10$. (Type.)

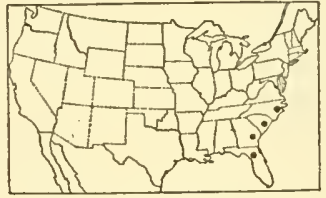

FigURE 1401.-Distribution of Panicum tenue.
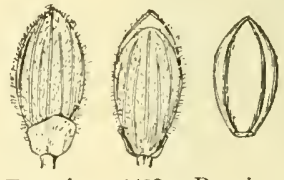

F I G ÜR E 1402.-Panic $u m$ albomarginatum. Two views of spikelet, and floret, $\times 10$. (Tspe.)

rather thick, the margin sartilaginous, puberulent beneath, glabrous on the upper surface; panicle 3 to $5 \mathrm{~cm}$ long; spikelets 1.6 to $1.7 \mathrm{~mm}$ long, puberulent. Autumnal culms erect or leaning, sparingly branching from the middle nodes, the branches in small fascicles. 2 -Moist sandy woods, eastern North Carolina to northern Florida (fig. 1401).

74. Panicum albomarginátum Nash. (Fig. 1402.) Vernal culms 15 to $40 \mathrm{~cm}$ tall, ascending or spreading; leaves crowded at the base; blades thick and firm, those of the midculm 4 to $6 \mathrm{~cm}$ long, 4 to $6 \mathrm{~mm}$ wide, with a prominent white cartilaginous margin, the uppermost much reduced; panicle 3 to $6 \mathrm{~cm}$ long; spikelet 1.4 to $1.5 \mathrm{~mm}$ long, puberulent. Autumnal culms spreading, branching at the base, 
forming bushy tufts. 2! - Low sandy soil, Coastal Plain, southeastern Virginia to Florida and Louisiana; Cuba; Guatemala (fig. 1403).

75. Panicum trifólium Nash. (Fig. 1404.) Vernal phase similar to that of $P$. albomarginatum, the culms more slender, 20 to $50 \mathrm{~cm}$ tall, the blades less crowded at the base, the upper blade not reduced. Autumnal culms erect or leaning, sparingly branching from the middle and upper nodes. 24 -Low mostly moist sandy woods, New Jersey to Florida and Louisiana (fig. 1405).

76. Panicum flavóvirens Nash. (Fig. 1406.) Vernal phase bright glossy green; culms very slender, ascending or spreading, 15 to $30 \mathrm{~cm}$

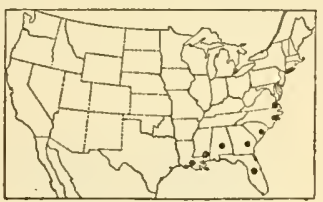

Figure 1403.-Distribution of Panicum albomarginatum.
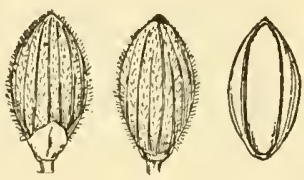

FIGURE 1404.-Panicum trifolium. Two views of spikelet, and floret, $\times 10$. (Type.)

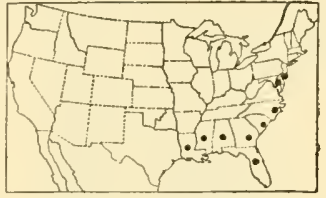

FIgURE 1405.-Distribution of Panicum trifolium.

tall; blades 2 to $5 \mathrm{~cm}$ long, 3 to $4 \mathrm{~mm}$ wide, thin; panicle fewflowered; spikelets 1.3 to $1.4 \mathrm{~mm}$ long, pubescent. Autumnal culms spreading, decumbent or prostrate, branching from the lower and middle nodes. 24-Moist shady or mucky soil, North Carolina to Florida and Mississippi (fig. 1407). Panicum albomarginatum, $P$. trifolium, and $P$. Alavovirens form a series of closely allied species.

77. Panicum concínnius Hitchc. and Chase. (Fig. 1408.) Vernal phase bright green; culms very slender, 12 to $50 \mathrm{~cm}$ tall; blades 5 to $7 \mathrm{~cm}$ long, 5 to $6 \mathrm{~mm}$ wide; panicle 3 to $6 \mathrm{~cm}$ long; spikelets 1.1 $\mathrm{mm}$ long, pubescent. Autumnal culms radiate-spreading, late in
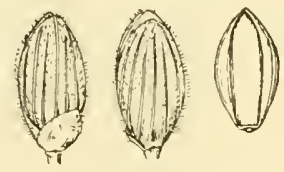

Figure 1406.-Panicum flavovirens. Two views of spikelet, and floret, $\times 10$. (Type.)

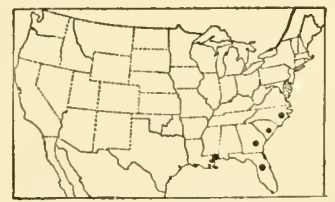

Figure 1407.-Distribution of Panicum flavovitens.

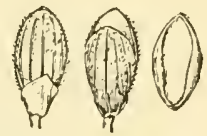

Figure 1408.-Panicum concinnius. T'wo views of spikelet, and floret, $\times 10$. (Type.)

the season bearing a few branches, with somewhat reduced blades. 21 -Moist sandy ground, northern Georgia, Florida, and northern Alabama, rare.

78. Panicum ensifólium Baldw. (Fig. 1409.) Vernal culms 20 to $40 \mathrm{~cm}$ tall, erect or reclining; blades distant, often reflexed, 1 to $3 \mathrm{~cm}$ long, 1.5 to $3 \mathrm{~cm}$ wide, puberulent beneath, at least toward the tip; panicle 1.5 to $4 \mathrm{~cm}$ long; spikelets 1.3 to $1.5 \mathrm{~mm}$ long, glabrous or puberulent. Autumnal culms spreading or reclining, sparingly branching from the middle nodes, the branches mostly simple. 24 Wet places, mostly sphagnum bogs or swamps, Coastal Plain, New Jersey to Florida and Louisiana (fig. 1410).

79. Panicum vernále Hitchc. and Chase. (Fig. 1411.) Vernal phase light green, soft in texture; culms 15 to $30 \mathrm{~cm}$ tall, very slender, 
ascending or spreading; leaves clustered at the base; blades thin, 2 to 7 $\mathrm{cm}$ long, 3 to $5 \mathrm{~mm}$ wide, the culm blades smaller; panicle 1.5 to $3 \mathrm{~cm}$ long, few-flowered; spikelets 1.4 to $1.5 \mathrm{~mm}$ long, elliptic, subacute, pubescent. Autumnal phase like the vernal in appearance, branching from the base, these culms simple and soon dying to the ground,

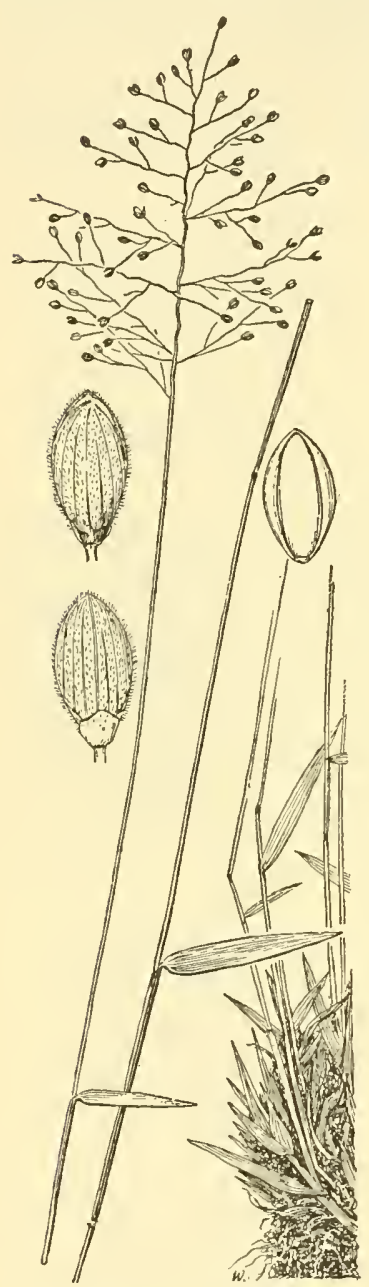

FIGURE 1409.-Panicum ensifoli$u m$. Plant, $\times 1$; two views of spikelet, and floret, $\times 10$. (Biltmore Herb., N.C.) rarely late in the season producing a few short fascicled branchlets from the nodes, the scarcely reduced flat blades spreading. 2 -Moist places, especially sphagnum bogs, Florida to Mississippi. 80. Panicum curtifólium $\mathrm{N}$ ash. (Fig. 1412.) Vernal culms 10 to $30 \mathrm{~cm}$ tall, slender, weak, angled, erect or spreading, sheaths striate-angled, sparsely pilose; ligule about $1 \mathrm{~mm}$ long; blades spreading or reflexed, 1.5 to $3 \mathrm{~cm}$ long, 2 to $5 \mathrm{~mm}$ wide, thin, soft, sparsely pilose on both surfaces or nearly glabrous above; panicle 2 to $3 \mathrm{~cm}$ long; spikelets $1.4 \mathrm{~mm}$ long, glabrous or minutely pubescent. Autumnal culms weakly spreading, branching from the middle nodes, the ultimate branches in small fascicles toward the summit of the culm. 24 - Boggy soil and shady moist places, sometimes forming a rather dense carpet, South Carolina to Tennessee, south to Florida and Louisiana (fig. 1413).

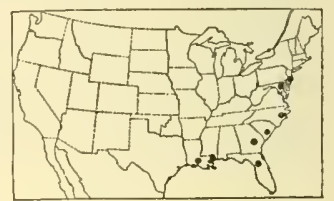

FIGURE 1410.-Distribution of Panicum ensifolium.

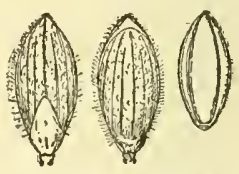

FiguRE 1411.-Panicum vernale. Two views of spikelet, and floret, $\times 10$. (Type.)

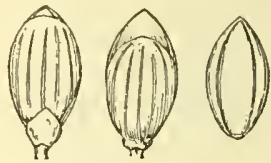

FigURE 1412.-Panicum curtifalium. Two views of spikelet, and floret, $\times 10$. ('Туре.)

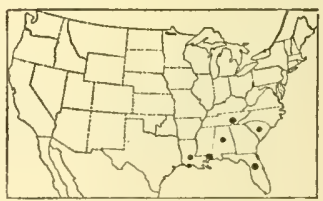

FIGURE 1413.-Distribution of Panicum curtifolium.

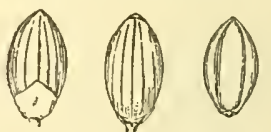

FIGURE 1414.-Panicum chamaelonche. Two views of spikelet, and floret, $\times 10$. (Type.)

81. Panicum chamaelónche Trin. (Fig. 1414.) Vernal culms densely tufted, 10 to $20 \mathrm{~cm}$ tall, ascending; blades firm, ascending or spreading, 1.5 to $4 \mathrm{~cm}$ long, 2 to $3 \mathrm{~mm}$ wide; panicle 2.5 to $5 \mathrm{~cm}$ long; spikelets 1.1 to $1.2 \mathrm{~mm}$ long, glabrous. Autumnal culms freely 
branching from the base and lower nodes, forming dense cushions as much as $50 \mathrm{~cm}$ across. 2 - Open sandy soil in low pine land North Carolina to Florida and Mississippi; Isla de Pinos (fig. 1415).

82. Panicum glabrifólium Nash. (Fig. 1416.) Vernal phase similar to that of $P$. chamaelonche; culms stouter, 15 to $50 \mathrm{~cm}$ tall, mostly erect; blades erect, 4 to $12 \mathrm{~cm}$ long, 2 to $4 \mathrm{~mm}$ wide, usually involute; panicle 4 to $9 \mathrm{~cm}$ long; spikelets 1.2 to $1.4 \mathrm{~mm}$ long, glabrous. Autumnal culms wiry, elongate, spreading, freely branching from the middle and upper nodes, the blades long and narrow. 24 -Low sandy woods, peninsular Florida. Closely allied to P. chamaelonche but taller and with difierent autumnal phase.

83. Panicum bréve Hitche. and Chase. (Fig. 1417.) Vernal phase purplish; culms 5 to $15 \mathrm{~cm}$ tall, erect, stiff and wiry; sheaths
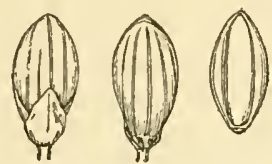

FI G URE 1416. - Panicum glabrifolium. Two views of spikelet, and floret, $\times 10$. (Type.)

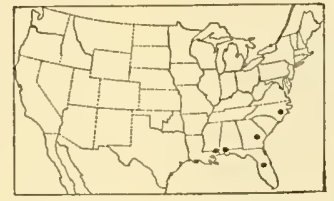

Figure 1415.-Distribution of Panicum chamaelonche.

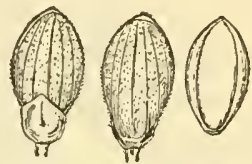

Figure 1417.-Panicum breve. Two views of spikelet, and floret. $\times 10$. (Type.)

crowded at the base; blades erect, 3 to $6 \mathrm{~cm}$. long, strongly involute, with a few stiff hairs at the base; panicle 1.5 to $4 \mathrm{~cm}$ long; spikelets 1.3 to $1.4 \mathrm{~mm}$ long, puberulent. Autumnal phase erect, branching from the middle nodes, the fascicled branches strict. 21-Low pine woods and hammocks, east coast of southern Florida.

12. Lanceária.- Olive green, often purplish; vernal culms usually wiry; ligules nearly obsolete; blades usually ciliate toward base; spikelets asymmetrically pyriform, strongly 7 - to 9-nerved. Autumnal culms spreading, freely branching.

84. Panicum portoricénse Desv. (Fig. 1418.) Vernal culms 15 to $30 \mathrm{~cm}$ tall, slender; crisp-puberulent to nearly glabrous; sheaths
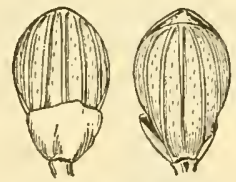

FIGURE 1418.-Panicum porloricense. Two views of spikelet, and floret, $\times 10$. (Ashe, N.C.)

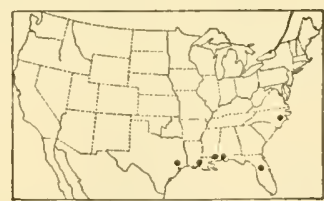

FIGURE 1419.-Distribution of Panicum portoricense.

glabrous or crisp-puberulent; blades firm, 2 to $5 \mathrm{~cm}$ long, 3 to $6 \mathrm{~mm}$ wide, glabrous to puberulent; panicle 2 to $4 \mathrm{~cm}$ long; spikelets 1.5 to $1.6 \mathrm{~mm}$ long, puberulent. Autumnal culms branching from all but the uppermost node, the reduced blades involute-pointed. $24(P$. pauciciliatum Ashe.)-Sandy woods of the Coastal Plain, mostly in moist places, North Carolina to Florida and Texas; Cuba; Puerto Rico (fig. 1419).

85. Panicum lanceárium Trin. (Fig. 1420.) Vernal culms 20 to $50 \mathrm{~cm}$ tall, minutely grayish crisp-puberulent; sheaths puberulent; blades firm, 2 to $6 \mathrm{~cm}$ long, 3 to $7 \mathrm{~mm}$ wide, usually glabrous on the upper surface, puberulent or nearly glabrous beneath; panicle 3 to 6 cm long; spikelets 2 to $2.1 \mathrm{~mm}$ long, glabrous or usually puberulent. 
Autumnal cuhms geniculate-spreading, branching from the middle nodes. 24 - Low sandy woods, Coastal Plain, southeastern Vir-

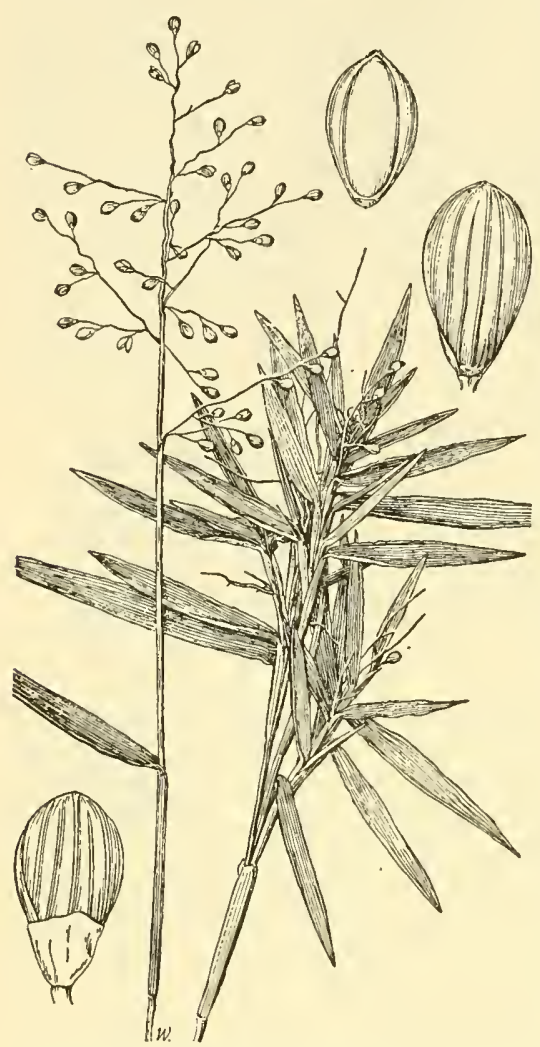

Figure 1420.-Panicum lancearium. Plant, $\times 1$; two views of spikelet, and floret, $X 10$. (Chase 4545, S.C.) 2.3 to $2.5 \mathrm{~mm}$ long, purple-stained at base, glabrous or minutely
pubescent. Autumnal culms spreading or decumbent, flabellately

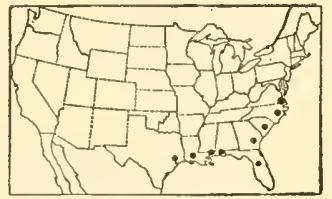

Figure 1421.-Distribution of Panicum lancearium.
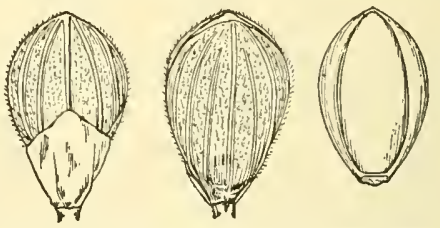

Figure 1422,-Panicum patulum. Two views of spikelet, and floret, $\times 10$. (Type.)

branched at the middle and upper nodes. 4 -Low pineland, North Carolina, Georgia, and Florida.

88. Panicum patentifólium Nash. (Fig. 1425.) Vernal culms widely decumbent-ascending, slender, 25 to $55 \mathrm{~cm}$ tall, minutely 
puberulent to nearly glabrous; blades stiffly spreading, 2.5 to $8 \mathrm{~cm}$ long, 2 to $5 \mathrm{~mm}$ wide, glabrous; panicle 3 to $7 \mathrm{~cm}$ long; spikelets 2.4 to $2.6 \mathrm{~mm}$ long, obovate, turgid, puberulent to nearly glabrous. Autumnal phase, decumbent or spreading, branching from the middle and upper nodes, the branches appressed. 24 -Dry sand, espe-

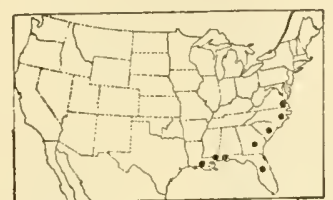

FIgure 1423.-Distribution of Panicum patulum.
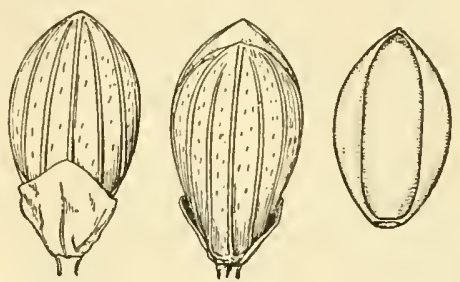

F1GUre 1424.-Panicum webberianum. Two views of spikelet, and floret, $\times 10$. (Type.)

cially in "scrub", Georgia to Florida and Mississippi (fig. 1426).

13. Oligosánthia.-Culms mostly relatively stout, usually erect; ligules inconspicuous except in $P$. ravenelii; blades firm; spikelets turgid, strongly 7 - to 9-nerved. Autumnal culms with branches more or less crowded toward the summit.

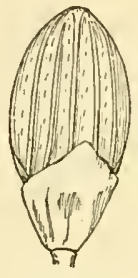

Figure 1425.- Panicum patentifolium. Two views of spikelet, and floret, $\times 10$. (Type.)
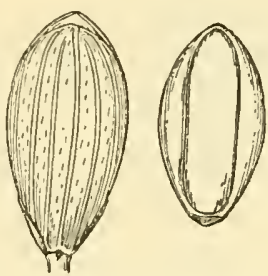

89. Panicum wilcoxiánum Vasey. (Fig. 1427.) Vernal culms 10 to $25 \mathrm{~cm}$ tall, copiously papillose-hirsute, as are sheaths and blades; ligule $1 \mathrm{~mm}$ long; blades firm, erect, 5 to $8 \mathrm{~cm}$ long, 3 to $6 \mathrm{~mm}$ wide, usually involute-acuminate; panicle 2 to $5 \mathrm{~cm}$ long; spikelets 2.7 to

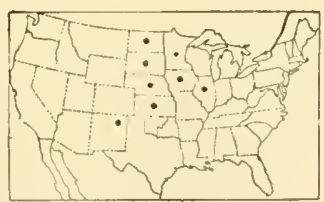

Figure 1428.-Distribution of Panicum vilcoxianum.
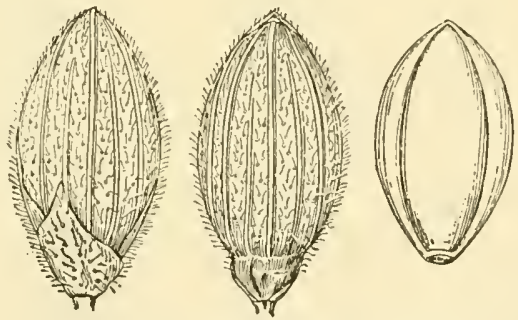

Figure 1427.-Panicum wilcoxianum. Two views of spikelet, and floret, $\times 10$. (Type.)

$3 \mathrm{~mm}$ long, papillose-pubescent. Autumnal culms branching from all the nodes, forming bushy tufts with rigid erect blades. 2! Prairies, Manitoba, and North Dakota to Illinois and Kansas; New Mexico (fig. 1428). 
90. Panicum malacophýllum Nash. (Fig. 1429.) Vernal phase velvety or velvety-pilose throughout; culms slender, 25 to $70 \mathrm{~cm}$ tall, ascending or spreading, the nodes retrorsely bearded; ligule 1 to 1.5 mm long; blades 7 to $10 \mathrm{~cm}$ long, 6 to $12 \mathrm{~mm}$ wide; panicle 3 to $7 \mathrm{~cm}$ long; spikelets 2.9 to $3 \mathrm{~mm}$ long, papillose-pilose. Autumnal phase spreading, forming bushy topheavy clumps with reduced blades. 2 - Sandy woods, Tennessee to Kansas and Texas (fig. 1430).

91. Panicum helléri Nash. (Fig. 1431.) Vernal culms 25 to 60 cm tall, ascending or spreading, appressed-pilose below, often glab-

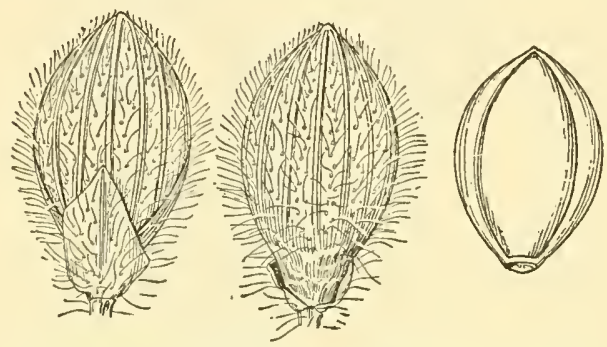

FIGURE 1429.-Panicum malacophyllum. Two views of spikelet, and floret, $\times 10$. (Type.)

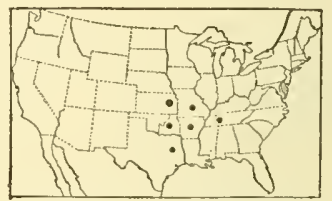

Figure 1430.-Distribution of Panicum malacophyllum.

rous above; sheaths sparsely papillose-hispid to glabrous; blades rather thin, glabrous on both surfaces or pubescent beneath, ciliate toward the base; panicle 6 to $12 \mathrm{~cm}$ long; spikelets 2.9 to $3 \mathrm{~mm}$ long, glabrous or with a few scattered hairs. Autumnal phase branching at all but the lowest nodes, forming loose sprawling tufts, the blades widely spreading, not much reduced, the long-pediceled spikelets rather conspicuous among the foliage. 21 -Open woods and prairies, Missouri and Oklahoma to Louisiana and New Mexico (fig. 1432). Closely related to $P$. scribnerianum.

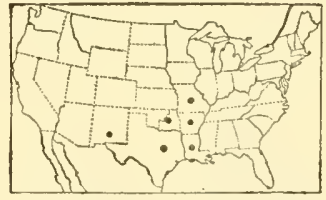

Figure 1432.--Distribution of Panicum helleri.
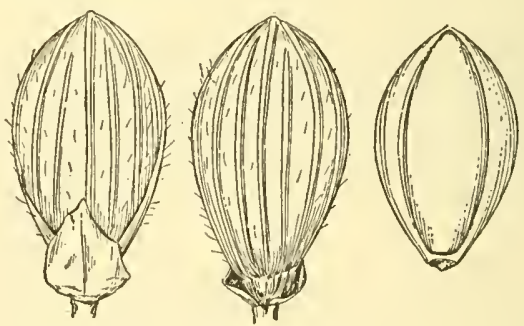

Figure 1431.-Panicum helleri. Two views of spikelet, and floret, $\times 10$. (Type.)

92. Panicum scribneriânum Nash. (Fig. 1433.) Vernal culms 20 to $50 \mathrm{~cm}$ tall, glabrous or harshly puberulent or sometimes ascending-pilose; sheaths striate, papillose-hispid to nearly glabrous; blades ascending or erect, 5 to $10 \mathrm{~cm}$ long, 6 to $12 \mathrm{~mm}$ wide, firm, rounded at the ciliate base, glabrous on the upper surface, appressed-pubescent to glabrous beneath; panicle 4 to $8 \mathrm{~cm}$ long; spikelets 3.2 to $3.3 \mathrm{~mm}$ long, obovate, blunt, sparsely pubescent to nearly glabrous. Autumnal phase branching from the middle and upper nodes. 24 -Sandy soil or dry prairies, Maine to British Columbia, south to Maryland, Tennessee, Texas, and Arizona (fig. 1434). 
93. Panicum oligosánthes Schult. (Fig. 1435.) Vernal culms 35 to $80 \mathrm{~cm}$ tall, appressed-pubescent, especially below; sheaths with ascending papillose pubescence; blades stiffly spreading or ascending, 6 to $14 \mathrm{~cm}$ long, 5 to $8 \mathrm{~mm}$ wide, glabrous or nearly so on the upper

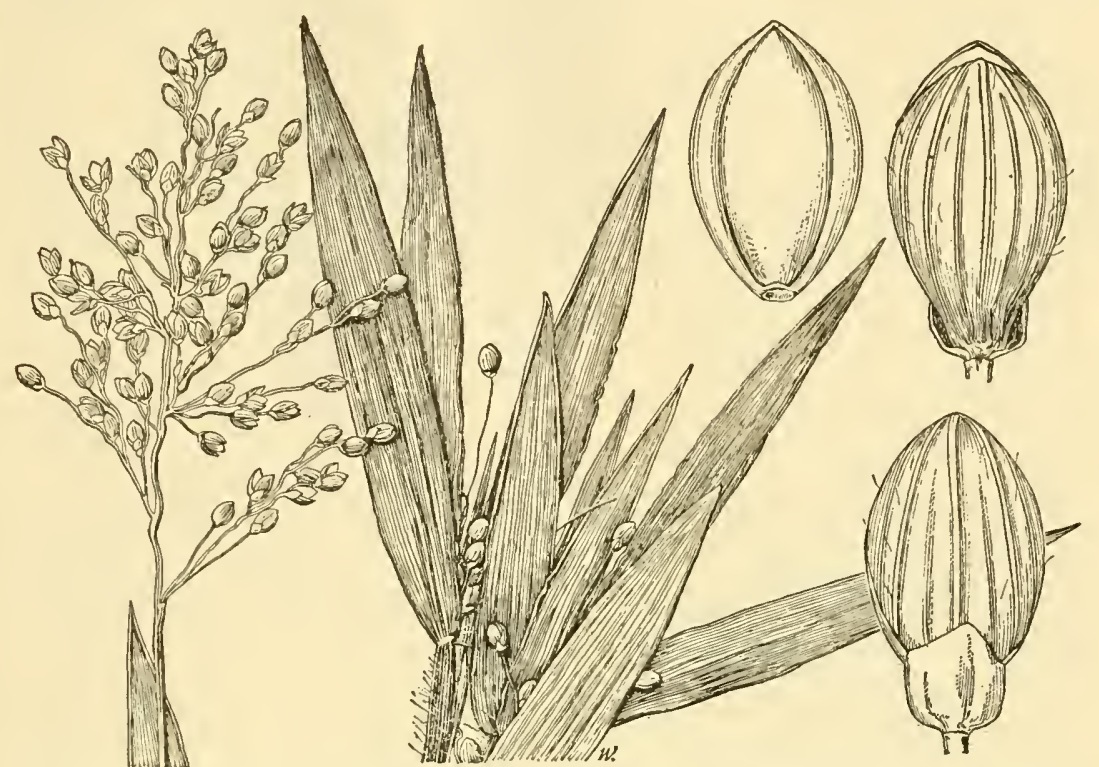

Figure 1433.-Panicum scribncrianum. Plant, $\times 1$; two views of spikelet, and floret, $\times 10$, (Vernal phase, McDonald 32, 111.; autumnal phase, Umbach 2365, Ill.)

surface, harshly puberulent beneath; panicle 6 to $12 \mathrm{~cm}$ long; spikelets long-pediceled, 3.5 to $4 \mathrm{~mm}$ long, subacute, sparsely hirsute. Autumnal phase erect to spreading, branching freely from the upper nodes. 24 - Sandy, usually moist woods, Massachusetts to Missouri, south to Florida and Texas (fig. 1436).

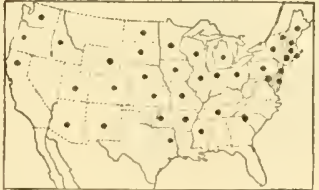

Figure 1434,-Distribution of Panicum scribnerianum.
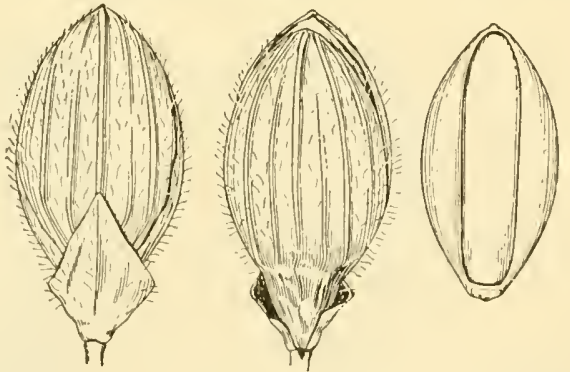

Figure 1435.-Panicum oligosanthes. Two views of spikelet, and floret, $\times 10$. (Type.)

94. Panicum ravenélii Scribn. and Merr. (Fig. 1437.) Ternal culms 30 to $70 \mathrm{~cm}$ tall, densely papillose-hirsute with ascending hairs, the nodes short-bearded; sheaths hirsute like the culm; ligule 3 to 4 $\mathrm{mm}$ long; blades thick, 8 to $15 \mathrm{~cm}$ long, 1 to $2 \mathrm{~cm}$ wide, glabrous on the upper surface, densely velvety-hirsute beneath; panicle 7 to 12 
em long; spikelets 4 to $4.3 \mathrm{~mm}$ long, sparsely papillose-pubescent. Autumnal phase more or less spreading, branching from the middle

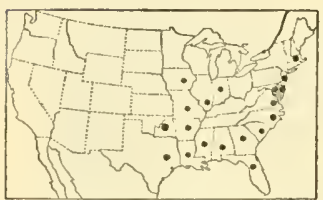

Figure 1436.-Distribution of Panicum oligosanthes.
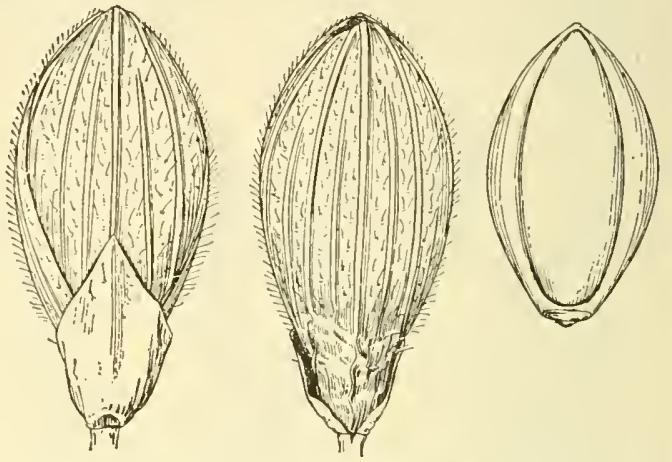

FIGURE 1437.-Panicum ravenelii. Two riews of spikelet, and floret, $\times 10$. (Type.)

and upper nodes, the short branches crowded at the summit. $\quad 4$ Sandy or gravelly woods or open ground, Delaware to Missouri, south to Florida and Texas (fig. 1438).

95. Panicum leibérgii (Vasey) Scribn. (Fig. 1439.) Vernal culms slender, 25 to $75 \mathrm{~cm}$ tall, erect from a more or less geniculate base, pilose or scabrous; sheaths papillose-hispid with spreading hairs; ligule obsolete or nearly so; blades ascending or erect, rather thin, 6 to $15 \mathrm{~cm}$ long, 7 to $15 \mathrm{~mm}$ wide, papillose-hispid on both surfaces, often sparsely so above; panicle 8 to $15 \mathrm{~cm}$ long, less than half as wide; spikelets 3.7 to $4 \mathrm{~mm}$ long, strongly papillose-hispid. Autumnal phase leaning, sparingly branching from the middle and lower nodes.

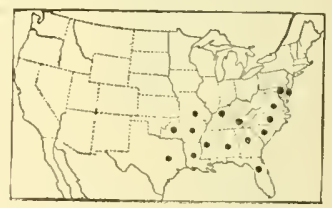

FIGURE 1438.-Distribution of Panicum ravenelii. 24 - Prairies, New York to Manitoba and North Dakota, south to Indiana and Kansas (fig. 1440).

96. Paxicum xanthophýsum A. Gray. (Fig. 1441.) Vernal phase
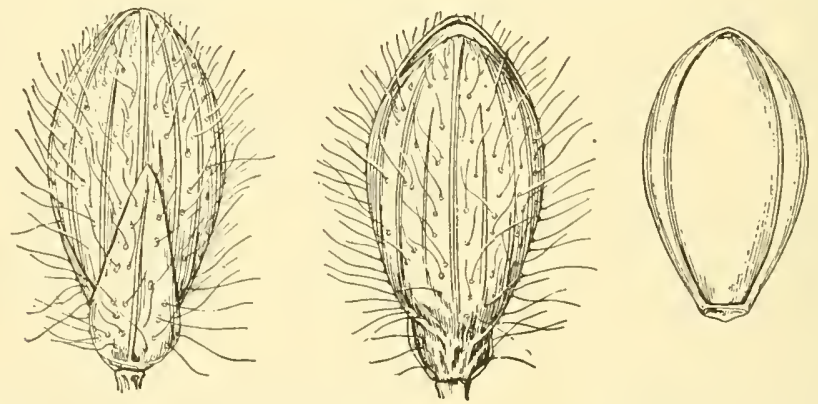

Figure 1439.-Panicum leibcrgii. Two riews of spikelet, and floret, $\times 10$. (Type.)

yellowish green; culms 20 to $55 \mathrm{~cm}$ tall, more or less scabrous; sheaths sparsely papillose-pilose; blades erect or nearly so, rather thin, prominently nerved, 10 to $15 \mathrm{~cm}$ long, 1 to $2 \mathrm{~cm}$ wide, glabrous except the ciliate base; panicle 5 to $12 \mathrm{~cm}$ long, very narrow, few-flowered, 
the stiff branches erect or nearly so; spikelets 3.7 to $4 \mathrm{~mm}$ long, blunt, pubescent. Autumnal phase erect or ascending, branching from the second and third nodes, the branches erect, mostly simple. 24 Sandy or gravelly soil, Quebec to Manitoba, south to Pennsylvania and Minnesota (fig. 1442).

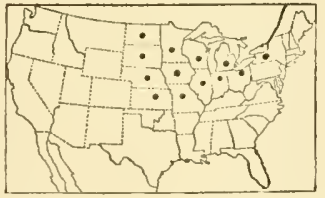

FIGURE 1440.-Distribution of Panicum leibergii.

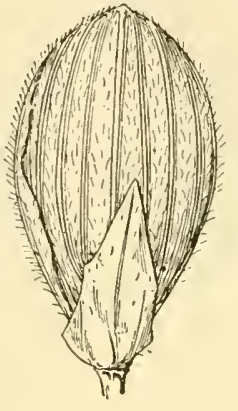

FIGUre 1441.-Panicum xanthophysum. Two viers of spikelet, and floret, $\times 10$. (Type.)

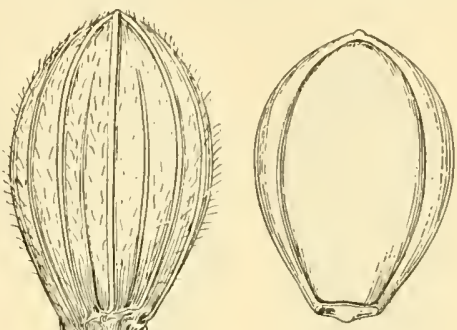

14. Pedicelláta.-Culms slender from a knotted crown; sheaths papillose-hirsute; ligules about $1 \mathrm{~mm}$ long; blades long-ciliate at least toward base; spikelets attenuate at base, 7- to 9-nerved, papillose-pubescent. Autumnal culms freely branching, the

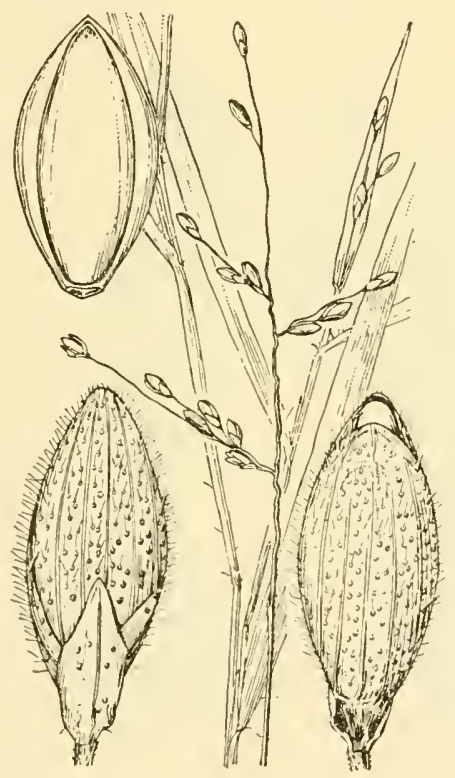

Figure 1443.-Panicum pedicellatum. Plant, $X 1$; two riews of spikelet, and floret, $\times 10$. (Heller, Tex.)

branches appearing before the matulrity of the primary panicle; no distinct winter rosette formed.

97. Panicum pedicellátum Vasey. (Fig. 1443.) Vernal culms erect or ascending, 20 to $50 \mathrm{~cm}$ tall, usually ascendinghirsute at least below; blades 5 to $9 \mathrm{~cm}$ long, 3 to $6 \mathrm{~mm}$ wide, glabrous or sometimes minutely hispid; panicle 3 to $6 \mathrm{~cm}$ long; spikelets 3.5 to $3.7 \mathrm{~mm}$ long, elliptic; first glume about half as long as the spikelet, acute, the second shorter than the fruit. Autumnal culms

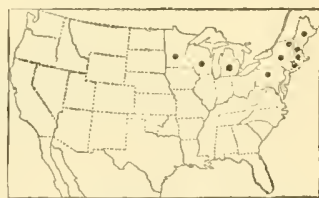

Figure 1442-Distribution of Panicum xanthophysum. erect or leaning, branching from all but the uppermost nodes, the branches spreading. 24 -Dry woods and prairies, central and southern Texas.

98. Panicum nodátum Hitche. and Chase. (Fig. 1444.) Vernal culms tufted, ascending or spreading, hard and wiry, 25 to $35 \mathrm{~cm}$ tall, fincly papillose, crisppuberulent; blades firm, ascending, 3 to $5 \mathrm{~cm}$ long, 3 to $6 \mathrm{~mm}$ wide, puberulent on both surfaces; panicle 4 to $5 \mathrm{~cm}$ long, few-flowered; spikelets $4 \mathrm{~mm}$ long, pyriform. Autumnal culms widely geniculatedecumbent, branching from all but the uppermost node, the branches somewhat divaricate, the nodes of the main culm swollen. $21-$ Oak woods in sand dunes, southern Texas and northern Mexico. 
15. Scopária.-Species of various habit, vernal culms tall; ligules $1 \mathrm{~mm}$ long or less; blades elongate, spikelets abruptly pointed, 7- to 9-nerved; autumnal culms branching from the middle or upper nodes.

99. Panicum scopárium Lam. (Fig. 1445.) Vernal phase grayish olive-green, velvety-pubescent throughout except on a viscid ring
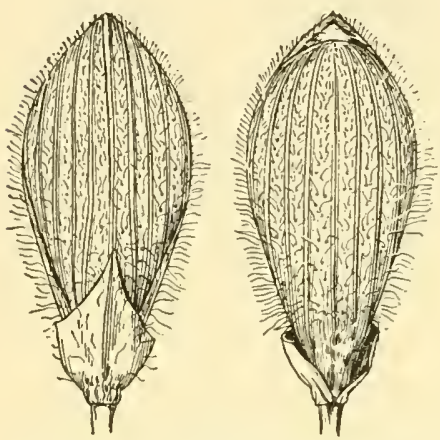

Figure 1444.-Panicum nodatum. Two views of spikelet, and floret, $\times 10$. (Type.)

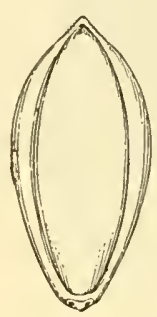

below the nodes and at the summit of the sheath; culms 80 to $130 \mathrm{~cm}$ tall, stout, erect or ascending, usually geniculate at base; blades rather thick, 12 to $20 \mathrm{~cm}$ long, 10 to $18 \mathrm{~mm}$ wide; panicle 8 to $15 \mathrm{~cm}$ long, the axis and branches with viscid blotches; spikelets 2.4 to $2.6 \mathrm{~mm}$ long, obovate, turgid, papillose-pubescent. Autumnal phase leaning or spreading, freely branching from the middle nodes, forming flabellate fascicles. 2

Wet or damp soil, Massachusetts to Florida, west through Kentucky to Missouri, Oklahoma, and Texas; Cuba (fig. 1446).

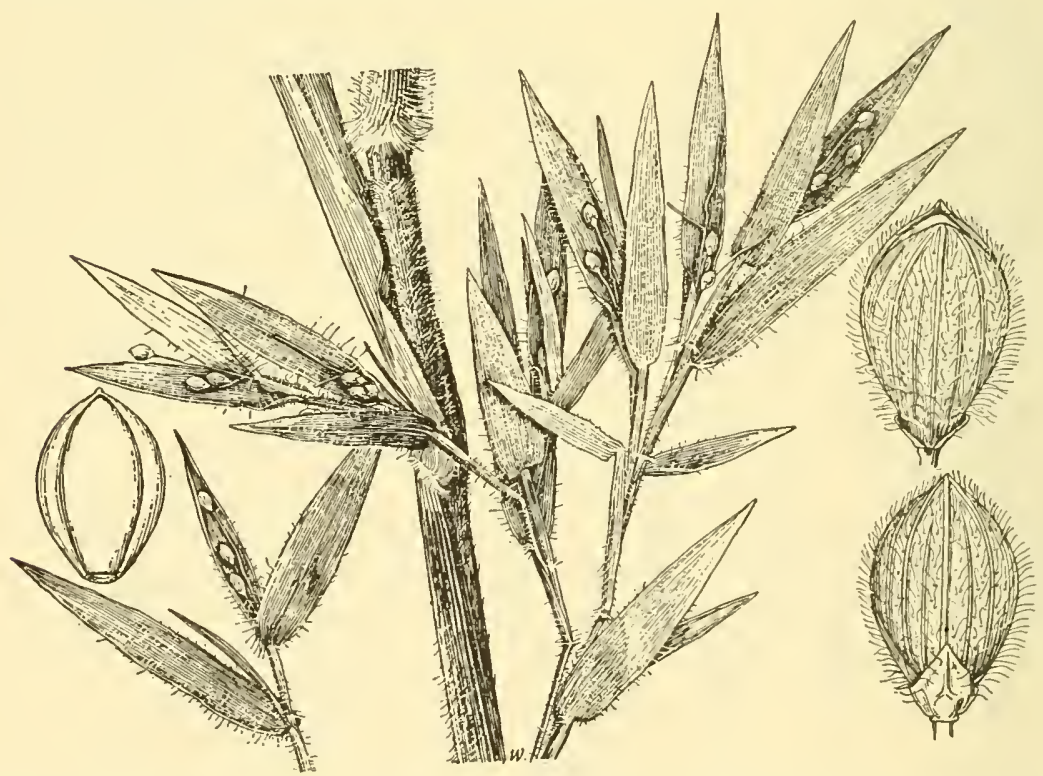

Figure 1445.-Panicum scoparium. Plant, $\times 1$; two views of spikelet, and floret, $\times 10$. (McGregor, 212 , S.C.)

100. Panicum aculeátum Hitchc. and Chase. (Fig. 1447.) Vernal culms in large clumps, slender, 70 to $100 \mathrm{~cm}$ tall, ascending, scabrous, harshly pubescent below; sheaths papillose-hispid with stiff sharppointed hairs, a puberulent ring at the summit, the uppermost usually 
glabrous; blades firm, stiffly ascending or spreading, 12 to $20 \mathrm{~cm}$ long, 9 to $13 \mathrm{~mm}$ wide, scabrous on the upper surface and toward the apex beneath; panicle 8 to $12 \mathrm{~cm}$ long, few-flowered; spikelets $3 \mathrm{~mm}$ long, elliptic, minutely pubescent, pointed beyond the fruit. Autumnal culms branching from the middle nodes, the branches more or less

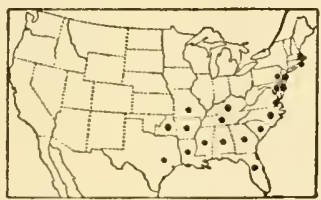

Figure 1446.-Distribution of Panicum scoparium.
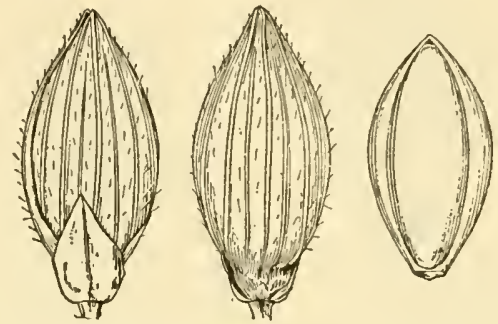

FIgURE 1447.-Panicum aculeatum. Two views of spikelet, and floret, $\times 10$. (Type.)

divaricate, the ultimate panicles wholly or partly included in the sheaths. 2| - Swampy woods, Connecticut to North Carolina, rare (fig. 1448).

101. Panicum scabriúsculum Ell. (Fig. 1449.) Vernal phase grayish olive green; culms erect, 1 to $1.5 \mathrm{~m}$ tall, scabrous at least below the nodes, sometimes puberulent; sheaths glabrous or more or less

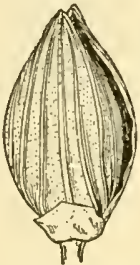
FIGURE 1449.-Panicum scabriusculum.
Two views of spikelet, and floret, $\times 10$. (Type.)

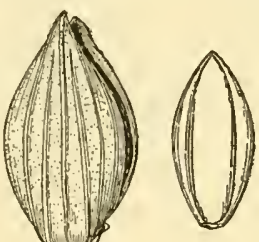

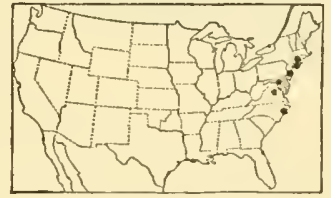

FIGURE 1448.-Distribution of Panicum aculeatum.

hispid at least toward the summit, often mottled or white-spotted, commonly swollen at the base and contracted toward the summit; blades stiffly ascending or spreading, often reflexed, 15 to $25 \mathrm{~cm}$ long, 9 to $12 \mathrm{~mm}$ wide, glabrous or scabrous, often more or less pubescent beneath, tapering to an involute point; panicle 10 to $20 \mathrm{~cm}$ long;

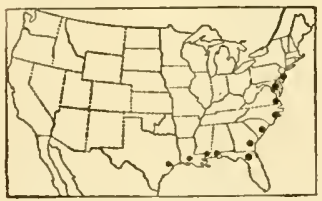

Figure 1450.-Distribution of Panicum scabriusculum. spikelets 2.3 to $2.6 \mathrm{~mm}$ long, ovate, glabrous or obscurely puberulent. Autumnal culms erect, branching from the middle and upper nodes, the branches appressed, finally forming dense oblong masses along the upper part of the primary culm, the panicles partly or entirely enclosed in the sheaths. 21-Moist ground, especially along ditches, streams, and swamps, Coastal Plain, New Jersey to Florida and Texas (fig. 1450)

102. Panicum cryptánthum Ashe. (Fig. 1451.) Vernal culms erect, 80 to $100 \mathrm{~cm}$ tall, glabrous except the usually bearded nodes; sheaths glabrous or the lowermosit sparsely hirsute, the upper somewhat inflated; blades stiff, glabrous, sparingly ciliate at base, 10 to 
$15 \mathrm{~cm}$ long, 7 to $9 \mathrm{~mm}$ wide; panicle 6 to $10 \mathrm{~cm}$ long, the axis and ascending branches viscid-spotted; spikelets 2.2 to $2.4 \mathrm{~mm}$ long, lanceolate-elliptic, pointed. Autumnal culms erect, sparingly branching from the middle nodes, the panicles partly hidden in the sheaths. 21 - Low swampy ground, New Jersey; North Carolina to Florida; Texas; rare (fig. 1452).

16. Commutáta.-Culms relatively stout, glabrous or puberulent; ligules obsolete or nearly so; blades cordate and more or less ciliate at base; spikelets elliptic, not very turgid, 7- to 9-nerved, pubescent. Autumnal culms usually rather sparingly branching.

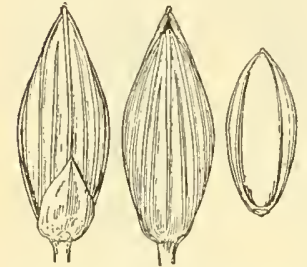

FigUre 1451.-Panicum cryp. tanthum. Two views of
spikelet, and floret, $\times 10$. spikelet,
('Type.)
103. Panicum áshei Pearson.

(Fig. 1453.) Vernal phase usually purplish, from a knotted crown; culms 25 to $50 \mathrm{~cm}$ tall, erect, stiff and wiry, densely crisp-puberulent; sheaths less densely puberulent; blades rather thick and firm, 4 to $8 \mathrm{~cm}$ long, 5 to $10 \mathrm{~mm}$ wide, glabrous; panicle 5 to 8 $\mathrm{cm}$ long, loosely flowered; spikelets 2.4 to $2.7 \mathrm{~mm}$ long. Autumnal culms

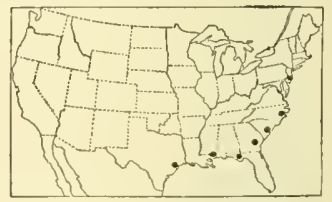

Figure 1452.-Distribution of Panicum cryptanthum.

erect or topheavy-leclining, bearing divergent branches from the middle and upper-nodes or from the upper nodes only. 24 -Dry, especially rocky woods, Massachusetts to Michigan and Missouri, south to northern Florida, Mississippi, and Olilahoma (fig. 1454).

104. Panicum commutátum Schult. (Fig. 1455.) Vernal culms 40 to $75 \mathrm{~cm}$ tall, erect; sheaths glabrous or nearly so; blades 5 to $12 \mathrm{~cm}$ long, 12 to $25 \mathrm{~mm}$ wide, glabrous on both surfaces or puberulent beneath; panicle 6 to $12 \mathrm{~cm}$ long;

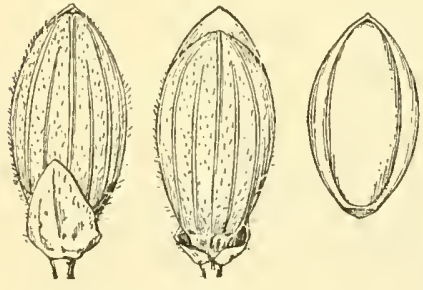
views of spikelet, and floret, $\times 10$. (Type coll.)
Figure 1453.-Panicum ashei. Two spikelets 2.6 to 2.8 $\mathrm{mm}$ long. Autumnal culms erect or leaning, branching from the middle nodes, the secondary branches crowded toward the summit. 2 -Woods and copses, Massachusetts to Michigan and Missouri, south to Florida and Texas (fig. 1456).

105. Panicum mutábile Scribn. and Smith.

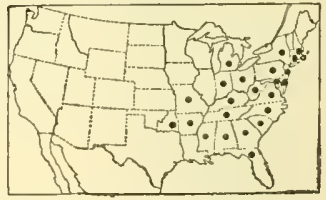

Figure 1454.-Distribution of Panicum ashei.

(Fig. 1457.) Vernal phase blue green, glaucous; culms solitary or few in a tuft, erect, 30 to $70 \mathrm{~cm}$ tall; sheaths glabrous; blades horizontally spreading, 6 to 15 $\mathrm{cm}$ long, 8 to $20 \mathrm{~mm}$ wide, tapering to both ends, glabrous, ciliate toward the cordate base or the lower ciliate nearly to apex; panicle 7 to $15 \mathrm{~cm}$ long; spikelets 2.9 to $3 \mathrm{~mm}$ long. Autumnal culms erect or reclining, sparingly branched from the middle and upper nodes. 2 -Sandy pine woods or hammocks, Coastal Plain, southeastern Virginia to Florida and Mississippi (fig. 1458).

106. Panicum joórii Vasey. (Fig. 1459.) Vernal culms 20 to $55 \mathrm{~cm}$ tall, slender, spreading or ascending from a decumbent base, at least 
the lower internodes purplish red; sheaths glabrous; blades 6 to 15 $\mathrm{cm}$ long, 7 to $18 \mathrm{~mm}$ wide, thin, of ten subfalcate, glabrous on both surfaces; panicle loosely flowered, 5 to $9 \mathrm{~cm}$ long; spikelets 3 to 3.1 $\mathrm{mm}$ long. Autumnal culms widely spreading, bearing more or less

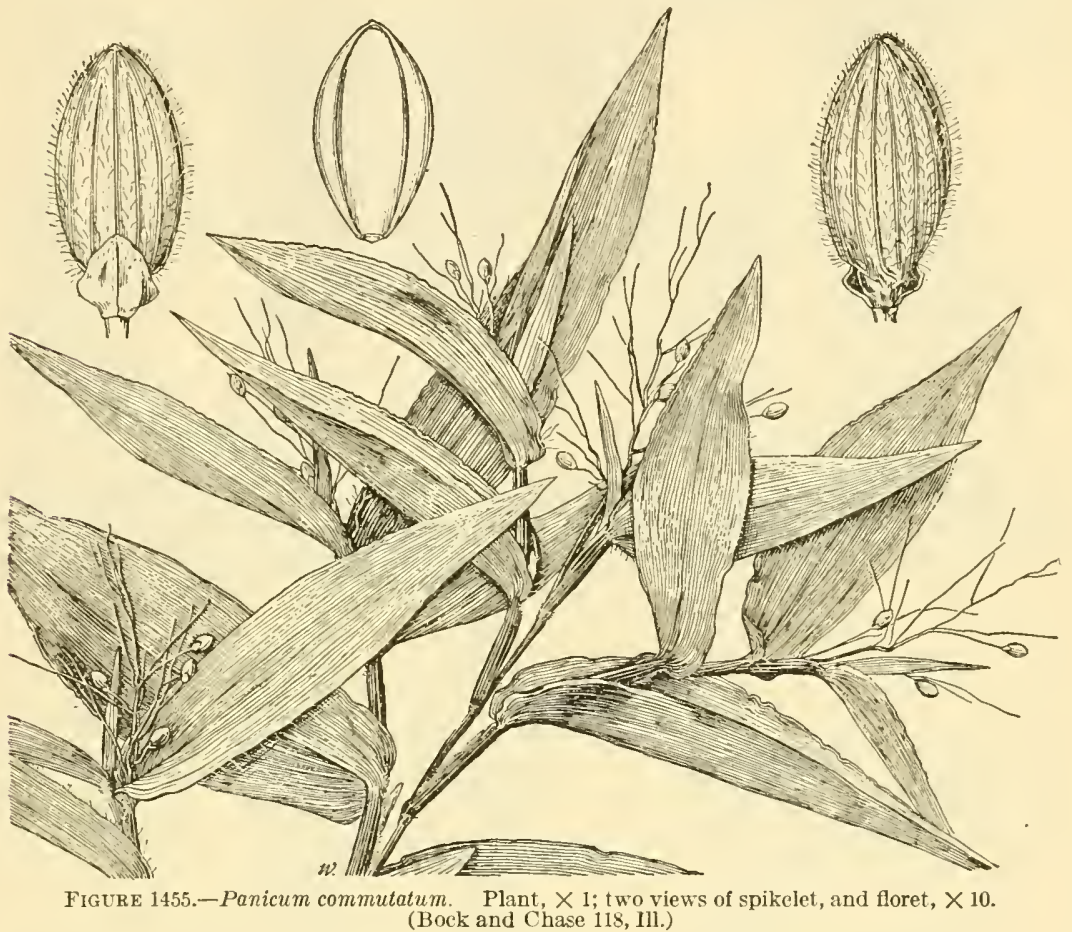

divaricate branches from all the nodes, the ultimate branches in short dense fascicles. 21 -Low or swampy woods, Coastal Plain, southeastern Virginia to Florida, west to Arkansas and Texas; Mexico (fig. 1460).

107. Panicum equilaterále Scribn. (Fig. 1461.) Vernal culms 25 to $70 \mathrm{~cm}$ tall, stiff and erect; sheaths glabrous,

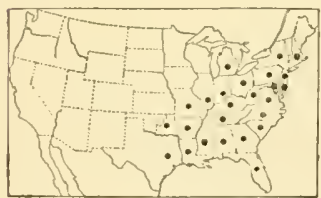

FIGURE 1456-Distribution of Panicum commutatum. the upper two often approximate; blades firm, widely spreading, 6 to $17 \mathrm{~cm}$ long, 6 to $14 \mathrm{~mm}$ wide, the margins nearly parallel, gla-
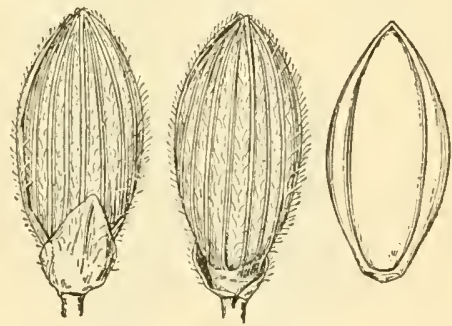

Figrre 1457 -Panicum mutabile Two riews of spikelet, and floret, $\times 10$. (Type.)

brous, often ciliate at the rounded or subcordate base; panicle 5 to $10 \mathrm{~cm}$ long; spikelets $3.2 \mathrm{~mm}$ long. Autumnal culms erect or leaning, branching from the upper and middle nodes. 24 -Pinelands, hammocks, and sandy woods, Coastal Plain, North Carolina, South Carolina, and Florida. 
17. Latifólia.-Culms rather stout, erect or suberect; ligules not more than $1 \mathrm{~mm}$ long; blades cordate, clasping; spikelets rather turgid, 7- to 9-nerved, pubescent. Autumnal phase usually rather sparingly branching.

108. Panicum clandestínum L. (Fig. 1462.) Vernal culms in large dense clumps, sometimes with strong rhizomes 5 to $10 \mathrm{~cm}$ long,

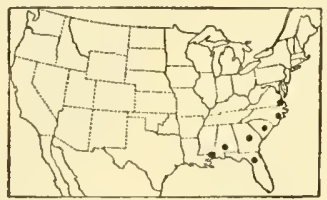

FIGURE 1458.-Distribution of Panicum mutabile.
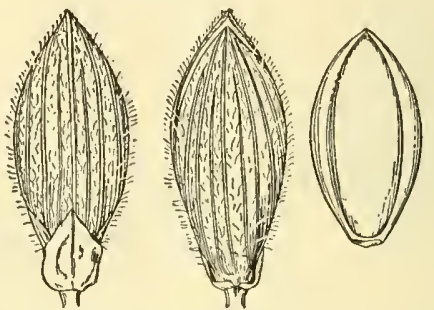

Figure 1459.-Panicum joorii. Two views of spikelet, and floret, $\times 10$ ('Type.)

70 to $150 \mathrm{~cm}$ tall, scabrous to papillose-hispid at least below the nodes; sheaths strongly papillose-hispid to nearly glabrous; blades spreading or finally reflexed, 10 to $20 \mathrm{~cm}$ long, 1.2 to $3 \mathrm{~cm}$ wide, scabrous on both

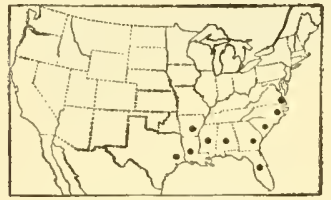

FIGURE 1460.-Distribution of Panicum joorii.
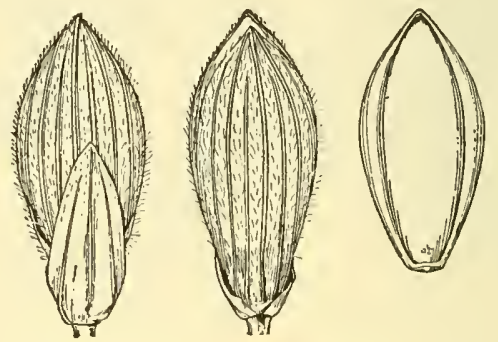

Figure 1461-Panicum equilaterale. Tw o views of spikelet, and floret, $\times 10$. (Type.)

surfaces, at least toward the end, usually ciliate at base; panicle 8 to 15 cm long; spikelets 2.7 to $3 \mathrm{~mm}$ long. Autumnal culms erect or leaning, the branches leafy, the swollen bristly sheaths overlapping and wholly or partly enclosing the panicles. 24 -Moist mostly sandy

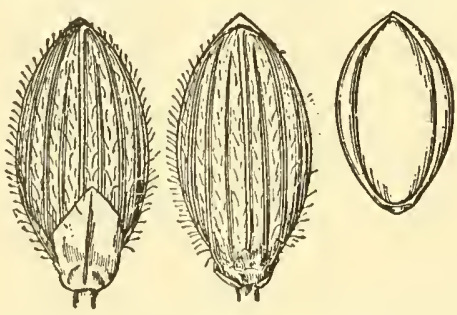

Figure 1462-Panicum clandestinum. Two views of spikelet, and floret, $\times 10$. (Torrey, N.Y.)

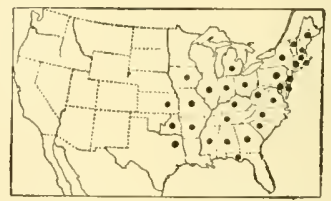

FigURE 1463.-Distribution of Panicum clandestinum.

ground, Nova Scotia and Quebec to Kansas, south to northern Florida and Texas (fig. 1463).

109. Panicum latifólium L. (Fig. 1464.) Vernal culms from a knotted crown; culms 45 to $100 \mathrm{~cm}$ tall, glabrous or the lower part 
sparsely pubescent; sheaths ciliate; blades 8 to $18 \mathrm{~cm}$ long, 1.5 to $4 \mathrm{~cm}$ wide, glabrous; panicle 7 to $15 \mathrm{~cm}$ long; spikelets 3.4 to $3.7 \mathrm{~mm}$ long. Autumnal culms more or less spreading, branching from the middle nodes, the upper leaves of the branches crowded and spread-

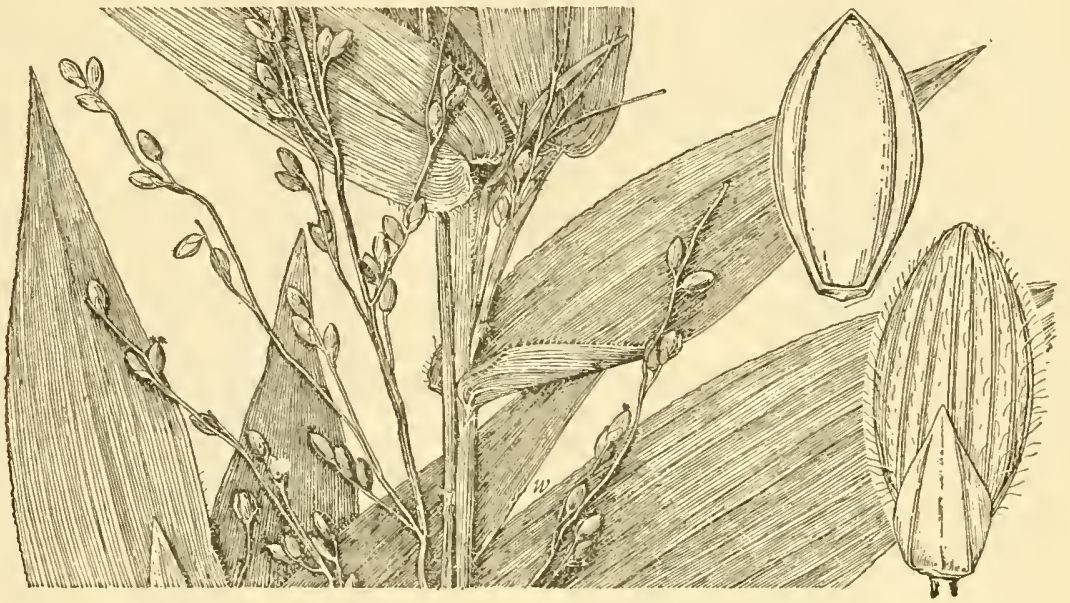

Figure 1464. - Panicum latifolium. Plant, $\times 1$; two views of spikelet, and floret, $\times 10$. (Schenck, Ill.)

ing, not much reduced. 24 -Rocky or sandy woods, Maine and Quebec to Minnesota, south to North Carolina and Kansas (fig. 1465). 110. Panicum bóscii Poir. (Fig. 1466.) Vernal phase resembling that of P. latifolium; culms 40 to $70 \mathrm{~cm}$ tall, glabrous or minutely puberulent, the nodes retrorsely bearded; sheaths glabrous or nearly

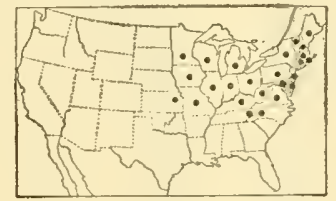

Figure 1465.-Distribution of Panicum latifolium.

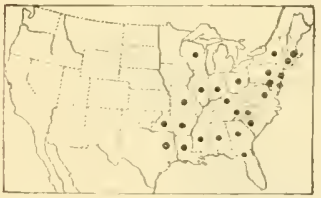

FIGURE 1467.-Distribution of Panicum boscii.
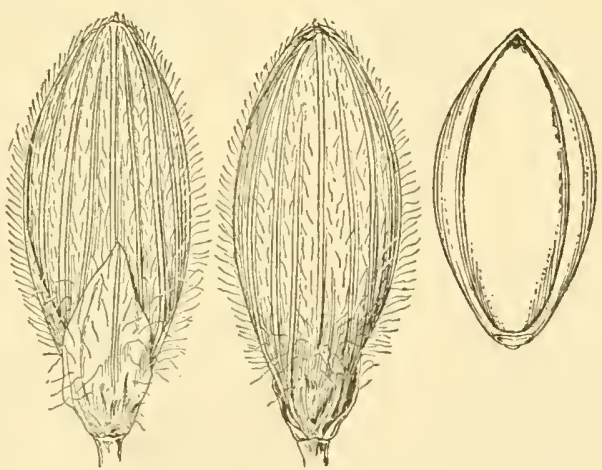

Figure 1466.-Panicum boscii. Two views of spikelet, and floret, $\times 10$. (Type.)

so; blades spreading, 7 to $12 \mathrm{~cm}$ long, 1.5 to $3 \mathrm{~cm}$ wide, sparsely ciliate at base, glabrous or nearly so; panicle 6 to $12 \mathrm{~cm}$ long; spikelets 4 to $4.5 \mathrm{~mm}$ long, about halt as wide, papillose-pubescent. Autumnal phase about as in $P$. latifolium, sometimes topheavy-reclining: 24 -Woods, Massachusetts to Wisconsin and Oklahoma, south to northern Florida and Texas (fig. 1467). PANICUM Boscil var. 


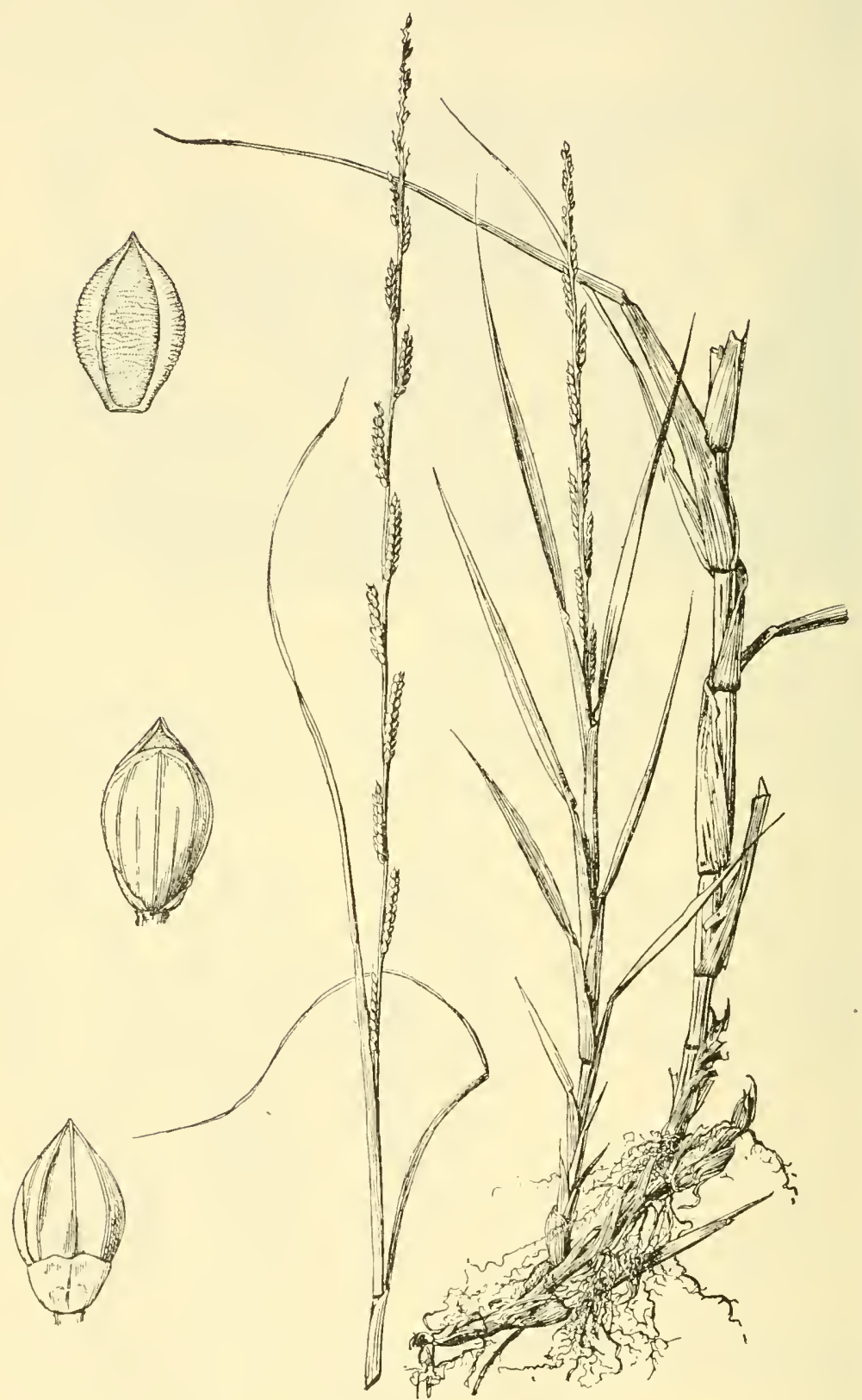

FIGURE 1468.-Panicum geminatum. Plant, $\times 1 / 2$; two views of spikelet, and floret, $\times 10$. (Tracy 9395, Fla.) 
mólle (Vasey) Hitchc. and Chase. Differing from P. boscii in the downy-villous culms and sheaths and the velvety blades. 24 About the same range as the species.

\section{Subgende 3. Eupánicom Godr.}

Spikelets in open or condensed panicles or in spikelike racemes, the branchlets not produced as bristles (the naked tip forming a short point in Geminata); not presenting vernal and autumnal phases of a distinctive character, with winter rosettes of leaves different from the culm leaves.

1. Gemináta.-Subaquatic glabrous perennials; inflorescence of several erect, spikelike racemes distant on an elongate axis; rachis ending in a short naked point; spikelets subsessile, abruptly pointed, glabrous, first glume truncate; fruit transversely rugose.

111. Panicum geminátum Forsk. (Fig. 1468.) Culms tufted, 25 to $80 \mathrm{~cm}$ tall, scarcely succulent, often decumbent at base or with stolons rooting at the nodes; blades 10 to $20 \mathrm{~cm}$ long, 3 to $6 \mathrm{~mm}$ wide, flat, or involute toward the apex; panicle 12 to $30 \mathrm{~cm}$ long, the appressed racemes 12 to 18 , the lower 2.5 to $3 \mathrm{~cm}$ long, the upper gradually shorter; spikelets 2.2 to $2.4 \mathrm{~mm}$ long, 5-nerved. 21 -Moist ground or shallow water, mostly near the coast, southern Florida, Louisiana, and Texas; warmer regions of both hemispheres.

112. Panicum paludívagum Hitchc. and Chase. (Fig. 1469.) Resembling $P$.geminatum, but the culms elongate from a long creeping rooting base, rather succulent, as much as $2 \mathrm{~m}$ long, the lower part submerged, loosely branching; blades 15 to $40 \mathrm{~cm}$ long, scabrous on the upper surface; spikelets 2.8 to $3 \mathrm{~mm}$ long, faintly 3-nerved; fruit obscurely rugose. 2 -More or less submerged in freshwater rivers and lakes, Florida, Texas; Mexico, Guatemala.

2. Purpurascéntia.-Stoloniferous robust perennial; a single species introduced.

\section{Panicum purpuráscens Raddi.}

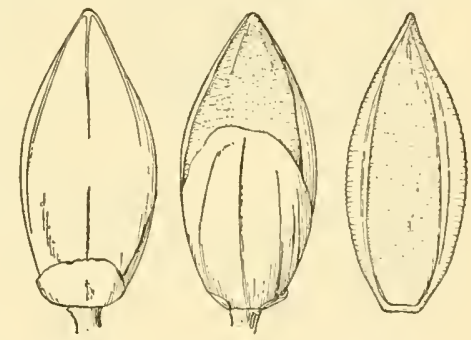

FIGURE 1469.-Panicum paıudiragum. Two views of spikelet, and floret, $\times 10$. (Type.)

PARA Grass. (Fig. 1470.) Culms decumbent and rooting at base, 2 to $5 \mathrm{~m}$ long, the nodes densely villous; sheaths villous or the upper glabrous, densely pubescent on the collar; blades 10 to $30 \mathrm{~cm}$ long, 10 to $15 \mathrm{~mm}$ wide, flat, glabrous; panicle 12 to $20 \mathrm{~cm}$ long, the rather distant subracemose densely flowered branches ascending or spreading; spikelets subsessile, $3 \mathrm{~mm}$ long, elliptic, 5-nerved, glabrous; fruit minutely transversely rugose. 24 ( $P$. barbinode Trin.)-Cultivated and waste ground in moist soil, borders of rivers, marshes, and swamps, Florida, Alabama (Mobile), Texas; Oregon (Limnton); throughout tropical America at low altitudes. Commonly cultivated in tropical America as a forage grass, being cut for green feed. It probably was introduced into Brazil at an eary date from Africa.

3. Fasciculáta.-Branching annuals; blades flat; ligules not more than

$1 \mathrm{~mm}$ long; panicles of ascending spikelike racemes along an angled axis; spikelets subsessile, abruptly pointed strongly 5- to 7-nerved; fruit transversely rugose. 


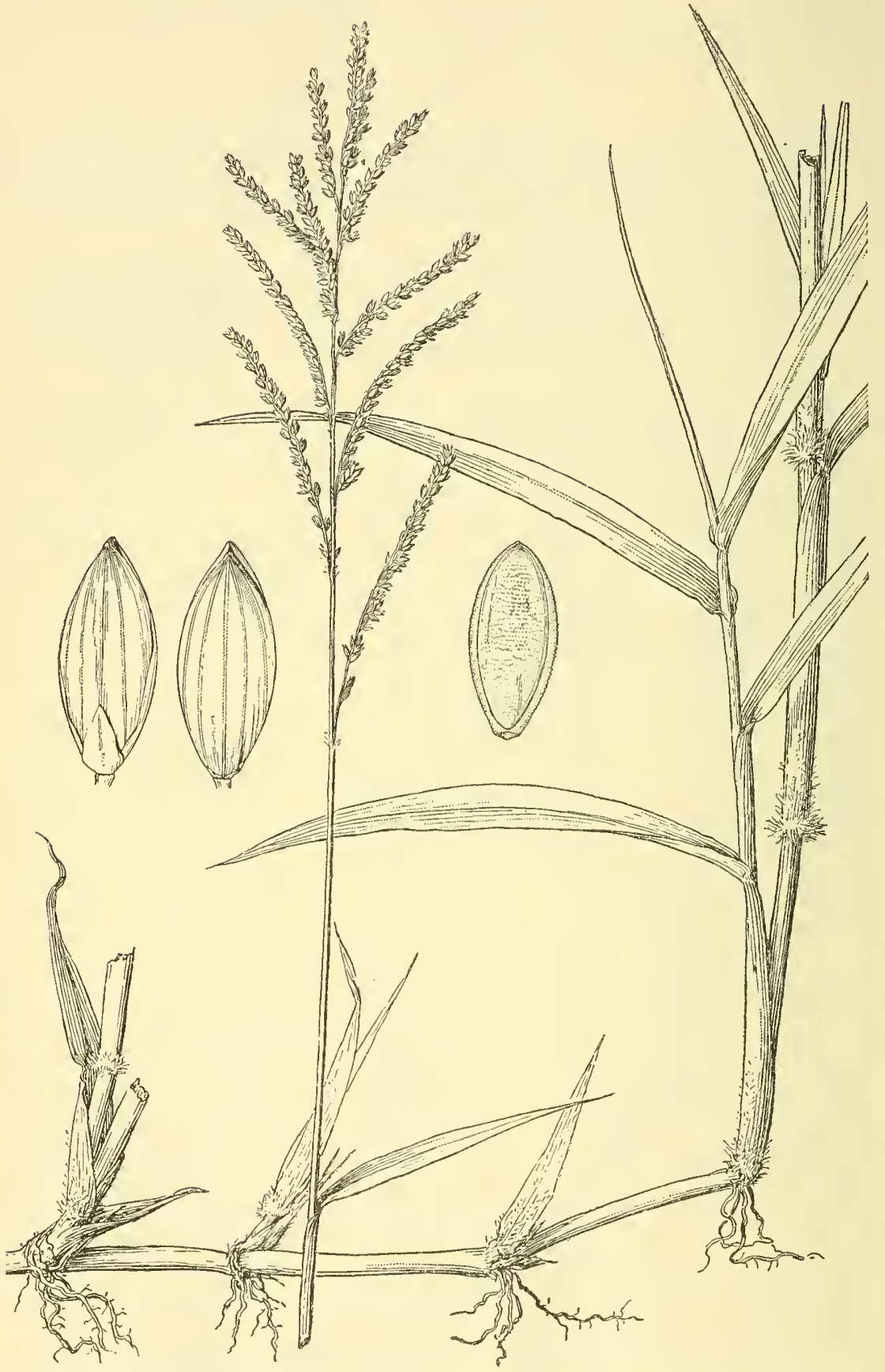

FIQURE 1470.-Panicum purpurascens. Plant, $\times 1 / 2$; two views of spikelet, and floret, $\times 10$. (Hitcheock 9693, Jamaica.) 
114. Panicum réptans L. (Fig. 1471.) Culms ascending 10 to 30 $\mathrm{cm}$ above the creeping base; blades 1.5 to $6 \mathrm{~cm}$ long, 4 to $12 \mathrm{~mm}$ wide, cordate, usually glabrous, ciliate on the undulate margin at base; pancle 2 to $6 \mathrm{~cm}$ long, the 3 to 12 ascending or spreading racemes 2

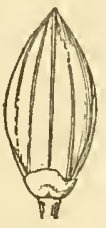

Figure 1471-Panicum reptans. Two views of spikelet, and floret, $\times 10$. (Type of $P$. prostratum Lam.)

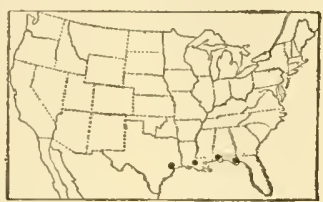

FIGURE 1472.-Distribution of Panicum reptans.

to $3 \mathrm{~cm}$ long, aggregate, the rachis usually pilose with long weak hairs; spikelets secund, about $2 \mathrm{~mm}$ long, glabrous, on pubescent pedicels about $1 \mathrm{~mm}$; first glume very short, truncate or rounded. $\odot-$ Moist open ground, or a weed in cultivated fields, Florida to Texas (fig. 1472); tropical regions of both hemispheres.

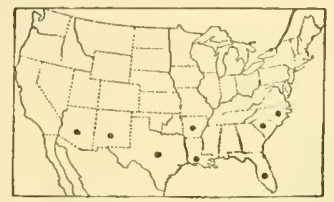

FIGURE 1474.-Distribution of Panicum fasciculatum.
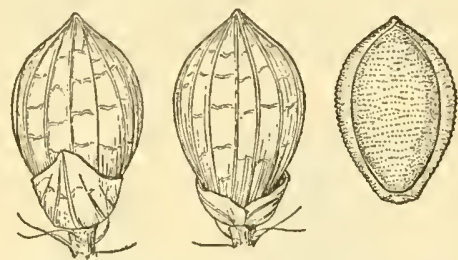

FIGURE 1473.-Panicum fasciculatum. Two views of spikelet, and floret, $\times 10$. (Type.)

115. Panicum fasciculátum Swartz. Browntop millet. (Fig. 1473.) Culms erect or spreading from a decumbent base, 30 to 100 $\mathrm{cm}$ tall, sometimes pubescent below the panicle or hispid below the appressed-pubescent nodes, the more robust freely branched from the lower nodes; sheaths glabrous to papillose-hispid; blades 4 to $30 \mathrm{~cm}$
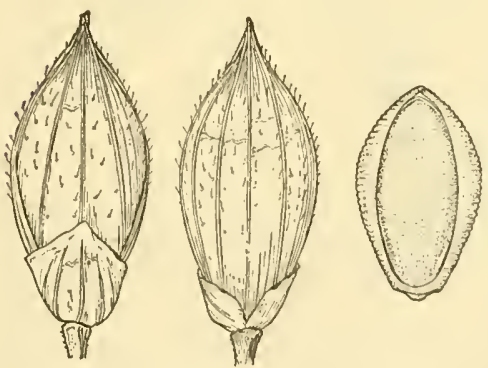

FIGURE 1475.-Panicum adspersum. 'Two views of spikelet, and floret, $X 10 . \quad$ (Type.)
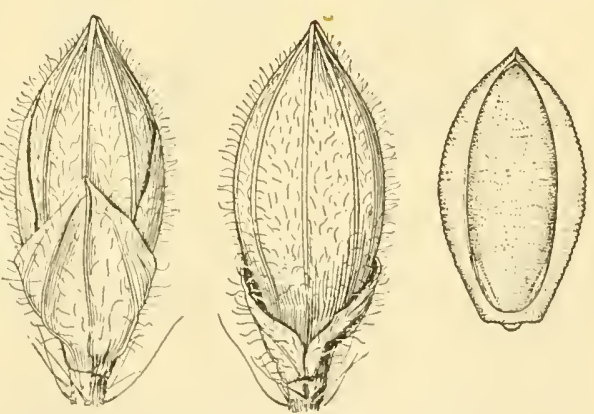

FIGURE 1476.-Panicum arizonicum. Two views of spikelet, and floret, $\times$ 10. (Palmer 159, Mex.)

long, 6 to $20 \mathrm{~mm}$ wide, glabrous; panicle 5 to $15 \mathrm{~cm}$ long; the racemes 5 to $10 \mathrm{~cm}$ long; spikelets yellow or bronze-brown, 2.1 to $2.5 \mathrm{~mm}$ long, rarely $3 \mathrm{~mm}$, obovate, turgid, glabrous, strongly transversely wrinkled 
or veined. $\odot \quad-$ Moist open ground, often a weed in fields, southern Florida, southern Texas; tropical America, at low altitudes (fig. 1474).

Panicum fasciculatum var. reticulátum (Torr.) Beal. Differing from $P$. fasciculatum in having smaller more compact panicles, narrower pubescent blades, less regular suberect racemes and larger, mostly mare yellowish spikelets 2.6 to $3 \mathrm{~mm}$ long. Many intergrades occur. $\odot$ (This has been erroneously referred to $P$. fasciculatum var.

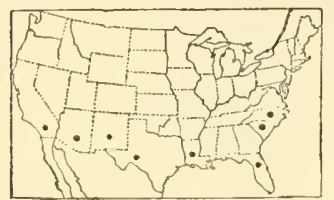

FIGURE 1477.-Distribution of Panicum arizonicum. chartaginense (Swartz) Doell.)-Prairies, fields, and waste ground, Arkansas and Louisiana to Arizona; introduced in North Carolina and South Carolina; Mexico.

116. Panicum adspérsum Trin. (Fig. 1475.) Culms ascending or spreading from a decumbent base, rooting at the lower nodes, 30 to $100 \mathrm{~cm}$ tall; blades 5 to $15 \mathrm{~cm}$ long, 8 to 20 $\mathrm{mm}$ wide; panicle 6 to $15 \mathrm{~cm}$ long, the racemes 3 to $10 \mathrm{~cm}$ long; spikelets 3.2 to $4 \mathrm{~mm}$ long, fusiform, abruptly acuminate, hispid or hispidulous, sometimes only at the summit, rarely glabrous, obscurely reticulate-veined. $\odot-$ Moist open ground, often on coral limestone, Florida; ballast, Philadelphia and Camden; Mobile; West Indies. The Florida specimens, commonly more robust than the typical form from the West Indies, bave been described as $P$. keyense Mez.
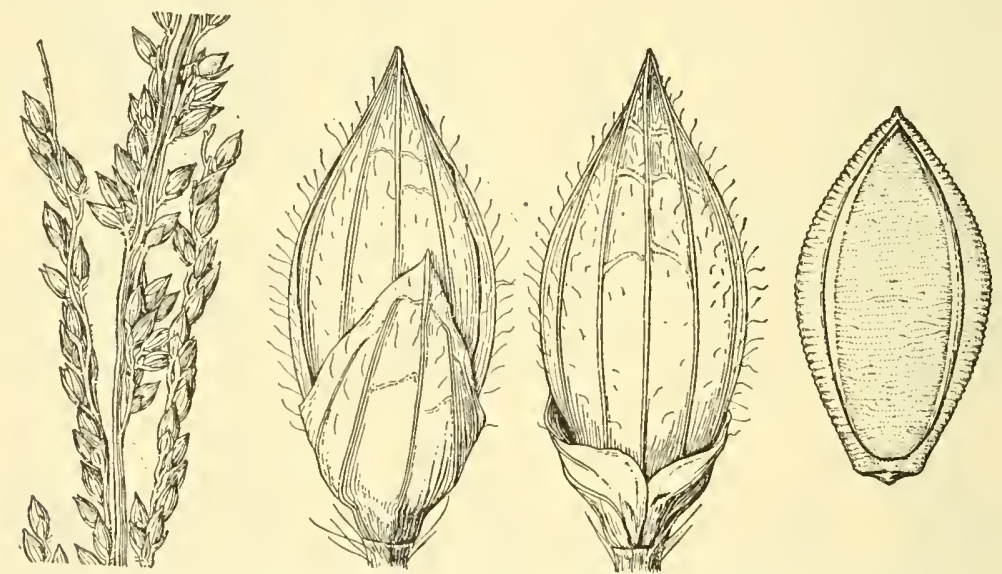

Figure 1478.-Panicum texanum. $\begin{gathered}\text { Panicle, } \times 1 \text {; two vi } \\ \text { (Hitcheock } 3187 \text {, Tex.) }\end{gathered}$

Panicum ramósum L. Resembling $P$. adspersum, but spikelets smaller, having a finely transverse rugose sterile lemma, in appearance much like the fertile lemma. $\odot$-Ballast, Alabama (Mobile); tropical Asia.

117. Panicum arizónicum Scribn. and Merr. Arizona Panicum. (Fig. 1476.) Culms erect or sometimes decumbent at base, 20 to 60 $\mathrm{cm}$ tall; sheaths glabrous to papillose-hispid; blades 5 to $15 \mathrm{~cm}$ long, 6 to $12 \mathrm{~mm}$ wide, glabrous or papillose-hispid beneath, ciliate near base; panicle 7 to $20 \mathrm{~cm}$ long, the branches rather loosely flowered, finely pubescent and papillose-hirsute; spikelets 3.5 to $3.8 \mathrm{~mm}$ long, 
obovate-elliptic, densely hirsute to glabrous. $\odot$-Open sandy or stony ground, or in cultivated soil, western Texas to southern California; introduced in North Carolina, South Carolina, Florida, and Mississippi; Mexico (fig. 1477).

118. Panicum texánum Buckl. Texas millet. (Fiğ. 1478.) Culms erect or ascending, often decumbent and rooting at the lower nodes, 50 to $150 \mathrm{~cm}$ or even to $3 \mathrm{~m}$ long, softly pubescent at least below the nodes and below the panicles; sheatlis softly pubescent, of ten papillose; blades 8 to $20 \mathrm{~cm}$ long, 7 to $15 \mathrm{~mm}$ wide, softly pubescent; panicle 8 to $20 \mathrm{~cm}$ long, the branches short, appressed, loosely flowered, the axis and rachises pubescent, with long hairs intermixed; spikelets 5 to $6 \mathrm{~mm}$ long, fusiform, pilose, often obscurely reticulate. $\odot$-Prairies and open ground, especially on low land along streams, often a weed in fields, Texas; introduced at several localities, North Carolina to Florida and Oklahoma; Arizona; northern Mexico (fig. 1479).

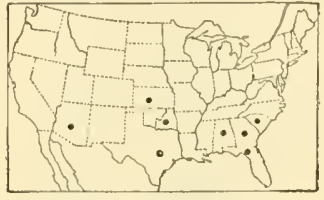

FIGURE 1479.-Distribution of Panicum texenum.

4. Dichotomiflóra.-Somewhat succulent branching annuals; blades flat, panicles many-flowered, the branchlets short and appressed along the rather stiff main branches; spikelets short-pediceled, 7-nerved, glabrous; first glume short, broad; fruit smooth and shining.

119. Panicum dichotomiflórum Michx. Fall panicum. (Fig. 1480.) Culns ascending or spreading from a geniculate base, 50 to

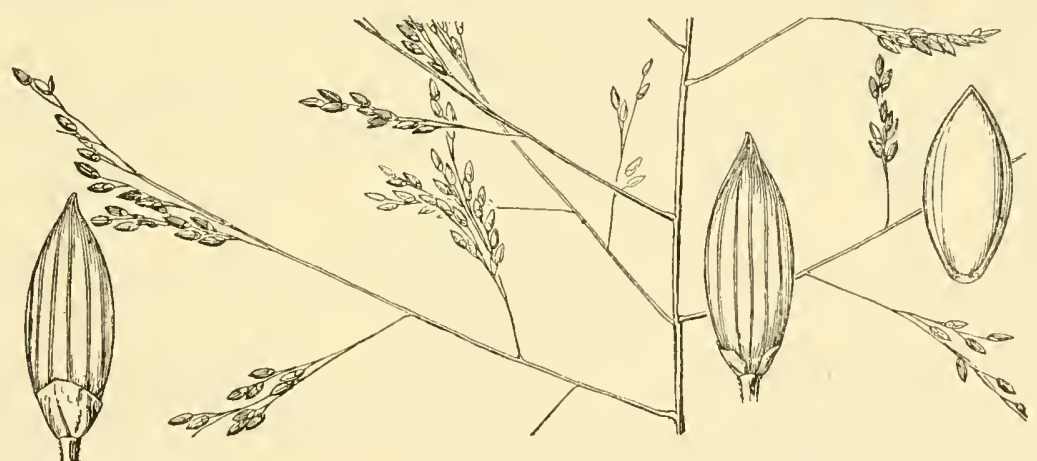

Figure 1480.- Panicum dichotomiflorum. Panicle, $\times 1$; two views of spikelet, and floret, $\times 10$. (Deam, Ind.)

$100 \mathrm{~cm}$ long, or in robust specimens as much as $2 \mathrm{~m}$ long; ligule a dense ring of white hairs 1 to $2 \mathrm{~mm}$ long; blades sometimes sparsely pilose on the upper surface, 10 to $50 \mathrm{~cm}$ long, 3 to $20 \mathrm{~mm}$ wide, the white midrib usually prominent; panicles terminal and axillary, mostly included at base, 10 to $40 \mathrm{~cm}$ long or more, the main branches ascending; spikelets narrowly oblong-ovate, usually about $2.5 \mathrm{~mm}$ long, acute. $\odot$ Moist ground, along streams, and a weed in waste places and cultivated soil, Maine to Nebraska, south to Florida and Texas, occasionally introduced further west; here and there in the West Indies (fig. 1481). Panicum Dichotomiflorum var. puritanóRuM Svenson. Differing in the shorter', more slender culms and 
looser panicles, and in the rather less pointed spikelets about $2 \mathrm{~mm}$ long. Intergrades with the species. $\odot$-Wet sandy or boggy shores of ponds, Massachusetts, Connecticut, Long Island; Indiana.

120. Panicum bartowẻnse Scribn. and Merr. (Fig. 1482). Resembling $P$. dichotomiflorum, mostly larger; culms erect, simple

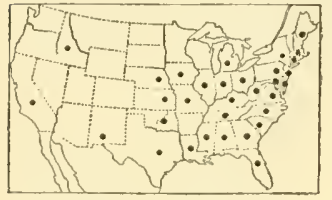

Figure 1481.-Distribution of Panicum dichotomiflorum. or sparingly branched as much as $2 \mathrm{~m}$ tall and $7 \mathrm{~mm}$ thick; sheaths papillosehispid; ligule 2 to 3 mm long. $\odot$ - Low ground often in shallow water, Florida; Bahamas.
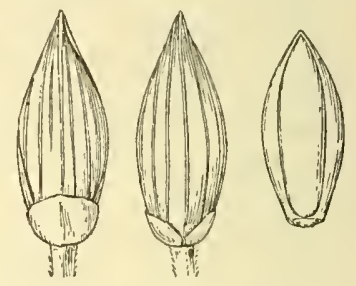

Figure 1482.-Panicum bartowense. Two views of spikelet, and floret, $\times 10$. (Type.)

5. Capillária.-Branching annuals, papillose-hispid at least on the sheaths; ligules 1 to $3 \mathrm{~mm}$ long; panicles many-flowered, mostly diffuse; spikelets pointed, 7- to 9-nerved, glabrous; first glume large, clasping; fruit smooth and shining, usually olive-brown at maturity.

121. Panicum fléxile (Gattinger) Scribn. (Fig. 1483.) Culms slender, erect, much branched from the base, 20 to $70 \mathrm{~cm}$ tall, somewhat

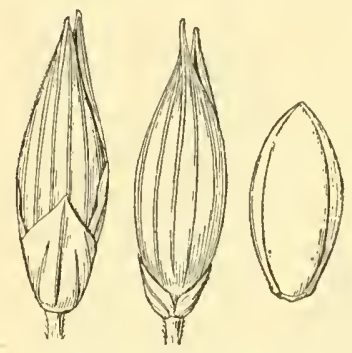

FIGURE 1483.-Panicum flexile. Two views of spikelet, and floret, $\times 10$. (Type.) hispid below, the nodes pubescent; blades erect but not stiff, glabrous or sparsely hispid, as much as $30 \mathrm{~cm}$ long, 2 to $6 \mathrm{~mm}$ wide; panicles relatively few-flowered, oblong, narrow, 10 to $20 \mathrm{~cm}$ long about onethird as wide; spikelets 3.1 to $3.5 \mathrm{~mm}$ long. $\odot$ -Sandy, mostly damp soil, meadows and open woods, New York and Quebec to South Dakota, south to Florida and Texas; introduced in

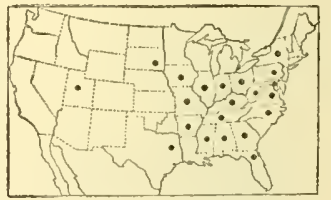

Figure 1484.-Distribution of Panicum flexile. Utah (fig. 1484).

122. Panicum gattingéri Nash. (Fig. 1485.) Culms at first erect, soon decumbent and rooting at the lower nodes, papillose-hispid, in robust specimens as much as $1 \mathrm{~m}$ long; blades 6 to $10 \mathrm{~mm}$ wide, more or less hispid or nearly glabrous; panicles numerous, terminal and axillary, oval or elliptic in outline, the terminal 10 to $15 \mathrm{~cm}$ long, the lateral smaller; spikelets $2 \mathrm{~mm}$ long. $\odot$-Open ground and waste places, often a weed in cultivated soil, New York and Ontario to Minnesota, south to North Carolina and Tennessee (fig. 1486).

123. Panicum philadélphicum Bernh. (Fig. 1487.) Plants light yellowish green; culms slender, usually erect, 15 to $50 \mathrm{~cm}$ tall, papillosehispid to nearly glabrous, more or less zigzag at base; blades usually erect, 5 to $15 \mathrm{~cm}$ long, 2 to $6 \mathrm{~mm}$ wide, rather sparsely hirsute; panicles 10 to $20 \mathrm{~cm}$ long, few-flowered, the branches solitary, rather stiffly ascending, the axillary pulvini hispid; spikelets 1.7 to $2 \mathrm{~mm}$ long, mostly in twos at the ends of the branchlets. $\odot-D r y$ open or 
sandy ground, Connecticut to Wisconsin, south to Georgia and Texas (fig. 1488).

124. Panicum tuckermáni Fernald. (Fig. 1489.) Resembling $P$. philadelphicum and intergrading with it; often spreading or prostrate and much branched at base; panicles more densely flowered, the branches more spreading, the axillary pulvini glabrous; spikelets somewhat racemosely arranged, rather than in twos at the end. $\odot \quad-$ Sandy or gravelly shores and open ground, Maine and Quebec to Connecticut and New York; Indiana, Wisconsin (fig. 1490).

125. Panicum capilláre L. Witchgrass. (Fig. 1491.) Culms erect or somewhat spreading at base, 20 to $80 \mathrm{~cm}$ tall, papillose-hispid
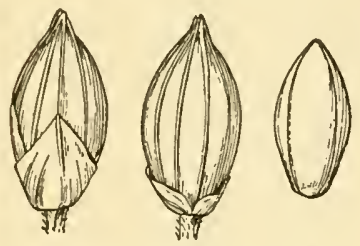

FIGURE 1485.-Panicum gattingeri. Two views of spikelet, and floret. $\times 10$. (Type.)

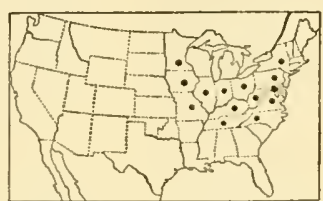

FrgURE 1486.-Distribution of Panicum gattingeri.

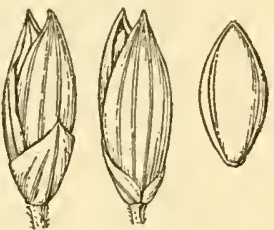

FrGURE 1487,-Panicum philadelphicum. T $\mathrm{T} 0$ views of spikelet, and floret, $\times 10$. (Type coll.)

to nearly glabrous; blades 10 to $25 \mathrm{~cm}$ long, 5 to $15 \mathrm{~mm}$ wide, hispid on both surfaces; panicles densely flowered, very diffuse, often half the length of the entire plant, included at the base until maturity, the branches finally divaricately spreading, the whole panicle breaking away and rolling before the wind; spikelets 2 to $2.5 \mathrm{~mm}$ long. $\odot-$ Open ground, fields and waste places, Maine to Montana, south to Florida and Texas, and occasionally west of this.

Panicum Capillare var. occidentále Rydb. Blades shorter, less pubescent, crowded toward the base, panicles more exserted and divaricate; spikelets usually about $3 \mathrm{~mm}$ long (2.5 to $3.3 \mathrm{~mm}$ ),

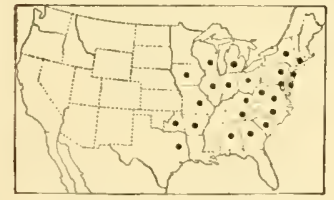

FIGURE 1488.-Distribution'of Panicum philadelphicum.

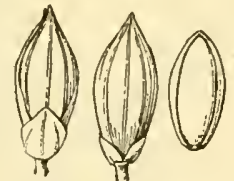

FrgURE 1489.-Panicum tuckermani. Two riews of spikelet, and floret, $\times 10$. (Type coll.)

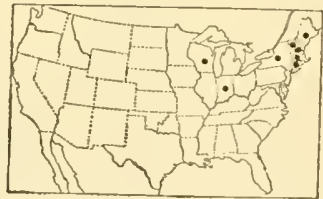

Figure 1490.-Distribution of Panicum tuckermani.

attenuate at tip; fruit 1.7 to $1.8 \mathrm{~mm}$ long. $\odot \quad$ (P. barbipulvinatum Nash.) - Open ground and waste places, Prince Edward Island and Quebec to British Columbia, south to New Jersey, Missouri, Texas, and California, more common westward.

126. Panicum hillmáni Chase. (Fig. 1492.) Resembling $P$. capillare, especially the var. occidentale, differing from this in having no short flowering branches at the base, in the stouter culms, firmer foliage, stiffer panicle branches with the lateral spikelets on shorter more appressed pedicels, in the well-developed sterile palea, and especially in the larger darker fruit $(2 \mathrm{~mm}$ long) with a prominent lunate scar at the base. $\odot \quad$-Prairies and plains, Kansas to Texas. 


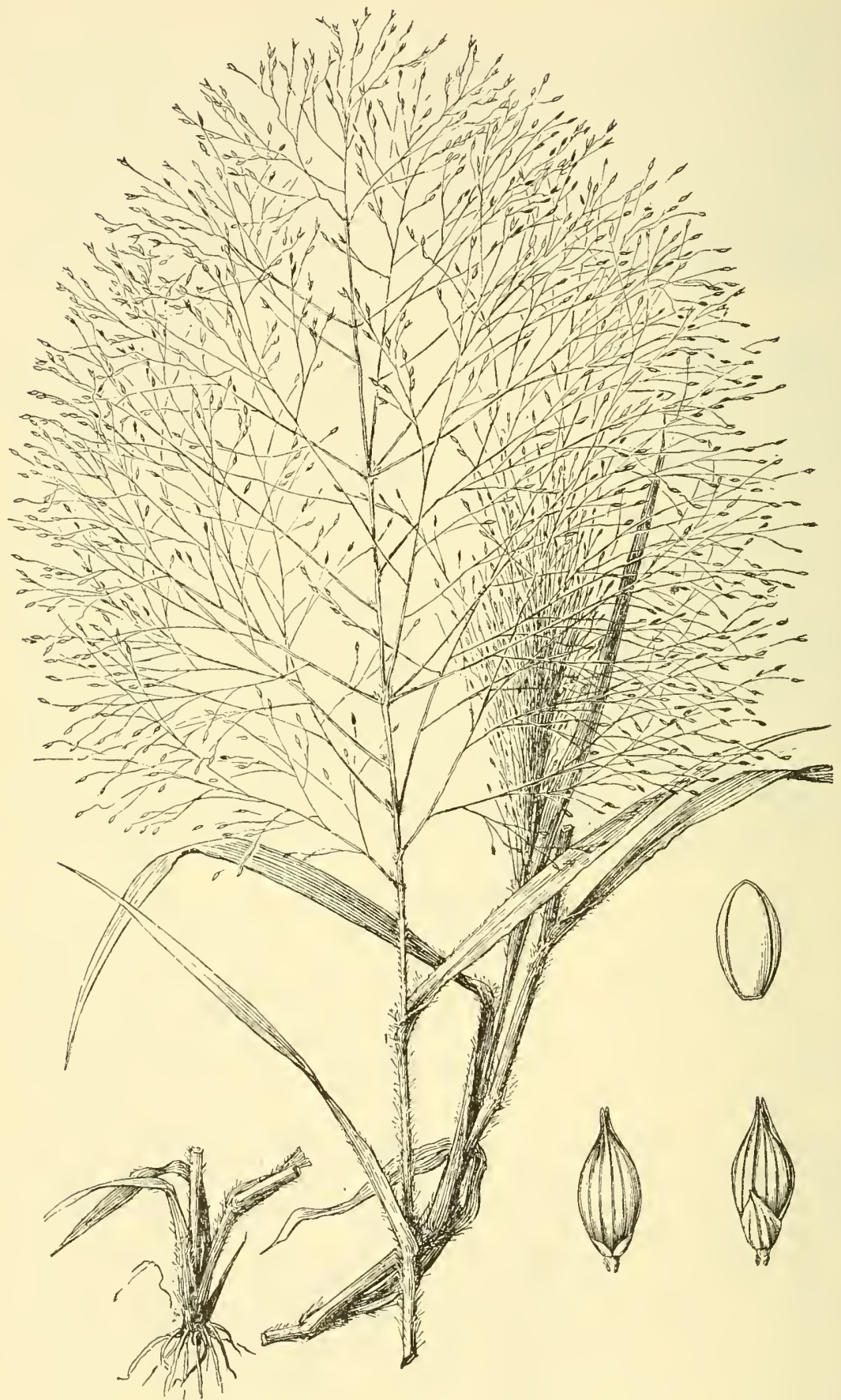

FIgURE 1491.-Panicum capillare. Plant, $\times 1 / 2 ;$ two views of spikelet, and floret, $\times 10$. (V. H. Chase 774 , Ill.) 
127. Panicum hirticaúle Presl. (Fig. 1493.) Culms usually simple or nearly so, 15 to $70 \mathrm{~cm}$ tall, papillose-hispid to nearly glabrous; blades 5 to $15 \mathrm{~cm}$ long, 4 to $13 \mathrm{~mm}$ wide, often cordate at base, sparsely hispid or nearly glabrous, ciliate toward base; panicles 5 to $15 \mathrm{~cm}$ long, scarcely one-third the entire height of the plant; spikelets 2.7 to $3.3 \mathrm{~mm}$ long, lanceolate-fusiform, acuminate, usually
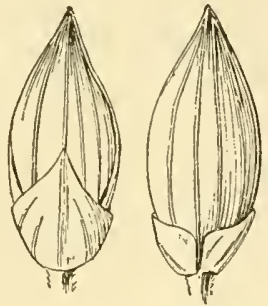

FIGURE 1492 -Panicum hillmani. Two views of spikelet, and floret, $\times 10$. (Type.)

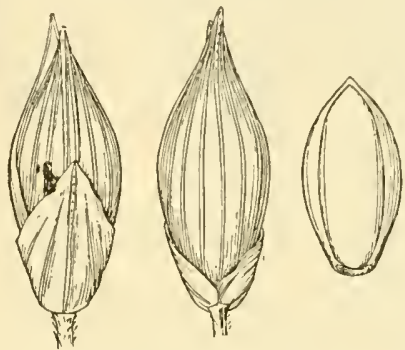

FIf U RE 1493.-Panicum hirticaule. Two views of spikelet, and floret, $\times 10$. (Type.)

reddish brown; first ghume half to three-fourths the length of the spikelet; fruit $2 \mathrm{~mm}$ long. $\odot \quad$-Rocky or sandy soil, Arkansas and western Texas to southern California; Mexico to Colombia (fig. 1494).

128. Panicum pampinósum Hitchc. and Chase. (Fig. 1495.) Resembling $P$. hirticaule, but freely branching; spikelets very turgid, about $4 \mathrm{~mm}$ long; first glume more than three-fourths the length of the spikelet; fruit $2.2 \mathrm{~mm}$ long. $\odot$-Mesas, New Mexico and Arizona; Mexico.

129. Panicum stramíneum Hitchc. and Chase. (Fig. 1496.) Resembling $P$.hirticaule, but freely branching and nearly glabrous throughout; blades longer; spikelets more turgid, less pointed, 3.2 to $3.7 \mathrm{~mm}$ long, the first glume about one-third the length of the spikelet; fruit $2.2 \mathrm{~mm}$ long, with

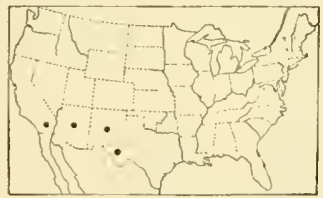

FIGURE 1494-Distribution of Panicum hirticaule.

a prominent lunate scar at base. $\odot \quad$-Rich bottom lands and damp soil, southern Arizona; northwestern Mexico.

\section{Panicum} miliáceum L.

BROOMCORN MILLET. (Fig. 1497.) Culms stout, erect or decumbent at base, 20 to $100 \mathrm{~cm}$ tall; blades more

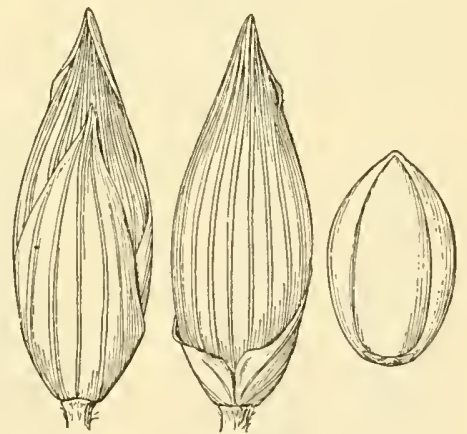

FIGURE 1495.-Panicum pampinosum. Two views of suikelet, and floret, $\times 10$. (Type.)

or less pilose on both surfaces or glabrate, as much as $30 \mathrm{~cm}$ long and $2 \mathrm{~cm}$ wide, rounded at base; panicles usually more or less included at base, 10 to $30 \mathrm{~cm}$ long, usually nodding, rather compact, the numerous branches ascending, very scabrous, spikelet-bearing toward the ends; spikelets 4.5 to $5 \mathrm{~mm}$ long, ovate, acuminate, strongly many-nerved; fruit $3 \mathrm{~mm}$ long, stramineous to reddish 
brown. $\odot$-Waste places, introduced or escaped from cultiva-
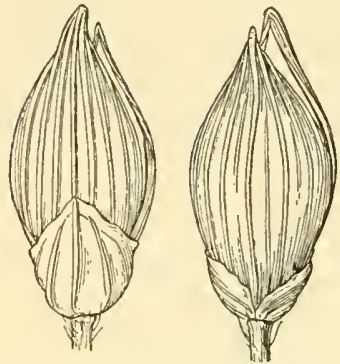

Fliure 1496.-Panicum stramineum. Two views of spikelet, and floret, $\times 10$. (Type.) tion, Northeastern States and occasional in other parts of the United States (fig. 1498); temperate parts of the Old World. Broomcorn millet is cultivated in the cooler parts of the United States to a limited extent for forage and occasionally the seed is used for feed for hogs, hence it is sometimes known as hog millet. Also called proso. Commonly cultivated in Europe and western Asia.

6. Diffúsa.-Perennials; culms stiff, mostly tufted; sheaths mostly hirsute; ligules membranaceous, ciliate; spikelets pointed, 7 - to 9 -nerved, glabrous; fruit smooth and shining.

131. Panicum capillarioídes Vasey. (Fig. 1499.) Culms erect or ascending from a knot-

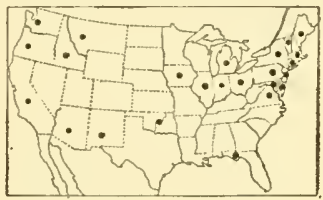

FIGURE 1498.-Distribution of Panicum miliaceum.

ted crown, 30 to $55 \mathrm{~cm}$ tall, appressed-pubescent or glabrate, the nodes densely ascendingpubescent; blades rather
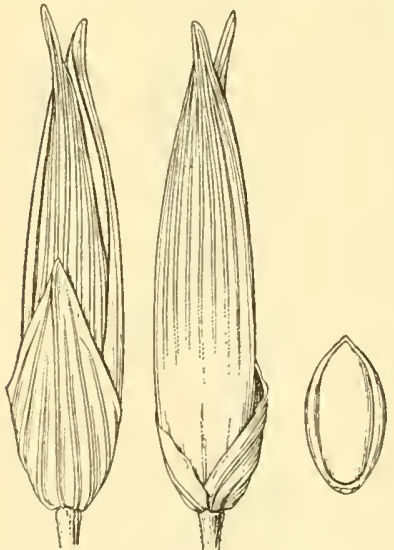

Figure 1499.-Panicum capillarioides. Two views of spikelet, and floret. $\times 10$. (Type.)
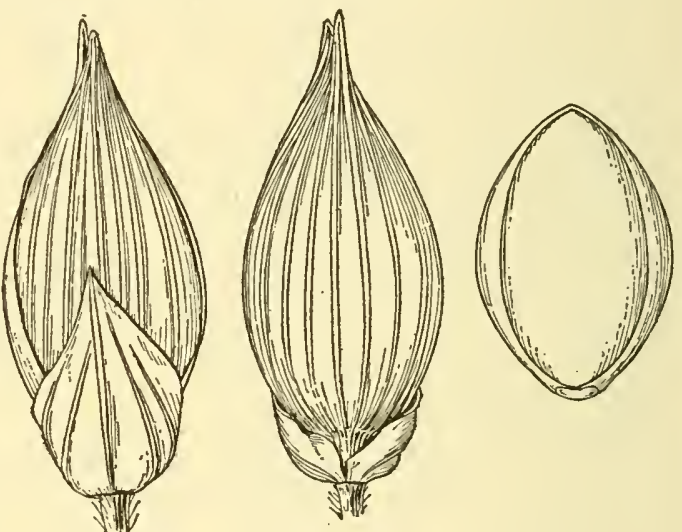

FIgURE 1497.-Panicum miliaceum. 'Two views of spikelet, and floret, $\times 10$. (Griffith 6490, India.)

stiff, 10 to $30 \mathrm{~cm}$ long, 2 to $10 \mathrm{~mm}$ wide, flat, harshly papillose-pubescent; panicle diffuse, few-flowered, 10 to $20 \mathrm{~cm}$ long, the capillary branches stiffly spreading at maturity; spikelets 5 to $6 \mathrm{~cm}$ long, lanceolate, longacuminate, fruit 1.6 to $1.8 \mathrm{~mm}$ long. 2 -Prairies and plains, Texas and northern Mexico.

Panicum bérgii Arech. Tufted, with numerous
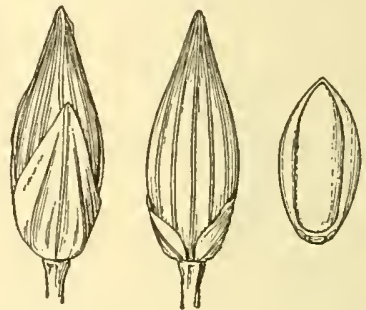

leaves clustered at base; sheaths hispid; blades involute; panicle very diffuse, a third or more the entire height of the plant, the lower branches verticillate, conspicuously pilose in the axils; spikelets 
short-pointed, 2.2 to $2.6 \mathrm{~mm}$ long. 4 -Ballast at Mobile, Ala., and at a few points in southeastern Texas. Adventive from South America.

132. Panicum fílipes Scribn. (Fig. 1500.) Culms 30 to $80 \mathrm{~cm}$ tall, erect or ascending; blades laxly ascending or spreading, 10 to $25 \mathrm{~cm}$ long, 3 to $8 \mathrm{~mm}$ wide, flat, glaucous, glabrous or sometimes sparsely hirsute beneath; panicles 7 to $25 \mathrm{~cm}$ long, usually equaled or exceeded by the upper blades, the distant branches spreading; spikelets 2 to $2.6 \mathrm{~mm}$ long. 2 - Low open ground or among chaparral, Louisiana (Shreveport) and Texas; northeastern Mexico. Distinguished from $P$. hallii by the longer blades, looser panicle, and smaller spikelets.

133. Panicum hâllii Vasey. Hall's Panicum. (Fig. 1501.) Somewhat glaucous green, leaves usually crowded toward the base, the blades curling like shavings with age; culms erect, 15 to $60 \mathrm{~cm}$ tall; sheaths sparsely papillose-hispid to glabrous; blades erect or nearly so, flat, 4 to $15 \mathrm{~cm}$ long, 2 to $6 \mathrm{~mm}$ wide, sparsely ciliate toward base, otherwise glabrous or nearly so; panicle 6 to $20 \mathrm{~cm}$

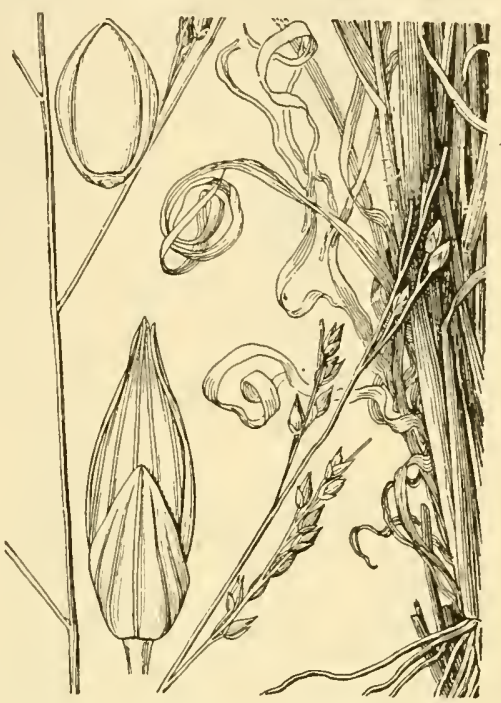

FIgURE 1501.-Panicum hallii. Plant, $\times 1$; two views of spikelet, and floret, $\times 10$. (Tspe.) long, the few branches stiffly ascending; spikelets 3 to $3.7 \mathrm{~mm}$ long. 21 -Dry prairie, rocky and gravelly hills and canyons, and in bottom lands and irrigated fields, Texas to Arizona; Mexico.
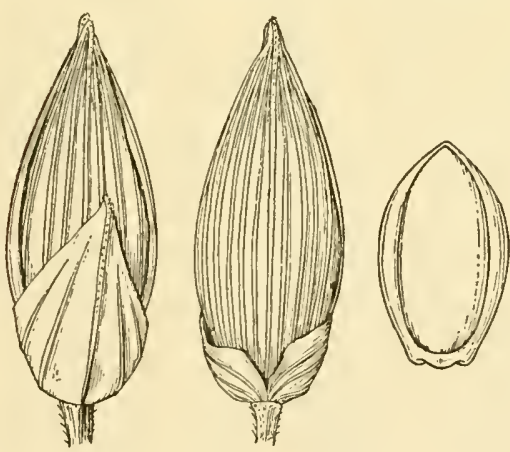

FIgURE 1502.-Panicum lepidulum. Two views of spikelet, and floret, $\times 10$. (Type.)

134. Panicum lepídulum Hitchc. and Chase. (Fig. 1502.) Culms 25 to $70 \mathrm{~cm}$ tall, erect, usually sparingly branching from lower nodes, sparsely pilose to scabrous; blades suberect, 7 to $30 \mathrm{~cm}$ long, 5 to 10 $\mathrm{mm}$ wide, sparsely papillose-pilose to nearly glabrous; panicle 7 to 20 cm long, usually scarcely half as wide, branches ascending with short spreading branchlets with 1 to 3 spikelets; spikelets 4 to $4.2 \mathrm{~mm}$ long, turgid. 21 -Moist places mostly in the uplands, New Mexico, Arizona, and Mexico.

135. Panicum ghiesbréghtii

Fourn. (Fig. 1503.) Culms erect, rather robust, ascending-hirsute, 60 to $80 \mathrm{~cm}$ tall, the nodes densely hirsute; blades as much as $60 \mathrm{~cm}$ long and $12 \mathrm{~mm}$ wide, flat, papillose-hirsute to glabrescent; panicles 20 to $30 \mathrm{~cm}$ long, usually less than half as wide, the branches ascending,

$55974^{\circ}-35-43$ 
naked at base, the branchlets more or less appressed; spikelets 3 mm long, $1 \mathrm{~mm}$ wide. 24 -Low moist ground, southern Texas; tropical America.

136. Panicum hirsútum Swartz. (Fig. 1504.) Culms robust, erect, as much as $1.5 \mathrm{~m}$ tall and $1 \mathrm{~cm}$ thick, simple or branched at base only; nodes appressed-pubescent; sheaths papillose-hirsute, the hairs stiff, spreading, fragile, causing mechanical irritation to the skin when handled; blades flat, as much as $60 \mathrm{~cm}$ long and $3.5 \mathrm{~cm}$ wide, glabrous; panicle 20 to $35 \mathrm{~cm}$ long, at first condensed, finally open, the branches

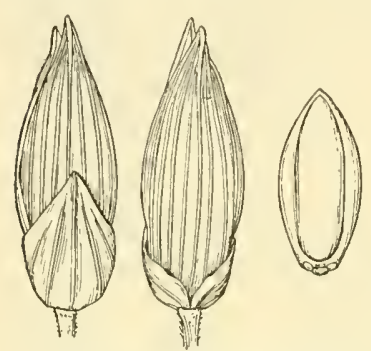

FIGURE 1503.-Panicum ghies. breghtii. Two views of spikelet, and floret, $\times 10$. (Type.) ascending; spikelets 2 to $2.2 \mathrm{~mm}$ long. 24 -Open moist ground, southern Texas; tropical America at low altitudes.

7. Máxima.-Tall robust perennials; ligules membranaceous, ciliate; blades linear, flat; panicles large, many-flowered; spikelets ellipsoid, faintly nerved, glabrous; fruit transversely rugose.

137. Panicum máximum Jacq. Guinea Grass. (Fig. 1505.) Plants light green, in large bunches from short stout rhizomes; culms mostly erect, the nodes usually densely hirsute; sheaths papillose-hirsute to glabrous, usually densely pubescent on the collar; ligule 4 to $6 \mathrm{~mm}$ long; blades 30 to $75 \mathrm{~cm}$ long, as much as $3.5 \mathrm{~cm}$ wide, glabrous, very scabrous on the margins, sometimes hirsute on the upper surface near the base; panicles 20 to $50 \mathrm{~cm}$ long, about one-third as wide, the long rather stiff branches ascending, naked at base, the lower in whorls, the axils pilose, the branchlets short, appressed, bearing more or less clustered short-pediceled spikelets; spikelets 3 to $3.3 \mathrm{~mm}$ long; first glume about one-third the length of the spikelet. 24-Fields and waste places, southern Florida, and southern Texas, introduced from Africa; tropical regions of both hemispheres at low altitudes. Guinea grass is the most important cultivated forage grass of tropical America. It grows in moderately dry ground and can be used for pasture or for soiling. Much of the green feed cut for forage is this species.

138. Panicum plénum Hitche. and Chase. (Fig. 1506.) Plants mostly in large clumps, mostly glaucous, from a stout rhizome; culms

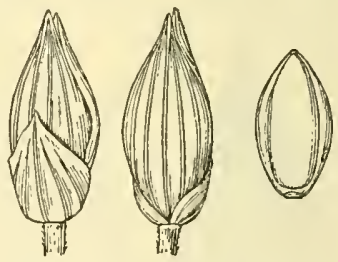

FIGURE 1504.-Panicum hirsutum. Two views of spikelet, and floret, $\times 10$. (Type.) 1 to $2 \mathrm{~m}$ tall, erect from a usually decumbent base, compressed; sheaths glabrous, somewhat keeled; blades 20 to $35 \mathrm{~cm}$ long, 7 to 17 $\mathrm{mm}$ wide, glabrous or nearly so; panicle 20 to $50 \mathrm{~cm}$ long, open; spikelets 3 to $3.4 \mathrm{~mm}$ long. 21 -Moist places in rocky hills and canyons, Texas to Arizona; Mexico. Differs from $P$. bulbosum in the absence of the basal corm.

139. Panicum bulbósum H.B.K. Bulb Panicum. (Fig. 1507.) Culms in tufts, 1 to $2 \mathrm{~m}$ tall, erect, the lowest internode thickened to a hard cormlike base 1 to $2 \mathrm{~cm}$ thick, budding at base, some- 


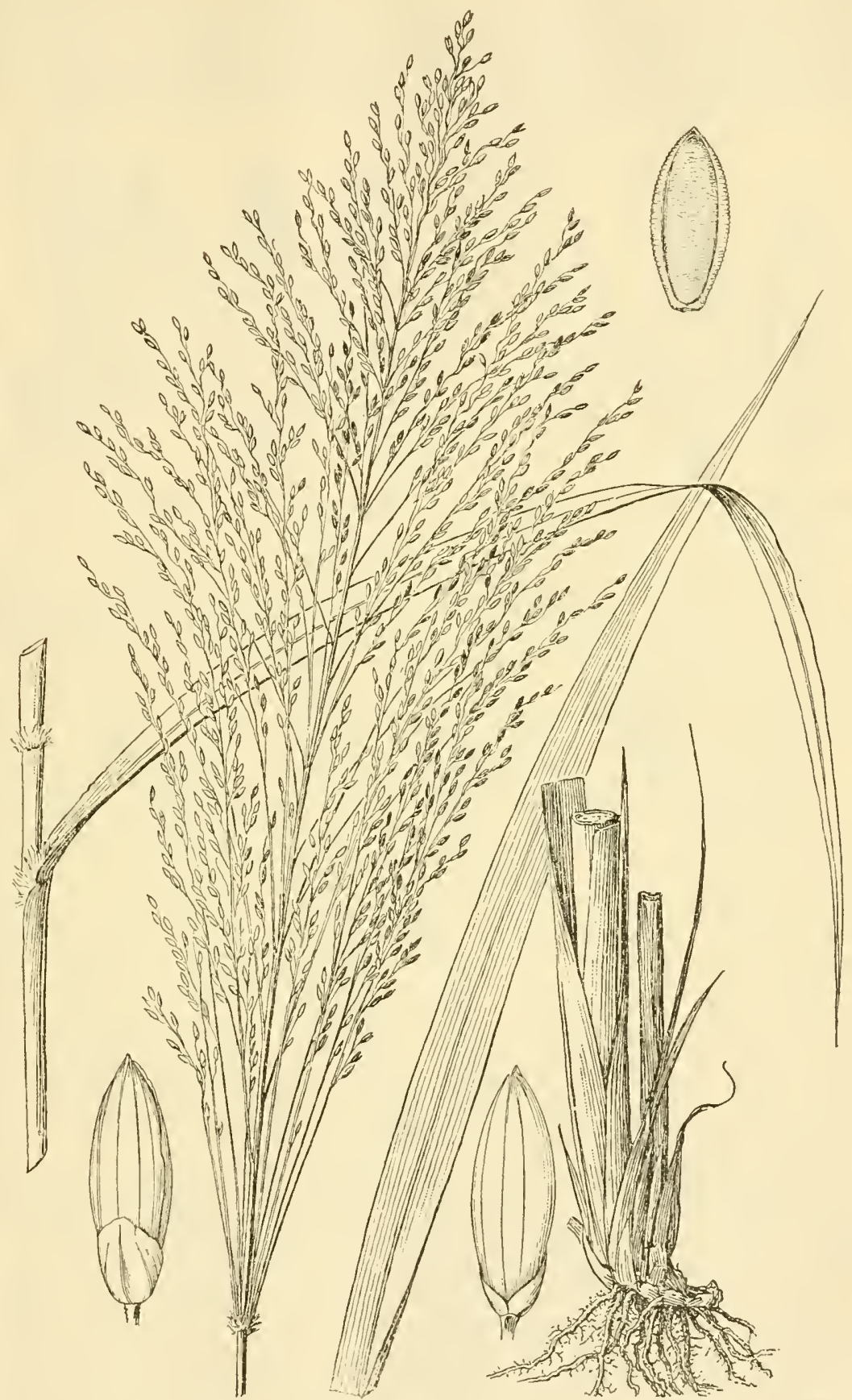

Figdre 1505.-Panicum maximum. Plant, $\times \frac{1}{2}$; two views of spikelet, and floret, $\times 10$. (Combs and Baker 1170, Fla.) 
times with one or more corms of previous years attached; sheaths glabrous, or pilose toward the summit; blades 25 to $60 \mathrm{~cm}$ long, 3 to $12 \mathrm{~mm}$ wide, scabrous above, glabrous beneath; panicle 20 to $50 \mathrm{~cm}$ long, open; spikelets 3.5 to $4.2 \mathrm{~mm}$ long. $21-$ Moist places in canyons and valleys. western Texas to Arizona; Mexico (fig. 1508).
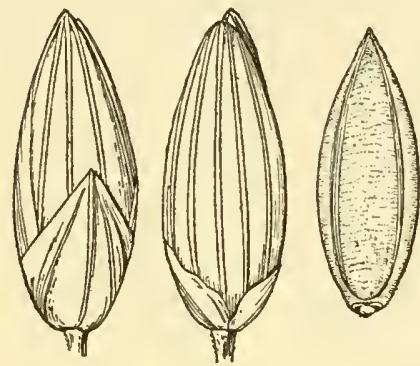

Figure 1506.-Panicum plenum. Two views of spikelet, and floret, $\times 10$. (Туре.)
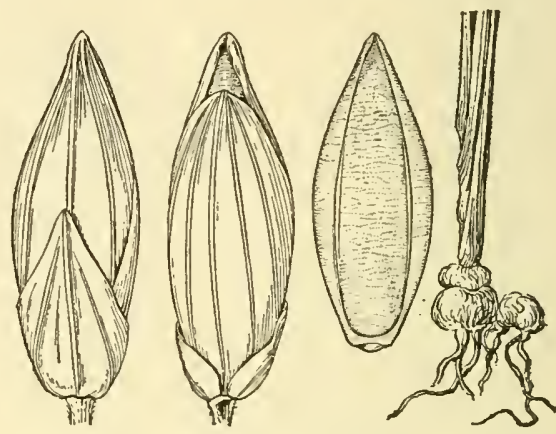

FIGURE 1507.-Panicum bulbosum. Base of culm, $\times 1 / 2$; two views of spikelet, and floret, $\times 10$. (Lemmon 2914, Ariz.)

Panicum bulbosum var. mínus Vasey. Culms slender, mostly less than $1 \mathrm{~m}$ tall, the corms smaller than in the species; blades mostly 2 to $4 \mathrm{~mm}$ wide; spikelets 2.8 to $3.2 \mathrm{~mm}$ long. 24 (P. bulbosum var. sciaphilum Hitchc. and Chase.)-Same range as species and more common with us.

8. Virgáta.-Perennials from stout rhizomes; culms mostly stout; ligules membranaceous, ciliate; blades linear, mostly firm; spikelets turgid, usually gaping, strongly 5- to 9-nerved, glabrous, pointed; lower floret usually staminate; fruit smooth and shining.

140. Panicum répens L. (Fig. 1509.) Culms rigid, 30 to $80 \mathrm{~cm}$ tall, erect from the nodes of strong horizontal often extensively creeping rhizomes, clothed at base with bladeless sheaths; sheaths more or less pilose; blades flat or folded, 2 to $5 \mathrm{~mm}$ wide, sparsely pilose to glabrous; panicle open, 7 to $12 \mathrm{~cm}$ long, the somewhat distant branches stiffly ascending; spikelets 2.2 to $2.5 \mathrm{~mm}$ long, ovate; first glume about one-fifth as long as the spikelet, loose, truncate. 24 -Sea beaches along the Gulf coast, Florida to Texas (fig. 1510);

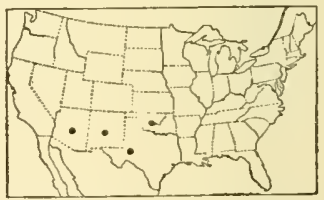

Figure 1508.-Distribution of Panicum bulbosum. tropical and subtropical coasts of both hemispheres, probably introduced in America.

141. Panicum gouíni Fourn. (Fig. 1511.) Resembling P. repens, but the culms usually less than $30 \mathrm{~cm}$ tall; sheaths and blades usually glabrous; panicle smaller, more densely flowered; first glume longer. 21 Sea beaches, Alabama to Louisiana; Gulf coast of Mexico.

142. Panicum virgátum L. Switcharass. (Fig. 1512.) Plants usually in large bunches, green or glaucous, with numerous scaly creeping rhizomes; culms erect, tough and hard, 1 to $2 \mathrm{~m}$ tall; sheaths glabrous; blades 10 to $60 \mathrm{~cm}$ long, 3 to $15 \mathrm{~mm}$ wide, flat, glabrous, or sometimes pilose above near the base, rarely pilose all over; panicle 15 to $50 \mathrm{~cm}$ long, open, sometimes diffuse; spikelets 3.5 to $5 \mathrm{~mm}$ long, 


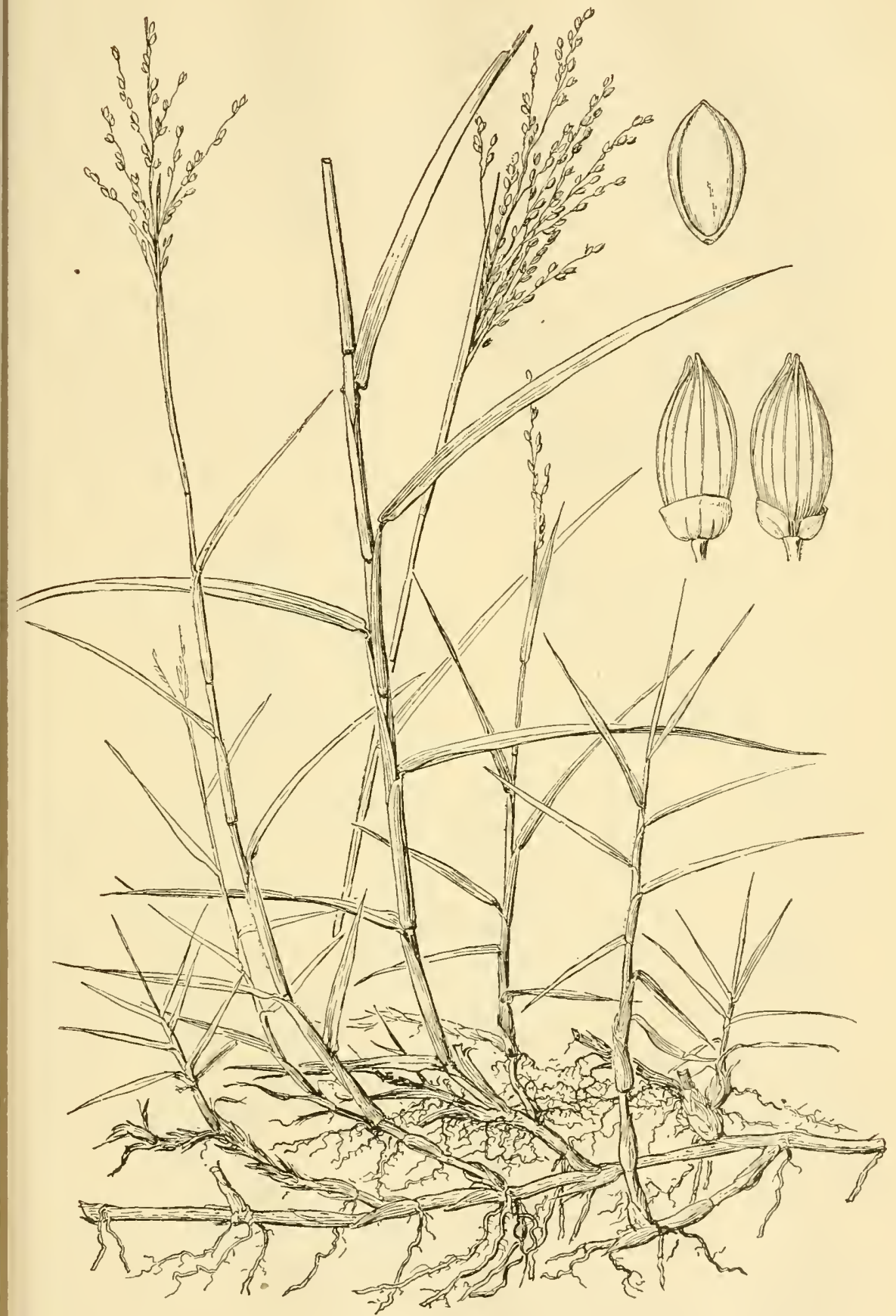

Figure 1509.-Panicum repens. Plant, $\times 1 \frac{1}{2}$; two views of spikelet, and floret, $\times, 10$. (Hitchcook 14145, Hawaii.) 
acuminate; first glume clasping, two thirds to three fourths as long as the spikelet, acuminate or cuspidate. 24 -Prairies and open ground, open woods, and brackish marshes, Quebee and Maine to Montana, south to Florida, Nevada, and Arizona; Mexico and Central America. Panicum virgatum var. cubénse Griseb. Culms more slender, usually solitary or few in a tuft; panicle narrower with ascending branches; spikelets 2.8 to $3.2 \mathrm{~mm}$ long, the second glume and sterile lemma not extending much beyond the fruit. 4 -Pine woods, Coastal Plain, Massachusetts to Florida and Mississippi; Michigan; Cuba. Panicum virgatum var. spíssum Linder. Culms from short stout knotty rhizomes. 24-Nova Scotia to Pennsylvania.

143. Panicum havárdii Vasey. (Fig. 1513.) Pale green, glaucous, glabrous throughout; culms robust, solitary, $1 \mathrm{~m}$ tall or more, erect from creeping rhizomes; blades 5 to $10 \mathrm{~mm}$ wide, tapering into long involute-setaceous tips; panicle as much as $40 \mathrm{~cm}$ long; spikelets 6 to $8 \mathrm{~mm}$ long. 2 -Arroyos and sand hills, western Texas and southern New Mexico; northern Mexico.

144. Panicum amárum Ell. (Fig. 1514.) Glaucous and glabrous throughout; culms solitary from the nodes of extensively creeping

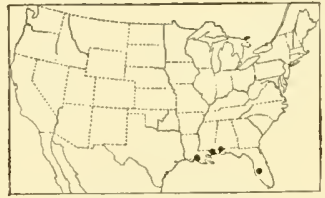

FIGURE 1510.-Distribution of Panicum repens.
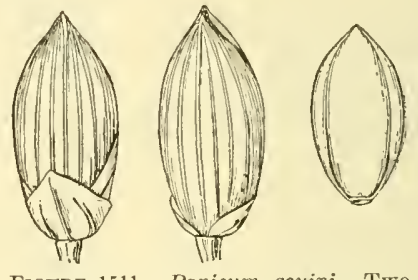

Figure 1511.-Panicum gouini. Two views of spikelet, and floret, $\times 10$. (Type.)

rhizomes, 30 to $100 \mathrm{~cm}$ tall; blades thick, 10 to $30 \mathrm{~cm}$ long, 5 to 12 $\mathrm{mm}$ wide, flat, involute toward the tip, the margins smooth; panicle one-fourth to one-third the height of the plant, not more than $3 \mathrm{~cm}$ wide, the branches appressed; spilielets 5 to $6.5 \mathrm{~mm}$ long, acuminate. 24 -Sandy seashores and coast dunes, Connecticut to Georgia; southern Mississippi; Texas (fig. 1515).

145. Panicum amárulum Hitchc. and Chase. (Fig. 1516.) Culms as much as $1 \mathrm{~cm}$ thick, in large bunches as much as $1 \mathrm{~m}$ across, 1 to $2 \mathrm{~m}$ tall, glaucous; rhizomes vertical or ascending; blades 20 to $50 \mathrm{~cm}$ long, 5 to $12 \mathrm{~mm}$ wide, more or less involute, pilose on the upper surface near the base; panicle large, rather compact, 5 to 10 cm wide, slightly nodding, densely flowered; spikelets 4.3 to $5.5 \mathrm{~mm}$ long, acuminate. 2 Sandy seashores and coast dunes, New Jersey to Virginia; Florida; Louisiana and Texas; Yucatan; Bahamas; Cuba (fig. 1517).

9. Ténera.-Perennials; culms subcompressed, wiry; ligules minute; spikelets short-pediceled; fruit smooth and shining:

146. Panicum ténerum Beyr. (Fig. 1518.) Culms in small tufts from a knotted crown, erect, 40 to $90 \mathrm{~cm}$ tall; lower sheaths pubescent toward the summit with spreading hairs; blades 7 to $15 \mathrm{~cm}$ long, 2 to $4 \mathrm{~mm}$ wide, erect, firm, subinvolute, pilose on upper surface toward base; panicles 3 to $8 \mathrm{~cm}$ long, very slender, terminal and axillary; spikelets 2.2 to $2.8 \mathrm{~mm}$ long, pointed, glabrous, the pedicel usually 


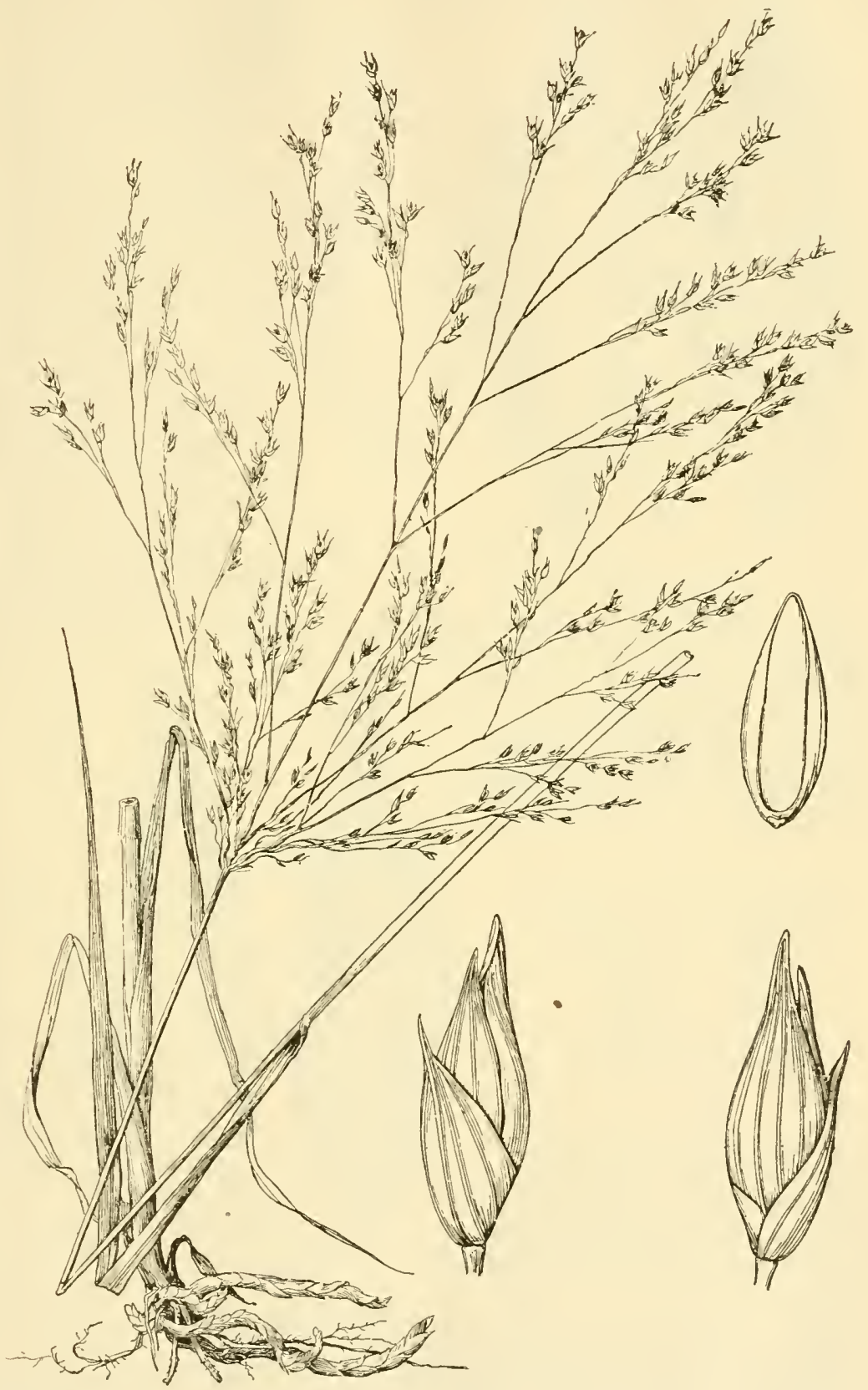

FIGURE 1512.-Panicum virgatum. Plant, $\times 1 / 2 ;$ two views of spikelet, and floret, $\times 10$. (V. H. Chase, Ill.) 
with a few long hairs. 24 -Margins of swamps and wet places in
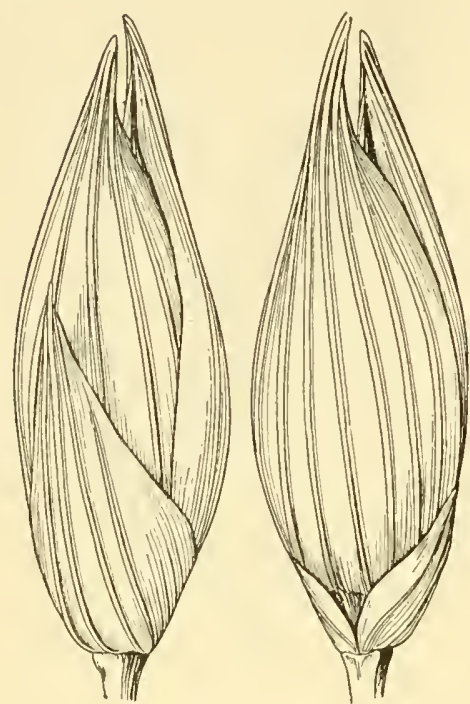

Figure 1513.-Panicum havardii. Two views of spikelet, and floret, $\times 10$. (Type.)

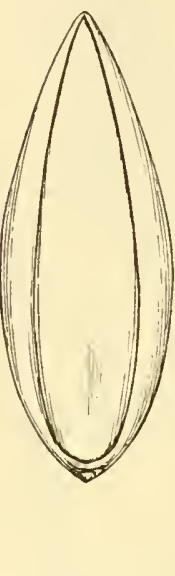

$$
\text { floret, } \times 10 \text {. (Type.) }
$$

pine barrens near the coast, North Carolina to Florida and Texas; West Indies (fig. 1519).

10. Agrostoídea.-Tufted perennials; culms erect, compressed; sheaths keeled; ligules membranaceous, mostly about 1 $\mathrm{mm}$ long; spikelets short-pediceled, lanceolate, pointed, 5- to 7-nerved, glabrous; glumes and sterile lemma mostly keeled; fruit smooth and shining with a minute tuft of thickish hairs at apex.

147. Panicum agrostoídes Spreng. (Fig. 1520.) In dense clumps

from a short crown, with numerous short-leaved innovations at base; culms 50 to $100 \mathrm{~cm}$ tall; blades erect, folded at base, flat above, 20 to $50 \mathrm{~cm}$ long, 5 to $12 \mathrm{~mm}$ wide; panicles terminal and axillary, 10 to $30 \mathrm{~cm}$ long, half to two-thirds as wide, sometimes more

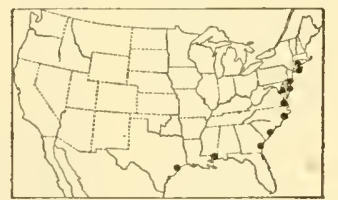

FigURE 1515.--Distribution of Panicum amarum.

diffuse, the densely flowered branchlets mostly on the under side of the branches, the pedicels usually bearing at the summit one to several delicate hairs; spikelets about $2 \mathrm{~mm}$ long. 21 -Wet
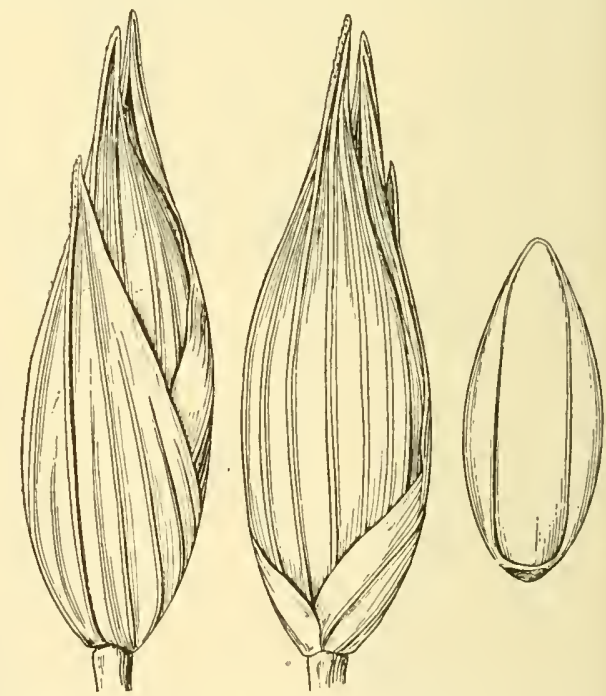

FIgUre 1514.-Panicum amarum. Two views of spikelet, and floret, $\times 10$. (Vasey, Va.) meadows and shores, Maine to Kiansas, south to Florida and Texas; Vancouver Island; California (fig. 1521).

148. Panicum condénsum Nash. (Fig. 1522.) Resembling $P$. agrostoides; culms on the average taller; blades often sparsely pilose 
on the upper side at the folded base; panicles 10 to $25 \mathrm{~cm}$ long, rarely more than $5 \mathrm{~cm}$ wide, the long branches erect, naked at base, with appressed branchlets bearing crowded spikelets, the pedicels not pilose; spikelets 2.2 to $2.5 \mathrm{~mm}$ long. 24 -Borders of streams and ponds and in wet places, Coastal Plain, Pennsylvania to Florida and Texas; West Indies (fig. 1523).

149. Panicum stipitátum Nash. (Fig. 1524.) Resembling $P$. agrostoides; often purple tinged throughout, especially the panicles; sheaths much overlapping, the blades usually equaling or exceeding the terminal panicle; panicles usually several to a eulm, 10 to $20 \mathrm{~cm}$ long, narrow, densely flowered, the numerous stiff branches ascending, with numerous divaricate branchlets, mostly on the lower side; spikelets 2.5 to $2.8 \mathrm{~mm}$ long, often curved at

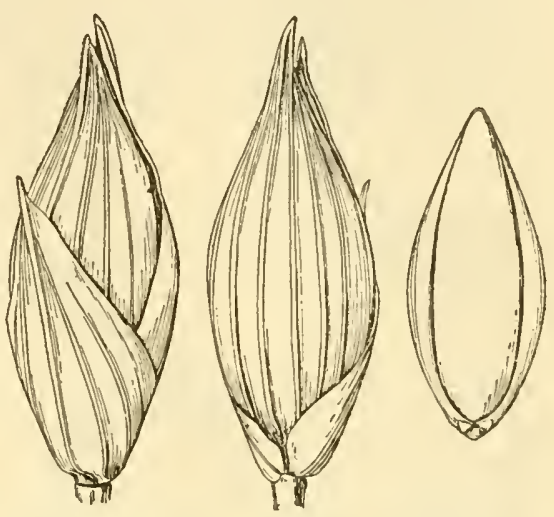

Figure 1516.-Panicum amatulum. Two views of spikelet, and floret, $\times 10$. (Type.) the tip. $24-$ Moist soil, Connecticut to Missouri, south to Georgia and Texas (fig. 1525).

150. Panicum longifólium Torr. (Fig. 1526.) Culms rather slender, 35 to $80 \mathrm{~cm}$ tall, in dense tufts, usuaily surrounded by basal leaves nearly half as long; sheaths usually villous near the summit; ligule fimbriate-ciliate, 2 to $3 \mathrm{~mm}$ long; blades elongate, 2 to $5 \mathrm{~mm}$ wide, pilose on the upper surface near the base; lateral panicles few or none, the terminal 10 to $25 \mathrm{~cm}$ long, the branches slender, ascend-

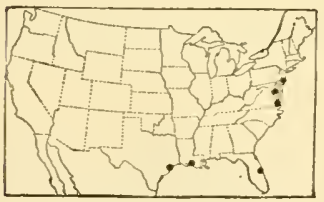

Figure 1517.-Distribution of Panicum amarulum.

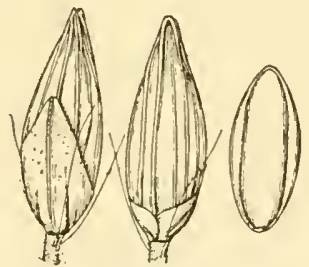

Figure 1518.-Panicum tenerum. Two views of spikelet, and floret, $\times 10$. (Type.)

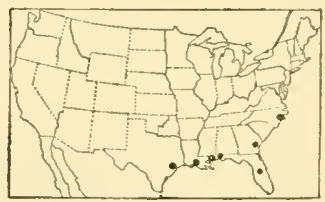

FigURE 1519.-Distribution of Panicum teneтum.

ing; spikelets 2.4 to $2.7 \mathrm{~mm}$ long. 21 -Moist sandy ground, Coastal Plain, Massachusetts to Florida and Texas (fig. 1527).

151. Panicum cómbsii Scribn. and Ball. (Fig. 1528.) Resembling $P$. longifolium; sheaths glabrous or nearly so; ligule less than $1 \mathrm{~mm}$ long; blades on the average shorter; spikelets 3 to $3.5 \mathrm{~mm}$ long, acuminate. 2l-Margins of ponds and wet woods, Georgia to Florida and Louisiana (fig. 1529).

152. Panicum ánceps Michx. (Fig. 1530.) Culms 50 to $100 \mathrm{~cm}$ tall, with numerous scaly rhizomes; sheaths glabrous or pilose; blades elongate, 4 to $12 \mathrm{~mm}$ wide, pilose above near the base; panicles 15 
to $40 \mathrm{~cm}$ long, the slender, remote branches somewhat spreading, bearing short mostly appressed branchlets with rather crowded somewhat curved subsecund spikelets, set obliquely on their pedicels; spikelets 3.4 to $3.8 \mathrm{~mm}$ long. 2 to Kansas, south to Florida and Texas (fig. 1531).

153. Panicum rhizomátum Hitchc. and Chase. (Fig. 1532.) Resembling $P$. anceps; culms less robust, the rhizomes more slender and numerous; sheaths densely to sparsely villous, especially at the

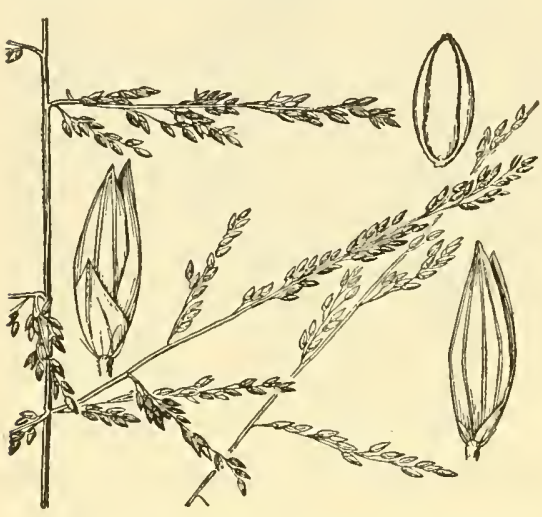

Figure 1520.-Panicum agrostoides. Panicle, $\times 1$; two views of spikelet, and floret, $\times 10$. (Fisher 30, N.J.) summit; blades usually pubescent on both surfaces; panicles more or less contracted; spikelets 2.4 to $2.8 \mathrm{~mm}$ long. 4 -Moist sandy woods and savannas, Coastal Plain, Maryland to Florida and Texas (fig. 1533).

11. Láxa.-Slender perennials; culms compressed; ligules minute; spikelets shortpediceled, 5-nerved, glabrous, the palea of the sterile floret becoming enlarged and indurate, expanding the spikelet at maturity; fruit minutely papillose-roughened, relatively thin in texture.

154. Panicum híans Ell. (Fig.

1534.) Culms 20 to $60 \mathrm{~cm}$ tall, mostly erect, sometimes more or less decumbent, or prostrate with erect branches; blades 5 to $15 \mathrm{~cm}$ long, 1 to $5 \mathrm{~mm}$ wide, flat or folded, pilose on the upper surface near base; panicles 5 to $20 \mathrm{~cm}$ long, usually loose and open, the primary branches few, slender, distant, spreading or drooping, the branchlets borne on the upper half or towards the ends only; spikelets in more or less secund clusters, 2.2 to $2.4 \mathrm{~mm}$ long, at maturity about twice as thick as wide. 24 -Damp soil

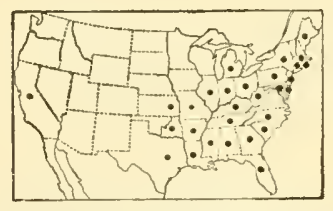

FIGURE 1521.-Distribution of Panicum agrostoides.

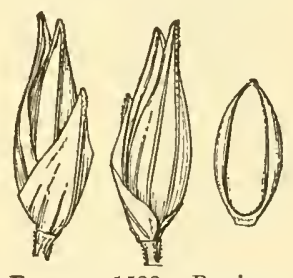

FIGURE 1522.-Panicum condensum. Two views of spikelet, and floret $\times 10$. (Type.)

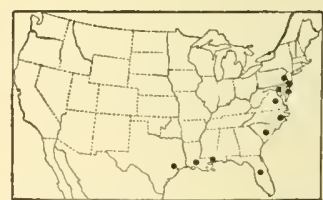

FIGURE 1523.-Distribution of Panicum condensum.

along ponds and streams, North Carolina to Florida and Texas, thence north to Oklahoma and southern Missouri; Mexico (fig. 1535). 12. Verrucósa.-Glabrous branching annuals; culms slender, weak, decumbent at base, usually with stilt-roots; ligules minute; panicles with divaricate capillary branches, spikelet-bearing toward the ends, the spikelets mostly in twos; spikelets tuberculate, nerves obscure or obsolete; first glume minute; fruit minutely papillose, margin of the lemma inrolled only at base. 
155. Panicum verrucósum Muhl. (Fig. 1536.) Bright green, at first erect, later widely spreading; culms 20 to $150 \mathrm{~cm}$ long; blades thin, flat, lax, 5 to $20 \mathrm{~cm}$ long, 4 to $10 \mathrm{~mm}$ wide; panicles 5 to $30 \mathrm{~cm}$

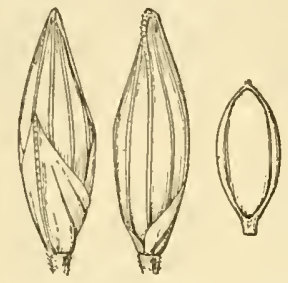

FIGURE 1524.-Panicum stipitatum. Two views of spikelet, and floret, $\times 10$. (Commons 305 ,
Del.)

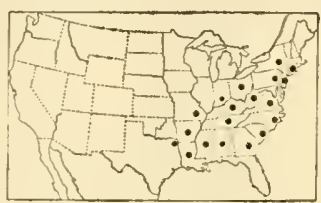

Figure 1525.-Distribution of Panicum stipitatum.

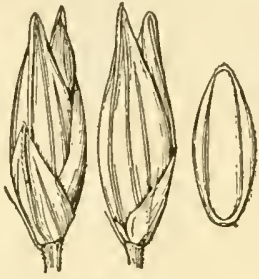

Figure 1526.- $P^{\prime} a n i c u l m$ longifolium. Two views of spikelet, and floret, $\times 10$. (Type.)

long, about as wide, diffuse, small panicles often produced at the lower nodes; spikelets 1.8 to $2.1 \mathrm{~mm}$ long, elliptic-obovate, subacute, roughened with small warts. $\odot$-Wet, mostly shady soil, Massachusetts to Florida, west to Michigan, Tennessee, and Texas (fig. 1537).

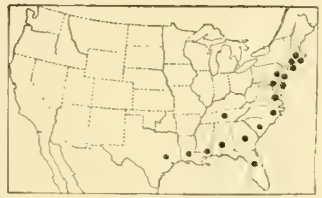

Figure 1527,-Distribution of Panicum longifolium.

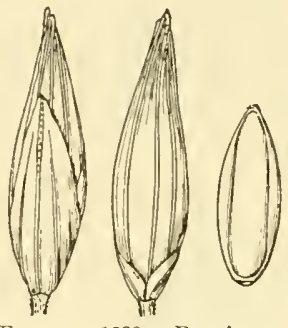

Figure 1528.-Panicum combsii. Two views of spikelet, and floret, $\times 10$. (Type.)

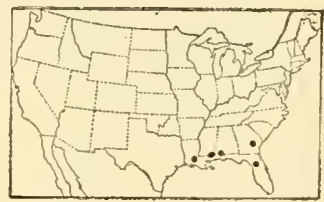

FIGURE 1529.-Distribution of Panicum combsii.

156. Panicum brachyánthum Steud. (Fig. 1538.) Culms 30 to $100 \mathrm{~cm}$ tall; blades 5 to $15 \mathrm{~cm}$ long, 2 to $3 \mathrm{~mm}$ wide; panicles 5 to 15

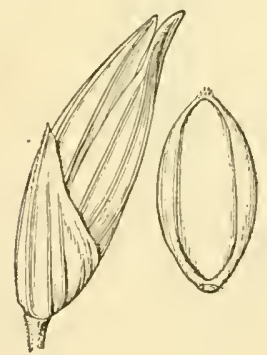

Figure 1530.-Panicum anceps. Spikelet and

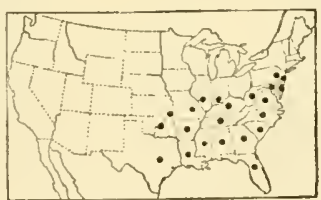

Figure 1531.-Distribution of Panicum anceps.

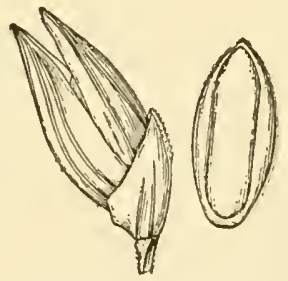

Figure 1532.-Panicu rhizomatum. Spikelet and floret, $\times 10$. (Type.)

cm long, the branches few; spikelets 3.2 to $3.6 \mathrm{~mm}$ long, fusiform, acute, tuberculate-hispid. $\odot$ - Sandy soil, Louisiana, Texas, and Oklahoma.

13. Urvilleána.-Robust perennials; spikelets large, densely villous; fertile lemma long-villous on the margin. 
157. Panicum urvilleánum Kunth. (Fig. 1539.) Culms solitary or few in a tuft, 50 to $100 \mathrm{~cm}$ tall, erect from a creeping rhizome; nodes densely bearded; sheaths overlapping, densely retror'se-villous; blades elongate, 4 to $7 \mathrm{~mm}$ wide, tapering from a flat base to a long involute setaceous point, strigose or glabrous; panicle 25 to $30 \mathrm{~cm}$ long, the slender branches ascending; spikelets 6 to $7 \mathrm{~mm}$ long, densely silvery-or tawny-villous; first glume clasping, from two-thirds

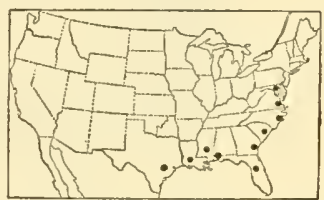

FIGURE 1533.-Distribution of Panicum rhizomatum.

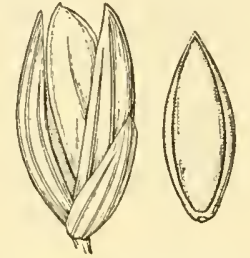

Figure 1534.-Panicum hians. Spikelet and floret, $\times 10$. (Type.)

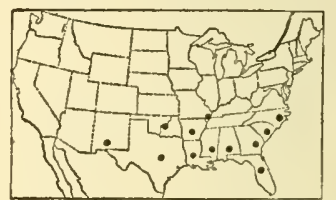

Figure 1535.-Distribution of Panicum hians.

to nearly as long as the spikelet. 24-Sandy deserts, Arizona and southern California; Argentina, Chile.

14. Obtúsa.-Stoloniferous wiry perennial; ligules about $1 \mathrm{~mm}$ long; panicles narrow, the few appressed branches densely flowered; spikelets short-pediceled, secund, glabrous; fruit smooth and shining.

158. Panicum obtúsum H. B. K. Vine-mesquite. (Fig. 1540.) Tufted from a knotted crown, the stolons sometimes $2 \mathrm{~m}$ long or more, with long internodes and geniculate, swollen, conspicuously villous nodes; culms compressed, 20 to $80 \mathrm{~cm}$ tall; blades mostly elongate, 2 to $7 \mathrm{~mm}$ wide, glabrous or nearly so; panicles 3 to $12 \mathrm{~cm}$

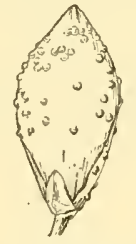

Figtre 1536.-Panicum verrucosum. Two views of spikelet, and floret, $\times 10$. (Type.)

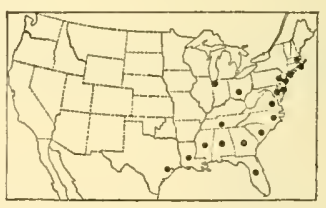

FIGURE 1537.-Distribution of Panicum verrucosum.

long, about $1 \mathrm{~cm}$ wide; spikelets 3 to $3.8 \mathrm{~mm}$ long, obovoid, brownish, obtuse; first glume nearly as long as the spikelet. 24 -Sandy or gravelly soil, mostly along banks of rivers, arroyos, and irrigation ditches, western Missouri to Colorado, south to Texas and Arizona; Mexico (fig. 1541).

15. Hemítoma.-Aquatic or subaquatic perennial; panicles elongate, very narrow; spikelets subsessile, 3- to 5-nerved, glabrous.

159. Panicum hemítomon Schult. Maidencane. (Fig. 1542.) With extensively creeping rhizomes, of en producing numerous sterile shoots with overlapping sometimes densely hirsute sheaths; culms 50 to $150 \mathrm{~cm}$ tall, usually hard; sheaths of fertile culms usually glabrous; blades 10 to $25 \mathrm{~cm}$ long, 7 to $15 \mathrm{~mm}$ wide, usually scabrous on the upper surface and smooth beneath; panicle 15 to $30 \mathrm{~cm}$ long, the 
branches erect, the lower distant, the upper approximate, 2 to 10 cm long; spikelets 2.4 to $2.7 \mathrm{~mm}$ long, lanceolate, acute; first glume about half the length of the spikelet; fruit less rigid than usual in the genus, the apex of the palea scarcely enclosed. 24 -Moist soil along river banks and ditches, borders of lakes and ponds, often in
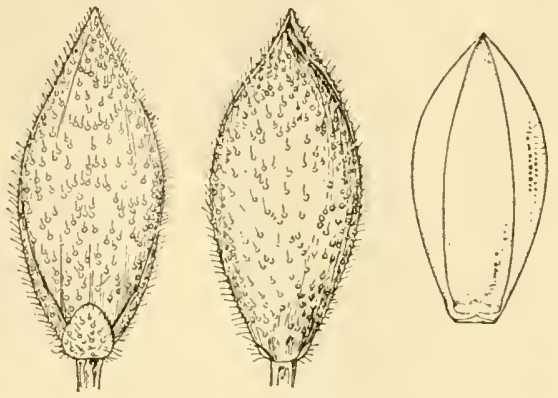

Figure 1538.-Panicum brachyanthum. Two views of spikelet, and floret, $\times 10$. (Type.)

the water, sometimes a weed in moist cultivated fields, Coastal Plain, New Jersey to Florida and Texas; Brazil (fig. 1543).

16. Gymnocárpa.-Succulent glabrous perennial; panicles of several to many long stiffly ascending racemes along a main axis; spikelets strongly 3 - to 5 -nerved, glabrous.

160. Panicum gymnocárpon Ell. (Fig. 1544.) Creeping, the base as much as $2 \mathrm{~m}$ long, rooting at the nodes; culms 60 to $100 \mathrm{~cm}$ tall;
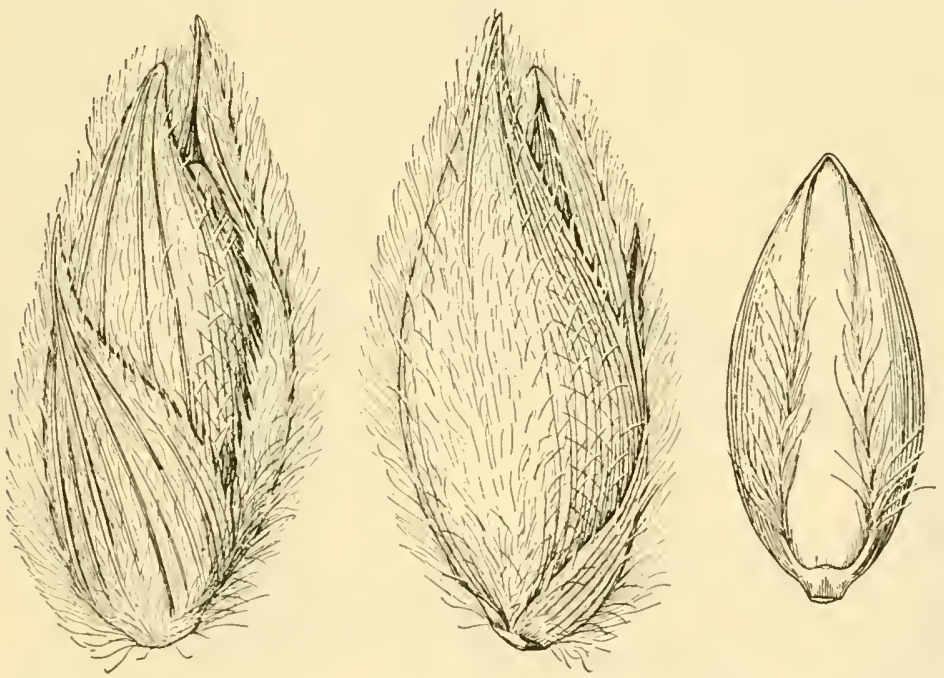

Figure 1539.-Panicum urvilleanum. Two views of spikelet, and floret, $\times 10$. (Type.)

blades elongate, 15 to $25 \mathrm{~mm}$ wide, flat, scarcely narrowed at the cordate, sparingly ciliate base, the margin very scabrous; panicle 20 to $40 \mathrm{~cm}$ long; spikelets 6 to $7 \mathrm{~mm}$ long; first glume nearly as long as the sterile lemma, the second glume exceeding the sterile lemma, all acuminate-pointed, much exceeding the obovate, stipitate fruit, this $2 \mathrm{~mm}$ long, smooth and shining. 2 -Ditches and muddy banks of streams and lakes, Georgia and Florida to Texas (fig. 1545). 
684 Misc. PUBLICATION 200, U. S. DEPT. OF AGRICULTURE

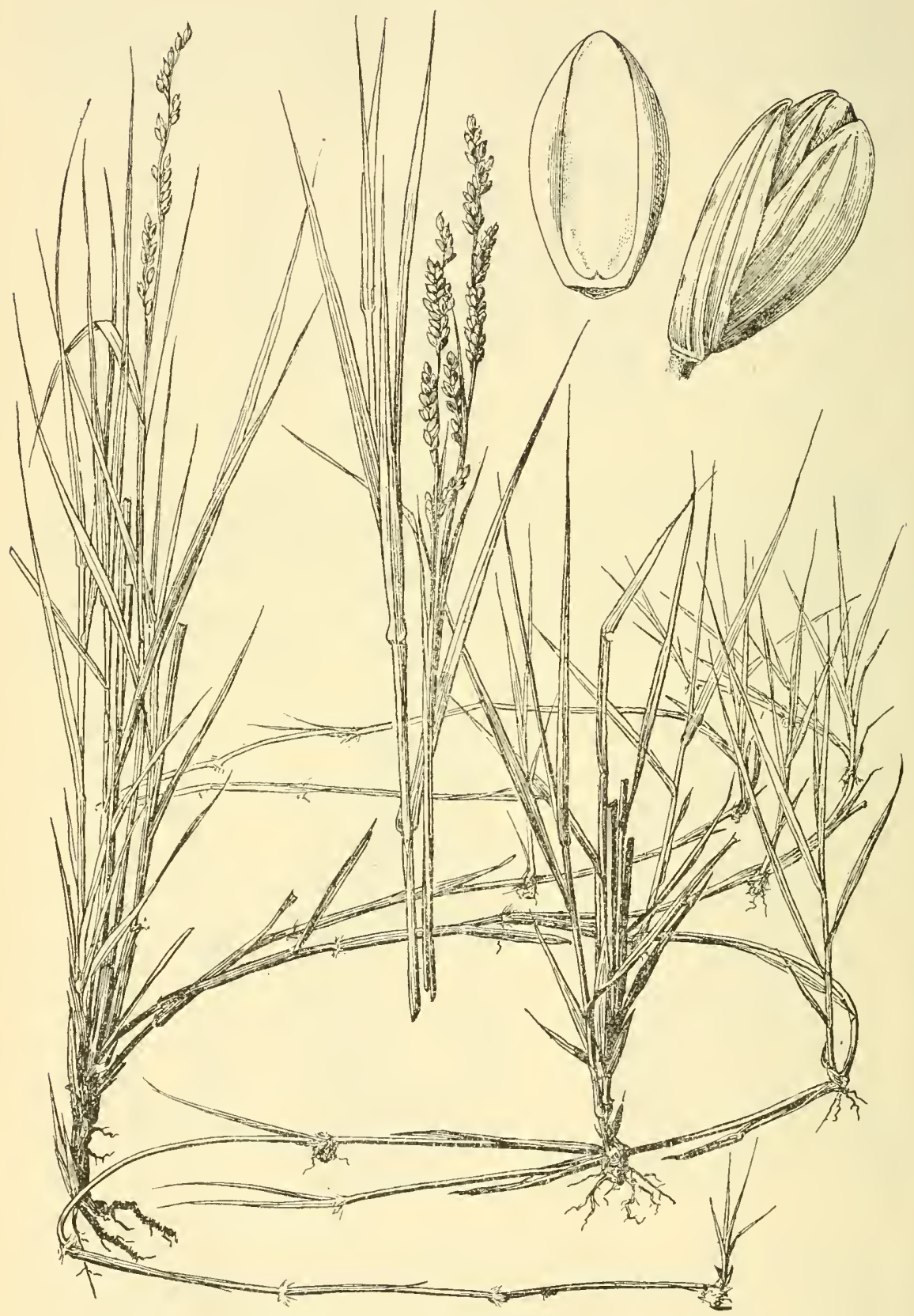

FigURe 1540.-Panicum obtusum. Plant, $\times \frac{1}{2} 2$; spikelet and floret, $\times 10$. (Hitchcock 13412, Tex.) 


\section{LASÍACIS (Griseb.) Hitchc.}

Spikelets subglobose, placed obliquely on their pedicels; first glume broad, somewhat inflated-ventricose, usually not more than one-third

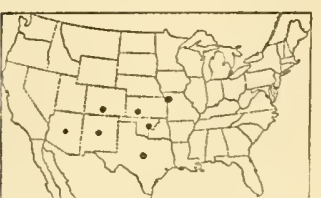

FigURE 1541.-Distribution of Panicum oblusum. semma white, bony-indurate, obovoid, obtuse, this and the palea of the same tex-

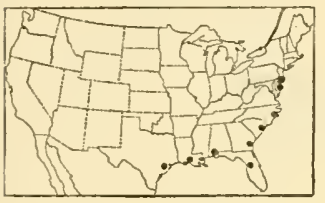

FIGURE 1543.-Distribution of Panicum hemitomon. the length of the spikelet, several-nerved; second glume and sterile lenma about equal, broad, abruptly apiculate, papery-chartaceous, shining, many-nerved, glabrous, or lanose at the apex only, the lemma enclosing a membranaceous palea and sometimes a ture, bearing at the apex in a slight depression a tuft of woolly hairs, the palea concave below, gibbous above, the apex often free at maturity. Large branching perennials, with woody culms often clambering several meters high into shrubs or trees, the blades firm, flat, usually lanceolate and narrowed into a petiole, the spikelets in an open panicle. Type species, Lasiacis

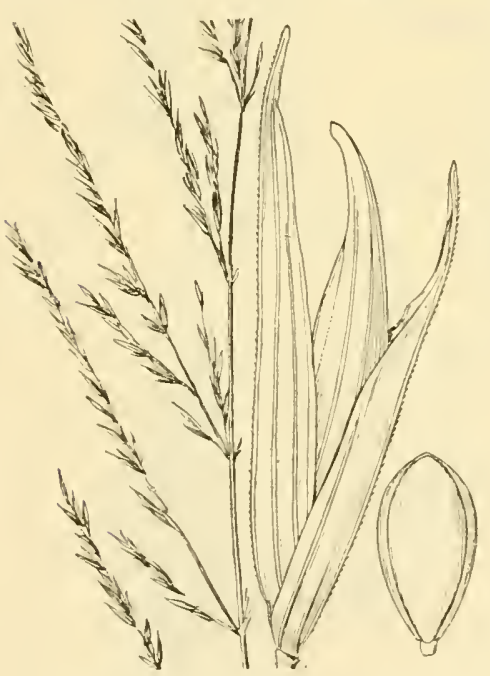

Figure 1544.-Panicum gymnocarpon. Panicle, $\times 1$; spikelet and floret, $\times 10$. (Type.)

divaricata. Name from Greek lasios,

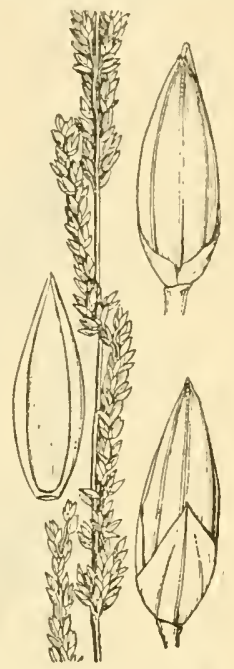

Figcre 1542.-Panicum hemitomion. Panicle, $\times 1$; spikelet and floret, $\times 10$. (Tracy 6731, Fla.) woolly, and akis, point, alluding to the tuft of wool at the tip of the fruit.

1. Lasiacis divaricáta (L.) Hitchc. Tibisee. (Fig. 1546.) Glabrous

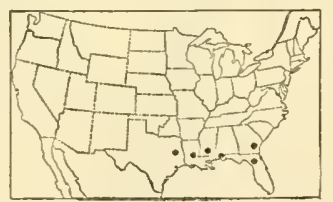

Figure 1545.-Distribution of Panicum gymnocarpon.

throughout except the margins of the sheaths; culms much branched, clambering over shrubs to the height of 3 or $4 \mathrm{~m}$, the main culm (cane) strong, as much as $6 \mathrm{~mm}$ in diameter, the main branches often fascicled, the vigorous secondary sterile shoots usually strongly divaricate or zigzag; blades narrowly lanceolate, 5 to $20 \mathrm{~cm}$ long, 5 to 15 $\mathrm{mm}$ wide, or larger on vigorous sterile shoots; panicles terminating 
the main culm and branches, 5 to $20 \mathrm{~cm}$ long, loosely few-flowered, the branches distant, spreading or reflexed; spikelets ovoid, about

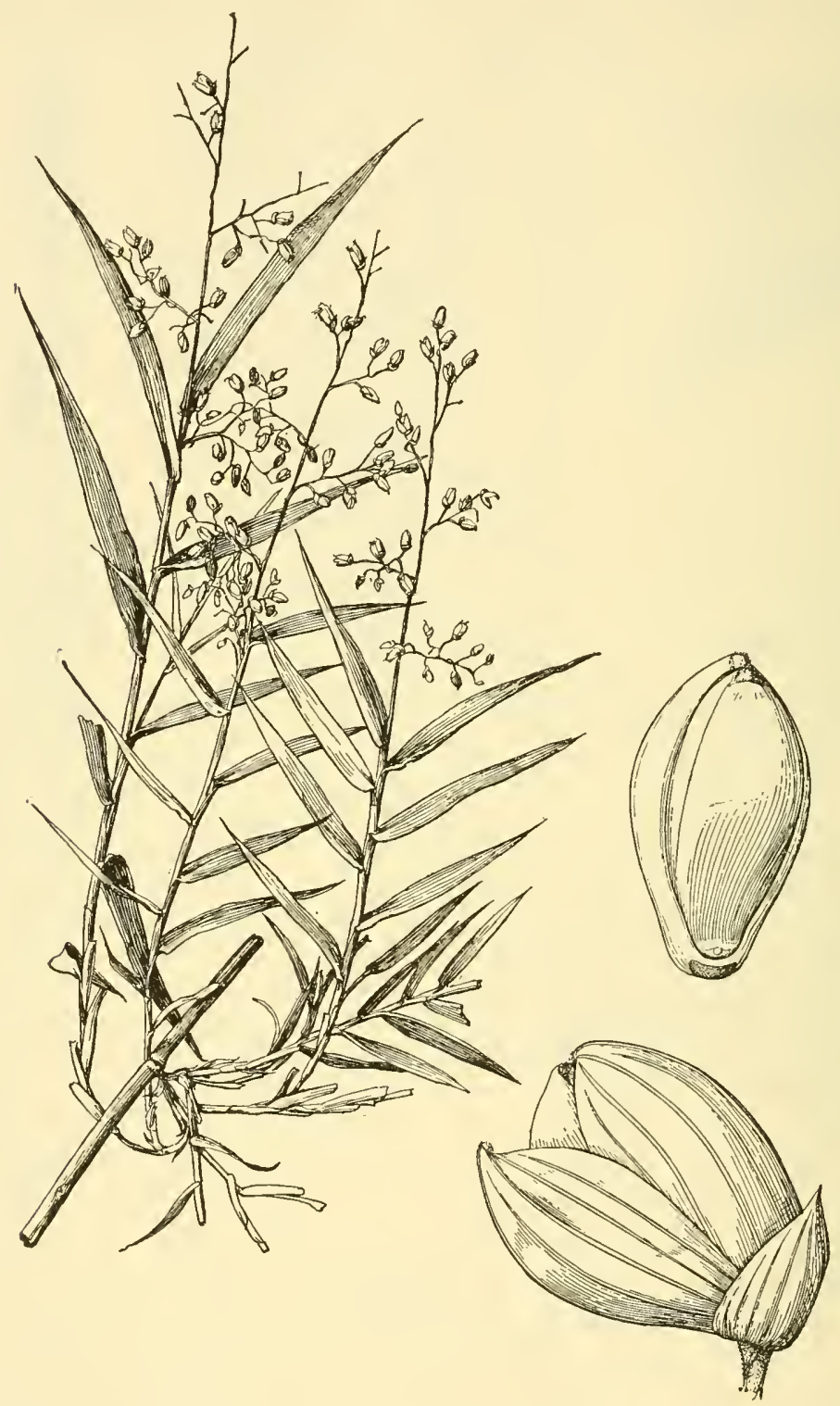

Figure 1546.-Lasiacis divaricata. Plant, $\times \frac{1}{2}$; spikelet and floret, $\times 10$. (Curtiss 5530, Fla.)

$4 \mathrm{~mm}$ long, black at maturity. 24 -Copses and edges of woods, southern Florida; tropical America, at low altitudes, especially near
the seacoast. 


\section{SACCIÓLEPIS Nash}

Spikelets oblong-conic; first glume much shorter than the spikelet; second glume broad, inflated-saccate, strongly many-nerved; sterile

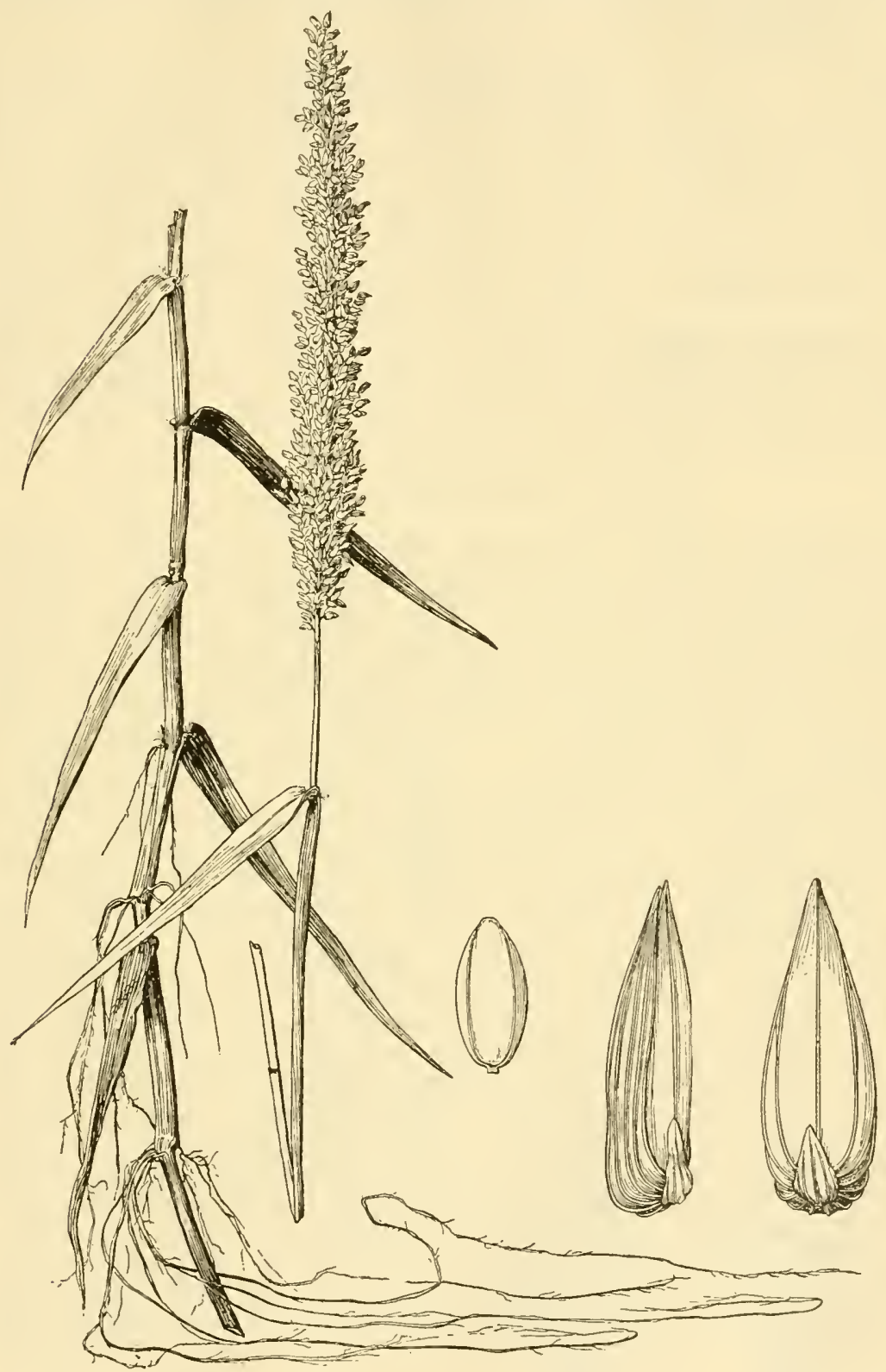

FIGURE 1547.-Sacciolepis striata. Plant, $\times 1 / 2$; two views of spikelet, and floret, $\times 10$. (Chase 4240, Fla.)

lemma narrower, flat, fewer nerved, its palea nearly as long, often subtending a staminate flower; fertile lemma stipitate, elliptic, chartaceous-indurate, the margins inrolled, the palea not enclosed at 
the summit. Annuals or perennials, of wet soil, usually branching, the inflorescence a dense, usually elongate, spikelike panicle. Type species, Panicum gibbum Ell. (Sacciolepis striata). Name from Greek sakkion, a small bag, and lepis, scale, alluding to the saccate second glume.

1. Sacciolepis striáta (L.) Nash. (Fig. 1547.) Perennial, gla-

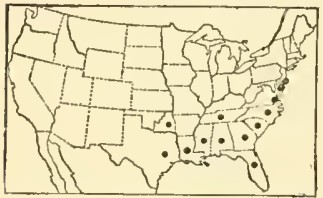

Figure 1548.-Distribution of Sacciolepis striata. brous, often decumbent and rooting at base; culms as much as 1 to $2 \mathrm{~m}$ tall; sheaths more or less papillose-hirsute; blades lanceolate, 4 to $20 \mathrm{~cm}$ long; panicles 6 to $30 \mathrm{~cm}$ long; spikelets about $4 \mathrm{~mm}$ long. 2 (Sacciolepis gibba Nash.)-M arshes, ditches, and wet places, Coastal Plain, New Jersey (Cape May) to Florida, Tennessee, Texas, and Oklahoma; West Indies (fig. 1548).

Sacciolepis índica (L.) Chase. Annual; culms slender, spreading, 20 to $60 \mathrm{~cm}$ tall; blades 2 to $4 \mathrm{~mm}$ wide; panicle spikelike, 1 to $4 \mathrm{~cm}$ long; spikelets about $2.5 \mathrm{~mm}$ long, glabrous. 2 Government pecan orchard, Thomasville, Ga. India.

\section{OPLÍSMENUS Beauv.}

Spikelets terete or somewhat laterally compressed, subsessile, solitary or in pairs, in two rows crowded or approximate on one side of a narrow scabrous or hairy rachis; glumes about equal, entire, or emarginate, awned from the apex or from between the lobes; sterile lemma exceeding the glumes and fruit, notched or entire, mucronate or short-awned, enclosing a hyaline palea; fertile lemma elliptic, acute, convex or boat-shaped, the firm margins clasping the palea, not inrolled. Freely branching, creeping, shade-loving annuals or perennials, with erect flowering shoots, flat, thin, lanceolate or ovate blades, and several one-sided, thickish, short racemes rather distant on a main axis. Type species, Oplismenus africanus Beauv. Name from Greek hoplismenos, armed, alluding to the awned spikelets.

1. Oplismenus setárius (Lam.) Roem. and Schult. (Fig. 1549.) Perennial; culms slender, lax, ascending or prostrate, 10 to $20 \mathrm{~cm}$ long, sometimes as much as $30 \mathrm{~cm}$; blades ovate to ovate-lanceolate, thin, 1 to $3 \mathrm{~cm}$ long, 4 to $10 \mathrm{~mm}$ wide; panicle long-exserted, usually not more than $5 \mathrm{~cm}$ long; racemes usually 3 to 5 , subglobose, distant or the upper approximate, the lower internodes sometimes as much as $2 \mathrm{~cm}$ long, the rachis 2 to $3 \mathrm{~mm}$ long, sometimes to $6 \mathrm{~mm}$; spikelets about 5 (4 to 8 ) on each rachis; awn of first glume 4 to $8 \mathrm{~mm}$ long. 2 - Shaded places along the coast, North Carolina to Florida, Arkansas, and Texas; tropical America at low altitudes (fig. 1550).

An allied species of the American tropics, Oplismenus hirtellus (L.) Beauv., basket grass, is cultivated by florists as a basket plant and for edging, under the name Panicum variegatum. It has been incorrectly referred to Oplismenus burmanni (Retz.) Beaur. The common form in cultivation is variegated, the blades being striped with white. 


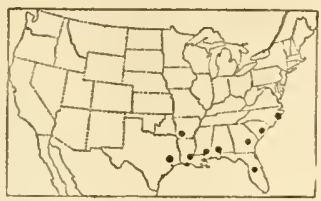

FIGURE 1550.-Distribution of Oplismenus setarius.
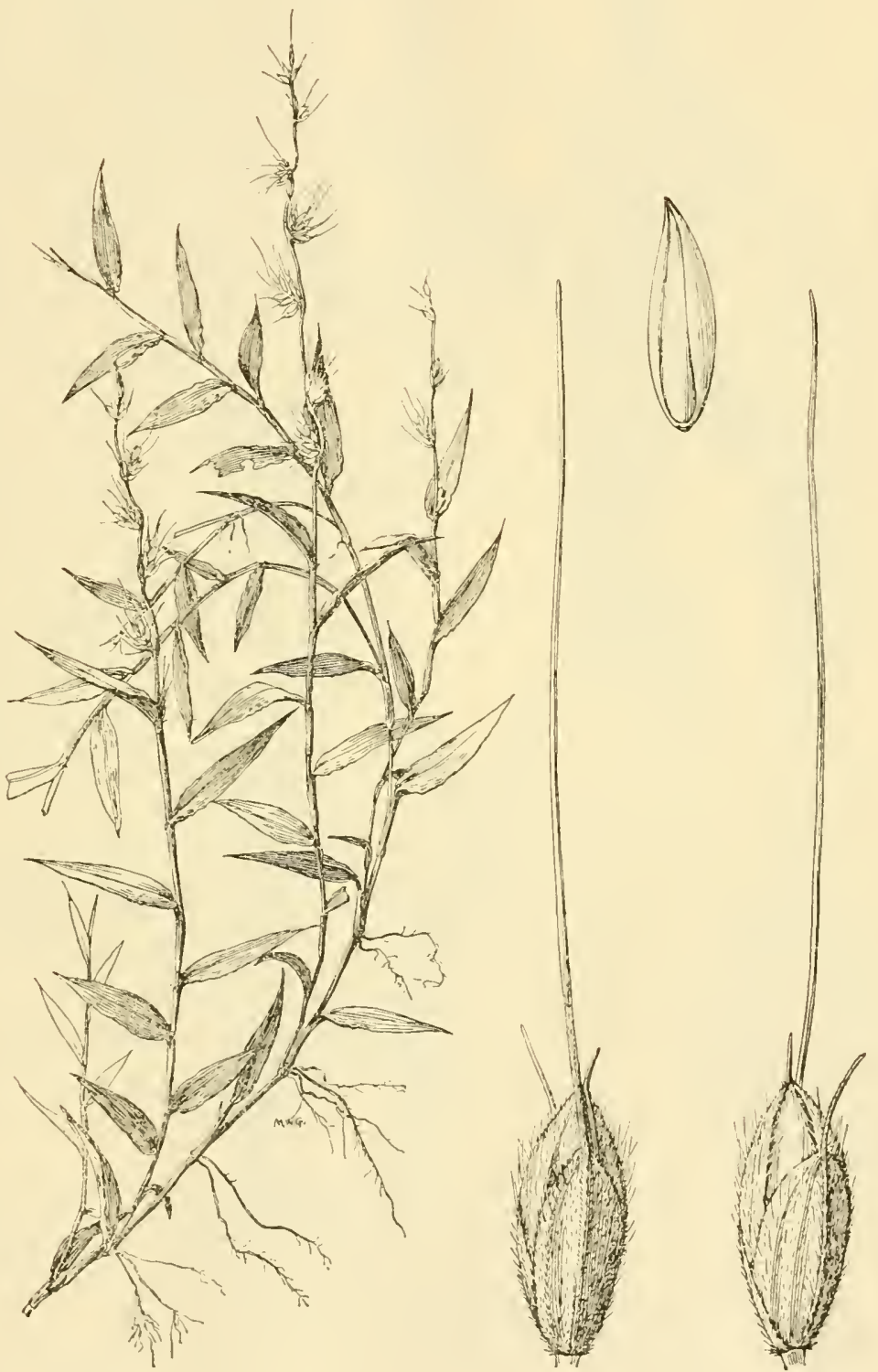

FIGURE 1549.-Oplismenus sctarius. Plant, $\times \frac{1}{2} ;$ two views of spikelet, and flore: $\times 10$. (Curtiss 5553, Fla.) 


\section{ECHINÓCHLOA Beauv.}

Spikelets plano convex, often stiffly hispid, subsessile, solitary or in

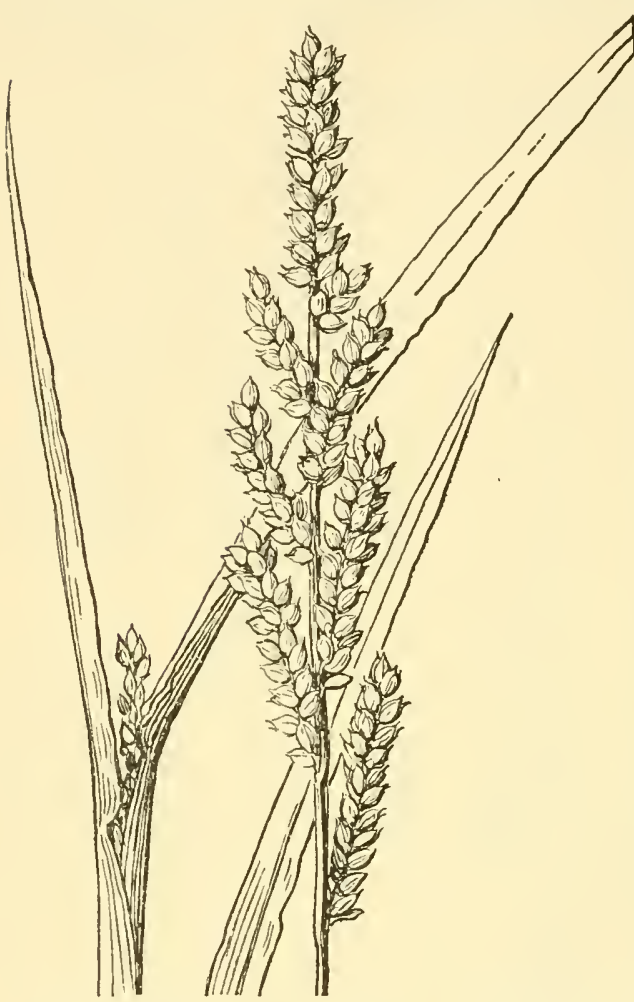

Figure 1551.-Echinochloa colonum, $\times 1$. (Bentley, Tex.) irregular clusters on one side of the panicle branches; first glume about half the length of the spikelet, pointed; second glume and sterile lemma equal, pointed, mucronate, or the glume short-awned and the lemma long-awned, sometimes conspicuously so, enclosing a membranaceous palea and sometimes a staminate flower; fertile lemma planoconvex, smooth and shining, acuminate-pointed, the margins inrolled below, flat above, the apex of the palea not enclosed. Coarse, often succulent, annuals or perennials, with compressed sheaths, linear flat blades, and rather compact panicles composed of short, densely flowered racemes along a main axis. Our species are annuals without ligules. Type species, Echinochloa crusgalli. Name from Greek echinos, hedgehog, and chloa, grass, alluding to the echinate spikelets.

All the species are grazed by stock but usually grow in sparse stands or in situations where they cannot well be utilized. E. crusgalli is occasionally cut for hay. Echinochloa crusgalli var. frumentacea, Japanese millet, has been advertised by seedsmen in this country as billion-dollar grass and recommended for forage. It has some forage value, but requires considerable moisture to produce abundantly,

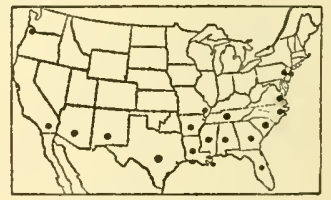

Figure 1552.-Distribution of Eichinochloa colonum. and is rather too succulent for hay. This and forms of E. colonum are cultivated in tropical Asia and tropical Africa for the seeds which are used for food.

Racemes simple, rather distant, 1 to $2 \mathrm{~cm}$ long; spikelets crowded in about 4 rows, the awn of the sterile lemma reduced to a short point; blades 3 to 6 mm wide... E. colonum. Racemes more or less branched, usually more than $2 \mathrm{~cm}$ long; spikelets irregularly crowded and fascicled, usually not arranged in rows, the awn of the sterile lemma variable; blades usually more than $5 \mathrm{~mm}$ wide.

Sterile floret staminate... F. PALUdigena. 
MANUAL OF THE GRASSES OF THE UNITED STATES 691

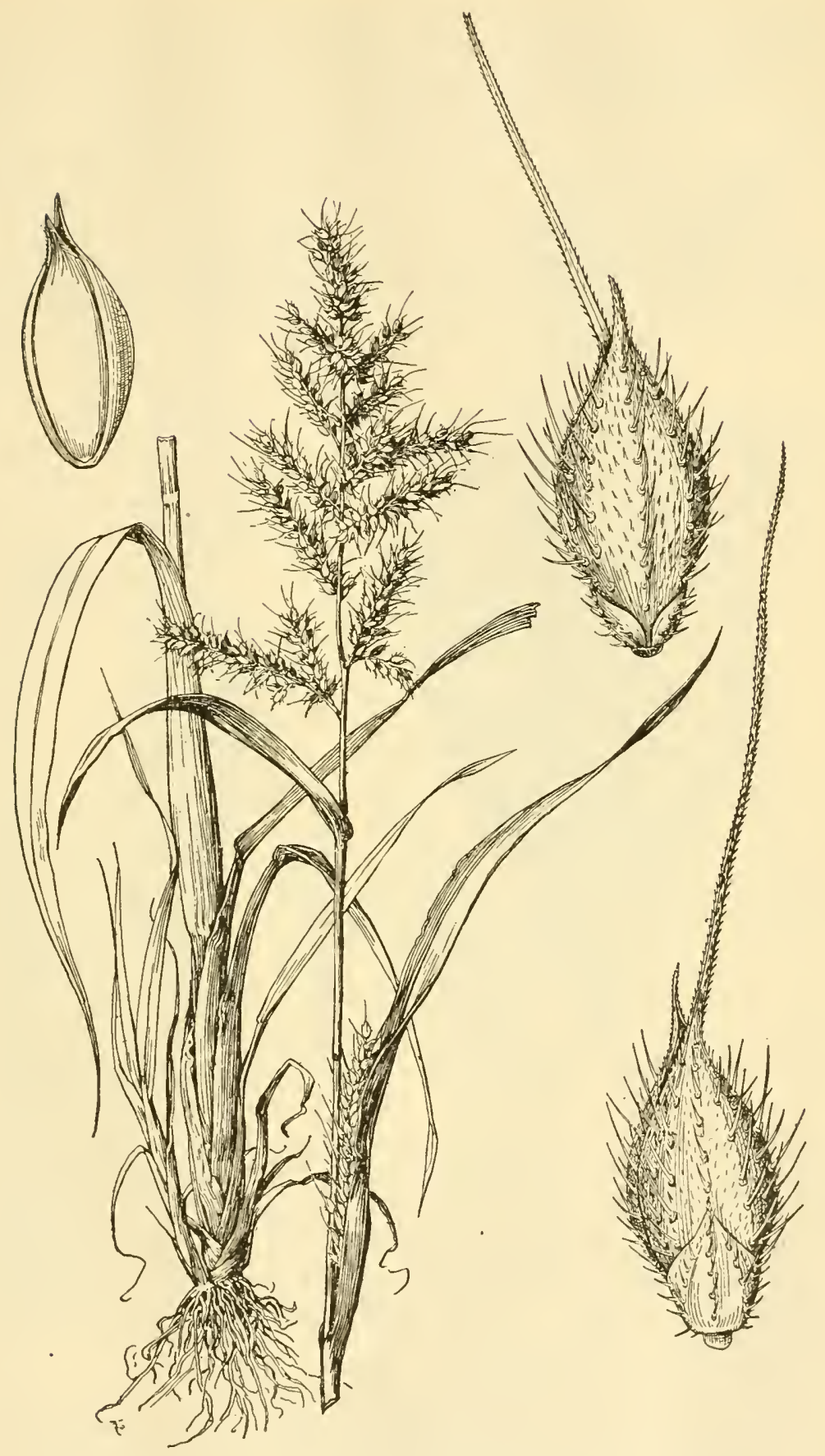

Figure 1553.-Echinochloa crusgalli. Plant, $X_{1 / 2}^{1 / 2}$ two views of spikelet, and floret, $\times 10$. (Somes 3725, lowa.) 
Sterile floret neuter.

Sheaths smooth; awns variable, but the panicle not a dense mass of longawned spikelets.

Panicles erect and rather stiff (heavy panicles somewhat nodding); spikelets conspicuously hispid .............. 2. E. CRUSGALLI.

Panicles soft and nodding; spikelets inconspicuously hispid.

3. E. CRUS-PAVONIS.

Sheaths, at least the lower, hispid or scabrous; panicle dense, the spikelets long-awned........ 5. WALTERI.

1. Echinochloa colónum (L.) Link. JungLe-RICE. (Fig. 1551.) Culms prostrate to erect, 20 to $40 \mathrm{~cm}$ long; blades rather lax, 3 to $6 \mathrm{~mm}$ wide, occasionally transversely zoned with purple; panicle 5 to $15 \mathrm{~cm}$ long; racemes several, 1 to $2 \mathrm{~cm}$ long, appressed or as-

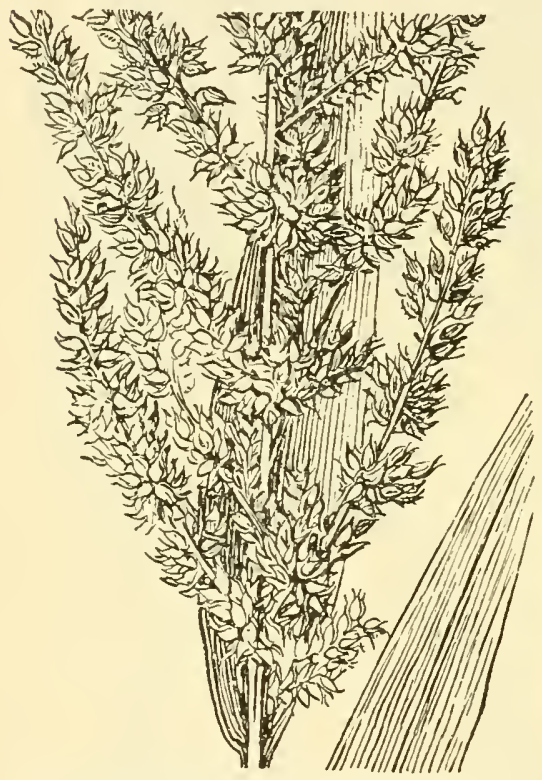

FIgURE 1554.-Echinochloa crusgalli var. mitis, $\times 1$. (Pammel and Cratty 791, lowa.)

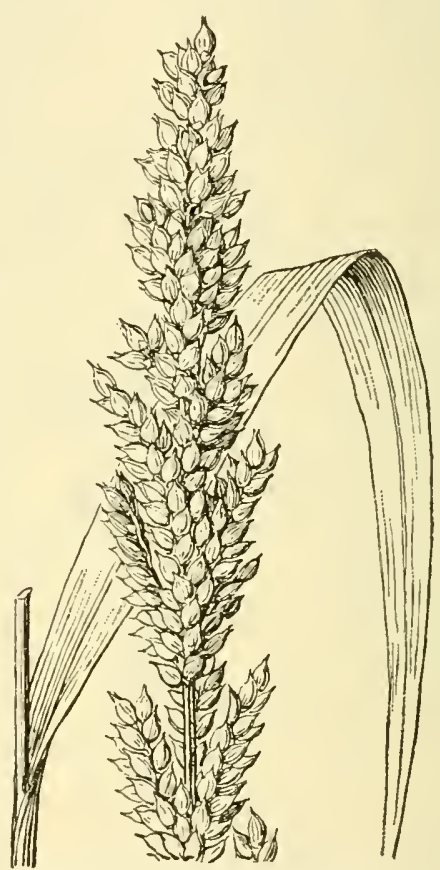

FIGURE 1555.-Echinochloa crusgalli var. zelayensis, $\times 1$. (Mearns 744, Mex.)

cending, single or occasionally two approximate, the lower usually distant as much as $1 \mathrm{~cm}$; spikelets about $3 \mathrm{~mm}$ long, crowded, nearly sessile; second glume and sterile lemma short-pointed, rather soft, faintly nerved, the nerves weakly hispid-scabrous. $\odot$-Ditches and moist places, Virginia to Missouri, south to Florida, Texas, and southeastern California; ballast, Camden, N.J., Philadelphia, Pa., and Portland, Oreg. (fig. 1552); tropical regions of both hemispheres; introduced in America.

2. Echinochloa crusgálli (L.) Beauv. Barryard grass. (Fig. 1553.) Culms erect to decumbent, stout, as much as $1 \mathrm{~m}$ or even $1.5 \mathrm{~m}$ tall, often branching at base; sheaths glabrous; blades elongate, 5 to $15 \mathrm{~mm}$ wide; panicle erect or nodding, purple tinged, 10 to $20 \mathrm{~cm}$ long; racemes spreading, ascending or appressed, the lower somewhat distant, as much as $10 \mathrm{~cm}$ long, sometimes branched, the 
upper approximate; spikelets crowded, about $3 \mathrm{~mm}$ long, excluding the awns; internerves hispidulous; nerves strongly tuberculatehispid; awn variable, mostly 5 to $10 \mathrm{~mm}$ long on at least some of the spikelets, sometimes as much as $3 \mathrm{~cm}$. $\odot$-Moist open places, ditches, cultivated fields, and waste ground, New Brunswick to Washington, south to Florida and California, mostly at low and medium altitudes; Eastern Hemisphere. Echinochloa muricata (Michx.) Fernald is differentiated by Fernald from $E$. crusgalli by the stiff hairs arising from papillae on the spikelets, true $E$. crusgalli as he understands it having hairs that lack the papillose base. The author has been unable to separate $E$. muricata, the European specimens having on the average as

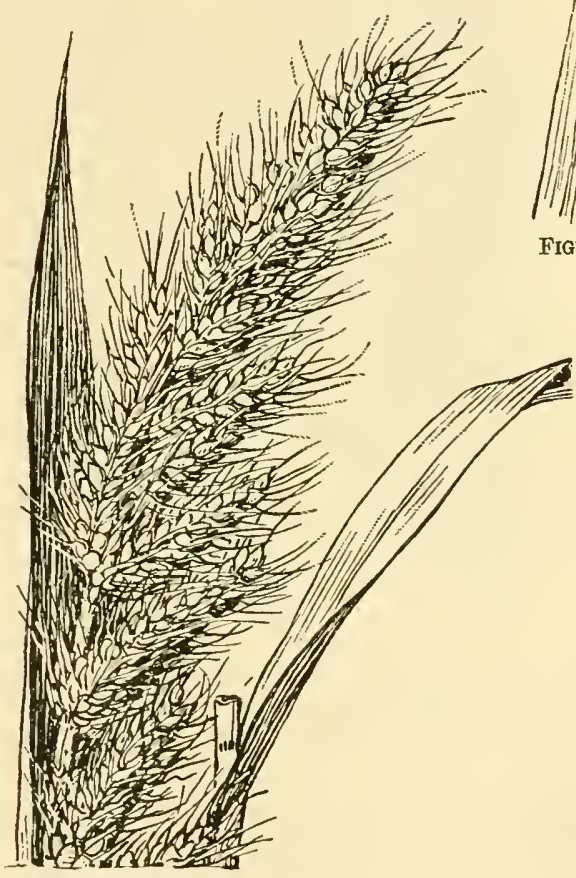

FIGURE 1557.-Echinochloa crus-pavonis, $\times 1$. (Sintenis 1889, P.R.)

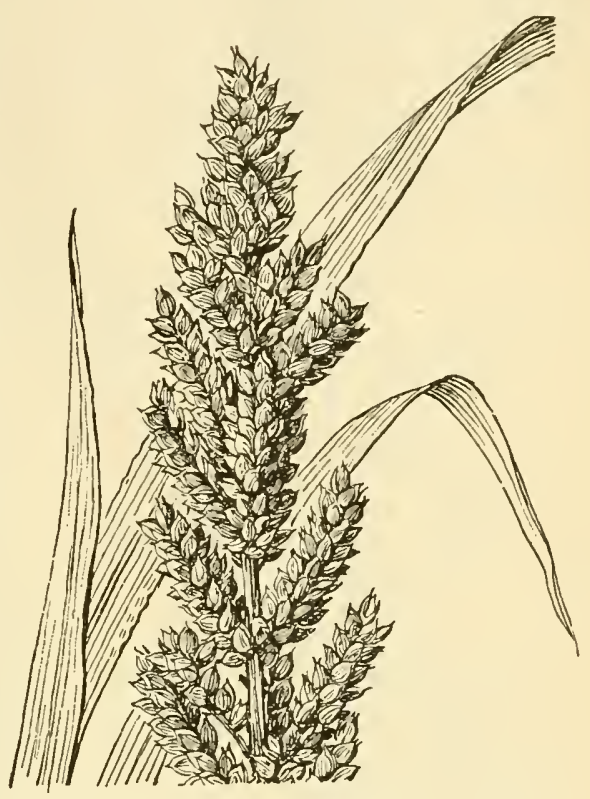

FiguRe 1556.-Echinochloa crusgalli var. frumentacea, $\times 1$. (Piper, Tex.)

strongly tuberculate spikelets as Michaux's specimen. The three following varieties intergrade and can be only arbitrarily distinguished.

ECHINOChLOA CRUSGALLI var. Mítis (Pursh) Peterm. (Fig. 1554.) Spikelets awnless or nearly so, the awns less than $3 \mathrm{~mm}$ long. $\odot$-Moist places over about the same area as the species and nearly as common.

ECHINOCHLOA CRUSGALLI var. zeLaYénsis (H.B. K.) Hitche. (Fig. 1555.) Differs from $E$. crusgalli var. mitis in having less succulent culms, mostly simple, more or less appressed racemes, the spikelets less strongly hispid but papillose, usually green. Small plants resemble $E$. colonum, but differ in the more distinctly pointed spikelets, more spreading racemes, and erect more robust culms. $\odot$-Moist, often alkaline places, Oklahoma to Oregon, south to Texas and Cali- 
fornia; Mexico to Argentina, in the tablelands. (Type from Zelaya, Mexico.)

Echinochloa CRUSGalli var. FrUmentácea. (Roxb.) Wight. JapANESE MILLET. (Fig. 1556.) Racemes thick, appressed, incurved; spikelets more turgid, awnless, mostly purple. $\odot$ (Var. edulis Hitchc.) - Occasionally cultivated as a forage grass and escaped here and there. Exploited at one time under the name billion-dollar grass.

3. Echinochloa crus-pavónis (H.B.K.) Schult. (Fig. 1557.) Culms erect or sometimes decumbent at base, as much as $1 \mathrm{~m}$ tall; blades 5 to $15 \mathrm{~mm}$ wide; panicle 10 to $20 \mathrm{~cm}$ long, nodding, rather soft,

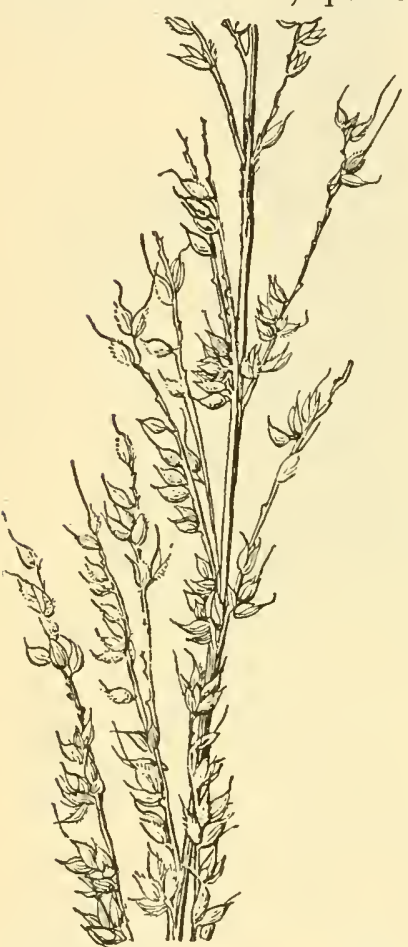

FIGURE 1558.-Echinochloa paludigena, $\times 1$. (Fredholm 6390, Fla.) pinkish or pale purple; racemes mostly ascending or appressed, the lower somewhat distant; spikelets about $3 \mathrm{~mm}$ long, hispid on the nerves, hispidulous on the internerves, the awn usually about $1 \mathrm{~cm}$

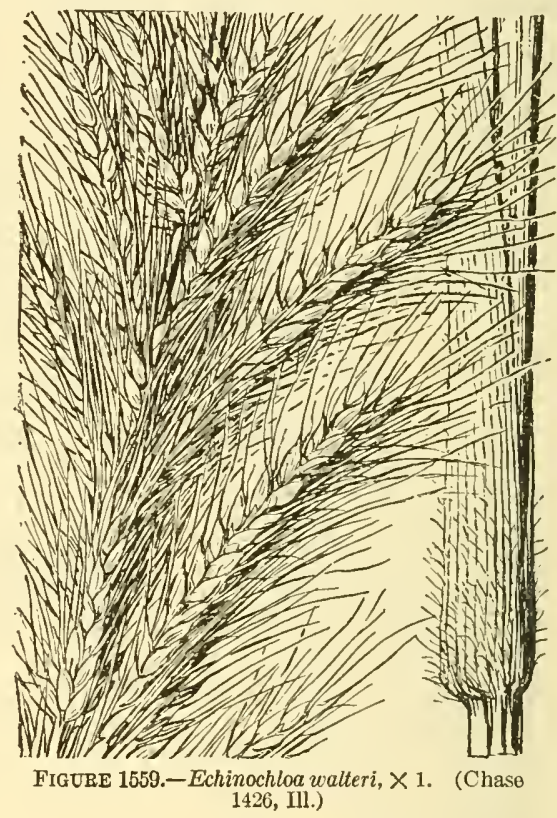

long. $\odot$ (E. crusgalli crus-pavonis Hitchc.)-Marshes and wet places, often in the water, Alabama, southern Texas, and through tropical America at low altitudes.

4. Echinochloa paludígena Wiegand. (Fig. 1558.) Culms mostly solitary, erect, rather stout, usually 1 to $1.5 \mathrm{~m}$ tall; blades elongate, 8 to $20 \mathrm{~mm}$ wide; panicle narrow, usually 20 to $30 \mathrm{~cm}$ long; racemes ascending, usually simple, rather evenly distributed on the axis, not closely crowded, sometimes remote; spikelets about as in E. crusgalli, but on the average less strongly tuberculate; sterile floret staminate. $\odot \quad$-Ditches, marshes, and wet places, often in shallow water, south and central Florida.

5. Echinochloa waltéri (Pursh) Heller. (Fig. 1559.) Culms usually stout, erect, 1 to $2 \mathrm{~m}$ tall; sheaths papillose-hispid or papillose only, sometimes only the lower sheaths hispid or the hairs on the 
margins only; panicle dense, as much as $30 \mathrm{~cm}$ long; spikelets somewhat less turgid than in E. crusgalli, the awns usually purple, 1 to 2 cm long or sometimes longer. $\odot-$ Wet places, often in shallow water, or brackish marshes, Coastal Plain, Massachusetts to Florida and Texas; New York to Wisconsin, Iowa, and Kentucky (fig. 1560). Sheaths rarely glabrous (E. longearistata Nash).

\section{TRICHOLAÉNA Schrad.}

Spikelets on short capillary pedicels; first glume minute, villous; second glume and sterile lemma equal, raised on a stipe above the first glume, emarginate or slightly lobed, shortawned, covered, except toward the apex, with long silky hairs, the palea of the sterile lemma well developed; fertile lemma shorter than the spikelet, cartilaginous, smooth, boat-shaped, obtuse, the margin thin, not inrolled, enclosing the margins of the palea. Perennial or annual grasses, with rather open panicles of silky spikelets. Type species, Tricholaena micrantha

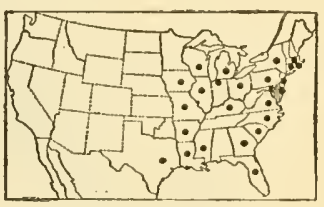

Figure 1560.-Distribution of Echinochloa walteri.

Schrad. Named from Greek thrix (trich-) hair, and chlaina, cloak, alluding to the silky spikelets.

1. Tricholaena rốsea Nees. Natal grass. (Fig. 1561.) Annual; culms slender, about $1 \mathrm{~m}$ tall; blades flat, 2 to $5 \mathrm{~mm}$ wide; panicle rosy purple, 10 to $15 \mathrm{~cm}$ long, the branches slender, ascending; spikelets about $5 \mathrm{~mm}$ long, the capillary pedicels flexuous or recurved. $\odot \quad$ Sandy prairies, open woods, fields, and waste places, Florida and Texas; naturalized from South Africa; drier parts of tropical America at low altitudes. Cultivated as a meadow grass in sandy soil in Florida and more rarely along the Gulf coast. Referred by some to Rhynchelytrum repens (Willd.) Hubb., a dubious name.

\section{CORIDÓCHLOA Nees}

Spikelets flattened, ovate, in 2 or 3's, subsessile along a slender rachis; glumes and sterile lemma papery, the second glume stiffly ciliate; fruit stipitate, awned. Annual, with several digitate racemes naked at base.

Coridóchloa cimicína (L.) Nees. Culms 20 to $60 \mathrm{~cm}$ tall; sheaths hispid; blades 3 to $8 \mathrm{~cm}$ long, 1.5 to $2.5 \mathrm{~cm}$ wide, subcordate; racemes mostly 4 to 8 , digitate, sometimes a second whorl below; spikelets about $3 \mathrm{~mm}$ long, the awn of the fruit curved, about $1 \mathrm{~mm}$ long.Sparingly introduced in Florida. Southern Asia.

\section{SETÁria Beauv.}

\section{(Chaetochloa Scribn.)}

Spikelets subtended by one to several bristles (sterile branchlets), falling free from the bristles, awnless; first glume broad, usually less than half the length of the spikelet, 3- to 5-nerved; second glume and sterile lemma equal, or the glume shorter, several-nerved; fertile lemma coriaceous-indurate, smooth or transversely rugose. Annual or perennial grasses, with narrow terminal panicles, these dense and spikelike or somewhat loose and open. Type species, Setaria viridis. 


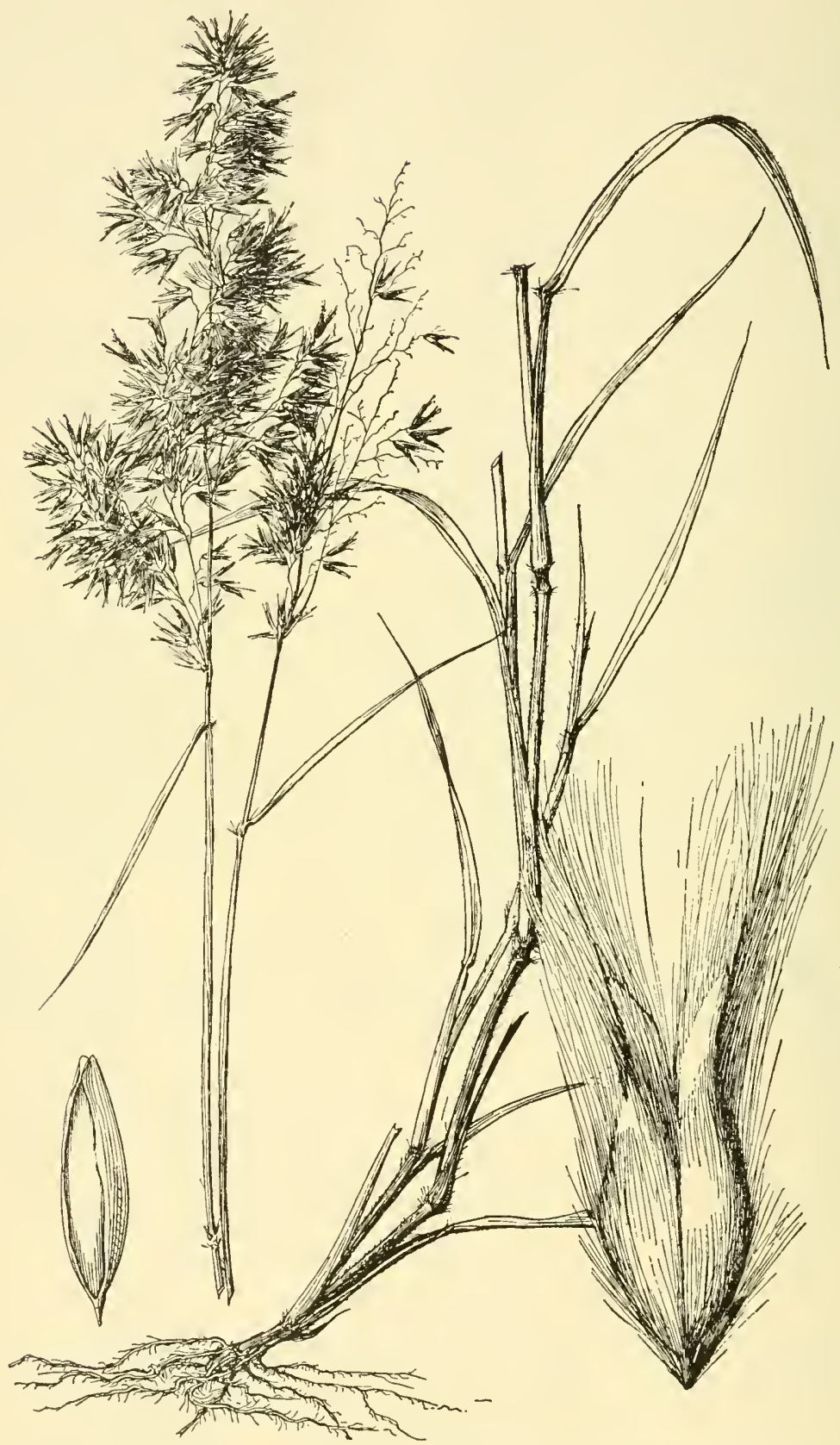

FigURE 1561.-T'richolaena rosea. Plant, $\times \frac{1}{2}$; spikelet and floret, $\times 10$. (Tracy 9365, Fla.) 
Name from Latin seta, a bristle, alluding to the numerous bristles of the inflorescence. The species are, in general, palatable and nutritious. A few species, especially S. macrostachya, form an appreciable part of the forage on southwestern ranges. Primitive peoples have cultivated S. italica, Italian or foxtail millet, since prehistoric times. The seed has been found in early remains such as those of the Swiss lake dwellings of the stone age. In America the species is used for hay. Another species, S. palmifolia, is cultivated for ornament in greenhouses.

Bristles below each spikelet numerous, at least more than 5. Panicle dense, cylindric, spikelike.

Plants ammual

1. S. LuTESCENS.

Plants perennial

Bristles below each spikelet 1 , or, by the abortion of the spikelets, 2 or 3 .

Bristles more or less retrorsely scabrous (antrorsely in var. ambigua)

Bristles antrorsely scabrous only.

Plants perennial.

Spikelets $3 \mathrm{~mm}$ long.

Blades scabrous............. S. Macrosperma.

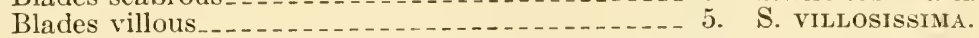

Spikelets 2 to $2.5 \mathrm{~mm}$ long.

Blades mostly less than $1 \mathrm{~cm}$ wide, often folded; panicles usually loosely or interruptedly spikelike, the branches usually not more than $1 \mathrm{~cm}$ long_... S. Macrostachy.

Blades flat, as much as $1.5 \mathrm{~cm}$ wide; panicles tapering from near the base, the lower branches as much as $3 \mathrm{~cm}$ long_... 7. S. SCHEELEI.

Plants annual.

Fertile lemma coarsely transversely rugose.

Panicle densely cylindric_._._. S. Corrugata.

Panicle loosely flowered... S. LiEmManNi.

Fertile lemma finely cross-lined or nearly smooth.

Panicle loosely flowered, tapering above_..... 10. S. GRISEBACHII.

Panicle compactly flowered, sometimes interrupted at base.

Culms as much as $3 \mathrm{~m}$ tall. Bristles 1 to $2 \mathrm{~cm}$ long; fertile lemma smooth or nearly so .............. S. MAGNA.

Culms mostly less than $1 \mathrm{~m}$ tall.

Panicle cylindric, tapering above, green; spikelets falling entire.

12. S. VIRIDIS.

Panicle lobed or interrupted, often large and heavy, purple or yellow; fruit deciduous from glumes and sterile lemma.

13. S. italica.

1. Setaria lutéscens (Weigel) F. T. Hubb. Yellow BRIstleGrAss. (Fig. 1562.) Annual, branching at base; culms erect to prostrate, mostly 50 to $100 \mathrm{~cm}$ tall, compressed; sheaths keeled; blades as much as $25 \mathrm{~cm}$ long and $1 \mathrm{~cm}$ wide, flat, twisted in a loose spiral, villous toward the base above; panicle dense, evenly cylindric, spikelike, yellow at maturity, mostly 5 to $10 \mathrm{~cm}$ long, about $1 \mathrm{~cm}$ thick, the axis densely pubescent; bristles 5 to 20 in a cluster, the longer 2 to 3 times as long as the spikelet; spikelets $3 \mathrm{~mm}$ long; fruit strongly rugose. $\odot$-Cultivated soil and waste places, New Brunswick to South Dakota, south to northern Florida and Texas, occasional from British Columbia to California and New Mexico; Jamaica, at high altitudes (fig. 1563); introduced from Europe; widely distributed in temperate regions. This species has been erroneously referred to S. glauca (L.) Beauv.

2. Setaria geniculáta (Lam.) Beauv. Kлотroot bristlegrass. (Fig. 1564.) Resembling S. lutescens but perennial, producing short knotty branching rhizomes as much as $4 \mathrm{~cm}$ long; base of plant slender, wiry; blades mainly straight (not twisted as in S. lutescens); bristles 
yellow or purple, 1 to 3 times or even 6 times as long as the spikelet; spikelets 2 to 2.5 or even $3 \mathrm{~mm}$ long. 24 -Open ground, pastures, cultivated soil, salt marshes, and moist ground along the coast, Massachusetts to Florida and Texas, in the interior north to West

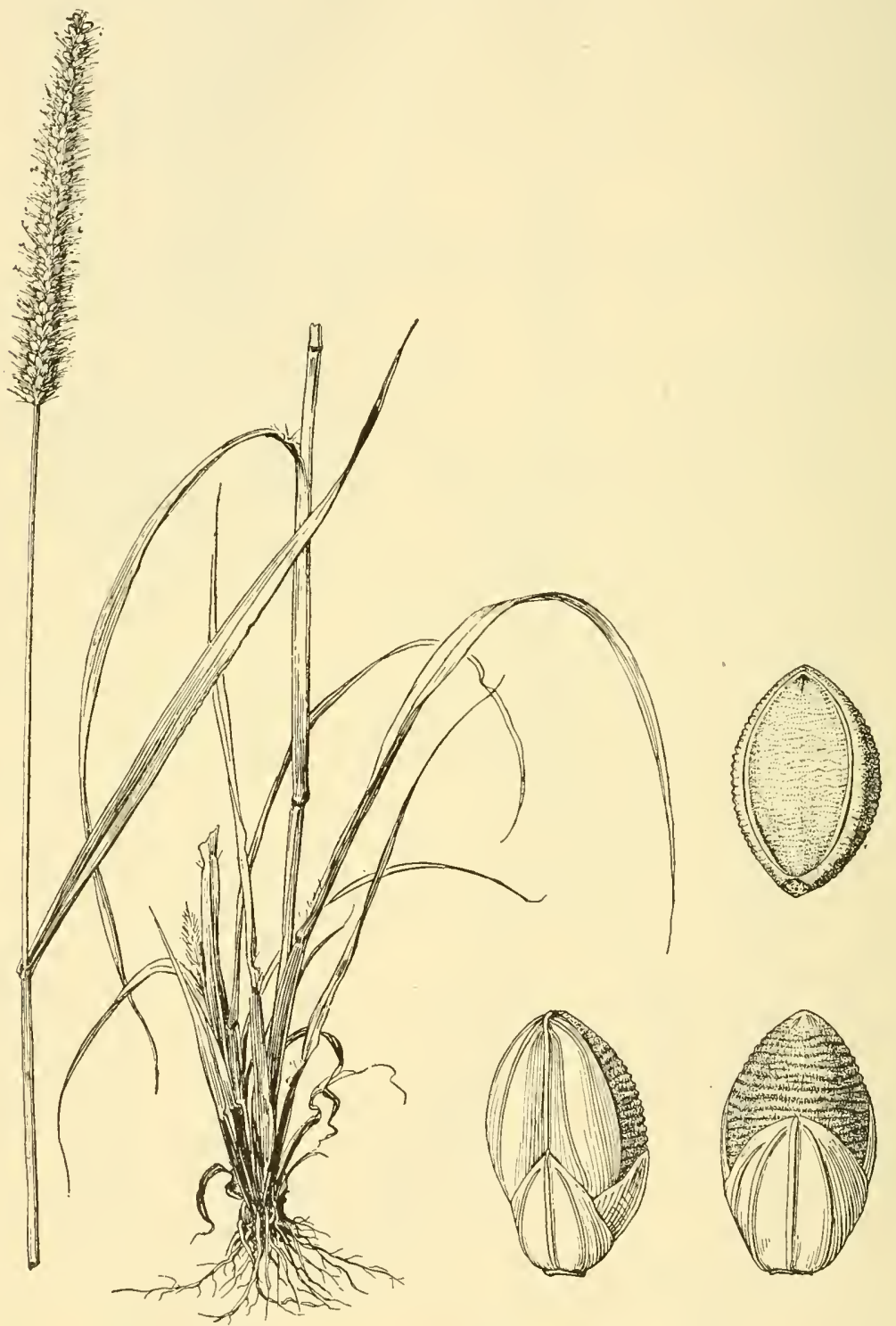

Figure 1562.-Setaria lutescens. Plant, $\times 1 / 2$; two views of spikelet, and floret, $\times 10$. (Chase 2986, D.C.)

Virginia, Illinois, and Kansas, west to California; tropical America to Argentina and Chile (fig. 1565).

Setaria nigriróstris (Nees) Dur. and Schinz. Perennial; resembling $S$. lutescens but the dense spikelike racemes purple or dark brown. 2 -Ballast, near Portland, Oreg.; South Africa. 
3. Setaria verticilláta (L.) Beauv. Bur bristlegrass. (Fig. 1566.) Annual, often much branched at base and geniculate-spreading, as much as $1 \mathrm{~m}$ long; blades flat, rather thin, scabrous and of ten more or less pilose, 10 to $20 \mathrm{~cm}$ long, 5 to $10 \mathrm{~mm}$ wide; panicle erect but not stiff, cylindric or somewhat tapering upward, more or

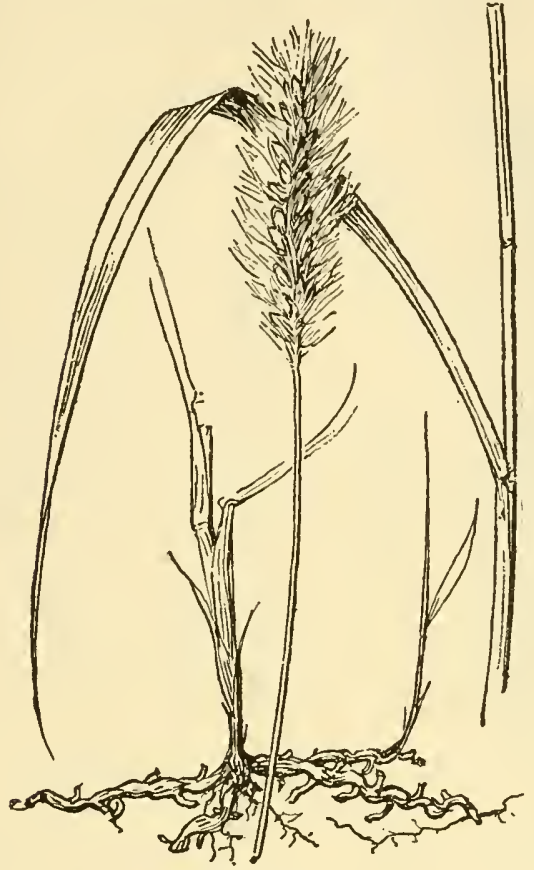

Figure 1564.-Setaria geniculata, $\times 1$. (Chase 2981, Md.)

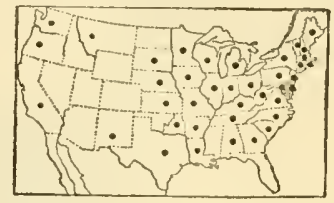

FigURe 1563.-Distribution of Setaria lutescens.

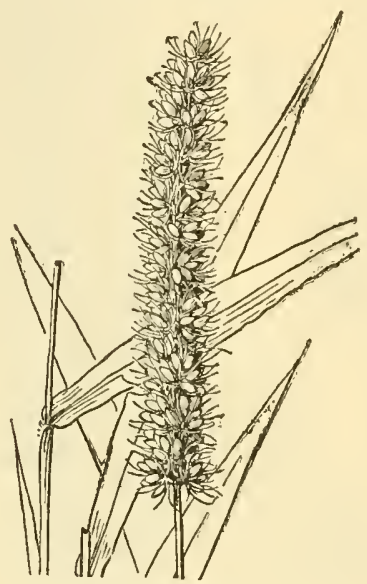

FIGURE 1566.-Setaria verticillata, $\times 1$. (Steele, D.C.)

less lobed or interrupted, especially toward base, 5 to $15 \mathrm{~cm}$ long, 7 to $15 \mathrm{~mm}$ wide; bristles single below each spikelet, 1 to 3 times as long as the spikelet, retrorsely scabrous; spikelets $2 \mathrm{~mm}$ long; fruit finely rugose. $\odot-$ Cultivated soil and waste places, Massachusetts to North Dakota, south to Alabama and Missouri, occasional west to

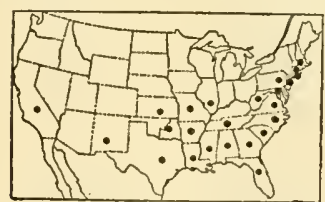

Figure 1565.-Distribution of Setaria genicutata.

California (fig. 1567); introduced from Europe; tropical America at medium altitudes.

Setaria verticillata var. ambígua (Guss.) Parl. Differing from $S$. verticillata in the scabrous but not pilose axis of the panicle and the antrorsely scabrous bristles, mostly 2 to 3 times as long as the spikelets, at maturity spreading and more or less implicate. $\odot-$

Sparingly introduced in the United States, ballast, and waste places, Albany, N.Y., Philadelphia, District of Columbia, and Mobile, Ala.; Europe.

4. Setaria macrospérma (Scribn. and Merr.) Schum. (Fig. 1568.) Perennial, often in large tufts, 1 to $1.5 \mathrm{~m}$ tall; sheaths keeled; blades elongate, 1 to $2 \mathrm{~cm}$ wide, scabrous on upper surface; panicle 15 to $30 \mathrm{~cm}$ long, 2 to $4 \mathrm{~cm}$ wide, tapering to both ends, rather loose, the secondary 
panicles smaller, compact, the branches of the terminal panicle as much as $2 \mathrm{~cm}$ long, about equally distributed; bristles single below each spikelet, 1.5 to $3 \mathrm{~cm}$ long; spikelets $3 \mathrm{~mm}$ long. 24 -Open ground, mostly on coral rock or coral sand, Florida; Bahamas.

5. Setaria villosíssima (Scribn. and Merr.) Schum. (Fig. 1569.) Perennial, as much as $1 \mathrm{~m}$ tall; blades flat, villous or scabrous only, 15 to $30 \mathrm{~cm}$ long, 5 to $10 \mathrm{~mm}$ wide; panicle rather loose, more or less interrupted, tapering above, as much as $25 \mathrm{~cm}$ long, the branches

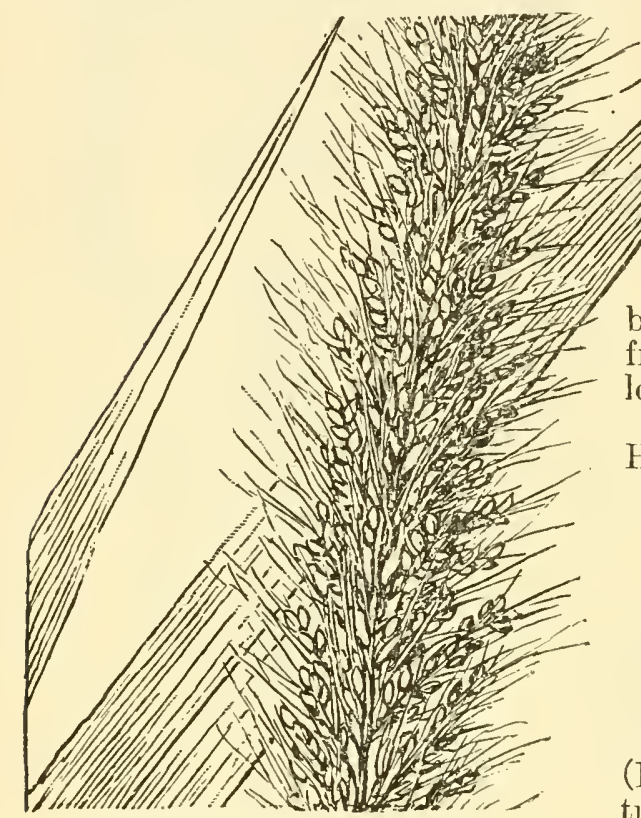

Figure 1568.-Setaria mactosperma, $\times 1$. (Curtiss 3617 , Fla.) ascending, the axis villous; bristles 1.5 to 2.5 cm long; spikelets about $3 \mathrm{~mm}$ long, the second glume slightly shorter; fruit finely rugose. 24 -A rare or little-known species from a few localities in Texas, and possibly from Arizona. Differing from S. macrosperrna in the villous blades and looser panicles.

6. Setaria macrostáchya H.B. K. Plains bristlegrass.

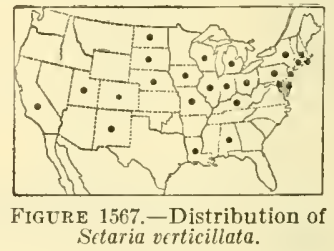

(Fig. 1570.) Perennial, densely tufted, usually pale or glaucous, 40 to $120 \mathrm{~cm}$ tall; blades flat or folded, scabrous on the upper surface, rarely pubescent on both surfaces, 15 to $40 \mathrm{~cm}$ long, 3 to $10 \mathrm{~mm}$ wide; panicle spikelike, 10 to $25 \mathrm{~cm}$ long, mostly 5 to $10 \mathrm{~mm}$ thick, somewhat tapering but not attenuate, more or less interrupted or lobed; bristles 10 to $15 \mathrm{~mm}$ long; spilielets 2 to $2.5 \mathrm{~mm}$ long, very turgid; fruit rugose. 2 4 - Open dry ground and dry woods, Texas to Colorado and Arizona; Mexico (fig. 1571). Variable, especially in the thickness of the panicle, sometimes very slender, occasionally to $15 \mathrm{~mm}$ thick. The type, from Mexico, is the robust form with thick panicles.

Setaria setósa (Swartz) Beauv. Panicle interrupted, attenuate at apex. $2 \mid$-Ballast, Camden, N.J., and Key West, Fla.; adventive from the West Indies.

Setaria rariflóra Mikan. Similar to $S$. setosa, the panicle and blades more slender. 24 -Mobile, Ala.; adventive from South America.

7. Setaria scheélei (Steud.) Hitchc. (Fig. 1572.) Perennial, 60 to $120 \mathrm{~cm}$ tall; sheaths compressed-keeled, glabrous or more or less hispid, the collar hispid; blades flat, elongate, as much as $1.5 \mathrm{~cm}$ wide, scabrous or more or less pubescent; panicle rather loose, mostly 15 to $20 \mathrm{~cm}$ long, tapering from near the base, the lower branches as much as $3 \mathrm{~cm}$ long, ascending, the axis scabrous-pubescent and rather 
sparsely villous; bristles 1 to $1.5 \mathrm{~cm}$ long, rather numerous, flexuous; spikelets about $2 \mathrm{~mm}$ long; fruit rugose. $24-$ Open or rocky woods, Texas and Arizona. Differing from $S$. macrostachya in the looser panicle and the longer lower branches.

8. Setaria corrugáta (Ell.) Schult. (Fig. 1573.) Annual, erect or geniculate-spreading; cul ms freely branching, as much as $1 \mathrm{~m}$ tall; blades flat, scabrous, as much as 30 $\mathrm{cm}$ long and $1 \mathrm{~cm}$ wide (commonly less than 5 $\mathrm{mm}$ ); panicle dense, cylindric, usually 5 to $10 \mathrm{~cm}$ long, the axis densely hispid-scabrous and also villous; bristles much exceeding the spikelets, sometimes as much as 2 cm long, green or purple; spikelets $2 \mathrm{~mm}$ long; fruit coarsely rugose. $\odot$ Sandy woods, cultivated
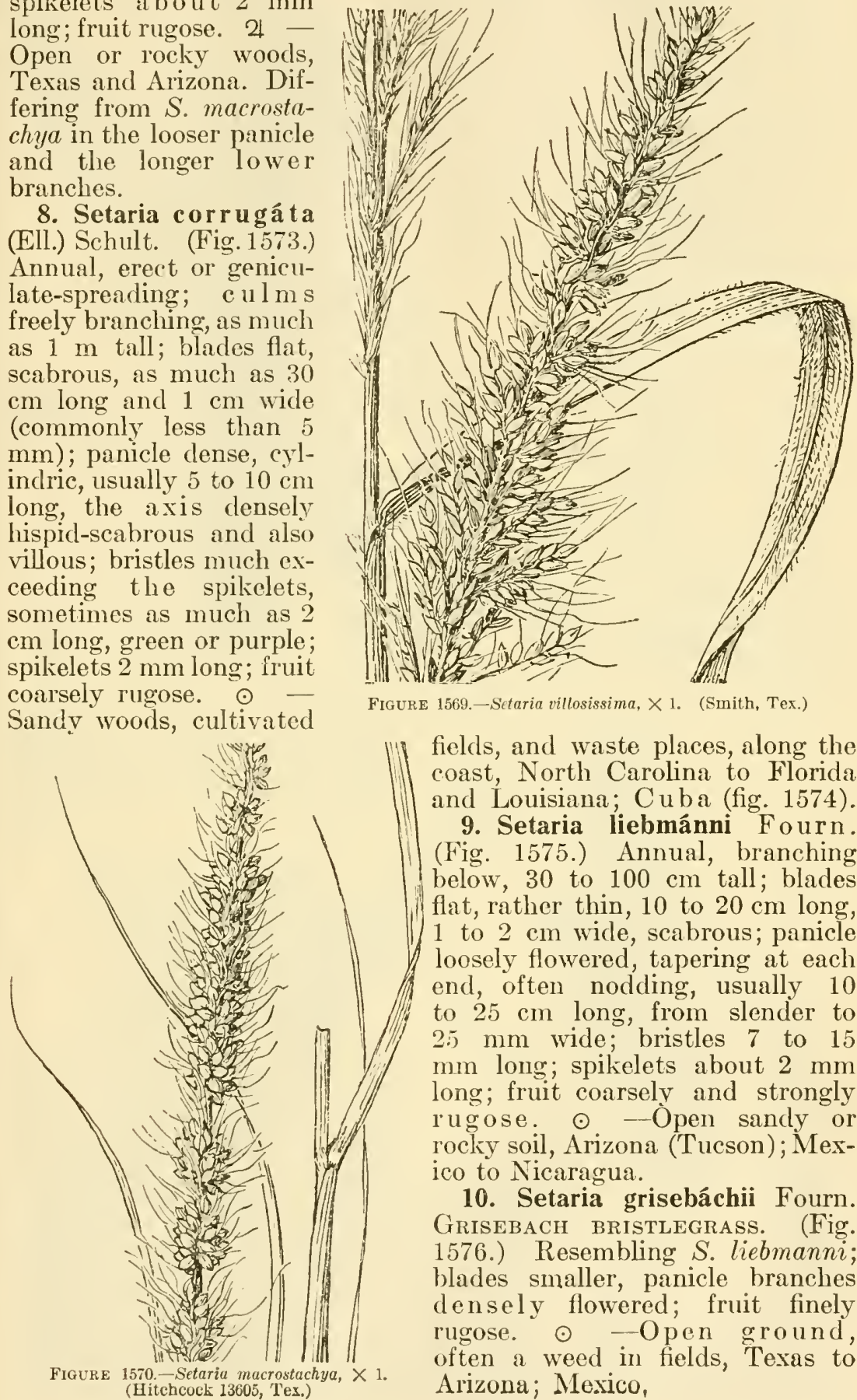

Figure 1569. - Setaria villosissima, $\times 1$. (Smith, Tex.)

III fields, and waste places, along the coast, North Carolina to Florida and Louisiana; Cuba (fig. 1574).

9. Setaria liebmánni Fourn. (Fig. 1575.) Annual, branching below, 30 to $100 \mathrm{~cm}$ tall; blades flat, rather thin, 10 to $20 \mathrm{~cm}$ long, 1 to $2 \mathrm{~cm}$ wide, scabrous; panicle loosely flowered, tapering at each end, often nodding, usually 10 to $25 \mathrm{~cm}$ long, from slender to $2.5 \mathrm{~mm}$ wide; bristles 7 to 15 $\mathrm{mm}$ long; spikelets about $2 \mathrm{~mm}$ long; fruit coarsely and strongly rugose. $\odot$ Open sandy or rocky soil, Arizona ('Tucson); Mexico to Nicaragua.

10. Setaria grisebáchii Fourn. Grisebach Bristlegrass. (Fig. 1576.) Resembling S. liebmanni; blades smaller, panicle branches densely flowered; fruit finely rugose. $\odot$-Open ground, often a weed in fields, Texas to Arizona; Mexico, 
11. Setaria mágna Griseb. Giant Bristlegrass. (Fig. 1577.) Annual, robust, erect; culms sparingly branching, as much as $4 \mathrm{~m}$ tall and $2 \mathrm{~cm}$ thick at base; blades flat, scabrous, as much as $50 \mathrm{~cm}$ long and $3.5 \mathrm{~cm}$ wide; panicles densely flowered, nodding, of ten interrupted at base, tapering at each end, as much as $50 \mathrm{~cm}$ long and $3 \mathrm{~cm}$ thick, those of the branches much smaller; bristles 1 to $2 \mathrm{~cm}$ long; spikelets about $2 \mathrm{~nm}$ long;

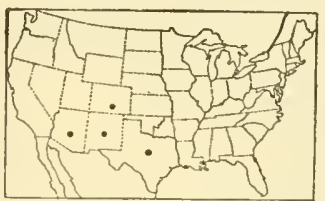
Setaria macrostachya.

fruit smooth or nearly so, brown and shining at maturity.

Marshes and wet places along the coast, $\mathrm{New}$ Jersey to Florida and Texas; West Indies (fig. 1578).

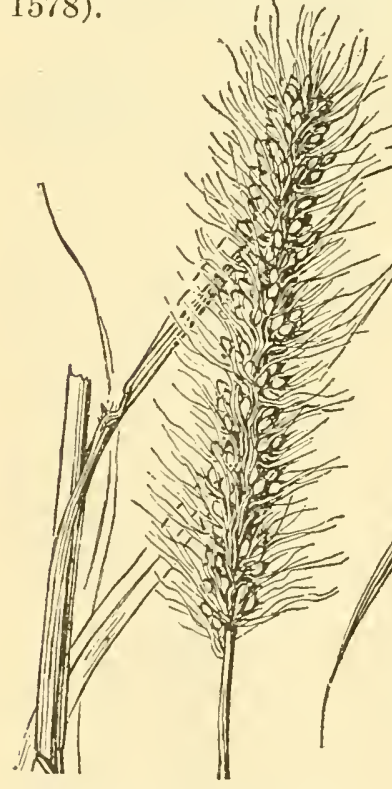

Figure 1573. - Setaria corrugata, $\times 1$. (Pollard and Collins 253, Fla.)

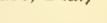

FIGURE 1571.-Distribution of

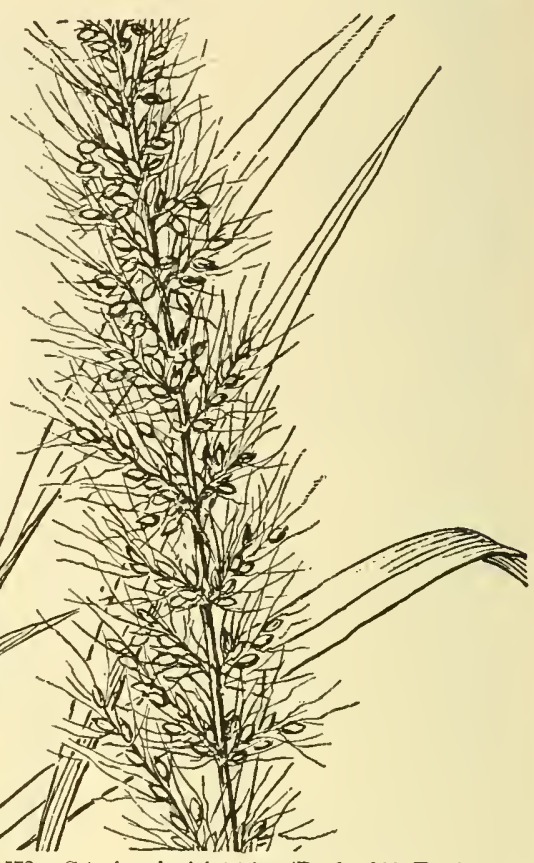

Figure 1572. - Setaria scheelei, $\times 1$. (Bush 1244, Tex.)

12. Setaria víridis (L.) Beauv. Green bristlegrass. (Fig.1579.) Annual, branching at base, sometimes geniculate-spreading, 20 to $40 \mathrm{~cm}$ tall (or even $1 \mathrm{~m}$ ); blades

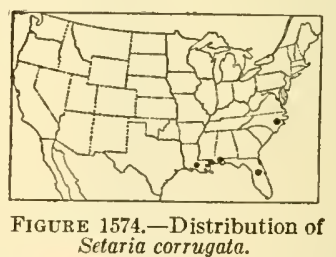

flat, usually less than $15 \mathrm{~cm}$ long and $1 \mathrm{~cm}$ wide; panicle erect or somewhat nodding, densely flowered, green or purple, cylindric but tapering a little at the summit, usually less than $7 \mathrm{~cm}$ long; bristles 1 to 3 below each spikelet, mostly 3 to 4 times their length; spikelets 2 to $2.5 \mathrm{~mm}$ long; fruit very finely rugose. $\odot-A$ weed in cultivated soil and waste places, common throughout the cooler parts of the United States, Newfoundland to British Columbia, south to Florida and California, infrequent in the Southern States and in the mountains; introduced from Europe. 
MANUAL OF THE GRASSES OF THE UNITED STATES 703
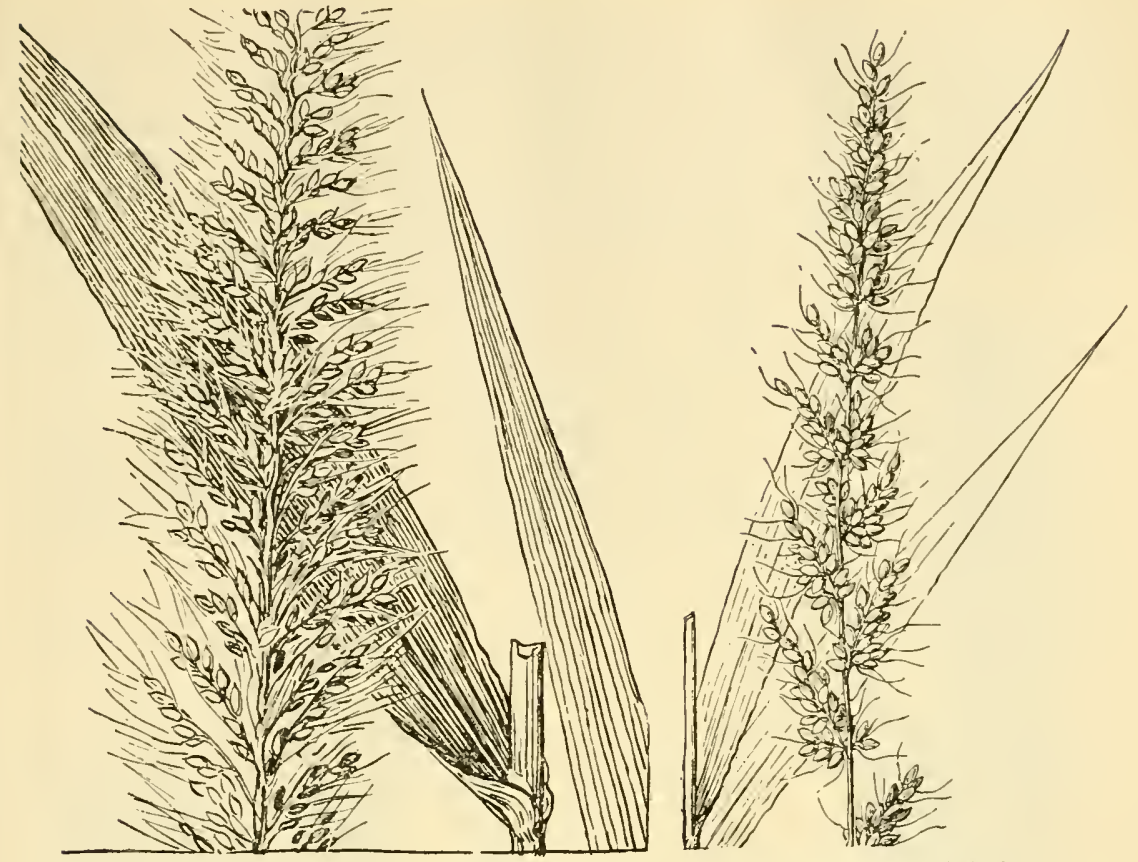

Figure 1575.-Setariu liebmanni, $\times$ 1. (Palmer 52, Mex.)

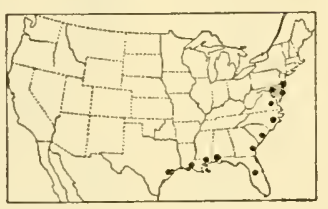

FIGURE 1578.-Distribution of

Figure 1576. - Setaria grisebachii, $\times 1$. (Metcalfe 1262, N.Mex.)

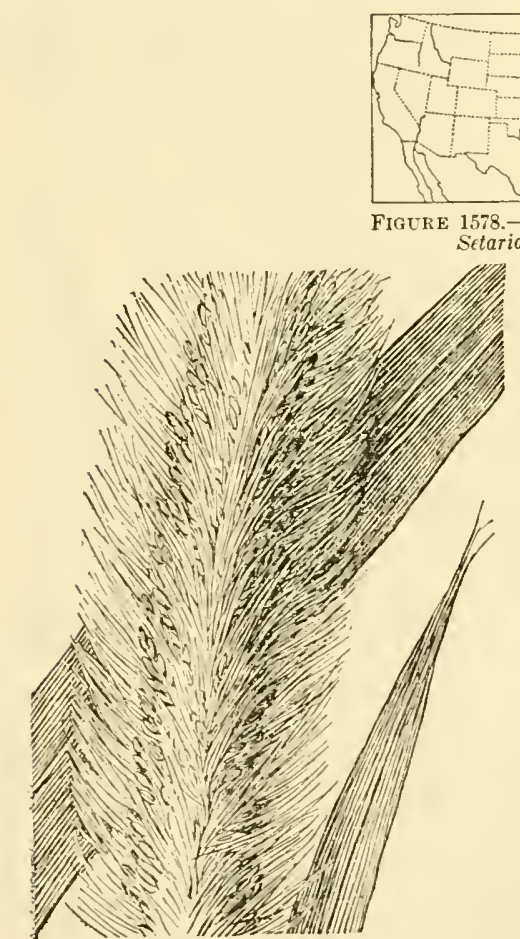

Figure 1577.-Setaria magna, $\times 1$. (Nash 1279, Fla.)

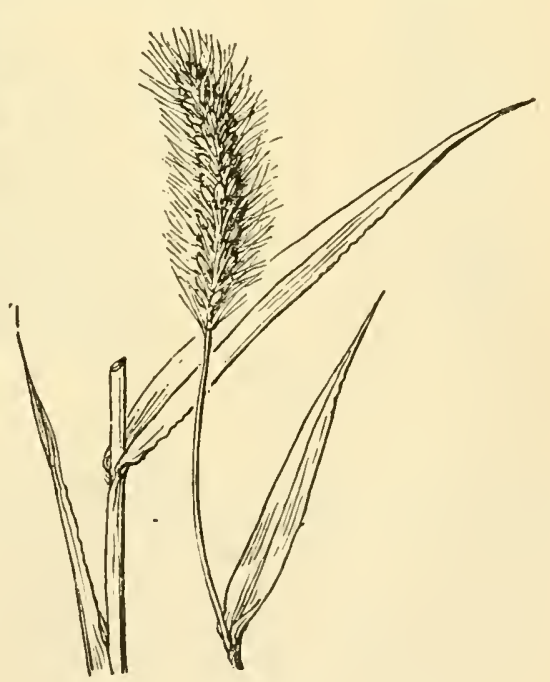

Figure 1579.-Setaria viridis, $\times 1$. (Thompson 129, Kans.) 
13. Setaria itálica (L.) Beauv. Foxtail millet. (Fig. 1580.) Cultivated form of $S$. viridis, more robust, with broader blades and larger lobed panicles, the fruit smooth or nearly so, shining at maturity, falling away from the remainder of the spikelet. In the larger forms the culms may be as much as $1 \mathrm{~cm}$ thick and the panicles as much as $30 \mathrm{~cm}$ long and $3 \mathrm{~cm}$ thick, yellow or purple; bristles from scarcely longer than the spikelets to 3 to 4 times as long; fruit tawny to red, brown, or black. The smaller forms are known as Hungarian

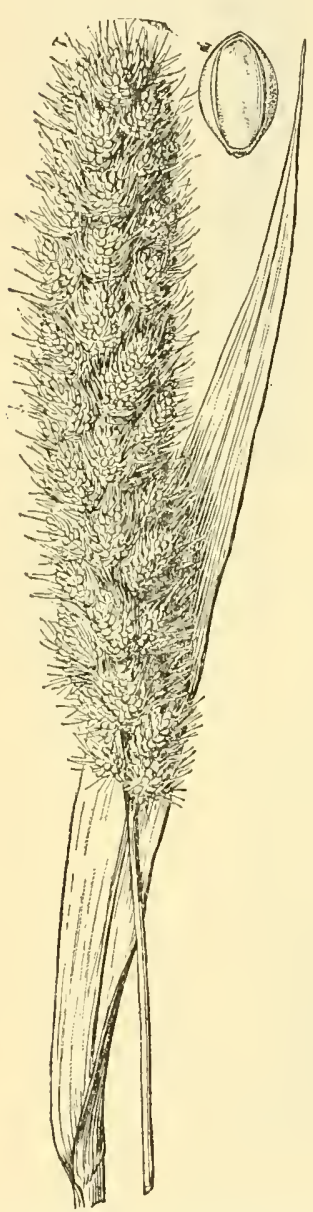

Figure 1580.-Setaria italica, $\times 1$; floret, $\times 5$. (W illiams 82 $\stackrel{\times}{\text { D.C.) }}$ grass. $\odot$-Cultivated in the warmer parts of the United States, especially from Nebraska to Texas; escaped from cultivation in waste places throughout the United States; Eurasia.

Setaria barbáta (Lam.) Kunth. Decumbent annual; blades thin, lightly plicate, 1 to $2.5 \mathrm{~cm}$ wide; panicles narrow, loose; bristles 5 to $10 \mathrm{~mm}$ long. $\odot \quad$-Ballast, Apalachicola and Miami, Fla.; adventive from East Indies.

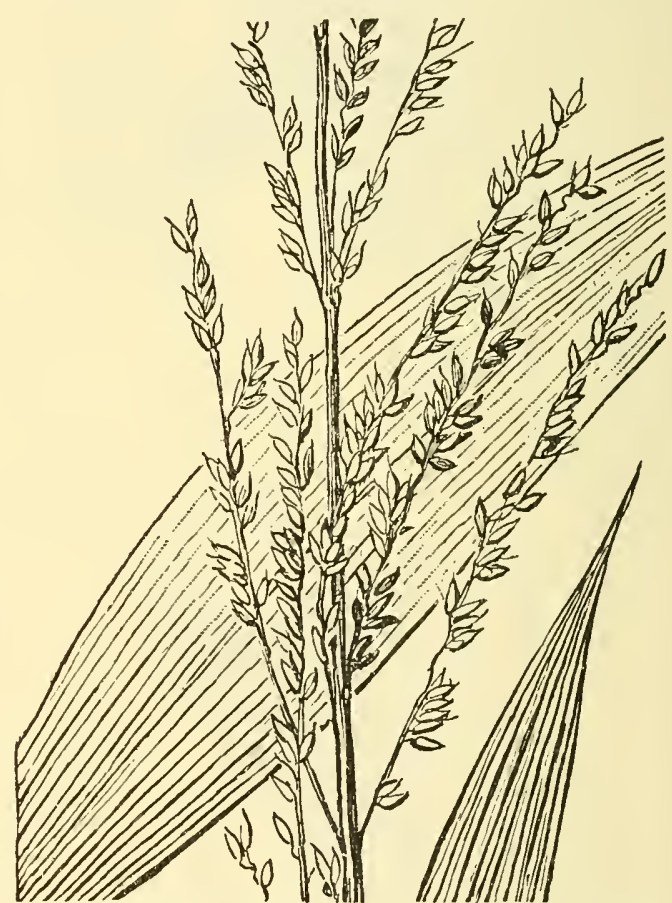

FIGURE 1581.-Setaria palmifolia, X 1. (Hitchcock 9727, Jamaica.)

Setaria palmifólia (Willd.) Stapf. Palmgrass. (Fig. 1581.) Tall perennial; blades plicate, as much as $50 \mathrm{~cm}$ long and $6 \mathrm{~cm}$ wide; panicle loose, 20 to $40 \mathrm{~cm}$ long; bristles inconspicuous. 24 -Cultivated in the South and in greenhouses for ornament. (Sometimes called Panicum plicatum.) Native of India.

Setaria poiretína (Schult.) Kunth. Differing from S. palmifolia in having a narrow panicle about $30 \mathrm{~cm}$ long with numerous ascending branches. 21 Occasionally cultivated for ornament. (Sometimes called Panicum sulcatum.) Tropical America. The last three species belong to the section Ptychophyllum. 


\section{PENNISÉTUM L. Rich.}

Spikelets solitary or in groups of two or threc, surrounded by an involucre of bristles (sterile branchlets), these not united except at the very base, often plumose, falling attached to the spikelets; first glume shorter than the spikelet, sometimes minute or wanting; second glume shorter than or equaling the sterile lemma; fertile lemma chartaceous, smooth, the margin thin, enclosing the palea. Annuals or perennials, often branched, with usually flat blades and dense spikelike panicles. Type species, Pennisetum typhoideum L. Rich. (P. glaucum). Name from Latin penna, feather, and seta, bristle, alluding to the plumose bristles of some species.

The most important species is $P$. glaucum, pearl millet, which is widely cultivated in tropical Africa and Asia, the seed being used for human food. It has been cultivated since prehistoric times, its wild prototype being unknown. In the United States pearl millet is used to a limited extent in the Southern States for forage, especially for soiling. Two species, $P$. villosum and $P$. ruppelii, are cultivated for ornament. An African species, $P$. purpureum, elephant or Napier grass, is used in the Southern States as a forage plant.

Plants annual; bristles of involucre about as long as the spikelets. Cultivated.

Plants perennial; bristles much longer than the spikelets.

1. P. GLaucun.

Longer bristles $1 \mathrm{~cm}$ long.

Bristles unlike, the inner silky, plumose _._. P. SEtosum.

Bristles all scabrous ... P. NERvosur.

Longer bristles 3 to $4 \mathrm{~cm}$ long, the panicles feathery.

Panicle oval, tawny.

4. P. villosum.

Panicle elongate, purple or rosy.

1. Pennisetum glaúcum (L.) R. Br. Pearl millet. (Fig. 1582.) Annual; culms robust, as much as $2 \mathrm{~m}$ tall, densely villous below the panicle; blades flat, cordate, sometimes as much as $1 \mathrm{~m}$ long and $5 \mathrm{~cm}$ wide; panicle cylindric, stiff, very dense, as much as 40 to $50 \mathrm{~cm}$ long and 2 to $2.5 \mathrm{~cm}$ thick, pale, bluish tinged, or sometimes tawny, the stout axis densely villous; fascicles peduncled, spikelets short-pediceled, 2 in a fascicle, 3.5 to $4.5 \mathrm{~mm}$ long, obovate, turgid, the grain at maturity protruding from the hairy-margined lemma and palea. (P. typhoideum L. Rich.; Penicillaria spicata Willd.)Cultivated to a limited extent in the Southern States for forage; Eastern Hemisphere.

Pennisetum purpúreum Schumach. Napier grass. Robust leafy perennial, 2 to $4 \mathrm{~m}$ tall; blades elongate, 2 to $3 \mathrm{~cm}$ wide; panicle dense, elongate, stiff, tawny or purplish, with sparsely plumose bristles about $1 \mathrm{~cm}$ long. 2 -Introduced from Africa; used as a forage plant in southern Florida; grown in the West Indies and South America. Also called clephant grass.

2. Pennisetum setósum (Swartz) L. Rich. (Fig. 1583.) Perennial; culms sometimes 30 or more in loose clumps, 1 to $2 \mathrm{~m}$ tall, geniculate, sometimes rooting at the lower nodes, bearing 1 to several flowering branches from the lower and middle nodes, scabrous below the panicle; blades elongate, 4 to $18 \mathrm{~mm}$ wide; panicle 10 to $25 \mathrm{~cm}$ long, 8 to $10 \mathrm{~mm}$ thick, excluding the bristles, rather dense, yellow to purple; fascicles reflexed at inaturity; bristles unequal, the outer delicate, mostly 


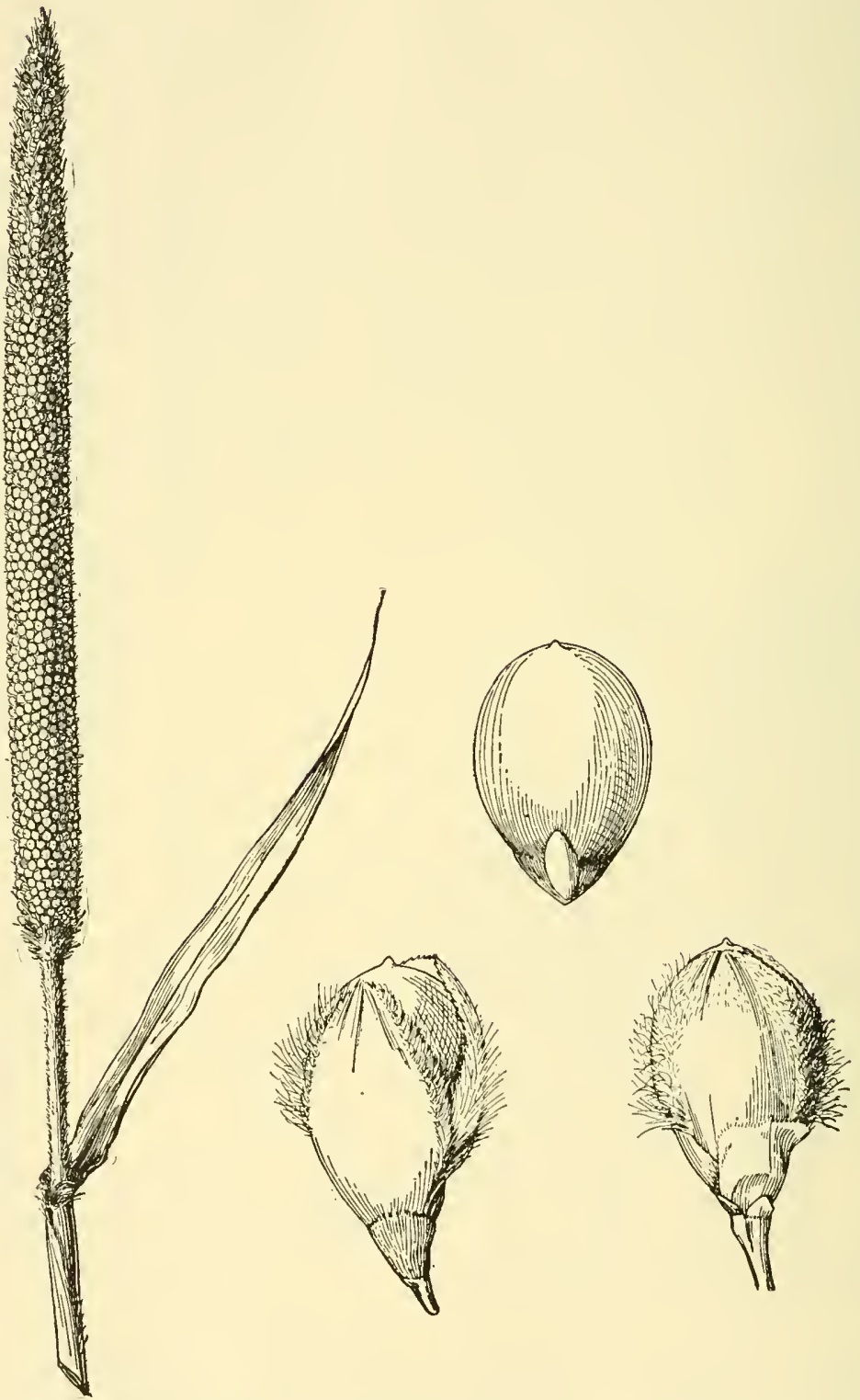

FIGURE 1582. - Pennisetum glaucum. Panicle, $\times 1 / 2$; two views of spikelet and grain, $\times 10$. (McCarthy, N.C.) 


$$
A C
$$


gate, scabrous; panicle 15 to $35 \mathrm{~cm}$ long, nodding, pink or purple; fascicles peduncled, rather loosely arranged, containing 1 to 3 spikelets; bristles plumose toward base, unequal,

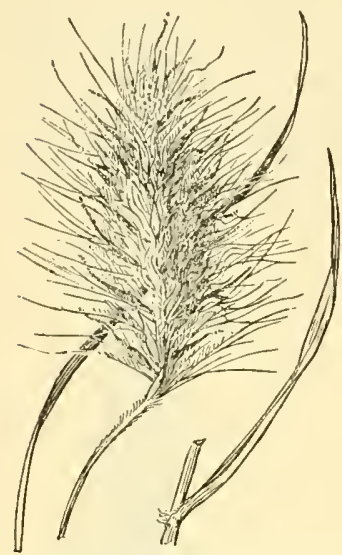

FIGURE 1585.-Pennisetum villosum, $\times 1 / 2$. (Eastwood 172 , Calif.)

the longer 3 to $4 \mathrm{~cm}$ long. 24 -Cultivated for ornament, especially as a border plant or around fountains. Introduced from Africa. Referred by some to $P$. setaceum (Forsk.) Chiov., a dubious name.

Pennisetum macrostáCHYUM (Brongn.) Trin. Resembling $P$. ruppelii; blades as much as $2.5 \mathrm{~cm}$ wide; panicle denser, brownish purple, fascicles smaller; bristles not plumose. 24 - Cultivated sparingly for ornament. East Indies.

Pennisetum alopecuroídes (L.) Spreng. Perennial; culms tufted, slender, 60 to $120 \mathrm{~cm}$ tall, pubescent below the panicle; blades long, narrow; panicle 5 to $20 \mathrm{~cm}$ long, tawny to purple; bristles prominent, of ten purple, scabrous. $24 \quad(P$. japonicum of gardens.)-Occasionally cultivated for

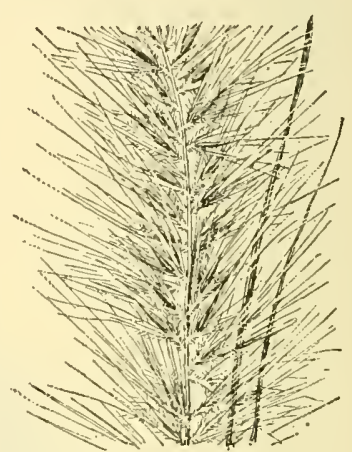

FIGURE 1586.-Pennisetum rup. pelii, $\times 1 / 2$. (Hitcheock, D.C.) ornament. China.

Pennisetdm latifóliom Spreng. Perennial; culms 100 to $150 \mathrm{~cm}$ tall, the nodes appressed-pubescent; blades 2 to $3 \mathrm{~cm}$ wide, tapering to a long point; panicles terminal and axillary, nodding, 5 to $8 \mathrm{~cm}$ long, the bristles prominent. 21 -Occasionally cultivated for ornament. South America.

\section{CÉNCHRUS L. SANDBUR}

Spikelets solitary or few together, surrounded and enclosed by a spiny bur composed of numerous coalescing bristles (sterile branchlets), the bur subglobular, the peduncle short and thick, articulate at base, falling with the spikelets and permanently enclosing them, the seed germinating within the old involucre, the spines usually retrorsely barbed. Annuals or sometimes perennials, commonly low and branching, with flat blades and racemes of burs, the burs readily deciduous. Type species, Cenchrus echinatus. Name from Greek kegchros, a kind of millet.

The species are excellent forage grasses before the burs are formed. Several species are weeds and become especially troublesome after the maturity of the burs.

Involucral lobes united at the base only. Racemes dense; plants perennial.

Involucral lobes united above the base.

1. C. MYOSUROIDES.

Involucre with a ring of slender bristles at base. Plants annual.

Burs, excluding the bristles, not more than $4 \mathrm{~mm}$ wide, numerous, crowded in a long raceme; lobes of the involucre interlocking, not spinelike.

2. C. viridis.

Burs, excluding the bristles, 5 to $7 \mathrm{~mm}$ wide, not densely crowded; lobes of the involucre erect or nearly so or rarely one or two lobes loosely interlocking, the tips spinelike._._._.

Involucre with flattened spreading spines, no ring of slender bristles at base.

Body of bur ovate, usually not more than $3.5 \mathrm{~mm}$ wide, tapering at base; plants perennial.

Burs glabrous; spines 4 to $6 \mathrm{~mm}$ long _......... 4. C. Gracillimos.

Burs pubescent; spines rarely more than $4 \mathrm{~mm}$ long, usually shorter.

5. C. INCERTUS. 
Body of bur globose, $5 \mathrm{~mm}$ wide or more, not tapering at base; plants annual. Burs, including spines, 7 to $8 \mathrm{~mm}$ wide, finely pubescent.

Burs, including spines, 10 to $15 \mathrm{~mm}$ wide, densely woolly.

6. C. PAUCIFLORUS.

7. C. tribuloides.

1. Cenchrus myosuroídes H. B. K. (Fig. 1587.) Stout glaucous woody perennial; culms erect from an often decumbent base, 1 to $1.5 \mathrm{~m}$
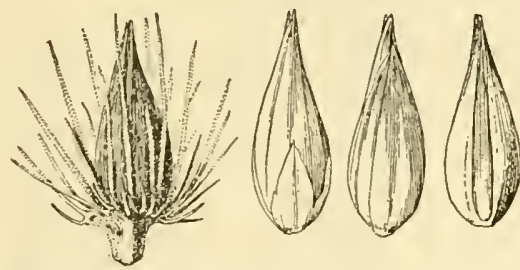

Figure 1597-Cenchrus myosuroides. Bur, two views of spikelet, and floret, $\times 5$. (Léon 835 , Cuba.)

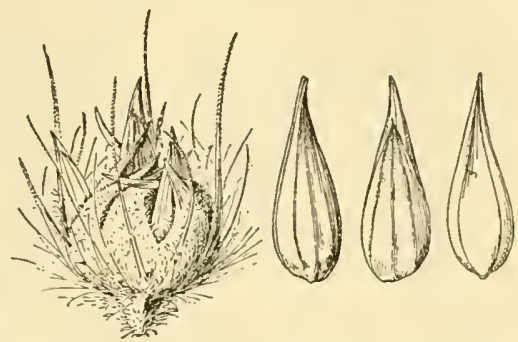

Figure 1588.-Cenchrus viridis. Bur, two views of spikelet, and floret, $\times 5$. (Type.)

tall, branching below; blades 5 to $12 \mathrm{~mm}$ wide; raceme 10 to $25 \mathrm{~cm}$ long, strict, erect, dense; burs 1 -flowered, about $5 \mathrm{~mm}$ wide, the bristles united at the base only, the outer shorter, the inner about as long as the spikelet; spikelet 4.5 to $5.5 \mathrm{~mm}$ long. 24 -Moist sandy open ground or scrubland near the coast, Georgia and Florida, southern Louisiana and southern Texas; tropical America.

Cenchrus barbátus Schum. Annual; culms 30 to $100 \mathrm{~cm}$ tall; raceme 8 to $10 \mathrm{~cm}$ long, the burs usually 2 -flowered, 4 to $6 \mathrm{~mm}$ long,

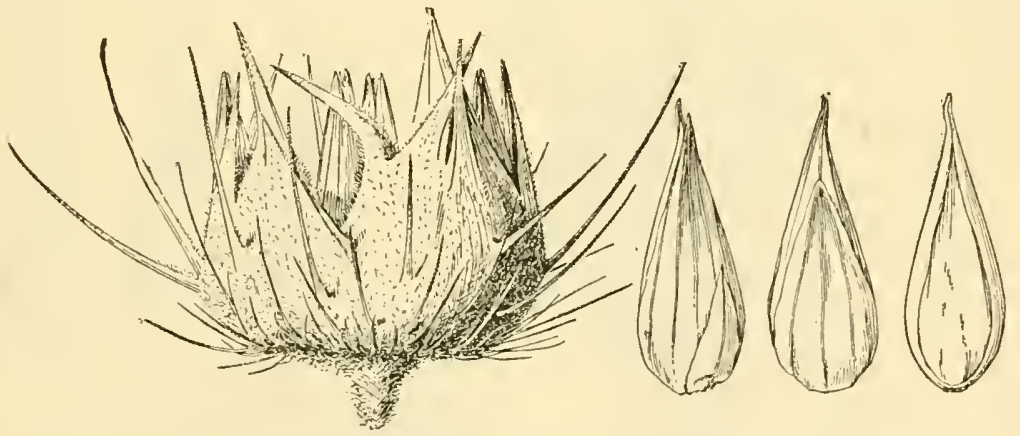
Figure 1589.-Cenchrus echinatus. Bur, two views of spikelet, and floret, $\times 5$. (Hitchcock
9379, Jamaica.)

the outer row of bristles short, spreading, the inner flattened, rigid, erect. $\odot \quad(C$. catharticus Del. $)$-Ballast, Mobile, Ala.; native of Nubia.

2. Cenchrus víridis Spreng. (Fig. 1588.) Annual, mostly erect, 30 to $100 \mathrm{~cm}$ tall; blades thin, flat, lax, 6 to $12 \mathrm{~mm}$ wide; raceme 4 to $10 \mathrm{~cm}$ long, dense; burs depressed globose, about $4 \mathrm{~mm}$ high, the outer bristles numerous, very slender, the inner somewhat exceeding the body, the lobes interlocking at maturity; spikelets usually $3 . \odot-$ Open ground, often a weed in waste places, Florida Keys; tropical America at low altitudes; introduced in Malaysia. 
3. Cenchrus echinátus L. (Fig. 1589.) Annual; culms, compressed, usually geniculate, branching at base, 25 to $60 \mathrm{~cm}$ long; blades 3 to $8 \mathrm{~mm}$ wide, pilose on the upper surface near the base; raceme 3 to $10 \mathrm{~cm}$ long, the burs larger, fewer, and less crowded than in $C$. viridis; bur 4 to $7 \mathrm{~mm}$ high, as broad or broader, pubescent, the lobes of the involucre erect or bent inward but not interlocking; spikelets usually 4 in each bur. $\odot-$ Open ground and waste places,

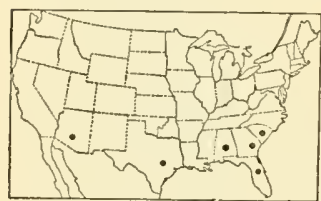

FigurE 1590.-Distribution of Cenchrus echinatus. South Carolina to New Mexico; a common weed in tropical America (fig. 1590); sparingly introduced in Hawaii and Malaysia.

4. Cenchrus gracíllimus Nash. (Fig. 1591.) Perennial, at length forming dense clumps, glabrous as a whole; culms slender, wiry, erect or ascending, 20 to $80 \mathrm{~cm}$ tall; blades usually folded, 2 to $3 \mathrm{~mm}$ wide; raceme 2 to $6 \mathrm{~cm}$ long, the burs relatively distant, about 3.5 , rarely as much as $5 \mathrm{~mm}$, wide (excluding spines), tapering at base, glabrous; spines spreading or reflexed, flat, 4 to $6 \mathrm{~mm}$ long, the lobes about 8 ; spikelets 2 or 3 in each bur. 2 - Sandy open ground and high pineland, Florida, southern Alabama; Cuba, Jamaica.

5. Cenchrus incértus M. A. Curtis. Coast sandbur (Fig. 1592.) Perennial, glabrous as a whole; culms 25 to $100 \mathrm{~cm}$ tall; blades commonly folded but sometimes flat, 2 to $5 \mathrm{~mm}$ wide; raceme 4 to $10 \mathrm{~cm}$

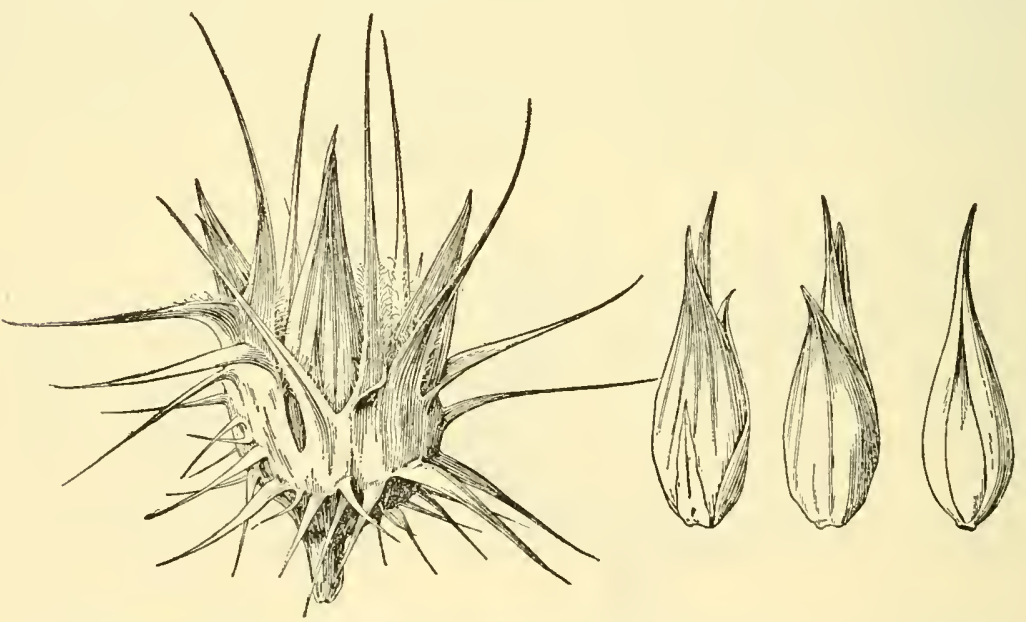

FIGURE 1591.-Cenchrus gracillimus. Bur, two views of spikelet, and floret, $\times 5$. (Type coll.)

long, the burs not crowded; burs about 3.5 (3 to 5) mm wide, the body finely and densely pubescent, the base glabrous; spines few, mostly less than $5 \mathrm{~mm}$ long, the lower of ten reduced or obsolete; spikelets 1 to 3 in each bur. 24 -Open sandy soil, Coastal Plain, North Carolina to Florida and 'Texas (fig. 1593).

6. Cenchrus pauciflórus Benth. Field sandbur. (Fig. 1594.) Annual, sometimes forming large mats; culms spreading, 20 to $90 \mathrm{~cm}$ long, rather stout; blades usually flat, 2 to $7 \mathrm{~mm}$ wide; raceme usually 3 to $8 \mathrm{~cm}$ long, the burs somewhat crowded; burs (excluding spines) mostly 4 to $6 \mathrm{~mm}$ wide, pubescent, often densely so; spines numerous, 
spreading or reflexed, flat, broadened at base, the lowermost shorter and relatively slender, some of the upper ones commonly 4 to $5 \mathrm{~mm}$ long, usually villous at the base; spikelets usually 2 in each bui. $\odot$ (Confused with $C$. tribuloides in early manuals; $C$. carolinianus of re-
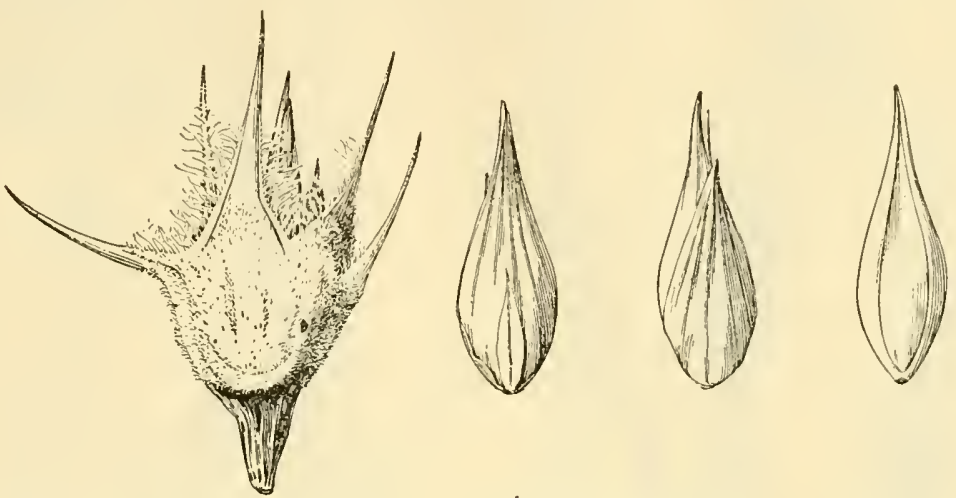

FIgURE 1592.-Cenchrus incertus. Bur, two views of spikelet, and floret, $\times 5$. (Curtiss, N.C.)

cent manuals, not of Walt.)-Sandy open ground, often a weed in

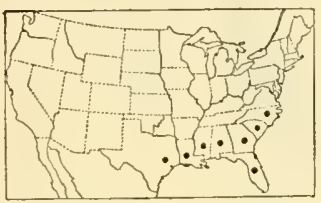

Figure 1593, -Distribution of Cenchrus incertus. sheaths usually much overlapping; burs
(excluding spines) 5 to $6 \mathrm{~mm}$ wide and 8 to $9 \mathrm{~mm}$ high, usually Texas, and California; Mexican plateau, coastal region of tropical America; southern South America.

7. Cenchrus tribuloídes L. DUNE SANDBUR. (Fig. 1595.) Resembling C. pauciflorus; culms stouter, soon branching and radiate-decumbent, rooting at the nodes; sandy fields, Maine to Oregon, south to Florida,

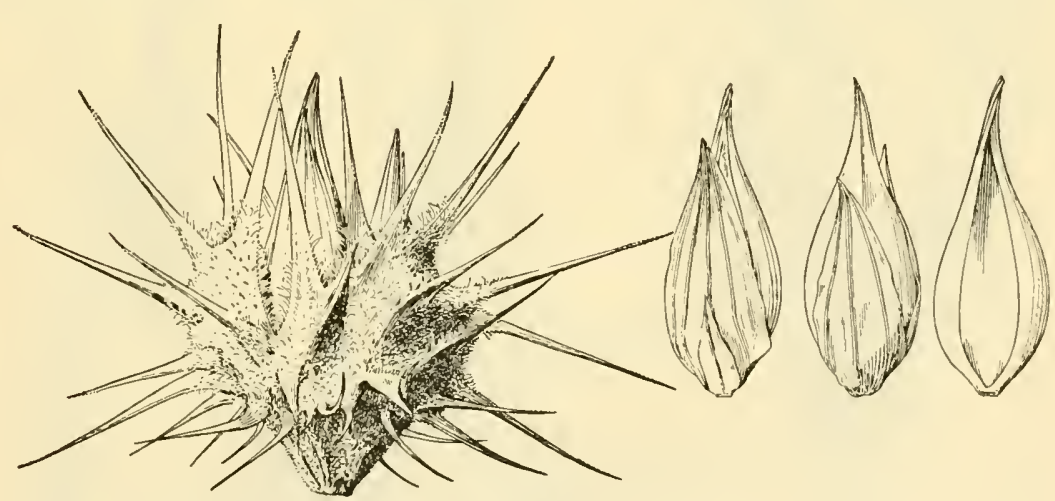

FigdRE 1594.-Cenchrus paucifiorus. Bur, two views of spikelet, and floret, $\times 5$. (Hitcheock 13582, N. Mex.)

conspicuously villous. $\odot$ - In loose sands of the coast, Staten Island to Florida and Louisiana; Atlantic coast of tropical America (fig. 1596). 

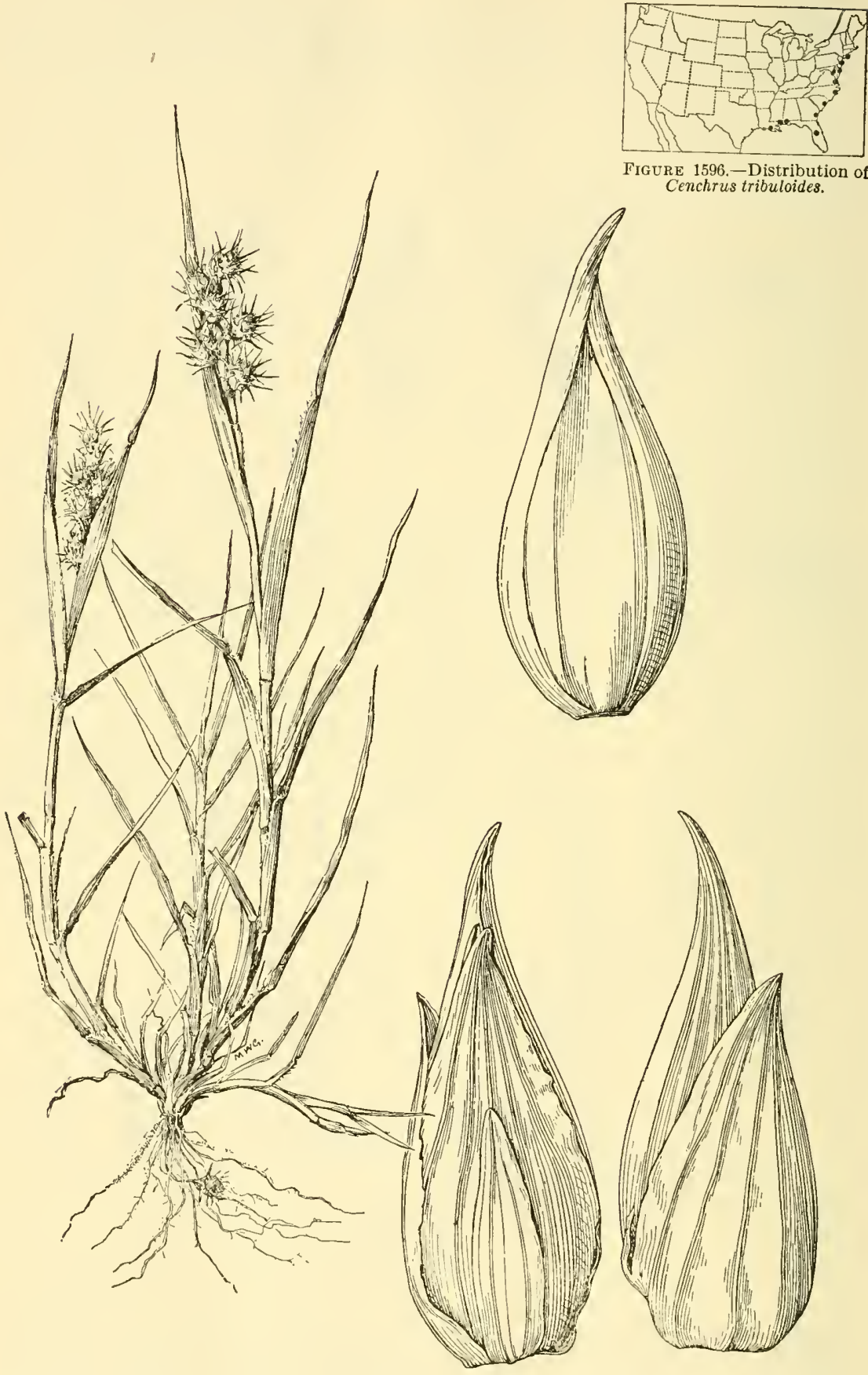
FIGURE 1596.-Distribution of
Cenchrus tribuloides.

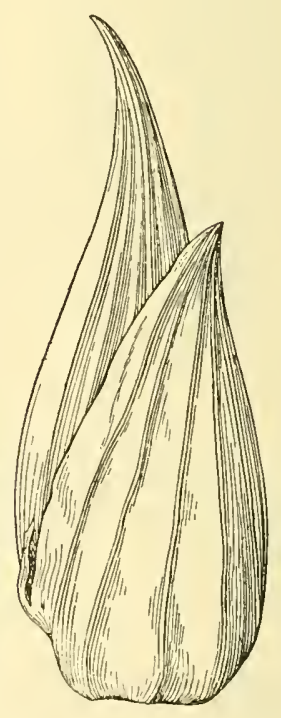

F1GURE 1595.-Cenchrus tribuloides. Plant, $\times 1 / 2$; two views of spikelet, and floret, $\times 10$. (Kearney, Va.) 


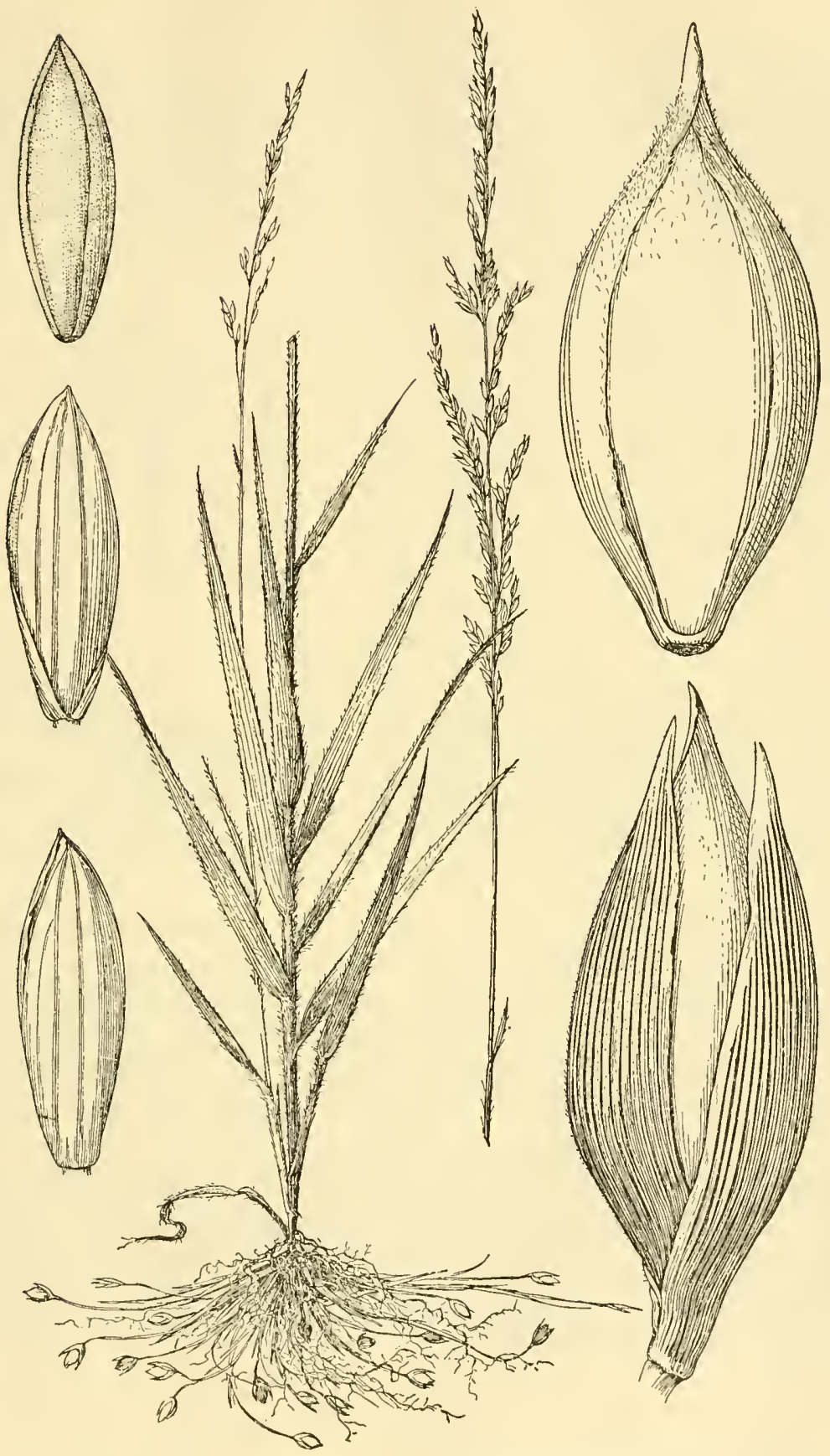

Figure 1597.-Amphicarpum purshii. Plant, $\times 1 / 2$; two views of aerial spikelet and floret, and subterranean spikelet and floret, $\times 10$. (Brinton, N.J.) 


\section{AMPHICÁRPUM Kunth}

\section{(Amphicarpon Raf.)}

Spikelets of two kinds on the same plant, one in a terminal panicle, perfect but not fruitful, the other cleistogamous on slender leafless subterranean branches from the base of the culm or sometimes also from the lower nodes; first glume of the aerial spikelets variable in size, sometimes obsolete; second glume and sterile lemma about equal; lemma and palea indurate, the margins of the lemma thin and flat; fruiting spikelets much larger, the first glume wanting; second glume and sterile lemma strongly nerved, subrigid, exceeded at maturity by the turgid, elliptic, acuminate fruit with

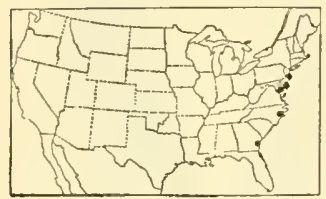

Figure 1598.-Distribution of Amphicarpum purshii. strongly indurate lemma and palea, the margins of the lemma thin and flat: stamens with small anthers on short filaments. Annual or perennial erect grasses, with flat blades and narrow terminal panicles. Type species, Milium amphicarpon Pursh (Amphicarpum purshii). Nàme from Greek a mphikarpos, doubly fruit-bearing, alluding to the two kinds of spikelets.

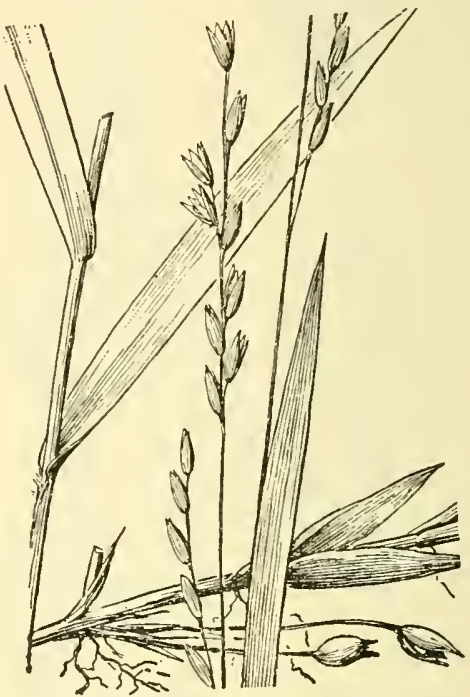

FIGURE 1599.-Amphicarpum muhlenbergianum, $\times 1$. (Chapman, Fla.)

Blades conspicuously hirsute

1. A. PURSHII. Blades glabrous or nearly so

1. Amphicarpum púrshii Kunth. (Fig. 1597.) Annual; culms erect, 30 to $80 \mathrm{~cm}$ tall, the leaves crowded toward the base, hirsute; hlades erect, 10 to $15 \mathrm{~cm}$ long, 5 to $15 \mathrm{~mm}$ wide, sharp-pointed; panicle 3 to $20 \mathrm{~cm}$ long; spikelets elliptic, 4 to $5 \mathrm{~mm}$ long; subterranean spikelets 7 to $8 \mathrm{~mm}$ long, plump, acuminate. $\odot$ (Amphicarpon amphicarpon Nash.) - Sandy pinelands, New Jersey to Georgia (fig. 1598).

2. Amphicarpum muhlenbergiánum (Schult.) Hitchc. (Fig. 1599.) Perennial; culms usually decumbent at base, 30 to $100 \mathrm{~cm}$ tall; leaves evenly distributed; blades firm, white-margined when dry, mostly less than $10 \mathrm{~cm}$ long, 5 to $10 \mathrm{~mm}$ wide; panicle long-exserted, few-flowered; spikelets narrowly lanceolate, 6 to $7 \mathrm{~mm}$ long; subterranean spikelets 6 to $9 \mathrm{~mm}$ long. 24 (A. floridanum Chapm.)-Low pinelands, South Carolina and Florida. 


\section{OLÝRA L.}

Plants monoecious; inflorescence paniculate; pistillate spikelets borne on the ends of the branches of loose panicles, the smaller staminate spikelets pedicellate below the pistillate ones, sometimes the upper branches all pistillate and the lower ones all staminate; pistillate spikelets rather large; first glume wanting; second glume and sterile lemma herbaceous, often caudate-acuminate; fruit bony-indurate; staminate spikelets readily deciduous; glumes and sterile lemma wanting, the lemma and palea membranaceous. Mostly tall perennials with broad flat blades, contracted into a petiole, and open or contracted panicles of glabrous spikelets. Type species, Olyra latifolia. Name from olura, an old Greek name for a kind of grain.

1. Olyra latifólia L. (Fig. 1600.) Glabrous perennial, bamboolike in aspect, commonly $5 \mathrm{~m}$ tall, with flat, firm, asymmetrically lanceolate-oblong, abruptly acuminate blades commonly $20 \mathrm{~cm}$ long and $5 \mathrm{~cm}$ wide, and ovoid panicles 10 to $15 \mathrm{~cm}$ long, the branches stiffly ascending or spreading, each bearing a single large long-acuminate pistillate spikelet at the thickened summit and several small slenderpediceled staminate spikelets along the branches. 21 - Said to occur in the region of Tampa Bay, Florida. but the record is doubtful; tropical America; Africa.

\section{TRIBE 13. ANDROPOGONEAE}

\section{IMPERATA Cyrillo}

Spikelets all alike, awnless, in pairs, unequally pedicellate on a slender continuous rachis, surrounded by long silky hairs; glumes about equal, membranaceous; sterile leinma, fertile lemma, and palea thin and hyaline. Perennial, slender, erect grasses, from hard scaly rhizomes, with terminal narrow silky panicles. Type species, Imperata cylindrica. Named for Ferrante Imperato.

Spikelets $4 \mathrm{~mm}$ long, the hairs at base twice as long; panicle oblong, rather lax 4 . Spikelets $3 \mathrm{~mm}$ long, the hairs 3 times as long; panicle elongate_-- 2. I. Hookeri.

1. Imperata brasiliénsis Trin. (Fig. 1601.) Culms 50 to $100 \mathrm{~cm}$ tall, from scaly rhizomes; leaves crowded below, 3 to $8 \mathrm{~mm}$ wide, the lower blades elongate, those of the culm short, the uppermost much reduced; panicle dense, pale or silvery, mostly about $10 \mathrm{~cm}$ long; spikelets $4 \mathrm{~mm}$ long: 21 -Pinelands, prairies, and Everglades, southern Florida; tropical America at low altitudes.

2. Imperata hookéri Rupr. Satintall. (Fig. 1602.) Resembling I. brasiliensis; culms 1 to $1.5 \mathrm{~m}$ tall; leaves less crowded at base, all but the uppermost elongate; panicle 15 to $30 \mathrm{~cm}$ long; spikelets 3 $\mathrm{mm}$ long, the hairs 3 times as long. 2 -Desert regions, western Texas to southern California and Nevada; Mexico (fig. 1603).

Imperata cylindrica (L.) Beaur. Spikelets 4 to $5 \mathrm{~mm}$ long, the hairs as long as in I. hookeri. 24 -Ballast, Portland, Oreg.; widespread in the Old World. 


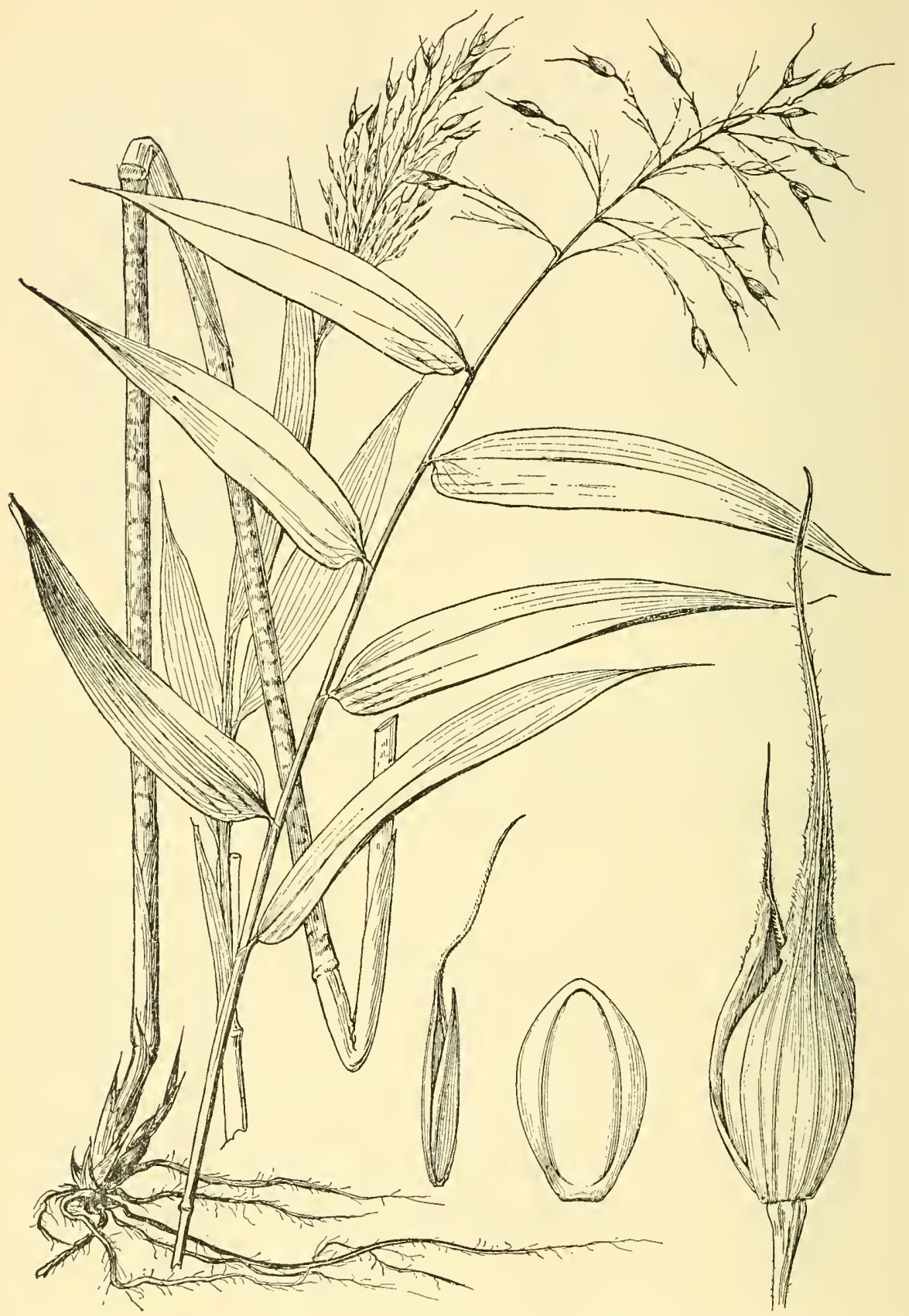

Figure 1600.-Olyra latifolia. Plant, $\times \frac{1}{2}$; pistillate and staminate spikelets, and fertile floret, $\times 5$. (Chase 6416, P.R.) 


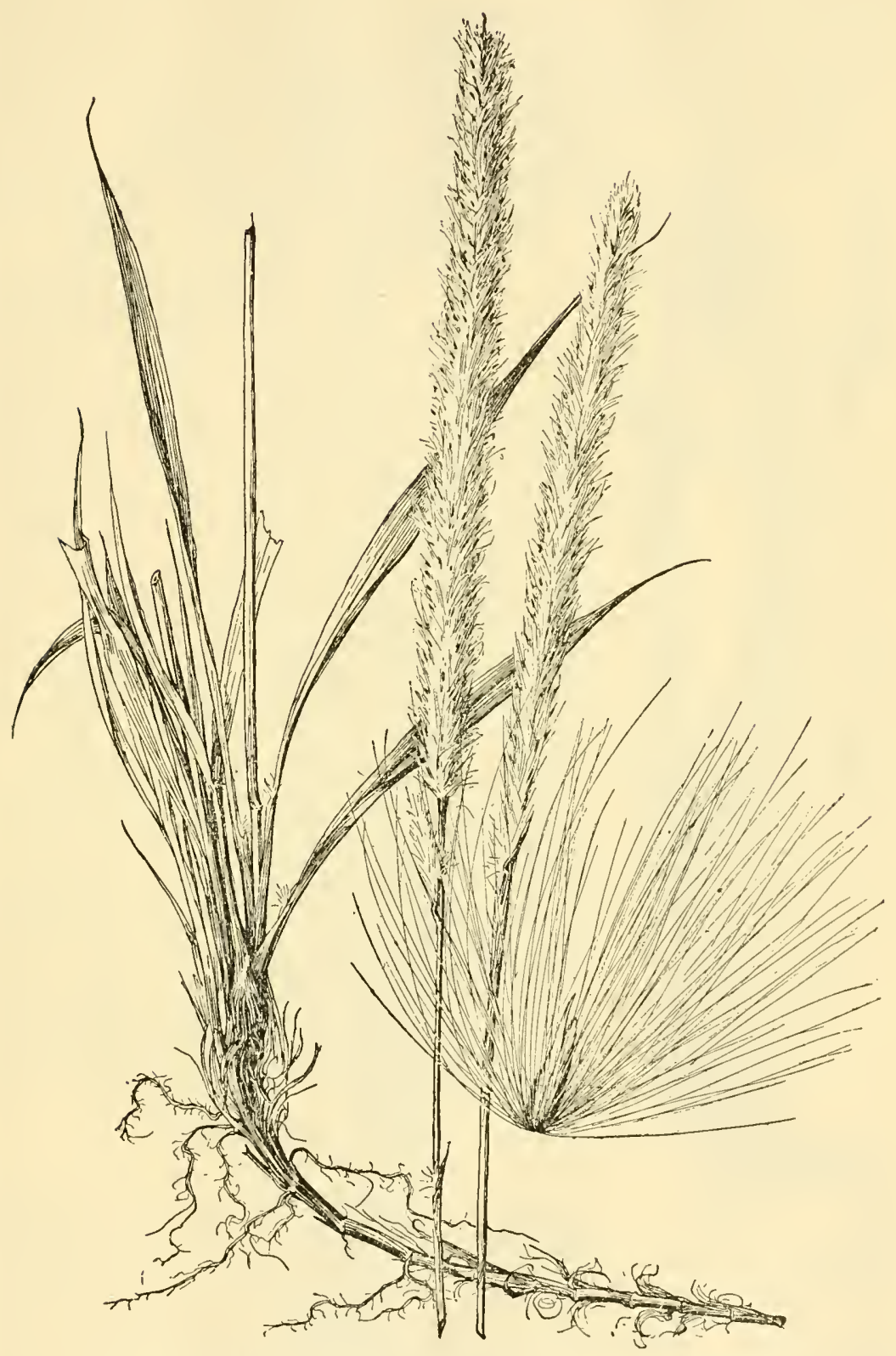

FIGURE 1601.-Imperata brasiliensis. Plant $\times 1 / 2$; spikelet $\times 5$. (Chapman, Fla.) 


\section{MISCÃNTHUUS Anderss.}

Spikelets all alike, in pairs, unequally pedicellate along a slender continuous rachis; glumes equal, membranaceous or somewhat coriaceous; sterile lemma a little shorter than the glumes, hyaline; fertile lemma hyaline, smaller than the sterile lemma, extending into a delicate bent and flexuous awn; palea small and hyaline. Robust perennials, with long flat blades and terminal panicles of aggregate spreading slender racemes. Type species, Miscanthus japonicus

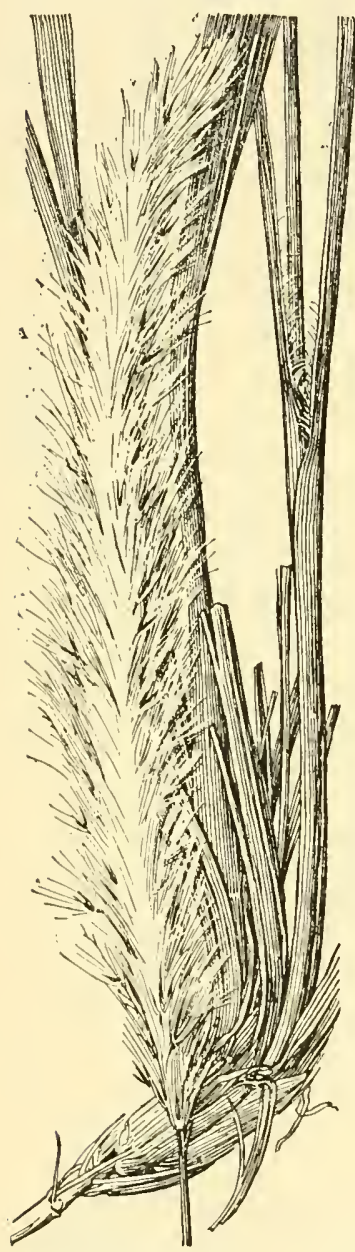

F1gURE 1602.-Impetata hookeri. Plant, $\times 1 / 2$; spikelet, $\times 5$. (Toumey 782, Ariz.) Anderss. Name from Greek mischos, pedicel, and anthos, flower, both spikelets of the pair being pediceled.

1. Miscanthus sinénsis Anderss. Eulalia. (Fig. 1604.) Culms robust in large bunches, erect, 2 to $3 \mathrm{~m}$ tall; leaves numerous, mostly basal, the blades flat, as much as $1 \mathrm{~m}$ long, about $1 \mathrm{~cm}$ wide, tapering to a slender point, the margin sharply serrate; panicle somewhat fan-shaped, consisting of numerous silky aggregate racemes, 10 to $20 \mathrm{~cm}$ long; spikelets with a tuft of silky hairs at base surrounding them and about as long as the glumes. 24 Cultivated for ornament and now growing wild in some localities in the Eastern States (fig. 1605); native of eastern Asia. There are three varieties in cultivation besides the usual form described above: $\mathrm{M}$. SINENSIS Var. VARIEGÁTUs Beal, with blades striped with white, $M$. SINENSIS var. ZEBRÍNUS

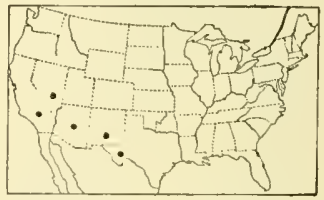

Figure 1603,-Distribution of Imperata hookeri.

Beal, with blades banded or zoned with white, and M. SINENSIS var. GRACíllimus Hitchc., with very narrow blades.

Miscanthus nepalénsis (Trin.) Hack. Panicles yellowish brown; spikelets about onefourth as long as the hairs at their base. 4 Occasionally cultivated under the name of Himalaya fairy grass. Nepal, India.

\section{SÁCCHARUM L.}

Spikelets in pairs, one sessile, the other pedicellate, both perfect, awnless, arranged in panicled racemes, the axis disarticulating below the spikelets; glumes somewhat indurate, sterile lemma similar but hyaline; fertile lemma hyaline, sometimes wanting. Robust perennials of tropical regions. Type species, Saccharum officinarum. Name from Latin saccharum (saccharon), sugar, because of the sweet juice.

1. Saccharum officinárum L. Sugarcane. (Fig. 1606.) Culms 3 to $5 \mathrm{~m}$ tall, 2 to $3 \mathrm{~cm}$ thick, solid, juicy, the lower internodes 


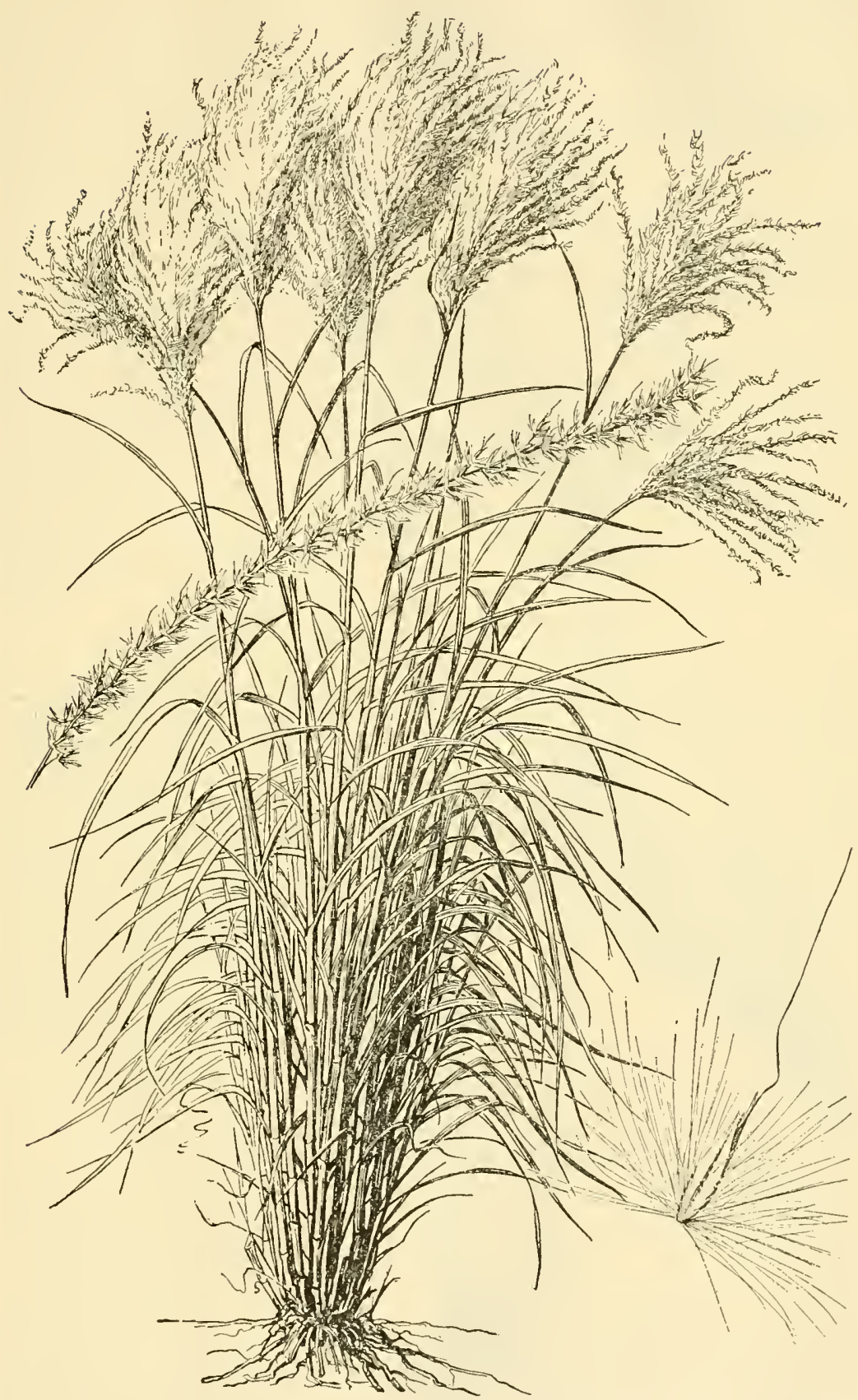

FIGURE 1604.-Miscanthus sinensis. Plant, much reduced; raceme, $\times 1 / 2$; spikelet, $\times 5$. (Cult.) $55974^{\circ}-35-46$ 


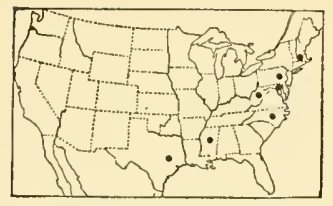

FIgURE 1605.-Distribution of Miscanthus sinensis.

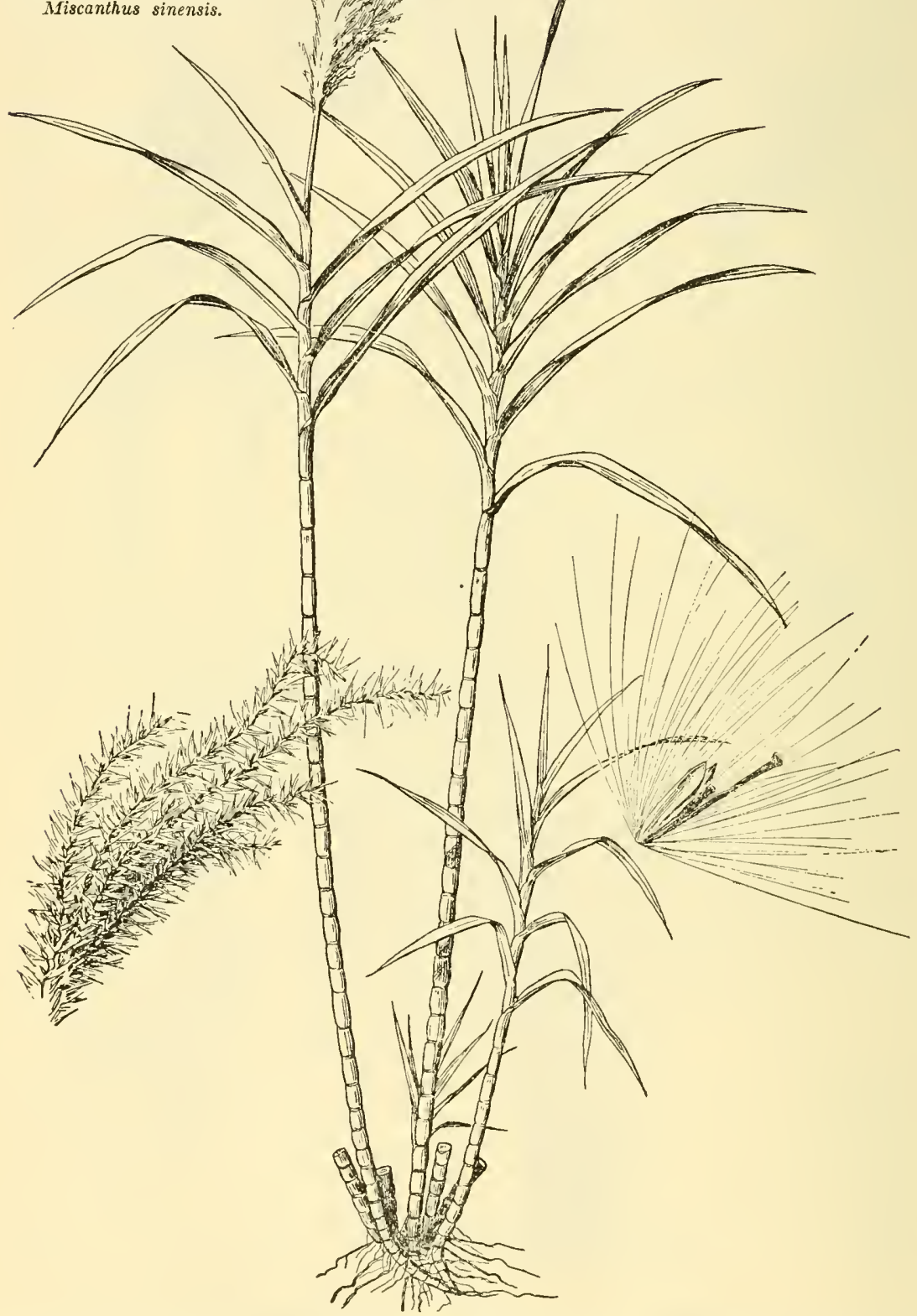

FIGURE 1606.-Saccharum officinarum. Plant, much reduced; racemes, $\times 1 / 2$; spikelet with pedicel and rachis joint, $\times 5$. (Pringle, Cuba.) 
short swollen; sheaths greatly overlapping, the lower usually falling from the culms; blades elongate, mostly 4 to $6 \mathrm{~cm}$ wide, with a very thick midrib; panicle plumelike, 20 to $60 \mathrm{~cm}$ long, the slender racemes drooping; spikelets about $3 \mathrm{~mm}$ long, obscured in a basal tuft of silky hairs 2 to 3 times as long as the spikelet. 24-Cultivated in the Southern States, especially Louisiana, for sugar and byproducts, and for sirup, and also used for forage; commonly cultivated in tropical regions.

The sugarcanes cultivated in the United States are derived chiefly from four species and their hybrids. In the Noble canes ( $S$. officinarum, chromosomes 40 ), described above, the axis of inflorescence is without long hairs. Chinese canes (S. sinensis Roxb., chromosomes about 58-60), with long hairs on the axis of inflorescence, are cultivated chiefly for sirup. Saccharum barberi Jeswiet (chromosomes about 45-46) from northern India, differs from the last in having narrower blades and more slender canes. Varieties of this species do not form an entirely homogeneous group and may later be separated into two or more species. The wild cane of Asia (S. spontaneum $\mathrm{L}$., chromosomes 56), is used as a basis for hybrids with other species. There are numerous hybrids and varieties of the species mentioned.

Saccharum ciliáre Anderss. Tall cane; blades very scabrous; panicle 70 to $80 \mathrm{~cm}$ long, narrow, dense, silvery. $\%$-Sometimes cultivated for ornament. India.

\section{ERIÁNTHús Michx. Plumegrass}

Spikelets all alike, in pairs along a slender axis, one sessile, the other pedicellate, the rachis disarticulating below the spikelets, the rachis joint and pedicel falling attached to the sessile spikelet; glumes coriaceous, equal, usually copiously clothed, at least at the base, with long silky spreading hairs; sterile lemma hyaline; fertile lemma hyaline, the midnerve extending into a slender awn; palea small, hyaline. Perennial reedlike grasses, with elongate flat blades and terminal oblong, usually dense silky panicles. Type species, Erianthus saccharoides. Name from Greek erion, wool, and anthos, flower, alluding to the woolly glumes.

Spikelets naked, or nearly so, at base _._._._._._. 1. E. strictus. Spikelets with a conspicuous tuft of hairs at base.

Awn flat, spirally coiled at base, the upper portion more or less bent and flexuous or loosely spiral.

Basal hairs about as long as the brownish spikelets; panicle not conspicuously hairy, the main axis and branches visible; culms usually glabrous below panicie........

Basal hairs copious, about twice as long as the yellowish spikelets; panicle conspicuously woolly, the hairs hiding the main axis and branches; culms villous below panicle _._........... 3. E. ALOpecurordes.

Awn terete, or flattened at base, not coiled, the upper portion straight or slightly flexuous.

Basal hairs rather sparse, shorter than the spikelet_._. 4. E. BREviBARBis.

Basal hairs copious, longer than the spikelet_...... 5. E. GIGANTEus.

1. Erianthus strictus Baldw. Narrow plumegrass. (Fig. 1607.) Culms 1 to $2 \mathrm{~m}$ tall, relatively slender, glabrous; nodes hirsute with stiff erect deciduous hairs; foliage glabrous, the lower sheaths narrow, crowded, the blades mostly 8 to $12 \mathrm{~mm}$ wide; panicle 20 to $40 \mathrm{~cm}$ long, strict, the branches closely appressed; spikelets brown, about $8 \mathrm{~mm}$ 
long, scabrous, nearly naked to sparsely short-hairy at base; awn

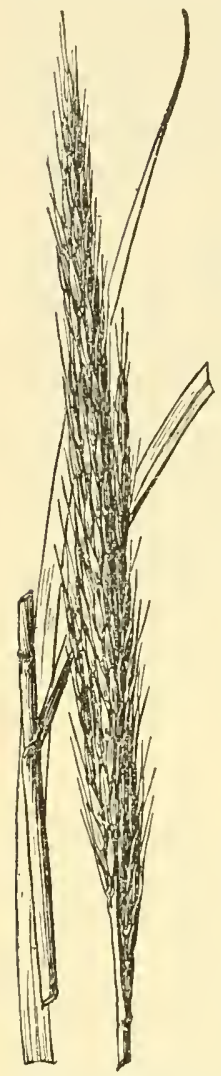

Fugure, 1607.-Erianthus strictus, $\times 1 / 2$. (Curtiss 6936 , Fla.) straight, about $15 \mathrm{~mm}$ long; rachis joint and pedicel scabrous. $21-$ Marshes and wet places, Coastal Plain, North Carolina to Florida and Texas, north to Tennessee and southern Missouri (fig. 1608).

\section{Erianthus con-} tórtus Ell. BeNT-AWN PLUMEGRAS. (Fig. 1609.) Culms 1 to 2 m tall, glabrous or sometimes sparsely appressed-pilose below the panicle; nodes glabrous or pubescent with erect deciduous hairs; sheaths sparsely pilose at summit or glabrous; blades 1 to $1.5 \mathrm{~cm}$ wide, scabrous; panicle 15 to $30 \mathrm{~cm}$ long, narrow, the branches ascending but not closely appressed; spikelets 6 to $8 \mathrm{~mm}$ long, brownish, basal hairs about as long as the spikelet, awn about $2 \mathrm{~cm}$ long, spirally coiled at base; rachis joints and

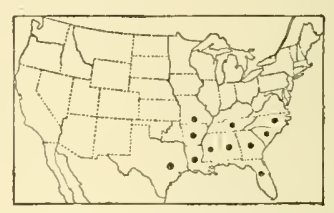

FIGtRe 1608.-Distribution of Erianthus strictus.

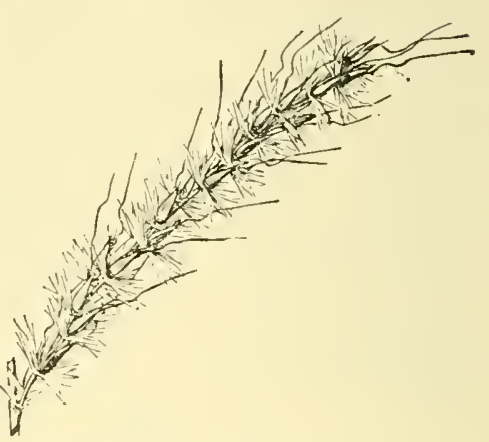

FIGURE 1603.-Erianthus contortus, $\times 1 / 2$. (Amer. Gr. Nat. Herb. 234, S.C.)

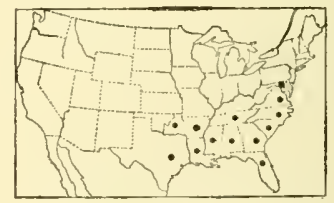

Figure 1610.-Distribution of Erianthus contortus. pedicels villous. 2 -Moist sandy pinelands or open ground, Coastal Plain, Maryland to Florida and Texas, north to Tennessee and Oklahoma (fig. 1610).

3. Erianthus alopecuroídes (L.) Ell. Silver Plumegrass. (Fig. 1611.) Culms robust, 1.5 to $3 \mathrm{~m}$ tall, appressed-villous below the panicle, and usually on the nodes; sheaths pilose at the summit; blades 1.2 to $2 \mathrm{~cm}$ wide, scabrous, pilose on upper surface toward the base; panicle 20 to $30 \mathrm{~cm}$ long, silvery to tawny or purplish; spikelets 5 to $6 \mathrm{~mm}$ long, pale, sparsely villous, shorter than the copious basal hairs; awn 1 to $1.5 \mathrm{~cm}$ long, flat,

FI GTRE 1611.-Erianthus a lopecuroides, $\times 1 / 2$. (Chase 4213, Fla.)

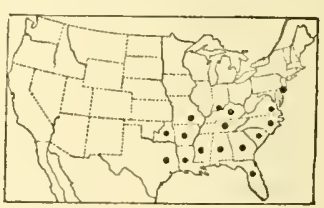

FIGURE 1612.-Distribution of Erianthus atopecuroides. loosely twisted; rachis joint and pedicel long-villous.

2 (E. divaricatus Hitchc.)-Damp woods, open ground, and borders 
of fields, southern New Jersey to southern Indiana, southern Missouri, and Olklahoma, south to Florida and Texas (fig. 1612). Eriantuus ALOPECUROIDES var. HiRśtus Nash. Sheaths and lower surface of the blades appressed-hirsute. 24 -Florida.

4. Erianthus brevibárbis Michx. Brown plumegrass. (Fig. 1613.) Culms 1 to $2 \mathrm{~m}$ tall, glabrous, even on the nodes; sheaths appressed-pilose toward the summit; blades 1 to $1.5 \mathrm{~cm}$ wide, pilose on upper surface toward the base; panicle 20 to $40 \mathrm{~cm}$ long, brown or purplish, not conspicuously woolly; spikelets 6 to 7 mm long, brown, scabrous, the basal hairs shorter than the spikelet; awn about $2 \mathrm{~cm}$ long, terete, scabrous, straight or slightly flexuous; rachis joint and pedicel with a few short hairs. 24 -Moist places, Coastal Plain, Delaware to Florida and Louisiana (fig. 1614).

5. Erianthus gigantéus (Walt.) Muhl. SugarCane plumegrass. (Fig. 1615.) Culms 1 to $3 \mathrm{~m}$ tall, appressed-villous below the panicle, the nodes appressed-hispid, the hairs deciduous; sheaths and blades from nearly glabrous to shaggy appressedvillous, the blades 8 to $15 \mathrm{~mm}$ wide; panicle 10 to $40 \mathrm{~cm}$ long, oblong or ovoid, tawny to purplish; spikelets 5 to $7 \mathrm{~mm}$ long, sparsely long-villous on the upper part, shorter than the copious basal

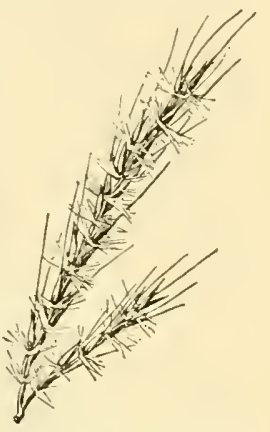

FIGTRE 1613.-ETianthus brevibarbis, $\times 1 / 2$. (Hitchcock, N.C.) hairs; awn 2 to $2.5 \mathrm{~cm}$ long, terete, straight or slightly flexuous; rachis joint and pedicel long-pilose. 21 (E. saccharoides Michx.) - Moist soil, Coastal Plain, New York to Florida and Texas, north to Kentucky; Cuba (fig. 1616). A common form with relatively small compact panicles has been segregated as E. compactus Nash; a robust form with long, copiously silky, tawny panicle, as E. tracyi Nash; and a form with rather looser panicle,

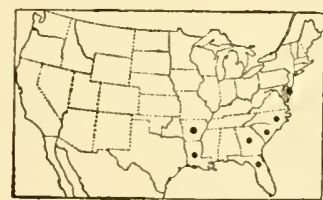

FigURe 1614,-Distribution of Erianthus brevibarbis. the lower rachis joints longer than the spikelets, and pubescent foliage was described from Florida as E. laxus Nash.

Erianthus ravénnae (L.) Beauv. Ravenna Grass. (Fig. 1617.) Culms stout, as much as $4 \mathrm{~m}$ tall; panicle as much as $60 \mathrm{~cm}$ long, silvery; spikelets awnless or nearly so. $24-$ Cultivated for ornament; hardy as far north as New York City; native of Europe. Established along irrigation ditches near Phoenix, Ariz.

\section{EULÁLIA Kunth}

\section{(Pollinia Trin.)}

Spikelets in pairs, alike, perfect on an articulate rachis, one sessile, one pediceled; racemes 2 to several, digitate or approximate.

Eulaiia vimínea (Trin.) Kuntze. Annual; culms slender, straggling, 50 to $100 \mathrm{~cm}$ long, freely branching; blades lanceolate, 3 to $8 \mathrm{~cm}$ long; racemes 2 to 6 , sometimes only one, approximate; spikelets about 5 $\mathrm{mm}$ long; awns delicate, 5 to $8 \mathrm{~mm}$ long or wanting. $\odot$-Introduced near Richmond, Va., Old Fort, N.C., and Knox County, Tenn.; tropical Asia. 


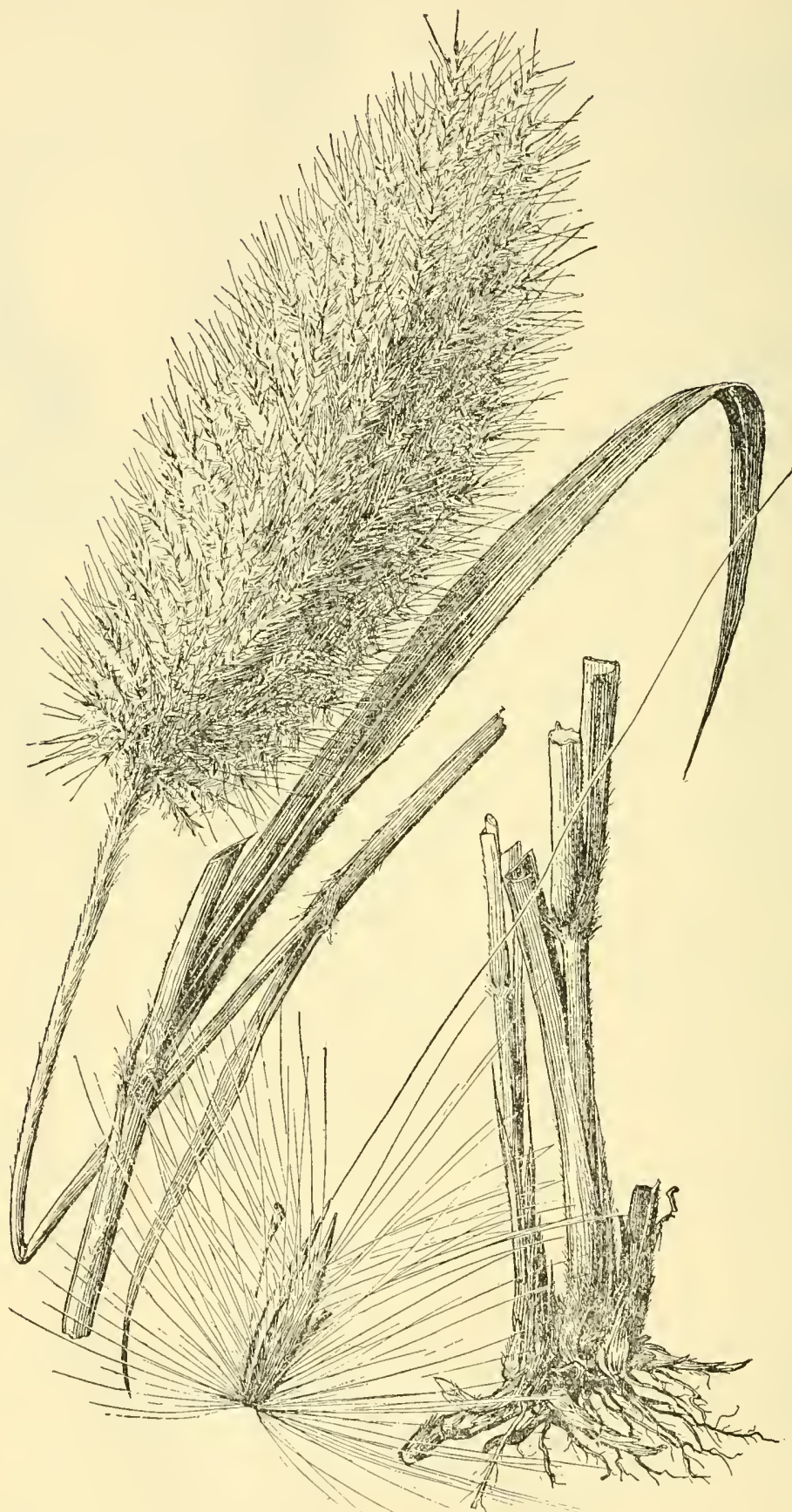

FIGURE 1615,-Erianthus giganteus. Plant, $\times 1 / 2$; spikelet with pedicol and rachis joint, $\times 5$. (Langlois 96, La.) 


\section{ARTHRÁXON Beauv.}

Perfect spikelets awned, sessile, the secondary spikelet and its pedicel wanting or present only at the lower joints of the filiform articulate rachis; racemes terminating the branches of a dichotomously forking panicle, in appearance subdigitate or fascicled. Usually low creeping grasses with broad cordate-clasping blades and subflabel-

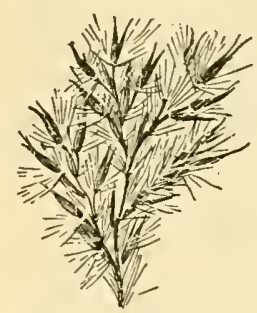

FIGURE 1617--Erianthus ravennae, $\times 1$. (Cult.)

late panicles. Type species, Arthraxon ciliaris Beauv. Name from Greek arthron, joint, and axon, axis, alluding to the jointed rachis.

1. Arthraxon híspidus var. CRYPTÁTHERUs (Hack.) Honda. (Fig. 1618.) Annual; culms slender, branching; decumbent or creeping, 30 to $100 \mathrm{~cm}$ long; sheaths hispid; blades ovate or ovate-lanceolate, 2 to $4 \mathrm{~cm}$ long, 5 to 15 $\mathrm{mm}$ wide, ciliate toward base;

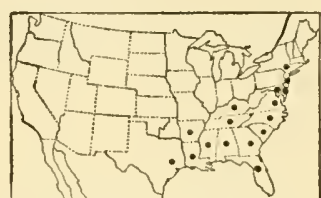

FIGURE 1616.-Distribution of Erianthus giganteus.

panicle mostly 3 to $4 \mathrm{~cm}$ long, flabellate, contracting toward maturity; rachis joints slender, glabrous; spikelets 3 to $4 \mathrm{~mm}$ long, nerved, aculeate-scabrous, the awn short or wanting, an occasional pedicellate spikelet developed at the base of the raceme, similar to the sessile spikelets. $\odot$-Pastures, lawns, and open ground in a few localities, Pennsylvania to Florida; Missouri, Arkansas; Portland, Oreg.; introduced from the Orient (fig. 1619).

\section{ANDROPOGON L. Beardgrass}

Spikelets in pairs at each node of an articulate rachis, one sessile and perfect, the other pedicel-

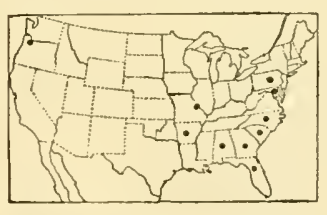

Figure 1619.-Distribution of Arthraton hispidus var. cryptatherus. late and either staminate, neuter, or reduced to the pedicel, the rachis and the pedicels of the sterile spikelets of ten villous, sometimes conspicuously so; glumes of the fertile spikelet coriaceous, narrow, awnless, the first rounded, flat, or concave

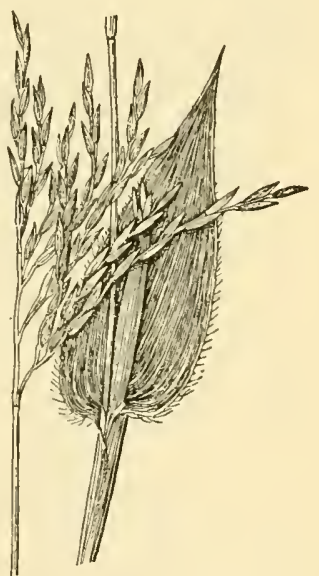

Figure 1618.-Arthraxon hispidus var. cryptatherus, $\times 1$. (Cult.)

on the back, several-nerved, the median nerve weak or wanting; sterile lemma shorter than the glumes, empty, hyaline; fertile lemma hyaline, narrow, entire or bifid, usually bearing a bent and twisted awn from the apex or from between the lobes; palea hyaline, small or wanting; pedicellate spikelet awnless, sometimes staminate and about as large as the sessile spikelet, sometimes consisting of one or more reduced glumes, sometimes wanting, only the pedicel present. Rather coarse grasses (perennial in the United States), with solid culms, the spikelets arranged in racemes, these numerous, aggregate on an exserted 
peduncle, or single, in pairs, or sometimes in threes or fours, the common peduncle usually enclosed by a spathelike sheath, these sheaths often numerous, the whole forming a compound inflorescence, usually narrow, but sometimes in dense subcorymbose masses. Standard species, Andropogon distachyus L. Name from Greek aner (andr-), man, and pogon, beard, alluding to the villous sterile pedicels.

Several of the species, especially in the Southwest, are regarded as good forage grasses but may soon become woody toward maturity and thus decrease in value. Andropogon furcatus, bluejoint turkeyfoot, is the most importaut constituent of the wild hay of the prairie States. The amount is decreasing rapidly because the rich land upon which it grows is being converted into cultivated fields. Prairie beardgrass (A. scoparius) is also a common constituent of wild hay.

Racenıes solitary on each peduncle. Apex of rachis joints obliquely cup-shaped.

Racemes 2 to numerous on each peduncle.

Section 1. Schizachy RIUM.

Racemes 2 to several on each peduncle, digitate; joints of rachis slender, sometimes with a shallow groove on one side..... SECTION 2. ARTHROLOPIIS.

Racemes several to numerous (rarely few) in a leafless panicle usually on a relatively long axis, the joints of the rachis flat, the margins thick and ciliate, the center very thin............ SECTION 3. Amphilophis.

\section{Section 1. Schizachyrium}

Blades slender, terete, the upper surface a mere groove_.... 1. A. Gracilis. Blades flat or folded, not terete.

First glume of sessile spikelet pubescent........... 3. A. hirtiflorus.

First glume of sessile spikelet glabrous.

Internodes of rachis relatively thick, glabrous or ciliate at base and near apex only; racemes straight.

Sessile spikelet $4 \mathrm{~mm}$ long; blades about $1 \mathrm{~mm}$ wide.... 2. A. Tener. Sessile spikelet 6 to $9 \mathrm{~mm}$ long; blades mostly 2 to $3 \mathrm{~mm}$ wide.

Sterile pedicel ciliate from below the middle to the apex; sterile spikelet about $3 \mathrm{~mm}$ long, the awn somewhat exserted _- 4. A. sEMIBERBIs.

Sterile pedicel ciliate only at the apex; sterile spikelet about $5 \mathrm{~mm}$ long, the awn wanting or included............ 5. A. cirratus. Internodes of rachis and sterile pedicels slender, villous throughout or nearly so; racemes flexuous.

Culms tufted; rhizomes wanting (base sometimes slightly rhizomatous in A. littoralis).

Lower sheaths not broad nor conspicuously keeled; hairs on rachis and pedicels 2 to $3 \mathrm{~mm}$ long -.......... 6 . A. SCOPARIUS.

Lower sheaths relatively broad, crowded and strongly keeled. Sheaths and blades glabrous; pedicellate spikelet reduced.

7. A. LitToralis. Sheaths and blades villous; pedicellate spikelet prominent.

10. A. DIVERGENS.

Culms solitary or few together; creeping rhizomes developed.

Sessile spikelets 5 to $7 \mathrm{~mm}$ long; sterile spikelets much reduced.

8. A. STOLONIFER.

Sessile spikelets 8 to $10 \mathrm{~mm}$ long; sterile spikelets mostly not much

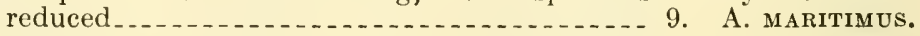

\section{Section 2. Arthrolophis}

1a. Pedicellate spikelet staminate, similar to the sessile spikelet.

Rhizomes short or wanting; rachis joint and sterile pedicel ciliate, the joints short-hispid at base; awn of sessile spikelet 1 to $2 \mathrm{~cm}$ long.

11. A. Furcatus.

Rhizomes well developed; rachis joint and sterile pedicel densely long-villous; awn of sessile spikelet rarely more than $5 \mathrm{~mm}$ long, often obsolete.

12. A. HALLII.

1b. Pedicellate spikelet reduced to 1 or 2 glumes, or obsolete, the pedicel only developed; racemes silky-villous. 
2a. Inflorescence very decompound, the profuse pairs of racemes aggregate in an elongate or corymbose mass; spathes rarely more than $2 \mathrm{~mm}$ wide; pedicellate spikelet obsolete (see also $A$. virginicus var. hirsutior.)

24. A. glomeratus.

2b. Inflorescence not conspicuously decompound nor dense (rather dense in A. virginicus var. hirsutior).

3a. Peduncle not more than $1 \mathrm{~cm}$ long, the dilated spathes exceeding the 2 (occasionally 3 or 4 ) racemes.

Upper sheathis inflated spathelike, aggregate, the late inflorescence a

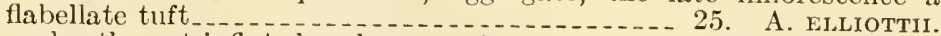
Upper sheaths not inflated and aggregate.

Blades of the innovations subfiliform; ligule acute, protruding from the folded blade; foliage usually glabrous ... 20. A. PERANGUSTATUS.

Blades 2 to $5 \mathrm{~mm}$ wide; ligule minute, concealed within the folded blade; foliage from obscurely to conspicuously pubescent.

Hairs of the racemes copious.......

Hairs of the racemes comparatively sparse.

Rachis joints shorter than the spikelets_-_._- 22. A. CAPILLipes.

Rachis joints as long as the spikelets_...- 23. A. virginicus.

3 b. Peduncles $2 \mathrm{~cm}$ long or more.

4a. Peduncles not more than $5 \mathrm{~cm}$ long, enclosed in the spathe or only slightly exserted (see also $A$. perangustatus).

Racemes usually not more than $15 \mathrm{~mm}$ long; ultimate branchlets capillary, spreading or recurved, long-villous at summit.

Racemes 2 to $5 \mathrm{~cm}$ long.

21. A. BRACHYSTACHYS.

Racemes 4 to 6 to a peduncle, tawny; sheaths villous._. 13 . A. монRII.

Racemes 2 to a peduncle, silvery or creamy white; sheaths glabrous or nearly so.

Pairs of racemes numerous; spathes inconspicuous, at least some of the peduncles as much as $5 \mathrm{~cm}$ long_-_ 17. A. FLORIDANUS.

Pairs of racemes not more than 10 to a culm; spathes dilated; peduncles 1 to $3 \mathrm{~cm}$ long ...... 18. A. TRACYI.

4b. Peduncles or most of them 5 to $15 \mathrm{~cm}$ long, long-exserted (shortexserted peduncles intermixed with long in A, elliottii and A. subtenuis).

Rachis joints longer than the spikelets; racemes 5 to $10 \mathrm{~cm}$ long, conspicuously slender and flexuous__._-27. A. CAMPYLORACHEUs.

Rachis joints not longer than the spikelets; racemes not more than $7 \mathrm{~cm}$ long, usually not more than $5 \mathrm{~cm}$.

Upper sheaths inflated, overlapping, conspicuous_ 25. A. ELLiotTir. Upper sheaths not inflated, overlapping, nor conspicuous.

Spikelets $4 \mathrm{~mm}$ long; racemes very flexuous, the rachis joints nearly as long as the spikelets_.._._. 26 . A. suBtenuis.

Spikelets 5 to $7 \mathrm{~mm}$ long; racemes slightly or not at all flexuous, the rachis joints distinctly shorter than the spikelets.

Sessile spikelets about $5 \mathrm{~mm}$ long, about $0.5 \mathrm{~mm}$ wide, the glume deeply grooved; hairs of racemes not obscuring the spikelets.

16. A. ARCTATUS.

Sessile spikelets somewhat more than $5 \mathrm{~mm}$ long, 1 to $1.5 \mathrm{~mm}$ wide, the glume concave but not grooved; hairs of racemes conspicuous to copious.

Racemes copiously long-villous, the hairs about twice as long as the spikelet and obscuring it; first glume of sessile spikelet nerveless and glabrous between the keels.

Racemes not copiously villous, the hairs about as long as the spikelet, not obscuring it; first glume of sessile spikelet scabrous and often 2-nerved between the keels.

14. A. Cabanisir.

\section{Section 3. Amphilophis}

Racemes 3 to 7 , not conspicuously woolly; pedicellate spikelet about as large as the sessile one. Sessile spikelet often pitted...... 28. A. WRIGHTII.

Racemes few to many, conspicuously woolly; pedicellate spikelet reduced.

Panicle subflabellate, of ten short-exserted or included at base in a dilated sheath; racemes few to many on a relatively short axis; spikelets 5 to $6 \mathrm{~mm}$ long.

30. A. BARBINODIS. 
Panicle oblong, usually long-exserted; racemes numerous on a long axis; spikelets 3.5 to $6 \mathrm{~mm}$ long.

First glume of sessile spikelet pitted

29. A. perforatus.

First glume of sessile spikelet not pitted.

Spikelets awned.

31. A. SACCHAROIDES.

Spikelets awnless

32. A. exaristatus.

Section 1. Schizachýridu (Nees) Trin.

Branching perennials; racemes solitary on each peduncle; rachis joints tapering to base, the apex obliquely cup-shaped; sessile spikelets awned, the awns twisted, geniculate.

1. Andropogon grácilis Spreng. (Fig. 1620.) Culms slender, wiry, densely tufted, erect, glabrous, 20 to $60 \mathrm{~cm}$ tall; blades terete, filiform; peduncles few to several, filiform, long-exserted, with a tuft of long

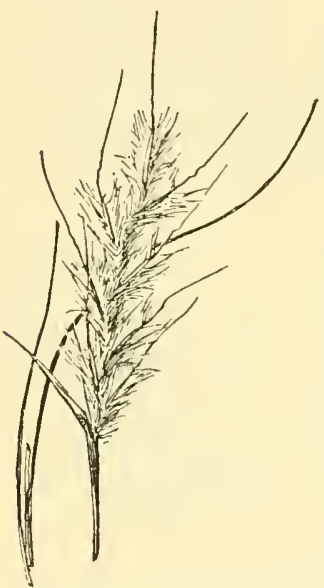

Figure 1620.-Andropogon gracilis, $\times$ 1. (Hitcheock 682, Ela.) white hairs at summit; raceme 2 to $4 \mathrm{~cm}$ long, silvery white; rachis slender, flexuous, copiously longvillous; sessile spikelet about 5 $\mathrm{mm}$ long, the awn 1 to $2 \mathrm{~cm}$ long; pedicellate spikelet reduced to an awned or awnless glume, the pedicel very villous. 24 - Rocky pine woods, southern Florida; West Indies.

\section{Andropogon téner (Nees)} Kunth. (Fig. 1621.) Culms slender, tufted, sometimes reclining or decumbent, 60 to 100 $\mathrm{cm}$ long, the upper half rather sparingly branching; blades scarcely $1 \mathrm{~mm}$ wide, flat or loosely involute, often sparingly long-pilose on upper surface near base; raceme finally long-exserted, slender, subterete, glabrous, 2 to 6

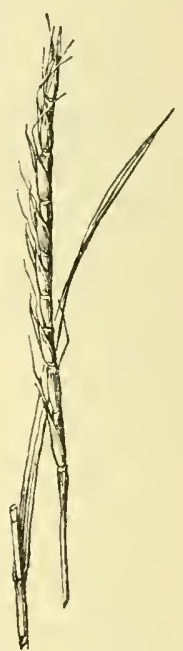

F I G U R E 1621.Andropogon tener, Fla.) (Rolfs 986, cm long; sessile spikelet about $4 \mathrm{~mm}$ long, the awn 7 to $10 \mathrm{~mm}$ long. 21 -Dry pine woods and prairies, Coastal Plain, Georgia to Florida and Texas; tropical America (fig. 1622).

3. Andropogon hirtiflorus (Nees) Kunth. (Fig. 1623.) Culms tufted, 60 to $120 \mathrm{~cm}$ tall, erect, reddish, the upper half sparingly branching; foliage often glaucous, the blades 2

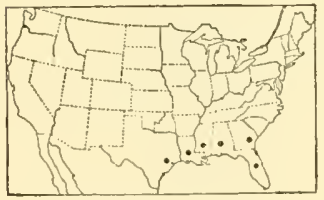

FIGURE 1622.-Distribution of Andropogon tener. to $4 \mathrm{~mm}$ wide; raceme 6 to $10 \mathrm{~cm}$ long, the base often included in the somewhat dilated sheath, the rachis joints, pedicels, and first glume of sessile spilielet pubescent, the rachis straight; sessile spikelet about $6 \mathrm{~mm}$ long, the awn 10 to $15 \mathrm{~mm}$ long; pedicellate spikelets much reduced, short-awned. 24 (A. oligostachyum Chapm.)-Pine woods, southern Georgia and Florida; tropical America (fig. 1624). ANDropogon HIRTIFlorus var. FEÉNsis (Fourn.) Hack. Blades scabrous; sessile spikelet as much as $9 \mathrm{~mm}$ long, the first glume minutely papillose, the 
pubescence less copious. 24-Canyons and rocky slopes, western Texas to Arizona; Mexico.

4. Andropogon semiberbis (Nees) Kunth. (Fig. 1625.) Culms

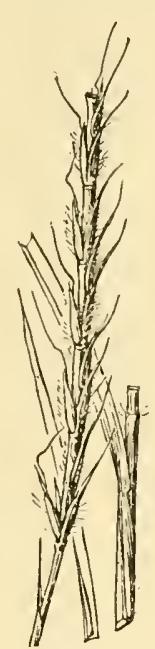

FigURE 1623.Andropogon hirtiflorus, $\times$ 1. (Chase 4193, Fla.)

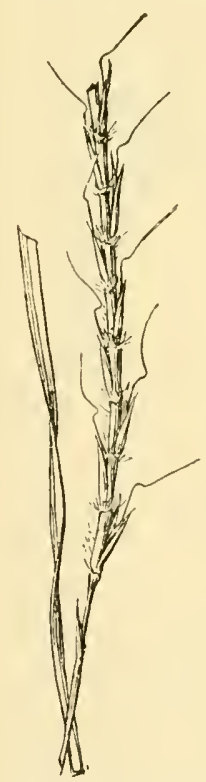

Figure 1625.-Andropogon semiberbis, $\times 1$. (C) H.Baker 327 , Fla.) usually in rather small tufts, 60 to $120 \mathrm{~cm}$ tall, erect, pinkish, compressed, the upper third to half freely branching; blades 2 to $4 \mathrm{~mm}$ wide, glabrous; raceme 5 to $8 \mathrm{~cm}$ long, the base often included in the sheath, the rachis straight, the joints short hispid at base with erect hairs; sessile spikelet about $6 \mathrm{~mm}$ long, the awn 10 to $15 \mathrm{~mm}$ long; pedicellate spikelet much reduced, short-awned, the pedicel more or less ciliate on one margin. 24 -Pine woods, Florida; tropical America.

5. Andropogon cirrátus Hack. Texas Beardgrass. (Fig. 1626.) Plants pale, glaucous to purplish; eulms slender, tufted, 30 to $70 \mathrm{~cm}$ tall, ereet, the upper half sparingly branching; blades flat, 1 to $4 \mathrm{~mm}$

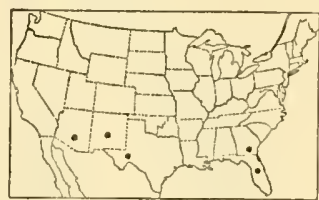

Figure 1624.-Distribution of Andropogon hirtifiorus. wide, usually scabrous; raceme exserted, 3 to $6 \mathrm{~cm}$ long, the rachis straight; sessile spikelet 8 to $9 \mathrm{~mm}$ long, the awn 5 to $10 \mathrm{~mm}$ long; pedicellate spikelet scarcely reduced, awnless, the pedicel stiffly eiliate on one side near the summit. 24 -Canyons and rocky slopes, western Texas to Arizona and southern California (Jamacha); northern Mexico.

\section{Andropogon scopárius}

Michx. Prairie Beardgrass. (Fig. 1627.) Plants green or glaucous, often purplish; culms tufted, from slender to robust, compressed, 50 to $150 \mathrm{cmr}$ tall, erect, the upper half freely branching; sheaths and blades commonly glabrous or nearly so, frequently sparsely pilose at their junction, rarely pubescent to villous throughout, the blades 3 to $6 \mathrm{~mm}$ wide, flat; raceme 3 to $6 \mathrm{~cm}$ long, mostly curved, the filiform peduncles mostly wholly or partly included in the sheaths, conmonly spreading, the rachis slender, flexuous, pilose, sometimes copiously so; sessile spikelet 6 to $8 \mathrm{~mm}$ long, seabrous, the awn 8 to $15 \mathrm{~mm}$ long; pedicellate spikelet reduced, short-awned, spreading, the pedicel pilose. 24 -Prairies, open woods, dry hills, and fields, Quebec and Maine to Alberta and Idaho,

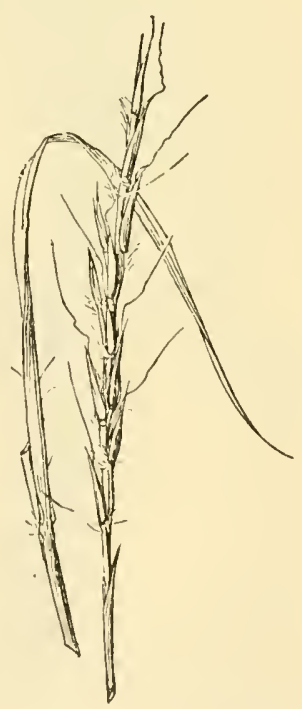

FIgURE 1626.-Andropogon cirratus, $\times 1$. (Greene 406, N. Mex.)

south to Florida and Arizona (fig. 1628). Also called little bluestem. A form with villous foliage has been segregated as $A$. scoparius var. 


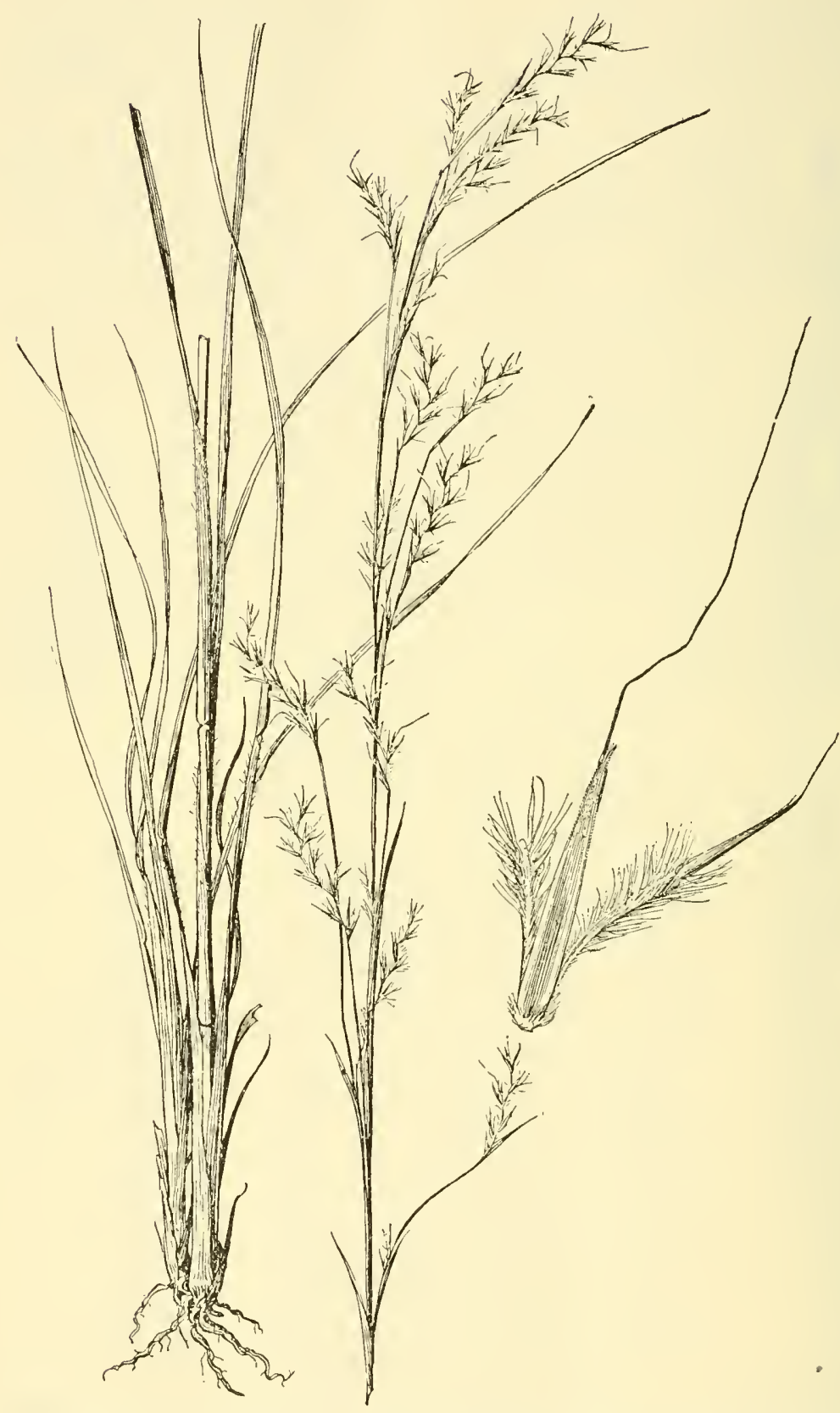

Figure 1627.-Andropogon scoparius. Plant, $\times 1 / 2$; pair of spikelets, $\times 5$. (Amer. Gr. Nat. Herb. 268, D.C.) 
villosissimus Kearney (Schizachyrium villosissimum Nash). Schizachyrium acuminatum Nash was described from a specimen, otherwise typical, having spikelets $10 \mathrm{~mm}$ long. ANDROPOGON SCOPARIUs var. NEOMEXICÁNus (Nash) Hitchc. (Fig. 1629.) Rachis and pedicels copiously villous, the rachis mostly nearly straight. In the Southwest the species verges into this variety. 24 (Schizachyrium neomexicanum Nash.)--Sandy soil and rocky hills, Texas to Arizona.

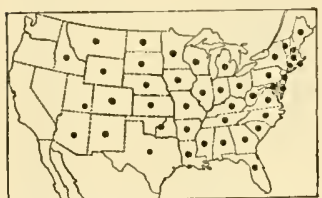

Figure 1628.-Distribution of Andropogon scoparius.

7. Andropogon littorális Nash. (Fig. 1630.) Rescmbling $A$. scoparius, but culns more compressed, with broad keeled overlapping lower sheaths, often bluish-glaucous, the flat tufts crowded on a short rhizome, decumbent or bent at base; blades 4 to $6 \mathrm{~mm}$ wide; rachis joints and pedicels copiously long-villous. 24 - Sandy seashores, Staten Island, N.Y.,

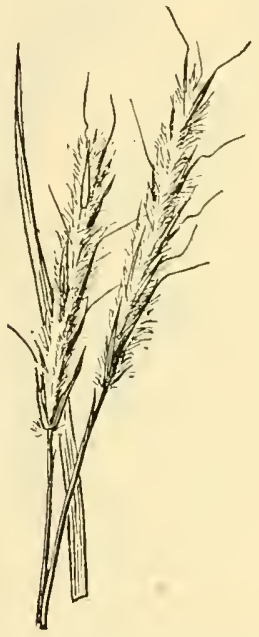

Figure 1629.-1ndropogon scoparius var neomexicanus, $\times 1$. (Wooton, $N$ Mex.) New Jersey, and Delaware; Ohio (Sandusky); Indiana (sand dunes of Lake Michigan); Texas (Padre Island). Typical specimens are strikingly different from $A$. scoparius, but Texas plants with copiously villous racemes are less distinct in habit.

8. Andropogon stolónifer (Nash) Hitche. (Fig. 1631.) Resembling $A$. scoparius, but the culms solitary or few in a tuft and with creeping scaly rhizomes; foliage usually glabrous, rarely villous; first glume of both sessile and pedicellate spikelets sometimes bifid at apex; sessile spikelet 5 to $7 \mathrm{~mm}$

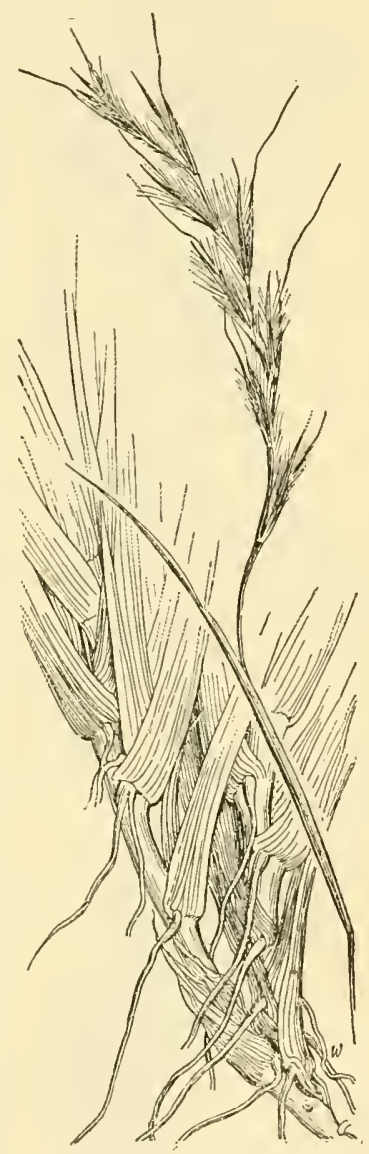

Figure 1630.-Andropogon littora. lis, X 1. (Burk, N.J.)

long. 2 (Schizachyrium triaristatum Nash.)-Sandy woods, southern Georgia and Florida.

9. Andropogon marítimus Chapm. (Fig. 1632.) Culms solitary, compressed, ascending from a decumbent, short-noded base, 50 to 60 $\mathrm{cm}$ long, branching toward the ends, and with long creeping rhizomes; sheaths overlapping on the short internodes, strongly keeled, commonly reddish; blades 3 to $5 \mathrm{~mm}$ wide, often folded and reflexed, the midnerve deeply impressed; raceme 4 to $6 \mathrm{~cm}$ long, the base included in the dilated sheath, the rachis very flexuous, the joints and pedicels copiously long-ciliate except at base; sessile spikelet $S$ to 
$10 \mathrm{~mm}$ long, the awn 8 to $12 \mathrm{~mm}$ long; pedicellate spikelet scarcely reduced, short-awned. 24-Sandy islands along the Gulf coast, western Florida, Mississippi (Horn Island), and Louisiana (Last Island).

10. Andropogon divérgens (Hack.) Anderss. (Fig. 1633.) Culms rather robust, 80 to $120 \mathrm{~cm}$ tall, sparingly branching toward the summit; sheaths grayish villous, the lower crowded, compressed-keeled;

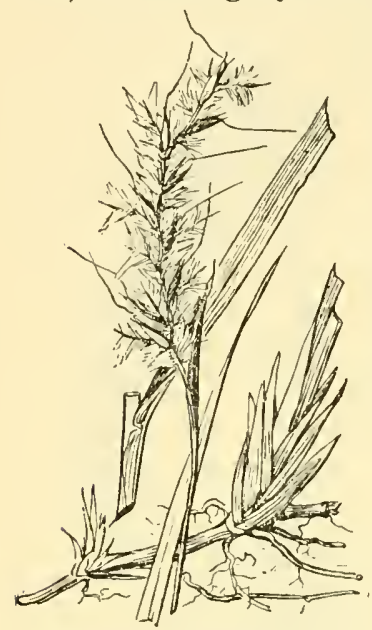

FIGURE 1631.-Andropogon stolonifer, $\times 1$. (Fredholm 6122, Fla.)

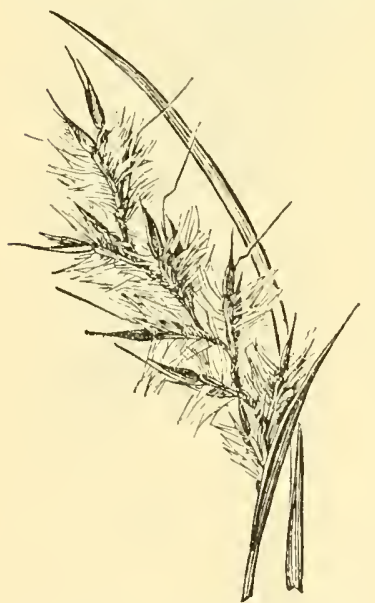

Figure 1632.-Andropogon maritimus, $\times 1$. (Chapman, Fla.) blades rather firm, 3 to $6 \mathrm{~mm}$ wide, villous, elongate, flat or folded; raceme mostly 3 to $4 \mathrm{~cm}$ long, mostly 6 - to 8-jointed, rather stout, usually partly included, the rachis slightly to strongly flexuous, rather stout, the joints and pedicels long-ciliate on the upper half and with a short tuft of hairs at base; sessile spikelet 6 to $8 \mathrm{~mm}$ long, minutely roughened, the awn 5 to $10 \mathrm{~mm}$ long; pedicellate spikelet about as long as the sessile one, the first glume a wn-tipped. 2 Pinelands, Texas.

\section{Section 2. Arthrólophis Trin.}

Branching perennials; racemes 2 to few on each peduncle; rachis joints slender, mostly pubescent; sessile spikelet awned.

\section{Andropogon furcá-}

tus Muhl. Bluejoint TURKE YFOOT. (Fig. 1634.) Plants often glaucous; culms robust, often in large tufts, sometimes with short rhizomes, 1 to $2 \mathrm{~m}$ tall, usually sparingly branching toward the summit; lower sheaths and blades sometimes villous, occasionally densely so, the blades flat, elongate, mostly 5 to $10 \mathrm{~mm}$ wide, the margins very scabrous; racemes on the long-exserted

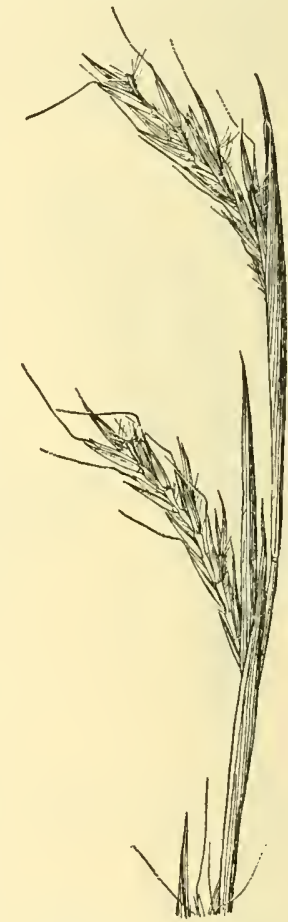

Figure 1633.-Andropogon divergens, $\times 1$. (Tharp 3094, Tex.)

terminal peduncle mostly 3 to 6 , fewer on the branches, 5 to $10 \mathrm{~cm}$ long, usually purplish, sometimes yellowish; rachis straight, the joints and pedicels stifily ciliate on one or both margins, the joints hispid at base; sessile spikelet 7 to $10 \mathrm{~mm}$ long, the first glume slightly sulcate, usually scabrous, the awn geniculate and tightly twisted below, 1 to $2 \mathrm{~cm}$ long; pedicellate spikelet not reduced, awnless, staminate. 


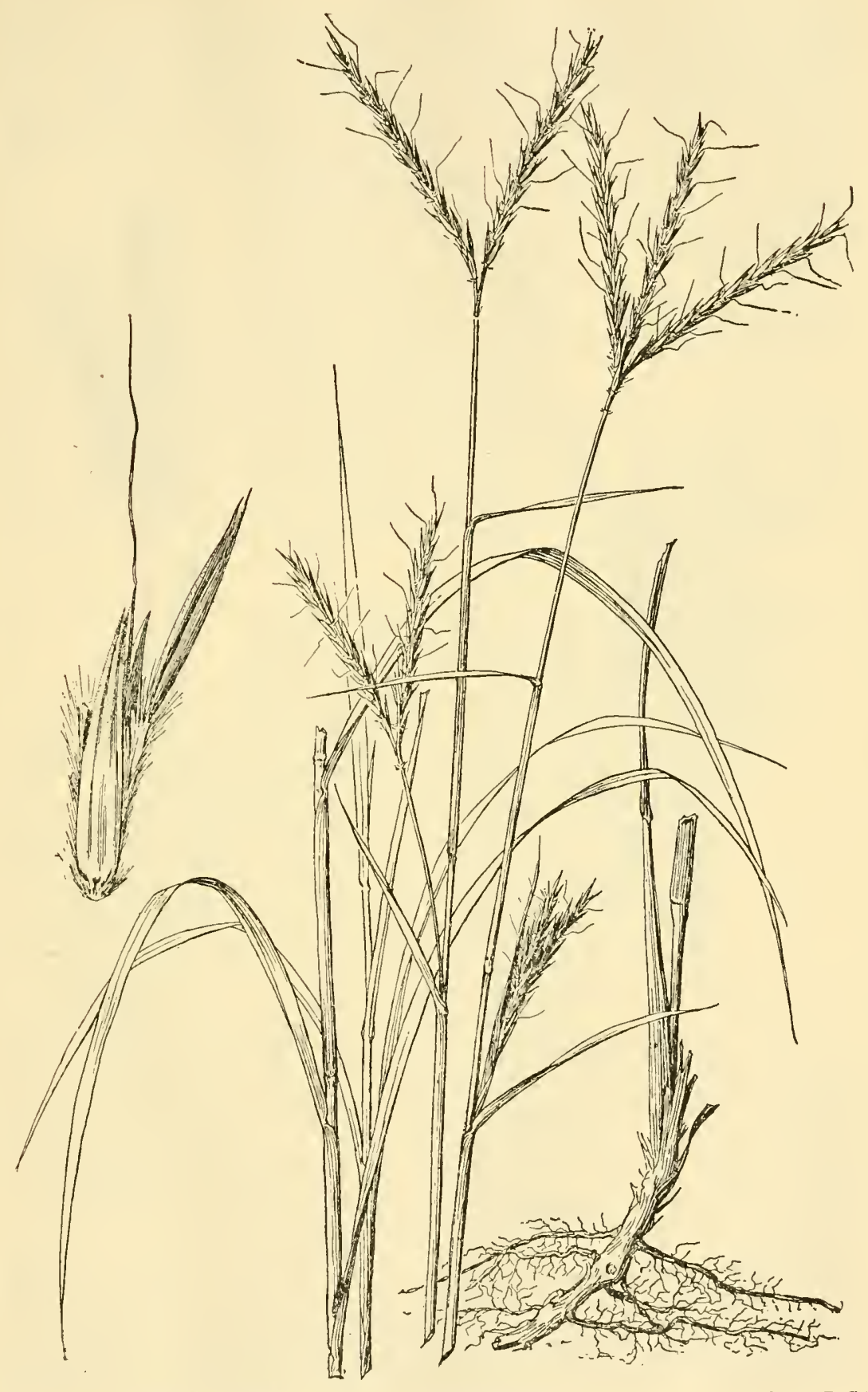

EIGURE 1634. -Andropogon furcatus. Plant, $\times 1 \frac{1}{2}$; pair of spikelets, $\times 5$ (Amer. Gr. Nat. Herb. 255, D.C.) 
24 (A. provincialis Lam.? not Retz.)-Dry soil, prairies, and open woods, Quebec and Maine to Saskatchewan and Montana, south to Florida, Wyoming, Utah, and Arizona; Mexico (fig. 1635). An important forage grass in the prairie States of the Mississippi Valley.

12. Andropogon hálii Hack. Turкеуғоот. (Fig. 1636.) Resembling $A$. furcatus, but with creeping rhizomes; racemes conspicuously villous, the hairs

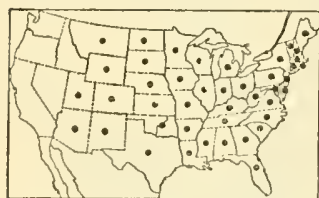

FIGURE 1635.-Distribution of Andropogon furcatus.

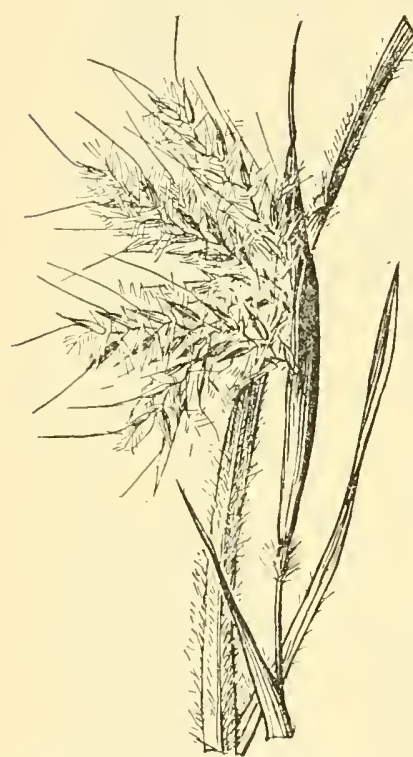

Figure 163S.-Andropogon mohrii, $\times$ (Mohr, Ala.) grayish to pale golden; awn of sessile spikelet rarely more than $5 \mathrm{~mm}$ long, often obsolete. 24 Sandhills and sandy soil, North Dakota and eastern Montana to Texas, Wyoming, Utah, and Arizona; Iowa (fig. 1637). Intergrades with $A$. furcatus. A form with yellow-villous racemes and awns 5 to $10 \mathrm{~mm}$ long has been segregated as A. chrysocomus Nash.

13. Andropogon móhrii Hack. (Fig. 1638.) Culms stout, com pressed, tufted, erect, 80 to $130 \mathrm{~cm}$ tall, the upper half sparingly to rather freely branching; leaves villous, the lower sheaths strongly keeled and glabrous at base, the blades elongate, 3 to $5 \mathrm{~mm}$ wide; inflorescence narrow, the

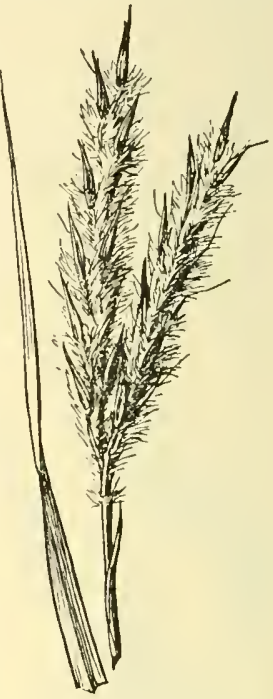

IGURE 1636.-Andropogon hollii, $\times$ i. (Hitcheock 584, Kans.)

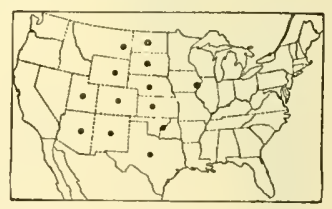

FIGURE 1637.-Distribution of Andropogon hallii.

branches approximate, the ultimate branchlets short, densely bearded at summit, the purplish spathes 4 to $6 \mathrm{~cm}$ long; racemes mostly 4, tawny, 2 to $4 \mathrm{~cm}$ long, on peduncles mostly about $2 \mathrm{~cm}$ long, or the terminal ones sometimes long-exserted; rachis scarcely flexuous, the joints shorter than the spikelets, copiously long-villous; sessile spikelet 4 to $5 \mathrm{~mm}$ long, the awn loosely twisted below, 1.5 to $2 \mathrm{~cm}$ long; pedicel long-villous, the spikelet reduced to a minute glume. 24 - Wet pine woods and sandy seacoast, North Carolina to Georgia and Louisiana (fig. 1639).

14. Andropogon cabanísii Hack. (Fig. 1640.) Culms in small tufts, erect, 80 to $150 \mathrm{~cm}$ tall, the upper half bearing long slender branches; sheaths villous to nearly glabrous; blades 2 to $3 \mathrm{~mm}$ wide; inflorescence loose; racemes 2 , pale grayish-tawny, with about 15 joints, 4 to $7 \mathrm{~cm}$ long on slender long-exserted peduncles, the spathes 
narrow, inconspicuous, or a few occasionally dilated; rachis not flexuous or but slightly so, the joints shorter than the spikelets, longvillous; sessile spikelets 6 to $7 \mathrm{~mm}$ long, the first glume firm, scabrous and often 2-nerved between the keels, the awn twisted below, about $1.5 \mathrm{~cm}$ long; pedicel long-villous, the spikelet reduced to a slender glume or obsolete. 24 -Dry pine woods, peninsular Florida.

15. Andropogon ternárius Michx. (Fig. 1641.) Culms tufted, erect, 80 to $120 \mathrm{~cm}$ tall, the upper half to two-thirds branching, the branches usually long, slender and erect; leaves often purplish-glaucous, glabrous, or the lower loosely villous, the blades 2 to $4 \mathrm{~mm}$ wide; inflorescence elongate, loose, of few to many pairs of silvery to creamy or grayish feathery racemes, usually on long-exserted peduncles

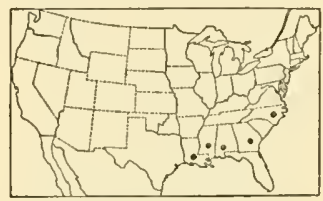

Figure 1639.-Distribution of Andropogon mohrii. from slender inconspicuous spathes, some of the lateral peduncles often short, from dilated spathes, rarely most of them so; racemes 3 to $6 \mathrm{~cm}$ long, with mostly less than 12 joints, the rachis not flexuous, the joints shorter than the spikelets, copiously long-villous; sessile spikelets 5 to $7 \mathrm{~mm}$ long, glabrous and nerveless between the keels,

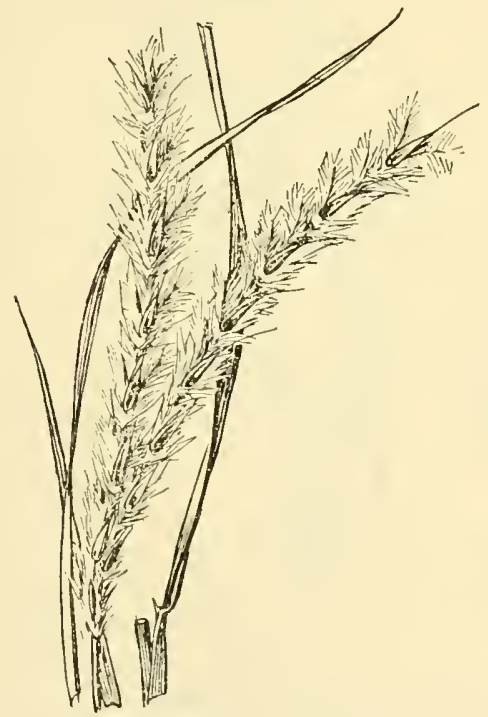

FIGURE 1640,-Andropogon cabanisii, $\times 1$. (Fredholm 6416, Fla.)

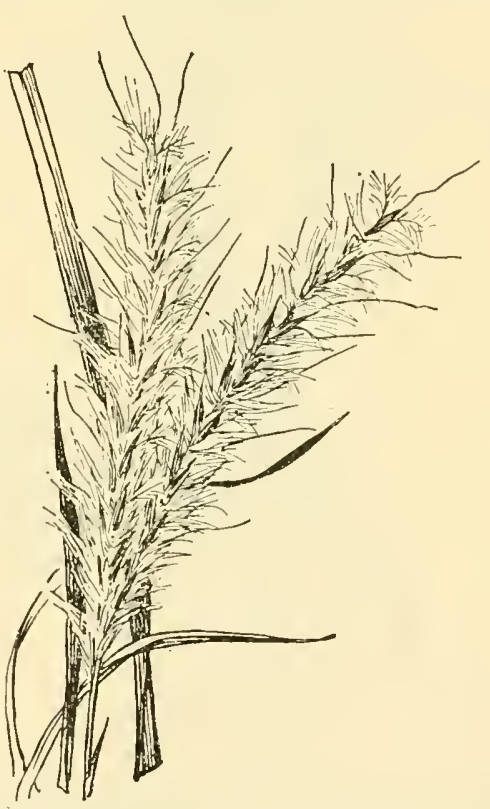

FIGURE 1641.-Andropogon ternarius, $\times 1$. (Chase 4557, N.C.)

the awn twisted below, 1.5 to $2 \mathrm{~cm}$ long; stamens 3 ; pedicel longvillous, the spikelet obsolete or nearly so. 24 - Dry sandy soil, open woods, mostly Coastal Plain, Delaware to Tennessee, Missouri, and Oklahoma, south to Florida and Texas. (Fig. 1642). Variable in the density and length of pubescence on the rachis and pedicels, the less hairy specimens verging toward $A$. arctatus. 
16. Andropogon arctátus Chapm. (Fig. 1643.) Resembling A. ternarius; culms 1 to $1.5 \mathrm{~m}$ tall; the blades often wider and firmer; branches of the inflorescence rather more slender; racemes 3 to $5 \mathrm{~cm}$ long, tawny, sessile spikelets 4 to $5 \mathrm{~mm}$ long, brown, the awn 1 to $5 \mathrm{~cm}$ long; first glume concave, the pale or tawny hairs of rachis and pedicels

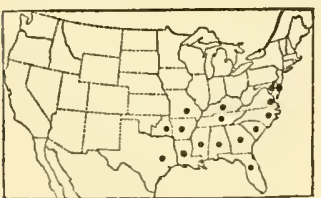

FIGURE 1642.-Distribution of Andropogon ternarius. shorter and less copious than in A. ternarius; sessile spikelet $5 \mathrm{~mm}$ long, $0.5 \mathrm{~mm}$ wide, the glume grooved; stamen 1. 21 -Low pine woods, Florida.

17. Andropogon floridánus Scribn. (Fig. 1644.) Culms often stout, 1 to $1.8 \mathrm{~m}$ tall; the upper one-third to half bearing long slender branches; blades elongate, 2 to $6 \mathrm{~mm}$ wide; inflorescence loosely subcorymbose, of usually numerous pairs of silvery white to creamy racemes on subcapillary peduncles mostly 2 to $8 \mathrm{~cm}$ long, included in very slender spathes or exserted, the ultimate branchlets filiform, often long-ciliate toward the summit; racemes 3 to $4 \mathrm{~cm}$ long, the slender rachis not flexuous, the joints a little shorter than the spikelets, rather copiously longvillous; sessile spikelets 4 to $4.5 \mathrm{~mm}$ long, the delicate awn straight,

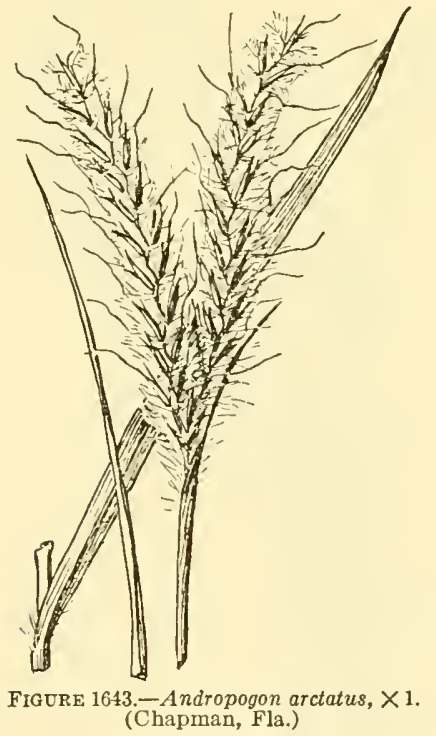

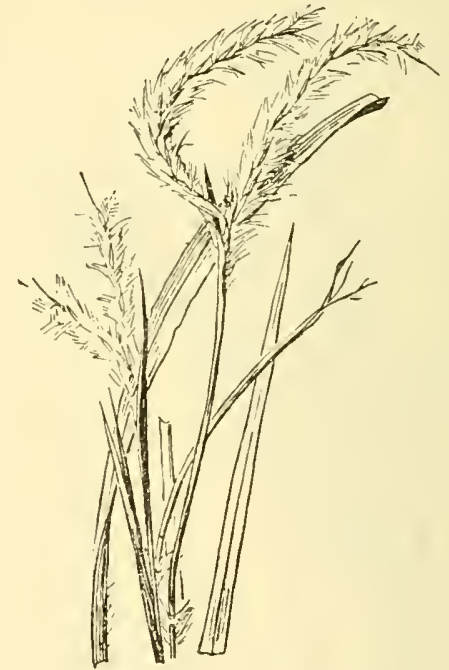

Figure 1644.-Andropogon floridanus, $\times 1$. (Type coll.)

6 to $10 \mathrm{~mm}$ long; pedicel long-villous, the spikelet obsolete. 2 -Low pine woods, Florida. An occasional peduncle bears 3 racemes.

18. Andropogon trácyi Nash. (Fig. 1645.) Culms in small tufts, slender, erect, the upper third sparingly branching; sheaths keeled, narrow, glabrous or nearly so; blades 2 to $3 \mathrm{~mm}$ wide, sometimes ciliate toward base; inflorescence of 8 to 10 relatively distant racemes, the slender ultimate branches often recurved, the dilated spathes 4 to $5 \mathrm{~cm}$ long, attenuate below, the enclosed peduncle 1 to $3 \mathrm{~cm}$ long; 
ultimate branchlets long-bearded toward the summit; racemes 2 or 3 , feathery, 2 to $4 \mathrm{~cm}$ long, the very slender flexuous rachis and the pedicel copiously long-villous; sessile spikelet about $4 \mathrm{~mm}$ long, the awn loosely twisted below, 1 to $2 \mathrm{~cm}$ long; pedicellate spikelet obsolete. 2 -Pine woods, Georgia and Florida to Louisiana (fig. 1646). Resembling $A$. longiberbis, mostly more slender and with nearly glabrous foliage.

19. Andropogon longibérbis Hack. (Fig. 1647.) Resembling $A$. virginicus; sheaths, especially of the innovations, appressed grayishvillous; inflorescence on the average less compound, the racemes more copiously long-

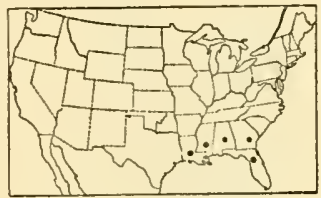

FIGURE 1646.-Distribution of Andropogon tracyi.

villous, the spikelets 4 to $4.5 \mathrm{~mm}$ long. 2 Pine woods, Florida. Intergrades with $A$. virginicus.

20. Andropogon perangustátus Nash. (Fig. 1648.) Culms in small tufts, slender, wiry, erect, the upper third to half sparingly branching; lower sheaths keeled, very narrow, occasionally sparsely villous; ligule about 1.5 $\mathrm{mm}$ long, firm; blades mostly folded, sub-

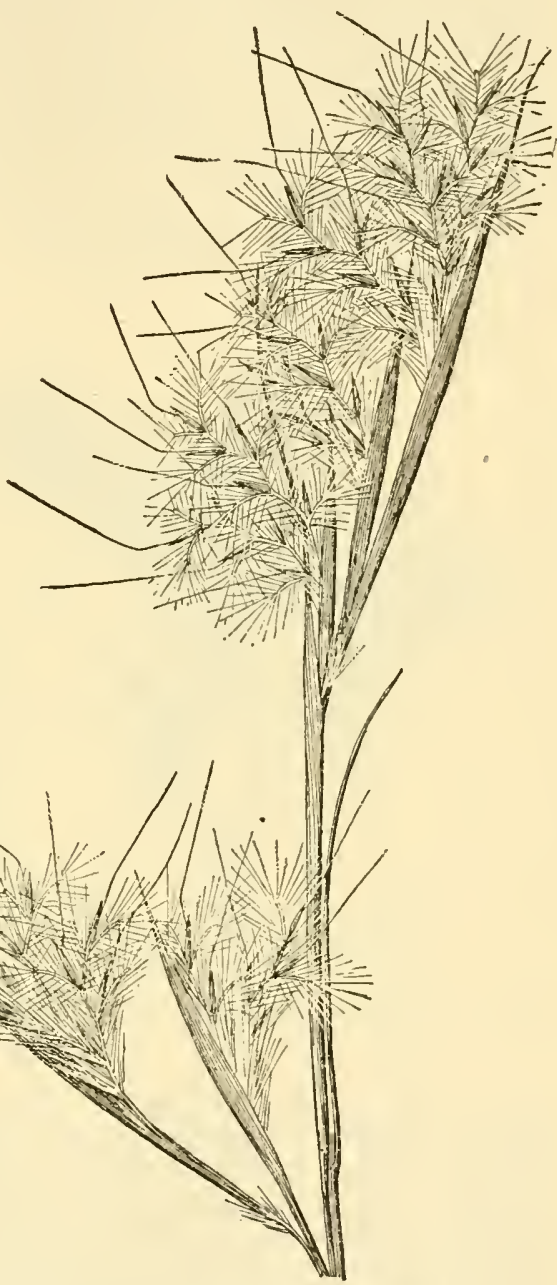

Figure 1645.-Andropogon tracyi, $\times 1$. (Type.)

filiform, flexuous, glabrous or rarely pilose; inflorescence slender, of few to several racemes, resembling that of slender specimens of A. virginicus, the peduncles usually short but the spathes sometimes attenuate to base, the peduncle 1 to $2 \mathrm{~cm}$ long; racemes as in $A$. virginicus. 21 -Bogs and moist pine woods, Florida and Mississippi.

21. Andropogon brachýstachys Chapm. (Fig. 1649.) Culms tufted, erect, 1 to $1.5 \mathrm{~m}$ tall, the upper half loosely branching; sheaths 
crowded at base, broad, strongly keeled; blades mostly folded, 4 to 6 $\mathrm{mm}$ wide; inflorescence decompound, loose, the ultimate capillary branchlets commonly recurved, long-villous toward the summit; spathes slender, the long peduncles often exserted from the summit; racemes 2, flexuous, mostly 1 to $1.5 \mathrm{~cm}$ long, the rachis joint and pedicel long-villous; sessile spikelet about $4 \mathrm{~mm}$ long, the awn scarcely $1 \mathrm{~cm}$ long. 24 -Moist pine woods, Florida. The racemes are frequently affected by a smut, making them shorter and denser, reducing the size of the spikelet and the awn. The inflorescence resembles that of $A$. capillipes, but the racemes mostly more numerous; the ultimate branchlets are long-villous toward the summit, and the spikelets larger.

22. Andropogon capillipes Nash. (Fig. 1650.) Plants conspicuously glaucous; culms tufted, slender, erect, 60 to $100 \mathrm{~cm}$ tall, the

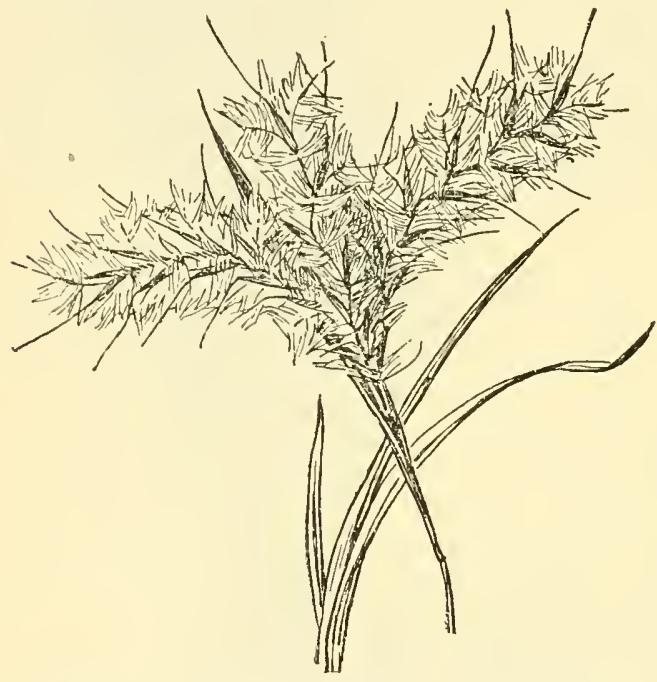

Figure 1647.-Andropogon longiberbis, $\times 1$. (Garber, Fla.)

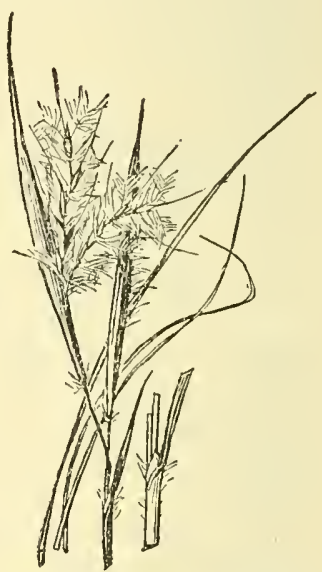

Figure 1648.-Andropogon perangustatus, $\times 1$. (Fredholm 6072, Fla.)

upper third to half with few to several slender branches; sheaths crowded at base, keeled, chalky-glaucous; blades mostly folded, 2 to $4 \mathrm{~mm}$ wide; inflorescence narrow but loose, the branches often flexuous to zigzag, the ultimate capillary branchlets finally spreading or recurved, glabrous, the dilated purplish-brown spathes 2 to $3.5 \mathrm{~cm}$ long, glabrous; racemes 2, less flexuous than in A. virginicus, 1 to $2.5 \mathrm{~cm}$ long; rachis joint about half as long as the sessile spikelet, the pedicel about equaling the spikelet, both copiously long-villous; sessile spikelet $3 \mathrm{~mm}$ long, the delicate straight awn about $1 \mathrm{~cm}$ long. 2 - Sandy pine and oak woods, southern North Carolina, South Carolina, and Florida.

23. Andropogon virgínicus L. Broonsedge. (Fig. 1651.) Culms erect, 50 to $100 \mathrm{~cm}$ tall, usually in rather small tufts, the upper twothirds mostly freely branching; lower sheaths compressed, keeled, equitant; sheaths glabrous or more or less pilose along the margins, occasionally conspicuously so; ligule strongly ciliate; blades flat or folded, 2 to $5 \mathrm{~mm}$ wide, pilose on the upper surface toward base; 
inflorescence elongate, narrow, the 2 to 4 racemes 2 to $3 \mathrm{~cm}$ long, partly included and shorter than the inflated tawny to bronze spathes; rachis very slender, flexuous, long-villous; sessile spikelet about $3 \mathrm{~mm}$ long, the delicate straight awn 1 to $2 \mathrm{~cm}$ long; pedicel long-villous, its spikelet obsolete or nearly so. 24 -Open ground, old fields, open woods, sterile hills, and sandy soil, Massachusetts, New York, Indiana, and Kansas, south to Florida and Texas; Mexico, Central America, West Indies (fig. 1652). Andropogon virginicus var. HIRsútior (Hack.) Hitche. Flowering branches more numerous than in the species, the inflorescence often rather dense, resembling that of A. glomeratus, but the spathes mostly larger and the peduncles usually shorter. 2 -Moist meadows and old fields, Florida to

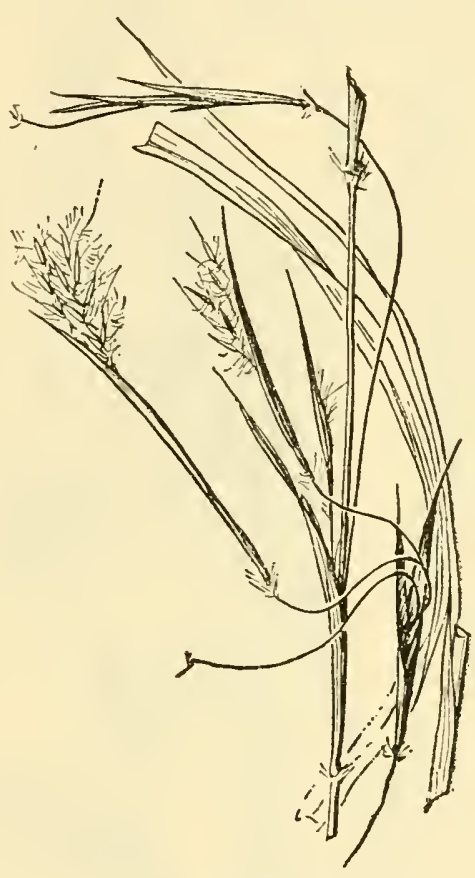

Figure 1649.-Andropogon brachystachys, $\times 1$. (Curtiss 3632, Fla.)

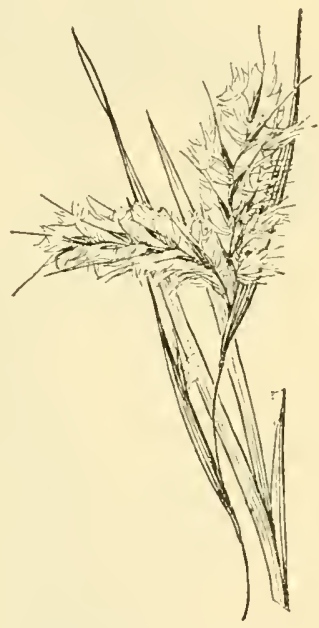

FIGURE 1650.-Andropogon capillipes, $\times 1$. (Curtiss $3638 \mathrm{~b}$, Fla.)

Texas and Mexico. Intergrades with A. virginicus and appears to be intermediate between that and $A$. glomeratus. Andropogon virginicus var. GLAUCóPsis (Ell.) Hitche. Resembling the species, but foliage, especially the lower sheaths, very glaucous; inflorescence sometimes as dense as in var. hirsutior, the spathes dull purple. 24 (A.glaucopsis Nash).-Moist sandy soil and low pine barrens, North Carolina to Florida and Mississippi.

24. Andropogon glomerátus (Walt.) B. S. P. Bushy beardarass. (Fig. 1653.) Culms erect, 50 to $150 \mathrm{~cm}$ tall, compressed, with broad keeled overlapping lower sheaths, the flat tufts often forming dense, usually glaucous clumps, the culms from freely to bushy branching toward the summit; sheaths occasionally villous; blades elongate, 3 to $8 \mathrm{~mm}$ wide; infloreseence dense, feathery, from flabellate to oblong, the paired racemes 1 to $3 \mathrm{~cm}$ long, about equaling the slightly dilated 


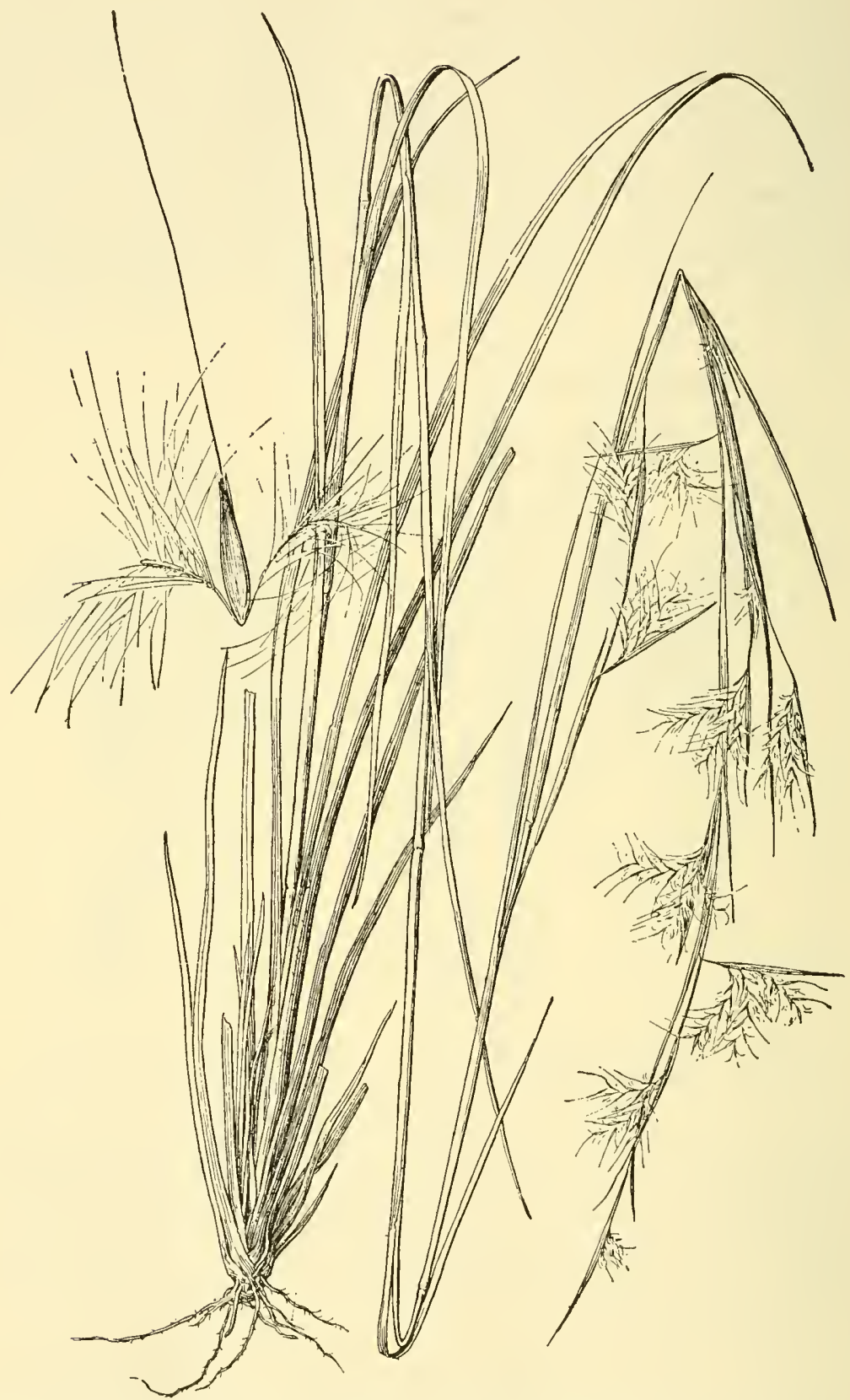

Figure 1651.-Andropogon virginicus. Plant, $\times 1 / 2$; spikelet with rachis joint and pedicel, $\times 5$. (Earle 4, Ala.) 
spathes, the enclosed peduncle and ultimate branchlets long-villous, the peduncle at least $5 \mathrm{~mm}$ long, of ten longer; rachis very slender, flexuous, long-villous; sessile spikelet 3 to $4 \mathrm{~mm}$ long, the awn straight, 1 to $1.5 \mathrm{~cm}$ long; sterile spikelet reduced to a subulate glume or wanting, the pedicel slender, long-villous. 24 - Low moist ground, marshes, and swamps, Massachusetts to Florida, west to Kentucky,

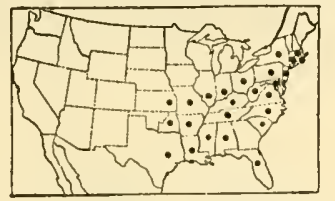

FIGURE 1652.-Distribution of Andropogon virginicus.

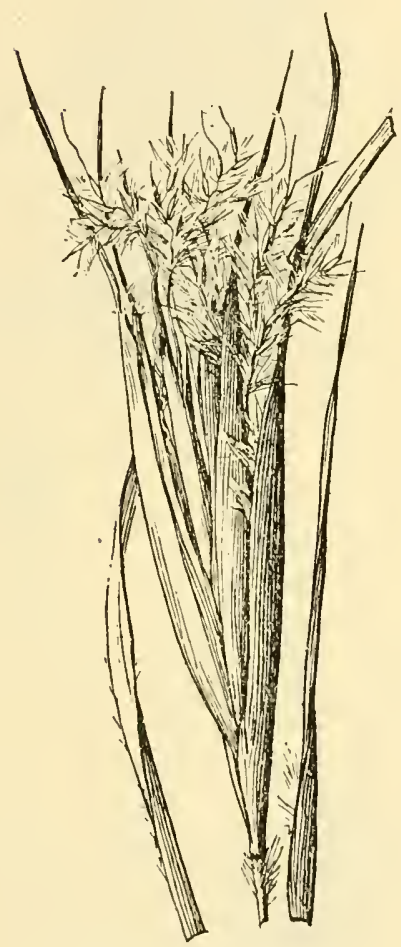

FIGURE 1655.-Andropogon elliottii. $\times 1$. (Commons 115, Del.)

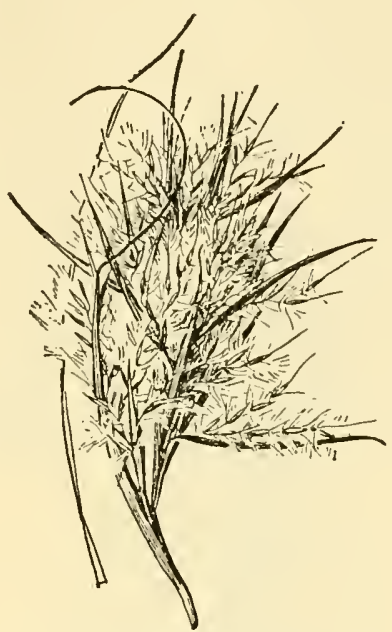

FigURE 1653.-Andropogon glomeratus, $\times 1$. (Hitchcock 437 , Fla.)

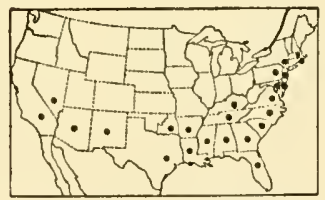

Figure 1654.-Distribution of Andropogon glomeratus.

southern California, and Nevada; West Indies, Yucatan, Central America (fig. 1654).

25. Andropogon ellióttii Chapm. Elliott BeArdgrass. (Fig. 1655.) Culms tufted, erect, 30 to $80 \mathrm{~cm}$ tall, at first nearly simple, later branching toward the summit; lower sheaths keeled, rather narrow, commonly loosely pilose, those near the summit inflated and spathelike, crowded, the very short internodes densely bearded; blades flat, 3 to $4 \mathrm{~mm}$ wide; primary inflorescence of few to several racemes, mostly in pairs, rarely 3's or 4's, on filiform, often strongly flexuous peduncles, long-exserted from inconspicuous spathes, theso 
on slender branchlets borne in the axils of the broad spathelike sheaths of the main culm; secondary inflorescence of numerous pairs of racemes on short peduncles subtended by broad spathes, these on short bearded often fascicled branchlets borne in the axils of the spathelike sheaths of the main culm and short primary branches, the whole forming a series of flabellate tufts with conspicuous purplish to copper-brown spathes, 5 to $10 \mathrm{~mm}$ wide, much exceeding the feathery racemes; racemes flexuous, 3 to 4 rarely to $5 \mathrm{~cm} \mathrm{long}$, the slender rachis joints and pedicels long-villous; sessile spikelets 4 to 5 $\mathrm{mm}$ long, those of the late enclosed racemes cleistogamous, the awn loosely twisted, 10 to $15 \mathrm{~mm}$ long; pedicellate spiliselets obsolete or nearly so. 2l -Open ground, old fields, and open woods, mostly in the Coastal Plain, New Jersey to Florida and Texas, north to southern Missouri, Indiana, and Tennessee (fig. 1656). The flattened ferrugineous upper sheaths are conspicuous in winter. The characteristic

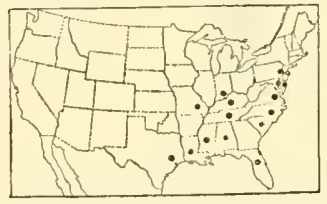

FIGURE 1656.-Distribution of Andropogon elliottii.

plant is very striking, but occasional individuals occur with less aggregate upper sheaths, and others with scarcely dilated sheaths, aggregate or scarcely aggregate. This form, which has been distinguished as A. elliottii var. gracilior Hack., appears to verge into $A$. subtenuis Nash.

26. Andropogon subténuis Nash. (Fig. 1657.) Culms in small tufts, slender, erect, 40 to $70 \mathrm{~cm}$ tall, the upper third sparingly branching; foliage glabrous or nearly so, the blades 1.5 to $2 \mathrm{~mm}$ wide; inflores-

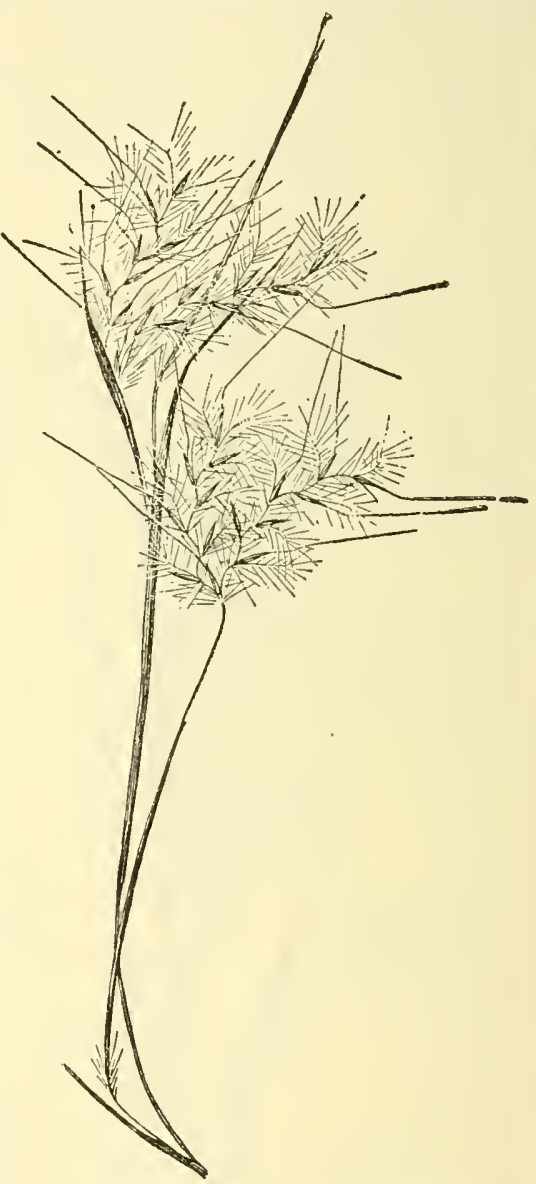

FIGURE 1657.-Andropogon subtenuis, $\times 1$. (Tracy 4701, Miss.) cence narrow, of few to several pairs of racemes on elongate filiform peduncles short-exserted from near the summit of the elongate slender spathe, the ultimate branches sometimes long-villous toward the summit; racemes 2 , flexuous, 2 to $3 \mathrm{~cm}$ long, very like the primary racemes of $A$. elliottii; spikelets $4 \mathrm{~mm}$ long. 2 1 -Dry sandy soil, northern Florida to Mississippi. Possibly a form of A. elliottii in which the cnlarged sheaths and cleistogamous inflorescence are not developed.

27. Andropogon campylorácheus Nash. (Fig. 1658.) Culnis tufted, erect, 40 to $80 \mathrm{~cm}$ tall, simple or with a few branches about 
the middle; sheaths and lower part of the blades appressed-villous, the blades about $2 \mathrm{~mm}$ wide; racemes 2 to 4 , mostly 2 , on long flexuous peduncles exserted from long narrow spathes, the slender rachis very flexuous, the joints and pedicels much longer than the sessile spikelet, long-villous, the lowermost rachis joint often elongate; sessile spikelet 5 to $6 \mathrm{~mm}$ long, slender, the awn loosely twisted, mostly about $2 \mathrm{~cm}$ long; pedicellate spikelet reduced to a slender glume or obsolete. 24-Dry sandy pine woods, Florida, Mississippi, and Louisiana.

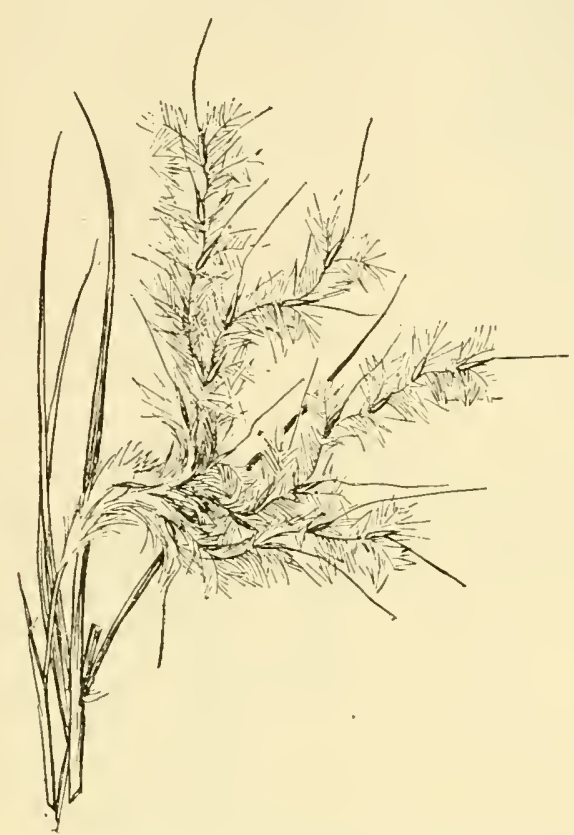

FIGURE 1658.-Andropogon campyloracheus, $\times 1$. (Combs 677, Fla.)

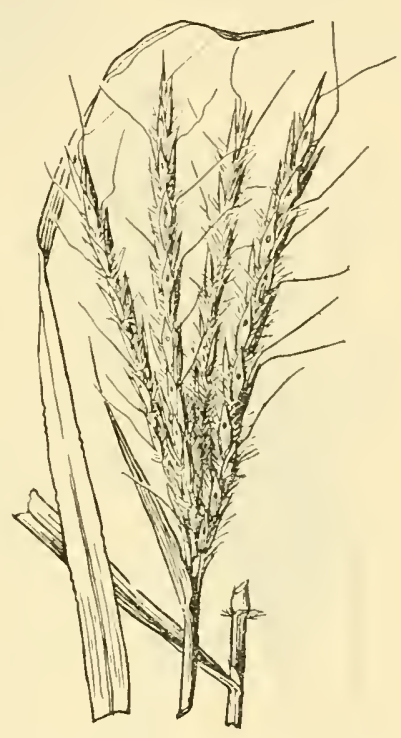

Figure 1659.-Andropogon u'rightii, $\times 1$. (Metcalfe 1371, N. Mex.)

\section{Section 3. Amphílophis Trin.}

Perennials, simple or sparingly branching; racemes several to numerous in a leafless panicle, at least the lower racemes short-peduncled, mostly on a relatively long axis; rachis straight, the joints and pedicels flat, with thick bearded margins, the center subhyaline.

28. Andropogon wríghtii Hack. (Fig. 1659.) Plants somewhat glaucous; culms tufted, 50 to $100 \mathrm{~cm}$ tall, simple, the nodes usually hispid; blades flat, 3 to $5 \mathrm{~mm}$ wide, tapering to a fine point; racemes 3 to 7 , suberect, mostly 3 to $6 \mathrm{~cm}$ long, green or tawny, not conspicuously woolly, the hairs of rachis joints and pedicels much shorter than the spikelets; peduncle usually long-exserted; sessile spikelet about $6 \mathrm{~mm}$ long, short-pilose at base, the first glume several-nerved toward the summit, stiffly short-ciliate on the keels above; awn twisted below, geniculate, 10 to $15 \mathrm{~mm}$ long; pedicellate spikelet about as large as the sessile one, awnless. 2 -Rocky hills and mesas, southern New Mexico, and northern Mexico. An occasional spikelet is found with a pitted first glume. In Mexican specimens the glumes are commonly pitted. 
29. Andropogon perforátus Trin. (Fig. 1660.) Culms densely tufted, geniculate at base, 50 to $100 \mathrm{~cm}$ tall, simple or with a few leafy shoots at base; nodes from obscurely appressed-pubescent to densely short-bearded; blades 2 to $4 \mathrm{~mm}$ wide, the apex attenuate; racemes few to several, mostly 5 to $7 \mathrm{~cm}$ long, one or more of them on slender individual peduncles aggregate on a short axis, the common peduncle usually long-exserted; margins of rachis joints and pedicels densely long-villous; sessile spikelet 4 to $6 \mathrm{~mm}$ long, short-pilose at base, the first glume sparsely hairy and with a small pit like a pinhole; awn twisted below, geniculate, 2 to $2.5 \mathrm{~cm}$ long; pedicellate spikelet reduced. 24 - Mesas, rocky hills, and dry woods, southern Texas; Mexico.

30. Andropogon barbinódis Lag. (Fig. 1661.) Culms tufted, 40 to $120 \mathrm{~cm}$ tall, spreading to ascending, often branching below, the nodes bearded with short spreading hairs; sheaths sparsely hairy in

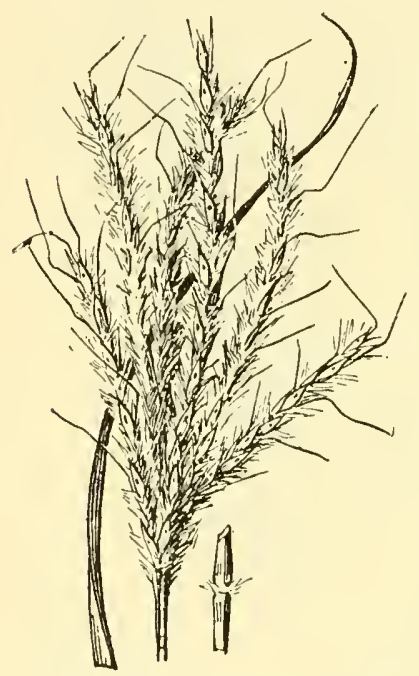

Figure 1660-Andropogon perforatus, $\times 1$. (Hitchcock 5218, Tex.) the throat, foliage otherwise glabrous or nearly so, the blades 2 to $7 \mathrm{~mm}$ wide, scabrous; panicles from rather long-exserted to included at base, those of the branches often partly included in dilated sheaths, silvery to creamy white, silky, subflabellate, mostly 7 to $10 \mathrm{~cm}$ long; racemes several to many, or sometimes few on the branches, 2 to $6 \mathrm{~cm}$ long, the common axis usually shorter than the racemes, rarely longer; rachis joints and pedicels copiously longvillous, the hairs on the average longer than in A. saccharoides; spikelets 5 to $6 \mathrm{~mm}$ long, the awn twisted below, geniculate, 20 to $25 \mathrm{~mm}$ long; pedicellate spikelet reduced. 2 -Mesas, rocky slopes, and open ground, Oklahoma and Texas to California and Arizona, south through Mexico (fig. 1662). Has been confused with $A$. saccharoides, differing chiefly in the subflabellate panicle and larger spikelets.

31. Andropogon saccharoídes Swartz. Silver beardgrass. (Fig. 1663.) Culms tufted, 60 to $130 \mathrm{~cm}$ tall, erect or ascending, often branching below, the nodes from appressed hispid to glabrous; foliage commonly glaucous, glabrous or nearly so, the blades 3 to $6 \mathrm{~mm}$ wide; panicle long-exserted or those of the branches short-exserted, silvery white, silky, dense, oblong, mostly 7 to $15 \mathrm{~cm}$ long; racemes 2 to $4 \mathrm{~cm}$ long, the common axis mostly at least twice as long, but readily breaking; rachis joints and pedicels longvillous; spikelets about $4 \mathrm{~mm}$ long, the delicate awn twisted below, geniculate, 10 to $15 \mathrm{~mm}$ long; pedicellate spikelet reduced. $24-$ Prairies and rocky slopes, especially in limestone areas, Missouri to Colorado, and Alabama to Arizona and southern California (Topango Canyon); Mexico and West Indies to Brazil (fig. 1664). Our plants, which have been differentiated as A. torreyanus Steud., are more freely branching than the typical form of the West Indies.

32. Andropogon exaristátus (Nash) Hitchc. (Fig. 1665.) Resembling $A$. saccharoides; panicle slender, spilepelets slightly smaller, awnless or nearly so; rare. 24 - Low open ground, southern Louisiana and eastern Texas, 
MANUAL OF THE GRASSES OF THE UNITED STATES 745

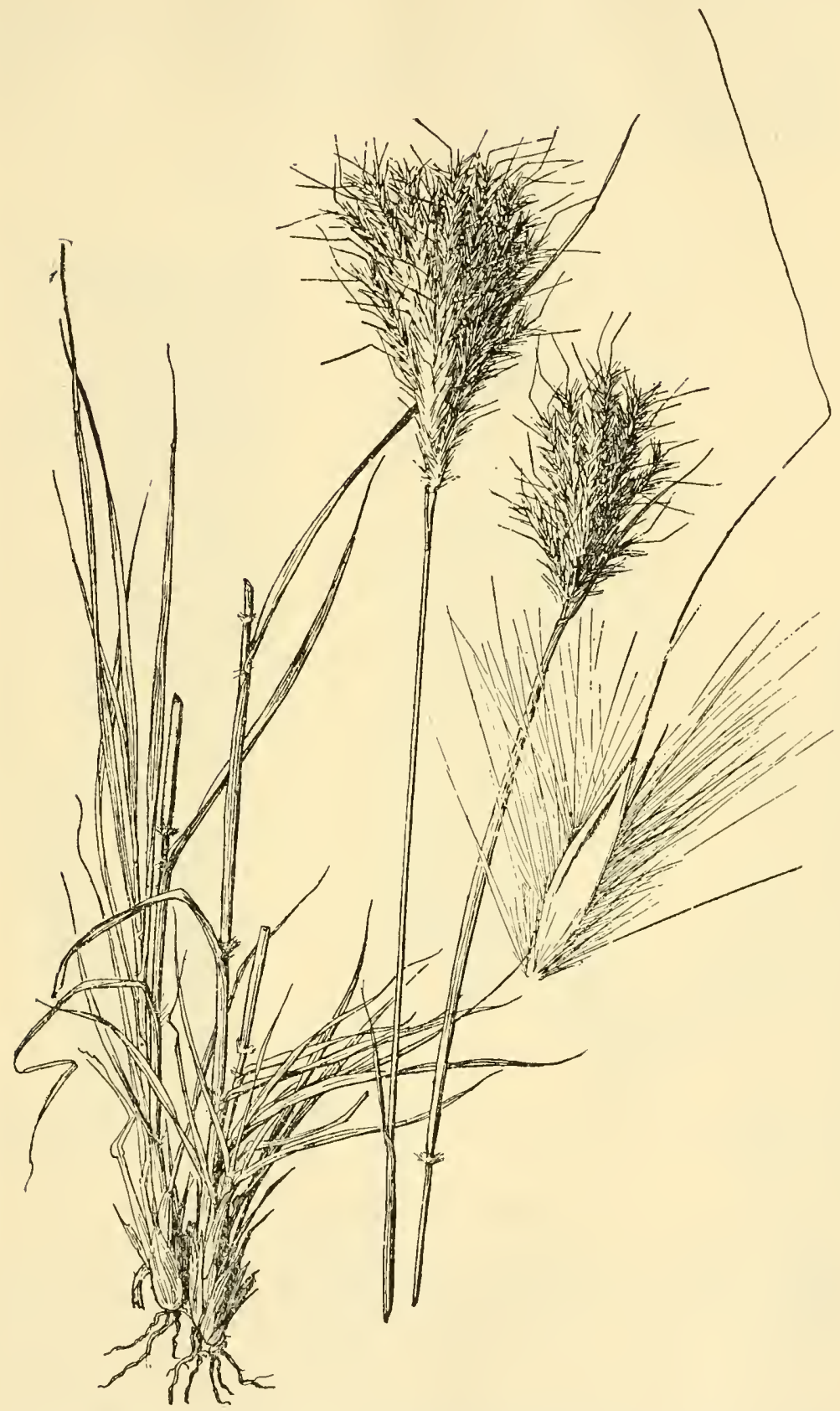

F1GURE 1661-Andropogon barbinodis. Plant, $\times 1 / 2$; pair of spikelets, $\times 5$. (Amer. Gr. Nat. Herb. 549, Ariz.) 
Andropogon nodósus (Willem.) Nash. Decumbent, freely branching, low perennial, with flat blades 2 to $8 \mathrm{~cm}$ long, and solitary or paired racemes, the sterile spikelets as conspicuous as the fertile ones, giving the appearance of a flat 2-ranked scaly spilie; awns slender, twisted and bent; peduncle pubescent below racemes. 2! - Old World species, established in a few of the West Indian islands; has been collected at Miami, Fla.

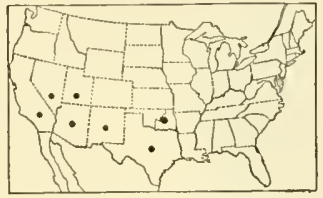

FIGURE 1662.-Distribution of Andropogon barbinodis.

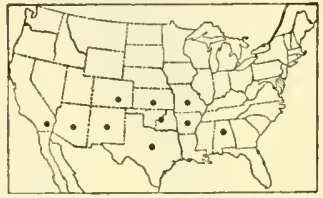

FIGURE 1664.-Distribution of Andropogon saccharoides.

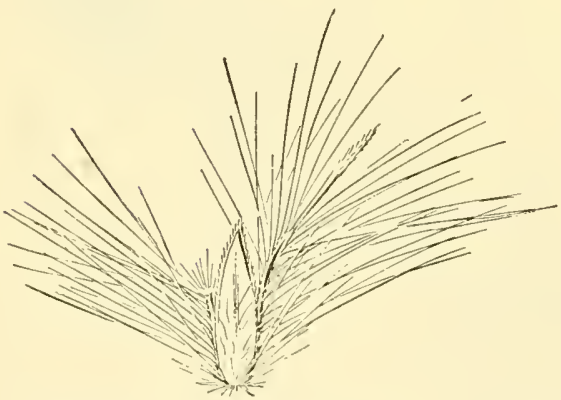

Figure 1665. - Andropogon exaristatus, $\times 5$. (Type.)

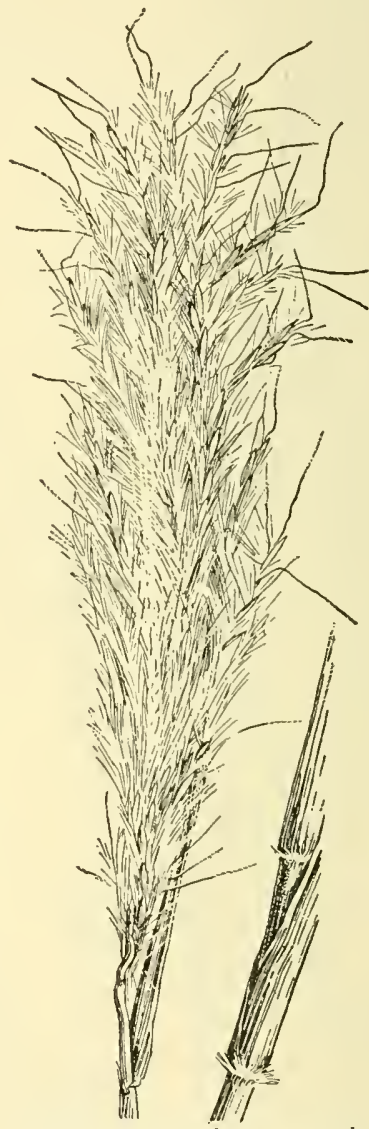

Figure 1663 -Andropogon saccharoides, $\times 1$. (Hitcheock 5370 , Tex.)

\section{CYMBOPÓGON Spreng. Oilgrass}

Closely allied to Andropogon; the pairs of racemes included in an inflated spathe, the spathes in a large compound inflorescence; sessile and pedicellate spikelets of lower pair alike, well developed, but staminate or neuter. Robust mostly aromatic perennials, including the oilgrasses of commerce. The most important are Cymbopogon NÁrdus (L.) Rendle, citronella grass, nard grass, in which the first glume of the sessile spikelet is flat on the back, and C. Citrátus(DC.) Stapf, lemon grass, in which the first glume is concave on the back. These species are sometimes cultivated in gardens in southern 
Florida and southern California but do not flower there. Name from Greek kumbe, boat, and pogon, beard, alluding to the boat-shaped spathes.

\section{Vetiveria zizanioídes} (L.) Nash. Vetiver. (Fig. 1666.) Robust densely tufted perennial with simple culms and large erect panicles, the slender whorled branches ascending, naked at the base, the arnuless spikelets muricate. Also called khuskhus and khas-khas. 2 - Native of the old World, frequently cultivated in tropical America for hedges and for the aromatic roots, these being used for making screens and mats which are fragrant when wet. Vetiver oil is much used in perfumery. Escaped from cultivation in Louisiana. Name from vettiver, the native Tamil name.

\section{HYPARRHÉNIA Anderss.}

Spikelets in pairs as in Andropogon, but spikelets of the lower pairs alike, sterile, and awnless; fertile spikelets 1 to few in each raceme, terete or fiattened on the back (koeled toward the sunmit in Hyparrhenia rufa), the base usually elongate into a sharp callus, the fertile lemma with a strong geniculate awn; sterile spikelets awnless; racemes

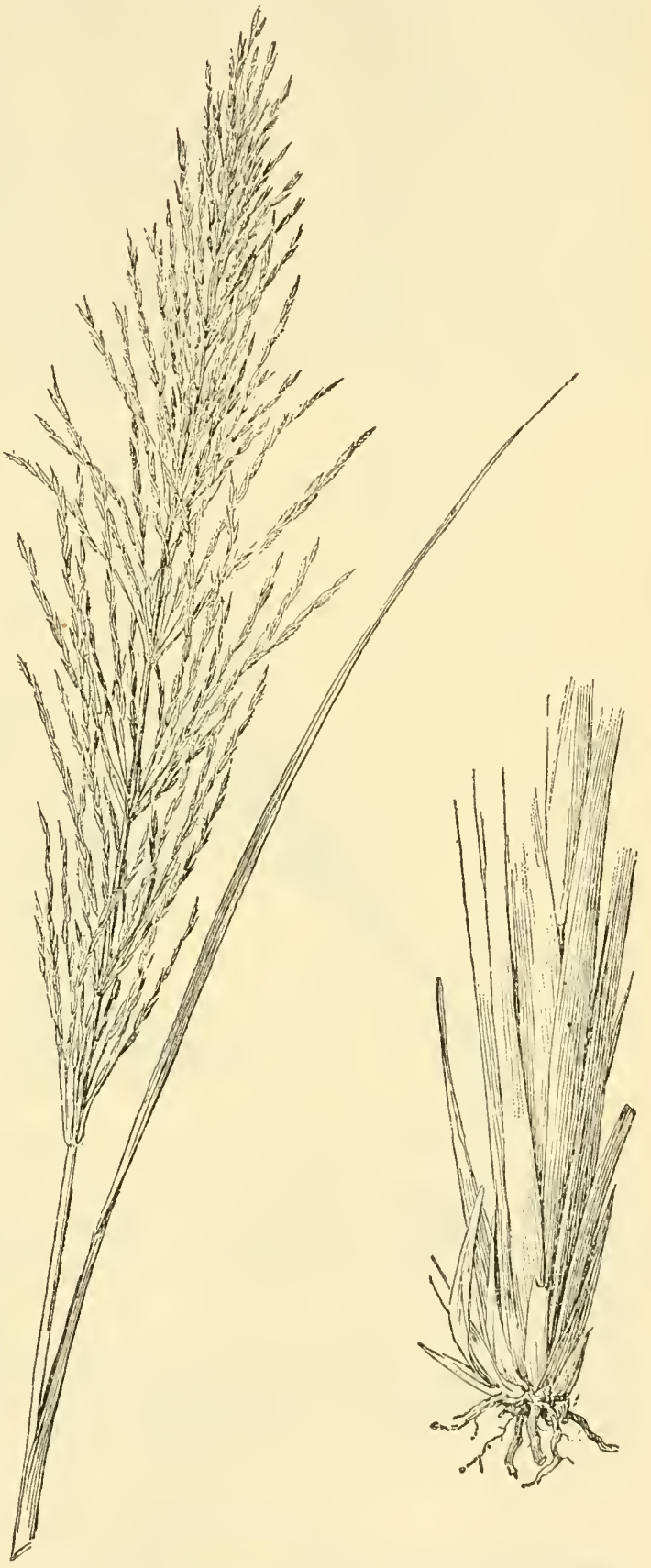

FIGURE 1666.-Vetiveria zizanioides, $\times 1 / 2$. (Hitcheock 9435 , Jamaica.) in pairs, on slender peduncles, and subtended by a spathe. Tall per.. 
ennials, the pairs of racemes and their spathes more or less crowded, forming a rather large elongate inflorescence. Type species, Hyparrhenia pseudocymbaria (Steud.) Stapf. Name from Greekhypo, under, and arren, masculine, alluding to the pair of staminate spikelets at the base of the raceme.

1. Hyparrhenia rúfa (Nees) Stapf. (Fig. 1667.) Culms erect, rather stout, 1 to $2.5 \mathrm{~m}$ tall; blades flat, elongate, 2 to $8 \mathrm{~mm}$ wide, sometimes wider, very scabrous on the margins; inflorescence 20 to 40 $\mathrm{cm}$ long, the pairs of racemes on long slender flexuous peduncles; raoemes about $2 \mathrm{~cm}$ long, reddish brown, fertile spikelets mostly 5 to 7 in each raceme, 3 to $4 \mathrm{~mm}$ long, flattened from the back, pubescent with dark-red hairs, the pedicels and rachis joints ciliate with red hairs; awn 15 to $20 \mathrm{~mm}$ long, twice geniculate, twisted, red-brown, hispidulous. 4 -Tropics of the Old World; introduced in tropical

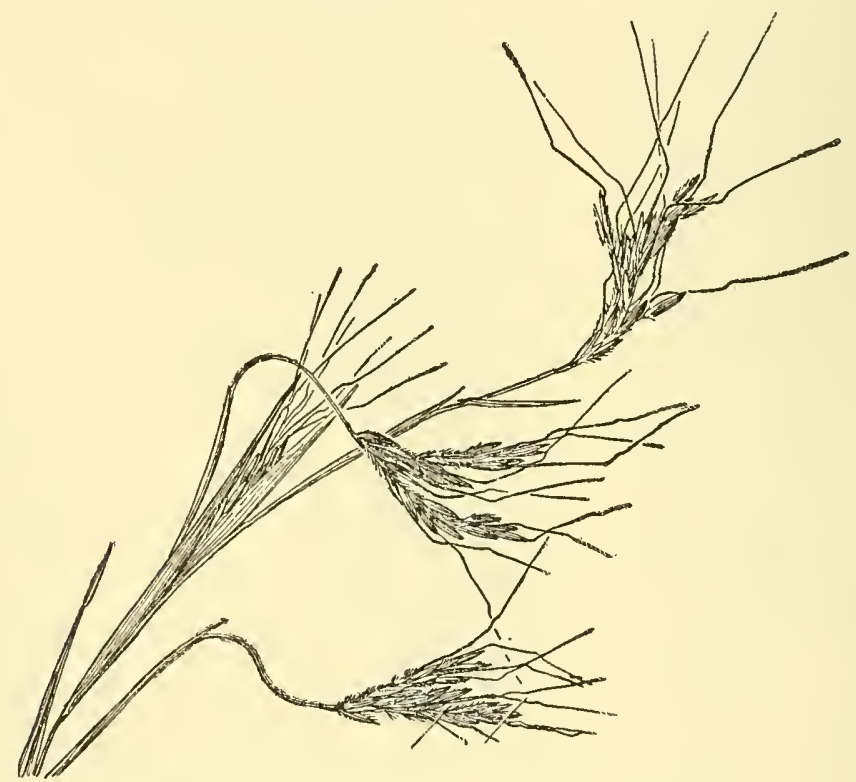

FiguRe 1667.-Hyparrhenia rufa, $\times 1$. (Moldenke 243, Fla.)

America; sparingly cultivated in Florida (where it has escaped) and along the Gulf coast. Adapted to conditions in the regions mentioned, but only moderately valuable as a forage grass. The native name in Brazil is jaragua.

Hyparrhenia hírta (L.) Stapf. Usually not more than $1 \mathrm{~m}$ tall; blades usually less than $3 \mathrm{~mm}$ wide, more or less involute, flexuous; racemes whitish or grayish silky-villous. 24 -Warmer parts of the Old World; cultivated at the Florida State Experiment Station and probably elsewhere. Appears to have little forage value.

\section{SORGHUM Moench}

Spikelets in pairs, one sessile and fertile, the other pedicellate, sterile but well developed, usually staminate, the terminal sessile spikelet with two pedicellate spikelets. Tall or moderately tall 

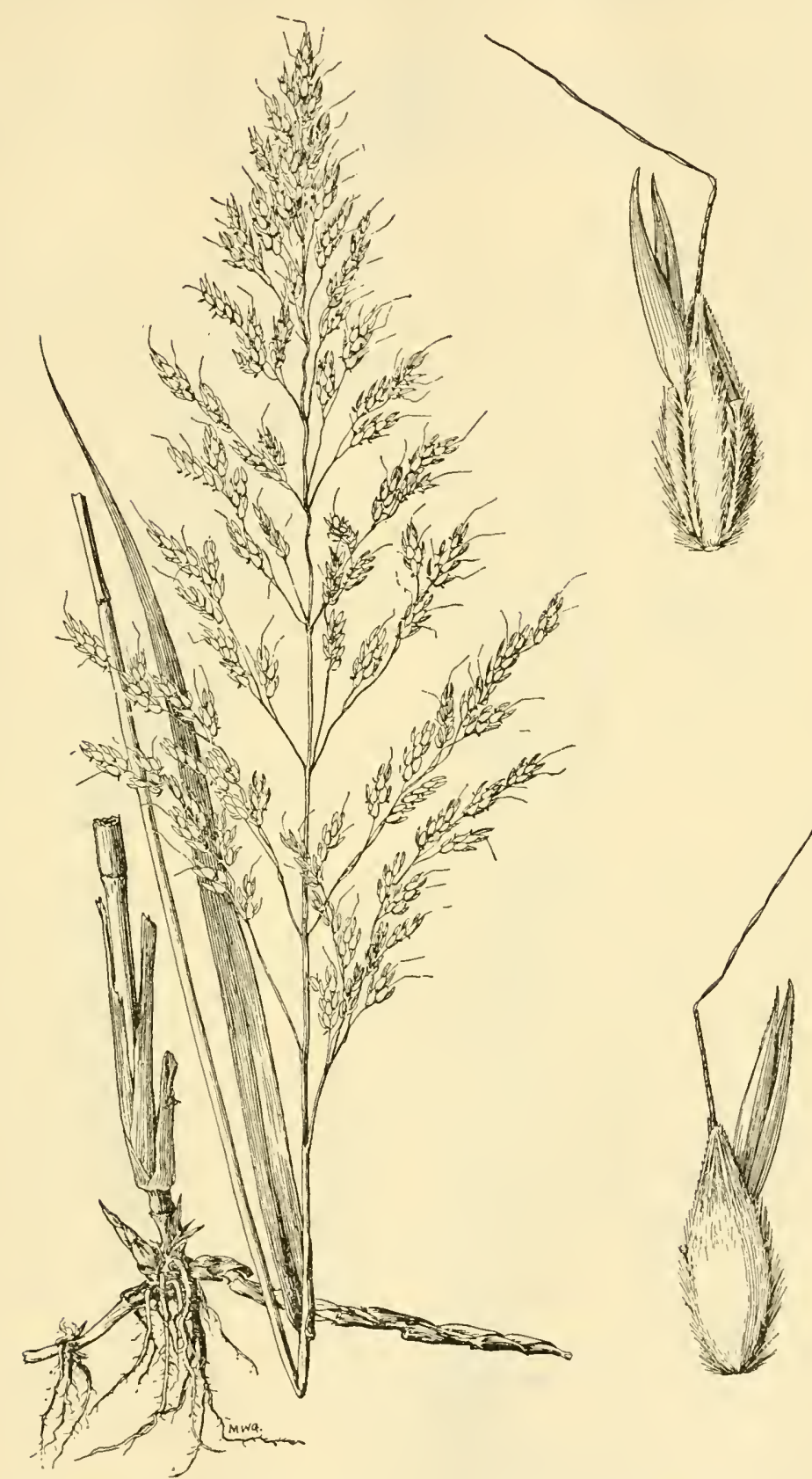

Figure 1668. $\rightarrow$ Sorghum halepense. Plant, $\times \frac{1}{2}:$ two views of terminal raceme, $\times 5$. (Small, Ga.) 
annuals or perennials, with flat blades and terminal panicles of 1- to 5 -jointed tardily disarticulating racemes. Type species, Sorghum saccharatum (L.) Moench. Name from Sorgho, the Italian name of the plant.

The sorghums and Johnson grass sometimes produce cyanogenetic compounds in sufficient abundance, especially in second growth, to cause prussic-acid poisoning in grazing animals. The leaves are often splotched with purple, due to a bacterial disease.

Plants perennial ....... S. HALEPENSE. Plants annual.

1. Sorghum halepénse (L.) Pers. Johnson grass. (Fig. 1668.) Culms 50 to $150 \mathrm{~cm}$ tall, from extensively creeping scaly rhizomes; blades mostly less than $2 \mathrm{~cm}$ wide; panicle open, 15 to $50 \mathrm{~cm}$ long; sessile spikelet 4.5 to $5.5 \mathrm{~mm}$ long, ovate, appressed-silky, the readily deciduous awn 1 to $1.5 \mathrm{~cm}$ long, geniculate, twisted below; pedicellate spikelet 5 to $7 \mathrm{~mm}$ long, lanceolate. 21 (Holcus halepensis L.) Open ground, fields, and waste places, Massachusetts to Iowa and Kansas, south to Florida and Texas, west to southern California (fig. 1669); native of the Mediterranean region, found in the tropical and

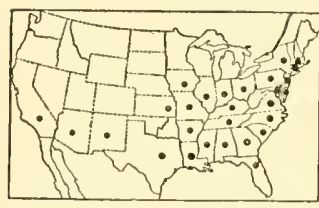

Figure 1669.-Distribution of Sorghum halepense. warmer regions of both hemispheres. Culti-y vated for forage; on account of the difficulty of eradication it becomes a troublesome weed.

2. Sorghum vulgáre Pers. Sorghum. Differing from $S$. halepense in being annual and more robust. $\odot$ (Holcus sorghum L.)-This species has been cultivated in warmer regions since prehistoric times for the seed, which has been used for food, for the sweet juice, and for forage. In the United States it is cultivated under the general name of sorghum.

There are many varieties or races of cultivated sorghums, all of which have the same chromosome number (10) and which fall naturally into distinct groups, the chief of which (in the United States) are sorgo, kafir, durra, milo, feterita, shallu, kaoliang, broomcorn, and Sudan grass. Sorgo includes the varieties known collectively as sweet or saccharine sorghums, in which the juice in the stems is abundant and very sweet. In this country sorgo is cultivated chiefly in the region from Kansas and Texas to North Carolina for forage and for the juice which is made into sirup. The large panicles of broomcorn, grown especially in Oklahoma and Illinois, furnish the material for brooms. The other forms are grown for forage or for the seed which is used for feed. Sudan grass ( $S$. vulgare var. sudanense (Piper) Hitchc.) is now grown extensively for pasture and for hay. This is a rather slender annual, 1 to $2 \mathrm{~m}$ tall with comparatively narrow blades and an open spreading panicle. This variety is more distinct than the others.

The differences between most of the varieties are so indistinct and so unstable because of intercrossing as to make it very difficult to assign descriptive limits. The application of botanical names is uncertain, and it seems best, therefore, not to assign to them definite varietal or specific Latin names.

The following names have been applied in American literature to some of the more important varieties. 


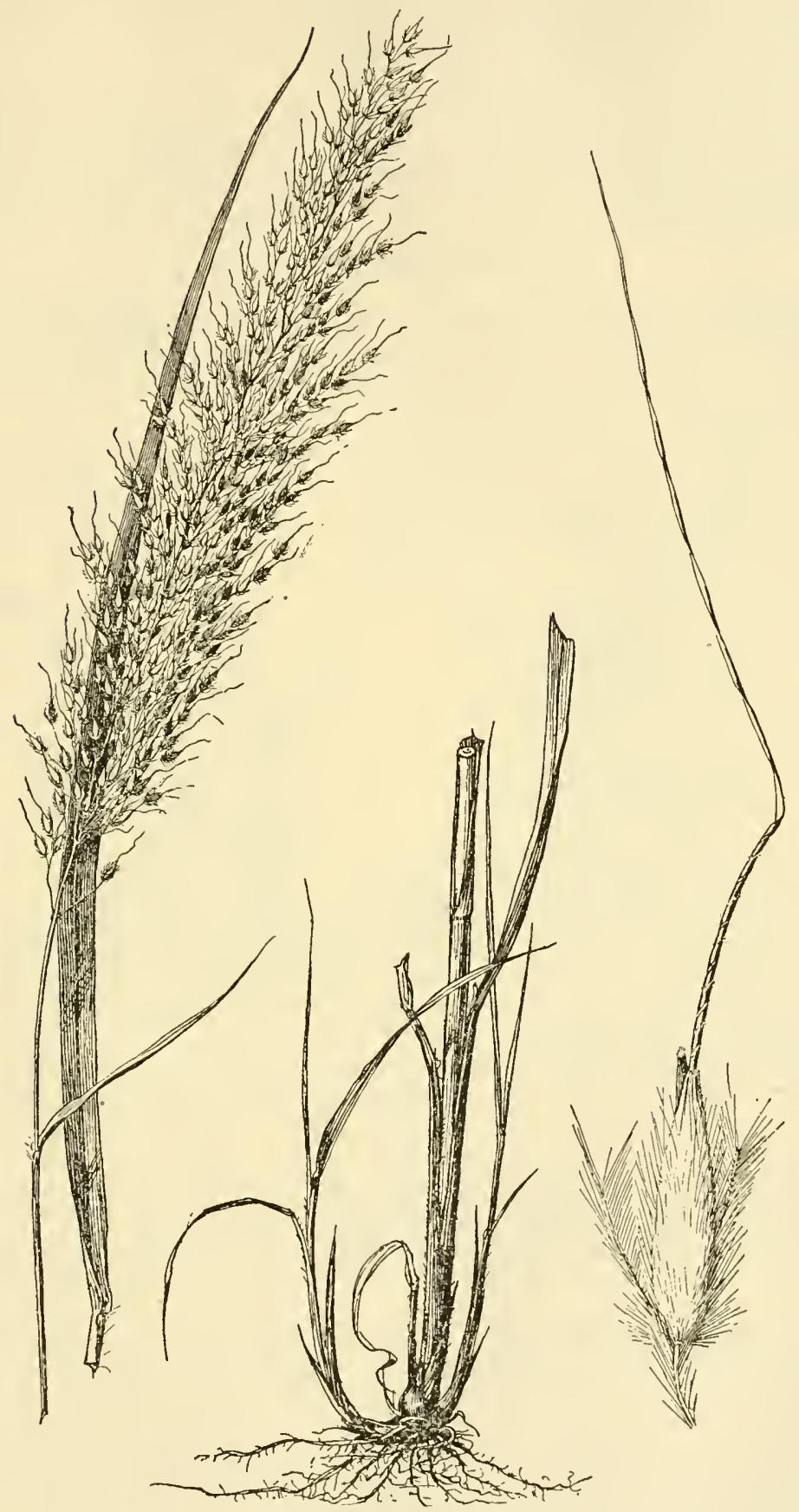

FIGURE 1670.-Sorghastrum nutans. Plant, $\times 1 / 2$; spikelet with pedicel and rachis joint, $\times 5$. (Deam, Ind.) $55974^{\circ}-35-48$ 
Kafir. S. vulgare var. caffrorum (Thunb.) Hubb. and Rehder.

Shallu. S. vulgare var. roxburghii (Stapf) Haines.

Durra. S. vulgare var. durra (Forsk.) Hubb. and Rehder.

Broomcorn. S. vulgare var. technicum (Koern.) Jav.

Sorgo. S. vulgare var. saccharatum (L.) Boerl.

Tunis grass (S. virgatum (Hack.) Stapf) is a tall annual with a narrow slender open panicle and narrowly-lanceolate green finely-awned spikelets.-Africa. Has been tried at experiment stations but has not been brought into commercial cultivation, being inferior to Sudan grass.

\section{SORGHĀSTRUM Nash}

Spikelets in pairs, one nearly terete, sessile, and perfect, the other wanting, only the hairy pedicel being present; glumes coriaceous, brown or yellowish, the first hirsute, the edges inflexed over the second; sterile and fertile lemmas thin and hyaline, the latter extending into a usually well-developed bent and twisted awn. Perennial, erect, rather tall grasses, with auricled sheaths, narrow flat blades, and

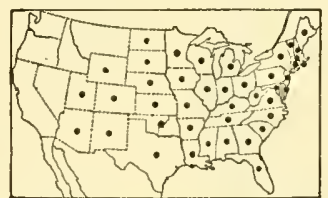

Figure 1671.-Distribution of Sorghastrum nutans.

narrow terminal panicles of one- to few-jointed racemes. Type species, Sorghastrum avenaceum (Michx.) Nash (S.nutans). Name from Sorghum and the Latin suffix astrum, a poor imitation of, alluding to the resemblance to Sorghum.

The most important species, $S$. nutans, is a common constituent of wild or prairie hay in the eastern part of the Great Plains region.

Awn usually $15 \mathrm{~mm}$ long or less, once geniculate. Panicle rather dense, yellowish _._. Awn 20 to $35 \mathrm{~mm}$ long, twice-geniculate, twisted below the second bend.

Spikelets chestnut-brown, the ultimate branchlets with a few long hairs at the tip only; panicle loose, not unilateral. ............ 2. S. ELLIoTTII. Spikelets yellowish brown, the upper portion of the ultimate branchlets conspicuously long-hairy toward the tip; panicle distinctly unilatera 3. S. SECUNDUM

1. Sorghastrum nutans. (L.) Nash. Indian Grass. (Fig. 1670.) Culms 1 to $2.5 \mathrm{~m}$ tall from short scaly rhizomes; blades elongate, flat, mostly 5 to $10 \mathrm{~mm}$ wide, tapering to a narrow base, scabrous; panicle narrow, yellowish, rather dense, 15 to $30 \mathrm{~cm}$ long, contracted and darker at maturity; summit of branchlets, rachis joints, and pedicels grayish-hirsute; spikelets 6 to $8 \mathrm{~mm}$ long, lanceolate, hirsute, the awn 1 to $1.5 \mathrm{~cm}$ long, once-geniculate. 24 -Prairies, open woods, and dry slopes, Quebec and Maine to Manitoba and North Dakota, south to Florida and Arizona; Mexico (fig. 1671). 
2. Sorghastrum ellióttii (Mohr) Nash. (Fig. 1672.) Culms 1 to $1.5 \mathrm{~m}$ tall, more slender than in $S$. nutans, without rhizomes; the base comparatively delicate, smooth or nearly so; blades on the average narrower; panicle loose, 15 to $30 \mathrm{~cm}$ long, nodding at apex, the filiform branchlets and pedicels flexuous but not recurved, with a few long hairs at the tip; spikelets 6 to $7 \mathrm{~mm}$ long, chestnut brown at maturity, with a short blunt bearded callus, the first glume hirsute or glabrescent on the back; awn 2.5 to $3.5 \mathrm{~cm}$ long, twice-geniculate. 21 -Open woods, dry hills, and sandy fields, eastern Maryland to Tennessee, south to Florida and Texas (fig. 1673).

3. Sorghastrum secúndum (Ell.) Nash. (Fig. 1674.) Culms 1 to $2 \mathrm{~m}$ tall, without rhizomes, the base robust and felty-pubescent; blades mostly less than $5 \mathrm{~mm}$ wide, flat or subinvolute; panicle narrow, 20 to 40

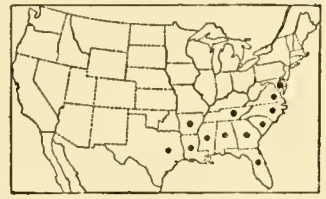

FIGURE 1673.-Distribution of Sorghastrum elliottii.

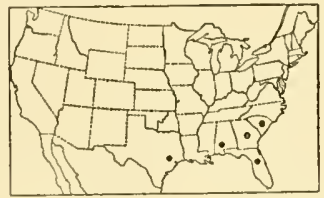

FIGURE 1675.-Distribution of Sorghastrum secundum.

cm long, 1-sided, the branches mostly in separated fascicles, the capillary branchlets and pedicels strongly curved or cir-

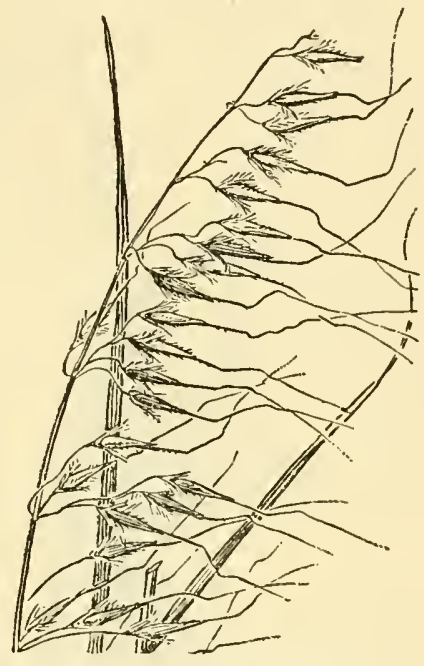

Figure 1674.-Sorghastrum secundum, $\times$ 1. (Hood, Fla.) cinately recurved, stiffly long-pilose below the tip; spikelets about $7 \mathrm{~mm}$ long, brownish, pilose, with an acute densely bearded callus 1 to $1.5 \mathrm{~mm}$ long. 24 -Pine barrens, South Carolina to Florida and Texas (fig. 1675).

\section{RHĀPHIS Lour.}

Spikelets in threes, one sessile and perfect, the other two pedicellate and sterile, or sometimes a pair below, one fertile and one sterile; fertile spikelet terete, the glumes coriaceous; sterile and fertile lemmas thin and hyaline, the latter awned. Perennial grasses, or, our species, annual, with open panicles, the three spikelets (reduced raceme) borne at the ends of long, slender, naked branches. Type species, Rhaphis trivialis Lour. (R. aciculatus Honda, Andropogon aciculatus Retz.). Name from Greek rhaphis, needle; alluding to the slender pointed callus.

1. Rhaphis pauciflórus (Chapm.) Nash. (Fig. 1676.) Annual; culms 60 to $120 \mathrm{~cm}$ tall, erect or somewhat decumbent at base; blades flat, mostly 4 to $8 \mathrm{~mm}$ wide; panicle loose, the axis 5 to 10 $\mathrm{cm}$ long, the branches few, very slender, 5 to $8 \mathrm{~cm}$ long; sessile spike- 


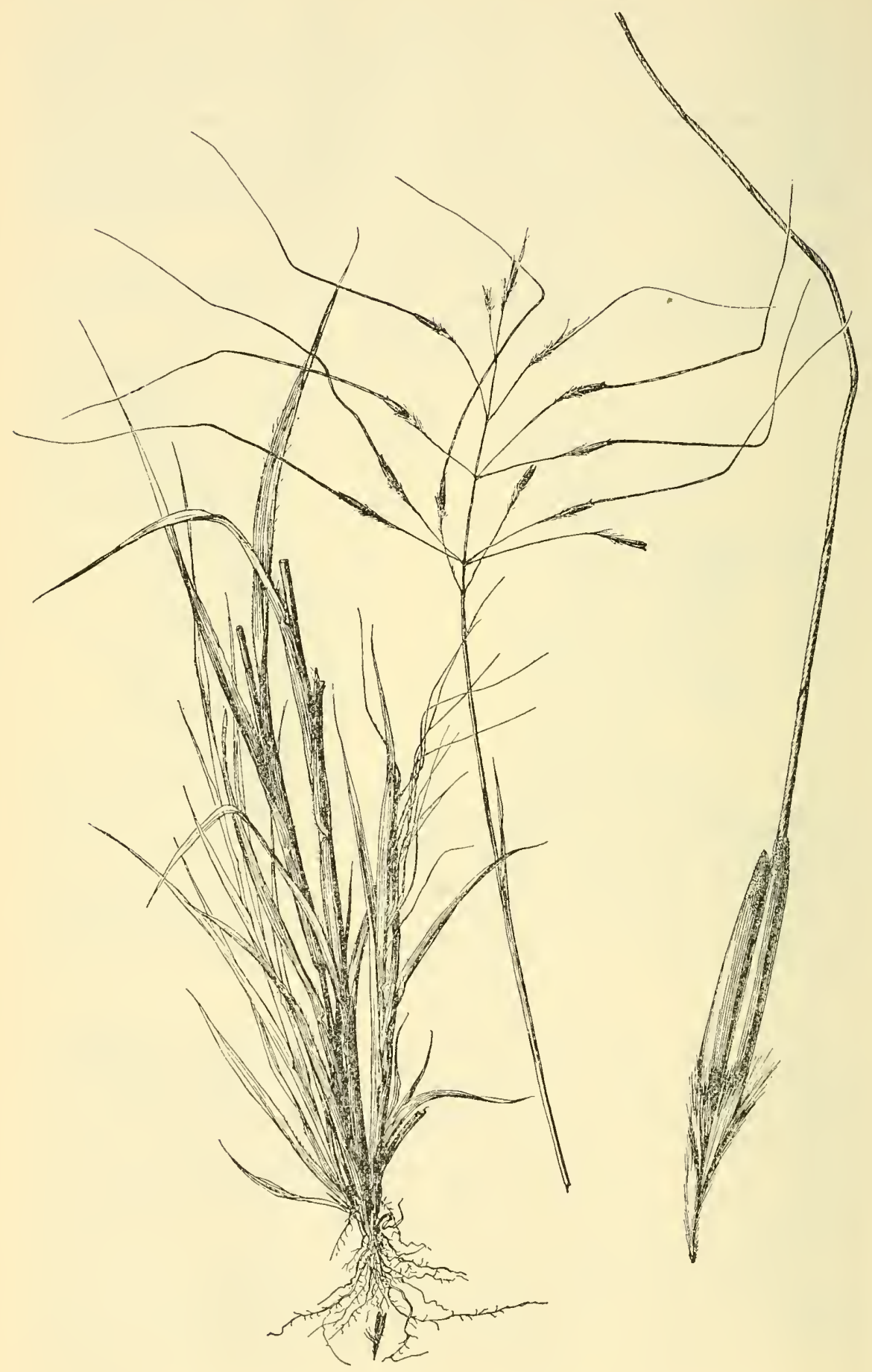

FIGURE 1676,-Rhaphis pauciflora. Plant, $\times 1 / 2$; fruiting spikelet, $\times 5$. (Combs 1359, Fla.) 
let about $1.5 \mathrm{~cm}$ long, including the slender villous callus about $7 \mathrm{~mm}$ long, this disarticulating by a long-oblique line, the tip of the pedicel thus villous on one side; awn stout, brown, geniculate, twisted below, about $15 \mathrm{~cm}$ long. $\odot-$ Sandy pine woods, open ground, and fields, Florida; Cuba. The fruits resemble those of certain species of Stipa such as S. spartea L.

\section{HETEROPÓGON Pers.}

Spikelets in pairs, one sessile, the other pedicellate, both of the lower few to several pairs staminate or neuter, the remainder of the sessile spikelets perfect, terete, long-awned, the pedicellate spikelets, like the lower, staminate, flat, conspicuous, awnless; glumes of the fertile spikelet equal, coriaceous, the first brown-hirsute, infolding the the second; lemmas thin and hyaline, the fertile one narrow, extending into a strong bent and twisted brown awn; palea wanting; glumes of the staminate spikelet membranaceous, the first green, faintly manynerved, asymmetric, one submarginal keel rather broadly winged, the other wingless, the margins inflexed, the second glume narrower, symmetric; lemmas hyaline; palea wanting. Annual or perennial, often robust grasses, with flat blades and usually solitary terminal racemes; rachis slender, the lower part, bearing the pairs of staminate spikelets, continuous, the remainder disarticulating obliquely at the base of each joint, the joint forming a sharp-barbed callus below the fertile spikelet, the pedicellate spikelet readily falling, its pedicel remaining, obscured in the hairs of the callus. Type species, Heteropogon glaber Pers. (H. contortus). Name from Greek heteros, different, and pogon, beard, alluding to the difference between the awnless staminate and awned pistillate spikelets.

One species, $H$. contortus, has a world-wide distribution. It is a good forage grass in the Southwest; if grazed constantly the troublesome awns do not develop. In the Hawaiian Islands, where it is called pili, it is an important range grass on the drier areas; also used there by the natives to thatch their grass huts. The mature fruits are injurious to sheep.

Plants perennial, less than $1 \mathrm{~m}$ tall; first glume of staminate spikelet usually papillose-hispid............. H. contontus. Plants annual, usually more than $1 \mathrm{~m}$ tall; first glume of staminate spikelet with a row of glands along the back, glabrous........-2. H. MELANOCARPUS.

1. Heteropogon contórtus (L.) Beauv. Tanglenead. (Fig. 1677.) Plants perennial, tufted; culms 20 to $80 \mathrm{~cm}$ tall, branched above, the branches erect; sheaths smooth, compressed-keeled; blades flat or folded, 3 to $7 \mathrm{~mm}$ wide; raceme 4 to $7 \mathrm{~cm}$ long, 1 -sided; sessile spikelets about $7 \mathrm{~mm}$ long, slender, nearly hidden by the imbricate pedicellate spikelets, the awns 5 to $12 \mathrm{~cm}$ long, bent and flexuous, commonly tangled; pedicellate spikelet about $1 \mathrm{~cm}$ long, the first glume papillosehispid toward the tip and margins, sometimes nearly glabrous. I - Rocky hills and canyons, Texas to Arizona; tropical and warmer regions of both hemispheres.

2. Heteropogon melanocárpus (Ell.) Benth. Sweet tanglehead. (Fig. 1678.) Plants annual, 1 to $2 \mathrm{~m}$ tall, freely branching; sheaths smooth, the upper part of the keel, especially of the upper sheaths, with a row of concave glands; blades 5 to $10 \mathrm{~mm}$ wide; raceme 3 to 6 $\mathrm{cm}$ long; looser than in $H$. contortus; sessile spikelets 9 to $10 \mathrm{~mm}$ long, 


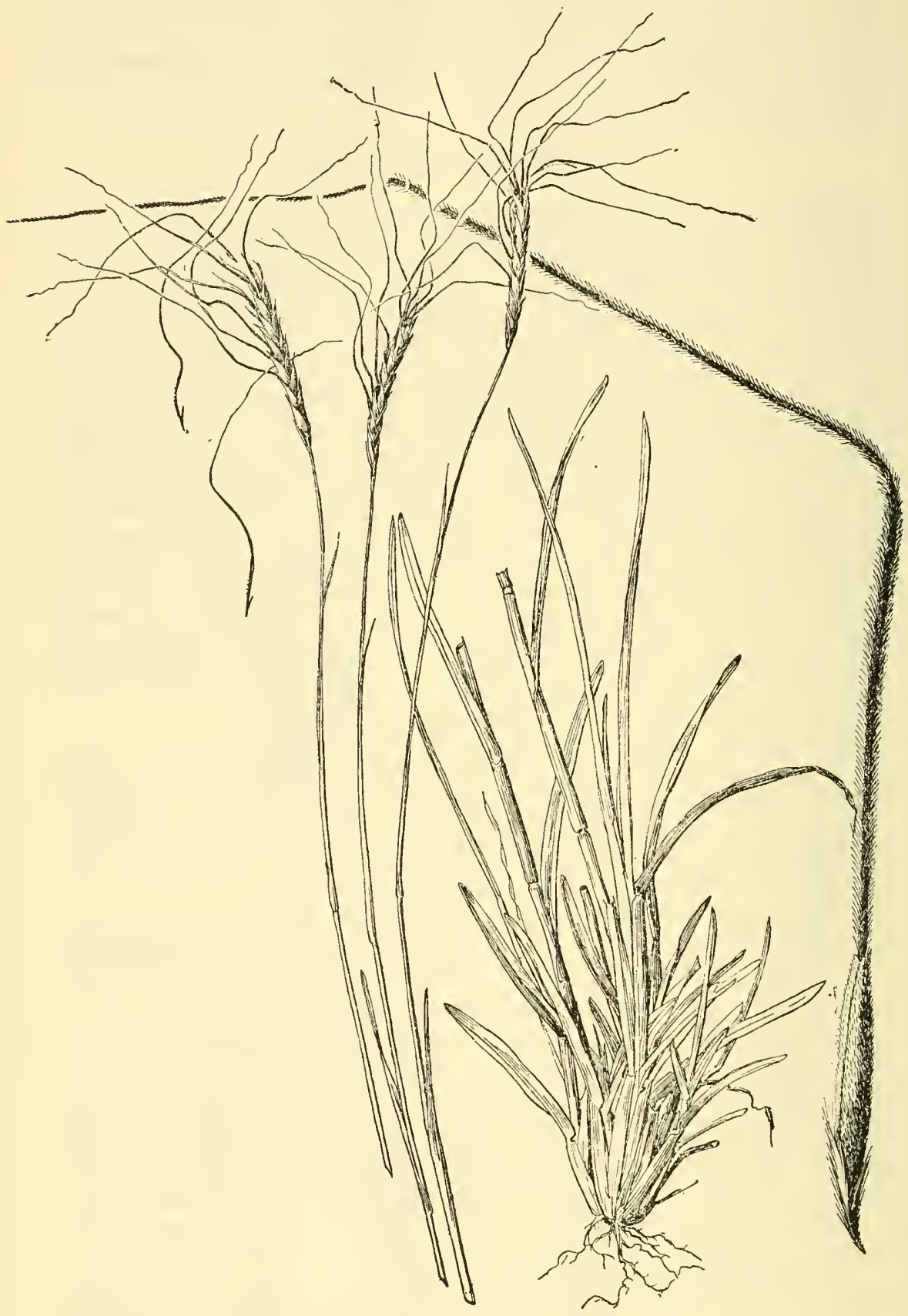

Figure 1677.-Heteropogon contortus. Plant, $\times 1 \frac{2}{2}$; fruiting spikelet, $\times 5$. (Griffiths 1844, Ariz.) 
relatively thick, the awns 10 to $15 \mathrm{~cm}$ long; pedicellate spikelet 1.5 to $2.5 \mathrm{~cm}$ long, the first glume with a line of punctate glands along the middle. $\odot$-Pine woods, fields, and waste places, Georgia, Florida, and Alabama; Arizona; tropical regions of both hemispheres. The plant when fresh emits an odor like that of citronella oil.

\section{TRACHYPÓGON Nees}

Spikelets in pairs, along a slender continuous rachis, one nearly sessile, staminate, awnless, the other pedicellate, perfect, long-awned; the pedicel of the perfect spikelet obliquely disarticulating near the base, forming a sharp-barbed callus below the spikelet; first glume firmmembranaceous, rounded on the back, several-nerved, obtuse; second glume firm, obscurely nerved; fertile lemma narrow, extending into a stout twisted and bent or flexuous awn; palea obsolete; sessile spikelet persistent, as large as the fertile spikelet and similar but awnless. Perennial, moderately tall grasses, with terminal spikelike solitary or fascicled racemes. Type species, Trachypogon montufari. Name from Greek trachus, rough, and pogon, beard, alluding to the plumose awn of the fertile spikelet.

1. Trachypogon montufári (H.B.K.) Nees. CrinkLE-AWN. (Fig. 1679.) Culms tufted erect, slender, hispid at the nodes, 60 to $120 \mathrm{~cm}$ tall; sheaths with erect auricles 2 to $5 \mathrm{~mm}$ long; blades flat to subinvolute, 3 to $8 \mathrm{~mm}$ wide; raceme solitary, rarely 2,10 to $15 \mathrm{~cm}$ long; spikelets 6 to $8 \mathrm{~mm}$ long, pubescent, the awns of perfect spikelets 3 to $6 \mathrm{~cm}$ long, short-plumose

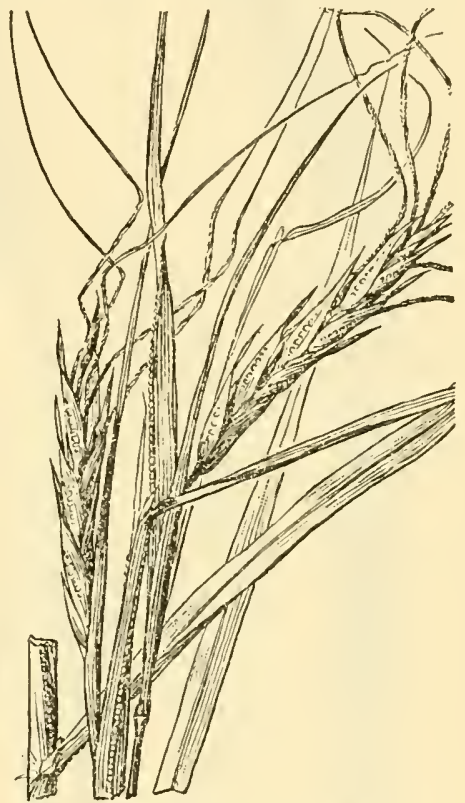

FIGURe 1678.-. Heteropogon melanocarpus, $\times 1$. (Fredholm 6405, Fla.) below, nearly glabrous toward the tip. 2 -Rocky hills and canyons, southern 'Texas, southwestern New Mexico, and southern Arizona; Mexico to Argentina.

\section{ELYONÚRUS Humb. and Bonpl.}

Spikelets in pairs along a somewhat tardily disarticulating rachis, the joints and pedicels short, thickened, and parallel, the sessile spikelets perfect, appressed to the concave side, the pedicellate spikelet staminate, similar to the sessile one, both awnless, the pair falling with a joint of the rachis; first glume firm, somewhat coriaceous, dorsally flattened, the margins inflexed around the second glume, a line of balsam glands on the marginal nerves, the apex entire and acute or acuminate, or bifid with aristate teeth; second glume similar to the first; sterile and fertile lemmas thin and hyaline; palea obsolete. Erect, moderately tall perennials, with solitary spikelike, often woolly racemes. Type species, Elyonurus tripsacoides. Name from Greek eluein, to roll, and oura, tail, alluding to the cylindric inflorescence. 


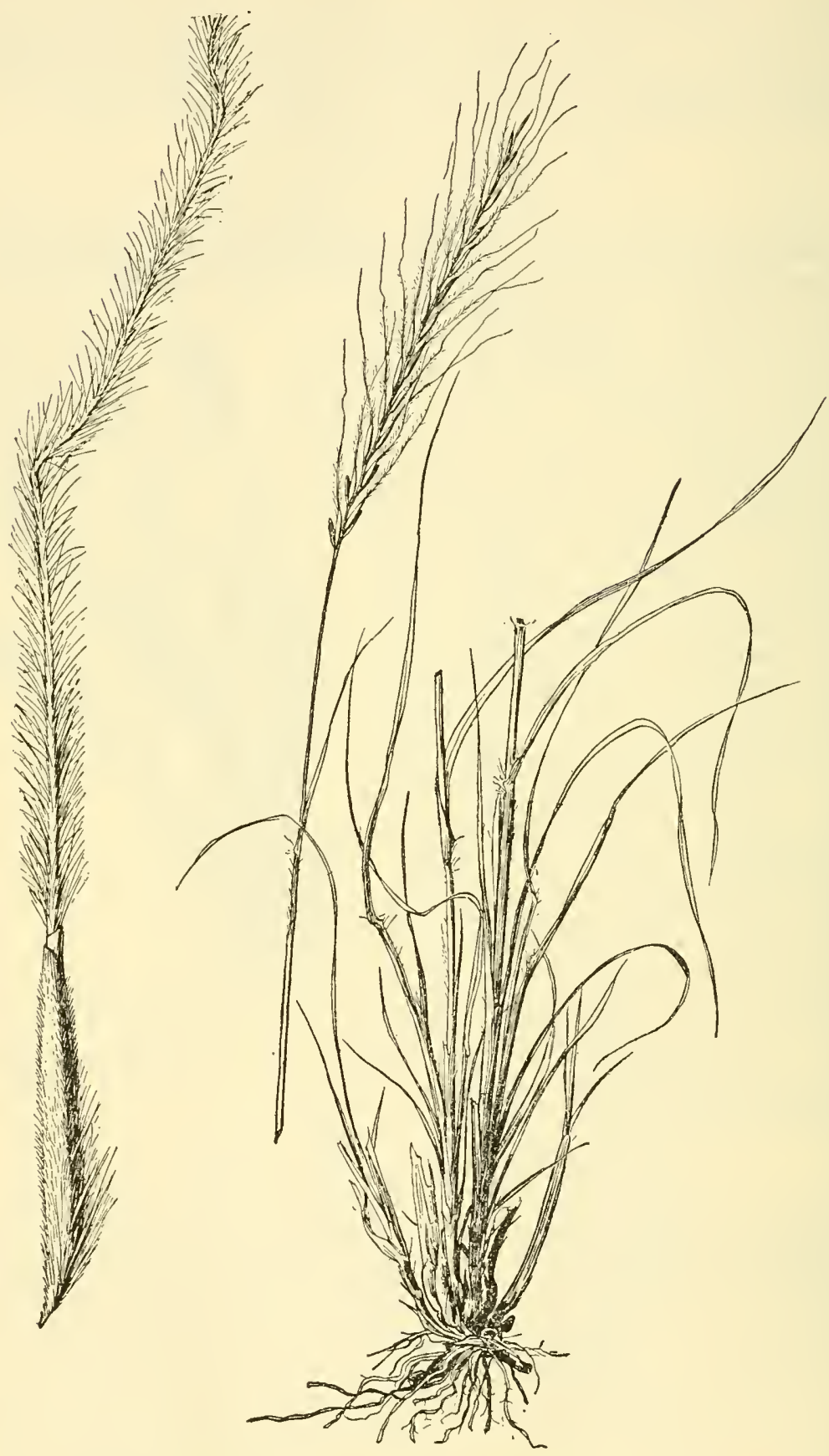

FIGURE 1679.-Trachypogon montufari. Plant, $\times 1 / 2$; fertile spikelet, $\times 5$. (Griffiths and Thornber 300, Ariz.) 


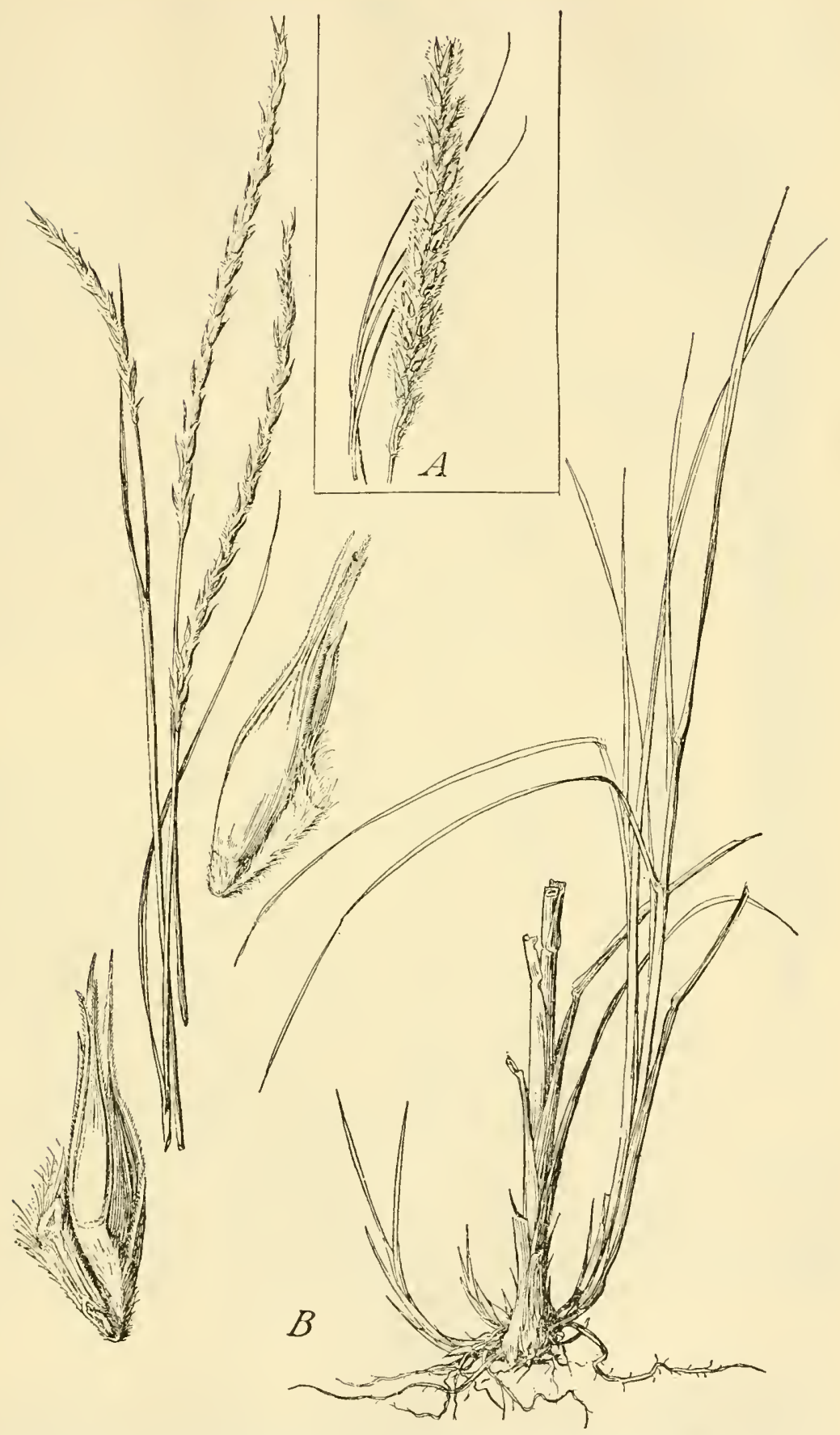

FIGUa $1680-A$ Elyonurus barbiculmis, $\times 1$. (Type coll.) $B, E$. tripsacoides. Plant, $\times 1 / 2$; two views of pair of spikelets with rachis joint, $\times 5$. (Chase 4144, Fla.) 
The species are important grazing grasses in the savannas and plains of tropical America, but they extend only a short distance into the United States.

Rhizomes wanting; culms hirsute below the nodes; racemes conspicuously woolly _... Rhizomes present; culms glabrous; racemes slightly pubescent, the first glume glabrous or nearly so on the back__._._._._._. 2. E. TRIPSACoIdES.

1. Elyonurus barbicúlmis Hack. (Fig. 1680, A.) Culms tufted, erect, simple or sparingly branching, 40 to $60 \mathrm{~cm}$ tall, pubescent below the nodes; blades involute, striate, about $1 \mathrm{~mm}$ thick, the upper surface usually long-pilose; raceme mostly 5 to $10 \mathrm{~cm}$ long, pale; rachis joints, pedicels, and spikelets densely woolly, the spikelets 6 to $8 \mathrm{~mm}$ long; first glume acuminate. 2 -Mesas,
rocky hills, and canyons, western Texas to southern
Arizona; northern Mexico.

2. Elyonurus tripsacoides Humb. and Bonpl. (Fig. $1680, B$.) Culms 60 to $120 \mathrm{~cm}$ tall, glabrous, rather freely branching and with short rhizomes; blades flat or involute, 2 to $4 \mathrm{~mm}$ wide, slightly pilose on the upper surface near the base; raceme 7 to $15 \mathrm{~cm}$ long; rachis joints ciliate, the pedicels pilose; spikelets 6 to $8 \mathrm{~mm}$ long, the first glume ciliate toward the acuminate 2-toothed apex, usually glabrous on the back. 24 -Moist pine woods and low prairies, Georgia, Florida, southern Mississippi, and southern 'Texas; Mexico to Argentina.

\section{ROTTBOELLIA L. f.}

Spikelets awnless, in pairs at the nodes of a thickened articulate rachis, one sessile and perfect, the other pedicellate, sterile; rachis joints hollow above, the thickened pedicel adnate to it, the pedicellate spikelet appearing to be sessile; sessile spikelet fitting closely against the concave side of the rachis joint, the first glume coriaceous, the second less coriaceous; sterile and fertile lemmas and palea hyaline. Coarse branching annual, with broad flat blades and subcylindric racemes, dwindling toward the summit and bearing abortive spikelets only. Type Figure 1681-- - species, Rottboellia exaltata. Named for C. F. Rot tboell. teta, $\times$ 1. (Rid- 1. Rotthoellia exaltáta L. f. (Fig. 1681.) Culms robust, ley, Jamaica.) 1 to $3 \mathrm{~m}$ tall, branching; sheaths papillose-hispid, especially toward the summit; blades flat, in robust specimens as much as $3 \mathrm{~cm}$ wide; racemes mostly 8 to $12 \mathrm{~cm}$ long, 3 to $4 \mathrm{~mm}$ thick, dwindling at the summit; sessile spikelet 5 to $7 \mathrm{~mm}$ long; first glume finely papillose; pedicellate spikelet about as long as the sessile one. $\odot$ (Manisuris exaltata Kuntze.) -Introduced at Miami, Fla.; West Indies; native of tropical Asia. The fragile hairs of the sheaths are irritating to the skin of persons handling the plant.

\section{MANISÚRIS L.}

Spikelets awnless, in pairs at the nodes of a thickened articulate rachis, one sessile and perfect, the other pedicellate, rudimentary (developed but sterile in $M$. altissima), the pedicel thickened and 
appressed to the rachis, the sessile spikelet fitting closely against the rachis (sometimes partly adnate in $M$. altissima), forming a cylindric or flattened raceme; glumes mostly obtuse, the first coriaceous, fitting over the hollow containing the spikelet, the keels winged at the summit, the second less coriaceous than the first; sterile lemma, fertile lemma, and palea thin and hyaline. Perennial slender, moderately tall, or tall grasses, with usually numerous glabrous cylindric or flattened solitary racemes. Type species, Manisuris myuros L. Name from Greek manos, necklace, and oura, tail, alluding to the jointed racemes, presumably. The species probably have some forage value but they are nowhere abundant.

Racemes flattened, tardily disarticulating; first glume of sessile spikelet smooth.

1. M. ALtissima.

Racemes cylindric, readily disarticulating at maturity; first glume of sessile spikelet marked with pits or wrinkles (sometimes smooth in $M$. tuberculosa).

Sheaths not compressed-keeled; first glume more or less pitted.

2. M. CYLINDRICA.

Sheaths compressed-keeled; first glume tessellated, wrinkled, tubercled, or smooth.

First glume tessellated, the depressions rectangular _. - 3. M. TESSELlata. First glume with prominent transverse wrinkles....... 4. M. RUGOSA.

First glume with a few low tubercles or smooth... 5. M. TUBERculosa.

1. Manisuris altissima (Poir.) Hitchc. (Fig. 1682.) Perennial; culms ascending from a long creeping base, compressed and 2-edged, 40 to $80 \mathrm{~cm}$ long, freely branching toward the ends; blades flat, 3 to $8 \mathrm{~mm}$ wide; flowering branches often short and fascicled, the racemes 3 to $5 \mathrm{~cm}$, sometimes $10 \mathrm{~cm}$ long, compressed; pedicel free or partly adnate to the rachis joint; sessile spikelet 5 to $7 \mathrm{~mm}$ long, the keels of the first glume very narrowly winged toward the apex; pedicellate spikelet 5 to $6 \mathrm{~mm}$ long, acute. 21 (M. fasciculatc Hitchc.)-Ponds and ditches, southern Texas; warm temperate and tropical regions of both hemispheres; introduced in America.

2. Manisuris cylíndrica (Michx.) Kuntze. (Fig. 1683, A.) Culms tufted, with short rhizomes, erect, rather slender, 30 to $100 \mathrm{~cm}$ tall, simple or with a few branches; sheaths not compressed-keeled; blades flat or folded, 2 to $3 \mathrm{~mm}$ wide; raceme cylindric, 5 to $15 \mathrm{~cm}$ long, slightly curved; sessile spikelet 4 to $5 \mathrm{~mm}$ long, the first glume pitted along the nerves. 24 -Pine woods and prairies, Coastal Plain, South Carolina to Florida and Texas, north to Missouri and Oklahoma (fig. 1684).

3. Manisuris tesselláta (Steud.) Scribn. (Fig. 1683, B.) Culms 80 to $120 \mathrm{~cm}$ tall, rather stout, branching; sheatis, especially the basal ones, compressed-keeled; blades elon-

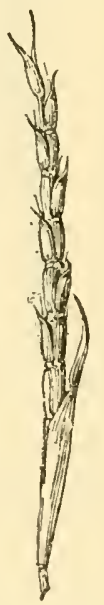

FIGURE 1682.Manisuris altissima, $\times 1$. (Hit cheock,
Tex.) gate, flat, mostly 5 to $8 \mathrm{~mm}$ wide; raceme 5 to $12 \mathrm{~cm}$ long; sessile spikelets 4 to $5 \mathrm{~mm}$ long; first glume tessellated with rectangular depressions, the keels narrowly winged at the apex. 24 -Moist pine woods, Coastal Plain, Florida to Louisiana (fig. 1685).

4. Manisuris rugósa (Nutt.) Kuntze. (Fig. 1686.) Culms mostly rather stout, 70 to $120 \mathrm{~cm}$ tall, freely branching; sheaths compressedkeeled; blades commonly folded, 3 to $8 \mathrm{~mm}$ wide; flowering branches often numerous, the racemes 4 to $8 \mathrm{~cm}$ long, partly included in brownish sheaths; rachis joint and pedicel contracted in the middle; 


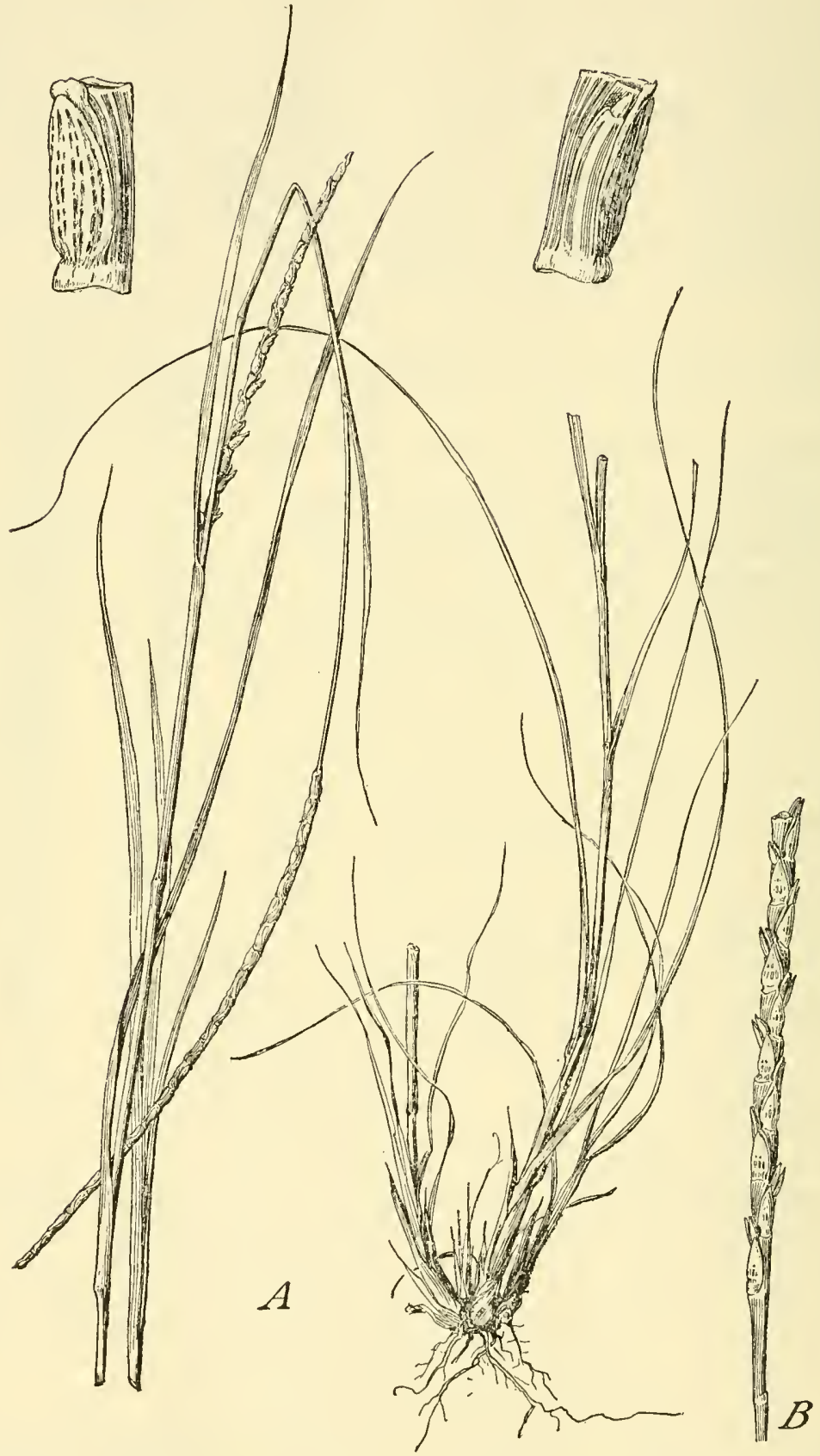

Figure 1683.- $A$, Manisuris cylindrica. Plant, $\times 1 / 2$; two views of rachis joint with fertile and sterile spikelets attached, $\times 5$. (Harvey, Ark.) $B$, M. tessellata, $\times 1$. (Tracy and Ball 1, Miss.) 
sessile spikelet 3.5 to $5 \mathrm{~mm}$ long, the first glume strongly and irregularly transwersely ridged, the keels narrowly winged toward the summit. 2 - Wet pine woods, Coastal Plain, southern New Jersey to Florida and Texas (fig. 1687).

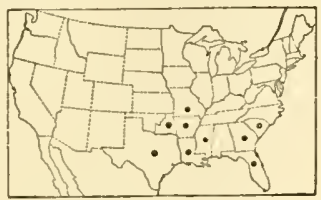

FIGTRE 168:-Distribution of Manisuris cylindrica.

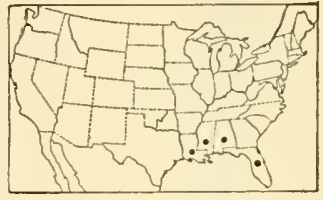

FIGURE 1685.-Distribution of Manisuris tessellata.

5. Manisuris tuberculósa Nash. (Fig. 1688.) Differing from $M$. rugosa chiefly in the straight rachis joints, not contracted in the middle, and in the smooth to obscurely ridged or tuberculate first glume of the sessile spikelet, varying in a single raceme. $24-$ Moist ground along lakes, central peninsular Florida. Apparently rare.

Eremóchloa ophiuroídes (Munro) Hack. Centipede grass. Low perennial, creeping by thick short-noded leafy stolons; racemes

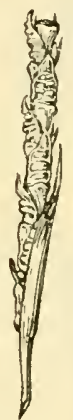

FIGURE 1686.-

Manisuris

rugosa, $\times 1$.

(Curtiss 3622 ,

Fla.) spikelike, smooth, subcylindric, terminal and axillary on slender peduncles, 2 to $6 \mathrm{~cm}$ long; rachis flat, not thickened as in Manisuris, the first glume of sessile spikelet winged at summit. 2 - Southeastern Asia; has been tested at southern experiment stations and has been recommended as a lawngrass for the South.

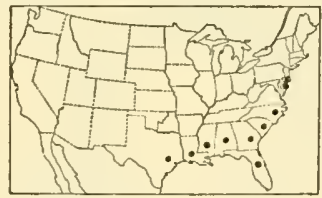

FIGURE 1687.-Distribution of Manisuris rugosa.

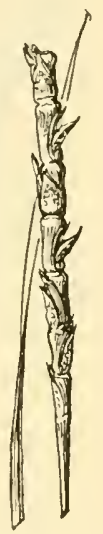

FIGURE 1688.Manisuris tuberculosa, $\times 1$. (Nash 1074, Fla.)

Eremochloa ciliáris (L.) Merr. Found near a Chinese warehouse in San Francisco. Southeastern Asia. Mentioned in the Botany of California (2: 262. 1880) under Ischaemum leersioides Munro. Not since collected in the United States.

\section{HACKELOCHLOA Kuntze}

\section{(Rytilix Raf.)}

Spikelets awnless, in pairs, the rachis joint and pedicel grown together, the two clasped between the edges of the globose alveolate first glume of the sessile spikelet; pedicellate spikelet conspicuous, staminate. Frecly branching annual with flat blades, the numerous racemes solitary and more or less enclosed in the spathes, these usually fascicled in the axils of the leaves. Type species, Hackelochloa granularis. Named for Eduard Hackel and Greek chloa, grass.

1. Hackelochloa granuláris (L.) Kuntze. (Fig. 1689.) Culms 30 to $100 \mathrm{~cm}$ tall; sheaths papillose-hispid; blades flat, 5 to $15 \mathrm{~cm}$ long, 
3 to $15 \mathrm{~mm}$ wide, papillose-hirsute, ciliate; racemes 1 to $2 \mathrm{~cm}$ long; sessile spikelet about $1 \mathrm{~mm}$ thick; pedicellate spikelet about $2 \mathrm{~mm}$
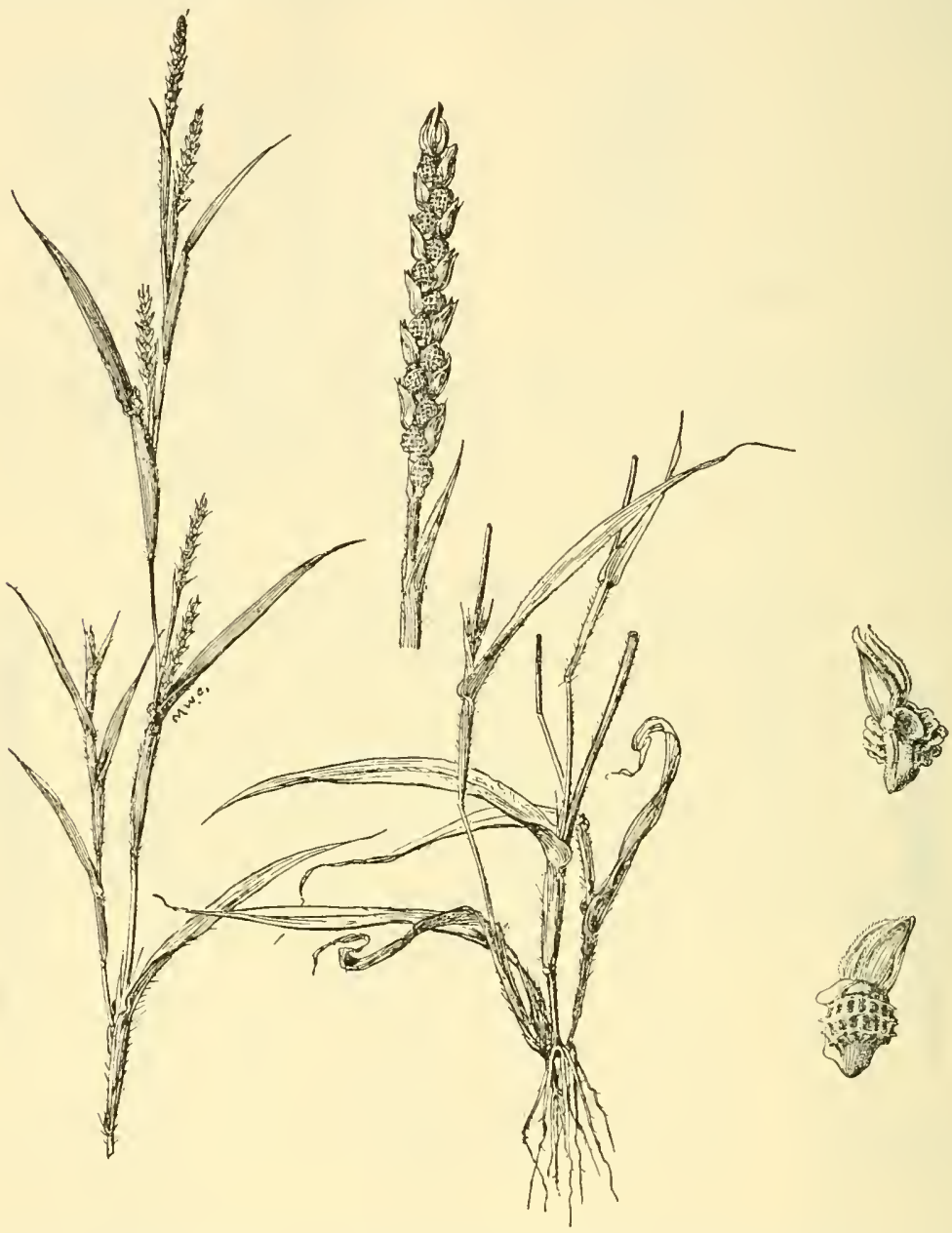

Figure 1639.-Hackelochloa granularis. Plant, $\times 132$; single raceme, $\times 2$; two views of spikelets with rachis joint, $\times 5$. (Pringle, Ariz.)

long. $\odot-$ Open ground, fields, and waste places, Georgia and Florida to Louisiana; New Mexico to Arizona (fig. 1690); tropics of both hemispheres, introducerl in America. Furnishes some forage in the Southwest.

TRIBE 14. TRIPSACEAE

156. COIX L. JOBS-TEARS

Spikelets unisexual; staminate spikelets 2-flowered, in twos or threes on the continuous rachis, the normal group consisting of a pair of ses-

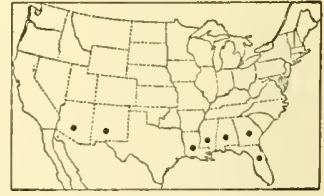

Figure 1690.-Distribution of Hackelochloa granularis. sile spikelets with a single pedicellate spikelet between, the latter 
sometimes reduced to a pedicel or wanting; glumes membranaceous, obscurely nerved; lemma and palea hyaline; stamens 3 ; pistillate spilielets 3 together, 1 fertile and 2 sterile at the base of the inflorescence; glunes of fertile spikelet several-nerved, hyaline below, chartaceous in the upper narrow pointed part, the first very broad, infolding the spikelet, the marmins infolded beyond the 2 lateral stronger pair of nerves; second glume narrower than the first, keeled, sterile lemma similar but a little narrower; fertile lemma and palea hyaline; sterile spikelets consisting of a single narrow tubular glume as long as the fertile spikelet, somewhat chartaceous. Tall branched grasses with broad flat blades, the monoecious inflorescences numerous on long, stout peduncles, these clustered in the axils of the leaves, each inflorescence consisting of an ovate or oval pearly white or drab, beadlike, very hard, tardily deciduous involucre (much modified sheathing bract) containing the pistillate lower portion of the inflorescence, the points of the pistillate spikelets and the slender axis of the staminate portion of the inflorescence protruding through the orifice at the apex, the staminate upper portion of the inflorescence 2 to $4 \mathrm{~cm}$ long, soon deciduous, consisting of several clusters of staminate spikelets. Type species, Coix lacryma-jobi. Name from Greek koix, a kind of palm, applied by Linnaeus to this grass.

1. Coix lácryma-jóbi L. JoвsTEArs. (Fig. 1691.) Annual; culms usually about $1 \mathrm{~m}$ tall; blades as much as $4 \mathrm{~cm}$ wide; beads white or bluishwhite, globular or ovoid, 6 to $12 \mathrm{~mm}$ long.

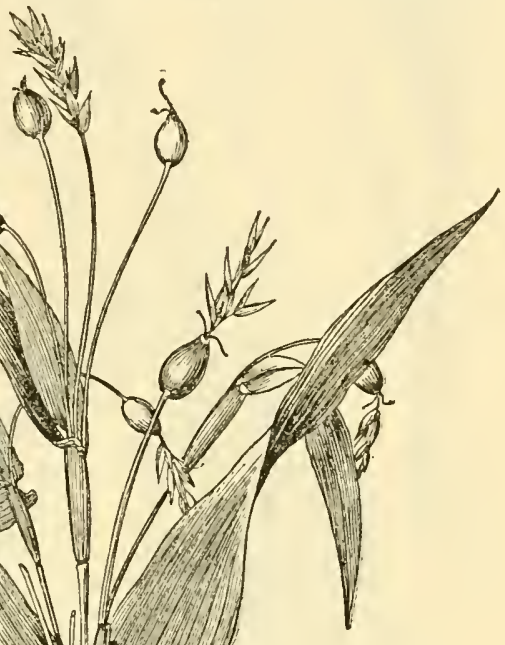

$\odot \quad-$ Occasionally cultivated for ornament, escaped into waste places in the Southern States; all tropical countries, introduced in America. The beadlike fruits are used as beads and for rosaries. A garden form (called by gardeners var, aurea zebrina) has yellow-striped blades.

\section{TRÍPSACUM L. Gamagrass}

Spikelets unisexual; staminate spikelets 2-flowered, in pairs on one side of a continuous rachis, one sessile, the other sessile or pedicellate, similar to those of Zea, the glumes firmer; pistillate spikelets solitary, on opposite sides at each joint of the thick, hard articulate lower part of the same rachis, sunken in hollows in the joints, consisting of one perfect floret and a sterile lemma; first glume coriaceous, nearly infolding the spikelet, fitting into and closing the hollow of the rachis; second glume similar to the first 


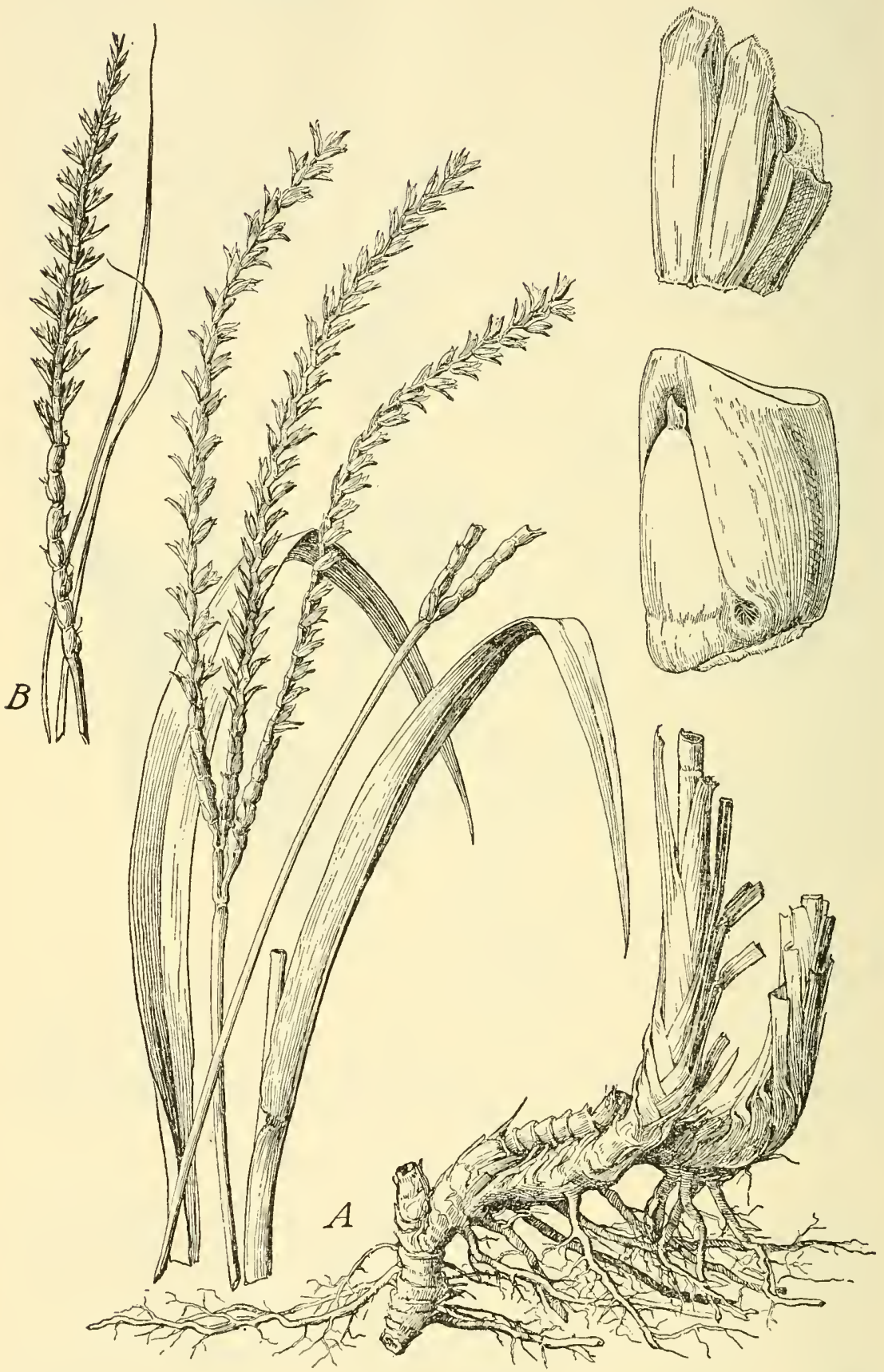

Figure 1692.-A, Tripsacum dactyloides. Plant, $\times 1 / 2$; pistillate spikelets with rachis joint and pair of staminate spikelets with rachis joint, $\times 5$. (Amer. Gr. Nat. Herb. 229, Va.) B, T. floridanum, $\times 1$. (Hitcheock 686, Fla.) 
but smaller, infolding the remainder of the spikelet; sterile lemma, fertile lemma, and palea very thin and hyaline, these progressively smaller. Robust perennials, with usually broad flat blades and monoecious terminal and axillary inflorescences of 1 to 3 spikes, the pistillate part below, breaking up into bony, seedlike joints, the staminate above on the same rachis, deciduous as a whole. Type species, Tripsacum dactyloides. Name of unknown origin, said by some to come from Greek tribein, to rub, alluding to the smooth joints.

The species are good forage grasses, but even the more widely spread $T$. dactyloides is not common enough to be of importance. Two large species not found in the United States, T. laxum Nash and T. latifolium Hitche., of Central America, are occasionally cultivated for forage in that region. The genus is of interest because it is related to maize. A hybrid between T. dactyloides and maize has recently been made. ${ }^{10}$

Staminate spikelets membranaceous, the members of the pair unequally pediceled, one nearly sessile, the other with a distinct pedicel.

3. T. LANCEOLATUM.

Staminate spikelets rather chartaceous, both members of the pair nearly sessile.

Blades 1 to $2 \mathrm{~cm}$ wide, flat; plants 1 to $2 \mathrm{~m}$ tall; terminal spikes usually more than one........ T. DACTYLoIdes.

Blades 1 to $4 \mathrm{~mm}$ wide, subinvolute; plants less than $1 \mathrm{~m}$ tall; all spikes usually

1. Tripsacum dactyloídes (L.) L.

EAstern GAMARAss. (Fig. $1692, A$.) Plants in large clumps, with thick knotty rhizomes, 2 to $3 \mathrm{~m}$ tall or sometimes taller, glabrous throughout; blades usually 1 to $2 \mathrm{~cm}$ wide, flat, scabrous on the margin; spikes 15 to $25 \mathrm{~cm}$ long, the pistillate part one-fourth the entire length or less, the terminal spikes usually 2 or 3 , sometimes only 1 , those of the branches usually solitary; pistillate spikelets 7 to $10 \mathrm{~mm}$ long, the joints rhombic; stam-

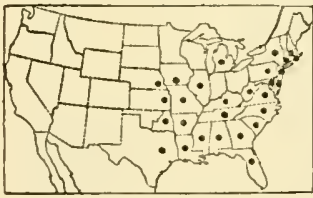

FIGURE 1693.-Distribution of Tripsacum dactyloides. inate spikelets 7 to $11 \mathrm{~mm}$ long, both of a pair nearly sessile, the glumes rather chartaceous. 2 - Swales, banks of streams, and moist places, Massachusetts to Michigan, Iowa, and Nebraska, south to Florida and Texas; West Indies and Mexico to Brazil (fig. 1693).

2. Tripsacum floridánum Porter. FLORIDA GAMAGRAS. (Fig. 1692, $B$.) Smaller than $T$. dactyloides in all ways, commonly less than $1 \mathrm{~m}$ tall; blades mostly 1 to $4 \mathrm{~mm}$ wide; terminal and axillary spikes usually solitary (rarely 2 or more). 4 - Low rocky pine lands, southern Florida.

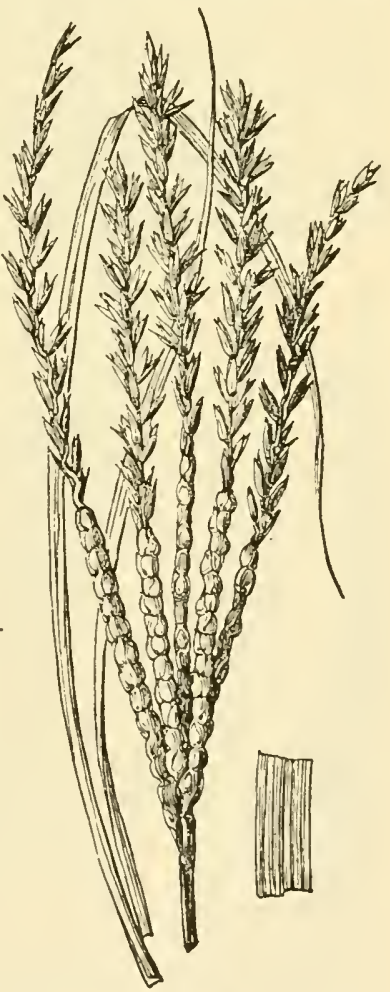

Figure 1694.-Tripsacum lanceolatum, $\times$ 1. (Lemmon, Ariz.)

10 Mangeisdorf, P. C., and Reeves, R. G. Jour. Hered. 22: 329-343. 1931.

$55974^{\circ}-35-49$ 
3. Tripsacum lanceolátum Rupr. Mexican gamagrass. (Fig. 1694.) Resembling $T$. dactyloides; sheaths, especially the lower, sometimes hispid; blades often hispidulous on the upper surface; spikes more slender with smaller spikelets than in $T$. dactyloides, the terminal spikes usually 3 to 5 ; staminate spikelets membranaceous, one of the pair distinctly pediceled. 24 ( $T$. lemmoni Vasey.) Rocky hills, Huachuca Mountains, Ariz.; Mexico to Guatemala.

\section{EUCHLAÉNA Schrad. Teosinte}

Staminate spikelets as in Zea; pistillate spikelets solitary on opposite sides, sunken in cavities in the hardened joints of an obliquely articulate rachis, the indurate first glume covering the cavity; second glume membranaceous, the lemma hyaline. Spikes infolded in foliaceous spathes or husks, 2 to several of these together enclosed in the leaf sheaths. Robust annuals and perennials with broad flat blades, terminal panicles of staminate spikelets, and axillary spikes of pistillate spikelets. Type species, Euchlaena mexicana. Name from Greek $e u$, well, and chlaina, cloak, alluding to the husks hiding the pistillate inflorescence.

1. Euchlaena mexicána Schrad. Teosinte. (Fig. 1695.) Tall annual, resembling maize, the culms branching at base, 2 to 3 or even $5 \mathrm{~m}$ tall; blades as much as $8 \mathrm{~cm}$ wide. $\odot$-Occasionally cultivated in the Southern States for green forage; Mexico. Thought to be one of the species from which maize originated (see note under Zea mays).

Euchlaena perénnis Hitche., Mexican TEosinte, a perennial species from Mexico, is cultivated at the substation of the Agricultural College, Angleton, Tex, and probably at other points. It propagates by creeping rhizomes.

\section{ZÉA L.}

Spikelets unisexual; staminate spikelets 2-flowered, in pairs, on one side of a continuous rachis, one nearly sessile, the other pedicellate; glumes membranaceous, acute; lemma and palea hyaline; pistillate spikelets sessile, in pairs, consisting of one fertile floret and one sterile floret, the latter sometimes developed as a second fertile floret; glumes broad, rounded or emarginate at apex; sterile and fertile lemmas hyaline, the palea developed; style very long and slender, stigmatic along both sides well toward the base. Robust annual, with terminal panicles (tassels) of staminate racemes, and short-peduncled, pistillate, 8- to many-rowed spikes (ears) enclosed in numerous spathes (husks). Type species, Zea mays. Name Greek $z e a$, or zeia, a kind of grain.

1. Zea máys L. Maize, Indian corn. (Fig. 1696.) Tall robust monoecious annual, with overlapping sheaths and broad, conspicuously distichous blades; staminate spikelets in long spikelike racemes, these numerous, forming large spreading terminal panicles; pistillate inflorescence in the axils of the leaves, the spikelets in 8 to 16 or even as many as 30 rows on a thickened, almost woody axis (cob), the whole enclosed in numerous large foliaceous bracts or spathes, the long styles (silk) protruding from the sumnit as a mass of silky threads; grains at maturity greatly exceeding the glumes. 


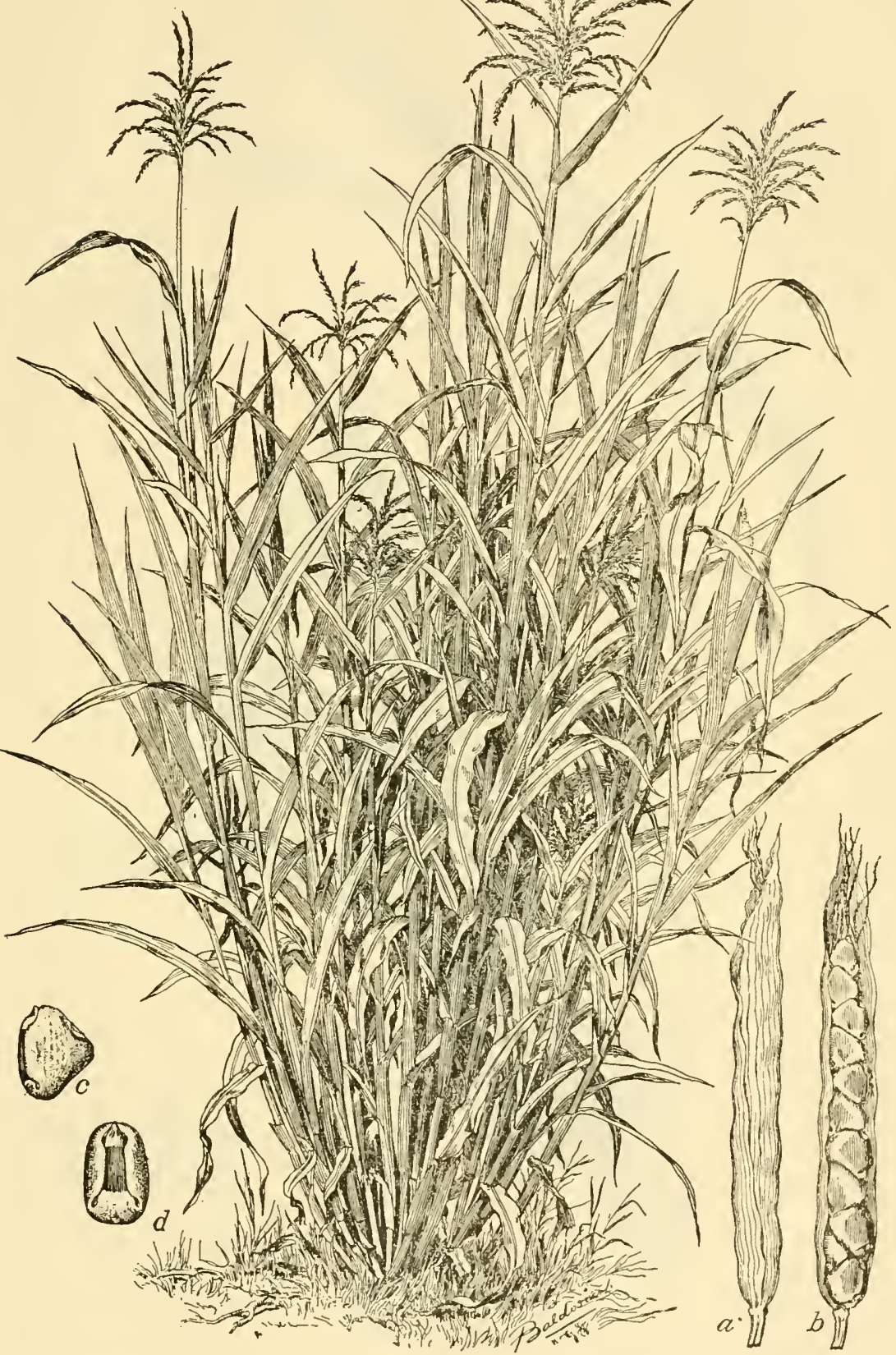

FIGURE 1695,-Euchlaena mexicana. Plant, much reduced; pistillate inflorescence enclosed in bract (a) and with portion of bract removed $(b), \times 1$; lateral view of rachis joint and fertile spikelet $(c)$, and dorsal view of same, showing first glume $(d), \times 2$. (Cult.) 


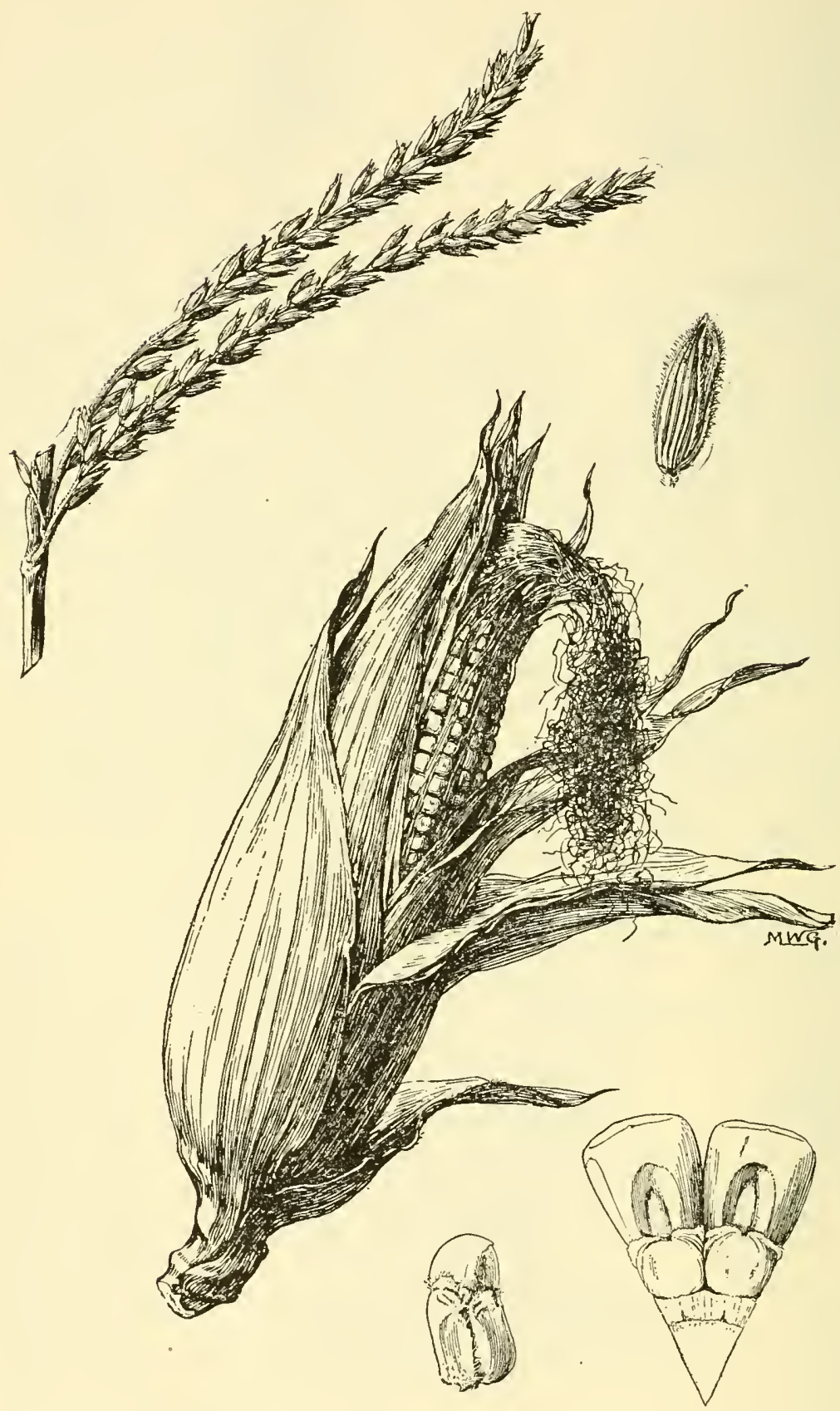

Figure 1696.-Zea mays. Pistillate inflorescence (ear) and 2 branches of staminate inflorescence (tassel), $\times 1 / 2$; pair of pistillate spikelets attached to rachis (cob) with mature grains, the second glume showing, $\times 2$; single pistillate spikelet soon after flowering, $\times 4$; staminate spikelet, $\times 2$. (Cult.) 
Maize or Indian corn is one of the important economic plants of the world, being eultivated for food for man and domestic animals and for forage. It originated ${ }^{11}$ in America, probably on the Mexican Plateau, and was cultivated from prehistoric times by the early races of American aborigines, from Peru to middle North America. Several races of maize are grown in the United States, ${ }^{12}$ the most important being dent, the common commercial field sort, flint, sweet, and pop. Pod corn ( $Z$. mays var. tunicáta Larr.), occasionally cultivated as a curiosity, is a variety in which each kernel is enveloped in the elongate glumes. A variety with variegated leaves ( $Z$. mays var. japónica Körn.) is cultivated for ornament.

$"$ For a note on the origin of maize, see Col.lins, G. N. THE origin of Maize. Jour. Wash. Acad. Sci. 2: $520-530.1912$.

12 See the following publications: MONTGOMERY, E. G. THE CORN CROPS, A DISCUSSION OF MAIZE, KAFIRS, AND SORGHUMS AS GROWN IN THE UNITED STATES AND CANADA. 347 pp., illus. New York. 1913

StUrteVant, E. L. VARieties of corn. U.S.Dept.Agr., Off. Expt. Stas. Bull. 57, 108 pp. 1899. 


\section{SYNONYMY}

The following names have appeared in American botanical literature as applied to grasses growing in the United States. For grasses introduced into the United States from other countries there are here given only the names appearing in American works. No attempt has been made to present the complex synonymy for these introduced grasses given in foreign works. The synonymy for the generic names will be found in The Genera of Grasses of the United States. ${ }^{13}$

For quick reference the names of genera and valid species are arranged in alphabetic order, the names in blackface type. The synonyms, in italics, are arranged chronologically under the names to which they are referred. The numbers in parentheses are the numbers these genera and species bear in the body of this work.

\section{(41) AEGILOPS L.}

(1) Aegilops cylindrica Host, Icon. Gram. Austr. 2: 6. pl. 7. 1802. Southern Europe.

Triticum cylindricum Ces., Pass. and Gib., Comp. Fl. Ital. 86. 1867. Presumably based on Aegilops cylindrica Host.

(3) Aegilops ovata L., Sp. Pl. 1050. 1753. Southern Europe.

Triticum ovatum Raspail, Ann. Sci. Nat., Bot. 5: 435. 1825. Based on A. ovata L.

(2) Aegilops triuncialis L., Sp. P1. 1051. 1753. Mediterranean region.

Triticum triunciale Raspail, Ann. Sci. Nat., Bot. 5: 435. 1825. Based on A. triuncialis L.

(89) AEGOPOGON Humb. and Bonpl.

(1) Aegopogon tenellus (DC.) Trin., Gram. Unifl. 164. 1824. Based on Lamarckia tenella DC., though Trinius cites not that but A. pusillus Beauv., in Roem. and Schult., Syst. Veg. 2: \$05. 1817. Roemer and Schultes cite $L$. tenella DC., obviously the basis of Trinius' name, as svnonym of A. pusillus Beauv., which, however, is the same as $A$. cenchroides II umb. and Bonpl. (not known from the U.S.).

Lamarckia tenella DC., Cat. Hort. Monsp. 120. 1813. Grown in Montpellier, origin unknown, probably Mexico.

Cynosurus tenellus Cav.; DC., Cat. Hort. Monsp. 120. 1813, as synonym of Lamarckia tenella DC.

Hymenothecium unisetum Lag., Gen. and Sp. Nov. 4. 1816. Grown from Mexican seed sent by Sessé.

Hymenothecium tenellum Lag., Gen. and Sp. Nov. 4. 1816. Based on Cynosurus tenellus Cav.

Aegopogon unisetus Roem. and Schult., Syst. Veg. 2: 805. 1817. Based on Hymenothecium unisetum Lag.

Schellingia tenera Steud., Flora 33: 232. 1850. Mexico, Galeotti 5750. Aegopogon geminiflorus var. unisetus Fourn., Mex. P1. 2: 71. 1886. Based on $A$. unisetus Roem. and Schult.

\section{(39) AGROPYRON 14 Gaertn.}

(9) Agropyron albicans Scribn. and Smith, U.S.Dept.Agr., Div. Agrost. Bull. 4: 32. 1897. Yogo Gulch, Mont., Rydberg 3405.

(4) Agropyron arenicola Davy, in Jepson, Fl. West. Mid. Calif. 76. 1901. Point Preyes, Calif., Davy 6879.

\footnotetext{
13 HITCHCOCK, A.S. THE GENERA OF GRASSES OF THE UNITED STATES, WITH SPECIAL REFERENCE TO THF ECONOMIC SPECIES. U.S.Dept.Agr. Bull. 772, 307 pp. illus. 1920.

it Spelled also Agropyrum and Agriopyrum.
} 
(20) Agropyron arizonicum Scribn. and Smith, U.S.Dept.Agr., Div. Agrost. Bull. 4: 27. 1897. New Mexico, Arizona [type, Rincon Mountains, Nealley 67], and Chihuahua, Mexico.

Agropyron caninum var. majus Scribn., Bull. Torrey Bot. Club 10: 32. 1883. Santa Rita Mountains, Ariz., Pringle.

Agropyron spicatum var. arizonicum Jones, Contrib. West. Bot. 14: 19. 1912. Based on A. arizonicum Scribn. and Smith.

(15) Agropyron bakeri E. Nels., Bot. Gaz. 38: 378. 1904. Pagosa Peak, Colo., Baker 139.

Agropyron caninum (L.) Beauv., Ess. Agrost. 102, 146. 1812. Based on Triticum caninum L.

Triticum caninum L., Sp. Pl. 86. 1753. Europe.

Zeia canina Lunell, Amer. Midl. Nat. 4: 226. 1915. Based on Triticum caninum L.

(1) Agropyron cristatum (L.) Gaertn., Nov. Comm. Petrop. 14: 540. 1770. Based on Bromus cristatus L.

Bromus cristatus L., Sp. Pl. 78. 1753. Northern Asia.

Triticum cristatum Schreb., Beschr. Gräs. 2: 12. pl. 23. f. 2. 1769 . Based on Bromus cristalus L.

Avena cristata Roem. and Schult., Syst. Veg. 2: 758. 1817, as synonym of Agropyron cristatum Gaertn.

Costia cristata Willk., Bot. Ztg. 16: 377. 1858. Based on Bromus cristatus L.

Zeia cristata Lunell, Amer. Midl. Nat. 4: 226. 1915. Based on Agropyron cristatum Gaertn.

(6) Agropyron dasystachyum (Hook.) Scribn., Bull. Torrey Bot. Club 10: 78. 1883. Based on Triticum repens var. dasystachyum Hook.

Triticum repens var. dasystachyum Hook., Fl. Bor. Amer. 2: 254.1840. Saskatchewan, Richardson. The type has villous lemmas.

Triticum repens var. subvillosum Hook., Fl. Bor. Amer. 2: 254.1840. Mackenzie River, Canada, Richardson. The type has scabrous-pubescent lemmas.

Triticum dasystachyum A. Gray, Man. 602. 1848. Based on T. repens var. dasystachyum Hook.

Agropyron dasystachyum subvillosum Scribn. and Smith, U.S.Dept.Agr., Div. Agrost. Bull. 4: 33. 1897. Based on Triticum repens var. subvillosum Hook.

Agropyron lanceolatum Scribn. and Smith, U.S.Dept.Agr., Div. Agrost. Bull. 4: 34. 1897. Idaho [type, Blackfoot, Palmer 266], Washington and Oregon.

Triticum repens acutum Vasey; Scribn. and Smith, U.S.Dept.Agr., Div. Agrost. Bull. 4: 34. 1897, as synonym of A. lanceolatum Scribn. and Smith.

Agropyron subvillosum E. Nels., Bot. Gaz. 38: 378. 1904. Based on Triticum repens var. subvillosum Hook.

Zeia dasystachya Lunell, Amer. Midl. Nat. 4: 226. 1915. Based on Triticum repens var. dasystachyum Hook.

(7) Agropyron elmeri Scribn., U.S.Dept.Agr., Div. Agrost. Bull. 11: 54. pl. 12. 1898. Snake River, Wash., Elmer 759.

(10) Agropyron griffithsi Scribn. and Smith; Piper, Biol. Soc. Wash. Proc. 18: 148. 1905. North Fork Clear River, Wyo., Williams and Griffiths 140.

(19) Agropyron inerme (Scribn. and Smith) Rydb., Bull. Torrey Bot. Club 36: 539. 1909. Based on $A$. divergens inerme Scribn. and Sinith.

Agropyron divergens inerme Scribn. and Smith, U.S.Dept.Agr., Div. Agrost. Bull. 4: 27. 1897. British Columbia to Utah and Idaho [type Henderson 3058 .

Agropyron spicatum inerme Heller, Cat. N.Amer. Pl. ed. 2. 3. 1900. Based on Agropyron divergens inerme Scribn. and Smith.

Agropyron intermedium (Host) Beauv., Ess. Agrost. 102, 146. 1812. Based on Triticum intermedium Host.

Triticum intermedium Host, Gram. Austr. 3: 23.1805. Austria.

Triticum glaucum Desf.; DC., Fl. Franc. 5: 281. 1815. Not T. glaucum Moench, 1794. France.

Agropyron glaucum Roem. and Schult., Syst. Veg. 2: 752. 1817. Based on Triticum glaucum Desf.

Braconotia glauca Godr., Fl. Lorr. 3: 192. 1844. Based on Triticum glaucum Desf.

Agropyron repens glaucum Scribn., Mem. Torrey Bot. Club 5: 57. 1894. Based on Triticum glaucum Desf., but misapplied to A. smithii Rydb.

Zeia glauca Lunell, Amer. Midl. Nat. 4: 226. 1915. Based on Triticum glaucum Desf., but misapplied to $A$. smithii Rydb. 
Agropyron japonicum Tracy, U.S.Dept.Agr., Div. Bot. Ann. Rept. 6. 1891 name only. Vasey; Wickson, Calif. Agr. Expt. Sta. Rept. 1895-1897: 275. pl. 14. f. 1. 1898. Name only. "A California-grown specimen", from New Zealand seed, said to have been sent to Dr. Vasey cannot be found in the U.S. National Herbarium. The plate seems to represent Brachypodium japonicum Miquel.

Agropyron junceum (L.) Beauv., Ess. Agrost. 102, 146, 180. 1812. Based on Triticum junceum L.

Triticum junceum L., Mant. Pl. 2: 327. 1771. Europe.

Festuca juncea Moench, Meth. Pl. 190. 1794. Based on Triticum junceum L.

Braconotia juncea Godr., Fl. Lorr. 3:192. 1844. Based on Triticum junceum L.

The names Agropyron junceum and A. intermedium are here applied in accord with Ascherson and Graebner (Syn. Mitteleur. Fl. 2: 654, 662. 1901) under Triticum. Triticum junceum L. (Cent. Pl. 1: 6. 1755; Amoen. Acad. 4: 266. 1759) which seems to have been generally ignored, appears to be the same as T. intermedium Host. Linnaeus later (Mant. Pl. 2: 327. 1771) published a different species under the same name. This second name is the one used by Ascherson and Graebner and other European botanists. The problem involves study of European types not here available.

(14) Agropyron latiglume (Scribn. and Smith) Rydb., Bull. Torrey Bot. Club 36: 539. 1909. Based on A. violaceum latiglume Scribn. and Smith.

Agropyron violaceum latiglume Scribn. and Smith, U.S.Dept.Agr., Div. Agrost. Bull. 4: 30. 1897. Montana [type, Lone Mountain, Gallatin County, Tweedy 1011] to Alaska.

Agropyron biflorum latiglume Piper, Bull. Torrey Bot. Club 32: 547. 1905. Based on A. violaceum latiglume Scribn. and Smith.

Agropyron caninum var. latiglume Pease and Moore, Rhodora 12: 73.1910. Based on A. violaceum var. latiglume Scribn. and Smith.

(21) Agropyron parishii Scribn. and Smith, U.S.Dept.Agr., Div. Agrost. Bull. 4: 28. 1897. San Bernardino Mountains, Calif., Parish 2054.

Agropyron Parishir var. Laeve Scribn. and Smith, U.S.Dept.Agr., Div. Agrost. Bull. 4: 28. 1897. Cuyamaca Mountains, Calif., Palmer 414. (Published as $A$. parishii laeve.)

Agropyron laeve Hitchc., in Jepson, Fl. Calif. 1: 181. 1912. Based on A.parishii laeve Scribn. and Smith.

(13) Agropyron pauciflorum (Schwein.) Hitchc., Amer. Jour. Bot. 21: 132.1934. Based on Triticum pauciflorum Schwein. [Agropyron pauciflorum Schur, 1859 , eited as synonym of $A$. caninum Roem. and Schult., has never been validly published, hence Schweinitz's name must be taken up.]

Triticum pauciflorum Schwein., in Kieat., Narr. Exped. St. Peter's River 2: 383. 1824. Prairies of the St. Peter [Minn.], Say in 1823.

Triticum missuricum Spreng., Syst. Veg. 1: 325. 1825. Missouri River. Festuca spicata Pursh erroneously cited as synonym. The type has not been found. A specimen of Agropyron pauciflorum in the Vienna Herbarium, collected by Geyer, "Missouri" in 1839, is labeled T. missuricum Spreng. There are no rhizomes. Sprengel's description is inadequate, but applies to $A$. pauciflorum. Triticum repens and other species having rhizomes are described as having "radice repente" while T. missuricum is not so described.

Triticum trachycaulum Link, Hort. Berol. 2: 189. 1833. Grown from seed collected by Richardson in North America.

Agropyron trachycaulon Steud., Syn. Pl. Glum. 1: 344. 1854. Garden name as synonym of Triticum trachycaulum Link.

Crithopyrum trachycaulon Steud., Syn. Pl. Glum. 1: 344. 1854. Garden name, as synonym of Triticum trachycaulum Jink.

Agropyron tenerum Vasey, Bot. Gaz. 10: 258. 1885. Rocky Mountains. [Type, Fort Garland, Colo., Vasey in 1884.]

Agropyron violaceum var. major Vasey, Contrib. U.S.Natl.Herb. 1: 280. 1893. Oregon, Cusick 1134.

Agropyron repens var. tenerum Beal, Grasses, N.Amer. 2: 637. 1896. Based on A. tenerum Vasey.

Agropyron tenerum longifolium Scribn. and Smith, U.S.Dept.Agr., Div. Agrost. Bull. 4: 30. 1897. Oregon, Giant's [error for Grant's] Pass, Howcll 256.

Agropyron tenerum ciliatum Scribn. and Smith, U.S.Dept.Agr., Div. Agrost Bull. 4: 30. 1897. Minnesota [type, Duluth, Vasey in 1881] to Nebraska and Utah. 
Agropyron novae-angliae Scribn., in Brain., Jones, and Eggl., Fl. Vt. 103.1900.

Westmore, Vt., Grout and Eggleston in 1894.

Agropyron tenerum majus Piper, Bull. Torrey Bot. Club 32: 543. 1905. Besed on A. violaceum var. major Vasey.

Agropyron tenerum trichocoleum Piper, Bull. Torrey Bot. Club 32: 546. 1905.

Based on A. tenerum ciliatum Seribn. and Smith.

Agropyron caninum var. tenerum Pease and Moore, Rhodora 12: 71. 1910. Based on $A$. tenerum Vasey.

Agropyron caninum var. tenerum forma ciliatum Pease and Moore, Rhodora 12: 72. 1910. Based on A. tenerum ciliatum Scribn. and Smith.

Agropyron caninum var. tenerum forma fernaldii Pease and Moore, Rhodora 12:

73. 1910. Quebee, Macoun Herb. Geol. Surv. Canada 63978.

Agropyron caninum var. hornemanni forma pilosifolium Pease and Moore, Rhodora 12: 75. 1910. Dead River, Maine, Fcrnald 576.

Zeia tenera Lunell, Amer. Midl. Nat. 4: 227. 1915. Based on Agropyron tenerum Vasey.

Agropyron tenerum var. novae-angliue Farwell, Mich. Aead. Sci. Rept. 21: 355. 1920. Based on A. novae-angliae Seribn.

Agropyron missuricum Farwell, Amer. Midl. Nat. 12: 48. 1930. Based on Triticum missuricum Spreng.

Agropyron trachycaulum Malte, Ann. Rept. Nat1. Mus. Canada 1930: 42.1932. Based on Triticum trachycaulum Link.

Agropyron trachycaulum var. tenerum Malte, Ann. Rept. Natl. Mus. Canada 1930: 44. 1932. Based on A. tenerum Vasey.

Agropyron trachycaulum var. glaucescens Malte, Ann. Rept. Natl. Mus. Canada 1930: 45. 1932. Saskatchewan, Malte.

Agropyron trachycaulum var. trichocoleum Maite, Ann. Rept. Natl. Mus. Canada 1930: 45. 1932. Based on A. tenerum trichocoleum Piper.

Agropyron trachycaulum var. fernaldii Malte, Ann. Rept. Natl. Mus. Canada 1930: 46. 1932. Based on A. caninum var. tenerum forma fernaldii Pease and Moore.

Agropyron trachycaulum var. majus Fernald, Rhodora 35: 171. 1933. Based on $A$. violaceum var. major Vasey.

Agropyron trachycaulum var. novae-angliae Fernald, Rhodora 35: 174. 1933. Based on A. novae-angliae Seribn.

Alpine forms of this species have been referred to Agropyron violaceum (Hornem.) Lange and to $A$. biflorum (Brign.) Roem. and Sehult.

(16) Agropyron pringlei (Seribn. and Smith) Hitche., in Jepson, Fl. Calif. 1: 183. 1912. Based on A. gmelini pringlei Seribn. and Smith.

Agropyron gmelini ${ }^{15}$ pringlei Seribn. and Smith, U.S.Dept.Agr., Div. Agrost. Bull. 4: 31. 1897. Wyoming and California [type, Summit Valley, Pringle in 1882].

Agropyron caninum var. gmelini forma pringlei Pease and Moore, Rhodora 12: 76. 1910. Based on A.gmelini pringlei Scribn and Smith.

Agropyron spicatum var. pringlei Jones, Contrib. West. Bot. 14: 19. 1912. Based on A. gmelini pringlei Scribn. and Smith.

Agropyron pseudorepens Seribn. and Smith, U.S.Dept.Agr., Div. Agrost. Bull. 4: 34. 1897. Texas and Arizona to Nebraska [type, Kearney, Rydberg 2018], Montana and British Columbia.

Agropyron pseudorepens magnum Seribn. and Smith, U.S.Dept.Agr., Div. Agrost. Bull. 4: 35. 1897. Enterprise, Colo., Rydberg 2401.

Agropyron tenerum magnum Piper, Bull. Torrey Bot. Club 32: 546. 1905. Based on A. pseudorepens magnum Scribn. and Smith.

Agropyron tenerum var. pseudorepens Jones, Contrib. West. Bot. 14: 19. 1912. Based on A. pseudorepens Scribn. and Smith.

Zeia pseudorepens Lunell, Amer. Midl. Nat. 4: 226. 1915. Based on Agropyron pseudorepens Scribn. and Smith.

(3) Agropyron pungens (Pers.) Roem. and Sehult., Syst. Veg. 2: 753.1817. Based on Triticum pungens Pers.

Triticum pungens Pers., Syn. P1. 1: 109. 1805. England.

Triticum repens var. pungens Duby, in DC., Bot. Gall. 1:529. 1828. Based on T. pungens Pers.

Braconotia pungens Godr., Fl. Lorr. 3: 192. 1844. Based on Triticum pungens Pers.

15 Triticum caninum var. gmelini Griseb., in Ledeb., Icon. Pl. Ross. 3: 16. pl. 248. 1831, the basis of Agropyron gmelini Seribn. and Smith, U.S. Dept. Agr., Div. Agrost. Bull. 4: 30. 1897, and of A. caninum var. gmelini Pease and Moore, Rhodora 12: 75. 1910, is a Siberian species not known from North America. See note under $A$. subsecundum. 
Agropyron repens subsp. pungens Hook. f., Stud. Fl. ed. 3: 504. 1884. Based on $A$. pungens Roem. and Schult.

Agropyron tetrastachys Scribn. and Smith, U.S.Dept.Agr., Div. Agrost. Bull. 4: 32. 1897. Cape Elizabeth, Maine, Scribner in 1895.

(2) Agropyron repens (L.) Beauv., Ess. Agrost. 102, 146, 180. pl. 20, f. 2. 1812. Based on Triticum repens $\mathrm{L}$.

Triticum repens L., Sp. Pl. 86. 1753. Europe.

Triticum infestum Salisb., Prodr. Stirp. 27. 1796. Based on T. repens L.

?Triticum vaillantianum Wulf. and Schreb., in Schweig. and Körte, Spec. Fl. Erland. 1: 143. 1804. Germany. [This work not in Washington. From the description in ed. 2. 1: 143. 1811, this appears to be an awned form of $A$. repens.]

Braconotia officinarum Godr., Fl. Lorr. 3: 192. 1844. Based on Triticum repens $\mathrm{L}$.

Agropyron repens var. pilosum Scribn., in Rand and Redfield, Fl. Mt. Desert 183. 1894. Mount Desert, Maine, Rand.

Agropyron repens forma geniculatum Farwell, Ann. Rept. Commr. Parks and Boul. Detroit 11: 48. 1900. Detroit, Mich., Farwell 1635.

Agropyron repens forma stoloniferum Farwell, Ann. Rept. Commr. Parks and Boul. Detroit 11: 48. 1900. Detroit, Farwell 1634.

Zeia repens Lunell, Amer. Midl. Nat. 4: 227. 1915. Based on Triticum repens L.

Agropyron repens forma pilosum Fernald, Rhodora 35: 184. 1933. Based on A. repens var. pilosum Scribn.

Agropyron repens var. subulatum forma heberhachis Fernald, Rhodora 35: 184. 1933. Yarmouth, Nova Scotia, Long and Linder 20,091.

Agropyron repens var. subulatum forma setiferum Fernald, Rhodora 35: 184. 1933. Chelsea Beach, Mass., Boott in 1868.

?Agropyron repens var. subulatum forma vaillantianum Fernald, Rhodora 35: 184. 1933. Based on Triticum vaillanitanum Wulf. and Schreb.

Agropyron leersianum (Wulf.) Rydb. (Brittonia 1: 85. 1931), based on "Triticum repens leersianum Wulfen" (apparently error for T. leersianum Wulf.) is applied to awned specimens of $A$. repens. The name, ultimately based on a deseription and figure named "Elymus caninus L." by Leers (Fl. Herborn. 46. pl. 12. f. 4. 1775), is uncertain. The figure, showing paired spikelets, appears to represent a species of Elymus.

(8) Agropyron riparium Scribn. and Smith, U.S.Dept.Agr., Div. Agrost. Bull. 4: 35. 1897. Montana [type, Garrison, Rydberg 2127].

Agropyron smithii var. riparium Jones, Contrib. West. Bot. 14: 19.1912. Based on $A$. riparium Scribn. and Smith.

Zeia riparia Lunell, Amer. Midl. Nat. 4: 227. 1915. Based on Agropyron riparium Scribn. and Smith.

(23) Agropyron saundersii (Vas ey) Hitchc., Biol. Soc. Wash. Proc. 41: 159. 1928. Based on Elymus saundersii Vasey.

Elymus saundersii Vasey, Bull. Torrey Bot. Club 11: 126. 1884. Veta Pass, Colo. [Vasey].

(22) Agropyron saxicela (Scribn. and Smith) Piper, Contrib. U.S. Natl. Herb. 11:148. 1906. Based on Elymus saxicola Seribn. and Smith.

Elymus saxicola Seribn. and Smith, U.S.Dept.Agr., Div. Agrost. Bull. 11: 56. pl. 15. 1898. Mt. Chapaca, Wash., Elmer 554.

Sitanion ficxuosum Piper, Erythea 7: 99. 1899. Wawawai, Wash., Piper 3004.

Sitanion lanceolatum J. G. Smith, U.S.Dept.Agr., Div. Agrost. Bull. 18: 20. 1899. Barker, Mont., Rydberg 3381.

Agropyron flexuosum Piper, Biol. Soc. Wash. Proc. 18: 149. 1905. Based on Sitanion flexuosum Piper.

Agropyron sitanioides J. G. Smith; Piper, Biol. Soc. Wash. Proc. 18: 149.1905. Rapid City, S.Dak., Griffiths 735.

(17) Agropyron scribneri Vasey, Bull. Torrey Bot. Club 10: 128. 1893. Montana, Scribner in 1883.

Elymus scribneri Jones, Contrib. West. Bot. 14: 20. 1912. Based on Agropyron scribneri Vasey.

Agropyron semicostatum (Steud.) Nees; Boiss., Fl. Orient. 5: 662. 1884. Presumably based on Triticum semicostatum Steud.

Triticum semicostatum Steud., Syn. Pl. Glum. 1: 346. 1854. Nepal. 
(5) Agropyron smithil Rydb., Mem. N.Y. Bot. Gard. 1: 64. 1900. (Feb.) Based on A. spicatum as described by Scribner and Smith (U.S.Dept.Agr., Div. Agrost. Bull. 4: 33. 1897), ["type * * * Geyer, upper Missouri"], not Festuca spicata Pursh, upon which they based the name.

Agropyron glaucum occidentale Scribn., Trans. Kans. Acad. 9: 119. 1885. Kansas. Seribner later (Mem. Torrey Bot. Club 5: 57. 1894) called this A. repens glaucum, but he based that name on Triticum glaucum Desf.

Agropyron occidentale Scribn., U.S.Dept.Agr., Div. Agrost. Circ. 27: 9. 1900. (Dec.) Based on A. glaucum occidentale Seribn.

Zeia occidentalis Lunell, Amer. Midl. Nat. 4: 226. 1915. Based on Agropyron occidentale Scribn.

Zeia smithii Lunell, Amer. Midl. Nat. 4: 227. 1915. Based on Agropyron smithii Rydb.

Agropyron spicatum var. viride Farwell, Mich. Acad. Sci. Rept. 21: 356. 1920. Detroit, Mich., Farwell 851e.

A groprron SMithil var. Molle Jones, Contrib. West. Bot. 14: 18. $1912 . \quad$ Based on A. spicatum molle Scribn. and Smith.

4gropyron spicatum molle Scribn. and Smith, U.S.Dept.Agr., Div. Agrost. Bull. 4: 33. 1897. Saskatchewan to Colorado, New Mexico, Idaho, and Washing. ton. [Type, Montana, Rydberg 3193.]

Agropyron molle Rydb., Mem. N.Y. Bot. Gard. 1: 65. 1900. Based on A. spicatum molle Scribn. and Smith.

Agropyron occidentale molle Scribn., U.S.Dept.Agr., Div. Agrost. Circ. 27: 9. 1900. Based on A spicatum molle Scribn. and Smith.

Zeia mollis Lunell, Amer. Midl. Nat. 4: 226. 1915. Based on Agropyron spicatum molle Scribn. and Smith.

Agropyron smithi var. Palmeri Heller, Cat. N.Amer. Pl. ed. 2: 3. 1900. Based on A. spicatum palmeri Scribn. and Smith. (Published as A. smithii palmeri.)

Agropyron spicatum palmeri Scribn. and Smith, U.S.Dept.Agr., Div. Agrost. Bull. 4: 33. 1897. Arizona [type, Palmer in 1869] and New Mexico.

Agropyron occidentale palmeri Scribn., U.S.Dept.Agr., Div. Agrost. Circ. 27:9. 1900. Based on A. spicatum palmeri Scribn. and Smith.

Agropyron palmeri Rydb., Colo. Agr. Expt. Sta. Bull. 100: 55. 1906. Based on A. spicatum palmeri Scribn. and Smith.

(18) Agropyron spicatum (Pursh) Scribn. and Smith, U.S.Dept.Agr., Div. Agrost. Bull. 4: 33. 1897. Based on Fcstuca spicata Pursh, but due to misidentification of Pursh's species, misapplied to Agropyron smithii Rydb.

Festuca spicata Pursh, Fl. Amer. Sept. 1: 83. 1814. Missouri and Columbia Rivers [type from Columbia River, Lewis and Clarke in 1806].

Schedonorus spicatus Roem. and Schult., Syst. Veg. 2: 707. 1817. Based on Festuca spicata Pursh.

Triticum divergens Nees; Steud., Syn. Pl. Glum. 1: 347. 1854. North America, Douglas.

Agropyron divergens Nees; Vasey, Descr. Cat. Grasses U.S. 96. 1885. Presumably based on Triincum divergens Nees.

Agropyron divergens var. tenue Vasey, Descr. Cat. Grasses U.S. 96. 1885. Name only; in Macoun, Cat. Can. Pl. 24: 242. 1888. Name only.

Agropyron divergens tenuispicum Scribn. and Smith, U.S.Dept.Agr., Div. Agrost. Bull. 4: 27. 1897. Washington and Oregon [type, Howell 181] to Wyoming and Montana.

Agropyron vaseyi Scribn. and Smith, U.S.Dept.Agr., Div. Agrost. Bull. 4: 27. 1897. Oregon and Washington to Wyoming and Colorado. [Type, Mon-
[Ty tana, Rydberg 2299.]

Agropyron spicatum tenuispicum Rydb., Mem. N.Y. Bot. Gard. 1: 61. 1900. Based on A. divergens tenuispicum Scribn. and Smith.

Agropyron spicatum var. vaseyi E. Nels., Bot. Gaz. 38: 378. 1904. Based on A. vaseyi Scribn. and Smith.

Zeia spicata Lunell, Amer. Midl. Nat. 4: 227. 1915. Based on Festuca spicata Pursh.

This is the species called Triticum strigosum Less., by Thurber (S. Wats. Bot. Calif. 2: 324. 1880), and Agropyron strigosum by Coulter (Man. Rocky Mount. 426. 1885, the name erroneously ascribed to Beauv.). Not T. strigosum Less., of the Caspian region, nor A. strigosum (Bieb.) Boiss. (1884) of Asia Minor.

Agropyon SPICATUM var. PUBEscens Elmer, Bot. Gaz. 36: 52. 1903. Mount Stuart, Wash., Elmer 1158. (Published as A. spicatum pubescens.)

Agropyron spicatum puberulentum Piper, Contrib. U.S. Natl. Herb. 11: 147. 1906. Based on Agropyron spicatum pubescens Elmer. 
(12) Agropyron subsecundum (Link) Hitchc., Amer. Jour. Bot. 21: 131. 1934. Based on Triticum subsecundum Link.

Triticum subsecundum Link, Hort. Berol. 2: 190. 1833. Garden plant, seed collected by Richardson in western North America.

Triticum richardsoni Schrad., Linnaea 12: 4667. 1838. North America.

Agropyron richardsoni Schrad., Linnaea 12: 467. 1838, as synonym of Triticum richardsoni Schrad.

Cryptopyrum richardsoni Heynh., Nom. 2: 174. 1846, as synonym of Triticum richardsoni Schrad.

Agropyron unilaterale Cassidy, Colo. Agr. Expt. Sta. Bull. 12: 63. 1890. Not A. unilaterale Beauv., 1812. Colorado.

Agropyron caninum var. unilaterale Vasey, Contrib. U.S. Natl. Herb. 1: 279. 1893. Based on $A$. unilaterale Cassidy, though Vasey adds: "Type specimen collected by F. Lamson-Scribner in Montana in 1883 (no. 422).'

Agropyron violaceum forma caninoides Ramaley, Minn. Bot. Studies 1: 108. 1894. Minnesota, Macmillan and Sheldon 84 .

Agropyron caninum forma violacescens Ramaley, Minn. Bot. Studies 1: 107. 1894. Based on A. caninum var. unilaterale Vasey.

Agropyron violacescens Beal, Grasses N.Amer. 2: 635. 1896. Based on $A$. caninum forma violacescens Pound (error for Ramaley).

Agropyron caninoides Beal, Grasses N.Amer. 2: 640. 1896. Based on $A$. violaceum forma caninoides Ramaley.

Agropyron caninum pubcscens Scribn. and Smith, U.S.Dept.Agr., Div. Agrost. Bull. 4: 29. 1897. British Columbia, Macoun 99.

Agropyron richardsoni ciliatum Scribn. and Smith, U.S.Dept.Agr., Div. Agrost. Bull. 4: 29. 1897. Montana, Belt Mountains, Scribner in 1883.

Agropyron caninum forma glaucum Pease and Moore, Rhodora 12: 71. 1910. Maine, Fernald 1367.

Agropyron caninum var. unilaterale forma ciliatum Pease and Moore, Rhodora 12: 76. 1910. Based on $A$. richardsoni ciliatum Scribn. and Smith.

Agropyron caninum var. richardsoni Jones, Contrib. West. Bot. 14: 18. 1912. Based on Triticum richardsoni "Trin." (error for Schrad.).

Zcia richardsoni Lunell, Amer. Midl. Nat. 4: 227. 1915. Based on Agropyron richardsoni Schrad.

Agropyron trachycaulum var. unilaterale Malte, Ann. Rept. Natl. Mus. Canada 1930: 46. 1932. Based on A. unilaterale Cassidy.

Agropyron trachycaulum var. ciliatum Malte, Ann. Rept. Natl. Mus. Canada 1930: 47. 1932. Based on A. richardsoni ciliatum Scribn. and Smith.

Agropyron trachycaulum var. caerulescens Malte, Ann. Rept. Natl. Mus. Canada 1930: 47. 1932. Vancouver Island, Malte.

Agropyron trachycaulum var. glaucum Malte, Ann. Rept. Natl. Mus. Canada 1930: 47. 1932. Based on A. caninum forma glaucum Pease and MIoore. Agropyron trachycaulum var. pilosiglume Malte, Ann. Rept. Natl. Mus. Canada 1930: 48. 1932. Victoria, Vancouver Island, Malte.

Agropyron trachycaulum var. hirsutum Malte, Ann. Rept. Natl. Mus. Canada 1930: 48. 1932. Victoria, Vancouver Island, Macoun.

This is the species which has been generally called Agropyron caninum (L.) Beauv. by American authors. Most of the specimens cited under A. gmelini Scribn. and Smith (U.S.Dept.Agr., Div. Agrost. Bull. 4: 30. 1897) belong to A. subsecundum, but the name was based on Triticum caninum var. gmelini Griseb., a Siberian species.

Agropyron subsecundum var. andinum (Scribn. and Smith) Hitche., Amer. Jour. Bot. 21: 132. 1934. Based on A. violaceum andinum Scribn. and Smith.

Agropyron violaceum andinum Scribn. and Smith, U.S.Dept.Agr., Div. Agrost. Bull. 4: 30. 1897. Colorado. [Type, Grays Peak, Jones 720.]

Agropyron brevifolium Scribn., U.S.Dept.Agr., Div. Agrost. Bull. 11: 55. pl. 13. 1898. Washington, Elmer 676.

Agropyron biflorum andinum Piper, Bull. Torrey Bot. Club 32: 547. 1905. Based on A. violaceum andinum Scribn. and Smith.

Agropyron andinum Rydb., Colo. Agr. Expt. Sta. Bull. 100: 54. 1906. Based on $A$. violaceum andinum Scribn. and Smith.

Agropyron caninum var, andinum Pease and Moore, Rhodora 12: 75. 1910.

Based on A. violaceum andinum Scribn. and Smith.

Agropyron trichophorum (Link) Richt., Pl. Eur. 1: 124. 1890. Based on Triticum trichophorum Link.

Triticum trichophorum Link, Linnaea 17: 395. 1843. Europe. 
Agropyron triticeum Gaertn., Nov. Comm. Petrop. 141 : 540. 1770. Russia. Secale prostratum Pall., Reise Prov. Russ. Reich. Anhang 1: 485.1771. Russia.

Triticum prostratum L. f., Suppl. Pl. 114. 1781. Based on Secale prostratum Pall.

Agropyron prostratum Beauv., Ess. Agrost. 102, 146. 1812. Based on Triticum prostratum L. f.

(11) Agropyron vulpinum (Rydb.) Hitchc., Amer. Jour. Bot. 21: 132. 1934. Based on Elymus vulpinus Rydb.

Elymus vulpinus Rydb., Bull. Torrey Bot. Club 36: 540. 1909. Grant County, Nebr., Rydberg 1617.

Agropyron richardsoni vulpinus Hitchc., Biol. Soc. Wash. Proc. 41: 159. 1928. Based on Elymus vulpinus Rydb.

\section{(64) AGROSTIS L.}

(5) Agrostis aequivalvis (Trin.) Trin., Mém. Acad. St. Pétersb. VI. Sci. Nat. $4^{1}$ : 362. 1841. Based on A. canina var. aequivalvis Trin.

Agrostis canina var. acquivalvis Trin., in Bong., Mém. Acad. St. Pétersb. VI. Nath. Phys. Nat. 2: 171. 1832. Sitka, Alaska.

Deycuxia aequivalvis Benth.; Vasey, Contrib. U.S.Natl. Herb. 3: 77. 1892, as synonym of Agrostis aequivalvis Trin.; Jacks., Ind. Kew. 2: 740. 1893. Based on $A$. aequivalvis Trin. (as indicated by the reference to Benth., Jour. Linn. Soc. Bot. 19: 91. 1881, the combination not there made).

Podagrostis aequivalvis Scribn, and Merr., Contrib. U.S.Natl.Herb. 13: 58. 1910. Based on Agrostis canina var. aequivalvis Trin.

(10) Agrostis alba L., Sp. Pl. 63. 1753; ed. 2. 1: 93. 1762. Europe. Iinnaeus' diagnosis is inadequate and his original application of the name is uncertain, but the specimen in his herbarium bearing the name in his own script belongs to the species for which the name has been generally used by European and American authors ever since. In recent American works this species has been called $A$. palustris Huds. But this name proves to belong to the creeping species with contracted panicle, the same as $A$. maritima Lam. See U.S.Dept.Agr., Bur. Plant Indus. Bull. 6S: 25. 1905, and U.S. Dept. Agr. Bull. 772: 128. 1920, for discussion of A. alba L. In the second edition of the Species Plantarum an undoubted reference to this species is added to the original uncertain one.

Agrostis dispar Michx., FI. Bor. Amer. 1: 52. 1803. South Carolina.

Decandolia alba Bast., Fl. Maine-et-Loire 29. 1809. Based on Agrostis alba L.

I'ilfa alba Beauv., Ess. Agrost. 16, 146, 181. 1812. Based on Agrostis alba L. Vilfa dispar Beauv., Ess. Agrost. 16, 147, 181. 1812. Based on Agrostis dispar Michx.

Agrostis alba var. maior Gaudin, Fl. Helv. 1: 189. 1828. Switzerland.

Agrastis alba var. dispar Wood, Class-book 774. 1861. Based on A. dispar Michx.

Agrestis alba Lunell, Amer. Midl. Nat. 4: 216. 1915. Based on Agrostis alba L.

Agrostis stolonifera var. major Farwell, Mich. Acad. Sci. Rept. 21: 351. 1920. Based on A. alba var. major Gaudin.

Agrostis stolonifera forma aristigera Fernald, Rhodora 35: 317. 1933. Granville, Mass., Seymour. (27) Agrostis bakeri Rydb.,
Peak, Colo., Baker 150.

(20) Agrostis blasdalei Hitchc., Biol. Soc. Wash. Proc. 41: 160. 1928. Fort Bragg, Calif., Davy and Blasdale 6159.

(31) Agrostis borealis Hartm., Handb. Skand. Fl. ed. 3. 77. 1838. Lapland. ?Agrostis rubra L., Sp. Pl. 62. 1753. Sweden. Identity uncertain.

Agrostis canina var. alpina Oakes, Cat. Vt. Pl. 32. 1842. Name only. Camels Hump Mountain, Vt., Robbins, Tuckerman, and Macrae.

Agrostis canina var. tenella Torr., Fl. N.Y. 2: 443. 1843. Northern New York.

Agrostis pickeringii Tuckerm., Mag. Hort. Hovey 9: 143. 1843. White Mountains, N.H. Tuckerm., Mag. Hort. Hovey 9: 143. 1843. Mount Agrostis concinna Tuckerm., Mag.
Monroe, White Mountains, N.H. 
Agrostis pickeringii var. rupicola Tuckerm., Amer. Jour. Sci. 45: 42.1843. White Mountains, N.H., Pickering and Oakes. Vermont, Camels Hump.

Trichodium concinnum Wood, Class-book ed. 2.600. 1847. Based on Agrostis concinna Tuckerm.

Agrostis rubra var. americana Scribn., in Macoun, Cat. Can. Pl. 25: 391. 1890. Based on "A. rupestris Chapm. (non All.), found on Roan Mountain, North Carolina"; Tenn. Agr. Expt. Sta. Bull. 7: 77. f. 100. 1894. (See below.)

Agrostis novae-angliae Vasey, Contrib. U.S. Natl. Herb. 3: 76. 1892. Not A. novae-angliae Tuckerm. [Mount Washington, N.H., Pringle.]

Agrostis rubra var. alpina MacM., Met. Minn. Vall. 65. 1892. Based on A. canina var. alpina Oakes.

Agrostis borealis var. macrantha Eames, Rhodora 11: 88. 1909. Blow-medown Mountains, Nova Scotia, Eames and Godfrey in 1908 [no. 5833, the spikelets abnormal].

Agrostis borealis var. americana Fernald, Rhodora 35: 205. 1933. Based on A. rubra var. americana Seribn.

Agrostis borealis forma macrantha Fernald, Rhodora 35: 205. 1933. Based on A. borcalis var. macrantha Eames.

This species was erroneously referred to Agrostis rupestris All. by A. Gray in a list of plants from Roan Mountain, N.C., and by Chapman (Fl. South. U.S. 551. 1860).

(23) Agrostis californica Trin., Mém. Acad. St. Pétersb. VI. Sci. Nat. $4^{1}: 359$. 1841. California. (Vilfa glomerata Presl erroneously cited as synonym.)

Agrostis densiflora Vasey, Contrib. U.S. Natl. Herb. 3: 72. 1892. Santa Cruz, Calif., Anderson.

Agrostis densiflora var. arenaria Vasey, Contrib. U.S. Natl. Herb. 3: 72. 1892. Mendocino County, Calif., Pringle.

Agrostis arcnaria Scribn., Contrib. U.S. Natl. Herb. 3: 72. 1892. Not $A$. arenaria Gouan, 1773. As synonym of $A$. densiflora var. arenaria Vasey.

(30) Agrostis canina L., Sp. Pl. 62. 1753. Europe.

Trichodium caninum Schrad., Fl. Germ. 1: 198. 1806. Based on Agrostis canina L.

Agraulus caninus Beauv., Ess. Agrost. 5, 146, 147. 1812. Based on Agrostis canina $\mathrm{L}$.

Agrostis canina var. alpina Wood, Amer. Bot. and Flor. pt. 2: 384. 1870. Not A. canina var. alpina Ducomm., 1869. Mountains of the Eastern States.

Agrostis alba var. vulgaris forma aristata Millsp., Fl. W.Va. 469. 1892. Monangalia, W.Va.

Agrestis canina Bubani, Fl. Pyr. 4: 286. 1901. Based on Agrostis canina L.

(19) Agrostis diegoensis Vasey, Bull. Torrey Bot. Club 13: 55. 1886. San Diego, Calif., Orcutt.

Agrostis foliosa Vasey, Bull. Torrey Bot. Club. 13: 55. 1886. Not A. foliosa Roem. and Schult., 1817. Oregon, Howell [type] and Bolander.

Agrostis diegoensis var. foliosa Vasey, Contrib. U.S. Natl. Herb. 3: 74. 1892. Based on A. foliosa Vasey.

Agrostis canina var. stolonifcra Vasey, Contrib. U.S. Natl. Herb. 3: 75. 1892. Not A. canina var. stolonifera Blytt, 1847. Oregon, Henderson [type] and Howell.

Agrostis muliculmis Vasey; Beal, Grasses N.Amer. 2: 328. 1896, as synonym of $A$. diegoensis Vasey.

Agrostis pallens foliosa Hitche., U.S. Dept. Agr., Bur. Plant Indus. Bull. 68: 34. pl. 14. f. 1. 1905. Based on A. foliosa Vasey.

(15) Agrostis elliottiana Schult., Mant. 2: 202. 1824. Based on A. arachnoides Ell.

Agrostis arachnoides Ell., Bot. S.C. and Ga. 1: 134. 1816. Not A. arachnoides Poir., 1810. Orangeburg, S.C., Bennett.

Notonema arachnoides Raf.; Jacks., Ind. Kew. 3: 319. 1894, as synonym of Agrostis arachnoides E]l.

(22) Agrostis exarata Trin., Gram. Unifl. 207. 1824. Unalaska, Eschscholtz.

Agrostis cxarata var. minor Hook., Fl. Bor. Amer. 2: 239. 1839. Rocky Mountains, Drummond, Douglas.

Agrostis grandis Trin., Mém. Acad. St. Pétersb. VI. Sci. Nat. 4¹: 316.1841. "Columbia (Hooker)."

Agrostis asperifolia Trin., Mćm. Acad. St. Pétersb. VI. Sci. Nat. 41: 317. 1841. "Amer. bor.? Chile? (Hooker)." Probably collected in the Rocky Mountains and received from Hooker. 
Agrostis scouleri Trin., Mém. Acad. St. Pétersb. VI. Sci. Nat. 41: 329.1841. Nootka Sound, Vancouver Island, [received from] Hooker.

Agrostis albicans Buckl. Acad. Nat. Sci. Phila. Proc. 1862: 91. 1S63. Columbia woods, Oreg., Nuttall.

Agrostis oregonensis Nutt.; A. Gray, Acad. ivat. Sci. Phila. Proc. 1862: 334. 1863 , as synonym of $A$. albicans Buckl.

Agrostis exarata forma asperifolia Vasey, U.S.Dept.Agr., Div. Bot. Bull. 13²:pl. 31. 1892. Presumably based on A. asperifolia Trin.

Agrostis filiculmis Jones, Contrib. West. Bot. 14: 13. 1912. Little De Motte Park on the Kaibab, northern Arizona [Jones 6056bb].

Agrostis exarata var. Ampla (Hitchc.) Hitchc., Amer. Jour. Bot. 2: 303. 1915. Based or A. ampla Hitchc. (Published as A. exarata ampla.)

?Agrostis exarata var pacifica Vasey, U.S.Dept.Agr., Div. Bot. Spec. Bull. (new ed.) 1889: 107. pl. 106. 188ะ. Pacific coast, California to Alaska. Agrostis ampla Hitchc., U.S. Dept. Agr., Bur. Plant Indus. Bull. 68: 38. pl. 20. 1905. Rooster Rock, Oreg., Suksdorf 135.

Agrostis exarata var. Monolepis (Torr.) Hitche., Amer. Jour. Bot. 21: 136. 1934. Based on Polypogon monspeliensis var. monolepis Torr.

Agrostis microphylla Steud., Syn. Pl. Glum. 1: 164. 1854. North America, Douglas.

Agraulus brevifolius Nees; Torr. U.S. Rept. Expl. Miss. Pacif. 4: 154. 1857, as synonym of Agrostis microphylla Steud.

Polypogon monspeliensis var. monolepis Torr., U.S. Rept. Expl. Miss. Pacif. 5: 366. 1857. Posé Creek, Walkers Pass, Calif., [Blake].

Polypogon alopecuroides Buckl., Acad. Nat. Sci. Phila. Proc. 1862: 88. 1863. Columbia Plains, Oreg., Nuttall.

Agrostis alopecuroides A. Gray, Acad. Nat. Sci. Phila. Proc. 1862: 333.1863. Not A. alopecuroides Lam., 1791. Based on Polypogon alopecuroides Buckl.

Deyeuxia alopecuroides Nutt.; A. Gray, Acad. Nat. Sci. Phila. Proc. 1862: 333. 1863, as synonym of Polypogon alopecuroides Buckl.

Agrostis microphylla var. major Vasey, Contrib. U.S. Natl. Herb. 3: 58, 72. 1892. [Truckee Valley, Ner., Watson 1284.]

Agrostis exarata var. microphylla S. Wats.; Vasey, Contrib. U.S. Natl. Herb. 3: 72. 1892 , as synonym of A. microphylla var. major Vasey.

Agrostis inflata Scribn., Canad. Rec. Sci. 152. 1894. Vancouver Island, Macoun 258.

Agrostis virescens microphylla Scribn., U.S. Dept. Agr., Div. Agrost. Circ. 30: 2. 1901. Based on A. microphylla Steud.

Agrostis exarata microphylla Hitchc., Amer. Jour. Bot. 2: 303. 1915. Based on A. microphylla Steud.

(14) Agrostis exigua Thurb., in S. Wats., Bot. Calif. 2: 275. 1880. Foothills of Sierras, Calif., Bolander.

(16) Agrostis hallii Vasey, Contrib. U.S. Natl. Herb. 3: 74. 1892. Oregon [type, Hall in 1872], Washington, and California.

Agrostis davyi Scribn., U.S. Dept.Agr., Div. Agrost. Circ. 30: 3. 1901. Point Arena, Calif., Davy and Blasdale 6062.

Agrostis occidentalis Scribn. and Merr., Bull. Torrey Bot. Club 29: 466. 1902. McMinnville, Oreg., Shear 1644.

Agrostis hallit var. Pringlei (Scribn.) Hitchc., U.S.Dept.Agr., Bur. Plant Indus. Bull. 68: 33. pl. 12. 1905. Based on A. pringlei Scribn. (Published as $A$. hallii pringlei.)

Agrostis pringlei Scribn., U.S. Dept. Agr., Div. Agrost. Bull. 7: 156. f. 138. 1897. Mendocino County, Calif., Pringle.

(13) Agrostis hendersonii Hitchc., Jour. Wash. Acad. Sci. 20: 381. 1930. Sams Valley, near Gold Hill, Jackson County, Oreg., Henderson 12387.

(25) Agrostis hiemalis (Walt.) B.S.P., Prel. Cat. N.Y. 68. 1888. Based on Cornucopiae hiemalis Walt.

Cornucopiae hyemalis Walt., Fl. Carol. 73. 1788. South Carolina.

Agrostis scabra Willd., Sp. Pl. 1: 370. 1797. North America.

Trichodium laxiflorum Michx., Fl. Bor. Amer. 1: 42. 1803. Hudson Bay to Florida, Michaux. to Florida, Michaux.
Agrostis laxiflora Poir., in Lam., Encycl. Sup. 1: 255. 1810. Carolina, Bosc.
Vilfa scabra Beauv., Ess. Agrost. 16, 182. 1812. Based on Agrostis scabra Willd.

Trichodium scabrum Muhl., Cat. Pl. 10. 1813. Based on Agrostis scabra Willd.

Agrostis laxa Schreb.; Pursh, Fl. Amer. Sept. 1: 61. 1814, as synonym of Trichodium laxiflorum Michx. 
Agrostis laxiflora Richards., Bot. App. Franklin Jour. 731. 1823. Based on Trichodium laxiflorum Michx.

Trichodium montanum Torr., Fl. North. and Mid. U.S. 84. 1823. Fishkill Mountains, N.Y.

Trichodium laxum Schult., Mant. 2: 157. 1824. Based on T. laxiflorum Muhl., Schultes supposing it to be different from T. laxiflorum Michx., but Muhlenberg's species is the same as Michaux's.

Trichodium album Presl, Rel. Haenk. 1: 244. 1830. Nootka Sound, Vancouver Island, Haenke.

Agrostis nutkaensis Kunth, Enum. PI. 1: 222. 1833. Based on Trichodium album Presl.

Agrostis nootkaensis Trin., Mém. Acad. St. Pétersb. VI. Sci. Nat. $4^{1}: 326$. 1841. Based on Trichodium album Presl.

Agrostis laxiflora var. montana Tuckerm., Amer. Jour. Sci. 45: 43.1843. Based on Trichodium montanum Torr.

Agrostis scabra var. tenuis Tuckerm., Amer. Jour. Sci. 45: 45. 1843. Lincoln, N.H.

Agrostis laxiflora var. caespitosa Torr., Fl. N.Y. 2: 442. 1843. New York. Agrostis laxiflora var. scabra Torr., Fl. N.Y. 2: 442. 1843. Based on A. scabra Willd.

Agrostis laxiflora var. tenuis Torr., Fl. N.Y. 2: 442. 1843. Based on A. scabra var. tenuis Tuckerm.

Agrostis torreyi Tuckerm., Mag. Hort. Hovey 9: 143. $1843 . \quad$ Not A. torreyi Kunth, 1830. Based on Trichodium montanum Torr.

Agrostis scabra var. oreophila Wood, Class-book 774. 1861. Based on $A$. [laxiflora var.] montana Tuckerm. (There is no reference to A. oreophila Trin.)

Agrostis scabriuscula Buckl., Acad. Nat. Sci. Phila. Proc. 1862: 90. 1863. Columbia Plains, Oreg., Nuttall.

Agrostis scabrata Nutt.; A. Gray, Acad. Nat. Sci. Phila. Proc. 1862: 334. 1863 , as synonym of $A$. scabriuscula Buckl.

Agrostis scabra var. montana Fernald, Portland Soc. Nat. Hist. Proc. 2: 91. 1895. Based on Trichodium montanum Torr. This combination was made by Vasey, giving Tuckerm. as author (Contrib. U.S. Natl. Herb. 3: 76. 1892), the basis not given, and erroneously cited as synonym of A.novae-angliae Vasey.

Agrostis canina var. hiemalis Kuntze, Rev. Gen. Pl. $3^{2}$ : 33s. 1898. Based on Cornucopiae hiemalis Walt.

Agrostis antecedens Bicknell, Bull. Torrey Bot. Club 35: 473. 1908. Nantucket, Bicknell in 1908.

Agrostis hiemalis nutkaensis Scribn. and Merr., Contrib. U.S. Natl. Herb. 13: 56. 1910. Based on A. nutkaensis Kunth.

Agrestis hyemalis Lunell, Amer. Midl. Nat. 4: 216. 1915. Based on Cornucopiae hiemalis Walt.

Agrostis scabra forma tuckermani Fernald, Rhodora 35: 207. 1933. Braintree, Mass., Churchill in 1911.

Agrostis hiemalis var. Geminata (Trin.) Hitchc., U.S.Dept.Agr., Bur. Plant Indus. Bull. 68: 44. 1905. Based on A. geminata Trin. (Published as $A$. hiemalis geminata.)

Agrostis geminata Trin., Gram. Unifl. 207. 1824. Unalaska, Eschscholtz.

Agrostis geminata forma exaristata Fernald, Rhodora 35: 211. 1933. Gaspé County, Quebec, Fernald, Dodge and Smith 25, 485.

(24) Agrostis howellii Scribn., Contrib. U.S. Natl. Herb. 3: 76. 1892. Hood River, Oreg., Howell 198.

(12) Agrostis humilis Vasey, Bull. Torrey Bot. Club 10: 21. 1883. Mount Paddo [Adams], Wash., Howell [85].

(26) Agrostis idahoensis Nash, Bull. Torrey Bot. Club 24: 42. 1897. Forest, Idaho, Heller 3431.

Agrostis tenuis Vasey, Bull. Torrey Bot. Club 10: 21. 1883. Not A. tenuis Sibth., 1794. San Bernardino Mountains, Calif., Parish Bros. [1085].

Agrostis tenuiculmis Nash, in Rydb., Mem. N.Y.' Bot. Gard. 1: 32. 1900. Based on A. tenuis Vasey.

Agrostis tenuiculmis recta Nash, in Rydb., Mem. N.Y. Bot. Gard. 1: 32. 1900. [Belt Pass, Mont., Rydberg 33271/2.]

Agrostis tenuis erecta Vasey; Nash, in Rydb., Mem. N.Y. Bot. Gard. 1: 32. 1900 , as synonym of $A$. tenuiculmis recta Nash.

(3) Agrostis interrupta L., Syst. Nat, ed. 10. 2: 872. 1759. Europe. 
Apera interrupta Beauv., Ess. Agrost. 151. 1812. Based on Agrostis interrupia L.

Anemagrostis interrupta Trin., Fund. Agrost. 129. 1820. Based on Agrostis interrupta L.

Muhlenbergia interrupta Steud., Syn. Pl. Glum. 1: 177. 1854. Based on Agrostis interrupta L.

Agrostis spica-venti var. interrupta Hook. f., Stud. Fl. 432. 1870. Based on A. interrupta L.

Agrostis anemagrostis subsp. interrupta Syme, in Sowerby, English Bot. ed. 3. 11: 44. 1873. Based on A. interrupta L.

Apera spica-venti var. interrupta Beal, Grasses N.Amer. 2: 357. 1896. Based on Agrostis interrupta $\mathrm{L}$.

Agrestis interrupta Bubani, Fl. Pyr. 4: 289. 1901. Based on A. interrupta L.

(17) Agrostis lepida Hitchc., in Jepson, Fl. Calif. 1: 121. 1912. Siberian Pass, Sequoia National Park, CaIif., Hitchcock 3455.

(32) Agrostis longiligula Hitche., U..S.Dept.Agr., Bur. Plant Indus. Bull. 68: 54. 1905. Fort Bragg, Calif., Davy and Blasdale 6110.

Agrostis nebulosa Boiss. and Reut., Bibl. Univ. Genève (n.s.) 3s: 21s. 1842. Spain.

(9) Agrostis nigra With., Bot. Arr. Veg. Brit. ed. 3. 2: 131. 1796. Europe.

(29) Agrostis oregonensis Vasey, Bull. Torrey Bot. Club 13: 55. $1886 . \quad$ Oregon, Howell [49].

Agrostis attenuata Vasey, Bot. Gaz. 11: 337. 1886. Mount Hood, Oreg., Howell [210].

Agrostis hallii var. californica Vasey, Contrib. U.S. Natl. Herb. 3: 74. 1892. California [Bolander 6103].

Agrostis schiedeana var. armata Suksdorf, Werdenda 12: 1. 1923. Krlickitat County, Wash., Suksdorf 6310.

(18) Agrostis pallens Trin., Mém. Acad. St. Pétersb. VI. Sci. Nat. 41' 328. 1S41. "Amer.-borealis? (Hooker)."

Agrostis exarata var. littoralis Vasey, Bull. Torrey Bot. Club 13: 54. 1886. Oregon, Howell [64].

Agrostis densiflora var. littoralis Vasey, Contrib. U.S. Natl. Herb. 3: 72. 1892. Based on A. exarata var. littoralis Vasey.

(8) Agrostis palustris Huds., Fl. Angl. 27. 1762. England.

Agrostis polymorpha var. palustris Huds., Fl. Angl. 32. 1778. Based on A. palustris Huds.

Agrostis maritima Lam., Encycl. 1: 61. 1783. France.

Agrostis alba var. palustris Pers., Syn. P1. 1: 76. 1805. Based on A. palustris Huds.

Milium maritimum Clem. y Pubio, Ensay. Vid Andaluc. 285. 1807. Based on Agrostis maritima Lam.

Agrostis decumbens Gaud.; Muhl., Descr. Gram. 68. 1817. Not A. decumbens Host, 1809. Pennsylvania, New Jersey.

Vilfa stolonifera var. maritima S. F. Gray, Nat. Arr. Brit. Pl. 2: 146.1821. Based on Agrostis maritima With. (error for Lam.)

Apera palustris S. F. Gray, Nat. Arr. Brit. P1. 2: 148. 1S21. Based on Agrostis palustris With. (error for Huds.).

Agrostis alba var. maritima G. Meyer, Chloris Hanov. 656. 1836. Based on A. maritima Lam.

Agrostis stolonifera var. maritima Koch, Syn. Fl. Germ. Helv. 781. 1837. Based on A. maritima Lam.

?Agrostis alba var. decumbens Eaton and Wright, N.Amer. Bot. ed. 8. 117. 1840. Not A. alba var. decumbens Gaudin, 1828. Eastern United States. Agrostis stolonifera var. compacta Hartm., Handb. Skand. Flora ed. 4. 24. 1843. Scandinavia.

Agrostis depressa Vasey, Bull. Torrey Bot. Club 13: 54. 18s6. Clear Creek Canyon, Colo., Patterson in 1885.

Agrostis exarata var. stolonifera Vasey, Bull. Torrey Bot. Club 13: 54.1886 Columbia River, Suksdorf.

Agrostis reptans Rydb., Fl. Rocky Mount. 54. 1917. Based on A. exaraía var. stolonifera Vasey.

Agrostis stolonifera var. palustris Farwell, Mich. Acad. Sci. Rept. 21: 351. 1920. Based on A. polymorpha var. plaustris Huds.

New England specimens of this species have been referred to A. alba vor. coarctata Scribn., based on A. coarctata Ehrh., of Germany, which appears to be a narrow-panicled form of A. stolonifera $\mathrm{L}$.

$55974^{\circ}-35-50$ 
(28) Agrostis perennans (Walt.) Tuckerm., Amer. Jour. Sci. 45: 44.1843. Based on Cornucopiae perennans Walt.

Cornucopiae perennans Walt., Fl. Carol. 74. 1788. South Carolina. Agrostis cornucopiae Smith, Gentleman's Mag. 59: 873. 1789. Based on Cornucopiae perennans Walt.

Agrostis elegans Salisb., Prodr. Stirp. 25. 1796. Based on Cornucopiae perennans Walt.

Agrostis anomala Willd., Sp. Pl. 1: 370. 1797. Based on Cornucopiae perennans Walt.

Alopecurus carolinianus Spreng., Nachtr. Bot. Gart. Halle 10. 1801. Not A. carolinianus Walt., 1788. [Kentucky, Peter.]

Trichodium decumbens Michx., Fl. Bor. Amer. 1: 42. 1803. Virginia to Florida, Michaux.

Trichodium perennans Ell., Bot. S.C. and Ga. 1: 99. 1816. Based on Cornucopiae perennans Walt.

Trichodium muhlenbergianum Schult., Mant. 2: 159. 1824. Pennsylvania, Muhlenberg. Based on Muhlenberg's Trichodium no. 4.

Agrostis michauxii Trin., Gram. Unifl. 206. 1824. Not A. michauxii Zucc. 1809. Based on Trichodium decumbens Michx.

Agrostis noveboracensis Spreng., Syst. Veg. 1: 260. 1825. New York, Torrey. Agrostis decumbens Link, Hort. Berol. 1: 80.1827 . Not A. decumbens Host, 1809. Based on Trichodium decumbens Michx.

Trichodium noveboracense Schult., Mant. 3 (Add. 1): 555. 1827. Based on Agrostis noveboracensis Spreng.

Trichodium scabrum [Muhl., misapplied by] Darl., Fl. Cestr. 1: 54. 1837. Pennsylvania.

Agrostis schweinitzii Trin., Mém. Acad. St. Pétersb. VI. Sci. Nat. $4^{1}: 311$. 1841. Pennsylvania, Schweinitz.

Agrostis oreophila Trin., Mém. Acad. St. Pétersb. VI. Sci. Nat. 41: 323. 1841. Bethlehem, Pa., Moser. (Trichodium montanum Torr. is erroneously cited

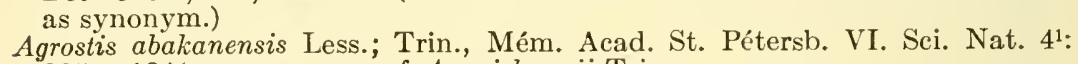
325. 1841, as synonym of $A$. michauxii Trin.

Agrostis schiedeana Trin., Mém. Acad. St. Pétersb. VI. Sci. Nat. 41: 327. 1841. Mexico, type received from Schrader.

Agrostis novae-angliae Tuckerm., Mag. Hort. Hovey 9: 143. 1843. White Mountains, N.H.

Agrostis campyla Tuckerm., Amer. Jour. Sci. II. 6: 231. 1848.' Based on A. scabra as described by Tuckerman.

Agrostis scabra var. perennans Wood, Class-book 774. 1861. Presumably based on $A$. perennans Tuckerm.

Agrostis perennans var. aestivalis Vasey, Contrib. U.S. Natl. Herb. 3: 76. 1892. Athens, Ill. [Hall]. The slender lax form.

Agrostis intermedia Scribn., Bull. Torrey Bot. Club 20: 476. 1893 . Not A. intermedia Balb.,1801. Pine Mountain, Harlan County, Tenn. Kearney 39. Agrostis pseudointermedia Farwell, Ann. Rept. Commr. Parks and Boul. Detroit 11: 46. 1900. Based on A. intermedia Scribn.

Agrostis scribneriana Nash, in Small, Fl. Southeast. U.S. 126. 1903. Based on A. intermedia Scribn.

Agrostis perennans var. humilis Farwell, Mich. Acad. Sci. Papers 1: 87. 1921. Detroit, Farwell $56721 / 2$.

Agrostrs Perennans var. Elata (Pursh) Hitchc., U.S.Dept.Agr., Bur. Plant Indus. Bull. 68: 50. 1905. Based on Trichodium elatum Pursh. (Published as $A$. perennans elata.)

?Cornucopiae altissima Walt., Fl. Carol. 74. 1788. South Carolina. Possibly Agrostis alba $\mathrm{L}$.

Trichodium elatum Pursh, Fl. Amer. Sept. 1: 61. 1814. New Jersey, Carolina. Agrostis elata Trin., Mém. Acad. St. Pétersb. VI. Sci. Nat. 41: 317.1841. Based on Trichodium elatum Pursh.

?Agrostis altissima Tuckerm., Amer. Jour. Sci. 45: 44. 1843. Based on Cornucopiae altissima Walt.

Cornucopiae altissima Walt.
?Trichodium altissimum Michx.; Wood. Class-book ed. 2. 599. 1847. Based

on Cornucopiac altissima Walt.
Agrostis hyemalis var. elata Fernald, Rhodora 23: 229. 1921. Based on Trichodium elatum Pursh.

Trichodium elatum Pursh.
Agrostis perennans forma chaetophora Fernald, Rhodora 35: 317. 1933. Huntington County, Pa., Lowrie. 
Agrostis perennans var. aestivalis forma atherophora Fernald, Rhodora 35: 317. 1933. Terrebonne, Quebec, Churchill.

(1) Agrostis retrofracta Willd., Enum. Pl. 1: $94.1809 . \quad$ Austraiia.

Vilfa retrofracta Beauv., Ess. Agrost. 16, 148, 182. 1812. Based on Agrostis retrofracta Willd.

Lachnagrostis retrofracta Trin., Fund. Agrost. 128. 1820. Based on Agrostis retrofracta Willd.

Lachnagrostis willdenovii Trin., Gram. Unifl. 217. 1824. Based on Agrostis retrofracta Willd.

Deyeuxia retrofracta Kunth, Rév. Gram. 1: 77. 1829. Based on Agrostis retrofracta Willd.

Calamagrostis retrofracta Link; Steud., Nom. Bot. ed. 2. 1:251. 1840. Based on Agrostis retrofracta Willd.

Calamagrostis willdenovii Steud., Syn. Pl. Glum. 1: 192. 1854. Based on Lachnagrostis willdenovii Trin.

(21). Agrostis rossae Vasey, Contrib. U.S. Natl. Herb. 3: 76. 1892. Yellowstone Park, Wyo., Edith Ross in 1890.

Agrostis varians Trin., Mém. Acad. St. Pétersb. VI. Sci. Nat. 41: 314.1841. Not A. varians Thuill., 1790. "America boreal? (Hoocker 217)." A duplicate type in the Torrey Herbarium (N.Y. Bot. Gard.) is labeled Rocky Mountains, Hooker 217.

Agrostis variabilis Rydb., Mem. N.Y. Bot. Gard. 1: 32. 1900. Based on A. varians Trin.

(2) Agrostis spica-venti L., Sp. Pl. 61. 1753. Europe.

Agrostis gracilis Salisb., Prodr. Stirp. 25. 1796. Based on A. spica-venti L.

Apera spica-venti Beauv., Ess. Agrost. 151. 1812. Based on Agrostis spicaventi $\mathrm{L}$.

Anemagrostis spica-venti Trin., Fund. Agrost. 129. 1820. Based on Agrostis spica-venti L.

Festuca spica-venti Raspail, Ann. Sci. Nat., Bot. 5: 445. 1825. Based on Agrostis spica-venti L.

Muhlenbergia spica-venti Trin., Mém. Acad. St. Pétersb. VI. Sci. Nat. $4^{1}: 285$. 1841. Based on Agrostis spica-venti L.

Agrostis ventosa Dulac, Fl. Haut. Pyr. 74. 1867. Based on Apera spica-venti Beauv.

Agrostis anemagrostis Syme, in Sowerby, English Bot. ed. 3. 11: 43. 1873. Based on Anemagrostis spica-venti Trin.

Agrostis anemagrostis subsp. spica-venti Syme, in Sowerby, English Bot. ed. 3. 11: 43. 1873. Based on A. spica-vcnti L.

(7) Agrostis stolonifera L., Sp. Pl. 62. 1753. Europe.

Decandolia stolonifera Bast., F1. Maine-et-Loire 29. 1809. Based on Agrostis stolonifera L.

Vilfa stolonifera Beauv., Ess. Agrost. 16, 148, 182. 1812. Based on Agrostis stolonifera L.

Agrostis alba var. stolonifera Smith, English Fl. 1: 93 . 1824. Based on A. stolonifera $\mathrm{L}$.

Agrostis vulgaris var. stolonifera Koch, Syn. Fl. Germ. Helv. 782. 1837. Based on $A$. stolonifera $\mathrm{L}$.

(11) Agrostis tenuis Sibth., Fl. Oxon. 36. 1794. Based on A. capillaris Huds.

Agrostis capillaris Huds., Fl. Angl. ed. 2. 27. 1762. Not A. capillaris L., 1753. England.

Agrostis sylvatica Huds., Fl. Angl. ed. 2. 28. 1762. England. A teratological form, the florets abnormally elongated. Name rejected, being based on a monstrosity.

Agrostis vulgaris With., Bot. Arr. Veg. Brit. ed. 3. 2: 132. 1796. Europe.

Vilfa vulgaris Beauv., Ess. Agrost. 16, pl. 5. f. 8. 1812. Based on Agrostis vulgaris With.

Agrostis alba var. sylvatica Smith, English Fl. 1: 93. 1824. Based on A. sylvatica Huds. Published as new by Scribner, Mem. Torrey Club 5: 40. 1894 , the basis given as "A. sylvatica L." error for Huds.

Agrostis alba var. vulgaris Coss. and Dur., Expl. Sci. Alger. 2:63. 1867. Based on A. vulgaris With.

Agrostis stolonifera var. vulgaris Celak., Prodr. Fl. Böhm. 710. 1881. Not A. stolonifera var. vulgaris Heuff., 1858. Based on A. vulgaris With.

Agrostis alba var. minor Vasey, Contrib. U.S. Natl. Herb. 3: 78. 1892. [Washington, D.C.] 
This species has been referred to Agrostis capillaris L., a European species not known from America.

Agrostis tendis var. Aristata (Parnell) Druce, I.ist Brit. Pl. 79. 1908. Presumably based on $A$. vulgaris var. aristata Parnell.

Agrostis stricta Willd., Sp. Pl. 1: 366. 1797. Not A. stricta Gmel., 1791. North America.

Agrostis stricta Muhl., Descr. Gram. 65. 1817. Not A. stricta Gmel., 1791. New England and Carolina.

Trichorium strictum Roem. and Schult., Syst. Veg. 2: 281. 1817. Based on Agrostis stricta Willd.

Agrostis diffusa Muhl.; Spreng., Syst. Veg. 1: 260. 1825. Not A. diffusa Host, 1809, nor Muhl., 1817. As synonym of A. stricta Muhl.

Agrostis vulgaris var. aristata Parnell, Grasses Scotl. 1': 34. pl. 13. 1842. Scotland.

Agrostis alba var. aristata A. Gray, Man. 578. 1848. Not A. alba var. aristata Spenner, 1825. Based on A. stricta Willd.

Agrostis stricta Buse, in Miquel, Pl. Jungh. 341. 1854. Not A. stricta Gmel., 1791. Based on Trichodium strictum Roem. and Schult.

Agrostis alba var. stricta Wood, Class-book 774. 1861. Based on A. stricia Willd.

Agrostis tenuis forma aristata (Pamell) Wiegand, Rhodora 26: 2. 1924. Based on A. vulgaris var. aristata Parnell.

Agrostis palustris var. stricta House, N.Y. State Mus. Bull. 254: 98. 1924. Based on Agrostis stricta Willd.

Agrostis capillaris var. aristata Druce, Fl. Oxfordsh. ed. 2. 474. 1927. Presumably based on A. vulgaris var. aristata Parnell.

Agrostis capillaris aristulata Hitchc., Biol. Soc. Wash. Proc. 41: 160. 1928. Alexandria, Va. Amer. Gr. Nat. Herb. 344.

(4) Agrostis thurberiana Hitchc., U.S.Dept.Agr., Bur. Plant Indus. Bull. 68: 23. pl. 1. f. 1. 1905. Skamania County, Wash., Suksdorf 1021.

Agrostis hillebrandii Thurb.; Boland. Agr. Soc. Calif. Trans. is64-1865: 136. 1866. Name only. Sierra Nevada, Calif., Hitlebrand.

Agrostis atrata Rydb., Bull. Torrey Bot. Club 36: 531. 1909. Yoho Valley, British Columbia, Macoun 64787.

\{6) Agrostis verticillata Vill., Prosp. Pl. Dauph. 16. 1779. France.

Agrostis alba var. verticillata Pers., Syn. Pl. 1: 76. 1805. Based on A. verticillata Vill.

Agrostis villarsii Poir., in Lam., Encycl. Sup. 1: 251. 1810. Based on A. verticillata Vill.

Vilfa verticillata Beauv., Ess. Agrost. 16, 148, 182. 1812. Based on Agrostis verticillata Vill.

Agrostis decumbens Muhl.; Ell., Bot. S.C. and Ga. 1: 136. 1816. Not A. decumbens Host, 1809. Charleston, S.C.

Agrostis stolonifera var. verticillata St. Amans, Fl. Agen. 28. 1821. Based on A. verticillata Vill.

Agrostis condensata Willd.; Steud., Nom. Bot. ed. 2. 1: 40. 1840, as synonym of A. verticillata Vill.

Agrostis leptos Steud., Syn. Pl. Glum. 1: 169. 1854. Louisiana.

Agrostis aquatica Buckl., Acad. Nat. Sci. Phila. Proc. 1862: 90. 1863. Not A. aquatica Pourr., 1783. San Saba County, Tex.

Agrestis verticillata Bubani, Fl. Pyr. 4: 282. 1901. Based on Agrostis verticillata Vill.

(56) AIRA L.

(3) Aira capillaris Host, Icon. Gram. Austr. 4: 20. pl. 35. 1809. Europe.

Avena capillaris Mert. and Kioch, in Roehl., Deut. Fl. ed. 3. 12: 573. 1823. Based on Aira capillaris Host.

Airopsis capillaris Schur, Oesterr. Bot. Ztschr. 9: 328. 1559. Based on Aira capillaris Host.

Fussia capillaris Schur, Enum. Pl. Transsilv. 754. 1866. Based on Aira capillaris Host.

Airella capillaris Dum., Bull. Soc. Bot. Belg. $7^{\mathrm{t}}$ : 68. 1868. Based on Aira capillaris Host.

Aspris capillaris Hitche., U.S. Dept. Agr. Bull. 772: 116. 1920. Based on Aira capillaris Host. 
(2) Aira caryophyllea L., Sp. Pl. 66. 1753. Europe.

Avena caryophyllea Wigg., Prim. Fl. Hols. 10. 1780. Based on Aira caryophyllea L.

Agrostis caryophyllea Salisb., Prodr. Stirp. 25. 1796. Based on Aira caryophyllea L.

Airopsis caryophyllea Fries, Nov. Fl. Suec. ed. 2. Cont. 3: 180. 1842. Based on Aira caryophyllea L.

Caryophyllea airoides Opiz, Sezn. Rostl. Ceské 27. 1852. Based on Aira caryophyllea $\mathrm{L}$.

Fussia caryophyllea Schur, Enum. Pl. Transsilv. 754. 1866. Based on Aira caryophyllea L.

Airella caryophyllea Dum., Bull. Soc. Bot. Belg. $7^{1}$ : 68. 1868. Based on Aira caryophyllea L.

Salmasia vulgaris Bubani, Fl. Pyr. 4:316. 1901. Based on Aira caryophyllea L.

Aspris caryophyllea Nash, in Britt. and Brown, Illustr. Fl. ed. 2. 1: 214. 1913. Based on Aira caryophyllea L.

(1) Aira praecox L., Sp. Pl. 65. 1753. Europe.

Agrostis praecox Salisb., Prodr. Stirp. 24. 1796. Based on Aira praecox L.

Avena praecox Beauv, Ess. Agrost. 89, 154. 1812. Based on Aira praecox L.

Trisetum praecox Dum., Obs. Gram. Belg. 122. pl. 8. f. 30. 1823. Based on Aira praecox L.

Airopsis praecox Fries, Nov. Fl. Suec. ed. 2. Cont. 3: 180. 1842. Based on Aira praecox L.

Caryophyllea praecox Opiz, Sezn. Rostl. Ceské 27. 1852. Based on Aira praecox L.

Fussia praecox Schur, Enum. Pl. Transsilv. 754. 1866. Based on Aira praecox $\mathrm{L}$.

Airella praecox Dum., Bull. Soc. Bot. Belg. $7^{1}$ : 68. 1868. Based on Aira praecox L.

Salmasia praecox Bubani, Fl. Pyr. 4: 316. 1901. Based on Aira praecox L. Aspris praecox Nash, in Britt. and Brown, Illustr. Fl. ed. 2. 1: 215.1913. Based on Aira praecox L.

\section{(69) ALOPECURUS L.}

(5) Alopecurus aequalis Sobol., Fl. Petrop. 16. 1799. Greece. Alopecurus aristulatus Michx., Fl. Bor. Amer. 1: 43. 1803. Canada, Michaux. Alopecurus fulvus J. E. Smith, in Sowerby, English Bot. 21: pl. 1467. 1805. England.

Alopecurus subaristatus Pers., Syn. Pl. 1: 80. 1805. Canada.

Alopccurus geniculatus var. natans Wahl., Fl. Lapp. 22. 1812. Lapland.

Alopecurus geniculatus var. aristulatus Torr., Fl. North. and Mid. U.S. 1: 97. 1823. Based on A. aristulatus Mich..

Alopecurus caespitosus Trin., Gram. Icon. 3: pl. 241. 1836. North America, [type, Northwest America, Douglas].

Alopecurus geniculatus var. fulvus Schrad., Linnaea 12: 424. 1838. Based on A. fulvus J. E. Smith.

Alopecurus geniculatus var. robustus Vasey, Bull. Torrey Bot. Club 15: 13. 1888. Vancouver Island, Macoun.

Alopecurus howellii var. merrimani Beal, Grasses N.Amer. 2: 278. 1896. Pribilof Islands, Alaska, "C. H. Merriman" [error for Mcrriam].

Alopecurus howellii var. merriami Beal; Macoun, in Jordan, Fur Seals North Pacif. 3: 573. 1899. (Correction of var. merrimani Beal.)

Alopecurus aristulatus var. natans Simmons, Arkiv Bot.617: 4. 1907. Based on A. geniculatus var. natans Wahl.

Tozzettia fulva Lunell, Amer. Midl. Nat. 4: 216. 1915. Based on Alopecurus fulvus J. E. Smith.

Alopecurus artistulatus var. merriami St. John, Canada Dept. Mines Mem. 126: 42. 1922. Based on A. howellii var. merriami Beal.

Alopecurus aequalis var. natans Fernald, Rhodora 27: 198. 1925. Based on Alopecurus geniculatus var. natans Wahl.

(3) Alopecurus alpinus J. E. Smith, in Sowerby, English Bot. pl. 1126. 1803. Scotland.

?Alopecurus borealis Trin., Fund. Agrost. 58. 1820. Asia and North America. Alopecurus occidentalis Scribn. and Tweedy, Bot. Gaz. 11: 170. 1886. Yellowstone National Park, Tweedy.

Alopecurus behringianus Gandog., Bull. Soc. Bot. France 667: 298. 1920. St. Paul Island, Alaska, Macoun. 
Vasey misapplied the name Alopecurus pratensis var. alpestris Wahl. to this species in Contrib. U.S. Natl. Herb. 3: 86. 1892.

(7) Alopecurus carolinianus Walt., Fl. Carol. 74. 1788. South Carolina. Alopecurus ramosus Poir., in Lam., Encycl. 8: 776. 1808. Carolina, Bosc. Alopecurus pedalis Bosc; Beauv., Ess. Agrost. 4. 1812. Name only. [Carolina, Bosc.]

Alopecurus gracilis Willd.; Trin., Mém. Acad. St. Pétersb. VI. Sci. Nat. 41: 38. 1840. Carolina [Bosc].

Alopecurus macounii Vasey, Bull. Torrey Bot. Club 15: 12. 1888. Oak Bay, Vancouver Island, Macoun.

Alopecurus geniculatus var. caespitosus Scribn., in Macoun, Cat. Can. Pl. $2^{5}$ : 389. 1890. Yale, British Columbia, Macoun.

Alopecurus geniculatus var. ramosus St. John, Rhodora 19: 167. 1917. Based on A. ramosus Poir.

Alopecurus creticus Trin., in Spreng., Neu. Entd. 2: 45. 1821. Crete.

(6) Alopecurus geniculatus L., Sp. Pl. 60. 1753. Europe.

Tozzettia geniculata Bubani, Fl. Pyr. 4: 275. 1901. Based on Alopecurus geniculatus L.

(8) Alopecurus howellii Vasey, Bull. Torrey Bot. Club 15: 12. 1888. [Medford], Oreg., Howell [215].

Alopecurus californicus Vasey, Bull. Torrey Bot. Club 15: 13. 1888. California [type, Santa Cruz, Anderson] and Oregon.

(1) Alopecurus myosuroides Huds., Fl. Angl. 23. 1762. England.

Alopecurus agrestis L., Sp. Pl. ed. 2. 1: 89. 1762. Europe.

Tozzettia agrestis Bubani, Fl. Pyr. 4: 274. 1901. Based on Alopecurus agrestis $\mathrm{L}$.

(4) Alopecurus pallescens Piper, Fl. Palouse 18. 1901. Pullman, Wash., Piper 1743.

(2) Alopecurus pratensis L., Sp. Pl. 60. 1753. Europe.

(9) Alopecurus saccatus Vasey, Bot. Gaz. 6: 290. 1881. Eastern Oregon, Howell.

\section{(62) AMMOPHILA Host}

(1) Ammophila arenaria (L.) Link, Hort. Berol. 1: 105. 1827. Based on Arundo arenaria L.

Arundo arenaria L., Sp. Pl. 82. 1753. Europe.

Calamagrostis arenaria Roth, Tent. Fl. Germ. 1: 34. 1788. Based on Arundo arenaria L.

Ammophila arundinacea Host, Icon. Gram. Austr. 4: 24. pl. 41. 1809. Based on Arundo arenaria L.

Psamma littoralis Beauv., Ėss. Agrost. 144. pl. 6. f. 1. 176.1812. Europe.

Psamma arenaria Roem. and Schult., Syst. Veg. 2: 845. 1817. Based on Calamagrostis arenaria Roth.

Phalaris maritima Nutt., Gen. Pl. 1: 48. 1818. Based on Arundo arenaria L., but misapplied to Ammophila breviligulata.

Phalaris ammophila Link, Enum. Hort. Berol. 1: 66. 1821. Based on Ammophila arundinacea Host.

Arundo littoralis Beauv.; Steud., Nom. Bot. ed. 2. 1: 144. 1840, as synonym of Calamagrostis arenaria Roth.

(2) Ammophila breviligulata Fernald, Rhodora 22: 71. 1920. Milford, Conn., Bissell in 1902.

Ampelodesmos mauritanicus (Poir.) Dur. and Schinz, Consp. Fl. Afr. 5: 874. 1894. Based on Arundo mauritanica Poir.

Arundo mauritanica Poir., Voy. Barb. 2: 104. 1789. Algeria.

Arundo tenax Vahl, Symb. Bot. 2: 25. 1791. Tunis.

Ampelodesmos tenax Link, Hort. Berol. 1: 136. 1827. Based on Arundo tenax Vahl.

\section{(138) AMPHICARPUM Kunth}

(2) Amphicarpum muhlenbergianum (Schult.) Hitchc., Bartonia 14: 34. 1932. Based on Milium muhlenbergianum Schult.

Milium? muhlenbergianum Schult., Mant. 2: 178. 1824. Based on Milium no. 3 of Muhlenberg's Descriptio Graminum. Muhlenberg's specimen is without locality.

Amphicarpon floridanum Chapm., Fl. South. U.S. 572. 1860. Apalachicola River, Fla. 
(1) Amphicarpum purshii Kunth, Rév. Gram. 1: 28. 1829. Based on Milium amphicarpon Pursh.

Milium amphicarpon Pursh, Fl. Amer. Sept. 1: 62. pl. 2. 1814. Egg Harbor, N.J.

Milium ciliatum Muhl., Descr. Gram. 77. 1817. Not M. ciliatum Moench. New Jersey.

Amphicarpon amphicarpon Nash, Mem. Torrey Bot. Club 5: 352.1894. Based on Milium amphicarpon Pursh.

\section{(145) ANDROPOGON L.}

(16) Andropogon arctatus Chapm., Bot. Gaz. 3: 20. 1878. West Florida, Chapman [in 1875].

Andropogon tetrastachyus var. distachyus Chapm., Fl. South. U.S. 581. 1860. No locality cited. [Type specimen of $A$. arctatus is also type of this.]

Sorghum arctatum Kuntze, Rev. Gen. Pl. 2: 791. 1891. Based on Andropogon arctatus Chapm.

(30) Andropogon barbinodis Lag., Gen. and Sp. Nov. 3. 1816. Mexico, Sessé. Andropogon leucopogon Nees, Linnaea 19: 694. 1845. Mexico, Aschenborn 141.

Andropogon saccharoides var. barbinodis Hack., in DC., Monogr. Phan. 6: 494. 1889. Based on A. barbinodis Lag.

Andropogon saccharoides var. leucopogon Hack., in DC., Monogr. Phan. 6: 496. 1889. Based on A. leucopogon Nees.

Amphilophis barbinodis Nash, in Small, Fl. Southeast. U.S. 65. 1903. Based on Andropogon barbinodis Lag.

Holcus saccharoides var. barbinodis Hack.; Stuck., An. Mus. Nac. Buenos Aires 11: 48. 1904. Presumably based on Andropogon barbinodis Lag.

Amphilophis leucopogon Nash, N.Amer. Fl. 17: 126. 1912. Based on Andropogon leucopogon Nees.

(21) Andropogon brachystachyus Chapm., Fl. South. U.S. ed. 2. 668. 1883. [Jacksonville], Fla., Curtiss [3632].

Sorghum brachystachyum Kuntze, Rev. Gen. Pl. 2: 791. 1891. Based on Andropogon brachystachyus Chapm.

(14) Andropogon cabanisii Hack., Flora 68: 133. 1885. "Pennsylvania" [erroneous] and Florida, Cabanis.

Sorghum cabanisii Kuntze, Rev. Gen. Pl. 2: 791. 1891. Based on Andropogon cabanisii Hack.

(27) Andropogon campyloracheus Nash, Bull. N.Y. Bot. Gard. 1: 431.1900. Eustis, Fla., Nash 1738.

Andropogon elliottii var. laxiflorus Scribn., Bull. Torrey Bot. Club 23: 146. 1896 (Apr.). Eustis, Fla., Nash 1738. Published as new in Beal, Grasses N.Amer. 2: 51.1896 (Nov.), Nash 1597 cited as type.

(22) Andropogon capillipes Nash, Bull. N.Y. Bot. Gard. 1: 431. 1900. Based on $A$. virginicus var. glaucus Hack.

Andropogon glaucus Muhl., Descr. Gram. 278. 1817. Not A. glaucus Retz., 1789. South Carolina.

Cymbopogon glaucus Scnult., Mant. 2: 459. 1824. Based on Andropogon glaucus Muhl.

Andropogon virginicus var. glaucus Hack., in DC., Monogr. Phan. 6: 411. 1889. [Jacksonville], Fla., Curtiss 3638b.

(5) Andropogon cirratus Hack., Flora 68: 119. 1885. El Paso, Tex., Wright 804 [error for 805].

Sorghum cirratum Kuntze, Rev. Gen. PI. 2: 791. 1891. Based on Andropogon cirratus Hack.

Schizachyrium cirratum Woot. and Standl., N.Mex. Coll. Agr. Bull. 81: 30. 1912. Based on Andropogon cirratus Hack.

(10) Andropogon divergens (Hack.) Anderss.; Hitchc., Jour. Wash. Acad. Sci. 23: 456. 1933. Based on A. scoparius subsp. maritimus var. divergens Hack.

Andropogon scoparius subsp. maritimus var. divergens Hack., in DC., Monogr. Phan. 6: 385. 1889. Texas.

Andropogon divergens Anderss.; Hack., in DC., Monogl. Phan. 6: 385.1889 , as synonym of $A$. scoparius subsp. maritimus var. divergens Hack.

(25) Andropogon elliottii Chapm., F1. South. U.S. 581. 1860. Florida to North Carolina. Chapman erroneously cites "A. argenteus Ell., not of DC." but his description, especially of the "dilated clustered sheaths" shows that he did not know Elliott's species (see synonymy under $A$. ternarius 
Michx.), but was describing plants of his own collection, one of which from Chapman's herbarium named "Andropogon Elliottii S. Fl." in his script is in the U.S. National Herbarium.

Andropogon clandestinus Wood, Class-book ed. 3: 809. 1861. Not A. clandestinus Nees, 1854. Western Louisiana.

Andropogon elliottii var. gracilior Hack., in DC., Monogr. Phan. 6: 415. 1889. [Jacksonville], Fla., Curtiss 3636a.

Sorghum elliottii Kuntze, Rev. Gen. Pl. 2: 791. 1891. Based on A. elliottii Chapm.

?Andropogon gyrans Ashe, Jour. Elisha Mitchell Sci. Soc. 15: 113.1898. Durham County, N.C., Ashe.

Andropogon gracilior Nash, in Small, Fl. Southeast. U.S. 63. 1903. Based on A. elliottii var. gracilior Hack.

(32) Andropogon exaristatus (Nash) Hitchc., Biol. Soc. Wash. Proc. 41: 163. 1928. Based on Amphilophis exaristatus Nash.

Andropogon saccharoides var. submuticus Vasey; Hack., in DC., Monogr. Phan. 6: 495. 1889. Not A. submuticus Steud., 1854. Texas, Nealley.

Amphilophis exaristatus Nash, in Sma1l, Fl. Southeast. U.S. 65. 1903. Based on Andropogon saccharoides var. submuticus Vasey.

(17) Andropogon floridanus Scribn., Bull. Torrey Bot. Club 23: 145.1896. [Eustis], Fla., Nash 1572.

Andropogon bakeri Scribn. and Ball, U.S.Dept.Agr., Div. Agrost. Bull. 24: 39. 1901. Grasmere, Fla., C. H. Baker 58.

(11) Andropogon furcatus Muhl., in Willd., Sp. Pl. 4: 919. 1806. North America [probably Pennsylvania].

?Andropogon ternarius [Michx. misapplied by] Bertol., Mem. Accad. Sci. Bologna 2: 600 . 1850. Alabama.

Andropogon provincialis subvar. furcatus Hack., in DC., Monogr. Phan. 6: 442. 1889. Based on A. furcatus Muhl.

Andropogon provincialis subvar. lindheimeri Hack., in DC., Monogr. Phan. 6: 443. 1889. Texas, Lindheimer 741.

Andropogon provincialis subvar. pycnanthus Hack., in DC., Monogr. Phan. 6: 443. 1889. Texas, Vinzent 69.

Andropogon provincialis var. tennesseensis Scribn., Tenn. Agr. Expt. Sta. Bull. $7^{2}: 23.1894$. Tennessee.

Andropogon hallii grandiflorus Scribn., U.S.Dept.Agr., Div. Agrost. Bull. 5: 21. 1897. Colorado, Shear 747 [type], 605, 2366.

Andropogon tennesseensis Scribn., U.S.Dept.Agr., Div. Agrost. Circ. 16: 1. 1899. Based on A. provincialis var. tennesseensis Scribn.

The name Andropogon provincialis Lam. (Encycl. 1: 376.1783 ), was applied to this species by Hackel (in DC., Monogr. Phan. 6: 441. 1889) and others, but Lamarck's species is uncertain. He states that he saw a plant in the Paris Botanical Garden, but his description is taken from Gerard (Fl. Gall. Prov. 107. pl. 4. 1761) and does not well apply to our species. Furthermore, A. provincialis Retz. (Obs. Bot. 3: 43. [31]. 1783), which appears to be a species of Chloris, was published the same year. The author is unable to determine which is the earlier. The part of Lamarck's Encyclopedie containing page 376 appeared in August 1783.

(24) Andropogon glomeratus (Walt.) B.S.P., Prel. Cat. N.Y.67. 1888. Based on Cinna glomerata Walt.

Cinna glomerata Walt., Fl. Carol. 59. 1788. South Carolina.

Andropogon macrourus Michx., Fl. Bor. Amer. 1: 56. 1803. Carolina to Florida, Michaux. [Type labeled "Virginia to Carolina."]

Andropogon spathaceus Trin., Fund. Agrost. 186.1820 , name only; Steud., Nom. Bot. ed. 2. 1: 93. 1840, as synonym of A. macrourus Michx.

Anatherum macrourum Griseb., Mem. Amer. Acad. (n.s.) 8: 534. 1863. Based on Andropogon macrourus Michx.

Andropogon macrourus var. abbreviatus Hack., in DC., Monogr. Phan. 6: 408. 1889. [Pleasant Bridge], N.J., Gray.

Andropogon macrourus var. corymbosus Chapm.; Hack., in DC., Monogr. Phan. 6: 409. 1889. [Jacksonville], Fla., Curtiss 3639c.

Sorghum glomeratum Kuntze, Rev. Gen. Pl. 2: 790. 1891. Based on Cinna glomerata Walt.

Dimeiostemon macrurus Raf.; Jacks., Ind. Kew. 2: 760. 1893, as synonym of Andropogon macrourus Michx.

Andropogon virginicus var. corymbosus Beal, Grasses N.Amer. 2: 52. 1896. [Jacksonville], Fla., Curtiss $3639 \mathrm{c}$. 
Andropogon glomeratus var. corymbosus Scribn., U.S.Dept.Agr., Div. Agrost. Bull. 7 (ed. 3): 15. 1900. Based on A. macrourus var. corymbosus Chapm. Andropogon glomeratus var. abbreviatus Scribn., U.S.Dept.Agr., Div. Agrost. Bull. 7 (td. 3): 15. 1900. Based on A. macronrus var. abbreviatus Hack. Andropogon corymbosus Nash, in Britton, Man. 69. 1901. Based on A. macrourus var. corymbosus Chapm.

Andropogon corymbosus abbreviatus Nash, in Britton, Man. 70. 1901. Based on A. macrourus var. abbreviatus Hack.

Andropogon glomeratus tenuispatheus Nash, in Small, Fl. Southeast. U.S. 61. 1903. Florida [type] to New Mexico.

Andropogon tenuispatheus Nash, N.Amer. Fl. 17: 113. 1912. Based on A. glomeratus tenuispatheus Nash.

(1) Andropogon gracilis Spreng., Syst. Veg. 1: 284. 1825. Hispaniola.

Andropogon juncifolius Desv.; Hamilt., Prodr. Pl. Ind. Occ. 9. 1825. St. Croix, Virgin Islands.

Andropogon louisianae Steud., Syn. Pl. Glum. 1: 383. 1854. Louisiana [doubtless erroneous].

Sorghum gracile Kuntze, Rev. Gen. Pl. 2: 791. 1891. Based on Andropogon gracilis Spreng.

Schizachyrium gracile Nash, in Small, Fl. Southeast. U.S. 60. 1903. Based on Andropogon gracilis Spreng.

(12) Andropogon hallii Hack., Sitzungsb. Akad. Wiss. Math. Naturw. (Wien) 891: 127. 1884. North America [Nebraska], Hall and Harbour 651.

Andropogon hallii var. flaveolus Hack., Sitzungsb. Akad. Wiss. Math. Naturw. (Wien) 891: 128. 1884. [Nebraska] Hall and Harbour 651.

Andropogon hallii var. incanescens Hack., Sitzungsb. Akad. Wiss. Math. Naturw. (Wien) 891: 128. 1884. [Nebraska] Hall and Harbour.

Andropogon hallii var. muticus Hack., in DC., Monogr. Phan. 6: 444. 1889. Brighton, Colo., Vasey.

Sorghum hallii Kuntze, Rev. Gen. Pl. 2: 791. 1891. Based on Andropogon hallii Hack.

Andropogon geminatus Hack.; Beal, Grasses N.Amer. 2: 55. 1896. Texas, Nealley.

Andropogon hallii var. bispicata Vasey; Beal, Grasses N.Amer. 2: 55. 1896, as synonym of $A$. geminatus Hack.

Andropogon chrysocomus Nash, in Britton, Man. 70. 1901. Kansas [type, Stevens County, Carleton 343] and Texas.

Andropogon paucipilus Nash, in Britton, Man. 70. 1901. Montana and Nebraska [type, Whitman, Rydberg 1607].

(3) And́ropogon hirtiflorus (Nees) Kunth, Rév. Gram. 1: Sup. XXXIX. 1830. Based on Schizachyrium hirtiflorum Nees.

Streptachne domingensis Spreng.; Schult., Mant. 2: 188. 1824. Not Andropogon domingensis Steud., 1821. Santo Domingo, Bertero.

Schizachyrium hirtiflorum Nees, Agrost. Bras. 334. 1829. Brazil, Sellow.

Aristida domingensis Kunth, Rév. Gram. 1: 62. 1829. Based on Streptachne domingensis Spreng.

Andropogon oligostachyus Chapm., Fl. South. U.S. 581. 1860. Middle Florida, Chapman.

Andropogon hirtiflorus var. oligostachyus Hack., in DC., Monogr. Phan. 6: 372. 1889. Based on A. oligostachyus Chapm.

Sorghum hirtiflorum Kuntze, Rev. Gen. P1. 2: 792. 1891. Based on Schizachyrium hirtiflorum Nees.

Schizachyrium oligostachyum Nash, in Small, Fl. Southeast. U.S. 59. 1903. Based on Andropogon oligosiachyus Chapm.

Schizachyrium domingense Nash, N.Amer. Fl. 17: 103. 1912. Based on Streptachne domingensis Spreng.

Andropogon domingensis F. T. Hubb., Amer. Acad. Sci. Proc. 49: 493. 1913. Not A. domingensis Steud., 1821. Based on Streptachne domingensis Spreng. ANDropogon hirtiflorus var. FEensis (Fourn.) Hack., in DC., Monogr. Phan. 6: 372. 1889. Based on A. feensis Fourn.

Andropogon feensis Fourn., Mex. Pl. 2: 62. 1886. Santa Fé, Mexico, Bourgeau 752.

Andropogon hirtiflorus var. brevipedicellatus Beal, Grasses N.Amer. 2: 44.1896. Chihuahua, Mexico, Pringle 383.

Schizachyrium feense A. Camus, Ann. Soc. Linn. Lyon 70: 89. 1923. Based on Andropogon feensis Fourn.

(7) Andropogon littoralis Nash, in Britton, Man. 69. 1901. New York [type, Staten Island, Nash in 1894] and New Jersey. 
Andropogon scoparius subsp. euscoparius Hack.; Beal, Grasses N.Amer. 2: 46. 1896. Cape May, N.J., Burk in 1881 (misprinted as 1888).

Andropogon scoparius var. littoralis Hitchc., Rhodora 8: 205. 1906. Based on A. littoralis Nash.

Schizachyrium littorale Bicknell, Bull. Torrey Bot. Club 35: 1S2. 1908. Based on Andropogon littoralis Nash.

(19) Andropogon longiberbis Hack., Flora 68: 131. 1885. Florida, Garber [in 1877].

Sorghum longiberbe Kuntze, Rev. Gen. Pl. 2: 792. 1891. Based on Andropogon longiberbis Hack.

(9) Andropogon maritimus Chapm., Fl. South. U.S. ed. 2: 668. 1883. West Florida, Chapman.

Andropogon scoparius subsp. maritimus Hack., in DC., Monogr. Phan. 6: 385. 1889. Based on A. maritimus Chapm.

Schizachyrium maritimum Nash, in Small, Fl. Southeast. U.S. 59. 1903. Based on Andropogon maritimus Chapm.

(13) Andropogon mohrii (Hack.) Hack.; Vasey, Contrib. U.S.Natl.Herb. 3: 11. 1892. Based on A. liebmanni subvar. mohrii Hack.

Andropogon liebmanni subvar. mohrii Hack., in DC., Monogr. Phan. 6: 413. 1889. Mobile, Ala., Mohr [in 1884].

Andropogon mohrii var. pungensis Ashe, Jour. Elisha Mitchell Sci. Soc. 15: 114. 1898. Washington County, N.C., Ashe.

Andropogon nodosus (Willem.) Nash, N.Amer. Fl. 17: 122. 1912. Based on Dichanthium nodosum Willem.

Dichanthium nodosum Willem., Ann. Bot. Usteri 18: 11. 1796. Mauritius. Andropogon mollicomus Kunth, Rév. Gram. 1: 365. 1830. Mauritius.

Andropogon caricosus var. mollicomus Hack., in DC., Monogr. Phan. 6: 569. 1889. Based on A. mollicomus Kunth.

(20) Andropogon perangustatus Nash, in Small, Fl. Southeast. U.S. 62. 1903. Based on A. virginicus var. [viridis subvar.] stenophyllus Haek.

Andropogon virginicus var. viridis subvar. stenophyllus Hack., in DC., Monogr. Phan. 6: 411. 1889. Not A. stenophyllus Roem. and Schult., 1817. Florida, Chapman [in 1884].

(29) Andropogon perforatus Trin.; Fourn., Mex. Pl. 2: 59. 1886. [Mexico City] Mexico, Berlandier 641.

Andropogon emersus Fourn., Mex. Pl. 2: 58. 1886. Orizaba, Mexico, Mueller 2033.

Andropogon saccharoidcs var. leucopogon subvar. perforatus Hack., in DC., Monogr. Phan. 6: 496. 1889. Based on A. perforatus Trin.

Andropogon saccharoides var. perforatus Hack.; L. H. Dewey, Contrib. U.S. Nati. Herb. 2: 497. 1894. Presumably based on A. perforatus Trin.

Amphilophis perforatus Nash, in Small, Fl. Southeast. U.S.66. 1903. Based on Andropogon perforatus Trin.

Holcus saccharoides var. perforatus Hack.; Stuck., An. Mus. Nac. Buenos Aires 11: 48. 1904. Presumably based on Andropogon perforatus Trin.

Amphilophis emersus Nash, N.Amer. Fl. 17: 126. 1912. Based on Andropogon emersus Fourn.

(31) Andropogon saccharoides Swartz, Prodr. Veg. Ind. Occ. 26. 1788. Jamaica, Swartz.

Andropogon argenteus DC., Cat. Hort. Monsp. 77. 1813. Mexico, Sessé.

Andropogon laguroides DC., Cat. Hort. Monsp. 78. 1813. Grown from Mexican seed.

Andropogon glaucus Torr., Ann. Lyc. N.Y. 1: 153. 1824. Not A. glaucus Retz. 1789. Canadian River, Tex., James.

Trachypogon argenteus Nees, Agrost. Bras. 348. 1829. Based on Andropogon argenteus DC.

Trachypogon laguroides Nees, Agrost. Bras. 349. 1829. Based on Andropogon laguroides DC.

Andropogon torreyanus Steud., Nom. Bot. ed. 2. 1: 93. 1840. Based on A. glaucus Torr.

Andropogon jamesii Torr., in Marcy, Expl. Red. Riv. 302. 1853. Based on A. glaucus Torr.

Andropogon saccharoides var. laguroides Hack., in Mart., Fl. Bras. 23: 293. 1883. Based on A. laguroides DC.

Andropogon saccharoides var. torreyanus Hack., in DC., Monogr. Phan. 6: 495. 1889. Based on $A$. torreyanus Steud.

Sorghum saccharoides Kuntze, Rev. Gen. Pl. 2: 792. 1891. Based on Andropogon saccharoides Swartz. 
Andropogon saccharoides var. glaucus Scribn., Mem. Torrey Bot. Club 5: 28. 1894. Based on A. glaucus Torr.

Amphilophis torreyanus Nash, in Britton, Man. 71. 1901. Based on Andropogon torreyanus Steud.

Holcus saccharoides Kuntze; Stuck., An. Mus. Nac. Buenos Aires 11: 48.1904. Presumably based on Andropogon saccharoides Swartz.

Holcus saccharoides var. laguroides Hack.; Stuck., An. Mus. Nac. Buenos Aires 11: 48. 1904. Presumably based on Andropogon laguroides DC.

Amphilophis saccharoides Nash, N.Amer. Fl. 17: 125. 1912. Based on Andropogon saccharoides Swartz.

Bothriochloa saccharoides Rydb., Brittonia 1: 81. 1931. Based on Andropogon saccharoides Swartz.

(6) Andropogon scoparius Nichx., Fl. Bor. Amer. 1: 57. 1803. Carolina, Michaux.

Andropogon purpurascens Muhl., in Willd., Sp. Pl. 4: 913. 1806. North America [probably Pennsylvania, since the type was received from Muhlenberg].

Andropogon flexilis Bosc; Poir., in Lam., Encycl. Sup. 1: 583. 1810. North America, Bosc [type, Carolina].

Pollinia scoparia Spreng., Pl. Pugill. 2: 13. 1815. Based on Andropogon scoparius Michx.

Andropogon halei Wood, Class-book ed. 3. 809. 1861. [Louisiana, Hale.]

Andropogon scoparius subvar. flexilis Hack., in DC., Monogr. Phan. 6: 384. 1889. Based on A. ficxilis Bosc.

Andropogon scoparius subvar. caesia Hack., in DC., Monogr. Phan. 6: 384. 1889. No locality cited. (Plants with pruinose sheaths.)

Andropogon scoparius subvar. scrpentinus Hack., in DC., Monogr. Phan. 6: 384. 1889. No locality cited. (Plants with strongly flexuous rachis.)

Andropogon scoparius subvar. simplicior Hack., in DC., Monogr. Phan. 6: 381. 1889. No lccality cited. (Sparingly branching plants.)

Sorghum scoparium Kuntze, Rev. Gen. Pl. 2: 792. 1891. Based on Andropogan scoparius Michx.

Andropogon scoparius polycladus Scribn. and Ball, U.S.Dept.Agr., Div. Agrost. Bull. 24: 40. 1901. "Braidentown" (Bradenton), Fla., Combs 1298.

Andropogon scoparius villosissimus Kearney, in Seribn. and Ball, U.S.Dept.Agr., Div. Agrost. Bull. 24: 41. 1901. Waynesboro, Miss., Kearney 136. (Foliage villous.)

Schizachyrium scoparium Nash, in Small, Fl. Southeast. U.S. 59. 1903. Based on Andropogon scoparius Michx.

Schizachyrium villosissimum Nash, in Small, Fl. Southeast. U.S. 59, 1326. 1903. Based on Andropogon scoparius villosissimus Kearney.

Schizachyrium acuminatum Nash, in Small, Fl. Southeast. U.S. 59. 1326. 1903. Starkville, Miss., Tracy in 1890 . (Sessile spikelets $10 \mathrm{~mm}$ long.)

Andropogon scoparius var. frequens F. T. Hubb. Rhodora 19: 103.1917. Block Island, R.I., Fernald, Long, and Torrey 8476.

Andropogon scoparius var, glaucescens House, N.Y. State Mus. Bull. 254: 68. 1924. West of Albany, N.Y. [House 3 in 1918].

Andropogon scoparius var. neomexicanus (Nash) Hitchc., Biol. Soc. Wash. Proc. 41: 163. 1928. Based on A. neo-mexicanus Nash.

Andropogon neo-mexicanus Nash, Bull. Torrey Bot. Club 25: S3. 1898. White Sands, Dona Ana County, N.Mex., Wooton [583] in 1897.

Schizachyrium nco-mexicanum Nash, N.Amer. Fl. 17: 107 1912. Based on Andropogon neo-mexicanus Nash.

(4) Andropogon semiberbis (Nees) Kunth, Rév. Gram. 1: Sup. XXXIX. 1830. Based on Schizachyrium semiberbe Nees.

Schizachyrium semiberbe Nees, Agrost. Bras. 336. 1829. Brazil, Sellow.

Andropogon vaginatus Presl, Rel. Haenk. 1: 336. 1830. Not A.vaginatus Ell., 1816. Mexico, Haenke.

Andropogon velatus Kunth, Rév. Gram. 1: Sup. XXXIX. 1830. Based on A. vaginatus Presl.

Andropogon semiberbis subvar. pruinatus Hack., in DC., Monogr. Phan. 6: 370. 1889. [Eau Gallie,] Fla., Curtiss 3633.

Andropogon tener Curtiss; Hack., in DC., Monogr. Phan. 6: 370. 1889. Not A. tener Kunth, 1830 . As synonym of $A$. semiberbis subvar. pruinatus Hack. Sorghum semiberbe Kuntze, Rev. Gen. Pl. 2: 792. 1891. Based on Schizachyrium semiberbe Nees.

Andropogon hirtiflorus var. semiberbis Stapf, in Dyer, Fl. Cap. 7: 337. 1898. Based on $A$. semiberbis Kunth. 
(8) Andropogon stolonifer (Nash) Hitchc., Amer. Jour. Bot. 2: 299.1915. Based on Schizachyrium stoloniferum Nash.

Schizachyrium stoloniferum Nash, in Small, Fl. Southeast. U.S. 59, 1326. 1903. Florida, Chapman.

Schizachyrium triaristatum Nash, in Small, Fl. Southeast. U.S. 60, 1326.1903. Florida, Chapman.

(26) Andropogon subtenuis Nash, in Small, Fl. Southeast. U.S. 63. 1903. Biloxi, Miss., Tracy 2243.

(2) Andropogon tener (Nees) Kunth, Rév. Gram. 1: Sup. XXXIX. 1830. Based on Schizachyrium tenerum Nees.

Schizachyrium tenerum Nees, Agrost. Bras. 336. 1829. Brazil, Sellow.

Andropogon gracilis Presl, Rel. Haenk. 1: 336. 1830. Not A. gracilis Spreng. 1825. Peru, Haenke.

Andropogon preslii Kunth, Rév. Gram. 1: Sup. XXXIX. 1830. Based on A. gracilis Presl.

Andropogon leptophyllus Trin., Mém. Acad. St. Pétersb. VI. Math. Phys. Nat. 2: 264. 1832. Based on Schizachyrium tenerum Nees.

Sorghum tenerum Kuntze, Rev. Gen. Pl. 2: 792. 1891. Based on Schizachyrium tenerum Nees.

(15) Andropogon ternarius Michx., Fl. Bor. Amer. 1: 57. 1803. Carolina, Michaux.

Andropogon argenteus Ell., Bot. S.C. and Ga. 1: 148. 1816. Not A. argentues DC., 1813. Presumably South Carolina.

Andropogon argyraeus Schult., Mant. 2: 450. 1824. Based on A. argenteus Ell. Andropogon muhlenbergianus Schult., Mant. 2: 455. 1824. Based on Muhlenberg's Andropogon no. 4. North Carolina.

Andropogon belvisii Desv., Opusc. 67. 1831. No locality eited.

Sorghum argenteum Kuntze, Rev. Gen. Pl. 2: 790. 1891. Based on Andro. pogon argenteus Ell.

Andropogon argyraeus var. tenuis Vasey, Contrib. U.S.Natl.Herb. 3: 12.1892. Texas [Dallas, Reverchon 1161].

Andropogon argyraeus macrus Scribn., U.S.Dept.Agr., Div. Agrost. Bull. 1: 20. 1895. [Jacksonville,] Fla., Curtiss 4952. Published as new by Scribner and Ball (Hackel given as author) U.S.Dept.Agr., Div. Agrost. Bull. 24: 39. 1900, Tracy 3891 cited as type.

Andropogon elliottii glaucescens Seribn., Bull. Torrey Bot. Club 23: 145. 1896. Eustis, Fla., Nash 473.

Andropogon scribnerianus Nash, Bull. N.Y.Bot.Gard. 1: 432. 1900. Based on A. elliottii glaucescens Scribn.

Andropogon mississippiensis Seribn. and Ball, U.S.Dept.Agr., Div. Agrost. Bull. 24: 40. 1901. Biloxi, Miss., Tracy 3818.

(18) Andropogon tracyi Nash, Bull. N.Y.Bot.Gard. 1: 433.1900. Columbus, Miss., Tracy 3083.

(23) Andropogon virginicus L., Sp. Pl. 1046. 1753. America. The type specimen bears no data indicating origin. Linnaeus had also a specimen from Gronovius, Clayton 460 from Virginia.

Cinna lateralis Walt., Fl. Carol. 59. 1788. South Carolina.

Andropogon dissitiflorus Michx., Fl. Bor. Amer. 1: 57. 1803. Carolina to Florida, Michaux.

Anatherum virginicum Spreng., Pl. Pugill. 2: 16. 1815. Based on Andropogon virginicus L.

Andropogon vaginatus Ell., Bot. S.C. and Ga. 1: 148. 1816. Presumably South Carolina.

Andropogon tetrastachyus Ell., Bot. S.C. and Ga. 1: 150. pl. 8. f. 4. 1816. Charleston, S.C.

Holcus virginicus Muhl.; Steud., Nom. Bot. ed. 2. 1: 773. 1840, as synonym of Andropogon virginicus L.

Andropogon eriophorus Scheele, Flora 27: 51. 1844. Not A. eriophorus Willd. 1806. Charles Town, W.Va.

?Andropogon curtisianus Steud., Syn. Pl. Glum. 1: 390. 1854. Carolina, M. A. Curtis. Referred by Hackel to A. virginicus var. tetrastachyus. Description does not well apply to any of our species.

Andropogon virginicus var. vaginatus Wood, Class-book 808. ed. 3. 1861. Based on $A$. vaginatus Ell.

Andropogon virginicus var. viridis Hack., in DC., Monogr. Phan. 6: 410. 1889. Group name for three subvarieties, 1. genuinus being $A$. virginicus $L$.

Andropogon virginicus var. tetrastachyus Hack., in DC., Monogr. Phan. 6: 411. 1889. Based on A. tetrastachyus Ell. 
Sorghum virginicum Kuntze, Rev. Gen. Pl. 2: 792. 1891. Based on Andropogon virginicus $\mathrm{L}$.

Dimeiostemon vaginatus Raf.; Jacks., Ind. Kew. 2: 760. 1893, as synonym of Andropogon virginicus $\mathrm{L}$.

Dimeiostemon tetrastachys Raf.; Jacks., Ind. Kew. 2: 760. 1893, as synonym of Andropogon virginicus $\mathrm{L}$.

Andropogon virginicus var. Glaucopsis (Ell.) Hitche., Amer. Jour. Bot. 21: 139. 1934. Based on A. macrourus var. glaucopsis Ell.

Andropogon macrourus var. glaucopsis Ell., Bot. S.C. and Ga. 1: 150. 1816. Presumably South Carolina.

Andropogon glaucopsis Steud., Nom. Bot. ed. 2. 1: 91. 1840. Not $A$. glaucopsis Steud. 1854. Based on A. macrourus var. glaucopsis Ell. Published as new by Nash, in Small, Fl. Southeast. U.S. 62.1903 , same basis.

Andropogom virginicus var. dealbatus Mohr; Hack., in DC., Monogr. Phan. 6: 411. 1889. Mobile, Ala., Mohr [in 1894].

Andropogon glomeratus var. glaucopsis Mohr, Bull. Torrey Bot. Club 24: 21. 1897. Based on A. macrourus var. glaucopsis Ell.

ANDROPOGON virginicus var. HiRsutior (Hack.) Hitchc., Jour. Wash. Acad. Sci. 23: 456. 1933. Based on A. macrourus var. hirsutior Hack.

Andropogon macrourus var. hirsutior Hack., in DC., Monogr. Phan. 6: 409. 1889. Mobile, Ala., Mohr [October 28, 1884].

Andropogon virginicus var. viridis subvar. ditior Hack., in DC., Monogr. Phan. 6: 411. 1889. [Jacksonville], Fla., Curtiss 3639d.

Andropogon macrourus var. viridis Curtiss; Hack., in DC., Monogr. Phan. 6: 411. 1889, as synonym of A. virginicus var. ditior Hack. Florida, Curtiss N.Amer. Pl. 3639d.

Andropogon macrourus var. pumilus Vasey, Bot. Gaz. 16: 27. 1891. [Seminole Cave, Val Verde County], western Texas, Nealley [256 in 1890].

Andropogon macrourus var. viridis Chapm.; Vasey, Contrib. U.S.Natl.Herb. 3: 11. 1892. Florida, Chapman.

Andropogon glomeratus var. pumilus Vasey; L. H. Dewey, Contrib. U.S.NatI. Herb. 2: 496. 1894. Presumably based on A. macrourus var. pumilus Vasey.

Andropogon glomeratus var. hirsutior Mohr, Bull. Torrey Bot. Club 24: 21. 1897. Based on A. macrourus var. hirsutior Hack.

(28) Andropogon wrightii Hack., Flora 68: 139. 1885. [Silver City,] N.Mex., Wright 2104.

Sorghum wrightii Kuntze, Rev. Gen. PI. 2: 792. 1891. Based on Andropogon wrightii Hack.

Amphilophis wrightii Nash, N.Amer. Fl. 17: 124. 1912. Based on Andropogon wrightii Hack.

(119) ANTHAENANTIA Beauv.

(1) Anthaenantia rufa (Ell.) Schult., Mant. 2: 258. 1824. Based on Aulaxanthus rufus Ell.

Aulaxanthus rufus Ell., Bot. S.C. and Ga. 1: 103. 1816. South Carolina.

Aulaxia rufa Nutt., Gen. Pl. 1: 47. 1818. Based on Aulaxanthus rufus Ell.

Panicum rufum Kunth, Rév. Gram. 1: 35. 1829. Based on Aulaxanthus rufus Ell.

Monachne rufa Bertol., Mem. Accad. Sci. Bologna 2: 596. pl. 41. f. 1. 1850. Based on Panicum rufum Kunth.

Leptocoryphium drummondii C. Muell., Bot. Ztg. 19: 314. 1861. Louisiana, Drummond.

Panicum ciliatiflorum var. rujum Wood, Amer. Bot. and Flor. pt. 2: 392. 1870. [Southern States.]

Panicum aulaxanthus Kuntze, Rev. Gen. PI. 32: 361. 1898. Based on Aulaxanthus rufus Ell.

Anthaenantia rufa scabra Nash, in Small, Fl. Southeast. U.S. 79. $1903 . \quad$ South Carolina to Louisiana.

(2) Anthaenantia villosa (Michx.) Beauv., Ess. Agrost. 48, 151. pl. 10. f. 7. 1812. Based on Phalaris villosa Michx.

Phalaris villosa Michx., F1. Bor. Amer. 1: 43. 1803. Carolina, Michaux.

Aulaxanthus ciliatus EIl., Bot. S.C. and Ga. 1: 102. 1816. South Carolina. Panicum erianthum Poir., Encycl. Sup. 4: 284. 1816. Carolina, Bosc.

Panicum hirticalycinum Bose; Roem. and Schult., Syst. Veg. 2: 468. 1817, as synonym of Anthaenantia villosa Beauv. 
Aulaxia ciliata Nutt., Gen. Pl. 1: 47. 1818. Based on Aulaxanthus ciliatus Ell.

Panicum hirticalycum Bosc; Spreng., Syst. Veg. 1: 315. 1825, as synonym of P. crianthum Poir.

Oplismenus erianthos Kunth, Rév. Gram. 1: 45. 1829. Based on Panicum erianthum Poir.

Panicum ignoratum Kunth, Rév. Gram. 2: 217. pl. 20. 1830. Based on Phalaris villosa Michx.

Leptocoryphium obtusum Steud., Syn. Pl. Glum. 1: 34. 1854. Louisiana, Riehl.

Panicum ciliatiflorum Wood, Class-book pt. 2: 786. 1861. Not P. ciliatiflorum Kunth, 1829. Southern States.

Panicum anthaenantia Kuntze, Rev. Gen. Pl. 32: 361. 1898. Based on Anthaenantia villosa Beauv.

\section{ANTHEPHORA Schreb.}

Anthephora hermaphrodita (I.) Kuntze, Rev. Gen. Pl. 2: 759. 1891. Based on

Tripsacum hermaphroditum L.
Tripsacum hermaphroditum L., Syst. Nat. ed. 10. 2: 1261. 1759. Jamaica. Anthephora elegans Schreb., Beschr. Gräs. 2: 105. pl. 44. 1810. Jamaica.

(33) ANTHOCHLOA Nees

(1) Anthochloa colusana (Davy) Scribn., U.S. Dept. Agr., Div. Agrost. Bull. 17: 221. f. 517. 1899. Based on Stapfia colusana Davy.

Stapfia colusana Davy, Erythea 6: 110. pl. 3. 1898. Colusa County, Calif., Dany.

Neostapfia colusana Davy, Erythea 7: 43. 1899. Based on Stapfia colusana Davy.

Davyella colusana Hack., Oesterr. Bot. Ztschr. 49: 134. 1899. Based on Stapfia colusana Davy.

\section{(109) ANTHOXANTHUM L.}

(2) Anthoxanthum aristatum Boiss., Voy. Bot. Esp. 2: 638. 1845. Southern Europe.

Anthoxanthum puelii Lec. and Lam., Cat. Pl. France 385. 1847. France. Anthoxanthum pueliz Lec. and Lam.i Cat. Pl. France 385. 1847. France. 21. 1854. Based on A. puelii Lec. and Lam.

Anthoxanthum gracile Bivon., Stirp. Rar. Sic. 1: 13. pl. 1. f. 2. 1813. Italy.

(1) Anthoxanthum odoratum L., Sp. Pl. 28. 1753. Europe.

Anthoxanthum odoratum var. altissimum Eaton and Wright, Man. Bot. North. States 10. 1817. Probably Connecticut, Ives.

Xanthonanthos odoratum St. Lag., Amn. Soc. Bot. Lyon 7: 119. 1880. Based on Anthoxanthum odoratum L.

\section{(85) ARISTIDA L.}

(14) Aristida adscensionis L., Sp. Pl. 82. 1753. Ascension Island.

Aristida interrupta Cav., Icon. Pl. 5: 45. pl. 471. f. 2. 1799. Mexico.

Chaetaria ascensionis Beauv., Ess. Agrost. 30, 151, 158. 1812. Based on $A$. adscensionis $\mathrm{L}$.

Aristida bromoides H.B.K., Nov. Gen. and Sp. 1: 122. 1816. Ecuador, Humboldt and Bonpland.

Aristida coarctata H.B.K., Nov. Gen. and Sp. 1: 122. 1816. Mexico, Humboldt and Bonpland.

Chaetaria bromoides Roem. and Schult., Syst. Veg. 2: 396. 1817. Based on Aristida bromoides H.B.K.

Chaetaria coarctata Roem. and Schult., Syst. Veg. 2: 396. 1817. Based on Aristida coarctata H.B.K.

Aristida fasciculata Torr., Ann. Lyc. N.Y. 1: 154. 1824. Canadian River [Texas or Oklahoina], James.

Chaetaria fasciculata Schult., Mant. 3 (Add. 1):578. 1827. Based on Aristida fasciculata Torr.

Aristida nigrescens Presl, Rel. Haenk. 1: 223. 1830. Mexico, Haenke.

Aristida dispersa Trin. and Rupr., Mém. Acad. St. Pétersb. VI. Sci. Nat. $5^{1}$ : 129. 1842. Chile. 
Aristida dispersa var. bromoides Trin. and Rupr., Mém. Acad. St. Pétersb. VI. Sci. Nat. $5^{1}$ : 130 . 1842. Based on A. bromoides H.B.K.

Aristida dispersa var. coarctata Trin. and Rupr., Mém. Acad. St. Pétersb. VI. Sci. Nat. $5^{1}: 130 . \quad 1842 . \quad B a s e d$ on A. coarctata H.B.K.

Aristida maritima Steud., Syn. PI. Glum. 1: 137. 1854. Guadeloupe.

Aristida schaffneri Fourn., Mex. Pl. 2: 78. 1886. Mexico, Schaffner.

Aristida grisebachiana Fourn., Mex. Pl. 2: 78. 1886. Mexico, Schaffner 175 iu part, 53.

Aristida grisebachiana var. decolorata Fourn., Mex. Pl. 2: 78. 1886. Mexico, Liebmann 663, 664.

Aristida adscensionis var. coarctata Kuntze, Rev. Gen. Pl. 3: 340. 1898. Based on A. coarctata H.B.K.

Aristida americana bromoides Scribn. and Merr., U.S.Dept.Agr., Div. Agrost. Circ. 32: 5. 1901. Based on A. bromoides H.B.K.

Aristida debilis Mez, Repert. Sp. Nov. Fedde 17: 151. 1921. Venezuela, Moritz [638]. [Moritz 1522 named $A$. debilis by Mez is different. It has been named A. moritzii Henr.] Jamaica, MacNab.

Aristida adscensionis var. bromoides Henr., Med. Rijks Herb. Leiden 54: 62. 1926. Based on A. bromoides H.B.K.

Aristida adscensionis var. mexicana Hack.; Henr., Med. Rijks Herb. Leiden 54A: 265. 1927, as synonym of A. adscensionis. Morelia, Mexico, Arsène.

(34) Aristida affinis (Schult.) Kunth, Rév. Gram. 1: 61. 1829. Based on Chaetaria affinis Schult.

Aristida racemosa Muhl., Descr. Gram. 172. 1817. Not A. racemosa Spreng., 1807. Presumably Pennsylvania.

Chaetaria affinis Schult., Mant. 2: 210. 1824. Based on Aristida racemosa Muhl.

Aristida purpurascens var. alabamensis Trin. and Rupr., Mém. Acad. St. Pétersb. VI. Sci. Nat. 51: 102.1842. Alabama.

Aristida virgata var. palustris Chapm., Fl. South. U.S. 555. 1860. Western Florida.

Aristida palustris Vasey, Descr. Cat. Grasses U.S. 35. 1885. Based on A. virgata var. palustris Chapm.

(29) Aristida arizonica Vasey, Bull. Torrey Bot. Club 13: 27. 1886. Arizona [Rusby 875; but the specimen bearing the name and diagnosis in Vasey's script was collected by G. R. Vasey at Las Vegas, N.Mex.].

(16) Aristida barbata Fourn., Mex. Pl. 2: 78. 1886. Valley of Mexico, Schaffiner 513.

Aristida havardii Vasey, Bull. Torrey Bot. Club 13: 27. 1886. Western Texas, Havard [28]. The date of publication is assumed to be subsequent to that of A. barbata.

(8) Aristida basiramea Engelm.; Vasey, Bot. Gaz. 9: 76. 1884. Minneapolis, Minn., Upham.

(3) Aristida californica Thurb.; S. Wats., Bot. Calif. 2: 289. 1880. California, Colorado Desert, Schott; Fort Mohave, Cooper.

Aristida jonesii Vasey, Contrib. U.S. Natl. Herb. 3: 48. 1892, as synonym of A. californica. [The Needles, Calif., Jones 68a.]

Aristida californica var. fugitiva Vasey, Contrib. U.S. Natl. Herb. 3: 49. 1892. Colorado Desert, California, Orcutt [1486].

(39) Aristida condensata Chapm., Bot. Gaz. 3: 19. 1878. Florida [Apalachicola, Chapman].

Aristida stricta var. condensata Vasey, Contrib. U.S. Natl. Herb. 3: 45. 1892. Based on A. condensata Chapm.

Aristida combsii Scribn. and Ball, U.S.Dept. Agr., Div. Agrost. Bull. 24: 43. f. 17. 1901. Grasmere, Fla., Combs and Baker 1069.

Aristida condensata var. combsii Henr., Med. Rijks Herb. Leiden 54: 108. 1926. Based on A. combsii Scribn. and Ball.

(10) Aristida curtissii (A. Gray) Nash, in Britton, Man. 94. 1901. Based on A. dichotoma var. curtissii A. Gray.

Aristida dichotoma var. curtissii A. Gray, Man. ed. 6. 640. 1890. [Bedford County, Va., Curtiss.]

(1) Aristida desmantha Trin. and Rupr., Mém. Acad. St. Pétersb. VI. Sci. Nat. $5^{1}: 109 . \quad 1842 . \quad$ Texas, Drummond 285 [type], 333.

(9) Aristida dichotoma Michx., Fl. Bor. Amer. 1: 41. 1803. Lincoln, N.C., Michaux.

Curtopogon dichotomus Beauv., Ess. Agrost. 32, 159. pl. 8. f. 7. 1812. Based on Aristida dichotoma Michx. 
Cyrtopogon dichotomus Spreng., Syst. Veg. 1: 266. 1825. Based on Aristida dichotoma Michx.

Avena setacea Muhl.; Trin., Mém. Acad. St. Pétersb. VI. Math. Phys. Nat. 1: 87. 1830. Not A. setacea Vill., 1787. As synonym of Aristida dichotoma Michx.

Avena paradoxa Willd.; Kunth, Enum. Pl. 1: 188. 1833, as synonym of Aristida dichotoma Michx.

(17) Aristida divaricata Humb. and Bonpl.; Willd., Enum. Pl. 1: 99.1809. Mexico, Humboldt and Bonpland.

Chataria divaricata Beauv., Ess. Agrost. 30, 158. 1812. Based on type of Aristida divaricata Humb. and Bonpl.

Aristida humboldtiana Trin. and Rupr., Mém. Acad. St. Pétersb. VI. Sci. Nat. $5^{1}: 118$. 1842. Based on type of A. divaricata Humb. and Bonpl.

Aristida palmeri Vasey, Bull. Torrey Bot. Club 10: 42. 1883. Southern Arizona, Palmer.

Aristida lemmoni Scribn., N.Y. Acad. Sci. Trans. 14: 23. 1894. Arizona [Fort Huachuca, Hilcox].

(27) Aristida fendieriana Steud., Syn. Pl. Glum. 1: 420. 1855. New Mexico, Fendler 973.

Aristida purpurea var. fendleri Vasey, Cat. Pl.Survey W.100th Merid.55. 1874. Name only.

Aristida purpurea var. fendleriana Vasey, Contrib. U.S. Natl. Herb. 3: 46. 1892. Based on A. fendlcriana Steud.

Aristida fasciculata var. fendleriana Vasev; L. H. Dewey, Contrib. U.S. Natl. Herb. 2: 515. 1894. Based on A. fendleriana Steud.

Aristida longiseta fendleriana Merr., U.S. Dept. Agr., Div. Agrost. Circ. 34: 5. 1901. Based on A. fendlcriana Steud.

Aristida subuniflora Nash, in Small, Fl. Southeast. U.S. 116. 1903. New Mexieo, Vasey.

(6) Aristida floridana (Chapm.) Vasey, Descr. Cat. Grasses U.S. 35. 1885. Based on Streptachne floridana Chapm.

Streptachne floridana Chapm., Fl. South. U.S. 554. 1860. South Florida,

Blodgett.
Ortachne floridana Nash, in Small, Fl. Southeast. U.S. 119. 1903. Based on Streptachne floridana Chapm.

(4) Aristida glabrata (Vasey) Hitche., Contrib. U.S. Natl. Herb. 22: 522. 1924. Based on A. californica var. glabrata Vasey.

Aristida californica var. major Vasey, Calif. Acad. Sci. Proc. II. 2: 212. 1889. Name only [Nagdalena Island, Brandegee in 1889].

Aristida californica var. glabrata Vasey, Calif. Acad. Sci. Proc. II. 3: 178. 1891. San José del Cabo, Baja California, [Brandegee 34 in 1890].

(22) Aristida glauca (Nees) Walp., Ann. Bot. [London] 1: 925. 1849. Based on Chaetaria glauca Nees.

Chactaria glauca Nees, Linnaea 19: 688. 1847. Mexico, Aschenborn 251.

Aristida reverchoni Vasey, Bull. Torrey Bot. Club 13: 52. 1886. Crockett County, Tex., Reverchon.

Aristida stricta var. nealleyi Vasey, Contrib. U.S. Natl. Herb. 1: 55. 1890. Chenate Mountains, Tex., Nealley [709].

Aristida nealleyi Vasey, Contrib. U.S. Natl. Herb. 3: 45. 1892. Based on A. stricta var. nealleyi Vasey.

Aristida reverchoni var. augusta [error for angusta] Vasey, Contrib. U.S. Natl. Herb. 3: 46. 1892. Comanche Peak, Tex., Reverchon.

Aristida vaseyi Woot. and Standl., N.Mex. Coll. Agr. Bull. 81: 55. 1912. Based on $A$. reverchoni var. augusta Vasey.

(40) Aristida gyrans Chapm., Bot. Gaz. 3: 18. 1878. Roberts Key, Caximbas Bay, Fla. [Chapman].

(18) Aristida hamulosa Henr., Med. Rijks Herb. Leiden 54:219. 1926. Tucson, Ariz., Toumey.

Aristida humboldtiana var. minor Vasey, Contrib. U.S. Nat1. Herb. 3: 47. 1892. Texas [Nealley].

Aristida imbricata Henr., Med. Rijks Herb. Leiden 54A: 253. 1927. El Paso, Tex., Griffiths 7433.

Aristida gentilis var. breviaristata Henr., Med. Rijks Herb. Leiden 54A: 255. 1927. Santa Rita Mountains, Ariz., Griffiths 7270.

(15) Aristida intermedia Scribn. and Ball, U.S. Dept. Agr., Div. Agrost. Bull. 24: 44. f. 18. 1901. Biloxi, Miss., Kearney 204. 
(28) Aristida lanosa Muhl.; Ell., Bot. S.C. and Ga. 1: 143. 1816. South Carolina.

Aristida lanata Poir., in Lam., Encycl. Sup. 1: 453. 1810. Not A. lanata Forsk., 1775. Carolina, Bosc.

Aristida gossypina Bosc; Beauv., Ess. Agrost. 30, 152. 1812. Name only. Chaetaria gossypina Bosc; Beauv., Ess. Agrost. 30, 152, 158. 1812. Name only; Roem. and Schult., Syst. Veg. 2: 391. 1817. Based on Aristida lanata Poir.

Aristida lanuginosa Bosc; Trin., Mém. Acad. St. Pétersb. VI. Sci. Nat. ${ }^{1}$ : 46. 1836, name only; Clarion in Trin. and Rupr., Mém. Acad. St. Pétersb. VI. Sci. Nat. 51: 103. 1842 . North America, Bosc.

Moulinsia lanosa Raf.; Jacks., Ind. Kew. 3: 267. 1894, as synonym of Aristida lanosa Muhl.

(13) Aristida longespica Poir., in Lam., Encycl. Sup. 1: 452. 1810. Carolina, Bosc.

Aristida gracilis Ell., Bot. S.C. and Ga. 1: 142. pl. 8. f. 3. 1816. Charleston, S.C.

Aristida geniculata Raf., Amer. Monthly Mag. 2: 119. 1817. Long Island, N.Y.

Curtopogon gracilis Nees; Trin. and Rupr., Mém. Acad. St. Pétersb. VI. Sci. Nat. $5^{1}$ : 101.1842 , as synonym of Aristida gracilis Ell.

Aristida gracilis var. depauperata A. Gray, Man. ed. 5. 618. 1867. Philadelphia, Smith.

Aristida simplicifolia [error for simpliciflora] var. texana Vasey, Contrib. U.S. Natl. Herb. 3: 44. 1892. Texas, [Marshall, Riggs 79].

Trixostis gracilis Raf.; Jacks., Ind. Kew. 4: 1131. 1S95, as synonym of Aristida gracilis Ell.

Aristida longespica var. geniculata Fernald, Rhodora 35: 318. 1933. Based on A. geniculata Raf.

(26) Aristida longiseta Steud., Syn. Pl. Glum. 1: 420. 1855. New Mexico, Fendler 978.

Aristida curtiseta Buckl., Acad. Nat. Sci. Phila. Proc. 1862: 92.1863. Northern Texas [Buckley. Spikelets of type aborted by smut]. (Erroneously given in Index Kewensis as A. breviseta.)

Aristida purpurea var. longiseta Vasey, in Wheeler, Rept. U.S. Survey 100 th Merid. 6: 286. 1878. Based on A. longiseta Steud.

Aristida fasciculata var. nuttallii Thurb.; Beal, Grasses N.Amer. 2: 208. 1896. Based on A. longiseta Steud., though Thurber's name probably referred to A. pallens as used by Nuttall.

Aristida longiseta var. Rariflora Hitchc., Contrib. U.S. Natl. Herb. 22: 565. 1924. Tom Green County, Tex., Tweedy. (Published as A. longiscta rariflora.)

Aristida rariflora Henr., Med. Rijks Herb. Leiden 54A: 314. 1927. Based on A. longiseta rariflora Hitchc.

Aristida longiseta var. Robusta Merr., U.S.Dept.Agr., Div. Agrost. Circ. 34: 5. 1901. Indian Creek, Mont., Scribner 336. (Published as A. longiseta robusta.)

Aristida purpurea robusta Piper, Contrib. U.S. Natl. Herb. 11: 107. 1906. Based on A. longiseta robusta Merr.

(37) Aristida mohrii Nash, Bull. N.Y. Bot. Gard. 1: 436. 1900. Spring Hill, near Mobile, Ala., Mohr.

(11) Aristida oligantha Michx., Fl. Bor. Amer. 1: 41. 1803. Illinois, Michaux.

?Aristida adscensionis [L. misapplied by] Walt., Fl. Carol. 74. 1788. South Carolina.

Chaetaria olygantha Beauv., Ess. Agrost. 30, 158. 1812. Based on Aristida oligantha Michx.

Aristida pallens [Cav. misapplied by] Nutt., Gen. Pl. 1: 51. 1818. Fort Mandan, N.Dak. [Nuttall].

Aristida micropoda Trin. and Rupr., Mém. Acad. St. Pétersb. VI. Sci. Nat. $5^{1}:$ 107. 1842. Arkansas, Beyrich.

Aristida macrochaeta Steud., Syn. Pl. Glum. 1: 134. 1854. Virginia, M. A. Curtis.

Aristida pauciflora Buckl., Acad. Nat. Sci. Phila. Proc. 1862: 92. 1863. Northern Texas [Buckley].

Aristida oligantha var. nervata Beal, Grasses N.Amer. 2: 202. 1896. Grants Pass, Oreg., Howell.

16 Med. Rijks Herb. L,eiden 54A: 439, 1927. (Critical Revis. Aristida.)

$55974^{\circ}-35--51$ 
(7) Aristida orcuttiana Vasey, Bull. Torrey Bot. Club 13: 27. 1886. Hansen's Ranch, Baja California, Orcutt [507].

Aristida hypomegas Mez, Repert. Sp. Nov. Fedde 17: 146. 1921. New Mexico, Bigelow [34].

This species has been referred to A. schiediana Trin. and Rupr., a Mexican species not known from the United States.

(20) Aristida pansa Woot. and Standl., Contrib. U.S.Natl.Herb. 16: 112. 1913. Tortugas Mountain, N.Mex., Wooton.

(33) Aristida parishii Hitchc., in Jepson, Fl. Calif. 1: 101. 1912. Agua Caliente, Calif., Parish Brothers 1029a.

(19) Aristida patula Chapm.; Nash, Bull. Torrey Bot. Club 23: 98. 1896. Based on A. scabra as described by Chapman (Fl. South. U.S. ed. 2. 663. 1883), not Kunth. Florida, Chapman.

(32) Aristida purpurascens Poir., in Lam., Encycl. Sup. 1: 452. 1810. South Carolina, Bosc.

Chaetaria purpurascens Beauv., Ess. Agrost. 30, 152, 158. 1812. Based on Aristida purpurascens Poir.

Aristida elliottiana Steud., Syn. Pl. Glum. 1: 133. 1854. Based on A. stricta as described by Elliott, not Michx.

Aristida geyeriana Steud., Syn. Pl. Glum. 1: 133, 1854. Illinois, Geyer.

Aristida stricta Steud., Syn. Pl. Glum. 1: 133. 1854. Not A. stricta Michx., 1803. As synonym of A. geyeriana Steud. Illinois.

Aristida purpurascens var. minor Vasey, Contrib. U.S.Natl.Herb. 1: 46. 1892. [Horn Island, Miss., Tracy 1564.]

Aristida purpurascens glaucissima Kearney; Scribn. and Ball, U.S.Dept.Agr., Div. Agrost. Bull. 24: 45. 1901. Biloxi, Miss., Kearney 321.

(23) Aristida purpurea Nutt., Amer. Phil. Soc. Trans. (n.s.) 5: 145.1837. Red River, Ark. [Nuttali].

Aristida purpurea var. hookeri Trin. and Rupr., Mém. Acad. St. Pétersb. VI. Sci. Nat. 51: 107. 1842. Texas, Drummond 293.

Aristida purpurea var. berlandieri Trin. and Rupr., Mém. Acad. St. Pétersb. VI. Sci. Nat. 5': 107. 1842. Bejar [Bexar], Tex., Berlandier 1777.

Aristida aequiramea Scheele, Linnaea 22: 343. 1849. New Braunfels, Tex., Lindheimer [562].

Aristida filipendula Buckl., Acad. Nat. Sci., Phila. Proc. 1S62: 93.1863. Western Texas [Buckley, the locality being northern Texas].

Aristida purpurea var. californi[c]a Vasey, Contrib. U.S.Natl.Herb. 3: 47. 1892. California [Capay Valley, Lemmon 5474].

Aristida fasciculata var. californica Vasey; L. H. Dewey, Contrib. U.S.Natl. Herb. 2: 515. 1894. Presumably based on $A$. purpurea var. californica Vasey.

Aristida fasciculata var. hookeri L. H. Dewey, Contrib. U.S.Natl.Herb. 2: 515. 1894. Presumably based on A. purpurea var. hookeri Trin. and Rupr.

Aristida longiseta hookeri Merr., U.S.Dept.Agr., Div. Agrost. Circ. 34: 5. 1901. Based on A. purpurca var. hookeri Trin. and Rupr.

Aristida purpurea aequiramea Merr., U.S.Dept.Agr., Div. Agrost. Circ. 34: 7. 1901. Based on A. aequiramea Scheele.

Aristida purpurea capillarifolia Merr., U.S.Dept.Agr., Div. Agrost. Circ. 34: 8. 1901. Texas, Nealley.

Aristida berlandieri Hitche., Contrib. U.S.Natl.Herb. 17: 280. 1913. Based on $A$. purpurea var. berlandieri Trin. and Rupr.

Aristida purpure a var. laxiflora Merr., U.S.Dept.Agr., Div. Agrost. Circ. 34: 8. 1901. Texas, Reverchon 12. (Published as A. purpurea laxiflora.)

(12) Aristida ramosissima Engelm.; A. Gray, Man. ed. 2. 550. 1856. Illinois, Engelmann [type] and Kentucky.

Arisida ramosissima var. uniaristata A. Gray, Man. ed. 5. 618. 1867. Odin, Ill., Vasey.

Aristida ramosissima var. chaseana Henr., Med. Rijks Herb. Leiden. 54B: 498. 1928. Lake Charles, La., Chase 4411.

(31) Aristida rhizomophora Swallen, Jour. Wash. Acad. Sci, 19: 196. f. 1. 1929. North of Lake Okeechobee, Fla., Weatherwax 1081.

(24) Aristida roemeriana Scheele, Linnaea 22: 343. 1849. New Braunfels, Tex., Römer.

Aristida muhlenbergioides Fourn., Mex. Pl. 2: 79. 1886. Mexico, Virlet 1424, Karwinsky 1008. 
Aristida purpurea var. micrantha Vasey, Contrib. U.S.Natl.Herb. 3: 47. 1892. Western Texas [Nealley].

Aristida fasciculata var. micrantha Vasey; L. H. Dewey, Contrib. U.S.Natl. Herb. 2: 515. 1894. Presumably based on A. purpurea var. micrantha Vasey.

Aristida micrantha Nash, in Small, Fl. Southeast. U.S. 117. 1903. Based on A. purpurea var. micrantha Vasey.

(36) Aristida simpliciflora Chapm., Bot. Gaz. 3: 18. 1878. West Florida [Chapman].

(21) Aristida spiciformis Ell., Bot. S.C. and Ga. 1: 141. 1816. Presumably South Carolina.

Aristida stricta Muhl., Descr. Gram. 174. 1817. Not A. stricta Michx. 1803. Georgia.

Aristida squarrosa Trin., in Spreng., Neu. Entd. 2: 62. 1821. North America.

Chataria squarrosa Schult., Mant. 3 (Add. 1): 577. 1827. Based on Aristida squarrosa Trin.

(30) Aristida stricta Michx., Fl. Bor. Amer. 1: 41. 1803. South Carolina, Michaux.

Chataria stricta Beauv., Ess. Agrost. 30, 152, 158. 1812. Based on Aristida stricta Michx.

Aristida beyrichiana Trin. and Rupr., Mém. Acad. St. Pétersb. VI. Sci. Nat. 51: 104. 1842. Georgia and Arkansas, Beyrich.

(38) Aristida tenuispica Hitchc., Contrib. U.S.Natl.Herb. 22: 581. 1224. Hillsboro, Fla., Combs 1384.

(5) Aristida ternipes Cav., Icon. Pl. 5: 46. 1799. Panama, Née.

Streptachne scabra H.B.K., Nov. Gen. and Sp. 1: 124. pl. 40. 1815. Near Toluca, Mex., Humboldt and Bonpland.

Streptachne tenuis H.B.K., Nov. Gen. and Sp. 1: 124. 1815. Venezuela, Humboldt and Bonpland.

Aristida scabra Kunth, Rév. Gram. 1: 62. 1829. Based on Streptachne scabra H.B.K.

Aristida tenuis Kunth, Rév. Gram. 1: 62. 1829. Based on Streptachne tenuis H.B.K.

Stipa tenuis Willd., Steud., Nom. Bot. ed. 2. 2: 643. 1841, as synonym of Aristida tenuis.

Muhlenbergia scabra Trin. and Rupr., Mém. Acad. St. Pétersb. VI. Sci. Nat. 51: 183. 1842. Based on Aristida scabra Kunth.

Streptachne cubensis A. Rich., in Sagra, Hist. Cuba 11: 311. 1850. Cuba, Sagra.

Ortachne scabra Fourn., Bull. Soc. Bot. France 27: 295. 1880. Based on Streptachne scabra H.B.K.

Ortachne tenuis Fourn., Bull. Soc. Bot. France 27: 295. 1880. Based on Streptachne tenuis H.B.K.

Aristida TERnipes var. MiNor (Vasey) Hitchc., Jour. Wash. Acad. Sci. 23: 453. 1933. Based on A. schiedeana var. minor Vasey.

Aristida schiedeana var. minor Vasey, Bull. 'Torrey Bot. Club 13: 28. 1886. Arizona, Pringle [type]; Bowie, Jones.

Aristida divergens Vasey, Contrib. U.S. Natl. Herb. 3: 48. 1892. Based on A. schiedeana var. minor Vasey.

Aristida ternipes divergens Hitchc., Contrib. U.S. Natl. Herb. 22: 525. 1924. Based on $A$. divergens Vasey.

(2) Aristida tuberculosa Nutt, Gen. Pl. 1: 57. 1818. Near Augusta, Ga.

Chaetaria tuberculosa Schult., Mant. 2: 211. 1824. Based on Aristida tuberculosa Nutt.

(35) Aristida virgata Trin., in Spreng., Neu. Entd. 2: 60. 1821. North America [Philadelphia, Pa.].

Aristida stricta Steud., Nom. Bot. ed. 2. 1: 132. 1840. Not A. stricta Michx., 1803. As synonym of $A$. virgata Trin.

Aristida perennis Panz., in Trin. and Rupr., Mém. Acad. St. Pétersb. VI. Sci. Nat. 51: 104. 1842. South Carolina. (Fide Henrard.) ${ }^{16}$

Aristida gracilis var. virgata Wood, Amer. Bot. and Flor. pt. 2: 389. 1870. Presumably based on A. virgata Trin.

Aristida purpurascens var. depauperata Vasey; Beal, Grasses N. Amer. 2: 201. 1896. [Ocean Springs,] Miss., Tracy [107].

Aristida chapmaniana Nash, in Small, Fl. Southeast. U.S. 118, 1327. 1903. Apalachicola, Fla., Chapman. 
(25) Aristida wrightii Nash, in Small, Fl. Southeast. U.S. 116. 1903. Dallas, Tex., Reverchon 1061.

\section{(58) ARRHENATHERUM Beauv.}

(1) Arrhenatherum elatius (L.) Mert. and Koch, in Roehl., Deut. Fl. 1: 546. 1823. Based on Avena elatior L.

Avena elatior L., Sp. Pl. 79. $1753 . \quad$ Europe.

Holcus avenaceus Scop., Fl. Carn. ed. 2. 2: 276. 1772. Based on Avena clatior L.

Avena elata Salisb., Prodr. Stirp. 23. 1796. Not A. elata Forsk., 1775. Based on $A$. elatior L.

Arrhenatherum avenaceum Beauv., Ess. Agrost. 55, 152, 164. pl. 11. f. 5. 1812. Based on Holcus avenaceus Scop.

Arrhenatherum americanum Beauv., Ess. Agrost. 56, 152, 1812. Name only. Hordeum avenaceum Wigg.; Beauv., Ess. Agrost. 165. 1812. Name only, referred to Arrhenatherum. Steud., Nom. Bot. 413. 1821, as synonym of Holcus avenaceus Scop.

Arrhenatherdm elatius var. bulbosum (Willd.) Spenner, Fl. Friburg. 1: 113. 1825. Based on Avena bulbosa Willd.

Avena tuberosa Gilib., Exerc. Phyt. 2: 538. 1790. France.

Avena bulbosa Willd., Ges. Naturf. Freund. Berlin Neue Schrift. 2: 116.1799. Switzerland.

Holcus bulbosus Schrad., Fl. Germ. 1: 248. 1806. Based on Avena bulbosa Willd.

Holcus avenaceus var. bulbosus Gaudin, Agrost. Helv. 1: 136. 1811. Based on H. bulbosus Schrad.

Avena elatior var. bulbosa St. Amans, Fl. Agen. 47. 1821. Based on A. bulbosa Willd.

Arrhenatherum tuberosum Schultz, Pollichia 20-21: 272. 1863. Based on Avena tuberosa Gilib.

Avena elatior var. tuberosa Aschers., Fl. Brand. 1: 826. 1864. Based on A. tuberosa Gilib.

Arrhenatherum elatius var. tuberosum Thiel., Bull. Soc. Bot. Belg. 12: 184. 1873. Eased on Avena tuberosa Gilib.

\section{(144) ARTHRAXON Beauv.}

(1) Arthraxon hispidus var. cryptatherus (Hack.) Honda, Bot. Mag. Tokyo 39: 277. 1925. Based on A. ciliaris subsp. langsdorffi var. cryptatherus Hack.

Arthraxon ciliaris subsp. langsdorffi var. cryptatherus Hack., in DC., Monogr. Phan. 6: 355. 1889. Japan.

\section{(1) ARUNDINARIA Michx.}

(1) Arundinaria gigantea (Walt.) Chapm., Fl. South. U.S. 561. 1860. Presumably based on Arundo gigantea Walt. That name is not cited, but Arundinaria macrosperma Michx. is cited as synonym.

Arundo gigantea Walt., Fl. Carol. 81. 1788. South Carolina.

Arundinaria macrosperma Michx., Fl. Bor. Amer. 1: 74. 1803. Banks of Mississippi, Carolina, Florida, Michaux.

Miegia macrosperma Pers., Syn. Pl. 1: 102. 1805. Based on Arundinaria macrosperma Michx.

Ludolfia macrosperma Willd., Ges. Naturf. Freund. Berlin Mag. 2: 320.1808. Based on Arundinaria macrosperma Michx.

Miegia gigantea Nutt., Gen. PI. 1: 39. 1818. "Alluvions of the Mississippi." Based (through Elliott) on Arundo gigantea Walt.

Arundinaria gigantea Nutt., Gen. Pl. 1: 39. 1818, as synonym of Miegia gigantea Nutt.

Nastus macrospermus Raspail, Ann. Sci. Nat., Bot. 5:442,458.pl.8. f. 1. 1825. Based on Arundinaria macrosperma Michx.

Arundinaria macrosperma var. arborescens Munro, Linn. Soc. Trans. 26: 15. 1868. Based on A. macrosperma Michx.

Miegia arundinacea Torr.; Munro, Lim. Soc. Trans. 26: 15. 1868, as synonym of Arundinaria macrosperma var. arborescens.

Bambusa hermanni E. G. Camus, Bamb., Monogr. 36. 1913, horticultural name as synonym of Arundinaria macrosperma Michx. 
(2) Arundinaria tecta (Walt.) Muhl., Descr. Gram. 191. 1817. Based on Arundo tecta Walt.

Arundo tecta Walt., Fl. Carol. 81. 1788. South Carolina.

Ludolfia tecta A. Dietr. Sp. Pl. 2: 24. 1833. Based on Arundo tecta Walt.

Miegia pumila Nutt., Amer. Phil. Soc. Trans. (n.s.) 5: 149. 1837. Junetion of Red and Kiamichi Rivers, [Okla.]

Arundinaria tecta var. pumila Rupr., Mém. Acad.'St. Pétersb. VI. Sci. Nat. $3^{1}$ : 112. 1839. Based on Miegia pumila Nutt.

?Arundinaria tecta var. colorata Rupr., Mém. Acad. St. Pétersb. VI. Sci. Nat. 31: 112. pl. 2. f. 1. $\delta$ 1839. North America.

?Arundinaria tecta var. distachya Rupr., Mém. Acad. St. Pétersb. VI. Sci. Nat. $3^{1}$ : 112. pl. 2. f. 1 r. 1839 . Philadelphia.

Arundinaria macrosperma var. suffruticosa Munro, Linn. Soc. Trans. 26: 15. 1868. Based on A. tecta Muhl.

Arundinaria macrosperma var. tecta Wood, Amer. Bot. and Flor. pt. 2: 404. 1870. Presumably based on Arundo tecta Walt. Published as new by Beal, Grasses N.Amer. 2: 659. 1896, same basis.

Arundinaria gigantea tecta Scribn., Bull. Torrey Bot. Club 20: 478. 1893. Based on Arundo tecta Walt.

Bambusa pumila Mitford, Garden 45: 530. 1894. "Arundinaria." Cultivated at Kew from North America. Possibly based on Miegia pumila Nutt.

\section{(24) ARUNDO L.}

(1) Arundo donax L., Sp. Pl. 81. 1753. Southern Europe.

Arundo sativa Lam., Fl. Franç. 3: 616. 1778. France.

Arundo latifolia Salisb., Prodr. Stirp. 24. 1796. Based on A. donax L.

Donax arundinaceus Beauv., Ess. Agrost. 78, 152, 161. 1812. Based on Arundo donax L.

Scolochloa arundinacea Mert. and Koch; Roehl., Deut. Fl. ed. 3. 12: 530. 1823. Based on Arundo donax L.

Cynodon donax Raspail, Ann. Sci. Nat., Bot. 5: 302. 1825. Based on Arundo donax L.

Scolochloa donax Gaudin, Fl. Helv. 1: 202. 1828. Based on Arundo donax L.

Donax donax Aschers. and Graebn., Fl. Nordostd. Flachl. 101. 1898. Based on Arundo donax L.

Arundo glauca Bubani, Fl. Pyr. 4: 303. 1901. Not A. glauca Bieb., 1808. Based on Arundo donax L.

Ardndo donax var. versicolor Stokes, Bot. Mat. Med. 1: 160. 1812. Presumably based on Arundo versicolor Mill.

Arundo versicolor Mill., Gard. Dict. ed. 8. No. 3. 1768. Cultivated from India.

Arundo donax var. variegata Vilm., Fl. Pl. Terre 90. 1863. France.

\section{(57) AVENA L.}

(3) Avena barbata Brot., Fl. Lusit. 1: 108. 1804. Europe. [Avena barbata Pott; Link, Jour. Bot. Schrad. 2: 315. 1799, inadequately described from garden plants and said to be wild about Lisbon, may be the same species.]

Avena brevis Roth, Bot. Abh. 42 . 1787. Europe.

Avena byzantina C. Koch, Linnaea 21: 392. 1848. Constantinople.

(1) Avena fatua L., Sp. Pl. 80. 1753. Europe.

Avena fatua var. glabrata Peterm., Fl. Bienitz 13.1841. Europe.

(5) Avena hookeri Scribn., in Hack., True Grasses 123. 1890. Based on $A$. versicolor as described by Hooker.

Avena pratensis var. americana Scribn., Bot. Gaz. 11: 177. 1886. Based on A. versicolor as described by Hooker (Fl. Bor. Amer. 2: 244. 1840) not A. versicolor Vill. Rocky Mountains, Drummond [209].

Avena americana Seribn., U.S.Dept.Agr., Div. Agrost. Bull. 7: 183. f. 165. 1897. Based on A. pratensis var. americana Scribn.

(6)) Avena mortoniana Scribn., Bot. Gaz. 21: 133. pl. 11. 1896. Silver Plume, Colo., Shear 697 [type]; Rydberg 2439.

Avena nuda I., Amoen. Acad. 3: 401. 1756. Europe.

(4) Avena pubescens Huds., Fl. Angl. 42. 1762. England.

Heuffelia pubescens Schur, Enum. Pl. Transsilv. 760. 1866. Based on Avenc pubescens I. (error for Huds.).

Avenula pubescens Dum., Bull. Soc. Bot. Belg. $7^{1}: 68$. 1868. Based on Avena pubescens Huds.

Avenastrum pubescens Jess.; Dalla Torre, Alpenfl. 44. 1899. Based on Avena pubescens L. (error for Huds.). 
(2) Avena sativa L., Sp. Pl. 79. 1753. Europe.

Avena sativa var. nigra Wood, Class-book ed. 2. 610. 1847. Not A. sativa var. nigra Schrank as to name but probably the same form. Cultivated.

Avena sativa var. secunda Wood, Class-book ed. 2. 610. 1847. A. sativa var. secunda Provancher, Fl. Canad. 2: 689. 1862, is probably the same form. Cultivated.

Avena fatua var. sativa Haesskn., Mitt. Geogr. Ges. Thüringen 3: 238. 1885. Presumably based on Avena sativa L.

Avena fatua subsp. sativa Thell., Vierteljahrs. Nat. Ges. Zürich 56: 325. 1911. Based on A. sativa L.

Avena sterilis L., Sp. P1. ed. 2. 118. 1762. Spain.

Avena algeriensis Trab., Bull. Agr. Alger. Tunis. 16: 354. 1910. Cult.

Avena sterilis algeriensis Trab., Jour. Hered. 5: 77. 1914. Presumably based on $A$. algeriensis Trab.

Avena strigosa Schreb., Spic. Fl. Lips. 52. 1771. Europe.

\section{(126) AXONOPUS Beauv.}

(2) Axonopus compressus (Swartz) Beauv., Ess. Agrost. 12. 1812. Based on Milium compressum Swartz.

Milium compressum Swartz, Prodr. Veg. Ind. Occ. 24. 1788. Jamaica.

Paspalum tristachyon Lam., Tabl. Encycl. 1: 176. 1791. South America, Richard.

Paspalum platicaulon Poir., in Lam., Encycl. Sup. 5: 34. 1801. Puerto Rico, Ledru.

Agrostis compressa Poir., in Lam., Encycl. Sup. 1: 259. 1810. Not A. compressa Poir, op. cit. 258, nor Willd., 1790. Based on Milium compressum Swartz.

Paspalum compressum Raspail, Ann. Sci. Nat., Bot. 5: 301. 1825. Based on Axonopus compressus Beauv.

Paspalum laticulmum Spreng., Syst. Veg. 1: 245. 1825. West Indies.

Digitaria platicaulis Desv., Opusc.62. 1831. Based on Paspalum plaitcaulon Poir.

Digitaria domingensis Desv.; Kunth, Enum. Pl. 1: 49. 1833, as synonym of Paspalum platicaulon Poir.

Paspalum platycaule Willd.; Steud., Nom. Bot. ed. 2. 2: $272 . \quad 1840$, erroneously cited as synonym of $P$. furcatum Flügge. Ecuador, Humboldt.

Paspalum guadaloupense Steud., Syn. Pl. Glum. 1: 18. 1854. Guadeloupe, Duchaissing.

Paspalum depressum Steud., Syn. Pl. Glum. 1: 20. 1854. Louisiana, Hartmann 51.

Paspalum filostachyum A. Rich.; Steud., Syn. Pl. Glum. 1: 20. 1854. West Indies, Sieber [365].

Anastrophus compressus Schlecht.; Doell, in Mart., Fl. Bras. 22: 102.1877. Presumably based on Milium compre'ssum Swartz.

Paspalum furcalum var. parviflorum Doell, in Mart., Fl. Bras. 22: 104.1877. [West Indies] Sieber 365; [Louisiana], Harimann 51.

Anastrophus platycaulis Schlecht.; Jacks., Ind. Kew. 1: 118. 1893, as synonym of Paspalum platicaulon.

Panicum platycaulon Kuntze, Rev. Gen. Pl. 32: 363. 1898. Based on Paspalum platicaulon Poir.

Paspalum raunkiaerii Mez, Repert. Sp. Nov. Fedde 15: 60. 1917. St. Jan, West Indies, Raunkiaer 1313.

(1) Axonopus furcatus (Flügge) Hitchc., Rhodora 8: 205. 1906. Based on Paspalum furcatum Flügge.

Paspalum furcatum Flügge, Monogr. Pasp. 114. 1810. Carolina, Bosc.

Paspalum digitaria C. Muell., Bot. Ztg. 19: 324. 1861. Not P. digitaria Poir., 1816. Texas, Drummond 276.

Paspalum michauxianum var. villosum Vasey, Bull. Torrey Bot. Club 13: 163. 1886. No locality cited. [Type, Orange County, Fla., Curtiss E.]

Paspalum furcalum var. villosum Vasey, Contrib. U.S. Natl. Herb. 3: 16. 1892. Presumably based on Paspalum michauxianum var. villosum Vasey.

Paspalum paspaloides var. villosum Scribn. and Ball, U.S.Dept.Agr., Div. Agrost. Bull. 24: 42. 1901. Based on P. furcatum var. villosum Vasey.

Anastrophus furcatus Nash, N. Amer. Fl. 17: 162. 1912. Based on Paspalum furcatum Flügge.

This species was called Paspalum paspaloides by Scribner (Mem. Torrey Bot. Club 5: 29. 1894) and Anastrophus paspaloides by Nash (in Britton, Man. 75. 1901), but Digitaria paspalodes Michx., upon which these names are based, is Paspalum distichum L. 
(98) BECKMANNIA Host

(1) Beckmannia syzigachne (Steud.) Fernald, Rhodora 30: 27. 1928. Based on Panicum syzigachne Steud.

Panicum syzigachne Steud., Flora 29: 19. 1846. Japan.

Beckmannia erucaeformis var. uniflora Scribn.; A. Gray, Man. ed. 6. 628. 1890. Iowa to Minnesota and westward.

Beckmannia erucaformis var. baicalensis Kuznezow, Bull. Angew. Bot. 6: 584. 1913. Siberia.

Beckmannia baicalensis Hultén, Svensk. Vet. Akad. Handl. III. 5: 119. 1927. Based on B. erucaeformis var. baicalensis Kuznezow.

In most Ameriçan botanical works this is referred to $B$. erucaeformis (L.) Host, a European species. Nuttall (Gen. Pl. 1: 48. 1818) misspells the name Bruchmannia.

\section{(35) BLEPHARIDACHNE Hack.}

(2) Blepharidachne bigelovii (S. Wats.) Hack., in DC., Monogr. Phan. 6: 261. 1889. Based on Eremochloe bigelovii S. Wats.

Eremochloe bigelovii S. Wats., in King, Geol. Expl. 40th Par. 5: 382. pl. 40. f. 1-9. 1871. [Frontera, near El Paso, Tex.], Wright 2028.

Eremochloe thurberi S. Wats., in King, Geol. Expl. 40th Par. 5: pl. 40. f. 1-9. 1871. Name inadvertently given on the plate illustrating $E$. bigelovii.

(1) Blepharidachne kingii (S. Wats.) Hack., in DC., Monogr. Phan. 6: 261. 1889. Based on Eremochloe kingii S. Wats.

Eremochloe kingii S. Wats., in King, Geol. Expl. 40th Par. 5: 382. pl. 40. f. 10-16. 1871. Trinity Mountains, Nev., Watson.

\section{(77) BLEPHARONEURON Nash}

(1) Blepharoneuron tricholepis (Torr.) Nash, Bull. Torrey Bot. Club 25: 88. 1898. Based on Vilfa tricholepis Torr.

Vilfa tricholepis Torr., U.S. Rept. Expl. Miss. Pacif. 4: 155. 1857. Sandia Mountains, N.Mex. [Bigelow].

Sporobolus tricholepis CouIter, Man. Rocky Mount. 411. 1885. Based on Vilfa tricholepis Torr.

\section{(104) BOUTELOUA Lag. ${ }^{17}$}

(1) Bonteloua aristidoides (H.B.K.) Griseb., Fl. Brit. W. Ind. 537. 1864. Based on Dinebra artistidoides H.B.K.

Dinebra aristidoides H.B.K., Nov. Gen. and Sp. 1: 171. 1816. Mexico, Hurnboldt and Bonpland.

Atheropogon aristidoides Roem. and Schult., Syst. Veg. 2: 415. 1817. Based on Dinebra aristidoides H.B.K.

Eutriana aristidoides Trin., Gram. Unifl. 242. 1824. Based on Atheropogon aristidoides Roem. and Schult.

Dineba hirsuta Presl, Rel. Haenk. 1: 292. 1830. Peru, Haenkc.

Eutriana hirsuta Kunth, Rév. Gram. 1: Sup. XXIII. 1830. Based on Dineba hirsuta Presl.

Aristida unilateralis Willd.; Steud., Nom. Bot. ed. 2. 1: 132.1840 , as synonym of Eutriana aristidoides Trin.

Boutcloua gracilis "Hook?"; Vasey, in Wheeler, Rept. U.S. Survey 100th Merid. 6: 287. 1878. Not B. gracilis Lag., 1840. Arizona, Rothrock 701.

Bouteloua ciliata Griseb., Abh. Ges. Wiss. Göttingen 24: 302. 1879. Juramento, Argentina, Lorenz and Hieronymus 352.

Triathera aristidoides Nash, in Small, Fl. Southeast. U.S. 137. 1903. Based on Dinebra aristidoides H.B.K.

Bouteloua aristidoides var. arizonica Jones, Contrib. West. Bot. 14: 13. 1912. Tucson, Ariz., Thornber 177.

(10) Bouteloua barbata Lag., Var. Cienc. 24: 141. 1805. Mexico.

Actinochloa barbata Roem. and Schult., Syst. Veg. 2: 420. 1817. Based on Bouteloua barbata Lag.

Eutriana barbata Kunth, Rév. Gram. 1: 96. 1829. Based on Boutcloua barbata Lag.

Chondrosium polystachyum Benth., Bot. Voy. Sulph. 56. 1844. Magdalena Bay, Baja California, Barclay.

17 Botelua Lag. Var. Cienc. 26: 134. 1805; Bouteloua Lag. Gen. and Sp. Nov. 5. 1816. 
Chondrosium subscorpiodes C. Muell., Bot. Ztg. 14: 347. 1856. Baja California, Barclay.

Bouteloua polystachya Torr., U.S. Rept. Expl. Miss. Pacif. 52: 366. pl. 10. 1857. Based on Chondrosium polystachyum Benth.

Bouteloua pumila Buckl., Acad. Nat. Sci. Phila. Proc. 1862: 93. 1863. Texas, II right 754.

Bouteloua polysiachya var. major Vasey, in Wheeler, Rept. U.S. Survey 100th Merid. 6: 287. 1878. Sonoyta Valley, Ariz., Rothrock 691.

Chondrosium exile Fourn., Mex. PI. 2: 137. 1886. Mexico, Berlandier 842.

Chondrosium microstachyum Fourn., Mex. Pl. 2: 138. 1886. Guadalupe, Mexico, Bourgeau 667.

Bouteloua arenosa Vasey, in S. Wats., Amer. Acad. Sci. Proc. 24: 81. 1889, name only; U.S.Dept.Agr., Div. Bot. Bull. 121: pl. 34. 1890. Guaymas, Mexico, Palmer 189.

Bouteloua microstachya L.H. Dewey, Contrib. U.S. Natl. Herb. 2: 531. 1894. Based on Chondrosium microstachyum Fourn.

Bouteloua micrantha Scribn. and Merr., U.S.Dept.Agr., Div. Agrost. Circ. 32: 8. 1901. Fort Lowell, Ariz., Griffiths 1556.

(15) Bouteloua breviseta Vasey, Contrib. U.S. Natl. Herb. 1: 58. 1890. (July 18.) Screw Bean, Presidio County, Tex., Nealley [669].

Bouteloua ramosa Scribn.; Vasey, U.S.Dept.Agr., Div. Bot. Bull. 121: pl. 44. 1890. (Oct. 13.) Mexico to Árizona and western Texas, [type, Nealley].

Bouteloua oligostachya var. ramosa Scribn.; Beal, Grasses N.Amer. 2: 418. 1896. Based on B. ramosa Scribn.

(6) Bouteloua chondrosioides (H.B.K.) Benth.; S. Wats., Proc. Amer. Acad. 18: 179. 1883. Based on Dinebra chondrosioides H.B.K.

Dinebra chondrosioides H.B.K., Nov. Gen. and Sp. 1: 173. pl. 53. 1816. Michoacan, Mexico, Humboldt and Bonpland.

Bouteloua ovata Lag., Gen. and Sp. Nov. 5. 1816. Mexico.

Atheropogon chondrosioides Roem. and Schult., Syst. Veg. 2: 416. 1817. Based on Dinebra chondrosioides H.B.K.

Actinochloa ovata Roem. and Schult., Syst. Veg. 2: 420. 1817. Based on Bouteloua ovata Lag.

Eutriana cristata Trin., Gram. Unifl. 241. 1824. Based on Atheropogon chondrosioides Roem. and Schult.

Chondrosium humboldtianum Kunth, Rév. Gram. 1: 93. 1829. Based on Dinebra chondrosioides H.B.K.

Bouteloua havardii Vasey; S. Wats., Amer. Acad. Sci. Proc. 18: 179.1883. Limpio Mountains, Tex., Havard in 1881.

(3) Bouteloua curtipendula (Michx.) Torr., in Emory, Notes Mil. Reconn. 154. 1848. Based on Chloris curtipendula Michx.

Chloris curtipendula Michx., Fl. Bor. Amer. 1: 59. 1803. Illinois, Michaux.

Bouteloua racemosa Lag., Var. Cienc. $2^{4}: 141.1805$. Mexico.

Bouteloua pendula Lag., Var. Cienc. 24: 141. 1805, as synonym of B. racemosa. Atheropogon apludoides Muhl.; Willd., Sp. Pl. 4: 937. 1806. North America. Bouteloua melicaeformis Brouss.; Hornem., Enum. Pl. Hort. Hafn. 7. 1807. Name only; Roem. and Schult., Syst. Veg. 2: 414. 1817, as synonym of Atheropogon apludoides Muhl.

Bouteloua melicoides Beauv., Ess. Agrost. 40, 155. pl. 9. f. 6. 1812. Based on B. melicoides Hornem., doubtless error for melicaeformis.

Dineba curtipendula Beaur., Ess. Agrost. 98, 158, 160. pl. 16. f. 1. 1812. Presumably based on Chloris curtipendula Michx.

Dineba melicoides Beauv., Ess. Agrost. 160. 1812, name only, probably same as Bouteloua melicoides Beauv.

Cynosurus secundus Pursh, Fl. Amer. Sept. 2: 728. 1814. "Upper Louisiana" [northern Middle Western States], Bradbury.

Atheropogon racemosus Roem. and Schult., Syst. Veg. 2: 414. 1817. Based on Bouteloua racemosa Lag.

Dineba secunda Roem. and Schult., Syst. Veg. 2: 711. 1817. Based on Cynosurus secundus Pursh.

Aristida secunda Rud.; Roem. and Schult., Syst. Veg. 2: 711. 1817, as synonym of Dincba secunda Roem. and Schult.

Eutriana curtipendula Trin., Fund. Agrost. 161. 1820. Based on Chloris curtipendula Michx.

Melica curtipendula Michx.; Steud., Nom. Bot. 1: 91, 519. 1821, as synonym of Atheropogon apludoides Muhl. 
Cynodon curtipendula Raspail, Ann. Sci. Nat., Bot. 5: 303. 1825. Based on Dineba curtipendula Beauv.

Cynodon melicoides Raspail, Ann. Sci. Nat., Bot. 5: 303. 1S25. Based on Bouteloua melicoides Beauv.

Andropogon curtipendulus Spreng.; Steud., Nom. Bot. ed. 2. 1: 90. 1840, as synonym of Eutriana curtipendula Trin.

Eutriana affinis Hook. f., Linn. Soc. Trans. 20: 174. 1851. St. Louis, Mo.; Texas, Drummond.

Heterostegon curtipendula Schwein., in Hook. f., Linn. Soc. Trans. 20: 175. 1851, as synonym of Eutriana affinis. North America, Schweinitz; Missouri and Texas, Drummond.

Bouteloua curtipendula var. aristosa A. Gray, Man. ed. 2. 553. 1856. Illinois, Geyer.

Atheropogon curtipendulus Fourn., Mex. Pl. 2: 138. 1856. Based on Bouteloua curtipendula A. Gray [error for Torrey].

Atheropogon medius Fourn., Mex. Pl. 2: 139. 1886. Mexico, Licbmann 581. Atheropogon affinis Fourn., Mex. Pl. 2: 141. 1886. Based on Eutriana affinis Hook. f.

Bouteloua racemosa var. aristosa Wats. and Coult.; Gray, Man. ed. 6. 656. 1890. Illinois, Geyer.

(5) Bouteloua eludens Griffiths, Contrib. U.S. Natl. Herb. 14: 401. 1912. Santa Rita Mountains, Ariz., Griffiths 7269.

(16) Bouteloua eriopoda (Torr.) Torr., U.S. Rept. Expl. Miss. Pacif. 4: 155. 1856. Based on Chondrosium eriopodum Torr.

Chondrosium eriopodum Torr., in Emory, Notes Mill. Reconn. 154. 1848. Del Norte [Rio Grande] River, N.Mex., [Bigelow].

Bouteloua brevifolia Buckl., Acad. Nat. Sci. Phila. Proc. 1862: 93. 1863. Northwestern Texas [Wright 748, Fendler 950].

(8) Bouteloua filiformis (Fourn.) Griffiths, Contrib. U.S. Natl. Herb. 14: 413. 1912. Based on Atheropogon filiformis Fourn.

Bouteloua juncifolia Vasey, Descr. Cat. Grasses U.S. 62. 1S55. Name only, Texas [Havard 89] to Arizona. (B. humboldtiana Griseb., doubtfully cited, is B. heterostega (Trin.) Griffiths of the West Indies.)

Atheropogon filiformis Fourn., Mex. Pl. 2: 140. 1S86. Mexico, Karwinsky $991 \mathrm{~b}$.

(14) Bouteloua gracilis (H.B.K.) Lag.; Steud., Non. Bot. ed. 2. 1: 219.1840. Based on Chondrosium gracile H.B.K.

Chondrosium gracile H.B.K., Nov. Gen. and Sp. 1: 176. pl. 5S. 1816. Mexico, Humboldt and Bonpland.

Actinochloa gracilis Willd.; Roem. and Schult., Syst. Veg. 2: 418.1817. Based on Chondrosium gracile H.B.K.

Atheropogon oligostachyus Nutt., Gen. Pl. 1: 78. 1818. Plains of the upper Missouri [Nuttall].

Eutriana gracilis Trin., Gram. Unifl. 240. 1824. Based on Actinochloa gracilis Willd.

Atheropogon gracilis Spreng., Syst. Veg. 1: 293. 1825. Based on Chondrosium gracile H.B.K.

Eutriana oligostachya Kunth, Rév. Gram. 1: 96. 1829. Based on Atheropogon oligostachyus Nutt.

Chondrosium gracile var. polystachyum Nees, Linnaea 19: 692. 1847. Mexico, Aschenborn $153 . \quad$ [Spikes 2 or 3.]

Chondrosium oligostachyum Torr., in Marcy, Expl. Red Riv. 300. 1852. Based on Atheropogon oligostachyum Nutt.

Bouteloua oligostachya Torr.; A. Gray, Man. ed. 2. 553. 1856. Based on Atheropogon oligostachyus Nutt.

Bouteloua oligostachya var. intermedia Vasey, Grasses U.S. 33. 1883. Name only. Texas to Arizona.

Bouteloua major Vasey, Bull. Torrey Bot. Club 14: 9. 1887. Name only, for a plant grown from seed collected in Mexico by Palner.

Bouteloua oligostachya var. major Vasey; L. H. Dewey, Contrib. U.S. Natl. Herb. 2: 531. 1834. Texas to Arizona [type, Lemmon 427].

Bouteloua oligostachya var. pallida Scribn.; Beal, Grasses N.Amer. 2: 418. 1896. Mexico, Pringle 407.

Bodteloua gracilis var. Stricta (Vasey) Hitche., Jour. Wash. Acad. Sci. 23: 454. 1933. Based on B. stricta Vasey.

Bouteloua stricta Vasey, Bull. Torrey Bot. Club 15: 49. 1S88. Western Texas, Nealley, scarcely described; U.S.Dept.Agr., Div. Bot. Bull. 12: pl. 45. 1890 . 
(13) Bouteloua hirsuta Lag., Var. Cienc. 24: 141. 1805. Mexico.

Bouteloua hirta Lag., Var. Cienc. $2^{4}$ : 141. 1805, as synonym of B. hirsuta Lag. Chondrosium hirtum H.B.K., Nov. Gen. and Sp. 1: 176. pl. 59.1816. Mexico, Humboldt and Bonpland.

Actinochloa hirsuta Roem. and Schult., Syst. Veg. 2: 419. 1817. Based on Bouteloua hirsuta Lag.

Eutriana hirta Trin., Gram. Unifl. 240. 1824. Based on Actinochloa hirsuta Roem. and Schult.

Atheropogon hirtus Spreng., Syst. Veg. 1: 293. 1825. Based on Chondrosium hirtum H.B.K.

Chondrosium hirsutum Sweet, Hort. Brit. 1: 455. 1826. Presumably based on Actinochloa hirsuta Roem. and Schult.

Atheropogon papillosus Engelm., Amer. Jour. Sci. 46: 104. 1843. Beardstown, Ill., Geyer.

Chondrosium aschenbornianum Nees, Linnaea 19: 692. 1847. Mexico, Aschenborn 331.

Chondrosium foeneum Torr., in Emory, Notes Mill. Reconn. 154. pl. 12.1848. Valley of the Del Norte, [N.Mex., Emory Exped.].

Chondrosium papillosum Torr., in Marcy, Expl. Red. Riv. 300. 1852. Based on Atheropogon papillosus Engelm.

Bouteloua foenea Torr., Cat. Pl. Survey W. 100th Merid. 18. 1874. Based on Chondrosium foeneum Torr.

Bouteloua aschenborniana Griseb.; Fourn., Mex. Pl. 2: 137. 1886, as synonym of Chondrosium aschenbornianum Nees.

Chondrosium drummondii Fourn., Mex. Pl. 2: 137. 1886. Texas, Drummond 323.

Bouteloua palmeri Vasey, Bull. Torrey Bot. Club 14: 9. 1887. Name only, later described as B. hirsuta var. palmeri Vasey; Beal.

Bouteloua hirsuta var. minor Vasey, U.S.Dept.Agr., Div. Bot. Bull. 121: pl. 39. f. 2. 1890, nomen seminudum. [Texas, Reverchon 1153.]

Bouteloua hirsuta var. major Vasey, U.S.Dept.Agr., Div. Bot. Bull. 121: pl. 39. f. 3. 1890. Without description. [Austin, Tex., Stiles in 1884.]

Bouteloua hirta Scribn., Contrib. U.S. Natl. Herb. 2: 531.1894. Based on Chondrosium hirtum H.B.K.

Bouteloua hirta var. major Vasey; L. H. Dewey, Contrib. U.S. Natl. Herb. 2: 531. 1894. Western Texas to Mexico.

Bouteloua hirta var. minor Vasey; L. H. Dewey, Contrib. U.S. Natl. Herb. 2: 531. 1894. Central Texas.

Bouteloua hirsuta var. palmeri Vasey; Beal, Grasses N.Amer. 2: 417.1896. Cultivated, seed collected by Palmer in Mexico.

Bouteloua bolanderi Vasey; Beal, Grasses N.Amer. 2: 417. 1896, as synonym of $B$. hirsuta var. palmeri Vasey.

Bouteloua pectinata Featherly, Bot. Gaz. 91: 103. f. 1-4. 1931. Oklahoma, English 71.

(11) Bouteloua parryi (Fourn.) Griffiths, Contrib. U.S. Natl. Herb. 14: 381. 1912. Based on Chondrosium parryi Fourn.

Bouteloua polystachya var. vestita S. Wats., Amer. Acad. Sci. Proc. 18: 177. 1883. Sierra Madre south of Saltillo, Mexico, Palmer 1357 in 1880.

Chondrosium parryi Fourn., Mex. Pl. 2: 150. 1886. San Luis Potosí, Parry and Palmer 9231/2 [error for 943\%1/2].

Bouteloua vestita Scribn.; L. H. Dewey, Contrib. U.S. Natl. Herb. 2: 531. 1894. Based on B. polystachya var. vestita S. Wats.

(7) Bouteloua radicosa (Fourn.) Griffiths, Contrib. U.S. Natl. Herb. 14: 411. 1912. Based on Atheropogon radicosus Fourn.

Dinebra bromoides H.B.K., Nov. Gen. and Sp. 1: 172. pl. 51. 1816. Not Bouteloua bromoides Lag., 1816. Mexico, Humboldt and Bonpland.

Atheropogon bromoides Roem. and Schult., Syst. Veg. 2: 415. 1817. Based on Dinebra bromoides H.B.K.

Eutriana bromoides Trin., Fund. Agrost. 161. 1820. Based on Dinebre bromoides H.B.K.

Nestlera festucaeformis Willd.; Steud., Nom. Bot. ed. 2. 2: 192. 1841, as synonym of Eutriana bromoides Trin.

Atheropogon radicosus Fourn., Mex. P1. 2: 140. 1886. Mexico City, Bourgeau 450.

Bouteloua bromoides var. radicosa Vasey, L. H. Dewey, Contrib. U.S. Natl. Herb. 2: 533. 1894. Based on Atheropogon radicosus Fourn. 
(4) Bouteloua rigidiseta (Steud.) Hitchc., Jour. Wash. Acad. Sci. 23: 453. 1933. Based on Aegopogon rigidisetus Steud.

Aegopogon rigidisetus Stend., Syn. Pl. Glum. 1: 146. 1854. Texas, Drummond.

Bouteloua texana S. Wats., Amer. Acad. Sci. Proc. 18: 196. 1883. Texas, Berlandier 1535, Drummond 340, 374.

Polyodon texanus Nash, in Small, Fl. Southeast. U.S. 138, 1327. 1903. Based on Bouteloua texana S. Wats.

(12) Bouteloua rothrockii Vasey, Contrib. U.S. Natl. Herb. 1: 268. 1893. Cottonwood, Ariz., Rothrock 347.

(9) Bouteloua simplex Lag., Var. Cienc. 24: 141. 1805. Peru.

Chloris procumbens Durand, Chlor. Sp. 16. 1808. Grown at Madria, seed said to come from the Philippine Islands (collected by Née) where the species is not known to occur. Probably from South America or Mexico, which regions Nce visited.

Chloris filiformis Poir., in Lam., Encycl. Sup. 2: 237. 1811. Grown at Paris, the source unknown.

Chondrosium procumbens Desv.; Beauv., Ess. Agrost. 41, 158. pl. 9. f. 7. 1812. Based on Chloris procumbens Durand.

Chondrosium humile Beauv., Ess. Agrost. 41, 158. 1812. Name only.

Chondrosium tenue Beauv., Ess. Agrost. 41, 158. 1812. Name only.

Atheropogon procumbens Jacq., Eclog. Gram. 2: 16. pl. 12. 1813. Based on Chloris procumbens Durand.

Bouteloua prostrata Lag., Gen. and Sp., Nov. 5. 1816. Mexico.

Chondrosium humile H.B.K., Nov. Gen. and Sp. 1: 175. pl. 56. 1816. Ecuador, Humboldt and Bonpland.

Chondrosium tenue Beauv.; H.B.K., Nov. Gen. and Sp. 1: 176. pl. 57. 1816. Mexico, Humboldt and Boripland.

Chloris tenuis Poir., in Lam., Encycl. Sup. J: 614. 1817. Based on C. filiformis Poir., p. 237, not C. filiformis Poir., op. cit. p. 238.

Actinochloa procumbens Roem. and Schult., Syst. Veg. 2: 417. 1817. Based on Chloris procumbens Durand.

Actinochloa humilis Willd.; Roem. and Schult., Syst. Veg. 2: 417. 1817. Based on Chondrosium humile H.B.K.

Actinochloa simplex Roem. and Schult., Syst. Veg. 2: 418. 1817. Based on Bouteloua simplex Lag.

Actinochloa tenuis Willd.; Roem. and Schult., Syst. Veg. 2: 418. 1817. Based on Chondrosium tcnue H.B.K.

Actinochloa prostrata Roem. and Schult., Syst. Veg. 2: 419. 1817. Based on Bouteloua prostrata Lag.

Eutriana humilis Trin., Gram. Unifl. 239. 1824. Based on Actinochloa humilis Willd.

Eutriana tenuis Trin., Gram. Unifl. 240. 1824. Based on Actinochloa tenuis Willd.

Atheropogon humilis Spreng., Syst. Veg. 1: 293. 1825. Based on Chondrosium humile H.B.K.

Cynodon procumbens Raspail, Ann. Sci. Nat., Bot. 5: 303. 1825. Based on Chondrosium procumbens Desv.

Chondrosium prostratum Sweet, Hort. Brit. 1: 455. 1826. Based on Bouteloua prostrata Lag.

Chondrosium simplex Kunth, Rév. Gram. 1: 94. 1829. Based on Boutcloua simplex Lag.

Bouteloua tenuis Griseb., Abh. Ges. Wiss. Göttingen 19: 211. 1874. Based on Chondrosium tenue Beauv.

Boutcloua humilis Hieron., Bol. Acad. Cienc. Córdoba 4: 495. 1882. Based on Chondrosium humile Beauv.

Bouteloua pusilla Vascy, Bull. Torrey Bot. Club 11: 6. 1884. Kingman, N.Mex., Vasey.

Bouteloua brachyathera Phil., An. Mus. Nac. Chile Bot. 8: 85. 1891. Tarapacá, Chile.

Bouteloua rahmeri Phil., An. Mus. Nac. Chile Bot. 8: 85. 1891. Tarapacá, Chile.

Bouteloua procumbens Griffiths, Contrib. U.S. Natl. Herb. 14: 364.1912. Based on Chloris procumbens Durand.

Bouteloua simplex var. rahmeri Henr., Med. Rijks Herb. Leiden no. 40: 66. 1921. Based on B. rahmeri Phil. 
(17) Bouteloua trifida Thurb., in S. Wats., Amer. Acad. Sci. Proc. 18: 177. 1883. Monclova, Coahuila, Palmer 1355 in 1880.

Bouteloua burkii Scribn., in S. Wats., Amer. Acad. Sci. Proc. 18: 179. 1883. Western Texas and New Mexico, Berlandier 167 and 1427.

Chondrosium trinii Fourn., Mex. Pl. 2: $136.1886 . \quad$ Laredo, Tex., Berlandier 1427.

Chondrosium polysiachyum Trin.; Fourn., Mex. Pl. 2: $136 . \quad 1886$, as synonym of C. trinii Fourn.

Chondrosium virletii Fourn., Mex. Pl. 2: 136. 1886. San Luis Potosí, Mexico, rirlet 1373.

Bouteloua trifida var. burkii Vasey; L. H. Dewey, Contrib. U.S. Natl. Herb. 2: 532. 1894. Based on B. burkii Scribn.

Bouteloua trinii Griffiths, Contrib. U.S. Natl. Herb. 14: 387. 1912. Based on Chondrosium trinii Fourn. Griffiths accepts 1881 as the date for Fournier's work.

(2) Bouteloua uniflora Vasey, Bot. Gaz. 16: 26. 1891. Crockett County, Tex., Nealley [222].

(125) BRACHIARIA (Trin.) Griseb.

(1) Brachiaria ciliatissima (Buckl.) Chase, in Hitchc., U.S. Dept. Agr. Bull. 772: 221. 1920. Based on Panicum ciliatissimum Buckl.

Panicum ciliatissimum Buckl., Prel. Rept. Geol. Agr. Survey Tex. App. 4. 1866. Northern Texas [Buckley].

Brachiaria erucaeformis (J. E. Smith) Griseb., in Ledeb., Fl. Ross. 4: 469. 1853. Based on Panicum erucaeforme J. E. Smith.

Panicum erucaeforme J. E. Smith, in Sibth., Fl. Graec. 1: 44. pl. 59. 1806. Greece.

Panicum isachne Roth, in Roem. and Schult., Syst. Veg. 2: 458. 1819. East Indies.

Echinochloa eruciformis Koch, Linnaea 21: 437. 1848. Based on Panicum erucaeforme J. E. Smith.

Panicum isachne var. mexicana Beal, Grasses N.Amer. 2: 114. 1896. Grown from seed said to come from Mexico.

Brachiaria isachne Stapf, in Prain, Fl. Trop. Afr. 9: 552. 1919. Based on Panicum isachne Roth.

(2) Brachiaria extensa Chase, Contrib. U.S. Natl. Herb. 28: 240. 1929. Based on Paspalum platyphyllum Griseb.

Paspalum platyphyllum Griseb., Cat. Pl. Cub. 230. 1866. Not P. platyphyllum Schult., 1827. Zarabanda, Cuba, Wright 3441.

Panicum platyphyllum Munro; Wright, An. Acad. Cienc. Habana 8: 206. 1871. Based on Paspalum platyphyllum Griseb.

Brachiaria platyphylla Nash, in Small, Fl. Southeast. U.S. 81, 1327. 1903. Based on Panicum platyphyllum Munro.

(3) Brachiaria plantaginea (Link) Hitchc., Contrib. U.S. Natl. Herb. 12: 212. 1909. Based on Panicum plantagineum Link.

Panicum plantagineum Link, Hort. Berol. 1: 206. 1827. Grown in Berlin, origin unknown.

Panicum leandri Trin., Gram. Icon. 3: pl. 335. 1836. Brazil.

Panicum distans Salzm.; Steud., Syn. Pl. Glum. 1: 61. 1854. Not P. distans Trin., 1829. Bahia, Brazil [Salzmann].

Panicum disciferum Fourn., Mex. Pl. 2: 19. 1886. San Luis Potosí, Mexico, Virlet 1292 .

\section{(80) BRACH YELYTRUM Beauv.}

(1) Brachyelytrum erectum (Schreb.) Beauv., Ess. Agrost. 155. 1812. Based on Muhlenbergia erecta Schreb.

?Dilepyrum aristosum Michx., F1. Bor. Amer. 1: 40. 1803. Georgia and Carolina, Michaux.

?Muhlenbergia aristata Pers., Syn. Pl. 1: 73. 1805. Based on Dilepyrum aristosum Michx.

Muhlenbergia erecta Schreb., in Spreng., Mém. Acad. St. Pétersb. 2: 287. 1807-08. Georgia and Carolina.

?Brachyelytrum aristatum Roem. and Schult., Syst. Veg. 2: 413. 1817. Based on Dilepyrum aristosum Michx.

Muhlenbergia brachyelytrum Trin., Gram. Unifl. 188. 1824. Based on Brachyelytrum erectum Beauv. 
Agrostis erecta Spreng., Syst. Veg. 1: 264. 1825. Based on Muhlenbergia erecta Schreb.

Brachyelytrum aristatum var. engelmanni A. Gray, Man. ed. 5. 614. 1867. "A western form."

?Brachyelytrum aristosum Trel., Brann. and Coville, in Branner, Rept. Ark. Geol. Survey 4: 235. 1891. Based on Dilepyrum aristosum Michx.

Brachyelytrum aristosum var. glabratum Vasey, in Millsp. W.Va. Agr. Expt. Sta. Bull. 24: 469. 1892. Fayette near Nuttallburg, W.Va., Nuttall.

Dilepyrum erectum Farwell, Amer. Midl. Nat. 8: 33. 1922. Based on Muhlenbergia erecta Schreb.

Brachypodium distachyon (L.) Beauv., Ess. Agrost. 101, 155. 1812. Based on Bromus distachyos L.

Bromus distachyos L., Cent. Pl. 2: 8. 1756; Amoen. Acad. 4: 304. 1759. Europe and the Orient.

Brachypodium sylvaticum (Huds.) Beauv., Ess. Agrost. 101, 155. 1810. Based ultimately on Festuca sylvatica Huds.

Festuca sylvatica Huds., Fl. Angl. 1: 38. 1762. England.

\section{(11) BRIZA L.}

(1) Briza maxima L., Sp. Pl. 70. 1753. Europe.

(3) Briza media L., Sp. Pl. 70. 1753. Europe.

(2) Briza minor L., Sp. Pl. 70. 1753. Europe.

\section{(2) BROMUS L.}

(3) Bromus aleutensis Trin.; Griseb., in Ledeb., Fl. Ross. 4: 361. 1853. Unalaska, Eschscholz.

(19) Bromus anomalus Rupr.; Fourn., Bull. Acad. Sci. Brux. 92: 236. 1840. Name only; Mex. Pl. 2: 126. 1886. Mexico, Galeotti 5757, 5815.

Bromus kalmii var. porteri Coult., Man. Rocky Mount. 425. 1885. Twin Lakes, Colo., Porter.

Bromus ciliatus var. minor Munro; L. H. Dewey, Contrib. U.S. Natl. Herb. 2: 548. 1894. West Texas [Chisos Mountains, Havard 20].

Bromus ciliatus porteri Rydb., Contrib. U.S. Natl. Herb. 3: 192.1895. Based on B. kalmii var. porteri Coult.

Bromus porteri Nash, Bull. Torrey Bot. Club 22: 512. 1895. Based on $B$. kalmii var. porteri Coult.

Bromus ciliatus var. montanus Vasey; Beal, Grasses N.Amer. 2: 619. 1896. Colorado, Patterson 264.

Bromus kalmii var. occidentalis Vasey; Beal, Grasses N.Amer. 2: 624. 1896. Montana [type, Canby and Scribner 384].

Bromus scabratus Scribn., U.S.Dept.Agr., Div. Agrost. Bull. 13: 46. 1898. Not B. scabratus Link, 1843. Vermilion Creek, Wyo., A. Nelson 3800.

Bromus kalmii var. major Vasey; Shear, U.S.Dept.Agr., Div. Agrost. Bull. 23: 35. 1900, as synonym of $B$. porteri Nash.

Bromus porteri havardii Shear, U.S.Dept.Agr., Div. Agrost. Bull. 23: 37. 1900. Based on B. ciliatus var. minor Munro.

Bromus anomalus var. Lanatipes (Shear) Hitche., Jour. Wash. Acad. Sci. 23: 449. 1933. Based on B. porteri lanatipes Shear.

Bromus porteri lanatipes Shear, U.S.Dept.Agr., Div. Agrost. Bull. 23: 37. 1900. Idaho Springs, Colo., Shear 739.

Bromus lanatipes Rydb., Colo. Agr. Expt. Sta. Bull. 100: 52. 1906. Based on $B$. porteri lanatipes Shear.

(30) Bromus arenarius Labill., Nov. Holl. Pl. 1: 23. pl. 28 . 1804. Australia.

(29) Bromus arvensis L., Sp. Pl. 77. 1753. Europe.

Bromus erectus var. arvensis Huds., Fl. Angl. ed. 2. 50. 1778. Based on B. arvensis L.

Serrafalcus arvensis Godr., Fl. Lorr. 3: 185. 1844. Based on Bromus arvensis L.

Forasaccus arvensis Bubani, Fl. Pyr. 4: 385. 1901. Based on Bromus arvensis $\mathrm{L}$. 
(4) Bromus breviaristatus Buckl., Acad. Nat. Sci. Phila. Proc. 1862: 98. 1863. Rocky Mountains, Nuttall.

Bromus parviflorus Nutt.; A. Gray, Acad. Nat. Sci. Phila. Proc. 1862: 336. 1863 , as synonym of $B$. breviaristatus Buckl.

Bromus subvelutinus Shear, U.S.Dept.Agr., Div. Agrost. Bull. 23: 52. 1900. Reno, Nev., Tracy 249.

Bromus pauciflorus Nutt.; Shear, U.S.Dept.Agr., Div. Agrost. Bull. 23: 53. 1900. This name, on Nuttall's ticket on the type of B. breviaristatus Buckl., was misread as "parviflorus" by Gray.

Bromus carinatus lincaris Shear, U.S.Dept.Agr., Div. Agrost. Bull. 23: 61. 1900. California, Vasey in 1875.

(22) Bromus brizaeformis Fisch. and Mey., Ind. Sem. Hort. Petrop. 3: 30. 1837. Europe.

(5) Bromus carinatus Hook. and Arn., Bot., Beechey Voy. 403. 1840. California.

Ceratochloa grandiflora Hook., Fl. Bor. Amer. 2: 253. 1840. Not Bromus grandiflorus Weige, 1772. Plains of the Columbia [Oregon], Scouler, Douglas.

Bromus oregonus Nutt.; Hook. f., Jour. Bot. Kew Misc. 8: 18. 1856. Name only for Geyer 244, "Upper Missouri and Oregon territories". Nutt.; Shear, U.S.Dept.Agr., Div. Agrost. Bull. 23: 59. 1900, as synonym of B. carinatus.

Bromus virens Buckl., Acad. Nat. Sci. Phila. Proc. 1862: 98. 1863. Rocky Mountains and Columbia River, Nuttall. The specimen in the herbarium of the Philadelphia Academy is the Pacific coast form with long awns, and probably came from the Columbia River.

Bromus californicus Nutt.; Buckl., Acad. Nat. Sci. Phila. Proc. 1862: 336. 1863, as synonym of B. virens Buckl. [California, Nuttall.]

Bromus nitens Nutt; A. Gray, Acad. Nat. Sci. Phila. Proc. 1862: 336.1863 , as synonym of $B$. virens Buckl. [Columbia woods, Nuttall.]

Bromus hookerianus Thurb., in Wilkes, U.S. Expl. Exped. Bot. 17: 493.1874. Based on Ceratochloa grandiflora Hook.

Bromus hookerianus var. minor Scribn.; Vasey, Descr. Cat. Grasses U.S. 92. 1885, name only, Oregon. Macoun, Cat. Can. Pl. 24: 238. 1888, without description, B. virens Buckl., cited as synonym.

Bromus virens var. minor Scribn.; Beal, Grasses N.Amer. 2: 614. 1896. Arizona and Oregon.

Bromus carinatus californicus Shear, U.S.Dept.Agr., Div. Agrost. Bull. 23: 60. 1900. [California, Nuttall.]

Bromus carinatus hookerianus Shear, U.S.Dept.Agr., Div. Agrost. Bull. 23: 60. 1900. Based on B. hookerianus Thurb.

Bromus carinatus densus Shear, U.S.Dept.Agr., Div. Agrost. Bull. 23: 61. 1900. San Nicolas Island, Calif., Trask [12].

Bromus carinatus arizonicus Shear, U.S.Dept.Agr., Div. Agrost. Bull. 23: 62. 1900. Santa Cruz Valley, Tucson, Ariz., Pringle in 1884.

Bromus Marginatus Nees; Steud., Syn. Pl. Glum. 1: 322.1854. Columbia River, Douglas.

Bromus hookeri var. marginatus Fourn., Mex. Pl. 2: 127. 1886. Based on B. marginatus Nees. [B. hookeri Fourn. (not B. hookerianus Thurb.) is based on "B. purgans Hook. f., Bot. of Capt. Beech. Voy. 119", name only.]

Ceratochloa marginata Nees; Steud.; Jacks., Ind. Kew. 1: 487. 1893, presumably referring to Bromus marginatus Nees.

Bromus marginatus seminudus Shear, U.S.Dept.Agr., Div. Agrost. Bull. 23: 55. 1900. Wallowa Lake, Oreg., Shear 1811.

Bromus marginatus latior Shear, U.S.Dept.Agr., Div. Agrost. Bull. 23: 55. 1900. Walla Walla, Wash., Shear 1615.

Bromus flodmanii Rydb., Bull. Torrey Bot. Club 36: 538. 1909. Sheep Creek, Mont., Flodman 187.

Forasaccus marginatus Lunell, Amer. Midl. Nat. 4: 225. 1915. Based on Bromus marginatus Nees.

Bromus latior Rydb., Fl. Rocky Mount. S9. 1917. Based on B. marginatus latior Shear.

Bromus maritmos (Piper) Hitche., in Jepson, Fl. Calif. 1: 177. 1912. Based on B. marginatus maritimus Piper.

Bromus marginatus maritimus Piper, Biol. Soc. Wash. Proc. 18: 148. 1905. Point Reyes, Calif., Davy 6798. 
Bromus polyanthus Scribn.; Shear, U.S.Dept.Agr., Div. Agrost. Bull. 23: 56. 1900. Based on B. multiflorus Seribn.

Bromus multiflorus Seribn., U.S.Dept.Agr., Div. Agrost. Bull. 13: 46. 1898. Not B. multiflorus Weigel, 1772. Battle Lake, Wyo., A. Nelson 4021.

Bromus polyanthus paniculatus Shear, U.S.Dept.Agr., Div. Agrost. Bull. 23: 57. 1900. West Mancos Canyon, Colo., Tracy, Earle, and Baker 333.

Bromus paniculatus Rydb., Fl. Rocky Monnt. 90. 1917. Based on B. polyanthus paniculatus Shear.

(1) Bromus catharticus Vahl, Symb. Bot. 2: 22. 1791. Lima, Peru.

Festuca unioloides Willd., Hort. Berol. 3. pl. 3. 1803. Described from a plant grown at Berlin from seed from "Carolina", where it must have been cultivated.

Ceratochloa unioloides Beauv., Ess. Agrost. 75. pl. 15. f. 7. 1812. Based on Festuca unioloides Willd.

Bromus unioloides H.P.K., Nov. Gen. and Sp., 1: 151. 1815. Quito, Ecuador, Humboldt and Bonpland.

Schedonorus unioloides Roem. and Schult., Syst. Veg. 2: 708. 1817. Based on Bromus unioloides H.B.K.

Bromus unioloides Raspail, Ann. Sci. Nat., Bot. 5: 439.1825. Based on Ceratochloa unioloides Beauv.

Bromus willdenovii Kunth, Rév. Gram. 1: 134. 1829. Based on Festuca unioloides Willd.

Ceratochloa pendula Schrad., Linnaea 6: Litt. 72. 1831. Grown at Göttingen from seed from Carolina.

Bromus schraderi Kunth, Enum. Pl. 1: 416. 1833. Based on Ceratochloa pendula Sehrad.

Bromus mucronatus Willd; Steud., Nom. Bot. ed. 2. 1: 228 . 1840, as synonym of $B$. uninloides H.B.K.

Ceratochloa breviaristata Hook., Fl. Bor. Amer, 2: 253. pl. 234. 1840. Lewis and Clarke River and near the sources of the Columbia. Douglas [in 1826].

Bromus breviaristatus Thurb., in Wilkes, U.S. Expl. Exped. Bot. 17²: 493. 1874. Not B. breviaristatus Buckl., 1863. Based on Ceratochloa breviaristata Hook.

Tragus unioloides Panz.; Jacks., Ind. Kew. 4: 1099. 1895, as synonym of Festuca unioloides Willd.

Forasaccus brebiaristatus [crror for breviaristatus] Lunell, Amer. Midl. Nat. 4: 225. 1915. Based on Ceratochloa breviaristata Hook.

Zerna unioloides Lindm., Svensk Fanerogamfl. 101. 1918. Based on Bromus unioloides H.B.K.

The form described by Shear (U.S.Dept.Agr., Div. Agrost. Bull. 23: 52. 1900) as Bromus unioloides haenkeanus (Presl) Shear is a form of rescue grass, but Ceraiochloa hacnkeana Presl, upon which the name is based, is a different speeies with purplish, awned spikelets, as shown by examination of the type, from Chile, at the herbarium of the German University at Prague.

(15) Bromus ciliatus L., Sp. Pl. 1: 76. 1753. Grown at Upsala from seed collected by Kalm in Canada.

Bromus canadensis Michx., Fl. Bor. Amer. 1: 65. 1803. Canada, Lae St. Jean, Michaux.

Bromus richardsoni link, Hort. Berol. 2: 281. 1833. Grown at Berlin from seed sent by Richardson from northwestern North America.

Bromus purgans var. longispicatus Hook., Fl. Bor. Amer. 2: 252. 1840. Rocky Mountains, Drummond.

Bronus purgans var. pallidus Hook., Fl. Bor. Amer. 2: 252. 1840. Saskatchewan to Rocky MIountains, Drummond.

Bromus inermis var. ciliatus Trant., Act. Hort. Petrop. 5: 135. 1877. Based on B. ciliatus L.

Bromus hookeri Var. canadensis Fourn., Mex. Pl. 2: 128. 1886. Based on B. canadensis Michx.

Bromus hookeri var. ciliatus Fourn., Mex. Pl. 2: 128. 1886. Based on B. ciliatus L.

Bromus ciliatus scariosus Scribn., U.S.Dept.Agr., Div. Agrost. Bull. 13: 46. 1898. Sheep Mountain, Wyo., A. Nelson 3305.

Bromus richardsoni pallidus Shear, U.S.Dept.Agr., Div. Agrost. Bull. 23: 34. 1900. Based on B. purgans var. pallidus Hook.

Forasaccus ciliatus Lunell, Amer. Midl. Nat. 4: 225. 1915. Based on Bromus ciliatus L. 
Bromus ciliatus forma denudatus Wiegand, Rhodora 24: 91. 1922. Ashfield, Mass., Willianis in 1909.

Bromus ciliatus var. denudatus Fernald, Rhodora 28: 20. 1926. Based on B. ciliatus forma denudatus Wiegand.

Bromus dudleyi Fernald, Rhodora 32: 63. pl. 196. f. 1-3. 1930. Deer Brook, Bonne Bay, Newfoundland, Fernald, Long and Fogg 1223.

Bromus ciliatus var. intonsus Fernald, Rhodora 32: 70. 1930. Ashfield, Mass., Williams, August 4, 1909. The form with more densely pilose sheaths. According to Fernald (Rhodora 32: 70. 1930) this, as shown by specimens so named in the Gray Herbarium, is the form described as B. asper Murray in Gray's Manual, eds. 5 and 6, and in Britton and Brown's Illustrated Flora. Shear in his revision of Bromus (U.S.Dept.Agr., Div. Agrost. Bull. 23: 30.1900 ) uses the earlier name $B$. ramosus Huds., but says he had seen no American specimens.

Bromus ciliatus var. Laeviglomis Seribn.; Shear, U.S.Dept.Agr., Div. Agrost. Bull. 23: 32. 1900. Galt, Ontario, Herriott in 1898. (Published as B. ciliatus laeviglumis.)

Forasaccus ciliatus var. laeviglumis Lunell, Amer. Midl. Nat. 4: 225. 1915. Based on Bromus ciliatus laeviglumis Scribn.

Bromus purgans forma glabriflor us Wiegand, Rhodora 24: 92. 1922. Ithaca, N.Y., Metcalf 5813.

Bromus laeviglumis Hitchc., Biol. Soc. Wash. Proc. 41: 157. 1928. Based on B. ciliatus laeviglumis Scribn.

(24) Bromus commutatus Schrad., Fl. Germ. 353. 1806. Germany.

Bromus pratensis Ehrh., Beitr. 6: 84. 1791. Name only; Hoffm. Deut. Fl. ed. 2. 2: 52. 1800. Not B. pratensis Lam., 1785. Europe.

Brachypodium commutatum Beauv., Ess. Agrost. 101, 155. 1812. Based on Bromus commutatus Lam. (error for Schrad.).

Serrafalcus commutatus Bab., Man. Brit. Bot. ed. 1. 374. 1843. Based on Bromus commutatus Schrad.

Bromus mutabilis var. commutatus Schultz, Flora 32: 234. 1849. Based on B. commutatus Schrad.

Bromus racemosus var. commutatus Coss. and Dur., Expl. Sci. Alger. 2: 165. 1867. Based on B. commutatus Schrad.

Bromus mollis var. commutatus Sanio, Verh. Bot. Ver. Brand. 23: Abh. 31. 1882. Based on B. commutatus Schrad.

Serrafalcus racemosus var. commutatus Husnot, Gram. Fr. Belg. 72. 1899. Based on Bromus commutatus Schrad.

Forasaccus commutatus Bubani, Fl. Pyr. 4: 387. 1901. Based on Bromus commutatus Schrad.

Bromus secalinus var. gladewitzii Farwell, Amer. Midl. Nat. 10: 24. 1926. Michigan, Farwell and Gladewitz 7434.

Bromus commutatus var. APricorum Simonkai, Enum., Fl. Transsilv. 583. 1886. Europe.

(8) Bromus erectus Huds., Fl. Angl. 39. 1762. England.

Festuca erecta Wallr., Sched. Crit. 35. 1822. Based on Bromus erectus Smith (error for Huds.).

Bromus macounii Vasey, Bull. Torrey Bot. Club 15: 48. 18ss. Vancouver Island, Macoun in 1887.

Forasaccus erectus Bubani, Fl. Pyr. 4: 384. 1901. Based on Bromus erectus Huds.

(21) Bromus frondosus (Shear) Woot. and Standl., N.Mex. Coll. Agr. Bull. 81: 144. 1912. Based on B. porteri frondosus Shear.

Bromus porteri frondosus Shear, U.S.Dept.Agr., Div. Agrost. Bull. 23: 37. 1900. Mangas, N.Mex., J. G. Smith in 1897.

(11) Bromus grandis (Shear) Hitchc., in Jepson, Fl. Calif. 1: 175. 1912. Based on $B$. orcuttianus grandis Shear.

Bromus orcuttianus grandis Shear, U.S.Dept.Agr., Div. Agrost. Bull. 23: 43. 1900. San Diego, Calif., Orcutt 472.

Bromus porteri assimilis Davy, Univ. Calif. Pubs., Bot. 1: 55. 1902. San Jacinto Mountains, Hall 2228.

(6) Bromus inermis Leyss., Fl. Hal. 16. 1761. Europe.

Festuca inermis DC. and Lam., Fl. Franc. 3: 49. 1805. Based on Bromus inermis Leyss.

Schedonorus inermis Beauv., Ess. Agrost. 99, 177. 1812. Based on Festuca inermis DC.

Festuca inermis var. villosa Mert. and Koch, Deutschl. Fl. 1: 675. 1823. Germany, 
Bromus inermis var. aristatus Schur, Enum. PI. Transsilv. 805. 1866. Europe. Bromus inopinatus Brues, Trans. Wis. Acad. Sci., Arts, and Letters 17: 73. 1911. Milwaukee, Wis. [Brues 78].

forasaccus inermis Lunell, Amer. Midl. Nat. 4: 225. 1915. Based on Bromus inermis Leyss.

Zerna inermis Lindm., Svensk Fanerogamfl. 101. 1918. Based on Bromus inermis Leyss.

Bromus inermis forma villosus Fernald, Rhodora 35: 316. 1933. Based on Festuca inermis var. villosa Mert. and Koch.

Bromus inermis forma aristatus Fernald, Rhodora 35: 316. $1933 . \quad$ Based on $B$. inermis var. aristatus Schur.

(28) Bromus japonicus Thunb., Fl. Japon. 52. 1784. Japan.

Bromus patulus Mert. and Koch, Deut. Fl. 1: 685. 1823. Europe.

Bromus arvensis var. patulus Mutel, Fl. Frans. 4: 134. 1837. Based on B. patulus Mert. and Koch.

Serrafalcus patulus Parl., Fl. Ital. 1: 394. 1848. Based on Bromus patulus Mert. and Kioch.

Bromus squarrosus var. patulus Regel, Act. Hort. Petrop. 7:602. 1881. Based on B. patulus Mert. and Koch.

Forasaccus patulus Bubani, Fl. Pyr. 4: 387. 1901. Based on Bromus patulus Mert. and Koch.

(20) Bromus kalmii A. Gray, Man. 600. 1848. Canada or northeastern United States, Kalm.

Browus Laciniatus Beal Grasses N.Amer. 2: $615.1896 . \quad$ Mexico.

Bromus pendulinus Sessé; Lag., Gen. and Sp. Nov. 4. 1816. Not B. pendulinus Schrad. 1810. Mexico.

(13) Bromus laevipes Shear, U.S.Dept.Agr., Div. Agrost. Bull. 23: 45.1900. West Klickitat County, Wash., Suksdorf 178.

(17) Bromus latiglumis Hitchc., Rhodora 8: 211. 1906. Based on B. purgans latiglumis Shear.

Bromus altissimus Pursh, Fl. Amer. Sept. 2: 728. 1814. Not B. altissimus Gilib., 1790. On the banks of the Missouri [Nuttall].

Bromus purgans latiglumis Shear, U.S.Dept.Agr., Div. Agrost. Bull. 23: 40. 1900. Dakota City, Iowa, Pammel 222.

Bromus ciliatus latiglumis Scribn.; Shear, U.S.Dept.Agr., Div. Agrost. Bull. 23: 40. 1900 , as synonym of B. purgans latiglumis Shear.

Bromus purgans incanus Shear, U.S.Dept.Agr., Div. Agrost. Bull. 23: 41. 1900. Canton, Ill., Wolf 3.

Bromus incanus Hitchc., Rhodora 8: 212. 1906. Based on B. purgans incanus Shear.

Forasaccus latiglumis Lunell, Amer. Midl. Nat. 4: 225. 1915. Based on Bromus latiglumis Hitchc.

Bromus ciliatus var. incanus Farwell, Amer. Midl. Nat. 10: 204. 1927. Based on B. purgans incanus Shear.

Bromus ciliatus var. incanus subvar. latiglumis Farwell, Amer. MidI. Nat. 10: 204. 1927. Based on B. ciliatus latiglumis Scribn.

Bromus latiglumis forma incanus Fernald, Rhodora 35: 316. 1933. Based on B. purgans incanus Shear.

Bromus macrostachys Desf., Fl. Atlant. 1: 96. pl. 19. f. 2. 1798. Algeria.

(34) Bromus madritensis L., Cent. Pl. 1: 5. 1755; Amoen. Acad. 4: 265.1759. Spain. (The name is spelled matritensis in Roem. and Schult., Syst. Veg. 2: 651 . 1817.)

Festuca madritensis Desf., Fl. Atlant. 1: 91. 1798. Based on Bromus madritensis L.

Zerna madritensis Panz.; Jacks., Ind. Kew. 4: 1249. 1895, as synonym of Bromus madritensis L.

(26) Bromus molliformis Lloyd, Fl. Loire-Inf. 315. $1844 . \quad$ France.

(25) Bromus mollis L., Sp. Pl. ed. 2. 1: 112. 1762. Europe.

Forasaccus mollis Bubani, Fl. Pyr. 4: 386. 1901. Based on Bromus mollis L.

This is the species referred to $B$. hordeaceus L. in recent American works. The specimen referred by Shear (U.S.Dept.Agr., Div. Agrost. Bull. 23: 19. 1900) to $B$. hordeaceus intermedius (Guss.) Shear belongs to B. mollis.

(10) Bromus orcuttianus Vasey, Bot. Gaz. 10: 223. 18s5. San Diego, Calif., Orcutt in 1884.

Bromus brachyphyllus Merr., Rhodora 4: 146. 1902. Crook County, Oreg., Cusick 2677.

$55974^{\circ}-35-52$ 
Bromos orcottianos var. Hallir Hitche., in Jepson, Fl. Calif. 1: 175. 1912. San Jacinto Mountains, Hall 2301.

(12) Bromus pacificus Shear, U.S.Dept.Agr., Div. Agrost. Bull. 23: 38. 1900. Seaside, Oreg., Scribner and Shear 1703.

Bromus magnificus Elmer, Bot. Gaz. 36: 53. 1903. Port Angeles, Wash., Elmer 1957.

(7) Bromus pumpellianus Scribn., Bull. Torrey Bot. Club 15: 9. 1888. Belt Mountains, Mont., Scribner 418.

Bromus purgans var. purpurascens Hook., Fl. Bor. Amer. 2: 252.1840. Bear Lake to Arctic seacoast, Richardson.

Bromus ciliatus var. coloradensis Vasey, Bull. Torrey Bot. Club 15: 10. 1888, name only; Beal, Grasses N.Amer. 2: 619. 1896. [Colo. Expl. 100th Merid. Wolf 1158.]

Bromus pumpellianus melicoides Shear, U.S.Dept.Agr., Div. Agrost. Bull. 23: 50. 1900. Beaver Creek Camp, Colo., Pammel in 1896.

Forasaccus pumpellianus Lunell, Amer. Midl. Nat. 4: 225. 1915. Based on Bromus pumpellianus Scribn.

Bromus pompellianus var. Tweedyi Scribn.; Beal, Grasses N.Amer. 2: 622. 1896. Yellowstone Park, Tweedy 587.

(16) Bromus purgans L., Sp. Pl. 1: 76. 1753. Canada, Kalm.

Bromus pubescens Muhl.; Willd., Enum. Pl. 120. 1809. Pennsylvania, Muhlenberg.

Bromus imperialis Steud., Nom. Bot. ed. 2. 1: 229. 1840, as synonym of B. purgans L.

Bromus steudelii Frank; Steud., Nom. Bot. ed. 2. 1: 229. 1840, as synonym of $B$. purgans L.

Bromus ciliatus var. purgans A. Gray, Man. 600. 1848. Based on B. purgans L.

Bromus hookeri var. pubescens Fourn., Mex. Pl. 2: 127. 1886. Based on B. pubescens Muhl.

Forasaccus purgans Lunell, Amer. Midl. Nat. 4: 225. 1915. Based on Bromus purgans $\mathbf{L}$.

Bromus purgans forma laevivaginatus Wiegand, Rhodora 24: 92. 1922. Ithaca, N.Y., Metcalf 5821.

Bromus ciliatus var. purgans subvar. laevivaginatus Farwell, Amer. Midl. Nat. 10: 204. 1927. Presumably based on B. purgans forma lacvivaginatus Wiegand.

(27) Bromus racemosus L., Sp. Pl. ed. 2. 1: 114. 1762. Europe.

Bromus arvensis var. racemosus Neilreich, Fl. Nieder-Oesterr. 81. 1859. Based on B. racemosus $\mathbf{L}$.

Bromus squarrosus var. racemosus Regel, Act. Hort. Petrop. 7: 602. 1881. Based on B. racemosus L.

Forasaccus racemosus Bubani, Fl. Pyr. 4: 387. 1901. Based on Bromus racemosus $\mathrm{L}$.

The specimens referred by Shear (U.S.Dept.Agr., Div. Agrost. Bull. 23: 20. 1900 ) to $B$. hordeaceus glabrescens (Coss.) Shear belong to B. racemosus.

(31) Bromus rigidus Roth, Mag. Bot. Roem. and Ust. 10: 21. 1790. Europe.

Bromus villosus Forsk., Fl. Aegypt. Arab. 23. 1775. Not B. villosus Scop., 1772. Egypt.

Bromus maximus Desf., Fl. Atlant. 1: 95. pl. 26. 1798. Not B. maximus Gilib., 1790. North Africa.

Bromus madritensis var. maximus St. Amans, Fl. Agen. 45. 1821. Based on B. maximus Desf.

Bromus rubens var. rigidus Mutel, Fl. Franç. 4: 133. 1837. Based on $B$. rigidus Roth.

Bromus madritensis var. rigidus Bab.; Syme in Sowerby, English Bot. ed. 3. 11: 161. 1873. Based on B. rigidus Roth.

Bromus villosus var. maximus Aschers. and Graebn., Syn. Mitteleur. Fl. 2: 595. 1901. Based on B. maximus Desf.

Bromus villosus var. rigidus Aschers. and Graebn., Syn. Mitteleur. Fl. 2: 596. 1901. Based on B. rigidus Roth.

Forasaccus maximus Bubani, Fl. Pyr. 4: 382. 1901. Based on Bromus maximuз Desf.

Bromus Rigidus var. gussonir (Parl.) Coss. and Dur., Expl. Sci. Alger. 2: 159. 1867. Based on B. gussonii Parl.

Bromus gussonii Parl., Rar. Pl. Sic. 2: 8. 1840. Europe.

Bromus maximus var. gussonii Parl., Fl. Ital. 1: 407. 1848. Basea on $B$. gussonii Parl. 
Bromus villosus var. gussonii Aschers. and Graebn., Syn. Mitteleur. Fl. 2: 595. 1901. Based on B. gussonii Parl.

(33) Bromus rubens L., Cent. Pl. 1: 5. 1755; Amoen. Acad. 4: 265.1759. Spain.

Festuca rubens Pers., Syn. Pl. 1: 94. 1805. Based on Bromus rubens L.

Bromus scoparius var. rubens St. Amans, Fl. Agen. 45. 1821. Based on B. rubens L.

Bromus madritensis subsp. rubens Husnot, Gram. Fr. Belg. 71. 1899. Based on B. rubens L.

Bromus scoparius L., Cent. Pl. 1: 6. 1755; Amoen. Acad. 4: 266. 1759. Spain. (23) Bromus secalinus L., Sp. P1. 76. 1753. Europe.

Bromus mollis var. sccalinus Huds., Fl. Angl. ed. 2. 49. 1778. Based on B. secalinus L.

Avena secalinus Salisb., Prodr. Stirp. 22. 1796. Based on Bromus secalinus L.

Serrafalcus secalinus Bab., Man. Brit. Bot. ed. 1. 374. 1843. Based on Bromus secalinus L.

?Bromus submuticus Steud., Syn. Pl. Glum. 1: 321. 1854. St. Louis, Mo.

Forasaccus secalinus Bubani, Fl. Pyr. 4: 3S8. 1901. Based on Bromus secalinus L.

Bromus secalinus var. velutinus Koch, Syn. Fl. Germ. Helv. 819. 1837. Based on $B$. velutinus Schrad.

Bromus velutinus Schrad., Fl. Germ. 1: 349. pl. 6. f. 3. 1806. Germany.

(2) Bromus sitchensis Trin., Mém. Acad. St. Pétersb. VI. Math. Phys. Nat. 2: 173. 1832. Sitka, Alaska [Mertens].

(32) Bromus sterilis L., Sp. Pl. 77. 1753. Europe.

Schedonorus sterilis Fries, Bot. Not. 131. 1843. Based on Bromus sterilis L.

Zerna sterilis Panz.; Jacks., Ind. Kew. 4: 1249. 1895, as synonym of Bromus steritis $\mathrm{L}$.

(9) Bromus suksdorfii Vasey, Bot. Gaz. 10: 223. 1885. Mount Adams, Wash., Suksdorf [74 in 1883].

(35) Bromus tectorum L., Sp. P1. 77. 1753. Europe.

Schedonorus tectorum Fries, Bot. Not. 131. 1843. Based on Bromus tectorum L.

Bromus sctaceus Buckl., Acad. Nat. Sci. Phila. Proc. 1862: 98. 1863. Northern Texas, Buckley.

Zerna tectorum Panz.; Jacks., Ind. Kew. 4: 1249. 1895, as synonym of Bromus tectorum $\mathrm{L}$.

Bromus tectorum var. glabratus Spenner, Fl. Friburg. 1: 152. 1825. Germany.

Bromus tectorum var. nudus Klett. and Richt., Fl. Leipzig 109. 1830. Germany.

(18) Bromus texensis (Shear) Hitchc., Contrib. U.S. Natl. Herb. 17: 381. 1913. Based on B. purgans texensis Shear.

Bromus purgans texensis Shear, U.S.Dept.Agr., Div. Agrost. Bull. 23: 41.1900. Bexar County, Tex., Jermy 230.

(36) Bromus trinii Desv., in Gay, Fl. Chil. 6: 441. 1853. Based on Trisetum hirtum Trin.

Trisetum hirtum Trin., Linnaea 10: 300. 1836. Not Bromus hirtus Lichtst., 1817. Chile.

Bromus trinii var. pallidiflorus Desv., in Gay, Fl. Chil. 6: 441. 1853. Chile.

Trisetum barbatum Steud., Syn. Pl. Glum. 1: 229. 1854. Not T. barbatum Nees, $1841 . \quad$ Chile, Bertero 806.

Danthonia pseudo-spicata C. Muell., Bot. Ztg. 14: 348. 1856. Valparaiso, Chile, Cuming 466.

Bromus barbatoides Beal, Grasses N.Amer. 2: 614. 1896. Based on Trisetum barbatum Steud.

Bromus barbatoides var. sulcatus Beal, Grasses N.Amer. 2: 615. 1896. Mexico, Palmer 667.

Trisetum barbatum var. major Vasey; Beal, Grasses N.Amer. 2: 615. 1896, as synonym of Bromus barbatoides var. sulcatus Beal.

Trisetum trinii Louis-Marie, Rhodora 30: 243. 1928. Based on Bromus trinii Desv.

Trisctum trinii var. pallidiflor us Louis-Marie, Rhodora 30: 243. 1928. Based on Bromus trinii var. pallidiflorus Desv.

Trisetum trinii var. majus Louis-Marie, Rhodora 30: 243. 1928. Based on T. barbatum var. major Vasey. 
Bromus trinir var. excelsus Shear, U.S.Dept.Agr., Div. Agrost. Bull. 23: 25. 1900. Panamint Mountains, Calif., Coville and Funsion 522.

(14) Bromus vulgaris (Hook.) Shear, U.S.Dept.Agr., Div. Agrost. Bull. 23: 43. 1900. Based on B. purgans var. vulgaris Hook.

Bromus purgans var. vulgaris Hook., Fl. Bor. Amer. 2: 252.1840. Canada, Goldie, Richardson; Red River, Douglas; Columbia River, Scouler.

Bromus ciliatus var. ligulatus Vasey; Macoun, Cat. Can. Pl. 24: 238. 1888. Name only, Vancouver Island, Macoun in 1887.

Bromus ciliatus var. pauciflorus Vasey; Macoun, Cat. Can. P1. 24: 238. 1888, name only. Beal, Grasses N.Amer. 2: 619. 1896. Oregon, Howell.

Bromus debilis Nutt.; Shear, U.S.Dept.Agr., Div. Agrost. Bull. 23: 43.1900 , as synonym of $B$. vulgaris. [Columbia River, Scouler.]

Bromus vulgaris eximius Shear, U.S.Dept.Agr., Div. Agrost. Bull 23: 44.1900. Near Wallowa Lake, Oreg., Shear 1791.

Bromus vulgaris robustus Shear, U.S.Dept.Agr., Div. Agrost. Bull. 23: 44. 1900. Seaside, Oreg., Shear 1710.

Bromus ciliatus var. glaberrimus Suksdorf, Deut. Bot. Monatsschr. 19: 93. 1901. Skamania County, Wash., Suksdorf in 1894 [2335].

Bromus eximius Piper, Contrib. U.S. Natl. Herb. 11: 143. 1906. Based on B. vulgaris eximius Shear.

Bromus eximius robustus Piper, Contrib. U.S. Natl. Herb. 11: 143. 1906. Based on B. vulgaris robustus Shear.

Bromus eximius umbraticus Piper, Contrib. U.S. Natl. Herb. 11: 144. 1906. Based on Bromus vulgaris Shear, not Bromus purgans var. vulgaris Hook., Piper considering the specimens referred by Shear to this species to be distinct from the form described by Hooker.

\section{(107) BUCHLÖ̈ Engelm.}

(1) Buchloë dactyloides (Nutt.) Engelm., St. Louis Acad. Sci. Trans. 1: 432. 1859. Based on Sesleria dactyloides Nutt.

Sesleria dactyloides Nutt., Gen. Pl. 1: 65. 1818. Grassy plains of the Missouri [Nuttall, type a staminate plant].

Anthephora axilliflora Steud., Syn. Pl. Glum. 1: 111. 1854. [Misspelled Antephora.] Texas, Drummond [pistillate plant].

Calanthera dactyloides Kunth; Hook., Jour. Bot. Kew Misc. 8: 18. 1856. Based on Sesleria dactyloides Nutt.

Lasiostega humilis Rupr.; Munro, in Benth., Pl. Hartw. 347. 1857. Name only (error for Casiostega). Ag das Calientes, Mexico, Hartweg 250.

Casiostega dactyloides Fourn., Bull. Soc. Bot. Belg. 15: 470. 1876. Based on Sesleria dactyloides Nutt.

Casiostega hookeri Rupr.; Fourn., Bull. Soc. Bot. Belg. 15: 471. 1876, as synonym of Buchloë dactyloides Engelm.

Bouteloua mutica Griseb.; Fourn., Bull. Soc. Bot. Belg. 15: 471. 1876, as synonym of Buchloë dactyloides Engelm., Mexico, Schaffner 134 [staminate plant].

Melica mexicana Link; Fourn., Bull. Soc. Bot. Belg. 15: 471. 1876, as synonym of Buchloë dactyloides Engelm.

Bulbilis dactyloides Raf.; Kuntze, Rev. Gen. Pl. 2: 763. 1891. Based on Sesleria dactyloides Nutt.

\section{(61) CALAMagrostis Adans.}

(1) Calamagrostis bolanderi Thurb., in S. Wats., Bot. Calif. 2: 280. 1880. Mendocino County, Calif., Bolander 6471 in part.

Calamagrostis varia Boland.; Thurb., in S. Wats., Bot. Calif. 2: 280. 1880. Not C. varia Host, 1809 . As synonym of C. bolanderi Thurb.

Deyeuxia bolanderi Vasey, Grasses U.S. 28. 1883. Based on Calamagrostis bolanderi Thurb.

(3) Calamagrostis breweri Thurb., in S. Wats., Bot. Calif. 2: 280. 1880. Carson Pass, Calif., Brewer 2128.

Deyeuxia breweri 'Vasey, Grasses U.S. 28. 1883. Based on Calamagrostis breweri Thurb.

Calamagrostis lemmoni Kearney, U.S.Dept.Agr., Div. Agrost. Bull. 11: 16. 1898. California, Lemmon in 1875.

Calamagrostis Cainii Hitche., Jour. Wash. Acad. Sci. 24: 480. 1934. Mount LeConte, Tenn., Cain 48. (See p. 993.)

Calamagrostis californica Kearney, U.S.Dept.Agr., Div. Agrost. Bull. 11: 37. 1898. Sierra Nevada, Calif., Lemmon 444 in 1895. Anomalous form. 
(16) Calamagrostis canadensis (Michx.) Beauv., Ess. Agrost. 15, 152, 157. 1812. Based on Arundo canadensis Michx.

Arundo canadensis Michx., FI. Bor. Amer. 1: 73. 1803. Canada, Michaux. Arundo agrostoides Pursh, Fl. Amer. Sept. 1: 86. 1814. New Jersey and Pennsylvania.

Calamagrostis mexicana Nutt., Gen. Pl. 1: 46. 1818. North America. "Agrostis mexicana? Persoon, Arundo agrostoides Pursh" are cited. Agrostis mexicana L., in Persoon's work is Muhlenbergia mexicana, but Nuttall's description agrees with Pursh's.

Calamagrostis agrostoides Pursh; Spreng., Syst. Veg. 1: 252. 1825. Presumably based on Arundo agrostoides Pursh.

Cinna purshii Kunth, Rév. Gram. 1: 67. 1829. Based on Arundo agrostoides Pursh.

Arundo fissa Willd.; Steud., Nom. Bot. ed. 2. 1: 144. 1840, as synonym of Calamagrostis michauxii Trin.

Calamagrostis michauxii Trin.; Steud., Nom. Bot. ed. 2. 1: 250. 1840. Based on Arundo canadensis Michx.

Deyeuxia canadensis Munro; Hook. f., Linn. Soe. Trans. 23: 345. 1861. Presumably based on Arundo canadensis Michx., indirect citations given. See also, Vasey, Grasses U.S. 28. 1883; Agr. Grasses U.S. 69. pl. 59. 1884; Cassidy, Colo. Agr. Expt. Sta. Bull. 12: 48, with plate. 1890.

Calamagrostis oregonensis Buckl., Acad. Nat. Sci. Phila. Proc. 1862: 92. 1863. Columbia River, Nuttall.

Calamagrostis columbiensis Nutt.; A. Gray, Acad. Nat. Sci. Phila. Proc. 1862: 334. 1863. Name only [Columbia River, Nuttall].

Calamagrostis canadensis var. robusta Vasey, in Wheeler, Rept. U.S. Survey 100 th Merid. 6: 285. 1878. Twin Lakes, Colo., Expl. 100th Merid. [Wolf] 1093.

Calamagrostis pallida Vasey and Scribn.; Vasey, Contrib. U.S. Natl. Herb. 3: 79. 1892. Not C. pallida C. Muell., 1861. Washington, Suksdorf in $18 \$ 3$. Calamagrostis blanda Beal, Grasses N.Amer. 2: 349. 1896. Based on C. pallida Vasey and Seribn.

Calamagrostis canadensis acuminata Vasey; Shear and Rydb., U.S.Dept.Agr., Div. Agrost. Bull. 5: 26. 1897. Georgetown, Colo., Shear 615 [type]; Montana, Idaho.

Calamagrostis canadensis campestris Kearney, U.S.Dept.Agr., Div. Agrost. Bull. 11: 31. 1898. Louis Plain, Assiniboia, Macoun 56.

Calamagrostis alaskana Kearney, U.S.Dept.Agr., Div. Agrost. Bull. 11: 32. 1898. Yukon River, Alaska, Funston 157.

Calamagrostis atropurpurea. Nash, Bull. N.Y. Bot. Gard. 2: 153. 1901. Dawson, Yukon Territory, R. S. Williams in 1899.

Calamagrostis anomala Suksdorf, Allg. Bot. Ztschr. 12: 43. 1906. Mount Paddo [Adams], Wash., Suksdorf 2824.

Calamagrostis langsdorfi var. acuminata Litw., Trav. Mus. Bot. Acad. Sci. Petrograd 18: 52. 1920. Based on C. canadensis var. acuminata Vasey.

Calamagrostis canadensis var. pallida Stebbins, Rhodora 32: 45. 1930. Based on C. pallida Vasey and Scribn.

Calamagrostis scribneri var. imberbis Stebbins, Rhodora 32: 46. 1930. Based on C. anomala Suksdorf "not Steud., in Lechl., Berb. Am. Aust. 56. (1857)," a name only.

Calamagrostis Canadensis var. macouniana Stebbins, Rhodora 32: 41. 1930. Based on Deyeuxia macouniana Vasey.

Deyeuxia macouniana Vasey, Bot. Gaz. 10: 297. 1885. Northwest Territory, Macoun.

Calamagrostis macouniana Vasey, Contrib. U.S. Natl. Herb. 3: S1. 1892. Based on Deyeuxia macouniana Vasey.

Calamagrostis canadensis var. scabra (Presl) Hitehe., Amer. Jour. Bot. 21: 135. 1934. Based on C. scabra Presl.

Calamagrostis scabra Presl, Rel. Haenk. 1: 234. 1830. Nootka Sound, Vancouver Island, Haenke.

Deyeuxia preslii Kunth, Rév. Gram. 1: Sup. XX. 1830. Based on Calamagrostis scabra Presl.

This variety has been referred to Calamagrostis langsdorfi (Link) Trin. by many American authors. A fragment of the type of Arundo langsdorfi Link, sent by Dr. Pilger from the Berlin Herbarium, shows that it is not an American species. The rachilla is very minute or wanting, the spikelets are smaller than in $C$. scabra, the glumes are thinner, showing the nerves distinctly, and the blades are 
narrower. The following names, typonyms of C. langsdorfi, found in American works, belong to the Old World species:

Arundo langsdorfi Link, Enum. Pl. 1: 74. 1821. Described from a garden specimen.

Calamagrostis langsdorfi Trin., Gram. Unifl. 225. pl. 4. f. 10. 1824. Based on Arundo langsdorfi Link.

Deyeuxia langsdorfi Kunth, Rév. Gram. 1: 77. 1829. Based on Arundo langsdorfi Link.

Calamagrostis canadensis var. langsdorfi Inman, Rhodora 24: 143.1922. Based on Arundo langsdorfi Link.

(18) Calamagrostis cinnoides (Muhl.) Barton, Compend. Fl. Phila. 1: 45. 1818. Based on Arundo cinnoides Muhl.

Agrostis glauca Muhl., Descr. Gram. 76. 1817. Not Calamagrostis glauca Reichenb., 1830. Pennsylvania, New Jersey, Carolina.

Arundo cinnoides Muhl., Descr. Gram. 187. 1817. Pennsylvania, Massachusetts.

Arundo coarctata Torr., Fl. North. and Mid. U.S. 1: 94. 1823. New Jersey.

Calamagrostis langsdorfi var. marylandica Trin., Gram. Unifl. 225. 1824. Based on Arundo cinnoides Muhl.

Arundo canadensis Nutt.; Steud., Nom. Bot. ed. 2. 1: 144.1840 , as synonym of Calamagrostis nuttalliana Steud. [Philadelphia, Nuttall.]

Calamagrostis nuttalliana Steud., Nom. Bot. ed. 2. 1: 251. 1840. Based on the species described by Nuttall [from specimen from Philadelphia] as C. canadensis (Nutt. Gen. Pl. 1: 46. 1818).

Calamagrostis coarctata Torr.; Hook., Fl. Bor. Amer. 2: 240. 1840. Presumably based on Arundo coarctata Torr. Published as new in Torr., Fl. N.Y. 2: 444. pl. 151. 1843. Based on A. coarctata Torr.

Deyeuxia nuttalliana Vasey, Grasses U.S. 28. 1883. Based on Calamagrostis nuttalliana Steud.

(22) Calamagrostis crassiglumis Thurb., in S. Wats., Bot. Calif. 2: 281. 1880. Mendocino County, Calif., Bolander 4766, 4787.

Deyeuxia crassiglumis Vasey, Grasses U.S. 28. 1883. Based on Calamagrostis crassiglumis Thurb.

Calamagrostis neglecta var. crassiglumis Beal, Grasses N.Amer. 2: 353.1896. Based on C. crassiglumis Thurb.

(12) Calamagrosíis densa Vasey, Bot. Gaz. 16: 147. 1891. Julian, San Diego County, Calif., Orcutt.

Calamagrostis koelerioides var. densa Beal, Grasses N.Amer. 2: 345. 1896. Based on C. densa Vasey.

Calamagrostis vilfaeformis Kearney, U.S.Dept.Agr., Div. Agrost. Bull. 11: 20. 1898. Based on C. densa Vaseỳ.

(23) Calamagrostis epigeios (L.) Roth, Tent. Fl. Germ. 1: 34. 1788. Based on Arundo epigeios L.

Arundo epigeios L., Sp. Pl. 81. 1753. Europe.

Calamagrostis georgica C. Koch, Linnaea 21: 387. 1848. Georgia (Russia) near Tiflis.

Calamagrostis epigejos var. georgica Ledeb., Fl. Ross. 4: 433. 1853. Based on C. georgica C. Koch. (Fide Fernald, Rhodora 35: 65. 1933.)

Calamagrostis arenicola Fernald, Rhodora 30: 203. 1928. Barnstable County, Mass., Fernald 757.

(5) Calamagrostis foliosa Kearney, U.S.Dept.Agr., Div. Agrost. Bull. 11: 17. 1898. Based on C. sylvatica var. longifolia Vasey.

Calamagrostis sylvatica var. longifolia Vasey, Contrib. U.S. Natl. Herb. 3: 83. 1892. Not C. longifolia Hook., 1840. [Humboldt County] Calif., Bolander 6470.

(2) Calamagrostis howellii Vasey, Bot. Gaz. 6: 271. 1881. Oregon, Howell.

Deyeuxia howellii Vasey, Grasses U.S. 28. 1883. Based on Calamagrostis howellii Vasey.

(20) Calamagrostis inexpansa A. Gray, Gram. and Cyp. 1: no. 20. 1834. Penn Yan, N.Y., Sartwell.

Calamagrostis hirtigluma Steud., Syn. Pl. Glum. 1: 188. 1854. Labrador.

Calamagrostis stricta var. brevior Vasey, in Wheeler, Rept. U.S. Survey 100th Merid. 6: 285. 1878. Mosquito, Colo., [Wolf] 1098.

Calamagrostis stricta var. robusta Vasey, in Wheeler, Rept. U.S. Survey 100th Merid. 6: 285. 1878. Twin Lakes, Colo., [Wolf] 1099.

Deyeuxia neglecta var. americana Vasey; Macoun, Cat. Can. Pl. 24: 206. 1888. Donald, Columbia Valley, Macoun in 1885. 
Deyeuxia neglecta var. robusta Vasey; Macoun, Cat. Can. Pl. 24: 206.1888. Alberta, Macoun.

Deyeuxia glomerata Vasey; Macoun, Bot. Gaz. 16: 2Ss. 1891. Name only. Rocky Mountains, British Columbia, $J$. and $J$. M. Macoun in 1890 .

Calamagrostis robusta Vasey, Contrib. U.S. Nat1. Herb. 3: 82. 1892. Not C. robusta Miuell., 1861. Presumably based on C. stricta var. robusta Vasey, the description being an amplification of that.

Calamagrostis americana Scribn., U.S.Dept.Agr., Div. Agrost. Bull. 5: 27. 1897. Based on Deyeuxia neglecta var. americana Vasey.

Calamagrostis inexpansa cuprea Kearney, U.S.Dept.Agr., Div. Agrost. Bull. 11: 37. 1S9S. Falcon Valley, Wash., Suksdorf 310.

Calamagrostis hyperborea stenodes Kearney, U.S.Dept.Agr., Div. Agrost. Bull. 11: 39. 1898. Marshall Pass, Colo., Clements 206.

Calamagrostis hyperborea elongata Kearney, U.S.Dept.Agr., Div. Agrost. Bull. 11: 40. 1898. Plummer County, Nebr., Rydberg 1494.

Calamagrostis hyperborea americana Kearney, U.S. Dept.Agr., Div. Agrost. Bull 11: 41. 1898. Based on Deyeuxia neglecta var. americana Vasey.

Calamagrostis micrantha var. sierrae Jones, Contrib. West. Bot. 14: 9. 1912. Prattville and Susanville, Calif. [Jones.]

Calamagrostis neglecta var. inexpansa Jones, Contrib. West. Bot. 14: 9. 1912. Based on C. inexpansa A. Gray.

Deyeuxia hyperborea elongata Luneil, Amer. Midl. Nat. 4:21S. 1915. Based on Calamagrostis hyperborea elongata Kearney.

Deyeuxia hyperborea stenodes Lunell, Amer. Midl. Nat. 4: 218. 1915. Based on Calamagrostis hyperborea stenodes Kearney.

Calamagrostis elongata Rydb., FI. Rocky Mount. 5S. 1917. Based on C. hyperborea elongata Kearney.

Calamagrostis wyomingensis Gandog., Bull. Soc. Bot. France 667: 299.1920. Granger, Wyo., Nelson 3884.

Calamagrostis scopulorum var. bakeri Stebbins, Rhodora 32: 47. 1930. Pagosa Peak, Colo., Baker 162.

Calamagrostis inexpansa var. robusta Stebbins, Rhodora 32: 48. 1930. Based on C. stricta var. robusta Vasey.

Calamagrostis inexpansa var. brevior Stebbins, Rhodora 32: 50. 1930. Based on $C$. stricta var. brevior Vasey.

This species has been referred by American authors to C. hyperborea Lange (C. neglecta var. hyperborea Jones, Deyeuxia hyperborea Lunell); and to C. stricta Trin.

Calamagrostis inexpansa var. Barbulata Kearney, U.S.Dept.Agr., Div. Agrost. Bull. 11: 37. 1898. Mason County, Wash., Piper 947.

Calamagrostis inexpansa var. Novae-Angliae Stebbins, Rhodora 32: 51. 1930. Mount Desert, Maine, Williams and Rand in 1899.

(13) Calamagrostis koelerioides Vasey, Bot. Gaz. 16: 147. 1S91. Julian, San Diego County, Calif., Orcutt.

(1.7) Calamagrostis lactea Beal, Grasses N.Amer. 2: 346. 1896. Washington, Suksdorf 1022.

Deyeuxia lactea Beal, Grasses N.Amer. 2: 346. 1896, as synonym of Calamagrostis lactea. Suksdorf, Deut. Bot. MIonatsschr. 19:92. 1901. Based on C. lactea Beal.

Calamagrostis langsdorfi lactea Kearney, U.S.Dept.Agr., Div. Agrost. Bull. 11: 28. 1898. Based on C. lactea Beal.

(7) Calamagrostis montanensis Scribn.; Vasey, Contrib. U.S. Natl. Herb. 3: 82 . 1892. Montana, Scribner.

Deyeuxia montanensis Scribn., Soc. Prom. Agr. Sci. Proc. 2: 52. 1855. Helena, Mont., Scribner.

Calamagrostis neglccta var. candidula Kearney, U.S.Dept.Agr., Div. Agrost. Bull. 11: 35. 189S. Crpress Hills, Assiniboia, Macoun 7483 .

(21) Calamagrostis neglecta (Ehrh.) Gaertn., Mey. and Scherb., Fl. Wett. 1: 94. 1799. Based on Arundo neglecta Ehrh.

Arundo neglecta Elrh., Beitr. 6: 137. 1791. Europe.

Deyeuxia neglecta Kunth, Rév. Gram. 1: 76. 1829. Based on Arundo neglecta Ehrh.

Deyeuxia neglecta var. gracilis Scribn., Bot. Gaz. 11: 175. 1S86. Yellowstone Park, Tweedy 582.

Deyeuxia vancouverensis Vasey, Bull. Torrey Bot. Club 15: 48. 18ss. Locality erroneously given as "Vancouver Island", Macoun in 1887. Correction made in Macoun, Cat. Can. Pl. 24: 207. 1888. Fort George, James Bay, Quebec. 
Deyeuxia neglecta var. brevifolia Vasey; Macoun, Cat. Can. Pl. 24: 206.1888. Pelly Banks, Northwest Territory, Dawson.

Deyeuxia borealis Macoun, Cat. Can. Pl. 24: 207. 18s8. Change of name for -D. vancouverensis Vasey, erroneously ascribed to Vancouver Island; collected at Fort George, James Bay, Quebec, J. M. Macoun.

Calamagrostis laxiflora Kearney, U.S.Dept.Agr., Div. Agrost. Bull. 11: 34 . 1898. Not C. laxiflora Phil., 1896. Based on "C. neglecta gracilis Scribn.", error for Deyeuxia neglecta gracilis Scribn.

Calamagrostis neglecta gracilis Scribn.; Kearney, U.S.Dept.Agr., Div. Agrost. Bull. 11: 34. 1898, as synonym of C. laxiflora Kiearney.

Calamagrostis micrantha Kearney, U.S.Dept.Agr., Div. Agrost. Bull. 11: 36. 1898. Prince Albert, Saskatchewan, Macoun 13111.

Calamagrostis neglecta var. micrantha Stebbins, Rhodora 32: 55. 1930. Based on C. micrantha Kearney.

(11) Calamagrostis nutkaensis (Presl) Steud., Syn. Pl. Glum. 1: 190. 1854. Based on Deyeuxia nutkaensis Presl.

Deyeuxia nutkaensis Presl, Rel. Haenk. 1: 250. 1830. Nootka Sound, Vancouver Island, Haenke.

Calamagrostis aleutica Trin., in Bong., Mém. Acad. St. Pétersb. VI. Math. Phys. Nat. 2: 171.1832 . Unalaska Island, Alaska.

Deyeuxia aleutica Munro; Hook. f., Limn. Soc. Trans. 23: 345. 1862. Based on Calamagrostis aleutica Trin.

Calamagrostis albicans Buckl., Acad. Nat. Sci. Phila. Proc. 1862: 92.1863. Columbia Plains, Oreg., Nuttall.

Calamagrostis pallida Nutt.; A. Gray, Acad. Nat. Sci. Phila. Proc. 1862: 334. 1863, as synonym of C. albicans Buckl. ["Columbia alluvions," Nuttall.]

Calamagrostis albescens Buckl.; A. Gray, Acad. Nat. Sci. Phila. Proc. 1862: 334. 1863, herbarium name, as synonym of C. albicans Buckl.

Deyeuxia breviaristata Vasey, Bull. Torrey Bot. Club 15: 48. 1888. Vancouver Island, Macoun in 1887.

Calamagrostis aleutica patens Kearney, U.S.Dept.Agr., Div. Agrost. Bull. 11: 20. 1898. Mendocino, Calif. [probably collected by Bolander].

(10) Calamagrostis perplexa Scribn., U.S.Dept.Agr., Div. Agrost. Circ. 30: 7. 1901. Based on C. nemoralis Kearney.

Calamagrostis breviseta lacustris Kearney, U.S.Dept.Agr., Div. Agrost. Bull. 11: 25. 1898. Fond du Lac, Minn., Wood in 1889.

Calamagrostis nemoralis Kearney, U.S.Dept.Agr., Div. Agrost. Bull. 11: 26. 1898. Not C. nemoralis Phil., 1896. Ithaca, N.Y., Dudley in 1884.

Calamagrostis pickeringii var. lacustris Hitchc., Rhodora S: 210. 1906. Based on C. breviseta lacustris Iiearney.

Calamagrostis lacustris Nash, in Britt. and Brown, Illus. Fl. ed. 2. 1: 208. 1913. Based on C. breviseta lacustris Kearney.

This species was erroneously referred to Calamagrostis porteri Gray by Dudley, Cavuga Fl. 125.1886 ?

(14) Calamagrostis pickeringii A. Gray, Man. ed. 2. 547. 1856. White Mountains, N.H., Pickering.

Calamagrostis syluatica var. breviseta A. Gray, Man. 582. 1848. White Mountains, N.H.

Deyeuxia pickeringii Vasey, Grasses U.S. 28. 1883. Based on Calamagrostis pickeringii A. Gray.

Calamagrostis breviseta Scribn., Mem. Torrey Bot. Club 5: 41. 1894. Based on C. sylvatica var. breviseta A. Gray.

Calamagrostis breviseta debilis Kearney, U.S.Dept.Agr., Div. Agrost. Bull. 11: 25. 1898. Newfoundland, Robinson and Schrenk 205.

Calamagrostis pickeringii var. debilis Fern. and Wieg., Rhodora 15: 135.1913. Based on C. breviseta debilis Kearney.

(9) Calamagrostis porteri A. Gray, Amer. Acad. Sci. Proc. 6: 79. 1862. Huntingdon County, Pa., Porter in 1862.

Deyeuxia porteri Vasey, Grasses U.S. 28. 1883. Based on Calamagrostis porteri A. Gray.

(6) Calamagrostis purpurascens R. Br., in Richards., Bot. App. Franklin Jour. 731. 1823. Northern British America.

Arundo purpurascens Schult., Mant. 2: 603. 1824. Based on Calamagrostis purpurascens $\mathrm{R}$. Br.

Deyeuxia purpurascens Kunth, Rév. Gram. 1: 77. 1829. Based on Calamagrostis purpurascens $\mathrm{R}$. Br.

Calamagrostis sylvatica var. purpurascens Thurb.; Vasev, Contrib. U.S. Natl. Herb. 3: 83. 1892. [Mount Dana,] Calif., Bolander 5071. 
Calamagrostis sylvatica var. americana Vasey, Contrib. U.S. Natl. Herb. 3: 83. 1892. British America to Colorado. [Type, Pen Gulch, Colo., Vasey in 1884.]

Calamagrostis arctica Vasey, U.S.Dept.Agr., Div. Bot. Bull. 132: pl. 55. 1893. St. Panl Island, Bering sea, J. M. Macoun.

Calamagrostis vaseyi Beal, Grasses N.Amer. 2: 344. 1896. Cascade Mountains, Wash., Vasey.

Calamagrostis purpurascens arctica Kearney, U.S.Dept.Agr., Div. Agrost. Bull. 11: 19. 1898. Based on C. arctica Vasey.

Calamogrostis yukonensis Nash, Bull. N.Y. Bot. Gard. 2: 154. 1901. Dawson, Yukon Territory, R. S. Williams.

Calamagrostis purpurascens var. vaseyi Jones, Contrib. West Bot. 14: 9. 1912. Based on C. vaseyi Beal.

This species has been referred to Deyeuxia sylvatica (DC.) Kunth by American authors.

(8) Calamagrostis rubescens Buckl., Acad. Nat. Sci. Phila. Proc. 1862: 92. 1863. Oregon, Nuttall.

Deyeuxia rubescens Vasey, Grasses U.S. 28. 1853. Based on Calamagrostis rubescens Buckl.

Deyeuxia cusiclii Vasey, Bot. Gaz. 10: 224. 1855. Eagle Mountains, Oreg., Cusick 1159.

Deyeuxia suksdorfi Scribn., Bull. Torrey Bot. Club 15: 9. pl. 76. 1888. Washington, Suksdorf 26.

Calamagrostis aleutica var. angusta Vasey, Contrib. U.S. Natl. Herb. 3: 80. 1892. Santa Cruz, Calif., Anderson.

Calamagrostis cusickii Vasey, Contrib. U.S. Natl. Herb. 3: \$1. 1892. Based on Dcyeuxia cusickii Vasey.

Calamagrostis sulisdorfi Scribn.; Vasey, Contrib. U.S. Natl. Herb. 3: \$2. 1892. Based on Deyeuxia sulsdorfi Seribn.

Calamagrostis angusta Kearney, U.S.Dept.Agr., Div. Agrost. Bull. 11: 21. 1898. Based on C. aleutica var. angusta Vasey.

Calamagrostis subflexuosa Kearney, U.S.Dept.Agr., Div. Agrost. Bull. 11: 22. 189s. Oakland, Calif., Bolander 2274.

Calamagrostis fasciculata Kearney, U.S.Dept.Agr., Div. Agrost. Bull. 11: 23. 189s. Mendocino County, Calif., Pringle in 1882.

Calamagrostis suksdorfii luxurians Kearney, U.S.Dept.Agr., Div. Agrost. Bull. 11: 24. 1898. Coeur d'Alene Lake, Idaho, Sandberg, Hcller and McDougal 630.

This species has been referred by some Anerican authors to Calamagrostis sylvatica DC., and to Deŷeuxia varia Kunth.

(19) Calamagrostis scopulorum Jones, Calif. Acad. Sci. Proc. II. 5: 722. 1895. Springdale, Utah, Jones 6075.

Calamagrostis scopulorum lucidula Kearney, U.S.Dept.Agr., Div. Agrost. Bull. 11: 33. 1898. Wasatch Mountains, Utah, Jones 1145.

(15) Calamagrostis scribneri Beal, Grasses N.Amer. 2: $343.1896 . \quad$ Based on Deyeuxia dubia Scribn. and Tweedy.

Deyeuxia dubia Scribn. and Tweedy, Bot. Gaz. 11: 174. 18s6. Not Calamagrostis dubia Bunge, 1854. Yellowstone Park, Tweedy.

Calamagrostis dubia S'cribn.; Vasey, Contrib. U.S. Natl. Herb. 3: S0. 1892. Based on Deyeuxia dubia Scribn. and Tweedy.

Calamagrostis canalensis var. dubia Vasey, Contrib. U.S. Natl. Herb. 3: 80. 1892. Based on C. dubia Scribn. and Tweedy.

Calamagrostis langsdorfi var. scribneri Jones, Contrib. West. Bot. 14: 9. 1912. Based on C. scribneri Beal.

(4) Calamagrostis tweedyi (Scribn.) Scribn.; Vasey, Contrib. U.S. Natl. Herb. 3: 83. 1892. Based on Deyeuxia tweedyi Seribn.

Deyeuxia tweedyi Scribn., Bull. Torrey Bot. Club 10: 64. 1883. Cascade Mountains, Wash., Tweedy.

\section{(63) CALAMOVILFA Hack.}

(2) Calamovilfa brevipilis (Torr.) Scribn., in Hack., True Grasses 113.1890. Based on Arundo brevipilis Torr.

Arundo brevipilis Torr., Fl. North. and Mid. U.S. 1: 95. 1823. Quaker Bridge, N.J.

Calamagrostis brevipilis 1. C. Beck, Bot. North. and Mid. States 401. 1833. Based on Arundo brevipilis Torr.

Ammophila brevipilis Benth.; Vasey, Grasses U.S. 29. 1883, Based on Calamagrostis brevipilis Beck. 
(1) Calamovilfa curtissii (Vasey) Scribn., U.S.Dept.Agr., Div. Agrost. Bull. 17: 199. f. 495 . 1S99. Based on Ammophila curtissii Vasey.

Ammophila curtissii Vasey, Bull. Torrey Bot. Club 11: 7. 1884. Indian River, Fla., Curtiss.

Calamagrostis curtissii Vasey, Bot. Gaz. 15: 269. 1890. Based on Ammophila curtissii Vasey.

(4) Calamovilfa gigantea (Nutt.) Scribn. and Merr., U.S.Dept.Agr., Div. Agrost. Circ. 35: 2. 1901. Based on Calamagrostis gigantea Nutt.

Calamagrostis gigantea Nutt., Amer. Phil. Soe. Trans. (n.s.) 5: 143. 1837. Great Salt River of the Arkansas.

Toxeumia gigantea Nutt.; Scribn. and Merr., U.S.Dept.Agr., Div. Agrost. Circ. 35: 2. 1901, as synonym of Calamoilfa gigantea. Salt River, Ark., Nuttall.

(3) Calamovilfa longifolia (Hook.) Scribn., in Hack., True Grasses 113. 1800. Based on Calamagrostis longifolia Hook.

Calamagrostis longifolia Hook., I1. Bor. Amer. 2: 241. 1840. Saskatchewan, Drummond.

Vilfa rigida Buckl., Acad. Nat. Sci. Phila. Proc. 1862: 89. 1863. "Oregon?" the locality probably erroneous.

Ammophila longifolia Benth.; Vasey, Grasses U.S. 29. 1983. Based on Calamagrostis longifolia Gray [error for Hook].

Atheronotus longifolius Lunell, Amer. Micll. Nat. 4: 218. 1915. Based on Calamagrostis longifolia Hook.

Calamovilfa longifolia var. Magna Scribn. and Merr., U.S.Dept.Agr., Div. Agrost. Circ. 35: 3. 1901. Mouth of Kalamazoo River, Mich., Taylor in 1894.

\section{(13) CATABRosA Beauv.}

(1) Catabrosa acuatica (L.) Beauv., Ess. Agrost. 97, 149, 157. pl. 19. f. 8. 1812. Based on Aira aquatica L.

Aira aquatica L. Sp. Pl. 64. 1753. Europe.

Molinia aquatica Wib., Prim. Fl. Werthem. 116. 1799. Based on Aira aquatica L.

Poa airoides Kicel., Deser. Gram. 194. 1802. Based on Aira aquatica L.

Glyceria aquatica Presl, F1. Cech. 25. 1819. Based on Aira aquatica L.

Hydrochloa airoides Hartm., Gen. Gram. Skand. 3. 1819. Based on Aira aquatica L.

Diarrhena aquatica Raspail, Ann. Sci. Nat., Bot. 5: 447. 1825. Based on Catabrosa aquatica Beauv.

Melica aquatica Loisel., Fl. Gall. ed. 2. 1: 59. 1828. Based on Aira aquatica L. Glyceria airoides Reichenb., in Moessl., Handb. Gewächsk. ed. 2. 3: 1827. 1829. Based on Poa airoides Kíoel.

Colpodium aquaticum Trin., Mém. Acad. St. Pétersb. VI. Math. Phys. Nat. 1: 395. 1830. Based on Aira aquatica L.

Glyceria catabrosa Klett and Richt., Fl. Leipzig 96. 1830. Based on Catabrosa aquatica Beauv.

Catapadium aquaticum Trin.; Willk. and Lange, Prodr. Fl. Hisp. 1: 77. 1861, as synonym of Catabrosa aquatica Beauv.

\section{(105) CATHESTeCUM Presl}

(1) Cathestecum erectum Vasey and Hack., Bull. Torrey Bot. Club 11: 37. pl. 45. 1884. Presidio, Tex., Havard.

This is the species described and figured by Scribner (U.S.Dept.Agr., Div. Agrost. Bull. 7: 242. f. 224. 1897) under the name Cathestecum prostratum Presl.

\section{(137) CENCHRUS L. ${ }^{18}$}

Cenchrus barbatus Schum., Beskr. Guin. Pl. 63. 1827. Guinea, Africa.

Cenchrus catharticus Delile, Cat. Hort. Monsp. 1838: 4. 1839. Grown from seed from Nubia, Africa.

(3) Cenchrus echinatus L., Sp. Pl. 1050. 1753. Jamaica, Curaçao.

Cenchrus pungens H.B.K., Nov. Gen. and Sp. 1: 115. 1815. Guayaquil, Ecuador, Humboldt and Bonpland.

Cenchrus brevisetus Fourn., Mex. Pl. 2: 50. 1886. Orizaba, Mexico, Schaffner 198; Bourgeau 3140; Botteri 133.

\footnotetext{
${ }^{15}$ For discussion of types see Chase, Contrib. U.S. Natl. Herb. 22: 52-76. 1920.
} 
Cenchrus echinatus brevisetus Scribn., in Millsp., Field Mus. Bot. 2: 26. 1900. Based on Cenchrus brevisetus Fourn.

(4) Cenchrus gracillimus Nash, Bull. Torrey Bot. Club 22: 299. 1895. Eustis, Fla., Nash 188 [type], 288.

(5) Cenchrus incertus M. A. Curtis, Jour. Bost. Soc. Nat. Hist. 1: 135. 1837. Smithville, N.C., Curtis.

?Cenchrus carolinianus Walt., Fl. Carol. 79. 1788. South Carolina.

Cenchrus strictus Chapm., Bot. Gaz. 3: 20. 1878. West Tlorida, [Chapman].

? Nastus carolinianus Lunell, Amer. Midl. Nat. 4: 214. 1915. Based on Cenchrus carolinianus Walt.

(1) Cenchrus myosuroides H.B.K., Nov. Gen. and Sp. 1: 115. pl. 35. 1815. Flamingo Key, Cuba, Humboldt and Bonpland.

Panicum cenchroides Ell., Bot. S.C. and Ga. 1: 111. 1816. Not P. cenchroides I. Rich., 1792. Jekyl Island, Ga., Baldwin.

Pennisetum pungens Nutt., Gen. Pl. 1: 54. 1818. Based on Panicum cenchroides Ell.

Setaria elliotitana Schult., Mant. 2: 279. 1824. Based on Panicum cenchroides Ell.

Pennisetum myosuroides Spreng., Syst. Veg. 1: 303. 1825. Based on Cenchrus myosuroides H.B.K.

Cenchrus elliottii Kunth, Rév. Gram. 1: 51. 1829. Based on Panicum cenchroides Ell.

Cenchrus alopecuroides Presl, Rel. Haenk. 1: 317. 1830. Not C. alopecuroides Thunb., 1794. Original locality unknown, probably Peru.

Cenchrus setoides Buckl., Prel. Rept. Geol. Agr. Survey Tex. App. 2. 1866. Northern Texas, [Linscum and Buckley].

Cenchropsis myosuroides Nash, in Small, Fl. Southeast. U.S. 109, 1327. 1903. Based on Cenchrus myosuroides H.B.K.

(6) Cenchrus pauciflorus Benth., Bot. Voy. Sulph. 56. 1840. Magdalena Bay, Baja California, [Barclay].

Cenchrus roseus Fourn., Mex. P1. 2: 50. 1886. Vera Cruz, Mexico, Gouin 42 in part, 43.

Cenchrus echinatus forma longispina Hack., in Kneucker, Allg. Bot. Ztschr. 9: 169. 1903. Oxford, Conn., Gram. Exs. Kneucker 426.

(7) Cenchrus tribuloides L., Sp. Pl. 1050. 1753. Seacoast of Virginia, [Clayton]. Cenchrus echinatus var. tribuloides Torr., Fl. North. and Mid. U.S. 1: 69. 1823. Based on C. tribuloides L.

Cenchrus vaginatus Steud., Syn. Pl. Glum. 1: 110. 1854. Cultivated in the botanical garden, Paris.

Cenchrus tribuloides var. macrocephalus Doell, in Mart., F1. Bras. 22: 312. 1877. Brazil, Martius.

Cenchrus macrocephalus Scribn., U.S.Dept.Agr., Div. Agrost. Bull. 17: 110. f. 406. 1899. Based on C. tribuloides var. macrocephalus Docll.

(2) Cenchrus viridis Spreng., Syst. Veg. 1: 301. 1825. Guadeloupe, [Bertero].

Cenchrus echinatus var. viridis Spreng.; Griseb., Fl. Brit. W. Ind. 556. 1864. Presumably based on C. viridis Spreng.

\section{(102) CHLORIS Swartz}

(7) Chloris andropogonoides Fourn., Mex. Pl. 2: 143. 1886. San Luis Potosí, Mexico, Virlet 1462.

Chloris tenuispica Nash, Bull. Torrey Bot. Club 25: 435. 189s. Texas, Nealley in 1889.

(6) Chloris chloridea (Presi) Hitchc., Biol. Soc. Wash. Proc. 41: 162. 1928. Based on Dineba chloridea Presl.

Dineba chloridea Presl, Rel. Haenk. 1: 291. 1830. Mexico, Hiaenke.

Eutriana chloridea Kunth, Rév. Gram. 1: Sup. XXIII. 1830. Based on Dineba chloridea Presl.

Gymnopogon longifolius Fourn., Mex. Pl. 2: 144. 1886. Vera Cruz, Mexico, Gouin 52.

Gymnopogon virletii Fourn., Mex. Pl. 2: 144. 1886. San Luis Potosí, ivexico, Virlet 1441.

Chloris longifolia Vasey, Contrib. U.S. Nat1. Herb. 1: 284. pl. 19. 1893. Not C. longifolia Steud., 1854. Based on Cymnopogon longifolius Fourn.

Chloris clandestina Scribn. and Merr., U.S.Dept.Agr., Div. Agrost. Bull. 24: 25. 1901. Based on Gymnopogon longifolius Fourn.

(11) Chloris ciliata Swartz, Prodr. Veg. Ind. Occ. 25. 1788. Jamaica, Swartz. 
Cynodon ciliatus Raspail, Ann. Sci. Nat., Bot. 5: 303. 1825. Based on Chloris ciliata Swartz.

Chloris propinqua Steud., Syn. Pl. Glum. 1: 204. 1854. Guadeloupe, Duchaissing.

Chloris ciliata var. texana Vasey, U.S.Dept.Agr., Div. Bot. Bull. 121: pl. 30. 1890. Brownsville, Tex., [Nealley].

Chloris texana Nash, Bull. Torrey Bot. Club 25: 441. 1898. Based on C. ciliata var. texana Vasey.

Chloris nashii Heller, Muhlenbergia 5: 120. 1909. Based on C. texana Nash.

(15) Chloris cucullata Bisch., Ann. Sci. Nat., Bot. III. 19: 357. 1853. Cultivated, seed from Matamoros, Mexico.

Chloris distichophylla Lag., Gen. and Sp. Nov. 4. 1816. Argentina and Chile. Eustachys distichophylla Nees, Agrost. Bras. 418. 1829. Based on Chloris distichophylla Lag.

(3) Chloris floridana (Chapm.) Wood, Amer. Bot. and Flor. pt. 2: 407. 1871. Based on Eustachys floridana Chapm.

Eustachys floridana Chapm., Fl. South. U.S. 557. 1860. Middle Florida.

(5) Chloris gayana Kunth, Rév. Gram. 1: 89. 1829. Senegal, Africa.

(1) Chloris glauca (Chapm.) Wood, Amer. Bot. and Flor. pt. 2: 407. 1871. Based on Eustachys glauca Chapm.

Eustachys glauca Chapm., Fl. South. U.S 557. 1860. West Florida.

(14) Chloris latisquamea Nash, Bull. Torrey Bot. Club 25: 439. 1898. Kerrville, Tex., Heller 1767.

Chloris verticillata var. intermedia Vasey, in Coult., Contr. U.S. Nat. Herb. 2: 528. 1894. Texas, [Houston, Hall 773].

(4) Chloris neglecta Nash, Bull. Torrey Bot. Club 22: 423. $1895 . \quad$ Orange Bend, Fla., Nash 2149.

Eustachys neglecta Nash, Bull. Torrey Bot. Club 25: 450. 1898. Based on Chloris neglecta Nash.

(2) Chloris petraea Swartz, Prodr. Veg. Ind. Occ. 25. 1788. Jamaica, Swartz. ?Aira aegilopsoides Walt., Fl. Carol. 78. 1788. South Carolina.

Agrostis complanata Ait., Hort. Kew. 1: 96. 1789. Grown in England, seed from Jamaica.

Eustachys petraea Desv., Nouv. Bull. Soc. Philom. Paris 2: 189.1810. Based on Chloris petraea Swartz.

Schultesia petraea Spreng., Pl. Pugill. 2: 17. 1815. Based on Chloris petraea Swartz.

Aira complanata Steud., Nom. Bot. ed. 2. 1: 44. 1840, as synonym of Chloris petraea Swartz.

Chloris swartzii C. Muell., Bot. Ztg. 19: 341. 1861. Based on C. petraea Swartz.

Chloris septentrionalis C. Muell., Bot. Ztg. 19: 340. 1861. Rio Brazos, Tex., Drummond.

Chloris swartziana Doell, in Mart., Fl. Bras. $2^{3}$ : 68. 1878. Based on $C$. petraea Swartz.

(10) Chloris polydactyla (L.) Swartz, Prodr. Veg. Ind. Occ. 26. 1785. Based on Andropogon polydactylon $\mathrm{L}$.

Andropogon barbatus L., Syst. Nat. ed. 10. 2: 1305. 1759. Jamaica. Not Chloris barbata Swartz, 1797, based on A. barbatus L., 1771, from the East Indies, which is C. inflata Link (C. paraguayensis Steud.).

Andropogon polydactylon L., Sp. Pl. ed. 2. 2: 1483. 1763. Jamaica. Diagnosis of $A$. barbatus L. (1759) copied.

Saccharum polydactylum Thunb., Fl. Jap. 42. 1784. Based on Andropogon polydactylon L.

Chloris barbata Nash, Bull. Torrey Bot. Club 25: 443. 1898. Not C. barbata Swartz, 1797. Based on Andropogon barbatus L. (1759).

Chloris prieurii Kunth, Rév. Gram. 1: 89. 1829. Senegambia, Africa.

Chloris radiata (L.) Swartz, Prodr. Veg. Ind. Occ. 26. 1788. Based on Agrostis radiata $\mathrm{L}$.

Agrostis radiata L., Syst. Nat. ed. 10. 2: 873.1759 . Jamaica.

Chloris glaucescens Steud., Syn. Pl. Glum. 1: 206. 1854. Guadeloupe, Duchaissing.

(13) Chloris subdolichostachya C. Muell., Bot. Ztg. 19: 341. 1861. Texas, Drummond 372 .

Chloris verticillata var. aristulata Torr. and Gray, U.S. Rep. Expl. Miss. Pacif. 2: $176 . \quad 1855$. Lower Rio Grande, Gregg.

Chloris brevispica Nash, Bull. Torrey Bot. Club 25: 438 1898. Nueces County, Tex., Heller 1471. 
(8) Chloris texensis Nash, Bull. Torrey Bot. Club 23: 151. 1896. Texas, Thurow; Nealley.

Chloris nealleyi Nash, Bull. Torrey Bot. Club 25: 435. 1898. Based on $C$. texensis Nash.

Chloris truncata R. Br., Prodr. Fl. Nov. Holl. $186.1810 . \quad$ Australia.

(12) Chloris verticillata Nutt., Amer. Phil. Soc. Trans. (n.s.) 5: 150.1837. Fort Smith, Ark., [Nuttall].

(9) Chloris virgata Swartz, Fl. Ind. Oce. 1: 203. 1797. Antigua, Swartz.

Chloris pubescens Lag., Var. Cien. 24: 143. 1805. Peru.

Rabdochloa virgata Beauv., Ess. Agrost. 84, 158. 1812. Presumably based on Chloris virgata Swartz.

Chloris compressa DC., Cat. Hort. Monsp. 94. 1813. Cultivated at Montpellier.

Chloris elegans H.B.IK., Nov. Gen. and Sp. 1: 166. pl. 49. 1816. Mexico, Humboldt and Bonpland.

Chloris alba Presl, Rel. Haenk. 1: 289. 1830. Mexico, Haenke.

Chloris penicillata Willd.; Steud., Nom. Bot. ed. 2. 1: 353. 1840, as synonym of C. elegans H.B.K.

Chloris alba var. aristulata Torr., U.S. Rept. Expl. Miss. Pacif. 4: 155. 1857. Banks of the upper Rio Grande [Emory Exped.]; Tex., Drummond 395 also mentioned.

Agrostomia barbata Cervant., Naturaleza 1870: 346. 1870. Cuernavaca, Mexico.

(67) CINNA L.

(1) Cinna arundinacea L., Sp. Pl. 5. 1753. Canada, Kalm.

Agrostis cinna Retz., Obs. Bot. 5: 18. 1789. Based on Cinna arundinacea L., but, according to Obs. Bot. 6: 12. 1791, misapplied to a species of Muhlenbergia.

Agrostis cinna Lam., Tabl. Encycl. 1: 162. 1791. Based on Cinna arundinacea L., but misapplied to Muhlenbergia mexicana.

Agrostis cinna Pursh, Fl. Amer. Sept. 1:64. 1814. Based on Cinna arundinacea Willd. (error for L.).

Cinna agrostoides Beauv.; Steud., Nom. Bot. 1: 20, 198. 1821, as synonym of Agrostis cinna Lam.

Muhlenbergia cinna Trin., Gram. Unifl. 191. 1824. Based on Agrostis cinna Lam.

(2) Cinna latifolia (Trevir.) Griseb., in Ledeb., Fl. Ross. 4: 435.1853. Based on Agrostis latifolia Trevir.

Agrostis latifolia Trevir.; Göpp., Beschr. Bot. Gart. Breslau 82. 1830. Europe. Miuhlenbergia pendula T́rin., Mém. Acad. St. Pétersb. VI. Math. Phys. Nat. 2: 172. 1832. Sitka.

Cinna expansa Link, Hort. Berol. 2: 236. 1833. Western North America, Richardson.

Cinna pendula Trin., Mém. Acad. St. Pétersb. VI. Sci. Nat. 4¹: 280. 1841. Norway, Sitka, Baikal. The earlier Muhlenbergia pendula Trin., not mentioned.

Cinna arundinacea var. pendula A. Gray, Man. ed. 2. 545. 1856. Based on C. pendula Trin.

Cinna pendula var. glomerula Scribn., Acad. Nat. Sci. Phila. Proc. 1884: 290. 1884. Washington, Twecdy.

Cinna bolanderi Scribn., Acad. Nat. Sci. Phila. Proc. 1884: 290. 1884. California, Bolander 6090 .

Cinna pendula var, acutiflora Vasey; Macoun, Cat. Can. Pl. 24: 203. 1888, name only, Vancouver Island; 25: 393 . 1890, as synonym of C. pendula var. glomerata Scribn. [error for var. glomerula].

Cinna pendula var. mutica Vasey, in Macoun, Cat. Can. Pl. 24: 202.1888. Name only for collection at Pelly Banks, Northwest Territory, Dawson in 1887. Vasey, Contrib. U.S. Nati. Herb. 3: 57. 1892. Oregon, [Cusick].

Cinna pendula var. bolanderi Vasey, Contrib. U.S. Nati. Herb. 3: 57. 1892. Based on C. bolanderi Seribn.

(156) COIX L.

(1) Coix lacryma-jobi L., Sp. Pl. 972. 1753. India.

Coix lacryma L., Syst. Nat. ed. 10.1261. 1759. Based on C. lacryma-jobi L. Lithagrostis lacryma-jobi Gaertn., Fruct. and Sem. 1: 7. 1788. Based on Coix lacryma-jobi L. 
Sphaerium lacryma Kuntze, Rev. Gen. Pl. 2: 793. 1891. Based on Coix lacryma L.

\section{(66) COLEANTHUS Seidel}

(1) Coleanthus subtilis (Tratt.) Seidel; Roem. and Schult., Syst. Veg. 2: 276. 1817. Based on Schmidtia subtilis Tratt.

Schmidtia subtilis Tratt., Fl. Austr. 1: 12. 1816. Bohemia.

Zizania subtilis Raspail, Ann. Sci. Nat., Bot. 5: 452, 458. 1825. Based on Coleanthus subtilis [Seidel] Roem. and Schult.

Wilibaldia subtilis Roth, Enum. Pl. Phan. Germ. 1: 92. 1827. Based on Schmidtia subtilis Tratt.

\section{CORIDOCHLOA Nees}

Coridochloa cimicina (L.) Nees; Jacks., Ind. Kew. 1: 618. 1893, as synonym of Panicum cimicinum. Chase, Biol. Soc. Wash. Proc. 24: 129. 1911. This name is usually credited to Nees, Edinb. New Phil. Journ. 15: 381. 1833, but though Nees adds, after briefly distinguishing the genus, that its type is Panicum cimicinum Retz., he does not transfer the name to Coridochloa.

Milium cimicinum L., Mant. Pl. 2: 184. 1771. Malabar, India.

Panicum cimicinum Retz., Obs. Bot. 3: 9. 1783. Based on Milium cimicinum L. Axonopus? cimicinus Beauv., Ess. Agrost. 12, 154. 1812. Based on Milium. simicinum L.

\section{(25) CORTADERIA Stapf}

Cortaderia rudiuscula Stapf, Gard. Chron. III. 22: 396. 1897. Argentina.

This is the species described by Stapf under C. quila (Nees) Stapf, but that name is ultimately based on Arundo quila Molino, a species of bamboo, Chusquea quila (Molino) Kunth.

(1) Cortaderia selloana (Schult.) Aschers. and Graebn., Syn. Mitteleur. Fl. 2: 325 . 1900. Based on Arundo sclloana Schult.

Arundo dioeca Spreng., Syst. Veg. 1: 361. 1825. Not A. dioica Lour. 1793. Monte Video, Uruguay, Sello.

Arundo selloana Schult., Mant. 3 (Add. 1):605. 1827. Based on $A$. dioeca Spreng. Schultes cites "A. dioeca Spreng., S.V. p. 361 ", hence the date is later than 1824 , the title-page date.

Gynerium argenteum Nees, Agrost. Bras. 462. 1829. Brazil.

Cortaderia argentea Stapf, Gard. Chron. III. 22: $396 . \quad$ 1897. Based on Gynerium argenteum Nees.

Cortaderia dioica Speg., An. Mus. Nac. Buenos Aires 7: 194. 1902. Based on Arundo dioica Spreng.

Corynephorus canescens (L.) Beauv., Ess. Agrost. 90, 149, 159. 1812. Based on Aira canescens $\mathbf{L}$.

Aira canescens L., Sp. Pl. 65. 1753. Europe.

Avena canescens Web., in Wigg., Prim. Fl. Hols. 9. 1780. Based on Aira canescens $\mathrm{L}$.

Weingaertneria canescens Bernh., Syst. Verz. Pfianz. 51. 1800. Based on Aira canescens $\mathrm{L}$.

\section{(36) COTTEA Kunth}

(1) Cottea pappophoroides Kunth, Rév. Gram. 1: 84. 1829. Peru.

(78) CRYPSIS Ait.

(1) Crypsis aculeata (L.) Ait., Hort. Kew. 1: 48. 1789. Based on Anthoxanthum aculeatum L. f.

Schocnus aculeatus L., Sp. Pl. 42. 1753. Southern Europe.

Agrostis aculeata Scop., Fl. Carn. ed. 2. 1: 62. 1772. Based on Schoenus aculeatus L.

Phleum aculeatum Lam., Fl. Franç. 3: 563. 1778. Based on Schoenus aculeatus L.

Anthoxa:ithum aculeatum L. f., Sup. Pl. 89. 1781. Based on Schoenus aculeatus L. 
Antitragus aculeatus Gaertn., Fruct. and Sem. 2: 7. 1791. Based on Schoenus aculeatus $\mathrm{L}$.

Pallasia aculeata Kuntze, Rev. Gen. Pl. 2: 781. 1891. Based on Crypsis aculeata Ait.

\section{(100) CTENIUM Panzer}

(1) Ctenium aromaticum (Walt.) Wood, Class-book 806. ed. 3. 1861. Based on Aegilops aromatica Walt.

?Nardus gangitis L., Sp. PI. 53. 1753. Garden specimen, southern France, (probably Montpellier). The specimen under this name in the Linnaean Herbarium is from Montpellier, and is said by Munro (Jour. Linn. Soc. Bot. 6: 35. 1862) to be Lepturus incurvatus Trin. (Pholiurus incurvus (L.) Schinz and Thell.). The Linnaean citations refer to Andropogon and to Rottboellia according to Trinius (Clav. Agrost. 346. 1822), except that to Morison (Pl. Hist. 3: Sect. 8, tab. 3, last figure) which is a species of Ctenium. Linnaeus gives as the origin of his plant "Habitat in G. Narbonensi" (Gallia Narbonensis is southern France). The application of the name N. gangitis is too uncertain to be accepted for Ctenium aromaticum, as proposed by Druce.

Aegilops aromatica Walt., Fl. Carol. 249. 1788. South Carolina.

Nardus scorpioides Lam., Tabl. Encycl. 1: 152. 1791. America.

Chloris monostachya Mlichx., Fl. Bor. Amer. 1: 59. 1803. South Carolina, Michaux.

Campulosus gracilior Desv., Nouv. Bull. Soc. Philom. (Paris) 2: 189.1810. Based on Chloris monostachya Michx.

Campulosus monostachyus Beauv., Ess. Agrost. 64, 157, 158. pl. 13. f. 1. 1812. Based on Chloris monostachya Michx.

Ctenium carolinianum Panz., Denkschr. Bayer. Akad. Wiss. 4: 311 . pl. 13. f. 1, 2. 1813. South Carolina.

Campuloa gracilis Desv., Jour. Bot. 1: 69. 1813. Based on Chloris monostachya Michx.

Monocera aromatica Ell., Bot. S.C. and Ga. 1: 177. pl. 11. f. 3. 1816. Based on Aegilops aromatica Walt.

Campuloa monostachya Roem. and Schult., Syst. Veg. 2: 516. 1817. Based on Chloris monostachya Michx.

Cynodon monostachyos Raspail, Ann. Sci. Nat., Bot. 5: 303. 1825. Based on Campulosus monostachyus Desv. [error for Beauv.].

Ctenium americanum Spreng., Syst. Veg. 1: 274. 1825. North America, Chloris monostachya Michx., cited as synonym.

Campulosus aromaticus Trin.; Steud., Nom. Bot. ed. 2. 1: 272. 1840, as synonym of $C$. monostachyus Beauv.

Chloris piperita Michx.; Steud., Nom. Bot. ed. 2. 1: 353. 1840, as synonym of Campulosus monostachyus Beauv.

Rottboellia scorpioides Poir.; Steud., Nom. Bot. ed. 2. 2: 474. 1841, as synonym of Ctenium americanum Spreng.

Campulosus gracilis Bertol., Mem. Accad. Sci. Bologna 2: 602. pl. 43. f.a.b.c. 1850. Alabama.

?Campulosus gangitis Kuntze, Rev. Gen. PI. 2: 764. 1891. Based on Nardus gangitis L., taken up for Ctenium aromaticum.

Campulosus aromaticus Scribn., Mem. Torrey Bot. Club 5: 45. 1895. Based on Aegilops aromaticus Walt.

?Ctenium gangitum Druce, Rept. Bot. Exch. Club Brit. Isles 3: 416. 1914. Based on Nardus gangitis L., taken up for C. aromaticum.

(2) Ctenium floridanum (Hitchc.) Hitchc., Biol. Soc. Wash. Proc. 41: 162. 1928. Based on Campulosus floridanus Hitchc.

Campulosus floridanus Hitchc., Amer. Jour. Bot. 2: 306. 1915. East Florida, Curtiss in 1875.

This is the species described by Scribner (U.S.Dept.Agr., Div. Agrost. Bull. 7: 197. f. 179. 1897) and by Nash (Small, Fl. Southeast. U.S. 133. 1903) under Campulosus chapadensis Trin. That is a Brazilian species not known from North America.

Cutandia memphitica (Spreng.) Richt. Pl. Eur. 1: 77. 1890. Based on Dactylis memphitica Spreng.

Dactylis memphitica Spreng., Nachtr. Bot. Gart. Halle 20. 1801. Egypt. 


\section{CYMBOPOGON Spreng.}

Cymbopogon citratus (DC.) Stapf, Kew Bull. Misc. Inf. 1906: 322. 1906. Based on Andropogon citratus DC.

Andropogon citratus DC., Cat. Hort. Monsp. 78. 1813, without description. DC.; Nees, Allg. Gartenz. 3: 266. 1835. Garden plant.

Cymbopogon nardus (L.) Rendle, Cat. Afr. Pl. Welw. 2: 155. 1899. Based on Andropogon nardus L.

Andropogon nardus L., Sp. Pl. $1046.1753 . \quad$ India.

Sorghum nardus Kuntze, Rev. Gen. Pl. 2: 792. 1891. Based on Andropogon nardus L.

\section{(95) CYNODON L. Rich.}

1) Cynodon dactylon (L.) Pers., Syn. Pl. 1: 85. 1805. Based on Panicum dactylon $\mathrm{L}$.

Panicum dactylon L., Sp. Pl. 58. 1753. Southern Europe.

Digitaria dactylon Scop., Fl. Carn. ed. 2. 1: 52. 1772. Based on Panicum dactylon L.

Dactilon officinale Vill., Hist. Pl. Dauph. 2: 69. 1787. Based on Panicum dactylon $\mathrm{L}$.

?Cynosurus uniflorus Walt., Fl. Carol. 82. 1788. South Carolina.

Paspalum dactylon Lam., Tabl. Encycl. 1: 176. 1791. Based on Panicum dactylon $\mathrm{L}$.

Digitaria littoralis Salisb., Prodr. Stirp. 19. 1796. Based on Panicum dactylon $\mathrm{L}$.

Milium dactylon Moench, Meth. Pl. Sup. 67. 1802. Based on Panicum dactylon L.

Fibichia umbellata Koel., Descr. Gram. 308. 1802. Based on Panicum dactylon L.

Digitaria stolonifera Schrad., FI. Germ. 1: 165. 1806. Based on Panicum dactylon $\mathrm{L}$.

Cynodon maritimus H.B.K., Nov. Gen. and Sp. 1: 170. 1816. Peru, Humbolelt and Bonpland.

Cynodon tenuis Trin., in Spreng., Neu. Entd. 2: 63. 1821. North America.

Chloris cynodon Trin., Gram. Unifl. 229. 1824. Based on Cynodon dactylon Pers.

Digitaria maritima Spreng., Syst. Veg. 1: 272. 1825. Based on Cynodon maritimus H.B.K.

Cynodon erectus Presl, Rel. Haenk. 1: 290. 1830. Mexico [type, Haenke] and Peru.

Agrostis bermudiana Tussac; Kunth, Enum. Pl. 1: 259. 1833, as synonym of Cynodon dactylon Pers.

Cynodon occidentalis Willd.; Steud., Nom. Bot. ed. 2. 1: 463. 1840, as synonym of $C$. dactylon Pers.

Cynodon portoricensis Willd.; Steud., Nom. Bot. ed. 2. 1: 463.1840 , as synonym of $C$. dactylon Pers.

Capriola dactylon Kuntze, Rev. Gen. Pl. 2: 764. 1891. Based on Panicum dactylon $\mathrm{L}$.

Fibichia dactylon Beck, Wiss. Mitt. Bosn. Herzeg. 9: 436. 1904. Based on Panicum dactylon L.

Cynodon dactylon var. maritimus Hack., in Fries, Arkiv Bot. 8: 40. 1909. Based on C. maritimus H.B.K.

Capriola dactylon maritima Hitche., U.S. Dept. Agr. Bull. 772: 179.1920. Based on Cynodon maritimus H.B.K.

\section{(22) CYNOSURUS L.}

(1) Cynosurus cristatus L., Sp. Pl. 72. $1753 . \quad$ Europe.

(2) Cynosurus echinatus L., Sp. Pl. 72. 1753. Europe.

Phalona echinata Dum., Obs. Gram. Belg. 114. 1823. Based on Cynosurus echinatus L.

\section{(21) DACTYLIS L.}

1) Dactylis glomerata L., Sp. Pl. 71. 1753. Europe.

Bromus glomeratus Scop., Fl. Carn. ed. 2. 1: 76. 1772. Based on Dactylis glomerata L.

Festuca glomerata All., Fl. Pedem. 2: 252. 1785. Based on Dactylis glomerata L.

Trachypoa vulgaris Bubani, Fl. Pyr. 4: 359. 1901. Based on Lactylis glomerata L. 


\section{(94) DACTYLOCTENIUM Will.}

(1) Dactyloctenium aegyptium (L.) Richt., Pl. Eur. 1: 68. 1890. Based on Cynosurus aegyptius L.

Cynosurus aegyptius L., Sp. Pl. 72. 1753. Africa, Asia, America.

Aegilops saccharinum IValt., Fl. Carol. 249. 1788. South Carolina.

Eleusine aegyptiaca Desf., Fl. Atlant. 1: 85. 1798. Based on Cynosurus aegyptius L.

Elerisine pectinatc Moencli, Meth. Pl. Sup. 68. 1802. Based on Cynosurus aegyptius L.

Chloris mucronata Miclix., Fl. Bor. Amer. 1: 59. 1803. Carolina, Michaux.

Eleusine aegyptia Pers., Syn. Pl. 1: 87. 1805. Based on Cynosurus aegyptius L.

Dactyloctenium aegyptiacum Willd., Enum. Pl. 1029. 1809. Based on Cynosurus aegyptius L.

Dactyloctenium mucronatum Willd., Enum. Pl. 1029. 1809. Based on Chloris mucronata Michx.

Eleusine mucronala Stokes, Bot. Mag. Med. 1: 150. 1812. Not E. mucronata Michx., 1803. Jamaica, Broughton.

Rabáochloa mucronata Beauv., Ess. Agrost. 84, 158, 176. 1812. Presumably based on Chloris mucronata Michx.

Cenchrus aegyptius L.; Beauv., Ess. Agrost. 157. 1812, as synonym of Dactyloctenium aegyptium, doubtless error for Cynosurus.

Eleusine cruciata Ell., Bot. S.C. and Ga. 1: 176. 1816. Presumably South Carolina.

Eleusine mucronata Hornem., Hort. Hafn. Sup. 116. 1819. Not E. mucronata Michx., 1803. Based on Dactyloctenium mucronatum Willd.

Dactyloctenium meridionale Hamilt., Prodr. P1. Ind. Occ. 6. 1825. West Indies and tropical America.

Cynosurus carolinianus Willd.; Steud., Nom. Bot. ed. 2. I: 465. 1840. Name only, referred to Dactyloctenium.

Dactyloctenium mucronatum var. erectum Fourn., Mex. Pl. 2: 144. $18 S 6$. Merico, Gouin 68; Karwinsky 989, 989b.

(60) DANTHONIA Lam. and DC.

(6) Danthonia californica Boland., Calif. Acad. Sci. Proc. 2: 182. 1863. Oakland and San Francisco, Calif., Bolander.

Merathrepta californica Piper, Contrib. U.S. Natl. Herb. 11: 122. 1906. Based on Danthonia californica Boland.

Pentameris californica Nels. and Macbr., Bot. Gaz. 56: 469. 1913. Based on Danthonia californica Boland.

Danthonia Californica var. Americana (Scribn.) Hitchc., Biol. Soc. Wash. Proc. 41: 160. 192S. Based on D. americana Scribn. (Published as D. californica americana.)

Danthonia grandiflora Phil., An. Univ. Chile 4S: 568. 1873. Not D. grandiflora Hochst., 1851. Province Nuble, Chile.

Danthonia americana Scribn., U.S.Dept.Agr., Div. Agrost. Circ. 30: 5. 1901. Based on D. grandiflora Phil.

Merathrepta americana Piper, Contrib. U.S. Natl. Herb. 11: 123. 1906. Based on Danthonia americana Scribn.

Pentameris americana Nels. and Macbr., Bot. Gaz. 56: 469. 1913. Based on Danthonia americana Seribn.

Danthonia macounii Hitchc., Amer. Jour. Bot. 2: 305. 1915. Nanaimo, Vancouver Island, Macoun 78825.

(2) Danthonia compressa Austin, in Peck, N.Y. State Mus. Ann. Rept. 22: 54. 1869. Herkimer County, N.Y., Austin in 1868.

Danthonia spicata var. compressa Wood, Amer. Bot. and Flor. pt. 2: 396.1870. Based on D. compressa Austin.

Danthonia alleni Austin, Bull. Torrey Bot. Club 3: 21. 1872. Rockaway, Long Island, Allen.

Danthonia faxoni Austin, Bull. Torrey Bot. Club 6: 190. 1877. White Mountains, N.H., Faxon in 1877.

Merathrepta compressa Heller, Muhlenbergia 5: 120. 1909. Based on Danthonia comprcssa Austin.

Pentameris compressa Nels. and Macbr., Bot. Gaz. 56: 469. 1913. Based on Danthonia compressa Austin.

(4) Danthonia intermedia Vasey, Bull. Torrey Bot. Club 10: 52. 1883. California; Rocky Mountains; Plains of British America to Mount Albert, Quebec, Allen [in 1881, type].

$55974^{\circ}-35-53$ 
Danthonia intermedia cusickii Williams, U.S.Dept.Agr., Div. Agrost. Circ. 30: 7. 1901. Oregon, Cusick 2427.

Merathrepta intermedia Piper, Contrib. U.S. Natl. Herb. 11: 122. 1906. Based on Danthonia intermedia Vasey.

Merathrepta intermedia cusickii Piper, Contrib. U.S. Natl. Herb. 11: 122. 1906. Based on Danthonia intermedia cusickii Williams.

Pentameris intermedia Nels. and Macbr., Bot. Gaz. 56: 470. 1913. Based on Danthonia intermedia Vasey.

Danthonia cusickii Hitchc., Amer. Jour. Bot. 2: 305. 1915. Based on D. intermedia cusickii Williams.

(5) Danthonia parryi Scribn., Bot. Gaz. 21: 133. 1896. Colorado, Parry.

Danthonia parryi var. longifolia Scribn., Bot. Gaz. 21: 134. 1896. Twin Lakes, Colo., Wolf 1170.

Merathrepta parryi Heller, Muhlenbergia 5: 120. 1909. Based on Danthonia parryi Scribn.

(3) Danthonia sericea Nutt., Gen. Pl. 1: 71. 1818. Carolina to Florida.

Danthonia glabra Nash, Bull. Torrey Bot. Club 24: 43. 1897. Not D. glabra Phil., 1896. Little Stone Mountain, Ga., Small in 1895.

Danthonia epilis Scribn., U.S.Dept.Agr., Div. Agrost. Circ. 30: 7. 1901. Based on D. glabra Nash.

Merathrepta sericea Heller, Muhlenbergia 5: 120. 1909. Based on Danthonia sericea Nutt.

Pentameris epilis Nels, and Macbr., Bot. Gaz. 56: 469. 1913. Based on Danthonia epilis Scribn.

Pentameris sericea Nels. and Macbr., Bot. Gaz. 56: 470. 1913. Based on Danthonia sericea Nutt.

This is the species described by Elliott (Bot. S.C. and Ga. 1: 174. 1816) under the name Avena spicata L.

(1) Danthonia spicata (L.) Beauv.; Roem. and Schult., Syst. Veg. 2: 690. 1817. Based on Avena spicata L.

Avena spicata L., Sp. Pl. S0. 1753. Pennsylvania.

Avena glumosa Michx., Fl. Bor. Amer. 1: 72. 1803. Pennsylvania; Carolina, Michaux. (In Index Kewensis this name is erroneously credited to Ell. Elliott cited $A$. glumosa Michx. as synonym of $A$. spicata L.)

Danthonia glumosa Beauv., Ess. Agrost. 92, 153, 160. 1812. Based on Avena glumosa Michx.

Avena spicacformis Beauv., Ess. Agrost. 154. 1812, name, only Roem. and Schult., Syst. Veg. 2: 690 . 1817, as synonym of Danthonia spicata L.

Triodia glumosa Beauv., Ess. Agrost. Atlas 12. pl. 18. f. 7. 1812. Evidently an error for Danthonia glumosa Beauv.

Merathrepta spicata Raf.; Jacks., Ind. Kew. 3: 211. 1894, as synonym of Danthonia spicata.

Danthonia spicata var. villosa Peck, N.Y. State Mus. Ann. Rept. 47: 168. 1894. Brownville [Peck] and Taberg, N.Y.

Danthonia spicata pinetorum Piper, Erythea 7: 103. 1899. Mason County, Wash., Piper 943.

Danthonia thermale Scribn., U.S.Dept.Agr., Div. Agrost. Circ. 30: 5. 1901. Yellowstone Park, Wyo., A. Nelson and E. Nelson 6140.

Danthonia spicata longipila Scribn. and Merr., U.S.Dept.Agr., Div. Agrost. Circ. 30: 7. 1901. Benton County, Ark., Plank 38.

Merathrepta pinetorum Piper, Contrib. U.S. Natl. Herb. 11: 122. 1906. Based on Danthonia spicata pinetorum Piper.

Merathrepta thermale Heller, Muhlenbergia 5: 120. 1909. Based on Danthonia thermale Scribn.

Merathrepta thermale var. pinetorum Piper; Fedde and Schust., in Just's Bot. Jahresber. 37: 128. 1911 (erroneously ascribed to Heller, Muhlenbergia 5: 120. 1909).

Pentamcris spicata Nels. and Macbr., Bot. Gaz. 56: 470. 1913. Based on Avena spicata L.

Pentameris thermale Nels. and Macbr., Bot. Gaz. 56: 470. 1913. Based on Danthonia thermale Scribn.

Danthonia pinetorum Piper; Piper and Beattie, Fl. Northw. Coast 46. 1915. Based on D. spicata pinetorum Piper.

(7) Danthonia unispicata (Thurb.) Munro; Macoun, Cat. Can. Pl. 24: 215. 1888. Based on D. californica var. unispicata Thurb. The name was earlier listed without description as follows: Thurb., in A. Gray, Proc. Acad. Phila., 1863: 78. 1863, name only, for Geyer 189. Thurb., in S. Wats., Bot. Calif. 2: 294. 1880, as synonym of D. californica var. unispicata Thurb. Munro; Vasey, Descr. Cat. Grasses U.S. 59. 1885. Name only. 
Danthonia californica var. unispicata Thurb., in S. Wats., Bot. Calif. 2: 294. 1880. San Diego to San Francisco, Calif., Bolander, Parry, Lemmon.

Merathrepta unispicata Piper, Contrib. U.S. Natl. Herb. 11: 123. 1906. Based on Danthonia unispicata Munro.

Pentameris unispicata Nels. and Macbr., Bot. Gaz. 56: 470. 1913. Based on Danthonia unispicata Munro.

\section{(55) DESCHAMPSIA Beauv.}

(3) Deschampsia atropurpurea (Wahl.) Scheele, Flora 27: 56. 1844. Based on Aira atropurpurea Wahl.

Aira atropurpurea Wahl., Fl. Lapp. 37. 1812. Lapland.

Avena atropurpurea Link, Hort. Berol. 1: 119. 1827. Based on Aira atropurpurea Wahl.

Holcus atropurpureus Wahl., Svensk Bot. pl. 687. 1826-29. Based on Aira atropurpurea Wahl.

Aira latifolia Hook., Fl. Bor. Amer. 2: 243. pl. 227. 1840. Rocky Mountains, Drummond.

Vahlodea atropurpurea Fries, Bot. Not. 178. 1842. Presumably based on Aira atropurpurea Wahl.

Deschampsia latifolia Vasey, Grasses U.S. 29. 1883. Not D. latifolia Hochst., 1851. Based on Aira latifolia Hook.

Deschampsia hookeriana Scribn., Bot. Gaz. 11: 97. 1886. Based on Aira latifolia Hook.

Deschampsia atropurpurea var. minor Vasey, Bull. Torrey Bot. Club 15: 48. 1888. Vancouver Island, Macoun in 1887.

Deschampsia atropurpurea var. latifolia Scribn.; Macoun, Cat. Can. Pl. $2^{4}: 209$. 1888. Based on Aira latifolia Hook.

(5) Deschampsia caespitosa (L.) Beauv., Ess. Agrost. 91, 149, 160. pl. 18. f. 3. 1812. Based on Aira caespitosa L.

Aira caespitosa L., Sp. Pl. 64. 1753. Europe.

Agrostis caespitosa Salisb., Prodr. Stirp. 25. 1796. Based on Aira caespitosa L. Aira ambigua Michx., Fl. Bor. Amer. 1: 61. 1803. Canada, Michaux.

Aira caespitosa var. ambigua Pursh, Fl. Amer. Sept. 1: 77. 1814. Based on A. ambigua Michx.

Aira cespitosa Muhl., Descr. Gram. 85. 1817. Pennsylvania; New England. Aira aristulata Torr., Fl. North. and Mid. U.S. 1: 132.1824. New York, Cooper.

Campbella caespitosa Link, Hort. Berol. 1: 122. 1827. Based on Aira caespitosa L.

Podionapus caespitosus Dulac, Fl. Haut. Pyr. 82. 1867. Based on Deschampsia caespitosa Beauv.

Avena caespitosa Kuntze, Taschenf. Leipzig 45. 1867. Based on Aira caespitosa L.

Aira major subsp. caespitosa Syme in Sowerby, English Bot. ed. 3. 11: 64. 1873. Based on A. caespitosa L.

Aira caespitosa var. montana Vasey, in Wheeler, Rept. U.S. Survey 100th Merid. 6: 294. 1878. Not A. caespitosa var. montana Reichenb., 1850. Utah, Colorado, and Arizona.

Deschampsia caespitosa var. maritima Vasey, Bull. Torrey Bot. Club 15: 48. 1888. Vancouver Island, Macoun in 1887.

Deschampsia ambigua Beauv.; Jacks., Ind. Kew. 2: 735. 1893. Name only, presumably referring to Aira ambigua Michx.

Deschampsia caespitosa var. alpina Vasey; Beal, Grasses N.Amer. 2: 368. 1896. Not D. caespitosa var. alpina Gaudin, 1869. Alaska, Elliott; Colorado, Letterman.

Deschampsia caespitosa var. confinis Vasey; Beal, Grasses N.Amer. 2: 369. 1896. Southern California, Palmer 231 in 1888.

Deschampsia caespitosa var. longiflora Beal, Grasses N.Amer. 2: 369.1896. Vancouver Island, Macoun in 1887.

Deschampsia alpicola Rydb., Bull. Torrey Bot. Club 32: 601. 1905. Based on D. caespitosa var. alpina Vasey.

Deschampsia confinis Rydb., Bull. Torrey Bot. Club 36: 533. 1909. Based on D. caespitosa var. confinis Vasey.

Deschampsia pungens Rydb., Bull. Torrey Bot. Club 39: 103. 1912. Banff, Alberta, McCalla 2309. 
Aira alpicola Rydb., Fl. Roeky Mount. ed. 2. 1112. 1922. Based on Deschampsia alpicola Rybd.

The following names based on Deschampsia brevifolia R. Br. (Sup. App. Parry's Voy. 191. 1821) described from Melville Island, Aretic America, and not known from the United States, have been misapplied to D. caespitosa by various American authors:

Aira arctica Spreng., Syst. Veg. 4: Cur. Post. 32. 1827. Based on Deschampsia brevifolia $\mathrm{R}$. Br.

Aira caespitosa var. arctica Thurb.; A. Gray, Acad. Nat. Sci. Phila. Proc. 1863: 78. 1863. Based on Deschempsia brevifolia R. Br.

Deschampsia brachyphylla Nash, in Rydb., Mem. N.Y. Bot. Gard. 1: 37. 1900. Not D. brachyphylla Phil., 1896. Based on D. brevifolia R. Br.

Deschampsia curtifolia Scribn., U.S.Dept.Agr., Div. Agrost. Circ. 30: 7. 1901. Based on D. brachyphylla Nash.

Deschampsia arctica Merr., Rhodora 4: 143. 1902. Based on Aira arctica Spreng.

Aira curtifolia Rydb., Fl. Rocky Mount. ed. 2. 1112. 1922. Based on Deschampsia curtifolia Scribn.

Other names based on Old World species were misapplied to Deschampsia caespitosa by Beal:

Deschampsia caespitosa var. bottrica Vasey; Beal, Grasses N.Amer. 2: 369. 1896. Based on Aira bottnica Wahl.

Deschampsia caespitosa var. brevifolia Vasey; Beal, Grasses N.Amer. 2: 369. 1896. Based on Aira brevifolia Bieb.

Deschampsia caespitosa var. montana Vasey; Beal, Grasses N.Amer. 2: 369. 1896. Based on D. montana Schur.

(1) Deschampsia danthonioides (Trin.) Munro; Benth., Pl. Hartw. 342. 1857. Based on Aira danthonioides Trin.

Aira danthonioides Trin., Mém. Acad. St. Pétersb. VI. Math. Phys. Nat. 1: 57. 1830. Western North America.

Deschampsia calycina Presl, Rel. Haenk. 1: 251. 1830. "Peru" is the published locality, but the type specimen is labeled Monterey, Calif., Haenke.

Aira calycina Steud., Syn. Pl. Glum. 1: 220. 1854. Based on Deschampsia calycina Presl.

Trisetum glabrum Buckl., Acad. Nat. Sci. Phila. Proc. 1S62: 100. 1863. "Texas Dr. Linsecum." [Locality probably erroneous, the plants bearing this ticket in the herbarium of the Academy of Sciences, Philadelphia, being very like two on the same sheet labeled "Rocky Mountains of Columbia, Nuttall." The species is not otherwise known east of Arizona.]

Deschampsia gracilis Vasey, Bot. Gaz. 10: 224. 1885. San Diego, Calif., Orcutt [1072].

(2) Deschampsia elongata (Hook.) Munro; Benth., Pl. Hartw. 342. 1857. Based on Aira elongata Hook.

Aira elongata Hook., Fl. Bor. Amer. 2: 243. pl. 228. 1840. Columbia River, Douglas.

Deschampsia elongata var. ciliata Vasey; Beal, Grasses N.Amer. 2: 371. 1896. Oregon, Howell; California, Anderson, [Santa Cruz, type].

Deschampsia elongata var. tenuis Vasey; Beal, Grasses N.Amer. 2: 372.1896. Santa Cruz, Calif., Jones 2201. Published as new in Jepson, Fl. West. Mid. Calif. 51. 1901, Davy 213 (error for 4213), Evergreen, Santa Clara County, Calif., cited as type.

Deschampsia ciliata Rydb., Fl. Rocky Mount. 60. 1917. Based on D. clongata var. ciliata Vasey.

Aira vaseyana Rydb., Fl. Rocky Mount. ed. 2. 1112. 1922. Based on Deschampsia elongata var. ciliata Vasey.

(4) Deschampsia flexuosa (L.) Trin., Mém. Acad. St. Pétersb. VI. Sci. Nat. $2^{1}$ : $9.1836 . \quad B a s e d$ on Aira flexuosa L.

Aira flexuosa L., Sp. Pl. 65. $1753 . \quad$ Europe.

Avena flexuosa Mert. and Koch, in Roehl, Deut. Fl. ed. 3. 12: 570. 1823. Based on Aira flexuosa L.

Avenella flexuosa Parl., Fl. Ital. 1: 246. 1849. Based on Aira flexuosa L.

Lerchenfeldia flexuosa Schur, Enum. Pl. Transsilv. 753. 1866. Based on Aira flexuosa L.

Podionapus flexuosus Dulac, Fl. Haut. Pyr. 83. 1867. Based on Deschampsia flexuosa Trin.

Salmasia flexuosa Bubani, Fl. Pyr. 4: 319. 1901. Based on Aira flexuosa L.

(6) Deschampsia holciformis Presl, Rel. Haenk. 1: 251. 1830. Monterey, Calif., Haenke. 
Aira holciformis Steud., Syn. Pl. Glum. 1:221. 1854. Based on Deschampsia holciformis Presl.

Desmazeria sicula (Jacr.) Dum., Comm. Bot. 27. 1822. Based on Cynosurus siculus Jacq. The generic name spelled Demazeria; later (Obs. Gram. Belg. 46. 1823) changed to Desmazeria by Dumortier.

Cynosurus siculus Jacq., Obs. Bot. 2: 22. pl. 43. 1767. Europe.

(15) DIARRHENA Beauv. ${ }^{19}$

(1) Diarrhena americana Beauv., Ess. Agrost. 142. pl. 25. f. 2. 1812. Based on Festuca diandra Michx.

Festuca diandra Michx., Fl. Bor. Amer. 1: 67. 1803. Not F. diandra Moench., 1794. "Kentucky, Tennessee, etc." Michaux.

Diarina festucoides Raf., Med. Repos. N.Y. 5: 352. 1808. Not Diarrhena festucoides Raspail, 1825. Based on Festuca diandra Michx.

Festuca americana Michx.; Beauv., Ess. Agrost. 162. 1812. Name only.

Korycarpus arundinaceus Zea; Lag., Gen. and Sp. Nov. 4. 1816. America.

Roemeria zeae Roem. and Schult., Syst. Veg. 1: 61, 287. 1817. Source unknown.

Diarina sylvatica Raf., Jour. Phys. Chym. 89: 104. 1819. Based on Festuca diandra Michx.

Diarrhena diandra Wood Class-book ed. 2: 612. 1847. Based on Festuca diandra Michx.

Corycarpus diandrus Kuntze, Rev. Gen. P1. 2: 772. 1891. Based on Festuca diandra Michx.

Diarrhena festucoides Fernald, Rhodora 34: 204. 1932. Not D. festucoides Raspail, 1825. Based on Diarina festucoides Raf.

\section{(121) DIGITARIA Heist.}

(8) Digitaria filiformis (L.) Koel., Descr. Gram. 26. 1802. Based on Panicum filiforme $\mathrm{L}$.

Panicum filiforme L., Sp. Pl. 57. 1753. North America, Kalm.

Paspalum filiforme Flügge, Monogr. Pasp. 139. 1810. Not P. filiforme Swartz, 1788. Based on Panicum filiforme L.

Paspalum furcatum var. filiforme Doell, in Mart., Fl. Bras. 22: 104. 1877. Based on Digitaria filiformis Muhl. (the same as Flügge) but misapplied to a species of Axonopus.

Syntherisma filiformis Nash, Bull. Torrey Club 22: 420. 1895. Based on Panicum filiforme $\mathrm{L}$.

Digitaria laeviglumis Fernald, Rhodora 22: 102. 1920. Manchester, N.H., Batchelder.

(4) Digitaria floridana Hitche., Biol. Soc. Wash. Proc. 41: 163. 1929. Hernando County, Fla., Hitch cock Fla. P1. 2517.

(11) Digitaria gracillima (Scribn.) Fernald, Khodora 22: 101. 1920. Based on Panicum gracillimum Scribn.

Panicum gracillimum Seribn., Bull. Torrey Bot. Club 23: 146. 1896. Eustis, Fla., Nash 1192.

Syntherisma gracillima Nash, Bull. Torrey Bot. Club 25: 295. 189S. Based on Panicum gracillimum Seribn.

Syntherisma bakeri Nash, Bull. Torrey Bot. Club 25: 296. 1898. Grasmere, Fla., C. H. Baker 47.

Digitaria bakeri Fernald, Rhodora 22: 102. 1920. Based on Syntherisma balieri Nash.

(2) Digitaria horizontalis Willd., Enum. P1. 92. 1809. Dominican Republic.

Phalaris velutina Forsk., Fl. Aegypt. Arab. 17. 1775. No exact locality given. Not Digitaria velutina Hitche., 1927. [D. velutina Beauv., 1812 is name only.]

Milium digitatum Swartz, Prodr. Veg. Ind. Occ. 24. 1788. Not Digitaria digitata Buse, 1854. Jamaica.

10 Diarina Raf., Med. Repos. N.Y. 5: 352. 1808, proposed in a review of Michaux's Flora, with a single species, $D$. festucnides Raf., based on Festuca diandra Michx., not $F$. diandra Moench., 1794 . Since there is no description, the genus is not validly published. Diurriena Beauv. (Ess. Agrost. 142, 160. pl. 25. f. 1. 1812 ) is described, with a single species, D. americana Beauv., based on Festuca diandra Michx. "The generic name is credited (p. 160) to Schmal. [Rafinesque-Schmalz], by typographical error given as " Smart" on page 1.12. The changed spelling is accepted with Beauvois as author. Furthermore, Diarricnct is a conserved name. 
Axonopus digitatus Beauv., Ess. Agrost. 12, 154. 1812. Based on Milium digitatum Swartz.

Digitaria setigera Roth; Roem. and Schult., Syst. Veg. 2: 474.1817. Asia.

Panicum horizontale G. Meyer, Prim. Fl. Esseq. 54. 1818. Based on Digitaria horizontalis Willd.

Digitaria jamaicensis Spreng., Syst. Veg. 1: 272. 1825. Jamaica.

Digitaria setosa Desv.; Hamilt., Prodr. Pl. Ind. Occ. 6. 1825. West Indies.

Paspalum digtatum Kunth, Rév. Gram. 1: 24. 1829. Based on Milium digitatum Swartz.

Panicum hamiltonii Kunth, Rév. Gram. 1: Sup. IX. 1830. Based on Digita-

ria setosa Desv.
Syntherisma setosa Nash, Bull. Torrey Bot. Club 25: 300. 1898. Based on Digitaria seiosa Desv.

Panicum sanguinale var. digitatum Hack.; Urban, Symb. Antill. 4: 86. 1903. Based on Milium digitatum Swartz.

Panicum sanguinale subsp. horizontale Hack., Ergeb. Bot. Exped. Akad. Wiss. Südbras. 8. 1906; Denkschr. Akad. Wiss. Math. Naturw. (Wien) 79: 69. 1908. Based on Digitaria horizontalis Willd.

Syntherisma digitata Hitche., Contrib. U.S. Natl. Herb. 12: 142. 1908. Based on Milium digitatum Swartz.

Digitaria digitata Urban, Symb. Antill. s: 24: 1920. Not D. digitata Buse, 1854. Based on Milium digitatum Swartz.

(3) Digitaria ischaemum (Schreb.) Muhl., Deser. Gram. 131. 1817. Pre-

Panicum ischaemum Schreb.; Schweigger, Spec. Fl. Erland. 16. 1804. Germany.

Digitaria humifusa Pers., Syn. Pl. 1: 85. 1805. France.

Syntherisma glabrum Schrad., Fl. Germ. 1: 163. pl.3. f. 6. 1806. Germany.

Panicum glabrum Gaudin, Agrost. Helv. 1: 22. 1811. Not P. glabrum L., 1762. Based on Syntherisma glabrum Schrad. (In Index Kewensis "Ell." is erroneously given as author of $P$. glabrum.)

Digitaria glabra Beauv., Ess. Agrost. 51. 1812. Presumably based on Syntherisma glabrum Schrad.

Paspalum humifusum Poir., Encycl. Sup. 4: 316. 1816. Based on Digitaria humifusa Pers.

Panicum humifusum Kunth, Rév. Gram. 1: 33. 1829. Based on Digitaria humifusa Pers.

Panicum phacocarpum var. drummondianum Nees, F1. Afr. Austr. 22. 1841.

St. Louis, Mo., Drummond.
Paspalum glabrum Wood, Amer. Bot. and Flor. pt. 2: 390. 1871. Not P. glabrum Poir., 1804. "(Gaud.)", given in parentheses by Wood, doubtless refers to Panicum glabrum Gaudin.

Paspalum glabrum Cassidy, Colo. Agr. Expt. Sta. Bull. 12: 91. 1890. Not P. glabrum Poir., 1804. Colorado.

Syntherisma humifusum Rydb., Mem. N.Y. Bot. Gard. 1: 469. 1900. Based on Digitaria humifusa Pers.

Syntherisma ischaemum Nash., N.Amer. Fl. 17: 151. 1912. Based on Panicum ischaemum Schreb.

The name Panicum lineare L. (Syntherisma lineare Nash) has been used for Digitaria is chaemum but the description does not apply (e.g. "calycis squama exterior brevior, patens, rachi adhaerens"). It is probably Cynodon dactylon.

Digitaria ischaemum var. Mississippiensis (Gattinger) Fernald, Rhodora 22: 103. 1920. Based on Panicum glabrum var. mississippiense Gattinger.

Panicum glabrum var. mississippiense Gattinger, Tenn. Fl. 95. 1887, name only, Nashville. Scribn., Tenn. Agr. Expt. Sta. Bull. 7: 39.1894. Knoxville, Temn.

Panicum lineare var. mississippiense Gattinger; Beal, Grasses N.Amer. 2: 111. 1896. Presumably based on P. glabrum var. mississippiense Gattinger.

Syntherisma linearis mississippiensis Nash, Bull. Torrey Bot. Club. 25: 300. 1898. Based on Panicum glabrum var. mississippiense Gattinger.

(10) Digitaria panicea (Swartz) Urban, Symb. Antill. 8: 23. 1920. Based on Milium paniceum Swartz.

Milium paniceum Swartz, Prodr. Veg. Ind. Occ. 24. 1788. Jamaica, Swartz. Agrostis jamaicensis Poir., in Lam., Encycl. Sup. 1: 258. 1810. Jamaica.

Axonopus paniceus Beauv., Ess. Agrost. 12, 154. 1812. Based on Milium

paniceum Swartz.
Syntherisma paniceum Nash, N.Amer., Fl. 17: 152. 1912. Based on Milium paniceum Swartz.

Digitaria dolicophylla Henr., Blumea 1: 94. 1934. Florida, A. A. Eaton 459. 
(13) Digitaria pauciflora Hitchc., Biol. Soc. Wash. Proc. 41: 162. 1928. Southern Florida, Eaton 207.

(15) Digitaria runyoni Hitchc., Jour. Wash. Acad. Sci. 23: 455. 1933. Mouth of Rio Grande, near Brownsville, Tex., Runyon 188.

(1) Digitaria sanguinalis (L.) Scop., Fl. Carn. ed. 2. 1: 52. 1772. Based on Panicum sanguinale L.

Panicum sanguinale L., Sp. Pl. 57. 1753. America and southern Europe.

Dactylon sanguinalis L.; Vill., Hist. Pl. Dauph. 2: 69. 1787. Based on Panicum sanguinale L.

Syntherisma praecox Walt., F1. Carol. 76. 1788. South Carolina.

Paspalum sanguinale Lam., Tabl. Encyc1. 1: 176. 1791. Based on Panicum sanguinale $\mathbf{L}$.

Digitaria praecox Willd., Enum. Pl. 91. 1809. Based on Syntherisma praecox Walt.

Panicum adscendens H.B.K., Nov. Gen. and Sp. 1: 97. 1S15. Venezuela, Peru, and Mexico, Humboldt and Bonpland.

Cynodon praecox Roem. and Schult., Syst. Veg. 2: 412. 1817. Based on Syntherisma praecox Walt.

Digitaria marginata Link, Enum. Pl. 1: 102. 1821. Brazil.

Digitaria fimbriata Link, Hort. Berol. 1: 226. 1827. Brazil.

Panicum fimbriatum Kunth, Rév. Gram. 1: 33. 1829. Based on Digitaria fimbriata Link.

Panicum linkianum Kunth, Rév. Gram. 1: 33. 1829. Based on Digitaria marginata Link.

Syntherisma sanguinalis Dulac, Fl. Haut. Pyr. 77. 1867. Based on Panicum sanguinale L.

Syntherisma fimbriatum Nash, Bull. Torrey Bot. Club 25: 302. 1898. Based on Digitaria fimbriata Link.

Syntherisma marginatum Nash, N.Amer. Fl. 17: 154. 1912. Based on Digitaria marginata Link.

Digitaria marginata var. fimbriata Stapf, in Prain, Fl. Trop. Afr. 9: 440. 1919. Based on D. fimbriata Link.

Panicum sanguinale subsp. marginatum Thell., Vierteljahrs. Nat. Ges. Zürich 64: 699. 1919. Based on Digitaria marginata Link.

Digitaria sanguinalis var. marginata Fernald, Rhodora 22: 103. 1920. Based on D. marginata Link.

Digitaria adscendens Henr., Blumea 1: 92. 1934. Based on Panicum adscendens H.B.K.

Digitaria nealleyi Henr., Blumea 1: 94. 1934. Texas, Nealley in 1884. A duplicate of the type in the National Herbarium is distorted by a fungus.

Described as Syntherisma barbata (Willd.) Nash in Small's Flora.

(6) Digitaria serotina (Walt.) Michx., Fl. Bor. Amer. 1: 46.1803. Based on Syntherisma serotinum Walt.

Syntherisma serotinum Walt., Fl. Carol. 76. 1788. South Carolina.

Paspalum serotinum Flügge, Monogr. Pasp. 145. 1810. Based on Digitaria serotina Michx.

(7) Digitaria simpsoni (Vasey) Fernald, Rhodora 22: 103. 1920. Based on Panicum sanguinale var. simpsoni Vasey.

Panicum sanguinale var. simpsoni Vasey, Contrib. U.S. Natl. Herb. 3: 25. 1892. Manatee, Fla., Simpson.

Panicum simpsoni Beal, Grasses N.Amer. 2: 109. 1896. Based on Panicum sanguinale var. simpsoni Vasey.

Syntherisma simpsoni Nash, Bull. Torrey Bot. Club. 25: 297. 1898. Based on Panicum sanguinale var. simpsoni Vasey.

14) Digitaria subcalva Hitchc., Amer. Jour. Bot. 21: 138. f. 4. 1934. Plant City, Fla., C. P. Wright.

(12) Digitaria texana Hitchc., Biol. Soc. Wash. Proc. 41: 162. 192S. Sarita, Tex., Hitchcock 5479.

9) Digitaria villosa (Walt.) Pers., Syn. Pl. 1: 85. 1805. Based on Syntherisma villosa Walt.

Syntherisma villosa Walt., Fl. Carol. 77. 1788. South Carolina.

Digitaria pilosa Michx., Fl. Bor. Amer. 1: 45. 1803. Carolina and Georgia, Michaux. Willdenow (Enum. Pl. 1: 91. 1809) uses this name, doubtfully citing $D$. pilosa Michx. The description suggests that Willdenow's plant, from Carolina, is also $D$. villosa.

Paspalum carolinianum Poir., in Lam., Encycl. Sup. 4: 311. 1816. Carolina and Georgia, Bosc. 
Syntherisma leucocoma Nash, Bull. Torrey Bot. Club 25: 295. 1898. Lake Ella, Fla., Nash 1155.

Panicum leucocomum Scribn., U.S.Dept.Agr., Div. Agrost. Bull. 7. 'ed. 2): 58. 1898. Based on Syntherisma leucocoma Nash.

Digitaria leucocoma Urban, Symb. Antill. 8: 24. 1920. Based on Syntherisma leucocoma Nash.

Digitaria filiformis var. villosa Fernald, Rhodora 36: 19. 1934. Based on Syntherisma villosa Walt.

(5) Digitaria violascens Link, Hort. Berol. 1: 229. 1827. Brazil.

Panicum violasccns Kuntl, Rév. Gram. 1: 33. 1829. Based on Digitaria violascens Link.

Paspalum chinense Nees, in Hook. and Arn., Bot. Beechey Voy. 231. 1836. Macao, China.

Syntherisma chinensis Hitchc., Contrib. U.S. Natl. Herb. 22: 468. 1922. Based on Paspalum chinense Nees.

Digitaria chinensis A. Camus, Not. Syst. Lecomte 4: 48. 1923. Not D. chinensis Hornem., 1819. Based on Paspalum chinense Nees.

(16) DISSANTHELIUM Trin.

(1) Dissanthelium californicum (Nutt.) Benth., in Hook. f., Icon. Pl. III. 4: 56. pl. 1375. 1881. Based on Stenochloa californica Nutt.

Stenochloa californica Nutt., Jour. Acad. Sci. Phila. II. 1: 189. 1848. Santa Catalina Island, Calif., Gambel.

\section{(19) DISTICHLIS Raf.}

(3) Distichlis dentata Rydb., Bull. Torrey Bot. Club 36: 536. 1909. Washington, Sandberg and Leiberg 463.

(1) Distichlis spicata (L.) Greene, Calif. Acad. Sci. Bull. 2: 415. 1887. Based on Uniola spicata L.

Uniola spicata L., Sp. Pl. 71. 1753. Atlantic coast of North America.

Briza spicata Lam., Encycl. 1: 465. 1785. Based on Uniola spicata L.

? Festuca multiflora Walt., Fl. Carol. 81. 1788. South Carolina.

Festuca triticoides Lan., Tabl. Encycl. 1: 191. 1791. Carolina, Fraser.

Festuca distichophylla Michx., Fl. Bor. Amer. 1: 67. 1803. Carolina, Michaux.

Uniola distichophylla Roem. and Schult., Syst. Veg. 2: 596. 1817. Based on Festuca distichophylla Michx.

Distichlis maritima Raf., Jour. Phys. Chym. 89: 104. 1819. Based on Uniola spicata L.

Distichlis nodosa Raf., Jour. Phys. Chym. 89: 104. 1819. Based on Festuca distichophylla Michx.

Brizopyrum americanum Link, Hort. Berol. 1: 160. 1827. Based on Uniola spicata L.

Poa michauxii Kunth, Rév. Gram. 1: 111. 1829. Based on Festuca distichophylla Michx.

Brizopyrum boreale Presl, Rel. Haenk. 1: 280. 1830. Nootka Sound, Vancouver Island, Haenke.

Poa borealis Kunth, Rév. Gram. 1: Sup. XXVIII. 1830. Based on Brizopyrum borcale Presl.

Festuca triticea Lam.; Kunth, Enum. Pl. 1: 325. 1833, as synonym of Poa michauxii Kunth. (Probably error for F. triticoides Lam.)

Brizopyrum spicatum Hook. and Arn., Bot. Beechey Voy. 403. 1841. Based on Uniola spicata L.

(2) Distichlis stricta (Torr.) Rydb., Bull. Torrey Bot. Club 32: 602. 1905. Based on Uniola stricta Torr.

Festuca spicata Nutt., Gen. Pl. 1: 72. 1818. Not F. spicata Pursh, 1814. "On the banks of the Missouri."

Uniola stricta Torr., Ann. Lyc. N.Y. 1: 155. 1824. Canadian River [Okla.].

Uniola multiflora Nutt., Amer. Phil. Soc. Trans. (n.s.) 5: 148.1837. Arkansas River, Nuttall.

Uniola flexuosa Buckl., Acad. Nat. Sci. Phila. Proc. 1862: 99.1863. Fort Belknap, Tex., Buckley.

Brizopyrum spicatum var. strictum A. Gray; S. Wats., in King, Geol. Expl. 40th Par. 5: 385. 1871. Based on Uniola stricta Torr.

Distichlis maritima var. stricta Thurb., in S. Wats., Bot. Calif. 2: 306.1880. Based on Uniola stricta Torr.

Distichlis spicata stricta Scribn., Mem. Torrey Bot. Club 5: 51. 1894. Based on Uniola stricta Torr. 
Distichlis spicata var. laxa Vasey; Beal, Grasses N.Amer. 2: 519. 1896. Lake Park, Utah, Tracy in 1887.

(4) Distichlis texana (Vasey) Scribn., U.S.Dept.Agr., Div. Agrost. Circ. 16: 2. 1899. Based on Poa texana Vasey.

Poa texana Vasey, Contrib. U.S. Natl. Herb. 1: 60. 1890. Region of Rio Grande, Tex., Nealley.

Sieglingia wrightii Vasey, Contrib. U.S. Natl. Herb. 1: 269. 1893. Valley of the Limpio, Tex., Wright 2038.

\section{(133) ECHINOCHLOA Beauv. ${ }^{20}$}

(1) Echinochloa colonum (L.) Link, Hort. Berol. 2: 209. 1833. Based on Panicum colonum L.

Panicum colonum L., Syst. Nat. ed. 10. 2: 870. 1759. Jamaica, Browne.

Miliumco lonum Moench, Meth. Pl. 202. 1794. Based on Panicum colonum L.

Oplismenus colonum H.B.K., Nov. Gen. and Sp. 1: 108. 1815. Based on Panicum colonum L.

Panicum zonale Guss., Fl. Sic. Prodr. 1: 62. 1827. Sicily.

Oplismenus repens Presl, Rel. Haenk. 1: 321. 1830. Mexico, Haenke.

Oplismenus colonum var. zonalis Schrad. Linnaea 12: 429. 1838. Based on Panicum zonale Guss.

Panicum incertum Bosc; Steud., Nom. Bot. ed. 2. 2: 258. 1841. Name only. Carolina.

Echinochloa zonalis Parl., Fl. Panorm. 1: 119. 1845. Based on Panicum zonale Guss.

Panicum prorepens Steud., Syn. Pl. Glum. 1: 46. 1854. Based on Oplismenus repens Presl.

Oplismenus crusgalli var. colonum Coss. and Dur., Expl. Sci. Alger. 2: 28. 1854. Based on Panicum colonum L.

Panicum crusgalli var. colonum Coss.; Richt., Pl. Eur. 1: 26. 1890. Based on P. colonum L.

Panicum colonum var. zonale L. H. Dewey, Contrib. U.S. Natl. Herb. 2: 502. 1894. Based on $P$. zonale Guss.

Echinochloa colonum var. zonalis Woot. and Standl., N.Mex. Coll. Agr. Bull. 81: 45. 1912. Based on Panicum zonale Guss.

Echinochloa crusgalli subsp. colonum Honda, Bot. Mag. Tokyo 37: 122.1923. Based on Panicum colonum L.

Panicum crusgalli subsp. colonum Makino and Nemoto, Fl. Jap. 1470. 1925. Based on P. colonum L.

(2) Echinochloa crusgalli (L.) Beauv., Ess. Agrost. 53, 161. 1812. Based on Panicum crusgalli L.

Panicum crusgalli L., Sp. Pl. 56. 1753. Europe; Virginia.

Milium crusgalli Moench, Meth. Pl. 202. 1794. Based on Panicum crusgalli L.

Panicum grossum Salisb., Prod. Stirp. 18. 1796. Based on P. crusgalli L.

Panicum muricatum Michx., Fl. Bor. Amer. 1: 47. 1803. Not P. muricatum Retz., 1786. Canada, Lake Champlain [type] and Lake Ontario, Michaux.

?Panicum echinatum Willd., Enum. P1. 1032. 1809. "America meridionali." Wiegand ${ }^{21}$ takes up this name for Echinochloa crus-pavonis. The specimen in the Willdenow Herbarium named P. echinalum (Magdalena, Colombia, Humboldt) is Pseudechinolaena polystachya (H.B.K.) Stapf. The brief description does not apply to the specimen so named nor to E. crus-pavonis. Willdenow differentiates the species from $P$. crusgalli (with "glumis aristatis hispidis") by "glumis aristatus muricato-echinatus", whereas in E. crus-pavonis the glumes are less strongly hispid than in E. crsugalli.

Setaria muricala Beauv., Ess. Agrost. 51, 170, 178. 1812. Based on Panicum muricatum Michx.

?Echinochloa echinata Beauv., Ess. Agrost. 53, 161, 169. 1812. Based on Panicum echinatum Willd.

Panicum crusgalli var. aristatum Pursh, Fl. Amer. Sept. 66. 1814. North America.

Panicum pungens Poir., in Lam., Encycl. Sup. 4: 273. 1816. Based on P. muricatum Michx.

Pennisetum crusgalli Baumg., Enum. Stirp. Transsilv. 3: 277. 1816. Based on Panicum crusgalli $\mathrm{L}$.

Echinochloa crusgalli var. aristata S. F. Gray, Nat. Arr. Brit. PI. 2: 158.1821. Great Britain.

20 For discussion of types see Hitchc., Contrib. U.S. Natl. Herb. 22: 138-153. 1920.

21 Rhodora 23: 60 . 1921 . 
Oplismenus crusgalli Dum., Obs. Gram. Belg. 138. 1823. Based on Panicum crusgalli L.

?Orthopogon echinatus Spreng., Syst. Veg. 1: 307. 1825. Based on Panicum echinatum Willd.

Orthopogon crusgalli Spreng., Syst. Veg. 1: 307. 1825. Based on Panicum crusgalli L.

Oplismenus muricatus Kunth, Rév. Gram. 1: 44. 1829. Based on Panicum muricatum Michx.

?Oplismenus echinatus Kunth, Rév. Gram. 1: 45. 1829. Based on Panicum echinatum Willd.

?Panicum crusgalli var. echinatum Doell, in Mart. Fl. Bras. 22: 143.1877. Based on $P$. echinatum Willd.

Echinochloa muricata Fernald, Rhodora 17: 106. 1915. Based on Panicum muricatum Michx.

Echinochloa crusgalli var. muricata Farwell, Mich. Acad. Sci. Rept. 21: 350. 1920. Based on Panicum muricatum Michx.

Echinochloa crusgalli var. michauxii House, N.Y. State Mus. Bull. 254: 71. 1924. Based on Panicum muricatum Michx.

Echinochloa pungens Ryab., Brittonia 1: 81. 1931. Based on Panicum pungens Poir.

Echinochloa crusgalli var. Frumentacea W. F. Wight, Cent. Dict. Sup. 810. 1909. Presumably based on Panicum frumentaceum Roxb. (Published as E. crusgalli frumentacea.)

Panicum frumentaceum Roxb., Fl. Ind. 1: 307. 1820. Not P. frumentaceum Salisb., 1796 . India.

Echinochloa frumentacea Link, Hort. Berol. 1: 204. 1527. Based on Panicum frumentaceum Roxb.

Oplismenus frumentaceus Kunth, Rév. Gram. 1: 445. 1829. Based on Panicum frumentaceum Roxb.

Panicum crusgalli var. frumentaceum Trimen, Syst. Cat. Ceylon Pl. 104. 1885. Based on P. frumentaceum Roxb.

Echinochloa crusgalli edulis Hitchc., U.S. Dept. Agr. Bull. 772: 238. 1920. Based on Panicum frumentaceum Roxb.

Echinochloa crusgalli subsp. colonum var. edulis Honda, Bot. Mag. Tokyo 37: 123. 1923. Based on E. crusgalli var. edulis Hitchc.

Echinochloa colonum var. frumentacea Ridl., Fl. Malay Pen. 5: 223.1925. Presumably based on Panicum frumentaceum Roxb.

Panicum crusgalli subsp. colonum var. edulis Makino and Nemoto, Fl. Jap. 1470. 1925. Based on P. frumentaceum Roxb.

Echinochloa cruscalli var. Mrmis (Pursh) Peterm., Fl. Lips. 82. 1838. Based on Panicum crusgalli var. mite Pursh.

Panicum crusgalli var. mite Pursh, Fl. Amer. Sept. 66. 1814. North America.

Panicum crusgalli var. purpureum Pursh, Fl. Amer. Sept. 65. 1814. North America.

Panicum crusgalli var. muticum Ell., Bot. S.C. and Ga. 1: 114. 1816. Probably South Carolina.

Panicum scindens Nees; Steud., Syn. Pl. Glum. 1: 47. 1854. St. Louis, [Drummond].

Oplismenus crusgalli var. muticus Wood, Amer. Bot. and Flor. pt. 2: 393. 1870. Eastern States.

Panicum crusgalli $\alpha$ normale var. mite forma hispidum Kuntze, Rev. Gen. Pl. 2: 783. 1891. Pennsylvania.

Echinochloa zelayensis var. macera Wiegand, Rhodora 23: 54. 1921. Matamoros, Mexico, Berlandier 890.

Echinochloa muricata var. ludoviciana Wiegand, Rhodora 23: 58. 1921. Baton Rouge, La., Billings 14.

Echinochloa muricata var. occidentalis Wiegand, Rhodora 23: 58. 1921. Grand Tower, Ill., Gleason 1720.

Echinochloa muricata var. microstachya Wiegand, Rhodora 23: 58. 1921. Cayuga Lake Basin, N.Y., Palmer 97.

Echinochloa muricata var. multiflora Wiegand, Rhodora 23: 59. 1921. Lincoln County, Okla., Blankenship.

Echinochloa microstachya Rydb., Brittonia 1: 82. 1931. Based on E. muricata var. microstachya Wiegand.

Echinochloa occidentalis Rydb., Brittonia 1: 82. 1931. Based on E. muricata var, occidentalis Wiegand. 
EchinochloA CRUsgalli var. zelayensis (H.B.K.) Hitchc., U.S. Dept. Agr. Bull. 772: 238. 1920. Based on Oplismenus zelayensis H.B.K. (Published as E. crusgalli zelayensis.)

Oplismenus zelayensis H.B.K., Nov. Gen. and Sp. 1: 108. 1515. Zelaya, Mexico, Humboldt and Bonpland.

Echinochloa zelayensis Schult., Mant. 2: 269. 1824. Based on Oplismenus zelayensis H.B.K.

Panicum zelayense Steud., Nom. Bot. ed. 2. 2: 265. 1841. Based on Oplismenus zelayensis H.B.K.

Panicum crus-pici Willd.; Doell, in Mart., Fl. Bras. 22: 143. 1877. Name only. South America.

?Panicum crusgalli $\alpha$ normale var. pygmaeum Kuntze, Rev. Gen. Pl. 2: 783. 1891. Colorado.

(3) Echinochloa crus-paronis (H.B.K.) Schult., Mant. 2: 269. 1S24. Based on Oplismenus crus-pavanis H.B.K.

Oplismenus crus-pavonis H.B.K., Nov. Gen. and Sp. 1: 108. 1815. Cumaná, Venezuela, Humboldt and Bonpland.

Panicum sabulicola Nees, Agrost. Bras. 25s. 1829. Pará, Brazil, Sieber; Uruguay and Paraguay.

Panicum crus-pavanis Nees, Agrost. Bras. 259. 1829. Based on Oplismenus crus-pavonis H.B.K.

Echinochloa composita Presl; Nees, Agrost. Bras. 259. 1829, as synonym of Panicum crus-pavanis Nees. Acapulco, Mexico, Haenke.

Oplismenus sabulicola Kunth, Rev. Gram. 1: Sup. XI. 1830. Based on Panicum sabulicola Nees.

Panicum aristatum Macfad., Bot. Misc. Hook. 2: 115. 1831. Jamaica, [Macfadden].

Oplismenus jamaicensis Kunth, Enum. Pl. 1: 147. 1833. Based on Panicum arisiatum Macfad.

Panicum jamaicense Steud., Nom. Bot. ed. 2. 2: 257. 1841. Based on Oplismenus jamaicensis İunth.

Panicum crusgalli var. sabulicola Doell, in Mart., Fl. Bras. 22: 142.1877. Based on P. sabulicola Nees.

Oplismenus angustifalius Fourn., Mex. Pl. 2: 40. 1S\$6. Vera Cruz, Mexico, Gouin 54 [error for 50].

Echinochloa sabulicala Hitchc., Contrib. U.S. Natl. Herb. 17: 257. 1913. Based on Panicum sabulicola Nees.

Echinochloa crusgalli crus-pavonis Hitchc., Contrib. U.S. Nat1. Herb. 22: 148. 1920. Based on Oplismenus crus-pavonis H.B.K.

Echinochloa zelayensis var. subaristata Wiegand, Rhodora 23: 54. 1921. Pierce, Texas, Tracy 7743.

(4) Echinochloa paludigena Wiegand, Rhodora 23: 64. 1921. Hillsborough County, Fla., Fredholm 6390.

Echinachlaa paludigena var. soluta Wiegand, Rhodora 23: 64. 1921. Manatee, Fla., T'racy 7754.

(5) Echinochloa walteri (Pursh) Heller, Cat. N.Amer. Pl. ed. 2. 21. 1900. Presumably based on Panicum walteri Pursh, Pursh being cited in parentheses.

Panicum hirtellum Walt., Fl. Carol. 72. 1788. Not P. hirtellum L., 1759. South Carolina.

Panicum walteri Pursh, Fl. Amer. Sept. 66. 1814. Based on P. hirtellum Walter.

Panicum crusgalli var. hispidum Ell., Bot. S.C. and Ga. 1: 114. 1816. Based on $P$. hispidum Muhl., in manuscript.

Panicum hispidum Muhl., Descr. Gram. 107. 1817. Not P. hispidum Forst., 1786. New York to Carolina.

Panicum longisetum Torr., Amer. Jour. Sci. 4: 58. 1822. Not. P. longisetum Poir., 1816. Fox River, Wis. [Douglass in 1820.]

Orthopogon hispidus Spreng., Syst. Veg. 1: 307. 1S25. Based on Panicum hispidum Muhl.

Oplismenus longisetus Kunth, Rév. Gram. 1: 45. 1829. Based on Panicum longisetum Torr.

Oplismenus hispidus Wood, Class-book ed. 2. 604. 1847. Based on Panicum hispidum Muhl.

Oplismenus crusgalli var. hispidus Wood, Amer. Bot. and Flor. pt. 2: 393. 1870. Presumably hased on Panicum hispidum Muhl.

Echinochloa longearistata Nash, in Small, Fl. Southeast. U.S. 84. 1903. Louisiana, Hale. 
Echinochloa walteri forma laevigata Wiegand, Rhodora 23: 62. 1921. Based on Panicum longisetum Torr.

Echinochloa crusgalli var. hispida Farwell, Amer. Midl. Nat. 9: 4. 1925. Based on Panicum hispidum Muhl.

Echinochloa crusgalli var. hispida subvar. laevigata Farwell, Amer. Midl. Nat. 9: 4. 1925. Based on E. walteri forma laevigata Wiegand.

\section{(93) ELEUSINE Gaertn.}

Eleusine coracana (L.) Gaertn., Fruct. and Sem. 1: 8. pl. 1. 1788. Based on Cynosurus coracanus $\mathrm{L}$.

Cynosurus coracanus L., Syst. Nat. ed. 10. 2: 875. 1759. East Indies.

(1) Eleusine indica (L.) Gaertn., Fruct. and Sem. 1: 8. 1788. Based on Cynosurus indicus L.

Cynosurus indicus L., Sp. Pl. 72. 1753. India.

Eleusine gracilis Salisb., Prodr. Stirp. 19. 1796. Based on Cynosurusindicus L.

Eleusine domingensis Sieber; Schult., Mant. 2: 323. 1824. Not E. domingensis Pers., 1805. As synonym of E. indica L.

Cynodon indicus Raspail, Ann. Sci. Nat., Bot. 5: 303. 1825. Based on Eleusine indica Lam. (error for Gaertn.).

Chloris repens Steud., Nom. Bot. ed. 2. 1: 353. 1840, as synonym of Eleusine indica Pers. (error for Gaertn.).

Eleusine scabra Fourn.; Hemsl., Biol. Centr. Amer. Bot. 3: 565. 1885, name only; Fourn., Mex. Pl. 2: 145. 1886. Mexico, Bourgeau 1030, 2378 in part, 2634, 2743; Virlet 1435; Bitimek 454; Müller 1392; Gouin 67.

Eleusine indica var. major Fourn., Mex. Pl. 2: 145.1886. Mexico, Liebmann $222,223,227$; Karwinsky 955.

Eleusine tristachya (Lam.) Lam., Tabl. Encycl. 1: 203. 1791. Based on Cynosurus tristachyus Lam.

Cynosurus tristachyus Lam., Tabl. Encycl. 2: 188. 1786. Uruguay, Commerson.

\section{(43) ELYMUS L.}

(9) Elymus ambiguus Vasey and Scribn., Contrib. U.S. Natl. Herb. 1: 280. 1893. Pen Gulch, Colo., Vasey in 1884.

Eurmos ambiguds var. strigosus (Rydb.) Hitchc., Amer. Jour. Bot. 21: 133. 1934. Based on E. strigosus Rydb.

Elymus strigosus Rydb., Bull. Torrey Bot. Club 32: 609. 1905. Boulder, Colo., Letterman 553 [type]; Wyoming, A. Nelson 7151.

Elymus villiflorus Rydb., Bull. Torrey Bot. Club 32: 609. 1905. Boulder, Colo., Tweedy 4818.

(5) Elymus arenicola Scribn. and Smith, U.S.Dept.Agr.. Div. Agrost. Circ. 9: 7. $1899 . \quad$ Suferts, Oreg., Leckenby in 1898.

(16) Elymus aristatus Merr., Rhodora 4: 147. 1902. Harney County, Oreg., Cusick 2712.

Elymus glaucus aristatus Hitchc., in Abrams, Illustr. Fl. 1: 252. 1923. Based on E. aristatus Merr.

(19) Elymus canadensis L., Sp. P1. 83. 1753. Canada, Kalm.

Elymus philadelphicus L., Cent. Pl. 1: 6. 1755; Amoen. Acad. 4: 266.1759. Pennsylvania, Kalm.

Hordeum patulum Moench, Meth. Pl. 199. 1794. Garden plant, Elymus canadensis L., cited as synonym.

Elymus glaucifolius Muhl.; Willd., Enum. PI. 1: 131. 1809. Pennsylvania, Muhlenberg.

Elymus canadensis var. glaucifolius Torr., Fl. North. and Mid. U.S. 1: 137. 1823. Based on E. glaucifolius Muhl.

Elymus canadensis var. pendulus Eaton and Wright, N.Amer. Bot. ed. 8. 232. 1840. No locality cited.

Sitanion brodiei Piper, Erythea 7: 100. 1899. Bishop's Bar, Snake River, Wash., Brodie in 1895.

Hordeum canadense Aschers. and Graebn., Syn. Mitteleur. Fl. 2: 745. 1902. Based on Elymus canadensis L.

Terrellia canadensis Lunell, Amer. Midl. Nat. 4: 228. 1915. Based on Elymus canadensis L.

Terrellia canadensis var. glaucifolia Lunell, Amer. Midl. Nat. 4: 228. 1915. Based on Elymus glaucifolius Muhl. 
Elymus robustus var. vestitus Wiegand, Rhodora 20: 90. 1918. Cedar Point, Ohio, MacDaniels 106.

Elymus canadensis var. philadelphicus Farwell, Mich. Acad. Sci. Rept. 21:357. 1920. Based on E. philadelphicus L.

Elymus philadelphicus var. hirsutus Farwell, Amer. Midl. Nat. 10: 314.1927. Name proposed for $E$. canadensis as described by Wiegand (Rhodora 20: 87 . 1918) "in large part."

Elymus philadelphicus var. pendulus Farwell, Amer. Midl. Nat. 10: 314. 1927. Based on E. canadensis var. pendulus Eaton and Wright.

Clinelymus canadensis Nevski, Bull. Jard. Bot. Acad. Sci. U.R.S.S. 30: 650. 1932. Based on Elymus canadensis L.

Elymus canadensis forma glaucifolius Fernald, Rhodora 35: 191. 1933. Based on E. glaucifolius Muhl.

Elymus wiegandii Fernald, Rhodora 35: 192. 1933. St. Francis, Maine, Fernald 197.

Elymus wiegandii forma calvescens Fernald, Rhodora 35: 192. 1933. Dead River, Maine, Fernald and Strong in 1896.

Elymus Canadensis var. BRachystachys Farwell, Mich. Acad. Sci. Rept. 21: 357. 1920. Based on E. brachystachys Scribn. and Ball.

Elymus brachystachys Scribn. and Ball, U.S.Dept.Agr., Div. Agrost. Bull. 24: 47. f. 21. 1901. Indian Territory [Oklahoma], Palmer 420.

Elymus philadelphicus var. brachystachys Farwell, Amer. Midl. Nat. 10: 314. 1927. Based on E. bracystachys Scribn. and Ball.

Elymus Canadensis var. Robustus (Scribn. and Smith) Mackenz. and Bush, Man. Fl. Jackson County 38. 1902. Based on E. robustus Scribn. and Smith.

Elymus canadensis forma crescendus Ramaley, Minn. Bot. Studies 1: 114. 1894. Springfield, Minn., Sheldon 1120.

Elymus robustus Scribn. and Smith, U.S.Dept.Agr., Div. Agrost. Bull. 4: 37. 1897. Illınols [type, Wolf], Iowa, Kansas, and Montana.

Elymus crescendus Wheeler, Minn. Bot. Studies 3: 106. 1903. Based on E. canadensis forma crescendus Ramaley.

Elymus canadensis villosus Bates, Amer. Bot. 20: 17. 1914. Loup City and Arcadia, Nebr., Bates in 1911.

Elymus glaucifolius crescendus Bush, Amer. Midl. Nat. 10: 83. 1926. Based on E. canadensis forma crescendus Ramaley.

Elymus glaucifolius robustus Bush, Amer. Midl. Nat. 10: 87. 1926. Based on E. robustus Scribn. and Smith.

Elymus philadelphicus var. robustus Farwell, Amer. Midl. Nat. 10: 314.1927. Based on E. robustus Scribn. and Smith.

(1) Elymus caput-medusae L., Sp. Pl. 84. 1753. Southern Europe.

Hordeum caput-medusae Coss. and Dur., Expl. Sci. Alger. 2: 198. 1867. Based on Elymus caput-medusae L.

(11) Elymus condensatus Presl, Rel. Haenk. 1: 265. 1830. Monterey, Calif. Haenke.

Elymus Condensatus var. PUBens Piper, Erythea 7: 101. 1899. Yakima City, Wash., Piper 2591. (Published as E. condensatus pubens.)

Elymus cinereus Scribn. and Merr., Bull. Torrey Bot. Club 29: 467. 1902. Pahrump Valley, Nev., Purpus 6050.

(4) Elymus flavescens Scribn. and Smith, U.S.Dept.Agr., Div. Agrost. Bull. S: 8. f. 1. 1897. Columbus, Wash., Suksdorf 916.

Elymus giganteus Vahl, Symb. Bot. 3: 10. 1794. Source unknown.

(12) Elymus glaucus Buckl., Acad. Nat. Sci. Phila. Proc. 1862: 99. 1863. Columbia River, Oreg., Nuttall.

Elymus villosus var. glabriusculus Torr., U.S. Rept. Expl. Miss. Pacif. $4^{5}: 157$. 1856. Napa Valley, Calif.

Elymus nitidus Vasey, Bull. Torrey Bot. Club 13: 120. 1886. Eagle Mountains, Oreg., Cusick [1130].

Elymus americanus Vasey and Scribn.; Macoun, Cat. Can. Pl. 24: 245.1888 , name only; Cassidy, Colo. Agr. Expt. Sta. Bull. 12: 57. 1890. Arapahoe Pass, Colo.

Elymus sibiricus var. americanus Wats. and Coult., in A. Gray, Man. ed. 6. 673. 1890. Michigan and westward.

Elymus sibiricus var. glaucus Ramaley, Minn. Bot. Studies 9: 112. 1894. Based on $E$. glaucus Buckl.

Elymus glaucus var. breviaristatus Davy, in Jepson, Fl. West. Mid. Calif. 79. 1901. Point Reyes, Calif., Davy. 
Elymus glaucus var. maximus Davy, in Jepson, Fl. West. Mid. Calif. 79. 1901. Napa Valley, Calif., Jepson.

Elymus hispidulus Davy, in Jepson, Fl. West. Mid. Calif. 79. 1901. Olema, Calif., Davy 4306 b.

Elymus angustifolius Davy, in Jepson, Fl. West. Mid. Calif. 80. 1901. San Francisco, Calif., Davy.

Elymus angusiffolius var. caespitosus Davy, in Jepson, Fl. West. Mid. Calif. 81. 1901. Berkeley Hills, Calif., Davy 4255.

Elymus marginalis Rydb., Bull. Torrey Bot. Club 36: 539. 1909. Lower Arrow Lake, British Columbia, Macoun 44.

Terrellia glauca Lunell, Amer. Midl. Nat. 4: 228. 1915. Based on Elymus glaucus Buckl.

Elymus mackenzii Bush, Amer. Midl. Nat. 10: 53. 1926. Eagle Rock, Mo., Bush 77.

Clinelymus glaucus Nevski, Bull. Jard. Bot. Acad. Sci. U.R.S.S. 30: 648. 1932. Based on Elymus glaucus Buckl.

Clinelymus glaucus subsp. californicus Nevski, Bull. Jard. Bot. Acad. Sci. U.R.S.S. 30: 649. 1932. California, Heller 5714-a, first of several cited from California.

Clinelymus glaucus subsp. coloratus Nevski, Bull. Jard. Bot. Acad. Sci. U.R.S.S. 30: 648. 1932. Washington, Heller 3965.

Elymus Gladuds var. JePsoni Davy, in Jepson, Fl. West. Mid. Calif. 79. 1901. Napa Valley, Calif., Jepson.

Elymus divergens Davy, in Jepson, Fl. West. Mid. Calif. 80. 1901. Petaluma, Calif., Davy 4037.

Elymus velutinus Scribn. and Merr., Bull. Torrey Bot. Club 29: 466. 1902. San Beruardino Mountains, Calif., Abrams 2056.

Elymus parishį Davy and Merr., Univ. Calif. Pubs., Bot. 1: 58. 1902. San Jacinto Mountains, Calif., Hall 2097.

Elymus edentatus Suksdorf, Werdenda 12: 4. 1923. Bingen, Wash., Suksdorf 10057.

Clinelymus glaucus subsp. californicus var. pubescens Nevski, Bull. Jard. Bot. Acad. Sci. U.R.S.S. 30: 649. 1932. California, Tiling 8822; Palmer 417.

Clinelymus velutinus Nevski, Bull. Jard. Bot. Acad. Sci. U.R.S.S. 30: 649. 1932. Based on Elymus velutinus Scribn. and Merr.

Elymus glaucus var. Tenuis Vasey (Contrib. U.S. Natl. Herb. 1: $280 . \quad 1893$ ). "Type specimen collected by John Macoun on Vancouver Island in 1887 (no. 3)" comprises two forms, all Macoun's no. 3. One specimen is a small form of $E$. glaucus var. jepsoni; the others have spikes with fragile rachises, spikelets with 5- to 6-nerved glumes and lemmas with divergent awns and apparently represent a form not found in the United States. There is another Macoun specimen upon which Vasey lias written the varietal name tenuis, this specimen having glabrous sheaths and divergent awns. The description states that the sheaths are glabrous or pubescent and that the awns are divergent. Hence the plant of number 3 with divergent awns is selected as the type of $E$. glaucus var. tenuis and the name is excluded from our flora.

(14) Elymus hirsutus Presl, Rel. Haenk. 1: 264. 1830. Nootka Sound, Vancouver Island, Haenke.

Elymus ciliatus Scribn., U.S.Dept.Agr., Div. Agrost. Bull. 11: 57. pl. 16. 1898. Not E. ciliaius Muhl., 1817. Sitka, Alaska, Evans 210.

Elymus borealis Scribn., U.S.Dept.Agr., Div. Agrost. Circ. 27: 9. $1900 . \quad$ Based on E. ciliatus Scribn.

Clinelymus borealis Nevski, Bull. Jard. Bot. Acad. Sci. U.R.S.S. 30: 645. 1932. Based on Elymus borealis Scribn.

(7) Elymus hirtiflorus Hitchc., Amer. Jour. Bot. 21: 132. f. 2. 1934. Green River, Wyo., Shear 284.

(6) Elymus innovatus Beal, Grasses N.Amer. 2: 650. 1896. Nortl Fork Sims River, Mont., Williams in 1887.

Elymus mollis R. Br., in Richards., Bot. App. Franklin Jour. 732. 1823. Not E. mollis Trin., 1821. Canada [Richardson].

Elymus brownii Scribn. and Smith, U.S.Dept.Agr., Div. Agrost. Bull. 8: 7. pl. 4. 1897. Banff, Alberta, Canby 24 in 1895 .

(18) Elymus interruptus Buckl., Acad. Nat. Sci. Phila. Proc. 1862: 99. 1863. Llano County, Tex., Buckley.

Elymus occidentalis Seribn., U.S.Dept.Agr., Div. Agrost. Bull. 13: 49.1898. Laramie River, Wyo., Nelson 4470. 
Elymus pringlei Scribn. and Merr., U.S.Dept.Agr., Div. Agrost. Bull. 24: 30. 1901. Hidalgo, Mexico, Pringle 6637.

Elymus diversiglumis Scribn. and Ball, U.S.Dept.Agr., Div. Agrost. Bull. 24: 48. f. 22. 1901. Bear Lodge Mountains, Wyo., Williams 2653.

Terrellia diversiglumis Lunell, Amer. Midl. Nat. 4: 22S. 1915. Based on Elymus diversiglumis Scribn. and Ball.

(15) Elymus macounii Vasey, Bull. Torrey Bot. Club 13: 119. 1886. Great Plains of British Columbia, Macoun.

Terrellia macounii Lunell, Amer. Midl. Nat. 4: 228. 1915. Based on Elymus macounii Vasey.

(2) Elymus mollis Trin., in Spreng., Neu. Entd. 2: 72. 1821. Kamchatka and the Aleutian Islands.

Elymus dives Presl, Rel. Haenk. 1: 265. 1830. Nootka Sound, Vancouver Island, Haenke.

Elymus arenarius var. villosus E. Mever, Pl. Labrad. 20. 1830. Labrador.

Elymus ampliculmis Provancher, Fl. Canad. 2: 706. 1862. Canada.

Elymus capitatus Scribn., U.S.Dept.Agr., Div. Agrost. Bull. 11: 55. pl. 14. 1898. Homer, Alaska, Evans 471. Abnormal form.

Elymus mollis brevispicus Scribn. and Snith, U.S.Dept.Agr., Div. Agrost. Bull. 11: 56. 1898. St. Lawrence Bay, Siberia.

Elymus villosissimus Scribn., U.S.Dept.Agr., Div. Agrost. Bull. 17: 326. f. 622. 1899. St. Paul Island, Macoun 16226.

Elymus arenarius forma compositus Abromeit, Bibl. Bot. 8: heft 42: 96.1899. Greenland.

Elymus arenarius var. mollis Koidzumi, Jour. Coll. Sci. Univ. Tokyo 27: 24. 1910. Based on E. mollis Trin.

Elymus arenarius var. compositus St. John, Rhodora 17: 102. 1915. Based on $E$. arenarius forma compositus Abromeit.

(20) Elymus riparius Wiegand, Rhodora 20: 84. 1918. Ithaca, N.Y., Eames and MacDaniels 3567.

(10) Ely mus salina Jones, Calif. Acad. Sci. Proc. II. 5: 725. 1895. Salina Pass, Utah, Jones 5447.

(8) Elymus triticoides Buckl., Acad. Nat. Sci. Phila. Proc. 1862: 99. 1863. "Rocky Mountains", Nuttall.

Elymus condensatus var. triticoides Thurb., in S. Wats., Bot. Calif. 2: 326. 1880. Based on E. triticoides Buckl.

Elymus orcuttianus Vasey, Bot. Gaz. 10: 258. 1885. San Diego, Calif., Orcutt.

Elymus simplex var. luxurians Scribn. and Williams, U.S.Dept.Agr., Div. Agrost. Bull. 11: 58. 1898. Green River, Wyo., Williams 2338.

Elymus acicularis Suksdorf, Werdenda 12: 3. 1923. Bingen, Wash., Suksdorf 7861.

Elymus triticoides var. pUbescens Hitchc., in Jepson, Fl. Calif. 1: 186. 1912. Griffin, Calif., Elmer 3748.

Elymus triticoides var. Simplex (Scribn.) Hitchc., Amer. Jour. Bot. 21: 132. 1934. Based on E. simplex Scribn. and Williams.

Elymus simplex Scribn. and Williams, U.S.Dept.Agr., Div. Agrost. Bull. 11: 57. pl. 17. 1898. Green River, Wyo., Williams 2334.

(3) Elymus vancouverensis Vasey, Bull. Torrey Bot. Club 15: 48. 1888. Vancouver Island, Macoun in 1887.

(17) Elymus villosus Muhl.; Willd., Enum. PI. 1: 131. 1809. Pennsylvania, Muhlenberg.

Elymus ciliatus Muhl., Descr. Gram. 179. 1817. North Carolina.

Elymus hirsutus Schreb.; Roem. and Schult., Syst. Veg. 2: 776. 1817, as synonym of $E$. villosus Muhl.

Elymus striatus var. villosus A. Gray, Man. 603. 1848. Based on E. villosus Muhl.

Elymus propinquus Fresen.; Steud., Syn. Pl. Glum 1: 349. 1854. Illinois.

Elymus arkansanus Scribn. and Ball, U.S.Dept.Agr., Div. Agrost. Bull. 24: 45. f. 19. 1901. Arkansas, Harvey.

Elymus striatus var. ballii Pammel, Sup. Rept. Iowa Geol. Survey 1903: 347. f. 246. 1905. Iowa [type, from which figure was drawn, Johnson County, Fitzpatrick].

Elymus striatus var. arkansanus Hitchc., Rhodora 8: 212. 1906. Based on E. arkansanus Scribn. and Ball.

Hordeum villosum Schenck, Bot. Jahrb. Engler 40: 109. 1907. Based on Elymus villosus Muhl. 
Elymus villosus forma arkansanus Fernald, Rhodora 35: 195. 1933. Based on E. arkansanus Scribn. and Ball.

(13) Elymus virescens Piper, Erythea 7: 101. 1899. Olympic Mountains, Wash., Piper 1988.

Elymus pubescens Davy, in Jepson, Fl. West. Mid. Calif. 78. 1901. Point Reyes, Calif.

Elymus howellii Scribn. and Merr., Contrib. U.S. Natl. Herb. 13: 88. 1910. Revillagigedo Island, British Columbia, Howell 1723.

Elymus strigatus St. John, Rhodora 17: 102. 1915, Westport, Mendocino County, Calif., Congdon in 1902.

(21) Elymus virginicus L., Sp. Pl. 84. 1753. Virginia.

Elymus carolinianus Walt., Fl. Carol. 82. 1788. South Carolina.

Hordeum cartilagineum Moench, Meth. 199. 1794. Grown in botanic garden, Marburg, Germany.

Elymus striatus Willd., Sp. Pl. 1: 470. 1797. North America.

Elymus hordeiformis Desf., Tabl. Ecol. Bot. Mus. 15. 1804, name only; Cat. Pl. Paris. ed. 3. 18, 387. 1829. Grown in botanical garden, Paris." "E. striatus Willd." cited as synonym.

Elymus durus Hedw.; Steud., Nom. Bot. ed. 2. 1: 550. 1840, as synonym of E. virginicus L.

Elymus virginicus var. minor Vasey; L. H. Dewey, Contrib. U.S. Natl. Herb. 2: 550.1892 . Northern Texas, [Buckley].

Elymus virginicus forma jejunus Ramaley, Minn. Bot. Stud. 9: 114. 1894. Lake Benton, Minn., Sheldon 1735 (error for 1375).

Hordeum virginicum Schenck, Bot. Jahrb. Engler 40: 109. 1907. Based on Elymus virginicus $\mathbf{L}$.

Hordeum striatum Schenck, Bot. Jahrb. Engler 40: 109. 1907. Based on Elymus striatus Willd.

Elymus jejunus Rydb., Bull. Torrey Bot. Club 36: 539. 1909. Based on E. virginicus forma jejunus Ramaley.

Terrellia virginica Lunell, Amer. Midl. Nat. 4: 22S. 1915. Based on Elymus virginicus L.

Terrellia striata Lunell, Amer. Midl. Nat. 4: 228. 1915. Based on Elymus striatus Willd.

Elymus virginicus var. jejunus Bush, Amer. Midl. Nat. 10: 65. 1926. Based on $E$. virginicus forma jejunus Ramaley.

Terrella jejuna Nevski, Bull. Jard. Bot. Acad. Sci. U.R.S.S. 30: 639. 1932. Based on Elymus virginicus forma jejunus Ramaley.

Terrella virginica Nevski, Bull. Jard. Bot. Acad. Sci. U.R.S.S. 30: 639. 1932. Based on Elymus virginicus L.

Elymos virginicus var. australis (Scribn. and Ball) Hitche., in Deam, Ind. Dept. Conserv. Pub. 82: 113. 1929. Based on E. australis Seribn. and Ball.

Elymus australis Scribn. and Ball, U.S.Dept.Agr., Div. Agrost. Bull. 24: 46. f. 20. 1901. Biltmore, N.C., Biltmore Herbarium 411b.

Elymus virginicus var. glabriflorus forma australis Fernald, Rhodora 35: 198. 1933. Based on E. australis Scribn. and Ball.

Elymus virginicus var. Glabriflorus (Vasey) Bush, Amer. Midl. Nat. 10: 62. 1926. Based on E. canadensis var. glabriflorus Vasey.

Elymus canadensis var. glabriflorus Vasey; L. H. Dewey, Contrib. U.S. Natl. Herb. 2: 550. 1894. Texas to Georgia [Louisiana, Langlois].

?Elymus virginicus var. glaucus Beal, Grasses N.Amer. 2: 653. 1S96. Agricultural College, Michigan, Beal 164, 165.

Elymus glabriflorus Seribn. and Ball, U.S.Dept.Agr., Div. Agrost. Bull. 24: 49. f. 23. 1901. Based on E. canadensis var. glabriflorus Vasey.

Elymus australis var. glabriflorus Wiegand, Rhodora 20: 84. 1918. Based on $E$. canadensis var. glabriflorus Vasey.

Elymus virginicus var. Halophilus (Bicknell) Wiegand, Rhodora 20: 83. 1918. Based on E. halophilus Bicknell.

Elymus halophilus Bicknell, Bull. Torrey Bot. Club 35: 201. 1908. Nantucket Island, Mass., Bicknell.

Terrella halophila Nevski, Bull. Jard. Bot. Acad. Sci. U.R.S.S. 30: 639. 1932. Based on Elymus halophilus Bicknell.

Elymus virginicus var. halophilus forma lasiolepis Fernald, Rhodora 35: 198. 1933. Nova Scotia, Fernald, Long, and Linder 20113.

Elymus virginicus var. intermedius (Vasey) Bush, Amer. Midl. Nat. 10: 60. 1926. Based on E. canadensis var. intermedius Vasey. 
Elymus canadensis var. intermedius Vasey; A. Gray, Man. ed. 6. 673. 1890. Northeastern United States. [Type, Lansingburg, N.Y., Howe in 1886.]

Elymus intermedius Scribn. and Smith, U.S.Dept.Agr., Div. Agrost. Bull. 4: 38. 1897. Not E. intermedius Bieb., 1808. Maine to Virginia, west to Illinois and Nebraska. [Herbarium evidence shows this to be based on E. canadensis var. intermedius Vasey.]

Elymus hirsutiglumis Scribn., U.S.Dept.Agr., Div. Agrost. Bull. 11: 58. 1898. Based on E. intermedius Scribn. and Smith.

Elymus virginicus var. hirsutiglumis Hitche., Rhodora 10: 65. 1908. Based on E. hirsutiglumis Scribn.

Terrella hirsutiglumis Nevski, Bull. Jard. Bot. Acad. Sci. U.R.S.S. 30: 639. 1932. Based on Elymus hirsutighumis Scribn.

Elymus virginicus var. typicus forma hirsutiglumis Fernald, Rhodora 35: 198. 1933. Based on E. hirsutiglumis Scribn.

Elymus virginicus var. submuticus Hook., Fl. Bor. Amer. 2: 255. 1840. Cumberland House Fort, Saskatchewan, Drummond.

?Elymus virginicus var. arcuatus Wood, Amer. Bot. and Flor. pt. 2: 405.1870. Southern States.

Elymus curvatus Piper, Bull. Torrey Bot. Club 30: 233. 1903. Stevens County, Wash., Kreager 375.

Elymus submuticus Smyth, Kans. Acad. Sci. Trans. 25: 99. 1913. Based on E. virginicus var. submuticus Hook.

Terrellia virginica var. submutica Lunell, Amer. Midl. Nat. 4: 228. 1915. Based on Elymus virginicus var. submuticus Hook.

Terrella curvata Nevski, Bull. Jard. Bot. Acad. Sci. U.R.S.S. 30: 639. 1932. Based on Elymus curvatus Piper.

\section{(152) ELYONURUS Humb. and Bonpl.}

(1) Elyonurus barbiculmis Hack., in DC., Monogr. Phan. 6: 339. 1889. Texas, Wright 804; New Mexico, Wright 2106; Arizona, Lemmon 2926 [type]; Rothrock 638 .

Elyonurus barbiculmis parviflorus Scribn., U.S.Dept.Agr., Div. Agrost. Cire. 32: 1. 1901. Arizona, Griffiths 1849.

(2) Elyonurus tripsacoides Humb. and Bonpl.; Willd., Sp. Pl. 4: 941. 1806. Caracas, Venezuela, Humboldt and Bonpland.

Rottboellia ciliata Nutt., Gen. Pl. 1: 83. 1818. Georgia, Baldwin.

Anatherum tripsacoides Spreng., Syst. Veg. 1: 290. 1825. Based on Elyonurus tripsacoides Humb. and Bonpl.

Andropogon tripsacoides Steud., Syn. Pl. Glum. 1: 364. 1854. Based on Elyonurus tripsacoides Humb. and Bonpl.

Andropogon nuttallii Chapm., Fl. South. U.S. 580. 1860. Based on Rottboellia ciliata Nutt.

Elyonurus nuttallianus Benth.; Vasey, Grasses U.S. 17. 1883. Based on Andropogon nuttallianus [error for nuttallii Chapm.].

Elyonurus nuttallii Vasey, Descr. Cat. Grasses U.S. 25. 1885. Based on Andropogon nuttallii Chapm.

\section{(12) ERAGROSTIS Host}

Eragrostis abyssinica (Jacq.) Link, Hort. Berol. 1: 192. 1827. Based on Poa abyssinica Jacq. (The name is published as "Eragrostis abessinica.") Poa abyssinica Jacq., Misc. Austr. 2: 364. 1781. [Abyssinia.]

(43) Eragrostis acuta Hitche., Biol. Soc. Wash. Proc. 41: 159. 1928. Punta Rassa, Fla., Hitchcock 263.

Eragrostis alba Presl, Rel. Haenk. 1: 279. 1830. "Hab. ad Monte-Rey, Californiae. 24" The label with the type specimen bears "Regio montana", indicating that the plant came from Peru. The species is not known from the United States.

(S) Eragrostis amabilis (L.) Wight and Arn.; Hook and Arn., Bot. Beechey Voy. 251. 1841. Based on Poa amabilis L.

Poa amabilis L., Sp. Pl. 68. 1753. India.

Poa plumosa Retz., Obs. Bot. 4: 20. 1786. East Indies.

Megastachya amabilis Beauv., Ess. Agrost. 74, 167, 173. 1812. Based on Poa amabilis L.

Cynodon amabilis Raspail, Ann. Sci. Nat., Bot. 5: 302. 1825. Based on Megastachya amabilis Beauv.

Eragrostis plumosa Link, Hort. Berol. 1: 192. 1827. Based on Poa plumosa Retz.

$55974^{\circ}-35-54$ 
Erochloë amabilis Raf.; Jacks., Ind. Kew. 2: 886. 1893, as synonym of Eragrosiis Poa amabilis L.

Erochloë spectabilis Raf.; Jacks., Ind. Kew. 2: 886. 1893, as synonym of Eragrostis amabilis.

Eragrostis ciliaris var. patens Chapm.; Beal, Grasses N.Amer. 2: 479.1896. Jesup, Ga., Curtiss 3493*.

Eragrostis tenella var. plumosa Stapf, in Hook. f., Fl. Brit. Ind. 7: 315. 1896. Based on Poa plumosa Retz.

Eragrostis amabilis var. plumosa E. G. and A. Camus in Lecomte, Fl. Gen. Ind.Chin. 7: 557. 1923. Based on Poa plumosa Retz.

(29) Eragrostis arida Hitche., Jour. Wash. Acad. Sci. 23: 449. 1933. Del Rio, Tex., Hitchcock 13650.

(46) Eragrostis bahiensis Schrad.; Schult., Mant. 2: 318. 1824. Brazil.

(25) Eragrostis barrelieri Daveau, in Morot., Jour. Bot. 8: 289. 1894. Southern Europe.

(5) Eragrostis beyrichii J. G. Smith, Rept. Mo. Bot. Gard. 6: 117. pl. 56. 1895. "Arkansas", Beyrich in 1834, but there is no recent record from that State. In 1834 the boundaries were as at present, but earlier included parts of Texas.

(14) Eragrostis capillaris (L.) Nees, Agrost. Bras. 505. 1829. Based on Poacapillaris L.

Poa capillaris L., Sp. PI. 68. 1753. Canada, Kalm.

Poa tenuis Ell., Bot. S.C. and Ga. 1: 156. 1816. South Carolina.

Eragrostis tenuis Steud., Syn. Pl. Glum. 1: 273. 1854. Based on Poa tenuis Ell.

(45) Eragrostis chariis (Schult.) Hitchc., Lingnan Sci. Jour. 7: 193. 1931. Based on Poa chariis Schult.

Poa elegans Roxb., Hort. Beng. 82; Fl. Ind. 1: $339.1820 . \quad$ Not P. elegans Poir., 1804. India.

Poa chariis Schult., Mant. 2: 314. 1824. Based on P. elegans Roxb.

Poa elegantula Kunth, Rév. Gram. 1: 114. 1829. Based on P. elegans Roxb.

Eragrostis elegantula Nees; Steud., Syn. Pl. Glum. 1: 266. 1854. Not E. elegantula Nees, 1851. Based on Poa elegantula Kunth.

Eragrostis chloromelas Steud., Syn. Pl. Glum. 1: 271. 1854. Based on the species described under $E$. atrovirens by Nees, that name based on Poa atrovirens Desf., a different species.

(23) Eragrostis cilianensis (All.) Link; Vign. Lut., Malpighia 18: 386. 1904. Based on Poa cilianensis All.

Briza eragrostis L., Sp. Pl. 70. 1753. Europe.

Poa cilianensis All., FI. Pedem. 2: 246. 1785. Italy.

?Briza caroliniana Walt., Fl. Carol. 79. 1788. Not B. caroliniana Lam. South Carolina.

Poa megastachya Koel., Descr. Gram. 181. 1802. Based on Briza eragrostis L.

Eragrostis major Host, Icon. Gram. Austr. 4: 14. pl. 24. 1809; Fl. Austr. 1: 135. 1827. Austria.

Briza purpurascens Muhl., Deser. Gram. 154. 1817. Carolina.

Poa obtusa Nutt., Gen. Pl. 1: 67. 1818. Not P. obtusa Muhl., 1817. Philadelphia, Barton.

Poa pennsylvanica Nutt., Gen. Pl. 2: errata. 1818. Based on P. obtusa Nutt.

Poa philadelphica Barton, Compend. Fl. Phila. 1: 62. 1818. Based on P. obtusa Nutt.

Megastachya obtusa Schult., Mant. 2: 326. 1824. Based on Poa obtusa Nutt.

Megastachya purpurascens Schult., Mant. 2: 326. 1824. Based on Briza purpurascens Muhl.

Poa nuttallii Spreng., Syst. Veg. 1: 344. 1825. Based on P. obtusa Nutt.

Calotheca purpurascens Spreng., Syst. Veg. 1: 348. 1825. Based on Briza purpurascens Muhl.

Eragrostis megastachya Link, Hort. Berol. 1: 187. 1827. Based on Poa megastachya Knel.

Briza megastachya Steud., Nom. Bot. ed. 2. 1: 225. 1840, as synonym of Poa megastachya.

Eragrostis vulgaris var. megastachya Coss. and Germ., Fl. Env. Paris 2: 641. 1845. Based on Poa megastachya Koel.

Eragrostis poaeoides var. megastachya A. Gray, Man. ed. 2. $563.1856 . \quad$ Based on E. megastachya Link.

Eragrostis virletii Fourn., Mex. Pl. 2: 116. 1886. San Luis Potosí, Mexico, Virlet 1391. 
Eragrostis eragrostis MacM., Met. Minn. Vall. 75. 1892. Not E. eragrostis Beauv., 1812. Based on Briza eragrostis L.

Megastachya eragrostis Beauv.; Jacks., Ind. Kew. 3: $186 . \quad$ 1894, as synonym of Eragrostis major Host.

Eragrostis megastachya var. cilianensis Aschers. and Graebn., Syn. Mitteleur. F1. 2: 371. 1900. Based on Poa cilianensis All.

Eragrostis minor var. megastachya Davy, in Jepson, Fl. West Mid. Calif. 60. 1901. Based on E. megastachya Link.

Eragrostis cragrostis var. megastachya Farwell, Mich. Acad. Sci. Rept. 17: 182. 1916. Based on Poa megastachya Koel.

?Eragrostis eragrostis subvar. leersioides Farwell, Amer. Midl. Nat. 10: 306. 1927. Based on E. multiflora var. leersioides Richt., this based on Megastachya leersioides Presl described from Sicily, the description not applying to American forms.

(7) Eragrostis ciliaris (L.) R. Br., in Tuckey, Narr. Exp. Congo App. 478. 1818. Based on Poa ciliaris L.

Poa ciliaris L., Syst. Nat. ed. 10. 2: 875. 1759. Jamaica.

Megastachya ciliaris Beauv., Ess. Agrost. 74, 167, 174, 1812. Based on Poa ciliaris L.

Eragrostis villosa Trin., Fund. Agrost. 137. 1820. Based on Poa ciliaris L.

Cynodon ciliaris Raspail, Ann. Sci. Nat., Bot. 5: 302. 1825. Based on Megastachya ciliaris Beauv.

Macroblepharus contractus Phil., Linnaea 19: 101. 1858. Chile, Gay 129.

Eragrostis ciliaris var. laxa Kuntze, Rev. Gen. PI. 2: 774. 1891. West Indies. Erosion ciliare Lunell, Amer. Midl. Nat. 4: 221. 1915. Based on Eragrostis ciliaris Link.

(3) Eragrostis curtipedicellata Buckl., Acad. Nat. Sci. Phila. Proc. 1862: 97. 1863. Northern Texas, Buckley.

Eragrostis brevipedicellata A. Gray, Acad. Nat. Sci. Phila. Proc. 1862: 336. 1863 , as synonym of E. curtipedicellata Buckl.

Eragrostis viscosa Scribn., U.S.Dept.Agr., Div. Agrost. Bull. 11: 51. pl. 7. 1898. Not E. viscosa Trin., 1830. Midland, Tex., J. G. Smith.

Eragrostis curvula (Schrad.) Nees, Fl. Afr. Austr. 397. 1841. Based on Poa curvula Schrad.

Poa curvula Schrad., Gött. Anz. Ges. Wiss. 3: 2073. 1821. Cape Good Hope.

Eragrostis cyperoides'(Thunb.) Beauv., Ess. Agrost. 71, 162, 174. 1812. Based on Poa cyperoides Thunb.

Poa cyperoides Thunb., Prodr. Pl. Cap. 22. 1794. South Africa.

(18) Eragrostis diffusa Buckl., Acad. Nat. Sci. Phila. Proc. 1862: 97. 1863. Northern Texas, Buckley.

Eragrostis purshii var. delicatula Munro; Scribn., Bull. Torrey Bot. Club 10: 30. 1883. Name only. Arizona, Pringle.

Eragrostis purshii var. diffusa Vasey, Contrib. U.S. Natl. Herb. 1: 59.1890. Based on E. diffusa Buckl.

(42) Eragrostis elliottii S. Wats., Amer. Acad. Sci. Proc. 25: 140. 1890. Based on Poa nitida Ell.

Poa nitida Ell., Bot. S.C. and Ga. 1: 162. 1816. Not P. nitida Lam., 1791. South Carolina.

Eragrostis nitida Chapm., Fl. South. U.S. 564. 1860. Not E. nitida Link, 1827. Based on Poa nitida Ell.

Eragrostis macropoda Pilger, in Urban, Symb. Antill. 4: 106. 1903. Puerto Rico, Sintenis 1233.

(33) Eragrostis erosa Scribn.; Beal, Grasses N.Amer. 2: 483.1896. Chihuahua, Mexico, Pringle 415.

(15) Eragrostis frankii C. Meyer; Steud., Syn. Pl. Glum. 1: 273. 1854. Ohio, Frank.

Poa parviflora Nutt., Gen. P]. 1: 67. 1818. Not P. parviflora R. Br. [United States].

Poa micrantha Schult., Mant. 2: 305. 1824. Not Eragrostis micrantha Hack., 1895. Based on P. parviflora Nutt.

Eragrostis erythrogona Nees; Steud., Syn. Pl. Glum. 1: 273. 1854. St. Louis, Drummond.

Eragrostis capillaris var. frankii Farwell, Mich. Acad. Sci. Rept. 17: 182.1916. Based on E. frankii "Steud."

Eragrostis Franki var. Brevipes Fassett, Rhodora 34: 95. 1932. Glenhaven Wis., Fassett 12899. 
(9) Eragrostis glomerata (Walt.) L. H. Dewey, Contrib. U.S. Natl. Herb. 2: 543. 1894. Based on Poa glomerata Walt.

Poa glomerata Walt., F1. Carol. 80. 1788. South Carolina.

Poa conferta Ell., Bot. S.C. and Ga. 1: 15S. 1816. South Carolina.

Megastachya glomerata Schult., Mant. 2: 327. 1824. Based on Poa glomerata Walt.

Poa walteri Kunth, Rév. Gram. 1: 116. 1829. Based on P. glomerata Walt.

Eragrostis conferta Trin., Mém. Acad. St. Pétersb. VI. Math. Phys. Nat. 1: 409. 1830. Based on Poa conferta Ell.

Eragrostis pallida Vasey, Contrib. U.S. Natl. Herb. 1: 285. 1893. Colima, Mexico, Palmer 1268.

(30) Eragrostis hirsuta (Michx.) Nees, Agrost. Bras. 508. 1829. Based on Poa hirsuta Michx.

?Poa simplex Walt., Fl. Carol. 79. 1788. Not Eragrostis simplex Scribn. South Carolina.

Poa hirsuta Michx., Fl. Bor. Amer. 1: 68. 1803. South Carolina, Michaux.

Eragrostis sporoboloides Smith and Bush, Rept. Mo. Bot. Gard. 6: 116. pl. 54. 1895. Sapulpa, Indian Territory [Okla.], Bush [766].

(11) Eragrostis hypnoides (Lam.) B.S.P., Prel. Cat. N.Y. 69. 1888. Based on Poa hypnoides Lam.

Poa hypnoides Lam., Tabl. Encycl. 1: 185. 1791. Tropical America.

Megastachya hypnoides Beauv., Ess. Agrost. 74, 167, 175. 1812. Based on Poa hypnoides Lam.

Poa reptans var. caespitosa Torr., Fl. North. and Mid. U. S. 1:115. 1823. New Jersey.

Neeragrostis hypnoides Bush, St. Louis Acad. Sci. Trans. 13: 180. 1903. Based on Poa hypnoides Lam.

Erosion hypnoides Lunell, Amer. Midl. Nat. 4: 221. 1915. Based on Poa hypnoides Lam.

(35) Eragrostis intermedia Hitchc., Jour. Wash. Acad. Sci. 23: 450. 1933. San Antonio, Tex., Hitchcock 5491.

(31) Eragrostis lugens Nees, Agrost. Bras. 505. 1829. Brazil.

Poa lugens Kunth, Rév. Gram. 1: Sup. XXVIII. 1830. Based on Eragrostis lugens Nees.

(22) Eragrostis lutescens Scribn., U.S.Dept.Agr., Div. Agrost. Circ. 9: 7. 1899. Almota, Wash., Piper 2624.

(27) Eragrostis mexicana (Hornem.) Link, Hort. Berol. 1: 190. 1827. Based on "Poa mexicana Lag. Hornem."

Poa mexicana Hornem., Hort. Hafn. 2: 953. 1815. Garden specimen from Mexican seed.

Poa mexicana Lag., Gen. and Sp. Nov. 3. 1816. Grown in Madridfrom Mexican seed.

Small specimens of this species have been referred to Eragrostis limbata Fourn., a Mexican species, not known from the United States.

(26) Eragrostis neo-mexicana Vasey, Contrib. U.S. Natl. Herb. 2: 542. 1894. New Mexico, Vasey.

Eragrostis obtusa Munro; Stapf, in Dyer, Fl. Cap. 7: 625. 1898. South Africa.

(1) Eragrostis obtusifiora Scribn., U.S.Dept.Agr., Div. Agrost. Bull. 8: 10. pl. 5. 1897. Laguna de Santa Maria, Mexican side of boundary, Wright 193, and Sulphur Springs Valley, Ariz., Toumey. Scribner doubtfully cites "Brizopyrum obtusiflorum Fourn.?" The description of that is inadequate for identification.

(21) Eragrostis orcuttiana Vasey, Contrib. U.S. Natl. Herb. 1: 269. 1893. San Diego, Calif., Orcutt 1313.

(34) Eragrostis palmeri S. Wats., Amer. Acad. Sci. Proc. 18: 182. 1883. Juarez, Coahuila, Palmer 1368.

(17) Eragrostis pectinacea (Michx.) Nees, Fl. Afr. Austr. 406. 1841., Based on Poa pectinacea Michx., the name given as "Er. pectinacea Michx."

Poa pectinacea Michx., Fl. Bor. Amer. 1: 69. 1803. Illinois, Michaux.

Poa caroliniana Spreng., Mant. Fl. Hal. 33. 1807. North Carolina.

Poa eragrostis Ell., Bot. S.C. and Ga. 1: 161. 1816. Not P. eragrostis L., 1753. South Carolina and Georgia.

Poa tenella Nutt., Gen. Pl. 1: 67. 1818. Not P. tencila L., $1753 . \quad$ North America.

Poa capillaris Link, Enum. Hort. Berol. 1: 88. 1821. Not P. capillaris L., 1753. Based on $P$. caroliniana Spreng.

Eragrostis brizoides Schult., Mant. 2: 319. 1824. Based on Poa tenella Nutt. 
Poa nuttallii Kunth, Rév. Gram. 1: 116. 1829. Not P. nuttallii Spreng., 1825. Based on Poa tenella Nutt.

Eragrostis purshii Schrad., Linnaea 12: 451. 1838. North America; description inadequate; Gray, Man. ed. 2. 564. 1856.

Poa diandra Schrad., Linnaea 12: 451. 1838, as synonym of Eragrostis purshii Schrad.

Eragrostis nuttalliana Steud., Nom. Bot. ed. 2. 1: 563. 1840. Based on Poa tenella Nutt.

?Eragrostis pennsylvanica Scheele, Flora 27: 58. 1844. Pennsylvania.

?Eragrostis unionis Steud., Svn. Pl. Glum. 1: 273. 1854. Miami, Ohio.

?Eragrostis cognata Steud., Syn. Pl. Glum. 1: 273. 1854. Ohio.

Eragrostis caroliniana Scribn., Mem. Torrey Bot. Club 5: 49. 1894. Based on Poa caroliniana Spreng.

Eragrostis pilosa var. caroliniana Farwell, Mich. Acad. Sci. Rept. 17: 182. 1916. Based on Poa caroliniana Spreng.

(20) Eragrostis peregrina Wiegand, Rhodora 19: 95. 1917. Based on E. pilosa var. condensata Hack.

Eragrostis pilosa var. damiensiana Bonnet, Naturaliste 3: 412, 1881. France.

Eragrostis pilosa var. condensata Hack., Allg. Bot. Ztschr. 7: 13. 1901. Karlsruhe, Germany, Kneucker Gram. Exs. 115.

Eragrostis damiensiana Thell., Repert. Sp. Nov. Fedde 24: 323.1928 . Based on $E$. pilosa var. damiensiana Bonnet.

Eragrostis damiensiana var. condensata Thell., Repert. Sp. Nov. Fedde 24: 328. 1928. Based on $E$. pilosa var. condensata Hack.

(40) Eragrostis pilifera Scheele, Linnaea 22: 344. 1849. New Braunfels, Tex., Lindheimer.

Eragrostis grandiflora Smith and Bush, Rept. Mo. Bot. Gard. 6: 117. pl. 55. 1895. Sapulpa, Indian Territory [Okla.], Bush [808].

(16) Eragrostis pilosa (L.) Beauv., Ess. Agrost. 71, 162, 175. 1812. Based on Poa pilosa L.

Poa pilosa L., Sp. Pl. 68. 1753. Italy.

Poa eragrostis Walt., Fl. Carol. 80. 1788. Not P. eragrostis L., 1753. South Carolina.

?Poa tenella [L. misapplied by] Pursh, Fl. Amer. Sept. 1: 80. 1814. New Jersey to Carolina. Elliott (Bot. S.C. and Ga. 1: 160. 1816) follows Pursh. According to Merrill (U.S.Dept.Agr., Div. Agrost. Circ. 29: 11. 1901) Elliott's plant is E. pilosa.

Eragrostis filiformis Link, Hort. Berol. 1: 191. 1827. North America.

Poa linkii Kunth, Rév. Gram. 1: 113. 1829. Based on Eragrostis filiformis Link.

Eragrostis linkii Steud., Syn. PI. Glum. 1: 273. 1854. Based on Poa linkii Kunth.

(24) Eragrostis poaeoides (L.) Beauv., Ess. Agrost. 162. 1812, name only; Roem. and Schult., Syst. Veg. 2: 574. 1817. Based on Poa eragrostis L.

Poa eragrostis L., Sp. Pl. 68. 1753. Italy.

Eragrostis minor Host, Icon. Gram. Austr. 4: 15. 1809 [name untenable because the genus was not validly published until 1812]; Fl. Austr. 1: 135. 1827. Based on Poa eragrostis L.

Eragrostis eragrostis Beauv., Ess. Agrost. 71, 174. pl. 14. f. 11. 1812. Based on Poa eragrostis L.

Eragrostis poaeformis Link, Hort. Berol. 1: 188. 1827. Based on Poa eragrostis $\mathrm{L}$.

Eragrostis vulgaris var. microstachya Coss. and Germ., Fl. Env. Paris 2: 641. 1845. Based on Poa eragrostis L.

Eragrostis eragrostis var. microstachya Farwell, Amer. Midl. Natl. 10: 306. 1927. Based on E. vulgaris var. microstachya Coss. and Germ.

(44) Eragrostis refracta (Muh1.) Scribn., Mem. Torrey Bot. Club 5: 49. 1894. Based on Poa refracta Muhi.

?Poa virginica Zucc.; Roemer, Coll. Bot. 1: 124. 1809. Virginia.

Poa refracta Muhl.; Ell., Bot. S.C. and Ga. 1: 162. 1816. South Carolina.

Eragrostis campestris Trin., Mém. Acad. St. Pétersb. VI. Sci. Nat. 2 ${ }^{1}$ : 72. 1836. North America.

Eragrostis longeradiata Steud., Syn. Pl. Glum. 1: 272. 1854. Carolina, Curtis.

?Eragrostis virginica Steud., Syn. Pl. Glum. 1: 273. 1854. Based on Poa virginica Zucc.

Eragrostis pectinacea var. refracta Chapm., Fl. South. U.S. 564. $1860 . \quad$ Based on Poa refracta Muhl. 
Eragrostis campestris var. refracta Chapm., Fl. South. U.S. ed. 3. 617. 1897. Based on Poa refracta Muhl.

Poa reflexa Ell.; Scribn. and Merr., U.S.Dept.Agr., Div. Agrost. Circ. 27: 5. 1900, as synonym of Eragrostis refracta Scribn.

This species was described under the name Poa capillaris L., in Michx., Fl. Bor. Amer. 1: 67.1803.

(10) Eragrostis reptans (Michx.) Nees, Agrost. Bras. 514. 1829. Based on Poa reptans Michx.

Poa reptans Michx., Fl. Bor. Amer. 1: 69. pl. 11. 1803. Illinois, Michaux.

Poa dioica Michx.; Poir., in Lam., Encycl. 5: 87.1804 , erroneously cited as synonym of $P$. hypnoides Lam. Kaskaskia River, Ill., Michaux.

Mcgastachya reptans Beauv., Ess. Agrost. 74, 167, 175. 1812. Based on Poa reptans Michx.

Poa weigeltiana Reichenb.; Trin., Mém. Acad. St. Pétersb. VI. Math. Phys. Nat. 1: 410. 1830, as synonym of Eragrostis reptans Nees. Dutch Guiana, Weigelt.

Poa dioica Vent.; Kunth, Enum. P1. 1: 336 . 1833, as synonym of P. reptans Michx.

Poa capitata Nutt., Amer. Phil. Soc. Trans. (n.s.) 5: 146. 1837. Arkansas River, Nuttall.

Eragrostis capitata Nash, in Britton, Man. 1042. 1901. Based on Poa capitata Nutt.

Neeragrostis weigeltiana Bush, St. Louis Acad. Sci. Trans. 13: 178.1903. Based on Poa weigeltiana Reichenb.

Eragrostis weigeltiana Bush, St. Louis Acad. Sci. Trans. 13: 180. 1903. Based on Poa weigeltiana Reichenb.

(4) Eragrostis secundiflora Presl, Rel. Haenk. 1: 276. 1830. Mexico, Haenke.

Poa secundiflora Kunth, Rév. Gram. 1: Sup. XXVIII. 1830. Based on Eragrostis secundiflora Presl.

Poa interrupta Nutt., Amer. Phil. Soc. Trans. (n.s.) 5: 146. 1837. Not P. interrupta Lam., 1791. Banks of the Arkansas [Nuttall].

Poa oxylepis Torr., in Marcy, Expl. Red Riv. 301. 1853. Based on Poa interrupta Nutt.

Eragrostis oxylepis Torr., U.S. Rept. Expl. Miss. Pacif. 4: 156. 1857. Based on Poa oxylepis Torr.

Eragrostis veraecrucis Rupr., Bull. Acad. Sci. Brux. 92: $235 . \quad 1842$, name only; Fourn., Mex. Pl. 2: 118. 1886, as synonym of Megastachya oxylepis var. capitata Fourn.

Megastachya oxylepis Fourn., Mex. Pl. 2: 118. 1886. Based on Poa oxylepis Torr.

Megastachya oxylepis var. capitata Fourn., Mex. P1. 2: 118. 1886. Vera Cruz, Mexico.

Eragrostis interrupta Trel., in Branner and Coville, Ann. Rept. Geol. Survey Ark. 4: 237. 1891. Not E. interrupta Beauv., 1812. Based on Poa interrupta Nutt.

(2) Eragrostis sessilispica Buckl. Acad. Nat. Sci. Phila. Proc. 1862: 97. 1863. Austin, Tex., Buckley.

Diplachne rigida Vasey, U.S.Dept.Agr., Div. Bot. Bull. 122: pl. 44.1891. Texas [type, Reverchon in 1879], and New Mexico, northward to Kansas.

Leptochloa rigida Munro; Vasey, U.S.Dept.Agr., Div. Bot. Bull. 122: pl. 44. 1891, as synonym of Diplachne rigida Vasey.

Eragrostis rigida Scribn., Acad. Nat. Sci. Phila. Proc. 1891: 304. 1891. Based on Diplachne rigida Vasey.

Acamptoclados sessilispicus Nash, in Small, Fl. Southeast. U.S. 140. 1903. Based on Eragrostis sessilispica Buckl.

(38) Eragrostis silveana Swallen, Amer. Jour. Bot. 19: 438. f. 3. 1932. Taft, Tex., Silveus 360 .

(12) Eragrostis simplex Scribn., U.S.Dept.Agr., Div. Agrost. Bull. 7 (ed. 3): 250. f. 244. 1900. Florida, Curtiss 6073.

Eragrostis brownei Kunth; Chapm., F1. South. U.S. ed. 2. 664. 1883. Not E. brownei Nees, 1841. East Florida, Garber. (Chapman probably had E. brownei (Kunth) Nees, an Australian species, in mind, but he cites nothing that can connect his publication with that. The name $E$. brownei Nees is used for E. simplex by Scribner, U.S.Dept.Agr., Div. Agrost. Bull. 7: 262. 1897.)

(41) Eragrostis spectabilis (Pursh) Steud., Nom. Bot. ed. 2. 1: 564. 1840. Based on Poa spectabilis Pursh. 
?Poa amabilis Walt., Fl. Carol. 80. 1788. Not P. amabilis L., 1753. South Carolina.

Poa spectabilis Pursh, Fl. Amer. Sept. 1: 81. 1814. New York to Carolina. Megastachya spectabilis Roem. and Schult., Syst. Veg. 2: 589. 1817. Based on Poa spectabilis Pursh.

Poa hirsuta var. spectabilis Torr., Fl. North. and Mid. U.S. 1: 114.1823. Based on Poa spectabilis Pursh.

?Eragrostis velutina Schrad., Linnaea 12: 451. 1838. Carolina.

?Poa villosa Beyr.; Schrad., Linnaea 12: 451. 1838, as synonym of E. velutina Schrad.

Eragrostis geyeri Steud., Syn. Pl. Glum 1: 272. 1854. Illinois, Geyer.

Poa pectinacea Geyer; Steud., Syn. Pl. Glum. 1: 272. 1854. Not P. pectinacea Michx., 1803. As synonym of Eragrostis geyeri Steud.

Eragrostis pectinacea var. spectabilis A. Gray, Man. ed. 2. 565. 1856. Based on Poa spectabilis Pursh.

Eragrostis spectabilis var. sparsihirsuta Farwell, Amer. Midl. Nat. 10: 306. 1927. Michigan.

This is the species called Poa pectinacea Michx. and Eragrostis pectinacea Nees by American authors, not Michaux's species.

(6) Eragrostis spicata Vasey, Bot. Gaz. 16: 146. 1891. Baja California, Brandegee.

Sporobolus tenuispica Hack., Repert. Sp. Nov. Fedde 6: 344. 1909. Pilcomayo River, Paraguay, Rojas 258.

Eragrostis stenophylla Hochst.; Miquel, An. Bot. Ind. 2: 27. 1851. Asia.

(28) Eragrostis suaveolens Becker, in Claus, Beitr. Pflanzenk. Russ. Reich. 8: 266. 1851. Serepta, Russia.

(36) Eragrostis swalleni Hitchc., Jour. Wash. Acad. Sci. 23: 451. 1933. Riviera, Tex., Swallen 1847.

Eragrostis tenella (L.) Beauv.; Roem. and Schult., Syst. Veg. 2: 576. 1817. Based on Poa tenella L.

Poa tenella L., Sp. Pl. 69. 1753. India.

Poa japonica Thunb., Fl. Japon. 51. 1784. Japan.

Eragrostis japonica Trin., Mém. Acad. St. Pétersb. VI. Math. Phys. Nat. 1: 405. 1830. Based on Poa japonica Thunb.

(19) Eragrostis tephrosanthos Schult., Mant. 2: 316. 1824. Martinique, Sieber.

Poa tephrosanthos Spreng.; Schult., Mant. 2: 316. 1824, as synonym of Eragrostis tephrosanthos Schult.

Eragrostis delicatula Trin., Mém. Acad. St. Pétersb. VI. Sci. Nat. 21: 73.1836. Brazil.

Eragrostis pilosa var. delicatula Hack.; Stuck., An. Mus. Nac. Buenos Aires 11: 133. 1904. Based on E. delicatula Trin.

(37) Eragrostis tracyi Hitchc., Amer. Jour. Bot. 21: 130. f. 1. 1934. Sanibel Island, Fla., Tracy 7168.

(32) Eragrostis trichocolea Arech., An. Mus. Nac. Montevideo 1: 444. 1896. Uruguay.

Eragrostis floridana Hitchc., Amer. Jour. Bot. 2: 308. 1915. Tampa, Fla., Curtiss 3494*.

(39) Eragrostis trichodes (Nutt.) Wood, Class-book 796. 1861. Based on Poa trichodes Nutt.

Poa trichodes Nutt., Amer. Phil. Soc. Trans. (n.s.) 5: 146. 1837. Arkansas, Nuttall.

Eragrostis tenuis var. texensis Vasey, Contrib. U.S. Natl. Herb. 1: 59. 1890.

Texas, Nealley.
Eragrostis tenuis A. Gray, Man. ed. 6. 661. 1890. Not E. tenuis Steud., 1854. Ohio to Illinois, Kansas and southward.

Eragrostis capillacea Jedw., Bot. Archiv Mez 5: 196. 1924. Nebraska, Rydberg 1832.

(13) Eragrostis unioloides (Retz.) Nees; Steud., Syn. Pl. Glum. 1: 264. 1854. Based on Poa unioloides Retz.

Poa unioloides Retz., Obs. Bot. 5: 19. 1789. East Indies.

Eragrostis virescens Presl, Rel. Haenk. 1: 276. 1830. Chile, Haenke.

Eremochloa ciliaris (L.) Merr., Philippine Jour. Sci. 1 (Sup. 5): 331. 1906. Based on Nardus ciliaris L.

Nardus ciliaris L., Sp. Pl. 53. 1753. India. 
Eremochloa ophiuroides (Munro) Hack., in DC., Monogr. Phan. 6: 261. 1889. Based on Ischaemum ophiuroides Munro.

Ischaemum ophiuroides Munro, Amer. Acad. Sci. Proc. 4: 363. 1860. Southern China.

\section{(143) ERIANTHUS Michx.}

(3) Erianthus alopecuroides (L.) Ell., Bot. S.C. and Ga. 1: 38. 1816. Based on Andropogon alopecuroides $\mathrm{L}$.

Andropogon divaricatus L., Sp. Pl. 1045. 1753. Virginia, [Clayton 70].

Andropogon alopecuroides L., Sp. Pl. 1045. 1753. Virginia, [Clayton 601].

Saccharum alopecuroideum Nutt., Gen. Pl. 1: 60. 1818. Based inferentially on Erianthus alopecuroides Ell.

Erianthus divaricatus Hitchc., Contrib. U.S. Natl. Herb. 12: 125.1908. Based on Andropogon divaricatus L.

Erianthus al.opecuroides var. hirsutus Nash, in Small, Fl. Southeast. U.S. 55. 1903. Florida [Chapman.] (Published as E. alopecuroides hirsutus.)

(4) Erianthus brevibarbis Michx., Fl. Bor. Amer. 1: 55. 1803. Tennessee and Carolina, Michaux.

Saccharum brevibarbe Pers., Syn. Pl. 1: 103. 1805. Based on Erianthus brevibarbis Michx.

Calamagrostis rubra Bosc; Kunth, Enum. Pl. 1: 478. 1833, as synonym of Erianthus brevibarbis Michx.

Erianthus alopecuroides var. brevibarbis Chapm., Fl. South U.S. 583. 1860. Based on E. brevibarbis Michx.

Erianthus saccharoides subsp. brevibarbis Hack., in DC., Monogr. Phan. 6: 131. 1889. Based on E. brevibarbis Michx.

(2) Erianthus contortus Baldw.; Ell., Bot. S.C. and Ga. 1: 40. 1816. Savannah, Ga., Baldwin.

Saccharum contortum Nutt., Gen. Pl. 1: 60. 1818. Based on Erianthus contortus Ell.

Erianthus alopecuroides var. contortus Chapm., Fl. South. U.S. 582. 1860. Based on E. contortus Ell.

Erianthus saccharoides subsp. contortus Hack., in DC., Monogr. Phan. 6: 131. 1889. Based on $E$. contortus Ell.

Erianthus smallii Nash, Bull. N.Y. Bot. Gard. 1: 429. 1900. Stone Mountain, Ga., Small in 1894.

(5) Erianthus giganteus (Walt.) Muhl., Cat. Pl. 4. 1813. Based on Anthoxanthum giganteum Walt. Later (Descr. Gram. 192. 1817) Muhlenberg uses the name for both $E$. saccharoides and $E$. alopecuroides (his herbarium specimen under this name including both species), but the description (awn twisted) applies better to E. alopecuroides. Erianthus giganteus was published as new by Hubbard (Rhodora 14: 166. 1912) based on Anthoxanthum giganteum Walt.

Anthoxanthum giganteum Walt., Fl. Carol. 65. 1788. South Carolina.

Erianthus saccharoides Michx., Fl. Bor. Amer. 1: 55. 1803. Carolina to Florida, Michaux.

Saccharum giganteum Pers., Syn. Pl. 1: 103. 1805. Based on Anthoxanthum giganteum Walt.

Saccharum erianthoides Raspail, Ann. Sci. Nat., Bot. 5: 308. 1825. Based on Erianthus saccharoides Rich. [same as Michx.].

Andropogon erianthus Link, Hort. Berol. 1: 243. 1827. Based on Erianthus saccharoides Michx.

Erianthus saccharoides var. michauxii Hack., in Mart., Fl. Bras. 23: 257. 1883. Based on E. saccharoides Michx.

Erianthus compactus Nash, Bull. Torrey Bot. Club 22: 419. 1895. New Jersey to North Carolina and Tennessee [type, Washington, D.C., Nash in 1895].

Erianthus laxus Nash, Bull. Torrey Bot. Club 24: 344. 1897. Near Paola, Fla., Swingle 1432a. Erianthus tracyi Nash, Bull. Torrey Bot. Club 24: $37 . \quad$ 1897. Starkville, Miss.,
Tracy in 1896.

Erianthus ravennae (L.) Beauv., Ess. Agrost. 14, 162, 177, 1812. Based on Saccharum ravennae $\mathrm{L}$.

Andropogon ravennae L., Sp. Pl. ed. 2. 2: 1481. 1763. Italy.

Saccharum ravennae Murr., in L., Syst. Veg. ed. 13. 88. 1774. Based on Andropogon ravennae $\mathrm{L}$.

Ripidium ravennae Trin., Fund. Agrost. 169. 1820. Based on Saccharum ravennae Murr. 
(1) Erianthus strictus Baldw.; Ell., Bot. S.C. and Ga. 1: $39.1816 . \quad$ Savannah, Ga., Baldwin.

Saccharum strictum Nutt., Gen. PI. 1: 60. 1818. Based on Erianthus strictus Baldw.

Saccharum baldwinii Spreng., Syst. Veg. 1: 282. 1825. Based on Erianthus strictus Baldw.

Pallinia dura Trin., Mém. Acad. St. Pétersb. VI. Sci. Nat. 21: 91. 1836.

Carolina.
Andropogon durus Steud., Nom. Bot. ed. 2. 1: 91. 1840. Based on Pollinia dura Trin.

(124) ERIOCHLOA H.B.K.

(1) Eriochloa aristata Vasey, Bull. Torrey Bot. Club 13: 229. 1886. Southwest Chihuahua, Palmer in 1885 [110e].

Eriochloa punctata var, aristata Jones, Contrib. West. Bot. 14: 11. 1912. Based on E. aristata Vasey.

(6) Eriochloa contracta Hitchc., Biol. Soc. Wash. Proc. 41: 163. 1928. Based on Helopus mollis C. Muell.

Helopus mollis C. Muell., Bot. Ztg. 19: 314. 1861. Not Eriochloa mollis Kunth, 1829. Texas, Drummond 370.

(5) Eriochloa gracilis (Fourn.) Hitchc., Jour. Wash. Acad. Sci. 23: 455. 1933. Based on Helopus gracilis Fourn.

Helopus gracilis Fourn., Mex. Pl. 2: 13. 1886. Oaxaca, Mexico, Liebmann 436. Eriochloa gracilis var. Minor (Vasey) Hitchc., Jour. Wash. Acad. Sci. 23: 456. 1933. Based on E. punctata var. minor Vasey.

Eriochloa punctata var. minor Vasey, Contrib. U.S. Natl. Herb. 3: 21.1892. Texas, Wright 2087, Ncalley.

Eriochloa texana Mez, Bot. Jahrb. Engler 56: Beibl. 125: 12. 1921. [El Paso] Tex., Jones 4177.

(3) Eriochloa lemmoni Vasey and Scribn., Bot. Gaz. 9: 185. pl. 2. 1884. [Huachuca Mountains], Ariz., Lemmon 2910.

(8) Eriochloa michauxii (Poir.) Hitchc., Contrib. U.S. Natl. Herb. 12: 147. 1908. Based on Panicum michauxii Poir.

Panicum molle Michx., Fl. Bor. Amer. 1: 47. 1803. Not P. molle Swartz, 1788. Florida, Michaux.

Panicum michauxii Poir., in Lam., Encycl. Sup. 4: 278. 1816. Based on P. molle Michx.

Panicum michauxianum Schult., Mant. 2: 227. 1824. Based on P. molle Michx.

Panicum georgicum Spreng., Syst. Veg. 1: 308. 1825. Based on P. molle Michx.

Eriochloa mollis Kunth, Rév. Gram. 1: 30. 1829. Based on Panicum molle Michx.

Eriachloa mollis var. longifolia Vasey, Bull. Torrey Bot. Club 13: 25. 1886. Key West, Fla., Curtiss.

Eriachloa longifolia Vasey, Contrib. U.S. Natl. Herb. 3: 21. 1892. Based on E. mollis var. longifolia Vasey.

Eriachloa debilis Mez, Bot. Jahrb. Engler 56: Beibl. 125: 12. 1921. [No-name Key], Fla., Curtiss 3600 . The same form as E. longifolia Vasey.

Eriochloa michauxil var. simpsoni Hitchc., Biol. Soc. Wash. Proc. 41: 163. 1928. Cape Romano, Fla., Simpson 262. (Published as E. michauxii simpsoni.)

Eriochloa nelsoni Seribn. and Smith, U.S.Dept.Agr., Div. Agrost. Bull. 4: 12. 1897. Oaxaca, Mexico, Nelsan 1707.

(4) Eriochloa procera (Retz.) Hubbard, Kew Bull. Misc. Inf. 1930: 256. 1930. Based on Agrostis procera Retz.

Agrostis procera Retz., Obs. Bot. 4: 19. 1786. India.

Milium ramosum Retz., Obs. Bot. 6: 22. 1791. Asia.

Paspalum annulatum Flügge, Monogr. Pasp. 133. 1810. Asia.

Agrostis ramosa Poir., in Lam., Encycl. Sup. 1: 257. 1810. Based on Milium ramosum Retz.

Eriochloa annulata Kunth, Rév. Gram. 1: 30. 1829. Based on Paspalum annulatum Flügge.

Helopus annulatus Nees, Agrost. Bras. 17. 1829. Based on Paspalum annulatum Flügge.

Eriochloa ramosa Kuntze, Rev. Gen. Pl. 2: 775. 1891. Based on Milium ramosum Retz. 
Eriochloa polystachya var. annulata Maid. and Betche, Cens. N.S. Wales Pl. 16. 1916. Based on E. annulata Kunth.

Thysanolaena procera Mez, in Janow., Bot. Archiv Mez 1: 27. 1922. Based on Agrostis procera Retz. but misapplied to T. maxima.

(7) Eriochloa punctata (L.) Desv.; Hamilt., Prodr. Pl. Ind. Occ. 5. $1825 . \quad$ Based on Milium punctatum L.

Milium punctatum L., Syst. Nat. ed. 10. 2: 872. 1759. Jamaica.

Agrostis punctata Lam., Encycl. 1: 58. 1783. Based on Milium punctatum L. Paspalum punctatum Flügge, Monogr. Pasp. 127. 1810. Based on Milium punctatum L.

Piptatherum punctatum Beauv., Ess. Agrost. 18, 173. 1812. Based on Milium punctatum L.

Eriochloa kunthii G. Meyer, Prim. Fl. Esseq. 47. 1818. British Guiana.

Oedipachne punctata Link, Hort. Berol. 1: 51. 1827. Based on Milium punctatum L.

Helopus punctatus Nees, Agrost. Bras. 16. 1829. Based on Milium punctatum L.

Helopus kunthii Trin.; Steud., Nom. Bot. ed. 2. 1: 747. 1840. Based on Eriochloa kunthii G. Meyer.

Monachne punctata Nash, Bull. Torrey Bot. Club 30: 374. 1903. Based on Milium punctatum L.

Eriochloa polystachya var. punctata Maid. and Betche, Cens. N.S. Wales Pl. 16. 1916. Based on E. punctata Desv.

(2) Eriochloa sericea (Scheele) Munro; Vasey, U.S.Dept.Agr., Div. Bot. Bull. $12^{1}$ : pl. 1. 1890. Based on Paspalum sericeum Scheele, as shown by Munro manuscript in Kew Herbarium.

Paspalum racemosum Nutt., Amer. Phil. Soc. Trans. (n.s.) 5: 145. 1837. Not P. racemosum Lam. Red River, Ark., [Nuttall].

Paspalum sericeum Scheele, Linnaea 22: 341. 1849. New Braunfels, Tex., Lindheimer.

Panicum sericatum Scheele; Steud., Syn. Pl. Glum. 1: 58. 1854. Based on Paspalum sericeum Scheele.

Helopus junceus C. Muell., Bot. Ztg. 19: 314. 1861. Texas, Drummond 305 and 368 .

\section{(158) EUCHLAENA Schrad.}

(1) Euchlaena mexicana Schrad., Ind. Sem. Hort. Goettingen 1832; reprinted in Linnaea 8: Litt. 25. 1833. Mexico, Muhlenfordt.

Reana luxurians Durieu, Bull. Soc. Acclim. II. 9: 581. 1872. This and the following are names only. They have, however, come into frequent use for teosinte.

Euchlaena luxurians Durieu and Aschers., Bull. Soc. Linn. Paris 1: 107.1877. Based on Reana luxurians Durieu.

Euchlaena mexicana var. luxurians Haines, Bot. Bihar and Orissa pt. 6: 1065. 1924. Based on Reana liuxurians "Brogn." (error for Durieu).

Euchlaena perennis Hitchc., Jour. Wash. Acad. Sci. 12: 207. 1922. Zapotlan, Jalisco, Mexico, Hitchcock 7146.

\section{EULALIA Kunth}

Eulalia viminea (Trin.) Kuntze, Rev. Gen. Pl. 2: 775. 1891. Based on Andropogon vimineus Trin.

Andropogon vimineus Trin., Mém. Acad. St. Pétersb. VI. Math. Phys. Nat. 2: 268. 1832. Nepal, India.

Pollinia viminea Merr., Enum. Philipp. Pl. 1: 35. 1922. Based on Andropogon vimineus Trin.

\section{(3) FESTUCA L.}

Festuca amethystina L., Sp. Pl. 74. 1753. Europe.

(9) Festuca arida Elmer, Bot. Gaz. 36: 52. 1903. North Yakima, Wash., Henderson 2196.

This species was referred by Piper to Festuca eriolepis Desv., a South American species not known from North America.

(34) Festuca arizonica Vasey, Contrib. U.S. Natl. Herb. 1: 277. 1893. Flagstaff, Ariz., Tracy 118.

Festuca ovina var. arizonica Hack.; Beal, Grasses N.Amer. 2: 598. 1896. Based on $F$. arizonica Vasey. 
Festuca vaseyana Hack.; Beal., Grasses N.Amer. 2: 601. 1896. Veta Pass, Colo., Vasey.

Festuca scabrella var. vaseyana Hack.; Beal, Grasses N.Amer. 2: 605. 1896. Veta Pass, Colo., Vasey.

Festuca altaica subsp. arizonica St. Yves, Candollea 2: 267. 1925. Based on F. arizonica Vasey.

(26) Festuca californica Vasey, Contrib. U.S. Natl. Herb. 1:277. 1893. Oakland, Calif., Bolander 1505.

Bromus kalmii var. aristulatus Torr., U.S. Rept. Expl. Miss. Pacif. 4: 157. 1856. Mark West Creek, Calif., Bigelow.

Festuca aristulata Shear; Piper, Contrib. U.S. Natl. Herb. 10: 32. 1906. Based on Bromus kalmii var. aristulatus Torr.

Festuca aristulata parishii Piper, Contrib. U.S. Natl. Herb. 10: 33. 1906. Mill Creek Falls, San Bernardino Mountains, Calif., Parish 5036.

Festuca parishii Hitchc., in Jepson, Fl. Calif. 1: 169. 1912. Based on $F$. aristulata parishii Piper.

Festuca californica parishii Hitche., in Abrams, Illustr. Fl. 1: 222.1923. Based on $F$. artistulata parishii Piper.

Festuca altaica var. aristulata St. Yves, Candollea 2: 273. 1925. Based on Bromus kalmii var. aristulatus Torr.

(32) Festuca capillata Lam., Fl. Franç. 3: 597. 1778. France.

Festuca ovina var. capillata Alefeld, Landw. Fl. 354. 1866. Based on F. capillata Lam.

(7) Festuca confusa Piper, Contrib. U.S. Natl. Herb. 10: 13. pl. 1. 1906. Western Klickitat County, Wash., Suksdorf 1140.

Festuca microstachya var. ciliata A. Gray, Amer. Acad. Sci. Proc. 8: 410. 1872. Name only, for Hall 639 in 1871, Silver Creek, Oreg.

Festuca suksdorfi Piper; Suksdorf, Werdenda 12:2. 1923. Bingen, Wash., Suksdorf 5604 .

(27) Festuca dasyciada Hack.; Beal, Grasses N.Amer. 2: 602. 1896. Utah, Parry in 1875.

(4) Festuca dertonensis (All.) Aschers. and Graebn., Syn. Mitteleur. Fl. 2: 588. 1900. Based on Bromus dertonensis All.

Bromus dertonensis All., Fl. Pedem. 2: 249. 1785. Italy.

Vulpia dertonensis Volk., in Schinz and Keller, Fl. Schweiz ed. 2: 57 (not in Washington); Dur. and Barr., Fl. Lib. Prodr. 269. 1910. Based on Festuca dertonensis Aschers. and Graebn.

This is the species referred by American authors to $F$. bromoides $L$. That seems to be a mixture; the name is referred to $F$. myuros by European authors.

(12) Festuca eastwocdae Piper, Contrib. U.S. Natl. Herb. 10: 16. 1906. Santa Lucia Mountains, Monterey County, Calif., Eastwood.

(17) Festuca elatior L., Sp. Pl. 75. 1753. Europe.

Festuca pratensis Huds., Fl. Angl. 37. 1762. England.

Festuca fluitans var. pratensis Huds., Fl. Angl. ed. 2. 47. 1778. Based on $F$. pratensis Huds.

Avena secunda Salisb., Prodr. Stirp. 22. 1796. Based on Festuca elatior L.

Bromus elatior Koel., Deser. Gram. 214. 1802. Based on Festuca elatior L.

Festuca poaeoides Michx., Fl. Bor. Amer. 1: 67. 1803. St. Lawrence River, Michaux.

Festuca poaeoides americana Pers., Syn. P1. 1: 94 . 1805. Based on F. poaeoides Michx.

Schedonorus elatior Beauv., Ess. Agrost. 99, 156, 177. 1812. Based on Bromus elatior Koel.

Schedonorus pratensis Beauv., Ess. Agrost. 99, 163, 177. 1812. Basèd on Festuca pratensis Huds.

Festuca americana F. G. Dietr., Vollst. Lex. Gärtn. Bot. Nachtr. 3: 332. 1817. Based on $F$. poaeoides americana Pers.

Schenodorus americanus Roem. and Schult., Syst. Veg. 2: 706. 1817. (Error for Schedonorus). Based on Festuca poaeoides americana Pers.

Bromus pratensis Spreng., Syst. Veg. 1: 359.1 1S25. Not B. pratensis Lam., 1785. Based on Festuca pratensis Huds.

Bucetum pratense Parnell, Grasses Scotl. 105. pl. 46. 1842. Based on Festuca pratensis Huds.

Bucetum elatius Parnell, Grasses Scotl. 107. pl. 46. 1842. Based on Festuca elatior L.

Festuca elatior var. pratensis A. Gray, Man. ed. 5. 634. 1867. Based on F. pratensis Huds. 
Tragus elatior Panz.; Jacks., Ind. Kew. 4: 1098. 1895, as synonym of Festuca elatior L.

Gnomonia elatior Lunell, Amer. Midl. Nat. 4: 224. 1915. Based on Festuca elatior $\mathrm{L}$.

Festuca elation var. arundinacea (Schreb.) Wimm., Fl. Schles. ed. 3. 59. 1857. Based on $F$. arundinacea Schreb.

F'estuca arundinacea Sehreb., Spic. Fl. Lips. 57. 1771. Germany.

Bromus arundinaceus Roth, Tent. Fl. Germ. 2: 141. 1789. Based on Festuca arundinacea Schreb.

(16) Festuca elmeri Scribn. and Merr., Bull. Torrey Bot. Club 29: 468. 1902. Stanford University, Calif., Elmer 2101.

Festuca eqmeri var. conferta (Hack.) Hitchc., Amer. Jour. Bot. 21: 128. 1934. Based on $F$. jonesii var. conferta Hack.

Festuca jonesii var. conferta Hack.; Beal, Grasses N.Amer. 2: 593. 1896. San Jose Normal School, California.

Festuca elmeri luxurians Piper, Contrib. U.S. Natl. Herb. 10: 38. 1906. Based on $F$. jonesii var. conferta Hack.

Festuca geniculata (L.) Cav., An. Cienc. Nat. Madrid 6: 150. 1803. Based on Bromus geniculatus L.

Bromus geniculatus L., Mant. Pl. 33. 1767. Portugal.

Festuca gigantea (L.) Vill., Hist. Pl. Dauph. 2: 110. 1787. Based on Bromus giganteus $\mathbf{L}$.

Bromus giganteus L., Sp. Pl. 77. 1753. Europe.

Forasaccus giganteus Bubani, Fl. Pyr. 4: 383. 1901. Based on Bromus giganteus L.

(8) Festuca grayi (Abrams) Piper, Contrib. U.S. Natl. Herb. 10: 14. pl. 3. 1906. Based on $F$. microstachys grayi Abrams.

Festuca microstachys var. ciliata A. Gray; Beal, Grasses N.Amer. 2: 585. 1896. Not $F$. ciliata Gouan, 1762. Grants Pass, Oreg., Howell. Beal's specimen is a mixture of $F$. grayi and $F$. confusa, but the description applies to $F$. grayi. Fcstuca microstachys grayi Abrams, F1. Los Angeles 52. 1904. Based on F. microstachys var. ciliata A. Gray; Beal.

(33) Festuca idahoensis Elmer, Bot. Gaz. 36: 53. 1903. Siniths Valley, Shoshone County, Idaho, Abrams 688.

Fesiuca ovina var. ingrata Hack.; Beal, Grasses N.Amer. 2: 598. 1896. Oregon, Howell.

Festuca ovina var. columbiana Beal, Grasses N.Amer. 2: 599. 1896. [Blue Mountains], Wash., Lake.

Festuca ovina var. oregona Hack.; Beal, Grasses N.Amer. 2: 599. 1896. Oregon, Cusick 753.

Festuca ingrata Rydb., Bull. Torrey Bot. Club 32: 608. 1905. Based on $F$. ovina var. ingrata Hack.

Fcstuca ingrata nudata Rydb., Colo. Agr. Expt. Sta. Bull. 100: 50. 1906. " $F$. ovina var. nudata Vasey", (herbarium name only), Colorado, [Beardslee in 1892j.

Festuca amethystina var. asperrima subvar. idahoensis St. Yves, Candollea 2: 260. 1925. Based on $F$. idahoensis Elmer.

Fcstuca amethystina var. asperrima subvar. robusta St. Yves, Candollea 2: 264. 1925. Walla Walla, Wash., Piper 2410.

(18) Festuca kingii Cassidy, Colo. Agr. Expt. Sta. Bull. 12: 36. 1890. On the North Poudre, Colo. It may be based on Poa kingii S. Wats., though that is not cited; there is a description. Proposed as new by Scribner, U.S.Dept. Agr., Div. Agrost. Bull. 5: 36. 1897. Based on Poa lingii S. Wats.

Poakingii S. Wats., in King, Geol. Expl. 40th Par. 5: 387. 1871. East Humboldt Mountains, Watson 1317. (Not invalidated by Festuca kingiana Steud., 1854.)

Festuca confinis Vasey, Bull. Torrey Bot. Club 11: 126. 1884. Pen Gulch, Colo., Vascy.

Festuca waisoni Nash, in Britt., Man. 148. 1901. Based on Festuca kingii Scribn.

IIesperochloa kingii Rydb., Bull. Torrey Bot. Club 39: 106. 1912. Based on Poa kingii S. Wats.

Wasatchia kingii Jones, Contrib. West. Bot. 14: 16. 1912. Based on Poa kingii S. Wats.

Festuca kingli var. rabiosa (Piper) Hitche., Amer. Jour. Bot. 21: 128. 1934. Based on $F$. confinis rabiosa Piper.

Festuca confinis rabiosa Piper, Contrib. U.S. Natl. Herb. 10: 41. 1906. Crazy Womans Creek, Wyo., Williams and Griffiths 25. 
(24) Festuca ligulata Swallen, Amer. Jour. Bot. 19: 436. f. 1. 1932. Guadalupe Mountains, Tex., Moore and Steyermark 3576.

(3) Festuca megalura Nutt., Jour. Acad. Phila. II. 1: 188. 1848. Santa Barbara, Calif., Gambel.

Vulpia megalura Rydb., Bull. Torrey Bot. Club 36: 538. 1909. Based on Festuca megalura Nutt.

(11) Festuca microstachys Nutt., Jour. Acad. Phila. II. 1: 187. 1848. Los Ángeles, Calif., Gambel.

Vulpia microstachya Munro; Benth., Pl. Hartw. 342. 1857. Based on Festuca microstachys Nutt.

?Vulpia microstachya var. ciliata Munro; Benth., Pl. Hartw. 342. 1857. Name only, for Hartweg 281, Sacramento, Calif.

Festuca microstachys var. subappressa Suksdorf, Werdenda 12: 3.1923. Bingen, Wash., Suksdorf 6236.

(5) Festuca myuros L., Sp. Pl. 74. 1753. Europe.

Avena muralis Salisb., Prodr. Stirp. 22. 1796. Based on Festuca myuros L.

Vulpia myuros K. Gmel., Fl. Badens. 1: 8. 1805. Based on Fesiuca myuros L.

Festuca myuros MIuhl., Descr. Gram. 160. 1817. Maryland; Georgia. Probably $F$. myuros $\mathbf{L}$. is referred to, Muhlenberg's specimen being a mixture of this and $F$. sciurea Nutt.

Distomomischus myuros Dulac, Fl. Haut. Pyr. 91. 1867. Based on Vulpia myuros K. Gmel.

Zerna myuros Panz.; Jacks., Ind. Kew. 4: 1249. 1895, as synonym of Festuca myuros L.

(21) Festuca obtusa Spreng., Mant. Fl. Hal. 34. 1807. Pennsylvania, Muhlenberg.

Panicum divaricatum Michx., Fl. Bor. Amer. 1: 50. 1803. Not P. divaricatum L., 1753. Carolina. (Michaux's plant an old specimen with all but the lowest floret fallen from the spikelets.)

Festuca nutans Spreng., Mant. Fl. Hal. 34. 1807. Not F. nutans Moench, 1794. Pennsylvania, Muhlenberg.

Panicum gracilentum Poir., in Lam., Encyel. Sup. 4: 276. 1816. Cultivated in Paris botanic garden.

Panicum debile Poir., in Lam., Encycl. Sup. 4: 283. 1816. Not P. debile Desf., 1798. Based on P. divaricatum Michx.

Panicum patentissimum Roem. and Schult., Syst. Veg. 2: 448. 1817. Not $P$. patentissimum Desv., 1816. Based on $P$. divaricalum Michx.

Schedonorus obtusus Spreng.; Roem. and Schult., Syst. Veg. 2: 710. 1817. Based on Festuca obtusa Spreng.

Poa festucoides LeConte; Torr., in Eaton, Man. Bot. ed. 2. 367. 181S. New York, LeConte.

Poa nutans Link, Enum. Pl. 1: 86. 1821. Based on Festuca nutans Spreng.

Poa brachiata Desv., Opusc. 100. 1831. Based on Panicum divaricalum Michx.

Festuca pseudoduriuscula Steud., Syn. Pl. Glum. 1: 312. 1854. Texas, Drummond 398.

Steinchisma divaricatum Raf.; Jacks., Ind. Kew. 4: 982. 1895, as doubtful synonym of Panicum debile. Rafinesque (Bull. Bot. Seringe 1:220. 1830) cites Panicum divaricatum [Michx.] under Steinchisma, but does not transfer the name.

Festuca nutans palustris Muhl.; Piper, Contrib. U.S. Natl. Herb. 10: 34. 1906, as synonym of $F$. obtusa Spreng.

Gnomonia nutans Lunell, Anier. Midl. Nat. 4: 224. 1915. Based on Festuca nutans Willd.

Festuca obtusa var. sprengeliana St. Yves, Candollea 2: 276. 1925. Based on F. obtusa Spreng.

(30) Festuca occidentalis Hook., Fl. Bor. Amer. 2: 249. 1840. Mouth of Columbia River, Scouler, Douglas.

Festuca ovina var. polyphylla Vasey; Beal, Grasses N.Amer. 2: 597. 1896. Cascade Mountains, Oreg., Howell.

(1) Festuca octoflora Walt., Fi. Carol. 81. 1788. South Carolina.

Festuca tenella Willd., Sp. Pl. 1: 419. 1797. North America.

Festuca setacea Poir., in Lam., Encyl. Sup. 2: 638. 1811. Grown in Jardin du Val de Grace, France, source unknown.

Schedonorus tenellus Beauv., Ess. Agrost. 99, 163, 177. 1812. Based on Festuca tenella Willd.

Festuca parviflora Ell., Bot. S.C. and Ga. 1: 170. 1816. Orangeburg, S.C. 
Diarrhena setacea Roem. and Schult., Syst. Veg. 1: 289. 1817. Based on Festuca setacea Poir.

Brachypodium festucoides Link, Enum. Pl. 1: 95. 1821. Based on Festuca tenella L. (error for Willd.).

Festuca tenella var. glauca Nutt., Amer. Phil. Soc. Trans. (n.s.) 5: 147. 1837. Fort Smith, Ark., Nuttall.

Vulpia tenella Heynh., Nom. 1: 854. 1840. Based on Festuca tenella Willd.

Festuca tenella var. aristulata Torr., U.S. Rept. Expl. Miss. Pacif. 45: 156. 1856. Name only. Napa Valley, Calif., Bigelow.

Festuca gracilenta Buckl., Acad. Nat. Sci. Phila. Proc. 1862: 97. 1863. Northern Texas, Buckley.

Festuca pusilla Buckl., Acad. Nat. Sci. Phila. Proc. 1S62: 98. 1863. California, Nuttall. Fernald (Rhodora 34:211. 1932) refers this to F. octoflora var. hirtella.

Festuca octoflora aristulata Torr.; L. H. Dewey, Contrib. U.S. Natl. Herb. 2: 547. 1894. Texas.

Vulpia octoflora Rydb., Bull. Torrey Bot. Club 36: 538. 1909. Based on Festuca octoflora Walt.

Gnomonia octoflora Lunell, Amer. Midl. Nat. 4: 224. 1915. Based on Festuca octoflora Walt.

Festuca octoflora var. tenella Fernald, Rhodora 34: 209. 1925. Based on F. tenella Willd.

Festuca octoflora var. glauca Fernald, Rhodora 34: 209. 1925. Based on F. tenella var. glauca Nutt.

Festuca octoflora var. hirtella Piper, Contrib. U.S. Natl. Herb. 10: 12. 1906. Santa Catalina Mountains, Ariz., Shear 1962. (Published as $F$. octoflora hirtella.)

(31) Festuca ovina L., Sp. Pl. 73. 1753. Europe.

Festuca ovina var. vivipara L., Sp. Pl. ed. 2. 1: 108. 1762. Sweden.

Bromus ovinus Scop., Fl. Carn. 1: 77. 1772. Based on Festuca ovina I.

Avena ovina Salisb., Prodr. Stirp. 22. 1796. Based on Festuca ovina L.

Festuca ovina var. duriuscula A. Gray; Port. and Coult., Syn. Fl. Colo. 150. 1874. Not $F$. ovina var. duriuscula Koch, 1837. Name only, for alpine specimens from Colorado [Hall and Harbour 665]. No reference to $F$. duriuscula L.

Festuca amethystina var. asperrima Hack.; Beal, Grasses N.Amer. 2: 601. 1896. Arizona, Rusby 901.

Festuca minutiflora Rydb., Bull. Torrey Bot. Club 32: 608. 1905. Cameron Pass, Colo., Baker.

Festuca ovina calligera Piper, Contrib. U.S. Natl. Herb. 10: 27. 1906. Based on $F$. amethystina var. asperrima Hack.

Festuca saximontana Rydb., Bull. Torrey Bot. Club 36: 536. 1909. Banff, Alberta, MacCalla 2331.

Festuca calligera Rydb., Bull. Torrey Bot. Club 36: 537. 1909. Based on F. ovina calligera Piper.

Gnomonia ovina Lunell, Amer. Midl. Nat. 4: 224. 1915. Based on Festuca ovina $\mathrm{L}$.

Festuca ovina subsp. saximontana St. Yves, Candollea 2: 245. 1925. Based on F. saximontana Rydb.

Festuca orina subsp. saximontana var. rydbergii St. Yves, Candollea 2: 245. 1925. Based on F. saximontana Rydb.

Festuca brevifolia var. utahensis St. Yves, Candollea 2: 257. 1925. Wasatch Mountains, Utah; Colorado, Baker 175.

Festuca ovina var. BRachyphylla (Schult.) Piper, Contrib. U.S. Natl. Herb. 10: 27. 1906. Based on F. brachyphylla Scbult. (Published as F. ovina brachyphylla.)

Festuca brevifolia R. Br., Sup. App. Parry's Voy. 289. 1824. Not F. brevifolia Muhl., 1817. Melville Island, Arctic America.

Festuca brachyphylla Schult., Mant. 3 (Add. 1): 646. 1827. Based on F. brevifolia R. Br.

Fesiuca ovina var. brevifolia S. Wats., in King, Geol. Expl. 40th Par. 5: 389. 1871. Based on $F$. brevifolia R. Br.

Festuca ovina subsp. saximontana var. purpusiana St. Yves, Candollea 2: 247. 1925. Farewell Gap, Calif., Purpus 3076, 5117.

Festuca ovina var. DuRidscula (L.) Koch, Syn. Fl. Germ. Helv. 812. 1837. Based on $F$. duriuscula $\mathrm{L}$.

Festuca duriuscula L., Sp. Pl. 74. 1753. Europe. 
Festuca ovina var. glauca (Lam.) Koch, Syn. Fl. Germ. Helv. 812. 1837. Based on F. glauca Lam.

Festuca glauca Lam., Encycl. 2: 459. 1788. France.

The following varieties of $F$. ovina, recognized by Piper (North American Species of Festuca, Contrib. U.S. Natl. Herb. 10: 26-28. 1906), are based on European types. The specimens cited by him are in this Manual referred as follows:

$F$. ovina sciaphila (Schur) Aschers. and Graebn., to $F$. ovina.

$F$. ovina supina (Schur) Hack., to $F$. ovina var. brachyphylla.

$F$. ovina pseudovina Hack., to $F$. ovina.

(6) Festuca pacifica Piper, Contrib. U.S. Natl. Herb. 10: 12. 1906. Pullman, Wash., Elmer 262.

Vulpia pacifica Rydb., Bull. Torrey Bot. Club 36: 538. 1909. Based on Festuca pacifica Piper.

Festuca subbiflora Suksdorf, Werdenda 12: 2. 1923. Bingen, Wash., Suksdorf 6144.

Festuca dives Suksdorf, Werdenda $1^{2}: 3$. 1923. Not $F$. dives Muell., 1863. Bingen, Wash., Suksdorf 6153.

(10) Festuca reflexa Buckl., Acad. Nat. Sci. Phila. Proc. 1862: 98. 1863. California.

Festuca microstachys var. pauciflora Scribn.; Beal, Grasses N.Amer. 2: 586. 1896. Oregon, Howell.

Vulpia reflexa Rydb., Bull. Torrey Bot. Club 36: 538. 1909. Based on Festuca reflexa Buckl.

Festuca rigescens (Presl) Kunth, Rév. Gram. 1: Sup. XXXI. 1830. Based on Diplachne rigescens Presl.

Diplachne rigescens Presl, Rel. Haenk. 1: 260. 1830. Peru, Haenke.

(29) Festuca rubra L., Sp. Pl. 74. 1753. Europe.

Festuca ovina var. rubra Smith, English FI. 1: 139. 1824. Based on F. rubra L.

Festuca duriuscula var. rubra Wood, Amer. Bot. and Flor. pt. 2: 399. 1870. Presumably based on F. rubra L.

Festuca oregona Vasey, Bot. Gaz. 2: 126. 1877. Oregon.

Festuca ovina subsp. rubra Hook. f., Stud. Fl. ed. 3. 497. 1884. Based on $F$. rubra L.

Festuca rubra var. littoralis Vasey; Beal, Grasses N.Amer. 2: 607. 1896. Tillamook Bay, Oreg., Howell in 1882.

Festuca vallicola Rydb., Mem. N.Y. Bot. Gard. 1: 57. 1900. Silver Bow, Mont., Rydberg 2108.

Festuca earlei Rydb., Bull. Torrey Bot. Club 32: 608. 1905. La Plata Canyon, Colo., Baker, Earle and Tracy 920.

Festuca rubra prolifera Piper, Contrib. U.S. Natl. Herb. 10: 21. 1906. Mount Washington, N.H., Pringle in 1877.

Festuca rubra var. densiuscula Hack.; Piper, Contrib. U.S. Natl. Herb. 10: 22. 1906. Crescent City, Calif., Davy and Blasdale 5931.

Festuca rubra var. prolifera Piper, in Robinson, Rhodora 10: 65. 1908. Based on $F$. rubra prolifera Piper.

Festuca prolifera Fernald, Rhodora 35: 133. 1933. Based on F. rubra prolifera

Piper.
Festuca Rubra var. commotata Gaud., Fl. Helv. 1: 287. 1828. Switzerland.

Festuca fallax Thuill., Fl. Env. Paris n.ed. 50. 1799. France.

Festuca rubra var. fallax Hack., Bot. Centralbl. 8: 407. 18S1. Based on F. fallax Thuill.

Festuca rubra var. heterophylla Mutel, Fl. Franç. 4: 103. 1837. Based on $F$. heterophylla Lam.

Festuca heterophylla Lam., Fl. Franç. 3: 600. 1778. France.

Festuca rubra var. Landginosa Mert. and Koch, Deut. Fl. ed. 3. 1: 654. 1823. Prussia.

Festuca arenaria Osbeck, in Retz. Sup. Prodr. Fl. Scand. 1: 4. 1805. Not F. arenaria Lam., 1791. Scandinavia.

Festuca rubra var. arenaria Fries, Fl. Halland. 28. 1818. Based on $F$. arenaria Osbeck.

Bromus secundus Presl, Rel. Haenk. 1: 263. 1830. Nootka Sound, Vancouver Island, Haenke.

Festuca richardsoni Hook., Fl. Bor. Amer. 2: 250. 1840. Arctic seacoast of North America, Richardson. 
Festuca rubra var. villosa Vasey; Macoun, Cat. Can. Pl. 24: 236. 1888. Name only, for specimen collected by Macoun at Dawson, Yukon Territory.

Festuca rubra var. pubescens Vasey; Beal, Grasses N.Amer. 2: 607. 1896. Not F. rubra var. pubescens Spenner, 1825. Oregon, Howell.

Festuca rubra var. secunda Scribn., Rept. Mo. Bot. Gard. 10: 39. 1899. Based on Bromus secundus Presl.

Festuca rubra var. subvillosa forma vivipara Eames, Rhodora 11: 89. 1909. Newfoundland, Governors Island, Eames and Godfrey.

The following varieties of Festuca rubra, recognized by Piper (North American Species of Festuca, Contrib. U.S. Nat1. Herb. 10: 21-23. 1906), are based on

European types. The specimens cited by him are in this Manual referred as follows:

F. rubra megastachya Gaud., to $F$. rubra.

$F$. rubra glaucodea Piper (based on F. glaucescens Hegetschw.), to F. rubra.

F. rubra multiflora (Hoffm.) Aschers. and Graebn., to F. rubra.

$F$. rubra pruinosa Hack., to $F$. rubra.

$F$. rubra lanuginosa Mert. and Koch, to $F$. rubra var. lanuginosa.

$F$. rubra kitaibeliana (Schult.) Piper, to $F$. rubra var. lanuginosa.

(25) Festuca scabrella Torr.; Hook., Fl. Bor. Amer. 2: 252. 1840. Rocky Mountains, Drummond.

Melica hallii Vasey, Bot. Gaz. 6: 296. 1881. Rocky Mountains, latitude $39^{\circ}$ to $41^{\circ}$ [north half of Colorado], Hall and Harbour 621.

Festuca hallii Piper, Contrib. U.S. Natl. Herb. 10: 31. 1906. Based on Melica hallii Vasey.

Daluca hallii Lunell, Amer. Midl. Nat. 4: 221. 1915. Based on Melica hallii Vasey.

Festuca altaica subsp. arizonica subvar. hallii St. Yves, Candollea 2: 271. 1925. Based on Melica hallii Vasey.

Festuca scabrella var. Major Vasey, Contrib. U.S. Natl. Herb. 1: 278. 1893. Spokane County, Wash., Suksdorf 118.

Festuca campestris Rydb., Mem. N.Y. Bot. Gard. 1: 57. 1900. Based on F. scabrella var. major Vasey.

(2) Festuca sciurea Nutt., Amer. Phil. Soc. Trans. (n.s.) 5: 147. 1837. Arkansas, Nuttall.

?Festuca quadriflora Walt., Fl. Carol. 81. 1788. Not F. quadriflora Honck., 1782. South Carolina.

Festuca monandra Ell., Bot. S.C. and Ga. 1: 170. 1816, as synonym of $F$. myuros L., as misapplied by Elliott.

Dasiola elliotea Raf., Neogenyt. 4. 1825. Not Festuca elliotii Hack. Based on Festuca monandra Ell.

Vulpia quadriflora Trin.; Steud., Nom. Bot. ed. 2. 2: 780. 1841. Based on Festuca quadriflora Walt.

(22) Festuca shortii Kunth; Wood, Class-book 794. 1861; A. Gray, Man. ed. 6. 669 . 1890. Noted in both as a variation of F. nutans. Vasey; L. H. Dewey, Contrib. U.S. Natl. Herb. 2: 548. 1894. Central Texas to Illinois. This is the first description of the species. In Wood the following note is appended to the description of $F$. nutans: "( $F$. shortii Kunth, when the grass is stouter and the spikelets about 5-flowered.)" In the National Herbarium are several specimens of this species named "Festuca shortii Kth" in Vasey's script, "Kth?" queried on some of them. On one, collected in Illinois by Vasey, is the note "Festuca nutans var. probably a good species, and I have a specimen from Mr. Wolf ticketed $F$. Shortii Kunth, but I do not find such a species published." Since Vasey in the herbarium credited the species to Kunth it may be assumed that Dewey inadvertently omitted that name. The original connection with Kunth remains obscure. In the Gray Herbarium is a specimen of this species with "Barrens of Ky." written on a label printed "C. W. Short, M.D., Kentucky, 1842."

?Festuca nutans var. palustris Wood, Amer. Bot. and Flor. pt. 2: 399. 1870. Eastern States.

Festuca nutans var. shortii Beal, Grasses N.Amer. 2: 589. 1896. Based on F. shortii Kunth.

Festuca nutans var. major Vasey, U.S. Dept. Agr. Spec. Rept. 63: 43.1883. Name only; Beal, Grasses N.Amer. 2: $5 \$ 9$. 1896, as synonym of $F$. nutans var. shortii Beal.

(19) Festuca sororia Piper, Contrib. U.S. Natl. Herb. 16: 197. 1913. Rincon Mountains, Ariz., Nealley 177.

Festuca subulata var. sororia St. Yves, Candollea 2: 285. 1925. Based on F. sororia Piper. 
(15) Festuca subulata Trin., in Bong., Mém. Acad. St. Pétersb. VI. Math. Phys. Nat. 2: 173. 1832. Sitka, Alaska, Mertens.

Festuca jonesii Vasey, Contrib. U.S. Natl. Herb. 1:278. 1893. Utah, Jones in 1880 .

Festuca subulata var. jonesii St. Yves, Candollea 2: 2S4. 1925. Based on F. jonesii Vasey.

(14) Festuca subulifiora Scribn.; Macoun, Cat. Can. Pl. 25: 396. 1890. Goldstream, Vancouver Island, Macoun 7. (By a slip of the pen the name is given as "subulifolia" in a note following.)

Festuca ambigua Vasev, Contrib. U.S. Natl. Herb. 1: 277. 1893. Not $F$. ambigua Le Gall. 1852. Oregon, Howell 19 in 1881.

Festuca denticulata Beal, Grasses N.Amer. 2: 589. 1896. Based on F. ambigua Vasey.

(23) Festuca thurberi Vasey, Cat. Pl. Survey W. 100th Merid.56. 1874. South Park, Colo., Wolf 1154 .

Poa festucoides Jones, Calif. Acad. Sci. Proc. II. 5: 723. 1895. Not P. festucoides Lam., 1791. Mount Ellen, Henry Mountains, Utah, Jones 5671.

Poa kaibensis Jones, Erythea 4: 36. 1896. Based on P. festucoides Jones.

Festuca tolucensis subsp. thurberi St. Yves, Candollea 2: 304. 1925. Based on $F$. thurberi Vasey.

(13) Festuca tracyi Hitchc., in Abrams, Illustr. Fl. 1: 220. 1923. Howell Mountain, Napa County, Calif., J.P. Tracy 1479.

(20) Festuca versuta Beal, Grasses N.Amer. 2: 589. 1896. Based on F. texana Vasey.

Festuca texana Vasey, Bull. Torrey Bot. Club 13: 119. 18s6. Not F. texana Steud., 1854. Upper Llano, Tex., Reverchon 1618.

Festuca nutans var. johnsori Vasey, Contrib. U.S. Natl. Herb. 2: 548. 1894. Harrison City, Tex., Johnson.

Festuca johnsoni Piper, Contrib. U.S. Natl. Herb. 10: 35. 1906. Based on F. nutans var. johnsoni Vasey.

Festuca obtusn subsp. versuta St. Yves, Candollea 2: 280. 1925. Based on $F$. versuta Beal.

(28) Festuca viridula Vasey, U.S.Dept.Agr., Div. Bot. Bull. 13²: pl. 93.1893. California (probably Summit Station), Bolander.

Festuca howellii Hack.; Beal, Grasses N.Amer. 2: 591. 1896. Oregon, Howell [248].

Gnomonia viridula Lunell, Amer. Midl. Nat. 4: 224. 1915. Based on Festuca viridula Vasey.

Festuca viridula var. vaseyana St. Yres, Candollea 2: 265. 1925. Based on $F$. viridula Vasey.

Festuca viridula var. howellii St. Yves, Candollea 2: 266. 1925. Based on $F$. howellii Hack.

(8) FLUMINEA Fries

(1) Fluminea festucacea (Willd.) Hitchc., U.S.Dept.Agr. Bull. 772: 38. f. 11. 1920. Based on Arundo festucacea Willd.

Festuca arundinacea Liljebl., Utk. Svensk Fl. ed. 2. 47. 179S. Not F. arundinacea Schreb., 1771 . Sweden.

Arundo fcstucacea Willd., Enum. Pl. 1: 126. 1809. Germany.

Scolochloa festucacea Link, Hort. Berol. 1: 137. 1827. Based on Arundo festucacea Willd.

Triodia festucacea Roth, Enum. Pl. Phaen. Germ. 1': 382. 1827. Based on Arundo festucacea Willd.

Graphephorum festucaceum A. Gray, Amer. Acad. Sci. Proc. 5: 191.1861. Based on Arundo festucacea Willd.

Scolochloa arundinacea MacM., Met. Minn. Vall. 79. 1892. Not S. arundinacca Mert. and Koch, 1823. Based on Festuca arundinacea Liljebl.

\section{(73) GASTRIDIUMI Beauv.}

(1) Gastridium ventricosum (Gouan) Schinz and Thell., Vierteljahrs. Nat. Ces Zürich 5S: 39. 1913. Based on Agrostis ventricosa Goulan.

Agrostis ventricosa Gouan, Hort. Monsp. 39. pl. 1. f. 2. 1762. France.

Milium lendigerum L., Sp. Pl. ed. 2. 91. 1762. Europe.

Agrostis australis L., Mant. Pl. 1: 30.1767. Portugal.

Alopecurus ventricosus Huds., Fl. Angl. ed. 2. 1: 28. 1778. Based on Agrostis ventricosa Gouan.

$55974^{\circ}-35-55$ 
Agrostis lendigera Neck., Elem. Bot. 3: 219. 1791. Based on Milium lendigerum L.

Avena lendigera Salisb., Prodr. Stirp. 23. 1796. Based on Milium lendigerum L.

Gastridium australe Beauv., Ess. Agrost. 21, 164. pl. 6. f. 6. 1812. Europe. Gastridium lendigerum Desv., Obs. Angers 48. 1818. Based on Milium lendigerum $\mathbf{L}$.

Chilochloa ventricosa Beauv.; Steud., Nom. Bot. ed. 2. 1: 350. 1840, as synonym of Alopecurus ventricosus Huds.

Lachnagrostis phlcoides Nees and Meyen; Nees, Nov. Act. Aead. Caes. Leop. Carol. 19: Sup. 1: 14. 1841; 146. 1843. Vaiparaiso, Chile.

\section{(6) GLYCERIA R. Br.}

(1) Glyceria acutiflora Torr., Fl. North. and Mid. U.S. 1: 104. 1823. New York, New Jersey, and Massachusetts, Festuca brevifolia Muhl. erroneously cited as synonym.

Festuca acutiflora Bigel., Fl. Bost. ed. 3. 39. 1840. Based on Glyceria acutiflora Torr.

Panicularia acutiflora Kuntze, Rev. Gen. Pl. 2: 783. 1891. Based on Glyceria acutiflora Torr.

(4) Glyceria arkansana Fernald, Rhodora 31: 49. 1929. Varner, Ark., Bush 9 in 1898.

(2) Glyceria borealis (Nash) Batchelder, Manchester Inst. Proe. 1: 74. 1900. Based on Panicularia borealis Nash.

Glyceria fluitans var. angustata Vasey; Fernald, Portland Soc. Nat. Hist. Proc. 2: 91. 1895. Maine, Fernald [193].

Panicularia borealis Nash, Bull. Torrey Bot. Club 24: 34S. 1897. Maine, Fernald.

(12) Glyceria canadensis (Michx.) Trin., Mém. Acad. St. Pétersb. VI. Math. Phys. Nat. 1: 366.1830 . Based on Briza canadensis Michx.

Briza canadensis Michx., Fl. Bor. Amer. 1: 71. 1803. Canada, Michaux.

Megastachya canadensis Michx.; Roem. and Schult., Syst. Veg. 2: 593. 1817. Based on Briza canadensis Michx.

?Briza canadensis Nutt., Gen. Pl. 1: erratum. 1818. Not op. cit. 69. New Jersey, near Philadelphia.

Nevroloma canadensis Raf., Jour. Phys. Chym. 89: 106. 1819. Based on Briza canadensis Miehx.

Pon canalensis Torr., Fl. North. and Mid. U.S. 1: 112. 1823. Based on Briza canadensis Michx.

Panicularia canadensis Kuntze, Rev. Gen. Pl. 2: 783. 1891. Based on Briza canadensis Michx.

Glyceria canadexsis var. Iuaxa (Seribn.) Hitche., Amer. Jour. Bot. 21: 128. 1934. Based on Panicularia laxa Scribn.

Panicularia laxa Scribn., Bull. Torrey Bot. Club 21: 37. 1894. Mount Desert, Maine, Redfield and Rand.

Glyceria laxa Scribn.; Rand and Redfield, Fl. Mt. Desert 1S0. 1S94. Based on Panicularia laxa Scribn.

Glyceria canadensis var. parviflora Fernald, Portland Soc. Nat. Hist. Proc. 2: 91 . 1895, as synonym of $G$. laxa Scribn.

(14) Glyceria elata (Nash) Hitchc., in Jepson, Fl. Calif. 1: 162. 1912. Based on Panicularia elata Nash.

Panicularia elata Nash, in Rydb., Mem. N.Y. Bot. Gard. 1: 51. 1900. Montana, Flodman 176.

Glyceria latifolia Cotton, Bull. Torrey Bot. Club 29: 573. 1902. Washington, Elmer 721.

Panicularia nervata elata Piper, Contrib. U.S. Natl. Herb. 11: 140. 1906. Based on P. elata Nash.

(9) Glyceria erecta Hitchc., in Jepson, Fl. Calif. 1: 161. 1912. Yosemite, Calif., Hitchcock $32501 / 2$.

Panicularia erecta Hitche., Amer. Jour. Bot. 2: $309 . \quad 1915 . \quad$ Based on Glyceria erceta Hitche.

(6) Glyceria fluitans (L.) R. Br., Prodr. Fl. Nov. Holl. 1: 179. 1810. Based on Festuca fluitans L.

Festuca fluitans L., Sp. Pl. 75. 1753. Europe.

Hydrochloa fluitans Hartm., Gen. Gram. Scand. 8. 1819. Presumably based on Festuca fluitans L. 
Melica fluitans Raspail, Ann. Sci. Nat., Bot. 5: 443. 1825. Based on Festuca fluitans L.

Devauxia fluitans Beauv.; Kunth, Enum. Pl. 1: 367. 1833, as synonym of Glyceria fluitans R. Br.

Panicularia fluitans Kuntze, Rev. Gen. Pl. 2: 782. 1891. Based on Festuca fluifans L.

Panicularia brachyphylla Nash, Bull. Torrey Bot. Club 24: 349. 1897. Near New York City, Nash.

(16) Glyceria grandis S. Wats.; A. Gray, Man. ed. 6. 667. 1890. [Type from Quebec, Munro in 1858]. New England to western New York, Michigan, Minnesota, and westward.

Poa aquatica var. americana Torr., Fl. North. and Mid. U.S. 1: 108. 1823. Massachusetts, Cooley.

Panicularia americana MacM., Met. Minn. Vall. 81. 1892. Based on Poa aquatica var. americana Torr.

Glyceria americana Pammel, Iowa Geol. Survey Sup. Rept. 1903: 271. 1905. Based on Poa aquatica var. americana Torr.

Glyceria flavescens Jones, Mont. Univ. Bull. Biol. Ser. 15: 17. pl. 2. 1910. Swan Lake, Mont., Jones [9697].

Panicularia grandis Nash, in Britt. and Brown, Illustr. Fl. ed. 2. 1:265. 1913. Based on Glyceria grandis S. Wats.

(3) Glyceria leptostachya Buckl., Acad. Nat. Sci. Phila. Proc. 1862: 95. 1863. Oregon, Nuttall.

Panicularia davyi Merr., Rhodora 4: 145. 1902. Sonoma County, Calif., Davy 6005.

Panicularia leptostachya Piper; Piper and Beattie, F1. Northw. Coast 59. 1915. Not P. lepiostachya Maclosk., 1904. Based on Glyceria leptostachya Buckl.

(11) Glyceria melicaria (Michx.) F. T. Hubb., Rhodora 14: 186. 1912. Based on Panicum melicarium Michx.

Panicum melicarium Michx., Fl. Bor. Amer. 1: 50. 1803. Carolina, Michaux [Michaux's specimen overmature, all the florets but the lowermost fallen from the spikelets.]

Poa torreyana Spreng., Neu. Entd. 2: 104. 1821. Massachusetts.

Poa elongata Torr.; Spreng., Neu. Entd. 2: 104. 1821. Not P. elongata Willd., $1809 . \quad$ As synonym of $P$. torreyana Spreng.

Poa elongata Torr., F1. North. and Mid. U.S. 1: 112. 1823. Not P. elongata Willd., 1809. Míassachusetts, Cooley.

Glyceria elongata Trin., Mém. Acad. St. Pétersb. VI. Sci. Nat. 21: 58. 1836. Based on Poa elongata Torr.

Panicularia elongata Kuntze, Rev. Gen. Pl. 2: 783. 1891. Based on Poa elongata Torr.

Panicularia torreyana Merr., Rhodora 4: 146. 1902. Based on Poa torreyana Spreng.

Glyceria torreyana Hitchc., Rhodora 8: 211. 1906. Based on Poa torreyana Spreng.

Panicularia melicaria Hitche., Contrib. U.S. Natl. Herb. 12: 149. 1908. Based on Panicum melicarium Michx.

(18) Glyceria neogaea Steud., Syn. Pl. Glum 1: 285. 1854. Newfoundland.

Clyceria pallida var. fernaldii Hitchc., Rhodora 8: 211. 1906. Maine, Fernald 191.

Glycerla fernaldii St. John, Rhodora 19: 76. 1917. Based on Glyceria pallida var. fernaldii Hitchc.

Panicularia fernaldii Hitche.; House, N.Y. State Mus. Bull. 233-234: 11. 1921. Based on Glyceria pallida var. fernaldii Hitchc.

Glyceria nubigena Anders., Rhodora 35: 321. f. B. 1933. Clingmans Dome, Great Smoky Mountains, Tenn., Anderson and Jennison 1418.

(10) Glyceria obtusa (Muhl.) Trin., Mém. Acad. St. Pétersb. VI. Math. Phys. Nat. 1: 366. 1830. Based on Poa obtusa Mull.

Poa obtusa Muhl., Deser. Gram. 147. 1817. Pennsylvania, Muhlenberg.

Panicularia obtusa Kuntze, Rev. Gen. Pl. 2: 783. 1891. Based on Poa obtusa Muhl.

(7) Glyceria occidentalis (Piper) J. C. Nels., Torreya 19: 224. 1919. Based on Panicularia accidentalis Piper.

Panicularia occidentalis Piper; Piper and Beattie, Fl. Nortliw. Coast 59. 1915. Vancouver, Wash., Piper 4905.

(15) Glyceria otisii Hitchc., Amer. Jour. Bot. 21: 128. 1934. Jefferson County, Wash., Otis 1548. 
(17) Glyceria pallida (Torr.) Trin., Mém. Acad. St. Pétersb. VI. Sci. Nat. $2^{1}$ : 57. 1836. Based on Windsaria pallida Torr.

Windsoria pallida Torr., Cat. Pl. N.Y. 91. 1819. New York.

Triodia pallida Spreng., Neu. Entd. 1: 246. 1820. New York, "Windsaria pallida Eddy in litt"; Spreng., Syst. Veg. 1:330. 1825. Based on Windsoria pallida Torr.

Paa dentata Torr., Fl. North. and Mid. U.S. 1: 107. 1823. Based on Windsaria pallida Torr.

Uralepis pallida Kunth, Rév. Gram. 1: 108. 1829. Based on Windsaria pallida Torr.

Panicularia pallida Kuntze, Rev. Gen. Pl. 2: 783. 1891. Based on Windsaria pallida Torr.

(8) Glyceria pauciftora Presl, Rel. Haenk. 1: 257. 1830. Nootka Sound, Vancouver Island, Haenke.

Glyceria microtheca Buckl., Acad. Nat. Sci. Phila. Proc. 1862: 96. 1863. Oregon, Nuttall.

Glyceria spectabilis var. flaccida Trin.; A. Gray, Acad. Nat. Sci. Phila. Proc. 1862: 336. 1863, as synonym of G. microtheca Buckl., G. leptostachya Buckl. confused with it.

Panicularia pauciflora Kuntze, Rev. Gen. Pl. 2: 783. 1891. Based on Glyceria pauciflora Presl.

Panicularia halmii Beal, Torreva 1: 43. 1901. Longs Peak, Colo., Holm 249.

Panicularia multifalia Elmer, Bot. Gaz. 36: 54. 1903. Olympic Mountains, Wash., Elmer 1939.

Panicularia flaccida Elmer, Bot. Gaz. 36: 55. 1903. Olympic Mountains, Wash., Elmer 1940.

(5) Glyceria septentrionalis Hitchc., Rhodora 8: 211. 1906. New Jersey, Van Sickle.

Panicularia septentrianalis Bicknell, Bull. Torrey Bot. Club. 35: 196.1908. Based on Glyceria septentrionalis Hitchc.

Panicularia fluitans var. septentrionalis Farwell, Mich. Acad. Sci. Rept. 21: 353. 1920. Basec on Glyceria septentrionalis Hitche.

(13) Glyceria striata (Lam.) Hitchc., Proc. Biol. Soc. Wash. 41: 157. 1928. Based on Poa striata Lam.

Paa striata Lam., Tabl. Encycl. 1: 183. 1791. Virginia; Carolina.

Poa nervata Willd., Sp. Pl. 1: 389.1797. North America.

Poa striata Michx., Fl. Bor. Amer. 1: 69. 1803. Pennsylvania, Michaux.

Poa lineata Pers., Syn. Pl. 1: 89. 1805. Based on P. striata Michx.

Paa parviflora Pursh, Fl. Amer. Sept. 1: 80. 1814. Not P. parviflora R. Br., 1810. New York to Virginia.

Poa sulcata Roem. and Schult., Syst. Veg. 2: 550. 1817. Not P. sulcata Lag., 1816. Based on P. striata Lam.

Briza conadensis Nutt., Gen. Pl. 1: 69. 1818. Not B. canadensis Michx., 1803. Canada and Pennsylvania. (Canada refers to Michaux's species, Nuttall misunderstanding it.)

Glyceria michauxii Kunth, Rév. Gram. 1: 118. 1829. Based on Poa striata Michx.

Glyceria nervata Trin., Mém. Acad. St. Pétersb. VI. Math. Phys. Nat. 1: 365. 1830. Based on Poa nervata Willd.

Poa lamarckii Kunth, Enum. Pl. 1: 362. 1833. Based on P. striata Lam.

Panicularia nervata Kuntze, Rev. Gen. Pl. 2: 783. 1891. Based on Poa nervata Willd.

Panicularia nervata forma major Millsp., Fl. W.Va.473. 1892. Monongalia, W.Va.

Panicularia nervata stricta Seribn., U.S.Dept.Agr., Div. Agrost. Bull. 13: 44. 1898. Colorado-IVyoming State line, A. Nelson 3818.

Panicularia nervata rigida Nash, in Rydb., Mem. N.Y. Bot. Gard. 1: 54. 1900. Montana, Rydberg 2068.

Panicularia nervata var. parviglumis Scribn. and Merr., U.S.Dept.Agr., Div. Agrost. Circ. 30: 8. 1901. Racine, Wis. Wadmond 36.

Glyceria nervata var. stricta Scribn.; Hitchc., in A. Gray, Man. ed. 7. 159. 1908. Based on Panicularia nervata stricta Seribn.

Glyceria nervata var. rigida Lunell, Amer. Midl. Nat. 4: 223. 1915. Based on Panicularia nervata rigida Nash.

Panicularia rigida Rydb., F1. Rocky Mount. 83. 1917. Based on P. nervata rigida Nash.

Panicularia nervata var. filifarmis Farwell, Mich. Acad. Sci. Rept. 20: 168. 1919. Michigan, Farwell $4514 \frac{1}{2}$. 
Panicularia nervata var. purpurascens Farwell, Mich. Acad. Sci. Rept. 20: 168. 1919. Michigan, Farwell $4495 \frac{1}{2}$ (first of several specimens cited).

Panicularia nervata var. viridis Farwell, Mich. Acad. Sei. Rept. 22: 180. 1921. Michigan, Farwell 5234.

Glyceria striata var. stricta Fernald, Rhodora 31: 47. 1929. Based on Panicularia nervata stricta Scribn.

\section{(101) GYMNOPOGON Beauv.}

(1) Gymnopogon ambiguus (Michx.) B.S.P., Prel. Cat. N.Y. 69. 1888. Pre sumably based on Andropogon ambiguus Michx.

Andropogon ambiguus Michx., Fl. Bor. Amer. 1: 58. 1803. Carolina, Michaux.

Gymnopogon racemosus Beauv., Ess. Agrost. 41, 164. pl. 9. f. 3. 1812. Based on Andropogon ambiguus Michx.

Anthopogon lepturoides Nutt., Gen. Pl. 82. 1818. Banks of the Potomac, near Harpers Ferry, Va.

Gymnopogon scoparius Trin., Gram. Unifl. 237. 1824. New Jersey.

Alloiatheros lepturoides Steud., Nom. Bot. ed. 2. 1: 55. 1840, as synonym of Gymnopogon racemosus Beauv.

Stipa expansa Willd.; Steud., Nom. Bot. ed. 2. 2: 643. 1841, as synonym of Gymnopogon racemosus Beauv.

Gymnopogon distichophyllus Steud., Syn. Pl. Glum. 1: 218. 1854. Texas, Seubert Herb. [coll. Vinzent] 128; Louisiana, Hartmann 57.

Sciadonardus distichophyllus Steud., Flora 33: 229. 1850; Syn. Pl. Glum. 1: 218. 1854, as synonym of Gymnopogon distichophyllus. Louisiana, Hartmann 57.

Agrostis boeckeleri Seubert; Steud., Syn. Pl. Glum. 1: $218 . \quad 1854$, as synonym of Gymnopogon distichophyllus. Texas [Vinzent 128].

Alloiatheros ambiguus Ell.; Jacks., Ind. Kew. 1: 83. 1893, as synonym of Gymnopogon racemosus.

Alloiatheros aristatus Raf.; Jacks., Ind. Kew. 1: 83. 1893, as synonym of Gymnopogon racemosus.

(2) Gymnopogon brevifolius Trin., Gram. Unifl. 238. 1824. Delaware. Anthopogon brevifolius Nutt.; Trin., Gram. Unifl. 238. 1824, as synonym of Gymnopogon brevifolius Trin.

Anthopogon filiforme Nutt., Amer. Phil. Soc. Trans. (n.s.) 5: 152.1837. Banks of the Arkansas and in Delaware.

(3) Gymnopogon chapmanianus Hitche., Amer. Jour. Bot. 2: 306.1915. Sanford, Fla., Chase 4135.

\section{GYNERIUM Humb. and Bonpl.}

Gynerium sagittatum (Aubl.) Beauv., Ess. Agrost. 138. 1812. Based on Saccharum sagittatum Aubl.

Saccharum sagittatum Aubl., Pl. Guian. 1: 50. 1775. French Guiana.

Arundo sagittata Pers., Syn. Pl. 1: 102. 1805. Based on Saccharum sagittatum Aubl.

Gynerium saccharoides Humb. and Bonpl., Pl. Aequin. 2: 105. pl. 115.1809. Venezuela, Humboldt and Bonpland.

Gynerium procerum Beauv., Ess. Agrost. Atlas, pl. 24. f. 6. 1812. Based on Saccharum sagittatum Aubl.

Arundo saccharoides Poir., in Lam., Encycl. Sup. 4: 703. 1816. Based on Gynerium saccharoides Humb. and Bonpl.

\section{(155) HACKELOCHLOA Kuntze}

(1) Hackelochloa granularis (L.) Kuntze, Rev. Gen. Pl. 2: 776. 1891. Based on Cenchrus granularis L.

Cenchrus granularis L., Mant. Pl. 2: 575. 1771. East Indies.

Manisuris granularis 'Swartz, Prodr. Veg. Ind. Occ. 25. 1788. Based on Cenchrus granularis L. The name was earlier given (L. f. Nov. Gram. Gen. 40. pl. 1. f. 4-7. 1779) without description or basis. Manisuris, based on this species, has been credited to Swartz (not Manisuris L.), but Swartz does not propose the genus as new. He includes the original $M$. myuros L. and adds $M$. granularis.

Tripsacum granulare Raspail, Ann. Sci. Nat., Bot. 5: 306. 1825. Based on Manisuris granularis Swartz. 
Rytilix glandulosa Raf., Bull. Bot. Seringe 1: 219. 1830. Change of name or slip of the pen for "granularis", "Manisuris granularis" being cited.

Rytilix granularis Skeels, U.S.Dept.Agr., Bur. Plant Indus. Bull. 282: 20. 1913. Based on Cenchrus granularis L.

\section{(79) HELEOCHLOA Host 22}

Heleochloa alopecuroides (Pill. and Mitterp.) Host, Icon. Gram. Austr. 1: 23 . pl. 29. 1801. Based on Phleum alopecuroides Pill. and Mitterp.

Phleum alopecuroides Pill. and Mitterp., Iter Posegan. 147. pl. 16. 1783. Europe.

Crypsis alopecuroides Schrad., Fl. Germ. 1: 167. 1806. Based on Heleochloa alopecuroides Host.

(1) Heleochloa schoenoides (L.) Host, Icon. Gram. Austr. 1: 23. pl. 30. 1801. Based on Phleum schoenoides $\mathrm{L}$.

Phleun schoenoides L., Sp. Pl. 60. 1753. Southern Europe.

Crypsis schoenoides Lam., Tabl. Encycl. 1: 166. pl. 42. 1791. Based on Phleum schoenoides L. This name is spelled C. schenoides by Beauv., Ess. Agrost. 23. 1812.

\section{(150) HETEROPOGON Pers.}

(1) Heteropogon contortus (L.) Beaur.; Roem. and Schult., Syst. Veg. 2: 836 1817. Based on Andropogon contortus L.

Andropogon contortus L., Sp. Pl. 1045. 1753. India.

Heteropogon glaber Pers., Syn. Pl. 2: 533. 1807. Europe.

Heteropogon hirtus Pers., Syn. P1. 2: 533. 1807. Based on Andropogon contortus L.

Andropogon glaber Raspail, Ann. Sci. Nat., Bot. 5: 307. 1825. Not A. glaber Roxb., 1820. Based on Heteropogon glaber Pers.

Andropogon secundus Willd.; Nees, Agrost. Bras. 364. 1829, as synonym of Heteropogon contortus Willd. Described in Griseb., Fl. Brit. W. Ind. 558. 1864. Not $A$. secundus Ell., 1821. Antigua, Wullschlaegel.

Heteropogon firmus Presl, Rel. Haenk. 1: 334. 1830. Mexico, Haenke.

Andropogon firmus Kunth, Rév. Gram. 1: Sup. XXXIX. 1830. Based on Heteropogon firmus Presl.

Heteropogon contortus var. hirtus Fenzl; Hack., in Mart. Fl. Bras. 23: 267. 1883. Based on $H$. hirtus Pers.

Heteropogon contortus var. glaber Hack., in Mart., Fl. Bras. 23: 268. 1883. Based on $H$. glabcr Pers.

Andropogon contortus subvar. secundus Hack., in DC., Monogr. Phan. 6: 587. 1859. Based on A. secundus Willd.

Andropogon contortus subvar. glaber Hack., in DC., Monogr. Phan. 6: 587. 1889. Based on Heteropogon glaber Pers.

Sorghum contortum Kuntze, Rev. Gen. Pl. 2: 791. 1891. Based on Andropogon contortus L.

Holcus contortus Kuntze; Stuck., An. Mus. Nac. Buenos Aires 11: 48. 1904. Based on Andropogon contortus L.

Heteropogon contortus subvar. secundus Domin, Bibl. Bot. 85: 276.1915. Based on Andropogon contortus var. secundus Hack.

(2) Heteropogon melanocarpus (Ell.) Benth., Jour. Linn. Soc. Bot. 19: 71. 1881. Based on Andropogon melanocarpus Ell.

Andropogon melanocarpus Ell., Bot. S.C. and Ga. 1: 146. 1816. Between Altamaha and Jefferson, Ga.

Stipa melanocarpa Muhl., Descr. Gram. 183. 1817. Georgia.

Cymbopogon melanocarpus Spreng., Syst. Veg. 1: 289. 1825. Based on Andropogon melanocarpus Ell.

Trachypogon scrobiculatus Nees, Agrost. Bras. 347. 1829. Piauhy, Brazil,

[Martius].
Andropogon scrobiculatus Kunth, Rév. Gram. 1: Sup. XL. 1830. Based on Trachypogon scrobiculatus Nees.

22 The nomenclature of this genus is much confused. Heleochloa Host (Icon. Gram. 1801) appears first 22 The nomenclature of this genus is much confused. Heleochlod Host (Icon. Gram. 1801) appears
without generic description, hence is not effectively published. Beauvois (Ess. Agrost. 23. pl. 7. f. 2. 1812) without generic description, hence is not effectives, H. juncea (Agrostis juncea) and H. phalaroides (Phleum phleoides), these not included in Heleochloa by Host. Hence Heleochloa Host, as used by Beauvois, is not the same genus as that of Host himself (loc. cit. and Gram. Austr. 1827). I have, nevertheless, retained Heleochloa as generally understood, that is, as figured, though not described, by Host. 
Heteropogon acuminatus Trin., Mém. Acad. St. Pétersb. VI. Math. Phys. Nat. 2: 254. 1832. Brazil.

Heteropogon scrobiculatus Fourn., Mex. Pl. 2: 64. 1886. Based on Trachypogon scrobiculatus Nees.

Sorghum melanocarpum Kuntze, Rev. Gen. Pl. 2: 792. 1891. Based on Andropogon melanocarpus Ell.

Heteropogon melanocarpus Coult., Contrib. U.S. Natl. Herb. 2: 493.1894. Based on Stipa melanocarpa Muhl.

Spirotheros melanocarpus Raf.; Jacks., Ind. Kew. 4: 967. 1895, as synonym of Heteropogon acuminatus.

\section{(108) HIEROCHLÖ̈ R. Br.}

(1) Hierochloë alpina (Swartz) Roem. and Schult., Syst. Veg. 2: 515. 1817. Based on Holcus alpinus Swartz.

Aira alpina Liljebl., Utk. Svensk F1. 49. 1792. Not A. alpina L., 1753. Sweden. Holcus alpinus Swartz; Willd., Sp. Pl. 4: 937. 1806. Lapland.

Holcus monticola Bigel., New England Jour. Med. and Surg. 5: 334. 1816; Eaton, Man. Bot. ed. 2. 273. 1818. White Hills, N.H., Bigelow.

Hierochloa alpina var. aristata Raspail, in Saig. and Rasp., Ann. Sci. Obs. 2: 85. 1829. Based on "H. alpina R. Br." (probably in Parry's Voyage), same as Roem. and Schult.

Dimesia monticola Raf.; Jacks., Ind. Kew. 2: 760. 1893, as synonym of Holcus monticola.

Savastana alpina Scribn., Mem. Torrey Bot. Club 5: 34. 1894. Based on Holcus alpinus Swartz.

Torresia alpina Hitchc., Amer. Jour. Bot. 2: 300. 1915. Based on Holcus alpinus Swartz.

(3) Hierochloë occidentalis Buckl., Acad. Nat. Sci. Phila. Proc. 1S62: 100. 1863. Columbia woods, [Oregon], Nuttall.

Hierochloë macrophylla Thurb.; Boland., Calif. Agr. Soc. Trans. 1864-65: 132. 1866; S. Wats., Bot. Calif. 2: 265. 1880. Coast Range, Calif., Bolander 2279.

Savastana macrophylla Beal, Grasses N.Amer. 2: 187. 1896. Based on Hierochloë macrophylla Thurb.

Torresia macrophylla Hitchc., Amer. Jour. Bot. 2: 300. 1915. Based on Hierochloë macrophylla Thurb.

(2) Hierochloë odorata (L.) Beauv., Ess. Agrost. 62, 164. pl. 12. f. 5. 1812. Based on Holcus odoratus L.

Holcus odoratus L., Sp. Pl. 1048. 1753. Europe.

Avena odorata Koel., Descr. Gram. 299. 1S02. Based on Holcus odoratus L.

Holcus fragrans Willd., Sp. Pl. 4: 936. 1806. Hudson Bay, Canada.

Holcus borealis Schrad., Fl. Germ. 1: 252. 1806. Germany.

Hierochloa borealis Roem. and Schult., Syst. Veg. 2: 513. 1817. Based on Holcus borealis Schrad.

Hierochloa fragrans Roem. and Schult., Syst. Veg. 2: 514. 1S17. Based on Holcus fragrans Willd.

Hierochloa arctica Presl, Rel. Haenk. 1: 252. 1830. Nootka Sound, Vancouver Island, Haenke.

Hierochloa odorata var. fragrans Richt., Pl. Eur. 1: 31. 1890. Based on Holcus fragrans Willd.

Dimesia fragrans Raf.; Jacks., Ind. Kew. 2: 760. 1893, as synonym of Hierochloë borealis.

Savastana odorata Scribn., Mem. Torrey Bot. Club 5: 34. 1894. Based on Halcus odoratus L.

Savastana nashii Bicknell, Bull. Torrey Bot. Club 25: 104. pl. 328. 1 S9s. Van Cortlandt Park, New York City [Bicknell in 1897].

Hierochlö̈ nashii Kaczmarek, Amer. Midl. Nat. 3: 19S. 1914. Based on Savastana nashii Bicknell.

Torresia odorata Hitchc., Amer. Jour. Bot. 2: 301. 1915. Based on Holcus odoratus L.

Savastana odorata var. fragrans Farwell, Mich. Acad. Sci. Rept. 21: 350. 1920. Based on Holcus fragrans Willd.

Torresia nashii House, N.Y. State Mus. Bull. 243-244: 58. 1923. Based on Savastana nashii Bicknell. 
(88) HILARIA H.B.K.

(1) Hilaria belangeri (Steud.) Nash, N.Amer. Fl. 17: 135. 1912. Based on Anthe phora belangeri Steud.

Anthephora belangeri Steud., Syn. Pl. Glum. 1: 111. 1854. "Mexico, Belanger 1428." Belanger is evidently an error for Berlandier, since Berlandier 1428 collected between Laredo and Bejar [Bexar], now Texas, agrees with the description. Belanger collected in India.

Schleropelta siolonifera Buckl., Prel. Rept. Geol. Agr. Survey Tex. App. 1. 1866. Northwestern Texas.

Hilaria cenchroides var. texana Vasey, Contrib. U.S. Natl. Herb. 1: 53.1890. Pena, Duval County, Tex., Nealley [600].

Hilaria texana Nash, in Small, Fl. Southeast. U.S. 68. 1903. Based on Hilaria cenchroides var. texana Vasey.

Hilaria Belangeri var. Longifolia (Vasey) Hitche., Biol. Soc. Wash. Proc. 41: 162. 1928. Based on H. cenchroides var. longifolia Vasey. (Published as $H$. belangeri longifolia.)

Hilaria cenchroides var. longifolia Vasey; Amer. Acad. Sci. Proc. 24: 80. 1889, name only; Beal, Grasses N.Amer. 2: 69. 1896. Islands in Guaymas harbor, Mexico, Palmer 347 in 1887.

(3) Hilaria jamesii (Torr.) Benth., Jour. Linn. Soc. Bot. 19: 62. 1881. Based on Pleuraphis jamesii Torr.

Pleuraphis jamesii Torr., Ann. Lyc. N.Y. 1: 148. pl. 10. 1824. Sources of the Canadian River [Texas or New Mexico], James.

Hilaria sericea Benth., Jour. Linn. Soc. Bot. 19: 62. 1881. Name only.

Pleuraphis sericea Nutt.; Benth., Jour. Linn. Soc. Bot. 19: 62. 1881, as synonym of Hilaria sericea Benth. [Harris Fork of the Colorado, Nuttall.]

(2) Hilaria mutica (Buckl.) Benth., Jour. Linn. Soc. Bot. 19: 62. 1881. Based on Pleuraphis mutica Buckl.

Pleuraphis mutica Buckl., Acad. Nat. Sci. Phila. Proc. 1862: 95. 1863. Northern Texas [Wright 760-2108].

(4) Hilaria rigida (Thurb.) Benth.; Scribn., Bull. Torrey Bot. Club 9: 86. 1882. Based on Pleuraphis rigida Thurb.

Pleuraphis rigida Thurb., in S. Wats., Bot. Calif. 2: 293. 1880. California, Fort Mojave and Providence Mountains, Cooper [2230, the type]; Fort Yuna, Thomas; Colorado Desert, Schott.

\section{(59) HOLCUS L.}

(1) Holcus lanatus L., Sp. Pl. 1048. 1753. Europe.

Aira holcus-lanata Vill., Hist. Pl. Dauph. 2: 87. 1787. Based on Holcus lanatus L.

Avena pallida Salisb., Prodr. Stirp. 24. 1796. Not A. pallida Thunb. 1794. Based on Holcus lanatus L.

Avena lanata Koel., Descr. Gram. 300. 1802. Based on Holcus lanatus L. Same published by Cav., Descr. Pl. 308. 1802.

Ginannia pubescens Bubani, Fl. Pyr. 4: 321. 1901. Based on Holcus lanatus L.

Notholcus lanatus Nash; Hitchc., in Jepson, Fl. Calif. 1: 126. 1912. Based on Holcus lanatus L.

Nothoholcus lanatus Nash, in Britt. and Brown, Illustr. Fl. ed. 2. 1: 214. 1913. Based on Holcus lanatus L.

Ginannia lanata F. T. Hubb., Rhodora 18: 234. 1916. Based on Holcus lanatus L.

(2) Holcus mollis L. Syst., Nat. ed. 10. 2: 1305. 1759. Europe.

Aira mollis Schreb., Spic. Fl. Lips. 51. 1771. Based on Holcus mollis L.

Aira holcus-mallis Vill., Hist. Pl. Dauph. 2: 88. 1787. Based on Holcus mollis L.

Avena sylvatica Salisb., Prodr. Stirp. 24. 1796. Based on Holcus mollis L.

Avena mollis Koel., Descr. Gram. 300. 1802. Not A. mollis Salisb., 1796. Based on Holcus mollis L.

Ginannia mollis Bubani, Fl. Pyr. 4: 321. 1901. Based on Holcus mollis L.

Notholcus mollis Hitchc., Amer. Jour. Bot. 2: 304. 1915. Based on Holcus mollis L. 


\section{(46) HORDEUM L.}

(6) Hordeum adscendens H.B.K., Nov. Gen. and Sp. 1: 280. 1816. Near Mexico City, Humboldt and Bonpland.

Hordeum distichon L., Sp. Pl. 85. 1753. Cultivated.

(5) Hordeum gussonianum Parl., Fl. Palerm. 1: 246. 1845. Italy.

Hordeum maritimum var. gussonianum Richt., Pl. Eur. 1: 131. 1890. Based on H. gussonianum Parl.

Hordeum nodosum depressum Scribn. and Smith, U.S.Dept.Agr., Div. Agrost. Bull. 4: 24. 1897. [Type, Lexington, Oreg., Leiberg 39.]

Hordeum marinum subsp. gussonianum Thell., Vierteljahrs. Nat. Ges. Zürich 52: 441. 1908. Based on H. gussonianum Parl.

Hordeum depressum Rydb., Bull. Torrey Bot. Club 36: 539. 1909. Based on $H$. nodosum depressum Scribn. and Smith.

Hordeum hexastichon L., Sp. Pl. 85. 1753. Cultivated.

(2) Hordeum jubatum L., Sp. Pl. 85. 1753. Canada, Kalm.

?Critesion geniculatum Raf., Jour. Plyys. Chym. 89: 103. 1819. Illinois.

?Elymus jubatus Link, Hort. Berol. 1: 19. 1827. Garden specimen, Hordeum jubatum L., doubtfully cited as synonym.

Hordeum Jobatum var. Caespitosum (Scribn.) Hitche., Biol. Soc. Wash. Proc. 41: 160. 1928. Based on H. caespitosum Scribn. (Published as $H$. jubatum caespitosum.)

Hordeum caespitosum Scribn., Davenport Acad. Sci. Proc. 7: 245. 1899. Edgemont, S.Dak., Pammel 143; Geranium Park, Wyo., Pammel 157 [type].

Hordeum marinum Huds., Fl. Angl. ed. 2. 57. 1778. England.

Hordeum maritimum With., Bot. Arr. Veg. Brit. ed. 2. 1: 127. 1787. Based on H. marinum Huds.

(1) Hordeum montanense Scribn.; Beal, Grasses N.Amer. 2: 644. 1896. Montana, Scribner 429, 430.

Hordeum pammeli Scribn. and Ball, Iowa Geol. Survey Sup. Rept. 1903: 335. 1905. Dakota City, Iowa, Pammel 3824.

(7) Hordeum murinum L., Sp. Pl. 85. 1753. Europe.

Triticum murale Salisb., Prodr. Stirp. 27. 1796. Based on Hordeum murinum L.

Zcocriton murinum Beauv., Ess. Agrost. 115, 182. 1812. Based on Hordeum murinum L.

(3) Hordeum nodosum L., Sp. Pl. ed. 2. 1: 126. 1762. Europe.

Hordeum pratense Huds., Fl. Angl. ed. 2. 56.1778. England.

Zeocriton nodosum Beauv., Ess. Agrost. 115, 165, 182. 1812. Based on IIordeum nodosum L.

Hordeum pratense var. nodosum Griseb., in Ledeb., Fl. Ross. 4: 329. 1853. Based on $H$. nodosum L.

Hordeum nodosum var. Boreale (Scribn. and Smith) Hitche., Amer. Jour. Bot. 21: 134. 1934. Based on H. boreale Scribn. and Snith.

Hordeum boreale Seribn. and Smith, U.S.Dept.Agr., Div. Agrost. Bull. 4: 24. 1897. Aleutian Islands [type, Atka Island, Turner 1193] and Alaska to California.

(4) Hordeum pusillum Nutt., Gen. Pl. 1: 87. 1818. Plains of the Missouri, [Nuttall].

Hordeum riehlii Steud., Syn. Pl. Glum. 1: 353. 1854. St. Louis, Mo., Riehl 181.

Hordeum pusillum var. PUbens Hitchc., Jour. Wash. Acad. Sci. 23: 453.1933. La Verkin, Utah, Jones $5196 \mathrm{~W}$.

Hordeum spontaneum C. Koch, Linnaea 21: 430. 1848. Caucasus.

(8) Hordeum vulgare L., Sp. Pl. 84. 1753. Cultivated in Europe.

Hordeum sativum Pers., Syn. Pl. 1: 108. 1805, as synonym of H. vulgare L.

IIordeum polystichum var. vulgare Doell, Rhein. Fl. 67. 1843. Based on H. vulgare L.

Hordeum sativum var. vulgare Richt., Pl. Eur. 1: 130. 1890. Based on H. vulgare L.

Hordeum vulgare var. Trifurcatum (Schlecht.) Alefeld, Landw. F1. 341.1866. Based on H. trifurcatum Jess. (probably error for Wender.).

Hordeum cocleste var. trifurcatum Schlecht., Limnea 11: 543. 1837. Cultivated at Halle, seed from Montpellier.

Hordeum trifurcatum Wender., Flora 26: 233. 1843. Cultivated in Marburg, Germany. 


\section{(116) HYDROCHLOA Beauv.}

(1) Hydrochloa caroliniensis Beauv., Ess. Agrost. 135, 165, 182. pl. 3. f. 18; pl. 24. f. 4. 1812. No specific description except explanation of figures. "Zizania natans Mich." (an unpublished name) is cited under the genus, and $Z$. fluitans Michx. is referred in the index to Hydrochloa. The name for pl. 3. f. 18 is given as $H$. caroliniana.

Zizania fluitans Michx., Fl. Bor. Amer. 1: 75. 1803. Not Hydrochloa fluitans Hartm., 1819. The published locality, Lake Champlain, is an error. The type specimen indicates Charleston, S.C., Michaux.

Zizania natans Michx.; Beauv., Ess. Agrost. 136. 1812, name only; Bosc, in Trin., Mém. Acad. St. Pétersb. VI. Sci. Nat. $3^{1}$ : $186 . \quad 1840$, as synonym of Hydrochloa caroliniensis Beauv. The name is misspelled Zizania nutans in Steud., Nom. Bot. ed. 2. 2: 799. 1841.

Luziola caroliniensis Raspail, Ann. Sci. Nat., Bot. 5: 304. 1825. Based on Hydrochloa caroliniensis Beauv.

Hydrochloa fluitans Torr., Comp. FI. North. Mid. States 354, 403.1826. Not H. fluitans Hartm., 1819. Based on Zizania fluitans Michx.

Hydropyrum fluitans Kunth, Rév. Gram. 1: 7. 1829. Based on Zizania fluitans Michx.

Luziola caroliniana Trin.; Steud., Nom. Bot. ed. 2. 2: 79. 1841. Based on Zizania natans Bosc.

(146) HYPARRHENIA Anderss.

Hyparrhenia hirta (L.) Stapf, in Prain, Fl. Trop. Afr. 9: 315. 1918. Based on Andropogon hirtus L.

Andropogon hirtus L., Sp. Pl. 1046. 1753. Southern Europe and Asia Minor. Trachypogon hirtus Nees, Agrost. Bras. 346. 1829. Based on Andropogon hirtus L.

Sorghum hirtum Kuntze, Rev. Gen. Pl. 2: 792. 1891. Based on Andropogon hirtus L.

(1) Hyparrhenia rufa (Nees) Stapf, in Prain, Fl. Trop. Afr. 9: 304. 1918. Based on Trachypogon rufus Nees.

Trachypogon rufus Nees, Agrost. Bras. 345. 1829. Piauhy, Brazil, Martius. Andropogon rufus Kunth, Rév. Gram. 1: Sup. XXXIX. 1830. Based on Trachypogon rufus Nees.

Sorghum rufum Kuntze, Rev. Gen. Pl. 2: 792. 1891. Based on Andropogon rufus Kunth.

Cymbopogon rufus Rendle, Cat. Afr. Pl. Welw. 2: 155. 1899. Based on Andropogon rufus Kunth.

(45) HYSTRIX Moench

(2) Hystrix californica (Boland.) Kuntze, Rev. Gen. Pl. 2: 778. 1891. Based on Gymnostichum californicum Boland.

Gymnostichum californicum Boland.; Thurb., in S. Wats., Bot. Calif. 2: 327. 1880. Near San Francisco, Bolander; Sausalito, Kellogg and Harford 1107.

Asperella californica Beal, Grasses N.Amer. 2: 657. 1896. Based on Gymnostichum californicum Boland.

Asprella californica Benth.; Beal, Grasses N.Amer. 2: 657. 1896, as synonym of Asperella californica.

(1) Hystrix patula Moench, Meth. Pl. 295. 1794. Based on Elymus hystrix L. Elymus hystrix L., Sp. Pl. 560. 1753. [Virginia, Clayton.]

Asperella hystrix Humb.; Mag. Bot. Roem. and Ust. 7: 5. 1790. Based on Elymus hystrix L.

Asprella hystrix Wild., Enum. Pl. 132. 1809. Based on Elymus hystrix L.

Gymnostichum hystrix Schreb., Beschr. Gräs. 2: 127. pl. 47. 1810. Based on Elymus hystrix L.

Zeocriton hystrix Beauv., Ess. Agrost. 115, 182. 1812. Presumably based on Elymus hystrix L.

Asperella echidnea Raf., Amer. Monthly Mag. 4: 190. 1819. Based on Elymus hystrix $\mathrm{L}$.

Elymus pseudohystrix Schult., Mant. 2: 427. 1824. Based on "Elymus hystrix Nutt." (error for L., Nuttall applying the Linnaean name correctly).

Asprella americana Nutt., Amer. Phil. Soc.Trans. (n.s.) 5: 151. 1837. Arkansas, Nuttall. 
Asprella angustifolia Nutt., Amer. Phil. Soc. Trans. (n.s.) 5: 151. 1837. Arkansas, Nuttall.

Asprella major Fres.; Steud., Nom. Bot. ed. 2. 1: 152. 1840, as synonym of Elymus hystrix L.

Hystrix hystrix Millsp., Fl. W.Va. 474. 1892. Based on Elymus hystrix L.

Hystrix elymoides Mackenz. and Bush, Man. Fl. Jackson County 39. 1902. Based on Elymus hystrix L.

Hordeum hystrix Schenck, Bot. Jahrb. Engler 40: 109. 1907. Not H. hystrix Roth, 1797. Based on Elymus hystrix L.

Gymnostichum patulum Lunell, Amer. Midl. Nat. 4: 228. 1915. Based on Hystrix patula Moench.

Asperella hystrix var. bigeloviana Fernald, Rhodora 24: 230. 1922. Hanover, Conn., Hilliams in 1910.

Hystrix patula var. bigeloviana Deam, Ind. Dept. Conserv. Pub. 82: 117. 1929. Based on Asperella hystrix var. bigeloviana Fernald.

\section{(140) IMPERATA Cyrillo}

(1) Imperata brasiliensis Trin., Mém. Acad. St. Pétersb. VI. Math. Phys. Nat. 2: 331 . 1832. Brazil.

Imperata brasiliensis var. mexicana Rupr., Bull. Acad. Sci. Brux. 92: 245. 1S42. Name only. Mexico, Galeotti 5678.

Imperata arundinacea var. americana Anderss., Öfv. Svensk. Vet. Akad. Förh. 12: 160. 1855. British Guiana, Schomburgk 665; Mexico, Galeotti 5678; Chile, D'Urville.

This is the species described as Imperata caudata Cyrillo, in Chapm., Fl. South. U.S. ed. 2. 668 . 1883.

Imperata cylindrica (L.) Beauv., Ess. Agrost. 8, 165, 166, 177. pl. 5. f. 1. 1812. Based on Lagurus cylindricus L.

Lagurus cylindricus L., Syst. Nat. ed. 10. 2: 878. 1759. Europe.

Saccharum cylindricum Lam., Encycl. 1: 594. 1783. Based on Lagurus cylindricus L.

Imperata arundinacea Cyrillo, Pl. Rar. Neap. 2: 27. pl. 11. 1788. Italy.

(2) Imperata hookeri Rupr.; Anderss., Off. Svensk. Vet. Akad. Förh. 12: 160. 1855. Texas, Drummond II. 283.

Imperata brevifolia Vasey, Bull. Torrey Bot. Club 13: 26. 1886. Southern California, Parish 1031 [type]; New Mexico, Wright 2001.

\section{(52) KOELERIA Pers.}

(1) Koeleria cristata (L.) Pers., Syn. Pl. 1: 97. 1805. "Poa cristata auctorum", presumably Poa cristata L., used by Willd. (Sp. Pl. 1: 402. 1797), Lamarck (Tabl. Encycl. 1: 182. 1791), and others.

Aira cristata L., Sp. P1. 63. 1753. Europe.

Poa cristata L., Syst. Nat. ed. 12. 94. 1767. Based on Aira cristata L.

Festuca cristata Vill., Hist. Pl. Dauph. 1: 250. 1786. Not F. cristata L., 1753. Based on Aira cristata L.

Koeleria gracilis Pers., Syn. P1. 1: 97. 1805. Europe.

Koeleria nitida Nutt., Gen. Pl. 1: 74. 1818. Plains of the Missouri.

Aira gracilis Trin., Fund. Agrost. 144. 1820. Based on Koeleria gracilis Pers.

Airochtoa cristata Link, Hort. Berol. 1: 127. 1827. Based on Aira cristata L. The specific name was misspelled "aristata" in Link, Handb. Gewächs. 1: 64. 1829.

Airochloa gracilis Link, Hort. Berol. 2: 276. 1827. Based on Koeleria gracilis Pers.

Koeleria cristata var. nuttali Wood, Class-book ed. 2. 613. 1847. Presumably based on K. nitida Nutt.

Koeleria cristata var. gracilis A. Gray, Man. 591. 1848. No definite locality cited. Presumably based on $K$. gracilis Pers.

Brachystylus cristatus Dulac, Fl. Haut. Pyr. 85. 1867. Based on Koeleria cristata Pers.

Kocleria nitida var. arkansana Scribn., Kans. Acad. Sci. Trans. 9: 118. 1885. [Arkansas.]

Koeleria arkansana Nutt.; Scribn., Kans. Acad. Sci. Trans. 9: 118.1885. [Arkansas, Nuttall], as synonym of $K$. nitida var. arkansana.

Achaeta geniculata Fourn., Mex. Pl. 2: $109.1886 . \quad$ Mexico, Liebmann 609.

Kocleria cristata var. major Vasey in Macoun, Cat. Can. Pl. 24: 218. 1888. Not $K$. cristata var. major Koch, 1837. Name only, for Macoun, Vancouver Island. 
Koeleria cristata var. pubescens Vasey; Davy, in Jepson, Fl. West. Mid. Calif. 61. 1901. Not $K$. cristata var. pubescens Mutel, 1837. San Francisco, Calif., Michener and Bioletti.

Koeleria cristata var. longifolia Vasey; Davy, in Jepson, Fl. West. Mid. Calif. 61. 1901. Santa Cruz County, Calif., Anderson.

Koeleria cristata pinetorum Abrams, Fl. Los Angeles 46. 1904. Based on K. cristata var. pubescens Vasey.

Koeleria pseudocristata var. californica Domin, Magyar Bot. Lapok 3: 264. 1904. San Diego, Calif., Pringle in 1882.

Koeleria elegantula Domin, Bibl. Bot. 65: 172. 1907. Gunnison, Colo., Baker 578.

Koeleria robinsoniana Domin, Bibl. Bot. 65: 172. 1907. Wenatchee, Wash., Whited 1131.

Koeleria robinsoniana var. australis Domin, Bibl. Bot. 65: 172. 1907. Blalocks, Oreg., Leckenby 28 in 1900.

Koeleria gracilis var. dasyclada Domin, Bibl. Bot. 65: 211. 1907. California, Lemmon in 1882.

Koeleria pseudocristata Domin, Bibl. Bot. 65: 222. 1907. With two American forms: densevestita, California, Hall 2206; laxa, California, Heller 7443.

Koeleria pseudocristata var. longifolia Domin, Bibl. Bot. 65: 224. 1907. California, Nuttall.

Koeleria pseudocristata var. oregana Domin, Bibl. Bot. 65: 224. 1907. Oregon, Nuttall.

Koeleria pseudocristata var. pseudonitida Domin, Bibl. Bot. 65: 224. 1907. Wyoming, Nelson 273.

Koeleria polyantha var. californiensis Domin, Bibl. Bot. 65: 226. 1907. San Jacinto Mountains, Calif., Hall 2131.

Koeleria nitida var. missouriana Domin, Bibl. Bot. 65: 233. 1907. St. Louis, Riehl 44; Courtney, Mo., Bush 773.

Koeleria nitida var. californica Domin, Bibl. Bot. 65: 233. 1907. Based on K. pseudocristata var. californica Domin. With three subvarieties from California: transiens, Brandegee 3678; multiflora, Parish Brothers 855; vestita, Palmer 405.

Kocleria nitida var. sublanuginosa Domin, Bibl. Bot. 65: 234. 1907. Miranda, S.Dak., Griffiths 235. With subvar. pubiflora, Washington, Lyall in 1860.

Koeleria nitida var. laxa Domin, Bibl. Bot. 65: 235. 1907. Arizona, Palmer in 1890; New Mexico, Metcalfe.

Koeleria nitida var. subrepens Domin, Bibl. Bot. 65: 235. 1907. Arboles, Colo., Baker 185.

Koeleria nitida var. munita Domin, Bibl. Bot. 65: 235. 1907. Montana, Rydberg 3294.

Koeleria nitida var. latifrons Domin, Bibl. Bot. 65: 236. 1907. Nebraska, Rydberg.

Koeleria nitida var. breviculmis Domin, Bibl. Bot. 65: 236. 1907. Colorado, Baker, Earle, and Tracy 114.

Koeleria nitida var. caudata Domin, Bibl. Bot. 65: 236. 1907. Wisconsin, Kumlien 99.

Koeleria idahoensis Domin, Bibl. Bot. 65: 237. 1907. Lewiston, Idaho, Heller 309 (error for 3091).

Koeleria idahoensis var. pseudocristatoides Domin, Bibl. Bot. 65: 238.1907. Nez Perce County, Idaho, Heller 3291.

Koeleria macrura Domin, Bibl. Bot. 65: 238. 1907. With three forms: quadriflora, Arizona, Nealley in 1891; triflora, Organ Mountains, N.Mex., Wooton 110; biflora, Chiricahua Mountains, Ariz., Toumey in 1896.

Koeleria latifrons Rydb., Brittonia 1: 84. 1931. Based on $K$. nitida var. latifrons Domin.

(2) Koeleria phleoides (Vill.) Pers., Syn. Pl. 1: 97. 1805. Based on Festuca phleoides Vill.

Festuca phleoides Vill., FI. Delph. 7. 1785. Europe.

Koeleria brachystachys DC., Cat. Hort. Monsp. 120. 1813. Europe.

Lophochloa phlcoides Reichenb., Fl. Germ. 42. 1830. Based on Festuca phleoides Vill.

(74) LAGURUS L.

(1) Lagurus ovatus L., Sp. Pl. 81. 1753. Southern Europe. 
(23) LAMARCKIA Moench

(1) Lamarckia aurea (L.) Moench, Meth. Pl. 201. 1794. Based on Cynosurus aureus $\mathrm{L}$.

Cynosurus aureus L., Sp. Pl. 73. 1753. Europe.

Chrysurus cynosuroides Pers., Syn. P1. 1: 80. 1805. Based on Cynosurus aureus $\mathrm{L}$.

Chrysurus aureus Beauv.; Spreng., Syst. Veg. 1: 296. 1825. Based on Cynosurus aureus L.

Achyrodes aureum Kuntze, Rev. Gen. Pl. 2: 758. 1891. Based on Cynosurus aureus L.

(130) LASIACIS (Griseb.) Hitchc.

(i) Lasiacis divaricata (L.) Hitchc., Contrib. U.S. Natl. Herb. 15: 16.1910. Based on Panicum divaricatum L.

Panicum divaricatum L., Syst. Nat. ed. 10. 2: S71. 1759. Jamaica, Browne. Panicum bambusioides Desv.; Hamilt., Prodr. Pl. Ind. Occ. 10. 1825. Puerto Rico.

Panicum chauvinii Steud., Syn. Pl. Glum. 1: 68. 1854. Guadeloupe, Duchaissing.

Panicum divaricatum var. stenostachyum Griseb., Fl. Brit. W. Ind. 551. 1864. Jamaica, Alexander, Wilson, March [type].

\section{(112) LEERSIA Swartz}

(4) Leersia hexandra Swartz, Prodr. Veg. Ind. Occ. 21. 1788. Jamaica, Swartz. Asprella hexandra Beauv., Ess. Agrost. 2, 153. 1812. Based on Leersia hexandra Swartz.

Leersia mexicana H.B.K., Nov. Gen. and Sp. 1: 195. 1816. Mexico, Humboldi and Bonpland.

Asprella mexicana Roem. and Schult., Syst. Veg. 2: 267. 1817. Based on Leersia mexicana H.B.K.

Leersia contracta Nees, Agrost. Bras. 516. 1829. Brazil, Sellow.

Leersia elongata Willd.; Trin., Mém. Acad. St. Pétersb. VI. Sci. Nat. 31: 172. 1840 , as synonym of $L$. mexicana H.B.K.

Oryza hexandra Doell, in Mart., Fl. Bras. 22: 10. 1871. Based on Leersia hexandra Swartz.

Oryza mexicana Doell, in Mart., Fl. Bras. 22: 10. 1871. Based on Leersia mexicana H.B.K.

Leersia gouinii Fourn., Mex. Pl. 2: 2. 1886. Vera Cruz, Mexico, Gouin.

Homalocenchrus gouinii Kuntze, Rev. Gen. PI. 2: 777. 1891. Based on Leersia gouinii Fourn.

Homalocenchrus hexandrus Kuntze, Rev. Gen. Pl. 2: 777. 1891. Based on Leersia hexandra Swartz.

Leersia dubia Areschoug, Svensk Freg. Eugenies Resa 1910: 115. 1910. Ecuador, Andersson.

(1) Leersia lenticularis Michx., Fl. Bor. Amer. 1: 39. 1803. Illinois, Michaux.

Asprella lenticularis Beaur., Ess. Agrost. 2, 153. 1812. Based on Leersia lenticularis Michx.

Zizania lenticularis Michx.; Beaur., Ess. Agrost. 182. 1812. Name only, doubtless error for Leersia lenticularis Michx.

Leersia ovata Poir., in Lam., Encycl. Sup. 3: 329. 1813. North America.

Asprella ovata Roem. and Schult. Syst. Veg. 2: 267. 1817. Based on Leersia ovata Poir.

Homalocenchrus lenticularis Kuntze, Rev. Gen. Pl. 2: 777. 1891. Based on Leersia lenticularis Michx.

Homalocenchrus ovata Kuntze, Rev. Gen. P1. 2: 777. 1891. Based on Leersia ovata Poir.

Endodia lenticularis Raf.; Jacks., Ind. Kew. 2: 840. 1893, as synonym of Leersia lenticularis Michx.

(5) Leersia monandra Swartz, Prodr. Veg. Ind. Occ. 21. 1788. Jamaica, Swartz.

Asprella monandra Beauv., Ess. Agrost. 2, 153. 1812. Based on Leersia monandra Swartz. 
Paspalum cubense Spreng., Neu. Entd. 3: 12. 1822. Cuba and neighboring islands.

Oryza monandra Doell, in Mart., Fl. Bras. 22: 9. 1871. Based on Leersia monandra Swartz.

Homalocenchrus monandrus Kuntze, Rev. Gen. Pl. 2: 777. 1891. Based on Leersia monandra Swartz.

(2) Leersia oryzoides (L.) Swartz, Prodr. Veg. Ind. Occ. 21. 1788. Based on Phalaris oryzoides L.

Phalaris oryzoides L., Sp. Pl. 55. 1753. Virginia.

Homalocenchrus oryzoides Poll., Hist. Pl. Palat. 1: 52. 1776. Based on Phalaris oryzoides $\mathrm{L}$.

Ehrhartia clandestina Web., Prim. Fl. Hols. 64. 1780. Based on Phalaris oryzoides L.

Asperella oryzoides Lam., Tabl. Encycl. 1: 167. 1791. Based on Phalaris oryzoides L.

Asprella oryzoides Beauv., Ess. Agrost. 2, 153. pl. 4. f. 2. 1812 . Based on Phalaris oryzoides L.

Leersia asperrima Willd.; Trin., Mém. Acad. St. Pétersb. VI. Sci. Nat. ${ }^{1}$ : 171. 1840 , as synonym of $L$. oryzoides Swartz.

Oryza clandestina A. Br., in Aschers., Fl. Brand. 799. 1864. Based on Ehrhartia clandestina Web.

Laertia oryzoides Gromow., in Trautv., Act. Hort. Petrop. 9: 354. 1884. Error for Leersia oryzoides Swartz.

Oryza clandestina forma inclusa Wiesb., in Baenitz., Deut. Bot. Monatsschr. 15: 19. 1897. Hungary.

Leersia oryzoides forma glabra A. A. Eaton, Rhodora 5: 118. 1903. Newburyport, Mass.

Oryza oryzoides Dalla Torre and Sarnth. Fl. Tirol 6: 142. 1906. Based on Phalaris oryzoides L.

Leersia oryzoides forma inclusa Dörfl., Herb. Norm. Sched. Cent. 55-56. 164. 1915. Based on Oryza clandestina forma inclusa Wiesb. (Published as new, Fogg, Rhodora 30: 84. 1928, same basis.)

(3) Leersia virginica Willd., Sp. Pl. 1: 325. 1797. North America.

Asprella virginica Beauv., Ess. Agrost. 2, 153. 1812. Based on Leersia virginica Willd.

Leersia imbricata Poir., in Lam., Encycl. Sup. 3: 329. 1813. Carolina, Bosc. Asprella imbricata Roem. and Schult., Syst. Veg. 2: 268. 1817. Based on Leersia imbricata Poir.

Leersia virgata Raf., Bull. Bot. Seringe 1: 220. 1830 [probably error for $L$. virginica]. Cited as type of the genus Aplexia, but the name not transferred.

Homalocenchrus virginicus Britton, N.Y. Acad. Sci. Trans. 9: 14.1889. Based on Leersia virginica Willd.

Aplexia virgata Raf.; Jacks., Ind. Kew. 1: 162. 1893, as synonym of Leersia virginica.

Aplexia virginica Raf.; Jacks., Ind. Kew. 1: 162. 1893, as synonym of Leersia virginica.

\section{(90) LEP'TOCHLOA Beauv.}

(2) Leptochloa chloridiformis (Hack.) Parodi, Physis 4: 184. 1918. Based on Diplachne chloridiformis Hack.

Diplachne chloridiformis Hack., in Stuck., An. Mus. Nac. Buenos Aires 13: 498. 1906. Prov. Córdoba, Argentina, Stuckert 2329.

(4) Leptochloa domingensis (Jacq.) Trin., Fund. Agrost. 133. 1820. Based on Cynosurus domingensis Jacq.

Cynosurus domingensis Jacq., Misc. Austr. 2: 363. 1781. Dominican Republic.

Festuca domingensis Lam., Tabl. Encycl. 1: 189. 1791. Based on Cynosurus domingensis Jacq.

Eleusine domingensis Pers., Syn. Pl. 1: 87. 1805. Based on Cynosurus domingensis Jacq.

Rabdochloa domingensis Beauv., Ess. Agrost. 84, 176. 1812. Based on Cynosurus domingensis Jacq.

Leptostachys domingensis G. Meyer, Prim. Fl. Esseq. 74. 1818. Based on Eleusine domingensis Pers.

Cynodon domingense Raspail, Ann. Sci. Nat., Bot. 5: 302. 1825. Based on Rabdochloa domingensis Beauv. 
Leptochloa virgata var. domingensis Link; Griseb., F1. Brit. W. Ind. 538. 1864. Based on L. domingensis Link (same as L. domingensis Trin.).

Diplachne domingcnsis Chapm., Fl. South. U.S. ed. 3. 609. 1897. Based on Leptochloa domingensis Link (same as L. domingensis Trin.).

(1) Leptochloa dubia (H.B.K.) Nees, Syll. Pl. Ratisb. 1: 4. 1824. Based on Chioris dubia H.B.K.

Chloris dubia H.B.K., Nov. Gen. and Sp. 1: 169. 1816. Mexico, Humboldt and Bonpland.

Leptostachys dubia G. Meyer, Prim. Fl. Esseq. 74. 1818. Based on Chloris dubia H.B.K.

Festuca obtusiflora Willd.; Spreng., Syst. Veg. 1: 356. 1825. Mexico.

Schismus patens Presl, Rel. Haenk. 1: 269. 1830. Chile, Haenke.

Leptochloa patens Kunth, Rév. Gram. 1: Sup. XXII. 1830. Based on Schismus patens Presl.

Leptochloa obtusiflora Trin.; Steud., Nom. Bot. ed. 2. 2: 30. 1841, as synonym of $L$. dubia Nees.

Diplachne patens Desv., in Gay, Fl. Chil. 6: 371. 1853. Based on Schismus patens Presl.

Uralepis brevicuspidata Buckl., Acad. Nat. Sci. Phila. Proc. 1862: 93. 1863. Texas, [Wright 767].

Ipnum mendocinum R. A. Phil., An. Univ. Chile 36: 211. 1870. Mendoza. Argentina.

Diplachne dubia Scribn., Bull. Torrey Bot. Club 10: 30. 1883. Based on Leptochloa dubia Nees.

Molinia retusa Griseb.; Fourn., Mex. Pl. 2: 147. 1886, as synonym of Leptochloa dubia Nees.

Diplachne dubia var. aristata Vasey, Calif. Acad. Sci. Proc. II. 2: 213.1889. Name only. Baja California, Brandegee.

Leptochloa pringlei Beal, Grasses N.Amer. 2: 436. 1896. Arizona, Pringle in 1884.

Diplachne pringlei Vasey; Beal, Grasses N.Amer. 2: 436. 1896, as synonym of Leptochloa pringlei.

Diplachne mendocina Kurtz, Bol. Acad. Cienc. Córdoba 15: 521. 1897. Based on Ipnum mendocinum R. A. Phil.

Diplachne dubia var. pringleana Kuntze, Rev. Gen. Pl. 32: 349. 1898. Chihuahua, Mexico, Pringle 422.

Diplachne dubia var. humboldtiana Kuntze, Rev. Gen. Pl. 32: 349. 1898. Presumably the original form collected by Humboldt and Bonpland.

Leptochola dubia pringleana Scribn. and Merr., U.S.Dept.Agr., Div. Agrost. Bull. 24: 27. 1901. Based on Diplachne dubia var. pringleana Kuntze.

Rabdochola dubia Kuntze; Stuck., An. Mus. Nac. Buenos Aires 11: 121. 1904. Based on Leptochloa dubia Nees.

Sieglingia dubia Kuntze; Stuck., An. Mus. Nac. Buenos Aires 11: 128. 1904. Based on Chloris dubia H.B.K.

Eragrostis mendozina Jedw., Bot. Archiv Mez 5: 192. 1924. Based on Ipnum mendocinum Phil.

(7) Leptochloa fascicularis (Lam.) A. Gray, Man. 588. 1848. Based on Festuca fascicularis Lam.

Festuca fascicularis Lam., Tabl. Encycl. 1: 189. 1791. South America.

Festuca polystachya Michx., Fl. Bor. Amer. 1: 66. 1803. Illinois, Michaux.

Diplachne fascicularis Beauv., Ess. Agrost. 81, 160. pl. 16. f. 9. 1812. Based on Festuca fascicularis Lam.

Festuca procumbens Muhl., Descr. Gram. 160. 1817. Carolina.

Festuca clandestina Muhl., Deser. Gram. 162. 1817. New York.

Festuca aquatica Bosc; Roem. and Schult., Syst. Veg. 2: 615. 1817, as synonyn of Diplachne fascicularis Beauv.

Cynodon fascicularis Raspail, Ann. Sci. Nat. Bot. 5: 303. 1825. Based on Diplachne fascicularis Beauv.

Leptochloa polystachya Kunth, Rév. Gram. 1: 91. 1829. Based on Festuca polystachya Michx.

Diachroa procumbens Nutt., Amer. Phil. Soc. Trans. (n.s.) 5: 147.1837. Based on Festuca procumbens Muhl.

Festuca texana Steud., Syn. Pl. Glum. 1: 310. 1854. Texas, Drummond 387.

Uralepsis composita Buckl., Acad. Nat. Sci. Phila. Proc. 1862: 94.1863. New Mexico, Woodhouse. 
Diplachne patens Fourn.; Hemsl., Biol. Centr. Amer. Bot. 3: 570. 1885, name only; Mex. Pl. 2: 148. 1886. Not D. patens Desv., 1853. Vera Cruz, Mexico, Gouin 93.

Diplachne tracyi Vasey, Bull. Torrey Bot. Club 15: 40. 1888. Reno, Nev., Tracy [216].

Leptochloa tracyi Beal, Grasses N.Amer. 2: 436. 1896. Based on Diplachne tracyi Vasey.

Festuca prostrata Muhl.; Scribn. and Merr., U.S.Dept.Agr., Div. Agrost. Circ. 27: 5 . 1900, as synonym of $F$. procumbens Muhl.

Diplachne procumbens Nash, in Britton, Man. 128. 1901. Not D. procumbens Arech., 1896. Based on Festuca procumbens Muhl.

Diplachne acuminata Nash, in Britton, Man. 128. 1901. Arkansas to Nebraska and Colorado. ['Type, Kansas, Thompson.]

Diplachne maritima Bicknell, Bull. Torrey Bot. Club 35: 195. 1908. Based on D. procumbens Nash.

(5) Leptochloa filiformis (Lam.) Beauv., Ess. Agrost. 71, 161, 166.1812. Based on Festuca filiformis Lam.

Festuca filiformis Lam., Tabl. Encycl. 1: 191. 1791. South America.

Eleusine mucronata Michx., Fl. Bor. Amer. 1: 65. 1803. Illinois, Michaux.

Eleusine filiformis Pers., Syn. Pl. 1: 87. 1805. South America.

?Eleusine sparsa Muhl., Descr. Gram. 135. 1817. Carolina and Georgia.

Oxydenia attenuata Nutt., Gen. Pl. 1: 76. 1818. New Orleans, La. [Nuttall].

Leptostachys filiformis G. Meyer, Prim. Fl. Esseq. 74. 1818. Based on Eleusine filiformis Pers.

Leptochloa mucronata Kunth, Rév. Gram. 1: 91. 1829. Based on Eleusine mucronata Michx.

Aira panicea Willd.; Steud., Nom. Bot. ed. 2. 1: 45. 1840, as synonym of Leptochloa filiformis Beauv.

Eleusine stricta Willd.; Steud. Nom. Bot. ed. 2. 1: 549. 1840. Not E. stricta Roxb., 1820 . As synonym of Leptochloa filiformis Beauv.

Eleusine elongata Willd.; Steud., Nom. Bot. ed. 2. 1: 549. 1840, as synonym of Leptochloa filiformis Beauv.

Leptochloa brachiata Steud., Syn. Pl. Glum. 1: 209. 1854. Guadeloupe, Duchaissing.

Leptochloa attenuata Steud., Syn. Pl. Glum. 1: 209. 1854. Based on Oxydenia attenuata Nutt.

Leptochloa pellucidula Steud., Syn. Pl. Glum. 1: 209. 1854. Panama, Duchaissing.

Leptochloa paniculata Fourn., Bull. Soc. Bot. France II. 27: 296. 1880. Nicaragua, Levy 1079.

Leptochloa mucronata pulchella Scribn., Bull. Torrey Club 9: 147. 1882. Santa Cruz Valley, Ariz., Pringle in 1881.

Oxydenia filiformis Nutt.; Jacks., Ind. Kew. 3: 392. 1894, as synonym of Leptochloa filiformis.

Leptochloa pilosa Scribn., U.S.Dept.Agr., Div. Agrost. Circ. 32: 9. 1901. Travis County, Tex., Bodin 294 in 1891.

(9) Leptochloa nealleyi Vasey, Bull. Torrey Bot. Club 12: 7. 1885. Texas, Nealley.

Leptochloa stricta Fourn., Mex. Pl. 2: 147. 1886. Vera Cruz, Mexico, Gouin 73.

(11) Leptochloa panicoides (Presl) Hitchc., Amer. Jour. Bot. 21: 137. 1934. Based on Megastachya panicoides Presl. (Not invalidated by L. panicoides Wight, 1854, listed as a synonym only.)

Megastachya panicoides Presl, Rel. Haenk. 1: 283. 1830. Acapulco, Mexico, Haenke.

Poa panicoides Kunth, Rév. Gram. 1: Sup. XXVIII. 1830. Based on Megastachya panicoides Presl.

Leptochloa floribunda Doell, in Mart., Fl. Bras. $2^{3}$ : 89. 1878. Amazon River, Brazil.

Diplachne halei Nash, Bull. N.Y. Bot. Gard. 1: 292. 1899. Louisiana, Hale.

Leptochloa halei Scribn. and Merr. U.S.Dept.Agr., Div. Agrost. Bull. 24: 27. 1901. Based on Diplachne halei Nash.

(10) Leptochloa scabra Nees, Agrost. Bras. 435. 1829. Amazon River, Brazil.

Leptochloa langloisii Vasey, Bull. Torrey Bot. Club 12: 7. 1885. Louisiana, Langlois.

Leptochloa liebmanni Fourn., Mex. Pl. 2: 147. 1886. Antigua, Mexico, Liebmann 244, 248. 
(8) Leptochloa uninervia (Presl) Hitchc. and Chase, Contrib. U.S. Natl. Herb. 18: 383. 1917. Based on Megastachya uninervia Presl.

Megastachya uninervia Presl, Rel. Haenk. 1: 283. 1830. Mexico, Haenke.

Poa uninervia Kunth, Rév. Gram. 1: Sup. XXVIII. 1830. Based on Megastachya uninervia Presl.

Diplachne verticillata Nees and Mey., Nov. Act. Acad. Caes. Leop. Carol. 19: Sup. 1: 27. 1841; 159. 1843. Chile and Peru, Meyen.

Uralepis verticillata Steud., Syn. Pl. Glum. 1:248. 1854. Based on Diplachne verticillata Nees and Mey.

Eragrostis uninervia Steud., Syn. Pl. Glum. 1: 278. 18j1. Based on Megastachya uninervia Presl.

Atropis carinata Griseb., Abh. Ges. Wiss. Göttingen 24: 291. 1879. Argentina.

Leptochloa imbricata Thurb., in S. Wats., Bot. Calif. 2: 293. 1880. California, Larken's Station, San Diego County, Palmer 404; Fort Yuma, Thomas; Gila Valley to Rio Grande.

Diplachne imbricata Scribn., Bull. Torrey Bot. Club 10: 30. 1883. Based on Leptochloa imbricata Thurb.

Brizopyrum uninervium Fourn., Mex. P1. 2: 121. 1886. Based on Megastachya uninervia Presl.

Leptochloa virletii Fourn., Mex. Pl. 2: 147. 1886. San Luis Potosí, Mexico, Virlet 1404.

Diplachne tarapacana Phil., An. Mus. Nac. Chile. Bot.8: S8. 1891. Tarapacá, Chile.

Rabdochloa imbricata Kuntze, Rev. Gen. Pl. 2: 788. 1891. Based on Leptochloa imbricata Thurb.

Diplachne carinata Hack., Bol. Acad. Cienc. Córdoba 16: 253. 1900. Based on Atropis carinata Griseb.

Diplachne uninervia Parodi, Univ. Nac. Buenos Aires Rev. Céntr. Estud. 18: 147. 1925. Based on Megastachya uninervia Presl.

(3) Leptochloa virgata (L.) Beauv., Ess. Agrost. 71, 161, 166. pl. 15. f. 1. 1812. Based on Eleusine virgata Pers., which is based on Cynosurus virgatus L.

Cynosurus virgatus L., Syst. Nat. ed. 10. 2: 876. 1759. Jamaica.

Festuca virgata Lam., Tabl. Encycl. 1: 189. 1791. Based on Cynosurus virgaius $\mathrm{I}$.

Eleusine virgata Pcrs., Syn. Pl. 1: 87. 1805. Based on Cynosurus virgatus L.

Chloris poaeformis H.B.K., Nov. Gen. and Sp. 1: 169. 1816. Colombia and Ecuador, Humboldt and Bonpland.

Leplostachys virgata G. Meyer, Prim. Fl. Esseq. 74. 1818. Based on Cynosurus virgatus Willd. [error for L.].

Cynodon virgatus Raspail, Ann. Sci. Nat., Bot. 5: 302. 1825. Based on Leptochloa virgata Beauv.

Eleusine unioloides Willd.; Steud., Nom. Bot. ed. 2. 1: $549 . \quad 1840$, as synonym of Leptochloa virgata Pers.

Leptochloa mutica Steud., Syn. Pl. Glum. 1: 208. 185.4. Surinam [Dutch Guiana], Kappler 1553.

Leptochloa virgata var. mutica Doell, in Mart., Fl. Bras. 23: 91. 1878. Based on L. mutica Steud.

Leptochloa virgata var, aristata Fourn., Mex. Pl. 2: 146.1886. Mexico.

Leptochloa virgala var. intermedia Fourn., Mex. Pl. 2: 146. 1886. Mexico, Iiebmann 243, 251.

Oxydenia virgata Nutt.; Jacks., Ind. Kew. 3: 392. 1894, as synonym of Leptochloa virgata.

Leptochloa perennis Hack., Inf. Est. Centr. Agron. Cuba 1: 411. 1906. Cuba, Baker 4617.

(6) Leptochloa viscida (Scribn.) Beal, Grasses N.Amer. 2: 434. 1896. Based on Diplachne viscida Scribn.

Diplachne viscida Scribn., Bull. Torrey Bot. Club 10: 30. 1883. Santa Cruz Valley, Tucson, Ariz., Pringle in 1881.

\section{(122) LEPTOLOMA Chase}

(1) Leptoloma cognatum (Sehult.) Chase, Biol. Soc. Wash. Proc. 19: 192. 1906. Based on Panicum cognatum Schult.

?Panicum nudum Walt., Fl. Carol. 73. 1788. South Carolina. Description inadequate, no specimen in the Walter Herbarium in the British Museum.

Panicuin divergens Muhl., Descr. Gram. 120. 1S17. Not P. divergens H.B.K., 1815. South Carolina.

$55974^{\circ}-35-56$ 
Panicum cognatum Schult., Mant. 2: 235. 1824. Based on P. divergens Muhl. Panicum autumnale Bosc; Spreng., Syst. Veg. 1: 320 . 1S25. Origin unknown. Panicum fragile Kunth, Rév. Gram. 1: 36. 1829. Based on P. divergens Muhl.

(48) LEPTURUS R. Br.

(1) Lepturus cylindricus (Willd.) Trin., Fund. Agrost. 123. 1820. Based on Rottboellia cylindrica Willd.

Rottboellia cylindrica Willd., Sp. Pl. 1: 464. 1797. Europe.

Ophiurus cylindricus Beauv., Ess. Agrost. 116, 168, 176. 1812. Based on Rottboellia cylindrica Willd.

Monerma cylindrica Coss. and Dur., Expl. Sei. Alger. 2: 214. 1867. Based on Rottboellia cylindrica Willd.

Lolium cylindricum Aschers. and Graebn., Syn. Mitteleur. Fl. 2: 761. 1902. Based on Rottboellia cylindrica Willd.

\section{(68) LIMNODEA L. H. Dewey}

(1) Limnodea arkansana (Nutt.) L. H. Dewev, Contrib. U.S. Natl. Ilerb. 2: 518. 1894. Based on Greenia arkansana Nutt.

Greenia arkansana Nutt., Amer. Phil. Soc. Trans. (n.s.) 5: 142. 1837. Red River, Ark.

Sclerachne arkansana Torr.; Trin., Mém. Acad. St. Pétersb. VI. Sci. Nat. 4" 274. 1841. Based on Greenia arkarsana Nutt.

Sclerachne pilosa Trin., Mém. Acad. St. Pétersb. VI. Sci. Nat. 4¹: 275. 1841. Texas, Drummond.

Limnas arkansana Trin.; Steud., Nom. Bot. ed. 2. 2: 45. $1841 . \quad$ Based on Greenia arkansana Nutt.

Stipa demissa Steud., Syn. Pl. Glum. 1: 130. 1854. New Orleans, La., Drummond 465.

Muhlenbergia hirtula Steud., Syn. Pl. Glum. 1: 180. 1854. Texas, Drummond.

Limnas pilosa Steud., Syn. Pl. Glum. 1: 421. 1854. Based on Sclerachne pilosa Trin.

Thurberia arkansana Benth.; Vasey, U.S. Dept. Agr. Spec. Rept. 63: 16.1883. Based on Greenia arkansana Nutt.

Thurberia pilosa Vasey, U.S. Dept. Agr. Spec. Rept. 63: 16. $1883 . \quad$ Based on Sclerachne pilosa Trin.

Limnodea arkansana pilosa Scribn., U.S.Dept.Agr., Div. Agrost. Bull. 7 (ed. 3): 139. 1900. Based on Sclerachne pilosa Trin.

\section{(47) LOLIUM L.}

(2) Lolium multiforum Lam., Fl. Franç, 3: 621. 1778. France.

Lolium scabrum Presl, Rel. Haenk. 1: 267. 1830. Peru, Haenke.

Lolium italicum A. Br., Flora 17: 241. 1834. Europe.

Lolium perenne var. italicum Parnell, Grasses Scotl. 1': 142. pl. 65.1842. Presumably based on $L$. italicum A. Br.

Lolium perenne var. multiflorum Parnell, Grasses Brit. 302. pl. 140. 1845. Presumably based on L. multiflorum Lam.

Lolium multiflorum forma microstachyum Uechtritz, Jahresb. Schles. Ges. Vaterl. Cult. 1876: 334. 1880. Germany.

Lolium temulentum var. multiflorum Kuntze, Rev. Gen. Pl. 2: 779.1891. Based on L. multiflorum Lam.

Lolium multiflorum var. italicum Beck., Wiss. Mitt. Bosn. Herzeg. 9: 459. 1904. Based on L. italicum A. Br.

Lolium multiflorum var. diminutum Mutel, as used by Harger et al. (Conn. State Geol. Nat. Hist. Survey Bull.48: 25. 1930) appears to be L. multiflorum. Mutel's variety, described from France, is uncertain.

(1) Lolium perenne L., Sp. Pl. 83. 1753. Europe.

Lolium brasilianum Nees, Agrost. Bras. 443. 1829. Montevideo, Sellow.

Lolium canadense Bernh., in Rouv., Monogr. Lolium 27. 1853. Not L. canadense Michx., 1817. As synonym of L. perenne.

Lolium perenne var. pacyi Sturtev., N.Y. State Agr. Expt. Sta. Rept. 1882': 77. 1883. Name only, Experiment Station, Geneva, N.Y..

Lolium Perenne var. CRistatum Pers. Syn. PI. 1: 110. 1805. Europe.

Lolium rigidum Gaudin, Agrost. Helv. 1: 334. 1811. Switzerland.

Lolium perenne var. rigidum Coss. and Dur., Expl. Sci. Alger. 2: 194. 1867. Based on L. rigidum Gaud. 
Lolium strictum Presl, Cyp. Gram. Sicul. 49. 1820. Sicily.

(4) Lolium subulatum Visiani, Fl. Dalm. 1: 90. pl. 3. 1842, Europe.

(3) Lolium temulentum L., Sp. Pl. 83. 1753. Europe.

Craepalia temulenta Schrank, Baier. Fl. 1: 382. 1789. Based on Lolium temulentum L.

Lolium temulentum var. leptochaeton A. Br., Flora 1: 252. 1834. Germany. Lolium arvense With., Bot. Arr. Veg. Brit. ed. 3. 2: 168. 1796. Great Britain.

Lolium temulentum var. arvense Bab., Man. Brit. Bot. 377. 1843. Based on L. arvense With.

(115) LUZIOLA Juss.

(2) Luziola bahiensis (Steud.) Hitchc., Contrib. U.S. Natl. Herb. 12: 234. 1909. Based on Caryochloa bahiensis Steud.

Caryochloa bahiensis Steud., Syn. Pl. Glum. 1: 5. 1854. Bahia, Brazil.

Luziola alabamensis Chapm., Fl. South. U.S. 584. 1860. Brooklyn, Conecuh County, Ala., Beaumont.

Luziola longivalvula Doell, in Mart., Fl. Bras. 22: 17. 1871. Bahia, Brazil, Salzmann [type]; Minas Geraes, Widgren, Regnell III. 1376. (Misspelled longivalvulva but correct in index.)

Luziola striata Bal. and Poitr., Bull. Soc. Hist. Nat. Toulouse 12: 231. pl. 4. f. 2. 1878. Paraguay, Balansa 181.

Luziola pusilla S. Moore, Linn. Soc. Bot. Trans. II. 4: 507 . pl. 37. f. 1-8. 1895. Santa Cruz, Matto Grosso, Brazil, Moore 760.

Luziola bahiensis var. alabamensis Prodoehl, Bot. Archiv Mez 1: 242.1922. Based on Luziola alabamensis Chapm.

(1) Luziola peruviana Gmel., Syst. Nat. 2: 637. 1791. Based on a species described but not named by Jussieu, Gen. Pl. 33. 1789. Peru, Dombey.

\section{(71) LYCURUS H.B.K.}

(1) Lycurus phleoides H.B.K., Nov. Gen. and Sp. 1: 142. pl. 45. 1815. Mexico, Humboldt and Bonpland.

Pleopogon setosum Nutt., Jour. Acad. Nat. Sci. Phila. II. 1: 189. 1848. Santa Fe, N.Mex., Gambel.

Lycurus phleoides var. glaucifolius Beal, Grasses N.Amer. 2: 271. 1896. Mexico, Pringle 426; Texas, Havard, Nealley.

\section{(154) MANISURIS L.}

(1) Manisuris altissimus (Poir.) Hitchc. Jour. Wash. Acad. Sci. 24: 292.1934. Based on Rottboellia altissima Poir.

Rottboellia altissima Poir. Voy. Barb. 2: 105. 1789. North Africa.

Rottboellia fasciculata Lam., Tabl. Encycl. 1: 204. 1791. North Africa.

Hemarthria fasciculata Kunth, Rév. Gram. 1: 153. 1829. Based on Rottboellia fasciculata Lam.

Rottbocllia compressa var. fasciculata Hack., in DC., Monogr. Phan. 6: 286. 1889. Based on R. fasciculata Lam.

Manisuris fasciculata Hitche., Amer. Jour. Bot. 2: 299. 1915. Based on Rottboellia fasciculata Lam.

(2) Manisuris cylindrica (Michx.) Kuntze, Rev. Gen. Pl. 2: 779. 1891. Based on Tripsacum cylindricum Michx.

? Ischaemum scariosum Walt., Fl. Carol. 249. 1788. South Carolina.

Tripsacum cylindricum Michx., Fl. Bor. Amer. 1: 60. 1803. Florida, Michaux.

Rottbocllia campestris Nutt., Amer. Phil. Soc. Trans. (n.s.) 5: 151.1837. Arkansas [Nuttall].

Rottboellia cylindrica Torr., U.S. Rept. Expl. Miss. Pacif. 4: 159. 1857. Not R. cylindrica Willd., 1797. Based on Tripsacum cylindricum Michx.

Coelorachis cylindrica Nash, N.Amer. Fl. 17: 85. 1909. Based on Tripsacum cylindricum Michx.

(4) Manisuris rugosa (Nutt.) Kuntze, Rev. Gen. Pl. 2: 780. 1891. Based on

Rottboellia rugosa Nutt.
Rottboellia rugosa Nutt., Gen. Pl. 1: 84. 1818. Florida, Baldwin.

Rottboellia corrugata Baldw., Amer. Jour. Sci. 1: 355. 1819. Camden County, Ga., Baldwin.

Hemarthria rugosa Kunth, Rév. Gram. 1: 153. 1829. Based on Rottboellia rugosa Nutt. 
Rottboellia rugosa var. chapmani Hack., in DC., Monogr. Phan. 6: 308. 1889. Florida, Chapman.

Manisuris corrugata Kuntze, Rev. Gen. Pl. 2: 779. 1891. Based on Rottboellia corrugata Baldw.

Manisuris rugosa var. chapmani Scribn., Mem. Torrey Bot. Club 5: 28. 1894. Based on Rottboellia rugosa var. chapmani Hack.

Manisuris chapmani Nash, in Small, Fl. Southeast. U.S. 56. 1903. Based on Rottboellia rugosa var. chapmani Hack.

Coelorachis rugosa Nash, N.Amer. Fl. 17: 86. 1909. Based on Rottboellia rugosa Nutt.

Coelorachis corrugata A. Camus, Ann. Soc. Linn. Lyon 68: 197. 1921. Based on Rottboellia corrugata Baldw.

(3) Manisuris tessellata (Steud.) Scribn., U.S.Dept.Agr., Div. Agrost. Bull. 20: 20. f. 9.1900 . Based on Rottboellia tesscllata Steud.

Rottboellia tessellata Steud., Syn. Pl. Glum. 1: 362. 1854. Louisiana, Riehl 60.

Rottboellia corrugata var. areolata Hack., in DC., Monogr. Phan. 6: 309.1889. Mobile, Ala., Mohr in 1884.

Manisuris corrugata var. areolata Mohr, Bull. Torrey Bot. Club 24: 21. 1897. Based on Rottboellia corrugata var. areolata Hack.

Manisuris tessellata var. areolata Scribn., U.S.Dept.Agr., Div. Agrost. Bull. 17 (ed. 2): 9. 1901. Presumably based on Rotiboellia corrugata var. areolata Hack.

Coelorachis tessellata Nash, N.Amer. F1. 17: 86. 1909. Based on Rottboellia tessellata Steud.

(5) Manisuris tuberculosa Nash, Bull. N.Y. Bot. Gard. 1:430. 1900. Eustis, Fla., Nash 1074.

Coelorachis tuberculosa Nash, N.Amer. F1. 17: 86. 1909. Based on Manisuris tuberculosa Nash.

Rottboellia tuberculosa Hitchc., Biol. Soc. Wash. Proc. 41: 163. 1928. Based on Manisuris tuberculosa Nash.

(28) MELiCA L.

Melica altissima L., Sp. Pl. 66. 1753. Siberia.

(2) Melica aristata Thurb.; Boland., Calif. Acad. Sci. Proc. 4: 103. 1870. "Number 4861 [Bolander] Catalogue, 1867", Clarks (now Wawona) [type]; Yosemite Valley; Shady Canyon to Summit; Bear Valley to Eureka, Calif.

Bromelica aristata Farwell, Rhodora 21: 77. 1919. Based on Melica aristata Thurb.

(7) Melica bulbosa Geyer; Port. and Coult., Syn. Fl. Colo. 149. 1874. Porter and Coulter cite Gray, Amer. Acad. Sci. Proc. 8: 409. 1872. Gray gives no description but cites M. bulbosa Geyer, Jour. Bot. Kew Misc. (Pl. Geyer.) 8: 19. 1856. In the latter work "Geyer no. 11, Upper Platte", is listed without description. The description by Porter and Coulter applies to this specimen as represented in the Gray Herbarium.

Melica bella Piper, U.S.Dept.Agr., Div. Agrost. Circ. 27: 10. 1900. Upper Platte, Geyer [11]. A new name for "M. bulbosa Geyer, in U.S.Dept.Agr., Div. Bot. Bull. 13: 63. pl. 63. 1893, not M. bulbosa Geyer, in Thurb., in S. Wats., Bot. Calif. 2: 304. 1880", the description by Porter and Coulter having been overlooked. The Thurber publication refers to $M$. californica (no. 17 of this work).

Melica bella intonsa Piper, Contrib. U.S. Natl. Herb. 11: 128. 1906. Wenas, Wash., Griffiths and Cotton 103.

(17) Melica californica Scribn., Acad. Nat. Sci. Phila. Proc. 18s5: 46. pl. 1. f. 6. 1885. Based on $M$. poaeoides as described by Torrey in Pacific Railroad Report (see below), the specimen cited by Torrey, in N.Y. Bot. Gard., being named " $M$. californica Scribn." in Scribner's script.

Melica poaeoides Nutt. [misapplied by] Torr., U.S. Rept. Expl. Miss. Pacif. 4: 157. 1857. Not M. poaeoides Nutt., 1848. Corte Madera, Calif., [Bigelow].

Melica bulbosa Geyer; Thurb., in S.Wats., Bot. Calif. 2: 304. 1880. Not M. bulbosa Geyer; Port. and Coult., 1874. Santa Inez, Calif., Brewer 569.

Melica longiligula Scribn. and Kearn., U.S.Dept.Agr., Div. Agrost. Bull. 17: 225. f. 521. 1899. Southern California, Parish Brothers 865.

Melica ciliata L., Sp. Pl. 66. $1753 . \quad$ Europe.

(16) Melica frutescens Scribn., Acad. Nat. Sci. Phila. Proc. 1885: 45. pl. 1. f. 15, 16. 1885. Southern California, Parry and Lemmon 401 [type, labeled by Scribner]. 
(8) Melica fugax Boland., Proc. Calif. Acad. 4: 104. 1870. Donner Lake, Calif., [Bolander and Kellogg].

Melica geyeri [Munro misapplied by] Thurb., in Wilkes, U.S. Expl. Exped. Bot. 17: 492. 1874. Cascade Mountains, Oreg.

Melica fugax madophylla Piper, Contrib. U.S. Nati. Herb. 11: 128.1906. Falcon Valley, Wash., Suksdorf 61.

Melica macbridei Rowland, in Nels., Bot. Gaz. 54: 404. 1912. Silver City, Idaho, Macbride 948.

Melica fugax var. inexpansa Suksdorf, Werdenda 12: 1. 1923. Falcon Valley, Wash., Suksdorf 6989.

(5) Melica geyeri Munro; Boland., Calif. Acad. Sci. Proc. 4: 103. 1870. [Ukiah], Calif., Bolander 7, the specimen examined by Munro (in U.S. Nat. Herb.). The same collection was later distributed as 6119 .

Glyceria bulbosa Buckl., Acad. Nat. Sci. Phila. Proc. 1862: 95. 1863. Columbia woods, Nuttall.

Bromus muticus Nutt.; A. Gray, Acad. Nat. Sci. Phila. Proc. 1862: $335 . \quad$ 1863, as synonym of Glyceria bulbosa Buckl.

Melica poaeoides var. bromoides Boland., Calif. Acad. Sci. Proc. 4: 103.1870 , as synonym of $M$. geyeri Munro. Bolander 40 and 6119 .

Melica bromoides Boland.; A. Gray, Amer. Acad. Sci. Proc. 8: 409. 1872. Based on M. poaeoides var. bromoides Boland. [Bolander 6119].

Melica poaeoides Boland.; Scribn., Acad. Nat. Sci. Phila. Proc. 1885: 47.1885 , as synonym of " $M$. bromoides Gray."

Melica bromoides var. howellii Scribn., Acad. Nat. Sci. Phila. Proc. 1885: 47. 1885. Near Waldo, Oreg., Howell 335 in 1884.

Melica pammeli Scribn., Davenport Acad. Sci. Proc. 7: 240. 1899. Geranium Park, Wyo., Pammel 159.

Bromelica geyeri Farwell, Rhodora 21: 78. 1919. Based on Melica geyeri Munro.

Bromelica geycri var. howellii Farwell, Rhodora 21: 78. 1919. Based on Melica bromoides var. howellii Scribn.

(3) Melica harfordii Boland., Calif. Acad. Sci. Proc. 4: 102. 1870. Santa Cruz, Bolander 53 [type]; Redwood, Bolander 6464; Yosemite Valley, and Bear Valley, both Bolander.

Melica harfordii var. minor Vasey, Bull. Torrey Bot. Club 15: 48. 1888. Siskiyou Mountains, Oreg., Howell in 1887.

Melica harfordii tenuior Piper, Contrib. U.S. Natl. Herb. 11: 127. 1906. Based on M. harfordii var. minor Vasey.

Bromelica harfordii Farwell, Rhodora 21: 78. 1919. Based on Melica harfordii Boland.

Bromelica harfordii var. minor Farwell, Rhodora 21: 78. 1919. Based on Melica harfordii var. minor Vasey.

Melica harfordii var. tenuis Suksdorf, Werdenda 1: 17. 1927. Bingen, Wash., Suksdorf 12018.

Melica harfordii var. viridifolia Suksdorf, Werdenda 1: 17. 1927. Bingen, Wash., Suksdorf $11686,11777$.

(15) Melica imperfecta Trin., Mém. Acad. St. Pétersb. VI. Sci. Nat. 2 $2^{1} 59$. 1836. California.

Melica colpodioides Nees, Ann. Nat. Hist. 1: 283. 1838. California, Douglas.

Melica panicoides Nutt., Jour. Acad. Nat. Sci. Phila. II. 1: 188. 1848. Santa Barbara, Calif., Gambel.

Melica poaeoides Nutt., Jour. Acad. Nat. Sci. Phila. II. 1: 188. 1848. Santa Catalina Island, Calif., Gambel. [The type at the British Museum is labeled San Diego.]

Melica imperfecta var. flexuosa Boland., Calif. Acad. Sci. Proc. 4: 101. 1870. "Mariposa to Clark's" [Yosemite Valley region] Calif., Bolander in 1866.

Melica imperfecta var. refracta Thurb., in S. Wats., Bot. Calif. 2: 303.1880. San Bernardino, Calif., Lemmon.

Melica imperfecta var. minor Scribn., Acad. Nat. Sci. Phila. Proc. 1885: 42. 1885. San Bernardino Mountains, Parish Brothers 856.

Melica parishii Vasey; Beal, Grasses N.Amer. 2: 500. 1896. Southern California, Parish 1997.

Melica imperfecta var. pubens Scribn., U.S.Dept.Agr., Div. Agrost. Cire. 30: 8. 1901. Santa Cruz Island, Calif., Brandegee 64.

The name is erroneously given as Melica imperforata Nees, in Hook. and Arn., Bot. Beechey Voy. 403. 1840. This is the species described and figured by Vasey (U.S.Dept.Agr., Div. Bot. Bull. 132: pl. 84. 1893) as Poa thurberiana Vasey, but the name is based on Panicularia thurberiana Kuntze. 
(9) Melica inflata (Boland.) Vasey, Contrib. U.S. Natl. Herb. 1: 269. 1893. Based on $M$. poaeoides var. inflata Boland.

Melica poaeoides var. inflata Boland., Calif. Acad. Sci. Proc. 4: 101. 1870. Yosemite Valley, Calif., Bolander 6121.

(12) Melica mutica Walt., Fl. Carol. 78. 1788. South Carolina.

Melica glabra Michx., Fl. Bor. Amer. 1: 62. 1803. Virginia to Florida, Michaux.

Melica rariflora Schreb., Beschr. Gräs. 2: 157. 1810. Based on M. glabra Michx.

Melica diffusa Pursh, Fl. Amer. Sept. 1: 77. 1814. Virginia and Carolina.

Melica speciosa Muhi., Descr. Gram. 87. 1817. Pennsylvania.

Melica racemosa Muhl., Deser. Gram. 88. 1817. Not M. racemosa Thunb., 1794. Carolina; Georgia.

Melica muhlenbergiana Schult., Mant. 2: 294. 1824. Based on M. racemosa Muhl.

Melica mutica var. glabra A. Gray, Man. ed. 5. 626. 1867. Based on $M$. glabra Pursh (error for Michx.).

Melica mutica var. diffusa A. Gray, Man. ed. 5. 626. 1867. Based on $M$. diffusa Pursh.

(13) Melica nitens (Scribn.) Nutt.; Piper, Bull. Torrey Bot. Club 32: 387. 1905. Based on $M$. diffusa var. nitens Scribn.

Melica scabra Nutt., Amer. Phil. Soc. Trans. (n.s.) 5: 148. 1837. Not $M$. scabra H.B.K., 1816. Fort Smith, Ark., Nuttall.

Melica diffusa var. nitens Scribn., Acad. Nat. Sci. Phila. Proc. 1885: 44. 1885. Arkansas, Nuttall. [The type in the Academy of Natural Sciences, Philadelphia, is labeled $M$. nitens Nutt.]

Melica nitens Nutt.; Scribn., Acad. Nat. Sci. Phila. Proc. 1885: 44. 1885, as synonym of $M$. diffusa var. nitens.

(11) Melica porteri Scribn., Acad. Nat. Sci. Phila. Proc. 1885: 44. pl. 1. f. 17, 18. 1885. Based on M. mutica var. parviflora Porter.

Melica mutica var. parviflora Porter, in Port. and Coult., Syn. Fl. Colo. 149. 1874. Glen Eyrie, Colo., Porter [type], Meehan; Sierra Madre Range, Coulter.

Melica parviflora Scribn., Mem. Torrey Bot. Club 5: 50. 1894. Based on $M$. mutica var. parvifora Porter.

(1) Melica smithii (Porter) Vasey, Bull. Torrey Bot. Club 15: 294. 1888. Based on Avena smithii Porter.

Avena smithii Porter; A. Gray, Man. ed. 5. 640. 1867. Sault Sainte Marie, Mich., C. E. Smith.

Melica retrofracta Suksdorf, Deut. Bot. Monatsschr. 19: 92. 1901. Skamania County, Wash., [Suksdorf 2334].

Bromelica smithii Farwell, Rhodora 21: 77. 1919. Based on Avena smithii Porter.

(6) Melica spectabilis Scribn., Acad. Nat. Sci. Phila. Proc. 1885: 45. pl. 1. f. 11, 12, 13. 1885. Montana, Crow Mountains, Scribner 385 [type]; Boseman Pass, Canby 368. Colorado, Porter in 1872. Yellowstone Park, Parry 295. Nevada (erroneously given as Utah), Watson 1303. Idaho, Watson 455. The synonyms cited by Seribner are erroneous, "M. bulbosa S. Wats., Bot. King Exp. 383 " being an error for $M$. poaeoides Nutt., Bot. King Exp. 383; "Porter and Coulter Fl. Colorado 149." refers to the valid M. bulbosa.

Melica scabrata Scribn., in Piper, Fl. Palouse 25. 1901. Pullman, Wash., Piper 1745.

(10) Melica stricta Boland., Calif. Acad. Sci. Proc. 3: 4. 1863. Silver City, Nev., Dunn.

(4) Melica subulata (Griseb.) Scribn., Acad. Nat. Sci. Phila. Proc. 1885: 47. 1885. Based on Bromus subulatus Griseb.

Bromus subulatus Griseb., in Ledeb., Fl. Ross. 4: 358. 1853. Unalaska, Eschscholtz.

Mclica acuminata Boland, Calif. Acad. Sci. Proc. 4: 104. 1870. Mendocino County, Calif., Bolander 4698.

Festuca acerosa Trin.; A. Gray, Amer. Acad. Sci. Proc. 8: 410. 1872, as synonym of Bromus subulatus Griseb.

Melica poaeoides var. acuminata Boland.; Scribn., Acad. Nat. Sci. Phila. Proc. 1885: 47. 1885, as synonym of $M$. subulata Scribn. California, Bolander 4698.

Bromelica subulata Farwell, Rhodora 21: 78. 1919. The name is based on Festuca subulata Bong., doubtless an error for Bromus subulatus Griseb., since Melica acuminata Boland. is also cited. 
This is the species to which Scribner (U.S.Dept.Agr., Div. Agrost. Circ. 30: 8. 1901) applied the name Mclica cepacea Scribn., based on Festuca cepacea Phil., a

(14) Melica torreyana Scribn. Acad. Nat. Sci. Phila. Proc. 1885: 43. pl. 1. f. 3,4 . 1855. California, Bigelow in 1853-1.

Metica imperfecta var. sesq, iflora Turn.; Srihn., : Na1. Sei. Phila. Pror

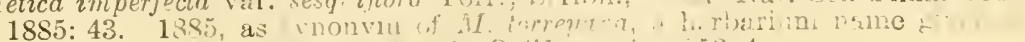

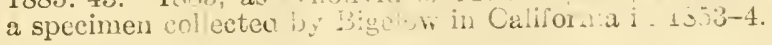

\section{(118) MELINIS Leiuv.}

(1) Melinis minutiflora Beauv., Ess. Agrust. 51. pl. 11. f. 4. 1812. Rio d. Janeiro, Brazil.

Tristegis glutinosa Nees, Hor. Phys Berol. 47, 54. pl. 7. 1820. Brazil.

Panicum minutiflorum Raspail, Ann. Bci. Nat., Bot. 5: 299. 1825. Based on Melinis minutiflora Beauv.

Panicum meinis Trin., Mém. Acad. St. Pétersb. VI. Sci. Nat. 1: 291. 1834. Based on Melinis minntiflora Beauv.

Muhlenbergia brasiliensis steud., Syn. Pl. Glum. 1: 177. 1854. Bahia, Brazil, Salzmann [652].

Agrostis polypogon Salzm.; Steud., Syn. Pl. Glum. 1: 177. 1854, as synonym of Muhlenbergia brasiliensis.

Mibora minima (L.) Desv., Obs. Angers 45. 181s. Based on Agrostis minima L. Agrostis minima L., Sp. Pl. 63. 1753. France.

\section{(81) MLLIUM L.}

(1) Milium effusum L., Sp. Pl. 61. 1753. Europe.

Miliarium effusum Moench, Meth. Pl. 204. 1794. Based on Milium effusum L.

Melica effusa Salisb., Prodr. Stirp. 20. 1796. Based on Milium effusum L.

Decandolia effusa Bast., Fl. Maine-et-Loire 28. 1808. Based on Milium e.fusum L.

Paspalum effusum Raspail, Ann. Sci. Nat. Bot. 5: 301. 1825. Based on Milium effusum L.

\section{(141) MISCANTHUS Anderss.}

Miscanthus nepalensis (Trin.) Hack., in DC., Monogr. Phan. 6: 104. 1889.

Based on Eulalia nepalensis Trin.
Eulalia nepalensis Trin., Mém. Acad. St. Pétersb. VI. Math. Phys. Nat. 2: 333. 1832. Nepal, India.

(1) Miscanthus sinensis Anderss., Öfv. Svensk, Vet. Akad. Förh. 12: 166. 1856.

China.
Saccharum japonicum Thunb., Linn. Soc. Trans. 2: 328 . 1794. Not Miscanthus japonicus Anderss., 1855. Japan.

Eulalia japonica Trin., Mém. Acad. St. Pétersb. VI. Math. Phys. Nat. 2: 333. 1832. Based on Saccharum japonicum Thunb.

Miscanthus sinensis var. variegatus Beal, Grasses N.Amer. 2: 25.1896. Cultivated.

Miscanthus sinensis var. zebrinus Beal, Grasses N.Amer. 2: 25. 1896. Cultivated.

Xiphagrostis japonica Coville, Contrib. U.S. Natl. Herb. 9: 400. 1905. Based on Saccharum japonicum Thunb.

Miscanthus sinensis var. gracillimus Hitchc., in Bailey, Cycl. Amer. Hort. 1021. f. 1408. 1901. Cultivated under the garden name Eulalia japonica var. gracillima.

Eulalia japonica var. gracillima Grier, Amer. Midl. Nat. 11:331. 1929. Based on Miscanthus sinensis var. gracillimus Hitchc.

\section{(14) MOLINIA Schrank}

(1) Molinia caerulea(L.) Moench, Meth. Pl.183. 1794. Based on Aira caerulea L. Aira caerulea L., Sp. Pl. 63.1753. Europe.

Festuca caerulea Lam. and DC., Fl. Franç. ed. 3. 3: 46. 1805. Based on Aira caerulea L. 
Enodium coeruleum Gaudin, Agrost. Helv. 1: 145. 1811. Based on Aira caerulea L.

Cynodon caeruleus Raspail, Ann. Sci. Nat., Bot. 5: 302. 1825. Based on Molinia caerulea Koel. (error for Moench).

Amblytes caerulea Dulac, Fl. Haut. Pyr. 80. 1867. Based on Molinia caerulea Moench.

\section{(18) MONANTHOCHLOË Engelm.}

(1) Monanthochloë littoralis Engelm., St. Louis Acad. Sci. Trans. 1: 437. pl. 13. 14. 1859. Texas, Drummond, Berlandier 3227 (M̄atamoros region), Galveston Island, Lindheimer; Florida, Key West, Blodgett.

\section{(75) MUHLENBERGIA Schreb.}

(32) Muhlenbergia andina (Nutt.) Hitchc., U.S. Dept. Agr. Bull. 772: 145. 1920. Based on Calamagrostis andina Nutt.

Calamagrostis andina Nutt., Jour. Acad. Nat. Sci. Phila. II. 1: 187. 1848. California, on the Colorado of the West, Gambel.

Vaseya comata Thurb., in A. Gray, Acad. Nat. Sci. Phila. Proc. 1863: 79. 1863. Nebraska [probably Wyoming, Hall and Harbour 685].

Muhlenbergia comata Thurb.; Benth., Jour. Linn. Soc. Bot. 19: 83. 1881. Based on Vaseya comata Thurb.

(12) Muhlenbergia arenacea (Buckl.) Hitchc., Biol. Soc. Wash. Proc. 41: 161. 1928. Based on Sporobolus arenaceus Buckl.

Sporobolus arenaceus Buckl., Acad. Nat. Sci. Phila. Proc. 1862: 89. 1863. Western Texas, [Wright 737].

Sporobolus asperifolius var. brevifolius Vasey, Contrib. U.S. Natl. Herb. 1: 56. 1890, name only, Pena, Duval County, Tex., Nealley; Contrib. U.S. Natl. Herb. 3: 64. 1892, as synonym of S. auriculatus Vasey.

Sporobolus auriculatus Vasey, Contrib. U.S. Nat1. Herb. 3: 64. 1892. Pena, Tex., Nealley.

(43) Muhlenbergia arenicola Buckl., Acad. Nat. Sci. Phila. Proc. 1862: 91. 1863. Western Texas, [Wright 735].

Podosaemum arenicola Bush, Amer. Midl. Nat. 7: 40. 1921. Based on Muhlenbergia arenicola Buckl.

(18) Muhlenbergia arizonica Scribn., Bull. Torrey Bot. Club 15: 8. pl. 76. f. A. 1888. Near Mexican Boundary, Arizona, Pringle in 1884.

(37) Muhlenbergia arsenei Hitchc., Biol. Soc. Wash. Proc. 41: 161. 1928. Sulphur Springs, N.Mex., Arsène and Benedict 16405.

(13) Muhlenbergia asperifolia (Nees and Mey.) Parodi, Univ. Nac. Buenos Aires Rev. Agron. 6: 117. f. 1. 1928. Based on Sporobolus asperifolius Nees and Mey.

Vilfa asperifolia Meyen, Reis. Erd. 1: 408. 1834, name only; Nees and Mey., Mém. Acad. St. Pétersb. VI. Sci. Nat. 41: 95. 1840. Chile, Meyen.

Sporobolus asperifolius Nees, Nov. Act. Acad. Caes. Leop. Carol. 19: Sup. 1: 9. 1841; 141. 1843. Based on Vilfa asperifolia Nees and Mey.

Agrostis distichophylla R. A. Phil., Fl. Atac. 54. 1860. Not A. distichophylla Roem. and Schult., 1817. Chile. (Fide Parodi.)

Sporobolus sarmentosus Griseb., Abhandl.Gesell. Wiss. Göttingen 24: 295. 1879. Argentina.

Sporobolus deserticolus Phil., An. Mus. Nac. Chile Bot. 8: 82. 1891. Chile. (Fide Parodi.)

Sporobolus asperifolius var. major Vasey, Contrib. U.S. Natl. Herb. 3: 64. 1892. [Marfa, Tex., Havard 10 in 1883.]

Sporobolus distichophyllus Phil., An. Univ. Chile 94: 7. 1896. Based on Agrostis distichophylla Phil.

Agrostis eremophila Speg., An. Mus. Nac. Buenos Aires 7: 190. 1902. Based on A. distichophylla Phil.

(24) Muhlenbergia brachyphylla Bush, Amer. Midl. Nat. 6: 41. 1919. Webb City, Mo., Palmer 2734. (Not invalidated by M. brachyphylla Nees; Jacks., Ind. Kew. 3: 269. 1894, a clerical error for Podosaemum brachyphyllum Nees.)

(21) Muhlenbergia californica Vasey, Bull. Torrey Bot. Club 13: 53. 1886. Based on $M$. glomerata var. brevifolia Vasey.

Muhlenbergia glomerata var. brevifolia Vasey, Bot. Gaz. 7: 92. 1882. [San Bernardino Mountains], Calif., Parish [1028].

Muhlenbergia sylvatica var. californica Vasey, Bot. Gaz. 7: 93. 1882. San Bernardino Mountains, Calif., Parish [1076]. 
Muhlenbergia parishii Vasey, Bull. Torrey Bot. Club 13: 53. 1886. Based on M. sylvatica var. californica Vasey.

Muhlenbergia racemosa var. brevifolia Beal, Grasses N.Amer. 2: 253.1896. Based on M. glomerata var. brevifolia Vasey.

(48) Muhlenbergia capillaris (Lam.) Trin., Gram. Unifl. 191. 1824. Based on Trichochloa capillaris DC.

Stipa diffusa Walt., FI. Carol. 78. 1788. Not Muhlenbergia diffusa Willd., 1798. South Carolina.

Stipa capillaris Lam., Tabl. Encycl. 1: 158. 1791. Carolina, Fraser.

Podosaemum capillare Desv., Nouv. Bull. Soc. Philom. (Paris) 2: 188. 1810. Based on Stipa capillaris Lain.

Tosagris agrostidea Beauv., Ess. Agrost. 29. pl 8. f. 3. 1812. United States.

Podosaemum agrostideum Beauv., Ess. Agrost. 176, 179. 1812. Based on Tosagris agrostidea Beauv.

Trichochloa capillaris DC., Cat. Hort. Monsp. 152. 1813. Based on Stipa capillaris Lam.

Trichochloa polypogon DC., Cat. Hort. Monsp. 152. 1813. Carolina, Fraser.

Muhlenbergia polypogon Ǩunth, Rév. Gram. 1: 64. 1829. Based on Trichochloa polypogon DC.

Agrostis setosa Willd.; Trin., Mém. Acad. St. Pétersb. VI. Sci. Nat. 41: 300. 1841 , as synonym of Muhlenbergia capillaris. "Willd. hb. 1682," received from Muhlenberg.

Muhlenbergia trichodes Steud., Syn. Pl. Glum. 1: 177. 1854. Said to be from South America, but Steudel's type is from Guadeloupe, West Indies.

Muhlenbergia capillaris var. Filipes (M. A. Curtis) Chapm.; Beal, Grasses N.Amer. 2: 256. 1896. Based on M. filipes M. A. Curtis.

Stipa sericea Michx., Fl. Bor. Amer. 1: 54. 1803. South Carolina, Michaux.

Agrostis sericea Ell., Bot. S.C. and Ga. 1: 135. 1816. Based on Stipa sericea Michx.

Polypogon sericea Spreng., Syst. Veg. 1: 243. 1825. Based on Stipa sericea Michx.

Muhlenbergia filipes M. A. Curtis, Amer. Jour. Sci. 44: 83. 1843. Sea Islands of North Carolina; Florida, [M. A. Curtis].

Podosaemum filipes Bush, Amer. Midl. Nat. 7: 29. 1921. Based on Muhlenbergia filipes M. A. Curtis.

(9) Muhlenbergia curtifolia Seribn., Bull. Torrey Bot. Club 38: 328. 1911. Between Kanab and Carmel, Utah, Jones 6047.

(31) Muhlenbergia curtisetosa (Scribn.) Bush, Amer. Midl. Nat. 6: 35. 1919. Based on M. schreberi curtisetosa Scribn.

Muhlenbergia schreberi curtisetosa Scribn., Rhodora 9: 17. 1907. Illinois, Wolf in 1881.

(10) Muhlenbergia cuspidata (Torr.) Rydb., Bull. Torrey Bot. Club 32: 599. 1905. Based on Vilfa cuspidata Torr.

Agrostis brevifolia Nutt., Gen. Pl. 1: 44. 1818. Fort Mandan, [N.Dak.].

Vilfa cuspidata Torr.; Hook., Fl. Bor. Amer. 2: 238. 1840. Saskatchewan River, Rocky Mountains, Drummond.

Vilfa gracilis Trin., Mém. Acad. St. Pétersb. VI. Sci. Nat. 41: 104.1840. Not V. gracilis Trin., op. cit. 74 . North America, received from Hooker.

Sporobolus cuspidatus Wood, Amer. Bot. and Flor. pt. 2: 385.1874 . Based on Vilfa cuspidata Torr.

Sporobolus brevifolius Scribn., Mem. Torrey Bot. Club 5: 39. 1894. Not S. brevifolius Nees, 1841. Based on Agrostis brevifolia Nutt. As new, Nash, in Britton, Man. 105. 1901, same basis.

Muhlenbergia brevifolia Jones, Contrib. West. Bot. 14: 12. 1912. Not M. brevifolia Scribn., 1896. Based on Agrostis brevifolia Nutt.

(3) Muhlenbergia depauperata Scribn., Bot. Gaz. 9: 187. 1884. Arizona, Pringle.

Muhlenbergia schaffneri Fourn., Mex. Pl. 2: 85. 1886. Mexico, Tacubaya, Schaffner 50, 514; Mirador, Schaffner 142.

Lycurus schaffneri Mez, Repert. Sp. Nov. Fedde 17: 212. 1921. Based on Muhlenbergia schaffneri Fourn.

(45) Muhlenbergia dubia Fourn. in Hemsl., Biol. Centr. Amer. Bot. 3: 540. 1885. Chinantla, Mexico, Liebmann [688].

Muhlenbergia acuminata Vasey, Bot. Gaz. 11: 337. 1886. New Mexico, Wright 1993.

Sporobolus ligulatus Vasey and Dewey, Contrib. U.S. Natl. Herb. 1: 268. 1893. Presidio County, Tex., Nealley, 127. 
Sporobolus inflatus Vasey and Dewey; Beal, Grasses N.Amer. 2: 289.1896. Error for S. ligulatus Vasey and Dewey.

Crypsinna breviglumis Jones, Contrib. West. Bot. 14: 8. 1912. Chihuahua, Mexico [Jones in 1903].

(19) Muhlenbergia dumosa Scribn.; Vasey, Contrib. U.S. Natl. Herb. 3: 71. 1892. Santa Catalina Mountains, Ariz., Pringle [in 1884], Lemmon; Mexico, Pringle; southern California, Orcutt.

Muhlenbergia dumosa var. minor Scribn.; Beal, Grasses N.Amer. 2: 261. 1896. Mexico, Pringle 2355.

(54) Muhlenbergia emersleyi Vasey, Contrib. U.S. Natl. Herb. 3: 66. 1892. Southern Arizona, Emersley.

Muhlenbergia vaseyana Scribn., Mo. Bot. Gard. Rept. 10: 52. 1899. Based on $M$. distichophylla as described by Vasey (Wheeler, Rept. U.S. Survey 100th Merid. 6: 283. 1878, Arizona, Rothrock 282, type).

Epicampes emersleyi Hitchc., U.S. Dept. Agr. Bull. 772: 144. 1920. Based on Muhlenbergia emersleyi Vasey.

Epicampes subpatens Hitchc., U.S. Dept. Agr. Bull. 772: 144. 1920. Guadalupe Mountains, N.Mex., Hitchcock 13541.

(49) Muhlenbergia expansa (Poir.) Trin.; Kunth, Enum. Pl. 1: 207. 1833. Based on Trichochloa expansa DC., this based on Stipa expansa Poir.

Stipa expansa Poir., in Lam., Encycl. 7: 453. 1806. Carolina, Bosc.

Agrostis arachnoidea Poir., in Lam., Encyci. Sup. 1: 249. 1810. Carolina, Bosc.

Trichochloa purpurea Beauv., Ess. Agrost. 29. pl. 8. f. 2. 1812. United States.

Vilfa arachnoidea Beauv., Ess. Agrost. 147, 181. 1812. Presumably based on Agrostis arachnoidea Poir.

Podosaemum purpureum Beauv., Ess. Agrost. 176, 179. pl. 8. f. 2. 1812. Based on Trichochloa purpurea Beauv.

Trichochloa expansa DC., Cat. Hort. Monsp. 151. 1813. Based on Stipa expansa Poir.

Agrostis rubicunda Bosc; DC., Cat. Hort. Monsp. 151. 1813, as synonym of Trichochloa expansa DC.

Agrostis trichopodes Ell., Bot. S.C. and Ga. 1: 135. pl. 8. f. 1. 1816. Chatham County, Ga., Baldwin.

Cinna arachnoidea Kunth, Rév. Gram. 1: 67. 1829. Based on Agrostis arachnoidea Poir.

Muhlcnbergia arachnoidea Trin.; Kunth, Enum. Pl. 1: 207. 1833. Based on Agrostis arachnoidea Poir.

Agrostis expansa Poir.; Steud., Nom. Bot. ed. 2. 1: 40. 1840, as synonym of Cinna arachnoidea Kunth.

Agrostis longiflora Willd.; Steud., Nom. Bot. ed. 2. 1: 41. 1840, as synonym of Cinna arachnoidea Kunth.

Muhlenbergia trichopodes Chapm., Fl. South. U.S. 553. 1860. Based on Agrostis trichopodes Ell.

Muhlenbergia caespitosa Chapm., Bot. Gaz. 3: 18. 1878. Apalachicola, Fla., Chapman.

Muhlenbergia capillaris var. trichopodes Vasey, Contrib. U.S. Natl. Herb. 3: 66. 1892. Based on Agrostis trichopodes Ell.

Podosaemum trichopodes Bush, Amer. Midl. Nat. 7: 30. 1921. Based on Agrostis trichopodes Ell.

(17) Muhlenbergia filiculmis Vasey, Contrib. U.S. Natl. Herb. 1: 267. 1893. Green Mountain Falls, Colo., Sheldon [321].

(4) Muhlenbergia filiformis ('Thurb.) Rydb., Bull. Torrey Bot. Club 32: 600. 1905. Based on Vilfa depauperata var. filiformis Thurb.

Vilfa depauperata var. filiformis Thurb.; S. Wats., in King, Geol. Expl. 40th Par. 5: 376. 1871. Yosemite Valley, Calif., Bolander 6091; Donner Lake, Torrey 565; East Humboldt Mountains, Nev., Watson 1280; Uinta Mountains, Utah, Watson 1281.

Vilfa gracillima Thurb., in S. Wats., Bot. Calif. 2: 268. 1880. Not Muhlenbergia gracillima Torr. 1856. California, Sierra Nevada, Brewer [2827]; Yosemite Valley, Bolander [6091].

Sporobolus gracillimus Vasey, Descr. Cat. Grasses U.S. 44. 1885. Based on Vilfa gracillima Thurb.

Sporobolus filiformis Rydb., Contrib. U.S. Natl. Herb. 3: 189. 1895. Based on Vilfa depauperata var. filiformis Thurb.

Sporobolus depauperatus var. filiformis Beal, Grasses N.Amer. 2: 296.1896. Montana, Williams; Utah, Jones. 
Sporobolus simplex Scribn., U.S. Dept. Agr., Div. Agrost. Bull. 11: 48.1898. Georgetown, Colo., Rydberg 2411.

Sporobolus aristatus Rydb., Bull. Torrey Bot. Club 28: 266. 1901. Big Horn Mountains, Wyo., Tweedy 2196.

Sporobolus simplex thermale Merr., Rhodora 4: 48. 1902. Lolo Hot Springs, Mont., Griffiths 302a.

Muhlenbergia simplex Rydb., Bull. Torrey Bot. Club 32: 600. 1905. Not M. simplex Kunth, 1829. Based on Sporobolus simplex Scribn.

Muhlenbergia aristulata Rydb., Bull. Torrey Bot. Club 32:600. 1905. Based on Sporobolus aristatus Rydb.

(29) Muhlenbergia foliosa (Roem. and Schult.) Trin., Gram. Unifl. 190. 1824. Based on Agrostis foliosa "Hortul." Roem. and Schult.

Agrostis filiformis Willd., Enum. Pl. 1: 95. 1809. Not A. fliformis Vill. 1787. [Pennsylvania], North America.

Agrostis foliosa "Hortul."; Roem. and Schult., Syst. Veg. 2: 373.1817. Garden specimen; seed from North America.

Trichochloa foliosa Trin., Fund. Agrost. 117. 1820. Based on Agrostis filiformis Willd.

Cinna filiformis Link, Enum. PI. 1: 70. 1821. Based on Agrostis filiformis Willd.

Agrostis lateriflora var. filiformis Torr. Fl. North. and Mid. U.S. 1: 86. 1823. Based on $A$. filiformis Muhl. (error for Willd.).

Trichochloa filiformis Trin.; Torr., Fl. North. and Mid. U.S. 86. 1823, as synonym of Agrostis lateriflora var. filiformis Torr.

Podosaemum foliosum Link, Hort. Berol. 1: 83. 1827. Based on Agrostis foliosa Roem. and Schult.

Muhlenbergia mexicana var. purpurea Wood, Amer. Bot. and Flor. pt. 2: 386. 1870. Illinois, Wolf.

Muhlenbergia sylvatica var. vulpina Wood, Amer. Bot. and Flor. pt. 2: 386. 1870. New York, Lord.

Calamagrostis compressa Doell, in Mart., Fl. Bras. 23: 56. 1878. "E seminibus a cl. Glaziou prope Rio de Janeiro lectis in horto bot. Monacensi anno 1869 cultura enata." A specimen named in Doell's script and bearing the above data is in Doell's herbarium in the Botanical Institute at Freiburg. This agrees perfectly with Doell's description. It is a characteristic specimen of Muhlenbergia foliosa except that the rachilla is minutely produced beyond the palea, a very rare occurrence in Muhlenbergia. Presumably the seed from Rio de Janeiro failed to germinate, and this species, probably in a neighboring plot, intruded.

Muhlenbergia mexicana var. fliformis Vasey, Grasses U.S. 23. 1883 . Name only.

Muhlenbergia mexicana filiformis Scribn., Mem. Torrey Bot. Club 5: 36. 1894. Based on A. filiformis Muhl. (error for Willd.).

Muhlenbergia polystachya Mackenz. and Bush, Man. Fl. Jackson County 23. 1902. Sibley, Mo., Mackenzie 637.

Muhlenbergia ambigua var. filiformis Farwell, Mich. Acad. Sci. Rept. 20: 168. 1919. Based on Agrostis filiformis Muhl. (error for Willd.).

Muhlenbergia Foliosa var. SEtiglumis (S. Wats.) Scribn., Rhodora 9: 20. 1907. Based on $M$. sylvatica var. seliglumis S. Wats. (Published as M. foliosa setiglumis.)

Muhlenbergia ambigua Torr., in Nicoll., Rept. Miss. 164. 1843. "Okaman Lake, Sioux Country," Geyer.

Muhlenbergia sylvatica var. setiglumis S. Wats., in King, Geol. Expl. 40th Par. 5: 378. 1871. Humboldt Pass, Nev., Watson 1288.

Muhlenbergia foliosa ambigua Scribn., Rhodora 9: 20. 1907. Based on $M$. ambigua Torr.

Muhlenbergia setiglumis Nels. and Macbr., Bot. Gaz. 61: 30. 1916. Based on M. sylvatica var. setiglumis $\mathrm{S}$. Wats.

Muhlenbergia foliosa forma ambigua Wiegand, Rhodora 26: 1. 1924. Based on $M$. ambigua Torr.

(27) Muhienbergia glabrifiora Seribn., Rhodora 9: 22. 1907. Texas, Reverchon 5.

(20) Muhlenbergia glauca (Nees) Mez, Repert. Sp. Nov. Fedde 17: 214. 1921. Based on Podosaemum glaucum Nees. In Index Kewensis this name is credited to Nees in Linnaea 19: 689. 1847, but the name there is Podosaemum glaucum.

Podosaemum glaucum Nees, Linnaea 19: 689. 1847. Mexico, Aschenborn 335. 
Agrostis glauca Steud., Syn. P. Glum. 1: 175. 1854. Not A. glauca Muhl. 1817. Based on Podosaemum glaucum Nees.

Muhlenbergia lemmoni Scribn., Contrib. U.S. Natl. Herb. 1: 56. 1890. Ballinger, Tex., Nealley; New Mexico; Arizona [Lemmon 2918, type, the species being named for Lemmon]; Mexico.

Muhlenbergia huachucana Vasey, Contrib. U.S. Natl. Herb. 3: 69. 1892. Huachuca Mountains, Ariz., Lemmon [2915].

(53) Muhlenbergia involuta Swallen, Amer. Jour. Bot. 19:436. f. 2. 1932. San Antonio, Tex., Silveus 358.

(33) Muhlenbergia jonesii (Vasey) Hitchc., in Jepson, Fl. Calif. 1: 111. 1912. Based on Sporobolus jonesii Vasey.

Sporobolus jonesii Vasey, Bot. Gaz. 6: 297. 1881. Soda Springs, Calif., Jones [303] in 1881.

(52) Muhlenbergia lindheimeri Hitchc., Jour. Wash. Acad. Sci. 24: 291. 1934. Texas, Lindheimer 725. (This species has been referred to Epicampes berlandieri Fourn., and to Muhlenbergia fournieriana Hitchc., based upon it, but that species is confined to Mexico.)

Epicampes gracilis Trin. Mém. Acad. St. Pétersb. VI. Sci. Nat. 41: 271. 1841. Not Muhlenbergia gracilzs Kunth, 1829. Mexico [Eastern Texas, probably Berlandier].

(51) Muhlenbergia longiligula Hitchc., Amer. Jour. Bot. 21: 136. 1934. Based on Epicampes ligulata Scribn.

Epicampes ligulata Scribn.; Vasey, Contrib. U.S. Natl. Herb. 3: 58. 1892. Not Muhlenbergia ligulata Scribn. and Merr. Texas to Arizona [type, Santa Rita Mountains, Pringle in 1884] and Mexico.

Epicampes distichophylla var. mutica Scribn.; Beal, Grasses N.Amer. 2: 308. 1896. Arizona, Toumey 740 [type]; Mexico, Pringle 1427. The other specimens cited do not agree with the description.

Epicampes anomala Scribn., in Beal, Grasses N.Amer. 2: 311. 1896. Not Muhlenbergia anomalis Fourn., 1886. Chihuahua, Mexico, Pringle 1423.

Melica anomala Seribn., in Beal, Grasses N.Amer. 2: 311. 1896, as synonym of Epicampes anomala.

Epicampes stricta var. mutica Jones, Contrib. West. Bot. 14: 6. 1912. Based on E. distichophylla var. mutica Scribn.

(47) Muhlenbergia metcalfei Jones, Contrib. West. Bot. 14: 12. 1912. Santa Rita Mountains, N.Mex., Mecalfe 1485. The name was published as "Metcalfi."

(26) Muhlenbergia mexicana (L.) Trin., Gram. Unifl. 189. 1824. Based on Agrostis mexicana L.

Agrostis mexicana L., Mant. Pl. 1: 31. 1767. Grown at Upsala, erroneously credited to tropical America.

Agrostis lateriflora Michx., Fl. Bor. Amer. 1: 53. 1803. Mississippi River [Illinois], Michaux.

Vilfa mexicana Beauv., Ess. Agrost. 16, 148, 181. 1812. Based on Agrostis mexicana $\mathrm{L}$.

Vilfa lateriflora Beauv., Ess. Agrost. 16, 147, 181. 1812. Based on Agrostis lateriflora Michx. (Appears erroneously as laterifolia on pages 16 and 147, but correctly on page 181.)

Cinna? mexicana Beauv., Ess. Agrost. 32, 148, 158. 1812. Based on Agrostis mexicana L.

Trichochloa mexicana Trin., Fund. Agrost. 117. 1820. Based on Agrostis mexicana L.

Podosaemum mexicanum Link, Hort. Berol. 1: 84. 1827. Based on Muhlenbergia mexicana "Linn."

Cinna lateriflora Kunth, Rév. Gram. 1: 67. 1829. Based on Agrostis lateriflora Michx.

Muhlenbergia lateriflora Trin.; Kunth, Enum. Pl. 1: 207. 1833. Based on Agrostis lateriflora Michx.

Cinna arundinacea Retz.; Steud., Nom. Bot. ed. 2. 1: 365. 1840. Not C. arundinacea L., 1753, as synonym of C. mexicana Beauv.

Polypogon canadensis Fourn., Mex. Pl. 2: 92. 1886. Based on Agrostis mexicana L.

Lepyroxis canadensis Beauv.; Jacks., Ind. Kew. Suppl. 1: 244. 1906, as synonym of Agrostis mexicana L.

Muhlenbergia mexicana var. Commutata Scribn., Rhodora 9: 18. 1907. (Of the five specimens cited the first two are $M$. foliosa var. setiglumis, the other three are the form described. Of these Fernald 522 in 1896, from Maine, is taken as type.) (Published as $M$. mexicana commutata.) 
Muhlenbergia mexicana var. commutata Farwell, Rep. Mich. Acad. Sci. 17: 181. 1916. Based on $M$. mexicana commutata Scribn.

Muhlenbergia commutata Bush, Amer. Midl. Nat. 6: 61. 1919. Based on M. mexicana commutata Seribn.

Muhlenbergia mexicana forma commutata Farwell, Rhodora 26: 1. 1924. Based on M. mexicana commutata Seribn.

(2) Muhlenbergia microsperma (DC.) Kunth, Rév. Gram. 1: 64. 1829. Based on Trichochloa microsperma DC.

Trichochloa microsperma DC., Cat. Hort. Monsp. 151. 1813. Mexico.

Podosaemum setosum H.B.K., Nov. Gen. and Sp. 1: 129. 1815. Mexico, Humboldt and Bonpland.

Podosaemum debile H.B.K., Nov. Gen. and Sp. 1: 128. 1815. Ecuador, Humboldt and Bonpland.

Agrostis microsperma Lag., Gen. and Sp. Nov. 2. 1816. Mexico, Sessé.

Trichochloa debilis Roem. and Sehult., Syst. Veg. 2: 385. 1817. Based on Podosaemum debile H.B.K.

Trichochloa setosa Roem. and Schult., Syst. Veg. 2: 386. 1817. Based on Podosaemum setosum H.B.K.

Muhlenbergia fasciculata Trin., Gram. Unifl. 192. 1824. North America.

Agrostis setosa Spreng., Syst. Veg. 1: 262. 1825. Based on Podosaemum setosum H.B.K.

Agrostis debilis Spreng., Syst. Veg. 1: 262. 1825. Not A. debilis Poir., 1810. Based on Podosaemum debile H.B.K.

Muhlenbergia setosa Kunth, Rév. Gram. 1: 63. 1829. Based on Podosaemum setosum H.B.K.

Muhlenbergia debilis Kunth, Rév. Gram. 1: 63. 1829. Based on Podosnemum debile H.B.K.

Agrostis microcarpa Steud., Nom. Bot. ed. 2. 1: 41. 1840; 2: 164 . 1841, as synonym of Muhlenbergia microsperma.

Muhlenbergia purpurea Nutt., Jour. Aead. Nat. Sci. Phila. II. 1: 186. 1848. Santa Barbara and Santa Catalina Island, Calif., Gambel.

Muhlenbergia ramosissima Vasey, Bull. Torrey Bot. Club 13: 231. 1886. Chihuahua, Mexico, Palmer [158] in 1885.

(34) Muhlenbergia montana (Nutt.) Hitchc., U.S. Dept.Agr. Bull. 772: 145, 147. 1920. Based on Calycodon montanum Nutt.

Calycodon montanum Nutt., Jour. Aead. Nat. Sci. Phila. II. 1: 186. 1848. Santa Fe, [New] Mexico, Gambel.

Muhlenbergia gracilis var. breviaristata Vasey, in Torr., Cat. Pl. Survey W. 100th Merid. 54. 1874. Twin Lakes, Colo., [1\%olf] 1090 in 1873.

Muhlenbergia gracilis var. major Vasey, in Wheeler, Rept. U.S. Survey 100 th Merid. 6: 284. 1878. Mount Graham, Ariz., Wheeler Exped. [Rothrock] 744 .

Muhlenhergia subalpina Vasey, Deser. Cat. Grasses U.S. 40. 18S5. Based on $M$. gracilis var. breviaristata Vasey.

Muhlenbergia trifida Hack., Repert. Sp. Nov. Fedde 8: 518. 1910. Michoaeán, Mexico, Arsène 3217.

This is the species referred to Muhlenbergia gracilis by American authors, not M. gracilis (H.B.K.) Kunth.

(38) Muhlenbergia monticola Buckl., Acad. Nat. Sci. Phila. Proc. 1862: 91. 1863. "Northwestern Texas," [Wright 731].

Muhlenbergia syltaticn var. flexuosa Vasey in Wheeler, Rep. U.S. Survey 100 th Merid. 6: 284. 1878. New Mexico, Wright 731; Camp Crittenden, Ariz., Rothrock 681.

(39) Muhlenbergịa parviglumis Vasey, Contrib. U.S. Natl. Herb. 3: 71. 1892. Texas, Nealley.

(40) Muhlenbergia pauciflora Buekl., Aead. Nat. Sci. Phila. Proc. 1862: 91. 1863. Western Texas, [Wright 732].

Muhlenbergia sylvatica var. pringlei Scribn., Bull. Torrey Bot. Club 9: 89. 1882. Santa Rita Mountains, N.Mex., Pringle 480.

Muhlenbergia neo-mexicana Vasey, Bot. Gaz. 11: 337. 1886. New Mexico [type, G.R. Vasey] and Arizona.

Muhlenbergia pringlei Seribn., in Vasey, Contrib. U.S. Natl. Herb. 3: 71. 1802. Santa Rita Mountains, N.Mex., Pringle 4 S0.

(36) Muhlenbergia polycaulis Seribn., Bull. Torrey Bot. Club. 38: 327. 1911. Chihuahua, Mexico, Pringle 1414.

(41) Muhlenbergia porteri Scribn.; Beal, Grasses N.Amer. 2: 259. 1896. Based on $M$. texana Thurb. 
Muhlenbergia texana Thurb.; Port. and Coult., Syn. Fl. Colo. 144. 1874. Not M. texana Buckl., 1863. Texas, Bigelow; Parry; Wright 734.

Podosaemum porteri Bush, Amer. Midl. Nat. 7: 36. 1921. Based on Muhlenbergia porteri Scribn.

(16) Muhlenbergia pungens Thurb., in A. Gray, Acad. Nat. Sci. Phila. Proc. 1863: 78. 1863. Rocky Mountains, Colo., Hall and Harbour 632.

Podosaemum pungens Bush, Amer. Midl. Nat. 7: 32. 1921. Not P. pungens Link, 1S27. Based on Muhlenbergia pungens Thurb.

(25) Muhlenbergia racemosa (Michx.) B.S.P., Prel. Cat. N.Y. 67. 1888. Presumably based on Agrostis racemosa Michx.

Agrostis racemosa Michx., Fl. Bor. Amer. 1: 53. 1803. Mississippi River [IIl.], Michaux.

Polypogon setosus Spreng., Mant. Fl. Hal. 31. 1807. Pennsylvania, Muhlenberg.

Polypogon glomeratus Willd., Enum. Pl. 87. 1809. North America.

Vilfa racemosa Beauv., Ess. Agrost. 16, 148, 182. 1812. Based on Agrostis racemosa Michx.

Alopecurus glomeratus Poir., in Lam., Encycl. 5: 495. 1817. Based on Polypogon glomeratus Willd.

Agrostis setosa Muhl., Descr. Gram. 68. 1817. Pennsylvania.

Agrostis festucoides Muhl.; Roem. and Schult., Syst. Veg. 1: 326. 1817, as synonym of Polypogon glomeratus Willd.

Polypogon racemosus Nutt., Gen. P1. 1: 51. 1818. Based on Agrostis racemosa Michx.

Trichochloa glomerata Trin., Fund. Agrost. 117. 1820. Based on Polypogon glomeratus Willd.

Trichochloa calycina Trin., Fund. Agrost. 117. 1820. "Agrostis setosa Spreng." (ined.) cited, no description.

Agrostis setosa Spreng.; Trin., Fund. Agrost. 117. 1820. As synonym of Trichochloa calycina Trin., not $A$. setosa Spreng. himself, 1S24, (see synonymy under Muhlenbergia microsperma).

Muhlenbergia glomerata Trin., Gram. Unifl. 191. pl. 5. f. 10. 1824. Based on Polypogon glomeratus Willd.

Muhlenbergia calycina Trin., Gram. Uniff. 193. 1824. Based on Trichochloa calycina Trin., and cited as synonym of Polypogon setosus Spreng.

Podosaemum glomeratum Iink, Hort. Berol. 1: 84. 1827. Based on Polypogon glomeratus Willd.

Cinna racemoso Kunth, Rév. Gram. 1: 67. 1829. Based on Agrostis racemosa Michx.

Dactylogramma cinnoides Link, Hort. Berol. 2: 248. 1833. Grown in Berlin, seed from Richardson, western North America.

Cinna glomerata Link, Hort. Berol. 2: 237. 1833. Not C. glomerata Walt., 1788. Based on Podosaemum glomeratum Link.

Muhlenbergia glomerata var. ram.osa Vasey, Descr. Cat. Grasses U.S. 40. 1885. Illinois to Colorado and Montana. [Type, collected by Vasey, marked "Dakota and Wisconsin."]

Muhlenbergia racemosa var. ramosa Vasey; Beal, Grasses N.Amer. 2: 253. 1896. Presumably based on M. glomerala var. ramosa Vasey.

Muhlenbergia racemosa violacea Scribn., Rhodora 9: 22. 1907. North Hannibal, N.Y., Pearce in 1883.

(5) Muhlenbergia repens (Presl) Hitchc., in Jepson, Fl. Calif. 1: 111. 1912. Based on Sporobolus repens Presl.

Sporobolus repens Presl, Rel. Haenk. 1: 241. 1830. Mexico, Haenke.

Vilfa repens Trin., Mém. Acad. St. Pétersb. VI. Sci. Nat. 4" 102. 1840. Based on Sporobolus repens Presl.

Muhlenbergia subtilis Nees, Linnaea 19: 689. 1847. Mexico, Aschenborn 206.

(50) Muhlenbergia reverchoni Vasey and Scribn., Contrib. U.S. Natl. Herb. 3: 66. 1892. Texas, Reverchon [73].

Podosaemum reverchoni Bush, Amer. Midl. Nat. 7: 38. 1921. Based on Muhlenbergia reverchoni Vasey and Scribn.

(55) Muhlenbergia rigens (Benth.) Hitchc., Jour. Wash. Acad. Sci. 23: 453. 1933. Based on Epicampes rigens Benth.

Cinna macroura (Kunth misapplied by) Thurb.; S. Wats., Bot. Calif. 2: 276. 1880. Not C. macroura (H.B.K.) Kunth, 1835. California.

Vilfa rigens Thurb.; S. Wats., Bot. Calif. 2: 276. 1880. Not V. rigens Trin., 1830. As synonym of C. macroura Kunth. "Sonora" [probably error for Sonoma] California, Bolander [6124]. 
Epicampes rigens Benth., Jour. Linn. Soc. Bot. 19: 88. 1881. Based on the species Thurber described as Cinna macroura, not that of (H.B.K.) Kunth.

Crypsinna rigens Jones, Contrib. West. Bot. 14: 8. 1912. Based on Epicampes rigens Benth.

(46) Muhlenbergia rigida (H.B.K.) Kunth, Rév. Gram. 1: 63. 1829. Based on Podosaemum rigidum H.B.K.

Podosaemum rigidum H.B.K., Nov. Gen. and Sp. 1: 129. 1815. Mexico, Humboldt and Bonpland.

Trichochloa rigida Roem. and Schult., Syst. Veg. 2: 386. 1817. Based on Podosaemum rigidum H.B.K.

Muhlenbergia berlandieri Trin., Mém. Acad. St. Pétersb. VI. Sci. Nat. 4¹: 299. 1841. Mexico, Berlandier.

(30) Muhlenbergia schreberi Gmel., Syst. Nat. 2: 171. 1791. Based on the species described by Schreber (Gen. Pl. 1: 44. 1789) under Muhlenbergia with no specific name, [Pennsylvania].

Muhlenbergia diffusa Willd., Sp. Pl. 1: 320. 1797. North America.

Dilepyrum minutiflorum Michx., Fl. Bor. Amer. 1: 40. 1803. Kentucky and Illinois, Michaux. Listed as Dylepyrum multiflorum by Beauv., Ess. Agrost. 160. 1812.

Dylepyrum diffusum Beauv., Ess. Agrost. 160. 1812. Name only, referred to Muhlenbergia. Probably the same as $M$. diffusa Willd.

Cynodon diffusus Raspail, Ann. Sci. Nat., Bot. 5: 303. 1825. Based on "Muhlenbergia Schr." (error for Willd.).

Agrostis apetala Bosc; Trin., Mém. Acad. St. Pétersb. VI. Sci. Nat. 41: 287. 1841 , as synonym of Muhlenbergia diffusa Schreb.

Muhlenbergia botteri Fourn., Mex. P1. 2: S5. 1886. Orizaba, Mexico, Botteri 87.

Muhlenbcrgia minutiflorum Hitchc., Kans. Acad. Sci. Trans. 14: 140. 1896. Based on Dilepyrum minutiflorum Michx.

Muhlenbergia schreberi var. Palustris (Scribn.) Scribn., Rhodora 9: 17. 1907. Based on $M$. palustris Scribn. (Published as M. schreberi palustris.)

Muhlenbergia palnstris Scribn., U.S.Dept.Agr., Div. Agrost. Bull. 11: 47. 1898. District of Columbia, Steele in 1896.

Muhlenbergia schreberi var. palustris Scribn.; Robinson, Rhodora 10: 65. 1908. Based on M. palustris Scribn.

(44) Muhlenbergia setifolia Vasey, Bot. Gaz. 7: 92. 1882. Guadalupe Mountains, Tex., Havard.

(22) Muhlenbergia sobolifera (Muhl.) Trin., Gram. Unifl. 189. pl. 5. f. 4. 1824. Based on Agrostis sobolifera Muhl.

Agrostis sobolifera Muhl.; Willd., Enum. Pl. 95. 1809. Pennsylvania.

Achnatherum soboliferum Beauv., Ess. Agrost. 20, 146. 1812. Based on Agrostis sobolifera Muhl.

Trichochloa sobolifera Trin., Fund. Agrost. 117. 1820. Based on Agrostis sobolifera Muhl.

Cinna sobolifera Link, Enum. PI. 1: 71. 1821. Based on Agrostis sobolifera Willd.

Podosaemum soboliferum Link, Hort. Berol. 1: 83. 1827. Based on Agrostis sobolifera Muhl.

Muilenbergia sobolifera var. setigera Scribn., Rhodora 9: 18.1907. Texas, Reverchon 70. (Published as M. sobolifera setigera.)

Muhlenbergia sobolifera forma setigera Deam, Ind. Dept. Conserv. Pub. 82: 163. 1929. Based on M. sobolifera setigera Scribn.

(7) Muhlenbergia squarrosa (Trin.) Rydb., Bull. Torrey Bot. Club 36: 531. 1909. Based on Vilfa squarrosa Trin.

Vilfa squarrosa Trin., Mém. Acad. St. Pétersb. VI. Sci. Nat. 4: 100.1840. Menzies Island [Columbia River, Wash.].

Vilfa richardsonis Trin., Mém. Acad. St. Pétersb. VI. Sci. Nat. 4¹: 103.1840. North America, Richardson.

Muhlenbergia aspericaulis Nees; Trin. Mém. Acad. St. Pétersb. VI. Sci. Nat. $4^{1}$ : 103. 1840, as synonym of Vilfa richardsonis Trin.

Vilfa depauperata Torr.; Hook., F1. Bor. Amer. 2: 257. pl. 36. 1840. Columbia River, from Menzies Island upward, Douglas.

Sporobolus depauperatus Scribn., Bull. Torrey Bot. Club 9: 103. 1882. Based on Vilfa depauperata Torr.

Sporobolus aspericaulis Scribn., Bot. Gaz. 21: 15. 1896. Based on Muhlenbergia aspericaulis Nees. 
Sporobolus richardsonii Merr., Rhodora 4: 46. 1902. Based on Vilfa richarasonis Trin.

Muhlenbergia richardsonis Rydb., Bull. Torrey Bot. Club 32: 600. 1905. Based on Vilfa richardsonis Trin.

Muhlenberqia brevifolia var. richardsonis Jones, Contrib. West. Bot. 14: 12. 1912. Based on Vilfa richardsonis Trin.

This is the species which Nash (Britton, Man. 105. 1901) called Sporobolus brevifolius, but that name is based on Agrostis brevifolius Nutt., which is Muhlenbergia cuspidata (which see).

(28) Muhlenbergia sylvatica Torr.; Trin., Mém. Acad. St. Pétersb. VI. Sci. Nat. 41: 292. 1S41. Based on Agrostis sylvatica Torr.

Agrostis diffusa Muhl., Descr. Gram. 64. 1817. Not A. diffusa Host, 1809. Pennsylvania.

Agrostis sylvatica Torr., Fl. North. and Mid. U.S. 1: 87. 1823. Not $A$. sylvatica L., 1762. Mountains of New Jersey.

Muhlenbergia sylvatica var. gracilis Scribn., Kans. Acad. Sci. Trans. 9: 116. 1885. Topeka, Kans., Popenoe.

Muhlenbergia umbrosa Scribn., Rhodora 9: 20. 1907. Based on Agrostis sylvatica Torr.

Muhlenbergia umbrosa attenuata "Scribn., Rhodora 9: 21. 1907. Aurora County, S.Dak., Wilcox 25.

Muhlenbergia diffusa Farwell, Mich. Acad. Sci. Rept. 20: 168. 1919. Not M. diffusa Willd., 1797. Based on Agrostis diffusa Muhl.

Muhlenbergia umbrosa forma attenuata Deam, Ind. Dept. Conserv. Pub. 82: 171. 1929. Based on M. umbrosa attenuata Scribn.

(23) Muhlenbergia tenuiflora (Willd.) B.S.P., Prel. Cat. N.Y. 67. 1888. Based on Agrostis tenuiflora Willd.

Agrostis tenuiflora Willd., Sp. Pl. 1: 364. 1797. North America.

Apera tenuiflora Beauv., Ess. Agrost. 151. 1812. Based on Agrostis tenuiflora Willd.

Trichochloa longiseta Trin., Fund. Agrost. 117. 1820. Based on Agrostis tenuiflora Willd. Erroneously given as T. longiflora Trin., in Kunth, Euum. Pl. 1: 601. 1833.

Cinna tenuiflora Link, Enum. PI. 1: 71. 1821. Based on Agrostis tenuiflora Willd.

Muhlenbergia willdenowii Trin., Gram. Unif. 188. pl. 5. f. 3. 1824. Based on Agrostis tenuiflora Willd.

Trichochloa tenuiflora Sweet, Hort. Brit. 443. 1826. Based on Agrostis tenuiflora Willd.

Podosaemum tenuiflorum Link, Hort. Berol. 1: 82. 1827. Based on Agrostis tenuiflora Willd.

Muhlenbergia tenuiflora variabilis Scribn., Rhodora 9: 18. 1907. Chimney Mountain, N.C., Billmore Herbarium 654a.

(1) Muhlenbergia texana Buckl., Acad. Nat. Ści. Phila. Proc. 1862: 91. 1863. Northern Texas.

Agrostis barbata Buckl.; A. Gray, Acad. Nat. Sci. Phila. Proc. 1862: 334.1863. Not A. barbata Pers., 1805 . As synonym of Muhlenbergia texana Bucki.

Muhlenbergia buckleyana Scribn., Contrib. U.S. Natl. Herb. 1: 56.1890. Based on M. texana Buckl.

Podosaemum texanum Bush, Amer. Midl. Nat. 7: 41. 1921. Based on Muhlenbergia texana Buckl.

(8) Muhlenbergia thurberi Rydb., Bull. Torrey Bot. Club 32: 601. 1905. Based on Sporobolus filiculmis Vasey; Beal. Vilfa filiculmis Thurb., also cited, is a name only, and no reference is made to Sporobolus thurberi Scribn.

Sporobolus filiculmis Vasey, Descr. Cat. Grasses U.S. 44. 1885, name only; Vasey; Beal, Grasses N.Amer. 2: 288. 1896. Not S. filiculmis L. H. Dewey, 1894. New Mexico, Whipple Exped. [Plaza Larga, Bigclow 778].

Vilfa filiculmis Thurb.; Vasey, Descr. Cat. Grasses U.S. 44. 1885, as synonym of Sporobolus filiculmis Vasey.

Sporobolus thurberi Scribn., U.S. Dept.Agr., Div. Agrost. Bull. 11: 48. f. 5. 1898. "Vilfa filiculmis Thurb." Plaza Larga, N.Mex., Bigelow.

Vilfa filiculmis Thurb.; Scribn., U.S.Dept.Agr., Div. Agrost. Bull. 11: 48. 1898, as synonym of Sporobolus thurberi Scribn.

Muhlenbergia filiculmis Jones, Contrib. West. Bot. 14: 12. 1912. Not M. filiculmis Vasey, 1893. Based on Vilfa filiculmis Thurb., name only.

Muhlenbergia curtifolia griffithsii Scribn., Bull. Torrey Bot. Club 38: 328. 1911. De Chelly Canyon, Ariz., Grifiths 5837. 
(14) Muhlenbergia torreyana (Schult.) Hitchc., Amer. Jour. Bot. 21: 136. 1934. Based on Agrostis torreyana Schult.

Agrostis compressa Torr., Cat. Pl. N.Y. 91. 1819. Not A. compressa Willd., 1790. New Jersey, Goldy.

Vilfa compressa Trin.; Spreng., Neu. Entd. 2: 58. 1821. Not V. compressa Beauv., 1812. North America.

Colpodium compressum Trin.; Spreng., Neu. Entd. 2: 58. 1821, as synonym of Vilfa compressa Trin.

Agrostis torreyana Schult., Mant. 2: 203. 1824. Based on Agrostis compressa Torr.

Sporobolus comprcssus Kunth, Enum. Pl. 1: 217. 1833. Based on Agrostis compressa Torr.

Sporobolus torreyanus Nash, in Britton, Man. 107. 1901. Based on Agrostis torreyana Schult.

(42) Muhlenbergia torreyi (Kunth) Hitchc.; Bush, Amer. Midl. Nat. 6: 84. 1919. Based on Agrostis torreyi Kunth.

Agrostis caespitosa Torr., Ann. Lyc. N.Y. 1: 152. 1824. Not A. caespitosa Salisb., 1796, nor Muhlenbergia caespitosa Chapm., 1878. Prairies of Missouri and Platte Rivers.

Agrostis torreyi Kunth, Rév. Gram. 1: Sup. XVII. 1830. Based on $A$. caespitosa Torr.

Muhlenbergia gracillima Torr., U.S. Rept. Expl. Miss. Pacif. 4: 155. 1856. Llano Estacado and near Antelope Hills, Canadian River, Tex. [Bigelow.]

Muhlenbergia nardifolia Griscb., Abh. Ges. Wiss. Göttingen 24: 294. 1879. Argentina.

Agrostis peckii House, Amer. Midl. Nat. 7: 126. 1921. Based on A. caespitosa Torr. The name misapplied to the awned form of Agrostis hiemalis.

Podosaemum gracillimum Bush, Amer. Midl. Nat. 7: 33. 1921. Based on Muhlenbergia gracillima Torr.

(15) Muhlenbergia uniflora (Muhl.) Fernald, Rhodora 29: 10. 1927. Based on Poa uniflora Muhl.

Poa? uniflora Muhl., Descr. Gram. 151. 1817. New England.

Agrostis serotina Torr., Fl. North. and Mid. U.S. 1: 88.1823 . Not $A$. serotina Lam., $1767 . \quad$ New Jersey.

Tilfa serotina Trin., Gram. Icon. 3: pl. 251. 1830. North America, "Agrostis serotina Nutt. ms."

Vilfa tenera Trin., Mém. Acad. St. Pétersb. VI. Sci. Nat. 41: 87. 1840. Boston, Boott.

Poa modesta Tuckerm., Amer. Jour. Sci. 45: 45. 1843. Cambridge, Mass. [Tuckerman.]

Sporobolus serotinus A. Gray, Man. 577. 1848. Based on Agrostis serotina Torr.

Sporobolus uniflorus Scribn. and Merr., U.S.Dept.Agr., Div. Agrost. Circ. 27: 5. 1900. Based on Poa uniflora Muhl.

Poa stricta uniflora Muhl.; Scribn. and Merr., U.S.Dept.Agr., Div. Agrost. Circ. 27: 5. 1900, as synonym of Sporobolus uniflorus Muhl.

Muhlenbergia uniflora var. terrae-novae Fernald, Rhodora 29: 11.1927. Newfoundland, Fernald, Long and Dunbar 26244.

(6) Muhlenbergia utilis (Torr.) Hitchc., Jour. Wash. Acad. Sci. 23: 453. 1933. Based on Vilfa utilis Torr.

Vilfa utilis Torr., U.S. Rept. Expl. Miss. Pacif. 52: 365. 1857. Between Tejon Pass and Lost Hills, Calif., [Blake].

Vilfa sacatilla Fourn., Mex. Pl. 2: 101. 1886. Chapultepec, Mexico, Schaffner; San Luis de Potosí, Virlet 1455; Texas, Wright.

Sporobolus sacatilla Griseb.; Fourn., Mex. Pl. 2: 101. 1886, as synonym of Vilfa sacatilla Fourn.

Sporobolus utilis Scribn., U.S.Dept.Agr., Div. Agrost. Bull. 17: 171. f. 467. 1899. Based on Vilfa utilis Torr.

(35) Muhlenbergia virescens (H.B.K.) Kunth, Rév. Gram. 1: 64. 1829. Based on Podosaemum virescens H.B.K.

Podosaemum virescens H.B.K., Nov. Gen. and Sp. 1: 132. 1815. Mexico, Humboldt and Bonpland.

Trichochloa virescens Roem. and Schult., Syst. Veg. 2: 389. 1817. Based on Podosacmon virescens H.B.K.

Muhlenbergia straminea Hitchc., Contrib. U.S. Natl. Herb. 17: 302. 1913. Chihuahua, Mexico, Endlich 1210.

$55974^{\circ}-35--57$ 
(11) Muhlenbergia wrightii Vasey in Coulter, Man. Rocky Mount. 409. 1885. Colorado and New Mexico, [type Wright 1986].

Muhlenbergia wrightii var. annulata Vasey, Descr. Cat. Grasses U.S. 41. 1885. Name only. [Arizona, Lemmon 3179.]

Muhlenbergia coloradensis Mez, Repert. Sp. Nov. Fedde 17: 213.1921. "Chiann [Cheyenne] Canyon", Colo., Jones [806].

\section{(106) MUNROA Torr.}

(1) Munroa squarrosa (Nutt.) Torr., U.S. Rept. Expl. Miss. Pacif. $4^{5}: 158$. 1857. Based on Crypsis squarrosa Nutt.

Crypsis squarrosa Nutt., Gen. Pl. 1: 49. 1818. Grand detour of the Missouri River, [S.Dak., Nuttall].

Munroa squarrosa var. floccuosa Vasey; Beal, Grasses N.Amer. 2: 456.1896. Arizona, [Peach Springs], Jones. (See p. 523.)

Nardus stricta L., Sp. Pl. 53. 1753. Europe.

Nassella major (Trin. and Rupr.) Desv., in Gay, Fl. Chil. 6: 265. 1853. Based on Urachne major Trin. and Rupr.

Urachne major Trin. and Rupr., Mém. Acad. St. Pétersb. VI. Sci. Nat. 5: 211. 1842. Chile.

(27) NEYRAUDIA Hook. f.

(1) Neyraudia reynaudiana (Kunth) Keng, in Hitchc., Amer. Jour. Bot. 21: 131. 1934. Based on Arundo reynaudiana Kunth.

Arundo reynaudiana Kunth, Rév. Gram. 2: 275. pl. 49. 1830. Burma, Reynaud.

(139) OLYRA L.

(1) Olyra latifolia L., Syst. Nat. ed. 10. 2: 1261. 1759. Jamaica, Sloane. Olyra paniculata Swartz, Prodr. Veg. Ind. Occ. 21. 1788. Jamaica, Swartz. Olyra arundinacea H.B.K., Nov. Gen. and Sp. 1: 197. 1816. Colombia, Humboldt and Bonpland.

Stipa latifolia Raspail, Ann. Sci. Nat., Bot. 5: 449. 1825. Based on Olyra latifolia L.

Olyra latifolia var. arundinacea Griseb., Fl. Brit. W.Ind. 535. 1864. Presumably based on $O$. arundinacea H.B.K.

\section{(132) OPLISMENUS Beauv. ${ }^{23}$}

Oplismenus hirtellus (L.) Beanv., Ess. Agrost. 54, 168, 170. 1812. Based on Panicum hirtellum L.

Panicum hirtellum L., Syst. Nat. ed. 10. 2: S70. 1759. Jamaica, [Browne]. This species is cultivated under the name Panicum variegatum Hort. (see Gard. Chron. 458. 1867).

(1) Oplismenus setarius (Lam.) Roem. and Schult., Syst. Veg. 2: 481. 1817. Based on Panicum setarium Lam.

Panicum setarium Lam., Tabl. Encycl. 1: 170. 1791. South America, Commerson.

Panicum velutinum G. Meyer, Prim. F1. Esseq. 51. 1818. British Guiana [Meyer].

Orthopogon parvifolium Nutt., Gen. Pl. 1: 55, errata. 1818. Florida and South Carolina. On page 55 this is described under Orthopogon hirtellus Nutt., the name based on Panicum hirtellum L., but misapplied.

Setaria hirtella Schult., Mant. 2: 276. 1824. Based on the species described by Muhlenberg (Descr. Gram. 103. 1817) under the name Panicum hirtellum.

Orthopogon setarius Spreng., Syst. Veg. 1: 306. 1825. Based on Panicum setarium Lam.

Oplismenus parvifolius Kunth, Rév. Gram. 1: 45. 1829. Based on Orthopogon parvifolium Nutt.

Orthopogon hirtellus Eaton and Wright, N.Amer. Bot. ed. S. 336.1840. Southern States. No reference to Nuttall, nor synonym cited.

Panicum nuttallianum Steud., Nom. Bot. ed. 2. 2: 260. 1841. Based on Orthopogon parvifolius Nutt.

${ }^{23}$ For discussion of types see Hitchc., Contrib. U.S. Nat1. Herb. 22: 126-130. 1920. 
Oplismenus compositus var. setarius F. M. Bailey, Queensl. Grasses 19. 1888. Based on Panicum setarium Lam.

Ifippagrostis setarius Kiuntze, Rev. Gen. Pl. 2: 777. 1891. Based on Panicum setarium Lam.

Oplismenus hirtellus subsp. setarius Mez; Ekman, Arkiv Bot. 11*: 26. 1912. Based on Panicum sctarium Lam.

\section{(34) ORCUTTIA Vasey}

(3) Orcuttia californica Vasey, Bull. Torrey Bot. Club 13: 219. pl. 60. 1886. San Quentin Bay, Baja California, Orcutt.

(1) Orcuttia greenei Vasey, Bot. Gaz. 16: 146. 1891. Chico, Calif., Greene.

(2) Orcuttia tenuis Hitche., Aner. Jour. Bot. 21: 131. 1934. Goose Valley, Shasta County, Calif., Easiwood 1013 (distributed in Amer. Gr. Nat. Herb. 110. 686 as Orcuttia californica).

\section{(111) ORYZA L.}

(1) Oryza sativa L., Sp. P1. 333. 1753. Africa and India.

Oryza sativa var. rubribarbis Desv., Jour. Bot. 1: 76. 1813. Cultivated in North America.

Oryza rubribarbis Steud., Nom. Bot. 577. 1821. Based on O. sativa var. rubribarbis Desv.

Oryza sativa var. savannae Koern., in Koern. and Wern., Handb. Getreidebau. 1: 233, 236. 1585. Cultivated, Savannah, Ga.

(82) ORYZOPSIS Michx.

(S) Oryzopsis asperifolia Michx. Fl. Bor. Amer. 1: 51. pl. 9. 1803. Hudson Bay to Quebec, Michaux.

Oryzopsis mutica Link, Enum. Pl. 1: 41. 1821. North America.

Urachne asperifolia Trin., Gram. Unifl. 174. 1824. Based on Oryzopsis asperifolia Michx.

Urachne leucosperma Link, Hort. Berol. 1: 94. 1827. Albany, N.Y.

Urachne mutica Steud., Nom. Bot. ed. 2. 2: 731. 1841. Based on Oryzopsis mutica Link.

Oryzopsis leucosperma Link; Walp., Ann. Bot. [London] 3: 728. 1853, as synonym of Urachne asperifolia Trin.

(10) Oryzopsis blooneri (Boland.) Ricker; Piper, Contrib. U.S. Natl. Herb. 11: 109. 1906. Based on Stipa bloomeri Boland.

Stipa bloomeri Boland., Proc. Calif. Acad. 4: 168. 1872. Bloody Canyon, near Mono Lake, Calif., Bolander [6116].

Oryzopsis caduca Beal, Bot. Gaz. 15: 111. 1890. Belt Mountains, Mont., Scribner.

Stipa caduca Scribn., Contrib. U.S. Natl. Herb. 3: 54. 1892. Based on Oryzopsis caduca Beal.

Eriocoma caduca Rydl)., Mem. N.Y. Bot. Gard. 1: 25. 1900. Based on Stipa caduca Scribn.

This is the species described by Beal (Grasses N.Amer. 2: 226.1896 ) under the name Oryzopsis sibirica Beal, but the name is based on Stipa sibirica Lam., not known from America.

(6) Oryzopsis canadensis (Poir.) Torr., Fl. N.Y. 2: 433. 1843. Based on Stipa canadensis Poir.

Stipa juncea Michx., Fl. Bor. Amer. 1: 54. 1803. Not S. juncea L., 1753. Hudson Bay, Canada, Michaux.

Stipa canadensis Poir., in Lam., Eneycl. 7: 452. 1806. Based on S. juncea Michx.

Urachne cunadensis Torr. and Gray, Gram. and Cyp. Exsicc. no. 114.1836. Based on Stipa canadensis Poir.

Oryzopsis juncea B.S.P., Prel. Cat. N.Y. 67. 1888. Based on Stipa juncea Michx.

Stipa macounii Scribn.; Macoun, Cat. Can. PI. $2^{5}$ : 390. 1890. New Brunswick.

Oryzopsis macounii Beal, Grasses N.Amer. 2: 229. 1896. Based on Stipa macounii Scribn.

This is the species to which the name Stipa richardsonii Link was applied by A. Gray in the earlier editions of the Manual. 
(4) Oryzopsis exigua Thurb., in Wilkes, U.S. Expl. Exped. Bot. 17: 481. 1874. Cascade Mountains, Oreg., Wilkes Expl. Exped.

(3) Oryzopsis hendersoni Vasey, Contrib. U.S. Natl. Herb. 1: 267. 1893. [Clements Mountain, near North Yakima], ${ }^{24}$ IEenderson 2249.

Oryzopsis exigua var. hendersoni Jones, Contrib. West. Bot. 14: 11. 1912. Based on $O$. hendersoni Vasey.

(12) Oryzopsis hymenoides (Roem. and Schult.) Ricker; Piper, Contrib. U.S. Natl. Herb. 11: 109. 1906. Based on Stipa hymenoides Roem. and Schult.

Stipa membranacea Pursh, Fl. Amer. Sept. 2: 728. 1814. Not S. membranacea L., 1753. Banks of the Missouri River, Bradbury.

Stipa hymenoides Roem. and Schult., Syst. Veg. 2: 339. 1817. Based on Stipa membranacea Pursh.

Eriocoma cuspidata Nutt., Gen. Pl. 1: 40. 1818. Grassy plains of the Missouri [type from "Platte Plains", Nuttall].

Milium cuspidatum Spreng., Syst. Veg. 1: 251. 1825. Based on Eriocoma cuspidata Nutt.

Urachne lanata Trin. and Rupr., Mém. Acad. St. Pétersb. VI. Sci. Nat. 1: 126. 1834. North America.

Eriocoma membranacea Steud., Nom. Bot. ed. 2. 1: 586. 1840, as synonym of Urachne lanata Trin.

Fendleria rhynchelytroides Steud., Syn. Pl. Glum. 1: 420. 1854. New Mexico, Fendler 979.

Oryzopsis cuspidata Benth.; Vasey, Grasses U.S. 23. 1883. Based on Eriocoma cuspidata Nutt.

Oryzopsis membranacea Vasey, U.S.Dept.Agr., Div. Bot. Bull. 12²: pl. 10. 1891. Based on Stipa membranacea Pursh.

Eriocoma membranacea Beal, Grasses N.Amer. 2: 232. 1896. Based on Stipa membranacea Pursh.

Eriocoma hymenoides Rydb., Bull. Torrey Bot. Club 39: 102. 1912. Based on Stipa hymenoides Roem. and Schult.

(7) Oryzopsis kingii (Boland.) Beal, Grasses N.Amer. 2: 229. 1896. Based on Stipa kingii Boland.

Stipa kingii Boland., Calif. Acad. Sei. Proc. 4: 170. 1872. Mount Dana, Calif., Bolander 6076 [error for 6097].

(2) Oryzopsis micrantha (Trin. and Rupr.) Thurb. Acad. Nat. Sci. Phila Proc. 1863:' 78. 1863. Based on Urachne micrantha Trin. and Rupr.

Urachne micrantha Trin. and Rupr., Mém. Acad. St. Pétersb. VI. Sci. Nat. 51: 16. 1842. North America [type from Saskatchewan].

(1) Oryzopsis miliacea (L.) Benth. and Hook.; Aschers. and Schweinf., Mém. Inst. Égypte 2: 169. 1887. Presumably based on Agrostis miliacea L.

Agrostis miliacea L., Sp. Pl. 61. 1753. Europe.

Achnatherum miliaceum Beauv., Ess. Agrost. 20, 146, 148. 1812. Based on Agrostis miliacea L.

Piptatherum miliaceum Coss., Notes Crit. 129. 1851. Based on Agrostis miliacea L.

(5) Oryzopsis pungens (Torr.) Hitchc., Contrib. U.S. Natl. Herb. 12: 151. 1908. Based on Milium pungens Torr.

Milium pungens Torr.; Spreng., Neu. Entd. 2: 102. 1821. "Schenectady in Massachusetana." [Error for New York.]

Oryzopsis parviflora Nutt., Jour. Acad. Nat. Sci. Phila. 3: 125. 1823. Bellows Falls, Vt.

Panicum firmum Kunth, Rév. Gram. 1: 37. 1829. Based on Milium pungens Torr.

Urachne brevicaudata Trin., Mém. Acad. St. Pétersb. VI. Sci. Nat. 1: 127. 1834. Lake Winnipeg, Canada.

Urachne canadensis Torr. and Gray; Trin. and Rupr., Mém. Acad. St. Pétersb. VI. Sci. Natl. 51: 17. 1842, as synonym of Urachne brevicaudata Trin.

(9) Oryzopsis racemosa (J. E.'Smith) Ricker; Hitchc., Rhodora S: 210. 1906. Based on Milium racemosum J. E. Smith.

Milium racemosum J. E. Smith, in Rees's Cycl. 23: Milium no. 15.1813. Lancaster, Pa., Muhlenberg.

Oryzopsis melanocarpa Muhl., Descr. Gram. 79. 1817. Pennsylvania, Muhlenberg.

Piptatherum nigrum Torr., Fl. North. and Mid. U.S. 1: 79. 1823. Williamstown and Deerfield, Mass.; Kingston and Fishkill Mountains, N.Y.; Pennsylvania, Muhlenberg.

21 See Piper, Contrib. U.S. Natl. Herb. 11: 109. 1906. 
Urachne racemosa Trin., Gram. Unifl. 174. 1824. Based on Milium racemosum J. E. Smith.

Urachne melanosperma Link, Hort. Berol. 1: 94. 1827. Based on Oryzopsis melanocarpa Muhl.

(11) Oryzopsis webberi (Thurb.) Benth.; Vasey, Grasses U.S. 23. 1883. Based on Eriocoma webberi Thurb.

Eriocoma webberi Thurb., in S. Wats., Bot. Calif. 2: 283. 1880. Sierra Valley, Calif., Bolander.

\section{(129) PANICUM L.25}

(14) Panicum aciculare Desv.; Poir., in Lam., Encycl. Sup. 4: 274. 1816. "Indes orientales", erroneous; probably from southeastern United States.

Panicum setaceum Muhl., Deser. Gram. 99. 1817. Georgia.

Panicum subuniflorum Bosc; Spreng., Syst. Veg. 1: 312. 1825. Carolina, Bosc.

Panicum arenicola Ashe, Jour. Elisha Mitchell Sci. Soc. 15: 56. 1898. Chapel Hill, N.C., Ashe.

Panicum pungens Muhl.; Scribn. and Merr., U.S.Dept.Agr., Div. Agrost. Bull. 27: 2. 1900. Not $P$. pungens Poir., 1816. As synonym of $P$. setaceum Muhl.

Panicum filirameum Ashe, Jour. Elisha Mitchell Sci. Soc. 16: 88. $1900 . \quad$ New Hanover County, N.C., Ashe.

This is the species described in Britton's Manual and in Small's Flora (ed. 1) under the name Panicum neuranthum Griseb.

(100) Panicum aculeatum Hitchc. and Chase, Rhodora 8: 209. 1906. District of Columbia, Chase 2520.

(65) Panicum addisonii Nash, Bull. Torrey Bot. Club 25: 83. 1898. Wildwood, N.J., Bicknell in 1897.

Panicum owenae Bicknell, Bull. Torrey Bot. Club 35: 185. 1908. Nantucket, Mass., Bicknell in 1907.

Panicum commonsianum addisonii Stone, N.J. State Mus. Ann. Rept. 1910: 205. 1911. Based on P. addisonii Nash.

(116) Panicum adspersum Triı., Gram. Pan. 146. 1826. Dominican Republic.

Panicum thomasianum Steud.; Doell, in Mart., Fl. Bras. $2^{2}: 188.1877$, as synonym of $P$. adspersum. St. Thomas, Duchaissing.

Panicum keyense Mez, Notizbl. Bot. Gart. Berlin 7: 61. 1917. Sand Key, Fla., Curtiss $3606^{* *}, 5431,6705$.

This is the species described as Panicum striatum Lam. by Chapman (Fl. South. U.S. ed. 2. 666.1883 ).

(147) Panicum agrostoides Spreng., Pl. Pugill. 2: 4. 1815. Pennsylvania, Muhlenberg.

Panicum rigidulum Bosc; Spreng., Syst. Veg. 1: 320. 1825; Nees, Agrost. Bras. 163. 1829. [South Carolina? Bosc.]

Agrostis polystachya Bosc; Steud., Nom. Bot. ed. 2. 1: $40 . \quad 1840$, errolleously cited as synonym of $A$. composita Poir. [Carolina, Bosc.]

Panicum elongatum var. ramosior Mohr, Contrib. U.S. Natl. Herb. 6: 357. 1901. Near Mobile, Ala., [Mohr].

(44) Panicum albemarlense Ashe, Jour. Elisha Mitchell Sci. Soc. 16: 84. 1900. Scranton, Hyde County, N.C., Ashe in 1899.

Panicum velutinum Bose; Spreng., Syst. Veg. 1: 315. 1825. Not P. velutinum Meyer, 1818. Name only. [Bosc.]

Panicum meridionale var. albemarlense Fernald, Rhodora 36: 76.1934. Based on $P$. albemarlense Ashe.

(74) Panicum albomarginatum Nash, Bull. Torrey Bot. Club 24: 40. 1897. Eustis, Fla., Nash 925.

(145) Panicum amarulum Hitchc. and Chase, Contrib. U.S. Natl. Herb. 15: 96. f. 87. 1910. Virginia Beach, Va., Williams 3090.

(144) Panicum amarum Ell., Bot. S.C. and Ga. 1: 121. 1816. Presumably South Carolina.

Panicum amarum var. minus Vasey and Scribn., U.S.Dept.Agr., Div. Bot. Bull. 8: 38. $1889 . \quad$ Fortress Monroe, Va., Vasey.

Panicum amaroides Scribn. and Merr., U.S.Dept.Agr., Div. Agrost. Circ. 29: 5. f. 1. 1901. Based on P. amarum var. minus Vasey and Scribu.

${ }^{23}$ For discussion of types see Hitche. and Chase, Contrib. U.S. Natl. Herb. 15: 23-327. 1910; 17: 465-522. 1915. 
Chasea amara Nieuwl., Amer. Midl. Nat. 2: 64. 1911. Based on Panicum amarum Ell.

(152) Panicum anceps Michx., Fl. Bor. Amer. 1: 48. 1803. Carolina, Michaux.

Panicum rostratum Muhl.; Willd., Enum. Pl. 1032. 1809. Pennsylvania [type, Muhlenberg] and Carolina.

Agrostis nutans Poir., in Lam., Encycl. Sup. 1: 255. 1810. Carolina, Bosc.

Vilfa nutans Beauv., Ess. Agrost. 16, 148, 181. 1812. Based on Agrostis nutans Poir.

Panicum nutans Desv., Opusc. 93. 1831. Based on Agrostis nutans Poir.

Panicum anceps var. angustum Vasey, U.S.Dept.Agr., Div. Bot. Bull. 8: 37. 1889. Texas, Nealley.

Panicum anceps var. densiflorum Vasey, U.S.Dept.Agr., Div. Bot. Bull. 8: 37. 1889. [Marshall], Tex., Riggs [91].

(17) Panicum angustifolium Ell., Bot. S.C. and Ga. 1: 129. 1816. Presumably South Carolina.

?Panicum ramulosum Michx., Fl. Bor. Amer. 1: 50. 1803. Carolina, Michaux.

Panicum curtisii Steud., Syn. Pl. Glum. 1: 66. 1854. South Carolina, M. A. Curtis.

Chasea angustifolia Nieuwl., Amer. Midl. Nat. 2: 64. 1911. Based on Panicum angustifolium Ell.

(27) Panicum annulum Ashe, Jour. Elisha Mitchell Sci. Soc. 15: 5S. 1898. Maryland to North Carolina and Georgia, Washington, D.C., Ward in 1892 [type].

Panicum bogueanum Ashe, Jour. Elisha Mitchell Sci. Soc. 16: 85. 1900. Based on P. annulum Ashe.

(19) Panicum arenicoloides Ashe, Jour. Elisha Mitchell Sci. Soc. 16: 89. 1900. Wilmington, N.C., Ashe in 1899.

Panicum orthophyllum Ashe, Jour. Elisha Mitchell Sci. Soc. 16: 90. 1900. New Hanover County, N.C., Ashe in 1899.

(117) Panicum arizonicun Scribn. and Merr., U.S.Dept.Agr., Div. Agrost. Circ. 32: 2. 1901. Camp Lowell, Ariz., Pringle 465.

Panicum fuscum var. majus Vasey, U.S.Dept.Agr., Div. Bot. Bull. 8: 26.1889. Mexico [southwestern Chihuahua, Palmer 1b in 1885].

Panicum dissitiflorum Vasey, in S. Wats., Amer. Acad. Sci. Proc. 24: S0. 1889. Name only. Guaymas, Mexico, Palmer 159 in part, 190.

Panicum fasciculatum var. majus Beal, Grasses N.Amer. 2: 117. 1896. Based on $P$. fuscum var. majus Vasey.

Panicum fasciculatum dissitiflorum Vasey; Scribn. and Merr., U.S.Dept.Agr., Div. Agrost. Circ. 32: 2. 1901, as synonym of P. arizonicum.

Panicum arizonicum tenue Scribn. and Merr., U.S.Dept.Agr., Div. Agrost. Circ. 32: 3. 1901. Fort Huachuca, Ariz., Vilcox in 1894.

Panicum arizonicum laeviglume Scribn. and Merr., U.S.Dept.Agr., Div. Agrost. Circ. 32: 3. 1901. Mescal, Ariz., Griffiths 1810.

Panicum arizonicum majus Scribn. and Merr., U.S.Dept.Agr., Div. Agrost. Circ. 32: 3. 1901. Based on P. fuscum var. majus Vasey.

(103) Panicum ashei Pearson; Ashe, Jour. Elisha Mitchell Sci. Soc. 15: 35. 1898. Ithaca, N.Y., Ashe in 189 S.

Panicum umbrosum LeConte; Torr., in Eaton, Man. Bot. 342. 1818. Not P. umbrosum Retz., 1786. New York.

Panicum commutatum var, ashei Fernald, Rhodora 36: S3. 1934. Based on P. ashei Pearson.

(49) Panicum auburne Ashe, N.C. Agr. Expt. Sta. Bull. 175: 115.1900. Auburn, Ala., Earle and Baker 1527.

(32) Panicum barbulatum Michx., FI. Bor. Amer. 1: 49. 1803. "Carolina" [but type from Canada].

Panicum dichotomum var. barbulatum Wood, Class-book ed. 3. 786. 1861. Presumably based on $P$. barbulatum Michx.

Panicum pubescens var. barbulatum Britton, Cat. Pl. N.J. 280. 18s9. Presumably based on $P$. barbulatum Michx.

Panicum nitidum var. barbulatum Chapn., Fl. South. U.S. ed. 3. 586. 1897. Based on P. barbulatum Michx.

Panicum gravius Hitchc. and Chase, Rhodora 8: 205. 1906. Between Centreville and Mount Cuba, Del., Chase 3620.

(120) Panicum bartowense Scribn. and Merr., U.S.Dept.Agr., Div. Agrost. Circ. 35: 3. 1901. Bartow, Fla., Combs 1220.

Panicum bergii Arech., An. Mus. Nac. Montevideo 1: 147. 1894. Uruguay. 
(22) Panicum bicknellii Nash, Bull. Torrey Bot. Club 24: 193. 1897. Bronx Park, N.Y., Bicknell in 1895.

Panicum nemopanthum Ashe, Jour. Elisha Mitchell Sci. Soc. 15: 42.1898. Raleigh N.C., Ashe in 1895.

Panicum bushii Nash, Bull. Torrey Bot. Club 26: 568. 1899. McDonald County, Mo., Bush 413.

Panicum bicknellii var. bushii Farwell, Mich. Acad. Sci. Papers 1: 85. 1921. Based on P. bushii Nash.

(30) Panicum boreale Nash, Bull. Torrey Bot. Club 22: 421. 1895. Cairo, N.Y., Nash in 1893.

(110) Panicum boscii Poir., in Lam., Encycl. Sup. 4: 278. 1816. Carolina, Bosc.

Panicum walheri Poir., in Lam., Encycl. Sup. 4: 282. 1816. Not P. ualteri Pursh, 1814. Based on P. latifolium as deseribed by Michaux.

Panicum latifolium var. australe Vasey, U.S.Dept.Agr., Div. Bot. Bull. 8: 34. 1889. Alabama [type, Thomasville, Mohr] to Texas.

Panicum porterianum Nash, Bull. Torrey Bot. Club 22: 420. 1895. Based on $P$. waltheri Poir.

Panicum boscí var. motle (Vasey) Hitche. and Chase, in Robinson, Rhodora 10: 64. 1908. Based on P. latifolium var. molle Vasey.

Panicum latifolium var. molle Vasey; Ward, Fl. Washington 135. 1881. District of Columbia, [Ward].

Panicum walteri var. molle Porter, Bull. Torrey Bot. Club 20: 194. 1893. Presumably based on $P$. latifolium var. molle Vasey.

Panicum pubifolium Nash, Bull. Torrey Bot. Club 26: 577. 1899. Based on $P$. latifolium var. molle Vasey.

(156) Panicum brachyanthum Steud., Syn. Pl. Glum. 1: 67. 1854. [Rusk County], Tex.. Tinzent 124 .

Panicum sparsiflorum Vasey, U.S.Dent.Agr., Div. Bot. Bull. 8: 36.1889. Not P. sparsiflorum Doell, 1877. South Carolina to Texas, [type, San Bernardino, Ridell 20].

This species was described as Panicum angustifolium Ell. by Chapman (Fl. Solth. U.S. 574. 1860).

(83) Panicum breve Hitche. and Chase, Contrib. U.S. Natl. Herb. 15: 271. f. 301. 1910. Jensen, Fla., Hitchcoch 734.

(139) Panicum bulbosum H.B.K., Nov. Gen. and Sp. 1: 99. 1815. Guanajuato, Mexico, Humboldt and Bonpland.

Panicum avenaccum H.B.K., Nov. Gen. and Sp. 1: 99. 1815. Ecuador, IIumboldt and Bonpland.

Panicum gongylodes Jaeq., Eclog. Gram. 30. pl. 21. 1815-1820. Cultivated at Vienna.

Panicum nodosum Willd.; Steud., Nom. Bot. od. 2. 2: 260. 1841, as synonym of $P$. bulbosum.

Panicum maximum var. gongylodes Doell, in Mart., Fl. Bras. 2²: 203.1877. Based on P. gongylodes Jacq.

Panicum maximum var. bulbosum Vasey, in Wheeler, Rept. U.S. Survey 100th Merid. 6: 295. 1878. Presumably based on P. bulbosum H.B.K.

Panicum polygamm var. gongylodes Fourn., Mex. Pl. 2: 28. 1386. Based on P. gongylodes Jaca.

Panicum bulbosuin subvar. violaceum Fourn., Mex. Pl. 2: 27. 1886. Chinantla, Mexico, Liebmann 451.

Panicum bulbosum var. avenaceum Beal, Grasses N.Amer. 2: 132.1896. Based on $P$. avenaceum H.B.K.

Panicum Bulbosum rar. minus Vasey, U.S.Dept.Agr., Div. Bot. Bull. 8: 38. 1889. Texas, New Mexico, and Arizona [type New Mexico, Rusby in 1880].

Panicum sciaphilum Rupr.; Fourn., Mex. l'l. 2: 19. 1886. Yavesia, Mexico, Galfotti 5759.

Panicrm bulbosum sciaphilum Hitche, and Chase, Contrib. U.S. Natl. Herb. 15: 83. f. 73. 1910. Based on P. sciaphilum Rupr.

(35) Panicum caerulescens Hack.; Hitchc., Contrib. U.S. Natl. Herb. 12: 219. 1909. Miami, Fla., Hitcheock 706.

(23) Panicum calliphyllum Ashe, Jour. Elisha Mitchell Sci. Soc. 15: 31. 1898. Watkins, N.Y., Ashe in 1898.

(125) Panicum capillare L., Sp. Pl. 58. 1753. Virginia, [Clayton 454].

Milium capillare Moench, Meth. Pl. 203. 1794. Based on P. capillare L.

Panicum bobarti Lam.. Eneycl. 4: 748. 1798. [Virginia, Bobart.]

Panicum capillare var. agreste Gattinger, Tenn. F1. 94. 1887. Tennessee, [Ridgetop, Gattinger]. 
Panicum capillare var. vulgare Scribn., Tenn. Agr. Expt. Sta. Bull. 7: 44. 1894. Presumably Knoxville, Tenn.

Chasea capillaris Nieuwl., Amer. Midl. Nat. 2: 64. 1911. Based on Panicum capillare $\mathrm{L}$.

Leptoloma capillaris Smyth, Kans. Acad. Sci. Trans. 25: 86. $1913 . \quad$ Based on Panicum capillare $\mathrm{L}$.

Panicum capillare var. occidentale Rydb., Contrib. U.S. Natl. Herb. 3: 186. 1895. Whitman, Nebr., Rydberg 1788.

Panicum capillare brevifolium Vasey; Rydb. and Shear, U.S.Dept.Agr., Div. Agrost. Bull. 5: 21. 1897. Manhattan, Mont., Shear 436.

Panicum barbipulvinatum Nash, in Rydb., Mem. N.Y. Bot. Gard. 1: 21. 1900. Based on P. capillare var. brevifolium Vasey.

Leptoloma barbipulvinata Snyth, Kans. Acad. Sei. Trans. 25: 86. 1913. Based on Panicum barbipulvinatum Nash.

Milium barbipulvinatum Lunell, Amer. Midl. Nat. 4: 212. 1915. Based on Panicum barbipulvinatum Nash.

Panicum barbipulvinatum var. hirsutipes Suksdorf, Werdenda 1: 17. 1927. Spokane, Wash., Suksdorf 9068.

Panicum elegantulum Suksdorf, Werdenda 1: 16. 1927. Not P. elegantulum Mez, 1917. Spokane, Wash., Suksdorf 9069. (No. 11792, also cited, is P. capillare.)

(131) Panicum capillarioides Vasey, in Coulter, Contrib. U.S. Natl. Herb. 1: 54. 1890. Point Isabel, Tex., Nealley [634].

(81) Panicum chamaelonche Trin., Gram. Pan. 242. 1826. North America, Enslin.

Panicum nitidum var. minus Vasey, Contrib. U.S. Natl. Herb. 3: 30. 1892. Florida, [type, St. Augustine, Canby].

Panicum baldwinii Nutt.; Kearney, U.S.Dept.Agr., Div. Agrost. Bull. 1: 21. 1895, name only; Chapm. Fl. South U.S. ed. 3. 586. 1897. Florida, Baldwin.

Panicum dichotomum var. nitidum Chapm.; Scribn., U.S.Dept.Agr., Div. Agrost. Bull. 11: 43. 1898, as synonym of P. baldwinii.

(1) Panicum chapmani Vasey, Bull. Torrey Bot. Club 11:61. 1884. Southern Florida, Chapman.

This is the species described as Panicum tenuiculmum Meyer by Chapman

(Fl. South. U.S. 572. 1860).

(15) Panicum chrysopsidifolium Nash, in Small, Fl. Southeast. U.S. 100, 1327. 1903. Leon County, Fla., Curtiss (no. D).

(11) Panicum ciliatum Ell., Bot. S.C. and Ga. 1: 126. 1816. Presumably South Carolina.

Panicum leucoblepharis Trin., Clav. Agrost. 234. 1822. North America, [type, Enslin].

Panicum ciliatifolium Kunth, Rév. Gram. 1: 36. 1829. Based on P. ciliatum Ell.

Panicum ciliatifolium Desv., Opuse. 88. 1831. North America.

(108) Panicum clandestinum L., Sp. Pl. 58. 1753. Pennsylvania, Kalm.

Milium clandestinum Moench, Meth. Pl. 204. 1794. Based on Panicum clandestinum $\mathrm{L}$.

Panicum latifolium var. clandestinum Pursh, Fl. Amer. Sept. 1: 68. 1814. Based on P. clandestinum L.

Panicum pedunculatum Torr., F1. North. and Mid. U.S. 141. 1823. "Island of New York."

Panicum clandestinum var. pedunculatum Torr., Fl. N.Y. 2: 426.1843. Based on $P$. pedunculatum Torr.

Panicum decoloratum Nash, Bull. Torrey Bot. Club 26: 570. 1899. Tullytown, Pa., Bicknell in 1899.

Chasea clandestina Nieuwl., Amer. Midl. Nat. 2: 64. 1911. Based on Panicum clandestinum L.

(29) Panicum clutei Nash, Bull. Torrey Bot. Club 26: 569. 1899. Between Tuckerton and Atsion, N.J., Clute.

(68) Panicum columbianum Scribn., U.S.Dept.Agr., Div. Agrost. Bull. 7: 78. f. 60 . 1897. District of Columbia, Scribner in 1894 .

Panicum heterophyllum Bose; Nees, Agrost. Bras. 227. 1829. Not P. heterophyllum spreng., 1822. North America, Bosc.

Panicum psammophilum Nash, Bull. Torrey Bot. Club 26: 576. 1899. Not $P$. psammophilum Welw., 1899. Toms River, N.J., Clute 175. 
Panicum colombianum var. Thiniom Hitchc. and Chase, in Robinson, Rhodora 10: 64. 1908. Based on P. unciphyllum thinium Hitche. and Chase.

Panicum unciphyllum thinium Hitche. and Chase, Rhodora 8: 209. 1906. Toms River, N.J., Chase 3577.

Panicum heterophyllum var. thinium F. T. Hubb., Rhodora 14: 172. 1912. Based on P. unciphyllum thrnium Hitche. and Chase.

(151) Panicum combsii Scribn. and Ball, U.S.Dept.Agr., Div. Agrost. Bull. 24: 42. f. 16. 1901. Chipley, Fla., Combs 583.

Panicum longifolium var. combsii Fernald, Rhodora 36: 69. 1934. Based on P. combsii Scribn. and Ball.

(64) Panicum commonsianum Ashe, Jour. Elisha Mitchell Sci. Soc. 15: 55. 1898. Cape May, N.J., Commons 341.

(104) Panicum commutatum Schult., Mant. 2: 242. 1824. Based on $P$. nervosum Muhl.

Panicum nitidum var. majus Pursh, Fl. Amer. Sept. 1: 67. 1814. North America.

Panicum nervosum Muhl.; Ell., Bot. S.C. and Ga. 1: 122. 1816. Not P. nervosum Lam., 1797. Carolina and Georgia.

Panicum enslini Trin., Gram. Pan. 230. 1826. North America, Enslin.

Panicum polyneuron Steud., Syn. Pl. Glum. 1: 91. 1854. Based on P. nervosum Muhl.

Panicum commutatum var. minus Vasey, U.S.Dept.Agr., Div. Bot. Bull. 8: 34. 1889. Southern States [type, Aiken, S.C., Ravenel].

Panicum commutatum var. latifolium Scribn., in Kearney, Bull. Torrey Bot. Club 20: 476. 1893. Pine Mountain, Ky., Kearney 299.

Panicum commelinaefolium Ashe, Jour. Elisha Mitchell Sci. Soc. 15: 29. 1898. Not $P$. commelinaefolium Rudge, 1805. Stone Mountain, Ga., Small in 1895.

Panicum currani Ashe, Jour. Elisha Mitchell Sci. Soc. 15: 113. 1899. Based on $P$. commelinaefolium Ashe.

Panicum subsimplex Ashe, N.C. Agr. Expt. Sta. Bull. 175: 115. 1900. Wilmington, Del., Commons.

(77) Panicum concinnius Hitche. and Chase, Contrib. U.S. Natl. Herb. 15: 263. f. 289. 1910. Based on P. gracilicaule Nash.

Panicum gracilicaule Nash, in Small, Fl. Southeast. U.S. 98. 1903. Not P. gracilicaule Rendle, 1899. Sand Mountain, Ala., Harbison 2415.

(148) Panicum condensum Nash, in Small, Fl. Southeast. U.S. 93. 1903. [Jacksonville], Fla., Curtiss 5576.

Agrostis purpurascens Bert.; Steud., Nom. Bot. ed. 2. 1: 42. 1840. Not A. purpurascens Swartz, 1788. Name only. Dominican Republic, Bertero, Balbis.

Panicum contractum Trin.; Steud., Nom. Bot. ed. 2. 2: 254. 1841. Name only. Guadeloupe and Dominican Republic, Balbis.

Panicum agrostoides var. condensum Fernald, Rhodora 36: 74. 1934. Based on P. condensum Nash.

(16) Panicum consanguineum Kunth, Rév. Gram. 1: 36. 1829. Based on P. villosum Eill.

Panicum villosum Ell., Bot. S.C. and Ga. 1: 124. 1816. Not. P. villosum Lam., 1791." Presumably South Carolina.

Panicum commutatum var. consanguineum Beal, Grasses N.Amer. 2: 141. 1896. Based on $P$. consanguineum Kunth.

Panicum georgianum Ashe, Jour. Elisha Mitchell Sci. Soc. 15: 36. 1898. Darien Junction, Ga., Small in 1895.

Panicum cahoonianum Ashe, Jour. Elisha Mitchell Sci. Soc. 15: 113.1899. Based on P. georgianum Ashe.

(102) Panicum cryptanthum Ashe, N.C. Agr. Expt. Sta. Bull. 175: 115. 1900. Wilsons Mills, N.C., Ashe in 1897.

(80) Panicum curtifolium Nash, Bull. Torrey Bot. Club 26: 569. 1899. Ocean Springs, Miss., Tracy 4598.

Panicum earlei Nash, Bull. Torrey Bot. Club 26: 571. 1899. Auburn, Ala., Earle and Baker 1532.

Panicum austro-montanum Ashe, Jour. Elisha Mitchell Sci. Soc. 16: 85. 1900. Northern Alabama and adjacent parts of Tennessee, Ashe.

(63) Panicum deamii Hitchc. and Chase, in Deam, Ind. Dept. Conserv. Pub. 82: 284. pl. 75. f. 18. 1929. Pine, Lake County, Ind., Deam 43287.

(5) Panicum depauperatum Muhl., Deser. Gram. 112. 1817. Pennsylvania, Carolina [type].

Panicum strictum Pursh, Fl. Amer. Sept. 1: 69. 1814. Not P. strictum R. Br., 1810. Pennsylvania. 
Panicum rectum Roem. and Schult., Syst. Veg. 2: 457. 1817. Based on P. strictum Pursh.

Panicum involutum Torr., Fl. North. and Mid. U.S. 144. 1S23. Deerfield, Mass., Cooley.

Panicum muhlenbergii Spreng., Syst. Veg. 1: 314. 1825. North America. [Type, New Jersey, Torrey].

Panicum junceum Trin., Gram. Pan. 220. 1826. North America.

Panicum sprengelii Kunth, Rév. Gram. 1: 39. 1829. Based on P. muhlenbergii Spreng.

Panicum depauperatum var. involutum Wood, Class-book 786. 1861. Based on P. involutum Torr.

?Panicum depauperatum var. laxum Vasey, U.S.Dept.Agr., Div. Bot. Bull. 8: 29. 1889. "Virginia, Florida, Texas, Arkansas, Missouri."

Panicum depauperatum var. psilophyllum Fernald, Rhodora 23: 193.1921. Canton, Maine, Parlin 1957.

(119) Panicum dichotomiftorum Michx., Fl. Bor. Amer. 1: 48. 1803. Western Allegheny Mountains, Michaux.

Panicum miliaceum Walt., Fl. Carol. 72. 1788. Not P. miliaceum L., 1753. South Carolina.

Panicum geniculatum Muhl., Cat. Pl. 9. 1813. Based on P. dichotomiflorum Michx.

Panicum multiflorum Poir., in Lam., Encycl. Sup. 4: 282. 1816. Carolina, Bosc.

Panicum brachiatum Bosc; Spreng., Syst. Veg. 1: 321. 1825. Not P. brachiatum Poir. Bermuda cited [but type probably from South Carolina, Bosc].

Panicum elliottii Trin.; Nees, Agrost. Bras. 170. 1829, as synonym of $P$. proliferum Lam. [misapplied to $P$. dichoiomiflorum].

Panicum retrofractum Delile; Desv., Opusc. 96. 1831. North America. [Type from Carolina.]

Panicum proliferum var. pilosum Griseb., Cat. Pl. Cub. 232. 1866. Hanábana, Cuba, Wright [186].

Panicum proliferum var. geniculatum Wood, Amer. Bot. and Flor. pt. 2: 392. 1870. Presumably based on P. geniculatum Muhl.

Panicum amplectans Chapm., Bot. Gaz. 3: 20. 1878. South Florida, [Blodget $]$.

Leptoloma dichotomiflora Smyth, Kans. Acad. Sci. Trans. 25: 86. 1913. Based on Panicum dichotomiflor $\mathrm{Pm}$ Michx.

This species has been referred to $P$. proliferum Lam., an Old World species.

Panicum dichotomiflordm var. pUritanorum Svenson, Rhodora 22: 154. f. 1-5. 1920. Barnstable, Mass., Fernald in 1919.

(31) Panicum dichotomum L., Sp. Pl. 58. 1753. Virginia, [Clayton 458].

Panicum angustifolium LeConte; Torr., in Eaton, Man. Bot. ed. 2: 342. 1818. Not P. angustifolium Ell., 1816. New York.

Panicum tremulum Spreng., Neu. Entd. 2: 103. 1821. New Jersey [Torrey].

Panicum dichotomum var. viride Vasey, U.S.Dept.Agr., Div. Bot. Bull. 8: 30. 1889. No locality eited. [Type, Washington, D.C., Ward in 1881.]

Panicum dichotomum var. divaricatum Vasey, U.S.Dept.Agr., Div. Bot. Bull. 8: 30. 1889. No locality eited. [Type, Jake, Miss., Tracy 127.]

Panicum nitidum var. pauciflor um Britton, N.Y. Acad. Sci. Trans. 9: 14. 1889. Morris County, N.J., Britton.

Panicum nitidum var. viride Britton, N.Y. Acad. Sci. Trans. 9: 14.1889. Based on $P$. dichotomum var. viride Vasey.

Panicum dichotomum var. commune Wats. and Coult., in A. Gray, Man. ed. 6: 633. 1890. No locality cited.

Panicum ramulosum var. viride Porter, Bull. Torrey Bot. Clıb 20: 194.1893. Presumably based on $P$. dichotomum var. viride Vasey.

Chasea dichotoma Nieuwl., Amer. Midl. Nat. 2: 64. 1911. Based on Panicum dichotomum $\mathrm{L}$.

(78) Panicum ensifolium Baldw.; Ell., Bot. S.C. and Ga. 1: 126. 1816. Georgia, Baldwin.

Panicum nitidum var. ensifolium Vasey, U.S.Dept.Agr., Div. Bot. Bull. 8: 29. 1889. Based on P. ensifolium Baldw.

Panicum brittoni Nash, Bull. Torrey Bot. Club 24: 194. 1897. Forked River, N.J., Britton in 1896.

Panicum cuthbertii Ashe, Jour. Elisha Mitchell Sci. Soc. 15: 48. 1898. St. Helena Island, S.C., Cuthbert. 
Panicum glabrissimum Ashe, Jour. Elisha Mitchell Sci. Soc. 15: 62. 1898. Manteo, N.C., Ashe in 1898.

Panicum shallotte Ashe, Jour. Elisha Mitchell Sci. Soc. 16: 84. 1900. Based on P. glabrissimum Ashe.

Panicum parvipaniculatum Ashe, Jour. Elisha Mitchell Sci. Soc. 16: 87. 1900. Onslow County, N.C., Ashe in 1899.

(107) Panicum equilaterale Scribn., U.S.Dept.Agr., Div. Agrost. Bull. 11: 42. pl. 2. 1898. Eustis, Fla., Nash 1674.

Panicum epilifolium Nash, Bull. Terrey Bot. Club 26: 571. 1899. Eustis, Fla., Nash 45.

(72) Panicum erectifolium Nash, Bull. Torrey Bot. Club 23: 148. 1896. Based on P. sphaerocarpon var. floridanum Vasey.

Panicum sphaerocarpon var. floridanum Vasey, U.S.Dept.Agr., Div. Bot. Bull. 8: 33. 1889. Not P. floridanum Trin., 1834. Florida, [type, Mosquito Inlet, Curtiss 3599].

Panicum floridanum Chapm., Fl. South. U.S. ed. 3. 585. 1897. Not $P$. floridanum Trin., 1834. Presumably based on P. sphaerocarpon var. floridanum Vasey.

(115) Panicum fasciculatum Swartz, Prodr. Veg. Ind. Occ. 22. 1788. Jamaica, Swartz.

Panicum chartaginense Swartz, Prodr. Veg. Ind. Occ. 22. 1788. Cartagena, Colombia.

Panicum fuscum Swartz, Prodr. Veg. Ind. Occ. 23. 1788. Jamaica, Swartz.

Panicum flavescens Swartz, Prodr. Veg. Ind. Oce. 23. 1788. Jamaica, Swartz.

Panicum fusco-rubens Lam., Tabl. Encycl. 1: 171. 1791. West Indies.

Panicum fastigiatum Poir., in Lam., Encycl. Sup. 4: 277. 1S16. Based on P. fasciculatum Swartz.

Panicum spithamaeum Willd.; Nees, Agrost. Bras. 152. 1829. Name only. South America, Humboldt.

Panicum illinoniense Desv., Opusc. 91. 1831. North America.

Panicum reticulatum Griseb., Abhandl. Gesell. Wiss. Göttingen 7: 264. 1857. Not $P$. reticulatum, Torr. 1852. West Indies or Panama.

Panicum fuscum var. fasciculatum Griseb., Fl. Brit. W.Ind. 547. 1864. Based on P. fasciculatum Swartz.

Panicum fasciculatum var. flavescens Doell, in Mart., Fl. Bras. 22: 205.1877. Based on P. flavescens Swartz.

Panicum fasciculatum var. fuscum Doell, in Mart., Fl. Bras. 22: 205. 1877. Based on P. fuscum Swartz.

Panicum fasciculatum var. carthaginense Doell, in Mart., Fl. Bras. 22: 205. 1877. Based on P. chartaginense Swartz.

Panicum Fasciculatum var. Reticulatum (Torr.) Beal, Grasses N.Amer. 2: 117. 1896. Based on $P$. reticulatum Torr.

Panicum reticulatum Torr., in Marcy, Expl. Red Riv. 299. 1852. Red River, Tex.

Panicum fuscum reticulatum Scribn. and Merr., U.S.Dept.Agr., Div. Agrost. Circ. 32: 4. 1901. Based on $P$. reticulatum Torr.

(132) Panicum filipes Scribn., in Heller, Contrib. Herb. Frankl. Marsh. Coll. 1:13. 1895. Corpus Christi, Tex., Heller 1809.

(4) Panicum firmulum Hitchc. and Chase, Contrib. U.S. Natl. Herb. 15: 27. f. 9. 1910. Elsordo, Tex., Griffiths 6446.

(76) Panicum flavovirens Nash, Bull. Torrey Bot. Club 26: 572. 1899. Lake County, Fla., Nash 2061.

(121) Panicum fiexile (Gattinger) Scribn., in Kearney, Bull. Torrey Bot. Club 20: 476. 1893. Bascd on P. capillare var. flexile Gattinger.

Panicum capillare var. flexile Gattinger, Tenn. Fl. 94. 1887. [Nashville, Tenn., Gattinger.]

Chasea flexilis Nieuwl., Amer. Midl. Nat. 2: 65. 1911. Based on Panicum flexile Scribn.

(18) Panicum fusiforme Hitchc., Contrib. U.S. Natl. Herb. 12: 222. 1909. Based on $P$. neuranthum var. ramosum Griseb.

Panicum neuranthum var. ramosum Griseb., Cat. Pl. Cub. 232. 1866. Not $P$. ramosum L., 1767. Western Cuba, Wright 3454.

(122) Panicum gattingeri Nash, in Small, Fl. Southeast. U.S. 92, 1327. 1903. Based on $P$. capillare var. campestre Gattinger.

Panicum capillare var. campestre Gattinger, Tenn. Fl. 94. 1887. Not P. campestre Nees. [Nashville, Tenn., Gattinger.] 
Panicum capillare var. geniculatum Scribn., in Kearney, Bull. Torrey Bot. Club 20: 447. 1893. Wasioto, Ky., [Kearney 378].

Panicum capillare gattingeri Nash, in Britt. and Brown, Illustr. Fl. 1: 123. 1896. Based on P. capillare var. campestre Gattinger.

(111) Panicum geminatum Forsk., Fl. Aegypt. Arab. 18. 1775. Rosetta, Egypt.

Paspalum appressum Lam., Tabl. Encycl. 1: 176. 1791. South America.

Digitaria appressa Pers., Syn. P1. 1: 85. 1805. Based on Paspalum appressum Lam.

Panicum beckmanniaeforme Mikan; Trin., in Spreng., Neu. Entd. 2: 83. 1821. Brazil.

Panicum brizaeforme Presl, Rel. Haenk. 1: 302. 1830. Luzon.

Panicum glomeratum Buckl., Prel. Rept. Geol. Agr. Survey Tex. App. 3. 1866. Not P. glomeratum Moench., 1794. Western Texas.

Panicum appressum Lam.; Doell, in Mart., Fl. Bras. 22: 184. 1877. Not P. appressum Forsk., 1775. Based on Paspalum appressum Lam.

Paspalidium geminatum Stapf, in Prain, Fl. Trop. Afr. 9: 585. 1920. Based on P. geminatum Forsk.

This species has been referred to Panicum paspalodes Pers., not known from America.

(135) Panicum ghiesbreghtii Fourn., Mex. Pl. 2: 29. 1886. Mexico, Ghiesbreght.

Panicum hirtivaginum Hitchc., Contrib. U.S. Natl. Herb. 12: 223. 1909. Cuba, Wright 758.

(82) Panicum glabrifolium Nash, Bull. Torrey Bot. Club 24: 196. 1897. Tampa, Fla., Nash 2415a.

(141) Panicum gouini Fourn., Mex. Pl. 2: 28. 1886. Vera Cruz, Mexico, Gouin 4.

Panicum gouini var. pumilum Fourn., Mex. Pl. 2: 28. 1886. Mexico, Vera Cruz, Virlet 1300; Antigua, Liebmann 450.

Panicum repens var. confertum Vasey, Bull. Torrey Bot. Club 13: 25. 1886. "Louisiana" [erroneous, type from Bay St. Louis, Miss., Langlois].

Panicum halophilum Nash, in Lloyd and Tracy, Bull. Torrey Bot. Club 28: 86. 1901. Based on $P$. repens var. confertum Vasey.

(160) Panicum gymnocarpon Ell., Bot. S.C. and Ga. 1: 117. 1816. Savannah, Ga., Baldwin.

Panicum monachnoides Dest., Opusc. 86. 1831. "Brazil" [locality erroneous].

Panicum drummondii Nees; Steud., Syn. Pl. Glum. 1: 63. 1854. New Orleans, La., Drummond [574].

Phanopyrum gymnocarpon Nash, in Small, Fl. Southeast. U.S. 104. 1903. Based on Panicum gymnocarpon Ell.

(133) Panicum hallii Vasey, Bull. Torrey Bot. Club 11: 61. 1884. Austin, Tex., Hall 816 (in part).

Panicum virletii Fourn., Mex. Pl. 2: 29. 1886. San Luis Potosí, Mexico, Virlet 1305, 1371.

(143) Panicum havardii Vasey, Bull. Torrey Bot. Club 14: 95. 1887. Described from type of $P$. virgatum var. macranthum Vasey.

Panicum virgatum var. macranthum Vasey, Bull. Torrey Bot. Club 13: 26. 1886. Not $P$. macranthum Trin., 1826. Guadalupe Mountains, Tex., Havard.

(91) Panicum helleri Nash, Bułl. Torrey Bot. Club 26: 572. 1899. Kerrville, Tex., Heller 1759.

Panicum pernervosum Nash, Bull. Torrey Bot. Club 26: 576. 1899. Houston, Tex., Hall 830.

Panicum oligosanthes var. helleri Fernald, Rhodora 36: 80. 1934. Based on $P$. helleri Nash.

(159) Panicum hemitomon Schult., Mant. 2: 227. 1824. Based on P. walteri Muhl.

Panicum dimidiatum Walt., Fl. Carol. 72. 1788. Not P. dimidiatum L., 1753. South Carolina. Referred by Elliott to P. walteri.

Panicum walteri Ell., Bot. S.C. and Ga. 1: 115. 1816. Not P. walteri Pursh, 1814. Charleston, S.C.; Savannah, Ga., [type].

Prnicum walteri Muhl., Descr. Gram. 108. 1817. Not P. walteri Pursh, 1814. No locality cited, probably Georgia.

Frnicum carolinianum Spreng., Syst. Veg. 1: 310. 1825. Based on $P$. walteri Ell. 
Oplismenus walteri Küunth, Rév. Gram. 1: 45. 1829. Based on Panicum walteri Muhl.

Panicum carinatum Torr., in Curtis, Bost. Jour. Nat. Hist. 1: 137. 1835. Not P. carinatum Presl, 1830. [Wilmington], N.C., [M. A. Curtis].

Panicum digitarioides Carpenter; Curtis, Amer. Jour. Sci. (II) 7: 410. 1849, not $P$. digitarioides Raspail, 1833 , as synonym of $P$. carinatum Torr. Steud., Syn. Pl. Glum. 1: 75. 1854. North America [type, Louisiana, Carpenter].

Panicum curtisii Chapm., Fl. South. U.S. 573. 1860. Not P. curtisii Steud., 1854. Based on P. walteri Ell.

Oplismenus colonum var. walteri Fourn., Mex. Pl. 2: 40. 1SS6. Based on O. walteri Kiunth.

Brachiaria digitarioides Nash, in Britton, Man. 77. 1901. Based on $P$. digitarioides Carpenter.

(154) Panicum hians Ell., Bot. S.C. and Ga. 1: 118. 1816. Charleston, S.C.

Panicum oblongiflorum Desv., Opusc. 89. 1831. Carolina, Bosc.

Panicum jejunum Trin., Mém. Acad. St. Pétersb. VI. Sci. Nat. 2: 103.1836. Louisiana.

Aira incompleta Bosc.; Steud., Nom. Bot. ed. 2. 1: 45. 1840. Name only. [Carolina, Bosc.]

Steinchisma hians Nash, in Small, Fl. Southeast. U.S. 105. 1903. Based on Panicum hians Ell. This name, credited to Raf., is listed in Index Kewensis (4: 982 . 1595.) as synonym of Panicum debile [Poir.] which is Festuca obtusa.

(126) Panicum hillmani Chase, Jour. Wash. Acad. Sci. 14: 345. f. 1. 1924. Amarillo, Tex., Hitchcock 16206.

(136) Panicum hirsutum Swartz, Fl. Ind. Occ. 1: 173. 1797. Jamaica, Hispaniola, Swartz.

Panicum elatum Willd.; Steud., Nom. Bot. ed. 2. 2: 256. 1841. Name only. South America, Humboldt.

(127) Panicum hirticaule Presl, Rel. Haenk. 1: 308. 1830. Acapulco, Mexico, Haenke.

Panicum flabellatum Fourn., Bull. Soc. Bot. France II. 27: 293.1880. Omotepe Island, Nicaragua, Lévy 1166.

Panicum polygamum var. hirticaule Fourn., Mex. Pl. 2: 28. 1886. Based on $P$. hirticaule Presl, but misapplied to P. maximum Jacq.

Panicum capillare var. glabrum Vasey; T. S. Brandeg. Proc. Calif. Acad. II. 2: 211. 1859. Name only. Baja California, Brandegee in 1889.

(46) Panicum huachucae Ashe, Jour. Elisha Mitchell Sci. Soc. 15: 51. 1898. Huachuca Mountains, Ariz., Lemmon in 1882.

Panicum nitidum var. pilosum Torr., Fl. North. and Mid. U.S. 146. 1824. Not $P$. pilosum Swartz. New York.

Panicum languinosum var. huachucae Hitchc., Rhodora 8: 208. 1906. Based on P. huachucae Ashe.

Panicum lindheimeri var. fasciculatum subvar. pilosum Farwell, Amer. Midl. Nat. 11: 45. 1928. New York.

Panicum HUaChUCAE var. Fasciculatum (Torr.) F. T. Hubb., Rhodora 14: 171. 1912. Based on $P$. dichotomum var. fasciculatum Torr.

Panicum dichotomum var. fasciculatum Torr., Fl. North. and Mid. U.S. 145. 1824. New Jersey.

Panicum nitidum var. ciliatum Torr., Fl. North. and Mid. U.S. 146.1824. New Jersey.

Panicum huachucae var. silvicola Hitchc. and Chase, in Robinson, Rhodora 10: 64. 1908. District of Columbia, Chase 2400.

Panicum lindheimeri var. fasciculatum Fernald, Rhodora 23: 228. 1921. Based on $P$. dichotomum var. fasciculatum Torr.

Panicum lanuginosum var. fasciculatum Fernald, Rhodora 36: 77.1934. Based on $P$. dichotomum var. fasciculatum Torr.

(45) Panicum implicatum Scribn., U.S.Dept.Agr., Div. Agrost Bull. 11: 43. f. 2. 1898. Cape Elizabeth, Maine, Scribner in 1895.

Panicum unciphyllum implicatum Scribn. and Merr., Rhodora 3: 123.1901. Based on P. implicatum Scribn.

Panicum lindheimeri var. implicatum Fernald, Rhodora 23: 22S. 1921. Based on P. implicatum Scribn.

Panicum lanuginosum var. implicatum Fernald, Rhodora 36: 77. 1934. Based on P. implicatum Seribn.

(106) Panicum joorii Vasey, U.S.Dept.Agr., Div. Bot. Bull. 8: 31. 1889. Louisiana, Joor. 
Panicum leiophyllum Fourn., Mex. PI. 2: 20. 1886. Not P. leiophyllum Nees, 1829. Córdoba, Mexico, Bourgeau.

Panicum manatense Nash, Bull. Torrey Bot. Club 24: 42. 1897. Manatee County, Fla., Nash 2428a.

(85) Panicum lancearium Trin., Gram. Pan. 223. 1826. North America, Enslin.

Panicum nashianum Scribn., U.S. Dept.Agr., Div. Agrost. Bull. 7: 79. f. 61. 1897. Eustis, Fla., Nash 466.

(56) Panicum languidum Hitchc. and Chase, Contrib. U.S. Natl. Herb. 15: 232. f. 245. 1910. Based on P. unciphyllum forma prostratum Scribn, and Merr.

Panicum unciphyllum forma prostratu in Scribn. and Merr., Rhodora 3: 124. 1901. Not $P$. prostratum Lam.,1791. South Berwick, Maine, Fcrnald in 1897.

(48) Panicum lanuginosum Ell., Bot. S.C. and Ga. 1: 123. 1816. Georgia, Baldwin.

Panicum dichotomum var. lanuginosum Wood, Class-book ed. 3. 786. 1861. Presumably based on P. laruginosum Ell.

Panicum orangense Ashe, Jour. Elisha Mitchell Sci. Soc. 15: 113. 1899. Orange County, N.C., Ashe in 1898.

Panicum ciliosum Nash, Bull. Torrey Bot. Club 26: 568. 1S99. Biloxi, Miss., Tracy 4580.

(109) Panicum latifolium L., Sp. Pl. 58. 1753. America.

Milium latifolium Moench, Meth. Pl. 204. 1794. Based on P. latifolium L.

Panicum macrocarpon LeConte; Torr., in Eaton, Man. Bot. ed. 2: 341. 1818. New York.

Panicum schnecki Ashe, N.C. Agr. Expt. Sta. Bull. 175: 116. 1900. Southern Indiana and Illinois [Schneck].

(9) Panicum laxiflorum Lam., Encycl. 4: 748. 1798. North America.

Panicum dichotomum var. laxiflorum Beal, Grasses N.Amer. 2: 139.1896. Based on Panicum laxiflorum Lam.

Panicum pyriforme Nash, Bull. Torrey Bot. Club 26: 579. 1899. Orange Bend, Fla., Nash 239.

Panicum aureum Muhl.; Scribn. and Merr., U.S.Dept.Agr., Div. Agrost. Circ. 27: 4. 1900, as synonym of P. laxiflorum Lam.

(95) Panicum leibergii (Vasey) Seribn., in Britt. and Brown, Illustr. Fl. 3: 497. 1898. Based on P. scoparium var. leibergii Vasey.

Panicum scoparium var. leibergii Vasey, U.S.Dept.Agr., Div. Bot. Bull. S: 32. 1889. Plymouth County, Iowa, Leiberg.

Panicum scribnerianum var. leibergii Scribn., U.S.Dept.Agr., Div. Agrost. Bull. 6: 32. 1897. Presumably based on P. scoparium var. lcibergii Vasey.

Milium leibergii Lunell, Amer. Midl. Nat. 4: 213. 1915. Based on Panicum scoparium var. leibergii Vasey.

(134) Panicum lepidulum Hitehe. and Chase, Contrib. U.S. Natl. Herb. 15: 75. f. 64. 1910. Chihuahua, Mexico, Pringle 497.

(40) Panicum leucothrix Nash, Bull. Torrey Bot. Club 24: 41. 1897. Eustis, Fla., Nash 1338.

Panicum parvispiculum Nash, Bull. Torrey Bot. Clnb 24: 347. 1897. Darien Junction, Ga., Small in 1895.

(39) Panicum lindheimeri Nash, Bull. Torrey Bot. Club 24: 196. 1897. [New Braunfels], Tex., Lindheimer 565.

Panicum funstoni Scribn. and Merr., U.S.Dept.Agr., Div. Agrost. Circ. 35: 4. 1901. Three Rivers, Calif., Coville and Funston 1286.

Panicum lindheimeri var. typicum Fernald, Rhodora 23: 227. 1921. Based on P. lindheimeri Nash.

Panicum lanuginosum var. lindheimeri Fernald, Rhodora 36: 77. 1934. Based on P. lindheimeri Nash.

(7) Panicum linearifolium Scribn., in Britt. and Brown, Illustr. FI. 3: 500. f. 268a. 1898. New York and New Jersey to Missouri. [Type, WVashington, D.C., Vasey in 1882.]

Panicum strictum var. linearifolium Farwell, Amer. Midl. Nat. 11: 44. 1928. Based on P. linearifolium Scribn.

(150) Panicum longifolium Torr., Fl. North. and Mid. U.S. 149. 1824. New Jersey, Goldy.

Panicum anceps var. pubescens Vasey, U.S.Dept.Agr., Div. Bot. Bull. 8: 37. 1889. Mobile, Ala., Mohr.

Panicum pseudanceps Nash, Bull. Torrey Bot. Club 25: 85. 1898. Florida, Simpson in 1889.

Panicum longifolium var. pubescens Fernald, Rhodora 36: 69. 1934. Based on $P$. anceps var. pubescens Vasey. 
(41) Panicum longiligulatum Nash, Bull. 'Torrey Bot. Club 26: 574. 1899. Apalachicola, Fla., Vuscy in 1892.

(36) Panicum lucidum Ashe, Jour. Elisha Mitchell Sci. Soc. 15: 47. 1898. Lake Mattamuskeet, N.C., Ashe in 1898.

Panicum taxodiorum Ashe, Jour. Elisha Mitchell Sci. Soc. 16: 91. 1900. Lake Charles, La., Mackenzie 460.

(62) Panicum malacon Nash, Bull. Torrey Bot. Club 24: 197. 1897. Eustis, Fla., Nash 628.

Panicum strictifolium Nash, Bull. Torrey Bot. Club 26: 579. 1899. Eustis, Fla., Nash 603.

(90) Panicum malacophyllum Nash, Bull. Torrey Bot. Club 24: 198. 1897. Sapulpa, Indian Territory [Okla.], Bush 1228.

Panicum scoparium var. minus Scribn., Tenn. Agr. Expt. Sta. Bull. 7: 4S. 1894. Tennessee, Gattinger.

(28) Panicum mattamuskeetense Ashe, Jour. Elisha Mitchell Sci. Soc. 15: 45. 1898. Lake Mattamuskeet, N.C., Ashe and Pearson in 1898.

?Panicum barbatum LeConte; Torr., in Eaton, Man. Bot. ed. 2. 342. 1814. Not P. barbatum Lam., 1791. New York.

?Panicum nitidum var. barbatum Torr. Fl. North. and Mid. U.S. 146. 1824. No locality cited.

Panicum flexuosum Muhl.; Scribn. and Merr., U.S.Dept.Agr., Div. Agrost. Circ. 27: 3. 1900. Not P. flexuosum Retz., 1791. Name only for specimen in Muhlenberg Herb. (See "(174)" Hitchcock, Bartonia 14: 39. 1932.)

(137) Panicum maximum Jacq., Coll. Bot. 1: 76. 1786. Guadeloupe.

Panicum polygamum Swartz, Prodr. Veg. Ind. Occ. 24. 1788. Not P. polygamum Forsk., 1775. [Jamaica, Swartz.]

Panicum laeve Lam., Tabl. Encyl. 1: 172. 1791. Dominican Republic.

Panicum jumentorum Pers., Syn. Pl. 1: 83. 1805. Based on P. polygamum Swartz.

Panicum scaberrimum Lag., Gen. and Sp. Nov. 2. 1816. Mexico, Sessé.

Panicum trichocondylum Steud., Syn. Pl. Glum. 1: 74. 1854. Guadeloupe, Duchaissing.

Panicum praticola Salzm.; Doell, in Mart., Fl. Bras. 22: 203. 1S77, as synonym of $P$. maximum. Bahia, Brazil, Salzmann 683.

(43) Panicum meridionale Áshe, Jour. Elisha Mitchell Sci. Soc. 15: 59. 1898. Chapel Hill and Burke County, N.C., Ashe.

Panicum filiculme Ashe, Jour. Elisha Mitchell Sci. Soc. 15: 59. 1898. Not P. filiculme Hack., 1895. Chapel Hill, N.C., Ashe in 1898; Stone Mountain, Ga., Small in 1895.

?Panicum microphyllum Ashe, Jour. Elisha Mitchell Sci. Soc. 15: 61. 1898. Chapel Hill, N.C., Ashe in 1898.

Panicum unciphyllum meridionale Scribn. and Merr., Rhodora 3: 123.1901. Based on P. meridionale Ashe.

Panicum lindheimeri var. implicatum subvar. meridionale Farwell, Amer. Midl. Nat. 11: 45. 1928. Based on P. meridionale Ashe.

(25) Panicum microcarpon Muhl.; Ell., Bot. S.C. and Ga. 1: 127. 1816. [Georyia, Baldwin.]

Panicum heterophyllum Muhl., Amer. Phil. Soc. Traus. 3: 160. 1793. Name only,

Punicum nitidum var. ramulosum Torr., Fl. North. and Mid. U.S. 146. 1824. Quaker Bridge, N.J.

(130) Panicum miliaceum L., Sp. Pl. 5S. 1753. India.

Milium panicum Mill., Gard. Dict. Milium no. 1. 1768. Based on Panicum miliaceum L.

Milium esculentum Moench, Meth. Pl. 203. 1794. Based on Panicum miliaceum $\mathrm{L}$.

Panicum milium Pers., Syn. Pl. 1: 83. 1805. Based on P. miliaceum L.

Leptoloma miliacea Smyth, Kans. Acad. Sci. Trans. 25: S6. 1913. Based on Panicum miliaceum L.

(105) Panicum mutabile Scribn. and Smith; Nash, in Small, Fl. Southeast. U.S. 103.1903. Biloxi, Miss., Tracy 3074.

(21) Panicum neuranthum Griseb., Cat. Pl. Cub. 232. 1866. Eastern Cuba, Wright 3453.

(26) Panicum nitidum Lam., Tabl. Encycl. 1: 172. 1791. Carolina, Fraser. Panicum nodiflorum Lam., Encycl. 4: 744. 1798. Carolina, Fraser; South Carolina, Michaux. 
Panicum dichotomum var. nitidum Wood, Class-book ed. 3. 786. 1861. Presumably based on $P$. nitidum Lam.

Panicum dichotomum var. nodiflorum Griseb., Cat. Pl. Cub. 234. 1866. Based on $P$. nodiflorum Lam.

Panicum subbarbulatum Scribn. and Merr., U.S.Dept.Agr., Div. Agrost. Circ. 29: 9. 1901. Based on P. barbulatum Michx. as described by Elliott, not Michaux's species. Presumably South Carolina.

(98) Panicum nodatum Hitche. and Chase, Contrib. U.S. Natl. Herb. 15: 293. 1910. Sarita, Tex., Hitchcock 3865.

(24) Panicum nudicaule Vasey, U.S.Dept.Agr., Div. Bot. Bull. 8: 31. 1889. Santa Rosa County, Fla., Curtiss [3583*].

(158) Panicum obtusum H.B.K., Nov. Gen. and Sp. 1: $98 . \quad 1815 . \quad$ Near Guanajuato, Mexico, Humboldt and Bonpland.

Panicum polygonoides C. Muell., Bot.Ztg. 19: 323. 1861. Not P. polygonoides Lam., 1798. Texas, Drummond 371.

Panicum repente Buckl., Prel. Rept. Geol. Agr. Survey Tex. App. 3. 1866. Texas [Buckley].

Brachiaria obtusa Nash, in Britton, Man. 77. 1901. Based on Panicum obtusum H.B.K.

(53) Panicum occidentale Scribn., Mo. Bot. Gard. Rept. 10: 48. 1899. Nootka Sound, Vancouver Island, Haenke.

Panicum dichotomum var. pubescens Munro; Benth., Pl. Hartw. 341. 1857. Name only. Sacramento, Calif., Hartweg 2024 (344).

(93) Panicum oligosanthes Schult., Mant. 2: 256. 1824. Based on P. pauciflorum Ell.

Panicum pauciflorum Ell., Bot. S.C. and Ga. 1: 120. 1816. Not P. pauciflorum R. Br., 1810. Georgia.

Panicum scoparium var. angustifolium Vasey, U.S.Dept.Agr., Div. Bot. Bull. 8: $32 . \quad 1889$. South Carolina, Ravenel.

Panicum scoparium var. pauciflorum Scribn., Tenu. Agr. Expt. Sta. Bull. 7: 48. 1894. Based on P. pauciflorum Ell.

(69) Panicum oricola Hitche. and Chase, Rhodora 8: 208. $1906 . \quad$ Lewes, Del., Hitchcock 47.

Panicum columbianum var. oricola Fernald, Rhodora 36: 79. 1934. Based on $P$. oricola Hitche. and Chase.

(59) Panicum ovale Ell., Bot. S.C. and Ga. 1: 123. 1816. St. Marys, Ga., Baldwin.

Panicum ciliiferum Nash, Bull. Torrey Bot. Club 24: 195. 1897. Eustis, Fla., Nash 147.

Panicum erythrocarpon Ashe, Jour. Elisha Mitchell Sci. Soc. 16: 90. 1900. New Hanover County, N.C., Ashe in 1899.

(20) Panicum ovinum Scribn. and Smith, U. S.Dept.Agr., Div. Agrost. Circ. 16: 3. 1899. Waller County, Tex., Thurow.

Panicum redivivum Trin.; Steud., Nom. Bot. ed. 2. 2: 262. 1841. Name only. [Jalapa], Mexico, Schiede.

(54) Panicum pacificum Hitche. and Chase, Contrib. U.S. Natl. Herb. 15: 229. f. 241. 1910. Castle Crags, Calif., Hitchcock 3070.

(112) Panicum paludivagum Hitche. and Chase, Contrib. U.S. Natl. Herb. 15: 32. f. 13. 1910. Eustis, Fla., Nash 746.

(128) Panicum pampinosum Hitchc. and Chase, Contrib. U.S. Natl. Herb. 15: 66. f. 48. 1910. Wilmot, Ariz., Thornber 193.

(88) Panicum patentifolium Nash, Bull. Torrey Bot. Club 26: 574. 1899. Eustis, Fla., Nash 72.

(86) Panicum patulum (Scribn. and Merr.) Hitchc., Rhodora 8: 209. 1906. Based on $P$. nashianum patulum Scribn. and Merr.

Panicum nashianum patulum Scribn. and Merr., U.S.Dept.Agr., Div. Agrost. Circ. 27: 9. 1900. "Braidentown" (Bradenton), Fla., Combs 1296.

Panicum lancearium var. patulum Fernald, Rhodora 36: 80. 1934. Based on $P$. nashianum patulum Scribn. and Merr.

(97) Panicum pedicellatum Vasey, U.S.Dept.Agr., Div. Bot. Bull. 8: 28. 1889. [Kimble County], Tex., Reverchon.

(6) Panicum perlongum Nash, Bull. Torrey Bot. Club 26: 575. 1899. Creek Nation, Okla., Carleton 98.

Panicum pammeli Ashe, N.C. Agr. Expt. Sta. Bull. 175: 116. 1900. Iowa [Cratty in 1881].

Panicum striclum var. perlongum Farwell, Amer. Midl. Nat. 11: 44.1928. Based on P. perlongum Nash. 
(123) Panicum philadelphicum Bernh.; Trin., Gram. Pan. 216. 1826; Nees, Agrost. Bras. 198. 1829. [Philadelphia, Pa., Bernhardi.]

Panicum capillare var. sylvaticum Torr., Fl. North. and Mid. U.S. 149. 1824. Not P. sylvaticum Lam., 1798. New York City.

Panicum torreyi Fourn., in Hemsl., Biol. Centr. Amer. Bot. 3: 497. 1885. Based on P. capillare var. sylvaticum Torr.

Panicum capillare var. minimum Engelm.; Gattinger, Tenn. Fl. 94. 1887. [Green Brier, Tenn., Gattinger.]

Panicum minus Nash, Bull. Torrey Bot. Club 22: 421. 1895. Based on "Panicum capillare var. minus Muhl."

Panicum capillare var. minus Muhl.; Nash, Bull. Torrey Bot. Club 22: 421. 1895, as synonym of $P$. minus Nash. Muhlenberg does not give this a varietal name, noting only "varietas minor occurrit ubique in cultis magis aridis."

Panicum minimum Scribn. and Merr., U.S.Dept.Agr., Div. Agrost. Circ. 27: 4. 1900. Based on $P$. capillare var. minimum Engelm.

(138) Panicum plenum Hitche. and Chase, Contrib. U.S. Natl. Herb. 15: 80. f. 69. 1910. Mangas Springs, N.Mex., Metcalfe 739.

(71) Panicum polyanthes Schult., Mant. 2: 257. 1824. Based on P. multiflorum Ell.

Panicum multiflorum El1., Bot. S.C. and Ga. 1: 122. 1816. Not P. mulliflorum Poir., 1816. Presumably South Carolina.

Panicum microcarpon Muhl., Descr. Gram.111. 1817. Not P. microcarpon Muhl.; Ell., 1816. Virginia, "Cherokee" [type], and Delaware.

Panicum firmandum Steud., Syn. Pl. Glum. 1: 418. 1854. North Carolina, II. A. Curtis.

Panicum microcarpon var. isophyllum Scribn., Tenn. Agr. Exp. Sta. Bull. 7: 51. f. 54. 1S94. [Alleghany Springs, Tenn., Gayle.]

(12) Panicum polycaulon Nash, Bull. Torrey Bot. Club 24: 200. 1897. Tampa, Fla., Nash 2420a.

Panicum dichotomum var. glabrescens Griseb., Fl. Brit. W.Ind. 555. 1864. Jamaica, Purdie.

(84) Panicum portoricense Desv.; Hamilt., Prodr. Pl. Ind. Occ. 11. 1825. Puerto Rico.

Panicum pauciciliatum Ashe, Jour. Elisha Mitchell Sci. Soc. 16: 87. 1900. Wilmington, N.C., Ashe in 1899.

(51) Panicum praecocius Hitche. and Chase, Rhodora 8: 206. 1906. Wady Petra, Ill., IT. H. Chase 649.

(58) Panicum pseudopubescens Nash, Bull. Torrey Bot. Club. 26: 577. 1899. Auburn, Ala., Earle and Baker 1537.

Panicum villosissimum var. pseudopubescens Fernald, Rhodora 36: 79.1934. Based on P. pseudopubescens Nash.

(113) Panicum purpurascens Raddi, Agrost. Bras. 47. 1823. Rio de Janeiro, Brazil, Raddi. (P. purpurascens Opiz, 1822, is a name only.)

Panicum barbinode Trin., Mém. Acad. St. Pétersb. VI. Sci. Nat. 1: 256. 1834. Bahia, Brazil.

Panicum guadaloupense Steud., Syn. Pl. Glum. 1: 61. 1854. Guadeloupe.

Panicum equinum Salzm.; Steud., Syn. Pl. Glum. 1: 67. 1854. Bahia, Brazil, Salzmann.

Panicum pictigluma Steud., Syn. Pl. Glum. 1: 73. 1854. Brazil.

This species has been referred to $P$. numidianum Lam. Together with that and P. barbinode Trin. it is included under Brachiaria mutica (Forsk.) Stapf, in Prain, Fl. Trop. Afr. 9: 526. 1919.

(2) Panicum ramisetum Scribn., U.S.Dept.Agr., Div. Agrost."Circ. 27: 9. 1900. Based on P. subspicatum Vasey.

Panicum subspicatum Vasey, U.S.Dept.Agr., Div. Bot. Bull. 8: 25.1889. Not P. subspicatum Desv., 1831. Texas, Nealley.

Chaetochloa ramiseta Smyth, Kans. Acad. Sei. Trans. 25: 89. 1913. Based on Panicum ramisetum Scribn.

Panicum ramosum L., Mant. Pl. 1: 29. 1767. "In Indiis."

(94) Panicum ravenelii Scribn. and Merr., U.S.Dept.Agr., Div. Agrost. Bull. 24: 36. 1901. Based on P. scoparium as described by Elliott. [South Carolina and Georgia.]

Panicum scoparium var. majus Vasey, U.S.Dept.Agr., Div. Bot. Bull. 8: 32. 1889. South Carolina, Ravenel.

Panicum scoparium var. genuinum Scribn., Tenn. Agr. Expt. Sta. Bull. 7: 48. 1894. Based on P. scoparium Lam., as described by Elliott.

(140) Panicum repens L., Sp. Pl. ed. 2. 87. 1762. Southern Europe.

Panicum littorale Mohr: Vasey, Bot. Gaz. 4: 106. 1879. Mobile, Ala., Mohr. $55974^{\circ}-35-58$ 
(114) Panicum reptans L., Syst. Nat. ed. 10. 2: 870. 1759. [Jamaica, Browne.] Panicum grossarium L., Syst. Nat. ed. 10. 2: 871. 1759. [Jamaica, Browne, typonym of $P$. reptans L.]

Panicum prostratum Lam., Tabl. Encycl. 1: 171. 1791. West Indies [type from Dominican Republic].

Panicum caespitosum Swartz, Fl. Ind. Occ. 1: 146. 1797. Jamaica, Swartz.

Panicum insularum Steud., Syn. Pl. Glum. 1: 61. 1854. Lesser Antilles, [Hohenacker].

Brachiaria prostrata Griseb., Abhandl. Gesell. Wiss. Göttingen 7: 263. 1857. Based on Panicum prostratum Lam.

Panicum aurelianum Hale, in Wood, Class-book ed. 3. 787. 1861. New Orleans, La., Hale.

Panicum prostratum var. pilosum Eggers, Fl. St. Croix and Virgin Isl. 104. 1879. St. Croix.

Urochloa reptans Stapf, in Prain, Fl. Trop. Afr. 9: 601. 1920. Based on Panicum reptans $\mathrm{L}$.

(3) Panicum reverchoni Vasey, U.S.Dept.Agr. Div. Bot. Bull. 8: 25. 1889. [Dallas], Tex., Reverchon.

Chaetochloa reverchoni Sinyth, Kans. Acad. Sci. Trans. 25: 88. 1913. Based on Panicum reverchoni Vasey.

(153) Panicum rhizomatum Hitchc. and Chase, Contrib. U.S. Natl. Herb. 15: 109. f. 104. 1910. Orangeburg, S.C., Hitcheock 450.

Panicum anceps var. rhizomatum Fernald, Rhodora 36: 73. 1934. Based on $P$. rhizomatum Hitche. and Chase.

(34) Panicum roanokense Ashe, Jour. Elisha Mitchell Sci. Soc. 15: 44. 1898. Roanoke Island, N.C., Ashe in 1898.

Panicum curtivaginum Äshe, Jour. Elisha Mitchell Sci. Soc. 16: 85. 1900. Petit Bois Island, Miss., Tracy [4584].

(101) Panicum scabriusculum Ell., Bot. S.C. and Ga. 1: 121. 1816. Savannah, Ga., Baldwin.

Panicum lanuginosum Bosc; Spreng., Syst. Veg. 1: 319. 1825. Not P. lanuginosum Ell., 1816. Georgia.

Panicum eriophorum Schult., Mant. 3 (Add. 1): 591. 1827. Based on $P$. lanuginosum Bose.

Panicum nealleyi Vasey, Bull. Torrey Bot. Club 13: 25. 1886. Texas, Nealley.

Panicum dichotomum var. elatum Vasey, U.S.Dept.Agr., Div. Bot. Bull. 8: 31. 1889. No locality cited. [Mobile, Ala., Mohr.]

Panicum viscidum var. scabriusculum Beal, Grasses N.Amer. 2: 143.1896. Based on "P. scabriusculum Chapm. non Ell." Chapman uses Elliott's name correctly.

(60) Panicum scoparioides Ashe, Jour. Elisha Mitchell Sci. Soc. 15: 53. 1898. Centreville, Del., Commons 283.

Panicum villosissimum var. scoparioides Fernald, Rhodora 36: 79. 1934. Based on P. scoparioides Ashe.

(99) Panicum scoparium Lam., Encycl. 4: 744. 1798. South Carolina, Michaux.

Panicum pubescens Lam., Encycl. 4: 748. 1798. South Carolina, Michaux.

Panicum viscidum Ell., Bot. S.C. and Ga. 1: 123. pl. 7. f. 3. 1816. Presumably South Carolina.

Panicum nitidum var. velutinum Doell, in Mart., Fl. Bras. 22: 247. 1877. Based on P. viscidum Ell.

Panicum laxiflorum var. pubescens Chapm., Fl. South. U.S. ed. 3. 586.1897. Not P. laxiflorum var. pubescens Vasey, 1892. Based on P. pubescens Lam., but misapplied to $P$. strigosum Muhl.

Chasea pubescens Nieuwl., Amer. Midl. Nat. 2: 64. 1911. Based on Panicum pubescens Lam.

(92) Panicum scribnerianum Nash, Bull. Torrey Bot. Club 22: 421. 1895. Based on $P$. scoparium as described by Watson in Gray's Manual. [Type, Pennsylvania, Carey in 1836.]

Panicum macrocarpon Torr., Fl. North. and Mid. U.S. 143.1823 . Not $P$. macrocarpon LeConte, 1s18. Deerfield, Mass., Cooley.

Panicum scoparium S. Wats.; Nash, Bull. Torrey Bot. Club 22: 421. 1895, as synonym of P. scribncrianum Nash.

Panicum oligosanthes var. scribnerianum Fernald, Rhodora 36: 80." 1934. Based on P. scribnerianum Nash.

(61) Panicum shastense Scribn. and Merr., U.S.Dept.Agr., Div. Agrost. Circ. 35: 3. 1901. Castle Crags, Calif., Greata in 1899.

(70) Panicum sphaerocarpon Ell., Bot. S.C. and Ga. 1: 125. 1816. Georgia, Baldwin. 
Panicum kalmii Swartz; Wikstr., Adnot. Bot. 6. 1829. Pennsylvania, ?Kalm. Panicum heterophyllum Swartz; Wikstr., Adnot. Bot. 6. 1829. Not P. heterophyllum Spreng., 1822. As synonym of $P$. kalmii Swartz.

Panicum dichotomm var. sphaerocarpon Wood, Class-book ed. 3. 786. 1861. Presumably based on P. sphaerocarpon Ell.

Panicum nitidum var. crassifolium A. Gray; Doell, in Mart., Fl. Bras. 22: 247. 1877. New Jersey.

Panicum microcarpon var. sphaerocarpon Vasey, Grasses U.S. 12. 1883. Based on P. sphaerocarpon Ell.

Panicum vicarium Fourn., Mex. Pl. 2: 20. 1886. Córdoba, Mexico, Schaffner 285.

Panicum sphaerocarpon var. Inflatum (Scribn. and Smith) Hitche., Contrib. U.S. Natl. Herb. 15: 253. f. 275. 1910. Based on P. inflatum Scribn. and Smith. (Published as $P$. sphaerocarpon inflatum.)

Panicum inflatum Scribll. and Smith, U.S.Dept.Agr., Div. Agrost. Cire. 16: 1899. Biloxi, Miss., Tracy 4622.

Panicum mississippiense Ashe, Jour. Elisha Mitchell Sci. Soc. 16: 91. 1900. Mississippi River below New Orleans, La., Ashe.

(37) Panicum sphagnicola Nash, Bull. Torrey Bot. Club 22: 422. 1895. Lake City, Fla., Nash 2500.

(38) Panicum spretum Schult., Mant. 2: 248. 1824. Based on Muhlenberg's Panicum no. 37. New England.

Panicum nitidum var. densiflorum Rand and Redfield, Fl. Mt. Desert 174. 1894. Mount Desert, Maine, Rand.

Panicum catoni Nash, Bull. Torrey Bot. Club 25: 84. 1898. Seabrook, N.H.,

Eaton.
Panicum octonodum Smith, U.S.Dept.Agr., Div. Agrost. Bull. 17: 73. f. 369. 1899. Waller County, Tex., Thurow in 1898.

Panicum paucipilum Nash, Bull. Torrey Bot. Club 26: 573. 1899. Wildwood, N.J., Bicknell in 1897.

Panicum nitidum octonodum Seribn. and Merr., U.S.Dept.Agr., Div. Agrost. Bull. 24: 34. 1901. Based on P. octonodum Smith.

(149) Panicum stipitatum Nash, in Scribn., U.S.Dept.Agr., Div. Agrost. Bull 17. (ed. 2): 56. f. 352. 1901. Based on P. elongatum Pursh.

Panicum elongatum Pursh, Fl. Amer. Sept. 1: 69. 1814. Not P. elongatum Salisb., 1796. New Jersey to Virginia. [Type, Delaware.]

Panicum agrostoides var. elongatum Scribn., Tenn. Agr. Expt. Sta. Bull. 7: 42. pl. 9. f. 34. 1894. Based on P. elongatum Pursh.

(129) Panicum stramineum Hitche. and Chase, Contrib. U.S. Natl. Herb. 15: 67. f. 50. 1910. Guaymas, Sonora, Palmer 206 in 1887.

(13) Panicum strigosum Muhl., in Ell., Bot. S.C. and Ga. 1: 126. 1816. [South Carolina and Georgia.]

Panicum laxiflorum var. pubescens Vasey, Contrib. U.S. Natl. Herb. 3: 30. 1892. No locality cited. [Type, Duval County, Fla., Curtiss (no. H).]

Panicum longipedunculatum Scribn., Tenn. Agr. Expt. Sta. Bull. 7: 53. pl. 16. f. 61. 1894. Tennessee, White Cliff Springs, [Scribner, type], Tullahoma.

(52) Panicum subvillosum Ashe, Jour. Elisha Mitchell Sci. Soc. 16: 86. 1900. Carlton, Minn., Ashe.

Panicum unciphyllum forma pilosum Scribn. and Merr., Rhodora 3: 124. 1901. Orono, Maine, Fernald 501.

(146) Panicum tenerum Beyr,, in Trin., Mém. Acad. St. Pétersb. VI. Sci. Nat. 1: 341. 1834. Georgia, Beyrich [62].

Panicum anceps var. strictum Chapm., Fl. South. U.S. 573. 1860. Florida, Chapman.

This species has been referred to Panicum stenodes Griseb., of tropical America.

(47) Panicum tennesseense Ashe, Jour. Elisha Mitchell Sci. Soc. 15: 52. 1898. La Vergne County, Tenn., Biltmore Herbarium 7087.

Panicum lindheimeri var. septentrionale Fernald, Rhodora 23: 227. 1921. Woodstock, New Brunswick, Fernald and Long 12527.

Panicum lindheimeri var. tennesseense Farwell, Amer. Midl. Nat. 11: 45. 1928. Based on Panicum tennesseense Ashe.

Panicum lanuginosum var. septentrionale Fernald, Rhodora 36: 77. 1934. Based on $P$. lindheimeri var. septentrionale Fernald.

(73) Panicum tenue Muhl., Deser. Gram. 118. 1817. No locality cited.

Panicum denstum Brickell and Enslin; Muhl., Deser. Gram. 119. 1817. Not $P$. deustum Thunb., 1794. As synonym of $P$. tenue. 
Panicum liton Schult., Mant. 2: 250. 1824. Based on P. tenue Muhl., that name changed because of $P$. tenue Roxb., name only, 1813, not described until 1820.

Panicum unciphyllum Trin., Gram. Pan. 242. 1826. North America.

Panicum macrum Kunth, Rév. Gram. 1: 40. 1829. Based on P. tenue Muhl.

Panicum parvulum Muhl.; Scribn. and Merr., U.S.Dept.Agr., Div. Agrost. Circ. 27: 4. 1900. Not $P$. parvulum Trin., 1834. As synonym of P. tenue Muhl.

(118) Panicum texanum Buckl., Prel. Rept. Geol. Agr. Survey Tex. App. 3. 1866. Austin, Tex.

(55) Panicum thermale Boland., Calif. Acad. Sci. Proc. 2: 181. 1862. Sonoma County, Calif.

(50) Panicum thurowii Scribn. and Smith, U.S.Dept.Agr., Div. Agrost. Circ. 16: 5. 1899. Waller County, Tex., Thurow in 1898.

(75) Panicum trifolium Nash, Bull. Torrey Bot. Club 26: 580. 1899. Macon, Ga., Small in 1895.

(67) Panicum tsugetorum Nash, Bull. Torrey Bot. Club 25: 86. 1898. Bronx Park, N.Y., Nash 287.

Panicum lanuginosum siccanum Hitchc. and Chase, Rhodora 8: 207. 1906. Starved Rock, Ill., Chase 1602.

(124) Panicum tuckermani Fernald, Rhodora 21: 112. 1919. Lake Memphremagog, Vt., Tuckerman.

Panicum soboliferum Tuckerm.; Scribn. and Merr., Rhodora 3: 106.1901 , as synonym of $P$. minimum. Lake Memphremagog, Vt., Tuckerman.

(157) Panicum urvilleanum Kunth, Rév. Gram. 2: 403. pl. 115. 1831. [Concepcion], Chile, Dumont-d' Crville.

Panicum megastachyum Presl, Rel. Haenk. 1: 305. 1830. Not P. megastachyum Nees, 1826. Huánuco, Peru, Haenke.

Panicum preslii Kunth, Rér. Gram. 1: Sup. X. 1830. Based on P. megastachyum Presl.

Panicum urvilleanum longiglume Scribn., U.S.Dept.Agr., Div. Agrost. Bull. 17 (ed. 2): 49. 1901. San Jacinto, Calif., Parish Brothers 887.

(79) Panicum vernale Hitchc. and Chase, Contrib. U.S. Natl. Herb. 15: 266. f. 293. 1910. Lake City, Fla., Hitchcock 1020 .

(155) Panicum verrucosum Muhl., Descr. Gram. 113. 1817. New Jersey, Delaware, and Georgia.

Panicum debile Ell., Bot. S.C. and Ga. 1: 129. 1816. Not P. debile Desf., 1798. Presumably South Carolina.

Panicum umbraculum Bosc; Spreng., Syst. Veg. 1: 314 . 1825, as synonym of P. verrucosum. [Bosc.]

Panicum rugosum Bose; Spreng., Syst. Veg. 1:314. 1825, as synonym of P. verrucosum. [Bosc.]

(57) Panicum villosissimum Nash, Bull. Torrey Bot. Club 23: 149. 1896. Macon, Ga., Small in 1895.

Panicum tectum. Willd.; Spreng., Syst. Veg. 1:313. 1825. Name only. North America.

Panicum dichotonum var. villosum Vasey, U.S.Dept.Agr., Div. Bot. Bull. 8: 31. 1889. [Type, District of Columbia, Vasey.]

Panicum nitidum var. pubescens Scribn., in Kearney, Bull. Torrey Bot. Club 20: 479. 1893. Name only. Harlan and Bell Counties, Ky., Kearney 58 and 141 in part.

Panicum atlanticum Nash, Bull. Torrey Bot. Club 24: 346. 1897. Bronx Park, N.Y., Nash.

Panicum haemacarpon Ashe, Jour. Elisha Mitchell Sci. Soc. 15: 55.1898. District of Columbia, Kearney in 1897 [type]; North Carolina, Ashe in 1898; Iowa, Carver 258.

Panicum xanthospermum Scribn. and Mohr, Contrib. U.S. Nat. Herb. 6: 348. 1901. Greenville, Ala., Mohr.

(142) Panicum virgatum L., Sp. P1. 59. 1753. Virginia [Clayton 578].

Panicum coloratum Walt., Fl. Carol. 73. 1788. Not P. coloratum L., 1767. South Carolina.

Eatonia purpurascens Raf., Jour. Phys. Chym. 89: 104. 1819. New York [type, Long Island].

Panicum pruinosum Bernh.; Trin., Gram. Pan. 191. 1826, as synonym of P. virgatum. North America [Delaware], Bernhardi.

Panicum giganteum Scheele, Linnaea 22:340. 1849. Between San Antonio and New Braunfels, Tex., Lindheimer. 
Panicum glaberrimum Steud., Syn. Pl. Glum. 1:94. 1854. Grown at Berlin, seed from North America.

Ichnanthus glaber Link; Steud., Syn. Pl. Glum. 1: 94 . 1854, as synonym of $P$. glaberrimum Steud.

Panicum kunthii Fourn.; Hemsl., Biol. Centr. Amer. Bot. 3: 490. 1885. Not $P$. kunthii Steud., 1841. Based on P. coloratum L. misapplied by Kunth.

Panicum virgatum var. confertum Vasey, Bull. Torrey Bot. Club 13: 26.1886. No locality cited. [Type, Atlantic City, N.J., Vasey.]

Panicum virgatum var. elongatum Vasey, Bull. Torrey Bot. Club 13: 26. 1886. No locality cited. [Type, White River, S.Dak., Wilcox 13.]

Panicum virgatum var. diffusum Vasey, Bull. Torrey Bot. Club 13: 26. 1886. "Kansas, Colorado, etc."

Panicum virgatum var. glaucephylla Cassidy, Colo. Agr. Expt. Sta. Bull. 12: 29. 1890. Colorado.

Chasea virgata Nieuwl., Amer. Midl. Nat. 2: 64. 1911. Based on Panicum virgatum L.

Milium virgatum Lunell, Amer. Midl. Nat. 4: 212. 1915. Based on Panicum virgatum $\mathrm{L}$.

Milium virgatum var. elongatum Lunell, Amer. Midl. Nat. 4: 212.1915. Based on Panicum virgatum var. elongatum Vasey.

Panicum virgatum var. CUBense Griseb., Cat. Pl. Cub. 233. 1866. [Hanábana], Cuba, Wright in 1865.

Panicum virgatum var. obtusum Wood, Amer. Bot. and Flor. pt. 2: 392.1870. New Jersey.

Panicum virgatum var. breviramosum Nash, Bull. Torrey Bot. Club 23: 150. 1896. Augusta, Ga., Small in 1895.

Panicum virgatum var. thyrsiforme Linder, Rhodora 24: 14. 1922. Indian River, Fla., Fredholm 5580.

Panicum Virgatca var. SPISscin Linder, Rhodora 24: 15. 1922. Great Pubnico Lake, Nova Scotia, Fernald, Long, and Linder 19766.

(87) Panicum webberianum Nash, Bull. Torrey Bot. Club 23: 149. 1896. Eustis, Fla., Nash 781.

Panicum onslowense Ashe, Jour. Elisha Mitchell Sci. Soc. 16: 88. 1900. Ward's Mill, Onslow County, N.C., Ashe.

(8) Panicum werneri Scribn., in Britt. and Brown, Illustr. Fl. 3: 501. f. 268b. 1898. New York and Ohio [type, Painesville, Werner 60].

Panicum delawarense Ashe, N.C. Agr. Expt. Sta. Bull. 175: 116. 1900. Centerville, Del., Commons [48] in 1878.

Panicum linearifolium var. werneri Fernald, Rhodora 23: 194. 1921. Based on P. werneri Scribn.

Panicum strictum var. lincarifolium subvar. werneri Farwell, Amer. Midl. Nat. 11: 44. 1928. Based on P. werneri Scribn.

(89) Panicum wilcoxianum Vasey, U.S.Dept.Agr., Div. Bot. Bull. \&: 32. 1889. Nebraska [Fort Niobrara], Wilcox in 1888.

Milium wilcoxianum Lunell, Amer. MidI. Nat. 4: 213. 1915. Based on Panicum wilcoxianum Vasey.

(66) Panicum wilmingtonense Ashe, Jour. Elisha Mitchell Sci. Soc. 16: 86. 1900. Wilmington, N.C., Ashe in 1899.

Panicum alabamense Ashe, N.C. Agr. Expt. Sta. Bull. 175: 116. 1900. Not P. alabamense Trin., 1854. Auburn, Ala., Alabama Biological Survey 1530.

(42) Panicum wrightianum Scribn., U.S.Dept.Agr., Div. Agrost. Bull. 11: 44. f. 4. 1898. Vueltabajo, Cuba, Wright 3463.

Panicum strictum Bosc; Roem. and Schult., Syst. Veg. 2: 447. 1817. Not P. strictum R.Br., 1810. North America [type, Carolina, Bosc].

Panicum minutulum Desv., Opusc. 87. 1833. Not P. minutulum Gaud., 1826. Carolina.

Panicum demizutivum Peck, N.Y. State Mus. Bull. 10: 27. 1907. Suffolk County, N.Y., Peck in 1906.

(10) Panicum xalapense H.B.K., Nov. Gen. and Sp. 1: 103. 1815. Xalapa [Jalapa], Mexico, Humboldt and Bonpland.

Panicrm pumilum Bosc; Nees, Agrost. Bras. 228. 1829. Not P. pumilum Lam., 1798. Name only. North America [Bosc].

Panicum rariflorum Rupr., Bull. Acad. Sci. Belg. 92: 240. 1842. Not $P$. rariflorum Lam., 1798. 'Name only. Jalapa, Mexico, Galeotti 5733.

Panicum ruprechtii Fourn., Mex. Pl. 2: 21. 1886. Not P. ruprechtii Fenzl., 1854. Described from type of $P$. rariflorum Rupr.

Panicum caricifolium Scribn.; Ashe, Jour. Elisha Mitchell Sci. Soc. 15: 57. 1898. Name only. Washington, D.C., Kearney in 1897. 
This is the species described as Panicum acuminatum Swartz by Muhlenberg (Descr. Gram. 125.1817 ).

Panicum xalapense var. strictiranedm Hitchc. and Chase, Contrib. U.S. Natl. Herb. 15: 161. f. 148. 1910. Jackson, Miss., Hitchcock 1311. (Published as P. xalapense strictirameum.)

Panicum laxifiorum var. strictirameum Fernald, Rhodora 36: 75. 1934. Based on P. xalapense strictirameum Hitch c. and Chase.

(96) Panicum xanthophysum A. Gray, Gram. and Cyp. 1: no. 28. 1834. Oneida Lake, N.Y.

Panicum xanthophysum forma amplifolium Scribn., in Brainerd, Jones, and Eggleston, Fl. Vt. 104. 1900. Burlington, Vt., Jones.

(33) Panicum yadkinense Ashe, Jour. Elisha Mitchell Sci. Soc. 16: 85. 1900. Based on Panicum maculatum Ashe.

?Panicum dumus Desv., Opuse. 88. 1831. Tropical America (locality erroneous). Panicum maculatum Ashe, Jour. Elisha Mitchell Sci. Soc. 15: 44. 1898. Not P. maculatum Aubl., 1775. Raleigh, N.C., Ashe in 1895.

\section{(37) PAPPOPHORUM Schreb.}

(3) Pappophorum bicolor Fourn., Mex. Pl. 2: 133. 1886. Toluca, Mexico, Karwinsky 1483.

(2) Pappophorum mucronulatum Nees, Agrost. Bras. 412. 1829. Bahia and Piauhy, Brazil, Martius.

Pappophorum vaginatum Buckl., Prel. Rept. Geol. Agr. Survey Tex. App. 1. 1866. Western Texas [type, Wright 803].

Pappophorum apertum Munro; Scribn., Bull. Torrey Bot. Club 9: 148. 1882. Camp Lowell, Ariz., Pringle.

Pappophorum apertum var. vaginatum Scribn.; L. H. Dewey, Contrib. U.S. Natl. Herb. 2: 535. 1894. Based on P. vaginatum Buckl.

(1) Pappophorum wrightii S. Wats. Amer. Acad. Sci. Proc. 18: 178. 1883. [Devils River, Tex.], Wright 751 and 2029.

Pappophorum mexicanum Griseb.; Fourn., Mex. Pl. 2: 133. 1886. Mexico, Guadalupe, Bourgeau; valley of Mexico, Schaffner 184.

(128) PASPALUM L. ${ }^{26}$

(2) Paspalum acuminatum Raddi, Agrost. Bras. 25. 1823. Rio de Janeiro, Brazil, Raddi.

(11) Paspalum almum Chase, Jour. Wash. Acad. Sci. 23: 137. f. 1. 1933. Beaumont, Tex., J. F. Combs in 1932.

(42) Paspalum bifidum (Bertol.) Nash, Bull. Torrey Bot. Club 24: 192. 1897. Based on Panicum bifidum Bertol.

Panicum floridanum Trin., Mém. Acad. St. Pétersb. VI. Sci. Nat. 1: 248. 1834. Not Paspalum floridanum Michx. Florida and Alabama.

Panicum bifidum Bertol., Mem. Accad. Sci. Bologna 2: 598. pl. 41. f. 2. e-h. 1850. Alabama.

Panicum alabamense Trin.; Steud., Svn. Pl. Glum. 1: 64. 1854. Alabama, locality erroneously eited as North Carolina.

Paspalum racemulosum Nutt.; Chapm., FI. South. U.S. 571. 1860. Florida to North Carolina and westward.

Paspalum interruptum Wood, Class-book 783. 1861. Louisiana and Texas, Hale.

(25) Paspalum blodgettii Chapm., Fl. South. U.S. 571. 1860. Key West, Fla.,

Blodgett.
Paspalum dissectum Swartz; Roem. and Schult., Syst. Veg. 2: 308. 1817. Not $P$. dissectum L. 1762 . Erroneously given as synonym of $P$. caespitosum Flügge. Jamaica, Swartz.

Paspalum simpsoni Nash, Bull. Torrey Bot. Club 24: 39. 1897. No-Name Key, Fla., Simpson 184.

Paspalum gracillimum Nash, in Small, Fl. Southeast. U.S. 73, 1326. 1903. Key West, Fla., Blodgett.

Paspalum yucatanum Chase, Contrib. U.S. NatI. Herb.28: 121. 1929. Mérida, Yucatan, Schott 597.

(41) Paspalum boscianum Flügge, Monogr. Pasp. 170. 1810. Carolina, Bosc. Paspalum virgatum Walt., Fl. Carol. 75. 1788. Not P. virgatum L., 1759. South Carolina.

${ }^{28}$ For discussion of ty pes see Chase, Contrib. U.S. Natl. Herb. 28: 7-239. 1929. 
Paspalum brunneum Bose; Flügge, Monogr. Pasp. 171. 1810, as synonym of P. boscianum. Carolina, Bosc.

Paspalum purpurascens Ell., Bot. S.C. and Ga. 1: 108. pl. 6. f. 3. 1816. South Carolina.

Paspalum confertum LeConte, Jour. Phys. Chym. 91: 285. 1820. Georgia, [LeContc].

Paspalum virgatum var. purpurascens Wiood, Class-book 781. 1861. Based on P. purpurascens Ell.

(26) Paspalum caespitosum Flügge, Monogr. Pasp. 161. 1810. Hispaniola, Poiteau and Turpin.

Paspalum gracile Poir., in Lam., Encycl. Sup. 4: 313. 1816. Not P. gracile Rudge, 1805. Dominican Republic.

Paspalum helerophyllum Desv.; Poir., in Lam., Encycl. Sup. 4: 31 ว. 1816.

Dominican Republic.
Paspalum poiretii Roem. and Schult., Syst. Veg. 2: 878. 1817. Based on $P$. gracile Poir.

Paspalum lineare Fourn., Mex. PI. 2: 12. 1886. Not P.lineare Trin., 1826. Mexico, Liebmann 187 [type; the other specimen cited, Liebmann 192, is $P$. langei].

Paspalum caespitosum var. longifolium Vasey, Bull. Torrey Bot. Club 13: 164. 1886. No locality cited. [Type, Garber in 1877.]

(19) Paspalum ciliatifolium Michx.,Fl. Bor. Amer. 1: 44. 1803. Carolina, Michaux.

Paspalum debile Muhl., Cat. Pl. 8. 1813; Deser. Gram. 91. 1817. Not $P$. debile Michx., 1803. Georgia.

Paspalum spathaceum Desv.; Poir., in Lam., Encycl. Sup. 4: 314.1816. America.

Paspalum latifolium LeConte, Jour. Phys. Chym. 91: 284. 1820. Columbia,

Paspalum ciliatifolium var. brevifolium Vasey, Acad. Nat. Sci. Phila. Proc. 1886: 285. 1856. Philadelphia, Pa., Burk.

Paspalum setaceum var. ciliatifolium Vasey, Contrib. U.S. Natl. Herb. 3: 17. 1892. Based on P. ciliatifolium Michx.

Paspalum chapmani Nash, Bull. N.Y. Bot. Gard. 1: 290. 1899. Florida, Chapman.

Paspalum eggertii Nash, Bull. N.Y. Bot. Gard. 1: 434. 1900. Arkansas, [type, Pine Bluff, Eggert in 1896].

Paspalum blepharophyllum Nash, in Small, Fl. Southeast. U.S. 71, 1326. 1903. Central Florida, Nash 1426.

Paspalum epile Nash, in Small, F1. Southeast. U.S. 72, 1326.1903. Key West, Fla., Blodgett.

(33) Paspalum circulare Nash, in Britton, Man. 73. 1901. New York to North Carolina; Missouri. [Type, Bergen County, N.J., Nash in 1889.]

Paspalum praelongum Nash, in Small, Fl. Southeast. U.S. 74, 1326. 1903. Washington, D.C., Nash in 1894.

Paspalum laeve var. circulare Stone, N.J. Mus. Ann. Rept. 1910: 187. 1911. Based on P. circulare Nash.

(28) Paspalum conjugatum Bergius, Act. Helv. Phys. Math. 7: 129. pl. 8. 1762. Duteh Guiana.

Paspalum tenue Gaertn., Fruct. and Sem. 2: 2. pl. 80. 1791. Apparently based on $P$. conjugatum Bergius.

Paspalum ciliatum Lam., Tabl. Encycl. 1: 175. 1791. Tropical America [French Guiana, Leblond].

Paspalum renggeri Steud., Syn. Pl. Glum. 1: 17. 1854. Paraguay, Rengger.

Paspalum longissimum Hochst.; Steud., Syn. Pl. Glum. 1: 19. 1854. Dutch Guiana, Ǩappler 1556.

Paspalum bicrurum Salzm.; Doell, in Mart., Fl. Bras. 22: $55 . \quad$ 1877, as synonym of $P$. conjugatum. Bahia, Brazil, Salzmann.

Paspalum conjugatum var. parviflorum Doell, in Mart., Fl. Bras. 22: 55. 1877. Brazil, Manáos, Spruce 894; Piauhy, Gardner 3502.

(14) Paspalum debile Michx., Fl. Bor. Amer. 1: 44. 1803. Carolina [type] and Georgia, Michaux.

?Paspalum dissectum Walt., Fl. Carol. 75. 1788. Not P. dissectum L. 1762. South Carolina.

Paspalum dubium DC., Cat. Hort. Monsp. 130. 1813. Native country unknown.

Paspalum infirmum Roem. and Schult., Syst. Veg. 2: 307. 1817. Based on Paspalum debile Michx. 
Paspalum villosissimum Nash, Bull. Torrey Bot. Club 24: 40. 1897. Eustis, Fla. Nash 946.

(36) Paspalum difforme LeConte, Jour. Phys. Chym. 91: 284. 1820. Georgia. (29) Paspalum dilatatum Poir., in Lam., Encycl. 5: 35.1804. Argentina, Commerson.

Paspalum platense Spreng., Syst. Veg. 1: 247. 1825. Montevideo, Uruguay.

Paspalum ovatum Nees; Trin., Gram. Pan. 113. 1826. Brazil, Besser.

Paspalum lanatum Spreng., Syst. Veg. 4: Cur. Post. 30. 1827. Not P. lanatum H.B.K., 1816. Brazil.

Paspalum eriophorum Schult., Mant. 2: 560. 1827. Based on P. lanatum Spreng.

Paspalum ovatum var. grandiflorum Nees, Agrost. Bras. 43. 1829. Montevideo, Uruguay, Sellow.

Paspalum selloi Spreng.; Nees, Agrost. Bras. 43. 1829, as synonym of $P$. ovatum var. grandiflorum Nees.

Paspalum pedunculare Presl, Rel. Haenk. 1: 217. 1830. Habitat unknown.

Paspalum dilatatum var. decumbens Vasey, Bull. Torrey Bot. Club. 13: 166. 1886. No locality cited. [Type, Point-a-la-Hache, La., Langlois 27.]

Paspalum dilatatum var. sacchariferum Arech., Au. Mus. Nac. Montevideo 1: $90.1894 . \quad$ Uruguay.

Panicum platense Kuntze, Rev. Gen. Pl. $3^{2}: 363$. 1898. Based on Paspalum platense Spreng.

Digitaria dilatata Coste, F1. France 3: 553. 1906. Based on Paspalum dilatatum Poir.

(1) Paspalum dissectum (L.) L. Sp. Pl. ed. 2. 81. 1762. Based on Panicum dissectum $\mathrm{L}$.

Panicum dissectum L., Sp. Pl. 57. 1753. Locality erroneously given as "Indiis", the type in the Linnaean Herbarium being from North America, collected by Kalm.

Paspalum dimidiatum L., Syst. Nat. ed. 10. 2: 855. 1759. Based on Panicum dissectum L.

Paspalum membranaceum Walt., Fl. Carol. 75. 1788. South Carolina.

Paspalum vaginatum Ell., Bot. S.C. and Ga. 1: 109. 1816. Not P. vaginatum Swartz, 1788. Savannal, Ga., Baldwin.

Paspalum walterianum Schult., Mant. 2: 166 . 1824. Based ou P. membranaceum Walt. In Chapman's Flora (570. 1860.) the name is givenas $P$. walteri Schult.

Paspalum tectum Steud., Syn. Pl. Glum. 1: 29. 1854. Florida, Chapman.

Paspalum drummondii C. Muell., Bot. Ztg. 19: 332. 1861. St. Louis, Mo., Drummond 182.

(5) Paspalum distichum L., Syst. Nat. ed. 10. 2: 855. 1759. [Jamaica, Browne.]

Digitaria paspalodes Michx., Fl. Bor. Amer. 1: 46. 1803. Charleston, S.C., Michaux.

Paspalum digitaria Poir., in Lam., Encycl. Sup. 4: 316. 1816. Charleston, S.C., Bosc.

Milium paspalodes Ell., Bot. S.C. and Ga. 1: 104. 1816. Based on Digitaria paspalodes Michx., but misapplied to Axonopus furcatus (Flügge) Hitche.

Milium distichum Muhl., Descr. Gram. 78. 1817. Presumably based on Paspalum distichum L.

Paspalum michauxianum Kunth, Rév. Gram. 1:25. 1829. Based on Digitaria paspalodes Michx.

Panicum paspaliforme Presl, Rel. Haenk. 1: 296. 1830. Peru, Haenke.

Panicum polyrrhizum Presl, Rel. Haenk. 1: 296. 1830. "Monterey, California" [but specimens probably collected in Baja California], Haenke.

Paspalum fernandezianum Colla, Mem. Accad. Sci. Torino 39: 27. pl. 59. 1836. Juan Fernandez, Chile, Bertero.

Paspalum chepica Steud., Syn. Pl. Glum. 1: 21. 1854. Juan Fernandez, Chile, Bertero 1223.

Paspalum vaginatum var. pubescens Doell, in Mart., Fl. Bras. 22: 75. 1877. Rio de Janeiro, Brazil, Glaziou 3612.

Paspalum schaffneri Griseb., in Fourn., Mex. Pl. 2: 6. 1886. Mexico, Chapultepec, Schaffner 19a; San Angel, Schaffner 19c; Mirador, Schaffner 19b.

Paspalum elliottii S. Wats., in A. Gray, Man. ed. 6. 629. 1890. Based on Milium paspalodes Ell. but misapplied to Axonopus furcatus (Flügge) Hitche.

Paspalum paspaloides Scribn., Mem. Torrey Bot. Club 5: 29. 1894. Based on Digitaria paspalodes Michx. but misapplied to Axonopus furcatus (Flügge) Hitche. 
Digitaria disticha Fiori and Paol., Icon. Fl. Ital. Illustr. 1: 16. f. 136.1895. Based on Paspalum distichum L.

Anastrophus paspaloides Nash, in Britton, Man. 75. 1901. Based on Paspalum paspaloides Scribn. but misapplied to Axonopus furcatus (Flügge) Hitche.

Paspalum distichum var. digitaria Hack.; Stuck., An. Mus. Nac. Buenos Aires 13: 424. 1906. Based on P. digitaria Poir.

Paspalum distichum subsp. paspalodes Thell., Mém. Soc. Sci. Nat. Cherbourg 3S: 77. 1912. Based on Digitaria paspalodes Michx.

(37) Paspalum floridanum Michx., Fl. Bor. Amer. 1: 44. 1803. Florida and Georgia, Michaux.

Paspalum macrospermum Flügge, Monogr. Pasp. 172. 1810. Carolina, Bosc.

Paspalum glabrum Bose; Flügge, Monogr. Pasp. 172. 1810, as synonym of P. macrospermum.

Paspalum laevigatum Bosc; Poir., Encycl. Sup. 4: 313. 1816, as synonym of P. floridanum Michx.

Paspalum lacve var. floridanum Wood, Class-book ed. 3. 7S2. 1S61. Presumably based on P. floridanum Michx.

Paspaldi FLORIDANUM var. GLABRATUM Engelm.; Vasey, Bull. Torrey Bot. Club 13: 166. 1856. No locality cited. [Type, Mobile, Ala., Mohr in 1884.]

?Paspalum altissimum LeConte, Jour. Phys. Chym. 91: 2S5. 1820. Salem, N.C.

?Paspalum laeve var. altissimum Wood, Class-book ed. 3. 782. 1861. Based on $P$. altissimum LeConte.

Paspalum glabratum Mohr, Bull. Torrey Bot. Club 24: 21. 1897. Based on P. floridanum var. glabratum Engelm.

(38) Paspalum giganteum Baldw.; Vasey, Bull. Torrey Bot. Club 13: 166. 1886. No locality cited. [Type, Pablo Creek, Fla., Curtiss in 1875.]

Paspalum longicilium Nash, Bull. N.Y. Bot. Gard. 1: 435. 1900. Eustis, Fla., Nash 1359.

(8) Paspalum hartwegianum Fourn., Mex. Pl. 2: 12. 1S86. León, Mexico. Hartweg 245.

Paspalum buclileyanum Vasey, Bull. Torrey Bot. Club 13: 167. 1886. Texas, Buckley. In Jacks., Ind. Kew. Sup. 1: 312. 1906, the name is erroneously listed under Panicum.

(31) Paspalum laeve Michx., Fl. Bor. Amer. 1: 44. 1803. Georgia, Michaux. Paspalum undulosum LeConte, Jour. Phys. Chym. 91: 284. 1820. Georgia, [LeConte].

Paspalum angustifolium LeConte, Jour. Phys. Chym. 91: 2S5. 1S20. Carolina and Georgia, [LeConte].

Paspalum lecomteanum Schult., Mant. 2: 168. 1S24. Based on P. undulosum LeConte.

Paspalum punctulatum Bertol., Mem. Accad. Sci. Bologna 2: 599. pl. 42. f. a-e. 1850. Alabama.

Paspalum alternans Steud., Syn. Pl. Glum. 1: 26. 1854. Louisiana, Hartman 40.

Paspalum tenue Darby, Bot. South. States 576. 1857. Not P. tenue Gaertn., 1791. Georgia and northward.

Paspalum laeve var. undulosum Wood, Class-book ed. 3. 782. 1861. Based on P. undulosum LeConte.

Paspalum angustifolium var. tenue Wood, Amer. Bot and Flor. pt. 2: 390. 1870. New Jersey and south.

Paspalum laeve var. angustifolium Vasey, Bull. Torrey Bot. Club 13: 165. 1856. Based on $P$. angustifolium LeConte.

Paspalum laeve var. brevifolium Vasey, Contrib. U.S. Natl. Herb. 3: 1S. 1892. No locality cited. [Type, Texas, Nealley in 1856.]

Paspalum australe Nash, in Britton, Man. 1039. 1901. Stone Mt., Ga., Small in 1895.

Paspalum laeve australe Nash, in Hitchc., Rhodora S: 205. 1906. Based on $P$. australe Nash.

(24) Paspalum langei Nash, N.Amer. Fl. 17: 179. 1912. Based on Dimorphostachys langei Fourn.

Panicum senescens Trin.; Steud., Nom. Bot. ed. 2. 2: 263. 1841, name only. [Mexico, Stchiede.]

Paspalum abbreviatum Trin.; Fourn., Mex. PI. 2: 10. 18s6, name only. Nexico, Schiede 888.

Dimorphostachys langei Fourn., Mex. Pl. 2: 14. 1886. Mexico, Liebmann 186. 
Dimorphostachys drummondii Fourn., Mex. PI. 2: 15. 1886. Not Paspalum drummondii C. Muell., 1861. Texas, Drummond [350].

Panicum squamatum Foum., Mex. Pl. 2: 18. 1886. Not Paspalum squamatum Steud., 1854. Mexico, Karwinsky 982.

Paspalum drummondii Vasey, Contrib. U.S. Natl. Herb. 3: 18. 1892. Not P. drummondii C. Muell., 1861. Based on Dimorphostachys drummondii Fourn.

Paspalum oricola Millsp. and Chase, Field Mus. Bot. 3: 28. f. 28. 29. 1903. Island of Cozumel, Yucatan, Millspaugh Pl. Uto. 1480.

Dimorphostachys ciliifera Nash, in Small, Fl. Southeast. U.S. 78, 1327. 1903. Manatee, Fla., Simpson 97.

Paspalum cilifferum Hitchc., Contrib. U.S. Natl. Herb. 12: 201. 1909. Based on Dimorphostachys ciliifera Nash.

(27) Paspalum Iaxum Lam., Tabl. Encycl. 1: 176. 1791. Tropical America [probably St. Croix], Richard.

Paspalum glabrum Poir., in Lam., Encycl. 5: 30. 1804. Puerto Rico, Ledru.

Paspalum miliodeum Desv.; Poir., in Lam., Encycl. Sup. 4: 315. 1816. Puerto Rico.

Paspalum miliare Spreng., Syst. Veg. 1: 247. 1825. Based on P. miliodeum Desv.

Paspalum ischnocaulon Trin., Gram. Icon. 2: pl. 126. 1828. Source erroneously given as East Indies, doubtless error for West Indies.

Paspalum floribundum Desv., Opusc. 58. 1831. West Indies.

Paspalum rhizomatosum Steud., Syn. Pl. Glum. 1: 17. 1854. Guadeloupe, Duchaissing.

Paspalum koleopodum Steud., Syn. Pl. Glum. 1: 18. 1854. Guadeloupe, Duchaissing.

Paspalum laxum var. lamarchianum Doell, in Mart., Fl. Bras. 22: 86. 1877. Based on P. laxum Lam., but misapplied to a Brazilian species.

Paspalum helleri Nash, Bull. Torrey Bot. Club 30: 376. 1903. Santurce, Puerto Rico, Heller 10.

Paspalum tenacissimum Mez, Bot. Jahrb. Engler 56: Beibl. 125: 10.1921. Puerto Rico, Hioram 804.

(35) Paspalum lentiferum Lam., Tabl. Encycl. 1: 175. 1791. Carolina, Fraser.

Paspalum lanuginosum Bose; Beauv., Ess. Agrost. 12. 1812. Name only. [Carolina, Bosc.]

Paspalum lanuginosum Willd.; Steud., Nom. Bot. ed. 2. 2: 271. 1841, as synonym of $P$. lentiferum Lam.

Paspalum curtisianum Steud., Syn. Pl. Glum. 1: 26. 1854. Carolina, M. A. Curtis.

Paspalum praecox var. curtisionum Vasey, Bull. Torrey Bot. Club 13: 165. 1886. Based on P. curtisianum Steud.

Paspalum glaberrimum Nash, in Small, Fl. Southeast. U.S. 76, 1326.1903. Central Florida, Nash 1619.

Paspalum tardum Nash, in Small, Fl. Southeast. U.S. 76, 1326. 1903. Florida, Nash 2047.

Paspalum kearneyi Nash, in Small, Fl. Southeast. U.S. 77, 1326.1903. Nicholson, Miss., Kearney 357.

Paspalum amplum Nash, in Small, F1. Southeast. U.S. 77, 1326. 1903. Marianna, Fla., Tracy 3682.

(7) Paspalum lividum Trin., in Schlecht., Linnaea 26: 383. 1854. Mexico, Schiede.

(12) Paspalum longepedunculatum LeConte, Jour. Phys. Chym. 91: 284. 1820. North Carolina, [LeConte].

Paspalum setaceum var. longepedunculatum Wood, Class-book 782.1861. Based on P. longepedunculatum LeConte.

Paspalum kentuckiense Nash, in Britton, Man. 1039. 1901. Poor Fork, Ky., Kearney in 1893.

(32) Paspalum longipilum Nash, Bull. N.Y. Bot. Gard. 1: 435. 1900. Eustis, Fla., Nash 1027.

Paspalum laeve var. pilosum Scribn., Tenn. Agr. Expt. Sta. Bull. 7: 34.1894. Tennessee, [type, Madisonville, Scribner].

Paspalum plenipilum Nash, in Britton, Man. 73. 1901. New Jersey, [type, Clifton, Nash in 1892].

(10) Paspalum minus Fouru., Mex. Pl. 2: 6. 1886. Mexico, Bourgeau 2298 [type], Liebmann 154. 
(23) Paspalum monostachyum Vasey; Chapm., Fl. South. U.S. ed. 2. 665. 1883. South Florida, Garber [224].

Paspalum rectum var. longispicatum Vasey, Bot. Gaz. 9: 54,55. 1884. Miami, Fla., Garber.

Paspalum solitarium Nash, in Small, Fl. Southeast. U.S. 77, 1326.1903. Based on Paspalum monostachyum "Vasey not Walp." Walper's is a name only.

(9) Paspalum notatum Flügge, Monogr. Pasp. 106. 1810. St. Thomas, West Indies.

Paspalum taphrophyllum Steud., Syn. Pl. Glum. 1: 19. 1854. Martinique, Sieber 365 [error for 364].

Paspalum distachyon Willd.; Doell, in Mart., Fl. Bras. 22: 73. 1877. Not $P$. distachyon Poit., 1834. As synonym of $P$. notatum.

Paspalum notatum var. latiflorum Doell, in Mart., Fl. Bras. 22: 73.1877. Brasil and Uruguay, Sellow.

Paspalum saltense Arech., An. Mus. Nac. Montevideo 1: 53. 1894. Department del Salto, Uruguay.

Paspalum paucispicatum Vasey, Contrib. U.S. Natl. Herb. 1: 281. 1893.

Guadalajara, Mexico, Palmer 243 in 1886.

(40) Paspalum plicatulum Michx., Fl. Bor. Amer. 1: 45. 1803. Georgia and Florida, Michaux.

Paspalum undulatum Poir., in Lam., Encycl. 5: 29. 1804. Puerto Rico, Ledru.

Paspalum plicatum Pers., Syn. Pl. 1: 86. 1805, error for plicatulum.

Paspalum lenticulare H.B.K., Nov. Gen. and Sp. 1: 92. 1815. Venezuela, Humboldt and Bonpland.

Paspalum gracile LeConte, Jour. Phys. Chym. 91: 285. 1820. Not P.gracile Rudge. Georgia, LeConte.

Paspalum leptos Schult., Mant. 2: 173. 1824. Based on P. gracile LeConte.

Paspalum montevidense Spreng., Syst. Veg. 1: 246. 1825. Montevideo, Uruguay, Sellow.

Paspalum tenue Kunth, Rév. Gram. 1: 26. 1829. Not P. tenue Gaertn., 1791. Based on P. gracile LeConte.

Paspalum multiflorum Desv., Opuse. 58. 1831. Brazil.

Paspalum orthos Schult.; Kunth, Enum. Pl. 1: 57. 1833. Apparently misprint for $P$. leptos.

Paspalum marginatum Spreng., in Steud., Nom. Bot. ed. 2. 2: 272.1841. Not P. marginalum Trin., 1826. As synonym of P. undulatum Poir. [Puerto Rico.]

Paspalum campestre Schlecht., Linnaea 26: 131. 1853. Not P. campestre Trin., 1834. Venezuela, Wagener 392.

Paspalum atrocarpum Steud., Syn. PI. Glum. 1: 25. 1854. Habitat unknown. Dumont-d'Urville.

Paspalum virgatum var. undulatum Wood, Amer. Bot. and Flor. pt. 2: 390. 1870. Eastern States.

Paspalum antillense Husnot, Bull. Soc. Linn. Normand. II. 5: 260. 1871. Guadeloupe, Husnot 76.

Paspalum saxatile Salzm.; Doell, in Mart., Fl. Bras. 22: 76. 1877, as synonym of P. plicatulum Michx. Brazil, Salzmann.

Paspalum decumbens Sagot; Doell, in Mart., Fl. Bras. 22: 77. 1877. Not $P$. decumbens Swartz, 1788. As synonym of P. plicatulum. French Guiana, Sagot 1342.

Paspalum plicatulum var. intumescens Doell, in Mart., Fl. Bras. 22: 78.1877. Lagoa Santa, Brazil, Warming.

Paspalum pauperculum Fourn., Mex. Pl. 2: 10. 1886. San Luis Potosí, Mexico, Virlet 1320.

Paspalum pauperculum var. altius Fourn., Mex. Pl. 2: 10. 1886. Orizaba, Mexico, Bourgeau 2033 [probably misprint for 2633].

Panicum plicatulum Kuntze, Rer. Gen. Pl. 32: 363. 1898. Based on Paspalum plicatulum Michx.

(34) Paspalum praecox Walt., Fl. Carol. 75. 1788. South Carolina.

(20) Paspalum propinquum Nash, Bull. N.Y. Bot. Gard. 1: 291. 1899. Eustis, Fla., Nash 1427.

(16) Paspalum psammophilum Nash, in Hitchc., Rhodora 8: 205. 1906. Based on $P$. prostratum Nash.

Paspalum prostratum Nash, in Britton, Man. 74. 1901. Not P. prostratum Scribn. and Merr., 1901 (earlier than the preceding). New York to Delaware, [type, Kingsbridge, N.Y., Nash 514]. 
(18) Paspalum pubescens Muhl., in Willd., Enum. Pl. 89. 1809. Carolina. Paspalum muhlenbergii Nash, in Britton, Man. 75. 1901. Massachusetts to Georgia, Missouri, Oklahoma, and Mississippi. [Type, Van Cortlandt Park, N.Y., Bicknell in 1896.]

Paspalum pubescens var. muhlenbergii House, N.Y. State Mus. Bull. 243-244: 39. 1923. Based on Paspalum muhlenbergii Nash.

Paspalum ciliatifolium var. muhlenbergii Fernald, Rhodora 36: 20. 1934. Based on $P$. muhlenbergii Nash.

(6) Paspalum pubiflorum Rupr.; Fourn., Mex. Pl. 2: 11. 1886. Mexico, Galeotti 5747.

Paspalum planifolium Fourn., Mex. Pl. 2: 10. 1886. Mexico, San Luis Potosí, Virlet [type; the other specimen cited, Müller 2062, is P. lividum].

Paspalum pubiflorum var. viride Foum., Mex. Pl. 2: 11. 18s6. San Luis Potosí, Virlet 1328.

Paspalum hallii Vasey and Scribn., Bull. Torrey Bot. Club 13: 165.1886 , as doubtful synonym of $P$. remotum Remy, a Bolivian species. Description drawn from Hall 804 , Texas.

Paspalum remotum var. glaucum Scribn., in Vasey, Bull. Torrey Bot. Club 13: 165. 1886. No locality eited. [Type, Grapevine Canyon, Tex. Havard in 1883.]

Paspalum pubiflorum var. glaucum Scribn., Contrib. U.S. Natl. Herb. 3: 19. 1892. Southwestern Texas and Mexico [type same as preceding].

Paspalum pubiflorum var. Glabrum Vasey; Scribn., Tenn. Agr. Expt. Sta. Bull. 7: 32. pl. 5. f. 18. 1894. Belle Meade, Tenn., Scribner in 1892.

Paspalum remotum var. glabrum Vasey, Bull. Torrey Bot. Club 13: 166.1886. No locality cited. [Type, Plaquemines Parish, La., Langlois 26.]

Paspalum geminum Nash, Bull. N.Y. Bot. Gard. 1: 434. 1900. Eustis, Fla., Nash 680.

Paspalum laeviglume Scribn.; Nash, in Small, Fl. Southeast. U.S. 75, 1326. 1903. Based on $P$. remotum var. glabrum Vasey.

Paspalum racemosum Lam., Tabl. Eneycl. 1: 176. 1791. Peru.

(3) Paspalum repens Bergius, Acta. Helv. Phys. Math. 7: 129. pl. 7. 1762. Dutch Guiana.

Paspalum gracile Rudge, Pl. Guian. 20. pl. 26. 1805. British Guiana.

Paspalum mucronatum Muhl., Cat. Pl. 8. 1813, name only; Georgia; Deser. Gram. 96. 1817. Mississippi and Georgia.

Ceresia fluitans Ell., Bot. S.C. and Ga. 1: 109. pl. 6. f. 4. 1816. Ogechee, Ga.

Paspalum natans LeConte, Jour. Phys. Chym. 91: 285. 1820. Georgia.

Paspalum fluitans Kunth, Rév. Gram. 1: 24. 1829. Based on Ceresia fluitans Ell.

Paspalum frankii Steud., Syn. Pl. Glum. 1: 19. 1854. New Orleans, La., Frank.

Frank.
Paspalum bistipulatum Hochst.; Steud., Syn. Pl. Glum. 1: 29. 1854. Dutch Guiana, Hostmann 707a.

Cymatochloa fluitans Schlecht., Bot. Ztg. 12: 822. 1854. Based on Ceresia fluitans Ell.

Cymatochloa repens Schlecht., Bot. Ztg. 12: 822. 1854. Based on Paspalum repens Bergius.

This is the species described under Paspalum paniculatum by Walter (Fl. Carol.

75. 1788). (21) Paspalum rigidifolium Nash, Bull. N.Y. Bot. Gard. 1: 292. 1899. Eustis, Fla., Nash 629.

Paspalum scrobiculatum L., Mant. pl. 1: 29. 1767. India.
(13) Paspalum setaceum Michx., Fl. Bor. Amer. 1: 43.1803. South Carolina, Michaux.

Michaux.
Paspalum hirsutum Retz., misapplied by Poir., in Lam., Encycl. 5: 28. 1804. Carolina, Bosc.

Carolina, Bosc.
Paspalum leptostachyum DC., Cat. Hort. Monsp. 130. 1813. Not P. leptostachyum Humb. and Bonpl., 1810. No locality cited, type without locality.

Paspalum incertum Roem. and Schult., Syst. Veg. 2: 308. 1817. Based on $P$. leptostachyum DC.

Paspalum eriophorum Willd.; Nees., Agrost. Bras. 56. 1829. Not P. eriophorum Schult., 1827. Native country unknown.

(17) Paspalum stramineum Nash, in Britton, Man. 74. 1901. Nebraska [type, Hooker County, Rydberg 1582], Kansas, and Indian Territory [Oklahoma].

Paspalum bushii Nash, in Britton, Man. 74. 1901. Missouri [type, Bernie, Bush 730]. 
Paspalum ciliatifolium var. stramineum Fernald, Rhodora 36: 20. 1934. Based on P. stramineum Nash.

(15) Paspalum supinum Bose; Poir., in Lam., Encycl. 5: 29. 1804. Carolina, Bosc.

Paspalum dasyphyllum Ell., Bot. S.C. and Ga. 1: 106. 1S16. South Carolina. Paspalum setaceum var. supinum Trin., Gram. Icon. 2: pl. 130. 1829. Based on P. supiuum Bose.

Paspalum ciliatifolium var. dasyphyllum Chapm., Fl. South. U.S. ed. 3. 578. 1S97. Based on P. dasyphyllum Ell.

(22) Paspalum unispicatum (Scribn. and Merr.) Nash, N.Amer. Fl. 17: 193. 1912. Based on Panicum unispicalum Scribn. and Merr.

Punicum unispicatum Scribn. and Merr., U.S.Dept.Agr., Div. Agrost. Bull. 24: 14. 1901. Oaxaca, Mexico, Pringle 6717.

(30) Paspalum urvillei Steud., Syn. Pl. Glum. 1: 24. 1854. [Brazil], Dumontd'Lrville.

Paspalum ovatum var. parviflorum Nees, Agrost. Bras. 43. 1829. Brazil, Martius.

Paspalum velutinum Trin.; Nees, Agrost. Bras. 43. 1829, as synonym of $P$. ovatum var. parviflorum Nees.

Paspalum dilatatum var. parviflorum Doell, in Mart., Fl. Bras. 22: 64. 1877. Peruambuco, Forsell; Lagoa Santa, Warming [type].

Paspalum virgatum var. parviflorum Doell, in Mart., Fl. Bras. 22: 89. 1877. Brazil, Raben.

Paspalum virgatum var. pubiflorum Vasey, Bull. Torrey Bot. Club 13: 167. 18S6. No locality cited. [Trpe, Atakopus, La., Langlois in 1SS4.]

Paspalum larranagai Arech., An. Mus. Nac. Montevideo 1: 60. pl. 2. 1894. Uruguay.

Paspalum vaseyanum Scribn., U.S.Dept.Agr., Div. Agrost. Bull. 17: 32 . f. 32 S. 1899. Based on P. virgatum var. pubiflorum Vaser.

Paspalum griseum Hack.; Corrêa, Fl. Brazil 12S. 1909. Name only. Brazil [Glaziou 16559].

(4) Paspalum vaginatum Swartz, Prodr. Veg. Ind. Occ. 21. 1788. Jamaica, Swartz.

Digitaria foliosa Lag., Gen. and Sp. Nov. 4. 1816. Habana, Cuba.

Paspalum tristachyum LeConte, Jour. Phys. Chym. 91: 285. 1820. Georgia [LeConte].

Digitaria tristachya Schult., Mant. 2: 261. 1824. Based on Paspalum tristachyum LeConte.

Paspalum brachiatum Trin.; Nees, Agrost. Bras. 62. 1S29, as synonym of $P$. vaginatum. Martinique, Sicber.

Paspalum foliosum Kinnth, Rév. Gram. 1: 25. 1829. Based on Digitaria foliosa Lag.

Paspalum hleineanum Presl, Rel. Haenk. 1: 209. 1830. Peru, Haenke.

Paspalum inflatum A. Rich., in Sagra, Hist. Cuba 11: 295. 1850. Habana, Cuba, Sagra.

Paspalum didactylum Salzm.; Steud., Syn. Pl. Glum. 1: 20. 1854, as synonym of P. vaginatum. Brazil, Salzmann.

Panicum vaginatum Gren. and Godr., Fl. France 3: 462. 1855. Not P. vaginatum Nees, 1S29. Based on Paspalum vaginatum Swartz.

Paspalum distichum var. tristachum Wood, Class-book 783. 1861. Presumably based on $P$. tristachyum LeConte.

Paspalum distichum var. vaginatum Swartz; Griseb., Fl. Brit. IV.Ind. 541. 186t. Based on P. vaginatum Swartz.

Paspalum reptans Poir.; Doell, in Mart., Fl. Bras. 22: 75. 1877, as symon!m of $P$. vaginatum.

Paspalum vaginatum var. nanum Doell, in Mart., Fl. Bras. 22: 75. 1877. Rio de Janeiro, Brazil, Glaziou 4346.

Paspalum reimarioides Chapm., Fl. South. U.S. 665. 1SS3. Not P. reimarioides Brongn., 1830. West Florida [Chapman].

Paspalum vaginatum var. reimarioides Chapm., Fl. South. U.S. ed.3.577. 1897. Presumably based on $P$. reimarioides Chapm.

Paspalum distichum var. nanum Stapf, in Dyer, Fl. Cap. 7: 371. 1S9S. Based on $P$. vaginatum var. nanum Doell.

Sanguinaria vaginata Bubani, F1. Pyr. 4: 258. 1901. Based on Paspalum vaginatum Swartz.

(39) Paspalum virgatum L., Syst. Nat. ed. 10. 2: S55. 1759. Jamaica.

Paspalum virgatum var. linneanum Flügge, Monogr. Pasp. 190. 1810. Based on $P$. virgatum $\mathrm{L}$. 
Paspalum virgatum var. jacquinianum Flügge, Monogr. Pasp. 190. 1810. West Indies, Jacquin.

Paspalum virgatum var. willdenowianum Flügge, Monogr. Pasp. 190.1810. Para, Brazil.

Paspalum virgatım var. stramineum Griseb., Fl. Brit. W.Ind. 543. 1864. Antigua, Wullschlaegel [the other specimen cited belongs to P. arundinaceum Poir.].

Paspalum leucocheilum Wright, An. Acad. Cienc. Habana 8: 203. 1871; Fl. Cub. 194. 1873. Isla de Pinos, Blain.

Paspalum virgatum var. ciliatum Doell, in Mart., Fl. Bras. 22: 88. 1877. Based on $P$, virgatum var. linneanum Flügge.

\section{(136) PENNISETUM L. Rich. ${ }^{27}$}

Pennisetum alopecuroides (L.) Spreng., Syst. Veg. 1: 303. 1825. Based on Panicum alopecuroides $\mathbf{L}$.

Panicum alopecuroides L., Sp. Pl. 55. 1753. China.

(1) Pennisetum glaucum (L.) R. Br., Prodr. Fl. Nov. Holl. 1: 195. 1810. Based on Panicum glaucum L.

Panicum glaucum L., Sp. Pl. 56. $1753.2^{28}$ India.

Holcus spicatus L., Syst. Nat. ed. 10. 2: 1305. 1759. India.

Pennisetum typhoideum L. Rich., in Pers., Syn. Pl. 1: 72. 1805. Based on Holcus spicatus L.

Penicillaria spicata Willd., Enum. Pl. 1037. 1809. Based on Holcus spicatus L.

Setaria glauca Beauv., Ess. Agrost. 51, 178. 1812. Based on Panicum glaucum L., but misapplied to S. lutescens (Weig.) F. T. Hubb.

Pennisetum spicatum Willd.; Roem. and Schult., Syst. Veg. 2: 499. 1817, as synonym of Penicillaria spicata Willd.; Koern., in Koern. and Wern., Handb. Getreidebau. 1: 281. 1885. Based on Holcus spicatus L.

Panicum spicatum Roxb., Fl. Ind. 1: 286. 1820. Based on Holcus spicatus L.

Penicillaria typhoidea Fig. and DeNot., Agrost. Aegypt. Frag. 55. 1853. Based on Pennisetum typhoideum "Delile" (same as L. Rich.).

Chamaeraphis glauca Kuntze, Rev. Gen. Pl. 2: 767. 1891. Based on Panicum glaucum L., but misapplied to Setaria lutescens (Weig.) F. T. Hubb.

Pennisetum spicatum var. typhoideum Dur. and Schinz, Consp. Fl. Afr. 5: 785. 1894. Based on Penicillaria typhoidea Fig. and DeNot.

Ixophorus glaucus Nash, Bull. Torrey Bot. Club 22: 423. 1895. Based on Panicum glaucum L., but misapplied to Setaria lutescens (Weig.) F. T. Hubb.

Chaetochloa glauca Seribn., U.S.Dept.Agr., Div. Agrost. Bull. 4: 39. 1897. Based on Panicum glaucum L., but misapplied to Setaria lutescens (Wieg.) F. T. Hubb.

Pennisetum americanum Schum. (in Engl. Pflanzenw. Ost-Afr. 5 ${ }^{\text {B: }}$ 51. 1895) based on Panicum americanum L. (Sp. Pl. 56. 1753) has been used for this species, but the Linnaean name was based on an unidentifiable figure in Clusius (Rar. Pl. Hist. 2: 215. 1601).

Pennisetum latifolium Spreng., Syst. Veg. 1: 302. 1825. Montevideo, Sello. Pennisetum macrostachyum (Brongn.) Trin., Mém. Acad. St. Pétersb. VI. Sci. Nat. 1: 177. 1834. Based on Gymnothrix macrostachys Brongn.

Gymnothrix macrostachys Brongn., in Duperrey, Bot. Voy. Coquille 22: 104. pl. 10. 1830. Moluccas.

(3) Pennisetum nervosum (Nees) Trin., Mćm. Acad. St. Pétersb. VI. Sci. Nat. 1: 177. 1834. Based on Gymnothrix nervosa Nees.

Gymnothrix nervosa Nees, Agrost. Bras. 277. 1829. Bahia, Brazil.

Cenchrus nervosus Kuntze, Rev. Gen. Pl. 32: 347. 1898. Based on Gymnothrix nervosa Nees.

Pennisetum purpureum Schumach., Beskr. Guin. Pl. 64. 1827. Guinea, Africa.

(5) Pennisetum ruppelii Steud., Syn. Pl. Glum. 1: 107. 1854. Abyssinia.

(2) Pennisetum setosum (Swartz) L. Rich., in Pers., Syn. Pl. 1: 72. 1805. Based on Cenchrus setosus Swartz.

Cenchrus setosus Swartz, Prodr. Veg. Ind. Oce. 26. 1788. West Indies.

Panicum cenchroides L. Rich., Act. Soc. Hist. Nat. (Paris) 1: 106.1792 French Guiana, Leblond.

Panicum crubescens Willd., Enum. Hort. Berol. 1031. 1809. St. Thomas.

${ }_{27}$ For discussion of types see Chase, Contrib. T.S. Natl. Herb. 22: 213-234. 1921.

${ }^{29}$ For discussion of this name see Chase, Amer. Jour. Bot. 8: $41-49.1921$. 
Setaria erubescens Beauv., Ess. Agrost. 51, 169, 178. 1812. Based on Panicum erubeseens Willd.

Pennisetum purpurascens H.B.K., Nov. Gen. and Sp. 1: 113. 1815. Jorullo, Mexico, Humboldt and Bonpland.

Pennisetum uniflorum H.B.K., Nov. Gen. and Sp. 1: 114. pl. 34. 1815. Venezuela, Humboldt and Bonpland.

Setaria cenchroides Roem. and Schult., Syst. Veg. 2: 495. 1817. Based on Panicum cenchroides L. Rich.

Gymnothrix geniculata Schult., Mant. 2: 284. 1824. Martinique, Sieber.

Pennisetum alopecuroides Desv.; Hamilt., Prodr. Pl. Ind. Occ. 11. 1825. Not P. alopecuroides Spreng., 1825. West Indies.

Pennisetum erubescens Link, Hort. Berol. 1: 215. 1827. Based on Panicum erubescens Willd.

Pennisetum hirsutum Nees, Agrost. Bras. 2S4. 1829. Brazil, [Martius].

Pennisetum pallidum Nees, Agrost. Bras. 285. 1829. Minas Geraes, Brazil, [Martius].

Pennisetum richardi Kunth, Rév. Gram. 1: 49. 1829. Based on Panieum cenchroides L. Rich.

Pennisetum sieberi Kunth, Rév. Gram. 1: 50. 1829. Based on Gymnothrix geniculata Schult.

Pennisetum flavescens Presl, Rel. Haenk. 1: 316. 1830. Mexico, Haenke.

Pennisetum hamiltonii Steud., Nom. Bot. ed. 2. 2: 297. 1841. Based on P. alopecuroides Desv.; Hamilt.

Pennisetum nicaraguense Fourn., Bull. Soc. Bot. France II. 27: 293.1880. Granada, Nicaragua, Levy 1304.

Pennisetum indicum var. purpuraseens Kuntze, Rev. Gen. Pl. 2: 787. 1891. Based on Panicum purpurascens H.B.K.

(4) Pennisetum villosum R. Br., in Salt, Yoy. Abyss. App. 62. 1814, name only; in Fres., Mus. Senckenb. Abh. 2: 134. 1837. Abyssinia.

Cenchrus villosus Kuntze, Rev. Gen. Pl. 32: 347. 1898. Not C. villosus Spreng. Based on Pennisetum villosum R. Br.

\section{(110) PHALARIS L.}

(6) Phalaris angusta Nees; Trin., Gram. Icon. 1: pl. 78. 1827. Uruguay and southern Brazil.

Phalaris ludoviciana Torr.; Trin., Mém. Acad. St. Pétersb. VI. Sci. Nat. $3^{1}$ : 56. 1839 , as synonym of $P$. angusta Nees.

Phalaris laxa Spreng.; Steud., Nom. Bot. ed. 2. 2: 315. 1841, as synonym of $P$. angusta Nees.

Phalaris intermedia var. angusta Chapm., Fl. South. U.S. 568. 1860. Based on $P$. angusta Nees.

Phalaris intermedia var. angustata Beal, Grasses N.Amer. 2: 182.1896. "P. angustata Hort." [San Diego] Calif., Pringle in 1882.

(9) Phalaris arundinacea L., Sp. Pl. 55. 1753. Europe. (P. arundinacea Michx., listed in Index Kewensis, is the Linnaean species.)

Arundo colorata Ait., Hort. Kew. 1: 116. 1789. Based on Phalaris arundinacea L.

Typhoides arundinacea Moench, Meth. P1. 202. 1794. Based on Phalaris arundinacea L.

Calamagrostis variegata With., Bot. Arr. Veg. Brit. ed. 3. 2: 124. 1796. Based on Phalaris arundinacea L.

Arundo riparia Salisb., Prodr. Stirp. 24. 1796. Based on Phalaris arundinacea $\mathrm{L}$.

Baldingera colorata Gaertn., Mey., and Scherb., Fl. Wett. 1: 96.1799. Based on Phalaris arundinacea L.

Digraphis arundinacea Trin., Fund. Agrost. 127. 1820. Based on Phalaris arundinacea $\mathrm{L}$.

Baldingera arundinacea Dum., Obs. Gram. Belg. 130. pl. 10. f. 40. 1823. Based on Phalaris arundinacea L.

Digraphis americana Ell.; Loud., Hort. Brit. 27. 1830. No description, Phalaris arundinacea Michx. cited, Loudon assuming the American form to be distinct from the European, and that Phalaris americana Ell. was the same as the American $P$. arundinacea.

Endallex arundinacea Raf.; Jacks., Ind. Kew. 2: 839. 1893, as synonym of Phalaris arundinacea L.

Phalaris Arundinacea var. Picta L., Sp. Pl. 55.1753. Europe. 
Phalaris americana var. picta Eaton and Wright, N.Amer. Bot. ed. 8. 352. 1840. Massachusetts, Connecticut, New York, Ontario.

Phalaris arundinacea var. variegata Parnell, Grasses Brit. 188. pl. 82. 1845. Scotland.

Digraphis arundinacea var. picta Pacher, Jahrb. Nat. Landesmus. Kärnt. 14: 119. 1880. Presumably based on Phalaris arundinacea var. picta I.

(3) Phalaris brachystachys Link, Neu. Jour. Bot. Schrad. 13: 134. 1806. Based on P. canariensis as described by Brotero (Fl. Lusit. 1: 79. 1804). Portugal.

Phalaris canariensis var. brachystachys Fedtsch., Bull. Jard. Bot. Prin. U.R.S.S. [Pierre le Grand] 14 (sup. 2): 47. 1915. Based on P. brachystachys Link.

(8) Phalaris californica Hook. and Arn., Bot. Beechey Voy. 161. 1841. California. This is the species referred to $P$. amethystina Trin., of Chile, by Thurber and others.

(2) Phalaris canariensis L., Sp. Pl. 54. 1753. Southern Europe and the Canary Islands.

Phalaris avicularis Salisb., Prodr. Stirp. 17. 1796. Based on P. canariensis L.

(5) Phalaris caroliniana Walt., Fl. Carol. 74. 1788. South Carolina.

Phalaris intermedia Bosc; Poir., in Lam., Encycl. Sup. 1: 300. 1810. Carolina, Bosc.

Phalaris microstachya DC., Cat. Hort. Monsp. 131. 1813. South Carolina, Fraser; Bosc.

Phalaris americana Ell., Bot. S.C. and Ga. 1: 101. pl. 5. f. 4. 1816. South Carolina.

Phalaris occidentalis Nutt., Amer. Phil. Soc. Trans. (n.s.) 5: 144.1837. Fort Smith, Ark., on the Arkansas to Red River [Nuttall].

Phalaris trivialis Trin., Mém. Acad. St. Pétersb. VI. Sci. Nat. 31: 55.1839. Charleston, S.C., Beyrich.

Phalaris intermedia var. microstachya Vasey; L. H. Dewey, Contrib. U.S. Natl. Herb. 2: 512 . 1894. Based on P. microstachya DC.

(7) Phalaris lemmoni Vasey, Contrib. U.S. Natl. Herb. 3: 42. 1892. Santa Cruz, Calif., Lemmon.

(4) Phalaris minor Retz., Obs. Bot. 3: 8. 1783. Orient.

(1) Phalaris paradoxa L., Sp. Pl. ed. 2. 2: 1665. 1763. Mediterranean region.

Phalaris Paradoxa var. Praemorsa (Lam.) Coss. and Dur., Expl. Sci. Alger. 2: 25. 1854. Based on P. praemorsa Lam.

Phalaris praemorsa Lam., Fl. Franç. 3: 566. 1778. France.

Phalaris tuberosa L., Mant. Pl. 2: 557. 1771. Europe.

Phalaris tuberosa var. stenoptera (Hack.) Hitchc., Jour. Wash. Acad. Sci. 24: 292. 1934. Based on P. stenoptera Hack.

Phalaris stenoptera Hack., Repert. Sp. Nov. Fedde 5: 333. 1908. Melbourne, Australia, Ewart, cultivated. This species has been referred to P. bulbosa (see under Phleum subulatum).

\section{(117) PHARUS L.}

(1) Pharus parvifolius Nash, Bull. Torrey Bot. Club 35: 301. 1908. Haiti Nash and Taylor 1482.

This is the species described under Pharus latifolius L. by Chapman.

(65) PHIPPSIA (Trin.) R. Br.

(1) Phippsia algida (Soland.) R. Br., Sup. App. Parry's Voy. 185 [err. for 285]. 1824. Based on Agrostis algida Soland.

Agrostis algida Soland., in Phipps Voy. 200. 1810. Arctic regions.

Trichodium algidum Roem. and Schult., Syst. Veg. 2: 283. 1817. Based on Agrostis algida Wahl. (same as A. algida Soland.).

Colpodium monandrum Trin., in Spreng., Neu. Entd. 2: 37. 1821. Based on Agrostis algida Phipps (error for Solander.).

Vilfa algida Trin., Gram. Unifl. 159. 1824. Based on Agrostis algida Plripps (error for Solander).

Vilfa monandra Trin., Gram. Unifl. 159. 1824. "Sin. Laurentii” [probably St. Lawrence Island, Alaska], Chamisso.

Phippsia monandra Trin., Gram. Unifl. 159. 1824, as synonym of Vilfa monandra Trin.; Hook and Arn., Bot. Beechey Voy. 132. 1841. Based on Vilfa monandra Trin. 
Catabrosa algida Fries, Nov. Fl. Suec. Mant. 3: Add. 173, 174. 1843. Based on Agrostis algida Soland.

Poa algida Rupr., Fl. Samoj. Cisural. 61. 1845. Not P. algida Trin. Based on Agrostis algida Soland.

\section{(72) PHLEUM L.}

(2) Phleum alpinum L., Sp. Pl. 59. 1753. Europe.

Phleum haenkeanum Presl, Rel. Haenk. 1: 245. 1830. Nootka Sound, Vancouver Island, Haenke.

Phleum pratense var. alpinum Celak., Prodr. Fl. Bölım. 38. 1869. Based on $P$. alpinum L.

Phleum alpinum var. americanum Fourn., Mex. PI. 2: 90. 1886. Nootka Sound, Vancouver Island, Haenke.

Phleum alpinum var. scribnerianum Pammel, Davenport Acad. Sci. Proc. 7: 238. 1899. Geranium Park, Wyo., Pammel 6.

Plantinia alpina Bubani, Fl. Pyr. 4: 272. 1901. Based on Phleum alpinum L.

Phleum arenarium L., Sp. Pl. 60. 1753. Europe.

Phleum paniculatum Huds., Fl. Angl. 23. 1762. England.

Phalaris aspera Retz., Obs. Bot. 4: 14. 1786. Europe.

Phleum asperum Jacq., Coll. Bot. 1: 110. 1786. Europe.

Plantinia aspera Bubani, Nuov. Gior. Bot. Ital. 5: 317. 1873. Based on Phleum asperum L. (error for Jacq.)

(1) Phleum pratense L., Sp. P1. 59. 1753. Europe.

Phleum nodosum var. pratense St. Amans, Fl. Agen. 23. 1821. Based on $P$. pratense L.

Plantinia pratensis Bubani, Fl. Pyr. 4: 270. 1901. Based on Phleum pratense Huds. (error for L.).

Stelephuras pratensis Lunell, Amer. Midl. Nat. 4: 216. 1915. Based on Phleum pratense $\mathrm{L}$.

Phleum subulatum (Savi) Aschers. and Graebn., Syn. Mitteleur. Fl. 2: 154. 1899. Based on Phalaris subulata Savi.

Phalaris bulbosa L., Cent. Pl. 1: 4. 1755; Amuen. Aead. 4: 264. 1759. Not Phleum bulbosum Gouan, 1765. "In Oriente."

Phalaris subulata Savi, Fl. Pis. 1: 57. 1798. Italy.

Phalaris bellardi Willd., Ges. Naturf. Freund. Berlin Neue Schrift. 3: 415. 1801. Europe.

Phalaris tenue Hust, Gram. Austr. 2: 27. pl. 36. 1802. Europe.

Phleum tenue Sclirad., Fl. Germ. 1: 191. 1806. Based on Phalaris tenue Host.

Phleum bellardi Willd., Enum. Pl. 1: 85. 1809. Based on Phalaris bellardi Willd.

Phleum bulbosum Richt., Pl. Eur. 1: 37. 1890. Not P. bulbosum Gouan, 1765. Based on Phalaris bulbosa $\mathrm{L}$.

\section{(49) PHOLIURUS Trin.}

(1) Pholiurus incurvus (L.) Schinz and Thell., Vierteljahrs. Nat. Gesell. Zürich 66: 265. 1921. Based on Aegilops incurva L.

Aegilops incurva L., Sp. Pl. 1051. 1753. Europe.

Aegilops incurvata L., Sp. Pl. ed. 2. 2: 1490.1763 . Europe.

Agrostis incurvata Scop., Fl. Carn. 1: 62. 1772. Based on Aegilops incurvata L.

Rottboellia incurvata L. f., Sup. Pl. 114. 1781. Based on Aegilops incurvata L. Ophiurus incurvalus Beauv., Ess. Agrost. 116, 168, 176. 1812. Based on Rottboellia incurvata L.

Rottboellia incurva Roem. and Schult., Syst. Veg. 2: 799. 1817. Presumably based on Aegilops incurva L.

Lepturus incurvatus Trin., Fund. Agrost. 123. 1820. Based on Aegilops incurvata L.

Lepturus filiformis var. incurvatus Hook. f., Stud. FI. 455. 1870. Based on L. incurvatus Trin.

Lepturus incurvus Druce, List Brit. PI. 85. 1908. Based on Aegilops incurea L.

Lepturus incurvus subsp. incurvatus Briq., Prodr. Fl. Corse 1: 183.1910. Based ou $L$. incurvatus Trin.

$55974^{\circ}-35-59$ 
Pholiurus incurvatus Hitchc., U.S. Dept. Agr. Bull. 772: 106. 1920. Based on Aegilops incurvata L.

This species has been called Lepturus filiformis (Roth) Trin. Rottboellia filiformis Roth, upon which that name is based, is considered a doubtful species by some European botanists and as a distinct species of Pholiurus by others ( $P$. filiformis Schinz and Thell.).

(26) PHRAGMites Trin.

(1) Phragmites communis Trin., Fund. Agrost. 134. 1820. Based on Arundo phragmites L.

Arundo phragmites L., Sp. Pl. 81. 1753. Europe.

Arundo vulgaris Lam., Fl. Franç. 3: 615. 1778. Based on A. phragmites L. The name is untenable

Arundo palustris Salisb., Prodr. Strip. 24. 1796. Based on A. phragmitcs L. Reimaria diffusa Spreng., Neu. Entd. 3: 14. 1822. Martinique, Sieber [31]. Cynodon phragmites Raspail, Ann. Sci. Nat., Bot. 5: 302. 1825. Based on Arundo phragmites L.

Phragmites vulgaris Crép., Man. F1. Belg. ed. 2. 345. 1866. Based on Arundo vulgaris Lam., an untenable name.

Phragmites berlandieri Fourn., Bull. Soc. Bot. France 24: 178. 1877. Laredo, Tex., Berlandier 1446.

Phragmites phragmites Karst., Deut. F1. 379. 1883. Based on Arundo phragmites L.

Trichoon phragmites Rendle, Cat. Afr. Pl. Welw. $2^{1}$ : 218. 1899. Based on Arundo phragmites L.

Oxyanthe phragmites Nieuwl., Amer. Midl. Nat. 3: 332. 1914. Based on Arundo phragmites L.

Phragmites communis var. berlandieri Fernald, Rhodora 34: 211. 1925. Based on $P$. berlandieri Fourn.

\section{(83) PIPTOCHAETIUM PresI}

(1) Piptochaetium fimbriatum (H.B.K.) Hitchc., Jour. Wash. Acad. Sci. 23: 453. 1933. Based on Stipa fimbriata H.B.K.

Stipa fimbriata H.B.K., Nov. Gen. and Sp. 1: 126. 1815. Guanajuato, Mexico, Humboldt and Bonpland.

Milium mexicanum Spreng., Syst. Veg. 1: 251. 1825. Mexico, Humboldt.

Piptatherum mexicanum Schult., Mant. 3 (Add. 1): 564. 1827. Based on Milium mexicanum Spreng.

Avena stipoides Willd.; Steud., Nom. Bot. ed. 2. 2: $146 . \quad 1841$, as synonym of Milium mexicanum Spreng.

Oryzopsis fimbriata Hemsl., Biol. Centr. Amer. Bot. 3: 538. 1885. Based on Stipa fimbriata H.B.K.

Oryzopsis seleri Pilger, Verh. Bot. Ver. Brand. 51: 192. 1909. Guatemala, Seler 3238.

\section{(9) PLEUROPOGON R. Br.}

(1) Pleuropogon californicus (Nees) Benth.; Vasey, Grasses U.S. 40. 1883. Based on Lophochlaena californica Nees.

Lophochlaena californica Nees, Ann. Nat. Hist. 1: 283. 1838. California, [Douglas].

Pleuropogon douglasii Trin.; Steud., Nom. Bot. ed. 2. 2: $355.1841 . \quad$ Name only, North America.

Lepitoma brevifolia Torr.; Steud., Nom. Bot. ed. 2. 2: $355 . \quad 1841$, as synonym of Pleuropogon douglasii Trin.

(2) Pleuropogon refractus (A. Gray) Benth.; Vasey, Grasses U.S. 40. 1883. Based on Lophochlaena refracta A. Gray.

Lophochlaena refracta A. Gray, Amer. Acad. Sci. Proc. 8: 409. 1872. Oregon, [Hall 636].

(10) POA L.

(43) Poa alpina L., Sp. Pl. 67. 1753. Lapland.

Uralepis mutica Fourn., Mex. Pl. 2: 110. 1886. Not U. mutica Fourn.; Hemsl. 1855. Mexico, Liebmann 611.

Poa alpina var. minor Scribm.; Beal, Grasses N.Amer. 2: 543. 1896. Not $P$. alpina var. minor Koch, 1837. Montana, Scribner [388] in 1883.

(24) Poa alsodes A. Gray, Man. ed. 2. 562. 1856. New England to Wisconsin. [Type, New Hampshire]. 
Poa dinantha Wood, Class-book 797. 1861. Montgomery, Ala.

This species was described as Poa nemoralis L., in Torr., Fl. North. and Mid. U.S. 1 : 111. 1823 .

(64) Poa ampla Merr., Rhodora 4: 145. 1902. Steptoe, Wash., G. R. Vasey 3009.

Pon lneviculmis Williams, Bot. Gaz. 36: 55. 1903. Several specimens from Washington and Oregon mentioned, the first being Steptoe, Wash., G. R. Trasey 3026.

Poa truncata Rydb., Bull. Torrey Bot. Club 32: 607. 1905. Dillon, Colo., Clements 373.

Poa confusa Rydb., Bull. Torrey Bot. Club. 32 : 607. 1905. Medieine Bow Mountains, Wro., Nelson 7787.

(5) Poa annua L., Sp. Pl. 68. 1753. Europe.

Aira pumila Pursh, Fl. Amer. Sept. 1: 76. 1814. Pennsylvania.

Poa infirma H.B.K., Nov. Gen. and Sp. 1: 158. 1816. Colombia, Humboldt and Bonpland.

Megastachya infirma Roem. and Schult., Syst. Veg. 2: 585. 1817. Based on Poa infirma H.B.K.

Catabrosa pumila Roem. and Schult., Syst. Veg. 2: 696. 1817. Based on Aira pumila Pursh.

Poa aestivalis Presl, Rel. Haenk. 1: 272. 1830. Peru, Haenke.

Eragrostis infirma Steud., Nom. Bot. ed. 2. 1: 563, 1840. Based on Poa infirma H.B.K.

Poa annua var. rigidiuscula L. H. Dewey, Contrib. U.S. Natl. Herb. 3: 262. 1895. Nez Perce County, Idaho, Sandberg 134.

(7) Poa arachnifera Torr., in Marcy, Expl. Red Riv. 301. 1853. Headwaters of the Trinity River [Ark., Marcy Exped.].

Poa densiftora Buckl., Acad. Nat. Sci. Phila. Proc. 1862: $96.1863 . \quad$ Northern Texas.

Poa arachnifera var. glabrata Vasey, Descr. Cat. Grasses U.S. 79. 1885, name only, [for staminate plants with glabrous spikelets]; Vasey; Beal, Grasses N.Ämer. 2: 535. 1896. [Texas, Buckley in 1881.]

Poa glabresccns Nash, in Small, FI. Southeast. U.S. 154, 1327. 1903. Based on $P$. arachnifera var. glabrata Torr. (error for Vasey).

(21) Poa aretica R. Br., Sup. App. Parry's Voy. 288 (err. typ. 188). 1823. Melville Island, Arctic America, Parry.

Poa grayana Vasey, Contrib. U.S. Natl. Herb. 1: 272. 1893. Grays Peak, Colo., Patterson 14 in 1885.

Poa laxa occidentalis Vasey; Rydb. and Shear, U.S.Dept.Agr., Div. Agrost. Bull. 5: 32. 1897. Name only, for Shear 690 and Rydberg 2440, Grays Peak, Colo.

Poa longipila Nash, in Rydb., Mem. N.Y. Bot. Gard. 1:46. 1900. Electric Peak, Yellowstone Park, Rydberg 3614.

Poa alpicola Nash, in Rydb., Mem. N.Y. Bot. Gard. 1:47. 1900. Based on $P$. laxa Haenke as misapplied by Thurber (in Watson, Bot. Calif. 2: 312. 1880).

Poa williamsii Nash, Bull. N.Y. Bot. Gard. 2: 156. 1901. White Pass, Alaska, Williams in 1899.

Poa aperta Scribn. and Merr., U.S.Dept.Agr., Div. Agrost. Circ. 35: 4. 1901. Telluride, Colo., Shear 98.

Poa callichroa Rydb., Bull. Torrey Bot. Club. 32: 603. 1905. Dead Lake, near Pikes Peak, Colo., Clements 457.

Poa phoenicea Rvdb., Bull. Torrey Bot. Club 32: 605. 1905. Pikes Peuk Valley, Colo., Clements 466.

Poa tricholepis Rydb., Bull. Torrey Bot. Club 32: 606. 1905. Pagosa Peak, Colo., Baker 210.

Poa chionogenes Gandog., Bull. Soc. Bot. France 667: 302. 1920. Grays Peak, Colo., Crandall [in 1898].

Colorado specimens of this species have been described as Poa cenisia All. by some recent American authors.

(19) Poa arida Vasey, Contrib. U.S. Natl. Herb. 1: 270. 1893. Socorro, N. Mex., G. R. Vasey in 1881.

Poa andina Nutt.; S. Wats., in King, Geol. Expl. 40th Par. 388. 1871. Not $P$. andina Trin., 1836. "Colorado, East and West Humboldt Mountains and in Clover Mountains, Nevada; also in the "Trinity Mountains, W'atson, 1319." The name is given as P. andina "Nutt., Ms. in Herb.; (not of Trin.).' 
Poa californica Munro; Coulter, Man. Rocky Mount. 420. 1885. Not $P$. californica Steud., 1854. Pased on P. andina Nutt.

Poa andina var. purpurea Vasey; Macoun, Cat. Can. P1. 24: 223. 1888. Name only, for Macomn 92, Reri Deer Lakes, Alberta.

Poa sheldoni Vasey, Contrib. U.S. Natl. Herb. 1: 276. 1893. Buena Vista, Colo., Sheldon 615.

Poa pseudopratensis Scribn. and Rydb., Contrib. U.S. Natl. Herb. 3: 531. pl. 20. 1896. Not P. pseudopratensis Beyer, 1819. Hot Springs, S.Dak. Rydberg 1151.

Poa pratericola Rydb. and Nash, Mem. N.Y. Bot. Gard. 1: 51. 1900. Based on P. arida Vasey.

Poa fendleriana var. arida Jones, Contrib. West. Bot. 14: 14. 1912. Based on P. arida Vasey.

Poa pratensis var. pseudopratensis Jones, Contrib. West. Bot. 14: 15. 1912. Based on P. pseudopratensis Scribn. and Rydb.

Paneion aridum Lunell, Amer. Midl. Nat. 4: 222. 1915. Based on Poa arida Vasey.

Paneion pratericola Lunell, Amer. Midl. Nat. 4: 223. 1915. Based on Poa pratericola Rydb. and Nash.

Poa pratensiformis Rydb., Fl. Rocky Mount. 79. 1917. Based on $P$. pseudopratensis Scribn. and Rydb.

Poa overi Rydb., Brittonia 1: 84. 1931. Custer County, S.Dak., Ozer 18100.

(12) Poa atropurpurea Scribn., U.S.Dept.Agr., Div. Agrost. Bull. 11: 53. pl. 10. 1898. Bear Valley, San Bernardino Mountains, Calif., Parish 2968.

(42) Poa autumnalis Muhl.; Ell., Bot. S.C. and Ga. 1: 159. 1816. Columbia, S.C., Herbemont.

Poa flexuosa Muhl., Deser. Gram. 148. 1817. Not P. flexuosa Smith, 1800. Virginia, Carolina, and Cherokee [Tenuessee].

Poa campyle Schult., Mant. 2: 304. 1824. Based on P. flexuosa Muhl.

Poa elliottii Spreng., Syst. Veg. 1: 338. 1825. Based on P. autumnalis Muhl.

Poa vestita Bosc; Steud., Nom. Bot. ed. 2. 2: 363. 1841. Name only. Carolina.

Poa hexantha Wood, Class-book 797. 1861. Atlanta, Ga.

(3) Poa bigelovii Vasey and Seribn.; Vasey, Deser. Cat. Grasses U.S. 81. 1885. Based on $P$. annua var. stricta Vasey.

Poa annua var. stricta Vasey, Bull. Torrey Bot. Club 10: 31. 1883. Rillita River, Ariz., Pringle.

(1) Poa bolanderi Vasey, Bot. Gaz. 7: 32. 1882. [Yosemite National Park], Calif., Bolander 6115 .

Poa howellii chandleri Davy, Univ. Calif. Pubs., Bot. 1: 60. 1902. Siskiyou County, Calif., Chandler 1703.

Poa bolanderi chandleri Piper, Contrib. U.S. Natl. Herb. 11: 132. 1906. Based on $P$. howellii chandleri Davy.

(35) Poa bulbosa L., Sp. Pl. 70. 1753. France.

Poa bulbosa var. vivipara Kioel., Descr. Gram. 189. 1802. Europe.

Paneion bulbosum var. viviparum Lunell, Amer. Midl. Nat. 4: 222.1915. Based on Poa bulbosum var. vivipara Koch (same as Koel.).

(60) Poa canbyi (Scribn.) Piper, Contrib. U.S. Natl. Herb. 11: 132. 1906. Based on Glyceria canbyi Scribn.

Aira brevifolia Pursh, Fl. Amer. Sept. 1: 76. 1814. Not Poa brevifolia DC. Plains of the Missouri, Lewis.

Airopsis brevifolia Roem. and Schult., Syst. Veg. 2: 578. 1817. Based on Aira brevifolia Pursh.

Poa tenuifolia Nutt.; S. Wats., in King, Geol. Expl. 40th Par. 5: 387. 1871. Not P. tenuifolia L. Rich., 1851. Nevada, Watson 1318.

Poa tenuifolia var. rigida Vasey, in Wheeler Rept. U.S. Survey 100th Merid. 6: 290. 1878. Name only. Nevada and Colorado [Wolf] 1138, 1140.

Poa tenuifolia var. elongata Vasey, in Wheeler, Rept. U.S. Survey 100th Merid. 6: 290. 1878. Nevada, Colorado [Twin Lakes, Wolf] 1141.

Glyceria canbyi Scribn., Bull. Torrey Bot. Club 10: 77. 1883. Cascade Mountains, Wash., Tweedy and Brandegee in 1882.

Aira missurica Spreng.; Jacks., Ind. Kew. 1: 68. 1893, as synonym of A. brevifolia Pursh, erroneously credited to "Spreng. Syst. 2: 578." Aira brevifolia Pursh is given in Spreng., Syst. 1: 276.1825.

Poa laevis Vasey, Contrib. U.S. Natl. Herb. 1: 273. 1893. Not P. laevis R. Br., 1810. Montana, Scribner in 1883.

Poa lucida Vasey, Contrib. U.S. Natl. Herb. 1: 274. 1893. Georgetown, Colo., Patterson' 73. 
Atropis lacvis Beal, Grasses N.Amer. 2: 577. 1896. Based on Pon lacvis Vasey.

Atropis laevis var. rigida Beal, Grasses N.Amer. 2: 578. 18:t6. [tall, demes. Atropis canbyi Beal, Grasses N.Amer. 2: 580. 1896. Based on Glyceria canbyi seribir.

Poa laevigala scribn., U.S.Dept.Agr., Div. Agrost. Bull. 5: 31. 1897. Based on P. laevis Vasey.

Poa uyomingensis Scribn., Darenport Acad. Sci. Proc. 7: 242. 1899. Big Horn, Sheridan County, Wro., Pammel 192.

Poa leckenbyi Scribn., C.S.Dept.Agr., Div. Agrost. Circ. 9: 2. 1899. Scott, Kilickitat County, Wash., Leckenby in 1S9S.

Poa helleri Rrdb., Bull. Torrey Bot. Club 36: 534. 1909. Lake Waha, Idaho, Heller 3274.

Poa buckleyana var. elongata Jones, Contrib. West. Bot. 14: 14. 1912. Based on "P. andina var. elongata Vasey", error for P. tenuifolia var. elongata Vaser.

Poa nevadensis var. laevigata Jones, Contrib. West. Bot. 14: 14. 1912. Based on P. laevigata Scribn.

Poa nevadensis var. leckenbyi Jones, Contrib. West. Bot. 14: 14. 1912. Based on P. leckenbyi Scribn.

(4) Poa chapmaniana Seribn., Bull. Torrey Bot. Club 21: 38. 1894. Knoxville, Tenu., Scribner. "P. cristata Chapm. not Walter" cited as synonym, but what Chapman described as Poa cristata Walt. is dubiolis. Scribner's description is ample, and the type is in the National Herbarium.

(6) Pca compressa L., Sp. Pl. 69. 1753. Europe and North America.

Poa compressa var. sylvestris Torr., Fl. North. and Mid. U.S. 1: 110. 1823. New York.

Poa compressa forma depauperata Millsp., Fl. W.Va. 472. 1892. Monongalia, along Faliing Run, W.Va.

Paneion compressum Lune1, Amer. Midl. Nat. 4: 222. 1915. Based on Poa compressa L.

(10) Poa confinis Vasey, U.S.Dept.Agr., Div. Bot. Bull. 132: pl. 75. 1893. Oregon to Alaska [type Tillamook Bay, Oreg., Howell 69 in 1882].

(13) Poa curta Rydb., Bull. Torrey Bot. Cluio 36: 534. 1909. Spread Creek [Jackson Hole], Wro., Tweedy 13.

(62) Poa curtifolia Scribn., U.S.Dept.Agr., Div. Agrost. Circ. 16: 3. 1899. Mit. Stuart, Wash., Elmer 1148 [type] and 1150.

(50) Poa cusickii Tasey, Contrib. U.S. Natl. Herb. 1: 271. 1893. Oregon. Cusick 1219.

Poa filifolia Vasey, Contrib. C.S. Natl. Herb. 1: 271. 1893. Hatwai Creek, Nez Perce County, Idaho, Sandberg 138.

Poa idahoensis Beal, Grasses N.Amer. 2: 539. 1896. Based on P. filifolia Vasey, not $P$. filifolia Schur, that name, however, published as synonym only.

Poa subaristata Scribn.; Beal, Grasses N.Amer. 2: 533. 1896. Not P. subaristata Phil., 1896 [earlier than P. subaristata Scribn.]. Yellowstone Park, Tweedy 633.

Poa scabrifolia Heller, Bull. Torrey Bot. Club 24: 310. 1897. Based on P. filifolia Vasey.

Poa spillmani Piper, Erythea 7: 102. 1999. Douglas County, Wash., Spillman in 1896.

Poa capillarifolia Scribn. and Williams, U.S.Dept.Agr., Div. Agrost. Circ. 9: 1. 1899. California, Hansen 2614.

Poa cottoni Piper, Biol. Soc. Wash. Proc. 1S: 146. 1905. Rattlesnake Mountains, Yakima County, Wash., Cotton 557.

Poa nematophylla Rydb., Bull. Torrey Bot. Club 32: 606. 1905. Meeker, Colo., Osterhout 2601.

Poa scaberrima Rydb., Bull. Torrey Bot. Club 36: 534. 1909. Beaver Canyon, Idaho, Rydberg 2055.

(18) Poa cuspidata Nutt., in Barton, Compend. Fl. Phila. 1:61. 1818. Based on P. pungens Nutt.

Aira triftora Ell., Bot. S.C. and Ga. 1: 153. 1\$16. Not Poa triflora Gilib., 1792. Athens, Ga., Green.

Poa brevifolia Muhl., Deser. Gram. 13s. 1817. Not P. brevifolia DC., 1806. Pennstrania.

Poa irinervata Willl.; Muhl., Descr. Gram. 138. 1517, as synonym of Poa brevifolia Muhl. 
Poa pungens Nutt., Gen. Pl. 1: 66. 1818. Not P. pungens Georgi, 1800, nor Bieb., 1808. Near Philadelphia.

Poa brachyphylla Schult., Mant. 2: 304. 1824. Based on P'. brevifolia Mluhl. Triodia greenii Spreng., Syst. Veg. 1: 330. 1825. Based on Aira triflora Ell. Graphephorum elliottii Kunth, Rév. Gram. 1:80. 1829. Based on Airc triflora Ell.

Graphephorum melicoides var. triflorum Wood, Amer. Bot. and Flor. pt. 2: 398. 1870. Based on Aira triflora E1l.

(9) Poa douglasii Nees, Ann. Nat. Hist. 1: 284. 1838. California, Douglas.

Poa californica Steud., Syn. Pl. Glum. 1: 261. 1854. California.

Brizopyrum douglasii Hook. and Arn., Bot. Beechey Voy. Suppl. 404. 1840. Based on Poa douglasii Nees.

(52) Poa epilis Seribn., U.S.Dept.Agr., Div. Agrost. Circ. 9: 5. $1899 . \quad$ Buffaio Pass, Colo., Shear and Bessey 1457.

Poa purpurascens Vasey, Bot. Gaz. 6: 297. 1881. Not P. purpurascens Spreng., 1819. Mount Hood, Howell [in 1881].

Poa alpina var. purpurascens Beal, Grasses N.Amer. 2: 543. 1896. Based on $P$. purpurascens Vasey.

Poa paddensis Williams, U.S.Dept.Agr., Div. Agrost. Bull. 17 (ed. 2): 261. f. 557. 1901. Based on P. purpurascens Vasev.

Poa subpurpurea Rydb., Bull. Torrey Bot. Club 32: 606. 1905. Based on P. purpurascens Vasey.

Poa purpurascens var. epilis Jones, Contrib. West. Bot. 14: 14. 1912. Based on $P$. epilis Scribn.

(40) Poa fendleriana (Steud.) Vasey, U.S.Dept.Agr., Div. Bot. Bull. 132: pl. 74. 1893. Based on Eragrostis fendleriana Steud.

Eragrostis fendleriana Steud., Syn. Pl. Glum. 1: 278. 1854. "Mexieo" [now New Mexico], Fendler 932.

Uralepis poaeoides Buckl., Acad. Nat. Sci. Phila. Proc. 1862: 94. 1863. New Mexico, Fendler 932.

Atropis californica Munro; A. Gray, Acad. Nat. Sci. Phila. Proc. 1862: 336. 1863. California, Douglas in 1833.

Poa eatoni S. Wats., in King, Geol. Expl. 40th Par. 5: 386. 1871. Wasatch Mountains, Utah, Eaton [in 1869].

Poa andina var. major Vasey, in Wheeler, Rept. U.S. Survey 160th Merid. 6: 290. 1878. Arizona; Colorado.

Poa andina var. spicata Vasey, in Wheeler, Rept. U.S. Survey 100th Merid.6: 290. 1878. Colorado. [ [Wolf] 1135 .

Atropis californica Munro; Thurb., in S. Wats., Bot. Calif. 2: 309. 1880. Near San Francisco, Bolander; Monterey, Hartweg.

Poa californica Scribn., Bull. Torrey Bot. Club 10: 31. 1883. Not P. californica Steud., 1854. Based on Atropis californica Munro.

Panicularia fendleriana Kuntze, Rev. Gen. Pl. 2: 782. 1891. Based on Eragrostis fendleriana Steud.

Atropis fendleriana Beal, Grasses N.Amer. 2: 576. 1896. Based on Eragrostis fendleriana Steud.

Poa fendleriana spicata Scribn., U.S.Dept.Agr., Div. Agrost. Bull. 5: 31. 1897. Based on $P$. arida var. spicata Vasey, error for $P$. andina var. spicata Vasey.

Poa longepedunculata Scribn., U.S.Dept.Agr., Div. Agrost. Bull. 11: 54. pl. 11. 1898. Laramie, Wyo., Nelson [3292].

Poa brevipaniculata Scribn. and Williams, U.S.Dept.Agr., Div. Agrost. Cire. 9: 2. 1899. Table Rock, Colo., Breninger 551 .

Poa scabriuscula Williams, U.S.Dept.Agr., Div. Agrost. Cire. 10: 4. 1899. Glenwood, Utah, Ward 136.

Poa longepedunculata viridescens Williams, U.S.Dept.Agr., Div. Agrost. Circ. 10: 4. 1899. Sheep Mountain [near Laramie], Wyo., Williams 2302.

Poa brevipaniculata subpallida Williams, U.S.Dept.Agr., Div. Agrost. Cire. 10: 5. 1899. Rocky Mountains, Colo., Hall and Harbour 674 in part.

Poa fendleriana arizonica Williams, U.S.Dept.Agr., Div. Agrost. Cire. 10: 5. 1899. Yavapai Creek, Ariz., Rusby in 1883.

(45) Poa glauca Vahl, Fl. Dan. pl. 964. 1790. Norway.

Poa caesia J. E. Smith, Fl. Brit. 1: 103. 1800. England.

Poa nemoralis var. glauca Gaud., Agrost. Helv. 1: 182. 1811. Based on $P$. glauca Vahl.

Poa glauca var. caesia Syme, in Sowerby, Englislı Bot. ed. 3. 11: 11S. 1873. Based on P. caesia Smith.

Paneion glaucum Lunell, Amer. Midl. Nat. 4: 222. 1915. Based on Poa glauca Vahl. 
(20) Poa glaucifolia Scribn. and Williams, U.S.Dept.Agr., Div. Agrost. Circ. 10: 6. 1899. Based on P. planifolia Seribn. and Williams.

Poa planifolia Seribn. and Williams, U.S.Dept.Agr., Div. Agrost. Circ. 9: 3. 1899. Not P. planifolia Kuntze, 1898. Spring Creek, Big Horn Basin, Wyo., Williams 2814.

Poa plattensis Rydb., Brittonia 1: 84. 1931. Lawrence Fork, Nebr., Rydberg 461.

(58) Poa gracillima Vasey, Contrib. U.S.Natl. Herb. 1: 272. 1893. Mount Adams, Wash., Suksdorf 33.

Sporobolus bolanderi Vasey, Bot. Gaz. 11: 337. 1886. Not Poa bolanderi Vasey, 18s2. Multnomah Falls, Oreg., Bolander. [The type an overmature specimen from which all but the lowermost floret had fallen from the spikelets.]

Atropis tenuifolia var. stenophylla Vasey; Beal, Grasses N.Amer. 2: 580. 1896. [Roseburg], Oreg., Howell in 1887.

Poa saxatilis Scribn. and Williams, U.S.Dept.Agr., Div. Agrost. Circ. 9: 1. 1899. Nt. Rainier, Wash., Piper 1964.

Poa tenerrima Scribn., U.S.Dept.Agr., Div. Agrost. Circ. 9: 4. 1899. California.

Poa invaginata Scribn. and Williams, U.S.Dept.Agr., Div. Agrost. Circ. 9: 6. 1899. Summit Camp, Sierra Nevada, Calif.

Poa multnomae Piper, Bull. Torrey Bot. Club 32: 435. 1905. Multnomah Falls, Oreg., Piper 6459.

Poa alcea Piper, Bull. Torrey Bot. Club 32: 436. 1905. Portland, Oreg., Piper 6463.

Poa buckleyana var. stenophylla Jones, Contrib. West. Bot. 14: 14. 1912. Based on Atropis tenuifolia var. stenophylla Vasey.

Poa gracillima var. saxatilis Hack., Allg. Bot. Ztschr. 21: 79. 1915. Based on $P$. saxatilis Scribn. and Williams.

Poa englishii St. John and Hardin, Mazama 11: 64. 1929. Mount Baker National Forest, Hardin and English 1391.

(2) Poa howellii Vasey and Scribn., U.S.Dept.Agr., Div. Bot. Bull. 132: pl. 78. 1893. California to Oregon. [Portland, Howell 25 in 1S81, type.]

Poa howellii var. microsperma Vasey, Contrib. U. S. Natl. Herb. 1: 273. 1893. Santa Cruz, Calif., Anderson 99.

Poa bolanderi var. howellii Jones, Contrib. West. Bot. 14: 15. 1912. Based on $P$. howellii Vasey and Scribn.

(39) Poa interior Rydb., Bull. Torrey Bot. Club 32: 604. 1905. Headwaters of Clear Creek and Crazy Woman River, Wyo., Tweedy 3706.

Poa caesia var. strictior A. Gray, Man. ed. 5. 629. 1867. "Lake Superior, C. G. Loring, especially Isle Royale, Prof. Whitney."

Poa coloradensis Vasey; Pammel, U.S.Dept.Agr., Div. Agrost. Bull. 9: 41. 1897. Name only, for a specimen collected by Pammel in Colorado in 189596.

Poa subtrivialis Rydb., Bull. Torrey Bot. Club 36: 536. 1909. Big Horn Mountains, Wyo., Tweedy 2141.

Poa glauca var. strictior Jones, Contrib. West. Bot. 14: 14. 1912. Based on P. caesia var. strictior A. Gray.

Paneion interius Lunell, Amer. Midl. Nat. 4: 222. 1915. Based on Poa interior Rydb.

(49) Poa involuta Hitche., Biol. Soc. Wash. Proc. 41: 159. 1928. Chisos Mountains, Brewster County, Tex., Ferris and Duncan 2811.

(63) Poa juncifolia Seribn., U.S.Dept.Agr., Div. Agrost. Bull. 11: 52. pl. 8. 1898. Point of Rocks, Sweetwater County, Wyo., Nelson 3721.

Poa brachyglossa Piper, Biol. Soc. Wash. Proc. 1S: 145. 1905. Douglas County, Wash., Sandberg and Leiberg 267.

Poa fendleriana var. juncifolia Jones, Contrib. West. Bot. 14: 14. 1912. Based on P. juncifolia Seribn.

(15) Poa kelloggii Yascy, U.S.Dept.Agr., Div. Bot. Bull. 13²: pl. 79. 1893. [Mendocino County], Calif., Bolander 4705.

Poa bolanderi var. lielloggii Jones, Contrib. West. Bot. 14: 15. 1912. Based on P. kelloggii Vasey.

(25) Poa languida Hitche., Biol. Soc. Wash. Proc. 41: 158. 1928. Based on $P$. debilis Torr.

Poa debilis Torr., FI. N.Y. 2: 459. 1843. Not P. debilis Thuill., 1799. [Gorham], New York. 
(46) Poa laxa Haenke, in Jirasek, Beob. Riesengeb. 118. 1791. Europe.

Poa laxa var. debilior Jones, Contrib. West. Bot. 14: 15. 1912. "The eastern plant", no particular locality nor specimen cited.

(16) Poa laxiflora Buckl., Acad. Nat. Sci., Phila. Proc. 1862: 96.1863. Columbia Woods, Oreg., Nuttall.

Poa leptocoma elatior Scribn. and Merr., Contrib. U.S. Natl. Herb. 13: 71. 1910. Cape Fox, Alaska, Trelease and Saunders 2982.

Poa remissa Hitehe., Biol. Soc. Wash. Proc. 41: 158. 1928. Sol Due Hot Springs, Olympic Mountains, Wash., Hitchcock 23468.

(56) Poa leibergii Scribn., U.S.Dept.Agr., Div. Agrost. Bull. 8: 6. pl. 2. 1897. Owyhee-Malheur Divide, Oreg., Leiberg 2171.

Poa hanseni Scribn., U.S.Dept.Agr., Div. Agrost. Bull. 11: 53. pl. 9. 1898. Silver Lake, Amador County, Calif., Hansen 605.

Poa pringlei var. hanseni. Smiley, Univ. Calif. Pubs., Bot. 9: 104. 1921. Based on $P$. hanseni Seribn.

(33) Poa leptocoma Trin., Mém. Acad. St. Pétersb. VI. Math. Phys. Nat. 1: 374. 1830. Sitka, Alaska, Mertens.

Poa stenantha var. leptocoma Griseb., in Ledeb., Fl. Ross. 4: 373.1853. Based on P. leptocoma Trin.

Poa crandallii Gandog., Bull. Soc. Bot. France 667 ${ }^{7}$ 301. 1920. Mountains of Larimer, Colo., Crandall in 1898.

(55) Poa lettermani Vasey, Contrib. U.S. Natl. Herb. 1: 273. 1893. Grays Peak, Colo., Letterman 7.

Poa brandegei Scribn.; Beal, Grasses N.Amer. 2: 544. 1896. Grays Peak, Colo., Jones 714.

Atropis lettermani Beal, Grasses N.Amer. 2: 579. 1896. Based on Poa lettermani Vasey.

(41) Poa longiligula Scribn. and Williams, U.S.Dept.Agr., Div. Agrost. Circ. 9: 3. 1899. Silver Reef, Utah, Jones 5149.

Poa montana Vasey, U.S.Dept.Agr., Monthly Rept. 155. 1874. Not P. montana All., 1785. Nevada, IVatson 1312.

Poa longiligula wyomingensis Williams, U.S.Dept.Agr., Div. Agrost. Circ. 10: 3. 1899. Tipton, Wyo., Nelson 4799a.

Paneion longiligulum Lunell, Amer. Midl. Nat. 4: 222. 1915. Based on Poa longiligula Seribn. and Williams.

This species was referred to Poa alpina L. by Watson, in King, Geol. Expl. 40th Par. 5: 386.1871.

(8) Poa macrantha Vasey, Bull. Torrey Bot. Club 15: 11. 1888. Mouth of Columbia River, Oreg., Howell [in 1887].

Melica macrantha Beal, Bull. Torrey Bot. Club 17: 153. 1890. Based on Poa macrantha Vasey.

(37) Poa macroclada Ryd1)., Bull. Torrey Bot. Club 32: 604. 1905. Rogers, Gunnison Watershed, Colo., Baker 802.

(23) Poa marcida Hitchc., Biol. Soc. Wash. Proc. 41: 158. 1928. Sol Duc Hot Springs, Olympic Mountains, Wash., Hitchcock 23466.

(36) Poa nemoralis L., Sp. Pl. 69. 1753. Europe.

Paneion nemorale Lunell, Amer. Midl. Nat. 4: 222. 1915. Based on Poa nemoralis L.

(14) Poa nervosa (Hook.) Vasey, U.S.Dept.Agr., Div. Bot. Bull. 132: pl. 81. 1893. Based on Festuca nervosa Hook.

Festuca nervosa Hook., Fl. Bor. Amer. 2: 251. p1. 232. 1840. Nootka Sound, Vancouver Island, Scouler.

Poa columbiensis Steud., Syn. Pl. Glum. 1: 261. 1S54. Columbia River, Douglas.

Poa wheeleri Vasey, Cat. P1. Survey W. 100th Merid. 55. 1874. South Park, Colo., [11 olf] 1131 [1131a].

Poa pulchella var. major Vasey, U.S.Dept.Agr., Div. Bot. Bull. 132: pl. 82. 1893. Southern Oregon, no specimen eited, and none so named by Vasey can be found.

Poa vaseyana Scribn.; Beal, Grasses N.Amer. 2: 532. 1896. [Georgetown], Colo., Patterson in 1885.

Poa cuspidata Vasey; Scribn., U.S.Dept.Agr., Div. Agrost. Circ. 9: 6. 1899. Not P. cuspidata Nutt., 1818. As synonym of P. wheleri Vasey.

Poa olneyae Piper, Erythea 7: 101. 1899. 'Spokane, Wash., Pipcr 2820.

Poa subreflexa Pydb., Bull. Torrey Bot. Club 36: 535. 1909. Steamboat Springs, Colo., State Agricultural College 3731.

(61) Poa nevadensis Vasey; Scribn., Bull. Torrey Bot. Club 10: 66. 1883. [Austin, Nev., Jones in 1882.] 
Atropis pauciflora Thurb., in S. Wats., Bot. Calif. 2: 310. 1880. Not Poa pruciflora Roem. and Schult., 1817. Sierra Talley, Calif., Lemmon 1871. (Though credited to Lemmon the type specimen appears to have been collected by Bolander, Lemmon's name not appearing on the label.)

Poa pauciflora Benth.; Vasey, Grasses U.S. 42. 1883. Not P. pauciflora Roem. and Schult., 1817. Based on Atropis pauciflora Thurb.

Poa tenuifolia var. scabra Vasey; Seribn., Bull. Torrey Bot. Club 10: 66. 18s3, as synonym of $P$. nevadensis. [California, Lemmon.]

Panicularia thurberiana Kuntze, Rev. Gen. Pl. 2: 783. 1891. Based on Atropis pauciflora Thurb.

Poa thurberiana Vasey, U.S.Dept.Agr., Div. Bot. Bull. 132: pl. 84. 1893. The name based on Panicularia thurberiana Kuntze, but the plant deseribed and figured is Melica imperfecta Trin.

Atropis nevadensis Beal, Grasses N.Amer. 2: 577. 1896. Based on Poa nevadensis Vasey.

(27) Poa occidentalis Vasey, Contrib. U.S. Natl. Herb. 1: 274. 1893. Las Vegas, N.Mex., G. R. Vasey in 1881.

Poa flexuosa var. occidentalis Vasey, in Wheeler, Rept. U.S. Survey 100th Merid. 6: 290. 1878. Twin Lakes, Colo. [Tolf] 1132.

Poa trivialis var. occidentalis Vasey, Descr. Cat. Grasses U.S. 85. IS85. Colorado and New Mexico, the type being the specimen later described as $P$. occidentalis Vaser.

Poa flexuosa var. robusta Vasey, Contrib. U.S. Natl. Herb. 1: 271. 1893. Rocky Mountains, Colo., Irasey 673 [Powell's Expedition].

Poa autumnalis var. robusta Beal, Grasses N.Amer. 2: 534. 1896. Based on P. Alexuosa var. robusía Vasey.

Poa occidentalis Rydb., Mem. N.Y. Bot. Gard. 1: 50. 1900. Based on P. flexuosa var. occidentalis Vasey.

Poa platyphylla Nash and Rydb., Bull. Torrey Bot. Club 28: 266. 1901. Based on $P$. occidentalis Vasey, the name changed because of $P$. flexuosa var. occidentalis Vasey, thought to be different.

Poa lacustris Heller, Muhlenbergia 6: 12. 1910. Based on P. flexuosa var. occidentalis Vasey.

(34) Poa paludigena Fern. and Wieg., Rhodora 20: 126. 1918. Wayne County, N.Y., Metcalf and II iegand 7572 .

Poa sylvestris var. palustris Dudley, Cornell Univ. Bull. 2: 128. 1886. Michigan Hollow, N.Y.

(38) Poa palustris L., Syst. Nat. ed. 10. 2: 874. 1759. Europe.

Poa serotina Ehrh., Beitr. Naturk. 6: 83 . 1791, name only; Schrad. Fl. Germ. 1: 299. 1806. Europe.

Poa triflora Gilib., Exerc. Plyyt. 2: 531. 1792. Europe.

Poa crocata Michx., F1. Bor. Amer. 1: 68. 1803. Lake Mistassini, Quebec, Michaux.

Poa glauca var. crocata Jones, Contrib. West. Bot. 14: 15. 1912. Based on $P$. crocata Michx.

Pancion triflorum I.unell, Amer. Midl. Nat. 4: 223. 1915. Based on Poa triflora Gilib.

(47) Poa pattersoni Vasey, Contrib. U.S. Natl. Herb. 1: 275. 1893. Grays Peak, Colo., Patterson 154.

(32) Poa paucispicula Seribn. and Merr., Contrib. U.S. Natl. Herb. 13: 69. pl. 15. 1910. Yakutat Bay, Alaska, Coville and Kearney 970.

(17) Poa pratensis L., Sp. Pl. 67. 1753. Europe.

?Poa viridis Schreb.; Pursh, F1. Amer. Sept. 1: 79. 1814. North America.

Poa angustifolia Ell., Bot. S.C. and Ga. 1: 160. 1816. South Carolina.

Paneion pratense Lunell, Amer. Midl. Nat. 4: 222. 1915. Based on Poa pratensis $\mathrm{L}$.

(54) Poa pringlei Scribn., Bull. Torrey Bot. Club 10: 31. 1853. Headwaters of the Sacramento River, Calif., Pringle [in 1882].

Poa argentca Howell, Bull. Torrey Bot. Club 15: 11. 1Sss. [Ashland Butte], Siskiyou Mountains, Oreg., Howell [in 1887].

Mclica argentea Beal, Bull. Torrey Bot. Club 17: 153. 1890. Based on Poa argentea Howell.

Melica nana Beal, Grasses N.Amer. 2: 504. 1896. Based on Poa argentea Howell. Name changed because of " $M$. argentea Desv." [error for $M$. argentata Desv.].

Atropis sulsdorfii Beal, Grasses N.Amer. 2: 574. 1896. [Momnt Adams]. Wash., Suksdorf 1116. Beal gives as synonym "Poa suksdorfii Vasey ined." 
Atropis pringlei Beal, Grasses N.Amer. 2: 578. 1896. Based on Poa pringlei Scribn.

Poa suksdorfii Vasey; Piper, Contrib. U.S. Natl. Herb. 11: 135. 1906. Based on Atropis suksdorfii Beal.

(30) Poa reflexa Vasey and Scribn., Contrib. U.S. Natl. Herb. 1: 276. 1893. Kelso Mountain, near Torrey Peak, Colo., Letterman in 1885.

Poa acuminata Scribn.; Beal, Grasses N.Amer. 2: 538. 1896. [Mount Blackmore], Mont., Tweedy 639 in 1885, 1027 in 1886.

Poa pudica Rydb., Bull. Torrey Bot. Club 32: 603. 1905. Near Grays Peak, Colo., Rydberg 2443.

Poa leptocoma var. reflexa Jones, Contrib. West. Bot. 14: 15. 1912. Based on $P$. reflexa Vasey and Scribn.

(11) Poa rhizomata Hitchc., in Jepson, Fl. Calif. 1: 155. 1912. Oro Fino, Siskiyou County, Calif., Butler 1205.

Poa piperi Hitche., in Abrams, Hlustr. Fl. 1: 201. f. 461. 1923. Waldo, Oreg., Piper 6496.

(48) Poa rupicola Nash, Men. N.Y. Bot. Gard. 1: 49. 1900. Based on P. rupestris Vasey.

Poa rupestris Vasey, Bull. Torrey Bot. Club 14: 94. 1887. Not P. rupcstris With., 1796. Rocky Mountains [Holf 341 in 1873].

(26) Poa saltuensis Fern. and Wieg., Rhodora 20: 122. 1918. Gaspé County, Quebec, Fernald and Collins 357.

Poa debilis var. acutiflora Vasey; Macoun, Cat. Can. Pl. 24: 225. 1888. Name only, for Macoun 28 and Burgess 12 and 13, Truro, Nova Scotia.

Poa saltuensis var. microlepis Fern. and Wieg., Rhodora 20: 124. 1918. Newfoundland, Fernald and Wiegand 4633.

(57) Poa scabrella (Thurb.) Benth.; Vasey, Grasses U.S. 42. 1883. Based on Atropis scabrella Thurb.

Sclerochloa californica Munro; Benth., Pl. Hartw. 342. 1857. Name only, for Hartweg 2035, Sacramento Valley, Calif.

Poa tenuifolia Buckl., Acad. Nat. Sci. Phila. Proc. 1862: 96. 1863. Not P. tenuifolia A. Rich., 1851. Columbia River, Nuttall.

Atropis scabrella Thurb., in S. Wats., Bot. Calif. 2: 310.1880. Oakland, Calif.. Bolander.

Atropis tenuifolia Thurb., in S. Wats., Bot. Calif. 2: 310. 1880. Based on Poa tenuifolia Buckl.; Thurb.

Poa orcuttiana Vasey, West Amer. Sci. 3: 165. 1887. San Diego, Calif., Orcutt [1070] in 1884 .

Panicularia scabrella Kuntze, Rev. Gen. Pl. 2: 783. 1891. Based on Atropis scabrella Thurb.

Panicularia nuttalliana Kuntze, Rev. Gen. Pl. 2: 783. 1891. Based on "Atropis tenuifolia Thurb., Poa tenuifolia Nutt., 1862" (error for Buckl.).

Poa buckleyana Nash, Bull. Torrey Bot. Clıb 22: 465. 1895. Based on P. tenuifolia Buckl.

Poa capillaris Scribn., U.S.Dept.Agr., Div. Agrost. Bull. 11: 51. f. 11. 1898. Not P. capillaris L., 1753. Potrero, Calif.

Poa nudata Scribn., Ú.S.Dept.Agr., Div. Agrost. Circ. 9: 1. 1899. Based on $P$. capillaris Scribn.

Poa acutiglumis Scribn., U.S.Dept.Agr., Div. Agrost. Circ. 9: 4. 1899. Grave Creek, Oreg., Howell in 1884.

Poa limosa Scribn. and Williams, U.S. Dept.Agr., Div. Agrost. Cire. 9: 5. 1899. Mono Lake, Calif., Bolander.

(59) Poa secunda Presl, Rel. Haenk. 1: 271. 1830. Chile, Haenke.

Poa sandbergii Vasey, Contrib. U.S. Natl. Herb. 1: 276. 1893. Lewiston, Idaho, Sandberg 164.

Poa incurva Scribn. and Williams, U.S.Dept.Agr., Div. Agrost. Circ. 9: 6. 1899. Duckaloose Glacier, Olympic Mountains, Wash., Piper 1989.

Poa buckleyana var. sandbergii Jones, Contrib. West. Bot. 14: 14. 1912. Based on P. sandbergii Vasey.

Paneion sandbcrgii Lunell, Amer. Midl. Nat. 4: 223. 1915. Based on Poa sandbergii Vasey.

(44) Poa stenantha Trin., Mém. Acad. St. Pétersb. VI. Math. Phys. Nat. 1: 376. 1830. Kamchatka, Unalaska, Sitka, Karaghinski Island.

(29) Poa sylvestris A. Gray, Man. 596. 1848. Ohio and Kentucky, Short, Sullivant, Michigan and southwestward [type from Ohio, Short in 1842].

(28) Poa tracyi Vasey, Bull. Torrey Bot. Club 15: 49. 1888. Raton, N.Mex., Tracy in 1887. 
Poa nervosa var. tracyi Beal, Grasses N.Amer. 2: 538. 1896. Based on $P^{\prime}$. tracyi Vasey.

(22) Poa trivialis L., Sp. Fl. 67. 1753. Europe.

Poa stolonifera Hall.; Mulıl., Deser. Granı. 139. 1817. Pennsylvania.

Poa trivialis var. filiculmis Scribn.; Beal, Grasses N.Aner. 2: 532. 1896. Van. couver Island, Macoun 282.

Poa callida Kivdb., Bull. Torrey Bot. Club 36: 533. 1909. Helena, Mont., Rydberg 2145.

(51) Poa unilateralis Seribn.; Vasey, U.S.Dept.Agr., Div. Bot. Bull. 1322: pl. 85. 1893. San Francisco, Calif., [Jones 15 in 1882].

Atropis unilateralis Beal, Grasses N.Amer. 2: 581. 1896. Based on Poa unilateralis Scribn.

Poa pachypholis Piper, Bicl. Soc. Wash. Proc. 1S: 146. 1905. Ilwaco, Wash., Piper [4900].

(53) Poa vaseyochloa Scribn., U.S.Dept.Agr., Div. Agrost. Circ. 9: 1. 1899. Based on P. pulchella Vasey.

Poa pulchella Vasey, Bot. Gaz. 7: 32. 18s2. Not P. pulchella Salisb., 1796. Columbia River [mountains, Klickitat County, Wash.], Suksdorf [in 1881].

Atropis pulchella Beal, Grasses N.Amer. 2: 574. 1896. Based on Poa pulchella Vasey.

Poa gracillima var. raseyochloa Jones, Contrib. West. Bot. 14: 14. 1912. Based on $P$. vascyochloa Scribn.

(31) Poa wolfii Scribn., Bull. Torrey Bot. Club. 21: 228. 1894. [Canton], Ill., Wolf [in 1882].

Poa alsodes var. wolfii I'asey; Scribn., Bull. Torrey Bot. Club 21: 228. 1894, as synonym of $P$. uolfii Scribn.

(70) POLYPOGON Desf.

(4) Polypogon austrails Brongn., in Duperrey, Bot. Voy. Coquille $2^{2}: 21.1830$. Concepción, Chile.

Polypogon crinitus Trin., Gram. Unifl. 171. 1824. Not P. crinitus Nutt., 1818. Chile, Chamisso.

Polypogon interruptus var. crinitus Hack.; Stuck., An. Mus. Nac. Buenos Aires 13: 473. 1906. Based on P. crinitus Trin.

(3) Polypogon lutosus (Poir.) Hitchc., U.S.Dept.Agr., Bull. 772: 138.1920. Based on Agrostis lutosa Poir.

Agrostis littoralis With., Bot. Arr. Veg. Brit. ed. 3. 2: 129. pl. 23. 1796. Not A. littoralis Lam., 1791. England.

Polypogon littoralis J. E. Smith, Comp. Fl. Brit. 13. 1800. Based on Agrostis littoralis With.

Agrostis lutosa Poir., in Lam., Encycl. Sup. 1: 249. 1810. Based on A. littoralis With.

Filfa lutosa Beanv., Ess. Agrost. 16, 148, 181. 1812. Based on Agrostis lutosa Poir.

Polypogon interruptus H.B.K., Nov. Gen. and Sp. 1: 134. pl. 44. 1815. Venezuela, Humboldt and Bonpland.

Alopecurus interruptus Poir., in Lam., Encycl. Sup. 5: 495. 1817. Based on Polypogon interruptus H.B.K.

Polypogon lutosus was thought by Duval-Jouve to be a hybrid between $P$. monspeliensis and Agrostis alba (Bull. Soc. Bot. France 2: 288. 1875).

(2) Polypogon maritimus Willd., Gesell. Naturf. Freund. Berlin (n.s.) 3: 443. 1801. France.

Alopecurus maritimus Poir., in Lam., Encycl. 8: 779. 1808. Based on Polypogon maritimus Willd.

Polypogon monspeliensis var. maritimus Coss. and Dur., Expl. Sci, Alger. 2: 70. 1867. Based on P. maritimus Willd.

(1) Polypogon monspeliensis (L.) Desf. Fl. Atlant. 1: 67. 1798. Based on Alopecurus monspeliensis $\mathrm{L}$.

Alopecurus monspeliensis L., Sp. Pl. 61. 1753. Europe.

Phleum crinitum Schreb., Beschr. Gräs. 1: 151. 1769. Based on Alopecurus monspcliensis L.

Alopecurus aristulatus var. monspeliensis Huds., Fl. Angl. 28. 1778. Based on A. monspeliensis $\mathrm{L}$.

Agrostis alopecuroides Lam., Tabl. Encycl. 1: 160. 1791. Based on Alopecurus monspeliensis L.

Phleum monspeliense Koel., Descr. Gram. 57. 1802. Based on Alopecurus monspeliensis L. 
Polypogon crinitus Nutt., Gen. Pl. 1: 50. 181S. Based or Phleum crinitum Smith (error for Sclrreb.).

Polypogon flavescens Presl, Rel. Haenk. 1: 234. 1830. Peru, Haenlie.

Santia monspeliensis Parl., Fl. Palerm. 1: 73. 1St5. Based on Alopecurus monspeliensis L.

\section{(5) PÚCCINELliA Parl.}

(7) Puccinellia distans (I.) Parl., Fl. Ital. 367. 1818. Based on Poa distans L. Poa distans L., Mant. Pl. 1: 32.1767. Europe.

Aira aquatica var. distans Huds., Fl. Angl. 34. 177s. Based on Poa distans L.

Hydrochloa distans Hartm., Gen. Gram. Skand. 8. 1819. Presunably based on Poa distans L.

Glyceria distans Wahl., Fl. Upsal. 36. 1820. Based on Poa distans L.

Festuca distans Kunth, Rév. Gram. 1: 129. 1829. Based on Poa distans L.

Sclerochloa distans Bab., Man. Brit. Bot. 370. 1843. Based on Poa distans L.

Catabrosa distans Link; Heyuh., Nom. 2: 126. 1846. Based on Glyceria distans Wahl.

Atropis distans Griseb., in Ledeb., Fl. Ross. 4: 388. 1853. Based on Poa distans L.

Glyceria distans var. tenuis Uechtr., in Crép., Notes Pl. Rar. Belg. 229. 1865. Germany.

Sclerochloa multiculmis subsp. distans Syme, in Sowerby, English, Bot. ed.3. 11: 104. 1873. Based on Poa distans L.

Panicularia distans Kuntze, Rev. Gen. Pl. 2: 782. 1891. Based on Poa distans $\mathrm{L}$.

Atropis distans var. tenuis Rouy, Fl. France 14: 195. 1913. Based on Glyceria distans var. tenuis Techtr.

Puccinellia distans var. tenuis Fern. and Weatlu., Rhodora 18: 12. 1916. Based on Glyceria distans var. tenuis Uechtr.

Puccinellia suksdorfi St. John, Wash. State Coll. Contrib. Dept. Bot. 2: 80. 1928. Rockland, Wash., Suksdorf 5089.

(4) Puccinellia fasciculata (Torr.) Bicknell, Bull. Torrey Bot. Club 35: 197. 1908. Based on Poa fasciculata Torr.

Poa fasciculata Torr., Fl. North. and Mid. U.S. 1: 107. 1823. New York [Torrey].

Poa delawarica Link, Hort. Berol. 1: 174. 1827. Delaware.

Festuca delawarica Kunth, Rév. Gram. 1: 129. 1829. Based on Poa delawarica Link.

Festuca borreri Bab., Linn. Soc. Trans. 17: 565. 1837. England.

Glyceria delawarica Heynh., Nom. 1: 360. 1840. Based on Poa delawarica Link.

Glyceria borreri Bab., in Smith and Sowerby, English Bot. Sup. 3: pl. 2797. 1843. England.

Sclerochloa borreri Bab., Man. Brit. Bot. 370. 1843. Based on Glyceria borreri Bab.

Poa borreri Parmell, Grasses Brit. 220. pl. 98. 1845. Based on Sclerochloa borreri Bab.

Sclerochloa arenaria var. fasciculata A. Gray, Man. 594. 1848. Based on Poa fasciculata Torr.

Sclerochloa multiculmis subsp. borreri Syme, in Sowerby, English Bot. ed. 3. 11: 105. 1873. Based on S. borreri Bab.

Atropis borreri Richt., Pl. Eur. 1: 92. 1890. Based on Glyceria borreri Bab. Puccinellia borreri Hitchc., Rhodora 10: 65. 1908. Based on Festuca borreri Bab.

(5) Puccinellia lemmoni (Vasey) Scribn., U.S.Dept.Agr., Div. Agrost. Bull. 17: 276. f. 572. 1899. Based on Poa lemmoni Vasey.

Poa lemmoni Vasey, Bot. Gaz. 3: 13. 1878. Sierra County, Calif., Lemmon. Glyceria lemmoni Vasey, Descr. Cat. Grasses US. 88. 1885, name only; Bull. Torrey Club 13: 119. 18S6. Based on Poa lemmoni Vaser.

Atropis lemmoni Vasey, U.S.Dept.Agr., Div. Bot. Bull. 132: pl.90. 1893. Based on Poa lemmoni Vásey.

Puccinellia rubida Elmer, Bot. Gaz. 36: 56. 1903. Prineville, Oreg., Cusick 2621.

(6) Puccinellia maritima (Huds.) Parl., FI. Ital. 1: 370. 1848. Based on Poa maritima Huds.

Poa maritima Huds., Fl. Angl. 35. 1762. England.

Poa maritima Muhl., Descr. Gram. 148. 1817. New England. 
Glyceria maritima Wallb., Fl. Gothob. 17. 1820. Based on Poa maritima Huds.

Festuca distans var. maritima Mutel, Fl. Franç. 4: 116. 1837. Based on Poa maritima Huds.

Poa maritima Bigel., Fl. Bost. ed. 3. 36. 1840. Cambridge and Dorchester, Mass.

Diachroa maritima Nutt.; Steud., Nom. Bot. ed. 2. 1: 497. 1840, as synonym of Glyceria maritima Wahlb.

Sclerochloa maritima Lindl., in Bab., Man. Brit. Bot. 370. 1843. Based on Glyceria maritima Smith (same as Wahlb.).

Sclerochloa arenaria var. maritima A. Gray, Man. 594. 1848. Based on Poa maritima Huds.

Atropis maritima Griseb., in Ledeb., Fl. Ross. 4: 389. 1853. Based on Poa maritima Huds.

Atropis distans var. maritima Coss. and Dur., Expl. Sci. Alger. 2: 141. 1867. Based on Poa maritima Huds.

Panicularia maritima Scribn., Mem. Torrey Bot. Club 5: 54. 1894. Based on Poa maritima Huds.

(10) Puccinellia nutkaensis (Presl) Fern. and Weath., Rhodora 18: 22. f. 49-53. 1916. Based on Poa nutkaensis Presl.

Poa nutkaensis Presl, Rel. Haenk. 1: 272. 1830. Nootka Sound, Vancouver Island, Haenke.

This species has been referred to Puccinellia festucaeformis (Host) Parl., of Europe.

(8) Puccinellia nuttalliana (Schult.) Hitchc., in Jepson, Fl. Calif. 1: 162. 1912. Based on Poa nuttalliana Schult.

Poa airoides Nutt., Gen. Pl. 1: 68. 1818. Not P. airoides Koel., 1802. Mandan, N.Dak., Nuttall.

Poa nuttalliana Schult., Mant. 2: 303. 1824. Based on P. airoides Nutt.

Festuca nuttalliana Kunth, Rév. Gram. 1: 129. 1829. Based on Poa nuttalliana Schult.

Glyceria montana Buckl., Acad. Nat. Sci. Phila. Proc. 1862: 96. $1863 . \quad$ Rocky Mountains, Nuttall.

Glyceria airoides A. Gray, Acad. Nat. Sci. Phila. Proc. 1862: 336.1863. Not G. airoides Reichenb., 1829. Based on Poa airoides Nutt.

Puccinellia airoides Wats. and Coult., in A. Gray, Man. ed. 6. 668. 1890. Based on Poa airoides Nutt.

Panicularia distans airoides Scribn., Mem. Torrey Bot. Club 5: 54. 1894. Based on Poa airoides Nutt.

Atropis airoides Holm, Bot. Gaz. 46: 427. 1908. Based on Poa airoides Nutt.

Puccinellia cusickii Weatherby, Rhodora 18: 182. 1916. Grande Ronde Valley, Oreg., Cusick 3271.

Atropis nuttalliana Pilger, Notizbl. Bot. Gart. Berlin 9: 291. 1925. Based on Poa nuttalliana Schult.

Wyoming specimens cited by Fernald and Weatherby (Rhodora 18: 16.1916 ) under Puccinellia lucida (the type from Quebec) are here referred to $P$. nuttalliana.

(1) Puccinellia parishii Hitche., Biol. Soc. Wash. Proc. 41: 157. 1928. Rabbit Springs, Calif., Parish 9799.

(9) Puccinellia pumila (Vasey) Hitchc., Amer. Jour. Bot. 21: 129. 1934. Based on Glyceria pumila Vasey.

Glyceria pumila Vasey, Torrey Bot. Club 15: 48. 1888. Vancouver Island, Macoun [in 1887].

Puccinellia maritima var. minor S. Wats., in A. Gray, Man. ed. 6. 668.1890. Mount Desert, Maine, Rand.

Glyceria paupercula Holm, Repert. Sp. Nov. Fedde 3: 337. 1907. Mansfield Island, Canada, Geol. Surv. 34782.

Puccinellia alaskana Scribn. and Merr., Contrib. U.S. Natl. Herb. 13: 78. 1910. St. Paul lsland, Alaska, Merriam.

Puccinellia paupercula Fern. and Weath., Rhodora 18: 18. 1916. Based on Glyceria paupercula Holm.

Puccinellia paupercula var. alaskana Fern. and Weath., Rhodora 18: 18.1916. Based on P. alaskiana Scribn. and Merr.

This is the species referred by American authors to Atropis angustata Griseb., Glyceria angustata Vasey, and Puccinellia angustata Nash. The names are based on Poa angustata R. Br., a species of Aretic America.

(3) Puccinellia rupestris (With.) Ferm. and Weath., Rhodora 18: 10. f. 17-22. 1916. Based on Poa rupestris With. 
Poa rupestris With., Bot. Arr. Veg. Brit. ed. 3. 2: $146.1796 . \quad$ England.

Poa procumbens Curtis, Fl. Lond. 6: pl. 11. 1798. England.

Sclerochloa procumbens Beauv., Ess. Agrost. 98. 1812. Based on Poa procumbens Curtis.

Festuca procumbens Kunth, Rév. Gram. 1: 129. 1829. Not F. procumbens Muhl., 1817. Based on Poa procumbens Curtis.

Scleropoa procumbens Parl., Fl. Ital. 1: 474. 1848. Based on Poa procumbens Curtis.

Atropis procumbens Thurb., in S. Wats., Bot. Calif. 2: 309. 1880. Based on Poa procumbens Curtis. [The specimen mentioned by Thurber (Bolander 6467 ) is Poa unilateralis Scribn., with a fragment of Puccinellia rupestris, which is not known to occur in California.] ${ }^{29}$

Panicularia procumbens Kuntze, Rev. Gen. Pl. 2: 782. 1891. Based on Poa procumbens Curtis.

(2) Puccinellia simplex Scribn., U.S.Dept.Agr., Div. Agrost. Circ. 16: 1. f. 1. 1899. Woodland, Calif., Blankinship.

\section{(17) REDFIELDIA Vasey}

(1) Redieldia flexuosa (Thurb.) Vasey, Bull. Torrey Bot. Club 14: 133. pl. 70. 1887. Based on Graphephorum flexuosum Thurb.

Graphephorum flexuosum Thurb.; A. Gray, Acad. Nat. Sei. Phila. Proc. 1863: 78. 1863. "Colorado Territory", latitude $41^{\circ}$ [probably Nebraska], Hall and Harbour 635.

\section{(127) REIMAROCHLOA Hitchc.}

(1) Reimarochloa oligostachya Hitche., Contrib. U.S. Natl. Herb. 12: 199. 1909. Based on Reimaria obligostachya Munro.

Reimaria oligostachya Munro; Benth., Jour. Linn. Soe. Bot. 19: 34. 1881. [Jacksonville], Fla., Curtiss 3566.

\section{(149) RHAPHIS Lour.}

(1) Rhaphis pauciflorus (Chapm.) Nash, in Small, Fl. Southeast. U.S. 67. 1903. Based on Sorghum pauciflorum Chapm.

Sorghum pauciflorum Chapm., Bot. Gaz. 3: 20. 1878. Jacksonville, Fla., Chapman.

Chrysopogon pauciflorus Benth.; Vasey, Grasses U.S. 20. '1883. Based on Sorghum pauciflorum Chapm.

Chrysopogon wrightii Munro; Vasey, Deser. Cat. Grasses U.S. 29.1885. Based on Sorghum pauciflorum Chapm.

Andropogon pauciflorus Hack., in DC., Monogr. Phan. 6: 548. 1889. Based on sorghum pauciflorum Chapm.

\section{(153) ROTTBOELLIA L. f.}

(1) Rottboellia exaltata L. f., Sup. Pl. 114. 1781. India.

Manisuris exaltata Kuntze, Rev. Gen. Pl. 2: 779. 1891. Based on Rottbocllia cxaltata L. f.

Stegosia exaltata Nash, N. Amer. Fl. 17: 84. 1909. Based on Rottboellia exaltata L. f.

\section{(142) SACCHARUM L.}

Saccharum ciliare Anderss., Öfv. Svensk. Vet. Akad. Förh. 12: 155. 1855. India.

(1) Saccharum officinarum L., Sp. Pl. 54. 1753. India.

\section{(131) SACCIOLEPIS Nash}

Sacciolepis indica (L.) Chase, Biol. Soc. Wash. Proc. 21: 8. 1908. Based on Aira indica $\mathrm{L}$.

Aira spicata L., Sp. Pl. 63. 1753. India.

20 See Hitcheock, in Jepson, W., Flora of California, pt. 1, p. 158. 1912. 
Aira indica L., Sp. Pl. in Errata. 1753. Based on Aira spicata L. (p. 63). A change of name because of Aira spicata on page 64 of the same work. (See footnote $32, \mathrm{p} .975$.)

Panicum indicum I., Mant. Pl. 2: 184. 1771. Not P. indicum Mill., 1768. Based on Aira indica I.

Hymcnachne indica Buse, in Miquel, Pl. Jungh. 377. 1854. Based on Panicum indicum L.

Sacciolepis spicata Honda, Tokyo Univ. Jour. Faculty Sci., sec. 3. Bot. 3: 261. 1930. Based on Aira spicata L., Sp. Pl. 63.

Panicum spicatum Farwell, Rhodora 32: 262. 1930. Not P. spicatum Roxb., 1820. Based on Aira spicata L. Sp. Pl. 63.

(1) Sacciolepis striata (L.) Nash, Bull. Torrey Bot. Club 30: 383. 1903. Based on Holcus striatus L.

Holcus striatus L., Sp. Pl. 1048. 1753. Virginia, [Clayton 590].

Panicum striatum Lam., Tabl. Encycl. 1: 172. 1791. Carolina, Fraser.

Sorghum striatum Beauv., Ess. Agrost. 132, 165. 1812. Based on Holcus striatus L.

Panicum gibbum Ell., Bot. S.C. and Ga. 1: 116. 1816. Presumably South Carolina.

Panicum aquaticum Muhl., Descr. Gram. 126. 1817. Not P. aquaticum Poir., 1816. No locality cited.

Panicum fluitans Brickell; Muhl., Descr. Gram. 126. 1817, as synonym of $P$. aquaticum Muhl.

Panicum hydrophilum Schult., Mant. 2: 237. 1824. Based on P. aquaticum Muhl.

Panicum elliottianum Schult., Mant. 2: 256. 1824. Based on P. gibbum Ell.

Panicum aquaticum Bosc; Spreng., Syst. Veg. 1: 319. 1825. Not P. aquaticum Poir., 1816. Bermuda.

Hymenachne striata Griseb., Fl. Brit. W. Ind. 554. 1864. Based on Panicum striatum Lam.

Sacciolepis gibba Nash, in Britton, Man. 89. 1901. Based on Panicum gibbum Ell.

\section{(97) SCHEDONNARDUS Steud.}

(1) Schedonnardus paniculatus (Nutt.) Trel., in Branner and Coville, Rep. Geol. Survey Ark. 18884: 236. 1891. Based on Lepturus paniculatus Nutt.

Lepturus paniculatus Nutt., Gen. Pl. 1: 81. 1818. Mandan, N.Dak.

Rottboellia paniculata Spreng., Syst. Veg. 1: 300. 1825. Based on Lepturus paniculatus Nutt.

Schedonnardus texanus Steud., Syn. Pl. Glum. 1: 146. 1854. Texas, Drummond 360.

Spirochloe paniculata Lunell, Amer. Midl. Nat. 4: 220. 1915. Based on Lepturus paniculatus Nutt.

\section{(51) SCHISMUS Beauv.}

(1) Schismus barbatus (L.) Chase, Contrib. U.S. Natl. Herb. 24: 182. 1925. Based on Festuca barbata L.

Festuca barbata L., Amoen. Acad. 3: 400. 1756. Spain.

Schismus fasciculatus Beauv., Ess. Agrost. 74, 177. 1812, name only; Trin., Fund. Agrost. 148. 1820. No locality cited.

Schismus marginatus Beauv., Ess. Agrost. 177. pl. 15. f. 4. 1812. No locality cited.

\section{(29) SCHIZACHNE Hack.}

(1) Schizachne purpurascens (Torr.) Swallen, Jour. Wash. Acad. Sci. 18: 204. f. 1. 1928. Based on Trisetum purpurascens Torr.

Avena striata Michx., Fl. Bor. Amer. 1: 73. 1803. Not A. striata Lam., 1783. Between Hudson Bay and Lake Mistassini, Michaux.

Trisetum purpurascens Torr., Fl. North. and Mid. U.S. 1: 127. 1823. Williamstown, Mass., Dewey; also Boston, Catskill Mountains, N.Y., and Montreal.

Avena callosa Turcz., in Ledeb., Fl. Ross. 4: 416. 1853. Siberia.

Avena striata forma albicans Fernald, Rhodora 7: 244. 1905. Mount Albert, Quebec, Collins and Fernald 26. 
Melica striata Hitchc., Rhodora 8: 211. 1906. Based on Avena striata Michx.

Melica purpurascens Hitchc., Contrib. U.S. NatI. Herb. 12: 156. 1908. Based on Trisetum purpurascens Torr.

Schizachne fauriei Hack., Repert. Sp. Nov. Fedde 7: 323. 1909. Sachalin Island, Faurie.

Avena torreyi Nash, in Britt. and Brown, Illustr. Fl. ed. 2. 1: 219. 1913. Based on Trisetum purpurascens Torr., not Avena purpurascens DC., 1813. Bromelica striata Farwell, Rhodora 21: 77. 1919. Based on Avena striata Michx.

\section{(7) SCLEROCHLOA Beauv.}

(1) Sclerochloa dura (L.) Beauv., Ess. Agrost. 98, 174, 177. pl. 19. f. 4. 1812. Based on Poa dura L. (error for Scop.).

Cynosurus durus L., Sp. Pl. 72. 1753. Southern Europe.

Poa dura Scop., Fl. Carn. ed. 2. 1: 70. 1772. Based on Cynosurus durus L. Crassipes annuus Swallen, Amer. Jour. Bot. 18: 684. f. 1-4. 1931. Between Salt Lake City and Ogden, foot of Wasatch Mountains, Utah, Fallas in 1928.

\section{(4) SCLEROPOA Griseb.}

(1) Scleropoa rigida (L.) Griseb., Spic. Fl. Rum. 2: 431. 1844. Based on Poa rigida $\mathrm{L}$.

Poa rigida L., Cent. Pl. 1: 5. 1755; Amoen. Acad. 4: 265. $1759 . \quad$ Europe.

Poa cristata Walt., Fl. Carol. 80. 1788. Not P. cristata L., 1767. South Carolina.

Sclerochloa rigida Link, Enum. Pl. 1: 90. 1821. Based on Poa rigida L.

Festuca rigida Raspail, Ann. Sci. Nat., Bot. 5: 445. 1825. Based on Poa rigida L.

Synaphe rigida Dulac, Fl. Haut. Pyr. 90. 1867. Based on Scleropoa rigida Griseb.

Diplachne rigida Munro; Chapm. Fl. South. U.S. ed. 3. 609. 1897. Based on Poa rigida L.

\section{(38) SCLEROPOGON Phil.}

(1) Scleropogon brevifolius Phil., An. Univ. Chile 36: 206. 1870. Mendoza, Argentina.

Festuca macrostachya Torr. and Gray, U.S. Rept. Expl. Miss. Pacif. 24:177. 1855. Name only. Pecos, Tex. [Staminate specimen.]

Tricuspis monstra Munro; Hemsl., Diag. Pl. Mex. 56. 1880, as synonym of Scleropogon brevifolius Phil.

Lesourdia karwinskyana Fourn., Bull. Soc. Bot. France 27: 102. pl. 4. f. 12. 1850. Mexico, Karwinsky 992.

Lesourdia multifiora Fourn., Bull. Soc. Bot. France 27: 102. pl. 3, 4. 1880. Tampico, Mexico, Bernier.

Scleropogon karwinskyanus Benth.; S. Wats., Amer. Acad. Sci. Proc. 18: 181. 1883. Based on Lesourdia karwinskyana Fourn.

(50) SCRIBNERIA Hack.

(1) Scribneria bolanderi (Thurb.) Hack., Bot. Gaz. 11: 105. pl. 5. 1886. Based on Lepturus bolanderi Thurb.

Lepturus bolanderi Thurb., Amer. Acad. Sci. Proc. 7: 401. 1868. Russian River Valley, Calif., Bolander.

\section{(42) SECALE L.}

(1) Secale cereale L., Sp. Pl. 84. 1753. Europe.

Triticum cereale Salisb., Prodr. Stirp. 27. 1796. Based on Secale cereale L.

(135) SETARIA Beauv. ${ }^{30}$

Setaria barbata (Lam.) Kunth, Rév. Gram. 1: 47. 1829. Based on Panicum barbatum Lam.

Panicum barbatum Lam., Tabl. Encycl. 1: 171. 1791. Mauritius.

Panicum costatum Roxb., Fl. Ind. ed. Carey 1: 314. 1820. Mauritius.

Panicum viaticum Salzm.; Doell, in Mart., Fl. Bras. 22: 155. 1877. Bahia, Brazil, Salzmann 706.

${ }^{30}$ For discussion of types see Hitchc., Contrib. U.S. Natl. Herb. 22: 156-208. 1920. 
Chamaeraphis viatica Kuntze, Rev. Gen. Pl. 2: 770. 1891. Based on Panicum viaticum Salzm.

Chamaeraphis costata Kuntze, Rev. Gen. Pl. 2: 771. 1891. Bused on Panicum costatum Roxb.

Chaetochloa barbata. Hitche. and Chase, Contrib. U.S. Natl. Herb. 18: 348. 1917. Based on Panicum barbatum Lam.

(8) Setaria corrugata (Ell.) Schult., Mant. 2: 276. 1824. Based on Panicum corrugatum Ell.

Panicum corrugatum Ell., Bot. S.C. and Ga. 1: 113. 1816. Savannah, Ga., Baldwin.

Pennisetum corrugatum Nutt., Gen. Pl. 1: 55. 1818. Presumably based on Panicum corrugatum Ell.

Setaria glauca var. corrugata Schrad., Linnaea 12: 429. 1838. Based on S. corrugata Schult.

Chamaeraphis corrugata Kuntze, Rev. Gen. Pl. 2: 770. 1891. Based on Paricum corrugatum Eill.

Chaetochloa corrugata Scribn., U.S.Dept.Agr., Div. Agrost. Bull. 4: 39.1897. Based on Panicum corrugatum Ell.

Chaetochloa hispida Seribn. and Merr., U.S.Dept.Agr., Dir. Agrost. Bull. 21: 25. f. 13.1900. Cuba, Wright.

Setaria hispida Schum., Just's Bot. Jallresber. 281: 417. 1902. Based on Chaetochloa hispida Scribn. and Merr.

(2) Setaria geniculata (Lam.) Beaur., Ess. Agrost. 51, 178. 1812. Based on Panicum geniculatum Lam.

Panicum geniculatum Lam., Encycl. 4: 727 (err. typ. 737). 1798. Guadeloupe.

Cenchrus parviflorus Poir., in Lam., Eneycl. 6: 52. 1804. Puerto Rico.

Setaria gracilis H.B.K., Nov. Gen. and Sp. 1: 109. 1815. Colombia, Humboldt and Bonpland.

Setaria purpurascens H.B.K., Nov. Gell. and Sp. 1: 110. 1815. Ecuador, Humboldt and Bonpland.

Pennisetum geniculatum Jacq., Eclog. Gram. 3: pl. 26. 1815-1820. Based on Panicum geniculatum Lam.

Panicum imberbe Poir., in Lam., Encycl. Sup. 4: 272. 1816. North America and Brazil.

Panicum laevigatum Muhl.; Ell., Bot. S.C. and Ga. 1: 112. 1816. Not P. laevigatum Lam. 1778. Eddings Island, S.C. (Published as new in Muhl., Descr. Gram. 100. 1817 for the same species.)

Panicum glaucum var. purpurascens Ell., Bot. S.C. and Ga. 1: 113.1816. Muhl., Paris Island and Charleston Neck, S.C.

Panicum medium Muhl.; Ell., Bot. S.C. and Ga. 1: 113. 1816, as synonym of $P$. glaucum var. purpurascens Ell.

Setaria imberbis Roem. and Sehult., Syst. Veg. 2: 891. 1817. Based on Panicum imberbe Poir.

Pennisetum laevigatum Nutt., Gen. P1. 1: 55. 1818. Presumably based on Panicum laevigatum Muhl.

Setaria laevigata Sehult., Mant. 2: 275. 1824. Based on Panicum laevigatum Muhl.

Setaria affinis Schult., Mant. 2: 276. 1824. Based on Muhlenberg's Panicum no. 4. Georgia and Pennsylvania.

Setaria berteroniana Sehult., Mant. 2: 276. 1824. Dominiean Republic, Bertero.

Setaria glauca var. purpurascens Torr., Fl. North. and Mid. U.S. 153.1824. Based on Sctaria purpurascens H.B.K. Published as new by Urban (Symb. Antill. 4: 96.1903 ) based on the same type.

Panicum flavum Nees, Agrost. Bras. 238. 1829. Brazil.

Panicum dasyurum Nees, Agrost. Bras. 241. 1829. Brazil, Hoffmansegg; Montevideo, Sellow.

Panicum fuscescens Willd.; Nees, Agrost. Bras. 241. 1829, as synonym of P. purpurascens H.B.K." [South America, Humboldt].

Panicum penicillatum Willd.; Nees, Agrost. Bras. 242. 1829. Not $P$. penicillatum Nees; Trin. 1S26. Brazil.

Panicum tejucense Nees, Agrost. Bras. 243. 1829. Tejuco, Brazil.

Setaria flava Kunth, Rév. Gram. 1: 46. 1829. Based on Panicum flavum Nees.

Setaria ventenatii Kunth, Rév. Gram. 1: 251. pl. 37. 1830. Puerto Rieo.

Setaria tejucensis Kunth, Rév. Gram. 1: Sup. XI. 1830. Based on Panicum tejuccrese Nees.

$55974^{\circ}-35-60$ 
Setaria penicillata Presl, Rel. Haenk. 1: 314. 1830. Based on Panicum penicillatum Willd.

Panicum ventenatii Steud., Nom. Bot. ed. 2. 2: 265. 1841. Based on Setaria ventenatii Kunth.

Panicum berteronianum Stend., Syn. PI. Glum. 1: 50. 1854. Based on Setaria berteroniana Schult.

Setaria glauca var. laevigata Chapm., Fl. South. U.S. 578. 1860. Based on Panicum laevigatum Muhl.

Setaria stipaeculmis C. Muell., Bot. Ztg. 19: 323. 1861. Rio Brazos, Tex., Drummond.

Setaria glauca var. penicillata Griseb., Fl. Brit. W.Ind. 554. 1864. Based on Panicum penicillatum Willd.

Setaria glauca var. imberbis Griseb., F1. Brit. W.Ind. 554. 1864. Based on Panicum imberbe Poir.

Panicum imberbe var. dasyurum Doell, in Mart., Fl. Bras. 23: 157. 1877. Based on $P$. dasyurum Nees.

Panicum imberbe var. purpurascens Doell, in Mart., Fl. Bras. 22: 157. 1877. Based on P. purpurascens H.B.K.

Setaria streptobotrys Fourn., Mex. Pl. 2: 47. 1886. Mexico, Galeotti 5832, Liebmann 358, and several other collections cited.

Chamaeraphis glauca var. imberbis Kuntze, Rev. Gen. Pl. 2: 767. 1891. Based on Panicum imberbe Poir.

Chamaeraphis glauca var, penicillata Kuntze, Rev. Gen. Pl. 2: 767. 1891. Based on Panicum penicillatum Willd.

Chamaeraphis glauca var. geniculata Kuntze, Rev. Gen. Pl. 2: 767. 1891. Based on Panicum geniculatum Lam.

Setaria perennis Hall; Smyth, Check List Pl. Kans. 26. 1892. [Hutchinson], Kans., Smyth.

Setaria gracilis var. dasyura Arech., An. Mus. Nac. Montevideo 1: 165. 1894. Based on Panicum dasyurum Nees.

Chamaeraphis ventenatii Beal, Grasses N.Amer. 2: 153. 1896. Based on Setaria ventenatii Kunth.

Chamaeraphis glauca var. laevigata Beal, Grasses N.Amer. 2: 155. 1896. Based on Panicum laevigatum Muhl.

Chamaeraphis glauca var. perennis Beal, Grasses N.Amer. 2: 156.1896. Florida, Curtiss 3614.*

Chaetochloa imberbis Scribn., U.S.Dept.Agr., Div. Agrost. Bull. 4: 39. 1897. Based on Panicum imberbe Poir.

Chaetochloa penicillata Scribn., U.S.Dept.Agr., Div. Agrost. Bull. 4: 39. 1897. Based on Panicum penicillatum Willd.

Chaetochloa flava Scribn., U.S.Dept.Agr., Div. Agrost. Bull. 4: 39. 1897. Based on Panicum flavum Nees.

Chaetochloa versicolor Bicknell, Bull. Torrey Bot. Club. 25: 105. pl. 329.1898. New York City, Bicknell.

Chaetochloa perennis Bicknell, Bull. Torrey Bot. Club 25: 107. 1898. Based on C. glauca var. perennis Beal.

Chaetochloa laevigata Scribn., U.S.Dept.Agr., Div. Agrost. Bull. 21: 10. 1900. Based on Panicum laevigatum Muhl.

Chaetochloa imberbis penicillata Scribn. and Merr., U.S.Dept.Agr., Div. Agrost. Bull. 21: 11. f. 2. 1900. Based on Panicum penicillatum Willd.

Chaetochloa imberbis perennis Scribn. and Merr., U.S.Dept.Agr., Div. Agrost. Bull. 21: 12. 1900. Based on Setaria perennis Hall.

Chaetochloa imberbis geniculata Scribn. and Merr., U.S.Dept.Agr., Div. Agrost. Bull. 21: 12. 1900. Based on Panicum geniculatum Lam.

Chaetochloa imberbis streptobotrys Scribn. and Merr., U.S.Dept.Agr., Div. Agrost. Bull. 21: 13. 1900. Based on Setaria streptobotrys Fourn.

Chaetochloa purpurascens Scribn. and Merr., U.S.Dept.Agr., Div. Agrost. Bull. 21: 13. 1900. Based on Setaria purpurascens H.B.K.

Chaetochloa gracilis Scribn. and Merr., U.S.Dept.Agr., Div. Agrost. Bull. 21: 15. 1900. Based on Setaria gracilis H.B.K.

Chaetochloa corrugata parviflora Scribn. and Merr., U.S.Dept.Agr., Div. Agrost. Bull. 21: 24. 1900. Based on Cenchrus parviflorus Poir.

Ixophorus glaucus-laevigata Chapm., Gattinger, Tenn. Fl. 38. 1901. Presumably based on Setaria glauca var. laevigata Chapm.

Panicum glaberrimum Ell.; Scribn. and Merr., U.S.Dept.Agr., Div. Agrost. Circ. 29: 3. 1901. Not P. glaberrimum Steud., 1854. As synonym of Chaetochloa imberbis Scribn. 
Chaetochloa ventenatii Nasl, in Kearney, Contrib. U.S. Natl. Herb. 5: 515. 1901. Based on Setaria ventenatii Kunth.

Chaetochloa occidentalis Nash, in Britton, Man. 90. 1901. Kansas [type, Hutchinson, S'myth] and Oklahoma.

Panicum imberbe var. gracile Kneucker, Allg. Bot. Ztschr. S: 13. 1902. Based on Setaria gracilis H.B.K.

Setaria glauca var. geniculata Urban, Symb. Antill. 4: 96. 1903. Based on Panicum geniculatum Lam.

Setaria glauca var. purpurascens Urban, Symb. Antill. 4: 96. 1903. Based on S. purpurascens H.B.K.

Chaetochloa geniculata Millsp. and Chase, Field Mus. Bot. 3: 37. 1903. Based on Panicum geniculatum Lam.

Chamaeraphis imberbis Kuntze; Stuck., An. Mus. Nac. Buenos Aires 11: 76. 1904. Based on Panicum imberbe Poir.

Chamaeraphis gracilis Kuntze; Stuck., An. Mus. Nac. Buenos Aires 11: 76. 1904. Not C. gracilis Hack., 1885. Based on Setaria gracilis H.B.K.

Chamaeraphis penicillata Presl; Stuck., An. Mus. Nac. Buenos Aires 11: 76. 1904. Based on Setaria penicillata Presl.

Setaria imberbis var. perennis Hitchc., Rhodora 8: 210. 1906. Based on S. perennis Hall.

Setaria imberbis var. purpurascens Hack., in Stuck., An. Mus. Nac. Buenos Aires 13: 442. 1906. Based on S. purpurascens H.B.K.

Chatochloa imberbis versicolor Stone, N.J. Mus. Ann. Rept. 1910: 213. 1911. Based on C. versicolor Bicknell.

Panicum versicolor Nieuwl., Amer. Midl. Nat. 2: 64. 1911. Not P. versicolor Doell, 1877. Based on Chactochloa versicolor Bicknell.

Panicum occidentale Nieuwl., Amer. Midl. Nat. 2: 64. 1911. Not P. occidentale Scribn., 1899. Based on Chactochloa occidentalis Nash.

Chatochloa geniculata var. perennis House, N.Y. State Mus. Bull. 254: 85. 1924. Based on Setaria perennis Hall.

Chaetochloa viridis var. purpurascens Honda, Bot. Mag. Tokyo 38: 197. 1924. Based on Setaria purpurascens H.B.K.

Panicum lutescens var. flavum Backer, Handb. Fl. Java 2: 142. 1928. Based on P. flavum Nees.

(10) Setaria grisebachii Fourn., Mex. P1. 2: 45. 1886. Orizaba, Mexico, [Schaffner 36].

Setaria laevis Fourn., Mex. Pl. 2: 45. 1886. Bernal, Mexico, Karwinsky 961.

Chactochloa grisebachii Scribn., U.S.Dept.Agr., Div. Agrost. Bull. 4: 39. 1897. Based on Setaria grisebachii Fourn.

Chaetochloa grisebachii an pla Scribn. and Merr., U.S.Dept.Agr., Div. Agrost. Bull. 21: 36. f. 21. 1900. Federal District, Mexico, Pringle 4670 [error for 6470$]$.

Chaetochloa grisebachii mexicana Scribn. and Merr., U.S. Dept. Agr., Div. Agrost. Bull. 21: 37. 1900. San Luis Potosí, Mexico, Schaffner 1044.

Setaria mexicana Schaffn.; Scribn. and Merr., U.S. Dept.Agr., Div. Agrost. Bull. 21: 37. 1900, as synonym of Chaetochloa grisebachii mexicana Scribn. and Merr.

(13) Setaria italica (L.) Beauv., Ess. Agrost. 51, 170, 178. 1812. Based on Panicum italicum L.

Panicum italicum L., Sp. Pl. 56. 1753. India.

Panicum germanicum Mill., Gard. Dict. ed. S. Panicum no. 1. 1768. Europe.

Panicum italicum var. germanicum Koel., Descr. Gram. 17. 1802. Europe.

Pennisetum italicum R. Br., Prodr. Fl. Nov. Holl. 1: 195. 1810. Based on Panicum italicum L.

Setaria germanica Beauv., Ess. Agrost. 51, 169, 178. 1812. Based on Panicum germanicum Willd. (same as Mill. 1768).

Pennisetum germanicum Baumg., Enum. Stirp. Transsilv. 3: 277. 1816. Based on Sctaria germanica Beauv.

Setaria italica var. germanica Schrad., Linnaea 12: 430. 1838. Based on Panicum germanicum Roth (same as Mill. 1768).

Setaria californica Kellogg, Calif. Acad. Sci. Proc. 1 (ed. 2):26. 1873. Shasta, Calif., Dash.

Panicum italicum var. californicum Koern. and Wern., Handb. Getreidebau 1: 272, 273. 1885. California.

Chamaeraphis italica Kuntze, Rev. Gen. Pl. 2: 767. 1891. Based on Panicum italicum L. 
Chamaeraphis italica var. germanica Kuntze, Rev. Gen. Pl. 2: 768. 1891. Based on Panicum germanicum L. (error for Mill.).

Ixophorus italicus Nash, Bull. Torrey Bot. Club 22: 423. 1895. Based on Panicum italicum $\mathrm{L}$.

Chaetochloa italica Scribn., U.S.Dept.Agr., Div. Agrost. Bull. 4: 39. 1897. Based on Panicum italicum L.

Chaetachloa italica germanica Scribn., U.S.Dept.Agr., Div. Agrost. Bull. 6: 32. 1897. Based on Panicum germanicum Mill.

Chaetochloa germanica Smyth, Trans. Kans. Acad. 25: 89. 1913. Based on Panicum germanicum Mill.

Setaria italica subsp. stramineofructa subvar. germanica F. T. Hubb., Amer. Jour. Bot. 2: 189. 1915. Based on Panicum germanicum Mill.

Setaria italica subsp. stramineofructa var. brunneoseta subvar. densior F. T. Hubb., Amer. Jour. Bot. 2: 192. 1915. Weston, Mass., Williams in 1895.

(9) Setaria liebmanni Fourn., Mex. Pl. 2: 44. 1886. Mexico, Liebmann 389.

Setaria rariflora Presl, Rel. Haenk. 1: 313. 1830. Not S. rariflora Mikan, 1821. Acapulco, Mexico, Haenke.

Panicum rariflorum Presl; Steud., Sym. Pl. Glum. 1:51. 1854. Not P. rariflorum Lann., 1798. Based on Setaria rariflora Pres!.

Chamaeraphis caudata var. pauciflora Vasey; Beal, Grasses N.Amer. 2: 158. 1896. [Baja] California [type, Guaymas, Mexico], Palmer 191.

Chaetochloa liebmanni Scribn. and Merr., U.S.Dept. Agr., Div. Agrost. Bull. 21: 31. 1900. Based on Setaria liebmanni Fourn.

Chactochloa liebmanni pauciflora Scribn. and Merr., U.S.Dept.Agr., Div. Agrost. Bull. 21: 33. 1900. Based on Chamaeraphis caudata var. pauciflora Vasey.

(1) Setaria lutescens (Weigel) F. T. Hubb., Rhodora 18: 232. 1916. Based on Panicum lutescens Weigel.

Panicum lutescens Weigel, Obs. Bot. 20. 1772. Germany.

Panicum glaucum var. elongatum Pers., Syn. P1. 1: 81.1805. America.

Panicum glancum var. flavescens Ell., Bot. S.C. and Ga. 1: 113. 1816. Presumably South Carolina.

Panicum glaucum var. laevigatum LeConte; Torr., in Eaton, Man. Bot. ed. 2. 339. 1818. Northern and Middle States.

Setaria glauca var. elongata Raddi, Agrost. Bras. 49. 1823. Based on Panicum glaucum var. elongatum Pers.

Panicum compressum Balb.; Steud., Nom. Bot. ed. 2. 2: 254. 1841, erroneously cited as synonym of P. glaucum R. Br. [Dominican Republic, Bertero.]

Chaetochloa lutescens Stuntz, U.S. Dept.Agr., Bur. Plant Indus. Inventory Seeds 31: 36, 86. 1914. Based on Paricum lutescens Weigel.

Panicum glaucum L. has been shown to apply to pearl millet (see Pennisetum glaucum, p. 924). The name at an early date came to be used for the species here called Setaria lutescens. The following names have been misapplied to this species:

Panicum glaucur, L., Sp. Pl. 56. 1753.

Setaria glauca Beauv., Ess. Agrost. 51, 178. 1812.

Chamaeraphis giauca Kuntze, Rev. Gen. Pl. 2: 767. 1891.

Ixophorus glaucus Nash, Bull. Torrey Bot. Club 22: 423.1895.

Chaetachloa glauca Scribn., U.S.Dept.Agr., Div. Agrost. Bull. 4: 39.1897.

(4) Setaria macrosperma (Scribn. and Merr.) Schum., Just's Bot. Jahresber. 281: 417. 1902. Based on Chaetochloa macrosperma Scribn. and Merr.

Chaetochloo macrosperma Scribn, and Merr., U.S.Dept.Agr., Div. Agrost. Bull. 21: 33. f. 18. 1900. St. Johns River, Fla., Curtıss 3617.

(6) Setaria macrostachya H.B.K., Nov. Gen. and Sp. 1: 110. 1815. [Guanajuato], Mexico, Humboldt and Bonpland.

Panicum macrostachyum Nees, Agrost. Bras. 245. 1829. Based on Setaria macrostachya H.B.K.

Chamaeraphis setosa var. macrostachya Kuntze, Rev. Gen. Pl. 2: 769. 1891. Based on Setaria macrostachya H.B.K.

Chaetochloa gibbosa Seribn. and Merr., U.S.Dept.Agr., Div. Agrost. Bull. 21: 24. 1900. Mexico [probably Tamaulipas] Berlandier 528.

Chaetochloa leucopila Seribn. and Merr., U.S.Dept. Agr., Div. Agrost. Bull. 21: 26. f. 14. 1900. Parras, Coahuila, Palmer 1363 in 1880.

Chaetochloa macrostachya Seribn. and Merr., U.S.Dept.Agr., Div. Agrost. Bull. 21: 29. f. 16. 1900. Based on Setaria macrostachya H.B.K.

Chaetochloa rigida Seribn. and Merr., U.S.Dept.Agr., Div. Agrost. Bull. 21: 30. 1900. La Paz, Baja California, Palmer 125 in 1890. 
Setaria leucopila Schum., Just's Bot. Jaliresber. 281: 417. 1902. Based on Chaetochloa leucopila Scribn. and Merr.

Setaria gibbosa Schum., in Just's Bot. Jahresber. 28': 417. 1902. Based on Chaetochloa gibbosa Scribn, and Merr.

Setaria rigida Schum., in Just's Bot. Jahresber. 281: 417. 1902. Not S. rigida Stapf, 1899. Based on Chaetochloa rigida Seribn. and Merr.

Chamacraphis macrostachya Kuntze; Stuck., An. Mus. Nac. Bucnos Aires 11: 76. 1904. Based on Setaria macrostachya H.B.K.

Setaria commutala Hack.; Stuck., An. Hist. Nat. Buenos Aires 13: 439. 1906. Based on Chactochloa composita as described and figured by Scribner and Merrill (U.S.Dept.Agr., Div. Agrost. Bull. 21: 27 f. 15. 1900), not Setariu composita H.B.K. on which the name Chaetochloa composita Scribn. is based. The name is published as "Setaria commutata (Scribn.) Hack."

(11) Setaria magna Griseb., F1. Brit. W. Ind. 554. 1864. Jamaica, Purdie.

Chamaeraphis magna Beal, Grasses N.Amer. 2: 152. 1896. Based on Sctario magna Griseb.

Chaetochloa magna Scribn., U.S.Dept.Agr., Div. Agrust. Bull. 4: 39. 1897. Based on Setaria magna Griseb.

Setaria nigrirostris (Nees) Dur. and Schinz, Consp. Fl. Afr. 5: 774. 1894. Based on Panicum nigrirostris Nees.

Panicum nigrirostris Nees, Fl. Afr. Austr. 55. 1841. Sunth Africa.

Chatochloa nigrirostris Skeels, U.S.Dept.Agr., Bur. Plant Indus. Bull. 207: 22. 1911. Based on Panicum nigrirostris Nees.

Setaria palmifolia (Willd.) Stapf, Jour. Linn. Soc. Bot. 42: 186. 1914. Based on Fanicum palmifolium Koen. (Naturforscher 23: 208. 1788, same as P. palmifolium Willd., but inadequately published.)

Panicum plicatum Willd., Enum. Pl. 1033. 1809. Asia. Not P. plicatum Lam., 1791.

Panicum palmifolium Willd.; Poir., in Lam., Encycl. Sup. 4: 282.1816. Based on P. plicatum Willd.

Chamaeraphis palmifolia Kuntze, Rev. Gen. Pl. 2: 771. 1891. Based on Panicum palmifolium Willd.

Chaetochloa palmifolia Hitche. and Chase, Contrib. U.S. Natl. Herb. 18: 348. 1917. Based on Panicum palmifolium Willd.

Setaria poiretiana (Schult.). Kunth, Rév. Gram. 1: 47. 1829. Based on Panicum poiretianum Schult.

Panicum elongatum Poir., in Lam., Encycl. Sup. 4: 278. 1816. Not P. elongatum Salisb., 1796, nor Pursh, 1814. Brazil.

Panicum poiretianum Schult., Mant. 2: 229. 1824. Based on P. elongatum Poir.

Chaetochloa poiretiana Hitchc., Contrib. U.S. Natl. Herb. 22: 159. 1920. Based on Panicum poiretianum Schult.

Setaria rariflora Mikan; Trin., in Spreng., Neu. Entd. 2: 78. 1821. Brazil. Chaetochloa rariflora Hitche. and Chase, Contrib. U.S. Natl. Herb. 18: 349. 1917. Based on Setaria rariftora Mikan.

Panicum rariflorum Makino and Nemoto, Fl. Jap. 1475. 1925. Not P. rariftora Lam., 1798. Based on Setaria rariflora Mikan.

(7) Setaria scheelei (Steud.) Hitchc., Biol. Soc. Wash. Proc. 41: 163. 1928. Based on Panicum scheelei Steud.

Setaria polystachya Scheele, Linnaea 22: 339. 1849. Not S. polystachya Schrad., 1824. New Braunfels, Tex., Lindheimer 564.

Panicum scheelei Steud., Syn. P1. Glum. 1: 51. 1854. Based on Setaria polystachya scheele.

Chaetochloa polystachya Scribn. and Merr., U.S.Dept.Agr., Div. Agrost. Bull. 21: 37. f. 22. 1900. Based on Setaria polystachya Scheele.

Chaetochloa scheelei Hitchc., Contrib. U.S. Natl. Herb. 12: 207. f. 62. 1920. Based on Panicum scheelei Steud.

Setaria setosa (Swartz) Beauv., Ess. Agrost. 51, 178. 1812. Based on Panicum setosum Swartz.

Panicum setosum Swartz, Prodr. Veg. Ind. Occ. 22. 1788. Jamaica, Swartz.

Panicum caudatum Lam., Tabl. Encycl. 1: 171. 1791. Brazil.

Setaria caudata Roem. and Schult., Syst. Veg. 2: 495. 1817. Based on Penicum caudatum Lam.

Setaria setosa var. caudata Griseb., FI. Brit. W.Ind. 555. 186t. Based on Setaria caudata Roem. and schult. 
Pennisetum swartzii F. Muell., Fragm. Phyt. Austr. 8: 110. 1873. Based on Panicum setosum Swartz.

Chamaeraphis setosa Kuntze, Rev. Gen. Pl. 2: 768. 1891. Based on Panicum setosum Swartz.

Chamaeraphis caudata Britton, Ann. N.Y. Acad. Sci. 7: 264. 1893. Based on Panicum caudatum Lam.

Chaetochloa setosa Scribn., U.S.Dept.Agr., Div. Agrost. Bull. 4: 39. 1897. Based on Panicum setosum Swartz.

Chaetochloa caudata Scribn., Mo. Bot. Gard. Rept. 10: 52. 1899. Based on Panicum caudatum Lam.

(3) Setaria verticillata (L.) Beauv., Ess. Agrost. 51, 178. 1812. Based on Panicum verticillatum $\mathrm{L}$.

Panicum verticillatum L., Sp. Pl. ed. 2. 1: 82. 1762. Europe.

Pennisetum verticillatum R. Br., Prodr. Fl. Nov. Holl. 195. 1810. Based on Panicum verticillatum $\mathrm{L}$.

Chamaeraphis italica var. verticillata Kuntze, Rev. Gen. Pl. 2: 768. 1891. Based on Panicum verticillatum L.

Chamaeraphis verticillata Porter, Bull. Torrey Bot. Club 20: 196. 1893. Based on Panicum verticillatum L.

Ixophorus verticillatus Nash, Bull. Torrey Bot. Club 22: 422. 1895. Based on Panicum verticillatum $\mathrm{L}$.

Chactochloa verticillata Scribn., U.S.Dept.Agr., Div. Agrost. Bull. 4: 39. 1 S97. Based on Panicum verticillatum L.

Chaetochloa brevispica Scribn. and Merr., U.S.Dept.Agr., Div. Agrost. Bull. 21: 15. f. 5. 1900. Published as a new name for Panicum verticillatum var. parviflorum Doell, the identity of which is uncertain. The plants deseribed and figured by Seribner and Merrill are S. verticillata.

Setaria brevispica Schum., in Just's Bot. Jahresber. 28': 417. 1902. Based on Chactochloa brevispica Seribn. and Merr.

Chaetochloa verticillata var. brcviscta (Godr.) Farwell, Mich. Acad. Sci. Papers 1: 86. 1921, is based on a European type I have not examined.

Setaria verticillata var. ambigua Parl., Fl. Palerm. 1: 36.1845. Based on Panicum verticillatum var. ambiguum Guss.

Panicum verticillatum var. ambiguum Guss., Fl. Sic. Prodr. S0. 1827. Sicily.

Setaria ambigua Guss., Fl. Sie. Syn. 1: 114. 1842. Not S. ambigua Merat, 1836. Based on Panicum verticillatum var. ambiguum Guss.

Setaria viridis var. ambigua Coss. and Dur., Expl. Sci. Alger. 2: 36. 1867. Based on S. ambigua Guss.

Panicum ambiguum Hausskn., Oesterr. Bot. Ztschr. 25: 345. 1875. Based on Sctaria ambigua Guss.

Chamacraphis italica var. ambigua Kuntze, Rev. Gen. Pl. 2: 768. 1891. Based on Setaria ambigua Guss.

Chaetochloa ambigua Seribn. and Merr., U.S.Dept.Agr., Div. Agrost. Bull. 21: 18. f. 7. 1900. Based on Setaria verticillata var. ambigua Guss.

(5) Setaria villosissima (Scribn. and Merr.) Schum., Just's Bot. Jahresber. 281: 417. 1902. Based on Chaetochloa villosissima Scribn. and Merr.,

Chaetochloa villosissima Scribn. and Merr. U.S.Dept.Agr., Div. Agrost. Bull. 21: 34. f. 19. 1900. San Diego, Tex., J. G. Smith in 1897.

(12) Setaria viridis (L.) Beauv., Ess. Agrost. 51, 178. 1812. Based on Panicum viride L.

Panicum viride L., Srst. Nat. ed. 10. 2: 870. 1759. Europe.

Pennisetum viride R. Br., Prodr. Fl. Nor. Holl. 1: 195. 1810. Based on Panicum viride $\mathbf{L}$.

Setaria weinmanni Roem. and Schult., Syst. Veg. 2: 490.1817. Europe.

Panicum viride var. brevisetum Doell, Rhein. Fl. 128. 1843. Europe.

Setaria viridis var. weinmanni Borbás, Math. Termesz. Közlem. 15: 310. 1878. Based on Setaria weinmanni Roem. and Schult.

Panicum italicum var. viride Koern., in Koern. and Wern., Handb. Getreidebau. 1: 277. 1885. Based on Panicum viride L.

Setaria viridis var. purpurascens Peck; Dudley, Cornell Univ. Bull. 2: 122. 1886. Not S. viridis var. purpurascens Peterm., 1838. New York, Peck.

Chamaeraphis italica var. viridis Kuntze, Rev. Gen. Pl. 2: 767. 1891. Based on Panicum viride $\mathbf{L}$.

Chamaeraphis viridis Millsp., W.Va. Agr. Expt. Sta. Bull. 2: 466. 1892. Based on Panicum viride $\mathbf{L}$.

Ixophorus viridis Nash, Bull. Torrey Bot. Club 22: 423. 1895. Based on Panicum viride $\mathbf{L}$. 
Chaetochloa viridis Seribn., U.S.Dept.Agr., Div. Agrost. Bull. 4: 39.1897 Based on Panicum viride L.

Setaria viridis var. breviseta Hitehe., Rhodora 8: 210. 1906. Based on Panicum viride var. brevisetum Doell.

Setaria italica subsp. viridis Thell., Mém. Soc. Sci. Nat. Cherbourg 38: 85. 1912. Based on Panicum viride L.

Chactochloa viridis val. breviseta Farwell, Mich. Acad. Sci. Papers 1: 86. 1921. Based on Panicum viride var. brevisetum Doell.

Chaetochloa viridis var. weinmanni House, N.X. State Mus. Bull. 243-244: 39. 1923. Based on Setaria weinmanni Roem, and Sehult.

Chaetochloa viridis var. major (Gaudin) Farwell, Mieh. Aead. Sci. Papers 1: S6. 1921, and C. viridis var. minor (Koeh) Farwell (l.e.) are based on European types I have not examined.

\section{(44) SITANION Raf.}

(1) Sitanion hanseni (Seribn.) J. G. Smith, U.S.Dept.Agr., Div. Agrost. Bull. 18: 20. 1899. Based on Elymus hanseni Scribn.

Elymus hanseni Scribn., U.S.Dept.Agr., Div. Agrost. Bull. 11: 56. f. 12. 1898. Amador County, Calif., Hansen 1742.

Sitanion planifolium J. G. Smith, U.S.Dept.Agr., Div. Agrost. Bull. 18: 19. 1899. Skamania County, Wash., Suksdorf 224.

Sitanion anomalum J. G. Smith, U'.S.Dept.Agr., Div. Agrost. Bull. 18: 20. pl. 4. 1899. Pasadena, Calif., Allen in 1885.

Sitanion leckenbyi Piper, Erythea 7: 100. 1899. Wawawai, Wash., Piper 3003.

Sitanion rubescens Piper, Bull. Torrey Bot. Club. 30: 234. 1903. Mount Rainier, Wash., Piper 1954.

Elymus leckenbyi Piper, Contrib. U.S. Natl. Herb. 11: 151. 1906. Based on Sitanion leckenbyi Piper.

Sitanion hanseni anomalum Hitchc., Biol. Soe. Wash. Proc. 41: 160. 1928. Based on S. anomalum J. G. Smith.

(3) Sitanion hystrix (Nutt.) J. G. Smith, U.S.Dept.Agr., Div. Agrost. Bull. 18: 15. pi. 2. 1899. Based on Aegilops hystrix Nutt.

Aegilops hystrix Nutt., Gen. Pl. 1: 86. 1818. Plains of the Missouri.

Sitanion elymoides Raf., Jour. Phys. Chym. 89: 103. $1819 . \quad$ Missouri [River].

Elymus sitanion Schult., Mant. 2: 426. 1824. Based on Sitanion elymoides Raf.

Polyanthrix hystrix Nees, Am. Nat. Hist. 1: 284. 1838. Based on Aegilops hystrix Nutt., but misapplied to $S$. jubatum.

Elymus elymoides Swezey, Nebr. Pl. Doane Coll. 15. 1891. Based on Sitanion elymoides Raf.

Sitanion minus J. G. Smith, U.S.Dept.Agr., Div. Agrost. Bull. 18: 12.1899. Jacumba Hot Springs, Calif., Schoenefeldt 3277.

Sitanion rigidum J. G. Smith, U.S.Dept.Agr., Div. Agrost. Bull. 18: 13. 1899. Cascade Mountains, Wash., Allen 178.

Sitanion californicum J. G. Smith, U.S.Dept.Agr., Div. Agrost. Bull. 18: 13. 1899. San Bernardino Mountains, Calif., Parish 3295.

Sitanion glabrum J. G. Smith, U.S.Dept.Agr., Div. Agrost. Bull. 18: 14.1899. Coso Mountains, Calif., Coville and Funston 914.

Sitanion cinereum J. G. Smith, U.S.Dept.Agr., Div. Agrost. Bull. 18: 14. 1899. Reno, Nev., Tracy 222.

Sitanion insulare J. G. Smith, U.S.Dept.Agr., Div. Agrost. Bull. 18: 14. 1899. Carrington Island, Salt Lake, Utah, Watson 1338.

Chretomeris trichoides Nutt.; J. G. Smith, U.S.Dept.Agr., Div. Agrost. Bull. 18: 15. 1899, as synonym of Sitanion hystrix.

Elymus difformis Nutt.; J. G. Snith, U.S.Dept.Agr., Div. Agrost. Bull. 18: 15. 1899 , as synonym of Sitanion hystrix.

Sitanion montanum J. G. Smith, U.S.Dept.Agr., Div. Agrost. Bull. 18: 16. 1899. Spanish Creek, Mont., Rydberg 3091.

Sitanion caespitosum J. G. Smith, U.S.Dept.Agr., Div. Agrost. Bull. 18: 16. 1899. Cliff, N.Mex., J. G. Smith in 1897.

Sitanion strigosum J. G. Smith, U.S.Dept.Agr., Div. Agrost. Bull. 18: 17. 1899. Sheep Creek, Mont., Rydberg 3298.

Sitanion molle J. G. Smith, U.S.Dept.Agr., Div. Agrost. Bull. 18: 17.1899. Larimer County, Colo., Shear and Bessey 1469.

Sitanion brevifolium J. G. Smith, U.S.Dept.Agr., Div. Agrost. Bull. 18: 17. 1899. Tueson, Ariz., Toumey 797. 
Sitanion longifolium J. G. Smith, U.S.Dept.Agr., Div. Agrost. Bull. 18: 18. 1899. Silverton, Colo., Shear 1213.

Sitanion pubiflorum J. G. Smith, U.S.Dept.Agr., Div. Agrost. Bull. 18: 19. 1899. Tueson, Ariz., Toumey 795.

Sitanion latifolium Piper, Erythea 7: 99. 1899. Blue Mountains, Walla Walla County, Wash., Piper in 1896.

Sitanion marginatum Scribn. and Merr., Bull. Torrey Bot. Club 29: 469. 1902. Leigh Lake, Teton Mountains, Wyo., Merrill and Wilcox 334.

Elymus glaber Davy, Univ. Calif. Pubs., Bot. 1: 57. 1902. Based on Sitanion glabrum J. G. Smith.

Elymus pubiflorus Davy, Univ. Calif. Pubs., Bot. 1: 58. 1902. Based on Sitanion pubiflorum J. G. Smith.

Sitanion velutinum Piper, Bull. Torrey Bot. Club 30: 233. 1903. Steptoe, Wash., G. R. Vasey in 1901.

Sitanion basalticola Piper, Bull. Torrey Bot. Club 30: 234. 1903. Coulee City, Wash., Piper 3924.

Sitanion albescens Elmer, Bot. Gaz. 36: 57. 1903. Ellensburg, Wash., Whited 670.

Sitanion ciliatum Elmer, Bot. Gaz. 36: 58. 1903. Wenatchee, Wash., Whited in 1901.

Hordeum elymoides Schenck, Bot. Jahrb. Engler 40: 109. 1907. Based on Sitanion elymoides Raf.

Elymus brevifolius Jones, Contrib. West. Bot. 14: 20. 1912. Based on Sitanion brevifolium J. G. Smith.

Elymus hystrix Jones, Contrib. West. Bot. 14: 20. 1912. Not E. hystrix L. Based on Aegilops hystrix Nutt.

Elymus insularis Jones, Contrib. West. Bot. 14: 20. 1912. Based on Sitanion insulare J. G. Smith.

Elymus minor Jones, Contrib. West. Bot. 14: 20. 1912. Based on Sitanion minus J. G. Smith.

Sitanion rigidum var. californicum Smiley, Univ. Calif. Pubs., Bot. 9: 99. 1921. Based on S. californicum J. G. Smith.

Sitanion hordeoides Suksdorf, Werdenda 1²: 4. 1923. Spangle, Wash., Suksdorf 8705 .

(2) Sitanion jubatum J. G. Smith, U.S.Dept.Agr., Div. Agrost. Bull. 18: 10. 1899. Waitsburg, Wash., Horner 573.

Elymus sitanion jubatum J. G. Smith, U.S.Dept.Agr., Div. Agrost. Bull. 18: 10. 1899 , as symonym of S. jubatum.

Sitanion villosum J. G. Smith, U.S.Dept.Agr., Div. Agrost. Bull. 18: 11. pl. 1. 1899. Almota, Wash., Elmer 266.

Sitanion multisetum J. G. Smith, U.S.Dept.Agr., Div. Agrost. Bull. 18: 11. 1899. Tehachapi Valley, Calif., Coville and Funston 1121.

Sitanion polyanthrix J. G. Smith, U.S.Dept.Agr., Div. Agrost. Bull. 18: 12. 1899. California, Douglas. New name given to the species deseribed by Nees under Polyanthrix hystrix, that name being based on Aegilops hystrix Nutt.

Sitanion breviaristatum J. G. Smith, U.S.Dept.Agr., Div. Agrost. Bull. 18: 12. 1899. Panamint Mountains, Calif., Coville and Funston 833.

Sitanion strictum Elmer, Bot. Gaz. 36: 59. 1903. Parker, Wash., Elmer in 1898.

Elymus multisetus Jones, Contrib. West. Bot. 14: 20. 1912. Based on Sitanion multisetum J. G. Smith.

\section{(148) SORGHASTRUM Nash}

(2) Sorghastrum elliottii (Mohr) Nash, N.Amer. Fl. 17: 130. 1912. Based on Chrysopogon elliottii Mohr.

Chrysopogon elliottii Mohr, Bull. Torrey Bot. Club. 24: 21. 1897. Based on Andropogon nutans as described by Elliott, not A. nutans L.

(1) Sorghastrum nutans (L.) Nash, in Small, Fl. Southeast. U.S. 66. 1903. Based on Andropogon nutans L.

Andropogon nutans L., Sp. Pl. 1045. 1753. "Virginia, Jamaica." [Type eastern America, Kalm ${ }^{31}$; eited localities erroneous.]

?Stipa villosa Walt., Fl. Carol. 78. 1788. South Carolina.

?Stipa stricta Lam., Tabl. Encycl. 1: 158. 1791; Eneycl. 7:453. 1806. South Carolina, Fraser.

\footnotetext{
${ }^{31}$ For discussion see Hitchcock, A. S. Contrib. U.S. Natl. Herb. 12: 125. 1908.
} 
Andropogon avenaceus Michx., Fl. Bor. Amer. 1: 58. 1S03. Illinois, Michaux. Andropogon ciliatus Ell., Bot. S.C. and Ga. 1: 144. 1S16. Port Royal, S.C.

Sorghum nutans A. Gray, Man. 617. 1St8. Based on Andropogon nutans L.

Sorghum avenaceum Chapm., Fl. South. U.S. 583. 1S60. Based on Andropogon arenaceus Michx.

Chrysopogon nutans Benth., Jour. Linn. Soc. Bot. 19: 73. 18S1. Based on Andropogon nutans L.

Chrysopogon avenaceus Benth., Jour. Linn. Soc. Bot. 19: 73. 1881. Based on Andropogon avenaceus Michx.

Sorghum nutans subsp. avenaceum Hack., in Mart., Fl. Bras. 23: 274.1883. Based oll Andropogon avenaceus Michx.

Sorghum nutans subsp. linnaeanum Hack., in Mart., F1. Bras. 23: 276.1883. Based on Andropogon nutans L.

Andropogon albescens Fourn., Mex. Pl. 2: 56. 1856. Tera Cruz, Mexico, Gouin 53.

Andropogon confertus Trin.; Fourn., Mex. Pl. 2: 55. 1S\$6. Texas, Berlandier 1873.

Andropogon nutans var. arenaceus Hack., in DC., Monogr. Phan. 6: 530. 1859. Based on Andropogon avenaceus Michx.

Andropogon nutans var. linnaeanus Hack., in DC., Nionogr. Phan. 6: 531. 1859. Based on Sorghum nutans subsp. linnaeanum Hack.

Chrysopogon nutans var. avenaceus Coville and Branner, Rep. Geol. Surv. Ark. 4: 234. 1891. Based on Andropogon avenaceus Michx.

Poranthera nutans Raf.; Jacks., Ind. Kew. 3: 606. 1894, as synonym of Chrysopogon nutans.

Poranthera ciliata Raf.; Jacks., Ind. Kew. 3: 606. 1891, as synonym of Chrysopogon avenaceus.

Chrysopogon nutans var. linnacanus Mohr, Bull. Torrey Bot. Club 24: 21. 1597. Based on Sorghum nutans subsp. linnaeanum Hack.

Sorghastrum arenaceum Nash, in Britton, Man. 71. 1901. Based on Andropogon avenaceus Michs.

Andropogon linnaeanus Scribn. and Kearn.; Scribn. and Ball., U.S.Dept.Agr., Div. Agrost. Bull. 24: 40. 1901. Based on Sorghum nutans subsp. linnaeanum Hack.

Sorghastrum linnaeanum Nash, in Small, Fl. Southeast. U.S. 66. 1903. Based on Andropogon nutans var. linnacanus Hack., but misapplied to S. clliottii (Mohr) Nash.

Holcus nutans Kuntze; Stuck., An. Nus. Nac. Buenos Aires 11: 48.1904. Presumably based on Andropogon nutans L.

Holcus nutans var. avenaceus Hack.; Stuck., An. Mus. Nac. Buenos Aires 11: 48. 1904. Presumably based on Andropogon avenaceus Michx.

Chalcoelytrum nutaris Lunell, Amer. Midl. Nat. 4: 212. 1915. Based on Andropogon mutans L.

(3) Sorghastrum secundum (Ell.) Nash, in Small, Fl. Southeast. U.S. 67. 1903. Based on Andropogon secundus Ell.

Andropogon secundus Ell., Bot. S.C. and Ga. 1: 580. 1821. Between Flint and Chattahoochee Rivers, Ga.

Sorghum secundum Chapm., Fl. Soutlı. U.S. 5S3. 1860. Based on Andropogon secundus Ell.

Chrysopogon sccundus Benth.; Vasey, Grasses U.S. 20. 1SS3. Based on Sorghum secundum Chapm.

Andropogon unilateralis Hack., in DC., Monogr. Phan. 6: 533. 1859. Based on Sorghum secundum Chapm.

\section{(147) SORGHUM Moench}

(1) Sorghum halepense (L.) Pers., Syn. Pl. 1: 101. 1805. Based on Holcus halepensis L.

Holcus halepensis L., Sp. Pl. 1047. 1753. Syria.

Blumenbachia halepensis Kioel., Descr. Gram. 29. 1802. Based on Holcus sorghum L.

Milium halepense Cav., Descr. PI. 306. 1802. Based on Holcus halepensis L.

Andropogon halepensis Brot., Fl. Lusit. 1: 89. 1801. Based on Holcus halepensis $\mathrm{L}$.

Andropogon sorghum subsp. halepensis Hack., in DC., Monogr. Phan. 6: 501. 1859. Based on Holcus halepensis L.

Andropogon halepensis var. anatherus Piper, Biol. Soc. Wash. Proc. 28: 28. 1915. Marco, Fla., Hitchcoch Fla. Pl. 1900. Spikelets awnless. 
Sorghum virgatum (Hack.) Stapf, in Prain, Fl. Trop. Afr. 9: 111. on Andropogon sorghum subsp. halepensis var. virgatus Hack.

Andropogon sorghum subsp. halepensis var. virgatus Hack., in DC., Monogr. Phan. 6: 504. 1889. Egypt.

Holcus virgatus Bailey, Gentes Herb. 1: 132. 1923. Based on Andropogon sorghum subsp. halepensis var. virgatus Hack.

(2) Sorghum vulgare Pers., Syn. P1. 1: 101. 1805. Based on Holcus sorghum L. Holcus sorghum L., Sp. Pl. 1047. 1753. India.

Andropogon sorghum Brot., Fi. Lusit. 1: 88. 1804. Based on Holcus sorghum $\mathrm{L}$.

Holcus cernuus Muhl., Deser. Gram 276. 1817. Garden plant.

Andropogon vulgaris Raspail, Ann. Sci. Nat., Bot. 5: 307. 1825. Based on Sorghum vulgare Pers.

Sorghum vulgare var. bicolor Eaton and Wright, N.Amer. Bot. ed. 8. 438. 1840. Not S. vulgare var. bicolor Schrad., 1838. North America.

Sorghum sorghum Karst., Deut. Fl. 367. f. 189. 1880. Based on Holcus sorghum L.

Andropogon sorghum var. sativus Hack., in DC., Monogr. Phan. 6: 505. 1889. Group name.

Andropogon sorghum subsp. sativus var. vulgaris Hack., in DC., Monogr. Phan. 6: 515. 1889. Based on Sorghum vulgare Pers.

Andropogon sorghum var. vulgaris Hack.; Hook. f., Fl. Brit. Ind. 7: 184. 1896. Based on $\boldsymbol{A}$. sorghum subsp. sativus var. vulgaris Hack.

Sorghum vulgare var. CafFrorum (Thumb.) Hubb. and Rehder, Bot. Mus. Leaflets Harvard Univ. 1: 10. 1932. Based on Holcus caffrorum Thunb.

Holcus caffrorum Thunb., Prodr. Pl. Cap. 1: 20. 1794. South Africa.

Sorghum caffrorum Beauv., Ess. Agrost. 131, 164, 178. 1812. Based on Holcus caffrorum Thunb.

Holcus sorghum var. caffrorum Bailey, Gentes Herb. 1: 133. 1923. Based on Holcus caffrorum Thunb.

Sorghum volgare var. Drummondi (Nees) Hitche., Amer. Jour. Bot. 21: 139. 1934. Based on Andropogon drummondii Nees.

Andropogon drummondii Nees, in Steud., Syn. Pl. Glum. 1: 393. 1854. New Orleans, La., Drummond 588.

Andropogon sorghum subsp. sativus var. drummondii Hack., in DC., Monogr. Phan. 6: 507. 1889. Based on Andropogon drummondii Nees.

Sorghum drummondii Nees; Hack., in DC., Monogr. Phan. 6: 507. 1889, as synonym of Andropogon sorghum subsp. sativus var. drummondii Hack.

Holcus sorghum drummondii Hitchc., Biol. Soc. Wash. Proc. 29: 128.1916. Based on Andropogon drummondii Nees.

Sorghum VUlgare var. DURRA (Forsk.) Hubb. and Rehder, Bot. Mus. Leaflets Harvard Univ. 1: 10. 1932. Based on Holcus durra Forsk.

Holcus durra Forsk., Fl. Aegypt. Arab. 174. 1775. Egypt and Arabia.

Andropogon sorghum subsp. sativus var. durra Hack., in DC., Monogr. Phan. 6: 516. 1889. Based on Holcus durra Forsk.

Holcus sorghum var. durra Bailey, Gentes Herb. 1: 132. 1923. Based on Holcus durra Forsk.

Sorghum vulgare var. roxburghi (Stapf) Haines, Bot. Bihar and Orissa pt. 5: 1034. 1924. Based on Sorghum roxburghii Stapf.

Sorghum roxburghii Stapf, in Prain, Fl. Trop. Afr. 9: 126. 1917. Africa.

Sorghum volgare var. saccharatum (L.) Boerl., Ann. Jard. Bot. Buitenzorg 8: 69. 1890. Based on Sorghum saccharatum Pers.

Holcus saccharatus L., Sp. Pl. 1047. 1753. India.

Sorghum saccharatum Moench. Meth. Pl. 207. 1794. Based on Holcus saccharatus L. Listed as new Pers., Syn. P1. 1: 101. 1805, same basis.

Andropogon saccharatus Raspail, Ann. Sci. Nat., Bot. 5: 307. 1825. Based on Sorghum saccharatum Pers.

Andropogon sorghum var. saccharatus Alefeld, Landw. Fl. 313. 1866. Based on Holcus saccharatus L.

Sorghum halepense var. saccharatum Goiran, Nuov. Gior. Bot. Ital. n. s. 17: 39. 1910. Based on Holcus saccharatus L.

Holcus sorghum var. saccharatus Bailey, Gentes Herb. 1: 132. 1923. Based on Holcus saccharatus L.

Sorghum volgare var. sudanense (Piper) Hitche., Jour. Wasll. Acad. Sci. 17: 147. 1927. Based on Andropogon sorghum sudanensis Piper. (Published as S. vulgare sudanense.)

Andropogon sorghum sudanensis Piper, Biol. Soc. Wash. Proc. 28: 33.1915. Grown at Arlington Farm (near Washington, D.C.), seed from Sudan. 
Ifolcus sorghum sudanensis Hitchc., Biol. Soc. Wash. Proc. 29: 128.1916. Based on Andropogon sorghum sudanensis Piper.

Sorghum sudanense Stapf, in Prain, Fl. Trop. Afr. 9: 113. 1917. Based on Andropogon sorghum sudanensis Piper.

Holcus sudanensis Bailey, Gentes Herb. 1: 132. 1923. Based on Andropogon sorghum sudanensis Piper.

Sorghum vulgare var. Technicum (Koerm.) Jav. Magyar Fl. 1: 63. 1924. Based on Andropogon sorghum var. technicus lioern.

Andropogon sorghum var. tcchnicus Koern.; Koern. and Wern., Handb. Getreidebau. 1: 308.1885. Cultivated.

Andropogon sorghum subsp. sativus var. technicus Koern.; Hack., in DC., Monogr. Phan. 6: 508. 1889. Based on A. sorghum var. technicus Koerı.

Holcus saccharatus var. technicus Farwell, Mich. Aead. Sci. Ann. Rept. 20: 163. 1918. Based on Andropogon sorghum var. technicus Koern.

Holcus sorghum var. technicus Bailey, Gentes Herb. 1: 132. 1923. Based on Andropogon sorghum var. technicus Koern.

\section{(99) SPARTINA Schreb.}

(4) Spartina alterniflora Loisel., Fl. Gall. 719. 1807. France.

Dactylis maritima Walt., Fl. Carol. 77. 1788. Not D. maritima Curtis, 1787. Soutli Carolina.

Trachynotia alterniflora DC., Fl. Franç. 5: 279. 1815. Based on Spartina alterniflora Loisel.

Spartina glabra Muhl.; Ell., Bot. S.C. and Ga. 1: 95. pl. 4.f.2. 1816. South Carolina and Georgia.

Limnetis glabra Nutt., Gell. Pl. 1: 38. 1818, name only; Eaton and Wright, N.Amer. Bot. 301. 1840. Presumably based on Spartina glabra Muhl.

Spartina lacvigata Bosc; Spreng., Schrad. and Link, Jahrb. Gewachsk. 133: 92. 1820. North America, Bosc.

Trachynotia alternifolia Steud., Nom. Bot. ed. 2. 2: 695. 1841, error for T. alterniflora.

Spartina stricta var. alterniflora A. Gray, Man. ed. 2. 552. 1856. Based on S. alterniflora Loisel.

Spartina stricta var. glabra A. Gray, Man. ed. 2. 552. 1856. Based on S. glabra Muhl.

Spartina stricta maritima Scribn., Mem. Torrey Bot. Club 5: 45. 1894. Based on Dactylis maritima Walt.

Spartina glabra alterniflora Merr., U.S.Dept.Agr., Bur. Plant Indus. Bull. 9: 9. 1902. Based on Spartina alterniflora Loisel.

Spartina glabra pilosa Merr., U.S.Dept.Agr., Bur. Plant Indus. Bull. 9: 9. 1902. Atlantie City, N.J., Scribner in 1895.

Spartina alterniflora var. glabra Fernald, Rhodora 18: 178. 1916. Based on S. glabra Muhl.

Spartina alterniflora var. pilosa Fernald, Rhodora 18: 179. 1916. Based on S. glabra pilosa Merr.

Spartina maritima subsp. glabra var. glabra Grav; St. Yves, Candollea 5: 24, 49. pl. 1. f.b-2. 1932. Based on S. glabra Muhl.

Spartina maritima subsp. glabra var. alterniflora Merr.; St. Yves, Candollea 5: 25, 53. pl. 2. f.a-4. 1932. Based on S. alterniflora Loisel.

Spartina maritima subsp. glabra subvar. pilosa St. Yves, Candollea 5: 51. pl. 1. f.e-3. 1932. Based on S. glabra pilosa Merr.

$\times$ Spartina mcrrillii Chevalier, Bull. Soc. France 80: 787. pl. 8. f. 3. 1933. Long Island, N.Y., Bicknell 11300.

(6) Spartina bakeri Merr., U.S.Dept.Agr., Bur. Plant Indus. Bull. 9: $14 . \quad 1902$. Lake Ola, Fla., C. H. Baker 14.

Spartina juncea var. bakeri St. Yves, Candollea 5: 27, 91. pl. 9. f. c. 1932. Based on S. bakeri Merr.

(2) Spartina cynosuroides (L.) Roth, Catal. Bot. 3: 10. 1806. Based on Dactylis cynosuroides L.

Dactylis cynosuroides L., Sp. Pl. 71. 1753. Virginia, Canada.

Trachynotia polystachya Michx., Fl. Bor. Amer. 1: 64. 1803. New England to Florida. [Type, South Carolina, Michaux.]

Trachynctia cynosuroides Michx., Fl. Bor. Amer. 1: 64. 1803. Based on Dactylis cynosuroides L., but misapplied to S. pectinata.

Paspalum cynosuroides Brot., Fl. Lusit. 1: 83. 1804. Based on Dactylis cynosuroides L. 
Limnctis cynosuroides L. Rich., in Pers., Syn. Pl. 1: 72. 1805. Based on Dactylis cynosuroides $\mathbf{L}$.

Limnetis polystachia L. Rich., in Pers., Sym. PI. 1: 72. 1805. Bassed on Trachynotia polysiachya Michx.

Spartina polystachya Beauv., Ess. Agrost. 25, 178, 179. 1812. Presumably based on Trachynotia polystachya Michx.

Cynodon cynosuroides Raspail, Ann. Sci. Nat., Bot. 5: 303. 1825. Based on Spartina cynosuroides Roth.

Spartina cynosuroides var. polystachya Beal, Grasses N.Amer. 2: 398. 1896. Based on Trachynotia polystachya Michx.

(7) Spartina gracilis Trin., Mém. Acad. St. Pétersb. VI. Sci. Nat. 4': 110. 1840. North America.

(3) Spartina leiantha Benth., Bot. Voy. Sulph. 56. 1840. (Feb. or March.) Bay of Magdalena, Baja California, [Barclay].

Spartina foliosa Trin., Mém. Acad. St. Pétersb. VI. Sci. Nat. 41: 114.1840 (later than Jume). California.

Spartina densiflora subvar. brongniarti forma acuia St. Yves, Candollea 5: 76, 81. 1932. Eureka, Calif. [Heller 13871.]

(8) Spartina patens (Ait.) Muhl., Descr. Gram. 55. 1817. Based on Dactylis patens Ait.

Dactylis patens Ait., Hort. Kew. 1: 104. 1789. Grown in England, seed from North America.

Trachynotia juncea Michx., I1. Bor. Amer. 1: 64. 1803. South Carolina and Georgia, Michaux.

Limnetis juncca L. Rich., in Pers., Srn. P1. 1: 72. 1805. Based on Trachynotia juncea Michx.

Spartina pumila Roth, Catal. Bot. 3: 10. 1806. New York.

Spartina juncea Willd., Enum. Pl. 81. 1809. Based on Trachynotia juncea Michx.

Spartina americana Roth; Trin., Mém. Acad. St. Pétersb. VI. Sci. Nat. 41: 109. 1840, as synonym of s. juncea Willd.

Spartina patens var. juncea IHitchc., Rhodora 8: 210. 1906. Based on Trachynotia juncea Michx.

Spartina juncea subvar. americana St. Yves, Candollea 5: 27, 84. pl. 8. f. b-20. 1932. Based on S'. juncea Willd.

Spartina juncea var. patens St. Yves, Candollea 5: 27, 86. 1932. Based on Dactylis patens Ait.

Spartina Patens var. caespitosa (A. A. Eaton) Ilitche., Rhodora S: 210.1906. Based on S. caespitosa A. A. Eaton.

Spartina caespitosa A. A. Eaton, Bull. Torrey Bot. Club 25: 33S. 1898. Seabrook, N. H., A. A. Eaton.

(1) Spartina pectinata Link, Jahrb. Gewächsk 13: 92. 1820. North America, [type collected by Bose probably at Wilmington, N.C.].

Spartina cynosuroides var. aureo-marginata Irving, Gard. Chron. 38: 372. 1905. Grown at Kew Gardens, received from New York Botanical Garden.

Spartina michauxiana Hitche., Contrib. U.S. Natl. Herb. 12: 153.1908. Based upon the plant described by Michaux as Trachynotia eynosuroides (that name based on Dactylis cynosuroides I.). [Near Hudson Bav, Michaux.]

Spartina michauxiana var. suttiei Farwell, Mich. Acad. Sci. Rept. 21: 352. 1920. Orehard Lake, Mich., Suttie.

Spartina michauxiana var. tenuior Farmell, Mich. Acad. Sci. Rept. 21: 352. 1920. River Rouge, Mich., [Farwell] 5138.

Spartina cynosuroides var. michauxiana St. Yves, Candollea 5: 58. pl. 3 f. a-7. 1932. Based on S. michauxiana Hitche.

Spartina cynosuroides var. michauxiana forma major St. Yves, Candollea 5: 61,62. 1932. Canada, Victorin 1135s; Victorin and Germain 9055; other specimens cited from Nova Scotia, Newfoundland, Massachusetts, Ohio, Illinois, Minnesota, and Missouri.

Spartina cynosuroides $\times$ gracilis St. Yves, Candollea 5: 66. pl. 4. f. b-10. 1932. * * * "Oregon, Ballards Landing, Cusick 221 in 1890" [error for 2221 in 1899].

Spartina pectinata var. suttiei Fernald, Rhodora 35: 260. 1933. Based on S. michauxiana var. suttiei Farwell.

(5) Spartina spartinae (Trin.) Merr. U.S.Dept.Agr., Bur. Plant Indus. Bull. 9: 11. 1902, as synonym of S. junciform is Engelm. and Gray; Hitchc., Contrib. U.S. Natl. Ileri. 17: 329. 1913. Based on Vilfa spartinae Trin.

Vilfa spurtinae Trin. Mém. Acad. St. Pétersb. V1. Sci. Nat. $4^{1}$ : 82. 1840. Texas. 
Spartina junciformis Engelm. and Gray, Jour. Bost. Sor. Nat. Hist. 5: 238. 1845. Texas, Lindheimer [207].

Spartina gouini Fourn., Mex. Pl. 2: 135. 1886. Vera Cruz, Cimuin 72.

Spartina multiflora Vasey; Beal, Grasses N.Aner. 2: 400. 1896, as synonym of S. junciformis Engelm. and Gray.

Spartina pittieri Hack., Oesterr. Bot. Ztschr. 52: 237. 1902. Costa Rica, Pittier 4209.

Spartina densiflora var. junciformis St. Yves, Candollea 5: 26, 77. pl. 7. f. a-16. 1932. Based on S. junciformis Engeln. and Gray.

\section{(53) SPHENOPHOLIS Seribn.}

(5) Sphenopholis filiformis (Chapm.) Seribn., Rhodora 8: 144. 1906. Based on Eatonia pennsylvanica var. filiformis Chàpm.

Eatonia pennsylvanica var. filiformis Chapm., Fl. South. U.S. 560. 1860. Florida [type, Chapman], to South Carolina.

Eatonia filiformis Vaser, Bot. Gaz. 11: 117. 1886. Based on Eatonia pennsylvanica var. filiformis Chapm.

Eatonia hybrida Vasey; Beal, Grasses N.Amer. 2: 491. 1896. Florida, Curtiss in 1886. (The Hunting Creek, Va., speeimen referred to is Trisetum pennsylvanicum (L.) Beany., which see.)

Reboulea filiformis Farwell, Mich. Acad. Sei. Rept. 17: 182. 1916. Based on Eatonia pennsylunica var. filiformis Chapm.

(2) Sphenopholis intermedia (Rydb.) Rydb., Bull. Torrey Bot. Club 36: 533. 1909. Based on Eatonia intermedia Rydb.

Koeleria truncata var. major Torr., Fl. North. and Mid. U.S. 1: 117. 1823. Deerfield, Mass., Cooley.

Kocleria? pennsyluanica var. major Torr., Fl. N.Y. 2: 469. 1843. Based on Koeleria truncata var. major Torr.

Reboulea pennsylvanica var. major A. Gray, Man. 591. 1848. Presumably based on Koeleria truncata var. major Torr.

?Aira controversa Steud., Syn. Pl. Glum. 1: 224. 1854. Cincinnati and Miami, Ohio.

?Aira capillacea Frank; Steud., Syn. Pl. Glum. 1: 224. 1854, as synonym of A. controversa Steud.

Eatonia pennsylwanica var. major A. Gray, Man. ed. 2. 558. 1856. Presumably based on Koeleria truncala var. major Torr.

Vilfa alba Buckl., Acad. Nat. Sci. Phila. Proc. 1862: 89. 1863. Not V. alba Beauv., 1812. "Oregon, Spalding" (locality probably erroneous, the ticket on the type specimen erossed out).

Eatonia intermedia Rrdb., Bull. Torrey Bot. Club 32: 602. 1905. East Gallatin Swamps, Mİont., Rydberg 3174.

Sphenopholis pallens major Scribn., Rhodora S: 145. 1906. Based on Koeleria truncata var. major Torr.

Sphenopholis pallens var. major Seribn.; Robinson, Rhodora 10: 65. 1908. Based on Koeleria truncata var. major Torr.

Reboulca jallens var. major Fartell, Mich. Acad. Sci. Rept. 17: 182.1916. Based on Koeleria truncata var. major Torr.

This is the species which has recently been called Sphenopholis pallens Scribu., but it is not the same as Aira pallens Spreng., on which that name is based.

(3) Sphenopholis Iongiflora (Vasey) Hitche., Jour. Wash. Acad. Sei. 23: 453. 1933. Based on Eatonia pennsylvanica var. longiflora Vasey.

Eatonia pennsyluanica var. longiflora Vases; L. H. Dewey, Contrib. U.S. Natl. Herb. 2: 541. 1894. Houston, Tex., Neallcy in 1892.

Eatonia longiftora Beal, Grasses N.Amer. 2: 494. 1896. Based on E. ponnsylvanica var. longiflora Vasey.

Sphenopholis pallens longiflora Seribn., Rhodora 8: 145. 1906. Based on Eatonia pennsyluanica var. longiflora Vasey.

Reboulea pallens var. longiflora Farwell, Mich. Acad. Sei. Rept. 17: 182. 1916. Based on Eatonia longiflora Beal.

(4) Sphenopholis nitida (Spreng.) Seribn., Rhodora S: 144. 1906. Based on Aira nitida Spreng.

Aira nitida Spreng., Mant. Fl. Hal. 32. 1807. Pennsylvania, Muhlenberg. Aira pennsylvanica Spreng., Mém. Acad. St. Pétersb. 2: 299. pl. 7. 1807-08. Pennsvlvaria.

Koeleria pennsylvanica DC., Cat. Itort. Monsp. 117. 1813. Based on Aira pennsyluanica Spreng.

Aira mollis Muhl., Deser. Gram. 82. 1817. Not A. mollis Senreb., 1771. Pennsylvania. 
Trisetum pennsylvanicum Trin., Mém. Acad. St. Pétersb. VI. Matl. Phys. Nat. 1: 66. 1830. Not T. pennsylvanicum Beauv. Based on Aira pennsylvanica Spreng.

Glyceria pennsylvanica Heynh., Nom. 1: 361. 1840. Based on Aira pennsylvanica Spreng.

Reboulea pennsylvanica A. Gray, Man.591. 1848. Based on Koeleria pennsylvanica DC.

Eatonia pennsyluanica A. Gray, Man. ed. 2: 558. 1856. Based on Koeleria pennsyluanica DC.

Eatonia dudleyi Vasey, Bot. Gaz. 11: 116. 1886. Michigan to Long Island, and Pennsylvania to North Carolina. [Tvpe, Ithaca, N.Y., Dudley in 1882.]

Eatonia nitida Nash, Bull. Torrey Bot. Club 22: 511. 1S95. Based on Airr nitida Spreng.

Eatonia glabra Nash, in Britton, Man. 1043. 1901. Madison County, Tenn., Bain 507.

Sphenopholis nitida glabra Scribn., Rhodora 8: 145. 1906. Based on Eatonia glabra Nash.

Sphenopholis nitida var. glabra Scribn.; Robinson, Rhodora 10: 65. 1908. Based on Eatonia glabra Nash.

Sphenopholis glabra Heller, Muhlenbergia 6: 12. 1910. Based on Eatonia glabra Nash.

Reboulea nitida Farwell, Mich. Aead. Sei. Rept. 17: 181. 1916. Based on Aira nitida Spreng.

Reboulea nitida var. glabra Farwell, Mich. Aead. Sei. Rept. 17: 181.1916. Based on Eatonia glabra Nash.

(1) Sphenopholis obtusata (Michx.) Seribn., Rhodora 8: 144. 1906. Based on Aira obtusata Michx.

Aira obtusata Michx., Fl. Bor. Amer. 1: 62. 1803. Carolina to Florida [type], Michaux.

Airopsis obtusata Desv., Jour. Bot. 1: 200. 1808. Based on "Agrostis" [error for Aira] abtusata Michx.

Festuca obtusata Michx.; Beauv., Ess. Agrost. 163. 1812. Name only, probably error for Aira obtusata Michx.

Aira truncata Muhl., Deser. Gram. 83. 1817. Pennsylvania.

Koeleria paniculata Nutt., Gen. Pl. 2: (Add. 2): 1818. East Florida, T. Say.

Koeleria truncata Torr., F1. North. and Mid. U.S. 1: 116. 1823. Based on Aira truncata Muhl.

Poa obtusata Link, Handb. Gewächs. 1: 71. 1829. Based on Aira obtusata Michx.

Réoulea gracilis Kunth, Rév. Gram. 2: 341. pl. 84. 1830. New England to Florida.

Trisctum lobatum Trin., Mém. Acad. St. Pétersb. VI. Math. Phys. Nat. 1: 66. 1830. North America.

Agrostis obtusata Steud., Nom. Bot. ed. 2. 1: 41. 1840, as synonym of Airopsis obtusata Desv.

Kacleria lobata Trin.; Steud., Nom. Bot. ed. 2. 1: 849.1840. Not K. lobata Roem. and Schult., 1817. As synonym of Reboulea gracilis Kunth.

Koeleria obtusata Trin.; Steud., Nom. Bot. ed. 2. 1:849. 1840, as synonym of Airopsis obtusata Desv.

Rebaulea obtusata A. Gray, Man. 591. 1848. Based on Aira obtusata Michx.

Eatonia obtusaia A. Gray, Man. ed. 2. 558. 1856. Based on Aira obtusate Michx.

Ricboulea truncata Torr.; Munro, Jour. Linn. Soc. Bot. 6: 43. 1862, as synonym of $R$. gracilis Kunth.

Graphephorum densiflorum Fourn., Bull. Soc. Bot. France 24: 182.1877. Name only. Mexico [Texas], Berlandier 1617.

Eatonia densiflora Fourn., Mex. Pl. 2: 111. 1886. Bejar, Tex., Berlandior 1617.

Aira mexicana Trin.; Fourn., Mex. Pl. 2: 111. 18S6, as synonym of Eatonia densiflora Fourn.

Eatonia obtusata var. robusta Vasey; L. H. Dewey, Contrib. U.S. Natl. Herb. 2: 544. 1894. Western Texas [Wallisville, Wallis in 1881] to Arizona.

Eatonia obtusata var. robusta Vasey; Rydb., Contrib. U.S. Natl. Herb. 3: 190. 1895. Mullen, Nebr., Rydberg 1807.

Eatonia abtusata var. purpurascens Vasey; Rydb. and Shear, U.S. Dept.Agr., Div. Agrost. Bull. 5: 30. 1897. "Vasey in U.S. Natl. Herb." This, the type, from False Washita, Okla., Palmer 404; Nebraska, Sheur 252, 2521/2, Rydberg 2002, Kearney 271, also cited. 
Eatonia pubescens Scribn. and Merr., T.S.Dept.Agr., Div. Agrost. Circ. 27: 6 1900. Starkville, Miss., Tracy.

Eatonia robusta Rydb., Bull. Torrey Bot. Club 32: 602. 1905. Based on E'. obtusata var. robusta Vasey.

Sphenopholis obtusata lobata Scribn., Rhodora 8: 144. 1906. Based on Trisetum lobatum Trin.

Sphenapholis obtusata pubescens Scribn., Rhodora 8: 144. 1906. Based ou Eatonia pubescens Scribn. and Merr.

Eatonia annua Suksdorf, West. Amer. Sci. 15: 50. 1906. Dalles on Columbia River, Oreg., Suksdorf 1553. [Plants depauperate, flowering first year.]

Sphenopholis abtusata var. pubescens Scribn.; Robinson, Rhodora 10: 65. 1908. Based on Eatonia pubescens Scribn. and Nierr.

Sphenopholis obtusata var. lobata Scribn.; Robinson, Rhodora 10: 65. 1908. Based on Trisctum lobatum Trin.

Sphenopholis annua Heller, Muhlenbergia 6: 12. 1910. Based on Eatoniu annua Suksdorf.

Sphenophalis pubescens Heller, Muhlenbergia 6: 12. 1910. Based on Eatonia pubcsens Scribn. and Merr.

Sphenophalis robusta Heller, Muhienbergia 6: 12. 1910. Based on Eatonia abtusata var. robusta Vasey.

Reboulea obtusata var. lobata Farwell, Mich. Acad. Sci. Rept. 17: 182. 1916. Based on Trisetum lobatum Trin.

Reboulea obtusata var. pubescens Farwell, Mich. Acad. Sci. Rept. 17: 181. 1916. Based on Eatonia pubescens Scribn. and Merr.

(6) Sphenopholis pallens (Spreng.) Scribn., Rhodora 8: 145. 1906. Based on Aira pallens Spreng.

Aira pallens Spreng., Mant. Fl. Hal. 33. 1507. Pennsylvania, Muhlenberg.

Aira pallens Muhl., Descr. Gram. 84. 1817. No locality cited. Aira pennsylvanica Spreng., erroneously given as synonym, Muhlenberg's description agreeing with that of $A$. pallens Spreng., not with that of $A$. pennsylvanica Spreng.

Eatonia aristata Scribn. and Merr., U.S.Dept.Agr., Div. Agrost. Circ. 27: 7. 1900. South Carolina, Curtiss in 1876.

Eatonia pallens Seribn. and Merr., U.S.Dept.Agr., Div. Agrost. Circ. 27: 7. 1900. Based on Aira pallens Spreng.

Trisetum aristatum Nash, in Small, Fl. Southeast. U.S. 130. 1903. Presumably based on Eatonia aristata Seribn. and Merr.

Sphenopholis aristata Heller, Muhlenbergia 6: 12. 1910. Based on Eatonia aristata Scribn. and Merr.

Reboulea pallens Farwell, Mich. Acad. Sci. Rept. 17: 181. 1916. Based on Aira pallens Spreng.

(76) SPOROBOLUS R. Br.

(26) Sporobolus airoides (Torr.) Torr., U.S. Rept. Expl. Miss. Pacif. 7: 21. 1856. Based on Agrostis airaides Torr.

Agrostis airoides Torr., Ann. Lye. N.Y. 1: 151. 1824. Branches of the Arkansas River near the Rocky Mountains, James.

Tilfa airoides Trin.; Stend., Nom. Bot. ed. 2. 2: 766. 1841. Based on Agrostis airoides Torr.

Sporobolus diffusissimus Bucki., Acad. Nat. Sci. Phila. Proc. 1862: 90. 1863. Western Texas [Wright 726].

(18) Sporobolus argutus (Nees) Kunth, Rév. Gram. 1: Sup. XVII. 1830. Based on Tilja arguta Nees.

Vilfa arguta Nees, Agrost. Bras. 395. 1829. Brazil.

Vilfa arkansana Trin., Mém. Acar. St. Pétersb. VI. Sci. Nat. 41: 64. 1840. Arkansas, Beyrich.

Vilfa subpyramidata Trin., Mém. Acad. St. Pétersb. VI. Sci. Nat. 41: 61. 1840. Texas [received from Hooker, the type being Drummond 377].

Vilfa richardi Steud., Syn. Pl. Glum. 1: 153. 1854. West Indies.

Agrostis pyramidalis Rich.; Steud., Syn. Pl. Glum. 1: 15:3. 1854, as synonym of I'ilfa richardi Steucl.

Vilfa agrostoidea Buckl., Acad. Nat. Sci. Phila. Proc. 1s62: 8s. 1863. Llano County, Tex.

Vilfa sabeana Bucli., Acad. Nat. S̀ci. Phila. Proc. 1562: 90. 1863. San Saba County, Tex., Buckley. Given as Vilfa (Sparobolus) subeana.

Sporobolus arkansanus Nutt.; Vasey, Contrib. U.S. Natl. Herb. 3: 6.1. 1892, as synonym of S. argutus Kuntl. 
Sporobolus sabeanus Buckl.; Vasey, Contrib. U.S. Natl. Herb. 3: 61. 1892, as synonym of $S$. argutus Kunth.

(8) Sporobolus asper (Michx.) Kunth, Rév. Gram. 1: 68. 1829. Based on Agrostis aspera Michx.

Agrostis aspera Michx., Fl. Bor. Amer. 1: 52. 1803. Illinois, Michaux.

Agrostis composita Poir., in Lam., Encycl. Sup. 1: 254. 1810. Carolina, Bosc. Tilfa aspera Beauv., Ess. Agrost. 16, 147, 181. 1812. Based on Agrostis aspera Michx.

Vilfa composita Beauv., Ess. Agrost. 16, 147, 181. 1812. Based on Agrostis composita Poir.

Agrostis involuta Muhl., Deser. Gram. 72. 1817. Susquehanna, Pa., and New Jersey.

Agrostis longifolia Torr., Fl. North. and Mid. U.S. 1: 90. 1823. Kingsbridge, N.Y.; Hoboken, N.J.; Deerfield, Mass.; Pennsylvania, Muhlenberg.

Muhlenbergia aspera Trin.; Kunth, Enum. Pl. 1: 210. 1833. Based on Agrostis aspera Michx.

Muhlenbergia composita Trin.; Kunth, Enum. Pl. 1: 229. 1833. Based on Agrostis composita Poir.

Vilfa longifolia Torr.; Trin., Mém. Acad. St. Pétersb. VI. Sci. Nat. 41: 107. 1S40. Based on Agrostis longifolia Torr.

Sporobolus longifolius Wood, Class-book 775. ed. 3. 1861. Based on Agrostis longifolia Torr.

Sporobolus compositus Merr., U.S.Dept.Agr., Div. Agrost. Circ. 35: 6. 1901. Based on Agrostis composita Poir.

Sporobolus asper var. hookeri (Trin.) Vasey, Deser. Cat. Grasses U.S. 43. 1885. Based on T'ilfa hookeri Trin.

Trilfa drummondii Trin., Mém. Acad. St. Pétersb. VI. Sci. Nat. 41: 106. 1840. Texas, received from Hooker and Endlicher [the type Drummond II. 306b].

Vilfa hookeri Trin., Mém. Acad. St. Pétersb. VI. Sci. Nat. 4¹: 106.1840.

Texas, received from Hooker [trpe Drummond II. 306].

Glyceria stricta Buckl., Acad. Nat. Sci. Phila. Froc. 1862: 95. 1S63. Middle Texas, Buckley. Inflorescence abnormal, the spikelets diseased, with 2 or 3 several-nerved lemmas.

Sporobolus drummondii Vasey, Deser. Cat. Grasses U.S. 44. 1855. Based on Vilfa arummondii Trin.

Sporobolus asper var. drummondii Vasev, Contrib. U.S. Natl. Herb. 3: 60. 1S92. Based on Vilfa drummondii Trin.

Sporobolus attenuatus Nash, in Small, Fl. Southeast. U.S. 123. 1903. Starkville, Miss., Kearney $\$ 3$.

Sporobolus Asper var. Pilosus (Vasey) Hitche., Biol. Soc. Wash. Proc. 41: 161. 1928. Based on S. pilosus Vasey. (Published as S. asper pilosus.)

Sporoboluts pilosus Vasey, Bot. Gaz. 16: 26.1891. Kansas, Smyth.

(25) Sporobolus buckleyi Vasey, Bull. Torrey Bot. Club 10: 128. 1883. Texas, Buckley.

(10) Sporobolus clandestinus (Spreng.) Hitchc., Contrib. U.S. Natl. Herb. 12: 150. 1908. Based on Agrostis clandestina Spreng.

Agrostis clandestina Spreng., Mant. Fl. Hal. 32. 1807. Pennsylvania, Muhlenberg.

Muhlenbergia clandesina Trin., Gram. Unifl. 190. 1824. Based on Agrostis clandestina Spreng.

Vilfa clandestina Nees; Steud., Nom. Bot. ed. 2. 2: 767. 1841. Based on Agrostis clandestina Spreng.

? Vilfa richlii Steud., Syn. Pl. Glum. 1: 154. 1854. North America.

Sporobolus canovirens Nash; Britton, Man. 1042. 1901. Tennessee to Kansas [type, St. George, Kellerman in 1890], Mississippi and Texas.

(23) Sporobolus contractus Hitchc., Amer. Jour. Bot. 2: 303. 1915. Based on Sporobolus strictus Merr.

Sporobolus cryptandrus var. strictus Scribn., Bull. Torrey Bot. Club 9: 103. 18S2. Camp Lowell, Ariz., Pringle.

Sporobolus strictus Merr., U.S.Dept.Agr., Div. Agrost. Circ. 32: 6. 1901. Not S. strictus Franch., 1893. Based on Sporobolus cryptandrus var. strictus Seribn.

(20) Sporobolus cryptandrus (Torr.) A. Gray, Man. 576. 1848. Based on Vilfa cryptandra Torr.

Agrostis cryptandra Torr., Ann. Lyc. N.Y. 1: 151. 1S24. Canadian River [Texas or Oklahoma], James.

Tilfa tenacissima var. fuscicola Hook., Fl. Bor. Amer. 2: 239. 1839. Menzies Island, Columbia River, Wash. 
Tilfa cryptandra Torr.; Trin., Mém. Acad. St. Pétersb. VI. Sei. Nat. 41: 69 1840. Based on Agrostis cryptandra Torr.

Vilfa triniana Steud. Syn. Pl. Glum. 1: 156. 1854. [British] Columbia.

Sporobolus cryptandrus vaginatus Lmell, Amer. Midl. Nat. 2: 123.1911. Benson County, N.Dak., Lunell in 1911.

Sporobolus cryptandrus var. involutus Farwell, Mich. Acad. Sci. Rept. 22: 179. 1921. Rochester, Nich., Faruell 5393.

(13) Sporobolus curtissii (Vasey) Small; Kearney, U.S.Dept.Agr., Div. Agrost. Bull. 1: 24. 1895. "S. flaridanus curtissii Vasey in Herb." cited; Scribn., U.S.Dept.Agr., Div. Agrost. Bull. 7: 142. f. 124. 1897. Based on S. floridanus var. curtissii Vasey; Beal.

Sporobolus floridanus var. curtissii Vasey; Kearney, U.S.Dept.Agr., Div. Agrost. Bull. 1: 24. 1895, as synonym of S. curtissii; Beal, Grasses N.Amer. 2: 290. 1896. Florida, Curtiss.

(19) Sporobolus domingensis (Trin.) Kunth, Rév. Gram. 1: Sup. XVII. 1830. Based on Vilfa domingensis Trin.

Tilfa domingensis Trin., in Spreng., Neu. Entd. 2: 59. 1821. Dominican Republic.

Agrostis domingensis Schult., Mant. 3 (Add. 1): 570. 1827. Based on Vilfa domingensis Trin.

Sporobolus inordinatus Mez, Repert. Sp. Nov. Fedde 17: 294. 1921. Cuba, Ramon de la Sagra.

(21) Sporobolus flexwosus (Thurb.) Rydb., Bull. Torrey Bot. Club 32: 601. 1905. Based on Sporobolus cryptandrus var. flexuosus Thurb.

Vilfa cryptandra var. flexuosa Thurb.; Vasey, in Wheeler Rep. U.S. Survey 100th Merid. 6: 282. 1878. Nevada and Arizona, Wheeler Exped.

Sporobolus cryptandrus var. flexuosus Thurb., in S. Wats., Bot. Calif. 2: 269. 1880. Based on Vilfa cryptandra var. flexuosa Thurb.

(15) Sporobolus floridanus Chapm., Fl. South. U.S. 550. 1860. Middle and west Florida, [Chapman].

(24) Sporobolus giganteus Nash, Bull. Torrey Bot. Club 25: 88. 1898. Doña. Ana County, N.Mex., Wooton 394.

Sporobolus cryptandrus var. robustus Vasey, Contrib. U.S. Natl. Herb. 1: 56 1890. Texas, Nealley [746].

Sporobolus cryptandrus var. giganieus Jones, Contrib. West. Bot. 14: 11.1912. Based on S. giganteus Nash.

(16) Sporobolus gracilis (Trin.) Merr., Rhodora 4: 48. 1902. Based on Vilfa gracilis Trin.

Agrostis juncea Michx., Fl. Bor. Amer. 1: 52. 1803. Not. A. juncea Lam., 17S3. Carolina, Michaux.

Heleochloa juncea Beaur., Ess. Agrost. 24, 147. 1812. Based on Agrostis juncea Michx.

Colpodium junceum Trin., in Spreng., Neu. Entd. 2: 37. 1821. Based on Agrostis juncea Michx.

Crypsis juncea Steud., Nom. Bot. 1: 242. 1821. Based on Agrostis juncea Michx.

Vilfa juncea Trin., Gram. Unifl. 157. 1824. Based on Agrostis juncea Michx.

Sporobolus junceus Kunth, Rér. Gram. 1: 68. 1829. Based on Agrostis juncea Michx.

I'ilfa schiedeana Trin., Mém. Acad. St. Pétersb. VI. Sei. Nat. 4' 73.1840. Arkansas, "Schiede." [Type specimen ammotated by Ruprecht "Beyrich non Schiede."']

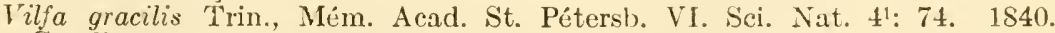
Carolina.

Vilfa fulvescens Trin., Mém. Acad. St. Pétersb. VI. Sci. Nat. 4' 76.1840. North America, Bosc, Willdenow Herb. no. 1750.

Agrostis thyrsoides Bosc; Trin., Mém. Acad. St. Pétersb. VI. Sci. Nat. 4: 76. 1840 , as synonym of Vilfa fulvescens Trin.

Vilfa subsetacea Trin., Mém. Acad. St. Pétersb. VI. Sci. Nat. 4': 133 (in note). 1840. Based on V. gracilis Trin., op. cit. (page 74 , not op. cit. page 104). (See synonymy under Muhlenbergia cuspidata.) Discovering that he had named two distinct species Vilfa gracilis, Trinius changed the first to $V$. subsetacea. Since V. gracilis has come into use under Sporabolus and is valid, it is retained over $V$. subsetacea, $V$. schiedeana, and $V$. fulvescens all of the same date.

Vilfa vinzenti Steud., Syn. Pl. Glum. 1: 155. 1854. [Rusk County], Tex.: Vinzent 62.

$55974^{\circ}-35-61$ 
Aira triglumis Steud., Syn. Pl. Glum. 1: 223. 1854. [Rusk County], Tex., Vincent 62.

Bennetia juncea Raf.; Jacks., Ind. Kew. 1: 291. 1893, as synonym of Sporobolus junceus. Rafinesque (Bull. Bot. Seringe 1: 220. 1830) cites Agrostis juncea Michx., after his description of the new genus Bennetia, but does not transfer the specific name.

Sporobolus ejuncidus Nash, in Britton, Man. 106. 1901. Based on Sporobolus junceus Kunth.

(12) Sporobolus heterolepis (A. Gray) A. Gray, Man. 576. 1848. Based on Vilfa heterolepis A. Gray.

Vilfa heterolepis A. Gray, Ann. Lyc. N.Y. 3: 233. 1835. Watertown, N.Y., Crawe.

Agrostis heterolepis Wood, Class-book ed. 2. 598. 1847. Based on Vilfa heterolepis Gray.

(5) Sporobolus indicus (L.) R. Br., Prodr. Fl. Nov. Holl. 170. 1810. Based on Agrostis indica L.

Agrostis indica L., Sp. Pl. 63. 1753. "India", but the type from Jamaica, sent by Patrick Browne.

Agrostis elongata Lam., Tabl. Encycl. 1: 162. 1791. Not Sporobolus elongatus R. Br., 1810. South America. Agrostis indica L. cited as symonym.

Vilfa elongata Beauv., Ess. Agrost. 16, 147, 181. 1812. Based on Agrostis elongata Lam.

Sporobolus lamarckii Desv.; Hamilt., Prodr. Pl. Ind. Occ. 4. 1825. Based on Agrostis elongata Lam.

Sporobolus jacquemontii Kunth, Rév. Gram. 2: 427. pl. 127. 1831. Dominican Republic.

Vilfa jacquemontii Trin., Mém. Acad. St. Pétersb. VI. Sci. Nat. 4': 92. 1840. Based on Sporobolus jacquemontii Kunth.

Vilfa indica Trin.; Steud., Nom. Bot. ed. 2. 2: 767. 1841. Based on Agrostis indica L.

Sporobolus littoralis var. elongatus Dur. and Sehinz, Consp. Fl. Afr. 5: 821. 1894. Based on Vilfa elongata Beauv.

(11) Sporobolus interruptus Vasey, Bull. Torrey Bot. Club 15: 8. 1888. Arizona, Coues and Palmer 66 in 1886; San Francisco Forest, Rusby 15 in 1883 [the Rusby specimen, distributed as no. 885, the type].

Sporobolus arizonicus Thurb.; Vasey, Bull. Torrey Bot. Club 15: 8. 1888, as synonym of Sporobolus interruptus Vasey.

(9) Sporobolus macrus (Trin.) Hitchc., Amer. Jour. Bot. 2: $303.1915 . \quad$ Based on Vilfa macra Trin.

Vilfa macra Trin., Mém. Acad. St. Pétersb. VI. Sci. Nat. 4' 79.1840. Louisiana.

(2) Sporobolus microspermus (Lag.) Hitchc., Jour. Wash. Acad. Sci. 23: 453. 1933. Based on Milium microspermum Lag.

Milium microspermum Lag., Gen. and Sp. Nov. 2. 1816. Grown from seed sent from Mexico by Sessé.

Agrostis minutissima Steud., Syn. Pl. Glum. 1: 171. 1854. New Mexico, Fendler 986.

Vilfa confusa Fourn., Mex. Pl. 2: 101. 1886. Mexico (several localities cited including Schiede and Deppe 913 which is the basis of "Vilfa ramulosa Schlecht." cited by Fournier); United States, Hall and Harbour 643.

Sporobolus confusus Vasey, Bull. Torrey Bot. Club 15: 293. 1888. Based on Vilfa confusa Fourn.

Sporobolus confusus var. aberrans Jones, Contrib. West. Bot. 14: 10. 1912. Bowie, Ariz., and Colonia Juárez, Mexico, [Jones].

Sporobolus minutissimus Hitche., Biol. Soc. Wash. Proc. 41: 161. 1928. Based on Agrostis minutissima Steud.

(22) Sporobolus nealleyi Vasey, Bull. Torrey Bot. Club 15: 49. 1888, name only; Contrib. U.S. Natl., Herb. 1: 57. 1890. Brazos Santiago, Tex., Nealley.

(7) Sporobolus neglectus Nash, Bull. Torrey Bot. Club 22: 464. 1895. Massachusetts to Kentucky, Tennessee, and Kansas. [Type, Woodruff Gap, N.J., Britton in 1887.j

Sporobolus vaginaeflorus neglectus Scribn., U.S.Dept.Agr., Div. Agrost. Bull. 17 (ed. 2): 170. f. 466. 1901. Based on S. neglectus Nash.

Sporobolus ozarkanus Fernald, Rhodora 35: 109. 1933. Webb City, Mo., Palmer 3133.

(4) Sporobolus poiretii (Roem. and Schult.) Hitche., Bartonia 14: 32. 1932. Based on Axonopus poiretii Roem. and Schult. 
Agrostis compressa Poir., in Lam., Encycl. Sup. 1: 258. 1810. Not A. compressa Willd., 1790, nor Poir. (op. cit.) 1: 259. 1810. Carolina, Bose.

Milium compressum Poir., in Lam., Encycl. Sup. 1: 25S. 1810. Not M. compressum Swaltz, 178S. As synonym of Agrostis compressa Poir.

Axonopus poiretii Roem. and Schult., Syst. Veg. 2: 318. 1817. Based on Agrostis compressa Poir., "n. 78," not A. compressa Willd., 1790, nor Poir. (op. cit.) no. 82, on the following page.

Agrostis lenuissima Spreng., Syst. Veg. 1: 258. 1825. West Indies and South America.

Vilfa exilis Trin., Mém. Acad. St. Pétersb. VI. Sci. Nat. 41: 89. 1840. Jalapa, Mexico, [Schiede].

Vilfa berteroana Trin., Mém. Acad. St. Pétersb. VI. Sci. Nat. 4: 100.1840. Dominican Republic, Bernhardi.

Sporobolus angustus Buckl., Acad. Nat. Sci. Phila. Proc. 1862: 88. 1863. "Buchanan county" [probably error for Buchanan] Tex., [Buclley].

Vilfa tenacissima var. exilis Fourn., Mex. Pl. 2: 99. 1886 . Based on Vilfa exilis Trin.

Sporobolus bertcroanus Hitchc. and Chase, Contrib. U.S. Natl. Herb. 18: 370. 1917. Based on Vilfa berteroana Trin.

This species has been included in Sporobolus indicus in some manuals.

(17) Sporobolus purpurascens (Swartz) Hamilt., Prodr. Pl. Ind. Occ. 5.

1825. Based on Agrostis purpurascens Swartz.

Agrostis purpurascens Swartz, Prodr. Veg. Ind. Occ. 25. 1788. Jamaica, Swartz.

Vilfa purpurascens Beauv., Ess. Agrost. 16, 182. 1812. Based on Agrostis purpurascens Swartz.

Vilfa grisebachiana Fourn., Mex. Pl. 2: 98. 1856. Cuba, Wright 3427a.

Vilfa liebmanni Fourn., Mex. Pl. 2: 100. 1886. Mexico, Liebmann 693.

(1) Sporobolus ramulosus (H.B.K.) Kunth, Rév. Gram. 1: 68. 1829. Based on Vilfa ramulosa H.B.K.

Vilfa ramulosa H.B.K., Nov. Gen. and Sp. 1: 137. 1815. Jorullo, Mexico, Humboldt and Bonpland.

Agrostis ramulosa Roem. and Schult., Syst. Veg. 2: 361. 1817. Based on Vilfa ramulosa H.B.K.

Tilfa minima Vasey, U.S.Dept.Agr. Monthly Rept. 1874: 155. 1874. Not V. minima Trin., 1854. Twin Lakes, Colo., Wolf 1077.

Sporobolus wolfii Vasey, Bull. Torrey Bot. Club 10: 52. 1883. Twin Lakes, Colo., II olf [1077].

Sporobolus racemosus Vasey, Bull. Torrey Bot. Club 14: 9. 1887. Chihuahua, Mexico, Palmer [4B in 1885].

Muhlenbergia wolfii Rydb., Bull. Torrey Bot. Club 32: 600. 1905. Based on Sporobolus wolfii Vasey.

(14) Sporobolus teretifolius Harper, Bull. Torrey, Bot. Club 33: 229. 1906. Near Moultrie, Ga., Harper 1642.

(28) Sporoboius texanus Vasey, Contrib. U.S. Natl. Herb. 1: 57. 1890. Screw Bean, Presidio County, Tex., Nealley [755].

(29) Sporobolus tharpii Hitche,, Biol. Soc. Wash. Proc. 41: 161. 1928. Padre Island, Tex., Tharp 4772.

(6) Sporobolus vaginiflorus (Torr.) Wood, Class-book 775. ed. 3. 1861. Based on Vilfa vaginiflora Torr.

Vilfa vaginiflora Torr.; Gray, Gram. and Cyp. 1: no. 3. 1834; Trin., Mém. Acad. St. Pétersb. V'I. Sci. Nat. 41: 56. 1840. New Jersey.

Cryptostachys vaginata Steud., Flora 33: 229. 1850, name only; Syn. Pl. Glum. 1: 181. 1854. North America.

Sporobolus minor Vasey; A. Gray, Man. ed. 6. 646. 1890. Not S. minor Kunth, 1830. Virginia to North Carolina [type, Boynton], Tennessee and Texas.

Sporobolus filiculmis L. H. Dewey, Contrib. U.S. Natl. Herb. 2: 519.1894. Not S. filiculmis Vasey, 1885. Based on S. minor Vasey.

Sporobolus ovatus Beal, Grasses N.Amer. 2: 300. 1896. Based on S. minor Vasey.

Sporobolus vaginatus Scribn., Bot. Gaz. 21: 15. 1896. Based on Cryptostachys vaginata Steud.

?Sporobolus vaginiflorus var. minor Scribn.; Chapm., Fl. South. U.S. ed. 3. 598. 1897. North Carolina and Tennessee.

Sporobolus vaginiflorus var. inaequalis Fernald, Rhodora 35: 109.1933. Concord, N.H., Batchelder in 1901. 
(3) Sporobolus virginicus (L.) Kunth, Rév. Gram. 1: 67. 1829. Based on Agrostis virginica $\mathrm{L}$.

Agrostis virginica L., Sp. Pl. 63. $1753 . \quad$ Virginia.

Agrostis littoralis Lan., Tabl. Encycl. 1: 161. 1791. South America, Richard.

I'ilfa littoralis Beauv., Ess. Agrost. 16, 147, 181. 1812. Based on Agrastis littoralis Lam.

Tilfa virginica Beauv., Ess. Agrost. 16, 182. 1812. Based on Agrostis virginica L.

Agrostis pungens Muhl., Deser. Gram. 72. 1817. Not A. pungens Schreb.. 1769. Eastern United States.

Crypsis virginica Nitt., Gen. Pl. 1: 49. 1818. Based on Agrastis virginica Willd. [error for L.].

Podosaemum virginicum Link, Hort. Berol. 1: 85. 1827. Based on Agrostis virginica L.

Sporobolus littoralis Kunth, Rév. Gram. 1: 68. 1829. Based on Agrastis littoralis Lam.

(27) Sporobolus wrightii Munro; Scribn., Bull. Torrey Bot. Club 9: 103.1882. Pantano, Ariz., Pringle.

Bauchea karwinskyi Fourn., Mex. Pl. 2: S7. 1886. Mexico, Karwinsky 1015, $1015 \mathrm{~b}$.

Sporobolus altissimus Vasey, Calií. Acad. Sci. Proc. II. 2: 212. 1889. San Diego, Calif., Palmer [in 1888].

Sporobolus altissimus var. minor Vaser, Calif. Acad. Sci. Proc. II. 2: 213. 1S89. San Enrique, Calif. [Brandegee].

\section{(123) STENOTAPHEUM Trin.}

(1) Stenotaphrum secundatum (Walt.) Kuntze, Rev. Gen. Pl. 2: 794. 1891 Based on Ischaemum secundatum Walt. Kuntze misspells the specific name "secundum."

Ischaemum secundatum Walt., Fl. Carol. 249. 1788. South Carolina.

Rottboellia stolonifera Poir., in Lam., Encycl. 6: 310. 1804. Puerto Rico, Ledru.

Slenotaphrum americanum Schrank, Pl. Rar. Hort. Monac. pl. 98. “1819." Since Schrank cites Trin., Fund. Agrost. 1820, his work must be later than that of Trinius. Greenhouse plant.

Sicnotaphrum sarmentosum Nees, Agrost. Bras. 93. 1829. Based on Rotlbocllia stolonifera Poir.

Stenotaphrum glabrum var. amcricanum Doell, in Mart., Fl. Bras. 22: 300. 1877. Based on Stenotaphrum amcricanum Schrank.

Stenotaphrum dimidiatum var. americanum Hack., in Stuck., An. Mus. Nac. Buenos Aires 21: 57. 1911. Based on Stenotaphrum americanum Schrank.

Stenataphrum dimidiatum var. secundum [secundatum] Domin, Bibl. Bot. 85: 332. 1915. Based on Ischaemum secundatum Walt.

Stenotaphrum secundaium var. variegatum Hitchc., in Bailey, Stand. Cycl. Hort. 6: 3237. 1917. Greenhouse plant.

(84) STIPA L.

(31) Stipa arida Jones, Calif. Acad. Sci. Proc. II. 5: 725. 1895. Marysvale, Utah, Jones 5377.

Stipa mormanum Mez, Repert. Sp. Nov. Fedde 17: 209. 1921. Utah, Jones [2106].

(8) Stipa avenacea L., Sp. Pl. 78. 1753. Virginia.

Stipa barbata Michx., Fl. Bor. Amer. 1: 53. 1803. Not S. barbata Desf. 1798. Virginia and Carolina, Michaux.

Stipa virginica Pers., Syn. Pl. 1: 99. 1805. Based on S. barbata Michx.

Stipa diffusa Willd.; Steud., Nom. Bot. ed. 2. 2: 643. 1841, as synonym of Stipa avenacea L.

Sitipa avenacea var. bicolor Eaton and Wright, N.Amer. Bot. ed. 8. 444, 1848. Philadelphia and Chester, Pa.; Boston, Mass.; Ontario; Florida.

Podopogon avenaceum Raf.; Jacks., Ind. Kew. 3: 580. 1894, as synonym of Stipa avenacea.

(7) Stipa avenacioides Nash, Bull. Torrey Bot. Club 22: 423. 1895. Cassia, Lake County, Fla., Nash 2051.

Stipa brachychaeta Godi., Mem. Acad. Monsp. (Sec. Medic.) 1: 450. 1853. Originally described from specimens from unknown source. Native of southern South America. 
(21) Stipa californica Merr. and Dary, Univ. Calif. Pubs., Bot. 1: 61. 1902. San Jacinto Mountains, Calif., Hall 2556.

(27) Stipa columbiana Macoun, Cat. Can. P1. 24: 191. 18s8. Yale, British Columbia, Macoun [28,940]; Victoria, Vancouver Island, Vacoun [28,941].

Stipa viridula rar. minor Vasey, Contrib. U.S. Natl. Herb. 3: 50. 1892. [Kelso Mountain, Colo., Leiterman 95.]

Stipa minor Scribn., U.S.Dept.Agr., Div. Agrost. Bull. 11: 46. 1898. Based on S. viridula var. minor Vasey.

Stripa columblana var. NElsoni (Scribn.) Hitche., Contrib. U.S. Nat1. Herb. 24: 254. 1925. Based on S. nelsoni Scribn. (Published as S. columbiana nelsoni.)

Stipa occidentalis [Thurb.; misapplied by] Boland., Proc. Calif. Acad. 4: 169. 1872. Larger plant with "awns almost entirely smooth", confused with true $S$. occidentalis.

Stipa nelsoni Scribn., U.S.Dept.Agr., Div. Agrost. Bull. 11: 46. 1898. Albany County, Wyo., A. Nelson 3963.

(10) Stipa comata Trin. and Rupr., Mém. Acad. St. Pétersb. VI. Sci. Nat. $5^{1}: 75$. 1842. Carlton House Fort, Saskatchewan River, Drummond; Columbia River, near Missouri Portage, Douglas.

Stipa comata intonsa Piper, Contrib. U.S. Natl. Herb. 11: 109. 1906. Rockland, K'lickitat County, Wash., Suksdorf 1026.

This is the species described by Pursh (Fl. Amer. Sept. 1: 72. 1814), and Nuttall (Gen. Pl. 1: 58. 1818) under Stipa juncea L., and by Hooker (Fl. Bor. Amer. 2: 257. 1849) under S. capillata L.

Stipa comata var. intermedia Scribn. and Tweedy, Bot. Gaz. 11: 171. 1886. Junction Butte, Yellowstone Park, Twcedy 610.

Stipa tweedyi Scribn., U.S.Dept.Agr., Div. Agrost. Bull. 11: 47. 1898. Based on S. comata intermedia Scribn.

Stipa spartea var. twecdyi Jones, Contrib. West. Bot. 14: 11. 1912. Based on S. tweedyi Scribn.

(5) Stipa coronata Thurb., in S. Wats., Bot. Calif. 2: 287. 1880. California, Julian, Bolander; San Bernardino, Parry and Lemmon 422.

Stipa coronata var. Depauperata (Jomes) Hitchc., Jour. Wash. Acad. Sci. 24: 292. 1934. Based on S. parishii var. depauperata Jones.

Stipa parishii Vasey, Bot. Gaz. 7: 33. 1882. San Bernardino Mountains, Calif., Parish 1079.

Stipa parishii var. depauperata Jones, Contrib. West. Bot. 14: 11.1912. Detroit, Utal [Jones].

Stipa coronata parishii Hitche., Contrib. U.S. Natl. Herb. 24: 227.1925. Based on S. parishii Vasey.

(22) Stipa curvifolia Swallen, Jour. Wash. Acad. Sci. 23: 456. 1933. Guadalupe Mountains, N.Mex., W'ilkins 1660.

Siipa elegantissima Labill., Nov. Holl. Pl. 1: 23. pl. 29. 1804. Australia.

(17) Stipa elmeri Piper and Brodie; Scribn., U.S.Dept.Agr., Div. Agrost. Bull. 11: 46. 1898. Based on S. viridula var. pubescens Vasey.

Stipa viridula var. pubescens Vasey, Contrib. U.S. Natl. Herb. 3: 50. 1892. Not S. pubescens R. Br., 1810. Washington, Suksdorf.

(13) Stipa eminens Cav., Icon. Pl. 5: 42. pl. 467. f. 1. 1799. Chalma, Mexico. Stipa erecta Fourn., Mex. Yl. 2: 75. 1886. Not S. erecta Trin., 1824. Tehuacan, Mexico, Liebmann 654.

Stipa flexuosa Vasey, Bull. Torrey Bot. Club 15: 49. 1888. Western Texas, [Chenate Mountains], Nealley.

(18) Stipa latiglumis Swallen, Jour. Wash. Acad. Sci. 23: 198. f. 1. 1933. Camp Lost Arrow, Yosemite Valley, Calif., Abrams 4469.

(24) Stipa lemmoni (Vasey) Scribn., U.S.Dept.Agr., Div. Agrost. Cire. 30: 3. 1901. Based on S. pringlei var. lemmoni Vasey.

Stipa pringlei var. lemmoni Vasey, Contrib. U.S. Natl. Herb. 3: 55. 1892. Plumas County, Calif., Lemmon [5456].

Stipa lemmoni var. jonesii Scribn., U.S.Dept.Agr., Div. Agrost. Cire. 30: 4. 1901. Emigrant Gap, Calif., Jones 3298.

(14) Stipa lepida Hitchc., Amer. Jour. Bot. 2: 302. 1915. Santa Ynez Forest, Calif., Chase 5611.

Stipa lepida var. Andersonir (Vasey) Hitchc., Amer. Jour. Bot. 2: 303.1915. Based o: S. eminens var. andersonii Vasey. (Published as S. lepida andersonii.) 
Nitipa eminens var. andersonii Yaser, Contrib. U.S. Natl. Herb. 3: 54. 1892. California, [Santa Cruz, Anderson 58, type]. "Lower California", cited by Vasey is erroneous.

Siipa hassei Vasey, Contrib. U.S. Natl. I1erb. 1: 267. 1893. Santa Monica, Calif., Hasse. Abnormal specimen, the spikelets distorted by a smut.

(28) Stipa lettermani Vasey, Bull. Torrey Bot. Club 13: 53. is86. Snake River, Idaho, Letterman [102].

Stipa viridula Var. lettermani Vasey, Contrib. U.S. Natl. Herb. 3: 50. 1892. Presumably based on S. lettermani Vasey.

(3) Stipa leucotricha Trin. and Rupr., Mém. Acrad. St. Pétersb. VI. Sci. Nat. 51: 54. 1842. Texas, from Hooker.

Stipa ciliata Scheele, Linnaea 22: 342. 1849. New Braunfels, Tex., Römer.

(20) Stipa lobata Swallen, Jour. Wash. Acad. Sci. 23: 199. f. 2.1933. Ranger Station, Queen, Guadalupe Mountains, N.Mex., Hitchcock (Amer. Gr. Nat. Herb. 819).

Stipa neesiana Trin. and Rupr., Mém. Acad. St. Pétersb. Ví. Sci. Nat. $5^{1}: 27$. 1S42. Montevideo, Sellow.

(1) Stipa neomexicana (Thurb.) Scribn., U.S.Dept.Agr., Div. Agrost. Bull. 17: 132. f. 428. 1899. Based on S. pennata var. neo-mexicana Thurb.

Stipa pennata var. neo-mexicana Thurb., in Coulter, Man. Rocky Mount. 408. 1885. New Mexico [type, Rio Mimbres, Thurber 269], Colorado, and Texas.

(19) Stipa occidentalis Thurb.; S. Wats, in King, Geol. Expl. 40th Par. 5: 380. 1871. Yosemite Trail, Calif., Bolander 5038.

Stipa stricta Vasey, Bull. Torrey Bot. Club 10: 42. 1883. Not S. stricia Lam. 1791. Washington (erroneously cited as Cregon), Suksdorf.

Stipa stricta var. sparsifiora Vasey, Contrib. U.S. Natl. Herb. 3: 51. 1892. Yosemite Trail, Calif., Bulander 5038.

Stipa orcgonensis Seribn., U.S.Dept.Agr., Div. Agrost. Bull. 17: 130. f. 426. 1899. Based on S. stricta Vasey.

Stipa occidentalis montana Merr. and Davy, Univ. Calif. Pubs., Bot. 1: 62. 1902. Yosemite Trail, Bolander 5038.

Stipa pernata L., Sp. Pl. 78. 1753. Europe.

(30) Stipa pinetorum Jones, Calif. Acad. Sci. Proc. II. 5: 724. 1895. Panguitch Lake, Utah, Jones 6023 p.

(15) Stipa porteri Rydb., Bull. Torrey Bot. Club 32: 599. 1905. Based on the plant described as S. mongolica Turez. by Porter and Coulter (Sym. Fl. Colo. 145. 1874). [Rocky Mountains, Hall and Haruour 648, [error for 646].

This is the species deseribed under the name Oryzopsis mongolica (Turcz.) Beal

(Bot. Gaz. 15: 111. 1890), but the name is based on Stipa mongolica Turez., an Asiatic species.

(12) Stipa pringlei Seribn.; Vasey, Contrib. U.S. Natl. Herb. 3: 54. 1892. Mexico, Pringle [1410 true], and Arizona, Pringle, Lemmon, Tracy. No reference to Oryzopsis pringlei Beal.

Oryzopsis pringlei Beal, Bot. Gaz. 15: 112. 1890. Chihuahua, Mexico, Pringle 1410.

Stipa pringlei Scribn.; Beal, Bot. Gaz. 15: 112. 1890, as synonym of Oryzopsis pringlei Beal.

Oryzopsis erecta Beal, Grasses N.Amer. 2: 230. 1896. Apparently based on O. pringlei Beal, Pringle 1410 being cited, the name changed beeause of O. pringlei Scribn.; Beal 1896 (page 226 of the same work). The latter is the same as Silpa virescens H.B.K. of Mexico, not known from the United States. Beal erroneously gives the authority of O. erecta as "(Scribn.) Beal."

(11) Stipa pulchra Hitche., Amer. Jour. Bot. 2: 301. 1915. Healdsburg, Sonoma County, Calif., Heller 52.52.

(6) Stipa richardsoni Link, Hort. Berol. 2: 245. 1833. Western North America. Grown at Berlin from seed sent by Richaraison.

Stipa richardsoni var. major Macoun, Cat. Can. Pl. $2^{4}$ : 191. 1888, without description. Columbia Valley, British Columbia, Macoun.

Oryzopsis richardsoni Beal, Bot. Gaz. 15: 111. 1890. Based on Stipa richardsoni Link, but misapplied to Oryzopsis canadensis.

(26) Stipa robusta Seribn., U.S.Dept.Agr., Div. Agrost. Bull. 5: 23. 1 S97. Based on S. viridula var. robusta Vasey. Not invalidated by S'. robusta Nutt.; Trin. and Rupr., published as synonym of S. spartea.

Stipa viridula var. robusta Vasey, Contrib. U.S. Natl. Herb. 1: 56. 1890. Presidio County, Tex., Nealley [714].

Stipa vaseyi Seribn., U.S.Dept.Agr., Div. Agrost. Bull. 11: 46. 1898. Based on S. viridula var. robusta Vasey. 
(23) Stipa scribneri Vasey, Bull. Torrey Bot. Club 11: 125. 1884. Santa Fe, N.Mex. [Vasey].

(9) Stipa spartea Trin., Mém. Acad. St. Pétersb. VI. Math. Phys. Nat. 1: 82. 1830. North America [Rocky Mountains near the Missouri]. By typographical error the name is spelled "sparta."

Stipa robusta Nutt.; Trin. and Rupr., Mém. Acad. St. Pétersb. VI. Sci. Nat. $5^{1}: 69$. 1842, as synonym of $S$. spartea.

Stipa Spartea var. curtiseta Hitchc., Contrib. U.S. Natl. Herb. 24: 230. 1925. Hound Creek Valley, Mont., Scribner 339. (Published as S. spartea curtiscta.)

(2) Stipa speciosa Trin. and Rupr., Mém. Acad. St. Pétersb. V1. Sci. Nat. $5^{1}$ : 45. 1842. Chile, Cuming.

Stipa californica Vasey, Amer. Acad. Proc. 24: 80. 1859. Name only for Palmer's no. 505 in 1887 from Los Angeles Bay, Baja California.

Stipa speciosa var. minor Vasey, Contrib. U.S. Natl. Herb. 3: 52.1892. Empire City, Nev., Jones.

Stipa humilis var. jonesiana Kuntze, Rev. Gen. Pl. 32: 371. 1898. Empire City, Nev., Jones 4111.

Stipa humilis var. speciosa Kuntze, Rev. Gen. P1. 32: 371. 1898. Based on S. speciosa Trin. and Rupr.

(4) Stipa stillmanii Boland., Calif. Acad. Sci. Proc. 4: 169. 1872. Blue Canyon, Sierra Nevada, Calif., Bolander.

Stipa tenacissima L., Cent. Pl. 1: 6. 1755; Amoen. Acad. 4: 266.1759. Spaill.

(32) Stipa tenuissima Trin., Mém. Acad. St. Pétersb. VI. Sci. Nat. 21: 36.1836. Mendoza "Chile", [Argentina], Gillies.

Stipa cirrosa Fourn., Mex. P1. 2: 75. 1886. Mexico, Karwinsky 1009.

Stipa subulata Fourn., Mex. Pl. 2: 75. 1886. Mexico, Karwinsky 1009b.

(16) Stipa thurberiana Piper, U.S.Dept.Agr., Div. Agrost. Circ. 27: 10.1900. Washington, north branch of the Columbia and Okanagan, Pickering and Brackenridge.

Stipa occidentalis Thurb., in Wilkes, U.S. Expl. Exped. Bot. 17: 483.1874. Not $S$. occidentalis Thurb.; S. Wats., 1871. North Braneh of the Columbia River [W Thington, Pickering and Brackenridge].

(25) Stipa viridula Trin., Mém. Acad. St. Pétersb. VI. Sci. Nat. 21: 39.1836. North America [Saskatchewan].

Stipa parviflora [Desf., misapplied by] Nuttall, Gen. Pl. 1: 59. 1818. Plains of the Missouri.

Stipa nuttalliana Steud., Nom. Bot. ed. 2. 2: 643. 1841. Based on Stipa parviflora as described by Nuttall.

Stipa sparta Trin.; Hook., Fl. Bor. Amer. 2: 237. 1840. Name only. S. parviflora Nutt., not Desf., cited as synonym.

(29) Stipa williamsii Seribn., U.S.Dept.Agr., Div. Agrost. Bull. 11: 45.1898. Big Horn Mountain, Wyo., Williams 2804.

Thysanolaena maxima (Poxb.) Kuntze, Rev. Gen. Pl. 2: 794. 1891. Based on Agrostis maxima Roxb.

Agrostis maxima Roxb., Fl. Ind. 1: 319.1820. India.

Thysanolaena agrostis Nees, Edinburgh New Phil. Jour. 18: 180. 1835. Based on Agrostis maxima Roxb.

\section{(151) TRACHYPOGON Nees}

(1) Trachypogon montufari (H.B.K.) Nees, Agrost. Bras. 342. 1829. Based on Andropogon montufari H.B.K.

Andropogon montufari H.B.K., Nov. Gen. and Sp. 1: 184. 1816. Ecuador, Humboldt and Bonpland.

Heteropogon stipoides Presl, Rel. Haenk. 1: 335. 1830. Mexico, Haenke.

Heteropogon secundus Presl, Rel. Haenk. 1: 335. 1830. Mexico, Haenke.

Andropogon secundus Kunth, Rév. Gram. 1: Sup. XXXIX. 1830. Not A. secundus Ell., 1821. Based on Heteropogon secundus Presl.

Andropogon stipoides Kunth, Enum. Pl. 1: 487. 1833. Not A. stipoides H.B.K. Based on Heteropogon stipoides Presl.

Trachypogon preslii Anderss. Öfvers. Svensk. Vetensk. Akad. Förhandl. 14: 50. 1857. Based on Heteropogon stipoides Presl.

Trachypogon preslii var. secundus Anderss., Öfers. Svensk. Vetensk. Akad. Förhandl. 14: 50. 1857, Based on Heteropogon secundus Presl. 
Trachypogon polymorphus var. montufari Hack., in Mart., Fl. Bras. $2^{3}$ : 263. 1883. Based on Andropogon montufari H.B.K.

Trachypogon polymorphus var. montufari subvar. secundus Hack., in DC., Monogr. Phan. 6: 326. 1889. Based on Heteropogon secundus Presl.

Trachypogon secundus Scribn., U.S.Dept.Agr., Div. Agrost. Circ. 32: 1. 1901. Based on Heteropogon secundus Presl.

Trachypogon plumosus var. montufari Hack.; Henr., Med. Rijks Herb. Leiden 40: 40. 1921. Based on Andropogon montufari H.B.K.

Tiachypogon plumosus var. montufari subvar. secundus Hack.; Henr., Med. Rijks Herb. Leiden 40: 40. 1921. Based on Heteropogon secundus Presl.

\section{(86) TRAGUS Hall.}

(1) Tragus berteronianus Schult., Mant. 2: 205. 1824. Dominican Republic, Bertero.

Tragus occidentalis Nees, Agrost. Bras. 286. 1829. Brazil.

Lappago berteroniana Schult.; Steud., Syn. Pl. Glum. 1: 112. 1854, erroneously cited as synonym of $\dot{L}$. aliena Spreng.

Tragus racemosus var. brevispicula Doell, in Mart., Fl. Bras. 2: 123. pl. 18. 1877. Brazil.

Nazia occidentalis Scribn., Zoe 4: 386. 1894. Based on Tragus occidentalis Nees.

Lappago occidentalis Nees; Hook. f., Fl. Brit. Ind. 7: 97. 1896. Presumably based on Tragus occidentalis Nees; erroneously cited as synonym of Tragus racemosus All.

The following two names refer to Trcgus berteronianus, though they are based on Lappago alienus Spreng., which is Pscudechinolaena polystachya (H.B.K.) Stapf.

Nazia racemosa aliena Scribn, and Smith, U.S.Dept.Agr., Div. Agrost. Bull. 4: 12. 1897. Based on Lappago aliena Spreng.

Nazia aliena Scribn., U.S.Dept.Agr., Div. Agrost. Bull. 17: 28. f. 324. 1899. Based on Lappago aliena Spreng.

(2) Tragus racemosus (L.) All., Fl. Pedem. 2:241. 1785. Based on Cenchrus racemosus $\mathrm{L}$.

Cenchrus racemosus L., Sp. P1. 1049. 1753. Southern Europe.

Lappago racemosa Honck., Syn. Pl. Germ. 1: 440. 1792. Based on Cenchrus racemosus $\mathrm{L}$.

Tragus muricatus Moench, Meth.Pl.53. 1794. Based on Cenchrus racemosus L.

Tragus racemosus var. longispicula Doell, in Mart., Fl. Bras. 22: 122.1877. Based on T.racemosus Desf. (Same as T. racemosus All.)

Nazia racemosa Kuntze, Rev. Gen. Yl. 2: 780. 1891. Based on Cenchrus racemosus $\mathrm{L}$.

\section{(120) TRICHACHNE Nees}

(2) Trichachne californica (Bentl.) Chase, Jour. Wash. Acad. Sci. 23: 455 1933. Based on Panicum californicum Benth.

Panicum caifornicum Benth., Bot. Voy. Sulph. 55. 1840. Bay of Magdalena, Baja California.

Panicum lachnanthum Torr., U.S. Rept. Expl. Miss. Pacif. 73:21. 1856. Not P. lachnanthum Hochst., 1855. Burro Mountains, N.Mex.

Panicum saccharatum Buckl., Prel. Rept. Geol. Agr. Survey Tex. App. 2. 1866. Texas, Buckley.

Trichachne saccharata Nash, in Small, Fl. Southeast. U.S. 83. 1903. Based on Panicum saccharatum Buckl.

Valota saccharata Chase, Biol. Soc. Wash. Proc. 19: 188. 1906. Based on Panicum saccharatum Buckl.

Digitaria californica Henr., Blumea 1: 99. 1934. Based on Panicum californicum Benth.

(4) Trichachne hitcheockii (Chase) Chase, Jour. Wash. Acad. Sci. 23: 454. 1933. Based on Valota hitchcockii Chase.

Valota hitchcockii Chase, Biol. Soc. Wash. Proc. 24: 110. 1911. San Antonio, Tex., Hitchcock 5329.

Digitaria hitchcockii Stuck., Ann. Cons. Jard. Genève 17: 287. 1914. Based on Valota hitchcockii Chase.

(1) Trichachne insularis (L.) Nees, Agrost. Bras. 86. 1829. Based on Andropogon insularis L.

Andropogon insularis L., Syst. Nat. ed. 10. 2: 1304. 1759. Jamaica, Sloane. 
Panicum lanatum Rottb., Act. Lit. Unir. Hafn. 1: 269. 1778. Dutch Guiana.

Milium villosum Swartz, Prodr. Veg. Ind. Occ. 24. 1788. Based on Andropogon insularis L.

Milinm hirsutum Beauv., Ess. Agrost. 13. pl. 5. f. 5. 1812. No locality cited.

Panicum leucophaeum H.B.K., Nov. Gen. and Sp. 1: 97. 1815. Venezuela and Colombia, Humboldt and Bonpland.

Panicum insulare G. Míeyer, Prin. Fl. Esseq. 60. 1818. Based on Andrupogon insularis L.

Saccharum polystachyum Sieb.; Kunth, Enum. Pl. 1: 124. 1833. Not S. polystachyum Swartz. As synonym of Panicum leucophaeum H.B.K.

Agrostis villosa Poir.; Steud., Nom. Bot. ed. 2. 1: 43. 1840. Not A. villosa Poir., 1786. As synonym of Milium villosum Swartz.

Panicum saccharoides A. Rich., in Sagra, Hist. Cuba 11: 306. 1850. Not $P$. saccharoides Trin., 1826. Cuba.

Panicum falsum Steud., Syı. Pl. Glum. 1: 67. 1854. Cuba.

Panicum duchaissingii Steud., Svn. Pl. Glum. 1: 93. 1854. Guadeloupe, Duchaissing.

Tricholaena insularis Griseb., Abhandl. Gesell. Wiss. Göttingen 7: 265.1857. Based on Andropogon insularis L.

Digitaria leucophaea Stapf, in Dyer, Fl. Cap. 7: 382. 1898. Based on Panicum leucophaeum Swartz (error for H.B.K.).

Syntherisma insularis Millsp. and Chase, Field Mus. Bot. 1: 473. 1902. Based on Andropogon insularis L.

Valota insularis Chase, Biol. Soc. Wash. Proc. 19: 188. 1906. Based on Andropogon insularis L.

Digutaria insularis Mez; Ekman, Arkiv Bot. 13: 22. 1913. Based on Andropogon insularis L.

Andropogon fabricii Herzog; Henr., Med. Rijks Herb. Leiden 40: 44. 1921. Jamaica, Swartz. (Sterile specimen with large galls.)

(3) Trichachne patens Swallen, Amer. Jour. Bot. 19: 442. f. 5. 1932. Near Lake Mitchell, San Antonio, Tex., Amer. Gr. Nat. Herb. 294 (Hitchcock 5328).

Digitaria patens Hemr., Blumea 1: 99. 1934. Based on Trichachne patens Swallen.

\section{(103) TRICHLORIS Fourn.}

(1) Trichloris mendocina (Phil.) Kurtz, Mem. Fac. Cienc. Exact. Univ. Córdoba 1896: 37. 1897. Based on Chloris mendocina Phil.

Chloris mendocina Phil., An. Univ. Chile 36: 208. 1870. Mendoza, Argentina [Philippi].

Trichloris blanchardiana Fourn.; Seribn., Bull. Torrey Bot. Club 9: 146. 1882. Tueson, Ariz., Pringle.

Chloridiopsis [error for Chloropsis] blanchardiana Gay; Scribn., Bull. Torrey Club 9: 146. 1882, as synonym of Trichloris blanchardiana Fourn.

Trichloris verticillata Fourn.; Vasey, Deser. Cat. Grasses U.S. 61. 1885, name only; U.S.Dept.Agr., Div. Bot. Bull. 12: pl. 25. 1891. Arizona ['Tucson, Pringle].

Trichloris fasciculata Fourn., Mex. Pl. 2: 142. 1886. San Luis de Potosí, Mexico, Virlet 1440.

Chloropsis blanchardiana Kuntze, Rev. Gen. P1. 2: 771. 1891. Based on Trichloris blanchardiana Hack. (error for Fourn.).

Chloropsis fasciculata Kuntze, Rev. Gen. Pl. 2: 771. 1891. Based on Trichloris fasciculata Fourn.

Chloropsis mendocina Kuntze, Rev. Gen. Pl. 32: 348. 1898. Based on Chloris mendocina Phil.

Trichloris mendocina forma blanchardiana Kurtz, Bol. Acad. Cienc. Córdoba 16: 270. 1900. Based on Trichloris blanchardiana Fourn.

Leptochloris greggii Munro; Merr., U.S.Dept.Agr., Div. Agrost. Circ. 32: 7. 1901, as synonym of Chloropsis mendocina Kuntze.

(2) Trichloris pluriflora Fourn., Mex. Pl. 2: 142. 1886. Mexico, Karwinsky; Texas, between Loredo and Bejar [Bexar], Berlandier 1430.

Trichloris latifolia Vasey, U.S.Dept.Agr. Spec. Rept. 63: 32. 1883. Texas and New Mexico [Wright 763]. Name only.

Chloropsis pluriflora Kuntze, Rev. Gen. Pl. 2: 771. 1891. Based on Trichloris pluriflora Fourn. 


\section{(134) TRICHOLAENA Schrad.}

(1) Tricholaena rosea Nees, "Cat. Sem. Hort. Vratisl. a. 1836"; Fl. Afr. Austr. 17. 1841. South Africa, Drège.

Panicum roseum Steud., Syn. Pl. Glum. 1: 92. 1854. Not P. roseum Willd. 1825. Based on Tricholaena rosea Nees.

Panicum teneriffae var. rosea F. M. Bailey, Queensl. Grass. 22. 1888. Based on Tricholaena rosea Nees.

Melinis rosea Hack., Oesterr. Bot. Ztschr. 51: 464. 1901. Based on Tricholaena rosea Nees.

Rhynchelytrum roseum Stapf and Hubb.; Bews, World's Grasses 223.1929 , basis not given; Prain, Fl. Trop. Afr. 9: 880. 1930. Based on Tricholaena rosea Nees.

\section{(91) TRICHONEURA Anderss.}

(1) Trichoneura elegans Swallen, Amer. Jour. Bot. 19: 439. f. 4. 1932. Devine, Tex., Silveus 343 .

(31) TRIODIA R. Br.

(12) Triodia albescens Vasey, U.S.Dept.Agr., Div. Bot. Bull. 122: pl. 33. 1891. Texas [trpe, Hall 782] and New Mexico. Tricuspis albescens Munro is erroneously cited as synonym (see this name under T. congesta).

Sieglingia albescens Kuntze, Rev. Gen. Pl. 2: 789. 1891. Based on Triodia albescens Vasey.

Rhombolytrum aibescens Nash, in Britton, Man. 129. 1901. Based on Triodia albescens Vasey.

Tridens albescens Woot. and Standl., N.Mex. Coll. Agr. Bull. 81: 129. 1912. Based on Triodia albescens Vasey.

(5) Triodia buckleyana (L. H. Dewey.) Vasey; Hitchc., Jour. Wash. Acad. Sci. 23: 452. 1933. Based on Sieglingia buckleyana L. H. Dewey.

Sieglingra buckleyana L. H. Dewey, Contrib. U.S. Natl. Herb. 2: 540. 1894. Southern Texas, Buckley.

Triodia buckleyana Vasey, Contrib. U.S. Natl. Herb. 2: 540. 1894, as synonym of Sieglingia buckleyana L. H. Dewey.

Tridens buckleyanus Nash, in Small, Fl. Southeast. U.S. 143. 1903. Southern Texas; Triodia buckleyana Vasey given as a synonym.

(4) Triodia congesta (L. H. Dewey) Bush, St. Louis Acad. Sci. Trans. 12: 67. pl. 10. 1902. Based on Sieglingia congesta L. H. Derrey.

Tricuspis albescens Munro; A. Gray, Acad. Nat. Sci. Phila. Proc. 1862: 335. 1863. Name only, for Drummond 314, Texas.

Sieglingia congesta L. H. Dewey, Contrib. U.S. Natl. Herb. 2: 538. 1894. Corpus Christi, Tex., Nealley 24.

Tricuspis congesta Heller, Cat. N. Amer. Pl. ed. 2. 28. 1900. Based on "Triodia" [error for Sieglingia] congesta L. H. Dewey.

Tridens congestus Nash, in Small, Fl. Southeast. U.S. 143. 1903. Based on Sieglingia congesta L. H. Dewey.

(6) Triodia drummondii Scribn. and Kearn., U.S.Dept.Agr., Div. Agrost. Bull. 4: 37. 1897. Jacksonville, "Fla." [Louisiana], Drummond.

Tridens drummondii Nash, in Small, Fl. Southeast. U.S. 143. 1903. Based on Triodia drummonaii Scribn. and Kearn.

(14) Triodia elongata (Buckl.) Scribn., U.S.Dept.Agr., Div. Agrost. Bull. 17 (ed. 2): 210. f. 506 . 1901. Based on Uralepis elongata Buckl.

Uralepis elongata Buckl., Acad. Nat. Sci. Phila. Proc. 1862: 89. 1863. Northern Texas.

Triodia trinerviglumis Benth.; Vasey, U.S.Dept.Agr. Spec. Rept. 63: 35. 1883, name only, with Tricuspis trinerviglumis MIunro, also name only, as synonym. Texas. Described in Vasey, U.S.Dept.Agr., Div. Bot. Bull. $12^{2}$ : pl. 40 . 1891. Texas to Arizona, northward to Colorado.

Tricuspis trinerviglumis Míunro; Vasey, U.S. Dept. Agr., Spec. Rept. 63: 35. 1883 , as synonym of Triodia trinerviglumis Benth.

Sieglingia trinerviglumis Kuntze, Rev. Gen. Pl. 2: 789. 1891. Based on Tricuspis trinerviglumis "Buckl." (error for Munro).

Sieglingia elongata Nash, in Britt. and Brown, Illustr. Fl. 3: 504. 1898. Based on Uralepis elongata Buckl.

Tricuspis elongata Heller, Cat. N.Amer. Pl. ed. 2. 28. 1900. Based on "Triodia" [error for Uralepis] elongata Buckl.

Tridens elongatus Nash, in Small, Fl. Southeast. U.S. 143. 1903. Based on Uralepis elorgata Buckl. 
(8) Triodia eragrostoides Vasey and Scribn., Contrib. U.S. Natl. Herb. 1: 5 S. 1890. Texas, Nealley.

Sieglingia eragrostoides L. H. Dewey, Contrib. U.S. Natl. Herb. 2: 539. 1894. Based on Triodia eragrostoides Vasey and Scribn.

Sieglingia eragrostoides var. scabra Vasey; Beal, Grasses N.Amer. 2: 465. 1896. Texas, Nealley [probably no. 96].

Triodia eragrostoides var. scabra Bush, Acad. Sci. St. Louis Trans. 12: 71. 1902. Based on Sieglingia eragrostoides var. scabra Vasey.

Tridens eragrostoides Nash, in Small, Fl. Southeast. U.S. 142. 1903. Based on Triodia eragrostoides Vasey and Scribn.

(9) Triodia flava (L.) Smyth, Kans. Acad. Sci. 'Trans. 25: 95. 1913. Based on Poa flava L.

Poa flava L., Sp. Pl. 68. 1753. Virginia.

?Poa laxa Lam., Tabl. Encycl. 1: 183. 1791. Not P. laxa Haenke, 1791. Yirginia.

Poa seslercides Michx., Fl. Bor. Amer. 1: 6S. 1803. Not P. seslerioides All., 1785. Illinois and the mountains of Carolina [type], Nichaux.

?Poa subverticillata Pers., Syn. Pl. 1: 92. 1805. Based on P. laxa Lam.

Tricuspis caroliniana Beauv., Ess. Agrost. 179. pl. 3. f. 29, pl. 15. f. 10.1812. South Carolina.

Tricuspis novae-boracensis Beaur., Ess. Agrost. 77, 179. 1812. Name only. New York, Delille.

Poa caerulescens Michx.; Beauv., Ess. Agrost. 77. 1812, name only; Kunth, Rév. Gram. 1: 108. 1829, as synonym of Uralepis cuprea Kunth.

Festuca quadridens Poir., in Lam., Encycl. Sup. 2: 640. 1812. Carolina, Bosc.

Triodia cuprea Jacq., Eclog. Gram. 2: 21. pl. 16. 1814. Grown in botanic garden, source unknown.

Poa quinquefida Pursh, Fl. Amer. Sept. 1: 81. 1814. New England to Carolina.

?Panicum festucoides Poir., in Lam., Encycl. Sup. 4: 283. 1816. East Indies, Desvaux, but Desvaus later (see Triodia festucoides below) corrects this to North America.

Poa arundinacea Poir., in Lam., Encycl. Sup. 4: 329. 1S16. Based on P. sesleroides Michx.

Tridens quinquefida Roem. and Schult., Syst. Veg. 2: 599. 1817. Based on Poa quinquefida Pursh.

Windsoria poaeformis Nutt., Gen. P1. 1: 70. 1818. Based on Poa sesleroidcs Michx.

Tricuspis sesleroides Torr., Fl. North. and Mid. U.S. 118. 1823. Based on Poa sesleroides MIichx.

Cynodon carolinianus Raspail, Ann. Sci. Nat., Bot. 5: 302. 1825. Based on Tricuspis caroliniana Beauv.

Tralepis cuprea Kunth, Rér. Gram. 1: 108. 1829. Based on Triodia cuprca Jacq.

Eragrostis tricuspis Trin., Mém. Acad. St. Pétersb. VI. Math. Phys. Nat. 1: 414. 1830. Based on Tricuspis caroliniana Beauv.

Tricuspis quinquefida Beauv.; Don, Loud. Hort. Brit. 31. 1830. Based on Poa caerulescens Michx.

?Triodia festucoides Desv., Opusc. 98. 1831. North America, Panicum festucoides Desv., in Poir., eited as synonym.

Triodia caerulescens Desv., Opusc. 99. 1831. Based on Poa caerulescens Michx.

Triodia novaeboracensis Desv., Opuse. 99. 1831. Based on Tricuspis novaeboracensis Beauv.

Uralepis tricuspis Steud., Nom. Bot. ed. 2. 1: 564. 1840. Based on Eragrostis tricuspis Trin.

Festuca purpurea Schreb.; Steud., Nom. Bot. ed. 2. 1: 632. 1840, as synonym of Uralepis cuprea Kunth.

Tricuspis sesleroides var. flexuosa Wood, Amer. Bot. and Flor. pt. 2: 398. 1870. Pennsylvania.

Festuca flava F. Míuell., Sel. Pl. Indust. Cult. 87. 1876. Based on Poa flava "Gronov" [L.].

Triodia sesleroides Benth.; Vasey, U.S. Dept. Agr. Spec. Rept. 63: 35. 1883. Based on Tricuspis sesleroides Torr.

Sieglingia flava Kuntze, Rev. Gen. P1. 2: 789. 1891. Based on Poa flara L. Sieglingia cuprea Millsp., FI. IT.Ta. 471. 1892. Presumably based on Triodia cuiprea Jacq.

Sieglingia sesleroides Seribn., Mem. Torrey Bot. Club 5: 48. 1894. Based on Poc sesleroides Michx. 
Sicglingia sesleroides var. intermedia Vasey; L. H. Dewey, Contrib. U.S. Natl. Herb. 2: 539. 1894. Texas to Oklahoma [Sheldon in 1891].

Sieglingia chapmani Small, Bull. Torrey Bot. Club 22: 365. 1895. Florida, Chapman.

Triodia sesleroides van, aristala Seribn. and Ball, U.S.Dept.Agr., Div. Agrost. Bull. 24: 45. 1901. Clarcona, Fla., Meislahn 90.

Triodia chapmani Bush, St. Louis Acad. Sci. Trans. 12: 74. 1902. Based on Sieglingia chapmani Small.

Tridens sesleroides Nash, in Small, Fl. Southeast. U.S. 142. 1903. Based on Poa sesleroides Miclix.

Tridens flavus Hitchc., Rhodora 8: 210. 1906. Based on Poa flava L.

Tricuspis flava F. T. Hubb., Rhodora 14: 186. 1912. Based on Poa flava L.

Eragrostis arundinacea Jedw., Bot. Archiv Mez 5: 192. 1924. Texas.

(2) Triodia grandifiora Vasey, Contrib. U.S. NatI. Herb. 1: 59. 1890. Chenate Mountains, Presidio County, Tex., Nealley $\$ 23$.

Triodia nealleyi Vasey, Bull. Torrey Bot. Club. 15: 49. 1888, name only; U.S.Dept.Agr., Div. Bot. Bull. 12: pl. 36. 1891. Western Texas, Nealley.

Sieglingia nealleyi L. H. Dewey, Contrib. U.S. Natl. Herb. 2: 538. 1894. Based on Triodia uealleyi Vasey.

Sieglingia avenacea var. grandiflora L. H. Dewey, Contrib. U.S. Natl. Herb. 2: 538. 1894. Based on Triodia grandiflora Vasey.

Sieglingia grandiflora Beal, Grasses N.Amer. 2: 47i. 1896. Based on Triodia grandiflora Vasey.

Tricuspis nealleyi Heller, Cat. N.Amer. Pl. ed. 2. 28. 1900. Presumably based on 'Triodia nealleyi Vasey.

Tridens nealleyi Woot. and Standi., N.Mex. Coll. Agr. Bull. 81: 129. 1912. Based on Triodia nealleyi Vasey.

Tridens grandiflorus Woot. and Standl., N.Mex. Coll. Agr. Bull. 81: 129. 1912. Based on Triodia grandiflora Vasey.

This species has been referred to Triodia avcnacea H.B.K., a Mexican species not known from the United States.

(7) Triodia langloisi (Nash) Bush, St. Louis Acad. Sci. Trans. 12: 72. 1902. Based on Tricuspis langloisii Nash.

Poa ambigua Ell., Bot. S.C. and Ga. 1: 165. 1816. Not Triodia ambigua R. Br., 1810. South Carolina and Georgia.

Windsoria ambigua Nutt., Gen. PI. 1: 70. 1818. Based on Poa ambigua Ell.

Tridens ambiguus Sehult., Mant. 2: 333. 1824. Based on Poa ambigua Ell.

Uralepis ambigua Kunth, Rév. Gram. 1: 108. 1829. Based on Poa ambigua Ell.

Tricuspis ambigua Chapm., Fl. South. U.S. 559. 1860. Based on Poa ambi-

gua Ell.
Triodia ambigua Benth.; Vasey, U.S. Dept. Agr. Spec. Rept. 63: 35. 1883. Based on Tricuspis ambigua Chapm.

Sieglingia ambigua Kuntze, Rev. Gen. Pl. 2: 789. 1891. Based on Poa ambigua Ell.

Tricuspis langloisii Nash, Bull. N.Y. Bot. Gard. 1: 293. 1899. Louisiana, Langlois.

Triodia elliottii Bush, St. Louis Acad. Sci. Trans. 12: 73. 1902. Based on Poa ambigua Ell.

Tridens langloisii Nash, in Small, Fl. Southeast. U.S. 142. 1903. Based on Tricuspis langloisii Nash.

(13) Triodia mutica (Torr.) Seribn., Bull. Torrey Bot. Club 10: 30. 1883. Based on Tricuspis mutica Torr.

Tricuspis mutica Torr., U.S. Rept. Expl. Miss. Pacif. 4: 156. 1857. Laguna Colorado, N.Mex., [Bigel.ow].

Uralepis pilosa Buckl., Acad. Nat. Sci. Phila. Proc. 1862: 95. 1863. Not $U$. pilosa Buckl., op. cit. 94. "Northern Texas" cited, but the type is from western Texas, collected by Wright.

Uralepis mutica Fourn.; Hemsl., Biol. Centr. Amer. Bot. 3: 569. 1885, as synonym of Triodia mutica Benth. (U. mutica Fourn., Mex. Pl. 2: 110. 1886, based on Liebmann 611, is Poa alpina.)

Sieglingia mutica Kuntze, Rev. Gen. Pl. 2: 789. 1891. Based on Tricuspis mutica Torr.

Tridens muticus Nash., in Small, Fl. Southeast. U.S. 143. 1903. Based on Tricuspis mutica Torr.

(8) Triodia pilosa (Buckl.) Merr., U.S.Dept.Agr., Div. Agrost. Circ. 32: 9. 1901. Based on Uraleyis pilosa Buckl. 
Uralepis pilos Buckl., Acad. Nat. Sci. Phila. Proc. 1862. 94. 1863. Middle Texas, [Buchley].

Tricuspis acuminata Munro; A. Gray, Acad. Nat. Sci. Phila. Proc. 1862: 335. 1863, as synonym of Uralepis pilosa Buckl.

Triodia acuminala Benth.; Vasey, L.S.Dept.Agr. Spcc. Rept. 63: 35. 1883, name only, with Tricupis acuminata Munro given as syuonym; Vasey, U.s. Dept.Agr., Div. Bot. Bull. 123: pl. 32. 1891. Texas [type, Austin, Hall 779] to Arizona and Mexico.

Sieglingia acuminata Kuntze, Rev. Gen. Pl. 2: 789. 1991. Based on Triodia acuminata Vaser.

Sieglingia pilusa Nash, in Britt. and Brown, 11lustr. Fl. 3: 504. 1898. Based on Uralepis pilosa Buckl.

Tricuspis pilosa Heller, Cat. N.Amer. P1. ed. 2: 28. 1900. Presumably based on Uralepis pilosa Buckl.

Erioneuron pilosum Nash, in Small, Fl. Southeast. U.S. 144. 1903. Based on Uralepis pilosa Buckl.

Tridens pilosus Hitchc., Contrib. U.S. Natl. Herb. 17: 357. 1913. Based on Uralepis pilosa Buckl.

(1) Triodia pulchella H.B.K., Nor. Gen. and Sp. 1: 155. pl. 47.1816. Mexico, Humboldt and Bonpland.

Kocleria pulchella Spreng., Syst. Veg. 1: 332. 1825. Based on Triodia pulchella H.B.K.

Uralepis pulchella Kunth, Rév. Gram. 1: 108. 1829. Based on Triodia pulchella H.B.K.

Dasyochloa pulchella Willd.; Steud., Nom. Bot. ed. 2. 1: 4St. 1840, as synonym of Uralepis pulchella Kunth; Rydb., Fl. Rocky Mount. 67. 1917. Based on Triodia pulchella H.B.K.

Tricuspis pulchella Torr., U.S. Rept. Expl. Miss. Pacif. 4: 15̌6. 1S5̄. Based on "Trichodia" [error for Triodia] pulchella H.B.K.

Trichodiclida prolifera Cervant., Naturaleza 1870: 346. 1870. Near Mexico City.

Sieglingia pulchella Kuntze, Rev. Gen. Pl. 2: 789. 1891. Based on Triadia pulchella H.B.K.

Sieglingia pulchella var. parviflora Vasey; Beal, Grasses N.Amer. 2: 468.1896. Southern California, Orcult.

Triders pulchellus Hitchc., in Jepson, Fl. Calif. 1: 141. 1912. Based on Triodia pulchella H.B.K.

(11) Triodia stricta (Nutt.) Benth.; Vasey, U.S. Dept. Agr. Spec. Rept. 63: 35. 1883. Based on "Tricuspis" [error for Windsoria] stricta Nutt.

Windsoria stricta Nutt., Amer. Phil. Soc. Trans. (n.s.) 5: 147. 1837. Arkansas (probably Arkansas Post), Nuttall.

Tricuspis stricta Wood, Class-book 792. 1861. Based on Windsoria stricta Nutt.

Uralepis densiflora Buckl., Acad. Nat. Sci. Phila. Proc. 1862: 94.1863. Middle Texas, [Buckley].

Sieglingia stricla Kuntze, Rev. Gen. P1. 2: 789. 1891. Based on IVindsoria stricta Nitt.

Tridens strictus Nash, in Small, Fl. Sortheast. U.S. 143. 1903. Based on IVindsoria stricta Nutt.

(10) Triodia texana S. Wats., Amer. Acad. Sci. Proc. 18: 180. 18S3. Coahuila, Mexico; western Texas and New Mexico, Wright 776, 777, and 2045 [error for 2055, type, from Texas].

Tricuspis texina Thurb.; S. Wats., Amer. Acad. Sci. Proc. 18: 180 . 1883, as synonym of Triodia texana S. Wats.

Sieglingia lexana Kuntze, Rev. Gen. Pl. 2: 7\$9. 1891. Based on Triodia texana S. Wats.

Tridens texanus Nash, in Sn!ll, Fl. Southeast. U.S. 142. 1903. Based on Triodia texana Thurb. (error for S. Wats.).

\section{(32) TRIPLASIS Beauv.}

(2) Triplasis americana Beauv., Ess. Agrost. 81. pl. 16. f. 10.1812 . United States, Delille.

Uralepsis cormuta Ell., Bot. S.C. and Ga. 1: 580. 1821. South Carolina and Georgia.

Tricuspis cornuta A. Gray, Man. 590. 1848. Based on Uralepsis cornuta Ell.

Triplasis cornuta Benth.; Jacks., Ind. Kew. 2: 1121. 1895, as synonym of Triplasis americana Beauv. 
Sieglingia americana Beal, Grasses N.Amer. 2: 466. 1896. Based on Triplusis americana Beauv.

(1) Triplasis purpurea (Walt.) Chapm., Fl. South. U.S. 560. 1860. Based on Aira purpurea Walt.

Aira purpurea Walt., Fl. Carol. 78. 1788. South Carolina.

Festuca brevifolia Mull., Descr. Gram. 167. 1817. Delaware, Georgia, and New York.

Diplocea barbata Raf., Amer. Jour. Sci. 1: 252. 1818. Carolina; Long Island.

Uralepsis purpurea Nutt., Gen. Pl. 1: 62. 1818. Based on Aira purpurea Walt.

Uralepsis aristulata Nutt., Gen. Pl. 1: 63. 1818. Wilmington, Del., Baldwin.

Glyceria ? brevifolia Schult., Mant. 2: 387. 1824. Based on Festuca brevifolia Muhl.

Tricuspis purpurea A. Gray, Man. 589. 1848. Based on Aira purpurea Walt.

Merisachne drummondii Steud., Syn. Pl. Glum. 1: 117. 1854. Texas, Drummond 330.

Festuca caroliniana Steud., Syn. Pl. Glum. 1: 312 . 1854. Carolina, Bosc.

Festuca purpurea F. Muell., Sel. Pl. Indust. Cult. 88. 1876. Based on Uralepsis purpurea Nutt.

Triplasis sparsiflora Chapm., Bot. Gaz. 3: 19. 1878. Punta Rassa, Fla., [Chapman, specimen affected by fungus.]

Sieglingia purpurea Kuntze, Rev. Gen. Pl. 2: 789. 1891. Based on Aira purpurea Walt.

Panicularia brevifolia Porter, Bull. Torrey Bot. Club 20: 205. 1893. Based on Festuca brevifolia Muhl.

Triplasis intermedia Nash, Bull. Torrey Bot. Club 25: 564. 1898. Tampa, Fla., Nash 2426.

Triplasis floridana Gandog., Bull. Soc. Bot. France 66 : 303. 1920. Punta Rassa, Fla., Hitchcock 533.

Triplasis glabra Gandog., Bull. Soc. Bot. France 667: 303. 1920. Rhode Island and Florida.

Triodia purpurea Smyth, Kans. Acad. Sci. Trans. 25: 95. 1913. Based on Triplasis purpurea Chapm.

\section{(92) TRIPOGON Roth}

(1) Tripogon spicatus (Nees) Ekman, Arkiv Bot. 114: 36. 1912. Based on Bromus spicatus Nees.

Bromus spicatus Nees, Agrost. Bras. 471. 1829. Piauhy, Brazil.

Diplachne spicata Doell, in Mart., Fl. Bras. 23: 159. pl. 28. f. 2. 1878. Based on Bromus spicatus Nees.

Triodia schaffneri S. Wats., Amer. Acad. Sci. Proc. 18: 181. 1883. Sau Luis Potosí, Mexico, Schafjner 1077.

Diplachne reverchoni Vasey, Bull. Torrey Bot. Club 13: 118. 1886. Llano County, Tex., Reverchon.

Leptochloa spicata Scribn., Acad. Nat. Sci. Phila. Proc. 1891: 304. 1891. Based on Diplachne spicata Doell.

Sieglingia schaffneri Kuntze, Rev. Gen. Pl. 2: 789. 1891. Based on Triodia schaffneri S. Wats.

Rabdochloa spicata Kuntze; Stuck., An. Mus. Nac. Buenos Aires 11: 121. 1904. Based on Bromus spicatus Nees.

Sieglingia spicata Kuntze; Stuck., An. Mus. Nac.Buenos Aires 11: 128.1904. Based on Bromus spicatus Nees.

(157) TRIPSACUM L.

(1) Tripsacum dactyloides (L.) L., Syst. Nat. ed. 10. 2: 1261. 1759. Based on Coix dactyloides L.

Coix dactyloides L., Sp. Pl. 972. 1753. America.

Coix angulatis Mill., Gard. Dict. ed. 8. Coix no. 2. 1768. North America.

Ischaemun glabrum Walt., Fl. Carol. 249. 1788. South Carolina.

Tripsacum monostachyum Willd., Sp. Pl. 4: 202. 1805. South Carolina.

Tripsacum dactyloides var. monostachyon Eaton and Wright, N.Amer. Bot. ed. 8. 461. 1840. Connecticut. Wood, Class-book 453. 1845. Gray, Man. Bot. 616. 1848. No basis given.

Dactylodes angulatum Kuntze, Rev. Gen. Pl. 2: 773. 1891. Based on Coix angulatis Mill. 
Tripsacum dactyloides var. monostachyum Vasey, Contrib U.S. Natl. Herb. 3: 6. 1892. Based on T. monosiachyum Willd.

Dactylodes dactylodes Kuntze, Rer. Gen. Pl. 32: 349. 1898. Based on Tripsacum dactyloides L.

(2) Tripsacum floridanum Porter; Vasey, Contrib. U.S. Natl. Herb. 3: 6. 1892. Florida, Garber.

Tripsacum dactyioides var. floridanum Beal, Grasses N.Amer. 2: 19.1896. Based on T. flnridanum Porter.

(3) Tripsacum lanceolatum Rupr.; Fourn., Mex. Pl. 2: 68. 1886. Aguas Calientes, Mexico, Hartueg 252.

Tripsacum acutiftorum Fourn., Bull. Soc. Bot. Belg. 15: 466. 1876, name only; Nash, N.Amer. Fl. 17: 81. 1909. Same type as T. lanceolatum Rupr.

Tripsacum lemmoni Vasey, Contrib. U.S. Nat1. Herb. 3: 6. 1892. Huachuca Mountains, Ariz., Lemman [2932].

Tripsacum dactyloides var. lemmoni Beal, Grasses N.Amer. 2: 19.1896. Based on T. lemmoni Vasey.

Tripsacum dactyloides hispidum Hitelıe, Bot. Gaz. 41: 295. 1906. Las Canóas, Mexico, Pringle 3811.

\section{(54) TRISETUM Pers.}

Trisetum aureum (Ten.) Ten., Fl. Napol. 2: 378. 1320. Based on Koeleria aurea Ten.

Koeleria aurea Ten., Cors. Bot. Lez. 1: 58. 1806. Europe.

(6) Trisetum eanescens Buckl., Acad. Nat. Sci. Phila. Proc. 1862: 100. 1863. Columbia Plains, Oreg., Nuttall.

Trisetum elatum Nutt.; A. Gray, Acad. Nat. Sci. Phila. Proc. 1862: 337.1 1863, as synonym of T. canescens Buckl.

Trisetum cernuum var. canescens Beal, Grasses N.Amer. 2: 380. 1896. Based on T. canescens Buckl.

Trisetum canescens forma tonsum Louis-Marie, Rhodora 30: 216. 1928. Trinity County, Calif., Yates 522.

Trisetum canescens forma velutinum Louis-Marie, Rhodora 30: 216. 1928. Lassens Feak, Calif., Austin in 1879.

Trisetum projectum Louis-Marie, Rhodora 30: 217. 1928. Fresno County, Calif., Hall and Chandler 359.

(4) Trisetum cernum Trin., Mém. Acad. St. Pétersb. VI. Math. Phys. Nat. 1:61. 1830. Sitka, Alaska.

Avena nutkaensis Pres. Rel. Haenk. 1: 254. 1830. Nootka Sound, Vancouver Island, Haevilic.

Avena cernua Kunth, Rév. Gram. 1: Sup. XXVI. 1830. Based on Trisetum cernuum Trin.

Trisetum sandbergii Beal, Grasses N.Amer. 2: 378. 1896. Mount Stuart, Wash., Sandberg and Leiberg 823.

Trisetum nutkaense Scribn. and Merr.; Davy, Univ. Calif. Pubs., Bot. 1: 63. 1902. Based on Avena nutkaensis Presl.

Trisetum cernuum var. luxurians Lolis-Marie, Rhodora 30: 213.1928. Seaside, Oreg., Shear and Scribner 1705.

Trisetum cernuum var. luxurians forma pubescens Louis-Marie, Rhodora 30: 213. 1928. Eureka, Calif.

Trisetum cernuum var. sandbergii Louis-Marie, Rhodora 30: 214. 1928. Based on T. sandbergii Beal.

(8) Trisetum flavescens (L.) Beauv., Ess. Agrost. 88, 153. pl. 18. f. 1. 1812. Based on Avera flavescens $\mathrm{L}$.

Avena flavescers L., Sp. Pl. 80. 1753. Europe.

Trisetum pratense Pers., Syn. Pl. 1: 97. 1805. Europe.

Trisctaria flavescens Baumg., Enum. Stirp. Transsilv. 3: 263. 1816. Based on Avena flarescens Schreb. (error for L.).

Rebentischia flavescens Opiz, Lotos 4: 104. 1854, as synonym of Trisetum flavescens Beauv.

(10) Trisetum interruptum Buckl., Acad. Nat. Sci. Phila. Proc. 1862: 100.1863. Middle Texas [Bucliley].

?Calamagrostis longirostris Buckl., Prel. Rept. Geol. Agr. Survey Tex. App. 2. 186b. Texas.

Trisetum hallii Scribn., Bull. Torrey Bot. Club 11: 6. 1884. Texas, Hall 799 in part. 
Sphenopholis interrupta Scribn., Rhodora 8: 145. 1906. Based on Trisetum interruptum Buckl.

Sphenopholis hallii Seribn., Rhodora 8: 146. 1906. Based on Trisetum hallii Scribn.

Trisetum interruptum hallii Hitche., Biol. Soc. Wash. Proe. 41: 160. 1928. Based on T. hallii Buckl.

(1) Trisetum melicoides (Michx.) Scribn., Bot. Gaz. 9: 169. 1884. Based on Aira melicoides Michx.

Aira melicoides Michx., Fl. Bor. Amer. 1: 62. 1803. Canada.

? Arundo airoides Poir., in Lam., Encycl. 6: 270. 1804. North America, Michaux.

Graphephorum melicoideum Desv., Nouv. Bull. Soc. Philom. Paris 2: 189. 1810. Based on Aira melicoides Michx.

?Deyeuxia airoides Beauv., Ess. Agrost. 44, 152, 160. 1812. Based on Arundo airoides Michx. [error for Poir.].

Poa melicoides Nutt., Gen. Pl. 1: 68. 1818. Based on Aira melicoides Michx.

Triodia melicoides Spreng., Syst. Veg. 1: 331. 1825. Based on Aira melicoides Michx.

?Agrostis airoides Raspail, Ann. Sci. Nat., Bot. 5: 449. 1825. Based on Deyeuxia airoides Beauv.

?Calamagrostis airoides Steud., Nom. Bot. ed. 2. 1:249. 1840. Based on Arundo airoides Poir.

Dupontia cooleyi A. Gray, Man. ed. 2. 556. 1856. Washington, Mich., [Cooley].

Graphephorum melicoides var. major A. Gray, Amer. Acad. Sci. Proc. 5: 191. 1861. Baserl on Dupontia cooleyi A Gray.

Graphephorum melicoideum cooleyi Seribn., Mem. Torrey Bot. Club 5: 53. 1894. Based on Dupontia cooleyi A. Gray.

Trisetum melicoideum cooleyi Seribn., Rhodora 8: 87. 1906. Based on Dupontia cooleyi A. Gray.

Trisetum melicoides var. majus Hitche,, in Robinson, Rhodora 10: 65. 1908. Based on Graphephorum melicoides var. major A. Gray.

Graphephorum cooleyi Farwell, Mich. Acad. Sci. Papers 1: 8S. 1921. Based on Dupontio cooleyi A. Gray.

(7) Trisetum montanum Vasey, Bull. Torrey Bot. Club 13: 118. 1886. No locality cited. [Type, Las Vegas, N.Mex., G. R. Vasey in 1881.]

Trisetumi argenterm Seribn., U.S.Dept.Agr., Div. Agrost. Bull. 11: 49. f. 8 1898. Not T. argenteum Roen. and Schult. Silverton, Colo., Shear 1214.

Trisetum shearii Seribn., U.S.Dept.Agr., Div. Arost. Circ. 30: 8. 1901. Based on 'T. argenteum Scribn.

Graphephorum shearii Rydb., Bull. 'Torrey Bot. Club 32: 602. 1905. Based on Trisetum shearii Seribn.

Trisetum canescens var. montanum Hitchc., Biol. Soc. TVash. Proc. 41: 160. 1928. Based on T. montanum Vasey.

Trisetum montanum var. pilosum Louis-Marie, Rhodora 30: 212.1928. Caroles, N.Mex., Standley 4536.

Trisetum montanum var. shearii Louis-Marie, Rhodora 30: 213. 1928. Based on Trisetum shearii Scribn.

(3) Trisetum orthochaetum Hitchc., Amer. Jour. Bot. 21: 134. f. 3. 1934. Lolo Hot Springs, Bitterroot Mountains, Mont., Chase 5129.

(9) Trisetum pennsylvanicum (L.) Beauv.; Roem. and Schult., Syst. Veg. 2: 658. 1817. Based on Avena pennsylvanica L.

Avena pennsylvanica L., Sp. Pl. 79. 1753. Pennsylvania, Kalm.

?Avena caroliniana Walt., Fl. Carol. 81. 1788. South Carolina.

Avena palustris Michx., Fl. Bor. Amer. 1: 72. 1803. Carolina and Georgia, Michaux.

Aira pallens var. aristata Muhl.; Ell., Bot. S.C. and Ga. 1: 151. 1816. South Garolina.

Avena pennsylvanica Muhl., Descr. Gram. 185. 1817. Pennsylvania and North Carolina. No authority cited but the Muhlenberg specimen belongs to the Limmaean species.

Trisetum palustre Torr., Fl. North. and Mid. U.S. 126. 1823. Based on Avena palustris Michx.

Arrhenatherum pennsylvanicum Torr., F1. North. and Mid. U.S. 1: 130.1823. Based on Avena pennsylvanica L.

?Arrhenatherum kentuckense Torr.; Steud., Nom. Bot. ed. 2. 1: 135. 1840. North America. Name only. "Avena pennsylvanica Muhl." doubtfully cited as synonym. 
Trisetum ludovicianum Vasey, Bull. Torrey Bot. Club 12: 6. 1885. Pointe à la Hache, La., Langlois.

Sphenopholis palustris Scribu., Rhodora S: 145. 1906. Based on Avena palustris Michx.

Sphenopholis palustris flexuosa Seribn., Rhodora 8: 143, 145. 1906. Wilmington, Del., Commons 274.

Sphenopholis palustris var. flexuosa Scribn.; Robinson, Rhodora 10: 65. 1908. Based on S. palusiris flexuosa Scribn.

Sphenopholis penusylvanica Hitche., Amer. Jour. Bot. 2: 304. 1915. Based on Avena pennsyluanica L.

Sphenopholis pennsylvanica var. flexuosa F. T. Hubb., Rhodora 18: 234. 1916. Based on S. palustris flexuosa Scribn.

The plant from Hunting Creek, Va., diseussed by Vasey (Bot. Gaz. 9: 165. 1884) as a hybrid between Trisetum palustre and Eatonia pennsylvanica, is all exceptional specimen of Trisetum pennsylvanicum (L.) Beauv. with short-awned and awnless spikelets.

(5) Trisetum spicatum (L.) Richt., Pl. Eur. 1: 59. 1890. Based on Air spicata L., Sp. Pl. 64.1753.

Aira spicata L., Sp. Pl. 64. 1753.32 Lapland.

Aira subspicata L., Syst. Nat. ed. 10. 2: 873. 1759. Based on A. spicata I. (Sp. Pl. 64. 1753), the diagnosis copied.

Avena airoides Koel., Descr. Gram. 298. 1802. Based on Aira subspicata L.

Avena mollis Michx., Fl. Bor. Amer. 1: 72. 1803. Canada. Not Avena mollis Salisb., 1796, nor Kioel., 1802.

Avena subspicata Clairv., Man. Herbor. 17. 1811. Based on a phrase name in Haller which refers to Aira spicata L.

Trisetum subspicatum Beauv., Ess. Agrost. 88, 149. 1812. Based on Aira subspicata L.

?Melica triflora Bigel., New England Jour. Med. and Surg. 5: 334.1816. Mount Washington, N.H., Boott.

Trisetaria airoides Baumg., Enum. Stirp. Transsilv. 3: 265. 1816. Based on Avena airoides Koel.

Trisetum airoides Beauv.; Roem. and Schult., Syst. Veg. 2: 666. 1817. Based on Avena airoides Koel.

Trisetum molle Kunth, Rév. Gram. 1: 101. 1829. Based on Avena mollis Michx.

Koeleria subspicata Rcichenb., Fl. Germ. 49. 1830. Based on Aira subspicata L.

Koeleria cancscens Torr., in Trin., Mém. Acad. St. Pétersb. VI. Sci. Nat. 21: 13. 1836, as synonym of Trisctum molle Kuntl.

Trisetum subspicotum var. wollc A. Gray, Man. ed. 2. 572. 1856. Based on Avena mollis Michx.

Koeleria spicata Reichenb.; Wilk. and Lange, Prodr. Fl. Hisp. 1: 72. 1861, as synonym of Trisetum subspicatum Beauv. Rupestrina pubescens Provancher, Fl. Canad. 689. 1862. Based on Avena
mollis Michx.

Trisetum spicatum var. molle Beal, Grasses N.Amer. 2: 377. 1896. Based on Avena mollis Miehx.

Trisetum brittonii Nash, Bull. N.Y. Bot. Gard. 1: 437. 1900. Marquette, Mich., Britton in 1883 .

Trisetum congdoni Scribn. and Merr., Bull. Torrey Bot. Clut 29: 470. 1902. Mariposa County, Calif., Congdon. (T. sesquiflorum Trill., to which $T$. congdoni has been referred, is a distinct Alaskan species.)

Trisetum americanum Gandog., Bull. Soc. Bot. France 49: 182. 1902. Colorado; Idaho.

Trisetum majus Rydb., Colo. Agr. Expt. Sta. Bull. 100: 34. 1906. “T. subspicatum major Vasey", an unpublished name, eited as basis. A tall specimen collected by Vasey, Pen Gulch, Colo., in 1884 and marked "var. major Vasey" in his script is taken as type. No deseription by Rydberg cxcept the distinctions given in the key.

Avena spicata Fedtsch., Act. Hort. Petrop. 28: 76. 1908. Not A. spicata I. Based on Aira spicata L.

Trisetum spicatum var. pilosiglume Fernald, Rhodora 18: 195.1916. Newfoundland, Fernald, Wiegand, and Bartram 4593.

32 On page 63 of this work is another Airn spicata L. In the errata at the end of the second volume of the Species Plantarum (issued a few months after the first volume) Linnaeus changes $A$. spicatn of page fi3 to A. indica (now referred to sicciolepis indica ( 1 .) Chase)

$55974^{\circ}-35-62$ 
Trisetum spicatum congdoni Hitchc., Biol. Soc. Wash. Proc. 41: 160. 1928. Based on Trisetum congdoni Scribn, and Merr.

Trisetum spicatum var. brittonii Louis-Marie, Rhodora 30: 239. 1928. Based on T. brittonii Nash.

(2) Trisetum wolfii Vasey, U.S. Dept. Agr. Monthly Rept. Feb. Mar. 156. 1874. Twin Lakes, Colo., TVolf.

Trisetum subspicatum var. muticum Boland., in S. Wats., Bot. Calif. 2: 296. 1880. Upper Tuohumne, Calif., Bolander 5019.

Trisetum brandegei Scribn., Bull. Torrey Bot. Club 10: 64. 1883. Cascade Mountains, Brandegce and Tweedy in 1882.

Graphephorum wolfii Vasey; Coult. Man. Rocky Mount. 423. 1885. Based on Trisetum wolfii Vasey.

Trisetum muticum Scribn., U.S.Dept.Agr., Div. Agrost. Bull. 11: 50. f. 10. 1898. Based on Trisetum subspicatum var. muticum Boland.

Graphephorum muticum Heller, Cat. N.Amer. Pl. ed. 2. 31. 1900. Presumably based on Trisetum subspicatum var. muticum Boland.

Trisetum wolfii muticum Scribn., Phodora 8: 88. 1906. Based on T. subspicatum var. muticum Thurb. (error for Boland.).

Graphephorum brandegei Rydb., Fl. Rocky Mount. 61. 1917. Based on Trisetum brandegei Scribn.

Trisetum wolfii var. brandegei Louis-Marie, Rhodora 30: 241. 1928. Based on T. brandegei Scribn.

Trisetum wolfii var. brandegei forma muticum Louis-Marie, Rhodora 30: 241. 1928. Based on T. wolfii muticum Seribn.

\section{(40) TRITICUM L.}

(1) Triticum aestivum L., Sp. Pl. 85. 1753. Cultivated in Europe.

Triticum hybernum L., Sp. Pl. 86. 1753. Cultivated in Europe.

Triticum compositum L., Syst. Veg. ed. 13. 108. 1774. Egypt. Form with branched spike.

Triticum sativum Lam., Fl. Franç. 3: 625. 1778. Cultivated in Europe.

Triticum vulgare Vill., Hist. Pl. Dauph. 2: 153. 1787. Cultivated in Europe.

Triticum vulgare var. aestivum Spenner, Fl. Friburg. 1: 163. 1S25. Based on T. aestivum L.

Triticum sativum var. aestivum Wood, Class-book ed. 2. 619. 1847. Presumably based on T. aestivum L.

Triticum sativum var. compositum Wood, Class-book ed. 2. 619. 1847. Presumably based on T. compositum L.

Triticum sativum var. vulgare Vilm., Blumengartn. 1: 1217. 1896. Based on T. vulgare Vill.

Triticum aestivum subsp. vulgare Thell., Mém. Soc. Sci. Nat. Cherbourg 38: 142. 1912. Based on T. vulgare Vill.

Zeia vulgaris var. aestiva Lumell, Amer. Midl. Nat. 4: 226. 1915. Based on "Triticum yulgare aestivum L." error for" T. aestiviim.

Triticum compactum Host, Gram. Austr. 4: 4. pl. 7. 1809. Cultivated in Austria.

Triticum dicoccoides Koern., Ber. Deut. Bot. Gesell. 26: 309. 1908. Pałestine. Triticum dicoccum Schrank, Baier. Fl. 1: 389. 1789. Cultivated in Europe.

Triticum aestivum subsp. dicoccum Thell., Mém. Soc. Sci. Nat. Cherbourg 38: 141. 1912. Based on T. dicoccum Schrank.

Triticum aestivum var. dicoccum Bailey, Gentes Herb. 1: 133. 1923. Based on T. dicoccum Schrank.

Triticum durum Desf., Fl. Atlant. 1: 114. 1798. North Africa.

Triticum aestivum subsp. durum Thell., Mém. Soc. Sci. Nat. Cherbourg 38: 143. 1912. Based on T'. durum Desf.

Triticum monococcum L., Sp. Pl. 86. 1753. Cultivated in Europe.

Triticum aestivum var. monococcum Bailey, Gentes Herb. 1: 133. 1923. Based on T. monococcum L.

Triticum polonicum L., Sp. Pl. ed. 2. 127. 1762. Cultivated in Europe.

Triticum aestivum var. polonicum Bailey, Man. Cult. Pl. 116. 1924. Based on T. polonicum L.

Triticum spelta L., Sp. Pl. 86. 1753. Cultivated in Europe.

I'riticum acstivum subsp. spelta Thell., Mitt. Naturw. Ges. Winterthur. 12: 147. 1918. Based on T. spelta L.

Triticum aestivum var. spelta Bailey, Gentes Herb. 1: 133. 1923. Based on T. spelta L.

Triticum turgidum L., Sp. Pl. 86. 1753. Cultivated in Europe. 
(20) UNIOLA L.

(2) Uniola latifolia Michx., F1. Bor. Amer. 1: 70. 1803. The locality as published is Allegleny Mountains, but the type specimen is from Illinois.

(6) Uniola laxa (L.) B.S.P., Prel. Cat. N.Y.69. 1858. Based on Holcus laxus L. Holcus laxus L., in. Pl. 1048. 1753. Virginia.

Uniola gracilis Nichx., Fl. Bor. Amer. 1: 71. 1803. Carolina to Georgia, Michaux.

Uniola virgata Bartr.; Pursh, Fl. Amer. Sept. 1: \$2. 1814, as synonym of Uniola gracilis Michx.

Chasmanthium gracile Link, Hort. Berol. 1: 159. 1827. Based on Uniola gracilis Michx.

Uniola uniflora Benke, Rhodora 31: 148. 1929. Memphis, Tenn., Benke 4874 .

(3) Uniola nitida Baldw; Ell., Bot. S.C. and Ga. 1: 167. 1816. Camden County, Ga., Baldwin.

Uniola intermedia Bosc; Beauv., Ess. Agrost. 75, 181. 1812. Name only. [A Bosc specimen so named in Padua is $U$. nitida; another in Paris is $U$. sessiliflora.]

(4) Uniola ornithorhyncha Steud., Syn. Pl. Glum. 1: 280. 1854. Alabama, Drummond 51 .

Chasmanthium ornithorhynchum Nees; Steud., Syn. Pl. Glum. 1: 280. 1854, as synonym of Uniola ornithorhyncha Steud.

(1) Uniola paniculata L., Sp. Pl. 71. 1753. Carolina.

Briza caroliniana Lam., Encycl. 1: 465. 1785. Carolina.

Uniola maritima Michx., Fl. Bor. Amer. 1: 71. 1803. Carolina, Michaux.

Trisiola paniculata Raf., Fl. Ludov. 144. 1817. Based on Uniola paniculata L.

Nevroctola maritima Raf.; Jacks., Ind. Kew. 3: 311. 1894, as synonym of Uniola paniculata L.

Nevroctola paniculata Raf.; Jacks., Ind. Kew. 3: 311. 1894, as synonym of Uniola paniculata L.

Uniola floridana Gandog., Bull. Soc. Bot. France 667: 304. 1920. Santa Rosa Island, Fla., Tracy 4545.

Uniola heterochroa Gandog., Bull. Soc. Bot. France 667: 304. 1920. Punta Rassa, Fla., Hitchcock 535.

Uniola macrostachys Gandog., Bull. Soc. Bot. France 667: 304. 1920. Breton Island, La., Tracy 462.

(5) Uniola sessiliflora Poir., in Lam., Encycl. 8: 185. 1808. Carolina, Bosc.

Poa scssiliftora Kunth, Rév. Gram. 1: 111. 1829. Based un Uniola sessiliftora Poir.

Uniola longifolia Scribu., Bull. Torrey Bot. Club 21: 229. 1894. Georgia [type, DeKalb County, Small in 1893], Florida, Mississippi, Tennessee.

(30) VASEYOCHLOA Hitchc.

(1) Vaseyochloa multinervosa (Vasey) Hitchc., Jour. Wash. Acad. Sci. 23: 452. 1933. Based on Melica multinervosa Vasey.

Melica multinervosa Vasey, Bot. Gaz. 16: 235. 1891. Brazos Santiago, Tex., Nealley.

Distichlis multinervosa Piper, Biol. Soc. Wash. Proc. 18: 147. 1905. Basedon Metica multinervosa Vasey.

Triodia multinervosa Hitchc., Biol. Soc. Wash. Proc. 41: 159. 1928. Based on Melica multinervosa Vasey.

Vetiveria zizanioides (L.) Nash, in Small, Fl. Southeast. U.S. 67. 1903. Based on Phalaris zizanioides $\mathrm{L}$.

Phalaris zizanioides L., Mant. Pl. 2: 183. 1771. India.

Andropogon muricatus Retz., Obs. Bot. 3: 43 [31]. 1783. India.

Anatherum muricatum Beauv., Ess. Agrost. 150. pl.22. f. 10. 1812. Based on Andropogon muricatus Retz.

Vetiveria muricata Griseb., Fi. Brit. W.Ind. 560. 1864. Based on Andropogon muricatus Retz.

Vetiveria arundinacea Griseb., Fl. Brit. W.Ind. 560. 1864. Jamaica and Trinidad, 
Sorghum zizanioides Kuntze, Rev. Ger. Pl. 2: 791. 1891. Based on Phalaris zizanioides L.

Andropogon zizanioides Urban, Symb. Antill. 4: 79. 1903. Based on Phalaris zizanioides L.

Holcus zizanioides Íuntze, Stuck., An. Mus. Nac. Buenos Aires 11: 48.1904. Based on Phalaris zizanioides L.

Anatherum zizanioides Hitchc. and Chase, Contrib. U.S. Natl. Herb. 18: 285. 1917. Based on Phalaris zizanioides L.

(96) WILLKOMMIA Hack.

(1) Willkommia texana Hitche., Bot. Gaz. 35: 283. f. 1. 1903. Ennis, Tex. J. G. Smith in 1897.

\section{(159) ZEA L.}

(1) Zea mays I., Sp. Pl. 971. 1753. America.

Zea americana Mill., Gard. Dict. ed. 8. Zea no. 1. 1768. West Indies.

Zea vulgaris Mill., Gard. Dict. ed. 8. Zea no. 3. 1768. Northern parts of America.

Mays zea Gaertn., Fruct. and Sem. 1: 6. pl. 1. f. 9. 1788. Based on Zea mays L.

Zea segctalis Salisb., Prodr. Stirp. 28. 1796. Based on Zea mays L.

Mays americana Baumg., Enum. Stirp. Transsilv. 3: 281. 1816. Based on Zea mays L.

Zea mays var. precox Torr., in Eaton, Man. Bot. ed. 2. 500. 1818. Northern and Middle States.

Mayzea cerealis Raf., Med. Fl. 2: 241. 1830. Based on Zea mays L.

Zea hirta Bonaf., Hist. Nat. Mais 29. pl. 4. 39. pl. 4. 1836. Cultivated, seed from California.

Zea mays pensylvanica Bonaf., Hist. Nat. Mais 33. pl. 7. f. 4. 1836. Cultivated.

Zea mays virginica Bonaf., Hist. Nat. Mais 37. pl. 10. f. 15.1836. Cultivated.

Zea erythrolepis Bonaf., Hist. Nat. Mais 30. pl. 5; 38. pl. 11. f. 17.1836. Cultivated along Missouri River.

Zea mais hirta Alefeld, Landw. Fl. 309. 1866. Based on Zea hirta Bonaf.

Zea saccharata Sturtev., N.Y. State Agr. Expt. Sta. Rept. 1884²: 156.1885 Group name for sweet corn.

Zea canina S. Wats., Amer. Acad. Sci. Proc. 26: 160. 1891. Mexico. Hybrid with Euchlaena mexicana Schrad., fide G. N. Collins.

Zea mays saccharata Bailey, Cycl. Hort. 4: 2006. 1902. Based on Z. saccharata Sturtev.

Zea mays var, everta Bailey, Cycl. Hort. 4: 2005. 1902. Based on Z. everta Sturtev.

Zea everta Sturtev., N.Y. State Agr. Expt. Sta. Rept. 18843: 183.1885. Group name for popcorn.

Zea Mays var. Japonica (Van Houtte) Wood, Amer. Bot. and Flor. pt. 2: 409. 1870. Presumably based on Z. japonica Van Houtte.

Zea japonica Van Houtte, Fl. Serr. Jard. 16: 121. 1865. Japan.

Zea mays var. tunicata St. Hil., Ann. Sci. Nat, Bot. 16: 144. 1829 . Uruguay.

Zea cryptosperma Bonaf., Hist. Nat. Mais 30,40. pl. 5 bis. 1836. Based on Z. mais var. tunicata St. Hil.

Zea tunicata Sturtev., Bull. Torrey Bot. Club 21: 335. 1894. Based on Z. mays var. tunicata St. Hil.

Of the many names published for forms of Zea mays only those based on material from the United States are given above, and of these only such as apply to the better-known races. See Sturtevant, N.Y. State Agr. Expt. Sta. Rept. and Bailey, Cycl. Hort. for additional names.

(113) ZIZANIA L.

(1) Zizania aquatica L., Sp. Pl. 991. 1753. Virginia. [Jamaica, also cited, is erroneous.]

Zizania clavulosa Michs., Fl. Bor. Amer. 1: 75. 1803. North America, Michaux.

Hydropyrum esculentum Link, Hort. Berol. 1: 252. 1827. North America.

Stipa angulata L.; Steud., Nom. Bot. ed. 2. 2: 642. 1841, as synonym of Ifydropyrum esculentum Link. 
Zizania effusa Munro, Jour. Proc. Linn. Soc. 6: 52. 1862, as syuonrm of Z. aquatica $\mathrm{L}$.

Ceratochaete aquatica Lunell, Amer. Midl. Nat. 4: 214. 1915. Based on Zizania aquatica L.

Zizania aquatica var. interior Fassett, Rhodora 26: 15S. 1924. Armstrong, Iowa, I'emmel and Cratty 764.

Zizania interior Rydh., Brittonia 1: 82. 1931. Based on Z. aquatica var. interior Fassett.

Zizania AQUAtica vitr. Angustifolia Hitchc., Rhodora 8: 210. 1906. Belgrade, Maine, Scribner in 1895.

Zizania palustris L., Mant. P1. 295. 1771. North America.

Melinum palustre link, Handb. Gewächs. 1: 96. 1829. Based on Zizanio, pulustris L.

(2) Zizania texana Hitche., Jour. Wash. Acad. Sci. 23: 454. 1933. San Marcos, Tex., silveus.

(114) ZIZANIOPSIS Doell and Aschers.

(1) Zizaniopsis miliacea (Michx.) Doell and Aschers.; Doell, in Mart., F1. Bras. $2^{2}$ : 13. 1871. Presumably based on Zizania miliacea Michx.

Zizania miliacea Michx., F. Bor. Aner. 1: 74. 1803. North America, Michaux.

\section{(87) ZOYSIA Willd.}

Zoysia japonica Steud., Syn. Pl. Glum. 1: 414. 1854. Japan.

Zoysia pungens var. japonica Hack., Bull. Herb. Boiss. 7: 642. 1899. Based on Z. japonica Stend.

Osterdamia japonica Hitehe., U.S. Dept. Agr. Bull. 772: 166. 1920. Baser on Zoysia japonica Steud.

Zoysia matrella (L.) Merr., Philippine Jour. Sci. Bot. 7: 230. 1912. Based on Agrostis matrella $\mathrm{L}$.

Agrostis matrella L., Mant. Pl. 2: 185. 1771. Malabar, India.

Zoysia pungens Willd., Gesell. Naturf. Freund. Berlin Neue Schrift. 3: 441. 1801. Malabar, India.

Osterdamia matrella Kinntze, Rev. Gen. Pl. 2: 781. 1891. Based on Agrostis matrella L.

Osterdamia zoysia Honda, Bot. Mag. [Tokyo] 36: 113. 1922. Based on Zoysia pungens Willd.

Zoysia tenuifolia Willd.; Trin, Mém. Acad. St. Pétersb. VI. Sci. Nat. 21: 96.1836. Mascarene Islands.

Osterdamia tenuifolia Kuntze, Rev. Gen. Pl. 2: 7S1. 1891. Based on Zoysio tenuifolia Willd.

Zoysia pungens var. tenuifolia Dur. and Schinz, Consp. Fl. Afr. 5: 734. 1894. Based on $Z$. teruifolia Willd.

Osterdamia zoysia var. tenuifolia Honda, Bot. Mag. [Tokyo] 36: 113.1922. Based on Zoysia tenuifolia Willd.

\section{UNDENTITIED NAMES}

The following names of grasses, based on specimens collected in the Inited States, cannot be identified from the descriptions, and the types have not been located. Several of these names are not effectively published.

Agrostis affinis Schult., Mant. 2: 195. 1S24. Based on Agrostis no. 17 in Muhlenberg's Descriptio Graminum p. 75. Sporobolus mulienbergii Kunth, Rév. Gram. 1: 6S. 1829, and Vilfa muhlenbergii Steud., Syn. PI. Cium. 1: 162. 1854, are also based on this. (See Hitcheock, Bartonia 14:33. 1932.)

Agrostis altissima var. laxa Tuckerm., Amer. Jour. Sci. 45: 44. 1843. White Mountains, N.H., Trichodium altissimum var, laxum Wood, Class-book erl. 2.600. 1847 , presumably based on this.

Agrostis michauxii Zuccagni, in Roemer, Coll. Bot. 123. 1809. Secd recrived from Thouin, collected in Kentucky by Michaux. Not A. michauxii Trin., 121? Agrostis pauciflora Pursh, Fl. Amer. Sept. 1: 63. 1814. Not A. pancifurer Schrad., 1806. "On high mountains in Virginia and Carolina." In the Ficw Herbarium is a specimen of Muhlenbergia schreberi marked "N. Amer. Mr. Fred. Pursh, Herb. propr." but with no name on the label. The description does not agree with this specimen, though it suggests some species of Muhienbergiu. A. oligantha Roem. and Sehult., Syst. Veg. 2: 372. 1817, Polypogon paucifiorus Spreng., Syst. Veg. 1: 243. 1825, and Muhlenbergia tenuiflora pauciflora Scribn., Mem. Torrey But. Club 5: 37. 1894, are based on this. 
Agrostis viridis Raf., Amer. Monthly Mag. 356. 1811. Not A. viridis Gouan, 1762. [United States.]

Aira capillacea Lam., Tabl. Encycl. 1: 177. 1791. Carolina, Fraser.

Aira compressa Raf., Amer. Monthly Mag. 356. 1811. [United States.] Name only.

Aira serotina Torr.; Trin., in Steud., Nom. Bot. ed. 2. 1: 45. 1840. North America. Name only.

Andropogon sessiliflorus Raf., Bull. Bot. Seringe 1: 221. 1830. [United States.] Name only, under section Dimciostemon. In Index Kewensis (1: 760 . 1893) the name is listed as Dimeiostemon sessiliflorus Raf.

Anthipsimus gonopodus Raf., Jour. Phys. Chym. 89: 105. 1819. Dry hills of the Ohio.

Apluda scirpoides Walt., Fl. Carol. 250. 1788. South Carolina. Not a grass, apparently a sedge.

Arundo confinis Willd., Enum. Pl. 127. 1809. North America. Calamagrostis confinis Beauv., Ess. Agrost. 15, 152. 1812, Deyeuxia confinis Kunth, Rév. Gram. 1: 76. 1829, and C. ncglecta var. confinis Beal, Grasses N. Amer. 2: 353. 1896 , are based on this.

Arundo glauca Hornem., Hort. Hafn. 1: 74. 1813. Not A. glauca Bieb., 1 sos.

North America.

Arundo pallens Mulkl.; Steud., Nom. Bot. ed. 2. 1: 144. 1840. Pennsyl-

vania. Name only, in Schrader Herbarium.

Briza virens Walt., Fl. Carol. 79. 1788. Not B. virens L., 1762. Sec Hitchcock, Rep. Missouri Bot. Gard. 16: 49. 1905. Poa virens Jacq., Eclog. Gram. 54. pl. 36.1820 , is based on this. The figure represents a species of Poa.

Calamagrostis pumila Nutt.; Gray, Acar. Nat. Sci. Phila. Proc. 1862: 334. 1863. Not C. mumila Hook., 1851. Name only for a plant collected in the Rocky Mountains by Nuttall.

Calotheca macrostachya Presl, Rel. Haenk. 1: 268, 351. 1830. In Addenda et Corrigenda (p.351) the original "in montanis Peruviae. . . " is changed to "ad Monte-Rey Californiae." This locality as in the case of several other species described by Presl, is erroneous. (See Hitcheock, Contrib. U.S. Natl. Herb. 24: 335. 1927.)

Cenchrus carolinianus Walt., Fl. Carol. 79. 1788. South Carolina. (See Chase, Contrib. U.S. Natl. Herb. 22: 76.1920.$)$

Cenchrus gracilis Beauv., Ess. Agrost. 57, 157. 1812. Name only for a specimen sent by Bose, presumably from the Carolinas.

Chloris longibarba Michx.; Beanv., Ess. Agrost. 79, 158. 1912. Name only.

Deyeuxia airoides Beanv., Ess. Agrost. 44, 152, 160. 1812. "Arundo airoides" Mich. ined." is referred to Deycuxin. Arundo airoirles Lam. was described from a plant collected in North America by Michaux and is probably the species Beauvois had in mind. Lamarck's description suggests Trisetum melicoides (Michx.) Scribner, which was collected by Michaux and described by him as Aira melicoides.

Deyeuxia halleriana Vasey, Descr. Cat. Grasses U.S. 50. 1885. Name only for a specimen from Washington Territory.

Eragrostis alba Presl, Rel. Haenk. 1: 279. 1830. "Monte-Rey, California", Haenke. Locality erroneous, the plant probably collected in Peru.

Eragrostis lugens var. major Vasey; L. H. Dewey, Contrib. U.S. Natl. Herb.

2: 542. 1894. "Texas to Arizona and eastward to Florida."

Festuca glabra Spreng., Syst. Veg. 1: 353. 1825. Not $F$. glabra Lightf., 1757.

Long Island, N.Y. The description suggests Puccincllia distans (L.) Parl.

Festuca grandiflora Lam., Tabl. Encycl. 1: 191. 1791. Carolina, Fraser.

Flexularia compressa Raf., Jour. Phys. Chym. 89: 105. 1819. Kentucky and

Ohio.

Koeleria airoides Nutt.; Steud., Nom. Bot.456. 1821. Name only. Referred doubtfully in Index Kevensis to Arundo airoides Lam.

Leptopyrum tenellum Raf., Med. Repos. N.Y. 5: 351. 1808. [United States.]

Name only.

Lolium canadense Michx.; Brouss., Elench. Pl. Hort. Monsp. 35. 1805, name only; Poem. and Schult., Syst. Veg. 2: 893. 1817. Grown in Montpellier. The description rather suggests a tall plant of $L$. perenne L. Lolium temulentum var. canadense Wood, Amer. Bot. and Flor. pt. 2: 406 . 1870, based on this.

Melica altissima Walt., F1. Carol. 78. 1788. Not M. altissima L., 1753. (See Hitchcock, Mo. Bot. Gard. Rept. 16: 47. 1905.)

Muhlenbergia anemagrostoides Trin.; Steud., Nom. Bot. ed. 2. 2: 164.1841.

America. Name only. 
Paneion buckleyanum var. maius Lunell, Amer. Midl. Nat. 4: 222.1915. Change of name for "Poa tenuifolia var. maior (Vasey)", but that name was never published, and no speeimen so named by Vasey ean be found.

Panicum americanum L., Sp. Pl. 56. 1753. America. This name and Pennisetum americanum Schum., based on it, have been used for P. glaucum (L.) R. Br. The original description is unidentifiable, probably based on a confusion of two or more species. (See Chase, Contrib. U.S. Natl. Herb. 22: 218. 1921; Amer. Jour. Bot. S: 43. 1921.)

Panicum anomalum Walt., Fl. Carol. 72. 1788. South Carolina. A species of Setaria. (See Hitchcock, Mo. Bot. Gard. Rept. 16: 35. 1905.)

Panicum barbatum LeConte; 'Torr., in Eaton, Man. Bot. ed. 2. 342. 1818. Not $P$. barbatum Lam., 1791. New York. The deseription rather suggests P. barbulatum Michx.

Panicum cartilagineum Muhl., Deser. Gram. 128. 1817. Georgia. (See Hitehcock. Bartonia 14: 41. 1932.)

Panicum debile Torr.; Steud., Nom. Bot. ed. 2. 255. 1841. Not P. debile Desf., 1798. As synonym of $P$. pubescens.

Panicum densum Muhl., Deser. Gram. 122. 1817. No locality given. The description suggests one of the Lanuginosa group.

Panicum dichotomum var. curvatum Torr., Fl. North. and Mid. U.S. 145. 1824.

No locality given.

Panicum dichotomum var. gracile Torr., Fl. North. and Mid. U.S. 145. 1824.

"Common in swamps, New York."

Panicum dichotomum var. pubcscens Munro, in Benth., Pl. Hartw. 341. 1857.

Sacramento, Calif., Hartweg. Name only.

Panicum dichotomum var. spathaceum Wood, Bot. and Flor pt. 2: 393. 1870.

No locality mentioned.

Panicum discolor Spreng., Mant. Fl. Hal. 31. 1807. Pennsylvania. A species of the subgenus Dichanthelium.

Panicum rlliottii Spreng.; Steud., Nom. Bot. ed. 2. 2: 256. 1841. Not P. elliottii Trin., 1829. As synonym of P. pubescens.

Panicum fimbriatum Willd.; Spreng., Syst. Veg. 1: 316 . 1825, as synonym of $P$. viscidum Ell. [P. scoparium Lam.] Soutl Carolina. A specimen in the Willdenow Herbarium so named is $P$. albomaculatum Scribn., from Mexico, collected by Humboldt.

Panicum flexuosum Raf., Jour. Bot. Desv. 4: 273. 1814. Not P. flexuosum Retz., 1791. New Jersey. P. rafinesquianum Schult., Mant. 2: 257. 1824, is based on this.

Panicum gracilescens Desv.; Poir., in Lam., Eneycl. Sup. 4: 279. 1816. Carolina. Desvaux gives a later description (Opuse. 95. 1831), which disagrees in some respects with that of Poiret.

Panicum iowense Ashe, N.C. Agr. Expt. Sta. Bull. 175: 115. 1900. Iowa to

Kansas. The deseription suggests $P$. huachucae or $P$. praecocius. (See Contrib.

U.S. Natl. Herb. 15: 330. 1910.)

Panicum muhlenbergianum Schult., Mant. 2: 230. 1824. Based on Panicum no. 27 of Muhienberg's Deseriptio Graninum, the deseription of which is copied. Muhlenberg gives "Habitat in Georgia."

Panicum nitidum var. glabrum Torr., Fl. North. and Mid. U.S. 146. 1824.

No locality cited. The deseription suggests $P$. commutatum Schult.

Panicum nitidum var. gracile Torr., Fl. North. and Mid. U.S. 146. 1824.

Near New York. The description applies fairly well to the vernal phase of $P$.

dichotomum $\mathrm{L}$.

Panicum nitidum var. majus Vasey, Contrib. U.S. Natl. Herb. 3: 30. 1892.

No loeality cited. Vasey says, "Here could be placed several variable forms."

Panicum pensylvanicum Spreng., Nachtr. Bot. Gart. Halle 30. 1801. Pennsylvania.

Panicum pumilum Raf., Med. Repos. N.Y. 5: 353. 1808. Name only.

Panicum speciosum Walt., Fl. Carol. 73. 1788. Soutl Carolina. The description faintly suggests Sporobolus gracilis (Trin.) Merr.

Panicum uniflorum Raf., Amer. Monthly Mag. 2: 120. 1817. Flatbush, N.Y.

Some species of subgenus Dichanthelium.

Panicum vilfiforme Wood, Class-book ed. 3. 785. 1861. East Tennessee.

Appears to be a species of the group Agrostoidia.

Paspalum compressum Raf., Fl. Ludov. 15. 1817. Louisiana prairies, Robin.

Paspalum dasyphyllum var. floridanum Wood, Amer. Bot. and Flor. pt. 2: 390.

1870. [Florida.]

Paspalum geniculatum Raf.. Fl. Ludov, 15. 1817. Louisiana, Robin. 
Paspalum supinum Rich.; Hornem., Hort. Hafn. 1: 77. 1813. Not $P$. supinum Bosc, 1804. Baltimore, introdueed in the Royal Botanic Garden in Copenhagen in 1807. Probably P. pubescens Muhl.

Paspalum virgatum var. latifolium Wood, Amer. Bot. and Flor. pt. 2: 309. 1870. Eastern States. Wood's P. virgatum appears to be Paspalum boscianum Fliigge; the variety may be a luxuriant form of this species.

Pennisetum glaucum var. purpurascens Eaton and Wright, N.Amer. Bot. ed. 8. 346. 1840. Virginia and northward.

Poa alata Desv., Opusc. 102. 1831. "Carolina?"

Poa nemoralis [L., misapplied by] Pursh, Fl. Amer. Sept. 1: 79. 1814. North America.

Poa tenuifolia Raf., Med. Repos. N.Y. 5: 353. 1808. [United States.] Name only.

Saccharifera spontanea Stokes, Bot. Mat. Med. 1: 132. 1812. South Carolina. Probably a species of Erianthus.

N.Y.

Setaria caudata var. pauciflora Jones, Contrib. West. Bot. 16: 13. 1930. No description, "(Vassey) as Chaetochloa" cited. There is nothing of Vasey's that can be associated with this (Chaetochloa was published 5 years after Vasey's death). Arizona, Jones 24697, 24698 cited. Mr. Jones states in a letter of September 28, 1932, that he could not recollect the basis for the name, and that he could not find the specimens cited.

Stipa spicata Walt., F. Carol. 78. 1788. Not S. spicata L. f., 1781. South Carolina. Apparently a species of Andropogon.

Triodia repens Vasey, Bull. Torrey Bot. Club 15: 49. 1888. Name only for a specimen coliected by "Nealley, Western Texas."

Triticum acgilopoides Thurb.; A. Gray, Acad. Nat. Sci. Phila. Proc. 1863: 79. 1863. Name only. Rocky Mts., Hall and Harbour 656.

Vilfa varians Buckl., Acad. Nat. Sci. Phila. Proc. 1S62: 89. 1863. Rocky Mountains, Nuttall. Apparently a species of Sporobolus.

\section{PERSONS FOR WHOM GRASSES HAVE BEEN NAMED}

This list includes names of persons for whom valid genera, species, or varieties of grasses in the Manual have been named.

Addison. See Brown.

Anderson, C. L. ( -1910). Botanist of Santa Cruz, Calif. Stipa lepida var. andersoni.

Arsène, Bro. Gerfroy (1867- ) . Professor in the Sacred Heart Training College, Las Vegas, N.Mex.; collected extensively in Mexico. Muhlenbergia arsenei.

Ashe, W. W. (1872-1932). Botanist and forester, United States Forest Service.

Panicum ashci.

Baker, C. F. (1872-1927). Botanist and entomologist, collected in the United

States, Cuba, and Philippine Islands. Agropyron bakeri; Agrostis bakeri.

Baker, C. H. (1848- ). Botanist of Florida. Spartina bakeri.

Barrelieri, Jacques (1606-73). French botanist. Eragrostis barrelieri.

Beckmann, Johann (1739-1811). German botanist. Beckmannia.

Bélanger, Charles. French botanist, who collected extensively in the Old

World. Stendel used belangeri as specific name for Anthephora belangeri (Hilaria belangeri), apparently through inadvertence, to commemorate Berlandier, collector of the type specimen.

Berg, F. G. C. (1843-1902). Director, Museo Nacional de Buenos Aires.

Panicum bergii.

Bertero, C. G. (1789-1831). Italian botanist. Tragus berteronianus.

Beyrich, H. K. (1796-1834). Prussian botanist, who collected from Georgia to

Texas. Eragrostis beyrichii.

Bicknell, L. P. (1859-1925). Botanist of New York City. Panicum bicknellii. Bigelow, J. M. (1804-78). Botanist, who collected in the Southwestern States. Blepharidachne bigelovii; Poa bigelovii.

Blasdale, W. C. (1871- ). Chemist of Califoruia, who collected grasses in that State. Agrostis blasdalei.

Blodgett, J. L. (1809-53). Physician of liey West, who collected in southern Florida. Paspalum blodgettii.

Bloomer, H. G. (1821-74). Botanist of California. Oryzopsis bloomeri.

Bolander, H. N. (1831-97). Botanist of California. Culamagrostis bolanderi; Poa bolanderi; Scribneria bolanderi. 
Bosc, L. A. G. (1759-1828). French botanist, who collected in North Carolina and South Carolina from 1798 to 1S00. Panicum boscii; Paspalum boscianum.

Boutelou, Claudio (1774-18ł2). The brothers, Claudio and Estéban, Spanish gardeners, are commemorated by the genus Bouieloza.

Brewer, W. H. (1S28-1910). Botanist of Califonia. Calamagrostis breweri.

Brown, Arldison (1830-1913). Botanist of New York; joiut author of Britton and Brown's Illustrated Flora. Panicum addisonii.

Buckley, S. B. (1809-81). Collected plants.firom Georgia to Texas; described grasses from Texas and Oregon. Sporobolus buckleyi; Triodia buclileyana.

Cabanis, Jean (1816-1906). Gernan ornithologist, who eolleeted piants in Florida. Andropogon cabanisii.

Cain, S. A. (1902- ). Botanist of Indiana. Calanagrostis cuinii.

Canby, W. M. (1831-1904). Botanist of Delaware. Poa canbyi.

Chapman, A. W. (1809-99). Botanist of Apalachiccla, Fla.; author of Flora of the Southern United States. Gymnopogon chapmanianus; Panicum chapmani; Poa chapmaniana.

Clute, W. N. (1869- ). Professor of botany, Butler University, Indianapolis, Ind. Panicum clutei.

Combs, Robert (1S72-99). Botanist, who collected in Florida and Cuba. Panicum combsii.

Commons, Albert (1829-1919). Botanist of Delaware. Panicum commonsianum.

Cotta, Heinrich (1763-1S14). German botanist. Cottea.

Curtiss, A. H. (1845-1907). Botanist of Jacksonville, Fla. Aristida curtissii;

Calamovilfa curtissii: Sporobolus curtissii.

Cusick, W. C. (1S $12-1922)$. Botanist of Oregon. Poa cusickii.

Danthoine, Etienne. Freneh botanist. Danthonia.

Deam, C. C. (1865- ). Botanist of Indiana. Panicum dermii.

Deschamps of St. Omer. Naturalist, who accompanied de la Billardiere on the expedition in search of la Pérouse in 1791.33 Deschampsia.

Desmazières, J. H. (1796-1862). French botanist, who wrote a work on the grasses of northem France. Desmazeria sicula.

Deyeux, Nicolas (1753-1837). French botanist. Deyeuxia.

Douglas, David (1798-1834). British botanist, who colleeted in California and northwest North America. Poa douglasii.

Drummond, Thomas (17S0-1835). Scotch nurseryman and botanist, curator of the Belfast Botanic Garden, who traveled with the Seeond Franklin Expedition, and collected in northwestern America and in Texas. Sorghum vulgare var. drummondii; Triodia drummondii.

Dumont-d'Urville, Jules S. C. (1790-1842). French explorer, who commanded the expedition of the Astrolabe and Zelee around the world. Panicum urvilleanum; Paspalum urvillei.

Eastwood, Alice (1859- ). Botanist of California. Festuca eastwoodae.

Elliott, Stephen (1771-1830). Botanist of Charleston, S.C., author of A Sketeh of the Botany of South Carolina and Georgia. Agrostis elliottiana; Andropogon elliottii; Eragrostis elliottii; Sorghastrum elliottii.

Elmer, A. D. E. (1870- ). Botanist, who collected in the State of Washington and later in the Philippine Islands. Agropyron elmeri; Festuca elmeri; Stipa elmeri.

Emersley, J. D. Botanist, who colfected in the Southwestern States. Muhlerbergia emersleyi.

Fendler, August (1813-1S83). Botanist, who collected in New Miexico, also in Panama and Venezuela. Aristida fendleriana; Poa fendleriana.

Frank, Joseph (-1835). Botanist, who collected in Ohio. Eragrostis frankii.

Gattinger, Augustin (1825-1903). Botanist of Tennessee. Panicum gattingeri. Gay, Jacques (1786-1864). French botanist, who traveled in Africa. Chloris gayana.

Geyer, C. A. (1809-53). Botanist, who collected in Illinois and Oregon. Melica geyeri.

Ghiesbreght, August (1810-93). Botanist, who collected in Mcxico. Panicum ghiesbreghtii.

Gouin. Freneh physician, who lived at Vera Cruz, Mexico. Panicum gouini. Gray, Asa (1818-88). Professor of botany, Harvard University. Festuca grayi.

${ }^{33}$ Lasègue, Mus. Bot. Deless. 75. 1845. 
Greene, E. L. (1843-1915). Professor of botany at the University of California, and later at Catholic University of America. Orcultia greenei.

Griffiths, David (1867- ). Botanist, United States Department of Agriculture. Agropyron griffilhsi.

Grisebach, A. H. R. (1814-79). German botanist, author of Flora of the British West Indian Islands and other works. Setaria grisebachii.

Gussone, Giovanni (1782-1866). Italian botanist. Bromus rigidus var. gussonii; Hordeum gussoneanum.

Hackel, Eduard (1850-1926). Eminent Austrian agrostologist. Hackclochloa. Hall, Elihu (1822-82). Botanist, who collected in Texas, Oregon, and the Rocky Mountains. Agrostis hallii; Andropogon hallii; Panicum hallii.

Hall, H. M. (1874-1932). Professor of botany, University of California. Bromus orcuttianus var. hallii.

Hansen, George (1863-1908). Botanist, who collected in California. Sitanion hanseni.

Harford, W. G. W. (1831-1911). Conchologist, colleague of Bolander. Collected in California and Oregon. Melica harfordii.

Hartweg, Theodor (1812-71). German botanist, sent by the Horticultural Society of London to Mexico to collect plants. Paspalum hartwegianum.

Havard, Valery (1846-1927). Army surgeon, who collected in Texas. Panicum havardii.

Heller, A. A. (1867- ). Botanist, who collected in the Western States, Puerto Rico, and Hawaii. Panicum helleri.

Heuderson, L. F. (1853- ). Curator, Oregon University Herbarium, Eugene. Collected plants in Oregon, Washington, and Idaho. Agrostis hendersonii; Oryzopsis hendersoni.

Hilaire, Auguste St. (1779-1853). French botanist (Saint-Hilaire). Hilaria.

Hillman, F.H. (1863- ). Botanist, United States Department of Agricul-

ture. Panicum hillmani.

Hitchcock, A. S. (1865- ). Agrostologist, United States Department of

Agriculture. Trichachne hitcheockii.

Hooker, W. J. (1785-1865). Director, Royal Botanic Gardens, Kew, England.

Avena hookeri; Imperata hookeri; Sporobolus asper var. hookeri.

Howell, Thomas (1842-1912). Botanist, who collected in Oregon; author of

Flora of Northwest America. Agrostis howellii; Alopecurus howellii; Calamagrostis

howellii; Festuca howellii; Poa howellii.

Imperato, Ferrante (1550-1625). Italian botanist. Imperata.

James, Edwin (1797-1861). Botanist of Major Long's Expedition to the

Rocky Mountains (1819-20). Hilaria jamesii.

Jepson, W. L. (1867- ). Professor of botany, University of California.

Elymus glaueus var. jepsoni.

Jones, M. E. (1852-1934). Curator of herbarium, Pomona College, Claremont,

Calif.; collected in the Western States. Muhlenbergia jonesii.

Joor, J. F. (1848-92). Professor of botany, Tulane Unirersity, New Orleans,

La. Panieum joori.

Kalm, Peter (1715-79). Swedish botanist, who traveled in Canada and the

northeastern United States. Bromus kalmii.

Kellogg, Albert (1813-87). Botanist of California. Poa kelloggii.

King, Clarence (1842-1901). Geologist in charge of exploration of the fortieth

parallel. Blepharidachne kingii; Festuca kingii; Oryzopsis kingii.

Koeler, G. L. (1765-1807). German botanist. Koeleria.

Lamarck, J. B. (1744-1829). Eminent French botanist. Lamarckia.

Lange, J. M. C. (1818-9S). Danish botanist. Paspalum langei.

Langlois, A. B. (1832-1900). Botanist of Louisiana. Triodia langloisii.

Leers, J. D. (1727-74). German botanist. Leersia.

Leiberg, J. B. (1853-1913). Botanist, who eollected in the Northwestern

States. Panicum leibergii; Poa leibergii.

Lemmon, J. G. (1832-1908). Botanist of California. Eriochloa lemmoni;

Phalaris lemmoni; Puccinellia lemmoni; Stipa lemmoni.

Leprieur, F. R. ( -1869). French botanist, who traveled in Senegal.

Chloris prieurii.

Letterman, G. W. (1841-1913). Botanist of Missouri, who collected in the

Rocky Mountains. Poa lettermani; Stipa lettermani.

Liebmann, F. M. (1813-56). Danish botanist, who collected in Mexico.

Setaria liebmanni.

Lindheimer, Ferdinand (1801-79). Botanist of New Braunfels, who collected

in Texas. Muhlenbergia lindheimeri; Panicum lindheimeri.

Macoun, James (1862-1920). Canarlian botanist, son of John Macoun. 
Calamagrostis canadensis var. macouniana.

Macoun, John. (1831-1920). Canadian botanist. Flymus macounii.

Metcalfe, O. B. (1878- ). Botanist, who collected in Ncw Mexico. Muhlenbergia metcalfei.

Michaux, André (1746-1802). French botanist, who collected in eastern United States. Author of Flora Boreali-Americana. Eriochloa michauxii.

Mohr, Charles (1824-1901). Botanist of Mobile, Ala. Andropogon mohrii; Aristida mohrii.

Molina, J. I. (1740-1829). Chilean missionary and botanist. Molinia.

Montufar, Carlos. Owner of an hacienda in Ecuador, visited by Humboldt. Trachypogon montufari.

Morton, J. S. (1832-1902). Secretary of Agriculture (1893-97). Avena mortoniana.

Muhlenberg, G. H. E. (1753-1815). Botanist of Pennsylvania, author of Descriptio Uberior Graminum. Muhlenbergia; Amphicarpum muhlenbergianum.

Murro William (1S1S-80). British botanist, who wrote on grasses. Munroa.

Nealley, G. C. Botanist, who collected in Texas. Leptochloa nealleyi; Sporcbolus nealleyi.

Nees, C. G. D. von Esenbeck. (1776-1858). Eminent German botanist. Stipa neesiana.

Nelson, Aven (1859-1934). Professor of botany, University of Wyoming, Laramie. Stipa columbiana var. nelsoni.

Nelson, E. W. (1855-1934). Zoologist, United States Department of Agriculture, who collected plants in Miexico. Eriocholoa nelsoni.

Nuttall, Thomas (1786-1859). Eminent botanist of Philadelphia (born in England) who collected widely in the Lnited States and published The Genera of North American Plants. Puccinellia nuttalliana.

Orcutt, C. R. (1S64-1929). Botanist of San Diego, Calif. Orcuttia; Aristida orcuttiana; Bromzls orcuttianus: Eragrostis orcuttiana.

Otis, Ira C. (1861- ). Potanist of the State of Washington. Glyceria otisii.

Palmer, Edward (1831-1911). Botanical explorer, who collected in the Southwestern States and in Mexico. Agropyron smithii var. palmeri; Eragrostis palmeri.

Parish, S. B. (1838-1928). Botanist of San Bernardino, Calif. Agropyron parishii; Aristida parishii; Puccinellia parishii.

Parry, C. C. (1S23-90). Botanist, who collected in the Western States and in Mexico. Boutelona parryi; Danthonia parryi.

Patterson, H. N. (1853-1919). Botanist of Illinois, who collected in Colorado. Poa pattersoni.

Phipps, C. J. (1744-92). British explorer, who led an expedition to the polar legions. Phippsia.

Pickering, Charles (1805-78). Botanist, who accompanied the Wilkes Exploring Expedition. Calamagrostis pickeringii.

Poiret, L. M. (1755-1834). French botanist. Sporobolus poiretii; Setaria poiretiana.

Porter, T. C. (1822-1901). Professor of botany, Lafayette College, Pennsrrvania; collected in Colorado. Calamagrostis porteri; Melica porteri; Muhlenbergia porteri: Stipa porteri.

Prieur. See Leprieur.

Pringle, C. G. (1838-1911). Botanical explorer, who collected in the Southwestern States and in Mexico. Agropyron pringlei; Agrostis hallii var. pringlei; Poa pringlei; Stipa pringlei.

Puccinelli, Benedetto (1808-50). Italian botanist, professor in Lyceum at Lucea. Puccinellia.

Pumpelly, Raphael (1837-1923). Geologist, United States Geological Survey. Bromus pumpellianus.

Pursh, Frederick (177t-1520). German botanist, who collected in the eastern part of the United States, author of Flora Americae Septentrionalis. Amphicarpum purshii.

Ravenel, H.W. (1814-8T). Botanist of South Carolina. Panicum ravenelii.

Redfield, J. H. (1815-95). Botanist of Philadelphia. Redfieldia.

Reimarus, J. A. H. (1729-1814). Gelman botanist. Reimarochloa.

Reverchon, Julien (1834-1905). Botanist of Dallas, Tex. Muhlenbergia reverchoni; Panicum reverchoni.

Reynaud, J. J. (1773-1842). Surgeon on the Chevrette, a French exploring vessel, who collected plants in the Orient. Neyraudia, an anagram of Reynaudia, a genus of West Indian grasses; Neyraudia reynaudiana. 
Richardson, Sir John (1787-1865). British botauist, who traveled in Canada. Stipa richardsoni.

Roemer, K. F. (1818-91). German botanist, who collected in Texas, 1844-47. Aristida roemeriana.

Ross, Edith. Collected in Yellowstone Park. Agrosiis rossae.

Rothrock, J. T. (1839-1922). Professor of botany, University of Pennsylvania. Bouteloua rothrockii.

Rottboell, C. F. (1727-97). Danish botanist. Rottboellia.

Roxburgh, William (1759-1815). Scotch botanist, director of the botanical garden at Calcutta. Sorghum vulgare var. roxburghii.

Rüppel, Edward (1794-1884). German botanist. Pennisetum ruppelii.

Runyon, Robert (1881- ). Photographer and amateur botanist, Brownsville, Tex. Digitaria runyoni.

Saunders, William (1836-1914). Horticulturist, United States Department of Agriculture. Agropyron saundersii.

Scheele, Adolf (1808-64). German botanist, who deseribed plants from Texas. Setaria scheelei.

Schreber, J. C. D. (1739-1810). German botanist, who wrote on grasses.

Muhlenbergia schreberi.

Scribner, F. Lamson (1851- ) ). Agrostologist, United States Department of Agriculture. Scribneria; Agropyron scribneri; Calamagrostis scribneri; Panicum scribnerianum; Stipa scribneri.

Sello (Sellow), Friedrich (1789-1831). German botanist, who traveled in israzil. Cortaderia selloana.

Short, C. W. (1794-1863.) Botanist of Kentucky. Festuca shortii.

Silveus, W. A. (1875- ). Botanist of San Antonio, Tex. Eragrostis silveana. Simpson, J. H. (1841-1918). Botanist who collected in Florida. Digitaria simpscni; Eriochloa michauxii var. simpsoni.

Smith, C. E. (1820-1900). Botanist, who collected in Michigan. Melica smithii.

Smith, J. G. (1866- ). Botanist, United States Department of Agriculture, later of Hawaii. Agropyron smithii.

Stillman, J. D. B. (1819-88). Pioneer botanist of California. Stipa stillmanii. Suksdorf, WV. M. (1850-1932). Botanist of Bingen, Wash. Bromus suksdorfi. Swallen, J. R. (1903- ). Agrostologist, United States Department of Agriculture. Eragrostis swalleni.

Tharp, B. C. (1885- ). Professor of botainy, University of Texas. Sporobolus tharpii.

Thurber, George (1821-90). Botanist of New York, who collected along the Mexican boundary and wrote on the grasses of California. Agrostis thurberiana; Festuca thurberi; Muhlenbergia thurberi; Stipa thurberiana.

Thurow, F. W. (1852- ). Botanist of Waller County, Tex. Panicum thurowii.

Torrey, John (1796-1873). Physician of New York City and eminent botanist. Melica torreyana; Muhlenbergia torreyana; Muhlenbergia torreyi.

Tracy, J. P. (1879- ). Botanist of Eureka, Calif. Festuca tracyi.

Tracy, S. M. (18i7-1920). Botanist of Biloxi, Miss., who collected in the Southern and Western States. Andropogon tracyi; Eragrostis tracyi; Poa tracyi.

Trinius, K. B. von (1778-1844). Agrostologist of St. Petersburg, Russia, who described many American grasses. Bromus trinii.

Tuckerman, Edward (1817-86). Botanist of New England. Panicum tuckermani.

Tweedy, Frank (1854- ). Topographic engineer, United States Geological Survey, collected in the Western States. Bromus pumpellianus var. tweedyi; Calamagrostis tweedyi.

Urville. See Dumont-d'Urville.

Vasey, George (1822-93). Botanist, United States Department of Agriculture, eminent agrostologist. Vaseyochloa; Poa vaseyochloa.

Walter, Thomas (1740-88). Botanist of Charleston, S.C., author of Flora Caroliniana. Echinochloa walteri.

TVebber, Dr. (1740-88). Physician of Sierra Valley, Calif. Oryzopsis webberi.

Webber, H. J. (1865- ). Botanist, United States Department of Agriculture, now of California, who collected in Nebraska and Florida. Panicum webberianum.

Werner, W. C. (1852- ). Botanist of Painesville, Ohio. Panicum werneri.

Wilcox, T. E. (1840-1932). Army surgeon, who collected in the Western states. Panicum wilcoxianum. 
Williams, T. A. (1865-1900). Agrostologist, United States Department of Agriculture. Stipa williamsii.

Willkomm, H. M. (1821-95). German botanist. Willkommia.

Wolf, John (1\$21-97). Botanist of Canton, Ill., who collected in Illinois and Colorado. Poa wolfi; Trisetum wolfii.

Wright, Charles (1811-85). Botanist, who collected in Texas and New Mexico, and in Cuba. Andropogon wrightii; Aristida wrightii; Muhlenbergia wrightii; Panicum wrightianum; Pappophorum wrightii; Sporobolus wrightii.

Zois, Karl von (1756-1S00), German botanist. Zoysia.

\section{GLOSSARY}

Abortive. Imperfectly clereloped.

Acuminate. Gradually tapering to a sharp point. Compare acute.

Acute. Sharp-pointed, but less tapering than acuminate.

Aggregate. Collected together in tufts, groups, or bumches. Applied especially to inflorescences. The racemes are aggregate in several species of Andropogon.

Annual. Within 1 year. Applied to grasses which do not live more than 1 year. Winter annual. A plant which germinates in the fall, lives over winter, and produces its seed the following spring, after which it dies.

Anthesis. The period during which a flower is open. In grasses, when the lemma and palea are expanded and the anthers and stigmas are mature.

Antrorse. Directed upwards or forwards. Applied especially to scabrous or pubescent stems, sheaths, awns, and so on. Opjosed to retrorse.

A piculate. Having a minute pointed tip. Applied especially to fertile lemmas in fruit, such as certain species of Eriochloa.

Appressed. Lying against an organ. The branches of an inflorescence may be appressed to the main axis or the hairs on a stem may be appressed to the surface.

Aristate. Awned; provided with a bristle at the end, rarely to the back or edge, of an organ. In grasses applies especially to the awns at the end of the bracts of the spikelet. Compare awn. Aristulate. Bearing a short awn.

Articulate. Jointed. Joined by a line of denarcation between two parts which at maturity separate by a clean-cut scar. Certain spikelets are articulate with the pedicel; certain awns with the lemma. Articulation. The point of union of two articulate organs.

Ascending. Sloping upward. Applied to stems which curve upward from the base, to the branches of an inflorescence which slope upward at angle of about $40^{\circ}$ to $70^{\circ}$, and to other parts such as blades and hairs. Compare appressed and spreading.

Attenuate. Gradually narrowed to a slender apex or base.

Auricle. An ear. Applied to earlike lobes at the base of blades and to the small lobes at the summit of the sheath in Hordeae. Auriculate. Provided with ears.

Awn. A slender bristle at the end (rarely on the back or edge), of an organ. In grasses the awn is usually a contimuation of the midnerve (sometimes also of the lateral nerves) of the glumes or lemmas, rarely of the palea.

Axil. The angle between an organ and its axis. Applied especially to the angle between a leaf and its stem and between a branch or pedicel and its axis. Axillary. Growing in an axil.

Axis. The main stem of an inflorescence, especially of a panicle. Compare rachis.

Barbed. Furnished with retrorse projections. Applied to the spines of Cenchrus.

Beak. A hard point or projection. Applied to seeds and fruits.

Bearded. Furnished with long stiff hairs, as the nodes of Andropogon barbinadis, the callus of Stipa spartea, the throat of the sheath of Sporobolus cryptandrus, and the main axils of the inflorescence of Eragrostis spectabilis.

Bifid. Two-cleft or two-lobed, applied to the summit of glumes, lemmas, and paleas. The lemmas of Bromus are usually bifid at apex.

Blade. The part of a leaf above the sheath.

Biact. The reduced leaves of the inflorescence and upper part of a shoot. Compare scale.

Branch. A lateral stem. Applied to the foliage stems or culms, and to the lateral stems of an inflorescence. Branchlet. A branch of the second or higher order.

In open much-branched panicles the main branches from the axis are branches of the first order, the branchlets from these are branches of the second orcles. and so on. 
Bristle. A stiff slender appendlage likenerl to a hog's bristle. An awn is a kind of bristle. In grasses the term is applied to the modified branchlets at the base of the spikelets in Setaria and allied genera, and to the prolongation of the rachis in Panicum, sect. Paurochaetium, and a few other groups.

Bulb. A subterrancan bud with fleshy scales like the onion. The so-ealled bulbs of grasses are corms (which see). Bulbous. Swollen at base like a bulb or corm. Said of the base of the stem of some species of Melica, Phleum, Phalaris, and so on. Bulblets. Small bulbs or eorms. Applied also to the proliferous buds in the infloreseence of eertain grasses, as Paa bulbosa, proliferous forms of $P$. arctica, $P$. alpina, and others.

Callus. The indurate downward extension of the mature lemma in Stipa, Aristida, and some other genera. Morphologieally sueh a callus is a part of the rachilla. In Heteropagon and other Andropogoneae the eallus is an oblique part of the rachis which extends downward from the spikelet. In Raphis the callus is a part of the peduncle. The term eallus is also applied to the thickened lower joint and first glume of Eriochloa (callus, a thickened part). Callus hairs. The hairs at the base of the floret of Calamagrostis and some other genera.

Canescent. Gray-pubescent or hairy.

Capillary. Very slender or hairlike.

Capitate. In a globular eluster or head.

Carinate. Keeled. Said of glumes, lemmas, and other parts when flattened laterally, with a sharp keel.

Cartilaginous. Hard and tough but elastic, like cartilage.

Caryopsis. The grain or fruit of grasses. The seed eoat is grown fast to the pericarp as in the grain of wheat or corn. In a few grasses the seed is free within the pericarp, as in Sporobalus and Eleusine.

Cespitose. Tufted; several or many stems in a elose tuft.

Chartaceous. Having the texture of writing paper.

Ciliate. Fringed with hairs on the margin (like an eyelash). Ciliolate. Minutely eiliate.

Circinate. Coiled from the top downward.

Clavate. Club-shaped; gradually thiekened upward, and more or less cireular in cross section.

Cleistogamous. Applied to flowers or florets when fertilized without opening. Cleistagene. A eleistogamous flower, such as found in Triplasis and Danthonia. Callar. The area on the outer side of a leaf at the junction of sheath and blade.

Column. The lower undivided part of the awns of certain species of Aristida; the lower twisted segment of the awn in Andrapogoneae.

Compact. Said of elosely flowered infloreseences. Compare dense.

Compressed. Flattened laterally, as the compressed spikelets of Uniala latifolia and the eompressed sheaths of Andropogon virginicus. If the organ is also sharply keeled, it is said to be eompressed-keeled.

Conduplicate. Folded together lengthwise with the upper surface within, as in the blades of many grasses.

Continuous. Said of the rachis or other organ which does not disartieulate. The opposite of articulate or disarticulating.

Contracted. Said of infloreseenees that are narrow or dense, the branches short or appressed. The opposite of open or spreading.

Convex. Rounded on the surface. Said especially of glumes and lemmas that are rounded on the back instead of keeled.

Convolute. Rolled longitudinally. Said mostly of blades, one edge being inside and the other outside.

Cordate. Heart-shaped. Said mostly of the base of blades. Cordate-clasping. Heart-shaped at base with the lobes overlapping around the stem.

Coriaceous. Leathery in texture.

Corm. The hard swollen base of a stem. In Melica the corm is a single enlarged lower internode. In Panicum bulbosum several internodes are involved. Compare $b u b b$.

Crown. The persistent base of a tufted perennial herbaceous grass. Also the hard ring or zone at the summit of some species of Stipa. The "pappuslike crown" of disseeted teeth is mentioned under Pappophorum.

Cuim. The jointed stem of grasses.

Cuneate. Wedge-shaped with the narrow part below.

Cuspidate. Tipped with a sharp short rigid point.

Deciduaus. Falling away, as the awn of Oryzopsis, the spikelets of some speeies with artieulate pedicels, and the blades of some bamboos. The opposite of persistent. 
Decumbent. Curved upward from a horizontal or inelined base. Said of stems or culms.

Decurrent. Extending down an organ below the insertion. Said especially of ligules decurrent on the margins of the sheath.

Dehiscence. Spontaneous opening of an organ, as the opening of anthers to let out the pollen.

Densc. Said of inflorescences in which the spikclets arc erowded. The opposite of open or loose. Compare compact.

Dcpauperate. Reduced or undeveloped. Said especially of impoverished or dwarfed plants below the average size.

Diffuse. Open and much-branched. Said of panicles.

Digitate. Several members arising from the summit of a support. Said especially of racemes or spikes from the summit of a peduncle, as in Digitaria and Cynodon.

Dioecious. Unisexual, the two kinds of flowers on separate plants, as in Buchloë.

Disarticulating. Separating at maturity. Compare articulate.

Distichous. Conspicuously two-ranked, as the leaves of Distichlis and Zea.

Divaricate. Widely and stiffly divergent as the branches of certain open panicles (e.g., Oryzopsis hymenoides).

Dorsal. Relating to the back of an organ.

Lorsiventral. With a distinct upper and lower surface. Said of shoots bearing broad flat blades in a horizontal position, the blades tumed into the same plane.

Drooping. Erect to spreading at base but inclining downward above, as the branches of a panicle.

Ellipsoid. An elliptic solid. Said of the shape of panicles, spikelets, and fruits.

Elliptic. Shaped like an ellipse. Said of blades and other flat surfaces.

Elongate. Narrow, the length many times the width or thickness.

Emarginate. Notched at the apex.

Equitant. Astride. Said of approximate compressed-keeled sheaths or blades at the base of a culn that infold each other like the leaves of Iris.

Erose. Irregularly notehed at apex as if gnawed. Said of glumes and lemmas.

Excurrent. Running beyond. The midnerve is excurrent from the lemma as an awn in many grasses.

Exserted. Protruding. The awns of some species of Calamagrostis are exserted, protruding beyond the spikelet.

Falcate. Scimiter-shaped, curved sidewise and flat, tapering upward. Said of certain asymmetric blades.

Fascicle. A little bundle or cluster. Said of clustered leaves, branches of a panicle, and spikes or racemes on an axis.

F'errugineous, ferruginous. Rust colored.

Fertile. Capable of producing fruit, having pistils. A fertile floret may be pistillate or perfect.

Fibrillose. Furnished with fibers. Said especially of the old basal sheaths of some grasses.

Filiform. Threadlike.

Fimbriate. Fringed, the hairs longer or coarser as compared with ciliate.

Flabellate. Fan-shaped. Said of the nerves of the lemmas of Anthochloa and the inflorescence of Miscanthus sinensis.

Flexuous. Bent altermately in opposite directions.

Fioret. The lemma and palea with included flower (stamens and pistil). Florets may be perfect, staminate, pistillate, neuter, sterile, and so on.

Folded. Conduplicate. Said chicfly of blades.

Fruit. The ripened pistil. In grasses the fruit is usually a earyopsis. The term fruit is also applied to the caryopsis and parts that may enclose it permanently at maturity. In Panicum the indurate fertile lemma and palea with the enclosed earyopsis is the fruit. In Cenchrus it is the entirc bur.

Fusiform. Spindle-shaped. A solid that is terete in the middle and tapering toward each end.

Geniculate. Bent abruptly. Said of awns and of the lower nodes of the eulm.

Gibbous. Swollen on one side as the glume of Sacciolepis.

Gland. A protuberance or depression, usually minute, that secretes, or appears to secrete a fluid. Glandular. Supplied with glands. The glands nuay be depressed as in Eragrostis cilianensis and Heteropogon melanocarpus.

Glaucous. Covered with a waxy coating that gives a bluc-green color as in the leaf of the cabbage, and the bloom of the grape.

Glomerate. Collected in heads.

Glumes. The pair of bracts at the base of a spikelet. 
Gregarious. Growing in groups or masses.

Herbaceous. Having the characters of an herb; opposed to woody; thin in texture and green in color, as the herbaceous lemmas of Poa.

Hirsute. Pubescent with straight rather stiff hairs. Hirsutulous, hirtellous. Minutely hirsute.

Hispid. Pubescent with stiff or rigid hairs. Hispidulous. Diminutive of hispid.

Hyaline. Thin and translucent or transparent.

Imbricate. Overlapping, as the lemmas in many spikelets.

Implicate. Tangled, as the branches of the panicle of Panicum implicatum.

Indurate. Hard. Compare chartaceous and coriaceous.

Inflated. Puffed up, bladdery.

Inflexed. Turned in at the margins. Said especially of the margin of the glumes or lemmas in some species.

Inflorescence. The flowering part of a plant.

Innovation. The basal shoot of a perennial grass.

Internerves. The spaces between the nerves. Said of glumes and lemmas.

Internode. The part of a stem between two successive nodes.

Interrupted. The continuity broken. Said especially of dense inflorescences whose continuity is broken by gaps.

Involucre. A circle of bracts below a flower or flower cluster. In grasses applied to the cluster of bristles or sterile branchlets below the spikelets in Pennisetum and a few other genera, and to the bony bead of Coix.

Involute. Rolled inward from the edges, the upper surface within. Said of blades.

Joint. The node of a grass culm. The internode of an articulate rachis.

Keel. The sharp fold at the back of a compressed sheath, blade, glume, or lemma. The palea and sometimes the glumes and lemmas may be two-keeled. Kieel is used because of the similarity to the keel of a boat.

Lacerate. Torn at the edge or irregularly cleft, as in some ligules.

Lanate. Woolly, clothed with long tangled hairs.

Lanceolute. Rather narrow (surface) tapering to both ends, the broadest part below the middle.

Laterally (compresil). Flattened from the sides, as certain spikelets, glumes, and lenmas.

Lax. Loose. Said of a soft or open inflorescence and of soft or drooping foliage.

Leaf. The lateral organ of a stem, in grasses consisting of sheath and blade.

Lemma. The bract of a spikelet above the pair of glumes.

Ligule. The thin appendage on the inside of a leaf at the junction of sheath and blade.

Linear. Long and narrow with parallel sides. Said of surfaces, such as a blade. Said also of spikelets and other organs, having in mind the shape of a longitudinal section.

Lobe. A segment of an organ, usually rounded or obtuse. Applied especially to the divisions of a cleft lemma.

Loose. Open. Said of panicles. The opposite of dense or compact.

Membranaceous. Thin like a membrane.

Monoecious. Unisexual, the two kinds of flowers on the same plant, as in $Z \epsilon c$ and Zizania.

Mucro. A minute awn or excurrent midnerve of an organ. Mucronatc. Provided with a mucro.

Navicular. Boat-shaped. Shaped like the bow of a canoe. Applied especially to the tip of blades.

Nerve. The vascular veins (mostly longitudinal) of the blades, glumes, ald leminas.

Neuter. Without stamens or pistils. Said of florets or spikelets.

Nodding. Inclined somewhat from the vertical. Said of panicles.

Node. The joint of a culm.

$O b$-. A prefix meaning inversely, as obovate.

Oblong. Longer than wide, with parallel sides, but not so long as linear. Applicd also to panicles and other parts, having in mind a longitudinal section.

Obsolcte. Almost wanting. Applied to organs usually present.

Obtuse. Romded at the apex. Contrasted witl acute.

Open. Louse. Said of panicles. Opposite of dense or compact.

Oeal. Broadly elliptic.

Ovatc. The shape of the longitudinal section of an egg, broadest below the middle.

Ovoit. An egg-shaped solid.

Dalea. The inner bract of a floret. 
Panicle. An inflorescence with a main axis and subdivided branches. It may be compact and spikelike (Phleum pratense) or open (Avena sativa).

Papery. See chartaceous.

Papilla. A minute nipple-shaped projection.

Papillose. Bearing papillae. Papillose-pilose. Bearing stiff hairs arising from papillae.

Pappus. In grasses mentioned under Pappophorum, referring to the awns as forming a pappuslike crown, similar to the pappus in certain species of Compositae.

Pectinate. Comblike. Used especially with some species of Bouteloua where the spikelets are set close together, parallel and divergent from the rachis like the teeth of a comb.

Pedicel. The stalk of a spikelet. Pedicellate. Having a pedicel. Opposed to sessile.

Peduncle. The stalk or stem of an inflorescence. Peduncled. Having a peduncle.

Pendent. Hanging down.

Perennial. I asting more than 1 year. Applied to grasses in which the underground parts last more than 1 year; and to woody culms to distinguish them from those which die to the ground (herbaceous) even though the underground parts are perennial.

Perfect. Applied to flowers having both stamens and pistil.

Pericarp. The ripened walls of the ovary when it becomes a fruit.

Persistent. Remaining attached, either after other parts have been shed, or for a considerable period. The paleas of certain species of Eragrostis persist after the fall of the lemmas. Also used as the opposite of deciduous.

Petiole. The stalk of a leaf blade. Used with the leaves of many bamboos, and with some other broad-leaved species in which the blade contracts into a petiole. Petiolati. Having a petiole.

Pilose. Pubescent with soft straight hairs.

Pistillate. Applied to flowers bearing pistils only and to an infloreseence or a plant with pistillate flowers.

Pitted. Marked with small depressions or pits. Applied to the fruit (fertile lemma) of certain species of Olyra. Also applied to the pinhole depression in the glume of certain species of Andropogoneae.

Plicate. Folded in plaits lergthwise as the blades of Panicum, sect. Ptycophyllum.

Plumbeous. Lead colored, greenish drab, as the spikelets of Eragrostis cilianensis.

Plumose. Feathered, having fine hairs on each side. Said chiefly of awns and slender teeth.

Proliferous. Bearing buds or bulblets in the inflorescence. Compare bulblets.

Pruinose. Having a waxy powdery secretion on the surface. Having a more pronounced bloom than when glaucous.

Puberulent. Diminutive of pubescent. Minutely pubescent.

Pubescent. Covered with hairs. Applied especially when the hairs are short and soft. Pubescence. A hairy covering.

Pulvinus. The swelling at the base of the branches of some panicles which eause them to spread.

Pustulose. Blistery, furnished with pustules or irregular raised pimples as in the spikelets of Panicum angustifolium. Not as definitely roughened as papillose.

Pyramidal. Pyramid-shaped. Applied sometimes to panicles that are actually conical.

Pyriform. Pear-shaped. Obovoid with attenuate base. Applied to the shape of spikelets.

Raceme. An inflorescence in which the spikelets are pediceled on a rachis. Racemose. In racemes.

Rachilla. A small rachis. Applied especially to the axis of a spikelet.

Rachis. The axis of a spike or raceme.

Reticulate. In a network. Applied especially to the cross-veining on some spikelets, as Panicum fasciculatum.

Retrorse. Pointing backward, as the hairs on the sheaths of certain species of Bromus.

Revolutc. Turned or rolled backward from both edges. Said ehiefly of blades. $55974^{\circ}-35-63$ 
Rhizome. An underground stem; rootstock. The rhizomes of grasses are usually slender and creeping. They bear scales at the nodes, the scales sometimes remote and inconspicuous ( $\dot{P}_{\text {oa }}$ pratensis), sometimes imbricate and prominent (Spartina). Rhizomatous. Having rhizomes or appearing like rhizomes, as the base of a decumbent stem.

Rosette. A cluster of spreading or radiating basal leaves, as in the overwintering stage of Panicum, sect. Dichanthelium.

Rudiment. An imperfectly developed organ or part. Rudimentary. Underdeveloped. Applied also to one or more rudimentary florets at the summit of the spikelet of some genera, as Melica, Bouteloua, Chloris.

Rugose. Wrinkled. Said especially of the fruit of some species of Panicum and allied groups.

Saccate. Bag or sac-shaped, as the second glume of Sacciolepis.

Scabrous. Rough to the touch. Covered with minute points, teeth, or very short stiff hairs. Scaberulous. Minutely scabrous.

Scale. The reduced leaves at the base of a shoot. Said especially of the reduced or rudimentary leaves on a rhizome.

Scarious. Thin, dry, and membranaceous, not green.

Secondary. Subordinate; below or less than primary. Said of branches arising from primary branches.

Secund. One-sided or arranged along one side.

Self-pollinated. Pollinated in the bud or by pollen from the same flower. The opposite of cross-pollinated.

Serrate. Saw-toothed; having sharp teeth. Serrulate. Minutely serrate.

Sessile. Without a pedicel or stalk. The opposite of pediceled. Said of blades, spikelets, and other organs.

Setaceous. Bristlelike. Said especially of slender teeth attenuate to an awn.

Sheath. The lower part of a leaf that encloses the stem.

Sinuous. Wavy.

Smooth. Not rough to the touch. Compare glabrous, without hairs but which may be rough to the touch.

Spathe. A sheathing bract of the inflorescence found especially in the Andropogoneae.

Spike. An unbranched inflorescence in which the spikelets are sessile on a rachis. Spikelike. A dense panicle in which the pedicels and branches are short and hidden by the spikelets as in Phleum.

Spikelet. The unit of the inflorescence in grasses, consisting of two glumes and one or more florets.

Spreading. Having an outward direction. Said especially of the branches of a panicle when they lie between ascending and the horizontal direction (right angles).

Squarrose. Spreading or recurved at the tip. Said of the tips of lemmas.

Stamen. The part of the flower that bears the pollen. Staminate. Containing stamens only. Also applied to an inflorescence or a plant with staminate flowers.

Sterile. Without pistils. A sterile floret may be staminate or neuter. It may even lack a palea, and consist of nothing but a lemma.

Stipe. A minute stalk to an organ. Applied especially to a pistil. Also sometimes to the prolongation of a rachilla as in Calamagrostis. Stipitate. Having a stipe.

Stolon. A modified propagating stem above ground creeping and rooting or curved over and rooting at the tip. Stoloniferous. Bearing stolons.

Stramineous. Straw-colored, pale yellow.

Striate. Marked with fine parallel lines or minute ridges.

Strict. Stiffly upright.

Strigose. Rough with stiff hairs; harshly pubescent.

Sub-. A prefix to denote somewhat, slightly, or in a less degree; as subacute, somewhat acute.

Subtend. To be below, as a bract subtends a branch in its axil.

Subulate. Awl-shaped.

Succulent. Fleshy or juicy.

Sulcate. Grooved or furrowed. Said chiefly of stems, sheaths, and slender blades.

Tawny. Pale brown or dirty yellow.

Teeth. Pointed lobes or divisions.

Terete. Cylindric and slender, as the usual unflattened stems or culms of grasses.

Tessellate. The surface marked with square or oblong depressions.

Trifid. Divided into three parts as the awns of Aristida. 
Truncate. Ending abruptly, as if cut off horizontally.

Tuberculate. Furnished with sinall projections.

Turgid. Swollen, as the pulvini of a panicle during anthesis.

Unilateral. One-sided or turned to one side.

Unisexual. Said of flowers containing only stamens or only pistils.

Verticillate. In verticils or whorls.

Villous. Pubescent with long soft hairs.

Virgate. Straight and erect; wand-shaped.

$W e b$. The eluster of slender soft hairs at the base of the floret in certain species of Poa.

Whorl. A cluster of several branches around the axis of an inflorescence.

Wing. A thin projection or border; for example, the thin borders on the rachis of certain species of Digitaria and Paspalum.

\section{ADDITIONS AND CORRECTIONS}

Page 77. Festuca idahoensis. Omit Arizona and New Mexico from range. Page 158. Eragrostis hirsula. Add Tennessee to range.

Page 204. The three varieties of Melica imperfecta should be in italies. They are scarcely worthy of formal varietal standing.

Page 231. Agropyron repens. Omit New Mexico from range.

Page 237. Agropyron pseudorepens. Reconsideration of this species in the light of collections received while the text was in press shows it to be distinct from A. pauciflorum. The variety magnum is doubtful, the underground parts are lacking in the type specimen and the blades are wide and rather lax.

Page 286. Trisetum montanum. Add Arizona to range.

Page 313, after Calamagrostis perplexa insert the following which was described while the Manual was in press.

Calamagrostis cainii Hitche. Culms slender, erect, scabrous below the panicle, 30 to $40 \mathrm{~cm}$ tall; sheaths glabrous; blades erect, flat, more or less involute toward the finely attenuate tip, glabrous beneath, scaberulous on the upper surface, narrowed toward the base, the basal ones as much as $35 \mathrm{~cm}$ long, 1 to 2 $\mathrm{mm}$ wide; panicle pale or whitish, loose, 6 to $10 \mathrm{~cm}$ long, the branclies ascending or somewhat spreading, verticillate, scabrous, naked below, 1 to $2 \mathrm{~cm}$ long, bearing 1 to few spikelets, the whorls 7 to $15 \mathrm{~cm}$ apart, the pedicels scabrouspubescent; glumes narrow, acuminate or slightly aristate, 5 to $6 \mathrm{~mm}$ long; lemma narrow, acuminate, minutely scabrous near the summit, the callus hairs about 1 $\mathrm{mm}$ long, the awn arising about $1 \mathrm{~mm}$ above the base, somewhat geniculate, twisted below, the tip bent to one side, somewhat exceeding the glumes; palea a little shorter than the lemma; prolongation of the rachilla very short, the hairs 1 to $2 \mathrm{~mm}$ long. Known only from the type collection, shrubby summit of Mount LeConte, Tenn.

Page 373. Muhlenbergia racemosa. Extend range to Virginia.

Page 445. Aristida basiramea. Add New Hampshire and New York to range. Probably extends to Maine as a native species. (Fide Rhodora 36: 406. 1934.)

Page 466, line 7 from bottom. For (II. longifolia Vasey), read (II. cenchroides var. longifolia Vasey).

Page 535. For Phleum tenue Schrad. read P. subulatum (Savi) Aschers. and Graebn. See page 727.

Page 626. Panicum annulum. Add Michigan to range:

Page 774. Transfer paragraph on Agropyron japonicum to Unidentified Names, page 979 .

Page 816, under (27) Bromus racemosus insert: Bromus mollis forma leiostachys Fernald, Rhodora 35: 316. 1933 . Based on B. mollis var. leiostachys Hartm.

Page 982. Setaria caudata var. pauciflora Jones. An examination of the cited specimens shows them to belong to Seteria macrostachya H. B. K. 



\section{INDEX}

[Synonyms are in italic type. The page numbers of the principal entries are set in heary-face type]

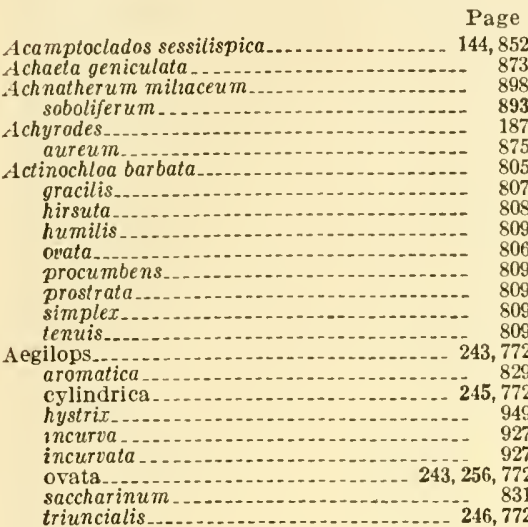

Aegopogon cenchroides........... 469 geminifior us var. unisetus............ 772

pusillus................................. 772

$\begin{array}{ll}\text { pusillus } & \\ \text { rigidisetus } & 772 \\ \text { tenellus } & \end{array}$

tenellus .

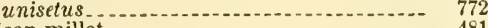

A frican millet

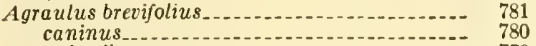

Agrestis alba........ 779

canina $\ldots \ldots$. 780

$\begin{array}{lll}\text { hyemalis } & \\ \text { interrupta } & \ldots \ldots & \\ \text { inticillata }\end{array}$

verticillata............... 786

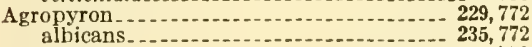

albicans...

a ndinum

arizonicum $\ldots \ldots \ldots$

bakeri ... 238,773

biflorum ............ 237, 775

andinum

latiglume

brevifolium_..................... 778

caninoides

andinum glaucum ........... 778

gmelini......... 775

pringlei._.

hornemanni.............. 775

pilosifolium

latiglume _....................... 77

pubescens.......

richardsonit.....

tenerum ........................ 775

unilaterale........

ciliatumn 778

riolacescens.... 778

cristatum

dasystachyum
subvillosum $\ldots \ldots \ldots$

divergens.

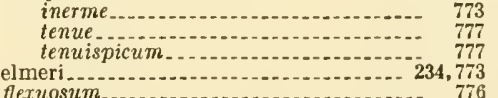

Agropyron-Continued. Page glaucum ............................... 773

occidentale _................... 777 gmelini. griffit thii inerme - 241,773

intermedium . . .

japonicum . . .

junceum

laeve ...

lanceolatum

latiglume.

leersianum .

missuricum ......................... 775

molle .................................. 777

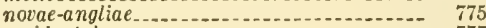

occidentale........... 777

molle........ 777

palmeri_... 777

palmeri........................... 777

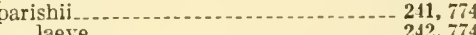

laeve ..............

pauciflorum........... 2, 3, 230, 237, 774

pringlei............ 238, 775

prostratum ........................ 779

pseudorepens $\ldots \ldots \ldots \ldots$ magnum........ 237,775

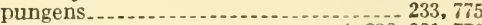

repens................. 4, 230, 231, 776

geniculatum

glaucum

pilosum_....................... 776

pungens...... 776

stoloniferum

subulatum .................. 776

heberhachis..... $\quad 776$

setiferum

vaillantianum ............... 776

tenerum

richardsoni..........

ciliatum . .

riparium _........

saundersii...... 242, 776

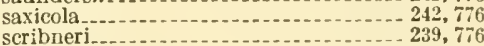

semicostatum_.............. 241, 776

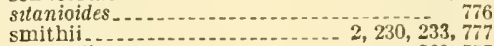

233, 777

molle...............

palmeri

spicatum

arizonicum
inerme

molle.......

palmeri........

pringlei.................. 777

puberulent $u m \ldots \ldots \ldots$

pubescens . . . . 210,777

tenuispicum ................ 777

taseyi_................ 777

$\begin{array}{lll}\text { viride } & \ldots \ldots & 777 \\ \text { trigosum } & \end{array}$

subsecundum

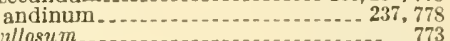

subvillosum

tener ciliatum

longifolium

magnum ....... $\quad 775$

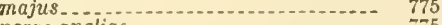

norue-angliae

pseudorepens...... 775

trichocoleum .................. 775

tetrastachys...................... 776 
Agropyron-Continued.

Page trachycaulon. trachycaulum.

(n)

ciliatum

fcrnaldii

glaucescens

glaucum

hirsutum

majus .

norae-angliae

pilosiglume.

trichocoleum

unilaterale.

trichophorum

triticeum.

vaseyi

violaceum

237,775

andinum

caninoides

Latiglume

778

major

violacescens.

vulpinum

774

778

Agrosti

Agrostis.

abakanensis

aculeata

aequivalvis

affinis.

airoides

alba

coarctata

coarctata.

dispar.

maritima

minor

palustris.

stolonifera

stricta.

sylvatica

verticillata

vulgaris

aristata.

albicans

aloida

alopecuroides

altissima

laxa.

anemagrostis

interrupta

spica-venti.

anomala.

antecedens

apetala

aquatica

arachnoidea

arachnoides

arenaria.

aspera.

asperifolia.

atrata....

attenuata

australis.

bakeri

barbata

bermudiana

blasdalei

boeckeleri -

borealis.

americana

780

breviculmis........... 334

brevifolia

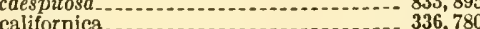

californica

canina..

340,780

aequivalvis ...................... 779

hiemalis

stolonifera............................ 780

tenella

capillaris............... $332,341,785,786$

aristata.

aristulata.
Agrostis-Continued.

Page

caryophyllea $\ldots$.

cinna_................. 826

clandestina

complanata... 826

composita ......................... 958

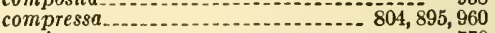

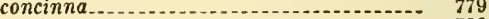

condensata _-

cornucopiae _........................ 784

cryptandra........................... 958

davyi

decumbens.......... 783, 784, 786

densifiora

arenaria...................... 780

littoralis

depressa

diegoensis.........

foliosa . . . . 780

diffusa

dispar .....

distichophylla......... 886

domingensis........ 959

elata.................................... 784

elegans -...-... 784

elliottiana...... 333,780

elongata............... 960

erecta

eremophila................... 886

exarata

ampla

ittoralis

microphylla

microphylla
minor

monolepis.........

pacifica

stolonifera........ 783

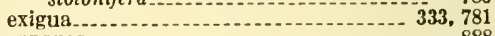

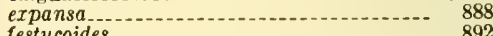

festucoides

fliculmis _

frliformis_...

geminata

exaristata

glauca........ 820,890

glomerata.......... 336

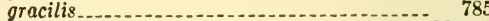

grandis

hallii. ...... californica . . pringlei.................... 333, 781

hendersoni 332,781

heterolepis _ . .

hiemalis............. 337, 781 geminata

nutkaensis 782

hillebrandii............................ 786

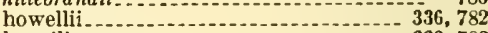

humilis .............................. 782

hyemalis var. elata

idahoensis............................. 7872

indica

inflata

intermedia .................... 78

interrupta

involuta

jamaicensis. 836

juncea

laleriflora

$\begin{array}{ll}\text { fliformis..... } & 890 \\ & \end{array}$

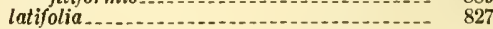

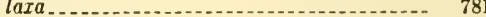

laxifiora

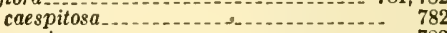

montana............... 782

scabra

tenuis 782

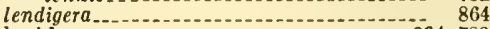

lepida... 334, 783

littoralis _.._.

longiflora.

longifolia

longiligula.......... 341, 783

lutosa

maritima

matrella

maxima.............. 965 
Agrostis-Continued.

mexicana

michaurii

microcarpa.

microphylla

$$
\text { major }
$$

miliacea

minima

minutissima

multiculmis

nebulosa

nigra

nootkaensis

novae-angliae

noveboracensis

nutans...

obtusata.

(2)

occidentalis .......................... 781

oligantha._.

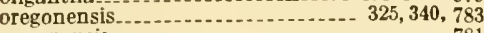

oregonensis.............................. 781

oreophila

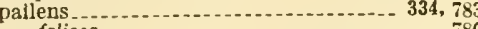

foliosa

palustris _...............

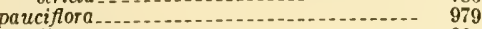

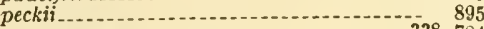

perennans

aestivalis_............................ 784

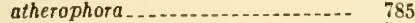

chaetophora

elata

humilis .

pickeringi

$\begin{array}{ll}\text { rupicola } & 780 \\ \text { polymor pha var. palustris } & \end{array}$

polymor pha var. palustris_-an

polystachya........................... 899

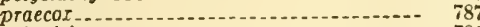

pringlei-_........... 781

procera

pseudointermedia

punctata................................ 856

pungens ............. 962

purpurascens ..................... 903, 961

pyramidalis............................. 957

racemosa

radiata

ramosa

ramulosa..... 783

reptrofracta

retrofracta

rubicunda

rubro

alpina_............... 780

americana....... 780

rupestris . . .

scabra.......-

montana 782

oreophila

perennans........................... 784

tenuis............................. 78

tuckermani-....................... 782

scabrata........................... 782

scabriuscula

schiedeana...... 78

$\begin{array}{ll}\text { armata } & \\ & \end{array}$

schweinit zii .

scribneriana...................................... 78

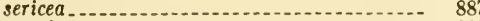

serotina -

setosa

sobolifera
spica-venti $-\ldots \ldots$

interrupta.

stolonifera

aristigera

compacta__.

maritima............ 783

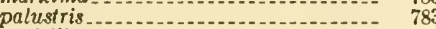

verticillata.............................. 786

vulgaris............................ 785

$\begin{array}{lr} & 786 \\ \text { stricta } & \end{array}$
Agrostis-Continued. Page

tenuiculmis............................ 782 recta....

tenuiflora
tenuis........................ aristata........... erecta.... 782

tenuissima

thurberi

thyrsoides

torreyana

torreyi

trichopodes............. 888

variabilis.................................. 785

varians_..................... 785

ventosa.................. 785

ventricosa

verticillata.

villarsii_......................... 786, 967

cirescens microphylla

virginica
viridis $-\ldots \ldots$

vulgaris_....................... 332, 785

aristata_........... 786

stolonifera

Agrostojdea, group of Panicum......... 678

Agrostomia barbata

aegilopsoides

alpicola.................. 834

alpina_.............. 869

a mbigua

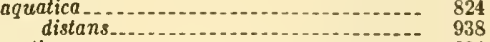

arctica................ 834

$\begin{array}{ll}\text { aristulata } & \\ \text { atropurpurea. } & 833 \\ \text { breifolia } & \end{array}$

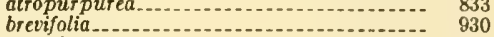

caerulea

caespitosa._............................ 833

ambigua............. 833

arctica

montana............... 833

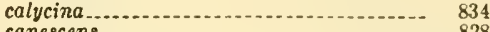

capescens........

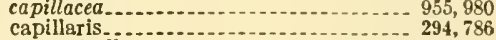

caryophyliea.................... 293,787

cespitosa................................ 833

complanata................................ 826

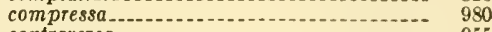

controversa............ 955

cristata

curtifolia

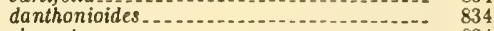

elongata...................................... 834

flexuosa......

foliis variegatis........................... 289

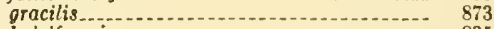

holciformis

holcus-lanatus........................... 870

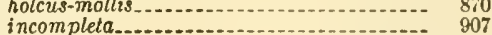

$\begin{array}{ll}\text { incompleta.......... } & 907 \\ \text { indica } & 941\end{array}$

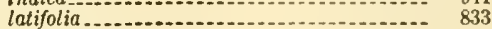

major ssp. caespitosa .................... 833

melicoides............................... 974

mexicana..................... 956

missurica .............................. 930

mollis _..................... 870, 955

nitida

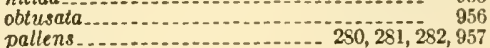

aristata............................ 974

panicea ............ 878

pennsylvanica... $\quad 955$

praecox $\ldots . . . . . . .292,787$

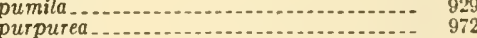

purpurea

spicata......... 940,975

subspicala.............................. 975

triflora

triglumis_............................... 959

truncata............. 956

vaseyana

Airella capillaris.............................. 786

$\begin{array}{ll}\text { caryophyllea } & \ldots \ldots \ldots \\ \text { proecox }\end{array}$ 
Page

Airochloa cristata

$$
\text { gracilis. }
$$
capillaris..

caryophyllea.

obtusata.

praecox

Alaska oniongrass wheat.

Alfa..

grass.-

Algerian oat cordgrass

Alkali-grass

Nuttall

sacaton. mbiguus

aristatus.

lepturoides

Alopecurus aequalis

$$
\text { natans... }
$$

agrestis.

alpinus.-

aristulatus .

merriami-...
monspeliensis
natans

natans..

borealis

caespitosus

californicus.

carolinianus

carolinianus.

creticus.

fulvus.

geniculatus

aristulatus

caespitosis

fulvus.

natans..

ramosus

glomeratus

gracilis -

$$
\text { merriami }
$$

merrimani

interruptus.

macounii

maritimus.

monspeliensis

myosuroides

occidentalis

pallescens

pedalis.

pratensis.

$$
\text { alpestris. }
$$

ramosus.

saccatus

subaristatus.

rentricosus.

Alpine bluegrass

fescue.

foxtail.

oat

Amblytes caerulea.

American dunegrass

$$
\text { mannagrass. }
$$

Ammophila

arenaria.

arundinacea.

breviligulata

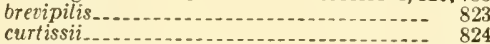

longifolia

A mpelodesma

Ampelodesmos mauritanicus $\operatorname{ten} a x$

Amphicarpon

$$
\text { a mphicarpon. }
$$

mphicarpum
Amphilophis, section of Andropogon........ 743

Amphilophis barbinodis

emersus.............................. 792

exaristatus....... 790

Leucopogon................... 789

perforatus

saccharoides.

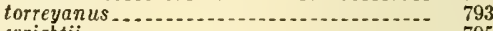

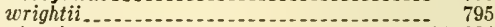

Anastrophus compressus.............. 575, 804

furcatus

paspaloides........

platycaulis................ 575,804

Anatherum macrourum................. 790

muricatum

tripsacoides....... 847

virginicum ............... 794

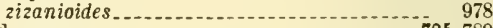

Andropogon . .

albescens....................... 951

alopecuroides...... 854

a mbigu us . . . . . .

arctatus ........ 736, 789

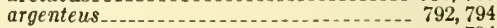

argyraeus.

macrus

tenuis _..... 794

avenaceus

bakeri_...

barbatus.

belrisii

brachystachys $\ldots$

cabanisii_........... 731, 789

campyloracheus _.... 742,789

capillipes................ 738, 789

caricosus var. mollicomus. . . . . . . 792

chrysocomus.... 734,791

ciliatus........................ 951

cirratus............... 729, 789

citratus............. 830

clandestinus.................................. 790

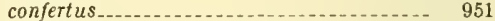

contortus.

glaber

secundus........................ 868

corymbosus.......... 791

abbreviatus _................ 791

curtipendulus

curtisianus........ 794

dissitiflor us_........................... 791

distachyus ........................... 726

divaricatus............... 854

divergens ........ 732,789

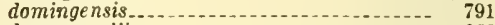

drummondii........................... 952

durus..................... 855

elliottii . glaucescens.......................... 794

gracilior

gracilior

emcrsus........ 792

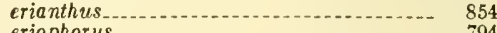

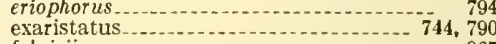

fabricii

feensis...

firmus........................... 868

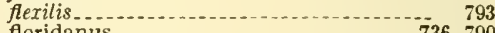

floridanus $\ldots .736,790$
furcatus $\ldots .2,3,726,732,790$

geminatus........................ 791

glaber... 868

glaucopsis... 739, 795

glaucus._.

glomeratus...

abbreviatus 791

corymbosus.... 791

glaucopsis........

hirsutior

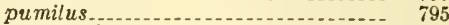

tenuispatheus....... 791

gracilior ...

gracilis

gracilis........ 794

gyrans........ $79 \mathrm{C}$ 
Andropogon-Continued.

halei.

anatherus.......................... 951

ballii.

734, 791

bispicatus

grandiflorus.............

incanescens_....................... 791

muticus_........................... 791

hirtiflorus ........................... 728, 791

brevipedicellatus................. 728,791

feensis._.

semiberbis

hirt us

insuloris -1006

jamesii

junciformis

leptophyllus.... 794

leucopogon

liebmanni subvar. mohrii

linneanus................ 951

littoralis

longiberbis

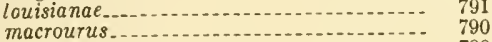

abbreviatus

corymbosus.

glaucopsis.

hirsutior.

pumilus$$
\text { virides }
$$

maritimus..

melanocarpus

mississippiensis.

mohrili-.

pungensis

mollicomus

montufari

muhlenbergianus...........................

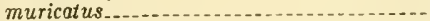

mardic

neo-mexicanus. ..................... 793

nodosus......................

nutans

$\begin{array}{ll}\text { avenaceus_...... } & 951 \\ \text { linneanus._. } & 951\end{array}$

nutlallii

oligostachyum

oligostachyus

pauciflorus.

paucipilus...

perangustatus

perforatus.

polydactylon.

preslii.

provincialis.

furcatus
lindheimeri
pycnanthus

tennesseensis

purpurascens...

ravennae.....

rufus.

saccharatus.

saccharoides

barbinodi..............................

glaucus.-

leucopogon

perjoratus

perforatus.

submuticus..... 792

torreyanus.

scoparius.

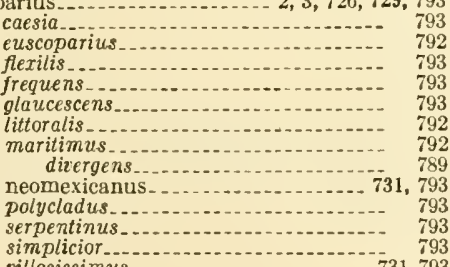

villosissimus.

731,793
Andropogon-Continued. Page

scribnerianus.............................. 794

scrobiculatus ......................... 868

secundus_._._.................... 868,951,965

semiberbis......................... 729, 793

pruinatus.............................. 793

sessiliflorus............................ 980

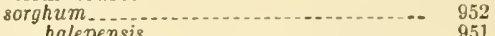

saccharates

$\begin{array}{ll}\text { saccharat } & \\ \text { sativus } & \end{array}$

drummondii

durra

technicus

vulgaris.................... 952

sudanensis........................ 952

technicus_........................... 952

$\begin{array}{ll}\text { rulgaris......... } & 952\end{array}$

spathaceus
stipoides_and

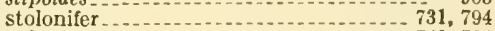

subtenuis_.................. 742,794

tener............... 728794

tener.............. 793

tennesseensis_.......................... 790

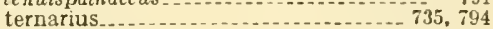

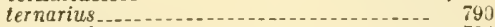

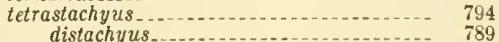

torreyanus

tracyi.

tripsacoides........... 847

unilateralis

vaginatus. . .

velatus
vimineus

virginicus

corymbosus . . . .

dealbatus

glaucopsis $\ldots \ldots$
glaucus...

hirsutior

tetrastachyus ....................... 794

vaginatus . . . .

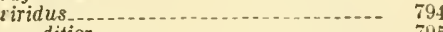

ditior
stenophyllus

vulgaris

wrightii ........ 743, 795

zizanioides......................... 978

A ndropogoneae....................... 27, 715

Anemagrostis interrupta .................. 783

spica-venti............................ 785

$\begin{array}{ll}\text { Angustifolia, group of Panicum-.-.- } & 620 \\ 295\end{array}$

Animated osts

hairgrass

wildrice

Antephora axillifiora........ 818

Anthaenantia _._.

rufa _...

villosa...

Anthephora ............. 463,796

axilliflora.
belangeri...................... 818

belangeri...
elegans.........

hermaphrodita........ 463,796

Anthipsimus gonopodus.................. 980

Anthocbloa

colusana........ 219,796

\begin{tabular}{ll} 
lepidula & 219 \\
\hline
\end{tabular}

Anthopogon brevifolius . . .................. 867

$\begin{array}{ll}\text { filiforme } & \text { lepturoides } \\ \end{array}$

Anthoxanthum

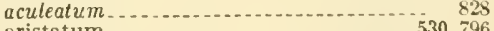

aristatum

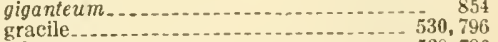

odoratum.................. 528, 796

altissimum . . . . .

pueliz_... 796

$\begin{aligned} \text { puelii } & \\ \text { ntitragus aculeatus } & \end{aligned}$

$\begin{array}{ll}\text { A } & \\ \text { A parejo grass } & \end{array}$

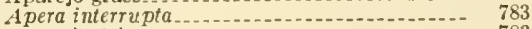

palustris

spica-venti

tenuiflora................................ 894 
Aplexia virgato

virginica.

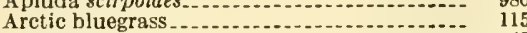
grass.

Aristida

bromoides

coarctata...........

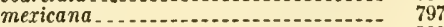

aеquiramea

affinis.............. 457,797

a mericana bromoides.
arizonica $\ldots \ldots \ldots \ldots \ldots$

barbata

basiramea

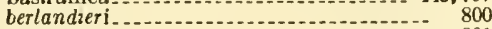

beyrichrana......................... 801

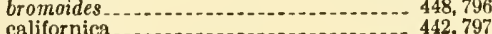

fugitiva

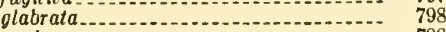

major

chapmaniana.

combsii condensata

condensata
combsii

curtiseta............ 799

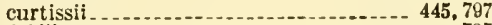

debilis

dichotoma 445, 79 ? curtissii_........... 797

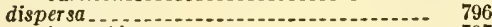

bromoides.......................... 797

coarctata...... 797

divaricata................449, 797

divergens

elliottiana................. 800

fasciculata............................ 448, 800

$\begin{array}{ll}\text { californica } & \\ \text { fendleriana } & \end{array}$

$\begin{array}{ll}\text { fendleriana } \ldots \ldots \ldots \ldots & \\ \text { hookeri. } & \end{array}$

micrantha........................... 801

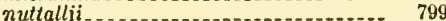

fendleriana . .......... 454,798

filipendula

floridana

gentilis var, breviaristata

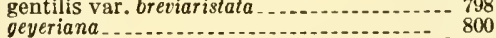

glabrata_......................... 442,798

glauca _. 451,798

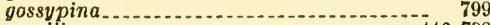

gracilis . . . depauperata...................... 799 virgata

grisebachiana......... 797

decolorata..................... 797

gyrans...............

hamulosa . . . . .

havardii 449,797

humbaldtiana minor

hypomegas........... 800

imbricala

intermedia

jonesii

lanata

lanosa ............. 455, 799

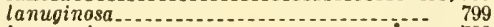

lemmoni_... 798

geniculata

ongiseta
fendleriana.

hookeri................... 800

rariflora........................ 454,799

robusta

macrochaeta.

maritima

micrantha . . . .

micropoda

mohrit ${ }_{\text {mii....... }}$

muhlenbergioides............................. 800

nealleyi
Aristida-Continued. Page

nigrescens . _. .

oligantha__._.

nervata -799

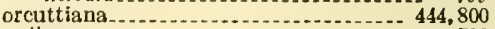

pallens _..... 799

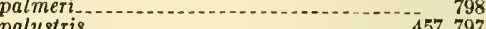

palustris_._.

parishii............

patula.

pauciflora

perennans 801

purpurascens..... 456, 800

alabamensis.................... 797

depauperata...................... 801

glaucissima................ 800

minot 800

purpurea......... 452,800

aequiramea.

berlandieri _..._........ 800

californica _..._. 800

capillarifolia........... 800

fendleri_.......... 798

fendleriana_...................... 798

hookeri........ 800

laxiflora

longiseta_......... 799

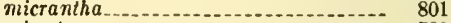

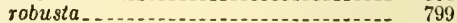

racemosa

ramosissima.......... 446, 800

chaseana............. 800

uniaristata_.................... 800

rariflora

reverchoni $1 . . . . . .452,798$

angusta............ 798

rhizomophora.

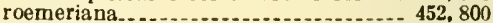

scabra.............. 444, 800, 801

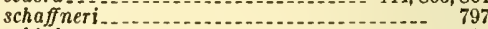

schiedeana................. 800

minor-... 801

secunda

simpliciflora

simplicifolia_............ 799

tcrana

spiciformis . ... 450, 801

squartosa $\ldots \ldots \ldots$.

stricta_................... 455, 801

condensata.................... 797

nealleyi

stricta

subunifora................. 798

tenuis

tenuispica...........
ternipes........... 460,801

ternipes......

minor

tuberculosa....... 442, 801

unilateralis............................ 805

vaseyi......... 798

virgata.......... 457, 801

palustris_... 797

wrightii

Arizona fescue

panicum

three-awn....................... 455

Aromatic grasses . . . .

Arrhenatherum _. 298, 802

americanum 802

avenaceum

elatius ................................ 298, 802

bulbosum

tuberosum 802

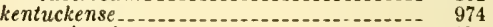

pennsylvanicum

tuberosum ............................ 802

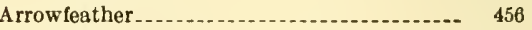

Arthratherum, section of A ristida.......... 441

Arthraxon . . . . . . .

ciliaris ...................................... 725

langsdorfi var. cryptatherus
hispidus var. cryptatherus $\ldots . .$.

Arthrolophis, section of A ndropogon ........ 732

Arundinaria......................... 29, 802

gigantea...
tecta

japonica 
Ardundinaria-Continued.

Page

macrosperma arborescen

suffruticosa...................... 803

tecta $-2-803$

colorata

distachya

Arundo . . ................. 187, 803

agrosioides............................ 819

airoides....... 974, 980

arenaria - bremipis

brevipilis........................................... 823

cala magrost is

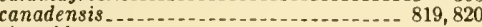

cinnoides................................ 820

coarctata

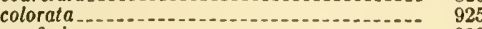

confinis............................. 980

dioeca_-_-_on 828

donax $\ldots \ldots \ldots, 187,191,803$ variegata ...................... 803 versicolor

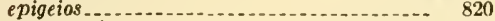

georgica....................... 820

fest ucacea-1- 863

fissa

gigantea...................... 802

glauca............ 803, 980

langsdorfit_. . .

latifolia

littoralis_............... 787

mauritanica.......................... 788

neglecta.............. 821

pallens

palustris

phragmites............................. 928

purpurascens.

quila

Tiparia

saccharoides......................... 867

sagittata............................ 867

sativa ............. 803

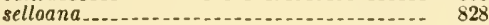

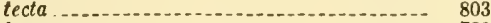

tenax

versicolor

vulgaris

$\begin{array}{ccc}\text { Asperella californica-_..._. } & 872 \\ \text { echidnea } & 872\end{array}$

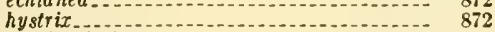

bigeloviana... 873

oryzoides

Asperella americana

angustifolia

californica

herandra

hystrix

imbricata

lenticularis.....................................

major

mexicana

oryzoides

oryzoide

virginica.

Aspris

capillaris.

capillaris

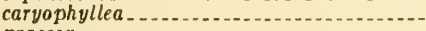

praecor.

A storia bent

Atheronotus longifolig -

Atheropogon, section of Bouteloua

Atheropogon affinis

apludoides.

aristidoides

chomoides

curtipendulus

filifor mis.

gracilis......

gracilis

humilis

medius.

oligostachyus

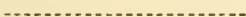

papillosus

procumbens.
Atheropogon-Continued. Page racemostus.............................. 806

Atropis airoides

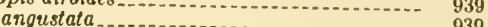

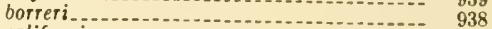

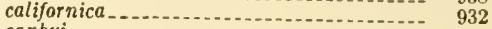

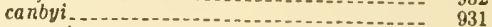

carmata

distans..........-...- 938

maritima_................... 939

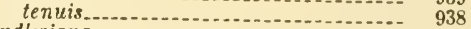

fendlcriana........ 932

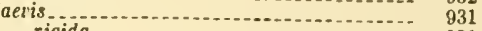

rigida... 931

lemmoni_._............. 938

lettermani

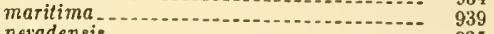

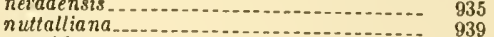

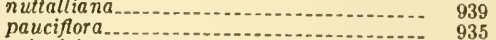

pringlei............................... 936

procumbens....-..... 940

pulchella....... 937

scabrella

suksdorfi

tenuifolia............... 936

stenophylla

unilatcralis_.......................... 937

Aulaxanth us ciliatus

rufus _........ 795

A ulaxia ciliata....... 796

$r u f a \ldots \ldots$

A ustralian chess...... 52

A utumn bent . . ........ 338

A rena

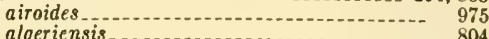

americana.......................... 803

atropurpurea

barbata

brevis . . .

bulbosa..................... 802

byzantina ........................... 295, 297, 803

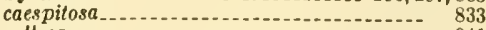

callosa_...

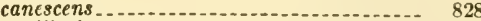

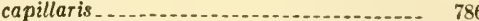

caroliniana............................ 974

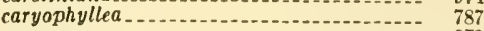

cernua................................ 973

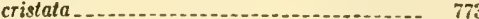

clata

elatior

bulbosa............... 802

tuberosa

glabrata
atua glabrata
satwva $\ldots \ldots$

flavescens............................ 973

flexuosa

glumosa

hookeri.-. 297,803

lanata................................ 870

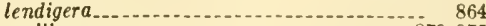

mollis

mortoniana ....

muralis............... 859

nuda_......................... 295, 297, 803

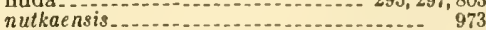

odorata.

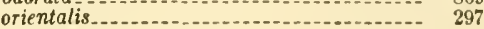

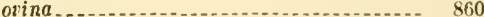

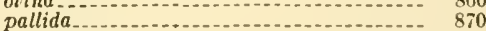

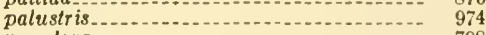

paradoxa............................. 798

pennsylianica............................. 974

praecox ................................. 757

pratensis var. a mericana

sativa..................... 294, 295, 297, 803

$\begin{array}{ll}\text { nigra } & \text { secunda }\end{array}$

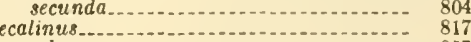

$\begin{array}{ll} & \text { secunda }\end{array}$

selacea
smithii

smithii
sipcaeformis............................ 832 
Avena-Continued.

spicata.

sterilis........... algeriensis.

Page

832,975

alger

striato

albicans.......................... 941

strigosa_........... 295, 804

subspicata.

sylvatica

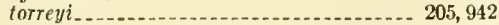

tuberosa

versicolor

A venastrum, section of A vena__._._._._._. 297

Avenastrum pubescens . ................. 803

A veneae. .......... 21,275

Avenella fiexuosa

Avenula pubescens............... 803

Axonopus

cimicinus........................ 828

compressus.................... 2, 573, 574,804

digitatus -

furcatus.......... 573,804

paniceus.

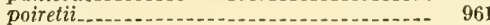

Bahia grass _.....-.-. 583

Baker wheatgrass

Baldingera arundinacea..................... 925

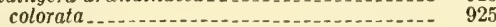

Bamboos ................... 15, 31

ornamental .......................... 15, 31

uses of ....... 3

Bambusa_........ 31

beecheyana............................ 4

hermanni _......... 802

nana

pumila._... 803

Barley__ 264, 268

beardless............................ 268

bobtail

foxtail

little

meadow _.. 265

Mediterranean_................................ 266

mouse................ 268

Barnyard grass.............................- 692

Basket grass ........-..- 688

Bauchea karwinskyi ...................... 962

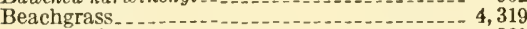

American . . .

European - _. 320

Bearded fescue . ...... 67

$\begin{array}{rr}\text { wheatgrass } & 236 \\ \text { Beardgrass_...... } & 725\end{array}$

bushy

Elliott

prairie

silver.

$3,726,729$

Beardless barley

wheatgrass

wild-rye

Beckmannia

erucaefornis

baicalensis uniflora

syzigachne

Beggartick grass

Bennetia juncea.

Bent, Astoria

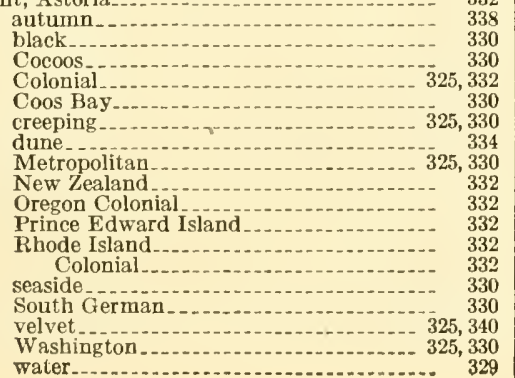

Page

Bent-awn plumegrass . . .

Bentgrass_. . . .

Bermuda grass _.

Bicknelliana, group of Panicum ............ 624

Bifida, group of Paspalum . . . ............ 601

Big bluegrass............................... 136

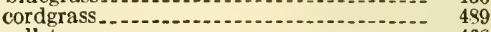

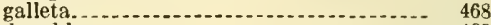

Blgelow bluegrass

Billion-dollar grass........... 690, 694

Black bent dropseed

grama.

Blackseed needlegrass _.................... 428

Blepharidachne...... 221, 805 bigelovii ............ 222, 805 kingii _..... 222, 805

Blepharoneuron _... 409,805 tricholepis.........

Blue fescue ............ 5,76 grama . . . wild-rye -

Bluebunch fescue........................ 35,76 wheatgrass _....................... 3, 230, 240

Bluegrass, alkali_.................... 136

alpine ................................. 126

annual _............ 105

arctic............. 115

big ........................................ 136

Bigelow............. 103

bog

bulbous

Canada.

Canby .

Cusick

English....... 69

fowl. ........... 124

Howell .

inland ................................. 125

Kentucky ...... 2, 99, 112

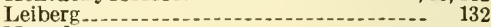

Nevada . . . ............... 135

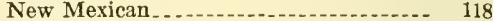

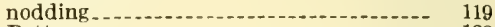

Patterson

pine

plains................................. 114

rough

Sandberg....

skyline...................................... 130

slender.............................-..... 134

Texas_............................ 99, 106

timberline............................................ 129

Wheeler

wood

turkeyfoot.............

Bluestem

Colorado_..... 230

Blumenbachia halepensis _._._._._._._... 951

Bobtail barley

Bog bluegrass .............................. 121

Botanists, acknowledgment of aid from -.... 15

Botelua._...... 805

Bothriochloa saccharoides................ 793

Bottlebrush $\ldots \ldots$
Bouteloua

arenosa

aristidoides

arizonica_..._._. 805

aschenbornianum............ 808

barbata _.

bolanderi. 808

brachyathera....... 809

brevifolia
breviseta

bromoides var, radicosa _..._._._._... 808

burkii

chondrosioides...

ciliata.

curtipendula _...

aristosa

eludens

eriopoda.....

filiformis _. . .

gracilis stricta..................

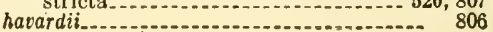


Bouteloua-Continued. hirsuta

major
minor
palmeri-a
major
minor

humboldtiana ... hulis......

juncifolia . . . . .

mojor

melicueformis..............................

melicoides

micrantha.

microstachya.

mutica

oligostachya

interya

intermedia...................... 807

major

pollida...................................

orata

$$
\text { ramosa.. }
$$

palmeri.

parryi .

pectinata.

pendula

polystachya

$$
\text { major }
$$$$
\text { restita. }
$$

procumbens.-.

prostrata

pumila

pusilla

$$
\text { rahmeri. }
$$

racemosa.

$$
\text { oristosa }
$$

radicosa

ramosa ...

rigidiseta .

rothrockii .

simplex...

$$
\text { rahmeri. }
$$

strict $a_{-}$

tenuis.

texana.

trifida

$$
\text { burkii - }
$$

trinii.

uniflora.

restita -

Brachiaria

ciliatissima

digitarioides

erucaeformis

extensa.

isachne

mutica.

pantaginea

platyphyllo

prostrata..

Brachyelytrum

aristatum......

aristosum.

glabratum.

$$
\text { erectum. }
$$

Brachypodium commutatum

distachyon.--

$$
\text { sylvaticum }
$$

festucoides.

japonicum

Brachystylus cristaius . . .....................

Braconotia glauca.

juncer.

officinarum

pungens

Bristlegrass, bur.....................................

giant.

green

Grisebach -

knotroot................................

plains...

yellow.

508

519,808

, 808

806

806
806 808 6,809 517,806 809 809

511,806 515,808 520,806

513. 809

$511,518,809$ 515, 809 809
807 809 513,809 $511,521,810$

521,810

512,810
-808

570,810

571, 810

907

572,810

810

910

572,810

572,810

810
810

811

811

14, 810

814

57,811

57,811 860 774 873

eragrostis.

848,977

maxima. 137,811
Briza-Continued.

Page media .

megastachya . . . . . . minor . . . . . . purpurascens ......................... 818

$\begin{array}{ll}\text { spicata } \ldots+\ldots & 835 \\ \text { virens } & 980\end{array}$

izens

boreale .......... $\quad 838$

obtusifiorum .............................. 850

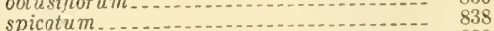

strictum .

uninercium ......... 879

Broadleaf uniola

Brome, California

Canada

Hungarian . . . .

nodding ........... 33, 39

smooth

Bromegrass_an

Bromelica, section of Melica-_en

Bromelica aristata......................... 882 geyeri...

howellit....... 883

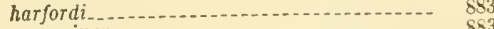

smithii

striata

subulata.

Bromidium, section of Bromus .

Bromopsis, section of Bromus

Bromus _...

altissimus................... 815

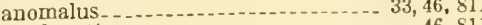

lanatipes............ 46,811

arenarius.............. 52, 811

arundinaceus

arvensis $\quad$ patulus.

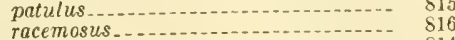

asper

$\begin{aligned} & \text { barbatoides... } 817 \\ & \text { sulcatus... }\end{aligned}$

brachyphyllus..... 815

breviaristatus............................

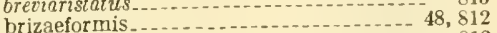

californicus . . . .

canadensis............

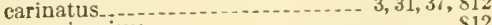

$\begin{array}{ll}\text { arizonic } \iota_{3} \ldots \ldots & \$ 12 \\ \text { califor nicus_. }\end{array}$

$\begin{array}{ll}\text { califor nicus_. } & 812 \\ \text { densus } & 812\end{array}$

hookerianus................. 812

lincaris_._.

catharticus _...

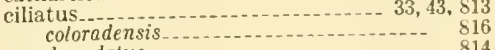

denudatus.

$\begin{array}{ll}\text { glaberrimus _._. } & 818 \\ \text { incenus } & 815\end{array}$

incanus_.... 815

intonsuls............. 45 , s14

ligulatus_............... 818

minor

pauciflorus......... 818

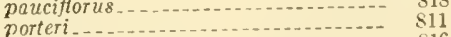

purgans.......................... 816

laeviraginatus_................. 816

commutatus

apricorum........ 50,814

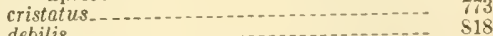

debilis.......

derionensis_................. 57,811

dudleyi_........... 814

elatior

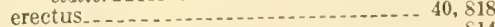

aтiensis.............................. 814

eximius

robustus.............................. 818

flodmant................................ 812 
Bromus-Continued.

frondescens.

geniculatus.

glomeratus

grandis

gussonii

canadensis

ciliatis.

marginatus pubescens.

hookerianus minor

hordeaceus

glabrescens.

intermedius

leptostachys.

imperialis

incanus.

inermis

aristatus.

ciliatus

inopinatus

japonicus

kalmil

aristulatus

major

occidentalis

porteri

laciniatus

laeviglumis

laevipes

lanatipes.

latiglumis.

$$
\text { incanus }
$$

latior.

macounii

macrostachys..

madritensis.

maximus

rigidus.

rubens.

magnificus

marginatu

matior

seminudus

maritimus

matritensis

maximus

$$
\text { gussonii- }
$$

molliformis

mollis

commutatus

$$
\text { leiostachys - - }
$$

mucronatus

mutabilis var. commutatus.

muticus.

nitens

orcuttianus

grandis.

$$
\text { hallii. }
$$

oregonus

$$
\text { ovinus. }
$$

pacificus

paniculatus

patulus.

pauciflorus

pendulinus

polyanthes

$$
\text { paniculatus }
$$

porteri

assimilis

frondosus

lanatipes

pratensis.

pubescens

pumpellianus

$$
\text { melicoides }
$$

tweedyi.

purgans

glabriflorus

incanus.

laevivaginatu

latiglumis.

longispicatus.
Page

47,814

858

41,814

816

812

813

813
812

816

812

812
0,815

51,816

815

51
816

5,815

814

815
813

815

51,815

46,815

857

811

811

39,815

814

43,815

45,815

815

812

51, 815

55,815

816

816
817

816

38,812

812
8,812

812

38,812

53,816

816

50,815

50,815

814
51,993

813

814
883

812

40,815

814

41, 816

812

860

42, 816

813
812

52,815

812

39,815

38,813

39,813

46,811

814

47,814

811

46,811

814,857

816
9,816

816

40,816

45,816

814
815
816

816

815

813
Bromus-Continued.

purgans-continued.

Page

pallidus

purpurascens........ 816

texensis

vulgaris

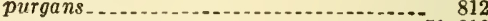

racemosus ......... 51,816

commutatus

ramosus _.............. 814

richardsoni _........... 45, 813

pallidus..... 813

rigidus.................... gussonei

rubens . . . .

rigidus

scabratus $s_{\ldots}$

schraderi

scoparius

rubens

secalinus _.

velutinus............. 48,817

secundus _............ 861

setaceus

sitchensis $\ldots$

spicatus_..._.

squarrosus var, patulus ............. 815

racemosus........................ 816

sterilis $\ldots \ldots \ldots$

steudelii

submuticus _....................... 817

subulatus _............... 884

subvelutinus

suksdorfii. .

tectorum

glabratus ..................... 55, 817

nudus........ 55,817

texensis. . . . .

55, 817 excelsus _...... 57,818 pallidiflor $u s$

unioloides ........ 36,813

haenkeanus.

velutinus_.............................. 817

villosus gussonii ................. 817 maximus........ 816

rigidus

virens.... minor

vulgaris _... eximius _..................... 43,818

robustus......... 43,818

willdenovii

Broomeorn

millet__.... 669

Broomsedge .......... 738

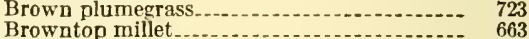

Bruchmannia._._...... 805

Bucetum elatius................... 857

pratense

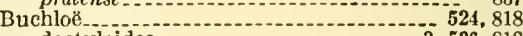

dactyloides . . . . . .

Buffalo grass ............ 3, 526

false

Bulb panicum

Bulbilis

dactyloides

$\begin{array}{ll}\text { Bulbous bluegrass. } & 123 \\ \text { Bull paspalum } & \end{array}$

Bullgrass_._.

Bunchgrass............ 408

Bur bristlegrass

$\begin{array}{lll}\text { Burro grass } & 229 \\ \text { Bush muhly } & \end{array}$

Bushy beardgrass . . . . .

Caespitosa, group of Paspalum

Calamagrostis....

agrostoides........ 819

airoides....

alaskana

albescens...... 822

albicans_...

aleutica

angusta

patens...... 822

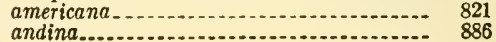


Calamagrostis-Continued.$$
\text { angusta }
$$

Calamagrostis-Continued. Page pickeringii . ........... 314, 822

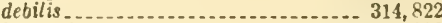

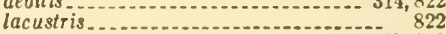
porteri

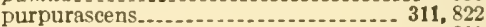

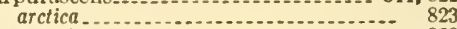
vaseyi retrofracta............................... 785 robusta rubra . . . scabra scopulorum _............... 318, 823 bakeri............................ 821 lucidula scribneri.

821 brevior ............................ 820 rabusta............... 820

subflexน0sa........................... 823

suksdorfi lururians.......................... 823

sylvatica .......................................... 823 americana..................... 823

breviseta........ 822

longifolia.......................... 820

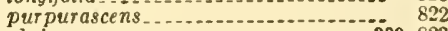
tweedyi . . . varia variegata vilfaeformis . . . . . . willdenorii............................. 785

wyomingensis....................... 821 yukonensis ............................. 823

Calamovilfa brevipilis..........................................

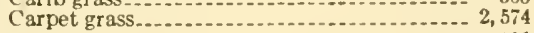

Carrizo................................. 191

Caryochloa bahicnsis....................... 881

Caryophyllea airoides praecar................................. 787

Casiostega dactyloides...................... 818 hookeri.............................. 818 
Page

Catabrosa _._... 168,824

algida

927

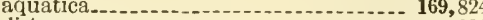

distans

Cataclastos, section of Eragrostis........

Catapodium aquaticum ............... 824

Catchlly grass............................. 537

Cathestechum.....
erectum erectum
prostratum

Cenchropsis myosuroides . . .

Cenchrus . . . . . aegyptius............... 831

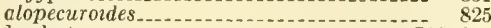
barbatus_..................... 709, 824 brevisetus _. 824 carolinianus ...... catharticus _............. 709,824 echinatus $708,710,824$ brevisetus._._. longispina_...
tribulordes..... viridis_........ 825

elliottii_... 825

gracillimus ..........

granularis .............................. 867

incertus .

macrocephalus........................ 825

myosuroides_._._.

ncrvosus
pauciflorus

pungens _............................ 824

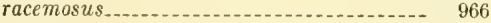

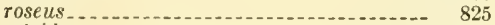

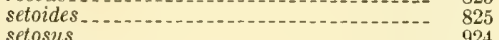

\begin{tabular}{ll} 
setosus & strictus \\
tributand & 924 \\
\hline
\end{tabular}

tribuloides macrocephalus................. 825

vaginatus...

villosus _.............................. 925

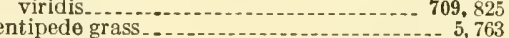

Cephalostachyum 31

Ceratochaete aquatica.......... 979

Ceratochloa, section of Bromus......... 35

Ceratochloa breviaristata . ._._. $\begin{array}{ll}\text { grandiflora } & 813 \\ & \end{array}$

haenkeana........................... 813

marginata................ 812

pendula._. 813

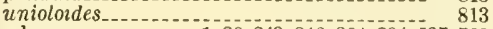

Cereals ......... 1, 20, 243, 246, 264, 294, 537, 768

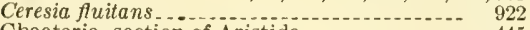

Chaetaria, section of Aristida

Chaetaria affints

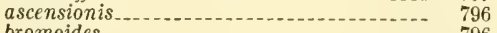

bromoides............ 796

coarctata_..... 796

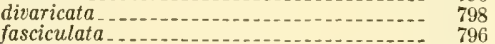

glauca

gossipina

olygantha

purpurascens......... 800

squarrosa

801

Chaetochloa

ambigua.............................. 948

barbata.......... 943

brevispica_............................ 948

caudata

composita

corrugata

flava

$$
\text { parvifiora. }
$$

geniculata

$$
\text { perennis. }
$$

germanica.

gibbosa

glauca.

gracalis.

grisebachii.

$$
\text { a mpla. . }
$$

mexicana.

hispida.
Chaetochloa-Continued. imberbis .

geniculata

penicillata

perennis

streptobotrys.

italica

versicolor.

germanica.

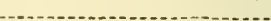

leucopila

liebmanni

$$
\text { pauciflora. }
$$

lutescens....

macrostachya

magna

nigrirostris

occidentalis

palmifolna.

-

perennis.

ploystachya.

purpurascens.

ramiscta.

rariflora.

reverchoni

rigida.

scheelei.

setosa

ventenatii

versicolor.

verticillata

$$
\text { breviseta. }
$$

villosissima

viridis

breviset

minor

purpurascen

weinmanni-

Chalcoelytrum nutans

Camaraphis caudata

caudata pauciflora

corrugata.

costata

glauca

ca.

geniculata

imberbis.

penicillata.

perennis.

gracilis.

imberbis.

italica

ambigua.

germanica

verticillata

viridis...

macrostachya.--

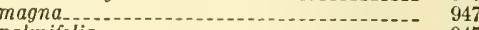

palmifolia

penicillata....... 945

setosa

macrostachya......... 946

ventenatii

verticillata.

viatica

viridis

Chasea amara..... 900

angust ifolia..... 900

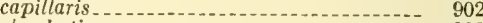

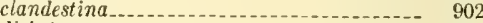

dichotoma..... 904

flexilis

pubescens_................. 912

virgata ............... 915

Chasmanthium gracile..... 977 ornithorhynchum

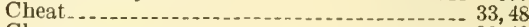

Chess....

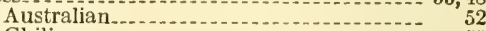

Chilian......... 55

downy

foxtail ............. 54

hairy..... 50

Japanese... 51

soft 
Page

Chewings fescue............ 75

Chilian chess

Chilochloa ventricosa_...................... 861

Chinese canes............................... 469

Chlorideae _.

Chloridiopsis blanchardiana $\ldots \ldots \ldots$
Chloris $\ldots \ldots \ldots$

aristulata

827

andropogonoides.......

barbata .

chloridea _........... 502, 825

ciliata

terana.

clandestina....... 502, 825

compressa

cruciata

cucullata......

curtipendula......................... 80

cynodon

distichophylla.................. 501, 826

dubio 877

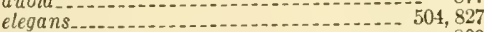

filifor $m$ is....................... 809

floridana.............. 501, 826

gayana _......... 2. $499, \mathbf{5 0 2}, 826$

glauca_._.

glaucescens

latisquamea._..... 50, 950

longifolia

monostach ya.......................... 829

mucronata ............ 831

nashii nealleyi

neglecta.......... 501, 826

penicillata ............................. 827

petraea $\ldots \ldots \ldots \ldots \ldots \ldots$

piperita........ 829

poaeform is $\ldots \ldots 5,826$

polydactyla_. 504,826

procumbens.... 804

propinqua......... 826

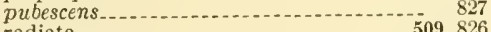

radiata_............... 509, 826

$\begin{array}{ll}\text { repens } & \\ \text { septentrionatis } \ldots \ldots & \end{array}$

subdolichostachya_... 508, 826

swartziana......................... 826

swartzii_......... 826

tenuis

tenuispica._.

texana $\ldots 502,827$

texensis. $\ldots \ldots \ldots \ldots$
truncata $\ldots \ldots \ldots \ldots \ldots$

verticillata_............... 507, 827

oristulata........... 826

intermedia. . . . . 826

virgata_..... 499, 504, 827

$\begin{array}{ll}\text { Chloropsis blanchardiana } & 967 \\ \end{array}$

mendocina

pluriflora

Chondrosium, section of Bouteloua........ 515

Chondrosium aschenbornian $u$ m........... 808

drummondii

eriopodum

exile.

foenum.

gracile.

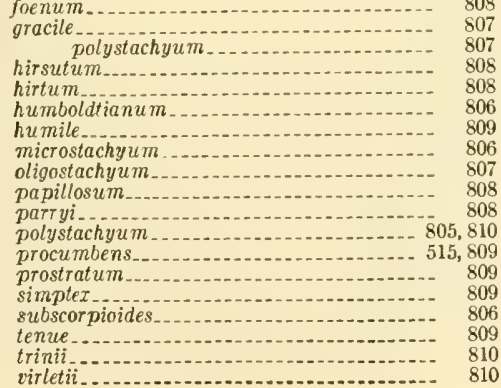

Chretomeris trichoides

Page

949

ysopogon avenaceus

ellioti

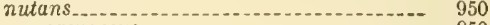

avenaceus__- 950

linneanus......... 950

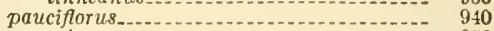

$\begin{array}{ll}\text { secundus } & \ldots \\ \text { wightii } \ldots \ldots \ldots & 950\end{array}$

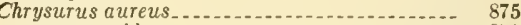

cynosuroides.............................. 875

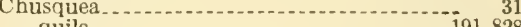

quila _.................... 191, 828

Cinna _...

agrostoides ........................ 827

arachnoidea .................. 888

arundinacea

pendula

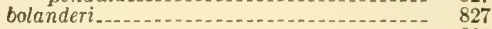

expansa....... 827

filiformis

glomerata.....

lateriflora

latifolia $\ldots \ldots \ldots$

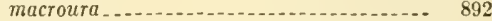

mexicana

pendula

acutiflora

bolanderi............... 827

glomerato _............ 827

glomerula.... 827

mutica...

purshii_................... 819

$\begin{array}{ll}\text { racemosa } & 892 \\ \text { sobolifera } & \end{array}$

sobolifera
tenuiflora............

Citronella grass

Classification of grasses .................. 10

Cleistogamous spikelets _.................. 9,10

Clinelymus borealis . . . .

canadensis................................ 843

glaucus

californicus. 844

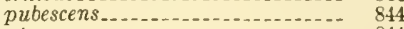

coloratus...... 844

relutinus_... 844

Cloudgrass _................ 341

Club wheat _................. 243

$\begin{array}{ll}\text { Coast sandbur } \ldots \ldots \ldots \ldots \ldots & 710\end{array}$

Cocksfoot _.............. 184

Coelorachis corrugata...................... 882

cylindrica................ 891

rugosa

tessellata............................. 882

tuberculosa........... 882

Coix. angulatus. 764,827

dactyloides...... 972

lacryma

Coleanthus

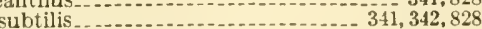

Colonial bent.............. 2, 4, 325, 332

Colorado bluestem................ 230

Colpodium a quaticum

compressum........ 895

junceum

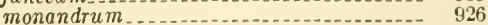

Columbia needlegrass._.

Columbiana, group of Panicum

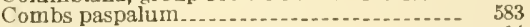

Common names

Conjugata, group of Paspalum .......... 590

Conserved names.......................... 13

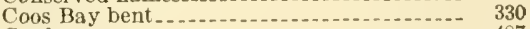

Cordgrass _................. 487

alkali....... 492

prairie_... 489

saltmeadow

smooth. 491

Coridochloa _.....

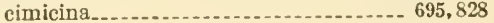

Corms............... 7

$55974^{\circ}-35-64$ 
Page uses of -..-

Cornephorus canescens. 768,771 rnucopiae altissi ma

hyemalis................................ 781

perennans............................. 784

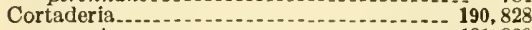
argentea......................... 191,828

dioica................................... 828

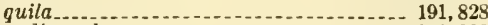

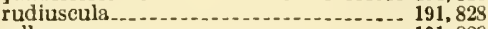
selloana

Corycarpus diandrus.................... 835

Costia cristata

Cottea

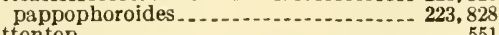

Cottontop....................................... 551

Craepalia temulenta............ 881

Crassipes annuus

Creeping bent muhly 362

Crested dogtail wheatgrass .............................. 2, 231

Crinkle-awn ............................... 757

Crinkled bairgrass........................... 289

Critesion geniculatum

Crithopyrum trachycaulon

Crypsinna breviglumis....................... 888 rigens

Crypsis

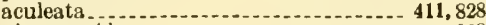
alopecuroides juncea ............................ 959

schoenoides_._......................... 868 squarrosa ............................ 896 virginica.....

Cryptopyrum richardsoni

Cryptostachys vaginata.................... 961

Ctenium .

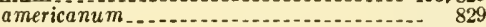
aromaticum . . carolinianum......................... 494, 829 flotidanum . . . . . . . gangitum

Cultivated oats........

Cupgrass prairie............ 569

Curly mesquite

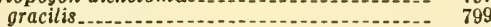

Cusick bluegrass ........--129

Cutandia memphitica. . ................ 169,829

Cutgrass, rice

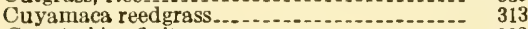

Cymalochloa fluitans........................... 922

repens

Cymbopogon...........746, 830 citratus................ 3, 746, 830

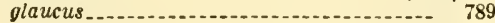

melanocarpus....................... 868

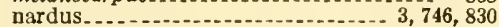
rufus_..................... 872

Cynodon

a mabilis.................................. 847

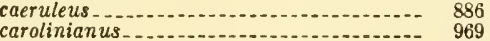

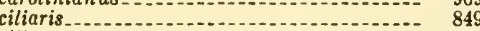

ciliatus.................................. 826

curtipendula............................. 807

cynosuroides $\ldots \ldots \ldots$
dactylon

dactylon

diffusus............................... 893

donax

erectus.

fascicularis............................. 877

indicus...-...... 842

maritimus . ................ 484, 830

melicoides

monostachyos . .......................... 829

occidentalis.................................... 830

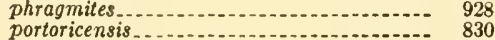

$\begin{array}{ll}\text { portoricensis } & \\ \text { praecox } & \end{array}$

procumbens............................. 809

$\begin{array}{ll}\text { tenuis_. } & 830 \\ \text { virgatus............... } & 879\end{array}$
Page

Cynosurus. .............................. 184, 830

aegyptius_............................. 831

aureus

carolinianus............................ 831

coracanus.............................. 842

eristatus .......... 186, 830

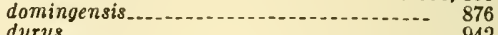

durus..................... 942

echinatus.................. 187, 830

indicus
secundus

siculus............................................ 835

tenellus................................. 772

tristachyus.............................. 842

uniflorus............. 830

virgatus.............. 879

Cyrtopogon dichotomus..................... 798

Dactilon officinale ..................... 830

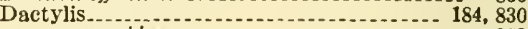

cynosuroides............................. 953

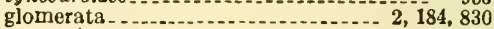

variegata...... 184

maritima_.......................... 953

memphitica...... 829

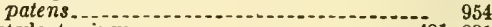

Dactyloctenium ........................ 481, 831

aegyptiacum - .............. 831

aegyptium

meridionale ........ 831

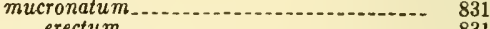

Dactylodes anguiatum

dactylodes................ 973

Dactylogramma cinnoides...................... 892

Dactvlon sanguinalis.............. 837

Dallis grass

Daluca hallii

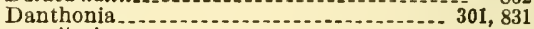

alleni.................................. 831

californica.

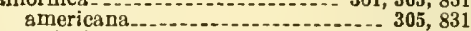

unispicata.................. 833

compressa. . . .................... 301,831

cusickii_._.

faroni-.............

glabra

glumosa...... 832

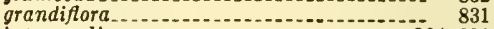

intermedia_. . . . .

cusickii.

macounii_.

parryi. longifolia................................... 832

pinetorum........... 832

pseudo-spicata_....................... 817

sericea_. . .

spicata............. 301, 303, 832

compressa

longipila............ 832

pinetorum....... 832

villosa.

ther male ................. 303, 832

unispicata........

Darnel................................... 269, 272

Dasiola elliotea

Dasyochloa pulchella........ 209, 971

Davyella colusana......................... 796

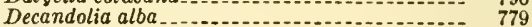

effusa

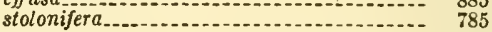

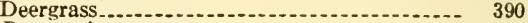

Demazeria......... 139

Dendrocalamus.

$\begin{array}{lr}\text { Depauperata, group of Panicum } & 618 \\ \text { Deschampsia } & \end{array}$

$\begin{array}{ll}\text { alpicola } & \\ \text { ambigua } & 833 \\ \text { arcica. } & 833\end{array}$

a mbigua
arctica $\ldots \ldots \ldots$

atropurpurea......... 288, 833

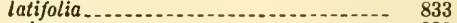

minor

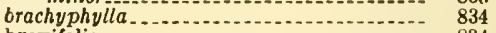

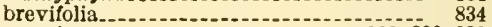

caespitosa._._.................... 288, 289, 833

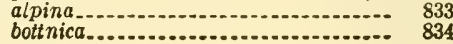


Deschampsia-Continued. caespitosa-continued.$$
\text { brevifalia. }
$$

confinis.

martima

montana

calycina ............

ciliata.

confinis.

curtifolia

danthonioides

elongata.

$$
\text { ciliata. }
$$

$$
\text { tenuis. }
$$

flexuosa

gracilis...

holciformis

latifolia

pesert needlegrass....

saltgrass.

Desmazeria

sicula

Devauxia fluitans....................... 865

Deyeuxia, section of Calamagrostis......... 306

Deyeuxia, aequiraltis _........................ 779 airoides

aleutica.

974,980

alopecuroides

bolanderi

borealis........... 822

breviaristata.......................... 822

breweri............... 818

canadensis ............................. 819

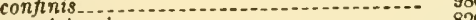

crassiglumis...._._._._._._. 820

cusickii. ................. 823

dubia.

glomerata.

howellii.

hyperborea elongata

lactea
langsdorfii.
macouniana

neglecta

americana.

brevifotia.

gracilis.

robusta.

nutkaensis.

nuttalliana

pickeringii.

porteri

preslii......

purpurascens........

retrajracta.

rubescens

sil

sylvatica

vancouverensis

varia.

Diachroa maritima procumbens.

Diarina

festucoides ........... 171,835

sylvatica........... 835

Diarrhena

americana.......... 171, 835

nquatica

diandra 835

festucoides ................ 835

setacea

Dichanthelium, subgenus of Panicum....... 612

Dichanthum nodosum ..................... 792

Dichotoma, group of Panicum

Dichotomiflora, group of Panicum

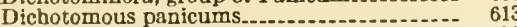

Diffusa, group of Panicum................. 670

Digitaria _... . . adscendens............ 837 appressa...............................
Digitaria-Continued. Page

bakeri........... 561,835

barbata ............ 555

californica _. 966

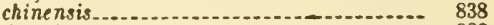

dactylon....... 830

digitata ...

dilatata.....

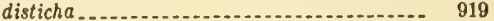

dolicophylla. 836

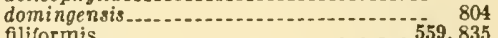

filiformis . . . . .

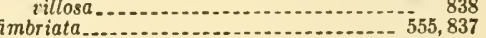

fimbriata
floridans $\ldots \ldots \ldots$

foliosa ...

glabra

hitch cockii._.

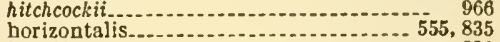

humifusa.................. 836

insularis

ischaemum....... mississippiensis....

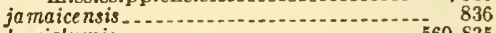

laeviglumis

leucocoma................. 560,838

leucophaea....... 967

littoralis _...... 830

marginata.... 837

fimbriata $\ldots \ldots \ldots$

$\begin{array}{ll}\text { maritima } & \ldots \\ \text { nealleyi } & \end{array}$

nealleyi $\ldots \ldots \ldots \ldots, 837$

paspalodes $\ldots \ldots \ldots 5,804,918$

paspalodes _...

pauciflora..........

pilosa

platicaulis_............. 804

praecor

runyoni.

marginata. 837

serotina........... 558,837

setigera

setosa

stolonifera
subcalva.

texana..........

tristachya.......................... 923

villosa_.

violascens
Digraphis americana.

crundinacea................ 925

picta........ 926

Dilatata, group of Paspalum.

Dilepyrum aristosum............. 810

erectum

Dimeiostemon macrourus............... 790

tetrastachys .............. 795

vaginatus............ 795

Dimesia fragrans.......... 869

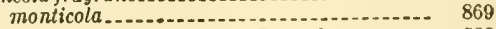

Dimorphostachys, group of Paspalum...... 588

Dimorphostachys ciliifera........_._._._._. 589, 920 drummondi.... 920

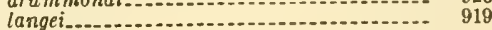

Dineba chloridea

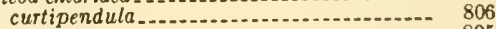

hirsuta............................... 805

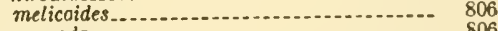

secunda 806

Dinebra aristidoides......................... 805 bromoides $\ldots 08$

chondrosioides _............ 806

$\begin{array}{ll}\text { Diplachne acuminata } \ldots \ldots \ldots & 878 \\ \end{array}$

$\begin{array}{ll}\text { carinata } & 879 \\ \text { chloridiformis } & \end{array}$

domingensis. 877

domingensis.................. $87 \mathrm{~L}$

aristata.

humboldtiana........... 877

pringleana

foscicularis.......................... 475,877 
Diplachne-Continued. halei imbricata

maritima

patens

pringlei.

(45, 878

reverchoni.......................... 972

rigescens_.............................. 861

rigida.

spicata_-_............................ 972

tarapacana_........................ 879

tracyi

uninervia............................. 879

rerticillata__...

viscida... 879

Diplocea barbata

Dissanthelium

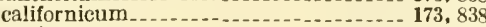
supinum ..................... 173

Dissecta, group of Paspalum - 579

Disticha, group of Paspalum

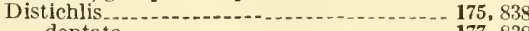
dentata_.................. 177, 838

maritima 838

stricta................ 838

multincrvosa............. 207, 977

nodosa................................. 839

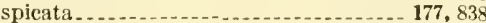
laxa stricta $\ldots \ldots \ldots \ldots \ldots . .1738$

stricta_._.

texana

Distomomischus myuros............... 859

$\begin{array}{lr}\text { Distribution of grasses.... } & 5 \\ \text { Ditch polypogon }-. . . & 350\end{array}$

crested

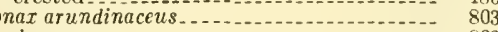
donax.

Downy chess

oatgrass

Drooping woodreed

Dropseed.................................. 392

black -

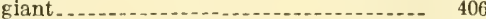

mesa

Nealley........ 406

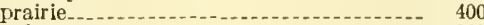

sand

sixweeks

spike.

Dune bent

sandbur

Dunegrass, American_..._.................. 249

Dupontia cooleyi

Durra

Dylepyrum diffusum

multiflorum

Eastern mannagrass................... 86

Eatonia annua aristata

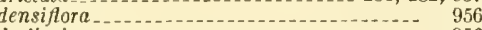
dudleyi

filiformis_.............................. 955

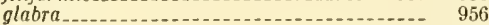

hybrida

intermedia .

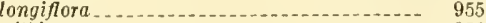

nitida

obtusata purpurascens.................... 956

robusta. _. _.

pallens.

pennsylvanica filfor mis longiflora.......................... 955

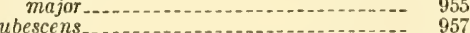

$\begin{array}{ll}\text { pubescens._. } & \\ \text { purpurascens. }\end{array}$

robusta

Echinochlon

690,839

colonum

$690,692,839$

frumentacea

zonalis.

composita
Echinochloa-Continued. crusgalli

Page aristata_._. 839

colonum edulis

crus-pavonis . . . .

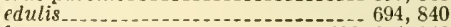

frumentacea . . . . . . . .

hispida lacvigata.......................... 842

michauxii ....................... 840

mitis . ....

muricata-

zelayensis............. 693,841

cruspavonis . . . . .

echinata...................... 839

eruciformis _

frumentacea

longearistata.

microstachya ..................... 840

muricata

ludoviciana................ 840

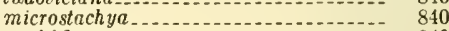

multiflara_..................... 840

accidentalis._._. 840

occidentalis

paludigena...... 694, 841

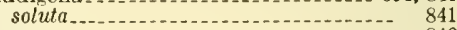

pungens............................. 840

sabulicola

walteri _..... 694, 841 laevigata.

zelayensis......................................... 841

macera

subaristata_........................ 841

zonalis...

Egyptian wheat

Ehrhartia clandestina $\ldots \ldots \ldots$

Einkorn

Elephant grass .........

Eleusine

aegyptia................................. 831

aegyptiaca

coracana . . . .

cruciata

domingensis_.......................... 842, 876

elongato - filiformis

filiformis................................ 878

gracilis
indieg 842

indiea

mucronata........... 831,878

pectinata....... 831

scabra............. 842

sparsa

stricto

tristachya......... 481, 842

unioloides

virgata

Elliott beardgrass . . . . . . . . . .

Elymus . .

acicularis .

ambiguus_.................. 252, 842

strigosus _. 252,842

americanus......................... 843

ampliculmis

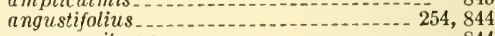
caespitosus_._._._._._........... 844

arenarius......................... 249

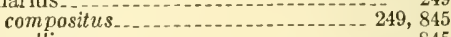
mallis_._....... 845

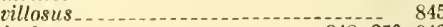

arenicola $\ldots$

aristatus

arkansanus........................ 845

australis_........... 846

glabriflorus..................... 846

borcalis

brachystachys........... 843

brevifolius

canadensis........................ 246, 842

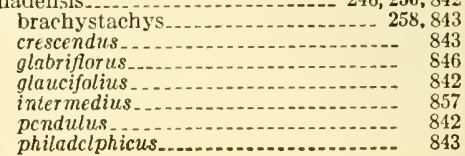


Elymus-Continued.

canadensis-continued. robustus.

Page rillosus.

258,843

(

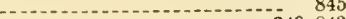

caput-medusae........ 248, 843

carolinianus ............ 846

cincreus -

condensatus - $248, \mathbf{2 5 2}, 843$

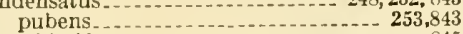

triticoides.......................... 845

crescendus.......................... 843

\begin{tabular}{lll} 
curvatus. & \\
difformis & & 847 \\
\hline
\end{tabular}

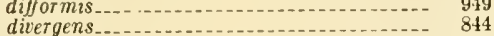

diversiglumis is

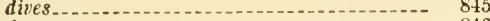

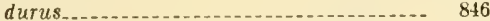

edentatus........ 844

elymoides

giganteus................. 259, 843

giganteus...
glaber

glabrifior us

glaucifolius............................... 842

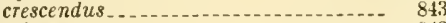

robustus . . 843

glaucus................ 246, 253,843

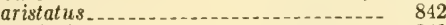

breviaristatus

jepsoni . . .

maximus........................... 841

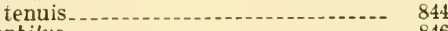

halophilus . . . .

hanseni
hirsutiglumis

hirsutiglumis
hirsutus $\ldots \ldots$

birtiflorus.......... 251,844

hispidulus............................. 844

hordeiformis........ 846

hovellii_.......

innovatus. ...

insularis ...... 950

intermedius .

interruptus

jejunus................................ 846

$\begin{array}{ll}\text { jubat } u s . \ldots \ldots & 871 \\ \text { leckenbyi } & \end{array}$

mackenzii._........... 844

macounii.................. 254, 845

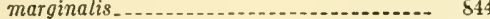

minor
mollis......

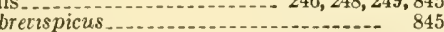

muttzetus_........................... 950

mitidus

occidentalis

orcuttianus._._.

parishii_........... 844

philadelphicus.....-. 842

brachystachys_...... 843

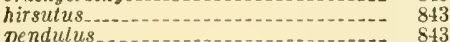

robustus

pringlei_.......... 845

$\begin{array}{ll}\text { propinquus. } & 845 \\ \text { pseudohystrix } & 872\end{array}$

pubescens............ 846

pubiflorus

riparius ...... 258,845

robustus............ 843

vestitus

salina

saundersii_.

scribirictis.

americanus........ 843

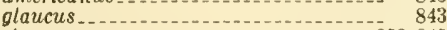

simplex

luxurians _..... 845

sitanion

jubatum......... 950

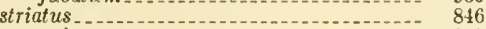

arkansanus...................... 845

ballii

villosus

strigalus................................... 846
Elymus-Continued. Page strigosus_.......................... 252, 842 submuticus ........................... 847 triticoides.................. 248, 251,845 pubescens. ..................... 251,845 simplex

vancouverensis............................. 250,845 velutinus_.......................... 844

villiflarus_......................... 252,842

villosissimus................... 845

villosus_....... 256,845 arkansanus. glabriusculus_................. 843

virescens . . . . . .

virginicus ................. 258, 846 arcuatus... australis......................... 259, 846 glabriflorus..................... 259, 846 australis........... 846

glaucus

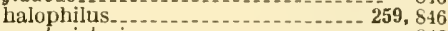
lasiolepis...................... 846

hirsutiglumts_...... 847

intermedius .................... 259, 846

jejunus. . . . . .

minor

submuticus._._................. 259, 847

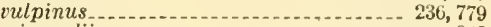

viegandii............. 843 calvescens

Elyonurus_.................. 757,847

parviflorus .............

nuttallianus... 847

nuttallii

tripsacoides_..................... $757,760,847$

$\begin{array}{ll}\text { Emmer } & \\ \text { Endallax arundinacea. } & \end{array}$

Endodia lenticularis...... 875

English bluegrass............... 69

ryegrass........ 269

$\begin{array}{ll}\text { Enneapogon, section of Pappophorum }-1 .-- & 227 \\ \text { Enodium coeruleum } & \end{array}$

Ensifolia, group of Panicum ............... 644

Epicampes a nomala

berlandieri

aistichophylta var. mutica............. 890

emersleyi............................... 888

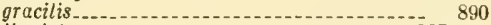

ligulala.......... 387, 890

rigens................. 390, 893

stricta var. mutica ....... 890

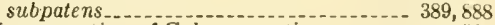

Epigeos, section of Calamagrostis............ 306

Eragrostis. -

abyssinica........... 168, 847

acuta._....... 164, 847

alba

amabilis_..... 147, 847 plumosa

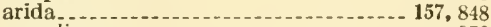

arundinacea......... 970

bahiensis............. 166, 848

barrelieri-...... 156, 848

beyrichii ......... 145, 848

brevipedicellata

brizoides ............ 850

brownei...................... 852

brownei__._.

campestris.

refracta...
pillacea capillaris

capitata................................ 148, 852

caroliniana........ 151, 851

chariis_..._.

chloromelas _. . . .

cilianensis ...................... 154, 848

ciliaris_._. . .

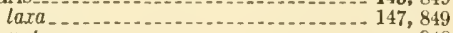
patens

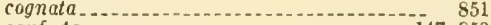

confert $a_{\ldots} \ldots \ldots \ldots \ldots \ldots \ldots . . .147,850$

curtipedicellata.

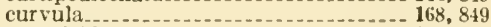

cyperioides _........................ 168, 849

damiensiana.......................... 851 condensata........... 851

delicatula.............................. 853 
Eragrostis-Continued.

Page diffusa

elegantula

151,849

elliot

164,849

eragrostis leersioides.................................... 849 megastachya

microstachya 851

erosa

erythrogona............................. 849

fendleriana............................. 932

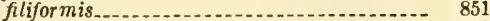

foridana..................... 853

frankii............ 150, 849 brevipes _. 150,849

geveri

glomerata

grandifiora

hypnoides

infirma

intermedia

interrupta......................... 852

japonica _.

limbata

linkii.............. 851

longeradiata........................... 851

lugens ..................................... 158, 850 major .......... 980

lutescens

macropoda

megastachya

cilianensis

mendozina.......... 877

mexicana ........

megastachya.............................

neomexicana........ 156, 850

nitida

nuttalliana
obtusa

obtusa
obtusiflora

orcuttiana

oxylepis.

pallida $a_{2} \ldots$

palmeri

pectinacea................... 850,853 refracta

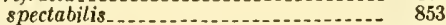

pennsylvanica ........ 851

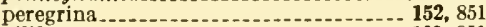

pilifera

pilosa

caroliniana...... 851

condensata

damiensiana ........- 851

delicatula.................... 853

plumosa_...... 147, 847

poaeoides............... 156, 851

megastachya

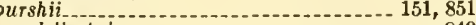

$\begin{array}{ll}\text { delicatula } & \\ \text { diffusa } & 849 \\ & \end{array}$

refracta........................... 166, 851

reptans ...

rigida

secundiflora.

sessilispica._._._._._._._._._._._._. 143, 852

silveana _ 162,852

simplex _._ 148,852

spectabilis

sparsihirsuta

spicata.

sporaboloides

stenophylla

suaveolens

swalleni

tenella

$$
\text { plumosa. }
$$

tenuis.

texensis

tracyi

trichocolea

145,853

66,850

157,853

161,853

168,853

$-848,853$

853

152,853

161,853

159,853

trichodes

tricuspis

969

uninervia.

879

unioloides

149,853

unionis.
Eragrostis-Continued.

Page velutina............................... 853

veraecrucis_............................ 852

villosa

virescens . .

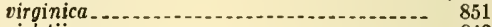

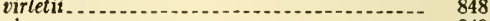

viscosa

vulgaris var. megastachya.............. 848

microstachya......... 851

wiegeltiana

Eremochloa ciliaris . ophiuroides

Eremochloé bigelovii. ........ 805

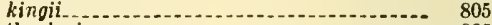

thurberi-1-nos 805

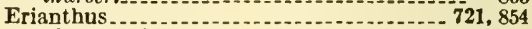
alopecuroides..... 722,854 brevibarbis . . .

contortus _....... 854

hirsutus

brevibarbis.-................. 723, 854

compactus........................ 723, 854

contortus

divaricatus........................ 722, 854

giganteus...............

laxus _.....................

ravennae $\ldots \ldots \ldots \ldots \ldots \ldots \ldots \ldots . . .5,723,854$

saccharoides

brevibarbis.............................. 854

contortus

michauxii_.................... 854

smallii

strictus . .

tracyii . . .

Eriochloa_...

acuminata..... 569

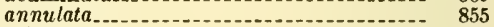

aristata

contracta

debilis

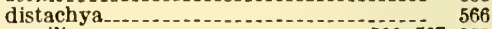

gracilis

minor....... 569, 855

kunthii................... 856

Jemmoni............ 567, 855

longifolia

michauxii_. _.

simpsonii....................... 570,855

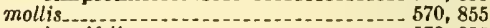
longifolia

nelsonii_............. 570, 855

polystachya........................... 566 annulata -856 punctata...... 856

procera................ 567, 855

punctata $\ldots \ldots \ldots \ldots$

aristata $\quad 855$

minor

ramosa

sericea

subglabra

texana

Eriocoma caduca...... 897

cuspidata . .

hymenaides _.. 898

membranacea $\quad 898$

webberi

Erioneuran pilosum

Erochloé amabilis.......................... 848

spectabilis

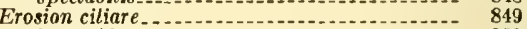

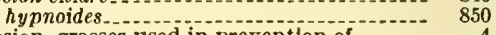

Erosion, grasses used in prevention of

Esparto _. _-

Euavana, section of Avena
Eubromus, section of Bromus.............

Euchlaena section of Bromus...........

luxurians.............................. 856

mexicana

lururians..................... 856

perennis...... 768,856

Euchloris, section of

Eufestuca, section of Festuca .............. 66

Euglyceria, section of Glyceria..r. 85

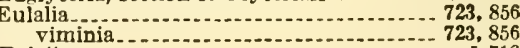

Eulalia ${ }_{\text {japonica }}$

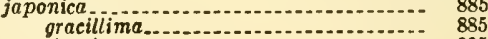

nepalensis ............................ 885 
Page

Eumelica, section of Melica................... 197

Eupanicum, subgenus of Panicum ........ 661

Eustachys, section of Chloris............... 500

Eustachys distichophylla ..................... 826 florida na......... 501,826 glauca neglecta..... 501,826 petraea

Eutriana afjinis........ 805 bristidoides.

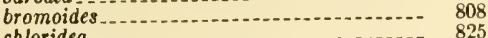
chloridea

$\begin{array}{ll}\text { cristata } & \\ \text { curtipendula } & \end{array}$

curtipendula

gracilis

hirsuta................ 808

humilis oligostachya.

Fall panicum...

False buffalo grass

Fasciculata, group of Panicum. Feather fingergrass

Feathergrass, New Mexican ................

Feather top

Fendler three-swn

Fendleria rhynchelytroides

Fescue, blue

(n)

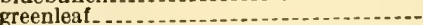

hard

meadow

red.

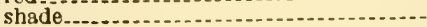

sheep.

Festuca

acerosa.

acutiflora altar. aristulata......... arizonica

ambigua

$$
\text { allit............ }
$$

americana

amethystina

asperrima

idahoensis

(1)

aquatica

arenaria

aridatulata

$$
\text { parishii. }
$$

arizonics.

arundinacea

barbata

borreri.

brachyphyilia.

brevifolia

$$
\text { utahensi }
$$

bromoides

caerulea.

californica.

$$
\text { parishit. }
$$

calligera..-

campestr is

capillats...

caroliniana.

clandestina

confinis....

$$
\text { rabiosa. }
$$

confusa.

cristatum.

dasyclads

denticulata.

dertonensis

diandra

distans

maritima

distichophylla

dives.

domingensis.

duriuscula.

$$
\begin{array}{ll}
\text { rubra } & 861 \\
&
\end{array}
$$

eastwoodae

66,857
Festuca-Continued. elatior.

Page

$2,58,67,857$ arundinsces pratensis.
elmeri conferta. 67,858
67,858 luxurians...................... 858 erecta 814 eriolepis.......... 856 fallax

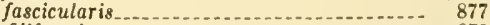

filiformis......... 878

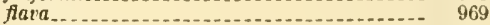

fluitans............. 864

pratensis_._._._._._._._._. 857

geniculata ............... 77, 858

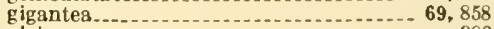

glabra.............
glauca

glomerala...................... 830

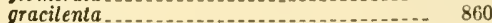

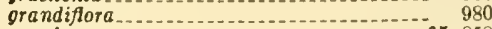

grayi

heterophylla..... 861

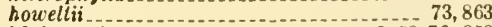

idahoensis

inermis ... 814

villosa

ingrata........... 858

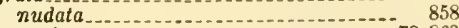

johnsoni.............. 70,863

jonesii

conferta.
juncea

kingii-a.

rabiosa $\ldots . . .698 .658$

ligulata.

macrostachya

madritensis ....... 81,859

megalura -......................

microstachys $\ldots \ldots \ldots \ldots$ ciliata_-_

paucifora............... 861

subappressa

minutiflora

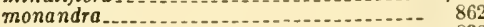

multiflora

myuros

myuros...

nutans...

johnsoni.......... 863

major

palustris

shortii............... 862

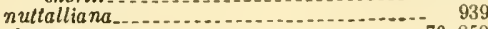

obtusa

sprengeliana................... 859

versuta...................................... 863

$\begin{array}{ll}\text { obtusata } & \\ \text { obtusiflora } & \end{array}$

occidentalis

occidentalis

aristulata.
actoflors

glauca........................... 860

hirtella

tenella

oregona................ 861

ovina

brachyphylia

brevifolia............................. 860

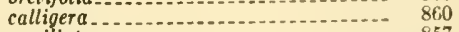

capillata_......... 857

coluriusina

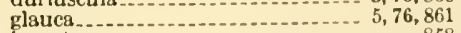

$\begin{array}{ll}\text { ingrata. } & 858 \\ \text { oregona } & 858\end{array}$

polyphylla........................ 859

pseudovina............................. 861

rubra.............................. 861

saximontana........................ 860

purpusana................... 860

rydbergii...................... 860

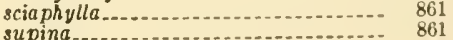

$\begin{array}{ll}\text { supina } & \\ \text { vivipara } & \ldots \ldots \ldots \ldots\end{array}$ 
Festuca-Continued. pacifica parishii

parviflcra

phleoides.

poaeoides.

$$
\text { a mericana }
$$

polystach ya

pratensis.

procumbens............ 877,940

prolifera.......... 75, 861

prostrata

pseudoduriuscula

purpurea

pusilla

quadridens_-_-_._. 969

quadriflora.............. 65,861

reflexa

rigescens

rigida_..._.

Tubens

rubra

arenaria...... 861

densiuscula

fallax

glaucodea.

heterophylla

kttaibeliana

littoralis_.....

megastachya

multiflora

prolifera....................... 75, 861

$\begin{array}{ll}\text { pruinosa } & 862 \\ \text { pubescens } & \end{array}$

pubescens.......................... 862

subvillosa forma rivipara...... 862

villosa

saximontana ................................. 76,860

scabrella _ _ 71, 862

major $\ldots \ldots \ldots \ldots$

vaseyana_..._................ 857

sciurea_.

shortii _._._. 70,862

sororia

spicata

spica-venti_...

subbiflora

subulata

jonesii

sororia

subuliflora_._._.

subulifolia........ 863

suksdorfii............ 857

syloatica............. 811

aristulata

glauca

texana...

thurberi

tolucensis ssp. thurberi__._._._........ 863

$70,863,877$

tracyi_.
traticea

triticoides........ 838

unioloides............................ 813

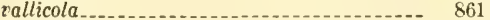

raseyana..... 857

$\begin{array}{ll}\text { versuta } & \\ \text { virgata } & \end{array}$

$3,58,73,863$

howellii.......

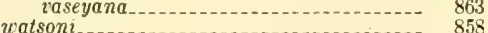

Festuceae _........ 17,31

Festucoideae

Feterita

Fiber-producing grasses..................... 33

Fibichia dactylon

Field sandbur

Fingergrass......... 498

feather

Fiorin.

Floral organs

Floridana, group of Paspalum...... 597

Flower of grasses. ........................... 10
Page

209

Fluffgrass
festucacea
feninea

festucacea . . . . . .

$25,168,179,243,246,253,264,268,294,295,392$,

$481,537,540,601,602,690,697,705,718,750,768$

Foothill needlegrass

432

Forage grasses.............. 1, 3, 31, 33, $36,57,58,73,78,84,95,99,100,139,143,175,194$, $223,229,230,243,269,276,278,282,288,301,306$, $325,345,349,352,353,357,392,408,410,415,423$, $439,466,469,484,487,494,499,511,526,534,549$, $551,553,563,566,575,601,602,672,690,694,697$, $705,708,726,734,748,750,755,764,767,768,771$

Forasaccus arvensis.................... 811 brebiaristatus......................... 813

ciliatus - 813

laeviglumis............. 814

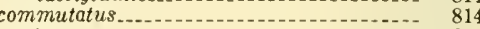

erectus

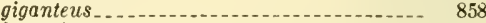

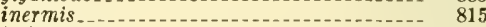

latiglumis.-..... 815

marginatus_..._. 812

maximus _- 816

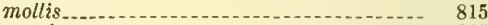

patulus

pumpellianus........ 816

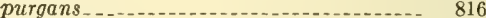

тасетоsus_._..................... 816

secalinus

Fountain grass .......... 5, 708

Fowl bluegrass ........................... 124

mannagrass

Foxtail _........... 345

alpine....... 347

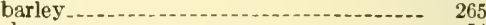

chess

meadow

meadow

muhly

shortawn

Washington........ 347

water

Fragrant grasses_........... $526,528,746,747,757$

Fringed brome ........... 43

Fussia capillaris

caryophyllea......................... 787

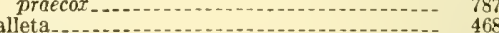

big-as

Gamagrass .. . .

eastern

Florida.......... 767

Mexican-_... 768

Gardener's garters

Gastridium

lendigerum

ventricosum 355,863

Geminata, group of Panicum _... 661

Geographic range of grasses.................. 5

Geyer oniongrass_.................... 197

Giant bristlegrass.................. 702

dropseed

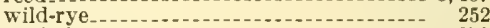

Ginannia lanata.......... 870 moldis_._. pubescens._................. 870

Glumes-1yceria.-1.. acutiflora airoides_.................... 824,939

americana

angustata_........ 939

aquatica

arkansana.

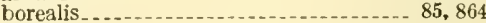

borreri

brevifolia

bulbosa

canadensis........

laxa_............ 89, 864

parriflora ........ 864

canbyi_.............. 930

catabrosa......... $\quad 824$

delawarica ............................. 938 
Glyceria-Continued.

Page distans. tenuis.

938

elata

elongata

erecta

fernaldii-

flavescens

fluitans

angustata

grandis

iatifolia

laxa...

lemmoni.

maritima

melicaria

michauxii

micratheca

montana

neogea

nervata rigida

stricta

obtusa

occidentalis.

otisii.

pallida. fernaldii

paueiflora.

paupercula

pennsylvanica

pumila

septentrionali

spectabilis var. flaccida

striata.

$$
\text { stricta }
$$

stricla...

torreyana

Gnomonia elatior

nutans.

octoflora.

oxina...

viridula

Goatgrass

barb

Goldentop

Golf courses, grasses for

Goosegrass

Grama

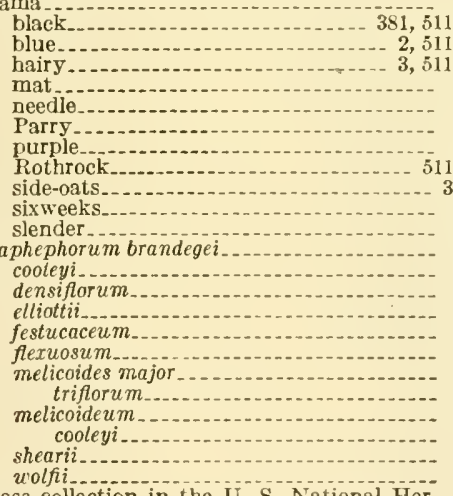

rass collection in the U. S. National Her-

barium

needlegrass

sprangletop

Greenia arkansana

Greenleaf fescue.

r.

Grisebach bristlegrass

$3,58,73$

Guinea grass.

$2,601,672$

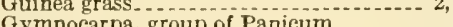

Gymnopogon.

ambiguus

496,867

brevifolius

chapmanianus
496. 867

496,867

865

94,865

865

864

864

864

865

9. 865

866
866

939

90,866

90,866

93,865

89.865
87.865

92,865

94,866

865
865

939

939

866
866

90,866

958
89,865

858

859

859
859

863

243

246
245

245
187

481

511

1, 519

515
512

517

1,518
3,512

516

515
976

974
956

932

863

940
974

932

974
974

974

976

14
702

702
435

471

73

2
3
67
87
87

Gymnopogon-Continued. Page distichopyllus _......... 867 longifolius . _....................... 825 racemosus....................... 496, 867 scoparius

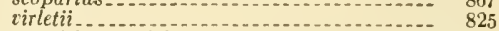

Gymnostich um californicum hystrix patula

Gymnothrix geniculata.............. 925

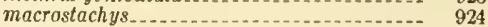

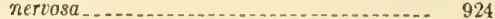

Gynerium .... 190, 867 argenteum . . . procerum saccharoides ...................... 190, 867 sagittatum

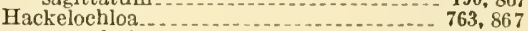
granularis.

Hair feseue . . .

Hairgrass, annual $\ldots \ldots 288$ crinkled..................... 289

mountain . .

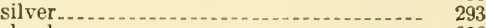

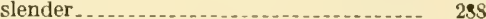

tufted

Hairy chess ......... 50 grama $\ldots \ldots \ldots \ldots, 511,519$

triodia . .

Hall's panicum.

Hard feseue . .

Harding grass.

Harford melic . . .

Havard three-aw $\mathrm{n} . \ldots$.
Hay grasses $69,95,184,229,230,231,243,294,298,301$. $306,325,345,353,408,484,487,489,499,511$, $534,553,601,602,695,726,750,752$.

marsh

Heleochloa. alopecuroides............. $411,412,868$ juncea._. 869,959 phalaroides........ 869 phalaroides
schoenoides $\ldots \ldots$

Helopus annulatus.... 855

gracilis.......................... 855

junceus_................ 856

kunthii

mollis

He marthria fasciculata _................ 881

rugosa

\begin{tabular}{ll} 
Hemitoma, group of Panieum & 682 \\
\hline
\end{tabular}

Hesperochloa kingii $\quad 69,858$

Heteropogon $\ldots$ acuminatus ................. 869 contortus ............

glaber
hirtus

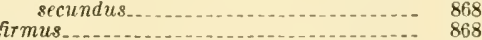

glaber

hirtus............................. 868

melanocarpus.

melanocarpus

scrobiculatus _...

secundus

stipoides

Ileterostegon curtipendulus............... 807

Heuffelia pubescens

$\mathbf{5} 26,869$
alpina $\ldots \ldots$ alpina
aristata $\ldots \ldots$ antarctica..... 526

arctica..... 869

borealis..... 869

fragrans

macrophylla.......

nashii... 528, 869

oceidentalis $\quad 528,869$

odorata..........

Gragrans.......... 869

belangeri...... $3,466,870$

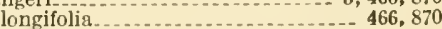

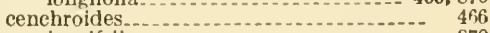
longifolia..... 870

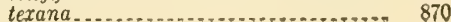


Hilaria-Continued

jamesii

mutica

Page

468,870

466,870

(468,870

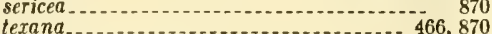

Himalaya fairy grass

Hippagrostis selarius..................... 897

Holcus

alpina.................... 869

atropurpurea..... 833

avenaceus ................ 802

borealis

bulbosus....... 802

caffrorum............................... 952

сегпuиs................................. 952

contortus............................. 868

durra........ 952

fragrans

halepensis _............... 750, 951

lanalus

larus

mollis

monticola

nutans___. 951

arenaceus ............... 951

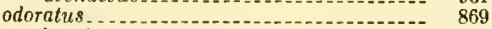

saccharatus ........................ 952

technicus_............................ 953

saccharoides

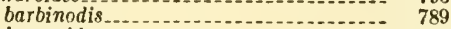

laguroides.......................... 793

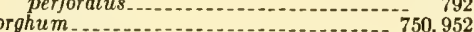

caffrorum

drummondii

durra_........... 952

saccharatus ................ 952

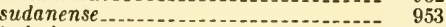

technicus _........... 953

spicatus............................... 924

$\begin{array}{lll}\text { striatus } & \\ \text { sudanensis } & 941 \\ \text { lirgatus } & \end{array}$

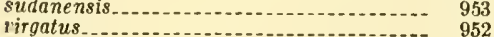

virginicus......... 794

zizanioides -

Holy grass ..................

Homalocenchrus gouini..................... 875

hexandrus............ 875

lenticularis..................... 875

monandrus_....................... 876

oryzoides..........

ovata

Hordeae

Hordeum

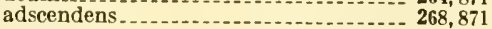

avenaceum ...

boreale . . . .

caespitosum .

canadense

caput-medusae

$\begin{array}{ll}\text { carlilagineum } & \\ \text { coeleste var. trifurcatum } & 846 \\ \text { depressur. } & 871\end{array}$

depressum

distichon

elymoides

gussoneanum

hexastichon

hy:trix

jubatum caespitosum

marinum gussonianum

maritimum

gussonianum

montanense.

murinum

nodosum

$$
\text { boreale. }
$$
depressum

pammeli.

patulum

potystichum var. vulgare

pratense nodosum

pusillum. pubens.
Hordeum-Continued. Page

riehlii................................ 871

salivum

vulgare.............................. 871

spontaneum

striatum

trifurcatum

villosum_.................. 845

virginicum............ 846

vulgare.............................. 264, 268, 871 trifurcatum .......... 268, 871

Howell bluegrass .......................... 103

Hungarian brome

grass _... 704

Hydrochloa. .

airoides............ 824

caroliniensis . . .

distans

fluitans

Hydropoa, section of Glyceria...... 88

Hydropyrum esculentum .................. 978

fluitans......... 872

Hymenachne indica. striata.

Hymenothecium tenellum.................... 772

unisetum 772

Hyparrhenia

hirta . ............. 748, 872

pseudocymbaria....................... 748

rufa....................................

Hystrix

californica............... 264,872

elymoides _............................ 873

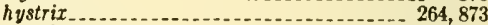

patula

bigeloviana............................. 264,873

Ichnanthus glaber..................... 915

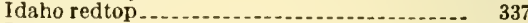

Imperata

arundinacea

brasiliensiana -an 873

brevifolia.......... 815,873

caudata

cylindrica.

hookeri _. 715,873

India lovegrass . .
Indian corn.... grass $\ldots$

Industrial arts, grasses in

Inflorescence...................................

$\underset{54,55,243,260,264,423,439,708,755,771}{ }$

Inland biuegrass

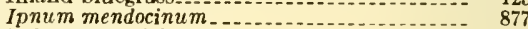

Ischaemum glabrum............ 972

leersioides............... 763

ophiuroides........................ 854

scariosum

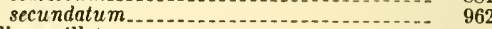

Italian millet.

ryegrass _...

Ixophorus glaucus ................... 924, 946

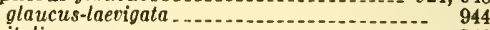

italicus .............. 946

verticillatus_.......................... 948

viridis

Japanese chess

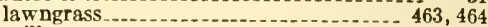

millet ...._.

Jaragua

Jobs-tears
Johnson grass

Johnson grass . $\ldots \ldots$
June grass _...

Jungle-rice

Kafir-

Kaoliang. -

Kau sun

Kentucky bluegrass.................. 2, 4, 99, 112

Khas-khas_...................... 747

Khus-khus.....

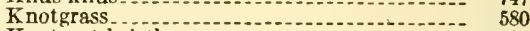

Knotroot bristlegrass.................... 697

Koeleria airoides . arkansana...... 873 aurea

brachystachys........................... 874

canescens 
Koeleria-Continued,

cristata

Page

longifolio

major

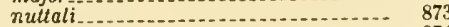

pinetor $u m$...................... 87

pubescens......................... 874

elegantula

gracilis_............................ 873

dasyclada........ 874

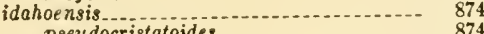

pseudocristatordes........... 874

\begin{tabular}{ll} 
latifrons_. & lobatg \\
\hline
\end{tabular}

macrura

biflora

quadriflora

nitida \begin{tabular}{ll} 
& 873 \\
\hline
\end{tabular}

Grkansana

treviculmis

californica

multiflora

transiens............-.

vestita.

caudata.

latifrons.

laxa

missoutiana

munita

subla nuginosa

pubiflora.

subrepens.

obtusato

paniculata

pennsyluanica

major -

phleoides

polyantha.

californiensis

pseudocristato.

californica

densevestita

laxa.

longifolia.

oregana.

pseudonitida

pulchella

robinsoniana

australis.

spicato.

subspicato

iruncota.

Korean lawngrass

velvet grass

Korycarpus arundinaceus .

Lacegrass

Lach nagrostis phleoides

$$
\text { retrofracta }
$$

willdenovii-

Laertia or yzoides

Laevia, group of Paspalum

Lagurus

cylindricus

ovatus.

Lamarckia

tenella.

tenella

Lanuginosa, group of Panicum

Lappago aliene.

berteroniona

occidentalis

racemosa

Lasiacis

divaricats

Lasiostega humilis

Lawngrass, Japanese . . . 463

Law ns, grasses for ... 4, 58, 76, 99, 114, 325, 330, 331 , $332,463,484,565,573$

Laxa, group of Panicum.

Laxiflora, group of Panicum

Leat of grasses.

Leersia.

asperrima

537,875

contracta.
Leersia-Continued.

Page

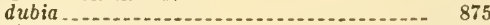

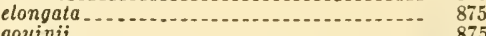

gouinit..................................... 875

hexandra

lenticularis.

mexicana.... 875

monandra $\ldots .5 \ldots \ldots \ldots, 575$

oryzoides
glabra $\ldots \ldots \ldots \ldots \ldots$

inclusa............... 539, 876

virgata 876

virginica.

Leiberg bluegrass......... 132

Lemmas ............. 935

Lemon grass........ 3,746

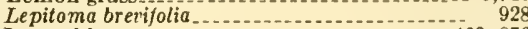

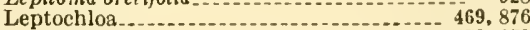

attenuata...................... 473, 878

brachiata.............................. 878

chloridiformis ........................ 47,8

domingensis ........................... 472, 876

dubia.._. $469,471,877$

pringleana................. 877

tascicularis..._._.

filiformis ........................................ 478

fioribunda .

halei ............................. 878

imbricata....... 475, 879

langloisii
liebmanni_.

liebmanni_... 58

pulchella...................... 878

mutica

nealleyi

obtusiflora .......................... 877

panicoides ........................ 476,878

paniculata.......... 878

patens_.............................. 877

pellucidula............................. 878

perennis................. 879

pilosa_._.......................... 878

$\begin{array}{ll}\text { polystachya....... } & 877 \\ \text { pringlei } & 877\end{array}$

pringlei_._. 852

scabra

scabra
spicata

stricta

tracyi_...................................... 878

uninervia . .

virgata.............. 469, 472, 879 aristata domingensis...................... 877

$\begin{array}{ll}\text { intermedia } \ldots \ldots & 879 \\ \text { mutica } & 879\end{array}$

mutica
irletii_and

viscida_........

Leptochloris greggii....................... 967

Leptocoryphium drummondii_.......... 795

obtusum

barbipulvinata.............. 902

capillaris _...

cognatum .............. 563,879

dichotomiflora

miliaceum

Leptopyrum tenellum
Leptostachys domingensis.o.

Leptostachys domingensis_...............
dubia

filiformis

virgata.................. 879

Lepturus

bolanderi
cylindricus

filiformis.............................. 928

incurvatus .................... 927

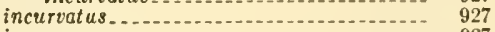

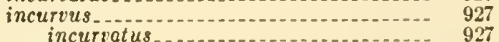

paniculatus.................... 941

repens................................ 273

$\begin{array}{ll}\text { Lepyroris canadensis } & \\ \text { Lerchenfeldia fleruosa } & \end{array}$

Lesourdia karwinskyana................. 942

multiflora

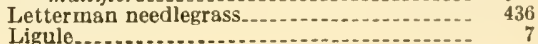




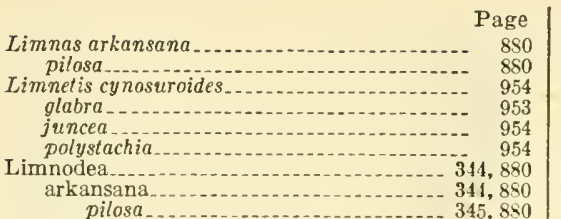

Lithagrost is lacryma-jobi_........ Little barley oniongrass 199

Littleseed mubly

Livida, group of Paspalum.............. 581

Lodicules.

Lolium artense
brasitianum canadense.... 880,980 cylindricum .................. 880 italicum _._. diminutum $2,269,272,880$ italicum

microstachyum

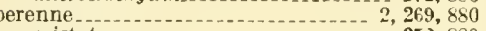
cristatum ............... 27, 880 italicum . ... 880 multiflorum pacyi...... 880 rigidum rigidum _... scabrum _....................... 880 strictum_... subulatum . . . . . . temulentum........... 269, 272, 881 artense.......................... 881 canadense leptochaeton $\ldots$ multiflor $u m$

Longtongue mutton grass.......... 126

Lophochlaena californica................... 928

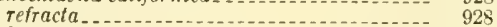

Lophochloa phleoides....... 874

Lovegrass .................... 139

India

Mexican

plains......

purple.................. 163

Ludolphia macrosperma................... 802 tecta.

Luziola.

atabamensis

$\mathbf{5 1 4}, 881$

bahiensis. alabamensis

caroliniana.

caroliniensis.

langiralvula

longivalvulra

peruviana.

pusilla.

striat

881

$\mathbf{5 4 4 , 8 8 1}$

881

872

881 881

544, 881 881

881

352,881

phleoides....... 352, 881 glaucifolius....... 851

$$
\text { schaffneri. }
$$

Lygeum spartum

Macoun wild-rye........

Macroblepharis contractus... 849

Maidencane........................... 682

Maize _...

Malojilla of

Manila grass.

Manisuris.-

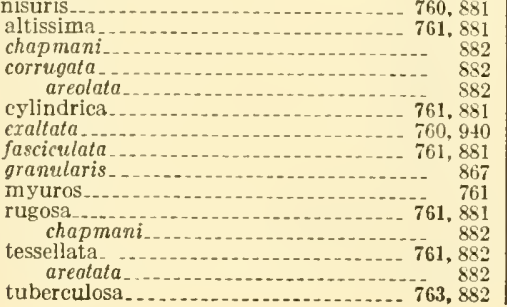

Page

Mannagrass .................................. 83,87

American_................. 84, 92

eastern ......

fowl. . .

northern _.................. 85

rattlesnake......................... 89

tall _...

weak

Marram

Marsh muhly

Mascarene grass ...................

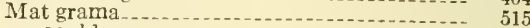

muhly _.........

Maxima, group of Panicum

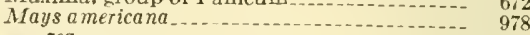

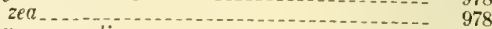

Mayzea cerealis ............................. 978

Meadow barley

fescue .....................

foxtail_...... 345,347

grass, rough stalked _.............. 116

Mediteranean barley........................ 1166

Megastachya a mabilis ............ 847

canadensis............................. 864

ciliaris

cragrostis......... 840

glomerata

hypnoides......................... 850

infirma $\ldots \ldots \ldots$

obtusa

orylepis......

capitata.... 852

panicoides................................ 878

purpurascens.... 848

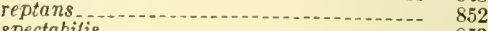

spectabilis_...

uninctvia

Melic, California_... 289

false.

Harford .......

Porter........

rock

Smith

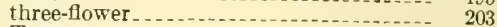

Torrey ............................ 203

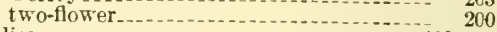

Melica ................ 193, 882

acuminata......................... 884

altissima $\ldots \ldots 4,882$

altissima_...

anomala

aquatica _........................ 824

argentea $\ldots \ldots \ldots$

aristata

bella

intonsa.

bromoides.......................... 883

howellii..................... 883

hulbosa $\ldots \ldots \ldots \ldots$ 198, 882

bulbosa

californica _. . . _........ 204, 882

cepacea $\ldots \ldots \ldots 5$

ciliata_...

colpodioides

curtipendula .......................... 886

diffusa

nitens. 884

eff $u s a \ldots$

fluitans....... 865

frutescens _......

fugax .......... 199, 883

inexpansa

madophytla $\ldots$

geyeri_....... 197, 883

geyeri

glabra

harfordi

minor

tenuior

tenuis

viridifolia $\ldots$

imperfecta

flexuosa

minor

pubens_......... 883

refracta $\ldots \ldots \ldots$ 204, 883

sesquiflara

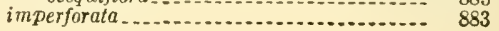


Molins-Continued.

inflata

longiligula

macbr.dei-.............................. 883

macrantha. ....................... 934

mericana

muhlenbergiana........................ 884

multinerrosa _........... 207, 977

mutica

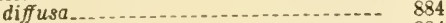

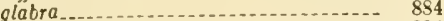

parifitora................ 884

nana

nitens................ 194

pammeli.-1.... 883

\begin{tabular}{ll} 
panicoides ............ & 883 \\
\hline
\end{tabular}

parishii.............. 884

parifiora

acuminata............ 884

bromoides...... 883

inflata

porteri........................ 194, 200, 884

purpurascens . . . 205, 942

racemosa

rariflora

$\begin{array}{ll}\text { retrofracta } & 854 \\ \text { scabra_... } & 884\end{array}$

scabrata.

smithii..

speciosa.

spectabilis

striata.

195, 884

stricta.

subulata

torreyana

triflora.

Melicgrass

Melinideae

Melinis

minutiflora

rosea

88

197,884

205,942
200,884

$194,197,884$

203,884

193

26,546

546,885

547,885

Merathrepta americana.................... 831

califor nica............................ 831

compressa

intermedia

$$
\text { cusickii. }
$$

parryi.

pinetorum

sericea.

spicata.

thermale.

pinetor $u m$.

unis picata.

Merisachne drummondii

Mesa dropseed. muhly

Mesquite, curly.

grass

vine

Metropolitan bent

Mexican lovegrass teosinte

Mibora minima

Miegia arundinaceo gigantea

macrosperma

pumila.

Milarium effusum -

Milarium effusum........................

$$
\text { amphicarpon }
$$

capillare.

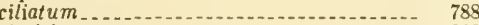

cimicinum ............................ 828

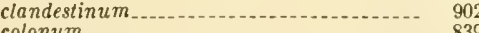

compressum

crusgalli....... 839

cuspidatum.

dactylon.............. 830

digitatum

distichum .

effusum

esculentum_...................... 909

halepense .......... 951

$\begin{array}{ll}\text { latifolium } & 908 \\ \text { leibergii } & \end{array}$
Milium-Continued. Page

lendigerum ........................ 355, 863

maritimum

mexicanum .

microspermum ................... 960

muhlenbergianum...... 788

paniceum ...................... 830

panicum

paspalodes

punctatum

pungens.............................. 898

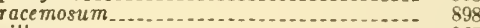

rillosum .

rirgatum

elongatum .................... 915

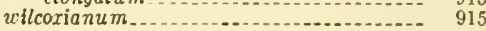

Millet _......... 2

African................... 481

broomeorn............ 669

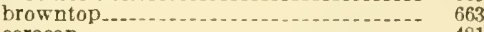

coracan ..................... 481

$\begin{array}{ll}\text { finger } & \\ \text { Italian } & \end{array}$

Japanese._.

pearl

proso..................................... 601

Texas

Milo..........

Miracle wheat............................... 243

Miscanthus: _.................. $5,6,718,885$ japonicus ........................... 718

nepalensis .........

sinensis _...... 718,885

gracillimus _...

variegatus........................... 718,885

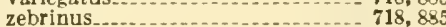

Molasses grass............ 547

Molinia_... 171, 885

aquatica ............................... 824

caerulea_..... 171, 885

retusa................ 877

Monachne punctata.... 856

Monanthochloe

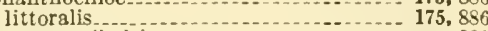

Monerma cylindrica

Monocera aromatica

Morphology of grasses.................... 6

$\begin{array}{lr}\text { Moulingia lanosa } & 799 \\ \text { Mountain bunchgrass..... } & 58\end{array}$

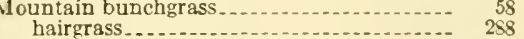
muhly

Mouse barley ............................ 268

Muhlenbergia_._. acuminata
a mbigua

filiformis $\quad 889$

andina

anemagrostoides

arach noidea

arenacea

arenicola
aristata

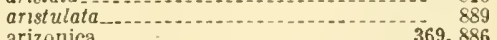

arizonica.....................

arsenei _............ 378,886

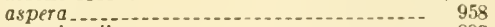

aspericaulis

asperifolia ........................... 366, 886

berlandieri............................ 384, 893

botteri-1............................ 893

brachyelytrum

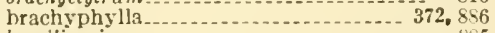

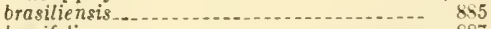

brerifolin ............................. 887

richardsonis........ 894

buckleyana....................... 894

caespitosa

californica

calycina
capillaris

filipes............. 386, 887

trichopodes_._... 888

cinna_.................. 827

$\begin{array}{ll}\text { clandestina } & \\ \text { coloradensis } & 958\end{array}$

comata

commutata

composita................ 958 
Muhlenbergia-Continued.

curtifolia

$$
\text { griffithsii }
$$

Page 364,887 curtisetosa 894 cuspidata 375,887 debilis

diffusa.....

dubia.

891

361,887

893,894

382,887

dumosa

$$
\text { minor }
$$

emersleyi

erecta

expansa.

fasciculata

filiculmis

filiformis

filipes.

foliosa

a mbigua

setiglumis

fournieriana

glabriflora

glance

glomerata

brevifolin

ramosa.

gracilis

377,89

major

gracillima

hirtula

huachucana

interrupta

involuta

jonesif

lemmoni

lindheimeri

Jongiligula

metcalfei

mexicana

commutata

filiformis

\section{purpurea}

microsperma

minutiflora

montana

monticola

nardifolia

nea-mexicana

palustris.

parishii

parviglumis

pauciflora

pendula

polycaulis

polypogon.

polystachyo

porteri.

pringlei.

pungens

purpurea

racemosa

$$
\begin{aligned}
& \text { brevifolia } \\
& \text { raniosa. } \\
& \text { riolacea. }
\end{aligned}
$$

mosissina

repens

reverchoni

richardsonis

rigens.

rigida

scabra.

schaffneri

schreheri

$$
\text { curtisttosa }
$$

palustris.

setifolia.

setiglumis

setosa

simplex

sobolifera.

$$
\text { setigera }
$$

spica-venti

squarrosa

straminea.

subalpina

subtilis.
Muhlenbergia-Continued. sylvatica

Page

374, 894

flexuosa

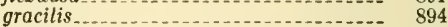

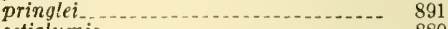

setiglumis _._._._. 889

vulpina _- 889

tenuiflora

pauciflora

variabilis .......... 360,894

texana
texana

texana-10ri

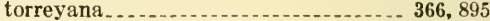

torreyi

trichodes . . . . . . . . . . . 887

trichopodes

trifida.

umbrosa.................... 374, 894

attenuata....................... 374,894

uniflora

terrae-novae ... .

utilis ....... 362,895

taseyana . . .

virescens

willdenowii

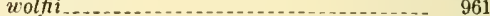

wrightii.......... 358, 365, 896 annulata ...................... 896

Muhly

bush - . 380

creeping

foxtail

littleseed

marsh

mat . .

mesa

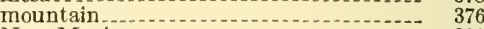

New Mexican . . . . . . . . . . . . 380

pine

plains........ 364

pull-up........ 361

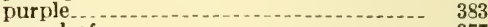

screwleaf

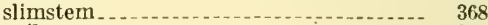

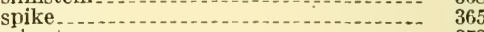

wirestem ............. 373

Mummy wheat

Munroa

squarrosa _. . . . . floccuosa . . . .

Mutton grass . .

longtongue

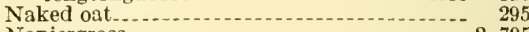

Napiergrass . . ........... 2, 705

Nard grass _.......... 746

Nardus ciliaris _ 853

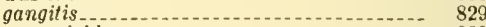

scoparioides ........................... 829

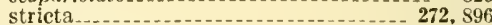

Narrow plumegrass

Nassella major
Nastus carolinianus.

Nastus carolinianus.....

Natal grass

Nazia- 462

aliena................. 463

occidentalis ......................... 966

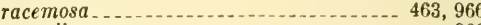

aliena

Nealley dropseed . . ...................... 406

Needle-and-thread

Needlegrass _............................ 423, 512

blackseed_............................. 428

$\begin{array}{ll}\text { Columbia. } & 436 \\ \text { desert } & 425\end{array}$

foothill -

green -

green

Letterman

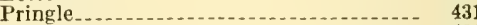

purple

Richardson

Scribner-.......... 434

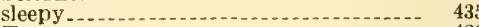

Texas................................... 426

Thurber .......... 432

western

Williams.................................. 437 
Neeragrostis hypnoides.

uriegeltiana

Neobromus, section of Bromus

Neosiap fia colusana.

Nestlera festucaeformis . .

Nevada bluegrass

Nerroctlon maritima paniculata.

Nerroloma canadensis

New Mexican bluegrass

feathergrass.

mubly

New Zealand bent

Neyraudia.

arundinace

madagascarensis

reynaudia.

Page

850

852

55

796

808

135

977

977

864

118

425

380

332

93,896

193

193

Nimblewill

Nitgrass

Noble canes. .....

Nodding bluegrass

brome

fescue -

trisetum

Nomenclature

Northern mannagrass

reedgrass

wildrice

Notata, group of Paspalum

Nothoholcus lanatus.

Notholcus.

$$
\begin{aligned}
& \text { lanatus } \\
& \text { mollis. }
\end{aligned}
$$

Notonema arachnoides

Nudicaulia, group of Panicum

Nuttall alkali-grass

Oat, Algerian

alpine

animated

cultivated

naked

red.

slender

spike.

Oatgrass

California

downy

one-spike.

Parry.

Poverty

tall.

timber.

tuber.

Oats, wild

Oedipachne punctata $\quad 856$

Oil grasses .

Oligosanthia, group of Panicum

715,896

arundinacea

latifolia

arundinacea.............. 896

paniculata ......... 896

One-spike oatgrass

Oniongrass _............ 198

Alaska. . . .

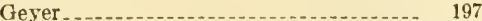

little

purple

Ophiurus cylindricus...................... 880

incurvatus

Oplismenus .......... 688, 896

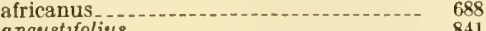

angustifolius

burmanni. 688

colonum

walteri

zonalis

crus-pavonis

crusgallt

colonum.

hispidus.

echinatus.

erianthos.

frumentaceus

birtellus setarius.
Oplismenus-Continued.

Page

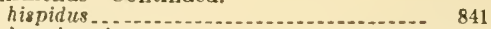

jamaicensis . . . . . .

longisctus _.............. 841

muricatus........... 840

parifolius

repens .............. 839

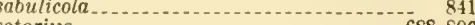

setarius

$\begin{array}{ll}\text { ualteri. } & 907 \\ \text { zelayensis } \ldots \ldots \ldots & 841\end{array}$

Orchard grass _....................... 2, 184

Orcuttia 220,897
californica_ . . $\ldots \ldots \ldots \ldots, 221,897$
greenei _. . . . . . . . 2 . 20,897

tenuis . 220,897

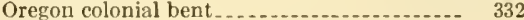

redtop .... 340

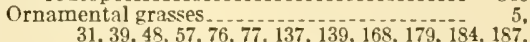

$190,191,204,259,262,356,439,549,565,688$, $697,705,707,708,718,721,723,765$

Ortachne floridana .......... 798 scabra

ten $u$ is . . . 801

Orthopogon crusgalli

echinatus............. 840

hirtellus........ 896

hispidus............. 841

parrifolius .... 896

setarius

Oryza

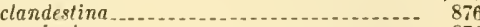

inclusa _......... 876

hexandra $\ldots \ldots \ldots \ldots \ldots$

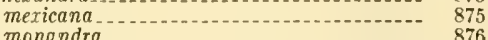

monandra $\ldots \ldots \ldots$.

rubribarbis

sativa rubribarbis $\ldots$

savannae

Oryzeae $\ldots r y 35,535$

asperifolia $\ldots \ldots$
blomeri. $\ldots \ldots$

caduca. 897

canadensis . .

$\begin{array}{ll}\text { cuspidata } \ldots \ldots & 898 \\ \text { erecta } & \end{array}$

exigua
hendersoni $i \ldots$

hendersoni
fimbriata
hendersoni.

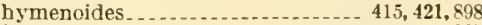

juncea $\ldots$

kingii _...

leucosperma .................... 897

macounit

membranacea.

micrantba.

miliacea . . .

mongolica. .................. 964

mutica

parviflora......... 898

pringlei................... 964

pungens _.......................... 417,898

racemosa

richardsoni.......... 964

$\begin{array}{ll}\text { seleri. } & 928 \\ \text { sibirica } & 897\end{array}$

sibitica

Osterdamia ............................... 463

japonica

matrella

tenuifolia ................................ 979

zoysia

tenuifolia

Oxyanthe phragmites................... 928

$\begin{array}{ll}\text { Oxydenia attenuata } \ldots \ldots \ldots \ldots \ldots & 878\end{array}$

$\begin{array}{ll}\text { filiformis...... } & 878 \\ \text { virgata } & \end{array}$

Palea.

Pallasia aculeata........................... 829

Palmgrass............ 704

Pampasgrass. . . . . . .

Paniceae.... 26,549

Panicoideae.......... 17 


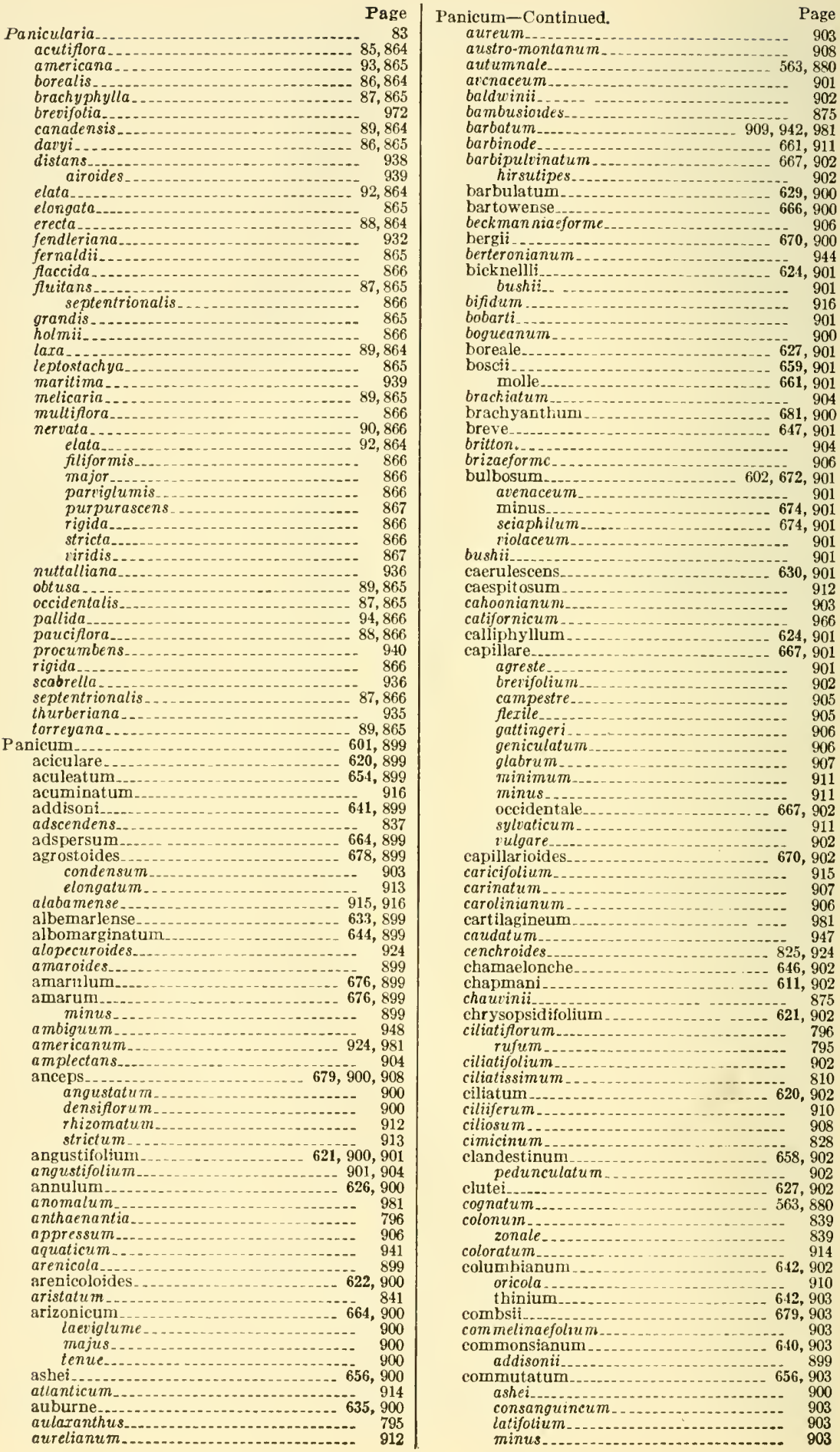


Panicum-Continued.

compressum .......

concinnius.

condensum

consanguineum.

contractum

corrugatum......... 942

costatum

crusgalli

aristatum....................... 839

colonum......... 839

edulis......................... 840

echinatum .................... 840

frumentaceum ........ 840

hispidum_................... 841

mite

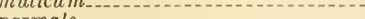

normale

$\begin{array}{ll}\text { mite } & 840 \\ \text { pygmaeum } & 841\end{array}$

purpureum

sabulicola

crus-pavonis...-pici

crusspici

currani............................ 903

curtifolium _............. 646, 903

curtisii ......................... 900, 907

curtivaginum

cuthbertii.............. 830

dasyurum

deamii

debile

decoloratum

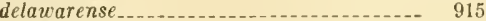

deminutivum

densum _.......... 981

depauperatum..................

$\begin{array}{ll}\text { ineolutum } & \text { laxum }\end{array}$

$\begin{array}{ll}\text { laxum } & \\ \text { psilophyllum }\end{array}$

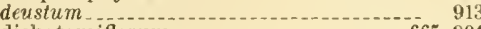

dichotomiflorum _._._. 665,901 puritanorum _..._............. 665, 904

dichotomum .

barbulatum.... 900

commune................ 904

curvatum . 981

divaricatum...... 904

elatum 912

glabrescens_..... 911

gracile _............. 981

lanuginosum

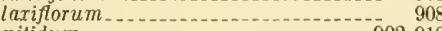

nitidum _..._... 902, 910

nodiflorum ............ 910

pubescens............. 910,981

spathaceum .................... 981

sphaerocarpon

villosum _..... 914

viride ............ 904

digitarioides_........ 907

dimidiatum_._._._.... 906

disciferum _........ 810

discolor

dissectum

dissitiflorum _.......... 900

divaricatum 859,875

stenostachyum_ 875

divergens

drummondii

\begin{tabular}{ll} 
dumus & 967 \\
\hline
\end{tabular}

earlei_....... 903

eatoni

echinatum._._.

elatum

elegantulum......... 902

elliottianum

elliottii____._._._. 904,981

elongatum _ 913, 917

ramosior - 899

ensifolium

enslini

epilifolium

equilaterale _...

equirum

$55974^{\circ}-35 \longrightarrow 65$
Panicum-Continued. Page

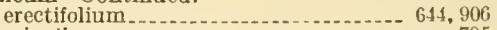

erianthum ........................... 795

eriophorum.......................... 912

erubescens _........ 924

erucaeforme

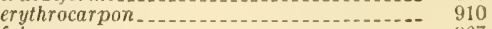

falsum
fasciculatum 967

chartaginense_..._._.

dissitiflorum . .

flavescens........... 905

fuscum ............................. 905

majus revlatum

fastigiatum

festucoides

filiculme

filifor me
filipes

filipes

fimbriatum

firmandum ........................ 911

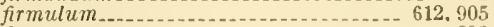

$\begin{array}{ll}\text { firmum } & 898 \\ \text { flabellatum } & 007\end{array}$

flavescens _...................... 905

flavovirens.....

flavum

flexile

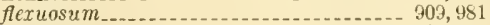

floridanum_______._._._. 905, 916

fluitans............................ 941

fragile.

frumentaceum_._-

fuscescens

fusco-rubens

fuscum ................................... 905

fasciculatum_..... 905

majus

reticulatum......... 905

fusiforme-_.

gattingeri.......

geminatum 661,906

geniculatum_.................... 904, 943

georgianum_....... 903

georgicum

germanicum _... 945

ghiesbreghtii

gibbum

giganteum

glaberrimum

glabrifolium_........ 647,906

glabrissimum_-_...-. 905

glabrum

mississippiense

glaucum _.

elongatum_......................... 946

flavescens ............ 916

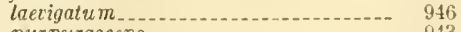

purpurascens_................ 913

glomeratum_....................... 906

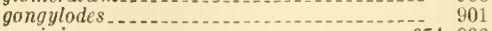

gouini _._._.

pumilum............... 906

gracilentum

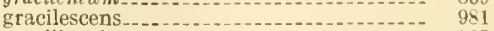

gracilicaule

gracillimum_........................ 835

gravius _._._. 900

grossarium

grossum_..... $\quad 839$

guadalou pense

hymnocarpon

haemacarpon
hallii

halophilum

hamiltonii_........

havardii

hemitomon

heterophyllum...................... 902, 909, 913

thinium ..... 903

hians_...

hillmani

hirsutum

hirtellum $m_{-\ldots} \ldots$

$\begin{array}{ll}\text { hirticalycinum } & \\ \text { hirticalycum } & \ldots\end{array}$ 
Panicum-Continued.

hirticaule.......

hispidum.

horizontale

huachuca

fasciculatuin

silvicola

-1.--1--

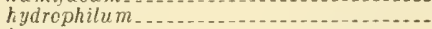

ignoratum

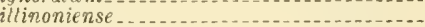

imberbe

dasyurum

grecile.

purpurascens

-

indicum $m$

inflatum.

insulare.

insularar

involutum.

iowense.

isachine.

$$
\text { mexicana }
$$

ischnemum

italicum

californicum

germanicum

iviride.

jamaicense.....

jejunum.

joori

jumentorum

junceum

kolmii...

beyense.

kuntnii

lachnanthum.

laere.

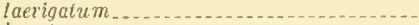

lanatum

lancearium

$$
\text { patulum }
$$

languidum.

lanuginosum

fasciculatum

huachucae

implicat $u$ m

lindheimeri.

septentrionale

siccanum.

lanuginosum.

latifolium.

australe....

clandestinum

molle.

laxiflor um....

pubescens...

lcandri

Jeibergii _

tciophyllqm

lepirlulum_............ 671,908

leucoblepharis ........ 902

leucocomum

leucophoeum

leucothrix.

lindheimeri

631,905

fasciculatum

pilosum

plicatuml... meridionait

septentrionale

tennesseense.

typicum

lineare $\quad 836$

mississippicnse

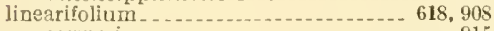$$
\text { verneri }
$$

linkianum

liton

longifolium combsii pubescers

longiligulatum

908

903

908

longipedunculater

909
913

longisetum

841

907

906

07

907
836

796

13

944

44

939

3

lucidum....

630,909
Panicum-Continued. Page

lutescens_...

flavum

macrocarpon

macrostachyum

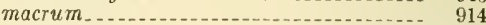

maculatum

malacon

malacophyllum _................. 650, 909

manatense

mattamuskeetense . . _._.......... 627, 909

maximum_.............. 2, 601, 672, 909

bulbosim

gongylodes.

medium

mcgastachyum

mcticarium_.......................... 865

melinis _ 885

meridionale albemarlense ......... 899

michauxianum ...................... 855

michaurii.......-... 855

microcarpon

microcarpon ........................ 911

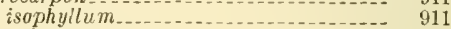

sphacrocarpon _.................... 913

microphyllum . . . .

miliaceum _.

miliaceum_............... 904

milium................... 909

minimum__... 911

minus ............................. 911

minutiflorum

minutulum....................... 915

mississippicnse__.__._. 913

molle........ 855

monachnoides...................... 906

muhlenbergianum......... 981

muhlenbergii_.......................... 904

mult iflor m . . .

muricatum

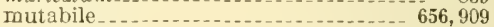

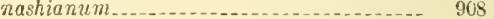

patulum....................... 910

nealleyi_......... 912

nemopanthum.... 901

neriosum _..._.................... 903

neuranthum..... 623, 899,909

таmosum_............. 905

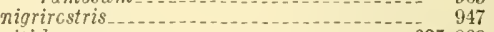

nitidum _... 625, 909

barbatum ................ 909

barbulatum ........... 900

ciliatum

crassifolium_._.... 913

densiflorum

ensifolium_..................... 904

glabrum

gracile _...._. 981

majus ... _.........

minus _._._.

octonodum

pauciflorum_............. 904

pilosum__._._._. 907

pubescens.................. 914

ramulosum.......................... 909

$\begin{array}{ll}\text { velutinum__._. } & 912 \\ \text { viride } & 904\end{array}$

datum _

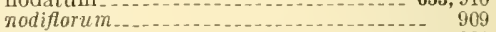

nodiflorum
nodosum

nudicaule

nudum_............. 879

numidianum ...._........ 911

nutans_........ 900

nutfallianum ......................... 896

oblongiflorum $602,682,910$

obtusum
occidentale $\ldots \ldots \ldots$

occidentale $\ldots$

octonodum

oligosanthes _ _. _ _ _ _ 651,910

$\begin{array}{lr}\text { helleri. } & 906 \\ \text { scribnerianum } & 912\end{array}$

onslowense

orangense _........................ 908

oricola

orthophyllum

orale _..._._. 639,910

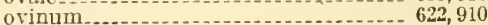


Panicum-Continued.

owerae

palmifolium

paludivagum

pammeli.

pampinosum

parvipaniculatum

parrispiculum - 908

parvulum 914

paspaliforme

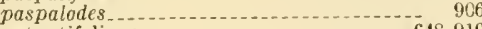

patentifolium _____._._. 648,910

patentissimum .................... 859

patulum

pauciciliatum _.................. 647, 911

pauciflorum.....- 910

paucipilum.......................... 913

pedicellatum _. _...

$\begin{array}{ll}\text { pedunculatum } \ldots \ldots & 902 \\ \text { penicillatum } & \end{array}$

pensylvanicum _. 981

perlongum ......... 618,910

pernercasum _........................... 906

phaeocarpum var. drummondia num . ..... 836

philadelphicum _ _

pictigluma_....................... 911

plantagineum....................... 810

platense

platycaulon

platyphyllunt $\ldots \ldots$
plenum

plenum

plicatum__... 701,947

poiretianum_anos

polyanthes $\ldots+\ldots$
polycaulon

polycaulon

pongylodes ................. 901

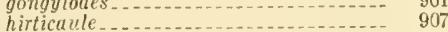

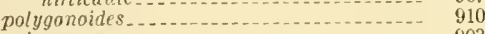

polyneuron

polyrrhizum

porterianum

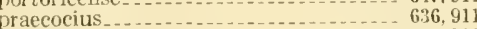

praticola

preslii 914

proliferum

geniculatum

pilosum

protepens _........ 839

prostratum_................... 912

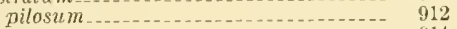

pruinosum

psammophilum _....... 902

pseudanceps............. 908

pseudopubescens . . . . 6 . 638, 911

pubescens _......................... 912

barbu!atum .............. 900

pubifolium

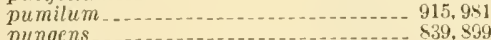

purpurascens..... 2, 601,661,911

pyriforme - 908

rafinesquianum

ramisetum_

ramosum .............. 664,911

ramulosum_... 900

viride

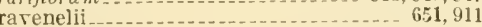

rectum

redivieum _._._._._._._._._._... 910

refractum......... 904

repens. ............. 694.911

$$
\text { confertum }
$$

repente

reptans

reticulatum

612, 912

rhizomatum 680,912

rigidulum _......................... 899

roanokense............ 630, 912

roscum_............. 968

rostratum ......... 900

rufum

rugosum
Panicum-Continued. Page

ruprechtii._......................... 915

sabulicola................................. 841

saccharatum ........................... 966

sacharoides-10 967

sanguinale

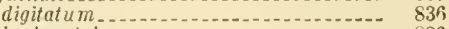

horizontale...................... 836

marginatum _.... 837

simpsoni..................................... 837

scaberrimum ............................ 909

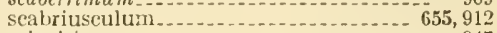

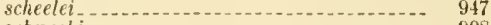

schnecki _._._._._._._._._. 908

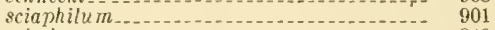

scindens

scoparioides_. _.

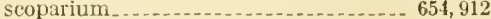

angustifiorum ..................... 910

genuinam_............ 911

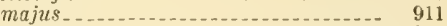

minus

pauciflorum

scoparium_..._._._........... 912

scribnerianum _...................... 650,912

leibergii _..._. 908

senescens_._.

sericatum

setaceum

sctarium_._._................... 896

setosum_............................ 947

shallotte

sliastense_...

soboliferum

solvorum.......... 602

sparsiflorum

seciosum _ 981

sphaerocarpon _..._. 643,912

foridanum 905

inflatum

sphagnicola_._._._._._._._._._._. 630,913

spicatum _... _...

spithamreum .................. 905

sprengelii_...................... 904

spretum _...

squrinatum - 920

stenodes............... 913

stipitatum

stramineuni.

striatum _._._._._._._._._._. 899,941

strictifolium...._._._._._._._._. 909

strictum linearifolium ............................ 908 perlongum

strigosum.

subbarbulatum.

subsimplex.......................... 903

subspicatum _-_-_- 911

subuniforum ....................... 899

Stabvillosum

taxodiorum

tcctum
tejucense

tejucense
teneriffae val. rosca.

tenerum

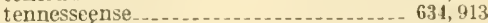

tenue ................ 644, 913

tenuiculmum................. 902

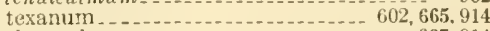

thermale_....................... 637,914

thomasianum........................ 899

thurowii

torreyi

tremulum

trichocondylum ............

trifolium

tuckermani

umbraculum ............................ 914

umbrosum ...................... 909

unciphyltum implicatum meridionale ..................... 909 pilosum $\begin{array}{ll}\text { prostratum } & 908 \\ \text { thinium } & \end{array}$ 
Panicum-Continued.

uniflorum

unispicatum

urvilleanum

$$
\text { longiglume }
$$

raginatum.

vclutinum

ventenatii

rernale

verrucosum

iersicolor...

ambiguum

riaticum

vicarium

vilfiforme

villosissimum pseudopubescens.

scoparioides

villosum.

violascens

virgatum

breviramosum

confertum.

cubense -

diffusum

elongatum

glaucephylla

macranthum

obtusum.

spissum..

viride

thyrsiforme

brevisetum

virletii-.

riscidum

scabriusculum

walteri molle

waltheri

webberianum

werneri.

wilcoxianum

wilmingtonense

wrightianum.

xalapense strictirameum

xanthophysum.

$$
\text { amplifolium }
$$

xanthospersum

yadkinense

zclayense

Panion aridum

buckleyanum var. majus.

bulbosum var. viviparum

compressum

glaucuin

interius

longiligulatum

nemorale

pratense...

pratericola

sandbergii -

triflorum.

Pappophorum

alopecuroideum

apertum

bicolor

mexicanum

mucronulatum

vaginatum
wrightii__.

Pappusgrass

spike.

Para grass

Parry grama.

$$
\text { oatgrass- }
$$

(1)

Ocminatum

aspalum _._._._._._. 575,916

abbreriatum

almum . .

Qlternans - 919

altissimum $m_{1}$

anptum

tcrue ................ 919
Paspalum-Continued. Page annulatum ...................... 855

antillense........................... 921

appressum - 906

atrocarpum................... 921

australe

bicrurum _..._._.

bifidum ................ 601,916

bistipulatum

blepharophyllum .

blodgettii . . . . . _ _ 589,916

boscianum ....... 600,916

brachiatum_...................... 923

brunneum_................. 917

buckleyanum.........

bushir_.............................. 586, 922

caespitosum _..._..... 589,917 longifolium campestre............................... 921

carolinianum ...................... 837

chapmani_..._._............. 5 $\$ 6,917$

chepica_........................... 918

chinense _.......... 838

ciliatifolium .....

brevifolium_........ 917

dasyphyllum ..... 923

muhlenbergii

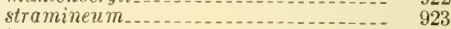

ciliatum _._._... 917

ciliiferum_.................... 589, 920

circulare

compressum

confertum

conjugatum _...

parviflorum

cubense _.

curtisianum_... 920

cynosuroides........................... 953

dactylon

dasyphyllum ...................... 923

floridanum....................... 981

debile . . . . . . 585, 917

debile .............. 917

decumbens

depressum

didactylum_..................... 923

difforme

digitaria _.................. 804, 918

digitatum ............ 836

dilatatum

decumbens._....................... 918

parviflorum ................... 923

sacchariferum.................... 918

dimidiatum ............... 918

dissectum _............. 575, 579,918

dissectum _ 916,917

distachyon . . .

distichum digitaria_....... 919

nanum 923

paspalodes.................. 919

tristachyum_.................. 923

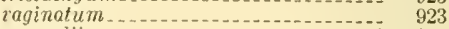

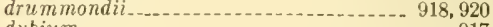

dubium_...... 917

effusum .

cggertii__.

elliottii_..._.........

epile_fiophorum
erion

fernandezianum_........... 918

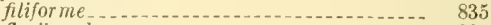

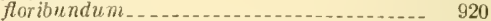

florídamum _... glabratum_._. 597,919

fluitans_._._._._. 922

foliosum............................... 923

frankii_.............................. 922

furcatum

filforme

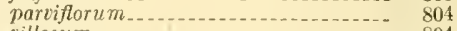

rillosum _... 804

geminum . . .

geniculatum-

giganteum -

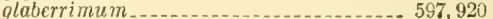

glabratum_................ 919

glabrum

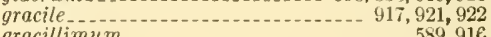

gracillimum......................... 589,916 
Paspalum-Continued.

Page griseum

guadaloupense.

hallit -

923

hart wegianum ....................... 582,919

helleri.

920

heterophyllum

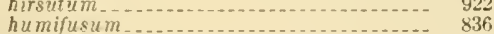

incertum .

infirmum

inflatum -

interruptum _...- 916

ischnocaulon ......................... 920

kearneyn _...
kentuckyzense

likineanum ....................... 923

koleopodum ........................ 920

laeve

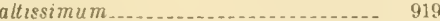

angustıfolium.................... 919

austrate 919

brctifotium

circulare........................... 917

fordanum......... 919

$\begin{array}{ll}\text { pilosum } & \\ \text { und } 10 \text { osum } & 920\end{array}$

$\begin{array}{lr}\text { undulosum } & 919 \\ \text { laevigatum } & 919\end{array}$

laeriglume

lanatum

918

langei.

588.919

lanuginosum $\begin{array}{r}920 \\ \text { larranagai }\end{array}$

laticulmum_.......... 804

latifolium - 917

laxum ..............

la marckianum ................. 920

lecomteanum

lentiferum

$\begin{array}{ll}\text { leptos._. } & \\ \text { leptostachyum } & 921 \\ \text { leucocilum } & 922\end{array}$

leucocheilum........................... 924

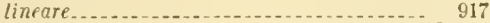

lividum

longepedunculatum. ............... 584, 920

longicilium

longissimum

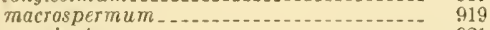

marginatum ........... 921

membranaceum 918

michauxianum

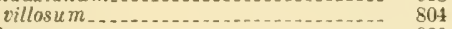

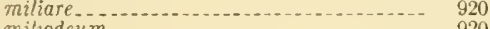

mitrodeum ........................... 920

minus $\quad 583,920$

monostachyum......................... 588, 921

montevidense

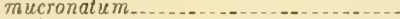

muhlenbergii - 5\&ô, 922

multiforum .................. 921

natans.

notatum

ricola

arthos

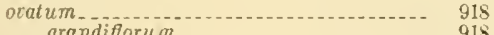

grandiftarum

parviflorum _..._................ 923

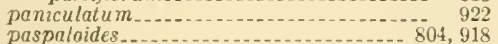
villosum

naucispicatum ................581,921

pauperculum. ..................... 921 altitus..................................... 921

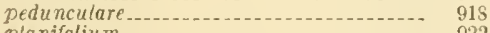

$\begin{array}{ll}\text { planifolium } & \\ \text { piatense. } & 918 \\ \text { platicauton }\end{array}$

$\begin{array}{ll}\text { piatense } & \\ \text { platicauton } & \end{array}$

platycau!e.......... 804

platyphyllum_................... 810

plenipilum..................... 595, 920

jicatulum ......................... 600, 921 intumescens..................... 921

$\begin{array}{lll}\text { plicatum } & \\ \text { poiretii } & \end{array}$

praecox

curtisianum............................. 99

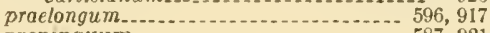

propınquum............... 587, 92
Paspalum-Continued. Page prostratum

psammophilum _...

pubescens muhlenbergii

pubiflorum ................... 5\$1, 922 glabrum_..._............... 575, 582, 922 glaисum . 922

viride ........................... 922

punctatum-a.s.

punctulatum......... 919

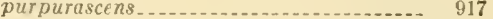

racemosum _. 579,922

racemosum

racemulosum...................... 916

rauntiaerii_............................... 804

rectum rar. longispicatum _.___._. 921

reimarioides....................... 923

remotum var. glabrum .................. 922 glaucum_......................... 922

renggeri-_-_-_an

repens

rhizomatosum.......... 920

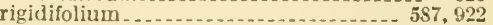

saltense 921

sanguinale.......... 837

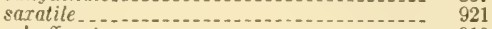

schaffneri_......................... 918

scrobiculatum _..._._._._._. $600,601,922$

selloi -

sericeum

serotinum_........................ 836

setaceum _........ 584,922

ciliatifolium.................... 917

lonqepedunculatum................... 920

supinum ....................... 923

simpsoni . . - . -

solitarium _.

spathaceum ........................... 917

stramineum

supinum .................... 585, 923

supinum -

taphrophyllum

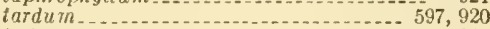

tectum..................... 918

tenacissimum_..................

tenue .

tristachyon ................................... 804

tristachyum

undulatum............ 921

undulosum ......................... 919

unispicatum

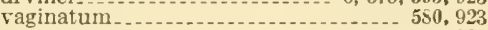

nanum ........................ 923

pubescens

reimarondes . . . . . . 923

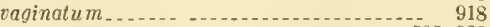

vaseyanum

velutinum - 923

villosissimum................................. 918

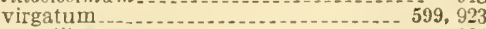

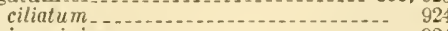

jacruinianum -..... 924

latifolium

linneanum............................ 923

parviflorum............................. 923

pubifiorum........................... 923

purpurascens

stramineum _................. 924

udulasum................................. 921

villdenowianum.................. 924

virgatum - 916

walteri-...... 918

walterianum.............................. 918

yucatanum........................ 916

Paspalum, Combs............. 583 grass ..... 575,594

Pasture grasses
$33,39,58,69,75,99,106,114,116,184,231$,

$33,39,5 \times, 69,75,99,106,114,116,184,231$,
$269,276,325,484,5.19,573,575,594,672,750$

Patterson bluegrass ............. 125

Paurochaetium, subgenus of Panicum...... 611

Pearl millet_.............. 2, 705

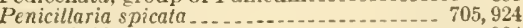

typhoidea. ...

Pennisetum

alopecuroides........................... 708,925 
Pennisetum-Continued.

Page americanum ........ 924

corrugatum _._._._._. 943

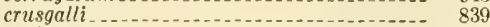

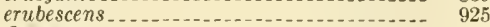

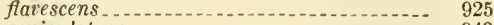

geniculatum

germanicum......................... 945

glaucum purpurascens _.................. 982

hamiltonii _....... 925

hirsutum ................ 925

indicum var, purpurascens

italicum ........... 945

japonicum _............................. 708

laevigatum

latifolium

macrostachyum _._._._._.

myosuroides

nervosum . .

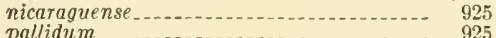

$\begin{array}{lll}\text { pallidum } & \ldots \\ \text { parviflorum } & \end{array}$

pungens

purpurascens........................... 925

purpureum

7ichardii - .

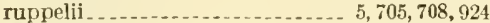

setaceum . . . . . . . . . . . 708

setosum ...... 705, 924

sieberi_.............................. 925

spicatum .................. 924

typhoideum....................... 924

swart zii

typhoideum ......... 705, 924

verticillatum

verticillatum

viride ................... 948

Pentameris a mericana............ 831

californica.

compressa_........... 831

epilis................................ 832

intermedia........................ 832

sericea . . . .

spicata...................................... 832

thermale

unispicata. . . _

Peruvian winter grass

Phalarideae

americana....... 926

picta
a methystina.

$\begin{array}{lr}\text { a methystina } & 926 \\ \text { ammophila } & 788\end{array}$

angusta $\ldots . . . .533,925$

arundinacea _. .

picta

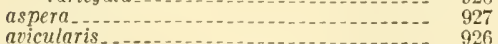

bellardi...........

brachystachys
bulbosa

bulbosa
californica

canariensis . . . _ _ _ $530,531,926$

brachystachys . . . . . 926

caroliniana

intermedia

angusta

angustata ............. 925

$\begin{array}{lr}\text { microstachya } \ldots \ldots \ldots \ldots \ldots & 926 \\ & 925\end{array}$

lemmoni.

tudoviciana

$\begin{array}{ll}\text { maritima } & \text { microstachya } \\ & \end{array}$

minor

occidentalis . . . . .

oryzoides . .

paradoxa .................. 330,926

praemorsa.... 531,926

praemorsa

stenophylla ................... 535, 926

stenoptera _............. 535, 926

subulata........ 927

tenuis.

trivialis.
Phalaris-Continued.

Page

tuberosa.

$\mathbf{5 3 4}, 535,926$

stenoptera.

$534,535,926$

velutina.......................... 835

villosa

zizanioides ..... 977

Phalona echinata........... 830

Phanopyrum gymnocarpon

Pharus_...

latifolius _... _. .

parvifolius . . . . \$46,926

Phippsia _._.

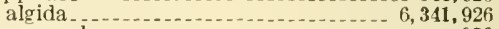
monandra........................... 926

Phleum _ _ 352,927 aculeatum

alopecuroides........................... 868

alpinum

americanum .................... 927

scribnerianum _..._.__ 927

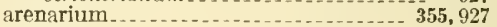

asperum__... 927

bellardi_._.

bulbosum - 535, 927

crinitum_....................... 937

haenkeanum........ 927

monspeliense_..._._._............. 937

nodosum var, praten se

paniculatum _...
pratense $\ldots \ldots \ldots \ldots$ alpinum

schoenoides.............................. 868

subulatum .............. 355,927

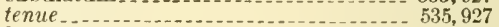

Pholiurus
$\quad$ filiformis

incurvatus

incurvus . . . . . . . . .

pannonica _......................... 274

Phrsgmites........................... 191,92

berlandieri_a 191,928

$\underset{\text { berlondieri }}{\text { communis }}$

phragmities vulgaris__........ 928

Phyllostachys _....... 5

aurea

edulis ... $\quad 4$

Pine bluegrass

Pine muhly . .

Pinegrass

Pineland three-awn . . . . .

Piptatherum mexicnnum - 928

miliaceum 898

nigrum

punctatum

Piptochaetium . . .

fimbriatum ........... 423,928

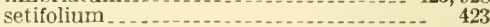

Plains bluegrass ...... 114

bristlegrass ...................... 700

lovegrass

muhly _...

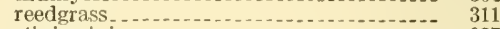

Plantinia alpina_.................... 927

aspera

pratensis ............................... 927

Pteopogon setosum

Pleuraphis jamesii

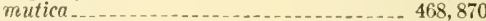

rigida _..._.

sericea

Pleuropogon

californicus _._.

dorglasii _._........................ 928

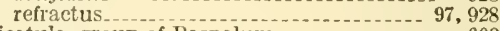

Plicatula, group of Paspalum......... 600

Plumegrass... 5, 721

bent-awn $\ldots \ldots \ldots$

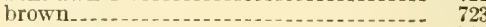

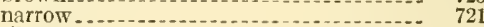

silver

Poa

abyssinica

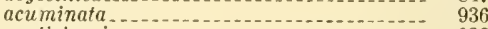

acutiglumis_......................... 936

aestivalis_..... 929 
Poa-Continued. airoides

Page alcea $\begin{array}{ll}\text { alcea } & \text { algida }\end{array}$ al picola alpina _....... _._. minar purpurascens ... 932 alsodes. wolfii_............. 937 amabitis .......................... a mbigua ........... andina elongata_.......... 931 major purpurea spicata angustifolia . . .

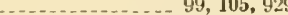
rigidiuscula _..................... 929 stricta _....................... 930

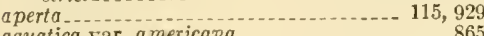
aquatica var. amesicana_a $-99,106,929$ arachnifera_..._._. glabrata $\ldots . .115,929$ arctica .......................... 99, 115, 929 argentea.................... 100, 114, 929 arida arundinacea autumnalis _ 126,930 robusta. . _ _ _ _ _ bigelovii _..._............. 100, 103,930 bolanderi _......................... 103, 930 chandleri........................................ horellii kelloggii borealis............ 838 borreri_.._........ $\quad 938$

brachiata...... 136, 933 brachyglossa
brachyphylla brandegei.............................. 93 brevifolia

breripaniculata subpallida........................ 932 buckleyana..................................... elongata.............................. 931 sandbergii ....................... 936 stenophylla $\ldots \ldots \ldots$

bulbosa rivipara ....................... 930 caerulescens_........................... 969 caesia strictior ........................ 933 californica _ _......... 930, 932

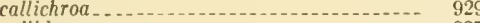
callida campyle ................................. 930 canadensis_........................ 864 canbyi................ 99, 135, 930 capillarifolia _....... 931 capillaris

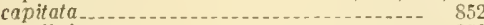
caroliniana_._._._._._._._._._._._. 850 cenesia _. _. chapmaniana ............ 105, 931 chariis 84 chionogenes_......... 929 cilianensis_.............................. 84

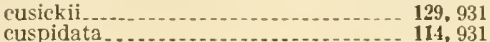

Poa-Continued. Page cuspidata.

cyperoides_._-_.......... 849

debilis_.

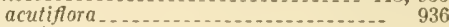

delauarica. ............................. 938

densiflora............................. 929

dentata

diandra ........................ 851

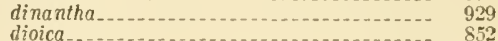

dioica

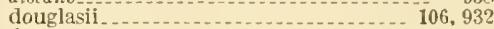

dura

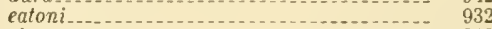

elegans.................................... 848

elegantula

elliottii

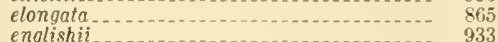

englishii . . $99,130,932$

eragrostis.......................... 850,851

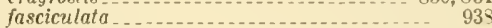

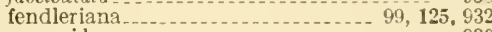

arida _................ 930

arizonica- 932

juncifolia

spicata

festucoides . . . . . . . . _........... 859, 863

filifolia........... 931

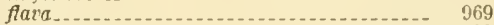

flexuosa

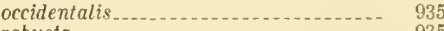

robusta $\ldots \ldots \ldots$

glabrescers _._... 929

glauca

caesia_............... 932

ctrictior

glaucifolia

glomerota saxatilis

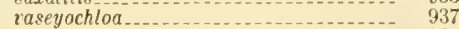
$\begin{array}{lll}\text { grayana_. } & 115,929\end{array}$

hanseni

helleri

herantha

hirsuta

howellii - 103,933

chandleri

microsperma

hypnoides........................... $\$ 50$

idahoensis

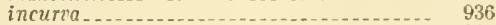

infirma

interior

interrupta

inraginata.....
involuta

japonica

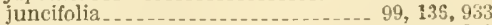

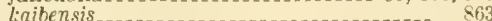

kelloggii

kingii

lacustris

laerigata

laeris_........ 930

la marckii ................. 866

languida ....... 117,933

laxa debilior .

occidentalis ....................

laxifiora

leckenbyi

leibergii

lemmoni

leptocoma _............. 121, 934

clatior
reflexa

lettermani

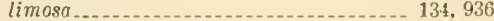

lineata ............. 866

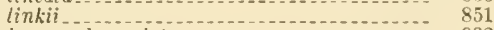

longepedunculata......................... 932

viridescens.......................... 932 
Poa-Continued.

Page

longiligula..

wyomingensis

99,126934

934

lugens

5,930

macrantha

$100,106,93$

macroc

124,934

marcisa

117,934

maritima

938, 939

megastachya

melicoides.

mexicar

michauxii

micrantha

modesta.

montana

mult nomae ......... 134, 933

nematophylla.................... 93

nemoralis. ...................... 123, 929, 934

glauca.
nemoralis........

nerrata.

nerrosa _. _ _ _ $99,109,934$

tracyi

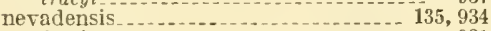

lacrigata_...... 931

nitida

nudata

nutans

nutkaensis..................... 939

nuttalliana--

nuttallii _..... 848, 851

obtusa_...... 818, 865

obtusata_........ 956

occidentalis $-118,935$

occidentalis_._.
olneyae

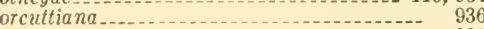

oreri

orylepis _........... 852

pachypholis...... 130, 937

paddensis

paludigena

polustris

panicoides

partiflora

$99,124,935$

(19, 866

paucispicula_...... 120, 935

pectinacea

pennsylvanica _....................... 818

philadelphica

phoenicea

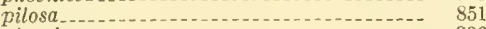

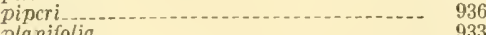

planifotia

plattensis_._._. 933

$\begin{array}{ll}\text { platyphylla } & 935 \\ \text { plumosa } & 947\end{array}$

plumosa-_.

pratensis

pseudopratensis ................. 930

pratericola........... 930

pringlei

hanseni.

procumbens

pscudopratensis.

pudica

pulchella

major

pungens.

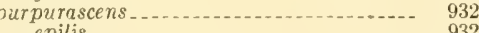

quinquifida _... 969

reflexa_._.

reflexa......... 852

refracta ...

remissa_.

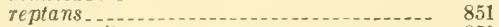

caespitosa_.

rhizomata_.......... 108, 936

Tupcstris

rupcicris
rupicola

saltuensis

microlepis..................... 936

sandbergii .......................... 135, 936

saratilis............ 933
Poa-Continued. Page scaberrima........................ 931

scabrella_._._._._._._._._. 99, 132,936

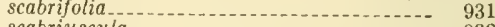

scabriuscula ........................... 932

secunda . .

secundiflora................ 852

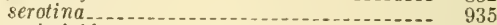

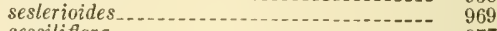

sessiliflora

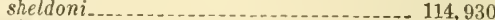

simplex

spectabilis............... 853

spillmani_._.

stenantha_............... 127,936

leptocoma

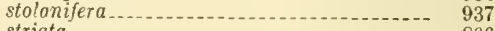

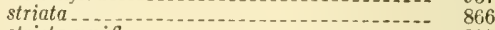

stricta uniflora

subaristata

subpurpurea._._._._._._._._._... 932

subreflexa._.

subtriviatis_..._........... 933

subverticillata.

suksdorfit_........................... 936

sulcata

sylvestris

tenella

tenerrima

tenuifolia

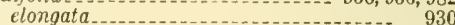

maior

rigida

scabra...

tenuis

tephrosanthos........................ 853

$\begin{array}{ll}\text { texana } & \\ \text { thurberiana. } & 839\end{array}$

tarreyana.................... 865

tracyi_........... 118, 936

trichodes ................ 853

tricholepis.......... 929

triflora

trinervata................ 931

trivialis _....._._. $\begin{array}{ll}\text { fliculmis } & 937 \\ \text { occidentalis } & 935\end{array}$

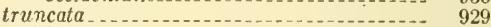

uniflora _.....-...- 895

unilateralis .

uninerria _._.

unioloides_... 853

vaseyana .......................... 934

vaseyochloa_........................ 131, 937

$v \in$ stita

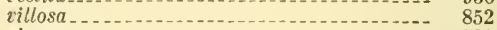

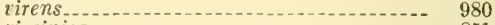

virginica $\ldots \ldots \ldots 51$

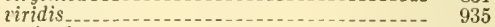

walteri

ueigettiana

wheeleri _._._._. 110, 934

villiamsii_.................... 929

wolfii . . . . 119, 937

wyomingensis...... 931

Podagrostis cequiralvis_..._._._._... 779

Podionapus caespitosus..................... 833

flexuosus

$\begin{array}{ll}\text { Padopogon avcnaceum } & \\ \text { Podosaemum agrostideum } & 962\end{array}$

Padosaemum agrostideum

$\begin{array}{ll}\text { arenicola } & \text { capillare }\end{array}$

$\begin{array}{ll}\text { capillare } & 887 \\ \text { debile } & 891\end{array}$

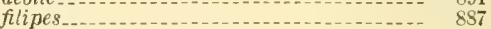

foliosum_..._._._. 889

glaucum......................... 889

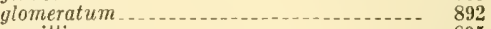

gracillimum $\ldots 95$

mexicanum _._. 890

porteri

pungens

purpureum $\ldots 58$

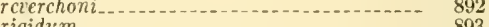

rigidum

setosum _.............. 891

soboliferum

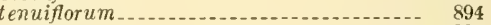

texanum ............................... 89

trichopodes........ 888 
Podosaemum-Continued.

Page virescens .

tirginicum

Polish wheat

Pollinia dura

scoparin -

riminea

Polyanthrix hystrix

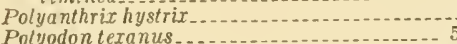

Polypogon .

alopecuroides_........... 781
australis

australis
canadensis $\ldots \ldots$

canadensis
crinitus .

flacescens ............................. 933

glomerat us.......................... 892

interruptus .

littoralis . . .

lutosus . .

maritimus........

monspeliensis ........ maritimus. . . .

monolepis..........................

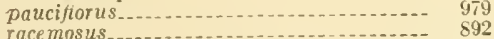

racemosus_..............

setosus

Polyraphis, section of Pappophorum .......- $\quad 227$

$\begin{array}{rr}\text { Poranthera ciliata ................. } & 951 \\ \text { nutans } & 951\end{array}$

nutans

Porcupine grass . . ........ 200

Porter melic

Poverty oatgrass............. 303

three-awn ............... 449

Prairie beardgrass . ............... 489

cordgrass .

cupgrass_...

three-awn ............................. 446

wedgegrass _............................... 278

Prince Edward Island bent_.__.

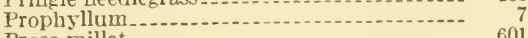

Proso millet........... 601

Psamma-1.

dittoralis

Pteroessa, section of Eragrostis _..........-. 149

Ptychophyllum, section of Panicum

Puccinellia_____.
airoides

alaskana._._._._._._.

angustata_......................... 939

borreri

cusichii__._. tenuis_...... 938

fasciculata. . . . . .

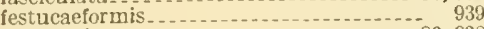

lemmoni. . . . . .

lucida

minor

nutkaensis _. _.

nuttalliana__._.

parishii............ 83, 939

paupercula
alaskana.......

pumila_._._._.......... 82, 939

rubida

rupestris _..
simplex _..

suksdorfit.

Pull-up muhly

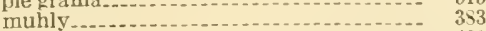

needlegrass..................... 431

oniongrass...................... 197

reedgrass . . .

three-awn................................ 452

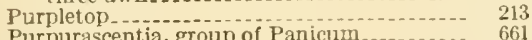

Purpurascentia, group of Panicum ........ 64,661

Quaking grass........................... 137

$\begin{array}{ll}\text { big } & 137 \\ \text { little } & 137\end{array}$

Rabbitfoot grass

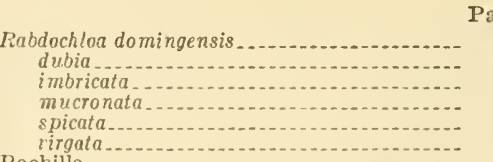

Page

876

877

879

972

9

Rachilla__._.

Range grasses $\ldots 3,39,73,99,139,229,230,24 \times, 252,301$, $306,325,345,357,392,415,423,439,466,511$, $551,566,697$.

Rattlesnake grass........................... 48

mannagrass_............................ 89

Ravenna grass ............................ 5, 723

Reana lururians.....-. 856

Rebentischia flatescens ...................... 973

Reboulea filiformis . . ..................... 955

gracilis

glabra

obtusata

lobata

pubescens

pallens_......................... 957

$\begin{array}{ll}\text { longiflora } & \text { major }\end{array}$

pennsylvanica............... 956

major

truncata

Red dropseed

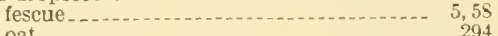

sprangletop_........ 472

sprangletop

Redfieldia _........ 173, 940

flexuosa .............................. 4, 173,940

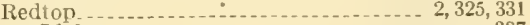

Idaho _...

\begin{tabular}{ll} 
Oregon $\ldots \ldots$ & 340 \\
\hline
\end{tabular}

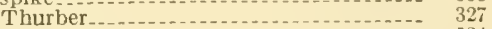

Reed canary grass .......................... 534

Reed, common

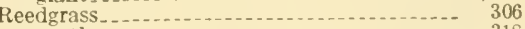

northern........... 318

plains .

purple

Reimaria diffusa........

eimarochloa _................... 575, 940

acuta

oligostachya_........ 575,940

Rescue grass $\ldots \ldots \ldots \ldots \ldots \ldots$

Reverchon three-awn........ 451

Rhaphis

pauciflorus.

tririalis

$\begin{array}{lr}\text { Rhizomes } & 7 \\ \text { Rhode Island bent }\end{array}$

$\begin{array}{ll}\text { Rhode Island bent } & 332 \\ \text { Colonial bent } & \end{array}$

Rhodes grass _...

Rhombolytrum albescens.................... 216

Rhynchelytrum repens .................. $\quad 695$

roseum

Ribbon grass . .

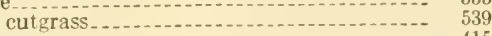

Ricegrass

Indian........... 415,421

little

Richardson needlegrass...... 427

Ringgrass _.......... 381

Ripgut grass

$\begin{array}{ll}\text { Ripidium ratennae } \ldots \ldots \ldots \ldots & \\ \text { Rock melic } & \end{array}$

Roemeria zeae

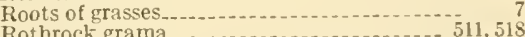

Rothrock grama......

Rottboellia.
altissima

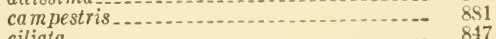

ciliata _............. 847

$\begin{array}{ll}\text { compressa var. fasciculata.............. } & 851 \\ \text { corrugata } & 881\end{array}$

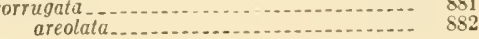


Rottboellia-Continued. cylindrica

exaltata

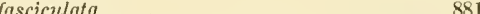

filiformis.......... 928

incurva.

incurvata

paniculata

chapmani

scarpioides.

tessell

tuberculose

Rough bluegrass

fescue

stalked meadow grass

Rupestrina pubescens.

Ryegrass

Australian

English

Italian

perennial

269,

granularis -

alkali_an

Saccharifera spontanea .................. 982

Saccharum alopecuroideum

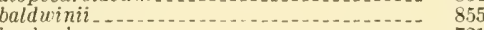

barberi _.......... 721

brevibarbe _.

contortum

cylindricum .............................. 873

erianthoides................ 854

giganteum_...

japonicum_........................ 885

officinarum _..._.

polydactylum ......................... 826

polystachyum ......................... 962

$\begin{array}{ll}\text { ravennae..... } & 851 \\ \text { sagittatum } & 567\end{array}$

sinensis................... 721

spontaneum ........................... 721

strictum

acciolepis

gibba

indica

striata_...

Saint Augustine grass

Salina wild-rye ........................ 252

Salmasia flexuosa - 834

praecox

vulgaris.

Saltgrass, desert

Saltmeadow cordgrass

Sand-binding grasses ...- $4,100, \overline{1} 4 \overline{3}, 1 \overline{7} 3,179,320,322$

Sand dropseed ....................... 402

Sandberg bluegrass . . . . . . . . . . . . . . . . . 99, 134

Sandbur-.......- 708

coast_.....- 710

field.

Sandreed, sea

Sanguinaria vaginat

Santia monospeliensis.

Sasa japonica

Satintail.

Savastana.

alpina.-. macrophylla.
nashii

nashii

odorata

$$
\text { fragrans }
$$

Schedonnardus paniculatus.

$$
\text { texanus }
$$

inermis

obtusus.

pratensis

spicatus.

sterilis.

tectorum

tenellus.

unioloides

Schellingia tenera

\section{DEX}

Page

Schenodorus americanus....................... 857

Schismus.......................... 275, 941

barbatus............................... 275, 941

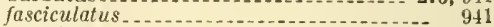

marginatus

patens.................... 877

Schizachne _._._._. 205, 941

fauriei_........ 205,941

purpurascens

Sclerochloa _..._._.

arenaria var. fasciculata

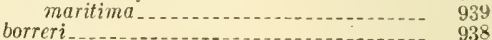

borreri

californica .......................... 936

distans.......-.... 933

dura . . .

maritima

multiculmis ssp. borreri

distans

procumbens _._.

rigida

Scleropoa

procumbens........................ 940

rigida _...... 77, 942

Schizachyrium acuminatum ............. 731, 793

cirratum _........ 789

domingense

feense_........... 791

gracile

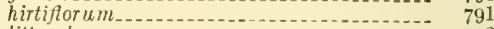

littorale _...e 792

maritimun .................. 792

neomericanum .

oligostachyum _..._................ 791

scoparium -.....-... 793

semiberbe........... 793

staloniferum

tenerum

triaristatum _........ 731,794

villosissimum .................... 731, $79^{3}$

Schleropelta stolonifera

Schmidtia subtilis _............................ 825

Schoenus aculeatus............... 82

Schrader's bromegrass

Schultesia petraea

Sciadonardus distichophyllus

Sclerachme arkansana.............. 880 pilosa

Scleropogon brevifolius............. 229,942 karwinskyanus.......................... 229, 942

Scolochlon arundinacea donax

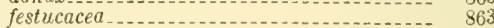

Scoparia, group of Panicum

Scratchgrass..... 366

Screwleaf muhly

Scribner needlegrass...

reedgrass . . . . . . .

Seribneria _... 275, 942

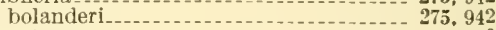

Sea oats

Seaside bent

Secale

cereale

montanum ....... 246

prostratum

Semaphore-grass__._._._._. nodding . .

Serrafalcus arvensis..... 811

commutatus......................... 814

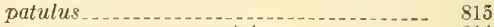

racemosus var. commutatus

secalinus............ 817

Sesleria americana..................... 982

dinctyloides $\quad 318$

$\begin{array}{lr}\text { Setacea, group of Paspalum } & 583 \\ \text { Setaria } & \end{array}$

Setaria $\quad$ affinis _.

a mbigua

barbata.

berteroniana

brevispica............ 948

californica........................... 945

caudata
pauciflora................. 
Setaria-Continued.

cenchroides

composita.

corrugata

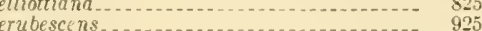

$\begin{array}{ll}\text { erubescens_. } & \\ \text { fiara } & 925\end{array}$

geniculata

germanica................................. 945

gibbosa

glauca...........

corrugata ........................ 943

clongata

geniculata....................... 945

imberbis _....... 944

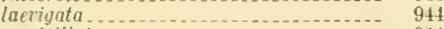

penicillata................. 914

purpurascens.....................

dasyura

grisebachii . . .

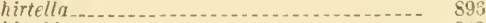

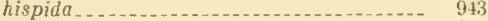

imberbis............ 943

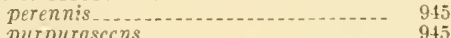

italica $2,697,704,945$ germanica stramineofructa var. brunneoseta _..... 915 germanica

laerigata

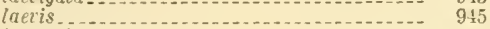

leucopila

liebmanni ....................... 01.949

lutescens

macrosnerma

magna _ _... _.

mexicane -

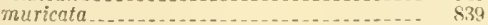

nigrirostris . . .

palmifolia................... $097,704,947$

penicillata .......................... 941

perennis........................ 94

poiretiana

polystachya ........................ 94

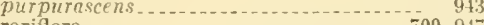

rarilora
rariflora
rigion

rigida

scheelei_..._._.

setosa

caudata_..................... 917

stipaeculmis

streptobal rys. ......................

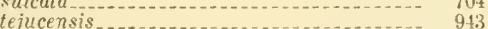

$\begin{array}{ll}\text { tejucensis } & \\ \text { rentenatii } & 913 \\ & \end{array}$

verticillata__._.

ambigua ................. 699, 9 ts

villosissima

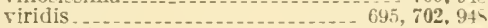

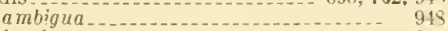
breviseta . . . . .

purpurascens................... 949

veinmanni..... 949

reinmanni....

Share fescue

Shaliu.

Sheep fescue

750,752

$5,58,76$

Shorthair

Shortleaf triodia -

Sickle grass

Side-ogts grama

Sieglingia acuminata

albescens

a mbigua

americana

avenacea var. grandifiora

bucklcyana.

chapmani.

congesta.

cuprea

dubia

elongata.

eragrastaides

scabra..
Steglingia-Continued. Page

flain

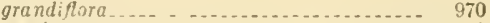

mutica.................... 970

neallogi........................... 970

pilasa............................ 971

pulchella 971

parriftora...... 971

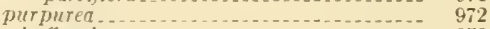

schaffneri_...................... 972

seslerioides

intermedia................... 970

spicata__._._._. 972

stricta _...

trinerviglumis

trinermiglumis

Silage grasses .................. 2, 705,768

silver heardgrass.

hairgrass . 293

plumegrass ........................ 722

Sitanion _...

albescens.......................... 950

tinoma!um _. . 260,9:9

tasalticola ........................ 950

breriaristatum . .

brerifolium ........ 261, 949

brodei ................................... 842

caespitosum ....................... 949

californicum _...................... 949

ciliatum

cinereum..................... 261, 949

e'ymoides _. _ _ _ _ _ 259, 949

flexиosum 796

$\begin{array}{lr}\text { glabratum } & 949 \\ \text { hanseni } & 949\end{array}$

anomalum ................... 949

hordeoides._. 950

hystrix

jubatum 260,950

lanceolatum ........................ 776

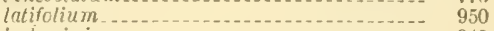

lectir nbyi

longifolium ...................... 261, 950

marginatum. . . . ..................... 261

minus_._.

molle _.............................. 949

montanum_....................... 261, 949

multisetum . . . . . .

planifolium

polyanthrix . . 950

pubiflorum

rigidum.......... 949

californicum ................ 950

$\begin{array}{ll}\text { rubescens. } & \\ \text { strictum } & 949 \\ \text { strigosum } & 950\end{array}$

strigosum _....................... 919

relutinum..................................... 261, 950

rillosum_.

Sixweeks dropseed

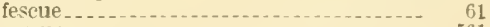

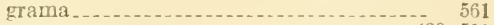

grass _......

three-awn ........ 446

Skyline bluegrass......................... 130

$\begin{array}{ll}\text { Sleepy grass _.... } & 135 \\ \text { Slen ler hluegrass } \ldots \ldots & \end{array}$

$\begin{array}{rr}\text { Slender hluegrass. } & 134 \\ \text { grama......... } & \end{array}$

hairgrass.........

oat

wedgegrass -

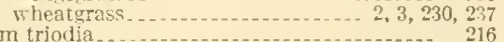

slimstem muhly ....................... 369

Smith melic

Smooth brome

cordgrass

crabgrass

$\begin{array}{lr}\text { Smut grass . } & \\ \text { Soft chess } & 595\end{array}$

50
Soft chess
Soil-holding grasses $\ldots$

$100,173,230,218,320,322,499,576$

Soiling grasses _............... 2, $672,705,768$

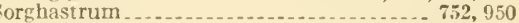

arenaceum

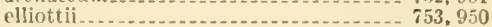

linneanum

nutans
secundum 
Page

Sorgho

750,752

Sorghum

arctatum
argenteum
arenaceum
brachystachyum
cabanisii
caffrorum
cirratum
contortum
drummondit
elliottii
glomeratum
gracile
halepense

halepense......

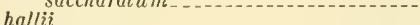

hirtiflorum

hirtum

longiberbe

melanocarpum

nordus.

nutans

avenaceum

linneonum ---

pauciflorum

roxburghii

rufum

saccharatum

saccharoides

scoparium

secundum

semiberbe

sorghum

striotum.

sudancnse-

virgotum

virginicum 795

vulgare

bicolor

caffrorum

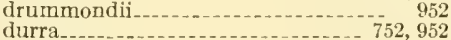

durra

saccharatum _..._._._._._._._. 752,952

sudanense___ 750,952

technicum

wrightii.

zizanioides

Sourgrass

551

South German bent...
Spartina

alterniflor glabra. pilosa

americana

bakeri

caes pitosa

cynosuroides.

aureo-marginata $\times$ gracilis

michaurione

major... polystachya

densiflora subv. brongniarti forma acuta.

foliose uncrformis

glabra

alternifiora. pilosa

gouinii.

gracilis

juncea.

americana

bakeri.

$$
\text { patens. }
$$

junciformis.-

laevigata.

leiantha.

maritima ssp. glabra

alterniflora glabra pilosa

michauriana

$$
\text { suttiei- }
$$$$
\text { tenuior }
$$

multiflora.
487,953
491,953

492, 953

492,953

492, 954

854

489,953

954

954

954

954

954

955

491, 954

953

953

953

955

492, 954

493,954

954
Spartina-Continued.

Page patens.

489, 493, 954 caespitosa.......... juncea pectinata ...... suttiei_._._. 954 pittien polystachya_._._............... 491, 954 pumila _.......................... 954 schreberi-... 487 spartinae stricta var. alternifiora glabra maritima_... 953 townsendii..... 4, 489 Spelt

Sphaerium lacryma....................... 828

Sphaerocarpa, group of Panicum _._._. 643 Sphenopholis.............. 278,955 annua

aristala filiformis

glabra

halhi_........ 974

intermedia___. $278,280,955$

interrupta

longiflora_-
nitida_. glabra

obtusata____ 278, 955 lobata_... 957 pubescens_._.

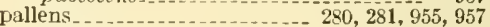
longifiora _. . _ _ _ _ major palustris flexuosa pennsylranica flexuosa

pubescens___._._................. 957

robusta_.._.

Spider grass _._._..... 443

spike dropseed

fescue _..... 69

muhly

oat

redtop

trisetum_-_... 284

Spikelet, structure of

Spirochloe paniculata

Spirotheros melanocarpus

Sporobolus _.................... 392, 957 airoides $\begin{array}{cc}\text { altissimus__._. } & 962 \\ \text { minor } & 962\end{array}$

angustus 961

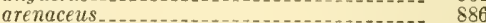

arenaceus

aristulatus........... 899

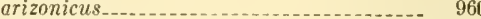

arkansanus ___- 957

asper drummondii.-.

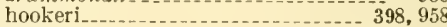
pilosus _ _.... 398, 958

aspericaulis_........................ 893 aspcrifolius brevifolius_..._._.

major

attenuatus_..................... 398, 958

auriculatus ......... 365, 886

berteroanus ....... 395, 961

bolanderi _......................... 933

brevifolius

buckleyi.

conovirens_._.

clandestinus_._._. 398,958

compositus_._- 958

compressus......... 367, 895

confusus_._.

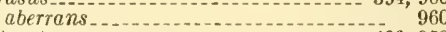

contractus _..........

cryptandrus........................... 392,958

flexuosus....... 959

giganteus......... 959

involutus_._._._._. 959

robustus $\quad 959$

strictus - .

vaginatus..... 959

curtissii . . ......................... 400, 959 
Sporobolus-Continued.

cuspidatus filifornis ............ 888

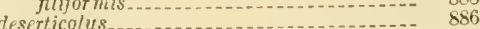
diffussimus ......................... 957 distichophyllas . 886 domingensis _...... 402,959 drummondi 398,953 ejuncidus......................... 960 elongatus _- 395

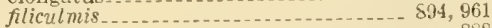

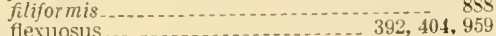
flexilosus ...................... 392, 404,959 Horidanus ................. 959 curtissit_and giganteus. gracilis. _............... gractllmus .................. 400,960 indicus indicus.......... 392, 395, 860, 961 incrdinatus interruptus _ $392,399,960$

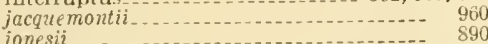
junceus lamarckii

lioulatus ........ 383,887 littoralis _... 395, 902

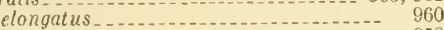
longifolizs _- 958 macrus _- 398, 960 mičospermus................. 393, 960 minor mulengergii -...-..-..-... 979 mulleni nealleyi__. oratus _._._. garkiens2s -397.960 pilosus pairetii ...... 395, 960

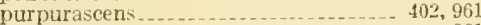
961 ramulosus........ 393, 901 repens. ....

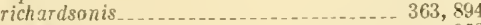
sabranus sacatilla sarmentosa......................... 886 serotinus _.......... 368, 895 simplex thermate 889 strictus_._._. tenuispica _............ 853 teretifolius _. texanus _.......... 408, 961 tharpii_..... thurberi.............. 891 tarreyanus...... tricholepis $u$ niflorus uniflorus._.
utilis $\ldots \ldots$ raginatus.

raginiflorus inaequalis . . . . minor neglect us....................... 960

rirginicus ............ 394, 962

urolfii
wrightii

Sprangletop_.............. $\quad 469$

grecu

red ............... 472

Spreading wheatgrass_........ 239

Spreta, group of Panicum ........ 631

Squirreltail

$\begin{array}{ll}\text { big_. } & \\ \text { Hansen } & \end{array}$

Strpfia colusana

Stargrass . .

Steogosia exaliata .......................... 940

Steinchisma divaricatum ................. 859

hians

Stelephuras pratensis................ 927

Stem of grasses ....

Stenochloa californica.
Stenotaphrum _................... 563,962

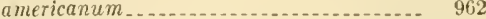

dimidiatum var, americanum secundum glabrum

americanum ....................... 962 sarmentosum secundatum . . . . . . . . .

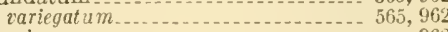
sicundum .......................... 96

Stinkgrass

Stipa_.............. 423,962

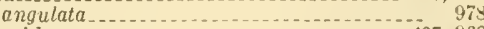

arida_......

aveuacea_._. 428, 962

bicolor

avenacioides_.......... 128,962

barbata

brachychaeta

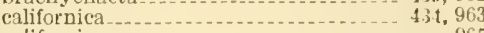

californica _. . . . _.................... 965

canadensis........................ 897

capillaris_.....................

capillata_........... 963

ciliata__._.

columbiana - 423, $13 \hat{\text { an }}, 963$ nelsoni-......................... 435, 963

comata .................... 2, 423, 130,963

intermedia_ . . . . . _ _.......... 430,963

intarsa _.. 430,963

coronata _... depauperata_.................. 427,963 parishii....................... 963

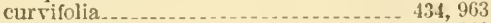

demissi

diffusa

elegantissima_.................. 439, 963

elmeri_... 433, 963

eminens_....... 431, 963

andersonii
recta

crpansa__._._. 867,883

fimbrinta-

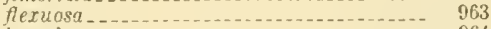

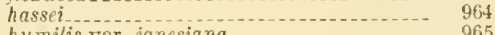

humilis var. jonesiana_................. 965 spcciosa

hymenoides ..................... 898

\begin{tabular}{ll} 
juncea.............. & 963 \\
\hline juncea
\end{tabular}

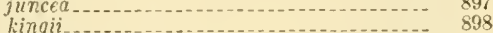

latifolia

latiglumis

lemmoni _._. _...

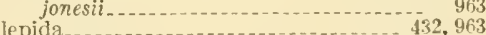

andersoni.

lettermani

leucotricha _................... 426, 964

Jobata

macounii

metanocarpa......................... $86 \mathrm{~S}$

membranacea

minor

mormonum neesiana

nelsoni -

neomexicana

nuttalliana

occidentalis mantana . ........... 964

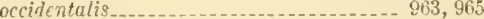

oregonensis_.......................... 961

parishii................ 963 depauperata.......... 963

parrifora

pennata neomexicana $\ldots$

pinetorum _.. _.....

porteri

priuglei ................................ 431, 964

lemmoni.-.................. 963

pulchra

richardsoni

richardsonii _...................... 897,964 major................................ 964 
Stipa-Continued. robusta.

robusta

scribneri.

sericea

sparta...

spartea

curtiseta tweedyi

speciosa

$$
\text { minor }
$$

spicata.

stillicta

$$
\text { sparsifiara. }
$$

$$
\text { subulata }
$$

tenacissima

tenuis.

tenuissima

thurberiana--

tweedyi.

vaseyi

villosa

virginica

viridula

$$
\begin{aligned}
& \text { lettermani. } \\
& \text { minor } \\
& \text { pubescens } \\
& \text { robusta. }
\end{aligned}
$$

williamsii

Page

$423,435,964$

434,965

887

965

, 430, 965

430,965 963

$23,425,96$

964

982

426, 965

950,964

Stolons

Stout woodreed

Streambank wheatgrass

Streptachne cubensts..

domingensis.

floridana

scabra

tenuis.

Sudan grass.

Sugarcane

plumegrass

Sweet tanglehead

vernalgrass.

Sweetgrass

$$
\text { California. }
$$

Switchgrass

Synaphe rigida.

Syntherisma

bakeri....... 553

barbatum

chinensis_..._..................... 838

digitatum

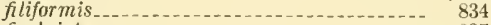

fimbriatum

$\begin{array}{ll}\text { glabrum } & \text { gracillima }\end{array}$

hracillima

insularis _...... 967

ischaemum_............. 836

leucocoma_...... 837

lineare

mississippiense

marginatum

paniceum

praecox

sanguinale

serotina

setosum

simpsoni

villosum.

Tabosa grass

Tall mannagrass

oatgrass

trisetum

Tanglehead

$$
\text { sweet. }
$$

Tares

Teff

Tenera, group of Panicum

Teosinte

$$
\text { Mexican. }
$$

Terrell grass.

Terrella curvato

halophila..

hirsutiglumis

jejuna

$$
\text { virginica }
$$

Terrellia canadensis

diversiglumis

glauca.
Terrellia -Continued.

Page

glaucifolia - 812

macounii._...................... 845

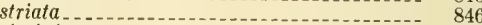

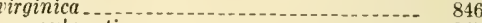

submutica

Texas beardgrass

bluegrass. ................

millet.

needlegrass........................... 426

wildrice

Thamnocalamus 31

Thickspike wheatgrass_._.

Thingrass . . . . . . .

Thintail _........- 274

Three awn, Arizona......... 455

Fendler-_... 454

Havard

pineland ......... 455

poverty ................. 449

prairie

purple_............. 452

red-...-..-.-.

$\begin{array}{ll}\text { Reverchon } & 451 \\ \text { sixweeks_. } & 446\end{array}$

Wooton ....... 450

Three-flower melic _..._._._. 203

Thurber fescue _............ 58,71

needlegrass ............ 432

redtop

Thurberia arkansana_..._._._._._._._. 880

pilosa _- 880

Thysanolaena agrostis . . . .

maxima ....... 549,965

procera. ........... 856

Tibisee_..._.

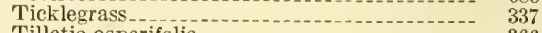

Tilletia asperifolia_._._._._. 366

Timber oatgrass...................... 304

Timberline bluegrass _............... 129

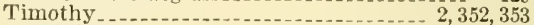
alpine.................................. 353

Toothache grass.................. 494

Torresia___._. 526

alpina_..._ 869

macrophylla

nashii__._._._. 869

odorata..... 869

Torrey melic _._.

Tosagris agrostidea

Toxeumia gigantea.................... 824

Tozzettia agrestis

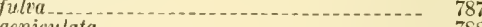

geniculata_........... 788

Trachynotia alterniftora........... 953

alternifolia

cynosuroides........................ 953

juncea

polystachya

Trachypoa vulgaris

Trachypogon

argenteus..._....... 792

hirtus

laguroides _....... 792

montufari

plumosus var, montufari..._._._... 966 secundus

polymorphus var. montufari......... 966 secundus_... preslii..._.

secundus_........... 965

rufus. ........................ 872

scrobiculatus.

secundus.......................... 966

Tragus _................ 462, 966

berteronianus_._._.

clatior _......... 858

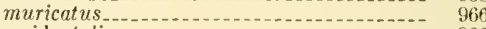

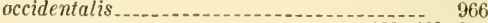

racemosus _................... 462, 463, 966

brevispicula ................... 963

longispicula

unioloides..................... 813

Triathera aristidoides $\ldots 512,805$

Trichachne _

californica

hiteheockii _.......... 551, 966

insularis ................. 551, 966

saccharata......... 551,966 
Page

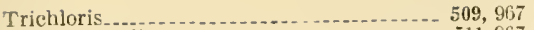
blanchardiana.................... 511,967 fasciculata.

tatifolia

mendoeina.......... błanchardiana pluriflora............... 509, 511, 967 verticillata $a$

Trichochloa calycina

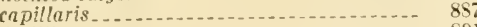

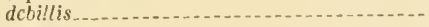

erpansa

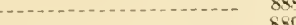

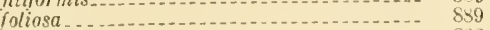

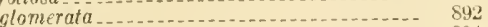

longiflora. ............................ 894

longiseta

mcricana......................... 890

microsperna ..................... 591

polypogon

purpurea............ is

$\begin{array}{ll}\text { rigida } & 893 \\ \text { setosa } & 891\end{array}$

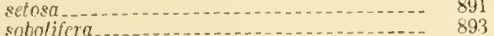

tenuiflora

rircscens -

$\begin{array}{ll}\text { Trichodiclida prolitera } & \\ \text { Trichodina } & 971 \\ 7 \$ 2\end{array}$

Trichodium album

a!gidum .......... 784

laxum_....................... 979

caninum

cancinnum .

datum

laxnflorum........... 781

larum

muhlenbergianum......... 784

noveboracense.

perennans

scabrum

strictum

Tricholaena

insularis..

micrantha

rosea

Trichoneura.

elegans.

hooberi-......

Tricuspis acuminata

albescens

a mbigua -..-.

congesta

cornuta.

flongata.

flava

langloisii

monsira.

mutica

movae-boracensis.

pilosa

pulchella.

purpurea

quinquifida

seslcrioides

flexuosa

texana-

trinerviglumis

781,784

695.959

967

695, 965

$476,90 \mathrm{~S}$

477, 968

477
928

971

968

970

965

971

217,958

970

970

969

971

972
969

15,969

969

216,971

971

Tridens

albescens

ambiguus.

207

drummondii

elongatus

cragrostoides.

flav'us

grandiftorus.

langloisii

(micus

pilosus

pulchellus.

quinquifida.

971

209,971

969
Tridens-Continued.

Page sesteriodidcs ......... . 215,970 strictus . _................ 216,971

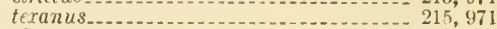

Triodia ........ acuminata. ...................... 211,971

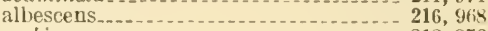
a mbigua ...................... 212, 970 a renacea....................... 209, 970

buckleyana_........................ 211, 968 caerulescens......................... 969

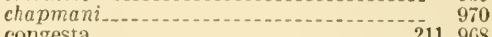
congesta_........ 211, 968 clprea..... elliottii elongata........... 207, 217, gri eragrostoides_... scrbra . . . . .

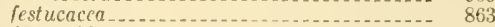

festucoides

flava . .

glumosa . ............ 832

grandiflora ... 207, 209, 970

langloisii ......................... 212, 970

melicoides............................ 97

multineriosa.

mutica _. .

nealleyi ................

noraeboracensis ..................... 969

pallida_an

pulchella_.

pungens................................... 207

purpurea........................... 872

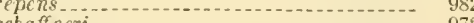

schaff neri_.............................. 972

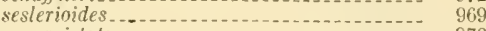

215,971

texana

texana

Triplasis _.......... 217,971

amerieana................... 217, 213,971

cornuta

floridana................... 972

clabra

intermedia.................... 219, 972

purourea_._..._._.

sparsifiora_.............. 972

Tripogon

hromoides............................ 477

spicatus____ 477,972

Tripsaceae
Tripsacum acutiflorum .............. 973

cylindricum

dactyloides ..... $76 \pi, 972$

floridanum ......................... 973

hispidum .

lernmoni_........................ 973

monostachyon .................. 972

monostachyam
floridanum $\ldots 9$

granuiare

herma phroditum

lancenlatum

latifolium

lemmoni

monostachyu m 972

Trisetaria airoides_._.
Pavescens.

Trisetum _

$\begin{array}{ll}\text { airoides } & \text { americanum. }\end{array}$

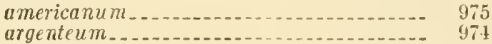

aristatum-10

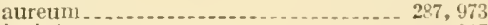

barbatum.

barbatum
major

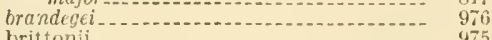

brittonii

cancscens.
montanum

cernuum

canescens.......................... 973

luxurians.......... 973

pubescens.................... 973

sandbergii 
Trisetum-Contiuued. congdoni. elatum

Page

tonsum 973

velutinum

flavescens.

glabrum............................. 834

hallit..._._.

hirtum _....... 817

interruptum hallii

lobatum

ludovicianum 975

majus

melicoides

cooleyi

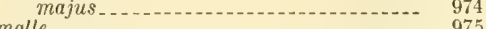

molle $m$ montanum 975

pilosum .......... 974

shearii

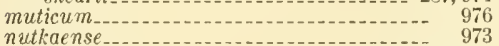

nutkaense
orthochaetum

palustre _....... 972, 975

pennsy]vanicum _............... 287, 974

pennsylvanicum ............. 956

praecox _.........

projectum 286,973

projectum

sandbergii $\ldots \ldots 73$

shearii....--

spicatum
brittoniz

brittonii

molle 284,975

pilosiglume

subspicatum ............... 975

molle.... 975

trinii nuticum.

wolnิi

gallidiforus.... 817

muturum 976

muticum

Trisiola paniculata._. 977

Tristegis glutinosa

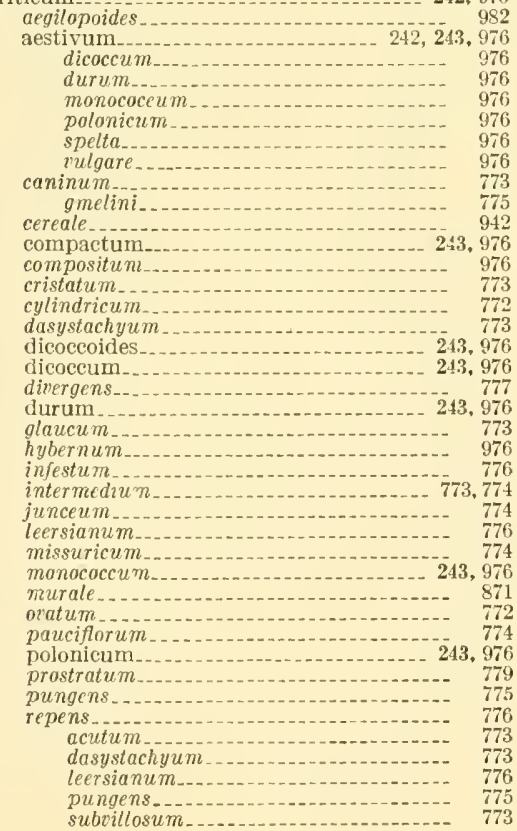

Triticum-Continued. Page

richardsani._. 788

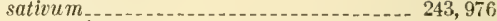

aestivum 976

compositum

vulgare

semicostatum _.......... 776

spelta _.._............ 243, 976

strigosum

subsecundum_....... 778

trachycaulum ........... 774

irichophorum

triunciale........... 772

turgidum . . . .

vaillantianum

vulgare _....... 243, 976

aestivum 976

Trixostis gracilis

Tuber oatgrass..... 298

Tufted hairgrass

Tumblegrass

Tunis grass.

Turkeyfoot

bluejoint

Two-flower melic _._...... 200

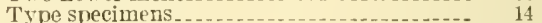

Typhoides ar undinacea _...

Eniola . .

distichophylla...

flexuosa

foridana..... 977

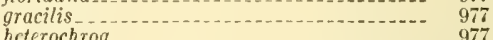

heterochroa

intermedia

latifolia_.

longifolia .

macrostachys_...................... 977

maritima . .

multiflora...

ornithorhyncha_

palmeri 179

paniculata... 179, 180, 97

sessiliflora

spicata

stricta

uniflora

virgata..... 977

Uniseta, section of Aristida........... 443

Urachne asperifolia..................... 897

brevicaudata

canadensis_....... 897,898

tanata_............... 898

leucosperma _........................ 897

major

melanosperma

micrantha...... 898

mutica $\ldots$

racemosa

Uralepis a mbigua

brevicuspidata..... 877

$\begin{array}{ll}\text { cuprea } a \ldots \ldots & 969 \\ \text { densiflora } & 971\end{array}$

densiflora
elongata

elongata

pallida

pilosa 970,971

poacoides........................... 932

pulchella

tricuspis $\ldots \ldots+\ldots$

verticillato _. 879

$\begin{array}{ll}\text { Uralepsis aristulata } \ldots \ldots \ldots \ldots & 972 \\ & 877\end{array}$

composita $\ldots \ldots \ldots$.

purpurea.

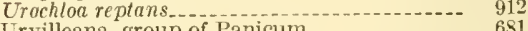

$\begin{array}{ll}\text { Urvilleana, group of Panicum _.......... } & 681 \\ \text { Uva grass } & 190\end{array}$

$\begin{array}{lll}\text { Uva grass _. } & 190 \\ \text { I'ahloded atropurpurea }\end{array}$

Valota

hitch cockii_..._._. 966

insularis

saccharata $\ldots$

Vasey grass _.................. 575, 595

Taseya comata $\ldots 56$
Vaseyochloa

aseyochloa $\ldots \ldots$
multinervosa

Tegetative organs $\ldots$

Telvet bent ............ 325,340

grass . . . . . . . 
Page
Vernalgrase

sweet.-

Verrucosa, group of Panicum

Vetiver

Vetiveria arundinacen

muricata

zizanioides.

Vilfa agrostoidea
airaides

airaides.
alba
algida
arachnoidea.
arguta...
ariansana
aspera
asperifotia.
berteraana
clandestina
composita
compressa.
confusa
cryptandra.
fexuasa.
cuspidata.

cuspidata.

depauperata fitiformis.

$$
\text { dispar }
$$

domingensis.

sis

drummondii

elongato

exilis

filiculmis

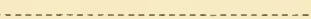

futcescens

glomerata

gracilis. -

yracillima.

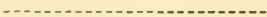

heterolepis.

hookeri-

indica.

jacquemontii

juncea.

lateriflora.

liebmanni

littoralis.

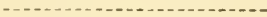

lutosa.

macra

mericana

minima

monandra.

muhlenbergii.

nutans.

purpurascens.

racemosa.

ramulosa

repens.

retrofracta

richardi

richardsonis

riehlii.

rigens

sabeana

sacatilla

scabra.

schiedeana.

serotina.

spartinae

squarrosa.

stolonifera

maritima.

subpyramidata

subsetacea

tenacissima var. exilis fuscicola

tenera

tricholepis

triniann

utilis

vaginiflora

varians...

verticillata

vinzenti.

virginica

vulgaris.

Vine-mesquite.

Virgata, group of Paspalum

$55974^{\circ}-35-66$
Page

irginia wild-rye

Vulpia, section of Festuca .............. 61

l'utpia dertonensis_..............

megalura

microstachyn $\quad 859$

citiata

myuros _._.

octoflora.

pacifica

quadriflora.

reflexa...... 861

tenella.

Wasatchia kingii ........ 858

Wasington beni foxtail. . .

Water bent_... 349

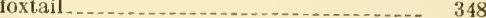

grass _...

paspalum $\ldots$

Weak mannagrass _.............. 84, 98

Wedgegrass _.............. 278

prairie

slender _._._.

Weingaertneria canescens $s_{\ldots} \ldots$

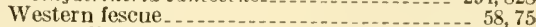

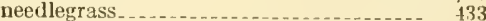

wheatgrass ......

Wheat
Wheatgrass $\ldots \ldots \ldots$

$\begin{array}{ll}\text { Baker } & \\ \text { bearded } & \ldots\end{array}$

bearded _...

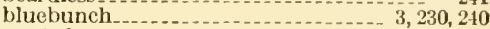

crested _._. 2,231

slender

spreading

streambank _... 234

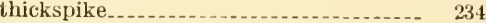

western

Wheeler bluegrass

White triodia.

Whitegrass _......................... 539

Wild cane

ehess......... 47

Wild-rye .......... 246

beardless............

blue

Canada

giant

Macoun ................. 254

Salina

Virginia_.............. 258

Wildrice

annual_................... 510

northern

southern

Texas

Williams needlegrass _................... 437

Willkommia__... 484, 978 Sarmentosa.

texana

Windmill grass

Windsoria ambigua pallida poaeformis

stricta_._................. 971

Wire-grass.......... 494

Wirestem inuhly.......

Witchgrass .......

Wolfs trisetum ........................ 283

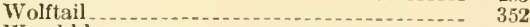

Wood bluegrass $\ldots \ldots \ldots \ldots$

Woodreed

drooping

stout.

Wooton three-awn

Xanthonanthos odoratum

Xiphagrostis japonica $\ldots \ldots \ldots$

Yellow bristlegrass _....

Zawadke alkali-grass _........ 78

Zea_. americana.

canina........ 978

cryptosperma

eryihrolepis............ 978

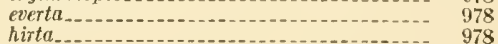




\section{INDEX}

\begin{tabular}{|c|c|c|}
\hline a-Continued. & Page & Page \\
\hline japonica..... & 978 & Zerna inermis. \\
\hline mais hirta.... & 978 & madritensis. \\
\hline mass...... & .973 & myuros..... \\
\hline everta & 978 & sterilis... \\
\hline japonica.. & .978 & tectorum. \\
\hline pensylvanica. & 978 & unioloides \\
\hline precox & 975 & Zizania..- \\
\hline saccharata. & & aquatica. \\
\hline tunicata.. & , 975 & angustifolia \\
\hline virginica. & 978 & interior \\
\hline saccharata.... & 978 & clavulosa.... \\
\hline segetalis & 975 & effusa... \\
\hline tunicata & 978 & jluitans.. \\
\hline vulgaris & 978 & interior . - \\
\hline eia caning & 773 & latifolia. \\
\hline cristato & 773 & lenticularis_. \\
\hline hya.. & 773 & miliacea \\
\hline glauca........ & 773 & natans..... \\
\hline mollis & 777 & palustris_. \\
\hline occidentalis..... & 777 & subtilis.... \\
\hline pseudorepcns_._. & 775 & texana..... \\
\hline repens & 776 & $\begin{array}{l}\text { Zizanieae } \\
\text { Zizaniopsis }\end{array}$ \\
\hline riehardsoni_..... & 778 & mierostachya. \\
\hline riparia & 776 & miliacea__o \\
\hline smithii_- & 777 & zoysia $\ldots \ldots \ldots$ \\
\hline spicata & 777 & 464,979 \\
\hline tenera................ & 775 & matrella_-_. \\
\hline vulgaris aestiva & 976 & $\begin{array}{l}\text { pungens } \\
\text { japonica }\end{array}$ \\
\hline eocriton hystrix & 872 & tenuifolia..... \\
\hline murium & 871 & tenuifolia _......... 464,979 \\
\hline nodosum.. & 871 & \\
\hline
\end{tabular}

nodosum. 





